

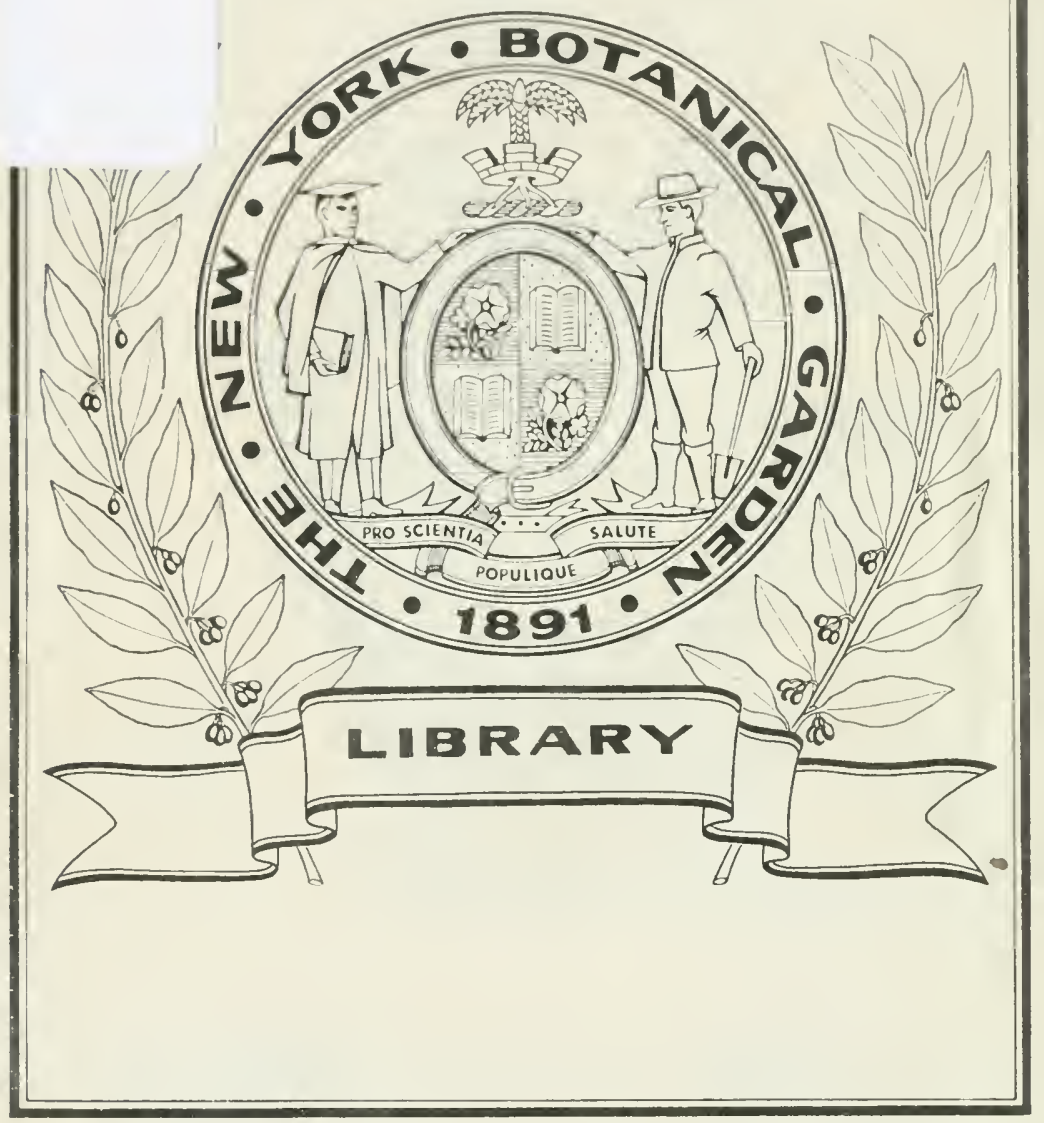









\section{Jjy Clartes \$prague \$argent}

A MANUAL OF THE TREES OF NORTH AMERICA, EXCLUSIVE OF MEXICO. With over 600 illustrations drawn by Charles Edward Faxon. In one octavo volume. $\$ 6.00$, net, postpaid.

THE SILVA OF NORTH AMERICA; OR A DESCRIPTION OF THE TREES WHICH GROW NATURALLY IN NORTH ANERICA, EXCLUSIVE OF MEXICO. With about 740 plates, drawn from Nature, by Charles Edward Faxon, describing 567 species belonging to the Forest Flora of North America, exclusive of varieties. I4 volumes. 4 to, $\$ 350.00$, net. (Sold only by subscription for the entire set.)

TREES AND SHRUBS. Illustrations of New or Little Known Ligneous Plants. Prepared chiefly from material at the Arnold Arboretum of Harvard University, and edited by Charles Sprague Sargent. Issued in 4to Parts, four Parts to a Volume. With Plates, by Charles Edward Faxon. Each Part, \$5.00, net. Volume I. now ready.

THE FOREST FLORA OF JAPAN. With illustrations. 4to, $\$ 7.50$, net.

HOUGHTON, MIFFLIN AND COMPANY Boston and New York 


\section{TREES OF NORTH AMERICA}






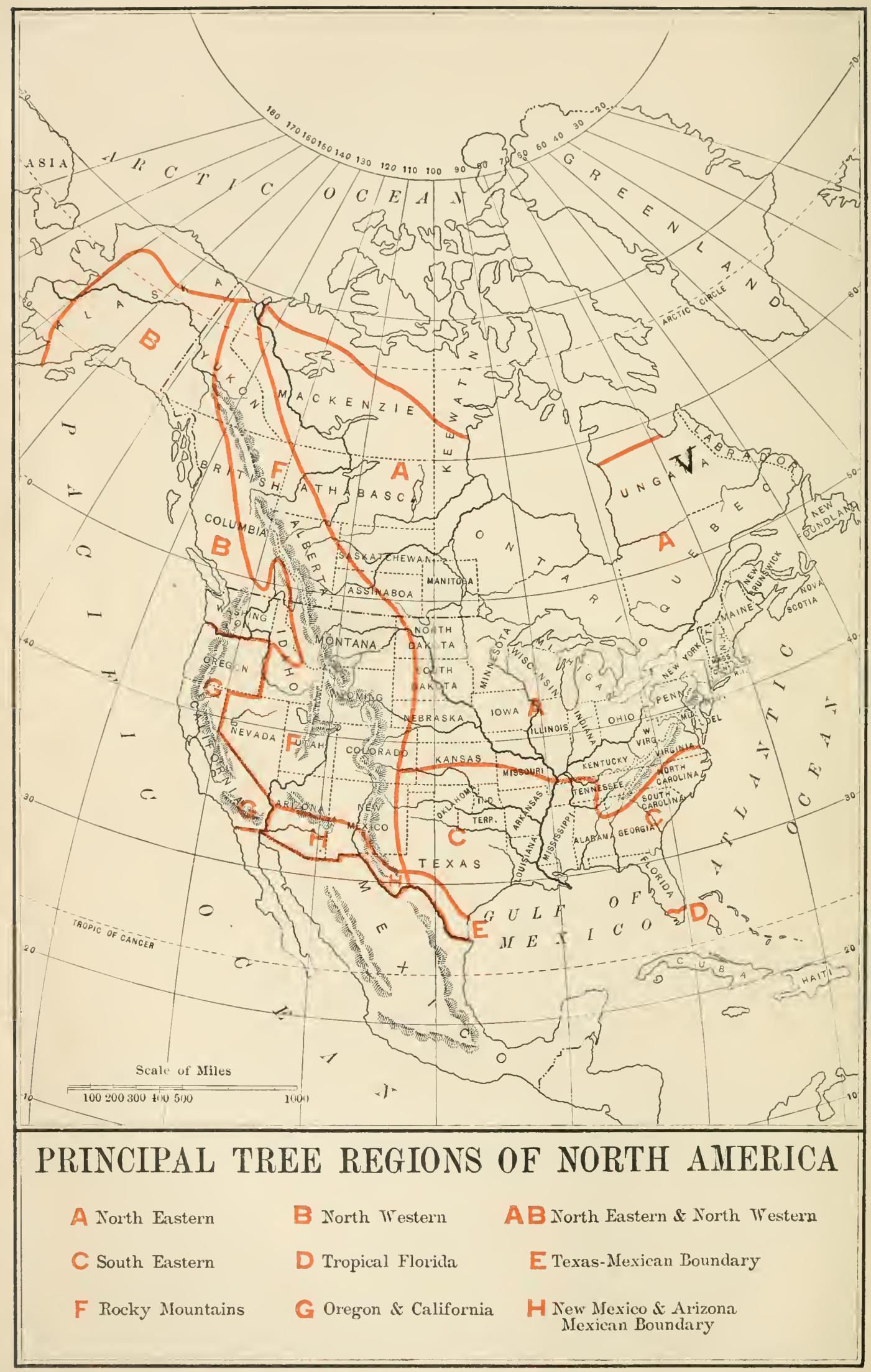




\section{MANUAL OF THE TREES}

OF NORTH AMERICA

(EXCLUSIVE OF MEXICO)

BY

\section{CHARLES SPRAGUE SARGENT}

Director of the Arnold Arboretum of Harvard University Author of The Silva of North America

WITH SIX HUNDRED AND FORTY-FOUR ILLUSTRATIONS FROM DRAWINGS BY

CHARLES EDWARD FAXON

\section{LIBRARY \\ NEW YORK \\ BOTANICAL \\ GARDEN}

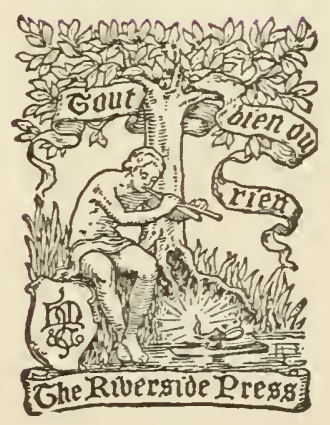

BOSTON AND NEW YORK HOUGHTON, MIFFLIN AND COMPANY

(Che taiturgide pregs, Cambrioge 
COPYRIGHT IQO5 BY CHARLES SPRAGUE SARGENT

ALL RIGHTS RESERVED

Published March, 1905 
To M. R. S.,

THE WISE AND KIND FRIEND OF THIRTY YEARS, THIS BOOK IS DEDICATED WITH GRATITUDE AND AFFECTION 
Oak in that region nced occupy himself only with those species which in the conspectus of the genus Quereus or Pinus are followed by the letter $(A)$, while a person wishing to determine an Oak or a Pine-tree in Oregon or California may pass over all speeies which are not followed by $(G)$, the letter which represents the Pacific coast region south of the state of Washington.

The sign of degrees $\left({ }^{\circ}\right)$ is used in this work to represent fect, and the sign of minutes (') inches.

The illustratious which accompany each specics and important varicty are one half the size of naturc, exeept in the case of a few of the large Pine concs, the flowcrs of some of the Magnolias, and the leaves and flower-clusters of the Palms. These are represented as less than half the size of nature in order to make the illustrations of uniform size. These illustrations are from drawings by Mr. Faxon, in which he has shown his usual skill and experience as a botanical draftsman in bringing out the most important characters of cach species, and in them will be found the chief value of this Manual. For aid in its preparation I am indebted to him and to my other associates, Mr. Alfred Rehder and Mr. George R. Shaw, who have helped me in compiling the most diffieult of the keys.

Arnold Arboretum, Jamaica Plain, Mass.

C. S. SARgent.

January, 1905. 


\section{TABLE OF CONTENTS}

Map of North America (exclusive of Mexico) showing the eight regions into which the country is divided according to the prevailing character of the trees . . . . . . Frontispiece Synopsis of Families of Plants . . . . . . . . xi Avalytical Key of Families of Plants, based on the character of their leaves . . . . . . . . . . . xvi Mavual of Trees

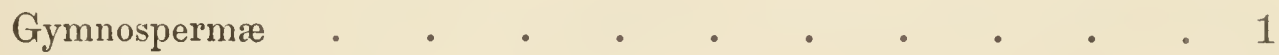

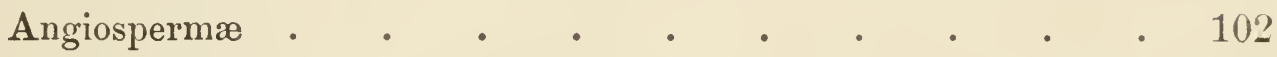
Monocotyledons . . . . . . . . . . . 102

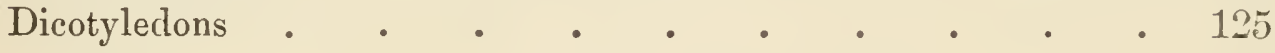

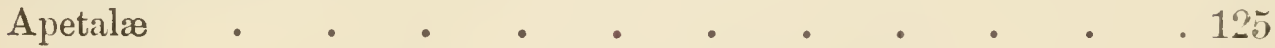
Petalæ . . . . . . . . . . • 315

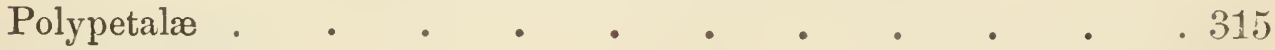
Gamopetalæ . . • . • . • • • 718 Glossary of Technical Terms . . . . . . . . . 815 INDEX • • • • • • • • • • • . 819 



\section{SYNOPSIS}

\section{OF THE FAMILIES OF PLANTS DESCRIBED IN THIS BOOK}

\section{Class I. GYMNOSPERMA.}

Resinous trees; stems formed of bark, wood, or pith, and increasing in diameter by the annual addition of a layer of wood inside the bark; flowers unisexual; stamens numerous; ovules and seeds 2 or many, borne on the face of a scale, not inclosed in an ovary; embryo with 2 or more cotyledons; leaves straight-veined, without stipules.

I. Coniferæ (p. 1). Flowers usually monœcious ; ovules 2 or several; fruit a woody cone (in Juniperus berry-like) ; cotyledons 2 or many; leaves needle-shaped, linear or scale-like, persistent (deciduous in Larix and Taxodium).

II. Taxaceæ (p. 97). Flowers diœcious, axillary, solitary; ovules 1; fruit surrounded by or inclosed in the enlarged fleshy aril-like disk of the flower; cotyledous 2; leaves linear, alternate, persistent.

\section{Class II. ANGIOSPERM丑.}

Carpels or pistils consisting of a closed cavity containing the ovules and becoming the fruit.

\section{Division I. MONOCOTYLEDONS.}

Stems with woody fibres distributed irregularly through them, but without pith or annual layers of growth; parts of the flower in 3's; ovary superior, 3-celled; embryo with a single cotyledon; leaves parallel-veined, persistent, without stipules.

III. Palmæ (p. 102). Ovule solitary; fruit baccate or drupaceous, 1 or rarely 2 or 3-seeded; leaves alternate, pinnate, flabellate or orbicular, persistent.

IV. Liliaceæ (p. 115). Ovules numerous in each cell ; fruit 3-celled, capsular or baccate; leaves linear-lanceolate.

\section{Division II. DICOTYLEDONS.}

Stems formed of bark, wood, or pith, and increasing by the addition of an annual layer of wood inside the bark; parts of the flower mostly in 4's or 5's ; embryo with a pair of opposite cotyledons; leaves netted-veined.

Subdivision 1. Apetal 1 . Flowers without a corolla and sometimes without a calyx.

Section 1. Flowers in unisexual aments (female flowers of Juglans and Quercus solitary or in spikes); ovary inferior (superior in Leitneriacece) when a calyx is present.

V. Juglandaceæ (p. 12.5). Flowers monœcious; fruit a nut inclosed in an indehiscent (Juglans) or 4-valved (Hicoria) fleshy or woody shell; leaves alternate, unequally pinnate, without stipules, deciduous. 
VI. Myricaceze (p. 146). Flowers monœecious or dicecious; fruit a dry drupe, covered witl waxy exudations ; leaves simple, alteruate, resinous-punctate, persistent.

VII. Leitneriaceæ (p. 150). Flowers dicecious, the staninate without a calyx ; ovary superior; fruit a compressed oblong drupe; leaves alternate, simple, without stipules, deciduous

VIII. Salicacere (p. 152). Flowers diœcions, without a calyx. Fruit a 2-4-valved capsule. Leaves simple, alteruate, with stipules, deciduous.

IX. Betulacez (p. 189). Flowers monceious; fruit a nut at the base of an open leaflike involncre (Carpinus), in a sack-like involucre (Ostrya), in the axil of a scale of an ament (Betula), or of a woody strobile (Alnus); leaves alternate, simple, with stipules, deciduous.

X. Fagaceæ (p. 216). Flowers monœcious; fruit a nut more or less inclosed in a woody of ten spiny involucre; leaves alternate, simple, with stipules, deciduous (in some species of Quercus und in Castanopsis and Pasania persistent).

Section 2. Flowers unisexual (perfect in Ulmus); calyx regular, the stamens as many as its lobes and opposite them; ovary superior, 1-celled; seed 1.

XI. Ulmaceæ (p. 257). Fruit a compressed winged samara (Ulmus) or a drupe (Celtis); leaves simple, alternate, with stipules, deciduous.

XII. Moraceæ (p. 302). Flowers in ament-like spikes or heads; fruit drupaceous, inclosed in the thickened calyx and united into a compound fruit, oblong and succulent (Morus), large, dry and globose (Toxylon), or immersed in the fleshy receptacle of the flower (Ficus); leaves simple, alternate, with stipules, deciduous (persistent in Ficus).

Section 3. Flowers usually perfect; calyx 5-lobed; ovary superior, 1-celled; fruit a nutlet inclosed in the thickened calyx; leaves simple, persistent.

XIII. Polygonaceæ (p. 311). Leaves alternate, their stipules sheathing the stems.

XIV. Nyctaginaceæ (p. 313). Leaves alternate or opposite, without stipules.

Subdivision 2. Petald. Flowers with both calyx and corolla (without a corolle in Lauracece, in Liquidambar in Hamamelidacece, in Cercocarpus in Rosacea, in Euphorbiacece, in some species of Acer, in Reynosia, Condalia, and Krugiodendron in Rhamnacea, in Fremontodendron in Sterculiacece, in Chytraculia in Myrtacece, and in Conocarpus in Combretacece).

Section 1. Polypetalæe. Corolla of separate petals.

A. Ovary superior (partly inferior in Hamamelidacece ; inferior in Malus, Sorbus, Cratcegus, and Amelanchier in Rosacea).

XV. Magnoliaceæ (p. 315). Flowers perfect; sepals and petals in 3 or 4 rows of 3 each ; fruit cone-like, composed of numerous cohering carpels; leaves simple, alternate, their stipules inclosing the leaf-buds, deciduous or rarely persistent.

XVI. Anonacez (p. 326). Flowers perfect; sepals 3 ; petals 6 in 2 series; fruit a pulpy berry developed from 1 or from the union of several carpels; leaves siniple, alternate, without stipules, deciduous or persistent.

XVII. Lauracez (p. 329). Flowers perfect or unisexual; corolla 0 ; fruit a 1 -seeded drupe or berry; leaves simple, alternate, punctate, without stipules, persistent (deciduous in Sassafras).

XVIII. Capparidaceæ (p.335). Flowers perfect; sepals and petals 4 ; fruit baceate, elongated, dehiscent; leaves alternate, simple, withont stipules, persistent.

XIX. Hamamelidaceæ (p. 339). Flowers perfect or unisexual; sepals and petals 5 (corolla 0 in Liquidambar); ovary partly inferior; fruit a 2-celled woody capsule opening at the summit; leaves simple, alternate, with stipules, deciduous. 
XX. Platanaceæ (p. 343). Flowers monœcious, in dense unisexual capitate heads; fruit an akene; leaves simple, alternate, with stipules, deciduous.

XXI. Rosaceæ (p. 348 ). Flowers perfect; sepals and petals 5 (petals 0 in Cercocarpus); ovary inferior in Malus, Sorbus, Cratcegus, and Amelanchier; fruit a drupe (Heteromeles, Prunus, and Chrysobalanus), a capsule (Vauquelinia and Lyonothamuus), an akene (Cercoearpus), or a pome (Malus, Sorbus, Cratægus, and Amelanchier); leaves simple or pinnately compound, alternate (opposite in Lyonothamnus), with stipules, deciduous or persistent.

XXII. Leguminosæ (p. 533). Flowers perfect, regular or irregular; fruit a legume ; leaves compound, or simple (Dalea), alternate, with stipules, decidnous or persistent.

XXIII. Zygophyllaceæ (p. 575). Flowers perfect; ealyx 5-lobed; petals $\tilde{5}$; fruit capsular, becoming fleshy; leaves opposite, pinnate, with stipules, persistent.

XXIV. Rutaceæ (p. 580). Flowers unisexual or perfect; fruit a capsule (Fagara), a samara (Ptelea), of indehiscent winged 1-seeded carpels (Helietta), or a drupe (Amyris); leaves alternate or opposite, compound, glandular-punctate, without stipules, persistent or rarely deciduous ( $O$ in Canotia).

XXV. Simarubaceæ (p. 589). Flowers diœcious, calyx 5-lobed; petals 5; fruit drupaceous; leaves alternate, equally pinnate, without stipules, persistent.

XXVI. Burseraceæ (p. 591). Flowers perfect; calyx 4 or 5-parter ; petals 5; fruit a drupe; leaves alternate, compound, without stipules, deciduous.

XXVII. Meliaceæ (p. 593). Flowers perfect; calyx 5-lobed ; petals 5; fruit a 5-celled dehiscent capsule; leaves alternate, equally pinnate, without stipules, persistent.

XXVIII. Euphorbiaceæ (p. 594). Flowers perfect; calyx t-6-parted (Drypetes), 3lobed (Hippomane), or 0 (Gymnanthes); petals 0 ; fruit a drupe (Drypetes and Hippomane), or a 3-lobed eapsule (Gymnanthes).

XXIX. Anacardiaceæ (p. 601). Flowers usually unisexual, diœcious or polygamodiœcious; fruit a dry drupe ; leaves simple or compound, alternate, without stipules, deciduous (persistent in one species of Rhus).

XXX. Cyrillaceæ (p. 610). Flowers perfect; calyx 5-S-lobed; petals 5-\$; fruit an indehiscent capsule; leaves alternate, without stipules, persistent (more or less deciduous in Cyrilla).

XXXI. Aquifoliaceæ (p. 613). Flowers polygamo-diœcious; calyx 4 or 5-lobed; petals 5 ; fruit a drupe, with 4-S 1-seeded nutlets; leaves alternate, simple, with stipules, persistent or deciduous.

XXXII. Celastraceæ (p. 619). Flowers perfect, polygamous or diœcious; calyx 4 or כ-lobed; petals 4 or $\check{~}$; fruit a drupe, or a capsule (Evonymus); leaves simple, opposite or alternate, with or without stipules, persistent (deciduous in Evonymus).

XXXIII. Aceraceæ (p.624). Flowers diœeious or monœciously polygamous; ealyx usually 5-parted; petals usually j, or 0 ; fruit of 2 long-winged samara joinerl at the base ; leaves opposite, simple or rarely pinuate, without or rarely with stipules, deciduous.

XXXIV. Hippocastanaceæ (p. 649). Flowers perfect, irregular; calyx 5-lobed; petals 4 or 5, unequal; fruit a 3-celled 3-valved capsule; leaves opposite, digitately compound, long-petiolate, without stipules, deciduous.

XXXV. Sapindaceæ (p. 649). Flowers polygamous; calyx 4 or 5-lobed; corolla of 4 or 5 petals ; fruit a berry (Sapindus and Exothea), a drupe (Hypelate), or a 3-celled capsule (Ungnadia) ; leaves alternate, compound, without stipules, persistent, or deciduous (Ungnadia).

XXXVI. Rhamnaceæ (p. 657). Flowers usually perfect; calyx 4 or 5 -lobed; petals 4 or 5 (O in Reynosia, Condalia, and Krugiodendron) ; fruit drupaceous ; leaves simple, alternate (mostly opposite in Reynosia and Krugiodendron), with stipules, persistent (deciduous in some species of Rhamnus).

XXXVII. Tiliaceæ (p. 669). Flowers perfect; sepals and petals 5 ; fruit a nut-like berry ; leaves simple, alternate, mostly oblique at the base, with stipules, deciduous. 
XXXVIII. Sterculiaceæ (p. 676). Flowers perfect; calyx 5-lobed; petals 0 ; fruit a 4 or 5-valved dehiscent capsule ; leaves simple, alternate, with stipules, persistent.

XXXIX. Theaceæ (p. 677). Flowers perfect; sepals and petals 5 ; fruit a 5-celled woody dehiscent capsule, loculicidally dehiscent; leaves simple, alternate, without stipules, persistent or deciduous.

XL. Canellaceæ (p. 680). Flowers perfect; sepals 3 ; petals 5; filaments united into a tube ; fruit a berry ; leaves simple, alternate, without stipules, persistent.

XLI. Kœberliniaceæ (p. 681). Flowers perfect; sepals and petals 4, minute; leaves bract-like, alternate, without stipules, caducous.

XLII. Caricaceæ (p. 682). Flowers unisexual or perfect; calyx 5-lobed; petals 5; fruit baccate ; leaves palmately lobed or digitate, alternate, without stipules, persistent.

\section{B. Ovary inferior (partly inferior in Rhizophora).}

XLIII. Cactaceæ (p.68t). Flowers perfect; petals and sepals numerous; fruit a berry ; leaves usually wanting.

XLIV. Rhizophoraceæ (p. 691). Flowers perfect; calyx 4-parted; petals 4 ; ovary partly inferior; fruit a 1-celled 1-seeded berry perforated at the apex by the germinating embryo; leaves simple, opposité, entire, with stipules, persistent.

XLV. Myrtaceæ (p. 693). Flowers perfect; calyx usually 4-lobed, or reduced to a single body forming a deciduous lid to the flower (Chytraculia); petals usually 4 ( 0 in Chytraculia) ; fruit a berry; leaves simple, opposite, pellucid-punctate, without stipules, persistent.

XLVI. Combretaceæe (p. 700). Flowers perfect or polygamous; calyx 5-lobed; petals 5 ( 0 in Conocarpus); fruit drupaceous; leaves simple, alternate or opposite, without stipules, persistent.

XLVII. Araliacere (p. 704). Flowers perfect or polygamous; sepals and petals usually 5 ; fruit a drupe ; leaves twice pinnate, alternate, with stipules, deciduous.

XLVIII. Cornaceæ (p. 706). Flowers perfect or polygamo-diœeious; calyx 4 or 5toothed; petals 4 or 5 ; fruit a fleshy drupe ; leaves simple, opposite (alternate in one species of Cornus), without stipules, deciduous.

Section 2. Gamopetalæ. Corolla of united petals (divided in Elliottia in Ericacece, 0 in some species of Fraxinus in Oleacece)

A. Ovary superior (inferior in Vaccinium in Ericacece, partly inferior in Symplocacece and Styracece).

XLIX. Ericaceæ (p. 718). Flowers perfect; calyx and corolla 5-lobed (in Elliottia corolla of 4 petals); (ovary inferior in Vaccinium) ; fruit capsular, drupaceous or baccate ; leaves simple, alternate, without stipules, persistent (deciduous in Elliottia and Oxydendrum).

L. Myrsinaceæ (p. 733). Flowers perfect; calyx and corolla 5-lobed; stamens 5; fruit a drupe ; leaves simple, alternate, entire, without stipules, persistent.

LI. Theophrastaceæ (p. 735). Flowers perfect, with staminodia; sepals and petals 5 ; stamens 5 ; fruit a berry; leaves simple, opposite or alternate, entire, without stipules.

LII. Sapotaceæ (p. 736). Flowers perfect; calyx 5-lobed; corolla 5-lobed (6-lobed in Mimusops), often with as many or twice as many internal appendages borne on its throat; fruit a berry; leaves simple, alternate, without stipules, persistent (deciduous in some species of Bumelia).

LIII. Ebenaceæ (p. 748). Flowers perfect, diœcious, or polygamous; calyx and corolla 4 -lobed; fruit a 1 or several seeded berry; leaves simple, alternate, entire, without stipules, deciduous.

LIV. Symplocacez (p. 752). Flowers perfect; calyx and corolla 5-lobed; ovary partly inferior ; fruit a drupe ; leaves simple, alternate, without stipules, deciduous ; pubescence simple. 
LV. Styraceæ (p. 704). Flowers perfect; calyx 4-toothed; corolla 4-lobed or divided nearly to the base; ovary partly inferior; fruit a drupe; leaves simple, alternate, without stipules, deciduous; pubescence mostly scurfy or stellate.

LVI. Oleaceæ (p. 757). Flowers perfect or polygamo-diœecious; calyx 4-lobed ( 0 in some species of Fraxinus) ; corolla 2-6-parted ( 0 in some species of Fraxinus); fruit a winged samara (Fraxinus) or a fleshy drupe (Chionanthus and Osmanthus); leaves pinnate (Fraxinus) or simple, opposite, without stipules, deciduous (persistent in Osmanthus).

LVII. Borraginaceæ (p. 7S1). Flowers perfect or polygamous; calyx and corolla j-lobed ; fruit a drupe ; leaves simple, alternate, scabrous-pubescent, without stipules, persistent or tardily deciduous.

LVIII. Verbenaceæ (p. 757 ). Flowers perfect; calyx ว-lobed; corolla 4 or 5-lobed; fruit a drupe or a 1-seeded capsule; leaves simple, opposite, withont stipules, persistent.

LIX. Bignoniaceæe (p. 791). Flowers perfect; calyx bilabiate; corolla bilabiate, うlobed ; fruit a woody capsule (Catalpa and Chilopsis) or a berry (Crescentia); leaves simple, opposite (sometimes alternate in Chilopsis), without stipules, deciduous (persistent in Crescentia).

\section{B. Ovary inferior (partly superior in Sambucus in Caprifoliacece).}

LX. Rubiaceæ (p. 79S). Flowers perfect; calyx and corolla 4 or 5-lobed; fruit a capsule (Exostema and Pinckneya), a drupe (Guettarda), or nut-like (Cephalanthus); leaves simple, opposite, or in verticils of $?$ (Cephalanthus), with stipules, persistent (deciduous in Pinckneya and Cephalanthus).

LXI. Caprifoliaceæ (p. S04). Flowers perfect; calyx and corolla 5-lobed; fruit a drupe; leaves unequally pinnate (Sambucus) or simple (Viburnum), opposite, without stipules, deciduous. 


\section{ANALYTICAL KEY}

\section{TO THE FAMILIES OF PLAN'TS INCLUDED IN THIS BOOK, BASED ON THE CHARACTER OF THE LEAVES}

1. Leaves opposite.

*Leaves simple.

$\rightarrow$ Leaves persistent.

$a$ Leaves witl stipules.

Leaves entire or sometimes sliglitly crenate or serrate.

Leaves emarginate at the apex, very short-stalked, $11^{\prime}-2^{\prime}$ long.

Leaves obovate, gradually narrowed into the petioles.

Gyminda in Celastraceæ (p. 621).

Leaves oval to oblong, rounded or broadly cuneate at the base (rarely alternate).

Reynosia and Krugiodendron in Rhamnaceæ (pp. 658, 660). Leaves obtusish, $3 \frac{1}{2}-5^{\prime}$ long.

Rhizophoraceæ (p. 691).

Leaves acute or acuminate.

Exostema and Guettarda in Rubiaceæ (pp. 800, 803).

Leaves serrate (usually compound). $\quad$ Lyonothamnus in Rosaceæ (p. 350). aa Leaves without stipules.

Petioles with 2 large glands; leaves obtuse, $1 \frac{1}{2}^{\prime}-2 \frac{1}{2}^{\prime}$ long.

Petioles not glandular.

Laguncularia in Combretaceæ (p. 703).

Leaves furnished on the under side with dark glands, obtuse to acute, aromatic; petioles short.

Myrtaceæ (p.693).

Leaves without glands on the under side.

Leaves obtuse or emarginate, rarely acute.

Leaves green and glabrous beneath, obovate to oblong-obovate, $1^{\prime}-1 \frac{1}{2}^{\prime}$ long (sometimes alternate).

Nyctaginaceæ (p. 313).

Leaves pubescent or canescent beneatl, generally obovate-oblong, $2^{\prime}-4^{\prime}$ long.

Verbenaceæ (p. 787).

Leaves acute or acuminate, glabrous. Osmanthus in Oleaceæ (p. 779).

$\rightarrow \rightarrow$ Leaves deciduous.

$a$ Leaves without lobes.

$b$ Leaves serrate.

Winter-buds with several opposite outer scales; leaves puberulous beneath.

Evonymus in Celastraceæ (p. 619).

Winter-buds enveloped by 2 large scales; leaves glabrous, or rufous-tomentu-

- lose along the midribs beneath. Viburnum in Caprifoliaceæ (p. 804).

$b b$ Leaves entire.

$c$ Leaves without stipules.

Leaves oval to oblong.

Winter-buds small, with several pairs of opposite scales.

Fraxinus anomala and Chionanthus in Oleaceæ (pp. 765, 777).

Winter-buds enveloped by 2 opposite scales.

Cornus in Cornaceæ (p. 712). 
Leaves broadly ovate, cordate at the base, acuminate, 5'-12 long, on long petioles.

Catalpa in Bignoniaceæ (p. 792).

Leaves linear to linear-lanceolate, short-stalked or sessile (sometimes alternate).

$c c$ Leaves with persistent stipules, entire.

Chilopsis in Bignoniaceæ (p. 791).

aa Leaves palmately lobed.

Pinckneya and Cephalanthus in Rubiaceæ (pp. 798, 802). **Leaves compound.

$\rightarrow$ Leaves persistent, with stipules.

Leaves equally pinnate; leaflets entire.

Zygophyllaceæ (p. 578)

Leares unequally pinnately parted into $3-S$ linear-lanceolate segments (sometimes entire).

Leaves trifoliate.

Lyonothamnus in Rosaceæ (p. 350). Helietta and Amyris in Rutaceæ (pp. 585, 588).

$\rightarrow+$ Leaves deciduous.

Leaves unequally pinnate or trifoliate.

Winter-buds with 1 or 2 pairs of obtuse outer scales, usually puberulous.

Leaflets $3-5$, incisely serrate; primary veins extending to the teeth.

Acer Negundo in Aceraceæ (p. 641).

Leaflets usually many, rarely 3 or 1 , crenate-serrate or entire, the veins arching and uniting within the margin.

Fraxinus in Oleaceæ (p. 758 ).

Winter-buds with many opposite acute glabrous scales; leaflets sharply serrate;

branches with thick pith.

Sambucus in Caprifoliaceæ (p. 805)).

Leaves digitate, with $5-7$ sharply serrate leaflets; terminal buds large.

2. Leaves alternate.

Hippocastanaceæ (p. 643).

*Leaves simple.

$\rightarrow$ Leaves persistent.

$a$ Leaves crowded at the end of simple or sparingly branched stems, parallel-nerved, without stipules.

Leaves flabellate, stem simple. Thrinax, Coccothrinax, Sabal, Washingtonia, Serenoa in Palmæ (pp. 103-111).

Leaves linear-lanceolate, stem often branched.

Liliaceæ (p. 115).

aa Leaves scattered singly or in fascicles along the branches.

$b$ Leaves linear or scale-like, without stipules.

Leaves linear, flattened, light green beneath; branchlets remaining green 2-4 years.

Taxaceæ (p. 97).

Leaves scale-like, needle-shaped or flattened; marked by white bands of stomata.

$b b$ Leaves orbicular to lanceolate.

Coniferæ (p. 1).

$c$ Leaves palmately lobed.

Leaves stellate-pubescent, about $1 \frac{1}{2}^{\prime}$ in diameter, with stipules.

Sterculiaceæ (p. 676).

Leaves glabrous, $1^{\circ}-2^{\circ}$ in diameter, without stipules. Caricaceæ (p. 682). cc Leaves not lobed.

$d$ Branches spinescent.

Leaves clustered at the ends of the branches, at least 2 '-3' long.

Bucida in Combretaceæ (p. 702).

Leaves scattered, not more than $\frac{1^{\prime}}{2}-1^{\prime}$ long, generally obovate, mucronate, glabrous and green or brownish tomentulose beneath.

Condalia in Rhamnaceæ (p. 657).

Leaves fascicled on lateral branchlets obtuse or emarginate, pale and glabrous beneath.

Bumelia angustifolia in Sapotaceæ (p. 744).

$d d$ Branches not spinescent.

$e$ Leaves serrate or lobed. 
f Juice watery.

$g$ Stipules present.

h Prinary veins extending straight to the teeth.

Pasania and some speeies of Quercus in Fagaceze (pp. 224,

hh Primary veins arehing and united within the margin.

Leaves 3-nerved from the base.

Leaves not:B-nerved.

Ceanothus in Rhamnaceæ (p. 665).

Leaves acute.

Leaves sinuately dentate, with few spiny teeth, glabrons.

Ilex opaca in Aquifoliaceæ (p. 614).

Leaves serrate.

Vauquelinia, Heteromeles, and Prunus Caroliniana and Prunus ilicifolia in Rosaceæ (pp. 349, $358,527,530)$

Leaves obtuse, sometimes mucronate.

Leaves spinose-serrate, glabrous.

Rhamnus crocea in Rhamnaceæ (p. 662).

Leaves crenate (often entire), oval to oblong.

Ilex vomitoria in Aquifoliaceæ (p. 616).

hhh Primary veins extending straight to the teeth.

Cercocarpus in Rosaceæ (p. 504).

gg Stipules wanting.

Leaves resinous-dotted, aromatic.

Myricaceæ (p. 146).

Leaves not resinous-dotted, crenately serrate, gradually narrowed into short stout petioles; bark red-brown.

ff Juice milky.

Gordonia Lasianthus in Theaceæ (p. 678).

Hippomane and Gymnanthes in Euphorbiaceæ (pp. 598, 599). ee Leaves entire (rarely sparingly toothed on vigorous branchlets).

$i$ Stipules present.

$j$ Stipules connate, at least at first.

Stipules persistent, forming a sheath surrounding the branch above the node; leaves obtuse.

Polygonaceæ (p.311).

Stipules deciduous, enveloping the young leaf before unfolding.

Leaves ferrugineous-tomentose beneath.

Magnolia fœtida in Magnoliaceæe (p. 316).

Leaves glabrous beneath, with milky juice.

Ficus in Moraceæ (p. 308).

jj Stipules free.

$k$ Juice milky.

Drypetes and Gymnanthes in Euphorbiaceæ

(pp. 595, 599).

$k k$ Juice watery.

$l$ Leaves obtuse or emarginate at the apex.

Leaves with ferrugineous scales beneath, their petioles slender. ctupus? Capparidaceæ (p. 338).

Leaves without ferrugineous scales.

Leaves rarely $2^{\prime}-3^{\prime}$ long, standing on the branch at acute angles.

Chrysobalanus in Rosaceæ (p. 532).

Leaves rarely more than 1' long, spreading (sometimes 3-nerved).

Ceanothus spinosus in Rhamnaceæ (pp. 667). 
$l l$ Leaves acute.

Petioles with 2 glands.

Petioles without glands.

Conocarpus in Combretaceæ (p. 700).

Leaves and branchlets more or less pubescent, at least while young.

Leaves fascicled except on young branchlets.

Leaves not fascicled.

Cercocarpus in Rosaceæ (p. 504).

Winter-buds minute, with few pointed scales.

Ilex Cassine in Aquifoliaceæ (p. 615).

Winter-buds conspicuous, with numerous scales.

Castanopsis, Pasania, and Quercus in

Fagaceæ (pp. 222, 224, 226).

Leaves and branchlets glabrous.

ii Stipules wanting.

Prunus (Cherry Laurels), in Rosaceæ (p. 527).

$m$ Leaves aromatic when bruised.

Leaves resinous-dotted.

Myricaceæ (p. 146).

Leaves not resinous-dotted.

Leaves obtuse, obvate, glabrous.

Canellaceæ (p. 680).

Leaves acute.

Leaves mostly rounded at the narrowed base, giabrous.

Anona in Anonaceæ (p. 328).

Leaves more or less wedge-shaped at the base.

Persea, Ocotea, and Umbellularia in Lauraceæ

(pp. 329, 332, 334).

$m m$ Leaves not aromatic.

$n$ Leaves acute or acutish.

Leaves obovate, gradually narrowed into short petioles.

Leaves 2'-2 $\frac{1}{2}$ ' long. Schæfferia in Celastraceæ (p. 622).

Leaves at least $6^{\prime}-S^{\prime}$ long.

Crescentia in Bignoniaceæ (p. 796).

Leaves elliptic to oblong or ovate.

Leaves rough above, pubescent below, subcordate to cuneate at the base.

Ehretia and Cordia in Borraginaceæ (pp. 781, 785)

Leaves smooth above.

Winter-buds scaly.

Rhododendron, Kalmia, Xolisma, Arbutus

in Ericaceæ (pp. $720,722,726,727$ ).

Winter-buds naked.

Leaves more or less pubescent below.

Sideroxylum, Dipholis, Chrysophyllum (with

milky juice), in Sapotaceæ (pp. 737, 738, 745).

Leaves glabrous beneath, marked by minute black dots.

Myrsinaceæ (p. 733).

$n n$ Leaves obtuse or emarginate at the apex.

o Leaves rounded or cordate at the base, emarginate, their petioles slender.

Leaves reniform to broadly ovate, cordate; juice watery.

Cercis in Leguminosæ (p. 551).

Leaves elliptic to oblong, rounded at base; juice milky or viscid. 
Leaves emarginate; petioles slender, rufous-tomentulose.

Mimusops in Sapotacea (p. 746).

Leaves obtuse at the apex ; petioles stont, grayish-tomentulose or glabrons.

Rhus integrifolia in Anacardiaceæ (p. 609).

oo Leaves cuneate at the base.

Petioles slender, $\frac{1^{\prime}}{2}$ long. Bourreria in Borraginacea (p. 784). Petioles short and stout.

Leaves coriaceous, with thiek revolute margins (sometimes opposite).

Leaves subeoriaceous, slightly revolute.

Leaves oval to obovate; branehes spreading.

Vaccinium in Ericaceæ (p. 731).

Leaves obovate-oblong to oblong-lanceolate; branches upright (sometimes deciruous in Cyrilla). Cyrillaceæ (p. 610).

+- Leaves deciduous.

+Leaves eonspicuous.

a Leaves entire, sometimes 3 or 4-lobed.

$b$ Stipules present.

Juice milky.

Juice watery.

Moraceæ (p. 302).

Stipules connate, enveloping the young leaves. Magnoliaceæ (p. 315). Stipules distinct.

Branches spinescent, leaves glandular, caducous (crenately serrate on vigorous shoots).

Dalea in Leguminosæ (p. 570).

Branches not spinescent; leaves without glands.

Winter-buds with a single pair of eonnate seales.

Salix in Salicaceæ (p. 166).

Winter-buds with several pairs of inbricate scales; branchlets without terminal buds.

$b b$ Stipules wanting.

Celtis Mississippiensis in Ulmaceæ (p. 300).

$c$ Leaves broad, oval to lanceolate.

Branchlets bright green and lustrous for the first 2 or 3 years; leaves sometimes 3-lobed, aromatic.

Sassafras in Lauraceæ (p. 335)).

Branchlets brown or gray.

Leaves acute or acuminate.

Leaves $10^{\prime}-12^{\prime}$ long, obovate-oblong, acuminate, glabrous, emitting a disagreeable odor.

Asimina in Anonaceæ (p. 326).

Leaves smaller.

Leaves glabrous, or pubescent below at maturity.

Petioles very slender $1^{\prime}-2^{\prime}$ long; leaves elliptic, acuminate.

Petioles short.

Cornus alternifolia in Cornaceæ (p. 717).

Branchlets without lenticels, light reddish brown.

Elliottia in Ericaceæ (p. 719).

Branchlets with small lenticels.

Branchlets with terminal buds.

Branchlets without terminal buds.

Nyssa in Cornaceæ (p. 707).

Diospyros Virginiana in Ebenaceæ (p. 749).

Leaves tomentose below, elliptic to lanceolate-oblong.

Leitneriaceæ (p. 150). 
Leaves obtuse or acute.

Branchlets not spinescent.

Leaves glabrous at maturity, their petioles slender.

Cotinús in Anacardiaceæ (p. 601).

Leares pubescent below at maturity; their petioles short and thick.

Diospyros Texana in Ebenaceæ (p. 750).

Branchlets spinescent; leaves often fascicled on lateral branchlets.

Bumelia in Sapotaceæ (p. 740). cc Leaves linear, fascicled and scattered on the young branches, or 2-ranked in Taxodium.

Larix and Taxodium in Coniferæ (pp. 34, 70). $a \boldsymbol{x}$ Leaves serrate or pinnately lobed.

$d$ Stipules present.

$e$ Winter-buds naked.

Leaves oblique at the base, the upper side rounded or subcordate, oborate, coarsely toothed.

Hamamelis in Hamamelidaceæ (p. 341).

Leaves equal at the base, cuneate, finely serrate or crenate.

Rhamnus Caroliniana and Rhamnus Purshiana in

ee Winter-buds corered by scales.

Rhamnaceæ (pp. 663, 664).

Winter-buds with a single pair of connate scales.

Primary veins arching and uniting within the margins; leaves simply serrate or erenate, sometimes entire.

Salix in Salicaceæ (p. 166).

Primary veins extending to the teeth, leaves doubly serrate, often slightly lobed. Alnus in Betulaceæ (p. 208).

cee Winter-buds with several pairs of imbricate scales.

Terminal buds wanting, branchlets prolonged by upper axillary buds. Leares distinctly oblique at the base.

Ulmaceæ (p. 2S7).

Leaves slightly or not at all oblique at the base.

Carpinus, Ostrya, and Betula in Betulaceæ (pp. 190,

Terminal buds present.

191, 194).

Primary veins arching and uniting within the margin (extending to the margin in the lobed leaves of Malus).

Winter-buds resinous; leaves crenate, usually truncate at the base; petioles slender.

Populus in Salicaceæ (p. 152).

Winter-buds not resinous.

Malus, Amelanchier, Prunus in Rosaceæ (pp. 351, $360,509)$.

Primary veins extending to the teeth or to the lobes.

Leaves lobed or remotely dentate or crenate; lobes not serrate, but occasionally coarsely toothed.

Fagus, Castanea, Quercus in Fagaceæ (pp. 217,

$219,226)$

Leaves doubly or simply serrate, or lobed, with serrate lobes; branches of ten furnished with spines.

$d d$ Stipules wanting.

Malus and Cratægus in Rosaceæ (pp. 351, 363).

$f$ Leaves not lobed.

Leaves subcoriaceous.

Leaves obovate, acute.

Gordonia Altamaha in Theaceæ (p. 679). 
Leaves oblong, narrowed at the ends, sometimes nearly entire.

Leaves inembranaceons.

Symplocacer (p. 752).

Leaves oblong or lanceolate, acuminate, glabrous or puberulons while young, turning searlet in the autumu.

Oxydendrum in Ericacere (p. 724).

Leaves ovate to elliptical, stellate-pubescent while young, turning yellow in the antumn.

Styraceæ (p. 754).

ff Leaves palmately lobed.

Stipules large, foliaceous, united; branchlets without terminal buds.

Stipules small, free, caducous; branchlets with terminal buds.

Platanaceæ (p. 343).

Liquidambar in Hamamelidaceze (p. 339).

++ Leaves inconspicuous or wanting; spiny or prickly trees.

Branches or stems succulent, armed with numerous prickles.

Branches rigid, spinescent.

Cactaceæ (p. 684).

Leaves minute, narrowly obovate.

Branchlets bright green.

Branchlets red-brown.

Leaves scale-like.

**Leaves compound.

- Leaves 3 -foliolate, without stipules.

Leaves persistent; leaflets entire.

Hypelate in Sapindacer (p. 654).

Leaves deciduous, strongly scented and bitter; leaflets serrate or entire, acute.

$\rightarrow$ Leaves pinnate.

Ptelea in Rutaceæ (p. 587).

$a$ Leaves twice pinnate; stipules present.

Branches and stem armed with scattered prickles; leaves $2^{\circ}-4^{\circ}$ long; leaflets serrate, $2^{\prime}-3$ 'long.

Araliaceæ (p. 704).

Branches unarmed, or armed with axillary or stipular spines; leaflets entire or crenate-serrate.

Zygia, Lysiloma, Acacia, Leucæna, Gymnocladus, Gleditsia in Leguminosæ (pp. 535, 538, 540, 545, 553, 555).

aa Leaves equally pinnate.

Stipules wanting; leaves persistent; leaflets entire.

Leaflets 2-4, generally oblong-obovate. Exothea in Sapindaceæ (p. 653).

Leaflets $6-12$.

Leaflets obtuse, $6-12$.

Leaflets 8-12, 2'-3' long; leaves occasionally opposite.

Simarubaceæ (p. 589).

Leaflets 6-8, $1^{\prime}-1 \frac{1}{2}^{\prime}$ long. Fagara coriacea in Anacardiaceæ (p. 584).

Leaflets acuminate, 6-8.

Meliaceæ (p. 593).

Stipules present; leaves deciduous or persistent.

Prosopis, Parkinsonia, Cercidium, Eysenhardtia, Olneya

aaa Leaves unequally pinnate.

in Leguminosæ (pp. 547, 559, 562, 569, 575).

$b$ Stipules present.

Leaflets sharply serrate; leaves deciduous; winter-buds resinous.

Sorbus in Rosaceæ (p. 356).

Leaflets entire or crenately serrate; leaves deciduous (persistent in Eysenhardtia, Olneya, and in Sophora secundiflora).

Gleditsia, Sophora, Cladrastis, Robinia, Olneya, Ichthyomethia in Leguminosæ (pp. 555, 564, 567, 571, 575, 577). 
$\checkmark b$ Stipules wanting.

$c$ Leaves clustered at the apex of simple stout stems, parallel-nerved, persistent.

Roystonea and Pseudophœnix in Palmæ (pp. 112, 114).

$c c$ Leaves scattered on branched stems.

$d$ Leaves persistent.

Leaflets long-stalked (sometimes nearly sessile in Fagara flava).

Leaflets ovate-oblong, wedge-shaped at the base.

Fagara flava in Rutaceæ (p. 583).

Leaflets broadly ovate, usually rounded or subcordate at the base.

Metopium in Anacardiaceæ (p. 603).

Leaflets sessile or nearly so.

Petiole and rachis winged.

Leaflets erenate, obovate, about $\frac{1}{2}^{\prime}$ long; branches prickly.

Fagara Fagara in Rutaceæ (p. 581).

Leaflets entire, oblong, usually acute, $3^{\prime}-4^{\prime}$ long ; branches unarmed.

Sapindus Saponaria in Sapindaceæ (p. 650).

Petiole and rachis not winged; leaflets acuminate, 7-19.

$d d$ Leares deciduous.

Sapindus marginatus in Sapindaceæ (p. 651).

Leaflets long-stalked, entire, acute, 3-7.

Leaflets sessile or nearly so.

Branches prickly; leaflets crenate.

Branches unarmed.

Fagara Clava-Herculis in Rutaceæ (p. 582).

Juice milky or viscid; leaflets serrate or entire; rachis sometimes winged.

Rhus in Anacardiaceæ (p. 604).

Juice watery; rachis without wings.

Leaflets entire, acuminate, 7-9.

Leaflets serrate or crenate.

Sapindus Drummondi in Sapindaceæ (p. 652).

Winter-buds large and scaly or naked; leaves aromatic.

Juglandaceæ (p. 125).

Winter-buds minute, globose, scaly; leaflets $5-7$, ovate, not aromatic.

Ungnadia in Sapindaceæ (p. 655). 



\title{
TREES OF NORTH AMERICA
}

\author{
(Exclusive of Mexico)
}

\section{Class 1. GYMNOSPERM Æ。}

Ovules and seeds borne on the face of a scale, not inclosed in an ovary; resinous trees, with stems increasing in diameter by the annual addition of a layer of wood inside the bark.

\section{CONIFER丑.}

Trees, with narrow or scale-like generally persistent clustered or alternate leaves and usually scaly buds. Flowers appearing in early spring, mostly surrounded at the base by an involucre of the more or less enlarged scales of the buds, unisexual, monœcious (dicecious in Juniperus), the staminate consisting of numerous 2-celled anthers, the pistillate of scales bearing on their inner face 2 or several ovules, and becoming at maturity a woody cone or rarely a berry. Seeds with or without wings; seed-coat of 2 layers; embryo axile in copious albumen; cotyledons 2 or several. Of the thirty-one genera scattered over the surface of the globe, but most abundant in northern temperate regions, thirteen occur in North America.

\section{CONSPECTUS OF THE NORTH AMERICAN GENERA.}

Scales of the pistillate flowers in the axils of persistent bracts; ovules and seeds borne directly on the scales.

Abietinez. Scales of the pistillate flower numerous, spirally arranged; ovules 2, inverted; seeds attached at the base in shallow depressions on the inner side of the scales, falling from them at maturity and usually carrying away a scarious wing; leaves fascicled or scattered (deciduous in Larix).

Fruit maturing in two or rarely in three seasons.

Leaves fascicled, needle-shaped.

Leaves in axillary 1-5-leaved clusters, inclosed at the base in a membranaceous sheath; cone-scales thick and woody, much longer than their bracts.

Fruit maturing in one season.

1. Pinus.

Leaves in many-leaved clusters on short spur-like branchlets, deciduous; conescales thin, usually shorter than their bracts.

Leaves scattered, linear.

2. Larix.

Cones pendulous, the scales persistent on the axis.

Branchlets roughened by the persistent leaf-bases ; leaves deciduous in drying; bracts shorter than the cone-scales.

Leaves sessile, 4 -sided, or flattened and stomatiferous above. 3. Picea. Leaves stalked, flattened and stomatiferous below, or angular. 4. Tsuga. 
Branchlets not ronghened by leaf-bases.

Leaves stalked, flattened; bracts of the cone 2-lobed, aristate, longer than the scales.

5. Pseudotsuga.

Cones erect, their scales deciduous from the axis, longer or shorter than the bracts.

Leaves sessile, flat or 4 -sided.

6. Abies.

Scales of the pistillate flowers without bracts; ovules and seeds borne on the face of minute scales adnate to the base of the flower-scales, enlarging and forming the scales of the cone.

TAxodre. Seales of the pistillate flowers nnmerous, spirally arranged, forming a woody cone; ovules erect, 2 or many mnder each scale; leaves linear, alternate, often of 2 forms (deciduous in Taxodium).

Ovules and seeds numerous under each scale; leaves persistent.

7. Sequoia.

Ovules and seeds 2 under each scale; leaves mostly spreading in 2 ranks, decidnous.

8. Taxodium.

Cupressinew. Scales of the pistillate flower few, decussate, forming a small cone, or rarely a berry; ovules 2 or many under each scale; leaves decussate or in 3 ranks, often of 2 forms, usially scale-like, mostly adnate to the branch, the earliest free and subulate.

Fruit a cone; leaves scale-like.

Cones oblong, their scales oblong, imbricated or valvate; seeds 2 under each scale, maturing the first year.

Scales of the cone 6 , the middle ones only fertile ; seeds unequally 2 -winged.

9. Libocedrus.

Scales of the cone S-12; seeds equally 2 -winged.

10. Thuya.

Cones subglobose, the scales peltate or wedge-shaped, maturing in one or two years; seeds few or many under each scale.

Fruit maturing in two seasons; seeds many under each scale.

11. Cupressus.

Fruit maturing in one season; seeds 2 under each scale.

12. Chamæcyparis.

Fruit a berry formed by the coalition of the scales of the flower; ovules in pairs or solitary; flowers diœeious; leaves decussate or in 3 's.

Leaves subulate or scale-like, often of 2 forms.

13. Juniperus.

\section{PINUS, Duham. Pine.}

Trees or rarely shrubs, with deeply furrowed and sometimes laminate or witl thin and scaly bark, hard or often soft heartwood often conspicuously marked by dark bands of summer cells impregnated with resin, pale nearly white sapwood, and large branch-buds formed during summer. Leaves needle-shaped, clustered, the clusters borme on rudimentary branches in the axils of scale-like primary leaves, inclosed in the bud by numerous scales lengthening and forming a more or less persistent sheath at the base of eacli cluster. Staminate flowers clustered at the base of leafy growing shoots of the year, each flower surrounded at the base by an involucre of 3-6 scalelike bracts, composed of numerous sessile anthers, imbricated in many ranks and surmounted by crest-like nearly orbicular comectives; the pistillate subterminal or lateral, their scales in the axils of non-accrescent bracts. Fruit a woody cone maturing at the end of the second or rarely of the third season, composed of the liardened and woody scales of the flower more or less thickened on the exposed surface (the apophysis), with the ends of the growth of the previous year appearing as terminal or dorsal brown protuberances or scars (the umbo). Seeds usually obovate, shorter or 
longer than their wings; outer seed-coat crustaceous or thick, hard, and bony, the inner membranaceous; cotyledons $3-18$, nsually much shorter than the inferior radicle.

Pinus is widely distributed through the northern hemisphere from the Arctic Circle to the West Indies, the mountains of Central America, the Canary Islands, northern Africa, Bermuda, the Philippine Islands, and Sumatra. About eighty species are recognized. Of exotic species the so-called Scotch Pine, Pinus sylvestris, L., of Europe and Asia, the Swiss Stone Pine, Pinus Cembra, L., and the Austrian Pine and other forms of Pinus Laricio, Poir., from central and southern Europe, are often planted in the northeastern states, and Pinus Pinaster, Ait., of the coast region of western France and the Mediterranean Basin is successfully cultivated in central and southern California. Pinus is the classical name of the Pine-tree.

The North American species can be conveniently grouped in two sections, Soft Pines and Pitch Pines.

\section{SOFT PINES.}

Wood soft, close-grained, light-colored, the sapwood thin and nearly white; sheaths of the leaf-clusters deciduous; leaves with one fibro-vascular bundle.

Leaves in 5-leaved clusters.

Cones long-stalked.

Cones bright green at maturity, becoming light yellow-brown, their scales thin, with terninal unarmed umbos. White PrNes.

Seeds shorter than their wings; leaves $4^{\prime}$ long or less.

Leaves slender, flexible.

Cones $5^{\prime}-6^{\prime}$ long.

1. P. Strobus (A).

Leaves stout, more rigid.

Cones $5^{\prime}-11^{\prime}$ long.

Cones $12^{\prime}-1 S^{\prime}$ long.

2. P. monticola (B, G).

3. P. Lambertiana $(\mathrm{G})$.

Seeds longer than their wings ; leaves slender, $3 \frac{1}{2}-t^{\prime}$ long.

Cones $5^{\prime}-9^{\prime}$ long, their scales strongly reflexed at the apex.

4. P. strobiformis (H).

Cones short-stalked.

Cones green or purple at maturity, becoming yellow-brown, their scales thick with terminal sometimes pointed umbos.

Seeds much longer than their wings; leaves $2^{\prime}$ long or less, stout and rigid. Stone Pines.

Cones $3^{\prime}-10^{\prime}$ long, their scales opening at maturity and losing their seeds.

5. P. flexilis (F).

Cones $\frac{1}{2}-3^{\prime}$ long, their scales remaining closed at inaturity.

6. P. albicaulis (B, F, G).

Cones pnrple at maturity, their scales thick, the dorsal umbos armed with slender prickles; seeds shorter than their wings; leaves in crowded clusters, incurved, less than $2^{\prime}$ long. Foxtail Pines.

Cones armed with minute incurved prickles.

Cones armed with long slender prickles:

Leaves in 1-4-leaved clusters.

7. P. Balfouriana $(G)$.

8. P. aristata $(\mathrm{F}, \mathrm{G})$.

Cones globose, green at maturity, becoming light brown, their scales few, concave, much thickened, only the middle scales seed-bearing; seeds large and edible, their wings rudimentary; leaves $2^{\prime}$ or less, often incurved. Nut PINEs.

Leaves stout, usually in 4-leaved clusters.

Leaves slender, usnally in 3-leaved clusters.

Leaves stout, in 2-leaved clusters.

Leaves stout, usually in 1-leaved clusters.
9. P. quadrifolia (G).

10. P. cembroides $(\mathrm{H})$.

11. P. edulis $(\mathrm{F})$.

12. P. monophylla (F, G). 
1. Leaves in 5-lcaved clusters.

* Cones long-stalked, their scales thin, unarmed.

+ Wings longer than the seeds.

\section{Pinus Strobus, L. White Pine.}

Leaves soft blnish green, whitened on the ventral side by $3-5$ bands of stomata, $3^{\prime}-5^{\prime}$ long, mostly turning yellow and falling in September in their second season,

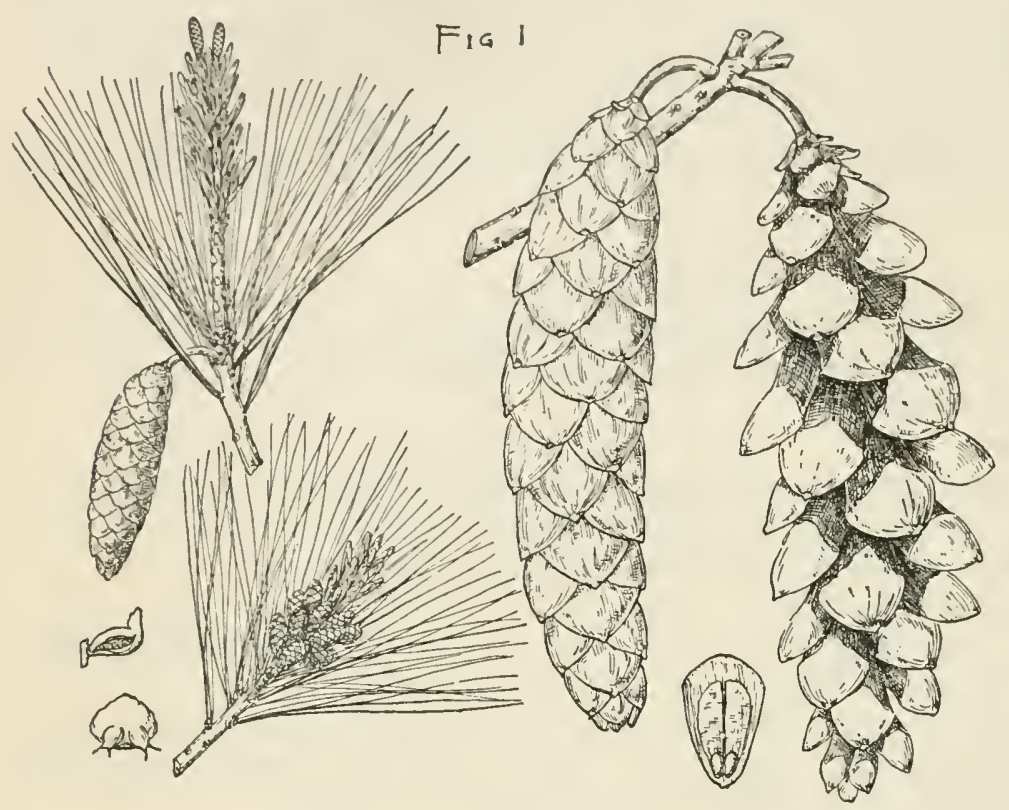

or persistent nutil the following June.

Flowers: staminate yellow, pistillate briglit pink, with purple scale margins. Fruit fully grown by July 1 st of the second season, $5^{\prime}-11^{\prime}$ long, opening and discluarging its seeds in September ; seeds narrowed at the ends, $\frac{1 \prime}{4}$ long, red-brown mottled with black, about one fourth as long as their wings.

A tree, while young with slender horizontal or slightly ascending branches in regular whorls usually of 5 branches; at maturity often $100^{\circ}$, occasionally $250^{\circ}$ high, with a tall straight stem $3^{\circ}-4^{\circ}$ or rarely $6^{\circ}$ in diameter; when crowded in the forest with short branches forming a narrow head, or rising above its forest companions with long lateral branches sweeping upward in graceful curves, the upper branches ascending and forming a broad open irregular head, and slender branchlets coated at first with rusty tomentum, soon glabrons, and orange-brown in their first winter. Bark on young stems and branches thin, smooth, green tinged with red, lustrous during the sunmer, becoming $1^{\prime}-2^{\prime}$ thick on old trunks and deeply divided by shallow fissures into broad comnected ridges covered with small closely appressed purplish scales. Wood light, not strong, straight-grained, easily worked, light brown often slightly tinged with red; largely manufactured into lumber, shingles, and laths, used in construction, for cabinet-making, the interior finish of buildings, woodenware, matches, and the masts of vessels.

Distribution. Newfoundland to Manitoba, through the northern states to Pennsylvania, Illinois, and Iowa, and along the Alleghany Mountains to eastern Kentucky and Tennessee and northern Georgia, forming nearly pure forests on sandy drift soils, or more often in small groves scattered in forests of deciduous-leaved trees on fertile well-drained soil, also on the banks of streams, river flats, or rarely in swamps.

Largely planted as an ornament of parks and gardens in the eastern states, and in many European countries, where it grows with vigor and rapidity. 


\section{Pinus monticola, D. Don. White Pine.}

Leaves blue-green, glaucous, whitened by $2-6$ rows of ventral and often by dorsal stomata. Flowers : staminate yellow; pistillate pale purple. Fruit $12^{\prime}-18^{\prime}$ long,

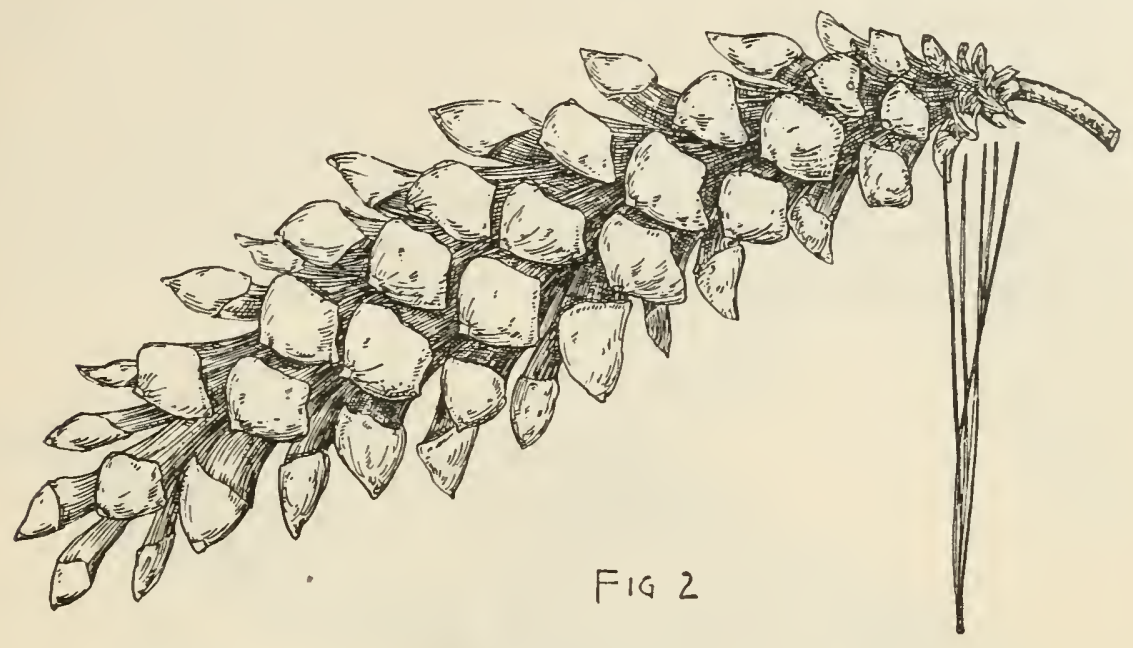

shedding its seeds late in the summer or in early autumn; seeds narrowed at the ends, $\frac{1}{3}^{\prime}$ long, pale red-brown mottled with black, about one third as long as their wings.

A tree, often $100^{\circ}$ or occasionally $150^{\circ}$ high, with a trunk frequently $4^{\circ}-5^{\circ}$ or rarely $7^{\circ}-8^{\circ}$ in diameter, slender spreading slightly pendulous branches clothing young stems to the ground and in old age forming a narrow open often unsymmetrical pyramidal head, and stout tough branchlets clothed at first with rusty pubescence, dark orange-brown and puberulous in their first and dark red-purple and glabrous in their second season. Bark of young stems and branches thin, smooth, light gray, becoming on old trees $\frac{3^{\prime}}{4}-1 \frac{1}{2}^{\prime}$ thick and divided into small nearly square plates by deep longitudinal and cross fissures covered by small closely appressed purple scales. Wood light, soft, not strong, close, straight-grained, light brown or red; sometimes mannfactured into lnmber, used in construction and the interior finish of buildings.

Distribution. Scattered through mountain forests from the basin of the Columbia River in British Columbia to Vancouver Island, along the western slopes of the Rocky Mountains to northern Montana, on the mountains of northern Idaho and Washington, on the coast ranges of Washington and Oregon, and on the Cascade and Sierra Nevada ranges southward to the Kern River valley, California ; most abundant and of greatest value in northern Idaho on the bottom-lands of streams tributary to Lake Pend Oreille; reaching the sea-level on the southeru shores of the Straits of Fuca, and elevations of $10,000^{\circ}$ on the California Sierras.

Often planted as an ornamental tree in Europe, and occasionally in the eastern United States where it grows more vigorously than any other Pine-tree of western America.

\section{Pinus Lambertiana, Dougl. Sugar Pine.}

Leaves stout, rigid, $3 \frac{1^{\prime}}{2}-4^{\prime}$ long, marked on the two faces by $2-6$ rows of stomata; deciduous during their second and third years. Flowers : staminate light yellow, pistillate pale green. Fruit fully grown in August and opening in October, 11'-18' or rarely $21^{\prime}$ long; seeds $1 \frac{1^{\prime}}{2}-5^{\prime}$ long, dark chestnut-brown or nearly black, and half 
the length of their firm dark brown obtuse wings broadest below the middle and $\frac{1}{2}$, wide.

A tree, in early life with remote regular whorls of slenter branches of ten clothing the stem to the ground and forming an open narrow pyramid; at maturity $200^{\circ}-220^{\circ}$ high, with a trunk $6^{\circ}-8^{\circ}$ or occasionally $12^{\circ}$ in diameter, a flat-topped crown frequently $60^{\circ}$ or $70^{\circ}$ across of comparatively slender branches sweeping ontward and downward in graceful enrves, and stont branchlets coated at first with pale or rufous pubescence, dirk orange-brown during their first winter, becoming dark purplebrown. Bark on yonng stems and branches thin, smooth, dark green, becoming on old trunks 2 '-3' thick and deeply and irregularly divided into long thick plate-like ridges covered with large loose rich purple-brown or cimmanon-red scales. Wood light, soft, straight-grained, light red-brown; largely manufactured into lumber and

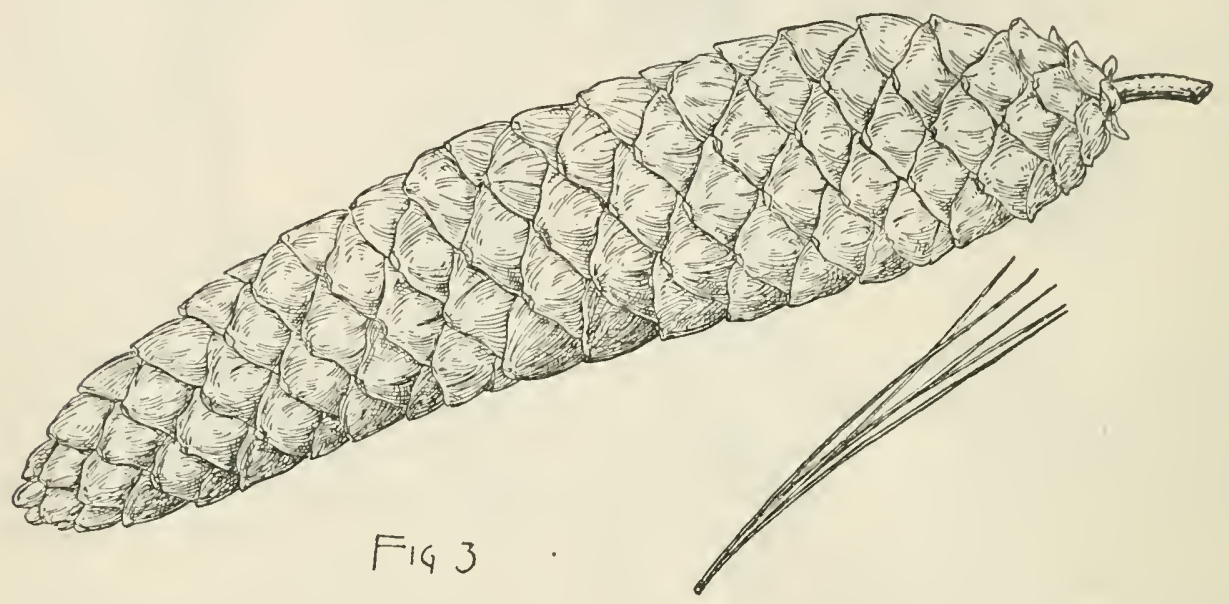

used for the interior finish of buildings, woodwork, and shingles. A sweet sugar-like substance exudes from wounds made in the heartwood.

Distribution. Mountain slopes and the sides of ravines and cañons; Oregon from the valley of the Santiam River southward along the Cascade and coast ranges; California along the northern and coast ranges to Sonoma County, along the western slopes of the Sierra Nevada, where it grows to its greatest size at elevations between $3000^{\circ}$ and $7000^{\circ}$, on the mountains in the southern part of the state; and on Mt. San Pedro Martir in Lower California.

Occasionally planted as an ornamental tree in western Europe and in the eastern states, the Sugar Pine has grown slowly in cultivation and shows little promise of attaining the large size and great beauty which distinguish it in its native forests.

\section{++ Wings shorter than the seeds.}

\section{Pinus strobiformis, Engelm. White Pine.}

Leaves slender, rigid, pale green, whitened on the ventral side by $3-4$ rows of stomata, $3 \frac{1}{2}-4^{\prime}$ long, deciduous during their third and fourth years. Fruit $5^{\prime}-9^{\prime}$ long, with scales much reflexed at the apex; seeds broadly ovate, $\frac{1}{2}^{\prime}$ long, about $\frac{1}{3}^{\prime}$ wide, dark red-brown, with a thin shell produced into a narrow margin, their wings rounded, about $\frac{1}{8}^{\prime}$ wide.

A tree, $80^{\circ}-100^{\circ}$ high, with a trunk rarely more than $2^{\circ}$ in diameter, a narrow 
pyramidal head of slender often pendulous branches and slender branchlets at first orange-brown, becoming purple, often covered with a glaucous bloom and coated while young with rufous pubescence. Bark $1^{\prime}-1 \frac{1}{2}^{\prime}$ thick and irregularly divided by deep connected fissures into narrow rounded ridges covered by small loose red-brown scales. Wood hard, light, not strong, pale red.

Distribution. Scattered usually singly or occasionally in small clusters on rocky ridges and the sides of caĨons of the Santa Catalina, Santa Rita, and Chiracahua

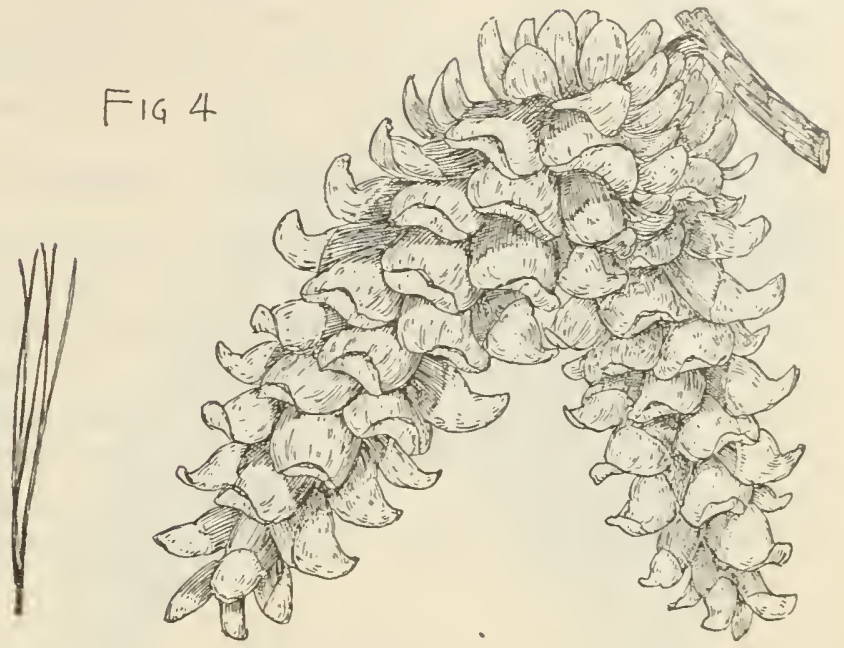
Mountains of southern Arizona, and on the Sierra Madre of Chihuahua.

** Cones short-stalked, their scales thickened; wings much shorter than the seeds.

\section{Pinus flexilis, James. Rocky Mountain White Pine.}

Leaves stout, rigid, dark green, marked on all sides by 1-4 rows of stomata, $1 \frac{1}{2}-3^{\prime}$ long, deciduous in their fifth and sixth years. Flowers: staminate reddish; pistillate clustered, bright red-purple. Fruit oval or subcylindrical, horizontal or slightly declining, green or rarely purple at maturity, $3^{\prime}-10^{\prime}$ long, with narrow and slightly reflexed scales opening at maturity; seeds compressed, $\frac{1^{\prime}}{3}-\frac{1}{2}^{\prime}$ long, dark red-brown mottled with black, with a thick shell produced into a narrow margin,

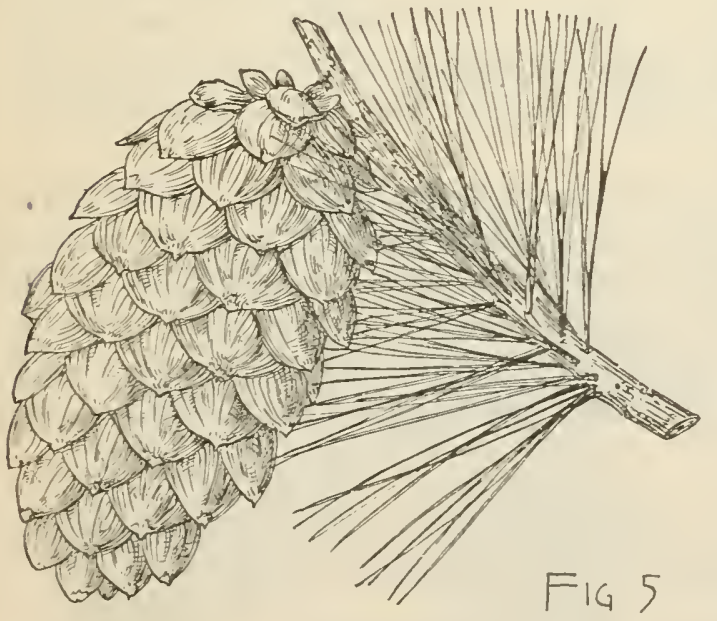
their wings about $\frac{1^{\prime}}{1^{2}}$ wide, generally persistent on the scale after the seed falls.

A tree, usinally $40^{\circ}-50^{\circ}$, occasionally $80^{\circ}$ ligh, with a short trunk $2^{\circ}-5^{\circ}$ in diameter, stout long-persistent branches ultimately forming a low wide round-topped head, and stout branchlets orange-green and covered at first with soft fine pubescence, usually soon glabrous and darker colored; at high elevations often a low-spreading shrub. Bark of young stems and branches thin, smooth, light gray or silvery white, becoming on old trunks $1^{\prime}-2$ ' thick, dark brown or nearly black, and divided by deep fissures into broad ridges broken into nearly square plates covered by small closely appressed scales. Wood light, soft, close-grained, pale clear yellow, turning red with exposure ; occasionally manufactured into lumber.

Distribution. Eastern slope of the Rocky Mountains from Alberta to western 
Texas, and westward on monntain ranges at ele vations of $5000^{\circ}$ to $12,000^{\circ}$ to $\mathrm{Montana}$, and sontheastern California, reaching the western slopes of the Sierra Yevada at the head of King's River; nsmally scattered singly or in small groves; forming open forests on the eastcrn foothills of the Rocky Monntains of Montana and on the ranges of central Nevada; attaining its largest size on those of northern New Mexico and Arizona.

\section{Pinus albicaulis, Engelm. White Pine.}

Leaves stont, rigid, slightly incurved, dark green, marked by 1-3 rows of dorsal stomata, chustered at the ends of the branches, $1 \frac{1}{2}-2 \frac{1}{2}$ long, persistent for five to eight years. Flowers opcning in Jnly, scarlet. Fruit ripening in August, oval or subglobose, horizontal, scssile, dark purple, $1_{\frac{1}{2}}^{\prime}-3^{\prime}$ long, with scales thickened, acute, often armed with stout pointed umbos, remaining closed at maturity; seeds acute, subcylindrical or flattened on one side, $\frac{1}{3}^{\prime}-\frac{1}{2}^{\prime}$ long, $\frac{1}{3}^{\prime}$ thick, with a thick dark chestnutbrown hard shell prodnced into a narrow border, and wings about $\frac{1^{\prime}}{3}$ broad.

A tree, usually $20^{\circ}-30^{\circ}$ or rarely $60^{\circ}$ high, generally with a short trunk $2^{\circ}-4^{\circ}$ in

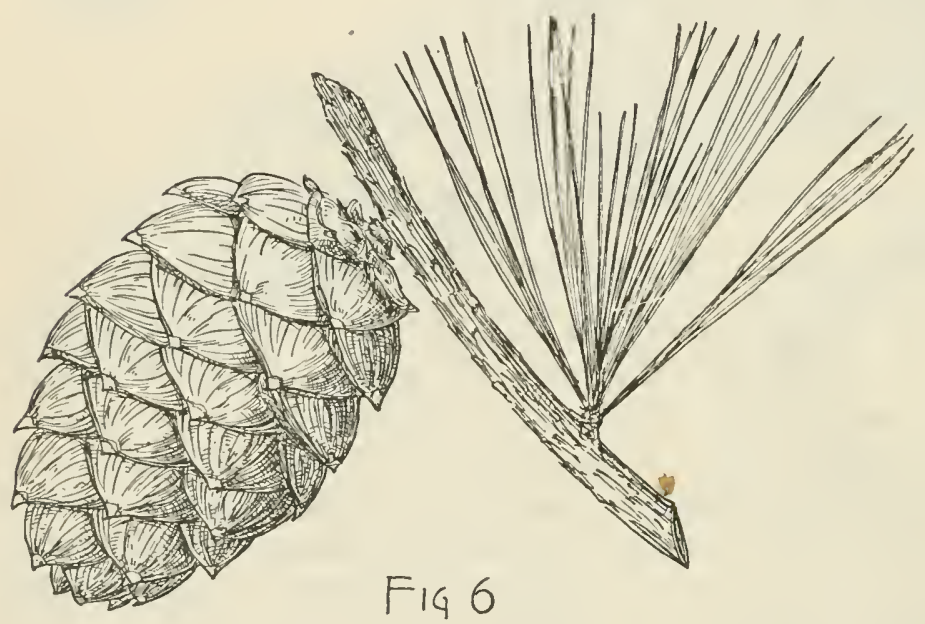
diameter, stont very flexible branches, finally often standing nearly erect and forming an open very irregular broad head, and stont dark red-brown or orange-colored branchlets puberulous for two years or sometimes glabrons; at high elevations of ten a low shrub, with widespreading nearly prostrate stems. Bark thin, except near the base of old trunks and broken by narrow fissures into thin narrow brown or creamy white plate-like scales. Wood light, soft, close-grained, brittle, light brown. The large sweet seeds are gathered and eaten by Indians.

Distribution. Alpine slopes and exposed ridges between $5000^{\circ}$ and $12,000^{\circ}$ elevation, forming the timber-line on many mountain ranges from latitude $53^{\circ}$ north in the Rocky Mountains and from the valley of the Iltasyonco River southward throngh British Columbia, along the Rocky Mountains to the Yellowstone platean, and on the mountains of eastern Washington and Oregon, the Cascade Range, on Mt. Shasta and along the Sierra Nevada to the San Bernardino Mountains of sonthern California.

*Cones short-stalked, subcylindrical, dark purple, their scales armed with slender prickles; wings longer than the seeds ; leaves in crowded clusters.

\section{Pinus Balfouriana, A. Murr. Foxtail Pine.}

Leaves stout, rigid, dark green and hustrous on the back, pale and marked on the ventral faces by numerous rows of stomata, $1^{\prime}-1 \frac{1}{2}^{\prime}$ long, persistent for ten or twelve years. Flowers: staminate dark orange-red ; pistillate dark purple. Fruit $3 \frac{1^{\prime}}{2}-5^{\prime}$ 
long, with scales armed with minute incurved prickles, dark purple, turning after opening dark red or mahogany color; seeds full and rounded at the apex, compressed at the base, pale, conspicuously mottled with dark purple, $\frac{1}{3}^{\prime}$ long, their wings narrowed and oblique at the apex, about $1^{\prime}$ long and $\frac{1}{4}^{\prime}$ wide.

A tree, usually $30^{\circ}-40^{\circ}$ or rarely $90^{\circ}$ high, with a trunk generally $1^{\circ}-2^{\circ}$ or rarely $5^{\circ}$ in diameter, short stout branches forming an open irregular pyramidal picturesque head, and long rigid more or less spreading puberulous, soon glabrous, dark orange-brown ultimately dark gray-brown or nearly black branchlets, clothed only at the extremities with the long dense brush-like

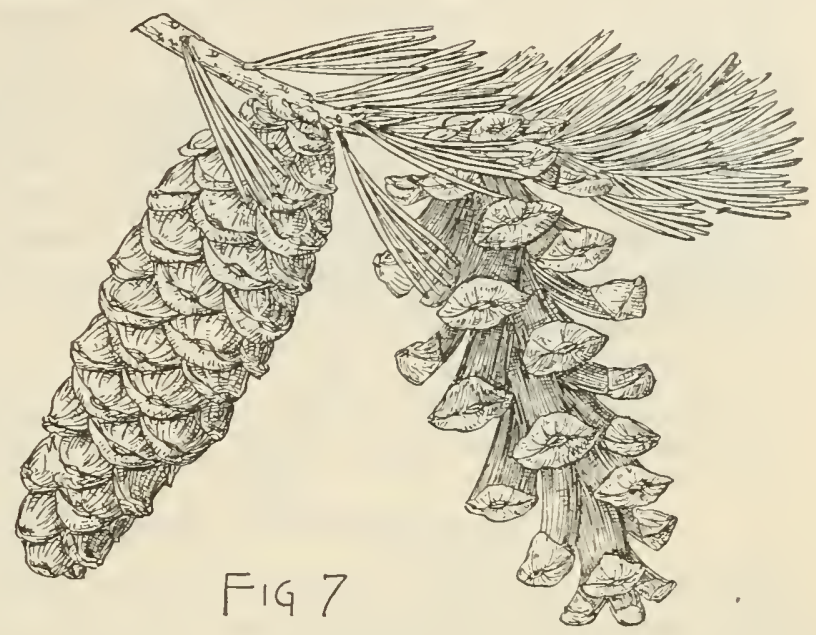
masses of foliage. Bark thin, smooth, and milky white on the stems and branches of young trees, beconing on old trees sometimes $\frac{3^{\prime}}{4}$ thick, dark red-brown, deeply divided into broad flat ridges, broken into nearly square plates separating on the surface into small closely appressed scales. Wood light, soft and brittle, pale reddish brown.

Distribution. California, on rocky slopes and ridges, forming scattered groves on Scott Mountain, Siskiyou Connty, at elevations of $5000^{\circ}-6000^{\circ}$, on the mountains at the head of the Sacramento River, on Mt. Yolo Bally in the northern Coast Range, and on the southern Sierra Nevada up to elevations of $11,500^{\circ}$, growing here to its largest size, and here at the highest elevations often a low shrub, with wide-spreading prostrate stems.

\section{Pinus aristata, Engelm. Foxtail Pine. Hickory Pine.}

Leaves stont or slender, dark green; lustrous on the back, marked by numerous

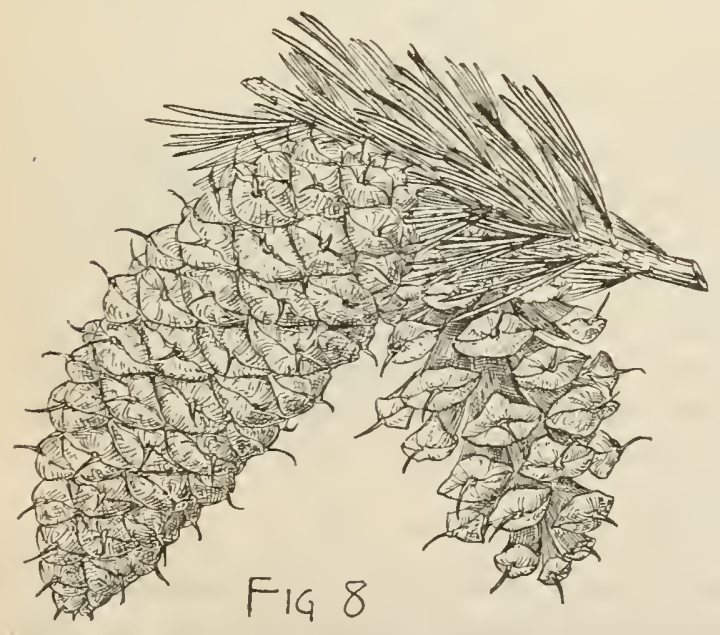
rows of stomata on the ventral faces, $1^{\prime}-1 \frac{1^{\prime}}{2}$ long, often deciduous at the end of ten or twelve years or persistent four or five years longer. Flowers : staminate dark orange-red, pistillate dark purple. Fruit $3^{\prime}-3 \frac{1^{\prime}}{2}$ long, with scales armed with slender incurved brittle prickles nearly $\frac{1^{\prime}}{4}$ long, dark purple-brown on the exposed parts, the remainder dnll red, opening and scattering their seeds about the 1 st of October ; seeds nearly oval, compresser, light brown mottled with black, $\frac{1}{4}$ long, their wings broadest at the middle, about $\frac{1^{\prime}}{3} \operatorname{long}$ and $\frac{1^{\prime}}{4}$ wide.

A bushy tree, occasionally $10^{\circ}-50^{\circ}$ high, with a short trunk $2^{\circ}-3 \circ$ in diameter, short stout branches in regular whorls 
while young, in old age growing very irregularly, the upper erect and much longer than the usually pendulous lower branches, and stont light orange-eolored, glabrous, or at first puberulous, ultimately dark gray-brown or nearly black branchlets clothed at the cuds with long compact brush-like tufts of foliage. Bark thin, smooth, milky white on the stems and branches of young trees, becoming on old trees $\frac{1}{2}-\frac{3}{4}$ thick, red-brown, and irregularly divided into flat connected ridges separating on the surface into small closely appressed scales. Wood light, soft, not strong, light red; oecasionally used for the timbers of mines and for fuel.

Distribution. Rocky or gravelly slopes at the upper limit of tree growth from the outer range of the Rocky Mountains of Colorado to those of sonthern Utah, central and southern Nevada, southeastern California, and the San Franeisco peaks of northern Arizona.

2. Leaves in 1-4-leaved clusters; cones short-stalked or nearly sessile, globose, with few much-thickened scales; seeds large and edible, with rudimentary wings.

\section{Pinus quadrifolia, Sudw. Nut Pine. Piñon.}

Leaves in 1-5 usually 4-leaved clusters, stout, incurved, pale glancous green, marked on the three surfaces by numerous rows of stomata, $1 \frac{1}{4}-1 \frac{1}{2}^{\prime}$ long, irregularly

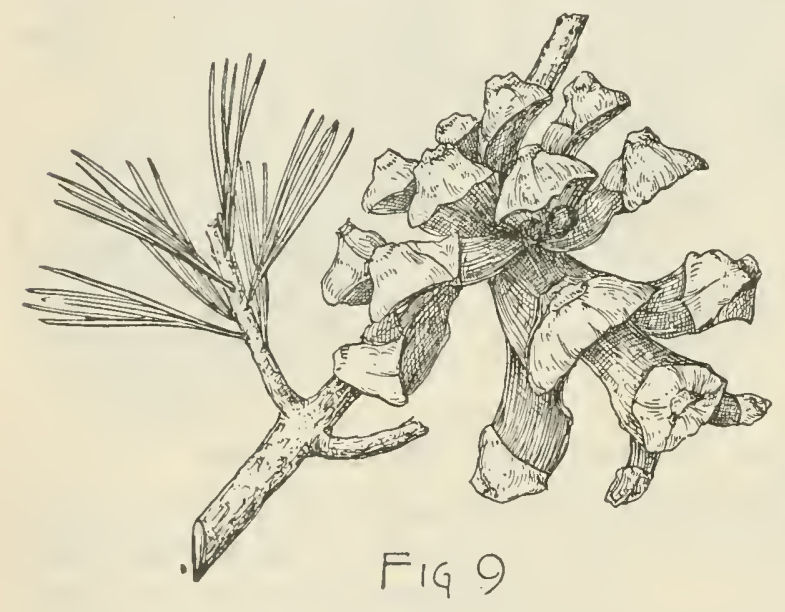
deciduous, mostly falling in their third year. Flowers: staminate in elongated spikes, the bracts of their involucres large and conspicnous; pistillate nearly sessile. Fruit subglobose, $1 \frac{1^{\prime}}{2}-2^{\prime}$ broad; seeds narrowed and compressed at the apex, rounded at the base, $\frac{5}{8}$ long, dark red-brown and mottled, their wings $\frac{1}{8}^{\prime}$ wide.

A tree, $30^{\circ}-40^{\circ}$ high, with a short trunk occasionally $18^{\prime}$ in diameter, and thick spreading branches forming a compact regular pyramidal or in old age a low round-topped irregular head, and stont branchlets coated at first with soft pubescence and light orange-brown. Bark $\frac{1}{2}-\frac{3^{\prime}}{4}$ thick, dark brown tinged with red, and divided by shallow fissures into broad flat connected ridges covered by thick closely appressed plate-like scales. Wood light, soft, close-grained, pale brown or yellow. The seeds form an important article of food for the Indians of Lower California.

Distribution. Arid mesas and low mountain slopes of Lower California southward to the foothills of Mt. San Pedro Martir, extending north ward across the boundary of California to the desert slopes of the Santa Rosa Mountains, Riverside County, where it is common at elevations of $5000^{\circ}$ above the sea-level.

\section{Pinus cembroides, Zucc. Nut Pine. Piñon.}

Leaves in 2 or 3-leaved clnsters, slender, much incurved, dark green, marked by rows of stomata on the 3 faces, $1^{\prime}-2^{\prime}$ long, deciduous irregularly during their third and fourth years. Flowers: staminate in short crowded clusters, yellow; pistillate 
dark red. Fruit subglobose, $1^{\prime}-2^{\prime}$ broad; seeds subcylindrical or obscurely triangular, more or less compressed at the pointed apex, full and rounded at the base, nearly black on the lower side and dark chestunt-brown on the upper, $\frac{1}{2}^{\prime}-3^{\prime}$ long, their wings light chestnut-brown, about $\frac{1}{32}^{\prime}$ wide.

A bushy tree, with a short trunk rarely more than a foot in diameter and a broad round-topped head, usually $15^{\circ}-20^{\circ}$ high, stout spreading branches, and slender dark orange - colored branchlets covered at first with matted pale deciduous hairs, dark brown and sometimes nearly black at the end of five or six years; in sheltered cañons on the mountains of Arizona and in Lower California occasionally $50^{\circ}$ or $60^{\circ}$ tall. Bark about $\frac{1^{\prime}}{2}$ thick, irregularly divided by remote shallow fissures and separated on the surface into

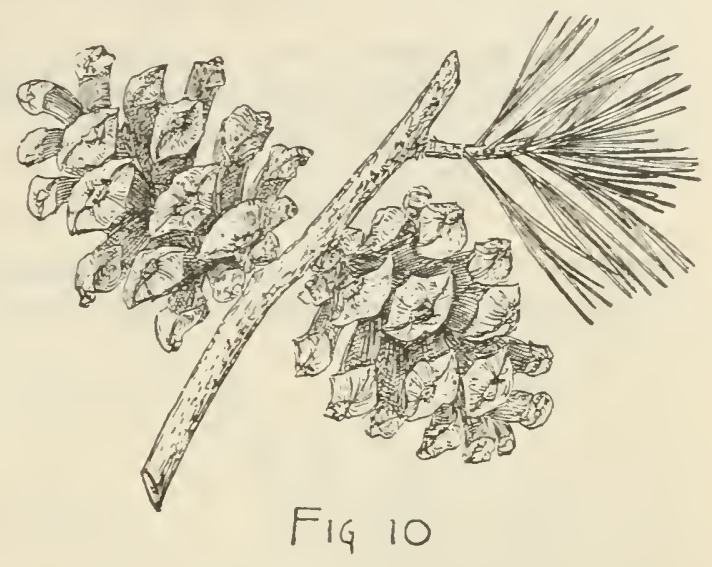
numerous large thin light red-brown scales. Wood light, soft, close-grained, pale clear yellow. The large oily seeds are an important article of food in northern Mexico, and are sold in large quantities in Mexican towns.

Distribution. Mountain ranges of central and sonthern Arizona, usually only above elevations of $6500^{\circ}$, of ten covering their upper slopes with open forests; Lower California, and over many of the mountain ranges of northern Mexico.

\section{Pinus edulis, Engelm. Nut Pine. Piñon.}

Leaves in 2 or rarely in 3-leaved clusters, stout, semiterete or triangular, rigid, incurved, dark green, marked by iumerous rows of stomata, $\frac{3^{\prime}}{4}-1 \frac{1}{2}^{\prime}$ long, deciduous during the third or not until the fourth or fifth year, dropping irregularly and sometimes persistent for eight or nine years. Flowers : staminate in elongated clusters, dark red; pistillate short-stalked. Fruit subcylindrical, $\frac{3^{\prime}}{4}-1 \frac{1}{2}^{\prime}$ long and almost as broad; seeds ovate, acute, full and rounded at the base, dark red-brown on the

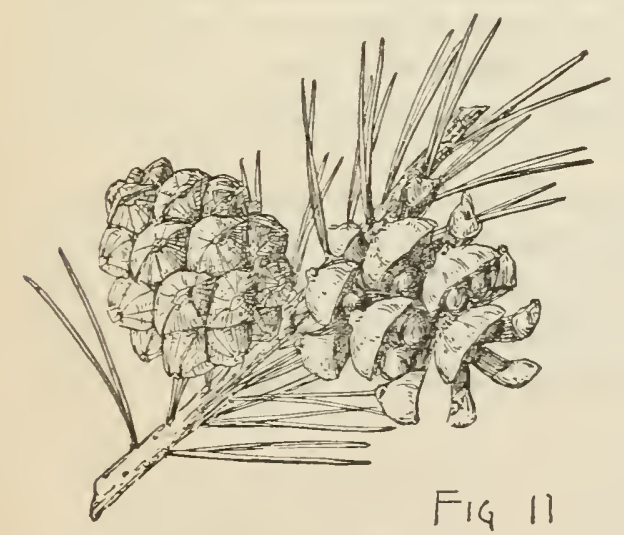
lower and light orange-yellow on the upper side, $\frac{1}{2}^{\prime}$ long, with a thin brittle shell, their wings light reddish brown and about $\frac{1^{\prime}}{8}$ wide.

A tree, rarely $30^{\circ}-40^{\circ}$ ligh, with a short often divided trunk occasionally $22^{\circ}$ in diameter, stout branches forming at first a broad compact pyramid, and in old age a dense low round-topped head, and stont branchlets orange color during their first and second years, finally becoming light gray or dark brown sometimes tinged with red. Bark $\frac{1^{\prime}}{2}-\frac{3^{\prime}}{4}$ thick and irregularly divided into connected ridges covered by small closely appressed light brown scales tinged with red or orange color. Wood light, soft, not strong, brittle, pale brown; largely used for fuel and fencing, and as charcoal nsed in smelting; in western Texas occasionally sawed into lumber. The seeds form an important article of food 
anıong Indians and Mexicans, and are sold in the markets of Colorado and New Mexico.

Distribution. Eastern foothills of the outer ranges of the Rocky Mountains, from Colorado to western Texas, westward to the eastern borders of Utah, southwestern Wyoming, northern and central Arizona, and over the mountains of northern Mexico; often forming extensive open forests at the eastern base of the Rocky Mountaius, on the Colorado platean, and on many mountain ranges of northern and central Arizona up to elevations of $7000^{\circ}$ above the sea.

\section{Pinus monophylla, Torr. Nut Pine. Piñon.}

Leaves in 1 or 2-leaved clusters, rigid, incurved, pale glaucous green, marked by $18-20$ rows of stomata, usually about $1 \frac{1}{2}$ long, sometimes deciduous during

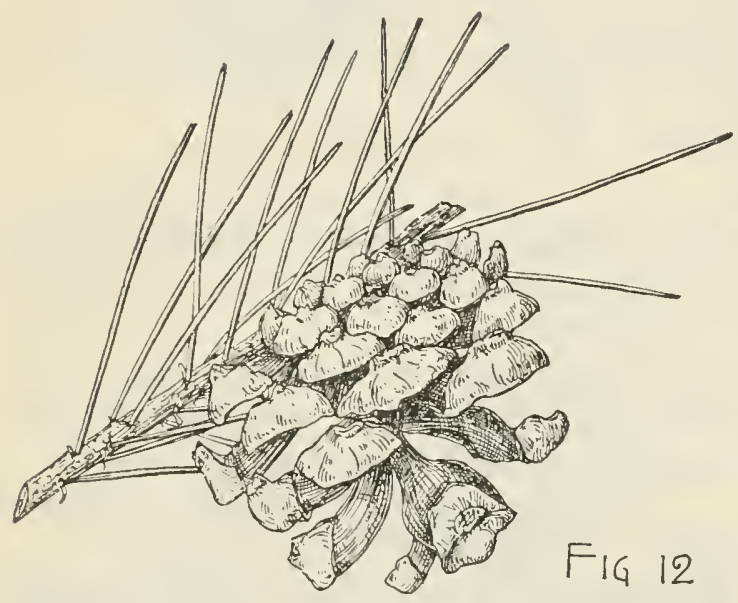
their fourth and fifth seasons, but frequently persistent until their twelfth year. Flowers: staminate dark red; pistillate short-stalked. Fruit short-oblong, $1 \frac{1}{2}^{\prime}-2 \frac{1}{2}^{\prime}$ long; seeds oblong, full and rounded at the base, acute at the apex, dark red-brown and rounded on the lower side, slightly compressed and pale yellow-brown on the upper side, about $\frac{5}{8}$ long and $\frac{1^{\prime}}{4}$ broad, with a thin brittle shell, their wings light brown, $\frac{1^{\prime}}{3}$ to $\frac{1}{2}^{\prime}$ wide.

A tree, usually $15^{\circ}-20^{\circ}$, occasionally $40^{\circ}-50^{\circ}$ high, with a short truuk rarely more than a foot in diameter and often divided near the ground into several spreading stems, short thick branches forming while the tree is young a broad rather compact pyramid, and in old age often pendulous and forming a low ronnd-topped often picturesque liead, and stout light orange-colored ultimately dark brown branchlets. Bark of the trunk about $\frac{3^{\prime}}{4}$ thick and divided by deep irregular fissures into narrow connected flat ridges broken on the surface into thin closely appressed liglit or dark brown scales tinged with red or orange color. Wood light, soft, weak, and brittle; largely used for fuel, and charcoal used in smelting. The seeds supply an important article of food to the Indians of Nevada and California.

Distribution. Dry gravelly slopes and mesas from the western base of the Wasatch Mountains of Utah, westward over the mountain ranges of Nevada to the eastern slopes of the sonthern Sierra Nevada, and to their western slope at the head-waters of King's River, and southward to northern Arizona and to the mountains of sonthern and Lower California; often forming extensive open forests at elevations between $5000^{\circ}$ and $7000^{\circ}$.

\section{PITCH PINES.}

Wood usually heavy, coarse-grained, generally dark-colored, with pale often thick sapwoor ; cones green at maturity (sometimes purple in 15 and 27 ) becoming various shades of brown; cone-scales more or less thickened, mostly armed; seeds shorter than their wings (except in 23 and 34); leaves with 2 fibro-vascular bundles. 
Sheaths of the leaf-clusters deciduous.

Cones $\frac{1^{\prime}}{2}-2^{\prime}$ long, maturing in the third year, leaves in 3-leaved elusters, slender, $2 \frac{1^{\prime}}{2}-t^{\prime}$ long.

13. P. Chihuahuana (H).

Sheaths of the leaf-clusters persistent.

Leaves in 3-leaved clusters (3 and 2-leaved in 15, 17, and 21, 5-leaved in 14).

Cones subterminal.

Cones $2^{\prime}-2 \frac{1^{\prime}}{2}$ long ; leaves in 5-leaved clusters.

14. P. Arizonica $(\mathrm{H})$.

Cones usually deciduous above the basal scales persistent on the branch.

Buds brown; leaves 112 and 3 -leaved clusters. 15. P. ponderosa (B, F, G, H).

Buds white.

16. P. palustris (C).

Cones lateral.

Cones synmetrical, their outer scales not excessively developed.

Young cones reflexed; leaves in 2 and 3-leaved clusters, $S^{\prime}-12^{\prime}$ long.

Cones oblong, prickles stout; leaves $66^{\prime}-9^{\prime}$ long.

17. P. Caribæa (C).

Cones ovate, prickles slender.

Leaves 3 '-5' long.

Leaves $6{ }^{\prime}-S^{\prime}$ long.

15. P. Tæda (A, C).

19. P. rigida (A)

20. P. serotina (C).

Cones unsymmetrical by the excessive development of the scales on the outer side.

Prickles of the cone-scales minute.

21. P. radiata $(G)$.

Prickles of the cone-seales stout.

22. P. attenuata $(\mathrm{G})$.

Cones $6^{\prime}-14^{\prime}$ long, their scales prolonged into stout straight or eurved spines;

leaves long and stout.

Cones broad-ovate; seeds longer than their wings. 23. P. Sabiniana (G).

Cones oblong-conical.

24. P. Coulteri (G).

Leaves in 2-leaved clusters (2 and 3-leaved in 29).

Cones subterminal.

Cones symmetrical, $2^{\prime}-2 \frac{1}{2}^{\prime}$ long, their seales unarmed ; leaves $5^{\prime}-6^{\prime}$ long, flexible.

25. P. resinosa (A).

Cones unsynmetrical by the greater development of the scales on the outer side, armed with slender prickles; leaves $1^{\prime}-4^{\prime}$ long.

26. P. contorta (B, F, G).

Cones lateral.

Cones about $2^{\prime}$ long, mostly unarmed and incurved, their scales very unevenly developed; leaves less than 2 ' long.

27. P. divaricata (A).

Cones about 2 ' long, their scales evenly developed, armed with weak or deciduous prickles; leaves $4^{\prime}$ long or less.

Bark of the branches and upper trunk smooth.

28. P. glabra (C).

Bark of the branches and upper trunk roughened. 29. P. echinata (A, C). Cones about $3^{\prime}$ long, armed with persistent spines.

Cone-scales evenly developed, their prickles slender, acuminate, from a broad base; leaves soft, $3^{\prime}$ long or less.

Cones opening at maturity.

30. P. Virginiana $(A, C)$

Cones often remaining closed for many years.

31. P. clausa (C).

Outer cone-scales excessively developed and armed with stout prickles.

Cones $2^{\prime}-3 \frac{1^{\prime}}{2}$ long, remaining closed ; leaves $4^{\prime}-6^{\prime}$ long. 32. P. muricata $(G)$.

Cone-scales armed with rery stout hooked spines.

Cones $2 \frac{1}{2}{ }^{\prime}-3$ ' long; leaves $2^{\prime}$ long or less.

33. P. pungens (A)

Leaves in 5-leaved clusters.

Cones $4^{\prime}-6^{\prime}$ long, unsymmetrical, their scales thick ; seeds shorter than their wings; leaves stout, $9^{\prime}-13^{\prime}$ long.

34. P. Torreyana $(\mathrm{G})$. 
1. Sheaths of the leaf-clusters deciduous; leaves in 3-leaved clusters.

\section{Pinus Chihuahuana, Engelm. Yellow Pine.}

Leaves slender, pale glaucous green, marked by 6-8 rows of conspicuous stomata on each of the 3 sides, $21^{\prime}-4^{\prime}$ loug, irregularly deciduous frou their fourth season, their sheatlis deeidnous. Flowers : staninate yellow; pistillate yellow-green. Fruit

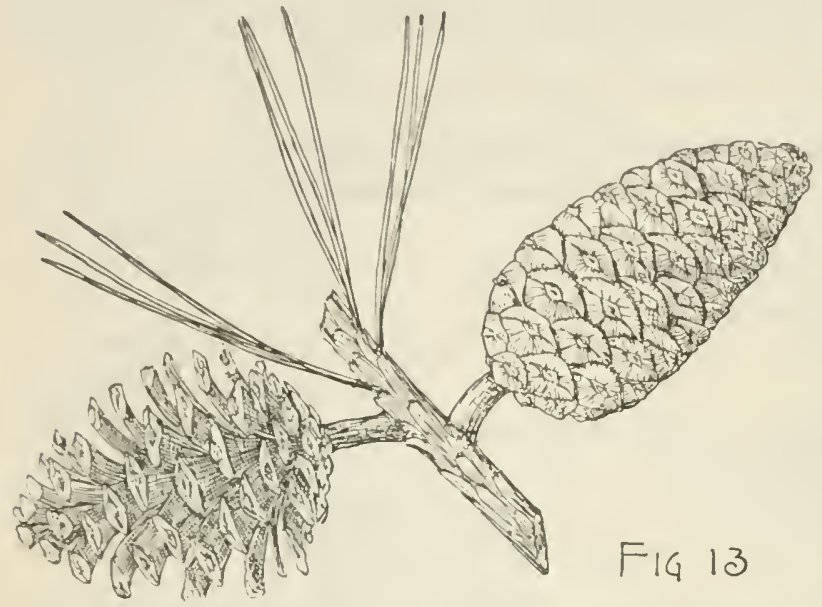
ovate, horizontal or slightly

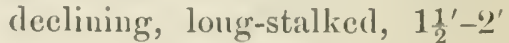
long, beconing light chestuntbrown and lustrous, maturing at the end of the thind scason, with scales only slightly thickened, their ultimately pale umbos armed with recurved decidıous prickles; seeds oval, rounded above and pointed below, about $\frac{1}{8}$ long, with a thin dark brown shell, their wings $\frac{1}{3}^{\prime}$ long and broadest near the middle.

A tree, rarely more than $40^{\circ}-50^{\circ}$ high, with a tall trunk sometimes $2^{\circ}$ in diameter, stout slightly ascending branches forming a narrow open pyramidal or round-topped head of thin pale foliage, and slender bright orangebrown branchlets, soon becoming dull red-brown. Bark of old trunks $\frac{3^{\prime}}{4}-1 \frac{1^{\prime}}{2}$ thick, dark reddish brown or sometimes nearly black, and deeply divided into broad flat ridges covered with thin closely appressed scales. Wood light, soft, not strong but durable, light orange color, with thick much lighter colored sapwood; occasionally used as fuel.

Distribution. Mountain ranges of southern New Mexico and Arizona, usually at elevations between $6000^{\circ}$ and $7000^{\circ}$; not common ; more abundant on the Sierra Madre of northern Mexico and on several of the short ranges of Chihuahua and Sonora, and of a larger size in Mexico than in the United States.

2. Sheaths of the leaf-clusters persistent.

* Leaves in 3-leaved clusters (3 and 2-leaved in 15, 1\%, and 21, 5-leaved in 14). $\rightarrow$ Cones subterminal.

\section{Pinus Arizonica, Engelm. Yellow Pine.}

Leaves tufted at the ends of the branches, in 5-leaved clusters, stout, rigid, dark green, stomatiferous on their 3 faces, $5^{\prime}-7^{\prime}$ long, deciduous during their third season. Flowers dark purple: staminate in short spikes; pistillate on stout peduncles, usually in pairs. Fruit oval, horizontal, $2^{\prime}-2 \frac{1}{2}^{\prime}$ long, becoming light red-brown, with thin scales much thickened at the apex and armed with slender recurved spines; seeds full and rounded below, slightly compressed towards the apex, $\frac{1}{8}^{\prime}$ long, with a thick shell, their wings broadest above the middle, about $\frac{1}{3}^{\prime}$ long and $\frac{1}{4}^{\prime}$ wide.

A tree, $80^{\circ}-100^{\circ}$ high, with a tall straight massive trunk $3 \circ-40^{\circ}$ in diameter, thick spreading branches forming a regular open round-topped or narrow pyramidal head, and stout branchlets orange-brown when they first appear, becoming dark gray- 
brown. Bark on young trunks dark brown or almost black and deeply furrowed, becoming on old trees $1 \frac{1^{\prime}}{2}-2^{\prime}$ thick and divided into large unequally shaped plates separating on the surface into thin closely appressed light cinnamon-red scales. Wood light, soft, not strong, rather brittle, light red or often yellow, with thick lighter yellow or white sapwood; in Arizona occasioually manufactured into coarse lumber.

Distribution. High cool slopes on the sides of cañous of the mountain ranges of southern Arizona at elevations between $6000^{\circ}$ and $8000^{\circ}$, sometimes forming nearly pure forests; more abundant and of its largest size on the mountains of Sonora and Chihuahua.

\section{Pinus ponderosa, Laws. Yellow Pine. Bull Pine.}

Leaves tufted at the ends of naked branches, in $2-$ or in 2 and 3-leaved clusters, stout, dark yellow-green, marked by numerous rows of stomata on the 3 faces, $5^{\prime}-11^{\prime}$ long, mostly deciduous during their third season. Flowers : staminate yellow; pistillate clustered or in pairs, dark red. Fruit oval, horizontal or slightly declining, nearly sessile or short-stalked, $3^{\prime}-6^{\prime}$ long, often clustered, bright green or purple when fully grown, becoming light reddish brown, with narrow scales much

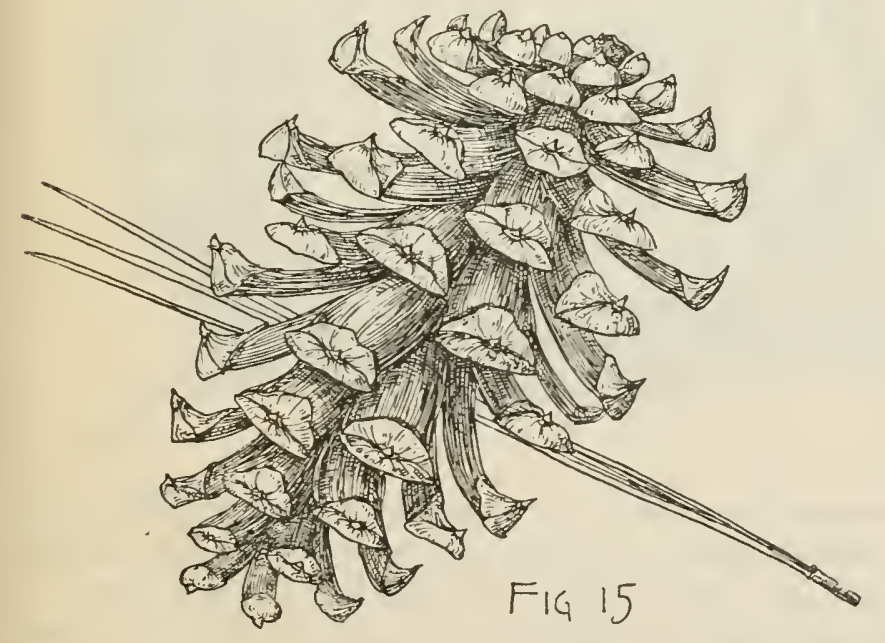
thickened at the apex and armed with slender prickles, mostly falling soon after they open and discharge their seeds, generally leaving the lower scales attached to the peduncle; seeds ovate, acute, compressed at the apex, full and rounded below, $\frac{1}{4}^{\prime}$ long, with a thin dark purple often mottled shell, their wings usuall: broadest below the middle, gradually narrowed at the oblique apex, $1^{\prime}-1 \frac{1}{4}^{\prime}$ long, about $1^{\prime}$ wide.

A tree, sometimes $150^{\circ}-$ $230^{\circ}$ high, with a massive stem $5^{\circ}-8^{\circ}$ in diameter, short thick many-forked often pendulous branches generally turned upward at the ends and forming a regular 
spire-like head, or in arid regrions a broader often romd-topped head surmounting a short trunk, and stont ormge-eolored branehlets frequently beeoming nearly black at the end of two or three years. Bark for 80-100 years broken into rombled ridges eovered with small elosely appressed seales, dark brown, nearly blaek or liglit cinnanon-red, on older trees beconning ' $2{ }^{\prime}-4^{\prime}$ thiek and deeply and irregnlarly divided into plates sometimes $4^{\circ}-5^{\circ}$ long and $12^{\prime}-18^{\prime}$ wide, and separating into thick bright cinnamon-red scales. Wood hard, strong, eomparatively fine-gramed, light red, with nearly white sapwood sometimes eomposed of more than :200 layers of anumal growtlı; largely mannfaetured into lumber used for all sorts of eonstruction, for railway-ties, fencing, and fuel.

Distribution. Mountain slopes, dry valleys, and high mesas from northwestern Nebraska and western Texas to the shores of the Pacifie Oeean, and from sonthern British Columbia to Lower California and northern Mexieo; extremely variable in different parts of the conntry in size, in the length and thickness of the leaves, size of the eones, and eolor of the bark. The form of the Roeky Mountains (var. scopulorum, Engelm.), ranging from Nebraska to Texas and over the mountain ranges of $\mathrm{Wy}$ oming, eastern Montana, and Colorado, and to northern New Mexieo and Arizona, where it forms on the Colorado plateau the most extensive Pine forests of the eontinent, has nearly blaek fnrrowed or bright einnamon-red bark, rigid leaves in elnsters of 2 or 3 and $3^{\prime}-6^{\prime}$ long, and smaller eones, with thin seales armed with slender priekles hooked baekward. More distinet is

\section{Pinus ponderosa, var. Jeffreyi, Vasey.}

This tree forms great forests about the sourees of the Pitt River in northern California, along the eastern slopes of the eentral and southern Sierra Nevada,

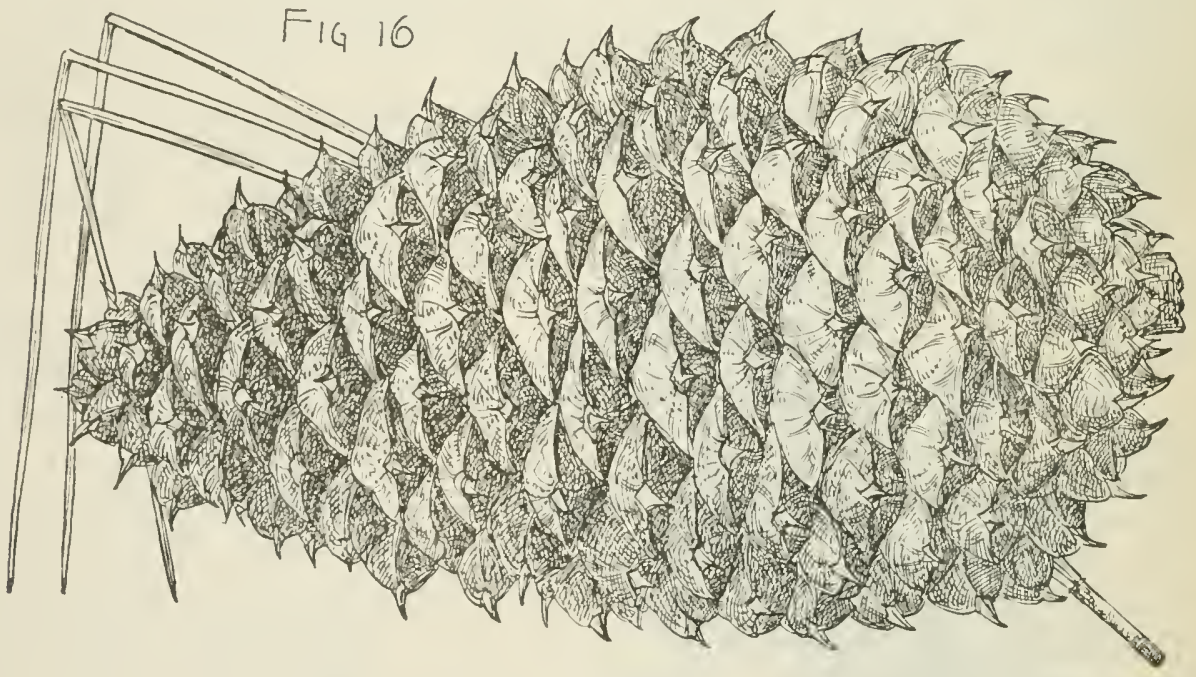

growing often on the most exposed and driest ridges, and in southern California on the San Bernardino and San Jaeinto ranges up to elevations of $8000^{\circ}$ above the sea, on the Cuyamaea Mountains, and in Lower California on Mt. San Pedro Martir.

A tree, $100^{\circ}$ to nearly $200^{\circ}$ high, with a tall massive trunk $4^{\circ}-6^{\circ}$ in diameter, covered with bright einnamon-red bark deeply divided into large irregular plates, stiffer and more elastie leaves $4^{\prime}-9^{\prime}$ long and persistent on the glaueons stonter branehlets for six to nine years, yellow-green staminate flowers, short-stalked usually 
purple cones $5^{\prime}-15^{\prime}$ long, their scales armed with stout or slender prickles usually hooked backward, and seeds often nearly $\frac{1}{2}^{\prime}$ long and larger wings.

Occasionally planted as an ornamental tree in eastern Europe, especially the variety Jeffreyi, which is occasionally successfully cultivated in the eastern states.

\section{Pinus palustris, Mill. Long-leaved Pine. Southern Pine.}

Leaves in crowded clusters, forming dense tufts at the ends of the branches, sleuder, flexible, pendulous, dark green, $8^{\prime}-18^{\prime}$ long, deciduous at the end of their

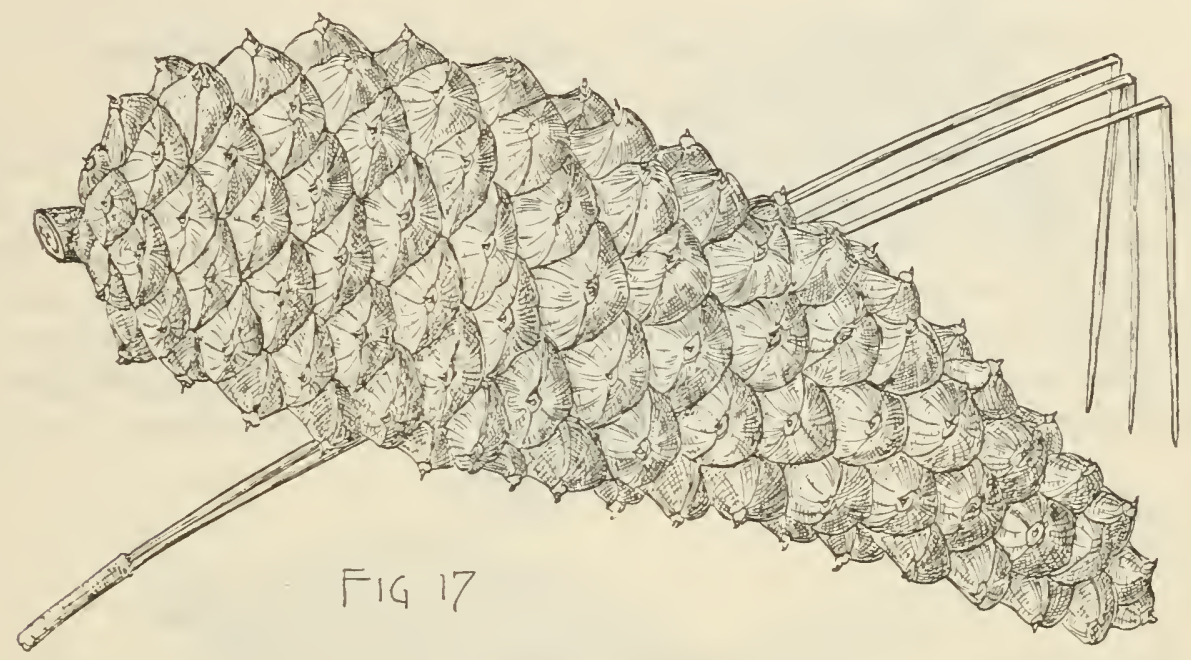

second year. Flowers in very early spring before the appearance of the new leaves, staminate in short dense clusters, dark rose-purple; pistillate just below the apex of the lengthening shoot in pairs or in clusters of 3 or 4, dark purple. Fruit cylindrical or conical-oblong, slightly curved, nearly sessile, horizontal or pendant, $6^{\prime}-10^{\prime}$ long, with thin flat scales rounded at the apex and armed with small reflexed prickles, becoming dull brown; in falling leaving a few of the basal scales attached to the stems; seeds almost triangular, full and rounded on the sides, prominently ridged, about $\frac{1}{2}$ long, with a thin pale shell marked with dark blotches on the upper side, and wings widest near the middle, gradually narrowed to a very oblique apex, about $1 \frac{3^{\prime}}{4}$ long and $\frac{77^{\prime}}{16}$ wide.

A tree, $100^{\circ}-120^{\circ}$ high, with a tall straight slightly tapering trunk usually $2^{\circ}-2 \frac{1}{2}^{\circ}$ or occasionally $3^{\circ}$ in diameter, stout slightly branched gnarled and twisted limbs covered with thin dark scaly bark and forming an open elongated and usually very irregular head one third to one half the length of the tree, thick orange-brown branchlets, and acute winter-buds covered by elongated silvery white lustrous scales divided into long spreading filaments forming a cobweb-like network over the bud. Bark of the trunk $\frac{1^{\prime}}{16}-\frac{1^{\prime}}{2}$ thick, light orange-brown, separating on the surface into large closely appressed papery scales. Wood heavy, exceedingly hard, strong, tough, coarse-grained, durable, light red to orange color, with rery thin nearly white sapwood ; largely used as "southern pine" or "pitch pine" for masts and spars, bridges, viaducts, railway-ties, fencing, flooring, the interior finish of buildings, the construction of railway-cars, and for fuel and charcoal. A large part of the naval stores of the world is produced from this tree, which is exceedingly rich in resinous secretions. 
Distribution. Generally confined to a belt of late tertiary sands and gravels stretching along the coast of the Atlantic and Gulf states and rarely more than 125 miles wide, from sontheasteru Virginia to Cape Canaveral and the shores of 'Tampa Bay, Florida, and along the Gulf eoist to the uplands east of the Mississippi River, extending northward in Alabama to the sonthern foothills of the Appalachian Mountains; west of the Mississippi River to the valley of the Trinity River, and through eastern Texiss and western Louisiana nearly to the northern borders of this state.

$\rightarrow+$ Cones lateral.

\section{Pinus Caribæa, Morelet. Slash Pine. Swamp Pine.}

(Pimus heterophylla, Silva N. Am. xi. 157.)

Leaves stout, in crowded 2 and 3-leaved clusters; dark green and lustrous, marked by numerous bands of stomata on each face, $8^{\prime}-12^{\prime}$ long, deciduous at the end of their second season. Flowers in January and February before the appearance of the new leaves, staminate in short crowded clusters, dark purple; pistillate on long peduncles, pink. Fruit ovate or elongated, reflexed during its first year, conical, pendant, $3^{\prime}-6^{\prime}$ long, with thin flexible flat scales armed with minute incurved or recurved prickles, becoming dark rich lustrous brown; seeds almost triangular,

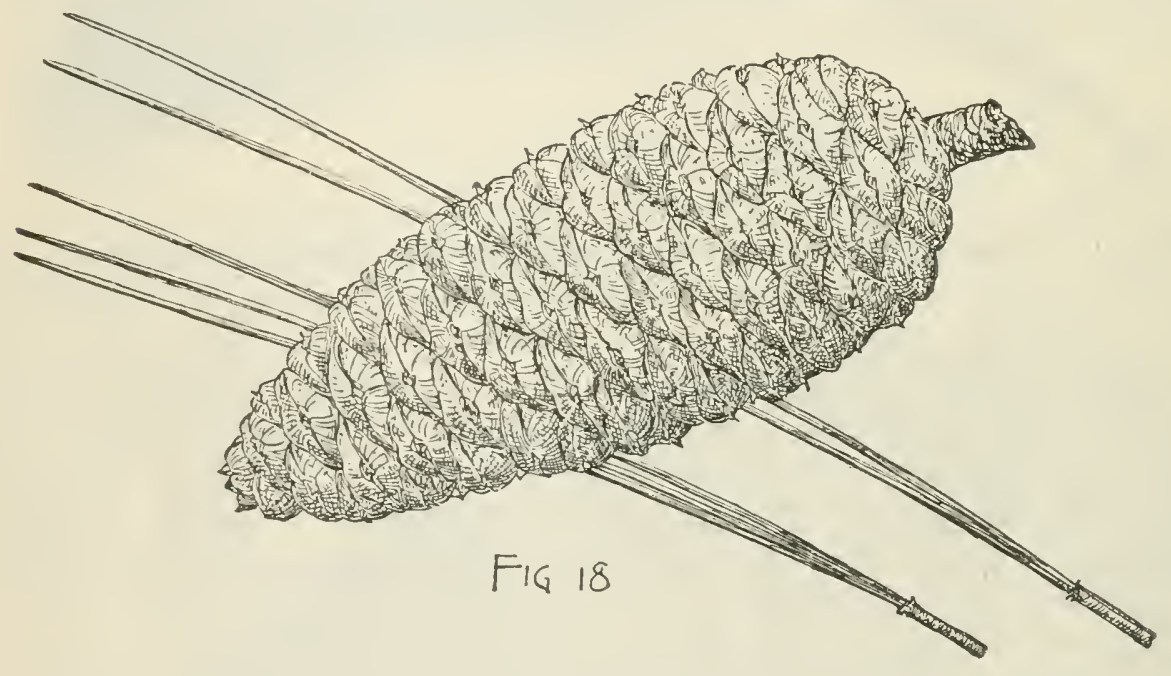

full and rounded on the sides, $1 \frac{1^{\prime}}{6}-1 \frac{1^{\prime}}{4}$ long, with a thin brittle dark gray shell mottled with black, and dark brown wings $\frac{\beta^{\prime}}{4}-1^{\prime}$ long and $\frac{1}{4}$ wide, their thickened bases encircling the seeds and often covering a large part of their lower surface.

A tree, often $100^{\circ}$ high, with a tall tapering trunk $2 \frac{1}{2}{ }^{\circ} 3^{\circ}$ in diameter, heavy horizontal branches forming a handsome round-topped head, and stout orange-colored ultimately dark branchlets. Bark $\frac{3^{\prime}}{4}-\frac{1}{2}$ thick, and irregularly divided by shallow fissures into thin dark red-brown scales. Wood heavy, exceedingly hard, very strong, durable, coarse-grained, rieh dark orange color, with thick nearly white sapwood; manufactured into lumber and used for construction and railway-ties. Naval stores are largely produced from this tree.

Distribution. ' Coast region of South Carolina southward over the coast plain to the keys of southern Florida and along the Gulf coast to the valley of the Pearl River, Louisiana; common on the Bahamas, on the Isle of Pines, and on the highlands of 
Central America; in the coast region of the southern states gradually replacing the Long-leaved Pine, Pinus palustris, Mill.

\section{Pinus Tæda, L. Loblolly Pine. Old Field Pine.}

Leaves slender, stiff, slightly twisted, pale green and somewhat glancous, $6^{\prime}-9^{\prime}$ long, marked by 10-12 rows of large stomata on each face, deciduous during their third year. Flowers opening from tine middle of March to the first of May; staminate crowded in short spikes, yellow; pistillate lateral below the apex of the growing shoot, solitary or clustered, short-stalked, yellow. Fruit ovateoblong to broadly conical, nuearly sessile, $3^{\prime}-5^{\prime}$ long, be-

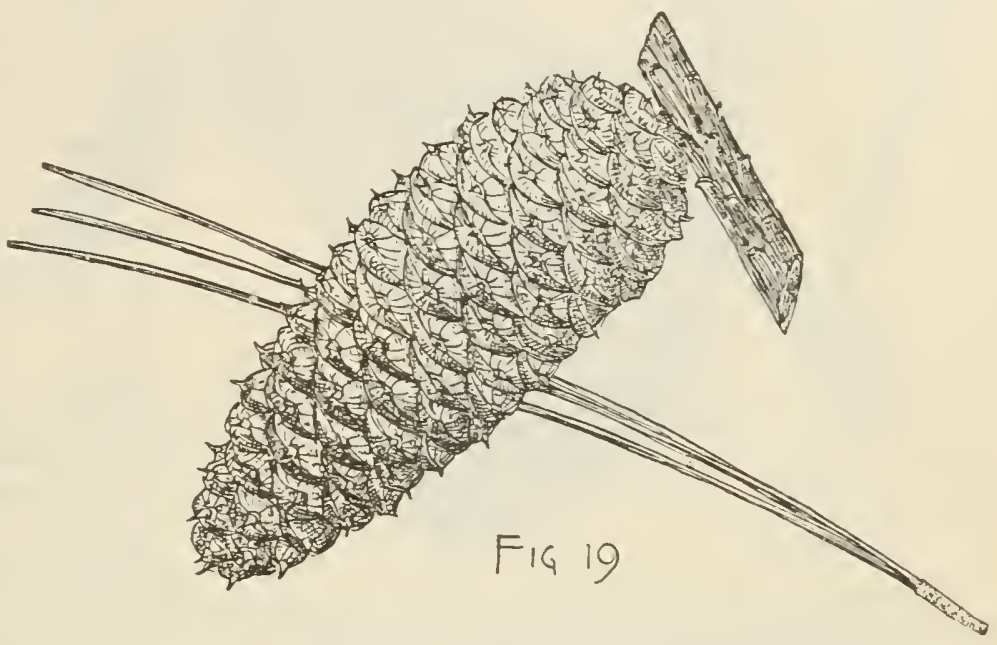
coming light reddish brown, with thin scales rounded at the apex and armed with short stout straight or reflexed prickles, opening irregularly and discharging their seeds during the autumn and winter, and usually persistent on the branches for another year; seeds rhomboidal, full and rounded, $\frac{1}{4}$ long, with a thin dark brown rough shell blotched with black, and produced into broad thin lateral margins, encircled to the base by the narrow border of their thin pale brown lustrons wings broadest above the middle, $1^{\prime}$ long and about $\frac{1}{4}{ }^{\prime}$ wide.

A tree, generally $80^{\circ}-100^{\circ}$ high, with a tall straight trunk usually about $2^{\circ}$ but occasionally $5^{\circ}$ in diameter, short thick much divided branches, the lower spreading, the upper ascending and forming a compact round-topped head, and comparatively slender glabrous branchlets brown tinged with yellow and covered with a glaucous bloom during their first season and gradnally growing darker in their second year. Bark of the trunk $\frac{3^{\prime}}{4}-1 \frac{1^{\prime}}{2}$ thick, bright red-brown, and irreg'ularly divided by shallow fissures into broad flat ridges covered with large thin closely appressed scales. Wood weak, brittle, coarse-grained, not dnrable, light brown, with orange-colored or often nearly white sapwood, often composing nearly half the trunk; largely manufactured into lumber, used for construction and the interior finish of buildings.

Distribution. Cape May, New Jersey, southward near the coast to Cape Malabar and the shores of Tampa Bay, Florida, westward to middle North Carolina and through South Carolina and Georgia and the eastern Gulf states to the Mississippi River, extending into southern Tennessee; west of the Mississippi River from sonthern Arkansas and the southwestern part of the Indian Territory throngh western Louisiana to the shores of the Gulf of Mexico, and through eastern Texas to the valler of the Colorado River; on the Atlantic coast often springing up on lands exhausted by agriculture; west of the Mississippi River one of the most important timber-trees, frequently growing in great nearly pure forests on rolling uplands. 


\section{Pinus rigida, Mill. Pitch Pine.}

Leaves stont, rigid, dark yellow-green, marked on the 3 faces by inany rows of stomata, $3^{\prime}-\overline{5}$ long. standing stifty and at right angles with the branches, decidn-

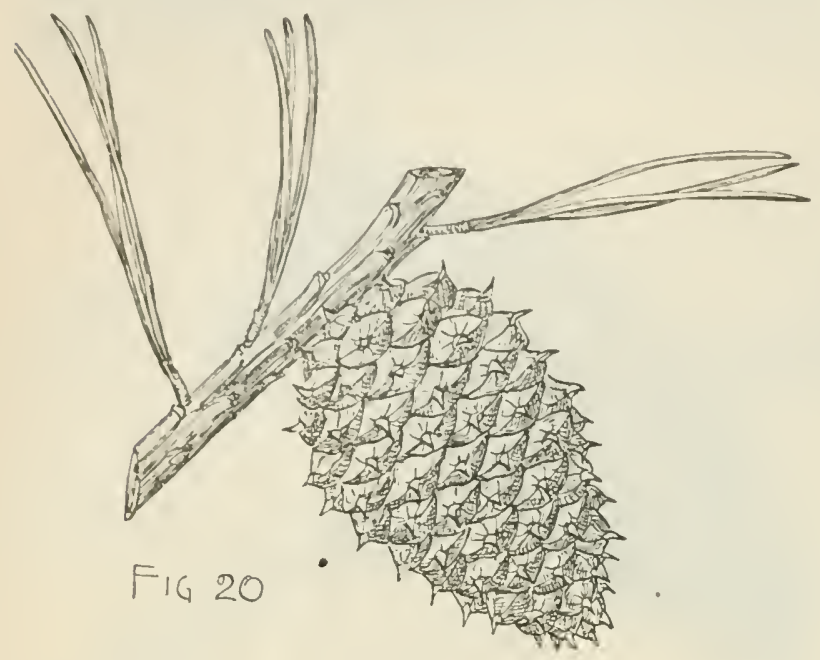
ous dining their second year. Flowers: staminate in short erowded spikes, yellow or rarely purple; pistillate often clustered and raised on short stont stems, light green more or less tinged with rose color. Fruit ovate-conieal or ovatc, ncarly sessile, often clustered, $1^{\prime}-3 \frac{1^{\prime}}{2}$ long, becoming light brown, with thin flat seales armed with recurved rigid prickles, often remaining on the branches for ten or twelve years ; seeds nearly triangular, full and rounded on the sides, $\frac{1}{4}$ long, with a thin dark brown mottled roughened shell and wings broadest below the middle, gradually narrowed to the very oblique apex, $\frac{3^{\prime}}{4}$ long, $\frac{1}{3}$ wide.

A tree, $50^{\circ}-60^{\circ}$ or rarely $80^{\circ}$ high, with a short trunk occasionally $3^{\circ}$ in diameter, thick contorted often pendulous branches covered with thick much ronghened bark, forming a round-topped thick hearl, often irregular and picturesque, and stout bright green branehlets becoming dull orange color during their first winter and dark gray-brown at the end of four or five years; often fruitful when only a few feet high. Bark of young stems thin and broken into plate-like dark red-brown scales, becoming on old trunks $\frac{3 \prime}{4}-1 \frac{1}{2}^{\prime}$ thick, deeply and irregularly fissured and divided into broad flat connected ridges separating on the surface into thick dark red-brown scales often tinged with purple. Wood light, soft, not strong, brittle, coarsegrained, very durable, light brown or red, with thick yellow or often white sapwood ; largely used for fuel and in the manufacture of charcoal; occasionally sawed into lumber.

Distribution. Sandy plains and dry gravelly uplands, or less frequently cold deep swamps; valley of the St. John River in New Brunswick to the northern shores of Lake Ontario, southward in the Atlantic states to northern Georgia; erossing the Alleghany Mountains to their western foothills in West Virginia, Kentncky, and Tennessee; very abundant on the Atlantic coast south of Massachusetts Bay; often forming extensive forests in sonthern New Jersey.

\section{Pinus serotina, Michx. Pond Pine. Marsh Pine.}

Leaves in clusters of 3 or occasionally of 4 , slender, flexuose, dark yellow-green, $6^{\prime}-8^{\prime}$ long, marked by numerous rows of stomata on the 3 faces, deciduous during their third and fourth years. Flowers: staminate in crowded spikes, dark orange color ; pistillate clustered or in pairs on stout stems. Fruit subglobose to ovate-oblong, full and rounded or pointed at the apex, subsessile or short-stalked, horizontal or slightly declinate, $2^{\prime}-2 \frac{1^{\prime}}{2}$ long, with thin nearly flat scales armed with 
sleuder incurved mostly deciduous prickles, becoming light yellow-brown at maturity, remaining closed for one or two years and after opening long-persistent on the branches ; seeds nearly triaugular, often ridged below, full and rounded at the sides, $\frac{1}{8}^{\prime}$ loug, with a thin nearly black ronghened shell produced into a wide border, and wings broadest at the middle, gradually narrowed at the ends, $\frac{3}{4}$ long, $\frac{1}{4}$ wide.

A tree, usually $40^{\circ}-50^{\circ}$ or occasionally $70^{\circ}-80^{\circ}$ high, with a short trunk sometimes $3^{\circ}$ but generally not more than $2^{\circ}$ in diame-

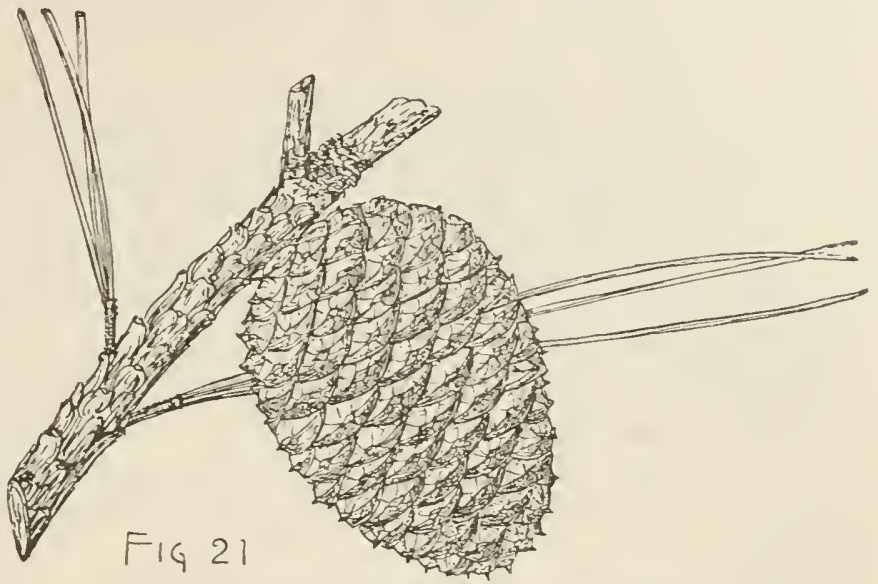
ter, stout often contorted branches more or less pendulous at the extremities, forming an open round-topped head, and slender branchlets dark green when they first appear, becoming dark orange color during their first winter and dark brown or often nearly black at the end of four or five years. Bark of the trunk $\frac{1^{\prime}}{2}-\frac{3}{1}$ thick, dark red-brown and irregularly divided by narrow shallow fissures into small plates separating on the surface into thin closely appressed scales. Wood very resinous, heary, soft, brittle, coarse-grained, dark orange color, with thick pale yellow sapwood; occasionally manufactured into lumber. In the coast region of Nortl Carolina turpentine is produced from this tree.

Distribution. Low wet flats or sandy or peaty swamps; North Carolina southward near the coast to the banks of the St. John's River, Florida.

+ Cones unsymmetrical by the excessive development of the scales on the outside.

\section{- 21. Pinus radiata, D. Don. Monterey Pine.}

Leaves in 3 rarely in 2-leaved elusters, slender, bright rich green, $4^{\prime}-6^{\prime}$ long,

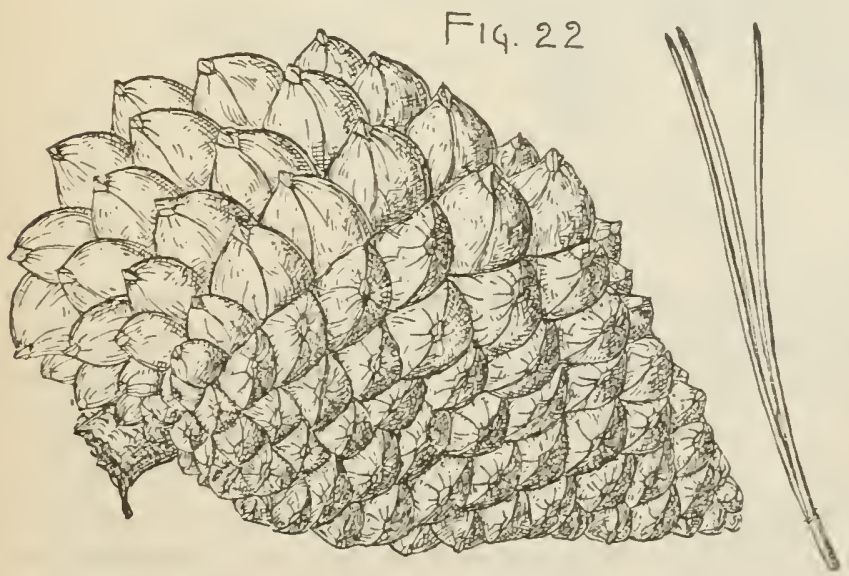
mostly deciduous during their third season. Flowers: staminate in dense spikes, yellow; pistillate clustered, dark purple. Fruit oval, pointed at the apex, very oblique at the base, short-stalked, deflexed, $3^{\prime}-\tilde{5}^{\prime}$ long, becoming deep chestuut-brown and lustrous, with scales much thickened and mammillate toward the base on the outer side of the cone, thimner on the inner side and at its apex, and armed with minute thickened incurved or straight prickles, long-persistent and 
often remaining closed on the branches for many years ; seeds oval, compressed, $\frac{1^{\prime}}{4}$ long, with a thin brittle rough nearly black shell, their wings light brown, longitudinally striped, broadest above the middle, gradually narrowed and oblique at the apex, $1^{\prime} \operatorname{long}$ and $\frac{1^{\prime}}{4}$ wide.

A tree, $80^{\circ}-100^{\circ}$ high, with a tall trunk usually $2^{\circ}-3^{\circ}$ but occasionally $5^{\circ}-6^{\circ}$ in dianeter, spreading branches forming a regular narrow open round-topped head, and slender branchlets light or dark orange eolor, at first often covered with a glancous bloom, ultimately dark red-brown. Bark of the trunk $1 \frac{1}{2}^{\prime}-2^{\prime}$ thick, dark redbrown, and deeply divided into broad flat ridges broken on the surface into thick appressed plate-like scales. Wood light, soft, not strong, brittle, close-grained ; occasionally used as fuel.

Distribution. Only in a narrow belt a few miles wide on the California coast from Pescadero to the shores of San Simeon Bay, on the islands of Santa Rosa and Santa Cruz of the Santa Barbara group; and on Guadaloupe Island off the coast of Lower California ; most abundant and of its largest size on Point Pinos sonth of the Bay of Monterey.

Largely planted for the decoration of parks in western and southern Europe, occasionally planted in the southeastern states and in Mexico, Australia, New Zealand, and other regions with temperate climates, and more generally in the coast region of the Pacific states from Vancouver Island southward than any other Pinetree.

\section{Pinus attenuata, Lemm. Knob-cone Pine.}

Leaves slender, firm and rigid, pale yellow or bluish green, marked by numerous rows of stomata on their 3 faces, $3^{\prime}-7^{\prime}$, 11sually $4^{\prime}-5^{\prime}$ long. Flowers: staminate

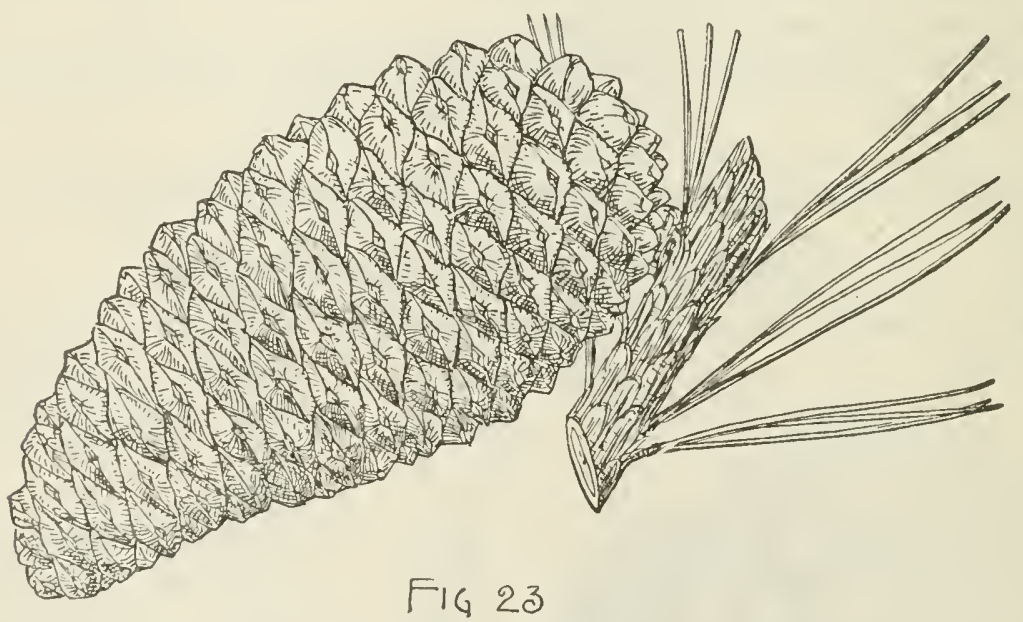

orange-brown; pistillate fascicled, often with several fascicles on the shoot of the year. Fruit elongated, conical, pointed, very oblique at the base by the greater development of the scales on the upper side, whorled, short-stalked, strongly reflexed and incurved, $3^{\prime}-6^{\prime}$ long, becoming light chestnut-brown, with thin flat scales rounded at the apex, those on the outer side being enlarged into prominent transversely flattened knobs armed with thick flattened incurved spines, those on the inner side of the cone slightly thickened and armed with minute recurved prickles, persistent on the stems and branches for thirty or forty years, often becoming completely imbedded in the bark of old trunks and usually not opening until the death of the tree; seeds 
nearly oval, compressed, acute at the apex, $\frac{1}{4}$ long, with a thin oblique shell, their wings broadest at the middle, gradually narrowed to the ends, $1 \frac{1}{4}{ }^{\prime}$ long,$\frac{1}{3}{ }^{\prime}$ wide.

A tree, usually about $20^{\circ}$ high, with a trunk a foot in diameter, and often fruitfu] when only $4^{\circ}$ or $5^{\circ}$ tall ; occasionally growing to the height of $80^{\circ}-100^{\circ}$, with a trunk $2 \frac{1}{2}^{\circ}$ thick, and frequently divided above the middle into two ascending stems, slender branches arranged in regular whorls while the tree is young, and in old age forming a narrow round-topped straggling head of sparse thin foliage, and slender dark orange-brown branchlets growing darker during their second season. Bark of young stems and branches thin, smooth, pale brown, becoming at the base of old trunks $\frac{1^{\prime}}{4}-\frac{1^{\prime}}{2}$ thick and dark brown often tinged with purple, slightly and irregularly divided by shallow fissures and broken into large loose scales. Wood light, soft, not strong, brittle, coarse-grained, light brown, with thick sapwood sometimes slightly tinged with red.

Distribution. Dry mountain slopes from the valley of the Mackenzie River in Oregon over the mountains of southwestern Oregon, where it is most abmudant and grows to its largest size, often forming pure forests over large areas, southward along the western slopes of the Cascade Mountains, the cross ranges of northern California, the western slopes of the Sierra Nevada, and over the California coast ranges from Santa Cruz to the southern slopes of the San Bernardino Mountains, where it is abundant up to elevations of $4000^{\circ}$ above the sea.

++ Cones very large, their scales prolonged into stout straight or curved spines.

\section{23. Pinus Sabiniana, Dougl. Digger Pine. Bull Pine.}

Leaves stout, flexible, pendant, pale blue-green, marked on each face with numerous rows of pale stomata, $8^{\prime}-12^{\prime} \mathrm{loug}$, deciduous usually in their third and fourth years. Flowers: staminate yellow; pistillate on stout peduncles, dark purple. Fruit oblong-ovate, full and rounded at the base, pointed, becoming light reddish brown, $6^{\prime}-10^{\prime}$ long, long-stalked, pendulous, with scales narrowed into prominent flattened knobs erect or incurved above the middle of the cone, strongly reflexed below, and armed with short sharp hooks and spur-like incurved

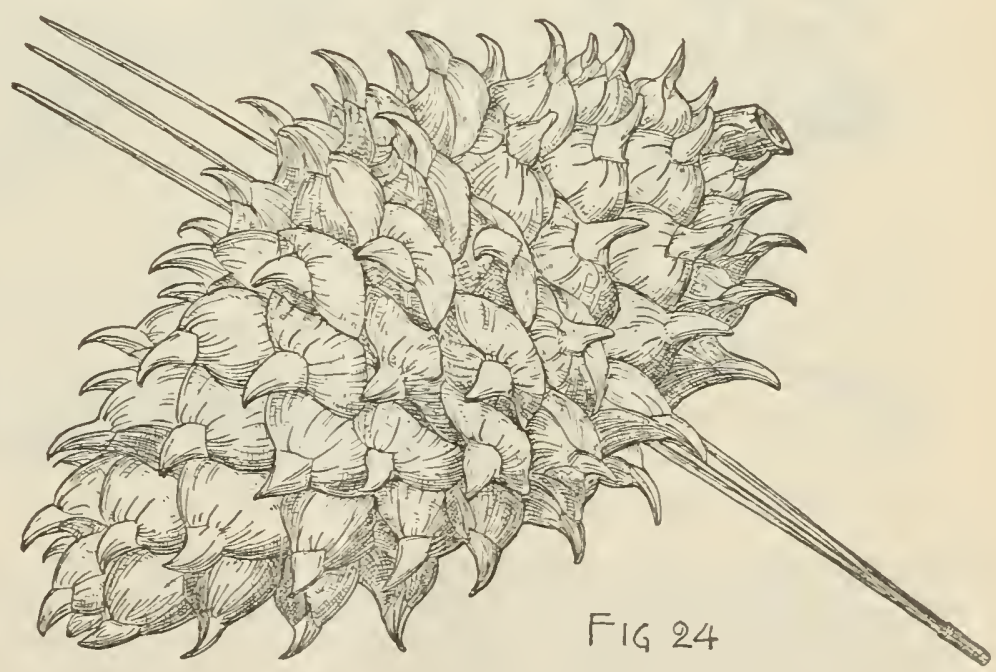
spines; seeds full and rounded below, somewhat compressed toward the apex, $\frac{3^{\prime}}{4}$ long, $\frac{1^{\prime}}{3}$ wide, dark brown or nearly black, with a thick hard shell, encircled by their wings much thickened on the inner rim, obliquely rounded at the broad apex and about $\frac{1}{8}$ ' longer than the seeds.

A tree, usually $40^{\circ}-50^{\circ}$ but occasionally $80^{\circ}$ high, with a trunk $3^{\circ}-4^{\circ}$ in diame- 
ter, divided generally $15^{\circ}-20^{\circ}$ above the gronnd into 3 or 4 thick secondary stems, elothed with short crooked branches pendant below and ascending toward the summit of the trec, and forming an open round-topped head remarkable for the sparseness of its foliage, and stont pale glaucons branchlets, beeoming dark brown or nearly black during their sccond season. Bark of the trunk $1 \frac{1}{2}-2^{\prime}$ thick, dark brown slightly tinged with red or nearly black and deeply and irregnlarly divided into thick conneeted ridges covered with small closely appressed scales. Wood light, soft, not strong, elose-grained, brittle, light brown or red, with thick nearly white sapwood. Abietine, a ncarly eolorless aronatic liquid with an odor of oil of oranges, is obtained by distilling the resinons juices. The large sweet slightly resinous seeds formed an important artiele of food for the Indians of California.

Distribution. Scattered singly or in small groups over the dry foothills of westcrn California, ranging from $500^{\circ}$ up to $4000^{\circ}$ above the sea-level and from the southern slopes of the northern cross range to the Tehachapi Mountains and the Sierra de la Licbre; most abundant and attaining its largest size on the eastern foothills of the Sierra Nevada ncar the centre of the state at elevations of about $2000^{\circ}$; liere often the most conspicnous feature of the vegetation.

\section{Pinus Coulteri, D. Don. Pitch Pine.}

Leaves tufted at the ends of the branches, stout, rigid, dark blue-green, marked by numerous bainds of stomata on the 3 faces, $6^{\prime}-12^{\prime}$ long, deciduous during their third and fourth seasons. Flowers: staminate yellow; pistillate dark reddish brown.

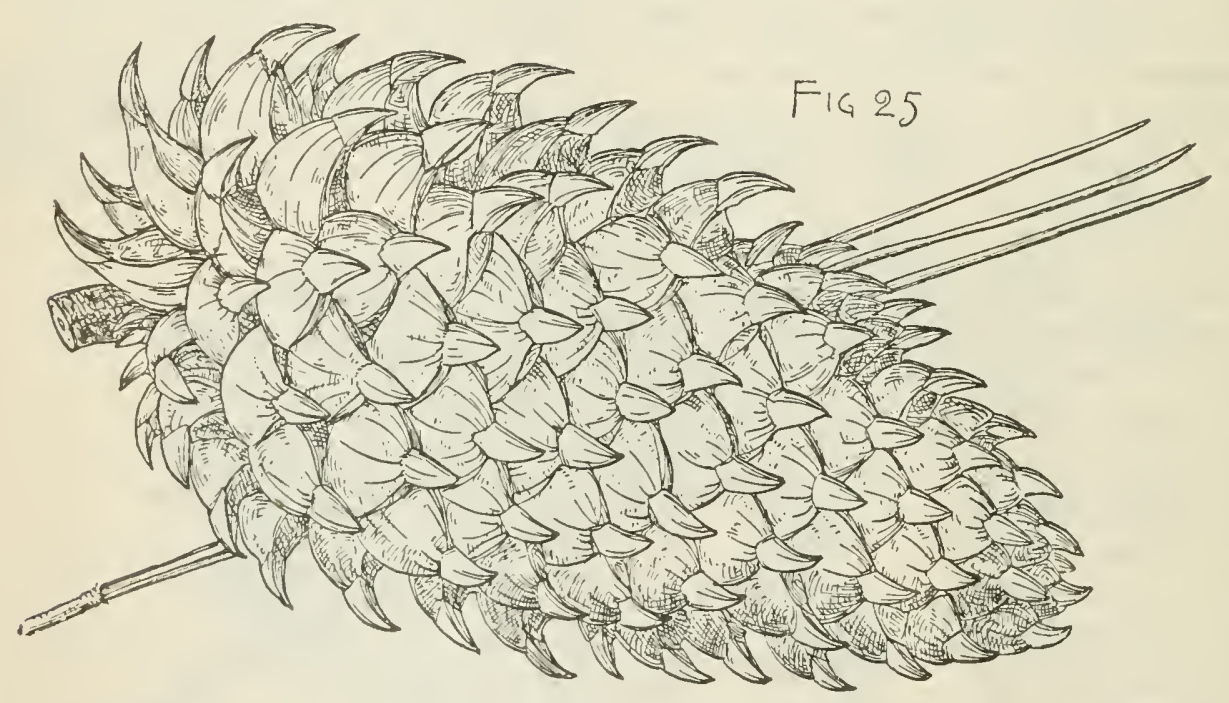

Fruit oval, acute, short-stalked and pendant, $10^{\prime}-14^{\prime}$ long, beeoming light yellowbrown, with thick broad scales terminating in flattened elongated knobs straight or enrved baekward and armed with flattened more or less ineurved spines $\frac{1}{2}^{\prime}-1 \frac{1}{2}^{\prime}$ long, gradually opening in the antumn and often persistent on the branches for several years ; seeds oval, compressed, $\frac{1^{\prime}}{2}$ long, $\frac{1^{\prime}}{4}-\frac{1^{\prime}}{3}$ wide, dark chestnut-brown, with a thick shell, inelosed by their wings broadest above the middle, obliqne at the apex, nearly $1^{\prime}$ longer than the seeds, about $\frac{5^{\prime}}{8}$ wide.

A trec, $50^{\circ}-70^{\circ}$ high, with a trunk sometimes $4^{\circ}$ in diameter, thick branches covered with dark scaly bark, long and mostly pendulous below, short and ascending above, 
and forming a loose unsymmetrical often picturesque head, and very stont branchlets dark orange-brown at first, becoming sometimes nearly black at the end of three or four years. Bark of the trunk $1 \frac{1}{2}^{\prime}-2^{\prime}$ thick, dark brown or nearly black and deeply divided into broad ronnded comnected ridges covered with thin closely appressed scales. Wood light, soft, not strong, brittle, coarse-grained, light red, with thick nearly white sapwood; occasionally nsed for fuel. The seeds were formerly gathered in large quantities and eaten by the Indians of sonthern California.

Distribution. Scattered singly or in small groves through coniferous forests on the dry slopes and ridges of the coast ranges of California at elevations of $3000^{\circ}-6000^{\circ}$ above the sea, from Mount Diablo and the Santa Lucia Mountains to the Cuyamaca Mountains ; most abundant on the San Bernardino and San Jacinto ranges at elevations of about $5000^{\circ}$.

**Leaves in 2-leaved clusters (2 and 3-leaved in 29 ). $\rightarrow$ Cones subterminal.

\section{Pinus resinosa, Ait. Red Pine. Norway Pine.}

Leaves slender, soft and flexible, dark green and lustrous, 5'-6' long, obscnrely marked on the ventral faces by bands of minute stomata, deciduous during their

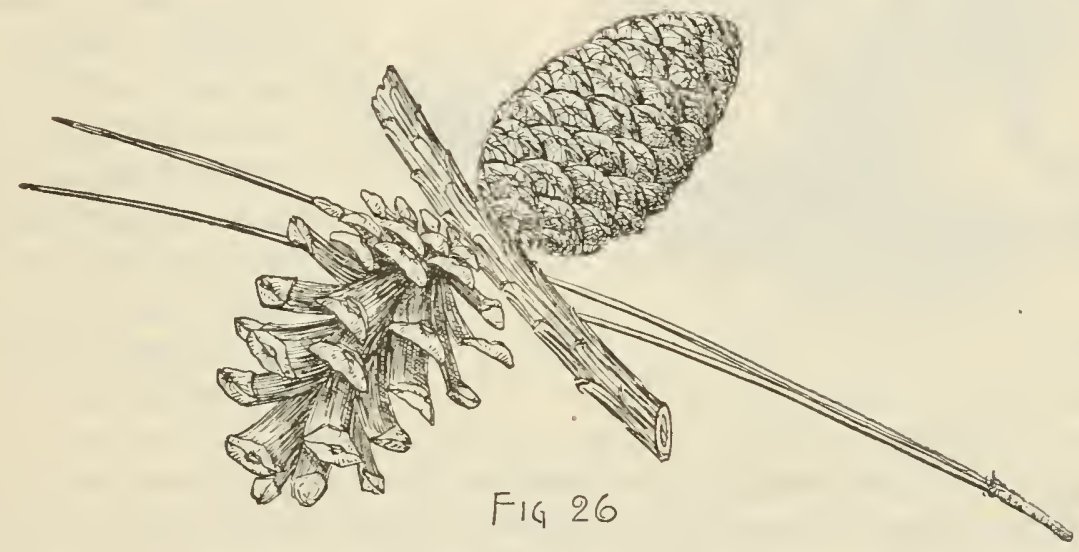

fourth and fifth seasons. Flowers: staminate in dense spikes, dark purple; pistillate terminal, short-stalked, scarlet. Fruit ovate-conical, subsessile, 2'-2 $\frac{1}{4}^{\prime}$ long, with thin slightly concave scales, -unarmed, becoming light chestnut-brown and lustrons at maturity; shedding their seeds early in the autumn and mostly persistent on the branches until the following summer; seeds oval, compressed, $\frac{1}{8}$ long, with a thin dark chestnut-brown more or less mottled shell and wings broadest below the middle, oblique at the apex, $\frac{3^{\prime}}{4}$ long, $\frac{1^{\prime}}{4}-\frac{1^{\prime}}{3}$ broad.

A tree, usually $70^{\circ}-80^{\circ}$ or occasionally $150^{\circ}$ high, with a tall straight trunk $2{ }^{\circ}-3^{\circ}$ in diameter, thick spreading more or less pendulons branches clothing the young stems to the ground and forming a broad irregular pyramid, and in old age an open round-topped pictnresque head, and stout branchlets at first orange color, tinally becoming light reddish brown. Bark of the trunk $\frac{3 \prime}{4}-1 \frac{1^{\prime}}{4}$ thick and slightly divided by shallow fissures into broad flat ridges covered by thin loose light redbrown scales. Wood light, hard, very close-grained, pale red, with thin yellow often nearly white sapwood; largely used in the construction of bridges and buildings, for piles, masts, and spars. The bark is occasionally used for tanuing leather. 
Distribution. Light sandy loam or dry roeky ridges, usually forming groves rarcly more than a few liundred acres in cxtent and seattered through forests of other Pincs and deciduons-leaved trees from Nova Seotia to Lake St. John, westward through Quebee and central Ontario to the valley of the Wimnipeg River, and southward to eastern Massachusetts, the mountains of Penusylvania; and to central Michigan, Wiseonsin, and Mimesota, most abundant and growing to its largest size in the northern parts of these states; rare and local in eastern Massachusetts and sonthward.

Often planted for the decoration of parks, and the most desirable as an ornamental tree of the Piteh Pines which flourish in the northern states.

\section{Pinus contorta, Loud. Scrub Pine.}

Leaves dark green, slender, $1^{\prime}-1 \frac{1}{2}^{\prime}$ long, marked by $6-10$ rows of stomata on each face, mostly deeiduous in their seventh and eighth years. Flowers orange-red: staminate in short crowded spikes; pistillate clustered or in pairs on stout stalks.

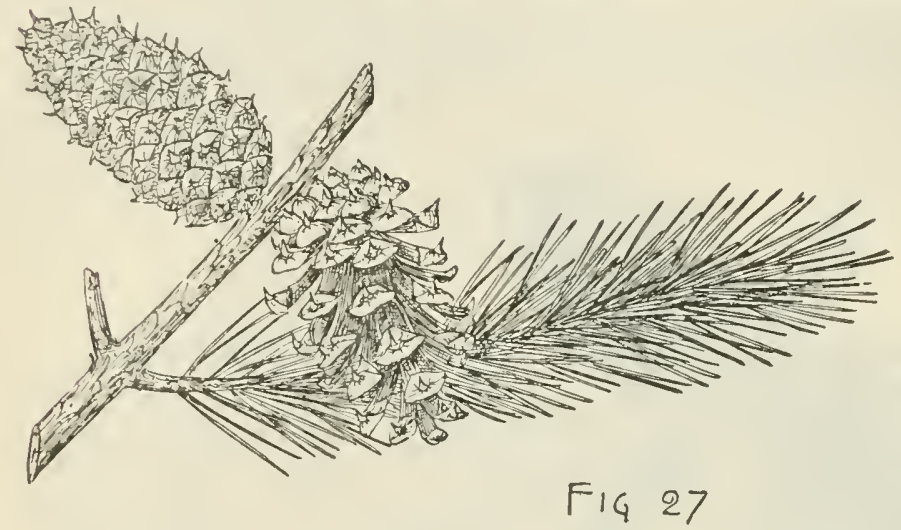

Fruit oval to subeylindrical, usually very oblique at the base, horizontal or deelining, often clustered, $\frac{3{ }^{\prime}-2}{4}-2^{\prime}$ long, with thin slightly concave scales armed with long slender more or less recurved often deeiduous prickles, and toward the base of the cone especially on the upper side developed into thiek mammillate knobs, beeoming light yellowbrown and lustrous, sometimes opening and losing their seeds as soon as ripe, or remaining closed on the branches and preserving the vitality of their seeds for many years; seeds oblique at the apex, acute below, abont $\frac{1}{6}^{\prime}$ long, with a thin brittle dark red-brown shell mottled with blaek and wings widest above the base, gradually tapering toward the oblique apex, $\frac{1^{\prime}}{2}$ long.

A tree, sometimes fertile when only a few inches high, usually $15^{\circ}-20^{\circ}$ or oceasionally $30^{\circ}$ tall, with a short trunk rarely morc than $18^{\prime}$ in diameter, comparatively thick branches forming a round-topped compact and symmetrical or an open picturesque head, and stont branchlets light orange eolor when they first appear, finally beeoming dark red-brown or occasionally almost black. Bark of the trunk $\frac{3}{4}-1^{\prime}$ thick, deeply and irregnlarly divided by vertieal and cross fissures into small oblong plates eovered with closely appressed dark red-brown scales tinged with purple or orange color. Wood light, hard, strong although brittle, coarse-grained, light brown tinged with red, with thiek nearly white sapwood; occasionally used for fuel.

Distribution. Coast of Alaska, usually in sphagnum-covered bogs southward in the immediate neighborhood of the coast to the valley of the Albion River, Mendocino County, California; south of the northern boundary of the United States generally inhabiting sand dunes and barrens or occasionally near the shores of Puget Sound the margius of tide pools and deep wet swamps; spreading inland 
and ascending the coast ranges and western slopes of the Cascade Mountains, where it is not common and where it gradually changes its habit and appearance, the thick deeply furrowed bark of the coast form being found only near the ground, while the bark higher on the stems is thin, light-colored, and inclined to separate into scales, and the leaves are often longer and broader. 'This is

\section{Pinus contorta, var. Murrayana, Engelm. Lodge Pole Pine.}

Leaves yellow-greell, usually about $2^{\prime}$ long, although varying from 1'-3' in length and from $\frac{1^{\prime}}{16}$ to mearly $\frac{1^{\prime}}{8}$ in width. Fruit occasionally opening as soon as ripe but usually remaining closed and preserving the vitality of the seeds sometimes for twenty years.

A tree, usually $70^{\circ}-80^{\circ}$ but often $150^{\circ}$ high, with a trunk generally $2^{\circ}-3 \circ$ but occasionally $5^{\circ}-6^{\circ}$ in diameter, slender muchforked branches frequently persistent nearly to the base of the stem, light orange-colored during their early years, somewhat pendulous below, ascending near the top of the tree, and forming a narrow pyrami-

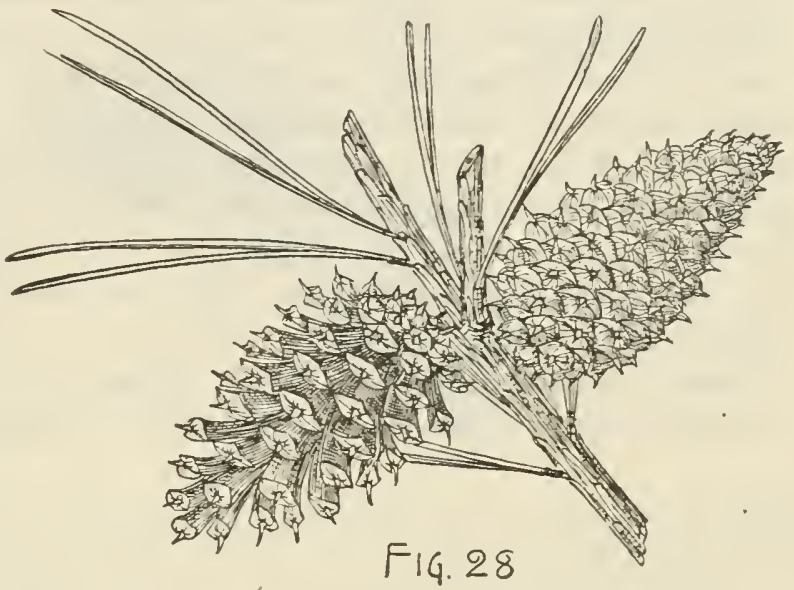
dal spire-topped head. Bark of the trunk rarely more than $\frac{1}{4}$ thick, close and firm, light orange-brown and covered by small thin loosely appressed scales. Wood light, soft, not strong, close, straight-grained and easily worked, not durable, light yellow or nearly white, with thin lighter colored sapwood; occasionally manufactured into lumber, also used for railway-ties, mine-timbers, and for fuel.

Distribution. Common on the Alaska hills in the valley of the Yukon River ; on the interior plateau of northern British Columbia, and eastward to the eastern foothills of the Rocky Mountains, covering with dense forests great areas in the basin of the Columbia River; forming forests on both slopes of the Rocky Mountains of Montana, on the Yellowstone plateau at elevations of $7000^{\circ}-8000^{\circ}$; common on the mountains of Wyoming, and extending southward to southern Colorado; common on the ranges of eastern Washington and Oregon, on the mountains of northern California, and southward along the Sierra Nevada, where it attains its greatest size and beauty in alpine forests at elevations between $8000^{\circ}$ and $9500^{\circ}$; in southern California forming the timber-line on the highest peaks of the Sam Bernardino and San Jacinto Mountains.

\section{++ Cones lateral.}

\section{Pinus divaricata, Du Mont de Cours. Gray Pine. Jack Pine.}

Leaves in remote clusters, stout, flat or slightly concave on the inner face, at first light yellow-green, soon becoming dark green, $\frac{8^{\prime}}{4}-1 \frac{1}{4}$ long, gradually and irregularly deciduous in their second or third year. Flowers : staminate in short crowder clusters, yellow ; pistillate clustered, dark purple, often with 2 clusters produced on 
tho same shoot. Fruit oblonir-conieal, aente, obligne at the base, sessile, usually erect and strongly incurved, $1 f^{\prime}-2$ ' longr, dull purplo or green when fully grown, becoming light yollow and lustrons, with thin stiff seales andmed with minnte incurved

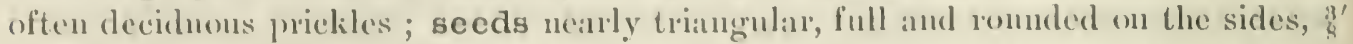
long, with an ahnost black ronghened shell and wings broadest at the middle, full and romuled at the apex, d' lomen, l' wide.

A tree, frequently 700 high, with a straight trunk sometimes free of branclies for 20 - $300^{\circ}$ and rarely execeding 20 in diameter, long spreading branclies forming an open symutrical head, and stender tongh flexible pale yollow-green branchlets turning dark purple during their first winter and darker the following year; often not more than $200^{\circ}-30^{\circ}$ tall, with a stem $10^{\prime}-12^{\prime}$ in diameter; generally finting when only a few years old; sometimes shrubby with several low slender stems. Bark of the trunk thin, dink brown slightly tinged with red, very irregnlarly divided into narrow rounded comected ridges separating on the surface into small thick closely appressed scales. Wood light, soft, not strong, elose-erraned, clear pale brown or rarely oramge eolor, with thick nearly white sapwood ; nsed for finel and occasionally for railwaties and posts; occusionally mamufactured into lumber.

Distribution. From Nora Seotia to the valley of the Athabasea liver and down the Mackenzie to about latitude 650 north, ranging sontluward to the eoast of Mine,

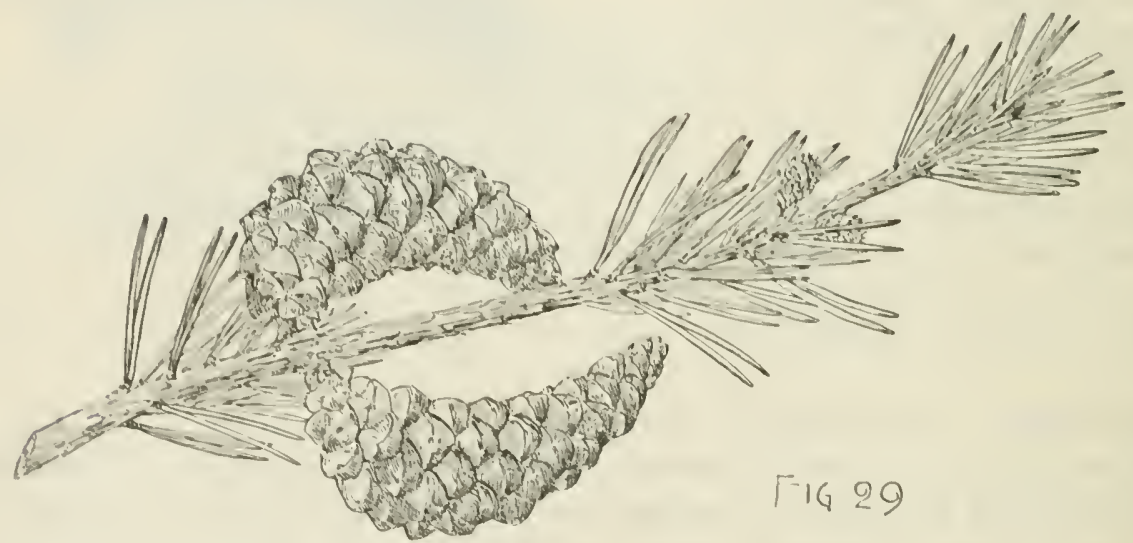

northeru New Haupshire and Vermont, northern New York, the sonthern shores of Lalie Mielrigan, northern Illinois, and central Minnesota; abundant in central Michignu, covering traets of barren lands; common and of large size in the region north of Lake Superior ; most abmulant and of its greatest size west of Lake Winniper and north of the Saskatehewan, here often spreading over great areas of sandy sterile soil.

\section{S. Pinus glabra, Walt. Spruce Pine. Cedar Pine.}

Leaves soft, slender, dark green, 12'1'-3' long, marked by nmerons rows of stomata, decidnous at the end of their second and in the spring of their third year. Flowers : staminate in slort crowded clusters, yellow; pistillate raised on slender slightly ascending pednucles. Fruit single or in elusters of "2 or 3, reflexed on short stout stalks, subghlobose to oblong-ovate, $\frac{1 \prime}{2}-2^{\prime}$ long, - beeoming reddish brown and rather lustrous, with thin slightly coneave seales armed with minute straight or incurved usually decidnous prickles; seeds nearly triangular, full and rounded on 
the sides, $\frac{1}{8}$ long, witl a thin dark gray shell mottled with blaek and wings broadest below the middle, $\frac{5}{8}$ long, ${ }^{\prime}$ ' wide.

A tree, usually $80^{\circ}-100^{\circ}$ or occasionally $120^{\circ}$ high, with a trunk $22^{\circ}-21^{\circ}$ or rarely $31^{\circ}$ in diameter, comparatively sınall lorizontal branches, and slender flexible branchlets at first light red more or less tinged with purple, ultimately dark reddish brown. Bark $\frac{1^{\prime}}{2}-3^{\prime}$ thick, slightly aud irregularly divided by shallow fissures into flat comnected ridges broken into sinall closely appressed light reddish brown scales. Wood light, soft, not strong, lirittle, closegrained, light brown, witlı thick nearly white sapwood; occasionally used for fuel and rarely manufactured into lumber.

Distribution. Valley

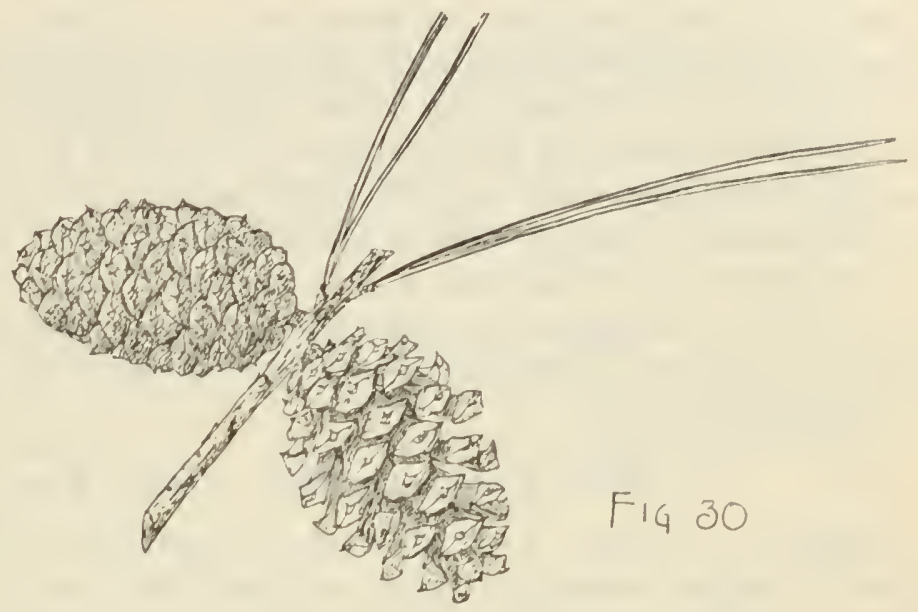
of the lower Santee River,

South Carolina to niddle and northwestern Floricla, and to central Mississippi and the swamps of Bayou Phalia, easter'n Louisiana; usually growing singly or in small groves; attaining its largest size and often oceupying areas of considerable extent in northwesterı Florida.

\section{Pinus echinata, Mill. Yellow Pine. Short-leaved Pine.}

Leaves in clusters of 2 and of 3 , slender, flexible, dark blue-green, $3^{\prime}-5^{\prime}$ long, beginning to fall at the end of their second season and dropping irregularly until their fiftl year. Flowers : staninate in short crowded clusters, pale purple; pistillate in

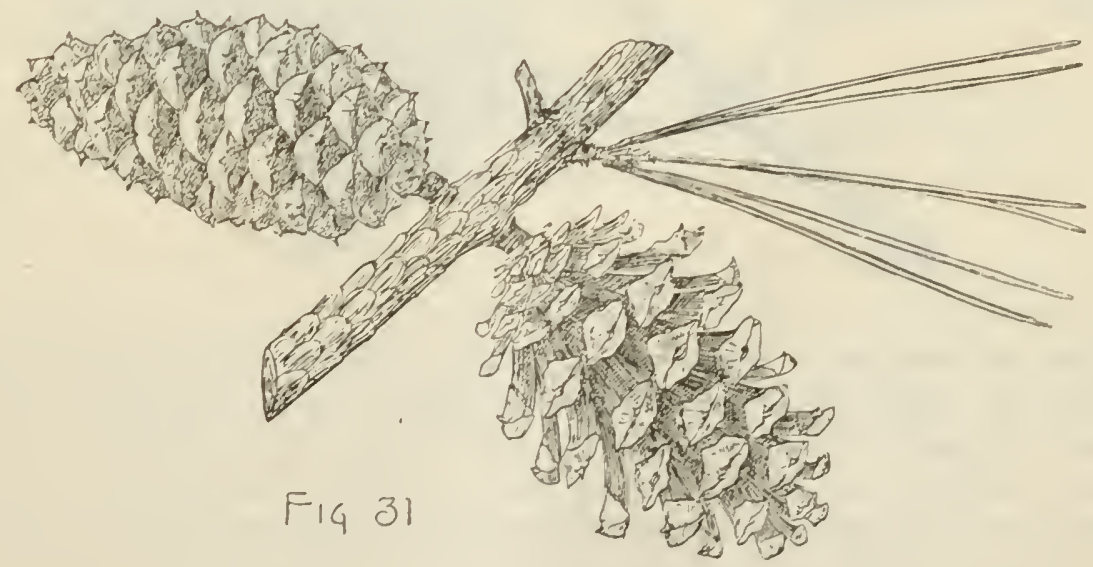

clusters of 2 or 3 on stont ascending stems, pale rose color. Fruit ovate to oblongconical, subsessile and nearly horizontal or short-stalked and pendant, generally clustered, $1 \frac{1}{2}-2 \frac{1}{2}$ long, becoming dull brown, with thin scales nearly flat below and rounded at the apex, armed with short straight or somewhat recurved frequently 
deciduous prickles; seeds nearly triangnlar, full and rounded on the sides, about $\frac{3}{16}$ ' long, with a thin pale brown hard shell conspicuously mottled with black, their wings broadest near the middle, $\frac{1{ }^{\prime}}{2}$ long, $\frac{1}{8}^{\prime}$ wide.

A trce, usually $80^{\circ}-100^{\circ}$ occasionally $120^{\circ}$ high, with a tall slightly tapering trink $3^{\circ}-4^{\circ}$ in diameter, a short pyramidal truncate head of comparatively slender branches, and stout brittle pale green or violet-colored branchlets covered at first with a glaucous bloom, becoming dark red-brown tinged with purple before the end of the first season, their bark beginning in the third year to separate into large scales. Bark of the trunk $\frac{3^{\prime}}{4}-1^{\prime}$ thick and broken into large irregularly shaped plates covered with small closely appressed light cimnamon-red scales. Wood very variable in quality, and in the thickness of the nearly white sapwood, heavy, hard, strong and usually conrse-grained, orange-colored or yellow-brown; largely mannfactured into lnmber.

Distribution. Staten Island, New York, to North Florida and to West Virginia and eastern Tennessee, and through the Gulf states to eastern Lonisiana, and southern Missouri to eastern Texas; most abundant and of its largest size west of the Mississippi River.

\section{Pinus Virginiana, Mill. Jersey Pine. Scrub Pine.}

Leaves in remote clusters, stout, gray-green, $1 \frac{1^{\prime}}{2}-3^{\prime}$ long, marked by many rows of minute stomata, gradually and irregularly deciduous during their third and fourth years. Flowers : staminate in crowded clusters, orange-brown; pistillate on opposite spreading peduncles near the middle of the shoots of the year, generally a little below and alternate with 1 or 2 lateral branchlets, pale green, the scale-

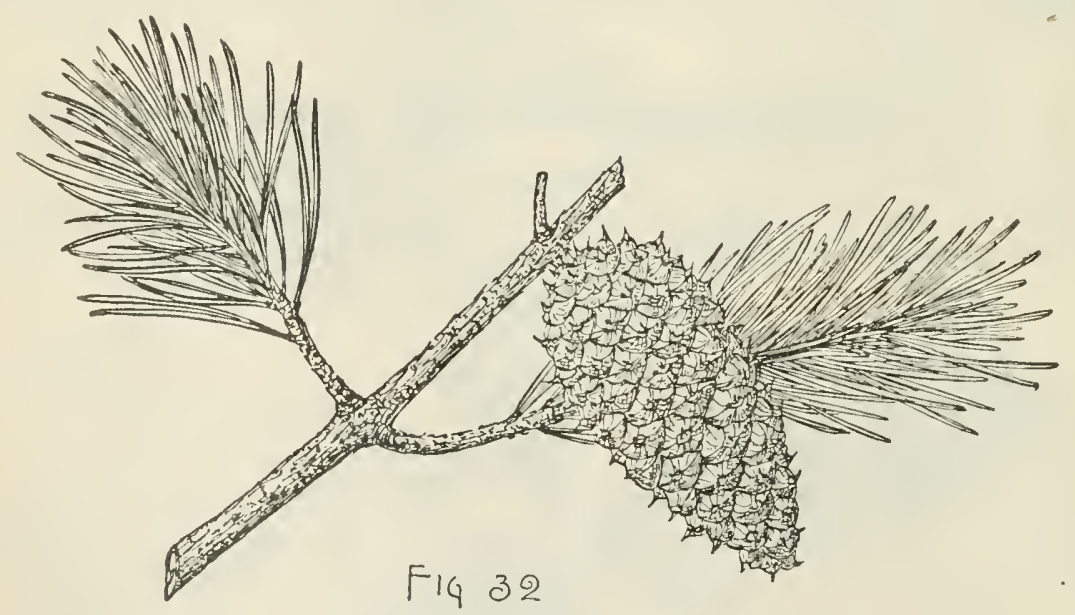

tips tinged with rose color. Fruit oblong-conical, often curved, dark green and lustrous, with thin nearly flat scales, bright red-brown umbos and stout or slender persistent prickles, $2^{\prime}-3^{\prime}$ long, becoming dark red-brown, opening in the autumn and slowly shedding their seeds, turning dark reddish brown, and remaining on the branches for three or four years; seeds nearly oval, full and rounded, $\frac{1}{4}^{\prime}$ long, with a thin pale brown rough shell, their wings broadest at the middle, $\frac{1}{3}^{\prime}$ long, about $\frac{1}{8}^{\prime}$ wide.

A tree, usually $30^{\circ}-40^{\circ}$ high, with a short trunk rarely more than $18^{\prime}$ in diameter, long horizontal or pendulous branches in remote whorls forming a broad open often flat-topped pyramid, and slender tough flexible branchlets at first pale green or green tinged with purple and covered with a glaucous bloom, becoming purple 
and later light gray-brown ; toward the western limits of its range a tree frequently $100^{\circ}$ tall, with a trunk $2 \frac{1}{2}^{\circ}-3^{\circ}$ in diameter. Bark of the trunk $\frac{1}{4}^{\prime}-\frac{1}{2}^{\prime}$ thick, broken by shallow fissures into flat plate-like scales separating on the surface into thin closely appressed dark brown scales tinged with red. Wood light, soft, not strong, brittle, coarse-grained, durable in contact with the soil, light orange color, with thick nearly white sapwood; often used for fuel and occasionally manufactured into lumber.

Distribution. Long Island, New York, southward generally near the coast to the valley of the Savannah River, Georgia, to northeastern Alabana and through eastern and middle Tenmessee and Kentucky to southern Indiana; usually small in the Atlantic states and only on light sandy soil, spreading rapidly over exhausted fields; attaining its largest size west of the Alleghany Mountains on the low hills of southern Indiana.

\section{Pinus clausa, Sarg. Sand Pine. Spruce Pine.}

Leaves slender, flexible, dark green, $2^{\prime}-3 \frac{1}{2}^{\prime}$ long, marked by 10-20 rows of stomata, deciduous during their third and fourth years. Flowers : staminate in short crowded spikes, dark orange color; pistillate lateral on stout peduncles. Fruit ovoid-conical, often oblique at the base, usually clustered and reflexed, 2'$3 \frac{1}{2}$ long, nearly sessile or shortstalked, with concave scales armed with short stout straight or recurved deciduous prickles, becoming dark reddish brown in the autumn; some of the cones opening at once, others remaining closed for three or four years before liberating their seeds, ultimately turning to an ashy gray color; others still un-

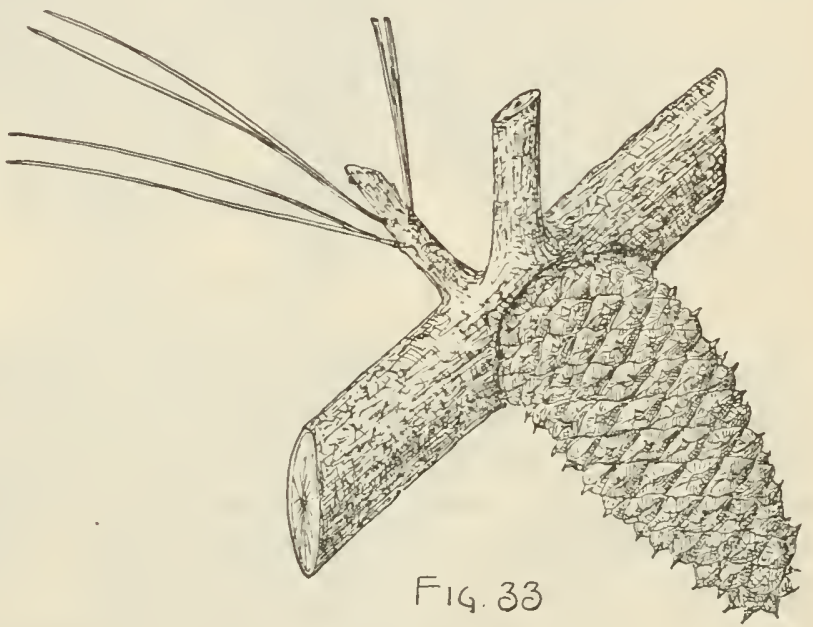
opened becoming enveloped in the growing tissues of the stem and branches and finally entirely covered by them ; seeds nearly triangular, compressed, $\frac{1}{4}$ long, with a black slightly roughened shell, their wings widest near or below the middle, $\frac{3^{\prime}}{4}$ long, about $\frac{1^{\prime}}{4}$ wide.

A tree, usually $15^{\circ}-20^{\circ}$ high, with a stem rarely a foot in diameter, generally clothed to the ground with wide-spreading branches forming a bushy flat-topped head, and slender tough flexible branchlets, pale yellow-green when they first appear, becoming light orange-brown and ultimately ashy gray; occasionally growing to the height of $70^{\circ}-80^{\circ}$ with a trunk $2 \circ$ in diameter. Bark on the lower part of the trunk $\frac{1}{3}^{\prime}-\frac{1}{2}^{\prime}$ thick, deeply divided by narrow fissures into irregularly shaped generally oblong plates separating on the surface into thin closely appressed bright red-brown scales; on the upper part of the trunk and on the branches thin, smooth, ashy gray. Wood light, soft, not strong, brittle, light orange color or yellow, with thick nearly white sapwood; occasionally used for the masts of small vessels.

Distribution. Coast of the Gulf of Mexico from southern Alabama to Peace 
Creek, Florida, seldom extending more than thirty miles inland; castern Florida from the neighborhood of St. Augustine to New River, oecupying a narrow belt usually not more than a mile or two wide, and covering sandy wind-swept plains; growing to its largest size on the east coast of Florida near the head of Halifax River.

\section{Pinus muricata, D. Don. Prickle-cone Pine.}

Leaves in crowded clusters, thick, rigid, dark yellow-green, $4^{\prime}-6^{\prime}$ long, beginning to fill in their seeond year. Flowers: staminate in elongated spikes, orange-

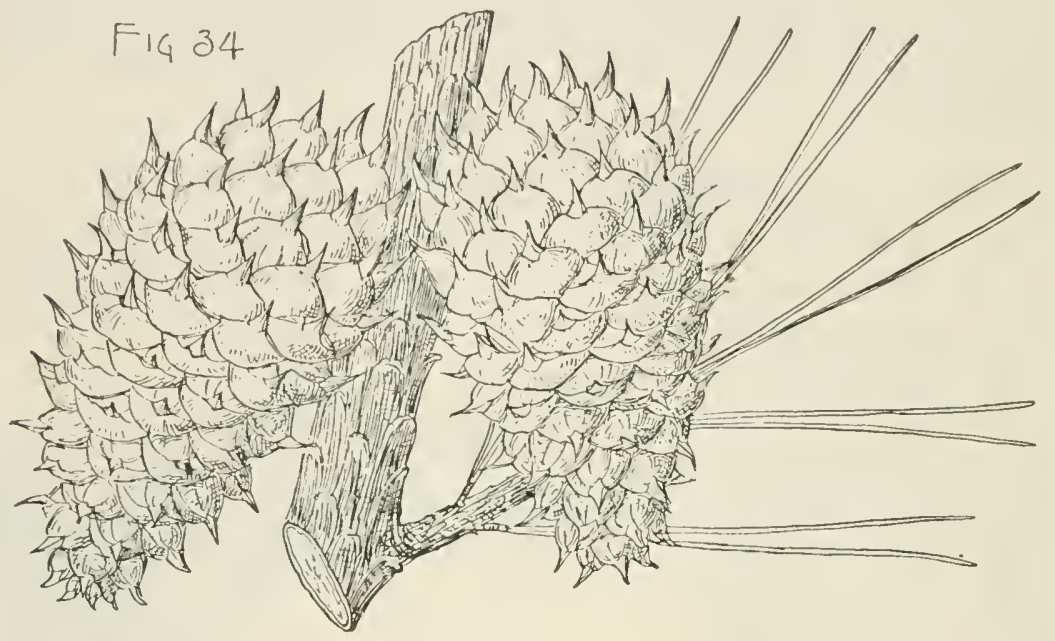

colored; pistillate short-stalked, whorled, 2 whorls often being produeed on the shoot of the year. Fruit ovate-oblong, oblique at the base, sessile, in clusters of 3-5 or sometimes of $7,2^{\prime}-3 \frac{1}{2}^{\prime}$ but usnally about $3^{\prime}$ long, becoming light chestnut-brown and lustrous, with seales much thickened on the outside of the cone, those toward its base produced into stout mammillate incurved knobs sometimes armed with stout flattened spur-like spines incurved above the mildle of the cone and reenrved toward its apex, and on the inside of the eone slightly flattened and armed with stout or slender straight prickles; often remaining closed for several years and usually persistent on the stem and branches during the entire life of the tree without becoming imbedded in the wood; seeds nearly triangular, $\frac{1}{4}{ }^{\prime}$ long, with a thin nearly black roughened shell, their wings broadest above the middle, oblique at the apex, nearly $1^{\prime}$ long and $\frac{1 \prime}{8}$ wide.

A tree, usually $40^{\circ}-50^{\circ}$ but oceasionally $90^{\circ}$ high, with a trunk $2^{\circ}-3^{\circ}$ in diameter, thick spreading branches covered with dark scaly bark, in youth forming a regular pyramid, and at maturity a handsome compact round-topped head of dense tufted foliage, and stout branchlets dark orange-green at first, turning orangebrown more or less tinged with purple. Bark of the lower part of the trunk often $4^{\prime}-6^{\prime}$ thick and deeply divided into long narrow rounded ridges roughened by closely appressed dark purplish brown scales. Wood light, very strong, hard, rather coarse-grained, light brown, with thiek nearly white sapwood; occasionally manufactured into lumber.

Distribution. California eoast region from Mendocino County south ward, usually in widely separated localities to Tomales Point, north of the Bay of San Franciseo, 
and from Monterey to San Luis Obispo County; in Lower California on Cedros Island, and on the coast between Ensanado and San Quintan; of its largest size and the most common Pine-tree on the coast of Mendocino County.

\section{Pinus pungens, Michx. Table Mountain Pine. Hickory Pine.}

Leaves in clouded clusters, rigid, usually twisted, dark blue-green, $1 \frac{1^{\prime}}{4}-2 \frac{1}{2}^{\prime}$ long, deciduous during their second and third years. Flowers : staminate in elongated loose spikes, yellow; pistillate clustered, long-stalked. Fruit oblong-conical, oblique at the base by the greater development of the scales on the upper than on the lower side, sessile, deflexed, in clusters nsually of 3 or 4 , or rarely of 7 or $8,2^{\prime}-3 \frac{1^{\prime}}{2}$ long, becoming light brown and lustrous, with thin tough scales armed with stout hooked spines incurved above the middle of the cone and recurved below it, those on the inner side of the cone slightly thickened, and on the outer, especially near the base of the cone, produced into much thickened mammillate knobs, opening as soon as ripe and gradually shedding their seeds, or often remaining closed for two or three years longer, and frequently persistent on the branches for eighteen or twenty years; seeds almost triangular, full and rounded on the sides, nearly $\frac{1}{4}^{\prime}$ long, with a thin conspicuously roughened light brown shell, their wings widest below the middle, gradually narrowed to the ends, $1^{\prime}$ long, $\frac{1}{4}^{\prime}$ wide.

A tree, when crowded in the forest occasionally $60^{\circ}$ high, with a trunk $2^{\circ}-3^{\circ}$ in diameter, and a few short branches near the summit forming a narrow round-topped liead; in open ground usually $20^{\circ}-30^{\circ}$ tall, and often fertile when only a few feet high, with a short thick trunk frequently clothed to the ground, and long horizontal branches, the lower pendulous toward the extremities, the uppersweeping in graceful upward curves and forming a flat-topped

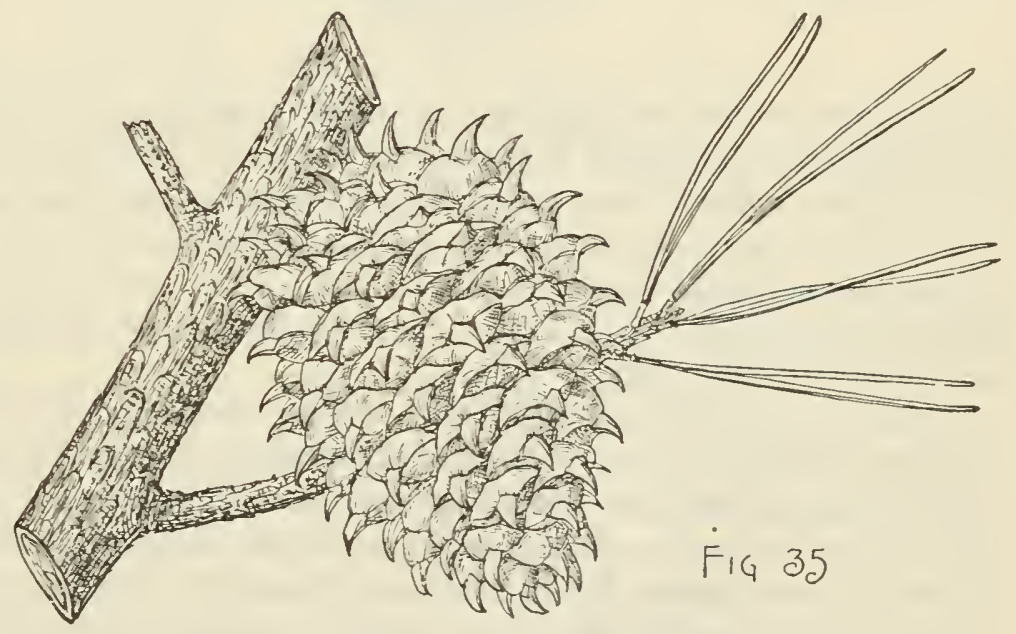
often irregular head, and stout branchlets, light orange color when they first appear, soon growing darker and ultimately dark brown. Bark on the lower part of the trunk $\frac{3^{\prime}}{4}-1^{\prime}$ thick and broken into irregularly shaped plates separating on the surface into thin loose dark brown scales tinged with red, higher on the stem, and on the branches dark brown and broken into thin loose scales. Wood light, soft, not strong, brittle, very coarsegrained, pale brown, with thick nearly white sapwood; somewhat used for fuel, and in Pennsylvania manufactured into charcoal.

Distribution. Dry gravelly slopes and ridges of the Appalachian Mountains from Pennsylvania to North Carolina and eastern Tennessee, sometimes ascending to elevations of 3000 , with isolated outlying stations in Virginia, eastern Pennsylvania, and western New Jersey; often forming toward the southern limits of its range pure forests of considerable extent. 
*** Leaves in 5-leaved clusters.

Seeds shorter than their wings.

\section{Pinus Torreyana, Torr. Torrey's Pine.}

Leaves forming great tufts at the ends of the branches, stont, dark green, conspicnously marked on the 3 faces by numerous rows of stomata, $8^{\prime}-13^{\prime}$ long. Flowers from Jannary to March ; staminate yellow, in short dense heads ; pistillate

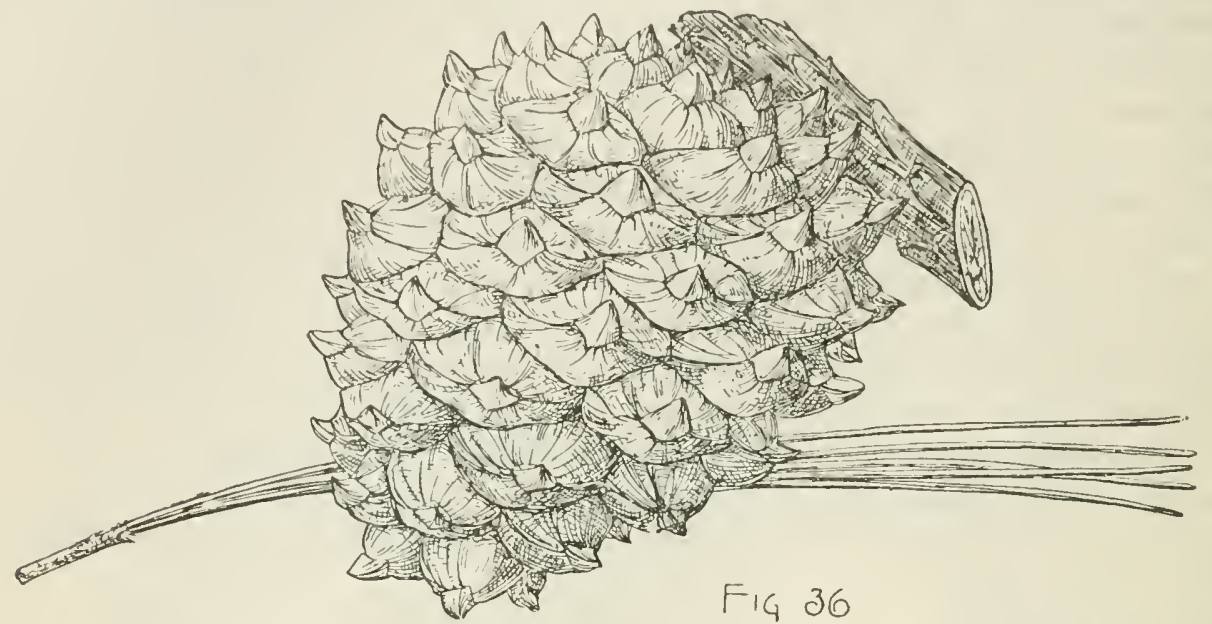

subterminal on long stout peduncles. Fruit broadly ovate, spreading or deflexed, on long stalks $4^{\prime}-6^{\prime}$ in length, becoming bright chestnut-brown, with thick scales armed with minute spines; mostly deciduous in their fourth year and in falling leaving a few of the barren scales on the stalk attached to the branch; seeds oval, more or less angled, $\frac{3}{4}-1^{\prime}$ long, dull brown and mottled on the lower side, light yellowbrown on the upper side, with a thick hard shell, nearly surrounded by their dark brown wings often nearly $\frac{1}{2}^{\prime}$ long.

A tree, usually $30^{\circ}-40^{\circ}$ high, with a short trunk about $1^{\circ}$ in diameter, or occasionally $50^{\circ}-60^{\circ}$ tall, with $\cdot$ a long straight slightly tapering stem $2 \frac{1}{2} \circ$ in diameter, stout spreading and often ascending branches, and very stout branchlets bright green in their first season, becoming light purple and covered with a metallic bloom the following year, ultimately nearly black. Bark of the trunk $\frac{3^{\prime}}{4}-1^{\prime}$ thick, deeply and irregularly divided into broad flat ridges covered by large thin closely appressed light red-brown scales. Wood light, soft, not strong, coarse-grained, light yellow, with thick yellow or nearly white sapwood; occasionally used for fuel. The large edible seeds are gathered in large quantities and are eaten raw or roasted.

Distribution. Only in a narrow belt a few miles long on the coast near the mouth of the Soledad River just north of San Diego, and on the island of Santa Rosa, California; the least widely distributed Pine-tree of the United States.

\section{LARIX, Adans. Larch.}

Tall pyramidal trees, with thick sometimes furrowed sealy bark, heavy heartwood, thin pale sapwood, slender remote horizontal of ten pendulous branches, elongated leading branchlets, short thick spur-like lateral branchlets, and small subglobose buds, their inner scales accrescent and marking the lateral branchlets with promi- 
nent ring-like scars. Leaves awl-shaped, triangular and rounded above, or rarely t-angled, spirally disposed and remote on leading shoots, on lateral branchlets in crowded fascicles, each leaf in the axil of a deciduous bud-scale, decidnons. Flowers solitary, terminal, the staminate globose, oval or oblong, sessile or stalked, on leafless branches, yellow, composed of numerons spirally arranged anthers with comnectives produced above them into short points, the pistillate appearing with the leaves, subglobose, composed of few or many green nearly orbicular stalked scales in the axes of much longer mucronate usually searlet bracts. Fruit a woody ovoid-oblong conical or subglobose short-stalked cone composed of slightly thickened suborbicular or oblong-obovate concave scales, shorter or longer than their bracts, gradually decreasing from the centre to the ends of the cone, the small scales usually sterile. Seeds nearly triangular, rounded on the sides, shorter than their wings; the outer seed-coat crustaceous, light brown, the inner membranaceous, pale chestnut-brown and lustrous; cotyledons usually 6 , much shorter than the inferior radicle.

Larix is widely distribnted over the northern and monntainous region of the northern hemisphere from the Arctic Circle to the mountains of Pennsylvania and Oregon in the New World, and to central Enrope, the Himalayas, central China, and Japan in the Old World. Nine species are recognized. Of the exotic species the European Larix Larix, Karst., has been much planted for timber and ornament in the northeastern states, where the Japanese Larix Kcempferi, Sarg., also flourishes.

Larix is the classical name of the Larch-tree.

\section{CONSPECTUS OF THE NORTH AMERICAN SPECIES.}

Cones small, subglobose; their scales few, longer than the bracts.
Leaves triangular.
1. L. Americana (A B, F).

Cones elongated; their scales numerous, shorter than the bracts.

Young branchlets pubescent, soon becoming glabrous; leaves triangular.

Foung branchlets tomentose; leares 4 -angled.

2. L. occidentalis $(B, G)$. 3. L. Lyallii (B, F).

\section{Larix Americana, Michx. Tamarack. Larch.}

Leaves linear, triangular, rounded above, prominently keeled on the lower surface, $\frac{3^{\prime}}{4}-1 \frac{1}{4}$ long, bright green, conspicuously stomatiferous when they first appear; turning yellow and falling in September or October. Flowers: staminate subglobose and sessile, pale yellow; pistillate oblong, with light-colored bracts produced into elongated green tips, and nearly orbicular rose-red scales. Fruit on stout incurved stems, oblong, rather obtuse, $\frac{1}{2}^{\prime}-\frac{3^{\prime}}{4}$ long, composed of about 20 scales slightly erose on their nearly entire margins, rather longer than broad and twice as long as their bracts, bright chestnut-brown at maturity, usually falling during their second year; seeds $\frac{1}{8}$ long, about one third as long as their light chestnut-brown wings broadest near the middle and obliquely rounded at the apex.

A tree, $50^{\circ}-60^{\circ}$ high, with a trunk $18^{\prime}-20^{\prime}$ in diameter, small horizontal branches forming during the early life of the tree a narrow regular pyramidal head always characteristic of this tree when crowded in the forest, or with abundant space sweeping out in graceful curves, often becoming contorted and pendulous and forming a broad open freqnently picturesque head, and slender leading branchlets often covered at first with a glaucous bloom, becoming light orange-brown during their first winter and conspicuous from the small globose dark red lustrous buds. Bark of the trunk $\frac{1^{\prime}}{2}-\frac{3}{4}$ thick, separating into thin closely appressed rather bright reddish brown 
scales. Wood heavy, hard, very strong, mather coarse-grained, very durable, light brown; largely used for the upper knces of small vessels, fence-posts, telegraph-poles, and railway-ties.

Distribution. At the north often on well-drained uplands, southward in cold deep swamps which it often clothes with forests of elosely crowded trees, from

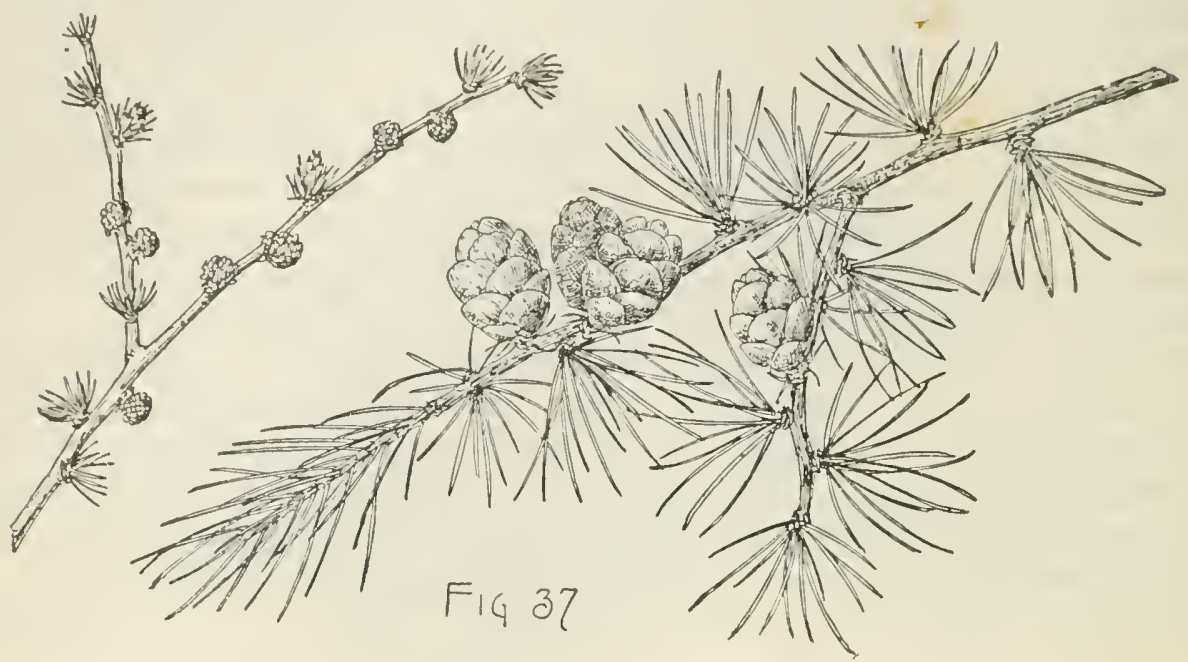

Labrador to the Arctic Circle, ranging west of the Rocky Mountains to latitude $65^{\circ} 35^{\prime}$ north, and southward through Canada and the northern states to northern Pennsylvania and Preston Connty, West Virginia, northern Indiana and Illinois, and central Minnesota, and along the eastern foothills of the Rocky Mountains to about latitude 53०; very abundant in the interior of Labrador, where it is the largest tree; common along the margins of the barren lands stretching beyond the subArctic forest to the shores of the Arctic Sea; attaining its largest size north of Lake Winnipeg on low benches which it occasionally covers with open forests; rare and local toward the southern limits of its range.

Often planted as an ornamental tree in the northeastern states, growing rapidly and attaining in cultivation a large size and picturesqne habit.

\section{Larix occidentalis, Nutt. Tamarack.}

Leaves triangnlar, rounded on the back, conspicuously keeled below, rigid, sharppointed, $1^{\prime}-1 \frac{3}{4}^{\prime}$ long, about $\frac{1}{32}^{\prime}$ wide, light pale green, turning pale yellow early in the antumn. Flowers: staminate oblong, pale yellow; pistillate oblong, nearly sessile, with orbicular scales and bracts produced into elongated tips. Fruit oblong, short-stalked, $1^{\prime}-1 \frac{1}{2}^{\prime}$ long, with numerous thin stiff scales nearly entire and sometimes a little reflexed on their margins, much shorter than their bracts, more or less thickly coated on the lower surface below the middle with hoary tomentum, and standing after the escape of the seeds at right angles to the axis of the cone, or often becoming reflexed; seeds nearly $\frac{1^{\prime}}{4}$ long, with a pale brown shell, one half to two thirds as long as the thin fragile pale wings broadest near the middle and obliquely ronnded at the apex.

A tree, sometimes $250^{\circ}$ high, with a tall tapering naked trunk $6^{\circ}-8^{\circ}$ in diameter, or on dry soil and exposed mountain slopes usually not more than $100^{\circ}$ tall, surmounted by a short narrow pyramidal head of small branches clothed with scanty 
foliage, or occasionally by a larger crown of elongated drooping branches, stout branchlets covered when they first appear with soft pale pubescence, usually soon glabrous, bright orange-brown in their first year, ultimately becoming dark graybrown, and dark chestnut-brown winter-buds about $\frac{1^{\prime}}{8}$ in diameter. Bark of young stems thin, dark-colored and scaly, becoming near the base of old trunks $5^{\prime}$ or $6^{\prime}$ thick and breaking into irregularly shaped oblong plates often $2^{\circ}$ long and covered with thin closely appressed light cimnamon-red scales. Wood very heavy, exceedingly hard and strong, close-grained, very durable in contact with the soil, bright light red, with thin nearly white sapwood; largely used for railway-ties and fence-posts, and manufactured into lumber used in cabinet-making and the interior finish of buildings.

Distribution. Moist bottom-lands and on high benches and dry momtain sides generally at elevations between $2000^{\circ}$ and $7000^{\circ}$ above the sea-level, usually singly or

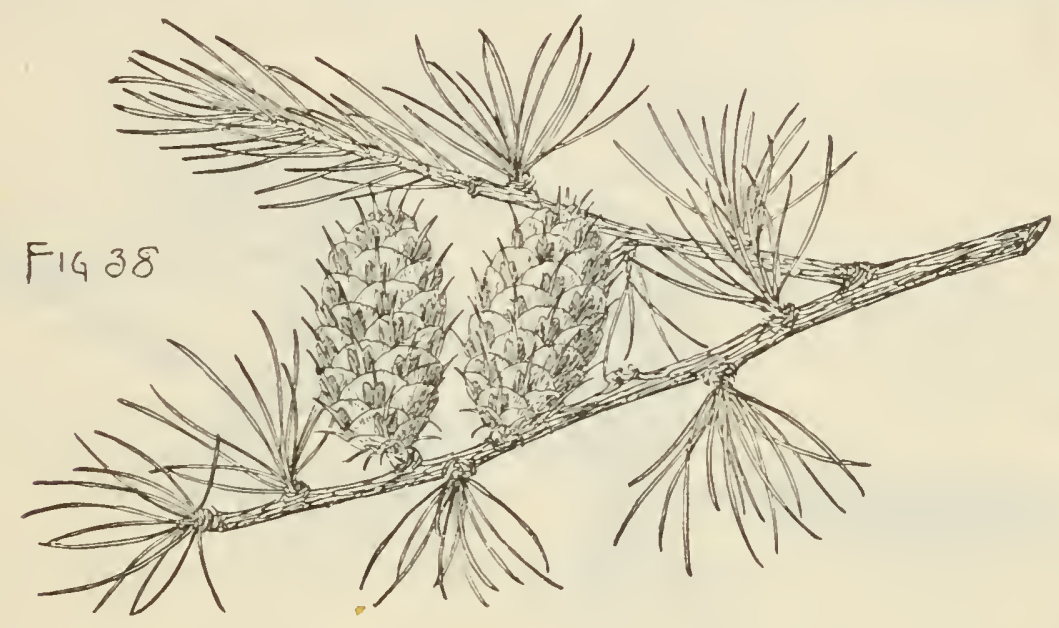

in small groves, through the basin of the upper Columbia River from southeru British Columbia to the western slopes of the continental divide of northern Montana, and to the eastern slopes of the Cascade Mountains of Oregon; most abundant and of its largest size on the bottom-lands of streams flowing into Flat Head Lake in northern Montana, and in northern Idaho.

Occasionally planted in the eastern states and in Europe, but in cultivation showing little promise of attaining a large size or becoming a valuable ornamental or timbertree.

\section{Larix Lyallii, Parl. Tamarack.}

Leaves 4-angled, rigid, short-pointed, pale blue-green, $1^{\prime}-1 \frac{1}{2}^{\prime}$ long. Flowers: staminate oblong, with pale yellow anthers; pistillate ovate-oblong, with dark red or occasionally pale yellow-green scales and dark purple bracts abruptly contracted into elongated slender tips. Fruit ovate, rather acute, $11^{\prime}-2^{\prime}$ long, subsessile or raised on slender stalks coated with hoary tomentum, with dark reddish purple or rarely green erose scales, fringed and covered on their lower surface with matted hairs and at maturity spreading nearly at right angles and finally much reflexed, much shorter than their dark purple very conspicuous long-tipped bracts; seeds full and rounded on the sides, $\frac{1}{8}^{\prime}$ long and about half as long as their light red lustrous wings broadest near the base with nearly parallel sides.

A tree, usually $40^{\circ}-50^{\circ}$ but occasionally $7 \check{\partial}^{\circ}$ high, with a trunk generally $18^{\prime}-20^{\prime}$ but rarely $3^{\circ}-4^{\circ}$ in diameter, and remote elongated exceedingly tough persistent 
branehes sometimes pendulous, developing very irregularly and of ten abruptly aseending at the extremities, stout branchlets eoated with hoary tomentum usually persistent until after their seeond winter, ultimately becoming nearly black, and prominent winter-buds with eonspicuons long white matted hairs fringing the margins of their seales and often almost entirely eovering the bud. Bark of young trees and of the branches thin, rather lustrous, smooth, and pale gray tinged with yellow, beeoming loose and scaly on larger stems and on the large branches of old trees, and on fully grown trunks $\frac{1}{2}-\frac{3^{\prime}}{4}$ thick and slightly divided by shallow fissures into irregularly shaped plates covered by thin dark red-brown loosely attached seales. Wood heavy, hard, coarse-grained, light reddish brown.

Distribution. Near the timber-line on mountain slopes at elevations of $4000^{\circ}$ $5200^{\circ}$, from southern Alberta on the eastern slope of the Roeky Mountains and the interior of sonthern British Columbia, sontliward along the Cascade Mountains of

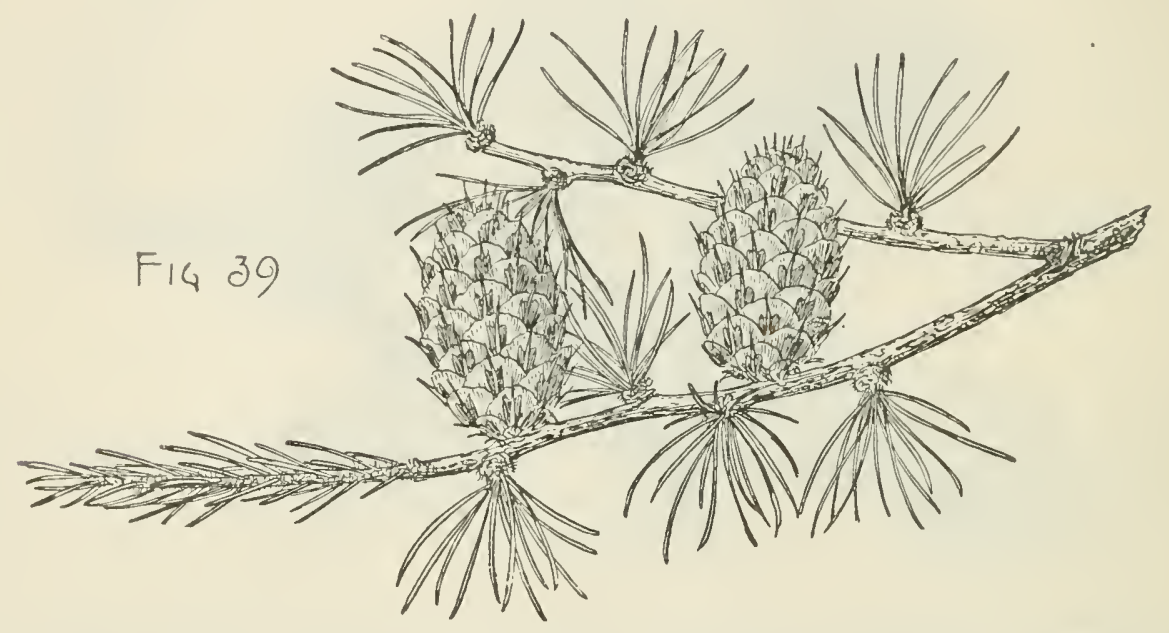

northern Washington to Mt. Stewart at the liead of the north fork of the Yakima River, and along the continental divide to the middle fork of Sum River, forming here a forest of eonsiderable size at elevations of $7000^{\circ}-8000^{\circ}$, and to Pend d'Oreille Pass, Montana.

\section{PICEA, Link. Spruce.}

Pyramidal trees, with tall tapering trunks often stoutly buttressed at the base, thin scaly bark, soft pale wood eontaining numerous resin eanals, slender whorled twiee or thrice ramified branehes, their ultimate divisions stout, glabrous or pubescent, and leaf-buds usually in 3's, the 2 lateral in the axils of upper leaves. Leares linear, spirally disposed, extending out from the branch on all sides or oceasionally appearing 2-ranked by the twisting of those on its lower side, mostly pointing to the end of the brancli, entire, articulate on prominent persistent rhombie ultimately woody bases, keeled above and below, 4-sided and stomatiferous on the 4 sides, or flattened and stomatiferous on the upper or oceasionally on the lower side, persistent from seven to ten years, deciduous in drying. Flowers terminal or in the axils of upper leaves, the staminate usually long-stalked, composed of numerous spirally arranged anthers with connectives produced into broad nearly eircular toothed erests, the pistillate oblong, oval or eylindrical, with rounded or pointed seales, each in the axis of an aecrescent bract shorter than the scale at maturity. Fruit an ovoid or oblong- 
cylindrical pendant cone, crowded on the upper branches or in some species scattered over the upper half of the tree. Seeds ovoid or oblong, usually acute at the base, much shorter than their wings ; outer seed-coat crustaceous, light or dark brown, the inner membranaceous, pale chestnut-brown ; cotyledons 4-15.

Picea is widely distributed through the colder and temperate regions of the northern hemisphere, some species forming great forests or plains and high mountain slopes. Eighteen species are now recognized, ranging from the Arctic Circle to the slopes of the southern Appalachian Mountains and to those of northern New Mexico and Arizona in the New World, and to central.and southeastern Europe, the Caucasus, the Himalayas, western China and Japan. Of exotic species the so-called Norway Spruce, Picea Abies, Karst., one of the most valuable timber-trees of Europe, has been largely planted for ornament and shelter in the eastern states, where the Caucasian Picea orientalis, Carr., and some of the Japanese species also flourish.

Picea was probably the classical name of the Spruce-tree.

\section{CONSPECTUS OF THE NORTH AMERICAN SPECIES.}

Leares 4 -sided, with stomata on the 4 sides.

Cone-scales rounded at the apex.

Cone-scales stiff and rigid at maturity; branchlets pubescent.

Cones ovate on strongly incurved stalks, persistent for many years, their scales erose or dentate; leaves blue-green.

1. P. Mariana (A B, F).

Cones ovate-oblong, early deciduous, their scales entire or denticulate; leaves dark 5ellow-green.

2. P. rubens (A).

Cone-scales soft and flexible at maturity ; branchlets glabrous.

Cones oblong-cylindrical, slender, their scales entire; leaves blue-green.

3. P. Canadensis (A B, F).

Cone-scales oblong or rliomboidal, narrowed to the truncate or acute apex; leaves bluegreen.

Cones oblong-cylindrical or oval; brancllets pubescent; leaves soft and flexible.

4. P. Engelmanni (F, B, G).

Cones oblong-cylindrical; branchlets glabrous; leaves rigid, spinescent.

5. P. Parryana (F).

Leaves flattened, usually with stomata only on the upper surface.

Cone-scales rounded, entire ; branchlets pubescent.

Cones oblong-cylindrical, leaves obtuse, with stomata only on the upper surface.

6. P. Breweriana (G).

Cone-scales oblong-oval, rounded, denticulate above the middle; branchlets glabrous.

Cones cylindrical-ovoid, leaves acute or acuminate, with stomata occasionally on the lower surface.

7. P. Sitchensis (B, G).

1. Leaves 4 -sided.

*Cone-scales rounded at the apex.

+ Branchlets pubescent.

\section{Picea Mariana, B., S. \& P. Black Spruce.}

Leaves slightly incurved above the middle, abruptly contracted at the apex into short callous tips, pale blue-green and glaucous at maturity, $\frac{1{ }^{\prime}}{4}-\frac{3^{\prime}}{4}$ long, hoary on the upper surface from the broad bands of stomata, and lustrous and slightly stomatiferous on the lower surface. Flowers: staminate subglobose, with dark red anthers ; pistillate oblong-cylindrical, with obovate purple scales rounded above, and oblong purple glaucous bracts rounded and denticulate at the apex. Fruit ovate, 
pointed, gradually narrowed at the base into short strongly incurved stalks, $\frac{1^{\prime}}{2}-1 \frac{1}{2}$ long, witl rigid puberulous seales rounded or rarely somewhat pointed at the apex and more or less erose on the notehed pale margins, turning as they ripen dull graybrown and becoming as the scales gradually open and slowly disclrarge their sceds alnost globose; sometimes remaining on the branches for twenty or thirty years, the oldest elose to the base of the branches near the trunk; seeds oblong, narrowed, to the acute base, about $\frac{1}{8}$ long, very dark brown, with delicate pale brown wings broadest above the middle, very oblique at the apex, about $\frac{1^{\prime}}{2}$ long and $\frac{1^{\prime}}{8}$ wide.

A tree, usually $20^{\circ}-30^{\circ}$ and oceasionally $100^{\circ}$ high, witl a trunk $6^{\prime}-12^{\prime}$ and rarely $3^{\circ}$ in diameter, and comparatively short branches generally pendulons with upward curves, forning an open irregular crown, light green branchlets coated with pale pubescence, soon beginning to grow darker, and during their first winter light cinnamonl-brown and covered with short rusty pubescence, their thin brown bark gradually becoming glabrous and beginning to break into small thin scales during their second year; at the extreme north sometimes a low semiprostrate shrub; frequently cone-bearing when only $2^{\circ}-3^{\circ}$ high. Winter-buds ovate, acute, light reddish brown, puberulous, about $\frac{1^{\prime}}{8}$ long. Bark $\frac{1^{\prime}}{4}-\frac{1}{2}^{\prime}$ thick and broken on the surface into thin rather closely appressed gray-brown scales. Wood light, soft, not strong, pale yellow-white, with thin sapwood; probably rarely used outside of Manitoba and Saskatchewan, except in the manufacture of paper pulp. Spruce-gum, the resinous

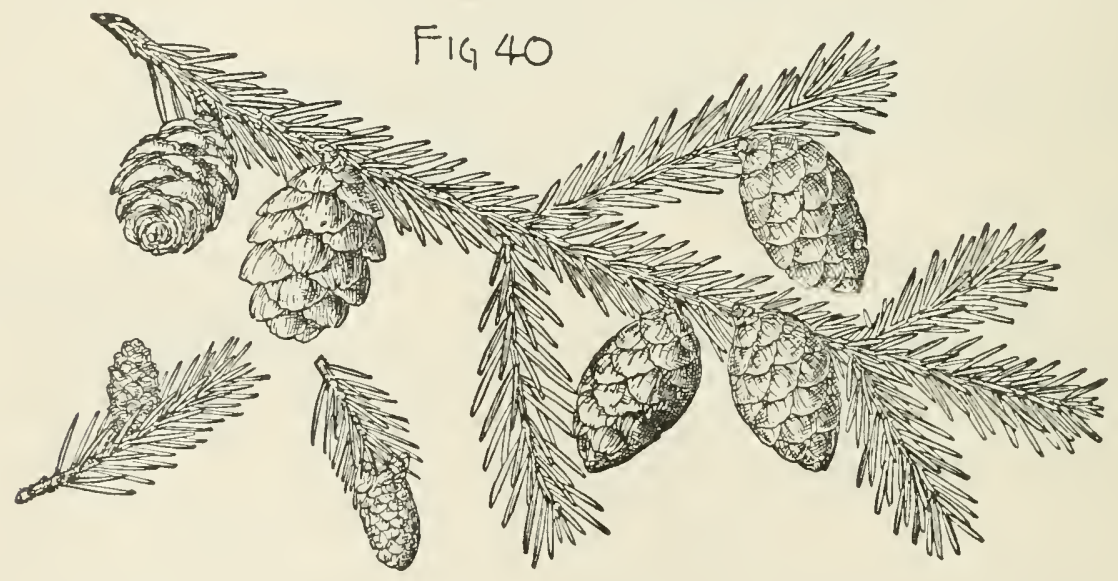

exudations of the Spruce-trees of northeastern America, is gathered in considerable quantities principally in northern New England and Canada, and is used as a masticatory. Spruce-beer is made by boiling the branches of the Black and Red Spruces.

Distribution. At the north on well-drained bottom-lands and the slopes of barren stony hills, and southward in sphagnum-covered bogs, swamps and on their borders, from Labrador to the valley of the Mackenzie River in about latitude $65^{\circ}$ north, and, crossing the Rocky Mountains, through the interior of Alaska to the valley of White River; southward through Newfoundland, the maritime provinces, eastern Canada and the northeastern United States to Pennsylvania, and along the Alleghany-Mountains to northern Virginia; and from the eastern foothills of the Rocky Mountains in Alberta, through Assiniboia, northern Saskatchewan and northern Manitoba, to central Wisconsin and Michigan; very abundant at the far north and the largest coniferous tree of Saskatchewan and northern Manitoba, covering here large areas 
and growing to its largest size ; common in Newfoundland and all the provinces of eastern Canada except southern Ontario; in the United States less abundant and usually only in cold sphagnum swamps.

Occasionally planted as an ornamental tree, the Black Spruce is short-lived in cultivation and one of the least desirable of all Spruce-trees for the decoration of parks and gardens.

\section{Picea rubens, Sarg. Red Spruce.}

Leaves more or less incurved above the middle, acute or rounded and furnished at the apex with short callous points, dark green often slightly tinged with yellow, very lustrous, marked on the upper surface by 4 rows of stomata and on the lower less conspicuously by 2 rows of stomata on each side of the prominent midrib, $\frac{1^{\prime}}{2}-\frac{5}{8}$ long, nearly $\frac{1}{16}$ wide. Flowers: staminate oval, almost sessile, bright red; pistillate oblong-cylindrical, with thin rounded scales

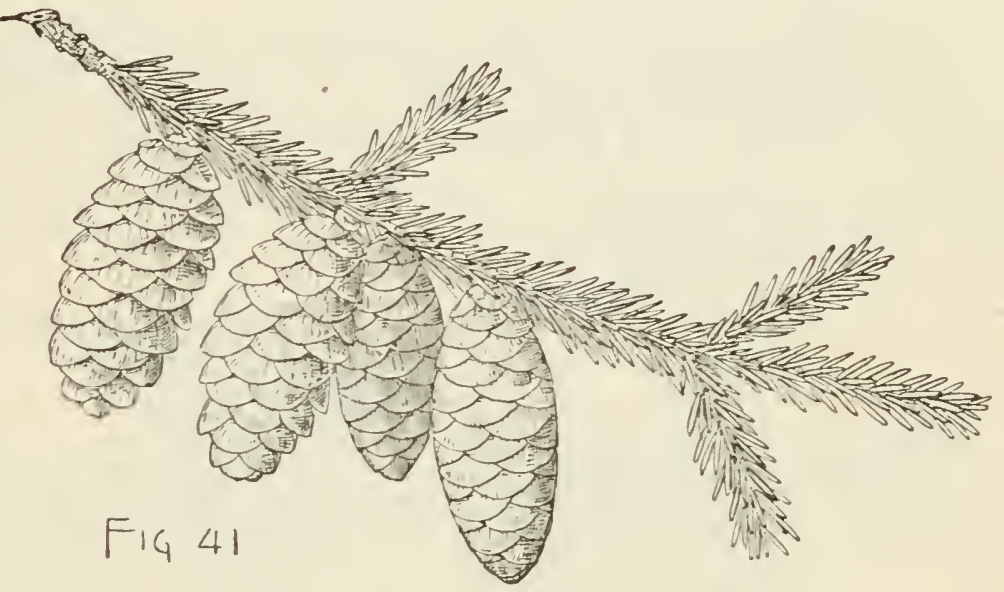
reflexed and slightly erose on their margins, and obovate bracts rounded and laciniate above. Fruit on very short straight or incurved stalks, ovate-oblong, gradually narrowed from near the middle to the acute apex, $1 \frac{1}{4}-2$ ' long, with rigid puberulous scales entire or slightly toothed at the apex; bright green or green somewhat tinged with purple when fully grown, becoming light reddish brown and lustrous at maturity, beginning to fall as soon as the scales open in the autumn or early winter, and generally disappearing from the branches the following summer; seeds dark brown, about $\frac{1}{8}^{\prime}$ long, with short broad wings full and rounded above the middle.

A tree, usually $70^{\circ}-80^{\circ}$ and occasionally $100^{\circ}$ higl, with a trunk $2^{\circ}-3^{\circ}$ in diameter, branches long-persistent on the stem and clothing it to the ground, forning a narrow rather conical head, or soon disappearing below fron trees crowded in the forest, stout pubescent light green branchlets, becoming bright reddish brown or orange-brown during their first winter, glabrous the following year, and covered in their third or fourth year with scaly bark. Winter-buds ovate, acute, $\frac{1{ }^{\prime}}{4}-\frac{1^{\prime}}{3}$ long, with light reddish brown scales. Bark $\frac{1^{\prime}}{4}-\frac{1}{2}^{\prime}$ thick, and broken into thin closely appressed irregularly shaped red-brown scales. Wood light, soft, close-grained, not strong, pale slightly tinged with red, with paler sapwood usually about $2^{\prime}$ thick; largely manufactured into lumber in the northeastern states, Pennsylvania, and western Virginia, and used for the flooring and construction of houses, for the sounding-boards of musical iustruments, and in the manufacture of paper pulp.

Distribution. Well-drained uplands and mountain slopes, often forming a large part of extensive forests, from Prince Edward Island and the valley of the St. Lawrence southward to the coast of Massachusetts, along the interior hilly part of 
New England and New York, and the Alleghany Mountains to the high peaks of North Carolina.

Occasionally planted in the eastern states and in Enrope as an ormamental tree, but growing in cultivation unore slowly than any other Spruce-tree.

++ Branchlets glabrous.

\section{Picea Canadensis, B., S. \& P. - White Spruce.}

Leaves crowded on the upper side of the branches by the twisting of those on the lower side, 4-sided, incurved, acute or acnminate and terminating in rigid callons tips, pale blue and hoary when they first appear, becoming dark blue-green or pale blue, marked on each of the 4 sides by 3 or 4 rows of stomata, $\frac{1^{\prime}}{3}-\frac{3^{\prime}}{4}$ long. Flowers: staminate pale red, soon appearing yellow from the thick covering of pollen; pistillate oblong-cylindrical, with round nearly entire pale red or yellow-green scales, broader than long, and nearly orbicular denticulate bracts. Fruit nearly sessile or borne on short thin straight stems, oblong-cylindrical, slender, slightly narrowed to the ends, rather obtuse at the apex, usually abont $2^{\prime}$ long, pale green sometimes

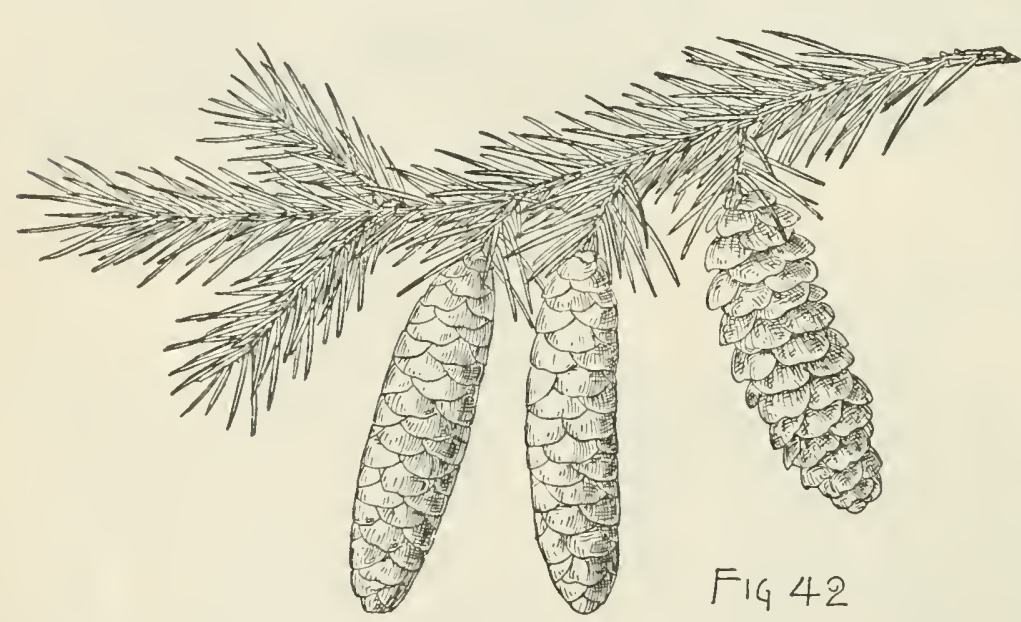

tinged with red when fully grown, becoming at maturity pale brown and lustrons, with nearly orbicular scales, rounded, truncate, and slightly emarginate, or rarely narrowed at the apex, and very thin, flexible and elastic at maturity, usually deciduous in the autumn or during the following winter; seeds about $\frac{1}{8}^{\prime}$ long, pale brown, with narrow wings gradually widened from the base to above the middle and very oblique at the apex.

A tree, with disagreeable smelling foliage, sometimes $150^{\circ}$ high, with a trunk $3^{\circ}-4^{\circ}$ in diameter, but east of the Rocky Mountains and especially toward the southeastern limits of its range rarely more than $60^{\circ}-70^{\circ}$ tall, with a trunk not more than $2^{\circ}$ in diameter, long comparatively thick branches densely clothed with stout rigid laterals sweeping out in graceful npward curves, and forming a broad-based rather open pyramid often obtuse at the apex, stout glabrous branchlets orangebrown during their first autumn and winter, gradually growing darker grayish brown. Winter-buds broadly ovate, obtuse, covered by light chestnut-brown scales with thin often reflexed ciliate margins. Bark $\frac{1^{\prime}}{4}-\frac{1}{2}^{\prime}$ thick, separating irregularly into thin plate-like light gray scales more or less tinged with brown on the surface. Wood light, soft, not strong, straight-grained, light yellow, with hardly distinguishable sapwood; manufactured into lumber in the eastern provinces of Canada and in Alaska, and used in construction, for the interior finish of buildings, and for paper pulp.

Distribution. Banks and borders of streams and lakes, ocean cliffs, and in the 
north the rocky slopes of low hills, from Labrador along the northern frontier of the forest nearly to the shores of the Arctic Sea, reaching Behring Strait in $66^{\circ} 44^{\prime}$ north latitude, and southward down the Atlantic coast to southern Maine, northern New Hampshire, Vermont, and New York, northern Michigan and Wisconsin, the Black Hills of Dakota, and through the interior of Alaska and along the Rocky Mountains to northern Montana.

Often planted in Canada, northern New England, and northern Europe as an ornamental tree; southward suffering from heat and dryness.

*** Cone-scales oblong or rhomboidal.

+ Branchlets pubescent.

\section{Picea Engelmanni, Engelm. White Spruce. Engelmann Spruce.}

Leaves soft and flexible, with acute callous tips, slender nearly straight or slightly incurved on vigorous sterile branches, stouter shorter and more incurved on fer-

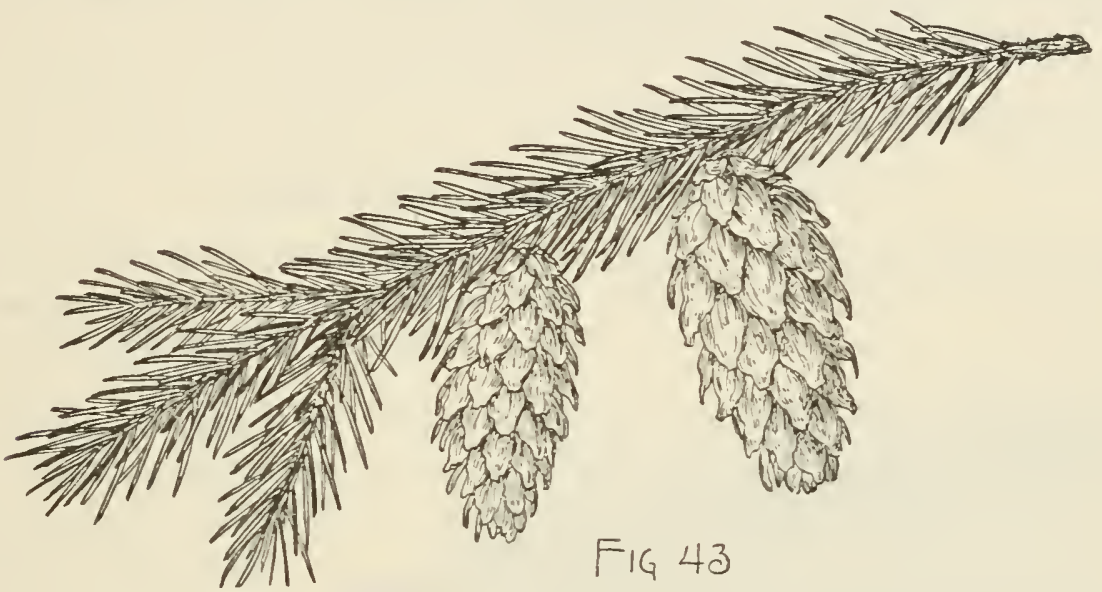

tile branches, $\mathbf{1}^{\prime}-1 \frac{1}{8}^{\prime}$ long, marked on each face by $3-5$. rows of stomata, covered at first with a glaucous bloom, soon becoming dark blue-green or pale steel-blue. Flowers : staminate dark purple; pistillate bright scarlet, with pointed or rounded and more or less divided scales, and oblong bracts rounded or acute or acuminate and denticulate at the apex or obovate-oblong and abruptly acuminate. Fruit oblong-cylindrical, oval, gradually narrowed to the ends, usually about 2' long, sessile or very short-stalked, produced in great numbers on the upper branches, horizontal and ultimately pendulous, light green somewhat tinged with scarlet when fully grown, becoming light chestnut-brown and lustrons, with thin flexible slightly concave scales, generally erose-dentate or rarely almost entire on the margins, usually broadest at the middle, wedge-shaped below, and gradually contracted above into a truncate or acute apex, or occasionally obovate and rounded above; mostly deciduous in the autumn or early in their first winter soon after the escape of the seeds ; seeds obtuse at the base, nearly black, about $\frac{1^{\prime}}{8}$ long and much shorter than their broad very oblique wings.

A tree, with disagreeable smelling foliage, often $150^{\circ}$ high, with a trunk $4^{\circ}-5^{\circ}$ in diameter, spreading branches produced in regular whorls and forming a narrow compact pyramidal head, gracefully hanging short lateral branches, and comparatively slender branchlets pubescent for three or four years, light or dark orange- 
brown or gray tinged with brown dnring their first winter, their bark beginning to separate into small flaky seales in their fourth or fifth year. Winter-buds conical or slightly obtuse, with pale ehestunt-brown scales scarions and often free and slightly reflexed on the margins. Bark of the trunk $y^{\prime}-1^{\prime}$ thiek, light einnamon-red, and broken into large thin loose seales. Wood light, soft, not strong, close-grained, pale yellow tinged with red, with thiek hardly distinguishable sapwood; largely manufactured into lumber nsed for the eonstruction of buildings; also employed for fuel and ehareoal. The bark is sometimes employed in tanning leather.

Distribution. High monntain slopes, often forming great forests from the mountains of Alberta and British Columbia, sonthward over the interior monntain systems of the eontinent to northern New Mexico and Arizona, from elevations of $5000^{\circ}$ at the north up to $11,500^{\circ}$ at the south, and westward through Montana and Idaho to the Cascade Mountains of Washington aud Oregon; attaining its greatest size and beanty uorth of the northern boundary of the United States.

Oeeasionally planted as an ormamental tree in the New England states and northern Europe, where it grows vigorously and promises to attain a large size; usnally injured in western Europe by spring frosts.

\section{$\rightarrow+$ Branchlets glabrous.}

\section{Picea Parryana, Sarg. Blue Spruce.}

Leaves strongly incurved, especially those on the upper side of the branch, stout, rigid, acuminate and tipped with long callous sharp points, $1^{\prime}-1 \frac{1^{\prime}}{8}$ long on sterile

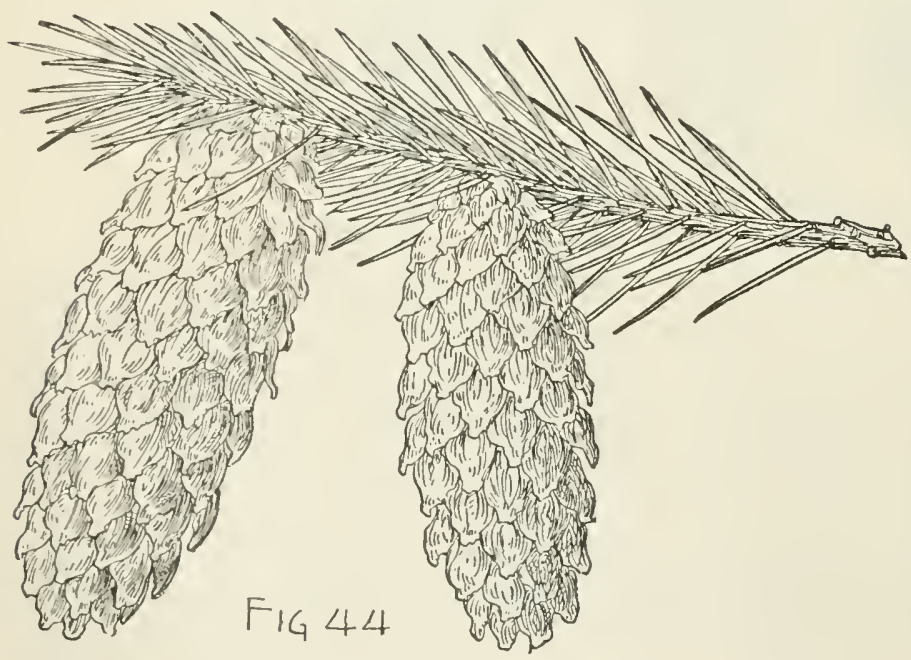
branches, often not more than half as long on the fertile branches of old trees, marked on each side by 4-7 rows of stomata, dull bluish green on some individuals and light or dark steel-blue or silvery white on others, the blue colors gradually ehanging to dull blue-green at the end of three or four years. Flowers: staminate yellow tinged with red ; pistillate with broad oblong or slightly obovate pale green scales truncate or slightly emarginate at the denticulate apex, and acute bracts. Fruit produced on the upper third of the tree, sessile or short-stalked, oblongcylindrical, slightly narrowed at the ends, usually abont $3^{\prime}$ long, green more or less tinged with red when fully grown at midsummer, becoming pale ehestnut-brown and lustrons, with flat tough rhomboidal scales flexuose on the margins, and acute, rounded, or truncate at the elongated erose apex; seeds $\frac{1}{8}^{\prime}$ long or about half the length of their wings, gradually widening to above the middle and full and rounded at the apex.

A tree, usually $80^{\circ}-100^{\circ}$ or occasionally $150^{\circ}$ high, with a trunk rarely $3^{\circ}$ in dia- 
meter and occasionally divided into 3 or 4 stout secondary stems, rigid horizontal branches disposed on young trees in remote whorls and decreasing regularly in length from below upward, the short stout stiff branchlets pointing forward and making flat-topped masses of foliage, on old trees short and remote, with stout pendant lateral branches forming a thin ragged pyramidal crown and stout rigid glabrous branchlets, pale glaucous green, becoming bright orange-brown during the first winter and ultimately light grayish brown. Winter-buds stout, obtuse or rarely acute, $\frac{1^{\prime}}{4}-\frac{1^{\prime}}{2}$ long, with thin pale chestnut-brown scales usually reflexed on the margins. Bark of young trees gray or gray tinged with cinnamon-red and broken into small oblong plate-like scales, becoming on the lower part of old trunks $\frac{3^{\prime}}{4}-1 \frac{1}{2}^{\prime}$ thick and deeply divided into broad rounded ridges covered with small closely appressed pale gray or occasionally bright cinnamon-red scales. Wood light, soft, close-grained, weak, pale brown or often nearly white, with hardly distinguishable sapwood.

Distribution. Banks of streams or on the first benclies above them singly or in small groves at elevations between $6500^{\circ}$ and $10,000^{\circ}$ above tlie sea; Colorado and eastern Utah northward to the Wind River Mountains of Wyoming.

Often planted as an ornamental tree in the eastern and northern states and in western and northern Enrope, especially individuals with blue foliage; very beautiful in early life but in cultivation soon becoming unsightly from the loss of the lower branches.

2. Leaves flattened.

* Cone-scales rounded at the apex.

\section{Picea Breweriana, Wats. Weeping Spruce.}

Leaves abruptly narrowed and obtuse at the apex, straight or slightly incurved, rounded and obscurely ridged and dark green and lustrous on the lower surface, flat-

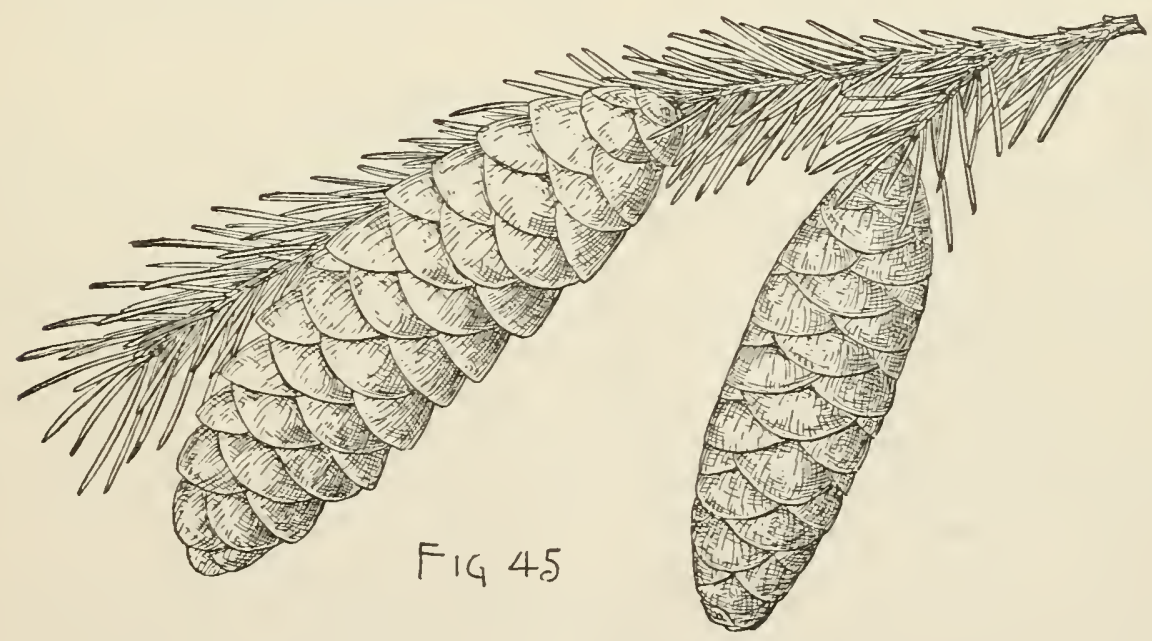

tened and conspicuously marked on the upper surface by 4 or 5 rows of stomata on each side of the prominent midrib, $\frac{3^{\prime}}{4}-1 \frac{1}{8}^{\prime}$ long, $\frac{1{ }^{\prime}}{16}-\frac{1}{1}^{\prime}$ wide. Flowers : staminate dark purple; pistillate oblong-cylindrical, with obovate scales rounded above and reflexed on the entire margins and oblong bracts laciniately divided at their rounded or acute apex. Fruit oblong, gradually narrowed from the middle to the ends, acute 
at the apex, rather oblique at the base, suspended on straight slender stalks, deep rich purple or green more or less tinged with purple when fully grown, becoming light orange-brown, 2'-4' long, with thin broadly ovate flat scales longer than broad, rounded at the apex, opening late in the antumin after the eseape of the sechs, often becoming strongly reflexed and very flexible; nsually remaining on the branches until the second winter; seeds acute at the base, full and rounded on the sides, $\frac{1}{8}$ long, dark brown, and about one quarter the leigth of their wings broadest toward the full and rounded apex.

A tree, usually $80^{\circ}-100^{\circ}$ high, with a trunk $2^{\circ}-3^{\circ}$ in diameter above the swelling of its enlarged and gradually tapering base, and furnished to the ground with crowded branches, those at the top of the tree short and slightly ascending, with comparatively short pendulous lateral branches, those lower on the tree horizontal or pendulous and clothed with slender flexible whip-like laterals often $7^{\circ}-8^{\circ}$ long and not more than $\frac{1^{\prime}}{4}$ thick and furnished with numerous long thin lateral branchlets, their ultimate divisions slender, coated with fine pubescence persistent until their third season, bright red-brown during their first winter, gradually growing dark gray-brown. Winter-buds conical, light chestnut-brown, $\frac{1^{\prime}}{4}$ long and $\frac{1^{\prime}}{8}$ thick. Bark of the trunk $\frac{1^{\prime}}{2}-\frac{3^{\prime}}{4}$ thick, broken into long thin closely appressed scales dull red-brown on the surface. Wood heavy, soft, close-grained, light brown or nearly white, with thick hardly distinguishable sapwood.

Distribution. Dry mountain ridges and peaks near the timber-line on both slopes of the Siskiyou Mountains on the boundary between California and Oregon, forming small groves at elevations of about $7000^{\circ}$ above the sea; on a high peak west of Marble Mountain in Siskiyou County, Califormia; on the Oregon coast ranges at the head-waters of the Illinois River at elevations of $4000^{\circ}-5000^{\circ}$.

\section{***ane-scales oblong-oval, denticulate above the middle.}

\section{Picea Sitchensis, Carr. Tideland Spruce. Sitka Spruce.}

Leaves standing out from all sides of the branches and often nearly at right angles to them, frequently bringing their white upper surface to view by a twist at their base, straight or slightly incurved, acute or acuminate, with long callous tips slightly rounded, green, lustrous, and occasionally marked on the lower surface with 2 or 3 rows of small conspicuous stomata on each side of the prominent midrib, flattened, obscurely ridged and almost covered with broad silvery white bands of numerous rows of stomata on the upper surface, $\frac{1}{2}^{\prime}-1 \frac{1}{8}^{\prime}$ long and $\frac{1}{16}-\frac{1}{12}$ wide. Flowers : staminate at the ends of the pendant lateral branchlets, dark red ; pistillate on rigid terminal shoots of the branches of the upper half of the tree, with nearly orbicular denticulate scales, often slightly truncate above and completely hidden by their elongated acuminate bracts. Fruit cylindrical-oval, short-stalked, yellow-green often tinged with dark red when fully grown, becoming lustrous and pale yellow or reddish brown, $2 \frac{1}{2}^{\prime}-4^{\prime}$ long, with thin stiff oblong-oval scales rounded toward the apex, denticulate above the middle, and nearly twice as long as their lanceolate denticulate bracts, deciduous mostly during their first autumn and winter; seeds full and rounded, acnte at the base, pale reddish brown, about $\frac{1}{8}^{\prime}$ long, witl narrow oblong slightly oblique wings $\frac{1}{3}^{\prime}-\frac{1}{2}^{\prime}$ in length.

A tree, usually about $100^{\circ}$ high, with a conspicuously tapering trunk often $3^{\circ}-$ $4^{\circ}$ in diameter above its strongly buttressed and much-enlarged base, occasionally $200^{\circ}$ tall, with a trunk $15^{\circ}-16^{\circ}$ in diameter, horizontal branches forming an open 
loose pyramid and on older trees clothed with slender pendant lateral branches frequently $2^{\circ}-3^{\circ} \mathrm{long}$, and stout rigid glabrous branchlets pale green at first, becoming dark or light orange-brown during their first autumn and winter and finally dark gray-brown; at the extreme northwestern limits of its range occasionally reduced to a low shrub. Winterbuds ovate, acute, or conical, $\frac{1^{\prime}}{4}-\frac{1^{\prime}}{2}$ long, with pale chestnut-brown acute scales, often tipped with short points and more or less

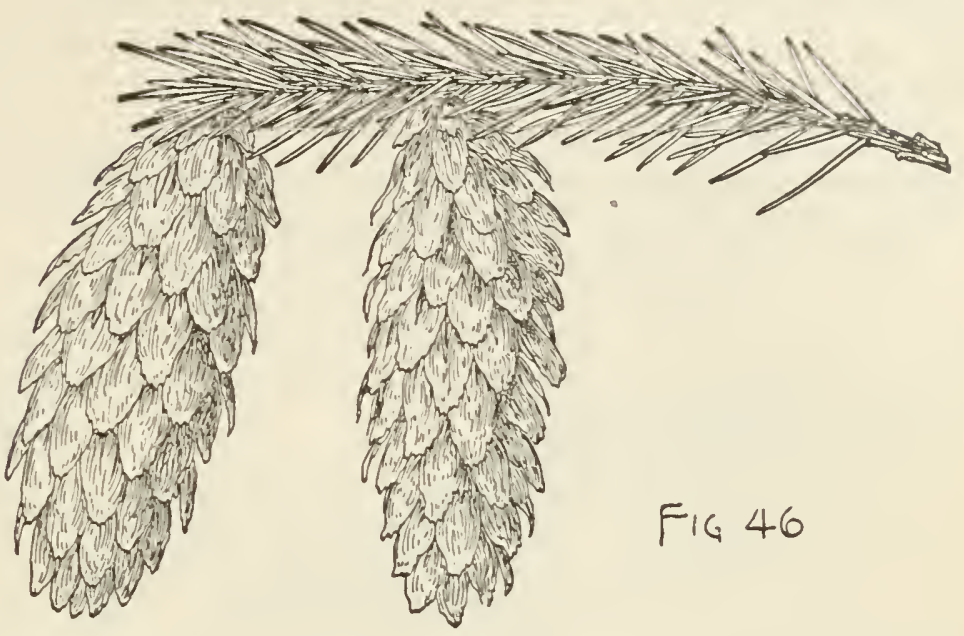
reflexed above the middle. Bark $\frac{1^{\prime}}{4}-\frac{1}{2}^{\prime}$ thick and broken on the surface into large thin loosely attached dark red-brown or on young trees sometimes bright cinnamon-red scales. Wood light, soft, not stroug, straight-grained, light brown tinged with red, with thick nearly white sapwood; largely manufactured into lumber used in the interior finish of buildings, for fencing, boat-building, cooperage, wooden-ware, and packing-cases.

Distribution. Moist sandy, often swampy soil, or less frequently at the far north on wet rocky slopes, from the eastern end of Kadiak Island southward through the coast region of Alaska, British Columbia, Washington, and Oregon to Mendocino County, California.

Often planted in western and central Europe and occasionally in the middle Atlantic states as an ornamental tree.

\section{TSUGA, Carr. Hemlock.}

Tall pyramidal trees, with deeply furrowed astringent bark bright cinnamon-red except on the surface, soft pale wood, nodding leading shoots, slender scattered horizontal often pendulous branches, the secondary branches three or four times irregularly pinnately ramified, with slender round glabrous or pubescent ultimate divisions, the whole forming graceful pendant masses of foliage, and minute winter-buds. Leares flat or angular, obtuse and often emarginate or acute at the apex, spirally disposed, usually appearing almost 2-ranked by the twisting of their petioles, those on the upper side of the branch then much shorter than the others, abruptly narrowed into short petioles jointed on ultimately woody persistent bases, with stomata on the lower surface; on one species not 2-ranked, and of nearly equal length, with stomata on both surfaces. Flowers solitary, the staminate in the axils of leaves of the previous year, globose, composed of numerous subglobose anthers, with connectives produced into short gland-like tips, the pistillate terminal, erect, with nearly circular scales slightly longer or shorter than their membranaceous bracts. Fruit an ovate-oblong, oval, or oblong-cylindrical obtuse usually pendulous nearly sessile green or rarely purple cone becoming light or dark reddish brown, with concare suborbicular or ovate-oblong scales thin and entire on the margins, much longer than 
their minute bracts, persistent on the axis of the cone after the escape of the seeds. Seeds furnished with resin-vesieles, ovate-obloug, compressed, nearly surrounded by their much longer obovate-oblong wings; outer seed-coat erustaceous, light brown, the inner nembranaceons, pale chestnut-brown, and lustrous ; cotyledons 3-6, much shorter than the inferior radiele.

'Tsuga is confined to temperate North America, Japan, ecntral and western China, and the Himalayas; seven species have been distinguished.

T'suga is the Japanese name of the Hemlock-tree.

\section{CONSPECTUS OF THE NORTH AMERICAN SPECIES.}

Leaves flat, obtuse or emarginate at the apex, with stomata only on the lower surface; cones ovate-oblong or oval.

Cones stalked.

Cone-scales orbicular-oblong, about as wide as long, their bracts broad and truncate.

1. T. Canadensis (A).

Cone-scales oblong, much longer than wide, their bracts obtusely pointed.

Cones sessile.

2. T. Caroliniana (A).

Cone-scales oblong, longer than broad, often abruptly contracted near the middle, their bracts gradually narrowed to an obtuse point.

3. T. heterophylla $(\mathrm{B}, \mathrm{F}, \mathrm{G})$. Leaves convex or keeled above, bluntly pointed, with stomata on both surfaces; cones oblong-cyndrical.

Cone-scales oblong-obovate, longer than broad, much longer than their acuminate short-pointed bracts.

4. T. Mertensiana (B, F, G).

\section{Tsuga Canadensis, Carr. Hemlock.}

Leaves oblong, rounded and rarely emarginate at the apex, dark yellow-green, lustrous and obscurely grooved especially toward the base on the npper surface, marked on the lower surface by 5 or 6 rows of stomata on each side of the low broad midrib, $\frac{1^{\prime}}{3}-\frac{2^{\prime}}{3}$ long, about $\frac{1}{1 \overline{6}}$ wide, deciduous in their third season from dark orange-colored persistent bases. Flowers : staminate light yellow; pistillate pale green, with broad bracts coarscly laciniate on the margins and shorter than their scales. Fruit on slender puberulous stalks often $\frac{1^{\prime}}{4}$ long, ovate-oblong, acute, $\frac{1^{\prime}}{2}-\frac{8^{\prime}}{4}$ long, with orbicular oblong scales almost as wide as long, and broad truncate bracts slightly laciniate on the margins, opening and gradually losing their seeds during the winter and mostly persistent on the branches until the following spring; seeds $\frac{1^{\prime}}{16}$ long, usually with 2 or 3 large oil-vesicles, nearly half as long as their wings broad at the base and gradually tapering to the romded apex.

A tree, usnally $60^{\circ}-70^{\circ}$, and occasionally $100^{\circ}$ high, with a trunk $2^{\circ}-4^{\circ}$ in diameter, gradually and conspicuously tapering toward the apex, long slender horizontal or pendulous branches, persistent until overshadowed by other trees and forming a broad-based rather obtuse pyramid, and slender light yellow-brown pubescent branchlets, growing darker during their first winter and glabrons and dark redbrown tinged with purple in their third season. Winter-buds obtuse, light chest-

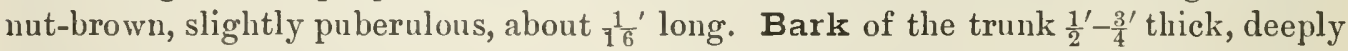
divided into narrow rounded ridges covered with thick closely appressed scales varying from cinnamon-red to gray more or less tinged with purple. Wood light, soft, not strong, brittle, coarse-grained, difficult to work, liable to wind-shake and splinter, not durable when exposed to the air, light brown tinged with red, with thin 
somewhat darker sapwood; largely manufactured into coarse lumber employed for the outside finish of buildings. The astringent inner bark affords the largest part of the material used in the northeastern states and Canada in tanning leather. From the young branches oil of hemlock is distilled.

Distribution. Scattered through upland forests and often covering the northern slopes of rocky ridges and the steep rocky banks of narrow river-gorges from Nova Scotia to eastern Minnesota, and southward through the northern states to Newcastle County, Delaware, southern Michigan, southwestern Wisconsin, and along the Appalachian Mountains to northwestern Alabama; most abundant and frequently

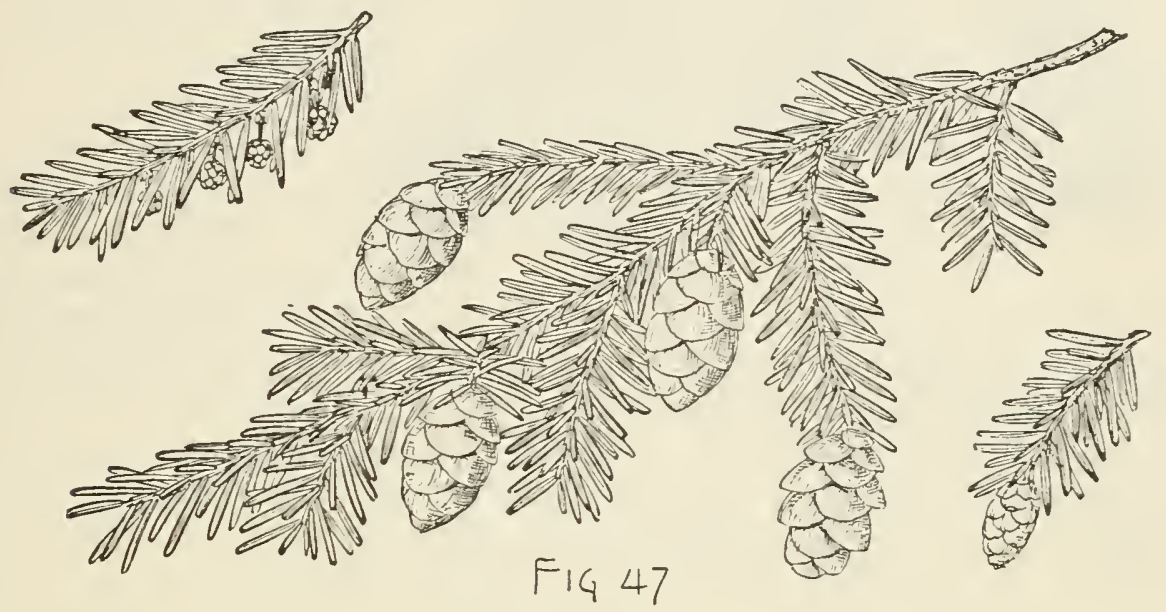

an important element of the forest in New England, northern New York, and western Pennsylvania; attaining its largest size near streams on the slopes of the high mountains of North Carolina and Tennessee.

Largely cultivated with numerous seminal varieties as an ornamental tree in the northern states, and in western and central Europe.

\section{Tsuga Caroliniana, Engelm. Hemlock.}

Leaves retuse or often emarginate at the apex, dark green, lustrous and conspicuously grooved on the upper surface, marked on the lower surface by a band of 7 or 8 rows of stomata on each side of the midrib, $\frac{1^{\prime}}{3}-\frac{3^{\prime}}{4}$ long, about $\frac{1^{\prime}}{1^{2}}$ wide, deciduous from the orange-red bases during their fifth year. Flowers: staminate tinged with purple; pistillate purple, with broadly ovate bracts, scarious and erose on the margins and about as long as their scales. Fruit on short stout stalks, oblong, $1^{\prime}-1 \frac{1^{\prime}}{2}$ long, with oblong scales gradually narrowed and rounded at the apex, rather abruptly contracted at the base into distinct stipes, thin, concave, puberulous on the outer surface, twice as long as their broad pale bracts, spreading nearly at right angles to the axis of the cone at maturity, their bracts rather longer than wide, wedge-shaped, pale, nearly truncate or slightly pointed at the broad apex; seeds $\frac{1^{\prime}}{6}$ long, with numerous small oil-vescicles on the lower side, and one quarter as long as the pale lustrous wings broad or narrow at the base and narrowed to the rounded apex.

A tree, usually $40^{\circ}-50^{\circ}$, or occasionally $70^{\circ}$ high, with a trunk rarely exceeding $2^{\circ}$ in diameter, short stout often pendulous branches forming a handsome compact pyramidal head, and slender light orange-brown pubescent branchlets, usually becoming glabrous and dull brown more or less tinged with orange during their 
third year. Winter-buds obtuse, dark chestunt-brown, pubeseent, nearly $\frac{1}{8}$ long. Bark of the trunk $\frac{8^{\prime}}{4}-11^{\prime}$ thick, red-brown, and deeply divided into broad flat con-

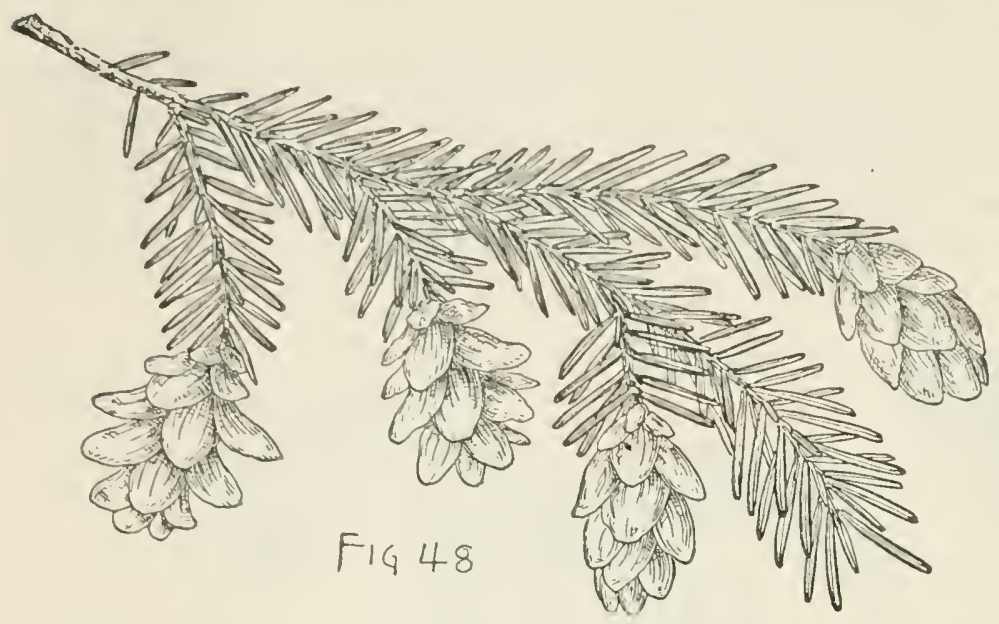
nected ridges covered with thin closely appressed plate-like scales. Wood light, soft, not strong, brittle, coarse-grained, pale brown tinged with red, with thin nearly white sapwood.

$\mathrm{D}$ is tribution. Rocky banks of streams usually at elevations between $2500^{\circ}$ and $3000^{\circ}$ on the Blue Ridge from southwestern Virginia to northern Georgia, generally singly or in small scattered groves of a few individuals.

Often planted as an ornamental tree in the northern states, and occasionally in western Europe.

\section{Tsuga heterophylla, Sarg. Hemlock.}

Leaves rounded at the apex, conspicuously grooved, dark green and very lustrous on the upper surface, marked below by broad white bands of 7-9 rows of stomata, abruptly contracted at the base into slender petioles, $\frac{1^{\prime}}{4}-\frac{3}{4}{ }^{\prime}$ long and $\frac{1}{16}-\frac{1}{1}^{\prime}{ }^{\prime}$ wide. Flowers: staminate yellow; pistillate purple and puberulous, with broad bracts gradually narrowed to an obtuse point and shorter than their broadly ovate

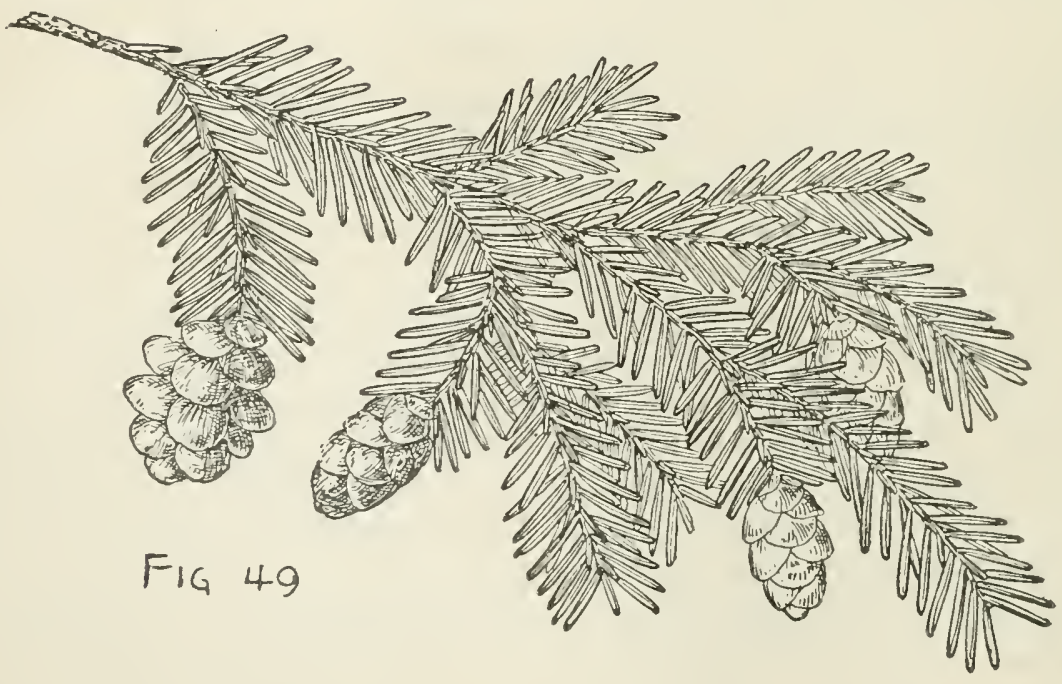

slightly scarious scales. Fruit oblong-oval, acute, sessile, $\frac{3{ }^{\prime}}{4}-1^{\prime}$ long, with slightly puberulous scales longer than broad, often abruptly narrowed near the middle, and 
dark purple puberulous bracts rounded and abruptly contracted at the apex; seeds $\frac{1}{8}$ long, with occasional oil-vesicles, one third to one half as long as their narrow wings.

A tree, frequently $200^{\circ}$ high, with a tall trunk $6^{\circ}-10^{\circ}$ in diameter, and short slender usually pendulous branches forming a narrow pyramidal head, and slender pale yellow-brown branchlets ultimately becoming dark reddish brown, coated at first with long pale hairs, and pubescent or puberulous for five or six years. Winter-buds ovate, bright chestnut-brown, about $\frac{1 \frac{1}{1}^{\prime}}{1^{6}}$ long. Bark on young trunks thin, dark orange-brown, and separated by shallow fissures into narrow flat plates broken into delicate scales, becoming on fully grown trees $1^{\prime}-1 \frac{1}{2}^{\prime}$ thick and deeply divided into broad flat connected ridges covered with closely appressed brown scales more or less tinged with cinnamon-red. Wood light, hard and tough, pale brown tinged with yellow, with thin nearly white sapwood; stronger and more durable than the wood of the other American hemlocks; now largely manufactured into lumber used principally in the construction of buildings. The bark is used in large quantities in tamning leather; from the inner bark the Indians of Alaska obtain one of their principal articles of vegetable food.

Distribution. Southeastern Alaska, southward near the coast to Marin County, California, extending eastward over the mountains of southern British Columbia, northern Washington and Idaho, to the western slopes of the continental divide, and through Oregon to the western slopes of the Cascade Mountains, sometimes ascending in the interior to elevations of $6000^{\circ}$ above the sea; most abundant and of its largest size on the coast of Washington and Oregon; often forming a large part of the forests of the northwest coast.

Frequently planted as an ornamental tree in temperate Europe.

\section{Tsuga Mertensiana, Sarg. Mountain Hemlock. Patton Spruce.}

Leaves standing out from all sides of the branch, remote on leading shoots and crowded on short lateral branchlets, rounded and occasionally obscurely grooved or

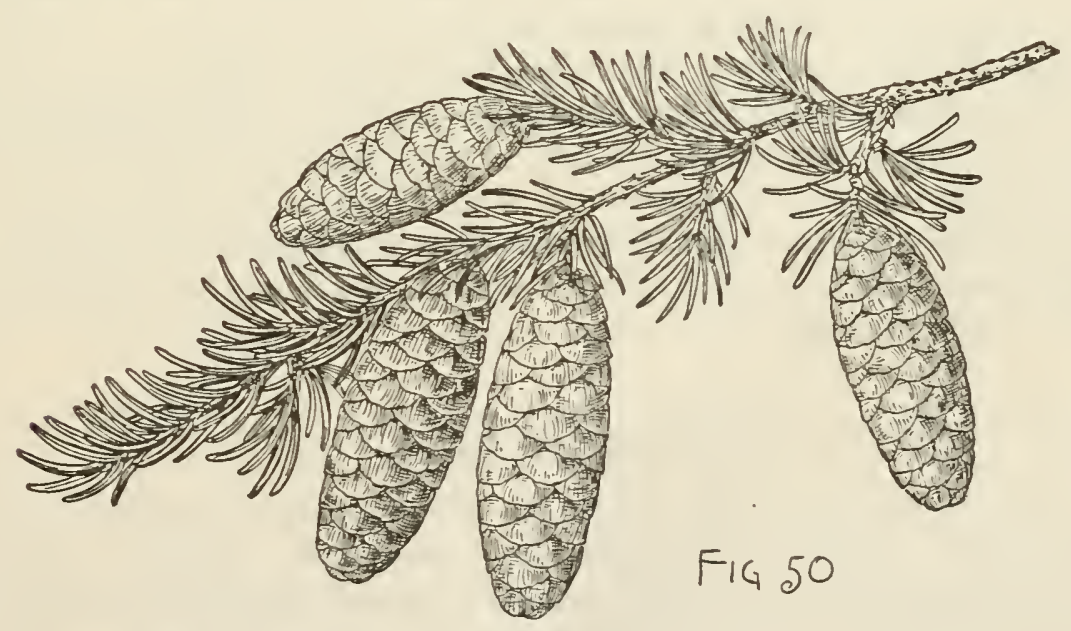

on young plants sometimes conspicuously grooved on the upper surface, rounded and slightly ribbed on the lower surface, bluntly pointed, often more or less curved, stomatiferous above and below, with about 8 rows of stomata on each surface, light bluish green or on some individuals pale blue, $\frac{x^{\prime}}{12}-1^{\prime}$ long, about $\frac{1}{1^{6}}{ }^{\prime}$ wide, abruptly 
narrowed into nearly straight or slightly twisted petioles articulate on bases as long or rather longer than the petioles, irregularly deciduous during their third and fourth years. Flowers : staminate borne on slender pubescent drooping stems, violetpurple; pistillate erect, with delicate lustrous dark purple or yellow-green bracts gradually narrowed above into slender often slightly reflexed tips and muclı longer than their scales. Fruit sessile, eylindrical-oblong, narrowed toward the blunt apex and somewhat toward the base, erect until more than lialf grown, pendulous or rarely erect at maturity, $\frac{5}{8}-3^{\prime}$ long, witl thin delicate scales usually as broad as long, and gradually contracted from above the middle to the wedge-shaped base, romided at the slightly thickened more or less erose margins, puberulous on the outer surface, usually bright bluish purple or occasioually pale yellow-green, four or five times as long as their short-pointed dark purple or brown bracts; seeds light brown, $\frac{1}{8}$ long, often marked on the surface next their scales with 1 or 2 large resin-vesicles, witlı wings nearly $\frac{1^{\prime}}{2}$ long, broadest above the middle, gradually narrowed below, slightly or not at all oblique at the rounded apex.

A tree, usually $70^{\circ}-100^{\circ}$ but occasionally $150^{\circ}$ high, with a slightly tapering trunk $4^{\circ}-5^{\circ}$ in diameter, gracefully pendant slender branches furnished with drooping frond-like lateral branches, their ultimate divisions erect and forming an open pyramid surmounted by the long drooping leading shoots, and thin flexible or sometimes stout rigid branchlets light reddish brown and covered for two or three years with short pale dense pubescence, becoming grayish brown and very scaly. Winterbuds acute, about $\frac{1}{8}^{\prime}$ long, the scales of the outer ranks furnished on the back with conspicuous midribs produced into slender deciduous awl-like tips. Bark of the trunk $1^{\prime}-1 \frac{1}{2}$ thick, deeply divided into connected rounded ridges broken into thin closely appressed dark cinnainon scales shaded with blue or purple. Wood light, soft, not strong, close-grained, pale brown or red, with thin nearly white sapwood; occasionally manufactured into lumber.

Distribution. Exposed ridges and slopes at high altitudes along the upper border of the forest from southeasteru Alaska, southward over the mountain ranges of British Columbia to the Olympic Mountains of Washington, and eastward to the western slopes of the Selkirk Mountains in the interior of southern British Columbia, northern Montana, northern Idaho, the Powder River Mountains, and along the Cascade Mountains of Washington and Oregon, on the mountain ranges of northern California, and along the Sierra Nevada to the cañon of the south fork of King's River, California; in Alaska occasionally descending to the sea-level, and toward the southern limits of its range often ascending to elevations of $10,000^{\circ}$.

Often planted as an ornamental tree in western and central Europe, and rarely in the eastern United States.

\section{PSEUdotsugA, Carr.}

Pyramidal trees, with thick deeply furrowed bark, hard strong wood, with spirally marked wood-cells, slender usually horizontal irregularly whorled branches clotlied with slender spreading lateral branches forming broad flat-topped masses of foliage, ovate acute leaf-buds, the lateral buds in the axils of upper leaves, their inner scales accrescent and marking the branchlets with ring-like scars. Leaves linear, flat, rounded and obtuse or acuminate at the apex, straight or incurved, grooved on the upper side, marked on the lower side by numerous rows of stomata on each side of the prominent midrib, spreading nearly at right angles with the branch. Flowers 
solitary, the staminate axillary, scattered along the branches, oblong-cylindrical, with numerous globose anthers, their connectives terminating in short spurs, the pistillate terminal or in the axils of upper leaves, composed of spirally arranged ovate rounded scales much shorter than their acutely 2-lobed bracts, with midribs produced into elongated slender tips. Fruit an ovate-oblong acute pendulous cone maturing in one season, with rounded concave rigid scales persistent on the axis of the cone after the escape of the seeds, and becoming dark red-brown, much shorter than the 2-lobed bracts with midribs ending in rigid woody linear awns, those at the base of the cone without scales and becoming linear-lanceolate by the gradual suppression of their lobes. Seeds nearly triangular, full, rounded and dark-colored on the upper side and pale on the lower side, shorter than their oblong wings infolding the upper side of the seeds in a dark corering; outer seed-coat thick and crustaceous, the inner thin and membranaceous; cotyledons 6-12, much shorter than the inferior radicle.

Pseudotsuga is confined to western North America and Japan. Three species are recognized.

Pseudotsuga, a barbarous combination of a Greek with a Japanese word, indicates the relation of these trees with the Hemlocks.

\section{CONSPECTUS OF THE NORTH AMERICAN SPECIES.}

Leaves usually rounded and obtuse at the apex, dark yellow-green or rarely blue-green; cones small, their bracts much exserted.

1. P. mucronata (B, E, F, G, H). Leares acuminate at the apex, bluish gray; cones large, their bracts slightly exserted.

2. P. macrocarpa $(G)$.

\section{Pseudotsuga mucronata, Sudw. Douglas Spruce. Red Fir.}

Leaves straight or rarely slightly incurved, rounded and obtuse at the apex, or acnte on leading shoots, $\frac{3^{\prime}}{4}-1 \frac{1^{\prime}}{4}$ long, $\frac{1}{1 \frac{1}{6}}-\frac{1}{12}$ wide, dark yellow-green or rarely light or dark bluish green, usually persistent until their eighth year. Flowers : staminate orange-red; pistillate with slender elongated bracts deeply tinged with red. Fruit pendant on long stout stems, $2^{\prime}-4 \frac{1}{2}^{\prime}$ long, with thin slightly concave scales rounded and occasionally somewhat elongated at the apex, usually rather longer than broad, when fully grown at midsummer slightly puberulous, dark blue-green below, purplish toward the apex, bright red on the closely appressed margins, and pale green bracts becoming slightly reflexed above the middle, $\frac{1}{5}^{\prime}-\frac{1}{4}^{\prime}$ wide, often extending $\frac{1}{2}$ ' beyond the scales; seeds light reddish brown and lustrous above, pale and marked below with large irregular white spots, $\frac{1}{4}^{\prime}$ long, nearly $\frac{1}{8}^{\prime}$ wide, almost as long as their dark brown wings broadest just below the middle, oblique above and rounded at the apex.

A tree, often $200^{\circ}$ high, with a trunk $3^{\circ}-4^{\circ}$ in diameter, frequently taller, with a trunk $10^{\circ}-12^{\circ}$ in diameter, but in the dry interior of the continent rarely more than $80^{\circ}-100^{\circ}$ high, with a trunk hardly exceeding $2^{\circ}-3^{\circ}$ in diameter, slender crowded branches densely clothed with long pendulous lateral branches, forming while the tree is young an open pyramid, soon deciduous from trees crowded in the forest, often leaving the trunk naked for two thirds of its length and surmounted by a comparatively small narrow head sometimes becoming flap-topped by the lengthening of the npper branches, and slender branchlets pubescent for three or four years, pale orange color and lustrous during their first season, becoming bright reddish brown and ultimately dark gray-brown. Winter-buds ovate, acute, the terminal bud often $\frac{1}{4}$ long 
and nearly twice as large as the lateral buds. Bark on young trees smooth, thin, rather lustrous, dark gray-brown, usually becoming on old trunks $10^{\prime}-12^{\prime}$ thick, and divided into oblong plates broken into great broad rounded and irregularly connected ridges separating on the surface into small thick closely appressed dark red-brown scales. Wood light red or yellow, with nearly white sapwood; very variable in density, quality, and in the thickness of the sapwood; largely manufactured into lumber in British Columbia, western Washington and Oregon, and used for all kinds of construction, fuel, railway-ties, and piles. The bark is sometines used in tanning leather.

Distribution. From about latitude $55^{\circ}$ north in the Rocky Mountains and from the head of the Skeena River in the coast range, south ward through all the Rocky Mountain system to the mountains of western Texas, southern New Mexico and Arizona, and of northern Mexico, and from the eastern base of the Rocky Mountains to the Pacific coast, but absent from the arid mountains in the great basin between the Wabsatch and the Sierra Nevada ranges; most abundant and of its largest size near the sea-level in the coast region of southern British Columbia and of Washington

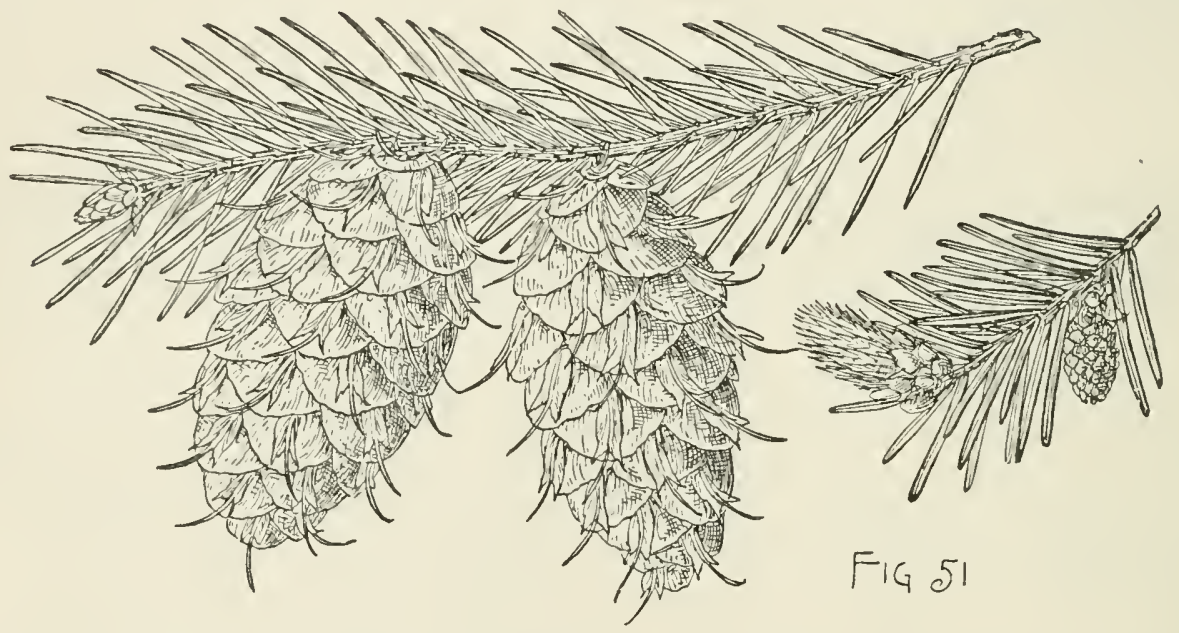

and Oregon, and on the western foothills of the Cascade Mountains; ascending on the California Sierras to elevations of $5500^{\circ}$ above the sea.

Often planted for timber and ornament in temperate Europe, and for ornament in the eastern and northern states, where only the form from the interior of the continent flourishes.

\section{Pseudotsuga macrocarpa, Mayr. Hemlock.}

Leaves acnte or acuminate, terminating in slender rigid callous tips, apparently 2-ranked by the conspicuous twist at their base, incurved above the middle, $\frac{8^{\prime}}{4}-1 \frac{1^{\prime}}{4}$ long, about $\frac{1}{16}$ wide, dark bluish gray. Flowers: staminate pale yellow, inclosed for half their length in conspicuous involucres of the lnstrous bud-scales; pistillate with pale green bracts tinged with red. Fruit produced on the upper branches and occasionally on those down to the middle of the tree, short-stalked, $4^{\prime}-6 \frac{1^{\prime}}{2}$ long, with scales near the middle of the cone $1 \frac{1}{2}^{\prime}-2^{\prime}$ across, stiff, thick, concave, rather broader than long, rounded above, abruptly wedge-shaped at the base, puberulous on the outer surface, often nearly as long as their comparatively short and narrow bracts with broad midribs produced into short flattened flexible tips; seeds full and rounded 
on both sides, rugose, dark chestnut-brown or nearly black and lustrous abore, pale

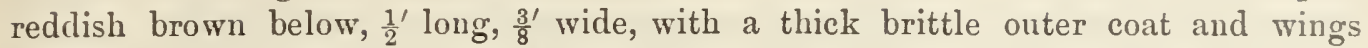
broadest near the middle, about $\frac{1}{2}^{\prime}$ long, nearly $\frac{1^{\prime}}{4}$ wide, and rounded at the apex.

A tree, usually $40^{\circ}-50^{\circ}$ and rarely $80^{\circ}$ high, with a trunk $3^{\circ}-4^{\circ}$ in diameter, remote elongated branches pendulous below, furnished with short stout pendant

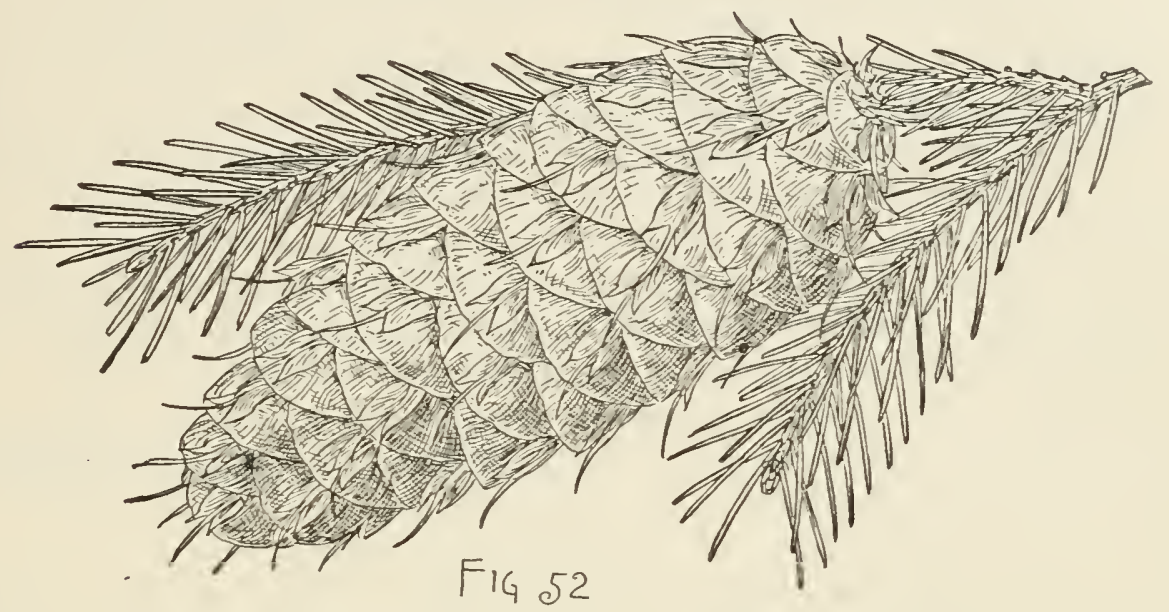

or often erect laterals forming an open broad-based symmetrical pyramidal head, slender branchlets dark reddish brown and pubescent during their first year, becoming glabrous and dark or light orange-brown and ultimately gray-brown. Winter-buds ovate, acute, usually not more than $\frac{1}{8}^{\prime}$ long, often nearly as broad as long. Bark $3^{\prime}-6^{\prime}$ thick, dark reddish brown, deeply divided into broad rounded ridges covered with thick closely appressed scales. Wood heavy, hard, strong, close-grained, not durable; occasionally manufactured into lumber; largely used for fuel.

Distribution. Steep rocky mountain slopes in sonthern California at elevations of $3000^{\circ}-5000^{\circ}$ above the sea, often forming open groves of considerable extent, from the Santa Inez Mountains in Santa Barbara County to the Cuyamaca Monntains.

\section{ABIES, Link. Fir.}

Tall pyramidal trees, with bark containing numerous resin-vesicles, smooth, pale, and thin on young trees, often thick and deeply furrowed in old age, pale and usually brittle wood, slender horizontal wide-spreading branches in regular remote 4 or 5-branched whorls, clothed with twice or thrice forked lateral branches forming flattopped masses of foliage gradually narrowed from the base to the apex of the branch, the ultimate divisions stout, glabrous, or pubescent, and small globose or oblong winter branch-buds usyally thickly covered with resin, or in one species large and acute, with thin loosely imbricated scales. Leaves linear, sessile, on young plants and on lower sterile branches flattened and mostly grooved on the npper side, or in one species 4-sided, rounded and usually emarginate at the apex, appearing 2-ranked by a twist near their base or occasionally spreading from all sides of the branch, only rarely stomatiferous above, on upper fertile branches and leading shoots usually crowded, more or less erect, often incurved or falcate, thick, convex on the upper side, or quadrangular in some species and then obtuse, and acute at the apex and 
frequently stomatiferous above; persistent usually for eight or ten years, in falling leaving small eirenlar scars. Flowers axillary, from luds formed the previous season on branchlets of the year, surrounded at the base by eonspienons involueres of enlarged bud-seales, the staminate very abundant on the lower side of branelies above the middle of the tree, oval or oblongreylindrieal, with yellow or searlet anthers surmomnted by short knob-like projections, the pistillate usually on the upper side only of the topmost branches, or in some species seattered also over the upper half of the tree, erect, globose, ovoid or oblong, their seales imbrieated in many series, obovate, romnded above, enneate below, mueh shorter than their aente or dilated mucronate bracts. Fruit an ercet ovoid or oblong cylindrical cone, its seales closely imbricated, thin, incurved at the broad apex and generally narrowed below into long stipes, decreasing in size and sterile toward the end of the cone, falling at maturity with their bracts and seeds from the stont tapering axis of the cone long-persistent on the branch. Seeds furnished with large conspicuous resin-vesicles, ovoid or oblong, acnte at the base, covered on the upper side and infolded below on the lower side by the base of their thin wings abruptly enlarged at the oblique apex; seed-coat thin, of 2 layers, the outer thick, coriaceous, the imner membranaceous; cotyledons 4-10, mucl shorter than the inferior radiele.

Abies is widely distributed in the New World from Labrador and the valley of the Athabasca River to the mountains of North Carolina, and from Alaska throngh the Pacific and Rocky Mountain regions to the highlands of Guatemala, and in the Old World from Siberia and the mountains of eentral Europe to southern Japan, central China, the Himalayas, Asia Minor, and the highlands of northern Afriea. Twentyfive species are now recognized. Several exotie species are cultivated in the northern and eastern states; of these the best known and most successful as ornamental trees are Abies Nordmanniana, Spach, of the Caucasus, Abies Cilicica, Carr., of , Asia Minor, Abies Cephalonica, Loud., a native of Cephalonia, Abies Veitchi, Lindl., and Abies homolepis, S. \& Z., of Japan, Abies Picea, Lindl., of the mountains of soutlern and central Europe, and Abies Pinsapo, Boiss., of the Spanish Sierra Nevada.

Abies is the elassical name of the Fir-tree.

\section{CONSPECTUS OF THE NORTH AMERICAN SPECIES.}

Leaves flat and grooved above, with stomata on the lower and sometimes on the upper surface, rounded and often notched, or on fertile branches frequently acute at the apex.

Leaves dark green and lustrous above, pale below.

Cones purple.

Bracts of the cone-scales much longer than their scales, reflexed.

1. A. Fraseri (A).

Bracts of the cone-scales shorter or rarely slightly longer than their scales.

2. A. balsamea (A).

Bracts of the cone-scales gradually narrowed into long slender tips half the length of their scales; leaves crowded, silvery white below. 3. A. amabilis (B, G). Cones green.

Bracts of the cone-scales laciniate and short-pointed at the apex; leaves conspicuously notched on fertile branches.

4. A. grandis $(B, G)$.

Leaves pale blue-green.

Cones purple.

Bracts of the cone-scales rounded, emarginate and long-pointed at the apex; leaves obtusely pointed and occasionally notched, and on fertile branclies thickened and acute at the apex.

5. A. lasiocarpa (B, F, G). 
Cones purple, green, or yellow.

Bracts of the cone-scales short-pointed; leaves more or less erect by the twist at their base, on fertile branches often falcate, thickened and keeled above.

6. A. concolor ( $\mathrm{F}, \mathrm{G}, \mathrm{H})$.

Bracts of the cone-scales produced into elongated rigid, flat tips many times longer than the obtusely pointed scales; leaves acuminate, dark yellow-green above, white below, similar on sterile and fertile branches; winter-buds large, with thin loosely imbricated scales.

7. A. venusta (G). Leaves often 4-sided, blue-green, usually glaucous, with stomata on all surfaces, bluntly pointed or acute, incurved and crowded on fertile branches; cones purple.

Leaves of sterile branches flattened and distinctly grooved above.

Bracts of the cone-scales rounded and fimbriate above, long-pointed, incurved, light green, much longer than and covering their scales. $\quad 8$. A. nobilis (G).

Leaves of sterile branches 4 -sided.

Bracts of the cone-scales acute or acuminate or rounded above, with slender tips shorter or longer than their scales.

9. A. magnifica (G).

\section{Leaves flat.}

* Leaves dark green.

$\rightarrow$ Cones purple.

\section{Abies Fraseri, Poir, Balsam Fir. She Balsam.}

Leaves obtusely short-pointed or occasionally slightly emarginate at the apex, dark green and lustrous on the upper surface, marked on the lower surface by

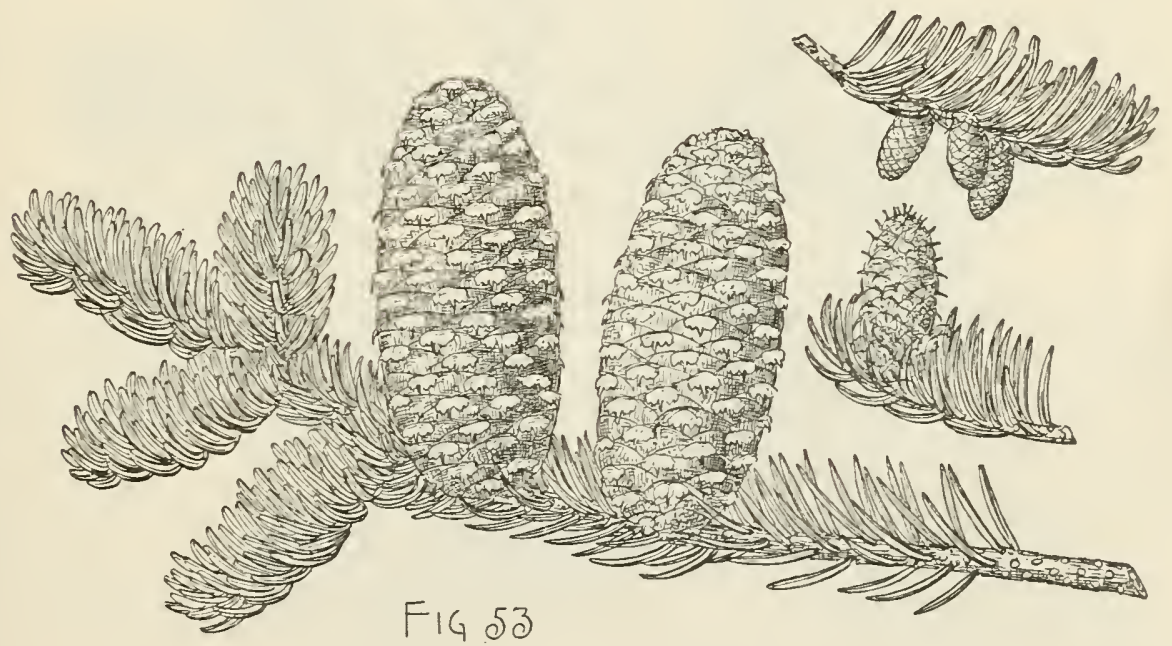

wide bands of $8-12$ rows of stomata, $\frac{1}{2}^{\prime}$ to nearly $1^{\prime}$ long, about $\frac{1^{\prime}}{1^{\prime}}$ wide. Flowers : staminate yellow tinged with red; pistillate with scales rounded above, much broader than long and shorter than their oblong pale yellow-green bracts rounded at the broad apex terminating in a slender elongated tip. Fruit oblong-ovate or nearly oval, rounded at the somewhat narrowed apex, dark purple, puberulous, about $2 \frac{1}{2}^{\prime}$ long, with scales twice as wide as long, at maturity nearly half covered by their pale yellow-green reflexed bracts; seeds $\frac{1^{\prime}}{8}$ long, with dark lustrous wings much expanded and very oblique at the apex.

A tree, usually $30^{\circ}-40^{\circ}$ and rarely $70^{\circ}$ high, with a trunk occasionally $21^{\circ}$ in diameter, and rather rigid branches forming an open symmetrical pyramid and often dis- 
appearing early from the lower part of the trunk, and stout branchlets pubescent for threc or four years, pale yellow-brown dhring their first season, becoming dark reddish brown often tinged with purple, and ohtuse orange-brown winter-lunds. Bark of the trmuk $\frac{f^{\prime}-1}{2}$ thick, and covered with thin closely appressed bright cinnamon-red scales, generally beconing gray on old trees. Wood light, soft, not strong, coarse-grained, pale brown, with nearly white sapwood; occasionally manufactured into hmber.

Distribution. Appalachian Mountains from southwestern Virginia to western North Carolina and eastern 'Tennessee, often forming forests of considerable extent at elerations between $4000^{\circ}$ and $6000^{\circ}$ above the sea-level.

Occasionally planted in the parks and gardens of the northern states and of Europe, but short-lived in cultivation and of little value as an ornamental tree.

\section{Abies balsamea, Mill. Balsam Fir.}

Leaves dark green and lustrous on the upper surface, silvery white on the lower surface, with bands of 4-8 rows of stomata, $\frac{1}{2}^{\prime}$ long on cone-bearing branches to $1 \frac{1}{4}^{\prime}$

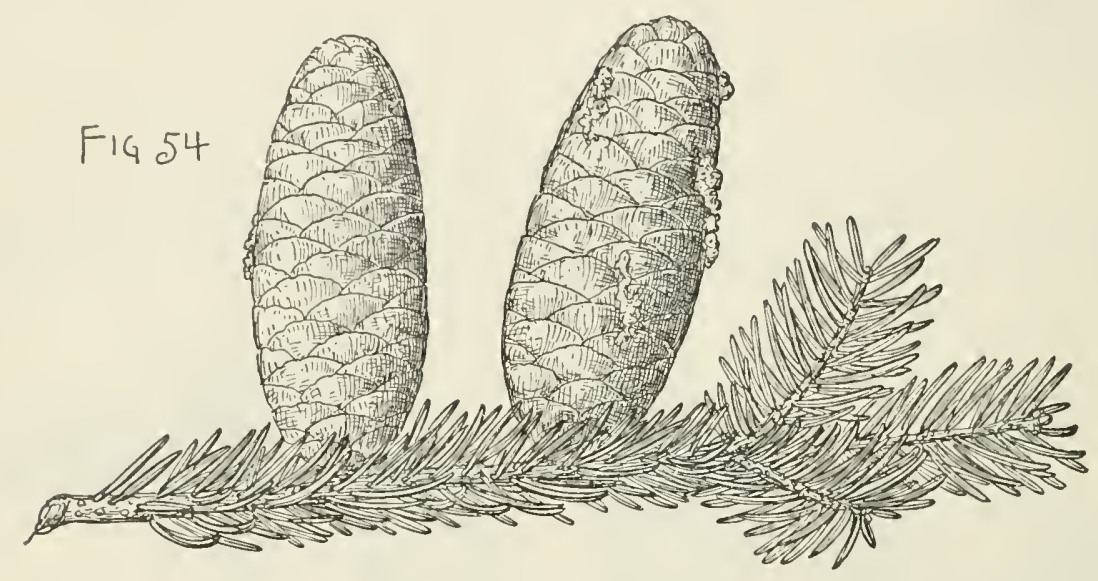

long on the sterile branches of young trees, straight, acute or acuminate, with short or elongated rigid callous tips, spreading at nearly right angles to the branch on young trees and sterile branches, on the upper branches of older trees often broadest above the middle, rounded or obtusely short-pointed at the apex, occasionally emarginate on branches at the top of the tree. Flowers: staminate yellow, more or less deeply tinged with reddish purple; pistillate with nearly orbicular purple seales much shorter than their oblong-obovate serrulate pale yellow-green bracts emarginate with a broad apex abruptly contracted into a long slender recurved tip. Fruit oblong-cylindrical, gradually narrowed to the rounded apex, puberulous, dark rich purple, $2^{\prime}-4^{\prime}$ long, with scales usually longer than broad, generally almost twice as long but rarely not as long as their bracts; seeds about $\frac{1^{\prime}}{4}$ long and rather shorter than their light brown wings.

A tree, $50^{\circ}-60^{\circ}$ high, with a trunk usually $12^{\prime}-18^{\prime}$, or rarely $30^{\prime}$ in diameter, spreading branches forming a handsome symmetrical open broad-based pyramid, the lower branches soon dying from trees crowded in the forest, and slender branchlets pale yellow-green and coated with fine pubescence at first, becoming light gray tinged with red, and often when four or five years old with purple. Winter-buds nearly globose, $\frac{1}{8}^{\prime}-\frac{1}{4}^{\prime}$ in diameter, with lustrous dark orange-green scales. Bark on old trees often $\frac{1}{2}^{\prime}$ thick, rich brown, much broken on the surface into small plates covered 
with scales. Wood light, soft, not strong, coarse-grained, perishable, pale brown streaked with yellow, with thick lighter colored sapwood; occasionally made into lumber principally used for packing-cases. From the bark of this tree oil of fir used in the arts and in medicine is obtained.

Distribution. From the interior of the Labrador peninsula northwestward to the shores of the Lesser Slave Lake, southward through Newfoundland, the maritime provinces of Canada, Quebec and Ontario, northern New England, northern New York, northern Michigan and Minnesota to northern and central Iowa; and along the Appalachian Mountains from western Massachusetts and the Catskills of New York to the high mountains of southwestern Virginia; common and often forming a considerable part of the forest on low swampy ground; on well-drained hillsides sometimes singly in forests of spruce or forming small almost impenetrable thickets; near the timber-line on the mountains of New England and New York reduced to a low almost prostrate shrub.

Often planted in the northern states in the neighborhood of farmhouses, but usually short-lived and of little value as an ornamental tree in cultivation; formerly but now rarely cultivated in European plantations.

\section{Abies amabilis, Forbes. White Fir.}

Leaves deeply grooved, very dark green and lustrous on the upper surface, silvery white on the lower, with broad bands of 6 or 8 rows of stomata between the prominent midribs and recurved margins, on sterile branches obtuse and rounded, or notched or occasionally acute at the apex, $\frac{8^{\prime}}{4}-1 \frac{1^{\prime}}{4}$ long, $\frac{1}{16}-\frac{1}{12}$ wide, often broadest above the middle, erect by a twist at their base, very crowded, those on the upper side of the branch much shorter than those on the lower and usually parallel with

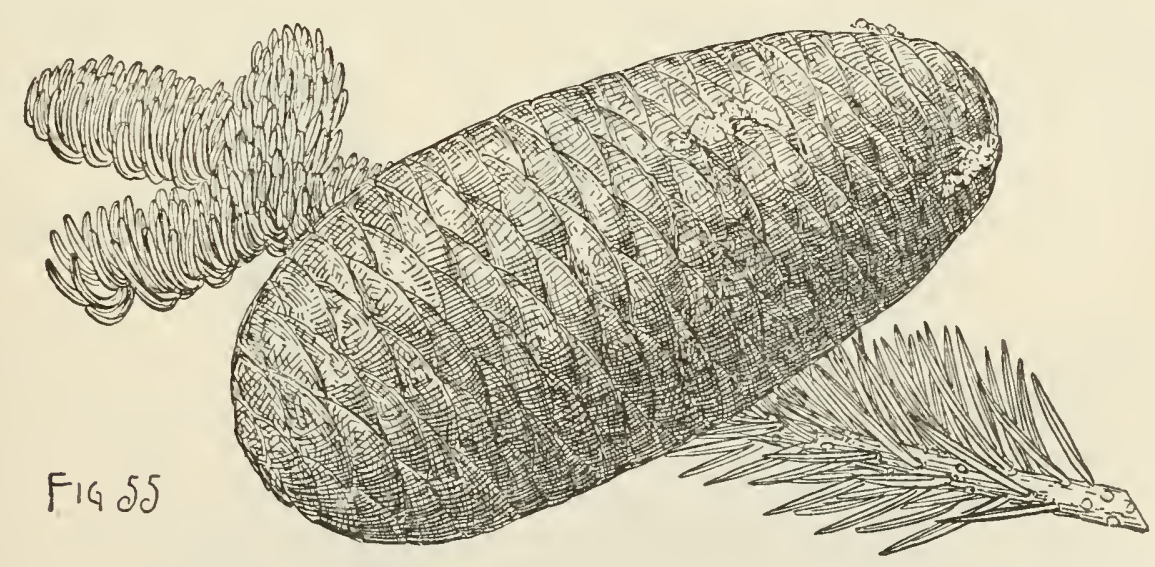

and closely appressed against it, on fertile branches acute or acuminate, with callous tips, occasionally stomatiferous on the upper surface near the apex, $\frac{1}{2}^{\prime}-\frac{3^{\prime}}{4} \operatorname{long}$, on vigorous leading shoots acute, with long rigid points, closely appressed or recurved near the middle, about ${ }_{4}^{3 \prime}$ long and nearly $\frac{1^{\prime}}{8}$ wide. Flowers: staminate red; pistil- late with broad rounded scales and rhombic dark purple lustrous bracts erose above the middle and gradually contracted into broad points. Fruit oblong, slightly narrowed to the rounded and often retuse apex, deep rich purple, puberulous, $3 \frac{1}{2}^{\prime}-6^{\prime}$ long, with scales $\mathbf{1}^{\prime}-1 \frac{1}{8}^{\prime}$ wide, nearly as long as broad, gradually narrowed from the rounded apex and rather more than twice as long as their reddish rhombic or oblong- 
obovate bracts terminating in long slender tips; seeds light yellow-brown, $\frac{1}{2}{ }^{\prime}$ long, with oblique pale brown lustrons wings abont $8^{\prime}$ long.

A tree, of ten $250^{\circ}$ tall, or at high altitudes and in the north usually not more than $70^{\circ}-80^{\circ}$ tall, with a trunk $4^{\circ}-6^{\circ}$ in diameter, in thick forests of ten naked for $150^{\circ}$, but in open situations densely elothed to the ground with comparatively short branches sweeping down in graecful curves, and stont branehlets clothed for four or five years with soft fine pubeseence, light orange-brown in their first season, becoming dark purple and nltimately reddish brown. Winter-buds nearly globose, $\frac{1}{8}-f^{\prime}$ thick, with closely imbricated lustrous purple seales. Bark on trees up to 150 years old thin, smooth, pale or silvery white, becoming near the ground on old trees $1_{2}^{1}$ $2 \frac{1}{2}$ thiek, and irregularly divided into comparatively small plates covered with small closely appressed reddish brown or reddish gray scales. Wood light, hard, not strong, close-grained, pale brown, with nearly white sapwood; in Washington oceasionally manufactured into lumber used in the interior finish of buildings.

Distribution. High mountain slopes and benches from British Columbia southward along the Cascadc Mountains to northern Oregon, and on the coast ranges of Oregon and Washington; attaining its largest size on the Olympic Mountains, where it is the most common Fir-tree.

Oecasionally eultivated as an ornamental tree in western Europe, but without dcveloping there the beauty which distinguishes this species in its native forests.

++ Cones green.

\section{Abies grandis, Lindl. White Fir.}

Leaves thin and flexible, deeply grooved, very dark green and lustrous on the upper surface, silvery white on the lower surface, with two broad bands of 7-10

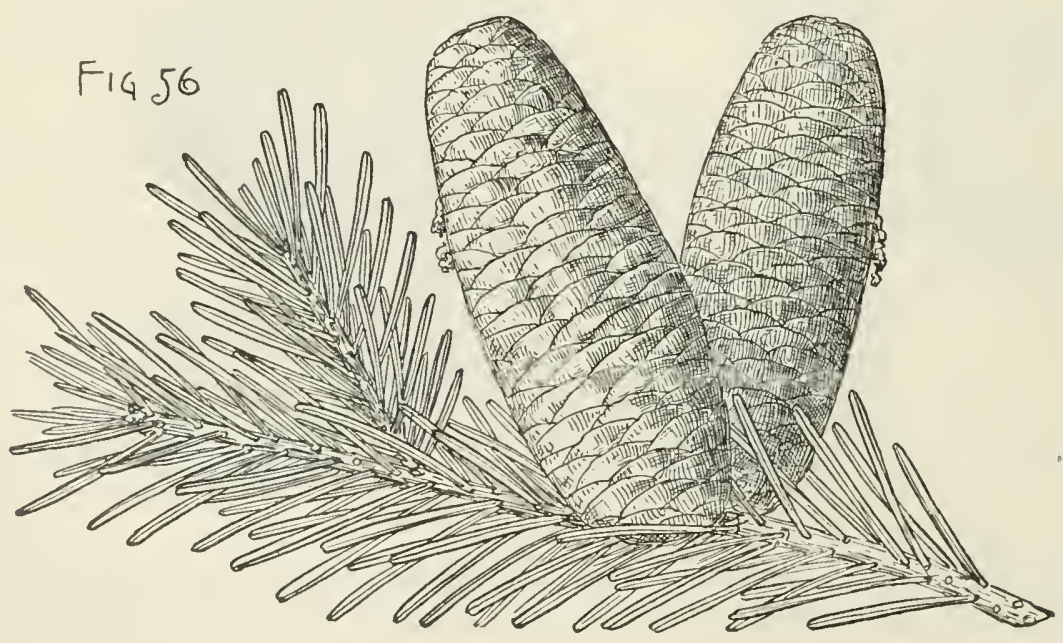

rows of stomata, on sterile branches remote, rounded and conspicuonsly emarginate at the apex, $1 \frac{1}{2}^{\prime}-2 \frac{1}{4}^{\prime}$ long, usually about $\frac{1^{\prime}}{8}$ wide, spreading in two ranks nearly at ${ }^{\circ}$ right angles to the branch, on cone-bearing branehes more crowded, usually $1^{\prime}-1 \frac{1^{\prime}}{2}$ long, less spreading or nearly erect, blunt-pointed or of ten notched at the apex, on vigorous young trees $\frac{1^{\prime}}{2}-\frac{8^{\prime}}{4}$ long, acute or acuminate. Flowers: staminate pale yellow sometimes tinged with purple; pistillate light yellow-green, with semiorbicular 
scales and short oblong bracts emarginate and denticulate at the broad obcordate apex furnished with a short strongly reflexed tip. Fruit cylindrical, slightly narrowed to the rounded and sometimes retuse apex, pubernlous, bright green, $2^{\prime}-4^{\prime}$ long, with scales usually about two thirds as long as wide, gradually or abruptly narrowed from their broad apex and three or four times as long as their short pale green bracts; seeds $\frac{3^{\prime}}{8}$ in length, light brown, with pale lustrous wings $\frac{1^{\prime}}{2}-\frac{5}{8}$ long and nearly as broad at their abruptly widened rounded apex.

A tree, in the neighborhood of the coast $250^{\circ}-300^{\circ}$ high, with a slightly tapering trunk often $4^{\circ}$ in diameter, long somewhat pendulous branches sweeping out in gracefnl curves, and comparatively slender pale yellow-green pubernlous branchlets becoming light reddish brown or orange-brown and glabrous in their second season; on the mountains of the interior rarely more than $100^{\circ}$ tall, with a trunk usually about $2^{\circ}$ in diameter, often smaller and much stunted at high elevations. Winterbuds globose, $\frac{1^{\prime}}{8}-\frac{1^{\prime}}{4}$ thick. Bark becoming sometimes $2^{\prime}$ thick at the base of old trees and gray-brown or reddish brown and divided by shallow fissures into low flat ridges broken into oblong plates ronghened by thick closely appressed scales. Wood light, soft, coarse-grained, not strong nor durable, light brown, with thin lighter colored sapwood; occasionally manufactured into lumber in western Washington and Oregon and used for the interior finish of buildings, packing-cases, and wooden-ware.

Distribution. Vanconver Island southward in the neighborhood of the coast to Mendocino County, California, and along the monntains of northern Washington and Idaho to the western slopes of the continental divide in northern Montana, and to the mountains of eastern Oregon; near the coast scattered on moist gronnd through forests of conifers; common in Washington and northern Oregon from the sea up to elevations of $4000^{\circ}$; in the interior on moist slopes in the neighborhood of streams from $2500^{\circ}$ up to $7000^{\circ}$ above the sea.

Occasionally planted in the parks and gardens of temperate Europe, where it grows rapidly and promises to attain a large size; rarely planted in the United States.

\section{**Leaves pale blue-green.}

Cones purple.

\section{Abies lasiocarpa, Nutt. Balsam Fir.}

Leaves marked on the npper surface but generally only above the middle with 4 or 5 rows of stomata on each side of the conspicuous midribs and on the lower surface by 2 broad bands each of 7 or 8 rows, crowded, nearly erect by the twist at their base, on lower branches $1^{\prime}-1 \frac{3}{4}^{\prime}$ long, about $\frac{1}{12}^{\prime}$ wide, and rounded and occasionally emarginate at the apex, on npper branches somewhat thickened, usually acute, generally not more than $\frac{1^{\prime}}{2}$ long, on leading shoots flattened, closely appressed, with long slender rigid points. Flowers : staminate dark indigo-blue, turning violet when nearly ready to open; pistillate with dark violet-purple obovate scales much shorter than their strongly reflexed bracts contracted into slender tips. Fruit oblong-cylindrical, rounded, truncate or depressed at the narrowed apex, dark purple, puberulous, $2 \frac{1}{2}^{\prime}-4^{\prime}$ long, with scales gradually narrowed from the broad rounded or nearly truncate apex to the base, usually longer than broad, about three times as long as their oblong-obovate red-brown bracts laciniately cut on the margins, rounded, emarginate and abruptly contracted at the apex into long slender tips; seeds $\frac{1}{4}$ long, with dark lustrous wings covering nearly the entire surface of the scales. 
A tree, usually $80^{\circ}-100^{\circ}$, occasionally $175^{\circ}$ high, with a trunk $2^{\circ}-5^{\circ}$ in diameter, short crowded tough branches, usually slightly pendulous near the base of the

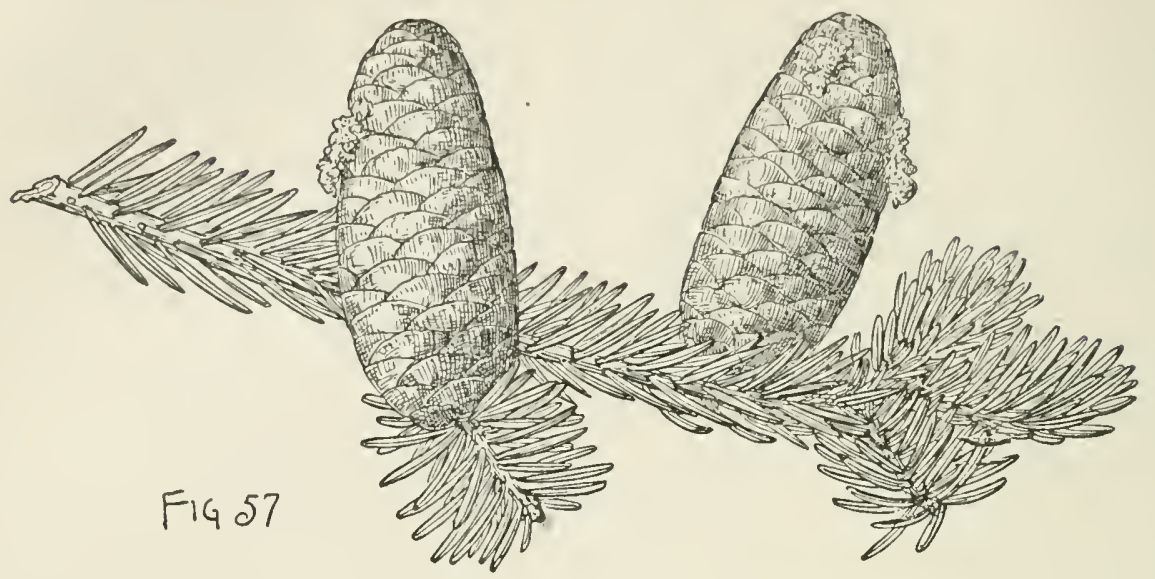

tree, generally clothing the trunks of the oldest trees nearly to their base and forming dense spire-like slender heads, and comparatively stout branchlets coated for three or four years with fine rufous pubescence, or rarely glabrous before the end of their first season, pale orange-brown, ultimately gray or silvery white. Winter-buds subglobose, $\frac{1}{8}^{\prime}-\frac{1}{4}^{\prime}$ thick, covered with light orange-brown scales. Bark becoming on old trees $\frac{3}{4}-1 \frac{1}{2}^{\prime}$ thick, divided by shallow fissures and roughened by thick closely appressed cinnamon-red scales. Wood light, soft, not strong, pale brown or nearly white, with light-colored sapwood; little used except for fuel.

Distribution. High mountain slopes and summits from about latitude $61^{\circ}$ in Alaska, southward along the coast ranges to the Olympic Mountains of Washington, over all the high mountain ranges of British Columbia and Alberta, and southward along the Cascade Mountains of Washington and Oregon, over the mountain ranges of eastern Washington and Oregon, and of Idaho, Wyoming, Colorado, and Utah to the San Francisco peaks of northern Arizona.

Occasionally planted as an ornamental tree in the northern United States and in northern Europe.

$\rightarrow$ Cones yellow, green, or purple.

\section{Abies concolor, Lindl. \& Gord. White Fir.}

Leaves crowded, spreading in 2 ranks and more or less erect from the strong twist at their base, pale blue or glancous, becoming dull green at the end of two or three years, with 2 broad bands of stomata on the lower, and more or less stomatiferous on the upper surface, on lower branches flat, straight, rounded, acute or acuminate at the apex, $2^{\prime}-3^{\prime}$ long, about $\frac{1^{\prime}}{1^{\prime}}$ wide, on fertile branches and on old trees frequently thick, keeled above, usually falcate, acute or rarely notched at the apex, $\frac{3^{\prime}}{4}-1 \frac{1}{2}^{\prime} l o n g$, often $\frac{1}{8}^{\prime}$ wide. Flowers: staminate dark red or rose color; pistillate with broad rounded scales, and oblong strongly reflexed obcordate bracts laciniate above the middle and abruptly contracted at the apex into short points. Fruit oblong, slightly narrowed from near the middle to the ends, rounded or obtuse at the apex, $3^{\prime}-5^{\prime}$ long, puberulons, grayish green, dark purple or bright canaryyellow, with scales much broader than long, gradually and regularly narrowed from 
the rounded apex, rather more than twice as long as their emarginate or nearly truncate bracts broad at the apex and terminating in short slender tips; seeds $\frac{1}{3}{ }^{\prime}-\frac{1}{2}$ ' long, acute at the base, dark dull brown, with lustrous rose-colored wings widest near the middle and nearly truncate at the apex.

A tree, on the California sierras $200^{\circ}-250^{\circ}$ high, with a trunk often $6^{\circ}$ in diameter or in the interior of the continent rarely more than $125^{\circ}$ tall, with a trunk seldom exceeding $3^{\circ}$ in diameter, a narrow spire-like crown of short stout branches clothed with long lateral branches pointing forward and forming great frond-like masses of foliage, and glabrous lustrous comparatively stout branchlets dark orange color during their first season, becoming light grayish green or pale reddish brown, and ultimately gray or grayish brown. Winter-buds globose, $\frac{1^{\prime}}{8}-\frac{1^{\prime}}{4}$ thick. Bark becoming on old trunks sometimes $5^{\prime}-6^{\prime}$ thick near the ground and deeply divided into broad rounded ridges broken on the surface into irregularly shaped plate-like scales.

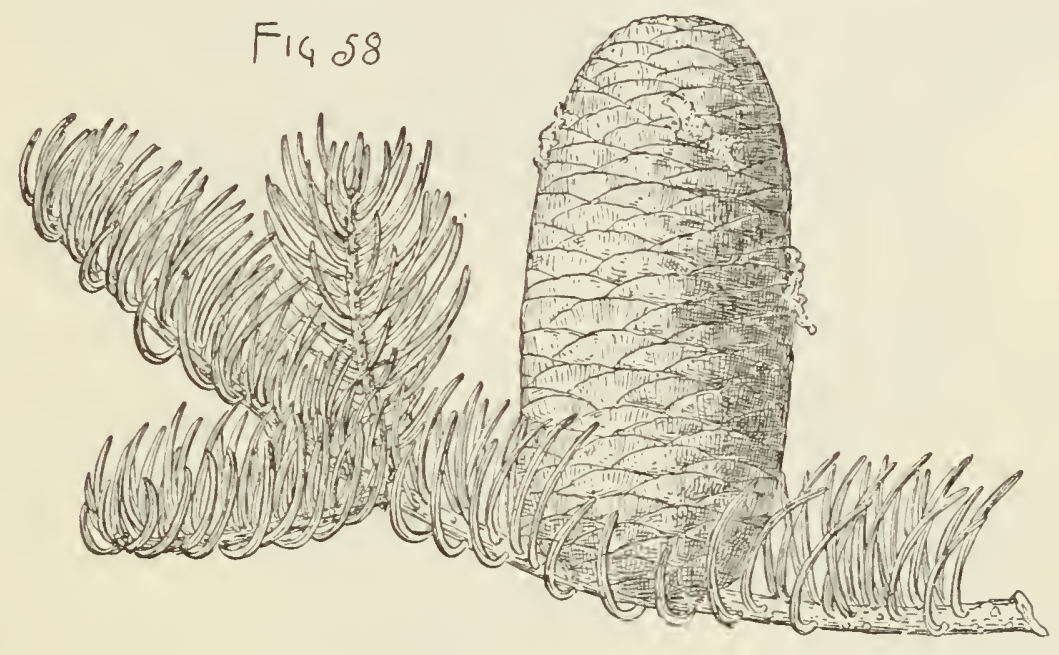

Wood very light, soft, coarse-grained and not strong nor durable, pale brown or sometimes nearly white; occasionally manufactured into lumber and in northern California used for packing-cases and butter-tubs.

Distribution. Rocky Mountains of southern Colorado, westward to the mountain ranges of California, extending northward into northern Oregon, and sonthward over the mountains of New Mexico and Arizona into northern Mexico; the only Firtree in the arid regions of the Great Basin and of southern New Mexico and Arizona.

Often planted as an ornamental tree in Europe, and in the eastern states where it grows more vigorously than other Fir-trees.

\section{**** Leaves yellow-green.}

Bracts of the cone-scales with long rigid flat tips; zinter-buds elongated, with loosely imbricated scales.

\section{Abies venusta, K. Koch. Silver Fir.}

Leaves thin, flat, rigid, linear or linear-lanceolate, gradually or abruptly narrowed toward the base, oftell falcate especially on fertile branches, acuminate, with long slender callous tips, dark yellow-green, lustrous and slightly rounded on the upper 
surface, marked below the middle with obscure grooves, silrery white or on old leaves pale on the lower surface, with bands of 8-10 rows of stomata between the broad midrib and the thickened strongly revolute margins, 2-ranked from the conspicuons twist near their base and spreading at nearly right angles to the branch or

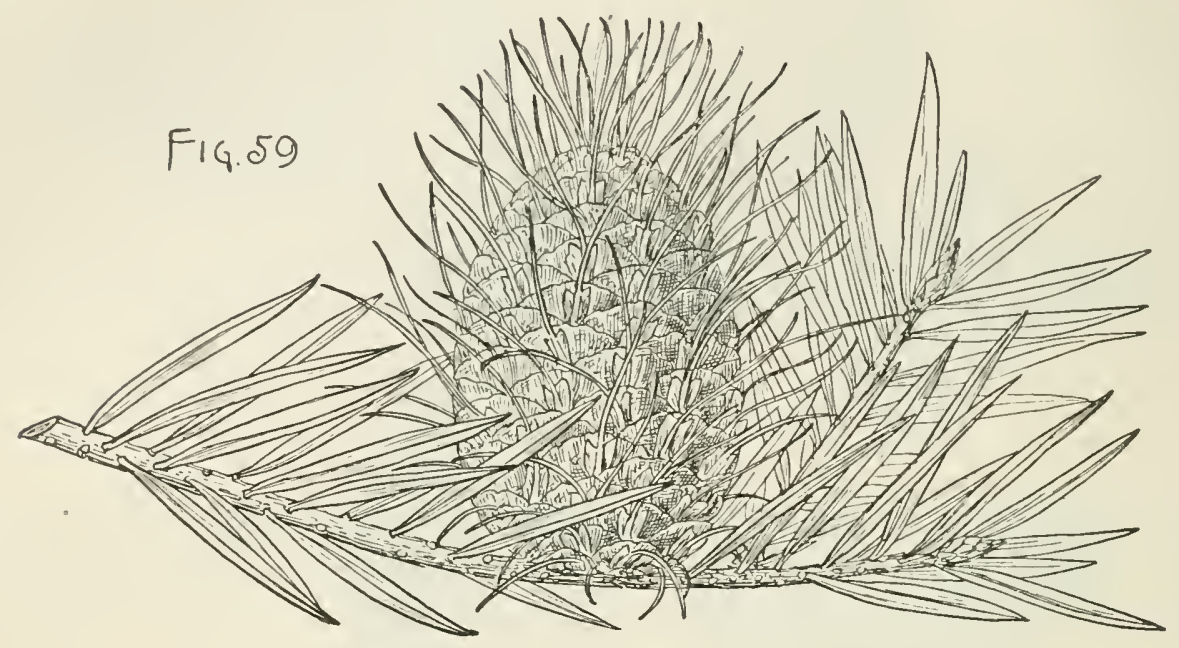

somewhat ascending on upper fertile branches, $1 \frac{1}{2}^{\prime}-2 \frac{1}{4}^{\prime}$ long, on leading shoots standing out at almost right angles, rounded on the upper surfacc, more or less incurved above the middle, $1 \frac{1}{2}^{\prime}-1 \frac{3}{4}^{\prime}$ long, about $\frac{1}{8}^{\prime}$ wide. Flowers : staminate produced in great numbers near the base of the branchlets on branches from the middle of the tree upward, pale yellow; pistillate near the ends of the branchlets of the upper branches only, with oblong scales rounded above and nearly as long as their cuneate obcordate yellow-green bracts ending in slender elongated awns. Fruit on stout peduncles sometimes $\frac{1^{\prime}}{2}$ long, oval or subcylindrical, full and rounded at the apex, glabrous, pale purple-brown, $3^{\prime}-4^{\prime}$ long, with thin seales strongly incurved above, obtusely short-pointed at the apex, obscurely denticulate on the thin margins, about one third longer than their oblong-obvate obcordate pale yellow-brown bracts terminating in flat rigid tips $1^{\prime}-1 \frac{3 \prime}{4}$ long, above the middle of the cone pointing toward its apex and often closely appressed to its sides, below the middle spreading toward its base and frequently much recurved, firmly attached to the cone-scales and deciduous with them from the thick conical sharp-pointed axis of the cone; seeds dark red-brown, about $\frac{3^{\prime}}{8}$ long, and nearly as long as their oblong-obovate pale reddish brown lustrous wings rounded at the apex.

A tree, $100^{\circ}-150^{\circ}$ high, with a trunk sometimes $3^{\circ}$ in diameter, comparatively short slender usually pendulous branches furnished with long sinuous rather remote lateral branches sparsely elothed with foliage, forming a broad-based pyramid abruptly narrowed $15^{\circ}-20^{\circ}$ from the top of the tree into a thin spire-like head, and stout glabrous light reddish brown branchlets covered at first with a glaucous bloom. Winter-buds ovate, acute, $\frac{s^{\prime}}{4}-1^{\prime}$ long, $\frac{1^{\prime}}{4}-1^{\prime}$ thick, with very thin loosely imbricated pale chestnut brown acute, boat-shaped scales. Bark becoming near the base of the tree $\frac{1^{\prime}}{2}-\frac{3^{\prime}}{4}$ thick, hight reddish brown, slightly and irregularly fissured and broken into thick closely appressed scales. Wood heavy, not hard, coarse-grained, light brown tinged with yellow, with paler sapwood.

Distribution. In a few isolated groves along the moist bottoms of cañons, nsually 
at elevations of about $3000^{\circ}$ above the sea on both slopes of the outer western ridge of the Santa Lucia Mountains in Monterey County, California.

Occasionally and successfully grown as an ornamental tree in the milder parts of Great Britain and in northern Italy.

\section{Leaves mostly 4-sided, blue-green.}

* Cones purple.

\section{Abies nobilis, Lindl. Red Fir. Larch.}

Leaves marked on the upper surface with deep sharply defined grooves, rounded and obscurely ribbed on the lower surface, stomatiferous above and below, dark or light blue-green, often very glaucous during their first season, crowded in several rows, those on the lower side of the branch two-ranked by the twisting of their bases, the others crowded, strongly incurved, with the points erect or pointing away from the end of the branch, on young plants and on the lower

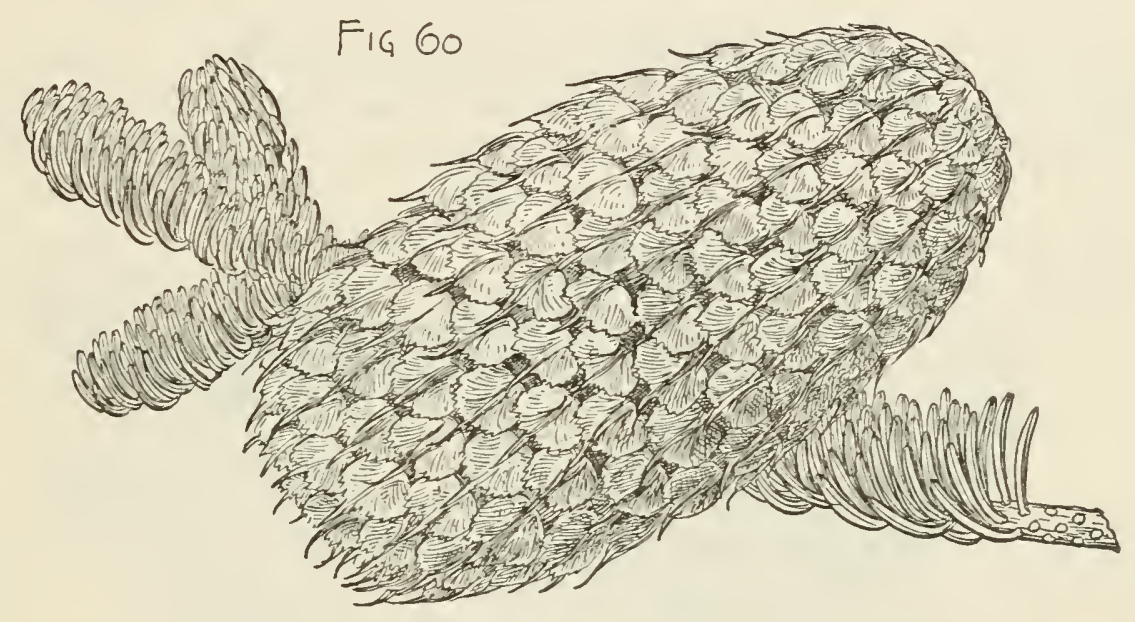

sterile branches of old trees flat, rounded, usually slightly notched at the apex, $1^{\prime}-1 \frac{1}{2}$ long, about $\frac{11}{16}$ wide, on fertile branches much thickened and almost equally 4 -sided, acuminate, with long rigid callous tips, $\frac{1^{\prime}}{2}-\frac{8^{\prime}}{4}$ long, on leading shoots flat, gradually narrowed from the base, acuminate, with long rigid points, about $1^{\prime}$ long. Flowers: staminate reddish purple; pistillate often scattered over the upper part of the tree, with broad rounded scales much shorter than their nearly orbicular bracts erose on the margins and contracted above into slender elongated strongly reflexed tips. Fruit oblong-cylindrical, slightly narrowed but full and rounded at the apex, $4^{\prime}-5^{\prime}$ long, purple or olive-brown, pubescent, with scales about one third wider than long, gradually narrowed from the rounded apex to the base, or full at the sides, rounded and denticulate above the middle and sharply contracted and wedge-shaped below, nearly or entirely covered by their strongly reflexed pale green spatulate bracts, full and rounded above, fimbriate on the margins, with broad foliaceous midribs produced into short broad flattened points; seeds $\frac{1^{\prime}}{2}$ long, pale reddish brown, about as long as their wings, gradually narrowed from below to the nearly truncate slightly rounded apex.

A tree, in old age with a comparatively broad somewhat rounded head, usually $150^{\circ}-200^{\circ}$ and occasionally $250^{\circ}$ ligh, with a trunk $6^{\circ}-8^{\circ}$ in diameter, short rigid 
branehes, short stout remote lateral branehes standing out at right angles, and slender reddish brown branchlets pubernlons for fonr or five years and grenerally pointing forward. Winter-buds ovoid-oblong, red-brown, about $\frac{1}{8}$ long. Bark beeoming on old trunks $1^{\prime}-2^{\prime}$ thick, bright red-brown, and deeply divided into broad flat ridges irregularly broken by cross fissures and covered with thick closely appressed seales. Wood light, hard, strong, rather close-grained, pale brown streaked with red, with darker eolored sapwood; occasionally manufactured into lumber and used under the name of lareh for the interior finish of buildings and for paeking-cases.

Distribution. Often forming extensive forests on the Cascade Mountains of Washington, ranging soutl ward to the valley of the Mackenzie River, Oregon; coast mountains of Washington to the Siskiyon Monntains, California; most abundant on the western slopes of the Caseade Range in Washington and northern Oregon at elevations of $2500^{\circ}$ to $5000^{\circ}$ above the sea; less abundant and of smaller size on the eastern and northern slopes of these mountains.

Often planted in western and eentral Europe as an ornamental tree, and in the eastern states hardy in sheltered positions as far north as Massachusetts.

\section{Abies magnifica, A. Murr. Red Fir.}

Leaves almost equally 4-sided, ribbed above and below, with 6-8 rows of stomata on each of the 4 sides, pale and very glaucous during their first season, later

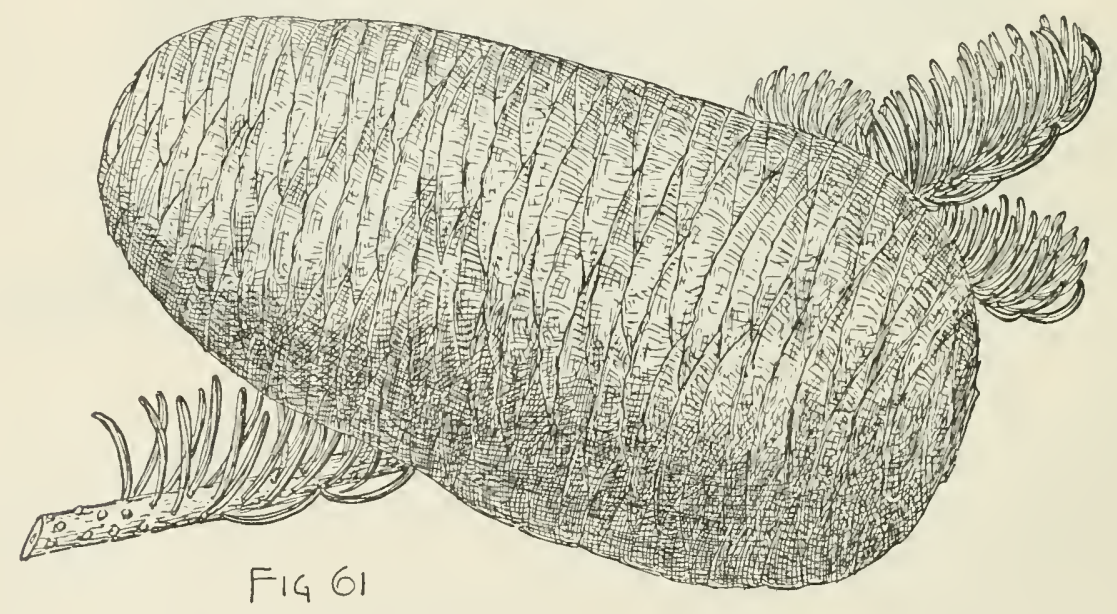

becoming blue-green, persistent usually for about ten years; on young plants and lower branches oblaneeolate, somewhat flattened, rounded, bluntly pointed, $\frac{8^{\prime}}{4}-1 \frac{1}{2}^{\prime}$ long, $\frac{1}{16}{ }^{\prime}$ wide, those on the lower side of the branch spreading in 2 nearly horizontal ranks by the twist at their base, on upper, especially on fertile branehes, much thickened, with more prominent midribs, aeute, with short callous tips, $\frac{1}{3}^{\prime}$ long on the upper side of the braneh to $1 \frac{1{ }^{\prime}}{4}$ long on the lower side, crowded, erect, strongly ineurved, eompletely hiding the upper side of the branch, on leading shoots $\frac{3^{\prime}}{4}$ long, erect and acnminate, with long rigid points pressed against the stem. Flowers: staminate dark reddish purple; pistillate with rounded seales much shorter than their oblong pale green bracts terminating in elongated slender tips more or less tinged with red. Fruit oblong-cylindrieal, slightly narrowed to the rounded truneate or retuse apex, dark purplish brown, puberulous, from $6^{\prime}-9^{\prime}$ long, with scales often $1 \frac{11}{2}$ wide and about two thirds as wide as long, gradually narrowed to the eordate base, 
somewhat longer or often two thirds as long as their oblong spatulate acute or acnminate bracts with slender tips slightly serrulate above the middle and often sharply contracted and then enlarged toward the base; seeds dark reddish brown, $\frac{8}{4}$ long, about as wide as their lustrous rose-colored obvate cuneate wings nearly truncate and often $\frac{3^{\prime}}{4}$ wide at the apex.

A tree, in old age occasionally somewhat round-topped, often $200^{\circ}$ ligh, with a trunk $8^{\circ}-10^{\circ}$ in diameter and often naked for half the height of the tree, comparatively short small branches, the upper somewhat ascending, the lower pendulous, and stout light yellow-green branchlets pointing forward, slightly puberulous during their first season, becoming light red-brown and lustrous and ultimately gray or silvery white. Winter-buds ovate, acute, $\frac{1^{\prime}}{4}-\frac{1^{\prime}}{3}$ long, their bright chestnut-brown scales with prominent midribs produced into short tips. Bark becoming $4^{\prime}-6^{\prime}$ thick near the ground, deeply divided into broad rounded ridges broken by cross fissures and covered by dark red-brown scales. Wood light, soft, not strong, comparatively durable, light red-brown, with thick somewhat darker sapwood; largely used for fuel, and in California occasionally manufactured into coarse lumber employed in the construction of cheap buildings and for packing-cases.

Distribution. Cascade Mountains of southern Oregon, southward over the mountain ranges of northern California, and along the entire length of the western slope of the Sierra Nevada; common in southern Oregon at elevations between $5000^{\circ}$ and $7000^{\circ}$ above the sea, forming sometimes nearly pure forests; very abundant on the Sierra Nevada, and the principal tree in the forest belt at elevations from $6000^{\circ}$ to $9000^{\circ}$; ascending towards the southern extremity of its range to over $10,000^{\circ}$.

Often planted as an ornamental tree in western and central Europe, and sometimes hardy in the United States as far north as eastern Massachusetts.

A distinct form is

\section{Abies magnifica, var. Shastensis, Lemm. Red Fir.}

On the mountains of southern Oregon and at high elevations on those of northern California, and on the southern Sierra Nevada, occurs this form distinguished only

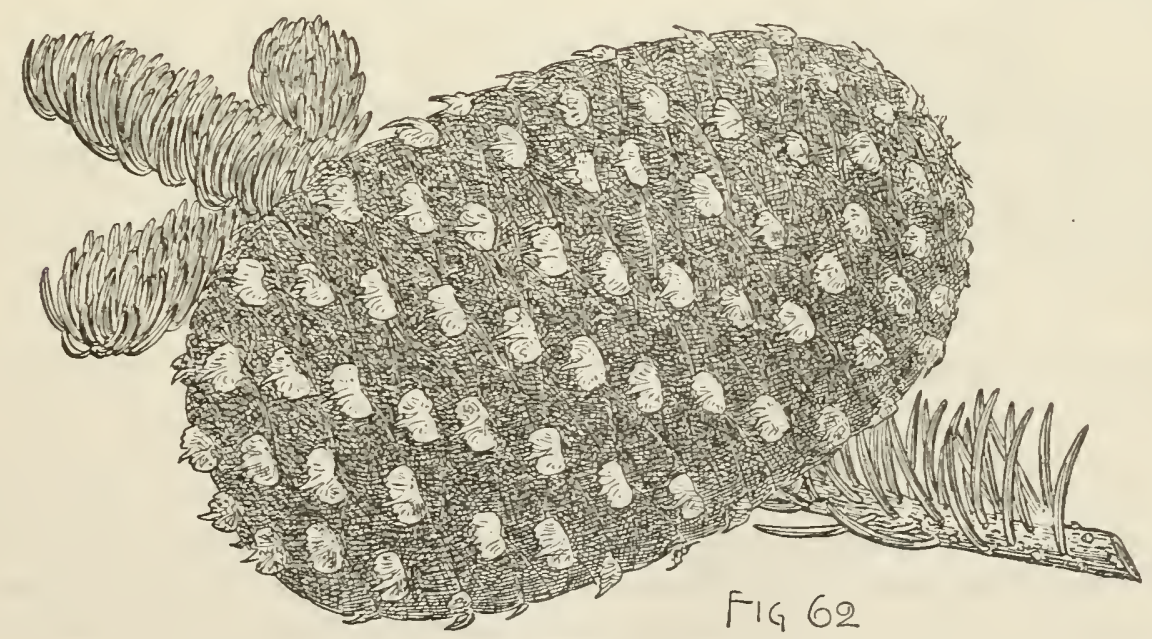

by the longer ronnded or obtusely pointed (not acute) bright yellow bracts which sometimes cover nearly half their scales. 


\section{SEQUOIA, Endl.}

Resinous aromatic trees, with tall massive lobed trunks, thick bark of 2 layers, the outer composed of fibrons scales, the inmer thin, close and firm, soft, durable, straightgrained red heartwood, thin nearly white sapwood, short stout horizontal branches, terete lateral branchlets decidnous in the antumn, and scaly or nalked buds. Leaves ovate-lanceolate or linear and spreading in 2 ranks especially on young trees and branches, or linear, acute, compressed, keeled on the back and closely appressed or spreading at the apex, the two forms appearing sometimes on the same branch or on different branches of the same tree. Flowers ninute, solitary, monœcions, appearing in early spring from buds formed the previous autumn, the staminate terminal in the axils of upper leaves, ovoid or oblong, surrounded by an involucre of numerous imbricated ovate acute and apiculate bracts, with numerous spirally disposed filaments dilated into ovate acute subpeltate connectives bearing on their inner face $2-5$ pendulous globose 2-valved anther-cells; the pistillate terminal, ovoid or oblong, composed of numerous spirally imbricated ovate scales abruptly keeled on the back, the keels produced into short or elongated points closely adnate to the short ovule-bearing scales rounded above and bearing below their upper margin in 2 rows $5-7$ ovules at first erect, becoming reversed. Fruit an ovoid or short-oblong pendulous cone maturing luring the first or second season, persistent after the escape of the seeds, its scales formed by the enlargement of the united flower and ovuliferous scales, becoming woody, bearing large decicluous resin-glands, gradually enlarged upward and widening at the apex into a narrow thickened oblong disk transversely depressed through the middle and sometimes tipped with small points. Seeds 5-7 under each scale, oblong-ovate, compressed; seed-coat membranaceous, produced into broad thin lateral wings; cotyledons 4-6, longer than the inferior radicle.

Sequoia, widely scattered with several species over the northern hemispliere during the cretaceons and tertiary epochs, is now confined to the mountains of California, where two species exist.

The name of the genus is formed from Sequoiah, the inventor of the Cherokee alphabet.

\section{CONSPECTUS OF THE NORTH AMERICAN SPECIES.}

Leaves of 2 forms, mostly spreading in 2 ranks; cones maturing in one season; buds scaly.

1. S. sempervirens (G).

Leaves ovate, acute or lanceolate, slightly spreading or compressed; cones maturing in their second season; bnds naked.

2. S. Wellingtonia (G).

\section{Sequoia sempervirens, Endl. Redwood.}

Leaves of secondary branches and of lower branches of young trees lanceolate, more or less falcate, acute or acuminate and usually tipped with slender rigid points, slightly thickened on the revolute margins, decurrent at the base, spreading in 2 ranks by a half-turn at their base, $\frac{1^{\prime}}{4}-\frac{1}{2}^{\prime}$ long, about $\frac{1}{8}^{\prime}$ wide, obscurely keeled and marked above by 2 narrow bands of stomata, glaucous and stomatiferous below on each side of their conspicuous midribs, on leading shoots disposed in niany ranks, more or less spreading or appressed, ovate or ovate-oblong, incurved at the rounded apicnlate apex, thickened, rounded, and stomatiferons on the lower surface, concave, prominently keeled and covered with stomata on the upper surface, usually about $\frac{1}{4}^{\prime}$ long; dying and turning reddish brown at least two years before falling. Flowers opening 
in late winter or very early spring; staminate ovate, obtuse; pistillate with about 20 broadly ovate acute scales tipped with elongated and incurved or short points. Fruit oblong, $\frac{3^{\prime}}{4}-1^{\prime}$ long, $\frac{1}{2}^{\prime}$ broad, its scales gradually enlarged from slender stipes abruptly dilated above into disks penetrated by deep narrow grooves, and usually without tips; seeds about $\frac{1}{16}$ ' long, light brown, with wings as broad as their body.

A tree, from $200^{\circ}-340^{\circ}$ high, with a slightly tapering and irregularly lobed trunk usually free of branches for $75^{\circ}-100^{\circ}$, usually $10^{\circ}-15^{\circ}$, rarely $28^{\circ}$ in diameter at the much buttressed base, slender branches, clothed with branchlets spreading in 2 ranks and forming while the tree is young an open narrow pyramid, on old trees becoming stout and horizontal, and forming a narrow rather compact and very irregular head remarkably small in proportion to the height and size of the trunk, and slender leading branchlets covered at the end of three or four years after the leaves fall with cinnamonbrown scaly bark. Buds with numerous

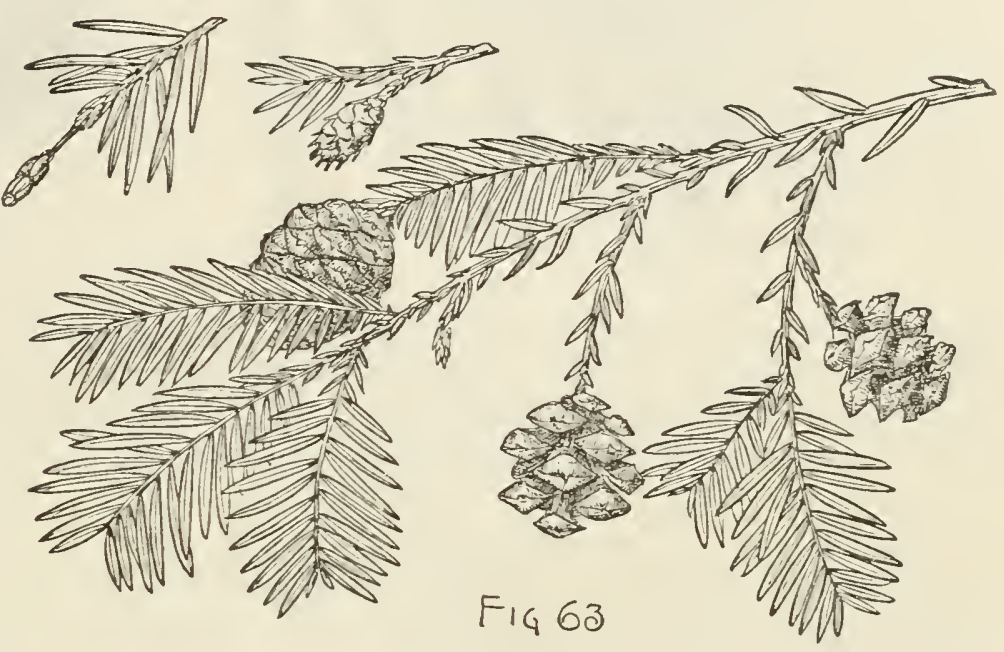
loosely imbricated ovate acute scales persistent on the base of the branchlet. Bark $6^{\prime}-12^{\prime}$ thick, divided into rounded ridges and separated on the surface into long narrow dark brown fibrous scales often broken transversely and in falling disclosing the bright cimnamonred inner bark. Wood light, soft, not strong, close-grained, easily split and worked, very durable in contact with the soil, clear light red; largely manufactured into lumber and used for shingles, fence-posts, railway-ties, wine-butts, and for building purposes.

Distribution. Southern borders of Oregon, southward near the coast to Monterey County, California, rarely found more than twenty or thirty miles from the coast, or beyond the influence of the ocean fogs, or over $3000^{\circ}$ above the sea-level; often forming in northern California pure forests occupying the sides of ravines and the banks of streams; southward growing usually in small groves scattered among other trees; most abundant and of its largest size uorth of Cape Mendocino.

Often cultivated as an ornamental tree in the temperate countries of Europe.

\section{Sequoia Wellingtonia, Seem. Big Tree.}

Leaves ovate and acuminate, or lanceolate, rounded and thickened on the lower surface, concave on the upper surface, marked by bands of stomata on both sides of the obscure midribs, rigid, sharp-pointed, decurrent below, spreading or closely appressed above the middle, $\frac{1}{8}^{\prime}-\frac{1}{4}^{\prime}$ or on leading shoots $\frac{1}{2}^{\prime}$ long. Flowers opening in late winter and early spring; staminate in great profusion over the whole tree, terminal, with ovate acute or acuminate connectives; pistillate witl $25-40$ pale yellow scales slightly keeled on the back and gradually narrowed into long slender points. 
Fruit maturing in the second year, ovate-oblong, $2^{\prime}-3 \frac{1}{2}^{\prime}$ long, $1 \frac{1^{\prime}}{2}-2 \frac{1^{\prime}}{4}$ wide, dark reddish brown, the scales gradually thickened upward from the base to the slightly

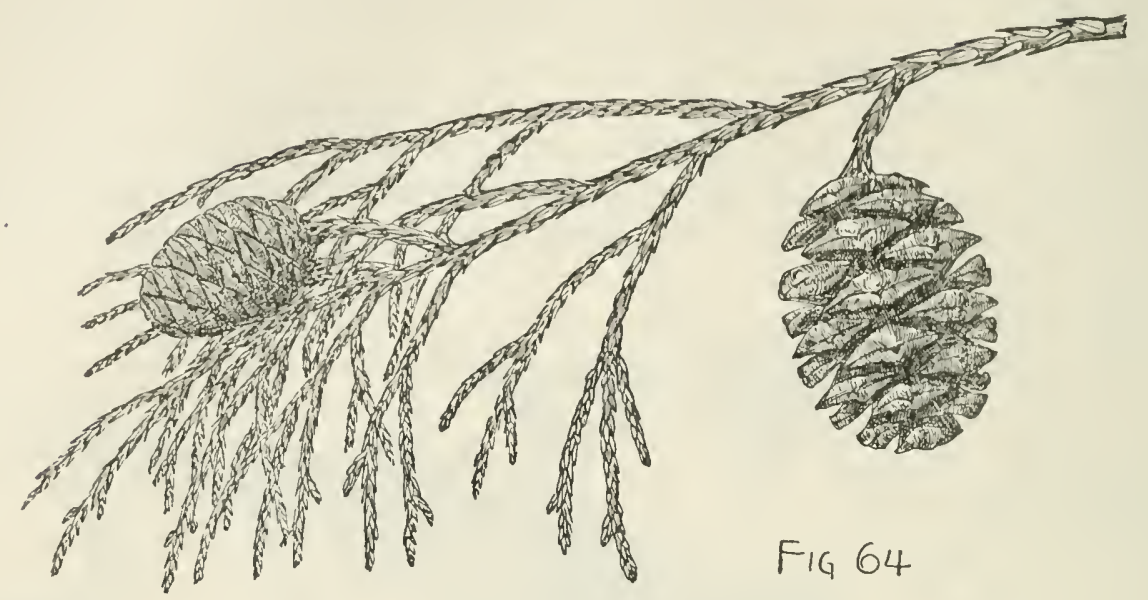

dilated apex, $\frac{3^{\prime}}{4}-1 \frac{1}{4}^{\prime}$ long and $\frac{1^{\prime}}{4}-\frac{1}{2}^{\prime}$ wide, deeply pitted in the middle and often furnished with an elongated reflexed tip; seeds linear-lanceolate, compressed, $\frac{1}{8}^{\prime}-\frac{1}{4}^{\prime}$ long, light brown, surrounded by laterally united wings broader than the body of the seed, apiculate at the apex, often very unequal.

A tree, at maturity usually about $275^{\circ}$ high, with a trunk $20^{\circ}$ in diameter near the ground, occasionally becoming $320^{\circ}$ tall, with a trunk $35^{\circ}$ in diameter, much enlarged and buttressed at the base, fluted with broad low rounded ridges, in old age naked often for $150^{\circ}$, with short thick horizontal branches, slender leading branchlets becoming after the disappearance of the leaves reddish brown more or less tinged with purple and covered with thin close or slightly scaly bark and naked buds. Bark $1^{\circ}-2^{\circ}$ thick, divided into rounded lobes $4^{\circ}-5^{\circ}$ wide, corresponding to the lobes of the trunk, separating into loose light cinnamon-red fibrous scales, the outer scales slightly tinged with purple. Wood very light, soft, not strong, brittle and coarsegrained, turning dark on exposure; manufactured into lumber and used for fencing, in construction, and for shingles.

Distribution. Western slopes of the Sierra Nevada of California, in an interrupted belt at elevations of $5000^{\circ}-8400^{\circ}$ above the level of the sea, from the middle fork of the American River to the head of Deer Creek just south of latitude $36^{\circ}$; north of King's River in isolated groves, southward forming forests of considerable extent, and best developed on the north fork of the Tule River.

Universally cultivated as an ornamental tree in all the countries of central and southern Europe; and occasionally in the eastern United States, where it does not flourish.

\section{TAXODIUM, Rich. Bald Cypress.}

Resinous trees, with furrowed scaly bark, light brown durable heartwood, thin white sapwood, erect ultimately spreading branches, deciduous usually 2-ranked lateral branchlets, scaly globose buds, and stout horizontal roots often producing erect woody projections (knees). Leaves spirally disposed, pale and marked with stomata below on both sides of the obscure midribs, dark green above, linear-lanceolate, spreading in 2 ranks, or scale-like and appressed on lateral branchlets, the two forms appearing 
on the same or on different branches of the same tree or on separate trees, deciduous. Flowers unisexual, from buds formed the previous year; staminate in the axils of scale-like bracts in long terminal drooping panicles, with 6-8 stamens, opposite in 2 ranks, their filaments abruptly enlarged into broadly ovate peltate yellow comnectives bearing on their inner face in 2 rows 4-9 2-valved pendulous anther-cells; pistillate scattered near the ends of the branches of the previous year, subglobose, composed of numerous ovate spirally arranged long-pointed scales adnate below to the thickened fleshy ovuliferous scales bearing at their base 2 erect bottle-shaped ovules. Fruit a globose or obovoid short-stalked woody cone maturing the first year and persistent after the escape of the seeds, formed from the enlargement and union of the flower and ovule-bearing scales abruptly dilated from slender stipes into irregularly 4 -sided disks often mucronate at maturity, bearing on the inner face, especially on the stipes, large dark glands filled with blood-red fragrant liquid resin. Seeds in pairs under each scale, attached laterally to the stipes, erect, unequally 3 -angled; seed-coat light brown and lustrons, thick, coriaceous or corky, produced into 3 thick unequal lateral wings and below into a slender elongated point; cotyledons 4-9, shorter than the superior radicle.

Taxodium, widely distributed through North America and Enrope in Miocene and Pliocene times, is now confined to the coast region of the south Atlantic and Gulf states and to Mexico. Two species are distinguished.

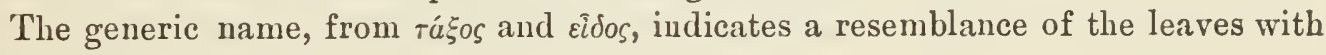
those of the Yew-tree.

\section{Taxodium distichum, Rich. Bald Cypress. Deciduous Cypress.}

Leaves on distichously spreading branchlets linear-lanceolate, apiculate, $\frac{1^{\prime}}{2}-\frac{3^{\prime}}{4}$ long, about $\frac{1^{\prime}}{1^{2}}$ wide, light bright yellow-green or occasionally silvery white below, or on

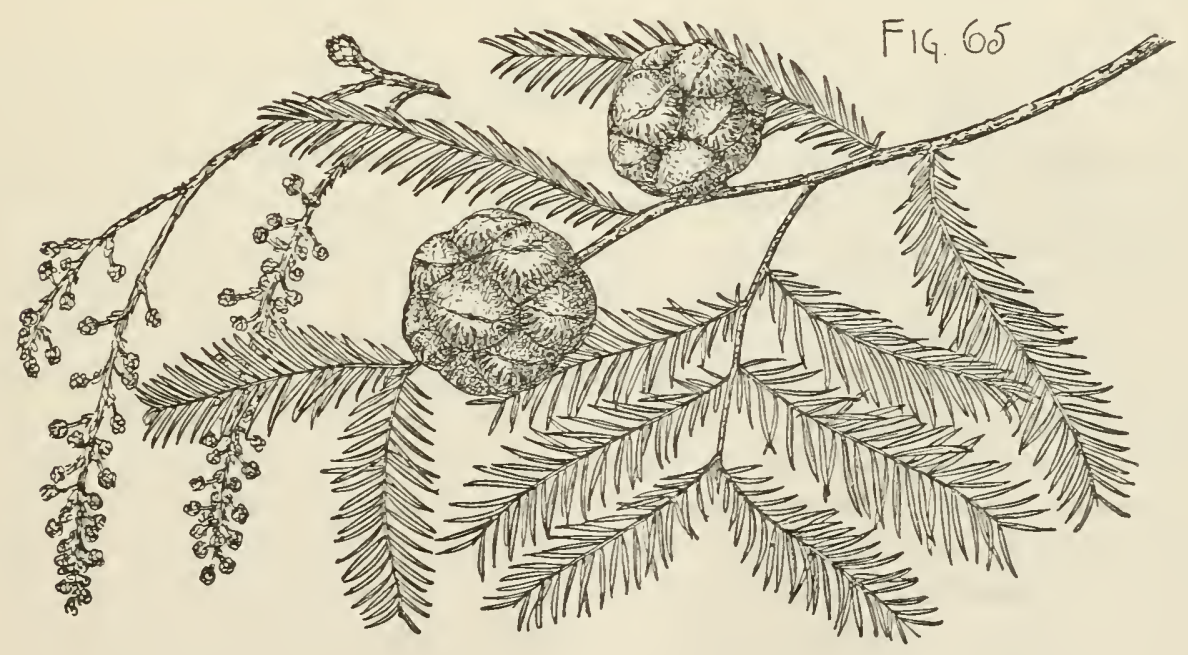

the form with pendulous compressed branchlets long-pointed, keeled and stomatiferous below, concave above, more or less spreading at the free apex, about $\frac{1^{\prime}}{2}$ loug; in the autumn turning with the branchlets dull orange-brown before falling. Flowers: panicles of staminate flowers $4^{\prime}-5^{\prime}$ long, $1 \frac{1^{\prime}}{2}-2^{\prime}$ wide, with slender red-brown stems, obovate flower-buds nearly $\frac{1}{8}^{\prime}$ long, pale silvery-gray during winter and purple when the flowers expand in the spring. Fruit usually produced in pairs at the extremity 
of the branch or irregularly scattered along it for scveral inches, nearly globose or obovate, rugose, about $\boldsymbol{I}^{\prime}$ in diameter, the scales generally destitute of tips; seeds with wings nearly $\frac{1 \prime}{4}$ long and $\frac{1 \prime}{8}$ wide.

A tree, with a tall lobed gradually tapcring trunk, rarcly $12^{\circ}$ and generally $4^{\circ}-5^{\circ}$ in diameter above the abruptly cularged strongly buttressed usually hollow base, occasionally $150^{\circ}$ tall, in youth pyramidal, with slender branches often becoming elongated and slightly pendulous, in old age sprcading ont into a broad low rounded erown often $100^{\circ}$ across, and slender branchlets light green when they first appear, light red-brown and rather lustrous during their first winter, bccoming darker the following year, deciduous lateral branchlets $3^{\prime}-4^{\prime}$ long, spreading at right angles to the branch, or in the form with acicular leaves pendulous or erect and often $6^{\prime}$ long. Bark 1'-2' thick, light cinnamon-red and divided by shallow fissures into broad flat ridges separating on the surface into long thin closely appressed fibrous scales. Wood light, soft, not strong, easily worked, light or dark brown, sometimes nearly black; largely used for construction, in cooperage, railway-ties, posts, and fences.

Distribution. River swamps usually submerged during several months of the year, low wet banks of streams, and the wet depressions of Pine-barrens from southern Delaware southward near the coast to the shores of Mosquito Inlet and Cape Romano, Florida, and through the Gulf coast region to the valley of Devil River, Texas, through Louisiana and Arkansas to southeastern Missouri, and throngh western Mississippi, Tennessee, and Kentucky to southern Illinois and Indiana; most common and of its largest size in the south Atlantic and Gulf states, often covering with nearly pure forests great river swamps. From South Carolina to western Florida and southern Alabama the form with acicular leaves (Taxodium distichum, var. imbricarium, Sarg.) is not rare as a small tree in Pine-barren ponds.

Often cultivated, especially the var. imbricarium, as an ornamental tree in the northern United States, and in the countries of temperate Europe.

\section{LIBOCEDRUS, Endl.}

Tall resinons aromatic trees, with scaly bark, spreading branches, flattened branchlets disposed in one horizontal plane and forming an open 2-ranked spray and often ultimately deciluous, straight-grained durable fragrant wood, and naked buds. Leaves scale-like, in 4 ranks, on leading shoots nearly equally decussate, closely compressed or spreading, dying and becoming woody before falling, on lateral flattened branchlets much compressed, conspicuously keeled, and nearly covering those of the other ranks; on seedling plants linear-laneeolate and spreading. Flowers monøecious, solitary, terminal, the two sexes on different branehlets; staminate oblong, with 12-16 decussate filaments dilated into broad connectives usually bearing 4 subglobose anther-cells; pistillate oblong, subtended at the base by several pairs of leaf-like scales slightly enlarged and persistent under the fruit, composed of 6 acuminate short-pointed scales, those of the ipper and middle ranks much larger than those of the lower rank, ovate or oblong, fertile and bearing at the base of a minute accrescent ovuliferous scale 2 erect ovules. Fruit an oblong cone maturing in one season, with subcoriaceous scales marked at the apex by the free thickened mucronulate border of the enlarged flowerscales, those of the lowest pair ovate, thin, reflexed, much shorter than the oblong thicker scales of the second pair widely spreading at maturity; those of the third pair confluent into an erect partition. Seeds in pairs, erect on the base of the scale; seed-coat membranaceous, of 2 layers, produced into thin unequal lateral wings, one 
narrow, the other broad, oblique, nearly as long as the scale; cotyledons 2, about as long as the superior radicle.

Libocedrus is confined to western North America, western South America, where it is distributed from Chili to Patagonia, New Zealand, New Caledonia, New Guinea, Formosa, and southwestern China. Eight species are distinguished.

Libocedrus, from $\lambda_{\iota} \beta \alpha$ s and Cedrus, relates to the resinous character of these trees.

\section{Libocedrus decurrens, Torr. Incense Cedar.}

Leaves oblong-obovate, decurrent and closely adnate on the branchlets except at the callous apex, $\frac{1}{8}^{\prime}$ long on the ultimate lateral branchlets to nearly $\frac{1}{2}^{\prime}$ long on leading

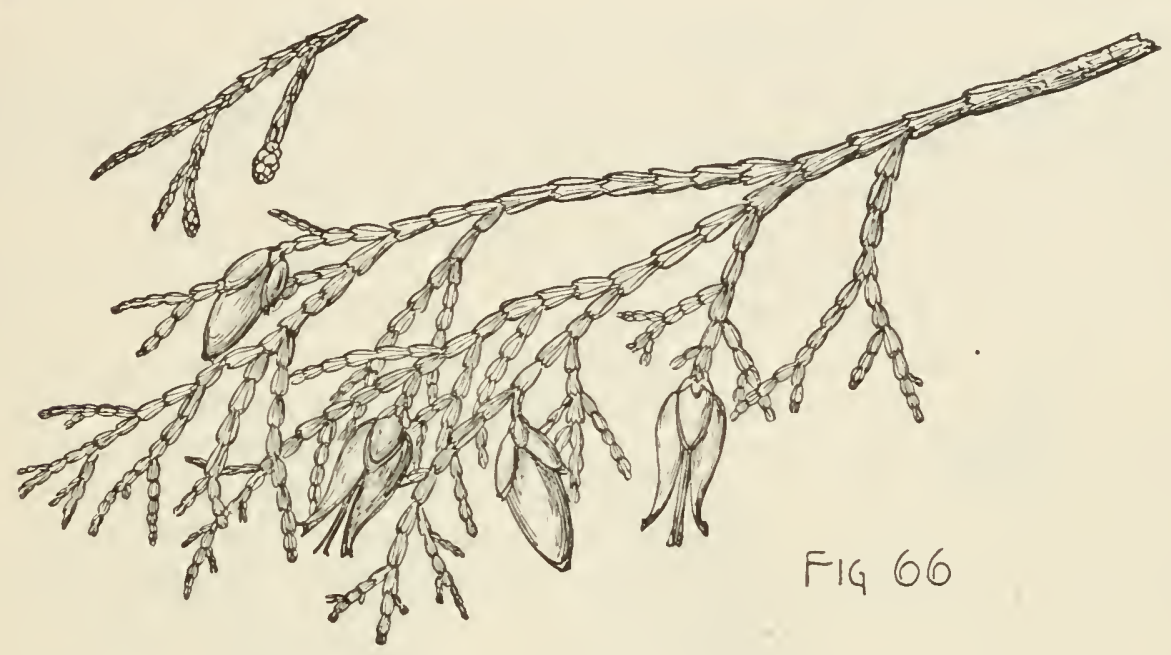

shoots, those of the lateral ranks gradually narrowed and acuminate at the apex, keeled and glandular on the back, and nearly covering the flattened obscurely glandular-pitted and abruptly pointed leaves of the inner ranks. Flowers appearing in January on the ends of short lateral branchlets of the previous year;staminate tingeing the tree with gold during the winter and early spring, ovate, nearly $\frac{1}{4}^{\prime}$ long, with nearly orbicular or broadly ovate connectives, rounded, acute or acuminate at the apex and slightly erose on the margins; pistillate subtended by $2-6$ pairs of leaf-like scales, with ovate acute light yellow-green slightly spreading scales. Fruit ripening and discharging its seeds in the autumn, oblong, $\frac{3^{\prime}}{4}-1^{\prime}$ long, pendulous, light redbrown; seeds oblong-lanceolate, $\frac{1^{\prime}}{8}-\frac{1^{\prime}}{2}$ long, semiterete and marked below by conspicuous pale basal hilums; inner layer of the seed-coat penetrated by elongated resin-chambers filled with red liquid balsamic resin.

A tree, frequently $150^{\circ}$ high, with a tall straight slightly and irregularly lobed trunk tapering from a broad base and sometimes $7^{\circ}$ in diameter, slender branches erect at the top of the tree, below sweeping downward in bold curves, forming a narrow open - feathery crown becoming in old age irregular in outline by the greater development of a few ultimately upright branches forming secondary stems, and stont branchlets somewhat flattened and light yellow-green at first, turning light red-brown during the summer and ultimately brown more or less tinged with purple, the lateral branchlets much flattened, $4^{\prime}-6^{\prime}$ long, and usually deciduous at the end of the second or third season. Bark $\frac{1^{\prime}}{2}-1^{\prime}$ thick, bright cinnamon-red, and broken into irregular ridges covered with closely appressed plate-like scales. Wood light, soft, close-grained 
very durable in contact with the soil, light reddish brown, with thin nearly white sapwood; often iujured by dry rot but largely used for fenciugr, laths and shingles, the interior finish of buildings, for furniture, and in the construction of flumes.

Distribution. Singly or in small groves from the basin of the Santiam River, Oregon, southward along the Cascade Monntains and the western slopes of the Sierra Nevada, and on the California coast ranges from Mendocino County to the mountains of southern California and Lower California; most abundant and of its largest size on the sierras of central California at elevations of $5000^{\circ}-7000^{\circ}$ above the sea.

Often cultivated as an ornamental tree in western and central Europe, where it grows rapidly and promises to attain to a large size; hardy and occasionally planted in the middle Atlantic states.

\section{THUYA, L. Arbor-vitæ.}

Resinous aromatic trees, with thin scaly bark, soft durable straight-grained heartwood, thin nearly white sapwood, slender spreading or erect branches, pyramidal heads, flattened lateral pendulous branchlets disposed in onc horizontal plane, forming a flat frond-like spray and often finally deciduous, and naked buds. Leaves decussate, scale-like, acute, stomatiferous on the back, on leading shoots appressed or spreading, rounded or slightly keeled on the back, narrowed into long slender points; on lateral branchlets much compressed in the lateral ranks, prominently keeled and nearly covering those of the other ranks; on seedling plants linearlanceolate, acuminate, spreading or reflexed. Flowers minute, monœeions, from buds formed the previous autumn, terminal solitary, the two sexes usually on different branchlets ; staminate ovoid, with 4-6 decussatc filaments, enlarged into suborbicular peltate connectives bearing on their inner face $2-4$ subglobose anther-cells; pistillate oblong, with 8-12 oblong acute scales opposite in pairs, the ovuliferous scales at their base bearing usually 2 erect bottle-shaped ovules. Fruit an ovoidsblong erect pale cinnamon-brown cone maturing in one season, its scales thin, leathery, oblong, acute, marked near the apex by the thickened free border of the enlarged flower-scales, those of the 2 or 3 middle ranks largest and fertile. Seeds usually 2, erect on the base of the scale, ovate, acute, compressed, light chestnutbrown; seed-coat membranaceous, usually produced into broad lateral wings distinct at the apex; cotyledons 2, longer than the superior radicle.

Thuya is confined to northeastern and northwestern America, to Japan and northern China. Four species are recognized. Of the exotic species the Chinese Thuya orientalis, L., with many varieties produced by cultivation, is frequently planted in the United States, especially in the south, for the decoration of gardens, and is distinguished from the Japanese and American species by the thick umbonate scales of the cone, only the 4 lower scales being fertile, and by the thick rounded dark redpurple seeds without wings.

Thuya is the classical name of some coniferous trees.

\section{CONSPECTUS OF THE NORTH AMERICAN SPECIES.}

Fruit with usually 4 fertile seales.

1. T. occidentalis (A). Fruit with usually 6 fertile scales.

2. T. plicata (B, F, G).

\section{Thuya occidentalis, L. White Cedar. Arbor-vitæ.}

Leaves on leading shoots often nearly $\frac{1}{4}$ long, long-pointed and usually conspicuously glandular, on lateral branchlets much flattened, rounded and apiculate at the 
apex, without glands or obscurely glandular-pitted, about $\frac{1}{8}^{\prime}$ long. Flowers opening in April and May, liver color. Fruit ripening and discharging its seeds in the early autumn, $\frac{1^{\prime}}{3}-\frac{1}{2}$ long; seeds $\frac{1}{8}^{\prime}$ long, the thin wings as wide as the body.

A tree, $50-60^{\circ}$ high, with a short often lobed and buttressed trunk, occasionally $6^{\circ}$ although usually not more than $2^{\circ}-3^{\circ}$ in diameter, often divided into 2 or 3 stout secondary stems, short horizontal branches soon turning upward and forming a narrow compact pyramidal head, light yellow-green branchlets paler on the lower surface than on the upper, changing with the death of the leaves during their second season to light cimnamon-red, growing darker the following year, gradually becoming terete and abruptly enlarged at the base and finally covered with smooth lustrous dark orange-brown bark, and marked by conspicuous sears left by the falling of the short pendulous lateral branchlets. Bark $\frac{1^{\prime}}{4}-\frac{1}{3}^{\prime}$ thick, light red-brown often tinged with orange color and broken by shallow fissures into narrow flat connected ridges separating into elongated more or less persistent scales. Wood light, soft, brittle, very coarse-grained, durable, fragrant, pale yellow-brown; largely

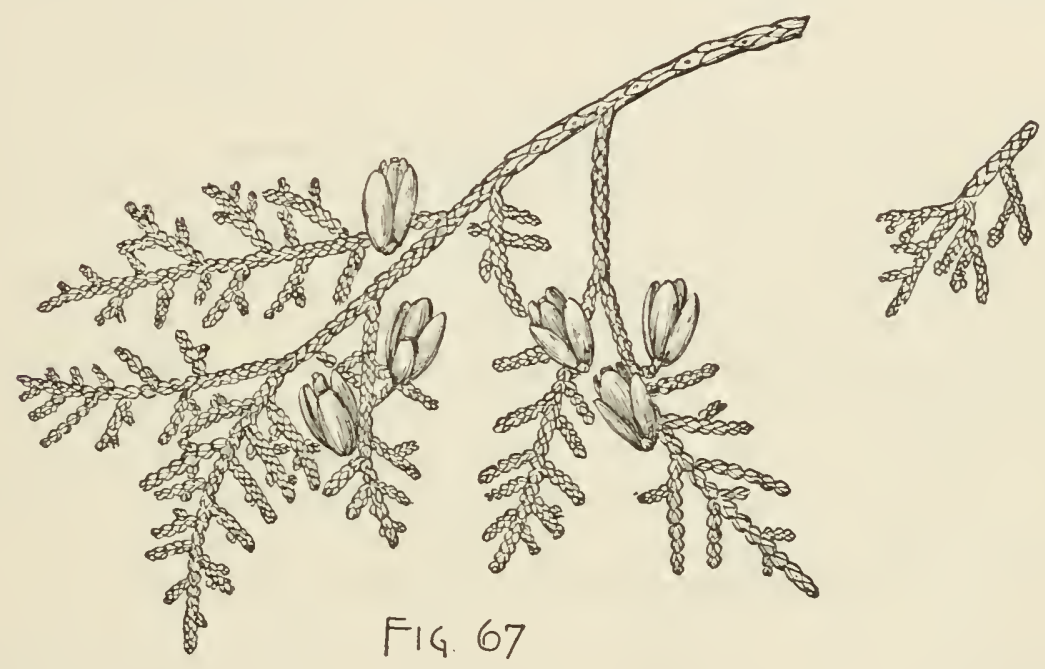

used in Canada and the northern states for fence-posts, rails, railway-ties, and shingles. Fluid extracts and tinctures made from the young branchlets are sometimes used in medicine.

Distribution. Frequently forming nearly impenetrable forests on swampy ground or often occupying the rocky banks of streams, from Nova Scotia and New Brunswick, northwestward to the mouth of the Saskatchewan, and southward through the northern states to southern New Hampshire, central Massachusetts and New York, northern Pennsylvania, central Michigan, northern Illinois, and central Minnesota, and along the high Alleghany Mountains to southern Virginia and northeastern Temnessee; very common at the north, less abundant and of smaller size southward; on the southern Alleghany Mountains only at high elevations.

Often cultivated, with many forms produced in nurseries, as an ornamental tree and for hedges; and in Europe from the middle of the sixteenth century.

\section{Thuya plicata. D. Don. Red Cedar. Canoe Cedar.}

Leaves on leading shoots ovate, long-pointed, often conspicuously glandular on the back, frequently $\frac{1}{4}$ l' long, on lateral branchlets ovate, apiculate, without glands 
or obsenrely glandnlar-pitted, usually not more than $\frac{y^{\prime}}{8}$ long. Flowers abont ${ }^{\prime}$ long, dark brown. Fruit ripening early in the antumn, elustered near the ends of the lianches, mueh reflexed,

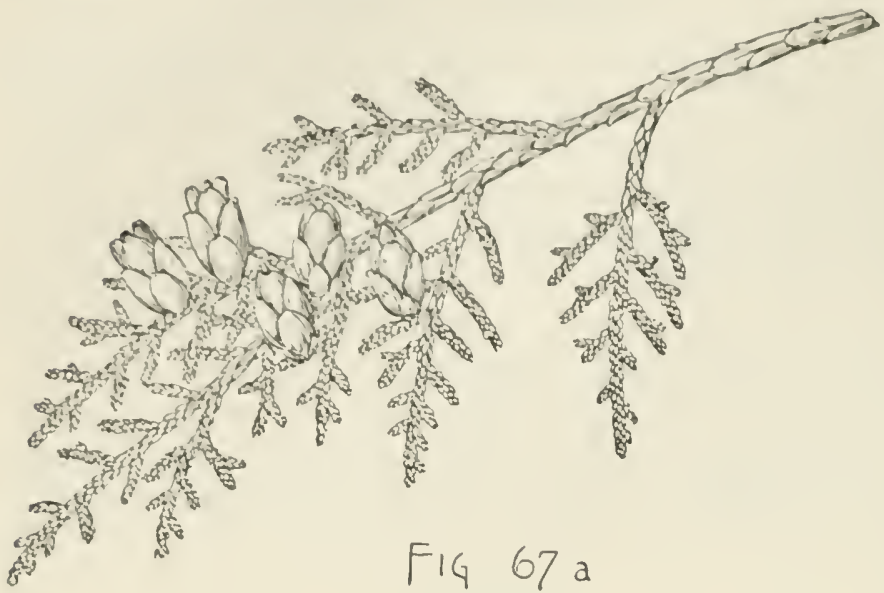

I' long, with thin leathery seales, conspicuonsly marked near the apex by the free border of the flower-seales furnished with short stont erect or recurved dark numeros; seeds often 3 mimder each fertile seale, rather shorter than their usually slightly unequal wings about $\frac{1}{4}$ long.

A tree, frequently $200^{\circ}$ high, with a broad gradually tapering buttressed base sometimes $15^{\circ}$ in $\mathrm{di}$ ameter at the ground and in old age often separating toward the summit into 2 or 3 erect divisions, short horizontal branches usnally pendulons at the ends forming a dense narrow pyramidal head, and slender much compressed branchlets often slightly zigzag, light bright yellow-green during their first year, then cinnamon-brown, and after the falling of the leaves, usually in their third year, lustrous and dark reddish brown often tinged with purple, the lateral branchlets $5^{\prime}-6^{\prime}$ long, light green and lustrous on the upper surface, somewhat paler on the lower surface, turning yellow and falling generally at the end of their second season. Bark bright cinnamon-red, $\frac{1^{\prime}}{2}-\frac{3^{\prime}}{4}$ thick, irregularly divided by narrow shallow fissures into broad ridges rounded on the back and broken on the surface into long narrow rather loose plate-like scales. Wood light, soft, not strong, brittle, coarse-grained, easily split, dull brown tinged with red; largely used in Washington and Oregon for the interior finish of buildings, doors, sashes, fences, shingles, and in cabinet-making and cooperage. From this tree the Indians of the northwest coast split the planks used in the construction of their lodges, carved the totems which decorate their villages, and hollowed out their great war canoes; and from the fibres of the inner bark made ropes, blankets, and thatch for their cabins.

Distribution. Singly and in small groves on low moist bottom-lands or near the banks of mountain streams, from the sea-level to elevations of $6000^{\circ}$ in the interior, and from Yas Bay, Alaska, southward along the coast ranges of British Columbia, western Washington and Oregon, where it is the most abundant and grows to its largest size, and throngh the California coast region to Mendocino County, spreading eastward along many of the interior ranges of British Columbia to the western slope of the continental divide, and along those of northern Washington and Idaho to the mountains of northern Montana.

Often cultivated as an ornamental tree in the parks and gardens of western and central Europe where it has grown rapidly and vigorously, and occasionally in the middle and north Atlantic states. 


\section{CUPRESSUS, L. Cypress.}

Resinous trees, with bark often separating into long shred-like scales, fragrant durable usually light brown heartwood, pale yellow sapwood, stout erect branches becoming horizontal in old age, slender 4-augled branchlets, and naked buds. Leaves scale-like, ovate, acute or acuminate or rarely rounded at the apex, with slender spreading or appressed tips, thickened, rounded, and often glandular on the back, opposite in pairs, becoming browl and woody before falling; on vigorous leading shoots and young plants needle-shaped or linear-lanceolate and spreading. Flowers minute, monœcious, terminal, yellow, the two sexes on separate branchlets; the staminate oblong, of numerous decussate stamens, with short filaments enlarged into broadly ovate connectives bearing 2-6 globose pendulous anther-cells; pistillate oblong or subglobose, composed of 6-10 thick decussate scales bearing in several rows at the base of the ovuliferous scale numerous erect bottle-shaped ovules. Fruit an erect nearly globose cone maturing in the second year, composed of the much thickened ovule-bearing scales of the flower, abruptly dilated, clavate, and flattened at the apex, bearing the remnants of the flower-scales developed into short central more or less thickened mucros or bosses; long-persistent on the branch after the escape of the seeds. Seeds numerous, in several rows, erect, thick, and acutely angled or compressed, with thin lateral wings; seed-coat of 2 layers, the outer thin and membranaceous, the inner thicker and crustaceous; cotyledons 3 or 4 , longer than the superior radicle.

Cupressus with ten or twelve species is confined to Pacific North America and Mexico in the New World and to southeastern Europe, southwestern Asia, the Himalayas, and China in the Old World. Of the exotic species Cupressus semperirens, L., of southeastern Europe and southwestern Asia, and especially its pyramidal variety, are often planted for ornament in the south Atlantic and Pacific states.

Cupressus is the classical name of the Cypress-tree.

\section{CONSPECTUS OF THE NORTH AMERICAN SPECIES.}

Leaves obscurely glandular.

Branchlets stout; leaves dark green.

1. C. macrocarpa (G).

Branchlets stout; leaves glaucous.

Branchlets slender; leaves dark green.

Branchlets stout; leaves dark green; seeds black.

2. C. Arizonica ( $\mathrm{F}, \mathrm{H})$. 3. C. Goveniana (G). 4. C. pygmæa $(G)$.

Leaves conspicuously glandular; branchlets slender; leaves dark green, often slightly glaucous.

5. C. Macnabiana (G).

\section{Cupressus macrocarpa, Gord. Monterey Cypress.}

Leaves about $\frac{1}{8}$ long, dark green, on young plants prominently ridged below and $\frac{1}{4}-\frac{1}{2}$ long; deciduous at the end of three or four years. Flowers opening late in February or early in March, yellow; staminate with 6 or 8 stanens, their connectives bearing 4 or 5 dark-colored pollen-sacs; pistillate oblong, with spreading acuminate scales. Fruit clustered on short stout peduncles, oblong, slightly puberulous, $1^{\prime}-1 \frac{1}{2}$ long, about $\frac{2^{\prime}}{3}$ broad, composed of 4 or 6 pairs of scales, with broadly ovate thickened or occasionally on the upper scales subconical bosses, the scales of the upper and lower pairs being smaller than the others and sterile; seeds about 20 under each fertile scale, angled, light chestnut-brown, about $\frac{1}{16}$ long.

A tree, often $60^{\circ}-70^{\circ}$ high, with a short trunk $2^{\circ}-3^{\circ}$ or exceptionally $5^{\circ}-6^{\circ}$ 
in diameter, slender erect branches forming a narrow or broad bushy pyramidal head, beeoming stout and spreading in old age into a broad flat-topped erown, stout

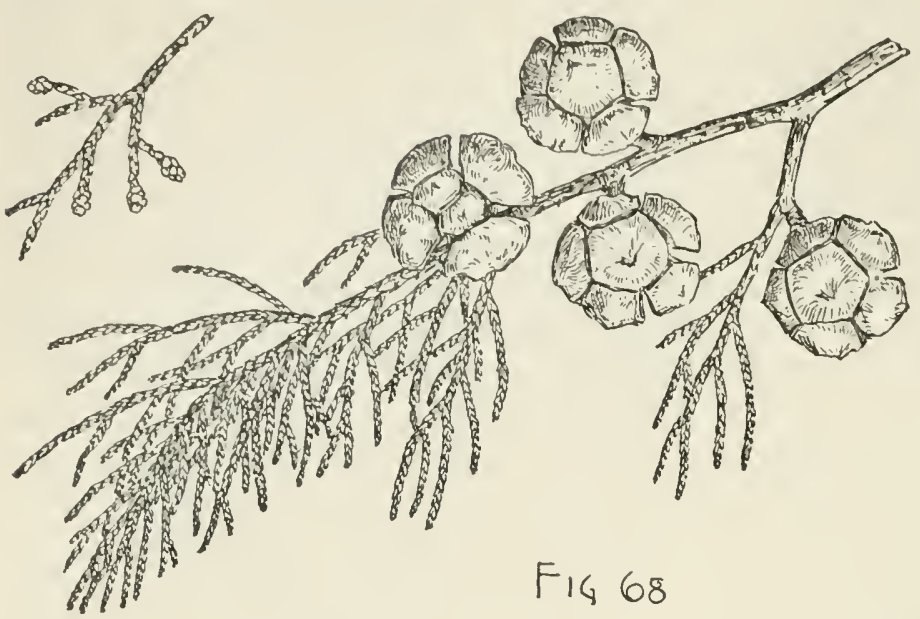
branehlets eovered when the leaves fall at the end of three or four years with thin light or dark reddish brown bark separating into small papery scales. Bark $\frac{8^{\prime}}{4}-1^{\prime}$ thick and irregularly divided into broad flat eonneeted ridges separating freely into narrow elongated thick persistent scales, dark red-brown oll young stems and upper branehes, becoming at last almost white on

old and exposed trunks. Wood heavy, hard and strong, very durable, elose-grained.

Distribution. Coast of California south of the Bay of Monterey, oecupying an area about two miles long and two hundred yards wide from Cypress Point to the shores of Carmel Bay, with a small grove on Point Lobos, the southern boundary of the bay.

Universally eultivated in the Paeific states from Vaneouver Island to Lower California, and often used in hedges and for wind-breaks; oeeasionally planted in the southeastern states; mueh planted in western and southern Europe, temperate South America, and in Australia and New Zealand.

\section{Cupressus Arizonica, Greene. Cypress.}

Leaves thiek, keeled, usually without glands, pale glaueous green, about $\frac{1}{8}^{\prime}$ long, dying and beeoming light red-brown and glaucons in their second season, and remaining on the branehes for two or three years longer. Flowers: staminate oblong, obtuse, their 6 or 8 stamens with broadly ovate acute yellow eonnectives slightly erose on the margins; pistillate not seen. Fruit on stout peduneles, $\frac{1^{\prime}}{4}-\frac{1}{3}^{\prime}$ long, subglobose, slightly puberulous, about $1^{\prime}$ in diameter, dark

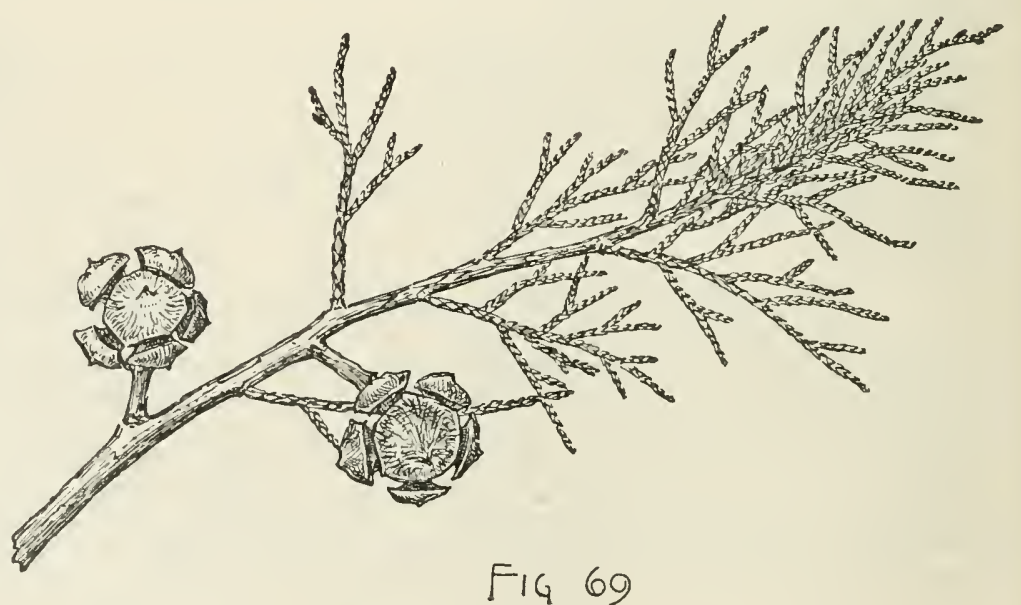
red-brown, eovered with a thick glancous bloom, their 6 or occasionally 8 seales with stout cylindrieal pointed or incurved prominent bosses; seeds oblong to nearly triangular, $\frac{11^{\prime}}{16}-\frac{1^{\prime}}{8}$ long, dark red-brown, with thin narrow wings. 
A tree, usually $30^{\circ}-40^{\circ}$ but occasionally $70^{\circ}$ high, with a trunk $2^{\circ}-4^{\circ}$ in diameter, horizontal branches forming a narrow pyramid or occasionally a broad flat head, and stout branchlets covered after the leaves have fallen with smooth close thin light red-brown bark more or less covered with a glaucous bloom. Bark of young trunks and branches broken into large irregular thin scales, becoming on old trees dark redbrown, and separating freely into long shreds $1^{\prime}-2^{\prime}$ wide, and often persistent for many years. Wood light, soft, close-grained, gray often faintly streaked with yellow.

Distribution. Mountains of central, eastern, and southern Arizona, often on northern slopes forming almost pure forests of considerable extent at elevations of $5000^{\circ}-6000^{\circ}$ above the sea; on the mountains of northern Sonora and Chihuahua.

Rarely cultivated as an ornamental tree in western Europe.

\section{Cupressus Goveniana, Gord. Cypress.}

Leaves obscurely glandular or without glands, dark green, $\frac{1 \overline{1}^{\prime}}{1 \frac{1}{8}}$ long, turning bright red-brown in drying and falling at the end of three or four years; on young plants $\frac{1^{\prime}}{8}-\frac{1^{\prime}}{4}$ long.

Flowers: staminate with thin slightly erose connectives; pistillate of 6 or 8 acute slightly spreading scales. Fruit subglobose or oblong, $\frac{1^{\prime}}{2}-1^{\prime}$ long, reddish brown or purple, lustrous, slightly puberulous, its 6 or 8 scales with broadly ovate generally rounded and flattened and

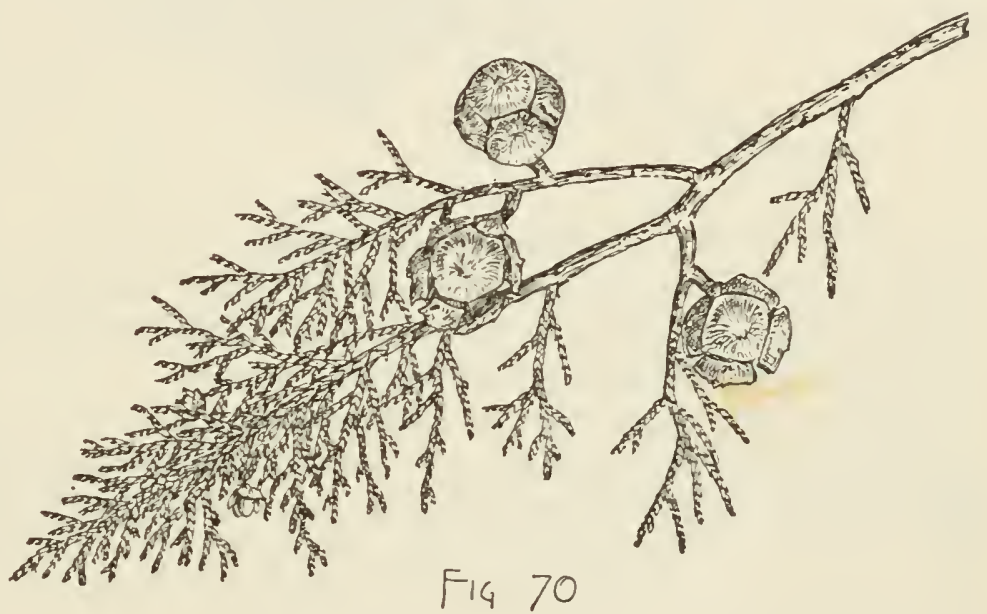
rarely short-obconical bosses; seeds light brown and lustrous, $\frac{1}{6}^{\prime}$ long, about 20 under each fertile scale.

A tree, occasionally $50^{\circ}$ high, with a short trunk $2^{\circ}$ in diameter, slender erect or spreading branches forming a handsome open head, and thin branchlets covered with close smooth bark, at first orange-colored, becoming bright reddish brown, and ultimately purple or dark brown; usually much smaller and often shrubby. Bark $\frac{1^{\prime}}{4}-\frac{1}{2}$ thick, dark brown tinged with red, irregularly divided into narrow ridges covered with thin persistent oblong scales. Wood light, soft, not strong, light brown, with thick nearly white sapwood.

Distribution. Widely distributed through the California coast regions from Sonoma County to the mountains of San Diego, frequently ascending in the cañons of the mountain ranges of the central part of the state to elevations of nearly $3000^{\circ}$ above the sea-level.

Occasionally cultivated in western and southern Europe as an ornamental tree.

\section{Cupressus pygmæa, Sarg. Cypress.}

Leaves dark green, without glands. Flowers: staminate obscurely 4-angled, with broadly ovate peltate connectives; pistillate with 6-10 ovate pointed scales. 
Fruit usually sessile, short-oblong, $f^{\prime}-\frac{7^{\prime}}{8}$ long, its scales terminating in small bosses; seeds compressed, black, about $\frac{1}{8}$ long.

A tree, sometimes $30^{\circ}$ high, often beginning to bear cones when only $1^{\circ}$ or $2^{\circ}$ tall, with a trunk rarely more tlian $1^{\circ}$ in diameter, ascendingr branches, and comparatively

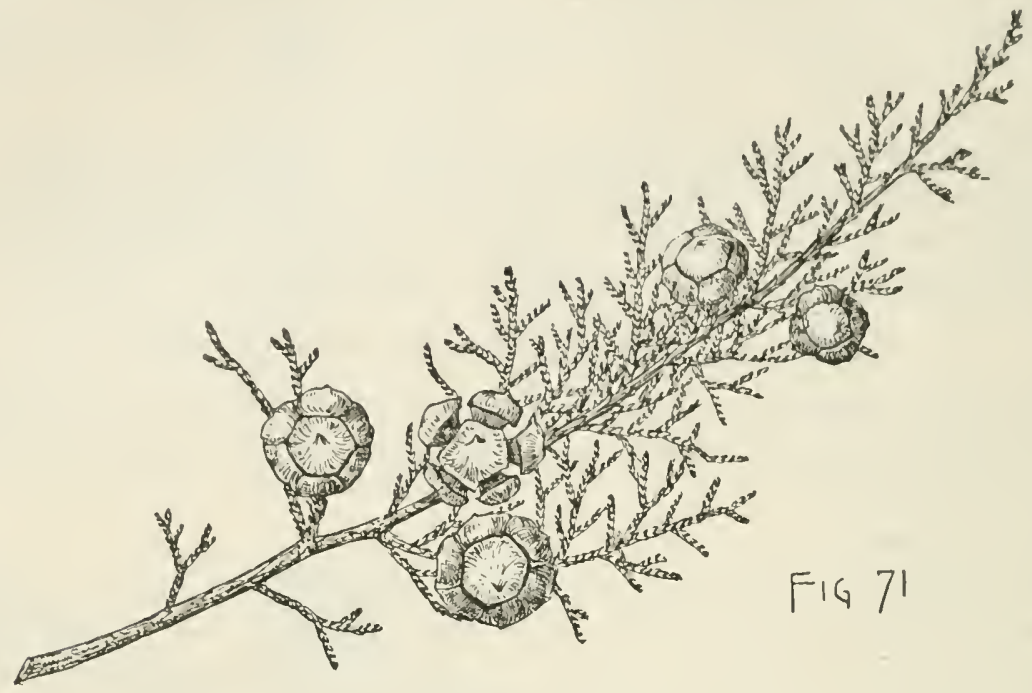

stout bright reddish brown branchlets, becoming purple and ultimately dark reddish brown. Bark bright reddish brown, about $\frac{1}{4}$ thick, and divided by shallow fissures into flat ridges separating on the surface into long thread-like scales. Wood soft, very coarse-grained, pale reddish brown.

Distribution. Sandy barrens of Mendocino County, California, in a narrow belt, beginning about three quarters of a mile from the ocean, and extending inland for three or four miles from Ten-Mile Run on the north to the Navarro on the south.

\section{Cupressus Macnabiana, A. Murr. Cypress.}

Leaves acute or rounded at the apex, rounded and conspicuously glandular on the back, deep green, often slightly glaucous, usually not more than $\frac{1}{1^{\prime}}$ long. Flowers in March and April, the

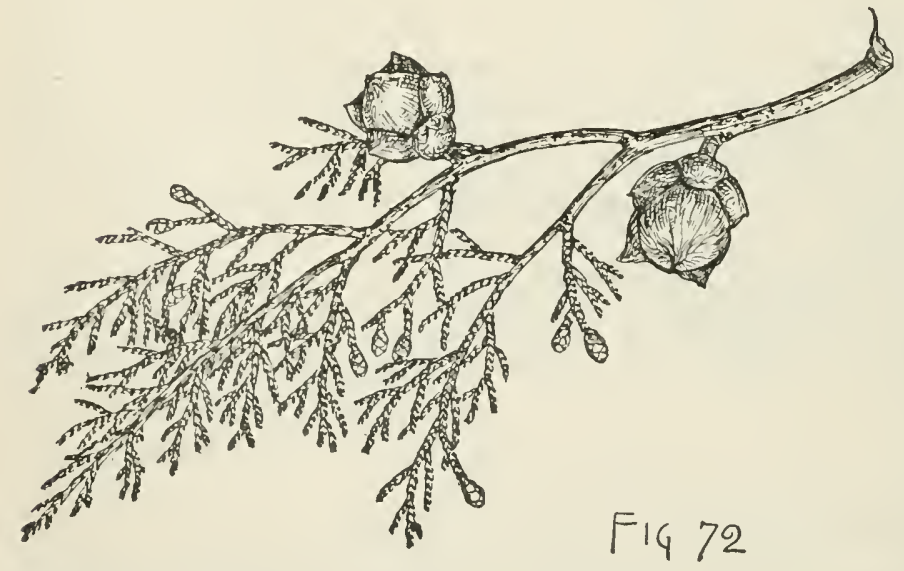
staminate nearly cylindrical, obtuse, with broadly ovate rounded connectives; pistillate subglobose, with broadly ovate scales shortpointed and rounded at the apex. Fruit oblong, subsessile or raised on a slender stalk, $\frac{3^{\prime}}{4}-1^{\prime}$ long, dark reddish brown more or less covered with a glancous bloom, slightly puberulous, especially along the margins of the 6 or rarely

8 scales, their prominent bosses thin and recurved on the lower scales, and much 
thickened, conical, and more or less incurved on the upper scales; seeds dark chestnut-brown, usually rather less than $\frac{1^{\prime}}{16}$ long, with narrow wings.

A busliy tree, rarely $30^{\circ}$ high, with a short trunk $12^{\prime}-15^{\prime}$ in diameter, slender branches covered with close smooth compact bark, bright purple after the falling of the leaves, soon becoming dark brown; more often a shrub with numerous stems $6^{\circ}-12^{\circ}$ tall forming a broad open irregular head. Bark thin, dark reddish brown, broken into brown flat ridges, and separating on the surface into elongated thin slightly attached long-persistent scales. Wood light, soft, very close-grained.

Distribution. California, dry hills and low slopes, Mt. Etna, in central Napa County through Lake County to Red Monntain on the east side of Ukiah Valley, Mendocino County, and in Trinity County between Shasta and Whiskeytown.

Occasionally cultivated in western and southern Europe as an ormamental tree.

\section{CHAM ÆCYPARIS.}

'Tall resinous pyramidal trees, with thin scaly or deeply furrowed bark, nodding leading shoots, spreading branches, flattened, often deciduous or ultimately terete branchlets 2-ranked in one horizontal plane, pale fragrant durable heartwood, thin nearly white sapwood, and naked buds. Leaves scale-like, ovate, acuminate, with slender spreading or appressed tips, opposite in pairs, becoming brown and woody before falling, on vigorous sterile branches and young plants needle-shaped or linearlanceolate and spreading. Flowers minute, monœcious, terminal, the two sexes on separate branchlets, the staminate oblong, of numerous decussate stamens, with short filaments enlarged into ovate connectives decreasing in size from below upward and bearing usually 2 pendulous globose anther-cells; the pistillate subglobose, composed of usually 6 decussate fertile peltate scales bearing at the base of the ovuliferous scales $2-5$ erect bottle-shaped ovules. Fruit an erect globose cone maturing at the end of the first season, surrounded at the base by the sterile lower scales of the flowers, formed by the eulargement of the ovule-bearing scales, abruptly dilated, club-shaped and flattened at the apex, bearing the remnants of the flower-scales as short prominent points or knobs; persistent on the branches after the escape of the seeds. Seeds 1-5, erect on the slender stalk-like base of the scale, subcylindrical and slightly compressed; seed-coat of 2 layers, the outer thin and membranaceous, the inner thicker and crustaceous, produced into broad lateral wings; cotyledons 2 , longer than the superior radicle.

Chamæcyparis is confined to the Atlantic and Pacific coast regions of North America, and to Japan and Formosa. Six species are distinguished. Of exotic species the Japanese Retinosporas, Chamcecyparis obtusa, Endl., and Chamcecyparis pisifera, Endl., with their numerous abnormal forms are familiar garden plants in all temperate regions.

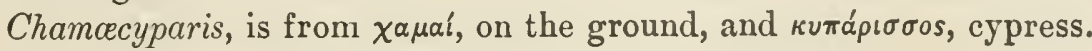

\section{CONSPECTUS OF THE NORTH AMERICAN SPECIES.}

Bark thin, divided into flat ridges.

Branchlets slender, often compressed; leaves dull blue-green, usually conspicuously glandular.

1. C. thyoides $(A, C)$.

Branchlets stout, slightly flattened or terete; leaves dark blue-green, usually without glands.

2. C. Nootkatensis $(B, G)$.

Bark thick, divided into broad rounded ridges.

Branchlets slender, compressed; leaves bright green, conspicuously glandular.

3. C. Lawsoniana (G). 


\section{Chamæcyparis thyoides, Britt. White Cedar.}

(Cupressus thyoides, Silva N.Am.x.111.)

Leaves closely appressed or spreading at the apex, especially on vigorous leading shoots, keeled and glandular or conspicnously glandular-punctate on the back, dark dull blue-green, at the north becoming russet-brown during the winter, $\frac{1}{1 \overline{1}^{\prime}}-\frac{1^{\prime}}{8}$ long, dying during the second season and then persistent for many years. Flowers : staminate composed of 5 or 6 pairs of stamcns, witl ovate connectives rounded at the apex, dark brown below the middle, nearly black toward the apex; pistillate subglobose, with ovatc acute spreading pale liver-colored scales and black ovules. Fruit globose, $\frac{1}{4}^{\prime}$ in diameter, sessile on a short leafy branch, light green covered with a glaucous

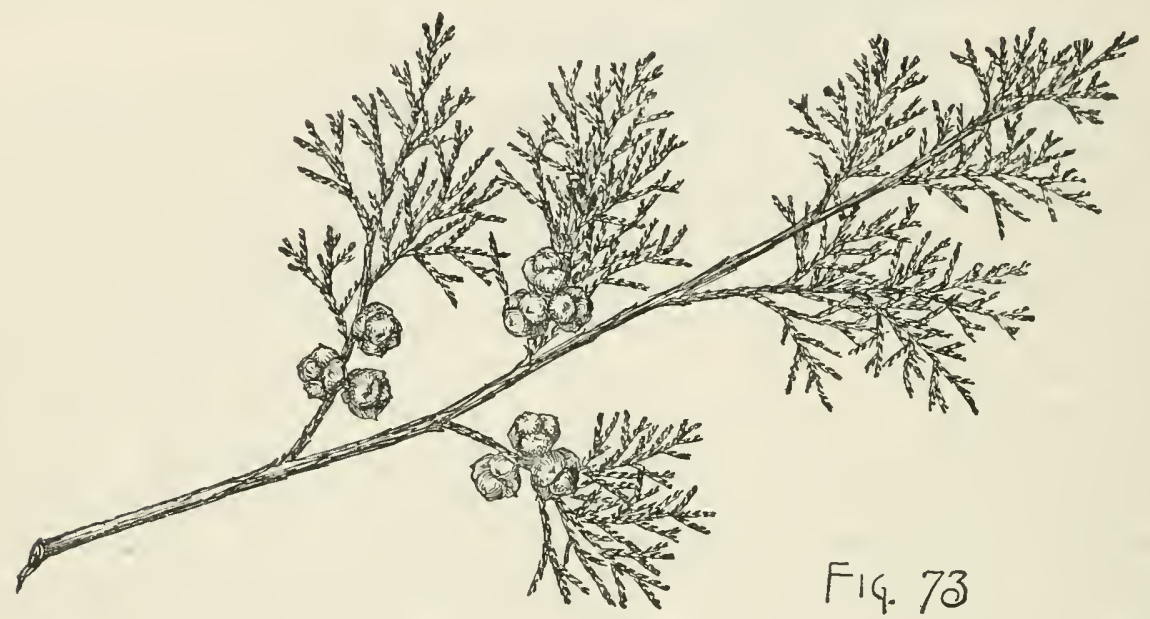

bloom when fully grown, then bluish purple and very glaucous, finally becoming dark red-brown, its scales terminating in ovate acute, often reflexed bosses; seeds 1 or 2 under each fertile scale, ovate, acute, full and rounded at the base, sightly compressed, gray-brown, about $\frac{1^{\prime}}{8}$ long, with wings as broad as the body of the seed and dark red-brown.

A tree, $70^{\circ}-80^{\circ}$ high, with a tall trunk usually about 2 and occasionally $3^{\circ}-4^{\circ}$ in diameter, slender horizontal branches forming a narrow spire-like head, 2-ranked compressed branchlets disposed in an open fall-shaped more or less deciduous spray, the persistent gradually becoming terete, light green tinged with red, light reddish brown during the first winter, and then dark browl, their thin close bark separating slightly at the end of three or four years into small papery scales. Bark $\frac{3 \prime}{4}-1^{\prime}$ thick, light reddish brown, and divided irregularly into narrow flat connected ridges often spirally twisted round the stem, separating on the surface into elongated loose or closely appressed plate-like scales. Wood light, soft, not strong, close-grained, slightly fragrant, light brown tinged with red; largely used in boat-building and cooperage, for woodenware, shingles, the interior finish of houses, fence-posts, and railway-ties.

Distribution. Cold swamps usually immersed during several montlis of the year, often forming dense pure forests, from southern Maine southward only near the coast to northern Florida, and westward to the valley of the Pearl River, Mississippi; most abundant south of Massachusetts Bay; comparatively rare east of Boston and west of Mobile Bay. 
Occasionally planted as an ornamental tree in the eastern states and in the countries of temperate Europe.

\section{Chamæcyparis Nootkatensis, Lamb. Yellow Cypress. Sitka Cypress.}

\section{(Cupressus Nootkatensis, Silva N.Am. x. 115.)}

Leaves rounded, eglandular or glandular-pitted on the back, dark blue-green, closely appressed, about $\frac{1}{8}^{\prime}$ long, on vigorous leading branchlets somewhat spreading and often $\frac{1^{\prime}}{4}$ long, with more elongated and sharper points; beginning to die at the end of their second year and usually falling during the third seasoll. Flowers : staminate on lateral branchlets of the previous year, composed of 4 or 5 pairs of stamens, with ovate rounded slightly erose light yellow connectives; pistillate clustered near the ends of

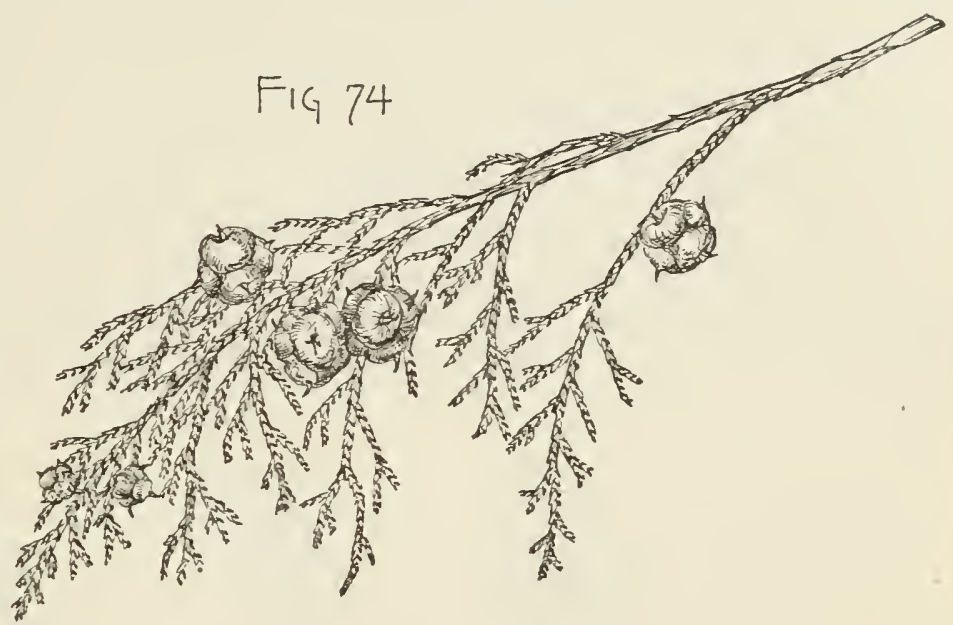
upper branchlets, dark liver color, the fertile scales bearing 2-4 ovules each. Fruit ripening in September and October, subglobose, nearly $\frac{1^{\prime}}{2}$ in diameter, dark redbrown, with usually 4 or 6 scales tipped with prominent erect pointed bosses and frequently covered with conspicuous resin-glands; seeds $2-4$ under each scale, ovate, acnte, slightly flattened, about $\frac{1^{\prime}}{4}$ long, dark red-brown, with thin light red-brown wings often nearly twice as wide as the body of the seed.

A tree, frequently $120^{\circ}$ high, with a tall trunk $5^{\circ}-6^{\circ}$ in diameter, horizontal branches forming a narrow pyramidal head, stout distichous somewhat flattened or terete light yellow branchlets often tinged with red at first, dark or often bright red-brown during their third season, ultimately paler and covered with close thin smooth bark. Bark $\frac{1^{\prime}}{2}-3^{\prime}$ thick, light gray tinged with brown, irregularly fissured and separated on the surface into large thin loose scales. Wood hard, rather brittle, very close-grained, exceedingly durable, bright clear yellow, with very thin nearly white sapwood; fragrant, with an agreeable resinous odor; used in boat and shipbuilding, the interior finish of houses, and the manufacture of furniture.

Distribution. Southwestern Alaska, and sonthward over the highlands and coast mountains of Alaska and British Columbia, and along the Cascade Mountains of Washington and Oregon to the valley of the Santiam River, extending eastward to the head-waters of the Yakima River on the eastern slope of the range; most abundant and of its largest size near the coast of Alaska and northern British Columbia, ranging from the sea-level up to elevations of $3000^{\circ}$; at high elevations on the Cascade Mountains sometimes a low shrub.

Occasionally cultivated, with its numerous abnormal forms, as an ornamental tree in the middle Atlantic states and in California, and commonly in the countries of western and central Europe. 


\section{Chamæcyparis Lawsoniana, A. Murr. Port Orford Cedar. Lawson Cypress.}

\section{(Cupressus Lawsoniana, Silva N. Am. x. 119.)}

Leaves bright green, conspicuously glandular on the back, usually not more than ${ }_{16}^{\frac{1}{6}}$ long on lateral branchlets, on leading shoots often spreading at the apex, $\frac{1^{\prime}}{8}$ to nearly $\frac{1}{4}$ long; usually dying, turning bright red-brown and falling during their third year. Flowers : staminate with bright red comectives bearing usually 2 pollen-sacs; pistillate with dark ovate acute spreading seales, each bearing $2-4$ ovules. Fruit clustered on the upper lateral branchlets and produced in great profusion, ripening in September and October, globose, abont $\frac{1}{3}$ in diameter, green and glaucous when full grown, red-brown and often covered with a bloom at maturity, its scales with thin broadly ovate acute reflexed bosses; seeds $2-4$ under each fertile scale, ovate, acute, slightly compressed, $\frac{1}{8}^{\prime}$ long, light chestnut-brown, with broad thin wings.

A tree, often $200^{\circ}$ high, with a tall trunk frequently $12^{\circ}$ in diameter above its abruptly enlarged base, a spire-like head of small horizontal or pendulous branches clothed with remote flat spray frequently $6^{\prime}-8^{\prime}$ long. Bark often $10^{\prime}$ thick at the

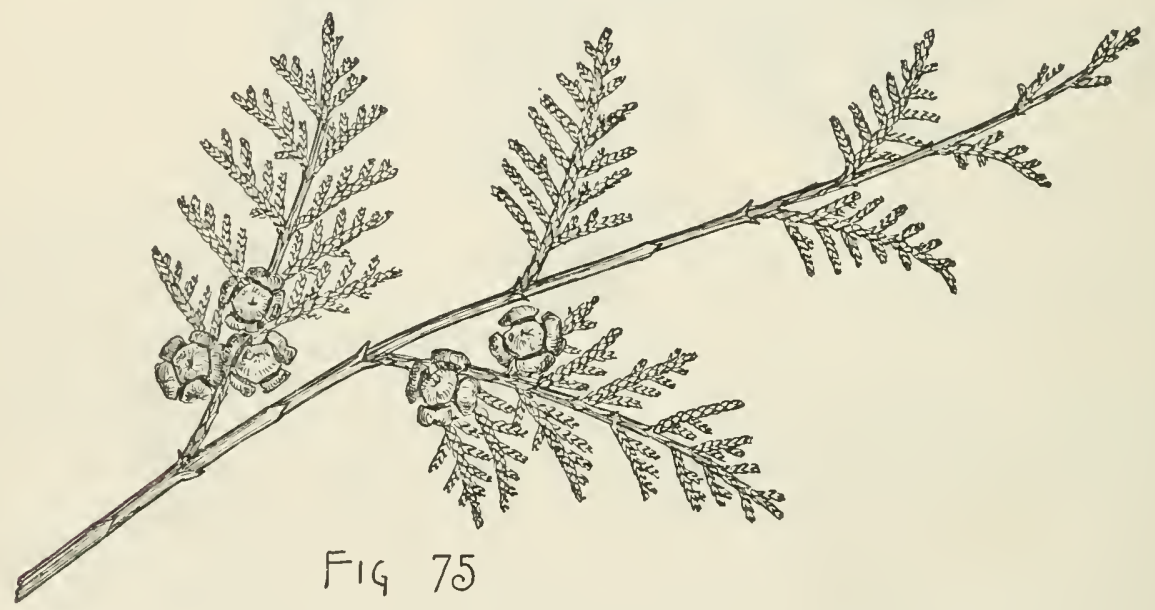

base of old trees and $3^{\prime}-^{\prime}$ thick on smaller stems, dark reddish brown, with 2 distinct layers, the inner $\frac{1}{8}^{\prime}-\frac{1}{4}^{\prime}$ thick, darker, more compact, and firmer than the onter, divided into great broad-based rounded ridges separated on the surface into small thick closely appressed scales. Wood light, hard, strong, very close-grained, abounding in fragrant resin, durable, easily worked, light yellow or almost white, with hardly distinguishable sapwood; largely manufactured into lumber used for the interior finish and flooring of buildings, railway-ties, fence-posts, and ship and boatbuilding, and on the Pacific coast almost exclusively for matches. The resin is a powerful diuretic.

Distribution. Usually scattered in small groves from the shores of Coos Bay, southwestern Oregon, south to the mouth of the Klamath River, California, ranging inland usually for about thirty miles; also near Waldorf, in Josephine County, Oregon, on the slopes of the Siskiyou Mountains, and on the southern flanks of Mt. Shasta; most abundant north of Rogue River on the Oregon coast and attaining its largest size on the western slopes of the Coast Range foothills, forming between Point 
Gregory and the mouth of the Coquille River a nearly continuous forest belt twenty miles long.

Often cultivated with the innumerable forms originated in nurseries, in the middle Atlantic states and California, and in all the temperate countries of Europe.

\section{JUNIPERUS, L. Juniper.}

Pungent aromatic trees or shrubs, with usually thin shreddy bark, soft close-grained durable wood, slender branches, and scaly or naked buds. Leaves sessile, in whorls of 3 , persistent for many years, convex on the lower side, concave and stomatiferous above, linear-subulate, sharp-pointed, without glands; or scale-like, ovate, opposite in pairs or ternate, closely imbricated, appressed and adnate to the branch, glandular on the back, becoming brown and woody on the branch, but on young plants and vigorous shoots often free and awl-shaped. Flowers minute, diœcious, axillary or terminal on short axillary branches from buds formed the previous autumn on branches of the year; the staminate solitary, oblong-ovate, with numerous stamens decussate or in 3's, their filaments enlarged into ovate or peltate yellow scale-like connectives bearing near the base 2-6 globose pollen-sacs; the pistillate ovoid, surrounded at the base by many minute scale-like bracts persistent and unchanged under the fruit, composed of 2-6 opposite or ternate pointed scales alternate with or bearing on their inner face at the base on a minute ovuliferous scale 1 or 2 ovules. Fruit a berry-like succulent fleshy blue, blue-black, or red strobile formed by the coalition of the flowerscales, inclosed in a uembranaceous epidermis covered with a glaucous bloom, ripening during the first, second, or rarely during the third season, smooth or marked by the ends of the flower-scales, or by the pointed tips of the ovules, closed, or open at the top and exposing the apex of the seeds. Seeds 1-12, ovate, acute or obtuse, terete or variously angled, often longitudinally grooved by depressions caused by the pressure of resin-cells in the flesh of the fruit, smooth or roughened and tuberculate, light chestnut-brown, marked below by the large conspicuous usually 2-lobed hilum; seed-coat of 2 layers, the outer thick and bony, the inner thin, membranaceous or crustaceous; cotyledons 2 , or $4-6$, about as long as the superior radicle.

Juniperus is widely scattered over the northern hemisphere from the Aretic Circle to the bighlands of Mexico, Lower California, and the West Indies in the New -World, and to the Azores and Canary Islands, northern Africa, Abyssinia, the mountains of east tropical Africa, Sikkim, central China, and the mountains of southern Japan in the Old World. About thirty-five species are now distinguished. Of the exotic species cultivated in the United States the most common are European forms of Juniperus communis, L., with fastigiate branches, and dwarf forms of Juniperus Sabina, L., and of Juniperus recurva, D. Don, of the Himalayas.

Juniperus is the classical name of the Juniper.

\section{CONSPECTUS OF THE NORTH AMERICAN SPECIES.}

Flowers axillary; stamens decussate; ovules 3, alternate with the scales of the flower, their tips persistent on the fruit; seeds usually 3 ; leaves in 3 's, awl-shaped, rigid, free and jointed at the base, without glands; buds scaly.

Fruit subglobose, bright blue corered with a glaucous bloom; leaves spreading, dark yellow-green, channeled and white glaucous on the upper surface.

1. J. communis $(A, B, F)$. Flowers terminal, on short axillary branchlets; stamens decussate or in 3's; ovules in the 
axils of small fleshy scales, often enlarged and conspicuous on the fruit; seeds 1-12; leaves in 3's or opposite, mostly scale-like, crowded, closely appressed and adnate on the branches, free and awl-shaped on vigorous sloots and young plants; buds naked.

Fruit large, reddish brown, with dry fibrous sweet flesh.

Seeds single or few ; cotyledons 4-6.

Fruit usually oblong; seeds 1 or 2 ; leaves in 3 's, rounded at the apex, conspicuously glandular on the back; branchlets stout.

2. J. Californica $(\mathrm{G})$.

Fruit mostly globose; seeds usually solitary; leaves in 3 's or in pairs, acute or acuminate, without glands; branchlets slender. $\quad 3$. J. Utahensis (F, G).

Seeds 4-12; cotyledons 2.

Fruit oblong or globose ; leaves in pairs, glandular, often slightly spreading at the acute or acuminate apex; branchlets slender.

4. J. flaccida (F).

Fruit globose ; seeds usually 4 ; leaves in pairs, acute, glandular ; branchlets slender; bark thin, broken into small oblong plates. 5. J. pachyphlæa (E, F, H).

Fruit small (large in 6), blue or blue-black (rarely copper color in 7), with resinous juicy flesh ; seeds 1-4; cotyledons 2.

Fruit subglobose or oblong, the flesh filled with large resin-glands; seeds 2 or 3 ; leaves in 3's, conspicuously glandular; branchlets stout.

6. J. occidentalis (B, G).

Fruit globose or oblong; seeds 1 or rarely 2 ; leaves usually without glands; branchlets slender.

7. J. monosperma (F).

Fruit globose; seeds 1-4; leaves obtuse or rarely acute, keeled and glandular; branchlets slender.

S. J. sabinoides (C).

Fruit subglobose; seeds 1-4; leaves acute, acuminate, or rarely obtuse, glandular; branchlets stout, often erect.

9. J. Virginiana $(A, C)$.

Fruit small, subglobose; seeds usually 2 ; leaves in pairs, acute or acuminate, glandular; branchlets very slender; pendulous. 10. J. Barbadensis (C).

Fruit subglobose, maturing the second season; seeds usually 2 ; leaves acute or acuminate; branchlets rigid, often erect.

11. J. scopulorum (B, F).

\section{Leaves awl-shaped, rigid, free and jointed at the base.}

\section{Juniperus communis, I. Juniper.}

Leaves in ternate whorls, spreading nearly at right angles to the branchlets, linearlanceolate, acute and tipped with sharp slender points, articulate and truncate at the base, thickened, rounded, obscurely ridged, dark green and lustrous on the lower surface, snowy white and covered with stomata on the upper surface, $\frac{1}{3}^{\prime}-\frac{1}{2}^{\prime}$ long, about $\frac{1}{32}{ }^{\prime}$ wide, turning during winter a deep rich bronze color on the lower surface, persistent for many years. Flowers : staminate composed of 5 or 6 whorls each of 3 stamens, with broadly ovate acute and short-pointed comnectives, bearing at the very base 3 or 4 globose anther-cells; pistillate surrounded by 5 or 6 whorls of ternate leaf-like scales, composed of 3 slightly spreading ovules abruptly enlarged and open at the apex, with 3 minute obtuse fleshy scales below and alteruate with them. Fruit maturing in the third season, subglobose or oblong, tipped with the remnants of the enlarged points of the ovules, about $\frac{1^{\prime}}{4}$ in diameter, with soft mealy resinous sweet flesil and 1-3 seeds; often persistent on the branches one or two years after ripening; seeds ovate, acute, irregularly angled or flattened, deeply penetrated by numerous prominent thin-walled resin-glands, about $\frac{1^{\prime}}{8}$ long, the outer coat thick and bony, the inner membranaceous.

In America only occasionally tree-like and $20^{\circ}-30^{\circ}$ tall, with a short eccentric irregularly lobed trunk rarely a foot in diameter, erect branches forming an irregular 
open head, slender branchlets, smooth, lustrous, and conspicuously 3-angled between the short nodes during their first and second years, light yellow tinged with red, gradually growing darker, their dark red-brown bark separating in the third season into small thin scales, and ovate acute buds about $\frac{1}{8}$ long and loosely covered with scale-like leaves; more often a shrub, with many short slender stems prostrate at the base and turning upward and forming a broad mass sometimes $20^{\circ}$ across and $3^{\circ}$ or $4^{\circ}$ high; at high elevations and in the extreme north prostrate, with long decumbent stems (var. Sibirica, Rydb.). Bark about $\frac{1}{1^{\prime} \overline{6}}$ thick, dark reddish brown, separating irregularly into many loose papery persistent scales. Wood hard, closegrained, very durable in contact with the soil, light brown, with pale sapwood. In

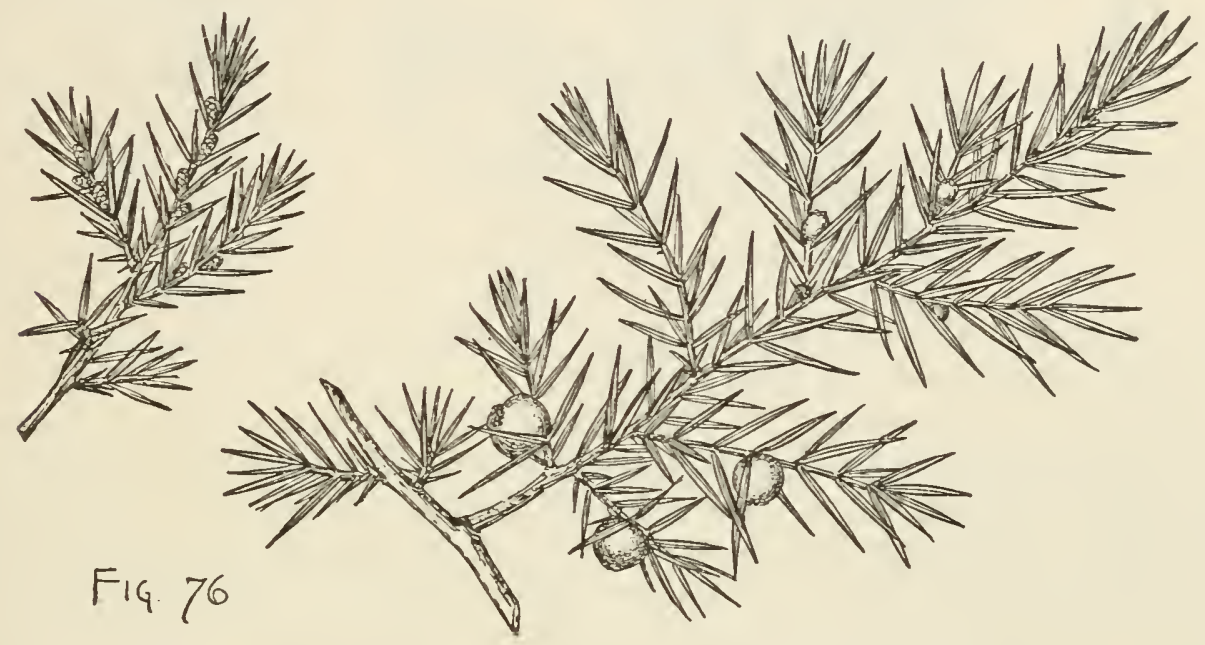

northern Europe the sweet aromatic fruit of this tree is used in large quantities to impart its peculiar flavor to gin; occasionally employed in medicine.

Distribution. Southern Greenland to the highlands of Pennsylvania, northern Nebraska, along the Rocky Mountains to western Texas, New Mexico, and Arizona, and on the Pacific coast from Alaska to northern California, only becoming truly arborescent in America on the limestone hills of southern Illinois; in the Old World widely distributed through all the northern hemisphere from arctic Asia and Europe to the Himalayas and the mountains of the Mediterranean Basin.

Often planted, especially in some of its pyramidal and dwarf forms, in the eastern United States and in the countries of western, central, and northern Europe.

2. Leaves scale-like, closely appressed and adnate to the branches.

* Fruit large, reddish brown.

$\rightarrow$ Seeds single or few.

\section{Juniperus Californica, Carr. Juniper.}

Leaves usually in 3's, closely appressed, thickened, slightly keeled and conspicuously glandular-pitted on the back, rounded at the apex, distinctly cartilaginously fringed on the margins, light yellow-green, about $\frac{1^{\prime}}{8}$ long, dying and turning brown on the branch at the end of two or three years; on vigorous shoots linear-lanceolate, rigid, sharp-pointed, $\frac{1}{4}^{\prime}-\frac{1}{2}^{\prime}$ long, whitish on the upper surface. Flowers from January to March; staminate of 18-20 stamens, disposed in 3's, with rhomboidal 
short-pointed connectives; scales of the pistillate flower nsually 6 , ovate, acute,
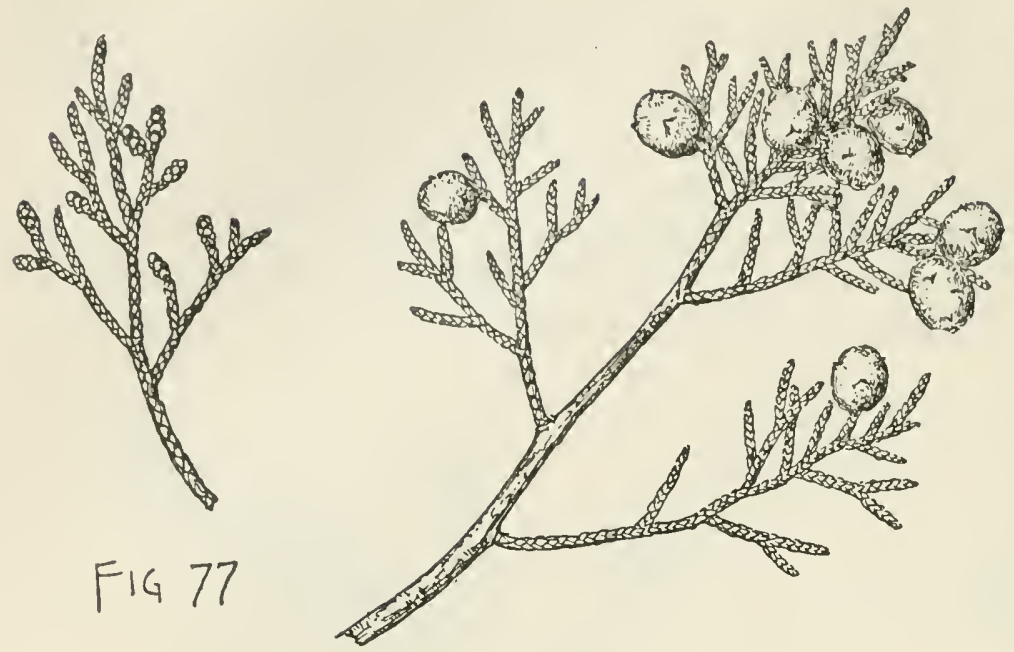

spreading, obliterated or ininute on the fruit. Fruit ripening in the autumn of the second season, globose or oblong, $\frac{1^{\prime}-3^{\prime}}{2}$ long, reddish brown, with a membranaceous loose epidermis covered with a thick glaucous bloom, thin fibrous dry sweet flesh, and 1 or 2 large seeds; seeds ovate, acute, sharppointed, irregularly

lobed and angled, with a thick shell, the outer coat hard and bony, the imer thin, white, and cartilaginous, and 4-6 cotyledons.

A conical tree, occasionally $40^{\circ}$ high, with a straight large-lobed unsymmetrical trunk $1^{\circ}-2^{\circ}$ in diameter; more often shrubby, with many stout irregular usually contorted stems forming a broad open head. Bark thin and divided into long loose plate-like seales ashy gray on the outer surface and persistent for many years. Wood soft, close-grained, durable in contact with the soil, light brown slightly tinged with red, with thin nearly white sapwood; used for fencing and fuel. The fruit is eaten by Indians fresh or ground into flour.

Distribution. Dry mountain slopes and plains from the valley of the lower Sacramento River southward through the California coast-ranges to Lower California, spreading inland along the southern coast mountains to their union with the Sierra Nevada, and northward along the western slopes of the sierras to the neighborhood of Keruville; also on the desert slopes of the Tehachapi Mountains, or the northern foothills of the San Bernardino Mountains, and on the eastern slopes of the San Jacinto and Cuyamaca ranges.

\section{Juniperus Utahensis, Lemm. Juniper.}

Leaves opposite or occasionally in 3's, rounded, mostly without glands on the back, acute or often acuminate, light yellow-green, rather less than $\frac{1}{8}^{\prime}$ long, persistent for many years, the elongated and long-pointed leaves of young shoots passing gradually into the, acerose leaves of more vigorous shoots and seedling plants. Flowers: staminate with 18-24 opposite or ternate stamens, their connectives rhomboidal; scales of the pistillate flower acute, spreading, often in pairs. Fruit ripening during the autumn of the second season, subglobose or oblong, marked by the more or less prominent tips of the flower-scales, reddish brown, with a thick firm epidermis covered with a glaucous bloom and closely investing the thin dry sweet flesh, $\frac{1}{8}^{\prime}-1^{\prime}$ long, with 1 or rarely 2 seeds; seeds ovate, acute, conspicuously acntely angled, marked nearly to the apex by the hilum, $\frac{1}{16}{ }^{\prime}-\frac{1}{2}$ ' long, with a hard bony shell, a membranaceous pale brown inner seed-coat, and 4-6 cotyledons.

A bushy tree, rarely exceeding $20^{\circ}$ in height, with a short usually eccentric trunk 
sometimes $2^{\circ}$ in diameter, generally divided near the ground by irregular deep fissures into broad rounded ridges, many erect contorted branches forming a broad open head, slender light yellow-green branchlets covered after the falling of the leaves with thin light red-brown scaly bark; more often with numerous stems spreading from the ground and frequently not more than $8^{\circ}-10^{\circ}$ high. Bark about $\frac{1^{\prime}}{4}$ thick,
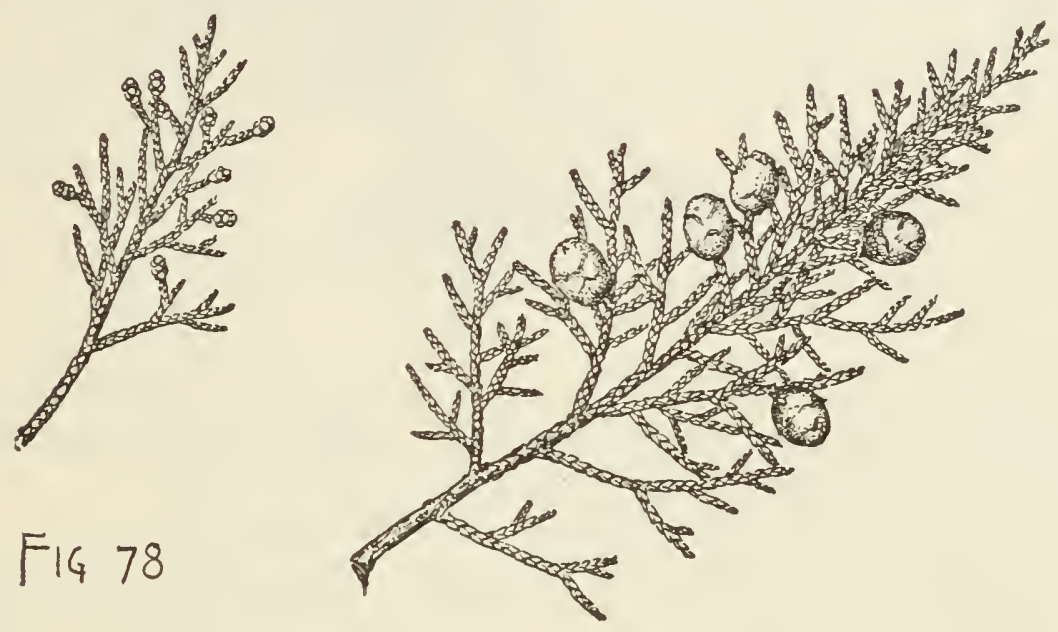

ashy gray or sometimes nearly white, and broken into long thin persistent scales. Wood light brown, slightly fragrant, with thick nearly white sapwood; largely used locally for fuel and fencing. The fruit is eaten by Indians fresh or ground and baked into cakes.

Distribution. In the desert region between the Rocky Mountains and the Sierra Nevada, where it is the most abundant and most generally distributed tree, from the western foothills of the Wahsatch Mountains in eastern Utah to southeastern California, northern Arizona, western Colorado, and southern Wyoming; in central Nevada often descending into the valleys and forming open stunted forests at elevations of about $5000^{\circ}$; more abundant and of larger size on arid slopes to elevations of $8000^{\circ}$ above the sea in dense nearly pure forests.

\section{$\rightarrow \rightarrow$ Seeds 4-12.}

\section{Juniperus flaccida, Schlecht. Juniper.}

Leaves opposite, long-pointed, and sometimes slightly spreading at the apex, rounded and conspicuously glandular on the back, light yellow-green, about $\frac{1}{8}$ ' long, turning cinnamon-red and dying on the branch; on vigorous young shoots ovatelanceolate, sometimes $\frac{1}{2}$ long, with elongated rigid callous tips. Flowers: staminate slender, composed of 16-20 stamens, with ovate pointed connectives prominently keeled on the back; pistillate with acute or acuminate spreading scales. Fruit globose or oblong, irregularly tuberculate, dull red-brown, more or less covered with a glaucous bloom, marked by the numerous reflexed tips of the flowerscales, $\frac{1}{2}-\frac{3^{\prime}}{4}$ long, with a close firm epidermis and dry mealy flesh; seeds 4-12, often abortive and distorted, about $\frac{1^{\prime}}{8}$ long, with 2 cotyledons.

A tree, occasionally $30^{\circ}$ high, with gracefully spreading branches and long sleuder drooping branchlets, covered after the leaves fall with thin bright cinnamon-brown bark separating into thin loose papery scales; often a shrub. 


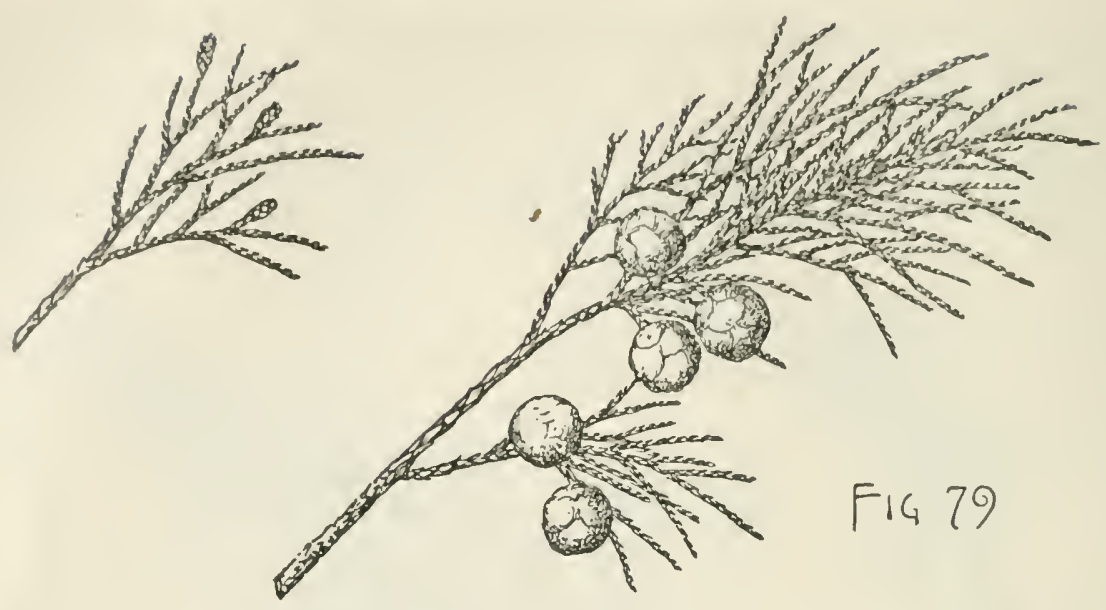

Distribution. In the United States only on the slopes of the Chisos Mountains in southwestern Texas; common in northeastern Mexico, growing at elevations of $6000^{\circ}-8000^{\circ}$ on the hills east of the Mexican table-lands.

Occasionally cultivated in the gardens of southern France and Algeria.

\section{Juniperus pachyphlæa, Torr. Juniper. Checkered-bark Juniper.}

Leaves in pairs, appressed, rounded and apiculate at the apex, thickened, obscurely keeled and glandular on the back, bluish green, rather less than $\frac{1}{8}^{\prime}$ long; on vigorous shoots and young branchlets linear-lanceolate, tipped with slender elongated points, and pale blue-green like the young branchlets. Flowers opening in February and March, the staminate stout, $\frac{1}{8}^{\prime}$ long, with 10 or 12 stamens, their connectives broadly ovate, obscurely keeled on the back, short-pointed; scales of the pistillate flower ovate, acuminate, and spreading. Fruit ripening in the autumn of the second season, globose or oblong, irregularly tuberculate, about $\frac{1}{2}^{\prime}$ long, usually marked

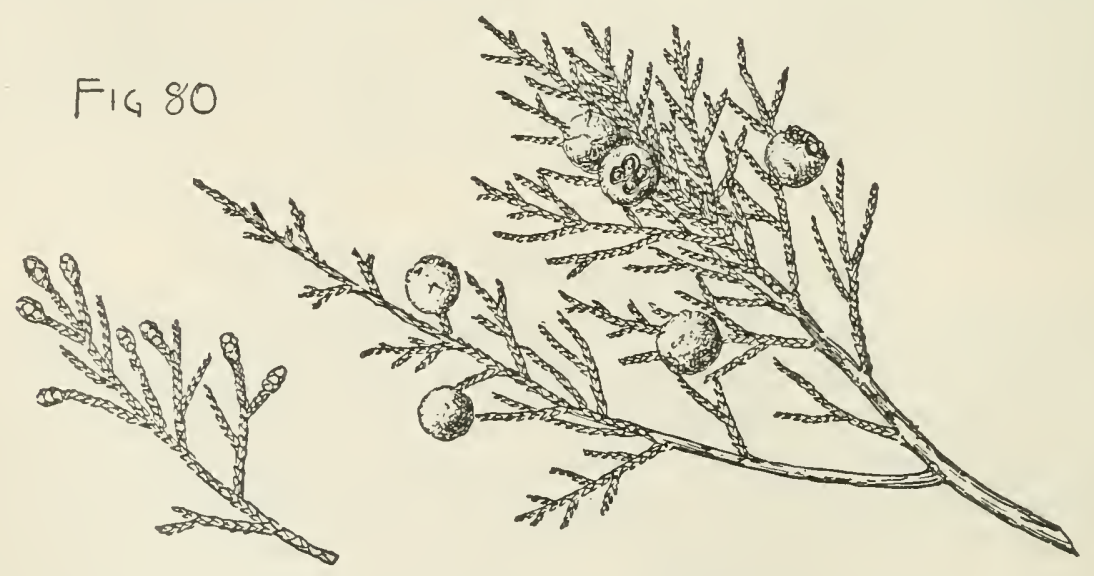

with the short tips of the flower-scales, occasionally opening and discharging the seeds at the apex, dark red-brown, more or less covered with a glaucous bloom, especially during the first season and then occasionally bluish in color, with a thin - epidermis closely investing the thick dry mealy flesh, and usually 4 seeds; seeds acute, conspicuously ridged and gibbous on the back, with a thick shell, a pale inner seed-coat, and 2 cotyledons. 
A tree, often $50^{\circ}-60^{\circ}$ high, with a short trunk $3^{\circ}-5^{\circ}$ in diameter, long stout spreading branches forming a broad-based pyramidal or ultimately a compact roundtopped head, and slender branchlets covered after the disappearance of the leaves with thin light red-brown usually smooth close bark occasionally broken into large thin scales. Bark $\frac{3^{\prime}}{4}-4^{\prime}$ thick, dark brown tinged with red, deeply fissured and divided into nearly square plates $1^{\prime}-2^{\prime}$ long, and separating on the surface into small thin closely appressed scales. Wood light, soft, not strong, brittle, close-grained, clear light red often streaked with yellow, with thin nearly white sapwood. The fruit is gathered and eaten by Indians.

Distribution. Dry arid mountain slopes usually at elevations of $4000^{\circ}-6000^{\circ}$ above the sea, from the Eagle and Limpio mountains in southwestern Texas, westward along the desert ranges of New Mexico and Arizona, south of the Colorado plateau, extending northward to the lower slopes of many of the high mountains of northern Arizona and southward into Mexico.

**Fruit small [large in 6$]$, blue or blue-black; seeds 1-4.

\section{Juniperus occidentalis, Hook. Juniper.}

Leaves in 3's, closely appressed, acute or acuminate, rounded and conspicuously glandular on the back, gray-green, about $\frac{1}{8}^{\prime}$ long. Flowers : staminate stout, obtuse, with 12-18 stamens, their connectives broadly ovate, rounded, acute or apiculate and
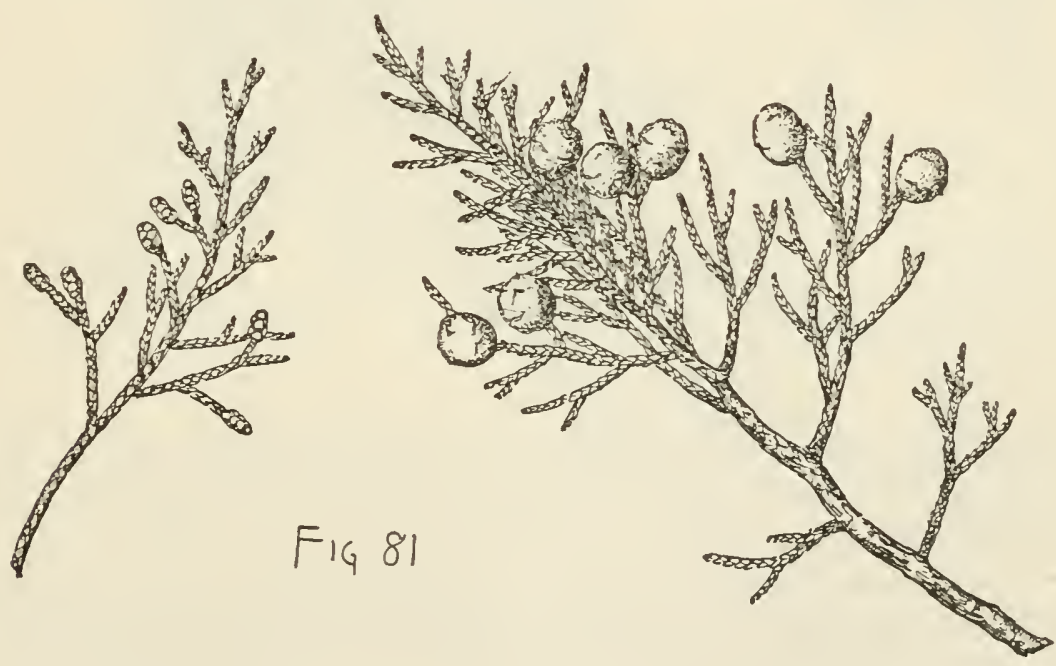

scarious or slightly ciliate on the margins; scales of the pistillate flower ovate, acute, spreading, mostly obliterated from the fruit. Fruit subglobose or oblong, $\frac{1}{4}^{\prime}-\frac{1^{\prime}}{3}$ long, with a thick firm blue-black epidermis coated with a glaucous bloom, thin dry flesh filled with large resin-glands, and 2 or 3 seeds; seeds ovate, acute, rounded and deeply grooved or pitted on the back, flattened on the inner surface, about $\frac{1}{8}^{\prime}$ long, with a thick bony shell, a thin brown inner seed-coat, and 2 cotyledons.

A tree, occasionally $60^{\circ}$ high, with a tall straight trunk $2^{\circ}-3^{\circ}$ in diameter, more often hardly exceeding $20^{\circ}$ in height, with a short trunk sometimes $10^{\circ}$ in diameter, enormous branches, spreading at nearly right angles and forming a broad low head, and stout branchlets covered after the leaves fall with thin bright red-brown bark broken into loose papery scales; frequently when growing on dry rocky slopes and 
toward the northern limits of its range shrubby, with many short ereet or semiprostrate stems. Bark about $\frac{1}{2}$ thick, bright cinnimon-red, divided by broad shallow fissures into wide flat irregularly connected ridges separating on the surface into thin lustrous scales. Wood light, soft, very close-grained, exceedingly durable, light red or brown, with thick nearly white sapwood; used for fencing and fucl. The fruit is gathered and eaten by the California Indians.

Distribution. Mountain slopes and ligh prairies of western Idaho and western Washington and Oregon, along the summits and upper slopes of the Sierra Nevada of California, sonthward to the San Bernardino Monntains; attaining its greatest trunk diameter on the wind-swept peaks of the California sierras, usually at elevations betwcen $6000^{\circ}$ and $10,000^{\circ}$ above the sea.

\section{Juniperus monosperma, Sarg. Juniper.}

Leaves in pairs or rarely in 3 's, often slightly spreading at the apex, acute or occasionally acuminate, much thickened and rounded on the back, usually withont

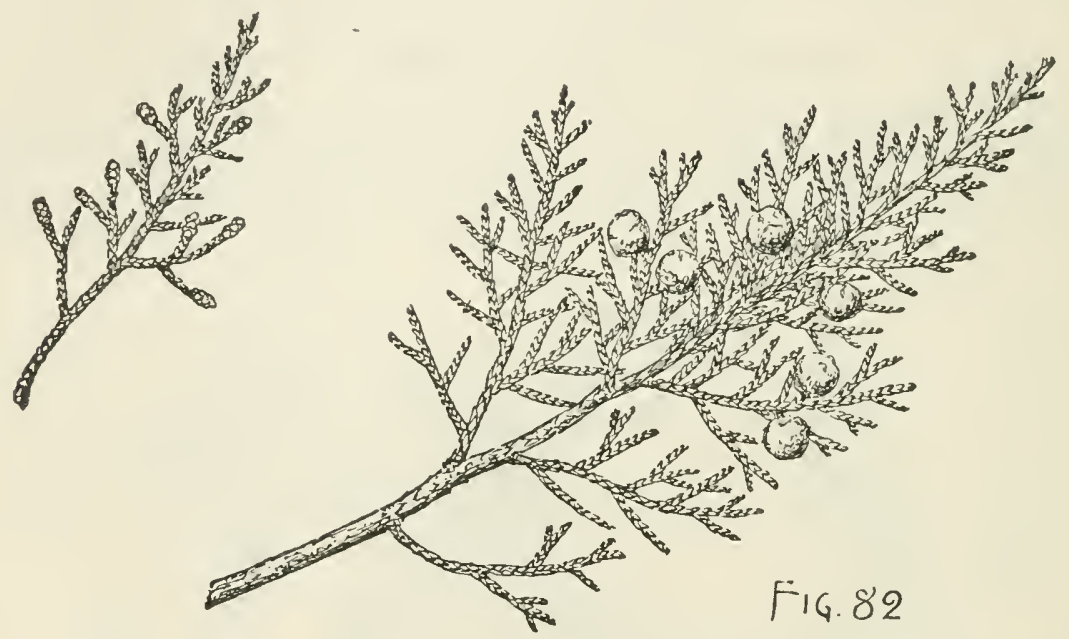

or occasionally with obscure dorsal glands, gray-green, rather less than $\frac{1}{8}^{\prime}$ long, turning bright red-brown before falling; on vigorous shoots and young plants ovate, acute, tipped with long rigid points, thin, conspicnously glandular on the back, often $\frac{1}{2}^{\prime}$ long. Flowers : staminate with 8-10 stamens, their broadly ovate, rounded, or pointed connectives slightly erose on the margins; pistillate with spreading pointed scales. Fruit globose or oblong, $\frac{1}{8}^{\prime}-\frac{1}{4}^{\prime}$ long, dark blue or occasionally copper color, with a thick firm epidermis covered with a thin glaucous bloom, thin resinous flesh, and 1 or rarely 2 or 3 seeds; seeds broadly ovate, often 4 -angled, somewhat obtuse at the apex, with numerous slender grooves between the ridges, a comparatively thin brittle shell, and 2 cotyledons.

A tree, occasionally $40^{\circ}-50^{\circ}$ high, with a stout much-lobed and buttressed trunk sometimes $3^{\circ}$ in diameter, short stout branches forming an open very irregular head, and slender branchlets covered after the falling of the leaves with light redbrown bark spreading freely into thin loose scales. Bark thin, ashy gray, divided into irregularly connected ridges, broken into long narrow persistent shreddy scales. Wood heavy, slightly fragrant, light reddish brown, with nearly white sapwood and eccentric layers of annual growth; largely used for fencing and fuel. The fruit is 
ground into flour and baked by the Indians, who use the thin strips of fibrous bark in making saddles, breechclotlıs, and sleeping-mats.

Distribution. Along the eastern base of the Rocky Mountains from the divide between the Platte and Arkansas rivers in Colorado to western Texas, spreading over the Colorado plateau, over the mountain ranges of Nevada, southern New Mexico and Arizona, and southward into northern Mexico; often covering, with the Nut Pine, in southern Colorado and Utah, and in northern and central New Mexico and Arizona, great areas of rolling hills $6000^{\circ}-7000^{\circ}$ above the sea-level; reaching its largest size in northern Arizona.

\section{Juniperus sabinoides, Nees. Cedar. Rock Cedar.}

Leaves in pairs, thickened and keeled on the back, obtuse or acute at the apex, mostly without glands, rather more than $\frac{1}{1 \overline{6}^{\prime}}$ long, dark blue-green; on vigorous young shoots and seedling plants lanceolate, long-pointed, rigid, $\frac{1^{\prime}}{4}-\frac{1^{\prime}}{2}$ long. Flowers : staminate with 12-18 stamens, their connectives ovate, obtuse, or slightly cuspidate; scales of the pistillate flower ovate, acute, and spreading, very conspicuous when the fruit is half grown, becoming obliterated at its maturity. Fruit subglobose, $\frac{1}{4}^{\prime}-\frac{1}{2}{ }^{\prime}$ in diameter, dark blue, with a thin epidermis covered with a glaucous bloom, sweet resinous flesh, and 1 or rarely 2 seeds; seeds broadly ovate, acute, slightly or
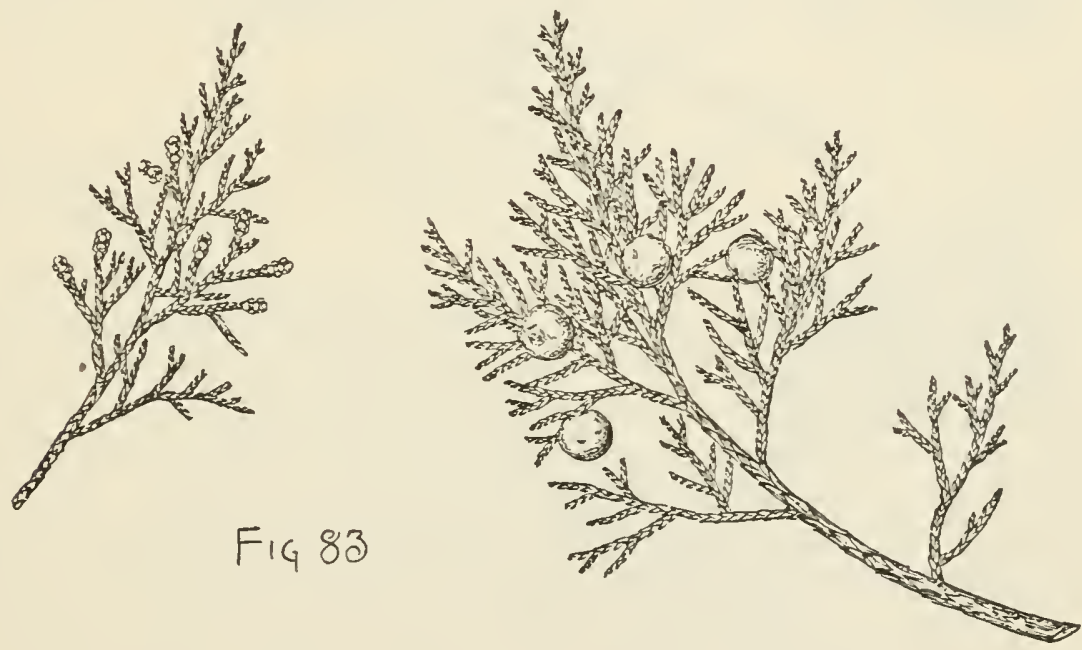

conspicuously ridged, rarely tuberculate, nearly $\frac{1}{4}^{\prime}$ long and $\frac{1}{8}^{\prime}$ thick, with a small hilum, a thin outer seed-coat, a membranaceous dark brown inner coat, and 2 cotyledons.

A tree, occasionally $100^{\circ}$ but generally not more than $20^{\circ}-30^{\circ}$ high, with a short or elongated slightly lobed trunk seldom exceeding a foot in diameter, small spreading branches forming a wide round-topped open and irregular or a narrow pyramidal head, slender sharply 4-angled branchlets becoming terete after the falling of the leaves, light reddish brown or ashy gray, with smooth or slightly scaly bark; often a shrub, with numerous spreading stems. Bark on young stems and on the branches gray tinged with red, covered with a network of flat plates, scaly on the surface and separated on the margins into thin pale shreds, becoming on old trees $\frac{1}{4}-\frac{1}{2}$ thick, brown tinged with red, and divided into long narrow slightly attached scales persistent for many years and clothing the trunk with a loose thatcl-like covering. 
Wood light, hard, not strong, slightly fragrant, brown streaked with red; largely used for fencing, fuel, telegraph-poles, and railway-ties.

Distribution. From Brazos County over the low limestone hills of western and southern Texas, and soutliward into Mexico; forming great thickets and growing to its largest size on the San Bernardo River; much smaller farther westward, and usually shrubby at the limits of vegetation on the high mountains of central Mexico.

\section{Juniperus Virginiana, L. Red Cedar. Savin.}

Leaves in opposite pairs, acute or acuminate witl short slender points or occasionally obtuse, rounded and glandular or eglandular on the back, about $\frac{1}{1 \frac{6}{}}$ long,

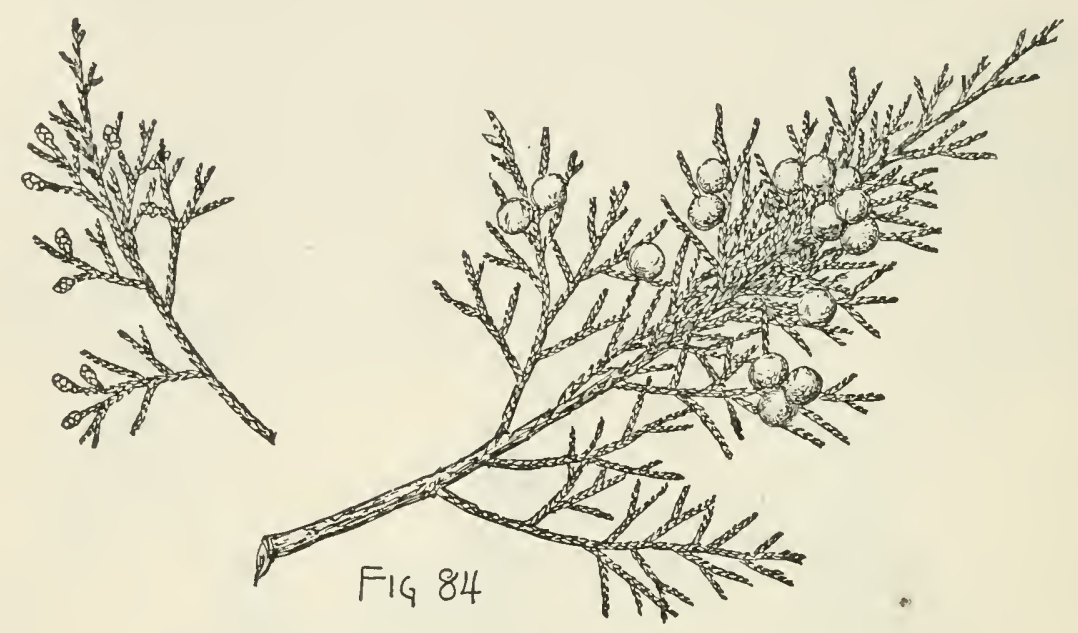

dark blue-green or glaucous, at the north turning russet or yellow-brown during the winter, beginning in their third season to grow hard and woody, and remaining two or three years longer on the branches; on young plants and vigorous branches linearlanceolate, long-pointed, light yellow-green, without glands, $\frac{1}{2}^{\prime}-\frac{3^{\prime}}{4}$ long. Flowers : diœcious or very rarely monœcious; staminate with 10 or 12 stamens, their connectives rounded and entire, with 4 or occasionally 5 or 6 pollen-sacs; scales of the pistillate flower violet color, acute and spreading, becoming obliterated from the fruit. Fruit subglobose, $\frac{1^{\prime}}{4}-\frac{1^{\prime}}{3}$ in diameter, pale green when fully grown, dark blue and covered with a glaucous bloom at maturity, with a firm epidermis, thin sweetish resinous flesh, and 1 or 2 or rarely 3 or 4 seeds; seeds acute and occasionally apiculate at the apex, marked below with a comparatively small 2-lobed hilum, $\frac{1^{\prime}}{6}-\frac{1^{\prime}}{8}$ long, with a thick bony outer coat, a pale brown membranaceous inner coat, and 2 cotyledons.

A tree, occasionally $100^{\circ}$ high, with a trunk $3^{\circ}-4^{\circ}$ in diameter, often lobed and eccentric, and frequently buttressed toward the base, generally not more than $40^{\circ}$ $50^{\circ}$ tall, with short slender branches horizontal on the lower part of the tree, erect above, forming a narrow compact pyramidal head, in old age usually becoming broad and round-topped or irregular, and slender 4-angled branchlets terete after the disappearance of the leaves and covered with close dark brown bark tinged with red or gray. Bark $\frac{1^{\prime}}{8}-\frac{1^{\prime}}{4}$ thick, light brown tinged with red, and separated into long narrow seales fringed on the margins, and persistent for many years. Wood light, closegrained, brittle, not strong, dull red, with thin nearly white sapwood, very fragrant, easily worked; largely used for posts, the sills of buildings, the interior finish of 
houses, the lining of elosets and chests for the preservation of woolens against the attacks of moths, and largely for pails and other small articles of woodenware. A decoction of the fruit and leaves is used in medicine, and oil of red cedar distilled from the leaves and wood as a perfume.

Distribution. Dry gravelly slopes and rocky ridges, often immediately on the seacoast, from southern Nova Scotia and New Brunswick to the coast of Georgia, the interior of southern Alabama and Mississippi, and westward to the valley of the lower Ottawa River, eastern Dakota, eastern Nebraska and Kansas, the Indian Territory and eastern Texas, not ascending the mountains of New England and New York nor the high southern Alleghanies; in middle Kentucky and Tennessee, and northern Alabama and Mississippi, covering great areas of low rolling limestone hills with nearly pure forests of small bushy trees.

Often cultivated in the northern and eastern states as an ornamental tree and occasionally in the gardens of western and central Europe.

\section{Juniperus Barbadensis, L. Red Cedar.}

Leaves opposite in pairs, narrow, acute or gradually narrowed above the middle and acuminate, marked on the back by conspicuous oblong glands. Flowers opening in early March, staminate elongated, $\frac{1^{\prime}}{8}$ to nearly $\frac{1^{\prime}}{4}$ long, with 10 or 12 stamens, their connectives rounded, entire, and bearing usually 3 pollen-sacs; pistillate with scales gradually narrowed above the middle, acute at the apex, and obliterated from

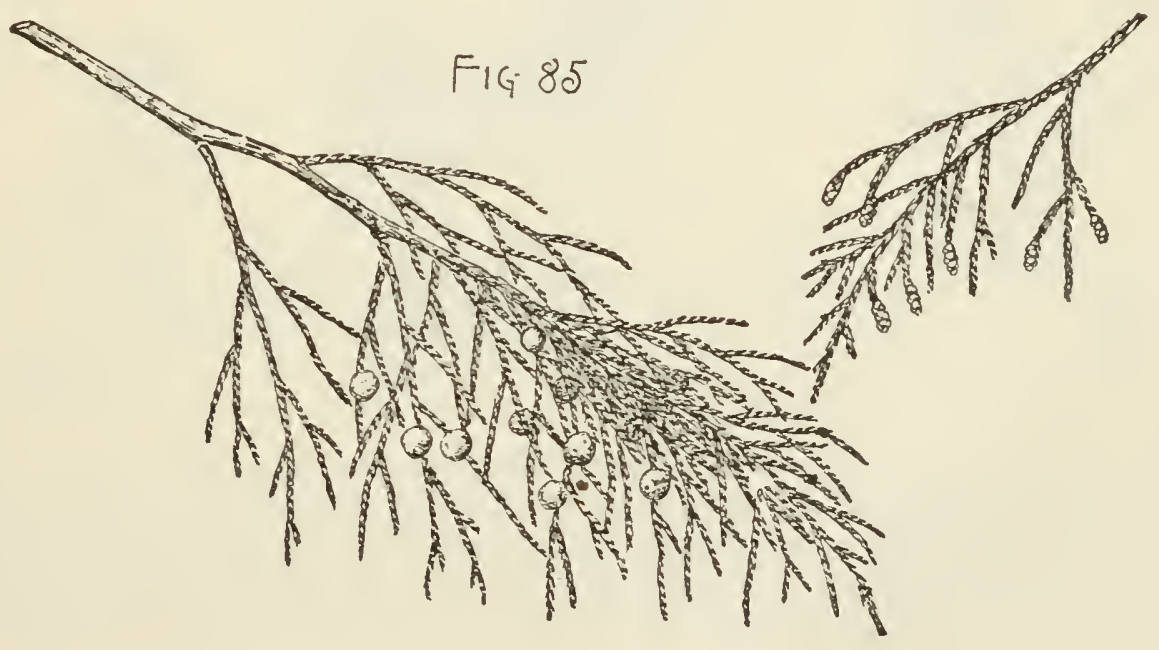

the ripe fruit. Fruit subglobose, dark blue, covered when ripe with a glaucous bloom, usually about $\frac{1}{8}^{\prime}$ in diameter, with a thin epidermis, sweet resinous flesh, and usually 2 seeds.

A tree, sometimes $50^{\circ}$ high, with a trunk occasionally $2^{\circ}$ in diameter, small branches erect when the tree is crowded in the forest, spreading when it has grown in open ground and forming a broad flat-topped head often $30^{\circ}$ or $40^{\circ}$ in diameter, long thin secondary branches erect at the top of the tree and pendulous below, and slender 4-angled pendulous branchlets becoming light red-brown or ashy gray at the end of four or five years after the disappearance of the leaves. Bark thin, light red-brown, separating into long thin scales. Wood light, close, straight-grained, 
fragrant, dull red; formerly exclusively used in the manufacture of the best lead pencils.

Distribution. Inundated river swamps from southern Georgia, southward to the shores of the Indian River, Florida, and on the west coast of Florida from the northeri shores of Charlotte Harbor to the valley of the Appalachicola River, often forming great thickets mnder the sliade of larger trees; common on the Bahamas, San Domingo, the mountains of Jamaica, and Antigua.

Often planted for the decoration of squares and cemeteries in the cities and towns in the neighborhood of the coast from Florida to western Lonisiana, and now often naturalized on the Gulf coast; occasionally cultivated in the temperate countries of Europe, and in cultivation the most beantiful of the Junipers.

\section{Juniperus scopulorum, Sarg. Red Cedar.}

Leaves opposite in pairs, closely appressed, acute or acuminate, marked on the back by obscure elongated glands, dark green, or of ten pale and very glaucous. Flowers : staminate with about 6 stamens, their connectives rounded and entire,

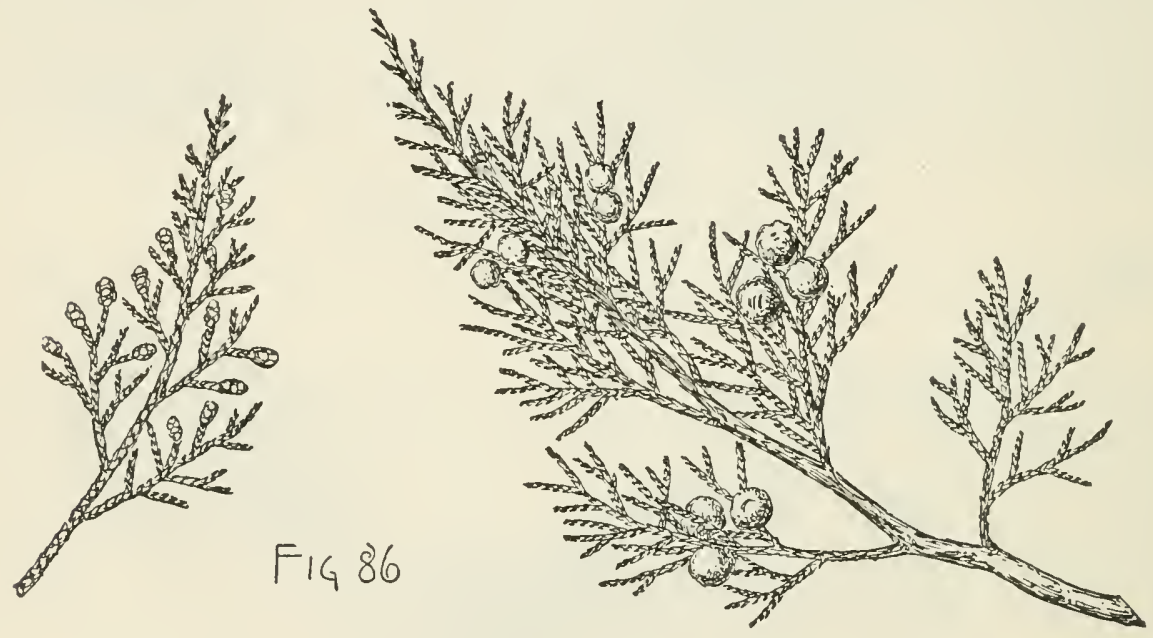

bearing 4 or 5 anther-sacs ; scales of the pistillate flower spreading, acute or acuminate, and obliterated from the mature fruit. Fruit ripening at the end of the second season, nearly globose, $\frac{1}{4}^{\prime}-\frac{1}{3}^{\prime}$ in diameter, bright blue, with a thin epidermis covered with a glaucous bloom, sweet resinous flesh, and 1 or usually 2 seeds; seeds acute, prominently grooved and angled, about $\frac{3}{16}{ }^{\prime}$ long, with a thick bony outer coat and a small 2-lobed hilum.

A tree, $30^{\circ}-40^{\circ}$ high, with a short stont trunk sometimes $3^{\circ}$ in diameter, often divided near the ground into a number of stout spreading stems, thick spreading and ascending branches covered with scaly bark, forming an irregular roundtopped head, and slender 4-angled branchlets becoming at the end of three or four years terete and clothed with smooth pale bark separating later into thin scales. Bark dark reddish brown or gray tinged with red, divided by shallow fissures into narrow flat connected ridges broken on the surface into persistent shredded scales.

Distribution. Scattered often singly over dry rocky ridges, except near the coast usually at elevations of more than $5000^{\circ}$ above the sea, from the eastern foot- 
hill region of the Rocky Mountains from Alberta to western Texas, and westward to the coast of British Columbia and Washington and to eastern Oregon, Nevada, and northern Arizona.

\section{TAXACE王。}

Slightly resinous trees and shrubs, producing when cut vigorous stump shoots, with fissured or scaly bark, light-colored durable close-grained wood. slender green branchlets, linear-lanceolate entire rigid acuminate sharp-pointed spirally disposed leaves, usually appearing 2-ranked by a twist in their short compressed petioles and persistent for many years, and small ovate acute buds. Flowers opening in early spring from buds formed the previous autumn, diœcious, axillary and solitary, surrounded by the persistent decussate scales of the buds, the staminate composed of numerous filaments united into a column, each filament surmounted by several more or less united pendant pollencells; the pistillate of a single erect ovule, becoming in fruit a seed with a hard bony shell, raised upon or more or less surrounded by the enlarged and fleshy aril-like disk of the flower; embryo axile, in fleshy ruminate or uniform albumen; cotelydons 2, shorter than the superior radicle. Of the ten genera widely distributed over the two hemispheres, two occur in North America.

\section{CONSPECTUS OF THE NORTH AMERICAN GENERA.}

Filaments dilated into 4 pollen-sacs united into a half ring; fruit drupe-like; alhumen ruminate.

1. Tumion.

Filaments dilated into a globose head of $4-S$ connate pollen-sacs; fruit berry-like, scarlet; albumen uniform.

2. Taxus.

\section{TUMION, Raf.}

Glabrous fœetid or pungent aromatic trees, with fissured bark and verticillate or opposite spreading or drooping branches. Leaves thin, long-pointed, abruptly contracted at the base, slightly rounded on the back, grooved below, with a broad stomatiferous groove on each side of the midvein, revolute and slightly thickened on the margins, dark green and lustrous on the upper surface, often pale on the lower surface. Flowers : the staminate crowded in the axils of adjacent leaves, oval or oblong, composed of 6 or 8 close whorls each of 4 stamens, subverticillately arranged on a slender axis; filaments stout and expanded above into 4 globose yellow pollensacs united into a half ring, their connectives produced above the cells; the pistillate less numerous and scattered, sessile, the ovule surrounded by and finally inclosed in an ovate urn-shaped fleshy sac, and becoming at maturity an ovoid or obovate drupe-like green or purple fruit pointed at the apex, separating when ripe from the basal scales persistent on the short stout stalk, covered with a thick leathery outer coat closely investing the seed. Seed ovoid, acute at the ends, apiculate at the apex, marked at the base by the large dark hilum; seed-coat thick and woody, its inner layer folded into the thick white albumen.

Tumion is now confined to Florida, western California, Japan, and central and northern China. Four species are recognized. Of the exotic species the Japanese Tumion nuciferum, Greene, is occasionally crltivated in the eastern states.

Tumion is from $\theta \dot{u} \mu$ iov, a name given by the ancients to some kind of Yew-tree. 


\section{CONSPECTUS OF THE NORTH AMERICAN SPECIES.}

Leaves slightly rounded on the back, pale on the lower surface; fruit more or less deeply tinged with purple; leaves, branches, and wood fotid.

1. T. taxifolium (C). Leaves nearly Hat, green below, elongated; fruit green slightly tinged with purple; leaves, branches, and wood pungent-aromatic.

2. T. Californicum (G).

\section{Tumion taxifolium, Greene. Stinking Cedar. Torreya.}

Leaves slightly falcate, $1_{\frac{1}{2}}^{\prime} \mathrm{long}$, about $\frac{1}{8}^{\prime}$ wide, somewhat rounded, dark green and lustrous above, paler and marked below with broad shallow grooves. Flowers appearing in March and April; staminate with pale yellow anthers; pistillate broadly ovate, with a dark purple fleshy covering to the ovule, $\frac{1}{8}$ long, and inclosed at the base.by broad thin rounded scales. Fruit fully grown at midsummer, slightly obovate, dark purple, $1^{\prime}-1 \frac{1}{4}^{\prime}$ long, $\frac{3^{\prime}}{4}$ broad, with a thin leathery covering, a light red-brown seed furnished on the inner surface of the brittle woody coat with 2 opposite longitudinal thin ridges extending from the base toward the apex, and conspicuously ruminate albumen penetrated by the brown inner seed-coat.

A tree, occasionally $40^{\circ}$ high, with a short trunk $1^{\circ}-2^{\circ}$ in diameter, whorls of spreading slightly pendulous branches forming a rather open pyramidal head

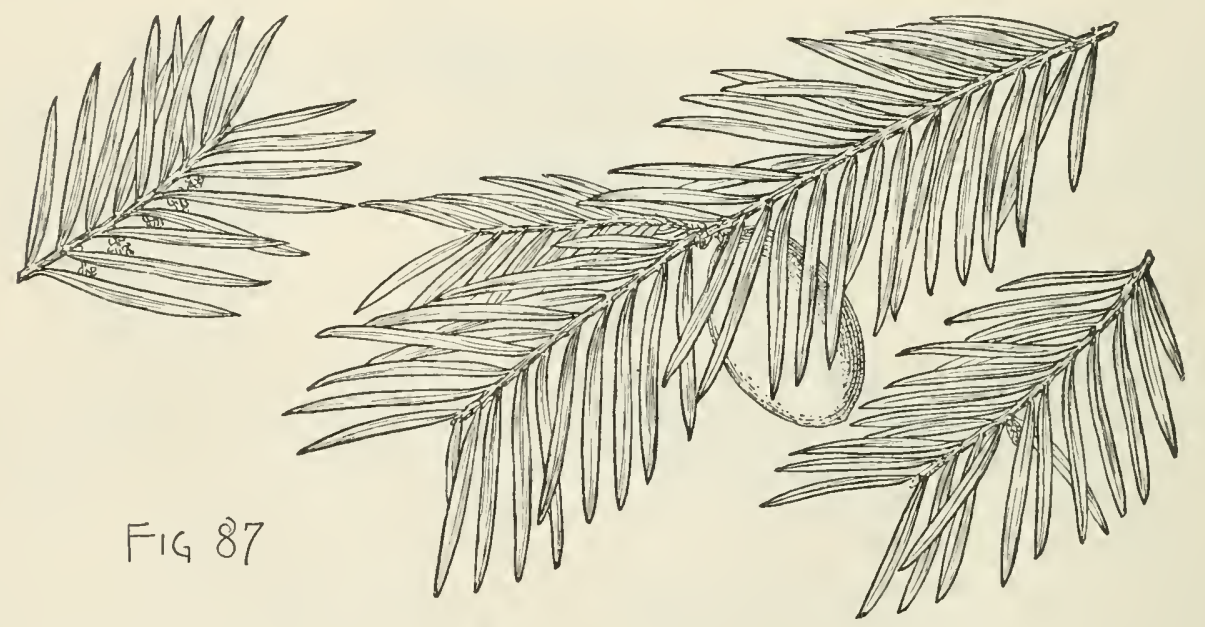

tapering from a broad base. Bark $\frac{1}{2}^{\prime}$ thick, brown faintly tinged with orange color, and irregularly divided by broad shallow fissures into wide low ridges slightly rounded on the back and covered with thin closely appressed scales. Wood hard, strong, clear bright yellow, with thin lighter colored sapwood; largely used for fence-posts.

Distribution. Limestone soil on bluffs along the eastern bank of the Appalachicola River, Florida, from River Junction to the neighborhood of Bristol, Gadsden County.

Occasionally cultivated in the northern states and in western Enrope.

\section{Tumion Californicum, Greene. California Nutmeg.}

Leaves slightly falcate, nearly flat, dark green and lustrous on the upper, somewhat lighter and marked with deep narrow grooves on the lower surface, tipped with slender callous points, $1^{\prime}-3 \frac{1^{\prime}}{2}$ long, $\frac{1}{1^{\prime}}-\frac{1}{8}^{\prime}$ wide. Flowers appearing in March and 
April; staminate with broadly ovate acute scales; pistillate nearly $\frac{1}{4}^{\prime}$ long, with oblong ovate rounded scales. Fruit ovate or oblong-ovate, $1^{\prime}-1 \frac{1^{\prime}}{2}$ long, light green more or less streaked with purple.

. A tree, $50^{\circ}-70^{\circ}$ but occasionally $100^{\circ}$ high, with a trunk $1^{\circ}-2^{\circ}$ or rarely $4^{\circ}$ in diameter, and whorls of spreading slender slightly pendulous branches forming a handsome pyramidal and in old age a round-topped head. Bark $\frac{1}{3}^{\prime}-\frac{1}{2}^{\prime}$ thick, gray-brown tinged with orange color, deeply and irregularly divided by broad fissures into narrow ridges covered with elongated loosely appressed plate-like scales.

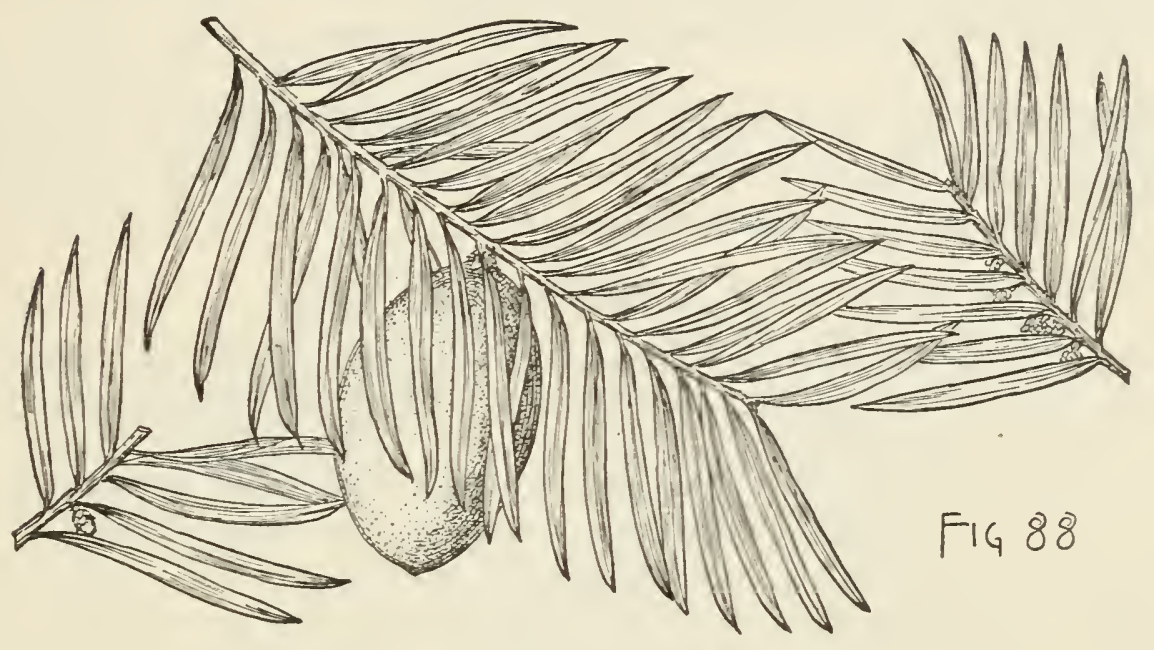

Wood light, soft, close-grained, clear light yellow, with thin nearly white sapwood; occasionally used for fence-posts.

Distribution. Borders of mountain streams, California, nowhere common but widely distributed from Mendocino County to the Santa Cruz Mountains in the coast region and along the western slopes of the Sierra Nevada from Eldorado to Tulare County at elevations of $3000^{\circ}-5000^{\circ}$ above the sea; most abundant and of its largest size on the northern coast ranges.

Rarely cultivated as an ornamental tree in western Europe.

\section{TAXUS, L. Yew.}

Trees or shrubs, with brown or dark purple scaly bark, and spreading usually horizontal branches. Leaves flat, often falcate, gradually narrowed at the base, dark green, smooth and keeled on the upper surface, paler, papillate, and stomatiferous on the lower surface, their margins slightly thickened and revolute. Flowers : the staminate composed of a slender stipe bearing at the apex a globular head of 4-8 pale yellow stamens consisting of 4-6 conical pendant pollen-sacs peltately connate from the end of a short filament; the pistillate sessile in the axils of the upper scale-like bracts of a short axillary branch, the ovule erect, sessile on a ring-like disk, ripening in the autumn into an ovate-oblong seed gradually narrowed and short-pointed at the apex, marked at the base by the much-depressed hilum, about $\frac{1}{3}^{\prime}$ long, entirely or nearly surrounded by but free from the now thickened succulent translucent sweet scarlet aril-like disk of the flower closed or open at the apex; seed-coat thick, of two layers, the outer thin and membranaceous or fleshy, the inwer much thicker and somewhat woody; albumen uniform. 
Taxus with six species, whieh can be distinguished only by their leaf eharaeters and habit, is widely distributed through the northern hemisphere, and is found in eastern North Ameriea where two speeies oceur, in Pacific North America, Mexico, Europe, northern Afriea, western and southern Asia, China and Japan. Of the exotie species the European, Afriean, and Asiatie Taxus baccata, L., and its numerous varieties, is often cultivated in the United States, espeeially in the more temperate parts of the country, and is replaced with advantage by the hardier Taxus cuspidata, S. \& Z., of eastern Asia in the northern states, where the native shrubby T'axus C'anadensis, Marsh, with monocious flowers is sometimes eultivated.

Taxus, from $\tau \alpha \dot{\xi}$ os, is the elassieal name of the Yew-tree.

\section{CONSPECTUS OF THE NORTH AMERICAN ARBORESCENT SPECIES.}

Leaves short, yellow-green.

Leaves elongated, usually falcate, dark green.
1. T. brevifolia (G).

2. T. Floridana (C).

\section{Taxus brevifolia, Nutt. Xew.}

Leaves $\frac{1^{\prime}}{2}-\frac{5}{8}$ long, about $\frac{1^{\prime}}{1^{\prime}}$ wide, dark yellow-green above, rather paler below, with stout midribs, and slender yellow petioles $\frac{1}{1}^{\prime}$ long, persistent for four or five years. Flowers and fruit as in the genus.

A tree, usually $40^{\circ}-50^{\circ}$ but oecasionally $70^{\circ}-80^{\circ}$ high, with a tall straight trunk $1^{\circ}-2^{\circ}$ or rarely $4 \frac{1}{2}^{\circ}$ in diameter, frequently unsymmetrieal, with one diameter much exeeeding the other, and irregularly lobed, with broad rounded lobes, and long slender horizontal or slightly pendulous branches forming a broad open conical head. Bark about $\frac{1^{\prime}}{4}$ thiek and eovered with small thin dark red-purple scales. Wood heavy, hard, strong, bright red, with thin light yellow sapwood; used for fenee-posts and by the Indians of the northwest eoast for paddles, spear-handles, bows, and other small artieles.

Distribution. Banks of mountain streams, deep gorges, and damp ravines, growing usually under large coniferous trees; nowhere abmulant, but widely distributed

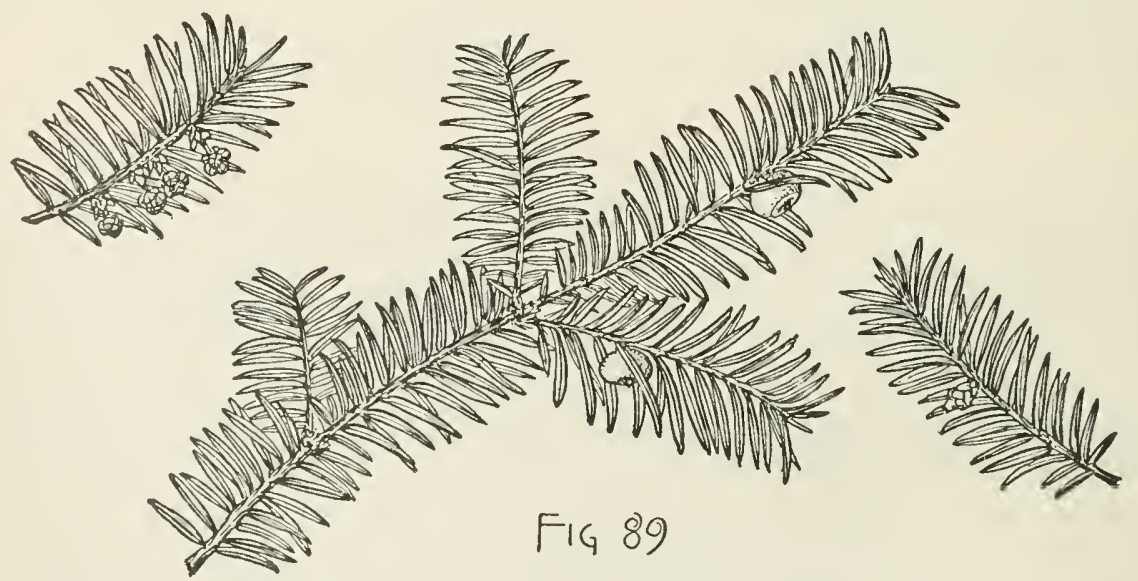

usually in single individuals or in small clumps from Queen Charlotte Islands and the valley of the Skeena River, southward along the coast ranges of British Columbia, Washington, and Oregon, where it attains its greatest size, along the eoast ranges of California as far south as the Bay of Monterey, and along the western slopes of 
the Sierra Nevada to Tulare County at elevations between $5000^{\circ}$ and $8000^{\circ}$ above the sea-level, ranging eastward in British Columbia to the Selkirk Mountains, and over the mountains of Washington and Oregon to the western slopes of the continental divide in Montana; in the interior mucl smaller than near the coast and often shrubby in habit.

Occasionally cultivated in the gardens of western Europe.

\section{Taxus Floridana, Chapm. Yew.}

Leaves usually conspicuously falcate, $\frac{3^{\prime}}{4}$ to nearly $1^{\prime}$ long, $\frac{1^{\prime}}{1^{\prime}}-\frac{1}{2}^{\prime}$ wide, dark green above, pale below, with obscure midribs and slender petioles about $\frac{1}{16}{ }^{\prime}$ long. Flowers appearing in March. Fruit ripens in October.

A bushy tree, rarely $25^{\circ}$ high, with a short trunk occasionally $1^{\circ}$ in diameter, and numerous stout spreading branches; more often shrubby in habit and $12^{\circ}-15^{\circ}$

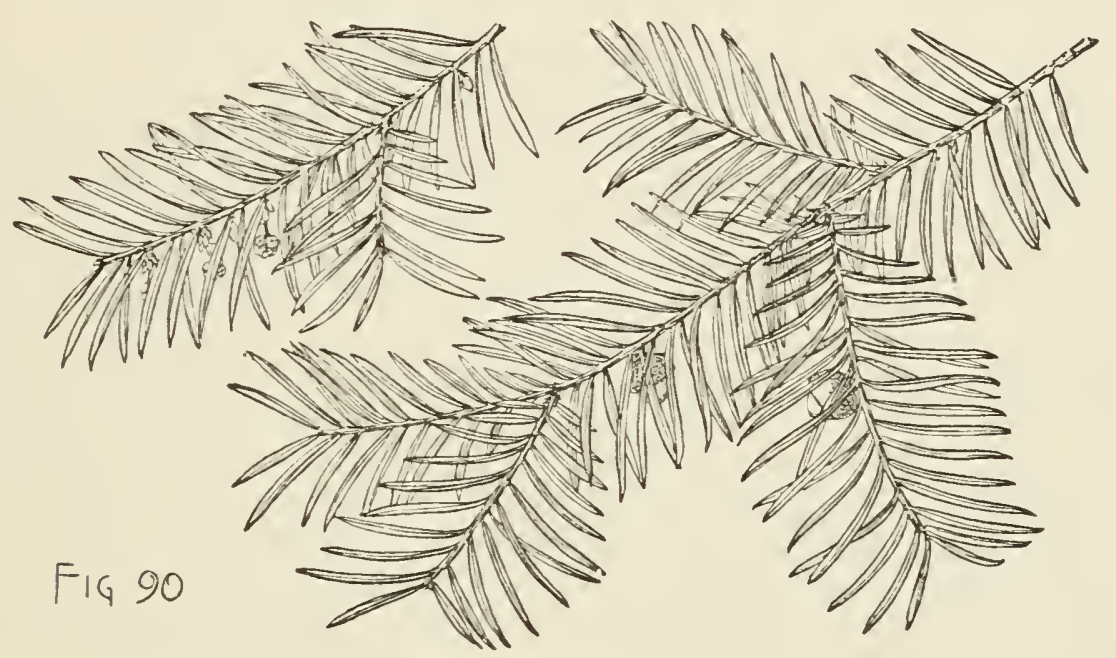

tall. Bark $\frac{1^{\prime}}{8}$ thick, dark purple-brown, smooth, compact, occasionally separating into large thin irregular plate-like scales. Wood heavy, hard, very close-grained, dark brown tinged with red, with thin nearly white sapwood.

Distribution. River bluffs and ravines on the eastern bank of the Appalachicola River, in Gadsden County, western Florida, from Aspalaga to the neighborhood of Bristol. 


\section{Class 2. ANGIOSPERMA.}

Carpels or pistils consisting of a closed cavity containing the ovules and becoming the fruit.

\section{Division I. Monocotyledons.}

Stems with woody fibres distributed irregularly through them, but without pith or annual layers of growth. Parts of the flower in 3's: ovary superior; embryo with a single cotyledon. Leaves parallelveined, alternate, long-persistent, without stipules.

\section{PALM五. PALMS.}

Trees, growing by a single terminal bud, with stems covered with a thick rind, usually marked below by the ring-like scars of fallen leaf-stalks, and clothed above by their long-persistent sheaths; occasionally stemless. Leaves clustered at the top of the stem, plaited in the bud, fan-shaped or pinnate, their rachises sometimes reduced to a narrow border, long-stalked, with petioles dilated into clasping sheaths of tough fibres (vaginas), on fan-shaped leaves, furnished at the apex on the upper side with a thickened concave body (ligule). Flowers minute, perfect or unisexual, in the axils of small thin mostly deciduous bracts, in large compound clusters (spadix) surrounded by boat-shaped bracts (spathes); sepals and petals free or more or less united; stamens usually 6 ; anthers 2-celled, introrse, opening longitudinally; ovary 3-celled, with a single ovule in each cell; styles 1-3. Fruit a drupe or berry; embryo cylindrical in a cavity of the hard albumen near the circumference of the seed. Of the 130 genera now usually recognized and chiefly inhabitants of the tropics, seven have arborescent representatives in the United States.

\section{CONSPECTUS OF THE NORTH AMERICAN ARBORESCENT GENERA.}

Leaves fan-shaped.

Leaf-stalks unarmed.

Calyx and corolla united into a short 6-lobed cup.

Fruit white, drupaceous; albumen even.

Fruit black, baccate; albumen channeled.

1. Thrinax.

Perianth of a distinct calyx and corolla.

Filaments subulate, united below into a slender cup adnate to the base of the corolla; fruit baccate.

3. Sabal.

Leaf-stalks armed with marginal spines.

Filaments slender, free; fruit baccate.

4. Washingtonia.

Filaments triangular, united into a cup adnate to the base of the corolla; fruit drupaceous.

5. Serenoa.

Leaves pinnate.

1 Flower-clusters produced on the stem below the leaves; fruit vioiet-blue.

6. Roystonea.

Flower-clusters produced from among the leaves; fruit bright orange-scarlet.

7. Pseudophœnix. 


\section{THRINAX, Sw.}

Small unarmed trees, with stems covered with pale gray rind. Leaves orbicular, or truncate at the base, thick and firm, usually silvery white on the lower surface, divided to below the middle into narrow acuminate parted segments with thickened margins and midribs; rachises narrow borders, with thin usually undulate margins; ligules thick, concave, pointed, lined while young with hoary tomentum; petioles compressed, rounded above and below, thin and smooth on the margins, with large clasping bright mahogany-red sheaths of slender matted fibres covered with thick hoary tomentum. Spadix interfoliar, stalked, its primary branches short, alternate, flattened, incurved, with numerous slender rounded flower-bearing branchlets; spathes numerous, tubular, coriaceous, cleft and more or less tomentose at the apex. Flowers opening in May and June, and occasionally irregularly in the,autumn, solitary, perfect; perianth 6-lobed; stamens inserted on the base of the perianth, with subulate filaments thickened and only slightly united at the base, or nearly triangular and united into a cup adnate to the perianth, and oblong anthers; ovary 1-celled, gradnally narrowed into a stout columuar style crowned by a large fumel-formed flat or oblique stigma; ovule basilar, erect. Fruit a globose drupe with juicy bitter ivory white flesh easily separable from the thin-shelled tawny brown nut. Seed free, erect, slightly flattened at the ends, with an oblong pale conspicnous subbasilar hilum, a short-branched raphe, a thin coat, and uniform albumen more or less deeply penetrated by a broad basal cavity; embryo lateral.

Thrinax is confined to the tropics of the New World and is distributed from southern Florida through the West Indies to the shores of Central America. Seven or eight species are now generally recognized.

The wood of the Florida species is light and soft, with numerous small fibro-vascular bundles, the exterior of the stem being much harder than the spongy interior. The stems are used for the piles of small wharves and turtle crawls, and the leaves for thatch, and in making hats, baskets, and small ropes.

Thrinax, from $\theta \rho \hat{i \nu \alpha \xi}$, is in allusion to the shape of the leaves.

\section{CONSPECTUS OF THE NORTH AMERICAN SPECIES.}

Flowers on elongated pedicels ; perianth obscurely lobed ; filaments subulate, barely united at the base; stigma oblique.

1. T. Floridana (D).

Flowers on short pedicels; lobes of the perianth ovate, acuminate ; filaments nearly triangular, united below into a cup; stigma flat.

Seeds pale chestnut-brown; spadix about $6^{\circ}$ long; leaves $3^{\circ}-4^{\circ}$ in diameter.

2. T. Keyensis (D).

Seeds dark chestnut-brown; spadix less than $3^{\circ}$ long ; leaves not over $2^{\circ}$ in diameter.

3. T. microcarpa (D).

\section{Thrinax Floridana, Sarg. Thatch.}

Leaves $2 \frac{1}{2}^{\circ}-3^{\circ}$ in diameter, rather longer than broad, yellow-green and lustrous on the upper surface, silvery white on the lower surface, with long-pointed, bright orange-colored ligules $\frac{3}{4}^{\prime}$ long and broad; their petioles $4^{\circ}-4_{\frac{1}{2}}^{\circ}$ long, pale yellow-green or orange color toward the apex, coated at first with hoary deciduous tomentum, much thickened and tomentose toward the base. Flowers: spadix $3^{\circ}-3 \frac{1}{2}^{\circ}$ long, the primary branches $6^{\prime}-8^{\prime}$ long and ivory-white, flower-bearing branches $1 \frac{1}{2}-2^{\prime}$ in length. Flowers on slender pedicels nearly $\frac{1^{\prime}}{8}$ long, ivory-white, very fragrant, with 
an obscurely-lobed perianth, much exserted stamens barely united at the base, and an oblique stigma. Fruit $\frac{3^{\prime}}{8}$ in diameter, somewhat depressed at the ends; seeds

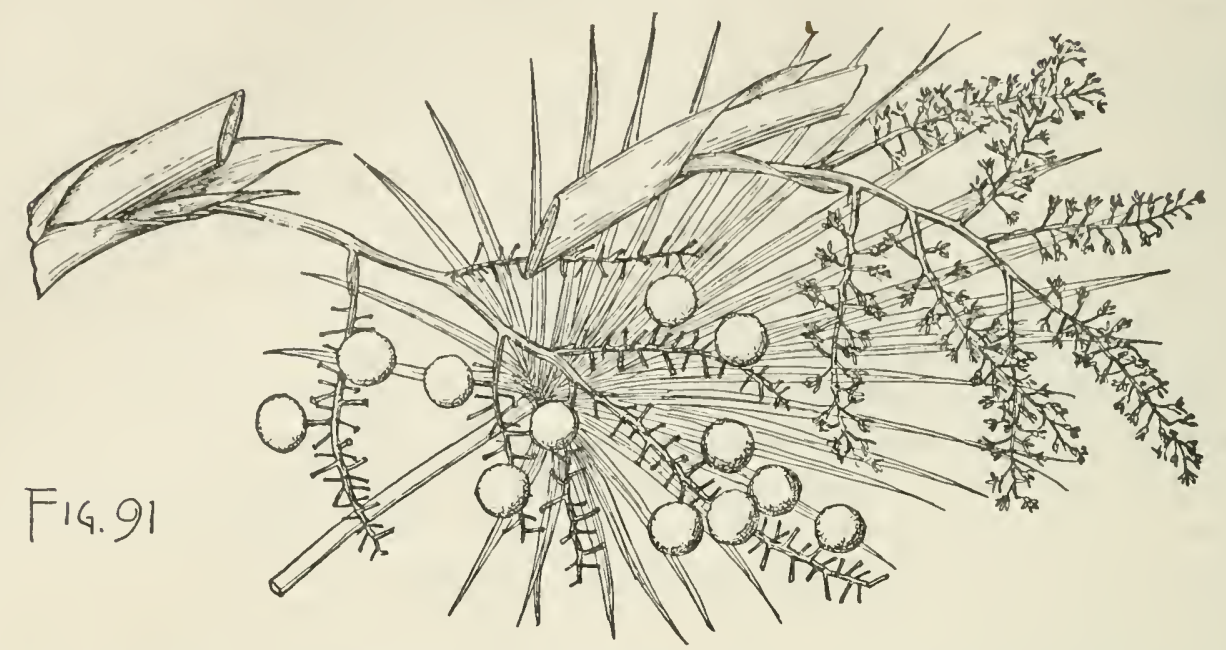

from $\frac{1^{\prime}}{8}$ to nearly $\frac{1}{4}^{\prime}$ in diameter, dark chestnut-brown, penetrated almost to the apex by the broad basal cavity.

A tree, with a slightly tapering stem $20^{\circ}-30^{\circ}$ high and $4^{\prime}-6^{\prime}$ in diameter, clothed to the middle and occasionally almost to the ground with the sheaths of dead leafstalks.

Distribution. Florida, dry coral ridges and sandy shores of keys from Long Key to Torch Key, and on the mainland from Cape Romano to Cape Sable.

\section{Thrinax Keyensis, Sarg. Thatch.}

Leaves rather longer than broad, $3^{\circ} \mathbf{4}^{\circ}$ long, the lowest segments parallel with the petiole or spreading from it nearly at right angles, light yellow-green and lustrous on the upper surface, with bright orange-colored margins, below coated while young

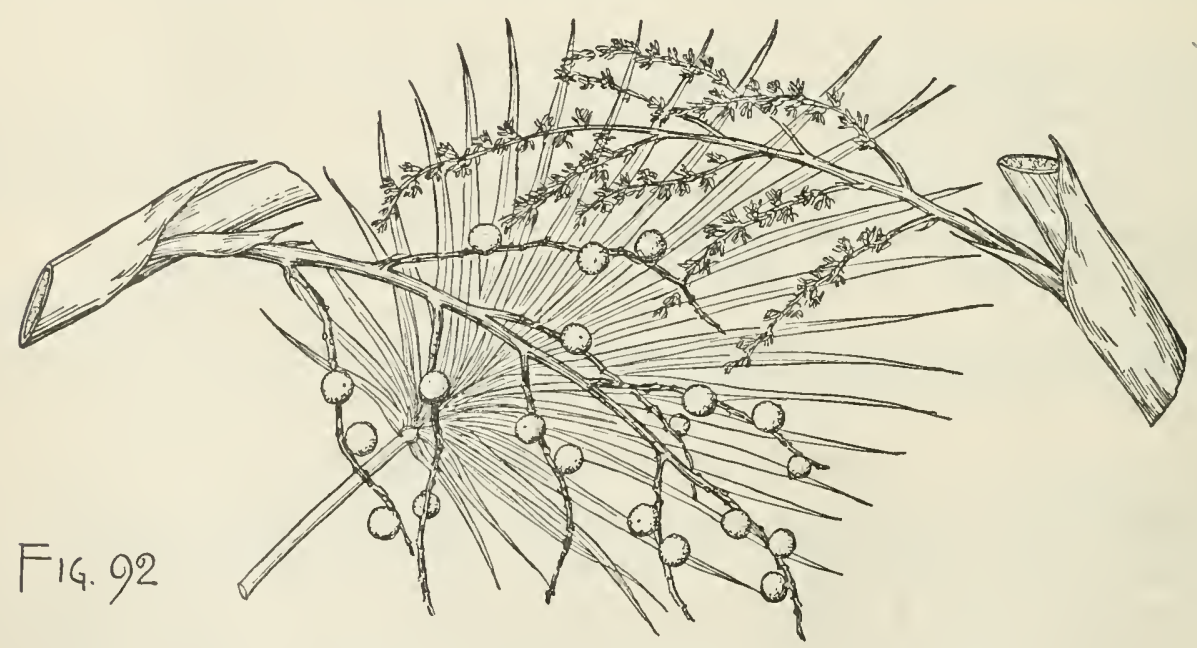

with deciduous hoary tomentum and pale blue-green and more or less covered with silvery white pubescence at maturity, with thick pointed ligules $1^{\prime}$ long and wide, lined at first with hoary tomentum; their petioles flattened above, obscurely 
ridged on the lower surface, tomentose while young, pale blue-green, $3^{\circ}-4^{\circ}$ long. Flowers: spadix usually about $6^{\circ}$ long, spreading and gracefully incurved, with spathes more or less coated with hoary tomentum, large compressed primary branches, and short bright orange-colored flower-bearing branches. Flowers on short thick disk-like pedicels, about $\frac{1}{8}^{\prime}$ long, white, slightly fragrant, with a tubular perianth, the lobes broadly ovate and acute, stamens with nearly triangular filaments united at the base, and a flat stigma. Fruit $\frac{1^{\prime}}{1^{\prime}}$ to nearly $\frac{1^{\prime}}{4}$ in diameter; seeds brown, $\frac{3}{16}$ in diameter, penetrated only to the middle by the basal cavity.

A tree, with a stem often $25^{\circ}$ high and $10^{\prime}-14^{\prime}$ in diameter, raised on a base of thick matted roots $2^{\circ}-3^{\circ}$ high and $18^{\prime}-20^{\prime}$ in diameter, and a broad head of leaves, the upper erect, the lower pendulous and closely pressed against the stem.

Distribution. Dry sandy soil close to the beach on the north side of the largest of the Marquesas Keys, and on Crab Key, a small island to the westward of Torch Key, one of the Bahia Honda group, Florida; on the Bahamas.

\section{Thrinax microcarpa, Sarg. Silver-top Palmetto. Brittle Thatch.}

Leaves $2^{\circ}-3^{\circ}$ across, pale green above, silvery white below, more or less thickly coated while young with hoary tomentum, especially on the lower surface, divided

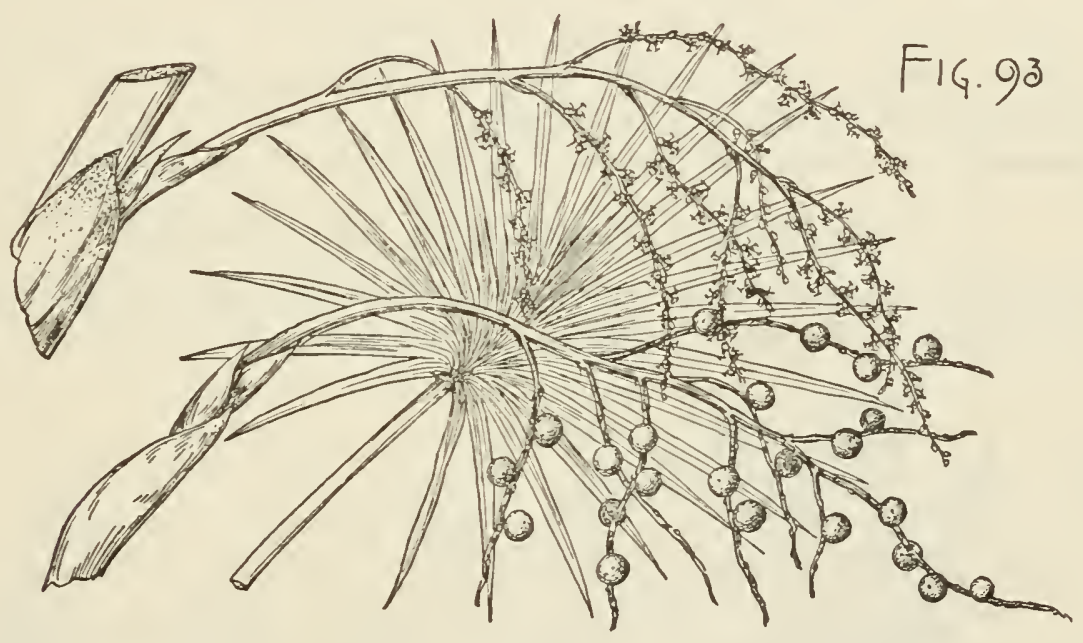

near the base almost to the rachis, with orbicular thick concave ligules lined with a thick coat of white tomentum; their petioles thin and flexuose. Flowers: spadix elongated, with short compressed erect branches slightly spreading below, numerous slender pendulous flower-bearing branches, and long acute spathes deeply parted at the apex, coriaceous and coated above the middle with thick hoary tomentum. Flowers on short thick disk-like pedicels, with a cupular perianth, the lobes broadly ovate and acute, stamens with thin nearly triangular exserted filaments slightly united at the base and oblong anthers becoming reversed and extrorse at maturity, and a deep orange-colored ovary narrowed above into a short thick style dilated into a large funnel-formed stigma. Fruit globose, $\frac{1}{8}$ in diameter; seeds subglobose, bright to dark chestnut-brown, depressed, penetrated nearly to the middle by the broad basal cavity.

A tree, rarely more than $30^{\circ}$ high, with a trunk $8^{\prime}-10^{\prime}$ in diameter.

Distribution. Dry coral soil, on the shores of Sugar Loaf Sound, and on No Name and Bahia Honda keys, Florida. 


\section{COCCOTHRINAX, Sarg.}

Small unarmed trees, with simple or clustered stems or rarely stemless. Leaves orbicular, or truncate at the base, pale or silvery white on the lower surface, divided into narrow obliquely-folded segments acuminate and divided at the apex; rachises narrow; ligules thin, frec, erect, concave, pointed at the apex; petioles compressed, slightly rounded and ridged above and below, thin and smooth on the margins, gradually enlarged below into elongated sheaths of coarse fibres forming an open network covered while young by thick hoary tomentum. Spadix interfoliar, paniculate, shorter than the leaf-stalks, its primary branches furnished with numerous short slender pendulous flower-bearing secondary branches; spathes numcrous, papery, cleft at the apex. Flowers solitary, perfect, jointed on elongated slender pedicels; perianth cup-shaped, obscurely-lobed; stamens 9, inserted on the base of the perianth, with subulate filaments enlarged and barely united at the base, and oblong anthers; ovary 1-celled, narrowed into a slender style crowned by a funnel-formed oblique stigma; ovule basilar, erect. Fruit a subglobose berry raised on the thickened torus of the flower, with thick juicy black flesh. Seed free, erect, depressed-globose, with a thick hard vertically-grooved shell deeply infolded in the bony albumen; hilum subbasilar, minute; raphe hidden in the folds of the seed-coat; embryo lateral.

Coccothrinax is confined to the tropics of the New World. Two species, of which one is stemless, inlıabit southern Florida, and at least two other species are scattered over several of the West Indian islands.

Coccothrinax, from коккоs and Thrinax, is in allusion to the berry-like fruit.

\section{Coccothrinax jucunda, Sarg. Brittle Thatch.}

Leaves nearly orbicular, the lower segments usually parallel with the petiole, thin and brittle, $18^{\prime}-24^{\prime}$ in diameter, divided below the middle of the leaf or toward its

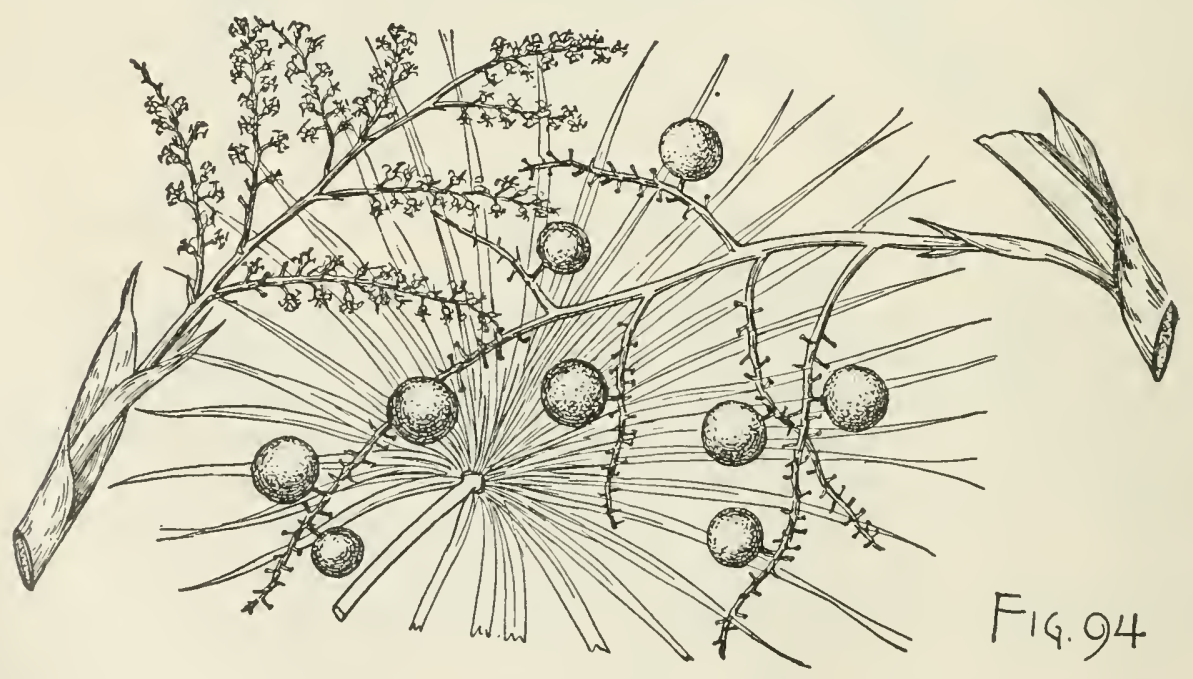

base nearly to the lignle, with much-thickened bright orange-colored midribs and margins, pale yellow-green and lustrous on the upper surface, bright silvery white and coated at first on the lower surface with hoary deciduous pubescence, with thin undulate obtusely short-pointed dark orange-colored rachises, thin concave crescent-shaped often oblique slightly undulate short-pointed and light or dark orange-colored ligules 
$\frac{3^{\prime}}{4}$ wide, $\frac{1}{3}^{\prime}$ deep, their petioles slender, pale, yellow-green, $2 \frac{1}{2}^{\circ}-3^{\circ}$ long. Flowers : spadix $18^{\prime}-24^{\prime}$ long, with flattened stalks, slender much-flattened primary branches $8^{\prime}-10^{\prime}$ long and light orange-colored slender terete flower-bearing branches $1 \frac{1}{2}-3^{\prime}$ long, and pale reddish brown spathes coated toward the ends with pale pubescence. Flowers opening in June and irregularly also in the autumn on ridged spreading pedicels $\frac{1^{\prime}}{8}$ long, with an orange-colored ovary surmounted by an elongated style dilated into a rose-colored stigma. Fruit ripening at the end of six months, from $\frac{1^{\prime}}{2}-\frac{3 \prime}{4}$ in diameter, bright green at first when fully grown, becoming deep violet color, with succulent very juicy flesh, ultimately black and lustrous; seeds light tawny brown.

A tree, with a stem slightly enlarged from the ground upward, $15^{\circ}-25^{\circ}$ high, $4^{\prime}-6^{\prime}$ thick, covered with pale blue rind, and surmounted by a broad head of leaves at first erect, then spreading and ultimately pendulous. Wood used for the piles of small wharves and turtle crawls. The soft tough young leaves are made into hats and baskets.

Distribution. Dry coral ridges and sandy flats from the shores of Bay Biscayne along many of the southern keys to the Marquesas group, Florida.

\section{SABAL, Adans. Palmetto.}

Unarmed trees, with stout columnar stems covered witlı red-brown rind. Leaves flabellate, tough and coriaceous, divided into many narrow long-pointed parted segments plicately folded at the base, often separating on the margins into narrow threads; rachises extending nearly to the middle of the leaves, rounded and broadly winged toward the base on the lower side, thin and acute on the upper side; ligules adnate to the rachises, acute, concave, with thin incurved entire margins; petioles rounded and concave on the lower side, conspicuously ridged on the upper side, acute and entire on the margins, with elongated chestnut-brown shining sheaths of stout fibres. Spadix interfoliar, stalked, decompound, with a flattened stem, short branches, slender densely flowered ultimate branches, and numerous acuminate spathes, the outer persistent and becoming broad and woody. Flowers solitary, perfect, calyx tubular, unequally lobed, the lobes slightly imbricated in the bud; corolla deeply lobed, with narrow ovate-oblong concave acute lobes valvate at the apex in the bud; stamens 6 , those opposite the corolla-lobes rather longer than the others, with subulate filaments united below into a shallow cup adnate to the tube of the corolla and ovate anthers, their cells free and spreading at the base; ovary of 3 carpels, 3 -lobed, 3-celled, gradually narrowed into an elongated 3-lobed style truncate and stigmatic at the apex; ovule basilar, erect. Fruit a small black 1 or 2 or 3 -lobed short-stemmed berry with thin sweet dry flesh. Seed depressed-globose, marked on the side by the prominent micropyle, with a shallow pit near the minute basal hilım, a thin seed-coat, and a ventral raphe; embryo minute, dorsal, in horny uniform albumen penetrated by a hard shallow basal cavity filled by the thickening of the seed-coat.

Sabal belongs to the New World, and is distributed from the Bermuda Islands and the south Atlantic and Gulf states of North America, through the West Indies to Venezuela and Mexico.

Of the eight species now recognized four inhabit the United States; of these two are small stemless plants.

The generic name is of uncertain origin. 


\section{CONSPECTUS OF THE NORTH AMERICAN ARBORESCENT SPECIES.}

Spadix short; fruit subglobose, 1-celled; seed-coat light chestnut color.

1. S. Palmetto (C). Spadix elongated; fruit often 2 or 3 -lobed, with 2 or 3 seeds ; seed-coat dark chestnutbrown.

2. S. Mexicana (E).

\section{Sabal Palmetto, R. \& S. Cabbage Tree. Cabbage Palmetto.}

Leaves $5^{\circ}-6^{\circ}$ long and $7^{\circ}-8^{\circ}$ broad, dark green and lustrous, deeply divided into narrow parted recurved segments, with ligules $4^{\prime}$ long; their petioles $6^{\circ}-7^{\circ}$ long and $1 \frac{1}{2}^{\prime}$ wide at the apex. Flowers : spadix $2^{\circ}-2 \frac{1}{2}^{\circ}$ long, with slender incurved branches, slender ultimate divisions, and thin secondary spathes flushed with red at the apex and conspicuously marked by pale slender longitudinal veins. Flowers in the axils of minute deciduous bracts much shorter than the perianth, opening in

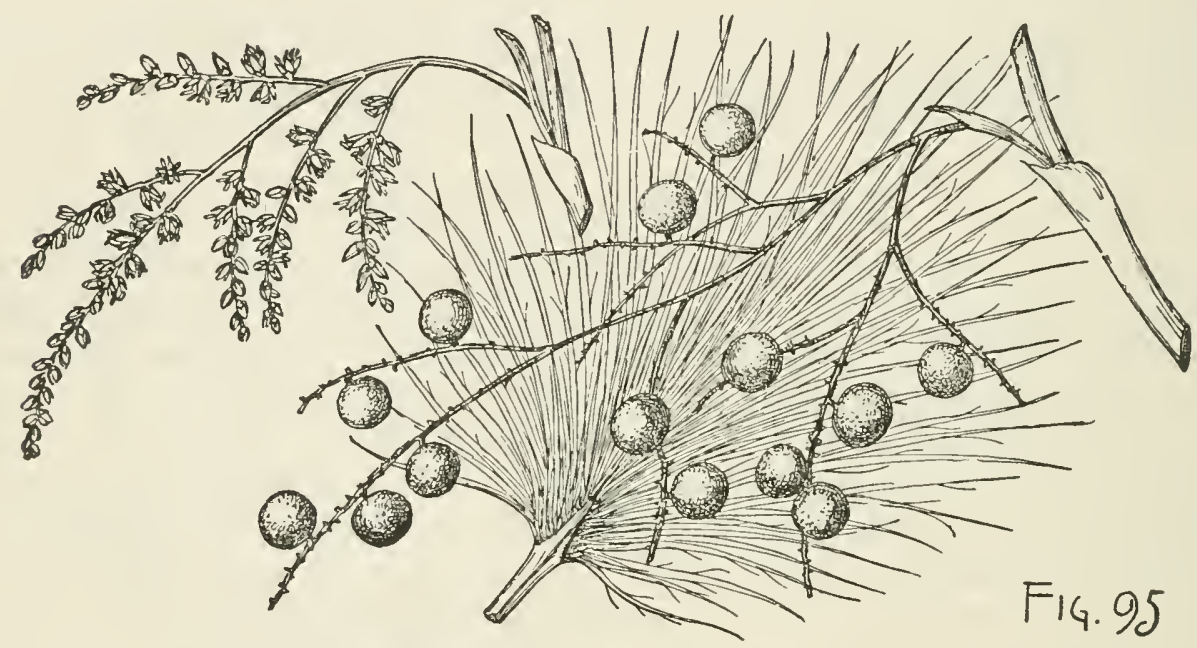

June. Fruit ripening late in the autumn, subglobose or slightly obovate, gradually narrowed at the base, 1 -seeded, about $\frac{1^{\prime}}{3}$ in diameter ; seeds light bright chestnutcolored, $\frac{1^{\prime}}{4}$ broad.

A tree, with a trunk often $30^{\circ}-40^{\circ}$ high, and $2^{\circ}$ in diameter, broken by shallow irregular interrupted fissures into broad ridges, with a short pointed knob-like underground stem surrounded by a dense mass of contorted roots often $4^{\circ}$ or $5^{\circ}$ in diameter and $5^{\circ}$ or $6^{\circ}$ deep, from which tough light orange-colored roots often nearly $\frac{1}{2}^{\prime}$ in diameter penetrate the soil for a distance of $15^{\circ}$ or $20^{\circ}$, and a broad crown of leaves at first upright, then spreading nearly at right angles with the stem, and finally pendulous. Wood light, soft, pale brown, with numerous hard fibro-vascular bundles, the outer rim about $2^{\prime}$ thick and much lighter and softer than the interior. In the southern states the trunks are used for wharf-piles, and polished cross sections of the stem sometimes serve for the tops of small tables; the wood is largely manufactured into canes. From the sheaths of young leaves the bristles of scrubbing-brushes are made. The large succulent leaf-buds are cooked and eaten as a vegetable, and coarse hats, mats, and baskets are made from the leaves. Pieces of the spongy bark of the stem are used as a substitute for scrubbing-brushes.

Distribution. Sandy soil in the immediate neighborhood of the coast from Smith Island at the mouth of Cape Fear River, North Carolina, to Key Largo, 
Florida, and along the Gulf coast to the mouth of the Appalachicola River; most abundant and of its largest size on the west coast of the Florida peninsula.

Occasionally cultivated for ornament in the cities of the south Atlantic states.

\section{Sabal Mexicana, Mart. Palmetto.}

Leaves dark yellow-green and lustrous, $5^{\circ}-6^{\circ}$ long, often $7^{\circ}$ wide, divided nearly to the middle into narrow divided segments, with thickened pale margins sepa-

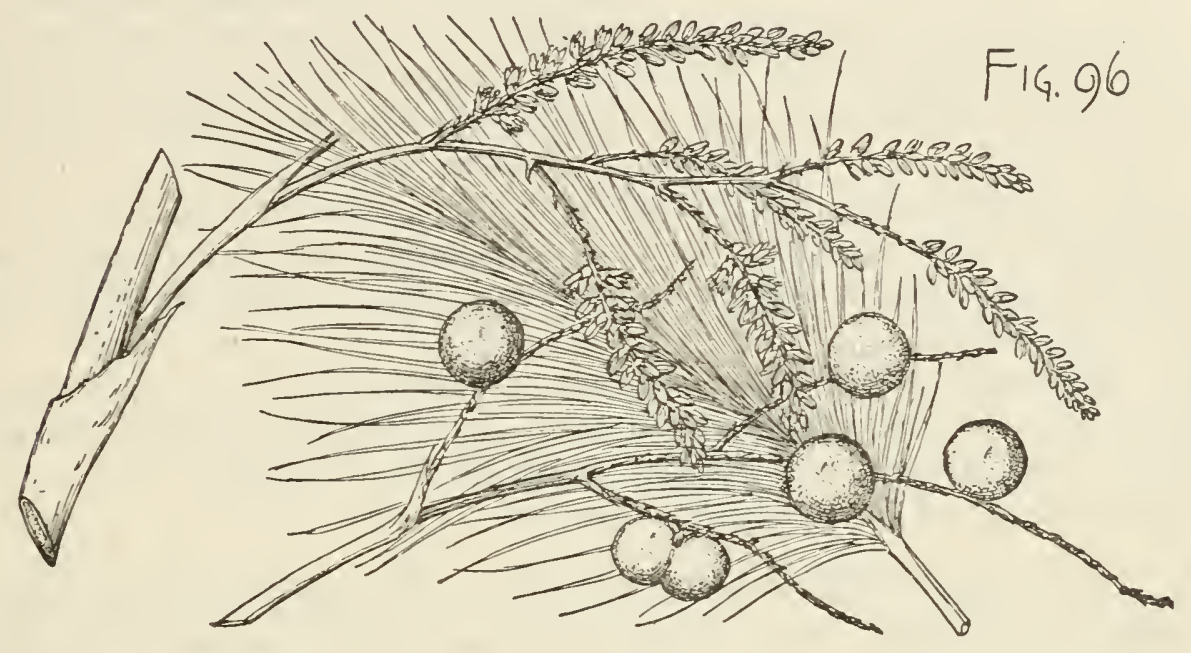

rating into long thin fibres, with ligules about $6^{\prime}$ long, their petioles $7^{\circ}-8^{\circ}$ long, $11^{\prime}$ wide at the apex. Flowers: spadix $7^{\circ}-8^{\circ}$ long, with stout ultimate divisions. Flowers in Texas appearing in March or April in the axils of persistent bracts half as long as the perianth. Fruit ripening early in the summer, globose, often 2 or 3 -lobed; seeds nearly $\frac{1}{2}^{\prime}$ broad and $\frac{1}{4}^{\prime}$ wide, dark chestnut-brown, with a broad shallow basal cavity and a conspicuous orange-colored lilım.

A tree, with a trunk $30^{\circ}-50^{\circ}$ high, often $2 \frac{1}{2}^{\circ}$ in diameter, and a broad head of erect ultimately pendulous leaves. Wood light, soft, pale brown tinged with red, with thick light-colored rather inconspicuous fibro-vascular bundles, the outer rim $1^{\prime}$ thick, soft, and light-colored. On the Gulf coast the trunks are used for wharf-piles, and on the lower Rio Grande the leaves for the thatch of houses.

Distribution. Rich soil of the bottom-lands near the mouth of the Rio Grande in Texas, and southward in Mexico in the neighborhood of the coast. Frequently planted as a street tree in the towus on the lower Rio Grande.

\section{WASHINGTONIA. H. Wendl.}

Trees, with stout columnar stems and broad crowns of erect and spreading finally pendulous leaves. Leaves flabellate, divided nearly to the middle into many narrow deeply parted recurved segments separating on the margins into numerous slender pale fibres; rachises short, slightly rounded on the back, gradually narrowed from a broad base, with concaved margins furnished below with narrow erect wings, and slender and acute above; ligules elongated, oblong, thin and laciniate on the margins; petioles elongated, broad and thin, flattened or slightly concave on the upper side, rounded on the lower, armed irregularly with broad thin large and small straight or hooked spines confluent into a thin bright orange-colored cartilaginous margin, 
gradually enlarged at the base into thiek broad eoncave bright ehestnut-brown sheaths composed of a network of thin strong fibres. Spadix interfoliar, stalked, elongated, panienlate, with pendulous flower-bearing ultimate divisions and numerous long spathes. Flowers perfeet, jointed on thiek disk-like pedieels; ealyx tubular, searious, thickened at the base, gradually enlarged and slightly lobed at the apex, the lobes imbricated in the bud; eorolla funnel-formed, with a fleshy tube inelosed in the ealyx and about half as long as the laneeolate lobes, thickened and glandular on the inmer surfaee at the base, imbrieated in the bud; stamens inserted on the tube of the eorolla, with free filaments thiekened near the middle and linear-oblong anthers; ovary 3-lobed, 3-eelled, with slender elongated flexuose styles stigmatie at the apex; ovules lateral, ereet. Fruit a small ellipsoidal short-stalked blaek berry with thin dry flesh. Seed free, ereet, oblong-ovate, eoneave above, with a flat base depressed in the eentre, a minute sublateral liilum, a broad eonspieuous raehis, a minute lateral micropyle, and a thin pale ehestnut-brown inner eoat elosely investing the simple horny albumen; embryo minute, lateral, with the radicle turned toward the base of the fruit.

Two speeies of Washingtonia are known: one inhabits the interior dry region of southern California and the adjacent parts of Lower California, and the seeond the inountain cañons of western Sonora and southern Lower California.

The genus is named for George Washington.

\section{Washingtonia filamentosa, O. Kuntze. Desert Palm. Fan Palm.}

Leaves $5^{\circ}-6^{\circ}$ long and $4^{\circ}-5^{\circ}$ wide, light green, slightly tomentose on the folds, their petioles $4^{\circ}-6^{\circ}$ long and about $2^{\prime}$ broad at the apex, with sheaths $16^{\prime}-18^{\prime}$ long and $12^{\prime}-14^{\prime}$ wide, and ligules $4^{\prime}$ long and eut irregularly into long narrow lobes.

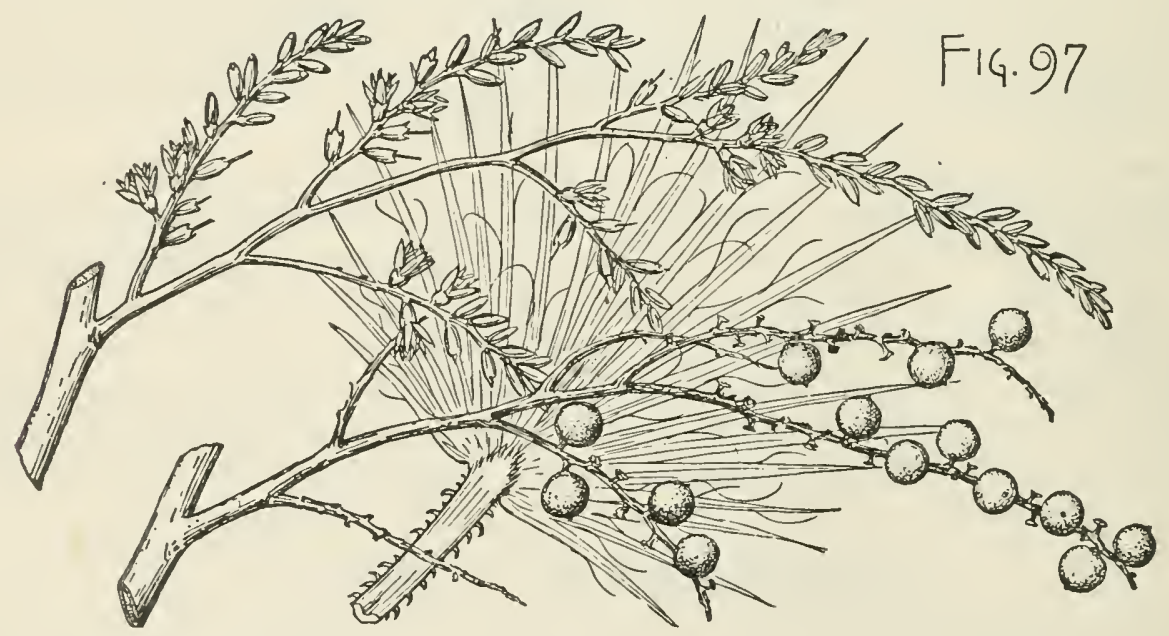

Flowers: spadix $10^{\circ}-12^{\circ}$ long, 3 or 4 being produced each year from the axils of upper leaves, the outer spathe inelosing the bud, narrow, elongated, and glabrous, those of the seeondary branehes eoriaeeous, yellow tinged with brown, and laeiniate at the apex. Flowers slightly fragrant, opening late in May or early in June. Fruit produced in great profusion, ripening in September, $\frac{1}{3}^{\prime}$ long; seeds $\frac{1}{4}^{\prime}$ long, $\frac{1}{8}^{\prime}$ thiek.

A tree, oceasionally $75^{\circ}$ high, with a trunk sometimes $50^{\circ}-60^{\circ}$ tall and $2^{\circ}-3^{\circ}$ in diameter, eovered with a thiek light red-brown sealy rind and elothed with a thiek 
thatch of dead pendant leaves descending in a regular cone from the broad crown of living leaves sometimes nearly to the ground. Wood light and soft, with numerous conspicuous dark orange-colored fibro-vascular bundles. The fruit is gathered and used as food by the Indians.

Distribution. Often forming extensive groves or small isolated clumps in wet usually alkali soil in depressions of the Colorado Desert in southern California, sometimes extending for several miles up the cañons of the San Bernardino and San Jacinto mountains, and in Lower Califoruia.

Now largely cultivated in southern California, southern Europe, and other temperate regions.

\section{SERENOA, Hook. f.}

Unarmed trees and slrubs, with tall often clustered stems, or on one species with subterranean stems. Leaves semiorbicular, truncate at the base, coriaceous, divided from the apex to below the middle into numerous parted segments obliquely folded at the base; rachises short, acute; ligules thin, concave, abruptly short-pointed, with a broad thin dark red deciduous border; petioles slender, flat on the upper, rounded and ribbed on the lower surface, denticulate on the margins, with thin light mahogany-red sheaths of slender fibres. Spadix interfoliar, paniculate, elongated, with a slender compressed stem and numerous slender elongated gracefully drooping flat branches coated with hoary tomentum, slender terete flowerbearing secondary branches, and flattened clavate spathes furnished at the apex with a thin red-brown border. Flowers perfect, sessile, solitary, or in 2 or 3-flowered clusters; calyx unequally lobed, the lobes valvate in the bud; corolla parted nearly to the base, its divisions valvate in the bud, oblong, thick, concave, acute, grooved on the inner surface with 2 or 3 deep depressions; stamens with nearly triangular filaments united below into a cup adnate to the tube of the corolla, and short-oblong anthers; ovary of 3 carpels, free below, united above into a long slender style tipped with a minute stigma; ovule erect from the bottom of the cell. Fruit a 1-seeded black drupe, the outer coat thin and fleshy, the inner orangebrown, resinous, fibrous, and strong-smelling, closely investing the pale brown thinshelled nut. Seed erect, with a hard chestnut-brown coat, lighter-colored with a conspicuous mark on the ventral side, a small subbasilar hilum, and an elongated ventral raphe; embryo lateral in homogeneous albumen.

Serenoa, with two species, is confined to the south Atlantic and Gulf region of North America. One species is arborescent, the other is a low shrub often occupying wide areas of sandy barren soil from South Carolina to Louisiana.

Serenoa commemorates the botanical labors of Sereno Watson.

\section{Serenoa arborescens, Sarg.}

Leaves about $2^{\circ}$ in diameter, light yellow-green on the upper surface, blue-green on the lower surface, divided nearly to the base into numerous lobes, slightly thickened at the pale yellow midribs and margins, their petioles $18^{\prime}-24^{\prime}$ long, armed with stout flattened curved orange-colored teeth. Flowers: spadix $3^{\circ}-4^{\circ}$ long, with a slender much-flattened stalk, panicled lower branches $18^{\prime}-20^{\prime}$ in length, and 6-8 thick firm pale green conspicuonsly ribbed spathes deeply divided and dilated at the apex into a narrow membranaceous border. Flowers solitary toward the ends of the branches and in 2 or 3-flowered clusters at their base, with a light chestnut-brown calyx and a pale yellow-green corolla. Fruit globose, $\frac{1}{3}^{\prime}$ in diameter; 
seeds subglobose, somewhat flattened below, witl a palc vertical mark on the lower side, and a minute hilum joined to the micropyle by a pale band.

A tree, from $30^{\circ}-40^{\circ}$ high, with 1 or several clustered erect inclining or occa-

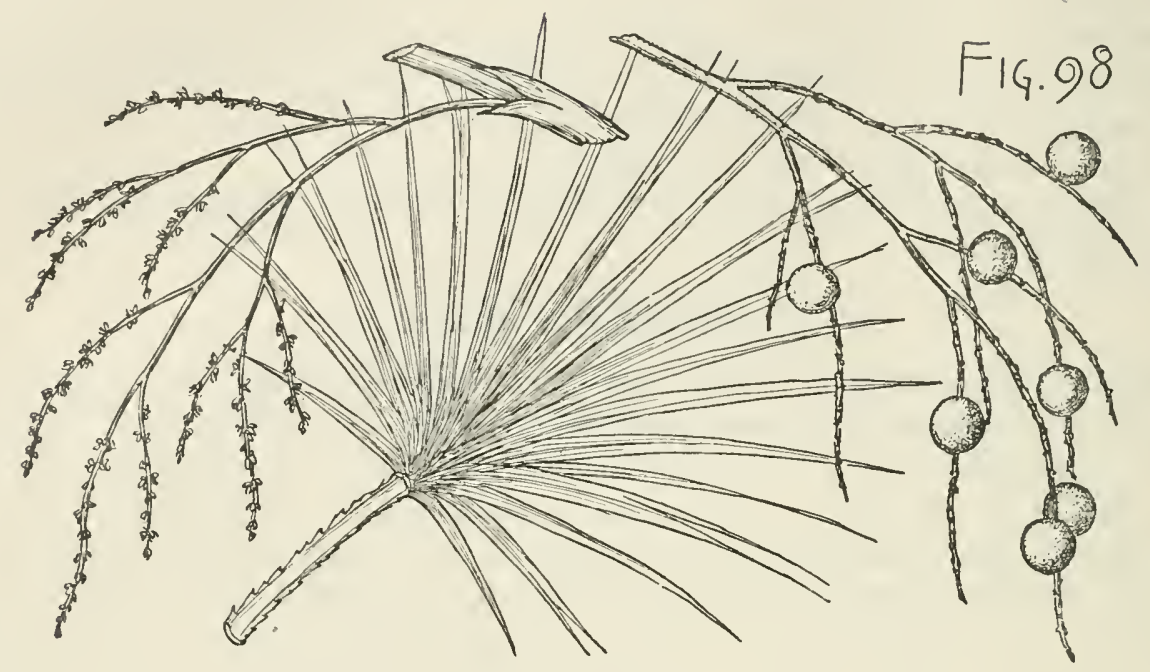

sionally semiprostrate stems $3^{\prime}-4^{\prime}$ in diameter, covered almost to the ground by the closely clasping bases of the leaf-stalks and below with a thick pale rind.

Distribution. Low undrained soil covered for many months of every year in water from $1^{\prime}-18^{\prime}$ deep, occasionally occupying almost exclusively areas of several acres in extent or more often scattered among Cypress-trees or Royal Palms, in the swamps and along the hummocks adjacent to the Chokoloskee River and its tributaries in southwestern Florida.

\section{ROYSTONEA, Cook. Royal Palm.}

Unarmed trees, with massive stems enlarged near the middle, and terminating in long slender bright green cylinders formed by the densely imbricated sheaths of the leaf-stalks. Leaves equally pimnate, with linear-lanceolate long-pointed unequally cleft plicately-folded pinnæ inserted obliquely on the upper side of the rachis, folded together at the base, with thin midribs and margins; rachises convex on the back, broad toward the base of the leaf and acute toward its apex; petioles semicylindrical, gradually enlarged into thick elongated green sheaths. Spadix large, decompound, produced near the base of the green part of the stem, with long pendulous branches and 2 spathes, the onter semicylindrical and as long as the spadix, the inner splitting ventrally and inclosing the branches of the spadix. Flowers monœcious, in a loose spiral, toward the base of the branch in 3-flowered clusters, with a central staminate and smaller lateral pistillate flowers, higher on the branch the staminate in 2-flowered clusters; calyx of the staminate flower of minute broadly ovate obtuse scarious sepals imbricated in the bud, much shorter than the corolla; petals nearly equal, valvate in the bud, ovate or obovate, acute, slightly united at the base, coriaceous; stamens 6,9 , or 12 , with subulate filaments united below and adnate to the base of the corolla, and large ovate-sagittate anthers, the cells free below; ovary rudimentary, subglobose or 3-lobed; pistillate flowers much smaller, ovoid-conical; sepals obtuse; corolla erect, divided to the middle into acute 
erect lobes incurved at the apex; staminodia 6 , scale-like, united into a cup adnate to the corolla; ovary subglobose, obscurely 2 or 3-lobed, 2 or 3-celled, gibbous, the cells crowned with a 3-lobed stigma becoming subbasilar on the fruit; ovule ascending. Fruit a short-stalked drupe with thin crustaceous flesh. Seed oblong-reniform, marked by the conspicuous fibrous reticulate branches of the raphe radiating from the narrow basal hilum, and covered with a thin crustaceous coat; embryo minute, cylindrical, lateral, in uniform albumen.

Roystonea is confined to the tropics of the New World, where two or three species occur.

The genus as here limited was named for General Roy Stone of the United States arimy.

\section{Roystonea regia, Cook. Royal Palm.}

(Oreodoxa regia, Silva $N . A m . x .31$.

Leaves $10^{\circ}-12^{\circ}$ long, closely pinnate, the pinnæ $2 \frac{1}{2}^{\circ}-3^{\circ}$ long, $1 \frac{1}{2}^{\prime}$ wide near the base of the leaf, and gradually decreasing in size toward its apex, deep green with slender conspicuous veins, and covered below with minute pale glandular dots, their petioles almost terete, concave near the base, with thin edges separating irregularly

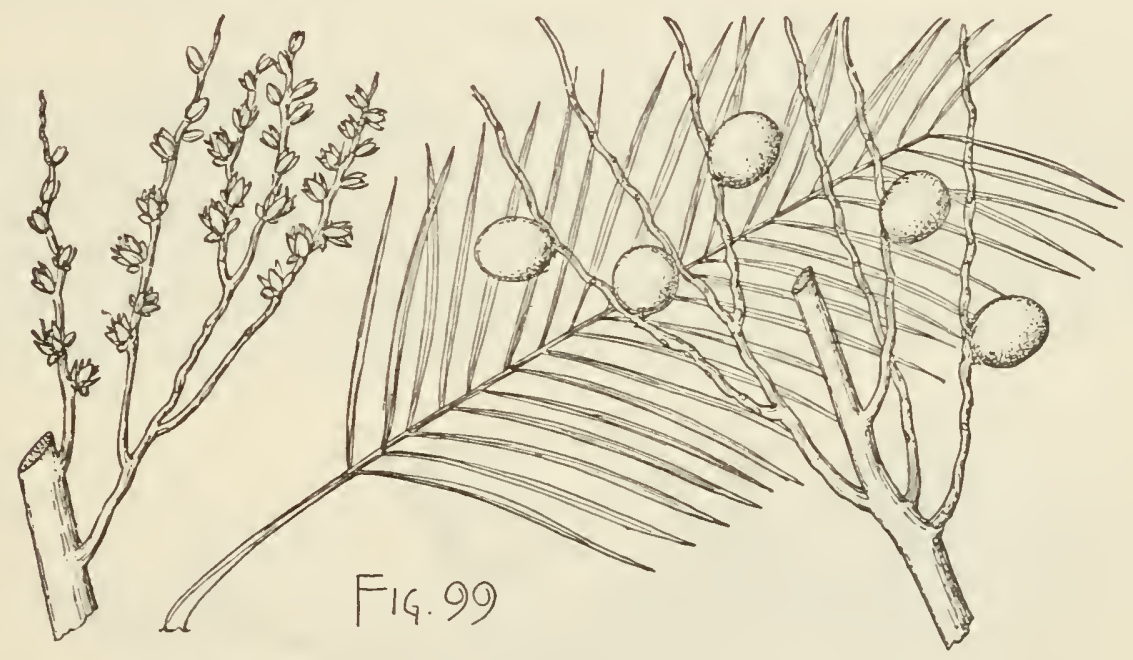

into pale fibres, and enlarged into bright green cylindrical clasping bases $8^{\circ}$ or $9^{\circ}$ long and more or less covered with dark chaffy scales. Flowers: spadix about $2^{\circ}$ long, with a nearly terete peduncle and slightly ridged primary and secondary branches compressed above, abruptly enlarged at the base, and simple slender flexuose longpointed flower-bearing brauchlets $3^{\prime}-6^{\prime}$ long, pendant and closely pressed against the secondary branches. Flowers opening in Florida in January and February, the staminate nearly $\frac{1^{\prime}}{4}$ long and rather more than twice as long as the pistillate. Fruit oblong-obovate, full and rounded at the apex, narrowed at the base, violet-blue, about $\frac{1}{2}^{\prime}$ long, with a thin outer coat and a light red-brown inner coat, loose and fibrous on the outer surface, and closely investing the thin light brown seed.

A tree, $80^{\circ}-100^{\circ}$ high, with a trunk rising from an abruptly enlarged base, gradually tapering from the middle to the ends and often $2^{\circ}$ in diameter, covered with light gray rind tinged with orange color, marked with dark blotches and irregularly broken into minute plates, the green upper portion $8^{\circ}-10^{\circ}$ long, and a broad head of gracefully drooping leaves. Wood of the interior of the stem spongy, pale brown, 
much lighter than the hard exterior rim, containing numerous dark conspicuous fibrovascular bundles. The outer portion of the stem is made into canes, and the trunks are sometimes used for wharf-piles and in construction.

Distribution. Florida, hummocks on Rogue River twenty miles east of Caximbas Bay, Long's Key, and the shores of Bay Biscayne near the moutl of Little River; common in the West Indies and Central America.

Largely cultivated as an ormanental tree in tropical countries, and often planted - to form avenues, for which its tall pale columnar stems and noble heads of graceful foliage make it valuable.

\section{PSEUDOPHCENIX, H. Wendl.}

A tree, with a slender stem abruptly enlarged at the base or tapering from the middle to the ends, covered with thin pale blue or nearly white rind, and cońspicuously marked by the dark scars of fallen leaf-stalks. Leaves erect, abruptly pinnate, with crowded linear-lanceolate acuminate leaflets increasing in length and width from the ends to the middle of the leaf, thick and firm in texture, dark yellow-green above, pale and glancous below; rachises convex on the lower side, concave on the upper side near the base of the leaf, with thin margins, becoming toward the apex of the leaf flat and narrowed below and acute above, marked on the sides at the base with dark gland-like excrescences; petioles short, concave above, with thin entire margins separating into slender fibres, gradually enlarged into broad thick sheaths of short brittle fibres. Spadix interfoliar, compound, pendulous, stalked, much shorter than the leaves, with spreading primary branches, stont and much flattened toward the base, slender and rounded above the middle, furnished at the base with a thickened ear-like body, slender secondary branches, short thin rigid densely flowered ultimate divisions, and compressed light green double spathes eroded on their

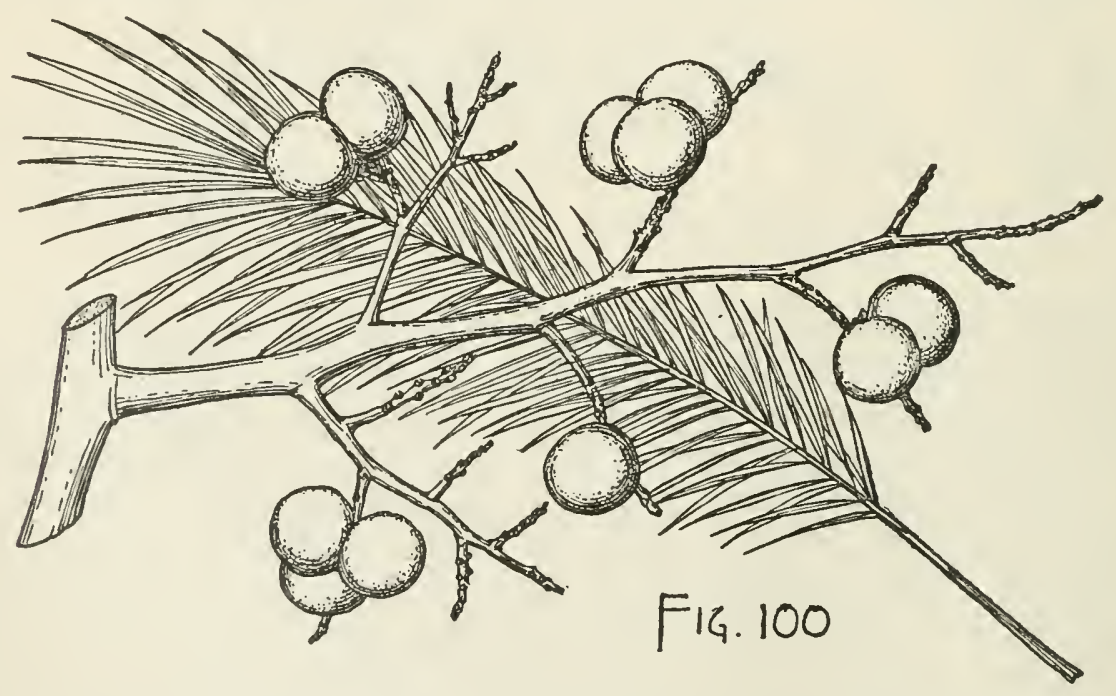

thin dark brown margins. Flowers unknown. Fruit a stalked globose 2 or 3-lobed orange-scarlet thin-fleshed drupe marked by the lateral style and surrounded below by the withered remnants of a 3-lobed calyx, oblong reflexed petals, and 6 slender spreading staminodia tipped with abortive anthers; peduncle abruptly enlarged at the base, articulate from a persistent cushion-like body furnished in the centre with 
a minute point penetrating a cavity in the base of the peduncle. Seed subglobose, free, erect, with a basal hilum and a thin light red-brown coat marked by the pale conspicuous ascending 2 or 3 -branched raphe; embryo minute, basal, in uniform horny albumen.

Pseudophœnix with a single species inhabits the keys of southern Florida, and the Bahamas.

The generic name is in allusion to a fancied resemblance to Phonix, a genus of Palms.

\section{Pseudophœnix Sargenti, H. Wendl.}

Leaves $5^{\circ}-6^{\circ}$ long, with pinnæ often $18^{\prime}$ long and $1^{\prime}$ wide near the middle of the leaf, becoming at its extremities not more than half as long and wide; their petioles $6^{\prime}-8^{\prime}$ in length. Flowers : spadix $3^{\circ}$ long and $2 \frac{1}{2}^{\circ}$ wide. Fruit ripening in May and June, $\frac{1^{\prime}}{2}-\frac{3^{\prime}}{4}$ in diameter on a peduncle $\frac{1^{\prime}}{4}$ long; seeds $\frac{1}{4}^{\prime}$ in diameter.

Distribution. Florida, east end of Elliott's Key, and east end of Key Largo near the southern shore, here forming a grove of 200 or 300 plants.

Occasionally cultivated in the gardens of southern Florida.

\section{LILIACEA.}

\section{(YUCCE.)}

Leaves, alternate, linear-lanceolate. Flowers in terminal panicles; sepals and petals nearly similar, subequal, withering-persistent; ovary with more or less deeply introduced dorsal partitions; ovules numerous, 2-ranked in each cell; embryo subuiate, obliquely placed across the seed; cotyledon arched in germination.

Yuccæ as here limited consists of two American genera, Hesperaloe, with two species, low plants of Texas and Mexico, and Yucca.

\section{YUCCA, L.}

Trees, with simple or branched stems prolonged by axillary naked buds, dark thick corky bark, light fibrous wood in concentric layers, and large stout horizontal roots. Leaves involute in the bud, at first erect, usually becoming reflexed, abruptly narrowed, above the broad thickened clasping base, usually widest near the middle, concave on the upper surface, involute toward the horny usually sharp-pointed apex, convex and often slightly keeled toward the base on the lower surface, the margins serrulate or filamentose, light or dull green. Flowers fertilized by insects and opening for a single night, on slender pedicels in 2 or 3-flowered clusters or singly at the base of the large compound panicle furnished with conspicuous leathery white or slightly colored bracts, those at the base of the pedicels thin and scarious; perianth cup-shaped, with thick ovate-lanceolate creamy white segments more or less united at the base, usually furnished with small tufts of white hairs at the apex, those of the outer rank narrower, shorter, and more colored than the more delicate petal-like segments of the inner rank; stamens 6, in 2 series, free, shorter than the ovary (as long in 1), white, with club-shaped fleshy filaments, obtuse and slightly 3-lobed at the apex, and cordate emarginate anthers attached on the back, the cells opening longitudinally, curling backward and expelling the large globose powdery pollengrains; ovary oblong, 6-sided, sessile or stalked, with nectar-glands within the partitions, dull greenish white, 3-celled, gradually narrowed into a short or elongated 
3-lobed ivory-white style forming a triangnlar stigmatic tube. Fruit oblong or oval, more or less distinctly 6 -angled, 6-celled, usually beaked at the apex, baceate and indehiscent or capsular and 3 -valved, the valves finally separating at the apex; pericarp of 2 coats, the outer at maturity thick, succulent and juicy, thin, dry and leathery, or thin and woody. Seeds compressed, triangular, obovate or obliquely ovate or orbicular, thick, with a narrow 2-edged rim, or thin, with a wide or narrow brittle margin; secd-coat thin, black, slightly rugose or smootlı; embryo in plain or rarely ruminate hard farinaceous oily albumen; cotyledon much longer than the short radicle turned toward the small oblong white hilum.

Yucea is confined to the New World and is distributed from Bermuda and the eastern Antilles, through the south Atlantic and Gulf states, and through New Mexico and northward along the eastern base of the Rocky Mountains to South Dakota, westward to middle California, and southward through Arizona, Mexico, and Lower California to Central America. About thirty species with many varieties and probable hybrids are recognized. Of the species which inhabit the territory of the United States nine assume the habit and attain the size of small trees. The root-stalks of Yucca are used as a substitute for soap, and ropes, baskets, and mats are made from the tough fibres of the leaves. Many of the species are cultivated, especially in countries of scanty rainfall, for their great clusters of beautiful flowers, or in hedges to protect gardens from cattle.

The generic name is from the Carib name of the root of the Cassava.

\section{CONSPECTUS OF THE ARBORESCENT SPECIES OF THE UNITED STATES.}

Flower-clusters usually sessile, or short-stalked.

Fruit pendulous, with thick succulent flesh ; seeds thick; albumen ruminate.

Segments of the perianth slightly united at the base.

Panicle glabrous or puberulous.

Ovary stipitate.

Leaves sharply toothed on their horny margins, smooth, dark green, slightly concave.

1. Y. aloifolia (C).

Ovary sessile.

Leaves concave, blue-green, rough on the lower surface.

2. Y. Treculeana (E).

Leaves coneave above the middle, smooth, light yellow-green.
Style elongated.
Style short.
3. Y. macrocarpa $(\mathrm{E}, \mathrm{H})$.
4. $\mathbf{Y}$. Mohavensis $\left(\mathrm{G},{ }^{\prime} \mathrm{H}\right)$.

Panicle coated with hoary tomentum.

Leaves concave, smooth, light yellow.-green.

5. Y. Schottii (H).

Segments of the perianth united below into a narrow tube.

Leaves flat, smooth, dark green.

6. Y. Faxoniana (E).

Fruit erect or spreading, the flesh becoming thin and dry at maturity ; seeds thin ; albumen entire.

Leaves concave above the middle, blue-green, sharply serrate.

7. $\mathbf{Y}$. arborescens $(F, G)$.

Leaves thin, flat or concave toward the apex, rough on the lower surface, dull or glaucous green, more or less plicately folded.

8. $\mathbf{Y}$.gloriosa (C).

Flower-clusters long-stalked; fruit capsular, erect, finally splitting between the carpels and through their backs at the apex; seeds thin; albumen entire.

Leaves thin, flat, filamentose on the margins, smooth, pale yellow-green.

9. $\mathrm{Y}$. radiosa $(\mathrm{E}, \mathrm{H})$. 
1. Fruit with thick succulent flesh.

* Segments of the flower slightly united at the base.

\section{Yucca aloifolia, L. Spanish Bayonet.}

Leaves $18^{\prime}-32^{\prime}$ long, $11^{\prime}-2 \frac{1}{2}^{\prime}$ wide, erect, rigid, conspicuously narrowed above the light green base, widest above the middle, slightly concave on the upper surface, smooth, dark rich green, with stiff dark red-brown spines and horny finely and irregularly serrate margins; long-persistent. Flowers from June until August on stout pedicels, in nearly sessile glabrous or slightly pubescent panicles $18^{\prime}-24^{\prime}$ long; perianth $1^{\prime}-1 \frac{1^{\prime}}{2}$ in length and $3^{\prime}$ or $4^{\prime}$ across when fully expanded, the segments ovate, thick and tumid toward the base, those of the outer rank rounded and often

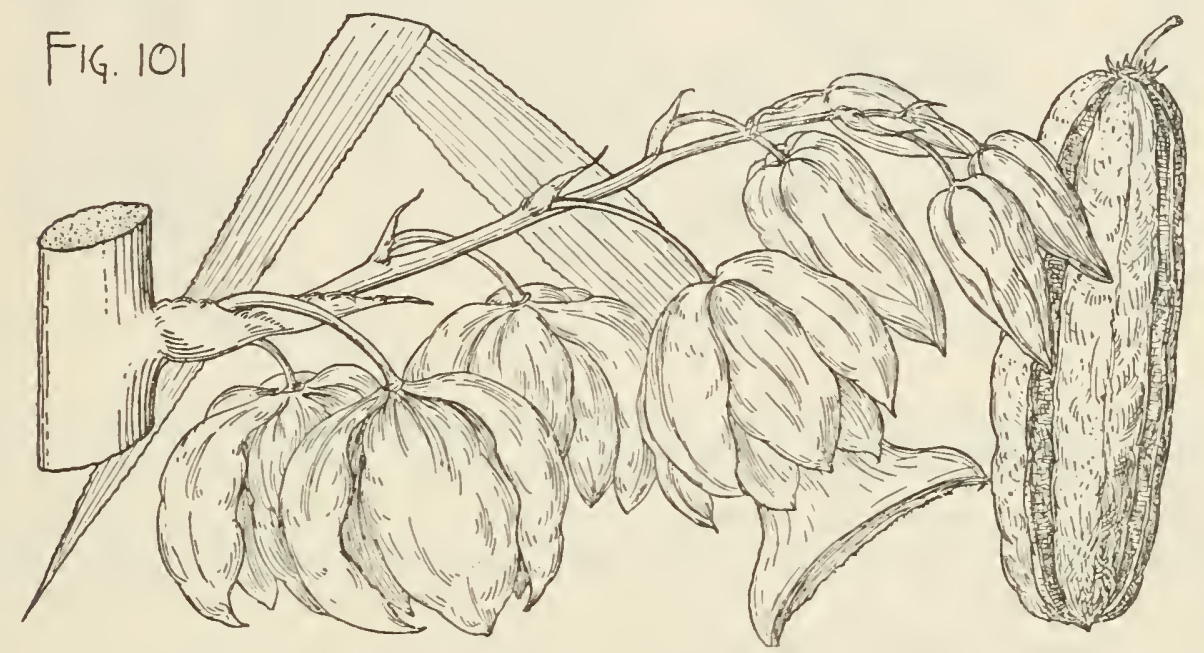

marked with purple at the apex, the inner acuminate and short-pointed; stamens as long or sometimes a little longer than the light green ovary raised on a short stout stipe. Fruit ripening from August to October, elongated, elliptical, hexagonal, $3^{\prime}-4^{\prime}$ long, $1 \frac{1^{\prime}}{4}-1 \frac{1}{2}^{\prime}$ thick, light green when fully grown, and in ripening turning dark purple, the outer and inner coats forming a thick succulent mass of bittersweet juicy flesh, fiully becoming black and drying on its stalk; seeds $\frac{1^{\prime}}{4}-\frac{1^{\prime}}{3}$ broad, about $\frac{1}{16}$ thick, with thin narrow ring-like borders to the rim.

A tree, occasionally $2 \tilde{5}^{\circ}$ high, usually much smaller, with an erect or more or less inclining simple or branched trunk slightly swollen at the base, and rarely more than $6^{\prime}$ in diameter; sometimes with numerous clustered stems. Bark near the base of the trunk thick, rough, dark brown, marked above by scars left by falling leaves.

Distribution. Sand dunes of the coast from North Carolina to eastern Louisiana; west of the Appalachicola River attaining its largest size and sometimes ranging inland through Pine forests for thirty or forty miles.

A common garden plant in all countries with a temperate climate, and long naturalized in some of the West Indian islands and on the Gulf coast of Mexico. Forms with leaves variously striped with white, yellow, and red are frequent in cultivation.

\section{Yucca Treculeana, Carr. Spanish Bayonet. Spanish Dagger.}

Leaves $2 \frac{1}{2}^{\circ}-4^{\circ}$ long, $2^{\prime}-3 \frac{1}{4}^{\prime}$ wide, slightly or not at all contracted above the dark red lustrous base, concave, stiff, rigid, dark blue-green, rough on the lower sur- 
face, nearly smooth on the upper, with short stout dark red-brown spines and dark brown margins roughened by minute decidnous teeth and ultimately separating into slender dark fibres; persistent for many years, the dead leaves hanging closely appressed against the trunk below the teminal crown of closely imbricated living leaves. Flowers in March and April on slender pedicels, in dense many-flowered

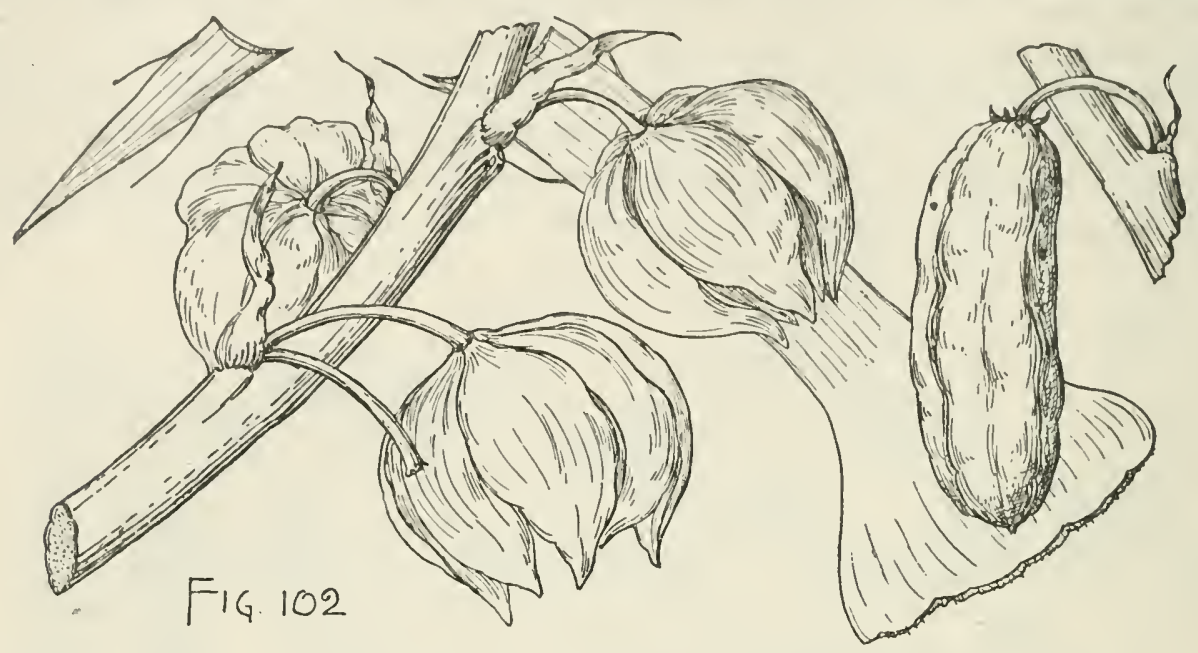

glabrous or puberulous panicles $2^{\circ} 4^{\circ}$ long and raised on short stout stalks; perianth $1^{\prime}-2^{\prime}$ long, $2^{\prime}-4^{\prime}$ in diameter when fully expanded, with narrow elongated ovatelanceolate to ovate segments, $\frac{1^{\prime}}{4}$ wide, acute, thin and delicate, furnished at the apex with conspicuous tufts of short pale hairs; filaments slightly papillose, about as long as the prismatic ovary gradually narrowed above and crowned by the deeply divided stigmatic lobes. Fruit ripening in the summer, $3^{\prime}-4^{\prime}$ long, about $1^{\prime}$ thick, dark reddish brown or ultimately black, with thin succulent sweetish flesh; seeds about $\frac{1^{\prime}}{8}$ broad, nearly $\frac{1}{1 \overline{1}^{\prime}}$ thick, with narrow borders to the rim.

A tree, occasionally $25^{\circ}-30^{\circ}$ high, with a trunk sometimes $2^{\circ}$ in diameter and numerons stont wide-spreading branches; usually smaller and often forming broad low thickets $4^{\circ}-5^{\circ}$ tall. Bark on old trunks $\frac{1}{4}^{\prime}-\frac{1}{2}^{\prime}$ thick, dark red-brown and broken into thin oblong plates covered by small irregular closely appressed scales. Wood light brown, fibrous, spongy, heavy, difficult to cut and work.

Distribution: Shores of Matagorda Bay, southward through western Texas into Nuovo Leon, and through the valley of the Rio Grande to the eastern base of the mountains of western Texas; forming open stunted forests on the coast dunes at the mouth of the Rio Grande; farther from the coast often spreading into great impenetrable thickets.

Cultivated as an ornamental plant in the gardens of central and western Texas, and occasionally in those of southern Europe.

\section{Yucca macrocarpa, Coville. Spanish Dagger.}

Leaves $1 \frac{1}{2}^{\circ}-2^{\circ}$ long, $1^{\prime}-2^{\prime}$ wide, gradually narrowed from the dark red lustrous bases to above the middle, rigid, concave, yellow-green, rough on the lower surface and frequently also on the upper surface, with stout elongated dark spines and thickened margins separated into stout gray flaments. Flowers in March and April in densely flowered sessile or short-stalked glabrous or occasionally pubescent panicles; perianth usually about $2^{\prime}$ long, with acuminate segnents, those of the outer and 
imner rows nearly of the same size; stamens shorter than the elongated style. Fruit $3^{\prime}-4^{\prime}$ long, about $1 \frac{1}{2}^{\prime}$ thick, abruptly contracted at the apex into a stout point,

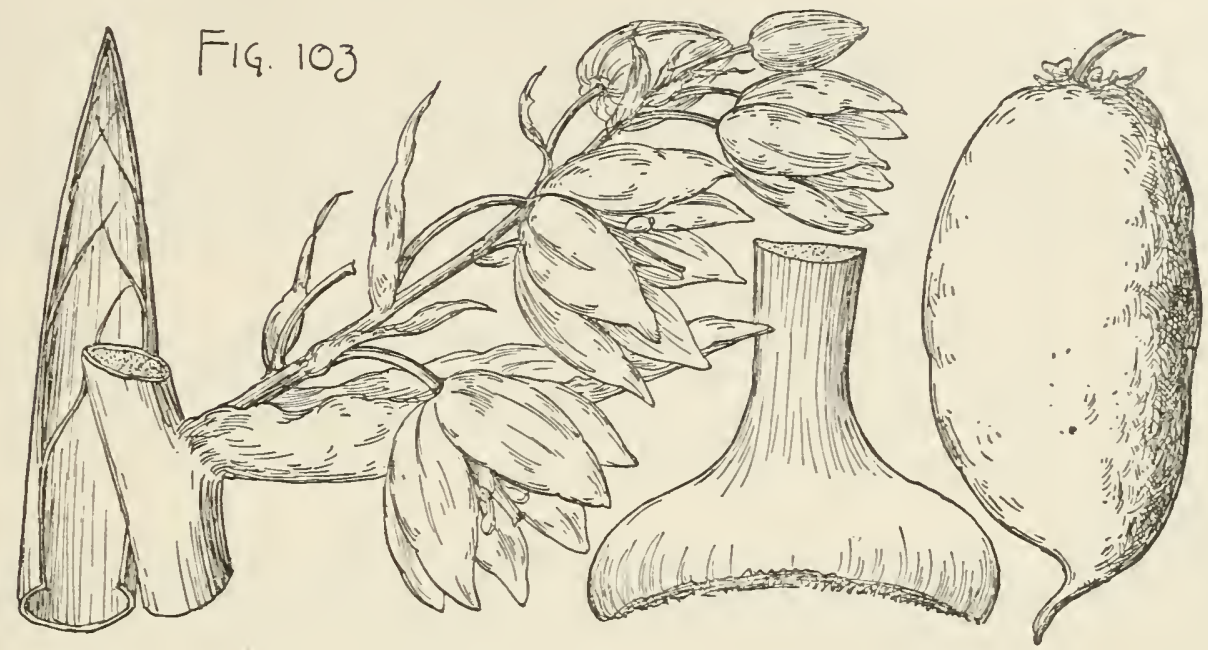

nearly black when fully ripe, with sweet succulent flesh; seeds about $\frac{1^{\prime}}{3}$ wide, $\frac{1}{8}^{\prime}$ thick, with narrow borders to the rim.

A tree, rarely exceeding $15^{\circ}$ in height, with a usually simple stem $6^{\prime}-8^{\prime}$ in diameter, and often clothed to the ground with living leaves. Bark dark brown and scaly.

Distribution. Arid plains from western Texas to eastern Arizona and southward in Chihuahua.

\section{Yucca Mohavensis, Sarg. Spanish Dagger.}

Leaves $18^{\prime}-20^{\prime}$ long, about $1 \frac{1}{2}^{\prime}$ wide, abruptly contracted above the dark red lustrous base, gradually narrowed upward to above the middle, thin and concave except
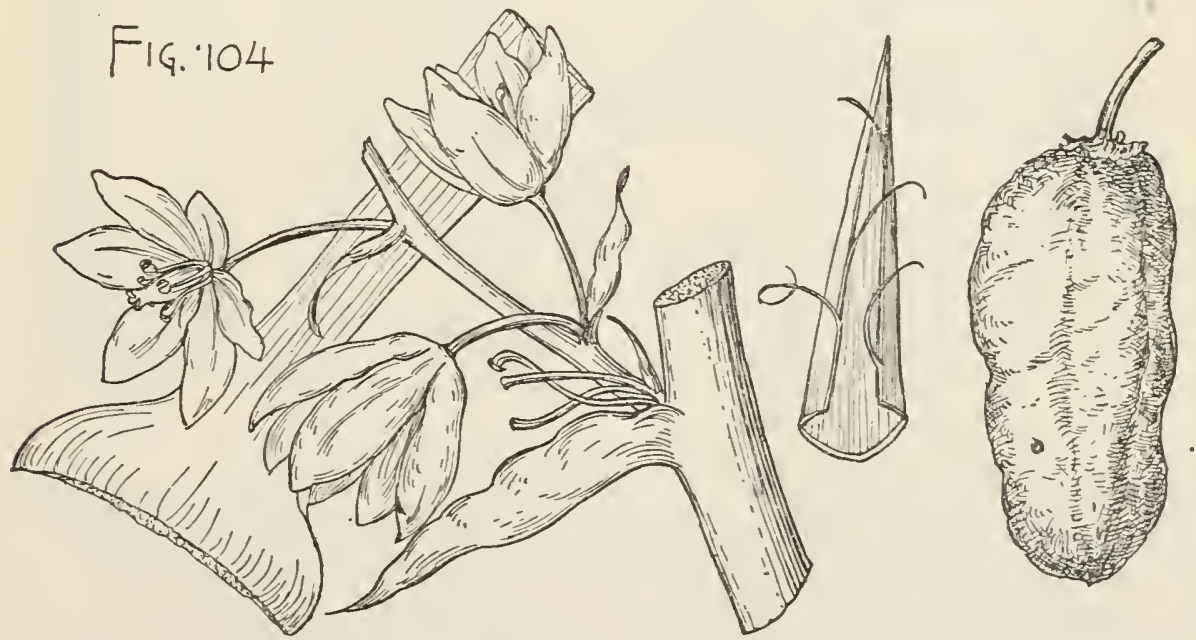

toward the slightly thickened base of the blade, dark green, smooth on both surfaces, with stout rigid sharp-pointed tips and entire bright red-brown margins soon separating into numerous long thick pale filaments. Flowers from March to 
May on slender erect ultinately, drooping pedicels $1^{\prime}-11^{\prime}$ long, in densely flowered sessile or short-stemmed panicles $12^{\prime}-1 S^{\prime}$ in length; perianth $1^{\prime}-2^{\prime}$ long, the segments united at the base into a short tube, thickened and hood-shaped at the apex, those of the onter rank often deeply flushed with purple, but little longer than the less prominently ribbed usually wider and thimer segments of the inner rank; stamens with more or less pilose filaments nearly as long as the short style. Fruit ripening in August and September, $3^{\prime}-1^{\prime}$ long, abont $1_{\frac{1}{2}}^{\prime}$ thick, usually much eonstrieted near the middle, abruptly eontracted at the apex into a short stout point, dark dull brown or nearly blaek, with flesh often nearly $\frac{1^{\prime}}{2}$ thick; seeds $\frac{1^{\prime}}{3}$ wide, rather less than $\frac{1^{\prime}}{8}$ thick, with narrow borders to the rim.

A tree, rarely exceeding $15^{\circ}$ in height, with a trunk usually simple or occasionally furnished with short spreading branches, and $6^{\prime}-\delta^{\prime}$ in diameter, nsually surrounded by a eluster of shorter more or less spreading stems and often clothed to the ground with living leaves. Bark dark brown and sealy. Wood soft, spongy, light brown.

Distribution. Southern Nevada and northwestern Arizona across the Mohave Desert to the Califormia coast, extending northward to the neighborhood of Monterey, California, and sonthward into northern Lower California; common and attaining its largest size on the Mohave Desert, and sometimes ascending arid mountain slopes to elevations of $4000^{\circ}$ above the sea.

\section{Yucca Schottii, Engelm. Spanish Dagger.}

Leaves $2 \frac{1}{2}^{\circ}-3^{\circ}$ long, about $1 \frac{1}{2}^{\prime}$ wide, gradually narrowed upward from the comparatively thin lustrous red base to above the middle, flat except toward the apex,
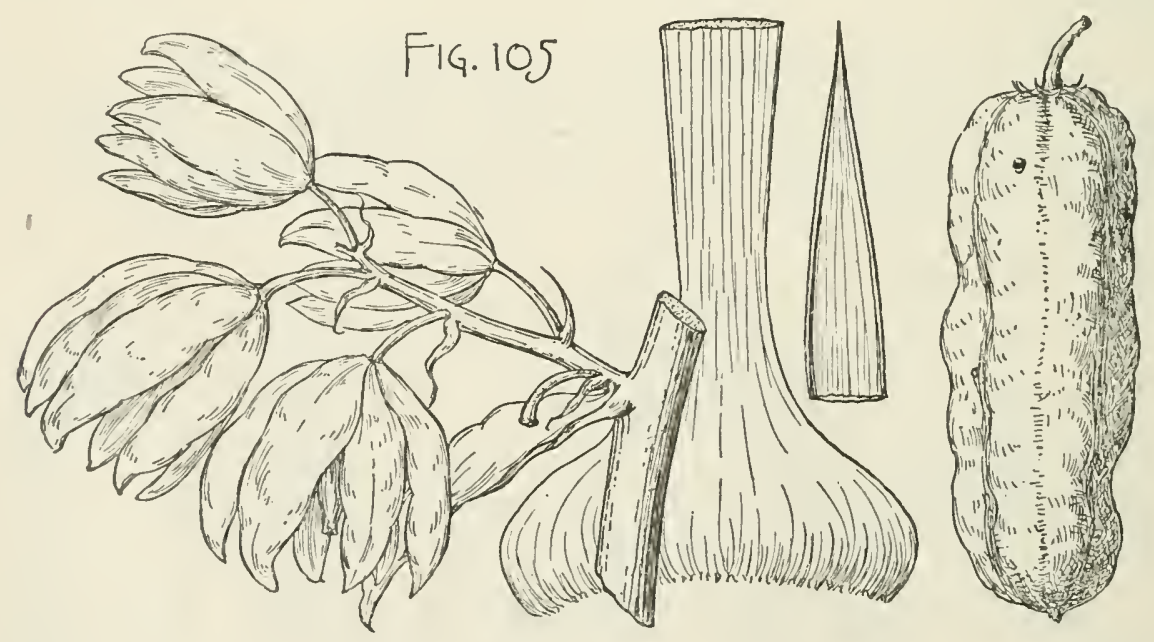

smooth, light yellow-green, with long rigid sharp light red points and thick entire red-brown margins finally separating into short thin brittle threads. Flowers from July to September in erect stalked tomentose panicles; perianth $1^{\prime}-1 \frac{3}{4}{ }^{\prime}$ long, the broad oval or oblong-obovate thin segments pubescent on the outer surface toward the base and furnished at the apex with conspicuous clusters of white tomentum; stamens about two thirds as long as the ovary, with filaments pilose at the base, and only slightly enlarged at the apex. Fruit ripening in October and November, obscurely angled, $3 \frac{1}{2}^{\prime}-4^{\prime}$ long, about $1 \frac{1}{4}^{\prime}$ thiek, often narrowed above the middle, with 
a stout thick point, and thin sweet succulent flesh; seeds $\frac{1^{\prime}}{4}$ broad, about $\frac{1^{\prime}}{8}$ thick, with thin conspicuous marginal rims.

A tree, in Arizona rarely $18^{\circ}-20^{\circ}$ high, with a trunk often crooked or slightly inclining and simple or furnished with 2 or 3 short erect branches, covered below with dark brown scaly bark, roughened for many years by persistent scars of fallen leaves, and clothed above by the pendant dead leaves of niany seasons.

Distribution. Dry slopes of the mountain ranges of Arizona near the Mexican boundary, usually at elevations between $5000^{\circ}$ and $6000^{\circ}$, and southward through Sonora.

** Segments of the flowers united below into a narrow tube.

\section{Yucca Faxoniana, Sarg., nov. nom. Spanish Dagger.}

(Yucca macrocarpa, Silva N. Am. x. 13.)

Leaves $2 \frac{1}{2}^{\circ}-4^{\circ}$ long, $2 \frac{1}{2}^{\prime}-3^{\prime}$ wide, abruptly contracted above the conspicuously thickened lustrous base, widest above the middle, flat on the upper surface, thickened and rounded on the lower surface toward the base, rigid, smooth and clear dark green, with short stout dark spines and brown entire margins breaking into numer-

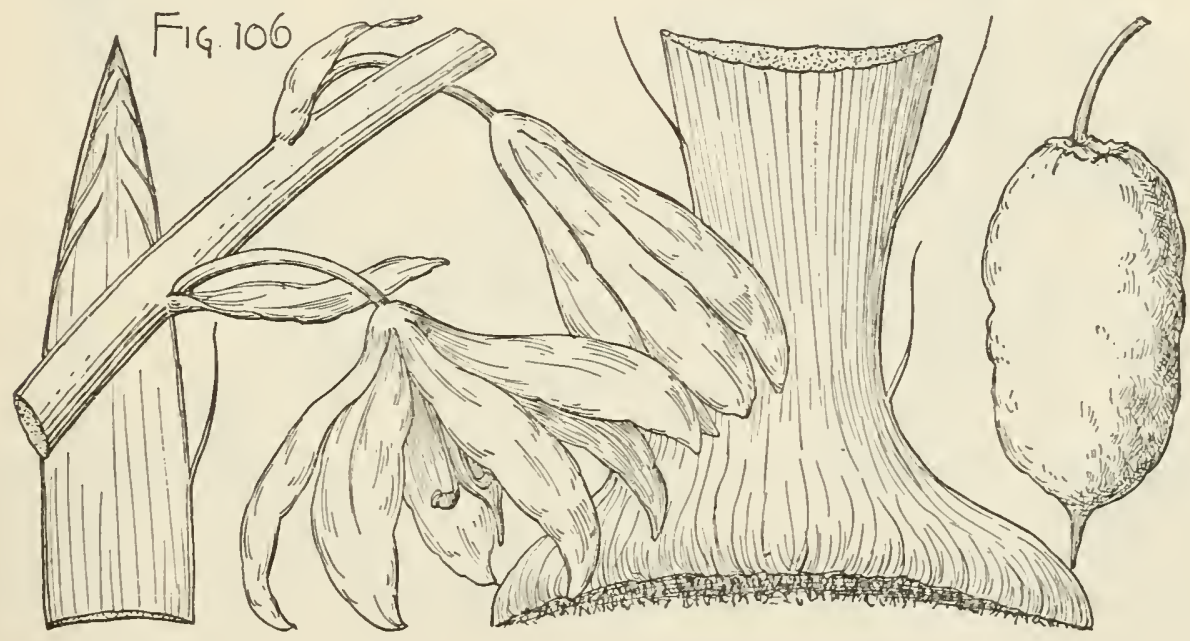

ous stout gray or brown fibres short and spreading near the apex of the leaf, longer, more remote, and forming a thick cobweb-like mass at their base. Flowers appearing in April on thin drooping pedicels, in dense many-flowered glabrous panicles $3^{\circ}-4^{\circ}$ long, with elongated pendulous branches; perianth $2 \frac{1}{2}^{\prime}$ long, the segments thin, concave, widest above the middle, narrowed at the ends, united at the base into a short tube, those of the outer rank being about half as wide as those of the inner rank and two thirds as long; stamens much shorter than the ovary, with slender filaments pilose above the middle and abruptly dilated at the apex; ovary conspicuously ridged, light yellow marked with large pale raised lenticels, and gradually narrowed into an elongated slender style. Fruit ripening in early summer, slightly or not at all angled, abruptly contracted at the apex into a long or short hooked beak, $3^{\prime}-1^{\prime}$ long, $1^{\prime}-1 \frac{1^{\prime}}{2}$ thick, light orange-colored and lustrous when first ripe, becoming nearly black, with thick succulent bitter-sweet flesh; seeds $\frac{1^{\prime}}{4}$ long, about $\frac{1}{8}^{\prime}$ thick, with narrow nearly obsolete margins to the rim.

A tree, often $40^{\circ}$ high, with a trunk sometimes $2^{\circ}$ in diameter above the broad 
abruptly enlarired base, mbranched or divided into several short branches, and covered above by a thick thateh of the pendant dead leaves of many seasons; frequently smaller and until ten or twelve years old clothed from the ground with erect living leaves. Bark near the base of old trees dark reddish brown, $\frac{1}{8}-\frac{1}{2}$ thick, broken on the surface into small thin loose seales.

Distribution. Common on the high desert plateau of southwestern Texas.

\section{Fruit with thin dry glesh.}

\section{Yucca arborescens, Trel. Joshua Tree.}

Leaves $55^{\prime}-S^{\prime}$ or on young plants rarcly $10^{\prime}-12^{\prime} \operatorname{long}, \frac{1}{4}{ }^{\prime}-\frac{1}{2}{ }^{\prime}$ wide, rigid, crowded in densely imbricated elusters, lanccolate, gradually tapcring from the bright redbrown lustrous base, bluish green and glaucous, smooth or slightly roughened, con-

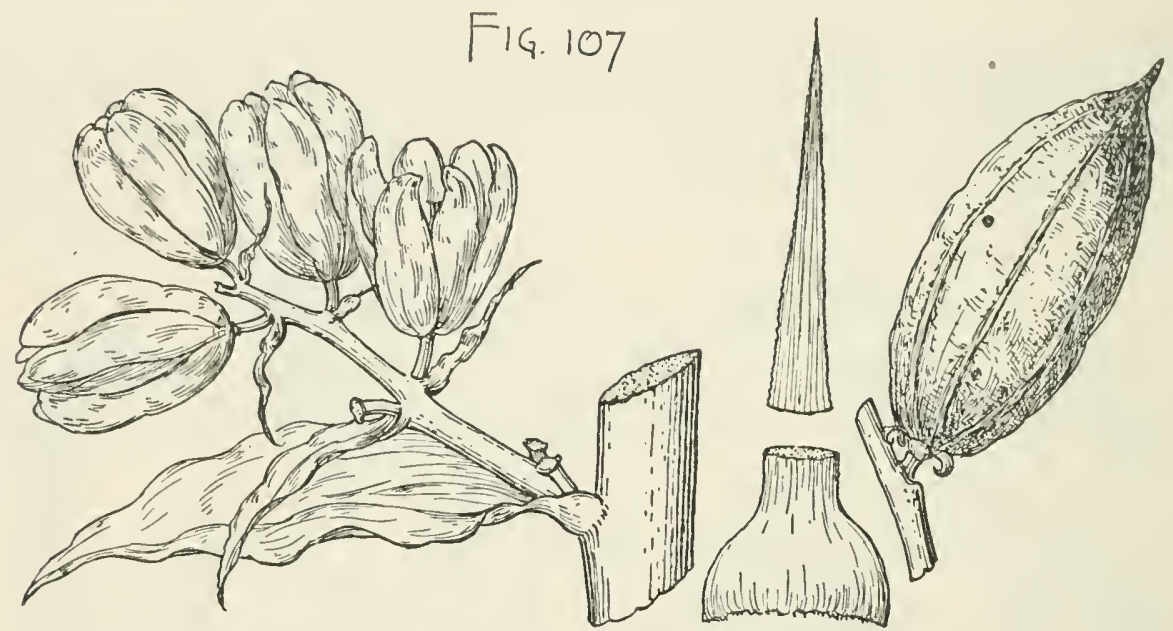

cave above the middle, with sharp dark brown points, and thin yellow margins armed with sharp minute teeth; persistent for many years. Flowers appearing from March until the beginning of May, the creamy white closely imbricated bracts of the nearly sessile pubescent panicle forming before its appearance a conspicuous cone-like bud $8^{\prime}$ or $10^{\prime}$ long; perianth globose to oblong, $1^{\prime}-2^{\prime}$ long, greenish white, waxy, dull or lustrous, its segments slightly united at the base, keeled on the back, thin below the middle, gradually thickened upward into the concave incurved rounded tip, those of the outer rank rather broader, thicker, and more prominently keeled than those of the inner rank, glabrous or pubescent; stamens about half as long as the ovary, with filaments villose-papillate from the base; ovary conical, 3-lobed above the middle, bright green, with narrow slightly developed septal nectarglands and a sessile nearly equally 6-lobed stigma. Fruit ripening in May or June, spreading or more or less pendant at maturity, oblong-ovate, acute, slightly 3-angled, $2^{\prime}-4^{\prime}$ long, $1 \frac{1}{2}-2^{\prime}$ broad, light red or yellow-brown, the outer coat becoming dry and spongy at maturity; seeds nearly $\frac{1}{2}^{\prime}$ long, rather less than $\frac{1^{\prime}}{16}$ thick, with broad well-developed margins to the rim and large conspicuous hilums.

A tree, $30^{\circ}-40^{\circ}$ high, with a trunk $2^{\circ}-3^{\circ}$ in diameter, rising abruptly from a broad thick basal disk, stout tongh roots descending deeply into the soil, and stout branches spreading into a broad, often symmetrical head formed by the continued forking of the branches at the base of the terminal flower-clusters; until $8^{\circ}-10^{\circ}$ 
high the stem simple and clothed to the ground with leaves erect until after the appearance of the first flowers, then spreading at right angles and finally becoming reflexed. Bark $1^{\prime}-1 \frac{1}{2}^{\prime}$ thick, deeply divided into oblong plates frequently $2^{\circ}$ long. Wood light, soft, spongy, difficult to work, light brown or nearly white; sometimes cut into thin layers and used as wrapping material or manufactured into boxes and other small articles. The seeds are gathered and eaten by the Indians.

Distribution. Sonthwestern Utah to the western and northern rim of the Mohave Desert in California; most abundant and of its largest size on the foothills on the desert slope of the Tehachapi Mountains.

\section{Yucca gloriosa, L. Spanish Dagger.}

Leaves $2^{\circ}-2 \frac{1}{2}^{\circ}$ long, gradually narrowed above the broad base and then gradually broadened to above the middle, thin, flat or slightly concave toward the apex, frequently longitudinally folded, dull often glaucous green, roughened on the under surface especially above the middle, with stout dark red points, and pale margins serrulate toward the base of the leaf, with minute early deciduous teeth, or occasionally separating into thin fibres. Flowers in October, in pubescent or glabrate panicles, $2^{\circ}-4^{\circ}$ long, on stout stalks sometimes $3^{\circ}-4^{\circ}$ in length, their large

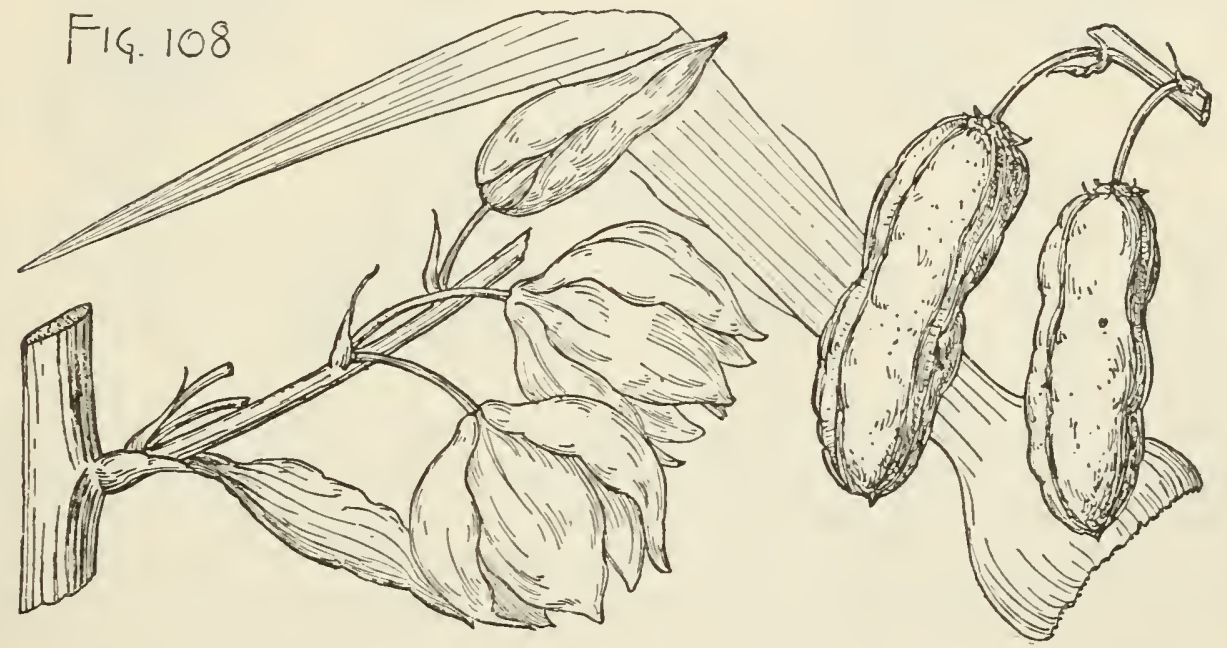

creamy white bracts forming before the panicle emerges a conspicuous egg-shaped bud $4^{\prime}-6^{\prime}$ long; perianth when fully expanded $3 \frac{1}{2}^{\prime}-4^{\prime}$ across, its segments thin, ovate, acute, or lance-ovate, often tinged with green or purple, slightly united at the base, pubescent at the apex; stamens about as long as the ovary, with hispid or slightly papillose filaments and deeply emarginate anthers; ovary slightly lobed, 6-sided, light green, gradually narrowed into the elongated spreading stigmatic lobes. Fruit very rarely produced, prominently 6 -ridged, pendulous, $3^{\prime}$ long, $1^{\prime}$ in diameter, cuspidate, raised on a short stont stipe, with a thin leathery almost black onter coat; seeds $\frac{1}{4}^{\prime}$ wide and about $\frac{1}{36}$ thick, with a smooth coat.

A tree, with a trunk occasionally $6^{\circ}-8^{\circ}$ high and $4^{\prime}-6^{\prime}$ in diameter, simple or rarely furnished with a few short branches and nsually clothed to the base with pendant dead leaves; in cultivation often becoming much larger, with a stout trunk covered with smooth light gray bark, and erect or in one form (var. recurvifolia, Engelm.) pendulous leaves. 
Distribution. Sand dunes and the borders of beaches of the South Carolina seacoast.

Often cultivated with many forms in the gardens and pleasure-grounds of all temperate countries.

3. Fruit a capsule.

\section{Yucca radiosa, Trel. Spanish Dagger.}

(Y ucca constrictu, Silva N. Am. x. 27.)

Leaves $20^{\prime}-30^{\prime}$ long, $\frac{1}{4}^{\prime}-\frac{1}{2}{ }^{\prime}$ wide, rigid, gradually narrowed from the thin base, tapering toward the apex, or sometimes somewhat broadest at the middle, thin, flat on the upper surface, slightly thickened and rounded on the lower surface toward

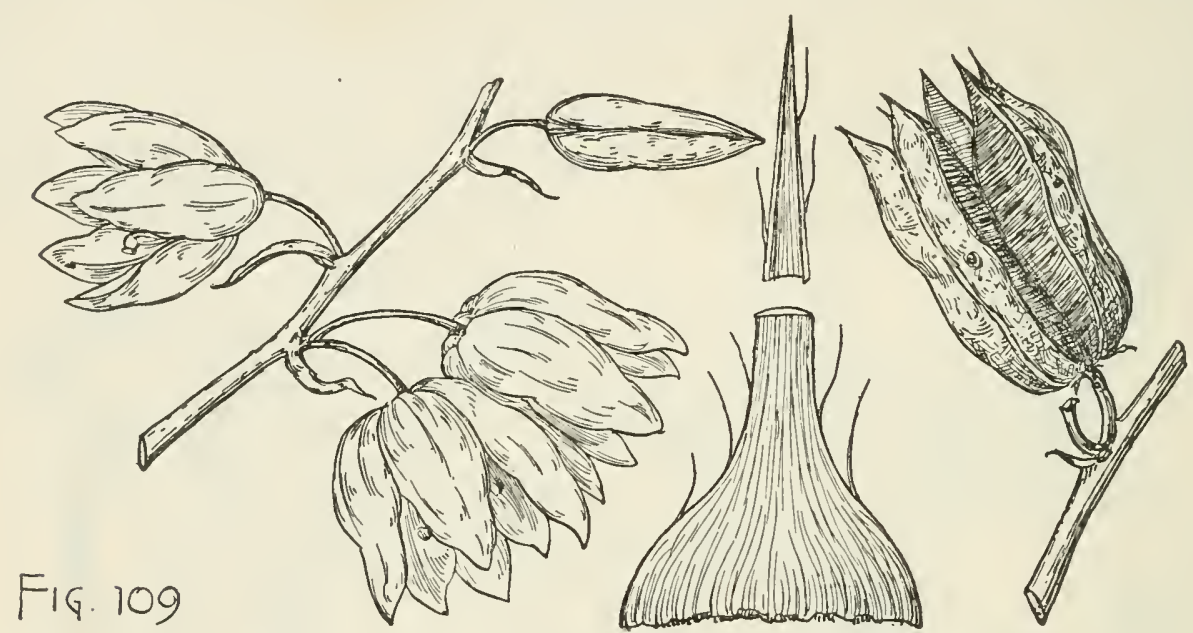

the base, smooth, pale yellow-green, with slender stiff red-brown points, and thickened entire pale margins soon splitting into long slender filaments. Flowers in May and June on slender spreading more or less recurved pedicels, in glabrous muchbranched panicles $4^{\circ}-6^{\circ}$ long, raised on stont naked stems $3^{\circ}-7^{\circ}$ in length; perianth ovate and acute in the bud, when fully expanded $3 \frac{1}{2}^{\prime}-4^{\prime}$ across, its segments united at the base into a short slender distinct tube, ovate or slightly obovate, those of the outer rank usually acute, not more than half as broad as those of the inner rank; stamens as long or a little longer than the ovary, with slender nearly terete filaments; ovary sessile, almost terete, pale green, abruptly contracted into the stout elongated style. Fruit an erect oblong capsnle rounded and obtuse at the ends, tipped by a short stont mucro, conspicuonsly 3-ribbed, with rounded ridges on the back of the carpels, $1 \frac{1}{2}^{\prime}-2^{\prime}$ long, $1^{\prime}-1 \frac{1}{2}^{\prime}$ wide, with a thin firm light brown ligneous outer coat closely adherent to the lustrous light yellow inner coat, in ripening splitting from the top to the bottom between the carpels and through their backs at the apex; seeds $\frac{1}{3}^{\prime}$ wide and about $\frac{1}{32}^{\prime}$ thick, with a smooth coat and thin brittle wide margins to the rim.

A tree, with a tough much-branched underground stem penetrating deep into the soil and a trunk often $10^{\circ}-12^{\circ}$ high and $7^{\prime}-8^{\prime}$ in diameter, covered above with a thick thatch of the pendant dead leaves of many years, simple, or branched with numerous short stout branches densely covered with leaves at first erect, then spreading nearly at right angles, and finally pendulous. Bark dark brown, irregu- 
larly fissured, broken into thin plates, about $\frac{1^{\prime}}{4}$ thick. Wood light, soft, spongy, pale brown or yellow.

Distribution. High desert plateaus from southwestern Texas to southern Arizona, southward into northern Mexico; most abundant and of its largest size on the eastern slope of the continental divide in southern New Mexico and along the northern rim of the Tucson Desert in Arizona.

\section{Division II. Dicotyledons.}

Stems formed of bark, wood, or pith, and increasing by the addition of an annual layer of wood inside the bark. Parts of the flower mostly in 4's and 5's; embryo with a pair of opposite cotyledons. Leaves netted-veined.

Subdivision 1. Apetalæ. Flowers without a corolla and sometimes without a calyx.

Section 1. Flowers in unisexual aments (female flowers of Juglans and Quercus solitary or in spilies); ovary inferior (superior in Leitneriacece) when calyx is present.

\section{JUGLANDACE丹丑.}

Aromatic trees, with watery juice, terete branchlets, scaly buds, the lateral buds usually superposed, 2-4 together, and alternate unequally pinnate deciduous leaves with elongated grooved petioles, and without stipules, the leaflets increasing in size from the lowest upward, penniveined, sessile, short-stalked or the terminal usually long-stalked. Flowers monœcious, opening after the unfolding of the leaves. the staminate in lateral aments and composed of a 3-6lobed calyx in the axil of and adnate to an ovate acute bract. and numerous stamens inserted on the inner and lower face of the calyx in 2 or several rows, with short distinct filaments and oblong anther's opening longitudinally; the pistillate in a spike terminal on a branch of the year and composed of a 1-3celled ovary subtended by an involucre free toward the apex and formed by the union of an anterior bract and 2 lateral bractlets, a 1 or 4 -lobed calyx inserted on the ovary, a short style with 2 plumose stigmas stigmatic on the inner face, and a solitary erect orthotropous ovule. Fruit a nut inclosed in an indehiscent or 4-valved husk, its walls and partitions more or less penetrated by interual longitudinal cavities filled with dry powder. Seed solitary, 2-lobed from the apex nearly to the middle, light brown, its coat thin, of 2 layers, without albumen ; cotyledons fleshy and oily, sinuose or corrugated, 2-lobed ; radicle short, superior, filling the apex of the nut. Of the six genera of the Walnut family two occur in North America.

\section{CONSPECTUS OF THE NORTH AMERICAN GENERA.}

Aments of staminate flowers simple, sessile, or short-stalked; husk of the fruit indehiscent; nut sculptured; pith in plates.

1. Juglans.

Aments of staminate flowers branched, long-stalked; husk of the fruit 4-valved; nut not sculptured; pith solid.

2. Hicoria. 


\section{JUGLANS, L. Walnut.}

Trees, with furrowed scaly bark, durable dark-colored wood, stout branchlets, laminate pith, terminal bucks with 2 pairs of opposite more or less open seales often obseurely pimite at the apex, those of the inner pair more or less leaf-like, and obtuse slightly flattened axillary buds formed before midsummer and covered with 4 ovate rounded scales, elosed or open during winter. Leaves with numerons leaflets, and terete petioles leaving in falling large couspicuons elevated obcordate 3-lobed leaf-scars displaying 3 cquidistant $\mathrm{U}$-shaped clusters of dark fibro-vaseular bundlesears; leaflets conduplicate in the bud, ovate, acute or acuminate, mostly unequal at the base, witl veins arcuate and united near the margins. Aments of the staninate flowers many-flowered, elongated, solitary or in pairs from lower axillary buds of upper nodes, appearing from between persistent bud-scales in the antumu and remaining during the winter as short cones covered by the closely imbricated bracts of the Howers; calyx 3-6-lobed, its bract free only at the apex; stanens 8-40, in 2 or several ranks, their anthers surmounted by a conspicuous dilated truncate or lobed connective; pistillate flowers in few-flowered spikes, their involncre villons, free only at the apex and variously cut into a laciniate border (corolla?) shorter than the ercet calyx-lobes; ovary rarely of 3 carpels; stigmas club-shaped, elongated, fimbriately plumose. Fruit ovoid, globose or pyriform, cylindrical or obscurely 4-angled, with a fleshy indehiscent glabrate or lirsute husk; nut ovoid or globose, more or less flattened, hard, thick-walled, longitudinally and irregularly rugose, the valves alternate with the cotyledons, and more or less ribbed along the dorsal sutures and in some species also on the marginal sntures. Seed more or less compressed, gradually narrowed or broad and deeply lobed at the base, with conspicuous dark veins radiating from the apex and from the minute basal hilum.

Juglans is confined to temperate North America, the West Indies, Sonth America from Venezuela to Peru, Persia, northwestern India, northern China, Manchuria, and Japan. Ten species are known. Of exotic species Juglans regia, L., an inhabitant probably of Persia and northwestern India, is cultivated in the middle Atlantic and sonthern states and largely in California for its edible muts, which are an important. article of commerce. 'The wood of several species is valued for the interior finish of houses and for furniture.

Juglans, from Jupiter and glands, is the classical name of the Walnut-tree.

\section{CONSPECTUS OF THE NORTH AMERICAN SPECIES.}

Fruit racemose ; nut prominently 4-ribbed at the sutures, 2-celled at the base; heartwood light brown.

Leaflets 11-17, oblong-lanceolate.

1. J. cinerea (A).

Fruit usually solitary or in pairs; nut without sutural ribs, 4-celled at the base ; heartwcod dark brown.

Leaflets 15-23, ovate-lanceolate; nut prominently and irregularly ridged, with often interrupted ridges.

2. J. nigra (A, C.)

Leaflets 9-23, lanceolate to ovate-lanceolate ; nut deeply grooved.

Leaflets 11-17, ovate-lanceolate; nut obscurely grooved.

3. J. rupestris (C, E, H).

4. J. Californica (G.)

\section{Juglans cinerea, L. Buttermut.}

Leaves $15^{\prime}-30^{\prime}$ long, with stont pubescent petioles, and 11-17 oblong-lanceolate acute or acuminate leaflets $2^{\prime}-3^{\prime}$ long, $1 \frac{1}{2}^{\prime}-2^{\prime}$ wide, finely serrate except at the 
unequal rounded base, glandular and sticky as they unfold, at maturity thin, yellowgreen and rugose above, pale and soft-pnbescent below, turning yellow or brown and falling early in the autumn. Flowers : staminate in thick aments $3^{\prime}-5^{\prime}$ long, calyx nsually 6-lobed, light yellow-green, puberulous on the lower surface, $\frac{1^{\prime}}{4}$ long, their

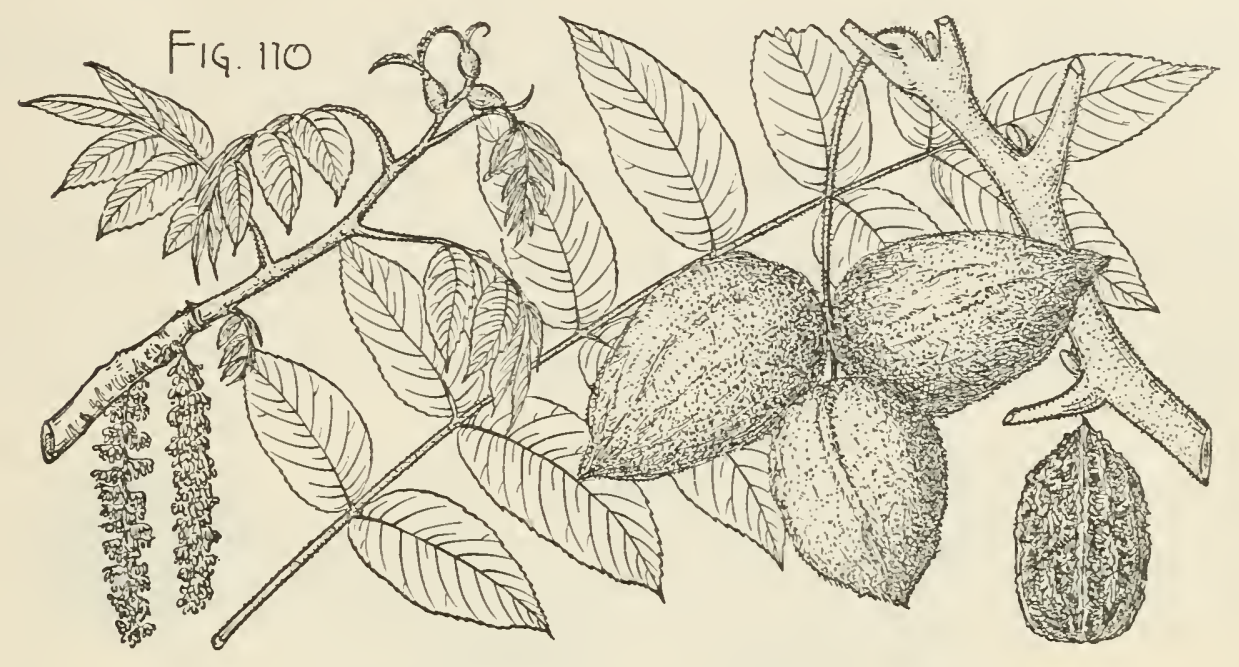

bracts rusty-pubescent, acute at the apex; stamens 8-12, with nearly sessile dark brown anthers and slightly lobed connectives; pistillate in 6-8-flowered spikes, constricted above the middle, about $\frac{1}{3}$ ' long, their bracts and bractlets coated with sticky white or pink glandular hairs and rather shorter than the linear-lanceolate calyxlobes; stigmas bright red, $\frac{1}{2}^{\prime}$ long. Fruit in 3-5-fruited drooping clusters, cylindrical, obscurely 2 or rarely 4 -ridged, ovate-oblong, coated with rusty clammy matted hairs, $1 \frac{1^{\prime}}{2}-2 \frac{1^{\prime}}{2}$ long; nut ovate, abruptly contracted and acuminate at the apex, with 4 prominent and 4 narrow less conspicuous ribs, light brown, deeply sculptured between the ridges into thin broad irregular longitudinal plates, 2-celled at the base and 1-celled above the middle, with a narrow pointed apical cavity; seed sweet, very oily, soon becoming rancicl.

A tree, occasionally $100^{\circ}$ high, with a tall straight trunk $2^{\circ}-3^{\circ}$ in diameter, and sometimes free of branches for half its height; more frequently divided $20^{\circ}$ or $30^{\circ}$ above the ground into many stout limbs spreading horizontally and forming a broad low symmetrical round-topped head, and dark orange-brown or bright green rather lustrous branchlets coated at first with rufons pubescence, covered more or less thickly with pale lenticels, gradually becoming pubernlous, brown tinged with red or orange in their second year and marked by light gray leaf-scars with large black fibro-vascular bundle-scars and elevated bands of pale tomentum separating them from the lowest axillary buds. Winter-buds : terminal $\frac{1}{2}^{\prime}-\frac{2}{3}^{\prime} \operatorname{long}, \frac{1}{4}^{\prime}$ wide, flattened and obliquely truncate at the apex, their onter scales coated with short pale pubescence; axillary ovate, flattened, rounded at the apex, $\frac{1^{\prime}}{8}$ long, covered with rusty brown or pale pubescence. Bark of young stems and of the branches smooth and light gray, becoming on old trees $\frac{3^{\prime}}{4}-1^{\prime}$ thick, light brown, deeply divided into broad ridges separating on the surface into small appressed plate-like scales, that of young trunks and branches smooth and light gray. Wood light, soft, not strong, coarse-grained, light brown, turning darker with exposure, with thin light-colored sapwood composed of 5 or 6 layers of annual growth; largely employed in the interior finish of 
houses, and for furuiture. The inner bark possesses mild eathartie properties. Sugar is made from the salp, aud the green husks of the fruit are used to dye eloth yellow or orauge color.

Distribution. Rich noist soil near the banks of streans and on low rocky hills, southeru New Brunswiek and the valley of the St. Lawrenee River iu Outario to eastern Dakota, southeasteru Nebraska, ecutral Kausas, northeru Arkansas, and Delaware, and ou the Appalachian Mountains to northern Georgia and northeru Alabana; nost abuudant and of its largest size northward.

\section{Juglans nigra, L. Black Walnut.}

Leaves $1^{\circ}-2^{\circ}$ long, with pubescent petioles, and 15-23 ovate-lanceolate leaflets $3^{\prime}-3 \frac{1}{2}^{\prime} \operatorname{long}, 1^{\prime}-1 \frac{1}{4}^{\prime}$ wide, often unequal at the base, long-pointed, sharply serrate except at the more or less rounded mequal base, thin, bright yellow-green, lustrous and glabrous above, soft-pubescent below, especially along the slender midribs and

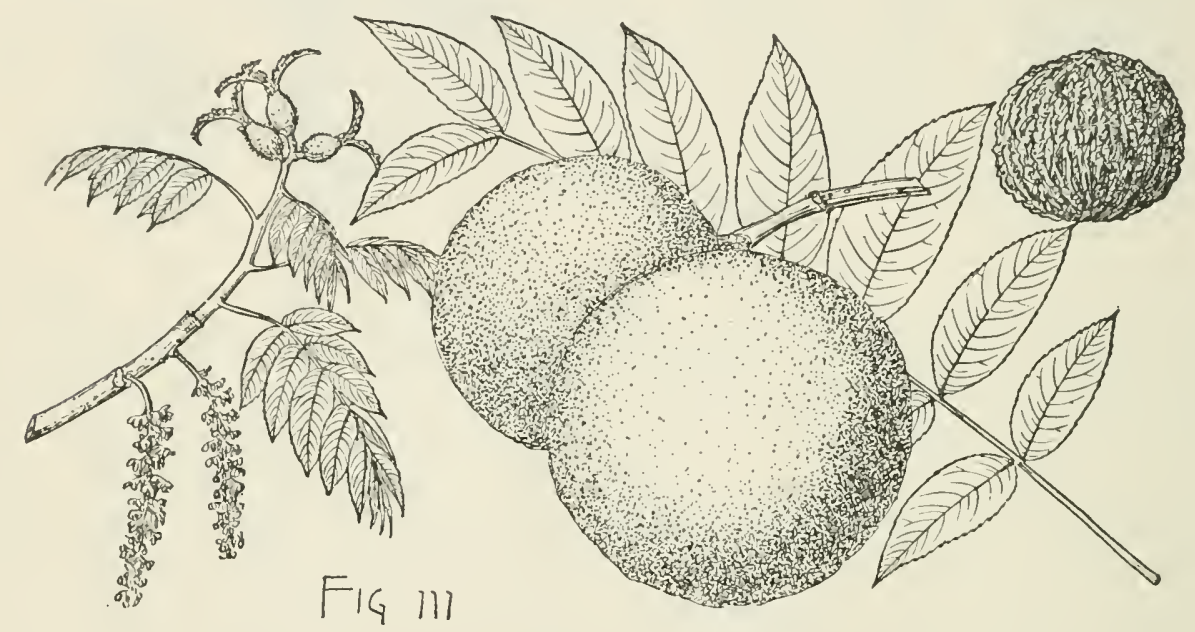

primary veins, turuing briglit clear yellow in the autumn before falling. Flowers: staminate in stout puberulous aments $3^{\prime}-5^{\prime}$ long, rotund, 6-lobed, with nearly orbicular lobes concave and pubescent on the onter surface, their bracts $\frac{1}{4}$ long, nearly triangular, coated with rusty brown or pale tomentum; stamens 20-30, arranged in many series, with ncarly sessile purple and truncate connectives; pistillate in 2-5-flowered spikes, ovate, gradnally narrowed at the apex, $\frac{1}{4}^{\prime}$ loug, their bracts and bractlets coated below with pale glandular hairs and green and puberulous above, sometimes irregularly cut into a laciniate border, or rednced to an obscure ring just below the apex of the ovary; calyx-lobes ovate, acute, light grecn, puberulons on the outer, glabrous or pilose on the inner surface; stigmas yellow-green, tinged on the margins with red, $\frac{1}{2}^{\prime}-\frac{3}{4}$ long. Fruit solitary or in pairs, globose, oblong or slightly pyriform, light yellow-green, roughened by clusters of short pale articulate hairs, $1 \frac{1}{2}^{\prime}-2^{\prime}$ in diameter; nut oval or oblong, slightly flattened, $1 \frac{1}{8}^{\prime}-1_{\frac{1}{2}}^{\prime}$ in diameter, dark brown tinged with red, deeply divided on the outer surface into thin or thick often interrupted irregular ridges, 4-celled at the base and slightly 2-celled at the apex; seed sweet, soon becoming rancid.

A tree, frequently $100^{\circ}$ and oecasionally $150^{\circ}$ ligh, with a straight trunk often clear of branches for $50^{\circ}-60^{\circ}$ and $4^{\circ}-6^{\circ}$ in diameter, thick limbs spreadiug gradually and forming a comparatively narrow shapely round-topped head of mostly upright 
rigid branches, and stout branchlets covered at first with pale or rusty matted hairs, dull orange-brown and pilose or puberulous during their first winter, marked with raised conspicuous orange-colored lenticels and elevated pale leaf-scars, gradually growing darker and ultimately light brown. Winter-buds: terminal ovate, slightly flattened, obliquely rounded at the apex, coated with pale silky tomentum, $\frac{1}{3}^{\prime}$ long, with usually 4 obscurely pinnate scales; axillary $\frac{1}{8}^{\prime}$ long, tomentose, their outer scales opening at the apex during the winter. Bark of young stems and branches light brown and covered with thin scales, becoming on old trees $2^{\prime}-3^{\prime}$ thick, dark brown slightly tinged with red, and deeply divided into broad rounded ridges broken on the surface into thick appressed scales. Wood heavy, hard, strong, rather coarsegrained, very durable, rich dark brown, with thin lighter colored sapwood of 10-20 layers of annual growth; largely used in cabinet-making, the interior finish of houses, gun-stocks, and in boat and shipbuilding.

Distribution. Rich bottom-lands and fertile hillsides, western Massachusetts to southern Ontario, southern Michigan and Minnesota, central and northern Nebraska, eastern Kansas, and southward to western Florida, central Alabama and Mississippi, and the valley of the San Antonio River, Texas; most abundant in the region west of the Alleghany Mountains, and of its largest size on the western slopes of the high mountains of North Carolina and Tennessee, and on the fertile river bottom-lands of southern Illinois and Indiana, southwestern Arkansas, and the Indian Territory; largely destroyed for its valuable timber, and now rare.

Occasionally cultivated as an ornamental tree in the eastern United States, and in western and central Europe.

\section{Juglans rupestris, Engelm. Walnut.}

Leaves $7^{\prime}-15^{\prime}$ long, with slender scurfy-pubescent petioles and 9-23 ovate-lanceolate leaflets unequal on the two edges, coarsely or finely crenulate-serrate nearly to

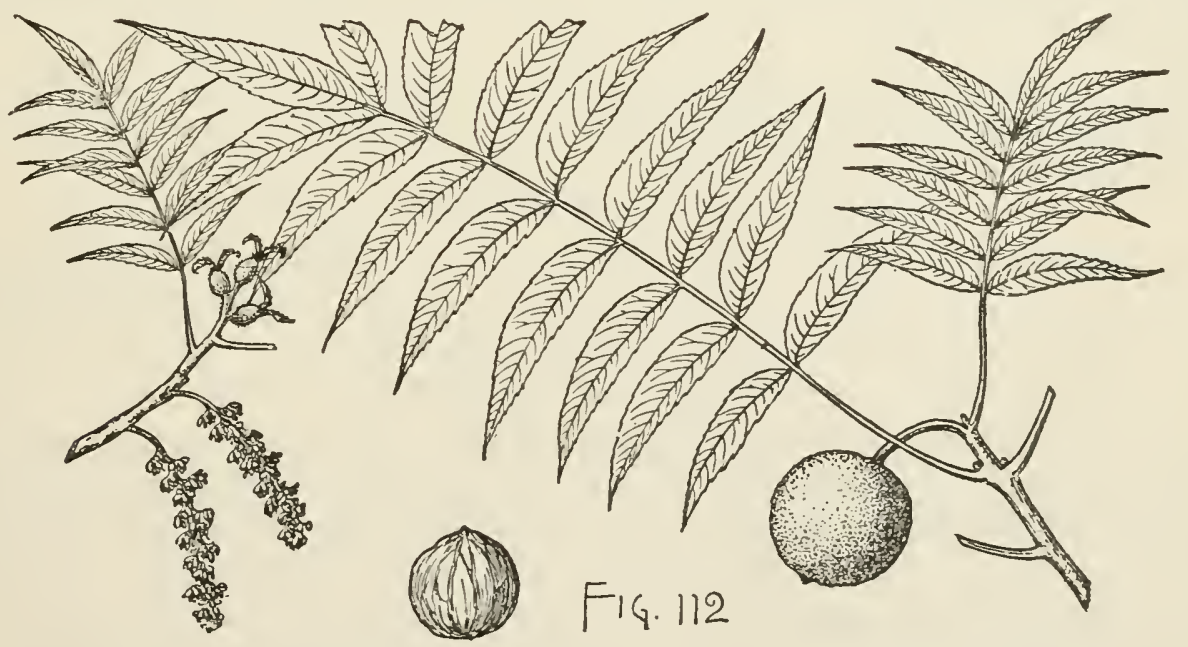

the rounded or unequal base, dark yellow-green and glabrois, $2 \frac{1}{2}^{\prime}-5^{\prime}$ long, $\frac{1}{3}^{\prime}-1 \frac{1}{2}^{\prime}$ wide, thin, dark yellow-green and glabrous, or pubescent on the lower surface, especially along the stont yellow midribs and primary veins, turning yellow before falling in the autumn. Flowers: staminate in slender aments $2 \frac{1^{\prime}}{2}-4^{\prime}$ long, $3-5$-lobed, nearly orbicular, light yellow-green, glabrous or slightly pubescent on the lower surface, short-stalked, their bracts ovate-lanceolate, acute, coated with thick pale 
tomentum; stamens abont 20, with nearly sessile yellow anthers and dark eonspienous slightly lobed eomeetives; pistillate in few-flowered spikes, narrowed at the ends, coated with pale or rufous tomentum, $\frac{1}{8}-f^{\prime}$ long, their bract and bractlets green abore, puberulous at the apex on the outer surfaee, aud irregularly divided iuto a laciniate border rather shorter than the ovate aente ealyx-lobes puberulous on the onter surfaee; stigrmas green, tinged with red, $\frac{1}{3}$ long. Fruit globose or rarely oblong, $\frac{1}{2}-1 y^{\prime}$ in diameter, with a thin hisk glabrate or eaated with short rufous hairs; mit globose, without ridges, often eompressed at the euls and sometimes flattened laterally, dark reddish brown to blaek, deeply grooved, with longitndiual simple or forked grooves, 4-eelled at the base, 2-eelled at the apex; seed small and sweet, retaining its flavor for a long time.

A tree, $50^{\circ}$ high, with a short trumk oceasionally $5^{\circ}$ in diameter, sometimes divided near the gromud or nsually $10^{\circ}-15^{\circ}$ above it into several stont nearly upright branches forming a narrow head, or in moist soil frequently spreading a few feet above the division of the trunk and becoming pendulous at the extremities, and branehlets coated at first with pale or light brown seurfy pubeseence or tomentum often persistent for two or three years, orange-red in their first winter, marked by many small pale lenticels, and nltimately pale or nearly white; often a shrub sending $n p$ from the ground a eluster of stems only a few feet tall. Winter-buds: terminal $\frac{1^{\prime}}{4}-\frac{1}{2}$ long, compressed, narrowed and often oblique at the apex, covered with rusty or pale tomentum; axillary $\frac{1}{8}^{\prime}$ long, compressed, coated with pale pubescence. Bark of young trunks and of the branches smooth, pale, often nearly white, becoming on old trees $1^{\prime}$ thick, deeply furrowed and broken on the surface into thin appressed seales. Wood heavy, hard, not strong, rich dark brown, with thick nearly white sapwood.

Distribution. Limestone banks of the streams of central and western Texas, here shrubby or rarely more than $30^{\circ}$ high; common and of larger size in eañons of the mountains of New Mexico and Arizona south of the Colorado plateau; in northern Mexico.

Oceasionally cultivated in the eastern United States, and hardy as far north as Massachusetts; and rarely in Europe.

\section{Juglans Californica, Wats. Walnut.}

Leaves $6{ }^{\prime}-9^{\prime}$ long, with slender puberulous petioles, and 11-17 ovate-lanceolate often somewhat faleate long-pointed leaflets $1 \frac{1}{2}^{\prime}-3^{\prime}$ long, $\frac{1}{2}^{\prime}-\frac{3}{4}^{\prime}$ wide, coarsely serrate except at the rounded or subeordate or wedge-shaped base, thin, light green, glabrons or furnished on the under surface with tufts of pale hairs in the axils of primary veins. Flowers: staminate in slender puberulous aments $2^{\prime}-3^{\prime}$ long, calyx elongated, light green, coated like its bract on the outer surface with rufous pubescence, divided into 5 or 6 acute lobes, short-stalked; stamens 30-40, with yellow anthers and short connectives bifid at the apex; pistillate broadly ovate or subglobose, glabrate or puberulous, $\frac{1^{\prime}}{8}$ long, the free border of their bract and bractlets ring-like, nearly entire and much shorter than the broad ovate pubescent ealyx-lobes; stigmas yellow, $\frac{1}{2}^{\prime}$ long. Fruit globose, $\frac{3^{\prime}}{4}-1 \frac{1}{4}^{\prime}$ in diameter, with a thin dark-colored husk coated with soft pubescence; nut nearly globose, without ridges, slightly compressed, sometimes flattened at the ends, dark brown, obseurely grooved, with remote shallow grooves, 4-celled at the base, imperfectly 2-celled at the apex; seed large and sweet, retaining its flavor for several months.

A tree, rarely $60^{\circ}$ high, with a trunk $18^{\prime}-20^{\prime}$ in diameter, and stout pendulous 
branches forming a graceful symmetrical round-topped head, and slender branchlets covered while young with rufous scurfy tomentum, dark reddish brown, puberulous, and marked during their first winter with pale scattered lenticels and small elevated obscurely 3-lobed leaf-scars, becoming darker and gradually glabrous in their second year and ultimately nearly white; often much smaller, sometimes shrubby in habit.
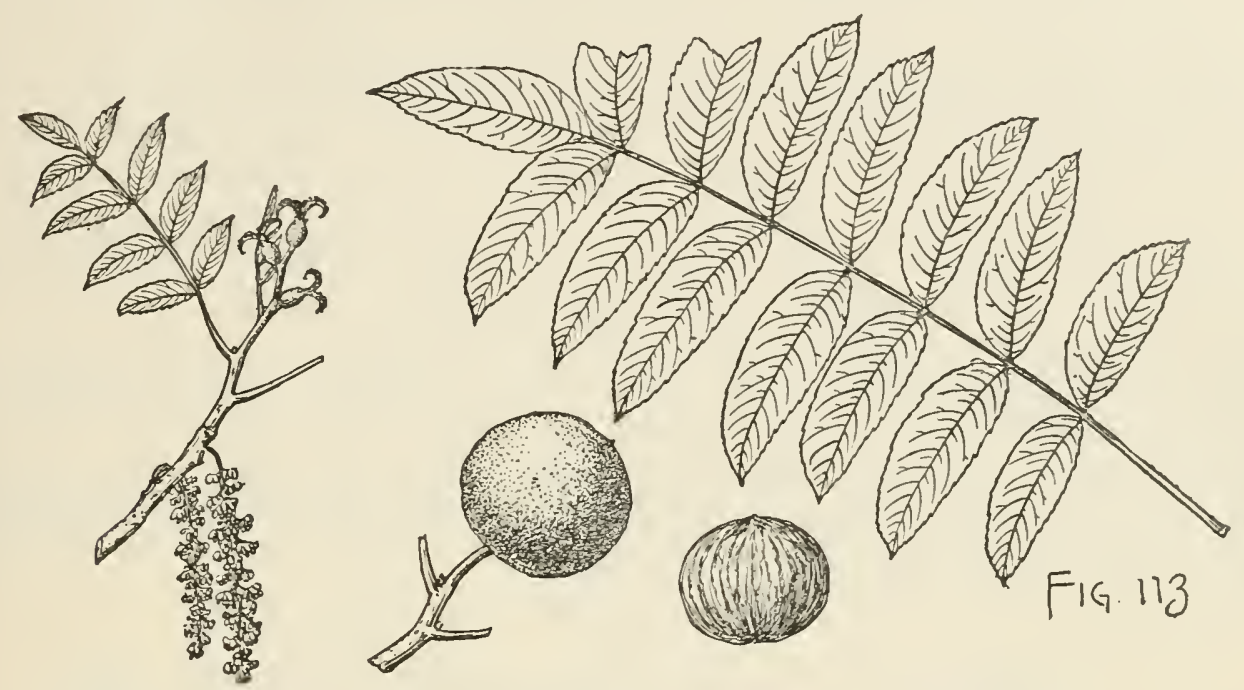

Winter-buds: terminal acute, compressed, more or less oblique at the apex, coated with pale tomentum, $\frac{1^{\prime}}{4}$ long; axillary usually solitary, nearly globose, $\frac{1{ }^{\prime}}{16}$ long, and covered with thick pale rufous tomentum. Bark of young stems and upper branches smooth, pale or nearly white, becoming on old trunks $\frac{1}{3}^{\prime}-\frac{1}{2}^{\prime}$ thick, dark brown or nearly black, deeply divided into broad irregular ridges separating on the surface into thin appressed scales. Wood heavy, hard, rather cross-grained, dark brown, often mottled, with thick pale sapwood of 8-10 layers of amnual growth.

Distribution. Banks of streams and bottom-lands in the California coast region, usually twenty or thirty miles from the sea, from the valley of the lower Sacramento River to the southern slopes of the San Bernardino Mountains.

Often cultivated in California as a shade-tree and as stock on which to graft varieties of Juglans regia, L.

\section{HICORIA, Raf. Hickory.}

Trees, with smooth gray bark becoming on old trunks rough and scaly, strong hard tough brown wood, tough terete flexible branches, solid pith, buds covered with few valvate or with numerous imbricated scales, the axillary buds often stalked and sometimes solitary. Leaves often glandular-dotted, their petioles sometimes persistent on the branches during the winter, and in falling leaving large elevated oblong or semiorbicular more or less 3-lobed emarginate leaf-scars displaying small marginal clusters and central radiating lines of dark fibro-vascular bundle-scars; leaflets involute in the bud, ovate or obovate, nsually acuminate, thick and firm, serrate, mostly unequal at the base, with veins forked and rumning to the margins, turning clear bright yellow in the autumn. Aments of the staminate flowers ternate, slender, solitary or fascicled in the axils of leaves of the previous year or at the base of branches of the year from the inner scales of the terminal bud, the lateral branches 
in the axils of lanceolate aente persistent brats; calyx usually 2 rarely 3-lobed, its bract free nearly to the base and usually mueh longer than the ovate rounded ealyx-lobes; stamens 3-10, in 2 or 3 series, their anthers ovate-oblong, emarginato or divided at the apex, pilose or hirsute, as long or longer than their slender connectives; pistillate flowers sessile, in 2-10-flowered spikes, with perianth-like involueres, slightly t-ridged, unequally 4-lobed at the apex, villous on the onter surface, the bract much longer than the bractlets and single ealyx-lobe; stignas short, papillose-stignatic. Fruit ovoid, globose or pyriform, with a thin or thiek lusk beeoming hard and woody at maturity, 4-valved, the sntures alternate with those of the nut, sometimes more or less broadly winged, splitting to the base or to the middle; nut oblong, obovate or subglobose, acnte, aeuminate, or ronnded at the apex, tipped by the hardened remmants of the style, narrowed and usually rounded at the base, cylindrieal or compressed contrary to the valves, the wall thin and brittle or thiek, hard, and bony, smooth or variously rugose or ridged on the outer surface, 4-celled at the base, 2-celled at the apex. Seed compressed, variously grooved on the back of the flat or coneave lobes, sweet or bitter.

Hicoria is confined to the temperate region of eastern North America from the valley of the St. Lawrence River to the highlands of Mexico. Of the twelve species, eleven inhabit the territory of the United States.

The generic name is formed from the popular name of these trees.

\section{CONSPECTUS OF THE NORTH AMERICAN SPECIES.}

Bud-scales few, valvate, the inner strap-shaped and only slightly accrescent; fruit more or less broadly winged at the sutures; shell of the nut thin and brittle, with large cavities (thick in 4).

Aments of staminate flowers nearly sessile, usually on branches of the previous year.

Leaflets 13-15, oblong-lanceolate, more or less falcate; nut ovate-oblong, cylindrical; kernel sweet.

1. H. Pecan (A, C).

Leaflets 7-11, lanceolate, often falcate; nut oblong, compressed; kernel bitter.

2. H. Texana (C).

Aments of staminate flowers long-stalked on branches of the year or of the previous year.

Leaflets 7-11, lanceolate or oblong-lanceolate; nut of ten broader than long, slightly 4-angled; kernel bitter.

3. H. minima $(\mathrm{A}, \mathrm{C})$.

Leaflets $7-11$, ovate-lanceolate to lanceolate-obovate; nut ellipsoidal, cylindrical, thick-shelled; kernel sweet.

4. H. myristicæformis (C).

Leaflets $7-13$, lanceolate, more or less falcate ; nut compressed, rugose, prominently ridged; kemel bitter.

5. H. aquatica (C).

Bud-scales numerous, imbricated, the inner becoming much enlarged, of ten highly colored and much reflexed and twisted before falling; aments of staminate flowers at the base of branches of the year, long-stalked; fruit without sutural wings (sometimes slightly winged in 11); shell of the nut thick and bony, with minute cavities.

Bark separable from old trunks in long loose plates.

Branchlets light red-brown; nut pale or nearly white.

Leaflets 5-7, ovate to oblong-lanceolate or obovate; nut thick or thin-shelled; branchlets stout.

6. H. ovata $(\mathrm{A}, \mathrm{C})$.

Leaflets usually 5 , lanceolate; nut thin-shelled; branchlets slender.

Branchlets pale orange color.

7. H. Carolinæ-septentrionalis (C).

Leaflets $\tilde{5}-9$, obovate or oblong-lanceolate, puberulous on the lower surface; nut ovate, thick-walled, prominently 4 -angled, dull white to light reddish brown.

8. H. laciniosa (A, C). 
Bark closely furrowed, rarely exfoliating in plate-like scales.

Leaflets 7-9, oblong-lanceolate to obovate-lanceolate, more or less tomentose on the lower surface, very fragrant ; nut globose or oblong, often long-pointed, t-ridged toward the apex, thick-shelled, reddish brown.

9. H. alba $(\mathrm{A}, \mathrm{C})$.

Leaflets usually $5-\bar{T}$, oblong to obovate-lanceolate, glabrous or villous-pubescent; fruit pyriform or globose; husk usually thin, slightly ridged at the sutures; nut oblong-oval or globose, thick or thin-shelled.

10. H. glabra (A, C).

Leaflets 5-9, lanceolate to oblanceolate, pubescent and covered below wlile young with silvery peltate scales; fruit subglobose to pyriform ; husk thin ; nut angled, thick-shelled.

11. H. villosa $(A, C)$.

1. Bud-scales few, valvate.

\section{Hicoria Pecan, Britt. Pecan.}

Leaves $12^{\prime}-20^{\prime}$ long, with slender glabrous or pubescent petioles, and 9-17 lanceolate to oblong-lanceolate more or less falcate loug-pointed coarsely often doubly serrate leaflets rounded or wedge-shaped at the unequal base, sessile, with the exception of the terminal leaflet, or short-stalked, thin and firm, dark yellowgreen and glabrous or pilose above, and pale and glabrous or pubescent below,

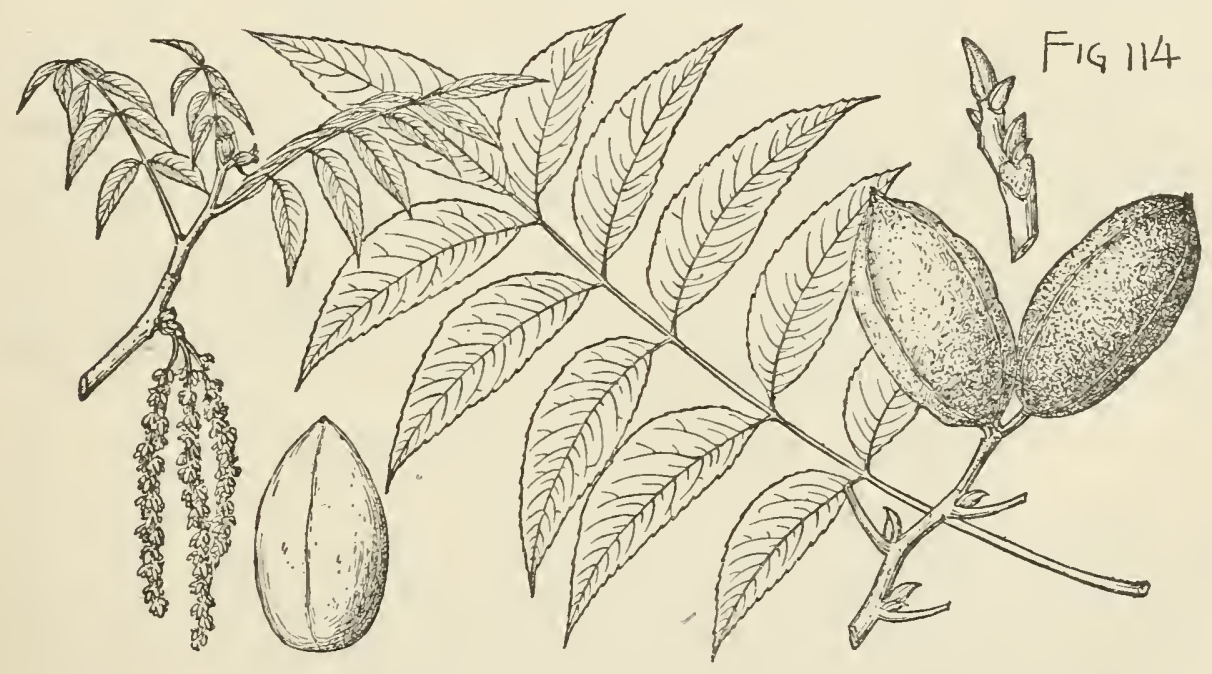

4'-8' long, $1^{\prime}-3^{\prime}$ wide, with narrow yellow midribs and conspicuous veins. Flowers: staminate in slender puberulous clustered aments $3^{\prime}-5^{\prime}$ long, from buds formed in the axils of leaves of the previous year or occasionally on shoots of the year, sessile or short-stalked; calyx light yellow-green and hirsute on the outer surface, with broadly ovate acute lobes rather shorter than the oblong or obovate bract, and nearly sessile yellow anthers; pistillate oblong, narrowed at the ends, slightly 4-angled and coated with yellow scurfy pubescence. Fruit in clusters of 3-11, pointed, 4-winged and angled, $1^{\prime}-2 \frac{1}{2}^{\prime}$ long, $\frac{1}{2}^{\prime}-1^{\prime}$ broad, dark brown and coated with clusters of yellow articulate hairs, with a thin hard and brittle husk splitting at maturity nearly to the base and often persistent on the branch during the winter after the discharge of the nut; nut ovoid to ellipsoidal, nearly cylindrical or slightly 4-angled toward the pointed apex, rounded and usually apiculate at the base, bright reddish browl, with irregular black markings, $1^{\prime}-2^{\prime}$ long, with thin brittle walls and papery partitions; 
seed sweet, red-brown, its nearly flat lohes grooved from near the base to the apex by 2 deep longitudinal grooves.

A tree, $100^{\circ}-170^{\circ}$ high, with a tall massive trunk oceasionally $6^{\circ}$ in diancter above its enlarged and buttressed base, stont slightly spreading branches forming in the forest a narrow symmetrieal and inversely pyrmidal head, or with abmulant room a broal ronnd-topped erown, and branchlets at first slightly tinged with red and conted with loose pille tomentmm, becoming glabrons or pubernlons in their first winter, and nurked with numerons oblong orange-colored lenticels and with large oblong eoncave leaf-sears snrromeded by a broad thin membranaceons border enlmacing the lower axillary bud. Winter-buds acnte, compressed, covered with clusters of bright yellow articulate lairs and pale tomentum, terminal $\frac{1}{2}$ long; axillary ovate, often stalked, especially the large upper one. Bark 1'-1 ${ }_{2}^{\prime}$ thick, light brown tinged with red, and decply and irregularly divided into narrow forked ridges broken on the surface into thick appressed seales. Wood heavy, hard, not strong, brittle, coarsegrained, light brown tinged with red, with thin light brown sapwood; less valuable than that of most Hickories, and used chicfly for ficl, and occasionally in the mannfacture of wagons and agricnltural implements. The nuts, which vary in size and shape and in the thickness of their shells and in the quality of the kernels, are an important article of commerce.

Distribution. Low rich ground in the neighborhood of streams from the valley of the Mississippi River in Iowa, through sonthern Illinois and Indiana, western Kentucky and Tenuessee, to central Mississippi and Alabama, and through Missouri and Arkansas to sontheastern Kansas, the Indian Territory, western Lonisiana and the valley of the Concho River, Texas, reappearing on the mountains of Mexico; most abundant and of its largest size in southern Arkansas, the Indian Territory, and eastern Texas.

Occasionally planted as a shade-tree, especially in the sonthern states, and now largely for its nuts in orchards of trees raised from selected seeds or by grafts of trees producing nuts of the largest size and best quality.

\section{Hicoria Texana, Le Conte. Bitter Pecan.}

Leaves $10^{\prime}-12^{\prime}$ long, with slender petioles, and 7-11 lanceolate acmminate finely serrate leaflets, hoary-tomentose at first, and more or less villous in the autumn, thin and firm, dark yellow-green, nearly glabrous above, pale yellow-green and puberulous below, $3^{\prime}-5^{\prime}$ long, about $1 \frac{1}{2}^{\prime}$ wide, the terminal leaflet gradually narrowed to the acute base and short-stalked, the lateral often falcate, unsymmetrical at the base, subsessile or short-stalked. Flowers: staminate in villous aments 2 '-3' long; calyx light yellow-green and villous on the outer surface, with oblong-ovate romded lobes, much shorter than the ovate acuminate bract; pistillate oblong, slightly 4 -angled, villose. Fruit in few-fruited clusters, oblong or oblong-obovate, apiculate at the apex, slightly 4-winged at the base, dark brown, more or less covered with articulate hairs, $1 \frac{1^{\prime}}{}{ }^{\prime}-2^{\prime}$ long, with a thin husk; nut oblong-ovate or oblong-obovate, compressed, acute at the ends, short-pointed at the apex, apiculate at the base, obscurely 4-angled, bright red-brown, rough and pitted and usually $1 \frac{1}{4}-1 \frac{1}{2}^{\prime}$ long, with a thin brittle shell, thin papery walls, and a low basal ventral partition; seed very bitter, bright red-brown, flattened, its lobes rounded and slightly divided at the apex, longitndinally grooved and deeply penetrated on the outer face by the prominent reticulated folds of the inuer surface of the shell of the nut.

A tree, sometimes $100^{\circ}$ high on the bottoms of the Brazos River, with a tall straight 
trunk $3^{\circ}$ in diameter, and ascending branches, or on the borders of prairies in low wet woods usually $15^{\circ}-25^{\circ}$ tall, with a short trunk $8^{\prime}-10^{\prime}$ in diameter, small spreading branches forming a narrow round-topped head; and slender branchlets coated at first with thick hoary tomentum sometimes persistent until the autumn, bright red-brown and marked by occasional large pale lenticels during their first

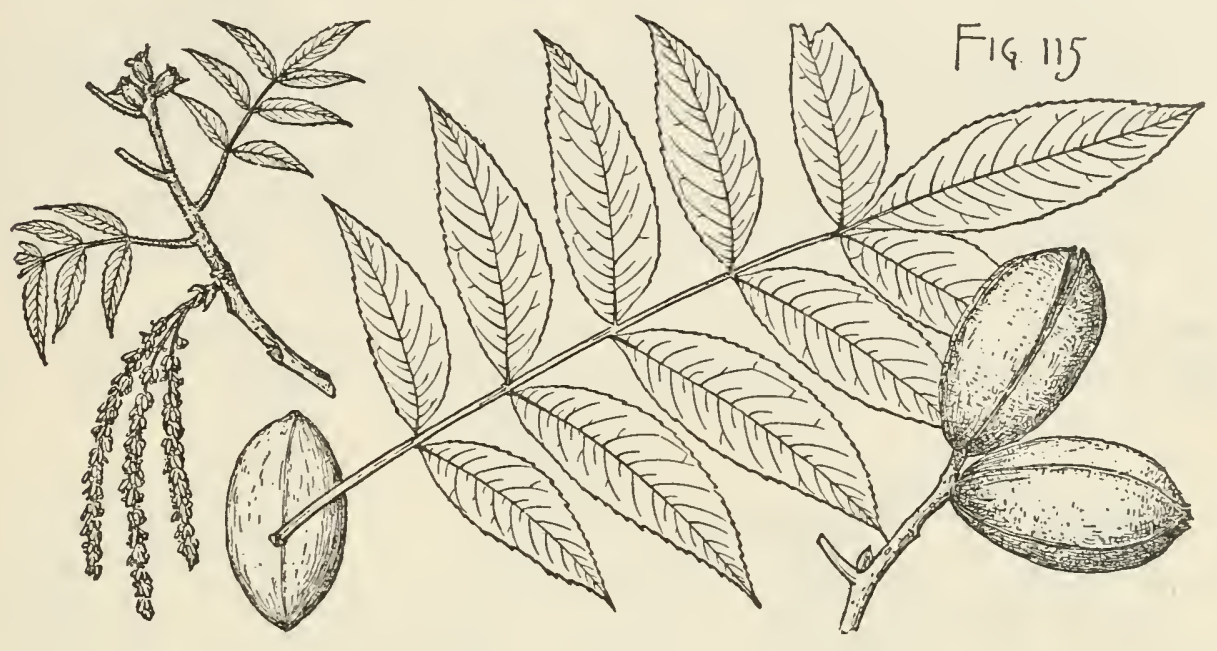

winter and by the large concave obcordate leaf-scars nearly surrounding the lowest axillary buds, becoming darker in their second season and dark or light gray-brown in their third year. Winter-buds covered with light yellow articulate hairs, terminal oblong, acute or acuminate, some what compressed, about $\frac{1^{\prime}}{4}$ long, and rather longer than the upper lateral bud. Bark $\frac{1^{\prime}}{2}-\frac{3^{\prime}}{4}$ thick, light reddish brown, and roughened by closely appressed variously shaped plate-like scales. Wood close-grained, tough and strong, light red-brown, with pale brown sapwood.

Distribution. Bottom-lands and low wet woods of eastern Texas for a distance of 100 to 150 miles from the coast.

\section{Hicoria minima, Britt. Bitternut. Swamp Hickory.}

Leaves $6^{\prime}-10^{\prime}$ long, with slender pubescent or hirsute petioles, and 5-9 lanceolate to oblong or ovate-lanceolate or obovate long-pointed sessile leaflets coarsely serrate except at the equally or unequally wedge-shaped or subcordate base, thin and firm, dark yellow-green and glabrous above, lighter and pubescent below, especially along the midribs, $4^{\prime}-6^{\prime}$ long, $\frac{3^{\prime}}{4}-1 \frac{1}{4}^{\prime}$ wide. Flowers : staminate in slightly pubescent aments $3^{\prime}-4^{\prime}$ long, with a slender peduncle often $1^{\prime}$ in length, usually on branches of the previous year or rarely from the base of shoots of the year; calyx coated with rufous hairs like its ovate acute bract; stamens 4 , with ovate yellow anthers deeply emarginate at the apex; pistillate $\frac{1}{2}^{\prime}$ long, slightly 4 -angled, covered with yellow scurfy tomentum. Fruit $\frac{3^{\prime}}{4}-1 \frac{1}{2}^{\prime}$ long, obovate to subglobose, 4 -winged from the apex to about the middle, with a thin husk, more or less thickly coated with yellow scurfy pubescence; nut ovate or oblong, often broader than long, compressed and marked at the base with dark lines along the sutures and alternate with them, depressed or obcordate, and abruptly contracted into a long or short point at the apex, gray tinged with red or light reddish brown, with a thin brittle shell; seed bright reddish brown, very bitter, much compressed, deeply rugose, with irregular cross-folds. 
A tree, often $100^{\circ}$ high, with a tall straight trunk $2^{\circ}-3^{\circ}$ in diameter, stont spreading branches forming a lroad handsome head, and slender branchlets marked with oblong pale lenticels, bright green and covered more or less thickly with rusty hairs at first, reddish brown and glabrous or puberulous during their first summer, reddish brown and histrons dnring the winter and nitimately light gray, with small elevated obseurcly 3-lobed obcordate leaf-scars. Winter-buds compressed, bright yellow, terminal $\frac{1}{3}-\frac{8}{4}$ long, obliqne at the apex, covered with 2 pairs of scales; lateral slightly 4 -angled, often stalked, $\frac{1{ }^{\prime}}{8}-\frac{1}{4}$ long, with ovate pointed slightly accrescent scales keeled on the back. Bark $\frac{1}{3}^{\prime}-\frac{z^{\prime}}{4}$ thick, light brown tinged with red, and broken into thin plate-like seales separating on the snrface into small thin flakes. Wood heavy, very hard, strong, tough, elose-grained, dark brown, with thick light brown or often nearly white sapwood; largely used for hoops and ox-yokes, and for fuel.

Distribution. Low wet woods near the borders of streams and swamps or high rolling uplands often remote from streams, southern Maine to Ontario, central

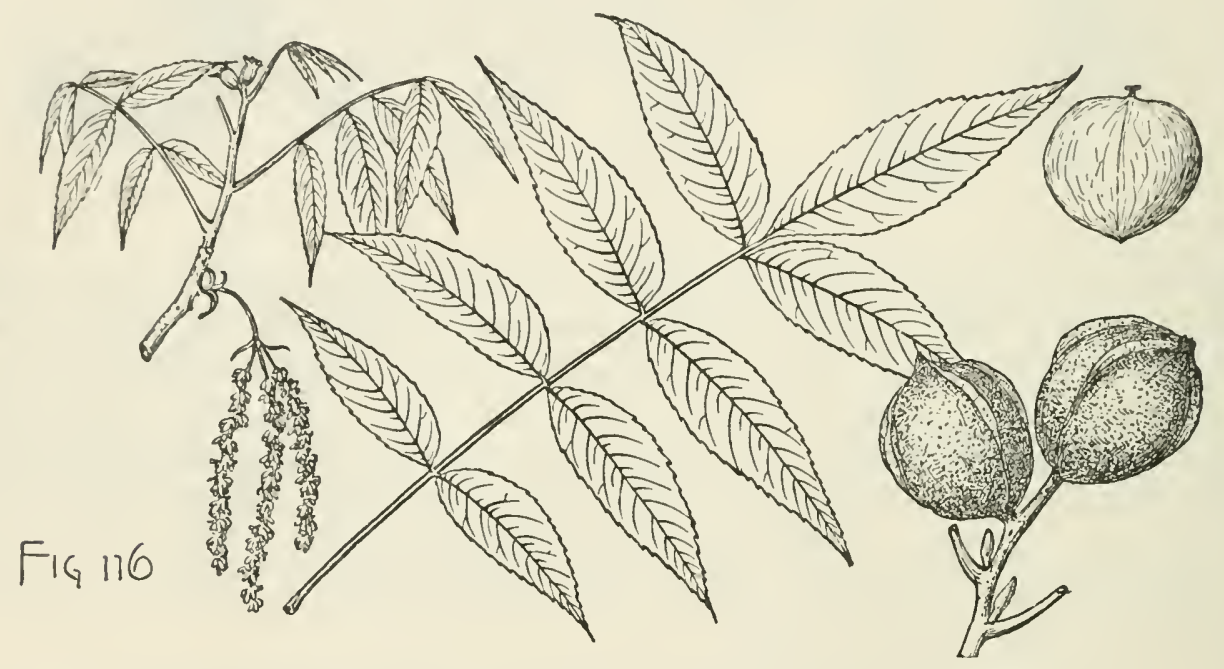

Michigan and Minnesota, southeastern Nebraska, eastern Kansas and the Indian Territory, and southward to northwestern Florida, northern Alabama, and eastern Texas; one of the largest and commonest Hickory-trees of southern New England, and abundant in all the central states east and west of the Appalachian Mountains; growing to its largest size on the bottom-lands of the lower Ohio basin; the common Hickory of Iowa, Nebraska, and Kansas.

\section{Hicoria myristicæformis, Britt. Nutmeg Hickory.}

Leaves $7^{\prime}-14^{\prime}$ long, with slender terete scurfy-pubescent petioles, and 5-11 ovatelanceolate to broadly obovate acute leaflets usually equally or sometimes unequally wedge-shaped or rounded at the narrow base, coarsely serrate, short-stalked or nearly sessile, thin and firm, dark green above, more or less pubescent or nearly glabrous and silvery white and very lnstrous below, $4^{\prime}-5^{\prime}$ long, $1^{\prime}-1 \frac{1}{2}^{\prime}$ wide, with pale scurfy pubescent midribs, changing late in the season to bright bronzy brown. Flowers: staminate in aments $3^{\prime}-4^{\prime}$ long and coated like the ovate-oblong acute bract and calyx of the flower with dark brown scurfy pubescence; stamens 6 , with oblong emarginate anthers; pistillate oblong, narrowed at the ends, slightly 4-angled, 
covered with thick brown scurfy pubescence. Fruit usually solitary, ellipsoidal or slightly obovate, 4-ridged to the base, with broad thick ridges, $1 \frac{1}{2}$ long, coated with yellow-brown scurfy pubescence, the husk not more than $\frac{1}{32}^{\prime}$ thick, and splitting

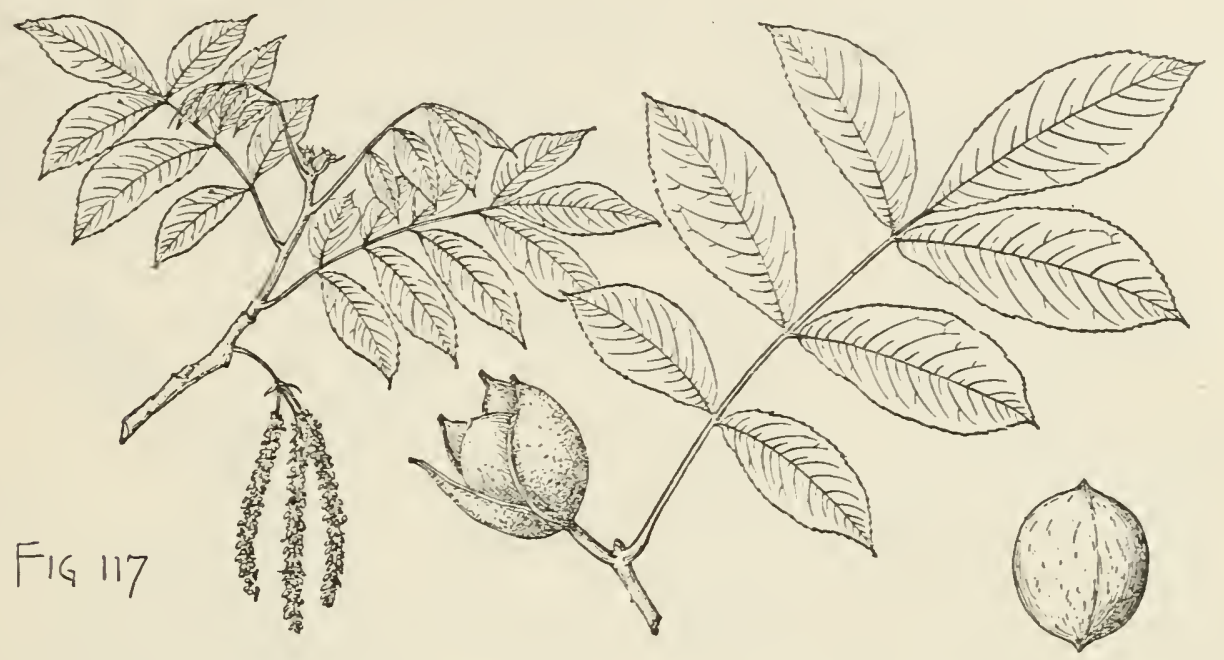

nearly to the base; nut ellipsoidal or sometimes slightly obovate, $1^{\prime}$ long, $\frac{3^{\prime}}{4}$ broad, rounded and apiculate at the ends, smooth, dark reddish brown, and marked with longitudinal broken bands of small gray spots covering the entire surface at the ends, the shell $\frac{1^{\prime}}{8}$ or more thick, hard and bony, with a thick partition, and a low thin dorsal division; seed sweet, small, dark brow11.

A tree, $80^{\circ}-100^{\circ}$ high, with a tall straight trunk often $2^{\circ}$ in diameter, stout slightly spreading branches forming a comparatively narrow rather open head, and slender branchlets coated with lustrous golden or brown scales often persistent until the second year, light brown or ashy gray during their first winter, nltimately dark reddish brown, and marked with small scattered pale lenticels and small oval emarginate elevated leaf-scars. Winter-buds covered with thick brown scurfy pubescence, terminal $\frac{1^{\prime}}{8}-\frac{1}{4}^{\prime}$ long, ovate, rather obtuse; axillary much smaller, acute, slightly flattened, sessile or short-stalked, often solitary. Bark $\frac{1^{\prime}}{2}-\frac{3^{\prime}}{4}$ thick, dark brown tinged with red, and broken irregularly into small thin appressed scales. Wood hard, very strong, tough, close-grained, light brown, with thick lighter colored sapwood of 80-90 layers of annual growth.

Distribution. Banks of rivers and swamps in rich moist soil or rarely on higher ground, eastern South Carolina, and through central Alabama and Mississippi to southern Arkansas; on the mountains of northeastern Mexico; rare and very local in the coast region of South Carolina; more abundant westward; common in southern Arkansas.

\section{Hicoria aquatica, Britt. Bitter Pecan. Water Hickory.}

Leaves $9^{\prime}-15^{\prime}$ long, with slender dark red puberulous or tomentose petioles, and 7-13 ovate lanceolate long-pointed falcate equilateral leaflets rounded or wedgeshaped at the base or oblique and very unequally wedge-shaped, finely or coarsely serrate, sessile or stalked, $3^{\prime}-5^{\prime}$ long, $\frac{1^{\prime}}{2}-1 \frac{1}{2}^{\prime}$ wide, covered with yellow glandular dots, thin and membranaceous, dark green above, brown and lustrous or tomentose on the lower surface, especially on the slender midribs and primary veins, the ter- 
minal leaflet more or less deenrent by its werlge-shaped base on a slender stalk or rarely nearly sessile. Flowers: staminate in solitary or fascicled hirsute aments $21^{\prime}-3$ ' long from branches of the previons year or at the base of branehes of the year; ealyx eovered like the braet with yellow glandular pubescenee; stamens 6 , with oblong slightly emarginate anthers; pistillate oblong, slightly flattened, 4-angled, glandular-pubescent. Fruit often in 3 or 4-fruited elusters, much eompressed, nsually broadest above the middle, romded at the slightly narrowed base, rounded or abruptly marrowed at the apex, conspieuously 4-winged, dark brown or nearly black, eovered more or less thiekly with bright yellow pubesecnee, $1 \frac{1}{2}$ long, $1^{\prime}-1 \frac{1}{4}$ wide, with a thin brittle husk splitting tardily and usnally only to the middle; nut flattened, slightly obovate, $\mathbf{1}^{\prime}-\mathbf{1}_{\frac{1}{2}}^{\prime}$ long, nearly as broad, ronnded and abruptly shortpointed at the apex, rounded at the narrow base, 4-angled and ridged, dark reddish brown, and lougitndinally and very irregularly wrinkled, with thin walls and partitions containing large irregular cavitics filled with dark red bitter powder; seed oblong, compressed, dark brown, irregularly and usually longitudinally furrowed.

A tree, occasionally $80^{\circ}-100^{\circ}$ high, with a trunk rarely exeeding $2^{\circ}$ in diameter, slender upright branehes forming a narrow head, and slender dark reddish brown or ashy gray lustrous branchlets marked with numerous pale lenticels, at first slightly glandular and coated with loose pale tomentum, glabrous or puberulous during the summer, and marked during the winter with small nearly oval or obscurely 3-lobed slightly elevated leaf-scars, growing dark red-brown and ultimately gray. Winterbuds slightly flattened, aeute, dark reddish brown, covered with caducons ycllow glands, terminal $\frac{1^{\prime}}{8}-\frac{1^{\prime}}{4}$ long, often villose; axillary much smaller, frequently nearly sessile, often solitary. Bark $\frac{1^{\prime}}{2}-\frac{2^{\prime}}{3}$ thick, separating freely into long loose plate-like

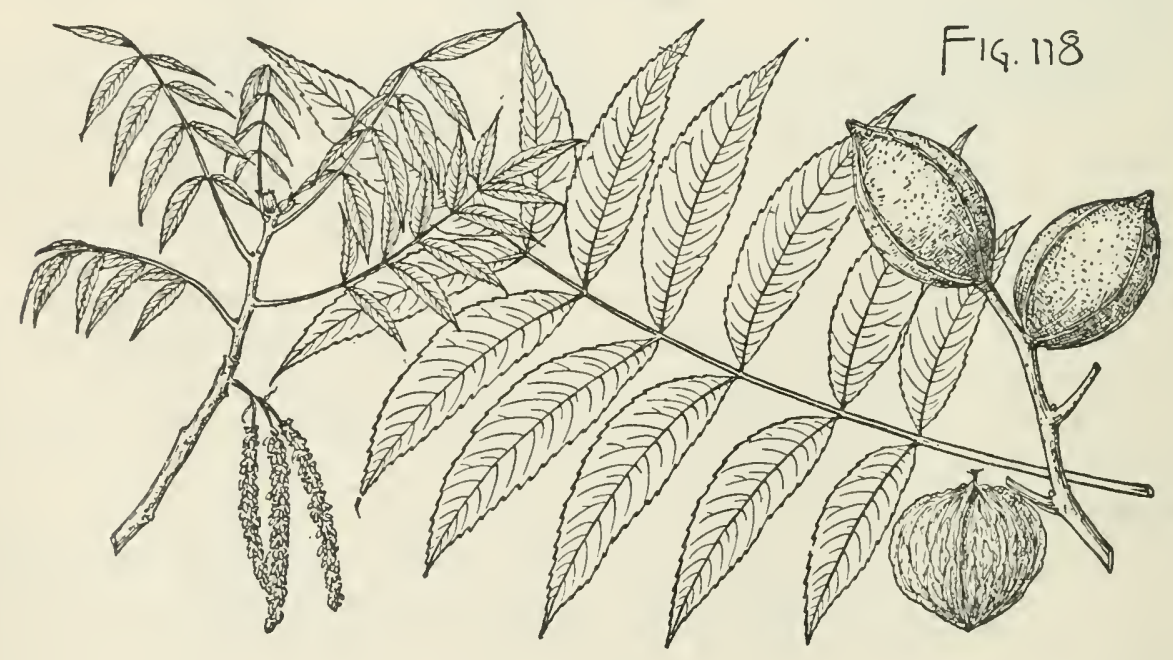

light brown scales tinged with red. Wood heavy, strong, close-grained, rather brittle, dark brown, with thick light-colored or often nearly white sapwood; oecasionally used for fencing and fuel.

Distribution. River swamps often inundated during a eonsiderable part of the year from southeastern Virginia southward through the coast regions to Cape Malabar and the valley of the Caloosa River, Florida, through the maritime portions of the Gulf states to the valley of the Brazos River in Texas, and northward through western Louisiana to northeastern Arkansas, western Mississippi, and southern Illi- 
nois; most abundant and of its largest size in western Mississippi, Arkansas, and Louisiana.

\section{Bud-scales numerous, imbricated.}

\section{Hicoria ovata, Britt. Shellbark Hickory. Shagbark Hickory.}

Leaves $8^{\prime}-14^{\prime}$ long, with stout glabrous or pubescent petioles, and 5 or rarely 7 ovate to ovate-lanceolate or obovate leaflets, acuminate or rarely rounded at the apex, sessile or short-stalked, more or less thickly ciliate on the margins, finely serrate except toward the usually cuneate base, thick and firm, dark yellow-green and glabrous

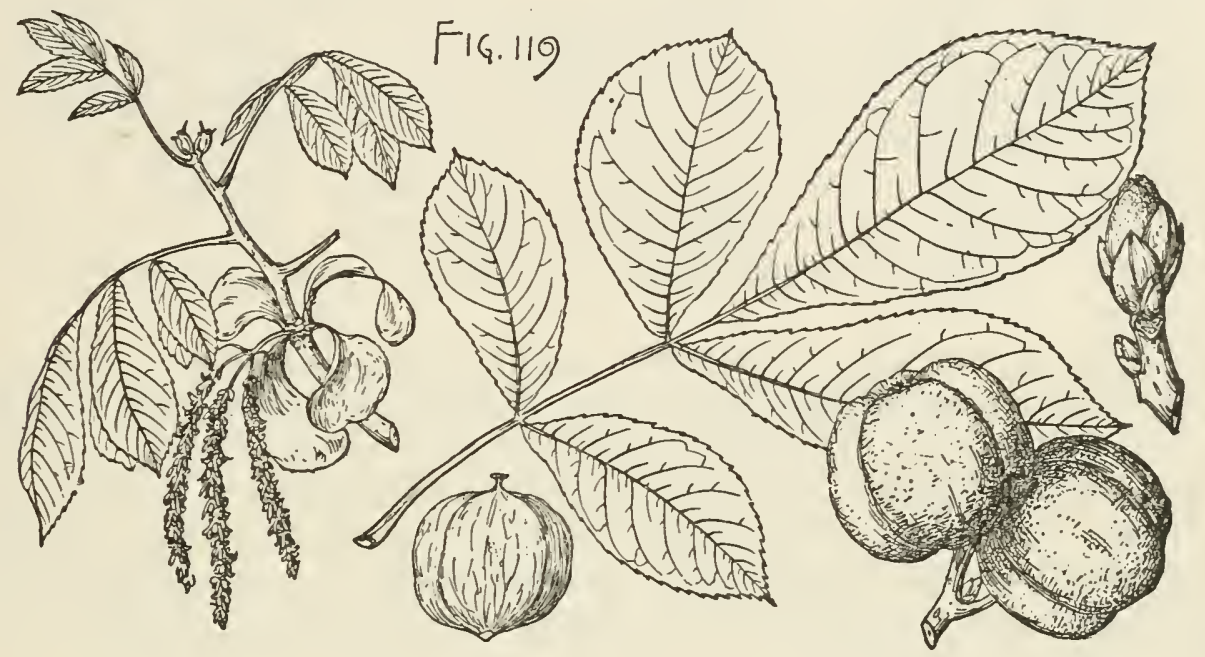

above, paler, glabrous and lustrous or puberulous below, the terminal leaflet decurrent on a slender stalk, $5^{\prime}-7^{\prime}$ long, $2^{\prime}-3^{\prime}$ broad, rather larger than the upper leaflets, and two or three times as large as those of the lowest pair. Flowers: staminate opening after the leaves have grown nearly to their full size, in sleuder light green glandular-hirsute aments $4^{\prime} I^{\prime}$ long, short-stalked, glandular-hirsute, their elongated ovate acute lanceolate bract two or three times as long as the ovate concave rounded or acute calyx-lobes; stamens 4, with nearly sessile yellow anthers tinged with red; pistillate in 2-5-flowered spikes, $\frac{1^{\prime}}{3}$ long, clothed with rusty tomentum. Fruit solitary or in pairs, subglobose, rather longer than broad or slightly obovate, depressed at the apex, dark reddish brown or nearly black at maturity, roughened by small pale lenticels, glabrous or pilose, $1^{\prime}-2 \frac{1}{2}^{\prime}$ long, the husk $\frac{1}{8}^{\prime}-\frac{1}{2}^{\prime}$ thick and splitting freely to the base; nut oblong, nearly twice as long as broad, or obovate and broader than long, compressed, prominently or obscurely 4-ridged and angled, acute and gradually or abruptly narrowed or rounded and nearly truncate at the apex, gradually narrowed and rounded at the base, pale or nearly white, thick or rarely thinwalled, $\frac{1^{\prime}}{2}-1^{\prime} \operatorname{long}, \frac{3}{4}^{\prime}-1^{\prime}$ wide; seed light brown, lustrous, sweet, with an aromatic flavor.

A tree, $70^{\circ}-90^{\circ}$ and occasionally $120^{\circ}$ high, with a tall straight trunk $3^{\circ}-4^{\circ}$ in diameter, in the forest often free of branches for $50^{\circ}-60^{\circ}$ above the ground and then divided into a few small limbs forming a narrow head, or with more space sometimes dividing near the ground or at half the height of the tree into stout slightly spreading limbs, forming a llarrow inversely conical round-topped head of more or 
less pendulous branches, and stout branchlets marked with oblong pale lenticels, covered at first with eaducons brown seurf and eoated with pale glandular pubeseenee, soou bright reddish brown and hustrous, glabrous or pulseseent, growing dark gray in their second year and nltinately light gray, and marked by pale and slightly clevated orate semiorbieular or obsenrely 3-lobed leaf-sears. Winter-buds: terminal broadly ovate, rather obtuse, $\frac{1}{2}-\frac{3}{4}$ loug, $\frac{1}{3}-\frac{1}{2}$ broad, the 3 or 4 outer seales nearly triangular, aente, clark brown, pubescent and hirsute on the onter surface, the cxterior scales often abruptly narrowed into long rigid points and deeidnons before the unfolding of the leaves, inner scales lustrous, eovered with resinous glands, yellow-green of ten tinged with red, oblong-obovate, pointed, beeoming $21_{2}^{\prime}-3^{\prime}$ long and $\frac{1}{2}$ broad, usually persistent until after the fall of the staminate aments; axillary coated at first with thiek white tomentum, beeoming $\frac{1}{3}-1_{2}^{\prime}$ long when fully grown. Bark light gray, $\frac{3{ }^{\prime}}{4}-1^{\prime}$ thick, separating in thiek stripes often a foot or more long and $6^{\prime}-S^{\prime}$ wide, and more or less elosely attached to the trunk by the middle, giving it the shaggy appearance to which the tree owes its eommon name. Wood heavy, very hard and strong, tough, elose-grained, flexible, light brown, with thin nearly whitc sapwood; largely used in the manufacture of agrieultural implements, carriages, wagrons, and for axe-handlcs, baskets, and fuel. 'The nut is the common hiekory nut of commeree.

Distribution. Low hills or near streams and swamps, in rich deep moderately moist soil from southern Maine to the valley of the St. Lawrence River near Montreal, southwestward along the northern shores of Lake Erie and Ontario to southern Michigan, central Minnesota, and southeastern Nebraska, southward to Pennsylvania and Delaware and along the Appalachian Mountains to western Florida, northern Alabama and Mississippi, and westward to central Kansas, the Indian Territory and eastern Texas; most common and of its largest size on the western slopes of the southern Alleghany Mountains and in the basin of the lower Ohio River.

\section{Hicoria Carolinæ-septentrionalis, Ashe. Shagbark Hickory.}

Leaves $4^{\prime}-8^{\prime}$ long, with slender glabrous petioles, usually 5 but occasionally 3 lanceolate long-pointed leaflets gradually narrowed at the acuminate symmetrical or unsymmetrical base, coarsely serrate, ciliatc with long white hairs as the leaves unfold, thin, dark green above, pale yellow-green and lustrous below, the upper leaflets $3^{\prime}-4^{\prime}$ long, $1^{\prime}-1 \frac{1^{\prime}}{2}$ wide, and about twiee as large as those of the lower pair, turuing dull brown or yellow-brown some time before falling. Flowers: staminate in slightly villous aments, pedicellate, glandular-hirsute on the outer surface, with linear elongated aeuminate villous braets; stamens 4; pistillate usually in 2flowered spikes, oblong and eovered with clustered golden hairs, their bract linear and eiliate on the margins. Fruit broader than high, or short-oblong, slightly depressed at the apex, $\frac{3^{\prime}}{4}-1 \frac{1}{2}^{\prime}$ wide, dark red-brown, roughened by small pale lenticels, with a husk $\frac{1^{\prime}}{8}-\frac{3^{\prime}}{8}$ thick, splitting freely almost to the base; mit ovate, compressed, prominently 4-angled, aente at the ends, nearly white or pale brown, $\frac{3 \prime}{4}-1^{\prime}$ long, with a thin shell; seed light brown, sweet.

A tree, on moist bottom-lands sometimes $80^{\circ}$ tall, with a trunk $2^{\circ}-3^{\circ}$ in diameter, and short small branches forming a narrow oblong head, or on dry hillsides usually not more than $20^{\circ}-30^{\circ}$ tall, with a trunk generally not exceeding a foot in diameter, and slender red-brown branchlets marked by numerous small pale lentieels and by the small low truneate or slightly obeordate leaf-sears, becoming ultimately dull gray-brown. Winter-buds: terminal ovate, gradually narrowed to the obtuse 
apex, about $\frac{1}{4}^{\prime}$ long, with glabrous bright red-brown and lustrous acute and apiculate strongly keeled spreading outer scales, the inner scales becoming when fully grown

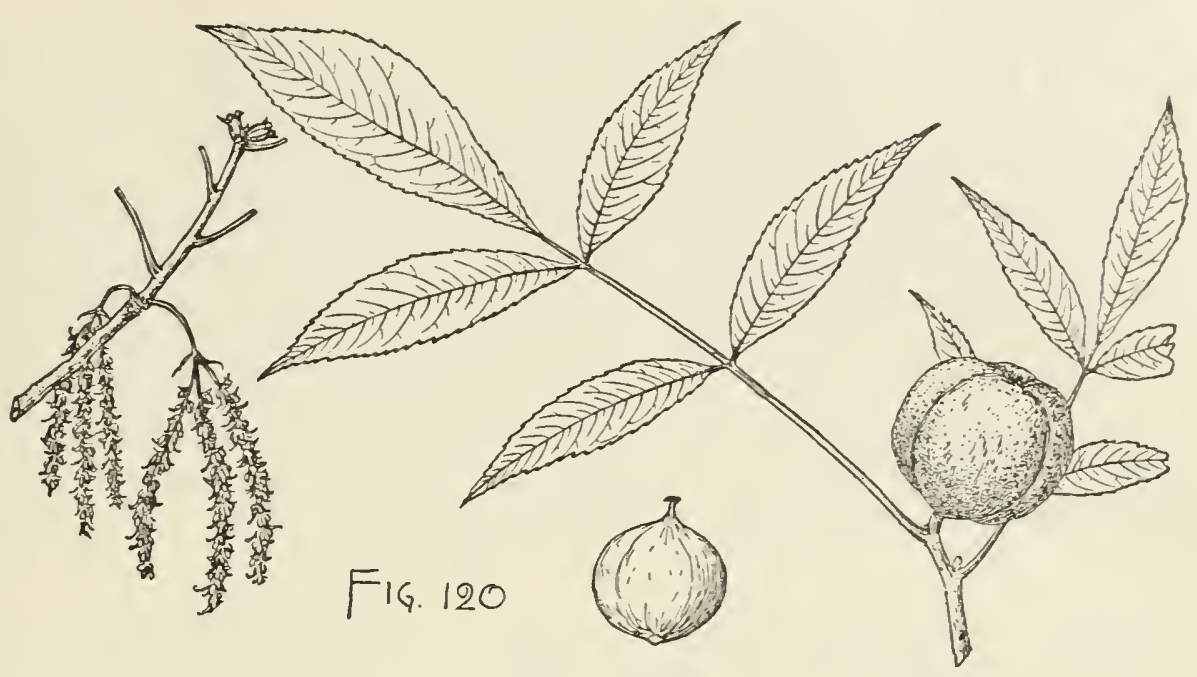

bright yellow, long-pointed, and sometimes 2' long; axillary oblong, obtuse, not more than $\frac{1^{\prime}}{1^{\prime}}$ long. Bark light gray, $\frac{1^{\prime}}{4}-\frac{3^{\prime}}{4}$ thick, separating freely into thick strips often a foot or more long, $3^{\prime}$ or $4^{\prime}$ wide, and long-persistent, giving to the trunk the shaggy appearance of the northern Shagbark Hickory. Wood hard, strong, very tough, light reddish brown, with thin nearly white sapwood.

Distribution. Dry limestone hills, and river-bottoms; central North Carolina to northern Georgia, and through western North Carolina to eastern Tennessee and central Alabama.

\section{Hicoria laciniosa, Sarg. Big Shellbark. Bottom Shellbark.}

Leaves $15^{\prime}-22^{\prime}$ long, with stout glabrous or pubescent petioles often persistent on the branches during the winter, and $5-9$, usually 7 , ovate to oblong-lanceolate or broadly obovate leaflets, the upper $5^{\prime}-9^{\prime}$ long and $3^{\prime}-\tilde{5}^{\prime}$ broad and generally two or three times as large as those of the lowest pair, usually equilateral, acuminate, equally or nnequally wedge-shaped or rounded at the often oblique base, finely serrate, sessile or short-stalked, dark green and lustrous above, pale yellow-green or bronzy brown and covered with soft pubescence below. Flowers: staminate in aments $5^{\prime}-8^{\prime}$ long and glabrous or covered with rufous scurfy tomentum, short-pedicellate, with linear-lanceolate acute bracts two or three times as long as the broader rounded calyx-lobes, and hirsute yellow subsessile more or less deeply emarginate anthers; pistillate in 2-5-flowered spikes, oblong-ovate, about twice as long as broad, slightly angled, clothed with pale tomentum, with linear acute bracts much longer than the nearly triangular bractlets and calyz-lobe. Fruit solitary or in pairs, ellipsoidal, ovate or subglobose, depressed at the apex, roughened with minute orange-colored lenticels, downy or glabrous, light orange-colored or dark chestnut-brown at maturity, $1 \frac{3^{\prime}}{4}-2 \frac{1}{2}^{\prime}$ long and $1 \frac{1}{4}-2^{\prime}$ broad, with a hard woody husk pale and marked on the inside with dark delicate veins, and $\frac{1}{4}^{\prime}-\frac{1}{3}^{\prime}$ thick ; nut ellipsoidal or slightly obovate, longer than broad or sometimes broader than long, flattened and rounded at the ends or gradually narrowed and rounded at the base, and occasionally acuminate at the apex, more or less compressed, prominently 4-ridged and angled or often 6-ridged, 


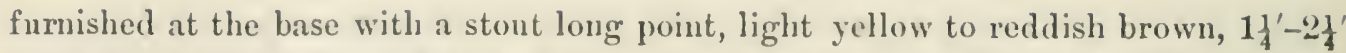

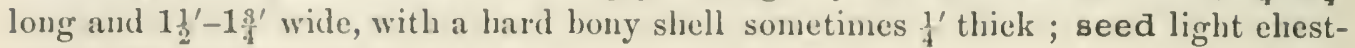
nut-brown, very sweet.

A tree, oecasionally $120^{\circ}$ high, with a straight slender trunk often free of branches for more than half its heigrlt and rarely exceeding $3^{\circ}$ in diameter, comparatively small spreading branches forming a narrow oblong head, and stout dark or light orange-colored branchlets at first pilose or eovered with pale or rufous pubescence or tomentum, roughened by scattered elevated long pale lenticels. orange-lorown and glabrous or puberulous during their first winter and marked with ollong 3-lobed emarginate leaf-scars. Winter-buds: terminal ovatc, rather obtuse, sometimes $1^{\prime}$ long and $\frac{2 \prime}{3}$ broad, and three or four times as large as the axillary buds, usually eovered by 11 or 12 scales, the outer dark brown, puberulous, generally keeled, with a long point at the apex, the inner scales obovate, pointed and rounded at the apex, light green tinged with red, or briglt red or yellow, eovered with silky pnbescence on the outer face, slightly resinous, becoming $2^{\prime}-3^{\prime}$ long and $1^{\prime}$ broad. Bark

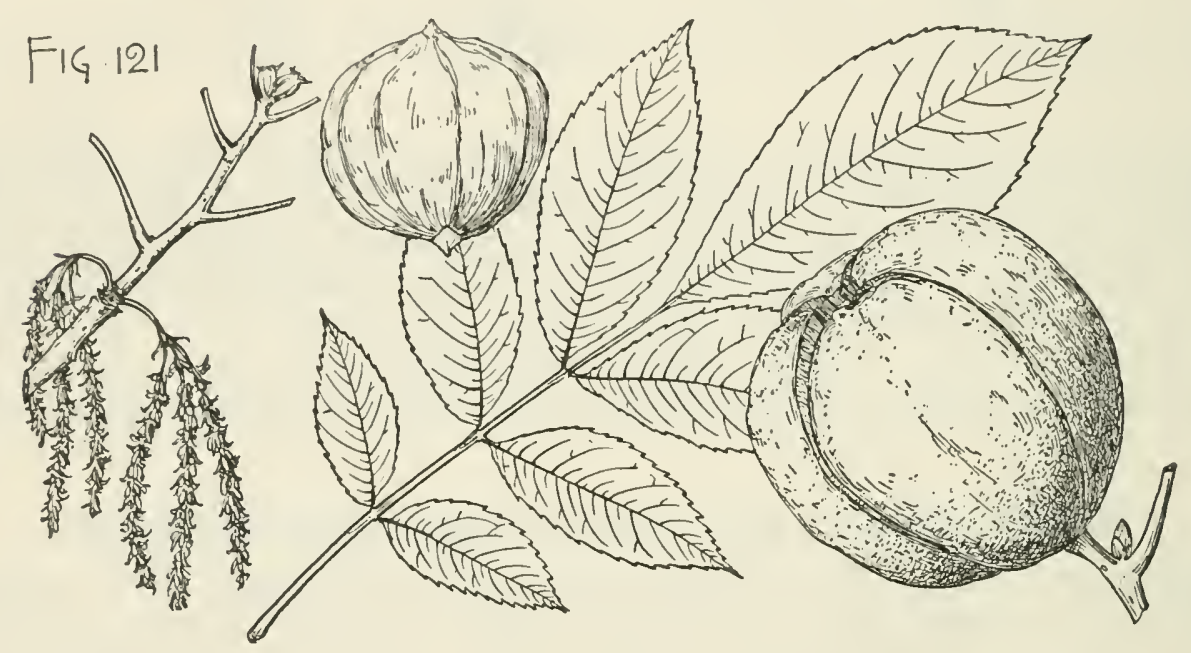

$1^{\prime}-2^{\prime}$ thick, light gray, separating into broad thick plates frequently $3^{\circ}-4^{\circ}$ long, sometimes remaining for many years hanging on the trunk. Wood heavy, very hard, strong and tough, elose-grained, very flexible, dark brown, with eomparatively thin nearly white sapwood. The large nuts are often sold in the markets of western eities and commereially are not often distinguished from those of the Shellbark Hickory.

Distribution. Rieh decp bottom-lands nsually innndated during several weeks of every year from Iowa to southeastern Nebraska, throngh Missouri and Arkansas, eastern Kansas and the eastern portion of the Indian Territory, through southern Illinois and Indiana to East Tennessee, sonthern Michigan, western and central New York, eastern Pennsylvania and middle North Carolina; rare and loeal east of the Alleghany Mountains and comparatively rare in Arkansas, Kansas, and the Indian Territory; one of the commonest trees of the great river swamps of central Missouri and the lower Ohio basin.

Occasionally cultivated on old estates in Virginia, and rarely in central and western Europe. 


\section{Hicoria alba, Britt. Mockernut. Big Bud Hickory.}

Leaves fragrant, with à powerful resinous pleasant odor, $8^{\prime}-12^{\prime}$ long, with hirsute or tomentose petioles, and 5-7 oblong-lanceolate to obovate-lanceolate leaflets gradually or abruptly acuminate, mostly equilateral, equally or unequally rounded or wedge-shaped at the base, minutely or coarsely serrate, sessile or short-stalked, dark yellow-green and rather lustrous above, lustrous, paler or light orange-colored or brown and clothed with soft pale pubescence on the lower surface, the upper leaflets $5^{\prime}-8^{\prime}$ long and $3^{\prime}-5^{\prime}$ wide, and two or three times as large as those of the lowest pair. Flowers: staminate in aments $4^{\prime}-5^{\prime}$ long, with slender light green stems coated with matted hairs, short-stalked, pale yellow-green, $\frac{1^{\prime}}{1^{\prime}}-\frac{1}{8}^{\prime}$ long, scurfy-pubescent, with elongated ovate-lanceolate bracts ending in tufts of long pale hairs, and three or four times as long as the calyx-lobes, and 4 stamens with nearly sessile oblong emarginate bright red hirsute anthers; pistillate in crowded 2-5̃-flowered spikes, slightly contracted above the middle, coated with pale tomentum, the bract ovate, acute, sometimes $\frac{1}{4}^{\prime}$ long, about twice as long as the broadly ovate nearly triangular bractlets and calyx-lobe; stigmas dark red. Fruit ellipsoidal or obovate, gradually narrowed at the ends, acute at the apex, abruptly contracted toward the base, pilose or nearly glabrous, dark red-brown, $1 \frac{1}{2}^{\prime}-2^{\prime}$ long, with a husk about $\frac{1}{8}^{\prime}$ thick splitting to the middle or nearly to the base; nut nearly globose, ellipsoidal or obvateoblong, narrowed at the ends, rounded at the base, acute and sometimes attenuated and long-pointed at the apex, much or only slightly compressed, obscurely or prominently 4-ridged, light reddish brown, becoming darker and sometimes red with age, $\frac{8^{\prime}}{4}-2^{\prime}$ long, $\frac{3}{4}-1 \frac{1{ }^{\prime}}{4}$ wide, with very thick hard walls and partitions; seed small, sweet, dark brown, and lustrous.

A tree, rarely $100^{\circ}$ high, usually much smaller, with a tall trunk occasionally $3^{\circ}$ in diameter, comparatively small spreading branches forming a narrow or often a

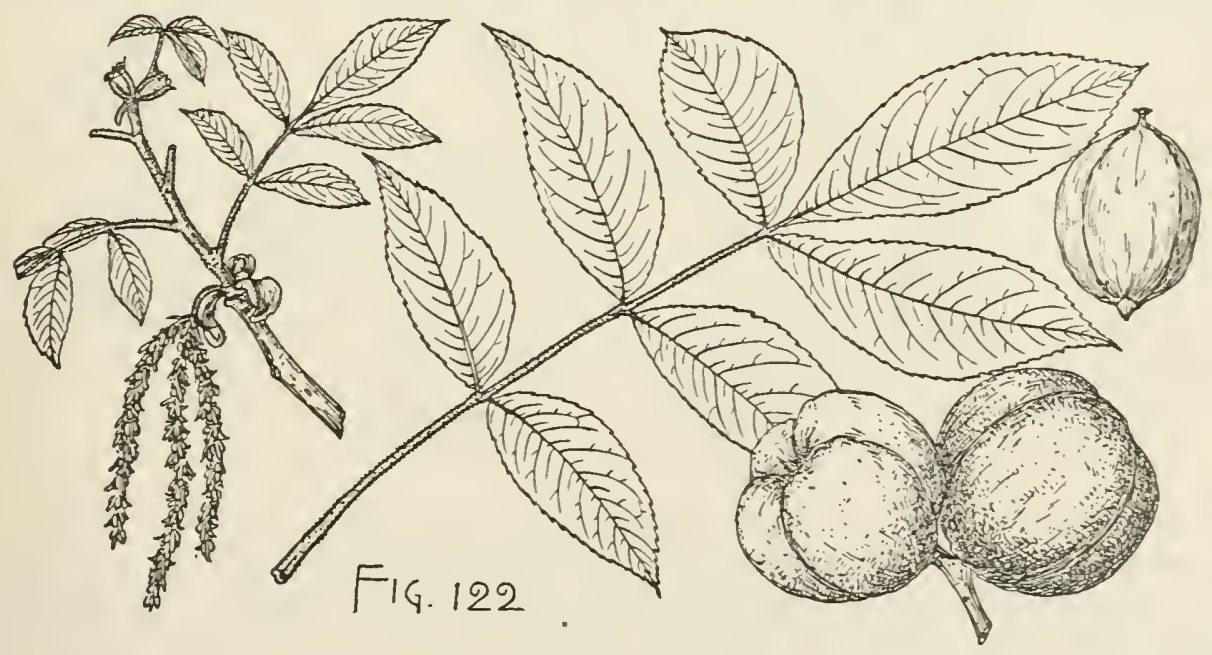

broad round-topped head of upright rigid or of gracefully pendulous branches, and stout branchlets clothed at first with thick pale tomentum, rather bright brown, nearly glabrous or pubescent or tomentose, and marked by conspicuous pale lenticels during their first season, becoming light or dark gray, witl pale emarginate leafscars almost equally lobed or elongated with the lowest lobe two or three times as 
long as the others. Winter-buds: terminal broadly ovate, aente or obtuse, $\frac{1}{2}-\frac{3}{4}$ loug, two or three times as large as the axillary buds, the three or four outer budseales ovate, aente, often keeled and apienlate, thiek and firm, dark reddish brown and pilose, usually deeiduous late in the autumn, the inner seales ovate, rounded or aente and short-pointed at the apex, light green eovered with soft silky pubeseence on the onter, and often bright red and pilose on the inner surface, beconing $\mathbf{1}^{\prime}-1 \frac{1}{2}$ long and ${ }_{2}^{\prime}$ broal. Bark $\frac{1}{2}{ }^{\prime}-\frac{3}{4}$ thiek, slightly ridged by shallow irregular interrupted fissures aud eovered by dark gray elosely appressed seales. Wood very heavy, hard, tough, strong, elose-grained, flexible, rieh dark brown, with thiek nearly white sapwood; used for the same purposes as that of the Shellbark Hickory.

Distribution. Southern Ontario southward to Cape Cauaveral and the shores of Tampa Bay, Florida, and westward to easteru Kansas, the Indian Territory, and easteru 'Texas; eomparatively rare at the north, growing on ridges and less frequently on alluvial river-bottons; the most abundant and generally distributed of the Hickory-trees of the south, attaining its largest size in the basin of the lower Olnio River and in Missouri and Arkansas; the only Hiekory in the southern maritime Pine-belt, growing in great abundanee on low sandy hummoeks close to the shores of bays and estuaries along the eoast of the south Atlantic and Gulf states.

\section{Hicoria glabra, Britt. Pignut.}

Leaves $8^{\prime}-12^{\prime}$ long, with slender glabrons petioles, and 5 or 7 or rarely 9 oblong to obovate-laneeolate leaflets gradually or abruptly long-pointed at the apex, equally

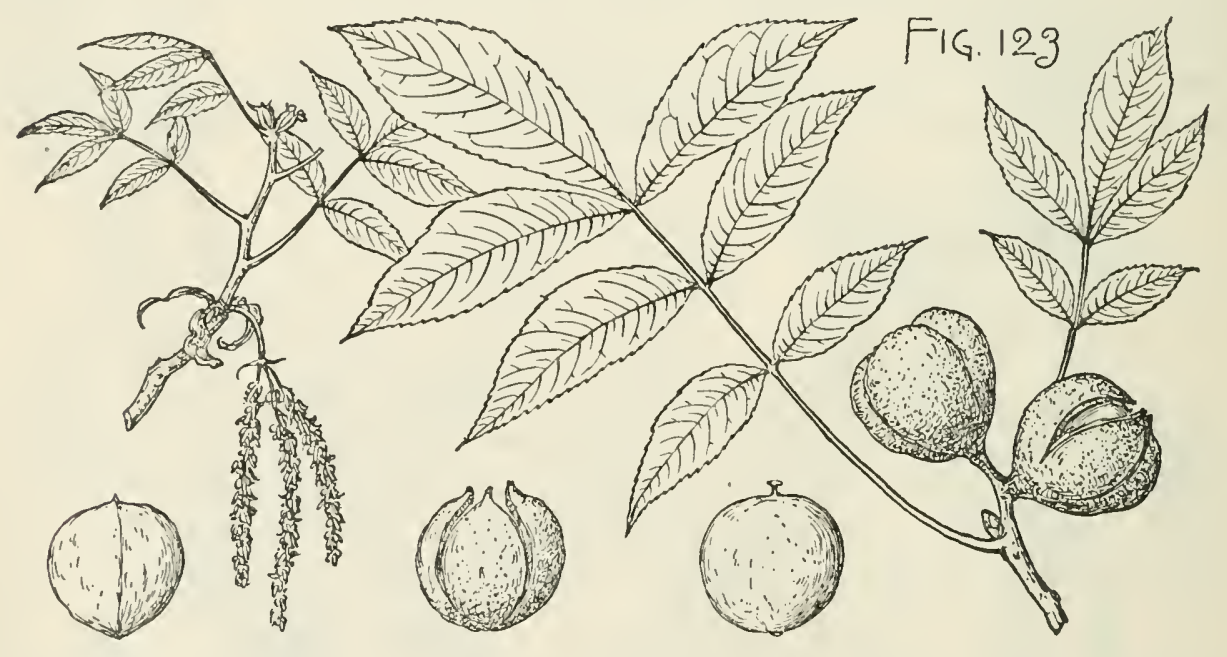

or unequally rounded at the base, sharply serrate, subsessile or short-stalkeã, thiel and firm, at first glandular-punetate and villose, beeoming glabrous, dark yellow-green above, paler and sometimes bright yellow or yellow-brown below, the upper $6^{\prime}-8^{\prime}$ long and $2^{\prime}-2 \frac{1^{\prime}}{2}$ broad, and three or four times larger than those of the lowest pair. Flowers: staminate in short-stalked seurfy pubeseent aments $3^{\prime}-7^{\prime}$ long, yellowgreen eoated with pale pubeseenee or tomentum, with braets laneeolate, aente and mueh longer than or ovate rounded and not longer than the ealyx-lobes, and 4 stamens, with nearly sessile ovate emarginate orange-eolored anthers slightly hirsute above the middle; pistillate in 2-5-flowered spikes, $\frac{1}{4}^{\prime}$ long, more or less prominently 4-ribbed, nearly glabrous or eoated with seurfy pubeseenee or pale tomentum, their 
bract lanceolate, acute, sometimes $\frac{1}{2}^{\prime}$ long, much longer than the ovate acute bractlets and the calyx-lobe; stigmas yellow. Fruit extremely variable in shape and size, pyriform, ellipsoidal, or subglobose (var. odorata, Sarg.), ronnded or of tell much depressed at the apex, abruptly or gradually narrowed at the base, cylindrical or often obscurely winged to the middle or nearly to the base, reddish brown, often pubescent or covered with scattered clusters of bright yellow hairs, $1 \frac{1}{2}-2^{\prime}$ long, $\frac{3^{\prime}}{4}-1 \frac{1}{2}^{\prime}$ broad, with valves $\frac{1^{\prime}}{3}-\frac{1}{2}^{\prime}$ thick, opening in some forms only at the apex and continuing to inclose the nut after it has fallen to the ground, in others splitting to the middle or nearly to the base; nut ellipsoidal to subglobose, often nearly as broad as long, rounded at the ends, or obcordate or rarely acuminate at the apex, obscurely 4-angled, compressed or cylindrical, $\frac{1}{2}^{\prime}-1 \frac{1}{2}^{\prime}$ long, with thick or thin hard walls and partitions; seed small, light brown, bitter or sweet.

A tree, $80^{\circ}-90^{\circ}$ high, with a tall slender often forked trunk occasionally $3^{\circ}$ or $4^{\circ}$ in diameter, spreading limbs forming a rather narrow head of slender more or less pendulous and often contorted branches, and slender branchlets marked with oblong pale lenticels, light green and nearly glabrous at first, rather light red-brown during their first season, turning dark red in their second year, with small semiorbicular to oblong obscurely lobed leaf-scars. Winter-buds: terminal usually about $\frac{1^{\prime}}{4}$ long, ellipsoidal, acnte or obtuse, and two or three times as large as the axillary buds, the outer scales acute or often slightly keeled and frequently long-pointed, light orangebrowl or dark reddish brown, lustrous and covered with short soft pubescence, usually deciduous early in the autumn, the inner scales yellow-green more or less tinged with red, covered with long pale hairs on the onter surface, lustrous on the inner, lanceolate and acute to broadly obovate and apiculate, frequently becoming $2 \frac{1}{2}^{\prime}$ long and $1 \frac{1}{4}^{\prime}$ wide. Bark of the trunk $\frac{1}{2}^{\prime}-\frac{3^{\prime}}{4}$ thick, light gray, with a firm close surface usually divided by small fissures, or rarely scaly, with loose thick plate-like scales $5^{\prime}$ or $6^{\prime}$ long. Wood heavy, hard, very strong and tough, flexible, light or dark brown, with thick lighter colored or often nearly white sapwood; used for the handles of tools and in the manufacture of wagons and agricultural implements, and largely for fuel.

Distribution. Dry ridges and hillsides, southern Maine to soutlern Ontario, and southward to the shores of the Indian River and Peace Creek, Florida, southern Alabama and Mississippi, and through southern Michigan to southeastern Nebraska, Missouri, eastern Kansas, Arkansas, the Indian Territory, and Texas; most common in Missouri and Arkausas; of its largest size in the basin of the lower Ohio River; ranging farther south in Florida than other Hickories, and, with the exception of the Pecan, farther to the sonthwest in Texas. The var. odorata from eastern New England to Michigan and Missouri, and southward to the District of Columbia.

\section{Hicoria villosa, Ashe. Hickory.}

Leaves $6^{\prime}-10^{\prime}$ long, with slender petioles pubescent in the spring and furnished with conspicuons tufts of pale or brownish hairs, and glabrous or puberulous in the autumn, and 5-9, nsually 7 , sessile or short-stalked lanceolate or oblanceolate acuminate leaflets gradually or abruptly narrowed and nearly symmetrical or unsymmetrical at the entire base, coarsely serrate above, with remote glandnlar incurved teeth, covered as they unfold with decidnous resinous globules and on the lower surface with soft hairs mixed with the peltate silvery scales characteristic of this tree in early spring and often deciduous before the leaves are fully grown; at maturity dark green and glabrous above, pale or bright yellow below, the largest $4^{\prime}-5^{\prime} \operatorname{long}, 1^{\prime}-1_{2}^{\prime \prime}$ 
wide, and more than twice as large as those of the lowest pair. Flowers: staminate in hairy eatkins $5^{\prime}-7^{\prime}$ long, with broad ronuded bracts and hractlets, senrfy, villous on the onter surface, and 4 nearly sessile hairy anthers; pistillate oblong, prominently 4-ribbed, eoated with scurfy yellow pubeseence, their bracts lanceolate, acnminate, much longer than the ovate acute bractlets and the ealyx-lobe. Fruit subghobose to pyriform, $\frac{3^{\prime}}{4}-1 \frac{3^{\prime}}{4}$ longr, 4-winged, more or less thickly covered with yellow scurfy

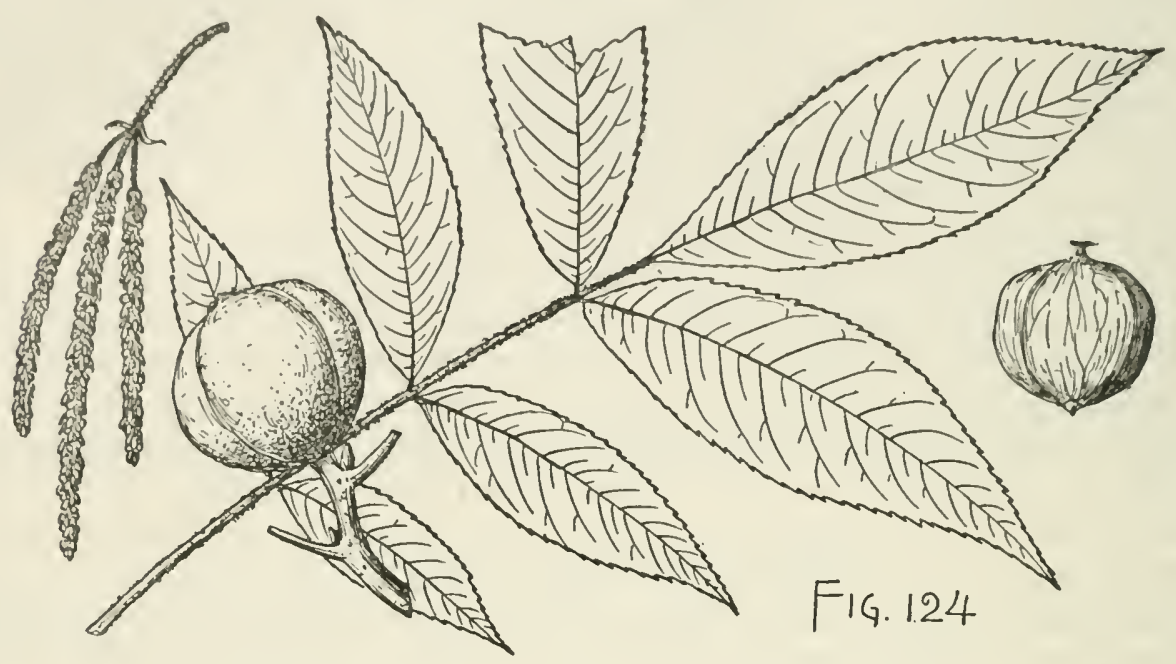

scales, with a thin husk splitting to below the middle or nearly to the base; nut slightly angled, somewhat compressed, narrowed at the ends, pale or light brown, with a thick shell; seed light brown, small, and sweet.

A tree, usually not more than $18^{\circ}-20^{\circ}$, or sometimes $40^{\circ}-50^{\circ}$ high, with a short trunk $12^{\prime}-18^{\prime}$ in diameter, and small branehes, the upper ascending, forming a narrow oblong head, the lower pendulous, and slender branchlets coated at first with pale tomentum or pubescence, mixed with silvery peltate scales, glabrous or puberulous, bright purplish brown during their first winter, and marked by occasional oblong light gray lenticels and by the small low nearly circular leaf-scars, becoming rather darker colored the following year. Winter-buds : terminal sessile or stalked, ovate, acute, $\frac{1^{\prime}}{8}$ to nearly $\frac{1}{4}^{\prime}$ long, with puberulous scales more or less eovered on the onter surface with yellow glands; axillary often solitary. Bark $\frac{1}{2}{ }^{\prime}-\frac{3}{4}$ thick, light gray or grayish brown, and irregularly divided by deep fissures into broad connected ridges covered with closely appressed scales.

Distribution. Sandy plains or sterile rocky ridges from sonthern New Jersey to eastern Florida, and from the valley of the Maramec River, Missouri, to eastern Texas; common on the sandy soil of southern Delaware and in the foothill region of the southern Appalachian Mountains; very abundant and often the only Hickorytree on the dry flinty soil of low hills in southern Missouri and Arkansas.

\section{MYRICACE王.}

Aromatic resinous trees and shrubs, with watery juice, terete branches, and small scaly buds. Leaves alternate, revolute in the bud, serrate, resinouspunctate, persistent, in falling leaving elevated semiorbicular leaf-scars showing the ends of three nearly equidistant fibro-vascular bundles. Flowers 
unisexual, diœcious or monœcious, usually subtended by minute bractlets, in the axils of the deciduous scales of unisexual or androgynous simple oblong aments from buds in the axils of the leaves of the year, opening in early spring, the staminate below the pistillate in androgynous aments; staminate, periantli 0 ; stamens 4 or many, inserted on the thickened base of the scales of the ament; filaments slender, united at the base into a short stipe; anthers ovate, erect, 2 -celled, introrse, opening longitudinally; ovary rudimentary or 0 ; pistillate flowers single or in pairs; ovary sessile, 1-celled; styles short, divided into 2 elongated filiform stigmas stigmatic on the inner face; ovule solitary, erect from the base of the cell, orthotropous, the micropyle superior. Fruit a globose or ovoid dry drupe usually covered with waxy exudations; nut hard, thickwalled; seed erect, with a thin coat, without albumen; embryo straight; cotyledons plano-convex, fleshy; radicle short, superior, turned away from the minute basal hilum.

The family consists of the genus Myrica, L., of about thirty or forty species of small trees and shrubs, widely distributed through the temperate and warmer parts of both hemispheres. Of the seven North American species three are trees. Wax is obtained from the exudations of the fruit of several species. The bark is astringent, and sometimes used in medicine, in tanning, and as an aniline dye. Myrica sapida, Wall., of eastern Asia and the Malay Archipelago, is cultivated for its succulent aromatic fruit.

The generic name is probably from the ancient name of some shrub, possibly the Tamarisk.

\section{CONSPECTUS OF THE NORTH AMERICAN SPECIES.}

Flowers diœcious.

Leaves oblong-spatulate, usually acute or rarely rounded at the apex, mostly coarsely serrate above the middle, yellow-green, coated below with conspicuous orange-colored glands.

1. M. cerifera $(A, C)$.

Leaves usually broadly oblong-obovate, rounded or rarely acute at the apex, entire, dark green, and lustrous.

Flowers monœcious.

2. M. inodora (C).

Leaves lanceolate-cuneate or oblong-lanceolate, sharply serrate, dark green, and lustrous.

3. M. Californica (G).

\section{Myrica cerifera, L. Wax Myrtle.}

Leaves lanceolate-cuneate or oblong-lanceolate, acute or rarely gradually narrowed and rounded at the apex, cuneate at the base, decurrent on short stout petioles, coarsely serrate above the middle or entire, yellow-green, covered above by minute dark glands and below by bright orange-colored glands, $1 \frac{1}{2}^{\prime}-4^{\prime}$ long and $\frac{1}{4}^{\prime}-\frac{1}{2}^{\prime}$ wide, with slender pale midribs often puberulous below, and few obscure arcuate veins, fragrant with a balsamic resinous odor, gradually deciduous at the end of their first year. Flowers in small oblong aments, with ovate acute ciliate scales, those of the staminate plant $\frac{1^{\prime}}{2}-\frac{3^{\prime}}{4}$ long, about twice as long as those of the pistillate plant; stamens few, with oblong slightly obcordate anthers at first tinged with red, becoming yellow; ovary of the pistillate flower gradually narrowed into 2 slender spreading stigmas longer than its scale. Fruit in short spikes, ripening in September and October and persistent on the branches during the winter, irregularly deciduous in the sjiring and early summer, globose, about $\frac{1}{8}^{\prime}$ in diameter, slightly papillose, light greer., coated with thick pale blue wax. 
A tree, ocensionally $40^{\circ}$ high, with a tall trunk $8^{\prime}-10^{\prime}$ in diameter, slender upriglit or sliglitly spreading branches forming a narrow round-topped licad, and sleuder branehlets marked by small pale lenticels, eoated at first with loose rufous tomentum and eaducous orange-colored glands, briglit red-brown or dark brown tinged with gray, nsually lustrous and nearly glabrous during their first winter, finally becoming dark browu; generally smaller, frequently shrubby, with many slender stems, sometimes only a few inches high. Winter-buds oblong, acute, ${ }_{16}^{\prime}{ }^{\prime}-\frac{x^{\prime}}{8}$ long, with numerous ovate aeute imbricated scales, the inner scales becoming

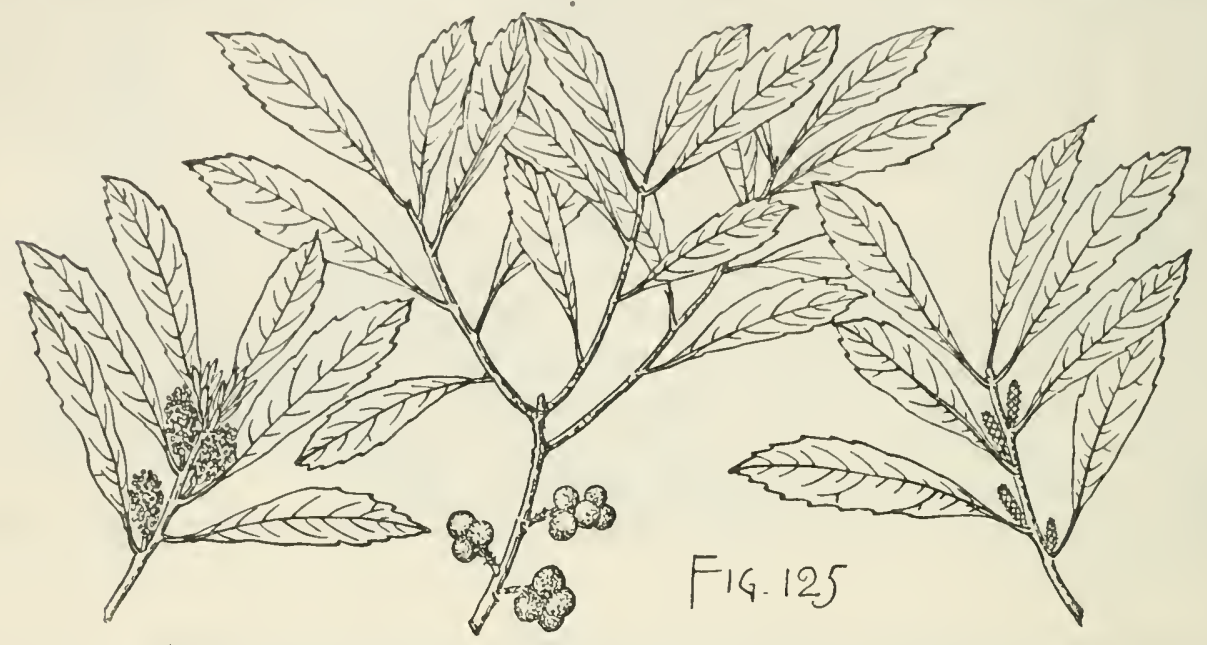

nearly $\frac{1^{\prime}}{2}$ long, and often persistent until the young branch has completed its growth. Bark of the trunk $\frac{1}{4}$ thick, compact, smooth, light gray. Wood light, soft and brittle, dark brown, with thin lighter-colored sapwood.

Distribution. Cape May, New Jersey, southern Delaware and Maryland to southern Florida in the neighborhood of the coast, through the Gulf states to the shores of Aransas Bay, Texas, and northward in the region west of the Mississippi River to the valley of the Washita River, Arkansas; on the Bermuda and Bahama islands and on several of the Antilles; most abundant and of its largest size on the south Atlantic and Gulf coasts in sandy swamps and pond holes; in the sandy soil of Pine-barrens and on dry arid hills of the interior, often only a few inches in height.

\section{Myrica inodora, W. Bartr. Wax Myrtle.}

Leaves broadly oblong-obovate or rarely ovate, rounded or sometimes pointed and oceasionally apiculate at the apex, narrowed at the base, decnrrent on short stout petioles, entire or rarely obscurely toothed toward the apex, thick and coriaceous, glandilar-punctate, dark green and very lustrous above, bright green below, $2^{\prime}-4^{\prime}$ long, $\frac{3^{\prime}}{4}-1 \frac{1}{2}^{\prime}$ wide, with broad conspieuously glandnlar midribs slightly pubescent on the lower side, and few remote slender obscure primary veins forked and arcuate near the much-thickened and revolute margins, gradually deciduous from May until midsummer. Flowers in aments $\frac{8^{\prime}}{4}-1^{\prime}$ long, with ovate acute glandular scales; stamens numerous, with oblong slightly emarginate yellow anthers; pistillate flowers usually in pairs, with ovate glabrous ovaries and slender bright red istyles. Fruit produced sparingly in elongated spikes, oblong, $\frac{1}{8}^{\prime}-\frac{1}{2}^{\prime}$ long, papillose, black, and covered with a thin coat of white wax. 
Usually a shrub, with numerous slender stems, occasionally arborescent and $18^{\circ}-$ $20^{\circ}$ high, with a straight trunk $6^{\circ}-8^{\circ}$ tall and $2^{\prime}-3^{\prime}$ in diameter, and stout branchlets

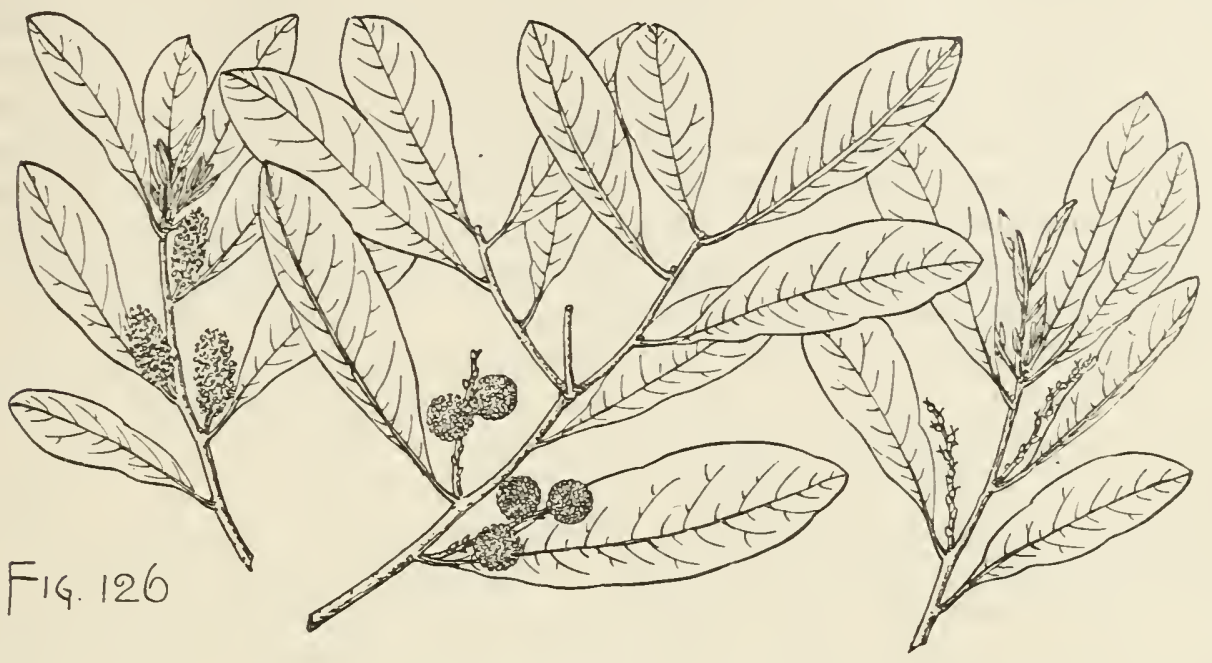

roughened with small scattered lenticels, coated at first with dense pale tomentum, soon becoming bright red-brown, scurfy, and glabrous or pubescent. Bark thin, smooth, nearly white. Winter-buds ovate, acute, nearly $\frac{1}{8}^{\prime}$ long, with numerous loosely imbricated lanceolate acute red-brown scurfy-pubescent scales.

Distribution. Deep swamps near Appalachicola, Florida, near Mobile and Stockton, Alabama, and near Poplarville in the valley of the Pearl River, Mississippi.

\section{Myrica Californica, Cham. Wax Myrtle.}

Leaves lanceolate-cuneate or oblong-lanceolate, acute, remotely serrate except at the gradually narrowed base, with small incurved teeth, decurrent on short stout petioles, thin and firm, dark green and lustrous above, yellow-green, glabrous or

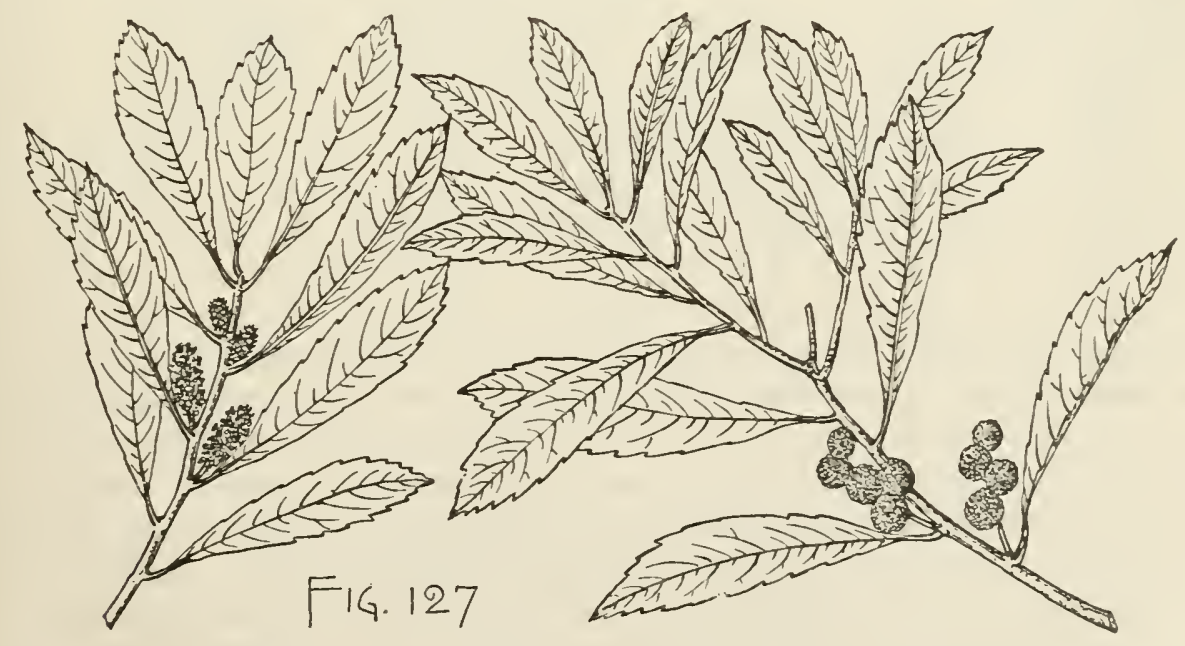

puberulous and marked with minute black glandular dots below, $2^{\prime}-4^{\prime}$ long, $\frac{1^{\prime}}{2}-\frac{3^{\prime}}{4}$ wide, with narrow yellow midribs and numerous obscure primary veins arcuate near 
the thickened and revolute margins, slightly fragrant, gradually deciduous after the end of their first year. Flowers subtended by conspienons bractlets, those of the two sexes on the same platut; staminate in oblong simple aments often $\mathbf{1}^{\prime}$ long, pistillate in shorter aments in the axils of upper leaves, androgynous aments ocenrring between the two with stanimate flowers at their base and pistillate flowers above, or with staminate flowers also mixed with the pistillate at their apex; seales of the aments ovate, acute, conted with pale tomentum; stamens numerous, with oblong slightly emarginate dark red-purple anthers soon becoming yellow; ovary ovate, with bright red exserted styles. Fruit in short crowded spikes ripening in the early antunu and usually falling during the winter, globose, papillose, dark purple, covered with a thin eoat of grayish white wax.

A trec, occasionally $40^{\circ}$ ligh, with a trunk $14^{\prime}-15^{\prime}$ in dianeter, short slender branches forming a narrow compact round-topped head, and stout branchlets, coated at first with loose tomentum, dark green or light or dark red-brown, glabrous or pubescent during their first season, becoming in the sccond year much roughened by the elevated leaf-scars, darker and ultimately ashy gray; usually smaller at the north and toward the northern and southern limits of its range reduced to a low slrub often only $3^{\circ}-4^{\circ}$ tall. Winter-buds ovate, acute, about $\frac{1^{\prime}}{3}$ thick, with loosely imbricated ovate acute dark red-brown tomentose scales nearly $\frac{1^{\prime}}{2}$ long when fully grown and long-persistent on the branch. Bark smooth, compact, $\frac{1}{16}^{\prime}-1^{\prime}$ thick, dark gray or light brown on the surface and dark red-brown internally. Wood heavy, very hard and strong, brittle, close-grained, light rose color, with thick lighter colored sapwood.

Distribution. Ocean sand-dunes and moist hillsides in the vicinity of the coast from the shores of Puget Sound to the neighborhood of Santa Monica, California; of its largest size on the shores of the Bay of San Francisco.

Occasionally used in California as an ornamental plant.

\section{LEITNERIACE円.}

A tree or shrub, with pale slightly fissured bark, scaly buds, stout terete pithy branchlets marked by pale conspicuous nearly circular lenticels and with elevated crescent-shaped angled or obscurely 3-lobed leaf-scars, very light soft wood, and thick fleshy stoloniferous yellow roots. Leaves involute in the bud, lanceolate to elliptical-lanceolate, acuminate or acute and short-pointed at the apex, gradually narrowed at the base, entire, with slightly revolute undulate margins, penniveined, with remote primary veins arcuate and united near the margins and conspicuous reticulate veinlets, petiolate, at first coated on the lower surface and on the petioles with thick pale tomentum and puberulous on the upper surface, thick and firm at maturity, bright green and lustrous above, pale and villose-pubescent below, deciduous. Flowers in unisexual aments, with ovate acute concave tomentose scales, the male and female on different plants, opening in early spring from buds formed the previous autumn and covered with acute chestnut-brown hairy scales; the staminate clustered near the ends of the branches, their scales bearing on the thickened stipes a ring of 3-12 stamens, with slender incurved filaments and oblong light yellow introrse 2-celled anthers opening longitudinally ; perianth 0 ; pistillate aments scattered, shorter and more slender than the staminate, their scales bearing in their axils a short-stalked pistil surrounded by a rudimentary perianth of small glandfringed scales, the 2 larger lateral, the others next the axis of the inflorescence; 
ovary superior, pubescent, 1-celled, with an elongated flattened style inserted obliquely, curving inward above the middle in anthesis, grooved and stigmatic on the inner face ; ovule solitary, attached laterally, ascending, semianatropous ; micropyle directed upward. Fruit an oblong compressed dry drupe thick and rounded on the ventral, narrowed on the dorsal edge, rounded at the base, thin and pointed at the apex, chestnut-brown, rugose, with a thick dry exocarp closely investing the thin-walled light brown crustaceous rugose nutlet. Seed flattened, rounded at the ends, light brown, marked on the thick edge with the oblong nearly black hilum ; embryo erect, surrounded by thin fleshy albumen; cotyledons oblong, flattened; radicle superior, conical, short, and fleshy.

The family consists of a single genus, Leitneria, Chapm., with one species of the southern United States, named for a German naturalist killed in Florida during the Seminole War.

\section{Leitneria Floridana, Chapm. Cork Wood.}

Leaves $4^{\prime}-6^{\prime}$ long, $1 \frac{1}{2}^{\prime}-2 \frac{1^{\prime}}{2}$ wide, with petioles $1^{\prime}-2^{\prime}$ in length. Flowers opening at the end of February or early in March; staminate aments $1^{\prime}-1 \frac{1^{\prime}}{4}$ long, $\frac{1^{\prime}}{4}$ thick, and twice as long as the pistillate. Fruit solitary or in clusters of $2-4$, ripening when the leaves are about half grown, $\frac{3^{\prime}}{4}$ long, $\frac{1^{\prime}}{4}$ wide.

A shrub or small tree, occasionally $20^{\circ}$ high, with a slender straight trunk $4^{\prime}-5^{\prime}$ in diameter above the swollen gradually tapering base, spreading branches form-

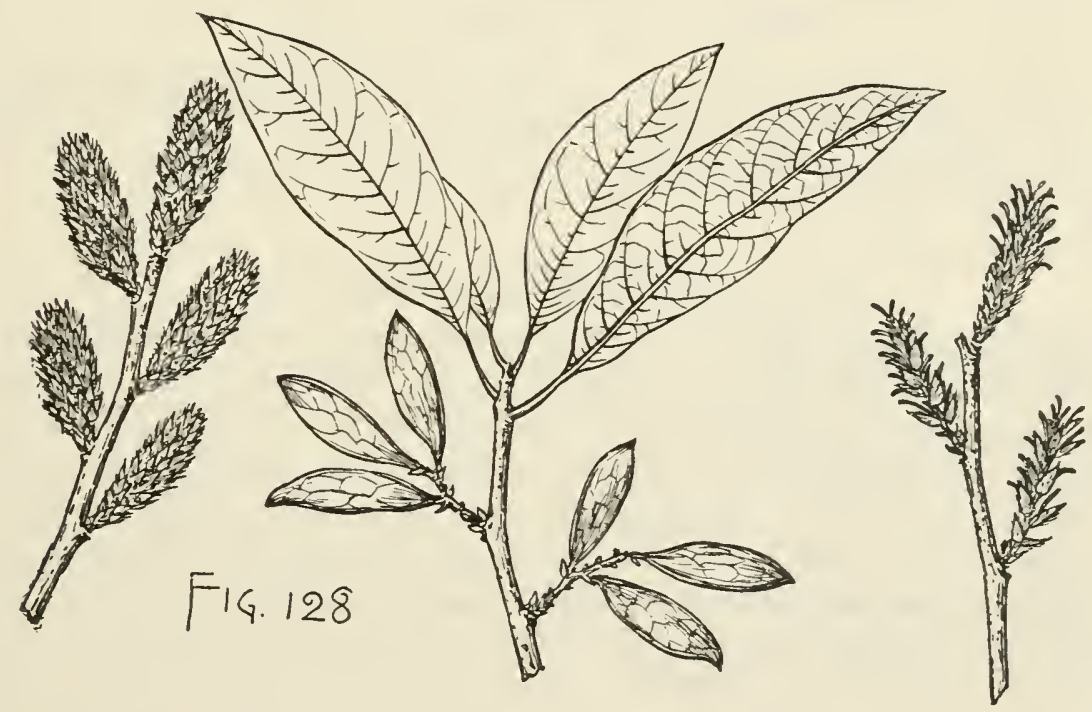

ing a loose open head, and branchlets at first light reddish brown and thickly coated with gradually deciduous hairs, becoming in their first winter glabrous or puberulous, especially toward the ends, and dark red-brown. Winter-buds: terminal broad, conical, $\frac{1}{8}^{\prime}$ long, covered by 10 or 12 oblong nearly triangular closely imbricated scales coated with pale tomentum and long-persistent at the base of the branch; lateral scattered, ovoid, flattened. Bark about $\frac{1}{16}$ thick, dark gray faintly tinged with brown, divided by shallow fissures into narrow rounded ridges. Wood soft, exceedingly light, close-grained, the layers of annual growth hardly distinguishable, pale yellow, without trace of heartwood; occasionally used for the floats of fishing-nets. 
Distribution. Muddy saline shores on the coast of the Gulf of Mexico near Appalachicola, Florida, swamps of the Brazos River near Columbia, Texas; and in Butler and Duncan counties, southeastern Missouri, liere sometines oceupying muddy sloughs of considerable extent to the exclusion of other woody plants.

\section{SALICACEA.}

Trees or shrubs, with watery juice, alternate simple stalked deciduous leaves with stipules, soft light usually pale wood, astringent bark, scaly buds, and often stoloniferous roots. Flowers appearing in early spring before the leaves, solitary in the axils of the scales of unisexual aments from buds in the axils of leaves of the previous year, the male and female on different plants; perianth 0 ; stamens 2 or many, their anthers introrse, 2-celled, the cells opening longitudinally; styles usually short or none; stigmas 2-4, often 2-lobed. Fruit a 1-celled 2-4-valved capsule, with 2-4 placentas bearing below their middle numerous ascending anatropous seeds without albumen and surrounded by tufts of long white silky hairs attached to the short stalks of the seeds and decidnous with them; embryo straight, filling the cavity of the seed; cotyledons flattened, much longer than the short radicle turned toward the minute hilum.

The two genera of this family are widely scattered but most abundant in the northern hemisphere, with many species, and are often conspicuous features of vegetation.

\section{CONSPECTUS OF THE GENERA.}

Scales of the aments laciniate; flowers surrounded by a cup-shaped often oblique disk; stamens numerous; buds with numerous scales.

1. Populus.

Scales of the ament entire; disk a minute gland-like body; stamens 2 or many ; buds with

a single scale.

2. Salix.

\section{POPULUS, L. Poplar.}

Large fast-growing trees, with pale furrowed bark, terete or angled branchlets, resinous winter-buds covered by several thin scales, those of the first pair small and opposite, the others imbricated, increasing in size from below upward, accrescent and marking the base of the branchlet with persistent ring-like scars, and thick roots. Leaves involute in the bud, usually ovate or ovate-lanceolate, entire, dentate, with usually glandular teeth, or lobed, penniveined, turning yellow in the autumn, long-stalked, the stalks sometimes laterally compressed, those of the lower leaves furnished at the apex on the upper side with 2 nectariferous glands, leaving in falling oblong often obcordate, elliptical, arcuate, or shield-shaped leaf-scars displaying the ends of 3 nearly equidistant fibro-vascular bundles; stipules caducous, those of the first leaves resembling the bud-scales, smaller higher on the branch, and linearlanceolate and scarious on the last leaves. Flowers in pendulous stalked aments, the pistillate lengthening and rarely becoming erect before maturity, their scales obovate, gradually narrowed into slender stipes, dilated and lobed, palmately cleft or fimbriate at the apex, membranaceous, glabrous or villose, more crowded on the staminate than on the pistillate ament, usually caducous; disk of the flower broadly cup-shaped, often oblique, entire, dentate or irregularly lobed, fleshy or membranaceons, stipitate, usually persistent under the fruit; stamens 4-12 or 12-60 or more, inserted on the disk, their filaments free, short, light yellow; anthers ovate or oblong, purple or red; ovary sessile in the bottom of the disk, oblong-conical, sub- 
globose or ovate-oblong, cylindrical or slightly lobed, with 2 or 3 or rarely 4 placentas; styles usually short; stigmas as many as the placentas, divided into filiform lobes or broad, dilated, 2-parted or lobed. Fruit ripening before the full growtl of the leaves, greenish, reddish brown, or buff color, oblong-conical, subglobose or ovateoblong, separating at maturity into $2-4$ recurved valves. Seeds broadly obovate or ovate, rounded or acute at the apex, light chestnut-brown; cotyledons eliiptical.

Populus in the extreme north often forms great forests, and is common on the alluvial bottom-lands of streams and on high mountain slopes, ranging from the Arctic Circle to northern Mexico and Lower California and from the Atlantic to the Pacific in the New World, and to northern Africa, the southern slopes of the Himalayas, central China, and Japan in the Old World. Of the twenty-five species now generally recognized eleven are found in North America. The wood of many of the American species is employed in large quantities for paper-niaking, and several species furnish wood used in construction and in the manufacture of small articles of woodenware. The bark contains tannic acid and is used in tanning leather and occasionally as a tonic, and the fragrant balsam contained in the buds of some species is occasionally used in medicine. The rapidity of their growth, their hardiness and ease with which they can be propagated by cuttings, make many of the species useful as ornamental trees or in wind-breaks, altlough planted trees often suffer severely from the attacks of insects boring into the trunks and branches. Of the exotic species, the Abele, or White Poplar, Populus alba, L., of Europe and western Asia, and its fastigiate form, and the so-called Lombardy Poplar, a tree of pyramidal habit and a form of the European and Asiatic Populus nigra, L., have been largely planted in the United States.

Populus, of obscure derivation, is the classical name of the Poplar.

\section{CONSPEC'TUS OF THE NOR'TH AMERICAN SPECIES.}

Stigmas 2, 2-lobed, their lobes filiform; capsule oblong-conical, thin-walled, 2-valved; leaf-stalks elongated, compressed laterally; buds slightly resinous.

Leaves ovate or semiorbicnlar, short-pointed, slightly cordate or truncate at the base, finely serrate; buds usually glabrous.

Leaves broadly ovate, coarsely crenate; bnds tomentose.

2. P. grandidentata' (A).

Stigmas 2-4, 2-lobed and dilated, the lobes variously divided; capsule subglobose to ovateoblong, usually thick-walled, 2-4-valved; buds resinous.

Leaf-stalks round.

Leaves broadly ovate, acute, short-pointed or rounded at the apex, crenatel 5 serrate.

3. P. heterophylla (A, C).

Leaves ovate-lanceolate, acute or acuminate, dark green and lustrons on the upper surface, pale and often rusty on the lower.

Leaves ovate or lanceolate, green on both surfaces.

4. P. balsamifera (AB, F, G).

Leaves rhomboid-lanceolate, long-pointed, green on both surfaces.

6. P. acuminata $(\mathrm{F})$.

Leaves usually broadly ovate, acuminate, rounded or cordate at the broad base, dark green on the upper surface, pale, rusty, or silvery on the lower; ovary tomentose.

7. P. trichocarpa (B, G).

Leaves rhombic to broadly deltoid, elongated, acute or acuminate, green on both surfaces.

8. P. Mexicana (H).

Leaf-stalks compressed laterally.

Pistillate flowers on short pedicels. 
Leaves deltoid or broadly ovate, usually abruptly acuminate, coarsely crenately serrate.

9. P. deltoidea $(\Lambda, C, F)$.

Leaves deltoid or reniform, usually short-pointed at the apex, coarsely and irregularly crenately serrate.

Pistillate flowers on long slender pedicels.

10. P. Fremontii (F, G).

Leaves deltoid, abruptly short-pointed, coarsely crenately serrate.

11. P. Wislizeni (E, H).

1. Stigmas 2 , capsule 2 -valved; leaf-stalks compressed laterally; buds slightly resinous.

\section{Populus tremuloides, Michx. Aspen. Quaking Asp.}

Leaves ovate or semiorbicular, abruptly narrowed at the apex into short broad points, regularly scrrate, with small incurved callous glandular teeth, except at the broad slightly cordate truncate or rarely wedged-shaped base, thin and firm, dark green and lustrous above, pale dull yellow-green below, $1 \frac{1^{\prime}}{2}-2^{\prime}$ long and broad, with slender veins forked and united near the margins and reticulate veinlets; their peti-

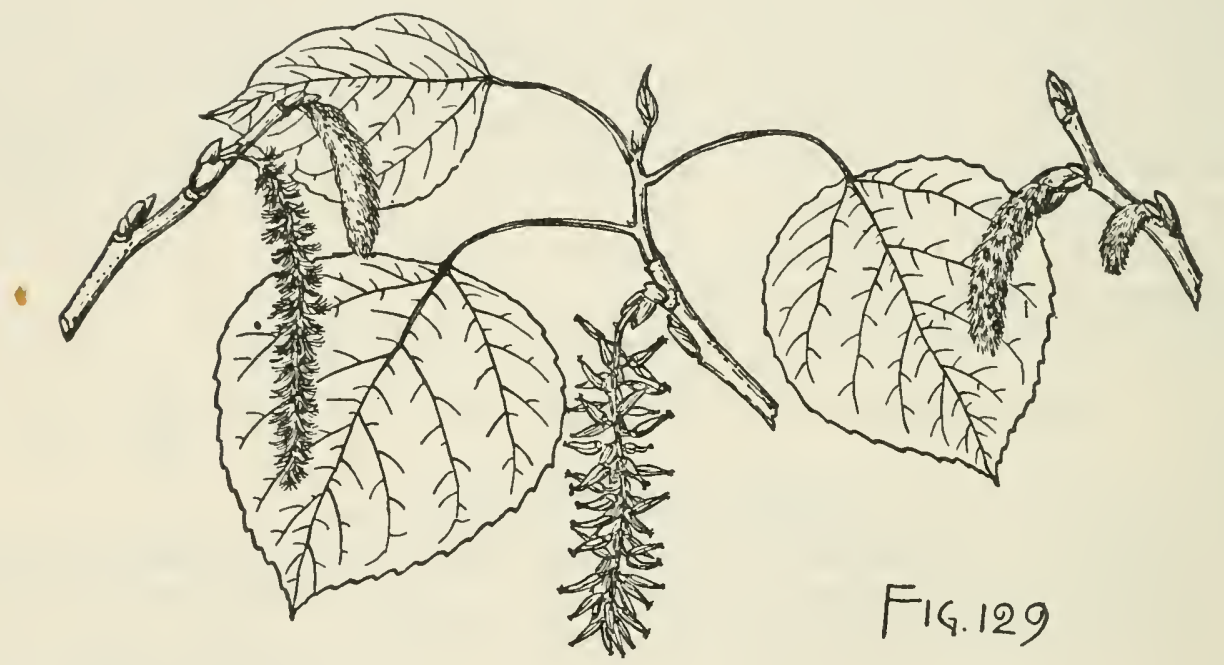

oles slender, compressed laterally, $1 \frac{1}{2}^{\prime}-3^{\prime}$ long. Flowers: aments $1 \frac{1}{2}^{\prime}-2 \frac{1}{2}^{\prime}$ long, the pistillate becoming $4^{\prime}$ long at maturity, their seales deeply divided into 3-5 linear acute lobes fringed with long soft gray hairs; disk oblique, the staminate entire, the pistillate slightly crenate; stamens $6-12$; ovary conical, with a short thick style and erect stigmas thickened and club-shaped below and divided into linear diverging lobes. Fruit maturing in May and June, oblong-conical, light green, thin-walled, nearly $\frac{1}{4}$ long; seeds obovate, light brown, about $\frac{1}{32}$ long.

A tree, often $100^{\circ}$ high, with a trunk occasionally $3^{\circ}$ but generally not more than $18^{\prime}-20^{\prime}$ in diameter, slender remote and often contorted branches somewhat pendulous toward the ends, forming a narrow symmetrical round-topped head, and slender branchlets covered with scattered oblong orange-colored lenticels, bright red-brown and very lustrous during their first season, gradually turning light gray tinged with red, ultimately dark gray, and much roughened for two or three years by the elevated leaf-scars. Winter-buds slightly resinous, conical, acute, often incurved, about $\frac{1^{\prime}}{4}$ long, narrower than the more obtuse flower-buds, with 6 or 7 lustrous glabrous red-brown seales scarious on the margins. Bark thin, pale yellow- 
brown, orange-green, or nearly white, often roughened by horizontal bands of circular wart-like excrescences, frequently marked below the branches by large rows of lunate dark scars, becoming near the base of old trees nearly black, $2^{\prime}$ thick, and deeply divided into broad flat ridges broken on the surface into small appressed plate-like scales. Wood light brown, with nearly white sapwood of 25-30 layers of annual growth.

Distribution. Southern Labrador to the southern shores of Hudson's Bay and northwesterly to the mouth of the Mackenzie River and the valley of the Yukon River, Alaska, through the northern states to the mountains of Pennsylvania, northeastern Missouri and northwestern Nebraska, and through all the mountain regions of the west, often ascending to elevations of $10,000^{\circ}$ above the level of the sea, to the sierras of central California, northern Arizona and New Mexico, the high mountain ranges of Chihuahua and to Mt. San Pedro Martir in Lower California; in the east common and generally distributed usually on moist sandy soil and gravelly hillsides; bordering the midcontinental prairie region with a wide belt, and growing with its greatest vigor and to its largest size on the western margin of the Atlantic forest north of the 49th degree; farther to the northwest forming with the Birch and the Spruce the forests of high ridges; in the west and southwest on the high slopes of mountains and along the banks of streams; most valuable in the power of its seeds to germinate quickly in soil made infertile by fire and of its seedlings to grow rapidly in exposed situations; now widely spread over vast areas of the slopes of the Rocky Mountains swept by fire of their former covering of coniferous trees.

\section{Populus grandidentata, Michx. Poplar.}

Leaves broadly ovate, short-pointed and coarsely and irregularly crenate, with stont incurved callous teeth except at the broad abruptly wedge-shaped truncate or rounded base, thin and firm in texture, dark green above, paler on the lower surface,

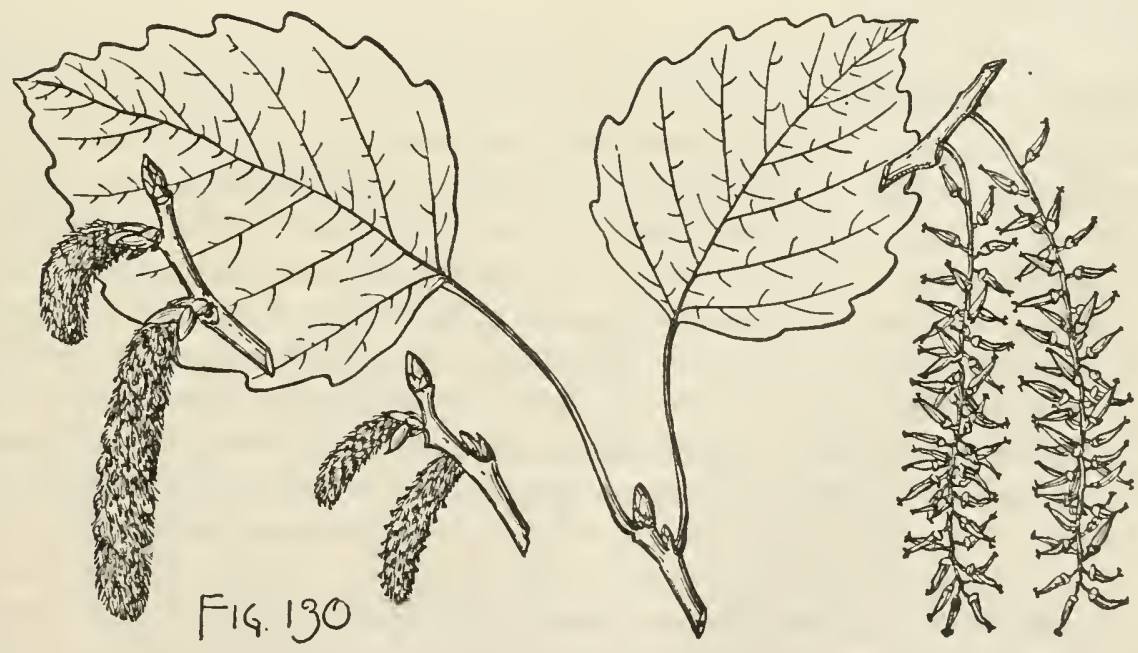

$3^{\prime}-4^{\prime}$ long, $2^{\prime}-3^{\prime}$ broad, with prominent yellow. midribs, conspicuously forked veins, and reticulate veinlets, their petioles slender, laterally compressed, $1 \frac{1}{2}^{\prime}-2 \frac{1}{2}^{\prime}$ long. Flowers: aments $1 \frac{1}{2}^{\prime}-2 \frac{1}{2}^{\prime}$ long, the pistillate becoming $4^{\prime}-5^{\prime}$ long at maturity, their scales pale and scarious below, divided above into 5 or 6 small irregular acute lobes covered with soft pale hairs; disk shallow, oblique, the staminate entire, 
the pistillate slightly crenate; stamens 6-12, with short slender filaments and light red anthers; ovary oblong-conical, bright green, puberulous, with a short style and spreading stignas divided nearly to the base into elongated filiform lobes. Fruit ripening as the leaves unfold, often more or less eurved above the middle, light green and puberulous, thin-walled, 2-valved, about $\frac{1}{8}$ long, and raised on a slender pubcscent stalk; seeds minute, dark brown.

A trec, often $60^{\circ}-70^{\circ}$ ligh, with a trunk occasionally $2^{\circ}$ in diameter, and slender rather rigid branches forming a narrow round-topped head, and stout branchlets marked with seattered oblong orange-colored lenticels, coatcd at first like the unfolding leaves, their petioles and stipules with thick short hoary decidnous tomentum, becoming during their first year dark red-brown or dark orange-colored and glabrous or lustrons, or covered with a delicate gray pubesccnce, and in their second year dark gray sometimes slightly tinged with green and much ronghened by the clevated 3 -lobed leaf-scars; generally smaller and usually not more than $30^{\circ}-40^{\circ}$ tall. Winter-buds terete, broadly ovate, acnte, with light bright chestnut-brown scales, puberulous during the winter especially on their thin scarious margins, about $\frac{1}{8}$ long and not more than half the size of the flower-buds. Bark thin, smootl, liglit gray tinged with green, becoming near the base of old trunks $\frac{3^{\prime}}{4}-\mathbf{1}^{\prime}$ thick, dark brown tinged with red, irregularly fissured and divided into broad flat ridges roughened on the surface by small thick closely appressed scales. Wood light brown, with thin nearly white sapwood of 20-30 layers of annual growth.

Distribution. Rich moist sandy soil near the borders of swamps and streams; Nova Scotia, through New Brunswick, sonthern Quebec and Ontario to northern Minnesota, southward through the northern states to northern Delaware, sonthern Indiana and Illinois, northeastern and central Iowa, and along the Alleghany Mountains to North Carolina, and westward to central Kentucky and Temnessee.

2. Stigmas $2-4$; capsules $2-4$-valved; buds very resinous.

*Leaf-stalks round.

\section{Populus heterophylla, L. Swamp Cottonwood. Black Cottonwood.}

Leaves broadly ovate, gradually narrowed and acute, short-pointed or rounded at the apex, slightly cordate or truncate or rounded at the broad base, usually furnished with a narrow deep sinus, finely or coarsely crenate, with small incurved glandular teeth, covered as they unfold with thick hoary tomentum soon deciduous from the upper surface, becoming thin and firm in texture, dark deep green above, pale and glabrous below, with stont yellow midribs, forked veins and conspicuous reticulate veinlets, $4^{\prime}-7^{\prime}$ long, $3^{\prime}-6^{\prime}$ broad, with slender terete tomentose or nearly glabrous petioles $2 \frac{1}{2}^{\prime}-3 \frac{1^{\prime}}{2}$ long. Flowers: staminate aments broad, densely flowered, $1^{\prime}$ Jong, erect when the flowers first open, becoming pendulous and $2^{\prime}-2 \frac{1}{2}$ long, their scales narrowly oblong-obovate, brown, scarious and glabrous below, divided into numerous elongated filiform light red-brown lobes; disk oblique, slightly concave; stamens 12-20, with slender filaments about as long as the large dark red ar:thers; pistillate aments slender, pendulous, few-flowered, $1^{\prime}-2^{\prime}$ long, becoming erect and $4^{\prime}-6^{\prime}$ long before maturing, their scales concave and infolding the flowers, linearobovate, brown and scarions, laterally lobed, fimbriate above the middle, caducous; disk thin, irregularly divided in numerous triangular acute teeth, long-stalked; ovary ovoid, terete or obtusely 3 -angled, with a short stont elongated style and 2 or 3 much-thickened dilated 2 or 3-lobed stigmas. Fruit on elongated pedicels, ripening 
when the leaves are about one third grown, ovate, acute, dark red-brown, rather thick-walled, 2 or 3 -valved, about $\frac{1}{2}^{\prime}$ long; seeds obovate, minute, dark red-brown.

A tree, $80^{\circ}-90^{\circ}$ high, with a tall trunk $2^{\circ}-3^{\circ}$ in diameter, short rather slender branches forming a comparatively narrow round-topped head, and stout branchlets,

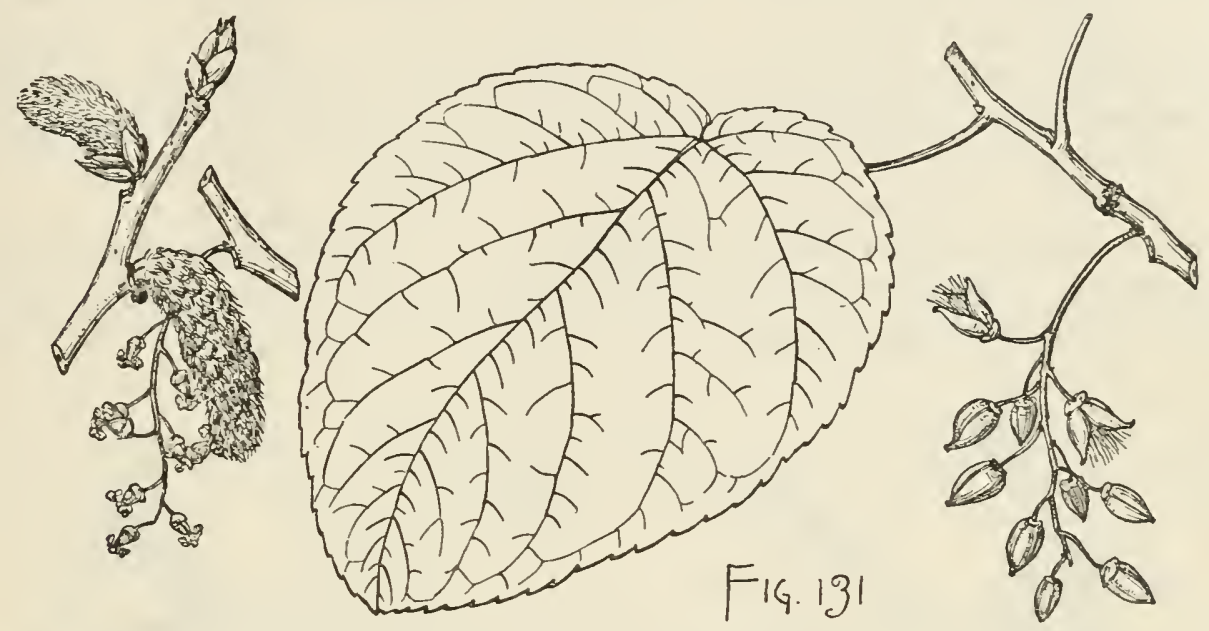

marked by small elongated pale lenticels, coated at first with hoary caducous tomentum, becoming dark brown and rather lustrous or ashy gray, or rarely pale orange color and glabrous or slightly puberulous, or covered with a glaucous bloom in their first winter, growing darker in their second year and much roughened by the large thickened leaf-scars; usnally much smaller and at the north rarely more than $40^{\circ}$ tall. Winter-buds slightly resinous, broadly ovate, acute, with bright redbrown scales, about $\frac{1}{4}^{\prime}$ long and about one half the size of the flower-buds. Bark on young trunks divided by shallow fissures into broad flat ridges separating on the surface into thick plate-like scales, becoming on old trunks $\frac{3^{\prime}}{4}-1^{\prime}$ thick, light brown tinged with red, and broken into long narrow plates attached only at the middle and sometimes persistent for many years. Wood dnll brown, with thin lighter brown sapwood of 12-15 layers of annual growth; now often manufactured into lumber in the valley of the Mississippi River and in the Gnlf states, and as black poplar used in the interior finish of buildings.

Distribution. Southington, Connecticut, and Northport, Long Island, southward near the coast to sonthern Georgia, through the Gulf states to western Louisiana, and through Arkansas to southeastern Missouri, western Kentucky and Tennessee, and southern Illinois and Indiana; in the north Atlantic states in low wet swamps, and rare and local; more common south and west on the borders of river swamps; very abundant and of its largest size in the valley of the lower Ohio and in southeastern Missouri, eastern Arkansas, and western Mississippi.

\section{Populus balsamifera, I. Balsam. Tacamahac.}

Leaves ovate-lanceolate, gradually narrowed and acute or acuminate at the apex, rounded or cordate at the broad or rarely narrowed base, finely crenately serrate, with slightly thickened revolnte margins, coated when they unfold with the gummy secretions of the bud and sometimes slightly puberulous, becoming thin and firm in texture, deep dark green and lustrous above, pale green and more or less rusty and conspicuously reticulate-venulose below, $3^{\prime}-5^{\prime}$ long, $1 \frac{1}{2}^{\prime}-3^{\prime}$ wide, with thin veins run- 
ning obliquely almost to the margins, and slender tercte petioles $1 \frac{1}{2}$ long, abruptly enlarged at the base. Flowers: aments long-stalked, the pistillate becoming $4^{\prime}-5^{\prime}$ long before the fruit ripens, their scales broadly obovate, light brown and scarious, often irregularly 3-parted at the apex, cut into short thread-like brown lobes; disk of the staminate flower oblique, short-stalked; stamens 20-30, with short filanents and large light red anthers; disk of the pistillate flower cup-shaped; ovary ovate, slightly 2-lobed, with 2 nearly sessile large oblique dilated crenulate stigmas. Fruit ovate-oblong, acute and often curved at the apex, 2-valved, light brown, about $\frac{1}{4}$ long, raised on a slender stalk $\frac{1}{12}^{\prime}-\frac{1}{8}^{\prime}$ long; seeds oblong-obovate, pointed at the apex, narrowed and truncate at the base, light brown, about $\frac{1}{12}$ long.

A trce, oftcn $100^{\circ}$ high, with a tall trunk $6^{\circ}-7^{\circ}$ in diameter, stout erect branches usually more or less contorted near the ends, forming a comparatively narrow open liead, and branchlets marked by oblong bright orangc-colored lenticels, much

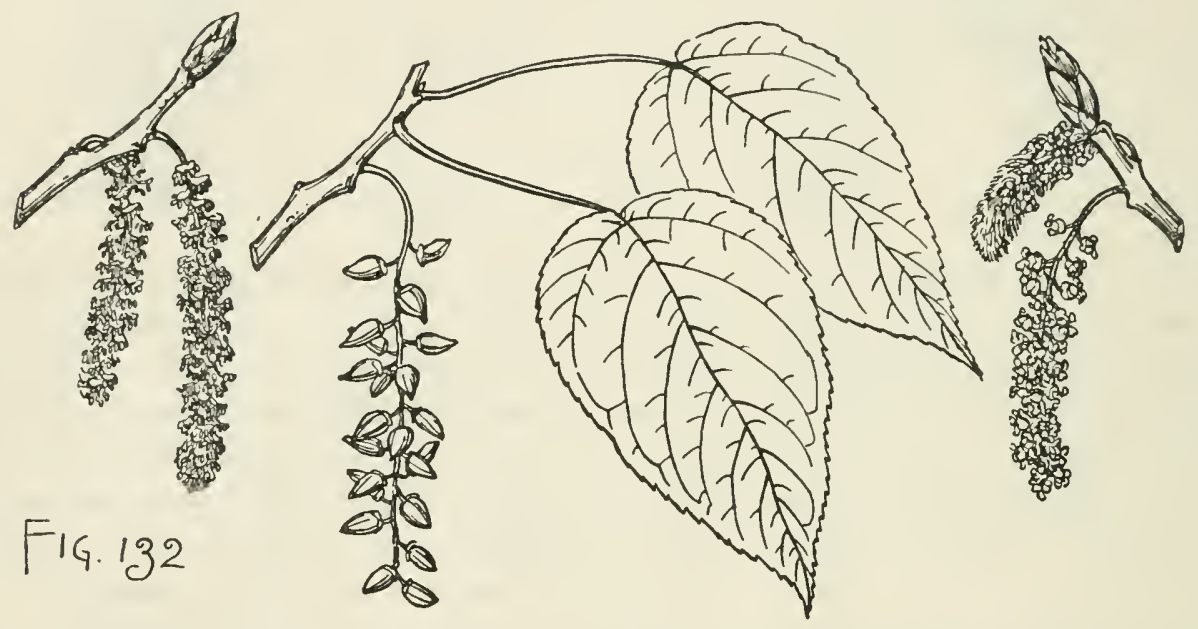

roughened by the thickened leaf-scars, at first red-brown and glabrous or pubescent, becoming bright and lustrous in their first winter, dark orange-colored in their second year, and finally gray tinged with yellow-greell; usually much smaller toward the southern limits of its range. Winter-buds saturated with a yellow balsamic sticky exudation, ovate, terete, long-pointed, terminal $1^{\prime}$ long and $\frac{1}{3}^{\prime}$ broad; axillary about $\frac{3^{\prime}}{4}$ long, $\frac{1^{\prime}}{16}$ broad, with 5 oblong pointed concave closely imbricated thick chestnut-brown lustrous scales. Bark light brown tinged with red, smooth or ronghened by dark excrescences, becoming on old trunks $\frac{8^{\prime}}{4}-1^{\prime}$ thick, gray tinged with red, and divided into broad rounded ridges covered by small closely appressed scales. Wood light brown, with thick nearly white sapwood.

Distribution. Low often inundated river-bottom lands and swamp borders; Labrador to latitude $65^{\circ}$ north in the valley of the Mackenzie River, and to the Alaskan coast, south to northern New England and New York, central Michigan and Minnesota, the Black Hills of Dakota, northwestern Nebraska, northern Montana, Idaho, Oregon, and Nevada; the characteristic tree on the streams of the prairie region of British America, attaining its greatest size on the islands and banks of the Peace, Athabasca, and other tributaries of the Mackenzie; common in all the region near the northern boundary of the United States from Maine to the western limits of the Atlantic forests; the largest of the sub-Arctic American trees, and in the far north the most conspicuous feature of vegetation.

Often planted at the north for shelter or ornament. 
In the northeastern United States and in Canada a form of this tree, var. candicans, Gray, Balm of Gilead, is frequently cultivated as a shade-tree and has sometimes escaped and become spontaneous. It differs from the common form in its more spreading branches, forming a broader and more open head, in its broader cordate coarsely serrate leaves, with gland-tipped teeth, more or less pubescent when young and at maturity paler on the lower surface, ciliate on the margins, with short white hairs and usually pubescent along the principal veins, and in its pubescent petioles and rather heavier wood; of uncertain origin, probably not indigenous in New England or eastern Canada.

\section{Populus angustifolia, James. Narrow-leaved Cottonwood.}

Leaves lanceolate, ovate-lanceolate or rarely obovate, narrowed to the tapering acute or rounded apex, gradually narrowed and wedge-shaped or rounded at the base, finely or on vigorous shoots coarsely serrate, thin and firm, bright yellow-green above, glabrous or rarely puberulous and paler below, $2^{\prime}-3^{\prime}$ long, $\frac{1}{2}^{\prime}-1^{\prime}$ wide, or on vigorous shoots occasionally $6^{\prime}-7^{\prime}$ long, and $1 \frac{1}{2}^{\prime}$ wide, with stout yellow midribs and numerous slender oblique primary veins arcuate and often united near the

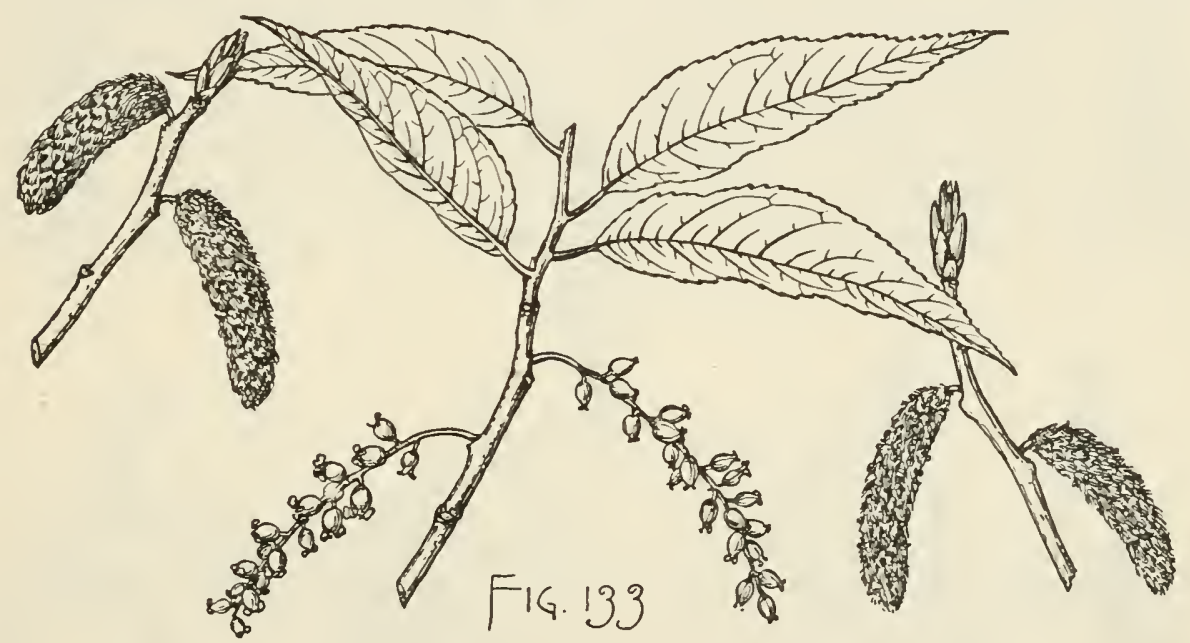

slightly thickened revolute margins; their petioles slender, somewhat flattened on the upper side, and in falling leaving small nearly oval obcordate scars. Flowers: aments densely flowered, glabrous, short-staiked, $1 \frac{1}{2}^{\prime}-2 \frac{1}{2}^{\prime}$ long, the pistillate becoming $21^{\prime}-4^{\prime}$ long before the fruit ripens, their scales broadly obovate, glabrous, thin, scarious, light brown, deeply and irregularly cut into numerous dark red-brown filiform lobes; disk of the staminate flower cup-shaped, slightly oblique, short-stalked; stamens 12-20, with short filaments and large light red anthers; disk of the pistillate flower shallow, cup-shaped, slightly and irregularly lobed, short-stalked; ovary ovate, more or less 2-lobed, with a short or elongated style and 2 oblique dilated irregularly lobed stigmas. Fruit broadly ovate, often rather abruptly contracted above the middle, short-pointed, thiu-walled, 2-valved, on stems of ten $\frac{1}{3}^{\prime}$ long; seeds ovate or obovate, rather obtuse, light brown, nearly $\frac{1^{\prime}}{8}$ long.

A tree, $50^{\circ}-60^{\circ}$ high, with a trunk rarely more than $18^{\prime}$ in diameter, slender erect branches forming a narrow and usually pyramidal head, and slender glabrous or rarely puberulous branchlets marked by pale lenticels, at first light yellowgreen, becoming bright or dark orange-colored during their first winter, pale yellow 
in their second, and nltimately ashy gray. Winter-buds very resinous, ovate, longpointed, covered by usnally 5 thin concave eliestunt-brown scales, the terminal $\frac{1^{\prime}-\frac{1}{2}}{2}$ long and nearly twice as large as the axillary buds. Bark ${ }_{4}^{\prime \prime}-1^{\prime}$ thick, light yellow-green, divided near the base of old trees by shallow fissures into broad flat ridges, smooth and much thinner above. Wood light brown, with thin nearly white sapwood of 10-30 layers of ammal growth.

Distribution. Banks of streams nsually at elevatious of $5000^{\circ}-10,000^{\circ}$ above the sea; sonthwestern Assiniboia to the Black Hills of Dakota and northwestern Nebraska, and sonthward along the momntain streams of the interior of the continent to central Nevada and New Mexico and sonthern Arizona; the common Cottonwood of northern Colorado, Utah, Wyoming, southern Montana, and eastern Idaho.

\section{Populus acuminata, Rydb. Cottonwood.}

Leaves rhombic-lanceolate, abruptly acuminate, gradually or abruptly narrowed and cuneate or concave-cuneate, or rarely broad and rounded at the mostly entire base, coarsely crenately serrate except near the apex, dark green and lustrons above, dull green below, $2^{\prime}-4^{\prime}$ long, $\frac{3^{\prime}}{4}-2^{\prime}$ wide, with slender yellow midribs, thin remote primary veins and obscure reticnlate veinlets; their petioles slender, nearly terete, $1^{\prime}-3^{\prime}$ long. Flowers: aments slender, short-stalked, $2^{\prime}-3^{\prime}$ long, the pistillate becoming $4^{\prime}$ or $5^{\prime}$ long before the frnit ripens, their scales scarions, light brown, glabrous, dilated and irregularly divided into filiform lobes; disk of the staminate flower wide, oblique, and membranaceous; stamens numerous, with short filaments and dark red anthers; disk of the pistillate flower deep cup-shaped; ovary broadly ovate, gradually

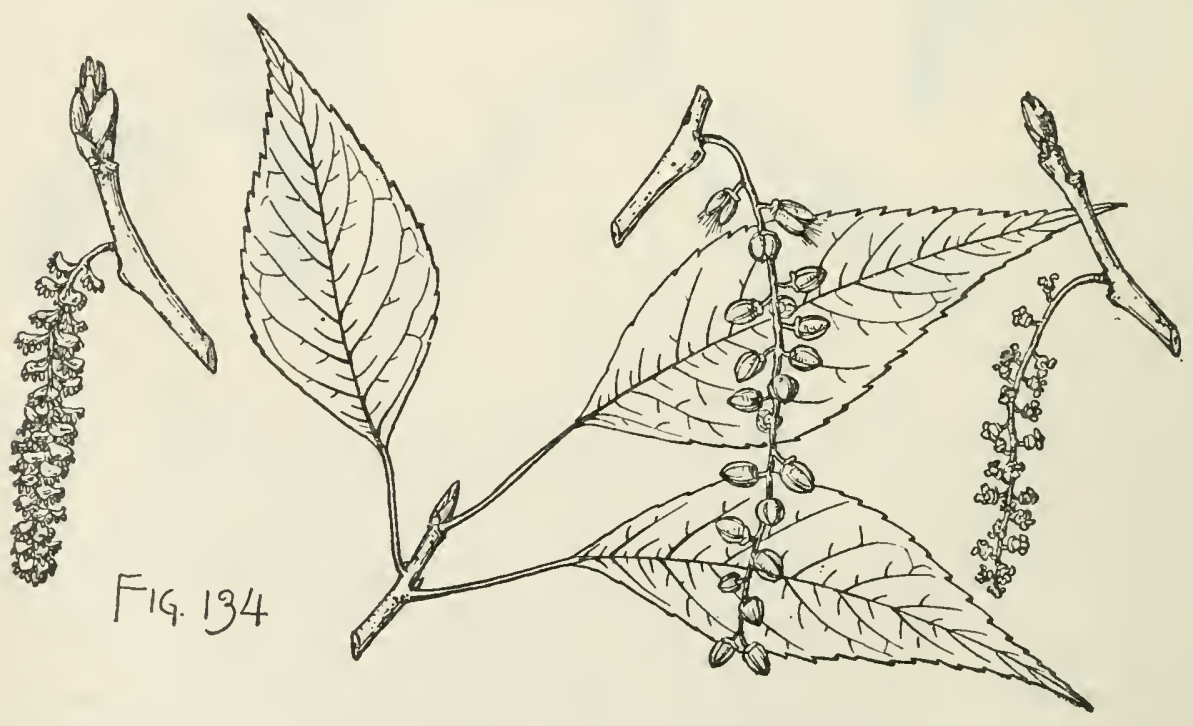

narrowed above, with large laciniately lobed nearly sessile stigmas. Fruit pedicellate, oblong-ovate, acute, thin-walled, slightly pitted, about $\frac{1^{\prime}}{3}$ long, 3 or rarely 2-valved; seeds oblong-obovate, rounded at the apex, light brown, about $\frac{1}{12}$ in length.

A tree, usually about $40^{\circ}$ high, with a trunk $12^{\prime}-18^{\prime}$ in diameter, stont spreading ascending branches forming a compact round-topped head, and slender terete or slightly 4-angled pale yellow-brown branchlets roughened for two or three years by 
the elevated oval horizontal leaf-scars. Winter-buds acuminate, resinous, about $\frac{1}{3}{ }^{\prime}$ long, with 6 or 7 light chestnut-brown lustrous scales. Bark on young stems and large branches smooth, nearly white, becoming on old trunks pale gray-brown, about $\frac{1^{\prime}}{2}$ thick, deeply divided into broad flat ridges.

Distribution. Banks of streams in the arid eastern foothill region of the Rocky Mountains ; Assiniboia to western Nebraska, eastern Wyoming, and southern Colorado.

Sometimes planted as a shade-tree in the streets of cities in the Rocky Mountain region.

\section{Populus trichocarpa, Hook. Black Cottonwood. Balsam Cottonwood.}

Leaves broadly ovate to oblong-rhombic, gradually narrowed and usually shortpointed or rarely acute at the apex, broad, rounded or slightly cordate or occasionally slightly narrowed and wedge-shaped at the base, finely crenately serrate, coated

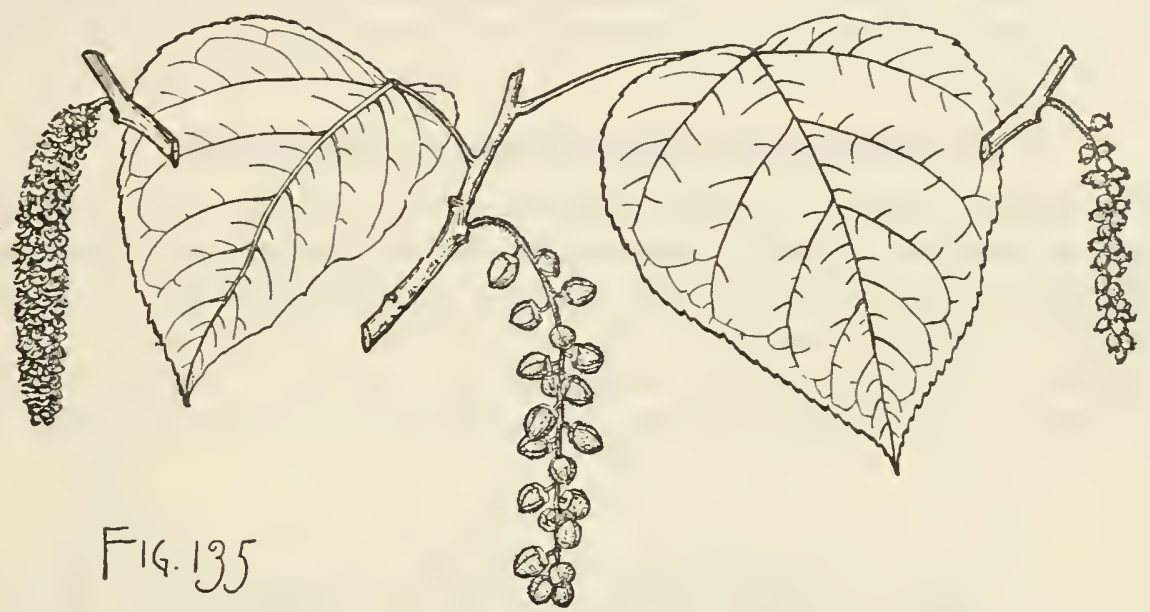

at first with rufous or pale pubescence, becoming thick and firm, dark rich green, glabrous or puberulous and lustrous above, pale and rusty or silvery white and conspicuously reticulate-venulose below, $3^{\prime}-4^{\prime}$ long, $1 \frac{1^{\prime}}{2}-3^{\prime}$ broad; their petioles slender, terete, puberulous, $1^{\prime}-2^{\prime}$ long. Flowers : aments stalked, the staminate densely flowered, $1 \frac{1}{2}^{\prime}-2^{\prime}$ long, $\frac{1^{\prime}}{3}$ thick, with slender glabrous stems, the pistillate loosely flowered, $2 \frac{1}{2}-3^{\prime}$ long, with stout hoary-tomentose stems becoming $4^{\prime}-5^{\prime}$ long before the fruit ripens, their scales dilated at the apex, irregularly cut into numerous filiform lobes, glabrous or slightly puberulous on the outer surface; disk of the staminate flower broad, slightly oblique; stamens 40-60, with slender elongated filaments longer than the large light purple anthers; disk of the pistillate flower deep cup-shaped, with irregularly crenate or nearly entire revolute margins; ovary subglobose, coated with thick hoary tomentum, with 3 nearly sessile broadly dilated deeply lobed stigmas. Fruit subglobose, nearly sessile, pubescent or rarely almost glabrous, thick-walled, 3-valved; seeds obovate, apiculate at the gradually narrowed apex, light brown, puberulous toward the ends, $\frac{1}{12}$ long.

A tree, often $200^{\circ}$ high, with a trunk $7^{\circ}-8^{\circ}$ in diameter, heavy upright branches forming a broad open head, and stout branchlets terete or slightly angled while young, marked by many orange-colored lenticels, coated at first with deciduous rufous or pale pubescence, light or dark orange-colored and lustrous during their 
first year, gradually becoming dark gray, and roughened by the greatly enlarged and thickened elevated leaf-scars. Winter-buds resinous, fragrant, ovate, longpointed, frequently curved above the middle, $\frac{3^{\prime}}{4}$ long and $\frac{1^{\prime}}{4}$ broad, with 6 or 7 light orange-brown slightly puberulous scales scarious on the margins. Bark $1 \frac{1}{2}{ }^{\prime}-2 \frac{1}{2}{ }^{\prime}$ thick, ashy gray, deeply divided into broad rounded ridges broken on the surface into thick closely appressed scales. Wood light, dull brown, with thin nearly white sapwood; largely used in Oregon and Washington for the staves of sugar barrels and in the manufacture of woodenware.

Distribution. In open groves by the banks of streams; sonthern Alaska, southward to western Oregon, along the mountains and islands of western California to the southern slopes of the San Bernardino Mountains, and eastward through British Columbia to the valley of the Columbia River; of its largest size near the level of the sea in all the coast region north of California; southward and beyond the influence of the ocean often not more than $30-^{\circ} 40^{\circ}$ tall; sometimes ascending to elevations of $6000^{\circ}$ above the sea on the western slope of the Sierra Nevada of central California; the largest of the broad-leaved trees of British Columbia, Washington, and Oregon.

\section{Populus Mexicana, Wesm. Cottonwood.}

Leaves rhombic and long-pointed, especially on young trees, or broadly deltoid and acute or acuminate, broadly or acutely cuneate or truncate or slightly cordate at the base, or often rounded at the apex and much broader than long, usually coarsely and irregularly crenately serrate except at the base and toward the apex, the broad and rounded leaves finely crenulate-serrate above the middle, as they unfold dark red, covered below with pale pubescence, puberulous above, ciliate on the

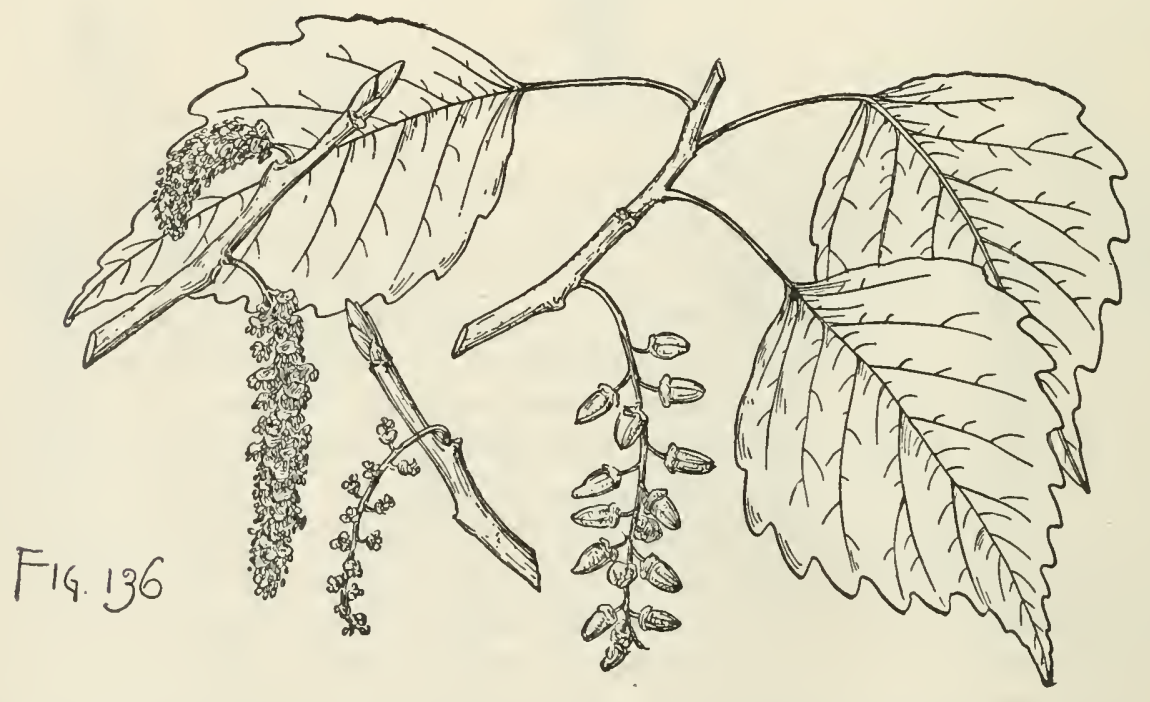

margins, thin, terete, glandular, with bright red caducous glands, soon becoming glabrous, and at maturity subcoriaceous, bright yellow-green, very lustrous, $2^{\prime}-3^{\prime}$ long and somewhat narrower or much broader than long, with slender yellow midribs and obscure primary veins; their petioles terete, at first puberulous, soon glabrous, $1 \frac{1}{2}^{\prime}-2^{\prime}$ long. Flowers: staminate aments dense, cylindrical, $1^{\prime}-1 \frac{1}{2}^{\prime}$ long; pistillate aments slender, many-flowered, $1 \frac{1^{\prime}}{2}-2^{\prime}$ long, $3^{\prime}-4^{\prime}$ long before the fruit ripens; 
disk of the staminate flower broad, oblong; stamens numerous; disk of the pistillate flower deep cup-shaped, nearly entire; ovary ovate, rounded at the apex, slightly 3 or 4-angled, short-stalked, nearly inclosed in the cup-shaped membranaceous disk. Fruit on short stout pedicels, round-ovoid, buff color, slightly 3 or 4-lobed, deeply pitted, thin-walled, about $\frac{1}{3}^{\prime}$ long.

A tree, sometimes $80^{\circ}$ high, with a trunk $3^{\circ}-4^{\circ}$ in diameter, gracefully spreading and ascending branches forming a broad open head, and slender branchlets, pale green and more or less pubescent or villose at first, soon becoming glabrous, and light yellow-brown during their first season. Winter-buds narrow, acute, light orange-brown, puberulous toward the base of the outer scales, the terminal about $\frac{1}{4}$ long, and two or three times as large as the nucli-compressed oblong lateral buds. Bark pale gray or rarely white, and deeply divided into broad flat ridges.

Distribution. Banks of mountain streams; southern Arizona and southwestern New Mexico; widely distributed through northern Mexico.

Often planted as a shade-tree in Mexican cities.

\section{**Leaf-stalks compressed laterally.}

\section{Populus deltoidea, Marsh. Cottonwood.}

Leaves deltoid or broadly ovate, acuminate, with entire points, or rarely rounded at the apex, truncate, slightly cordate or occasionally abruptly wedge-shaped at the entire base, coarsely crenately serrate above, with incurved glandular teeth, as they
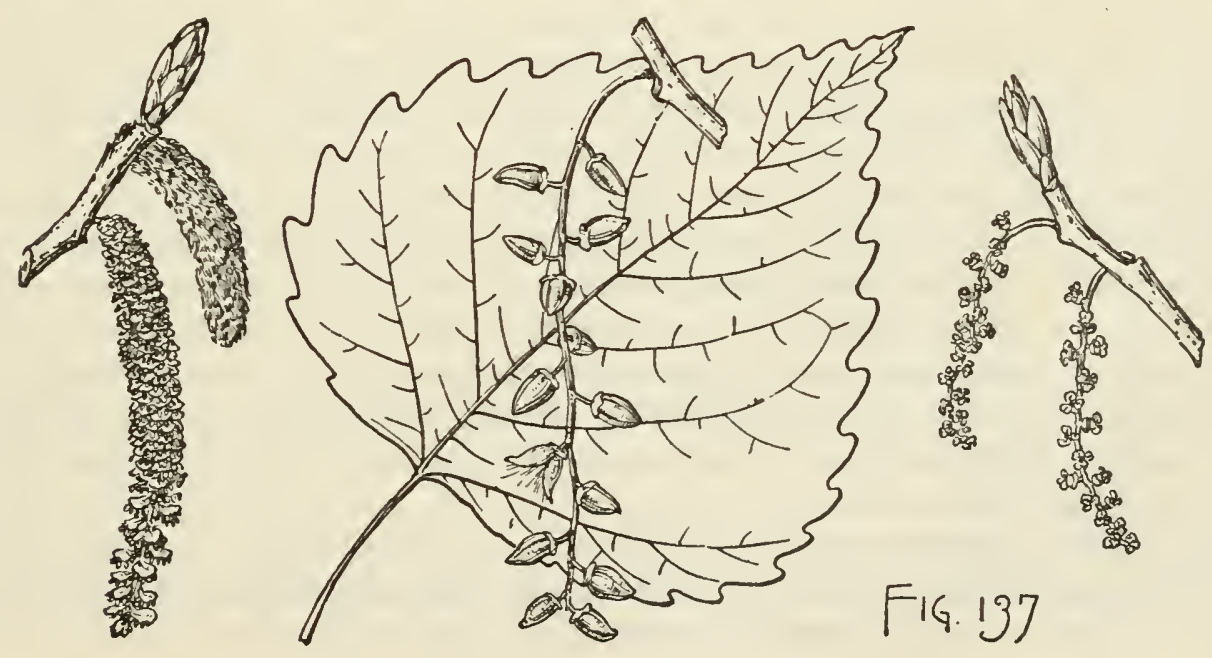

unfold gummy, fragrant with a balsamic odor, covered more thickly below than above with soft white caducous hairs, and tomentose on the margins, at maturity thick and firm, light bright green and lustrous, paler on the lower than on the upper surface, $3^{\prime}-5^{\prime}$ long and broad, with stout yellow midribs often tinged with red toward the base, raised and rounded on the upper side, and conspicuous primary veins; their petioles slender, pilose at first, soon glabrous, compressed laterally, yellow more or less tinged with red, $2 \frac{1}{2}^{\prime}-3 \frac{1}{2}^{\prime}$ long. Flowers : aments short-stalked, the staminate densely flowered, $3^{\prime}-4^{\prime}$ long, $\frac{1^{\prime}}{2}$ thick, with stout glabrous stems, the pistillate sparsely flowered, thin-stemmed, often becoming a foot long before the fruit ripens, their scales scarious, light brown, glabrous, dilated and irregularly divided at the apex 
into filiform lobes; disk of the staninate flower broad, oblique, slightly thickened and revolute on the margins; stamens 60 or more, with short flaments and large dark red anthers; disk of the pistillate flower broad cup-shaped; ovary subglobose, with 3 or 4 nearly sessile dilated or laciniatcly lobed stigmas. Fruit oblong-ovate, rather abruptly contracted and acute at the apex, slightly pitted, thin-walled, $\frac{1}{4}-\frac{1}{2}$ long, dark green, 3 or 4 -valved, its stem $\frac{1^{\prime}}{3}-\frac{1}{2}$ long; seeds oblong-obovate, rounded at the apex, light brown, about $\frac{1}{1 \frac{1}{2}}$ long.

A trce, sometimes $100^{\circ}$ high, with a trunk occasionally $7^{\circ}-8^{\circ}$ in diameter, divided oftcn $20^{\circ}-30^{\circ}$ above the ground into several massive limbs spreading gradually and becoming pendulous toward the cnds, and forming a graceful rather open head frequently $100^{\circ}$ across, or on young trees nearly erect above and spreading below almost at right angles with the stem, and forming a symmetrical pyramidal head, and stout branchlets marked with long pale lenticels, terete or, especially on vigorous trees, becoming angled in their second year, with thin more or less prominent wings extending downward from the two sides and the bases of the large 3-lobed leafscars. Winter-buds very resinous, ovate, acute, the lateral much flattened, $\frac{1}{2}$ long, with 6 or 7 light chestnut-brown lustrous scales. Bark thin, smooth, light yellow tinged with green on young stems and branches, becoming on old trunks $1 \frac{1^{\prime}}{2}-2^{\prime}$ thick, ashy gray, and decply divided into broad rounded ridges broken into closely appressed scales. Wood dark brown, with thick nearly white sapwood, warping badly in drying and difficult to season.

Distribution. Banks of streams, often forming extensfve open groves; Province of Quebec and the shores of Lake Champlain, through western New England and New York, Pennsylvania west of the Alleghany Mountains, and the Atlantic states south of the Potomac River to western Florida, and westward to the base of the Rocky Mountains from southern Alberta to northern New Mexico; westward passing into the var. occidentalis, Rydb., with deltoid more abruptly acuminate and more coarsely toothed leaves with longer points, and broader at the base, and the common Cottonwood in the region along the eastern base of the Rocky Mountains from Alberta to New Mexico and throngh western Texas. Comparatively rare and of smaller size in the east and in the coast region of the south Atlantic and east Gulf states, and the largest and one of the most abundant trees along the streams between the Appalachian and the Rocky Mountains, marking their course over the midcontinental platean to the extreme limit of tree-growth, and growing to its largest size as far west as the 100th meridian.

Often planted for shelter and ornament on the treeless plains and prairies between the Mississippi River and the Rocky Mountains, and as an ornamental tree in the eastern United States, and largely in western and northern Europe.

\section{Populus Fremontii, Wats. Cottonwood.}

Leaves deltoid or reniform, generally contracted into broad short entire points, or rarely rounded or emarginate at the apex, truncate, lightly cordate or abruptly wedge-shaped at the entire base, coarsely and irregularly serrate, with few or many incurved gland-tipped teeth, coated like the petioles when they unfold with short spreading caducous pubescence, at maturity thick and firm, bright green and lustrous, $2^{\prime}-2 \frac{1}{2}^{\prime}$ long, $2 \frac{1^{\prime}}{2}-3^{\prime}$ broad, with thin yellow midribs and 4 or 5 pairs of slender veins; their petioles flattened, yellow, $1 \frac{1}{2}^{\prime}-3^{\prime}$ long. Flowers: staminate aments densely flowered, $1 \frac{1}{2}^{\prime}-2^{\prime}$ long, nearly $\frac{1}{2}^{\prime}$ broad, with slender glabrous stems; the pistillate sparsely flowered, with stout glabrous or puberulons stems, $2^{\prime}$ long, becom- 
ing before the fruit ripens $4^{\prime}$ or $5^{\prime}$ long, their scales light brown, thin and scarious, dilated and irregularly cut at the apex into filiform lobes; disk of the staminate
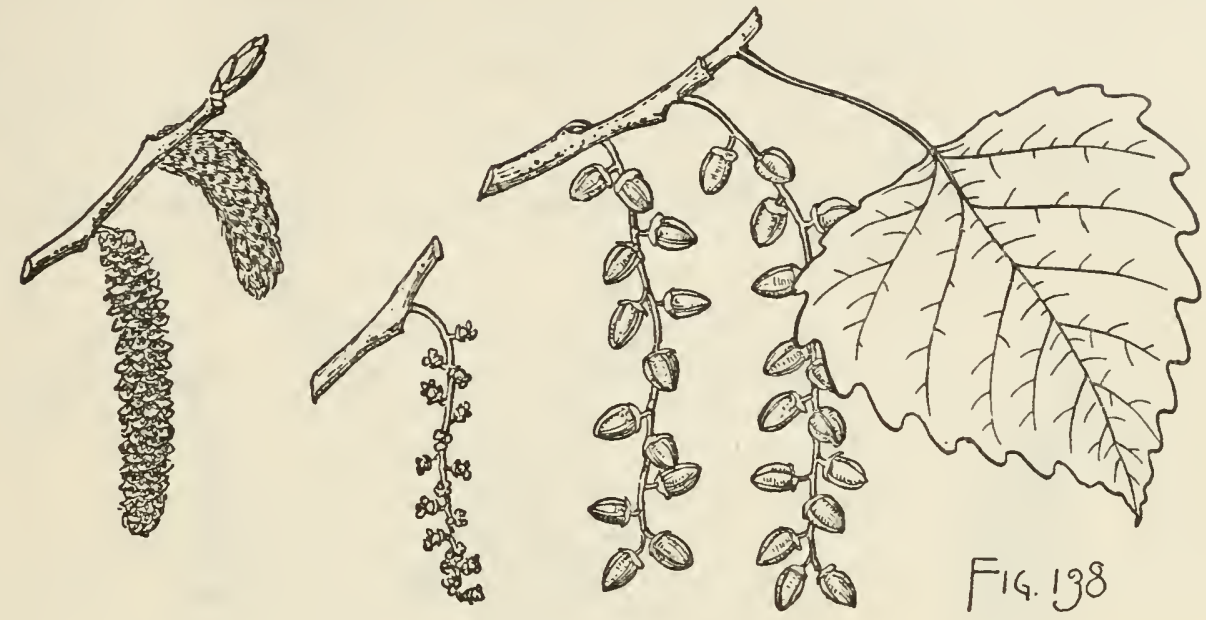

flower broad, oblique, slightly thickened on the entire revolute margins; stamens 60 or more, with large dark red anthers; disk of the pistillate flower cup-shaped; ovary ovate or ovate-oblong, with 3 broad irregularly crenately lobed stigmas. Fruit ovate, acute or obtuse, slightly pitted, thick-walled, 3 or rarely 4-valver, $\frac{1^{\prime}}{3}-\frac{1}{2}^{\prime}$ long, its stalk stout, from $\frac{1}{20}{ }^{\prime}-\frac{1}{6}^{\prime}$ long; seeds ovate, acute, light brown, and nearly $\frac{1}{8}^{\prime}$ long.

A tree, occasionally $100^{\circ}$ high, with a short trunk $5^{\circ}-6^{\circ}$ in diameter, and stout spreading branches pendulous at the ends and forming a broad rather open graceful head, and slender terete branchlets light green and covered at first with short pale caducous pubescence, becoming light yellow before winter, dark or light gray more or less tinged with yellow in their second year, and only slightly roughened by the small 3-lobed leaf-scars. Winter-buds ovate, acute, with light green lustrous scales, the terminal usually about $\frac{1}{3}^{\prime}$ long and usually two or three times as large as the lateral buds. Bark on young stems light gray-brown, thin, smooth or slightly fissured, becoming on old trees $1 \frac{1}{2}-2^{\prime}$ thick, dark brown slightly tinged with red, and deeply and irregularly divided into broad connected rounded ridges covered with small closely appressed scales. Wood light brown, with thin nearly white sapwood.

Distribution. Banks of streams ; valley of the upper Sacramento River southward through western California to Lower California and eastward to central Nevada, southern Utah, southern Colorado, and western Texas.

Often planted in southern California as a shade-tree, and for the fuel produced quickly and abundantly from pollarded trees.

\section{Populus Wislizeni, Sarg. Cottonwood.}

Leaves broadly deltoid, abruptly short-pointed, truncate or sometimes cordate at the broad entire base, coarsely and irregularly crenately serrate except toward the entire apex, coriaceous, glabrous, yellow-green and lustrous, $2^{\prime}-2 \frac{1}{2}^{\prime}$ long, usually about $3^{\prime}$ wide, with slender yellow midribs, thin remote primary veins and conspicuous reticulate veinlets; their petioles slender, glabrous, $1 \frac{1}{2}^{\prime}-2^{\prime}$ long. Flowers: aments $2^{\prime}-4^{\prime}$ long, the pistillate becoming $4^{\prime}-5^{\prime}$ long before the fruit ripens, their scales scarious, light red, divided at the apex into elongated filiform lobes; disk of the 
staminate flower broad and oblique; stamens numerous, witl large oblong anthers and short filaments; disk of the pistillate flower enp-shaped, irregularly dentatc, inclosing to the middle the long-stalked ovary full and rounded at the apcx, with 3 broad crenulate lobed stigmas raised on the short branches of the style. Fruit oblong-ovate, thick-walled, acute, 3 or 4-valved, slightly ridged, buff color, $\frac{1}{4}$ long, on slender pedicels $\frac{1^{\prime}}{2}-3^{\prime}$ in length and placed rather remotely on the slender glabrous rachis of the ament.

A large tree, with wide-spreading branches, stout light orangc-colored glabrous
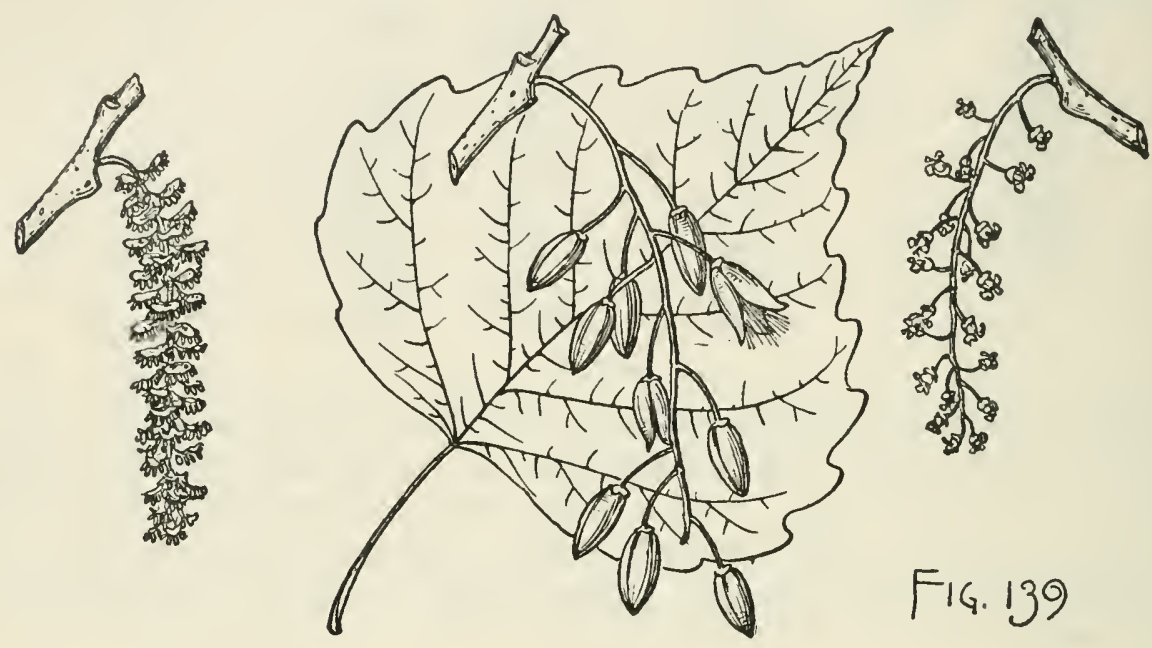

branchlets, and acute lustrous buds. Bark pale gray-brown, deeply divided into broad flat ridges.

Distribution. The common Cottonwood in the valley of the Rio Grande of western Texas and New Mexico, and the adjacent parts of Mexico.

\section{SALIX, L. Willow.}

Trees or shrubs, with watery juice, scaly bark, soft wood, slender terete tough branchlets often easily separated at the joints, and winter-buds covered by a single scale of 2 coats, the inner membranaceous, stipular, rarely separable from the outer, inclosing at its base 2 minnte opposite lateral buds alternate with 2 small scale-like caducous leaves coated with long pale or rufous hairs. Leaves variously folded in the bud, alternate, simple, lanceolate, obovate, rotund or linear, penniveined; their petioles sometimes glandular at the apex, and more or less covering the bud, in falling leaving U-shaped or arcuate elevated leaf-scars displaying the ends of 3 small equidistant fibro-vascular bundles; stipules oblique, serrate, small and deciduous, or foliaceous and often persistent, generally large and conspicuous on vigorous young branches, leaving in falling minute persistent scars. Flowers in sessile or stalked aments, terminal and axillary on leafy branchlets; scales of the ament lanceolate, concave, rotund or obovate, entire or glandular-dentate, of uniform color or dark-colored toward the apex, more or less hairy, deciduous or persistent; disk of the flower nectariferons, composed of an anterior and posterior or of a single posterior gland-like body; stamens 3-12 or 2, inserted on the base of the scale, with slender filaments free or rarely united and usually light yellow, glabrous or hairy toward the base, and small ovate or oblong anthers generally rose-colored before 
anthesis, becoming orange or purple; ovary sessile or stipitate, conical, obtuse to subulate-rostrate, glabrous, tomentose or villous, with an abbreviated style divided into 2 short recurved retuse or 2-parted stigmas; ovules 4-8 on each of the 2 placentas. Fruit an acuminate 1-celled capsule separating at maturity into 2 recurved valves. Seeds minute, narrowed at the ends, dark chestnut-brown or nearly black; cotyledons oblong.

Salix inhabits the banks of streams and low moist ground, the alpine summits of mountains, and the Arctic and sub-Arctic regions of the northern hemisphere, ranging southward in the New World, with a few species, through the West Indies and Central America to the Andes of Chili, and in the Old World to Madagascar, southern Africa, the Himalayas, Burmah, the Malay peninsula, Java, and Sumatra. Of the 160 or 170 species which are now recognized about seventy are found in North America. Of these twenty-one attain the size and habit of trees, the others being small and sometimes prostrate shrubs. Of exotic species, Salix alba, L., and Salix fragilis, L., important European timber-trees, are now generally naturalized in the northeastern states. The flexible tough branches of several species are used in making baskets; the bark is rich in tannic acid and is used in tanning leather and yields salicin, a bitter principle valuable as a tonic. Many of the species are cultivated as ornamental trees.

Salix is the classical name of the Willow-tree.

\section{CONSPECTUS OF THE NORTH AMERICAN ARBORESCENT SPECIES.}

Scales of the aments of uniform color; aments usually on leafy branches.

Stamens 3 or more; aments terminal.

Petioles without glands.

Leaves green on both surfaces, narrowly lanceolate, long-pointed, often falcate.

Leaves pale below, lanceolate or ovate-lanceolate.

Leaves silvery white below, short-petiolate.

Leaves pale or glaucous below, slender-petiolate.

1. S. nigra (A, C, E, G, H).

2. S. longipes (A, C, H).

3. S. amygdaloides (A, B, F).

Leaves pale blue-green, lanceolate to oblong-lanceolate, acute or acuminate, minutely denticulate or nearly entire, coriaceous, subpersistent.

Leaves pale or glaucous below.

Leaves often falcate, silvery white below, distinctly serrulate.

4. S. lævigata (G).

5. S. Bonplandiana (H.)

Petioles glandular; leaves lanceolate, taper-pointed.

Leaves pubescent as they unfold, pale or glaucous below.

6. S. lasiandra (B, F, G).

Leaves glabrous, coriaceous, dark green and lustrous above, pale below.

7. S. Iucida (A).

Stamens 2 ; aments terminal and axillary; leaves linear-lanceolate.

Leaves denticulate, usually green on both surfaces, mostly glabrous.

8. S. fluviatilis (A, B, C, E, F, G, H).

Leaves entire or nearly so, light yellow-green, villous below, with lustrous pale hairs.

9. S. sessilifolia $\cdot(B, G)$.

Leaves small, entire or nearly so, pale gray-green and puberulous.

10. S. taxifolia $(\mathrm{H})$.

Scales of the aments dark-colored at the apex; aments on short branches, with leaves usually reduced to scales; stamens 2 , 
Capsules glabrous.

Leaves acute.

Leaves ovate or lanceolate, glaucous and conspicuously reticulate-reined below.

11. S. balsamifera (A).

Leaves oblanceolate to lanceolate-oblong, pale or glancous below.

12. S. lasiolepis $(\mathrm{G}, \mathrm{H})$.

Leaves acmininate, lanceolate to oblanceolate.

Leaves glabrous and glaucous below; branchlets glabrous.

13. S. cordata var. Mackenzieana $(F, G)$.

Leaves pale, often silvery white below, pubescent, at least while young ; branch.

lets pubescent.

Capsules pubescent (glabrous in 19).

14. S. Missouriensis (A).

Leaves glabrous or nearly so at maturity (pubescent sometimes in 15); style short.

Leaves elliptic-oblong to lanceolate, acute, with a usually twisted apex, serrate or sometimes entire.

Leaves usually glabrous, glaucous below; pedicel of the ovary shorter than the scale; branchlets glabrous or rarely puberulous.

15. S. discolor (A).

Leaves pubescent or tomentose below, of ten nearly glabrous at maturity; pedicel of the ovary much longer than the scale; branchlets pubescent.

16. S. Bebbiana (A, B, F).

Leaves obovate to oblong, obtuse to acute, entire or nearly so; style elongated.

Leaves yellow-green.

Leaves glaucous below.
17. S. Nuttallii (F, G).

18. S. amplifolia (B).

Leaves pubescent or tomentose below.

Leaves hoary-tomentose below, elliptic to oblong-obovate; capsule glabrous; aments thick.

19. S. Hookeriana (B, G).

Leaves densely covered below with a shiny white tomentum; aments slender.

Leaves oblong-obovate to oblanceolate; stamens united.

20. S. Sitchensis (B, G).

Leaves elliptic-lanceolate to obovate; stamens distinct.

21. S. Alaxensis (B).

1. Scales of the aments of uniform color.

* Stamens 3 or more; aments terminal.

$\rightarrow$ Petioles without glands.

\section{Salix nigra, Marsh. Black Willow.}

Leaves involute in the bud, lanceolate, gradually narrowed above into long tapering usually curved tips, wedge-shaped or rounded below, finely serrate, thin bright light green, rather lustrous, with obscure reticulate veins, glabrous or often pubescent on the under side of the midribs and veins and on the short slender petioles, $3^{\prime}-6^{\prime}$ long, $\frac{1^{\prime}}{8}-\frac{3^{\prime}}{4}$ wide, sometimes conspicuously scythe-shaped (var. falcata, Torr.); at the north turning light yellow before falling in the autumn; stipules semicordate, acuminate, foliaceous, persistent, or ovoid, minute, and deciduous. Flowers : aments terminal on leafy branches, narrowly cylindrical, $1^{\prime}-3^{\prime}$ long, with short yellow scales rounded at the apex and coated on the inner surface with pale hairs; stamens $3-5$, with filaments hairy toward the base; ovary ovate, long-stalked, glabrous, gradually narrowed above the middle to the apex, with nearly sessile thick slightly divided stigmatic lobes. Fruit ovate-conical, short-stalked, glabrous, about $\frac{1}{8}^{\prime}$ long, light reddish brown.

A tree, usually $30^{\circ}-40^{\circ}$ high, with usually several clustered stout stems, occa- 
sionally $120^{\circ}$ high, with a trunk $3^{\circ}$ in diameter, stout spreading upright branches forming a broad somewhat irregular handsome open head, and rather bright reddish brown to pale orange-colored branchlets, glabrous or coated at first with pale pubescence or snowy tomentum and easily separated at the joints. Winter-buds acute, about $\frac{1}{8}^{\prime}$ long. Bark $1^{\prime}-1 \frac{1}{4}^{\prime}$ thick, dark brown or nearly black or light brown tinged with orange color, and deeply divided into broad flat connected ridges separating freely into thick plate-like scales and becoming shaggy on old trunks. Wood light, soft, weak, light reddish brown, with thin nearly white sapwood.

Distribution. Low moist alluvial banks of streams and lakes; southern New Brunswick and the northern shores of Lakes Huron and Superior to southern Florida, and to eastern Dakota, Nebraska, Kansas, and the Indian Territory; through western Texas, southern New Mexico and Arizona, and southward in Mexico; along the western foothills of the Sierra Nevada, and northward in western California to the

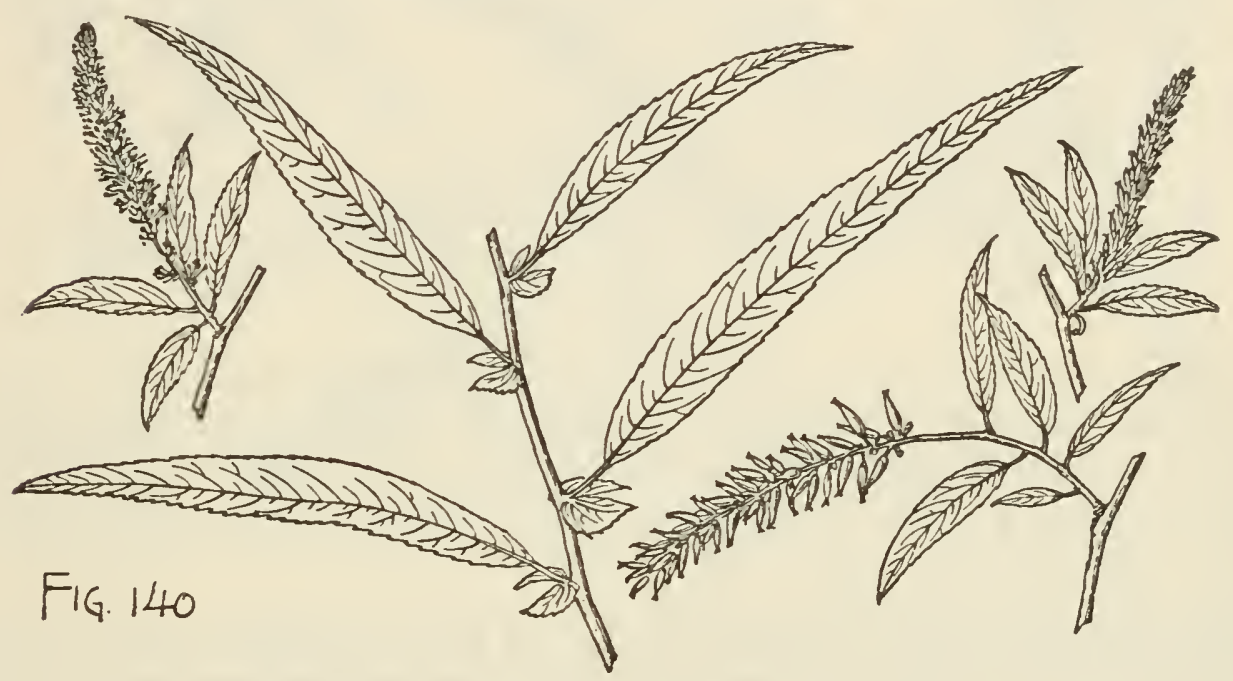

valley of the Sacramento River and the eastern base of the Coast Range in Caloosa County ; the largest and most conspicuous native Willow of eastern North America; most abundant in the basin of the Mississippi River, and of its largest size in southern Indiana and Illinois and in the valley of the lower Colorado River in Texas; rare in California.

\section{Salix longipes, Anders. Black Willow.}

(Salix Wardi, and Salix occidentalis, Silva N. Am. ix. 107, 109.)

Leaves involute in the bud, finely and unequally serrate, lanceolate to ovate-lanceolate, often slightly falcate, rounded or cordate at the base, obliquely long-pointed, $4^{\prime}-7^{\prime}$ long, $1^{\prime}-1 \frac{1}{2}^{\prime}$ wide, or linear-lanceolate, acute, rounded or auriculate at the base and often less than $\frac{1}{2}^{\prime}$ wide, often puberulous, becoming glabrous and bright light green above, silvery white below, pubescent along the under side of the midribs and veins, their petioles broad, flat, sometimes $\frac{3^{\prime}}{4}$ long; stipules foliaceous, reniform, rhomboidal or oblong, obtuse, serrate above the middle, frequently $\frac{1}{2}^{\prime}$ long, sometimes persistent. Flowers: aments terminal on leafy glabrous or hoary-pubescent branches, narrowly cylindrical, the staminate $3^{\prime}$ or $4^{\prime}$ long, rather longer than the pistillate, their scales ovate, obtuse, villous, orange-yellow; stamens 3-7, with filaments furnished at the base with numerous long slender hairs; anthers yellow; ovary 
globose, ovate or ovate-conical, long-stalked, with nearly sessile slightly divided stigmatic lobes. Fruit globose-conical, about $\frac{1^{\prime}}{4}$ long, light reddish brown, minutely glandular.

A tree, occasionally $30^{\circ}$ high, with a trunk $6^{\prime}-8^{\prime}$ in diameter, slender spreading slightly drooping branclies, and slender branchlets not easily separated at the joints,

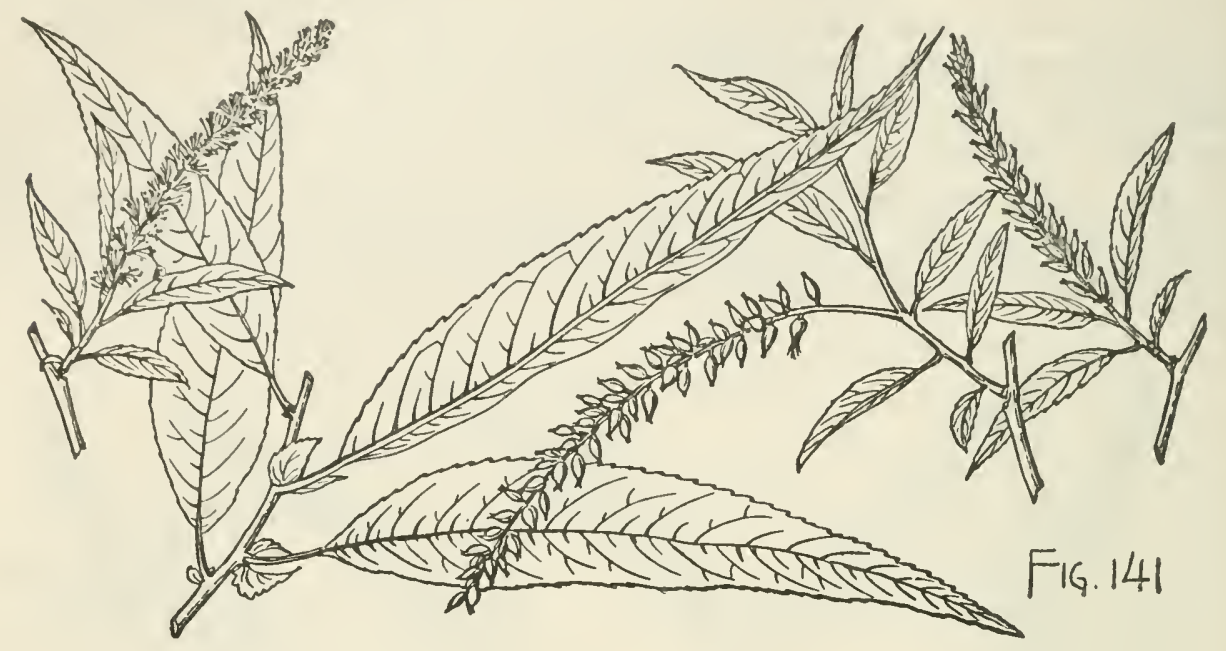

hoary-pubescent sometimes into their second year, becoming in their first winter reddish brown and gray tinged with brown the following year; usually smaller, frequently shrubby in habit. Winter-buds bright chestnut-brown, lustrous, about $\frac{1}{16}$ ' long. Bark $\frac{11^{\prime}}{4}-\frac{1}{2}$ thick, dark reddish brown or nearly black, deeply ridged and crosschecked, covered by small closely appressed plate-like scales. Wood dark redbrown, with thin nearly white sapwood.

Distribution. Rocky or gravelly banks and beds of streams; near the city of Washington, near Lexington, Kentucky, central Tennessee and western Illinois, central Missouri, and southward to southern Florida, the Indian Territory, southern Texas, and New Mexico; very abundant and a conspicuous feature of vegetation in the Ozark region of southwestern Missouri and in northwestern and western Arkansas.

\section{Salix amygdaloides, Anders. Peach Willow. Almond Willow.}

Leaves revolute in the bud, lanceolate to ovate-lanceolate, frequently falcate, wedge-shaped or gradually rounded and often unequal at the base, gradually or abruptly narrowed into long slender points, finely serrate, slightly puberulous when they unfold, becoming at maturity thin and firm in texture, light green and lustrous above, pale and glaucous below, $2 \frac{1^{\prime}}{2}-4^{\prime}$ long, $\frac{3^{\prime}}{4}-1 \frac{1^{\prime}}{4}$ wide, with stout yellow or orangecolored midribs, prominent veins and reticulate veinlets; their petioles elongated, slender, nearly terete; stipules reniform, serrate, often $\frac{1}{2}^{\prime}$ broad on vigorous shoots, usually caducous. Flowers: aments elongated, cylindrical, slender, arcuate, stalked, pubescent or tomentose, $2^{\prime}-3^{\prime}$ long, on leafy branches; their scales yellow, sparingly villous on the outer, densely villous on the inner face, the staminate broadly ovate, rounded at the apex, the pistillate oblong-obovate, narrower, cadncous; stamens 5-9, with free filaments slightly hairy at the base; ovary oblong-conical, long-stalked, glabrous, with a short style and emarginate stigmas. Fruit globose-conical, light reddish yellow, about $\frac{1^{\prime}}{4}$ long. 
A tree, sometimes $60^{\circ}-70^{\circ}$ higl, with a single straight or slightly inclining trunk rarely more than $2^{\circ}$ in diameter, straight ascending branches, and slender glabrous branchlets marked with scattered pale lenticels, dark orange color or red-brown and lustrous, becoming in their first winter light orange-brown. Winter-buds broadly ovate, gibbous, dark chestnut-brown, very lustrous above the middle, light orange-brown below, $\frac{1^{\prime}}{8}$ long. Bark $\frac{1^{\prime}}{2}-\frac{8^{\prime}}{4}$ thick, brown somewhat tinged with red, and divided by irregular fissures into flat connected ridges separating on the surface into thick plate-like scales. Wood light, soft, close-grained, light brown, with thick nearly white sapwood.

Distribution. Banks of streams; near Montreal and in Cayuga County, New York, to the valley of the Saskatchewan, southward to Ohio and Missouri, and

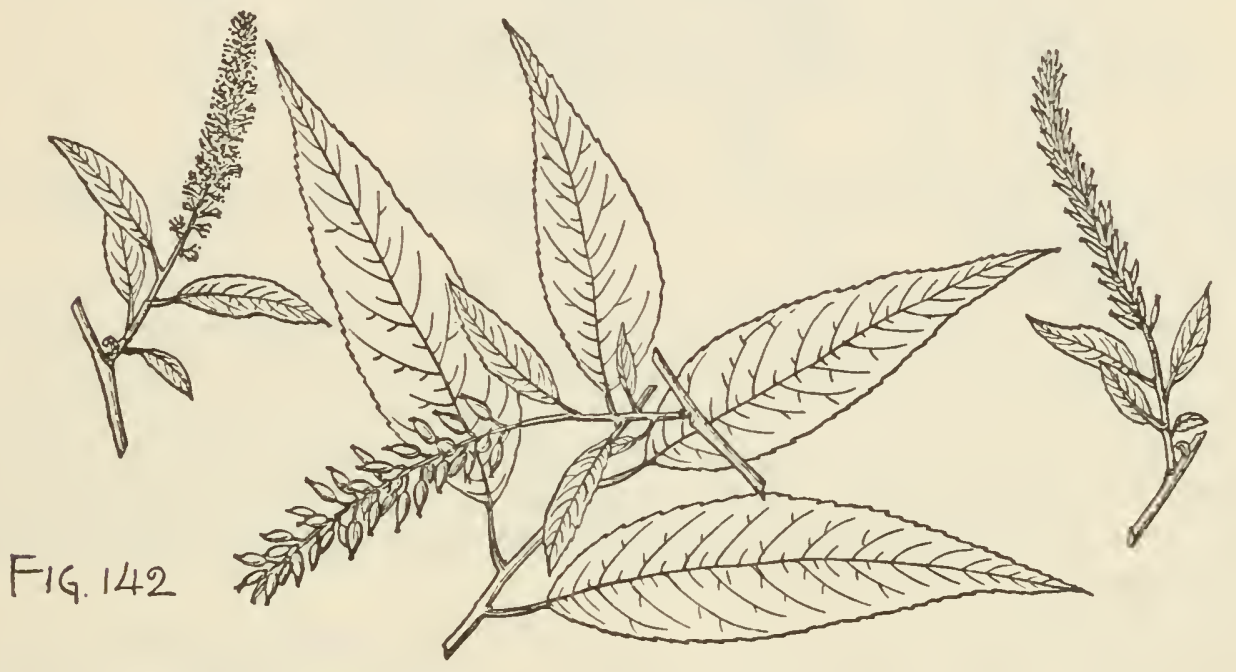

westward over the great plains and through the Rocky Mountains from southwestern Texas to Oregon, Washington, and British Columbia; comparatively rare in the east; abundant in the lower Ohio valley; the common arborescent Willow on the streams flowing eastward from the Rocky Mountains and in all the central mountain region of the continent.

\section{Salix lævigata, Bebb. Black Willow.}

Leaves involute in the bud, obovate, gradually narrowed and wedge-shaped at the base, narrowed and rounded or acute and mucronate at the apex, with slightly revolute obscurely serrate margins, on sterile branches lanceolate or oblong-lanceolate, acute or acuminate; in one form narrow, long-pointed, and falcate (var. angustifolia, Bebb); when they unfold light blue-green and coated on the lower surface with long pale or tawny deciduous hairs, at maturity glabrous, dark blue-green and lustrous above, paler and glaucous below, $3^{\prime}-7^{\prime}$ long, $\frac{8^{\prime}}{4}-1 \frac{1}{2}^{\prime}$ wide, with broad flat yellow midribs, their petioles broad, grooved, puberulous, rarely $\frac{1}{2}^{\prime}$ long; stipules ovate, acute, finely serrate, usually small and caducous. Flowers: aments cylindrical, slender, lax, elongated, $2^{\prime}-4^{\prime}$ long, on leafy branches; their scales peltate, dentate at the apex, covered with long pale hairs, the staminate obovate, rounded, the pistillate narrower and more or less truncate; stamens usually 5 or 6 , with free filaments hairy at the base; ovary conical, acute, rounded below, rather short-stalked, glabrous, with broad spreading emarginate stigmatic lobes. Fruit elongated, conical, long- 

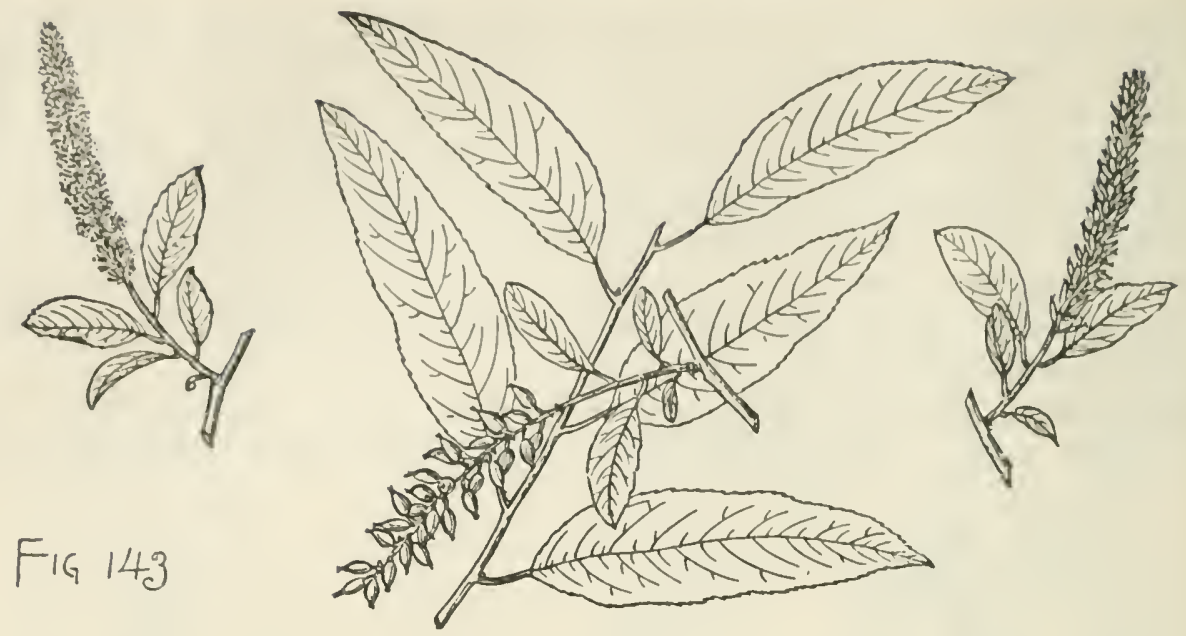

stalked, nearly $\frac{1}{4}^{\prime}$ in length, or in one form globose-conical and short-stalked (var. congesta, Bebb).

A tree, $40^{\circ}-50^{\circ}$ high, with a straight trunk nearly $2^{\circ}$ in diameter, slender spreading branches, and slender light or dark orange-colored or bright red-brown branchlets coated at first with hoary deciduous pubescence; often much smaller, with all average height of $20^{\circ}-30^{\circ}$. Winter-buds ovate, somewhat obtuse, pale chestnutbrown, $\frac{1}{8}-\frac{1}{4}^{\prime}$ long. Bark $\frac{8^{\prime}}{4}-1^{\prime}$ thick, dark brown slightly tinged with red and deeply divided into irregular connected flat ridges broken on the surface in to thick closely appressed scales. Wood light, soft, light brown tinged with red, with thick nearly white sapwood.

- Distribution. Banks of streams; western California from the Oregon bouudary to the southern borders of the state, ascending to elevations of $3000^{\circ}$ on the western slopes of the Sierra Nevada.

\section{Salix Bonplandiana, H. B. K. Willow.}

Leaves involute in the bud, $4^{\prime}-6^{\prime}$ long, $\frac{1}{2}^{\prime}-\frac{8}{4}^{\prime}$ wide, linear-lanceolate to oblonglanceolate, gradually narrowed and often unequal at the wedge-shaped base, acuminate, with long slender points, obscurely serrate, with glandular teeth, or entire, with revolute margins, thick and firm, reticulate-venulose, yellow-green and lustrous above, silvery white below, with broad yellow midribs, falling irregularly during the winter; their petioles stout, grooved, reddish; stipules ovate, rounded, slightly undulate, thin and scarious, $\frac{1^{\prime}}{8}-\frac{1^{\prime}}{4}$ broad, often persistent during the summer. Flowers: aments on leafy branches, cylindrical, erect, slender, short-stalked, the staminate $1^{\prime}-1 \frac{1}{2}^{\prime}$ long and somewhat longer than the pistillate; their scales broadly obovate, rounded at the apex, light yellow, villose on the outer face and glabrous or slightly hairy above the middle on the inner face; stamens usually 3 , with free filaments slightly hairy at the base; ovary slender, oblong-conical, short-stalked, glabrous, with nearly sessile much-thickened club-shaped stigmas, surrounded below by a large irregular cup-shaped glandular disk. Fruit ovate-conical, rounded at the base, light reddish yellow.

A tree, rarely more than $30^{\circ}$ high, with a trunk $12^{\prime}-15^{\prime}$ in diameter, slender erect and spreading branches often pendulous at the ends, forming a broad roundtopped head, and slender glabrous branchlets marked with occasional pale lenticels, 
light yellow, becoming light or dark red-brown and lustrous, and paler orangebrown in their second year. Winter-buds narrowly ovate, long-pointed, more or less falcate, bright red-brown, lustrous, $\frac{1^{\prime}}{4}$ long. Bark $\frac{1^{\prime}}{2}-\frac{3^{\prime}}{4}$ thick, dark brown or

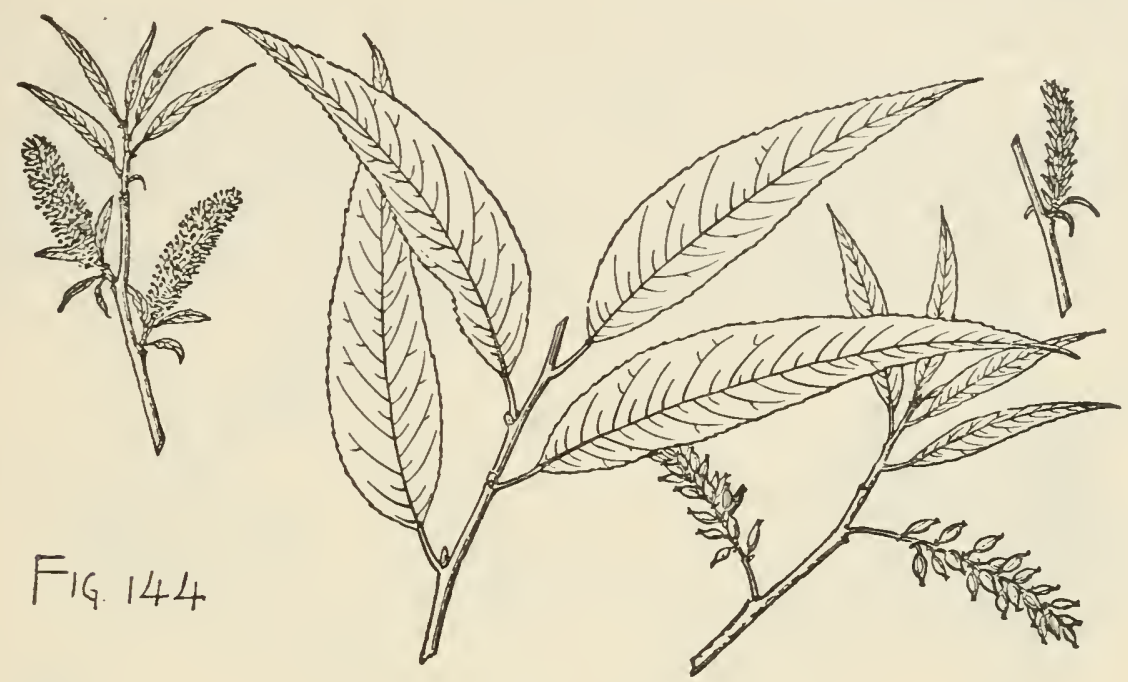

nearly black, and deeply divided by narrow fissures into broad flat ridges separating on the surface into closely appressed scales.

Distribution. Banks of streams in the cañons of the mountains of southern Arizona; through central and southern Mexico.

\section{++ Petioles glandular.}

\section{Salix lasiandra, Benth. Black Willow.}

Leaves involute in the bud, linear-lanceolate, long-pointed, gradually rounded at the narrowed base, finely serrate, when they unfold pilose on the upper surface and pubescent or tomentose on the lower, at maturity dark green and lustrous above, pale or glaucous below, $4^{\prime}-5^{\prime}$ long, $\frac{1^{\prime}}{2}-1^{\prime}$ wide, with broad orange-colored midribs; their petioles glabrous or pubescent, $\frac{1}{4}^{\prime}-\frac{1}{2}^{\prime}$ long, furnished at the apex with 2 or more large dark glands; stipules semilunar, glandular-serrate, small and deciduous, or on vigorous shoots large and foliaceous. Flowers : aments terminal, erect, cylindrical, $1 \frac{1}{2}{ }^{\prime}-2^{\prime}$ long, on leafy branches, the staminate sometimes $\frac{1}{3}$ in diameter and nearly twice as broad as the pistillate, their scales obovate, yellow, more or less villous below the middle, glandular-dentate, scales of the pistillate ament narrower and sometimes nearly entire ; stamens 5-9, with free filaments hairy at the base; ovary cylindrical, short-stalked, glabrous, with a short style and spreading slightly emarginate stigmas. Fruit light reddish brown, about $\frac{1^{\prime}}{4}$ long.

A tree, often $60^{\circ}$ high, with a trunk $2^{\circ}-3^{\circ}$ in diameter, straight ascending branches forming an open irregular head, rather stout branchlets, at first dark purple, reddish brown or yellow, pilose, with scattered hairs, or pubescent or tomentose or often covered with a glaucous bloom, becoming at the end of the first season dark purple, bright red-brown, or light orange color ; toward the southern limits of its range and in the interior of the continent much smaller, sometimes shrubby. Winterbuds broadly ovate, acute, light chestnut-brown and lustrous above the middle, pale 
at the base, $\frac{1^{\prime}}{4}$ long. Bark $\frac{1^{\prime}}{2}-\frac{8}{4}$ thick, dark brown slightly tinged with red aud divided by shallow fissures into broad flat scaly ridges broken by cross fissures into oblong plates. Wood light, soft, brittle, light brown, with lighter colored or often nearly white sapwood.

Distribution. River banks and the shores of lakes; California west of the Sierra Nevada; in western Oregon, Washington, and southern British Columbia often replaced by the var. Lyallii, Sarg., with leaves tapering from a rounded or subcordate base, usually white below and often $7^{\prime}-8^{\prime}$ long, more glandular petioles, and narrow and less hairy scales of the pistillate ament, and in western Oregon and Washington one of the commonest trees on river banks, with tall clustered stems; in the interior from the sierras of northern California to northern Montana, Colorado, and northern

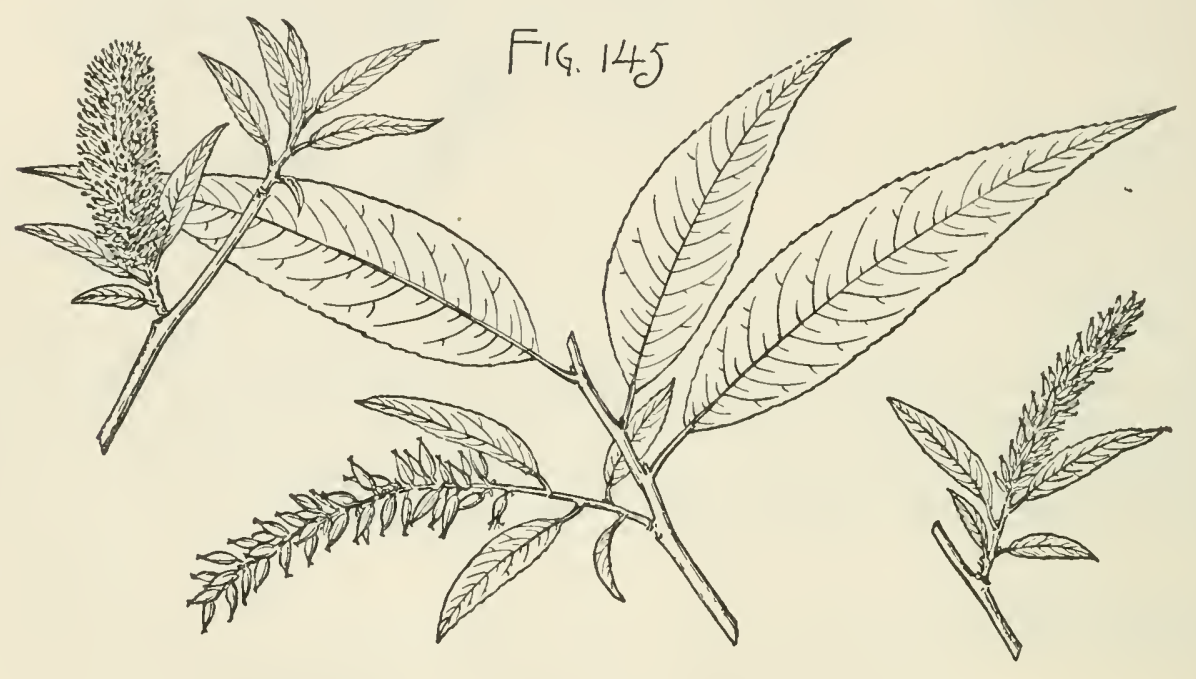

New Mexico by the var. caudata, Sudw., with smaller thicker and more coriaceous often more or less falcate leaves, wedge-shaped at the base, green above and below, with thicker and more densely flowered staminate aments, yellow branchlets, and larger often villous winter-buds.

\section{Salix lucida, Muehl. Shining Willow.}

Leaves involute in the bud, lanceolate, gradually or abruptly narrowed and wedge-shaped or rounded at the base, acute at the apex, with long tapering points, finely serrate, $3^{\prime}-5^{\prime} \operatorname{long}, 1^{\prime}-1 \frac{1}{2}^{\prime}$ wide, covered when they unfold with scattered pale caducous hairs, at maturity coriaceous, smooth and lustrous, dark green above, paler below, with broad yellow midribs, and slender primary veins arcuate and united near the margins; their petioles stout, yellow, puberulous, glandular at the apex, with several dark or yellow conspicuous glands, $\frac{1}{4}^{\prime}-\frac{1}{2}^{\prime}$ long ; stipules nearly semicircular, glandular-serrate, membranaceous, $\frac{1^{\prime}}{8} \frac{1}{4}^{\prime}$ broad, often persistent during the summer. Flowers: aments erect, tomentose, on stout puberulous peduncles terminal on short leafy branches, the staminate oblong-cylindrical, densely flowered, about $1 \frac{1}{2}$ broad, the pistillate slender, elongated, $1 \frac{1}{2}^{\prime}-2^{\prime}$ long, often persistent until late in the season; their scales oblong or obovate, rounded, entire, erose or dentate at the apex, light yellow, nearly glabrous or coated on the back with pale hairs, often ciliate on the margins; stamens usually 5 , with elongated free filaments slightly hairy at the base; 
ovary narrowly cylindrical, long-stalked, elongated, glabrous, with nearly sessile emarginate stigmas. Fruit cylindrical, about $\frac{1}{3}^{\prime}$ long, lustrous.

A tree, occasionally $25^{\circ}$ high, with a short trunk $6^{\prime}-8^{\prime}$ in diameter, erect branches forming a broad round-topped symmetrical head, and stout glabrous branchlets dark

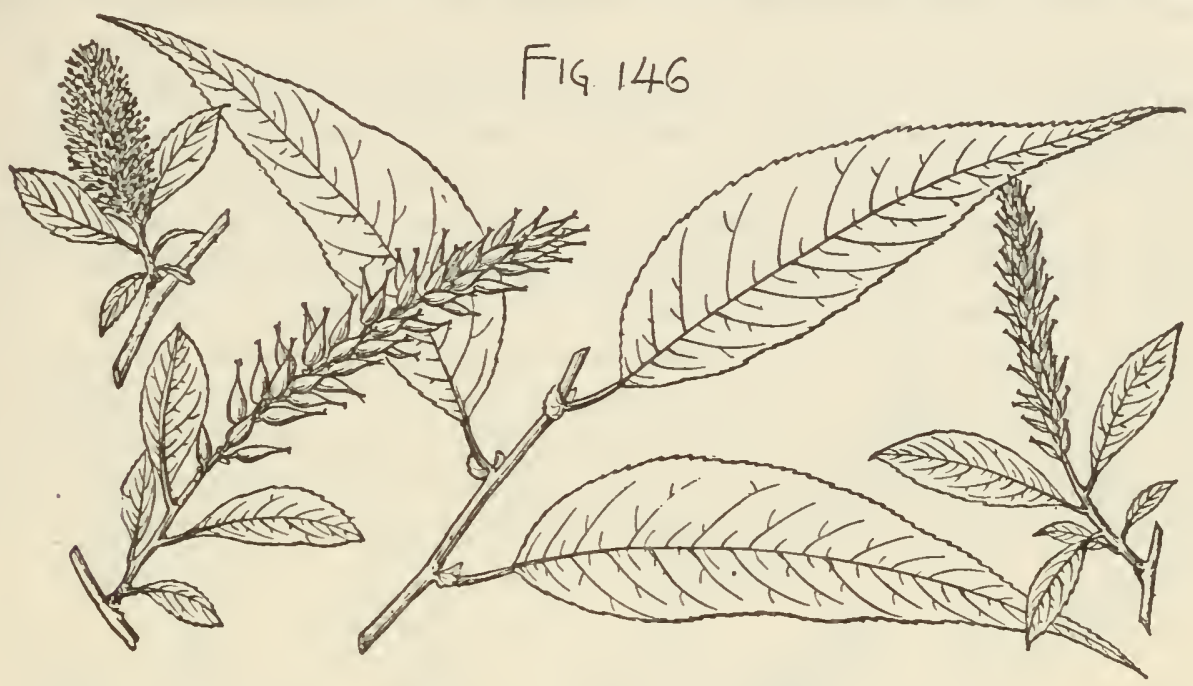

orange color and lustrous in their first season, becoming darker and more or less tinged with red the following year; usually smaller and shrubby in habit. Winterbuds narrowly ovate, acute, light orange-brown, lustrous, about $\frac{1^{\prime}}{4}$ long. Bark thin, smooth, dark brown slightly tinged with red.

Distribution. Banks of streams and swamps; Newfoundland to the shores of Hudson's Bay and northwestward to the valley of the Mackenzie River and the eastern base of the Rocky Mountains, southward to sonthern Pennsylvania and westward to eastern Nebraska; very abundant at the north, rare southward.

\section{***amens 2; aments terminal and axillary.}

\section{Salix fluviatilis, Nutt. Sand Bar Willow.}

Leaves involute in the bud, linear-lanceolate or often somewhat falcate, gradually narrowed at the ends, long-pointed, dentate, with small remote spreading callous glandular teeth, $2^{\prime}-6^{\prime}$ long, $\frac{1}{8}^{\prime}-\frac{1}{3}^{\prime}$ wide, when they unfold coated below with soft lustrous silky hairs, at maturity thin, glabrous, light yellow-green, darker on the upper than on the lower surface, with yellow midribs, slender arcuate primary veins, and slender reticulate veinlets, their petioles grooved, $\frac{1}{8}^{\prime}-\frac{1}{4}^{\prime}$ long; stipules ovate-lanceolate, foliaceous, about $\frac{1}{4}^{\prime}$ long, deciduous. Flowers: aments on stout peduncles covered with soft silky pale pubescence, the pistillate oblong-cylindrical, about $\mathbf{1}^{\prime}$ long, $\frac{1}{3}^{\prime}$ broad, terminal or axillary on short or elongated lateral branches, the staminate cylindrical, elongated, $2^{\prime}$ or $3^{\prime}$ long, about $\frac{1^{\prime}}{4}$ broad, terminal on leafy branches; their scales obovate-oblong, entire, erose or dentate above the middle, light yellow-green, densely villous on the outer surface, slightly hairy on the inner; stamens 2, with free filaments slightly hairy at the base; ovary oblong-cylindrical, acute, short-stalked, glabrous or pubescent, with large sessile deeply lobed stigmas. Fruit light brown, glabrous or villous, about $\frac{1^{\prime}}{4}$ long.

A tree, usually about $20^{\circ}$ high, with a trunk only a few inches in dianeter, spread- 
ing by stoloniferous roots into broad thickets, short slender erect branches, and slender glabrous light or dark orange-colored or purplish red branchlets, growing darker after their first season; occasionally $60^{\circ}-70^{\circ}$ high, witl a trunk $2^{\circ}$ in diameter; often a shrub not more than $5^{\circ}-6^{\circ}$ tall. Winter-buds narrowly ovate, acute, chestnut-brown, about $\frac{1^{\prime}}{8}$ long. Bark $\frac{1^{\prime}}{8}-\frac{1^{\prime}}{4}$ thick, smooth, dark brown slightly tinged with red and covered with small closely appressed irregularly shaped scales. Wood light, soft, light brown tinged with red, with thin light brown sapwood.

Distribution. River banks and sand-bars; shores of Lake St. John and the Island of Orleans in the Province of Quebec, southward through western New England to the valley of the Potomac River, northwestward to within the Arctic Circle in the valley of the Mackenzie River and to British Columbia and California, and southward through the basin of the Mississippi River to northern Mexico and Lower California; exceedingly common in the valley of the Mississippi, attaining its largest size in southern Indiana and Illinois and in southern Arkansas; gradually becoming smaller and less conmon toward the Atlantic seaboard; abundant in all the prairie region of British America and lining the banks of streams flowing eastward through the central platean of the continent, where it is the commonest Willow; common in Texas west of the

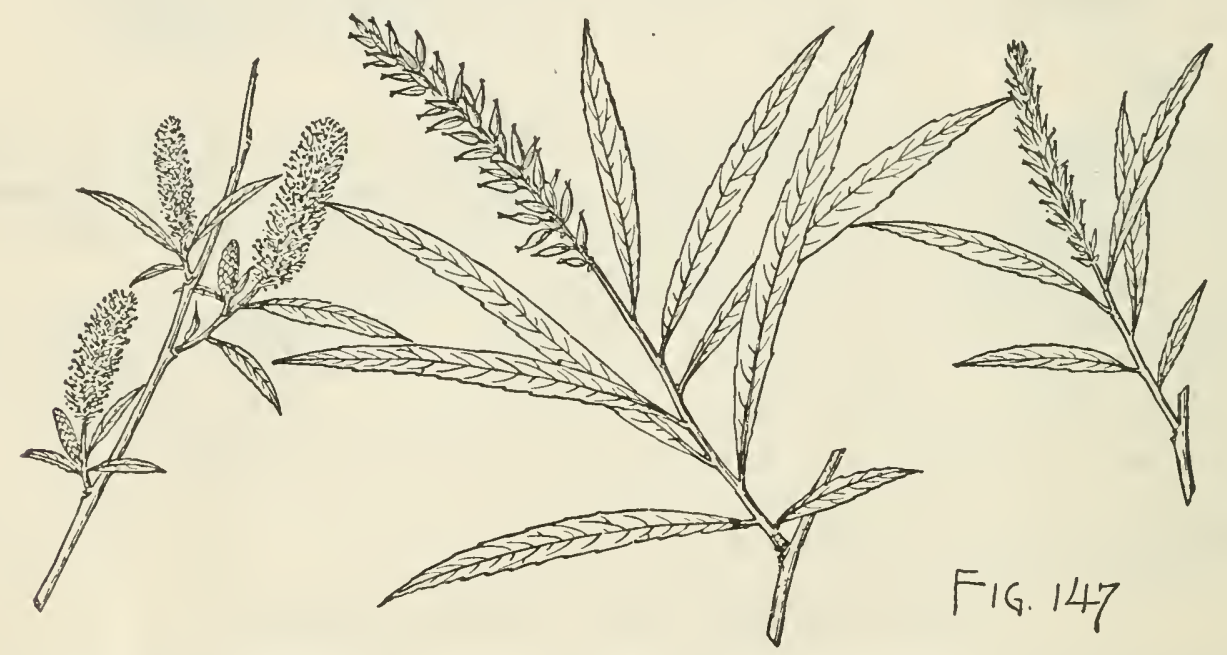

valley of the Pecos River; rare in New Mexico and Arizona south of the Colorado platean; common in the region adjacent to the Pacific coast from Lower California to northern British Columbia. From western Texas to northern California often replaced by the var. argyrophylla, Sarg., with leaves and capsules covered with silky pale tomentum, and by the var. exigua, Sarg., with very short linear leaves.

\section{Salix sessilifolia, Nutt. Willow.}

Leaves involute in the bud, lanceolate or linear-lanceolate, often slightly falcate, narrowed at the ends, long-pointed at the apex, entire or dentate above the middle, covered as they unfold with hoary tomentum, at maturity light yellow-green, glabrous or puberulous above, villous below, with silky lustrous white hairs, $\mathbf{1}_{2}^{\prime}-\mathbf{5}^{\prime}$ long, $\frac{1}{12}-\frac{1}{4}{ }^{\prime}$ wide, with yellow midribs and obscure arcuate veins; their petioles stout, pubescent, rarely more than $\frac{1}{8}^{\prime}$ long; stipules acute, hoary pubescent, about $\frac{1^{\prime}}{4}$ long, deciduous. Flowers: aments cylindrical, densely flowered, terminal and axillary on leafy branches, $3^{\prime}$ long on the pistillate plant, not more than one half as long and 
broader on the staminate plant; their scales oblong-obovate, erose and denticulate above the middle, pale yellow-green and villous on the back, with pale silky hairs, those of the staminate ament rather broader than those of the pistillate; stamens 2, with free glabrous filaments; ovary oblong-cylindrical, short-stalked, villous, crowned with a nearly sessile bifid stigma. Fruit elongated, cylindrical, bright redbrown, more or less villous, about $\frac{1^{\prime}}{4}$ long.

A tree, occasionally $30^{\circ}$ high, with a trunk $1^{\circ}$ in diameter, slender erect branches forming a narrow head, and slender branchlets coated at first with hoary pubescence gradually deciduous during the summer, becoming reddish brown; or often, especially at the south, reduced to a tall or a low shrub. Winter-buds narrow, ovate, acute, nearly $\frac{1^{\prime}}{8}$ long. Bark nearly $\frac{1}{2}^{\prime}$ thick, dark brown, slightly fissured and cov-

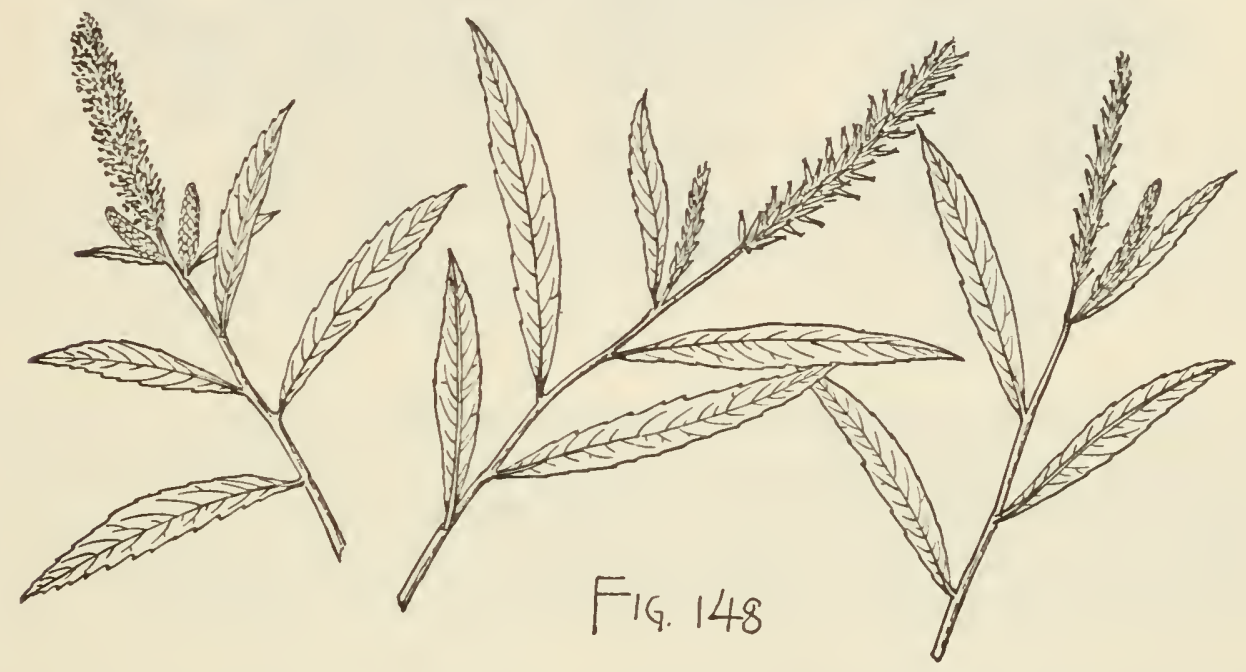

ered with thick irregular closely appressed scales. Wood light, soft, close-grained, light red, with thin nearly white sapwood.

Distribution. Banks of streams from the shores of Puget Sound, southward through western Washington and Oregon and along the western slopes and foothills of the Sierra Nevada to the valleys and foothills of the coast ranges of southern California, where it is one of the commonest Willows.

\section{Salix taxifolia, H. B. K. Willow.}

Leaves involute in the bud, linear-lanceolate, narrowed at the ends, acute, slightly falcate and mucronate at the apex, entire and obscurely dentate above the middle, coated as they unfold with long soft white hairs, at maturity pale gray-green, slightly puberulous, $\frac{1}{3}^{\prime}-\mathbf{1}^{\prime}{ }^{\prime}$ long, $\frac{1}{1}^{\prime}-\frac{1}{8}^{\prime}$ wide, with slender midribs, thin arcuate veins, and thickened slightly revolute inargins; their petioles stout, puberulous, rarely $\frac{1}{12}$ 'long; stipules ovate, acute, scarious, minute, caducous. Flowers: aments densely flowered, oblong-cylindrical or subglobose, $\frac{1}{4}^{\prime}-\frac{1}{2}^{\prime}$ long, terminal, or terminal and axillary on the staminate plant, on short leafy branches; their scales oblong or obovate, rounded or acute and sometimes apiculate at the apex, coated on the onter surface with hoary tomentum and pubescent or glabrous on the inner; stamens 2, with free filaments hairy below the middle; ovary ovate-conical, short-stalked or subsessile, villous, with pale hairs, with nearly sessile deeply emarginate stigmas. Fruit cylindrical, longpointed, bright red-brown, more or less villous, short-stalked, about $\frac{1^{\prime}}{4}$ long. 
A tree, often $40^{\circ}-50^{\circ}$ ligh, with a trunk $18^{\prime}$ in diameter, crect and drooping branches forming a broad open liead, and slender branchlets covered during their first season with hoary tomentum, becoming light reddish or purplish brown and much roughened by the elevated persistent leaf-sears. Winter-buds ovate, acute,
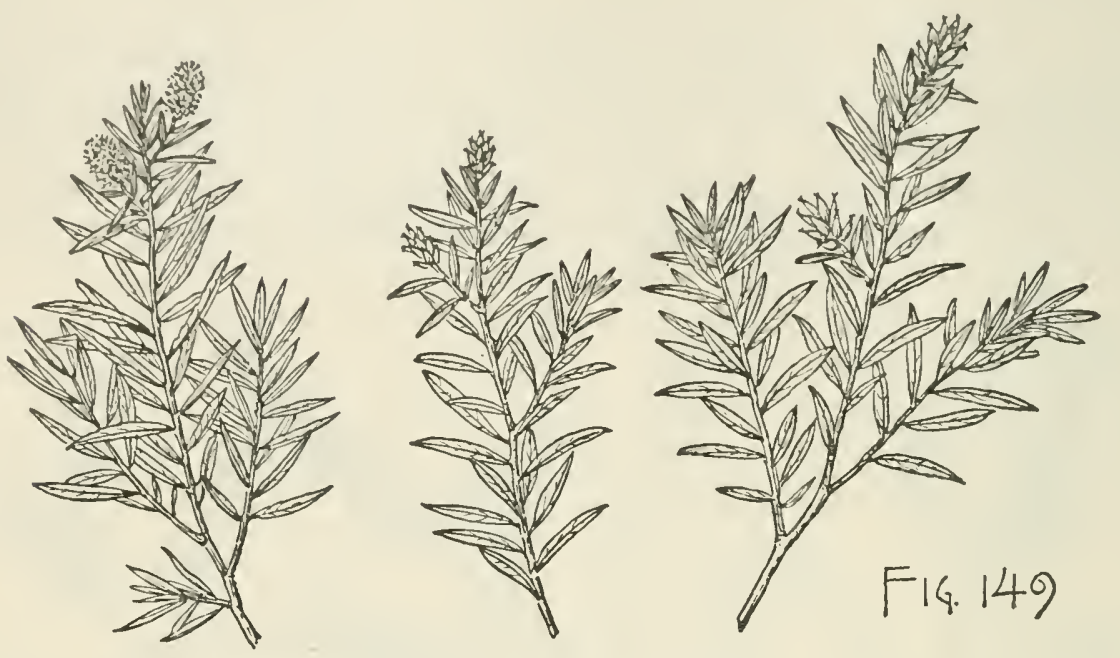

dark chestnut-brown, puberulous, about $\frac{1{ }^{\prime}}{16}$ long and nearly as broad as long. Bark of the trunk $\frac{3^{\prime}}{4}-\mathbf{1}^{\prime}$ thick, light gray-brown, and divided by deep fissures into broad flat ridges covered by minute closely appressed scales.

Distribution. Near El Paso, Texas, and along mountain streams in southern Arizona, southward through Mexico to Guatemala, and in Lower California.

\section{Scales of the aments dark-colored at the apex; stamens 2. \\ * Capsule glabrous.}

\section{Salix balsamifera, Barr. Willow.}

Leaves involute in the bud, ovate to ovate-lanceolate, acute or acuminate, broad and rounded and usually subcordate at the base, finely serrate, witl glandular teeth, balsamic particularly while young, when they unfold thin, pellucid, red and coated below with long slender caducous hairs, at maturity thin and firm, dark green above, pale and glancous below, $2^{\prime}-4^{\prime}$ long, $1^{\prime}-1 \frac{1}{2}^{\prime}$ wide, with yellow midribs and conspicuous reticulate veinlets; their petioles reddish or yellow, $\frac{1}{3}^{\prime}-\frac{1}{2}^{\prime}$ long; stipules often wanting or on vigorous shoots foliaceous, broadly ovate and acute. Flowers: aments cylindrical, $1^{\prime}-1_{\frac{1}{2}}^{\prime}$ long, on long slender leafy branches; their scales obovate, acute, rose-colored, coated with long white hairs; stamens 2, with free filaments and reddish ultimately yellow anthers; ovary narrow, long-stalked, gradually contracted above the middle, with nearly sessile emarginate stigmas. Fruit ovate-conical, long-stalked, $\frac{1}{4}$ long, dark orange color.

Usually a shrub, often making clumps of crowded slender erect stems generally destitute of branches except near the top, rarely arborescent, with a height of $25^{\circ}$, a trunk $12^{\prime}-11^{\prime}$ in diameter, erect branches, and comparatively stout reddish brown branchlets becoming olive-green in their second year and marked with narrow slightly raised leaf-scars. Winter-buds acute, much-compressed, bright scarlet, very lustrous, about $\frac{1^{\prime}}{4}$ long. Bark thin, rather smooth, dull gray. 


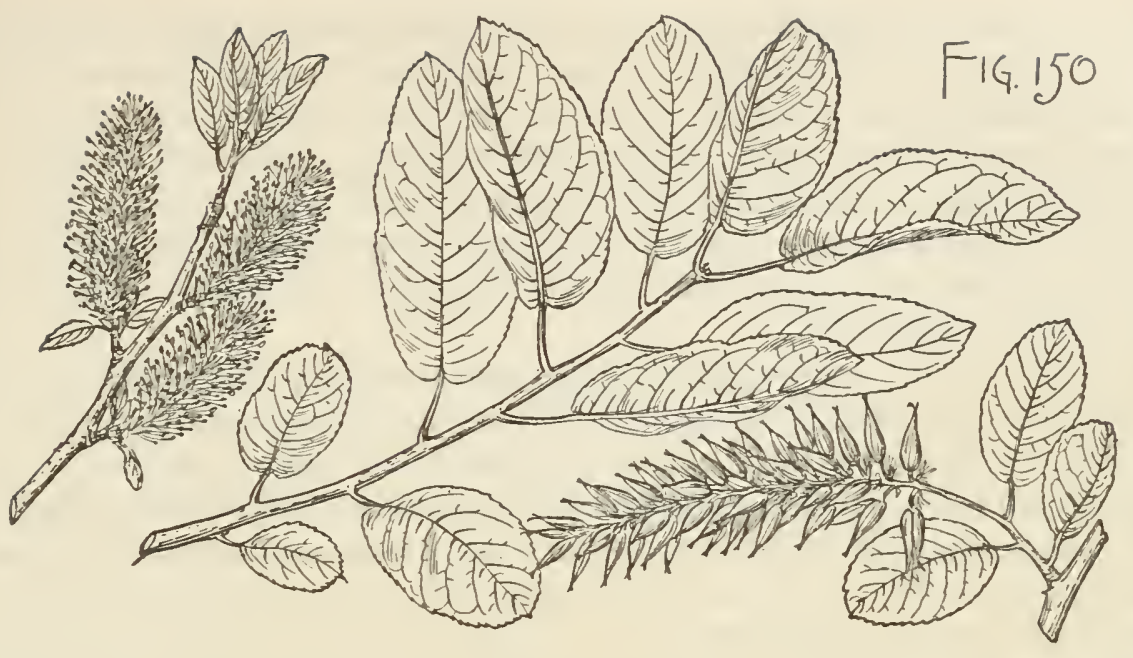

Distribution. Cold wet bogs; coast of Labrador to northern Maine, northern New Hampshire and New York, and westward to the valley of the Saskatchewan, and to northern Michigan and Minnesota; known to become arborescent only near Fort Kent on the St. John River, Maine.

\section{Salix lasiolepis, Benth. White Willow.}

Leaves involute in the bud, oblanceolate to lanceolate-oblong, of ten inequilateral and occasionally falcate, gradually or abruptly wedge-shaped or rounded at the base, acute or acuminate or rarely rounded at the apex, entire or remotely serrate, pilose above and coated below with thick hoary tomentum when they unfold, at maturity thick and subcoriaceous, conspicuously reticulate-venulose, dark green and glabrous above, pale or glaucous and pubescent, or puberulous below, $3^{\prime}-6^{\prime}$ long, $\frac{1^{\prime}}{2}-1^{\prime}$ wide, with broad yellow midribs and slender arcuate veins forked and united within the slightly thickened and revolute margius; their petioles slender, $\frac{1}{8}^{\prime}-\frac{1}{2}^{\prime}$ long; stipules

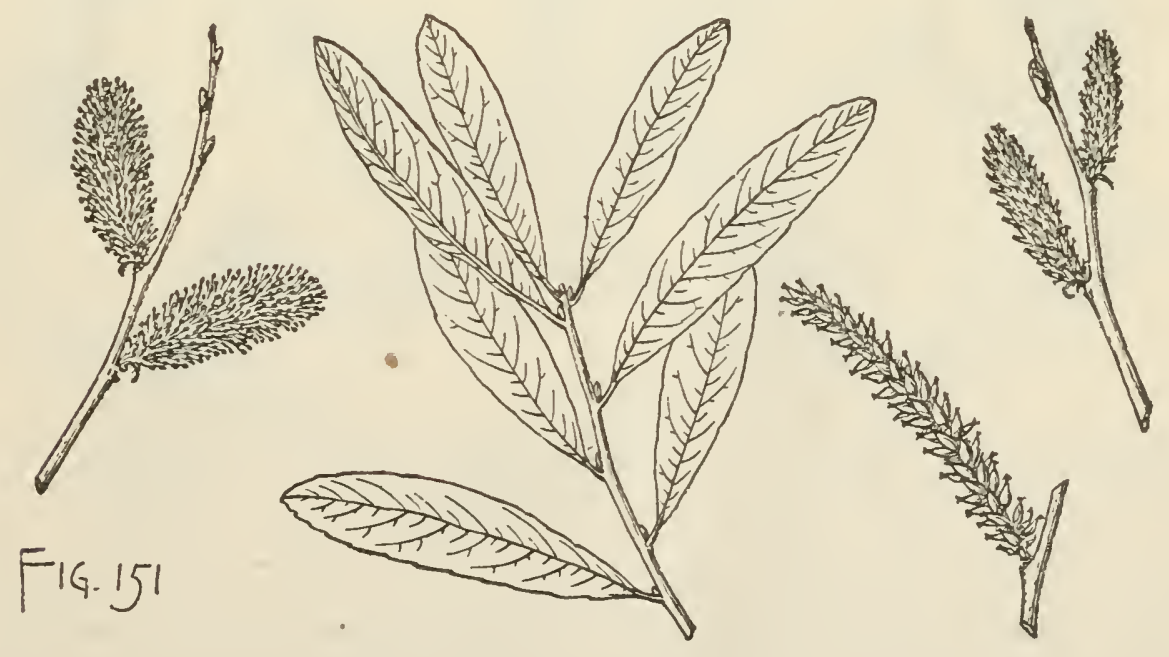

ovate, acute, coated with hoary tomentum, minute and caducous, or sometimes foliaceous, semilunar, acute or acuminate, entire or denticulate, dark green above, pale 
below, persistent. Flowers: aments erect, cylindrieal, slightly flexuose, densely Howered, nearly sessile, on short tomentose branehlets, $1 \frac{1}{2}$ ' long, the staminate $\frac{1}{2}$ thick, and nearly twiee as thick as the pistillate; their seales oblong-obovate, romnded or aeute at the apex, dark-eolored, elothed with long erisp white hairs, persistent under the frnit; stamens 2, with elongated glabrous filaments more or less united below the middle; ovary narrow, eylindrieal, aente and long-pointed, dark green, glabrous, with a short style and broad nearly sessile stigmas. Fruit oblong, cylindrical, light reddish brown, about $t^{\prime}$ long.

A tree, $20^{\circ}-30^{\circ}$, or occasionally $50^{\circ}$ high, with a trunk $12^{\prime}-18^{\prime}$ in diameter, slender erect branehes forming a loose open head, and stont branchlets eoated at first witl hoary tomentum, bright yellow or dark reddish brown and puberulous or pubeseent during their first year, beeoming darker and glabrous in their second season; or often at the north and at high elevations a low shrnb. Winter-buds ovate, acute, compressed, contracted laterally into thin wing-like margins, light brownish yellow, glabrous or puberulous. Bark on young stens and on the branehes thin, smooth, light gray-brown, beeoming on old trunks dark, about $\frac{1}{3}$ thiek, ronghened by small lenticels and broken into broad flat irregularly eomected ridges. Wood light, soft, close-grained, light brown, with thick nearly white sapwood; in southern California often used as fuel.

Distribution. Banks of streams in low moist ground; valley of the Klamath River southward through western California to Lower California, and on the mountains of southern Arizona; one of the eommonest and most variable of the California Willows, growing at the south at low altitudes as a large tree; on the western slopes of the Sierra Nevada and in Arizona reduced to a many-stemmed shrub.

\section{Salix cordata, var. Mackenzieana, Hook. Willow.}

Leaves involute in the bud, lanceolate to oblanceolate, gradually narrowed or wedge-shaped or rounded at the base, long-pointed, occasionally slightly falcate

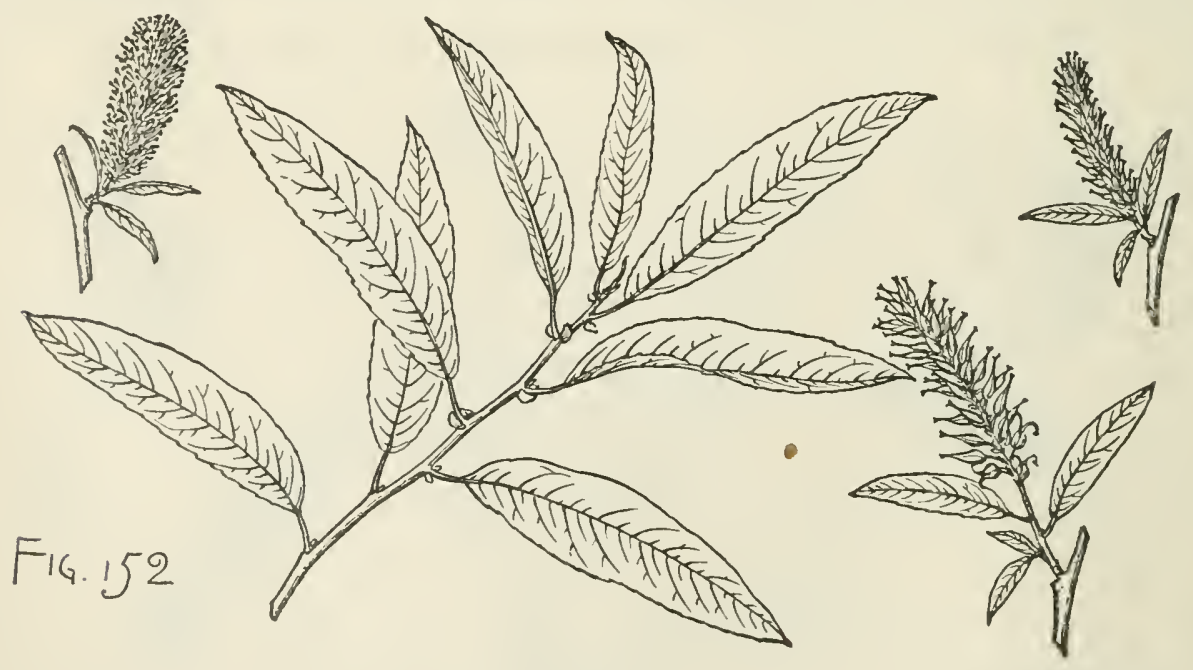

above the middle, finely and obscurely crenately serrate or entire, reddish and pilose with caducous pale hairs when they unfold, at maturity thin and firm in texture, dark green above, pale below, $2^{\prime}-3^{\prime}$ long, about $\frac{1}{2}^{\prime}$ wide, with slender yellow midribs, arcuate veins, and obscure reticulate veinlets; their petioles thin, yellow, 
about $\frac{1^{\prime}}{3}$ long; stipules reniform, conspicuously veined, about $\frac{1}{16}$ broad, usually persistent during the season. Flowers: aments densely flowered, oblong, cylindrical, erect, often more or less curved, about $1 \frac{1}{2}^{\prime}$ long, terminal on short branches ; their scales oblong-obovate, acute, dark-colored, glabrous except at the base, persistent under the fruit; stamens 2, with elongated free glabrous filaments; ovary cylindrical, long-stalked, elongated, gradually narrowed into a slender style, with spreading emarginate stigmas. Fruit elongated, light brown slightly tinged with red, about $\frac{1^{\prime}}{4}$ long,

A small tree, with a slender trunk and upright branches forming a narrow shapely head, and slender branchlets marked with scattered lenticels, glabrous or slightly puberulous and often tinged with red at first, soon becoming yellow and lustrous, growing lighter colored in their second year. Winter-buds ovate, rounded on the back, compressed and acute at the apex, bright orange color, about $\frac{1}{8}^{\prime}$ long.

Distribution. Shores of Great Slave Lake southward through the region at the eastern base of the Rocky Mountains to northern Idaho, and to Lake County, California, and now regarded as a western form of the shrubby Salix cordata, Muehl., one of the commonest and most variable of American Willows, ranging from the Arctic Circle to the northern United States, and from the shores of the Atlantic Ocean to British Columbia and California.

\section{Salix Missouriensis, Bebb. Willow.}

Leaves involute in the bud, lanceolate or oblanceolate, gradually narrowed from above the middle to the wedge-shaped or rounded base, acuminate and long-pointed at the apex, finely serrate, with glandular teeth, coated with pale hairs on the lower

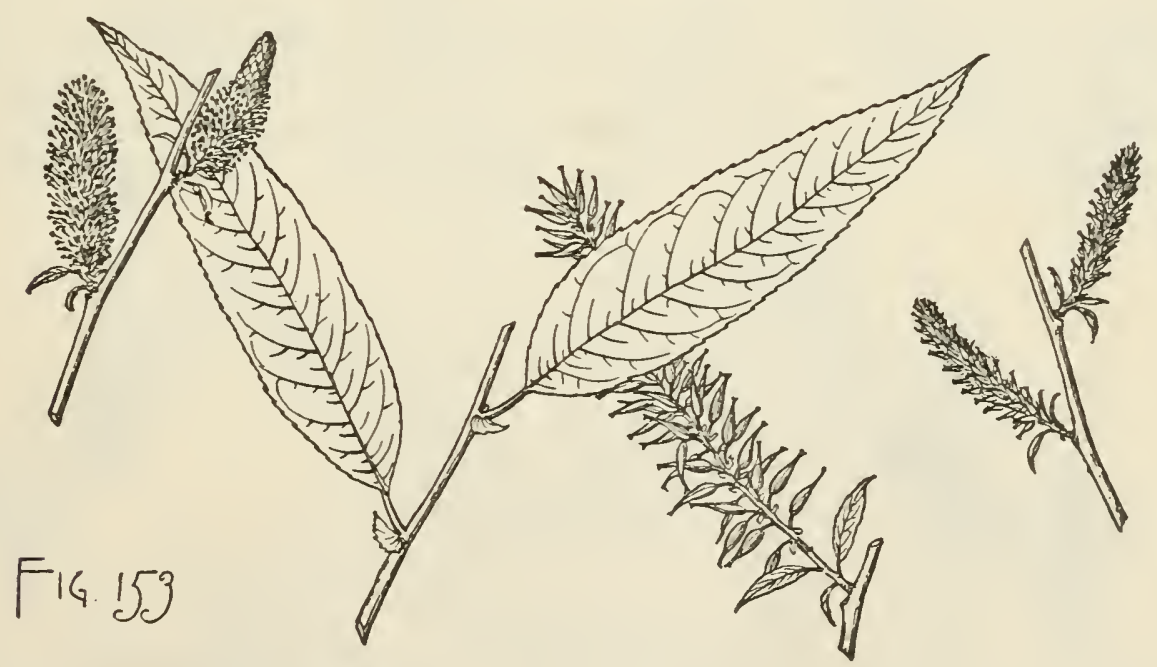

surface and pilose on the upper surface when they unfold, soon becoming nearly glabrous, at maturity thin and firm, dark green above, pale and often glaucous below, $4^{\prime}-6^{\prime}$ long, $1^{\prime}-1 \frac{1}{2}^{\prime}$ wide, with slender veins often united near the margins and connected by reticulate coarse veinlets; their petioles stout, pubescent, or tomentose, $\frac{1}{2}^{\prime}-\frac{3^{\prime}}{4}$ long; stipules foliaceous, semicordate, pointed or rarely reniform and obtuse, serrate, with incurved teeth, dark green and glabrous on the upper side, coated on the lower with hoary tomentum, reticulate-venulose, often $\frac{1}{2}^{\prime}$ long, deciduous or persistent during the season. Flowers: aments oblong-cylindrical, erect, densely flowered, 
appearing early in February on short leafy. branches, the staminate $1^{\frac{1}{2}}$ long and nearly $\frac{1}{2}^{\prime}$ wide and rather longer than the more slender pistillate aments becoming at maturity lax and $3^{\prime} \mathbf{4}^{\prime}$ long ; their scales oblong-obovate, light green, and clothed on the outer surface with long straight silvery hairs; stamens 2, with elongated free glabrous filaments; ovary cylindrical, short-stalked, beaked, glabrous, with a short style and spreading entire or slightly emarginate stigmas. Fruit narrow, longpointed, light reddish browll, long-stalked.

A tree, $40^{\circ}-50^{\circ}$ high, with a tall straight trunk $10^{\prime}-12^{\prime}$ or rarely $18^{\prime}$ in diameter, rather slender upright slightly spreading branches forming a narrow open symmetrical head, and slender branchlets marked by small scattered orange-colored lenticels, light green and coated during their first year with thick pale pubescence, becoming reddish brown and glabrous or puberulous in their second winter. Winter-buds ovate, rounded on the back, flattened or acute at the apex, reddish brown, hoarytomentose, nearly $\mathbf{l}^{\prime}$ long. Bark thin, smooth, light gray slightly tinged with red, and covered with minute closely appressed plate-like scales. Wood dark red-brown, with thin pale sapwood; durable, used for fence-posts.

Distribution. Deep sandy alluvial bottom-lands of the Missouri River in western Missouri, throngh northeastern Kansas, and from the neighborhood of St. Louis to northwestern Iowa.

***apsule pubescent (glabrous in 19).

+ Leaves glabrous or nearly so at maturity (pubescent sometimes in 15).

\section{Salix discolor, Muehl. Glaucous Willow.}

Leaves convolute in the bud, oblong or oblong-obovate or rarely lanceolate, gradually narrowed at the ends, remotely crenulate-serrate, as they unfold thin, light green often tinged with red, pubescent above and coated with pale tomentum below, at maturity thick and firm, glabrous, conspicuously reticulate-venulose, bright green above, glancous or silvery white below, $3^{\prime}-5^{\prime}$ long, $\frac{3^{\prime}}{4}-1 \frac{1}{2}^{\prime}$ wide, with broad yellow

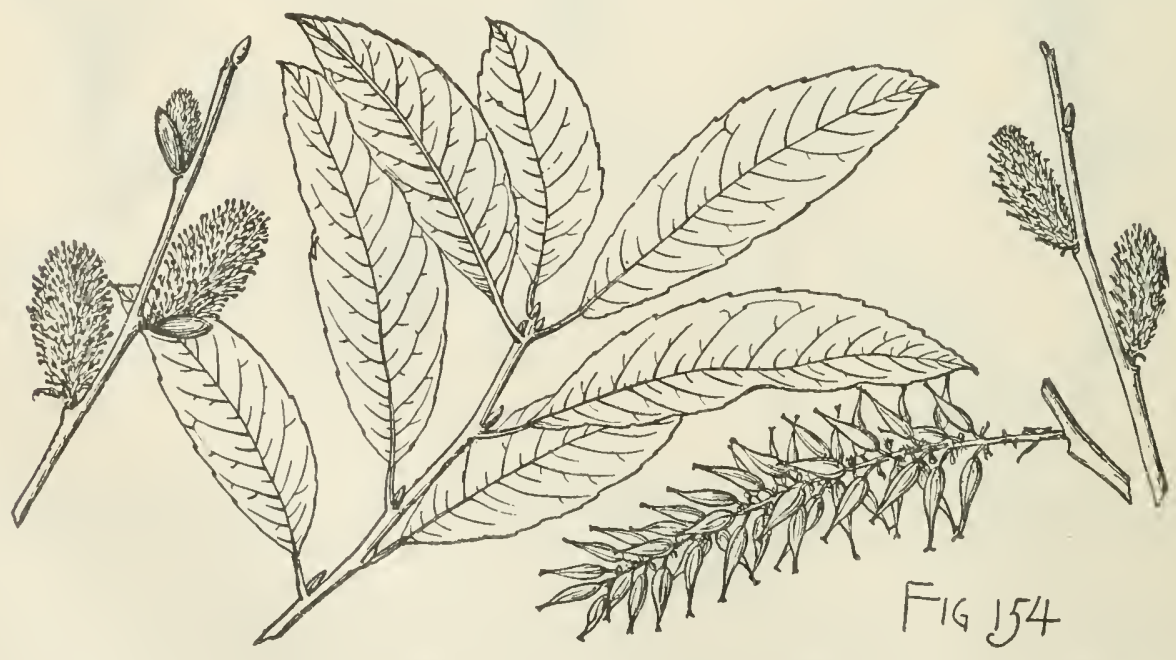

midribs and slender arcuate primary veins; their petioles slender, $\frac{1}{2}^{\prime}-1^{\prime}$ long; stipules foliaceous, semilunar, acute, glandular-dentate, about $\frac{1^{\prime}}{4}$ long, deciduous. Flowers : aments appearing late in winter or in very early spring, erect, terminal on abbre- 
viated branches coated with thick white tomentum, with leaves reduced to minute deciduous scales, oblong-cylindrical, about $1^{\prime}$ long and $\frac{2}{3}$ thick, the staminate soft and silky before the flowers open and densely flowered; their scales oblong-obovate, dark reddish brown toward the apex, covered on the back with long silky silvery white hairs; stamens 2, with elongated glabrous filaments; ovary oblong-cylindrical, longstalked, narrowed above the middle, villous, with a short distinct style and broad spreading entire stigmas. Fruit cylindrical, more or less contracted above the middle, long-pointed, light brown, coated with pale pubescence.

A tree, rarely more than $25^{\circ}$ high, with a trunk about $1^{\circ}$ in diameter, stout ascending branches forming an open round-topped head, and stout branchlets marked by occasional orange-colored lenticels, dark reddish purple and coated at first with pale deciduous pubescence; more often shrubby, with numerous tall straggling stems. Winter-buds semiterete, flattened and acute at the apex, about $\frac{3^{\prime}}{8}$ long, dark reddish purple and lustrous. Bark $\frac{1^{\prime}}{4}$ thick, light brown tinged with red, and divided by shallow fissures into thin plate-like oblong scales. Wood light, soft, close-grained, brown streaked with red, with lighter brown sapwood.

Distribution. Moist meadows and the banks of streams and lakes; Nova Scotia to Manitoba, and southward to Delaware, southern Indiana and Illinois, and northeastern Missouri; common.

\section{Salix Bebbiana, Sarg. Willow.}

Leaves conduplicate in the bud, oblong-obovate to oblong-elliptical or lanceolate, gradually narrowed and wedge-shaped or rounded at the base, acuminate and short-

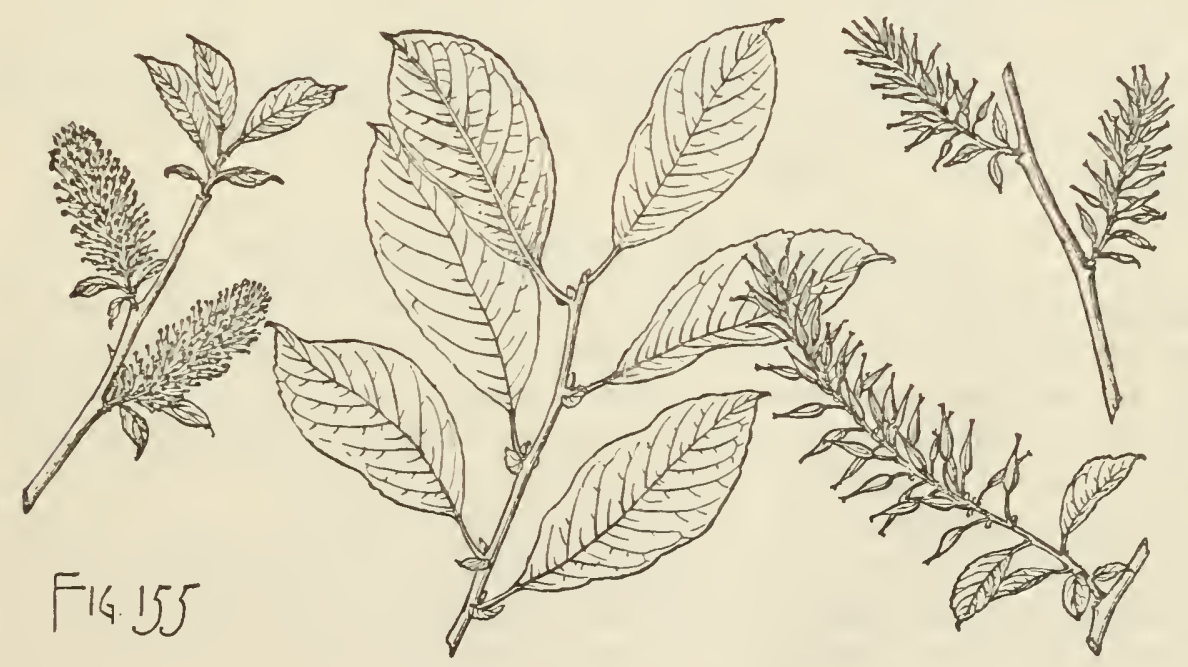

pointed or acute at the apex, remotely and irregularly serrate usually only above the middle, or rarely entire; when they unfold pale gray-green, glabrous or villous, and often tinged with red on the upper surface and coated on the lower with pale tomentum or pubescence, at maturity thick and firm, dull green and glabrous or puberulous above, blue or silvery white and covered with pale rufous pubescence below, especially along the midribs, veins, and conspicuous reticulate veinlets, $1^{\prime}-3^{\prime}$ long, $\frac{1^{\prime}}{2}-1^{\prime}$ wide; their petioles slender, often pubescent, reddish, $\frac{1}{4}^{\prime}-\frac{1}{2}^{\prime}$ long; stipules foliaceous, semicordate, glandular-dentate, sometimes nearly $\frac{1^{\prime}}{2}$ long on vigorous shoots, deciduous. Flowers: aments erect and terminal on short leafy branches; their scales 
ovate or oblong, rounded at the apex, broader on the staminate than on the pistillate plant, yellow below, rose color at the apex, villose, with long pale silky hairs, persistent under the fruit; staminate eylindrical, obovate, narrowed at the base, densely

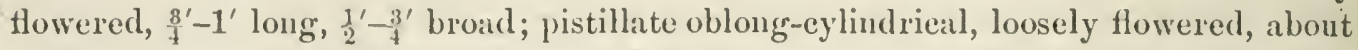
1'long; stamens 2, with free glabrous filaments; ovary cylindrical, villous, with long silky white hairs, gradually narrowed at the apex into broad sessile entire or emarginate spreading yellow stigmas. Fruit elongated-cylindrical, gradually narrowed into a long thin beak, and raised on a slender stalk sometimes $\frac{1^{\prime}}{2}$ long.

A bushy tree, occasionally $25^{\circ}$ high, with a short trunk $6^{\prime}-8^{\prime}$ in diameter, stout ascending branches forming a broad round head, and slender branchlets coated at first with hoary deciduous tomentun, varying during their first winter from reddish purple to dark orange-brown, marked by scattered raised lenticels and roughened by conspicuous elevated leaf-scars, growing lighter colored and reddish brown in their second year; usually much smaller and often shrubby in habit. Winter-buds oblong, gradually narrowed and rounded at the apex, full and rounded on the back, bright light chestnut-brown, nearly $\frac{1^{\prime}}{4}$ long. Bark thin, reddish or olive-green or gray tinged with red, and slightly divided by shallow fissures into appressed platelike scales.

Distribution. Borders of streams, swamps, and lakes, hillsides, open woods and forest margins, usually in moist rich soil; valley of the St. Lawrence River to the shores of Hudson's Bay, the valley of the Mackenzie River within the Aretic Circle, Cook Inlet, Alaska, and the coast ranges of British Columbia, forming in the region west of Hudson's Bay almost impenetrable thickets with twisted and often inclining stems; common in all the northern states, ranging southward to Pennsylvania and westward to Minnesota, through the Rocky Mountain region from western Idaho and northern Montana to the Black Hills of Dakota and western Nebraska, and southward through Colorado to northern Arizona; ascending as a low shrub in Colorado to elevations of $10,000^{\circ}$.

\section{Salix Nuttallii, Sarg. Black Willow.}

Leaves involute in the bud, oblong-obovate, gradually narrowed and wedgeshaped at the often unequal base, acute or abruptly acuminate, with short or long points, or broad and rounded at the apex, entire or remotely and irregularly crenately serrate, pilose above and coated below witl pale pubescence or tomentum when they unfold, at maturity thin and firm, dark yellow-green and lustrous above, pale and glabrous or pilose below, $1 \frac{1}{4}^{\prime}-4^{\prime}$ long, $\frac{1}{2}-1 \frac{1}{2}^{\prime}$ wide, with broad yellow pubescent midribs and slender veins forked and areuate within the slightly thickened and revolute margins and connected by conspicuous reticulate veinlets, their petioles slender, puberulous, $\frac{1}{4}^{\prime}-\frac{1}{2}$ long; stipules foliaceous, semilunar, glandular-serrate, $\frac{1^{\prime}}{8}-\frac{1^{\prime}}{4}$ long, caducous. Flowers: aments oblong-cylindrical, erect, nearly sessile, on short tomentose branches, the staminate abont $1^{\prime}$ long and rather more than $\frac{1^{\prime}}{2}$ thick, the pistillate $1 \frac{1}{2}$ long, about $\frac{3 \prime}{4}$ thick, their scales oblong, narrowed at the ends, acute at the apex, dark-colored, covered with long white hairs, persistent under the fruit; stamens 2, with free glabrous filaments; ovary cylindrical, short-stalked, long-pointed, coated with hoary pubescence, with broad nearly sessile emarginate stigmas. Fruit light reddish brown, covered with pale pubescence, about $\frac{1}{3}^{\prime}$ long.

A tree, occasionally $30^{\circ}$ high, with a short trunk rarely exceeding $1^{\circ}$ in diameter, slender pendulous branches forming a rather compact round-topped shapely head, and stout branchlets marked by scattered yellow lenticels, coated at first with pale 
early deciduous pubescence, becoming bright yellow or dark orange color, and in their second year dark red-brown and much roughened by the conspicuous leaf-scars. Winter-buds ovate, acute, nearly terete or slightly flattened, with narrow lateral wing-like margins, light or dark orange color, glabrous or pilose at the base, about $\frac{1 \prime}{4}$ long. Bark thin, dark brown slightly tinged with red, and divided into broad flat ridges. Wood light, soft, close-grained, light brown tinged with red, with thick nearly white sapwood.

Distribution. Borders of mountain streams usually at high elevations; southern Assiniboia and the banks of the Columbia River in Britisl Columbia, southward through the Rocky Mountain region to northern New Mexico and Arizona; in California on the Sierra Nevada and on the San Bernardino Mountains as a low shrub

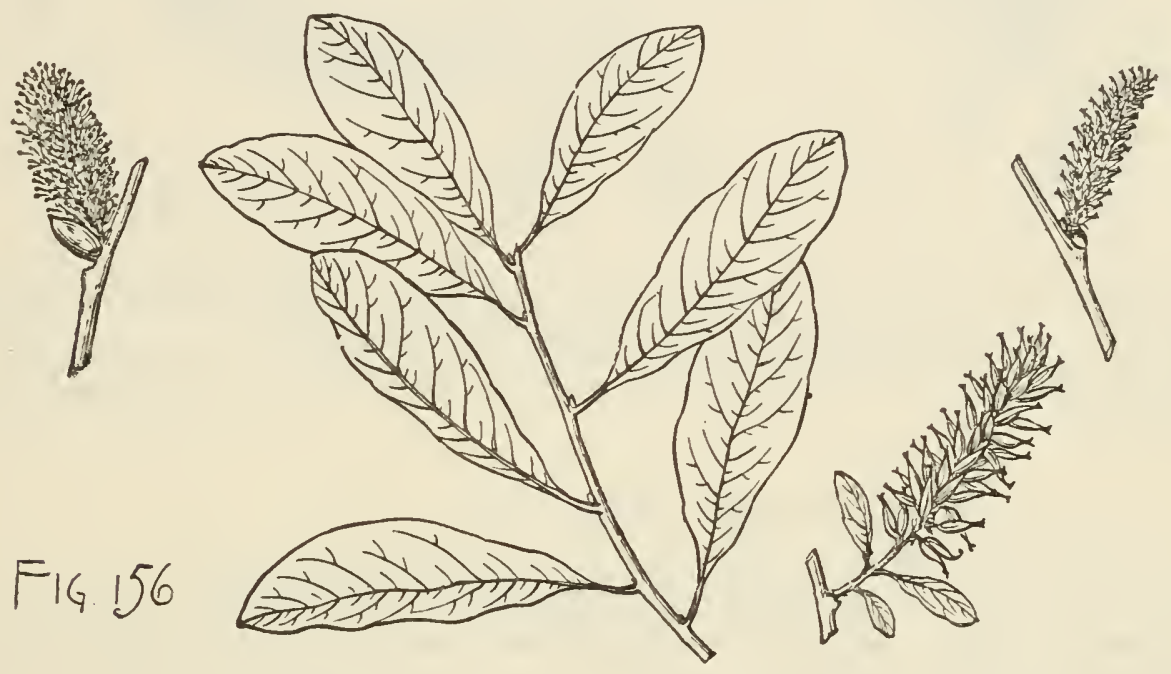

up to elevations of $10,000^{\circ}$ above the sea. In the Pacific coast region from Alaska to Santa Barbara, California, represented by the var. brachystachys, Sarg., a tree sometimes $70^{\circ}$ high, with a tall trunk often $2 \frac{1}{2}^{\prime}$ in diameter, stouter branches, larger pubescent winter-buds, larger obovate leaves, and rather shorter pistillate aments; the most abundant Willow of western Washington and Oregon, and of its largest size in swamp and bottom-lands near the shores of Puget Sound.

\section{Salix amplifolia, Cov. Willow.}

Leaves revolute in the bud, oval to broadly obovate, rounded or broadly pointed at the apex, gradually or abruptly narrowed at the cuneate base, dentate-serrulate or entire, densely villous when they unfold, with long matted white hairs, at maturity nearly glabrous, pale yellow-green above, slightly glaucons below, $2^{\prime}-2 \frac{1}{2}^{\prime}$ long, $1^{\prime}-1 \frac{1}{2}^{\prime}$ wide, with midribs broad and hoary-tomentose toward the base of the leaf and thin and glabrous above the middle; their petioles slender, tomentose. Flowers: aments appearing about the middle of June, stont, pedunculate, tomentose, on lateral leafy branchlets, the staminate $1 \frac{1^{\prime}}{2}-2^{\prime}$ long and shorter than the pistillate, their scales oblanceolate or lanceolate, dark brown or nearly black, covered with long pale hairs; stamens 2, with slender elongated glabrous filaments; ovary ovate-lanceolate, shortstalked, glabrous or slightly pubescent, gradually narrowed into the elongated slender style crowned with a 2-lobed slender stigma. Fruit ovoid-lanceolate, glabrous, short-stalked, $\frac{1^{\prime}}{4}$ long. 
A tree, occasionally $25^{\circ}$ ligh, with a trunk a foot in dianeter, and stout branchlets conspicuously roughened by the large elevated U-shaped leaf-scars, and marked

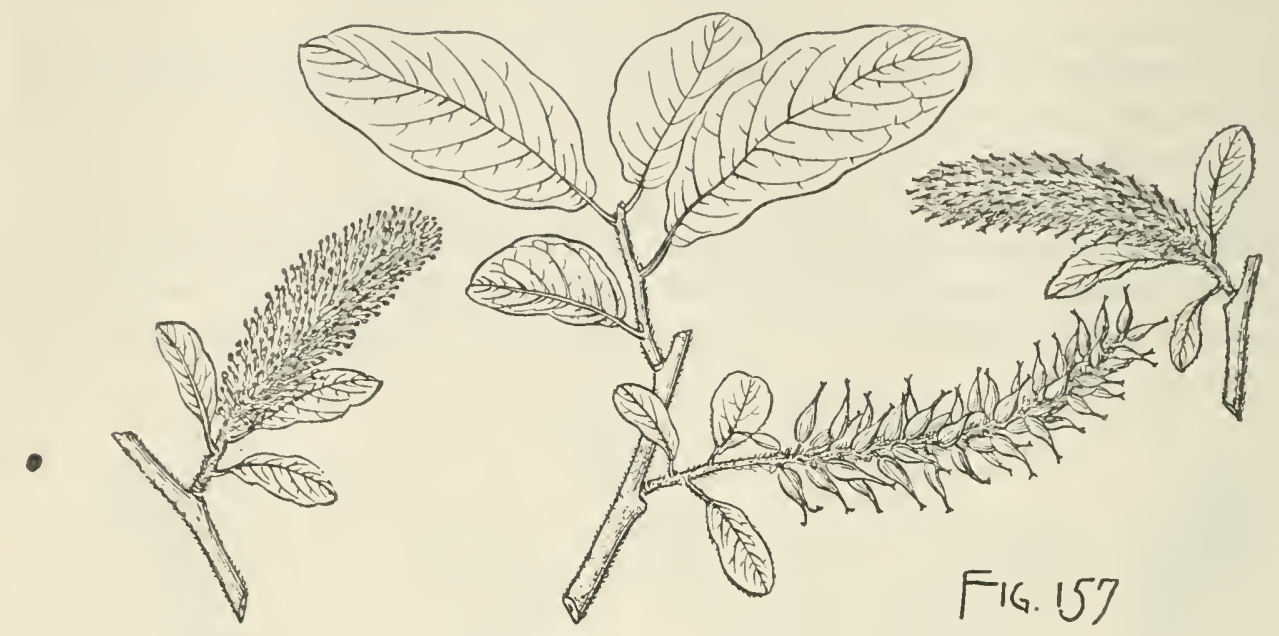

by occasional pale lenticels, coated at first with thick villous pubescence, becoming during their second and third years dark dull reddish purple.

Distribution. Sand dunes on the shores of Yakutat Bay and Disenchantment Bay, Alaska.

$\rightarrow+$ Leaves pubescent or tomentose below.

\section{Salix Hookeriana, Hook. Willow.}

Leaves oblong to oblong-obovate, gradually narrowed and wedge-shaped or rounded at the base, acute or abruptly acuminate, with short points, or rarely rounded and frequently apiculate at the apex, coarsely crenately serrate, especially those on vigorous shoots, or entire, when they unfold villous, with pale hairs, or

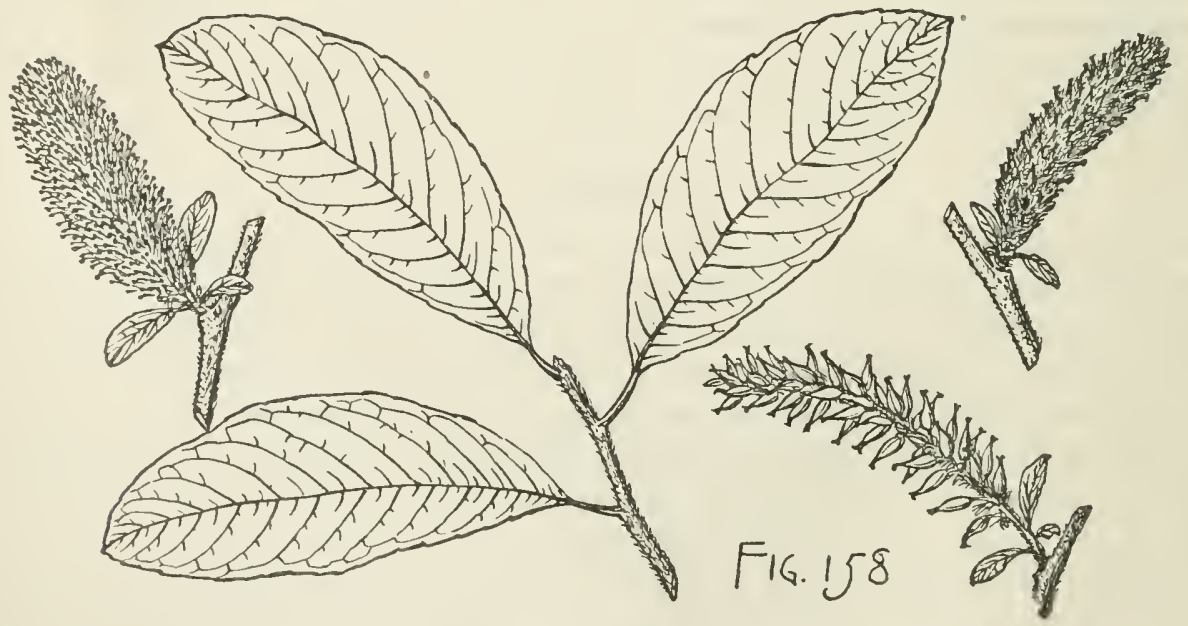

tomentose above and clothed below with silvery white tomentum, at maturity thin and firm, bright yellow-green and lustrous, nearly glabrous or tomentose on the upper surface, pale and glaucous and tomentose or pubescent on the lower surface, 
especially along the midribs and slender arcuate primary veins and conspicuous reticulate veinlets, $2^{\prime}-6^{\prime}$ long, $1^{\prime}-1 \frac{1}{2}^{\prime}$ wide; their petioles stout, tomentose, $\frac{1}{4}^{\prime}-\frac{1}{3}^{\prime}$ long. Flowers: aments oblong-cylindrical, erect, rather lax, often more or less curved, about $1 \frac{1^{\prime}}{2}$ long, on short tomentose branchlets, the staminate $\frac{2^{\prime}}{3}$ thick and rather thicker than the pistillate; their scales oblong-obovate, yellow, coated with long pale hairs, the staminate rounded above and rather shorter than the more acute scales of the pistillate ament persistent under the fruit; stamens 2 , with free elongated glabrous filaments; ovary conical, stalked, with a slender stalk about one third as long as the scale, gradually narrowed above, with a slender elongated bright red style and broad spreading entire stigmas. Fruit oblong-cylindrical, narrowed above, about $\frac{1^{\prime}}{4}$ long.

A tree, occasionally $30^{\circ}$ high, with a trunk $1^{\circ}$ in diameter, and stout branchlets marked by large scattered orange-colored lenticels, covered during their first season with hoary tomentum and rather bright or dark red-brown and pubescent in their second summer; more often shrubby, with numerous stems $4^{\prime}-S^{\prime}$ thick and $15^{\circ}-20^{\circ}$ high; frequently a low bush, with straggling almost prostrate stems. Winter-buds ovate, acute, nearly terete, dark red, coated with pale pubescence, about $\frac{1^{\prime}}{4}$ long. Bark nearly $\frac{1}{8}^{\prime}$ thick, light red-brown, slightly fissured and divided into closely appressed plate-like scales. Wood light, soft, close-grained, light brown tinged with red, with thin nearly white sapwood.

Distribution. Borders of salt marshes and ponds and sandy coast dunes; Vancouver Island southward along the shores of Puget Sound and the Pacific Ocean to southern Oregon.

\section{Salix Sitchensis, Bong. Willow.}

Leaves conduplicate in the bud, oblong-obovate to oblanceolate, entire or dentate, with remote minute spreading glandular teeth, gradually narrowed and wedge-shaped at the base, acute or acuminate, or rounded and short-pointed, or rounded at the

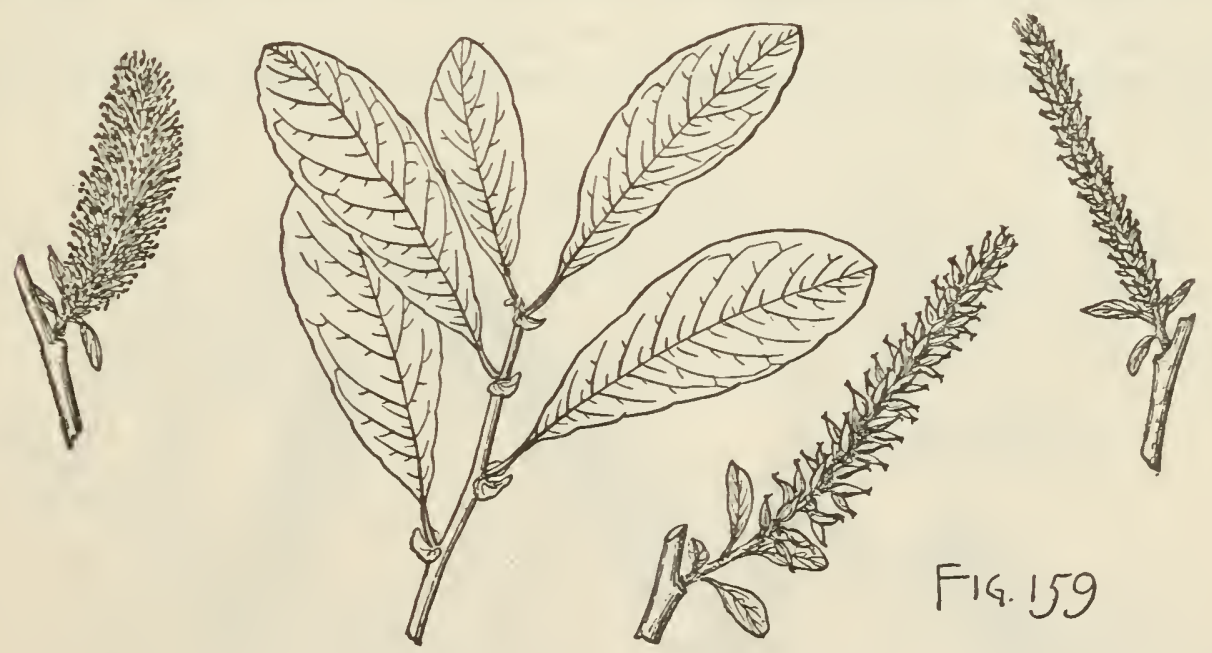

apex, when they unfold pubescent or tomentose on the upper surface, and coated on the lower with lustrous white silky pubescence or tomentum persistent during the first season or sometimes deciduous from the leaves of vigorous young shoots, at maturity thin and firm, dark green, lustrous and glabrous above, with the exception of the pubescent midribs, $2^{\prime}-5^{\prime}$ long, $\frac{3^{\prime}}{4}-1 \frac{1}{2}^{\prime}$ wide, with conspicuous slender veins 
areuate and united within the margins and prominent reticulate veinlets; their petioles stont, pubesecnt, rarely $\frac{1}{2}$ long; stipules foliaceous, semilunar, acute or rounded at the apex, glandular-dentate, eoated below with hoary tomentum, of ten $\frac{1}{2}$ long, eaducous. Flowers: aments cylindrieal, densely flowered, ereet on short tomentose branches, the staminate $1 \frac{1}{2}-2^{\prime}$ long and $\frac{1}{2}$ broad, the pistillate $2 \frac{1}{2}^{\prime}-3^{\prime}$ loug, and $\frac{1}{4}^{\prime}$ broad; their scales yellow or tawny, the staminate oblong-obovate, rounded at the apex, covered with long white hairs, mueh longer than the more acute pubescent seales of the pistillate ament; stamen 1, with an elongated glabrous filament, or very rarely 2, with filaments united below the middie or nearly to the apex; ovary short-stalked, ovate, conical, acute, and gradually narrowed into the elongated style, with entirc or slightly emarginate stigmas. Fruit ovate, narrowed above, light red-brown, about $\frac{1}{4}$ long.

- A much-branched tree, occasionally $25^{\circ}-30^{\circ}$ high, with a short contorted often inclining trunk sometimes $1^{\circ}$ in diameter, and slender branchlets eoated at first with hoary tomentum, pubescent and tomentose and dark red-brown or orange color dnring their first winter, becoming darker, pubescent or glabrous, and sometimes covered with a glaucous bloom in their second season; more often shrubby and $6^{\circ}-15^{\circ}$ tall. Winter-buds acute, nearly terete, light red-brown, pubescent or puberulous, about $\frac{1}{4}$ long. Bark about $\frac{1}{8}^{\prime}$ thick and broken into irregular closely appressed dark brown seales tinged with red. Wood light, soft, close-grained, pale red, with thick nearly white sapwood.

Distribution. Banks of streams and low moist ground; Cook Inlet and Kadiak Island, Alaska, southward in the neighborhood of the coast to Santa Barbara, California.

\section{Salix Alaxensis, Cov. Feltleaf Willow.}

Leaves revolute in the bud, elliptical-lanceolate to obovate, acute or occasionally rounded at the apex, gradually narrowed below into short thick petioles, coated above as they unfold with thin pale deciduous tomentum and covered below with a thick mass of snowy white lustrous hairs persistent on the mature leaves, entire, often somewhat wrinkled, dull yellow-green above, $2^{\prime}-4^{\prime}$, long, $1^{\prime}-1 \frac{1}{2}^{\prime}$ wide, with broad yellow midribs; stipules linear-lanceolate to filiform, entire, $\frac{1}{2}^{\prime}-\frac{3}{4}^{\prime}$ long, usually

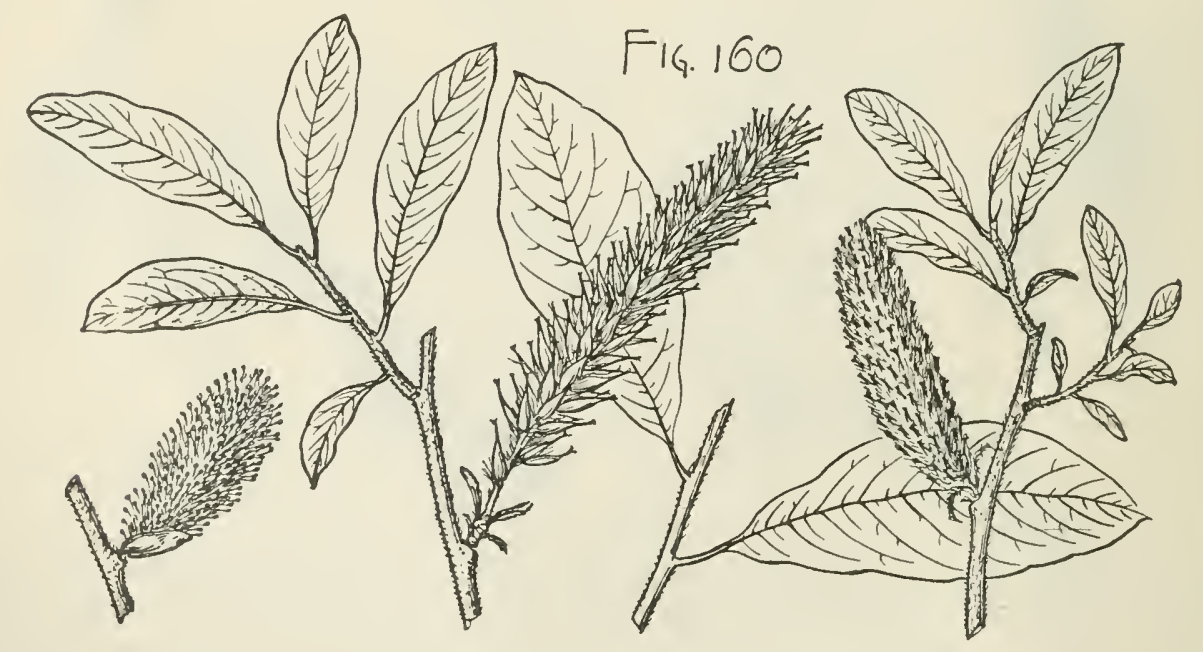

persistent until midsummer. Flowers: aments appearing in June when the leaves are nearly fully grown, stout, erect, tomentose, stalked, on lateral pendulous branchlets. 
the staminate $1^{\prime}-1 \frac{1}{2}^{\prime}$ long, much shorter than the pistillate; their scales oblong-ovate, rounded at the apex, dark-colored, and coated with long silvery white soft hairs; stamens 2, with slender elongated filaments; «ovary acuminate, short-stalked, covered with soft pale hairs, gradually narrowed into the elongated slender style with 2-lobed stigmas. Fruit nearly sessile, ovate, acuminate, covered with close dense pale tomentum, $\frac{1^{\prime}}{t}$ long.

A tree, sometimes $30^{\circ}$ high, with a trunk $4^{\prime}-6^{\prime}$ in diameter, and stout branchlets thickly coated at first with matted white hairs, becoming in their second year glabrous, dark purple, lustrous, marked by large elevated pale scattered lenticels and much roughened by large U-shaped leaf-scars; often shrubby and in the most exposed situations frequently only a foot or two high, with semiprostrate stems.

Distribution. Coast of Alaska from the Alexander Archipelago to Cape Lisbourne, and eastward to the valley of the Mackenzie River and to the shores of Coronation Gulf; the only arborescent Willow in the coast region west and north of Kadiak Island; attaining its largest size from the Shumagin Islands eastward.

\section{BETULACEA.}

Trees, with sweet watery juice, without terminal buds, their slender terete branchlets marked by numerous pale lenticels and lengthening by one of the upper axillary buds formed in early summer, and alternate simple penniveined usually doubly serrate deciduous stalked leaves, obliquely plicately folded along the primary veins, their petioles in falling leaving small semioval slightly oblique scars showing three equidistant fibro-vascular bundle-scars; stipules inclosing the leaf in the bud,fugacious. Flowers vernal, appearing with or before the unfolding of the leaves, or rarely autumnal, monœeious, the staminate 1-3 together in the axils of the scales of an elongated pendulous lateral ament and composed of a 2-4-parted membranaceous calyx and 2-20 stamens inserted on a receptacle, with distinct filaments and 2-celled erect extrorse anthers opening longitudinally, or without a calyx, the pistillate in short lateral or capitate aments, with or without a calyx, a 2-celled ovary, narrowed into a short style divided into two elongated branches longer than the scales of the ament and stigmatic on the inner face or at the apex, and a single anatropous pendulous ovule in each cell of the ovary. Fruit a small mostly 1-celled 1 -seeded nut, the outer layer of the shell light brown, thin and membranaceous, the inner thick, hard, and bony. Seed solitary by abortion, filling the cavity of the nut, suspended, without albumen, its coat membranaceous, light chestnutbrown; cotyledons thick and fleshy, inuch longer than the short superior radicle turned toward the minute hilum.

Of the six genera, all confined to the northern hemisphere, five are found in North America; of these only Corylus is shrubby.

\section{CONSPECTUS OF THE NORTH AMERICAN ARBORESCENT GENERA.}

Scales of the pistillate ament deciduous; nut wingless, more or less inclosed in an iuvolucre formed by the enlargement of the bract and bractlets of the flower; staminate flowers solitary in the axjls of the scales of the ament; calyx 0 ; pistillate flowers with a calyx.

Staminate aments covered during the winter: involucre of the fruit flat, 3.cleft, foliaceous.

1. Carpinus.

Staminate aments naked during the winter: involucre of the fruit bladder-like, closed. 
Scales of the pistillate ament persistent and forming a woody strobile; nut without an involucre, more or less broadly winged; staminate flowers $3-6$ together in the axils of the scales of the ament; calyx present; pistillate flowers without a calyx.

Pistillate aments solitary, their scales 3 -lobed, becoming thin, brown, and woody, decidnous; stamens 2 ; filaments 2-branched, each division bearing a half-anther; winter-buds covered by imbricated scales.

3. Betula.

Pistillate aments racemose, their scales erose or 5-toothed, becoming thick, woody, and dark-colored, persistent; stamens $1-3$ or 4 ; filaments simple ; wings of the nut of ten reduced to a narrow border; winter-buds without scales.

4. Alnus.

\section{CARPINUS, I. Hornbeam.}

Trees, with smooth close bark, hard strong close-grained wood, elongated conical buds covered by numerous imbricated scales, the inner lengthening after the opening of the buds. Leaves open and concave in the bud, ovate, acute, often cordate; stipules strap-shaped to oblong-obovate. Flowers: staminate in aments emerging in very early spring from buds produced the previous season near the ends of short lateral branchlets of the year and inclosed during the winter, and composed of 3-20 stamens crowded on a pilose receptacle adnate to the base of a nearly sessile ovate acute coriaceous scale longer than the stamens; filaments short, slender, 2-branched, each branch bearing a 1-celled oblong yellow half-anther hairy at the apex; pistillate in lax semierect aments terminal on leafy branches of the year, in pairs at the base of an ovate acute leafy deciduous scale, each flower subtended by a small acute bract with two minute bractlets at its base; calyx adnate to the ovary and dentate on the free narrow border. Nuts ovate, acute, compressed, conspicuously longitudinally ribbed, bearing at the apex the remnants of the calyx, marked on the broad base by a large pale scar and separating at maturity in the autumn from the leaf-like 3-lobed conspicuously serrate green involucres formed by the enlargement of the bract and bractlets of the flowers and inclosing only the base of the nuts, fully grown at midsummer and loosely imbricated into a long-stalked open cluster.

Carpinus is confined to the northern hemisphere, and is distributed from the Province of Quebec through the eastern United States to the highlands of Central America in the New World, and from Sweden to southern Europe, Asia Minor, the temperate Himalayas, central China and Japan in the Old World. Ten or twelve species are recognized; one only is American. Of the exotic species, the European and west Asian Carpinus Betulus, L., is frequently planted as an ornamental tree in the northeastern United States, where some of the species of eastern Asia promise to become valuable.

Carpinus is the classical name of the Hornbeam.

\section{Carpinus Caroliniana, Walt. Hornbeam. Blue Beech.}

Leaves often somewhat falcate, long-pointed, sharply doubly serrate, with stout spreading glandular teeth, except at the rounded or wedge-shaped often unequal base, pale bronze-green, and covered with long white hairs when they unfold, at maturity thin and firm, pale dull blue-green above, light yellow-green and glabrous or puberulous below, with small tufts of white hairs in the axils of the veins, $2^{\prime}-4^{\prime}$ long, $1^{\prime}-1 \frac{3^{\prime}}{4}$ wide, with slender yellow midribs, numerous slender veins deeply impressed and conspicuous above, and prominent cross veinlets, turning deep scarlet and orange color late in the autumn; their petioles slender, terete, hairy, about $\frac{1^{\prime}}{3}$ long, bright red while young; stipules ovate-lanceolate, acute, pubescent, hairy on the 
margins, bright red below, light yellow-green at the apex, $\frac{1^{\prime}}{3}$ long. Flowers: staminate aments $1 \frac{1}{2}^{\prime}$ long when fully grown, with broadly ovate acute boat-shaped scales green below the middle, bright red above; pistillate aments $\frac{1}{2}-\frac{8^{\prime}}{4}$ long, with ovate acute hairy green scales; styles scarlet. Fruit: nuts $\frac{1}{3}^{\prime}$ long, their involucres

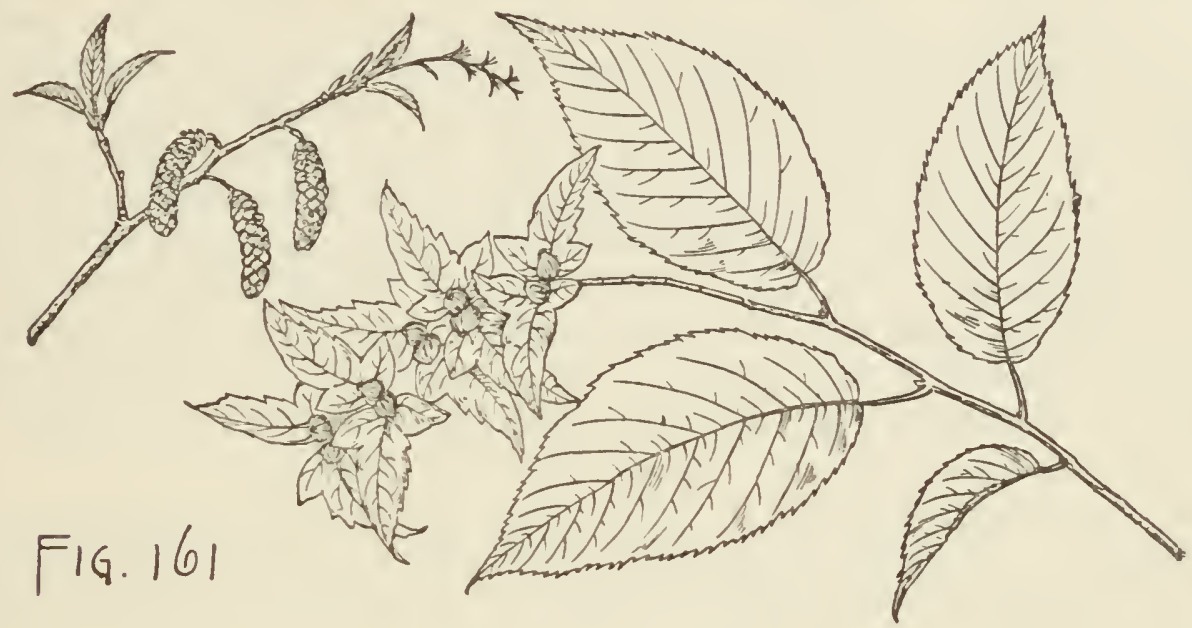

short-stalked, with one of the lateral lobes often wanting, coarsely serrate, but usually on one margin only of the middle lobe, $1^{\prime}-1 \frac{1^{\prime}}{2}$ long, nearly $1^{\prime}$ wide, on slender terete pubescent red-brown stems $5^{\prime}-6^{\prime}$ long.

A bushy tree, rarely $40^{\circ}$ high, with a short fluted trunk occasionally $2^{\circ}$ in diameter, long slightly zigzag slender tough spreading branches pendulous toward the ends, and furnished with numerous short thin lateral branches growing at acute angles, and branchlets at first pale green coated with long white silky hairs, orangebrown and sometimes slightly pilose during the summer, becoming dark red and lustrous during the first winter and ultimately dull gray tinged with red. Winterbuds ovate acute, about $\frac{1^{\prime}}{8}$ long, with ovate acute chestnut-brown scales white and scarious on the margins. Bark light gray-brown, sometimes marked with broad dark brown horizontal bands, $\frac{1}{16}-\frac{1}{8}$ thick. Wood light brown, with thick nearly white sapwood; sometimes used for levers, the handles of tools, and other small articles.

Distribution. Borders of streams and swamps, generally in deep rich moist soil; southern and western Quebec to the northern shores of Georgian Bay, southward to Cape Malabar and the shores of Tampa Bay, Florida, and westward to northern Minnesota, eastern Nebraska and Kansas, the Indian Territory, and eastern Texas; reappearing on the mountains of southern Mexico and Central America; common in the eastern and central states, most abundant and of its largest size on the western slopes of the southeru Alleghany Mountains and in southern Arkansas and Texas.

\section{OSTRYA, Scop. Hop Hornbeam.}

Trees, with scaly bark, heavy hard strong close-grained wood, and acute elongated winter-buds formed in early summer and covered by numerous imbricated scales, the inner lengthening after the opening of the bud. Leaves open and concave in the bud; their petioles slender, nearly terete, hairy; stipules strap-shaped to oblongobovate. Flowers: staminate in long clustered sessile or short-stalked aments de- 
veloped in early summer from lateral buds near the ends of short lateral branchlets of the year and coated while yomg with hoary tomentum, naked and conspicnous during the winter, and composed of 3-14 stamens erowded on a pilose receptacle adnate to the base of an ovate eoncave seale rounded and abruptly short-pointed at the apex, eiliate on the margins, longer than the stamens; filaments short, 2-branched, each branelı bearing a 1-celled laalf-anther hairy at the apex; pistillate in erect lax aments terminal on short leafy branches of the year, in pairs at the base of an elongated ovate acute leaf-like ciliate scale persistent until midsummer, each flower inelosed in a hairy sack-like involucre formed by the union of a bract and 2 bractlets; calyx adnate to the ovary, denticulate on the free narrow border. Nuts ovate, acite, flattened, obscurely longitudinally ribbed, crowned with the remnants of the calyx, marked at the narrow base by a small circular pale scar, inelosed in the much enlarged pale membranaeeous conspienonsly longitndinally veined reticulate-venulose involucres of the flower, short, pointed and hairy at the apex, hirsute at the base, with sharp rigid stinging hairs, imbricated into a short strobile fully grown at midsummer, and suspended on a slender hairy stem.

Ostrya is widely distributed in the northern hemisphere from Nova Scotia to Texas, northern Arizona, and to the highlands of southern Mexico and Guatemala in the New World, and through southern Europe and southwestern Asia and in northern Japan in the Old World. Of the four speeies now recognized two are American.

Ostrya is the elassical name of the Hop Hornbeam.

\section{CONSPECTUS OF THE NORTH AMERICAN SPECIES.}

Leaves oblong-lanceolate, acuminate or acute at the apex.

Leaves oval or obovate, acute or rounded at the apex.
1. O. Virginiana $(A, C)$. 2. O. Knowltoni (F).

\section{Ostrya Virginiana, K. Koch. Hop Hornbeam. Ironwood.}

Leaves oblong-lanceolate, gradually narrowed into long slender points or acute at the apex, narrowed and rounded, cordate or wedge-shaped at the often unequal

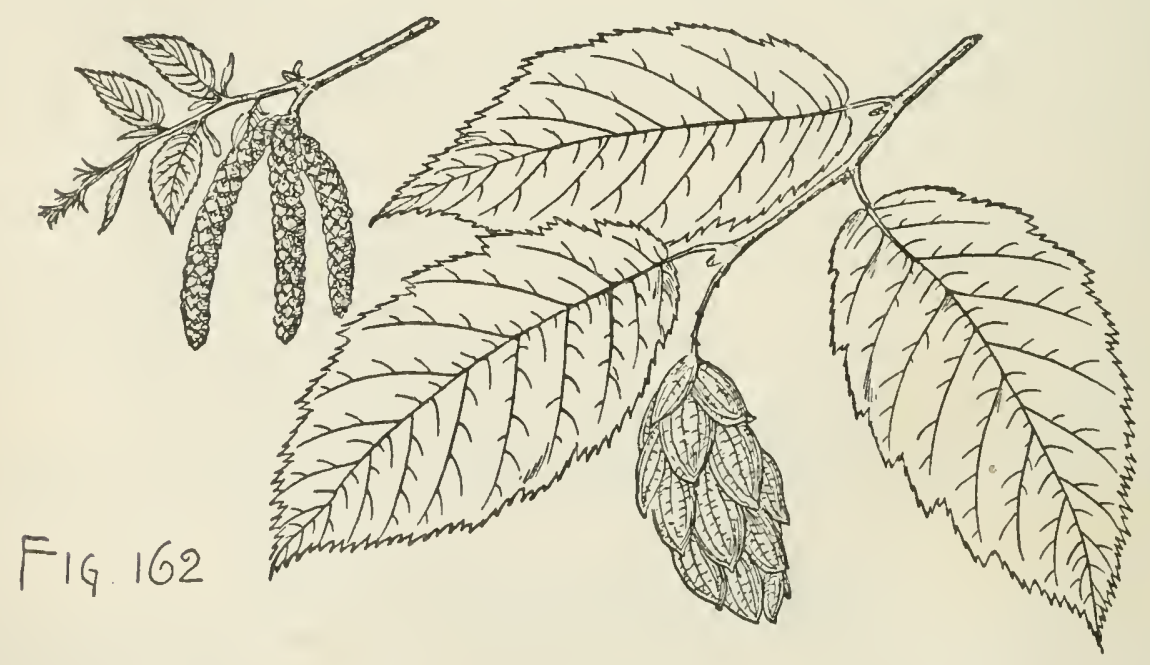

base, sharply serrate, with slender incurved callous teeth terminating at first in tufts of caducous hairs, when they unfold light bronze-green, glabrous above and coated below on the midribs and primary veins with long pale hairs, at maturity thin and 
extremely tough, dark dull yellow-green above, light yellow-green and furnished with conspicuous tufts of pale hairs in the axils of the veins below, $3^{\prime}-5^{\prime}$ long, $1 \frac{1}{2}-2^{\prime}$ wide, with slender midribs impressed and puberulous above, light yellow and pubescent below, and numerous slender veins forked near the margins, turning clear yellow before falling in the autumn; their petioles about $1^{\prime}$ long; stipules rounded and often short-pointed at the apex, ciliate on the margins, with long pale hairs, hairy on the back, about $\frac{1}{2}^{\prime}$ long and $\frac{1^{\prime}}{8}$ broad. Flowers: staminate aments about $\frac{1^{\prime}}{2}$ long during their first season, with light red-brown rather loosely imbricated scales narrowed into long slender points, becoming when the flowers open $2^{\prime}$ long, with broadly obovate scales rounded and abruptly contracted at the apex into short points, ciliate on the margins, green tinged with red above the middle, light brown toward the base; pistillate aments slender, about $\frac{1^{\prime}}{4}$ long, on thin hairy stems, their scales lanceolate, acute, light green, often flushed with red above the middle, hirsute at the apex, decreasing in size from the lowest. Fruit: nuts $\frac{1}{3}^{\prime}$ long, about $\frac{1}{8}^{\prime}$ wide, rather abruptly narrowed below the apex, their involucres in clusters $1 \frac{1}{2}^{\prime}-2^{\prime}$ long and $\frac{2^{\prime}}{3}-1^{\prime}$ wide, on slender stems about $1^{\prime}$ in length.

A tree, occasionally $50^{\circ}-60^{\circ}$ high, with a short trunk $2^{\circ}$ in diameter, usually not more than $20^{\circ}-30^{\circ}$ tall, with a trunk $18^{\prime}-20^{\prime}$ thick, long slender branches drooping at the ends and forming a round-topped or open head frequently $50^{\circ}$ across, and slender, very tough branchlets, light green, coated with pale hairs when they first appear, becoming light orange color and very lustrous at midsummer, dark red-brown and lustrous during their first winter, and then gradually darker brown and losing their lustre. Winter-buds ovate, light chestnut-brown, slightly puberulous, $\frac{1}{4}^{\prime}$ long. Bark about $\frac{1^{\prime}}{4}$ thick, broken into thick narrow oblong closely appressed plate-like light brown scales slightly tinged with red on the surface. Wood strong, hard, tough, durable, light brown tinged with red or often nearly white, with thick pale sapwood of 40-50 layers of annual growth; used for fence-posts, handles of tools, mallets, and other small articles.

Distribution. Dry gravelly slopes and ridges of ten in the shade of oaks and other large trees; Island of Cape Breton and the shores of the Bay of Chalenr, through the valley of the St. Lawrence River, and along the northern shores of Lake Huron to western Ontario, northern Minnesota, the Black Hills of Dakota, eastern and northern Nebraska, eastern Kansas and southward to northern Florida and eastern Texas; most abundant and of its largest size in southern Arkansas and Texas.

\section{Ostrya Knowltoni, Cov. Ironwood.}

Leaves oval to obovate, acute or rounded at the apex, gradually narrowed and often unequal at the rounded wedge-shaped rarely cordate base, sharply serrate, with small triangular callous teeth, covered with loose pale tomentum when they unfold, at maturity dark yellow-green and pilose above, pale and soft-pubescent below, $1^{\prime}-2^{\prime}$ long, $1^{\prime}-1 \frac{1}{2}^{\prime}$ wide, with slender yellow midribs slightly raised on the upper side, few slender primary veins connected by obscure reticulate veinlets, turning dull yellow in the antumn before falling; their petioles $\frac{1^{\prime}}{4}-\frac{1}{2}^{\prime}$ long; stipules pale yellowgreen, often tinged with red toward the apex, $\frac{1}{2}^{\prime}$ long, about $\frac{1}{2}^{\prime}$ wide. Flowers: staminate aments on stout stalks covered with rufous tomentum and sometimes $\frac{1^{\prime}}{2}$ long, rarely sessile, about $\frac{1^{\prime}}{2}$ long during their first season, with dark brown puberulous scales gradually contracted into long slender subulate points, becoming when the flowers open $1^{\prime}-1 \frac{1^{\prime}}{4}$ long, with broadly ovate concave scales abruptly narrowed into nearly triangular points, yellow-green near the base, bright red above the mid- 
dle; pistillate aments about $\frac{1}{1}$ long, with ovate-lanceolate light yellow-green puberulous scales ciliate on the margins. Fruit: nuts $\frac{1 \prime}{4}$ long, gradually narrowed at the

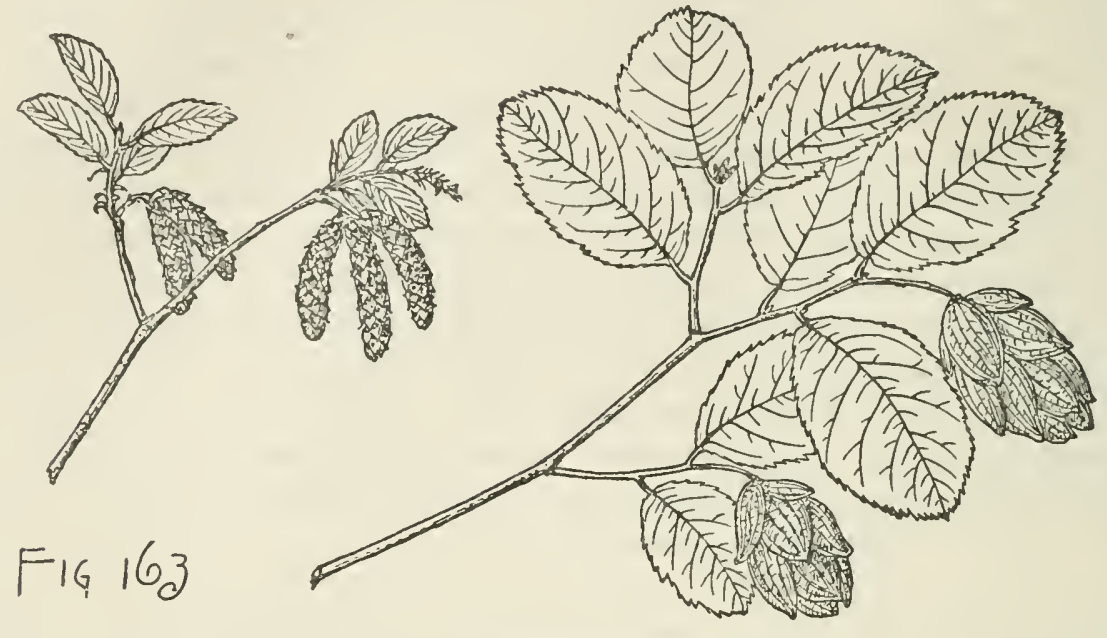

apex, their involucres $\mathbf{1}^{\prime}$ long, nearly glabrons at the apex, sometimes slightly stained with red toward the base, in clusters $1^{\prime}-1 \frac{1}{2}^{\prime}$ long and about $\frac{3^{\prime}}{4}$ broad, on stems $\frac{1}{2}^{\prime}$ long.

A tree $20^{\circ}-30^{\circ}$ high, with a trunk $12^{\prime}-18^{\prime}$ in diameter, usually divided $1^{\circ}$ or $2^{\circ}$ above the ground into 3 or 4 stout upright stems $4^{\prime}-5^{\prime}$ thick, slender pendulous often much contorted branches forming a narrow round-topped synmetrical head, and slender branchlets dark green and coated with hoary tomentum when they appear, dark red-brown and pubescent during their first summer, becoming light cinnamonbrown, glabrous, and lustrous in the winter, and ultimately asly gray. Winterbuds ovate, dark red-brown, about $\frac{1^{\prime}}{8}$ long. Bark internally bright orange color, $\frac{1}{8}$ ' thick, separating into loose hanging plate-like scales light gray slightly tinged with red, $1^{\prime}-2^{\prime}$ long and $1^{\prime}$ or $2^{\prime}$ wide. Wood light reddish brown, with thin sapwood.

Distribution. Only on the southern slope of the cañon of the Colorado River in Arizona at elevations of $6000^{\circ}-7000^{\circ}$ above the sea near Talfrey, seventy miles north of Flagstaff.

\section{BETULA, L. Birch.}

Trees, with smooth resinous bark marked by long longitudinal lenticels, often separating freely into thin papery plates, becoming thick, deeply furrowed, and scaly at the base of old trunks, short slender branches more or less erect and forming on young trees a narrow symmetrical pyramidal head, becoming horizontal and often pendulous on older trees, tough branchlets, short stout spur-like 2-leaved lateral branchlets much roughened by the crowded leaf-scars of many years, and elongated winterbuds covered by numerous ovate acute scales, and fully grown and bright green at midsummer. Leaves open and convex in the bud, often incisely lobed; stipules ovate and acute or oblong-obovate, scarious. Flowers in 3-flowered cymes, the lateral flowers of the cyme subtended by bractlets adnate to the base of the scale of the ament; staminate aments long, pendulous, solitary or clustered, appearing in summer or autumn in the axils of the last leaves of a branchlet of the year or near the ends of the short lateral branchlets, erect and naked during the winter, their scales in the spring broadly ovate, rounded, short-stalked, yellow or orange-color below the middle 
and dark chestnut-brown and lustrous above; staminate flowers composed of a membranaceous 4-lobed calyx often 2-lobed by suppression, the anterior lobe obovate, rounded at the apex, as long as the stamens, much longer than the minute posterior lobe, and of 2 stamens inserted on the base of the calyx, with short 2-branched filaments, each branch bearing an erect half-anther; pistillate aments oblong or cylindrical, terminal on the short spur-like lateral branchlets, their scales closely imbricated, oblong-ovate, 3-lobed, light yellow, often tinged with red above the middle, accrescent, becoming brown and woody at maturity, and forming sessile or stalked erect or pendulous short or elongated strobiles usually ripening in the autumn, deciduous with the nuts from the slender rachis; calyx of the pistillate flower 0 ; ovary sessile, compressed, with styles stigmatic at the apex. Nut minute, oval or obovate, compressed, bearing at the apex the persistent stigmas, marked at the base by a small pale scar, the outer coat of the shell produced into a marginal wing interrupted at the apex.

Betula is widely distributed from the Arctic Circle to Texas in the New World, and to southern Europe, the Himalayas, China, and Japan in the Old World, some species forming great forests at the north, or covering high mountain slopes. Of the twenty-eight or thirty species now recognized thirteen are found in North America; of these ten are trees. Of exotic species the European and Asiatic Betula alba, L., in a number of forms is a common oruamental tree in the northeru states, where several of the Birch-trees of eastern Asia also flourish. Many of the species produce wood valued by the cabinet-maker, or used in the manufacture of spools, shoe-lasts, and other small articles. The thin layers of the bark are impervious to water and are used to cover buildings, and for shoes, canoes, and boxes. The sweet sap provides an agreeable beverage.

Betula is the classical name of the Birch-tree.

\section{CONSPECTUS OF THE NORTH AMERICAN ARBORESCENT SPECIES.}

Strobiles oblong-ovoid, nearly sessile, erect, the lateral lobes of their scales broad and slightly divergent; wing not broader than the nut; leaves with 9-11 pairs of veins; bark of young branches aromatic.

Leaves heart-shaped or rounded at the base; scales of the strobiles glabrous; bark dark brown, not separating into thin layers.

1. B. lenta $(A, C)$.

Leaves wedge-shaped or slightly heart-shaped at the base; scales of the strobiles pubescent; bark yellow or silvery white, separating into thin layers.

2. B. lutea (A).

Strobiles oblong or cylindrical, erect, spreading or pendant, on slender peduncles; wing broader than the nut; leares with $5-9$ pairs of veins.

Strobiles oblong, erect, ripening in May or June, their scales pubescent, deeply lobed, the lateral lobes erect.

Leaves rhombic-ovate, glaucescent and more or less silky-pubescent beneath; bark light reddish brown, separating freely into thin persistent scales.

3. B. nigra $(A, C)$.

Strobiles cylindrical, pendant or spreading.

Scales of the strobiles pubescent, with recurved lateral lobes, the middle lobe triangular, nearly as broad as long; leaves long-pointed, their petioles slender, elongated.

Leaves triangular to rhomboidal, bright green and lustrous; bark chalky white, not separable into thin layers.

4. B. populifolia (A). 
Leaves ovate, wedge-shaped to truncate or rounded at the base, dull blue-green; bark white tinged with pink, lustrous, not easily separable into thin layers.

5. B. corulea (A).

Scales of the strobiles with ascending or spreading lateral lobes, the middle lobe usually acuminate, longer than broad; leaves acute or acuminate, their petioles more or less stout.

Bark separating freely into thin layers.

Bark creamy white and lustrous.

Leaves ovate, dull dark green; scales of the strobiles glabrous.

6. B. papyrifera $(\mathrm{A}, \mathrm{F})$.

Bark reddish brown to grayish white; scales of the strobiles ciliate.

Leaves ovate, mostly rounded or cordate at the broad base; scales of the strobiles puberulous.

7. B. occidentalis (B).

Leaves ovate, cuneate; scales of the strobiles glabrous except on the margins; young branches not or only slightly glandular.

8. B. Kenaica (B).

Leaves rhomboidal to deltoid; scales of the strobiles glabrous except on the margins ; young branchlets thickly covered with glands.

9. B. Alaskana (A, B).

Bark not separable into thin layers, dark brown; scales of the strobiles glabrous or puberulous.

Leaves ovate, truncate or rounded at the broad base, dull green.

10. B. fontinalis $(B, F, G)$.

1. Strobiles oblong-ovoid, erect; wing not broader than the nut; leaves with 9-11 pairs of veins.

\section{Betula lenta, L. Cherry Birch. Black Birch.}

Leaves ovate to oblong-ovate, acute or acuminate, gradually narrowed and often unequal at the cordate or rounded base, sharply serrate, with slender incurved teeth, when they unfold light green, coated on the lower surface and the margins with

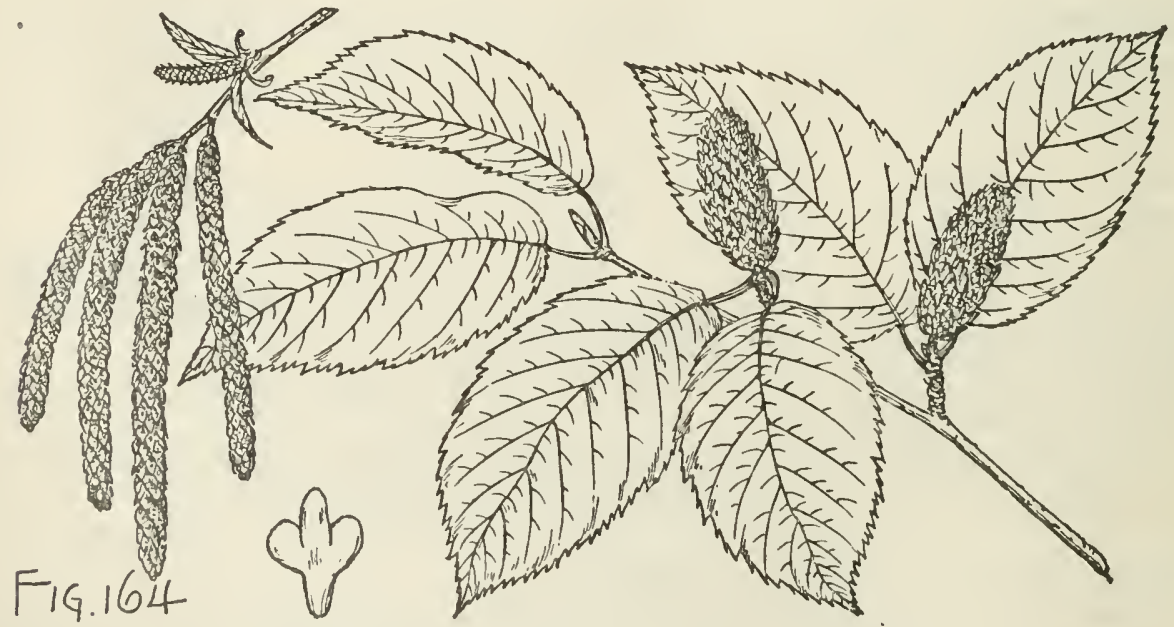

long white silky hairs, and slightly hairy on the upper surface, at maturity thin and membranaceous, dark dull green above, light yellow-green below, with small tufts of white hairs in the axils of the veins, $2 \frac{1}{2}^{\prime}-6^{\prime}$ long, $1 \frac{1}{2}^{\prime}-3^{\prime}$ wide, with yellow midribs and primary veins prominent and hairy on the lower surface, and obscure reticulate 
cross veinlets, turuing bright clear yellow late in the autumm; their petioles stout, hairy, deeply grooved on the upper side, $\frac{3 \prime}{4}-1^{\prime} l o n g ;$ stipules ovate, acute, light green or nearly white, searious and ciliate above the middle. Flowers: staminate aments during the winter about $\frac{3}{4}$ long, nearly $\frac{1^{\prime}}{4}$ thick, with orate acute apiculate scales bright red-brown above the middle and light brown below, beeoming $3^{\prime}-4^{\prime}$ long; pistillate aments $\frac{1^{\prime}}{2}-\frac{3}{4}$ long, about $\frac{1}{8}^{\prime}$ thick, with ovate pale green scales rounded at the apex; styles light pink. Fruit: strobiles oblong-ovoid, sessile, ereet, glabrous, $1^{\prime}-1 \frac{1}{2}^{\prime}$ long, about $\frac{1}{2}^{\prime}$ thick; nut obovate, pointed at the base, rounded at the apex, abont as broad as its wing.

A tree, with aromatie bark and leaves, $70^{\circ}-80^{\circ}$ high, with a trunk $2^{\circ}-5^{\circ}$ in diameter, slender branehes finally spreading almost at right angles, becoming pendulous toward the ends and gradually forming a narrow round-topped open graceful head, and brauchlets light green, slightly viscid and pilose when they first appear, soon turning dark orange-brown, lustrous during the summer, bright red-brown in their first winter, beeoming darker and finally dark dull brown slightly tinged with red. Winter-buds ovate, aeute, about $\frac{1}{4}^{\prime} \operatorname{long}$, with ovate acute light chestnut-brown loosely imbrieated scales, those of the inner ranks beeoming $\frac{1^{\prime}}{2}-\frac{3}{4}$ long. Bark on young stems and branches elose, smooth, lustrous, dark brown tinged with red, and marked by elongated horizontal pale lenticels, beeoming on old trunks $\frac{1^{\prime}}{2}-\frac{3^{\prime}}{4}$ thiek, dull, deeply furrowed and broken into large thick irregular plates covered. with closely appressed seales. Wood heavy, very strong and hard, elose-grained, dark brown tinged with red, with thin light brown or yellow sapwood of 70-80 layers of annual growth; largely used in the manufacture of furniture and for fuel, and oecasionally in ship and boatbuilding. Oil used medieinally as a flavor is distilled from the wood, and beer is obtained by fermenting the sugary sap.

Distribution. Rieh uplands from Newfoundland and the valley of the Saguenay River to northwestern Ontario, and eentral Iowa, and southward to Delaware, soutlern Indiana and Illinois, and along the Alleghany Mountains to western Florida, central Kentueky and Tennessee; a eommon forest tree at the north, and of its largest size on the western slopes of the southern Appalaehian Mountains.

\section{Betula lutea, Michx. Yellow Birch. Gray Birch.}

Leaves ovate to oblong-ovate, acuminate or aeute at the apex, gradually narrowed to the rounded cuneate or rarely heart-shaped usually oblique base, sharply doubly serrate, when they unfold bronze-green or red and pilose, with long pale hairs above and on the under side of the midribs and veins, at maturity dark dull green above, yellow-green below, $3^{\prime}-4 \frac{1}{2}^{\prime} \operatorname{long}, 1 \frac{1}{2}^{\prime}-2^{\prime}$ wide, with stout midribs and primary veins eovered below near the base of the leaf with short pale or rufous hairs, turning elear bright yellow in the autumn before falling; their petioles slender, pale yellow, hairy, $\frac{3^{\prime}}{4}-1^{\prime}$ long; stipules ovate, acnte, light green tinged with pink above the middle, about $\frac{1^{\prime}}{2}$ long. Flowers: staminate aments during the winter $\frac{3^{\prime}}{4}-1^{\prime}$ long, about $\frac{1^{\prime}}{8}$ thick, with ovate rounded scales light ehestnut-brown and lustrous above the middle, eiliate on the margins, becoming $3^{\prime}-3 \frac{1}{2}^{\prime}$ long and $\frac{1}{3}^{\prime}$ thick; pistillate aments about $\frac{2}{3}^{\prime}$ long, with acute seales, pale green below, light red and tipped with elusters of long white hairs at the apex, and pilose on the back. Fruit: strobiles ereet, sessile, short-stalked, pubescent, $1^{\prime}-1 \frac{1}{2}^{\prime}$ long, about $\frac{3^{\prime}}{4}$ thiek; nut oval or obovate, about $\frac{1^{\prime}}{8}$ long, rather broader than its wing.

A tree, with slightly aromatic bark and leaves, oecasionally $100^{\circ} \mathrm{high}$, with a trunk $3^{\circ}-4^{\circ}$ in diameter, spreading and more or less pendulous branehes forming 
a broad round-topped head, and branchlets at first green and eovered with long pale hairs, light ormge-brown and pilose during their first summer, heeoning glabrous and hight brown slightly tinged with or:mge, and ultinately dull and darker. Winter-buds about I $^{\prime}$ long, somewhat viseid and eovered with loose pale hairs dnring the summer, beeoming light ehestnut-brown, aente, and slightly puberulons in winter. Bark of young stems and of the branches bright silvery gray or light orange eolor, very lustrous, separating into thin loose persistent seales nore or less rolled on the margins, becoming on old trees $\frac{1}{2}$ thick, reddish brown, and divided by narrow irregular fissnres into large thin plates eovered with ninute elosely appressed seales. Wood

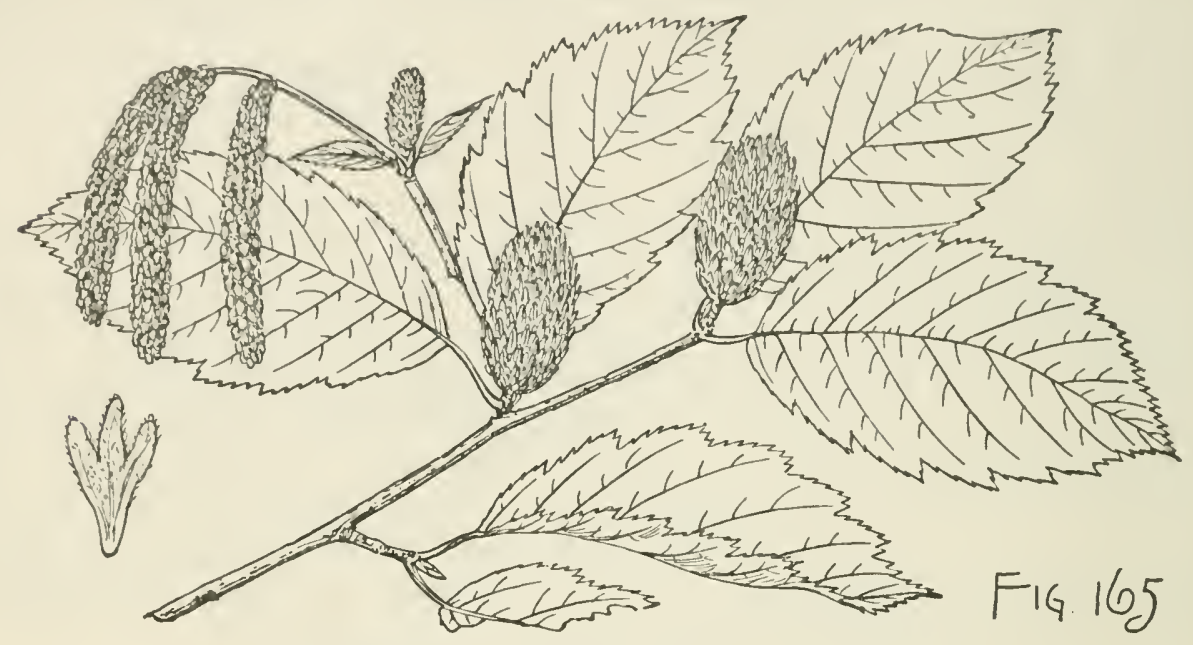

heavy, very strong, hard, elose-grained, light brown tinged witl red, with thin nearly white sapwood; largely used in the manufaeture of furuiture, button and tassel moulds, boxes, the hubs of wheels, and for fuel.

Distribution. Moist uplands, in rich soil, and one of the largest deeiduous-leaved trees of northeastern America; Newfoundland and along the northern shores of the Gulf of St. Lawrence to the valley of Rainy River, and southward to northern Delaware and northern Minnesota, and along the Alleghany Mountains to the high peaks of North Carolina and Tennessee; very abundant and of its largest size in the eastern provinces of Canada and in northern New York and New England; small and rare in southern New England and southward.

2. Strobiles oblong or cylindrical; wing broader than the nut; leaves with 5-9 pairs of veins.

* Strobiles oblong, erect, ripening in May or June.

\section{Betula nigra, L. Red Birch. River Birch.}

Leaves rhombic-ovate, acute, abruptly or gradually narrowed and wedge-shaped at the base, doubly serrate, on vigorous young branches often more or less laciniately cut into acute doubly serrate lobes, when they unfold light yellow-green and pilose above and coated below, especially on the midribs and petioles, with thick white tomentum, at maturity thin and tough, $1 \frac{1^{\prime}}{2}-3^{\prime}$ long, $1^{\prime}-2^{\prime}$ wide, deep green and lustrous above, glabrescent, pubescent, or ultimately glabrous below, exeept on the stout midribs and remote primary veins, turning dull yellow in the autumu; their 
petioles slender, slightly flattened, tomentose, about $\frac{1}{2}^{\prime}$ long; stipules ovate, rounded or acute at the apex, pale green, covered below with white hairs. Flowers: staminate aments clustered, during the winter about $\frac{7^{\prime}}{8}$ long and $\frac{1 \overline{1}^{\prime}}{16}$ thick, with ovate rounded dull chestnut-brown lustrous scales, becoming $2^{\prime}-3^{\prime}$ long and $\frac{1}{8}^{\prime}$ thick; pistillate aments about $\frac{1^{\prime}}{3}$ long, with bright green ovate scales pubescent on the back, rounded or acute at the apex, and ciliate, with long white hairs. Fruit ripening in May and June; strobiles cylindrical, pubescent, $1^{\prime}-1 \frac{1}{2}^{\prime}$ long, $\frac{1}{2}^{\prime}$ thick, erect on stout tomentose peduncles $\frac{1}{2}^{\prime}$ long; nut ovate or oval, $\frac{1}{8}^{\prime}$ long, pubescent or puberulous at the apex, about as broad as its thin puberulous wing ciliate on the margin.

A tree, $80^{\circ}-90^{\circ}$ high, with a trunk often divided $15^{\circ}-20^{\circ}$ above the ground into 2 or 3 slightly diverging limbs, and sometimes $5^{\circ}$ in diameter, slender branches forming in old age a narrow irregular picturesque crown, and branchlets coated at first with thick pale or slightly rufous tomentum gradually disappearing before winter, becoming dark red and lustrous, dull red-brown in their second year, and then gradually growing slightly darker until the bark separates into the thin flakes of the older branches; or often sending up from the ground a clump of several

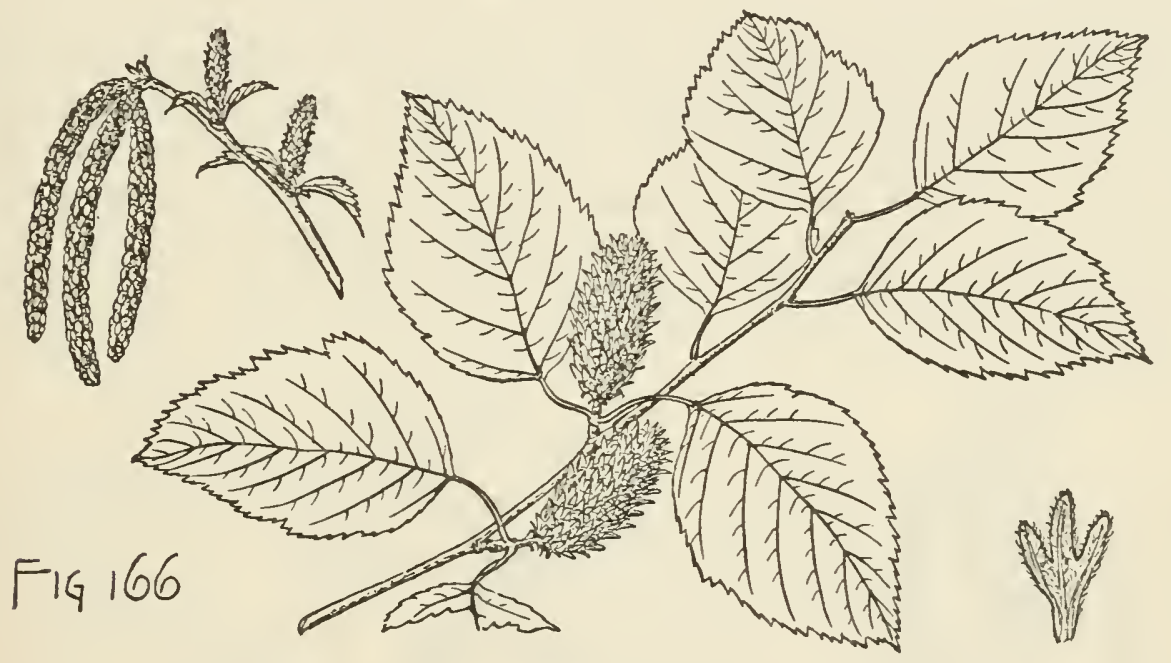

small spreading stems forming a low bushy tree. Winter-buds ovate, acute, about $\frac{1}{1}$ long, covered in summer with thick pale tomentum, glabrous or slightly puberulous, lustrous and bright clestnut-brown in winter, the inner scales strap-shaped, light brown tinged with red, and coated with pale hairs. Bark on young stems and large branches thin, lustrous, light reddish brown or silvery gray, marked by narrow slightly darker longitudinal lenticels, separating freely into large thin papery scales persistent for several years, and turning back and showing the light pink-brown tints of the freshly exposed inner layers, becoming at the base of old trunks from $\frac{3^{\prime}}{4}-\mathbf{1}^{\prime}$ thick, dark red-brown, deeply furrowed and broken on the surface into thick closely appressed scales. Wood light, rather hard, strong, close-grained, light brown, with pale sapwood of 40-50 layers of annual growth; used in the manufacture of furniture, woodenware, wooden shoes, and in turnery.

Distribution. Banks of streams, ponds, and swamps, in deep rich soil often inundated for several weeks at a time; northeastern Massachusetts, Long Island, Ner York, southward to western Florida through the region east of the Alleghany Mountains except in the immediate neighborhood of the coast, through the Gulf 
states to the valley of the Trinity River, Texas, and through the Mississippi valley to the Indian Territory, eastern Kansas, the bottom-lands of the Missouri River, in eastern Nebraska, central Minnesota, southern Wisconsin, and Ohio; the only semiaquatic species and the only species ripening its seeds in the spring or early summer; attaining its largest size in the damp semitropical lowlands of Florida, Louisiana, and 'Texas, and the only Birch-tree of such warm regions.

Often cultivated in the northeastern states as an ornamental tree, and growing rapidly in cultivation.

\section{** Strobiles cylindrical, pendant or spreading. \\ $\rightarrow$ Scales of the strobiles pubescent, with recurved lateral lobes, the middle lobe nearly as broad as long; leaves long-pointed, their petioles slender, elongated.}

\section{Betula populifolia, Marsh. Gray Birch. White Birch.}

Leaves nearly triangular to rhomboidal, long-pointed, coarsely doubly serrate, with stout spreading glandular teeth except at the broad truncate or slightly cordate or wedge-shaped base, thin and firm, dark green and lustrous and somewhat roughened on the upper surface early in the season by small pale glands in the axils of the conspicuous reticulate veinlets, $2 \frac{1{ }^{\prime}}{2}-3^{\prime}$ long, $1 \frac{1^{\prime}}{2}-2 \frac{1^{\prime}}{2}$ wide, with stout yellow midribs covered with minute glands, and raised and rounded on the upper side, and obscure yellow primary veins, turning pale yellow in the autumn; their petioles slender, terete, covered with black glands, often stained with red on the upper side, $\frac{3^{\prime}}{4}-1^{\prime}$ long; stipules broadly ovate, acute, membranaceous, light green slightly tinged with red. Flowers : staminate aments usually solitary or rarely in pairs, $1 \frac{1}{4}^{\prime}-1 \frac{1}{2}^{\prime}$
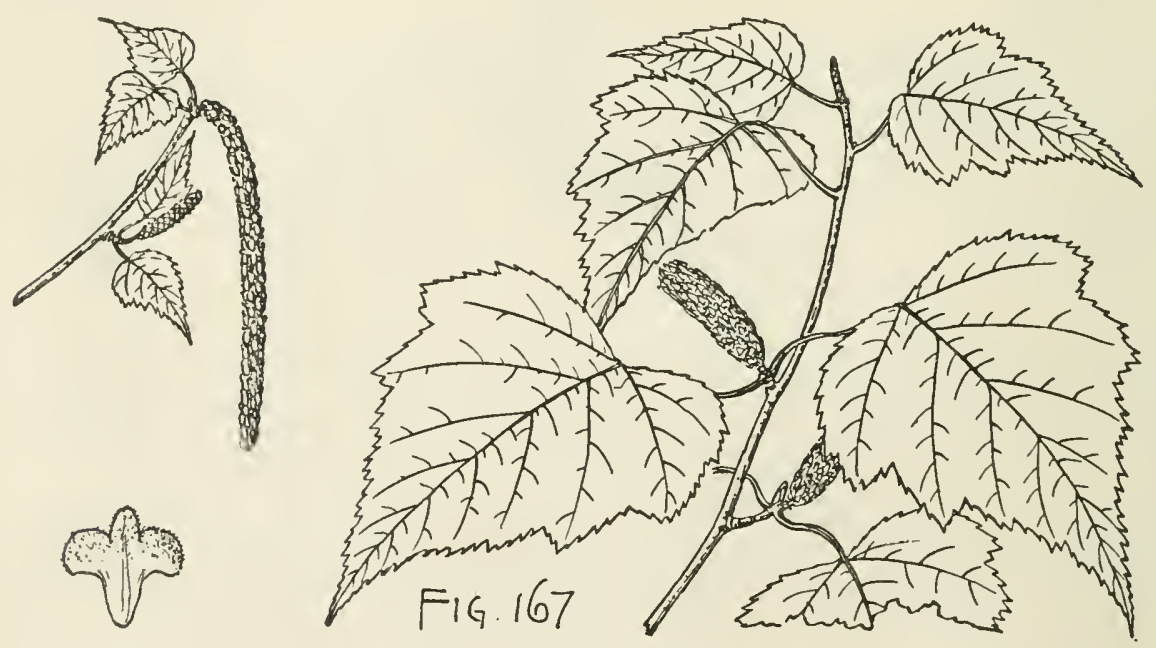

long, about $\frac{1}{8}^{\prime}$ thick during the winter, becoming $2 \frac{1}{2}^{\prime}-4^{\prime}$ long, with ovate acute apiculate scales; pistillate aments on glandular peduncles about $\frac{1}{2}^{\prime}$ long, slender, about $\frac{1}{2}^{\prime}$ long, with ovate acute pale green glandular scales, Fruit: strobiles cylindrical, pubescent, obtuse at the apex, about $\frac{3}{4}^{\prime}$ long and $\frac{1}{3}^{\prime}$ thick, pendant or spreading on slender stems; nut oval or obovate, acute or rounded at the base, a little narrower than its obovate wing.

A short-lived tree, $20^{\prime}-30^{\prime}$ or exceptionally $40^{\circ}$ high, with a trunk rarely $18^{\prime}$ in diameter, short slender often pendulous more or less contorted branches usually 
clothing the stem to the ground and forming a narrow pyramidal pointed head, and branchlets roughened by small raised lenticels, resinous-glandular when they first appear, like the unfolding leaves, gradually growing darker, bright yellow and lustrous before autumn like the young stems, bright reddish brown during the first winter, and ultimately white near the trunk; often growing in clusters of spreading stems springing from the stumps of old trees. Winter-buds ovate, acute, pale chestnut-brown, glabrous, about $\frac{1^{\prime}}{4}$ long. Bark about $\frac{1^{\prime}}{3}$ thick, dull chalky white on the outer surface, bright orange on the inner, close and firm, with dark triangular markings at the insertion of the branches, becoming at the base of old trees thicker, nearly black, and irregularly broken by shallow fissures. Wood light, soft, not strong, close-grained, not durable, light brown, with thick nearly white sapwood; used in the manufacture of spools, shoe-pegs and wood pulp, for the hoops of barrels, and largely for fuel.

Distribution. Dry gravelly barren soil or on the margins of swamps and ponds; Nova Scotia and the valley of the lower St. Lawrence River southward to northern Delaware, and westward through northern New England and New York, ascending sometimes to altitudes of $1800^{\circ}$, to the southern shores of Lake Ontario; rare and local in the interior, very abundant in the coast region of New England and the middle states; springing up in great numbers on abandoned farm-lands or on lands stripped by fire of their original forest covering; most valuable in its ability to grow rapidly in sterile soil and to afford protection to the seedlings of more valuable and less rapidly growing trees.

\section{Betula cœrulea, Blanch. Blue Birch.}

Leaves ovate, long-pointed, broadly or narrowly concave-cuneate at the entire often unequal base, sharply mostly doubly serrate above, with straight or incurved

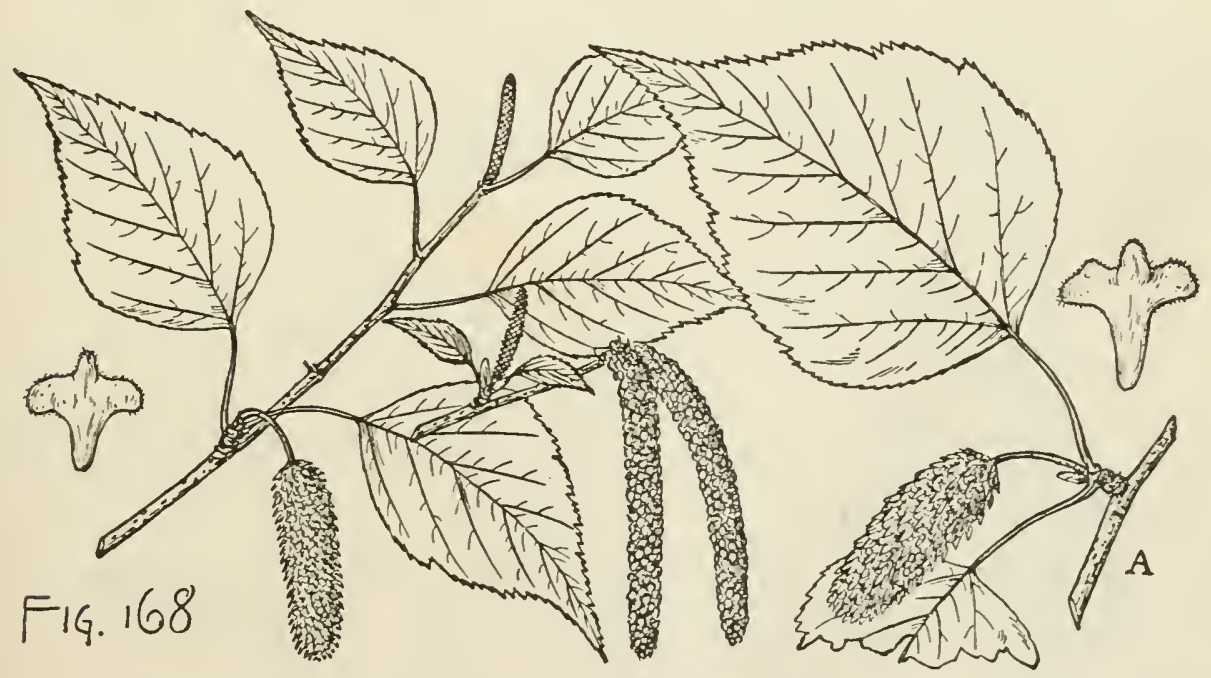

glandular often apiculate teeth, covered above when they unfold with pale deciduous glands, at maturity dull bluish green on the upper surface, pale yellow-green on the lower, and sparingly villose along the under side of the slender yellow midribs and primary veins, $2^{\prime}-2 \frac{1}{2}^{\prime}$ long, $1^{\prime}-1 \frac{1}{2}^{\prime}$ wide, their petioles slender, $\frac{3}{4}^{\prime}-1 \frac{1}{4}^{\prime}$ long, yellow more or less deeply tinged with red. Flowers: staminate aments usually in pairs, or singly or in 3 's, $1 \frac{1}{4}-2^{\prime}$ long, about $\frac{8}{16}$ ' thick, with ovate rounded short-pointed 
seales; pistillate aments slender, about $\frac{1}{3}$ ' long, with acuminate pale green much reflexed scales. Fruit: strobiles cylindrieal, pubescent, slightly narrowed at the obtuse apex, abont $1^{\prime}$ long and $\frac{1}{4}^{\prime}$ thick, pendant on slender peduneles $\frac{1^{\prime}-\frac{1}{2}}{2}$ in length; nut oval, much narrower than its broad wing.

A tree, rarely more than $30^{\circ}$ high, with a trunk $8^{\prime}-10^{\prime}$ in diameter, small ascending finally spreading branches, and slender branehlets marked by numerous small raised pale lenticels, purplish and sparingly villons when they first appear, soon glabrous, becoming bright red-brown; often forming elumps of several stems. Bark thin, white tinged with rose, lustrous, not readily separable into layers, the inner bark light orange color.

Distribution. Moist slopes, Stratton and Windham, Vermont, at elevations of about $1800^{\circ}$ ( W. H. Blanchard), Haystack Mountain, Aroostook County, Maine (M. S. Fernald); the American representative of the European Betula pendula, Roth., and probably widely distributed over the hills of northern New England and eastern Canada.

Apparently passing into a form with larger leaves often rounded and truncate at the broad base and $3^{\prime}-3 \frac{1}{2}^{\prime}$ long and $2^{\prime}$ wide, stouter staminate aments, and strobiles frequently $1 \frac{1}{2}^{\prime}$ long and $\frac{1}{2}^{\prime}$ thiek (var. Blanchardi, Sarg. nov. nom. fig. $168 \mathrm{~A}$ ). This under favorable conditions is a tree $60^{\circ}-70^{\circ}$ high, with a trunk $18^{\prime}$ in diameter, and possibly when better known may be considered a distinct speeies; common with Betula corulea at Windham and Stratton, Vermont (H.W. Blanchard), and on a hill near the coast in Washington County, Maine ( $M$ L. Fernald).

$\rightarrow+$ Scales of the strobiles with ascending or spreading lateral lobes, the middle lobe longer than broad; leaves acute or acuminate.

+ Bark creamy white to reddish brown, separating freely into thin layers.

\section{Betula papyrifera, Marsh. Canoe Birch. Paper Birch.}

Leaves ovate, acute or acuminate, with short broad points, coarsely usually doubly and often very irregularly serrate except at the rounded abruptly wedgeshaped, gradually narrowed, or deeply cordate (var. cordifolia, Fern.) base, bright

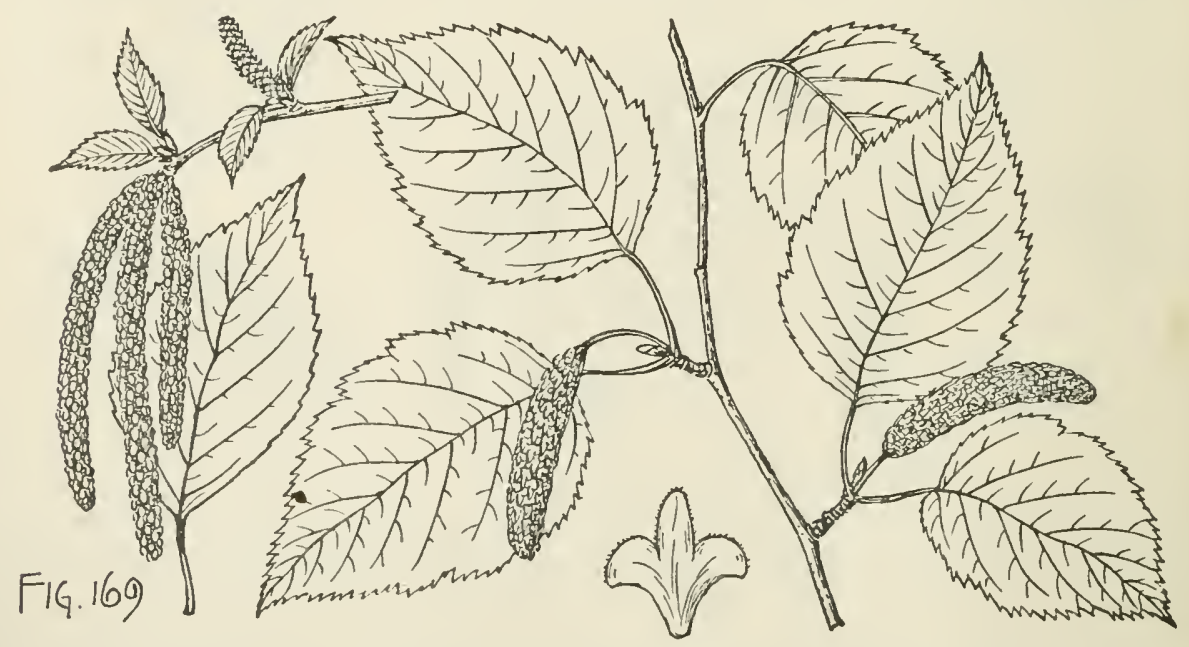

green, glandular-resinous, pubescent and elothed below on the midribs and primary veins and on the petioles with long white hairs when they unfold, at maturity thick 
and firm, dull dark green and glandless or rarely glandular on the upper surface, light yellow-green and glabrous or puberulous, with small tufts of pale hairs in the axils of the primary veins and covered with many black glands on the lower surface, $2^{\prime}-3^{\prime}$ long, $1 \frac{1}{2}^{\prime}-2^{\prime}$ wide, with slender yellow midribs marked, like the remote primary veins, with minute black glands, turning light clear yellow in the autumn; their petioles stout, yellow, glandular, glabrous or pubescent, $\frac{1}{2}^{\prime}-\frac{3 \prime}{4}$ long; stipules orate, acute, ciliate on the margins, with pale hairs, light green. Flowers: staminate aments clustered, during the winter $\frac{3^{\prime}}{4}-1 \frac{1}{4}$ long, about $\frac{1}{8}^{\prime}$ thick, with ovate, acute scales light brown below the middle, dark red-brown above, becoming $3 \frac{1^{\prime}}{2}-4^{\prime}$ long, and about $\frac{1^{\prime}}{3}$ thick; pistillate aments $1^{\prime}-1 \frac{1^{\prime}}{4}$ long, about $\frac{1^{\prime}}{1^{\prime}}$ thick, with light green lanceolate scales long-pointed and acute or rounded at the apex; styles bright red. Fruit : strobiles cylindrical, glabrous, about $1 \frac{1}{2}^{\prime}$ long and $\frac{1}{3}^{\prime}$ thick, hanging on slender stalks; nut oval, about $\frac{1 \sigma^{\prime}}{16}$ long, much narrower than its thin wing.

A tree, usually $60^{\circ}-70^{\circ}$ tall, with a trunk $2^{\circ}-3^{\circ}$ in diameter, becoming in old age, or when crowded by other trees, branchless below and supporting a narrow open head of short pendulous branches, and branchlets at first light green, slightly viscid, marked by scattered orange-colored oblong lenticels and covered with long pale hairs, dark orange color and glabrous or pubescent during the summer, becoming dull red in their first winter, gradually growing dark orange-brown, lustrous for four

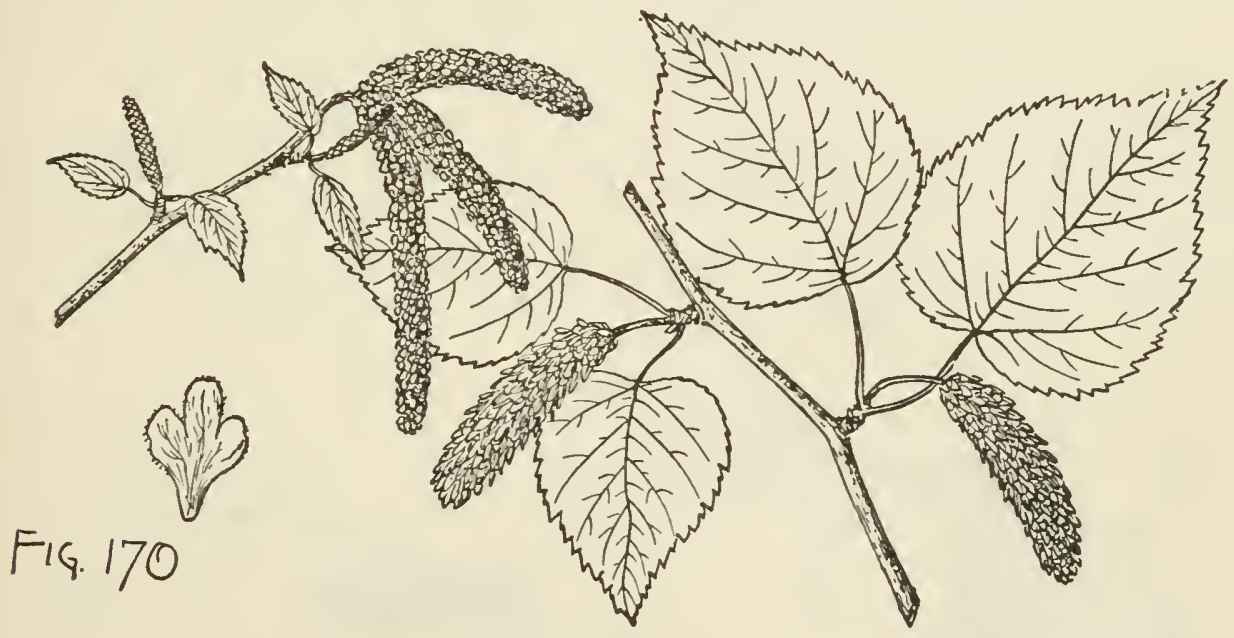

or five years and ultimately covered with the white papery bark of older branches. Winter-buds ovate, acute, about $\frac{1^{\prime}}{4}$ long, pubescent below the middle and coated with resinous gum at midsuinmer, dark chestnut-brown, glabrous and slightly resinous during the winter, their inner scales becoming strap-shaped, rounded at the apex, about $\frac{1}{2}^{\prime}$ long and $\frac{1}{8}^{\prime}$ wide. Bark on young trunks and large limbs thin, creamy white, lustrous on the outer surface, bright orange color on the inner, marked by long narrow slightly darker colored raised lenticels, separating into thin papery layers pale orange color when first exposed to the light, becoming on old trunks for a few feet above the ground sometimes $\frac{1}{2}^{\prime}$ thick, dull brown or nearly black, sharply and irregularly furrowed and broken on the surface into thick closely appressed scales. Wood light, strong, hard, tough, very close-grained, light brown tinged with red, with thick nearly white sapwood; largely used for spools, shoe-lasts, pegs, and in turnery, the manufacture of wood-pulp, and for fuel. The tough resinous durable bark impervious to water is used by all the northern Indians in their canoes and for baskets, 
bags, drinking-cups, and other small articles, and often to cover their wigwams in winter.

Distribution. Rich wooded slopes and the borders of streams, lakes, and swamps, scattered through forests of other trees; Labrador to the southern shores of Hudson's Bay and Great Slave Lake, and southward to Long Island, New York, northern Penusylvania, central Michigan, ecntral Iowa, northern Nebraska, the Black Hills of Dakota, northern Montana and northwestern Washington; common in the maritime provinces of Canada and north of the Great Lakes, and in northern New England and New York; small and comparatively rare in the coast region of southern New England and southward; not common in the Rocky Mountain region; on the highest mountains of New England the var. cordifolia (Fig. 170) is common as a small tree or shrub, and also occurs northward and on the Rocky Mountains.

Often planted in the northeastern states as an ornamental tree.

\section{Betula occidentalis, Hook. Birch.}

Leaves ovate, acute, usually rounded, occasionally cordate or rarely cuneate at the broad base, coarsely and generally doubly serrate, with straight or incurved glandular teeth, while young light yellow-green, covered with dark reddish resinous viscid glands, and villous along the midribs and veins, with long white hairs often also in large persistent tufts in the axils of the primary veins, and at maturity thin and firm in texture, marked by the scars of the fallen glands, dull dark green above, pale yellow-green below, and puberulous on both sides of the stout yellow midribs and slender primary veins, $3^{\prime}-4^{\prime}$ long, $1 \frac{1^{\prime}}{2}-2^{\prime}$ wide ; their petioles stout, glandular, at first tomentose, ultimately pubescent or puberulous, about $\frac{3^{\prime}}{4}$ long ; stipules oblongobovate, rounded or acute and apiculate at the apex, ciliate on the margins, puberulous, glandular-viscid, about $\frac{1^{\prime}}{2}$ long, $\frac{1}{8}^{\prime}-\frac{1}{4}^{\prime}$ wide. Flowers: staminate aments during the winter about $\frac{3^{\prime}}{4}$ long and $\frac{1^{\prime}}{8}$ thick, with ovate scales rounded or abruptly

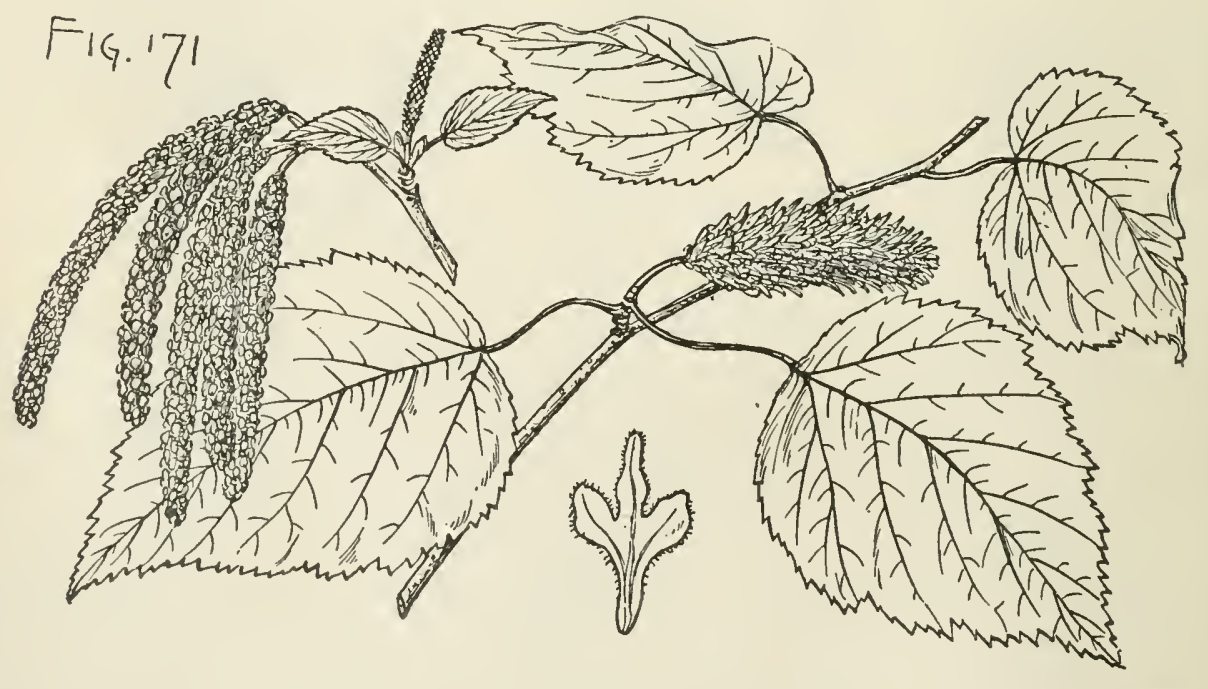

narrowed and acute at the apex, puberulous on the outer surface, ciliate on the margins, becoming $3^{\prime}-4^{\prime}$ long and about $\frac{1^{\prime}}{4}$ wide; pistillate aments about $1^{\prime}$ long and $\frac{1}{16}$ thick, with acuminate bright green scales. Fruit : strobiles cylindrical, puberulous, spreading, $11^{\prime}-1 \frac{1}{2}^{\prime}$ long, $\frac{1}{4}^{\prime}-\frac{1}{2}^{\prime}$ thick, on stout peduncles $\frac{3^{\prime}}{4}$ in length, their scales ciliate on the margins; nut oval, about $\frac{1}{16}{ }^{\prime}$ long, and nearly as wide as its wings. 
A tree, $100^{\circ}-120^{\circ}$ high, with a trunk $3^{\circ}-4^{\circ}$ in diameter, comparatively small branches often pendulous on old trees, and pale orange-brown branchlets more or less glandular and coated with long pale hairs when they first appear, becoming bright orange-brown and marked by numerous minute pale lenticels and pubescent or puberulous during their first winter and nearly destitute of glands, and in their second year orange-brown, glabrous, and very lustrous. Winter-buds acute, bright orange-brown, $\frac{1}{8}-\frac{1}{4}^{\prime}$ long, their light brown inner scales sometimes becoming $\frac{8^{\prime}}{4}$ long. Bark thin, marked by large oblong horizontal raised lenticels, dark orange-brown, very lustrous, separating freely into thin papery layers displaying in falling the bright orange-yellow inner bark.

Distribution. Banks of streams and lakes; southwestern British Columbia and northwestern Washington; nowhere common and probably of its largest size on the alluvial banks of the lower Fraser River, and on the islands of Puget Sound.

\section{Betula Kenaica, Evans. Red Birch. Black Birch.}

Leaves ovate, acute or acuminate, broadly cuneate or somewhat rounded at the entire base, irregularly coarsely often doubly serrate above, puberulous on the upper

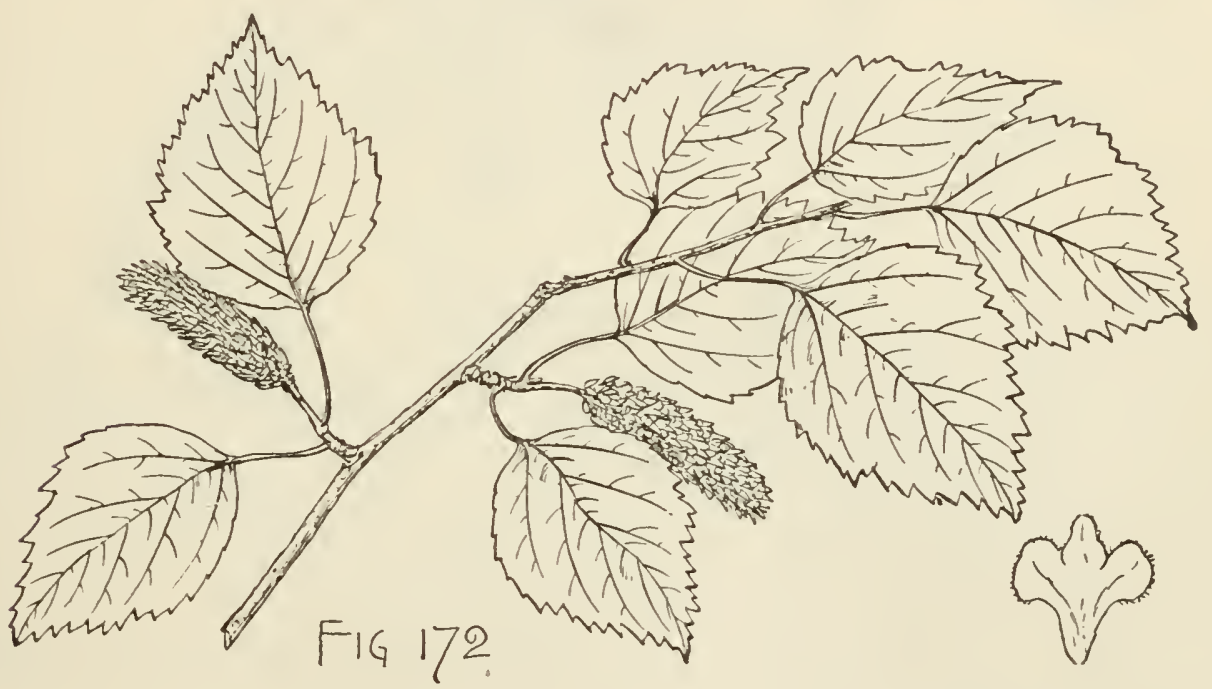

surface and ciliate on the margins when they unfold, at maturity glabrous, dark dull green above, pale yellow-green below, $1 \frac{1^{\prime}}{2}-2^{\prime}$ long, $1^{\prime}-1 \frac{3^{\prime}}{4}$ wide, with slender yellow midribs and 5 pairs of thin primary veins; their petioles slender, $\frac{8^{\prime}}{4}-1^{\prime}$ long. Flowers: staminate aments clustered, $1^{\prime}$ long, with ovate acute scales apiculate at the apex, puberulous on the outer surface; pistillate aments $\frac{1^{\prime}}{3}-\frac{1^{\prime}}{2}$ long, about $\frac{1}{1} \overline{6}^{\prime}$ wide, on slender glandular pubescent peduncles $\frac{1^{\prime}}{2}-\frac{3^{\prime}}{4}$ loug, with acuminate light green strongly reflexed scales; styles bright red. Fruit: strobiles cylindrical, glabrous, $1^{\prime}$ long, their scales ciliate on the margins; nut oval, somewhat narrower than its thin wing.

A tree, $30^{\circ}-40^{\circ}$ high, with a trunk $12^{\prime}-20^{\prime}$ in diameter, wide-spreading branches, stout branchlets marked by numerous small pale lenticels, bright red-brown during 2 or 3 years, gradually becoming darker. Bark thin, more or less furrowed, very dark brown or nearly black near the base of the trunk, grayish white or light reddish brown and separating into thin layers higher on the stem and on the branches. 
Distribution. Coast of Alaska from Cook Inlet southward to the head of the Lym11 Canal.

\section{Betula Alaskana, Sarg. White Birch.}

Leaves rhomboidal to deltoid-ovate, long-pointed, truncate, rounded or broadly cuncate, or on leading shoots occasionally cordate at the entire base, coarsely and often doubly glandular-serrate above, when they unfold yellow-green and covered with resinous glands, lustrous and villous above and slightly puberulous below, at

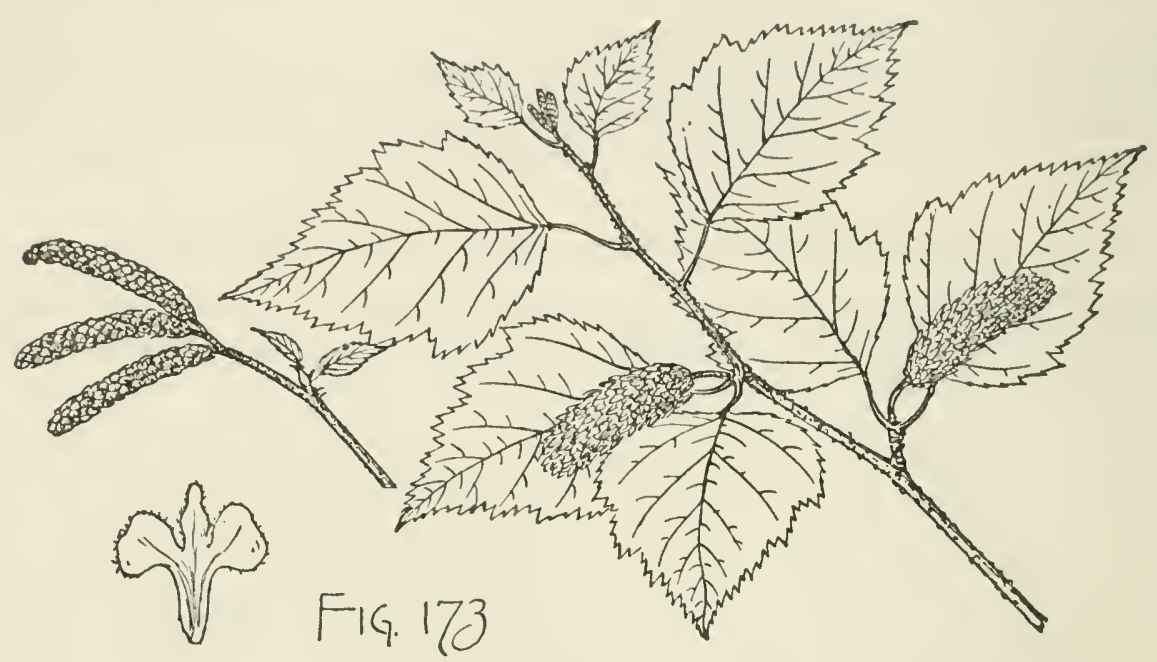

maturity thin, dark green above, pale and yellow-green below, $1 \frac{1^{\prime}}{2}-3^{\prime}$ long, $1^{\prime}-1 \frac{1}{2}^{\prime}$ wide, with slender midribs and primary veins pubescent or ultimately glabrous below ; their petioles often bright red, somewhat hairy at first, finally glabrous, about $1^{\prime}$ long; stipules oblong, gradually narrowed and rounded at the apex, villous particularly toward the margins. Flowers: staminate aments clustered, sessile, $1^{\prime}$ long, $\frac{1}{8}^{\prime}$ thick, with ovate acuminate scales puberulous on the outer surface, bright red, with yellow margins; pistillate aments slender, cylindrical, glandular, $1^{\prime}$ long, $\frac{1}{8}^{\prime}$ thick, on stout peduncles nearly $\frac{1}{2}^{\prime}$ long. Fruit : strobiles glabrous, pendulous or spreading, $1^{\prime}-1 \frac{1}{4}^{\prime}$ long, $\frac{1}{3}^{\prime}-\frac{1}{2}^{\prime}$ thick, their scales ciliate on the margins; nut oval, narrower than its broad wing.

A tree, usually $30^{\circ}-40^{\circ}$, occasionally $80^{\circ}$, high, with a trunk $6^{\prime}-12^{\prime}$ in diameter, slender erect and spreading or pendulous branches, and glabrous briglit red-brown branchlets more or less thickly covered during their first year with resinous glands sometimes persistent until the second or third season. Winter-buds ovate, obtuse at the gradually narrowed apex, about $\frac{1}{4}^{\prime}$ long, with light red-brown shining outer scales sometimes eiliate on the margins, and oblong rounded scarious inner scales hardly more than $\frac{1}{2}^{\prime}$ long when fully grown. Bark thin, marked by numerous elongated dark slightly raised lenticels, dull reddish brown or sometimes nearly white on the outer surface, light red on the inner surface, close and firm, finally separable into thin plate-like scales.

Distribution. Valley of the Saskatchewan northwestward to the valley of the Yukon, growing sparingly near the banks of streams in forests of coniferous trees and in large numbers on sunny slopes and hillsides; the common Birch-tree of the Yukon basin. 
++++ Bark dark brown, not separable into thin layers.

\section{Betula fontinalis, Sarg. Black Birch.}

Leaves broadly ovate, acute, sharply and often doubly serrate, except at the rounded abruptly wedge-shaped truncate subcordate and often unequal base, and sometimes slightly laciniately lobed, pale green, pilose above, and covered by conspicuous resinous glands when they unfold, at maturity thin and firm, dark dull green above, pale yellow-green, rather lustrous and covered by minute glandular dots below, $1^{\prime}-2^{\prime}$ long, $\frac{3^{\prime}}{4}-1^{\prime}$ wide, with slender pale midribs, remote glandular veins, and rather conspicuous reticulate veinlets, turning dull yellow in the autumn before falling; their petioles stout, puberulous, light yellow, glandular-dotted, flattened on the upper side, often flushed with red, $\frac{1}{3}^{\prime}-\frac{1}{2}^{\prime}$ long; stipules broadly ovate, acute or rounded at the apex, slightly ciliate, bright green soon becoming pale and scarious. Flowers: staminate aments clustered, $\frac{1^{\prime}}{2}-3^{\prime}$ long and $\frac{1}{16}$ thick during the winter, with ovate acute light chestnut-brown scales pale and slightly ciliate on the margins, becoming

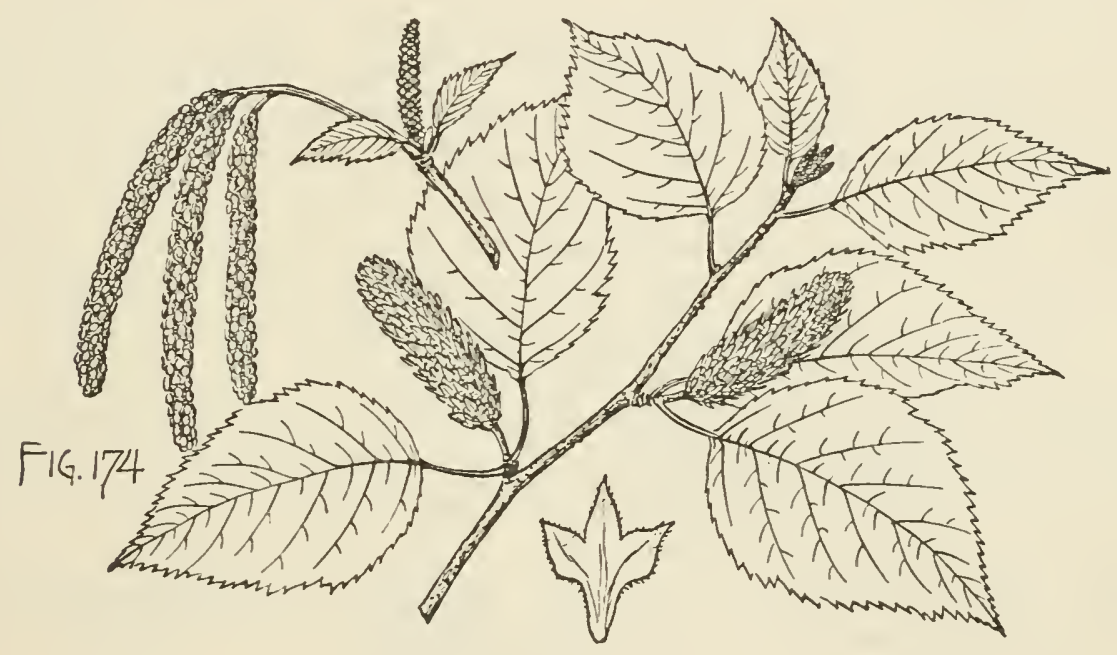

$2^{\prime}-2 \frac{1}{2}$ long, and about $\frac{1}{8}^{\prime}$ thick, with apiculate scales; pistillate aments short-stalked, about $\frac{3^{\prime}}{4}$ long, with ovate acute green scales; styles bright red. Fruit: strobiles cylindrical, rather obtuse, puberulous or nearly glabrous, $1^{\prime}-1 \frac{1}{4}^{\prime}$ long, erect or pendulous on slender glandular stalks, $\frac{1^{\prime}}{4}$ to nearly $\frac{3^{\prime}}{4}$ long; nut ovate or obovate, puberulous at the apex, much narrower than its wing.

A tree, occasionally $30^{\circ}-40^{\circ}$ high, with a trunk $12^{\prime}-18^{\prime}$ in diameter, slender spreading gracefully pendulous branches forming an open feathery head, and branchlets light green and much roughened at first by large lustrous resinous glands persistent until the second season, soon becoming dark orange color, rather bright red-brown during their first winter, dark reddish brown or bronze color and very lustrous the following summer, and marked by conspicuous pale lenticels; more commonly shrubby, with many thin spreading stems forming open clusters, $15^{\circ}-20^{\circ}$ high, often much lower, and frequently crowded in almost impenetrable thickets. Winter-buds oval to ovate, acute, very resinous, chestnut-brown, $\frac{1^{\prime}}{4}$ long. Bark about $\frac{1}{4}^{\prime}$ thick, dark bronze color, very lustrous, marked by pale brown longitudinal lenticels becoming on old trunks often $6^{\prime}-8^{\prime}$ long and $\frac{1}{4}^{\prime}$ wide. Wood soft and 
strong, light brown, with thick lighter colored sapwood; sometimes used for fuel and feneing.

Distribution. Moist soil near the banks of streams in mountain cañons; generally distributed, although nowhere very common, from the basin of the upper Fraser and Peace rivers in British Columbia, southward to the valleys of Mt. Shasta and the eastern slopes of the northern Sierra Nevada, California, eastward through Alberta and along the valley of the Saskatchewan, and southward along the Rocky Mountains and the interior ranges of Nevada, Utah, and northern New Mexico, extending eastward in the United States to the Black Hills of Dakota, northwestern Nebraska, and the eastern base of the Rocky Mountains in Colorado.

\section{ALNUS, L. Alder.}

Trees and shrubs, with astringent scaly bark, soft straight-grained wood, naked stipitate winter-buds formed in summer and nearly inclosed by the united stipules of the first leaf, becoming thick, resinous, and dark red. Leaves open and eonvex in the bud, falling without change of color; stipules of all but the first leaf ovate, acute, and searious. Flowers vernal or in one species autumnal, in 1-3-flowered cymes in the axils of the peltate short-stalked scales of stalked aments formed in summer or autumn in the axils of the last leaves of the year or of those of minute leafy bracts; staminate aments elongated, pendulous, paniculate, naked and erect during the winter, each staminate flower subtended by 3-5 minute bractlets adnate to the scales of the ament, and composed of a 4-parted calyx, 1-3 or usually 4 stamens inserted on the base of the calyx opposite its lobes, with short simple filaments; pistillate aments ovoid or oblong, erect, stalked, produced in summer in the axils of the leaves of a branch developed from the axils of an upper leaf of the year, and below the staminate infloreseence, inelosed at first in the stipules of the first leaf, emerging in the autumn and naked during the winter, or remaining covered until early spring; pistillate flowers in pairs, each flower subtended by $2-4$ minute bractlets adnate to the fleshy seale of the anent beeoming at maturity thick and woody, obovate, 3-5-lobed or truncate at the thickened apex, forming an ovoid or subglobose strobile persistent after the opening of its elosely imbricated scales; calyx 0; ovary compressed; nut minute, bright chestnut-brown, ovate to oblong, flat, bearing at the apex the remnants of the style, marked at the base by a pale sear, the outer coat of the shell produced into lateral wings often reduced to a narrow membranaceous border.

Alnus inhabits swamps, river bottom-lands, and high mountains, and is widely and generally distributed through the northern hemisphere, often forming the most conspicuous feature of vegetation on mountain slopes, ranging at high altitudes southward in the New World through Central America to Colombia, Peru, and Bolivia, and to upper Assam and Japan in the Old World. Of the eighteen or twenty species now recognized nine are North American; of these six attain the size and habit of trees. Of the exotic species, Alnus glutinosa, Gaert., a common European, North African, and Asiatic timber-tree, was introdueed many years ago into the northeastern states, where it has become locally naturalized. The wood of Alnus is very durable in water, and the astringent bark and strobiles are used in tanning leather and in medicine.

Alnus is the classical name of the Alder. 


\section{CONSPECTUS OF THE NORTH AMERICAN ARBORESCENT SPECIES.}

Flowers opening in spring with or after the leaves; stamens 4 ; pistillate aments inclosed during the winter; nut furnished with a broad wing.

Leaves ovate, sinuately lobed, lustrous on the lower surface.

1. A. Sitchensis (B, F, G).

Flowers opening in winter or early spring before the unfolding of the leaves; pistillate aments usually naked during the winter.

Wing of the nut broad.

Leaves ovate or elliptical, rusty-pubescent on the lower surface; pistillate aments often inclosed during the winter; stamens 4.

2. A. Oregona $(B, G)$.

Wing of the nut reduced to a narrow border.

Leaves oblong-ovate, glabrous or puberulous on the lower surface; stamens 4.

Stamens usually 2 or 3 .

3. A. tenuifolia $(B, F, G)$.

Leaves ovate or oval, pale and slightly puberulous on the lower surface.

4. A. rhombifolia (B, F, G).

Leaves oblong-lanceolate, acute, pale and sometimes puberulous on the lower surface.

5. A. oblongifolia $(\mathrm{H})$.

Flowers opening in autumn from aments of the year; stamens 4 ; wing of the nut reduced to a narrow border.

Leaves oblong-ovate or obovate, dark green and lustrous above, pale yellow-green below.

6. A. maritima (A).

1. Flowers opening in spring with or after the leaves: pistiliate aments inclosed during the winter.

\section{Alnus Sitchensis, Sarg. Alder.}

Leaves ovate, acute, full and rounded and often unsymmetrical and somewhat oblique, or abruptly narrowed and cuneate at the base, divided into numerous short acute lateral lobes, sharply and doubly serrate, with straight glandular teeth, glandu-

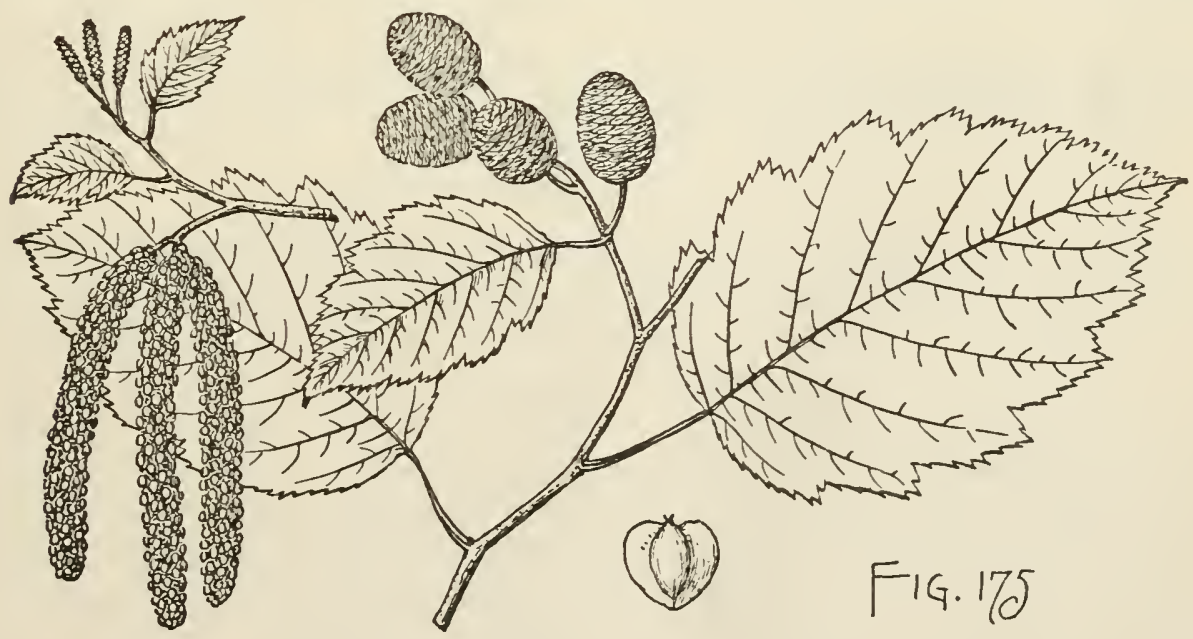

lar-viscid as they unfold, at maturity membranaceous, yellow-green on the upper surface, pale and very lustrous on the lower surface, glabrous, or villous along the under side of the stout midribs, with short brown hairs also forming tufts in the axils of the numerous slender primary veins, $3^{\prime}-6^{\prime}$ long, $1 \frac{1^{\prime}}{2}-4^{\prime}$ wide ; their petioles stout, 
grooved, abruptly enlarged at the base, $\frac{1}{2}-\frac{8^{\prime}}{4}$ long; stipules oblong to spatulate, rounded and apiculate at the apex, puberulons, about $\frac{1}{4}$ long. Flowers: staminatc aments in pairs in the axils of the upper lcaves somctimes reduced to small bracts, and single in the axil of the leaf next below it, sessile, during the winter about $\frac{1}{2}^{\prime}$ long and $\frac{1}{8}$ thick, with dark red-brown shining puberulous apiculate scales, becoming when the flowers open from spring to midsummer $4^{\prime}$ or $5^{\prime}$ long, with a puberulons light red rachis and ovate acute apiculate 3-flowered scales; calyx-lobes rounded, shorter than the 4 stamens; pistillate aments in elongated panicles, inclosed during winter in buds formed the previous summer in the axils of the leaves of short lateral brauchlets, long-pedunculate, $\frac{1}{8}^{\prime}$ long, $\frac{1}{6}^{\prime}$ thick. Fruit: strobiles on slender peduncles in elongated sometimes leafy panicles $4^{\prime}-6^{\prime}$ long, oblong, $\frac{1}{2}^{\prime}-\frac{5^{\prime}}{8}$ long, about $\frac{1}{3}^{\prime}$ thick, their truncate scales thickened at the apex; nut oval, about as wide as its wings.

A tree, sometimes $40^{\circ}$ high, with a trunk $7^{\prime}-8^{\prime}$ in diameter, short small nearly horizontal branches forming a narrow crown, and slender slightly zigzag branchlets puberulons and very glandular when they first appear, bright orauge-brown and lustrous and marked by numerous large pale lenticels during their first season, much roughened during their second year by the elevated crowded leaf-scars, becoming light gray. Winter-buds acuminate, dark purple, covered especially toward the apex with close fine pubescence, about $\frac{1}{2}$ long; often a shrub only a few feet tall spreading into broad thickets.

Distribution. Northwest coast from the borders of the Arctic Circle to Oregon; common in the valley of the Yukon and eastward through British Columbia to Alberta, and through Washington and Oregon to the western slopes of the Rocky Mountains; at the north with dwarf Willows, forming great thickets; in southeastern Alaska often a tall tree on rich moist bottom-lands near the mouths of mountain streams, or at the upper limits of tree growth a low shrub; very abundant in the valley of the Yukon on the wet banks of streams and often arborescent in habit; in British Columbia and the United States generally smaller, growing usually only at elevations of more than $3000^{\circ}$ above the sea, and often forming thickets on the banks of streams and lakes.

2. Flowers opening in winter or early spring before the unfolding of the leaves; pistillate aments usually naked during the winter.

\section{Alnus Oregona, Nutt. Alder.}

Leaves ovate to elliptical, acute, abruptly or gradually narrowed and wedgeshaped at the base, crenately lobed, dentate, with miuute gland-tipped teeth, and slightly revolute on the margins, covered when they unfold with pale tomentum, at maturity thick dark green and glabrous or pilose, with scattered white hairs above, clothed below with short rusty pnbescence, $3^{\prime}-5^{\prime}$ long, $1 \frac{3^{\prime}}{4}-3^{\prime}$ broad, or on vigorons branches sometimes $8^{\prime}-10^{\prime}$ long, with broad midribs and primary veius green on the. upper side and orange-colored on the lower, the prinary veins running obliquely to the points of the lobes and connected by conspicuous slightly reticulate cross veinlets; their petioles orange-colored, nearly terete, slightly grooved, $\frac{1^{\prime}}{2}-\frac{3^{\prime}}{4}$ long; stipules ovate, acute, pale green flushed with red, tomentose, $\frac{1}{8}^{\prime}-\frac{1}{4}^{\prime}$ long. Flowers: staminate aments in red-stemmed clusters $2^{\prime}-3^{\prime}$ long, during the winter $1 \frac{1}{4}^{\prime}$ long, $\frac{1}{8}^{\prime}$ thick, with dark red-brown lustrous closely appressed scales, becoming $4^{\prime}-6^{\prime}$ long and $\frac{1}{4}^{\prime}$ thick, with ovate acute orange-colored glabrous scales; calyx yellow, with ovate rounded lobes rather shorter than the 4 stamens; pistillate aments in short 
racemes usually inclosed during the winter in buds formed during the early summer and opening in the early spring, $\frac{1}{3}^{\prime}-\frac{1}{2}^{\prime}$ long, about $\frac{1}{16}$ thick, with dark red acute scales; styles bright red. Fruit: strobiles raised on stout orange-colored peduncles

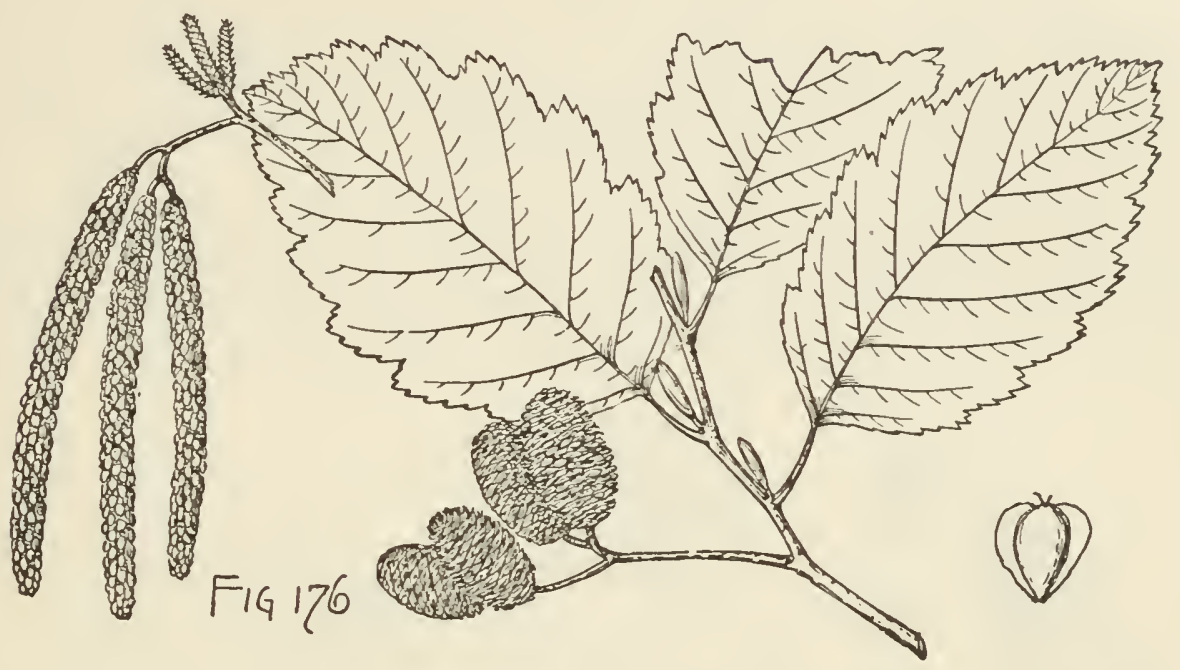

sometimes $\frac{1}{2}^{\prime}$ long, ovate or oblong, $\frac{1}{2}^{\prime}-1^{\prime}$ long, $\frac{1^{\prime}}{3}-\frac{1}{2}^{\prime}$ wide, with truncate scales much thickened toward the apex; nut orbicular to obovate, surrounded by a membranaceous wing.

A tree, usually $40^{\circ}-50^{\circ}$, occasionally $80^{\circ}$ high, with a trunk sometimes $3 \frac{1}{2}^{\circ}$ in diameter, slender somewhat pendulous branches forming a narrow pyramidal head, and slender branchlets marked by minute scattered pale lenticels, light green and coated at first with hoary tomentum sometimes persistent until their second year, becoming during the first winter bright red and lustrous and ultimately ashy gray. Winter-buds about $\frac{1}{3}^{\prime}$ long, dark red, covered with pale scurfy pubescence. Bark rarely more than $\frac{1}{4}^{\prime}$ thick, close, roughened by minute wart-like excrescences, pale gray or nearly white, with a thin outer layer, and bright red-brown inner bark. Wood light, soft, brittle, not strong, close-grained, light brown tinged with red, with thick nearly white sapwood; in Washington and Oregon largely used in the manufacture of furniture; by the Indians of Alaska the trunks are hollowed into canoes.

Distribution. Southeastern Alaska southward, near the coast to the cañons of the Santa Inez Mountains, California; common along the banks of streams, and of its largest size near the shores of Puget Sound.

\section{Alnus tenuifolia, Nutt. Alder.}

Leaves ovate-oblong, acute or acuminate, broad and rounded or cordate, or occasionally abruptly narrowed and wedge-shaped at the base, usually acutely laciniately lobed and doubly serrate, when they unfold light green often tinged with red, pilose on the upper surface and coated on the lower with pale tomentum, at maturity thin and firm, dark green and glabrous above, pale yellow-green and glabrous or puberulous below, $2^{\prime}-4^{\prime}$ long, $1 \frac{1}{2}^{\prime}-2 \frac{1}{2}^{\prime}$ wide, with stout orange-colored midribs impressed on the upper side and slender primary veins running to the points of the lobes; their petioles stout, slightly grooved, orange-colored, $\frac{1}{2}^{\prime}-1^{\prime}$ long; stipules ovate, acute, thin, and scarious, $\frac{1}{2}^{\prime}$ long, about $\frac{1^{\prime}}{8}$ wide, covered with pale pubescence. Flowers: stami- 
nate aments 3 or 4 in number in slender-stemmed racemes, nearly sessile or raised on stout peduncles often $\frac{1^{\prime}}{2}$ long, during the winter light purple, $\frac{8^{\prime}}{4}-1^{\prime}$ long and $\frac{1^{\prime}}{4}$ thick, becoming $1 \frac{1}{2}^{\prime}-2^{\prime}$ long; calyx-lobes rounded, shorter than the 4 stamens; pistillate aments naked during the winter, dark red-brown, nearly $\frac{1}{4}$ long, witl acute apiculate loosely imbricated scales, only slightly enlarged when the flowers open. Fruit : strobiles ovatc-oblong, $\frac{1}{3}^{\prime}-\frac{1^{\prime}}{2}$ long, their scales much thickened, truncate and 3-lobed at the apex; nut nearly circular to slightly obovate, surrounded by a thin membranaceous border.

A tree, occasionally $30^{\circ}$ tall, with a trumk $6^{\prime}-8^{\prime}$ in diameter, small spreading slightly pendulous branches forming a narrow round-topped head, and slender branchlets marked at first by a few large orange-colored lenticels and coated with fine pale or rusty caducous pubescence, becoming light brown or ashy gray more or less

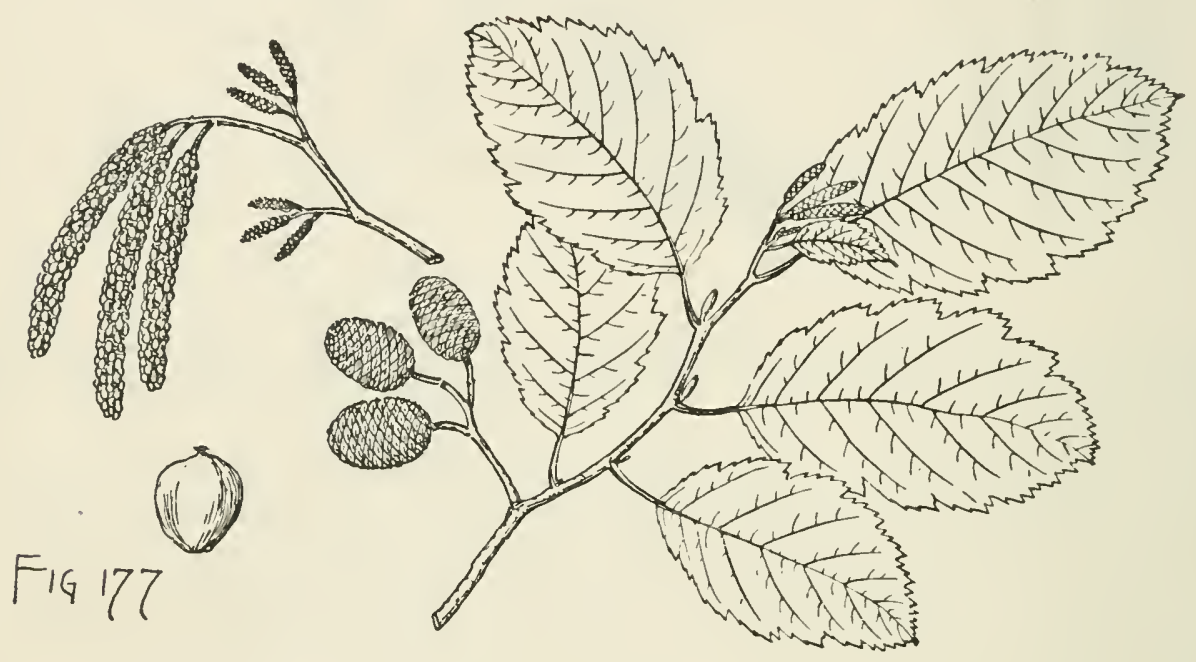

deeply flushed with red in their first winter and ultimately paler; more often shrubby, with several spreading stems, and at the north and at high elevations frequently only $4^{\circ}-5^{\circ}$ tall. Winter-buds $\frac{1}{4}^{\prime}-\frac{1}{3}^{\prime}$ long, bright red, and puberulous. Bark rarely more than $\frac{1}{4}^{\prime}$ thick, briglt red-brown, and broken on the surface into small closely appressed scales.

Distribution. Banks of streams and mountain cañons from Francis Lake in latitude $61^{\circ}$ north, to the valley of the lower Fraser River, British Columbia, eastward along the Saskatchewan to Prince Albert, and southward through the Rocky Mountains to northern New Mexico; on the Sierra Nevada of southern California, and in Lower California; the common Alder of mountain streams in the northern interior region of the continent; very abundant on the eastern slopes of the Cascade Mountains, and on the southern California sierra, forming great thickets at $6000^{\circ}-$ $7000^{\circ}$ above the sea along the head-waters of the rivers of southern California flowing to the Pacific Ocean; the common Alder of eastern Washington and Oregon, and of Idaho and Montana; very abundant and of its largest size in Colorado and northern New Mexico.

\section{Alnus rhombifolia, Nutt. Alder.}

Leaves ovate or oval or sometimes nearly orbicular, rounded or acute at the apex, especially on vigorous shoots, gradually or abruptly narrowed and wedge-shaped at 
the base, finely or sometimes coarsely and occasionally doubly serrate, slightly thickened and reflexed on the somewhat undulate margins, when they unfold pale green

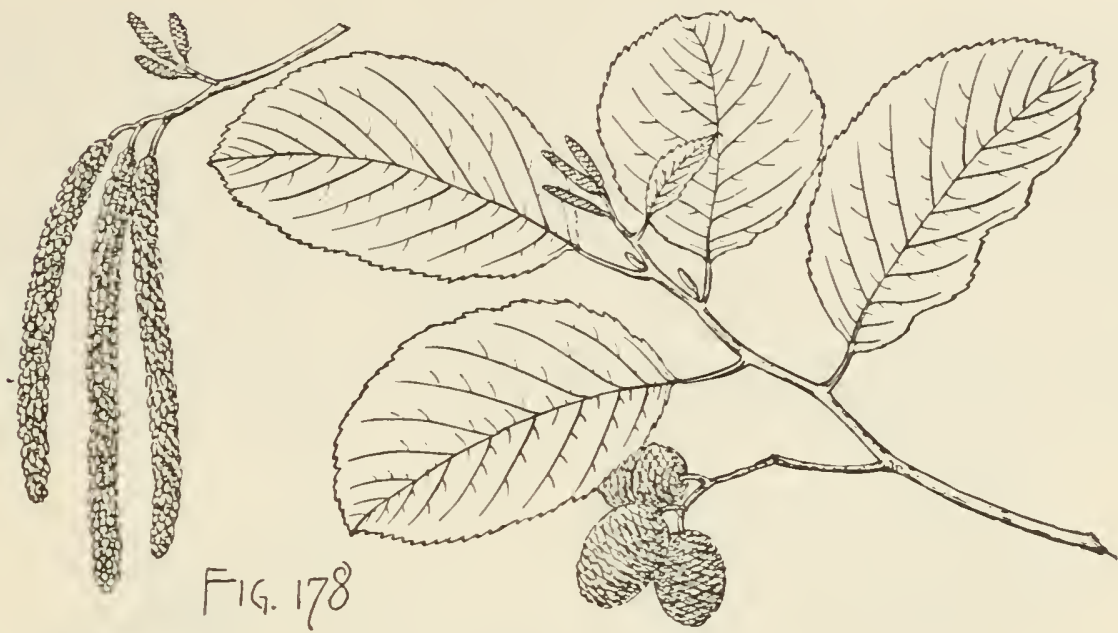

and covered with deciduous matted white hairs, at maturity dark green and lustrous on the upper suface, frequently marked, especially on the midribs, with minute glandular dots, light yellow-green and slightly puberulous below, $2^{\prime}-3^{\prime}$ long, $1 \frac{1}{2}-2^{\prime}$ wide, with stont yellow midribs and primary veins; their petioles slender, yellow, hairy, flattened and grooved on the upper side, $\frac{1^{\prime}-3^{\prime}}{4}$ long; stipules ovate, acute, scarious, puberulous, about $\frac{1}{4}$ long. Flowers: staminate aments in slender-stemmed pubescent clusters, usually short-stalked, during the summer dark olive-brown and lustrous, $\frac{3^{\prime}}{4}-1^{\prime}$ long and about $\frac{1^{\prime}}{16}$ thick, beginning to lengthen late in the antumn before the leaves fall, fully grown and $4^{\prime}-6^{\prime}$ long and $\frac{1^{\prime}}{4}$ thick in January, with dark orangebrown scales, and deciduous in February before the appearance of the new leaves; calyx yellow, 4-lobed, rather shorter than the 2 or occasionally 3 or rarely single stamen; pistillate aments in short pubescent racemes emerging from the bud in December, their scales broadly ovate and rounded. Fruit: strobiles oblong, $\frac{1^{\prime}}{3}-\frac{1^{\prime}}{2}$ long, with thin scales slightly thickened and lobed at the apex, fully grown at midsummer, remaining closed until the tress flower the following year; nut broadly ovate, with a thin acute margin.

A tree, frequently $70^{\circ}-80^{\circ}$ high, with a tall straight trunk $2^{\circ}-3^{\circ}$ in diameter, long slender branches pendulous at the ends, forming a wide round-topped open head, and slender branchlets marked by small seattered lenticels, at first light green and coated with pale caducous pubescence, soon becoming dark orange-red and glabrous, and darker during the winter and following summer. Winter-buds nearly $\frac{1^{\prime}}{2}$ long, very slender, dark red, and covered with pale scurfy pubescence. Wood light, soft, not strong, brittle, close-grained, light brown, with thick lighter colored often nearly white sapwood.

Distribution. Banks of streams from northern Idaho to the eastern slope of the Cascade Mountains of Washington and southwestern Oregon and soutliward over the coast ranges and along the western slopes of the Sierra Nevada to the mountains of southern California; the common Alder of the valleys of central California, and the only species at low altitudes in the southern part of the state. 


\section{Alnus oblongifolia, Torr. Alder.}

(Alnus acuminata, Silva, N. Am. ix. 79.)

Leaves oblong-lanceolate, aeute or rarely obovate and ronnded at the apex, gradually narrowed and wedge-shaped at the base, sharply and usually doubly serrate, more or less thickly covered, especially early in the season, with black glands, dark yellow-green and glabrons or slightly pubernlous above, pale and glabrous or puberulous below, especially along the slender yellow midribs and veins, with small tufts of rusty hairs in the axils of the primary veins, $2^{\prime}-3^{\prime}$ long, about $1 \frac{1}{2}^{\prime}$ wide; their petioles slender, grooved, pubescent, $\frac{3^{\prime}}{4}$ long; stipules ovate-lanceolate, brown and searions, about $\frac{1^{\prime}}{4}$ long. Flowers: staminate aments in short stont-stemmed racemes, during the winter light yellow, $\frac{1}{2}^{\prime}-\frac{3}{4}$ long and abont $\frac{1^{\prime}}{1^{\prime}}$ thick, becoming when the flowers open at the end of February before the appearance of the leaves $2^{\prime}-2 \frac{1}{2}^{\prime}$

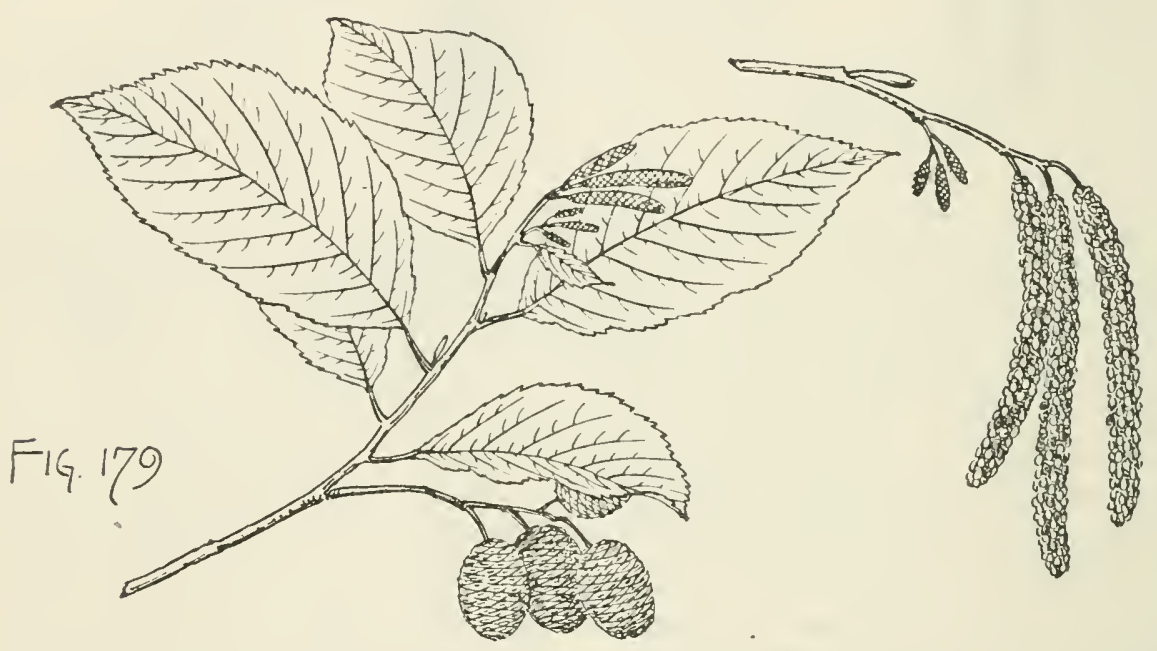

long, with ovate pointed dark orange-brown scales; calyx 4-lobed; stamens 3 or occasionally 2, with pale red anthers soon becoming light yellow; pistillate aments naked dnring the winter, $\frac{1^{\prime}}{8}$ to nearly $\frac{1^{\prime}}{4}$ long, with light brown ovate rounded scales; stigmas bright red. Fruit : strobiles $\frac{1^{\prime}}{2}-1^{\prime}$ long, with thin scales slightly thiekened and nearly truncate at the apex; nnt broadly ovate, with a narrow membranaceous border.

A tree, in the United States rarely more than $20^{\circ}-30^{\circ}$ high, with a trunk sometimes $8^{\prime}$ in diameter, long slender spreading branches forming an open round-topped head, and slender branchlets slightly puberulons when they first appear, light orangered and lustrous during their first winter, and marked by small conspieuous pale lentieels, becoming in their second year dark red-brown or gray tinged with red and much roughened by the elevated leaf-scars. Winter-buds aeute, bright red, lustrous, glabrous, $\frac{1^{\prime}}{2}$ long. Bark thin, smooth, light brown tinged with red.

Distribution. Banks of streams in cañons of the mountains of southern New Mexico and Arizona at elevations of $4000^{\circ}-6000^{\circ}$ above the sea; and on the mountains of northern Mexico. 
3. Flowers opening in autumn from aments of the year.

\section{Alnus maritima, Nutt. Alder.}

Leaves oblong, ovate, or obovate, acute, acuminate, or rounded at the apex, gradually narrowed and wedge-shaped at the base, remotely serrate, with minute incurved glandular teeth, and somewhat thickened on the slightly undulate margins,

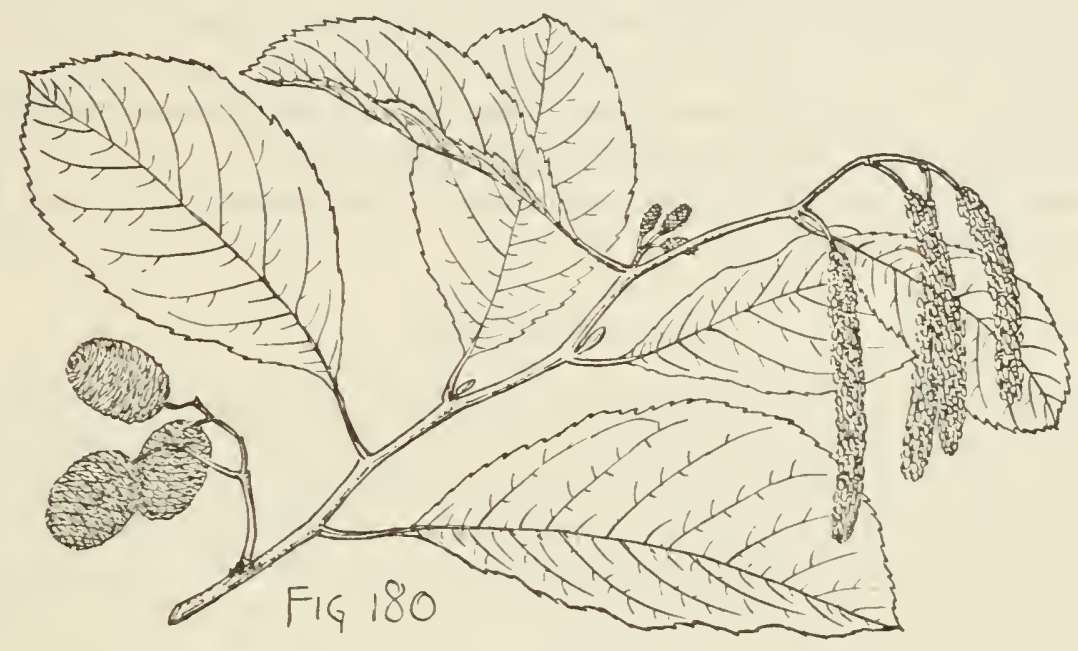

when they unfold, light green tinged with red, hairy on the midribs, veins, and petioles, and coated above with pale scurfy pubescence, at maturity dark green, very lustrous, and covered below by minute pale glandular dots, $3^{\prime}-4^{\prime}$ long, $1 \frac{1^{\prime}}{2}-2^{\prime}$ wide, with stout yellow midribs and primary veins prominent and glandular on the upper side and slightly puberulous below; their petioles stout, yellow, glandular, flattened and grooved on the upper side, $\frac{1^{\prime}-3^{\prime}}{2}$ long; stipules oblong, acute, about $\frac{11}{8}$ long, dark reddish brown, caducous. Flowers: aments appearing in July on branches of the year and fully grown in August or early in September; staminate in short scurfy-pubescent glandular-pitted racemes on slender peduncles sometimes $\frac{1}{3}^{\prime}$ in length from the axils of upper leaves; pistillate nsually solitary from those of the lower leaves; staminate aments covered at first with ovate acute dark green very lustrous scales slightly ciliate on the margins and furnished at the apex with minute red points, at maturity $1 \frac{1}{2}^{\prime}-2 \frac{1}{2}^{\prime}$ long, $\frac{1^{\prime}}{4}$ to nearly $\frac{1}{2}^{\prime}$ thick, with dark orangebrown scales raised on slender stalks, and bright orange-colored stamens; pistillate aments on stout pubescent peduncles, bright red at the apex and light green below before opening, with ovate acute scales slightly ciliate on the margins, about $\frac{1}{8}$ long when the styles protrude from between the scales, beginning to enlarge the following spring. Fruit attaining full size at midsummer and then stalked, broadly ovate, rounded and depressed at the base, gradually narrowed to the rather obtuse apex, about $\frac{5^{\prime}}{8}$ long and $\frac{1}{2}^{\prime}$ broad, with thin lustrous scales slightly thickened and crenately lobed at the apex, turning dark reddish brown or nearly black and opening late in the autumn and remaining on the branches until after the flowers unfold the following year; nut oblong-obovate, gradually narrowed and apiculate at the apex, with a thin membranaceous border.

A tree, occasionally $30^{\circ}$ high, with a tall straight trunk $4^{\prime}-5^{\prime}$ in diameter, small spreading branches forming a narrow round-topped head, slender slightly zigzag 
branchlets, light green and hairy at first, pale yellow-green, very lustrous, slightly puberulous, marked with occasional small orange-colored lenticels, and glandular, witl minute dark glandular dots during their first summer, becoming dull light orange or reddish brown in the winter, and ashy gray often slightly tinged with red the following season; more often shrubby, with numerous slender spreading stems $15^{\circ}-20^{\circ}$ tall. Winter-buds acute, dark red, coated with pale lustrous scurfy pubescence, about $\frac{1^{\prime}}{4}$ long. Bark $\frac{1^{\prime}}{8}$ thick, smooth, light brown or brown tinged with gray. Wood light, soft, close-grained, light brown, with thick hardly distinguishable sapwood.

Distribution. Banks of streams and ponds in southern Delaware and Maryland, and on the banks of the Red River in the Indian Territory.

Occasionally cultivated as an ornamental tree in the eastern states and hardy as far north as Massachusetts.

\section{FAGACE王.}

Trees, with watery juice, slender terete branchlets marked by numerous usually pale lenticels, alternate stalked penniveined leaves, and narrow mostly deciduous stipules. Flower's monœcious, the staminate in unisexual heads or aments, composed of a 4-8-lobed calyx, and 4 or 8 stamens, with free simple filaments and introrse 2-celled anthers, the cells parallel and contiguous, opening longitudinally; the pistillate solitary or clustered, in terminal unisexual or bisexual spikes or heads, subtended by an involucre of more or less united imbricated bracts becoming woody and partly or entirely inclosing the fruit, and composed of a 4-8-lobed calyx adnate to the 3-7-celled ovary with as many styles as its cells and 1 or 2 pendulous anatropous ovules in each cell. Fruit a nut 1-seeded by abortion, the outer coat cartilaginous, the inner membranaceous or bony. Seed filling the cavity of the nut, without albumen; seed-coat membranaceous; cotyledons fleshy, including the minute superior radicle; hilum basal, minute.

The six genera of this widely distributed family are represented in the North American silva with the exception of Nothofagus, separated from Fagus to receive the Beech-trees of the southern hemispliere.

\section{CONSPECTUS OF THE NORTH AMERICAN GENERA.}

Staminate flowers fascicled in globose-stalked heads; the pistillate in 2-4-flowered clusters. Nut triangular.

1. Fagus.

Staminate flowers in slender aments.

Pistillate flowers in 2-5-flowered clusters below the staminate, in bisexual aments.

Fruit inclosed in a prickly burr.

Leaves deciduous ; ovary 6-celled; fruit maturing in one season; branchlets lengthening by an upper axillary bud; bud-scales 4 .

2. Castanea.

Leaves persistent; ovary 3 -celled; fruit maturing at the end of the second season; branchlets lengthening by a terminal bud; bud-scales numerous.

3. Castanopsis.

Fruit inclosed only partly in a shallow cup covered by slender recurved scales united only at the base, free above.

4. Pasania.

Pistillate flowers solitary, in few-flowered unisexual spikes.

Fruit more or less inclosed in a cup covered by thin or thickened scales, closely appressed or often free toward its rim.

5. Quercus. 


\section{FAGUS, L. Beech.}

Trees, with smooth pale bark, liard close-grained wood, and elongated acute bright chestnut-brown buds, their inmer scales accrescent and marking the base of the branchlets with persistent ring-like scars. Leaves convex and plicate along the veins in the bud, thick and firm, deciduous; their petioles short, nearly terete, in falling leaving small elevated semioval leaf-scars, with marginal rows of minute fibro-vascular bundle-scars; stipules linear-lanceolate, infolding the leaf in the bud. Flowers vernal after the unfolding of the leaves; staminate short-pedicellate, in globose many-flowered heads on long drooping bibracteolate stems at the base of the shoots of the year or from the axils of their lowest leaves, and composed of a subcampanulate 4-8-lobed calyx, the lobes imbricated in æstivation, ovate and rounded, and 8-16 stameus inserted on the base of and longer than the calyx, with slender filaments and oblong green anthers; pistillate in 2-4-flowered stalked clusters in the axils of upper leaves of the year, surrounded by numerous awl-shaped hairy bracts, the outer bright red, longer than the flowers, deciduous, the inner shorter and united below into a 4-lobed involucre becoming at maturity woody, ovoid, thick-walled, and covered by stont recurved prickles, inclosing the usually 3 nuts and ultimately separating into 4 valves; calyx urn-shaped, villous, divided into 4 or 5 linear-lanceolate acute lobes, its 3-angled tube adnate to the 3-celled ovary surmounted by 3 slender recurved pilose styles green and stigmatic toward the apex and longer than the involucre; ovules 2 in each cell. Nut ovate, unequally 3 -angled, acute or winged at the angles, concave and longitudinally ridged on the sides, chestnut-brown and lustrous, tipped with the remnants of the styles, marked at the base by a small triangular scar, with a thin shell covered on the inner surface with rufous tomentum. Seed dark chestuut-brown, suspended with the abortive ovules from the tip of the hairy dissepiment of the ovary pushed by the growth of the seed into one of the angles of the nut; cotyledons sweet, oily, plano-convex.

Fagus as here limited is confined to the northern hemisphere, with a single American species and four or five Old World species; of these one is widely distributed through Europe to southwestern Asia, and the others are confined to eastern temperate Asia. Of exotic species, the European Fagus sylvatica, L., an important timber-tree, is frequently planted for ornament in the eastern states in several of its forms, especially those with purple leaves, and with pendulous branches. The wood of Fagus is hard and close-grained. The sweet seeds are a favorite food of swine, and yield a valuable oil.

Fagus is the classical name of the Beech-tree.

\section{Fagus Americana, Sweet. Beech.}

Leaves remote at the ends of the branches and clustered on short lateral branchlets, oblong-ovate, acuminate, with long slender points, coarsely serrate, with spreading or incurved triangular teeth except at the gradually narrowed wedgeshaped rounded or cordate base, when they unfold pale green and clothed on the lower surface and margins with long pale lustrous silky hairs, at maturity dull dark bluish green above, light yellow-green and very lustrous below, with tufts of long pale hairs in the axils of the veins, $2 \frac{1}{2}^{\prime}-5^{\prime}$ long, $1^{\prime}-3^{\prime}$ broad, with slender yellow midribs covered above with short pale hairs, and slender primary veins running obliquely to the points of the teeth, turning bright clear yellow in the autumn; their petioles hairy, $\frac{1}{4}^{\prime}-\frac{1^{\prime}}{2}$ long; stipules ovate-lanceolate on the lower leaves, strap-shaped 
to linear-lanceolate on the upper, brown or often red below the middle, membranaceous, lustrous, $1^{\prime}-1 \frac{1^{\prime}}{2}$ long. Flowers opening when the leaves are about one third grown; staminate in globose heads $\mathbf{1}^{\prime}$ in diameter, on slender hairy peduncles about $2^{\prime}$ long; pistillate in usually 2-flowered clusters, on short clavate hoary peduncles $\frac{1^{\prime}}{2}-\frac{3}{4}^{\prime}$ long. Fruit: involucres about $\frac{3^{\prime}}{4}$ in length, on stout hairy club-shaped peduncles $\frac{1^{\prime}}{\frac{1}{4}-\frac{3^{\prime}}{4}}$ long, fully grown at midsummer, and puberulous, dark orange-green, and covered by slender straight or slightly recurved prickles red above the middle, becoming at maturity in the autumn light brown, tomentose, with much recurved pubescent prickles, persistent on the branch after opening late into the winter; nut about $\frac{3^{\prime}}{4}$ long.

A tree, usually $70^{\circ}-80^{\circ}$ but exceptionally $120^{\circ}$ high, sending up from the roots numerous small stems sometimes extending into broad thickets round the parent tree, in the forest with a long comparatively slender stem free of branches for more than half its length, and short branclues forming a narrow head, in open situations

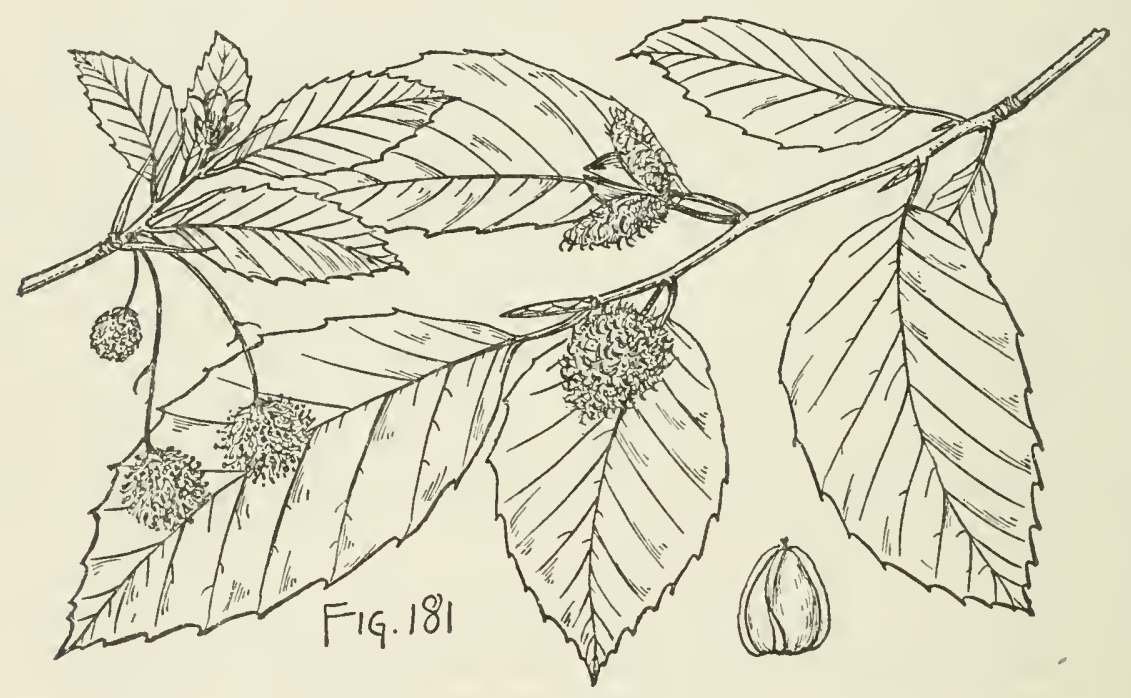

short-stemmed, with a trunk often $3^{\circ} \mathcal{4}^{\circ}$ in diameter, and numerous limbs spreading gradually and forming a broad compact round-topped head of slender slightly drooping branches clothed with short leafy laterals, and branchlets pale green and coated with long soft caducous hairs when they first appear, olive-green or orangecolored during their first summer and conspicuously marked by oblong bright orange lenticels, gradually growing red, bright reddish brown during their first winter, darker brown in their second season and ultimately ashy gray. Winterbuds puberulous, especially toward the apex, $\frac{3^{\prime}}{4}$ to nearly $1^{\prime}$ long, about $\frac{1}{8}^{\prime}$ broad, the inner scales hirsute on the inner surface and along the margins and when fully grown often $1^{\prime}$ long, lustrous, brown above the middle, and reddish below. Bark $\frac{1^{\prime}}{4}-\frac{1}{2}$ thick, with a smooth light steel gray surface. Wood hard, strong, tough, very close-grained, not durable, difficult to season, dark or often light red, with thin nearly white sapwood of 20-30 layers of annual growth; largely used in the manufacture of chairs, shoe-lasts, plane-stocks, the handles of tools, and for fuel. The sweet nuts are gathered and sold in the markets of Canada and of some of the western and middle states.

Distribution. Rich uplands and mountain slopes, often forming nearly pure 
forests, and southward on the bottom-lands of streams and the margins of swamps; valley of the Restigouche River, the northern shores of Lake Huron and nortliern Wisconsin, southward to western Florida, and through southern Illinois and southeastern Missouri to the valley of the Trinity River, Texas; one of the most widely distributed trees of eastern North America; of its largest size in the forests on intervale lands in the basin of the lower Ohio River, and on the slopes of the southern Alleghany Mountains.

Often planted in the northern states as an ornamental tree.

\section{CASTANEA, Adans. Chestnut.}

Trees or shrubs, with astringent juice, furrowed bark, porons brittle wood, terete branchlets withont terminal buds, axillary buds covered by 2 pairs of slightly imbricated scales, the outer lateral, the others accrescent, becoming oblong-ovate and acute and marking the base of the branch with narrow ring-like scars, stout perpendicular tap-roots; producing when cut numerous stont shoots from the stump. Leaves convolute in the bud, ovate, acute, coarsely serrate, except at the base, with thin veins running to the points of the slender glandular teeth, deciduous; their petioles leaving in falling small elevated semioval leaf-scars marked by an irregular marginal row of minute fibro-vascular bundle-scars; stipules ovate to linear-lanceolate, acute, scarions, infolding the leaf in the bud, cadncons. Flowers monœeious, opening in early summer, nnisexual, strong-smelling; the staminate, in 3-7-flowered cymes, in the axils of minute ovate bracts, in elongated simple deciduons aments first appearing with the unfolding of the leaves from the inner scales of the terminal bud and from the axils of the lower leaves of the year, composed of a pale straw-colored slightly puberulous calyx deeply divided into 6 ovate rounded segments imbricated in the bud, and 10-20 stamens inserted on the slightly thickened torus, with filiform filanents incurved in the bud, becoming elongated and exserted, and ovoid or globose pale yellow anthers; the pistillate scattered or spicate at the base of the shorter persistent androgynous aments from the axils of later leaves, sessile, 2 or 3 together or solitary within a short-stemmed or sessile involncre of closely imbricated oblong acute bright green bracts scurfy-pubescent or tomentose below the middle, subtended by a bract and 2 lateral bractlets, each flower composed of an urn-shaped calyx, with a short limb divided into 6 obtuse lobes, minnte sterile stamens shorter than the calyx-lobes, an ovary 6 -celled after fecundation, with 6 linear spreading white styles hairy below the middle and tipped by minute acute stigmas, and 2 ovules in each cell, attached on its inner angle, descending, semianatropous. Fruit maturing in one season, its involucre inclosing 1-3 nuts, globose or oblong, pubescent or tomentose and densely spiny on the outer surface, with elongated ridged bright green ultimately brown branched spines fascicled between the deciduous scales, coated on the inner surface with lustrous pubescence, splitting at maturity into $2-4$ valves; nut ovate, acute, crowned by the remnants of the style, bright chestnut-brown and lustrous, tomentose or pubescent at the apex, cylindrical, or when more than 1 flattened, marked at the broad base by a large couspicuous pale circular or oval thickened scar, its shell lined with rufous or hoary tomentum. Seed usually solitary by abortion, dark chestnut-brown, marked at the apex by the abortive ovules, with thick and fleshy more or less undulate ruminate sweet farinaceous cotyledons.

Castanea is confined to the northern hemisphere, and is widely distributed throngh eastern North America, southern Europe, northern Africa, western Asia, and central 
and northern China and Japan. Four species are distinguished. Of the exotic species, the European Castanea Castanea, Karsten, a trec frequently cultivated in Europe and Japan for its large sweet secds which are an important article of food in the eountries of southern Europe and in eastern Asia, has been oceasionally planted in the middle states. Of the American species two are trees, and one, Castanea alnifolia, Nutt., is a low shrnb. Castanea produces coarse-grained wood very durable in eontaet with the soil, and rich in tannin.

Castanea is the classical name of the Chestnut-trce.

\section{CONSPECTUS OF THE NORTH AMERICAN ARBORESCENT SPECIES.}

Leaves oblong-lanceolate, long-pointed, green and glabrous on both surfaces; nuts 2 or 3 in each involucre, flattened.

1. C. dentata (A, C). Leaves oblong, acute, silvery white and pubescent on the lower surface; nut solitary, cylindrical.

2. C. pumila (A, C).

\section{Castanea dentata, Borkh. Chestnut.}

Leaves oblong-lanceolate, acute and long-pointed at the apex, gradually narrowed and wedge-shaped at the base, when they unfold puberulous on the upper surface and clothed on the lower with fine cobweb-like tomentum, at maturity thin, glabrous,

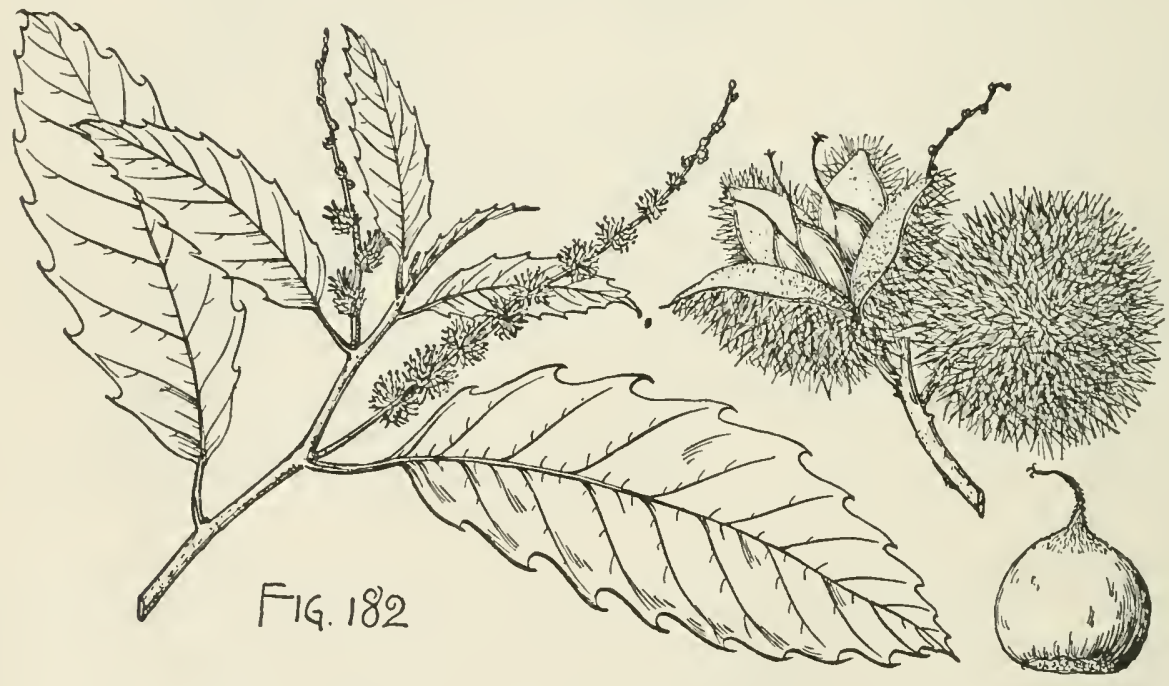

dark dull yellow-green above, pale yellow-green below, $6^{\prime}-8^{\prime}$ long, about $2^{\prime}$ wide, with pale yellow midribs and primary veins, turning bright elear yellow late in the autumn; their petioles stont, slightly angled, puberulous, $\frac{1}{2}^{\prime}$ long, often flushed with red; stipules ovate-laneeolate, acute, yellow-green, puberulous, about $\frac{1}{2}^{\prime}$ long. Flowers: staminate aments abont $\frac{1}{2}^{\prime}$ long when they first appear, green below the middle and red above, becoming when fully grown $6^{\prime}-8^{\prime}$ long, with stout green puberulous stems eovered from the base to the apex with erowded flower-clusters; androgynous aments, slender, puberulous, $2 \frac{1}{2}^{\prime}-5^{\prime}$ long, with 2 or 3 irregularly scattered involucres of pistillate flowers near their base. Fruit: involucres attaining their full size by the middle of August, $2^{\prime}-2 \frac{1^{\prime}}{2}$ in diameter, sometimes a little longer than broad, somewhat flattened at the apex, glabrous and covered on the outer surface with erowded faseicles of long slender glabrous much-branched spines, opening with the first frost and gradually shedding their nuts; nuts usually much compressed, $\frac{1}{2}^{\prime}-1^{\prime}$ wide, 
usually rather broader than long, coated at the apsx or nearly to the middle with thick pale tomentum, the interior of the shell lined with thick rufous tomentum; seed very sweet.

A tree, occasionally $100^{\circ}$ high, with a tall straight columnar trunk $3^{\circ}-4^{\circ}$ in diameter, or often when uncrowded by other trees with a short trunk occasionally $10^{\circ}-12^{\circ}$ in diameter, and usually divided not far above the ground into 3 or 4 stout horizontal limbs forming a broad low round-topped head of slightly pendulous branches frequently $100^{\circ}$ across, and branchlets at first light yellow-green sometimes tinged with red, somewhat angled, lustrous, slightly puberulous, soon becoming glabrous and olive-green tinged with yellow or brown tinged with green and ultimately dark brown. Winter-buds ovate, acute, about $\frac{1^{\prime}}{4}$ long, with thin dark chestnut-brown scales scarious on the margins. Bark from $1^{\prime}-2^{\prime}$ thick, dark brown and divided by shallow irregular often interrupted fissures into broad flat ridges separating on the surface into small thin closely appressed scales. Wood light, soft, not strong, liable to check and warp in drying, easily split, reddish brown, with thin lighter colored sapwood of 3 or 4 layers of annual growth; largely nsed in the manufacture of cheap furniture and in the interior finish of houses, for railway-ties, fence-posts, and rails. The nuts, which are superior to those of the Old World Chestnut in sweetness and flavor, are gathered in great quantities in the forest and sold in the markets of the eastern cities.

Distribution. Southern Maine to the valley of the Winooski River, Vermont, and southern Ontario, along the southern shores of Lake Ontario to southern Michigan, southward to Delaware and southeastern Indiana, and along the Alleghany Mountains to central Alabama and Mississippi, and to central Kentucky and Tennessee; very common on the glacial drift of the northern states and, except at the north, mostly confined to the Appalachian hills; attaining its greatest size in western North Carolina and eastern Tenness̄ee.

Occasionally planted in the eastern states as an ornamental and timber tree, and for its nuts, of which several varieties are now recognized.

\section{Castanea pumila, Mill. Chinquapin.}

Leaves oblong-oval to oblong-obovate, acute, coarsely serrate, with slender rigid spreading or incurved teeth, gradually narrowed and usually unequal and rounded or wedge-shaped at the base, when they unfold tinged with red and coated above with pale caducous tomentum and below with thick snowy white tomentum, at maturity rather thick and firm in texture, bright yellow-green on the upper surface, hoary or silvery-pubescent on the lower, $3^{\prime}-5^{\prime} \operatorname{long}, 1_{2}^{\prime}-2^{\prime}$ wide, turning dull yellow in the autumn; their petioles stont, pubescent, flattened on the upper side, $\frac{1}{4}^{\prime}-\frac{1}{2}^{\prime}$ long; stipules light yellow-green, pubescent, those of the 2 lowest leaves broad, ovate, acute, covered at the apex by rufons tomentum, on later leaves ovate-lanceolate, often oblique and acute, becoming linear at the end of the branch. Flowers : staminate aments $\frac{1}{2}^{\prime}$ long when they first appear, pnbescent, green below, bright red at the apex, becoming when fully grown $4^{\prime}-6^{\prime}$ long, with stout hoary tomentose stems and crowded or scattered flower-clusters; androgynous aments silvery tomentose, $3^{\prime}-4^{\prime}$ long; involucres 1-flowered, scattered at the base of the ament or often spicate and covering its lower half, sessile or short-stalked. Fruit : involucres $1^{\prime}-1 \frac{1}{2}^{\prime}$ in diameter, with thin walls coated on the inner surface with pale silky hairs, tomentose and covered on the onter surface with crowded fascicles of slender spines tomentose toward the base, or with scattered clusters of stonter spines; nut ovate, cylindrical, 
rounded at the slightly narrowed base, gradnally narrowed and pointed at the apex, more or less coated with silvery white pubescence, dark chestuut-brown, very hnstrons, $\frac{3^{\prime}}{4}-1^{\prime}$ long, $\frac{1^{\prime}}{3}$ broad, with a thin shell lined with a coat of lustrous hoary tomentim, and a sweet seed.

A round-topped tree, rarely $50^{\circ}$ high, with a short straight trunk $2^{\circ}-3^{\circ}$ in diameter, slender spreading branches, and branchlets coated at first with pale tomentnm, becoming during their first winter pubescent or remaining tomentose at the apex,

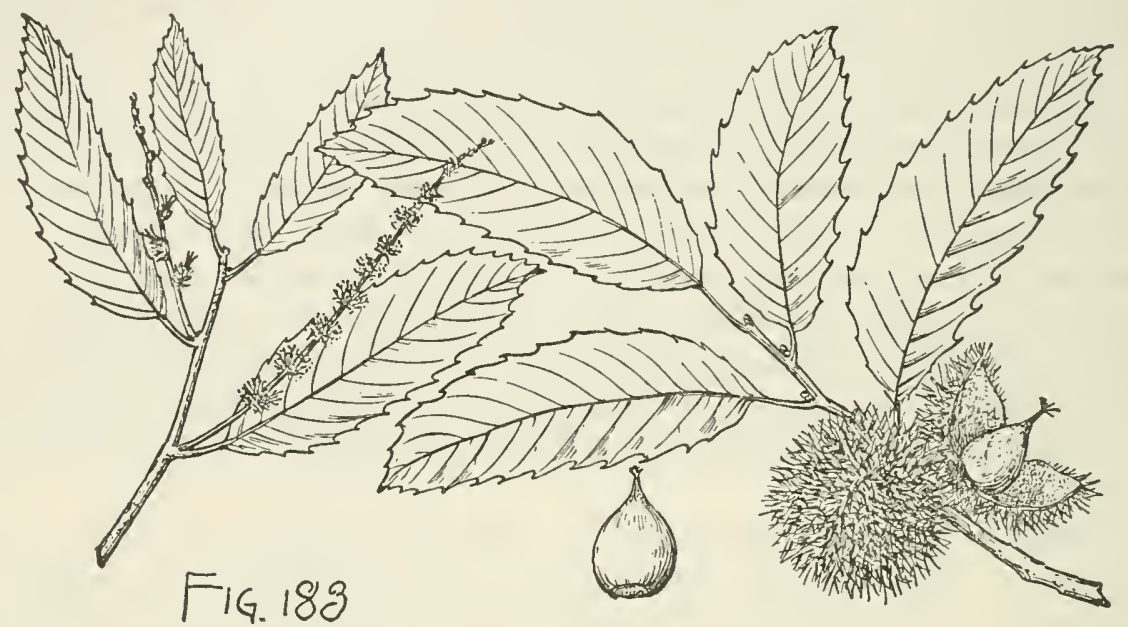

bright red-brown, glabrous, lustrous, olive-green or orange-brown during their second season and nltimately darker; nsially a shrub spreading into broad thickets by prolific stolons, with numerous intricately branched stems often only $4^{\circ}$ or $5^{\circ}$ tall. Winter-buds ovate, or oval, about $\frac{1}{8}^{\prime}$ long, clothed when they first appear in summer with thick hoary tomentum, becoming red during the winter and scurfy-

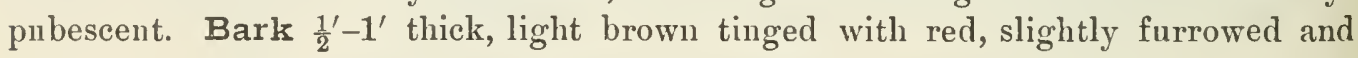
broken on the surface into loose plate-like scales. Wood light, hard, strong, coarse-grained, dark brown, with thin hardly distinguishable sapwood of 3 or 4 layers of annual growth; used for fence-posts, rails, and railway-ties. The sweet nuts are sold in the markets of the western and southern states.

Distribution. Dry sandy ridges, rich hillsides and the borders of swamps; southern Pennsylvania to northern Florida and the valley of the Neches River, Texas; usually shrubby in the region east of the Alleghany Mountains; arborescent west of the Mississippi River; most abundant and of its largest size in southern Arkansas and eastern Texas.

\section{CASTANOPSIS, Spach.}

Trees, with scaly bark, astringent wood, and winter-buds covered by numerous imbricated scales. Leaves convolute in the bud, 5-ranked, coriaceous, entire or dentate, penniveined, persistent; stipules obovate or lanceolate, scarious, mostly caducous. Flowers in 3-flowered cymes, or the pistillate rarely solitary or in pairs, in the axils of minute bracts, on slender erect aments from the axils of leaves of the year; the staminate on usually elongated and panicled aments, and composed of a campanulate 5 or 6 -lobed or parted calyx, the lobes imbricated in the bud, usually 10 or 12 stamens inserted on the slightly thickened torus, with elongated exserted filiform 
filaments and oblong anthers, and a minute hirsute rudimentary ovary; the pistillate on shorter simple or panicled aments or scattered at the base of the staminate inflorescence, the cymes urrounded by an involucre of imbricated scales; calyx uri-shaped, the short limb divided into 6 obtuse lobes; abortive stamens inserted on the limb of the calyx and opposite its lobes; ovary sessile on the thin disk, 3-celled after fecundation, with 3 spreading styles terminating in minute stigmas, and 2 ovules in each cell attached to its interior angle. Fruit maturing at the end of the second season, its involucre inclosing 1-3 nuts, ovoid or globose, sometimes more or less depressed, rarely obscurely angled, dehiscent or indehiscent, covered by stout spines, tuberculate or marked by interrupted vertical ridges; nut more or less angled by mutual pressure when more than 1, often pilose, crowned with the remnants of the style, marked at the base by a large conspicuous circular depressed scar, the thick shell tomentose on the inner surface. Seed usually solitary by abortion, bearing at the apex the abortive ovules; cotyledons plano-convex, fleshy, farinaceous.

Castanopsis inhabits California with one species, and southeastern Asia where it is distributed with abont twenty-five species from southern China to the Malay Archipelago and the eastern Himalayas.

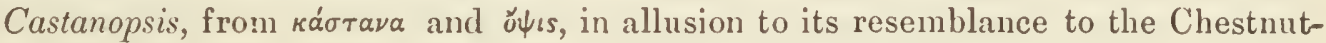
tree.

\section{Castanopsis chrysophylla, A. DC. Chinquapin. Golden-leaved Chestnut.}

Leaves lanceolate or oblong, gradually narrowed at the ends or sometimes abruptly contracted at the apex into short broad points, entire, with slightly thickened revolute margins, when they unfold thin, coated below with golden yellow persistent scales and above with scattered white scales, at maturity thick and coriaceous, dark

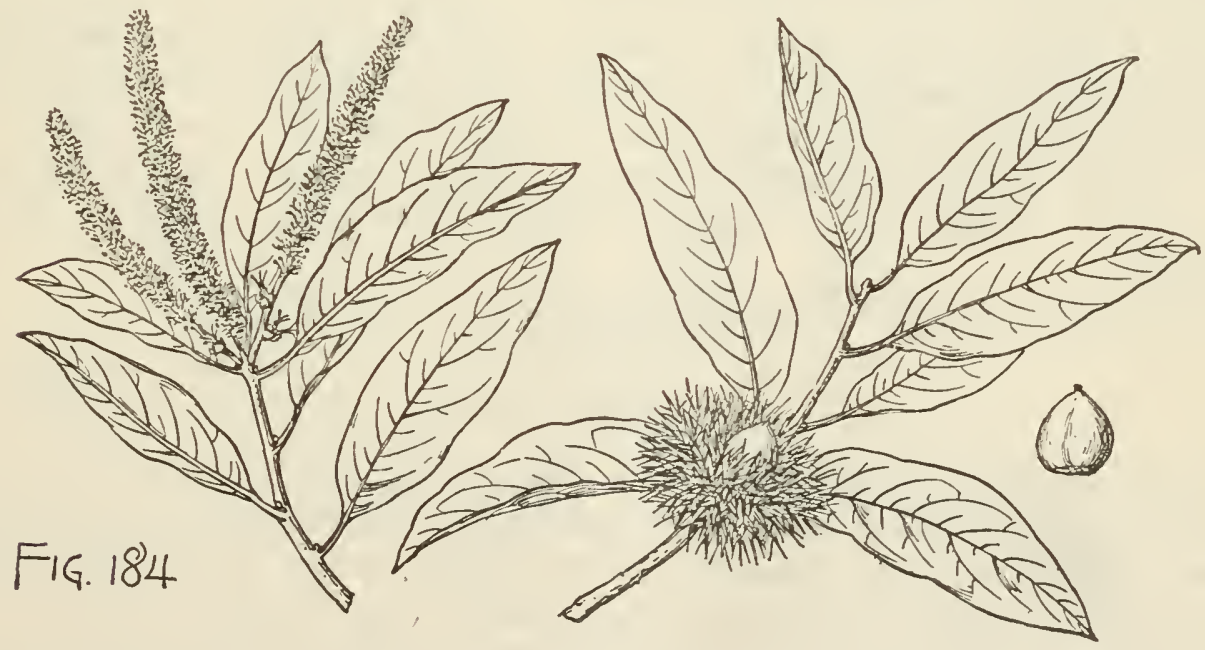

green and lustrous above, $2^{\prime}-6^{\prime}$ long, $\frac{1}{2}^{\prime}$ to nearly $2^{\prime}$ broad, with stont midribs raiseci and rounded on the upper side, turning yellow at maturity and falling gradually at the end of their second or in their third year; their petioles $\frac{1^{\prime}}{4}-\frac{1^{\prime}}{3}$ long; stipules ovate, rounded or acute at the apex, brown and scarious, puberulous, $\frac{1^{\prime}}{4}-\frac{1}{3}{ }^{\prime}$ long. Flowers appearing irregularly from June until February in the axils of broadly ovate a piculate pubescent bracts on staminate and androgynous scurfy stout-stemmed 
aments 2 '-21' long and crowded at the ends of the branches; calyx of the staminate flower coated on the onter surface with hoary tomentum, divided into broadly ovate ronnded lobes numeh shorter than the slender staniens; calyx of the pistillate flower oblong-campannlate, free from the ovary, elothed with hoary tomentmm, divided at the apex into short ronuded lobes, rather shorter than the mimute abortive stamcus, with red anthers; ovary conical, hirsute, with elongated slightly spreading thick pale stigmas. Fruit : involucres globose, dehiscent, irregnlarly 4 -valved, sessile, solitary or clustered, tomcntose and covered on the outer surface lyy long stont or

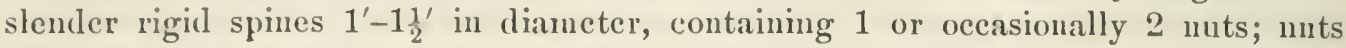
broadly ovate, acute, obtuscly 3-angled, light yellow-brown and lustrous; seeds dark purple-red, sweet and edible.

A tree, $100^{\circ}-150^{\circ}$ high, with a massive trunk $5^{\circ}-10^{\circ}$ in diameter, frequently frec of branches for $80^{\circ}$, stout spreading branches forming a broad compact roundtopped or conical head, and rigid branchlets coated when they first appear with bright golden-yellow scurfy scales, dark reddish brown and slightly scurfy during their first winter, and gradually growing darker in their second season; generally much smaller and sometimes, especially at high elcvations and sonthward, reduced to a low shrub, with slender diverging stems. Winter-buds fully grown at midsummer, usually crowded near the end of the branch, ovate or subglobose, with broadly ovate apiculate thin and papery light brown scales slightly puberulous on the back, ciliate on the scarious often reflexed margins, the terminal bud abont $1^{\prime}$ long and broad and rather larger than the often stipitate axillary buds. Bark $1^{\prime}-2^{\prime}$ thick and deeply divided into rounded ridges $2^{\prime}-3^{\prime}$ broad, broken into thick platelike scales, dark red-brown on the snrface and bright red internally. Wood light, soft, close-grained, not strong, light brown tinged with red, with thin lighter colored sapwood of 50-60 layers of annual growth; occasionally used in the manufacture of plonghs and other agricultural implements.

Distribution. Valley of the Columbia River, Oregon, sonthward along the western slopes of the Cascade Mountains, and in California along the western slopes of the Sierra Nevada and through the coast ranges to the elevated'valleys of the Sàn Jacinto Mountains, sometimes ascending to elevations of $4000^{\circ}$ above the sea; usually shrubby at high elevations and on the California coast ranges south of the Bay of San Francisco; of its largest size in the humid coast valleys of northern California.

Occasionally cultivated in the gardens of temperate Europe.

\section{PASANIA, Örst.}

Trees, with astringent properties, stellate pubescence, deeply furrowed scaly bark, hard close-grained brittle wood, stout branchlets, and winter-buds covered by few erect or spreading foliaceous scales. Leaves convolute in the bud, petiolate, persistent, entire or dentate, with stout midribs, primary veins running obliquely to the points of the teeth, or on entire leaves forked and united near the margins, and reticulate veinlets; stipules oblong-obovate to linear-lanceolate, those of the upper leaves persistent and surrounding the buds during the winter. Flowers in erect unisexual and in bisexual tomentose aments from the axils of leaves of the year, from the inner scales of the terminal bud or from separate buds in the axils of leaves of the previous year; staminate in 3-flowered clusters in the axils of ovate rounded bracts, the lateral flowers subtended by similar but smaller bracts, each flower composed of a 5 -lobed 
tomentose calyx, with nearly triangular acute lobes, 10 stamens, with slender elongated filaments and small oblong or emarginate anthers, and an acute abortive hairy ovary; pistillate scattered at the base of the upper aments below the staminate flowers, solitary, in the axils of acute bracts, furnished with minute lateral bractlets, and composed of a 6-lobed ovate calyx, with rounded lobes, inclosed in the tomentose involucral scales, 6 stamens, with abortive anthers, an ovate-oblong 3-celled ovary, 3 elongated spreading light green styles thickened and stigmatic at the apex, and 2 anatropous ovules in each cell. Fruit an oval or ovate nut maturing at the end of the second season, 1-seeded by abortion, surrounded at the base by the accrescent woody cupular involucre of the flower, marked at the base by a large pale circular scar, the thick shell tomentose on the inner surface. Seed red-browu, filling the cavity of the nut, bearing at the apex the abortive ovules; cotyledons thick and fleshy, yellow and bitter.

Pasania is intermediate between the Oaks and the Chestuuts, and, with the exception of one California species, is confined to southeastern Asia, where it is distributed with many species from southern Japan and southern China through the Malay Peninsula to the Indian Archipelago.

Pasania is from the veruacular name of one of the Java species.

\section{Pasania densiflora, Örst. Tan Bark Oak. Chestnut Oak.}

\section{(Quercus densiflora, Silva N. Am. viii. 183.)}

Leaves oblong or oblong-obovate, rounded or acute or rarely cordate at the base, occasionally rounded at the apex, repand-dentate, with acute callous teeth, or entire, with thickened revolute margins, coated when they unfold with fulvous tomentum and glandular on the margins, with dark caducous glands, at maturity pale green, lustrous and glabrous or covered with scattered stellate pubescence on

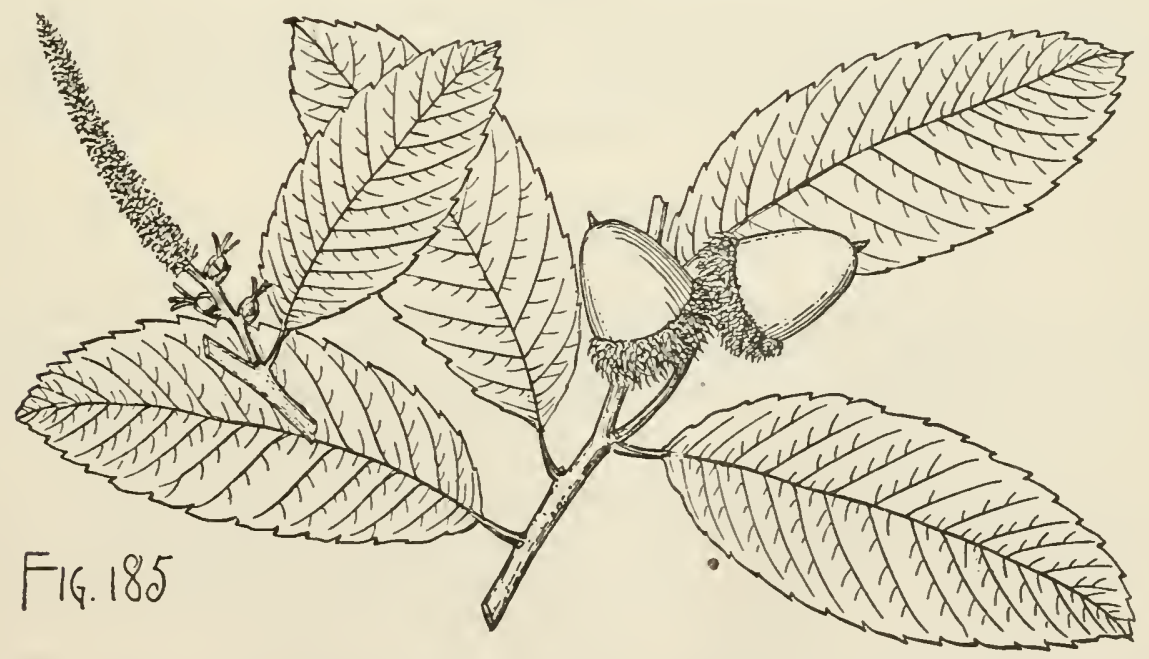

the upper surface, rusty-tomentose on the lower, ultimately becoming glabrous above and glabrate and bluish white below, $3^{\prime}-5^{\prime}$ long, $\frac{3^{\prime}}{4}-3^{\prime}$ wide, with midribs raised and rounded on the upper side, thin or thick primary veius and fine conspicuous reticulate veinlets, persistent until the end of their third or fourth years; their petioles stout, rigid, tomentose, $\frac{1}{2}^{\prime}-\frac{8^{\prime}}{4}$ long; stipules brown and scarious, hirsute on the outer surface. Flowers in early spring and frequently also irregularly during 
the antumu; aments stont-stemmed, $3^{\prime}-4^{\prime}$ long; staminate flowers crowded, hoarytomentose in the bud, their bracts tomentose. Fruit solitary or often in pairs, on a stont tomentose peduncle $\frac{1}{2}^{\prime}-1^{\prime}$ long; nut full and rounded at the base, gradually narrowed and acute or rounded at the apex, scurfy-pubescent when fnlly growu, beconing light yellow-brown, glabrous and lustrous at maturity, $\frac{8^{\prime}}{4}-1^{\prime}$ long, $\frac{1^{\prime}}{2}-1^{\prime}$ broad, its cup sliallow, tomentose, witl lustrons red-brown hairs on the inner surface, and covered by long liuear rigid spreading or recnrved light browu scales coated with stellate hairs, freqnently tipped, especially while young, with dark red glands and often tomentose near the base of the cup.

A tree, nsually $70^{\circ}-80^{\circ}$ but sometimes nearly $100^{\circ}$ ligh, with a trunk $3^{\circ}-6^{\circ}$ in diameter, stout branches ascending in the forest and forming a narrow spire-like head, or in open positions spreading horizontally and forming a broad dense symmetrical round-topped crown, aud branchlets coated at first with a thick fulvous tomeutum of stellate hairs often persistent until the second or third year, becoming dark reddish brown and frequently covered with a glaucons bloom; or sometimes reduced to a shrub, with slender stems only a few feet high (var. echinoides, Sarg.). Winter-buds ovate, obtuse, $\frac{1}{4}^{\prime}-\frac{1}{3}^{\prime}$ long, of ten surrounded by the persistent stipules of the upper leaves, with tomentose loosely imbricated scales, those of the outer ranks linear-lanceolate, increasing in width toward the interior of the bud, those of the inner ranks ovate or obovate and rounded at the apex. Bark $\frac{3^{\prime}}{4}-1 \frac{1}{2}^{\prime}$ thick, deeply divided by narrow fissures into broad rounded ridges broken into nearly square plates covered by closely appressed light red-brown scales. Wood hard, strong, close-grained, brittle, reddish brown, with thick darker brown sapwood; largely used as fuel. The bark is exceedingly rich in tannin and is largely used for tanning leather.

Distribution. Valley of the Umpqua River, Oregon, southward through the coast ranges to the Santa Inez Mountains, California, and along the western slope of the Sierra Nevada up to elevations of $4000^{\circ}$ above the sea to Mariposa County; very abundant in the lumid coast region north of San Francisco Bay and of its largest size in the Redwood forest of Napa and Mendocino counties; southward and on the Sierras less abundant and of smaller size.

\section{QUERCUS, L. Oak.}

Trees or shrubs, with astringent properties, stellate pubescence, scaly or dark and furrowed bark, hard and close-grained or porous brittle wood, slender branchlets marked by pale lenticels and more or less prominently 5 -angled. Winter-buds clustered at the ends of the branchlets, with numerous membranaceous chestnnt-brown slightly accrescent caducous scales closely imbricated in 5 ranks, in falling marking the base of the branchlet with ring-like scars. Leaves 5-ranked, lobed, dentate or entire, often variable on the same branch, membranaceous or coriaceous, the primary veins prominent and extending to the margins or united within them and connected by more or less reticulate veinlets, deciduons in the antumn or persistent until spring or until their third or fourth year; their petioles in falling leaving slightly elevated semiorbicular more or less obcordate leaf-scars broader than high, marked by the ends of numerons scattered fibro-vascular bundles; stipules obovate to lanceolate, scarious, caducous, or those of npper leaves occasionally persistent through the season. Flowers vernal with or after the unfolding of the leaves; staminate solitary, in the axils of lanceolate acute caducous bracts, or without bracts, in graceful pen- 
dulous clustered aments, from separate or leafy buds in the axils of leaves of the previous year, or from the axils of the inner scales of the terminal bud or from those of the leaves of the year; calyx campanulate, lobed or divided to the base into $4-7$, usually 6 , membranaceous lobes; stameus $4-6$, rarely 2 , or $10-12$, inserted on the slightly thickened torus, .with free filiform exserted filaments and ovate-oblong or subglobose glabrous or rarely hairy 2-celled usually yellow anthers; pistillate solitary, subtended by a caducous bract and 2 bractlets, iu short or elongated fewflowered spikes from the axils of leaves of the year; calyx urn-shaped, with a short campanulate 6 -lobed limb, the tube adnate to the incompletely 3 or rarely 4 or $\tilde{\jmath}$-celled ovary inclosed more or less completely by an accrescent involucre of imbricated scales, becoming the cup of the fruit; styles as many as the cells of the ovary, short or elongated, erect or incurved, dilated above, stigmatic on the inner face or at the apex only, generally persistent on the fruit; ovules anatropons or semianatropous, 2 in each cell. Fruit a nut (acorn) maturing in one or in two years, ovoid, globose, or turbinate, short-pointed at the apex, 1-seeded by abortion, marked at the base by a large conspicuous circular scar, with a thick shell, glabrous or coated on the inner surface with pale tomentum, more or less surrounded or inclosed in the accrescent cupular involucre of the flower (cup), its scales thin or thickened, loosely or closely imbricated. Seed marked at the base or at the apex or rarely on the side by the abortive ovules; cotyledons thick and fleshy, usually plano-convex and entire.

Quercus inhabits the temperate regions of the northern hemisphere and high altitudes within the tropics, ranging in the New World sonthward to the mountains of Colombia and in the Old World to the Iudian Archipelago. Two hundred and seventy-five species have been described; fifty-two are Nortl American; of these five are shrubs. Of exotic species, the European Quercus pedunculata, Ehrh., and Quercus sessiliflora, Salisb., have been frequently cultivated as ornamental trees in the eastern United States, where, however, they are usually short-lived and unsatisfactory. Many of the species are important timber-trees; their bark is often rich in tannin and is used in tanning leather, and all produce wood valuable for fuel and in the manufacture of charcoal.

Quercus is the classical name of the Oak-tree.

\section{CONSPECTUS OF THE NORTH AMERICAN ARBORESCENT SPECIES.}

1. Fruit maturing at the end of the second season (except 22); shell of the acorn silkytomentose on the inner surface; leaves or their lobes bristle-tipped. BLACK OAKs.

*Stamens usually 4-6; styles elongated, finally recurved; abortive ovules basal.

+ Leaves deciduous in their first autumn or winter.

+ Leaves pinnately lobed, convolute in the bud.

Leaves green on both sides.

Cup saucer-shaped; leaves glabrons, with exception of axillary tufts of hairs ; winter-buds glabrous or puberulous.

Cup broad and thick.

Leaves dull green above, pale yellow-green below, oblong-obovate to oblong, the lobes tapering gradually from broad bases and acute and usually dentate at the apex.

Cup thin and narrow; leaves lustrous.

1. Q. rubra (A).

Leaves obovate, sinuate-lobed by deep wide sinuses, the spreading lobes acute or obtuse, usually coarsely repand-dentate.

2. Q. palustris $(A, C)$.

Leaves oval or obovate, glabrous, sinuately lobed, their lobes usually acute and entire.

3. Q. Georgiana (C). 
Cup turbinate or hemispherical (sometimes saucer-shaped in 6).

Scales of the cup small, closely appressed; leaves hustrous, glabrous with the exception of axillary tufts of hairs; winter-buds glabrous or pubernlous.

Leaves oval to obovate-orbicular, deeply 5-7-lobed, dark green and linstrous on the upper surface.

4. Q. ellipsoidalis (A).

Leaves obovate, truncate or abruptly wedge-shaped at the base, deeply lobed, with broad rounded sinuses, the lobes sinuate-dentate at the usually broad apex.

5. Q. Texana $(A, C)$.

Leaves oblong or obovate, deeply lobed, with broad rounded sinuses, the slender lobes coarsely repand-dentate toward the apex, glabrons.

6. Q. coccinea (A).

Scales of the cup large, more or less loosely imbricated, forming a free margin ; leaves usually pubescent below.

Winter-buds tomentose; leaves ovate or obovate, slightly or deeply lobed, with broad or narrow nearly entire or dentate lobes, more or less pubescent below.

Winter-buds glabrous or puberulous.

7. Q. velutina $(A, C)$.

Leaves oblong or obovate, deeply lobed, the lobes tapering, acute, or broad and obovate at the apex, repand-dentate or entire, glabrous or pubescent below.

S. Q. Californica $(\mathrm{G})$.

Leaves oblong-obovate or triangular, distinctly cuneate, deeply lobed, with acute spreading of ten falcate lobes, glabrous or rusty-pubescent below, short-stalked.

9. Q. Catesbæi (C).

Leaves whitish or grayish tomentulose below.

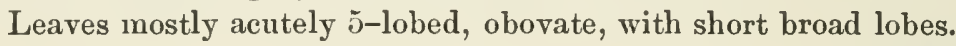

Leaves with elongated mostly falcate lobes.

10. Q. nana (A).

Leaves oblong or obovate, fulvous or pale pubescent below, the lobes usually elongated and falcate, or broad and 3 -lobed at the apex.

11. Q. digitata $(\mathrm{A}, \mathrm{C})$.

Leaves oval to oblong, deeply 5 -11-lobed, the lobes acuminate, mostly falcate, white-tomentose below.

12. Q. pagodæfolia (A, C).

Leaves widening upward, often abruptly dilated at the broad sinuate or obscurely $3-5$-lobed apex.

Leaves broadly obovate, rusty-pubescent below.

13. Q. Marilandica (A, C).

Leaves obovate-spatulate or narrowly wedge-shaped, glabrous.

14. Q. nigra (C).

+++ Leaves lanceolate to oblong or lanceolate-obovate, usually entire, involute in the bud. Willow OAKs.

Leaves glabrous.

Leaves lanceolate, narrowed and acute at the ends.

15. Q. Phellos (A, C).

Leaves oblong to oblong-obovate, dark green and lustrous above, somewhat paler below. 16. Q. laurifolia (C).

Leaves tomentulose or pubescent below, oblong-lanceolate to oblong-obovate.

Leaves pale blue-green, coated below with hoary tomentum.

17. Q. brevifolia (C).

Leaves dark green and lustrous above, pubescent below.

1S. Q. imbricaria (A).

+- Leaves persistent until the appearance of those of the following year, revolute in the bud (involute in 21 ).

Leaves lanceolate, oblong-lanceolate or elliptical, entire or spinose- 
toothed toward the apex, covered below with pale or fulvous tomentum.

19. Q. hypoleuca (E, H).

Leaves oblong-lanceolate, entire or sinuate-dentate, dark green and lustrous.

20. Q. Wislizeni (G).

Leaves oval to oblong-obovate, rounded or acute at the apex, mostly entire, with thickened revolute margins, involute in the bud.

21. Q. myrtifolia (C).

Leaves oval, orbicular to oblong, entire or sinuately spinose-toothed, convex on the upper surface; fruit maturing at the end of the first season.

22. Q. agrifolia $(G)$.

**Stamens usually 6-S; styles dilated ; abortive ovules basal or lateral ; leaves persistent, involute in the bud.

Leaves oblong, acute or cuspidate, entire or dentate or sinuate-toothed, fulvoustomentose and ultimately pale on the lower surface. 23. Q. chrysolepis $(G, H)$.

Leaves oblong-lanceolate, acute, crenate-dentate or entire, conspicuously veined, pubescent or tomentose below.

24. Q. tomentella (G).

2. Fruit maturing at the end of the first season; shell of the acorn glabrous on the inner surface (hoary-tomentose in 47); abortive ovules basal; stamens 6-S; styles dilated. White OAKS.

*Leaves and their lobes usually without bristle-tips, except on vigorous shoots, yellowgreen, deciduous in their first autumn or winter, convolute in the bud (conduplicate in 25 and 23 ).

+ Leaves lyrate or sinuate-pinnatifid, rarely nearly entire.

Leaves glabrous, obovate-oblong, obliquely 3-9-lobed or pinnatifid, pale below, conduplicate in the bud.

25. Q. alba $(A, C)$.

Leaves pubescent beneath.

Leaves oblong-obovate, deeply lobed, usually stellate-pubescent above, pale below, conduplicate in the bud.

Leaves obovate or oblong, coarsely pinnatifid-lobed.

Leaves obovate or oblong-lanceolate, lobed or pinnatifid.

27. Q. Garryana (B, G).

2S. Q. Gambelii (F).

Leaves oblong-obovate, usually 5-lobed, stellate-pubescent above; anthers hirsute.

29. Q. minor (A, C).

Leaves entire or slightly sinuate-lobed toward the apex, oblong or oblongobovate; anthers hirsute.

30. Q. Chapmani (C).

Leaves white-tomentulose beneath.

Leaves obovate or oblong, lyrately pinnatifid or deeply sinuate-lobed or divided; cup fringed by the awned scales. 31 . Q. macrocarpa (A, C).

Leaves obovate-oblong, deeply 5-9-lobed or pinnatifid; nut often nearly inclosed in its cup.

32. Q. lyrata (C).

$+\rightarrow$ Leaves coarsely sinuate-toothed. Chestndt OAKs.

Fruits on peduncles much longer than the petioles; leaves obovate or oblongobovate, generally sinuate-dentate or lobed, pubescent, and usually hoary on the lower surface.

33. Q. platanoides $(\mathrm{A}, \mathrm{C})$.

Fruits on peduncles about as long or shorter than the petioles.

Leaves obovate or oblong-obovate, wedge-shaped or rounded at the broad or narrow base, tomentose or pubescent, and often silvery white below.

34. Q. Michauxii (A, C).

Leaves obovate or oblong to lanceolate, acuminate, with rounded or acute teeth.

35. Q. Prinus (A).

Fruits sessile or nearly so; leaves oblong to lanceolate, acute or acuminate, or broadly obovate, puberulous and pale, often silvery white on the lower surface. 36. Q. acuminata (A, C). 
*** Leaves of ten dentate or spinescent, or sometimes entire.

- Leaves decidnous in their first autumm or winter, blue-green, convolnte in the bud. Leaves obovate or oblong, mndnlate-lobed or entire, pale, and of ten silvery white and pubescent on the lower surface.

37. Q. breviloba (C).

Leaves oblong, sinuate-dentate, entire, pimatifid-lobed or spinescent, pubcscent below.

Leaves oblong, lobed, spinescent or entire, pubescent below.

3S. Q. undulata $(\mathrm{F}, \mathrm{H})$.

39. Q. Douglasii (G).

$\rightarrow-$ Leaves mostly persistent mitil the appearance of those of the following spring, revolute in the bud (convolute in 45).

Leaves blue-green.

Fruit solitary or in pairs.

Cup hemispherical or turbinate, inclosing about one third of the acorn, raised on a short peduncle or nearly sessile.

Leaves oblong-obovate, usually obtuse and rounded at the apex, entire or remotely dentate.

40. Q. Engelmanni (G).

Leaves ovate, oval or obovate, usually cordate, entire or remotely spinulose-dentate.

41. Q. oblongifolia ( $\mathrm{E}, \mathrm{H})$.

Leaves oblong-lanceolate or broadly obovate, cordate or rounded at the base, spinose-dentate, pubescent and conspicuously reticulatevenulose on the lower surface.

42. Q. Arizonica $(\mathrm{H})$.

Cup saucer-shaped, inclosing about one fourth of the acorn, sessile; leaves ovate or ovate-oblong or oval, entire or remotely spinose-dentate.

43. Q. Toumeyi (H).

Fruits several on a long and slender peduncle. Leaves broadly obovate, cordate, usually rounded and obtuse at the apex, repandly spinose-dentate, coarsely reticulate-venulose.

44. Q. reticulata $(\mathrm{H})$.

Leaves dark green.

Leaves oblong or obovate, entire, sinnate-toothed or lobed, pubescent and often pale below, convolute in the bud. 45 . Q. dumosa (G).

Leaves oblong, elliptical or obovate, entire or remotely spinose-dentate, pale or silvery white on the lower surface; anthers hirsute.

46. Q. Virginiana (C).

Leaves oblong-lanceolate, entire or repand-serrate, coriaceous; inner surface of the shell of the acorn hoary-tomentose. 47. Q. Emoryi (F, H).

1. Fruit maturing at the end of the second season (except 22); shell of the acorn tomentose on the inner surface; leaves or their lobes bristle-tipped. BLACK OAKS.

* Stamens usually 4-6; abortive ovules basal.

$\rightarrow$ Leaves deciduous in their first autumn or winter. + Leaves pinnately lobed.

\section{Quercus rubra, L. Red Oak.}

Leaves obovate or oblong, acute or acuminate, abruptly or gradually wedgeshaped or rounded at the broad or narrow base, usually divided about lialf way to the midribs by wide oblique sinuses ronnded at the bottom into 11 or sometimes into 7 or 9 acute oblique ovate lobes tapering from broad bases and mostly sinuately 3-toothed at the apex, with elongated bristle-pointed teeth, or sometimes oblongobovate, gradually narrowed and wedge-shaped at the base, and sinuately lobed, with broad acute usually entire or slightly dentate lobes, when they unfold pink, covered with soft silky pale pubescence on the upper surface and below.with thick white tomentum, soon glabrous, and at maturity thin and firm, dark green, dull and gla- 
brous above, pale yellow-green, glabrous or rarely puberulous and sometimes furnished with small tufts of rusty hairs in the axils of the veins below, $5^{\prime}-9^{\prime}$ long, $4^{\prime}-6^{\prime}$ broad, falling early in the autumn after turning dull or sometimes bright orangecolor or brown; their petioles stont, yellow or red, $1^{\prime}-2^{\prime}$ long. Flowers: staminate in pubescent aments $4^{\prime}-5^{\prime}$ long; calyx deeply divided into 4 or 5 narrow ovate rounded

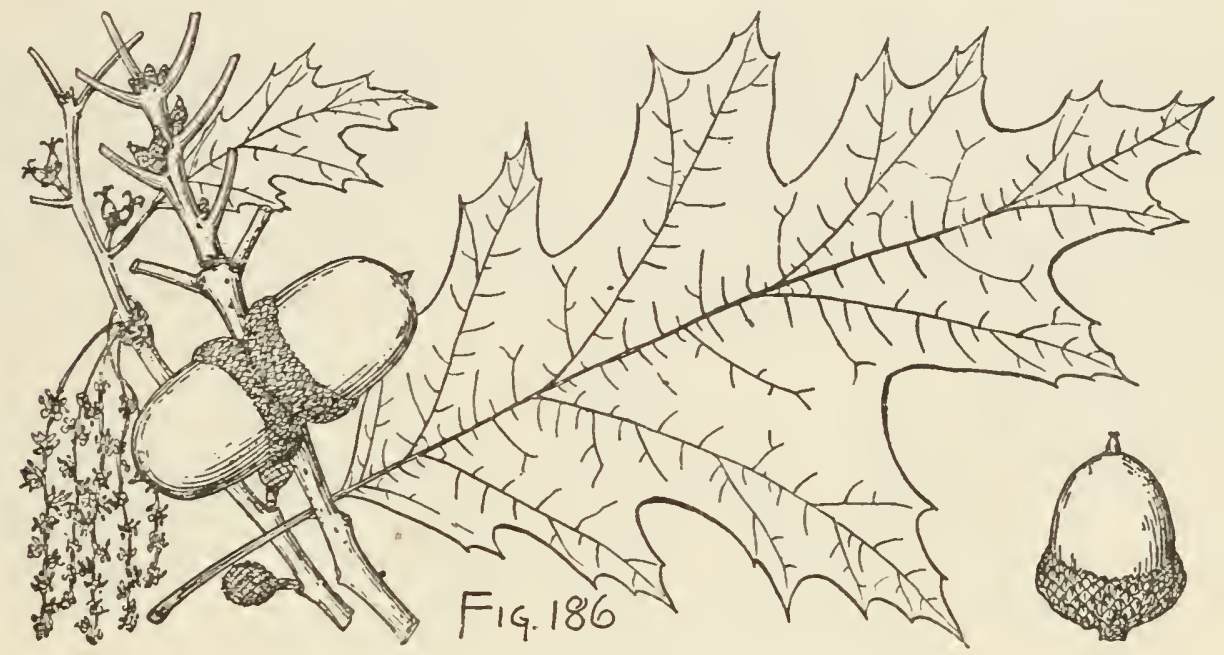

lobes shorter than the stamens; pistillate on short glabrous peduncles, their involucral scales broadly ovate, dark reddish brown, shorter than the conspicuous linear acute bract of the flower and as long as the lanceolate acute calyx-lobes; stigmas bright green. Fruit solitary or in pairs, sessile or stalked; acorn ovate or oval, with a broad base, gradually narrowed and rounded at the apex, $\frac{3^{\prime}}{4}-1 \frac{1}{4}^{\prime}$ long, $\frac{1}{2}^{\prime}-1^{\prime}$ wide, usually inclosed only at the base in the thick shallow sancer-shaped cup reddish brown and puberulous within, and covered by thin closely appressed ovate acute bright red-brown puberulous scales.

A tree, usually $70^{\circ}-80^{\circ}$ or occasionally $150^{\circ}$ high, with a trunk $3^{\circ}-4^{\circ}$ in diameter, and stout branches spreading gradually ard usually forming a comparatively narrow round-topped head, or growing at right angles to the stem into a broad round-topped crown, and slender lustrous branchlets bright green and covered when they first appear with pale scurfy caducous pubescence, dark red during their first winter, becoming more or less tinged with orange-green in their second and third years and ultimately dark brown. Winter-buds ovate, gradually narrowed at the acute apex, about $\frac{1^{\prime}}{4}$ loug, with thin ovate acute light chestnut-brown scales. Bark on young stems and on the upper part of the limbs of large trees smooth, light gray, becoming on older trunks $1^{\prime}-1 \frac{1^{\prime}}{2}$ thick, dark brown tinged with red, and divided into small thick appressed plates scaly on the surface. Wood heavy, hard, strong, close-grained, light reddish brown, with thin darker colored sapwood; used in construction, for the interior finish of louses, and in furniture.

Distribution. Nova Scotia and southern New Brunswick through Quebec to the northern shores of Lake Huron and to Lake Namekagon, sonthward to middle Tennessee and Virginia, and along the high Appalachian Mountains to northern Georgia, and westward to eastern Nebraska and central Kansas; rare and of small size toward the northern limits of its range; abundant in southern Nova Scotia, Quebec, and Ontario; one of the largest and most common trees of the forests of the northern 
states, and of its largest size in the region north of the Ohio River; less common and usually of smaller size southward.

Often planted as an ornamental or shade tree in the northeastern states and in the countries of western and northern Europe; generally more successful in Europe than other American Oaks.

\section{Quercus palustris, Muench. Pin Oak. Swamp Spanish Oak.}

Leaves obovate, narrowed and wedge-shaped or broad and truncate at the base, divided by wide deep sinuses rounded at the bottom into 5-7 lobes, the terminal lobe ovate, acute, 3 -toothed toward the apex or entire, the lateral lobes spreading or oblique, sometimes falcate, especially those of the lowest pair, gradually tapering and acute at the dentate apex or obovate and broad at the apex, when they unfold light bronze-green stained with red on the margins, lustrous and puberulous above,

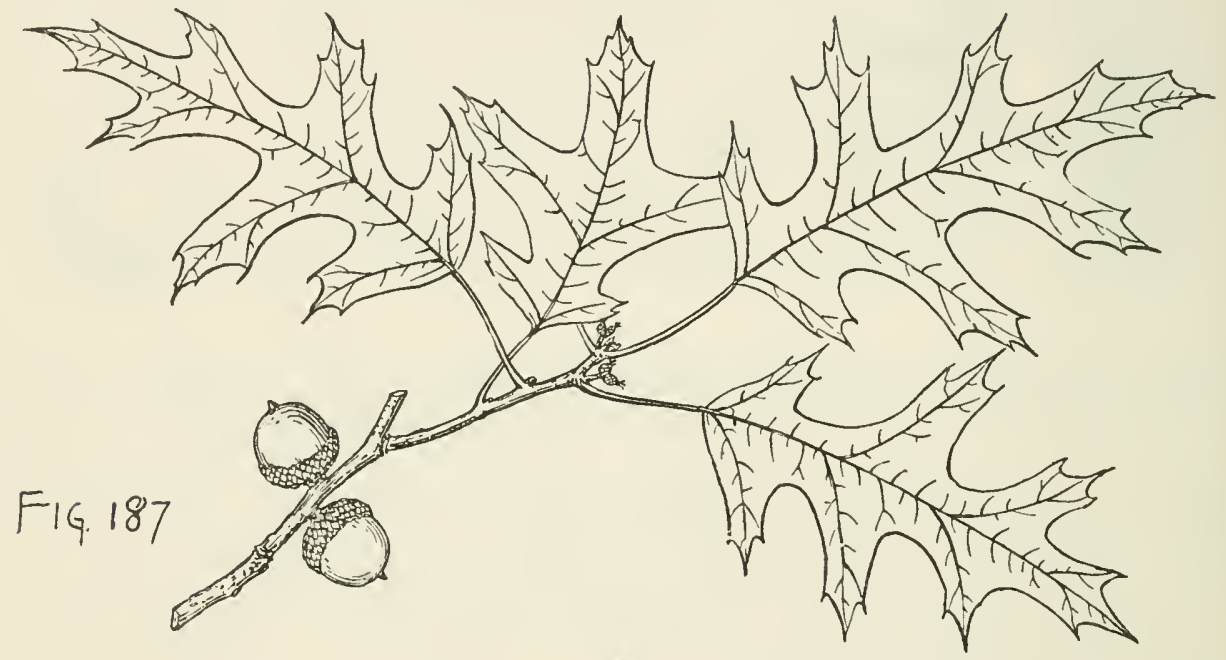

coated below and on the petioles with pale scurfy pubescence, at maturity thin and firm, dark green and very lustrous above, pale below, with large tufts of pale hairs in the axils of the primary veins, $4^{\prime}-6^{\prime}$ long, $2^{\prime}-4^{\prime}$ wide, with stout midribs and conspicuous primary veins, late in the autumn turning gradually deep scarlet; their petioles slender, yellow, $\frac{1^{\prime}}{2}-2^{\prime}$ long. Flowers : staminate in hairy aments $2^{\prime}-3^{\prime}$ long; calyx puberulons and divided into 4 or 5 oblong rounded segments more or less laciniately cut on the margins, shorter than the stamens; pistillate on short tomentose peduncles, their involucral scales broadly ovate, tomentose, shorter than the acuminate calyx-lobes; stigmas bright red. Fruit sessile or short-stalked, solitary or clustered; acorn nearly hemispherical, about $\frac{1}{2}$ ' in diameter, light brown, often striate, inclosed only at the base in a thin saucer-shaped cup dark red-brown and lustrous within, and covered by closely appressed ovate light red-brown thin puberulous scales.

A tree, usually $70^{\circ}-80^{\circ}$ high, with a trunk $2^{\circ}-3^{\circ}$ in diameter, often clothed with small tough drooping branches, or when crowded in the forest sometimes $120^{\circ} \mathrm{high}$, with a trunk $60^{\circ}-70^{\circ}$ tall and $4^{\circ}-5^{\circ}$ in diameter, slender branches beset with shortridged spur-like laterals a few inches in length, forming while young a broad symmetrical pyramidal head, becoming open and irregular, with rigid and more pendulous branches often furnished with small drooping branchlets, and slender tough 
branchlets dark red and covered at first by short pale silvery tomentum, soon becoming green and glabrous, lustrous, dark red-brown or orange color in their first winter, growing darker in their second year and ultimately dark gray-brown. Winter-buds ovate, gradually narrowed and acute at the apex, about $\frac{1}{8}^{\prime}$ long, with imbricated light chestnut-brown scales puberulous toward the thin sometimes ciliate margins. Bark of young trunks and branches smootl, lustrous, light brown frequently tinged with red, becoming on older trunks $\frac{3^{\prime}}{4}-1_{4}^{1}{ }^{\prime}$ thick, light gray-brown, generally smooth and covered by small closely appressed scales. Wood heavy, hard, strong, coarse-grained, light brown, with thin rather darker colored sapwood; sometimes used in construction, and for shingles and clapboards.

Distribution. Borders of swamps and river-bottoms in deep moist rich soil; valley of the Connecticut River in western Massachusetts to southern Missouri, and southward to the valley of the lower Potomac River, Virginia, central Kentucky, southwestern Tennessee, northern Arkansas and the eastern borders of the Indian Territory; rare and of small size in New England; exceedingly common on the coast plain south of the Hudson River; of its largest size and very abundant on the bottom-lands of the streams of the lower Ohio basin.

Often cultivated as an ornamental tree in the northeastern states and in the countries of western and central Europe.

\section{Quercus Georgiana, M. A. Curtis.}

Leaves convolute in the bud, oval or obovate, gradually narrowed and wedgeshaped at the base, divided generally about half way to the midribs by wide or narrow oblique sinuses rounded at the bottom into $3-7$ lobes, the terminal lobe orate, acute, or rounded and entirê or frequently furnished with 1 or 2 small lateral teeth, the lateral lobes oblique or spreading, mostly triangular, acute and entire, or those

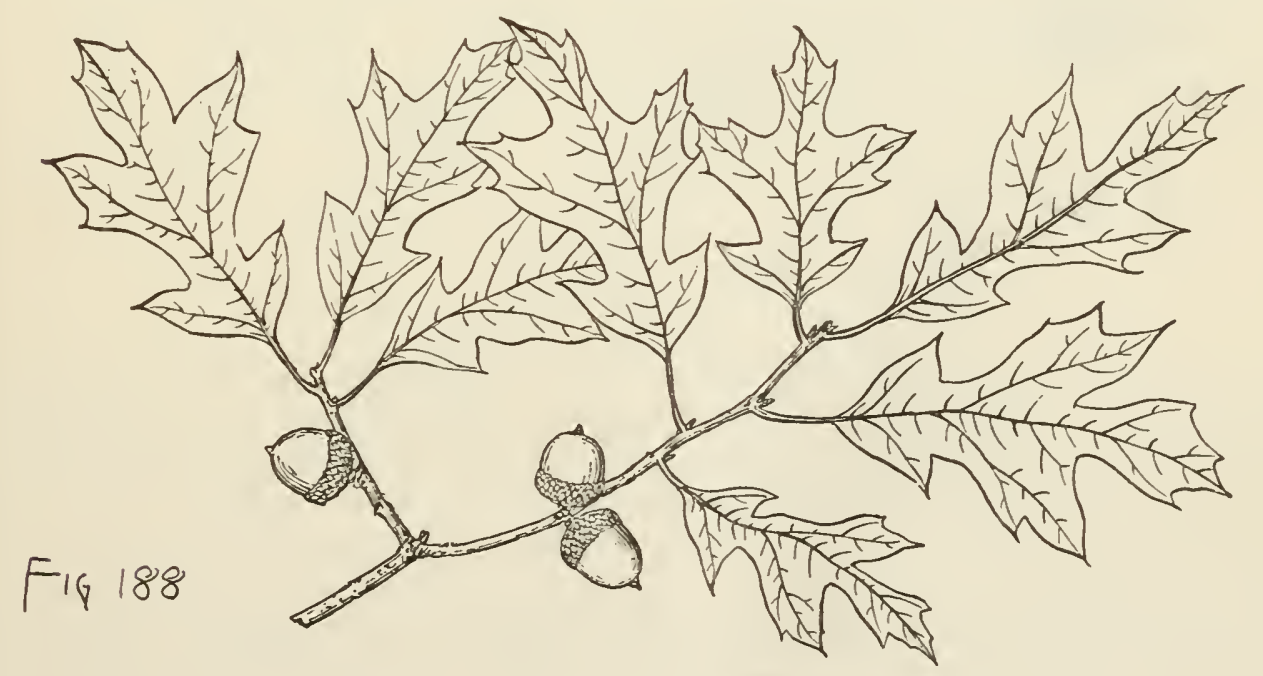

of the upper or of the middle pair often broad and repand-lobulate at the oblique ends, sometimes gradually 3 -lobed at the broad apex and narrowed and entire below, or equally 3-lobed, with broad or narrow spreading lateral lobes, or occasionally pinnatifid, when they unfold bright green tinged with red, ciliate on the margins and coated on the midribs, veins, and petioles with loose pale stellate pubescence, at maturity thin, bright green and lustrous above, paler below, and glabrous or fur- 
nished with tufts of hairs in the axils of the primary veins, usually about $2 \frac{1{ }^{\prime}}{2}$ long and $1 \frac{1}{2}$ wide, turning dull orange and scarlet in the antumn before falling; their petioles slender, $\frac{1^{\prime}}{2}-{ }^{\prime \prime}$ long. Flowers: staninate in slender glabrous or pubescent aments $2^{\prime}-3$ ' long; calyx divided into 4 or 5 broadly ovate rounded segments rather shorter than the stamens; pistillate on short glabrous slender stalks, their involucral scales rather shorter than the acute calyx-lobes, pubescent or puberulous; stigmas bright red. Fruit short-stalked; acorn ellipsoidal or subglobose, $\frac{1}{3}^{\prime}-\frac{1}{2}^{\prime}$ long, light red-brown and lustrous, inclosed for one third to nearly one half its length in a thick cup-shaped cup light red-brown and lustrous on the inner surface, and covered by thin ovate bright light red-brown truncale erose scales.

Distribution. Central Georgia, on Stone Mountain, Dekalb County, and on a few other granite hills between the Yellow and Oconee rivers in the region south and east of Stone Mountain.

\section{Quercus ellipsoidalis, E. J. Hill. Black Oak.}

Leaves oval to obovate-orbicular, acute or acuminate, truncate or broadly cuneate at the base, deeply divided by wide sinuses rounded at the bottom into 5-7 oblong lobes repandly dentate at the apex, or often, especially those of the upper

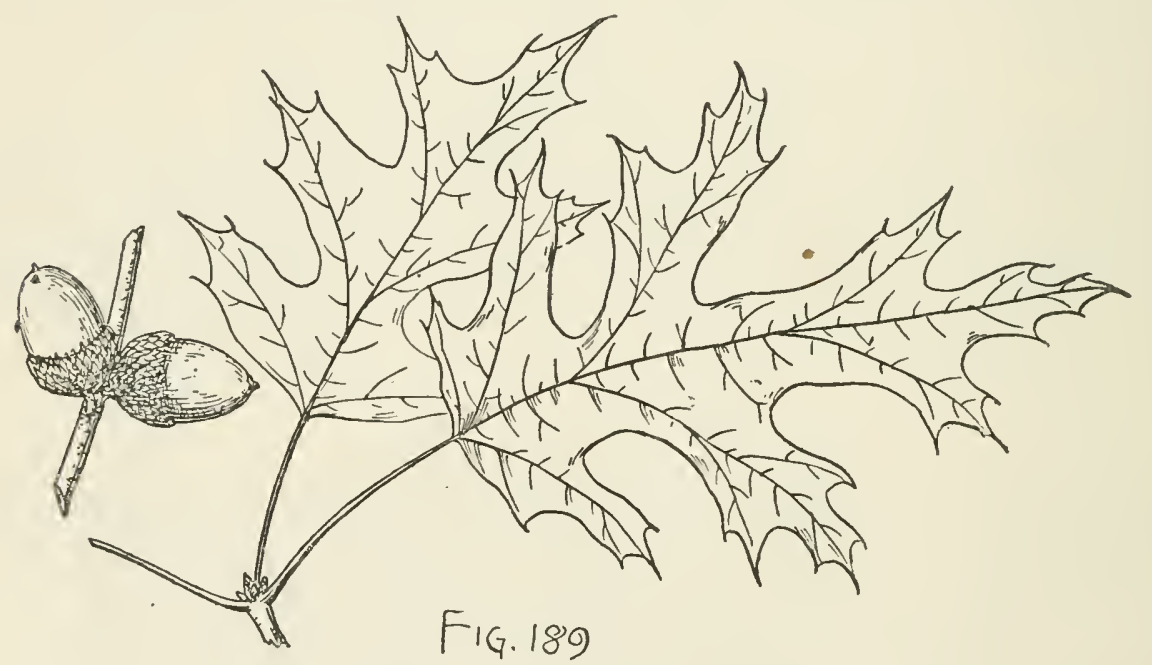

pair, repandly lobulate, when they unfold slightly tinged with red and hoary-tomentose, soon becoming glabrous with the exception of small tufts of pale hairs in the axils of the principal veins, at maturity thin and firm, bright green and lustrous above, paler and sometimes entirely glabrous below, $3^{\prime}-5^{\prime}$ long, $21_{2}^{\prime}-4^{\prime}$ wide, with stout midribs and primary veins and prominent reticulate veinlets, late in the autumn turning yellow or pale brown more or less blotched with purple; their petioles slender, glabrous or rarely puberulous, $1 \frac{1}{2}^{\prime}-2^{\prime}$ long. Flowers: staminate in puberulous aments $1 \frac{1^{\prime}}{2}-2^{\prime}$ long; calyx membranaceous, campanulate, usually tinged with red, 2-5-lobed or parted into oblong-ovate or rounded segments, glabrous or slightly villous, fringed at the apex with long twisted hairs, about as long as the $2-5$ stamens with short filaments and oblong anthers; pistillate on stout tomentose 1-3flowered peduncles, red, their involucral scales broad, hairy, oblong, acute; calyx campanulate, 4-7-lobed, ciliate on the margins. Fruit short-stalked or nearly sessile, solitary or in pairs; acorn ellipsoidal, cylindrical to subglobose, chestnut-brown, 
often striate and puberulous, inclosed for one third to one half its length in a turbinate or cup-shaped cup gradually narrowed at the base, thin, light red-brown, puberulous on the inner surface, and covered by narrow ovate obtuse or truncate brown pubescent closely appressed scales.

A tree, $60^{\circ}-70^{\circ}$ high, witl a short trunk rarely $3^{\circ}$ in diameter, much forked branches ascending above and often pendulous low on the stem, forming a narrow oblong head, and slender branchlets covered at first with matted pale hairs, bright reddish brown during their first winter, becoming dark gray-brown or reddish brown in their second season. Winter-buds ovate, obtuse, or acute, sometimes slightly angled, about $\frac{1}{8}$ long, with ovate or oval red-brown lustrous slightly puberulons outer scales ciliate on the margins. Bark thin, light yellow internally, close, rather smooth, divided by shallow connected fissures into thin plates, dark brown near the base, dull above, gray-brown and only slightly furrowed on the large branches.

Distribution. In the neigliborhood of Chicago, Illinois, to eastern Iowa and southeastern Minnesota.

\section{Quercus Tezana, Buckl. Red Oak.}

Leaves obovate, truncate or abruptly or rarely gradually wedge-shaped at the base, divided by wide or narrow oblique sinuses rounded at the bottom into usually 7 rarely 9 or sometimes 5 lobes, the terminal lobe oblong, dentate or entire toward the acute apex, with two spreading lateral teeth, the lateral lobes contracted below the broad apex or occasionally tapering from the base and coarsely repand-dentate above the middle, when they unfold light red and covered with pale scurfy pubescence, at maturity thin and firm, bright green, lustrous and glabrous above, paler,

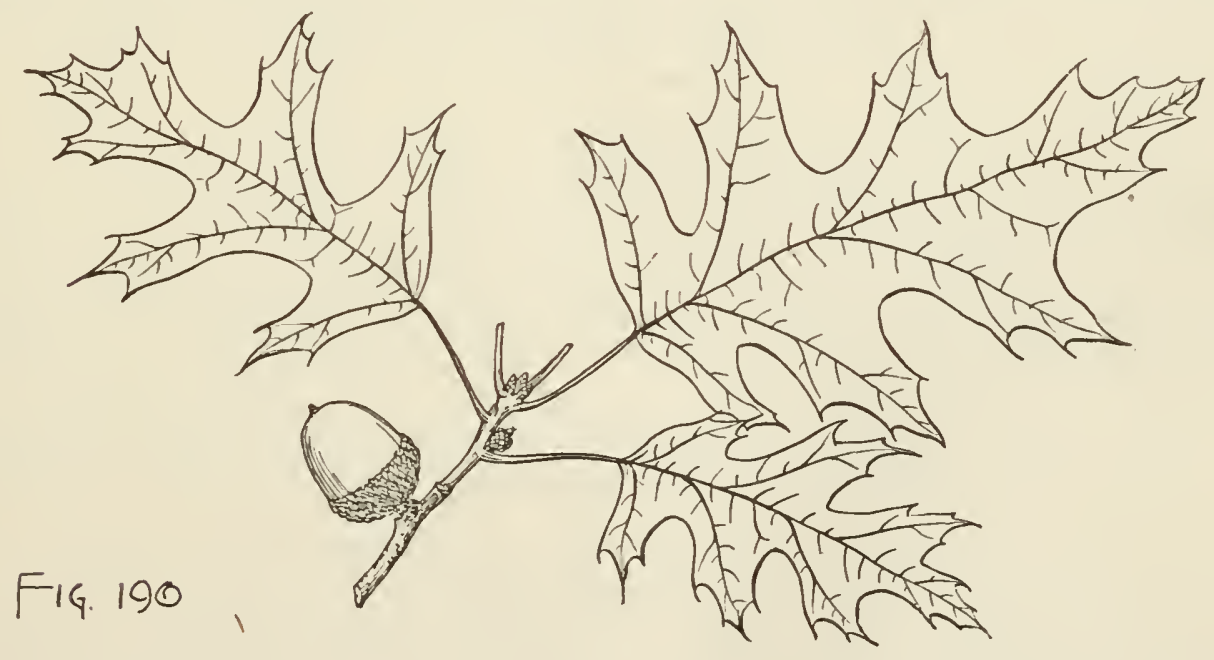

with large tufts of pale hairs in the axils of the primary veins below, $2 \frac{1}{2}^{\prime}-6^{\prime}$ long, $2^{\prime}-5^{\prime}$ wide, with slender red or yellow midribs, late in the autumn turning gradually dark vinous red or brown, or often falling with only a slight change of color; their petioles slender, nearly terete, reddish, $1^{\prime}-2^{\prime}$ long. Flowers : staminate in slender slightly pubescent aments $2^{\prime}-3^{\prime}$ long; calyx thin, villous on the outer surface, divided into 4 or 5 acute laciniately cut segments; pistillate on short hoary-tomentose peduncles, their involucral scales brown tinged with red, pubescent; stigmas bright red. Fruit sessile or stalked, usually solitary; acorn oval, abruptly narrowed and 
rounded at the base, full and rounded or gradually or abruptly narrowed and rounded at the apex, puberulons, light reddish brown, sometimes conspicuously striate, with broad dark bands, $\frac{1}{2}-1 \frac{1}{2}$ long, inclosed for one third to nearly one half its length in a turbinate or deeply cup-shaped cup, light reddish brown and puberulous within, covered by thin closely imbricated light brown scales rounded at the ends and hoarytomentose, except on their red-browu margins.

A tree, occasionally ncarly $200^{\circ}$ ligh, with a trunk frec of branches for $80^{\circ}-90^{\circ}$, and $7^{\circ}-S^{\circ}$ in diameter above the much enlarged buttressed base, comparatively small branches spreading into a narrow head, and stout brittle branchlets coated at first with hoary pubescence, soon glabrous and bright grecu, lustrous, orange or reddish brown during their first wiuter, bccoming ashy gray or dark brown the following year; often nuch smaller toward the western limits of its range in Texas and usually $30^{\circ}-40^{\circ}$ tall; sometimes reduced to a shrub. Winter-buds ovate or obovate, full and abruptly rounded at the apex, $\frac{1}{8}^{\prime}-\frac{1}{4}^{\prime}$ long, with thin closcly iubricated dark brown scales. Bark of young stems and branches thin, smooth, light gray, becoming on old trunks $\frac{3}{4}-1 \frac{1}{2}$ thick, liglit brown tinged with red, aud divided into broad ridges broken into thick square plate-like scales. Wood heavy, hard, close-graiued, light reddish brown; now often manufactured into lumber in the Mississippi valley and considered more valuable than that of the eastern Red Oak.

Distribution. Northeastern Iowa and central Illinois, through southern Illinois and Indiana and western Kentucky and Tennessee to the valley of the Appalachicola River, Florida, northern Georgia, central South Carolina, and the coast plain of North Carolina, and through southern Missouri, Arkansas, and Louisiana to the mountains of western Texas; most abundant and of its largest size on the low bottom-lands of the Mississippi basin, often forming a considerable part of lowland forests; less abundant in the eastern Gulf states; in western Texas on the low limestone hills and on bottom-lands in the neighborhood of streams.

\section{Quercus coccinea, Moench. Scarlet Oak.}

Leaves oblong-obovate or oval, truncate or wedge-shaped at the base, deeply divided by wide sinuses rounded at the bottom into 7 or rarely 9 lobes repand-dentate at the apex, the terminal lobe ovate, acute, and 3 -toothed, the middle division the largest and furnished with 2 small lateral teeth, the lateral lobes obovate, oblique or spreadiug, sometimes falcate, usually broad and oblique at the coarsely toothed apex, when they unfold bright red covered with loose pale pubescence above and below with silvery white tomentum, green at the end of a few days, at maturity thin and firm, bright green, glabrous and very lustrous above, paler and less lustrous and sometimes furnished with small tufts of rusty pubescence in the axils of the veins below, $3^{\prime}-6^{\prime}$ long, $2 \frac{1}{2}-4^{\prime}$ broad, with yellow midribs and primary veins, late in the autumn turning brilliant scarlet; their petioles slender, terete, $1 \frac{1^{\prime}}{2}-2 \frac{1}{2}^{\prime}$ long. Flowers: staminate in slender glabrous aments $3^{\prime}-4^{\prime}$ long; calyx pubescent, bright red before opening, divided into 4 or 5 ovate acute segments shorter than the stamens; pistillate on pubescent peduncles sometimes $\frac{1}{2}$ long, bright red, their involucral scales ovate, pubescent, shorter than the acute calyx-lobes. Fruit sessile or stalked, solitary or in pairs; acorn oval, oblong-ovate or hemispherical, truncate or rounded at the base, rounded at the apex, $\frac{1}{2}^{\prime}-1^{\prime}$ long, $\frac{1}{3}^{\prime}-\frac{2}{3}^{\prime}$ broad, liglit reddish brown and occasionally striate, inclosed for one third to one half its length in a deeply cupshaped or turbinate thin cup light reddish brown on the inner surface, and covered by closely imbricated oblong-ovate acute light reddish brown slightly puberulous scales. 
A tree, $70^{\circ}-80^{\circ}$ high, with a trunk $2^{\circ}-3^{\circ}$ in diameter, comparatively small branches spreading gradually and forming a rather narrow open head, and slender branchlets coated at first with loose scurfy pubescence, soon pale green and lustrous, light red

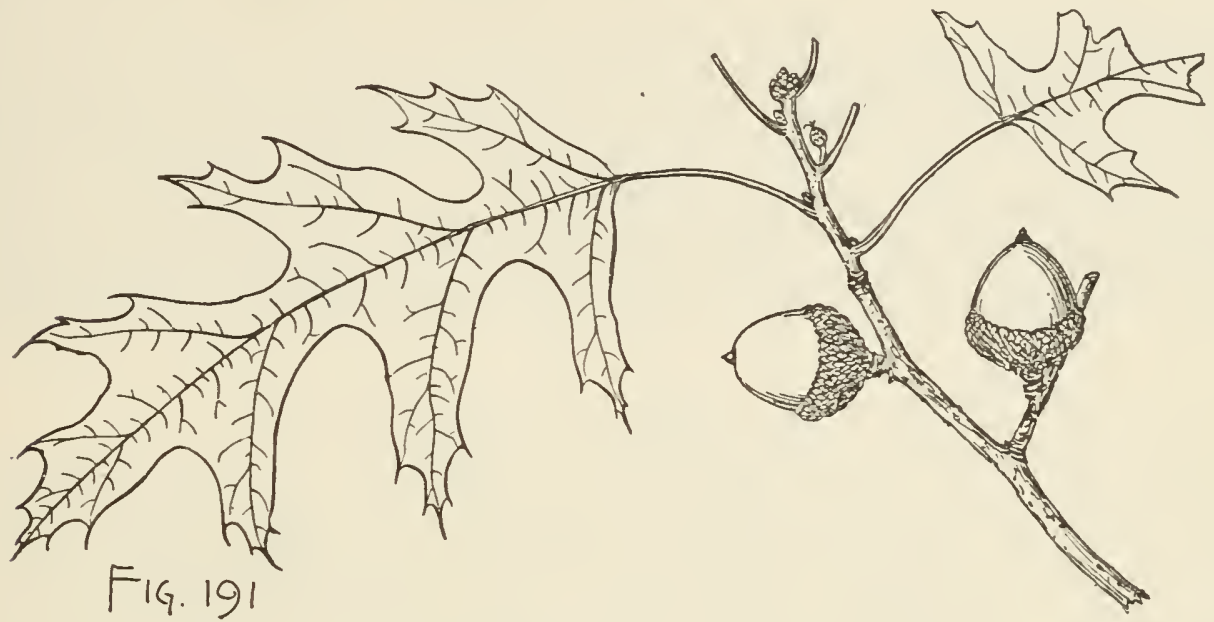

or orange-red in their first winter and light or dark brown the following year; usually much smaller. Winter-buds oval or ovate, gradually narrowed at the acute apex, $\frac{1^{\prime}}{8}-\frac{1^{\prime}}{4}$ long, dark reddish brown, and pale-pubescent above the middle. Bark of young stems and branches smooth, light brown, becoming on old trunks $\frac{1}{2}^{\prime}-\mathbf{1}^{\prime}$ thick and divided by shallow fissures into irregular ridges covered by small light brown scales slightly tinged with red. Wood beavy, hard, strong, coarse-grained, light or reddish brown, with thicker darker colored sapwood.

Distribution. Light dry usually sandy soil; valley of the Androscoggin River, Maine, through southern New Hampshire and Vermont and central New York to southern Ontario, westward through central Michigan and Minnesota to southeastern Nebraska, and southward to the District of Columbia and northern Illinois, and along the Alleghany Mountains to North Carolina; very abundant in the coast region from Massachusetts Bay to southern New Jersey; less common in the interior, growing on dry gravelly uplands, and on the prairies skirting the western margins of the eastern forest.

Occasionally planted in the northeastern states and in Europe as an ornamental tree valued chiefly for the brilliant autumn color of the foliage.

\section{Quercus velutina, Lam. Black Oak. Yellow-bark Oak.}

Leaves ovate or oblong, rounded, wedge-shaped or truncate at the base, mostly 7-lobed and sometimes divided nearly to the middle by wide rounded sinuses into narrow obovate more or less repand-dentate lobes, or into elongated nearly entire nucronate lobes tapering gradually from a broad base, the terminal lobe oblong, elongated, acute, furnished with small lateral teeth, or broad, rounded, and coarsely repand-dentate, or slightly divided into broad dentate lobes or sinuate-dentate, bright crimson when they unfold, and covered, above by long loose scattered white hairs and below with thick pale or silvery white tomentum, hoary-pubescent when half grown, and at maturity thick and firm or subcoriaceous, dark green and lustrous above, below yellow-green, brown or dull copper color and more or less pubescent or glabrous with the exception of tufts of rusty hairs in the axils of the principal 
vcins, $3^{\prime}-12^{\prime}$ long and $2^{\prime}-10^{\prime}$ wide, but usually $5^{\prime}-6^{\prime}$ long and $3^{\prime}-4^{\prime}$ wide, witl stout midribs and primary veins, late in the antumn turning dull red, dark orange color, or brown, and falling gradually during the winter; their petioles stout, yellow, glabrous or puberulous, $3^{\prime}-6^{\prime}$ long. Flowers: staminate on tomentose or pubescent aments $4^{\prime}-6^{\prime}$ long; calyx coated with pale hairs, with ovate acute lobes; pistillate on short tomentose peduncles, thicir involucral scales ovate, shorter than the acute calyx-lobes; stigmas bright red. Fruit sessile or short-stalked, solitary or in pairs; nut ovate-oblong, obovate, oval or hemispherical, broad and rounded at the base, full and rounded at the apex, light red-brown, of ten striate, freqnently coated with soft rufous pubescence, $\frac{1^{\prime}}{2}-\frac{3^{\prime}}{4}$ long, inclosed for about onc half its length in the thin deeply cut-shaped turbinate cup dark red-brown and puberulous on the inner surface,

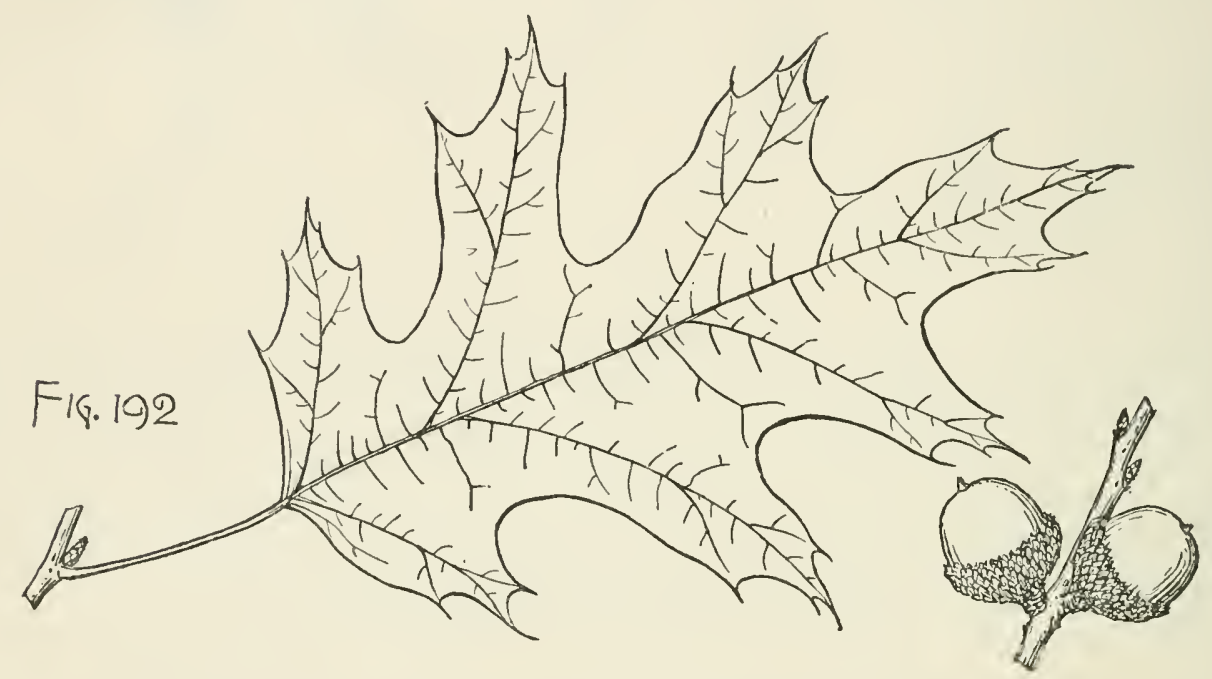

covered by thin light chestnut-brown acute hoary scales closely appressed at the base of the cup, loosely imbricated above the middle, with free scarious tips forming a fringe-like border to its rim.

A tree, often $70^{\circ}-80^{\circ}$ and occasionally $150^{\circ}$ high, with a trunk $3^{\circ}-4^{\circ}$ in diameter, slender branches spreading gradually into a narrow open head, stout branchlets coated at first with pale or fulvous scurfy tomentum, becoming in their first winter glabrous, dull red or reddish brown, growing dark brown in their second year or brown slightly tinged with red. Winter-buds ovate, strongly angled, gradually narrowed and obtuse at the apex, hoary-tomentose, $\frac{1}{4}^{\prime}-\frac{1}{2}^{\prime}$ long. Bark of young stenis and branches smooth, dark brown, deep orange color internally, becoming $\frac{8^{\prime}}{4}-1_{\frac{1}{2}}^{\prime}$ thick on old trunks, and deeply divided into broad rounded ridges broken on the surface into thick dark brown or nearly black closely appressed plate-like scales. Wood heavy, hard, strong, coarse-grained, bright brown tinged with red, with thin lighter colored sapwood; of little value except as fuel. The bark abounds in tannic acid and is largely used in tanning, as a yellow dye, and in medicine.

Distribution. Dry gravelly uplands and ridges; coast of southern Maine to northern Vermont, southern and western Ontario and central Minnesota, and southward to northern Florida, southern Alabama and Mississippi, southeastern Nebraska, eastern Kansas, the Indian Territory and eastern Texas; one of the commonest Oaks on the gravelly drift of sonthern New England and the middle states; of ten forming a large part of the forest growth in the foothill regions of the southern Appalachian 
Mountains; abundant in all parts of the Mississippi basin, and of its largest size in the valley of the lower Ohio River; the common species of the Black Oak group reaching the south-Atlantic and Gulf coast, and here generally scattered on dry ridges through the maritime Pine belt.

Quercus velutina, which is more variable in the form of its leaves than the other North American Black Oaks, is easily recognized by the bright yellow color of the inner bark, in early spring by the deep red color of the unfolding leaves, becoming pale and silvery in a few days, and by the large tomentose winter-buds. From western Missouri to northwestern Arkansas a form occurs (var. Missouriensis, Sarg., nov. var.) with the mature leaves stellate-pubescent above, and coated below and on the petioles and summer branchlets with rusty pubescence, and with broader more loosely imbricated lıary-tomentose cup-scales.

\section{Quercus Californica, Coop. Black Oak.}

Leaves oblong or obovate, truncate, wedge-shaped or rounded at the narrow base, 7 or rarely 5 -lobed by wide and deep or shallow and oblique sinuses rounded at the bottom, the terminal lobe ovate, 3 -toothed at the acute apex, the lateral lobes tapering gradually from the base or broad and obovate, coarsely repand-dentate, with acute pointed teeth, or rarely entire, when they unfold dark red or purple and pilose above and coated below and on the petioles with thick silvery white tomentum, at

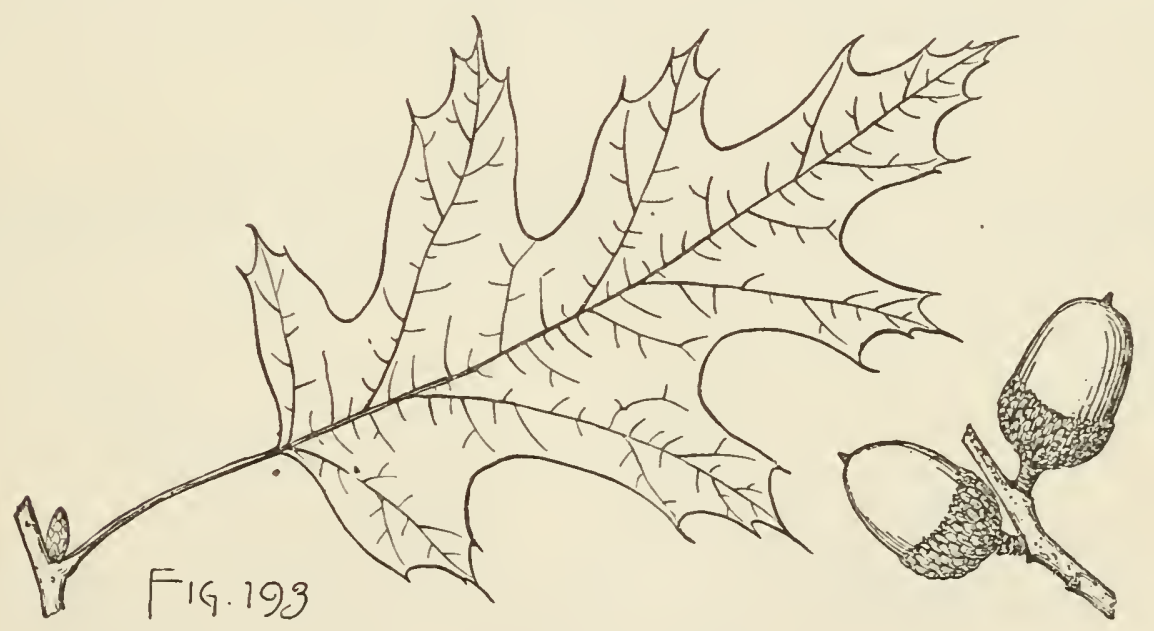

maturity thick and firm, lustrous, dark yellow-green and glabrous or rarely stellatepubescent above, light yellow-green or brownish and glabrous or pubescent, or occasionally hoary-tomentose beiow, $3^{\prime}-6^{\prime}$ long, $2^{\prime}-4^{\prime}$ wide, turning yellow or brown in the autumn before falling; their petioles slender, yellow, $1^{\prime}-2^{\prime}$ long. Flowers : staminate in hairy aments $4^{\prime}-5^{\prime}$ long; calyx pubescent, divided into 4 or 5 ovate acute segments shorter than the stamens, with bright red anthers; pistillate on short tomentose peduncles, their involucral scales ovate, coated like the acute calyx-lobes with pale tomentum; stigmas dark red. Fruit short-stalked, solitary or clustered; acorn oblong, oval or obovate, broad and rounded at the base, full and rounded or gradually narrowed and acute at the puberulous apex, $1^{\prime}-1 \frac{1}{2}^{\prime}$ long, about $\frac{3^{\prime}}{4}$ broad, light chestnut-brown, often striate, inclosed for one fourth to two thirds its length in the deep cup-shaped cup light brown and puberulous on the inner surface, and covered by thin ovate-lanceolate lustrous light chestnut-brown scales, sometimes 
rounded and thiekened on the back toward the base of the cup, their tips elongated, thin and erose on the margins, often forming a narrow fringe-like border to the rim of the cup.

A tree, oecasionally $100^{\circ}$ high, with a trunk $3^{\circ}-4^{\circ}$ in diameter, stout spreading branehes forming an open round-topped head, and branchlets eoated at first with thick hoary eadueous tomentum, bright red or brown tinged with red, and usually glabrous or pubescent or puberulous during their first winter, beeoming dark redbrown in their seeond year; frequently much smaller and at high elevations a small shrub. Winter-buds ovate, gradually narrowed and aente at the apex, about $\frac{1{ }^{\prime}}{4}$ long, with elosely imbricated pale chestnut-brown seales ciliate on the thin searious margins and pubescent toward the point of the bud. Bark of young stems and branches smooth, light brown, beeoming on old trunks $1^{\prime}-1 \frac{1^{\prime}}{2}$ thiek, dark brown slightly tinged with red or nearly blaek, divided into broad ridges at the base of old trees and broken above into thiek irregular oblong plates covered by minute elosely appressed scales. Wood heavy, lard, strong, very brittle, bright red, with thin lighter colored sapwood; oeeasionally used as fuel.

Distribution. Valleys and mountain slopes; basin of the Mackenzie River in western Oregon, southward over the California eoast ranges, and along the western slopes of the Sierra Nevada up to elevations of $7000^{\circ}-8000^{\circ}$ to the Cuyamaea Mountains near the southern boundary of California; rare in the immediate neighborhood of the coast; the largest and most abundant Oak-tree of the valleys of southwestern Oregon and of the Sierra Nevada, sometimes forming groves of considerable extent in coniferous forests; of its largest size at elevations of about $6000^{\circ}$ above the sea.

\section{Quercus Catesbæi, Michx. Turkey Oak.}

Leaves oblong or obovate or nearly triangular, gradually narrowed and wedgeshaped at the base, deeply divided by wide rounded simuses into 3 or 5 or rarely 7

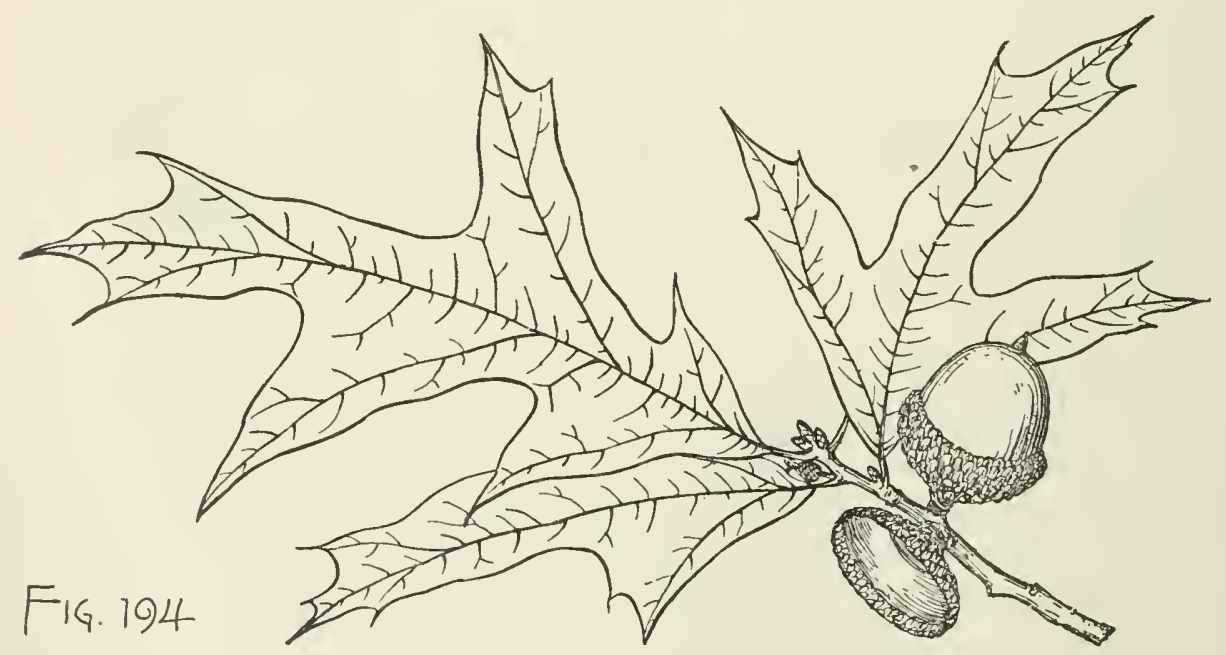

lobes, the terminal lobe ovate, elongated, aeute and entire or repand-dentate, or obovate and eoarsely equally or irregularly 3 -toothed at the apex, the lateral lobes spreading, usually falcate, entire and acute, tapering from their broad bases, and broad, oblique, and repand-lobulate at the apex; or 3-toothed at the broad apex and gradually narrowed to the base, eoated when they unfold with rufous artieulate 
hairs, and when fully grown thick and rigid, bright yellow-green and lustrous above, paler, lustrous, and glabrous below, with large tufts of rusty hairs in the axils of the veins, $3^{\prime}-12^{\prime}$ long, $1^{\prime}-10^{\prime}$ wide, but usually about $5^{\prime}$ long and broad, with broad yellow or red-brown midribs, turning brown or dull yellow before falling in the autumn; their petioles stout, grooved, $\frac{1}{4}^{\prime}-\frac{3}{4}^{\prime}$ long. Flowers: staminate in slender hairy redstemmed aments $4^{\prime}-5^{\prime}$ long; calyx puberulous and divided into 4 or 5 ovate acute lobes; pistillate on short stout tomentose peduncles, their involucral scales bright red, pubescent, hairy at the margins; stigmas dark red. Fruit short-stalked, usually solitary; acorn oval, full and rounded at the ends, about $1^{\prime}$ long and $\frac{3^{\prime}}{4}$ broad, dull light brown, covered at the apex by a thin coat of snow-white tomentum, inclosed for about one third its length in a thin turbinate cup often gradually narrowed into a stout stalk-like base, light red-brown, lustrous, and puberulous on the inner surface, covered by ovate-oblong rounded scales extending above the rim of the cup and down over the npper third of the immer surface, and hoary-pubescent except on their thin bright red margins.

A tree, usually $20^{\circ}-30^{\circ}$, or occasionally $50^{\circ}-60^{\circ}$ high, with a trunk rarely exceeding $2^{\circ}$ in dianreter, stout spreading more or less contorted branches forming a narrow open irregular generally round-topped head, and stout branchlets coated at first with stellate articulate hairs, nearly glabrous and deep red when the leaves are half grown, dark red in their first winter, gradually growing dark brown; generally much smaller and sometimes shrubby. Winter-buds elongated, acute, $\frac{1}{2}^{\prime}$ long, with light chestnut-brown scales erose on the thin margins, and coated, especially toward the point of the bud, with rusty pubescence. Bark $\frac{1^{\prime}}{2}-1^{\prime}$ thick, red internally, dark gray tinged with red on the surface, and at the base of old trunks becoming nearly black, deeply and irregularly furrowed and broken into small appressed scales. Wood heavy, hard, strong, rather close-grained, light brown tinged with red, with thick lighter colored sapwood; largely used for fuel.

Distribution. Dry barren sandy ridges and sandy bluffs and hummocks in the neighborhood of the coast; North Carolina to Cape Malabar and the shores of Peace Creek, Florida, and to eastern Louisiana; comparatively rare toward the western limits of its range, and most abundant and of its largest size on the high bluff-like shores of bays and estuaries in South Carolina and Georgia.

\section{Quercus nana, Sarg. Bear Oak. Scrub Oak.}

Leaves obovate or rarely oblong, gradually or abruptly wedge-shaped at the base, divided by wide shallow sinuses into $3-7$, usually 5 , acute lobes, the terminal lobe ovate, elongated, rounded and 3-toothed or acute and dentate or entire at the apex, the lateral lobes spreading, mostly triangular and acute, or those of the upper pair broad, oblique and repand-lobulate, or broad at the apex, slightly 3-lobed and entire below, or deeply 3-lobed above and sinuate below, or occasionally oblong to oblong-obovate and entire, with undulate margins, dull red and puberulous or pubescent on the upper surface and coated on the lower and on the petioles with thick pale tomentum whell they unfold, when half grown light yellow-green, lustrous, slightly pubescent above and tomentose below, with conspicuous tufts of silvery white hairs in the axils of the veins, at maturity thick and firm, dark green and lustrous above, covered below with pale or silvery white pubescence, $2^{\prime}-5^{\prime}$ long, $1 \frac{1}{2}^{\prime}-3^{\prime}$ wide, with stout yellow midribs and slender primary veins, turning dull scarlet or yellow before falling in the autumn; their petioles slender, glabrous, or pubescent, $1^{\prime}-1 \frac{1^{\prime}}{2}$ long. Flowers: staminate in hairy aments $4^{\prime}-\tilde{5}^{\prime}$ long, and often 
persistent until midsummer; calyx red or green tinged with red and irregularly divided into 3-5 ovate rounded lobes shorter than the stamens, with bright red ultimately yellow anthers; pistillate on stont tomentose peduncles, their involucral scales ovate, about as long as the acute calyx-lobes, red, and tomentose; stigmas

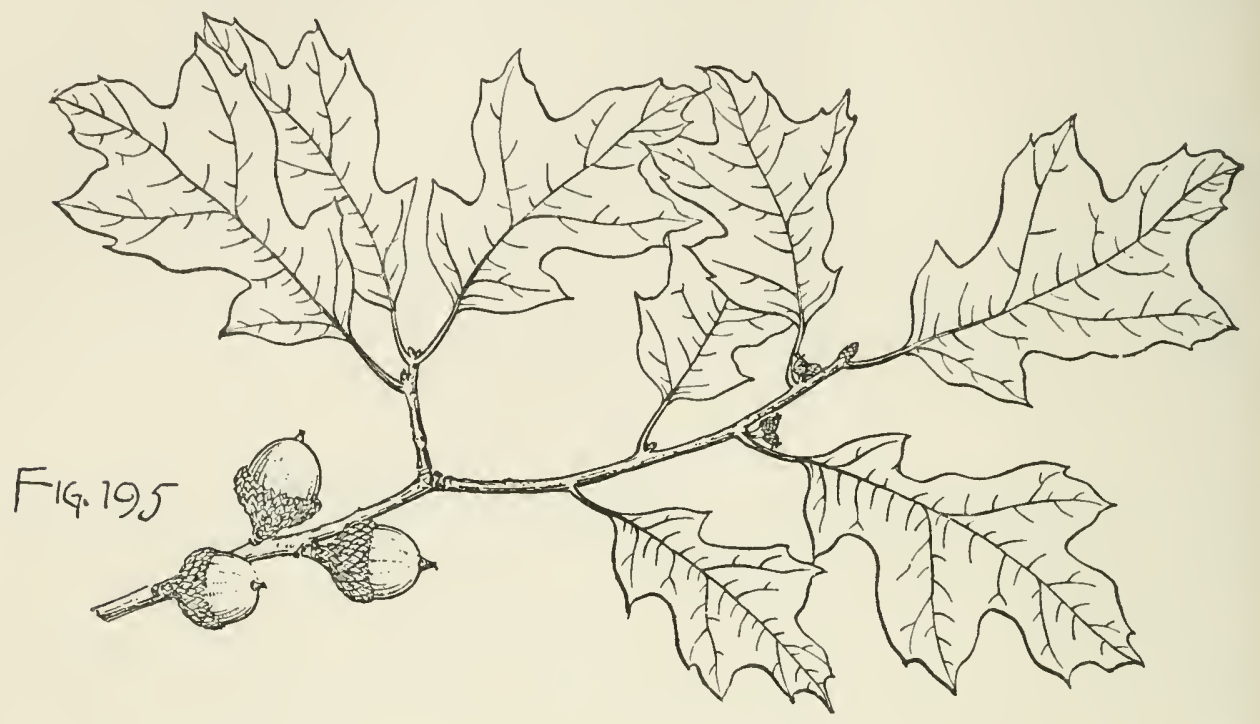

dark red. Fruit prodnced in great profusion, sessile or stalked, in pairs or rarely solitary; acorn ovoid, broad, flat or rounded at the base, gradually narrowed and acute or rounded at the apex, about $\frac{1}{2}^{\prime}$ long and broad, light brown, lustrous, usually faintly striate, inclosed for about one half its length in the cup-shaped or saucershaped cup often abruptly enlarged above the stalk-like base, thick, light reddish brown and puberulous within, and covered by thin ovate closely imbricated redbrown puberulous scales acute or truncate at the apex, the minute free tips of the upper scales forming a fringe-like border to the cup.

A tree, occasionally $18^{\circ}-20^{\circ}$ high, with a trunk $5^{\prime}-6^{\prime}$ in diameter, with slender spreading branches usually forming a round-topped head, and slender branchlets dark green more or less tinged with red and hoary-pubescent at first, during their first winter red-brown or ashy gray and pubescent or puberulous, becoming glabrous and darker in their second year and ultimately dark brown or nearly black; more frequently an intricately branched shrub, with numerous contorted stems $3^{\circ}-10^{\circ}$ tall. Winter-buds ovate, obtuse, about $\frac{1}{8}^{\prime}$ long, with dark chestnut-brown rather loosely imbricated glabrous or pilose scales. Bark thin, smooth, dark brown, covered by small closely appressed scales.

Distribution. Dry sandy barrens and rocky hillsides; coast of eastern Maine southward through eastern and southern New England to eastern Pennsylvania and along the Alleghany Mountains to southern Virginia, and westward to the shores of Lake George and the valley of the Hudson River; common in eastern and southern New England, in the Pine barrens of New Jersey, and in eastern Pennsylvania.

\section{Quercus digitata, Sudw. Spanish Oak.}

Leaves oblong or obovate, generally narrowed and wedge-shaped or abruptly wedge-shaped or rounded and slightly narrowed at the base, sometimes divided by deep wide sinuses rounded at the bottom into 3,5 , or 7 lobes, the terminal lobe 
generally much elongated, often falcate, acute, entire or repand-dentate at the apex, the lateral lobes oblique and spreading or often falcate, gradually narrowed from a broad base, acute, and entire; or oblong-obovate and divided at the broad apex by wide or narrow sinuses broad and rounded at the bottom into 3 rounded or acute entire or dentate lobes, and entire and gradually narrowed below into an acute or rounded base, the two forms usually occurring on different but sometimes on the same tree; hanging closely appressed against the stem when they unfold, when fully grown thin and firm, dark green and lustrous above, coated below with soft close pale or rusty pubescence, $6^{\prime}-7^{\prime}$ long and $4^{\prime}-5^{\prime}$ wide, obscurely reticulate-venulose, with stout tomentose midribs and primary veins, turning brown or dull orange color in the autumn before falling; their petioles slender, flattened, $1^{\prime}-2^{\prime}$ long. Flowers: staminate in tomentose aments, $3^{\prime}-5^{\prime}$ long; calyx thin and scarious, pubescent on the outer surface, divided into 4 or 5 ovate rounded segments; pistillate on stout tomentose peduncles, their involucral scales coated with rusty tomentum, as long or rather

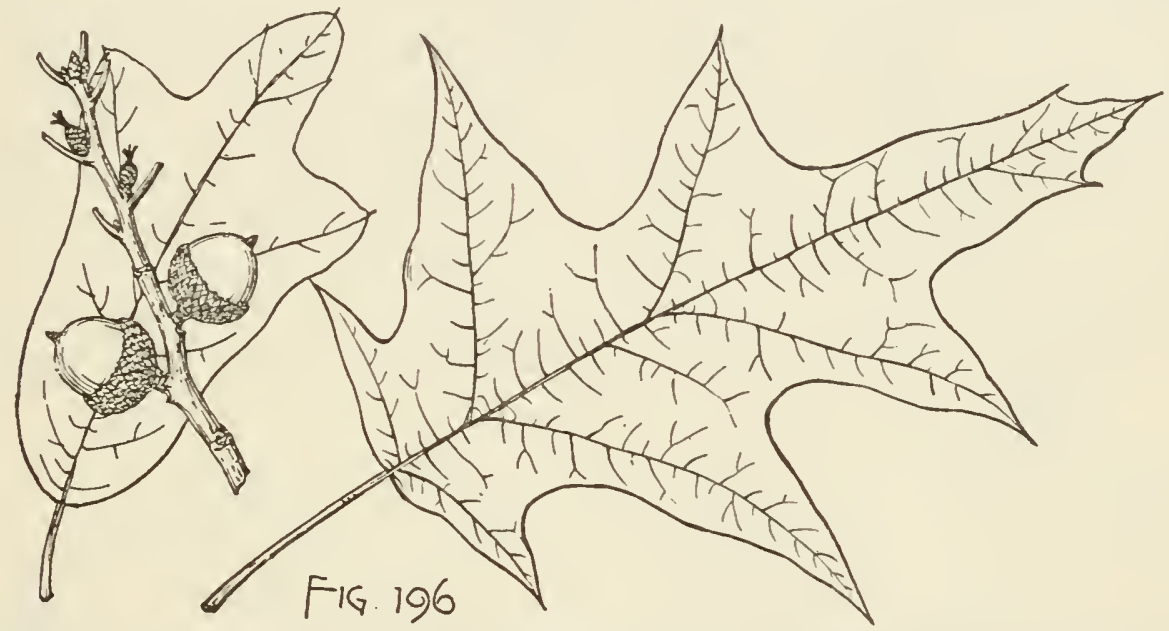

shorter than the acute calyx-lobes; stigmas dark red. Fruit sessile or short-stalked; acorn subglobose to ellipsoidal, full and rounded at the apex, truncate and rounded at the base, about $\frac{1}{2}^{\prime}$ long, bright orange-brown, inclosed only at the base or sometimes for one third its length in a thin saucer-shaped cup flat on the bottom or gradually narrowed from a stalk-like base, or deep and turbinate, bright red-brown and puberulous on the inner surface, covered by thin ovate-oblong reddish scales acute or rounded at the apex and pale-pubescent except on the margins.

A tree, usually $70^{\circ}-80^{\circ}$ high, with a trunk $2^{\circ}-3^{\circ}$ in diameter, stout spreading branches forming a broad round-topped open head, and stout branchlets coated at first, like the young leaves, with a thick rusty or orange-colored clammy tomentum of articulate hairs, dark red or reddish brown and pubescent or rarely glabrous during their first winter, becoming in their second year dark red-brown or ashy gray. Wincer-buds ovoid or oval, acute, $\frac{1^{\prime}}{8}-\frac{1}{4}^{\prime}$ long, with bright chestnut-brown puberulous or pilose scales ciliate, with short pale hairs. Bark $\frac{3^{\prime}}{4}-\mathbf{1}^{\prime}$ thick, dark brown, and divided by shallow fissures into broad ridges covered by thin closely appressed scales. Wood hard, strong, not durable, coarse-grained, light red, with thick lighter colored sapwood; sometimes used in construction, and largely as fuel. The bark is rich in tannin, and is used in tanning leather and occasionally in medicine.

Distribution. Southern New Jersey southward to central Florida, through the Gulf states to the valley of the Brazos River, Texas, through Arkansas and south- 
western Missouri to central Tennessee and Kentucky, and southern Indiana and Illinois; in the north Atlantic states only in the neighborhood of the coast and comparatively rare; very common in the sonth Atlantic and Gulf states on dry hills between the coast plain and the Appalachian Mountains; less abundant in the southern maritime Pine belt.

\section{Quercus pagodæfolia, Ashe. Swamp Spanish Oak. Red Oak.}

Leaves oval to oblong, acuminate, gradually narrowed and cuneate, or full and rounded or rarely truncate at the base, deeply divided by wide sinuses rounded at the bottom into 5-11 acuminate usually entire repand-dentate lobes often falcate and spreading at right angles to the midrib or pointed toward the apex of the leaf, when they unfold coated with pale tomentum, thickest on the lower surface, and dark red on the upper surface, at maturity dark green and very lustrous above, pale and tomentose below, $6^{\prime}-8^{\prime}$ long and $5^{\prime}-6^{\prime}$ wide, with stout midribs usually puberulous on the upper side, slender primary veins arched to the points of the lobes, and conspicuous reticulate veinlets, turning bright clear yellow before falling in the autumn; their petioles stout, pubescent or tomentose, $11^{\prime \prime}-2^{\prime}$ long. Flowers : staminate in clustered slender villous aments $2^{\prime}-3^{\prime}$ long; calyx thin, scarious, pubescent on the outer surface, more or less deeply tinged with red, divided into 4 or 5 rounded segments; pistillate on 1-3-flowered tomentose peduncles, their involucral scales hoary-tomentose, about as long as the acute calyx-lobes; stigmas dark red. Fruit short-stalked or nearly sescile; acorn ovate to subglobose, light yellow-brown, puberulous toward the rounded apex, about $\frac{5 \prime}{8}$ in diameter, inclosed for nearly one half its

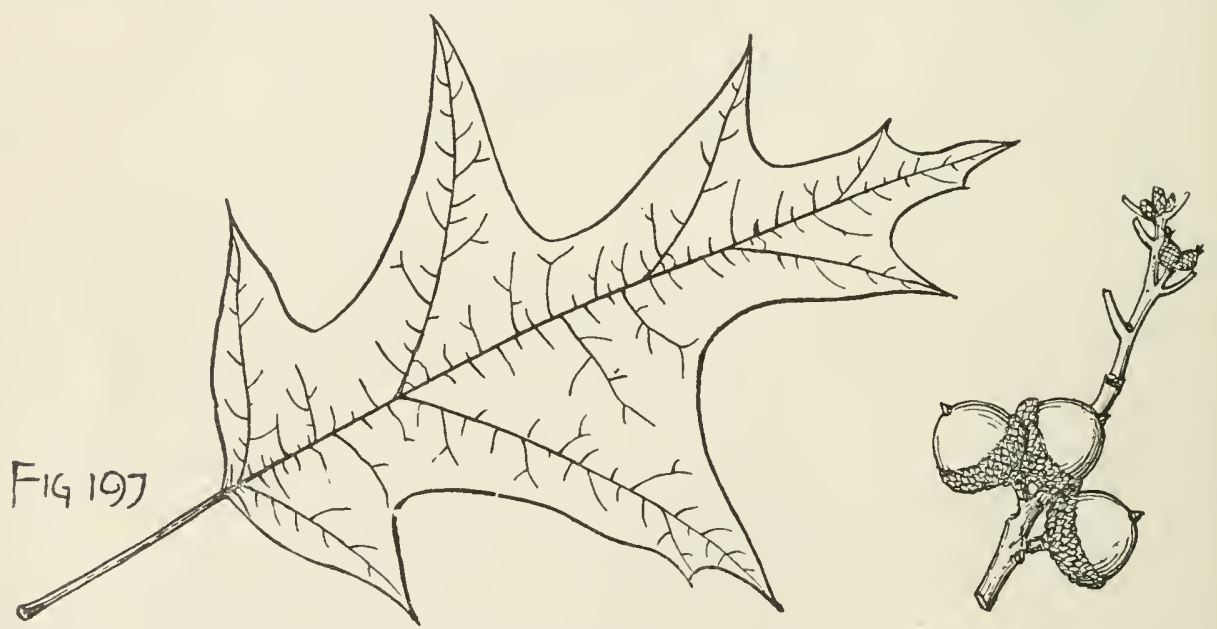

length in a flat or slightly turbinate cup thin, slightly lobed on the.border, glabrous on the inner surface, and covered by oblong rather loosely imbricated scales palepubescent except on their dark margins.

A tree, sometimes $120^{\circ}$ high, with a trunk $4^{\circ}-5^{\circ}$ in diameter, heavy branches forming in the forest a short narrow crown, or in more open situations wide-spreading or ascending and forming a great open head, and slender branchlets hoary tomentose at first, tomentose or pubescent during their first winter, and dark reddish brown and puberulous during their second year. Winter-buds ovoid, acute, of ten prominently 4-angled, about $\frac{1^{\prime}}{4}$ long, with light red-brown puberulous scales sometimes ciliate at the apex. Bark about $1^{\prime}$ thick and roughened by small rather closely appressed plate-like light gray or gray-brown scales. Wood light reddish 
brown, with thin nearly white sapwood; largely manufactured into lumber in the Mississippi valley and valued almost as highly as white oak.

Distribution. Rich bottom-lands and the alluvial banks of streams; southwestern Virginia to northern Florida, and through the Gulf states and Arkansas to southern Missouri, western Tennessee and Kentucky, and sonthern Illinois and Indiana; most abundant and one of the largest and most valuable timber-trees in the river swamps of the Yazoo basin, Mississippi, and of eastern Arkansas.

\section{Quercus Marilandica, Muench. Black Jack. Jack Oak.}

Leaves broadly obovate, rounded or cordate at the narrow base, usually 3 or rarely 5-lobed at the broad and often abruptly dilated apex, with short or long, broad or narrow, rounded or acute, entire or dentate lobes, or entire or dentate at the apex, sometimes oblong-obovate, undulate-lobed at the broad apex and entire below or

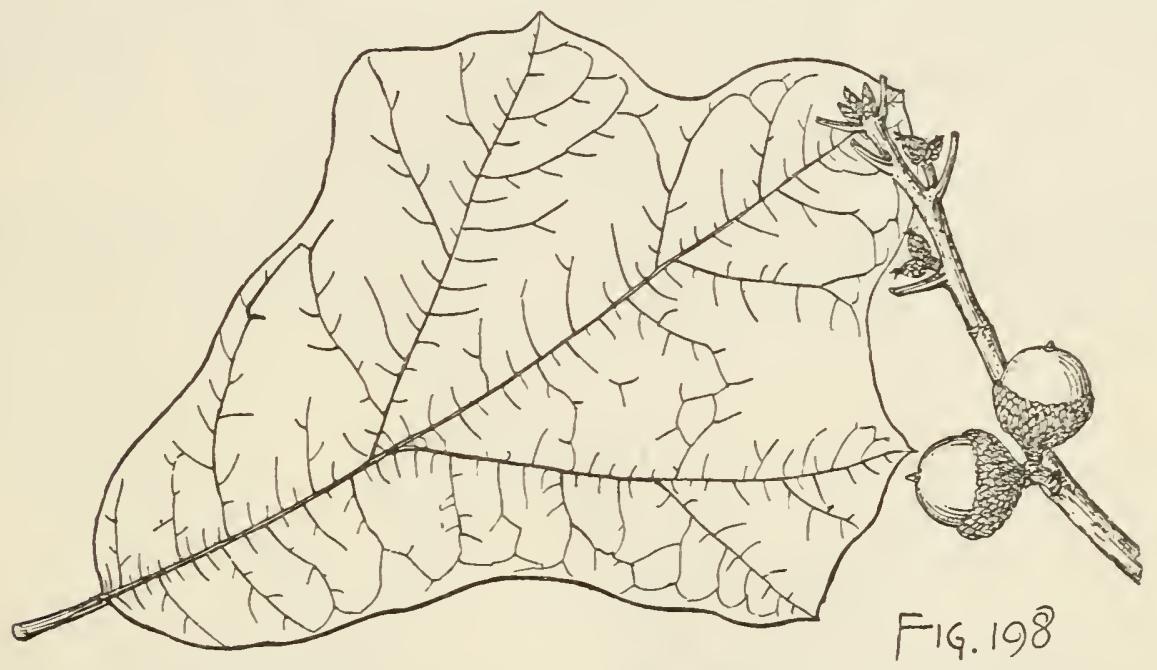

equally 3-lobed, with elongated spreading lateral lobes broad and lobulate at the apex, when they unfold coated with a clammy tomentum of articulate hairs, and bright pink on the upper surface, at maturity thick and firm or subcoriaceous, dark yellow-green and very lustrous above, yellow, orange color, or brown and scurfypubescent below, usually $6^{\prime}-7^{\prime}$ long and broad, with thick broad orange-colored midribs, turning brown or yellow in the autumn before falling; their petioles stout, yellow, glabrous or pubescent, $\frac{1^{\prime}}{2}-\frac{3^{\prime}}{4}$ long. Flowers: staminate in hoary aments $2^{\prime}-4^{\prime}$ long; calyx thin and scarious, tinged with red above the middle, pale-pubescent on the onter surface, divided into 4 or 5 broad ovate rounded lobes; anthers apiculate, dark red; pistillate on short rusty-tomentose peduncles coated like their involucral scales with thick rusty tomentum; stigmas dark red. Fruit, solitary or in pairs, usually pedunculate; acorn oblong, full and rounded at the ends, rather broader below than above the middle, about $\frac{3^{\prime}}{4}$ long, light yellow-brown and often striate, the shell lined with dense fulvous tomentum, inclosed for one third to nearly two thirds its length in a thick turbinate light brown cup puberulous on the inner surface, and covered by large reddish brown loosely imbricated scales often ciliate and coated with loose pale or rusty tomentum, the upper scales smaller, erect, inserted on the top of the cup in several rows, and forming a thick rim round its inner surface, or occasionally reflexed and covering the upper half of the inner surface of the cup.

A tree, $20^{\circ}-30^{\circ}$, or occasionally $40^{\circ}-50^{\circ}$ high, with a trunk rarely more than $18^{\prime}$ 
in diameter, short stout spreading often contorted branches forming a narrow compact round-topped or sometimes an open irregular head, and stout branchlets coated at first witl a thick pale tomentum of articulate and stellate hairs, light brown and scurfy-pubescent during their first summer, becoming reddish brown and glabrous or puberulous in the winter, and ultimately brown or ashy gray. Winter-buds ovate or oval, prominently angled, light red-brown, coated with rusty brown hairs, about $\frac{1^{\prime}}{4}$ long. Bark $1^{\prime}-1 \frac{1}{2}^{\prime}$ thick, and deeply divided into nearly square plates $1^{\prime}-3^{\prime}$ long covered by small closely appressed dark brown or nearly black scales. Wood heavy, hard, strong, dark rich brown, with thick lighter colored sapwood; largely used as fuel and in the manufacture of charcoal.

Distribution. Dry sandy or clay barrens; Long Island, New York, throngh northern Olio and Indiana to southeastern Nebraska, central Kansas, and the Indian Territory, and southward to the shores of Matanzas Inlet and Tampa Bay, Florida, and to the valley of the Nueces River, Texas; rare in the north; very abundant sonthward; west of the Mississippi River often forming on sterile soils a great part of the forest growth; of its largest size in southern Arkansas and eastern Texas.

\section{Quercus nigra, L. Water Oak.}

Leaves usually oblong-obovate, gradually narrowed and wedge-shaped at the base, enlarged sometimes abruptly at the broad generally rounded or sometimes pointed entire or slightly or deeply 3-lobed apex, or of ten acute at the ends, and on upper

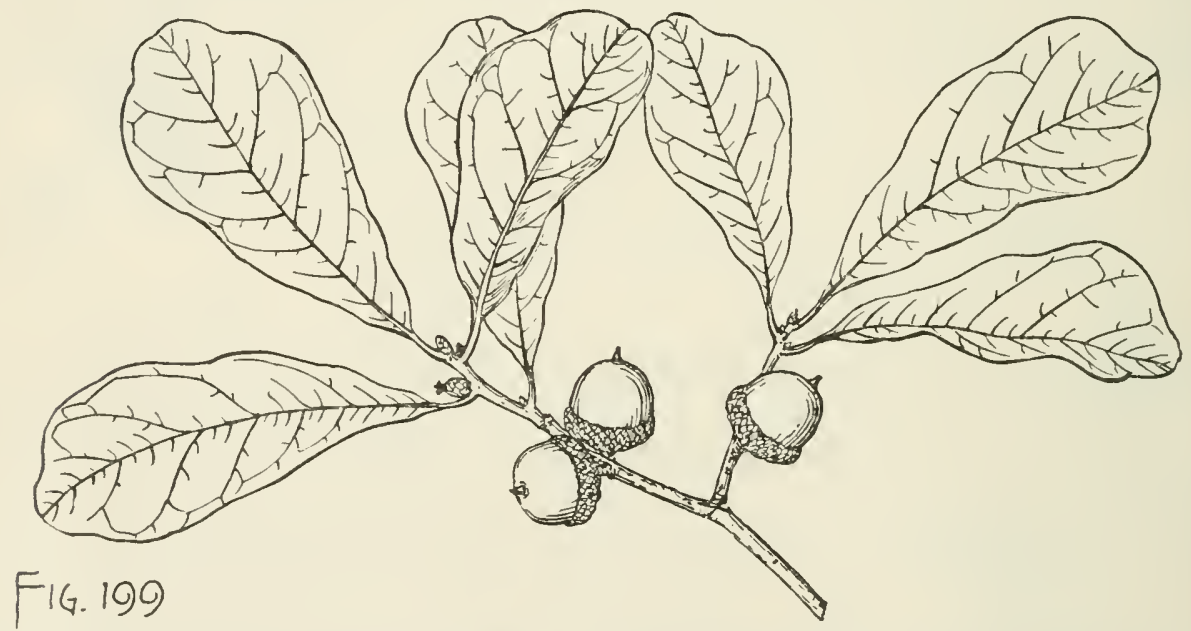

branchlets sometimes linear-lanceolate to linear-obovate, acute or rounded at the apex, divided above the middle by deep wide rounded sinuses into elongated lanceolate acute entire lobes, or pinnatifid above the middle, when they unfold thin, light green more or less tinged with red, and covered by fine caducous pubescence, with conspicuous tufts of pale hairs in the axils of the veins below, at maturity thin dull bluish green, paler below than above, glabrous or with axillary tufts of rusty hairs, usually about $2 \frac{1}{2}^{\prime}$ long and $1^{\prime}{ }^{\prime}$ wide, or on fertile branches sometimes $6^{\prime}$ long and $2 \frac{1}{2}{ }^{\prime}$ wide, falling gradually during the winter; their petioles stout, flattened, $\frac{1^{\prime}}{8}-\frac{1}{2}^{\prime}$ long. Flowers : staminate in red hairy-stemmed aments $2^{\prime}-3^{\prime}$ long; calyx thin and scarious, covered on the outer surface with short liairs, deeply divided into 4 or 5 ovate rounded segments; pistillate on short tomentose peduncles, their involucral scales a little shorter than the acute calyx-lobes and coated with rusty hairs; stigmas deep red. Fruit usually solitary, sessile or short-stalked; acorn ovoid, broad and flat 
at the base, full and rounded at the pubescent apex, light yellow-brown, often striate, $\frac{1}{3}-\frac{2}{3}$ long and nearly as broad, usually inclosed only at the base in a thin saucershaped cup, or occasionally for one third its length in a cup-shaped cup, coated on the inner surface with pale silky tomentum and covered by ovate acute closely appressed light red-brown scales clothed with pale pubescence except on their darker colored margins.

A tree, occasionally $80^{\circ}$ high, with a trunk $2^{\circ}-3 \frac{1}{2}^{\circ}$ in diameter, numerous slender branches spreading gradually from the stem and forming a symmetrical round-topped head, and slender glabrous branchlets light or dull red during their first winter, becoming grayish brown in the second season. Winter-buds ovate, acute, strongly angled, covered by loosely imbricated dark red-brown puberulous scales slightly ciliate on the thin margins. Bark $\frac{1^{\prime}}{2}-\frac{3^{\prime}}{4}$ thick, with a smooth light brown surface slightly tinged with red and covered by smooth closely appressed scales. Wood heavy, hard, strong, close-grained, light brown, with thick lighter colored sapwood; little valued except as fuel.

Distribution. High sandy borders of swamps and streams and the rich bottomlands of rivers; southern Delaware southward to Cape Malabar and the shores of Tampa Bay, Florida, ranging inland through the south Atlantic states to the base of the Appalachian Mountains, west through the Gulf states to the valley of the Colorado River, Texas, through the eastern borders of the Indian Territory, and through Arkansas to southeastern Missouri and to central Tennessee and Kentucky.

Commonly planted as a shade-tree in the streets and squares of the cities and towns of the southern states.

++++ Leaves lanceolate to oblong or lanceolate-obovate, usually entire. WILlow OAKS.

\section{Quercus Phellos, L. Willow Oak.}

Leaves ovate-lanceolate or rarely lanceolate-obovate, often somewhat falcate, gradually narrowed and acute at the ends, and entire, with slightly undulate margins, when they unfold light yellow-green and lustrous on the upper surface, coated on the lower with pale caducous pubescence, at maturity glabrous, light green and rather lustrous above, dull and paler or rarely hoary-pubescent below, conspicuously reticulate-venulose, $2 \frac{1}{2}^{\prime}-5^{\prime}$ long, $\frac{1^{\prime}}{4}-1^{\prime}$ wide, with slender yellow midribs and obscure primary veins forked and united about half way between the midribs and margins, turning pale yellow in the autumu before falling; their petioles stout, about $\frac{1^{\prime}}{8}$ long. Flowers : staminate in slender-stemmed aments $2^{\prime}-3^{\prime}$ long; calyx yellow, hirsute, with 4 or 5 acute segments; pistillate on slender glabrous peduncles, their involucral scales brown covered by pale hairs, about as long as the acute calyx-lobes; stigmas bright red. Fruit short-stalked or nearly sessile, solitary or in pairs; acorn hemispherical, light yellow-brown, coated with pale pubescence, inclosed only at the very base in the thin pale reddish brown saucer-shaped cup silky-pubescent on the inner surface and covered by thin elongated ovate truncate hoary-pubescent scales dark red-brown on the margins.

A tree, occasionally $70^{\circ}-80^{\circ}$ high, with a trunk $2^{\circ}$ or rarely $4^{\circ}$ in diameter, small branches spreading into a comparatively narrow open or conical round-topped head, and slender glabrous reddish brown branchlets roughened by dark lenticels, becoming in their second year dark brown tinged with red or grayish brown; usually much smaller. Winter-buds ovate, acute, about $\frac{1}{8}^{\prime}$ long, with dark chestnut-brown scales pale and scarious on the margins. Bark $\frac{1^{\prime}}{2}-3^{\prime}$ thick, light red-brown slightly 
tinged with red, generally smooth but on old trees broken by shallow narrow fissures into irregular plates covered by small closely appressed scalcs. Wood heavy, strong, not hard, rather coarse-grained, light brown tinged with red, with thin lighter colored sapwood; occasionally used in construction, for clapboards and the fellies of wheels.

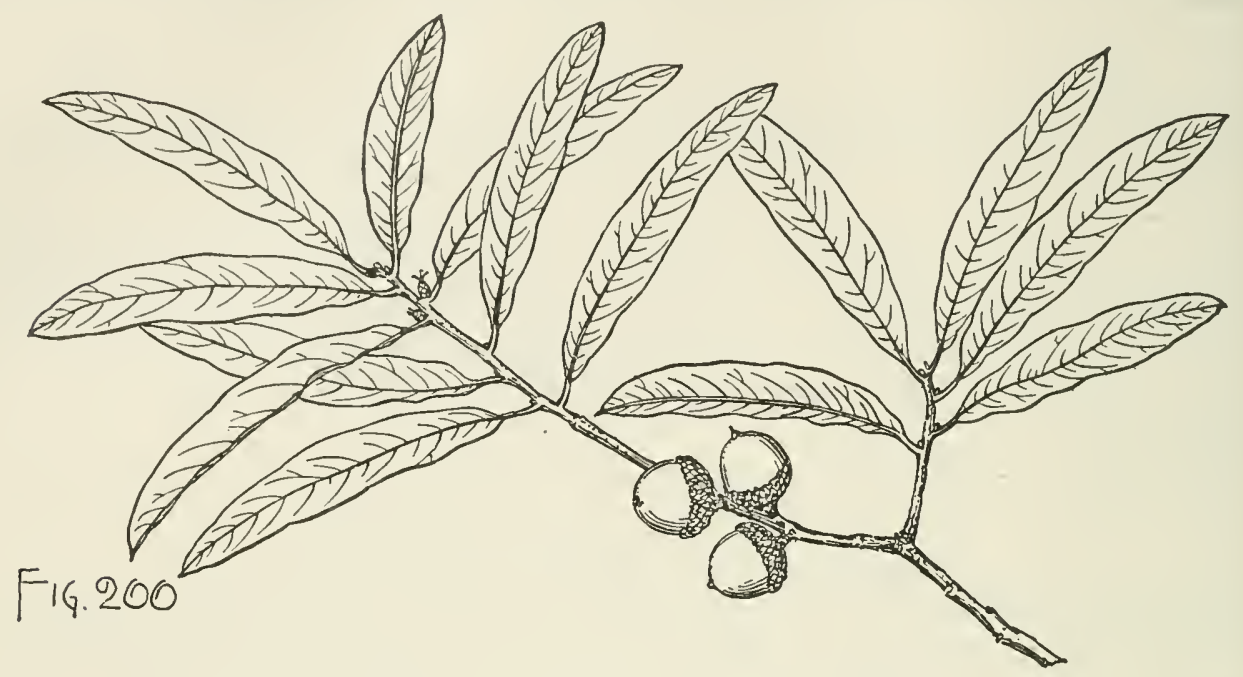

Distribution. Low wet borders of swamps and streams and rich sandy uplands; Staten Island, New York, to northeastern Florida, through the Gulf states to the valley of the Sabine River, Texas, and through Arkansas and southeastern Missouri to central Tennessee and southern Kentucky; in the Atlantic states usually confined to the maritime plain; less common in the middle districts, rarely extending to the Appalachian foothills.

Occasionally planted as a shade-tree in the streets of southern towns, and rarely in western Europe.

Quercus Rudkini, Britt., a supposed bybrid between Quercus Phellos and Quercus Marilandica, is common on Staten Island and in southern New Jersey.

\section{Quercus heterophylla, Michx. f.}

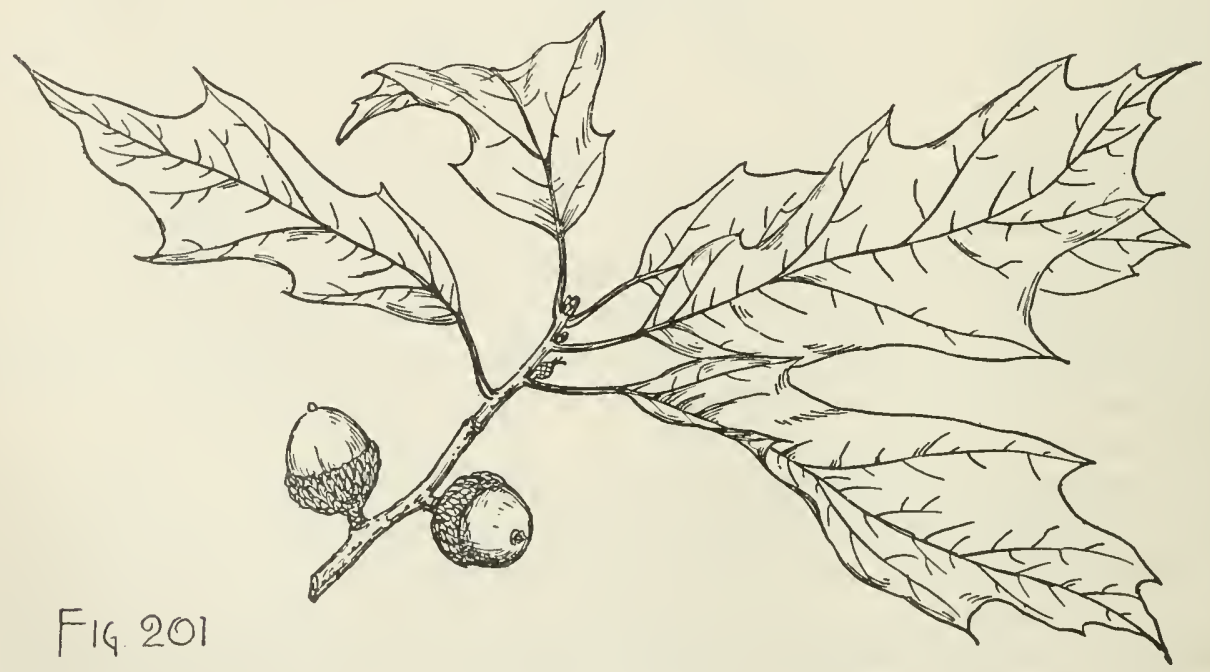

This is perhaps a hybrid between Quercus Phellos and Quercus velutina. It was first 
known in the eighteenth century from an individual growing in a field belonging to John Bartram on the Schuylkill River, Philadelphia. What appears to be the same form has since been discovered in a number of stations from New Jersey to Texas, and it is possible that Quercus heterophyllu may, as many botanists have believed, best be considered a species.

\section{Quercus laurifolia, Michx. Water Oak.}

Leaves oblong-oval to oblong-obovate, sometimes falcate, gradually narrowed and acute or rarely rounded at the ends, entire, with slightly thickened often undulate margins, or on vigorous branches of young trees frequently nnequally lobed,

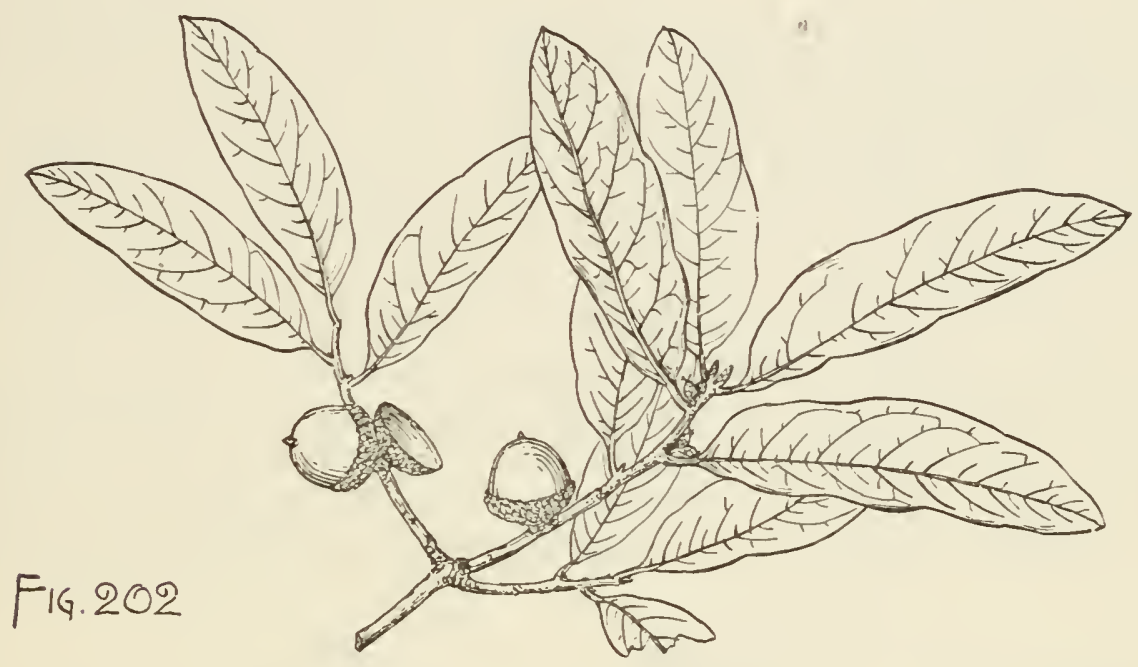

with small almost triangular lobes, when they unfold green tinged with dark red and slightly puberulous, at maturity thin, green, and very lustrous above, light green and less lustrous below, usually $3^{\prime}-4^{\prime}$ long and $\frac{3^{\prime}}{4}$ wide, with conspicuous yellow midribs, falling irregularly during the winter; their petioles stout, yellow, rarely more than $\frac{1}{4}^{\prime}$ long. Flowers: staminate in red-stemmed hairy aments $2^{\prime}-3^{\prime}$ long; calyx thin and scarious, pubescent on the outer surface, deeply divided into 4 ovate rounded lobes; pistillate on stout glabrous peduncles, their involucral scales brown and hairy, about as long as the acute calyx-lobes; stigmas dark red. Fruit sessile or subsessile, generally solitary; acoru nearly ovoid to hemispherical, broad and slightly rounded at the base, full and rounded at the puberulous apex, dark brown, becoming striate in drying, with brown and dark olive-green stripes, about $\frac{1}{2}^{\prime}$ long, inclosed for about one fourth its length in a thin saucer-shaped cup red-brown and silky-pubescent on the inner surface, and covered by thin ovate light red-brown scales rounded at the ends and pale-pubescent except on their darker colored margins.

A tree, occasionally $100^{\circ}$ high, with a tall trunk $3^{\circ}-4^{\circ}$ in diameter, and comparatively slender branches spreading gradually into a broad dense round-topped shapely head, and slender glabrous branchlets dark red when they first appear, dark redbrown during their first winter, becoming reddish brown or dark gray in their second season. Winter-buds broadly ovate or oval, abruptly narrowed and acute at the apex, $\frac{1}{1 \overline{6}^{\prime}}-\frac{1^{\prime}}{8}$ long, with numerous thin closely imbricated bright red-brown scales ciliate on the margins. Bark of young trees $\frac{1^{\prime}}{2}-1^{\prime}$ thick, dark brown more or less tinged with red, roughened by small closely appressed scales, becoming at the base 
of old trees $1^{\prime}-2^{\prime}$ thick, nearly black, and divided by deep fissures into broad flat ridges. Wood heavy, very strong and liard, coarse-grained, liable to check badly in drying, dark brown tinged with red, with thick lighter colored sapwood; probably used only as fuel.

Distribution. Sandy banks of streams and swamps and rich hummocks in the neiginborlood of the coast; Dismal Swamp, Virginia, southward to the shores of Mosquito Inlet and Cape Romano, Florida, and along the Gulf coast to Lonisiana; nowhere abundant, but most common and of its largest size in eastern Florida.

\section{Quercus brevifolia, Sarg. Blue Jack.}

Leaves oblong-lanceolate to oblong-obovate, gradually narrowed and wedgeshaped or sometimes rounded at the base, acute or rounded and apiculate at the apex, entire, with slightly thickened undulate margins, or at the ends of vigorous sterile branches occasionally 3-lobed at the apex and variously lobed on the margins, when they unfold bright pink and pubescent on the upper surface, coated on the lower with thick silvery white tomentum, at maturity firm in texture, blue-green, lustrous, conspicuously reticulate-venulose above, pale-tomentose below, $2^{\prime}-5^{\prime}$ long, $\frac{1}{2}^{\prime}-1 \frac{1}{2}^{\prime}$ wide, with stout yellow midribs and remote obscure primary veins forked and united within the margins, deciduous late in the autumn or in early winter; their petioles stout, $\frac{1^{\prime}}{4}-\frac{1^{\prime}}{2}$ long. Flowers: staminate in hoary-tomentose aments $2^{\prime}-3^{\prime}$ long; calyx pubescent, bright red, furnished at the apex with a thick tuft of silvery white hairs before opening, divided into 4 or 5 ovate acute segments, becoming yellow as it unfolds; stamens 4 or 5 ; anthers apiculate, dark red in the bud, becoming yellow; pistillate on short stout tomentose peduncles, their involucral scales about

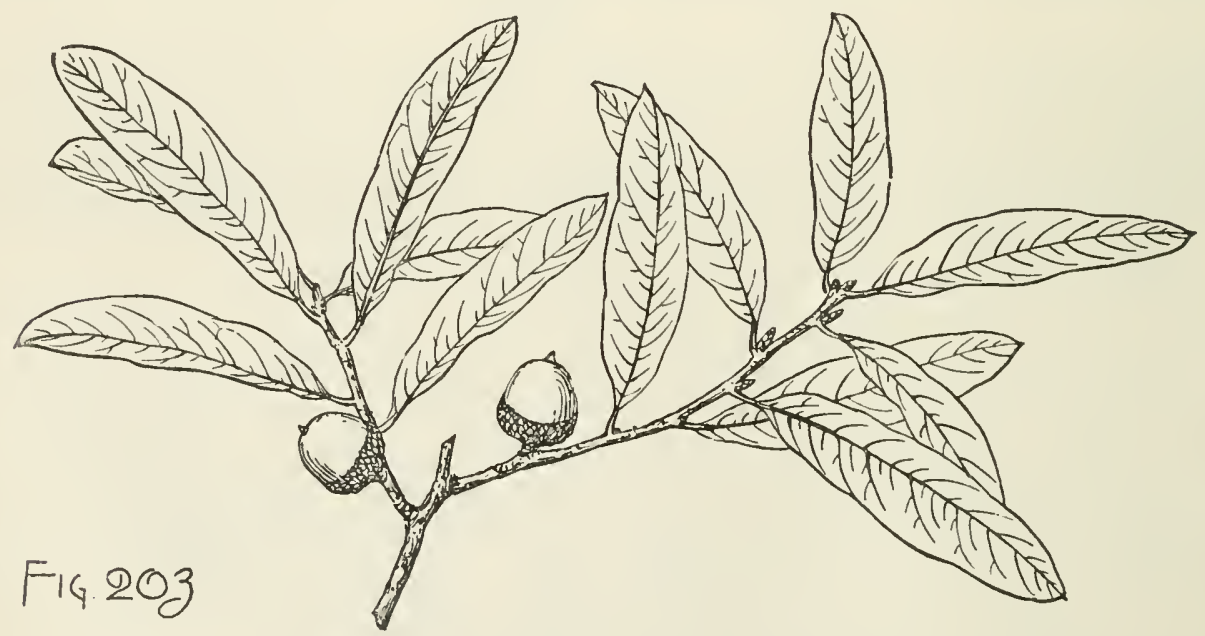

as long as the acute calyx-lobes and coated with pale tomentum; stigmas dark red. Fruit produced in great profusion, sessile or raised on a short stem rarely $\frac{1^{\prime}}{4}$ long; acorn ovate, full and rounded at the ends, subglobose, about $\frac{1}{2}^{\prime}$ long, often striate, and hoary-pubescent at the apex, inclosed only at the bottom or for oue half its length in a thin saucer-shaped or cup-shaped cup bright red-brown and coated with lustrous pale pubescence on the inner surface, and covered by thin closely imbricated ovateoblong scales hoary-tomentose except on the dark red-brown margins.

A tree, usually $15^{\circ}-20^{\circ}$ high, with a trunk $5^{\prime}-6^{\prime}$ in diameter, stout branches form- 
ing a narrow irregular head, and thick rigid branchlets coated at first with a dense fulvous hoary tomentum of articulate and stellate hairs, soon becoming glabrous or puberulous, dark brown sometimes tinged with red during their first winter and darker in their second year; or occasionally $50^{\circ}$ high, with a trunk $18^{\prime}-20^{\prime}$ in diameter, and a broad round-topped shapely head. Winter-buds ovate, acute, with numerous rather loosely imbricated bright chestnut-brown scales ciliate on the margins, often $\frac{1^{\prime}}{4}$ long on vigorous branches, frequently obtuse and occasionally much smaller. Bark $\frac{3^{\prime}}{4}-1 \frac{1}{2}^{\prime}$ thick, and divided into thick nearly square plates $1^{\prime}-2^{\prime}$ long, and covered by small dark brown or nearly black scales slightly tinged with red. Wood hard, strong, close-grained, light brown tinged with red, with thick darker colored sapwood; probably used only as fuel.

Distribution. Sandy barrens and upland ridges; North Carolina south to Cape Malabar and the shores of Peace Creek, Florida, and westward along the Gulf coast to the valley of the Brazos River, Texas; in the Atlantic and middle Gulf states usually confined to a maritime belt $40-50$ miles wide; extending across the Florida peninsula, and in Texas ranging inland to the neighborhood of Dallas in about latitude 33.

\section{Quercus imbricaria, Michx. Shingle Oak. Laurel Oak.}

Leaves oblong-lanceolate to oblong-obovate, apiculate and acute or rounded at the apex, gradually narrowed and wedge-shaped or rounded at the base, entire, with

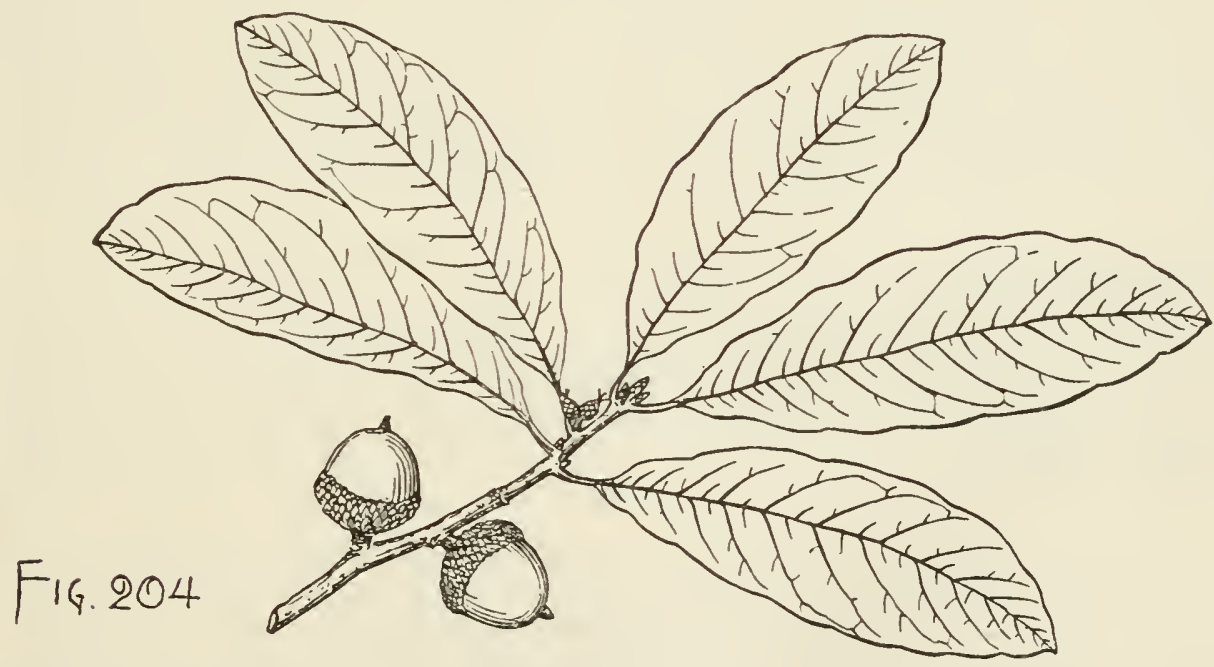

slightly thickened revolute often undulate margins, or sometimes more or less 3lobed, or on sterile branches occasionally repand-lobulate, when they unfold bright red, soon becoming yellow-green, covered with scurfy rusty pubescence on the upper surface and hoary-tomentose on the lower, at maturity thin, glabrous, dark green, and very lustrous above, pale green or light brown and pubescent below, $4^{\prime}-6^{\prime}$ long, $\frac{3^{\prime}}{4}-2^{\prime}$ wide, with stout yellow midribs, numerous slender yellow veins arcuate and united at some distance from the margins, and reticulate veinlets, late in the autumn before falling turning dark red on the upper surface; their petioles stout, pubescent, rarely more than $\frac{1}{2}^{\prime}$ long. Flowers: staminate in hoary-tomentose aments $2^{\prime}-3^{\prime}$ long; calyx light yellow, pubescent, and divided into 4 acute segments; pistillate on slender tomentose peduncles, their involucral scales covered with pale pubescence 
and about as long as the acute calyx-lobes; stigmas greenish yellow. Fruit solitary or in pairs, on stout peduncles nearly $\frac{1}{2}^{\prime}$ long; acorn nearly as broad as long, full and rounded at the ends, dark chestuut-brown, often obseurely striate, $\frac{1}{2}{ }^{\prime}-\frac{2}{3}$ long, inclosed for one third to one half its length in a thin cup-shaped or turbinate cup bright red-brown and lustrous on the inner surface, and covered by thin ovate light red-brown scales rounded and acute at the apex and pubescent except on their darker colored margins.

A tree, nsually $50^{\circ}-60^{\circ}$ high, with a trunk rarely exceeding $3^{\circ}$ in diameter, or rarely $100^{\circ}$ ligh, with a long naked stem $3^{\circ}-4^{\circ}$ in diameter, slender tough horizontal or somewhat pendulous branches forming a narrow round-topped picturesque head, and slender branchlets dark green, lustrous, and often suffused with red when they first appear, soon glabrous, light reddish brown or light brown during their first winter and dark brown in their second year. Winter-buds ovate, acute, about $\frac{1}{8}$ long, obscurely angled and covered by closely imbricated light chestnut-brown lustrous scales erose and often ciliate on the margins. Bark on young stems and on their branches thin, light brown, smooth, and lustrous, becoming on old trunks $\frac{3{ }^{\prime}}{4}-1 \frac{1}{2}^{\prime}$ thick, and slightly divided by irregular shallow fissures into broad ridges covered by close slightly appressed light brown scales somewhat tinged with red. Wood heavy, hard, rather coarse-grained, light brown tinged with red, with thin lighter colored sapwood; occasionally used in construction, and for clapboards and shingles.

Distribution. Rich uplands and the fertile bottom-lands of rivers; Lehigh County, Pennsylvania, westward through southern Michigan and Wisconsin to northern Missouri and northeastern Kansas, southward to the District of Columbia, and along the Alleghany Mountains to northern Georgia and Alabama, middle Tennessee and northern Arkansas; comparatively rare in the east; one of the most abundant Oaks of the lower Ohio basin; probably growing to its largest size in southern Indiana and Illinois.

Occasionally planted as an ornamental tree in the northern states, and hardy as far north as Massachusetts.

Quercus Leana, Nutt., scattered usually in solitary individuals from the District of Columbia and western North Carolina to southern Michigan, central and northern Illinois and sontheastern Missouri, is believed to be a hybrid between this species and Quercus velutina.

\section{** Leaves persistent until the appearance of those of the following year.}

\section{Quercus hypoleuca, Engelm.}

Leaves lanceolate or oblong-lanceolate to elliptical, occasionally somewhat falcate, acute and often apiculate at the apex, wedge-shaped or rounded or cordate at the narrow base, entire or repandly serrate above the middle, with occasionally small minute rigid spinose teeth, or on vigorous shoots serrate-lobed, with oblique acute lobes, when they unfold light red, covered with close pale pubescence above and coated below with thick hoary tomentum, at maturity thick and firm, dark yellowgreen and lustrous on the upper surface, covered on the lower with thick silvery white or fulvous tomentum, $2^{\prime}-4^{\prime}$ long, $\frac{1^{\prime}}{2}-1^{\prime}$ wide, with thickened revolute margins, turning yellow or brown and falling gradually during the spring after the appearance of the new leaves; their petioles stout, flattened, pubescent or tomentose, $\frac{1}{8}^{\prime}-\frac{1}{4}^{\prime}$ long. Flowers: staminate in slender aments $4^{\prime}-5^{\prime}$ long; calyx thin and scarious, slightly tinged with red, covered with pale hairs and deeply divided into 4 or 5 
broadly ovate rounded lobes; anthers acute, apiculate, bright red becoming yellow; pistillate mostly solitary, sessile or short-stalked, their involucral scales and calyx-

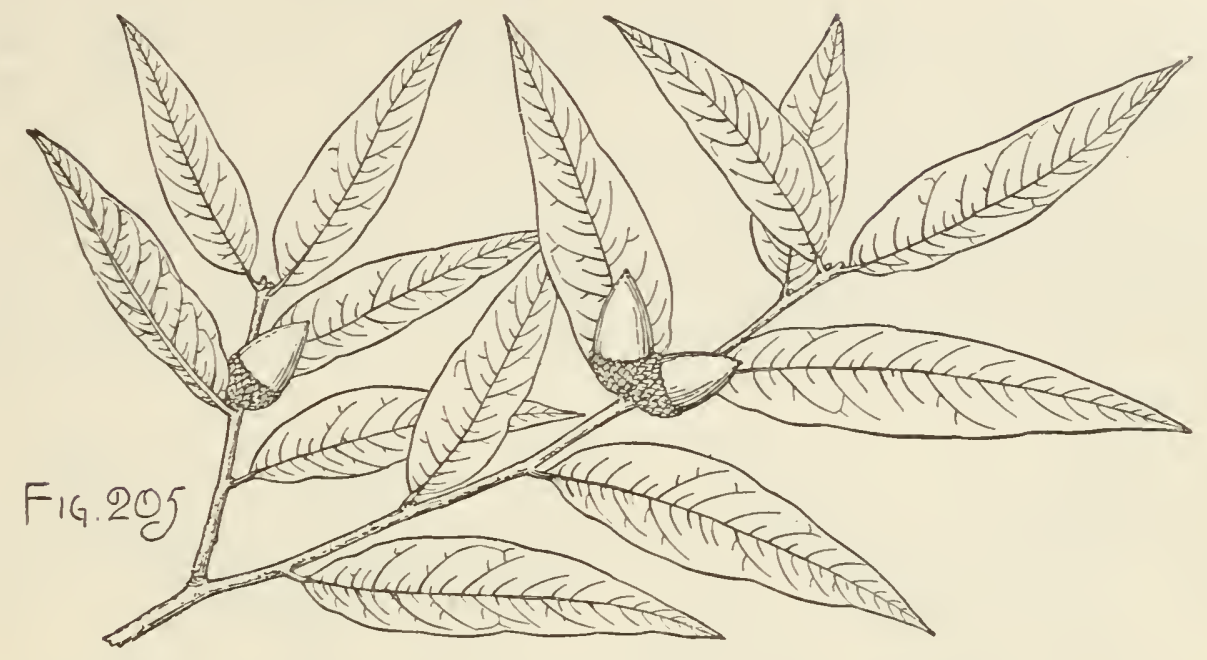

lobes thin, scarious, and soft-pubescent; stigmas dark red. Fruit sessile or borne on a stout peduncle $\frac{1^{\prime}}{2}$ long, usually solitary; acorn ovate, acute or rounded at the narrow hoary-pubescent apex, dark green and often striate when ripe, becoming light chestunt-brown in drying, $\frac{1^{\prime}}{2}-\frac{2^{\prime}}{3}$ long, the shell lined with white tomentum, inclosed for about one third its length in a turbinate thick cup pubescent on the inner surface, and covered by thin broadly ovate light chestnut-brown scales rounded at the apex and clothed, especially toward the base of the cup, with soft silvery pubescence.

A tree, usually $20^{\circ}-30^{\circ}$ or sometimes $60^{\circ}$ high, with a tall trunk $10^{\prime}-15^{\prime}$ in diameter, slender branches spreading into a narrow round-topped inversely conical head, and stout rigid branchlets coated at first with thick hoary tomentum disappearing during the first winter, becoming light red-brown often covered with a glaucous bloom and ultimately nearly black; frequently a shrub. Winter-buds ovate, obtuse, about $\frac{1}{8}^{\prime}$ long, with thin light chestnut-brown scales. Bark $\frac{3^{\prime}}{4}-1^{\prime}$ thick, nearly black, deeply divided into broad ridges broken on the surface into thick plate-like scales. Wood heavy, very strong, hard, close-grained, dark brown, with thick lighter colored sapwood.

Distribution. Scattered but nowhere abundant through Pine forests on the slopes of cañons and on high ridges usually from $6000^{\circ}-7000^{\circ}$ above the sea on the mountains of western Texas, and of New Mexico and Arizona south of the Colorado plateau; in northern Chihuahua and Sonora.

\section{Quercus Wislizeni, A. DC. Live Oak.}

Leaves narrowly lanceolate to broadly oval, mostly oblong-lanceolate, acute or rounded and generally apiculate at the apex, rounded or truncate or gradually narrowed and wedge-shaped at the base, entire, serrulate or serrate or sinuate-dentate, with spreading rigid spinescent teeth, when they unfold thin, dark red, ciliate, and covered with pale scattered stellate hairs, at maturity thick and coriaceous, glabrous and lustrous, dark green on the upper and paler and yellow-green on the lower surface, usually $1^{\prime}-1 \frac{1^{\prime}}{2}$ long and about $\frac{2 \prime}{3}$ wide, with obscure primary veins and conspicuous reticulate veinlets, gradually deciduous during their second summer aud 
autumn; their petioles coated at first with hoary tomentum, nsually pubescent or puberulous at maturity, $\frac{1}{8}^{\prime}$ to nearly $1^{\prime}$ long. Flowers: staminate in hairy aments $3^{\prime}-4^{\prime}$ long; calyx tinged with red in the bud, deeply divided into broadly ovate ciliate glabrous light yellow lobes shorter than the 3-6 stamens; pistillate sessile or short-stalked, their involucral scales and peduncle hoary-tomentose. Fruit sessile, short-stalked or occasionally spicate; acorn slender, oblong-oval, abruptly narrowed at the base, pointed and pilose at the apex, $\frac{3}{4}^{\prime}-1_{\frac{1}{2}}^{\prime}$ long, about $\frac{1^{\prime}}{3}$ wide, light chestmutbrown, often striate, the shell lined with a scanty coat of pale tomentum, more or less inclosed in the thin turbinate sometimes tubular eup $\frac{1^{\prime}}{2}-1^{\prime}$ deep, or rarely cup-shaped and shallow, light green and puberulous within, and covered by oblonglanceolate light brown closely imbricated thin scales, sometimes towards its base
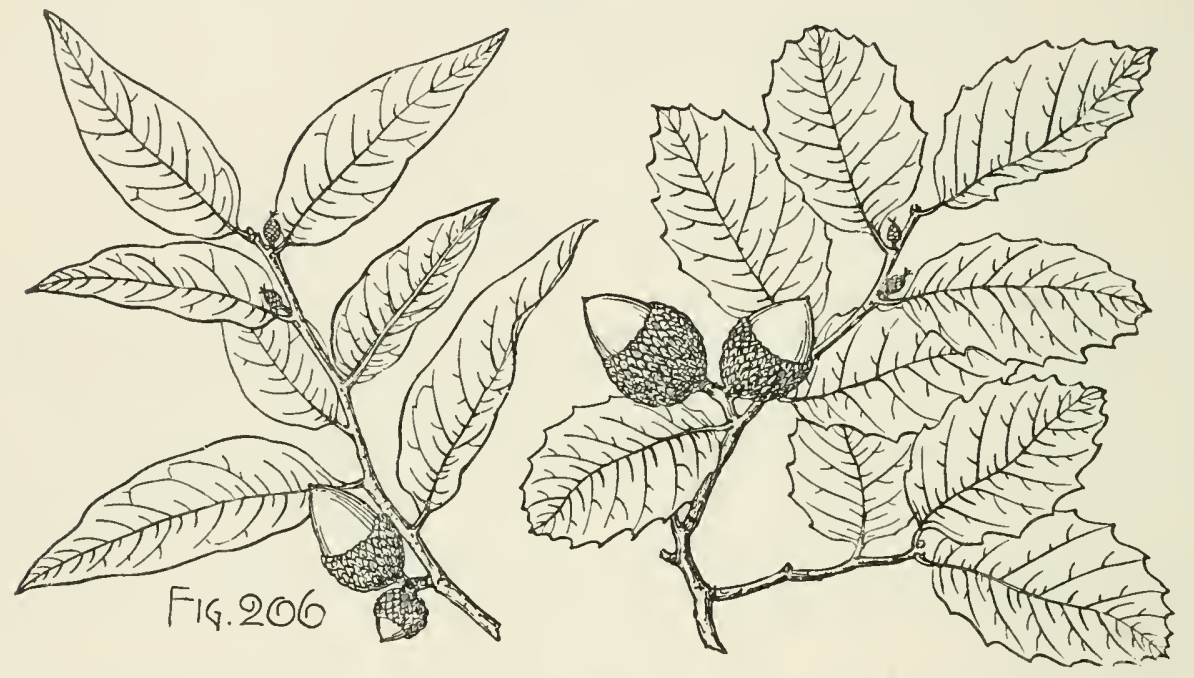

thickened and rounded on the back, usually pubescent or puberulons, especially above the middle, and frequently ciliate on the margins.

A tree, usually $70^{\circ}-80^{\circ}$ high, with a short trunk $4^{\circ}-6^{\circ}$ in diameter, stont spreading branches forming a round-topped liead, and slender rigid branchlets coated at first with hoary tomentum or covered with loose scattered stellate pubescence, puberulous or glabrous and rather light brown during their first season, gradually growing darker in their second year; nsually much smaller and sometimes reduced to an intricately branched shrub, with numerous stems only a few feet tall. Winterbuds ovate or oval, acute, $\frac{1}{8}^{\prime}-\frac{1}{4}^{\prime}$ long, with closely imbricated light chestnut-brown ciliate scales. Bark on young trees and large branches thin, generally smooth and light-colored, beconing on old trunks $2^{\prime}-3^{\prime}$ thick, and divided into broad rounded often connected ridges separating on the surface into small thick closely appressed dark brown scales slightly tinged with red. Wood heavy, very hard, strong, closegrained, light brown tinged with red, with thick lighter colored sapwood; sometimes used for fuel.

Distribution. Lower slopes of Mt. Shasta south ward through the coast region of California to the Santa Lucia Mountains, and to Santa Rosa and Santa Cruz Islands, and along the slopes of the Sierra Nevada to the Tejon Pass; as a shrub on the desert slopes of the San Bernardino, San Jacinto and Cuyamaca mountains, and on San Pedro Martir in Lower California; nowhere common as a tree, but most abundant and of its largest size in the valleys of the coast region of central California at some 
distance from the sea, and on the foothills of the Sierra Nevada; very common as a shrub in the cañons of the desert slopes of the mountains of southern California; near the coast and on the islands small and mostly shrubby.

Quercus Morehus, Kell., a supposed hybrid between this species and Quercus Californica, occurs in Lake County, California.

\section{Quercus myrtifolia, Willd. Scrub Oak.}

Leaves oval to oblong-obovate, acute and apiculate or broad and rounded at the apex, gradually narrowed and wedge-shaped or broad and rounded or cordate at the base, entire, with much thickened revolute sometimes undulate margins, or on vigorous shoots sinuate-dentate and lobed above the middle, when they unfold, thin, dark red, coated below and on the petioles with clammy rusty tomentum and covered above with stellate pubescence, at maturity thick and coriaceous, lustrous, dark green, glabrous, and conspicuously reticulate-venulose on the upper surface, paler, yellow-green, or light orange-brown, glabrous or pubescent, on the lower surface, with tufts of rusty hairs in the axils of the veins, $\frac{1^{\prime}}{2}-2^{\prime}$ long and $\frac{1^{\prime}-1^{\prime}}{4}$ wide, falling gradually during their second year; their petioles stout, pubescent, yellow, rarely
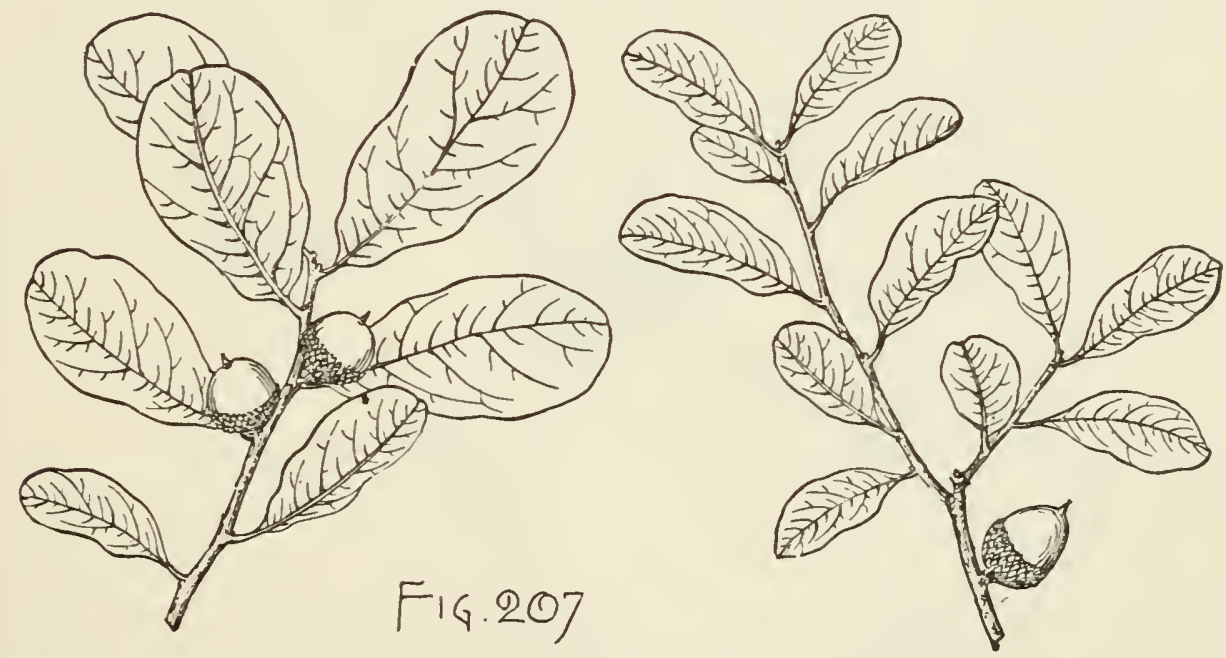

more than $\frac{1^{\prime}}{8}$ long. Flowers: staminate in hoary stellate pubescent aments $1^{\prime}-1 \frac{1}{2}^{\prime}$ long; calyx coated on the outer surface with rusty hairs and divided into 5 ovate acute thin segments shorter than the 2 or 3 stamens; pistillate sessile or nearly sessile, solitary or in pairs, their involucral scales tomentose and tinged with red. Fruit solitary or in pairs, sessile or short-stalked; acorn subglobose or ovate, acute, $\frac{1^{\prime}}{4}-\frac{1^{\prime}}{2}$ long, dark brown, lustrous and often striate, puberulous at the apex, the shell lined with a thick coat of rusty tomentum, inclosed for one fourth to one third its length in a saucer-shaped or turbinate cup light brown and puberulous within, and covered by closely imbricated broad ovate light brown pubescent scales ciliate on the margins and rounded at their broad apex.

A slender tree, rarely $20^{\circ}$ high, with a trunk $4^{\prime}-5^{\prime}$ in diameter, with short spreading branches and slender branchlets coated at first with a thick pale fulvous tomentum of articulate hairs usually persistent during the summer, light brown more or less tinged with red or dark gray, and pubescent or puberulous during their first winter, becoming darker and glabrous in their second season; more often an intri- 
cately branched shrub, with slender rigid stems $3^{\circ}-4^{\circ}$ or rarely $15^{\circ}-20^{\circ}$ high and $1^{\prime}-3^{\prime}$ in diameter. Winter-buds ovate or oval, gradually narrowed to the acute apex, with closely imbricated dark chestnut-brown slightly puberulous scales. Bark thin and smooth, beconing near the ground dark and slightly furrowed.

Distribution. Dry sandy ridges on the seashore and islands from South Carolina to eastern Florida and from the shores of Bay Biscayne to eastern Louisiana; most abundant on the islands off the coast of Alabama and Mississippi, often covering large areas with low impenetrable thickets; probably only arborescent near the mouth of the Appalachicola River, Florida.

\section{Quercus agrifolia, Née. Live Oak. Encina.}

Leaves oval, orbicular or oblong, rounded or acute and apiculate at the apex, rounded or cordate at the base, entire or sinuate-dentate, with slender rigid spinose teeth, when they unfold tinged with red and coated with caducous hoary tomentum, at maturity subcoriaceous, convex, dark or pale green, dull and obscurely reticulate

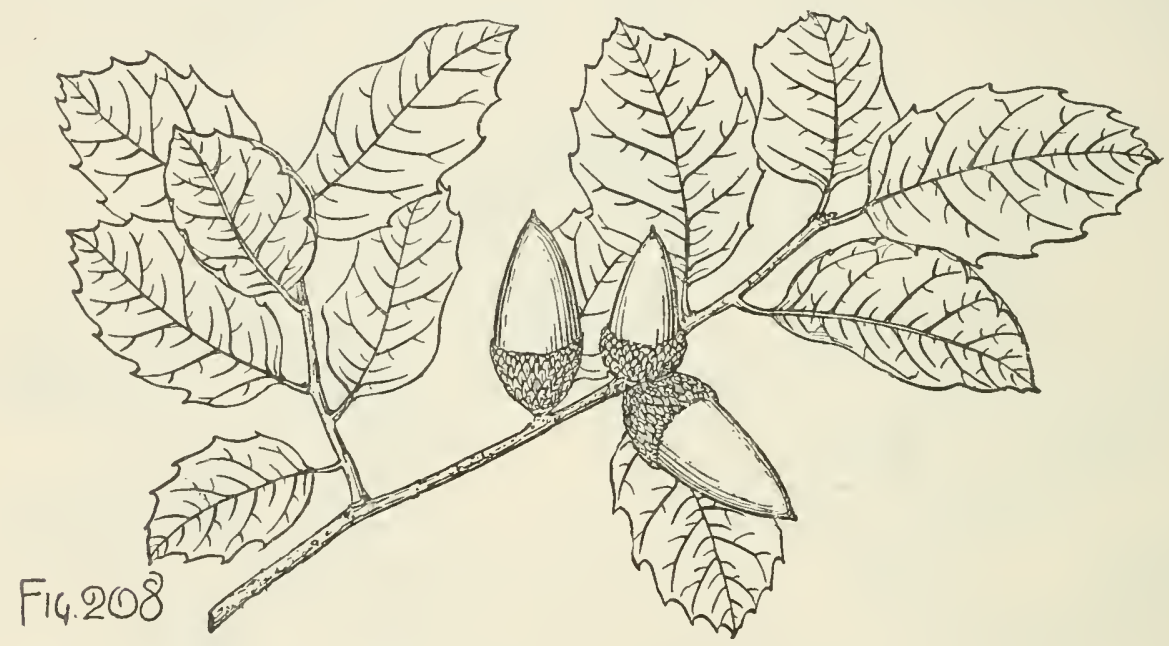

above, paler, rather lustrous, glabrous, or stellate-pubescent below, with tufts of rusty hairs in the axils of the principal veins, or sometimes covered above with stellate hairs and coated below with thick hoary pubescence, varying from $\frac{3}{4}^{\prime}-4^{\prime}$ long and from $\frac{1}{2}-3^{\prime}$ wide, with thickened strongly revolute margins, falling gradually during the winter and early spring; their petioles stout or slender, pubescent or glabrous, $\frac{1^{\prime}}{2}-1^{\prime}$ long. Flowers: staminate in slender hairy aments $3^{\prime}-4^{\prime}$ long; calyx bright purple-red in the bud, sometimes furnished with a tuft of long pale hairs at the apex, glabrous or glabrate, divided nearly to the base into 5-7 ovate acute segments reddish above the middle; pistillate sessile or short-stalked, their involucral scales bright red and covered with thick hoary tomentım, or glabrous or puberulous; stigmaŝ bright red. Fruit sessile or nearly so, solitary or in few-fruited clusters; acorn elongated, ovate, abruptly narrowed at the base, gradually narrowed to the acute puberulous apex, light chestnut-brown, $\frac{3^{\prime}}{4}-1 \frac{1^{\prime}}{2} \operatorname{long}, \frac{1^{\prime}}{4}-\frac{3^{\prime}}{4}$ broad, the shell lined with a thick coat of pale tomentum, inclosed for one third its length or only at the base in a thin turbinate light brown cup coated on the inner surface witl soft pale silky pubescence, and covered by thin papery scales rounded at the narrow apex, and slightly puberulous, especially toward the base of the cup. 
A treę, occasionally $80^{\circ}-90^{\circ}$ high, with a short trunk $3^{\circ}-4^{\circ}$ or rarely $6^{\circ}-7^{\circ}$ in diameter, lividing a few feet above the base into numerous great limbs often resting on the ground and forming a low round-topped head frequently $150^{\circ}$ across, and slender dark gray or brown branchlets tinged with red, coated at first with hoary tomentum persistent until the second or third year; or sometimes the trunk, rising to the height of $30^{\circ}$ or $40^{\circ}$, is crowned by a narrow head of small branches; often much smaller; frequently shrubby in habit, with slender stems only a few feet high. Winter-buds globose and usually about $\frac{1}{16}$ ' long, or ovate-oblong, acute, and sometimes on vigorous shoots nearly $\frac{1}{4}$ in length, with thin broadly ovate closely imbricated light chestnut-brown glabrous or pubescent scales. Bark of young stems and branches thin, close, light brown or pale bluish gray, becoming on old trunks $2^{\prime}-3^{\prime}$ thick, dark brown slightly tinged with red, and divided into broad rounded ridges separating on the surface into small closely appressed scales. Wood heavy, liard, close-grained, very brittle, light brown or reddish brown, with thick darker colored sapwood; valued and largely used for fuel.

Distribution. Usually in open groves of great extent from Mendocino County, California, southward through the coast ranges and islands to Mt. San Pedro Martir, Lower California; less common at the north; very abundant and of its largest size in the valleys south of San Francisco Bay; frequently covering with semiprostrate and contorted stems the sand dunes on the coast in the central part of the state; in southwestern California the largest and most generally distributed Oak-tree between the mountains and the sea, often covering low hills and ascending to elevations of $2800^{\circ}$ in the cañons of the San Gorgonio Pass.

Occasionally cultivated as an ornamental tree in temperate western and southern Europe.

** Stamens usually $6-8$; stigmas dilated; abortive ovules basal or lateral; leaves persistent.

\section{Quercus chrysolepis, Liebm. Live Oak. Maul Oak.}

Leaves oblong-ovate to elliptical, acute or cuspidate at the apex, cordate, rounded or wedge-shaped at the base, mostly entire on old trees or often dentate or sinuate-

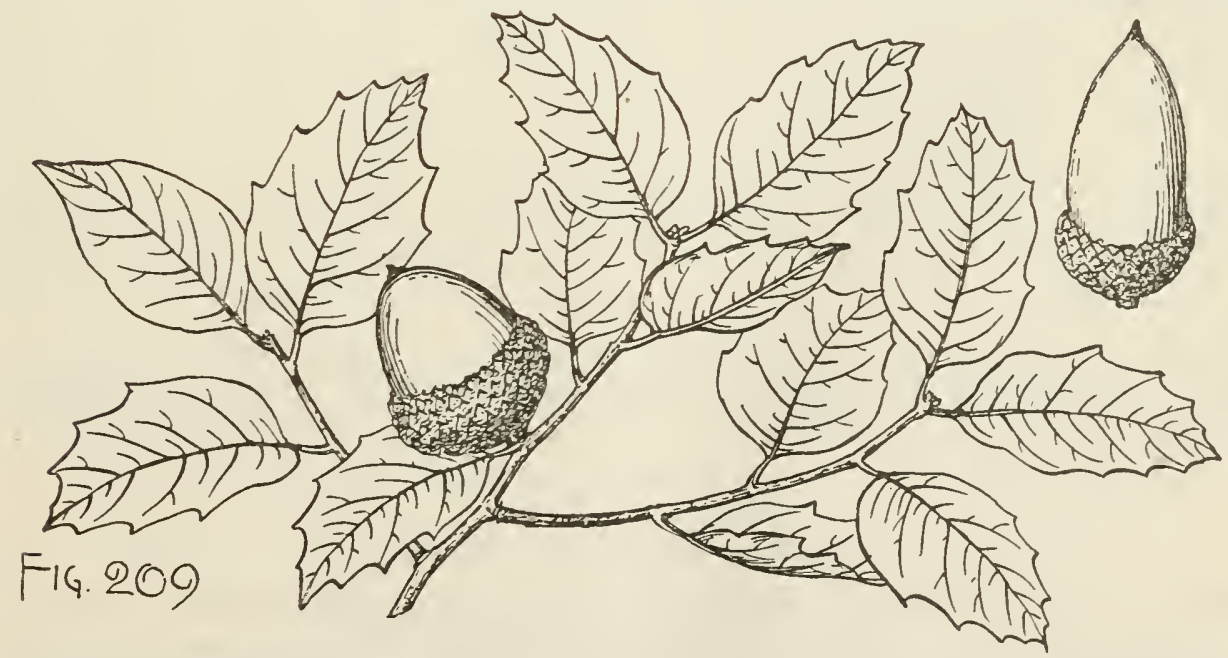

dentate on young trees, with 1 or 2 or many spinescent teeth, the two forms often appearing together on vigorous shoots, clothed when they unfold with a thick tomen- 
tum of fulvous articulate hairs soon deciduous from the upper and more gradually from the lower surface, at maturity thick and coriaceons, bright yellow-green and glabrous above, more or less fulvous-tomentose below during their first year, nltimately becuning glabrate and bluish white, $1^{\prime}-4^{\prime}$ long, $\frac{1}{2}^{\prime}-2^{\prime}$ wide, with thickened revolute margins; deciduous during their third and fourth years; their petioles slender, yellow, rarely $\frac{1^{\prime}}{2}$ long. Flowers: staminate in slender tomentose aments 2'-4' long; calyx light yellow, pubescent, divided usually into 5-7 broadly ovate acute ciliate lobes often tinged with red above the middle; pistillate sessile or subsessile or rarely in short few-flowered spikes, their broadly ovate involucral scales coated with fulvous tomentum; stigmas bright red. Fruit usually solitary, sessile or short-stalked; acorn oval or ovate, acute or rounded at the full or narrow slightly puberulous apex, light chestnut-brown, $\frac{1^{\prime}}{2}-2^{\prime}$ long and about as broad, the shell lined with a thin coat of loose tomentum, with abortive ovules scattered irregnlarly over the side of the seed, inclosed only at the base in a thin hemispherical or in a thick turbinate broad-rimmed cup pale green or dark reddish brown within, and covered by small triangular closely appressed scales, with short free tips clothed with hoary pubescence, or often hidden in a dense coat of fulvous tomentum.

A tree, usually not more than $40^{\circ}-50^{\circ}$ high, with a short trunk $3^{\circ}-5^{\circ}$ in diameter, dividing into great horizontal limbs sometimes forming a head $150^{\circ}$ across, and slender rigid or flexible branchlets coated at first with thick fulvous tomentum, becoming during their first winter dark brown somewhat tinged with red, tomentose, pubescent, or glabrous, and nltimately light brown or ashy gray; occasionally in sheltered cañons producing trunks $8^{\circ}-9^{\circ}$ in diameter; on exposed mountain sides forming dense thickets $15^{\circ}-20^{\circ}$ high; and on high subalpine slopes a low prostrate shrub (var. vaccinifolia, Engelm.), with small leaves and acorns and thin shallow cups covered by thin red-brown slightly pubescent scales. Winter-buds broadly ovate or oval, acute, about $\frac{1^{\prime}}{8}$ long, with closely imbricated light chestnut-brown usually puberulous scales. Bark $\frac{3^{\prime}}{4}-1 \frac{1^{\prime}}{2}$ thick, light or dark gray-brown tinged witl red, and covered by small closely appressed scales. Wood heavy, very strong, hard, tough, close-grained, light brown, with thick darker colored sapwood; used in the manufacture of agricultural implements and wagons.

Distribution. Southern Oregon, along the California coast ranges and the western slopes of the Sierra Nevada to the San Bernardino and San Jacinto mountains, and on Mt. San Pedro Martir in Lower California; on the high summits of the mountain ranges of southern Arizona, New Mexico, and northern Sonora, and here usually small or shrubby; of its largest size in the cañons of the coast ranges of central California and on the foothills of the Sierra Nevada, ascending to elevations of $8000^{\circ}-9000^{\circ}$ above the sea; in its Alpine shrubby form covering great areas with dense thickets; near the southern boundary of California usually shrubby, with rigid branches, rigid coriaceous oblong or semiorbicular spinose-dentate leaves, subsessile or pedunculate fruit, with ovate acute acorns $1-1 \frac{1}{2}^{\prime}$ long, their shell lined with thick or thin pale tomentum, and purple cotyledons (Q. chrysolepis, var. Palmeri, Engelm.).

\section{Quercus tomentella, Engelm.}

Leaves oblong-lanceolate, acute, sometimes cuspidate or occasionally rounded at the apex, broad and rounded or gradually narrowed and abruptly wedge-shaped at the base, remotely crenate-dentate, with small remote spreading callous tipped teeth, or entire, when they unfold light green tinged with red, covered above with scat- 
tered pale stellate hairs and below and on the petioles with thick hoary tomentum, at maturity thick and coriaceous, dark green, glabrous and lustrous on the upper surface, pale and covered with stellate hairs on the lower surface, $2^{\prime}-4^{\prime}$ long, $1^{\prime}-2^{\prime}$ wide, with thickened strongly revolute margins, and pubescent midribs, gradually deciduous during their third season; their petioles stout, pubescent, about $\frac{1}{2}^{\prime}$ long. Flowers: staminate in pubescent aments $21^{\prime}-14^{\prime}$ long, calyx light yellow, stellatepubescent, divided into 5-7 ovate acute lobes; pistillate subsessile or in few-flowered

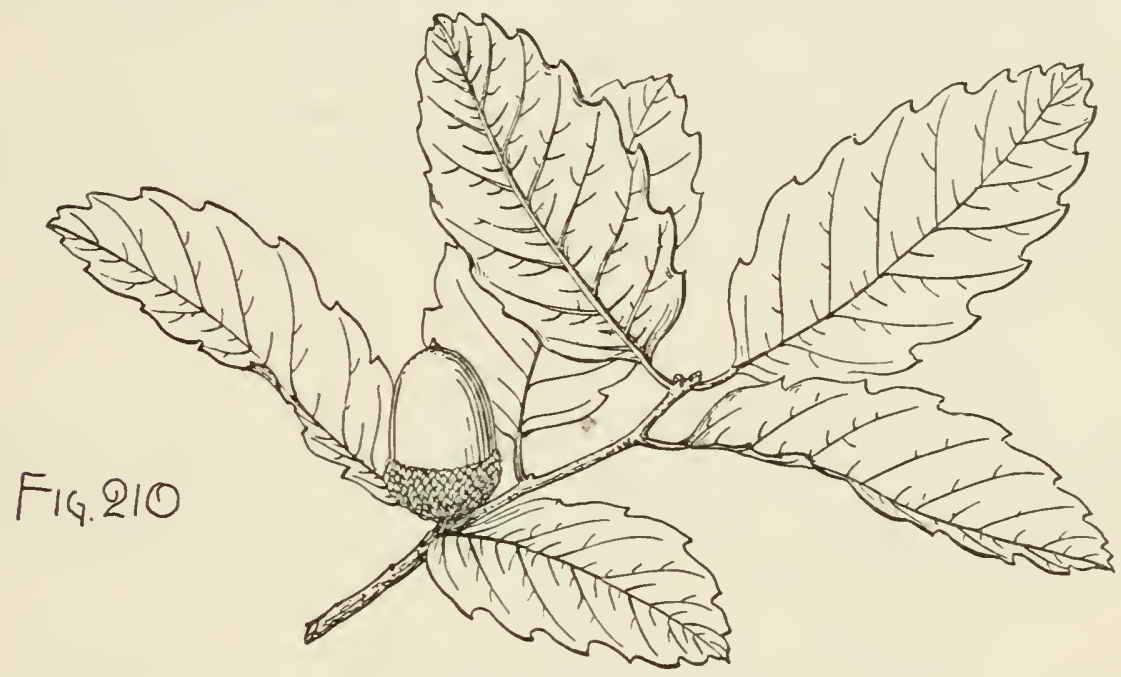

spikes on short or elongated pubescent peduncles, their involucral scales like the calyx coated with stellate hairs; stigmas red. Fruit subsessile or short-stalked; acorn oval, broad at the base, full and rounded at the apex, about $1 \frac{1}{2}^{\prime}$ long and $\frac{3^{\prime}}{4}$ wide, inclosed only at the base in a cup-shaped shallow cup thickened below, light brown and pubescent on the imner surface, and covered by thin ovate acute scales, with free chestnut-brown tips more or less hidden in a thick coat of hoary tomentum.

A tree, $30^{\circ}-40^{\circ}$, or occasionally $60^{\circ}$ high, with a trunk $1^{\circ}-2^{\circ}$ in diameter, spreading branches forming a shapely round-topped head, and slender branchlets coated at first with hoary tomentum, becoming light brown tinged with red or orange color. Winter-buds ovate, acute or obtuse, nearly $\frac{1^{\prime}}{4}$ long, with many loosely imbricated light chestnut-brown scales more or less clothed with pale pubescence. Bark thin, reddish brown, broken into large closely appressed scales. Wood heavy, hard, close-grained, compact, pale yellow-brown, with lighter colored sapwood.

Distribution. Deep narrow cañons and high wind-swept slopes of Santa Rosa, Santa Cruz, and Santa Catalina islands, California; on Guadaloupe Island off the coast of Lower California.

2. Stamens usually $6-8$; stigmas dilated; fruit maturing at the end of the first season; shell of the acorn glabrous on the inner surface (hoary-tomentose in 47); abortive ovules basal. Whiте Оакs.

*Leaves or their lobes usually without bristle tips except on vigorous shoots. + Leaves deciduous in their first autumn or winter. + Leaves lyrate or sinuate-pinnatifid, rarely entire.

\section{Quercus alba, I. White Oak.}

Leaves obovate-oblong, acute or rounded at the apex, gradually narrowed and wedge-shaped at the base, divided into usually 7 oblique broad or narrow mostly 
entire lobes, the lateral lobes sometimes slightly lobed, when they unfold bright red above, pale below and coated with soft pubeseence, soou becoming silvery white and very lustrous, at maturity thin, firm, glabrous, bright green and lustrous or dull above, pale or glaucous below, $5^{\prime}-9^{\prime}$ long, $2^{\prime}-4^{\prime}$ broad, with stout bright yellow midribs, conspicnous primary veins, turning late in the autumn deep rich vinous red, gradually withering and sometimes remaining on the branches nearly throngh the winter; their petioles stout, glabrous, $\frac{1^{\prime}}{2} \mathbf{1}^{\prime}$ loug. Flowers: staminate in hirsute or nearly glabrous aments $2 \frac{1}{2}^{\prime}-3^{\prime}$ long; calyx bright yellow and pubescent, with acute lobes; pistillate bright red, their involucral scales broadly ovate, hirsute, about as long as the ovate acute calyx-lobes. Fruit sessile or raised ou a slender peduncle $1^{\prime}-2^{\prime}$ long, the two forms sometimes appearing on the same brauch; acorn ovoid to oblong, rounded at the apex, lustrous, $\frac{3^{\prime}}{4}$ long, green when fully grown, becoming light chestnut-brown, inclosed for about one fourth its length in the cup-shaped cup

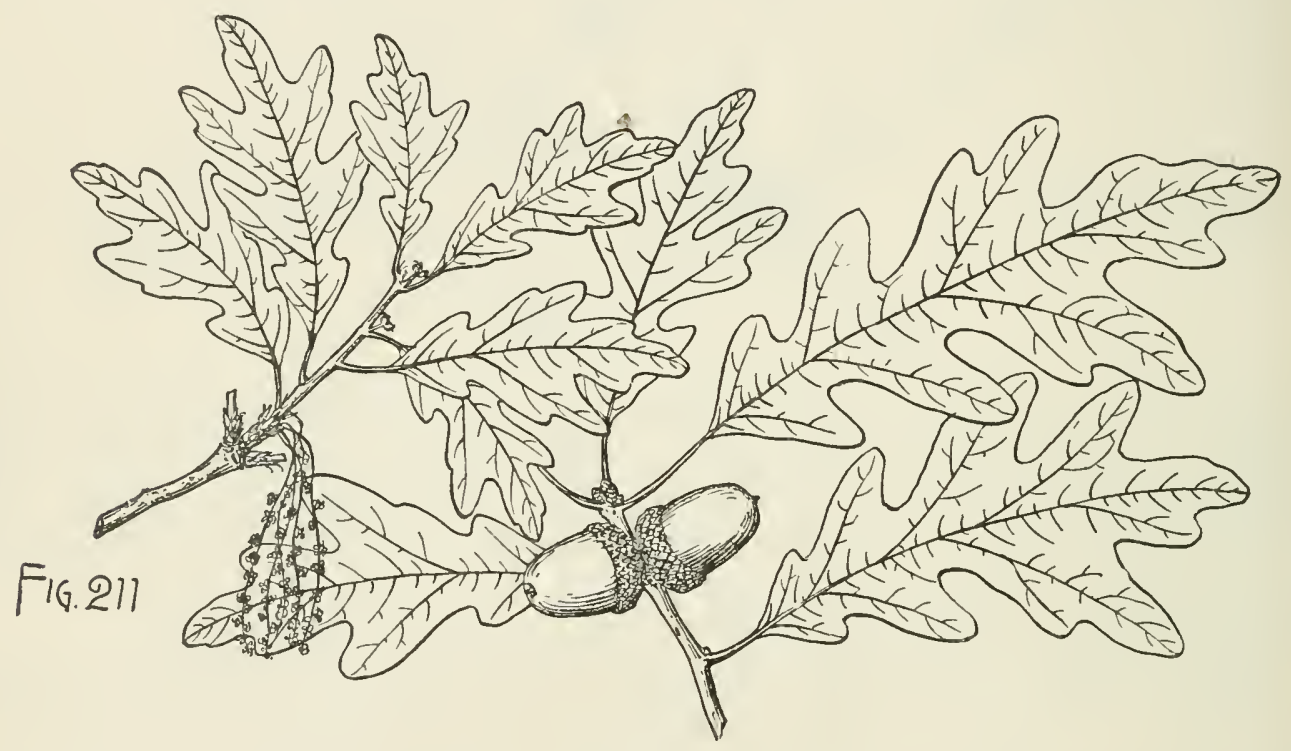

coated with pale or light brown tomentum, its scales at the base much thickened, united and produced into short obtuse membranaceous tips, and thinner toward the rim of the cup.

A tree, $80^{\circ}-100^{\circ}$ high, with a trunk $3^{\circ}-4^{\circ}$ in diameter, tall and naked in the forest, short in the open, and surmounted by a broad round-topped head of stout limbs spreading irregularly, small rigid branches, and slender branchlets at first bright green, often tinged with red, and coated with a loose mass of long pale or ferrugineous deciduous hairs, reddish brown during the summer, bright red and lustrous or covered with a glaucous bloom during their first winter, becoming ultimately ashy gray. Winter-buds broadly ovate, rather obtuse, dark red-brown, about $\frac{1}{8}^{\prime}$ long. Bark light gray slightly tiuged with red or brown, or occasionally nearly white, broken into thiu appressed scales, becoming on old trunks sometimes $2^{\prime}$ thick and divided into broad flat ridges. Wood strong, very heavy, hard, tough, close-grained, durable, light brown, with thin light brown sapwood; used in shipbuilding, for construction and in cooperage, the manufacture of carriages, agricultural implements, baskets, the interior finish of houses, cabinet-making, for railway-ties and fences, and largely as fuel. 
Distribution. Sandy plains and gravelly ridges, rich uplands, intervales, and moist bottom-lands, sometimes forming nearly pure forests; southern Maine to southwestern Quebec, westward through southern Ontario, the lower peninsula of Michigan, and southern Minnesota to southeastern Nebraska and eastern Kansas, and southward to northern Florida and the valley of the Brazos River, 'Texas; most abundant and of its largest size on the western slopes of the southern Alleghany Mountains, and on the bottom-lands of the lower Ohio basin.

\section{Quercus lobata, Née. White Oak. Valley Oak.}

Leaves oblong to obovate, deeply $7-11$ obliquely lobed, rounded at the narrowed apex, narrowed and wedge-shaped or broad and rounded or cordate at the base, the lateral lobes obovate, obtuse or retuse, or ovate and rounded, thin, $2 \frac{1}{2}^{\prime}-3^{\prime}$ or rarely $4^{\prime}$ long, $1^{\prime}-2^{\prime}$ broad, dark green and stellate-pubescent above, pale and pubescent below, with stout pale midribs, and conspicuons yellow veins running to the slightly thickened and revolute margins; their petioles stout, hirsute, $\frac{1}{4}^{\prime}-\frac{1}{2}^{\prime}$ long. Flowers: staminate in hirsute aments $2^{\prime}-3^{\prime}$ long; calyx light yellow and divided into 6 or 8 acute pubescent ciliate lobes; pistillate solitary, sessile or rarely in elongated fewflowered spikes, their involucral scales broadly ovate, acute, coated with dense pale tomentum, about as long as the narrow calyx-lobes. Fruit solitary or in pairs, nearly sessile; acorn conical, elongated, rounded or pointed at the apex, $1 \frac{1}{4}^{\prime}-2 \frac{1}{4}^{\prime}$ long,

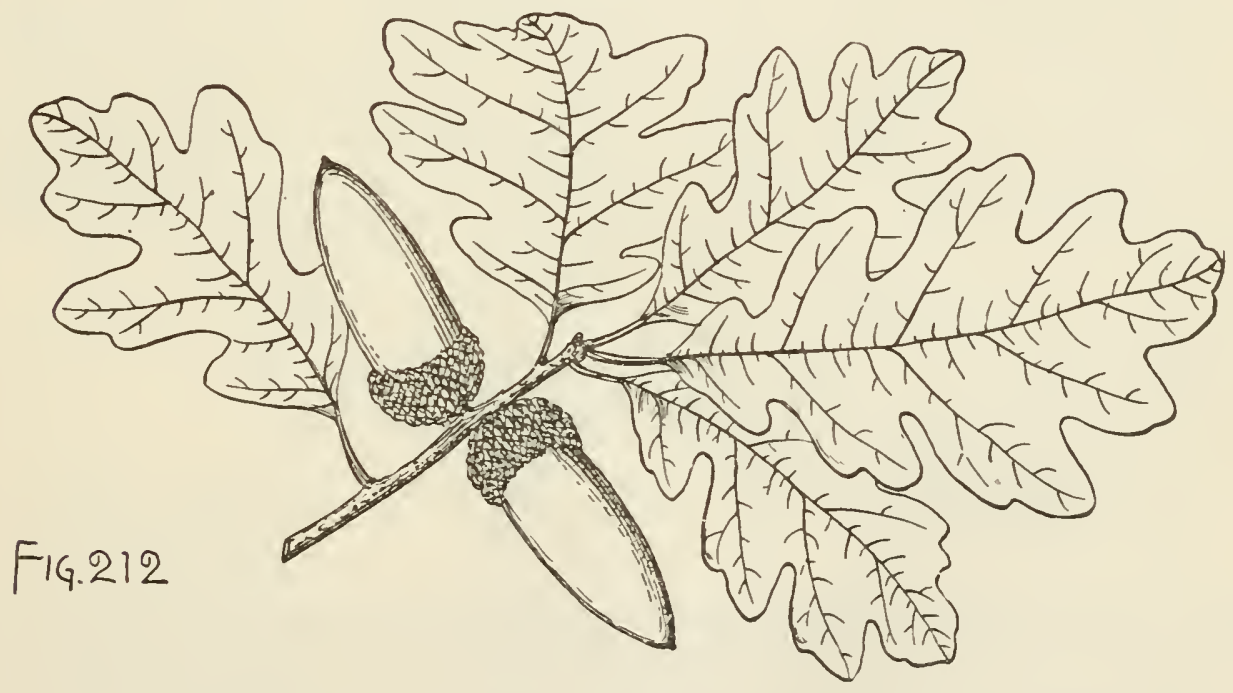

bright green and lustrous when fully grown, becoming bright chestnut-brown, usually inclosed for about one third its length in the cup-shaped cup coated with pale tomentum on the outer surface, usually irregularly tuberculate below, all but the much-thickened basal scales elongated into acute ciliate chestnut-brown free tips longest on the upper scales and forming a short fringe-like border to the rim of the cup.

A tree, often $100^{\circ}$ high, with a trunk generally $3^{\circ}-4^{\circ}$, but sometimes $10^{\circ}$ in diameter, divided near the ground or usually $20^{\circ}-30^{\circ}$ above it into great limbs spreading at wide angles and forming a broad head of slender branches hanging gracefully in long sprays and sometimes sweeping the ground; less frequently with upper limbs growing almost at right angles with the trunk and forming a narrow rigid head of 
variously contorted erect or pendant branches, and slender branchlets coated at first with short silky canescent pubescence, ashy gray, light reddish brown, or palc orangebrown and slightly pubesecnt in their first winter, becoming glabrous and lighter colored during their sccond year. Winter-buds ovate, acute, usually about $\frac{1}{4}$ long, with orange-brown pubescent seales searious and frequently ciliate on the margins. Bark $\frac{3}{4}-11_{2}^{\prime}$ thick and covered by small looscly appressed light gray scales slightly tinged with orange or brown, beconing at the base of old trees frequently $5^{\prime}-6^{\prime}$ thick and divided by longitudinal fissures into broad flat ridges, broken horizontally into short plates. Wood hard, fine-grained, brittle, light brown, with thin lighter colored sapwood; used only for fuel.

Distribution. Valleys of western California between the Sierra Nevada and the ocean from the upper Sacramento to the Tejon Pass; most abundant and forming open groves in the central valleys of the state.

\section{Quercus Garryana, Hook. White Oak.}

Leaves obovate to oblong, pointed at the apex, wedge-shaped or rounded at the base, coarsely pinnatifid-lobed, with slightly thickened revolute margins, coated at first with soft pale lustrons pubescence, at maturity thick and firm or subcoriaceous,

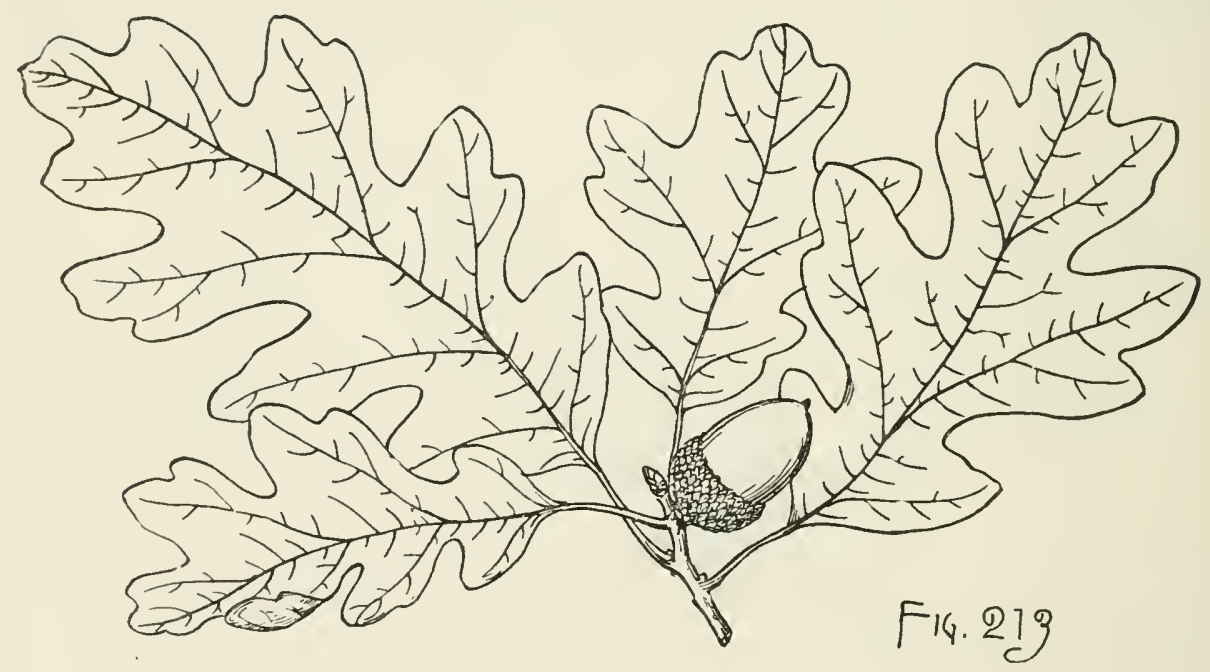

dark green and lustrous and glabrous above, light green or orange-brown and pubescent or glabrate on the lower surface, $4^{\prime}-6^{\prime}$ long, $2^{\prime}-5^{\prime}$ broad, with stout yellow midribs, and conspicuous primary veins spreading at right angles, or gradually diverging from the midrib and running to the points of the lobes, sometimes turning bright scarlet in the autumn; their petioles stout, pubescent, $\frac{1^{\prime}}{2}-1^{\prime}$ long. Flowers: staminate in hirsute aments; calyx glabrous, laciniately cut into ovate acute slightly ciliate or linear-lanceolate much elongated segments; pistillate sessile and coated with pale tomentum. Fruit sessile or short-stalked; acorn oval to slightly obovate and obtuse, $1^{\prime}-1 \frac{1^{\prime}}{4}$ long and $\frac{1}{2}^{\prime}-1^{\prime}$ broad, inclosed at the base in a shallow cup-shaped or slightly turbinate cup puberulous and light brown on the inner surface, pubescent or tomentose on the outer, and covered by ovate acute scales with pointed and often elongated tips, thin, free, or sometimes thickened and more or less united toward the base of the cup, decreasing from below upward.

A tree, usually $60^{\circ}-70^{\circ}$ or sometimes nearly $100^{\circ}$ high, with a trunk $2^{\circ}-3^{\circ}$ in 
diameter, stout ascending or spreading branches forming a broad compact head, and stout branchlets coated at first with thick pale rufous pubescence, pubescent or tomentose and light or dark orange color during their first winter, becoming glabrous and rather bright reddish brown in their second year and ultimately gray; or frequently at high elevations, or when exposed to the winds from the ocean, reduced to a low shrub. Winter-buds ovate, acnte, $\frac{1}{3}^{\prime}-\frac{1}{2}^{\prime}$ long, densely clothed with light ferrugineous tomentmm. Bark $\frac{1^{\prime}}{8}-1^{\prime}$ thick, divided by shallow fissures into broad ridges separating on the surface into light brown or gray scales sometimes slightly tinged with orange color. Wood strong, hard, close-grained, frequently exceedingly tough and valuable, light brown or yellow, with thin nearly white sapwood; in Oregon and Washington used in the manufacture of carriages and wagons, in cabinet-making, shipbuilding, and cooperage, and largely as fuel.

Distribution. Valleys and the dry gravelly slopes of low hills; Vancouver Island and the valley of the lower Fraser River southward through western Washington and Oregon and the California coast-valleys to the Santa Cruz Mountains; rare and local and the only Oak-tree in British Colnmbia; abundant and of its largest size in the valleys of western Washington and Oregon, and ascending in its shrubby forms to considerable elevations on the western slopes of the Cascade Mountains; abundant in northwestern California; less common and of smaller size southward.

\section{Quercus Gambelii, Nutt. White Oak. Shin Oak.}

Leaves broadly obovate to oblong-lanceolate, rounded at the narrow apex, wedgeshaped or sometimes narrowed and rounded or broad and cordate at the base, variously lobed or pinnatifid, the lobes entire, emarginate, or lobed, when they unfold coated below with thick white tomentum and above with scattered stellate pubescence, at maturity thick and firm, glabrous and rarely stellate-pubescent, lustrous and dark yellow-green or dull yellow-green above, and paler and soft-pubescent

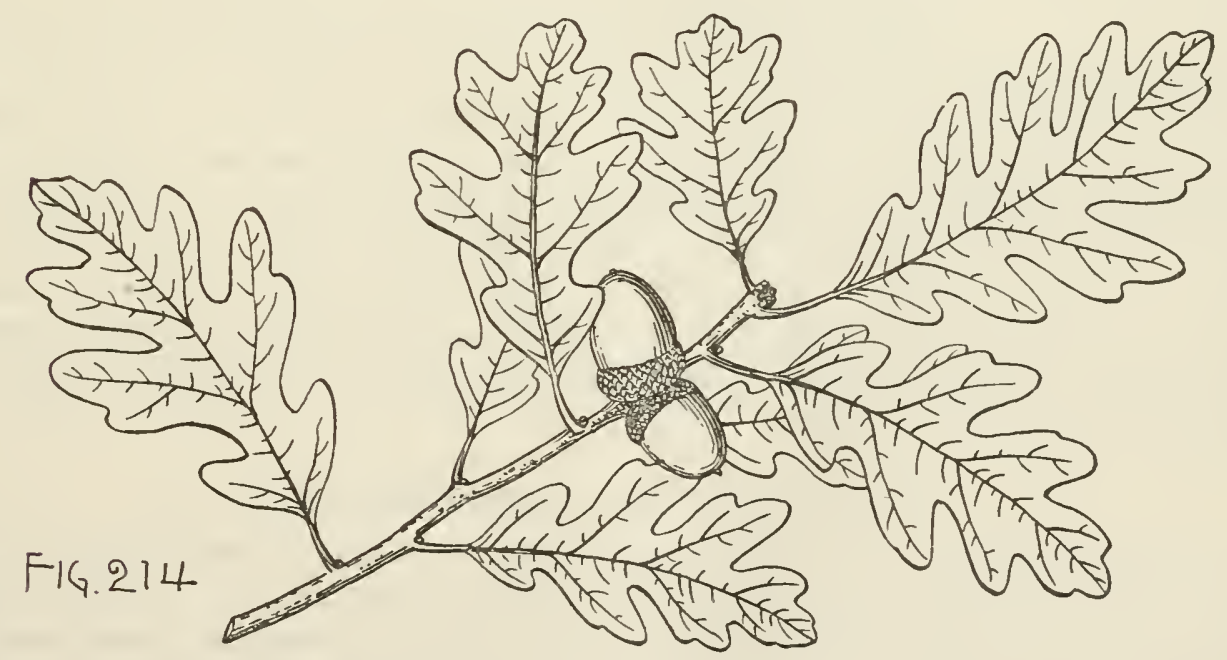

below, $3^{\prime}-5^{\prime}$ long, $1^{\prime}-5^{\prime}$ wide, with prominent pale midribs hirsute below and occasionally above, primary veins rmnning to the points of the lobes, secondary veins arcuate and united near the margins, and conspicuous veinlets, turning scarlet or orange-colored in the autumn; their petioles stout, glabrous, $\frac{1^{\prime}}{4}-\frac{1^{\prime}}{2}$ long. Flowers: staminate in slender hirsute aments; calyx yellow, divided into 5 or 6 acute lobes; 
pistillate bright red, sessile or short-stalked, solitary or in elongated few-flowered spikes, their involueral scales ovate, rounded, eated with soft pale tomentum, about as long as the aeute ealyx-lobes. Fruit sessile or peduneulate; acorn oval, broad at the base, obtuse and rounded or sometimes narrowed and acute at the apex, usually about $\frac{s^{\prime}}{4}$ long and $\frac{5^{\prime}}{8}$ wide, frequently mueh sualler, dark ehestmut-brown or nearly black, ultimately becoming light chestunt-brown, nore or less deeply inelosed in the saneer-shaped, enp-shaped, or rarely turbinate enp light browu and pubeseent on the imer surface, eoated ou the outer surface with pale tomentum, and mueh roughened below by the thiekened mostly united seales rounded on the baek and narrowed exeept at the base of the eup into short pointed free tips, or rarely with the lower seales only slightly thickened, with long free tips.

A tree, $20^{\circ}-25^{\circ}$ ligh, with a trunk $1^{\circ}$ in diameter, or rarely $40^{\circ}-50^{\circ}$ high, with a trunk $18^{\prime}$ in diameter, snall branehes spreading nearly at right angles and forming a narrow round-topped head, and slender branehlets eoated at first with short pale ferrugineous tomentum, beeoming light orange-brown or reddish brown and glabrous or puberulous in their first winter, growing gradually darker or sometimes ashy gray during their seeond and third years and ultimately dark brown or gray; more often shrubby, forming by vigorous stolons broad low thiekets $3^{\circ}-4^{\circ}$ or $15^{\circ}-20^{\circ}$ high, with a single stem often rising high above the others. Winter-buds ovate, aeute, or obtuse, about $\frac{1}{8}^{\prime}$ long, with light ehestnut-brown pubeseent seales. Bark $\frac{1^{\prime}}{2}-\frac{8 \prime}{4}$ thiek, and deeply divided into broad irregular and often conneeted flat ridges separating on the surface into thin dark gray seales frequently tinged with red or brown. Wood heavy, hard, strong, often tough, dark red-brown, with thin lighter eolored sapwood; largely used for fuel. The bark is oeeasionally used in tanning leather.

Distribution. Eastern slopes of the Rocky Mountains of Colorado at elevations of $6000^{\circ}-7000^{\circ}$ above the sea, westward to the Wasateh Mountains of Utah and sonthward over mountain ranges and high plateaus to the mouth of the Peeos River, Texas, the Charleston Mountains of south western Nevada, and the mountains of northern Sonora; common and usually shrubby on the eastern foothills of the Roeky Monntains; more abundant and the only Oak in southern and southwestern Colorado, often aseending to elevations of nearly $10,000^{\circ}$, and frequently eovering hillsides with interrupted thickets thousands of aeres in extent; very abundant on the mountains of northern New Mexico and western Texas; the common Oak of the Colorado platean, and of its largest size in southern' Utah and northern Arizona at elevations of $6000^{\circ}-7000^{\circ}$ above the sea; on the mountains of southern New Mexico and Arizona forming a narrow fringe above the groves of Evergreen Oaks and below the forests of Nut Pines.

\section{Quercus minor, Sarg. Post Oak.}

Leaves oblong-obovate, usually deeply 5-lobed, with broad sinuses oblique at the bottom, and short wide lobes, broad and obtusely pointed at the apex, gradually narrowed and wedge-shaped or oceasionally abruptly narrowed and wedge-shaped or rounded at the base, when they unfold dark red above and densely pubeseent, at maturity thick and firm, deep dark green and roughened by seattered stellate pale hairs above, eovered below with gray, light yellow, or rarely silvery white pubeseence, usually $4^{\prime}-5^{\prime}$ long and $3^{\prime}-4^{\prime}$ across the lateral lobes, with broad lightcolored midribs pubeseent on the npper side and tomentose or pubeseent on the lower, stout lateral veins arenate and united near the margins and conneeted by 
conspicuous coarsely reticulated veinlets, turning dull yellow or brown in the autumn; their petioles stout, pubescent, $\frac{1}{2}^{\prime}$ to nearly $1^{\prime}$ long. Flowers: staminate in aments $3^{\prime}-4^{\prime}$ long; calyx hirsute, yellow, usually divided into 5 ovate acute laciniately cut segments; anthers covered by short scattered pale hairs; pistillate sessile or stalked,

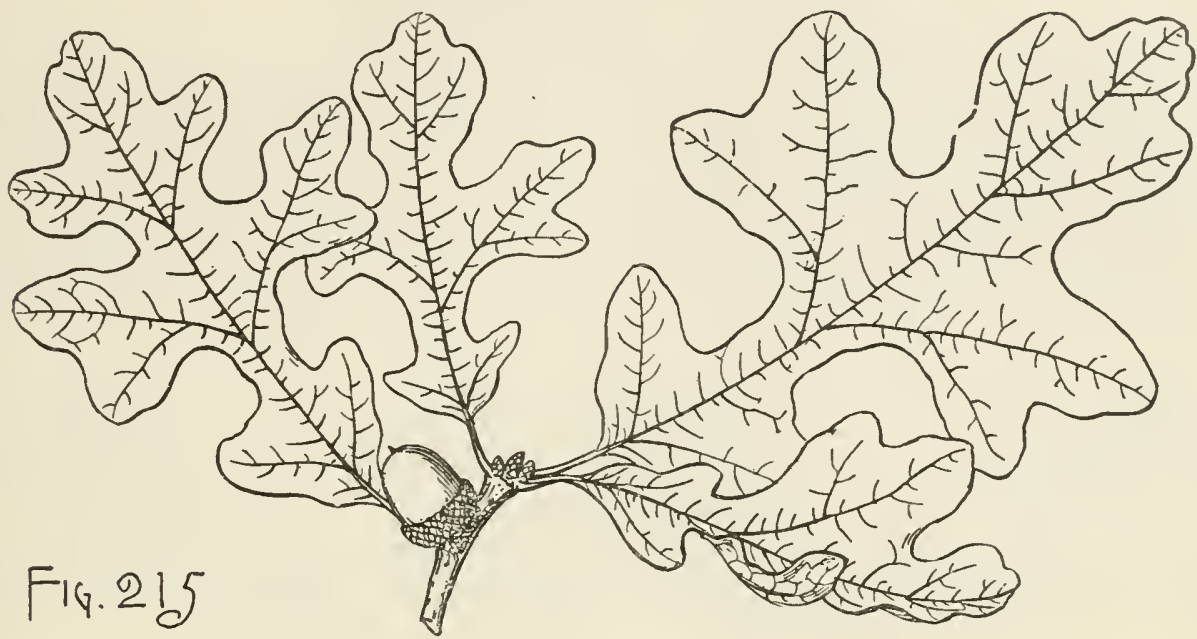

their involucral scales broadly ovate, hirsute; stigmas bright red. Fruit sessile or short-stalked; acorn oval to ovate or ovate-oblong, broad at the base, obtuse and naked or covered with pale persistent pubescence at the apex, $\frac{1^{\prime}}{2}-1^{\prime}$ long, $\frac{1}{4}^{\prime}-3^{\prime}$ broad, sometimes striate, with dark longitudinal stripes, inclosed for one third to one half its length in the cup-shaped turbinate or rarely saucer-shaped cup pale and pubescent on the inner surface, hoary-tomentose on the outer surface, and covered by thin ovate scales rounded and acute at the apex, reddish brown and sometimes toward the rim of the cup ciliate on the margins, with long pale hairs.

A tree, rarely $100^{\circ}$ high, with a trunk $2^{\circ}-3^{\circ}$ in diameter, and stout spreading branches forming a broad dense round-topped head, and stout branchlets coated at first, like the young leaves and petioles, the stalks of the aments of staminate flowers and the peduncles of the pistillate flowers, with thick orange-brown tomentum, light orange color to reddish brown, and covered by short soft pubescence during their first winter, ultimately gray, dark brown, or nearly black or bright brown tinged with orange color; usually not more than $50^{\circ}-60^{\circ}$ tall, with a trunk $1^{\circ}-2^{\circ}$ in diameter, and at the northeastern limits of its range generally reduced to a shrub. Winter-buds broadly ovate, obtuse or rarely acute, $\frac{1^{\prime}}{8}-\frac{1}{4}^{\prime}$ long, with bright chestnut-brown pubescent scales coated toward the margins with scattered pale hairs. Bark $\frac{1^{\prime}}{2}-1^{\prime}$ thick, red more or less deeply tinged with brown, and divided by deep fissures into broad ridges covered on the surface with narrow closely appressed scales. Wood very heavy, hard, close-grained, durable in contact with the soil, difficult to season, light or dark brown, with thick lighter colored sapwood; largely used for fuel, fencing, railway-ties, and sometimes in the mannfacture of carriages, for cooperage, and in construction.

Distribution. Cape Cod and islands of southern Massachusetts, Rhode Island, and Long Island, New York to nortleern Florida and southern Alabama and Mississippi, and from New York westward to Missouri, eastern Kansas, the Indian Territory, and Texas; most abundant and of its largest size on dry gravelly uplands in 
the Mississippi basin; the common Oak of central Texas on limestone lills and sandy plains; usually shrubby and rare and local in southern Massachusetts; more abundant soutliward from the coast of the south $\Lambda$ tlantic and the eastern Gulf states to the lower slopes of the Apalachian Mountains.

\section{Quercus Chapmani, Sarg.}

Leaves oblong to oblong-obovate, rounded at the narrow apex, narrowed and wedge-slaped or rounded or broad and rounded at the base, entire, with slightly undulate margins, or obscurely sinuate-lobed above the middle, when they unfold coated below with thick bright yellow pubescence and covered above witlı pale stellate decidnous hairs, at maturity thick and firm or subcoriaceous, dark green, glabrous and lustrous above, light green or silvery white and glabrous below except on

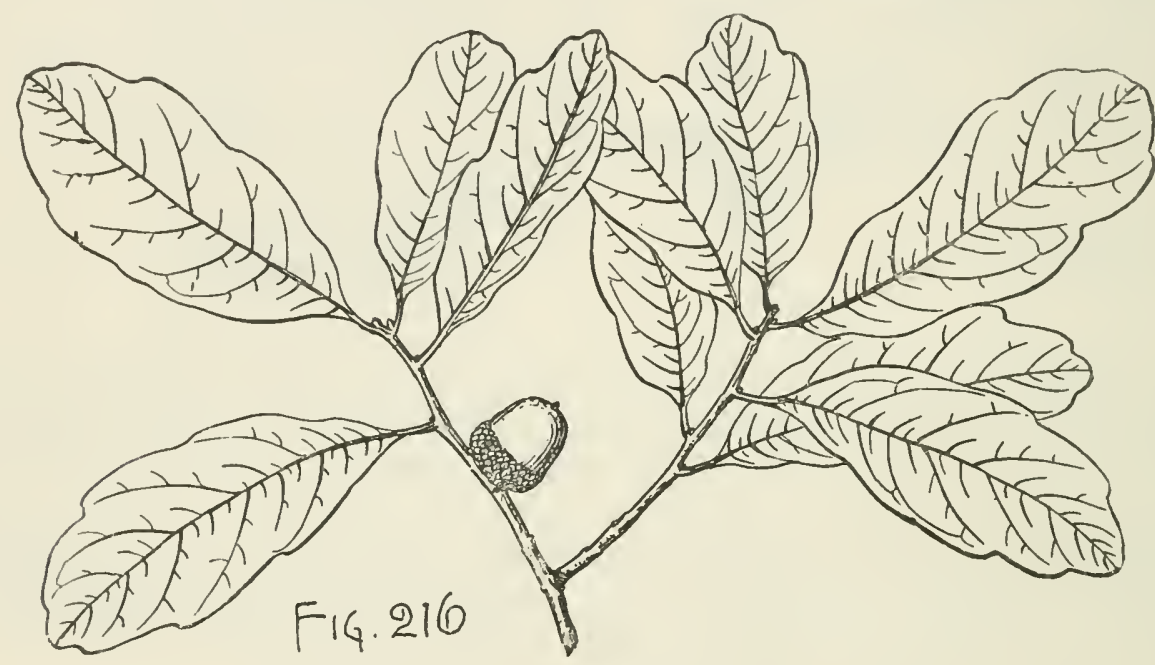

the slender often pubescent midribs, usually $2^{\prime}-3^{\prime}$ long and $1^{\prime}$ wide, but varying from $1^{\prime}-3^{\prime}$ in length and $\frac{3^{\prime}}{4}-1^{\prime}$ in width, falling gradually during the winter or sometimes persistent until the appearance of the new leaves in the spring; their petioles tomentose, rarely $\frac{1}{8}$ long. Flowers: staminate in short hirsnte aments; calyx hirsute, divided into 5 acute laciniately cut segments; anthers hirsute; pistillate sessile or shortstalked, their involucral scales coated with dense pale tomentum. Fruit usually sessile, solitary or in pairs; acorn oval, abont $\frac{5^{\prime}}{8}$ long and $\frac{3^{\prime}}{8}$ broad, pubescent from the obtuse rounded apex nearly to the iniddle, inclosed for nearly one half its length in the deep cup-shaped light brown cup slightly pubescent on the inner surface, and covered by ovate-oblong pointed scales thickened on the back, especially toward the base of the cup, and coated with pale tomentum except on their thin reddish brown margins.

Occasionally a tree, $30^{\circ}$ high, with a trunk $1^{\circ}$ in diameter, stout branches forming a round-topped head, and slender branchlets coated at first with dense bright yellow pubescence, becoming light or dark red-brown and puberulous during their first winter and ultimately ashy gray; more often a rigid shrub sometimes only $1^{\circ}-2^{\circ}$ tall. Winter-buds ovate, acute, obtuse, about $\frac{1{ }^{\prime}}{8}$ long, with glabrous or puberulous light chestnut-brown scales. Bark dark, separating into large irregular plate-like scales.

Distribution. Sandy barren Pine lands usually in the immediate neighborhood of the coast from South Carolina to Florida; comparatively rare on the Atlantic sea- 
board and in the interior of the Florida peninsula; very abundant in western Florida from the shores of Tampa Bay to Appalachicola and Santa Rosa Island.

\section{Quercus macrocarpa, Michx. Burr Oak. Mossy Cup Oak.}

Leaves obovate or oblong, wedge-shaped or occasionally narrow and rounded at the base, divided by wide sinuses sometimes penetrating nearly to the midrib into 5-7 lobes, the terminal lobe large, oval or obovate, regularly crenately lobed, or smaller and 3-lobed at the rounded acute apex, when they unfold yellow-green and pilose above and silvery white and coated below with long pale hairs, at maturity thick and firm, dark green, lustrous and glabrous, or occasionally pilose on the upper surface, pale green or silvery white and covered on the lower surface with soft pale or rarely rufous pubescence, $6^{\prime}-12^{\prime}$ long, $3^{\prime}-6^{\prime}$ wide, with stout pale midribs sometimes pilose on the npper side and pubescent on the lower, large prinary veins running to the points of the lobes, and conspicuous reticulate veinlets, turning dull yellow or yellowish brown in the autumn; their petioles stout, $\frac{1}{3}^{\prime}-1^{\prime}$ in length. Flowers: staminate in slender aments $4^{\prime}-6^{\prime}$ long, with yellow-green stems coated with loosely matted pale hairs; calyx yellow-green, pubescent, divided into 4-6 laciniately cut acute segments ending in tufts of long pale hairs; pistillate sessile or stalked; their involucral scales broadly ovate, often somewhat tinged with red toward the margins

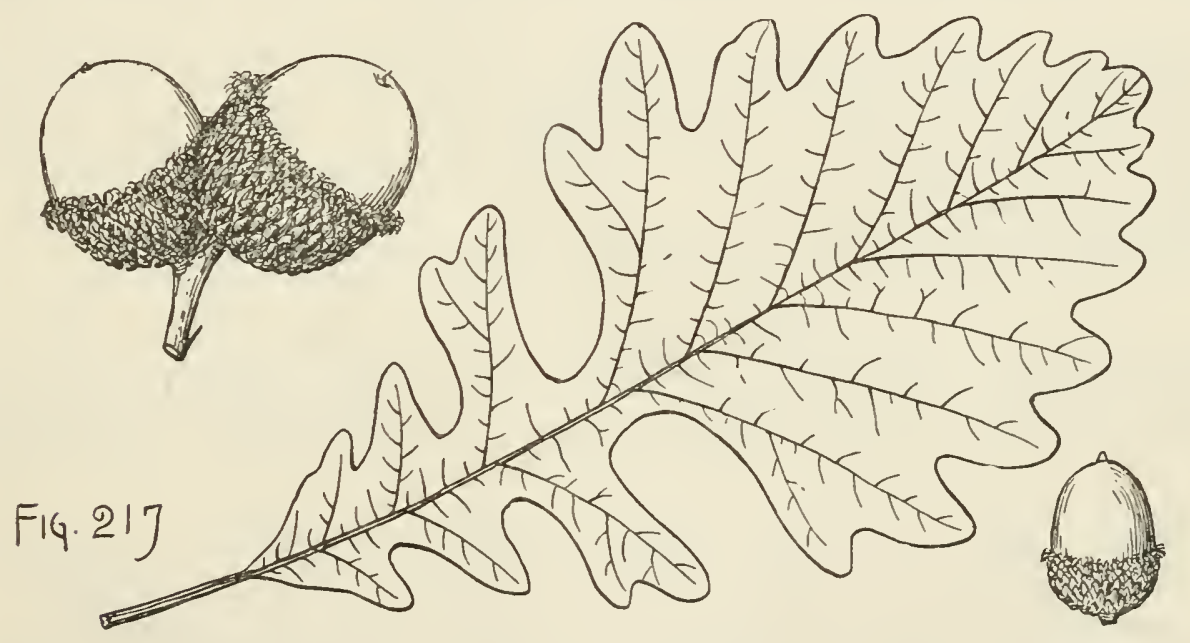

and coated, like the peduncles, with thick pale tomentum; stigmas bright red. Fruit usually solitary, sessile or long-stalked, exceedingly variable in size and shape; acorn oval or broadly ovate, broad at the base and romded at the obtuse or depressed apex covered by soft pale pubescence, $\frac{3 \prime}{5}$ long and $\frac{1^{\prime}}{3}$ wide at the north, sometimes $2^{\prime}$ long and $1 \frac{1}{2}^{\prime}$ wide in the south, its cup thick or thin, light brown and pubescent on the inner surface, hoary-tomentose and covered on the onter surface by large irregularly imbricated ovate pointed scales, at the base of the cup thin and free or sometimes much thickened and tuberculate, and near its rim generally developed into long slender pale awns forming on northern trees a short inconspicuous and at the south a long conspicuous matted fringe-like border inclosing only the base or nearly the entire acorn.

A tree, sometimes $170^{\circ}$ high, with a trunk $6^{\circ}-7^{\circ}$ in diameter, clear of limbs for $70^{\circ}-80^{\circ}$ above the ground, a broad head of great spreading branches, and stout branchlets coated at first with thick soft pale deciduous pubescence, light orange 
color, usually glabrous or occasionally puberulous during thcir first winter, becoming ashy gray or light brown and ultimately dark brown, sometimes developing corky wings often $1^{\prime}-1 \frac{1^{\prime}}{2}$ wide; usually not more than $80^{\circ}$ ligh, with a trunk $3^{\circ}-4^{\circ}$ in diameter; toward the northwestern limits of its range sometimes a low shrub. Winterbuds broadly ovate, acute or obtuse, $\frac{1{ }^{\prime}}{8}-\frac{1}{4}$ long, with light red-brown scales coated with soft pale pubescence. Bark $1^{\prime}-2^{\prime}$ thick, deeply furrowed and broken on the surface into irregular plate-like brown scales often slightly tinged with red. Wood heavy, strong, hard, tough, close-grained, very durable, dark or rich light brown, with thin much lighter colored sapwood; used in ship and boatbuilding, for construction of all sorts, cabinet-making, cooperage, the manufacture of carriages, agricultural implements, baskets, railway-ties, fencing, and fuel.

Distribution. Low rich bottom-lands and intervales or rarcly in the northwest on low dry hills; Nova Scotia and New Brunswick westward through the valley of the St. Lawrence River to Ontario, and along the northern shores of Lake Huron to southern Manitoba, southward to the valley of the Penobscot River, Maine, to the shores of Lake Champlain, Vermont, western Massachusetts, Lancaster County, Pennsylvania, central Tennessee, the Indian Territory and the valley of the Nueces River, Texas, westward to the eastern foothills of the Rocky Mountains of Montana, western Nebraska and central Kansas; attaining its largest size in southern Indiana and Illinois; the common Oak of the "oak openings" of western Minnesota, and in all the basin of the Red River of the North, ranging farther to the northwest than the other Oaks of eastern America; common and generally distributed in Nebraska, and of a large size in cañons or on river bottoms in the extreme western part of the state; the most generally distributed Oak of Kansas, growing to a large size in all the eastern part of the state.

Occasionally planted as an ornamental tree in the eastern United States.

\section{Quercus lyrata, Walt. Overcup Oak. Swamp White Oak.}

Leaves obovate-oblong, gradually narrowed and wedge-shaped at the base, $\dot{\mathrm{d}}$ ivided into 5-9 lobes by deep or shallow sinuses, rounded, straight, or oblique at the

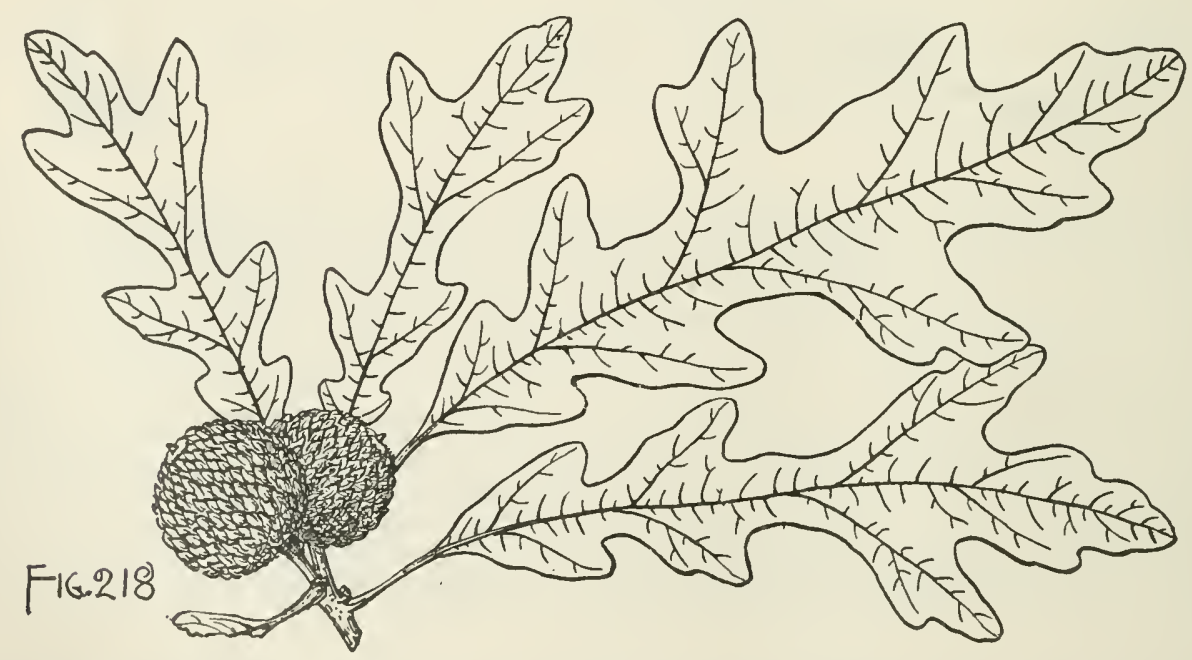

bottom, the terminal lobe oblong-ovate, usually broad, acute at the elongated apex, and furnished with 2 small entire nearly triangular lateral lobes, the upper lateral 
lobes broad, more or less emarginate, much longer than the acute or rounded lower lobes, when they unfold bronze-green and pilose above, with caducous hairs, and coated below with thick pale tomentum, at maturity thin and firm, dark green and glabrous above, silvery white or rarely light green, and coated with pale pubescence below, $7^{\prime}-8^{\prime}$ long, $1^{\prime}-4^{\prime}$ broad, turning bright scarlet or scarlet and orange in the autumn; their petioles glabrous or pubescent, $\frac{1}{3}^{\prime}-1^{\prime}$ long. Flowers: staminate in slender hairy aments $4^{\prime}-6^{\prime}$ long; calyx light yellow, coated on the outer surface with pale hairs and divided into acute segments; pistillate sessile or stalked, their involucral scales covered, like the peduncles, with thick pale tomentum. Fruit sessile or borne on slender pubescent peduncles sometimes $1 \frac{1}{2}^{\prime}$ long; acorn subglobose to ovate or rarely to ovate-oblong, $\frac{1}{2}^{\prime}-1^{\prime}$ long, nsually broader at the base than long, light chestnut-brown, more or less covered above the middle with short pale pubescence, almost or entirely or rarely for only half its length inclosed in the ovate or rarely deeply cup-shaped or nearly spherical thin cup, bright red-brown and pubescent on the inner surface, hoary-tomentose and covered on the onter by ovate united scales produced into acute tips, much thickened and contorted at its base, gradually growing thinner and forming a ragged edge to the thin often irregularly split margin of the cup.

A tree, rarely $100^{\circ}$ high, with a trunk $2^{\circ}-3^{\circ}$ in diameter, generally divided $15^{\circ}-$ $20^{\circ}$ above the ground iuto comparatively small often pendulous branches forming a landsome symmetrical round-topped head, and slender branchlets green more or less tinged with red and pilose or pubescent when they first appear, light or dark orangecolor or grayish brown and usually glabrous during their first winter, ultimately becoming ashy gray or light brown. Winter-buds ovate, obtuse, about $\frac{1}{8}^{\prime}$ long, with light chestnut-brown scales clothed, especially near their margins, with loose pale tomentum. Bark $\frac{3^{\prime}}{4}-1^{\prime}$ thick, light gray tinged with red and broken into thick plates separating on the surface into thin irregular appressed scales. Wood heavy, hard, strong, tough, very durable in contact with the ground, rich dark brown, with thick lighter colored sapwood; confounded commercially with the wood of Quercus alba, and used for the same purpose.

Distribution. River swamps and small deep depressions on rich bottom-lands, usually wet throughout the year; valley of the Patuxent River, Maryland, southward near the coast to western Florida, through the Gulf states to the valley of the Trinity River, Texas, and through Arkansas and southeastern Missouri to central Tennessee, southern Indiana and Illinois; rare in the Atlantic and east Gulf states; most common and of its largest size in the valley of the Red River, Lonisiana, and the adjacent parts of Texas and Arkansas.

Occasionally cultivated in the northeastern states and hardy in eastern Massachusetts.

++ Leaves coarsely sinuate-toothed. Chestnut Oaks.

\section{Quercus platanoides, Sudw. Swamp White Oak.}

Leaves obovate to oblong-obovate, rounded at the narrowed apex, acute or rounded at the gradually narrowed and wedge-shaped entire base, coarsely sinuate-dentate, or sometimes pinnatifid, with oblique rounded or acute entire lobes, when they unfold light bronze-green and pilose above, covered below with silvery white tomentum, with conspicuous glands on the teeth, at maturity thick and firm, dark green and lustrous on the upper surface, pale or often silvery white or tawny on the lower 
surface, $5^{\prime}-6^{\prime}$ long, $2^{\prime}-4^{\prime}$ wide, with slender yellow midribs, primary veins rumning to the points of the lobes, and conspicuous reticulate veinlets, turning in the autumn dull yellow-brown or occasionally orange-color or red before falling; their petioles stout, pilose at first, becoming glabrous, $\frac{1}{2}-\frac{8^{\prime}}{4}$ long. Flowers: staninate in hairy aments $3{ }^{\prime}-4^{\prime}$ long; ealyx light yellow-green, hirsute, with pale hairs, and deeply divided into 5 -9 lanceolate acute segments rather shorter than the stamens; pistillate in few-flowered spikes on elongated peduncles covered like their involucral

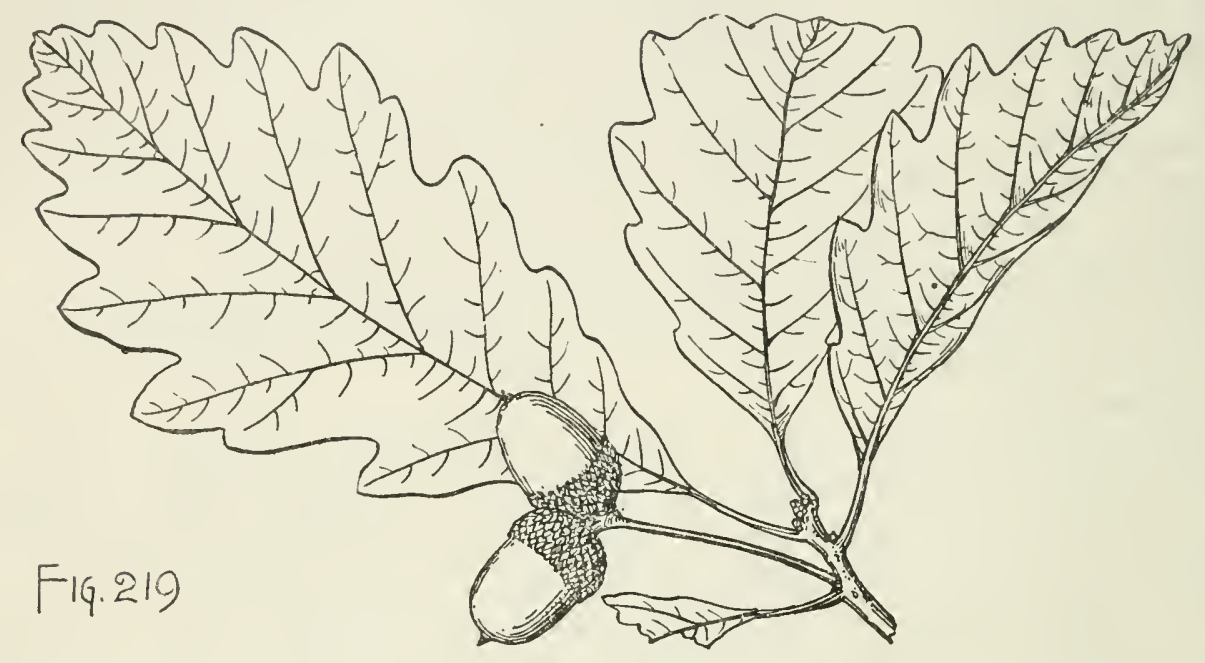

scales with thick white or tawny tomentum, stigmas bright red. Fruit usually in pairs on slender dark brown glabrous puberulous or pubescent stalks $1_{2}^{\prime}-4^{\prime}$ long; acorn oval, with a broad base, rounded, acute, and pubescent at the apex, light chestnut-brown, $\frac{3 \prime}{4}-1 \frac{1^{\prime}}{4}$ long, $\frac{1^{\prime}}{2}-\frac{3}{4}$ wide, inclosed for about one third its length in the thick cup-shaped light brown cup pubescent on the imner surface, hoary-tomentose and sometimes tuberculate or roughened toward the base on the outer surface by the thickened contorted tips of the ovate acute scales, thin, free, acute, and chestnutbrown higher on the cup, and often forming a short fringe-like border on its margin, or sometimes in a cup entirely covered by thin scales with free acute tips.

A tree, usually $60^{\circ}-70^{\circ}$ or exceptionally $100^{\circ}$ high, with a trunk $2^{\circ}-3^{\circ}$ or oceasionally $8^{\circ}-9^{\circ}$ in diameter, rather small limbs generally pendulous below and rising above into a narrow round-topped open head and often furnished with short pendulous laterals, and stout branchlets, green, lustrous, and slightly scurfy-pubescent when they first appear, light orange color or reddish brown and glabrous or puberulons during their first winter, becoming darker and often purplish and clothed with a glaucous bloom. Winter-buds broadly ovate, obtuse or subglobose to ovate and acute, $\frac{1}{8}^{\prime}$ long, with light chestnut-brown scales usually pilose above the middle. Bark of young stems and small branches smootl, reddish or purplish brown, separating freely into large papery persistent scales curling back and displaying the bright green inner bark; becoming on old trunks $1^{\prime}-2^{\prime}$ thick, and deeply and irregularly divided by continnous or interrupted fissures into broad flat ridges covered by small appressed gray-brown scales often slightly tinged with red. Wood heavy, hard, strong, tough, light brown, with thin hardly distinguishable sapwood; used in construction, the interior finish of houses, cabinet-making, carriage and boatbuilding, cooperage, railway-ties, fencing, and fuel. 
Distribution. Borders of streams and swamps in moist fertile soil; southern Maine to northern Vermont and southwestern Quebec, westward through Ontario and the southern peninsula of Michigan to southeastern Iowa and western Missouri, and southward to the District of Columbia, northern Kentucky and Arkansas, and along the Appalachian Mountains to northern Georgia; widely scattered, usually in small groves but nowhere very abundant; most common and of its largest size in western New York and northern Ohio.

\section{Quercus Michauxii, Nutt. Basket Oak. Cow Oak.}

Leaves broadly obovate to oblong-obovate, acute or acmminate at the apex, with short broad points, wedge-shaped or rounded at the broad or narrow entire base, regularly crenately lobed, with oblique rounded entire lobes sometimes furnished with glandular tips, or rarely entire, with undulate margins, when they unfold bright yellow-green, lustrous and pubescent above, coated below with thick silvery white ferrugineous tomentum, at maturity thick and firm or sometimes membranaceous,

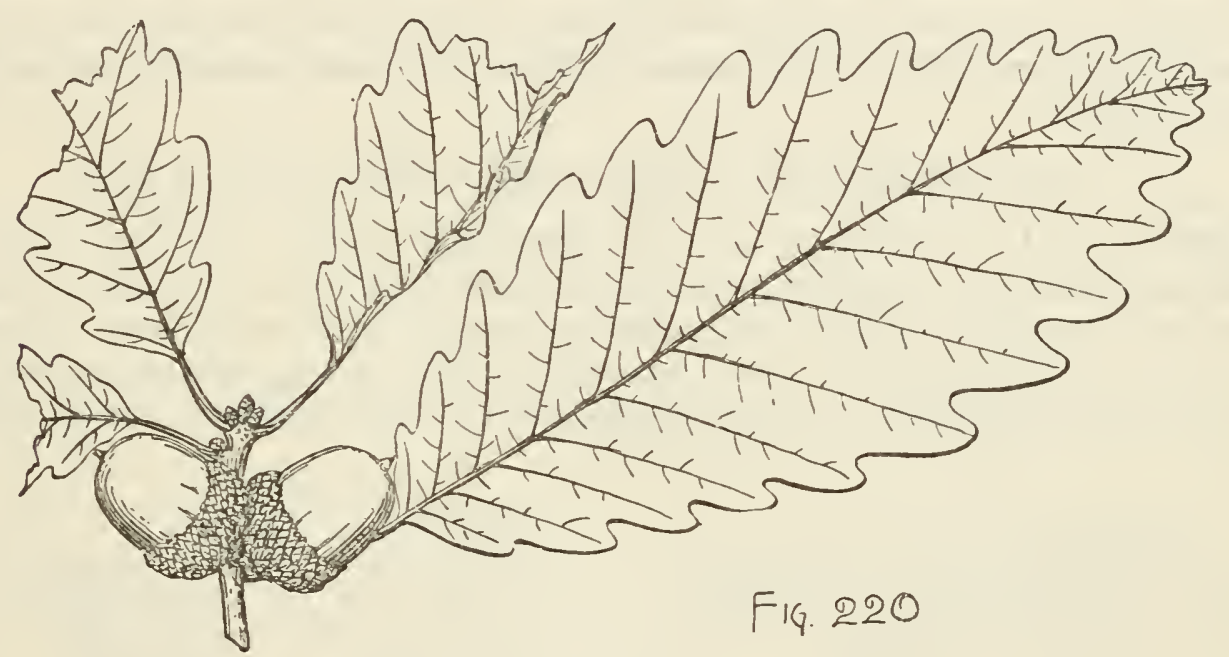

especially on young and vigorous branches, dark green, lustrous, glabrous or occasionally roughened by scattered stellate hairs on the upper surface, more or less densely pubescent on the pale green or silvery white lower surface, $6^{\prime}-\delta^{\prime}$ long, $3^{\prime}-5^{\prime}$ wide, turning in the autumn dark rich crimson; their petioles stout, $\frac{1}{2}^{\prime}-1 \frac{1}{2}^{\prime}$ long. Flowers: staminate in slender hairy anents $3^{\prime}-4^{\prime}$ long; calyx light yellow-green, pilose, with long pale hairs, and divided into 4-7 acute lobes; pistillate in few-flowered spikes on short peduncles, coated like their involucral scales with dense pale rufous tomentum; stigmas dark red. Fruit solitary or in pairs, sessile or subsessile, or borne on short stout puberulous stalks rarely $\frac{1}{2}^{\prime}$ long; acorn oval or ovate, with a broad base, and acute, rounded, or occasionally truncate at the apex surrounded by a narrow ring of rusty pubescence, or sometimes pilose nearly to the middle, bright brown, rather lustrous, $1^{\prime}-1 \frac{1}{2}^{\prime}$ long, $\frac{3^{\prime}}{4}-1 \frac{1}{4}^{\prime}$ broad, inclosed for about one third its length in the thick cup-shaped cup often broad and flat on the bottom, reddish brown and pubescent withiu, hoary-tomentose and covered on the outer surface by regularly imbricated ovate acute scales rounded and much thickened on the back, their short tips sometimes forming a rigid fringe-like border to the rim of the cup; seed sweet and edible. 
A tree, often $100^{\circ}$ high, with a trunk sometimes free of branches for $40^{\circ}-50^{\circ}$, and $3^{\circ}-7^{\circ}$ in diameter, stout branches ascending at narrow angles and forming a roundtopped rather compact head, and stout branchlets at first dark green and eovered by pale caducous hairs, becoming bright red-brown or light orange-brown during their first winter and ultimately ashy gray. Winter-buds broadly ovate or oval, acute, $\frac{1}{4}$ long, with thin closely and regularly imbricated dark red puberulous scales with pale margins, those of the inner ranks coated on the outer surface with loose pale tomentum. Bark $\frac{1^{\prime}}{2}-1^{\prime}$ thick, separating into thin elosely appressed silvery white or ashy gray scales more or less decply tinged with red. Wood heavy, hard, very strong, tough, close-grained, durable, casy to split, light-brown, with thin darker colored sapwood; largely used in all kinds of construction, for agricultural implements and wheels, in cooperage, for fences and fuel, and the manufacture of baskets.

Distribution. Borders of streams, swamps, and bottom-lands often covered with water; Wilmington, Delaware, southward through the coast and middle districts to northern Florida, through the Gulf states to the valley of the Trinity River, Texas, and through Arkansas and southeastern Missouri to ccntral Tennessce and Kentucky, and to the valley of the lower Wabash River in Illinois and Indiana; conspicuous from the silvery white bark, the massive trunk, and the broad crown of large brightcolored foliage.

\section{Quercus Prinus, L. Chestnut Oak. Rock Chestnut Oak.}

Leaves obovate or oblong to lanceolate, acute or acuminate or rounded at the apex, gradually or abruptly wedge-shaped or rounded or subcordate at the narrowed entire base, irregularly and coarsely crenulate-toothed, with rounded, acute, or sometimes nearly triangular oblique teeth, when they unfold orange-green or bronze-red, very lustrous, and glabrous with the exception of the slightly pilose midribs above,

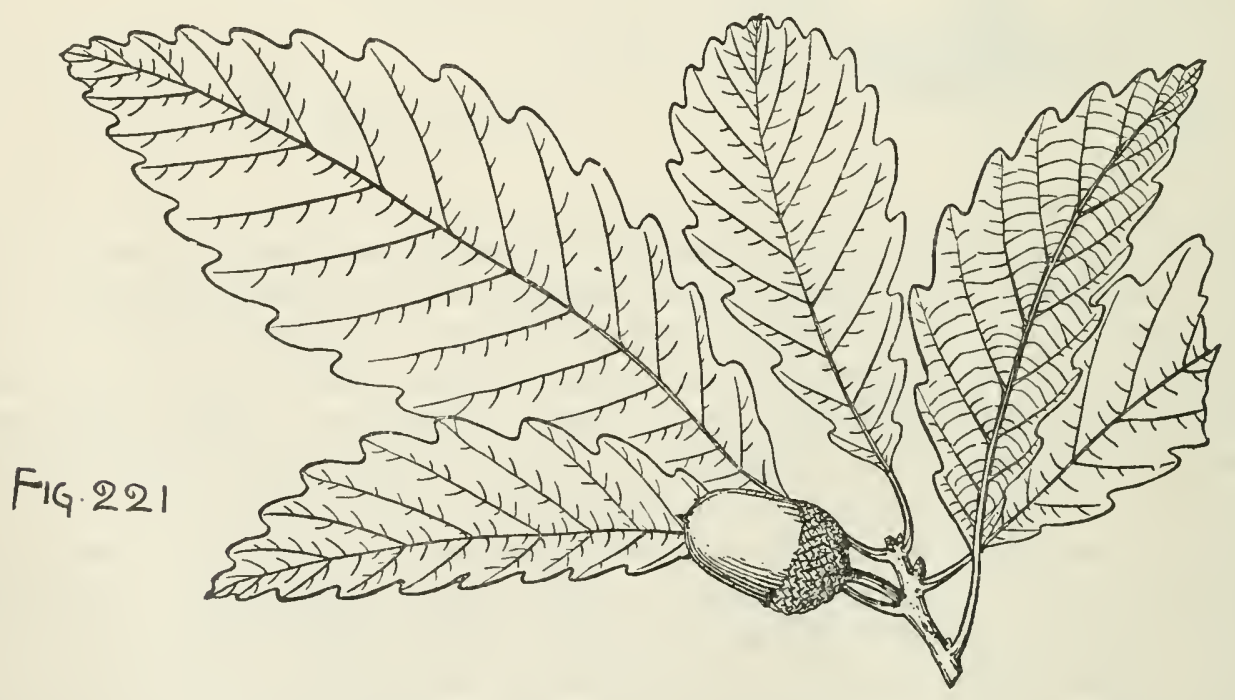

green and coated below with soft pale pubescence, at maturity thick and firm or subcoriaceous, yellow-green and rather lustrous on the upper surface, paler and covered by fine pubescence on the lower surface, $4 \frac{1^{\prime}}{2}-9^{\prime} \operatorname{long}, 1 \frac{1}{2}^{\prime}-3^{\prime}$ wide, with stout yellow midribs and conspicuous primary veins, often much broader near the bottom of the tree than on fertile upper branches, turning a dull orange color or rusty brown 
in the autumn before falling; their petioles stout or slender, $\frac{1}{2}-1^{\prime}$ long. Flowers: staminate in elongated hirsute aments; calyx light yellow, pilose and deeply divided into 7-9 acute segments tipped with clusters of pale hairs; pistillate in short spikes on stout puberulous dark green peduncles, their involucral scales covered with pale hairs; stigmas dark red. Fruit on short stout stems singly or in pairs; acorn oval or ovate, rounded and rather obtuse or pointed at the apex, bright chestnut-brown, very lustrous, $1^{\prime}-1 \frac{1^{\prime}}{2}$ long, $\frac{5^{\prime}}{8}-1^{\prime}$ broad, inclosed for about one half its length or sometimes only at the base in a turbinate cup-shaped thin cup light brown and pubescent on the inner surface, reddish brown, hoary-pubescent, and roughened or tuberculate, especially toward the base, on the outer surface by small seales thickened and knob-like, with neariy triangular free light brown tips.

A tree, usually $60^{\circ}-70^{\circ}$ or occasionally $100^{\circ}$ higb, with a trunk $3^{\circ}-4^{\circ}$ or rarely $6^{\circ}-7^{\circ}$ in diameter, divided generally $15^{\circ}$ or $20^{\circ}$ above the ground into large limbs spreading into a broad open rather irregular head, and stout branchlets green tinged with purple or bronze color and glabrous or pilose when they appear, light orange color or reddish brown during their first winter, becoming dark gray or brown; on dry exposed mountain slopes often not more than $20^{\circ}-30^{\circ}$ tall, with a trunk $8^{\prime}-12^{\prime}$ in diameter. Winter-buds ovate, acute or acuminate, $\frac{1^{\prime}}{4}-\frac{1}{2}^{\prime}$ long, with bright chestnut-brown scales pilose toward the apex and ciliate on the margins. Bark of young stems and small branches thin, smooth, purplish brown, often lustrous, becoming on old trunks and large limbs $\frac{3^{\prime}}{4}-1 \frac{1}{2}^{\prime}$ thick, dark reddish brown or nearly black, and divided into broad rounded ridges separating on the surface into small closely appressed scales. Wood heavy, hard, strong, rather tough, close-grained, durable in contact with the soil, largely used for fencing, railway-ties, and fuel. The bark, which is rich in tannin, is consumed in large quantities in tauning leather.

Distribution. Hillsides and the high rocky banks of streams in rich and deep or sometimes in sterile soil; coast of southern Maine, the Blue Hills of eastern Massachusetts, southward to Delaware and the District of Columbia, and along the Appalachian Mountains to northern Georgia and Alabama, westward to the shores of Lake Champlain and the valley of the Genesee River, New York, the northern shores of Lake Erie, and to central Kentucky and Temnessee; rare and local in New England and Ontario; abundant on the banks of the lower Hudson River and on the Appalachian hills from southern New York to Alabama; most common and of its largest size on the lower slopes of the mountains of the Carolinas and Tennessee, here often forming a large part of the forest.

\section{Quercus acuminata, Sarg. Yellow Oak. Chestnut Oak.}

Leaves usually crowded at the ends of the branches, oblong-lanceolate or broadly obovate, acute or acuminate, with long narrow or with short broad points, abruptly or gradually narrowed and wedge-shaped or slightly narrowed and rounded or cordate at the base, equally serrate except at the base, with acute and often incurved or broad and rounded teeth tipped with small glandular mucros, or rarely slightly undulate, when they unfold bright bronzy green and puberulous above, tinged with purple and coated below with pale tomentum, at maturity thick and firm, light yellow-green on the upper surface, pale often silvery white and covered with short fine pubescence on the lower surface, $4^{\prime}-7^{\prime}$ long, $1^{\prime}-5^{\prime}$ broad, with stout yellow midribs and conspicuous primary veins rumning to the points of the teeth, turning in the autumn orange color and scarlet; their slender petioles $\frac{3^{\prime}}{4}-1 \frac{1^{\prime}}{2}$ long. Flowers: staminate in pilose aments $3^{\prime}-4^{\prime}$ long; calyx light yellow, hairy, deeply divided into 5 or 
6 lanceolate ciliate segments; pistillate sessile or borne in short spikes coated like their involucral seales with thick white tomentum; stigmas bright red. Fruit sessile or raised on a short stout peduncle, solitary or often in pairs; acorn broadly ovate to oval, narrowed and rounded at the apex, $\frac{1}{2}^{\prime}$ to nearly $1^{\prime}$ long, light ehestnut-brown, inclosed for about one half its length in a thin cup-shaped light brown cup pubescent on the interior, hoary-tomentose on the exterior, and covered by small obtuse scales

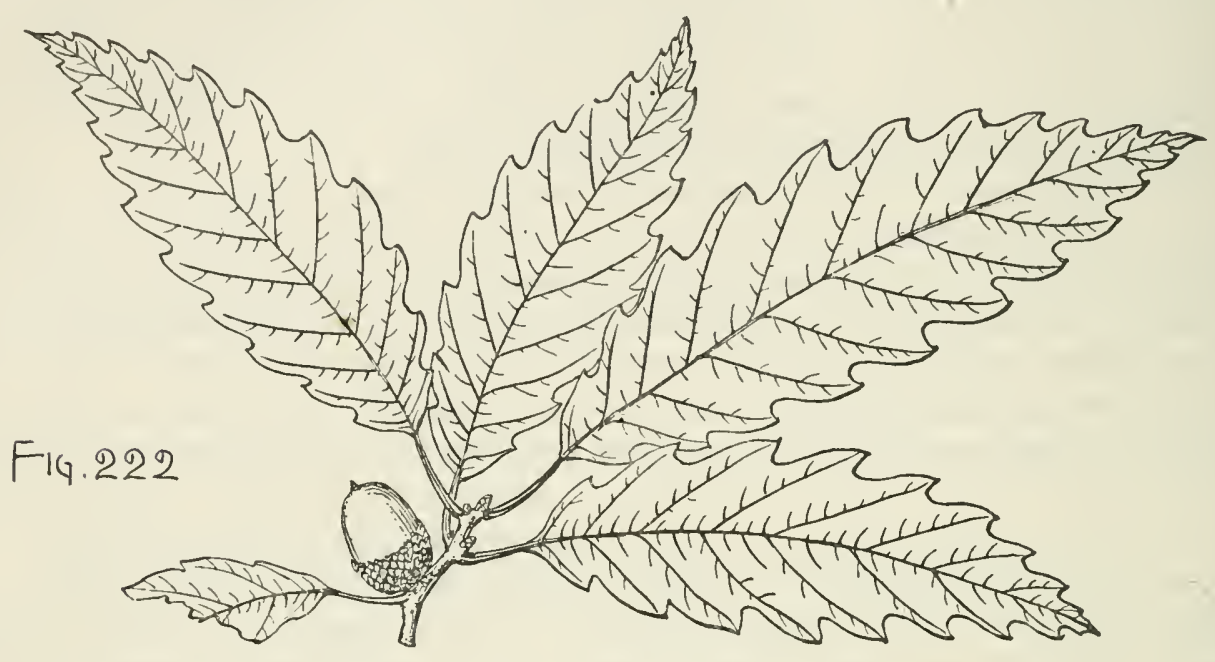

more or less thickened and rounded on the back toward the base of the crip, the small free red-brown tips of the upper ranks forming a minute fringe-like border to its margin; seed sweet and sometimes edible.

A tree, $80^{\circ}-100^{\circ}$, occasionally $160^{\circ}$ high, with a tall straight trunk $3^{\circ}-4^{\circ}$ in diameter above the broad and often buttressed base, comparatively small branches forming a narrow shapely round-topped head, slender branchlets, green more or less tinged with red or purple and pilose when they first appear, light orange color or reddish brown during their first winter, and ultimately gray or brown; east of the Alleghany Mountains and on dry lills often not more than $20^{\circ}-30^{\circ}$ tall. Winter-buds ovate, acute, $\frac{1}{8}^{\prime}-\frac{1}{4}$ long, with chestnut-brown scales white and scarious on the margins. Bark rarely $\frac{1}{2}^{\prime}$ thick, broken on the surface into thin loose silvery white scales sometimes slightly tinged with brown. Wood heavy, very hard, strong, close-grained, durable, with thin light-colored sapwood; largely used in cooperage, for wheels, fencing, and railway-ties.

Distribution. Gardner's Island, Lake Champlain, western Massachusetts and Connecticut, and near the city of Newburg, New York, westward through southern Ontario to southeastern Nebraska and eastern Kansas, sonthward in the Atlantic states to the District of Columbia and the valley of the upper Potomac River, and west of the Alleghany Mountains to central Alabama and Mississippi, through Arkansas and northern Louisiana, to the eastern borders of the Indian Territory and to the valley of the Nueces River and the Guadalonpe Mountains, Texas; rare and comparatively local in the Atlantic states, usually on limestone soil; very abundant in the Mississippi basin, growing on limestone ridges, dry flinty hills, or deep rich bottom-lands and the rocky banks of streams; of its largest size on the lower Wabash River and its tributaries in sonthern Indiana and Illinois. 
** Leaves often dentate or spinescent.

+ Leaves blue-green, deciduous in their first autumn or winter.

\section{Quercus breviloba, Sarg. White Oak.}

Leaves obovate or oblong, broad and rounded or rarely acute at the apex, usually gradually narrowed and acute, or rarely broad and equally or unequally rounded at the base, undulate-lobed, with 4-7 broad lobes, or obscurely 3-lobed at the broad apex and entire below, or undulate or coarsely and remotely dentate, with acute spinescent teeth, or often entire, on vigorous shoots frequently oblong-obovate and more or less deeply divided by wide sinuses into broad lobes, when they unfold thin, covered with scattered stellate pale hairs on the upper surface and pale pubescent on the lower, at maturity thin in the eastern Gulf states, thicker and often subcoriaceous in the drier climate of 'Texas, light blue or yellow-green, usually lustrous above, pubescent

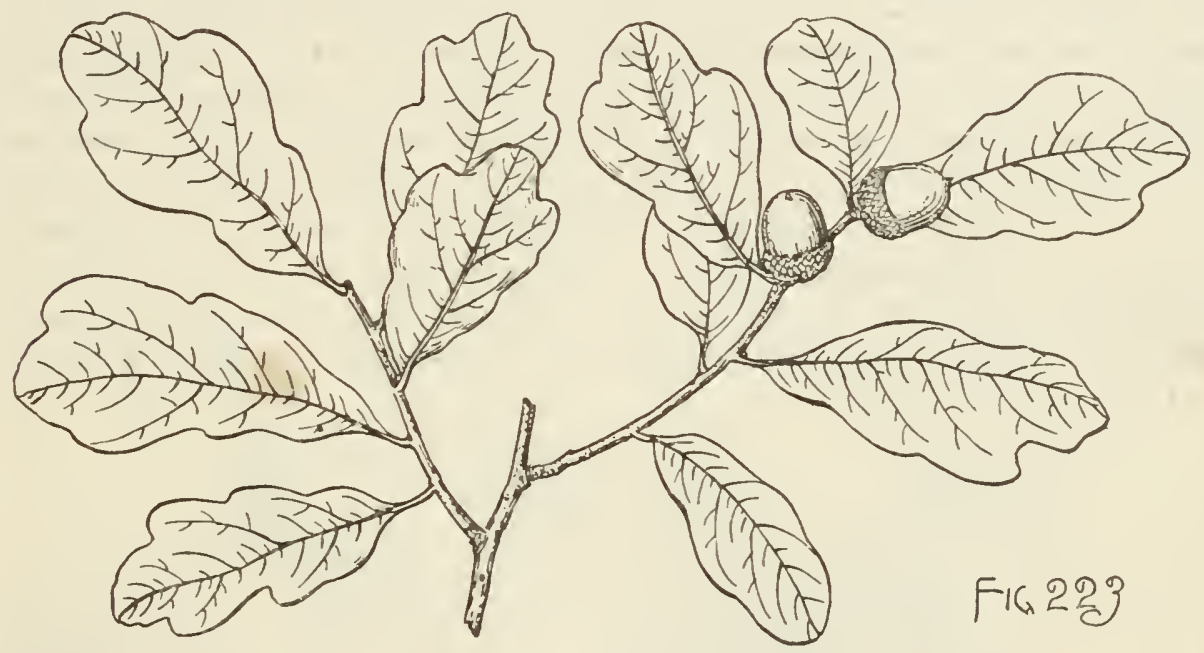

and paler and often silvery white below, usually $1 \frac{1}{2}-3^{\prime}$ long, $\frac{3^{\prime}}{4}-1 \frac{1}{2}^{\prime}$ wide, or east of the Mississippi River and on young and vigorous branches sometimes $4^{\prime}-6^{\prime}$ long and $2 \frac{1^{\prime}}{2}$ broad, with slender yellow midribs and veins and reticulate veinlets, turning pale yellow and falling in the autumn, or in western Texas sometimes irregularly during the winter and early spring; their petioles stout, rarely more than $\frac{1}{4}^{\prime}$ long. Flowers: staminate in hairy aments $1 \frac{1}{2}{ }^{\prime}-2^{\prime}$ long; calyx pale yellow, divided into nearly triangular segments much shorter than the stamens; pistillate on short peduncles coated like their involucral scales with thick hoary tomentum; stigmas dull red. Fruit sessile or subsessile, usually solitary; acorn, ovate, obovate, or oval, acute or rounded and sometimes depressed at the broad apex usually furnished with a narrow ring of pale pubescence, $\frac{1^{\prime}}{2}-1^{\prime}$ long, $\frac{3^{\prime}}{8}-\frac{3^{\prime}}{5}$ wide, inclosed only at the base in the thin saucer-shaped cup, bright reddish brown and pubescent on the inner surface, covered on the outer by closely imbricated ovate bright red scales hoary-pubescent except at their acute or rounded appressed tips.

A tree, east of the Mississippi River $80^{\circ}-90^{\circ}$ high, with a tall straight trunk $2^{\circ}-3^{\circ}$ in diameter, in Texas much smaller and rarely more than $20^{\circ}-30^{\circ}$ high, with a short trunk usually divided at the ground into 2 or 3 spreading limbs and rarely more than $12^{\prime}-15^{\prime}$ in diameter, and slender branchlets coated at first with hoary tomentum, gray faintly tinged with red or ashy gray during their first winter, 
becoming darker in their second and third years; frequently, especially in western Texas, small and shrubby and often forming extensive thickets. Winter-buds broadly ovate or oval, acmminate, $1_{1 \frac{1}{6}-\frac{1}{8}}^{\prime}$ long, with light chestnut-brown closely imbricated puberulous scales. Bark $\frac{1{ }^{\prime}-1^{\prime}}{2}$ thick, scparatiug into long and narrow plate-like scales, silvery white tinged with reddish brown on the surface. Wood heavy, hard, strong, brittle, brown, with thick lighter colored sapwood; most valuable east of the Mississippi River.

Distribution. Rich limestone prairies of central Alabama and Mississippi, banks of the Red River at Shreveport, Louisiana, and in Texas on dry limestone banks of streams and rocky bluffs from the neighborhood of the city of Dallas westward to the central part of the state and southward to the mountains of Nuevo Leon.

\section{Quercus undulata, Torr. Scrub Oak. Shin Oak.}

Leaves oblong, acute or rarely rounded at the apex, broad and rounded or cordate or rarely cuneate at the base, sinuate-dentate, entire, pinnatifid, lobed or spinescent, when they unfold coated with hoary tomentum, at maturity thick and firm, light blne-green, more or less covered with stellate hairs above and clothed below with pale or yellow pubescence, $1^{\prime}-3^{\prime}$ long, $\frac{1^{\prime}}{4}-\frac{3^{\prime}}{4}$ wide, with pale slender midribs and few conspicuous primary veins rumning to the points of the teeth or arcuate and united with the thickened and revolute margins, deciduous in the autumn at the north and at high elevations, southward often remaining on the branches until the appearance of the leaves of the following year; their petioles stout, pubescent or tomentose, $\frac{1}{4}-1^{\prime}$ long. Flowers: staminate in tomentose aments $1^{\prime}-2^{\prime}$ long; calyx

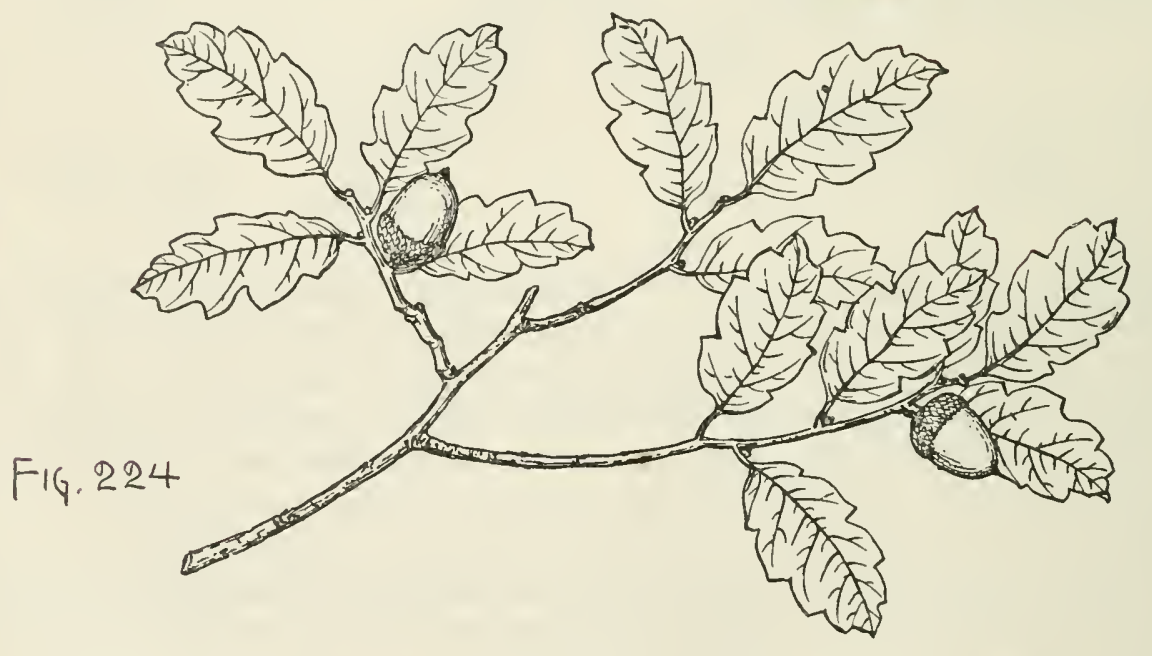

hairy, divided into acute segments; pistillate sessile or raised on peduncles tomentose like their involucral scales; stigmas red. Fruit solitary or in pairs, sessile or on stout hoary peduncles sometimes nearly $2^{\prime}$ long; acorn oval, rounded and rather obtuse or acute at the apex, $\frac{3^{\prime}}{4}-1^{\prime}$ long, inclosed for about one third its length in a thick cup-shaped cup reddisl brown and pubescent on the inner surface, hoarytomentose and covered on the outer by ovate acute scales nsually thickened and tumid toward its base and above the middle ending in thin bright red free ciliate tips; seed sweet.

A tree, occasionally $25^{\circ}-30^{\circ}$ high, with a straight trnuk $6^{\prime}-8^{\prime}$ in diameter, and 
slender branchlets coated at first with dense hoary tomentum, light reddish brown or ashy gray and pubescent or tomentose during their first winter, ultimately glabrous and dark brown or gray; usually a shrub, forming small thickets by vigorous stolons, with stout more or less contorted stems $2^{\circ}-8^{\circ}$ tall. Winter-buds oval, about $\frac{1}{8}^{\prime}$ long, with few thin light red-brown scales often ciliate on the margins. Bark thin, scaly, pale gray slightly tinged with reddish brown.

Distribution. Dry rocky mountain ridges; cliffs above the cañon of the Arkansas River, and the eastern foothills of the Rocky Mountains of Colorado, to western Texas, and through New Mexico and Arizona to southern Utah and Nevada, and southward into northern Mexico; in central Arizona south of the Colorado plateau covering low mountain ranges with vast thickets; less common in southern Utah and Nevada; arborescent only in the cañons of the mountain ranges of southeastern Arizona.

\section{Quercus Douglasii, Hook. \& Arn. Blue Oak. Mountain White Oak.}

Leaves oblong, acute or rounded at the apex, gradually narrowed and wedgeshaped to broad and rounded or subcordate at the base, divided by deep or shallow, wide or narrow sinuses acute or rounded at the bottom into 4 or 5 broad or narrow

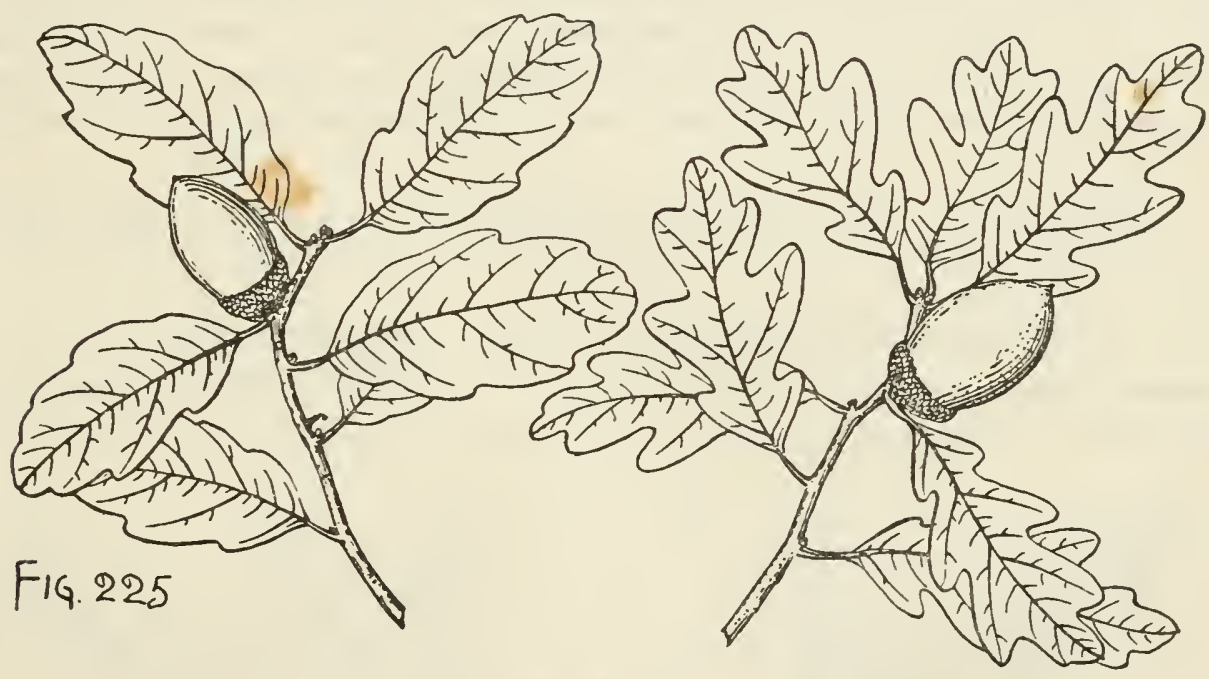

acute or rounded often mucronate lobes, $2^{\prime}-5^{\prime}$ long, $1^{\prime}-1 \frac{3}{4}^{\prime}$ broad, or oval, oblong or obovate, rounded or acute at the apex, equally or unequally wedge-shaped or rounded at the base, regularly or irregularly sinuate-toothed, with rounded acute rigid spinescent teeth, or denticulate toward the apex, $1^{\prime}-2^{\prime}$ long, $\frac{1^{\prime}}{4}-1^{\prime}$ wide, when they unfold covered by soft pale pubescence, at maturity thin, firm and rather rigid, pale blue, with scattered stellate hairs above, often yellow-green and covered by short pubescence below, with hirsute or puberulous prominent midribs and more or less conspicuous reticulate veinlets; their petioles stout, tomentose, $\frac{1}{4}^{\prime}-\frac{1}{2}^{\prime}$ long. Flowers: staminate in hairy aments $1 \frac{1}{2}^{\prime}-2^{\prime}$ long; calyx yellow-green, coated on the outer surface with pale hairs, deeply divided into broad acute laciniately cut segments; pistillate in short few-flowered spikes coated like the involucral scales with hoary tomentum. Fruit sessile or short-stalked, solitary or in pairs; acorn broadly oval, sometimes ventricose, with a narrow base, gradually narrowed and acute at the apex, $\frac{3^{\prime}}{4}-1^{\prime}$ long, $\frac{1^{\prime}}{2}-1^{\prime}$ broad, or often ovate and acute, green and lustrous, turning 
dark chestnut-brown in drying, with a narrow ring of hoary pubeseenec at the apex, inclosed at the base only in a thin shallow eup-shaped enp light green and pubeseent on the imner surface, covered on the outer by small acute and usnally thin or sometimes, especially in the south, thicker tumid scales coated with pale pubescence or tomentum and ending in thin reddish brown tips.

A tree, usually $\tilde{5} 0^{\circ}-60^{\circ}$, rarely $50^{\circ}-90^{\circ}$ high, with a trunk $3^{\circ}-4^{\circ}$ in diameter, short stout branches sprealing nearly at right angles and forming a dense roundtopped symmetrical head, stont branchlets brittle at the joints, coated at first with short dense loary tomentum, lark gray or reddish brown and tomentose, pubescent, or puberulous during their first winter, becoming ultimately ashy gray or dark brown; frequently not more than $20^{\circ}-30^{\circ}$ high, and sometimes, especially southward, shrubby in habit. Winter-buds ovate, obtuse, $\frac{1^{\prime}}{8}-\frac{1}{4}^{\prime}$ long, with iight rather briglit red pubescent scales. Bark $\frac{1}{2}^{\prime}-1^{\prime}$ thick, generally pale, and covered by small scales sometimes tinged with brown or light red. Wood hard, lieavy, strong, brittle, dark brown, beconing nearly black with exposure, with thick light brown sapwood; largely used as fuel.

Distribution. Scattered over low hills, dry mountain slopes and valleys; California, Mendocino County, and the upper valley of the Sacramento River, soutliward along the western slopes of the Sierra Nevada up to elevations of $4000^{\circ}$, and through valleys of the coast ranges to the Tehachapi Pass and the borders of the Mohave Desert; most abundant and of its largest size in the valleys between the coast mountains and the interior ridges of the coast ranges south of the Bay of San Francisco.

++ Leaves mostly persistent until the appearance of those of the following spring. + Leaves blue-green.

\section{Quercus Engelmanni, Greene. Evergreen Oak.}

Leaves oblong to obovate, usually obtuse and rounded or sometimes acute at the apex, gradually or abruptly wedge-shaped or rounded or cordate at the base, entire,
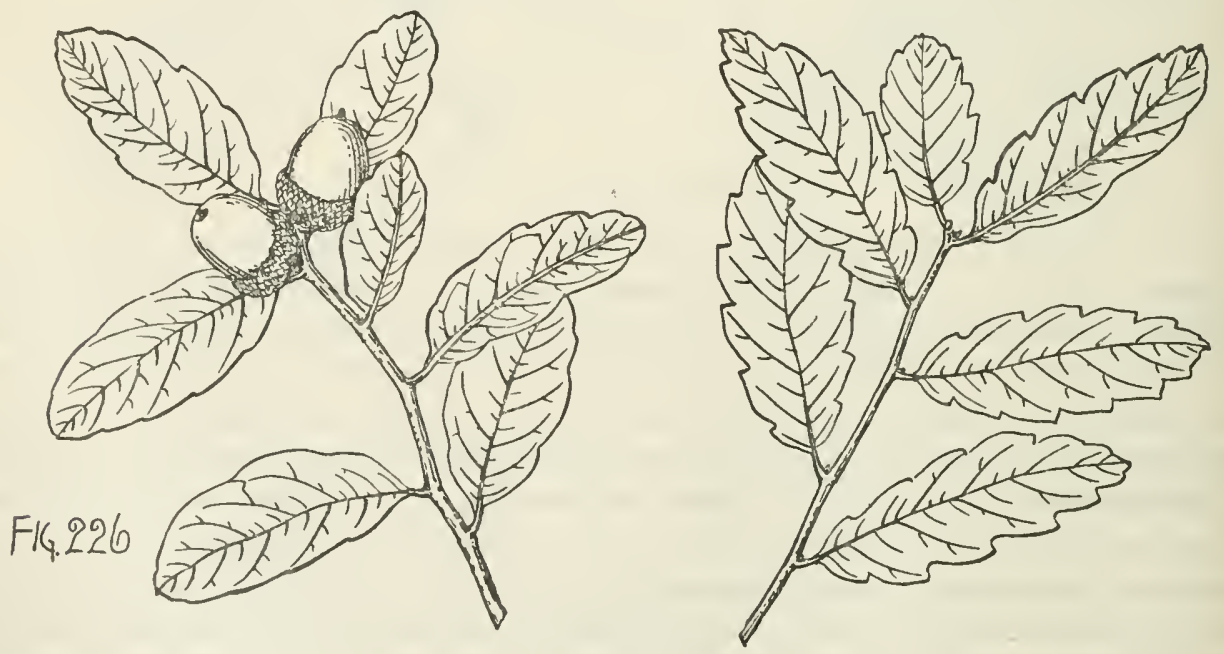

often undulate, or sinuate-toothed, with occasionally rigid teetl, or at the ends of sterile branches frequently coarsely crenately serrate, with incurved teeth, or rarely lobed, with acute oblique rounded lobes, when they unfold bright red and coated 
with thick pale rufous tomentum, at maturity thick, dark blue-green, and glabrous or covered witl scattered stellate hairs above, pale, usually yellow-green and clotlied with light brown pubescence, or puberulous or often glabrous below, $1^{\prime}-3^{\prime}$ long, $\frac{1}{2}-2^{\prime}$ broad, deciduous in the spring with the appearance of the new leaves; their petioles slender, tomentose, becoming pubescent, $\frac{1^{\prime}}{4}-\frac{1^{\prime}}{2}$ long. Flowers: staminate in slender hairy aments $2^{\prime}-3^{\prime}$ long; calyx light yellow, pilose, with lanceolate acute segments; pistillate on slender peduncles, clothed like their involucral scales with dense pale tomentum. Fruit sessile or on slender pubescent stalks sometimes $\frac{3^{\prime}}{4}$ long; acorn oblong, oval, and gradually narrowed and acute or broad and rounded at the obtuse apex, broad or narrow at the base, dark chestnut-brown more or less conspicuously marked by darker longitudinal stripes, turning light chestuut-brown in drying, $\frac{8^{\prime}}{4}-1^{\prime}$ long, about $\frac{1^{\prime}}{2}$ broad, inclosed for about one half its length in a deep saucer-shaped cup-shaped or turbinate cup light brown and puberulous within, and covered by ovate light brown scales coated with pale tomentum, usually thickened, united and tuberculate at the base of the cup, and near its rim produced into small acute ciliate tips.

A tree, $50^{\circ}-60^{\circ}$ high, with a trunk $2^{\circ}-3^{\circ}$ in diameter, thick branches spreading nearly at right angles and forming a broad rather irregular head, and stout rigid branchlets coated at first with hoary tomentum, light or dark brown tinged with red and pubescent during their first winter, becoming glabrous and light brown or gray in their second or third years. Winter-buds oval or ovate, about $\frac{1}{8}$ long, with thin light red pubescent scales. Bark $1 \frac{1}{2}^{\prime}-2^{\prime}$ thick, light gray tinged with brown and deeply divided into narrow fissures separating on the surface into small thin appressed scales. Wood very heavy, hard, strong, close-grained, brittle, dark brown or nearly black, with thick lighter brown sapwood; used only as fnel.

Distribution. Low hills of southwestern California west of the coast range, occupying with Quercus agrifolia, Née, a belt about fifty miles wide, and extending to within fifteen or twenty miles of the coast, from the neighborlood of Sierra Madre to the mesa east of Sall Diego.

\section{Quercus oblongifolia, Torr. White Oak.}

Leaves ovate, oval, or slightly obovate, rounded and occasionally emarginate or acute at the apex, usually cordate or occasionally rounded at the base, entire and sometimes undulate, with thickened revolute margins, or remotely dentate, with small callous teeth, on vigorous shoots and young plants oblong, rounded or cuneate at the narrow base, coarsely sinuate or undnlate-tootlied or 3-toothed at the broad apex and entire below, when they unfold bright red and coated with deciduous hoary tomentum, at maturity thin and firm, blue-green and lustrous above, paler below, $1^{\prime}-2^{\prime}$ long, $\frac{1}{2}-\frac{3 \prime}{4}$ broad, or on vigorous shoots sometimes $3^{\prime}-4^{\prime}$ long, with prominent pale midribs, slender primary veins, and conspicuous reticulate veinlets, persistent during the winter without change of color, gradually turning yellow in the spring and falling at the appearance of the new leaves; their petioles stout, nearly terete, about $\frac{1}{4}$ long. Flowers: staminate in short hoary-tomentose aments; calyx bright yellow, pilose, divided into 5 or 6 laciniately cut or entire acute segments tinged with red above the middle; pistillate usually sessile, or on peduncles tomentose like the involncral scales; stigmas bright red. Fruit usually solitary and sessile, rarely long-stalked; acorn ovate, oval, or slightly obovate, full and rounded at the apex, surrounded by a narrow ring of white pubescence, dark chestnut-brown, striate, and very lustrous, soon becoming light browl in drying, $\frac{1^{\prime}}{2}-\frac{3^{\prime}}{4}$ long, about $\frac{1}{3}^{\prime}$ broad, inclosed for about one third its length in a shallow cup-shaped or rarely turbinate 
thin cup yellow-green and pubescent on the inner surface and covered by ovateoblong seales slightly thickened on the back, coated with hoary tomentum and ending in thin acute bright red tips ciliate on the margins and sometimes forming a minute fringe to the rim of the cup.

A tree, rarely more than $30^{\circ}$ high, with a short trunk $18^{\prime}-20^{\prime}$ in diameter, many stont spreading often contorted branches forming a handsome romd-topped symmetrical head, slender rigid branchlets coated at first with pale or fulvous tomentum,

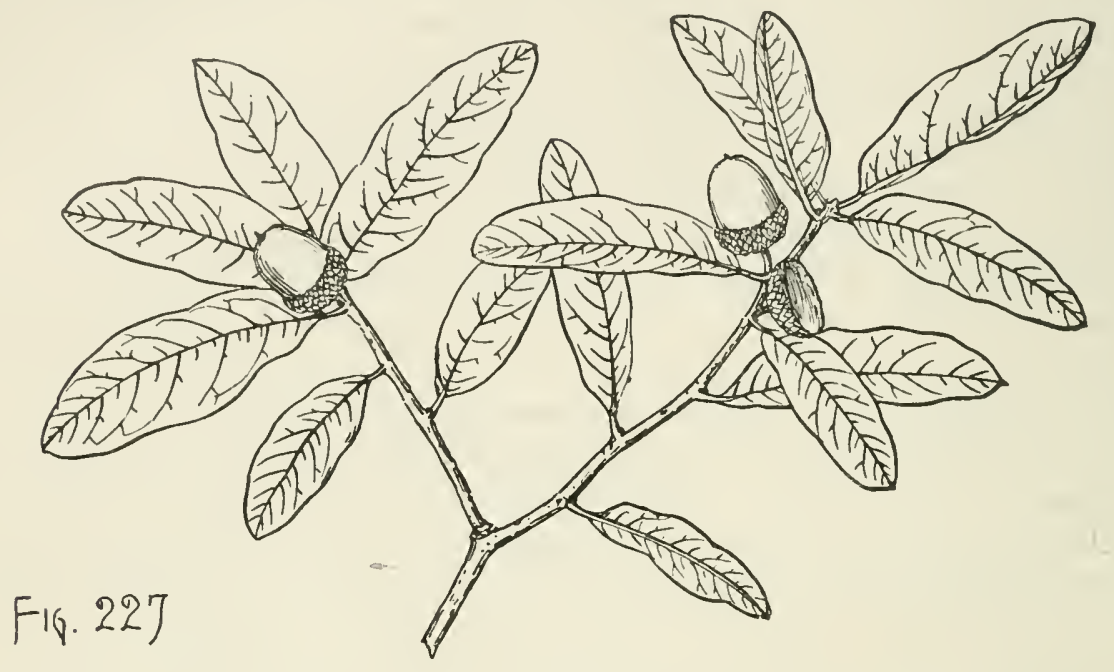

light red-brown, dark brown or dark orange color in their first winter, becoming ashy gray in their second or third year. Winter-buds subglobose, obtuse, $\frac{1}{16}-\frac{1}{8}^{\prime}$ long, with thin light chestnut-brown scales. Bark $\frac{3^{\prime}}{4}-1 \frac{1^{\prime}}{4}$ thick, ashy gray, and broken into small nearly square or oblong close plate-like scales. Wood very heavy, hard, strong, brittle, dark brown or nearly black, with thick brown sapwood; sometimes used as fuel.

Distribution. Chisos Mountains, western Texas, through southern New Mexico and Arizona, and southward into northern Mexico; comparatively rare in Texas; abundant on the foothills of all the mountain ranges of New Mexico and Arizona south of the Colorado platean at elevations of abont $5000^{\circ}$, and dotting the upper slopes of the mesa where narrow cañons open to the plain.

\section{Quercus Arizonica, Sarg. White Oak.}

Leaves oblong-lanceolate to broadly obovate, generally acute or sometimes rounded at the apex, rounded or cordate at the base, repandly spinose-dentate usually, except on vigorous shoots, only above the middle or toward the apex, or entire, and sometimes mdulate on the margins, when they unfold light red clothed with bright fulvous tomentum and furnished with dark dental glands, at maturity thick, firm and rigid, dark blue-green and glabrous or stellate pubescent above, yellowgreen or pale blue and covered with thick fulvous or pale pubescence below, $1^{\prime}-4^{\prime}$ long, $\frac{1}{2}-2^{\prime}$ broad, with broad yellow midribs, slender primary veins, arcuate and united near the thickened revolute margins, and coarsely reticulate veinlets, falling in the early spring just before the appearance of the new leaves; their petioles stout, tomentose, $\frac{1}{4}^{\prime} \frac{1}{2}^{\prime}$ long. Flowers: staminate in tomentose aments $2^{\prime}-3^{\prime}$ long; calyx pale yellow, pubescent, and divided into 4-7 broad acute ciliate lobes; anthers 
red or yellow; pistillate on short stems tomentose like their involucral scales. Fruit sessile or on hoary-tomentose stalks rarely $\frac{1^{\prime}}{2}$ long, usually solitary, ripening irregularly from September to November; acorn oblong, oval or slightly obovate, obtuse and rounded at the puberulous apex, $\frac{3^{\prime}}{4}-1^{\prime}$ long, $\frac{1^{\prime}}{2}$ broad, dark chestnut-brown, lustrous and often striate, soon becoming light brown, inclosed for one half its length in a cup-shaped or hemispherical cup light brown and pubescent within, covered by regularly and closely imbricated scales coated with pale tomentum and ending in thin light red pointed tips, those below the middle of the cup much thickened and rounded on the back; seed dark purple, very astringent.

A tree, occasionally $50^{\circ}-60^{\circ}$ tall, with a trunk $3^{\circ}-4^{\circ}$ in diameter, and thick contorted branches spreading nearly at right angles and forming a handsome roundtopped symmetrical head, and stout branchlets clothed at first with thick fulvous tomentum persistent during their first winter, reddish brown or light orange color and pubescent or puberulous in their second season, ultimately glabrous and darker; usualiy not more than $30^{\circ}-40^{\circ}$ tall; at high elevations reduced to a low shrub. Winter-buds subglobose, about $\frac{1}{16}^{\prime}$ long, with loosely imbricated bright chestnutbrown puberulous scales ciliate on the margins. Bark of young stems and branches thin, pale, scaly, with small appressed scales, becoming on old trunks about $1^{\prime}$ thick

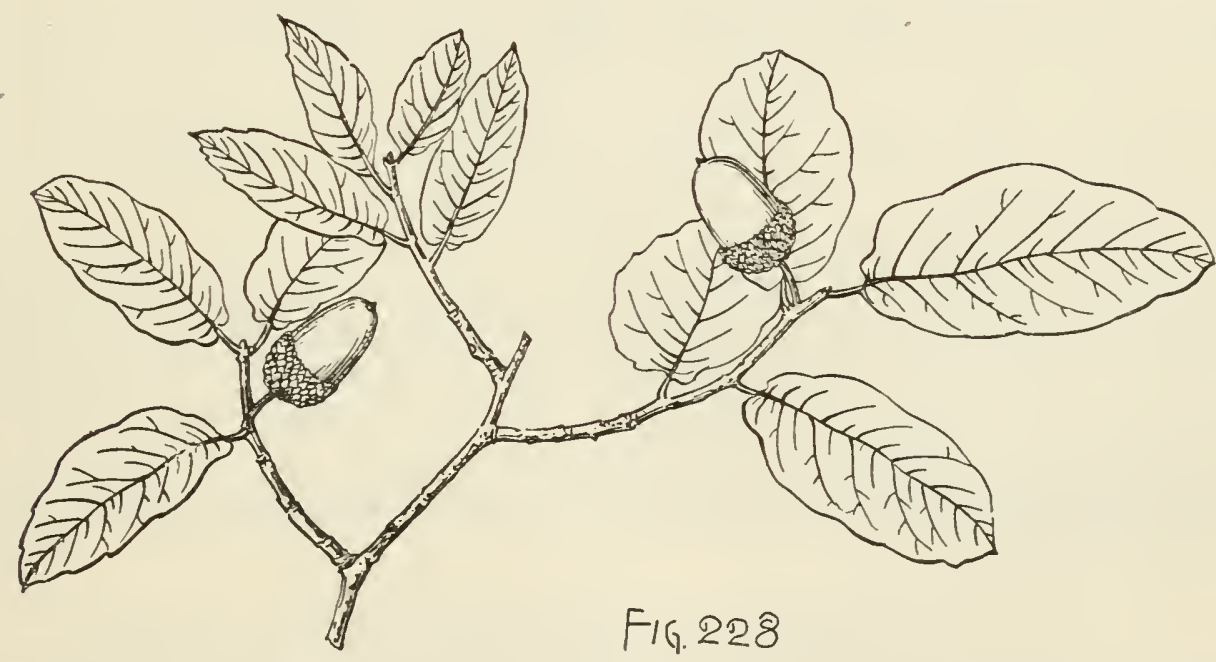

and deeply divided by narrow fissures into broad ridges broken into long thick platelike scales pale or ashy gray on the surface. Wood heavy, strong, hard, closegrained, dark brown or nearly black, with thick lighter colored sapwood; used only for fuel.

Distribution. The most common and generaliy distributed White Oak of southern Arizona and New Mexico, covering the slopes of cañons of the mountain ranges south of the Colorado plateau at elevations of $5000^{\circ}-10,000^{\circ}$ above the sea, often ascending nearly to the summits of the high peaks; and in northern Mexico.

\section{Quercus Toumeyi, Sarg.}

Leaves ovate or ovate-oblong or oval, acute and apiculate at the apex, rounded or cordate at the base, entire, with thickened slightly revolute margins, or remotely spinulose-dentate, often minutely 3 -toothed at the apex, thin but firm in texture, light blue-green, glabrous and lustrous above, pale and puberulous below, $\frac{1^{\prime}}{2}-\frac{3^{\prime}}{4}$ long, 
$\frac{1^{\prime}}{4}-1^{\prime}$ ' wide, conspicuously reticulate-venulose, falling early in the spring with the appearance of the new leaves; their petioles stout, tomentose, about $\frac{1}{16^{\prime}}$ long. Flowers unknown. Fruit sessile, solitary or in pairs, ripening in June; acorn oval

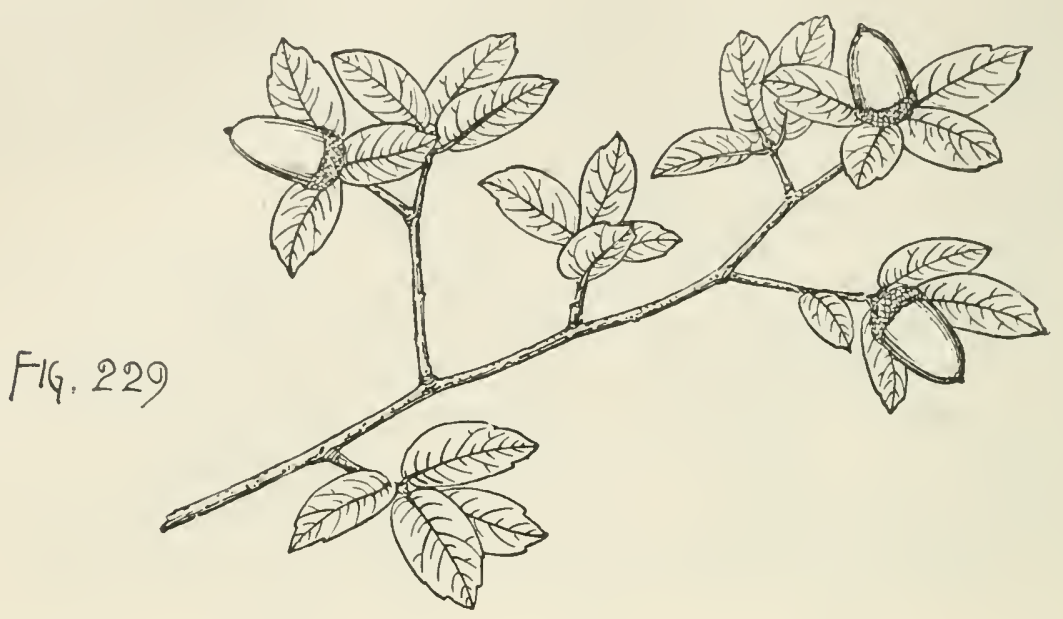

or ovate, $\frac{1}{2}^{\prime}-\frac{2}{3}^{\prime}$ long, $\frac{1^{\prime}}{4}$ broad, light brown and lustrous, furnished at the acute apex with a narrow ring of pale pubescence, inclosed for about one half its length in a thin shallow tomentose cup light green and pubescent within, and covered by thin ovate regularly and closely imbricated light red-brown scales ending in short rounded tips and coated on the back with pale tomentum.

A tree, $25^{\circ}-30^{\circ}$ high, with a short trunk $6^{\prime}-8^{\prime}$ in diameter, dividing not far from the ground into numerous stout wide-spreading branches forming a broad irregular head, and slender branchlets brighit red-brown more or less thickly coated with pale tomentum at midsummer, covered during their second and third years with thin dark brown nearly black bark broken into small thin closely appressed scales. Wood light brown, with thick pale sapwood.

Distribution. Forming an open forest on the Mule Mountains, Cochise County, southeastern Arizona.

\section{Quercus reticulata, H. B. K.}

Leaves broadly obovate, obtuse and rounded or rarely acute at the apex, usually cordate or occasionally rounded at the narrow base, repandly spinose-dentate above the middle or only toward the apex, with slender teeth, and entire below, when they unfold coated with dense fulvous tomentum, at maturity thick, firm, and rigid, dark blue and covered with scattered stellate clusters of hairs above, paler and coated with thick fulvous pubescence below, $1^{\prime}-5^{\prime}$ long, $\frac{3^{\prime}}{4}-4^{\prime}$ broad, with thick midribs, running to the points of the teeth or arcuate and united within the slightly revolute margins, and very conspicuous reticulate veinlets; their stout petioles about $\frac{l^{\prime}}{4}$ long. -Flowers: staminate in short tomentose aments in the axils of leaves of the year; calyx light yellow, hirsute, with pale hairs, divided into 5-7 ovate acute segments; pistillate in spikes on elongated peduncles, clothed like their involucral scales with hoary tomentum; stigmas dark red. Fruit usually in many-fruited spikes or occasionally in pairs, or rarely solitary, on slender hirsute or glabrous peduncles $2^{\prime}-5^{\prime}$ long; acorn oblong, rounded or acute at the pilose apex, broad at the base, about $\frac{1^{\prime}}{2}$ long, inclosed for about one fourth its length in a shallow cup-shaped cup dark 
brown and pubescent within, hoary tomentose without and covered by small ovate acute scales with thin free scarious tips, slightly thickened and rounded on the back at the bottom of the cup.

A tree, rarely more than $40^{\circ}$ high, with a trunk $1^{\circ}$ in diameter, and stout branchlets coated at first with thick fulvous tomentum, light orange color and more or less thickly clothed with pubescence during their first winter, becoming ashy gray or light brown; in the United States usually shrubby in habit and sometimes only a few feet tall; becoming on the Sierra Madre of Mexico a large tree. Winterbuds ovate to oval, often surrounded by the persistent stipules of the upper leaves,

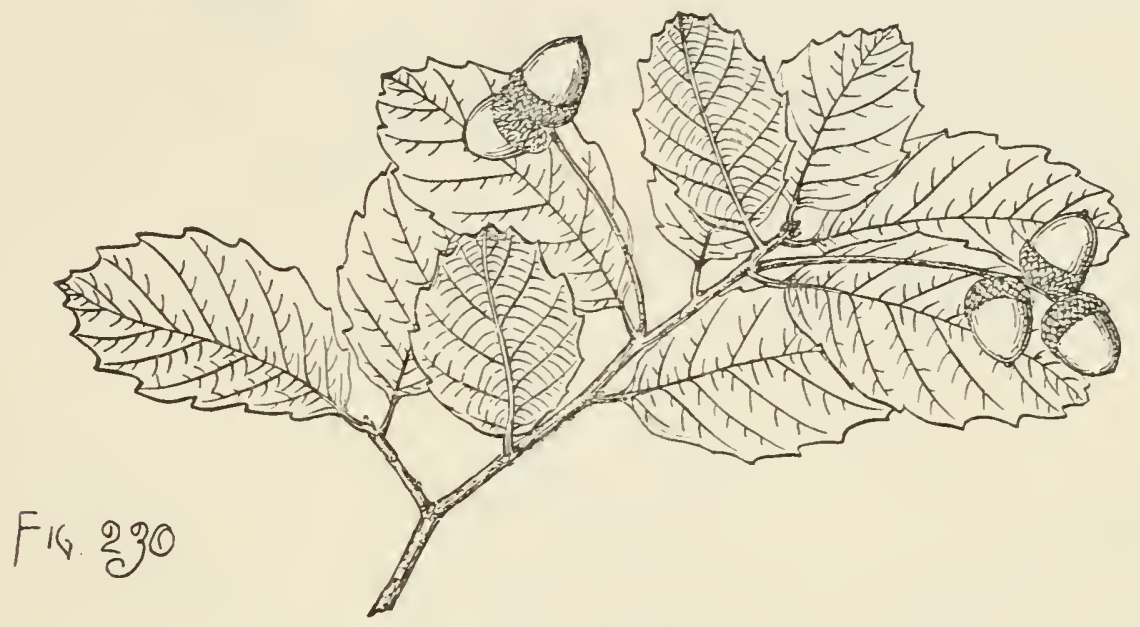

about $\frac{1}{8}^{\prime}$ long, with thin loosely imbricated' light red scales ciliate on the margins. Bark about $\frac{1}{4}$ thick, dark or light brown, and covered by small thin closely appressed scales. Wood very heavy, hard, close-grained, dark brown, with thick lighter colored sapwood.

Distribution. Near the summits of the mountain ranges of southern Arizona, on the San Luis and Animas mountains of southern New Mexico, and southward in Mexico.

++ Leaves dark green.

\section{Quercus dumosa, Nutt. Scrub Oak.}

Leaves oblong, rounded and acute at the apex, broad and abruptly wedge-shaped or rounded at the base, usually about $\frac{3^{\prime}}{4}$ long and $\frac{1}{2}^{\prime}$ broad, spinescent, with few minute teeth, or undulate and entire or coarsely spinescent, with obscure midribs and primary veins, conspicuous reticulate veinlets, and stout petioles rarely $\frac{1}{8}^{\prime}$ long; or sometimes oblong to oblong-obovate and divided by deep sinuses into 5-9 oblong acute rounded or emarginate bristle-tipped lobes, the terminal lobe 3-lobed, rounded or acute, $2^{\prime}-4^{\prime}$ long and $1^{\prime}-1 \frac{1}{2}$ broad, with primary veins running to the points of the lobes, obscure reticulate veinlets, and petioles sometimes $1^{\prime}$ long; thin when they unfold and clothed with scattered stellate hairs, or rarely tomentose above and coated below and on the petioles with hoary tomentum, at maturity thick and firm, dark green and lustrous on the upper surface, paler and more or less pubescent on the lower surface, mostly deciduous during the winter. Flowers: staminate in pubescent aments; calyx divided into 4-8 ovate lanceolate hairy segments; pistillate ses- 
sile or stalked, in long many-flowered tomentose spikes, their involucral scales and calyx hoary-tomentose; stigmas red. Fruit sessile or short-stalked; acorn oval,

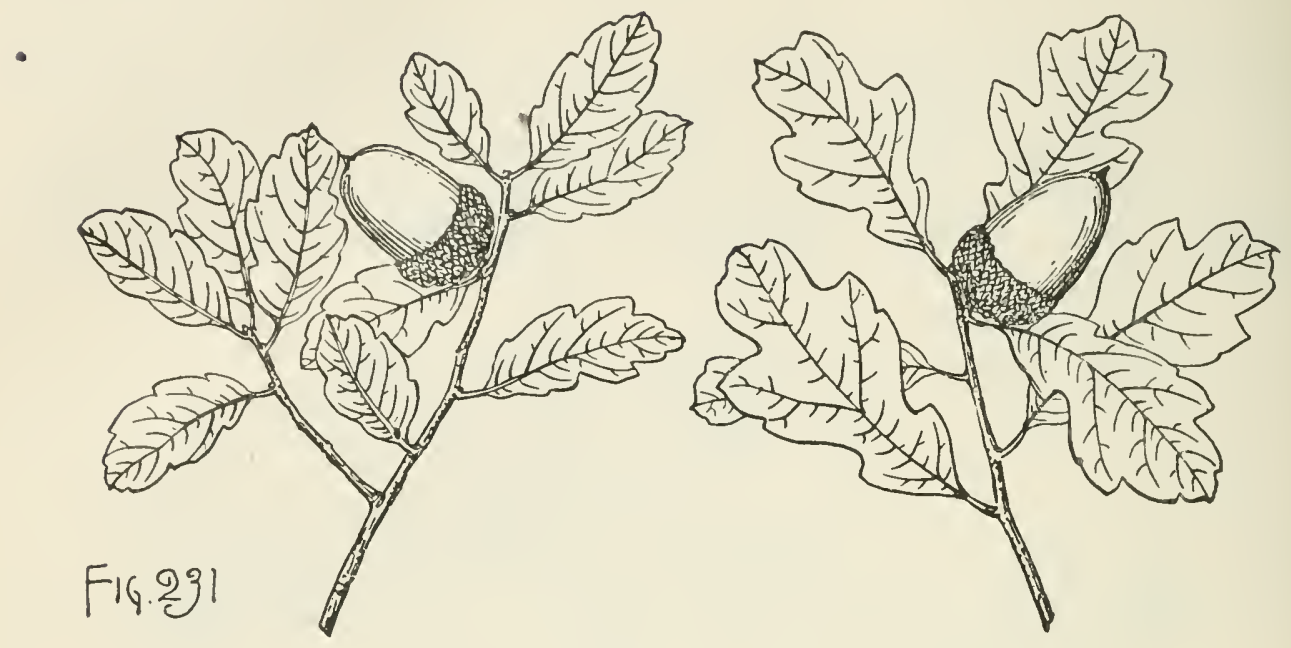

broad at the base, broad and rounded or acute at the apex, $\frac{1}{2}^{\prime}-1 \frac{1}{2}^{\prime}$ long, $\frac{1}{3}^{\prime}-\frac{2^{\prime}}{3}$ broad, inclosed for one half to two thirds its length in a deep cup-shaped or hemispherical cup light brown and pubescent within, covered by ovate pointed scales coated with pale or rufous tomentum, usually much thickened, united and tuberculate, those above with free acute tips forming a fringe to the rim of the cup, or frequently with basal scales but little thickened and furnished with long free tips.

A tree, occasionally $25^{\circ}-30^{\circ}$ high, with a trunk $12^{\prime}-18^{\prime}$ in diameter, small branches forming a round-topped head, and slender branchlets coated at first with hoary tomentum, becoming in their first winter ashy gray or light or dark reddish brown and usually pubescent or tomentose; more often an intricately branched rigid shrub, with stout stems covered by pale gray bark and usually $6^{\circ}-8^{\circ}$ high, often forming dense thickets. Winter-buds oval, generally acute, $\frac{1}{16}-\frac{1^{\prime}}{8}$ long, with thin pale red often pilose and ciliate scales. Bark of the trunk bright brown and scaly.

Distribution. California; western slopes of the central Sierra Nevada; common on the coast ranges south of San Francisco Bay and the islands off the coast of the southern part of the state, ranging inland to the borders of the Mohave Desert and to the cañons of the desert slopes of the San Bernardino and San Jacinto mountains, and southward into Lower California; arborescent only in sheltered cañons of the islands; north of San Francisco Bay replaced by the variety revoluta, Sarg., ranging to Mendocino County and to Napa valley.

\section{Quercus Virginiana, Mill. Live Oak.}

Leaves oblong, elliptical or obovate, rounded or acute at the apex, gradually narrowed and wedge-shaped or rarely rounded or cordate at the base, usually entire, with thickened strongly revolute margins or rarely spinose-dentate above the middle; when they unfold light green tinged with red, covered by scattered stellate pale hairs above and coated below with thick hoary tomentum, at maturity thick and coriaceous, dark green and lustrous on the upper surface, pale and silvery white and pubescent or puberulous on the lower surface, $2^{\prime}-5^{\prime}$ long, $\frac{1}{2}^{\prime}-2 \frac{1}{2}^{\prime}$ wide, and conspicuously or inconspicuously reticulate-venulose, with narrow yellow midribs and few slender 
obscure primary veins forked and united at some distance from the margins, gradually turning yellow or brown at the end of the winter and falling with or soon after the appearance of the new leaves in the spring; their petioles stout, rarely more than ${ }^{\prime}$ long. Flowers : staminate in hairy aments $2^{\prime}-3$ ' long; calyx light yellow, hairy, divided into 5-7 ovate rounded segments; anthers hirsute; pistillate in spikes on sleuder pubescent peduncles $1^{\prime}-3^{\prime}$ long, their involucral scales and ovate calyx-lobes coated with hoary pubescence; stigmas bright red. Fruit nsually in 3-5-fruited spikes or rarely in pairs or single on stout light brown puberulous peduncles $1^{\prime}-5$, long; acorn oval or slightly obovate, narrowed at the base, rounded or acute at the apex, dark chestnut-brown and lustrous, about $\mathbf{1}^{\prime}$ long and $\frac{1}{3}^{\prime}$ wide, inclosed for about one fourth its length in a turbinate light reddish brown cup puberulous within, its scales thin, ovate, acute, slightly keeled on the back, covered by dense lustrous hoary tomentum and ending in small closely appressed reddish tips; seed sweet, with light yellow comnate cotyledons.

A tree, $40^{\circ}-50^{\circ}$ high, with a trunk $3^{\circ}-4^{\circ}$ in diameter above its swollen buttressed base, usually dividing a few feet from the ground into 3 or 4 horizontal wide-spreading limbs forming a low dense round-topped head sometimes $150^{\circ}$ across, and slender rigid branchlets coated at first with hoary tomentum, becoming ashy gray or light brown and pubescent or puberulous during their first winter and darker and glabrous

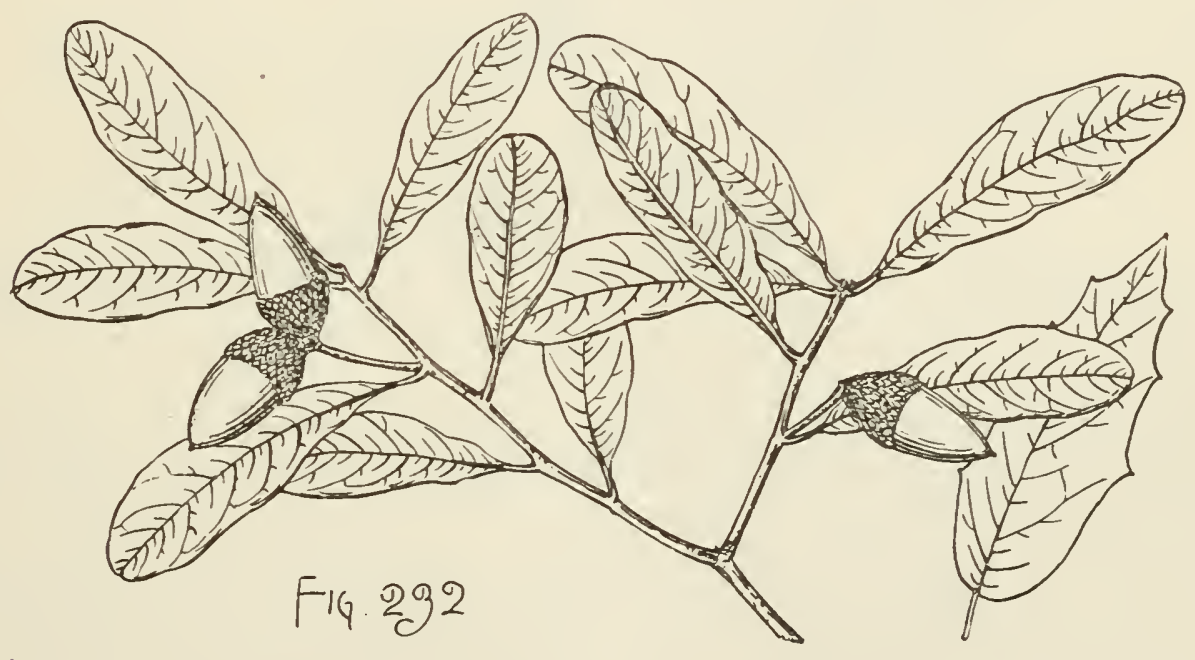

the following season; occasionally $60^{\circ}-70^{\circ}$ tall, with a trunk $6^{\circ}-7^{\circ}$ in diameter; of ten shrubby and occasionally not more than a foot high. Winter-buds globose or slightly obovate, about $\frac{1^{\prime}}{6}$ long, with thin light chestnut-brown scales white and scarious on the margins. Bark of the trunk and large branches $\frac{1^{\prime}}{2}-1^{\prime}$ thick, dark brown tinged with red, slightly furrowed, separating on the surface into small closely appressed scales. Wood very heavy, hard, strong, tough, close-grained, light brown or yellow, with thin nearly white sapwood; formerly largely and still occasionally used in shipbuilding.

Distribution. Shores of Mobjack Bay, Virginia, southward along the coast and islands to southern Florida, and along the shores of the Gulf of Mexico to northeastern Mexico, spreading inland through Texas to the valley of the Red River and to the mountains in the extreme western part of the state; on the mountains of Cuba, southern Mexico, Central America, and Lower California; most abundant and of its 
largest size on the Atlantic and east Gnlf coasts on rich hummocks and ridges a few feet above the level of the sea; abnudant in Texas, in the coast region near the banks of streams, and westward toward the valley of the Rio Grande often forming the principal part of the shrubby growth on low moist soil; in sandy barren soil in the immediate vicinity of the seacoast or on the shores of salt water estuaries and bays often a shrub, sometimes bearing fruit on stems not more than a foot high (var. maritima, Sarg., and var. minima, Sarg.).

Often planted as a shade and ornamental tree in the southern United States.

\section{Quercus Emoryi, Torr. Black Oak.}

Leaves oblong-lanceolate, acute and mucronate at the apex, cordate or ronnded at the slightly narrowed base, entire or remotely repand-serrate, with $1-5$ pairs of

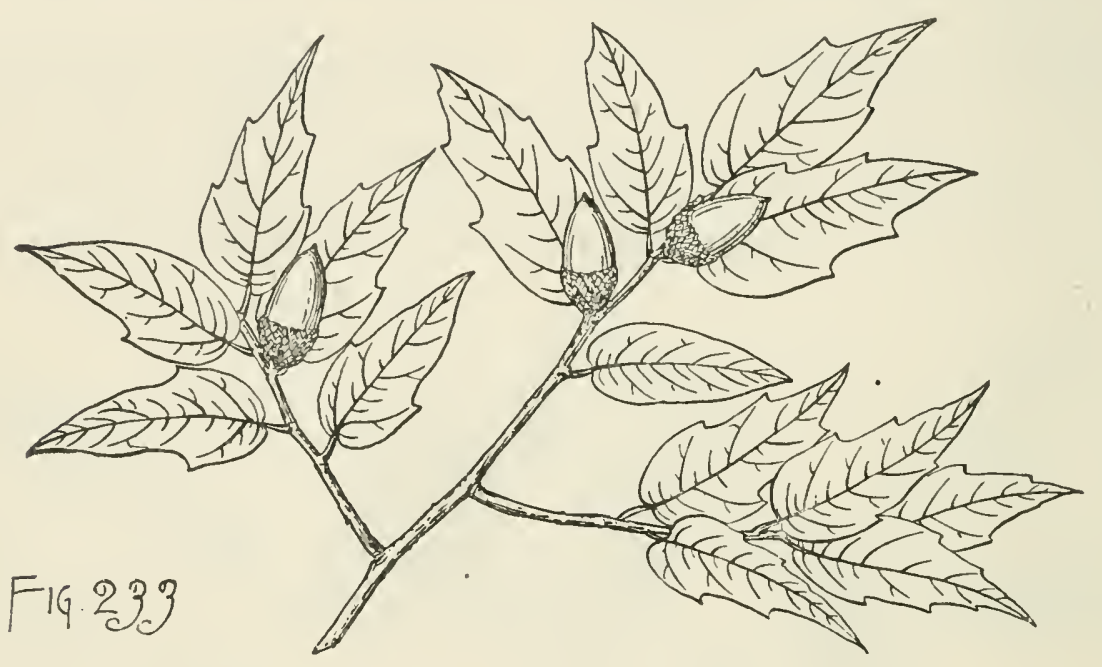

acute rigid oblique teeth, when they unfold thin, light green more or less tinged with red and covered with silvery white tomentum, at maturity thick, rigid, coriaceons, dark green, very lustrous and glabrous or coated with minute stellate hairs above, pale and glabrons or puberulous below, usually with 2 large tufts of white hairs at the base of the slender midrib, obscurely reticulate-venulose, $1^{\prime}-2 \frac{1}{2}^{\prime}$ long, $\frac{1}{2}-1^{\prime}$ broad, falling gradnally in April with the appearance of the new leaves; their petioles stout, pubescent, about $\frac{1^{\prime}}{4}$ long. Flowers: staminate in hoary-tomentose aments; calyx light yellow, hairy on the outer surface, divided into 5-7 ovate acute lobes; pistillate sessile or short-stalked, their involucral scales covered with hoary tomentum. Fruit ripening irregularly from Jnne to September, sessile or shortstalked; acorn oblong, oval, or ovate, narrowed at the base, rounded at the narrow pilose apex, $\frac{1}{2}^{\prime}-\frac{3 \prime}{4}$ long, about $\frac{1}{3}^{\prime}$ wide, light dull green when fully grown, dark chestnut-brown or nearly black at maturity, with a thin shell lined with thick white tomentum, inclosed for one third to one half its length in the deeply cup-shaped or nearly hemispherical cup light green and pubescent within and covered by closely imbricated broadly ovate acute thin and scarious light brown scales clothed with short soft pale pubescence.

A tree, usually $30^{\circ}-40^{\circ}$ high, with a short trunk $2^{\circ}-3^{\circ}$ in diameter, stont rigid rather drooping branches forming a round-topped symmetrical head, and slender rigid branchlets covered at first with close hoary tomentum, bright red, pubescent or 
tomentose in their first winter, ultimately glabrous and dark red-brown or black; sometimes $60^{\circ}-70^{\circ}$ high, with a trunk $4^{\circ}-5^{\circ}$ in diameter, with a head occasionally $100^{\circ}$ across; or at high elevations or on exposed mountain slopes a low shrub. Winter-buds oval, acute, about $\frac{1^{\prime}}{4}$ long, pale pubescent toward the apex, with thin closely imbricated light chestuut-brown ciliate scales. Bark $1^{\prime}-2^{\prime}$ thick, dark brown or nearly black, deeply divided into large oblong thick plates separating into small thin closely appressed scales. Wood heavy, strong, brittle, close-grained, dark brown or almost black, with thick bright browll sapwood tinged with red. The sweet acorns are an important article of food for Mexicans and Indians, and are sold in the towns of southern Arizona and northern Mexico.

Distribution. Mountain ranges of western Texas, southern New Mexico and Arizona south of the Colorado plateau, and of northeru Mexico; in 'Texas common in the cañons and on the southeru slopes of the Limpio and Chisos mountains; the most abundant Oak of southern New Mexico and Arizona, forming a large part of the forests covering the mountain slopes and extending from the upper limits of the mesas nearly to the highest ridges; attaining its largest size and beauty in the moist soil of sheltered cañons.

\section{Section 2. Flowers unisexual (usually perfect in Ulmus);} calyx regular; stamens as many as its lobes and opposite them; ovary superior, 1-celled (rarely 2-celled in Ulmus); seed 1.

\section{ULMACE王.}

Trees, with watery juice, scaly buds, terete branchlets prolonged by an "upper lateral bud, and alternate simple serrate pinnately veined deciduous stalked 2 -ranked leaves unequal and often oblique at the base, conduplicate in the bud, their stipules usually fugaceous. Flowers perfect or monœciously polygamous, clustered, or the pistillate sometimes solitary; calyx 4-9-parted or lobed; stamens 4-6; filaments straight; anthers introrse, 2-celled, opening longitudinally; ovary usually 1-celled; ovule solitary, suspended from the apex of the cell, anatropous or amphitropous; styles 2. Fruit a samara, nut, or drupe; albumen little or none; embryo straight or curved; cotyledons usually flat or conduplicate. Five of the thirteen genera of the Elm family occur in North America. Of these three are represented by trees.

\section{CONSPECTUS OF THE NORTH AMERICAN ARBORESCENT GENERA.}

Fruit a samara; flowers perfect.

1. Ulmus.

Fruit nut-like, tuberculate.

Fruit a drupe; pistillate flowers usually solitary.

2. Planera.

3. Celtis.

\section{ULMUS, L. Elm.}

Trees, or rarely shrubs, with deeply furrowed bark, brallchlets often furnished with corky wings, and buds with numerous ovate rounded chestunt-brown scales closely imbricated in two ranks, increasing in size from without inward, the outer sterile, the inner accrescent, replacing the stipules of the first leaves, deciduous, marking the base of the branchlet with persistent ring-like scars. Leaves simply or doubly serrate; stipules linear, lanceolate to obovate, entire, free or connate at the 
base, scarious, inclosing the leaf in the bud, caducous. Flowers from axillary buds near the cnds of the branches similar to but larger than the leaf-buds, the outer scales sterile, the inner bearing flowers and rarely leaves. Flowers perfect, jointed on slender bibracteolate pedicels from the axils of linear acute scarious bracts, in pedunculate or subsessile fascicles or cymes, appcaring in early spring before the leares in the axils of those of the previous year, or autumnal in the axils of leaves of the year; calyx campamnlate, 5-9-lobed, membranaceous, marcescent; stamens 5 or 6 inserted under the ovary; filaments filiform or slightly flattened, erect in the bud, becoming exserted; anthers oblong, emarginate, and subcordate; ovary sessile or stipitate, compressed, crowned by a simple deeply 2-lobed style, the spreading lobes papillo-stigmatic on the immer face, usually 1 -celled by abortion, rarely 2-celled; ovule amphitropous; micropyle extrorse, superior. Fruit an ovate or oblong, often oblique, sessile or stipitate samara surrounded at the base by the rcmnants of the calyx, membranaceous, the seminal cavity compressed, slightly thickened on the margin, chartaceons, produced into a thin reticulate-venulose membranaceous light brown broad or rarely narrow wing naked or ciliate on the margin, tipped with the, remnants of the persistent style, or more or less deeply notched at the apex, and often marked horizontally by the thickened line of the union of the two carpels. Seed ovate, compressed, without albumen, marked on the ventral edge by the thin raphe; testa membranaceous, light or dark chestnut-brown, of two coats, rarely produced into a narrow wing; embryo erect; cotyledons flat or slightly convex, much longer than the superior radicle tnrned toward the oblong linear pale hilum.

Ulmus, with fifteen or sixteen species, is widely distributed through the boreal and temperate regions of the northern hemisphere with the exception of western North America, reaching in the New World the mountains of sonthern Mexico and in the Old World the Sikkim Himalaya, northern China, and Japan. Of the exotic species, Ulmus campestris, L., and Ulmus glabra, Huds., have been largely planted for shade and ornament in the north Atlantic states, where old and large specimens of the former can be seen, especially in the neighborhood of Boston.

Ulmus produces heavy, hard, tough, light-colored wood, often difficult to split. The tough inner bark of some of the species is made into ropes or woven into coarse eloth, and in northern China nourishing mucilaginous food is prepared from the inner bark.

Ulmus is the classical name of the Elm-tree.

\section{CONSPECTUS OF THE NORTH AMERICAN SPECIES.}

Flowers vernal, appearing before the leaves.

Flowers on slender drooping pedicels; fruit ciliate on the margins.

Wing of the fruit broad.

Bud-scales and fruit glabrous; branchlets destitute of corky wings; leaves obovateoblong to oval, usually smooth on the upper, soft-pubescent on the lower surface.

1. U. Americana (A, C).

Bud-scales puberulous; branches often furnished with corky wings; fruit hirsute; leaves obovate to oblong-oval, smooth on the upper, soft-pubescent on the lower surface.

2. U. Thomasi (A).

Wing of the fruit narrow.

Bud-scales glabrous or slightly puberulous; branchlets furuished with broad corky wings; fruit hirsute, stipitate; leaves ovate-oblong to oblong-lanceolate, smooth on the upper, soft-pubescent on the lower surface.

3. U. alata $(A, C)$. 
Flowers on short pedicels; fruit naked on the margins.

Bud-scales coated with rusty hairs; branchlets destitute of corky wings; fruit pubescent; leaves ovate-oblong, scabrous on the upper, pubescent on the lower surface.

4. U. fulva (A, C).

Flowers autumnal, appearing in the axils of leaves of the year; branchlets furnished with corky wings; fruit hirsnte.

Bud-scales puberulous; flowers on short pedicels; leaves ovate, scabrous on the upper, soft-pubescent on the lower surface.

5. U. crassifolia (C).

Bud-scales glabrous; flowers on long pedicels; leaves oblong to oblong-obovate, acuminate, glabrous on the upper, pale and puberulous on the lower surface.

6. U. serotina (C).

1. Flowers vernal, appearing before the leaves.

\section{Ulmus Americana, L. White Elm.}

Leaves obovate-oblong to oval, abruptly narrowed at the apex into long points, full and rounded at the base on one side and shorter and wedge-shaped on the other, coarsely doubly serrate, with slightly incurved teeth, when they unfold coated below with pale pubescence and pilose above, with long scattered white hairs, at maturity $4^{\prime}-6^{\prime}$ loug, 1'-3' wide, dark green and glabrous or scabrate above, pale and softpubescent or sometimes glabrous below, with narrow pale midribs and numerous

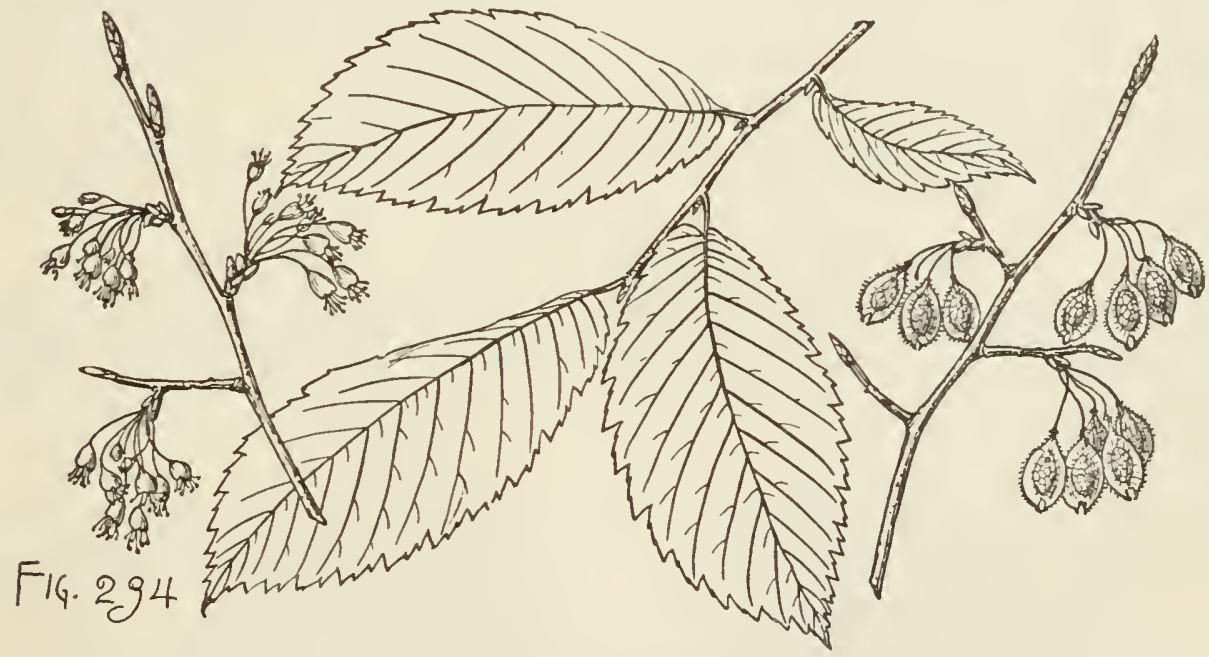

slender straight primary veins running to the points of the teeth and connected by fine cross veinlets, turning bright clear yellow in the autumn before falling; their petioles stout, $\frac{1^{\prime}}{4}$ long; stipules linear-lanceolate, $\frac{1}{2}^{\prime}-2^{\prime}$ long. Flowers on long slender drooping pedicels sometimes $1^{\prime}$ in length, in 3 or 4 -flowered short-stalked fascicles; calyx irregularly divided into 7-9 rounded lobes ciliate on the margins, often somewhat oblique, puberulous on the outer surface, green tinged with red above the middle; anthers bright red; ovary light green, ciliate on the margins, with long white hairs; styles light green. Fruit on long stems in crowded clusters, ripening as the leaves unfold, ovate to obovate-oblong, slightly stipitate, conspicuously reticulatevenulose, $\frac{1^{\prime}}{2}$ long, ciliate on the margins, the sharp points of the wings incurved and inclosing the deep notch.

A tree, sometimes $100^{\circ}-120^{\circ}$ high, with a tall trunk $6^{\circ}-11^{\circ}$ in diameter, frequently enlarged at the base by great buttresses, occasionally rising with a straight undi- 
vided shaft to the height of $60^{\circ}-80^{\circ}$ and separating into short spreading branches, more eommonly divided $30^{\circ}-40^{\circ}$ from the gromd into numerous upright limbs gradually spreading and forming an inverscly eonical round-topped head of long graeeful branches, often $100^{\circ}$ or rarcly $150^{\circ}$ in diameter, and slender branchlets frequently fringing the trunk and its principal divisions, light green and eoated at first with soft pale pubescence, becoming in their first winter light reddish brown, glabrous or sometimes puberulous and marked by seattered pale lenticels and by large elevated semiorbicular leaf-scars showing the ends of three large equidistant fibro-vaseular bundles, later beeoming dark reddish brown and finally ashy gray. Winter-buds ovate, acute, slightly flattened, about $\frac{1^{\prime}}{8}$ long, with broadly ovate rounded light ehestnut-brown glabrons seales, the iuner briglit green, ovate, aeute, becoming on vigorous shoots often nearly $1^{\prime}$ long. Bark $1^{\prime}-1 \frac{1^{\prime}}{2}$ thiek, ashy gray, divided by deep fissures into broad ridges separating on the surface into thin appressed seales. Wood leavy, hard, strong, tough, difficult to split, coarse-grained, light brown, with thiek somewhat lighter colored sapwood; largely used for the hubs of wheels, saddle-trees, in flooring and eooperage, and in boat and shipbuilding.

Distribution. River bottom-lands, intervales, low rich hills, and the banks of streams; southern Newfoundland to the northern shores of Lake Superior and the easteru base of the Roeky Mountains, southward to Cape Canaveral and the shores of Peaee Creek, Florida, westward to the Black Hills of Dakota, western Nebraska, western Kansas, the Indian Territory, and the valley of the Rio Concho, Texas; very eommon nortlıward, less abundant and of smaller size southward; abundant on the banks of streams flowing through the mideontinental plateau.

Largely planted as an ornamental and shade tree in the northern states, and rarely in western and northern Europe.

\section{Ulmus Thomasi, Sarg. Rock Elm. Cork Elm.}

Leaves obovate to oblong-oval, rather abruptly narrowed at the apex into short broad points, equally or somewhat unequally rounded, wedge-shaped or subeordate

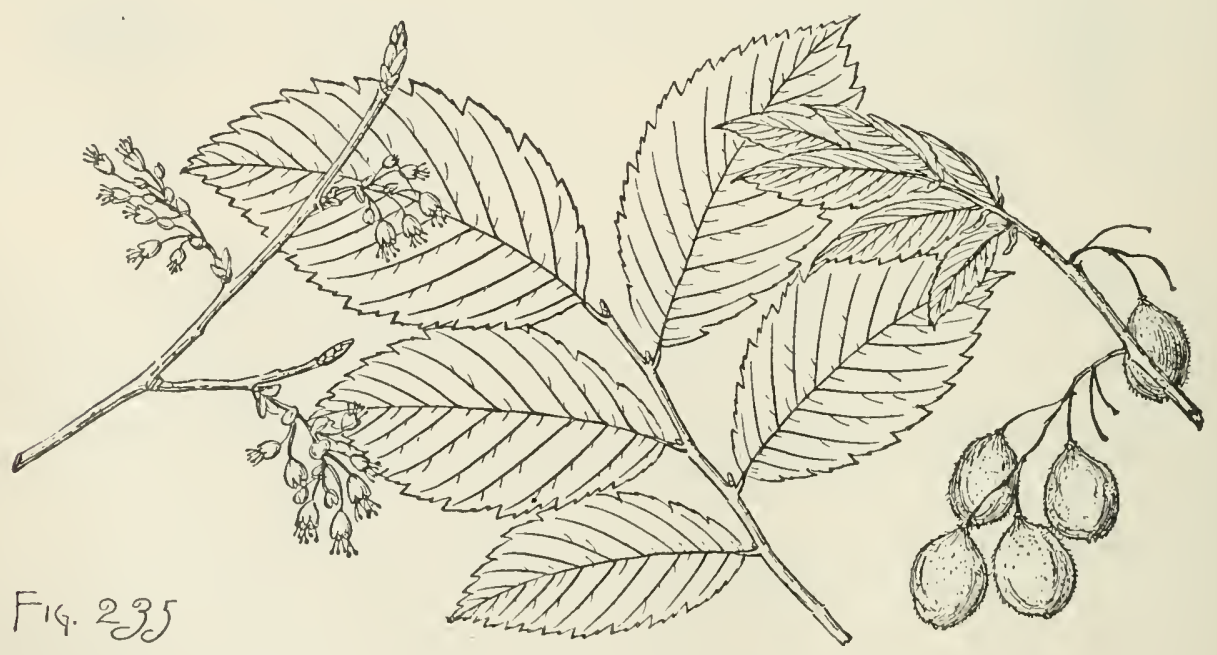

at the base and coarsely doubly serrate, when they unfold pilose on the upper surface and eovered on the lower with soft white hairs, at maturity $2^{\prime}-2 \frac{1}{2}^{\prime}$ long, $\frac{3^{\prime}}{4}-1^{\prime}$ wide, thick and firm, smooth, dark green and lustrous above, paler and soft-pubes- 
cent below, especially on the stout midribs and the numerous straight veins running to the points of the teeth and connected by obscure cross veinlets, turning in the autumn bright clear yellow; their petioles pubescent, about $\frac{1}{4}^{\prime}$ long; stipules ovatelanceolate, conspicuously veined, light green, marked with dark red on the margins above the middle, $\frac{2}{3}$ long, clasping the stem by their abruptly enlarged cordate bases, conspicuously dentate, with $1-3$ prominent teeth on each side, falling when the leaves are half grown. Flowers on elongated slender drooping pedicels often $\frac{1}{2}$ long, in 2-4, usually in 3, flowered puberulous cymes becoming more or less racemose by the lengthening of the axis of the inflorescence, and when fully grown sometimes 2 ' in length; calyx green, divided nearly to the middle into 7 or 8 rounded dark red scarious lobes; anthers dark purple; ovary coated with long pale hairs most abundant on the margins; styles light green. Fruit ripening when the leaves are about half grown, ovate or obovate-oblong, $\frac{1}{2}^{\prime}$ long, with a shallow open notch at the apex, obscurely veined, pale pubescent, ciliate on the slightly thickened border of the broad wing, the margin of the seminal cavity scarcely thickened.

A tree, $80^{\circ}-100^{\circ}$ high, with a trunk occasionally $3^{\circ}$ in diameter, and often free of branches for $60^{\circ}$, short stout spreading branches forming a narrow round-topped head, and slender rigid branchlets, light brown when they first appear, and coated with soft pale pubescence often persistent until their second season, becoming light reddish brown, puberulous or glabrons and lustrous in their first winter, and marked by scattered oblong lenticels and large orbicular or semiorbicular leaf-scars displaying an irregular row of 4-6 fibro-vascular bundle-scars, ultimately dark brown or ashy gray, and usually furnished with 3 or 4 thick corky irregular wings often $\frac{1}{2}$ broad, and beginning to appear in the first or more often during the second year. Winter-buds ovate, acute, $\frac{1^{\prime}}{4}$ long, with broadly ovate rounded chestnut-brown scales pilose on the outer surface, ciliate on the margins, the inner scales becoming ovate-oblong to lanceolate, and $\frac{1}{2}^{\prime}$ long, often dentate at the base, with 1 or 2 minute teeth on each side, bright green below the middle, marked with a red blotch above, and white and scarious at the apex. Bark $\frac{3^{\prime}}{4}-1^{\prime}$ thick, gray tinged with red, and deeply divided by wide irregular interrupted fissures into broad flat ridges broken on the surface into large irregularly shaped scales. Wood heavy, hard, very strong and tough, close-grained, light clear brown often tinged with red, with thick lighter colored sapwood; largely employed in the manufacture of many agricultural implements, for the framework of chairs, hubs of wheels, railway-ties, the sills of buildings, and other purposes demanding toughness, solidity, and flexibility.

Distribution. Dry gravelly uplands, low heavy clay soils, rocky slopes and river cliffs; Province of Quebec westward through Ontario, southward through northern New Hampshire to southern Vermont, and to northern New Jersey, and westward through northern New York, southern Michigan, and central Wisconsin to northeastern Nebraska and western Missouri; rare in the east and toward the extreme western and southern limits of its range; most abundant and of its largest size in Ontario and the southern peninsula of Michigan.

Occasionally planted as a shade and ornamental tree in the northern states.

\section{Ulmus alata, Michx. Wahoo. Winged Elm.}

Leaves ovate-oblong to oblong-lanceolate, often somewhat falcate, acute or acuminate, unequally wedge-shaped or rounded or subcordate at the base, and coarsely doubly serrate, with incurved teeth, when they unfold pale green often tinged with red, coated on the lower surface with soft white pubescence and gla- 
brous or nearly so on the upper surface, at maturity thick and firm or subcoriaceous, dark green and smooth above, pale and soft-pubesecnt below, especially on the stout yellow midribs and numerous straight prominent veins of ten forked near the margins of the leaf and connceted by rather conspicuous reticulate veinlets, turning dull yellow color in the autumn; their petioles stont, pubeseent, $1_{3}^{\prime}$ long ; stipules linearobovate, thin and searions, tinged with red above the middle, of ten nearly $1^{\prime}$ long.

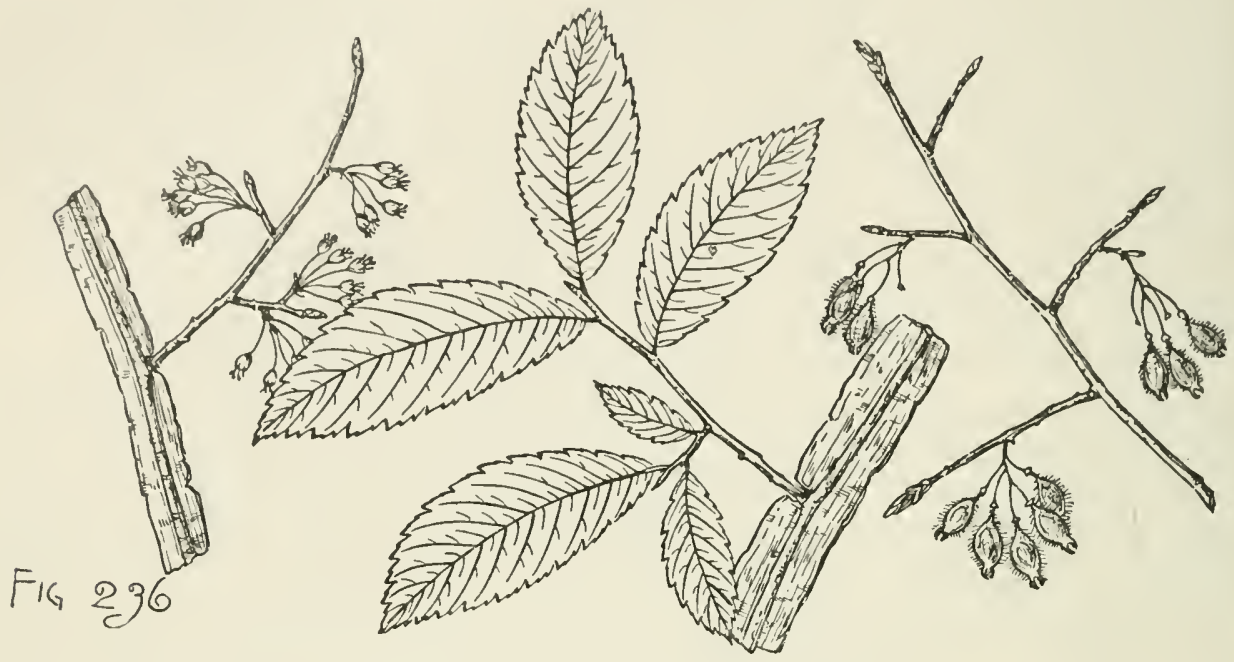

Flowers on drooping pedicels, in short few-flowered fascicles ; calyx glabrous and divided nearly to the middle into 5 broad ovate rounded lobes as long as the hoarytomentose ovary raised on a short slender stipe. Fruit ripening before or with the unfolding of the leaves, oblong, $\frac{1}{3}^{\prime}$ in length, contracted at the base into a long slender stalk, gradually narrowed and tipped at the apex with long incurved awns, covered with long white hairs most numerous on the thickened margin of the narrow wing; seed ovate, pointed, $\frac{1^{\prime}}{8}$ long, pale chestnut-brown, slightly thickened into a narrow wing-like margin.

A tree, $40^{\circ}-50^{\circ}$ high, with a trunk rarely $2^{\circ}$ in diameter, short stout straight or erect branches forming a narrow oblong rather open round-topped head, and slender branchlets glabrous or puberulous and light green tinged with red when they first appear, becoming light reddish brown or ashy gray and glabrous, or on vigorous individuals frequently pilose in their first winter, marked by occasional small orangecolored lenticels and by small elevated horizontal semiorbicular leaf-scars, sometimes naked, more often furnished with nsually 2 thin corky wings beginning to grow during the first or more often during their second season, abruptly arrested at the nodes, often $\frac{1}{2}^{\prime}$ wide, and persistent for many years. Winter-buds slender, acute, $\frac{1 \prime}{8}$ long, dark chestnut-brown, with glabrous or puberulous scales, those of the inner ranks becoming oblong or obovate, rounded and tipped at the apex with minute tips, thin and scarious, light red, especially above the middle, and $\frac{1^{\prime}}{2}$ long. Bark rarely exceeding $\frac{1^{\prime}}{4}$ in thickness, light brown tinged with red, and divided by irregular shallow fissures into flat ridges covered by small closely appressed scales. Wood heavy, hard, not strong, close-grained, difficult to split, light brown, with thick lighter colored sapwood; sometimes employed for the hubs of wheels and the handles of tools; rope used for fastening the covers of cotton bales is sometimes made from the inner bark. 
Distribution. Usually on dry gravelly uplands, less commonly in rich alluvial soil along the borders of swamps and the banks of streams, southern Virginia through the middle districts to western Florida, and from southern Indiana and Illinois through western Kentucky and Tennessee to the shores of the Gulf of Mexico, and through southern Missouri, Arkansas, and the eastern part of the Indian Territory to the valley of the Trinity River, Texas; of its largest size and most abundant west of the Mississippi River.

Often planted as a shade-tree in the street of towns and villages of the southern states.

\section{Ulmus fulva, Michx. Slippery Elm. Red Elm.}

Leaves ovate-oblong, abruptly contracted into long slender points, rounded at the base on one side and short-oblique on the other, and coarsely doubly serrate, with incurved callous-tipped teeth; when they unfold thin, coated on the lower surface with pale pubescence, pilose on the upper, with scattered white hairs, at maturity

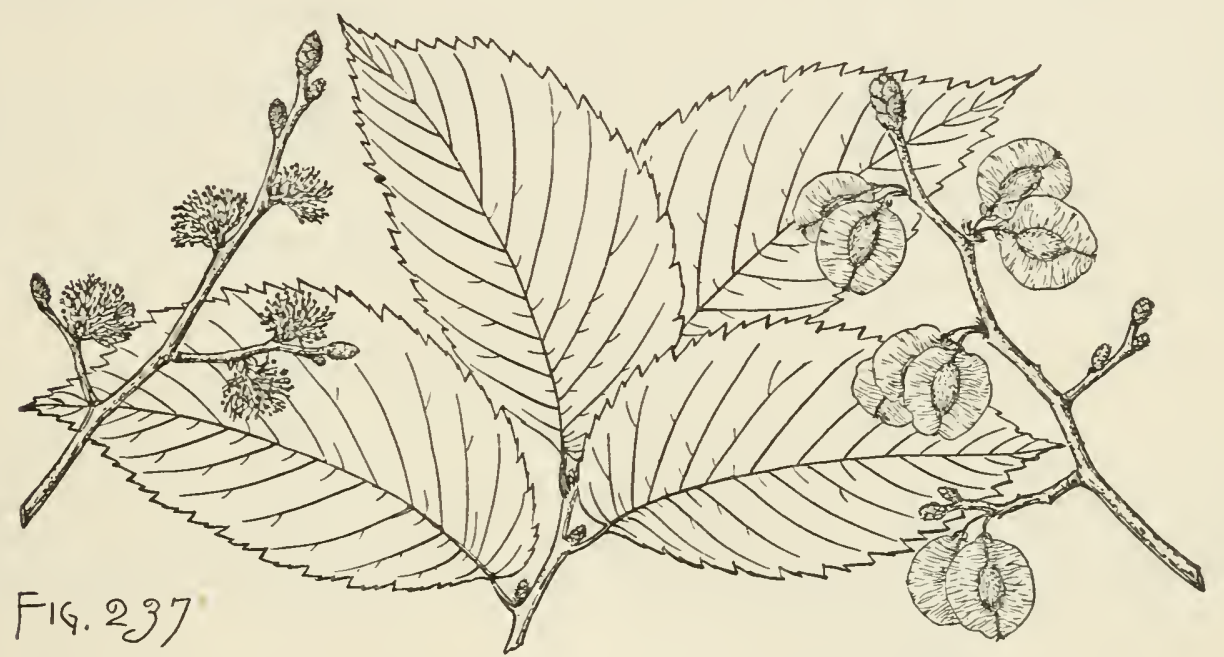

thick and firm, dark green and rugose with crowded sharp-pointed tubercles pointing toward the apex of the leaf, soft, smooth, and coated below, especially on the thin midribs and in the axils of the slender straight veins, with white hairs, $5^{\prime}-\bar{t}^{\prime}$ long, $2^{\prime}-3$ broad, turning a dull yellow color in the autumn; their petioles stont, pubescent, $\frac{1^{\prime}}{3}$ long; stipules obovate-oblong to oblong-lanceolate, thin and scarious, pale-pubescent, and tipped with clusters of rusty brown hairs. Flowers on short pedicels, in crowded fascicles; calyx green, covered with pale hairs, divided into 5-9 short rounded thin equal lobes; stamens with slender light yellow slightly flattened filaments and dark red anthers; stigmas slightly exserted, reddish purple, papillose, with soft white hairs. Fruit ripening when the leaves are about half grown, semiorbicular, rounded and bearing the remnants of the styles, or slightly emarginate at the apex, rounded or wedge-shaped at the base, $\frac{1}{2}^{\prime}$ broad, the seminal cavity coated with thick rusty brown tomentum, the broad thin wing obscurely reticulate-veined, naked on the thickened margin, and marked by the dark conspicuous horizontal line of union of the two carpels; seed ovate, with a large oblique pale hilum, a light chestnut-brown coat produced into a thin border wider below than above the middle of the seed.

A tree, $60^{\circ}-70^{\circ}$ high, with a trunk occasionally $2^{\circ}$ in diameter, spreading branches 
forming a broad open flat-topped head, and stont branchlets bright green, scabrate, and coated with soft pale pubescence when they first appear, becoming light brown by midsummer, often roughened by small pale lenticels, and in their first winter ashy gray, orange color, or light red-brown, and marked by large elevated semiorbicnlar leaf-scars showing the ends of 3 conspicuons equidistant fibro-vascular bundles, ultimately dark gray or brown. Winter-buds ovate, obtuse, $\frac{1}{4}$ long, with abont 12 scales, the onter broadly ovate, rounded, dark chestnut-brown, and covered by long scattered rusty lairs, the immer when fully grown $\frac{1}{2}^{\prime}$ long, $\frac{1}{8}^{\prime}-\frac{1}{4}^{\prime}$ wide, light green, strap-shaped, rounded and tipped at the apex with tufts of rusty hairs, pnberulous on the outer surface, slightly ciliate on the margins, gradually growing narrower and passing into the stipules of the upper leaves. Bark frequently $\mathbf{1}^{\prime}$ thick, dark brown tinged with red, divided by shallow fissures and covered by large thick appressed scales. Wood heavy, hard, strong, very close-grained, durable, easy to split, dark brown or red, with thin lighter colored sapwood; largely used for fence-posts, railway-ties, the sills of buildings, the hubs of wheels, and in agricultural implements. The thick fragrant inner bark is mucilaginors and demulcent, and is employed in the treament of acute febrile and inflammatory affections.

Distribution. Banks of streams and low rich rocky hillsides in deep fertile soil; comparatively common from the valley of the St. Lawrence River through Ontario to north Dakota, eastern Nebraska, and northern and western Kansas, and sonthward to western Florida, central Alabama and Mississippi, and the valley of the Sall Antonio River, Texas.

\section{Flowers autumnal, appearing in the axils of leaves of the year.}

\section{Ulmus crassifolia, Nutt. Cedar Elm.}

Leaves oblong-oval, acute or rounded at the apex, unequally rounded or wedgeshaped and often oblique at the base, coarsely and unequally doubly serrate, with callous-tipped teeth, when they unfold thin, light green tinged with red, pilose above

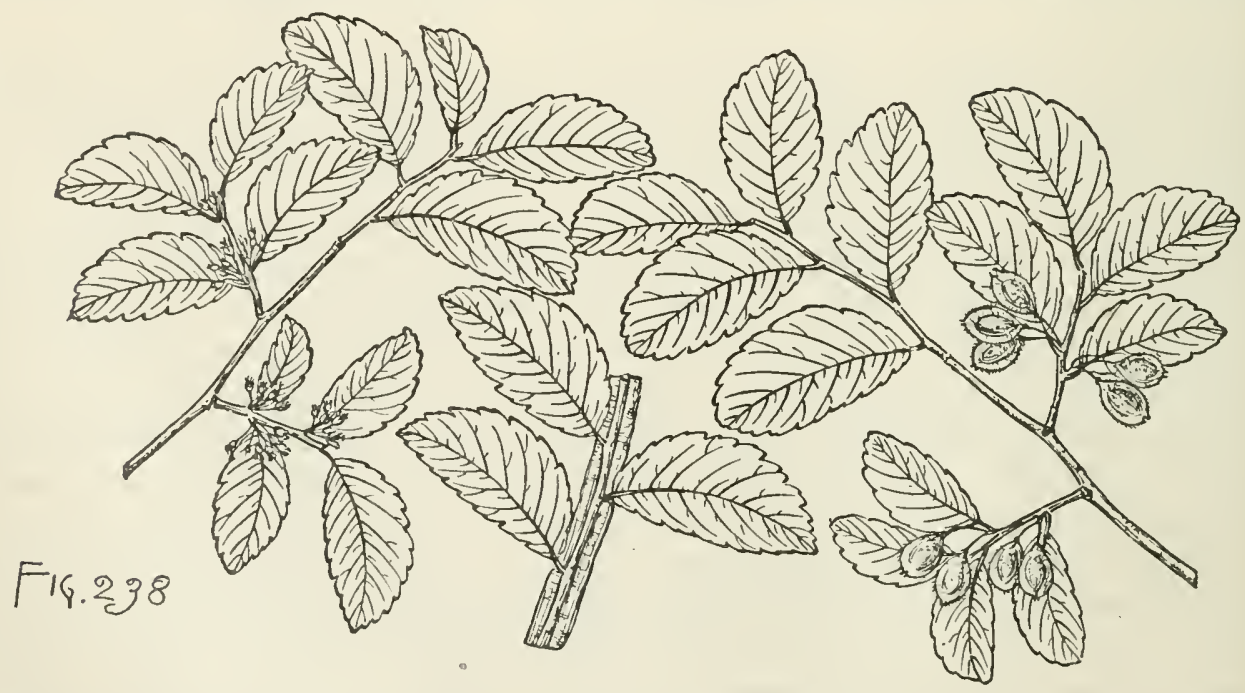

and covered below with soft pale pubescence, at maturity thick and subcoriaceous, dark green, lustrous and roughened by crowded minute sharp-pointed tubercles on the upper surface and soft pubescent on the lower surface, $1^{\prime}-2^{\prime}$ long, $\frac{1^{\prime}}{2}-1^{\prime}$ wide, 
with stout yellow midribs, prominent straight veins connected by conspicuous more or less reticulate cross veinlets, usually turning bright yellow late in the autumn; their petioles stout, tomentose, $\frac{1}{4}^{\prime}-\frac{1}{2}^{\prime}$ in length; stipules $\frac{1}{2}^{\prime}$ long, linear-lanceolate, red and scarious above, clasping the stem by their green and hairy bases, deciduous when the leaves are about half grown. Flowers usually opening in August and sometimes also in October, on slender pedicels $\frac{1^{\prime}}{3}-\frac{1}{2}^{\prime}$ long, covered with white hairs, in 3-5-flowered pedunculate fascicles; calyx divided to below the middle into oblong narrow-pointed lobes hairy at the base; ovary hirsute, crowned with two short slightly exserted stigmas. Fruit ripening in September and rarely also in Novenber, oblong, gradually and often irregularly narrowed from the middle to the ends, short-stalked, deeply notched at the apex, $\frac{1}{3}^{\prime}$ to nearly $\frac{1}{2}^{\prime}$ long, covered with soft white hairs, most abundant on the slightly thickened margin of the broad obscure wing; seed oblique, pointed, and covered by a dark chestnut-brown coat.

A tree, often $80^{\circ}$ high, with a tall straight trunk $2^{\circ}-3^{\circ}$ in diameter, sometimes free of branches for $30^{\circ}$ or $40^{\circ}$, divided into numerons stout spreading limbs forming a broad inversely conical round-topped head of long pendulous branches, or while young or on dry uplands a compact round head of drooping branches, and slender branchlets, when they first appear tinged with red and coated with soft pale pubescence, becoming light reddish brown, puberulons and marked by scattered minute lenticels and by small elevated semiorbicular leaf-scars showing the ends of 3 small fibro-vascular bundles, and furnished with 2 corky wings covered with lustrous brown bark, $\frac{1^{\prime}}{4}$ broad and continuous except when abruptly interrupted by lateral branchlets or often irregularly developed. Winter-buds broadly ovate, acute, $\frac{1}{8}$ long, with closely imbricated chestnut-brown scales slightly puberulous on the outer surface, those of the inner ranks at maturity oblong, concave, rounded at the apex, thin, bright red, sometimes $\frac{3^{\prime}}{4}$ long. Bark sometimes nearly $1^{\prime}$ thick, light brown slightly tinged with red and deeply divided by interrupted fissures into broad flat ridges broken on the surface into thick scales. Wood heavy, hard, strong, brittle, light brown tinged with red, with thick lighter colored sapwood; in central Texas used in the manufacture of the hubs of wheels, for furniture, and largely for fencing.

Distribution. Valley of the Sunflower River, Mississippi, throngh sonthern Arkansas and 'Texas to Nuevo Leon, ranging in western Texas from the coast to the valley of the Pecos River; in Arkansas usually on river cliffs and low hillsides, and in Texas near streams in deep alluvial soil and on dry limestone hills; the common Elm-tree of Texas and of its largest size on the bottom-lands of the Guadalupe and Trinity rivers.

Occasionally planted as a shade-tree in the streets of the cities and towns of Texas.

\section{Ulmus serotina, Sarg. Red Elm.}

Leaves oblong to oblong-obovate, acuminate, very oblique at the base, coarsely and doubly crenulate-serrate; when they unfold coated below with shining white hairs and puberulous above, at maturity thin and firm in texture, yellow-green, glabrous and lustrous on the upper surface, pale and puberulous on the midribs and principal veins on the lower surface, $2^{\prime}-4^{\prime}$ long, $1^{\prime}-1 \frac{3^{\prime}}{4}$ wide, with prominent yellow midribs, about 20 pairs of primary veins extending obliquely to the points of the teeth and often forked near the margins of the leaf, and numerous reticnlate veinlets, turning clear orange-yellow in the autumn; their petioles stont, about $\frac{1^{\prime}}{4}$ long; stipules abruptly narrowed from broad clasping bases, linear-lanceolate, usually about $\frac{1^{\prime}}{}$ long, persistent until the leaves are nearly fully grown. Flowers opening in 
September on slender conspienously jointed pedicels often $\frac{1^{\prime}}{8}$ long, in many-flowered glabrous racemes from $1^{\prime}-1 \frac{1}{2}^{\prime}$ in length; calyx 6 -parted to the base, with oblongobovate red-brown divisions rounded at the apex; ovary sessile, narrowed below, villous. Fruit ripening carly in Novenber, stipitate, oblong-elliptical, deeply divided at the apex, fringed on the margins with long silvery white hairs, about $\frac{1}{2}$ long.

A tree, $50^{\circ}-60^{\circ}$ high, with a trunk $2^{\circ}-3^{\circ}$ in diameter and comparatively small spreading or pendulous branches often forming a broad handsome head, and slender

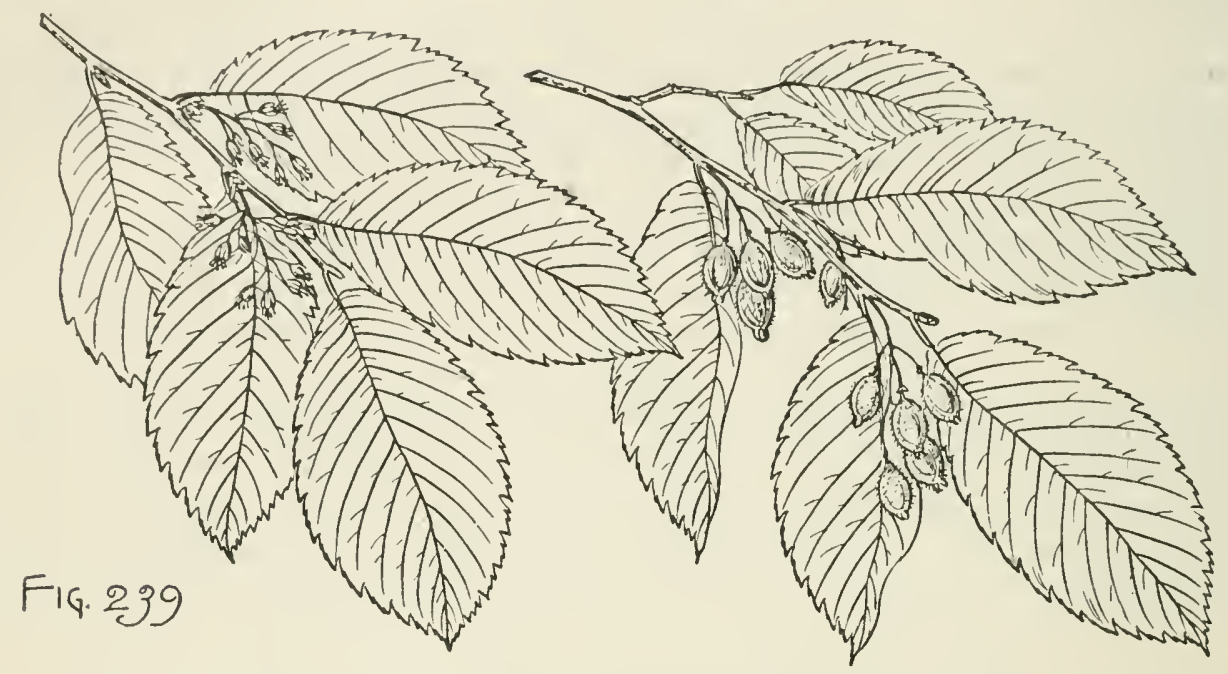

pendulous branchlets glabrous or occasionally puberulous when they first appear, brown, lustrous, and marked by occasional oblong white lenticels during their first year, becoming darker the following season and ultimately dark gray-brown, and often furnished with 2 or 3 thiek corky wings developed during their second or third years. Winter-buds ovate, aeute, $\frac{1^{\prime}}{4}$ long, their outer scales oblong-obovate, dark ehestnut-brown, glabrous, the imner often scarious on the margins, pale yellow-green, lustrous, and sometimes $\frac{3^{\prime}}{4}$ long when fully grown. Bark $\frac{1^{\prime}}{4}-\frac{3^{\prime}}{8}$ thiek, light brown slightly tinged with red, and divided by shallow fissures into broad flat ridges broken on the surfaee into large thin closely appressed seales. Wood hard, close-grained, very strong and tough, light red-brown, with pale yellow sapwood.

Distribution. Limestone hills and river banks; southern Kentucky to northern Alabama and northeastern Georgia.

Occasionally planted as a slade-tree in the streets of cities in northern Georgia and northern Alabama.

\section{PLANERA, Gmel.}

A tree, with scaly puberulous branchlets roughened by scattered pale lenticels, and at the end of their first season by small nearly orbicular leaf-scars marked by a row of fibro-vascular bundle-scars, minute subglobose winter-buds covered by numerous thin closely imbrieated chestmut-brown seales, the outer more or less scarious on the margins, the inner aecrescent, becoming at maturity ovate-oblong, scarious, bright red, $\frac{1^{\prime}-1^{\prime}}{3}$ long, marking in falling the base of the branchlet with pale ringlike scars. Leaves alternate, 2-ranked, ovate-oblong, acute or rounded at the narrowed apex, unequally wedge-shaped or rounded at the base, coarsely erenately serrate, with unequal gland-tipped teeth, petiolate, with slender terete puberulous 
petioles, numerous straight conspicuous veins forked near the margin and connected by cross reticulate veinlets more conspicuous below than above, when they unfold puberulous on the lower and pilose on the upper surface, at maturity thick or subcoriaceous and scabrate; stipules lateral, free, ovate, scarious, bright red. Flowers polygamo-monœcious, the staminate fascicled in the axils of the outer scales of leaf-bearing buds, short-pedicellate, the pistillate or perfect on elongated puberulous pedicels in the axils of leaves of the year in 1-3-flowered fascicles; pedicels without bracts; calyx campanulate, divided nearly to the base into 4 or 5 lobes rounded at the apex, greenish yellow often tinged with red; stamens inserted under the ovary in the pistillate flower, sometimes few or 0 ; filaments filiform, erect, exserted; anthers broadly ovate, emarginate, cordate; ovary ovate, stipitate, glandular-tuberculate, narrowed into a short style divided into 2 elongated reflexed stigmas papillo-stigmatic on the inner face, 0 in the staminate flower; orule, anatropous; micropyle extrorse, superior. Fruit an oblong oblique drupe, narrowed below into a short stipe, inclosed at the base by the withered calyx crowned by the remnants of the style, its pericarp crustaceous, prominently ribbed on the anterior and posterior faces, irregularly tuberculate, with elongated projections, and light chestnut-brown; seed ovate, oblique, pointed at the apex, rounded below, without albumen; testa thin, lustrous, dark brown or nearly black, of two coats; raphe inconspicuous; embryo erect; cotyledons thick, unequal, bright orange color, the apex of the larger hooded and slightly infolding the smaller, much longer than the minute radicle turned toward the linear pale hilum.

The genus is represented by a single species.

The generic name is in memory of Johamn Jacob Planer, a German botanist and physician of the eighteenth century.

\section{Planera aquatica, Gmel. Water Elm.}

Leaves $2^{\prime}-2 \frac{1}{2}^{\prime}$ long, $\frac{3^{\prime}}{4}-1^{\prime}$ wide, on petioles varying from $\frac{1}{8}^{\prime}-\frac{1}{4}^{\prime}$ in length, dark dull green on the upper surface, paler on the lower surface, with yellow midribs and veins. Flowers appearing with the leaves. Fruit ripening in April, $\frac{1}{3}$ long.
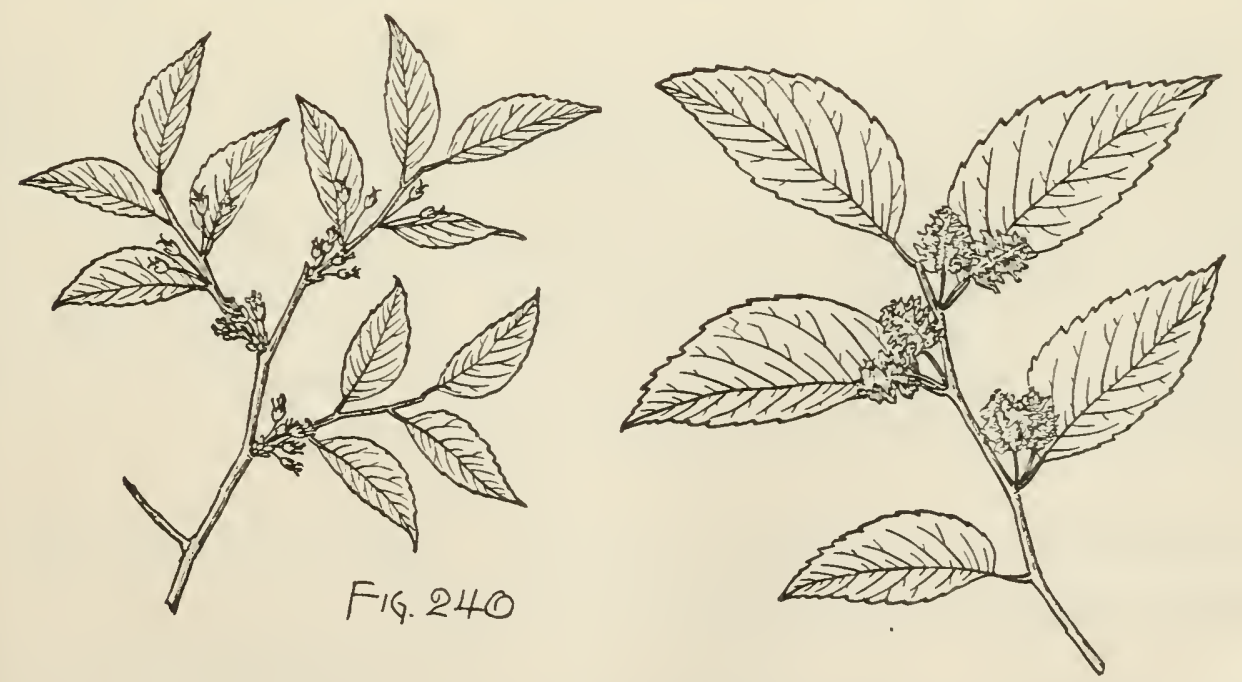

A tree, $30^{\circ}-40^{\circ}$ high, with a short trunk rarely exceeding $20^{\prime}$ in diameter, rather slender spreading branches forming a low broad head, and branchlets brown tinged 
with red when they first appear, dark red during their first winter, and ultimately reddish browu or ashy gray. Bark about $\frac{1}{4}$ thick, light brown or gray, separating into large seales disclosing in falling the red-brown inuer bark. Wood light, soft, not strong, close-grained, light brown, with thick nearly white sapwood of 20-30 layers of annual growtl.

Distribution. Swamps covered with water during several mouths of every year, from the valley of the Cape Fear River, North Carolina, to western Florida, and through sonthern Alabana and Mississippi to the valley of the 'Trinity River, Texas, and northward through western Louisiana and Arkansas to southern Missouri, central Kentucky, and the valley of the lower Wabash River, Illinois; comparatively rare, and only in the neighborhood of the coast in the Atlantic and east Gulf states; abundant and of its largest size in western Louisiana and southern Arkansas.

\section{CELTIS, L.}

Trees or shrubs, with thin, smooth often more or less muricate barls, unarmed or spinose branchlets, and scaly buds. Leaves serrate or entire, 3 or rarely 4 or 5-nerved, membranaceous or subcoriaceous, deciduous; stipules lateral, free, usually scarions, inclosing their leaf in the bud, caducous. Flowers polygamo-monœcious or rarely monœcious, appearing soon after the unfolding of the leaves, miunte, pedicellate on branches of the year, the staminate cymose or fascicled at their base, the pistillate solitary or in few-flowered fascicles from the axils of upper leaves; calyx divided nearly to the base into 4 or 5 lobes, greenish yellow, deciduous; stamens inserted on the margin of the discoid torus; filaments subulate, incurved in the bud, those of the sterile flower straightening themselves abruptly and becoming erect and exserted. shorter and remaining recurved in the perfect flower; anthers ovate, attached on the back just above the emarginate base; ovary ovate, sessile, green and lustrous, crowned with a short sessile style divided into diverging elongated reflexed acumiuate entire lobes papillo-stigmatic on the inner face and mature before the anther's of the sterile flower, deciduous; minute and rudimentary in the staminate flower; ovule anatropous. Fruit an ovoid or globose drupe tipped with the remunts of the style, with thin flesh covered by a thick firm skin, and a thick-walled bony smooth or rugose mutlet. Seed filling the semiual cavity; albumen scanty, gelatinous, nearly inclosed between the folds of the cotyledons, or 0 ; testa membranaceous, of 2 confluent coats; chalaza colored, close to the minute hilum; embryo curved; cotyledons broad, foliaceous, conduplicate or rarely flat, variously folded, corrugate, incumbent, or iuclosing the short superior ascending radicle.

Celtis is widely distributed through the temperate and tropical regions of the world, fifty or sixty species being distinguished. The North American species vary greatly in the form of their leaves in different parts of the country, and it is not improbable that a larger number of species than are here enumerated may be conveniently recognized when these trees can be more fully studied.

Celtis was the classical name of a species of Lotus.

\section{CONSPECTUS OF THE NORTH AMERICAN ARBORESCENT SPECIES.}

Leaves ovate to ovate-lanceolate, sharply and coarsely serrate.

1 C. occidentalis (A, B, C, F).

Leaves ovate-lanceolate, ovate or oblong-lanceolate. entire or occasionally obscurely and remotely serrate, thin or in one form subcoriaceous.

2. C. Mississippiensis (A, C, E, G, H). 


\section{Celtis occidentalis, L. Hackberry. Sugarberry.}

Leaves broadly ovate, more or less falcate, gradually or abruptly contracted into long narrow points, rounded and usually very oblique at the base, coarsely serrate, with callous-tipped teeth except at the entire ends, 3-ribbed, when they unfold pale yellow-green, coated on the lower surface with soft silky white hairs and pilose on the upper surface, at maturity thin, light green and lustrous, smooth, scabrate or scabrous above, paler and glabrous or slightly hairy below on the prominent midribs and primary veins, arcuate and united near the margins and connected by conspicuous reticulate veinlets, $2 \frac{1}{2}^{\prime}-4^{\prime}$ long, $1^{\prime}-2^{\prime}$ wide, turning light yellow late in the autumn before falling; their petioles slender, hairy, $\frac{1^{\prime}}{2}-\frac{2^{\prime}}{3}$ long; stipules linear, strap-shaped, white and scarious, nearly $\frac{1}{2}^{\prime}$ long, or on sterile shoots orate, acute, concave, sometimes $\frac{2^{\prime}}{3}$ long and $\frac{1}{4}^{\prime}$ wide. Flowers on slender drooping pedicles; calyx divided usually into 5 linear acute thin and scarious lobes rounded on the

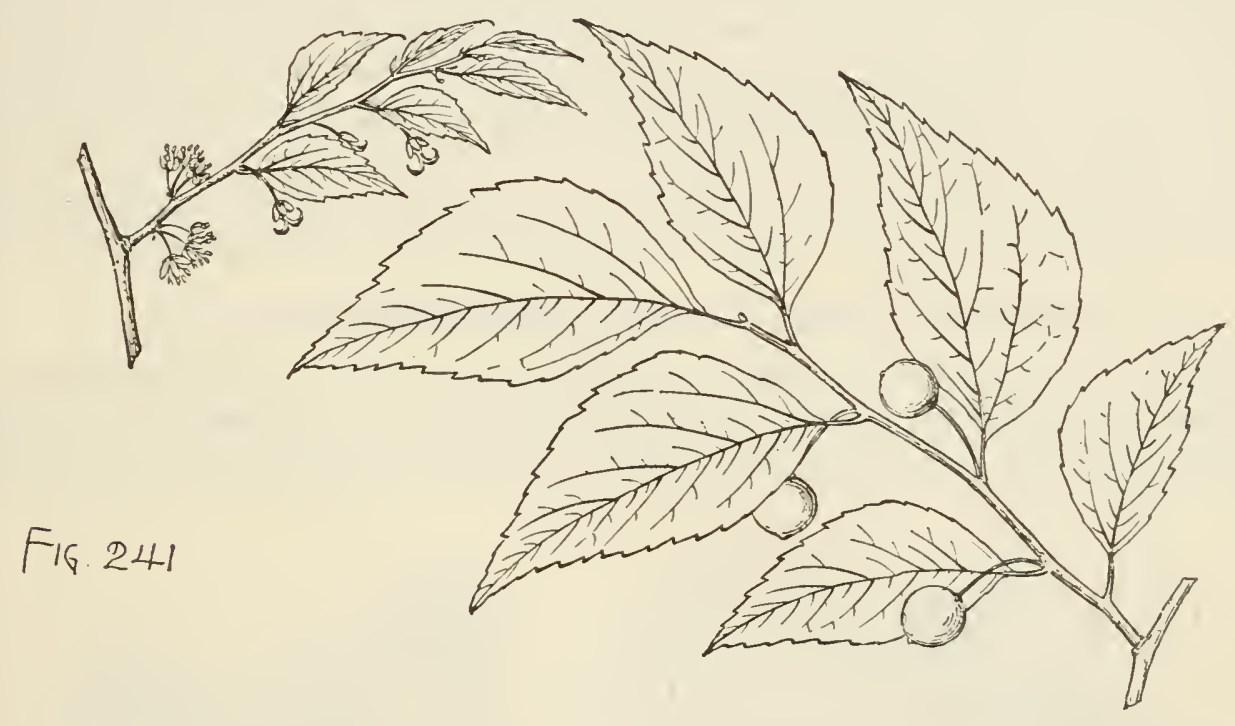

back, more or less laciniately cut at the apex, tinged with red, and often furnished with a tuft of pale hairs; torus hoary-tomentose. Fruit on slender stem $\frac{1^{\prime}}{2}-3^{\prime}$ long, ripening in September and October and often remaining on the branches during the winter, oblong, about $\frac{1}{4}$ ' long, dark purple, with a thick tough skin, dark orange-colored flesh, and a smooth thick-walled oblong pointed light brown nut; seed pale brown.

A tree, sometimes $130^{\circ}$ high, with a straight slender trunk $21^{\circ}-3^{\circ}$ in diameter, often free of branches for $70^{\circ}$ or $80^{\circ}$, and slender slightly zigzag and glabrous or puberulous branchlets containing a thick light-colored pith, light green when they first appear, gradually becoming tinged with red and in their first winter bright redbrown, rather lustrous, and marked by horizontal semioval or oblong leaf-scars showing the ends of 3 fibro-vascular bundles, darker in their second or third year, and ultimately dark brown slightly tinged with red; nsually much smaller and in the eastern states generally short-trunked, with stout spreading rigid or frequently pendulous branches forming a handsome round-topped tree. Winter-buds ovate, pointed, flattened, about $\frac{1 \prime}{4}$ long, with 3 pairs of chestnut-brown ovate acute pubescent caducous scales closely imbricated in 2 ranks, increasing in size from without inward and gradually passing into the stipules of the lower leaves. Bark $1^{\prime}-1 \frac{1}{2}^{\prime}$ thick, 
light brown or silvery gray, broken on the surface into thick appressed seales, and sometimes roughened by irregular wart-like excrescences or ridges also found on the large branches. Wood heavy, rather soft, not strong, coarse-grained, clear light yellow, with thick lighter colored sapwood; largely used for fencing and in the manufacture of cheap furniture.

Distribution. Valley of the St. Lawrence River near Montreal, westward to southern Ontario, and in the United States from the shores of Massachusetts Bay to northwestern Nebraska, North Dakota, southern Idaho, eastern Washington and Oregon, western Washington, Nevada, New Mexico, and southward to the shores of Bay Biscayne and Cape Romano, Florida, and to Missouri and eastern Texas; rare east of the Hudson River, more abundant in western New York and the middle states, and of its largest size on the rich bottom-lands of the lower Ohio basin; growing usually in rich moist soil and often, especially in the east, on dry gravelly or rocky hillsicies; west of the Rocky Mountains, a small tree or shrub rarely $30^{\circ} \mathrm{high}$, with thick rigid scabrous reticulate leaves, exceedingly rare and only on the banks of streams. A dwarf shrubby form found usually on the rocky banks of streams with stems $4^{\circ}-10^{\circ}$ tall and small usually rugose leaves is not uncommon in the south Atlantic states, ranging westward to Missouri, Colorado, Utah, and Nevada (var. pumila, Gray).

Often planted as a shade and ornamental tree in the states between the Mississippi River and the Rocky Mountains and occasionally in the eastern states and in Europe.

\section{Celtis Mississippiensis, Bosc. Sugarberry. Hackberry.}

Leaves ovate to oblong-lanceolate, long-pointed, more or less falcate, unequally rounded or very oblique or unequally wedge-shaped at the base, entire or occasionally serrate, with minute incurved teeth, or rarely furnished above the middle

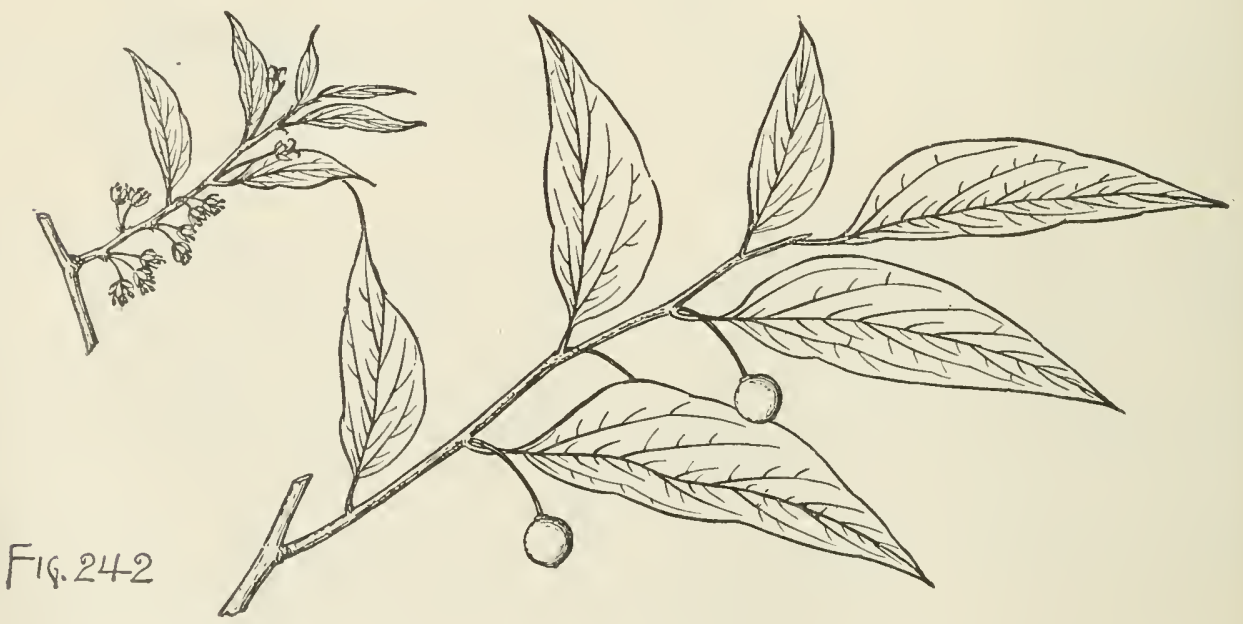

with 1 or 2 broad sharp teeth, when they unfold light yellow-green and nearly glabrous or coated with pale pubescence, at maturity firm, smooth, glabrous, dark green on the upper and pale on the lower surface, $3^{\prime}-4^{\prime}$ long, $\frac{8^{\prime}}{4}-3^{\prime}$ wide, with narrow yellow midribs and slender veins arcuate and united near the margins and connected by conspicuous reticulate veinlets; their petioles slender, $\frac{1}{4}^{\prime}-\frac{1}{2}^{\prime}$ long; stipules linear-strap-shaped, coated with soft white hairs. Flowers on slender hirsute pedicels; calyx divided into 5 ovate lanceolate glabrous or puberulous searious lobes 
furnished at the apex with tufts of long white hairs. Fruit ovate, $\frac{1}{8}-\frac{1}{4}$ long, bright orange-red, with thin dry flesh and a smooth light brown nut.

A tree, $60^{\circ}-80^{\circ}$ high, with a short trunk $2^{\circ}-3^{\circ}$ in diameter, spreading sometimes pendulous branches forming a broad and often graceful head, and branchlets light green, glabrous or covered with pale pubescence when they first appear, bright reddish brown, rather lustrous, and marked by oblong pale lenticels and narrow elevated horizontal leaf-scars showing the ends of 3 fibro-vascular bundles during their first winter; often much smaller and sometimes shrubby. Winter-buds ovate, pointed, $\frac{1}{16}-\frac{1}{8}^{\prime}$ long, with chestuut-brown puberulous scales. Bark $\frac{1^{\prime}}{2}-\frac{2}{3}$ thick, light bluegreen, and covered with prominent excrescences. Wood rather soft, not strong, close-grained, light yellow, with thick lighter colored sapwood; confounded commercially with the wood of Celtis occidentalis and used for the same purposes.

Distribution. Rich bottom-lands and the banks of streams or occasionally dry limestone hills from southern Indiana and Illinois through Kentucky, Temnessee, and Alabama to the shores of Bay Biscayne,Florida, and through Missouri, Arkansas, and Texas to Nuevo Leon; also in Bermuda; very abundant and of its largest size in the basin of the Lower Ohio River; the common species in central and western Kentucky and Temnessee; rare in the Gulf states; exceedingly common west of the Mississippi River, especially in Arkansas, Louisiana, and Texas, and in Nuevo Leon. In Texas gradually passing into a form with thicker and more conspicuously reticulate-venulose leaves. This is

\section{Celtis Mississippiensis, var, reticulata, Sarg.}

Leaves broadly ovate, acute or acuminate, rounded or cordate and usually oblique and very unequal at the base, entire or rarely furnished above the middle with few large teeth, thick and coriaceous, dark green and glabrous or scabrate above, pale

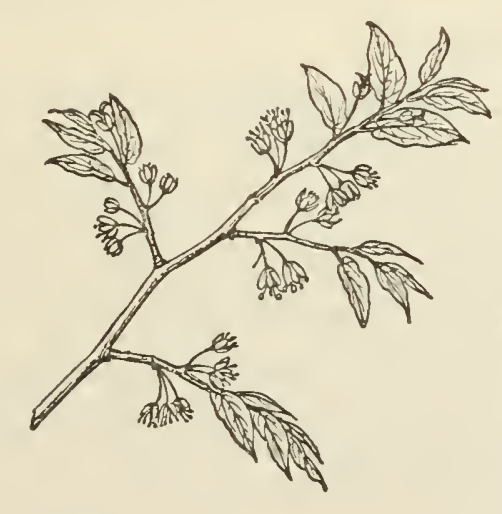

FIG. 243

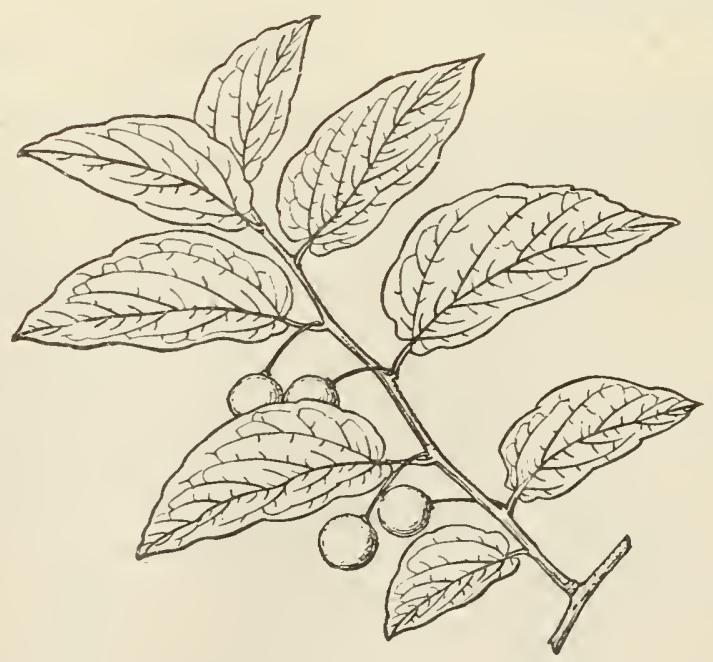

yellow-green, glabrous or hirsute, and covered by a network of prominent yellow veinlets below. Fruit $\frac{1}{4}^{\prime}-\frac{1}{2}^{\prime}$ long, dark orange-red.

A small bushy tree, $40^{\circ}-50^{\circ}$ high, with stout branches, a short trunk covered with smooth blue-gray bark roughened by prominent excrescences usually intexrupted or broken into short lengths; in arid regions often a low shrub.

Distribution. Texas, in the neighborhood of Dallas, southward to the Rio 
Grande, and westward through New Mexico and Arizona to sonthern Utah and Nevada, and the western rim of the Colorado Desert in California; and in Lower California; in eastern Texas usually on dry linestone hills; westward only near the banks of streans in monntain cañons.

\section{MORACE正.}

Trees or shrubs, with milky juice, scaly or naked buds, and stalked alternate simple leaves with stipules. Flowers monœcious or diœcious, in amentlike spikes or heads on the outside of a receptacle or on the inside of a closed receptacle; calyx of the staminate flower 3 or 4 -lobed or parted; stamens 1-4 inserted on the base of the calyx; calyx of the pistillate flower of $3-5$ partly united sepals; ovary 1-2 celled; styles 1 or 2 ; ovule pendulous. Fruits drupaceous, inclosed in the thickened calyx of the flower and united into a compound fruit. 'The Mulberry family is widely distributed with fifty-four genera confined largely to the warmer parts of the world. 'Three genera only, all arborescent, are indigenous in North America, although Broussonetia papyrifera, Vent., the Paper Mulberry, a tree related to the Mulberry and a native of eastern Asia, and the Hop and the Hemp are more or less generally naturalized in the eastern and southern states.

\section{CONSPECTUS OF THE NORTH AMERICAN GENERA.}

Flowers on the outside of the receptacle; buds scaly.

Flowers in ament-like spikes; compound fruit oblong and succulent.

1. Morus. Staminate flowers racemose, the pistillate capitate; compound fruit dry and globose.

2. Toxylon.

Flowers on the inside of a closed receptacle; buds naked; compound fruit subglobose to ovoid, succulent.

3. Ficus.

\section{MORUS, L. Mulberry.}

Trees or shrubs, with slender terete unarmed branches prolonged by one of the upper axillary buds, scaly bark, and fibrous roots. Winter-buds covered by ovate scales closely imbricated in 2 ranks, increasing in size from withont inward, the inner accrescent, marking in falling the base of the branch with ring-like scars. Leaves conduplicate in the bnd, alteruate, serrate, entire or 3-lobed, 3-5-nerved at the base, membranaceous or subcoriaceous, deciduous; stipules inclosing their leaf in the bud, lateral, lanceolate, acnte, cadncous. Flowers monœcious or divecious, the staminate and pistillate on different branches of the same plant or on different plants, minute, vernal, in pedunculate clusters from the axils of caducous bud-scales or of the lower leaves of the year, the staminate in elongated cylindrical spikes; calyx deeply divided into 4 equal rounded lobes; stamens 4 , inserted opposite the lobes of the calyx under the minute rudimentary ovary; filaments filiform, incurved in the bud, straightening elastically and becoming exserted; anthers attached on the back below the middle, introrse, 2-celled, the cells reniform, attached laterally to the orbicular connective, opening longitudinally; the pistillate sessile, in shortoblong densely flowered spikes; calyx 4-parted, the lobes ovate or obovate, thickened, often unequal, the 2 outer broader than the others, persistent; ovary ovoid flat, sessile, included in the calyx, crowned by a central style divided nearly to the base into 2 equal spreading filiform villous white stigmatic lobes; ovule suspended from the apex of the cell, campylotropous; micropyle superior. Drupes ovate or 
obovate, crowned with the remnants of the styles, inclosed in the succulent thickened and colored perianth of the flower and more or less united into a more or less juicy compound fruit (syncarp); flesh subsucenlent, thin; walls of the nutlet thin or thick, crustaceous. Seed oblong, pendulous; testa thin, membranaceous; hilum minute, apical; embryo incurved in thick fleshy albumen; cotyledons oblong, equal; radicle ascending, incumbent.

Morus with six or seven species is confined to eastern temperate North America, the elevated regions of Mexico, Central America and western South America, western Asia, Indo-China, Japan, and the ligh mountains of the Indian Archipelago. Two species occur in North America. The most valuable species, Morus alba, L., a native of northern China and Japan, and largely cultivated in many comitries for its leaves, which are the best food of the silkworm, has been planted in large quantities in the eastern United States; and Morus nigra, L., probably a native of Persia, has been introduced into the southern and Pacific states for its large dark-colored juicy fruit. Morus produces straight-grained durable light brown or orange-colored valuable wood, and sweet acidulous and refreshing fruits.

Morus is the classical name of the Mulberry-tree.

\section{CONSPECTUS OF THE NORTH AMERICAN SPECIES.}

Leaves coated below with pale pubescence; lobes of the stigma long; fruit oblong, dark purple.

1. M. rubra $(A, C)$.

Leaves glabrous or pubescent on the lower surface; lobes of the stigma short; fruit subglobose or short ovate, nearly black.

2. M. celtidifolia (C, E, H).

\section{Morus rubra, L. Red Mulberry.}

Leaves ovate, oblong-ovate or semiorbicular, abruptly contracted into long broad points or acute at the apex, more or less deeply cordate or occasionally truncate at

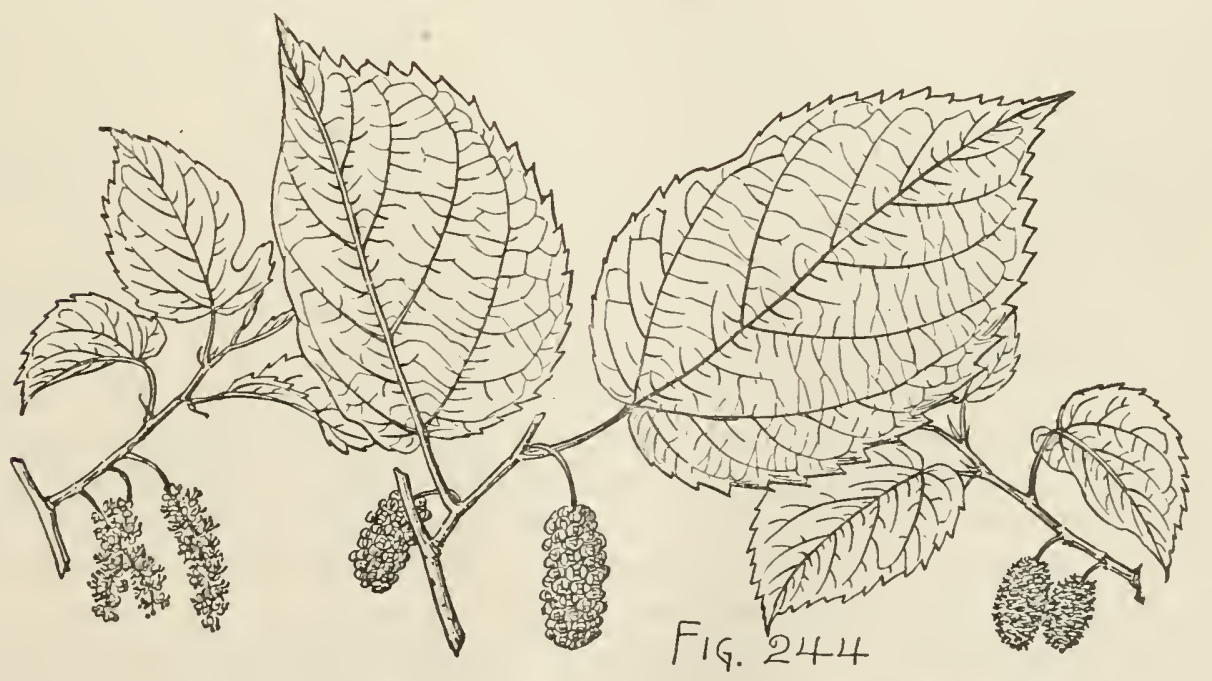

the base, coarsely and occasionally doubly serrate, with incurved callous-tipped teeth, often, especially on vigorous young shoots, 3-lobed by broad deep oblique lateral rounded sinuses, when they unfold yellow-green, slightly pilose on the upper surface and hoary-tomentose on the lower surface, at maturity thin, dark bluish green, 
glabrous, smooth, or seabrate above, pale and more or less pubescent below, with short white hairs thickest on the orange-colored midribs and primary veins areuate and nnited near the margins and connected by reticulate veinlets, or sometimes hoary-tomentose below, $3^{\prime}-{ }^{\prime}$ long, $2 x_{2}^{\prime}-4^{\prime}$ broad, turning bright yellow in the antmmm; their petioles stont, hoary-tomentose at first, becoming glabrons, $\frac{3{ }^{\prime}}{4}-1 \frac{1}{4}$ long; stipules lanceolate, aente, abruptly enlarged and thickened at the base, sometimes tinged with red above the midlle, coated with long white hairs, and often $\mathbf{1}^{\prime}$ ị! length. Flowers appearing with the mnfolding of the leaves, staminate in narrow spikes '2'-21' long; on stout light green peduneles covered with pale hairs; ealyx divided nearly to the base into 4 oblong concave lobes rounded at the apex and hirsute on the outer surface; stamens with slightly flattened filaments narrowed from the base to the apex, and bright green anthers, their connectives orbicular, conspicuous, bright green; pistillate in oblong densely flowered spikes, 1' long, on short hairy peduncles, a few male flowers being sometimes mixed with them; calyx divided nearly to the base into 4 thick concave lobes rounded at the apex, rounded or slightly keeled on the back, the 2 outer lobes twice as wide as the others, as long as and closely investing the glabrous light green ovary. Fruit: syncarp at first bright red when fully grown, $1^{\prime}-1 \frac{1}{4}$ long, becoming dark purple or nearly black and sweet and juicy when fully ripe; drupes about $\frac{1}{32}$ ' long, with a thin fleshy outer coat and a light brown nutlet; seed ovate, acute, with a thin membranaceous light brown coat.

A tree, $60^{\circ}-70^{\circ}$ high, with a short trumk rarely exceeding $3^{\circ}-4^{\circ}$ in diameter, stont spreading smooth branches forming a dense broad round-topped shapely head, and slender slightly zigzag branchlets dark green often tinged with red, glabrous, more or less coated with pale pubescence, and covered with oblong straw-colored spots when they first appear, becoming in their first winter light red-brown to orange color and marked by pale lenticels and by large elevated horizontal nearly orbicular concave leaf-scars displaying a row of prominent fibro-vascular bundle-scars, and in their second and third years dark brown slightly tinged with red. Winter-buds ovate, rounded or pointed at the apex, $\frac{1}{4}^{\prime}$ long, with 6 or 7 chestnut-brown scales, those of the outer rows broadly ovate, rounded, and slightly thickened on the back, puberulous, eiliate on the margins, and much shorter than those of the next rows, the inner scales scarious, coated with pale hairs, oblong-lanceolate, rounded or acute at the apex, and $\frac{1^{\prime}}{2}-2^{\prime}$ long at maturity. Bark $\frac{1^{\prime}}{2}-\frac{3^{\prime}}{4}$ thick, dark brown tinged with red and divided into irregnlar elongated plates separating on the surface into thick appressed scales. Wood light, soft, not strong, rather tough, coarse-grained, very durable, light orange color, with thick lighter colored sapwood; largely used for fencing, in cooperage, and in ship and boatbuilding.

Distribution. Intervales in rich soil and on low lills; western Massachusetts, Connecticut, and Long Island to southern Ontario and central Michigan, southeastern Nebraska, eastern Kansas, and southward to the shores of Bay Biscayne and Cape Romano, Florida, and to the valley of the Colorado River, Texas; most abundant and of its largest size in the basin of the lower Ohio River and on the foothills of the sonthern Appalachian Mountains.

Occasionally planted, especially in the southern states, for its fruit valued for fattening hogs and as food for poultry. A few natural varieties, distinguished for the large size and good quality of their fruit, or for their productiveness, are occasionally propagated by pomologists. 


\section{Morus celtidifolia, H. B. K. Mulberry. Mexican Mulberry.}

Leaves ovate, acute or acuminate, rounded or rarely truncate, or often on vigorous shoots cordate at the broad base, and 3-lobed, with shallow lateral sinuses and broad coarsely serrate lobes, when they unfold coated below with pale tomentum, and puberulous above, at maturity thin and firm in texture, dark green and often roughened on the upper surface, with minute pale tubercles, and paler, smooth or scabrate,

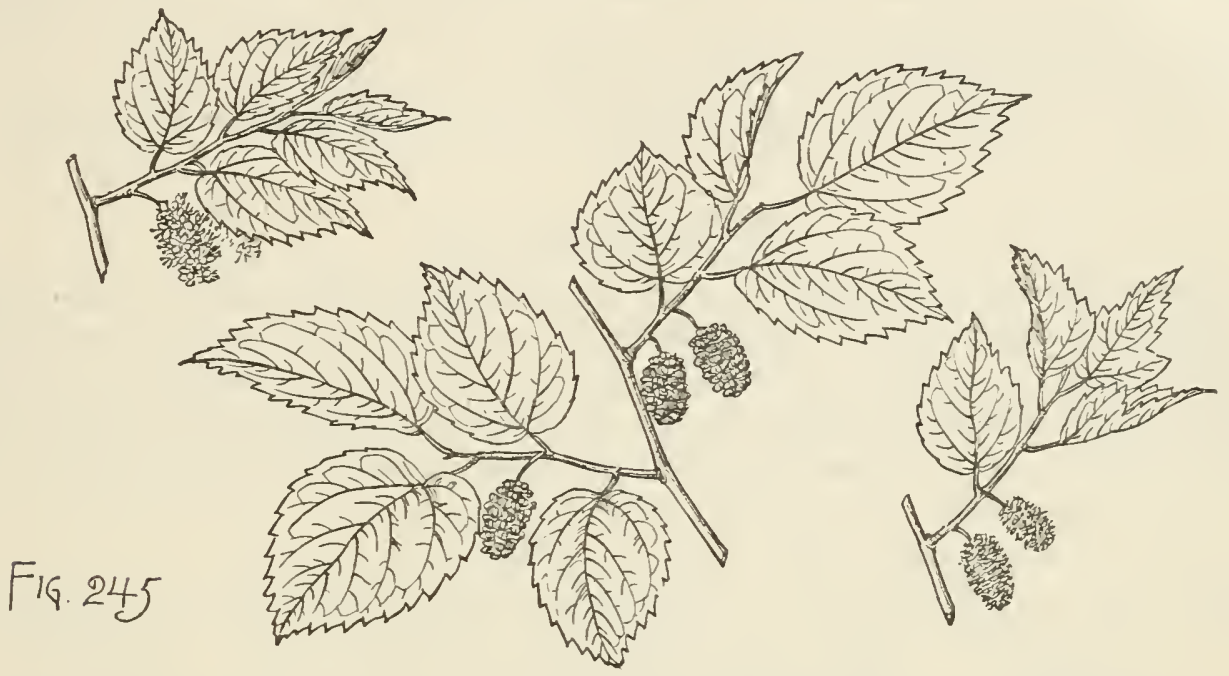

and glabrous or coated with soft pubescence on the lower surface, and often hirsute, with short stiff pale hairs on the broad orange-colored midribs and primary veins connected by conspicuous reticulate veinlets, in the United States rarely more than $1 \frac{1}{2}^{\prime}$ long and $\frac{3}{4}^{\prime}$ wide, turning yellow in the autumm; their petioles slender, hoarytomentose, becoming pubescent, $\frac{1^{\prime}}{3}$ long, and on trees cultivated in northern Mexico often $4^{\prime}-5^{\prime}$ long, and $2^{\prime}-3^{\prime}$ wide; stipules linear-lanceolate, acute, sometimes falcate, white, and scarious, coated with soft pale tomentum, about $\frac{1}{2}^{\prime}$ long. Flowers usually diœecious, staminate short-pedicellate, in short many-flowered spikes, $\frac{1}{2}-\frac{3 \prime}{4}$ long, calyx dark green, covered on the outer surface with soft pale hairs, deeply divided into 4 equal rounded lobes reddish toward the apex; stamens with bright yellow anthers, their connectives conspicuous, dark green; pistillate sessile, in few-flowered spikes, rarely $\frac{1^{\prime}}{3}$ long; calyx divided to the base into 4 thick rounded lobes, the 2 outer lobes much broader than the others, dark green, covered with pale scattered hairs; ovary green and glabrous, with short stigmatic lobes. Fruit : syncarp $\frac{1}{2}{ }^{\prime}$ long, dark purple or nearly black, sweet and palatable; drupe 2 lines long, ovate, rounded at the ends, with a thin fleshy outer covering and a thick-walled light brown nutlet; seed ovate, pointed, pale yellow.

A tree, sometimes $30^{\circ}$ high, with a trunk occasionally $12^{\prime}-14^{\prime}$ in diameter, and slender branchlets covered when they first appear with soft white hairs, soon becoming glabrous or nearly so, and in their first winter light orange-red and marked by small lenticels, and by small horizontal nearly obicular elevated concave leaf-scars displaying a ring of fibro-vascular bundle-scars. Winter-buds ovate, acute, sharp-pointed, and covered by thin lustrous chestnut-brown ovate rounded scales scarious on the margins, those of the inner rows ovate-oblong, rounded at the apex, pale-pubescent on the outer surface, and nearly $\mathbf{1}^{\prime}$ long when fully grown. Bark smooth, some- 
times nearly $\frac{1^{\prime}}{2}$ thick but usually thinner, light gray slightly tinged with red, deeply furrowed and broken on the surface into slightly appressed scales. Wood heavy, hard, close-grained, dark orange eolor or sometimes dark brown, with thick lightcolored sapwood.

Distribution. Dry limestone hills, or westward only in elevated mountain cañons in the neighborhood of streams; from the valley of the Colorado River, Texas, southward into Mexico, and through the nountain regions of western Texas and southern New Mexico to the Santa Rita Mountains of Arizona; common on the mountain ranges of northern Mexico from Nuevo Leon to Chihnahua, and southward through southern Mexieo and Central America to Peru.

Frequently planted in the countries south of the United States as a fruit-tree.

\section{TOXYLON, Raf.}

A tree, with thiek milky slightly acrid juiee, thick deeply furrowed dark orangecolored bark, stout tough terete pale branehlets, with thiek orange-eolored pith, lengthening by an upper axillary bud, marked by pale orange-colored lentieels and armed with stout straight axillary spines, short stout spur-like lateral branelilets from buds at the base of the spines, and thiek fleshy roots covered by bright orange-eolored bark exfoliating freely in long thin persistent papery scales. Leaves involute in the bud, ovate to oblong-lanceolate, acuminate and apiculate at the apex, rounded, wedgeshaped or subcordate at the base, entire, penniveined, the veins arcuate near the margins and conneeted by conspieuous reticulate veinlets; their petioles elongated, slender, terete, pubeseent; stipules lateral, nearly triangular, minute, hoary-tomentose, caducous. Flowers diœcious, light green, minute, appearing in early summer; calyx 4-lobed, the lobes imbrieated in æstivation; corolla 0; the staminate long-pedieellate, in short or ultimately elongated racemes borne on long slender drooping peduncles from the axils of crowded leaves on the spur-like branchlets of the previous year; calyx ovate, gradually narrowed into the slender pubescent pedieel, coated on the outer surface with pale hairs, divided to the middle into equal acute boat-shaped lobes; stamens 4, inserted opposite the lobes of the ealyx on the margins of the minute thin pulvinate disk; filaments flattened, light green, glabrons, infolded above the middle in the bud, with the anthers inverted and back to back, straightening abruptly in anthesis and becoming exserted; anthers oblong, attached on the back near the middle, introrse, 2-celled, the cells attached laterally to a minute oblong or semiorbieular conneetive, free and spreading above and below, opening by longitudinal lateral slits; the pistillate sessile in dense globose many-flowered heads on short stout peduneles axillary on shoots of the year; ealyx ovate, divided to the base into oblong thiek concave lobes, ronnded, thickened, and covered with pale liairs at the apex, longer than the ovary and elosely investing it, the 2 outer lobes mueh broarler than the others, persistent and inelosing the fruit; ovary ovate, eompressed, sessile, green, and glabrous; style covered by elongated slender filiform white stigmatic hairs; ovule suspended from the apex of the cell, anatropous. Drupes oblong, eompressed, rounded and often notehed at the apex, aente at the base, with thin sueculent flesh, and a thin erustaceous light brown nutlet, joined by the union of the thickened and mueh elongated perianths of the flowers into a globose compound fritit saturated with milky juiee, mammillate on the surface by their thiekened romded summits, light yellow-green, usually of full size but seedless on isolated pistillate individuals. Seed oblong, compressed, rounded at the base, oblique and marked at the apex by the 
conspicuous oblong pale hilum, without albumen; seed-coat membranaceous, light chestnut-brown; embryo recurved; cotyledons oblong, nearly equal; radicle elongated, incumbent, ascending.

The genus is represented by a single species of eastern North America.

The generic name, from $\tau \delta \xi \circ \nu$ and $\xi u ́ \lambda o \nu$, alludes to the Indian use of the wood.

\section{Toxylon pomiferum, Raf. Osage Orange. Bow Wood.}

Leaves $3^{\prime}-5^{\prime}$ long, $2^{\prime}-3^{\prime}$ wide, turning bright clear yellow before falling in the autımn; their petioles $1 \frac{1^{\prime}}{2}-2^{\prime}$ long. Flowers : racemes of the staminate flowers $1^{\prime}-1 \frac{1^{\prime}}{2}$ long; heads of the pistillate flowers, $\frac{3^{\prime}}{4}-1^{\prime}$ in diameter. Fruit $4^{\prime}-5^{\prime}$ in diameter, ripening in the autumn, and soon falling to the ground.

A tree, sometimes $\tilde{5} 0^{\circ}-60^{\circ}$ high, with a short trunk $2^{\circ}-3^{\circ}$ in diameter, and stout erect ultimately spreading branches forming a handsome open irregular roundtopped head, and branchlets light green often tinged with red and coated with soft pale pubescence when they first appear, soon becoming glabrous, light brown slightly tinged with orange color during their first winter, and ultimately paler. Winterbuds depressed-globose, partly immersed in the bark, covered by few closely imbricated ovate rounded light chestnut-brown ciliate conspicuous scales. Bark $\frac{2^{\prime}}{3}-1^{\prime}$ thick and deeply and irregularly divided into broad rounded ridges separating on

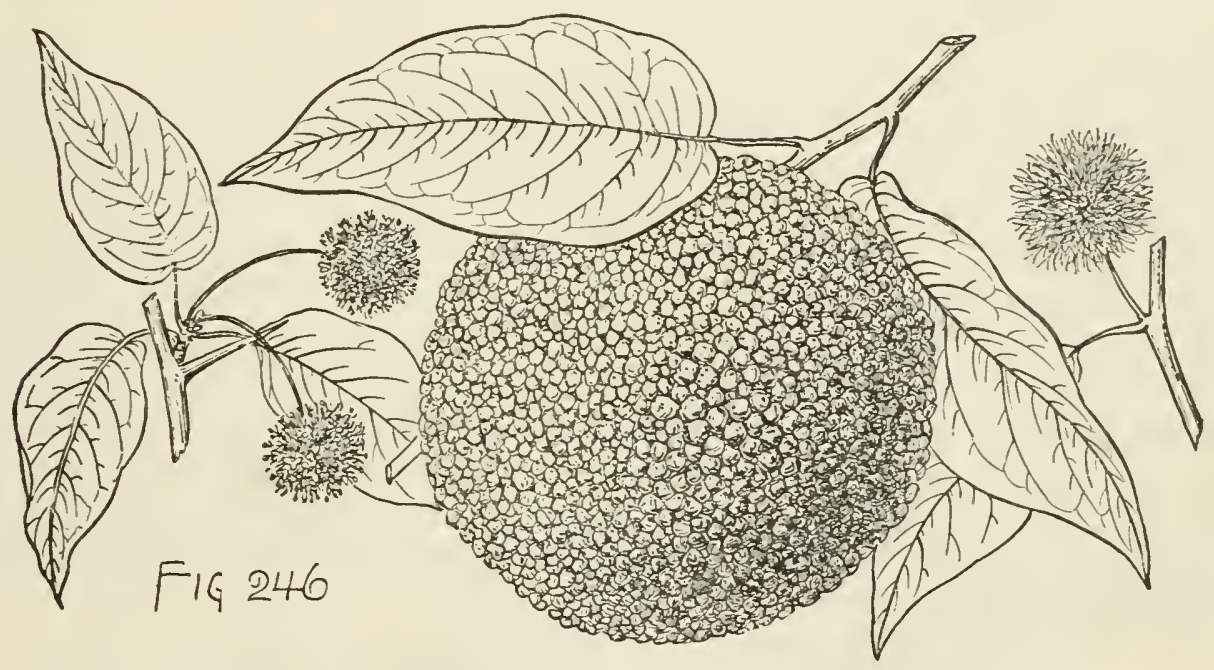

the surface into thin appressed scales. Wood heavy, exceedingly hard, very strong, flexible, coarse-grained, very durable, bright orange color turning brown on exposure, with thin light yellow sapwood of $\tilde{5}-10$ layers of annual growth; largely used for fence-posts, railway-ties, wheel-stock, and formerly by the Osage and other Indians west of the Mississippi River for bows and war-clubs. The bark of the roots contains moric and morintannic acid, and is used as a yellow dye. The bark of the trunk is sometimes used in tanning leather.

Distribution. Rich bottom-lands; southern Arkansas to the sonthern portions of the Indian Territory, southward in Texas to about latitude $3 \tilde{5}^{\circ} 36^{\prime}$; most abundant and of its largest size in the valley of the Red River in the Indian Territory.

Largely planted in the prairie regions of the Mississippi basin as a hedge plant, and occasionally in the eastern states; hardy in New England. 


\section{FICUS, L. Fig.}

Trecs, with milky juice, naked buds, stout branclılets, thick fleshy roots frequently produced from the branches and developing into supplementary stems. Leaves alternate, involute in the bud, entire, pemniveined, persistent; stipnles inclosing the leaf in a slender sharp-pointed bud-like cover, intcrpetiolar, embracing the leaf-bearing axis and inclosing the young leaves, deciduous. Flower-bearing receptacle subglobose to ovoid, sessile or stalked, solitary by abortion or in pairs in the axils of existing or fallen leaves, surrounded at the base by 3 anterior bracts distinct or united into an involucral cup bearing on the interior at the apex numerous rows of minute triangular viscid bracts closing the orifice, those of the lower rows turned downward and infolding the upper flowers, those immediately above these horizontal and forming a more or less prominent umbilicus. Flowers sessilc or pedicellate, the pedicels thickening and becoming succulent with the ripening of the fruit, unisexual, often separated by chaffy scales or lairs; calyx of the staminate flower usually divided into 2-6 sepals; stamens 1; filaments short, erect; anther imnate, ovate, broad and subrotund, 2-celled, the cells opening longitudinally, 0 in the pistillate flower; sepals or lobes of the calyx of the pistillate flower usually narrower than those of the staminate flower; ovary sessile, erect, or oblique, surmounted by the lateral elongated style crowned by a 2-lobed stigma; ovule suspended from the apex or lateral below the apex of the cell, anatropous. Fruit drupaceous, mostly immersed in the thickened succulent receptacle, obovoid or reniform; flesh thin, mucilaginous; nutlet with a flat crustaceons minutely tuberculate shell. Seed suspended; testa membranaceous; embryo incurved, in thin fleshy albumen; cotyledons equal or unequal, longer than the incumbent radicle.

Ficus, of which six hundred species have been described, is largely distributed through the tropics of both hemispleres, the largest number of species being found on the islands of the Indian Archipelago and the Pacific Ocean. A few species extend beyond the tropics into southern Florida, Mexico, Argentina, southern Japan and China, the countries bordering the Mediterranean, the Canary Islands, and South Africa. Two species of the section Urostigma with monœcious flowers occur in tropical Florida. Ficus Carica, L., probably a native of the Mediterranean basin, is cultivated in the southern states and in California for its large sweet succulent fruits, the figs of commerce.

\section{CONSPECTUS OF THE NORTH AMERICAN SPECIES.}

Receptacles subglobose, sessile or short-stalked; leaves oblong, usually pointed at the ends.

1. F. aurea (D).

Receptacles oblong, long or short-stalked; leaves broadly ovate, cordate at the base.

2. F. populnea (D).

\section{Ficus aurea, Nutt. Wild Fig.}

Leaves oblong, usually narrowed at the ends, acute or acnminate, with short broad points at the apex, wedge-shaped or rarely broad and rounded at the base, $2^{\prime}-5^{\prime}$ long, $1 \frac{1}{2}-3^{\prime}$ wide, thick and coriaceous, dark yellow-green and lustrous above, paler and less lustrous below, with broad light yellow midribs slightly grooved on the upper side and numerous obscure primary veins arcuate and united near the margins, and connected by fine closely reticulated veinlets, continuing to unfold during a large part of the year, and usually falling during their second season; their 
petioles stout, slightly grooved, $\frac{1^{\prime}}{2}-1^{\prime}$ long; stipules ovate-lanceolate, thick, firm, tinged with red, abont $1^{\prime}$ long. Flowers: receptacles developing in succession as the branch lengthens, axillary, subglobose, sessile or short-pedunculate, solitary or in pairs, the lateral orifice closed and marked by a small point formed by the union of the

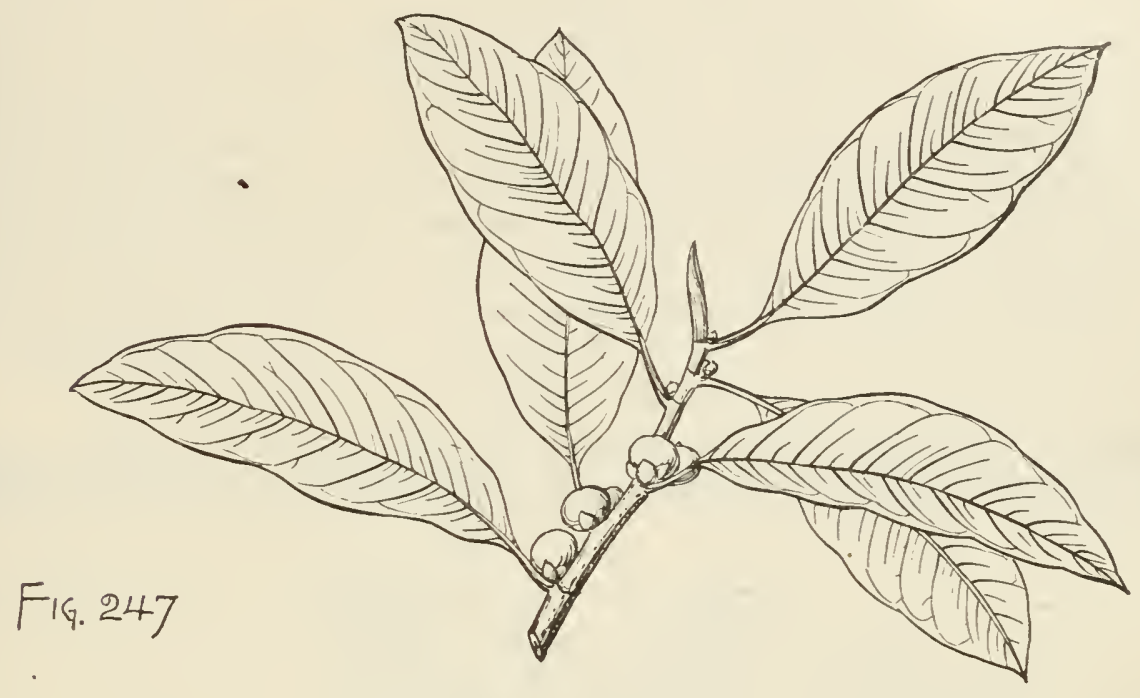

minute bracts, becoming $\frac{1}{3}^{\prime}$ in diameter and yellow when fully grown, ultimately turning bright red; flowers reddish purple, separated by minute reddish chaff-like scales more or less laciniate at the apex, sessile or long-pedicellate; calyx of the staminate flower divided to below the middle into 2 or 3 broad lobes rather shorter than the stout flattened filament; lobes of the anther oblong, attached laterally to the broad connective; calyx of the pistillate flower divided to the middle into 4 or 5 narrow lobes, closely investing the ovate sessile ovary. Fruit ovate, immersed in the thickened reddish purple walls of the receptacle; seed ovate, rounded at the ends, with a thin light brown coat and a large lateral oblong pale hilum.

A broad round-topped parasitic tree, $50^{\circ}-60^{\circ}$ high, germinating and growing at first on the branches and trunks of other trees and sending down to the ground stout aerial roots which gradually growing together form a trunk often $3^{\circ}-4^{\circ}$ in diameter, the growth of additional roots from the branches extending the tree over a large area, and stont terete pithy light orange-colored branchlets marked by pale lenticels, conspicuous stipular scars, large slightly elevated horizontal oval leaf-scars displaying a marginal ring of large pale fibro-vascular bundle-scars, and smaller elevated concave circular scars left by the receptacles in falling. Bark smooth, ashy gray, light brown tinged with red, $\frac{1^{\prime}}{2}$ thick, and broken on the surface into minute appressed scales disclosing in falling the nearly black inner bark. Wood exceedingly light, soft, very weak, coarse-grained, very perishable in contact with the ground, light brown, with thick lighter colored sapwood.

Distribution. Hummocks on the shores and islands of southern Florida; from the Indian River on the east coast and Tampa Bay on the west coast, to the southern keys, attaining its largest size in the neighborhood of Bay Biscayne; on the Bahama Islands. 


\section{Ficus populnea, Willd. Fig. Wild Fig.}

Leaves broadly ovate or rarely obovate, contracted into short broad points or occasionally rounded at the apex, rounded, truncate or cordate at the base, $2 \frac{1^{\prime}}{2}-5^{\prime}$ long, $1 \frac{1}{2}-5^{\prime}$ wide, thin and firm, dark green and lustrous on the upper surface, paler on the lower, with light yellow midribs, slender remote primary veins arcuate and nnited near the margins and connected by finely reticulate veinlets; their petioles slender, sometimes $1^{\prime}$ long; stipules ovate-lanceolate, $\frac{1}{2}^{\prime}$ long, tinged with red. Flowers: receptacles obovate, axillary, solitary or in pairs, yellow until fully grown, ultimately turning bright red and becoming $\frac{1}{4}^{\prime}-\frac{1}{2}^{\prime}$ long, on stout drooping peduncles $\frac{1}{4}-1^{\prime}$ in length; flowers sessile or pedicellate, separated by minute chafflike scales more or less laciniate at the apex; calyx of the staminate flower divided nearly to the base into three or four broad acute lobes; calyx of the pistillate flower with narrow lobes shorter than the ovate pointed ovary. Fruit ovate; seed ovate, with a membranaceous light brown coat and an oblong lateral pale hilum.

An epiphytal tree, rarely $40^{\circ}-50^{\circ}$ high, with a trunk $12^{\prime}-18^{\prime}$ in diameter, spreading branches occasionally developing aerial roots and forming an open irregular head, and

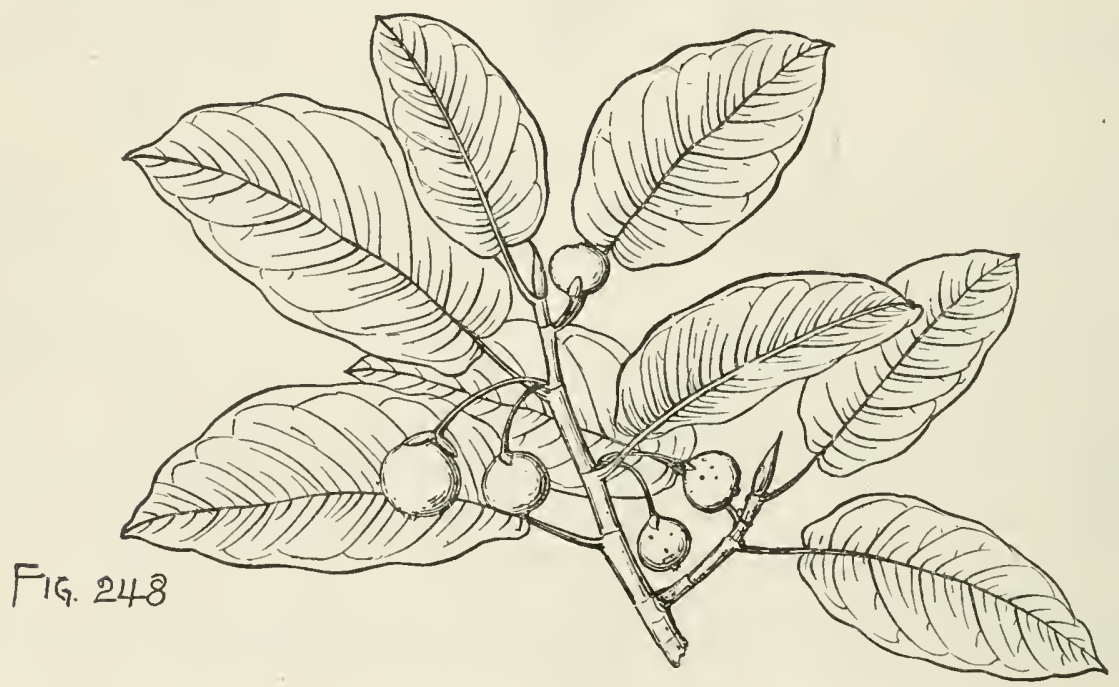

stont terete branchlets light red and slightly puberulous when they first appear, becoming brown tinged with orange and later with red, and marked by minute pale lenticels, narrow stipular scars, large elevated horizontal oval or semiorbicular leafscars showing a marginal row of conspicuous fibro-vascular bundle-scars, and elevated concave receptacle scars. Wood light, soft, close-grained, light orange-brown or yellow, with thick hardly distinguishable sapwood.

Distribution. Usually on dry slightly elevated coral rocks; comparatively rare in Florida from the shores of Bay Biscayne and on several of the keys to Key West; in the West Indies. 
Section 3. Flowers perfect or unisexual; calyx 5-lobed; ovary superior, 1-celled; ovule solitary, rising from the bottom of the cell; fruit inclosed in the thickened calyx; leaves persistent.

\section{POLYGONACEA.}

Trees, with alternate coriaceous stalked leaves, their stipules sheathing the stem. Flowers perfect; calyx 5-lobed; stamens 8 ; ovary 3 -celled; ovule orthotropous. Fruit a nutlet, inclosed in the thickened calyx-tube; seed erect; embryo axillary in ruminate farinaceous albumen ; radicle superior, ascending, turned toward the hilum. Of this, the Buckwheat family with thirty widely distributed genera, only Coccolobis is arborescent in North America.

\section{COCCOLOBIS, P. Br.}

Trees or shrubs. Leaves coriaceous, entire, orbicular, ovate, obovate, or lanceolate, petiolate, their stipules inclosing the branch above the node with membranaceous truncate entire brown persistent sheaths. Flowers jointed on ebracteolate pedicels, in 1 or few-flowered fascicles subtended by a minute bract and surrounded by a narrow truncate membranaceous slieath, each pedicel and those above it being surrounded by a similar sheath, the fascicles gathered in elongated terminal and axillary racemes inclosed at the base in the sheath of the nearest leaf and sometimes also in a separate sheath; calyx cup-shaped, the lobes ovate, rounded, thin, and white, reflexed after anthesis, and thickening and inclosing the nut; stameus with filiform or subulate filaments dilated and united at the base into a short discoid cup adnate to the tube of the calyx; anthers ovate, introrse, 2-celled, the cells parallel, opening longitudinally; ovary free, sessile, 3 -angled, contracted into a short stont style, divided into three short or elongated stigmatic lobes. Fruit ovoid or globose, rounded or acute and crowned at the apex by the persistent lobes of the calyx, narrowed at the base; flesh thin and acidulous, more or less adnate to the thin crustaceous or bony wall of the nutlet often divided on the inner surface near the base into several more or less intrusive plates. Seed subglobose, acuminate at the apex, 3-6-lobed; testa membranaceous, minutely pitted, dark red-brown, and lustrons.

Coccolobis is confined to the tropics of the New World, with about one hundred and twenty species distributed from southern Florida to Mexico, Central America, Brazil, and Peru. It possesses astringent properties sometimes utilized in medicine. Many of the species produce hard dark valuable wood.

Coccolobis, from кóккоs and $\lambda o \beta b s$, is in allusion to the character of the fruit.

\section{CONSPECTUS OF THE NORTH AMERICAN SPECIES.}

Fruits crowded, in drooping racemes; leaves broadly ovate to suborbicular, cordate at the base.

1. C. uvifera (D).

Fruits not crowded, in erect or spreading racemes; leaves ovate to oblong-lanceolate.

2. C. laurifolia (D).

\section{Coccolobis uvifera, Jacq. Sea Grape.}

Leaves broadly ovate to suborbicular, rounded or sometimes short-pointed at the apex, deeply cordate at the base, with undulate margins, thick and coriaceous, minutely reticulate-venulose, dark green and lustrous above, paler and puberulous 
below, $4^{\prime}-5^{\prime}$ long, $5^{\prime}-6^{\prime}$ wide, with stout often bright red midribs frequently covered below with pale hairs, and abont 5 pairs of conspicnous primary veins red on the upper side, arcuate near the margins and comnected by cross veinlets, gradually turning red or scarlet and falling during their second or third ycars; their petioles short, stout, flattened, puberulous, abruptly enlarged at the base, leaving in falling
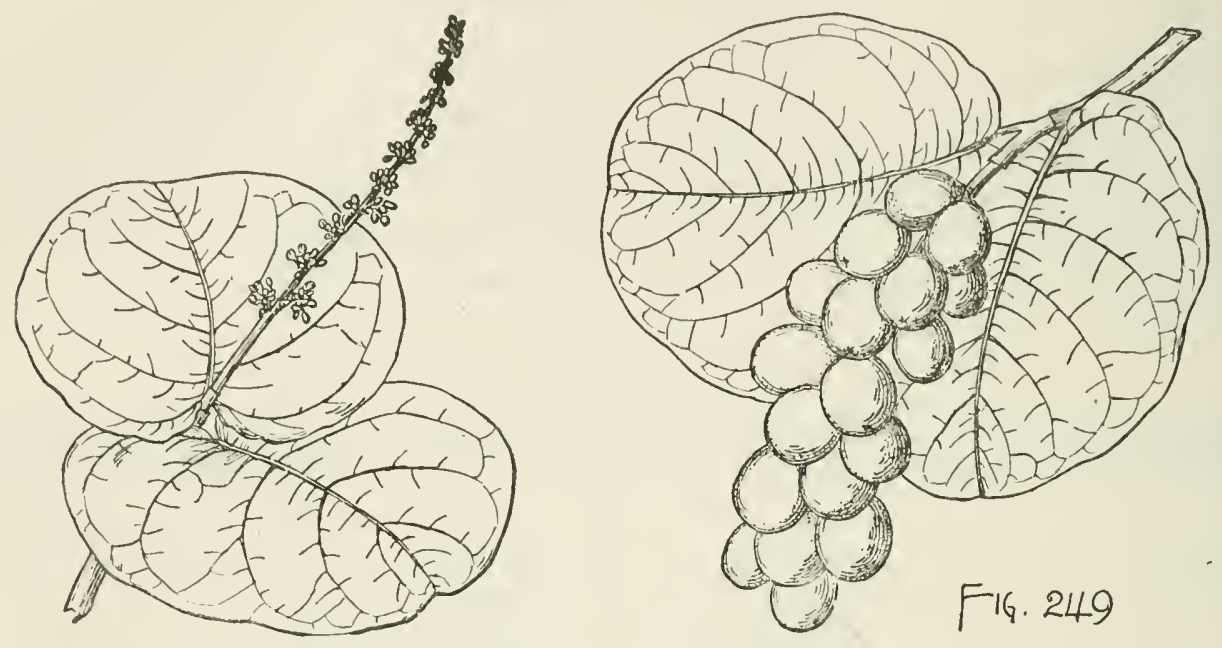

large pale elevated orbicular or semiorbicular scars; stipular sheath $\frac{1}{8}^{\prime}$ broad, slightly puberulous, persistent during 2 or 3 years. Flowers appearing almost continually throughout the year on slender puberulous pedicels $\frac{1^{\prime}}{8}$ long, in 1 -6-flowered subsessile fascicles, in terminal and axillary thick-stemmed many-flowered racemes $6^{\prime}-14^{\prime}$ long; calyx $\frac{1}{8}^{\prime}$ across when expanded, the lobes puberulous on the inner surface and ratlier longer than the red stamens; ovary oblong, with short stigmatic lobes. Fruit crowded, in long hanging racemes, ovoid to obovoid, $\frac{3}{4}$ long, gradually narrowed into a stalk-like base, purple or greenish white, translucent, with thin juicy flesh, and a thin-walled light red nutlet.

A tree, in Florida rarely more than $15^{\circ}$ high, with a short gnarled contorted trunk $3^{\circ}-4^{\circ}$ in diameter, stout branches forming a round compact head, and stout terete branchlets, with thick pith, light orange color, marked by oblong pale lenticels, gradually growing darker in their second and third years; frequently a shrub, with semiprostrate stems; in the West Indies often $50^{\circ}$ tall. Bark about $\frac{1^{\prime}}{16^{\prime}}$ thick, smooth, light brown, and marked by large irregnlar pale blotches. Wood very heavy, hard, close-grained, dark brown or violet color, with thick lighter colored sapwood; sometimes used in cabinet-making.

Distribution. Saline shores and beaches, Florida, from Mosquito Inlet to the southern keys on the east coast, and from Tampa Bay to Cape Sable on the west coast; common on the Bermuda and Bahama Islands, in the Antilles, and in South America from Colombia to Brazil.

\section{Coccolobis laurifolia, Jacq. Pigeon Plum.}

Ieaves ovate, ovate-lanceolate or obovate-oblong, rounded or acute at the apex, rounded or wedge-shaped at the base, with slightly undulate revolute margins, thick and firm, bright green above, paler below, $3^{\prime}-4^{\prime}$ long, $1 \frac{1}{2}^{\prime}-2^{\prime}$ broad, with conspicuous pale midribs and 3 or 4 pairs of remote primary veins comnected by prominent reticu- 
late veinlets; their petioles stout, flattened, $\frac{1}{2}^{\prime}$ long, abruptly enlarged at the base; stipular sheaths glabrous, $\frac{1}{2}^{\prime}$ wide. Flowers in early spring, on slender pedicels $\frac{1^{\prime}}{4}$ long, in few or 1-flowered fascicles on racemes terminal on short axillary branches of the previous year, and $2^{\prime}-3^{\prime}$ in length; calyx $\frac{1^{\prime}}{8}$ across, the cup-shaped lobes rather shorter than the stamens, with slender yellow filaments enlarged at the base, and dark orange-colored anthers; ovary oblong, with elongated stigmatic lobes. Fruit in erect or spreading sparsely-fruited racemes, ripening during the winter and early spring, ovoid, narrowed at the base, rounded at the apex, dark red, $\frac{1^{\prime}}{3}$ long, with thin acidulous flesh and a hard thin-walled light brown nutlet.

A glabrous tree, $60^{\circ}-70^{\circ}$ high, with a tall straight trunk $1^{\circ}-2^{\circ}$ in diameter, spreading branches forming a dense round-topped head, slender terete slightly zigzag

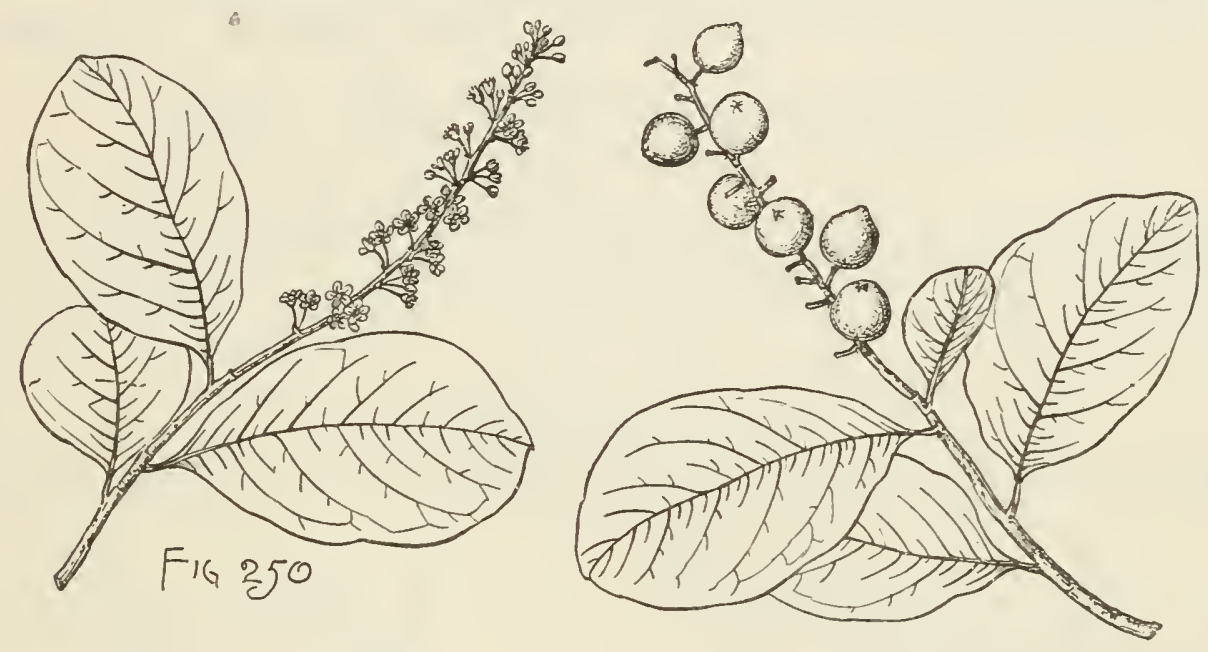

branchlets usually contorted and covered with light orange-colored bark, becoming darker and tinged with red in their second or third year. Wood heavy, exceedingly hard, strong, brittle, close-grained, rich dark brown tinged with red, with thick lighter colored sapwood; occasionally used in cabinet-making.

Distribution. One of the largest and most abundant of the tropical trees of the seacoast of southern Florida from Cape Canaveral to the keys and on the west coast from Cape Romano to Cape Sable; common on the Bahama Islands, on many of the Antilles, and in Venezuela.

\section{NYCTAGINACE王。}

Trees, with alternate stalked persistent leaves without stipules. Flowers perfect or unisexual; calyx corolla-like, 5-lobed ; stamens 5-8; orule campylotropous. Fruit a nutlet inclosed in the thickened calyx and crowned by its persistent teeth. Seed erect; cotyledons unequal, folded around the soft scanty albumen ; radicle short, inferior, turned toward the hilum. "A family of about twenty genera widely distributed chiefly in the warmer and tropical parts of the New World, with a single arborescent representative in North America.

\section{PISONIA, L.}

Glabrous or pubescent trees or shrubs, unarmed or rarely spinescent, erect or semiscandent. Leaves opposite or alternate, entire, short-stalked. Flowers perfect, 
dicecious or rarely monœcious; calyx, 5 -lobed or toothed, the divisions induplicatevalvate in the bud, petaloid, tubular or funnel-shaped in the staminate flower, elongated and often notehed at the base of the tube in the pistillate flower, the limb 5-lobed, the lobes plaited in the bud, ereet or spreading; stamens 5-8, inserted on the base of the calyx under the ovary, minute or rudinentary in the unisexual pistillate flower ; filaments folded in the bud, filiform, unequal, free; anthers oblong, introrse, 2-celled, the cells parallel, opening longitudinally; ovary oblong-ovoid, sessile, 1-celled, gradually narrowed into a columnar style; stigmas capitate, lacerate. Fruit fleshy, cylindrical, eostate, smooth; utricle elongated, witl a thin membranaceous wall eonfluent with the thin transparent coat of the erect seed.

Pisonia is chiefly tropical, with the largest number of species in the New World. 'Two speeies extend into southern Florida; of these one is arborescent.

Pisonia was named in honor of Willem Piso, a Dutch physician and naturalist.

\section{Pisonia longifolia, Sarg., nov. nom. Blolly.}

(Pisonia obtusata, Silva N. Am. vi. 111.)

Leaves opposite and sometimes alternate, obovate-oblong, rounded or oceasionally emarginate at the apex, gradually narrowed at the base, $1^{\prime}-1 \frac{1}{2}^{\prime}$ long, $\frac{1}{2}^{\prime}$ broad, thick and firm, with slightly thickened undulate margins, light green and glabrous, paler on the lower than on the upper surface, with stout midribs and obscure veins; their petioles stout, channeled, $\frac{1}{2}$ 'long. Flowers perfeet or unisexual, autumnal, greenish yellow, short-pedicellate, in terminal long-stalked few-flowered panicled cymes, with slender divergent branches, the ultimate divisions 2 or 3-flowered; bracts and

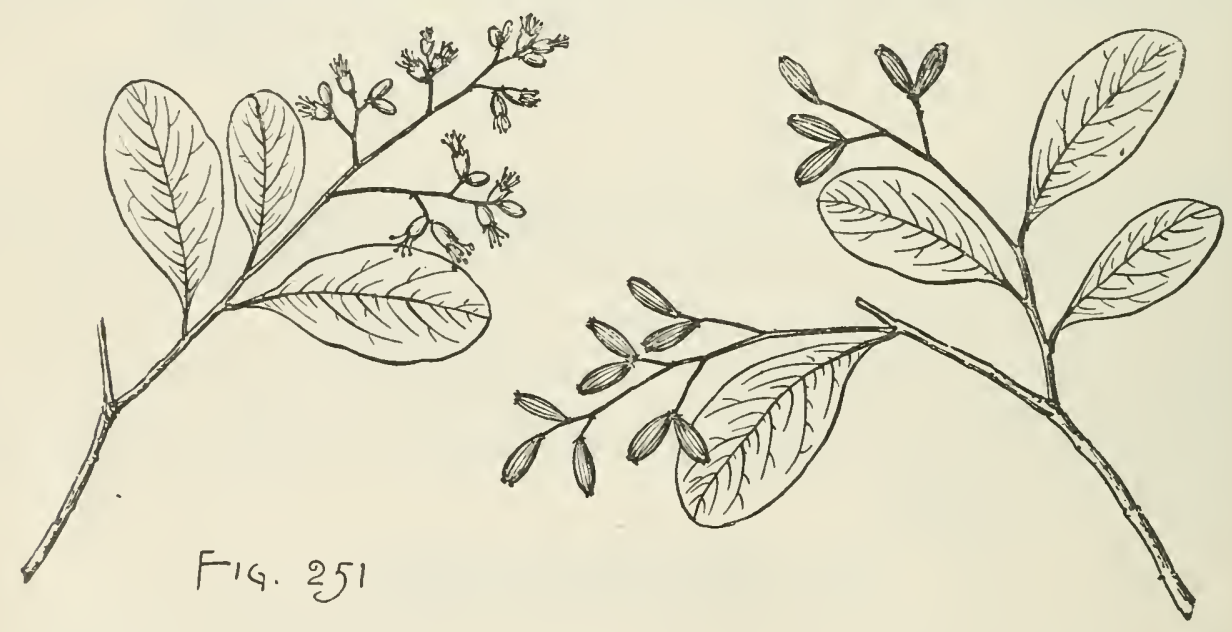

bractlets minute, acute; calyx funmel-shaped, divided nearly to the middle into acute erect lobes about half as long as the stamens and as long as the style. Fruit ripening in the winter or early spring, prominently eostate, with ten rounded ribs, fleshy, smooth, bright red, ' $\frac{3}{4}$ ' long; utriele terete, light brown.

A tree, $30^{\circ}-50^{\circ}$ high, with an erect or inclining trunk $15^{\prime}-20^{\prime}$ in diameter, stout spreading branches forming a compact round-topped head, and slender terete branchlets light orange color when they first appear, later often producing numerous short spur-like lateral branchlets, light reddish brown or ashy gray, and marked by large elevated semiorbicular or lunate leaf-scars ; usually much smaller. Bark about $\frac{1}{1-}{ }^{\prime}$ thick, light red-brown, and broken into thin appressed seales. Wood heavy, rather 
soft, weak, coarse-grained, yellow tinged with brown, with thick darker colored sapwood.

Distribution. Sea-beaches and the shores of salt water lagoons; Cape Canaveral, Florida to the southern keys, attaining its largest size in Florida on Elliott's Key and Old Rhodes Key; common on many of the West Indian islands and southward to Brazil.

Subdivision 2. Petalæ. Flowers with both calyx and corolla (without a corolla in Lauracece, in Liquidambar in Hamamelidacece, in Euphorbiacece, in some species of Acer, in Reynosia, Condalia, and Krugiodendron in Rhamnacea, in Fremontodendron in Sterculiacece, in Chytraculis in Myrtacere, and in Conocarpus in Combretacece).

Section 1. Polypetalæ. Corolla of separate petals ( $O$ in Cercocarpus in Rosacece).

A. Ovary superior (partly inferior in Hamamelidacece; inferior in Malus, Sorbus, Cratcegus, and Amelanchier in Rosacece).

XV. MAGNOLIACEA.

Trees or shrubs, with watery juice, branchlets lengthening by large terminal or the flower-bearing branchlets by upper axillary buds, the other axillary buds obtuse, flattened, and rudimentary, bitter aromatic bark, and thick fleshy roots. Leaves alternate, conduplicate and inclosed in their stipules in the bud, featherveined, petiolate. Flowers perfect, large, solitary, terminal, pedunculate, inclosed in the bud in a stipular caducous spathe; sepals and petals imbricated in the bud, inserted under the ovary, deciduous; stamens and pistils numerous, imbricated in many ranks, the stamens below the pistils on the surface of an elongated receptacle ripening into a compound fruit of 1-2-seeded follicles or samara; ovules 2, collateral, anatropous. Four of the ten genera of the Magnolia family are represented in North America; of these two are arborescent.

\section{CONSPECTUS OF THE NORTH AMERICAN ARBORESCENT GENERA.}

Anthers introrse ; mature carpels, fleshy, opening on the back at maturity, persistent ; seedcoat thick, pulpy, and bright scarlet; leaves entire, or auriculate at the base.

1. Magnolia.

Anthers extrorse ; mature carpels dry, indehiscent, deciduous ; seed-coat dry and coriaceous ; leaves lobed or truncate.

2. Liriodendron.

\section{MAGNOLIA, L. Magnolia.}

Trees, with ashy gray or brown smooth or scaly bark, branchlets conspicuously marked by large horizontal or longitudinal leaf-scars and by narrow stipular rings, and large terete acuminate or often obtusely-pointed more or less gibbous winterbuds usually broadest at the middle, their scales large membranaceous stipules adnate to the base of the petioles and deciduous with the unfolding of each successive leaf, the petiole of the outer stipule rudimentary, adnate on the straight side of the bud, and marked at its apex by the scar left by the falling of the last leaf of the 
previous season. Leaves entire, sometimes auriculate, persistent or deciduous, often minutely punctate, their numerons primary veins arenate and more or less united within the margins. Flowers appearing in the Ameriean speeies after the leaves, their stipular spathes thin and nembranaceous; sepals 3, spreading or reflexed; petals 6-1:2 in series of 3's, eoncave, ereet or spreading; stamens early deeiduous, their filanents shorter than the 2-celled introrse anther's and terminating in apiculate fleshy eonnectives; ovary sessile, 1-celled; style short, recurved, stigmatic on the inner face; ovules horizontal. Frnit a searlet or rusty brown eone formed of the coalescent 2-seeded drupaeeous persistent follicles opening on the baek; seeds suspended at maturity by long thin cords of unrolled spiral vessels; seed-coat thiek, drupaceous, the onter portion becoming fleshy and at maturity pulpy, red or scarlet, the inner erustaceous; enbryo minute at the base of the fleshy homogeneous albumen, its radicle next the hilum; eotyledons short and spreading.

Magnolia with about twenty speeies is confined to eastern North America, sontlern Mexico, and eastern and southern Asia, seven speeies growing naturally in the United States. All the parts are slightly bitter and aromatie, and the dried flowerbuds are sometimes used in medicine. Several speeies from eastern Asia and their hybrids produeing flowers before the appearance of the leaves are favorite garden plants in the United States.

The genus is named in honor of Pierre Magnol (1638-1715), professor of botany at Montpellier.

\section{CONSPECTUS OF THE NORTH AMERICAN SPECIES.}

Leaves scattered along the branches; leaf-buds tomentose or silky-pubescent.

Leares persistent; fruit tomentose.

1. M. fœtida (C).

Leaves deciduous or subpersistent ; fruit glabrous.

Leaves deciduous.

2. M. glauca $(\mathrm{A}, \mathrm{C})$.

Leaves oblong-ovate or subcordate; flowers small, gręen or yellow.

3. M. acuminata $(\mathrm{A}, \mathrm{C})$.

Leaves obovate or oblong, cordate at the narrow base; flowers large and white.

4. M. macrophylla (C).

Leaves crowded at the summit of the flowering branches; leaf-buds glabrous.

Leaves oblong-lanceolate, pointed at the ends.

5. M. tripetala $(\mathrm{A}, \mathrm{C})$.

Leaves obovate-spatulate, auriculate at the base.

Leaves acute; tips of the mature carpels elongated, nearly straight.

Leaves mostly abruptly pointed ; tips of the mature carpels short, incurved.

6. M. Fraseri (A).

7. M. pyramidata (C).

\section{Magnolia fœtida, Sarg. Magnolia.}

Leaves oblong or ovate, coriaceous, bright green and shining above, more or less densely coated below with thick rusty tomentum, $5^{\prime}-8^{\prime}$ long, $2^{\prime}-3^{\prime}$ wide, with prominent midribs and primary veins, deeiduous in the spring at the end of their second year; their petioles stont, rusty-tomentose, $1^{\prime}-2^{\prime}$ long. Flowers on stout loarytomentose peduneles $\frac{1^{\prime}}{2}-1^{\prime}$ long, opening from April or May until July or August, fragrant, $7^{\prime}-8^{\prime}$ aeross, the petaloid sepals and 6 or sometimes 9 or 12 petals abruptly narrowed at the base, oval or ovate, those of the inner ranks often somewhat acuminate, coneave, and coriaceous, $3^{\prime}-4^{\prime}$ long and $1 \frac{1}{2}^{\prime}-2^{\prime}$ wide; base of the receptacle and lower part of the filaments bright purple. Fruit ovate or oval, rusty brown, covered while young with thiek lustrous white tomentum, at maturity rusty-tomen- 
tose, $3^{\prime}-4^{\prime}$ long, $1_{\frac{1}{2}}^{\prime}-2 \frac{1}{2}^{\prime}$ wide; seeds obovoid or triangular obovoid, more or less flattened, $\frac{1}{2}^{\prime}$ long.

A tree, of pyramidal habit, $60^{\circ}-^{\circ} 80$ ligh, with a tall straight trunk occasionally $4^{\circ}-4 \frac{1}{2}^{\circ}$ in diameter, rather small spreading branches, and branchlets hoary-tomentose at first, slightly tomentose in their second year, and much roughened by the elevated

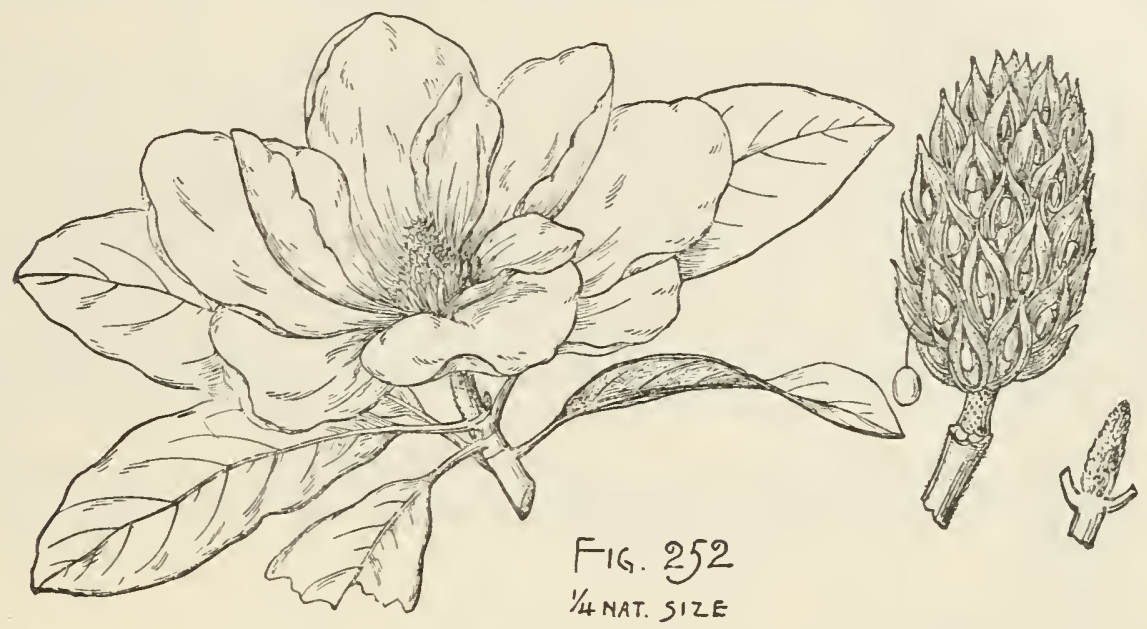

leaf-scars displaying a marginal row of conspicuous fibro-vascular bundle-sears. Winter-buds pale or rusty-tomentose, the terminal $1^{\prime}-1 \frac{1}{2}^{\prime}$ long. Bark $\frac{1^{\prime}}{2}-3_{4}^{\prime}$ thick, gray or light brown and covered with thin appressed scales, rarely more than $1^{\prime}$ long. Wood hard, heavy, creamy white, soon turning brown with exposure, hardly distinguishable from the heartwood of 60-80 layers of annual growth; little used except for fuel.

Distribution. Rich moist soil on the borders of river swamps and Pine-barren ponds, or rarely on high rolling hills; coast of North Carolina soutlıward to Mosquito Inlet and the shores of Tampa Bay, Florida, extending across the peninsula, and through the maritime portions of the other Gulf states to the valley of the Brazos River, Texas, through western Louisiana to southern Arkansas, and on the bluffs of the lower Mississippi River northward to the mouth of the Yazoo River; best developed and often the characteristic and most conspicuous feature of the forest in western Louisiana.

Largely cultivated as an ornamental tree in all countries of temperate climate; in the eastern United States precariously hardy as far north as Philadelphia. Numerous varieties, differing in the form of the leaf and in the duration of the flowering period, have appeared in European murseries; of these, the most distinct is the variety Exoniensis, Loud., with a rather fastigiate habit and broadly elliptical leaves densely clothed with rusty tomentum on the lower surface, which begius to flower when only a few feet high.

\section{Magnolia glauca, L. Sweet Bay. Swamp Bay.}

Leaves oblong or oval and obtuse or somewhat oblong-lanceolate, covered when they unfold with long white silky deciduous hairs, at maturity bright green, lustrous and glabrous on the upper surface, minutely pubescent and pale or nearly white on the lower surface, $4^{\prime}-6^{\prime}$ long, $\frac{1}{2}^{\prime}-2 \frac{1}{2}^{\prime}$ wide, with conspicuous midribs and primary veins, falling in the north late in November and in early winter, at the south remain- 
ing on the branches with little change of color until the appearance of the new leaves in the spring; their petioles slender, $\frac{1}{2}-\frac{3}{4}$ long. Flowers on slender glabrous peduncles $\frac{1^{\prime}}{2}-3^{\prime}$ long, creany white, fragrant, globular, $2^{\prime}-3^{\prime}$ across, continuing to open during several weeks in spring and early summer; sepals membranaceous, obtuse, concave, shorter than the 9-12 obovate often short-pointed concave petals. Fruit oval, dark red, glabrous, 2 ' long and $\frac{1}{2}$ broad; seeds obovoid, oval, or suborbicular, much flattened, $\frac{1 \prime}{4}$ long.

A slender tree, $50^{\circ}-70^{\circ}$ high, with a trunk $2^{\circ}-3 \frac{1}{2}^{\circ}$ in diameter, with small mostly erect ultimately spreading branches and slender bright grcen branchlets hoarypubescent when they first appear, soon glabrous, marked by narrow horizontal pale lenticels, gradually turning bright red-brown in their second summer; often much smaller, and at the north reduced to a low shrub. Winter-buds covered with fine silky pubescence, the terminal $\frac{1}{2}-\frac{3^{\prime}}{4}$ long. Wood soft, light brown tinged with red, with thick creamy white sapwood of 90-100 layers of annual growtl, occasionally used in the southern states in the manufacture of broom handles and other articles of woodenware.

Distribution. At the north in deep wet swamps, southward along the borders of Pine-barren ponds and in shallow swamps; Magnolia, Essex County, Massachusetts,

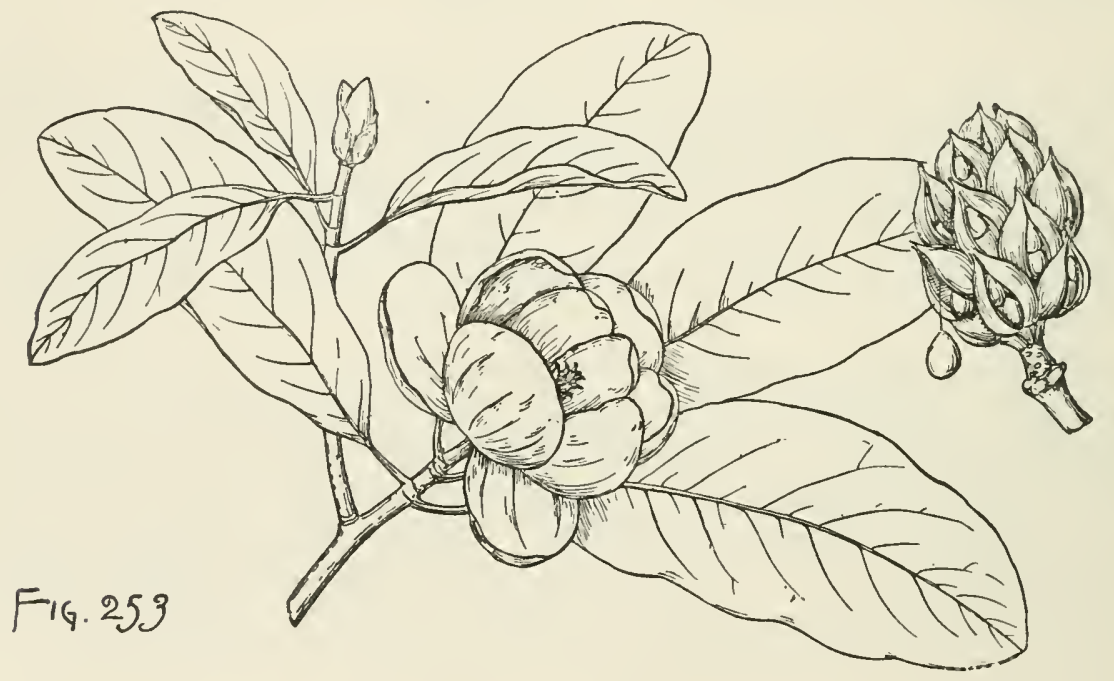

Suffolk County, Long Island, and southward from New Jersey generally near the coast to the shores of Bay Biscayne and Tampa Bay, Florida, in Pennsylvania ranging inland to Franklin County, and through the Gulf states to southwestern Arkansas and the valley of the Trinity River, Texas; most abundant and of its largest size in the interior of the Florida peninsula on fertile hummocks rising above the level of the Pine-lands.

Often cultivated as a garden plant in the eastern states and in Europe. Magnolia glauca longifolia with lanceolate leaves, and a blooming period extending through two or three months, is probably of garden origin. Magnolia major or Thornpsoniana, a probable hybrid between Magnolia glauca and Magnolia tripetala, raised in an English nursery a century ago, and still a favorite garden plant, is intermediate in character between these species. 


\section{Magnolia acuminata, L. Cucumber-tree. Mountain Magnolia.}

Leaves oblong, pointed, sometimes rounded or slightly cordate at the base, covered when they first appear with white silky caducous hairs longest and most abundant on the lower surface, at maturity thin, glabrous above, slightly pubescent below, $7^{\prime}-10^{\prime}$ long, $4^{\prime}-6^{\prime}$ wide, with prominent midribs and primary veins, turning yellow in the autumn before falling; their petioles slender, $1^{\prime}-1 \frac{1}{2}^{\prime}$ long. Flowers on hairy soon glabrous peduncles $\frac{1^{\prime}}{2}-\frac{3^{\prime}}{4}$ long, bell-shaped, glaucous, green or pale yellow; sepals membranaceous, acute, $1^{\prime}-1 \frac{1}{2}^{\prime}$ long, soon reflexed; petals 6 , ovate or obovate, concave, pointed, erect, $2 \frac{1}{2}^{\prime}-3 \frac{1}{2}^{\prime}$ long, those of the outer row rarely more than $1^{\prime}$ broad and much broader than those of the inner row. Fruit ovate or oblong, often curved, glabrous, dark red, $2 \frac{1}{2}^{\prime}-3^{\prime}$ long, rarely more than $1^{\prime}$ broad; seeds obovoid, acute, compressed, about $\frac{1}{2}^{\prime}$ long.

A pyramidal tree, $60^{\circ}-90^{\circ}$ high, with a trunk $3^{\circ}-^{\circ}$ in diameter, comparatively small branches spreading below and erect toward the top of the tree, and slender branchlets coated at first with soft pale caducous hairs, soon bright red-brown,

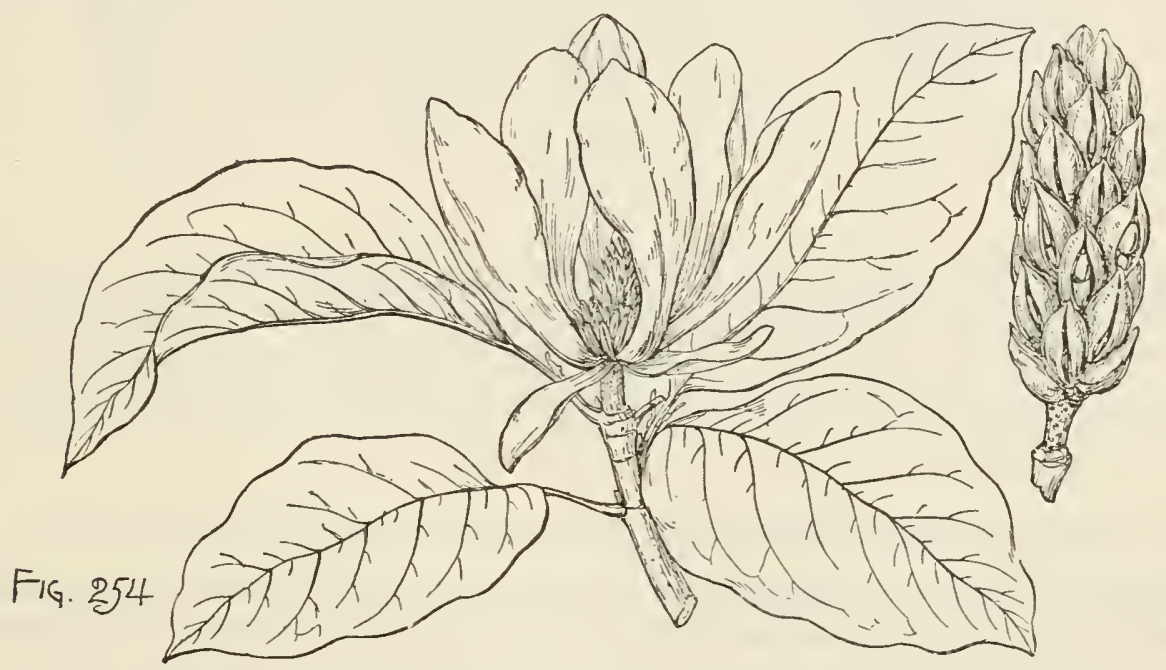

lustrous, and marked by numerous small pale lenticels, turning gray during their third season. Winter-buds thickly covered with long lustrous white hairs, the terminal $\frac{1^{\prime}}{2}-3^{\prime}$ long, and about three times as long as the obtuse lateral buds nearly surrounded by the narrow elevated leaf-scars conspicuously marked by a double row of large fibro-vascular bundle-scars. Bark $\frac{1}{3}^{\prime}-\frac{1}{2}^{\prime}$ thick, furrowed, dark brown, and covered by numerous thin scales. Wood light, soft, not strong, close-grained and durable, light yellow-brown, with thin lighter colored often nearly white sapwood of usually 25-30 layers of annual growth; occasionally manufactured into lumber used for flooring and cabinet-making.

Distribution. Low mountain slopes and rocky banks of streams; western New York, westward through southern Ontario to southern Illinois, and southward along the Appalachian Mountains to sonthern Alabama, central Kentucky and Tennessee and northeastern Mississippi, and in northeastern, southern, and southwestern Arkansas; rare at the north; most abundant and of its largest size in the narrow valleys at the base of the high mountains of the Carolinas and Tennessee.

Often planted as an ornamental tree in the eastern states and in northern and central Europe. 
What is probably a varicty of this species is

\section{Magnolia acuminata, var. cordata, Sarg.}

This tree has been eultivated in gardens for nearly a century, and is distinguished by its broader darker green more persistent leaves somctimes cordate at the base,

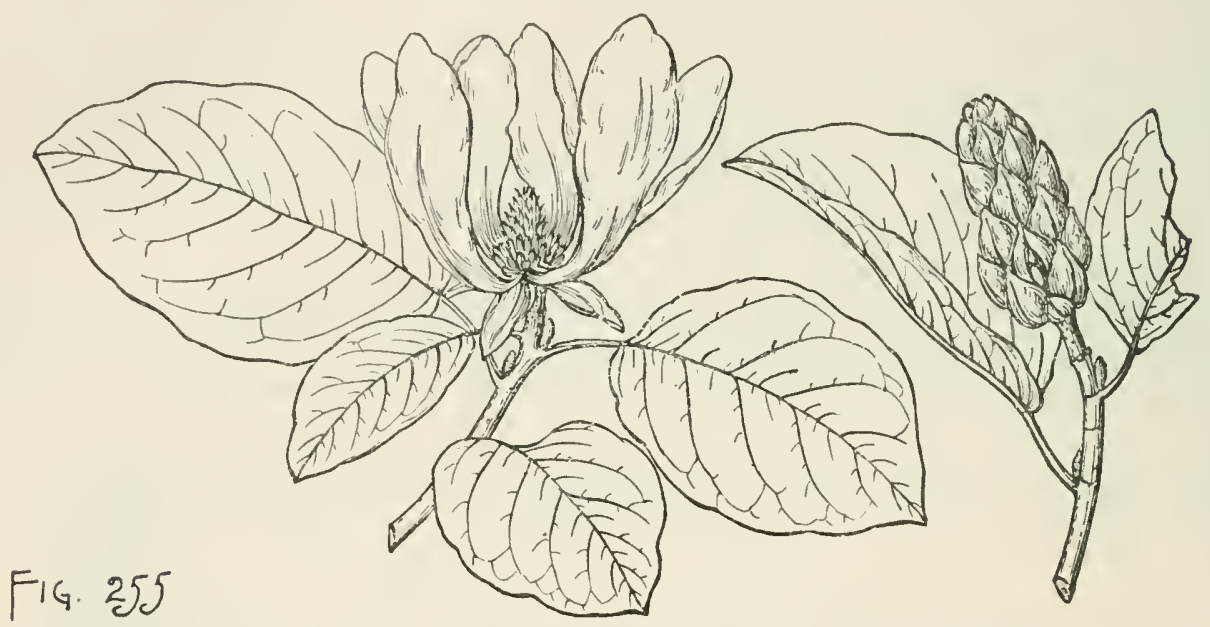

and by its smaller bright canary-yellow flowers. Forms approaching the cultivated plant in the shape and texture of the leaves and in the size and color of the flowers are occasionally found on the Blue Ridge in South Carolina, and in central Alabama, although none of these resemble exactly the cultivated plant, which is not known in a wild state.

\section{Magnolia macrophylla, Michx. Large-leaved Cucumber-tree.}

Leaves obovate or oblong, acute or often abruptly narrowed and acute or rounded at the apex, narrowed and cordate at the base, bright green and glabrous on the upper surface, silvery gray, and pubescent, especially along the stout midribs and primary veins on the lower surface, $20^{\prime}-30^{\prime}$ long, $9^{\prime}-10^{\prime}$ wide, falling in the autumn with little change of color; their petioles stout, $3^{\prime}-4^{\prime}$ long, at first tomentose, becoming pubescent. Flowers on stout hoary-tomentose peduncles, $1^{\prime}-1 \frac{1}{2}^{\prime}$ long, soon becoming glabrous or puberulous, white, cup-shaped, fragrant, $10^{\prime}-12^{\prime}$ across when expanded; sepals membranaceous, ovate or oblong, rounded at the apex, $5^{\prime}-6^{\prime}$ long, much narrower than the 6 ovate concave thick creamy white petals $6^{\prime}-7^{\prime}$ long and $3^{\prime}-4^{\prime}$ wide, at maturity reflexed above the middle, those of the inner row narrower and often somewhat acuminate. Fruit ovate to nearly globose, pubescent, $2 \frac{1^{\prime}}{2}-3^{\prime}$ long, bright rose color when fully ripe; seeds obovoid, compressed, $\frac{2}{3}$ ' long.

A tree, $30^{\circ}-50^{\circ}$ high, with a straight trunk $18^{\prime}-20^{\prime}$ in diameter, stout widespreading branches forming a broad symmetrical round-topped head, and stout brittle branchlets hoary-tomentose when they first appear, light yellow-green, pubescent, and conspicuonsly marked during their first winter by the large irregularly shaped sometimes longitudinal slightly raised leaf-scars, with many scattered fibro-vascular bundle-sears, turning reddish brown during the second and gray during their third season. Winter-buds: terminal, bluntly pointed, covered with a thick coat of snowy white tomentum, $1 \frac{3^{\prime}}{4}-2^{\prime}$ long, $\frac{1^{\prime}}{2}-\frac{3^{\prime}}{4}$ wide; lateral, much flattened, 
brownish, pubescent, $\frac{1}{8}^{\prime}-\frac{1}{4}^{\prime}$ long. Bark generally less than $\frac{1}{4}^{\prime}$ thick, smooth, light gray, divided on the surface into minute scales. Wood hard, close-grained, light, not strong, light brown, with thick light yellow sapwood of about 40 layers of annual growth.

Distribution. Sheltered valleys in deep rich soil; nowhere common, and growing generally in isolated groups of a few individuals in the region about the base of

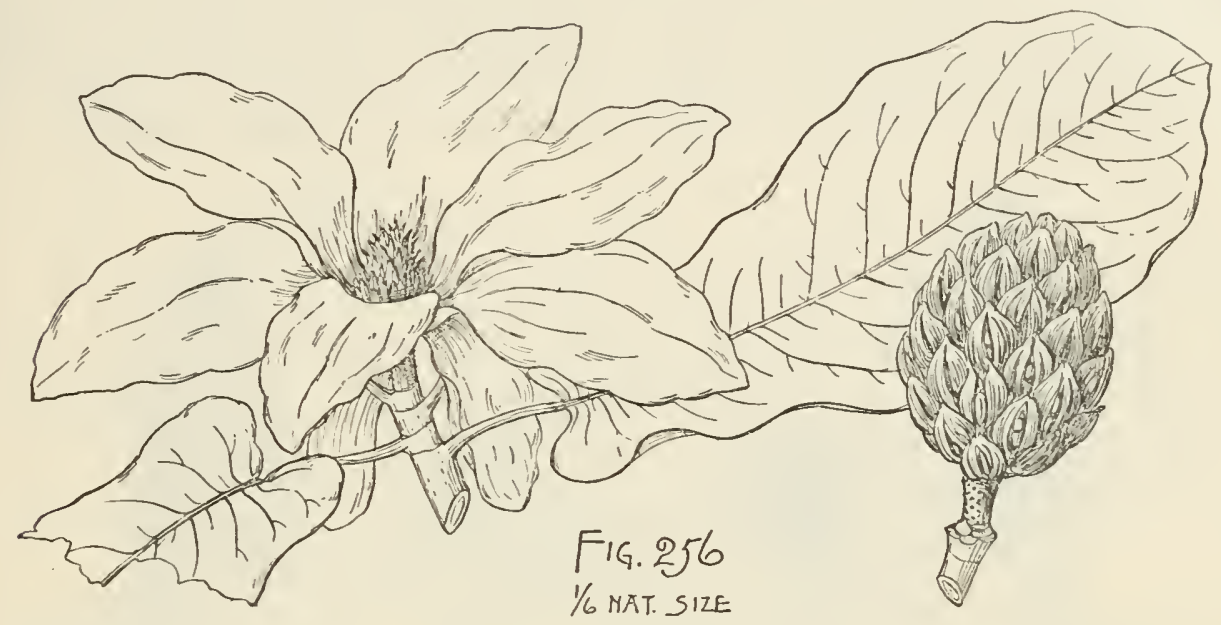

the southern Alleghany Mountains from North Carolina and sontheastern Kentucky to middle and western Florida, southern Alabama, northern Mississippi, and the valley of the Pearl River, Louisiana, and in central Arkansas.

Occasionally cultivated as an ornamental tree in the eastern states, and in the temperate countries of Europe; hardy as far north as eastern Massachusetts.

\section{Magnolia tripetala, L. Umbrella-tree. Elkwood.}

Leaves obovate-lanceolate, narrowed at the ends, acute or bluntly pointed at the apex, when they unfold nearly glabrous above, covered below with thick silky caducous tomentum, at maturity membranaceous, glabrous, $18^{\prime}-20^{\prime}$ long, $8^{\prime}-10^{\prime}$ wide, with thick prominent midribs and numerous slender primary veins, falling in the autumn with little change of color; their petioles stont, $1^{\prime}-1 \frac{1}{2}^{\prime}$ long. Flowers on slender glabrous peduncles covered with a glancons bloom and $2^{\prime}-2 \frac{1}{2}^{\prime}$ long, cupshaped, creamy white, $4^{\prime}-5^{\prime}$ deep; sepals narrowly obovate, $5^{\prime}-6^{\prime}$ long, $1_{2}^{\prime \prime}$, wide, thin, light green, becoming reflexed; petals 6 or 9 , concave, coriaceous, ovate, shortpointed, erect, those of the outer row $4^{\prime}-5^{\prime}$ long and sometimes $2^{\prime}$ wide, much longer and broader than those of the inner rows; filaments bright purple. Fruit ovate, glabrous, $2 \frac{1}{2}^{\prime}-4^{\prime}$ long, rose color when fully ripe; seeds obovoid, $\frac{1^{\prime}}{2}$ long.

A tree, $30^{\circ}-40^{\circ}$ high, with a straight or often inclining trunk rarely more than $18^{\prime}$ in diameter, stout irregularly developed contorted branches wide-spreading nearly at right angles with the stem or turning up toward the ends and growing parallel with it, and stout brittle branchlets green during their first season, becoming in their first winter bright reddish brown, very lustrous, and marked by occasional minute scattered pale lenticels, and by the large oval horizontal slightly raised leaf-scars, with scattered fibro-vascular bundle-scars, and brown during their second and gray during their third season; generally much smaller, sometimes surrounded by several stems springing from near the base of the trunk and growing into a large bush 
surmounted by the head of the central stem. Winter-buds: terminal, acute or bluntly pointed, purple, glabrous, covered with a glacous bloom, usually about $\mathbf{1}^{\prime}$ long; axillary globose, the color of the branch. Bark $\frac{1}{2}^{\prime}$ thick, light gray, smooth, and marked by many small bristle-like excrescences. Wood light, soft, closegrained, not strong, light brown, with creamy white sapwood of 35-40 layers of amulal growth.

Distribution. Deep rather moist rich soil along the banks of mountain streams or the margins of swanıs, and widely distributed in the Appalachian Mountain region, but nowhere very common; valley of the Susquehanna River, Pennsylvania, to southern Alabama, middle Kentucky and Tennessee, northeastern Mississippi, and

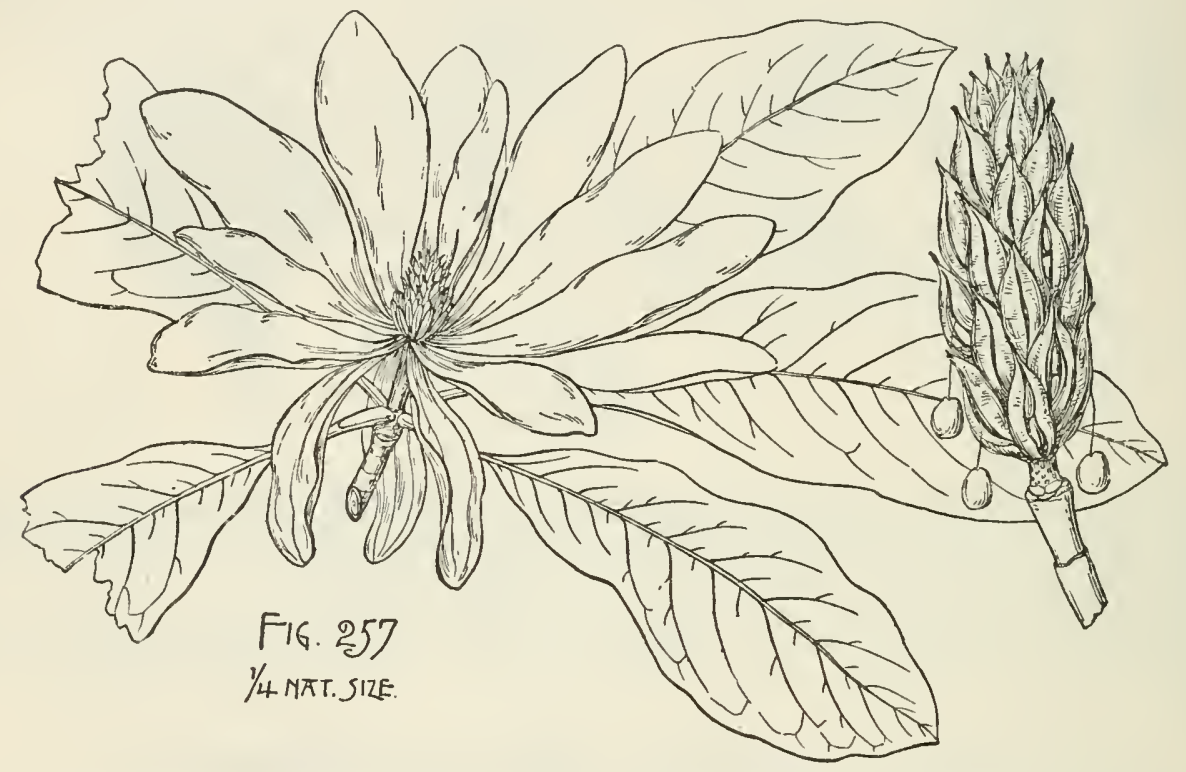

in central and southwestern Arkansas, extending in the south Atlantic states nearly to the coast; of its largest size in the valleys along the western slopes of the Great Smoky Mountains in Teunessee.

Oftell cultivated as an ornamental tree in the northern States, and in northern and central Europe.

\section{Magnolia Fraseri, Walt. Mountain Magnolia. Long-leaved Cucumber- tree.}

Leaves obovate-spatulate, acute or bluntly pointed at the apex, cordate and conspicuously auriculate at the base, bright green and often marked on the upper surface when young with red along the principal veins, glabrous, $10^{\prime}-12^{\prime}$ long, $6^{\prime}-7^{\prime}$ wide, or on vigorous young plants sometimes of twice that size, falling in the autumn without change of color; their petioles slender, $3^{\prime}-4^{\prime}$ long. Flowers on stout glabrous peduncles covered with a glaucous bloom and $1^{\prime}-1 \frac{1}{2}^{\prime}$ long, creamy white, sweetly scented, $8^{\prime}-10^{\prime}$ in diameter; sepals narrowly obovate, rounded at the apex, $4^{\prime}-5^{\prime}$ long, deciduous almost immediately after the opening of the bud, shorter than the 6 or 9 obovate acuminate membranaceous spreading petals contracted below the middle, those of the inner rows narrower and conspicuously narrowed below. Fruit oblong, glabrous, bright rose-red when fully ripe, $4^{\prime}-5^{\prime}$ long, $1 \frac{1}{2}-2^{\prime}$ wide, the mature carpels ending in loug subulate persistent tips; seeds obovoid, compressed, $\frac{5}{8}^{\prime}$ long. 
A tree, $30^{\circ}-40^{\circ}$ high, with a straight or inclining trunk $12^{\prime}-18^{\prime}$ in diameter, often undivided for half its length or separating at the ground into a number of stout diverging stems, regular wide-spreadiug or more or less contorted and erect branches, and stout brittle branchlets soon becoming bright red-brown, lustrous, marked by numerous minute pale lenticels and in their first winter by the low horizontal leaf-scars with crowded compressed fibro-vascular bundle-scars, and grayish in their second year. Winter-buds: terminal, glabrous, purple, $1 \frac{1}{2}^{\prime}-2^{\prime}$ long, $\frac{1^{\prime}}{2}$ wide; axillary, minute, and obtuse. Bark rarely more than $\frac{1}{3}^{\prime}$ thick, dark brown, smooth, covered

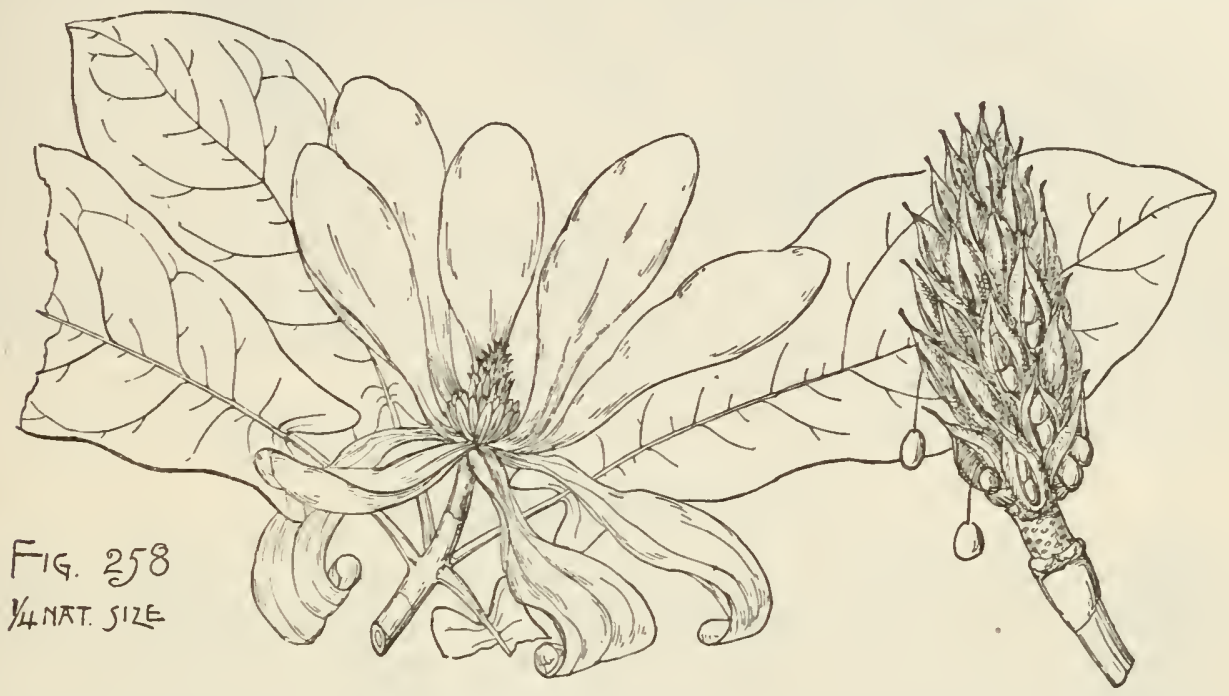

by small excrescences, or on old trees broken into minute scales. Wood light, soft, close-grained, not strong, light brown, with thick creamy white sapwood of 30-40 layers of annual growth.

Distribution. Valleys of the streams of the southern Appalachian Mountains from southwestern Virginia to northern Georgia and Alabama, eastern Tennessee and northern Mississippi; probably most abundant and of its largest size on the upper waters of the Savannah River in South Carolina.

Often cultivated as an ormamental plant in the eastern states, and occasionally in the temperate countries of Europe; hardy as far north as eastern Massachusetts.

\section{Magnolia pyramidata, Pursh.}

Leaves obovate-spatulate, the apex usually abruptly narrowed into a short blunt point, auriculate at the base, with more or less spreading lobes, thin, glabrous, light yellow-green on the upper, pale and glaucous on the lower surface, particularly while young, $5 \frac{1}{2}^{\prime}-8 \frac{1}{2}^{\prime}$ long, from $3 \frac{1}{2}^{\prime}-4 \frac{1}{2}^{\prime}$ wide, with slender yellow midribs, numerous slender forked primary veins and conspicuously reticulate veinlets; their petioles slender, $1 \frac{1}{4}^{\prime}-$ $2 \frac{1}{2}^{\prime}$ in length. Flowers creamy white, $3 \frac{1}{2}^{\prime}-4^{\prime}$ in diameter when fully expanded; sepals oblong-obovate, abruptly narrowed to the short pointed apex, much shorter than the oblong-acuminate petals gradually narrowed from near the middle to the base. Fruit oblong, $2^{\prime}-2 \frac{1^{\prime}}{2}$ long, bright rose color, the mature carpels ending in short incurved persistent tips; seeds ovate, compressed.

A slender tree, $20^{\circ}-30^{\circ}$ high, with ascending branches, slender branchlets bright red-brown and marked by small pale lenticels and by the small low oval leaf-scars, with many crowded fibro-vascular bundle-scars, later becoming ashy gray. 


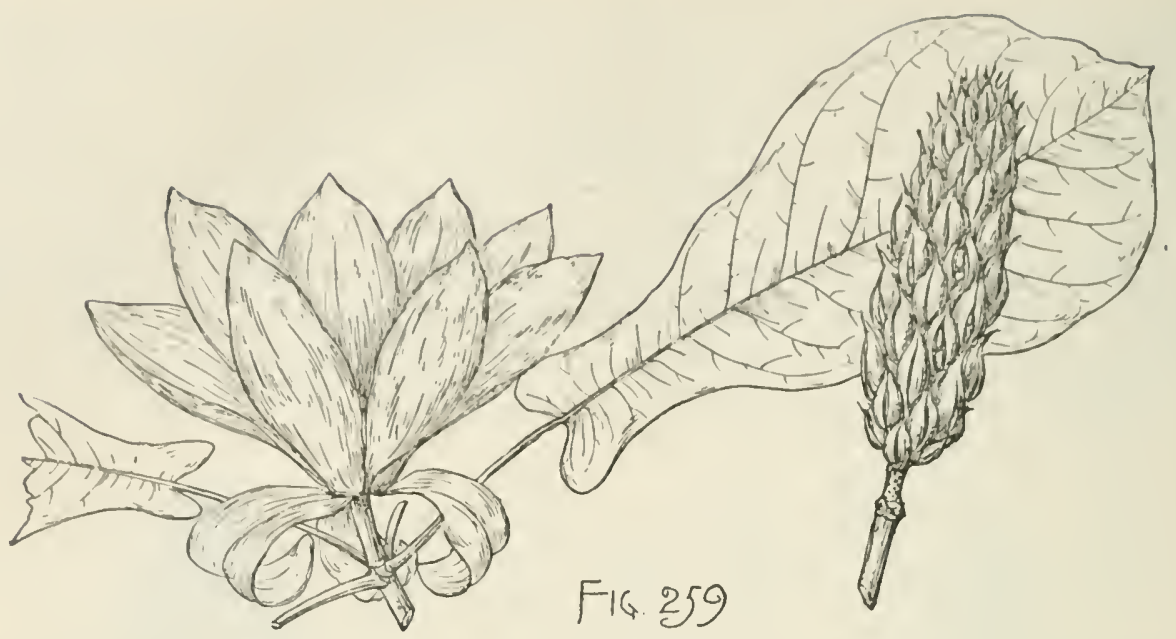

Distribution. Low rich soil near the streams of the coast region from southern Georgia through western Florida to southern Alabama.

Occasionally cultivated as an ornamental tree in western Europe.

\section{LIRIODENDRON, L.}

'Trees, with deeply furrowed brown bitter bark and slender branchlets marked by elevated leaf-scar's and narrow stipular rings, and compressed obtuse winter-buds, their scales membranaceous stipules joined at the edges, accrescent, strap-shaped, often slightly falcate, oblique at the unequal base, tardily deciduous after the unfolding of the leaf. Leaves recurved in the bud by the bending down of the petiole near the middle, bringing the apex of the blade to the base of the bud, sinuately 4-lobed, heart-shaped, truncate or slightly wedge-shaped at the base, truncate at the apex by a broad shallow sinus and minutely apiculate. Flowers appearing after the unfolding of the leaves, cup-shaped, conspicuous, inclosed in the bud in a 2-valved stipular membranaceous caducous spathe; sepals spreading or reflexed, ovate-lanceolate, concave, greenish white, early deciduous; petals erect, rounded at the base, early deciduous; filaments filiform, half as long as the linear 2-celled extrorse anthers adnate to the outer face of the connective terminating in a short fleshy point; pistils imbricated on the elongated sessile receptacle into a spindle-shaped column; ovary inserted by a broad base; style narrowly acuminate, laterally flattened, appressed; stigmas short, recurved at the summit; ovules 2, suspended from near the middle of the ventral suture. Fruit a narrow light brown cone formed of the closely imbricated dry and woody indehiscent carpels consisting of a laterally compressed 4-ribbed pericarp, the lateral ribs confluent into the margins of the large wing-like lanceolate compressed style marked vertically by a thin sutural line, the carpels deciduous when ripe in the autumn from the slender elongated axis of the fruit persistent on the branch during the winter. Seeds suspended, 2 or single by abortion; testa thin, coriaceous, and marked by a narrow prominent raphe; embryo minute at the base of the fleshy albumen, its radicle next the hilum.

Liriodendron, widely distributed in North America and Europe during the crustaceous period, is now represented by two species, one in eastern North America, the other in central China.

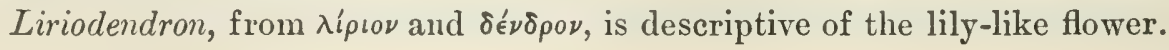




\section{Liriodendron Tulipifera, L. Yellow Poplar. Tulip-tree.}

Leaves dark green and shining on the upper, paler on the lower surface, $5^{\prime}-6^{\prime}$ long and broad, turning clear yellow in the autumn before falling; their petioles slender, angled, $5^{\prime}-6^{\prime}$ long. Flowers $1 \frac{1^{\prime}}{2}-2^{\prime}$ deep, on slender peduncles $\frac{3^{\prime}}{4}-1^{\prime}$ long. Fruit $2 \frac{1}{2}^{\prime}-3^{\prime}$ long, about $\frac{1}{2}^{\prime}$ wide, ripening late in September and in October, the mature carpels $1^{\prime}-1 \frac{1}{2}^{\prime}$ long and about $\frac{1}{4}^{\prime}$ wide.

A tree, sometimes nearly $200^{\circ}$ high, with a straight trunk $8^{\circ}-10^{\circ}$ in diameter, destitute of branches for $80^{\circ}-100^{\circ}$ from the ground, short, comparatively small branches forning a narrow pyramidal, or in old age a broader spreading head, and slender branchlets light yellow-green and often covered with a glaucous bloom during their first summer, reddish brown, lustrous, and marked by many small pale lenticels and roughened by the elevated orbicular or semiorbicular leaf-scars marked by numerous small scattered fibro-vascular bundle-scars during their first winter, and dark gray during their third year. Winter-buds dark red covered by a glaucous bloom, the terminal $\frac{1^{\prime}}{2}$ long, much longer than the lateral buds. Bark thin and scaly

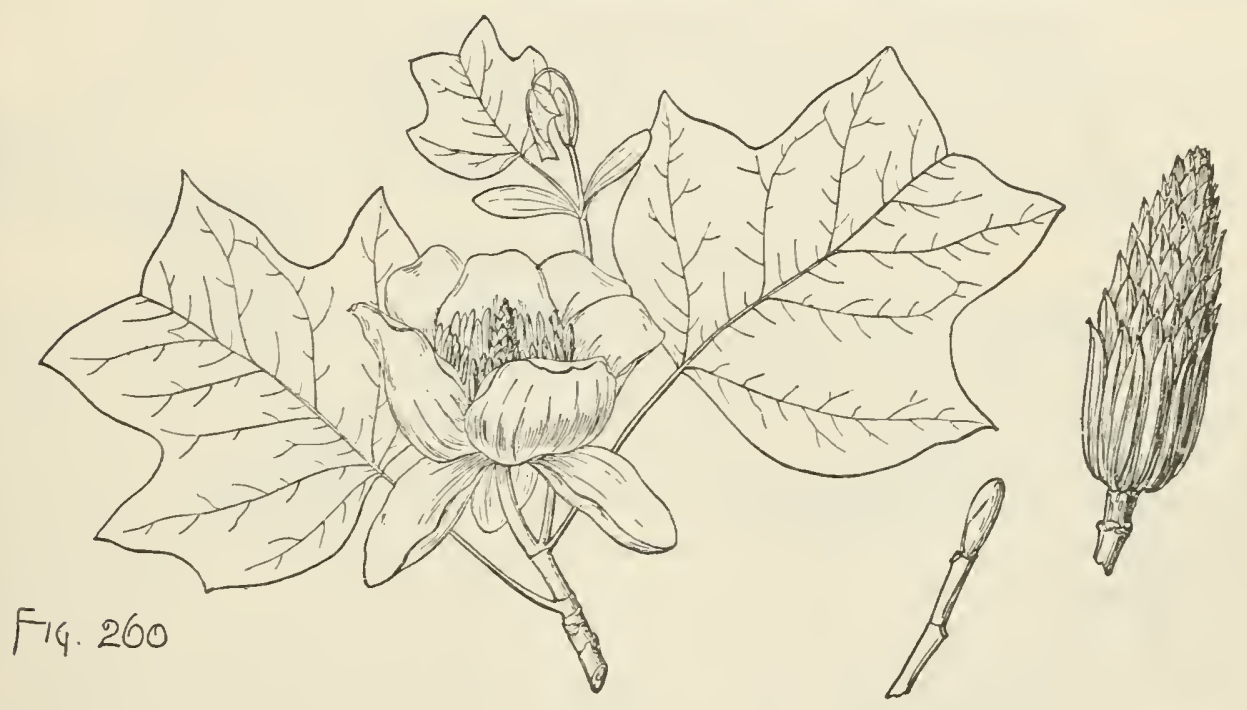

on young trees, becoming deeply furrowed, brown, and $1^{\prime}-2^{\prime}$ thick. Wood light, soft, brittle, not strong, easily worked, light yellow or brown, with thin creamy white sapwood; largely manufactured into lumber used in construction, the interior finish of houses, boatbuilding, and for shingles, brooms, and woodenware. The intensely acrid bitter inner bark, especially of the root, is used domestically as a tonic and stimnlant, and hydrochlorate of tulipiferine, an alkaloid separated from the bark, possesses the property of stimulating the heart.

Distribution. Deep rich rather moist soil on the intervales of streams or on mountain slopes; Rhode Island to southwestern Vermont, and westward to the southern shores of Lake Michigan, southward to northern Florida, southern Alabama and Mississippi, and in southeastern Missouri and northeastern Arkansas; most abundant and of its largest size in the valleys of the lower Ohio basin, and on the lower slopes of the high mountains of North Carolina and Tennessee.

Often cultivated as an ornamental tree in the eastern states, and in western and central Europe. 


\section{ANONACEA.}

Trees or shrubs, with watery juice, slender terete branchlets marked by conspicuous leaf-scars, and fleshy roots. Leaves alternate, conduplicate in the bud. entire, feather-veined. petiolate, without stipules. Flower's perfect, solitary, axillary or opposite the leaves; sepals 3 , valvate in the bud; petals 6 , in '2 series, imbricated or valvate in the bud; stamens numerons, inserted on the subglobose or hemispherical receptacle, with distinct filaments shorter than their fleshy connectives terminating in a broad uncate glandular appendage; anther's introrse, "2-celled, opening longitudinally; pistils inserted on the summit of the receptacle; ovary 1 -celled; ovules 1 or many, anatropous. Fruit baccate or compound. Seeds inclosed in an aril; seed-coat thin, cristaceous, smootl. brown, and lustrous; albumen ruminate, deeply penetrated by the folds of the inner layer of the seed-coat; embryo minute; radicle next the hilum. Two of the forty-eight or fifty genera of the Custard-apple family, confined almost exclusively to the tropics and more numerous in the Old World than in the New, occur in North America.

\section{CONSPECTUS OF THE NORTH AMERICAN GENERA.}

Petals imbricated in the bud; ovules numerous; fruit developed from one pistil.

1. Asimina. Petals valvate in the bud; ovule solitary; fruit developed from several confluent pistils.

2. Anona.

\section{ASIMINA, Adans.}

Trees or shrubs, emitting a heavy disagreeable odor when bruised, with minute buds covered with cinereo-pubescent caducous scales, and branchlets marked by conspicuous leaf-scars. Leaves membranaceous, feather-veined, reticulate-venulose, deciduous. Flowers pedunculate, nodding, purplish, bad-smelling; sepals ovate, smaller than the petals, green, deciduous; petals imbricated in the bud, hypogynous, sessile, ovate or obovate-oblong, reticulate-veined, accrescent, the three exterior alternate with the sepals, spreading, those of the interior row opposite the sepals, erect, and much smaller than those of the onter row; stamens linear-cuneate, densely packed on the receptacle; filaments shorter than the fleshy connective; anther-cells separated on the connective; pistils sessile on the summit of the receptacle, projecting from the globular mass of stamens; ovary 1-celled; style oblong, slightly recurved toward the apex and stigmatic along the margin; ovules 4-20, horizontal, 2-ranked on the ventral suture, the raphe toward the suture. Fruit baccate, sessile or stipitate, oval or oblong, smooth. Seeds in 1 or 2 ranks, ovate, apiculate, compressed, marked at the base by a large pale hilum.

Asimina is confiued to eastern North America. Six species are distinguished; of these one is a small tree; the others are low shrubs of the south Atlantic and Gulf regions.

Asimina is from Asiminier, the old colonial name of the French in America for the Pawpaw.

\section{Asimina triloba, Dunal. Pawpaw.}

Leaves obovate-lanceolate, sharp-pointed at the apex, gradually and regularly narrowed to the base, when they unfold covered below with short rusty brown caducous tomentum and slightly pilose above, and at maturity light green on the upper surface, pale on the lower surface, $10^{\prime}-12^{\prime}$ long, $4^{\prime}-6^{\prime}$ wide, with prominent midribs 
and primary veins. Flowers nearly $2^{\prime}$ across when fully grown, on stout clubshaped peduncles $1^{\prime}-1_{\frac{1}{2}}^{\prime}$ long and covered with long seattered rusty brown hairs; sepals ovate, acuminate, pale green, densely pubescent on the outer surface; petals green at first, covered with short appressed hairs, gradually turning brown and at maturity deep vinous red and conspicuously venulose, those of the outer row broadly ovate, rounded or pointed at the apex, reflexed at maturity above the middle and 2 or 3 times longer than the sepals, those of the inner row pointed, erect, their base concave, glandular, nectariferous, marked by a broad band of a lighter color. Fruit attached obliquely to the enlarged torus, oblong, nearly cylindrical, rounded or sometimes slightly pointed at the ends, more or less falcate, often irregular from the imperfect development of some of the seeds, $3^{\prime}-5^{\prime}$ long, $1^{\prime}-1 \frac{1}{2}^{\prime}$ in diameter, greenishyellow, becoming when fully ripe in September and October dark brown or almost black, with thick semitransparent sweet and luscious flesh; seeds separating readily from the aril, $\mathbf{1}^{\prime}$ long, $\frac{1}{2}^{\prime}$ broad, ovate, and rounded at the ends.

A shrub or low tree, sometimes $35^{\circ}-40^{\circ}$ high, with a straight trunk rarely exceeding a foot in diameter, small spreading branches, and slender light brown branchlets

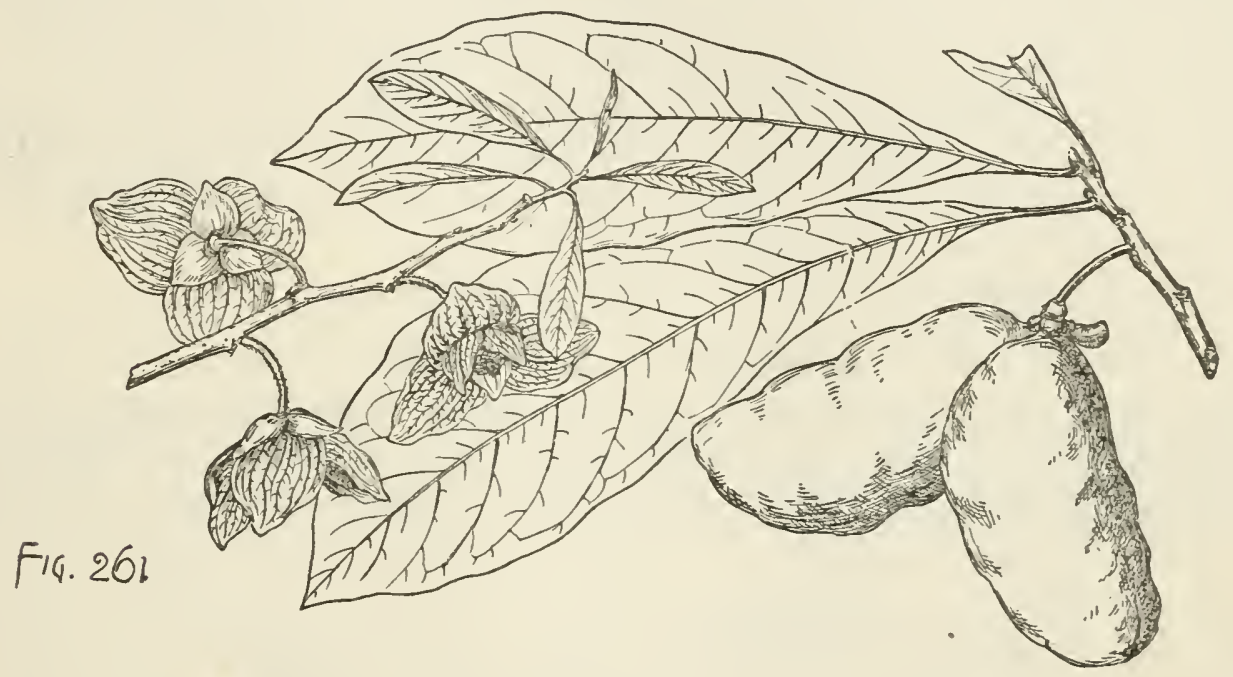

tinged with red and marked by longitudinal parallel or recticulate narrow shallow grooves. Winter-buds acuminate, flattened, $\frac{1}{8}^{\prime}$ long, and clothed with rusty brown hairs. Bark rarely more than $\frac{1}{8}^{\prime}$ thick, dark brown, marked by large ash-colored blotches, covered by small wart-like excrescences and divided by numerous shallow reticulate depressions. Wood light, soft and weak, coarse-grained, spongy, light yellow shaded with green, with thin darker colored sapwood of 12-20 layers of annual growth. The inner bark stripped from the branches in early spring is used by fishermen of western rivers for stringing fish. The sweet and luscious wholesome fruit is sold in large quantities in the cities and towns in those parts of the country where the tree grows naturally.

Distribution. Deep rich moist soil; western New Jersey to the northern shores of Lake Ontario, and eastern central Pennsylvania, westward to southern Michigan, eastern Nebraska, eastern Kansas, and southward to middle Florida, and to the valley of the Sabine River, Texas; comparatively rare in the region adjacent to the Atlantic seaboard; very common in the Mississippi valley, forming the thick forest undergrowth on rich bottom-lands, or thickets many acres in extent. 
Occasionally cultivated in the eastern states, and precariously hardy as far north as eastern Massachnsetts; interesting as the most northern represcntative of the Custard-apple family and its only species extending far beyond the tropies.

\section{ANONA, L.}

Trees or shrubs, with glandular often reticulated bark, tercte branchlets marked by conspicuous leaf-scars, and often pubescent during their first season. Leaves coriaceous, often glandnlar-punctate, persistent or tardily deciduous. Flowers nodding on bracted pedmeles; calyx small, 3-lobed, green, deciduous; petals 6 in 2 series, valvate in the bud, hypogynous, sessile, ovate, concave, 3 -angled at the apex, thick and fleshy, white or yellow, the exterior alternate with the sepals, those of the inner row opposite the sepals and often much smaller than those of the outer row; stamens club-shaped, densely packed on the receptacle; filaments shorter than the fleshy connective; anther-cells confluent; pistils sessile on the receptacle, free or united; ovary 1-celled; style sessile or slightly stipitate, oblong; stigmatic on the inner face, ovule 1, erect; raphe ventral. Fruit compound, many-celled, fleshy, ovate or globose, many-seeded. Seeds ovate to elliptical; cotyledons appressed.

Of the fifty species of Anona widely distributed in the tropics of the two worlds, a single species reaches the coast of southern Florida. Of exotic species, Anona muricata, L., the Soursop, and Anona reticulata, L., of the West Indies, and Anona Cherimolia, Mill., of western tropical America, are now occasionally cultivated as fruit-trees in Florida.

Anona is the name given by early authors to the Soursop.

\section{Anona glabra, L. Pond Apple.}

Leaves oval or oblong, acute, tapering or rounded at the base, bright green on the upper, paler on the lower surface, coriaceous, $3^{\prime}-5^{\prime}$ long, $1 \frac{1^{\prime}}{2}-2^{\prime}$ broad, with prominent midribs; their stout petioles $\frac{1}{2}^{\prime}$ long. Flowers nodding on short stout

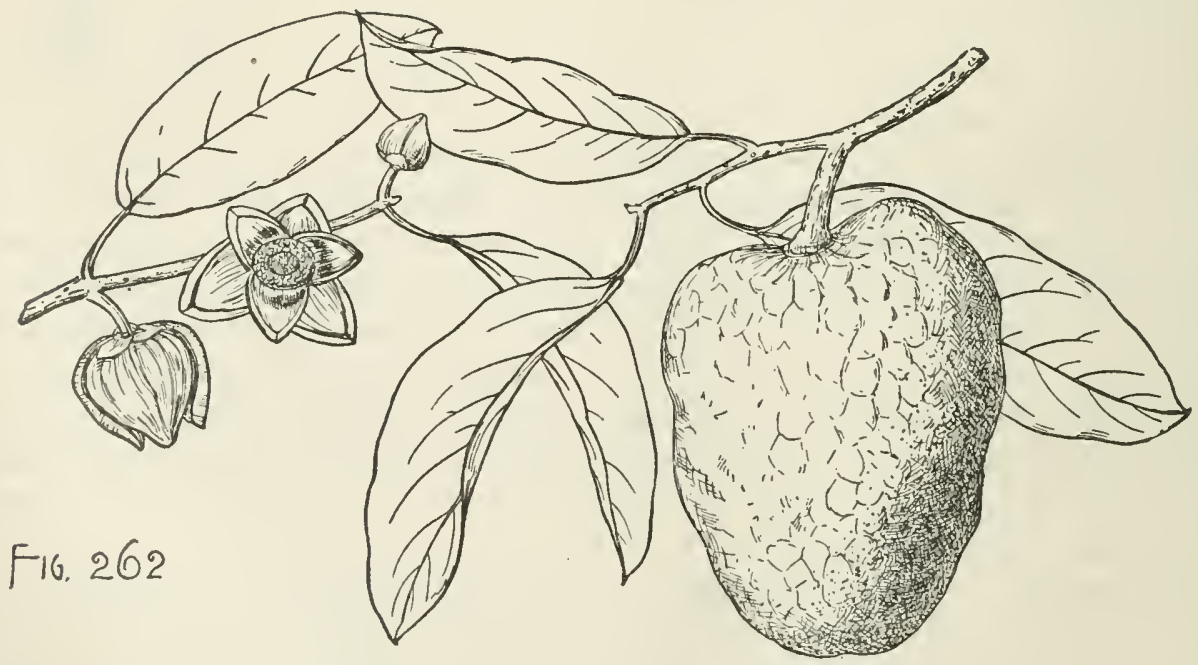

peduncles thickened at the ends, opening in April from an ovoid 3-angled bud; calyx 3-lobed, with broadly ovate acute divisions; petals connivent, acute, concave, pale yellow or dirty white, those of the outer row marked on the inner surface near the 
base by a bright red spot, and broader and somewhat longer than those of the inner row. Fruit ripening in November, broadly ovate, truncate or depressed at the base, rounded at the apex, $3^{\prime}-5^{\prime}$ long, $2^{\prime}-3 \frac{1^{\prime}}{2}$ broad, light green when fully grown, beconiing yellow and often marked by numerous dark brown blotches when fully ripe, with a thick elongate fibrous torus and light green slightly aromatic insipid flesh of no comestible value; seeds $\frac{1^{\prime}}{2}$ long, slightly obovate, turgid, rounded at the ends, their margins contracted into a narrow wing formed by the thickening of the outer coat.

A tree, $30^{\circ}-40^{\circ}$ high, with a short trunk often $18^{\prime}$ in diameter above the swell of the thickened tapering base sometimes enlarged into spreading buttresses, stout wide-spreading often contorted branches, slender branchlets brown òr yellow during their first season, becoming in their second year brown and marked by small scattered wart-like excrescences. Bark $\frac{1}{8}^{\prime}$ thick, dark reddish brown, divided by broad shallow fissures separating on the surface into numerous small scales. Wood light, soft, not strong, light brown streaked with yellow.

Distribution. Florida from Cape Malabar to the shores of Bay Biscayne, and on the west coast from Peace Creek to the Caloosa River; in shallow fresh water ponds, on swampy hummocks, or on the borders of fresh water streams flowing from the everglades; of its largest size on the shores of Bay Biscayne near the Miami River, growing in the shade of larger trees; on the Bahama Islands and on several of the Antilles.

\section{LAURACEA}

Aromatic trees and shrubs, with slender terete branchlets, naked or scaly buds, and alternate punctate leaves without stipules. Flowers small, perfect or polygamo-diøecious, yellow or greenish; calyx 6 -lobed, the lobes in 2 series, imbricated in the bud; corolla 0 ; stamens 9 or 12 , inserted on the base of the calyx in 3 or 4 series of 3 's, distinct, those of the fourth series sterile; anthers 4-celled, superposed in pairs, opening from below upward by persistent lids; ovary 1-celled; stigma discoid or capitate; ovule solitary. suspended from the apex of the cell, anatropous. Fruit a 1-seeded berry; seed without albumen : testa thin and membranaceous, of 2 coats; embryo erect; cotyledons thick and fleshy; radicle superior. turned toward the hilum, included between thick and fleshy cotyledons. The Laurel family with about forty genera, confined mostly to the tropics, is represented in North America by six genera; of these four are arborescent.

\section{CONSPECTUS OF THE YORTH AMERICAN ARBORESCENT GENERA.}

Leaves entire, persistent; stamens 12.

Calyx-lobes persistent under the fruit.

- 1. Persea.

Calyx-lobes deciduous.

Flower cymose in axillary or subterminal panicles.

2. Ocotea.

Flowers in axillary many-flowered umbels inclosed before anthesis in an involucre of deciduous scales.

3. Umbellularia.

Leaves entire or lobed, deciduous; stamens 9; flowers diœcious in few-flowered drooping racemes.

4. Sassafras.

\section{PERSEA, L.}

Trees, with naked buds. Leaves revolute in the bud, alternate, scattered, penniveined, subcoriaceous, rigid, tomentose or rarely glabrous, persistent. Flowers per- 
fect, vernal, in 2 or :3-flowered cymes in short axillary or axillary and terminal panicles on slender pedumeles from axils of the leaves of the year, pedicellate, their pedicels bibracteolate near the middle, the lateral flowers of the nltinate divisions of the inflorescence in the axils of small decidnons lanceolate acute bracts; calyx campanulate, divided nearly to the base into 6 lobes, those of the onter series shorter than the other's, enlarged and persistent nnder the fruit; stamens 12, in 4 series, about as long as the inner lobes of the ealyx; filaments flattened, longer than the anthers, hirsute, those of the third series furnished near the base with 2 ncarly sessilc orange-colored glands rounded on the back and slightly 2-lobed on the imer face; anthers ovate, flattened, erect, those of the onter series introrse or subintrorse, those of the third series extrorse or laterally dehiscent, the upper cells rather larger than the lower; staminodia large, sagittate, stipitate, 2-lobed on the immer facc, beaded at the apex; ovary sessile, subglobose, glabrous, narrowed into a slender simple style gradually enlarged at the apex into a discoid obscurely 2-lobed stigma. Fruit ripening in the antumn, oblong-obovate to subglobose, more or less fleshy, surromded at the base by the enlarged spreading persistent lobes of the calyx. Seed globose, pendulous, without albumen; testa thin and membranaceous, separable into 2 coats, the outer cartilaginous, grayish brown, the inner gray or nearly white, closely adherent to the thick dark red cotyledons.

About fifty species of Persea are distinguished. With the exception of one species of the Canary Islands they are confined to the New World, where they are distributed from the coast region of the southern United States to Brazil and Chili. Persea Persea, Cockerell, the Avocado or Alligator Pear, a native of the Antilles and cultivated for its edible fruit in all tropical countries, is now sparingly naturalized in southern Florida. Many species yield hard dark-colored handsome wood valued in cabinet-making.

Persea was the classical name of a tree of the Orient, transferred by Plumier to one of the tropical species of this genus.

\section{CONSPECTUS OF THE NORTH AMERICAN SPECIES.}

Peduncles short; leaves oblong to oblong-lanceolate, obscurely veined, glabrous; branchlets puberulous.

1. P. Borbonia (C).

Peduncles elongated; leaves oval to lanceolate, conspicuously veined, tomentose on the lower surface; branchlets tomentose.

2. P. pubescens (C).

\section{Persea Borbonia, Spreng. Red Bay.}

Leaves oblong to oblong-lanceolate, entire, often slightly contracted into long points rounded at the apex, gradually narrowed below, when they unfold thin, pilose, and tinged with red, and at maturity thick and coriaceous, bright green and lustrous above, pale and glaucous below, $3^{\prime}-4^{\prime} \operatorname{long}, \frac{3}{4}^{\prime}-1 \frac{1}{2}^{\prime}$ wide, with thickened revolute margins, narrow orange-colored midribs, remote obscure primary veins arcuate near the margins, and thin closely reticulated veinlets, unfolding early in the spring, gradually turning yellow a year later and falling during their second spring and summer; their petioles stout, rigid, red-brown, $\frac{1}{2}^{\prime}-\frac{2}{3}^{\prime} l o n g$, flattened and somewhat grooved on the upper side, in falling leaving small circular leaf-scars displaying the ends of a single fibro-vascular bundle. Flowers: peduncles glabrous, $\frac{1^{\prime}}{2} \mathbf{1}^{\prime}$ long; calyx pale yellow or creamy white, about $\frac{1}{8}^{\prime}$ long, with thin lobes ciliate on the margins, the outer broadly ovate, rounded and minutely apiculate, puberulous, about 
half as long as the oblong-lanceolate acute lobes of the inner series covered within by long pale hairs. Fruit $\frac{1}{2}^{\prime}$ long, dark blue or nearly black, very lustrous; flesh thin and dry, not readily separable from the ovate slightly pointed seed.

A tree, $60^{\circ}-70^{\circ}$ high, with a trunk $2 \frac{1}{2}^{\prime}-3^{\prime}$ in diameter, stout erect branches forming a dense shapely head, thick fleshy yellow roots, and branchlets many-angled, light brown, glabrous or coated with pale or rufous pubescence when they first appear, becoming in their second year terete and dark green; usually much smaller. Winter-buds coated with thick rufous tomentum, $\frac{1}{4}^{\prime}$ long. Bark $\frac{1^{\prime}}{2}-3^{\prime}$ thick, dark

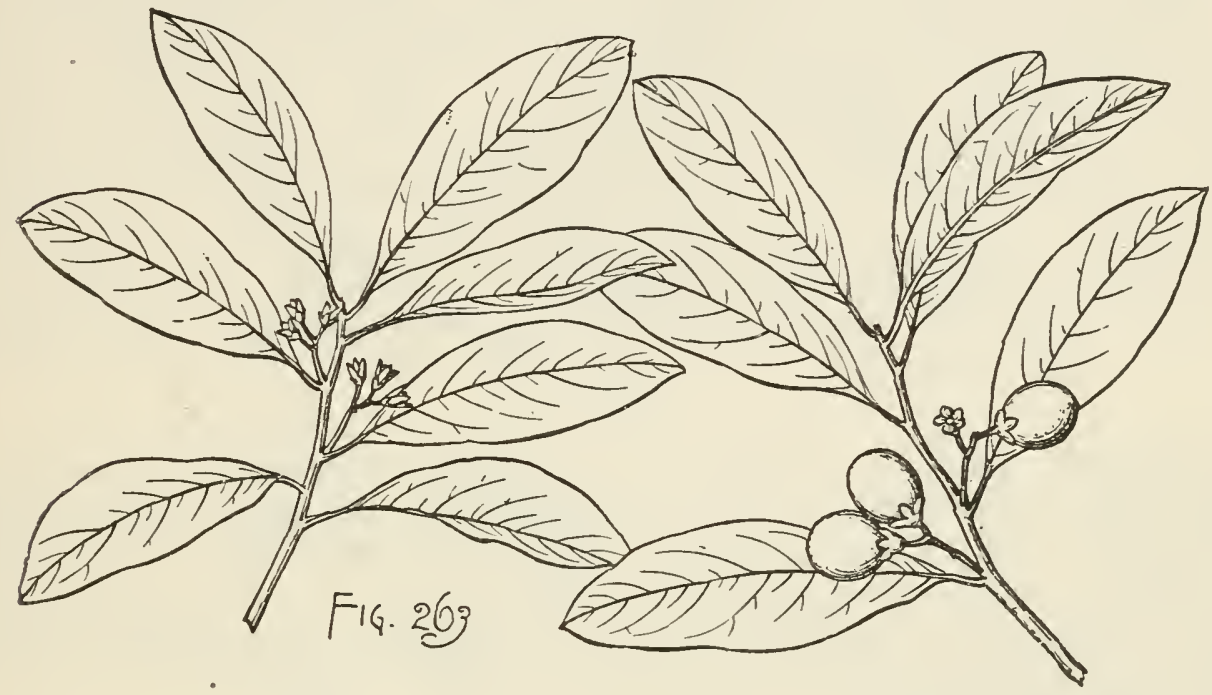

red, deeply furrowed and irregularly divided into broad flat ridges separating on the surface into small thick appressed scales. Wood heavy, hard, very strong, rather brittle, close-grained, bright red, with thin lighter colored sapwood of 4 or 5 layers of annual growth; occasionally used for cabinet-making, the interior finish of houses, and formerly in ship and boatbuilding.

Distribution. Borders of streams and swamps in rich moist soil, or occasionally in dry sandy loam in forests of the Long-leaved Pine; coast region from Virginia to the shores of Bay Biscayne and Cape Romano, Florida, along the Gulf coast to the valley of the Brazos River, Texas, and northward through Louisiana to southern Arkansas.

\section{Persea pubescens, Sarg. Swamp Bay.}

Leaves oval or lanceolate, entire, often narrowed toward the apex into long points, gradually narrowed at the base, when they unfold dark red, thin, and tomentose, at maturity thick and coriaceous, pale green and lustrous above, pale and pubescent and rusty-tomentose on the midribs and primary veins below, $4^{\prime}-6^{\prime}$ long, $\frac{3^{\prime}}{4}-1 \frac{1}{2}^{\prime}$ wide, with thick conspicuous veins and slightly revolute margins, persistent until after the beginning of their second year and then turning yellow and falling gradually; their petioles stout, rusty-tomentose, $\frac{1^{\prime}}{2}-\frac{3^{\prime}}{4}$ long. Flowers: peduncles tomentose, $2^{\prime}-3^{\prime}$ long; calyx pale yellow or creamy white, often nearly $\frac{1^{\prime}}{4}$ long, with thick firm lobes coated on the outer surface with rusty tomentum, those of the outer series broadly ovate, abruptly pointed at the apex, pubescent on the inner surface, about half as long as the ovate lanceolate lobes of the inner series, slightly thickened at the apex, and hairy within. Fruit nearly black, $\frac{8^{\prime}}{4}$ long. 
A slender tree, occasionally $30^{\circ}-40^{\circ}$ high, with a trunk rarely exceeding a foot in diameter, and stont branchlets terete or slightly angled while young, coated when

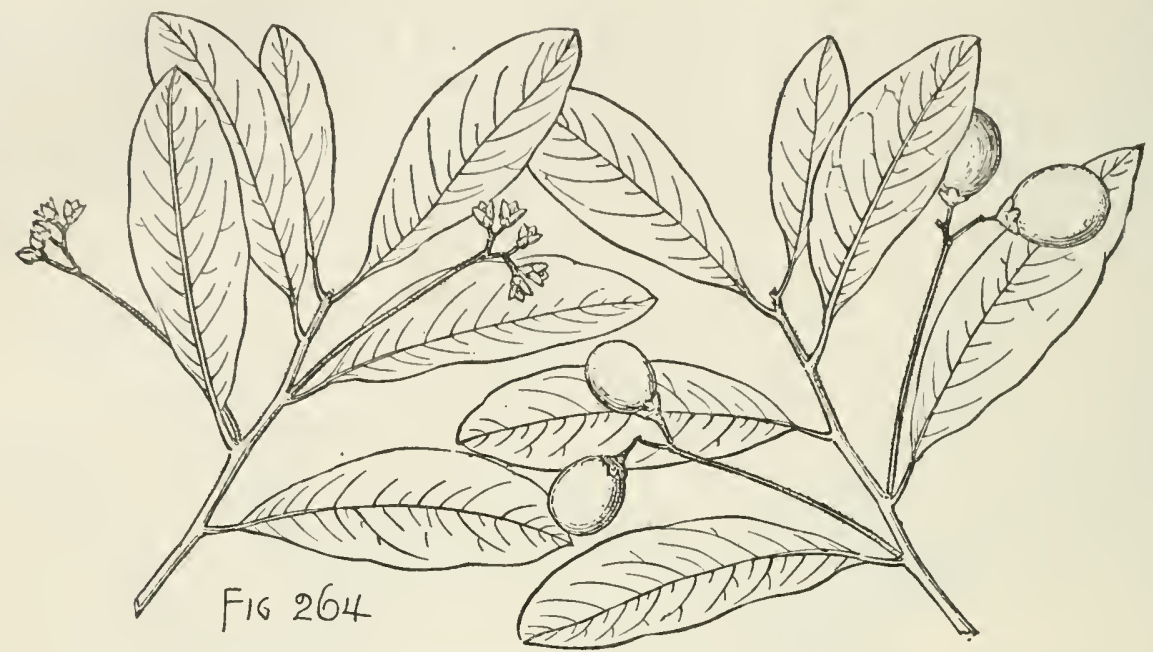

they first appear with rusty tomentum reduced in their second season to fine pubescence persistent nntil the end of their second or third year. Bark rarely exceeding $\frac{1^{\prime}}{4}$ in thickness, dull browu, irregularly divided by shallow fissures, the surface separating into thick appressed scales. Wood heavy, soft, strong, close-grained, orange color streaked with brown, with thick light brown or gray sapwood of 36-40 layers of annual growth.

Distribution. Pine-barren swamps, almost to the exclusion of other plants, in the immediate neighborhood of the coast of the sonth Atlantic and Gulf states from North Carolina to Mississippi.

\section{OCOTEA, Aubl.}

Aromatic trees. Leaves scattered, alternate or rarely subopposite, penniveined, coriaceous, rigid, glabrous or more or less covered with pubescence. Flowers glabrons or tomentose on slender bibracteolate pedicels from the axils of lanceolate acute minute bracts, in cymose clusters in axillary or subterminal stalked panicles; calyx-tube campanulate, the 6 lobes of the limb nearly equal, decidnons; stamens 12 , in 4 series, those of the inner series reduced to lineal staminodia, with minnte abortive anthers; filaments inserted on the tnbe of the calyx; those of the outer series opposite its exterior lobes, shorter or sometimes rather longer than the anthers, glabrous or hirsute, furnished in the third series near the base with two conspicuous globose stalked yellow glands; anthers oblong, flattened, 4-celled, introrse in the 2 outer series, extrorse, subextrorse, or very rarely introrse in the third series, in the pistillate flower rudimentary and sterile; ovary ovate, glabrons, more or less immersed in the tube of the calyx, gradually narrowed into a short erect style dilated at the apex into a capitate obscurely lobed stigma; in the staminate flower linear-lanceolate, effete or minnte, sometimes 0 ; raphe ventral; micropyle superior. Fruit nearly inclosed while young in the thickened tube of the calyx, exserted at maturity, surromnded at the base by the cup-like truncate or slightly lobed calyxtube; pericarp thin and fleshy. Seed ovate, pendulons; testa thin, membranaceous.

Ocotea with nearly two hundred species is confined principally to the tropical 
region of the New World from southeru Florida to Brazil and Peru, with Old World representatives in the Canary Islands, South Africa, and the Mascarene Islands. One species grows naturally in Florida.

Ocotea produces hard strong durable beautifully colored wood often employed in cabinet-making.

The name is derived from the native name of one of the species of Guiana.

\section{Ocotea Catesbyana, Sarg.}

Leaves oblong-lanceolate, entire, slightly contracted above into long points rounded at the apex, when they unfold thin, membranaceous, light green tinged with red, and sonetimes puberulous on the lower surface, and at maturity thick and coriaceous, dark green and lustrous above, pale below, $3^{\prime}-6^{\prime}$ long, $1^{\prime}-2^{\prime}$ wide, with thickened slightly revolute margins, broad stout midribs, slender remote primary veins arcuate and united near the margins and connected by coarsely reticulate conspicuous veinlets; their petioles broad, flat, $\frac{1}{3}^{\prime}-\frac{1}{2}^{\prime}$ long. Flowers perfect, appearing in early summer in elongated panicles, their stalks slender, glabrous, light red, solitary or 2 or 3 together from the axils of the leaves of the year or from those of

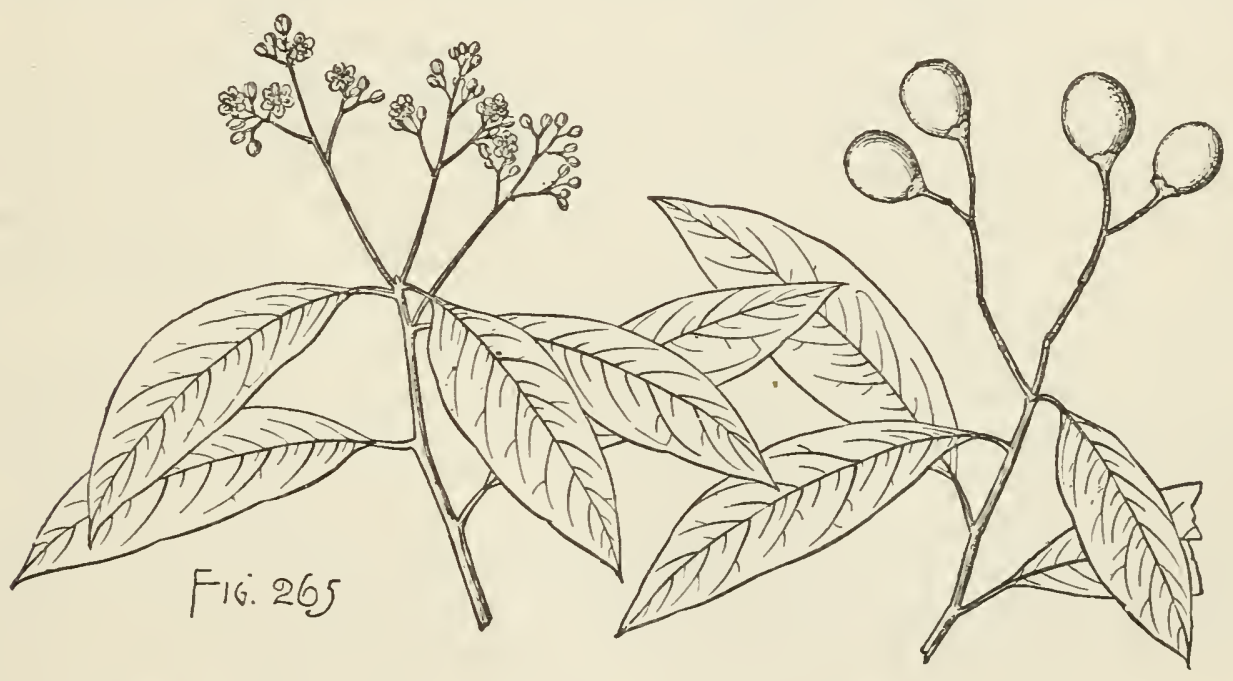

the previous year, and $3^{\prime}-4^{\prime}$ long; calyx nearly $\frac{1^{\prime}}{4}$ across when expanded, pubescent on the outer surface, tomentose on the inner surface, about twice as long as the stamens; filaments of the 2 outer series slightly hirsute at the base and shorter than their introrse anthers; filaments of the third series as long or longer than their extrorse anthers. Fruit ripening in the autumn, ovate or subglobose, $\frac{2 \prime}{3}$ long, lustrous, dark blue or nearly black, the thickened cup-like tube of the calyx truncate or obscurely lobed and bright red like the thickened pedicels; flesh thin and dry; seed with a thin brittle red-brown coat, the inner layer lustrous on the inner surface and marked by broad light-colored veins radiating from the small hilum; embryo $\frac{1}{3}$ long, light red-brown.

A tree, $20^{\circ}-30^{\circ}$ high, with a trunk rarely exceeding $18^{\prime}$ in diameter, slender spreading branches forming a narrow round-topped head, and thin terete branchlets glabrous and dark reddish brown when they first appear, soon becoming lighter colored, and in their second year light brown or gray tinged with red and often marked by minute pale lenticels, and in their second or third year by small semi- 
orbicular leaf-scars, displaying a single central fibro-vascular bundle-scar. Bark about $\frac{1}{8}$ thick, dark reddish brown, and roughened on the otherwise smooth surface by numerous small excrescences. Wood heavy, hard, close-grained, rich dark brown, with thick bright yellow sapwood of 20-30 layers of annual growth.

Distribution. Shores and islands of Florida south of Cape Canaveral on the east coast and of Cape Romano on the west coast; comparatively common except on some of the western keys, and most abundant and of its largest size on the rich wooded hummocks adjacent to Bay Biscayne; also in the Bahamas.

\section{UMBELLULARIA, Nutt.}

A pungent aromatic tree, with dark brown scaly bark, slender terete branchlets marked in their second and third years by small semicircular or nearly triangular elevated leaf-scars displaying a horizontal row of minute fibro-vascular bundle-scars, naked buds, and thick fleshy brown roots. Leaves alternate, involute in the bud, lanceolate or ovate-lanceolate, acute or rounded at the narrow apex, cuneate or somewhat rounded at the base, entire, with thickened slightly revolute margins, petiolate, coated when they appear on the lower surface witl pale soft pubescence and puberulous on the upper surface, at maturity thick and coriaceous, dark green and lustrous above, dull and paler below, with slender light yellow midribs, and remote, obscure, arcuate veins more or less united near the margins, and connected by conspicuous reticulate veinlets. Flowers in axillary stalked many-flowered umbels, inclosed in the bud by an involucre of 5 or 6 imbricated broadly ovate or obovate pointed concave yellow caducous scales, the latest umbels subsessile at the base of terminal leaf-buds; pedicels slender, puberulous, without bractlets, from the axils of obovate membranaceous puberulous deciduous bracts decreasing in size from the outer to the inner; calyx divided almost to the base into 6 nearly equal broadly obovate rounded pale yellow lobes spreading and reflexed after anthesis; stamens inserted on the short slightly thickened tube of the calyx; filaments flat, glabrous, pale yellow, rather shorter than the anthers, those of the third series furnished near the base with 2 conspicuous stipitate orange-colored orbicular flattened glands; anthers oblong, flattened, light yellow, those of the first and second series introrse, those of the second and third series extrorse; stamens of the fourth series reduced to minute ovate acute yellow staminodia; ovary sessile, ovate, often more or less gibbous, glabrous, abruptly contracted into a stout columnar style rather shorter than the lobes of the calyx and crowned by a simple capitate discoid stigma. Fruit ovate, surrounded at the base by the enlarged and thickened truncate or lobed tube of the calyx, yellow-green sometimes more or less tinged with purple; pericarp thin and fleshy. Seed ovate, light brown; testa separable into 2 coats, the outer thick, hard, and woody, the inner thin and papery, closely investing the embryo, chestnut-brown, and lustrous on the inner surface.

Umbellularia consists of a single species.

The generic name, a diminutive of Umbella, relates to the character of the inflorescence.

\section{Umbellularia Californica, Nutt. California Laurel. Spice-tree.}

Leaves $2^{\prime}-5^{\prime}$ long, $\frac{1}{2}^{\prime}-1 \frac{1}{2}^{\prime}$ wide, unfolding in winter or early in the spring and continuing to appear as the branches lengthen until late in the autumn, beginning to fade during the summer, turning to a beautiful yellow or orange color and falling one 
by one during their second season, or often remaining on the branches until the sixth year; their petioles $\frac{1^{\prime}}{4}-1^{\prime}$ long. Flowers appearing in January before the unfolding of the young leaves on pedicels sometimes $1^{\prime}$ in length. Fruit about $1^{\prime}$ long, in

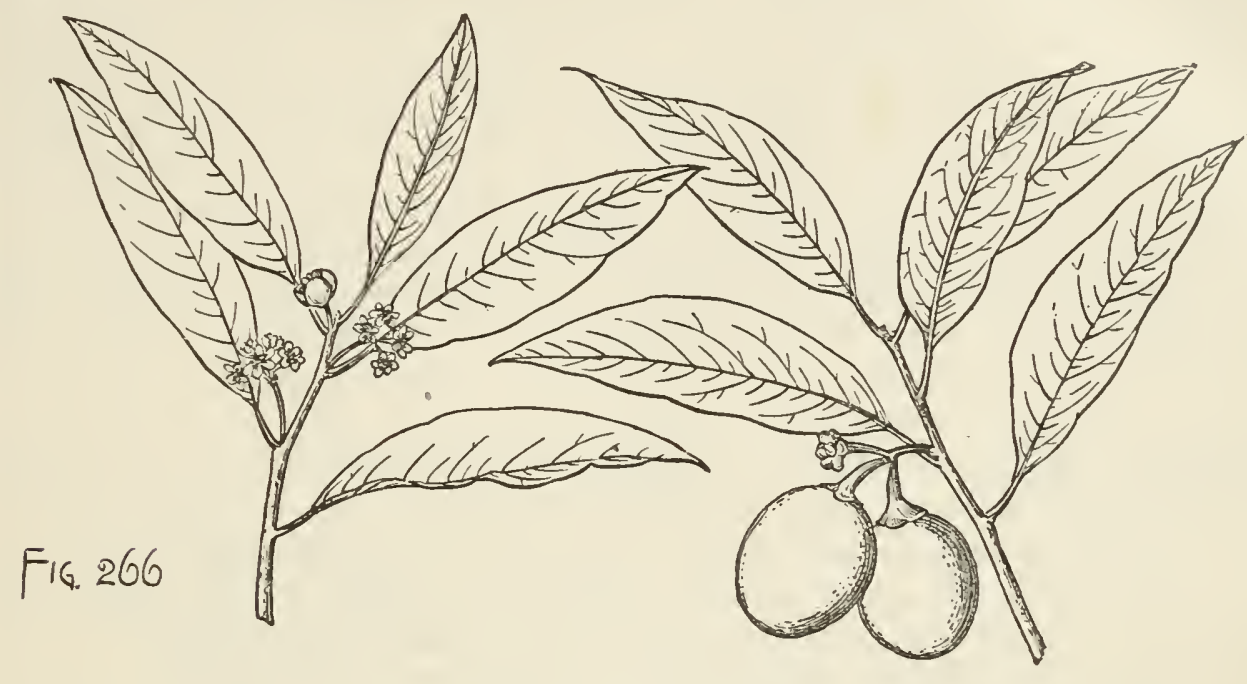

clusters of 2 ur 3, on elongated thickened stalks, persistent on the branch after the fruit ripens and falls late in the autumn; seeds germinating soon after they reach the ground, the fruit remaining below the surface of the soil and attached to the young plant until midsummer.

A tree, $80^{\circ}-90^{\circ}$ high, with a trunk $4^{\circ}-5^{\circ}$ in diameter, sometimes tall and straight but usually divided near the ground into several large diverging stems, stout spreading branches forming a broad round-topped head, and branchlets light green and coated with soft pale pubescence when they first appear, soon becoming glabrous and yellow-green, and in their second and third years light brown tinged with red; at high elevations above the level of the sea and in southern California mucls smaller and often reduced to a low shrub. Bark $\frac{3^{\prime}}{4}-1^{\prime}$ thick, dark brown tinged with red, separating on the surface into thin appressed scales. Wood heavy, hard, strong, close-grained, light rich brown, with thick lighter colored sapwood of $30-40$ layers of annual growth; the most valuable wood produced in the forests of Pacific North America for the interior finish of houses and for furniture. The leaves yield by distillation a pungent volatile oil, and from the fruit a fat containing umbellulic acid has been obtained.

Distribution. Valley of Rogue River, Oregon, through the California coast ranges and along the high western slopes of the Sierra Nevada to the southern slopes of the San Bernardino Mountains up to elevations of $2500^{\circ}$; usually near the banks of watercourses and sometimes on low hills; common where it can obtain an abundant supply of water; most abundant and of its largest size in the rich valleys of southwestern Oregon, forming with the Broad-leaved Maple a considerable part of the forest growth.

\section{SASSAFRAS, Nees. Sassafras.}

Aromatic trees, with thick deeply furrowed dark red-brown bark, scaly buds, slender light green lustrous brittle branchlets containing a thick white mucilaginous pith and marked by small semiorbicular elevated leaf-scars displaying single hori- 
zontal rows of minnte fibro-vascular bundle-scars, and stout spongy stoloniferons roots covered by thick yellow bark. Flower-bearing buds terminal, ovate, acute, with 9 or 10 imbricated scales increasing in size from withont inward, the 3 outer scales ovate, romded, of ten apiculate at the apex, keeled and thickencel on the back, pale yellow-green below, dull yellow-brown above the middle, loosely inbricated, slightly or not at all accrescent, decidnous at the opening of the bud, much smaller than the thin accrescent light yellow-green scales of the next rows turning dull red before falling, and obovate, rounded at the apex, cuneatc bclow, concave, coated on the outer surface with soft silky pubesecnec, glabrous or lustrous on the inner surface, reflexed, $\frac{3^{\prime}}{4}$ long, nearly $\frac{1}{2}^{\prime}$ broad, tardily deciduous, the 2 inner scales foliaceous, lanceolate-acute, light green, coated on the outer surfacc with delicate pale hairs, glabrous on the inner surface, infolding the leaves; sterile and axillary buds much smaller. Leaves involute in the bud, ovate or obovatc, entire or often 1-3lobed at the apex, the lobes broadly ovate, acute, divided by deep broad sinuses, gradually narrowed at the base into elongated slender petioles, featlier-veined, with alternate veins arcuate and united or rumning to the points of the lobes, the lowest parallel with the margins, conspicuously reticulate-venulose, mucilaginous, deciduous, as they unfold light green and somewhat pilose above, with scattered white hairs, ciliate, clothed below with a loose pubescence of long lustrous white hairs, at maturity membranaceous, dark dull green above, pale and glabrous or pubescent below. Flowers opening in early spring with the first unfolding of the leaves, the males and females usually on different individuals, in lax drooping few-flowered racemes in the axils of large obovate bud-scales, their pedicles slender, rarely forked and 2-flowered, without bracts, pilose, from the axils of linear acute scarious hairy deciduous bracts, or that of the terminal flower often without bracts; calyx pale yellow-green, divided nearly to the base into narrow obovate concave lobes spreading or reflexed after anthesis, those of the inner row a little larger than the others; stamens 9, inserted in 3 series on the somewhat thickened margin of the shallow concave calyx-tube, those of the outer series opposite its outer lobes; filaments flattened, elongated, light yellow, those of the inner series furnished at the base with 2 conspicuous orange-colored stipitate glands rounded on the back, obscurely lobed on the inner face; anthers oblong, flattened, truncate or slightly emarginate at the apex, rounded or wedge-shaped at the base, orange-colored, introrse, in the female flower reduced to flattened ovate pointed or slightly 2-lobed dark orange-colored stipitate staminodia, or occasionally fertile and similar to or a little smaller than those of the staminate flower; ovary ovate, light green, glabrous, nearly sessile in the short tube of the calyx, narrowed into an elongated simple style gradually enlarged above into a capitate oblique obscurely lobed stigma. Fruit an oblong dark blue lustrous berry surrounded at the base by the enlarged and thickened obscurely 6-lobed or truncate scarlet limb of the calyx, raised on a much elongated scarlet stalk thickened above the middle; pericarp thin and fleshy. Seed oblong, pointed, light brown; testa thin, membranaceous, barely separable into 2 coats, the inner coat much thinner than the outer, dark chestnut-brown, and lustrous.

Sassafras is confined to temperate eastern North America and to China, where a species, not now distinguishable from the American tree but still imperfectly known, has recently been discovered.

Sassafras was first used as a popular name for this tree by the French in Florida. 


\section{Sassafras Sassafras, Karst. Sassafras.}

Leaves $4^{\prime}-6^{\prime}$ long, $2^{\prime}-4^{\prime}$ wide, turning in the antumn delicate shades of yellow or orange more or less tinged with red; their petioles $\frac{3^{\prime}}{4}-1 \frac{1}{2}^{\prime}$ long. Flowers $\frac{1^{\prime}}{3}$ long when fully expanded, in racemes about 2 ' long. Fruit ripening in September and October, $\frac{1}{3}^{\prime}$ long, on stalks $1_{\frac{2}{2}}^{\prime}-2^{\prime}$ in length, separating when ripe from the thick calyx-lobes persistent with the stalks of the fruit on the branches until the beginning of winter.

A tree, occasionally $80^{\circ}-90^{\circ}$ high, with a trunk nearly $6^{\circ}$ in diameter, short stout more or less contorted branches spreading almost at right angles and forming a narrow usually flat-topped head, and slender branchlets light yellow-green and

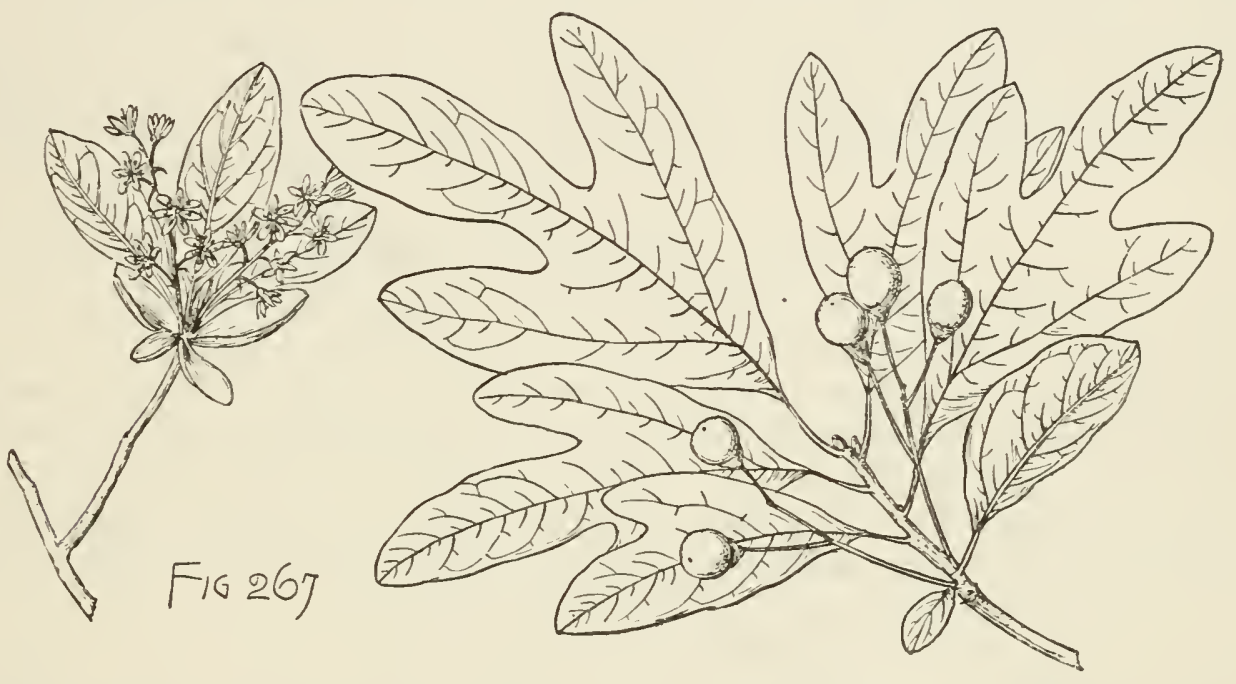

coated when they first appear with pale pubescence, soon glabrous, bright green and lustrous, gradually turning reddish brown at the end of two or three years; frequently not more than $40^{\circ}-50^{\circ}$ tall; at the north generally smaller and often shrubby. Winter-buds $\frac{1}{4}-\frac{3 \prime}{8}$ long. Bark of young stems and branches thin, reddish brown, divided by shallow fissures, becoming on old trunks sometimes $1 \frac{1}{2}^{\prime}$ thick, dark red-brown, and rleeply and irregularly divided into broad flat ridges separating on the surface into thick appressed scales. Wood soft, weak, brittle, coarsegrained, very durable in the soil, aromatic, dull orange-brown, with thin light yellow sapwood of 7 or 8 layers of annual growth; largely used for fence-posts and rails, in the construction of light boats, ox-yokes, and in cooperage. The roots and especially their bark are a mild aromatic stimulant, and oil of sassafras, used to perfume soap and other articles, is distilled from them. Gumbo filet, a powder prepared from the leaves by the Choctaw Indians of Louisiana, gives flavor and consistency to gumbo soup.

Distribution. Usually in rich sandy well-drained soil, southern Maine and eastern Massachusetts, through sonthern Vermont, southern Ontario, central Michigan, and southeastern Iowa to eastern Kansas and the Indian Territory, and sonthward to central Florida and the valley of the Brazos River, Texas; in the south Atlantic and Gulf states often taking possession of abandoned fields.

Occasionally cultivated in the easteru states as an ornamental tree. 


\section{CAPPARIDACEII.}

Annual or perennial herbs, trees, or shrubs, with acrid often pungent juices. altermate or rarely opposite leaves, and regular or irregular usually perfect flower's in terminal cymes or racemes, or solitary, numerous ovules inserted in two rows on each of the two placentas, capsular or baccate 1-celled fruit, and seeds without albumen. A family of thirty-four genera, mostly confined to the warmer parts of the world and widely distributed in the two hemispheres. Of the seven genera which occur in North America only one has an arborescent represeutative.

\section{CAPPARIS, L.}

Trees, with naked buds. Leaves conduplicate in the bud, entire, feather-veined, coriaceous, persistent, without stipules. Flowers regular, in terminal cymes; sepals 4, valvate in the bud, glandular on the inner surface; petals 4, inserted on the base of the short receptacle; stamens numerous, inserted on the receptacle, their filaments free, elongated, much longer than the introrse 2-celled anthers opening longitudinally; ovary long-stalked, 2-celled, with 2 parietal placentas; stigmas sessile, orbicular; ovules campylotropous. Fruit baccate, siliquiform (in the North American species) separating into 3 or 4 valves. Seeds reniform, numerous, surrounded by pulp; seed-coat coriaceous; embryo convolute; cotyledons foliaceous, fleshy.

Capparis, with more than one hundred species, mostly tropical, is found in the two hemispheres, the largest number of species occurring in Central and South America. Two of the West Indian species reach the shores of southern Florida, the most northern station of the genus in America; of these one is arborescent.

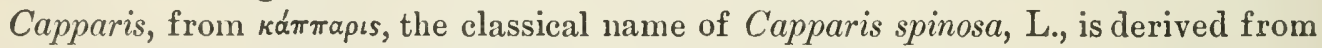
the Persian kabor, capers, the dried flower-buds of that species.

\section{Capparis Jamaicensis, Jacq.}

Leaves oblong-lanceolate, rounded and emarginate at the apex, slightly revolute, coriaceous, light yellow-green, smooth and lustrous on the upper surface, covered on

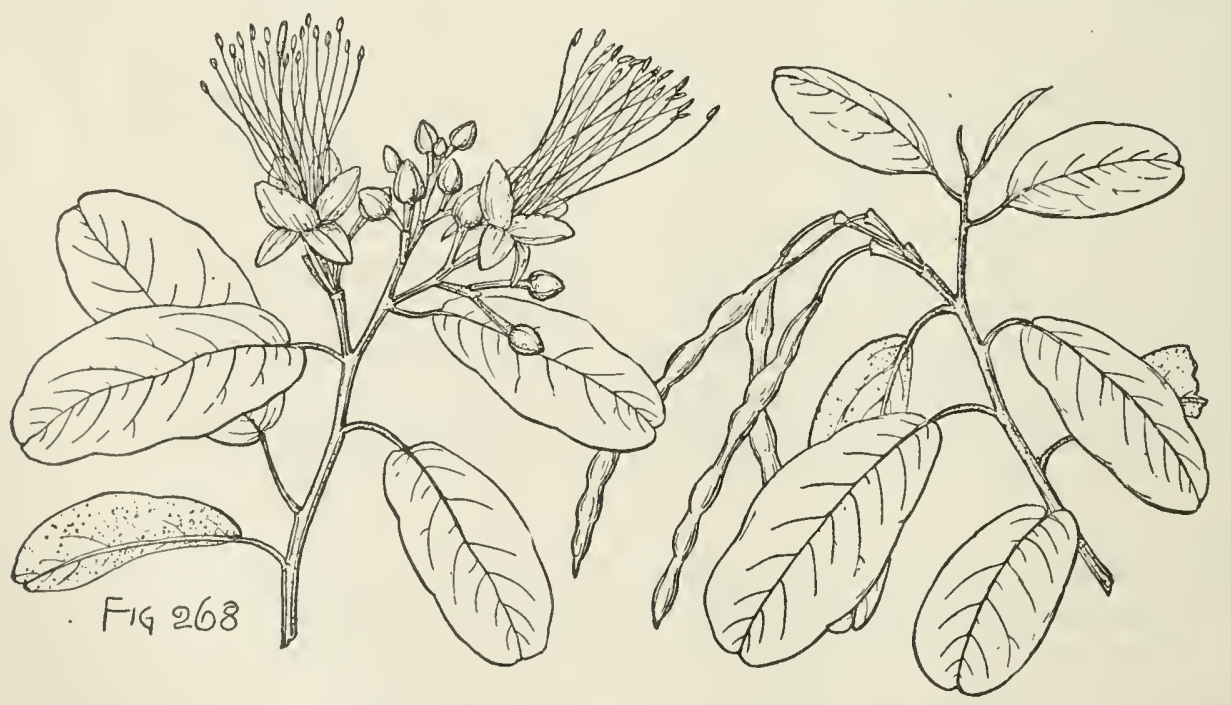

the lower by minute ferrugineous scales, $2^{\prime}-3^{\prime}$ long, $1^{\prime}-1 \frac{1}{2}^{\prime}$ broad, with prominent midribs and inconspicuous primary veins. Flowers $1 \frac{1}{4}$ in diameter, opening in Florida 
in April and May from obtuse or acute 4-angled buds; sepals ovate, acute, lepidote on the outer surface, furnished on the inner with a small ovate gland, recurved when the flower is fully expanded, and about half the size of the roundish white petals turning purple in fading; stamens 20-30, with purple filaments villose toward the base, $1 \frac{1^{\prime}}{2}-2^{\prime}$ long; anthers yellow; ovary raised on a slender stipe about $1 \frac{1}{2}^{\prime}$ long. Fruit $9^{\prime}-12^{\prime}$ long, terete, sometimes slightly torulose, pubescent-lepidote, the long stalk appearing jointed by the enlargement of the pedicel and torus below the insertion of the stipe; seed light brown, $1 \frac{1}{4}$ long.

A small slender shrubby tree, $18^{\circ}-20^{\circ}$ high, with a trunk sometimes $5^{\prime}-6^{\prime}$ in diameter, and thin angled branchlets dark gray, smooth or slightly rugose, and covered with minute ferrugineous scales. Bark rarely more than $\frac{11}{8}$ thick, slightly fissured, the dark red-brown surface broken into small irregularly shaped divisions. Wood heavy, hard, close-grained, yellow faintly tinged with red, with lighter colored sapwood of about 15 layers of annual growth.

Distribution. Florida coast from Cape Canaveral to the southern keys; generally distributed, but nowhere abundant; common on several of the Antilles.

\section{HAMAMELIDACE円.}

'Trees or shrubs, with watery juice, slender terete branchlets, naked or scaly buds, and fibrous roots. Leaves alternate, petiolate, stipulate, deciduous. Flowers perfect or unisexual; calyx 4 -parted or 0 ; petals 4 or 0 ; stamens 4-8; anther's attached at the base, introrse, 2-celled; ovary inserted in the bottom of the receptacle, 2-celled; ovules 1 or many, anatropous, suspended from an axile placenta; micropyle superior; raphe ventral. Fruit a woody capsule opening at the summit. Seed usually 1 ; embryo surrounded by fleshy albumen; cotyledons oblong, flat, longer than the terete radicle turned toward the hilum. The Witch Hazel family with eighteen genera is confined to eastern North America, southwestern, southern, and easter'n Asia, the Malay Archipelago, Madagascar, and South Africa. Of the three North American genera two are arborescent.

\section{CONSPECTUS OF THE NORTH AMERICAN ARBORESCENT GENERA.}

Flowers usually unisexual, capitate, without petals, the pistillate without sepals ; capsules consolidated by their bases into a globose head; seed with a terminal wing; leaves palmately lobed.

1. Liquidambar.

Flowers usually perfect, with calyx and corolla; carpels not consolidated into a head; seed without a wing.

2. Hamamelis.

\section{LIQUIDAMBAR, L.}

Trees, with balsamic juices, scaly bark, terete often winged branchlets, scaly buds, and fibrous roots. Leaves plicate in the bud, alternate, palmately lobed, glandularserrate, long-petiolate; stipules lanceolate, acute, caducous. Flowers monœcious or rarely perfect in capitate heads surrounded by involucres of 4 deciduous bracts, the staminate in terminal racemes, the pistillate in solitary long-stalked heads from the axils of upper leaves; staminate flowers without a calyx and corolla; stamens indefinite, interspersed with minute scales; filaments filiform, shorter than the oblong obcordate anthers opening longitudinally; pistillate flowers surrounded by longawned scales, the whole confluent into globular heads; calyx obconic, its limb short 
or nearly obsolete; stamens usually 4 , inserted on the summit of the calyx; anthers minute, usnally rudimentary or abortive, rarely fertile; ovary partly inferior, of '2 united carpels terminating in elongated subulate recurved persistent styles stigmatic on the imner face; ovules nunerous. Capsules armed with the hardened inenrved elongated styles, free above, septicidally dehiscent at the apex, consolidated by their bases into a globose head; pericarp thick and woody; endoearp thin, corneons, lustrous on the inner surface. Seeds nsually solitary or 2 by the abortion of many ovnles, compressed, angulate; seed-eoat opaque, crustaceons, produced into a short membranaceous obovate terminal wing rounded at the oblique apex.

Liquidambar with about fonr species is confined to the eastern United States, to sonthern and central Mexico, Central America, sonthwestern Asia, middle and southeastern China, and Eormosa. 'The species produce hard straight-grained handsome dark-colored wood and valuable balsamic exudations. Liquid storax, an opaque grayish brown resin, is derived from Liquidambar orientalis, Mill., a native of Asia Minor.

\section{Liquidambar Styraciflua, L. Sweet Gum. Bilsted.}

Leaves generally round in outline, truncate or slightly heart-shaped at the base, deeply 5-7-lobed, with acutely pointed divisions finely serrate, with rounded appressed teeth, when they unfold pilose on the lower surface, soon becoming

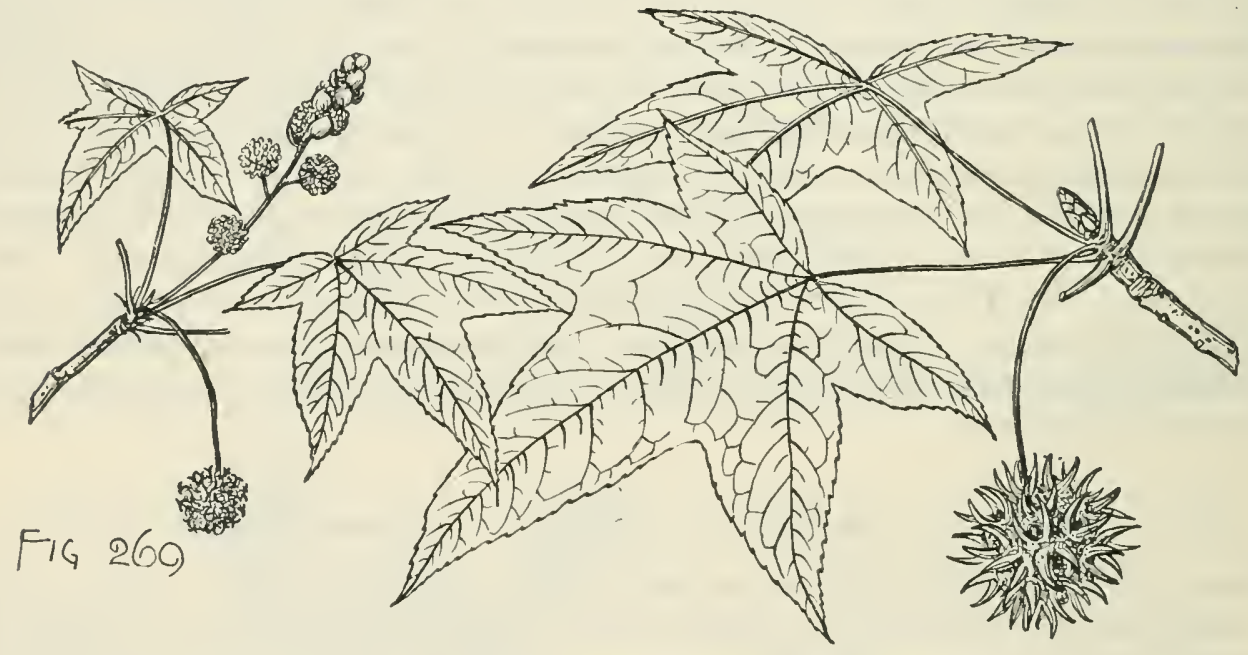

glabrous with the exception of large tufts of pale rufous hairs in the axils of the principal veins, at maturity thin, bright green, smooth and lustrous, $6^{\prime}-7^{\prime}$ across, with broad primary veins and finely reticulate veinlets, exhaling when bruised a pleasant resinous fragrance, in the autumn turning deep crimson; their petioles slender, covered at first near the base with rufous caducous hairs, and $5^{\prime}-6^{\prime}$ long; stipules entire, glabrous, $\frac{1^{\prime}}{3}-\frac{1^{\prime}}{2}$ long. Flowers: staminate in racenues $2^{\prime}-3^{\prime}$ long, covered with rufous hairs, in heads stalked toward the base of the raceme and nearly sessile above, $\frac{1 \prime}{4}$ in diameter and surrounded by ovate acute deciduons hairy bracts much larger than the lanceolate acute bracts of the female inflorescence $\frac{1}{2}^{\prime}$ across and conspicuous from the broad stigmatic surfaces of the recurved and contorted styles. Fruit $1^{\prime}-1 \frac{1}{2}^{\prime}$ in diameter, persistent during the winter, the carpels opening in the autumn; seed $\frac{1^{\prime}}{2}$ long and rather longer than its wing, with a light brown coat conspicuously marked by oblong resin-ducts. 
A tree, $80^{\circ}-140^{\circ}$ high, with a straight trunk $4^{\circ}-5^{\circ}$ in diameter, slender branches forming while the tree is young a pyramidal head, and in old age a comparatively small oblong crown, and slender branchlets containing a large pith, slightly manyangled, covered when they first appear with callucous rufous hairs, light orange color to reddish brown in their first winter, marked by occasional minute dark lenticels and by large arcuate leaf-scars showing the ends of 3 conspicuous fibrovascular bundles, developing in their second season corky wings appearing on the upper side of lateral branches in 3 or 4 parallel ranks and irregularly on all sides of vertical branches and increasing in width and thickness for many years, sometimes becoming $2^{\prime}-3^{\prime}$ broad and $1^{\prime}$ thick. Winter-buds acute, $\frac{1}{4}^{\prime}$ long, and covered by ovate acute minutely apiculate orange-brown scales rounded on the back, those of the inner rows accrescent, tipped with red, and about $1^{\prime}$ long at maturity. Wood lreavy, hard, straight, close-grained, not strong, bright brown tinged with red, with thin almost white sapwood of 60-70 layers of annual growth; used for the outside finish of houses, in cabinet-making, for street pavement, wooden dishes, and fruit boxes.

Distribution. Fairfield County, Connecticut, to southeastern Missouri, southward to Cape Canaveral and the shores of Tampa Bay, Florida, and through Arkansas and the Indian 'Territory to the valley of the Trinity River, Texas, reappearing on the mountains of central and southern Mexico and on the highlands of Guatemala; in the maritime region of the south Atlantic states and in the basin of the lower Mississippi River one of the most common trees of the forest, covering rich river bottom-lands usually inundated every year; in the northern and middle states on the borders of sivamps and low wet swales; at the north rarely more than $60^{\circ}-70^{\circ}$ tall, with a trunk usually not more than $2^{\circ}$ in diameter.

Unsurpassed in the brilliancy of the autumnal colors of the leaves; and often planted as an ornamental tree in the eastern states.

\section{HAMAMELIS, L. Witch Hazel.}

Trees or shrubs, with scaly bark, terete zigzag branchlets, naked buds, and fibrous roots. Leaves involute in the bud, unsymmetrical at the base, crenate-toothed, the primary veins conspicuous and nearly parallel with the margins; stipules acute, infolding the bud, deciduous. Flowers autumnal, perfect, in terminal 3-flowered clusters on axillary simple peduncles furnished near the middle with 2 acute deciduous bractlets, each flower surrounded by 2 or 3 ovate acute bracts, the onter slightly united at the base into a 3-lobed involucre; calyx 4-parted, persistent on the base of the ovary, the lobes reflexed; petals inserted on the margin of the cupshaped receptacle, alternate with the sepals, strap-shaped; stamens 8 , inserted in 2 rows on the margin of the receptacle, the 4 opposite the lobes of the calyx fertile, the others reduced to minute strap-shaped scales; filaments free, shorter than the calyx, prolonged into a thickened pointed connective; anthers elliptical, opening laterally from without by persistent valves; ovary of 2 carpels, free at their apex, inserted in the bottom of the receptacle, partly superior; styles subulate, spreading, stigmatic at the apex, persistent; ovule solitary. Fruit a capsule, 2-beaked at the apex, the thick and woody outer layer splitting from above loculicidally before the opening of the thin crustaceous inner layer. Seed oblong, acute, suspended; testa crustaceous, chestnut-brown, shining, forcibly discharged when ripe by the contraction of the edges of the valves of the bony endocarp; embryo surrounded by thick 
Heshy albumen; cotyledons oblong, foliaceous, longer than the radicle turned toward the oblong depressed hilum.

Hamamelis is confined to eastern North America and eastern Asia, with one American and two or three Asiatic species.

The name is from $\alpha^{\prime} \mu \alpha$, at the same time with, and $\mu \eta \lambda$ ís an Apple-tree, and was applied by the ancients to the Medlar or some similar tree.

\section{Hamamelis Virginiana, L. Witch Hazel.}

Leaves obovate, acuminate, long-pointed or sometimes rounded at the apex, very unequal at the base, the lower side rounded or subcordate, the upper usually wedgeshaped and smaller, irregularly and coarsely serrate-toothed above the middle, entire or dentate below, when they unfold with veins, especially on the lower surface, petioles, and stipules coated with stellate ferrugineous pubescence, at maturity membranaceous, dull dark green and glabrous or pilose above, lighter colored, lustrous, and pubescent or puberulous on the stout midribs and 6 or 7 pairs of primary veins below, $4^{\prime}-6^{\prime}$ long, $2^{\prime}-2 \frac{1}{2}{ }^{\prime}$ broad, turning delicate yellow color in the autumn; their

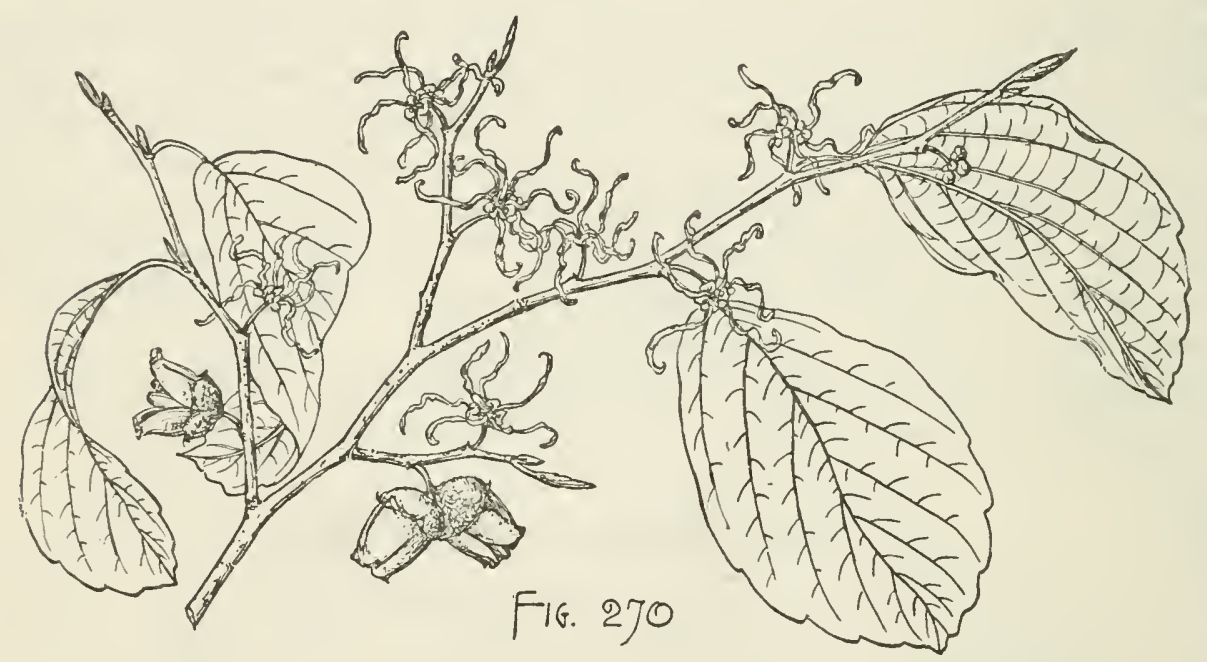

stipules lanceolate, acute, coriaceous, $\frac{1}{3}^{\prime}-\frac{1}{2}^{\prime}$ long. Flowers from buds appearing in August on short recurved peduncles developed from the axils of leaves of the year, covered like the acute bracts and bractlets with dark ferrugineous pubescence, opening from the middle of September to the middle of November; calyx in the autumn coated on the outer surface with thick pale pubescence, orange-brown on the inner surface, the rounded lobes ciliate on the margins; petals bright yellow, $\frac{1}{2}^{\prime}-\frac{2}{3}$ long, falling like the stamens as soon as the ovules are fertilized; ovary remaining during the winter without enlarging and surrounded and protected by the pubescent calyx. Fruit ripening in the autumn, usually 2 from each flower-cluster, discharging its seeds when the flowers of the season are expanding, $\frac{1}{2}$ long, pubescent, dull orange-brown and surrounded for half its length by the large persistent calyx bearing at its base the blackened remnants of the floral bracts; seed $\frac{1}{4}^{\prime}$ long.

A tree, occasionally $25^{\circ}-30^{\circ}$ high, with a short trunk $12^{\prime}-14^{\prime}$ in diameter, spreading branches forming a broad open head, and slender flexible branchlets coated at first witlı scurfy rusty stellate hairs, gradually disappearing during the summer, and in their first winter glabrous or slightly puberulous, light orange-brown and marked 
by small white dots, becoming in their second year dark or reddish brown; usually a stout shrub sending up from the ground numerous rigid diverging stems $5^{\circ}-20^{\circ}$ tall. Winter-buds acute, slightly falcate, light orange-brown, covered with short fine pubescence, $\frac{1^{\prime}}{4}-\frac{1^{\prime}}{2}$ long. Bark $\frac{1^{\prime}}{8}$ thick, light brown, generally smooth but brokell into minute thin appressed scales disclosing in falling the dark reddish purple inner bark. Wood heavy, hard, very close-grained, light brown tinged with red, with thick nearly white sapwood of 30-40 layers of annual growth. The bark and leaves are slightly astringent and although not known to possess essential properties are largely used in the form of fluid extracts and decoctions and in homœopathic practice, Pond's Extract being made by distilling the bark in diluted alcohol.

Distribution. Nova Scotia, New Brunswick, and the valley of the St. Lawrence River to sonthern Ontario, Wisconsin and eastern Nebraska, and south ward to northern Florida and eastern Texas, growing usually on the borders of the forest in low rich soil or on the rocky banks of streams; of its largest size and probably only arborescent on the slopes of the high Alleghany Mountains in North and South Carolina and Telinessee.

Occasionally cultivated as an ornamental plant in the northern states, and in western and northern Europe.

\section{PLATANACE王.}

Trees, with watery juice, thick deeply furrowed scaly bark exfoliating from the branches and young trunks in large thin plates, terete zigzag pithy branchlets prolonged by an upper axillary bud, and fibrous roots. Winter-buds axillary, conical. large, smooth, and lustrous, nearly surrounded at the base by the narrow leaf-scars displaying a row of conspicuous dark fibro-vascular bundle-scars, covered by 3 deciduous scales, the 2 inner accrescent, strapshaped, rounded at the apex at maturity, marking in falling the base of the branchlet with narrow ring-like scars, the outer scale surrounding the bud and splitting longitudinally with its expansion, the second light green, covered by a gummy fragrant secretion and usually inclosing a bud in its axil, the third coated with long rufous hairs. Leaves longitudinally plicate in vernation, alternate, broadly ovate, cordate, truncate, or wedge-shaped and decurrent on the petiole at the base, more or less acutely 3-7-lobed, and occasionally furnished with a more or less enlarged basal lobe, the lobes entire, dentate, with minute remote callous teeth, or coarsely sinuate-toothed, penniveined, the veins arcuate and united near the margins and connected by inconspicuous reticulate veinlets, clothed while young like the petioles, stipules, and young branchlets with caducous stellate sharp-pointed branching hairs, pale on the lower and rufous on the upper surface, long-petiolate, turning brown and withering in the autumn before falling; their petioles abruptly enlarged at the base and inclosing the budds, stipules membranaceous, laterally united below into a short tube surrounding the branchlet above the insertion of their leaf, acute, more or less free above, dentate or entire, thin and scarious on flowering shoots, broad and leaf-like on vigorous sterile branchlets, caducous, marking the branchlet in falling with narrow ring-like scars. Flowers minute, appearing with the unfolding of the leaves in dense unisexual pedunculate solitary or spicate heads, the staminate and pistillate heads on separate peduncles or rarely united on the same peduncle; staminate heads dark red on axillary peduncles; pistillate heads light green tinged with red, on long terminal peduncles, the 
lateral heads in the spicate clusters sessile and embracing at maturity the peduncle, usually persistent on the branches during the winter; calyx of the staminate flower divided into 3-6 minute scale-like sepals slightly united at the base, about half as long as the 3-6 cuneiform sulcate scarious pointed petals; stamens as many as the divisions of the calyx, opposite them, with short nearly obsolete filaments, and elongated clavate 2-celled anthers, their cells opening longitudinally, crowned by a capitate pilose truncate connective; calyx of the pistillate flower divided into 3-6, usually 4, rounded sepals much shorter than the acute petals; stamens scale-like, elongated-obovate, pilose at the apex ; ovaries as many as the divisions of the calyx, superior, sessile, oblong, surrounded at the base by long ridged jointed pale liairs persistent round the fruit, gradually narrowed into long simple bright red styles papillose-stigmatic to below the niddle along the ventral suture; ovules 1 or rarely 2 , suspended laterally, orthotropous. Heads of fruit composed of elongated obovate akenes rounded and obtuse or acute at the apex, surmounted by the persistent styles, 1-seeded, light yellow-brown; pericarp thin, coriaceous. Seed elongated, oblong, suspended; testa thin and firm, light chestnut-brown; embryo erect in thin fleshy albumen; cotyledons oblong, about as long as the elongated cylindrical erect radicle turned toward the minute apical hilum. A family of a single genus.

\section{PLATANUS, L. Plane-tree.}

Characters of the family.

A genus of six or seven species of eastern and western North America, Mexico, Central America, and of southwestern Asia, all resembling each other except in the form of the lobes of the leaves and the amount of pubescence on their lower surface, in the pointed or obtuse apex of the akene, and in the number of heads of pistillate flowers on their peduncle.

Of the exotic species, the Old World Platanus orientalis, L., now a common street tree in all the countries of temperate Europe, has been used as a shade-tree in the eastern states and in California.

Platanus is the classical name of the Plane-tree.

\section{CONSPECTUS OF THE NORTH AMERICAN SPECIES.}

Leaves broadly ovate, shallowly 3 -う̌-lobed, the lobes mostly serrulate-toothed, truncate or rarely wedge-shaped at the base; head of fruit usually solitary.

1. P. occidentalis $(\mathrm{A}, \mathrm{C})$.

Leaves deeply 5-lobed, the lobes entire, remotely and obscurely dentate or rarely sinuatetoothed, truncate or rarely slightly cordate or wedge-shaped at the base; heads of fruit racemose.

2. P. racemosa $(G)$.

Leares deeply $3-7$-lobed, the lobes elongated, slender, entire or rarely remotely dentate, deeply cordate or rarely wedge-shaped or truncate at the base; heads of fruit racemose.

3. P. Wrightii $(\mathrm{H})$.

\section{Platanus occidentalis, L. Sycamore. Buttonwood.}

Leaves broadly ovate, more or less 3-5-lobed by broad shallow sinuses rounded at the bottom, the lobes broad, acuminate, sinuate-toothed, with long straight or curved remote acuminate teeth, or entire, with undulate margins, truncate or slightly cordate, or wedge-shaped and decurrent on the petioles at the base, thin and firm, bright green on the upper surface, paler on the lower, glabrous with the exception of a coat of pale pubescence along the midribs and principal veins 
below, $4^{\prime}-7^{\prime}$ long and broad, or twice as large on vigorous shoots and then frequently furnished witl dentate basal lobes, with stout yellow midribs and veins; their petioles stout, terete or slightly angled, puberulous; stipules $1^{\prime}-1 \frac{1}{2}^{\prime}$ long, entire or sinuatetoothed. Flowers: peduncles coated with pale tomentum, bearing 1 and sometimes 2 heads of flowers. Fruit: heads $1^{\prime}$ in diameter, on slender glabrous stems $3^{\prime}-6^{\prime}$ in length; akene about $\frac{2 \prime}{3}$ long and truncate or obtusely rounded at the apex.

A tree, occasionally $140^{\circ}-170^{\circ}$ high, with a trunk sometimes $10^{\circ}-11^{\circ}$ in diameter above its abruptly enlarged base, often divided near the ground into several large secondary trunks, or rising $70^{\circ}-80^{\circ}$, with a straight column-like shaft free of

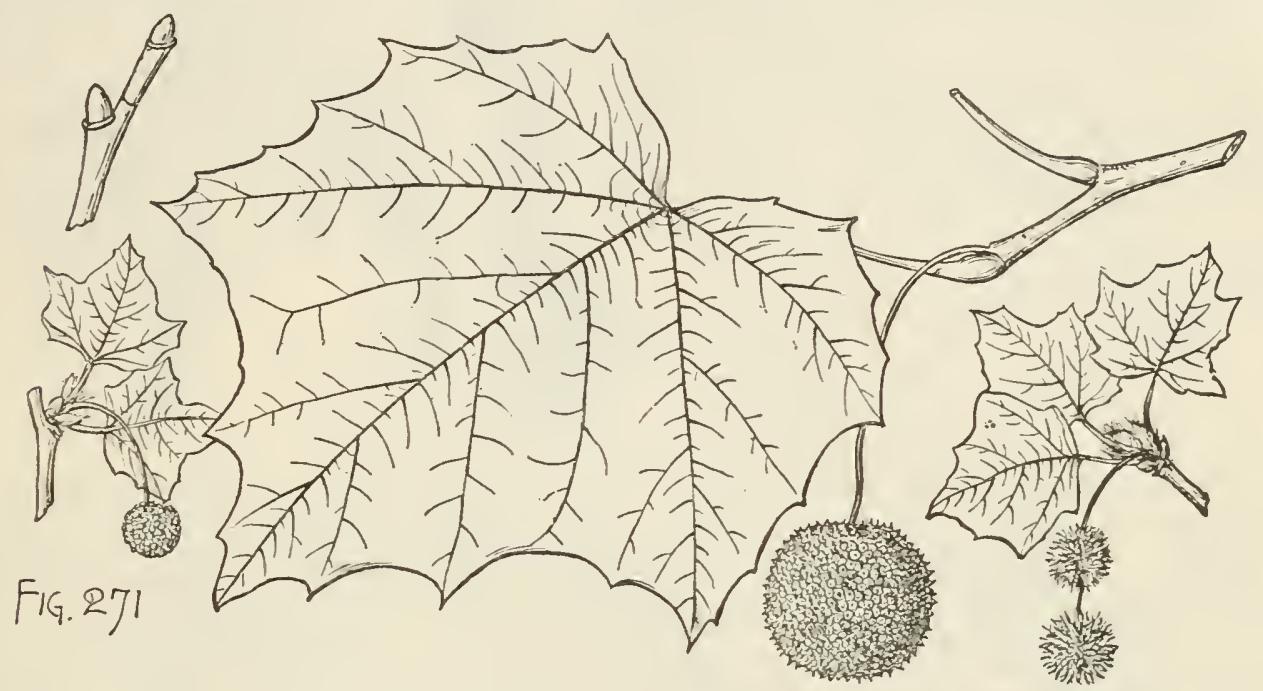

branches and with little diminution of diameter, massive spreading limbs forming a broad open irregular head sometimes $100^{\circ}$ in diameter, their extremities usually erect or more or less pendulous, and slender branchlets coated at first like the leaves, petioles, and stipules with thick pale deciduous tomentum, during their first summer dark green and glabrous, marked by minute oblong pale lenticels, becoming dark orangebrown and rather lustrous during their first winter and light gray in their second year. Winter-buds $\frac{1^{\prime}}{4}-\frac{3^{\prime}}{8}$ long. Bark of young trunks and large branches rarely more than $\frac{1^{\prime}}{2}$ thick, dark reddish brown, broken into small oblong thick appressed platelike scales, smooth, light gray, and separating higher on the tree into large thin scales, in falling exposing large irregular surfaces of the pale yellow, whitish, or greenish inner bark, becoming at the base of large trunks $2^{\prime}-3^{\prime}$ thick, dark brown, and divided by deep furrows into broad rounded ridges covered by small thin appressed scales. Wood the favorite material for tobacco boxes, ox-yokes, and butcher's blocks, and now largely used for furniture and the interior finish of houses.

Distribution. Borders of streams and lakes on rich bottom-lands; southeastern New Hampshire, northern Vermont and the northern shores of Lake Ontario, westward to eastern Nebraska and Kansas, and southward to northern Florida, central Alabama and Mississippi, and the valley of the Brazos River, and through Texas to the valley of the Devil's River, everywhere common but most abundant and of its largest size on the bottom-lands of streams in the basin of the lower Ohio and Mississippi rivers. The most massive if not the tallest deciduous-leaved tree of North America.

Rarely planted in the eastern states or in Europe as an oruamental tree. 


\section{Platanus racemosa, Nutt. Sycamore. Plane-tree.}

Leaves 3-5-lobed to below the midlle, with acute or acuminate lobes, entire, dentate, with remote callous tipped tecth, or occasionally coarsely simnate-tootlied,

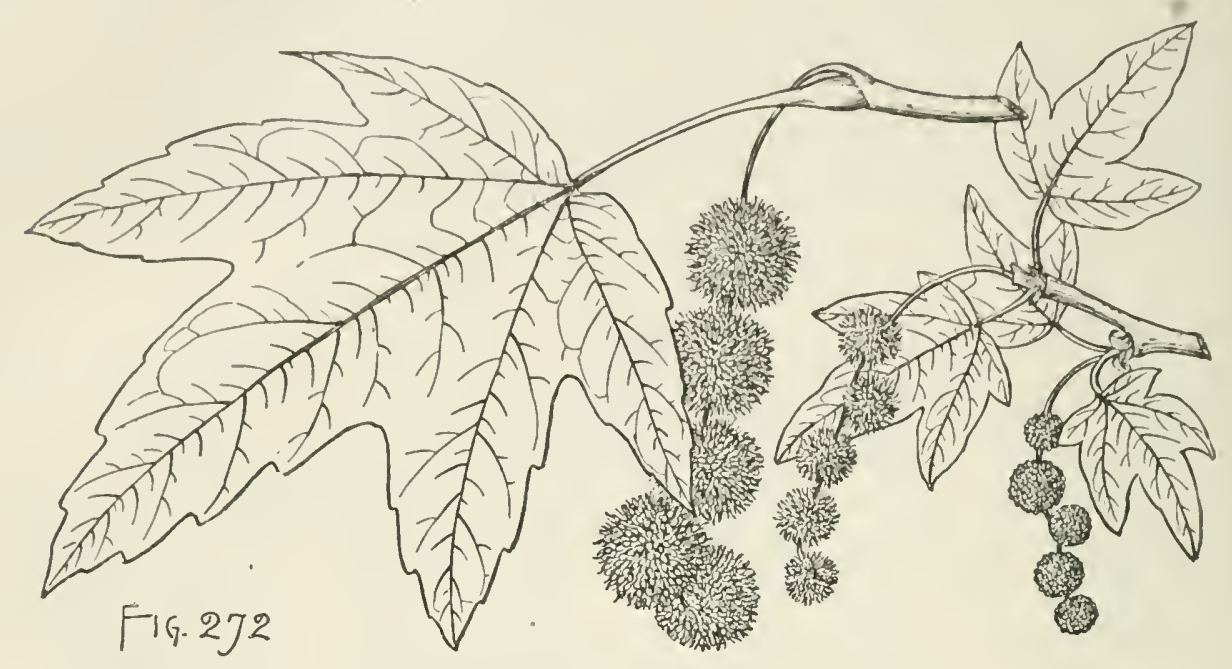

and broad sinuses acutc or rounded at the bottom, usually cordate or sometimes truncate and wedge-shaped or decurrent on the petioles at the base, thick and firm, light green above, paler and more or less thickly coated below with pale pubescence most abundant along the midribs and primary veins, $6^{\prime}-10^{\prime}$ long and broad; their petioles stout, pubescent, $1^{\prime}-3^{\prime}$ long; stipules $1^{\prime}-1 \frac{1^{\prime}}{2}$ long, entire or dentate, often persistent until the spring. Flowers: pedıncles hoary-pubescent, bearing usually 4 or 5 heads of staminate flowers and 2-7 heads of pistillate flowers, a head of the staminate flowers occasionally appearing on the pistillate peduncles above the heads of fertile flowers. Fruit: heads $\frac{3^{\prime}}{4}$ in diameter, on slender zigzag glabrous or pubescent stems $6^{\prime}-9^{\prime}$ long; akene acute or rounded at the apex, $\frac{1}{3}^{\prime}$ long, tomentose while young, becoming glabrous.

A tree, occasionally $100^{\circ}-120^{\circ}$ high, with a trunk sometimes $9^{\circ}$ in diameter above the broad tapering base, erect and free of branches for half its height, more often dividing near the ground into secondary stems erect, inclining, or prostrate for $20^{\circ}-30^{\circ}$ at their base, thick heavy more or less contorted spreading branches forming an open irregular round-topped head, and branchlets coated at first with thick pale deciduous tomentum, light reddish brown, and marked by numerous small lenticels in their first winter, becoming gradually darker in their second and third years; usually smaller and generally $70^{\circ}-80^{\circ}$ tall, with a trunk $2^{\circ}-4^{\circ}$ in diameter. Winter-buds nearly $\frac{1}{2}^{\prime}$ long. Bark at the base of old trunks $3^{\prime}-4^{\prime}$ thick, dark brown, deeply furrowed, with broad rounded ridges separating on the surface into thin scales, thinner, smooth, and pale, or almost white higher on the trunk and on the branches.

Distribution. Valley of the lower Sacramento River, California, southward through the interior valleys and coast ranges; and on Mount San Pedro Martir in Lower California; an inhabitant of the banks of streams; exceedingly common in all the valleys of the California coast range from Monterey to the southern borders of the state, and ascending the southern slopes of the San Bernardino Mountains to elevations of $3000^{\circ}$. 


\section{Platanus Wrightii, Wats. Sycamore.}

Leaves divided by narrow sinuses to below the middle and sometimes neariy to the centre into 3-7 but usually into 3-5 elongated acute lobes entire or dentate, with callous-tipped teeth, or occasionally furnished with 1 or 2 lateral lobes, sometimes deeply cordate by the downward projection of the lower lobes, or often truncate or wedge-shaped at the base, thin and firm in texture, light green and glabrous above, covered below with pale pubescence, $6^{\prime}-8^{\prime}$ long and broad, with slender ribs, and primary veins connected by conspicuous reticulate veinlets; their petioles stout, glabrous or puberulous, $1 \frac{1}{2}-3^{\prime}$ long. Flowers: peduncles hoary-tomentose, bearing $1-4$ heads of flowers. Fruit: heads on slender glabrous stems $6^{\prime}-8^{\prime}$ long, about $\frac{3^{\prime}}{4}$ in diameter; akenes glabrous, $\frac{1^{\prime}}{4}$ long, truncate at the apex.

A tree, often $60^{\circ}-80^{\circ}$ high, with a straight trunk $4^{\circ}-5^{\circ}$ in diameter, gradually tapering and free of branches for $20^{\circ}-30^{\circ}$, or with a trunk divided at the ground into 2 or 3 large stems usually more or less reclining and of ten nearly prostrate for

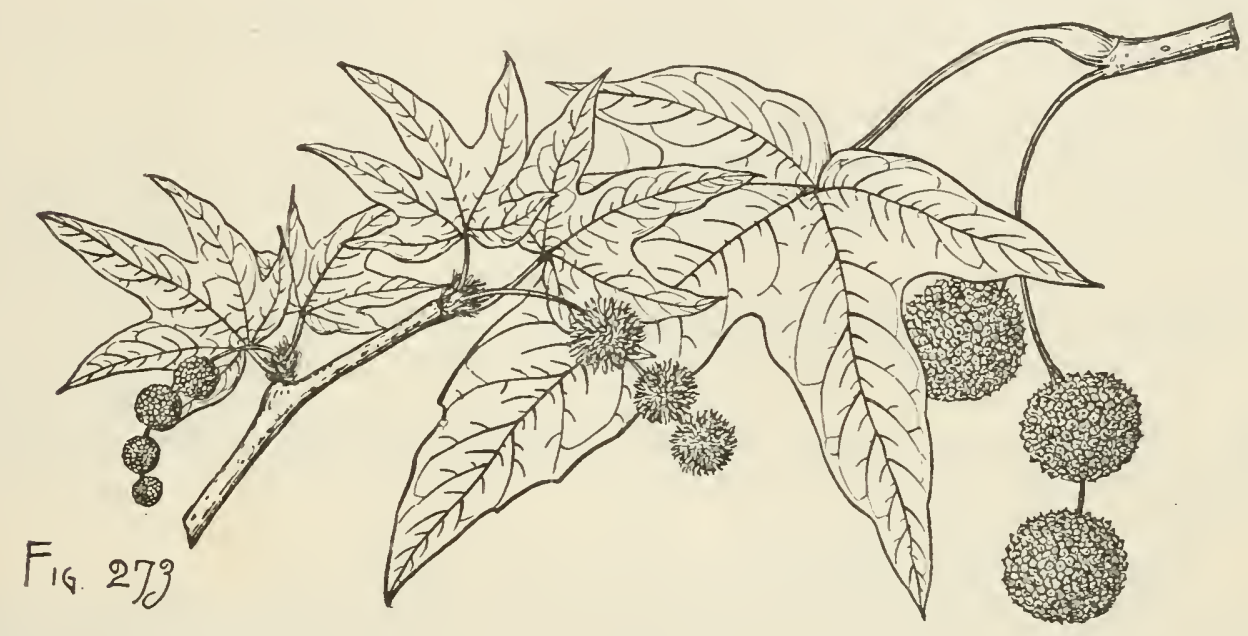

$15^{\circ}-20^{\circ}$, thick contorted branches, the lowest growing almost at right angles to the trunk and $50^{\circ}-60^{\circ}$ long, the upper usually erect at first, finally spreading into a broad open handsome head, and slender branchlets coated at first with thick pale tomentum, becoming glabrous or slightly puberulous during their first winter, marked by minute scattered lenticels, and light brown tinged with red or ashy gray, and gradually darker in their second or third year. Winter-buds hardly more than $\frac{1^{\prime}}{8}$ long. Bark at the base of the trunk dark, $3^{\prime}-4^{\prime}$ thick, deeply and irregularly divided into broad ridges, and covered on the surface with small appressed scales, thinner and separating into large scales $10^{\circ}-15^{\circ}$ above the ground, and gradually passing into the smooth much thinner creamy white bark faintly tinged with green of the upper branches.

Distribution. Banks of streams in the mountain cañons of southwestern New Mexico and southern Arizona; and in Sonora; the largest and one of the most abundant of the deciduous-leaved trees on all the mountain ranges of southern New Mexico and Arizona, extending from the mouths of cañons up to elevations of $5000^{\circ}-6000^{\circ}$ above the sea. 


\section{XXI, ROSACE平}

Trees or shrubs, with watery juices, terete branchlets, scaly buds, and alternate leaves (opposite in Lyonothumnus), with stipules. Flowers perfect; calyx 5 -lobed: petals 5 ( 0 in Cercocurpus), imbricated in the bud, inserted with the numerous distinct stamens on the edge of a disk lining the calyx-tube; anthers introrse (extrorse in Vuuqueliniu), 2-celled, the cells opening longitudinally; ovary superior in Lyonothammus and Heteromeles, often partly superior in Amelanchier ; ovules 2 in each cell ( 1 in Cercocarpus, 4 in Lyonothamnus), anatropous. Seeds without albumen (albuminons in Lyonothamnus). A family of about ninety genera chiefly confined to the temperate parts of the world and producing many of the most valuable fruits, including the apple, pear. quince, strawberry, raspberry, and blackberry. Of the six tribes into which the genera of the family are grouped, five have arborescent representatives in North America.

\section{CONSPECTUS OF THE NORTH AMERICAN ARBORESCENT GENERA.}

Tribe 1. Srireondea. Fruit a woody capsule.

Flowers in terminal cymose corymbs; calyx-lobes persistent; ovary 5-celled; ovules ascending; mature carpels adherent below and opening down the back; albumen 0 ; leaves simple.

1. Vauquelinia.

Flowers in terminal cymose corymbs ; calyx-lobes deciduous ; ovary 2-celled; ovules 4 in each cell, pendulous; mature carpels opening on the ventral and partly on the dorsal suture; albumen thin; leaves opposite, simple or pinnately divided.

2. Lyonothamnus.

Tribe 2. PomoIDEж. Fruit a pome composed of the thickened and succulent calyx-tube inclosing the papery or bony carpels; stipules free from the petioles.

Mature carpels papery.

Carpels as many as the styles.

Flowers in simple terminal cymes on short spur-like lateral branchlets; ovary 3-5-celled; styles more or less united below; leaves simple; winter-buds small.

3. Malus.

Flowers in broad compound terminal cymes; ovary $2-4$, usually 3 -celled; styles distinct ; fruit subglobose; leaves unequally pinnate; winter-buds large.

4. Sorbus.

Flowers in large terminal corymbose panicles; ovary nearly superior, 2-celled; styles distinct; fruit obovoid. 5. Heteromeles.

Carpels becoming at maturity twice as many as the styles; flowers in erect or nodding racemes; ovary inferior or partly superior; styles 2-5, more or less united below; fruit subglobose or pyriform; leaves simple, deciduous.

6. Amelanchier.

Mature carpels bony; flowers in terminal cymose corymbs; ovary 1-5-celled; styles distinct; fruit globose to pyriform ; leaves simple, deciduous.

7. Cratægus.

Tribe 3. Cercocarpez. Carpels free from the persistent calyx, becoming akenes.

Flowers axillary, solitary; petals 0 ; ovary 1 or rarely 2 -celled ; ovule 1 ; fruit tipped with the elongated persistent plumose style; leaves simple, persistent.

8. Cercocarpus.

Tribe 4. Prunordez. Fruit a 1-seeded drupe; ovary 1-celled; style terminal; ovules pendulous.

Flowers in fascicled umbels or racemes; leaves simple, deciduous or persistent.

9. Prunus. 
Tribe 5. Chrysobalanoidea. Fruit a 1-seeded drupe; ovary 1-celled; style lateral, ovules ascending.

Flowers in axillary or terminal cymose panicles; leaves simple, persistent.

10. Chrysobalanus.

\section{VAUQUELINIA, Corr.}

Trees or shrubs, with slender terete branchlets, and scaly bark. Leaves alternate or rarely opposite, lanceolate, serrate, long-petiolate, reticulate-veined, coriaceous, persistent; stipules minute, acute, deciduous. Flowers on slender bibracteolate pedicels, in compound terminal leafy cymose corymbs; calyx short-turbinate, coriaceous, כ-lobed, the lobes ovate, obtuse or acute, erect, persistent; petals $\tilde{5}$, orbicular or oblong, white, becoming reflexed, persistent; stamens $15-25$, inserted in 3 or 4 series, equal or semiequal, those of the outer row opposite the petals; filaments subulate, exserted, persistent; anthers versatile, extrorse; carpels 5, opposite the sepals, inserted on the thickened base of the calyx-tube and united below into a 5-celled ovoid tomentose ovary crowned with 5 short spreading styles dilated into capitate stigmas; ovules subbasilar, ascending, prolonged at the apex into thin membranaceous wings; raphe ventral; micropyle superior. Fruit a woody ovoid 5-celled tomentose capsule inclosed at the base by the remnants of the flower, the mature carpels adherent below and at maturity splitting down the back. Seeds 2 in each cell, ascending, compressed; testa membranaceous, expanded into a long terminal membranaceous wing; embryo filling the cavity of the seed; cotyledons flat; radicle straight, erect.

Vauquelinia is confined to the New World and is distributed from Arizona and Lower California to southern Mexico. Three species are distinguished; of these one inhabits the mountain ranges of southern Arizona.

The generic name is in honor of the French chemist Louis Nicholas Vauquelin (1763-1829).

\section{Vauquelinia Californica, Sarg.}

Leaves narrowly lanceolate, acuminate or rarely rounded at the apex, abruptly wedge-shaped or slightly rounded at the base, and remotely serrate, with minute

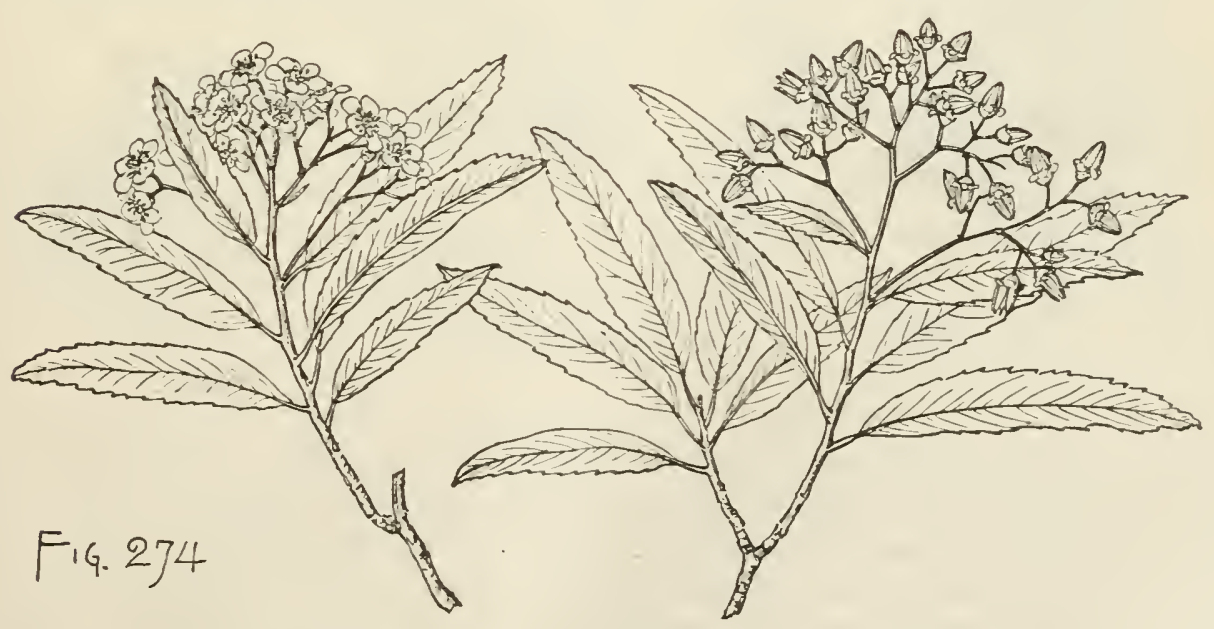

glandular teeth, when they unfold puberulous above and densely tomentose below, at maturity coriaceous, bright yellow-green and glabrous on the upper and tomentose 
on the lower surface, $1 \frac{1}{2}-3^{\prime}$ long, $f^{\prime}-\frac{1}{2}$ wide, with thick conspicuous midribs grooved on the npper side, and mmerous thin primary veins connected by reticnlate veinlets, decidnons in spring or early summer; their petioles thinck, $\frac{1}{3}-\frac{1}{2}$ long. Flowers appearing in Junc, $\frac{1}{4}$ in diameter, in hoary-tomentose panicles '2'-3' across; petals oblong; inner surface of the disk pilose. Fruit fully grown by the end of August, $\frac{1}{4}$ long, persistent on the branches after opening nutil the spring of the following year; conspicnons from the contrast of the bright red faded petals and the white silky pubescence of the calyx and carpels; seed $\frac{1}{12}$ long, and one third as long as its wing.

A tree, $18^{\circ}-20^{\circ}$ high, with a slender often hollow trunk $5^{\prime}-6^{\prime}$ in diameter, rigid upright contorted branches, and slender branchlets at first bright reddish brown and more or less thickly covered with hoary tomentum, becoming light brown or gray in their second year and marked by large elevated leaf-scars; or more often a low shrub. Bark about $\frac{1^{\prime}}{16}$ thick, dark red-brown, and broken on the snrface into small square persistent plate-like scales. Wood very heavy, hard, close-grained, dark rich brown screaked with red, with 14 or 15 layers of annual growth.

Distribution. Mountain ranges of southern Arizona, Sonora, and Lower California; arborescent and of its largest size in Arizona on the Santa Catalina Monntains at elevations of about $5000^{\circ}$ above the sea; on the bottoms and rocky sides of gulches, or on grassy slopes.

\section{LYONOTHAMNUS, Gray.}

A tree or shrub, with scaly bark exfoliating in long strips, stout terete pubescent nltimately glabrous branchlets, and scaly buds. Leaves opposite, long-petiolate, lanceolate, acuminate, rounded or wedge-shaped at the base, entire, finely crenulate-

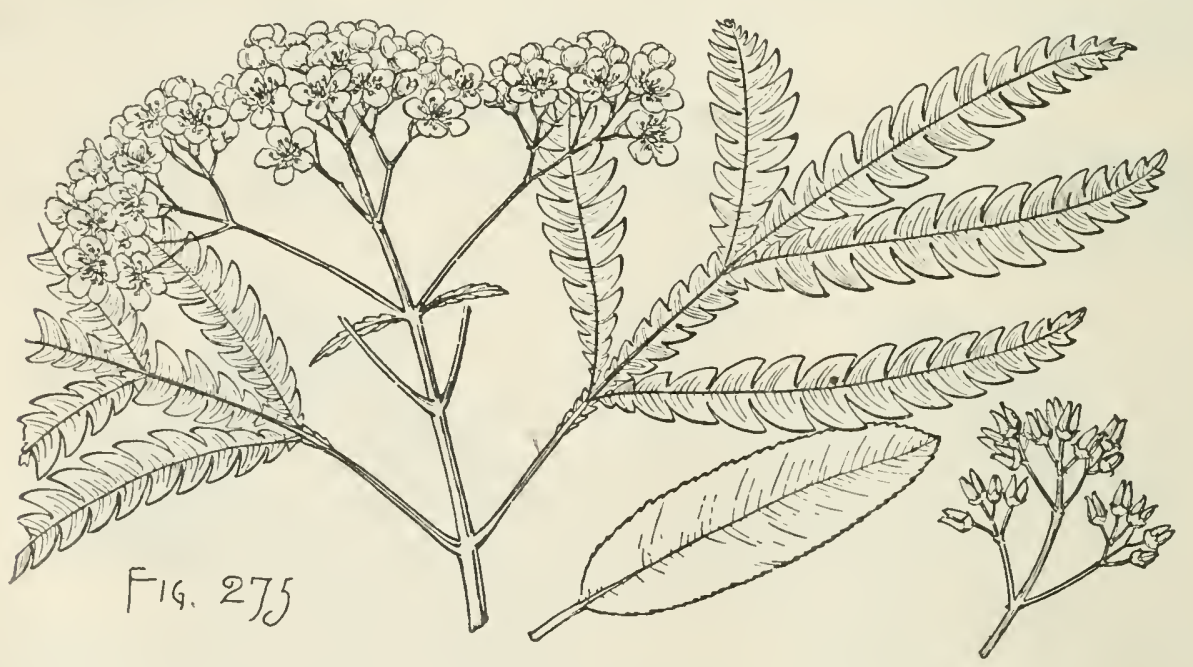

serrate or serrulate-lobulate below the middle, or sometimes irregularly pinnately parted into 3-8 linear-lanceolate remote lobulate segments, coriaceous, transversely many-veined, dark green above, paler and more or less pubescent below, persistent; stipules lanceolate, acute, minute, caducous. Flowers on slender pedicels, in broad compound terminal pubescent cymose corymbs, with minute acute persistent bracts and bractlets; calyx-tube hemispherical, with 1-3 bractlets, tomentose on the outer surface, the lobes nearly triangular, slightly keeled, apiculate, persistent; disk 10-lobed. 
with a slightly thickened margin; petals 5, orbicular, sessile, white; stamens 15 , inserted in pairs opposite the petals and singly opposite the sepals; filaments subulate, incurved, as long as the petals; anthers oblong, 2-celled, the cells opening longitudinally; carpels 2, inserted in the bottom of the calyx-tube, forming a superior glandular-hairy ovary; styles 2, spreading; stigmas eapitate, truncate; ovules 4 in each cell, suspended; micropyle superior; raphe ventral. Fruit of 2 woody ovate glandular 4-seeded carpels, dehiscent on the ventral and partly dehiscent on the dorsal suture. Seeds ovate-oblong, pointed at the ends; seed-coat light brown, thin and membranaceous; hilum orbicular, apical; raphe broad and wing-like; cotyledons oblong-acuminate, twice as long as the straight radicle directed toward the hilum.

Lyonothamnus is represented by a single species found only on the islands off the coast of southern California.

Lyonothamnus, in honor of its discoverer, William S. Lyon.

\section{Lyonothamnus floribundus, Gray. Ironwood.}

Leaves $4^{\prime}-8^{\prime}$ long, $\frac{1^{\prime}}{2}$ wide when entire, or $4^{\prime}$ wide when pinnately divided, when they unfold covered below with hoary deciduous tomentum, at maturity dark green and lustrous above and yellow-green, glabrous, or pubescent below, with orange-colored midribs. Flowers in June and July, $\frac{1^{\prime}}{8}-\frac{1^{\prime}}{4}$ in diameter, in clusters varying from $4^{\prime}-8^{\prime}$ across. Fruit ripens in August and September, $\frac{3}{16}{ }^{\prime}$ long.

A bushy tree, rarely $30^{\circ}-40^{\circ}$ high, with a single straight trunk $8^{\prime}-10^{\prime}$ in diameter, and slender branches at first pale orange color and coated with deciduous pubescence, becoming at the end of their first season bright red and lustrous; usually shrubby, with several tall stems, or in exposed situations a low bush. Bark $\frac{1}{3}^{\prime}$ thick, dark red-brown, and composed of numerous thin papery layers, forming after exfoliating long loose strips persistent on the stem. Wood heavy, hard, closegrained, bright clear red faintly tinged with orange.

Distribution. Steep slopes of eañons in dry rocky soil on the islands of Santa Catalina, Santa Cruz, and San Clemente, California; most abundant and of its largest size on the northern shores of Santa Cruz; on Santa Catalina much smaller and rarely arborescent.

\section{MALUS, Hall. Apple.}

Trees, with scaly bark, slender terete branchlets, small obtuse buds covered by imbricated scales, those of the inner ranks accrescent and marking the base of the branchlet with conspicuous ring-like scars, and fibrous roots. Leaves involute in the bud, simple, often incisely lobed, petiolate, deciduous, the petioles in falling leaving narrow horizontal scars marked by the ends of three equidistant fibro-vascular bundles; stipules free from the petioles, filiform, early deciduous. Flowers in simple terminal cymes, with filiform deciduous bracts and bractlets, on short lateral spurlike often spinescent branchlets; calyx-tube urn-shaped, 5-lobed, the lobes imbricated in the bud, acuminate, becoming reflexed, persistent and erect on the fruit or deciduous; petals rounded, contracted below into stalk-like bases, white, pink or rose color; stamens usually 20 in 3 series, those of the outer series opposite the petals; carpels $3-5$, usually 5 , alternate with the petals, united into an inferior ovary; styles united at the base; ovules 2 in each cell, ascending; raphe dorsal; micropyle inferior. Fruit a pome with homogeneous flesh, and papery carpels joined at the apex, free in the middle; seeds 2 , or by abortion 1 in each cell, ovate, acute, erect, without 
albumen; seed-coat cartilaginous, chestuut-brown, and lustrous; embryo erect; cotyledons plano-convex, fleshy; radicle short, iuferior.

Malus is confined to North Ameriea, where four species occur, and to sontheastern, northeastern, and eastern Asia. Of exotie species, Malus Malus, Britt., the Appletree, of uncertain origin, but probably a native of some of the comtries of southwestern or central Asia, is now widely natnralized in northeastern North Aneriea. Several of the speeies of eastern Asia and their hybrids are cultivated for their handsome flowers, or for their fruits, the crab apples of the orchard.

Malus is the elassical name of the Apple-tree.

\section{CONSPECTUS OF THE NORTH AMERICAN SPECIES.}

Calyx-]obes persistent; fruit depressed-globose, hollowed at the base, leaves convolute in the bud.

Mature leaves glabrous or nearly so.

Leaves oblong, lanceolate, or oval, acute at the base, crenulate-serrate or nearly entire, subcoriaceous.

1. M. angustifolia $(\mathrm{A}, \mathrm{C})$.

Leaves ovate, truncate or subcordate at the base.

2. M. coronaria (A).

Mature leaves tomentose below, ovate to oblong, narrow at the base.

3. M. Ioensis (A, C).

Calyx-lobes decidnous; fruit oblong, full and rounded at the base; leaves ovate-lanceolate, serrulate, often 3 -lobed, conduplicate in the bud.

4. M. rivularis (B, G).

\section{Malus angustifolia, Michx. Crab Apple.}

Leaves lanceolate-oblong, acute or rounded and apiculate at the apex, acute at the base, coarsely erenulate-serrate above the middle, or sometimes nearly entire, more or less coated when they first appear with pale tomentum below and pilose above, at maturity subcoriaceous, dark green and lustrous on the upper surface, paler and

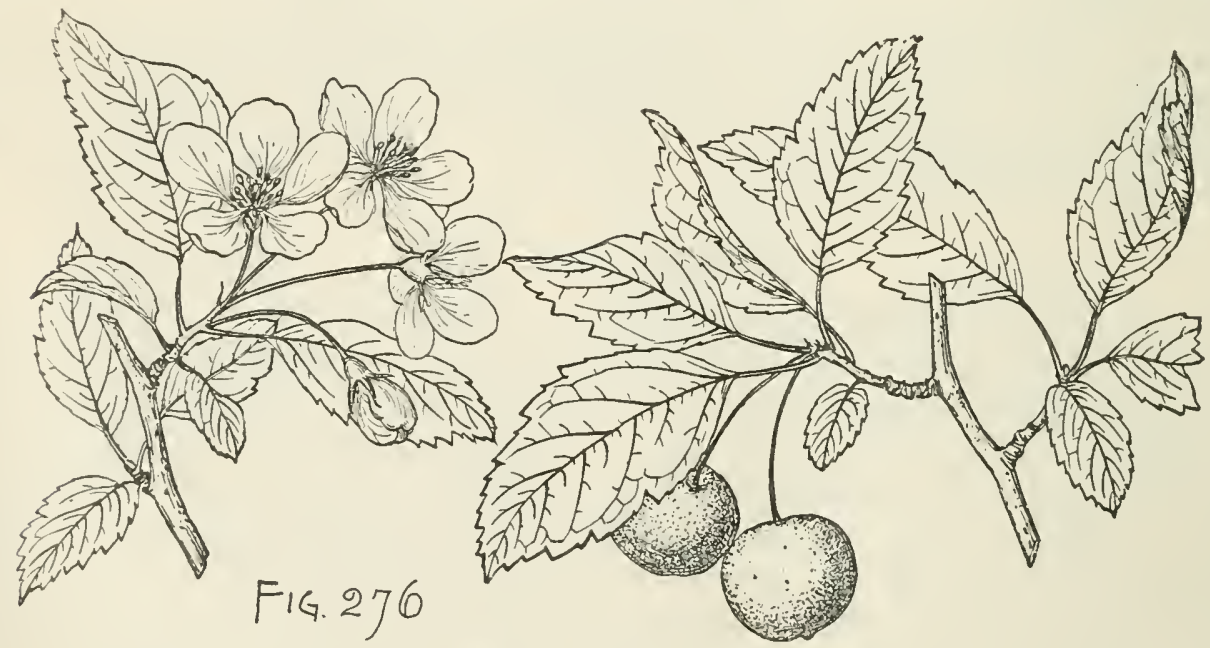

glabrous or nearly so on the lower surface, $1 \frac{1^{\prime}}{2}-3^{\prime}$ long, about $1^{\prime}-1 \frac{1^{\prime}}{2}$ wide, with slender midribs and obscure primary veins; their petioles slender, rigid, glabrous or puberulous, $\frac{3^{\prime}}{4}-1^{\prime}$ long; stipules rose color, $\frac{1^{\prime}}{2}$ long. Flowers $1^{\prime}$ in diameter, very fragrant, on slender glabrous or hoary-tomentose pedicels $\mathbf{1}^{\prime}-\mathbf{1}^{\prime}{ }^{\prime}$ long, in few-flowered elusters; calyx-tube glabrous, pubescent or tomentose, the lobes narrow, acuminate, with rigid tips, and hoary-tomentose on the inner surface; petals distinct, 
narrowly obovate, rounded above, undulate and sometimes irregularly dentate at the base of the blade, white, pink, or rose color; ovary and the lower part of the styles densely hoary-tomentose. Fruit depressed-globose, $\frac{3^{\prime}}{4}-1^{\prime}$ in diameter, pale yellow-green, very fragrant when fully ripe, with hard acid flesh.

A tree, rarely $30^{\circ}$ high, with a short trunk $8^{\prime}-10^{\prime}$ in diameter, rigid branches forming a broad open head, and young branchlets clothed at first with pale caducous pubescence, becoming in their first winter brown slightly tinged with red, and in their second year light brown and marked by occasional orange-colored lenticels. Winter-buds $\frac{1}{1^{\prime}}$ long, chestnut-brown, slightly pubescent. Bark $\frac{1^{\prime}}{8}-\frac{1^{\prime}}{4}$ thick, dark reddish brown, and divided by deep longitudinal fissures into narrow ridges broken on the surface into small persistent plate-like scales. Wood heavy, hard, closegrained, light brown tinged with red, with thick yellow sapwood; occasionally employed for levers, the handles of tools and other small objects. The fruit is used for preserves.

Distribution. Allegheny County, Pennsylvania, and southern Delaware, through the coast region of the south Atlantic states to the valley of the Chattahoochee River, Florida, through the Gulf states to the valley of the Red River, Lonisiana, and northward to middle Tennessee; in the Atlantic states in forest glades, usually in the neighborhood of streams; in the Gulf states often in the sandy soil of dry depressions of the Pine-covered uplands.

\section{Malus coronaria, Mill. Crab Apple. Fragrant Crab.}

Leaves ovate or sometimes almost triangular, isually acute, often truncate or subcordate and occasionally acute at the base, incisely serrate, with glandular teeth,

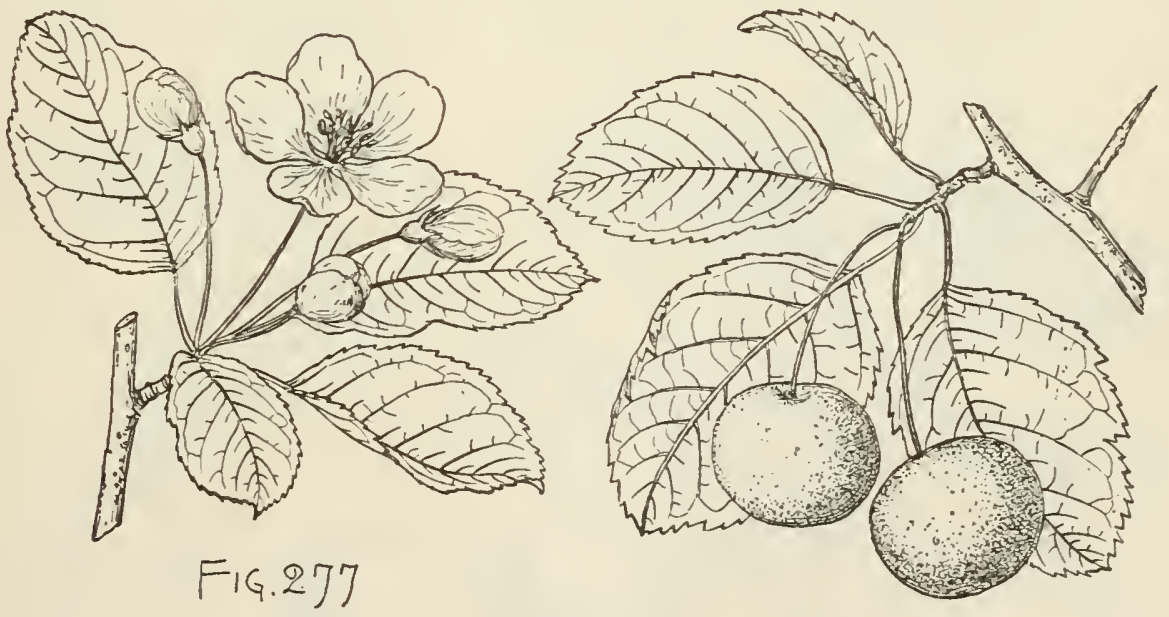

often 3-lobed, especially on vigorous shoots, when they unfold red-bronze, coated below with pale tomentum and pilose above, at maturity membranaceous, bright green on the upper surface, paler, glabrous or sometimes slightly pilose on the lower surface, $3^{\prime}-4^{\prime}$ long, $1 \frac{1}{2}^{\prime}-2 \frac{1}{2}^{\prime}$ wide, with broad midribs and primary veins, and conspicuous veinlets, turning yellow in the autumn before falling; their petioles slender, $1 \frac{1^{\prime}}{2}-2^{\prime}$ long, at first tomentose or pubescent, ultimately glabrous, often glandular near the middle, with 2 dark glands; stipules acuminate, $\frac{1^{\prime}}{2}$ long. Flovsers $1 \frac{1}{2}^{\prime}-2^{\prime}$ across when expanded, in 5 or 6 -flowered umbels, on slender pedicels, very fragrant; calyx-tube coated with thick white tomentum, its lobes elongated, acute, ending in 
rigid subulate points, hoary-tomentose on the inner surfaee; petals white or rose eolor, obovate, often erenately serrate or undulate at the apex, sonetimes irregularly and unequally dentate below; ovary and base of the styles hirsute. Fruit on long slender stems, $1^{\prime}-1 \frac{1}{2}^{\prime}$ in diameter, green when fully grown, yellow-green and somewhat translueent at maturity, very fragrant and eovered with a waxy exudation.

A tree, $25^{\circ}-30^{\circ}$ high, with a trunk $12^{\prime}-14^{\prime}$ in dianeter, dividing $8^{\circ}-10^{\circ}$ above the ground into several stout spreading branehes forming a wide open head, and branehlets hoary-tomentose when they first appear, glabrous or slightly pubeseent, briglit red-brown, and marked by oeeasional small pale lentieels in their first winter, and developing in their seeond year stout, spur-like, somewhat spineseent lateral branehlets. Winter-buds minnte, obtuse, with bright red seales searious and eiliate on the dark margins. Bark $\frac{1^{\prime}}{3}$ thiek, longitudinally fissured, the outer layer separating into long narrow persistent red-brown seales. Wood heavy, elose-grained, not strong, light red, with yellow sapwood of 18-20 layers of annual growth; used for levers, the handles of tools, and many small domestie artieles.

Distribution. Rieh rather moist soil in forest glades, often forming wide thiekets; less eommonly on dry limestone hills; valley of the Humber River, Ontario, westward along the northern shores of Lake Erie, and southward throngh western New York and Pennsylvania to the Distriet of Columbia, and along the Alleghany Mountains to eentral Alabama, and westward to northern Missouri.

Often planted as an ornamental tree in the eastern and northern states.

\section{Malus Ioensis, Britt. Crab Apple.}

Leaves ovate, oval, or oblong, aente or rounded at the apex, usually aeute or narrowed and rounded at the base, erenately serrate, and on vigorous shoots wedgeshaped at the broad base and usually incisely lobed, with aeute eoarsely serrate

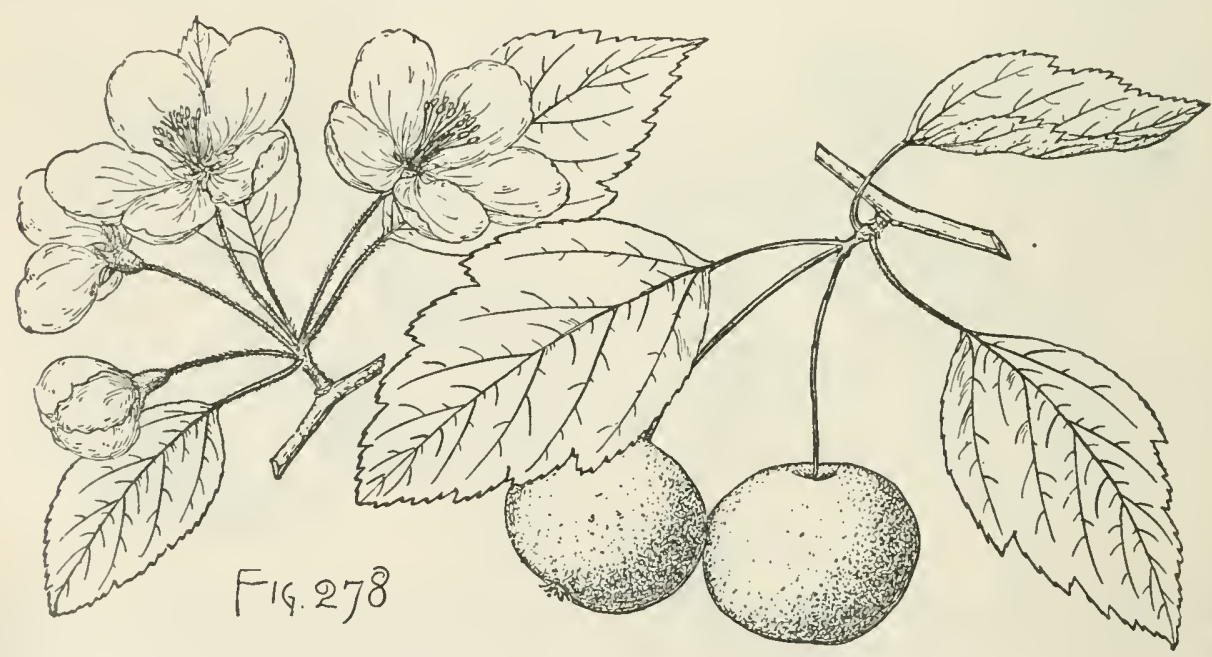

lobes, when they unfold hoary-tomentose below and nearly glabrous above, and at maturity thiek and firm, dark green and lustrous on the upper surfaee, pale yellowgreen and tomentulose on the lower surface, $3^{\prime}-4^{\prime}$ long, $1 \frac{1}{2}^{\prime}-2 \frac{1}{2}^{\prime}$ wide, with slender remote primary veins, turning yellow in the autumn before falling; their petioles stout, eovered at first with hoary tomentum, beeoming tomentulose, $\mathbf{1}^{\prime}-\mathbf{1}^{\prime}{ }^{\prime}$ long. Flowers $1 \frac{1}{2}-2^{\prime}$ aeross when expanded, in few-flowered elusters, on hoary-tomentose pedieels $1^{\prime}-1 \frac{1}{2}^{\prime}$ long; ealyx eoated with thiek matted snow-white hairs, the 
acute lobes tomentose on the inner surface; petals white or rose color, obovate; ovary and base of the styles hirsute. Fruit $1 \frac{1}{4}^{\prime}-1 \frac{1}{2}^{\prime}$ in diameter, greenish yellow, fragrant, on stout tomentose or villose stalks $1^{\prime}-1 \frac{1}{2}^{\prime}$ long.

A tree, $20^{\circ}-30^{\circ}$ high, with a trunk $12^{\prime}-18^{\prime}$ in diameter, stout spreading branches forming a wide open head, and branchlets hoary-tomentose when they first appear, glabrous or slightly pubescent, bright red-brown and marked by oceasional small pale lenticels in their first winter, the lateral branchlets usually spinescent. Winterbuds minute, obtuse, pubescent above the middle. Bark $\frac{1}{3}$ thick, covered with long narrow persistent red-brown scales.

Distribution. Minnesota and Wisconsin, Illinois and western Kentucky to eastern Nebraska, Missouri, Kansas, the Indian Territory, Louisiana, and Texas; the common Crab Apple of the Mississippi basin.

The Bechtel Crab, a form with large double rose-colored flowers, is often cultivated in the eastern and central states as an ornament of gardens. Malus Soulardi, Britt., the Soulard Crab, with ovate, elliptic, or obovate usually obtuse leaves rugose and tomentose on the lower surface, and larger fruit, occurring occasionally from Minnesota to eastern Texas, is believed to be a natural hybrid between the common Apple-tree and Malus Ioensis.

\section{Malus rivularis, Roem. Crab Apple.}

Leaves ovate-lanceolate, acute or acuminate, wedge-shaped or rounded at the base, sharply serrate, with appressed glandular teeth, occasionally obscurely 3-lobed, when they unfold pubescent on the lower and puberulous on the upper surface, at maturity thick and firm, dark green and glabrous above, pale and slightly pubescent
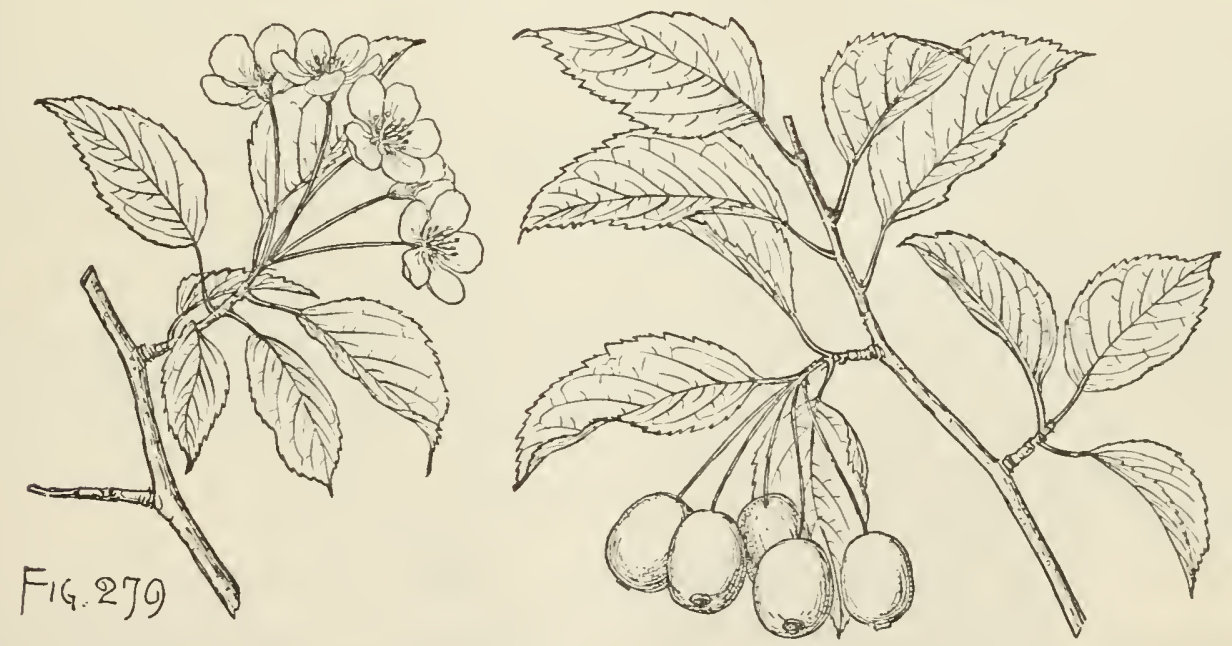

below, $1^{\prime}-3^{\prime}$ long, $\frac{1}{2}^{\prime}-1 \frac{1}{2}^{\prime}$ wide, with prominent midribs and primary veins and conspicuous reticulate veinlets, before falling in the autumn turning bright orange and scarlet; their petioles stout, rigid, pubescent, $1^{\prime}-1 \frac{1}{2}^{\prime}$ long; stipules narrowly lanceolate, acute, $\frac{1}{2}^{\prime}-\frac{3^{\prime}}{4}$ long. Flowers $\frac{1^{\prime}}{2}$ in diameter, on slender pubescent pedicels, in shor't racemose many-flowered cymes; calyx-tube narrowly obconic, glabrous or puberulous, the acute lobes minutely apiculate, hoary-tomentose on the inner surface, deciduous from the mature fruit; petals orbicular to obovate, erose or undulate on the margins; styles 2-4, glabrous. Fruit obovate-oblong, $\frac{1}{2}^{\prime}-\frac{3}{4}^{\prime}$ long, yellow-green, light yellow flushed with red or sometimes nearly red; flesh thin and dry. 
A tree, $30^{\circ}-40^{\circ}$ high, with a trunk $12^{\prime}-15^{\prime}$ in diameter, and slender branchlets coated at first with long pale hairs soon deciduous or persistent until the autumn, becoming bright red and lustrous, and later dark brown and marked by minute remote pale lenticels; of ten a shrub with numerous slender stems. Winter-buds obtuse, $\frac{1}{16}$ ' long, chestnnt-brown, the inner seales at maturity lanceolate, usually bright red and nearly $\frac{1^{\prime}}{2}$ in length. Bark $\frac{1}{4}$ thick, and covered by large thin loose light red-brown plate-like scales. Wood heavy, hard, very close, light brown tinged with red, with lighter colored sapwood of 20-30 layers of ammal growth; used for mallets, mauls, the handles of tools, and the bearings of machinery. The fruit has a pleasant subacid flavor.

Distribution. Decp rich soil in the neighborhood of streams, often forming almost impenetrable thickets of considerable extent; Aleutian Islands sonthward along the coast and islands of Alaska and British Columbia to Sonoma and Plumas counties, California; of its largest size in the valleys of Washington and Oregon.

Occasionally cultivated as an ornamental plant in the eastern states, and in western Europe.

\section{SORBUS, L. Mountain Ash.}

Trees or shrubs, with smooth aromatic bark, stout terete branchlets, large buds covered by imbricated scales, the inner accrescent and marking the base of the branchlet by conspicuous ring-like scars, and fibrous roots. Leaves alternate, pinnate in the American species, the pinmæ conduplicate in the bud, serrate, deciduous; stipules free from the petioles, foliaceous. Flowers in broad and terminal leafy cymes; calyx-tube urn-shaped, 5-lobed, the lobes imbricated in the bud, persistent; petals rounded, abruptly narrowed below, white; stamens usually 20 in 3 series, those of the outer series opposite the petals; carpels $2-5$, usually 3 ; styles usually 3, distinct; ovules 2 in each cell, ascending; raphe dorsal; micropyle inferior. Fruit a small subglobose red or orange-red pome with acid flesh, and papery carpels free at the apex. Seeds 2 , or by abortion 1, in each cell, ovate, acute, erect; seed-coat cartilaginous, chestnut-brown, and lustrous; embryo erect; cotyledons plano-convex, flat; radicle short, inferior.

Sorbus is widely distributed through the northern and elevated regions of the northern hemisphere with three or four species in North America of which one is arborescent. Of exotic species, Sorbus Aucuparia, L., the European Mountain Ash, is often cultivated as an ornamental tree in Canada and the northern states and has become sparingly naturalized north ward.

Sorbus is the classical name of the Pear or of the Service-tree.

\section{Sorbus Americana, Marsh. Mountain Ash.}

Leaves $6^{\prime}-8^{\prime}$ long, with slender grooved dark green or red petioles, often with tufts of dark hairs at the base of the petiolules, and 13-17 lanceolate acute taperpointed leaflets unequally wedge-shaped or rounded and entire at the base, sharply serrate above, with acute often glandular teeth, sessile or short-stalked, or the terminal leaflet on a stalk sometimes $\frac{1}{2}$ long; when they unfold slightly pubescent below, at maturity membranaceous, glabrous, dark yellow-green on the upper and pale on the under surface, $2^{\prime}-3^{\prime} \operatorname{long}, \frac{1}{2}^{\prime}-\frac{2}{3}^{\prime}$ wide, with prominent midribs and thin veins, turning bright clear yellow before falling in the autumn; stipules broad, nearly triangular, variously toothed, caducons. Flowers appearing after the leaves are fully grown, $\frac{1}{8}^{\prime}$ in diameter, on short stout pedicels, in flat cymes $3^{\prime}-4^{\prime}$ across, with 
acute minute caducous bracts and bractlets; calyx broadly obconic and puberulous, with short, nearly triangular lobes tipped with minute glands and about half as long as the nearly orbicular creamy white petals. Fruit $\frac{1^{\prime}}{4}$ in diameter, subglobose or slightly pyriform, bright red, with thin flesh; seeds pale chestnut color, rounded at the apex, acute at the base, about $\frac{1}{8}^{\prime}$ long.

A tree, $20^{\circ}-30^{\circ}$ high, with a trunk rarely more than a foot in diameter, spreading slender branches forming a narrow round-topped head, and stout branchlets pubescent at first, soon glabrous, becoming in their first winter brown tinged with red, and

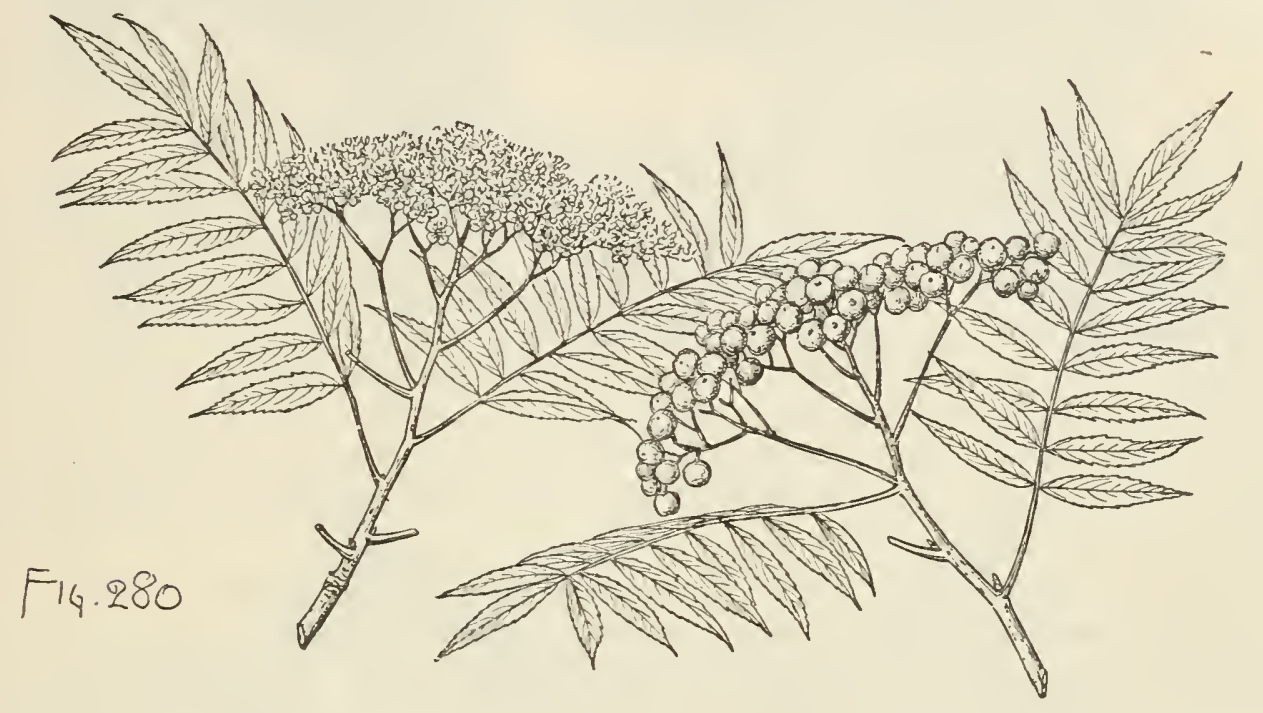

marked by the large leaf-scars and by oblong pale remote lenticels, and darker in their second year, the thin papery onter layer of bark then easily separable from the bright green fragrant inner layers; more often a tall or sometimes a low shrub, with mumerous stems. Winter-buds acute, $\frac{1^{\prime}}{4}-\frac{3^{\prime}}{4}$ long, with dark vinous red acuminate scales ronnded on the back, more or less pilose, covered with a gummy exudation, the inner scales hoary-tomentose in the bud. Bark $\frac{1}{8}^{\prime}$ thick, with a smooth light gray surface irregularly broken by small appressed plate-like scales. Wood close-grained, light, soft and weak, pale brown, with lighter colored sapwood of 1520 layers of annual growth. The astringent fruit is employed domestically in infusions and decoctions, and in homœopathic remedies.

Distribution. Borders of swamps and rocky hillsides; Newfoundland to Manitoba and southward through the maritime provinces of Canada, Quebec and Ontario, the elevated portions of the northeastern United States and the region of the Great Lakes to the high mountains of Virginia and North Carolina; probably of its largest size on the northern shores of Lakes Huron and Superior; in the United States, except in New England, more often a shrub than a tree; on the Alleghany Mountains usually low, with narrower leaflets and smaller fruit than northward. Of its various forms the most distinct is

Sorbus Americana, var. decora, Sarg., nov. nom.

(Pyrus Americana, var. decora, Silva N. Am. xiv. 101.)

Leaves $4^{\prime}-6^{\prime}$ long, with stout usually red petioles of ten furnished with tufts of dark hairs at the base of the petiolules, and 7-13 oblong-oval to lance-ovate leaflets 
blunt and rounded, abruptly short-pointed or acuminate at the apex, pubescent below as they unfold, at maturity glabrous, dark bluish green on the upper surface and pale

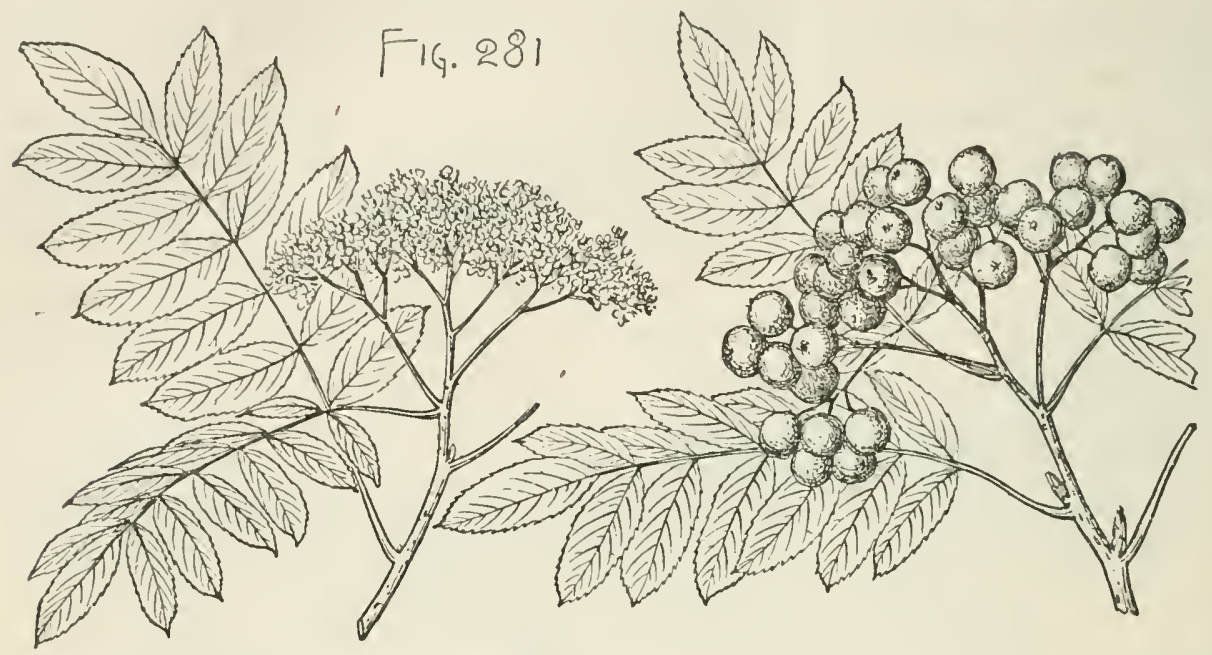

on the lower surface. Flowers $\frac{1}{4}^{\prime}$ in diameter, in rather narrower clusters, appearing eight to ten days later than those of the type. Fruit subglobose, bright scarlet, oftell $\frac{1}{2}^{\prime}$ in diameter.

A tree, occasionally $30^{\circ}$ high, with a trunk sometimes a foot in diameter, and spreading branches forming a round-topped handsome head.

Distribution. Coast of Labrador to the northern shores of Lake Superior and Minnesota, southward to the mountains of northern New Hampshire, Vermont, and New York. Distinct in its extreme forms but apparently connected with Sorbus Americana by many intermediate forms.

Often cultivated in Canada and the northeastern states as an ornamental tree, especially the var. decora, which is the most beautiful of the Mountain Ashes when the large and brilliant fruits cover the branches in autumu and early winter.

\section{HETEROMELES, Roem.}

A tree, with smooth pale aromatic bark, stout terete brancllets pubescent or puberulous while young, acute winter-buds covered by loosely imbricated red scales, and fibrous roots. Leaves oblong-lanceolate, acute at the ends, sharply and remotely serrate, with rigid glandular teeth, or rarely almost entire, dark green and lustrous above, paler below, petiolate, with stout petioles often furnished near the apex with 1 or 2 slender glandular teeth, feather-veined, with broad nidribs and conspicuous reticulate veinlets; stipules free from the petioles, subulate, rigid, minute, early deciduous. Flowers on short stout pedicels, in ample tomentose terminal corymbose leafy panicles, their bracts and bractlets acute, minute, usually tipped with small glands, cadncous; calyx-tube turbinate, tomentose below, glabrate above, the lobes short, nearly triangular, spreading, persistent; disk cup-shaped, obscurely sulcate; petals flabellate, erose-denticulate or emarginate at the apex, contracted below into short broad claws, thick, glabrous, pure white; stamens 10, inserted in 1 row with the petals in pairs opposite the calyx-lobes; filaments subulate, incurved; anthers oblong-ovate, emarginate, carpels 2 , adnate to the calyx-tube, and slightly united into a subglobose tomentose nearly superior ovary; styles distinct, slightly spreading, 
enlarged at the apex into broad truncate stigmas; ovules 2 in each cell, ascending; raphe dorsal; micropyle inferior. Fruit obovoid, fleshy, the thickened calyx-tube counate to the middle only with the membranaceous carpels coated above with long white hairs filling the cavity closed by the infolding of the thickened persistent calyxlobes, their tips erect and crowning the fruit. Seed usually solitary in each cell, ovate, obtuse, slightly ridged on the back; seed-coat membranaceous, slightly punctate, light brown; hilum orbicular, conspicuous; embryo filling the cavity of the seed; cotyledons plano-convex; radicle short, inferior.

The genus is represented by a single species of western North America.

The generic name, from ${ }^{\prime \prime} \tau \epsilon \rho o s$ and $\mu \hat{\eta} \lambda o \nu$, is in reference to its difference from related genera.

\section{Heteromeles arbutifolia, Roem. Tollon. Toyon.}

Leaves appearing with the flowers in early summer, $3^{\prime} 4^{\prime}$ long, $1^{\prime}-1 \frac{1}{2}^{\prime}$ wide, usually persistent during at least two winters; their petioles $\frac{1^{\prime}}{2}-\frac{2^{\prime}}{3}$ long. Flowers opening from June to August in clusters $4^{\prime}-6^{\prime}$ across and often more or less hidden by young lateral branchlets rising above them. Fruit ripening in November and December, mealy, astringent, and acid, remaining on the branches until late in the winter.

A tree, sometimes $30^{\circ}$ high, with a straight trunk $12^{\prime}-18^{\prime}$ in diameter, dividing a

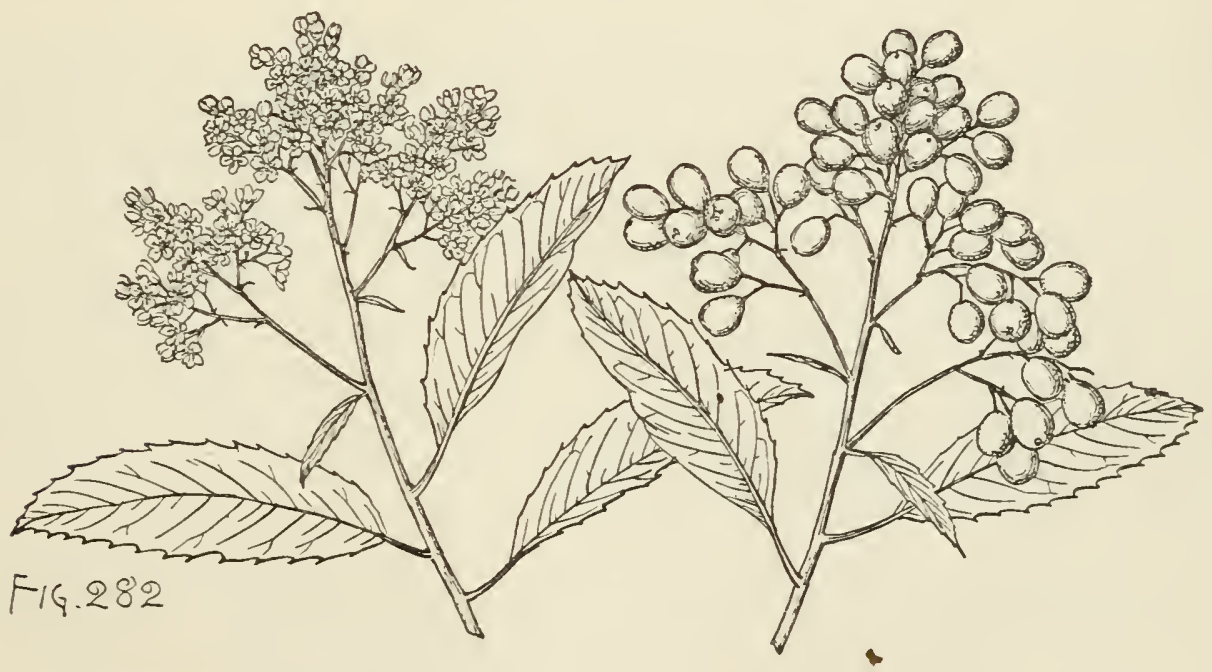

few feet above the ground into many erect branches forming a handsome narrow round-topped head, and slender branchlets covered at first with pale pubescence, in their first winter dark red and slightly puberulous, ultimately becoming darker and glabrous. Winter-buds $\frac{1^{\prime}}{4}$ long. Bark $\frac{2^{\prime}}{3}-\frac{1^{\prime}}{2}$ thick, light gray, with a generally smooth surface roughened by obscure reticulate ridges. Wood very heavy, hard, close-grained, dark red-brown, with thin lighter colored sapwood of 7 or 8 layers of annual growth. The fruit-covered branches are gathered in large quantities and used in California in Christmas decorations.

Distribution. Usually in the neighborhood of streams or on dry hills and especially on their northern slopes and often on steep sea-cliffs ; California coast region from Mendocino County to Lower California; most common and of its largest size on the islands off the California coast; on the foot hills of the Sierra Nevada and on the San Bernardino Mountains up to elevations of $2000^{\circ}$ above the sea and usually 
shrubby; very abundant and forming groves of considerable extent on the island of Santa Catalina.

Occasionally cultivated as an ornamental plant in California, and rarely in the countries of southern Europe.

\section{AMELANCHIER, Med.}

Trees or shrubs, with scaly bark, slender terete branchlets, acute buds, with imbrieated scales, those of the inner rows accrescent and bright-colored, and fibrous roots. Leaves alternate, conduplicate in the bud, simple, entire or serrate, penniveined, petiolate, deeiduous; stipules free from the petioles, linear, elongated, rose color, caducous. Flowers in erect or nodding racemes, on slender bibracteolate pedicels developed from the axils of lanceolate acuminate pink deciduous bracts; ealyx-tube campanulate or urceolate, the lobes acute or subulate, recurved, persistent; disk green, entire or crenulate, nectariferous; petals white, obovate-oblong, spatulate or ligulate, rounded, acute, or truncate at the apex, gradually eontraeted below into short slender claws; stamens usually 20, inserted in 3 rows, those of the otter row opposite the petals; filaments subulate, persistent on the fruit; anthers oblong; ovary inferior or superior, more or less adnate to the ealyx-tube, glabrous or puberulous above, 5celled, each cell incompletely divided by a false partition; styles $2-5$, connate below, spreading and dilated above into broad truncate stigmas; ovules 2 in each eell, erect; mieropyle inferior. Fruit globose or pyriform, dark blue, open at the summit, the cavity surrounded by the lobes of the ealyx and the remnants of the filaments; flesh sweet, rather juicy; carpels membranaceous, free or eonnate, glabrous or villous at the apex. Seeds 10 or often 5 by the abortion of 1 of the ovules in each cell, ovateelliptical; seed-coat eoriaceous, dark ehestnut-brown, mucilaginous; embryo filling the cavity of the seed; eotyledons plano-convex; radicle inferior.

Amelanchier is widely distributed through the temperate, northern, and the mountainons regions of eastern and western North Ameriea, and occurs in southern Europe, northern Africa, southwestern Asia, eentral China and in Japan. Several species, still imperfectly known, oceur in North America; of these three are arborescent. The fruit of all the species is more or less succulent and edible, and many species are cultivated in gardens for the beauty of their early and conspicuous flowers.

\section{CONSPECTUS OF THE NORTH AMERICAN ABORESCENT SPECIES.}

Leaves ovate to ovate-oblong, acute or acuminate at the apex, cordate or rounded at the base, dark red-brown and pilose when they unfold, soon glabrous.

1. A. Canadensis (A, C).

Leaves oblong to elliptical, acute or rounded at the apex, hoary-tomentose below when they unfold, becoming glabrous at maturity.

2. A. obovalis $(A, C)$.

Leaves broadly ovate to orbicular, obtuse or rarely acute, hoary-tomentose below when they unfold, becoming glabrous.

3. A. alnifolia (A, B).

\section{Amelanchier Canadensis, T. \& G. Shad Bush. Service Berry.}

Leaves ovate to ovate-oblong, acute, eordate or rounded at the base, finely serrate, with straight incurved rigid subulate teeth, when they unfold dark red-brown and pilose, with scattered deciduous white hairs, at maturity thick and firm, glabrous, dark green and dull above, pale below, $3^{\prime}-4^{\prime}$ long and $1^{\prime}-1 \frac{1}{2}^{\prime}$ wide, with prominent midribs and slender veins, turning bright elear yellow in the autumn before falling; their petioles slender, $\frac{1}{2}^{\prime}-1^{\prime}$ long. Flowers appearing when the leaves are about one third 
grown on slender pedicels $\frac{1^{\prime}}{2}-1^{\prime}$ long, in erect or nodding glabrous racemes $3^{\prime}-4^{\prime}$ long; calyx campanulate, with lanceolate acute lobes, villous on the inner surface; petals strap-shaped or slightly obovate, rounded or acute at the apex, thin, $\frac{1}{2}^{\prime}$ to nearly $1^{\prime}$ long, $\frac{1}{4}^{\prime}-\frac{1}{2}^{\prime}$ wide. Fruit ripening in early summer, depressed-globose, $\frac{1}{3}^{\prime}-\frac{1}{2}^{\prime}$ broad,

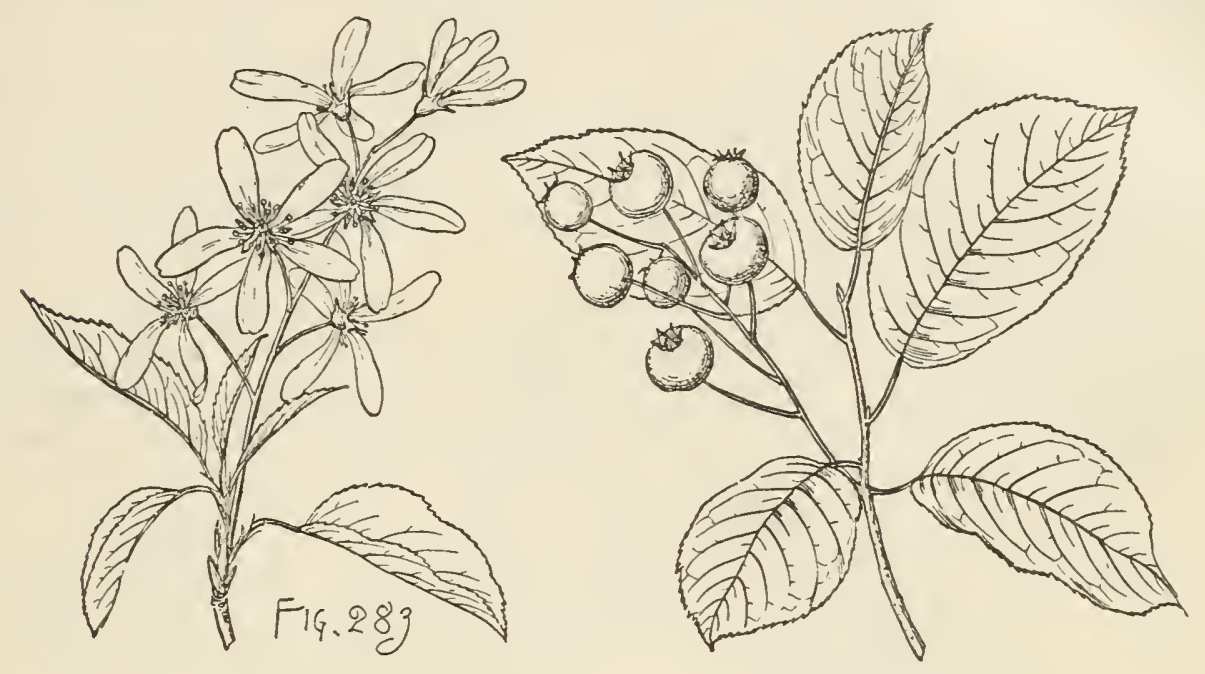

on elongated slender stems conspicuously marked by the scars of the fallen bractlets, bright red when fully grown, becoming dark purple and covered with a glaucous bloom when ripe; seeds $\frac{1}{8}^{\prime}$ long, with a dark red-brown opaque coat.

A tree, sometimes $40^{\circ}-50^{\circ}$ high, with a tall trunk $12^{\prime}-18^{\prime}$ in diameter, small spreading branches forming a narrow oblong round-topped head, and slender branchlets, at first light green and glabrous or slightly puberulous, dark red marked by numerous pale lenticels in their first winter, later becoming dark brown or reddish brown. Winter-buds $\frac{1}{4}^{\prime}$ long, with pale chestnut-brown ovate apiculate slightly pubescent scales, those of the inner ranks becoming lanceolate, acute, bright red above the middle, ciliate, with silky hairs, and sometimes $1^{\prime}$ long when fully grown. Bark $\frac{1^{\prime}}{4}-\frac{1^{\prime}}{2}$ thick, pale red-brown, divided by shallow fissures into narrow longitudinal ridges, and covered by small square persistent scales. Wood heavy, exceedingly hard, strong, close-grained, dark brown often tinged with red, with thick lighter colored sapwood of 40-50 layers of annual growth; occasionally used for the handles of tools and other small implements.

Distribution. Upland woods in rich soil; Newfoundland, through the maritime provinces of Canada, and westward along the shores of the Great Lakes, ranging southward to northern Florida and westward to Minnesota, eastern Nebraska, eastern Kansas, and southern Arkansas. A form with acuminate leaves cordate or rarely rounded at the base and pale-tomentulose below even at maturity (var. tomentula, Sarg., nov. var.) is referred provisionally to this species. Vermont (Ferrisburg, C. E. Faxon, June, 1881) to Ontario, and to Delaware, central Georgia, Missouri, and eastern Louisiana.

Often cultivated as an ornament of gardens.

\section{Amelanchier obovalis, Ashe. Shad Bush. Service Berry.}

Leaves oblong to broadly elliptical, acute or rounded at the apex, finely serrate, with slender incurved teeth except at the rounded or subcordate base, when they 
unfold villose above and coated below with hoary tomentum, at maturity thin and glabrous, dark dull green on the upper surface, paler on the lower surface, $11_{2}^{\prime}-2^{\prime}$ long, $\frac{3^{\prime}}{4}-1^{\prime}$ wide, with slender midribs and primary veins, turning yellow in the autumn before falling; their petioles slender, $\frac{1^{\prime}}{2}-\frac{3^{\prime}}{4}$ long. Flowers appearing when the leaves are about one third grown, on slender pedicels $\frac{1^{\prime}}{2}-\frac{3^{\prime}}{4}$ long, in erect or nodding villose racemes soon becoming glabrous, and $1 \frac{1^{\prime}}{2}-2 \frac{1}{2}^{\prime}$ long; calyx campanulate, at first tomentose, soon glabrous, with linear acute lobes villose on the inner surface, and oblong-obovate petals about $\frac{8^{\prime}}{8}$ long and $\frac{1{ }^{\prime}}{1 \overline{6}}$ wide. Fruit ripening early in the summer, depressed-globose, about $\frac{1^{\prime}}{3}$ in diameter, bright red when fully grown, becoming dark purple and covered with a glaucous bloom; seeds $\frac{1}{8}^{\prime}$ long, with a dark red-brown opaque coat.

A tree, sometimes $25^{\circ}-30^{\circ}$ high, with a single stem, erect branches forming a dense round-topped head, and slender branchlets covered when they first appear with hoary tomentum, soon glabrous, and bright red-brown and marked by numerous minute pale lenticels in their first winter, later becoming darker; often with numerous
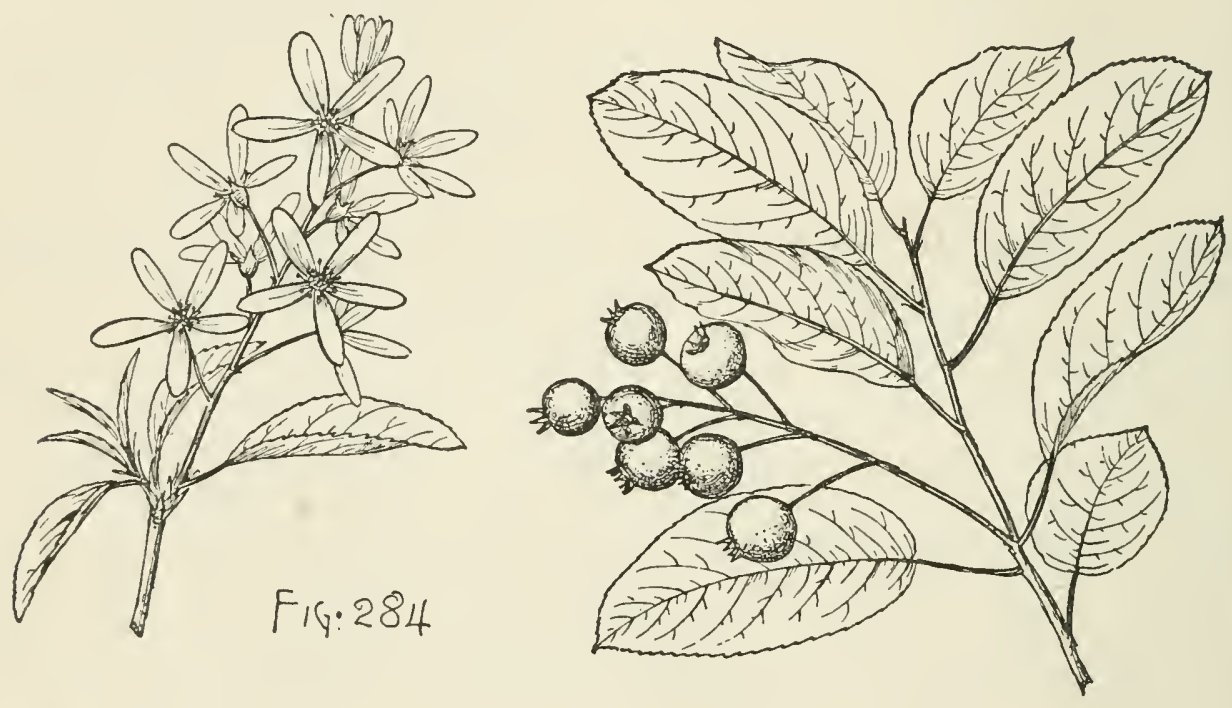

spreading stems forming a broad tall bush. Winter-buds $\frac{1}{4}^{\prime}$ long, pale chestnutbrown, and pubescent above the middle. Bark $\frac{1}{4}^{\prime}-\frac{1}{2}^{\prime}$ thick, pale reddish brown and scaly, with small persistent scales.

Distribution. Borders of streams and swamps in low wet soil; Nova Scotia and New Brunswick to Ontario, and northward to the valley of the Mackenzie River in latitude $65^{\circ}$ north, and southward through the northern states and along the Alleghany Mountains to Virginia and westward to Minnesota; as a small shrub with narrower petals in the coast region of the south Atlantic and Gulf states from North Carolina to Alabama.

A large-fruited variety is occasionally planted in the middle west for its juicy agreeably subacid fruit.

\section{Amelanchier alnifolia, Nutt. Service Berry.}

Leaves broadly ovate to orbicular, obtuse or rarely acute, rounded or subcordate at the base, sharply and coarsely serrate above the middle, with incurved rigid teeth, when they unfold floccose-tomentose below and often pilose above, soon becoming 
glabrous and at maturity membranaceous to subcoriaceous, dark green on the upper and pale on the lower surface, $1^{\prime}-1 \frac{1^{\prime}}{2}$ long and broad, with slender midribs; their petioles sleuder, $\frac{1}{2}^{\prime}$ long; stipules linear, acute, red-brown, sometimes $1^{\prime}$ long. Flowers on short pedicels, in erect villose racemes $1^{\prime}-1 \frac{1}{2}^{\prime}$ long, with acute colored bractlets;

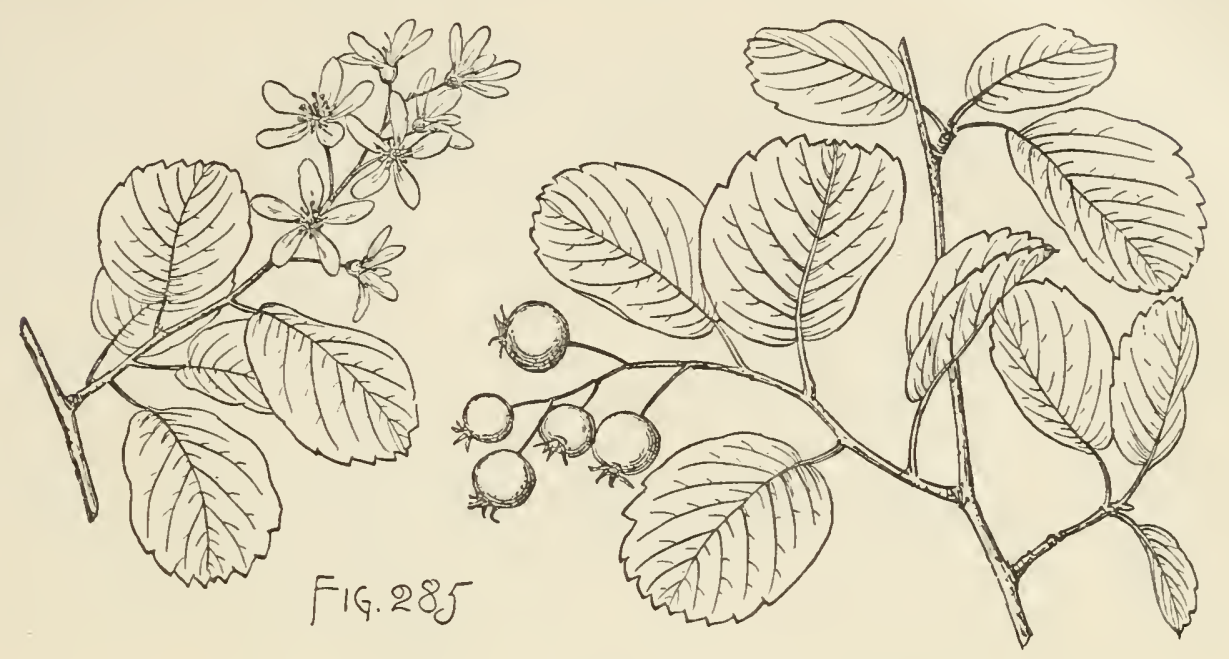

calyx cup-shaped, floccose-tomentose or soon glabrous, with linear acute lobes villose on the inner surface; petals narrowly oblong to obovate, rounded or acute at the apex, $\frac{1^{\prime}}{4}-1^{\prime}$ long; glabrous. Fruit subglobose, dark blue or almost black, with a glaucous bloom, sweet and juicy, $\frac{1}{2}^{\prime}$ to nearly $1^{\prime}$ in diameter; seeds $\frac{1}{8}^{\prime}$ long, with a lustrous redbrown coat.

A tree, occasionally $20^{\circ}$ high, with a single straight trunk $6^{\prime}-10^{\prime}$ in diameter, and slender branches green, glabrous, pilose, with long pale hairs, or pubescent when they first appear, in their first winter bright red or plum color, glabrous or rarely puberulous, and marked by small pale lenticels; more often a shrub, with clustered slender stems. Winter-buds acute, $\frac{1}{4}^{\prime}$ long, with chestnut-brown glabrous occasionally pilose scales, those of the inner ranks becoming ovate, acute, brightly colored, coated with pale silky hairs, $\frac{1^{\prime}}{2}-\frac{3^{\prime}}{4}$ long. Bark about $\frac{1^{\prime}}{8}$ thick, smooth or slightly fissured, and light brown slightly tinged with red. Wood heavy, hard, close-grained, light brown. The nutritious pungent fruit is an important article of food with the Indians of southwestern America, who gather and dry it in large quantities.

Distribution. Valley of the Yukon River in about latitude $62^{\circ} 50^{\prime}$, southward through the coast ranges to northern California, and eastward to Saskatchewan, Manitoba, the western shores of Lake Superior, and to northern Michigan; of its largest size on the islands and rich bottom-lands of the lower Columbia River and on small prairies in the neighborhood of Puget Sound.

\section{CRAT瓜GUS. Hawthorn.}

Trees or shrubs, with usually dark scaly bark, rigid terete more or less zigzag branchlets marked by oblong mostly pale lenticels, and by small horizontal slightly elevated leaf-scars, light green when they first appear, becoming red or orange-brown and lustrous or gray, rarely unarmed or armed with stout or slender short or elongated axillary simple or branched spines generally similar in color to that of the branches or trunk on which they grow, often bearing while young linear elongated 
caducous bracts, and usually producing at their base one or rarely two buds often developing the following year into a branch, a leaf, or a cluster of flowers, or sometimes lengthening into a leafy branch. Winter-buds small, globose or subglobose, covered by numerous imbricated seales, the outer rounded and obtuse at the apex, bright chestnut-brown and lustrous, the imer accrescent, green or rose color, often glandular, soon deciduous. Leaves conduplicate in the bud, simple, generally serrate, sometimes 3-nerved, often more or less lobed, cspecially on vigorous leading branchlets, membranaceous to coriaceous, petiolate, deciduous; stipules often glandularserrate, linear, acuminate, frequently bright-colored, deciduous, or on vigorous branchlets often foliaceous, coarsely serrate, usually lunate and stalked and mostly persistent until autumn. Flowers pedicellate, in few or many-flowered simple or compound cymose corymbs terminal on short lateral leafy branchlets, with linear usually briglit-colored often glandular caducous bracts and bractlets leaving prominent glandlike scars, the lower branches of compound corymbs usually from the axils of upper leaves; branches of the inflorescence mostly 3 -flowered, the central flower opening before the others; calyx-tube usually obconic, 5 -lobed, the lobes acute or acuminate and usually gland-tipped, rarely foliaceous, glandular-serrate or entire, green or reddish toward the apex, reflexed after the flowers open, persistent and of ten enlarged on the fruit, or deciduous; disk thin or fleshy, entire, lobed or slightly sulcate, concave or somewhat convex; petals imbricated in the bud, orbicular, entire or somewhat erose or rarely toothed at the apex, white or rarely rose color, spreading, soon deciduous; stamens often variable in number in the same species by imperfect development, but normally 5 in 1 row and alternate with the petals, or 10 in 5 pairs in 1 row alternate with the petals, or 15 in 2 rows, those of the outer row in 5 pairs opposite the sepals and alternate with and rather longer than those of the inner row, or 20 in 3 rows, those of the inner row shorter and alternate with those of the $2 d$ row, or 25 in 4 rows, those of the 4th row alternate with those of the $3 \mathrm{~d}$ row; filaments broad at the base, subulate, incurved, often persistent on the fruit; anthers pale yellow to nearly white, or pink to ligltt or dark rose color or purple; ovary composed of 1-5 carpels inserted in the bottom of the calyx-tube and united with it; styles free, with dilated truncate stigmas, persistent on the mature carpels; ovules ascending; raphe dorsal; micropyle inferior. Fruit subglobose, ovate, short-oblong or pear-shaped, scarlet, orange-colored, red, yellow, blue, or black, generally open and concave at the apex; flesh usually dry and mealy; nutlets 1-5; united below, more or less free and slightly spreading above the middle, thick-walled, rounded, acute, or acuminate at the apex, full and rounded or narrowed at the base, rounded or conspicuously ridged and grooved on the back, flattened, or nearly round when only 1 , their ventral faces plane or plano-convex or penetrated by longitudinal cavities or hollows. Seed solitary by abortion, erect, compressed, acute, with a membranaceous light chestnut-brown coat; embryo filling the cavity of the seed; cotyledons plano-convex, radicle short, inferior.

Cratægus is most abundant in eastern North America, where it is distributed from Newfoundland to the mountains of northern Mexico, and is represented by a large number of arborescent and shrubby species. A few species occur in the Rocky Mountain and Pacific-coast regions, and in China, Japan, Siberia, central and southwestern Asia, and in Europe. The genus is still very imperfectly known in North America, and in the absence of sufficient information concerning them several arborescent species are necessarily excluded from the following enumeration. The beautiful and abundant flowers and showy fruits make many of the species desirable 
ornaments of parks and gardens, and several are cultivated. Of exotic species, the Old World Cratcogus Oxyacantha, L., early introduced into the United States as a hedge plant, has now become naturalized in many places in the northeastern and middle states. Cratægus produces heavy hard tough close-grained red-brown heartwood and thick lighter colored usually pale sapwood; useful for the handles of tools, mallets, and other small articles.

The number of the stamens, although it differs on the same species within certain usually constant limits, and the color of the anthers, which appears to be specifically constant with two exceptions, afford the most satisfactory characters for distinguishing the species in the different groups.

Cratcegus, from крátos, is in reference to the strength of the wood of these trees.

\section{CONSPECTUS OF THE NATURAL GROUPS OF THE NORTH AMERICAN ARBORESCENT SPECIES.}

1. Nutlets withont ventral cavities.

*Veins of the leaves extending to the points of the lobes only.

$\rightarrow$ Petioles short, glandless or with occasional minute glands; leaves obovate to oblong, cuneate at the base.

- Corymbs many-flowered.

Leaves coriaceous or subcoriaceous, rarely thin, dark green and shining above, usually serrate only above the middle, their veins thin except on vigorous shoots; fruit mostly globose to short-oblong, $\frac{l^{\prime}}{3}-1^{\prime}$ long, with thin bright usually greenish flesh; nutlets $1-3$, thick, usually obtuse and rounded at the ends, prominently ridged on the back.

I. Crus-galli (page 367).

Leaves membranaceous or subcoriaceous, mostly acute, their veins prominent; fruit oblong to globose, often conspicuously punctate, $\frac{1}{3}^{\prime}-1^{\prime}$ long; flesh dry and mealy; nutlets $2-0$, prominently ridged on the back.

II. Punctatæ (page 388). +- Corymbs few-flowered; flowers appearing with or before the unfolding of the leaves; stamens 20-25; anthers large, dark rose color.

III. \#stivales (page 399).

+- Petioles elongated, slender, glandless or with occasional minute glands; leaves membranaceous to subcoriaceous, acute or acuminate at the ends, on one species broad at the base; corymbs many-flowered ; fruit subglobose to oblong, $\frac{1^{\prime}}{8}-\frac{5^{\prime}}{8}$ long.

IV. Virides (page 400). ++- Petioles elongated, usually slender, glandular only at the apex (in Intricatce and Bracteatce sparingly glandular throughout).

$\rightarrow$ Leaves mostly broad at the base; corymbs many-flowered (few-flowered in one species of Dilatatoe):

Fruit subglobose to short-oblong, $\frac{1}{2}^{\prime}-\frac{5}{8}{ }^{\prime}$ in diameter, red or green, often slightly 5 -angled, pruinose ; nutlets 5 , grooved on the back; stamens 20 ; anthers rose color; leaves blue-green, subcoriaceous, nearly glabrous.

V. Pruinosæ (page 411).

Fruit short-oblong to obovate, scarlet, $\frac{1}{2}-\frac{5}{8}$ l long, globose and greenish red in one species; flesh succulent, sometimes juicy; anthers rose color or purple; leaves membranaceous, at maturity glabrous below.

VI. Tenuifoliæ (page 413).

Fruit subglobose, oblong or pyriform, crimson, scarlet, or rarely yellow, usually about $1^{\prime}$ in diameter; flesh thick, succulent, often edible ; nutlets usually 5 , occasionally 4 , thin, pointed at the ends, mostly obscurely 
grooved or ridged on the back; corymbs tomentose or pubescent; leaves membranaceons to subeoriaceons, broad, rounded or cuneate at the base, at maturity usually pubescent or tomentose below.

VII. Molles (page 422).

Fruit oblong, scarlet, $\frac{1^{\prime}}{2}-\frac{3 \prime}{4}$ long ; flesh succulent; nutlets $8-5$, prominently grooved and usually ridged on the back; corymbs glabrous or tomentose; leaves nembranaceous or rarely subcoriaceous, oblong, more or less acutely lobed; anthers rose or purple.

VIII. Flabellatæ (page 442).

Fruit subglobose to short-oblong, erinison or red tinged with green, about 3' long, its calyx enlarged and prominent; nutlets 5, prominently ridged on the back; corymbs rarely few-flowered; stamens 20 ; anthers rose color; leaves membranaceous, on vigorous shoots as broad or broader than long.

$\ldots+$ Leaves cuneate at the base.

IX. Dilatatæ (page 455).

Corymbs many-flowered; leaves subcoriaceous; fruit subglobose, rarely oblong, $\frac{1^{\prime}}{2}-\frac{3^{\prime}}{4}$ long ; nutlets 2 or 3 , obtuse at the ends, conspicuously ridged on the back; corymbs glabrous or tomentose; leaves dark green and lustrous above.

X. Coccineæ (page 459).

Corymbs few-flowered (many-flowered in one species of Bracteatce); leaves membranaceous.

Fruit subglobose to oblong, rarely more than $\frac{1^{\prime}}{2}$ long, greenish or yellowish ; nutlets $3-5$, rounded at the ends, conspicuously ridged on the back ; leaves subcoriaceous, yellow-green.

XI. Intricatæ (page 462).

Fruit subglobose, rarely more than $\frac{1^{\prime}}{4}$ long, red or orange-red; nutlets 3-5, slightly grooved on the back; stamens 20 ; anthers rose color; leaves incisely lobed.

XII. Pulcherrimæe (page 466).

Fruit subglobose to short-oblong, $\frac{1^{\prime}}{2}-\frac{5{ }^{\prime}}{8}$ long; nutlets $3-5$, narrowed at the ends, prominently ridged on the back; corymbs in one species fewflowered, villose; bracts large and conspicuous ; calyx-lobes foliaceous; stamens 20; anthers yellow; leaves coriaceous to subcoriaceous, dark green and lustrous, their petioles sparingly glandular through their whole length.

XIII. Bracteatæ (page 468).

+-+- Petioles, leaves and corymbs conspicuously glandular; corymbs few-flowered; fruit subglobase to short-oblong or pyriform, $\frac{1^{\prime}}{2}-\frac{3^{\prime}}{4}$ long, green, orange, or red, flesh usually hard and dry; branchlets conspicuously zigzag.

XIV. Flavæ (page 471).

***ins of the leaves extending to the points of the lobes and to the sinuses; corymbs many-flowered; stamens 20.

Fruit depressed-globose to oblong, not more than $\frac{1^{\prime}}{4}$ long, scarlet; nutlets 2-5, obtuse at the ends, prominently ridged on the back; anthers rose color or purple.

XV. Microcarpæe (page 486).

Fruit subglobose, $\frac{1}{3}^{\prime}-\frac{1}{2}$ in diameter, blue or blue-black; nutlets $3-5$, obtuse at the ends slightly ridged on the back; leaves dark green and lustrous.

XVI. Brachyacanthæ (page 489).

2. Nutlets with longitudinal cavities on their ventral faces.

Fruit pyriform to subglobose or short-oblong, $\frac{1^{\prime}}{4}-\frac{1}{2}$ long, lustrous, orange or scarlet; nutlets 2 or 3 , obtuse at the ends, prominently ridged on the back; leaves membranaceous to subcoriaceous, mostly pubescent below.

XVII. Tomentosæ (page 491).

Fruit short-oblong to subglobose, $\frac{1}{2}$ long, black; nutlets 5 , obtuse at the ends, obscurely ridged on the back; stamens 20 ; leaves subcoriaceous.

XVIII. Douglasianæ (page 502). 


\section{CRUS-GALLI.}

Corymbs, leaves, and young branchlets slightly hairy while young, soon becoming glabrous (glabrous while young in 1, 6, 8, and 11).

Stamens 10.

Anthers rose color or purple.

Leaves glabrous, obovate-cuneiform, coriaceous, their veins within the parenchyma ; fruit short-oblong to subglobose, dull red often covered with a glaucous bloom.

1. C. Crus-galli (A).

Leaves oblong to ovate, usually acute, coriaceous ; fruit short-oblong to subglobose, dark crimson, lustrous.

2. C. Canbyi (A).

Leaves obovate, usually short-pointed at the broad apex, subcoriaceous; fruit short-oblong to obovate, bright scarlet.

3. C. Peoriensis (A).

Leaves oblong-obovate to oval, or broadly ovate, their petioles glandular, with minute stipitate glands; fruit short-oblong to subglobose, orange-red, villose until nearly fully grown.

4. C. fecunda (A).

Anthers yellow.

Leaves oval to elliptic, acute or acuminate, subcoriaceous; fruit short-oblong, green tinged with red.

5. C. regalis (C).

Leaves glabrous, obovate, acute, acuminate, or rounded at the apex, subcoriaceous; fruit short-oblong, dull dark crimson.

6. C. Arduennæ (A).

Leaves obovate to oblong-cuneiform, rounded or acute at the apex, subcoriaceous ; fruit subglobose to obovoid, dull red, or green flushed with red.

7. C. algens $(\mathrm{A}, \mathrm{C})$.

Leaves ovate to obovate, acute, comparatively thin, dull green above; fruit subglobose, flattened at the ends, dark dull crimson.

S. C. erecta (A).

Leaves oval to oblong-obovate, acute or acuminate, comparatively thin; fruit short-oblong, full and rounded at the ends, bright scarlet.

Stamens 20.

9. C. acutifolia (A).

Anthers rose color; leaves obovate to elliptic, broad and rounded or acute at the apex, coriaceous; fruit short-oblong, green tinged with dark red.

10. C. Bushii (C).

Anthers yellow; leaves obovate to oblanceolate, acute or rounded at the apex, subcoriaceous; fruit globose to subglobose, red.

11. C. arborea (C).

Corymbs, leaves, and branchlets more or less villose or pubéscent throughout the season.

Stamens 10.

Anthers rose color; leaves broadly obovate to elliptic coriaceous, scabrous above; fruit globose, bright orange-red, with a yellow cheek. 12. C. Engelmanni (A). Anthers yellow (doubtful in 13 and 14.)

Leaves oval, oblong-obovate or elliptic, acute, thin to subcoriaceous; fruit globose to subglobose, orange-red.

13. C. denaria (C).

Leaves obovate to obovate-cuneiform, rounded or acute at the apex, thin ; fruit shortoblong, dark red, more or less pruinose.

14. C. signata (C).

Leaves broadly oval to oblong, rounded or acute or short-pointed at the apex, coriaceous; fruit subglobose, dull green tinged with red or cherry-red.

Stamens 20.

15. C. Palmeri (C).

Anthers rose color.

Leaves oblong-obovate, acute, coriaceous, scabrate ; fruit short-oblong, dull green tinged with red, slightly pruinose.

16. C. edita (C).

Leaves oblong to obovate-cuneiform, rounded and obtuse or occasionally acute at the apex, coriaceous, glabrous or scabrate above ; fruit globose to subglobose or short-oblong, dark red.

17. C. tersa (C). 
Anthers yellow.

Leaves oblong-obovate, rounded or gradually narrowed at the apex, subcoriaceous, pale below; fruit subglobose, orange color, with a red cheek.

18. C. berberifolia (C).

Leaves cuneate, oblong or obovate-cuneiform, rounded and obtuse or rarely acute at the apex, coriaceous, glabrate or slightly scabrous above; fruit subglobose, orange or yellow, with a red cheek.

19. C. edura (C).

Leaves oblong to obovate-cuneiform, rounded or acute at the apex, subcoriaceous, glabrous or glabrate above, pale below; fruit oval to short-oblong, yellow.

20. C. crocina (C).

Leaves oblong to obovate-cuneiform, rounded or obtuse or rarely truncate at the apex, coriaceous, scabrate above; fruit globose to subglobose, bright red or scarlet.

21. C. fera (C).

Leaves obovate, acute, thin to subcoriaceous; fruit subglobose to short-oblong, somewhat flattened at the apex, bright orange-red.

22. C. Mohri (C).

\section{Glabrous at maturity.}

* Stamens 10.

+ Anthers rose color or purple.

\section{Cratægus Crus-galli, L. Cock-spur Thorn.}

Leaves glabrous, obovate, acute or rounded at the apex, cuneate and gradually narrowed to the slender entire base, sharply serrate above, with minute appressed

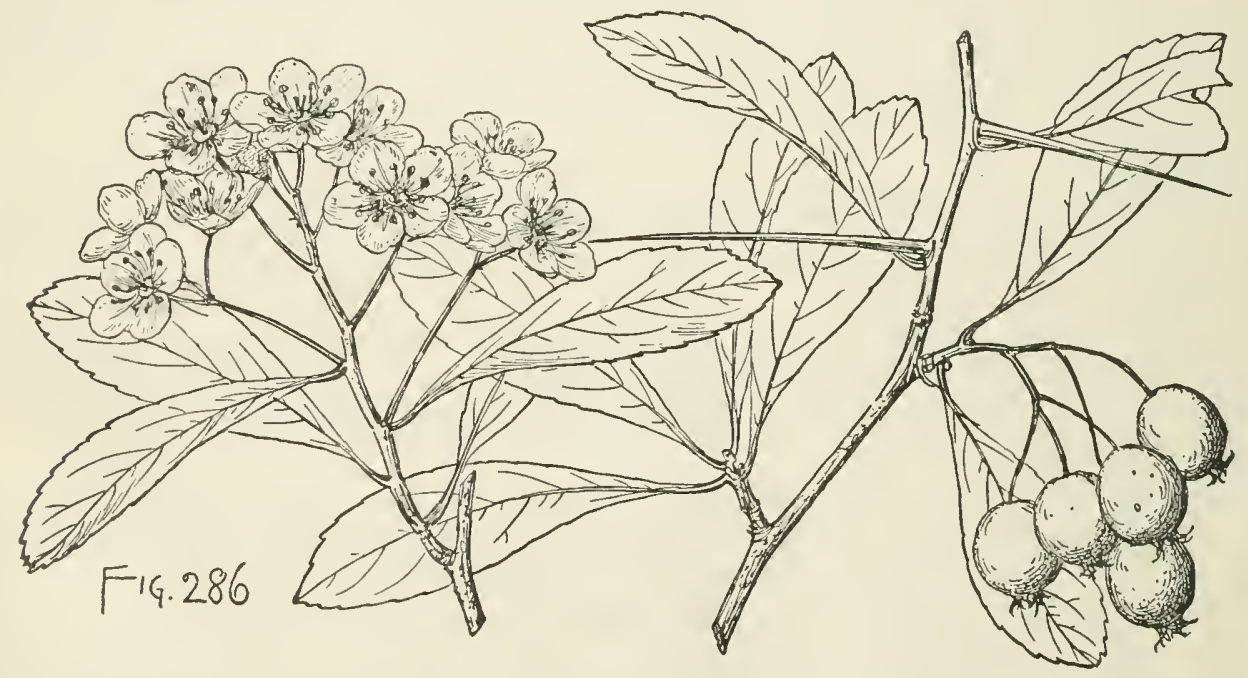

usually gland-tipped teeth, when they unfold tinged with red, membranaceous and nearly fully grown when the flowers open about the 1st of June, and at maturity thick and coriaceous, dark green and lustrous above, pale below, reticulate-veined, $\mathbf{1}^{\prime}-4^{\prime}$ long, $\frac{1}{4}^{\prime}-1^{\prime}$ wide, with slender midribs, and primary veins within the parenchyma, turning bright orange and scarlet in the autumn before falling; their petioles stout, wing-margined toward the apex, $\frac{1}{2}^{\prime}-\frac{3^{\prime}}{4}$ long; on vigorous shoots acute or accuminate, coarsely serrate, often $5^{\prime}-6^{\prime}$ long. Flowers $\frac{2^{\prime}}{3}$ in diameter, on slender pedicels, in many-flowered glabrous corymbs; calyx-tube narrowly obconic, glabrous, the lobes linear-lanceolate, entire or minutely glandular-serrate; stamens 10; anthers rose color; styles usually 2, surrounded at the base by tufts of pale hairs. Fruit 
ripening late in October and persistent on the branches until spring, short-oblong to subglobose, $\frac{1^{\prime}}{2}$ long, dull red often covered with a glaucous bloom; flesh dry and mealy; calyx little enlarged; nutlets usually 2 , full and rounded at the ends, prominently ridged on the back, with a high rounded grooved ridge, $\frac{1^{\prime}}{4}$ long.

A tree, sometimes $25^{\circ}$ high, with a trunk a foot in diameter, and stout rigid spreading branches forming a broad round-topped head, glabrous, light brown or gray branchlets armed with stout straight or slightly curved sharp-pointed chestnut-brown or ashy gray spines $3^{\prime}-4^{\prime}$ long and becoming on the trunks and large branches $6^{\prime}-8^{\prime}$ long and furnished with slender lateral spines.

Distribution. Usually on the slopes of low hills in rich soil; valley of the St. Lawrence River near Montreal, southward to Delaware and along the Appalachian foothills to North Carolina, and westward through western New York and Pennsylvania to southern Michigan.

A form, var. pyracanthifolia, Ait., with narrower elliptical to obovate leaves acute or rounded at the apex, and slightly pubescent while young on the upper side of the midribs, and with rather smaller flowers and smaller bright red fruit, is not rare in eastern Pennsylvania and northern Delaware; a form, var. salicifolia, Ait., cultivated in European gardens, but not known in a wild state, with thinner narrower and more elongated lanceolate or oblanceolate leaves, should also probably be referred to this species. A form, var. oblongata, Sarg., with rather brighter colored oblong fruit often $1^{\prime}$ long, and nutlets acute at the ends, is not rare near Wilmington, Delaware, and at Durham, Bucks County, Pennsylvania. A form, var. capillata, Sarg., with thinner leaves, slightly villose corymbs, and 1 or rarely 2 nutlets, occurs near Wilmington, Delaware.

Often cultivated as an ornamental plant and for hedges in the eastern United States, and very frequently in the countries of eastern and northern Europe.

\section{Cratægus Canbyi, Sarg.}

Leaves oblong-ovate to ovate or rarely obovate, acute or rarely rounded at the apex, gradually narrowed, cuneate and entire at the base, and coarsely and often doubly serrate above the middle, more than half grown when the flowers open about

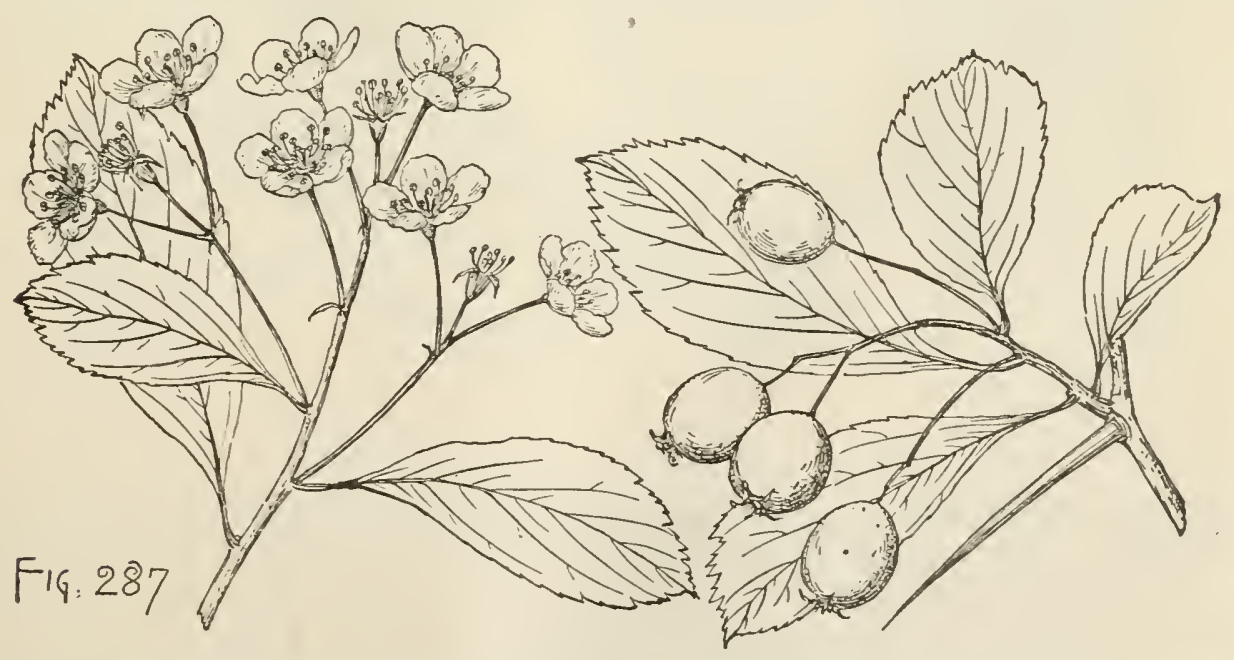

the 1st of May and then glabrous or very rarely with a few scattered hairs on the upper side of the midribs and on the corymbs, at maturity coriaceous, glabrous, dark 
green and very lustrous above, pale and dull below, $2^{\prime}-2 \frac{1^{\prime}}{2}$ long, $1^{\prime}-1 \frac{1_{2}^{\prime}}{}$ wide, with thiek pale midribs and 4 or 5 pairs of remote primary veins eonspicuous on the lower surfaee; their petioles more or less winged above, glandular, with seattered dark red persistent glands, red below the middle, $\frac{1{ }^{\prime}}{2}-\frac{8^{\prime}}{4}$ long; on vigorous leading shoots often deeply and irregularly divided into broad aeute lobes, and frequently $3^{\prime}-4^{\prime}$ long and $2^{\prime}$ wide. Flowers $\frac{5^{\prime}}{8}$ in diameter, on long slender pedieels, in broad loose manyflowered long-branehed eorymbs; ealyx-tube narrowly obeonie, the lobes entire or serrate, with minute seattered glandular teeth; stamens usually 10 , oecasionally 12 or 13; anthers, small, rose eolor; styles $3-5$. Fruit ripening in Oetober but persistent until after the beginning of winter, on elongated slender stems, in loose many-fruited drooping clusters, short-oblong to subglobose, full and rounded at the ends, with a distinct depression at the insertion of the stalk, lustrous, dark erimson, marked by oeeasional large pale dots, $\frac{1^{\prime}}{2}-\frac{5^{\prime}}{8}$ long; calyx-lobes reflexed, elosely appressed, often deeiduous before the fruit ripens; flesh thiek, bright red, very juiey; nutlets $3-5$, prominently ridged, with broad rounded ridges, bright chestnutbrown, about $\frac{11}{4}$ long.

A bushy tree, sometimes $20^{\circ}$ high, with a trunk $12^{\prime}-18^{\prime}$ in diameter, large ascending wide-spreading branehes forming a broad open irregular head occasionally $30^{\circ}-35^{\circ}$ in diameter, and branehlets armed with thick usually straight ehestnutbrown spines $\frac{3^{\prime}}{4}-1 \frac{1^{\prime}}{2}$ long.

Distribution. Hedges and thiekets, Wilmington, Delaware, to the shore of Chesapeake Bay, Maryland, and to eastern Pennsylvania.

\section{Cratægus Peoriensis, Sarg.}

Leaves obovate, short-pointed or oeeasionally rounded at the broad apex, gradually narrowed, euneate and entire below, sharply and often doubly serrate usually

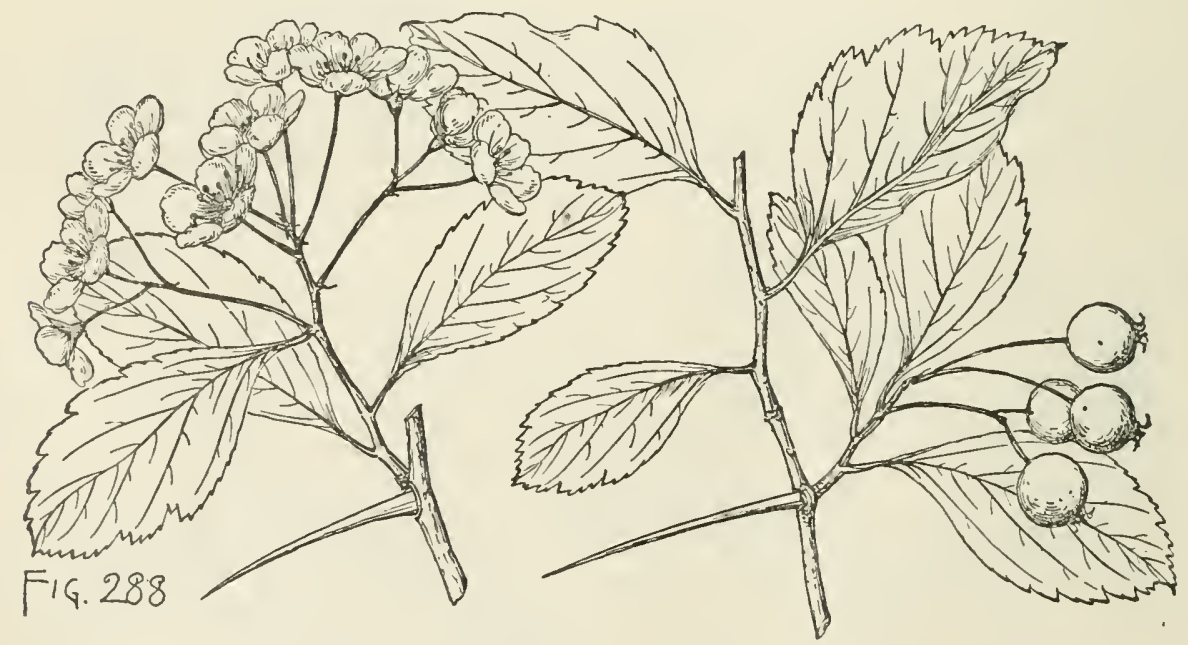

only above the middle, sometimes irregularly lobed, with short broad terminal lobes, when they unfold villose above, espeeially toward the base of the midribs, and bright bronze eolor, beeoming at maturity thiek and firm, glabrous, dark green and very lustrous above, pale below, $1 \frac{1^{\prime}}{2}-2^{\prime}$ long, $\frac{3^{\prime}}{4}$ wide, with 4 or 5 pairs of thin primary veins eonspieuous on the under side and extending obliquely from the slender midribs to the ends of the lobes; their petioles usually about $\frac{1^{\prime}}{4}$ long, more or less 
wing-margined and slightly glandular above the middle, and covered at first with short pale deciduous hairs; on vigorous shoots deeply divided into broad acute lateral lobes, $2^{\prime}-3^{\prime}$ long, and $1 \frac{1}{2}^{\prime}$ wide, with lunate, coarsely glandular-serrate stipules, sometimes $1^{\prime}$ long. Flowers cup-shaped, about $\frac{1^{\prime}}{2}$ in diameter, on slender elongated pedicels, in broad loose compound many-flowered glabrous corymbs; calyxtube narrowly obconic, the lobes narrow and acuminate, entire or irregularly glandular-serrate, pubescent below the middle on the inner surface; stamens 10; anthers small, rose color; styles 2 or 3, surrounded at the base by a narrow ring of pale tomentum. Fruit ripening early in October, on slender elongated pedicels, in drooping many-fruited clusters, oblong or obovate, full and rounded at the ends, slightly depressed at the insertion of the stalk, bright scarlet, marked by many small dark dots, $\frac{1^{\prime}}{2}-\frac{3^{\prime}}{4}$ long; calyx-lobes enlarged, erect, incurved, and persistent; flesh thick, nearly white, firm and dry; nutlets 2 or 3 , prominently ridged on the back, about $\frac{1^{\prime}}{4}$ long.

A nearly glabrous tree, $20^{\circ}-25^{\circ}$ high, with a trunk occasionally $1^{\circ}$ in diameter, stout spreading branches forming a broad flat-topped symmetrical head, and branchlets armed with straight or slightly curved thin dull chestnut-brown spines $2^{\prime}-2 \frac{1^{\prime}}{}$ long.

Distribution. Open woods, the moist borders of streams and depressions in the prairie, and on hillsides in clay soil, Short and Peoria counties, Illinois.

\section{Cratægus fecunda, Sarg.}

Leaves oblong-obovate to oval, or broadly ovate, acute or rarely rounded and short-pointed at the apex, gradually or abruptly narrowed below, and coarsely and usually doubly serrate except toward the base, when they unfold dark green, lustrous and roughened above by short pale appressed caducous hairs and pale yellow-green
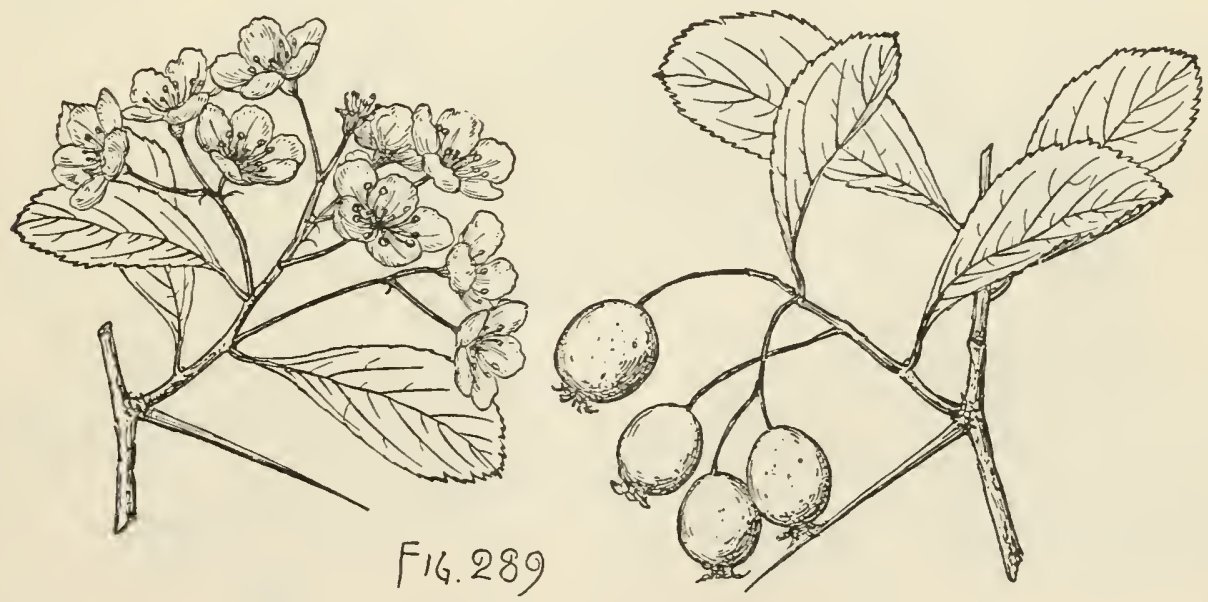

and villose along the midribs and primary veins below, about half grown when the flowers open early in May and at maturity thin but firm in texture, dark green and lustrous above, pale yellow-green below, $2^{\prime}-2 \frac{1}{2}^{\prime}$ long, $1 \frac{1^{\prime}}{2}-2^{\prime}$ wide, with stout midribs and remote primary veins after midsummer often bright red below, turning late in the autumn brilliant shades of orange or scarlet or deep rich bronze color; their petioles more or less winged, often glandular, at first coated with pale hairs, soon glabrous, dull red at maturity, $\frac{1^{\prime}}{2}-\frac{3^{\prime}}{4}$ long; on vigorous shoots often slightly lobed, 
with short broad acute lobes, convex by the hanging down of the margins, $3^{\prime}-4^{\prime}$ long, and $2^{\prime}-3^{\prime}$ wide, their stipules semilunate, coarsely glandular-serrate, often $\frac{8^{\prime}}{4}$ long. Flowers $\frac{3}{4}$ in diameter, on slender pedicels, in wide many-flowered slightly villose corymbs, with large glandular braets and braetlets; ealyx-tube narrowly obconie, more or less villose, the lobes elongated, aeute, and eoarsely serrate, with stipitate dark red glands, villose on the inner surfaee; stamens usually 10 , oeeasionally 12-15; anthers small, dark purple; styles 2 or 3 . Fruit on slender pedicels often $\frac{1^{\prime}}{2}$ long, in broad many-fruited drooping elusters, short-oblong to subglobose, full and rounded at the ends, eovered until nearly fully grown with long soft pale hairs, and at maturity orange-red marked by many sinall dark dots, $\frac{7^{\prime}}{8}-1^{\prime}$ long; calyxlobes linear-laneeolate, ereet and incurved, coarsely glandular-serrate above the middle, dark red on the upper side toward the base; flesh very thiek, firm and hard, pale green, dry and sweet; nutlets 2 or 3 , rounded and prominently ridged on the back, $\frac{1}{3}$ ' long.

A tree, $20^{\circ}-25^{\circ}$ high, with a trunk $10^{\prime}-12^{\prime}$ in diameter, stout wide-spreading branches forming a broad symmetrical round-topped rather open head, and stout branchlets eovered at first with soft matted pale hairs, soon glabrous, light orangegreen, beeoming ashy gray in their seeond season, and armed with numerous very slender straight or slightly curved chestnut-brown shining spines $22^{\prime}-2 \frac{1^{\prime}}{2}$ long.

Distribution. Rich woodlands near Alton, Missouri, and on the bottom-lands of the Mississippi River in Illinois opposite St. Louis.

\section{Cratægus regalis, Beadl.}

Leaves oval to elliptic, acute or aeuminate, gradually narrowed and concavecuneate at the entire base, coarsely and often doubly serrate above, with acute straight or incurved teeth, when they unfold tinged with red and sparingly villose

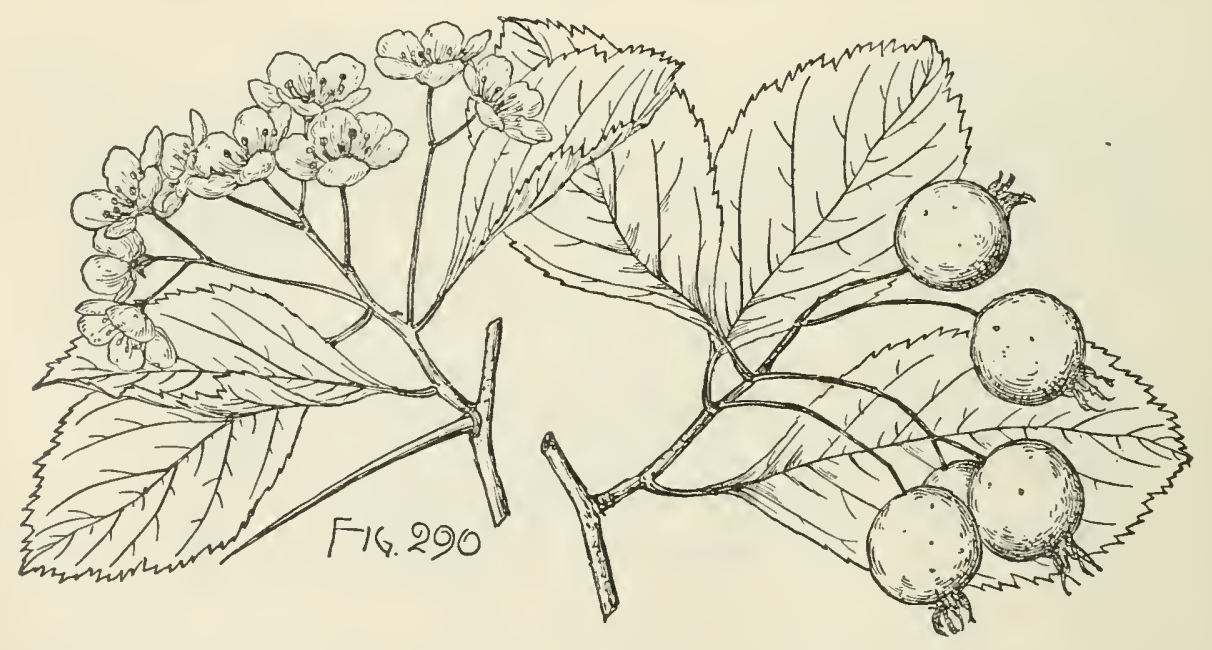

above and on the midribs below, soon glabrous, nearly fully grown when the flowers open at the end of April, beeoming at maturity thick and firm or subeoriaceous, bright green and lustrous above, pale below, $1 \frac{1}{2}^{\prime}-2 \frac{1}{2}^{\prime}$ long, $1^{\prime}-1 \frac{1}{4}^{\prime}$ wide, with stout yellow midribs and primary veins, turning in the autumn yellow, orange, and brown; their petioles stout, about $1^{\prime}$ long, broadly winged, reddish brown toward the base; on vigorous shoots broadly oval, coarsely serrate, mostly slightly incisely lobed, $3^{\prime}-4^{\prime}$ 
long, $1 \frac{1}{2}-2^{\prime}$ wide, with thicker midribs and veins. Flowers $\frac{1 \prime}{2}$ in diameter, on long slender pedicels, in broad many-flowered glabrous corymbs; calyx-tube narrowly obconic, the lobes linear-lanceolate, entire or remotely serrate; stamens 10 ; anthers yellow; styles 2 or 3 . Fruit ripening in September or October, on slender stems, in few-fruited drooping clusters, short-oblong, $\frac{3}{8}^{\prime}-\frac{1}{2}$ ' long, green tinged with red; calyx-lobes slightly enlarged, reflexed and often deciduous from the ripe fruit; flesh yellow, dry and mealy; nutlets 2 or 3 , prominently ridged on the back, $\frac{1}{4}^{\prime}$ long, about $\frac{3}{16}$ wide.

A tree, often $20^{\circ}$ high, with a tall trunk $8^{\prime}-12^{\prime}$ in diameter, stout ascending or spreading branches forming a broad symmetrical head, and branchlets armed with stout or slender nearly straight spines $1 \frac{1}{2}-2^{\prime}$ long.

Distribution. Low woods, northwestern Georgia and northern Alabama; common in the flat woods near Rome, Georgia.

$\rightarrow-$ Anthers yellow.

\section{Cratægus Arduennæ, Sarg.}

Leaves obovate, acute, acuminate or rounded at the apex, gradually narrowed from near the middle to the entire cuneate base, finely crenulate-serrate above, with

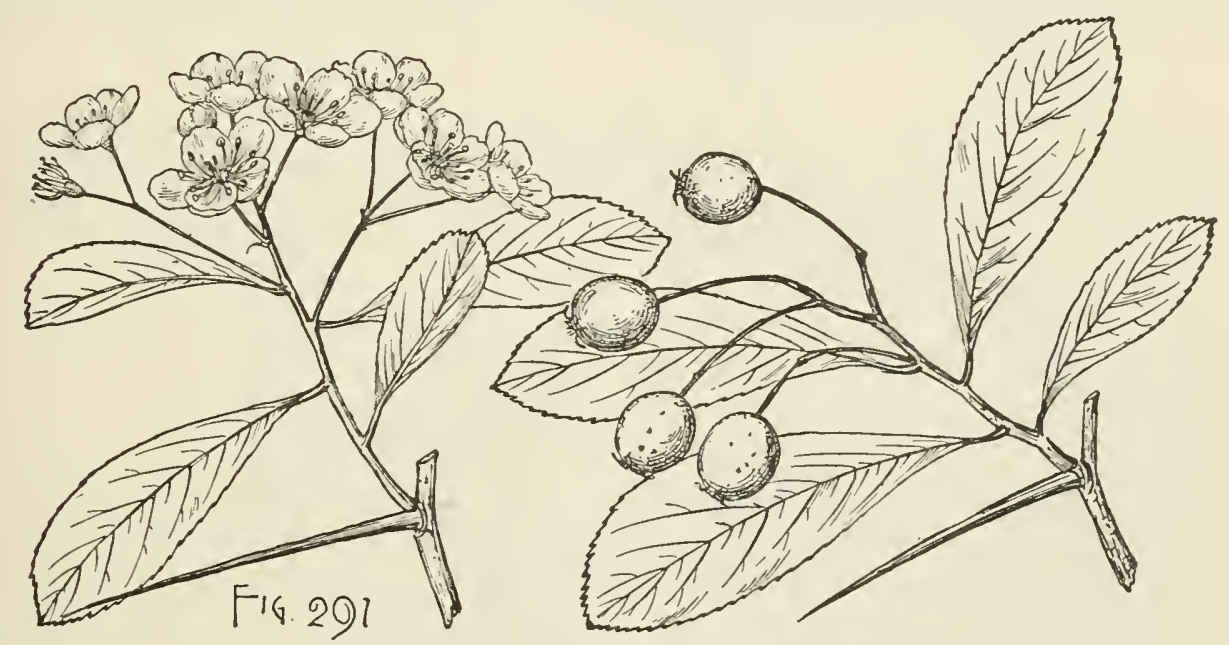

glandular teeth, glabrous and deeply tinged with red as they unfold, nearly fully grown when the flowers open at the end of May or early in June, at maturity subcoriaceous, dark green and very lustrous above, pale below, $1 \frac{1^{\prime}}{2}-2 \frac{1}{2}^{\prime}$ long, and $\frac{1^{\prime}}{2}-1^{\prime}$ wide, with slender yellow midribs and obscure primary veins mostly within the parenchyma; their petioles stout, winged to below the middle, occasionally sparingly glandular, $\frac{1^{\prime}}{4}-\frac{5}{8}$ in length; on vigorous shoots mostly elliptical, short-pointed, very coarsely serrate, usually laterally lobed, and often $2 \frac{1}{2}^{\prime}-3^{\prime}$ long and $1 \frac{1^{\prime}}{2}-2^{\prime}$ wide, with stout midribs and prominent slender primary veins, their stipules foliaceous, lunate, coarsely glandular-serrate, stalked, sometimes $\frac{5^{\prime}}{8}$ long. Flowers $\frac{1}{2}^{\prime}-\frac{5^{\prime}}{8}$ in diameter, on long slender pedicels, in broad many-flowered compound glabrous corymbs; calyx-tube narrowly obconic, the lobes abruptly narrowed from the base, linear, acuminate, tipped with small dark red glands, entire or slightly and irregularly serrate; stamens 5-12; usually 10; anthers small, pale yellow; styles 1 or 2 . Fruit 
on slender pedicels, in drooping many-fruited clusters, short-oblong, dull dark crimson marked by large pale dots, about $\frac{1^{\prime}}{2}$ long and $\frac{3^{\prime}}{8}-\frac{1^{\prime}}{2}$ wide; calyx only slightly enlarged, the lobes reflexed and appressed; flesh thin, yellow, dry and mealy; nutlet 1 , gradually narrowed from the middle to the obtuse ends, grooved and irregularly ridged on the dorsal face, or 2 and then broad, rounded at the ends, prominently ridged on the back, with a high wide rounded ridge, about $\frac{5}{16}$ long.

A tree, sometimes $20^{\circ}$ high, witli a trunk $8^{\prime}-12^{\prime}$ in diametcr, covered with smooth light gray bark, spreading branches forming a round-topped head, and slender slightly zigzag branchlets light orange-green when they first appear, becoming dark purple and lustrous and ultimately grayish browu, and armed with many slender straight or slightly curved dark purple-brown shining spines $\mathbf{1}^{\prime}-2^{\prime}$ long.

Distribution. Neighborhood of Chicago to Joliet, Illinois, and on Belle Isle in the Detroit River, Michigan.

\section{Cratægus algens, Beadl.}

Leaves obovate to oblong or elliptic, rounded or acute at the apex, gradually narrowed and concave-cuneate at the entire base, sharply serrate above, villose on the upper side of the midribs and nearly fully grown when the flowers open at the end of May, and at maturity glabrous, subcoriaceous, dark green and lustrous above, pale below, $1 \frac{1}{2}-2^{\prime}$ long, $\frac{3^{\prime}}{4}-1 \frac{1^{\prime}}{4}$ wide, with thin midribs and slender primary veins, turning in the autumn to shades of orange, yellow, and brown; their petioles slender,

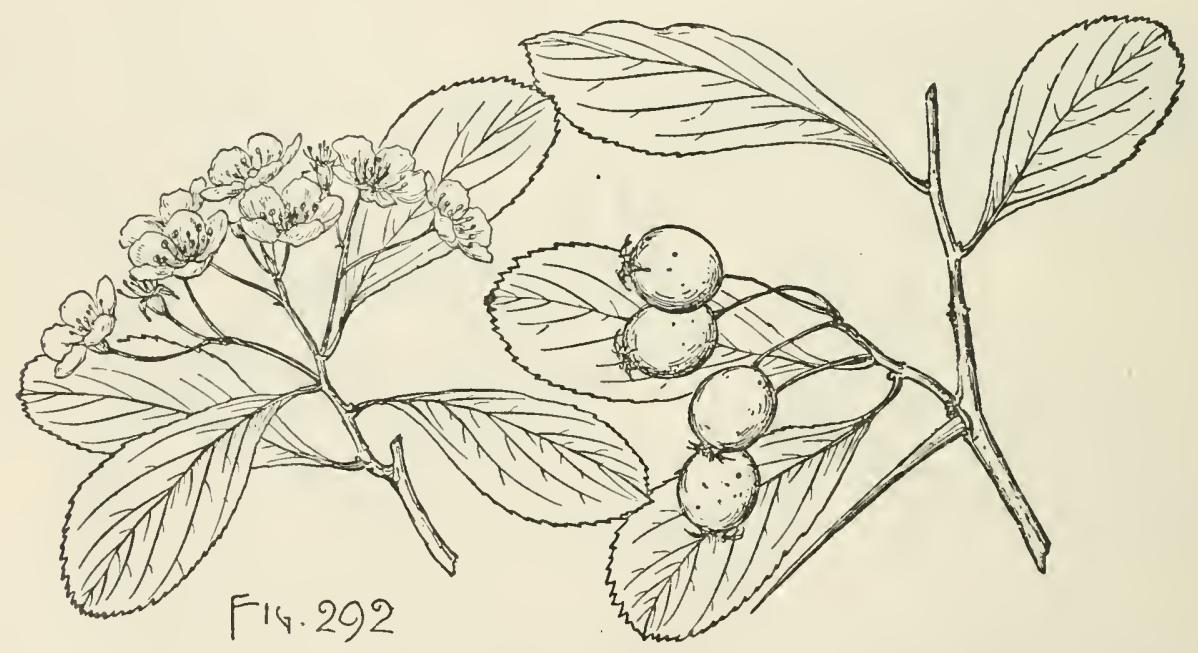

wing-margined above, rarely glandular, with minute glands, about $\frac{1^{\prime}}{4}$ long. Flowers $\frac{1}{2}$ 'in diameter, on slender elongated pedicels, in broad many-flowered glabrous corymbs; calyx-tube narrowly obconic, glabrous, the lobes slender, acuminate, entire or remotely serrate; stamens 10; anthers yellow; styles 1-3. Fruit ripening in September and October, on slender pedicels, in few-fruited hanging clusters, subglobose to obovoid, $\frac{3^{\prime}}{8}-\frac{1}{2}^{\prime}$ in diameter, dull red, or green flushed with red, $\frac{3^{\prime}}{8}-\frac{1}{2}^{\prime}$ long; calyx somewhat enlarged, with reflexed persistent lobes; flesh thin, yellow, dry and mealy; nutlets usually 1 or 2 , promincntly ridged on the back, $\frac{1}{4}^{\prime}-\frac{3^{\prime}}{8}$ long.

A tree, $15^{\circ}-18^{\circ}$ high, with a short trunk occasionally $7^{\prime}-8^{\prime}$ in diameter, stout ascending wide-spreading branches forming a wide round-topped head, and branchlets armed with stout nearly straight spines $1^{\prime}-2^{\prime}$ long. 
Distribution. Borders of woods and fields; western North Carolina to northern Georgia and Alabama, and to easteru Tennessee; one of the commonest species in the neighborhood of Asheville, North Carolina.

\section{Cratægus erecta, Sarg.}

Leaves oval to obovate, or nearly orbicular on leading vigorous shoots, acute and short-pointed at the apex, cuneate and entire at the base, and finely glandular-serrate,
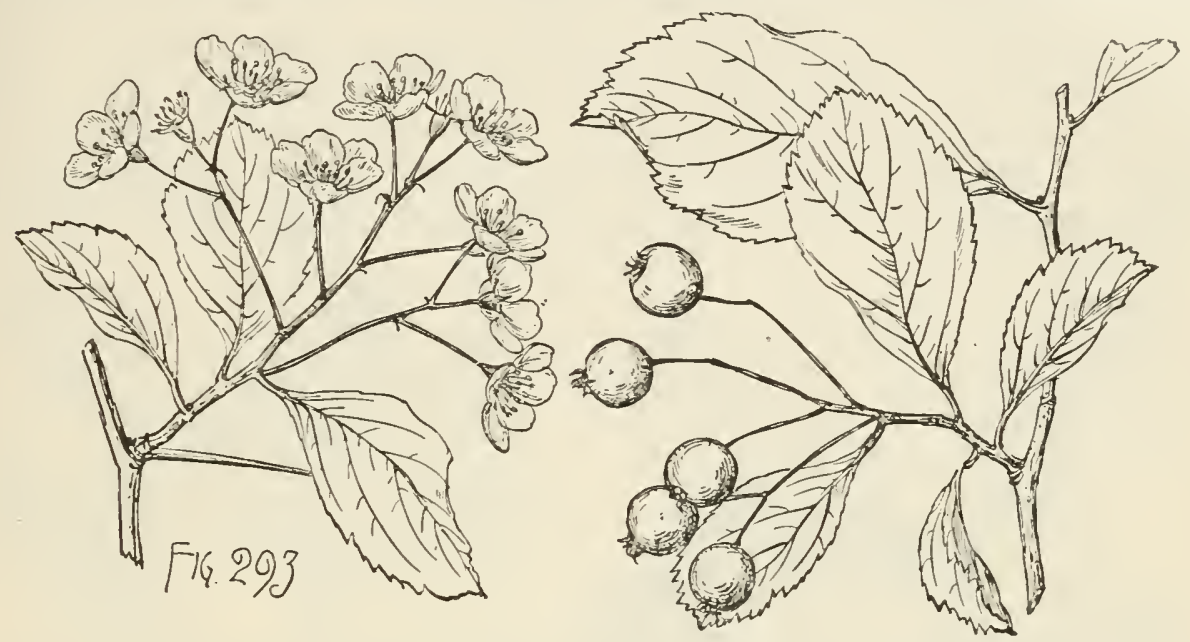

when they unfold often villose, with a few short caducous pale hairs on the upper side of the midribs, nearly fully grown when the flowers open early in May, and at maturity thin but firm in texture, dark dull green on the upper surface, pale on the lower surface, $1 \frac{1^{\prime}}{2}-2^{\prime}$ long, $1^{\prime}-1 \frac{1^{\prime}}{4}$ wide, with slender midribs and thin prominent primary veins, in the autumn turning dull orange color; their petioles slender, often wing-margined toward the apex, glandular, with minute dark glands, usually dark red after midsummer, $\frac{1}{4}^{\prime}-\frac{1}{2}^{\prime}$ long; on vigorous leading shoots coarsely serrate, with broad nearly straight glandular teeth, and sometimes $3^{\prime}$ long and $2 \frac{1}{2}^{\prime}$ wide. Flowers $\frac{1^{\prime}}{2}-\frac{5}{8}$ in diameter, on slender pedicels, in broad loose many-flowered glabrous corymbs; calyxtube narrowly obconic, the lobes narrow, elongated, acuminate, entire or occasionally obscurely and irregularly serrate; stamens usually 10, occasionally 11-13; anthers small, pale yellow; styles 3 or 4 , surrounded at the base by a narrow ring of short pale hairs. Fruit on elongated pedicels, in few-fruited drooping clusters, subglobose and usually a little longer than broad, full and flattened at the ends, dark dull crimson marked by occasional dark-colored dots, $\frac{1}{4}^{\prime}-\frac{1}{3}{ }^{\prime}$ long; calyx-tube short, the lobes closely appressed, gradually narrowed from broad bases and usually persistent on the ripe fruit ; flesh thin, yellow, dry and mealy; nutlets 3 or 4, prominently ridged on the back, with a broad high grooved ridge, $\frac{3^{\prime}}{16}$ long.

A tree, $25^{\circ}-30^{\circ}$ high, with a trunk $1^{\circ}-3^{\circ}$ in diameter, thick ascending branches forming a wide open rather symmetrical head, and spreading branchlets armed with thin straight chestnut-brown spines $1^{\prime}-2^{\prime}$ long.

Distribution. Rich bottom-lands of the Mississippi River in Illinois opposite, the city of St. Louis,

\section{Cratægus acutifolia, Sarg.}

Leaves oval to oblong-obovate, acute or acuminate or rarely rounded at the apex, cuneate at the usually entire base, finely crenulate-serrate often only above the 
middle, with glandular teeth, nearly fully grown when the flowers open about the 10th of May, and then membranaceous and lustrous above, with occasional short scattered pale caducous hairs along the upper side of the midribs, and at maturity thin and firm, dark green and lustrous above, pale yellow-green below, about $1 \frac{1}{2}$ long and $1^{\prime}$ wide, with slender light yellow midribs and about 4 or 5 pairs of thin primary veins; their petioles more or less winged above, glandular when they first appear, with minute dark glands, $\frac{1}{4}^{\prime}-\frac{1}{2}^{\prime}$ long; on vigorous leading shoots frequently divided at the apex into 2 or 3 pairs of short acute lobes, and often $3^{\prime}$ long and $2^{\prime}$ wide. Flowers $\frac{1^{\prime}}{2}$ in diameter, on slender pedicels, in many-flowered compact corymbs; calyx-tube narrowly obconic, the lobes lanceolate, acuminate, entire or obscurely and irregularly glandular-serrate; stamens 10; anthers small, pale yellow; styles 2 or 3. Fruit ripening and falling at the end of September, on slender pedicels $\frac{1^{\prime}}{2}-\frac{3}{4}$ long, in few-fruited drooping clusters, short-oblong, full and rounded at
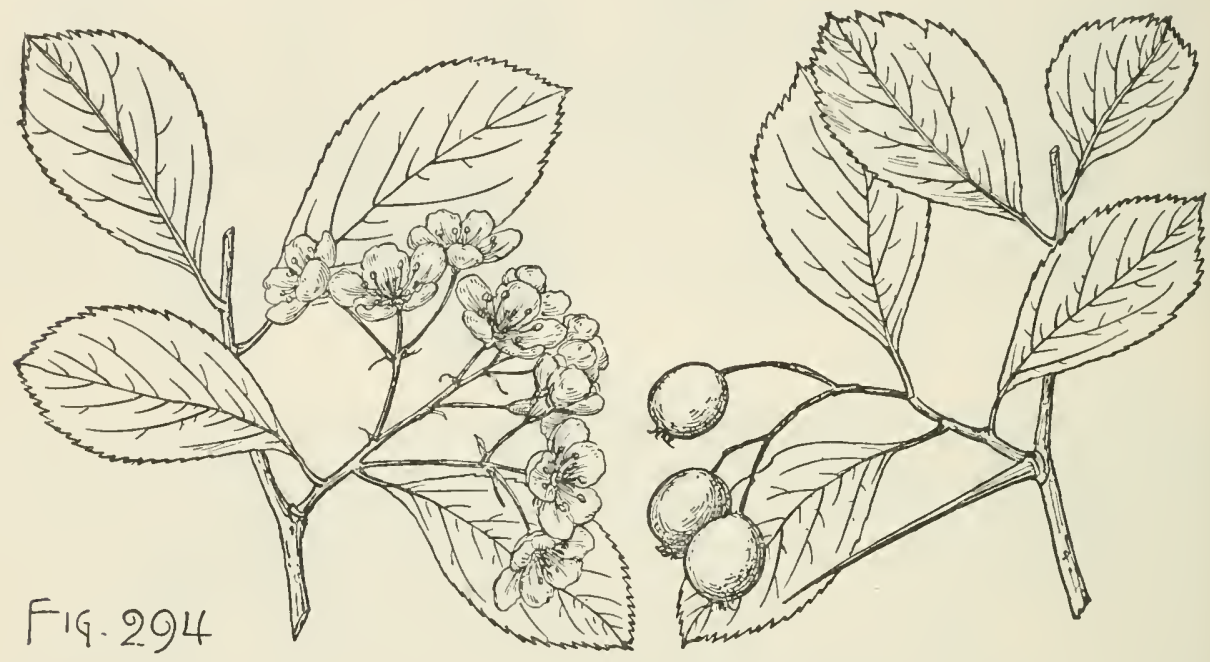

the ends, bright scarlet, marked by occasional dark dots, $\frac{1}{2}^{\prime}$ long; calyx-tube prominent, with closely appressed lobes often deciduous before the fruit ripens; flesh thin, dry and mealy; nutlets 2 or 3 , prominently ridged on the back, with broad rounded ridges, about $\frac{3}{16}$ long.

A tree, often $30^{\circ}$ high, with a trunk $18^{\prime}$ in diameter, stout wide-spreading branches forming a symmetrical round-topped rather open head, and branchlets occasionally armed with scattered thin straight chestnut-brown spines $1^{\prime}-2^{\prime}$ long.

Distribution. Open woods on bluffs of the Mississippi River, in South St. Louis, Missouri.

** Stamens 20.

$\rightarrow$ Anthers rose color.

\section{Cratægus Bushii, Sarg.}

Leaves obovate, broad and rounded or acute at the apex, or elliptical and acute, gradually narrowed from near the middle and cuneate and entire at the base, and coarsely serrate above, when they unfold dark green above, pale below and villose, with short white hairs, on both sides of the midribs and veins, nearly fully grown when the flowers open at the end of April, and at maturity coriaceous, lustrous, glabrous, $1 \frac{1}{4}^{\prime}-1 \frac{1}{2}^{\prime}$ long, $\frac{1}{2}^{\prime}-1^{\prime}$ wide, with stout yellow midribs and few slender promi- 
nent primary reins; their petioles villose, ultimately glabrous, usually about $\frac{1}{2}^{\prime}$ long; on vigorous leading shoots usually elliptical, acute, coarsely serrate, frequently $3^{\prime}$ long and $1 \frac{1}{2}^{\prime}$ wide, with stouter and more broadly winged petioles. Flowers $\frac{3^{\prime}}{4}-1^{\prime}$ in diameter, on slender pedicels, in broad compound many-flowered glabrous corymbs; calyx-tube broadly obconic, glabrous, the lobes elongated, linear-lanceolate, entire or occasionally slightly dentate; stamens 20; anthers large, bright rose color; styles two or three, surrounded at the base by conspicuous tufts of white hairs. Fruit ripening late in October or in November, on slender pedicels about $\frac{1^{\prime}}{2}$ long, in fewfruited drooping clusters, short-oblong, green tinged with dull red, $\frac{1}{8}^{\prime}$ long, with

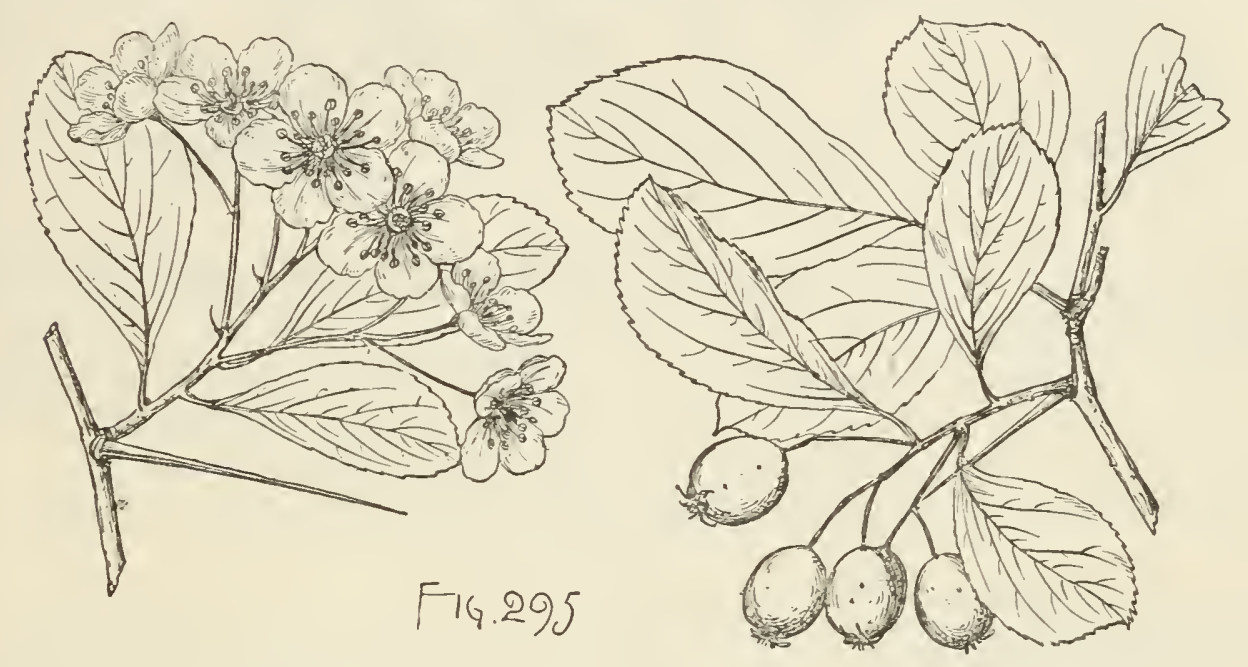

only slightly enlarged erect and incurved calyx-lobes mostly deciduous before the fruit ripens; flesh thin, green, dry and hard; nutlets 2 or 3, prominently ridged on the back, with high rounded ridges, $\frac{1}{4}$ long.

A tree, $15^{\circ}-20^{\circ}$ high, with a trunk $8^{\prime}-10^{\prime}$ in diameter, covered with scaly bark, small spreading branches forming a broad open irregular head, and nearly straight branchlets unarmed or sparingly armed with stout straight chestnut-brown spines $1 \frac{1^{\prime}}{2}-1 \frac{3^{\prime}}{4}$ long.

Distribution. Rich upland woods near Fulton on the Red River, southern Arkansas.

$\rightarrow$ Anthers yellow.

\section{Cratægus arborea, Beadl.}

Leaves obovate to oblanceolate, narrowed, acute or rounded at the apex, gradually narrowed and concave-cuneate at the long tapering entire base, and finely serrate above the middle, with minute straight teeth, nearly fully grown when the flowers open the middle of April and then glabrous, and at maturity subcoriaceous, bright green and lustrous above, pale below, $1 \frac{3^{\prime}}{4}-2^{\prime}$ long, abont $\frac{3^{\prime}}{4}$ wide, turning in the autumn orange, yellow, and brown; their petioles $\frac{1^{\prime}}{3}-\frac{2^{\prime}}{3}$ long; on vigorous shoots often $3^{\prime}$ long, $1 \frac{1}{2}^{\prime}$ wide, coarsely serrate and occasionally slightly lobed. Flowers $\frac{1}{2}{ }^{\prime \prime}$ in diameter, on slender pedicels, in broad many-flowered glabrous corymbs; calyx narrowly obconic, glabrous, the lobes slender, elongated, acuminate, slightly serrate; stamens 20; anthers pale yellow; styles usually 2. Fruit ripening in September and October, globose to subglobose, $\frac{1}{4}^{\prime}-\frac{1}{3}^{\prime}$ in diameter, red, the calyx enlarged, with 


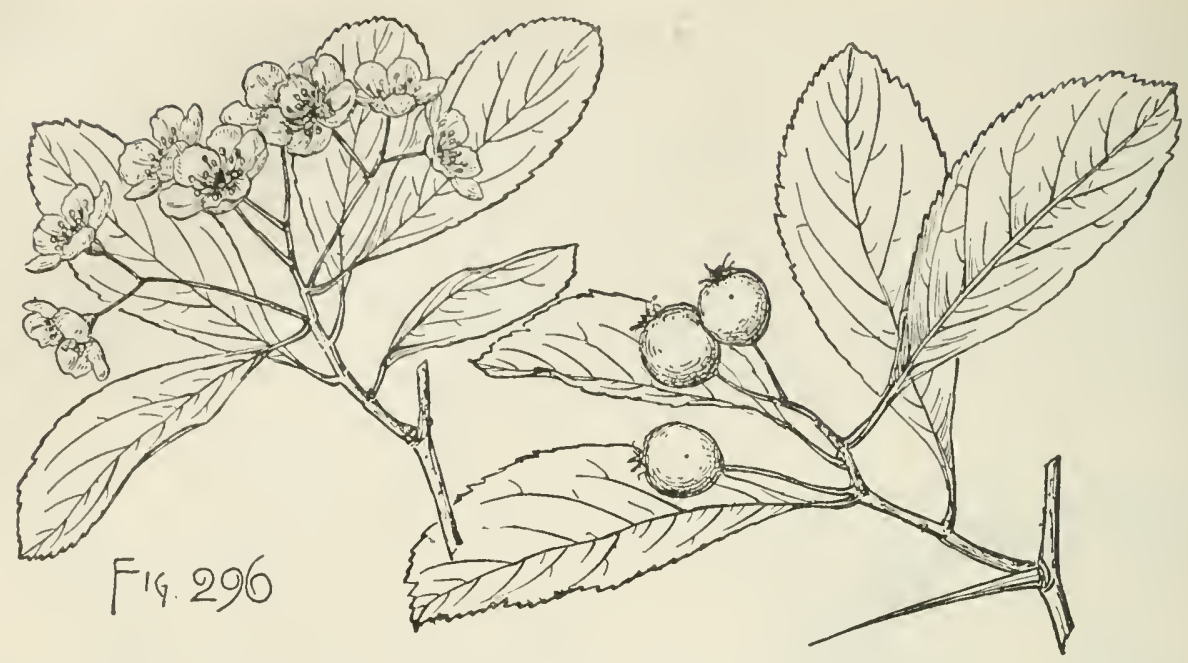

elongated coarsely glandular-serrate reflexed lobes; nutlets usually 2 , ridged on the back, about $\frac{1^{\prime}}{4}$ long.

A tree, sometimes $30^{\circ}$ high, with a trunk $12^{\prime}-18^{\prime}$ in diameter, spreading or ascending branches forming a broad handsome head, and branchlets orange-green in their first season, becoming reddish in their first winter, and usually unarmed.

Distribution. In open woods usually in clay soil near Montgomery, Alabama.

2. More or less villose throughout the season.

* Stamens 10.

$\rightarrow$ Anthers rose color.

\section{Cratægus Engelmanni, Sarg.}

Leaves broadly obovate or rarely elliptical, rounded or often short-pointed and acute at the apex, gradually narrowed or entire below, finely crenulate-serrate

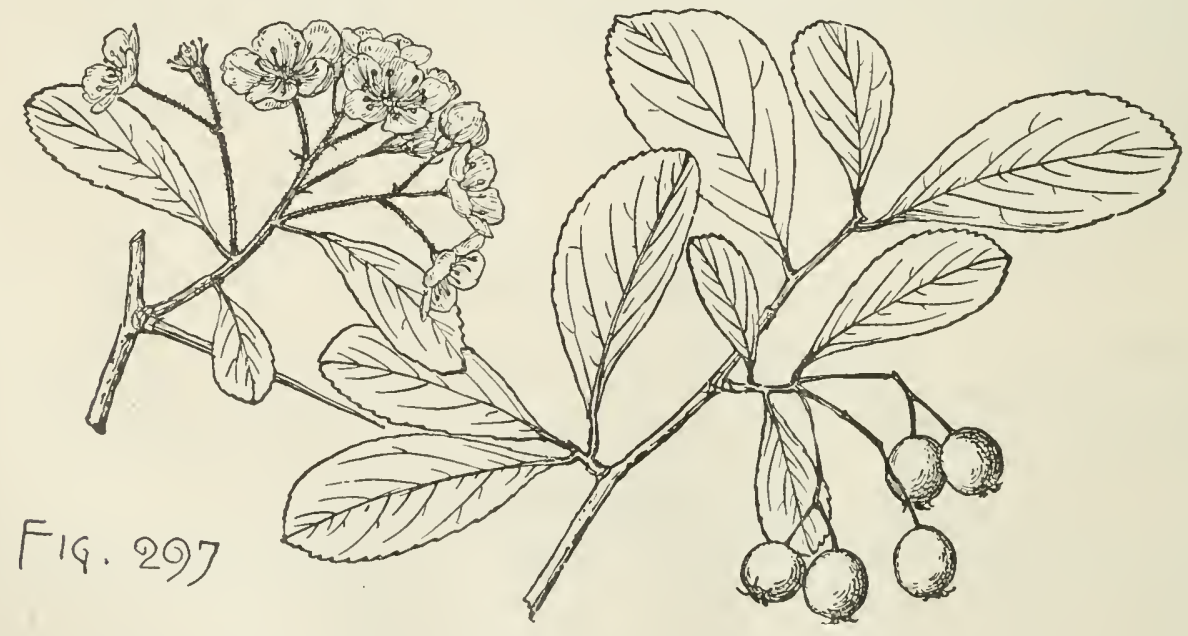

usually only above the middle and generally only at the apex, nearly fully grown and roughened on the upper surface by short rigid pale hairs when the flowers open about the middle of May, and at maturity coriaceous, dark green, lustrous and 
scabrous above, pale below, and pilose above and below along the slender midribs and obscure primary veins and veinlets, $1^{\prime}-1 \frac{1}{2}^{\prime}$ long, $\frac{1}{2}^{\prime}-1^{\prime}$ wide; their petioles glandular, winged abore, at first villose, soon glabrous, usually about $\frac{1^{\prime}}{4}$ long. Flowers $\frac{3}{4}$ in diameter, on slender pedicels, in broad loose 8-11-flowered villose corymbs; calyx-tube narrowly obconic, villose or nearly glabrous, the lobes narrow, acuminate, entire, glabrous on the outer surface, usually puberulous on the inner surface; stamens 10; anthers small, rose color; styles 2 or 3. Fruit ripening early in November, on slender pedicels, in drooping many-fruited glabrous clusters, globose or short-oblong, bright orange-red, with a yellow cheek, about $\frac{1}{3}^{\prime}$ in diameter; calyx prominent, with large spreading lobes usually deciduous before the fruit ripens; flesh thin, dry and mealy; nutlets 2 or 3 , thick, prominently ridged on the back, with broad rounded ridges, $\frac{1^{\prime}}{4}$ long.

A tree, $15^{\circ}-20^{\circ}$ high, with a trunk $5^{\prime}-6^{\prime}$ in diameter, wide-spreading usually horizontal branches forming a low flat-topped or rounded head, and branchlets covered with long pale hairs when they first appear, soon glabrous and bright red-brown, becoming gray or gray tinged with red during their second year, and armed with few thin straight or slightly curved spines $1 \frac{1}{2}^{\prime}-2 \frac{1}{2}^{\prime}$ long.

Distribution. Dry limestone slopes and ridges in central and southern Missouri; common near Allenton and Pacific.

$\rightarrow+$ Anthers yellow.

\section{Cratægus denaria, Beadl.}

Leaves oval, oblong-obovate or elliptic, acute or acuminate at the apex, gradually narrowed from near the middle and cuneate and entire below, coarsely often doubly serrate, with straight teeth, when they unfold tinged with red and slightly pilose abore and glabrous below, nearly fully grown when the flowers open toward the end

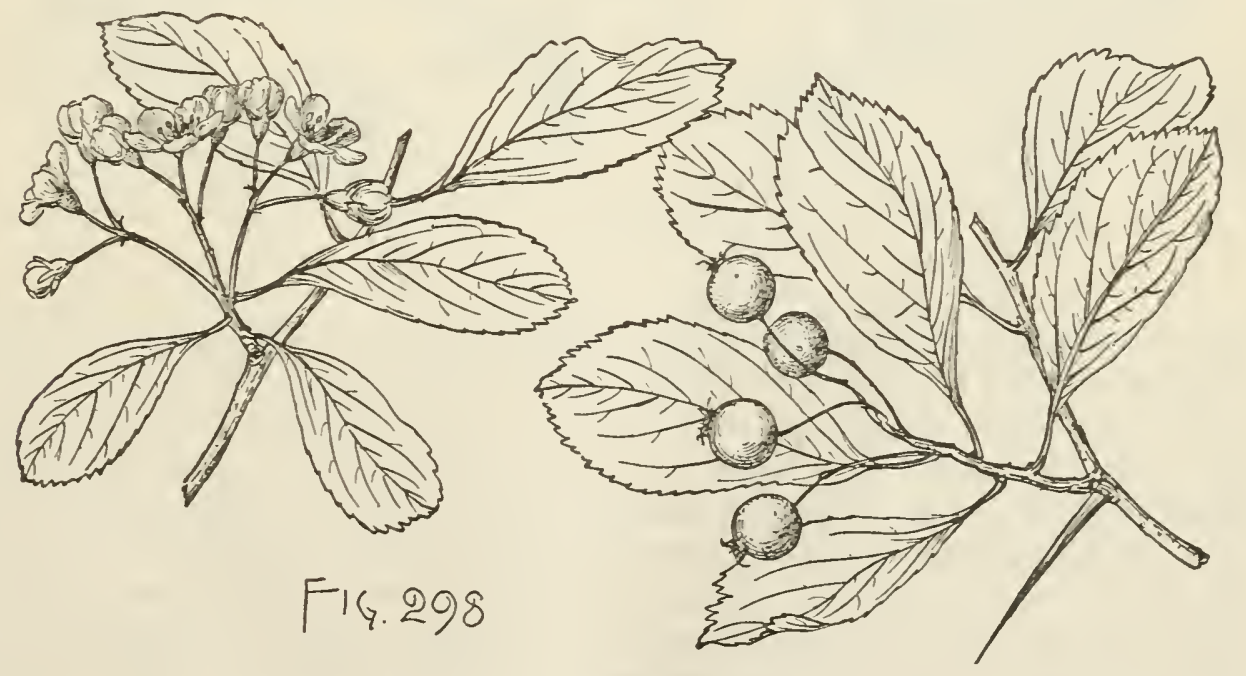

of May, and at maturity firm to subcoriaceous, bright green and lustrous abore, pale below, $2 \frac{1}{2}^{\prime}-3^{\prime}$ long, $\frac{3^{\prime}}{4}-1 \frac{1}{4}^{\prime}$ wide, with slender midribs and few remote thin primary veins, turning in the autumn orange, yellow, or brown; their petioles stout, conspicuously glandular, winged above, and about $\frac{1}{4}^{\prime}$ long; on leading shoots broadly oval to ovate or obovate, occasionally incisely lobed, $2 \frac{1}{2}^{\prime}-3^{\prime}$ long, and $1 \frac{1}{2}^{\prime}-2^{\prime}$ wide. 
Flowers $\frac{1^{\prime}}{2}-\frac{2}{3}$ in diameter, on long slender pedicels, in broad lax many-flowered sparingly villose corymbs; calyx narrowly obconic, glabrous, the lobes slender, elongated, acuminate and glandular at the apex, mostly entire or slightly serrate; stamens usually 10; styles $3-5$. Fruit on long slender pedicels, in drooping fewfruited clusters, globose to subglobose, $\frac{\frac{1}{4}^{\prime}-\frac{5}{16}}{16}$ in dianeter, orange-red, the ealyx somewhat enlarged, with spreading or closely appressed lobes; flesh thin and firm; nutlets $3-5$, rounded at the ends, slightly ridged on the back, about $\frac{3}{16}$ long.

A tree, $18^{\circ}-20^{\circ}$ high, with a trunk sometimes $8^{\prime}$ in diameter, spreading branches, and branchlets sparingly villose, with long matted white hairs when they first appear, soon glabrous, and nnarmed or armed with occasional straight slender spines about $1 \frac{1}{2}^{\prime}$ long.

Distribution. Banks of streams in eastern Mississippi; common in the neighborhood of Columbus.

\section{Cratægus signata, Beadl.}

Leaves obovate, rounded and of ten short-pointed or acute at the apex, gradually narrowed from near the middle and cuneate at the entire base, sharply glandularserrate usually only above the middle, about half grown when the flowers open early

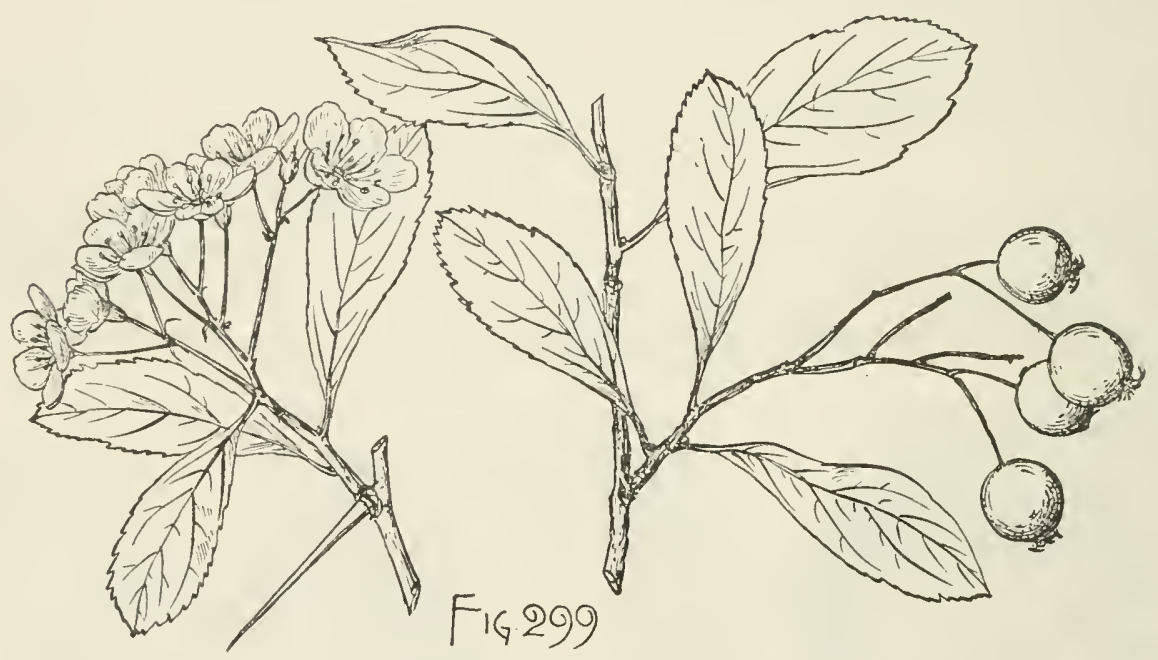

in April, and then gray-green and coated above and on the lower side of the midribs and principal veins with short pale hairs, and at maturity thin but firm in texture, dark green, lustrous and slightly pilose above, paler and pubescent below along the slender midribs and $2-5$ pairs of prinary veins, $1 \frac{1^{\prime}}{2}-2^{\prime}$ long, $\frac{3^{\prime}}{4}-1^{\prime}$ wide; their petioles slender, grooved above, glandular, usually about $\frac{1^{\prime}}{3}$ long; on leading shoots often broadly oval, coarsely dentate or sometimes incisely lobed, frequently $2 \frac{1}{2}^{\prime}$ long and $2^{\prime}$ wide, with lunate coarsely glandular-dentate stipules. Flowers about $\frac{3^{\prime}}{4}$ in diameter, on slender pedicels, in few-flowered compact hairy corymbs ; calyx-tube narrowly obconic, villose, with long matted hairs, the lobes narrow, acute, entire or irregularly glandular-serrate, usually glabrous on the outer surface, villose on the inner surface; stamens 10 ; styles $3-5$, surrounded at the base by a few pale hairs. Fruit ripening and falling toward the end of October, in few-fruited drooping slightly villose clusters, short-oblong, full and rounded at the ends, dark red, more or less pruinose, marked by numerous pale dots, and about $\frac{1}{2}^{\prime}$ long; calyx enlarged, 
with elongated closely appressed lobes usually persistent on the ripe fruit; flesh thin and yellow; nutlets $3-5$, prominently ridged and grooved on the back, about $\frac{1{ }^{\prime}}{4}$ long.

A tree, usually $15^{\circ}-18^{\circ}$ high, with a tall trunk $4^{\prime}-5^{\prime}$ in diameter, covered with ashy gray bark, often nearly black near the base of old stems, and separating freely into thin plate-like scales, numerous ascending or spreading branches forming a roundtopped or oval compact head, and branchlets armed with stout, nearly straight bright chestnut-brown spines $1^{\prime}-22^{\prime}$ long.

Distribution. Open glades and dry copses of the Pine-covered coast plain of southern Alabama.

\section{Cratægus Palmeri, Sarg.}

Leaves broadly oval to oblong, rounded or acute or short-pointed at the apex, gradually narrowed and cuneate at the entire base, coarsely serrate above, with straight gland-tipped teeth, nearly fully grown when the flowers open during the first week in May, and then very thin, dark green and lustrous above, pale bluish green below, and at maturity coriaceous, dark green and lustrous on the upper surface,

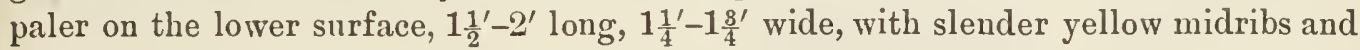
4 or 5 pairs of very thin primary veins; their petioles stout, slightly wing-margined toward the apex, rose-colored in the autumn, about $\frac{3^{\prime}}{8}$ long; on vigorous shoots oblongovate to elliptic, usually acute, coarsely serrate, occasionally laterally lobed, glandular at the base, $2 \frac{1}{2}^{\prime}-3^{\prime}$ long and $1 \frac{1}{2}^{\prime}-2^{\prime}$ wide. Flowers about $\frac{1^{\prime}}{2}$ in diameter, on slender pedicels, in many-flowered compound corymbs; calyx-tube narrowly obconic, the
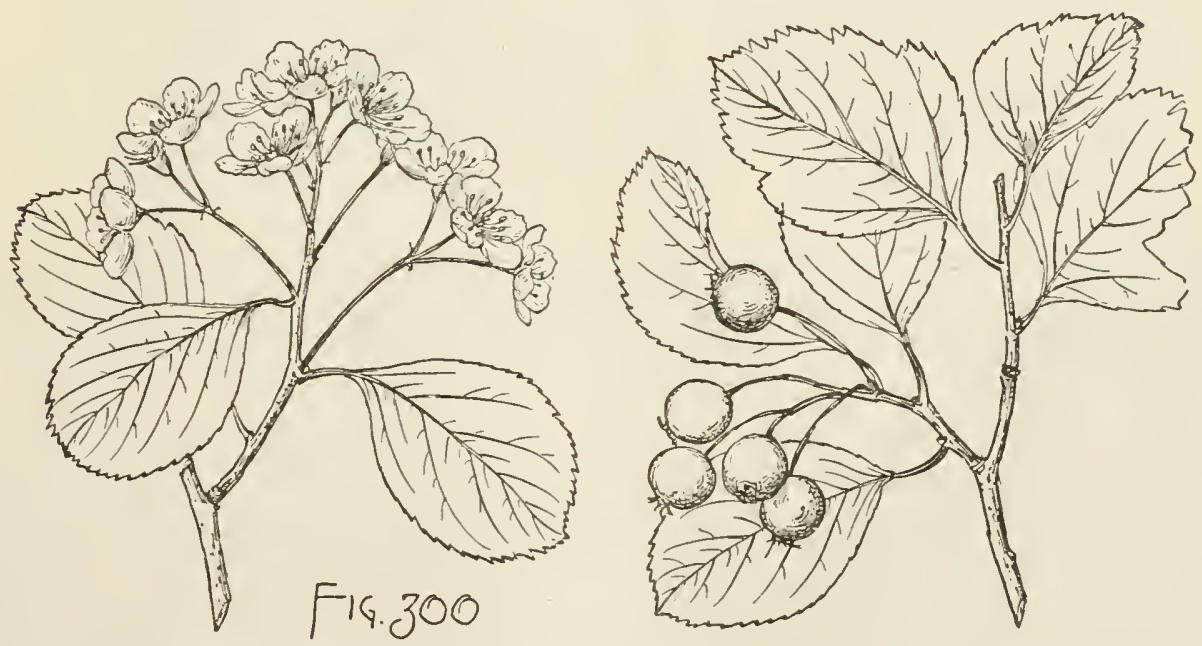

lobes slender, acuminate, tipped with small dark glands, entire or slightly serrate; stamens 10; anthers pale yellow; styles 3 , surrounded at the base by a thin ring of pale tomentum. Fruit ripening in October, on slender elongated pedicels, in fewfruited drooping clusters, subglobose, dull green tinged with red or cherry-red, marked by large pale dots, about $\frac{1}{3}$ in diameter ; calyx sessile, with erect and incurved lobes mostly persistent on the ripe fruit ; flesh thin, yellow, dry and mealy ; nutlets 3 , thin, acute at the ends, slightly and irregularly ridged on the back, with a low grooved ridge, $\frac{1^{\prime}}{4}-\frac{5}{16}$ long.

A tree, sometimes $25^{\circ}$ high, with a trunk often a foot in diameter, covered with smooth pale bark, stout wide-spreading branches forming a broad round-topped 
symmetrical head, and slender nearly straight branchlets armed with thin straight dark red-brown shining spines $\frac{g^{\prime}}{4}-3^{\prime}$ long.

Distribution. Southwestern Missouri, usually in low rich soil ; common near Carthage and Webb City.

** Stanens 20.

$\rightarrow$ Anthers rose color.

\section{Cratægus edita, Sarg.}

Leaves oblong-obovate or rarely oval, acute at the gradually narrowed apex, gradually narrowed from near the middle and cuneate at the entire base, and coarsely and of ten doubly serrate above, when the flowers open from the 15th to the 20th

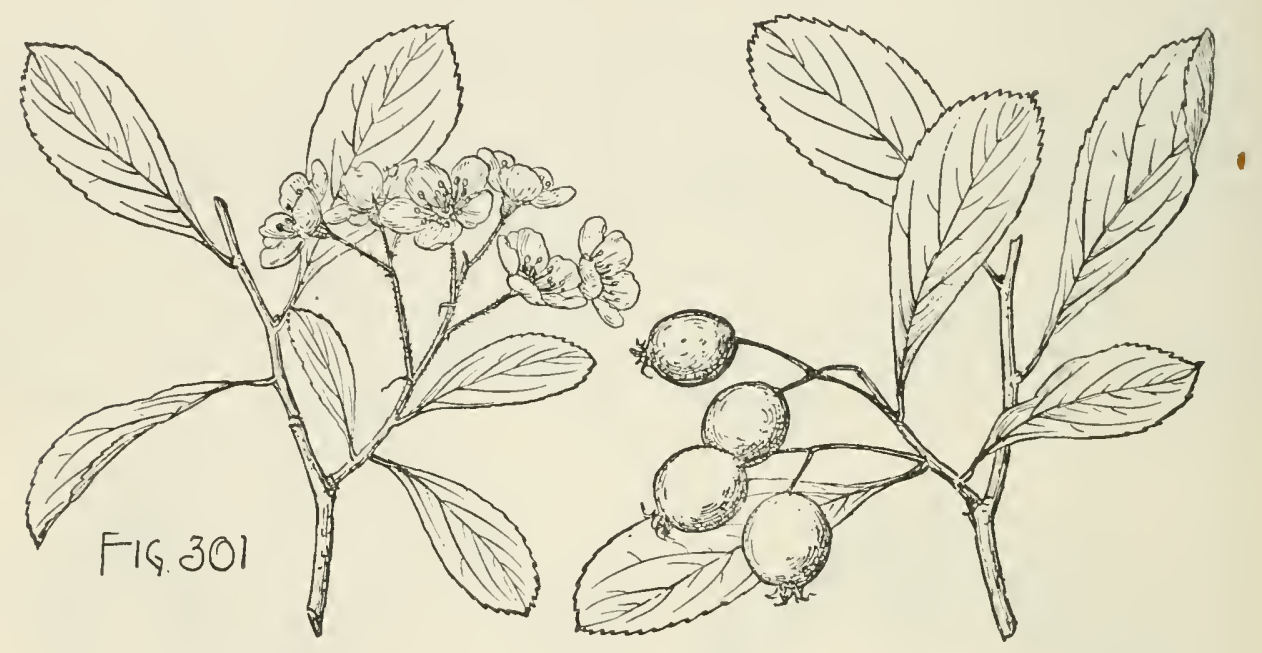

of April lustrous and scabrous on the upper surface, with short rigid pale hairs and puberulous on the lower surface, and at maturity coriaceous, dark green, lustrous, and slightly roughened above, pale yellow-green and scabrous below, $1 \frac{1}{2}^{\prime}-2^{\prime}$ long and $\frac{1^{\prime}}{2}-1^{\prime}$ wide; their petioles stout, winged above, villose, ultimately pubescent or puberulous, $\frac{1^{\prime}}{3}-\frac{1^{\prime}}{2}$ long; on vigorous leading shoots often slightly divided into lateral lobes, more coarsely serrate and sometimes $3^{\prime}$ long and $1 \frac{1}{2}^{\prime}$ wide, with stout broadly winged petioles. Flowers $\frac{1^{\prime}}{2}-\frac{2^{\prime}}{3}$ in diameter, on slender villose pedicels, in villose few-flowered compound narrow corymbs; calyx-tube narrowly obconic, glabrous or slightly bairy below, the lobes linear-lanceolate, usually entire or obscurely glandular-serrate, glabrous on the outer surface and puberulous on the imner surface; stamens 20 ; anthers small, rose color; styles 2 or 3 . Fruit ripening early in October or in November, on stout glabrous or slightly villose pedicels usually about $\frac{1}{2}$ long, in drooping few-fruited clusters, short-oblong, full and rounded at the ends, slightly pruinose, dull green tinged with red, $\frac{1^{\prime}}{4}-\frac{1}{3}^{\prime}$ long, with a promineut calyx-tube and elongated spreading lobes puberulous on the inner surface and often deciduous before the ripening of the fruit; flesh very thin, green, dry and hard; nutlets 2 or 3 , thick, prominently ridged on the back, with a broad low rounded ridge, $\frac{1}{4}^{\prime}$ long.

A tree, in low moist ground sometimes $40^{\circ}$ high, with a trunk $1^{\circ}$ in diameter, free of branches for $18^{\circ}-20^{\circ}$, stout horizontal branches forming a broad rounded symmetrical head, and nearly straight branchlets villose when they first appear, soon 
glabrous, and armed with few seattered stout straight chestnut-brown ultimately dull gray spines $1^{\prime}-2^{\prime}$ long; or on the dry soil of low hills much smaller and generally $20^{\circ}-25^{\circ}$ high.

Distribution. Low wet woods on the borders of streams, and on dry hills in forests of Oak and Pine; valley of the Sabine River, Texas, to western Louisiana.

\section{Cratægus tersa, Beadl.}

Leaves oblong to obovate, cuneiform, rounded and obtuse, or on leading shoots acute at the apex, gradually narrowed, concave-cuneate and entire below, coarsely serrate above, with acute or rounded teeth, when they unfold tinged with red, sparingly villose above and tomentulose below, nearly fully grown when the flowers open the middle of April, and at maturity coriaceous, dark green, lustrous, and glabrous or scabrate above, pale and pubescent below, $1 \frac{1}{2}^{\prime}-2^{\prime}$ long, $1^{\prime}-11^{\prime}{ }^{\prime}$ wide, with slender midribs and thin primary veins, turning in the autumn yellow, orange, and brown; their petioles stout, wing-margined above, at first hoary-tomentose, glabrous at maturity, about $\frac{1}{2}^{\prime}$ long. Flowers $\frac{5^{\prime}}{8}-\frac{3^{\prime}}{4}$ in diameter, on short stout hairy pedicels, in usually 8-10-flowered very compact corymbs densely clothed with long matted pale hairs; calyx-tube narrowly obconic, hairy, the lobes acuminate, glandular-serrate,

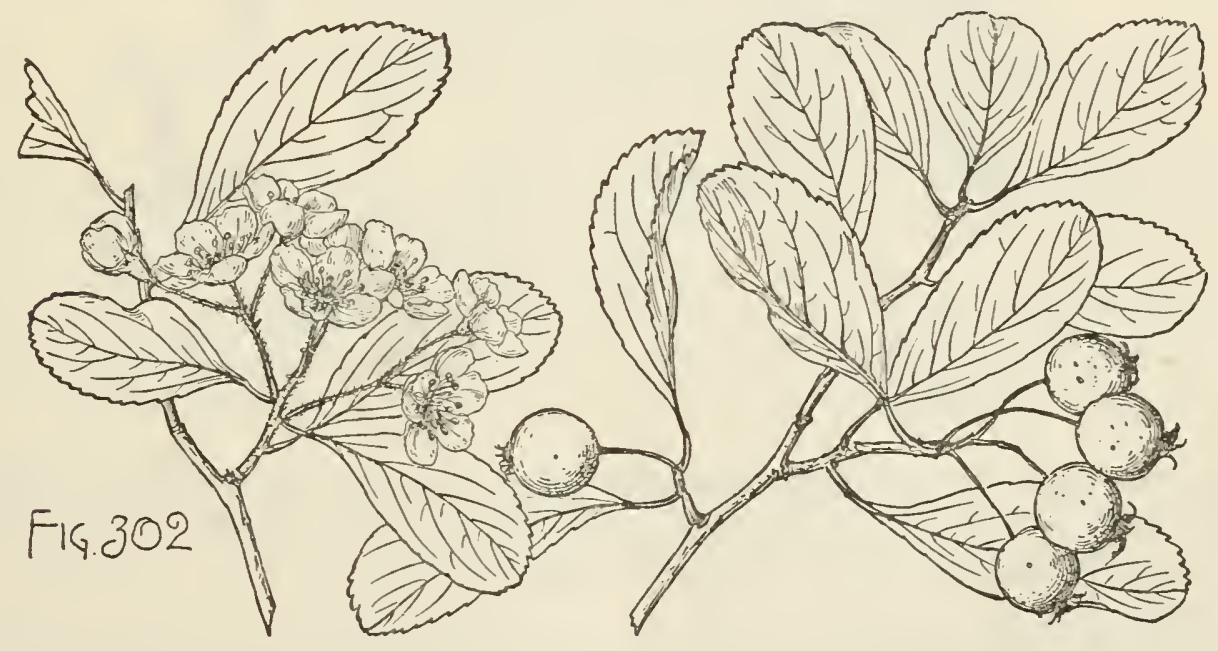

villose on the outer and slightly pilose on the inner surface; stamens 18-20; anthers pale rose color, styles usually 2 or 3 . Fruit ripening in October, on stout glabrous stems, in compact drooping ferv-fruited clusters, globose to subglobose or shortoblong, about $\frac{3^{\prime}}{8}$ long, dark red; calyx prominent, with enlarged erect or spreading glandular-serrate lobes; flesh thin, yellow, dry and mealy; nutlets 2 or 3 , mostly obtuse and rounded at the ends, prominently ridged on the back, about $\frac{1^{\prime}}{4}$ long.

A tree, sometimes $18^{\circ}-20^{\circ}$ high, with a trunk $6^{\prime}-8^{\prime}$ in diameter, spreading branches forming a broad flat-topped head, and stout branchlets at first pilose, becoming glabrous before autumn, and usually unarmed.

Distribution. Upland woods near Opelousas, Louisiana.

$\rightarrow+$ Anthers yellow.

\section{Cratægus berberifolia, T. \& G.}

Leaves obovate-oblong, rounded or gradually narrowed at the apex, narrowed from above the middle to the cuneate entire base, and serrate above, with straight 
or incurved teeth, nearly fully grown when the flowers open at the end of March or early in April and then roughened above by short rigid white hairs, whitish and pubescent below, at maturity subcoriaceous, dark green, lustrous and nearly glabrous on the upper surface, on the lower surface palc and pubescent, especially on the thin midribs and slender primary veins, $11_{2}^{\prime}-2^{\prime}$ long, $\frac{8^{\prime}}{4}-\mathbf{1}^{\prime}$ wide; their petioles comparatively slender, winged above, at first densely villose, becoming glabrous, usually about $\frac{1}{2}^{\prime}$ long. Flowers $\frac{2^{\prime}}{3}-\frac{1}{2}^{\prime}$ in diameter, on slender villose pedicels, in compact mostly 4-5-flowered compound villose corymbs; calyx-tube narrowly obconic, thickly coated with long matted pale hairs, the lobes slender, acuminate, sparingly villose or nearly glabrous on the outer surface, villose on the inner surface, entire or slightly serrate; stamens 20 ; anthers yellow; styles 2 or 3 , surrounded at the base by a narrow ring of pale hairs. Fruit ripening early in October, on

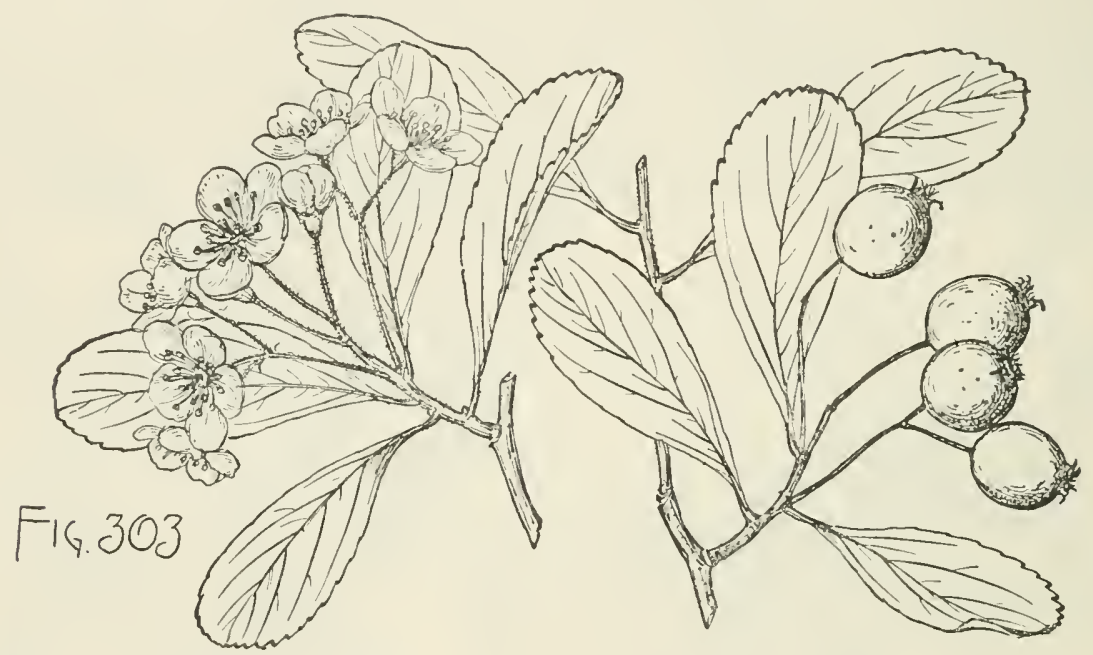

slender pedicels, in few-fruited drooping puberulous clusters, subglobose, orange with a red cheek, about $\frac{1}{3}^{\prime}$ in diameter; calyx-tube slightly enlarged, with spreading or incurved lobes; flesh thin and yellow; nutlets 2 or 3, slightly ridged on the back, about $\frac{1^{\prime}}{4}$ long.

A tree, $20^{\circ}-25^{\circ}$ high, with a tall trunk $8^{\prime}-10^{\prime}$ in diameter, covered with dark gray scaly bark, stout branches spreading into a broad flat-topped head, and slender branchlets covered at first with matted white hairs, becoming glabrous and light orange-brown at the end of their first season, and pale gray-brown the following year, and unarmed or armed with occasional slender nearly straight red-brown spines.

Distribution. Borders of prairies and low moist soil a few miles west of Opelousas, Louisiana.

\section{Cratægus edura, Beadl.}

Leaves oblong-obovate, rounded and obtuse or occasionally acute at the apex, gradually narrowed from above the middle to the wedge-shaped base, entire below, serrate only at the apex, nearly fully grown when the flowers open early in April and then thin, dark green and puberulous above especially along the midribs, very pale and villose below, at maturity thick and coriaceous, $1 \frac{1}{4}^{\prime}-1^{\prime}{ }^{\prime}$ long, $1 \frac{1}{2}^{\prime}-1 \frac{3}{4}^{\prime}$ wide, with slender midribs, and primary veins within the parenchyma, turning in the autumn orange, yellow, or brown; their petioles slender, winged above, light yellow, 
pilose, $\frac{1}{8}^{\prime}-\frac{1}{4}^{\prime}$ long. Flowers $\frac{3}{8}^{\prime}-\frac{1}{2}$ in diameter, on short sparingly villose pedicels, in compact hairy 5-12-flowered corymbs; calyx narrowly obconic, glabrous or with a few hairs at the base, the lobes narrow, acuminate, glabrous; stamens 16-20; anthers pale yellow or nearly white; styles 2 or 3 . Fruit ripening and falling in September, in few-fruited drooping clusters, subglobose, orange or yellow, with a

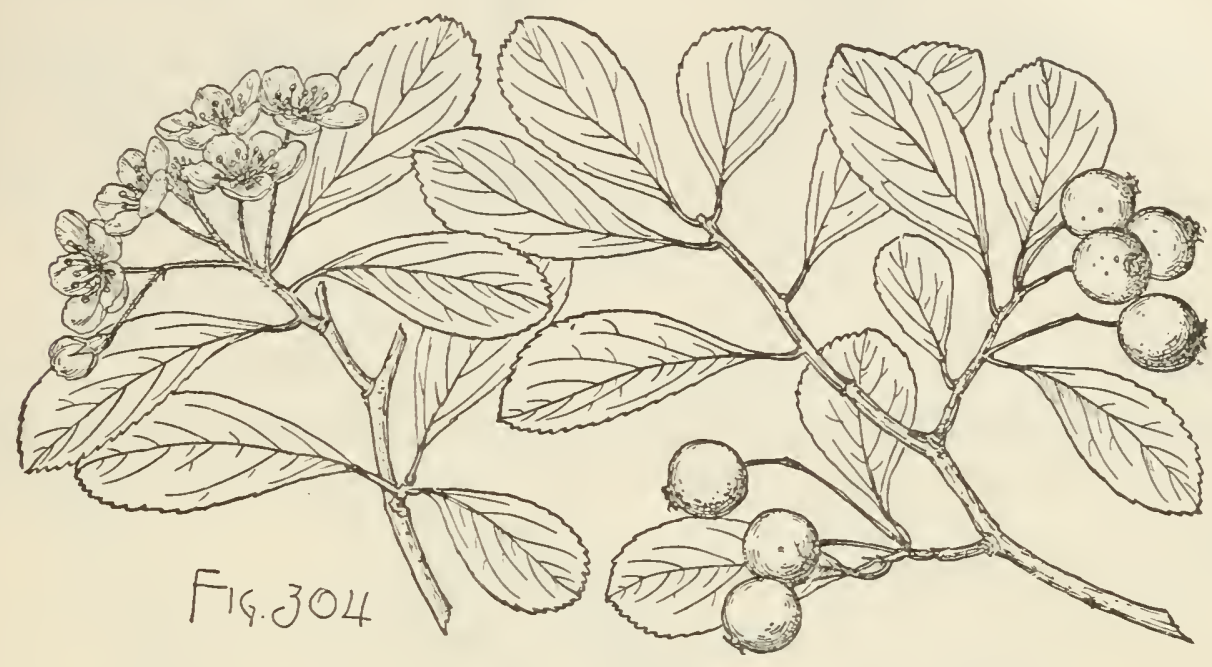

red cheek, about $\frac{5}{16}$ in diameter; calyx-lobes little enlarged, closely appressed, often deciduous; flesh thin, dry and mealy; nutlets 2 or 3 , full and rounded and rather obscurely ridged on the back, about $\frac{1^{\prime}}{4}$ long and $\frac{3^{\prime}}{16}$ wide.

A tree, $20^{\circ}-25^{\circ}$ high, with a trunk $6^{\prime}-8^{\prime}$ in diameter, branches spreading out into a broad flat-topped head, and branchlets pilose when they first appear, soon glabrous, becoming reddish brown, unarmed or armed with chestnut-brown or gray spines $1 \frac{1}{2}-2^{\prime}$ long.

Distribution. Upland woods near Opelousas, Louisiana.

\section{Cratægus crocina, Beadl.}

Leaves oblong or obovate-cuneiform, rounded or acute at the apex, gradually narrowed and wedge-shaped at the slender entire base, and sharply serrate above the middle, with straight or incurved glandular teeth, when they unfold more or less pubescent on the two surfaces, and at maturity subcoriaceous, dark green, lustrous and glabrous or glabrate above, pale and covered below with short matted pale hairs most abundant on the thin midribs and obscure primary veins, $1 \frac{1}{4}^{\prime}-2^{\prime}$ long, $\frac{1^{\prime}}{2}-1^{\prime}$ wide, turning in the autumn orange, yellow, or brown; their petioles slender, narrowly winged above, puberulous, about $\frac{1}{4}$ long. Flowers opening at the end of April when the leaves are fully grown, $\frac{1^{\prime}}{2}-\frac{5}{8}$ in diameter, on short villose pedicels, in compact few-flowered villose corymbs; calyx narrowly obconic, coated with matted white hairs, the lobes uarrowed, acute, entire or sparingly serrate, glabrous on the outer, slightly villose on the inner surface toward the apex; stamens 20; anthers yellow; styles usually 2 or 3 . Fruit ripening in October, oval or oblong, nearly $\frac{1^{\prime}}{2}$ long, yellow, the calyx prominent, with elongated mostly recurred lobes; flesh thin, dry and mealy; nutlets usually 2 , narrowed and acute at the ends, ridged on the back, about $\frac{1^{\prime \prime}}{4}$ long.

A tree, $18^{\circ}-20^{\circ}$ high, with a short trunk $4^{\prime}-6^{\prime}$ in diameter, spreading branches 


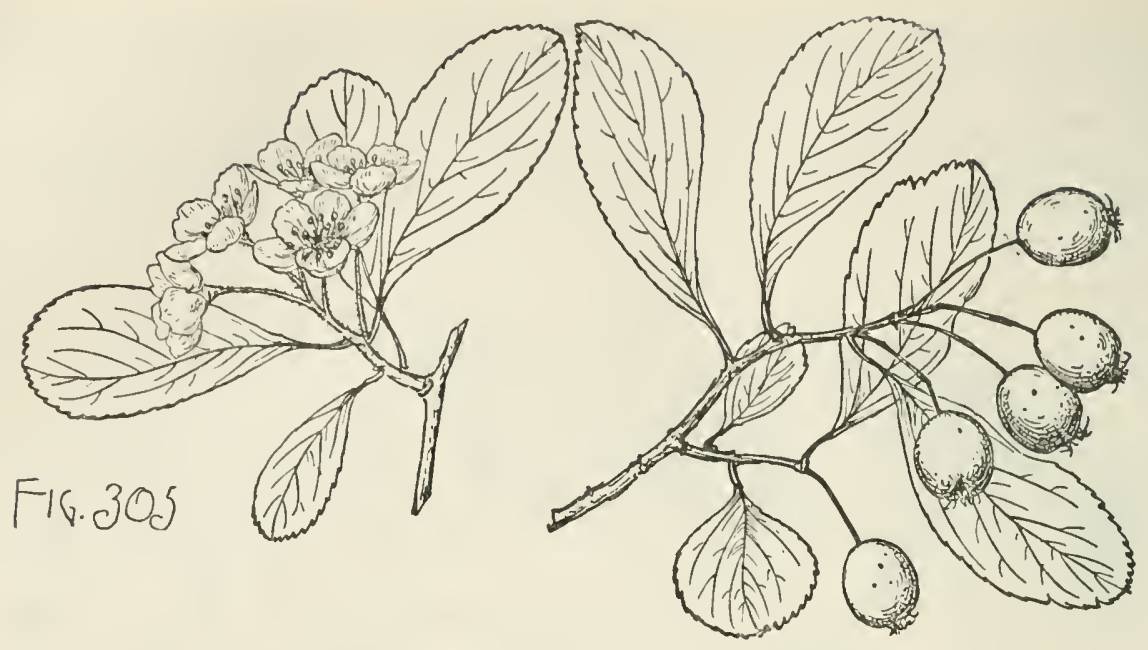

forming a wide flat-topped head, and slender mostly unarmed branchlets covered at first with matted pale hairs and dark orange-brown and puberulous in their first winter.

Distribution. Low woods near Opelousas, Louisiana.

\section{Cratægus fera, Beadl.}

Leaves oblong-obovate, rounded or rarely acute at the apex, gradually narrowed and concave-cuneate at the slender entire base, sharply serrate above the middle, with straight or incurved teeth, fully grown when the flowers open the middle of April and then thin, covered above by short white hairs, and slightly villose along the midribs and veins below, and at maturity coriaceous, dark green, scabrate and very lustrous on the upper surface, pale and puberulous on the lower surface along the slender midribs and obscure primary veins, $2 \frac{1}{2}^{\prime}-3^{\prime}$ long, about $\frac{3^{\prime}}{4}$ wide, turning in the autumn

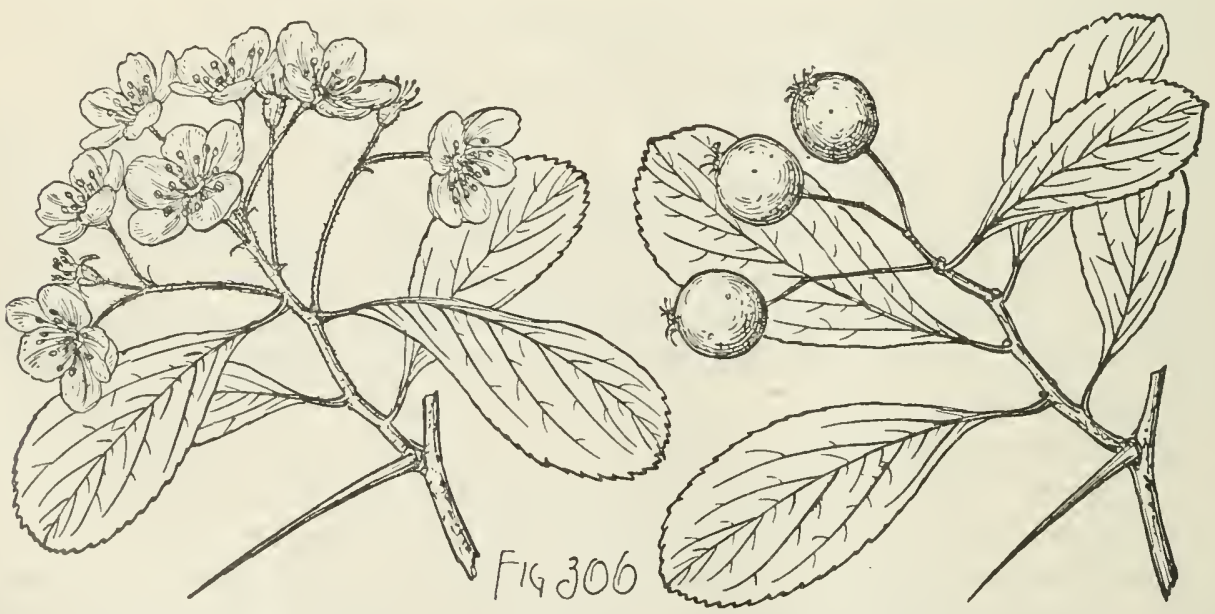

orange, yellow, or brown; their petioles slender, wing-margined nearly to the base, pubescent at first, becoming puberulous, $\frac{3^{\prime}}{8}-\frac{5}{8}^{\prime}$ long. Flowers: $\frac{1}{2}^{\prime}$ in diameter, on elongated slender villose pedicels, in broad lax compound many-flowered corymbs covered more or less thickly with white hairs; calyx-tube narrowly obconic, slightly hairy near the base, glabrous above, the lobes narrow, acuminate, entire or sparingly 
glandular-dentate, glabrous on the outer and puberulous on the inner surface; stamens 16-20; anthers light yellow; styles usually 2 or 3. Fruit ripening in September and October, on long slender pedicels, in few-fruited drooping clusters, globose or subglobose, bright red or scarlet, $\frac{3^{\prime}}{8}$ in diameter; flesh thin and mealy; calyx enlarged, with spreading or erect persistent lobes; nutlets 2 or 3 , rounded and ridged on the back, with a high narrow ridge, $\frac{1{ }^{\prime}}{4}-\frac{5}{16}{ }^{\prime}$ long.

A tree, sometimes $20^{\circ}$ high, with a trunk $8^{\prime}-9^{\prime}$ in diameter, spreading branches forming a broad flat-topped head, and slender nearly straight branchlets, villose at first, becoming glabrous, pale reddish brown, and ultimately ashy gray, and sometimes armed with slender straight spines $1^{\prime}-1 \frac{1^{\prime}}{4}$ long.

Distribution. Low open Oak and Hickory woods near Opelousas, Louisiana.

\section{Cratægus Mohri, Beadl.}

Leaves obovate or rhomboidal, acute or acuminate, gradually narrowed and cuneate at the entire base, coarsely and occasionally doubly serrate above, with straight or incurved teeth, when they unfold glabrous and slightly villose along the midribs

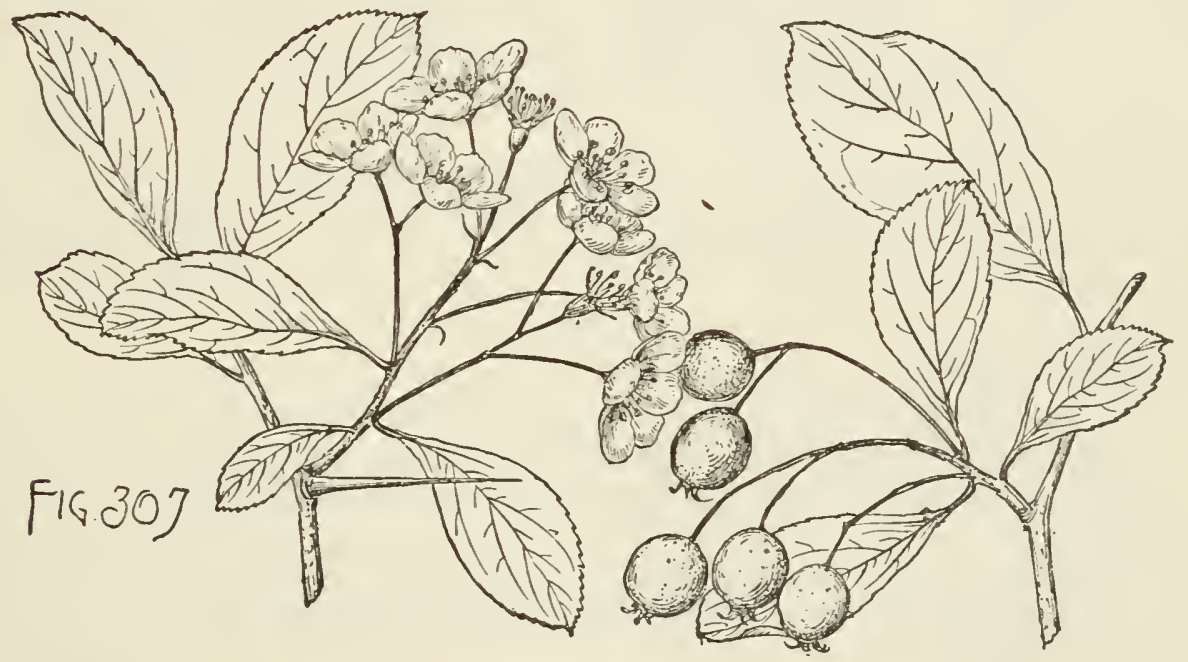

and the lower side of the principal veins, nearly fully grown when the flowers open early in May, and at maturity thin and firm or subcoriaceous, dark green, and very lustrous above, pale below, $1^{\prime}-1 \frac{1}{2}^{\prime}$ long, $\frac{2^{\prime}}{3}-1^{\prime}$ wide, usually with 4 pairs of thin primary veins, stout midribs sometimes puberulous on the under side and bright red in the autumn; their petioles more or less winged above, frequently red at maturity; on vigorous leading shoots sometimes $3^{\prime}$ long and $2^{\prime}$ wide, and mostly broadly oval and rounded at the apex, or ovate and acute, coarsely doubly serrate and frequently divided toward the apex into short broad acute lobes, with broadly winged petioles occasionally glandular, with minute dark glands. Flowers cup-shaped, about $\frac{3}{4}$ in diameter, on slender elongated pedicels, in loose thin-branched many-flowered compound glabrous or villose corymbs; calyx-tube narrowly obconic, glabrous or occasionally pilose below, the lobes linear-lanceolate, entire or finely glandular-serrate; stamens 20; anthers small, light yellow; styles $3-5$, surrounded at the base by a narrow ring of pale hairs. Fruit ripening about the middle of October, gracefully drooping on elongated thin bright red pedicels, in many-fruited clusters, subglobose to short-oblong, somewhat flattened at the apex, full and rounded at the 
base, bright orange-red, about $\frac{1}{3}$ in diameter; calyx prominent, with a short tube and usually erect lobes often decidnons before the fruit ripens; flesh thin, yellow, dry and mealy; nutlets usually 3 , prominently grooved and ridged on the back, about $\frac{1}{4}$ long.

A tree, from $20^{\circ}-30^{\circ}$ high, with a tall straight stem $6^{\prime}-8^{\prime}$ in diameter, eovered with thin ashy gray or light red-brown bark, sometimes armed with long slender or branched spines, spreading slightly pendulons branches forming a rather open broad symmetrieal head, and branehlets furnished with thin nearly straight bright chestnutbrown shining spines $1^{\prime}-1 \frac{1}{2}^{\prime}$ long.

Distribution. Western Georgia to eentral Alabama and Mississippi, and northward to middle Tennessee; abundant and of its largest size in the low flat woods of central Alabama, and aseending into the poorer and drier soils of the neighboring hillsides and low mountain slopes.

\section{PUNCTATAE.}

Fruit usually short-oblong.

Anthers rose color or yellow; stamens 20 ; leaves obovate, rounded or acute at the apex, often acutely lobed above the middle, especially on vigorous shoots; fruit on stout pedicels, short-oblong, flattened at the ends, marked by large pale dots, dull red or bright yellow.

23. C. punctata (A).

Anthers rose color; stamens 10-20; leaves oblong-obovate or oval, rounded or acute at the apex; fruit on elongated slender pedicels, short-oblong to slightly obovate, dull brick-red, marked by large pale dots.

Fruit usually globose or subglobose.

Stamens 20.

Anthers pale yellow.

Leaves obovate to oval or rarely rhomboidal, acutc; fruit globose, or sometimes broader than high, dull red, marked by small pale dots. 25. C. collina (A, C).

Leaves obovate, oval, or ovate, acute or acuminate, incisely lobed ; fruit globose, dull red.

26. C. amnicola (C).

Leaves broadly oval to ovate, rounded or acute at the apex, occasionally rounded at the base, subcoriaceous; fruit subglobose to short-oblong, dull orange-red, marked by large pale dots.

27. C. fastosa (C).

Anthers rose color.

Leaves obovate to rhomboidal, acute or rarely rounded at the apex; corymbs thickly covered with matted hairs; fruit subglobose, flattened and puberulous at the ends, dull red.

28. C. verruculosa (C).

Leaves obovate to rhomboidal, acute or rounded at the apex; corymbs slightly villose; fruit globose, dark dull red. 29. C. sordida (C).

Leaves oval to obovate, acute or acuminate; fruit subglobose, often rather longer than broad, bright canary-yellow.

30. C. Brazoria (C).

Leaves obovate, acnte, acuminate, or rounded at the apex; corymbs densely villose, fruit subglobose, dark dull red.

Stamens 10.

31. C. Dallasiana (C).

Anthers pale yellow; leaves obovate, acute or acuminate or rounded and short-pointed at the apex; fruit subglobose, pubescent at the ends, dull orange-red.

32. C. Lettermani (A).

Anthers rose color; leaves oblong-obovate, acute or rounded at the apex; fruit globose, bright scarlet, slightly pruinose.

33. C. pratensis (A). 


\section{Cratæegus punctata, Jacq.}

Leaves obovate, pointed or rounded at the apex, gradually narrowed to the cuneate entire base, sharply and often doubly serrate above the middle, with minute teeth, and sometimes, especially on vigorous shoots, more or less incisely lobed; when they unfold thickly covered below with pale hairs and pilose above, about half grown

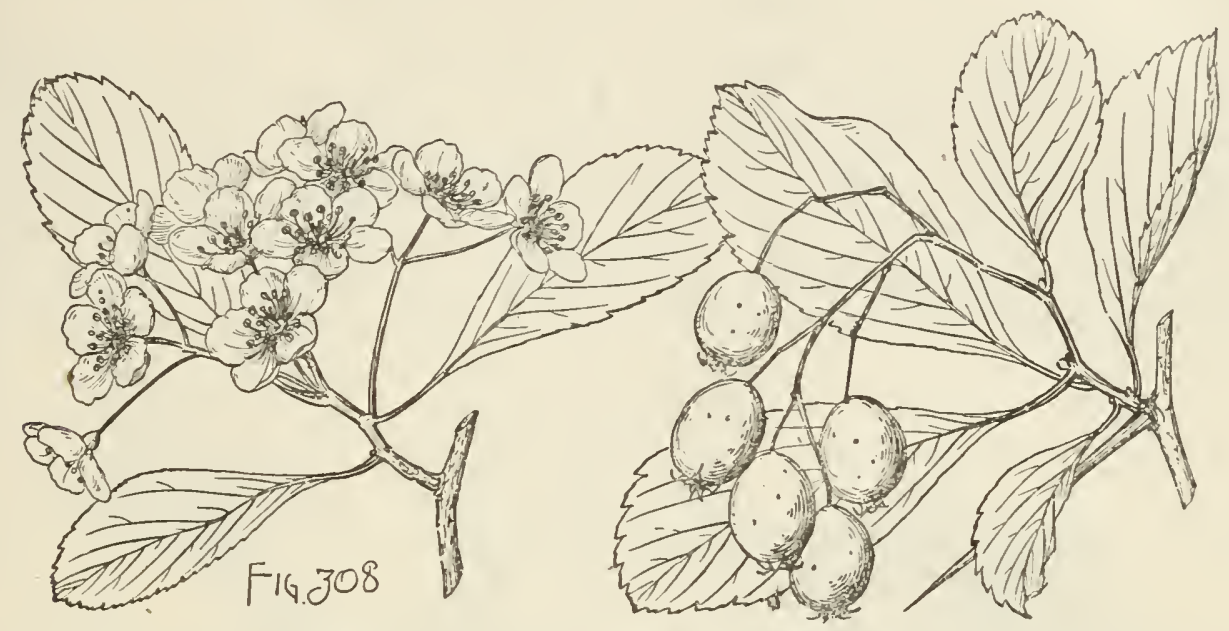

when the flowers open from the middle of May until early in June and then pilose on the midribs and veins below and nearly glabrous above, and at maturity thick and firm, pale gray-green and glabrous on the upper surface, more or less villose on the lower surface, $2^{\prime}-3^{\prime}$ long, $\frac{\beta^{\prime}}{4}-1 \frac{1}{2}^{\prime}$ wide, and on vigorous shoots sometimes $3^{\prime}-4^{\prime}$ long, and $1 \frac{1}{3}-2^{\prime}$ wide, with broad prominent midribs and primary veins deeply impressed on the upper surface, turning bright orange or orange and scarlet in the autumn; their petioles stout, wing-margined above, at first villose or tomentose, becoming pubescent or glabrous, $\frac{1}{4}^{\prime}-\frac{1}{2}^{\prime}$ long. Flowers $\frac{1}{2}^{\prime}-\frac{3}{4}^{\prime}$ in diameter, in broad tomentose or villose compound many-flowered corymbs; calyx-tube narrowly obconic, villose or tomentose, the lobes narrow, acute, nearly entire or minutely glandular-serrate, villose on the inner surface; stamens 20; anthers rose color or yellow; styles 5, surrounded at the base by conspicuous tufts of white hairs. Fruit ripening and falling in October, on stout pedicels, in many-fruited drooping clusters, short-oblong or subglobose, dull red or sometimes bright yellow and usually agreeing with the anthers in color, marked by numerous small white dots, $\frac{1}{2}^{\prime}-1^{\prime}$ long; flesh thin and dry; nutlets 5, rounded and prominently ridged on the back, about $\frac{1}{4}^{\prime}$ long.

A tree, $20^{\circ}-30^{\circ}$ high, with a trunk occasionally a foot in diameter, stout branches spreading nearly at right angles and forming a round or flat-topped head, or sometimes ascending and forming a narrow open irregular head, and branchlets coated at first with pale deciduous pubescence, becoming light orange-brown or ashy gray, and armed with slender straight light orange-brown or gray spines $2^{\prime}-3$ ' long.

Distribution. Rich hillsides; valley of the Chateangay River, Quebec, to the valley of the Detroit River, Ontario, southward through western New England, and along the Appalachian Mountains to northern Georgia, ascending in North Carolina and Tennessee to nearly $6000^{\circ}$ above the sea, westward through New York and Ohio to southern Michigan and Illinois. A form, var. canescens, Britt., densely hoarytomentose on the under surface of the leaves, petioles, and corymbs, occurs in Bucks County, Pennsylvania. 


\section{Cratægus pausiaca, Ashe.}

Leaves oblong-obovate to oval, rounded or acute at the apex, gradually narrowed from near the middlc to the concave-cuneate entire base, and finely doubly serrate above, with straight glandular tceth, more than half grown when the flowers open from the 20th to the end of May and then membranaceous, dark yellow-green, and slightly villose above and along the under side of the midribs and veins, and at maturity glabrous, dark yellow-green above, paler below, $2^{\prime}-2 \frac{1}{2}^{\prime}$ long, $1 \frac{1}{4}^{\prime}-1 \frac{1}{2}^{\prime}$ wide, with slender yellow midribs and 5 or 6 pairs of primary veins extending very obliquely to the end of the leaf; their petioles slender, wing-margined above the middle, villose only early in the season, $\frac{5^{\prime}}{8}-1^{\prime}$ long; on vigorous shoots elliptical to rhomboidal, long-pointed, slightly or deeply divided into broad lateral lobes, very coarsely serrate, often $3 \frac{1}{2}^{\prime}-4^{\prime}$ long and $2^{\prime}-2 \frac{1}{2}^{\prime}$ wide, with foliaceous lunate glandularserrate stipules often $\frac{1}{2}^{\prime}$ long and rather longer than the stout petioles. Flowers $\frac{1}{2}^{\prime}$

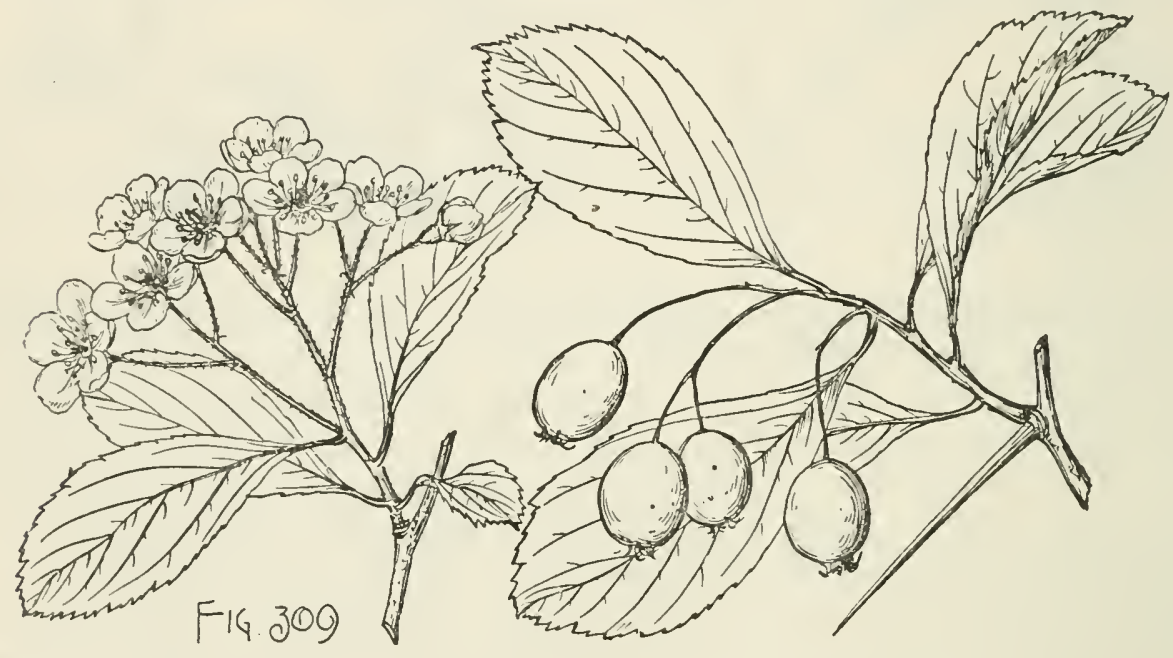

in diameter, on long slender hairy pedicels, in broad many-flowered thin-branched villose corymbs, the linear bracts and bractlets mostly deciduous before the flowers open; calyx-tube narrowly obconic, villose below, with closely appressed white hairs, glabrous above, the lobes abruptly narrowed from the base, slender, acuminate, tipped with minute dark glands, entire or occasionally obscurely toothed above the middle, glabrous on the outer, villose on the inner surface; stamens 10-15, rarely 20; anthers dark rose color; styles 2 or 3 , surrounded at the base by a broad ring of pale tomentum. Fruit ripening about the middle of October, in drooping many-fruited clusters, on elongated slender slightly hairy pedicels, oblong to slightly obovate, full and rounded at the ends, dull brick-red, marked by large pale dots, $\frac{5{ }^{\prime}}{16}-\frac{9}{16}{ }^{\prime}$ long, about $\frac{3^{\prime}}{8}$ wide; calyx small, with spreading appressed lobes mostly deciduous from the ripe fruit; flesh thin, hard, slightly juicy, green or greenish yellow; nutlets 3 or 4 , thin, acute or obtuse at the ends, very prominently ridged on the back, with a high broad deeply grooved ridge, about $\frac{1^{\prime}}{4}$ long.

A tree, $20^{\circ}-25^{\circ}$ high, with a tall straight trunk often a foot in diameter, covered with dark brown scaly bark, stout wide-spreading branches forming a broad symmetrical round or flat-topped head, slender straight branchlets light orange-green and sparingly villose at first, becoming light orange-brown during their first season, light or dark gray-brown the following year, and armed with numerous stout slender 
straight orange-brown shining spines $1 \frac{1}{2}^{\prime}-2^{\prime}$ long, long persistent on the branches and trunk, finally ashy gray, and becoming sometimes a foot long, with long slender lateral spines.

Distribution. Dry limestone hills and fow moist bottom-lands, Bucks and Delaware counties, eastern Pennsylvania.

\section{Cratægus collina, Chapm.}

Leaves obovate to oval or occasionally to rhomboidal, acute, gradually narrowed or broadly cuneate at the entire base, and irregularly and of ten doubly serrate above, with glandular incurved or straight teeth, when they unfold bright red and covered with soft pale hairs most abundant along the under side of the midribs and principal veins, less than one third grown when the flowers open at the end of April, and at maturity subcoriaceous, yellow-green on the upper surface, paler on the lower surface, glabrous with the exception of a few hairs on the under side of the stout yellow midribs and 4 or 5 pairs of slender primary veins, $1 \frac{1^{\prime}}{2}-2^{\prime}$ long, $1^{\prime}-1 \frac{1}{4}^{\prime}$ wide; their petioles slender, villose, soon glabrous, more or less winged toward the apex, $\frac{1}{4}^{\prime}-\frac{1}{2}^{\prime}$ long; on vigorous shoots frequently divided into short broad acute lateral lobes, more coarsely dentate and often $3^{\prime}$ long and $2 \frac{1}{2}^{\prime}$ wide, with stout broadly winged petioles generally light red like the lower side of the base of the midribs. Flowers $\frac{3^{\prime}}{4}$ in diameter, on long stout pedicels, in broad many-flowered villose corymbs; calyxtube broadly obconic, villose particularly toward the base, the lobes gradually narrowed from broad bases, acuminate, usually glabrous on the onter surface, villose

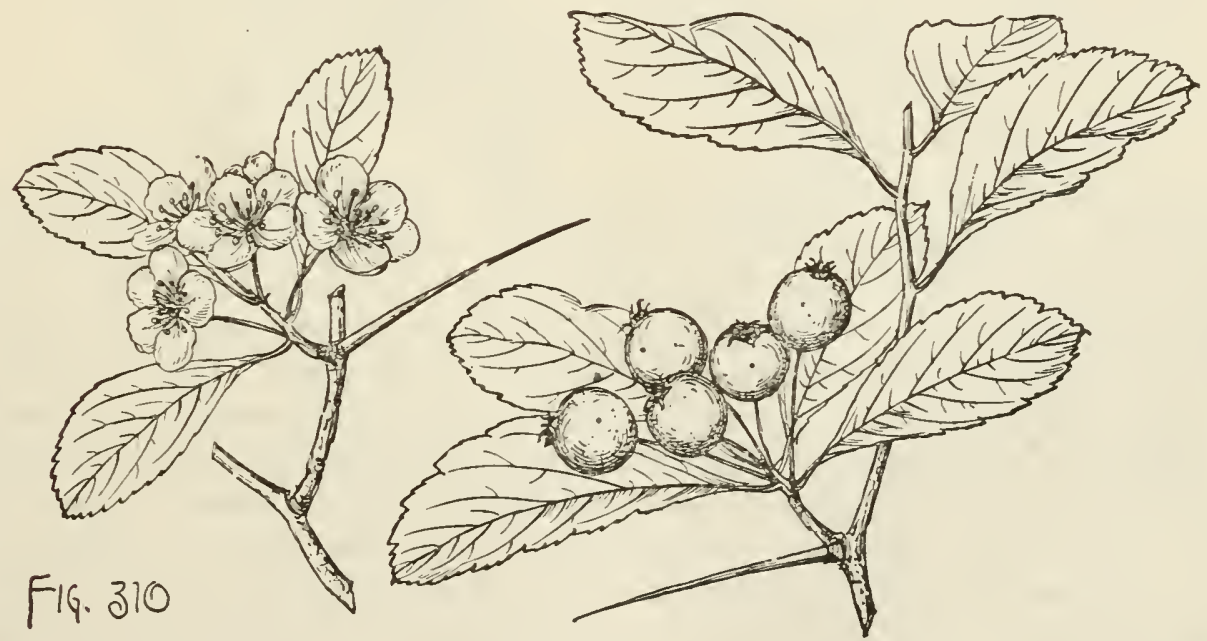

on the inner surface, finely glandular-serrate, with dark glands, bright red toward the apex; stamens usually 20; anthers large, pale yellow; styles 5. Fruit ripening in September, on stout elongated pedicels, in few-fruited erect or drooping puberulous clusters, globose but sometimes rather broader than long, dull red, marked by small pale dots, $\frac{1}{8}^{\prime}-\frac{1}{2}^{\prime}$ in diameter; calyx enlarged, prominent, the lobes closely appressed, glandular-serrate, mostly persistent; flesh yellow, dry and mealy; nutlets 5, broad and rounded at the ends, ridged and often grooved on the back, about $\frac{1^{\prime}}{4}$ long.

A tree, usually $15^{\circ}-20^{\circ}$ but occasionally $25^{\circ}$ high, with a tall straight stem often buttressed at the base, frequently armed with numerous large much-branched spines sometimes $6{ }^{\prime}-8^{\prime}$ long, stout wide-spreading branches forming a handsome flat-topped 
symmetrical head, and branchlets tinged with red and villose, with long matted silky white hairs, when they first appear, soon puberulous, and furnished with stont lustrous spines $2^{\prime}-3^{\prime}$ loug.

Distribution. Hillsides in rich soil in the foothill region of the southern Appalachian Mountains from sonthwestern Virginia to eentral Georgia and westward to middle Temessec and central Alabama, asecnding to elevations of $2500^{\circ}$ above the sea.

\section{Cratægus amnicola, Beadl.}

Leaves obovate, oval or ovate, acute or acuminate at the apex, gradually narrowed and concave-cuncate at the cntire base, coarscly sometimes doubly serrate above,

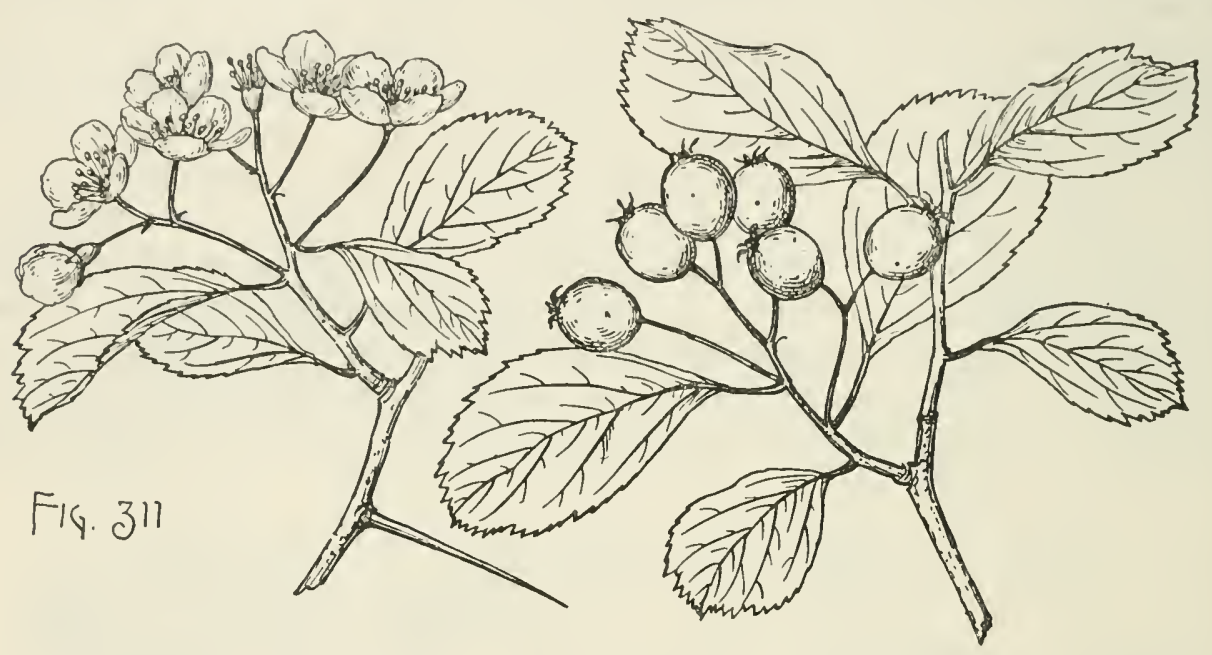

with straight or incurved glandular teeth, and incisely lobed above the middle, with short acute or acuminate lobes, when they unfold deeply tinged with red and covered with short pale mostly caducous hairs, about half grown and sparingly villose on the midribs and veins when the flowers open late in April or early in May, and at maturity subcoriaceous, bright green, glabrous, $1 \frac{1}{4}^{\prime}-1_{\frac{1}{2}}^{\prime}$ long, $1^{\prime}-1 \frac{1}{4}^{\prime}$ wide, and on vigorous shoots sometimes $2^{\prime}$ long and $1 \frac{1^{\prime}}{2}$ wide, turning in the autumn yellow, orange, red, and brown; their petioles slender, broadly wing-margined at the apex, sparingly villose at first, becoming glabrous, sometimes slightly glandular, $\frac{1}{4}^{\prime}-\frac{1}{3}^{\prime}$ long. Flowers about $\frac{5^{\prime}}{8}$ in diameter, on elongated slender slightly villose pedicels, in narrow compound many-flowered villose corymbs; calyx-tube narrowly obconic, glabrous or with a few seattered hairs at the base, the lobes narrow, aeuminate, glandular-serrate, glabrous; stamens 20; anthers nearly white; styles 3-5. Fruit on slender elongated glabrous pedicels, in drooping few-fruited clusters, subglobose, dull red, about $\frac{1}{3}^{\prime}$ in diameter; calyx enlarged, with elongated coarsely serrate reflexed conspicuous lobes; flesh yellow, thin, and firm; nutlets 3-5, rounded or slightly grooved on the back, nearly $\frac{1^{\prime}}{4}$ long.

A tree, occasionally $25^{\circ}$ higl, with a trunk $8^{\prime}-12^{\prime}$ in diameter, spreading or ascending branches forming a large wide head, and branchlets villose at first, with long matted white hairs, soon glabrous, becoming orange-brown and ultimately ashy gray, and unarmed, or armed with stout spines $1 \frac{11^{\prime}}{4} 2^{\prime}$ long.

Distribution. Low moist woods and the borders of streams, southeastern Tennessee, northwestern Georgia, and northeastern Alabama; common. 


\section{Cratægus fastosa, Sarg.}

Leaves broadly oval to ovate, rounded or acute at the apex, concave-cuneate or rounded at the entire base, coarsely doubly serrate above, with straight glandular teeth, and rarely on vigorous shoots slightly lobed, with broad acute lobes, when they unfold covered above with long pale hairs and provided below with large tufts of snow-white tomentum in the axils of the primary veins, when the flowers open from the 20th to the 25th of April dark yellow-green and nearly glabrous on the upper surface and still tomentose in the axils of the veins below, and at maturity subcoriaceous, glabrous, yellow-green and lustrous above, pale yellow-green below, $1 \frac{3}{4}{ }^{\prime}-2^{\prime}$ long, $1^{\prime}-2^{\prime}$ wide, with prominent light yellow midribs deeply impressed on the upper side, and usually 3-5 pairs of primary veins; their petioles slender, slightly wingmargined toward the apex, at first densely villose, becoming puberulous, $\frac{1}{2}^{\prime}-\frac{3^{\prime}}{4}$ long. . Flowers about $\frac{3^{\prime}}{4}$ in diameter, on slender pedicels, in compact many-flowered glabrous corymbs, with large conspicuous oblong-obovate and acute to lanceolate
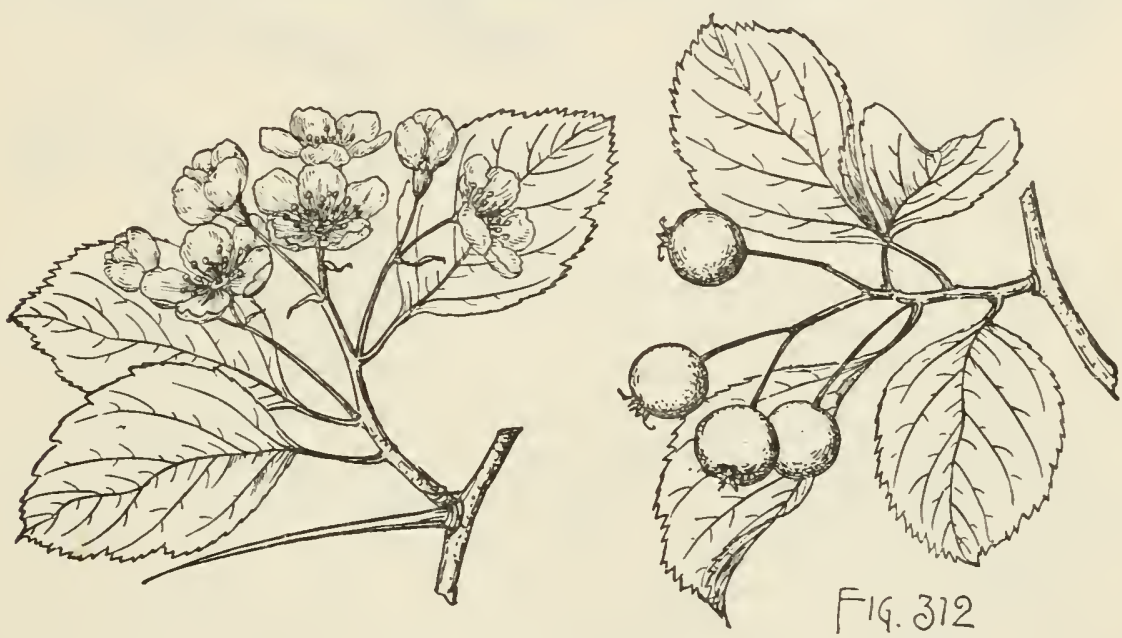

coarsely glandular-serrate bracts and bractlets usually persistent until after the petals fall; calyx broadly obconic, the lobes abruptly narrowed at the base, slender, acuminate, coarsely glandular-serrate, glabrous on the outer, villose on the inner surface; stamens 20 ; anthers pale yellow; styles 5 , surrounded at the base by a broad ring of pale tomentum. Fruit ripening from the middle to the end of October, on thin reddish pedicels, in few-fruited drooping clusters, subglobose to shortoblong, dull orange-red, marked by large pale dots, $\frac{3}{8}^{\prime}$ in diameter; calyx enlarged, with spreading serrate lobes villose on the upper side, mostly decidnous from the ripe fruit; flesh thin, yellow-green, dry and mealy; nutlets $3-5$, thin, narrowed at the ends, obscurely ridged on the back, with a broad low often grooved ridge, about $\frac{5}{16}$ long.

A tree, $18^{\circ}-20^{\circ}$ high, with a short trunk $8^{\prime}-12^{\prime}$ in diameter, covered with dark brown or nearly black scaly bark, small ascending branches forming an irregular open head, and slender nearly straight branchlets, dark orange-green tinged with red when they first appear, becoming before autumn bright reddish brown and very lustrous, and dull reddish brown the following year, and armed with numerous stout nearly straight bright chestnut-brown shining spines $1_{\frac{1}{2}}^{\prime}$ to $2^{\prime}$ long.

Distribution. Low woods near Fulton, Arkansas, in the valley of the Red River; not common. 


\section{Cratægus verruculosa, Sarg., n. sp.}

Leaves obovate to rhomboidal, acute or rarely rounded at the apex, euneate and entire at the base, and sharply of ten doubly serrate above, with straight or ineurved glandular tecth, when they unfold dark red, covered above by sliort pale liairs and

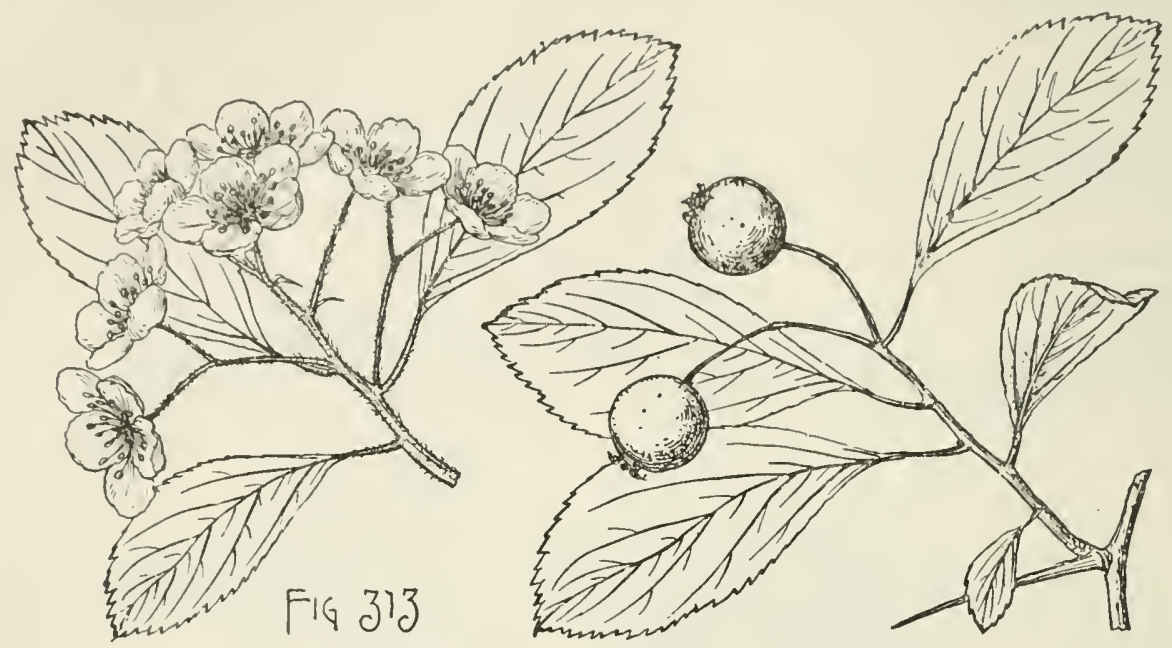

below by long matted white hairs most abundant on the midribs and veins, about half grown when the flowers open from the 1st to the 10th of May and then thin, dark yellow-green, and scabrate on the upper surface and paler and pubescent on the lower surface, and at maturity subcoriaceous, dark green, lustrous, and nearly smooth above, pale and still pubescent below on the stout midribs and conspicuous primary veins extending very obliquely toward the end of the leaf, $1 \frac{1}{2}-2^{\prime}$ long, $1^{\prime}-1 \frac{1}{4}$ wide; their petioles stout, wing-margined at the apex, at first villose, becoming pubescent or puberulous, $\frac{1}{4}-\frac{1}{2}$ long; on vigorous shoots often broadly ovate to oval, sharply doubly serrate, with straight teeth, sometimes slightly lobed above the middle, with short acute lobes, and frequently $3^{\prime}$ long and 2' wide. Flowers $\frac{3^{\prime}}{4}$ in diameter, on long slender villose pedicels, in broad lax compound 6-12 usually 9-flowered villose corymbs, with reddish purple minutely glandular caducous bracts and bractlets; calyx-tube broadly obconic, thickly covered with matted pale hairs, the lobes gradually narrowed from broad bases, slender, acute, tinged with red at the apex, sparingly glandular-serrate, pubescent; stamens 20 ; anthers pale rose color; styles $3-5$ surrounded at the base by a broad ring of long pale hairs. Fruit ripening the 1st of October, on stout pubescent pedicels, in drooping few-fruited clusters, subglobose, somewhat flattened and pubescent at the ends, dark red; calyx prominent, with more or less deciduous lobes; nutlets 3-5, narrowed and acute at the ends, rounded and very irregularly ridged and sometimes obscurely grooved on the back, about $\frac{1}{4}^{\prime}$ long.

A tree, $20^{\circ}-25^{\circ}$ high, with a tall trunk $10^{\prime}-12^{\prime}$ in diameter, thick spreading branches forming a broad compact round-topped symmetrical head, and stout nearly straight branchlets thickly covered with matted pale hairs when they first appear, becoming reddish or orange-brown, nearly glabrous and roughened by minute tubercles at the end of their first season, gray-brown tlie following year, and armed with numerous straight stout or slender dark chestnut-brown very lustrous spines $\frac{3^{\prime}}{4}-1^{\prime}$ long.

Distribution. Springfield, Missouri; not rare. 


\section{Cratægus sordida, Sarg.}

Leaves rhomboidal, acute, or occasionally obovate and very rarely rounded at the apex, cuneate and entire below, serrate above, with narrow straight or incurved glandular teeth, and occasionally irregularly divided above the middle into short acute lobes, about half grown when the flowers open the first week of May and then membranaceous, bright green, lustrous and glabrous with the exception of a few short caducous hairs on the upper surface, particularly along the midribs and principal veins, and at maturity subcoriaceous, dark green and lustrous above, paler below, generally about $1 \frac{1}{2}^{\prime}$ long and $1 \frac{1}{4}^{\prime}$ wide ; their petioles stout, slightly winged toward the apex, at first villose, soon glabrous, about $\frac{1}{2}{ }^{\prime}$ long, often bright red in the autumu; on vigorous shoots sometimes oblong or oval, coarsely dentate, usually divided above the middle into short acute lobes, $3^{\prime}-4^{\prime}$ long, $2^{\prime}-2 \frac{1^{\prime}}{2}$ wide, and decurrent on the stout glandular petioles. Flowers $1^{\prime}-1 \frac{1^{\prime}}{4}$ in diameter, on slender pedicels, in few-flowered compact slightly villose corymbs; calyx-tube narrowly obconic, the lobes narrow, acuminate, villose on the inner surface; petals

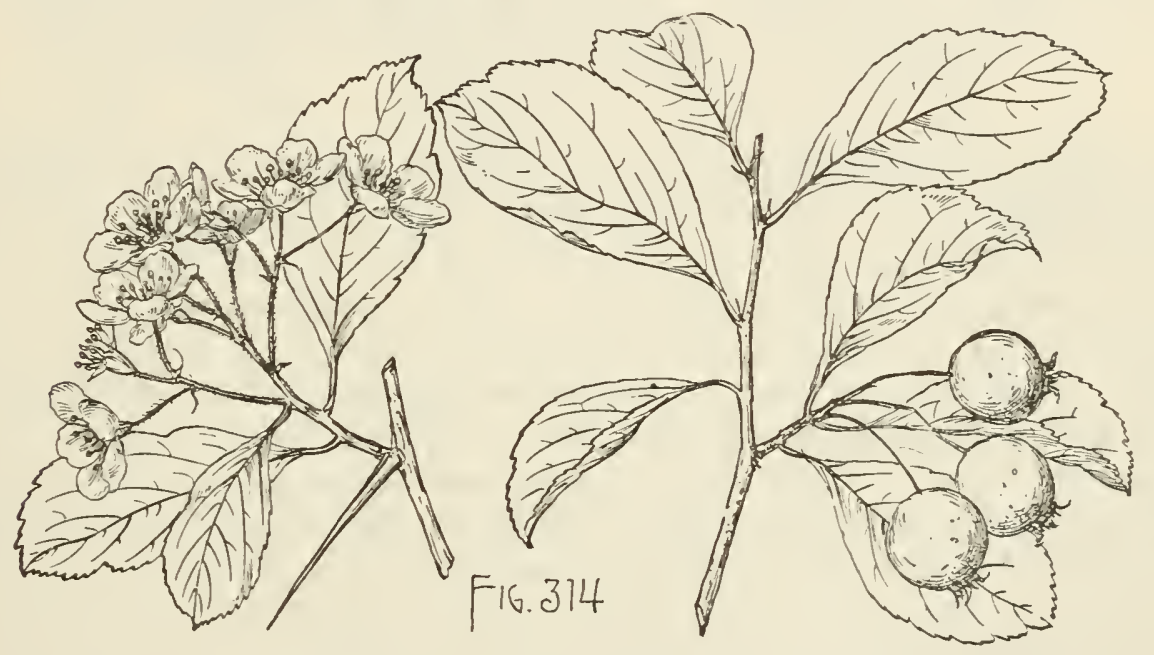

dull sordid white; stamens 20; anthers small, rose color; styles 2 or 3, surrounded at the base by a narrow ring of pale hairs. Fruit ripening and falling the middle of September, on short pedicels, in few-fruited drooping clusters, globose, $\frac{1^{\prime}}{3}-\frac{1}{2}$ in diameter, dark dull red; calyx prominent, with elongated coarsely serrate appressed or incurved lobes; flesh thin, yellow, dry and mealy; nutlets 2 or 3 , broad, rounded and ridged on the back, with a low rounded ridge, $\frac{1}{4}$ long.

A slender tree, $20^{\circ}-25^{\circ}$ high, with a tall trunk $5^{\prime}-6^{\prime}$ in diameter, often armed with long-branched spines, small ascending branches forming a narrow oval head, and slender nearly straight branchlets, at first dark orange-green and villose, with long scattered pale hairs sometimes persistent until autumn, and furnished with numerous thin nearly straight bright chestnut-brown shining spines $1^{\prime}-2 \frac{1}{2}$ long, or often unarmed.

Distribution. Low woods and the gravelly banks of streams; Ripley County, southeastern Missouri.

\section{Cratægus Brazoria, Sarg.}

Leaves oval to obovate, acute or acuminate, gradually narrowed, cuneate and entire at the base, and coarsely and irregularly glandular-serrate above, with straight 
spreading teeth, when they unfold coated with hoary tomentum and often bright red, nearly fully grown and covered with short soft pale hairs most abundant on the under side of the thin midribs and 3 or 4 pairs of primary veins when the flowers open
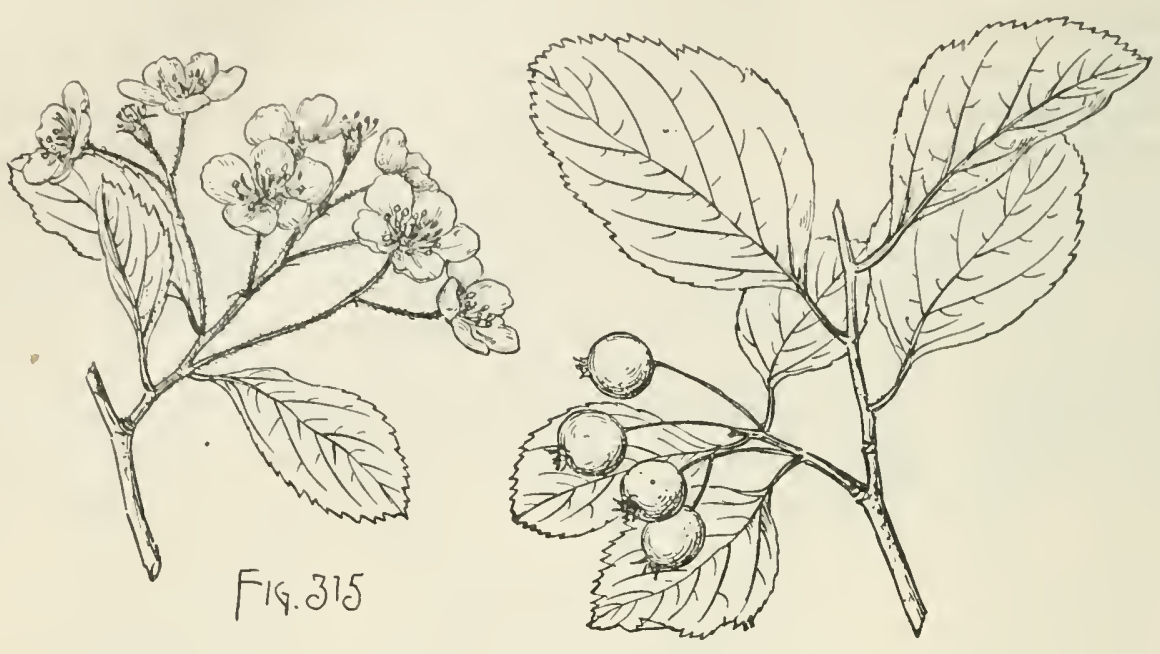

from the middle to the end of March, and at maturity thin and firm in texture, glabrous, dark green and lustrous above, paler below, $2^{\prime}-2 \frac{1}{2}^{\prime}$ long and $1 \frac{1}{4}^{\prime}-1 \frac{1}{2}^{\prime}$ wide; their petioles slender, more or less winged toward the apex, at first tomentose, becoming glabrous or puberulous, $\frac{1^{\prime}}{2}-\frac{3 \prime}{4}$ long; on vigorous shoots broadly ovate or oblong, full and rounded or broadly cuneate at the base, very coarsely dentate, $5^{\prime}$ long and $2 \frac{1^{\prime}}{2}$ wide. Flowers $\frac{3^{\prime}}{4}$ in diameter, on slender elongated pedicels, in broad slightly villose 7 or 8 -flowered corymbs; calyx-tube narrowly obconic, coated with long matted pale hairs, the lobes narrow, acuminate, obscurely glandular-serrate or nearly entire, villose on both surfaces; stamens 20; anthers small, dark red; styles 5 , surrounded at the base by a thin ring of hoary tomentum. Fruit ripening after the 1st of October, in spreading or drooping few-fruited clusters, subglobose and often rather longer than broad, bright canary-yellow, marked by occasional dark dots, $\frac{1^{\prime}}{3}-\frac{1}{2}$ ' long; calyx prominent, the lobes usually deciduous before the fruit ripens; flesh thin, light yellow, rather dry but sweet and edible, nutlets 5 , rounded and grooved on the back, $\frac{1^{\prime}}{4}$ long.

A tree, $20^{\circ}-25^{\circ}$ high, with a tall straight trunk $8^{\prime}-10^{\prime}$ in diameter, numerous ascending branches forming a handsome symmetrical round-topped head, and branchlets covered when they first appear with matted pale hairs, soon glabrous, and unarmed or occasionally armed with long thin gray spines.

Distribution. Low rich woods near the banks of the Brazos River, Brazoria, Texas.

\section{Cratægus Dallasiana, Sarg.}

Leaves oblong, acute, acuminate or rounded at the apex, gradually narrowed to the concave-cuneate entire base, coarsely doubly serrate above, with straight glandular teeth, and usually slightly lobed above the middle, coated below with thick hoary tomentum and villose above as they unfold, nearly fully grown and villose or tomentose below when the flowers open early in April, and at maturity thin but firm in texture, dark yellow-green, glabrous and lustrous on the upper surface, pale and pubescent on the lower surface along the slender midribs and 3 or 4 pairs of thin 
arching veins, $1 \frac{3}{4}^{\prime}-2 \frac{1}{2}^{\prime}$ long and $1 \frac{1}{4}^{\prime}-1 \frac{1}{2}^{\prime}$ wide; their petioles slender, wing-margined toward the apex, hoary-tomentose early in the season, becoming glabrous, about $\frac{1}{2}$ ' long. Flowers about $\frac{5}{8}$ in diameter, on long slender hairy pedicels, in many-flowered densely villose compound corymbs; calyx-tube narrowly obconic, densely coated with long matted pale hairs, the lobes slender, acuminate, tipped with minute red glands, sparingly and irregularly glandular-serrate, villose; stamens 20; anthers light rose color; styles 5. Fruit ripening at midsummer, on stout erect slightly hairy pedicels, in few-fruited clusters, subglobose, dull dark red, $\frac{3}{8}^{\prime}-\frac{1}{2}^{\prime}$ in diameter;

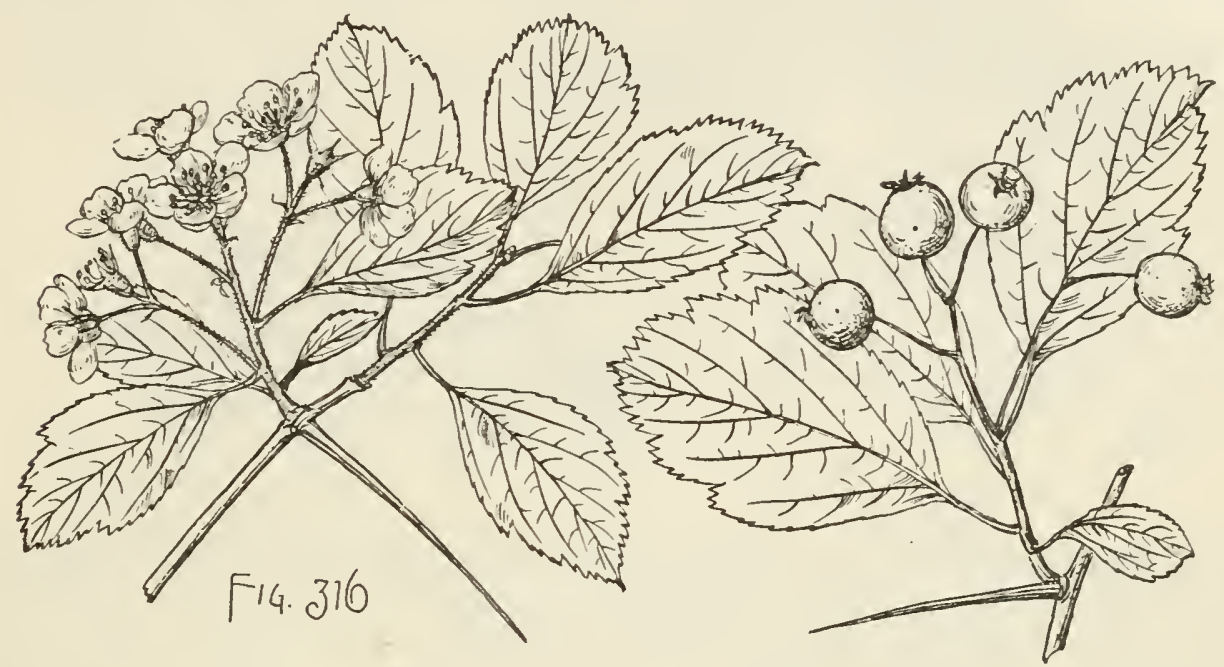

calyx prominent, with spreading lobes bright red on the upper side at the base; nutlets 5 , acute at the narrowed ends, thin, rounded and grooved, with a broad shallow groove, or irregularly ridged on the back, $\frac{1^{\prime}}{4}-\frac{5}{1}{ }^{\prime}$ long.

A tree, $20^{\circ}-25^{\circ}$ high, with a tall trunk $4^{\prime}-6^{\prime}$ in diameter, covered with pale bark, slightly erect branches forming an open irregular head, and slender somewhat zigzag branchlets thickly coated at first with hoary tomentum, reddish brown and lustrous before autumn, ultimately ashy gray, and armed with straight slender gray spines $1 \frac{1}{4}^{\prime}-1 \frac{1}{2}^{\prime}$ long.

Distribution. Forest-covered bottom-lands of the small tributaries of the Trinity River, Dallas County, Texas; not common.

\section{Cratægus Lettermani, Sarg.}

Leaves obovate, acute or acuminate or rounded and short-pointed at the apex, gradually uarrowed from near the middle and cuneate at the mostly entire base, coarsely and often doubly serrate above, with straight or incurved glandular teeth, frequently slightly and irregularly divided above the middle into 3 or 4 pairs of short acute lobes, strongly plicate when they unfold and covered with a thick coat of pale tomentum, nearly half grown, roughened above by short pale hairs and pubescent below when the flowers open early. in May, and at maturity thick and firm in texture, bright yellow-green and scabrous above, pale and pubescent below along the stout midribs and 4 or 5 pairs of primary veins, and about $2^{\prime}$ long and $1 \frac{1}{2}^{\prime}$ wide; their petioles stout, more or less winged above the middle, at first tomentose, becoming pubescent or nearly glabrous, usually about $\frac{3^{\prime}}{4}$ long; on vigorous shoots broadly oval, acute or acuminate, more coarsely serrate, $2 \frac{1}{2}^{\prime}-3^{\prime}$ long, $2^{\prime}-2 \frac{1}{2}^{\prime}$ wide, with broad lunate 
coarsely glandular-serrate stipules frequently $\frac{1}{2}^{\prime}$ in length. Flowers about $\frac{8^{\prime}}{4}$ in diameter, in compact many-flowered thick-branched tomentose corymbs; calyx-tube narrowly obconic and tomentose, the lobes narrow, acuminate, fincly glandnlar-serrate, villose; stamens 10 ; anthers small, pale yellow; styles 5 , surrounded at the base by a broad ring of hoary tomcntum. Fruit ripeinng early in October, on

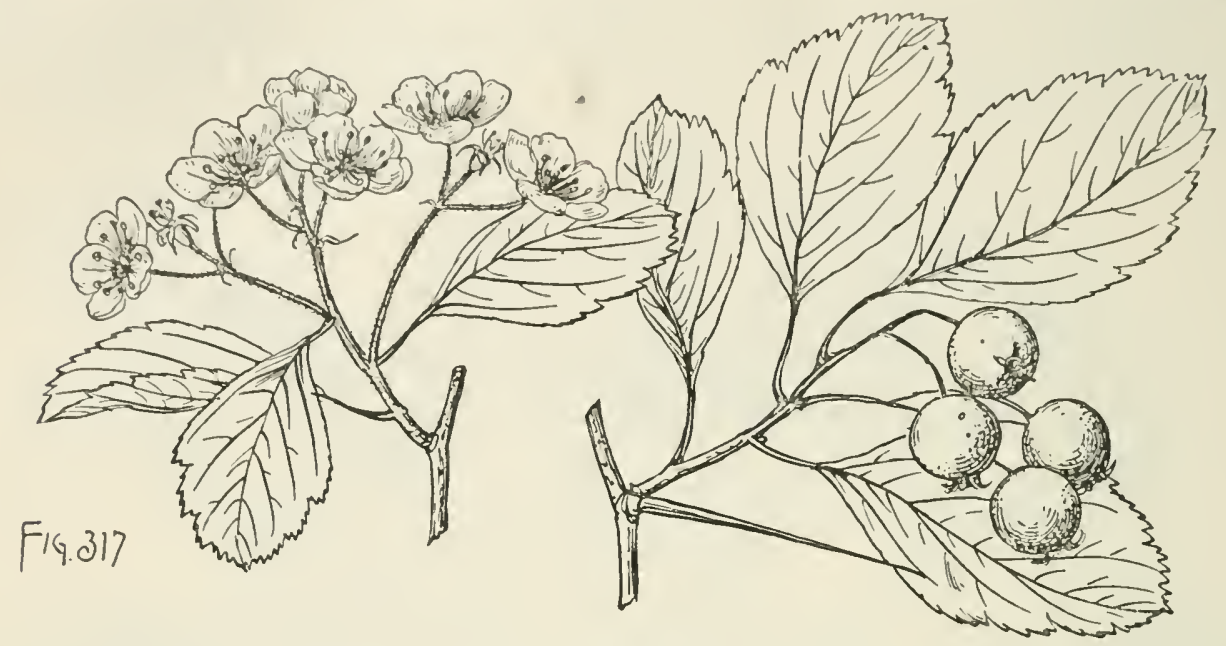

stout pubeseent pedicels, in few-fruited spreading or drooping clusters, subglobose or occasionally slightly obovate, full and rounded and puberulous at the ends, dull orange-red, marked by large pale dots, about $\frac{1}{2}^{\prime}$ in diameter; calyx broad, the lobes enlarged, coarsely glandular-serrate, reflexed, often deciduous before the fruit ripens; flesh thin, dry and mealy; nutlets 5, prominently ridged on the back, with a high rounded ridge, dark brown, $\frac{1}{4}^{\prime}$ long.

A tree, $18^{\circ}-20^{\circ}$ high, with a trunk $6^{\prime}-8^{\prime}$ in diameter, with thin dark brown or nearly black bark separating freely into small plate-like scales, and often armed with thin much-branched spines frequently $7^{\prime}-8^{\prime}$ long, small erect branches forming a wide open head, and branchlets coated when they first appear with hoary tomentum, dull red-brown, villose or pubescent during their first season, and furnished with stout straight bright red-brown shining spines $1 \frac{1}{2}^{\prime}-2^{\prime}$ long.

Distribution. Low rich soil inundated during several weeks in winter, anong Oaks and Hickories; near Allenton, Missouri.

\section{Cratægus pratensis, Sarg.}

Leaves oblong-obovate, acute or rounded at the apex, gradually narrowed below from near the middle to the cuneate and entire base, sharply and often doubly serrate usually only above the middle, with straight or incurved teeth tipped early in the season with minute dark red caducous glands, and often more or less deeply divided toward the apex into short broad acute lobes, when they unfold bright bronze-yellow or dark red, and covered with short pale hairs, almost smooth and nearly fully grown when the flowers open at the end of May, and at maturity glabrous, thick and firm, dark green and lustrons above, pale below, $1 \frac{1{ }^{\prime}}{2}-2^{\prime} \operatorname{long}, 1^{\prime}-1_{\frac{1}{2}}^{\prime}$ wide, with thin midribs and 4 or 5 pairs of primary veins extending obliquely toward the end of the leaf and raised and prominent below; their petioles slender, glabrous, more or less winged toward the apex, usually about $\frac{1}{2}^{\prime}$ long; on vigorous shoots often oval or broadly ovate, frequently $3^{\prime}$ long and $2 \frac{1}{2}^{\prime}$ wide, with foliaceous lunate stalked coarsely glandular- 
dentate stipules often $1^{\prime}$ in length. Flowers $\frac{1}{3}^{\prime}$ in diameter, on slender elongated pedicels, in broad loose many-flowered compound corymbs pubescent or puberulous at first but soon glabrous; calyx-tube narrowly obconic, coated toward the base with long matted pale hairs, the lobes narrow, acuminate, coarsely glandular-serrate, glabrous on the outer surface, villose on the inner surface; stamens 10; anthers small, rose color; styles 2 or 3 , surrounded at the base by a narrow ring of pale tomentum. Fruit ripening early in October and remaining on the branches until November, on elongated pedicels, in loose drooping many-fruited clusters, globose, bright scarlet, slightly pruinose, marked by occasional large pale dots, about $\frac{1^{\prime}}{3}$ in diameter; calyx prominent, with much enlarged coarsely glandular-serrate lobes, often deciduous before the fruit becomes entirely ripe; flesh thin, yellow, dry and mealy; nutlets 2 or

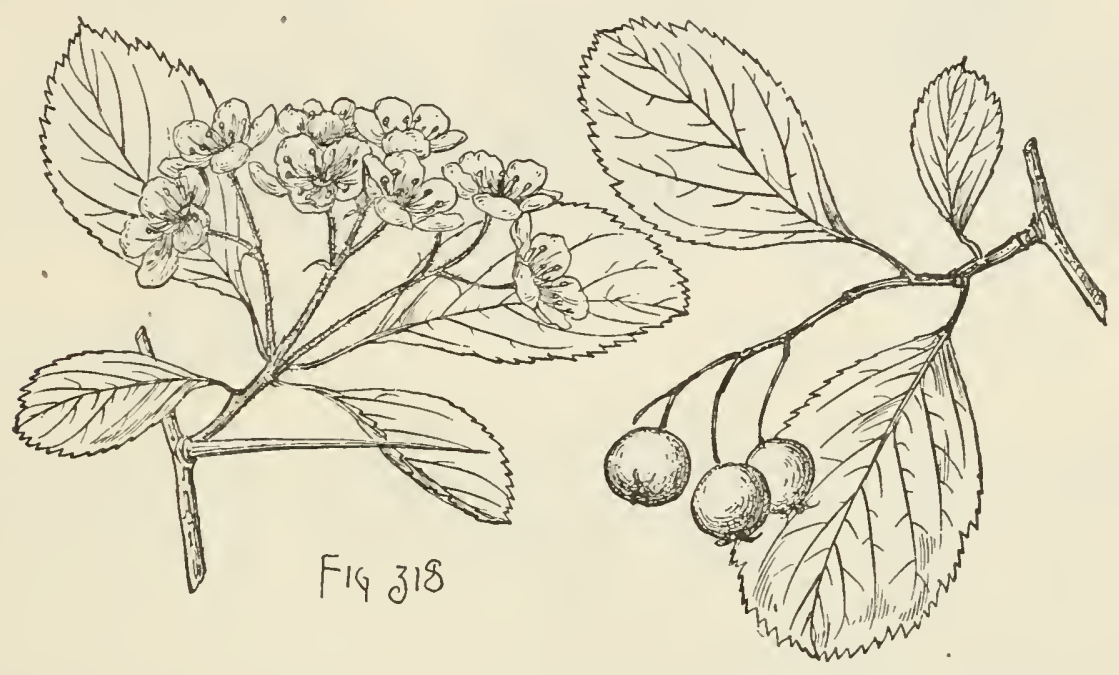

3 , thick and broad, rounded and conspicuously ridged on the back, with a prominent grooved ridge, about $\frac{1}{4}^{\prime}$ long.

A tree, occasionally $20^{\circ}$ high, with a tall trunk $3^{\prime}-7^{\prime}$ in diameter, often armed with long slender much-branched ashy gray spines, spreading branches forming a roundtopped symmetrical head, and branchlets occasionally slightly villose when they first appear, soon glabrous, and furnished with numerous thin straight or slightly curved shining chestnut-brown spines $2^{\prime}-2 \frac{1^{\prime}}{2}$ long.

Distribution. Open woods near the banks of small streams in the prairie region of Stark and Peoria counties, Illinois.

\section{III. ÆSTIVALES.}

\section{Cratægus æstivalis, T. \& G. May Haw. Apple Haw.}

Leaves elliptical to oblong-cuneiform, acute or rounded at the apex, gradually narrowed and entire below, irregularly sinuate-toothed or angled above the middle, or crenately serrate, with minute gland-tipped teeth, when they unfold covered above with deciduous pale hairs and coated below with dense hoary tomentum rufous on the midribs and veins, and at maturity subcoriaceous, dark green, lustrous, glabrous or sometimes scabrate above and clothed below, especially along the broad midribs and primary veins, with thick rusty pubescence, $1 \frac{1^{\prime}}{2}-2^{\prime}$ long and $\frac{1^{\prime}}{2}-1^{\prime}$ wide; their petioles at first rusty-tomentose, becoming pubescent, $\frac{1}{4}^{\prime}-1^{\prime}$ long; on vigorous shoots 
sometimes unequally 3-lobed by deep narrow lateral sinuses. Flowers appearing with the unfolding of the leaves in February and early Mareh, $1^{\prime}$ in diameter, on long slender pedicels, in ¿-5-1lowered simple glabrous eorymbs; ealyx-tube broadly obeonie to subglobose, glabrous, the lobes nearly triangular, entire or minutely glandular-serrate, often flushed with red toward the apex. Fruit ripening in May,

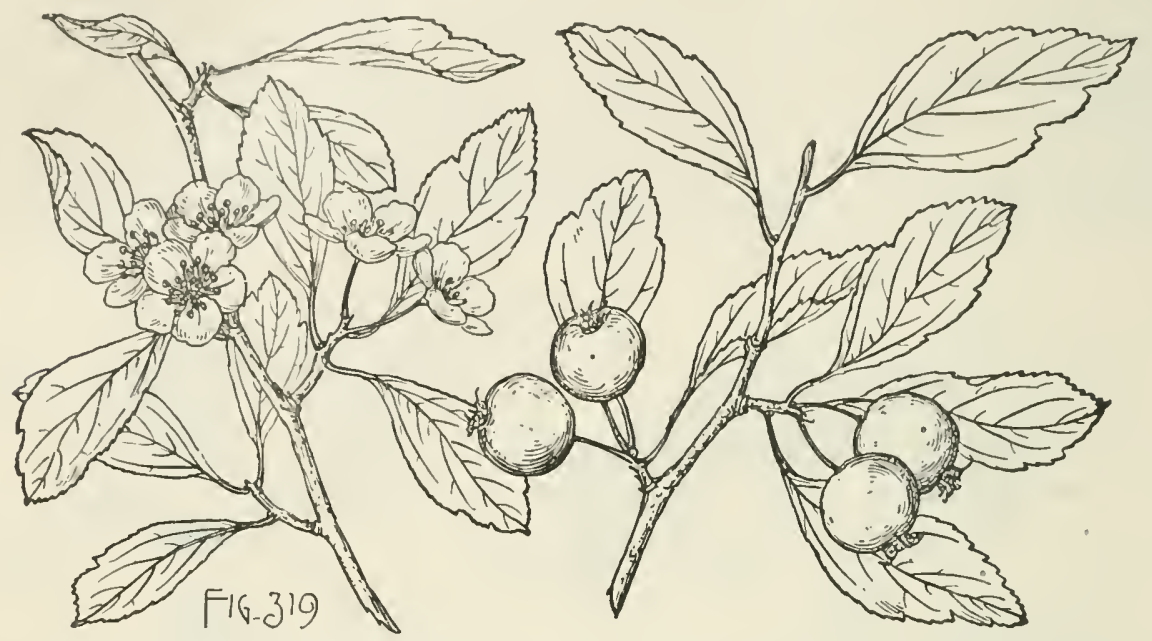

on slender pedieels, in 1-3-fruited elusters, depressed-globose, very fragrant, bright red, dotted with pale spots, $\frac{1}{2}^{\prime}-2^{\prime}$ in diameter; ealyx prominent, with enlarged ineurved mostly persistent lobes; flesl thick, juicy, subaeid; nutlets $3-5$, rounded at the ends, prominently ridged, with a high narrow or rounded and slightly grooved ridge, $\frac{1^{\prime}}{4}$ long.

A tree, $20^{\circ}-30^{\circ}$ high, with a trunk $12^{\prime}-18^{\prime}$ in diameter, sometimes tall and straight or divided elose to the surface of the ground into several large upright stems forming a round eompact bushy head, and branchlets eovered at first with rufous or oceasionally pale hairs, beeoming at the end of their first season glabrous, lustrous, bright red or sometimes light brown, and often unarmed or armed with stout straight shining spines $1^{\prime}-1 \frac{1^{\prime}}{2}$ long. The fruit is gathered in large quantities and is made into preserves and jellies.

Distribution. Moist sandy soil near the margins of streams and Pine-barren ponds, often submerged during several weeks in winter; northern Florida and through the Gulf states to southern Arkansas and the valley of the Sabine River, Texas; comparatively rare in the Atlantic states; most eommon and of its largest size in western Louisiana and eastern Texas.

Stamens 20.

\section{VIRIDES.}

Anthers pale yellow (color not known in 42).

Fruit not exceeding $\frac{1}{3}^{\prime}$ in diameter.

Leaves ovate to oblong-obovate, acute or acuminate, or sometimes rounded at the apex ; fruit depressed-globose, bright scarlet or orange. 35 . C. viridis (A, C).

Leaves ovate, acute, often broadly cuneate at the base; fruit subglobose. orange-red. 36. C. ovata (A).

Leaves oval or ovate, acute, rounded or broadly cuneate at the base; fruit globose, yellow-green flushed with red.

37. C. vulsa (C). 
Leaves oblong-ovate to semiorbicular, acute, often short-pointed or rarely rounded at the apex, subcoriaceous; fruit short-oblong to obovate or globose, dull orange color.

38. C. glabriuscula (C).

Leaves oval to rhomboidal, acute or acuminate; fruit subglobose to short-oblong; bright orange-red.

39. C. blanda (C).

Fruit $\frac{1^{\prime}}{2}-\frac{3^{\prime}}{4}$ in diameter.

Leaves lanceolate to oblong-obovate, acuminate ; fruit short-oblong, dull brick red covered with a glaucous bloom.

40. C. nitida (A).

Leaves obovate to oval or rhomboidal, acute or rarely rounded at the apex; fruit subglobose to short-oblong, dark crimson.

41. C. mitis (A).

Leaves ovate, acute, usually broad and rounded at the base ; fruit subglobose to shortoblong, dark red.

Anthers purple or rose color.

42. C. atrorubens (A).

Leaves obovate, oval or ovate, acute; fruit globose to subglobose, red; anthers bright purple.

43. C. ingens (C).

Leaves broadly obovate, oval or ovate, acute or acuminate ; fruit globose or depressedglobose; anthers pale rose color.

44. C. penita (C.)

Stamens usually 10 , occasionally 12-20 ; anthers bright red; leaves oblong-obovate to oval, usually acute or acuminate; fruit subglobose to short-oblong, bright orange-red.

45. C. micracantha (C).

* Stamens 20 .

-Anthers pale yellow.

35. Cratægus viridis, $\mathbf{L}$.

Leaves ovate to oblong-obovate, acute or acuminate or sometimes rounded at the apex, gradually narrowed to the cuneate wedge-shaped base, finely serrate above, with incurved glandular teeth, and sometimes 3-lobed toward the apex, especially on vigorous shoots, tinged with red and slightly hairy above when they unfold, nearly fully grown when the flowers open, and at maturity membranaceous to subcoriaceous, dark green and lustrous on the upper surface, paler on the lower surface, with large

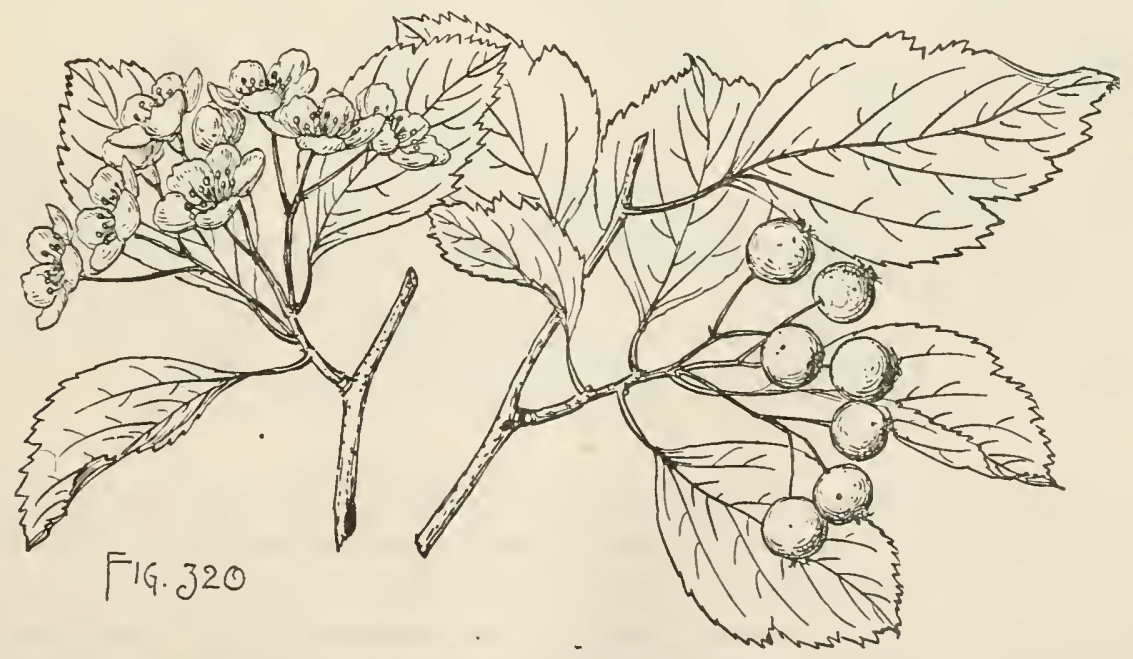

axillary tufts of pale hairs, $1^{\prime}-3^{\prime}$ long, $\frac{1}{2}^{\prime}-1 \frac{1}{2}^{\prime}$ wide, with thick midribs and conspicuous primary veins; often turning brilliant scarlet late in the autumn before falling; their petioles slender, $1^{\prime}-1 \frac{1^{\prime}}{2}$ long. Flowers $\frac{z^{\prime}}{4}$ in diameter, on long slender pedicels, in many-flowered glabrous corymbs ; calyx-tube narrowly obconic, glabrous, the lobes 
lanceolate, entire; stamens 20 ; anthers pale yellow; styles $2-5$, usually 5 , surrounded at the base by conspicuous tufts of pale hairs. Fruit ripening in the autumn and mostly persistent on the branches through the winter, on long slender pedicels, in drooping many-fruited clusters, depressed-globose, bright scarlet or orange, $\frac{1}{8}^{\prime}-\frac{1}{4}^{\circ}$ in dianeter; calyx little enlarged, the lobes often deciduous from the ripe fruit; flesh thin and dry; nutlets usually 5, narrowed and rounded at the ends, rounded and

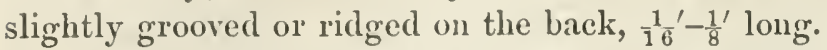

A trec, $20^{\circ}-35^{\circ}$ high, with a straight often fluted trunk $8^{\circ}-12^{\circ}$ tall and $18^{\prime}-20^{\prime}$ in diameter, covered with gray or palc orange-colored bark, spreading branches forming a round rather compact head, and slender glabrous branchlets ashy gray to light redbrown in their first winter, and unarmed or occasionally armed with slender sharp pale spines $\frac{3^{\prime}}{4}-1^{\prime}$ long.

Distribution. Borders of streams and swamps in low moist soil; valley of the Savamnah River, South Carolina, to western Florida, through the Gulf states and northward to the neighborhood of St. Louis, Missouri, and to the valley of the Colorado River, Texas; rare in the east; abundant and of its largest size in westeru Louisiana and eastern Texas, of ten forming great thickets.

\section{Cratægus ovata, Sarg., n. sp.}

Leaves ovate, acute, broadly or acutely concave-cuneate at the entire base, coarsely often doubly serrate above, with glandular teeth, and occasionally slightly divided into short lateral lobes, nearly fully grown when the flowers open early in May and then dark green, very smooth and glabrous above with the exception of a

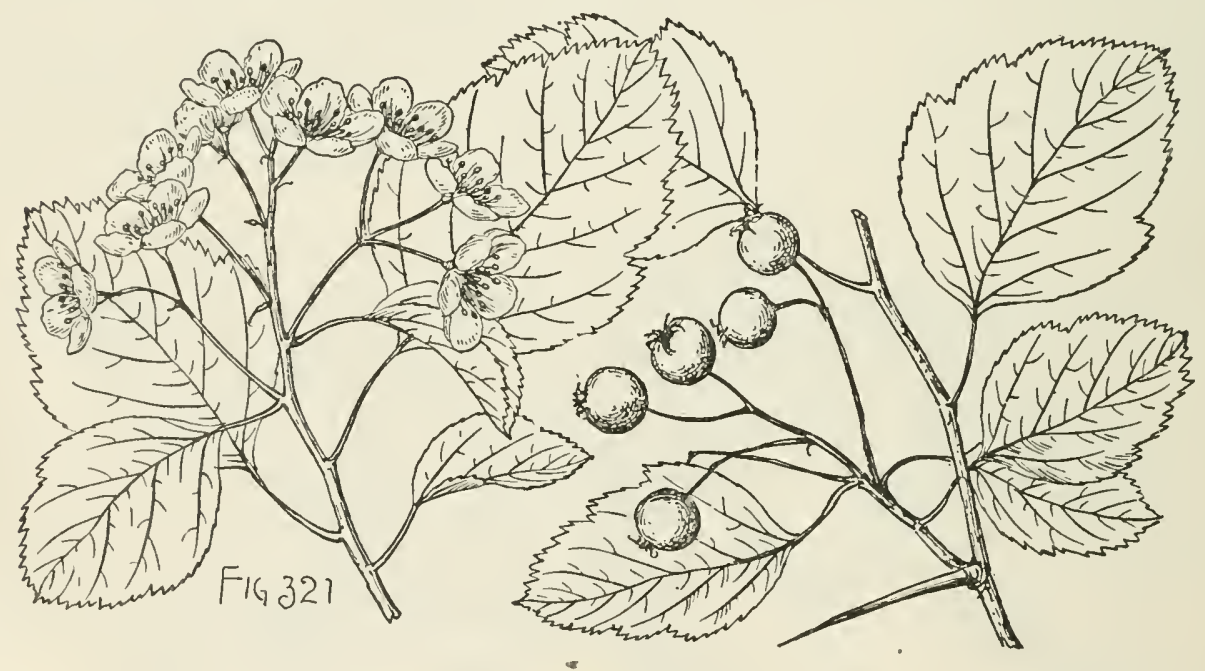

few short scattered hairs near the base of the midribs, paler below, with small persistent axillary tufts of white hairs, and at maturity membranaceous, $2^{\prime}-2 \frac{1}{2}^{\prime}$ long and $1 \frac{1}{2}-2^{\prime}$ wide, with slender yellow midribs and primary veins; their petioles slender, slightly winged at the apex, rose-colored in the autumn, about $\frac{3^{\prime}}{4}$ long; on vigorous shoots rounded or truncate at the broad base, coarsely serrate and sometimes $3^{\prime}$ long and broad. Flowers about $\frac{1}{2}^{\prime}$ in diameter, on long slender pedicels, in broad loose manyflowered glabrous compound corymbs; calyx-tube narrowly obconic, glabrous, the lobes broad, acute, entire or coarsely glandular-serrate toward the apex, glabrous; styles 5. Fruit ripening in October, on elongated pedicels, in long drooping clusters, 
subglobose or a little longer than broad, orange-red, $\frac{1^{\prime}}{4}-\frac{5}{16}$ long; calyx enlarged, with elongated closely appressed lobes sometimes deciduous from the ripe fruit; flesh thin, dry and mealy; nutlets 5 , acute at the ends, rounded or slightly ridged on the back, about $\frac{3}{16}$ long.

A tree, $25^{\circ}-30^{\circ}$ high, with a tall trunk sometimes a foot in diameter, covered with smooth gray bark, slender glabrous branchlets light reddish brown and lustrous during their first year, becoming grayish brown in their second season, and unarmed or armed with occasional dark purple slender slightly curved shining spines $1^{\prime}$ long.

Distribution. Low moist soil on the banks of the River Desperes, St. Louis, Missouri (John D. Kellogg, October 1901, May 1902).

\section{Cratægus vulsa, Beadl.}

Leaves oval or ovate, acute, full and rounded or broadly cuneate at the entire base, irregularly and often doubly serrate above, with straight or incurved glandtipped teeth, and often divided into several short acute lateral lobes, when they unfold dark bronze-red and pilose, with scattered caducous hairs, and with tufts of pale

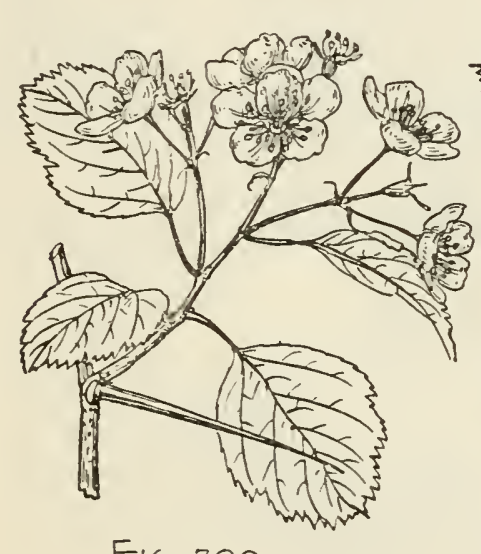

FIG 322

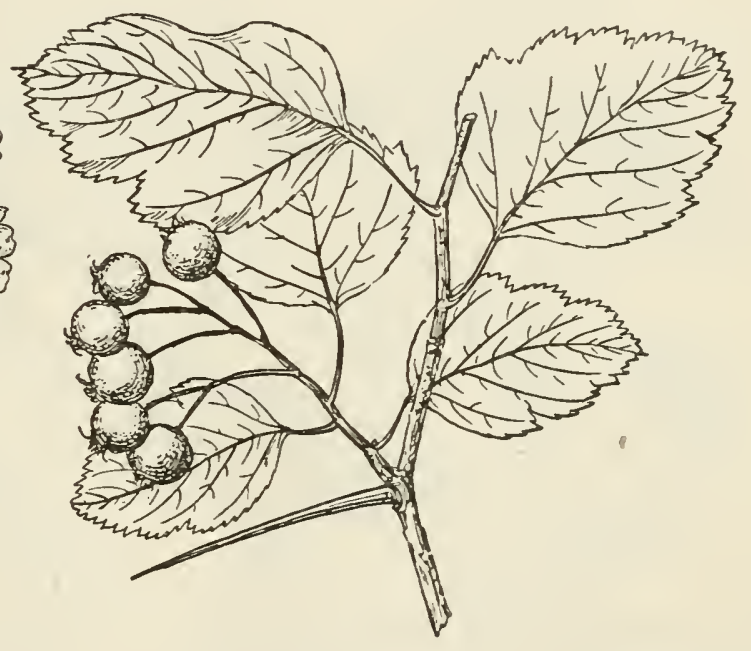

often persistent hairs in the axils of the principal veins, nearly fully grown when the flowers open late in April, and at maturity thin, bright green on the upper surface, paler on the lower surface, about $2^{\prime}$ long and $1 \frac{1}{2}^{\prime}$ wide, with slender midribs and 4 or 5 pairs of thin pale yellow primary veins, turning in the autumn yellow or brown; their petioles slender, somewhat villose at first, soon becoming glabrous, about $\frac{3^{\prime}}{4}$ long; on vigorous shoots broadly ovate, acute or acuminate, full and rounded or occasionally truncate and broadly cuneate at the base, more coarsely dentate and more deeply lobed, often $3^{\prime}$ long and $2 \frac{1^{\prime}}{2}$ wide, with stout winged glandular petioles and narrow falcate acuminate glandular stipules. Flowers ${ }^{\frac{3}{4}}$ in diameter, on slender pedicels, in compact compound 3-10-flowered glabrous corymbs, with linear acuminate glandular red bracts and bractlets; calyx-tube broadly obconic, glabrous, the lobes gradually narrowed from broad bases, acuminate, entire or occasionally obscurely serrate toward the apex, glabrous; stamens 20 ; anthers pale yellow; styles $3-5$, surrounded at the base by a thin ring of pale hairs. Fruit ripening at the end of September or early in October, on slender pedicels, in few-fruited drooping clusters, globose, yellow-green flushed with red, $\frac{1}{3}$ in diameter, the calyx prominent, with 
closely appressed lobes; flesh yellow-green, thin, dry and mealy; nutlets $3-5$, thin, rounded, sometimes slightly ridged and grooved on the baek, about $\frac{8}{16}$ long.

$A^{\prime}$ tree, oceasionally $20^{\circ}$ high, with a tall trunk $5^{\prime}-6^{\prime}$ in diameter, covered with thin fissured bark separating into light gray scales tinged with brown, and often armed with long componnd spines, aseending or spreading branches forming an oval nsually compact symmetrieal head, and slender nearly straight glabrous branehlets furnished with thin nearly straight bright chestnut-brown shining spincs $1^{\prime}-1 \frac{1}{2}^{\prime}$ long; sometimes a shrub, with numerous stems.

Distribution. Rich moist soil in the ncighborhood of streams; northwestern Georgia and northeastern Alabama.

\section{Cratægus glabriuscula, Sarg.}

Leaves oblong-ovate to semiorbienlar, acutc or often short-pointed or rarely rounded at the apex, gradually narrowed from below the middle to the slender entire base, coarsely and often doubly serrate usually only above the middle, with

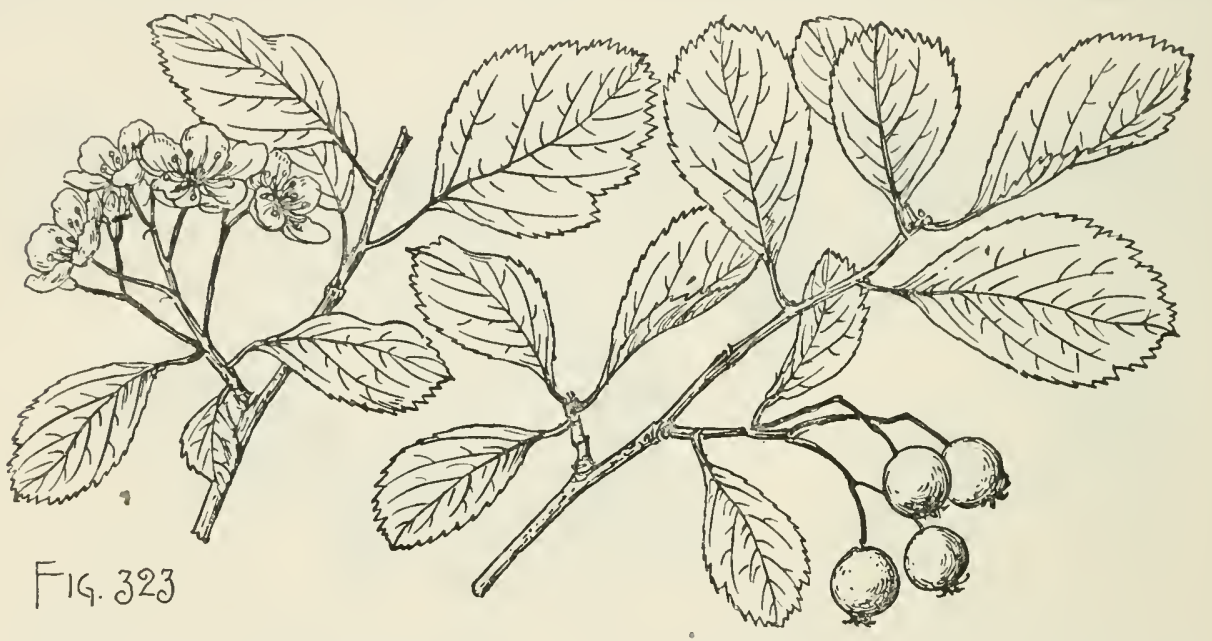

broad straight gland-tipped teeth, and sometimes divided toward the apex into 2 or 3 short acute lobes, nearly fully grown when the flowers open the 1st of April, and then membranaceous and slightly pilose above, with scattered hairs most abundant along the base of the midribs, and at maturity subcoriaceous, hard and firm, dark green and lustrous on the upper surface, pale on the lower surface, $11^{\prime}-2^{\prime}$ long, $\frac{3^{\prime}}{4}-1^{\prime}$ wide, with thin light yellow midribs and primary veins extending obliquely toward the end of the leaf, conspicuous secondary veins and reticulate veinlets; their petioles slender, wing-margined, $\frac{1}{3}^{\prime}$ long; on vigorous shoots often ovate, broadly cuneate at the base, much more coarsely dentate and more frequently lobed, $2^{\prime}-2 \frac{1}{2}^{\prime}$ long and wide, their stipules foliaceous, lunate, coarsely glandular-serrate, sometimes $1^{\prime}$ broad. Flowers about $\frac{1^{\prime}}{2}$ in diameter, on long slender glabrous pedicels, in few-flowered rather compact glabrons eorymbs; calyx-tube broadly obconic, glabrous, the lobes short, gradually narrowed from broad bases, entire, villose on the upper surface; stamens 20; anthers nearly white; styles 5. Fruit ripening in September and often persistent until late into the winter, on long slender pedicels, in compact manyfruited drooping clusters, short-oblong to obovate or nearly globose, dull orange color, marked by minute dark dots, about $\frac{1^{\prime}}{4}$ long; calyx enlarged, conspicuous, with spreading or closely appressed lobes, dull red on the upper side at the base, often 
deciduous before the fruit ripens; flesh very thin, yellow, dry and hard; nutlets 5, rounded and sometimes obscurely grooved on the back, about $\frac{3}{16}$ long.

A tree, $20^{\circ}-25^{\circ}$ high, with a tall straight trunk often a foot in diameter, covered with thin dark brown scaly bark, long ascending branches forming a narrow head, and slender nearly straight branchlets unarmed or armed with occasional slender straight chestnut-brown lustrous spines $\frac{3^{\prime}}{4}-1^{\prime}$ long.

Distribution. Bottom-lands of the Trinity River and its branches near Dallas, Texas, in forests of Elms and Nettle-trees.

\section{Cratægus blanda, Sarg.}

Leaves oval to rhomboidal, acute or acuminate, and occasionally slightly lobed toward the apex, broadly cuneate or concave-cuneate at the entire base, coarsely crenately serrate above the middle, with gland-tipped teeth, coated with soft pale hairs when they unfold, fully grown when the flowers opell about the 1st of May, and then membranaceous, dark green and lustrous above and glabrous below with the exception of large axillary tufts of snow-white tomentum, and at maturity subcoriaceous, yellow-green and lustrous on the upper surface, paler on the lower surface, $1 \frac{1^{\prime}}{2}-2^{\prime}$ long, $1^{\prime}-1 \frac{1}{3}^{\prime}$ wide, with slender midribs and 2 or 3 pairs of thin primary veins extending very obliquely toward the end of the leaf; their petioles slender, slightly winged above, at first villose along the upper side, soon becoming glabrous, $\frac{3^{\prime}}{4}-1^{\prime}$ long; on vigorous shoots often broadly ovate, full and rounded at the base, more deeply lobed above the middle, $2^{\prime}-2 \frac{1^{\prime}}{2}$ long and $1 \frac{1^{\prime}}{2}-2^{\prime}$ wide. Flowers $1^{\prime}$ in diameter, on slender elongated pedicels, in broad many-flowered compound

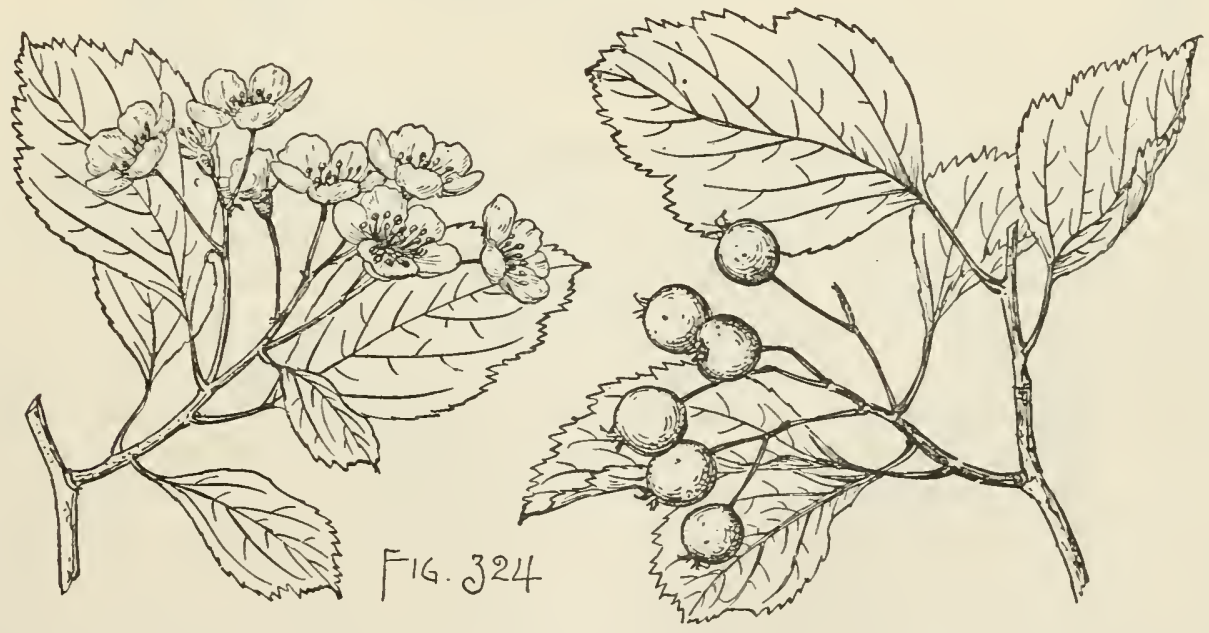

glabrous corymbs, with linear entire bracts and bractlets; calyx-tube broadly obconic, glabrous, the lobes gradually narrowed from broad bases, acuminate, entire or obscurely dentate, glabrous; stamens 20; anthers canary-yellow; styles 5. Fruit ripening about the middle of October, on slender pedicels, in many-fruited drooping clusters, subglobose to short-oblong, bright orange-red, $\frac{1^{\prime}}{4}$ in diameter ; calyx prominent, with spreading lobes usually deciduous from the ripe fruit; flesh thin, yellow, dry and mealy; nutlets 5 , thin, narrowed at the ends, deeply grooved -on the back, $\frac{1 /}{4}$ long.

An unarmed tree, $25^{\circ}-30^{\circ}$ high, with a tall trunk $10^{\prime}-12^{\prime}$ in diameter, covered with dark brown or nearly black bark divided by shallow fissures and broken on the 
surface into small plate-like seales, stout ascending branches forming a broad irregular head, and nearly straiglit glabrous branchlets dark orange-green at first, becoming dull red-brown during their first season and darker brown the following year.

Distribution. Dry uplands and low rolling lills near Fulton, Arkansas, in the valley of the Red River.

\section{Cratægus nitida, Sarg.}

Leaves lanceolate to oblong-obovate, acuminate, abruptly or gradually narrowed and cuncate at the entire base, coarsely serratc above, with straight or incurved glandular teeth, and often more or less divided into 2 or 3 pairs of broad acute

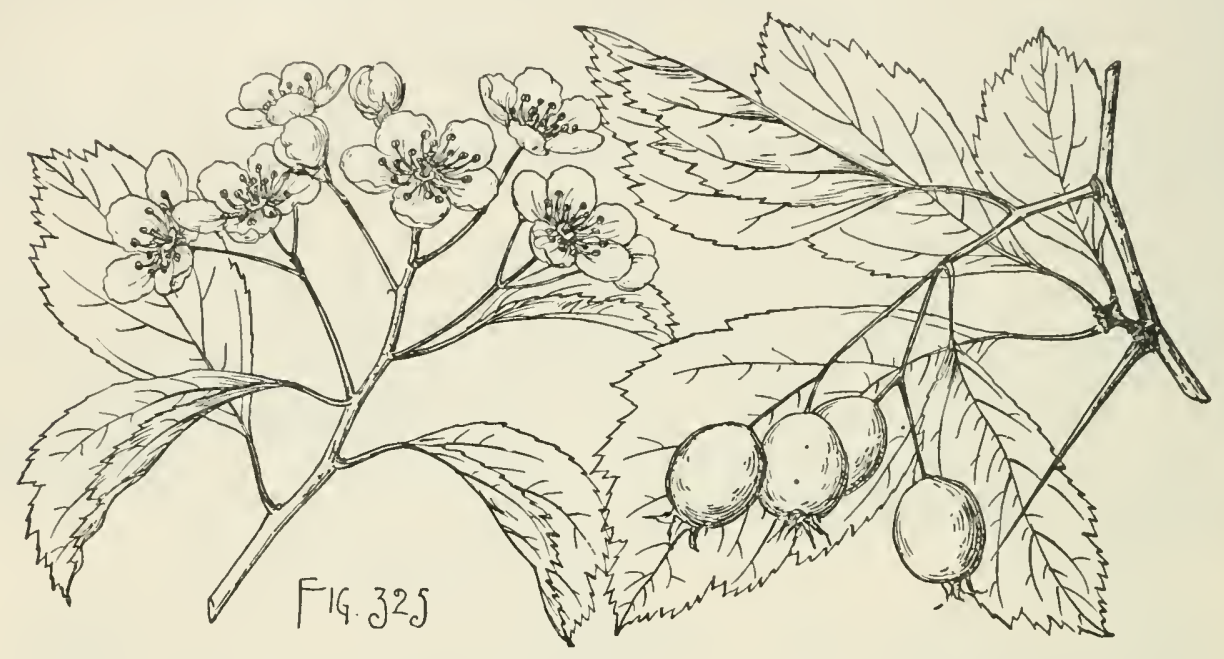

lobes, when they unfold dark red and slightly villose along the upper side of the midribs, with scattered caducons hairs, nearly fully grown when the flowers open early in May, and at maturity thick and coriaceous, dark green, very lustrous on the upper surface, pale and dull on the lower surface, $2^{\prime}-3^{\prime}$ long, and $1^{\prime}-1 \frac{1}{2}^{\prime}$ wide, with prominent midribs usually red on the lower side and few thin prominent primary veins generally extending to the points of the lobes, turning in the autumn rich orange color through shades of bronze and orange-red; their petioles stout, glandular, more or less winged above, villose while young on the upper side, soon becoming glabrous, $\frac{1^{\prime}}{2}-\frac{3 \prime}{4}$ long; on vigorous shoots more deeply lobed and frequently $5^{\prime}$ long and $2 \frac{1}{2}^{\prime}$ wide, with lunate stipitate coarsely glandular stipules occasionally $\frac{1}{2}^{\prime}$ long. Flowers $\frac{3 \prime}{4}$ in diameter, on slender elongated pedicels, in broad compound many-flowered glabrous corymbs; calyx-tube narrowly obconic, glabrous, the lobes slender, elongated, acuminate, entire or sparingly glandular-serrate; stamens 1520 ; anthers pale yellow; styles 2-5. Fruit ripening at the end of October, on slender elongated pedicels, in many-fruited drooping clusters, oblong, full and rounded at the ends, pruinose, with a glaucous bloom, marked by small dark dots, $\frac{1^{\prime}}{2}-\frac{5}{8}$ long and about $\frac{1^{\prime}}{3}$ thick; calyx only slightly enlarged, the lobes dark red at the base on the upper side, usually erect, often deciduous before the fruit ripens; flesh thick, yellow, dry and mealy; nutlets $2-5$, rounded and ridged on the back, with a broad low rounded ridge, light-colored, $\frac{1^{\prime}}{4}$ long.

A tree, $30^{\circ}$ high, with a tall straight trunk sometimes $18^{\prime}$ in diameter, covered with close dark bark broken into thick plate-like scales, stout spreading lower 
branches and erect upper branches forming a broad often irregular head, and slender glabrous branchlets bright orange-brown and lustrous during their first and seeond seasons, becoming pale reddish brown in their third year, and ultimately ashy gray, and unarmed or armed with occasional straight thin bright chestnut-brown lustrous spines $1^{\prime}-1 \frac{1}{2}^{\prime}$ long.

Distribution. Bottoms of the Mississippi River, Illinois, opposite the city of St. Louis; common.

\section{Craætgus mitis, Sarg., n. sp.}

Leaves obovate to oval or rhomboidal, acute or rarely rounded at the apex, gradually narrowed and concave-cuneate at the entire base, and coarsely serrate above, with straight glandular teeth, nearly fully grown when the flowers open during the first week of May, and then light yellow-green above, paler below, and glabrous with the exception of a few short hairs on the upper side of the midribs, and at maturity subcoriaceous, dark green and lustrous on the upper surface, pale yellowgreell on the lower surface, $1 \frac{1}{2}^{\prime}-2 \frac{1}{2}^{\prime}$ long, $1^{\prime}-1 \frac{1}{2}^{\prime}$ wide, with prominent midribs and slender primary veins; their petioles stout, wing-margined at the apex, occasionally glandular, with minute glands, $1 \frac{1}{3}^{\prime}-1 \frac{1}{2}^{\prime}$ long. Flowers $\frac{1}{2}^{\prime}-5^{\prime}$ in diameter, on long slender pedicels, in compact compound 8-15-flowered glabrous corymbs, with red glandular bracts and bractlets; calyx-tube narrowly obconic, glabrous, the lobes abruptly narrowed from broad bases, acuminate, finely glandular-serrate below the

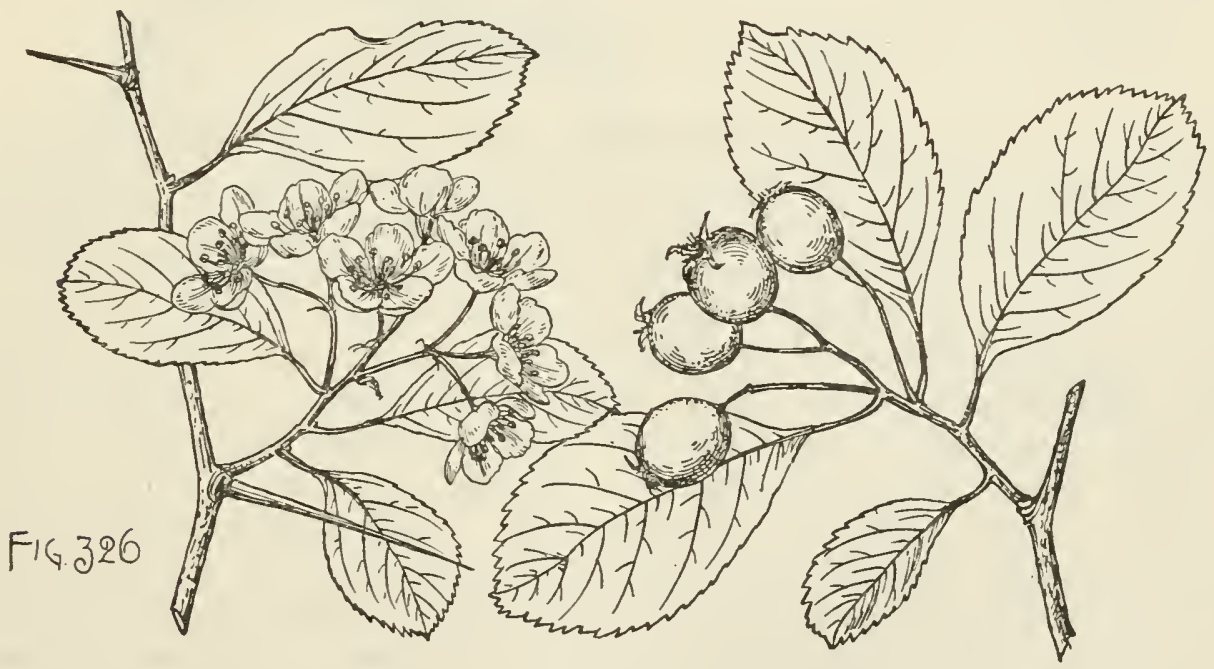

middle, with minute stipitate red glands; stamens 20 ; anthers yellow; styles $2-4$, usually 3. Fruit ripening the middle of October, on slender pedicels, in manyfruited drooping clusters, subglobose to short-oblong, full and rounded the ends, dark crimson marked by occasional large dark dots, $\frac{1}{2}^{\prime}-\frac{5^{\prime}}{8}$ long, about $\frac{1}{2}^{\prime}$ wide; calyx only slightly enlarged, the lobes serrate, closely appressed, often deciduous from the ripe fruit; flesh thick, pale orange color, and juicy; nutlets usually 3 , thick, full and rounded at the ends, prominently ridged on the back, with a broad high rounded deeply grooved ridge, about $\frac{1^{\prime}}{4}$ long.

A tree, $25^{\circ}-30^{\circ}$ high, with a tall trunk sometimes a foot in diameter, covered with dark scaly bark, large spreading branches forming a broad round-topped head, and glabrous branchlets dull light reddish brown during their first season, becoming 
dark brown or ashy gray, and armed with stout straight or slightly curved dull redbrowu or purplish spines usually about $1_{2}^{\prime \prime}$ long.

Distribution. Low moist rich soil on the bottoms of the Mississippi River near the village of Kahokia, Illinois, a few miles south of East St. Louis (John D. Kellogg, October 1902, May 1903).

\section{Cratægus atrorubens, Ashe.}

Leaves ovate, acute, usually full and rounded or sometimes broadly cuneate or truncate at the entire base, coarsely and usually doubly serrate above, and often

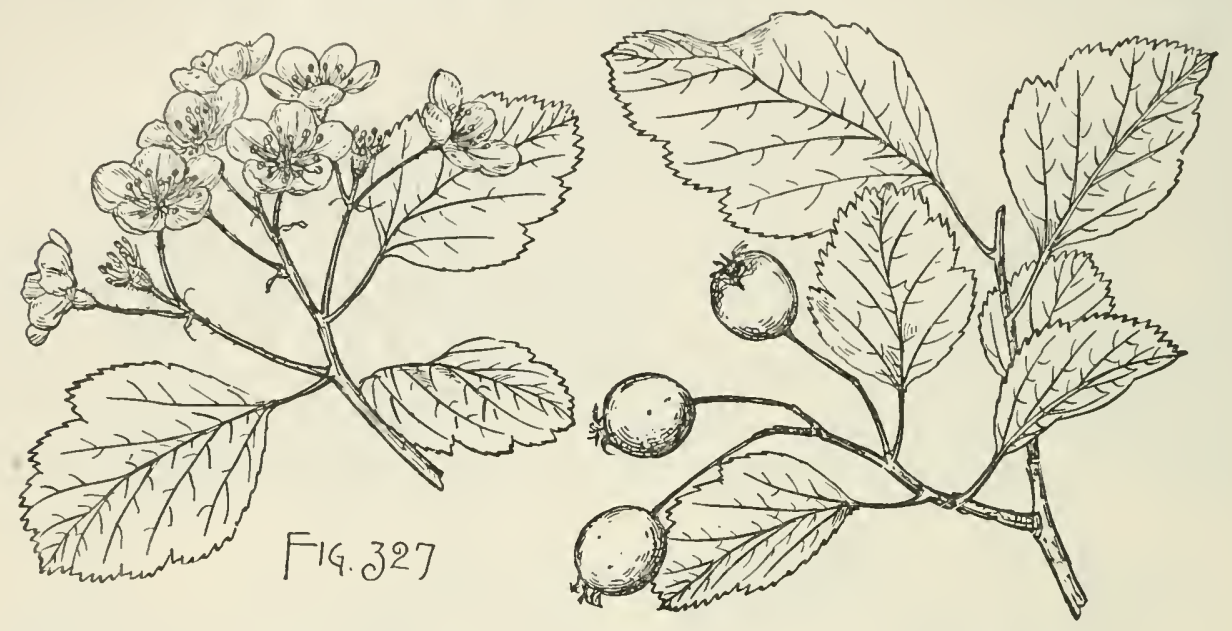

divided into 2 or 3 pairs of short acute lobes, about half grown when tle flowers open late in A pril or early in May and then slightly roughened above by short scattered white hairs, and furnished below with conspicuous axillary tufts of pale tomentum, and at maturity thin, glabrous, dark dull green and smooth on the upper surface, light yellow-green on the lower surface, about $2^{\prime}$ long and $1 \frac{1}{2}^{\prime}$ wide, or on leading shoots frequently $3^{\prime}$ long, and $2 \frac{1}{2}^{\prime}$ wide, with thin midribs and 4 or 5 pairs of slender primary veins; their petioles slender, nearly terete, more or less densely villose at first, soon becoming glabrous, $1^{\prime}-1 \frac{1^{\prime}}{2}$ long. Flowers about $\frac{5^{\prime}}{8}$ in diameter, on slender elongated villose pedicels, in broad loose compound glabrous or villose corymbs; calyx-tube narrowly obconic, coated throughout or only at the base with hoary tomentum, the lobes slort, acute, finely glandular-serrate, villose particularly on the inner surface; stamens 20 ; styles 4 or 5 , surrounded at the base by a narrow ring of pale tomentum. Fruit ripening and falling early in October, on slender pedicels, in drooping few-fruited clusters, subglobose to short-oblong, full and rounded at the ends, dark red; calyx somewhat enlarged, with spreading lobes nsually deciduous before the fruit ripens; nutlets 4 or 5 , thin, rounded and sometimes obscurely grooved on the back, about $\frac{8}{16}$ long.

A tree, sometimes $30^{\circ}$ high, with a tall trunk $12^{\prime}-18^{\prime}$ in diameter, covered with dark red-brown scaly bark, thin erect and spreading brainches forming a compact rather narrow head, and slender glabrous branchlets marked by occasional dark lenticels, dark green more or less tinged with red when they first appear, becoming dark chestnut-brown and very lustrous and bright reddish brown in their second year, and usually mnarmed.

Distribution. Rich bottom-lands of the Mississippi River, East St. Louis, Illinois; not common. 


\section{Cratægus ingens, Beadl.}

Leaves obovate-oval or ovate, broadly or narrowly wedge-shaped at the entire base, crenately serrate above, and often slightly lobed toward the acute apex, about half grown when the flowers open at the end of April or early in May and then roughened above by short rigid hairs and villose below along the midribs and remote slender veins extending very obliquely to the points of the lobes, and at maturity subcoriaceous, dark green and scabrate on the upper surface, paler and nearly glabrous on the lower surface, $1 \frac{1}{2}^{\prime}-2^{\prime}$ long, $1 \frac{1}{4}-1 \frac{1^{\prime}}{2}$ wide, turning in the autumn yellow, orange, red, or brown; their petioles stout, narrowly wing-margined to the middle, pubescent while young, becoming glabrous, about $\frac{3^{\prime}}{4}$ long; on vigorous shoots more deeply lobed and often 3 ' $-3 \frac{1}{2}$ ' long, and ' 2 ' wide, with stout broad-winged petioles sometimes $1 \frac{1}{2}^{\prime}$ in length. Flowers $\frac{1^{\prime}}{2}-\frac{5}{8}$ in diameter, on slender hairy pedicels, in many-flowered compact hairy corymbs; calyx narrowly obconic, coated, especially toward the base, with matted pale hairs, the lobes slender, elongated, acute, glandular, with bright red glands, glabrous on the outer, sparingly villose on the inner surface; stamens 20; anthers bright purple; styles $3-5$. Fruit ripening in October,

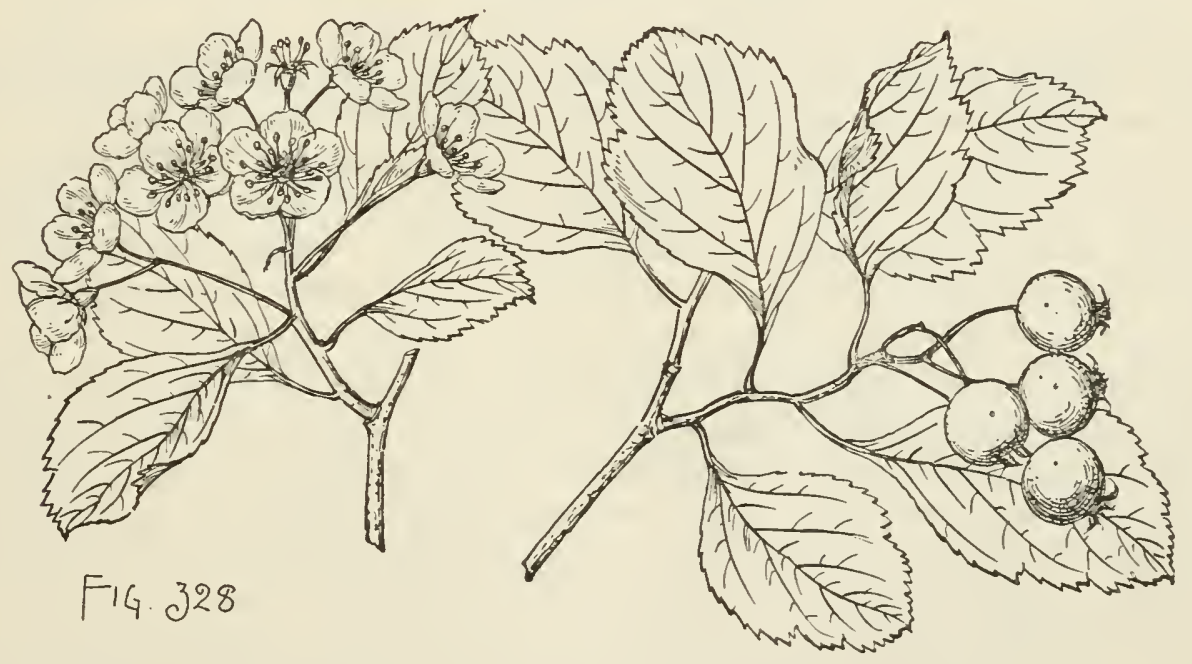

on stout puberulous pedicels, in few-fruited drooping clusters, globose to subglobose, red, about $\frac{3^{\prime}}{8}$ in diameter; calyx little enlarged, with reflexed appressed nearly glabrous lobes; flesh firm; nutlets $3-5$, rounded or slightly grooved and ridged on the back, $\frac{1}{4}$ long.

A tree, sometimes $25^{\circ}$ high, with a trunk a foot in diameter, spreading branches forming a wide round-topped head, and unarmed branchlets covered at first with matted pale hairs, soon becoming glabrous.

Distribution. Moist woods and the low banks of streams; southeastern Tennessee and northwestern Georgia.

\section{Cratægus penita, Beadl.}

Leaves broadly obovate, oval, or ovate, acute or acuminate at the apex, broadly or acutely concave-cuneate at the entire base, sharply often doubly serrate above, with glandular mostly straight teeth, and often slightly lobed above the middle, 
deeply tinged with red and covered with pale hairs when they unfold, nearly fully grown when the flowers open about the 1st of May and then smooth above and glabrous below with the exception of axillary tufts of pale hairs, and at maturity subeoriaceons, dark green and lustrous on the upper surface, paler on the lower

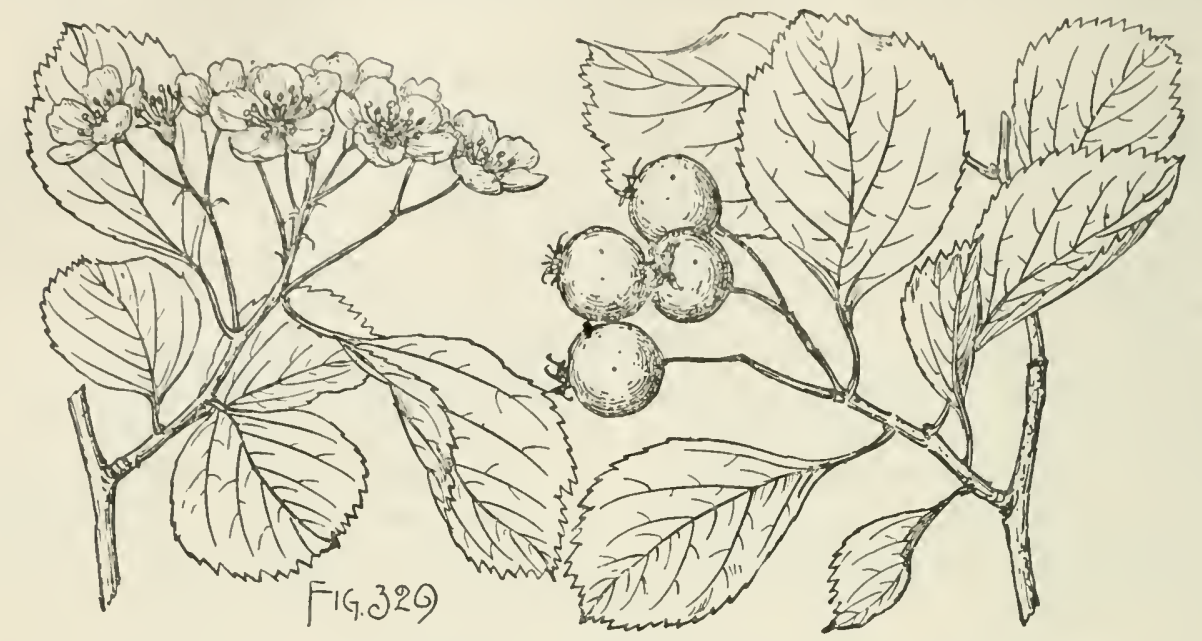

surface, $1 \frac{3^{\prime}}{4}-2^{\prime}$ long, $1^{\prime}-1 \frac{3^{\prime}}{4}$ wide, with prominent midribs and slender primary veins, turning orange, yellow, and brown in the autumn; their petioles slender, covered while young like the upper side of the base of the midrib with pale deciduous hairs, $\frac{1}{2}-\frac{3}{4}$ ' long; on vigorous shoots often rounded or subcordate at the base, more or less deeply lobed and $2 \frac{1^{\prime}}{2}-3^{\prime}$ long and broad, with stout broadly winged glandular petioles. Flowers about $\frac{5 \prime}{8}$ in diameter, on elongated glabrous or sparingly hairy pedicels, in compact few-flowered nearly glabrous corymbs; calyx broadly obconic, glabrous, the lobes gradually narrowed from broad bases, slender, acuminate, entire, or furnished with occasional minute glandular teeth, slightly villose on the inner surface; stamens 20; anthers white faintly tinged with pink; styles 3-5. Fruit ripening in October, on elongated slender pedicels, in few-fruited drooping clusters, globose or depressed-globose, red, about $\frac{1}{4}^{\prime}$ in diameter, with firm flesh; calyx enlarged, with spreading or reflexed lobes, villose on the upper side; nutlets 3-5, narrowed and acute at the ends, rounded and broadly grooved on the baek, about $\frac{1^{\prime}}{4}$ long.

A tree, $18^{\circ}-20^{\circ}$ high, with a short trunk sometimes $10^{\prime}$ in diameter, stout ascending or spreading branches forming a wide head, unarmed branchlets puberulous while young, soon glabrous, and becoming light reddish brown.

Distribution. Low moist woods and the banks of streams; southeastern Tennessee.

** Stamens usually 10; anthers bright red.

\section{Cratægus micracantha, Sarg.}

Leaves oblong-obovate to oval, acute, acuminate, or rarely rounded at the apex, gradually or abruptly narrowed from above or below the middle to the cuneate entire base, coarsely crenulate-serrate and occasionally 3 -lobed above, with short broad aeute lateral lobes, when they unfold villose on the upper and hoary-tomentose on the lower surface, more than half grown when the flowers open about the middle of May and then membranaceous and slightly villose above, with short scattered pale hairs, and at maturity thin but firm in texture, dark yellow-green, lustrous, and smooth 
above, paler and tomentose below aloug the slender midribs and 3 or 4 pairs of very obscure primary veins, $2^{\prime}-2 \frac{1}{2}^{\prime}$ long, $1^{\prime}-11_{4}^{\prime \prime}$ wide; their petioles slender, more or less wing-margined toward the apex, tomentose early in the season, beconing glabrous or pubescent, $\frac{1^{\prime}}{2}-\mathbf{1}^{\prime}$ long; on leading shoots often broadly rhomboidal to obovate, acuminate, frequently deeply 3 -lobed or divided into 2 or 3 pairs of short lateral lobes, usually $2 \frac{1}{2}^{\prime}-3^{\prime}$ loug. Flowers cup-shaped, $\frac{1}{4}^{\prime}$ in diameter, on long slender pedicels thickly coated with matted white hairs, in broad lax many-flowered compound hairy corymbs; calyx-tube narrowly obconic, villose, the lobes linear, acuminate, entire, slightly villose, tipped with minute dark glands; stamens usually 10 , occasionally 12, 15, or 20; anthers snall, deep bright red; styles 5. Fruit ripening the middle of October, on slender pubescent pedicels, in drooping many-fruited clusters, subglobose to short-oblong, full and rounded at the ends, bright orange-red,

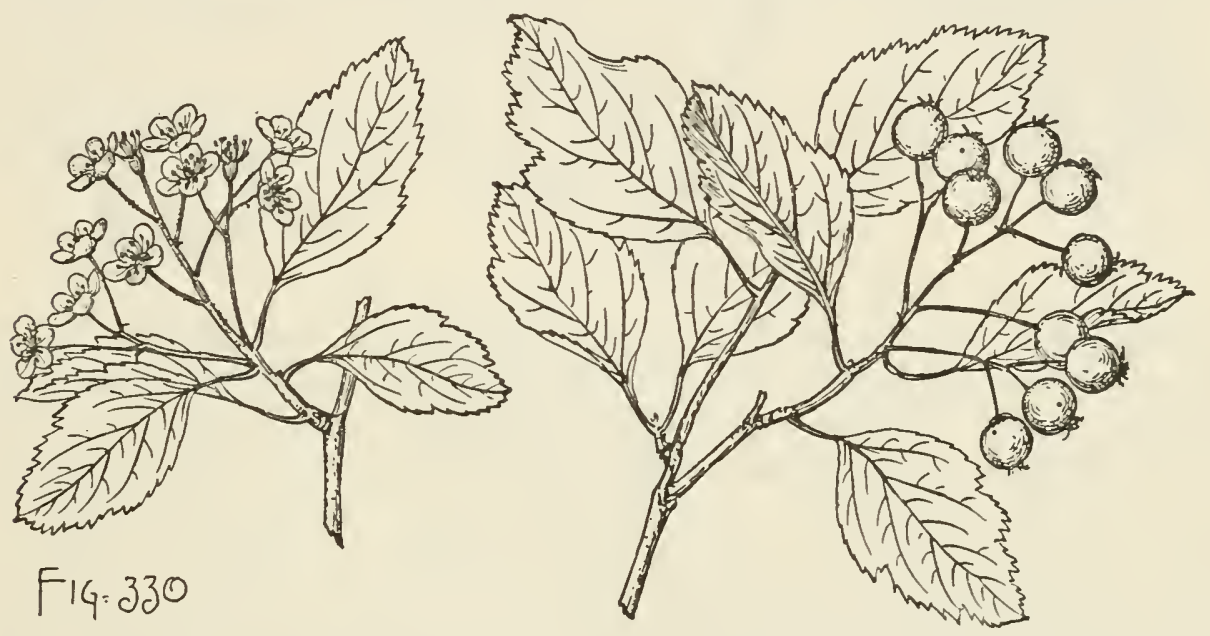

lustrous, marked by occasional large pale dots, about $\frac{1^{\prime}}{4}$ long; calyx prominent, with a short villose tube, and spreading erect hairy lobes often deciduous from the ripe fruit; flesh thin, yellow, dry and mealy; nutlets 5, thin, acute at the narrowed ends, rounded and sometimes slightly grooved on the back, about $\frac{3}{16}^{\prime}$ long.

An unarmed tree, sometimes $25^{\circ}$ high, with a tall trunk $8^{\prime}-12^{\prime}$ in diameter, covered with light or dark brown bark separating freely into thin narrow scales, stout spreading branches forming a broad flat-topped handsome head, and slender nearly straight branchlets coated until after the flowering time with thick hoary tomentum, bright red-brown and puberulous during their first season, becoming light or dark dull reddish brown the following year.

Distribution. Common in low woods in rich moist soil near Fulton, Arkansas, in the valley of the Red River.

\section{PRUINOSÆ.}

Leaves elliptical; fruit subglobose, green, and pruinose when fully grown, becoming dark purple-red and very lustrous; anthers large, deep rose color. 46. C. pruinosa (A, C). Leaves ovate, acute or acuminate; fruit oblong, dull russet green ; anthers small, light rose color.

47. C. Georgiana (C).

46. Cratægus pruinosa, K. Koch.

Leaves elliptical, acute, gradually or abruptly narrowed and cuneate at the entire base, irregularly and often doubly serrate above, with glandular straight or 
incurved teeth, and divided in 3 or 4 pairs of short acute or acuminate lateral lobes, when they unfold bright red and glabrous with the exception of a few short caducous hairs on the upper side of the base of the midribs, nearly fully grown when

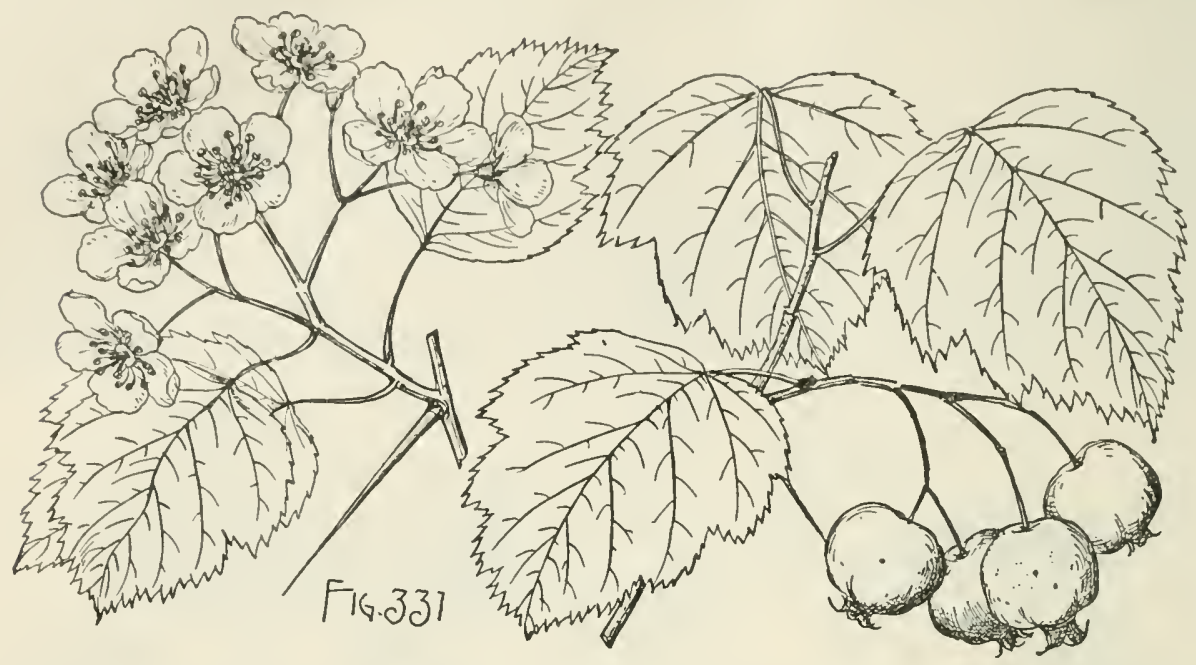

the flowers open from the middle to the end of May and then membranaceous and bluish green, and at maturity subcoriaceous, dark blue-green and of ten glaucous above, pale below, $1^{\prime}-1 \frac{1}{2}^{\prime}$ long, $\frac{3^{\prime}}{4}-1^{\prime}$ wide, with slender midribs and 3 or 4 pairs of thin primary veins running to the points of the lobes, late in the autumn turning dull orange color; their petioles slender, glandular, slightly winged at the apex, $1^{\prime}-1 \frac{1}{4}^{\prime}$ long, often bright red in early spring and in the autumn; on vigorous shoots broadly ovate, often rounded at the base, more coarsely dentate and more deeply lobed, frequently $2 \frac{1}{2}$ long and wide, with stouter and more broadly winged petioles. Flowers $\frac{z^{\prime}}{4}-1^{\prime}$ in diameter, on long slender pedicels, in few-flowered glabrous corymbs; calyxtube broadly obconic, glabrous, the lobes gradually narrowed from wide bases, longpointed, finely glandular-serrate below the middle; stamens 20; anthers large, deep rose color; styles 5, surrounded at the base by a thick band of hoary tomentum. Fruit on long thin light green ultimately bright red pedicels, in few-fruited drooping clusters, 5 -angled, apple green, and covered with a glaucous bloom until nearly fully ripe, at maturity late in October subglobose but rather broader than long, barely angled, $\frac{1^{\prime}}{2}-\frac{5}{8}$ in diameter, dark purple-red, marked by many small dull dots, very lustrons; calyx prominent, with a long well-developed tube and enlarged usually erect lobes often deciduous before the fruit ripens; flesh thick, light yellow, sweet, dry and mealy; nutlets 5, light-colored, acute at the apex, narrowed and rounded at the base, deeply grooved on the back, $\frac{1^{\prime}}{4}$ long.

A tree, $15^{\circ}-20^{\circ}$ high, with a stem a few inches in diameter, spreading horizontal branches forming a broad open irregular head, and branchlets armed with numerous stout straight light chestnut-brown spines $1^{\prime}-1 \frac{1}{2}^{\prime}$ long; often shrubby, with several intricately branched stems.

Distribution. Slopes of low hills often in limestone soil; southwestern Vermont, southward to the foothill region of the southern Appalachian Mountains, and westward to central Illinois and Missouri. 


\section{Cratægus Georgiana, Sarg.}

Leaves ovate, acute or acuminate at the apex, full and rounded or broadly cuneate at the base, finely and often doubly serrate, with straight or incurved glandtipped teeth, and divided into numerous short acute lateral lobes, glabrous with the exception of a few pale caducous hairs on the upper surface and bronze-yellow when they unfold, nearly half grown when the flowers opeu about the 20th of April and then thin, dark yellow-green above, pale below, and at maturity thin but firm in texture, dark blue-green on the upper surface, pale on the lower surface, $1 \frac{1}{2}^{\prime}-2^{\prime}$ long, $\mathbf{1}^{\prime}-\mathbf{1} \frac{1^{\prime}}{4}$ wide, with slender yellow midribs and 3 or 4 pairs of thin primary veins; their petioles sleuder, often short-winged at the apex, usually about $\frac{3^{\prime}}{4}$ long; on leading shoots often $3^{\prime}$ long and $2^{\prime}$ wide, sometimes deltoid and usually much more deeply lobed. Flowers $\frac{3^{\prime}}{4}$ in diameter, on slender pedicels, in usually 5-7-flowered compact glabrous corymbs; calyx-tube broadly obconic, glabrous, the lobes gradually narrowed from broad bases, acuminate, entire or obscurely and irregularly serrate, glabrous; stamens 20; anthers small; light rose color; styles 5; surrounded at the base by a narrow ring of pale tomentum. Fruit ripening and falling early in October, on slender pedicels, in drooping few-fruited clusters, oblong, full and rounded at the

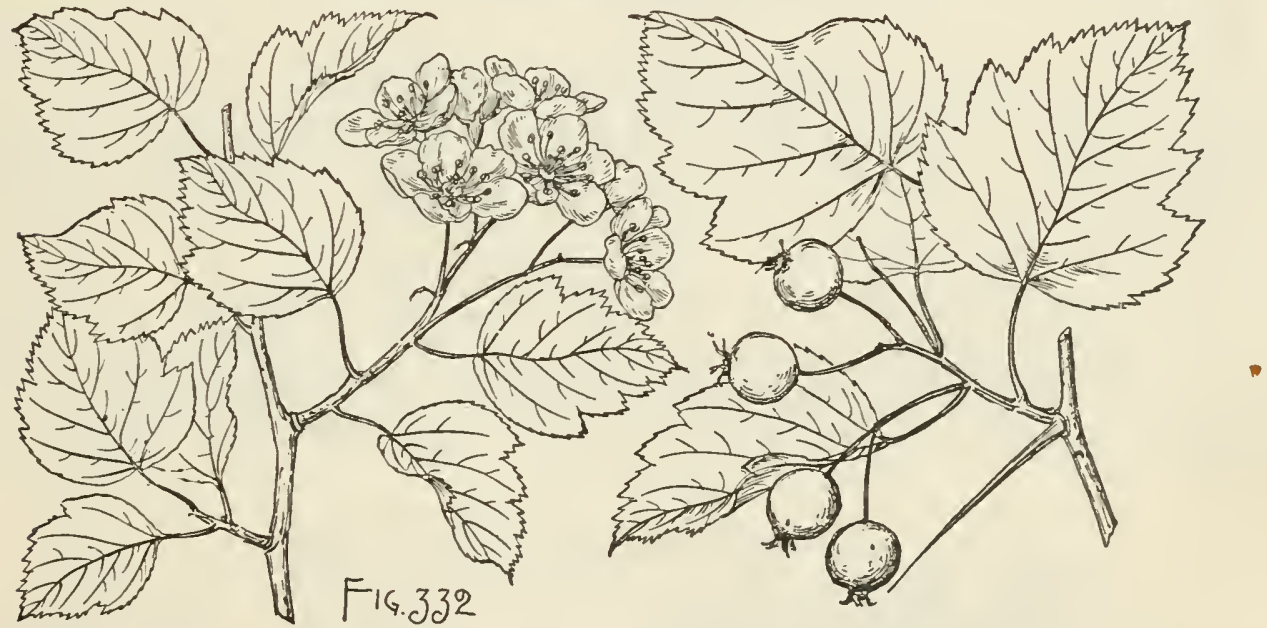

ends, often obscurely 5-angled, dull russet-green, $\frac{3}{8}^{\prime}-\frac{1}{2}^{\prime}$ long; calyx-lobes only slightly enlarged, mostly deciduous before the fruit ripens, leaving a well-defined ring at the summit of the short calyx-tube; flesh thin, light green, dry and hard; nutlets 5, thin, rounded and irregularly grooved on the back, about $\frac{1}{4}^{\prime}$ long.

A tree, sometimes $25^{\circ}-30^{\circ}$ high, with a tall trunk $10^{\prime}-12^{\prime}$ in diameter, stout widespreading branches forming a broad symmetrical round-topped head, and branchlets armed with straight or slightly curved thin bright chestnut-brown lustrous spines rarely more than $1 \frac{1^{\prime}}{2}$ long.

Distribution. Low rich river bottoms and meadows in the neighborhood of Rome, Georgia.

Stamens $\check{0}-10$.

\section{TENUIFOLIÆ.}

Fruit obovate; leaves oblong-ovate, acuminate, dark blue-green.

Stamens usually 5 ; anthers pink; fruit bright reddish purple; leaves mostly scabrate ; calyx-lobes entire or sparingly glandular; spines more than $1^{\prime}$ long.

48. C. apiomorpha (A). 
Stanens 10; anthers bright reddish purple; fruit crimson or purplish; leaves smooth; spines $\frac{1^{\prime}}{2}-s^{\prime}$ longr.

49. C. paucispina (A).

Fruit short-oblong, dark crinson; leaves oval or ovate, dark green and scabrate above; stanens usually 5 ; anthers dark red-purple.

50. C. pentandra (A).

Frnit subglobose, often broader than high, red or greenish yellow, with a rosy cheek;

leaves ovate, dark yellow-green, smooth or scabrate above; stamens 10; anthers purple.

51. C. silvicola (C).

Stamens usually 20.

Leaves broadly ovate to oval, dark dull green and smooth above; fruit short-oblong to obovate, erimson, anthers dark purple.

5:. C. lucorum (A).

Leaves ovate, yellowish to bluish green and smooth above; fruit subglobose to broadobovate, dark red to reddish purple; anthers pale rose color.

53. C. depilis $(A)$.

Leaves orate, bright green and scabrate above; fruit subglobose, scarlet, with a glaucous bloom ; anthers purple.

54. C. basilica (A).

Leaves rhomboidal to broadly ovate or rarely obovate, light yellow green; fruit shortoblong, bright cherry-red; anthers rose color.

55. C. lacera (C).

* Stamens 5-10.

\section{Cratægus apiomorpha, Sarg.}

Leaves oblong-ovate, acuminate, rounded or rarely cuneate at the entire often unsymmetrical base, finely doubly serrate above, with slender glandular teeth, and slightly divided above the middle into 4 or 5 pairs of triangular acute lobes, about half grown when the flowers open early in May and then membranaceous, light yellow-green and tinged with red or bronze color, and covered above with short white hairs and pale and glabrous below, and at maturity thick and firm in texture, dark blue-green and smooth and lustrous or.sometimes dull and scabrate on the upper surface, pale blue-green on the lower surface, $1 \frac{1}{2}^{\prime}-2 \frac{1}{4}^{\prime}$ or on leading shoots often $3^{\prime}$ long, $1 \frac{1}{8}^{\prime}-1 \frac{1}{2}^{\prime}$ wide, with stout midribs and primary veins arching obliquely to the points of the lobes; their petioles slender, slightly winged at the apex, often sparingly

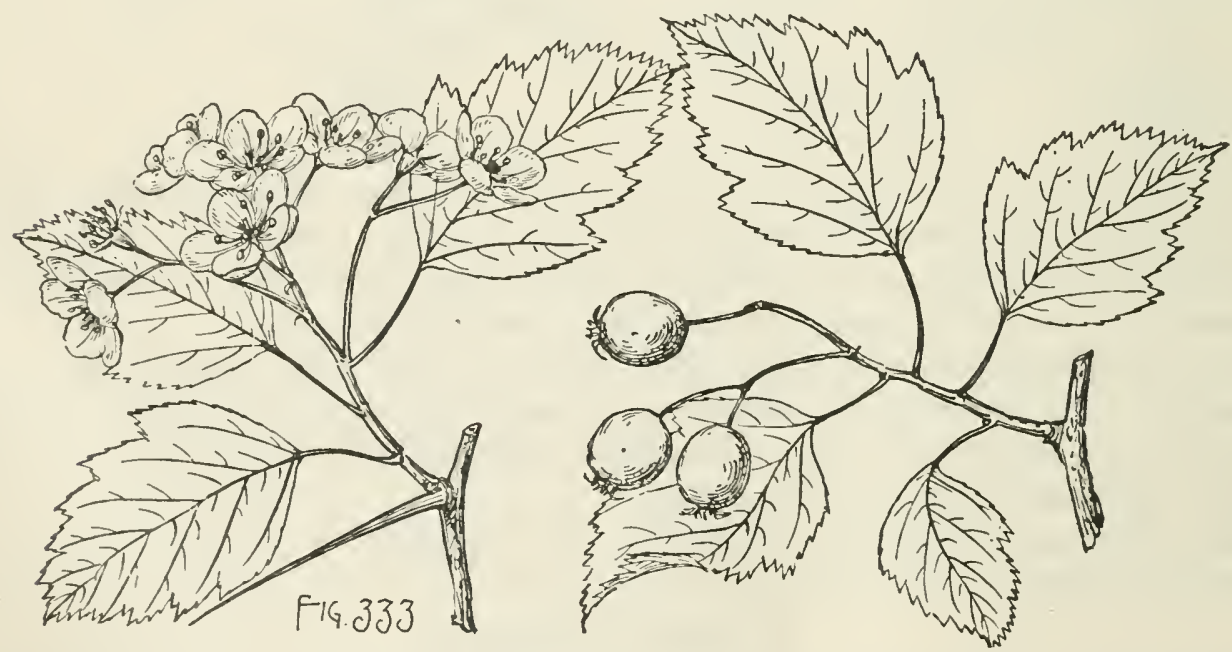

glandular, $\frac{3 \prime}{8}-1^{\prime}$ long. Flowers $\frac{1^{\prime}}{2}-\frac{3 \prime}{4}$ in diameter, on short villose or glabrous pedicels, in compact many-flowered usually hairy compound corymbs; bracts and bractlets linear to oblong-obovate, finely glandular-serrate, with stipitate dark red or purple glands, turning red before falling, mostly persistent until after the flowers 
open; calyx-tube narrowly obconic, glabrous, the lobes abruptly narrowed at the base, slender, acuminate, entire or sparingly glandular on the margins; stamens 510 , usually 5 ; anthers pink; styles $3-5$, surrounded at the base by tufts of pale hairs. Fruit ripening the 1st of September and soon falling, on slender pedicels, in fewfruited drooping clusters, obovate or rarely short-oblong, bright reddish purple, marked by small scattered pale dots, $\frac{3^{\prime}}{8}-\frac{5}{8}^{\prime}$ long, $\frac{1}{4}^{\prime}-\frac{1}{3}^{\prime}$ wide; calyx much enlarged, with spreading lobes, their tips mostly deciduous from the ripe fruit; flesh thin, yellow, juicy, pleasantly acid; nutlets $3-5$, thin, rounded and ridged on the back, with a low ridge, about $\frac{1}{4}^{\prime}$ long.

A tree, sometimes $25^{\circ}$ high, with a trunk $6^{\prime}$ in diameter and $3^{\circ}-6^{\circ}$ long, covered with dark gray bark separating into thin plates, in falling disclosing the yellow inner bark, numerous ascending branches forming an oblong or pyramidal crown, and slender branchlets dark dull red-brown during their first season, becoming dark graybrown the following year, and unarmed or armed, with slender nearly straight dull red-brown ultimately ashy gray spines $1^{\prime}-1_{\frac{1}{2}}^{\prime}$ long; or often shrubby, with numerous stems spreading into small clumps.

Distribution. Dry open places, borders of woods, and the margins of the high banks of streams; common and generally distributed in the neighborhood of Chicago, Illinois.

\section{Cratægus paucispina, Sarg.}

Leaves oblong-obovate, acuminate, rounded, concave-cuneate to truncate or subcordate at the entire base, sharply doubly serrate above, with straight glandular

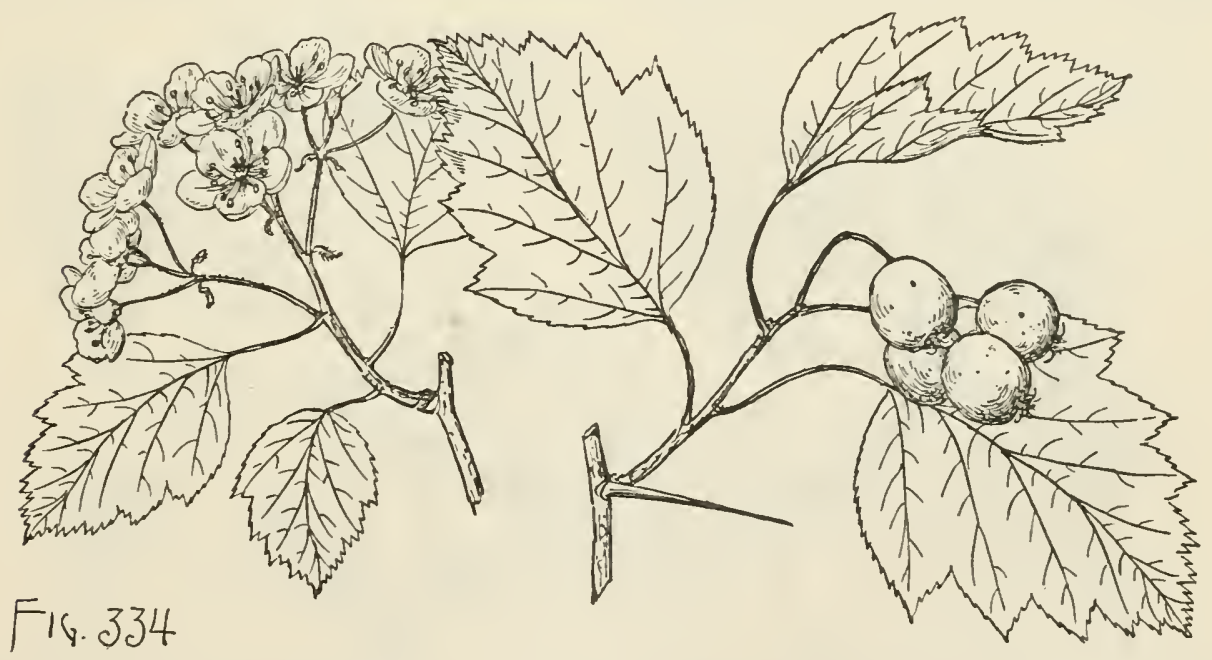

teeth, and deeply divided into 4 or 5 pairs of acute lateral lobes spreading or pointing toward the apex of the leaf, about half grown when the flowers open early in May and then light yellow-green and slightly roughened above by short white hairs and paler and glabrous below, and at maturity membranaceous, dark blue-green and scabrate on the upper surface, pale blue-green on the lower surface, $2 \frac{1}{2}^{\prime}-3^{\prime}$ long, $1 \frac{1}{2}{ }^{\prime}-$ $2 \frac{1}{2}^{\prime}$ wide, with slender yellow midribs and thin primary veins extending obliquely to the points of the lobes; their petioles slender, usually without glands, tinged with purple in the autumn, $\frac{3^{\prime}}{4}-1 \frac{1}{2}^{\prime}$ long. Flowers $\frac{5}{8}^{\prime}-\frac{8}{4}^{\prime}$ in diameter, on slender hairy pedicels, in broad 12-20-flowered slightly villose compound corymbs, with linear to oblong-obovate glandular red bracts and bractlets mostly persistent until after the 
flowers open; calyx-tube narrowly obconic, glabrous, the lobes narrow, acuminate, glandular-serrate, with small dark red stipitate glands, glabrous on the outer, pubescent on the imner surface; stamens 10; anthers bright reddish purple; styles 4 or 5 , surrounded at the base by tufts of pale hairs. Fruit ripening during the first half of September and soon falling, on slender glabrous pedicels, in drooping clusters, obovate to subglobose, crimson or purplish, marked by numerous small pale dots, slightly pruinose, $\frac{1}{2}^{\prime}-\frac{5}{8}$ long, about $\frac{1}{2}^{\prime}$ wide; calyx small, with reflexed and appressed or erect and incurved serrate lobes dark red on the upper side below the middle, often deciduous from the ripe fruit; flesh thin, yellow, juicy, acid, and edible; nutlets 4 or 5 , thin, narrowed and acute at the ends, rounded and slightly grooved or obscurely ridged on the back, about $\frac{1^{\prime}}{4}$ long.

A tree, sometimes $25^{\circ}$ high, with a trunk $4^{\prime}-6^{\prime}$ in diameter and often $6^{\circ}$ long, covered with dark gray or nearly black bark separating into thin plate-like scales, numerous branches forming a round-topped head, and slender glabrous branchlets dark yellow-green when they first appear, becoming dark reddish brown at the end of their first season, olive-green in their second year, and ultimately dark graybrown, and armed with small straight light red-brown shining spines $\frac{1^{\prime}}{2}-3^{\prime}$ long.

Distribution. Woods and river banks in dry clay soil; Maywood, near Chicago, Illinois.

\section{Cratægus pentandra, Sarg.}

Leaves oval or ovate, acuminate, broadly cuneate or rarely rounded at the entire base, divided above the middle into numerous short acute or acuminate lobes, and coarsely and often doubly serrate, with straight or incurved teeth tipped with small

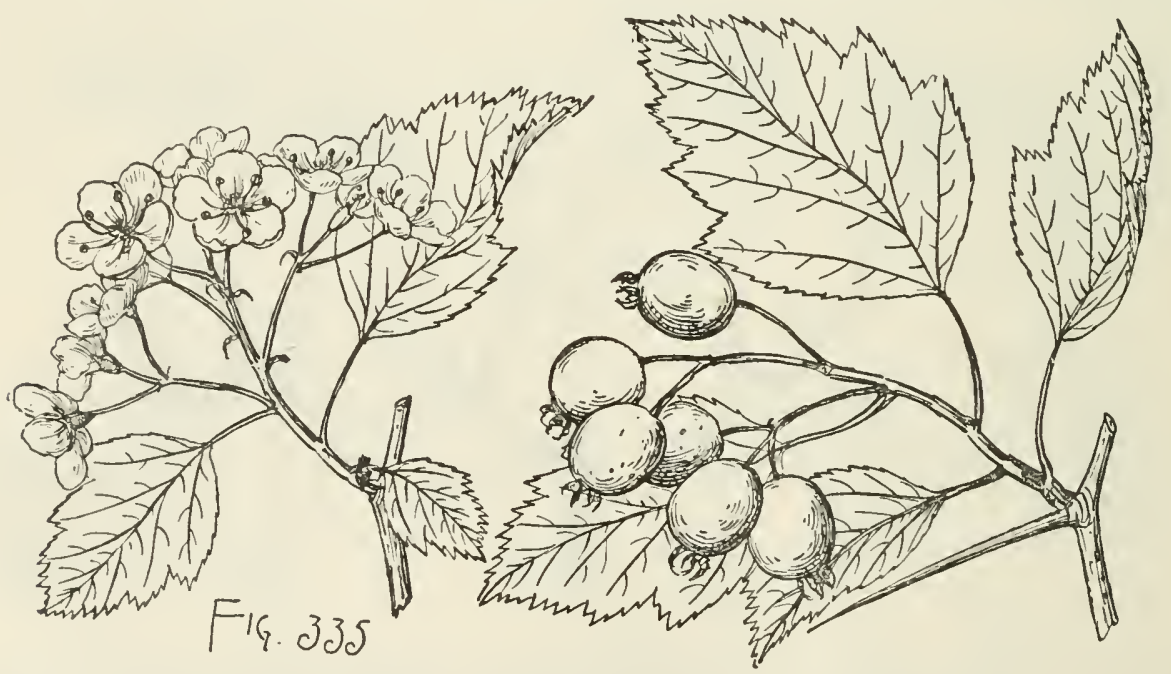

dark glands, nearly fully grown and very thin when the flowers open at the end of May, and at maturity membranaceous, dark green and roughened above by short rigid pale hairs, pale and glabrous below, $2^{\prime}-2 \frac{1}{2}^{\prime}$ long, $1 \frac{1}{2}^{\prime}-2^{\prime}$ wide, with slender yellow midribs and thin primary veins extending to the points of the lobes; their petioles slender, often winged toward the apex, glandular, with minute dark glands, usually about $1^{\prime}$ long; on vigorous shoots more deeply lobed and often $4^{\prime}$ long and $3^{\prime}$ wide, their stipules foliaceons, lunate, very coarsely glandular-serrate, often $\frac{1}{2}^{\prime}$ long. Flowers $\frac{5^{\prime}}{8}-\frac{8^{\prime}}{4}$ in diameter, on elongated slender pedicels, in compact compound few-flowered glabrous corymbs; calyx-tube narrowly obconic, glabrous, dark 
red, the lobes linear-lanceolate, entire or finely glandular-serrate; stamens usually 5 , occasionally 6-10; anthers large, dark red-purple; styles 3 , surrounded at the base by a thin ring of hoary tomentum. Fruit ripening about the middle of September and soon falling, on stout pedicels, in drooping narrow clusters, short-oblong, full and rounded at the ends, dark crimson, lustrous, marked by minute pale dots, usually about $\frac{5}{8}$ long and $\frac{1}{2}$ 'thick; calyx enlarged and persistent, the lobes elongated, strongly incurved, often deciduous before the fruit ripens; flesh thick, dry and = 1ealy; nutlets 3 , thick, narrowed and acute at the ends, prominently ridged on the back, with a high broad ridge, $\frac{1^{\prime}}{3}$ long.

A tree, rarely more than $15^{\circ}$ high, with a straight trunk $5^{\prime}-6^{\prime}$ in diameter, covered with thin bark separating into papery lustrous pale scales, stout branches forming a broad open head irregular in outline, and slender glabrous branchlets bright chestnut-brown during their first season, becoming ashy gray the following year, and armed with many thick straight or curved bright chestnut-brown or redbrown spines $1^{\prime}-1 \frac{1}{2}^{\prime}$ long.

Distribution. Low hills and limestone ridges; southern and southwestern Vermont.

\section{Cratægus silvicola, Beadl.}

Leaves ovate, acute or acuminate at the apex, full and rounded at the entire base, sharply and often doubly serrate above, with gland-tipped teeth, and slightly and irregularly divided into short acute lateral lobes, when they unfold dark red and

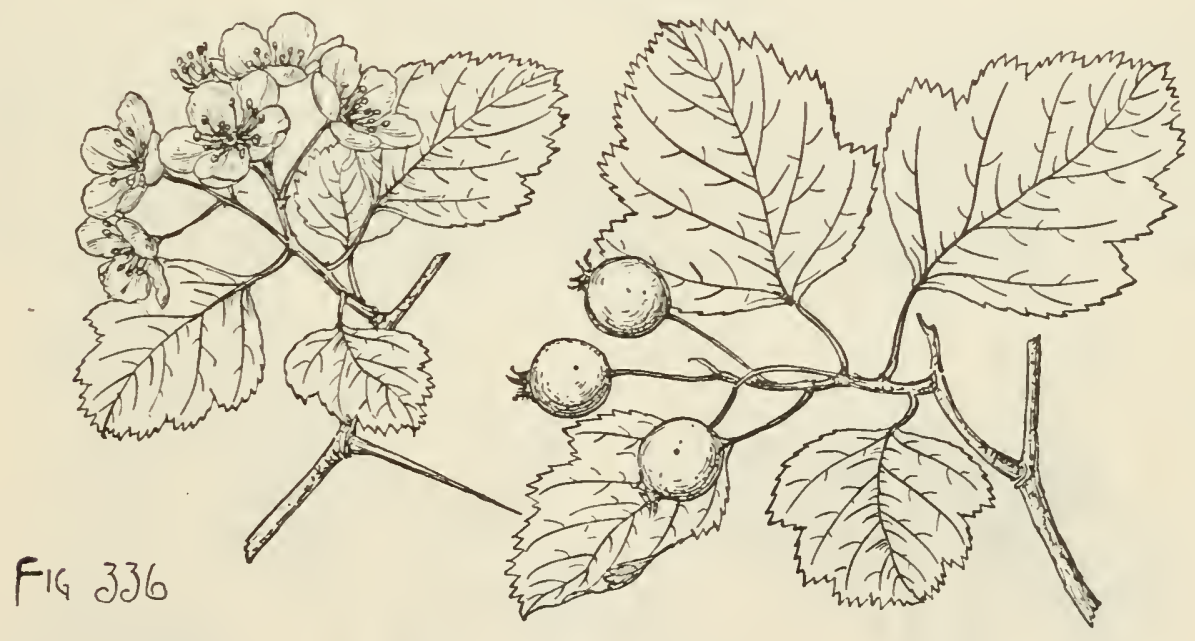

coated with short soft pale hairs most abundant on the upper surface, about half grown when the flowers open at the end of April and then nearly glabrous, and at maturity thin, dark yellow-green and smooth or scabrous above, pale and glabrous below, or occasionally villose along the under side of the slender midribs and 3 or 4 pairs of thin primary veins extending to the points of the lobes, about $2^{\prime}$ long and $1 \frac{1^{\prime}}{2}-1 \frac{3^{\prime}}{4}$ wide; their petioles slender, glandular, about $\mathbf{1}^{\prime}$ long; on vigorous shoots often deltoid, and truncate or cordate at the base, more coarsely serrate and more deeply lobed, and frequently $2 \frac{1^{\prime}}{2}$ long and broad. Flowers about $\frac{3^{\prime}}{4}$ in diameter, on slender pedicels, in compact few-flowered thin-branched compound glabrous corymbs, with linear glandular bright red caducous bracts and bractlets ; caylx-tube narrowly obconic and glabrous, the lobes gradually narrowed, acuminate, glabrous, entire or 
glandnlar-serrate; stamens 10; anthers large, purple; styles 3-5, surrounded at the base by a narrow ring of pale hairs. Fruit ripening at the end of September and soon falling, on short pedicels, in erect few-fruited elnsters, subglobose and often a little broader than long, red or greenish yellow, with a rosy cheek, about $\frac{1^{\prime}}{2}$ in diameter; calyx little enlarged, with spreading lobes nsually decidnons before the fruit ripens; flesh thin, yellow, dry and mealy; nutlets $3-5$, thick, prominently ridged and grooved on the back, witl a high broad ridge, abont $\frac{1}{4}$ long.

A tree, sometimes $30^{\circ}$ high, with a tall straight trunk $6^{\prime}-8^{\prime}$ in diameter, covered with close or slightly fissured bark broken into small gray or red-brown scales, and often armed with long stout branched gray spines, ascending or spreading branches forming a narrow irregnlar or round-topped head, and slender branchlets dark green tinged with red and covered with long pale scattered whitc lairs when they first appear, soon becoming glabrous, bright red-brown during their first year, and ultimately ashy gray, with few or many thin straight or somewhat curved bright chestnut-brown spines $1 \frac{1^{\prime}}{2}$ to nearly $2^{\prime}$ long; or in the dry soil of upland forests usually a shrub, witlı mumerons stems.

Distribution. Low moist flat woods; northern Alabama and northwestern and central Georgia, and occasionally on the drier uplands of the surrounding country; common.

** Stamens usually 20.

\section{Cratægus lucorum, Sarg.}

Leaves broad-ovate to obovate or rarely oval, broadly cuneate or full and rounded at the entire base, coarsely serrate above, with straight teeth tipped with large persistent bright red finally dark glands, and deeply divided above the middle into 3 or 4 pairs of wide acute or acuminate lobes, rather more than a third grown when the flowers open early in May and then light yellow-bronze color, covered on the upper surface with short soft pale hairs and glabrous on the lower surface, and at maturity

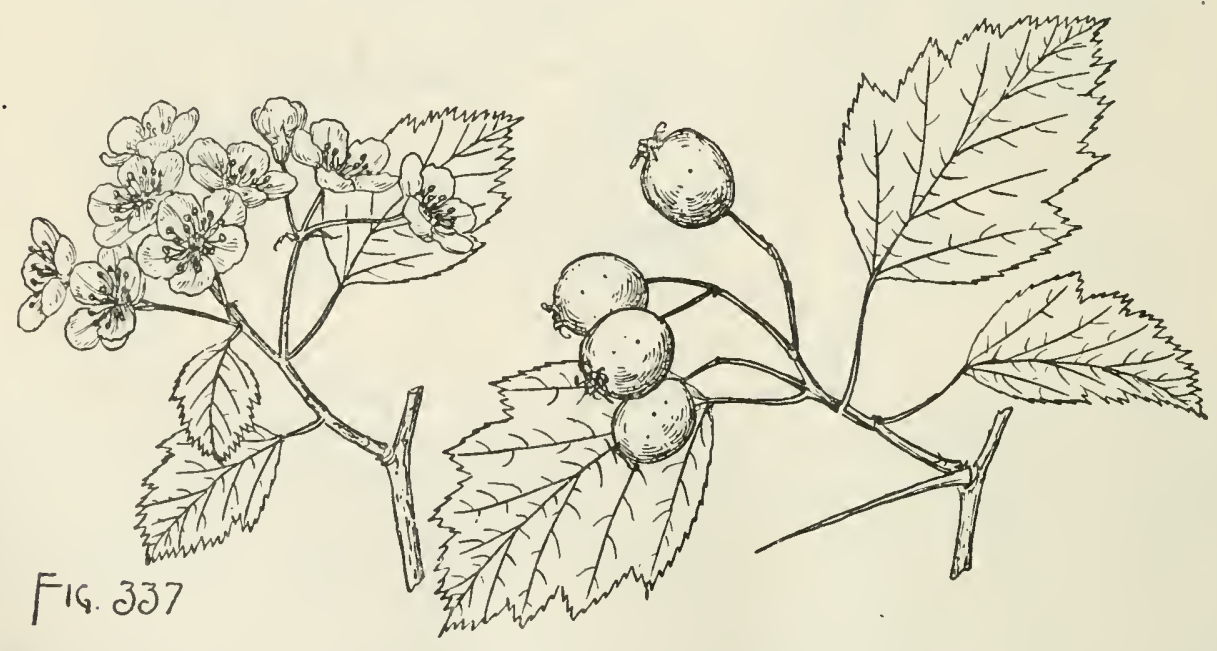

membranaceous, smooth, dark dull green and glabrous above, pale yellow-green below, about $2^{\prime}$ long and $1 \frac{1}{4}$ ' wide, with slender yellow midribs and 3 or 4 pairs of thin primary veins extending obliquely to the points of the lobes; their petioles slender, glandular, often somewhat winged toward the apex, $1^{\prime}-1 \frac{1^{\prime}}{2}$ long; on vigorous 
shoots usually ovate and rounded at the broad base, more deeply lobed and sometimes $3^{\prime}$ long and broad. Flowers $\frac{3^{\prime}}{4}$ in diameter, on thin pedicels, in narrow compact few-flowered small villose corymbs; calyx broadly obconic, glabrous, the lobes narrow, acuminate, coarsely glandular-serrate, villose on the upper surface; stamens 20; anthers small, dark purple; styles 4 or 5 . Fruit ripening about the middle of September and soon falling, on short stout pedicels, in erect few-fruited slightly villose clusters, pear-shaped until nearly fully grown and then short-oblong or somewhat obovate, full and rounded at the ends, crimson, lustrous, marked by small pale dots, $\frac{1^{\prime}}{2}-\frac{5 \prime}{8}$ long; calyx enlarged, the lobes elongated, coarsely glandular-serrate, villose above, closely appressed, often deciduous before the fruit ripens; flesh thick, yellow, dry and mealy; nutlets 4 or 5 , thin, rounded, and sometimes obscurely ridged on the back, about $\frac{1^{\prime}}{4}$ long.

A tree, $20^{\circ}-25^{\circ}$ high, with a tall straight trunk $6^{\prime}-8^{\prime}$ in diameter, covered with close dark red-brown bark, slender ascending branches forming a narrow open head, and thin branchlets dark green and somewhat villose when they first appear, becoming dull orange-brown in their first summer and ultimately dark gray-brown, and armed with straight or slightly curved bright red-brown lustrous spines $1^{\prime}-1 \frac{1}{2}^{\prime}$ long.

Distribution. Rich moist soil along the margins of Oak groves on the banks of sloughs; Barrington, Illinois.

\section{Cratægus depilis, Sarg., n. sp.}

Leaves ovate, acnte or acuminate, rounded or broadly cuneate and often unsymmetrical at the entire base, sharply doubly serrate above, with straight glandular

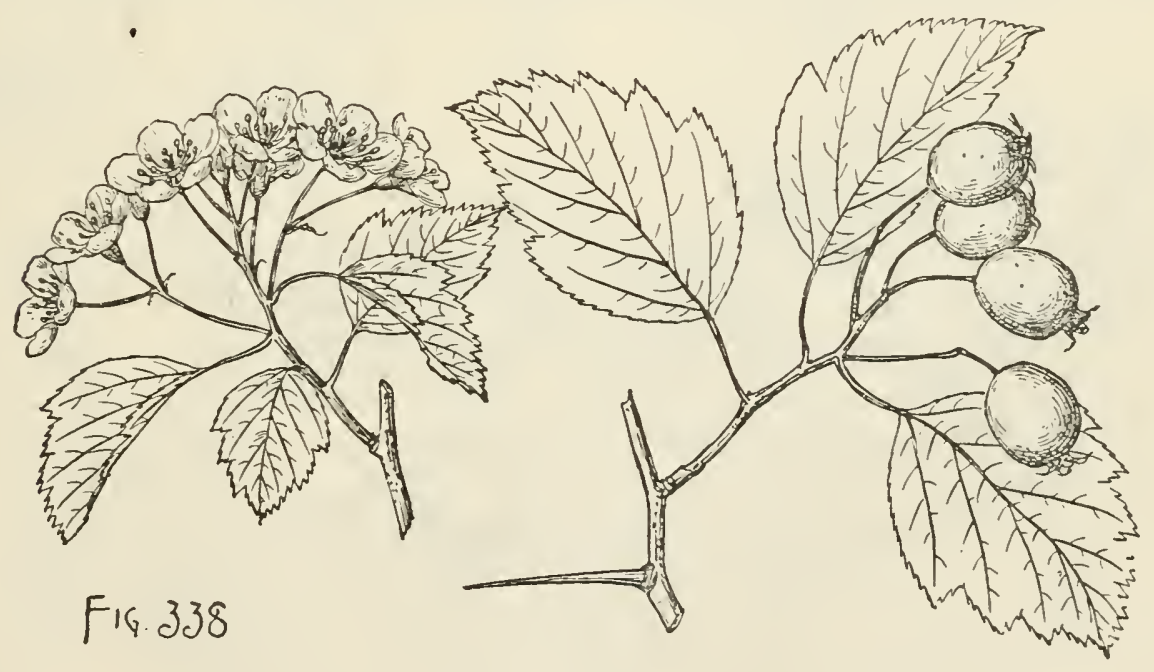

teeth, and often divided into 4 or $\mathbf{5}$ pairs of short acute lobes, when they unfold deeply tinged with red and covered above with fine short caducous hairs, nearly half grown when the flowers open during the second week of May, and at maturity membranaceous, glabrous, smooth, yellowish to bluish green on the upper surface, pale on the lower surface, $1 \frac{1}{2}^{\prime}-2^{\prime}$ long; $1^{\prime}-1 \frac{1}{4}^{\prime}$ wide, and on vigorous shoots often $2 \frac{1}{2}^{\prime}$ long and $1 \frac{1}{2}^{\prime}$ wide, with slender midribs and 5 or 6 pairs of thin primary veins, turning yellowish and brown or russet color in the autumn; their petioles slender, glabrous, sparingly glandular, with minute glands, $\frac{8^{\prime}}{4}-1^{\prime}$ long; stipules linear, acuminate, glandular-serrate, reddish, caducous. Flowers $\frac{3^{\prime}}{4}$. in diameter, on slender pedicels, 
in broad eompound glabrons 8-12-flowered corymbs, witl linear or oblong glandular braets and braetlets; ealyx narrowly obeonie, glabrous, the lobes lanceolate, glandular-serrate, deeply tinged with purple; stamens 20; anthers pale rose eolor; styles 4 or 5. Fruit ripening early in September and soon falling, on slender pedieels, in drooping few-fruited elusters, subglobose to broad-obovate, dark red to reddish purple, lustrous, $\frac{1^{\prime}}{2}-\frac{3^{\prime}}{4}$ long, $\frac{8^{\prime}}{8}-\frac{5^{\prime}}{8}$ wide; ealyx ouly slightly enlarged, the lobes reflexed, glandular-serrate, and red on the upper side toward the base; flesh thiek, yellow, sweet, juicy, and slightly acid; nutlets 4 or 5 , full and rounded at the apex, narrowed and aente at the base, and prominently but irregularly ridged on the baek, with a high sometimes grooved ridge, $\frac{1^{\prime}}{4}-\frac{5}{16}$ long.

A tree, $20^{\circ}-25^{\circ}$ high, with a trunk $4^{\prime}-8^{\prime}$ in diameter and $6^{\circ}-9^{\circ}$ long, eovered with dark gray or gray-brown flaked bark, spreading branehes forming an oblong or rounded open head, and slender glabrous branehlets bright red-brown and very lustrous during their first summer, becoming light gray-brown the following year, and armed with stout or slender nearly straight spines $\frac{3^{\prime}}{4}-1 \frac{1}{2}^{\prime}$ long.

Distribution. Rich elay or gravelly soil in pastures and on the borders of woods; northeastern Illinois, at Lake Forest, Glendon, and New Lenox (E. J. Hill).

\section{Cratægus basilica, Beadl.}

Leaves ovate, acute or aeuminate, broadly cuneate or rounded at the entire or erenate base, sharply and often doubly serrate above, with straight slender glandular teeth, and divided into numerous short aeute lateral lobes, more than half grown when the flowers open early in May and then roughened above by short pale hairs

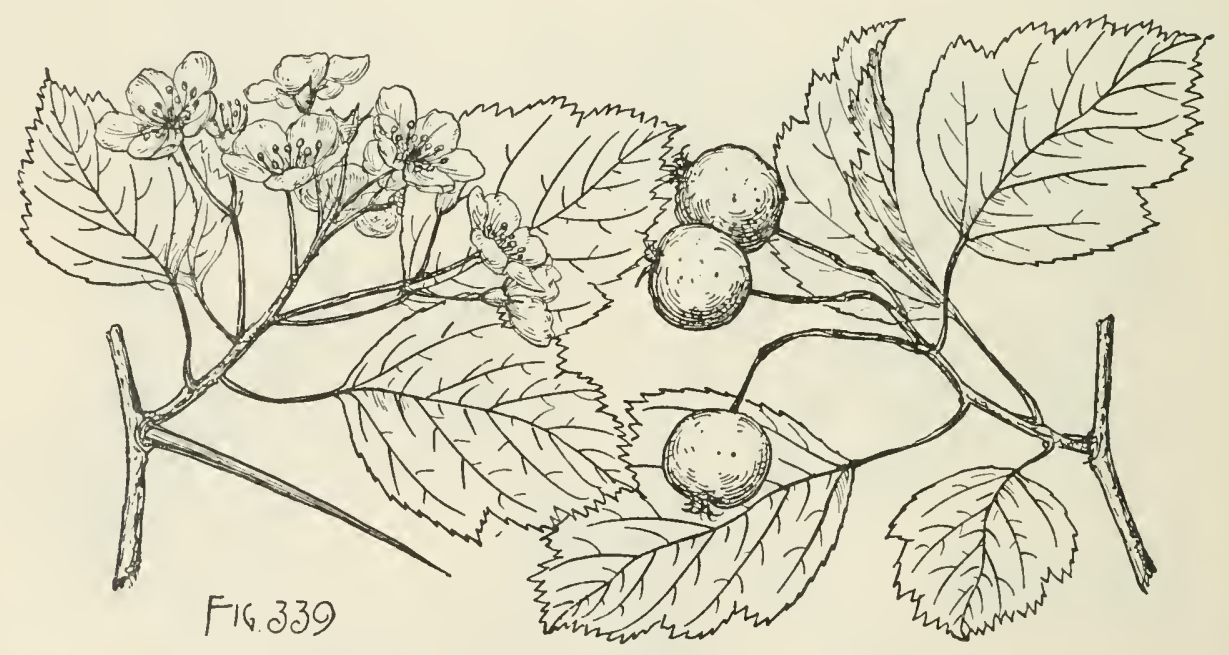

and glabrous below, and at maturity thin but firm in texture, bright green and scabrate above, paler below, $2 \frac{1}{2}^{\prime}-3^{\prime}$ long, $1 \frac{1^{\prime}}{2}-2^{\prime}$ wide, with slender yellow midribs and thin veins arching to the points of the lobes, turning yellow and brown in the autumn; their petioles slender, slightly winged at the apex, $1^{\prime}-1 \frac{1}{2}^{\prime}$ long. Flowers $\frac{1}{2}-\frac{5}{8}$ in diameter, on elongated slender pedicels, in 5-15-flowered glabrous eompaet corymbs; ealyx-tube broadly obeonie, glabrous, the lobes slender, aeuminate, glabrous, entire or oeeasionally serrate; stamens 15-20; anthers purple; styles 3-5. Fruit ripening and falling early in September, on slender pedicels, in few-fruited 
drooping clusters, subglobose, scarlet, covered with a glaucous bloom, and $\frac{1^{\prime}}{2}-\frac{5}{8}$ in diameter; flesh soft, sweet, and edible; nutlets 3-5, narrowed and acute at the ends, prominently ridged on the back, with a high broadly grooved ridge, $\frac{1^{\prime}}{4}-\frac{5}{1^{6}}{ }^{\prime}$ long.

A tree, sometimes $20^{\circ}$ high, with a trunk $7^{\prime}-8^{\prime}$ in diameter, covered with dark gray or brown scaly bark, ascending or slightly spreading branches forming a narrow irregular head, and stoat branchlets armed with numerous slender bright chestnutbrown lustrous ultimately gray spines $2^{\prime}-2 \frac{1}{2}^{\prime}$ long.

Distribution. Open woods and the borders of fields and roads, western North Carolina, usually at elevations of $2000^{\circ}-3000^{\circ}$ above the sea.

\section{5๊. Cratægus lacera, Sarg.}

Leaves rhomboidal to broadly ovate or rarely obovate, acute at the apex, broadly cuneate and entire at the base, divided above the middle into numerous acute lobes,

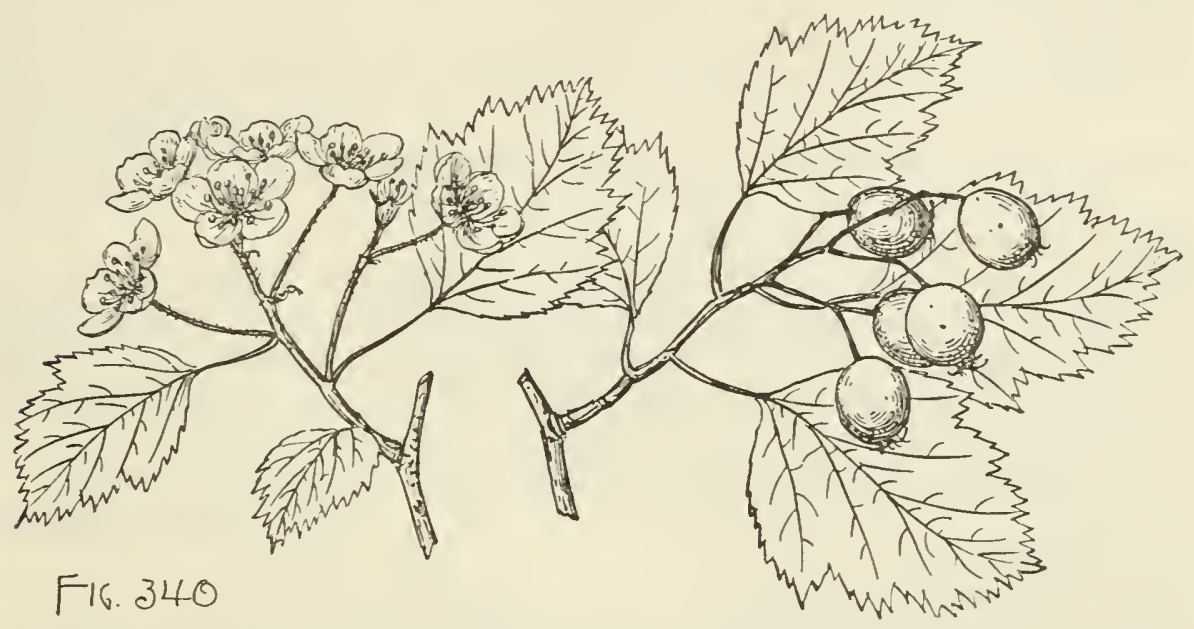

and coarsely often doubly serrate above, with straight glandular teeth, when they unfold coated below with thick hoary tomentum and villose above, nearly fully grown when the flowers open about the 20th of April and then glabrous on the lower surface and covered on the upper surface with short scattered pale hairs, and at maturity glabrous, light yellow-green, paler below than above, thin but firm in texture, about $1 \frac{1}{2}^{\prime}$ long and $1 \frac{1}{4}^{\prime}$ wide, with thin yellow midribs and few remote primary veins; their petioles slender, villose, becoming glabrous or puberulous, slightly winged at the apex, often red toward the base, $\frac{1^{\prime}}{4}-\frac{1^{\prime}}{3}$ long; on vigorous shoots broadly ovate, often deeply 3-lobed, very coarsely serrate, $3^{\prime}-4^{\prime}$ long and broad, with lunate long-pointed coarsely glandular-serrate stipules sometimes $\frac{1^{\prime}}{4}$ in length. Flowers $\frac{3^{\prime}}{4}$ in diameter, on long slender pedicels, in sparingly villose few-flowered compound corymbs; calyx-tube narrowly obconic, glabrous, the lobes linear-lanceolate, elongated, coarsely glandular-serrate, glabrous on the outer surface, villose on the inmer surface; stamens 20; anthers small, rose color; styles 4 or 5. Fruit ripening toward the end of October, on short stout glabrous pedicels, in erect few-fruited clusters, short-oblong, full and rounded at the ends, bright cherry-red, lustrous, marked by occasional large dark dots, about $\frac{1}{2}^{\prime}$ long; calyx only slightly enlarged, with small nearly triangular villose spreading lobes mostly deciduous before the fruit ripens; flesh thick, orange color; nutlets $3-5$, thin, broad, narrowed at the ends, only slightly ridged on the rounded back, light brown, $\frac{5}{16}$ long. 
A slender tree, $25^{\circ}-30^{\circ}$ high, with a tall trunk $4^{\prime}-5^{\prime}$ in diameter, eovered with pale scaly bark, small short branches forming a narrow head, and slender branehlets dark olive-green and villose when they first appear, becoming light red-brown and glabrous during their first summer, and ultimately dull light gray, and armed with thin straight bright chestnut-brown lustrous spines $\frac{8^{\prime}}{4}-1 \frac{8^{\prime}}{4}$ long.

Distribution. Low rieh forest glades near Fulton, on the Red River, Arkansas. .

Stamens 20.

\section{MOLLES.}

Anthers pale vellow (color unknown in 59).

Leaves mostly broad and rounded at the base.

Leaves broadly ovate, thick and firm; fruit short-oblong to subglobose, scarlet, pubescent, ripening in August and September.

56. C. mollis (A, C).

Leaves oblong-ovate, membranaceous; fruit obovate-oblong, dull dark red, slightly villose or pubescent, ripening in October.

57. C. sera (A).

Leaves oblong-ovate to oval, thick and leathery ; fruit short-oblong or rarely obovate, bright crimson, very lustrous, slightly tomentose, ripening at the end of October.

58. C. Arkansana (C).

Leaves broadly ovate, thin; fruit depressed-globose, red, ripening in August and September.

59. C. gravida (C).

Leaves mostly narrowed at the base.

Leaves ovate to oval, membranaceous; fruit subglobose, often broader than ligh, crimson, lustrous, pubescent, ripening late in September. 60. C. Treleasei (C).

Leaves ovate, thin and firm; fruit short-oblong to subglobose, crimson, lustrous, slightly villose, ripening early in October. 61. C. Canadensis (A).

Leaves oblong-obovate to oval, thin and firm, dark green and lustrous above; fruit short-oblong to subglobose, scarlet, ripening after the middle of October.

62. C. Berlandieri (C).

Anthers rose color.

Leaves mostly broad at the base.

Leaves ovate, firm and rigid, dark yellow-green, bright and lustrous ; fruit shortoblong to obovate, bright cherry-red, lustrous, ripening at the end of September.

63. C. corusca (A).

Leaves ovate to suborbicular, thin and firm, dark yellow-green and smooth above; fruit subglobose to short-ovate, bright yellow, ripening at the end of September.

64. C. Kelloggii (A).

Leaves mostly narrowed at the base.

Leaves broadly ovate, thick and firm, dark green and lustrons above; fruit shortoblong to slightly obovate, bright scarlet, puberulous at the apex, ripening at the end of October.

65. C. Texana (C).

Leaves ovate to obovate, membranaceous, dark green and scabrate above, canescent below; fruit subglobose, dark red and glabrons, ripening after the middle of October.

66. C. quercina (C).

Leaves oval to broadly ovate, thin and firm, lustrous, scabrate above ; fruit obovate, bright cherry-red, ripening in October. 67. C. pyriformis (C).

Leaves ovate to suborbicular, subcoriaceous, dark blue-green, lnstrous and scabrate above; fruit subglobose to short-oblong, dark crimson, slightly hairy at the ends, ripening late in October. 68. C. lanuginosa (C).

Leaves oblong-ovate, membranaceous, dark yellow-green and scabrate above; fruit short-oblong, crimson or reddish yellow, lustrous, ripening the middle of October.

Stamens 10.

69. C. induta (C).

Anthers yellow:; leaves mostly broad and rounded at the base. 
Leares usually ovate, rarely oval, membranaceous, dark green and smooth above; fruit subglobose, bright crimson, villose, ripening the middle of August and soon falling.

70. C. Arnoldiana (A).

Leares ovate, subcoriaceous, glabrous and conspicuously blue-green above; fruit obovate or oblong, bright scarlet, villose or pubescent, ripening early in September, long persistent on the branches.

71. C. Champlainensis (A).

Leaves ovate, membranaceous, dark yellow-green and scabrate above; fruit obovate, bright orange-red, lustrous, puberulous at the base, ripening and falling early in September.

72. C. submollis (A).

Anthers rose color.

Leaves ovate, mostly broadly cuneate at the base, membranaceous, yellow-green, smooth and glabrous above; fruit obovate to short-oblong, crimson, lustrous, slightly villose.

7.. C. anomala (A).

Leaves oval, rounded or broadly cuneate at the base, membranaceous, light green and scabrous above; fruit short-oblong, light crimson, lustrous, villose at the ends, ripening and falling late in September.

74. C. Ellwangeriana (A).

\section{* Stamens 20.}

$\rightarrow$ Anthers pale yellow.

\section{Cratægus mollis, Scheele. Red Haw.}

Leaves broadly ovate, acute, usually cordate or rounded at the broad base, coarsely and generally doubly serrate, with straight glandular teeth, and more or less deeply divided into 4 or 5 pairs of acute lateral lobes, when they unfold covered above with short pale hairs and hoary-tomentose below, about half grown when the

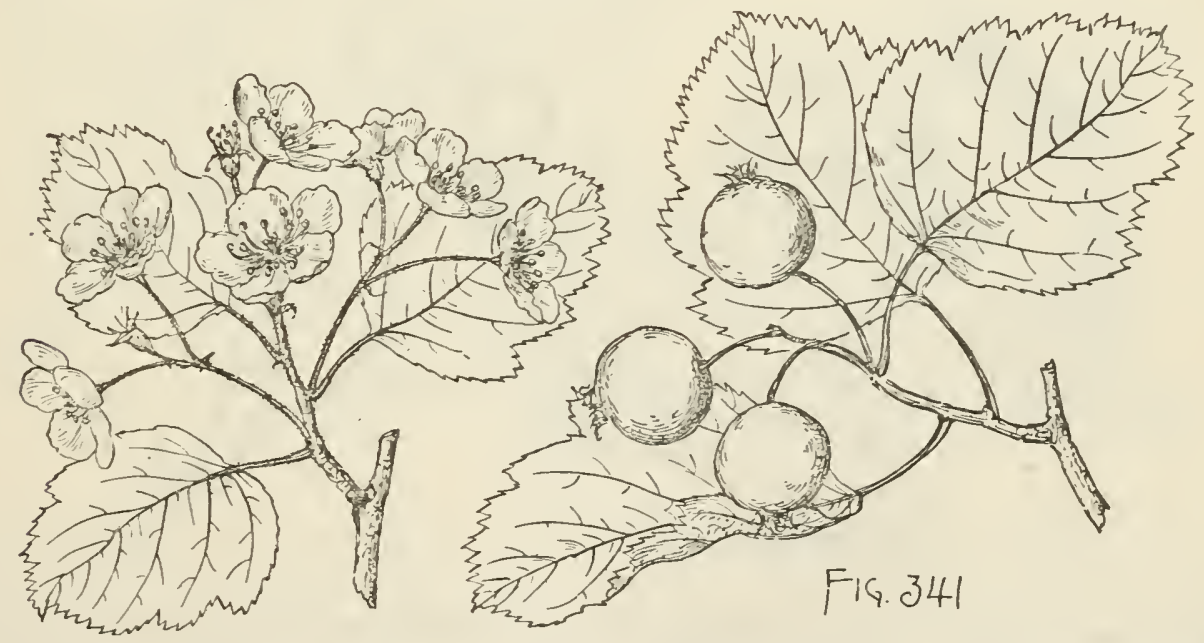

flowers open early in May and then membranaceous, light yellow-green and hairy abore and pubescent or tomentose below, and at maturity thick and firm in texture, dark yellow-green and slightly rugose on the upper surface and paler and pubescent or puberulous on the lower surface along the stout midribs and 4 or 5 pairs of primary veins extending to the points of the lobes, $3^{\prime}-4^{\prime}$ long and broad; their petioles stout, terete, at first tomentose, ultimately pubescent or nearly glabrous, often slightly

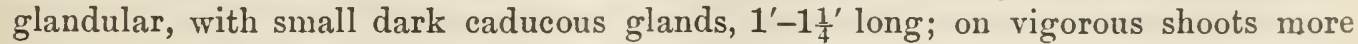
deeply lobed, with a deeper basal sinus, and frequently $5^{\prime}-6^{\prime}$ long and broad, with foliaceous coarsely serrate lunate stipules sometimes $1^{\prime}$ in length. Flowers $1^{\prime}$ in diameter, on stout pedicels, in broad compound many-flowered tomentose corymbs, 
with conspicnous bracts and bractlets; calyx-tube narrowly obeonic, hoary-tomentose, the lobes narrow, acuminate, eoarsely glandnlar-serrate, with bright red glands, villose on the outer, tomentose on the imner surfaee; stamens 20; anthers large, light yellow; styles 4 or 5 , surrounded at the base by a broad ring of hoary tomentum. Fruit ripening late in Angust and early in September, on stont pedieels, in drooping few-fruited villose clnsters, short-oblong to subglobose, full and rounded at the ends, more or less pubescent, searlet marked by occasional large dark dots, $\frac{3^{\prime}}{4}-1^{\prime}$ in dianeter; calyx prominent, hairy, with large erect and incurved lobes usually deeidnous before the fruit ripens; flesh thiek, yellow, subaeid, dry and mealy; nutlets 4 or 5 , thin, rounded and obseurely ridged on the back, light brown, $\frac{1}{4}$ long.

A tree, sometimes $40^{\circ}$ high, with a tall trunk often $18^{\prime}$ in diameter, heavy widespreading smooth ashy gray branches forming a broad round-topped and often symmetrical head, and stout branchlets covered at first with a thick coat of long white matted hairs, villose during their first season, becoming glabrous in their second year, and armed with occasional straight thick bright chestnut-brown shining spines $1^{\prime}-2^{\prime}$ long.

Distribution. Low rich soil usually on the bottom-lands of streams; northern Ohio to eastern Dakota, eastern Nebraska, and eastern Kansas.

\section{Cratægus sera, Sarg.}

Leaves oblong-ovate, acute or acuminate, rounded, truncate, or slightly cordate at the broad base, irregularly divided into 4 or 5 pairs of short acute lateral lobes, and

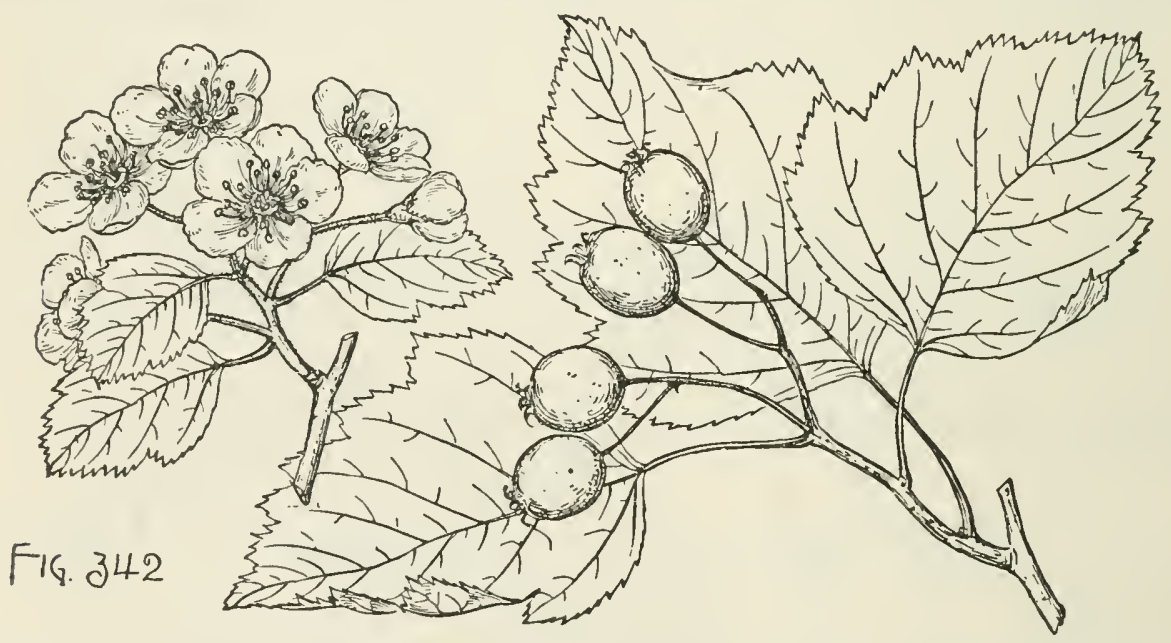

sharply and sometimes doubly serrate nearly to the base, with straight glandular teeth, unfolding about the 1st of May with the opening of the flowers and then covered above with short soft white hairs and tomentose below, and at maturity membranaceous, dark yellow-green and glabrous on the upper surface, pubeseent on the lower surface, $2^{\prime}-4^{\prime}$ long, $2 \frac{1}{2}^{\prime}-3^{\prime}$ wide, with slender midribs appressed above and thin remote primary veins extending to the points of the lobes; their petioles slender, tomentose, ultimately pubeseent, $1^{\prime}-1 \frac{1}{2}^{\prime}$ long; on vigorous shoots more deeply lobed and often $4^{\prime}-5^{\prime}$ long and $3^{\prime}-4^{\prime}$ wide. Flowers $\frac{3^{\prime}}{4}$ in diameter, on stout pedieels, in compact componnd many-flowered tomentose corymbs; ealyx-tube broadly obconie, coated with broad matted pale hairs, the lobes broad, acute or acuminate, glandular-serrate, with large dark glands, tomentose on the outer surface and villose on the inner 
surface; stamens 20; anthers pale yellow; styles 4, or usually 5. Fruit ripening about the 1st of October, on stout puberulous pedicels, in drooping few-fruited clusters, obovate or oblong, dull dark red, marked by small pale dots, usually slightly villose or pubescent at the ends, $\frac{2^{\prime}}{3}$ long, $\frac{1^{\prime}}{2}$ wide; calyx enlarged, coarsely glandular-serrate, with erect and incurved lobes often deciduous before the ripening of the fruit; flesh thick, dry and mealy; nutlets usually 5, or 4, thin, light brown, irregularly grooved on the back, with a broad shallow groove, $\frac{1^{\prime}}{4}$ long.

A tree, $30^{\circ}-40^{\circ}$ high, with a tall straight trunk $12^{\prime}-18^{\prime}$ in diameter, thick branches forming a broad round-topped symmetrical head, and branchlets hoary-tomentose at first, becoming light red-brown and puberulous and ultimately pale orange-brown, and armed with occasional straight or slightly curved chestnut-brown bright lustrous spines $1 \frac{1}{4}^{\prime}-1 \frac{1}{2}^{\prime}$ in length.

Distribution. Low moist ground in the neighborhood of streams; Belle Isle in the Detroit River, Michigan, and near Chicago and Joliet, Illinois.

\section{Cratægus Arkansana, Sarg.}

Leaves oblong-ovate or oval, acute, rounded, broadly cuneate or truncate at the base, usually divided above the middle into 3 or 4 pairs of short broad acute lobes, and serrate sometimes to the base, with short straight glandular teeth, when the

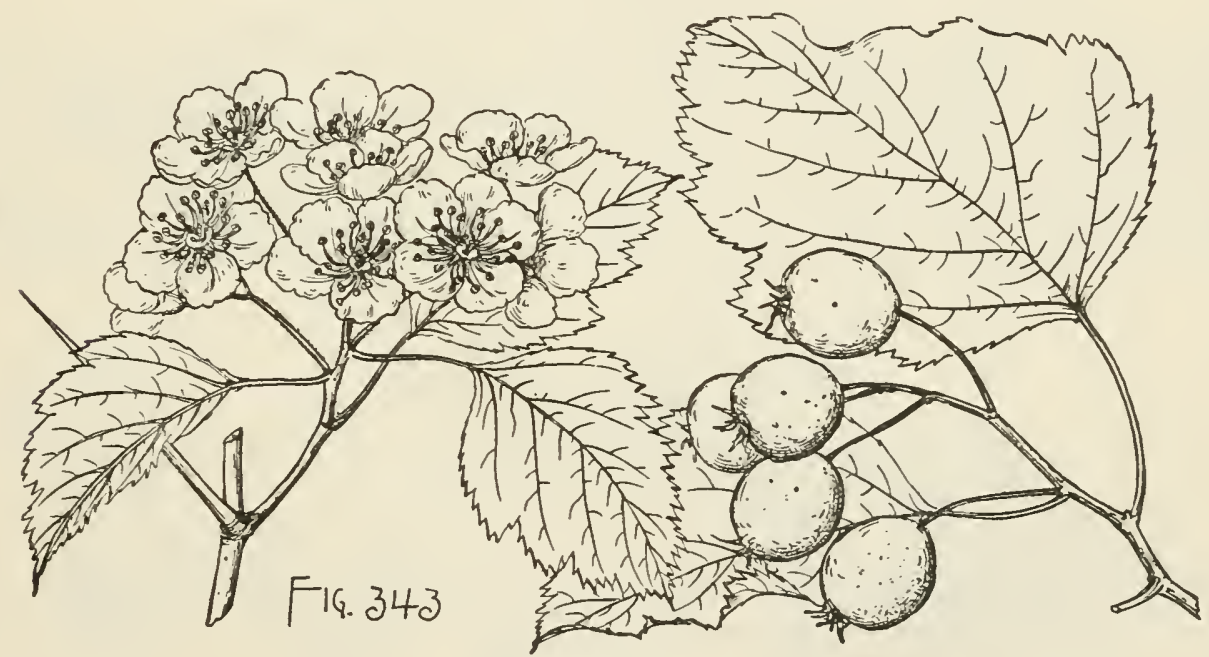

flowers open about the middle of May nearly one third grown and coated with soft white hairs most abundant on the under surface of the midribs and veins, and at maturity thick and leathery, dull dark green and glabrous on the upper surface, pale yellow-green on the lower surface, $2^{\prime}-3^{\prime}$ long, $1 \frac{3^{\prime}}{4}-2^{\prime}$ wide, with stout light yellow midribs and primary veins slightly villose below, conspicuous secondary reins and reticulate veinlets, late in October and November turning bright clear yellow; their petioles stout, deeply grooved, more or less winged toward the apex, glandular, with minute usually deciduous dark glands, at first tomentose, ultimately glabrous or puberulous, turning dark red after midsummer, $1^{\prime}-1 \frac{1}{2}^{\prime}$ long; on vigorous shoots broadly ovate, rounded or truncate at the base, often $4^{\prime}$ long and $3^{\prime}$ wide, with foliaceous lunate coarsely glandular-dentate stipules almost $1^{\prime}$ long. Flowers nearly $1^{\prime}$ in diameter, on short stout pedicels, in broad rather compact many-flowered villose compound corymbs; calyx-tube narrowly obconic, coated with long matted pale hairs, 
the lobes short, acute, very coarsely glandular-serrate, glabrous or slightly villose; stamens 20; anthers large, pale yellow; styles 5. Fruit ripening at the end of October and falling gradually at the end of several weeks, on stout villose pedicels, in few-fruited drooping clusters, oblong or rarely obovate, full and rounded and slightly tomentose at the ends, bright crimson, very lustrous, marked by few large dark dots, $\frac{3^{\prime}}{4}-1^{\prime}$ long, about $\frac{8^{\prime}}{4}$ thick; calyx little enlarged, with small linear-lanceolate coarsely glandular-serrate erect and persistent lobes; flesh thick, yellow, subacid; nutlets 5 , small in comparison to the size of the fruit, thin, rounded or slightly and irregularly ridged on the back, $\frac{1}{3}$ long.

A tree, $20^{\circ}$ high, with a tall straight stem, thick slightly ascending wide-spreading branches forming a broad open irregular head, and stout branchlets dark green and covered when they appear with long pale hairs, becoming orange-brown, glabrous, and very lustrous in their first winter, and unarmed, or armed with occasional straight light chestnut-brown shining spines gradually narrowed from broad bases, $\frac{1}{3}^{\prime}-\frac{1}{2}^{\prime}$ in length.

Distribution. Bottom-lands of the White River near Newport, Arkansas; hardy as far north as eastern Massachusetts, and unsurpassed late in the autumn in the beauty of its large brilliant abundant fruits long persistent on the branches.

\section{Cratægus gravida, Beadl.}

Leaves broadly ovate, acute, rounded or truncate at the base, and coarsely and often doubly serrate, with incurved glandular teeth, and slightly incisely lobed, when they unfold roughened above by short pale hairs and hoary-tomentose below, nearly half grown when the flowers open about the 1st of May, and at maturity thin, firm, dark green, lustrous and scabrate above, paler and pubescent or puberulous below, particularly on the slender midribs and veins, $1_{4}^{\frac{3}{}}-2 \frac{1}{2}^{\prime}$ long, about

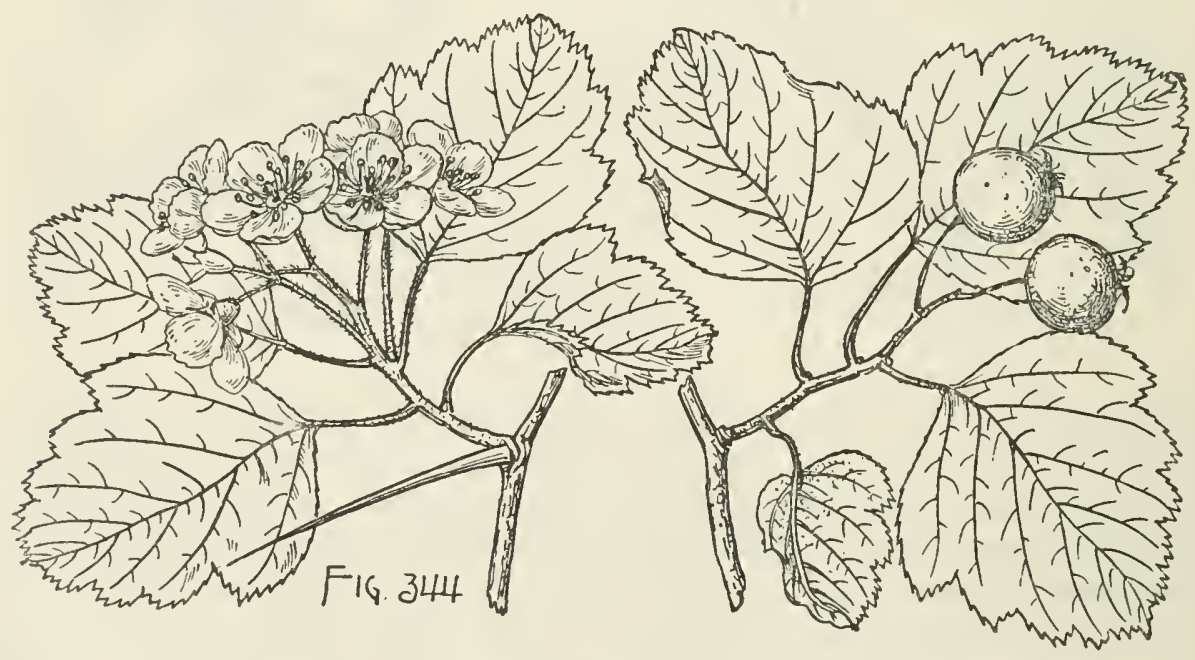

$1 \frac{1{ }^{\prime}}{2}$ wide, turning in the autumn yellow, orange, and brown; their petioles slender,

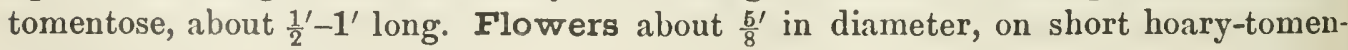
tose pedicels, in narrow crowded many-flowered compound hoary-tomentose corymbs; calyx-tube broadly obconic, covered with matted pale hairs, the lobes gradually narrowed from broad bases, acuminate, glandular-serrate, villose; stamens 20 ; styles 5 . Fruit ripening in August and September, on elongated tomentose pedicels, in few- 
fruited drooping clusters, depressed-globose, red; flesh thin, yellow, dry and mealy; calyx enlarged, the lobes conspicuously serrate, puberulous on the upper surface, reflexed and closely appressed, sometimes deciduous from the ripe fruit; nutlets 5, thin, narrowed and rounded at the base, acute at the apex, rounded and obscurely grooved on the back, about $\frac{5}{16}$ ' long.

A tree, sometimes $20^{\circ}$ high, with a trunk $8^{\prime}-10^{\prime}$ in diameter, heavy wide-spreading branches forming a broad round-topped head, and stout branchlets covered at first with a thick coat of matted pale hairs, orange-red and puberulous at the end of their first season, glabrous and reddish brown the following year, and armed with slender nearly straight spines about $1 \frac{1}{2}^{\prime}$ long.

Distribution. Limestone hills in the neighborhood of Nashville, Tennessee.

\section{Cratægus Treleasei, Sarg.}

Leaves ovate to oval, concave-cuneate or rounded at the narrow base, sharply doubly serrate above, with straight glandular teeth, and slightly divided into 3 or 4 pairs of narrow acuminate lateral lobes, unfolding with the opening of the flowers at

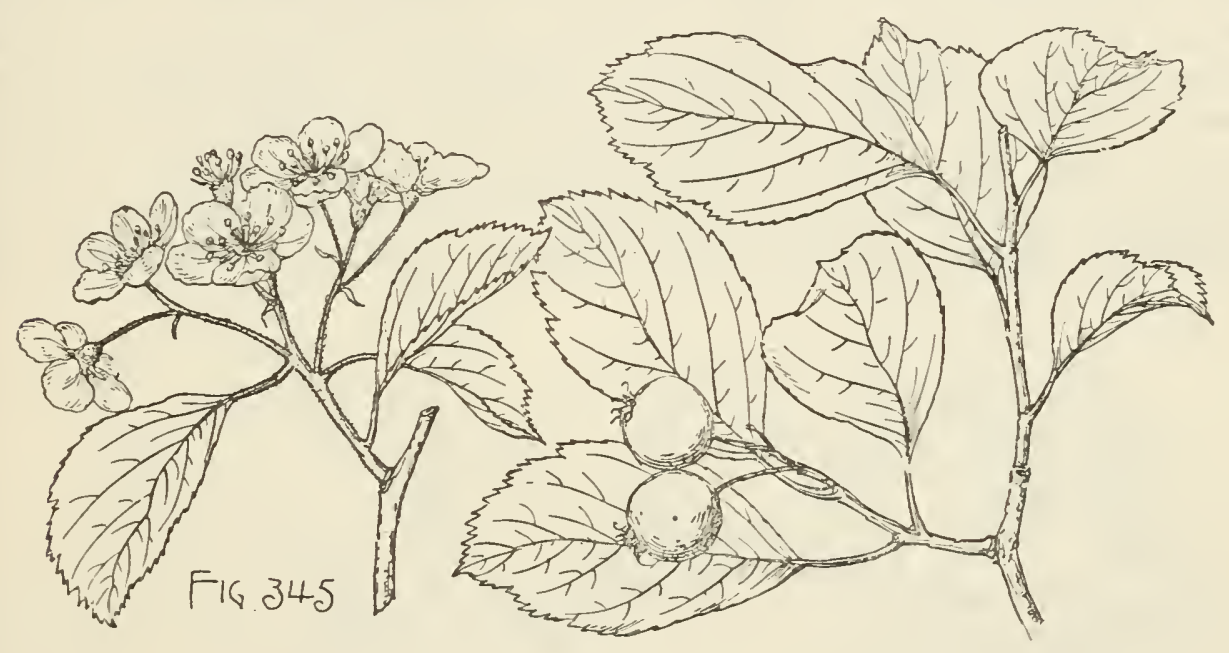

the end of April or early in May and then light yellow-green tinged with bronze color, lustrous and covered above with short shining caducous white hairs and hoarytomentose below, and at maturity membranaceous, light yellow-green and scabrate on the upper surface, paler and pubescent on the lower surface, particularly along the slender midribs and 4 or 5 pairs of thin primary veins extending obliquely to the points of the lobes, $1 \frac{3^{\prime}}{4}-2 \frac{1^{\prime}}{4}$ long, $1 \frac{1}{2}^{\prime}-2^{\prime}$ wide; their petioles slender, more or less wingmargined at the apex, villose early in the season, pubescent in the autumn. Flowers $1^{\prime}$ in diameter, on short stout pedicels covered with matted pale hairs, in 3-10-flowered compact compound or rarely simple villose corymbs; calyx-tube broadly obconic, covered with matted pale hairs, the lobes glabrous, narrowed from the base, with wide rounded sinuses between them, slender, acuminate, tipped with small red glands, and glandular-serrate, with stipitate red glands; stamens 20; anthers pale yellow; styles 4 or 5, usually 5. Fruit ripening at the end of September, on stout erect villose pedicels, in few-fruited clusters, subglobose or often broader than high, crimson, lustrous, marked by numerous large pale dots, pubescent at the ends, and $\frac{1^{\prime}}{2}-\frac{3^{\prime}}{4}$ in diameter; calyx prominent, with a short villose tube, and reflexed appressed 
villose lobes often deciduous from the ripe fruit; flesh thick, light yellow, dry and mealy; nutlets 4 or 5 , thin, full and rounded at the apex, narrowed and acute at the base, grooved with a broad shallow groove and sometimes irregularly ridged on the back, about $\frac{51^{\prime}}{16}$ long.

A tree, $20^{\circ}-25^{\circ}$ high, with a tall trunk sometimes $6^{\prime}$ in diameter, slender branches forming a narrow open head, and thin nearly straight branchlets thickly covered at first with long lustrous white hairs, dull light reddish brown and puberulous at the end of their first season, becoming dark gray-brown, and armed with stout straight or slightly curved dark purple shining spines usually about $1 \frac{1}{4}$ long, or unarmed.

Distribution. Banks of small streams in moist soil from Doe Run to Bismarck, St. François County, Missouri.

\section{Cratægus Canadensis, Sarg.}

Leaves ovate, short-pointed, slightly lobed usually only above the middle, with short broad acute lobes, and coarsely and frequently doubly serrate to the broadly cuneate or on leading shoots truncate base, with spreading glandular teeth, coated above in early spring with soft white hairs, and below with dense hoary tomentum, about one third grown when the flowers open at the end of May, and at maturity thin and firm in texture, blue-green, glabrous or scabrate on the upper surface, pale and pubescent on the lower surface along the midribs and primary veins, $2^{\prime}-2 \frac{1}{2}^{\prime}$ long, $1 \frac{1}{2}$ to nearly $3^{\prime}$ wide ; their petioles slender, glandular, of ten more or less winged above, at first tomentose, ultimately nearly glabrous, $\frac{3^{\prime}}{4}-1^{\prime}$ long. Flow ers about $\frac{3^{\prime}}{4}$ in diameter, in broad loose tomentose corymbs; calyx-tube broadly obconic, villose, with

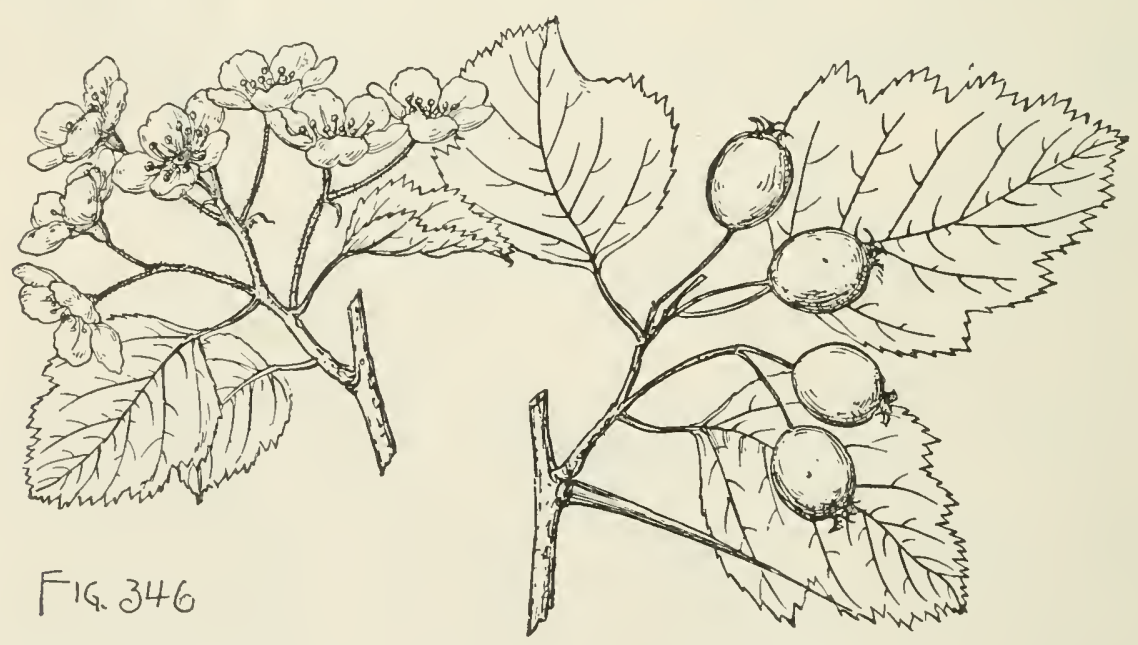

long matted hairs, the lobes lanceolate, villose, and glandular, with large red stipitate glands; stamens 20 ; anthers small, nearly white; styles 5, surrounded at the base by a thin ring of pale tomentum. Fruit ripening early in October and falling gradually until after midwinter, on stout pedicels, in erect slightly villose few-fruited clusters, short-oblong to subglobose, crimson, lustrous, marked by large scattered pale dots, slightly hairy toward the ends, $\frac{1{ }^{\prime}}{2}-\frac{5}{8}$ long, $\frac{1}{3}^{\prime}-\frac{1}{2}^{\prime}$ wide; calyx prominent, the lobes gradually narrowed from broad bases, elongated, glandular, villose, spreading or reflexed, often deciduous before the fruit ripens; flesh thin, pale yellow, dry and mealy; nutlets 5 , thin, rounded and irregularly ridged on the back, $\frac{1}{4}^{\prime}$ long. 
A tree, $18^{\circ}-30^{\circ}$ high, with a trunk $6^{\prime}-8^{\prime}$ in diameter, stout spreading branches forming a broad round-topped symmetrical head, and branchlets dark green and covered with matted pale hairs when they first appear, soon becoming light orangebrown and very lustrous, and armed with numerous stout straight or slightly curved dark chestnut-brown shining spines $2^{\prime}-2 \frac{1}{2}^{\prime}$ long.

Distribution. Limestone ridges near the St. Lawrence River at Chateaugay, Caughnawaga, and La Tortue in the Province of Quebec.

\section{Cratægus Berlandieri, Sarg.}

Leaves oblong-obovate or oval, acute or acuminate, gradually narrowed, cuneate and entire below the middle, unequally divided above into numerous acute or acuminate lobes, and coarsely and often doubly serrate above, with broad straight or incurved glandular teeth, when the flowers open from the middle to the end of

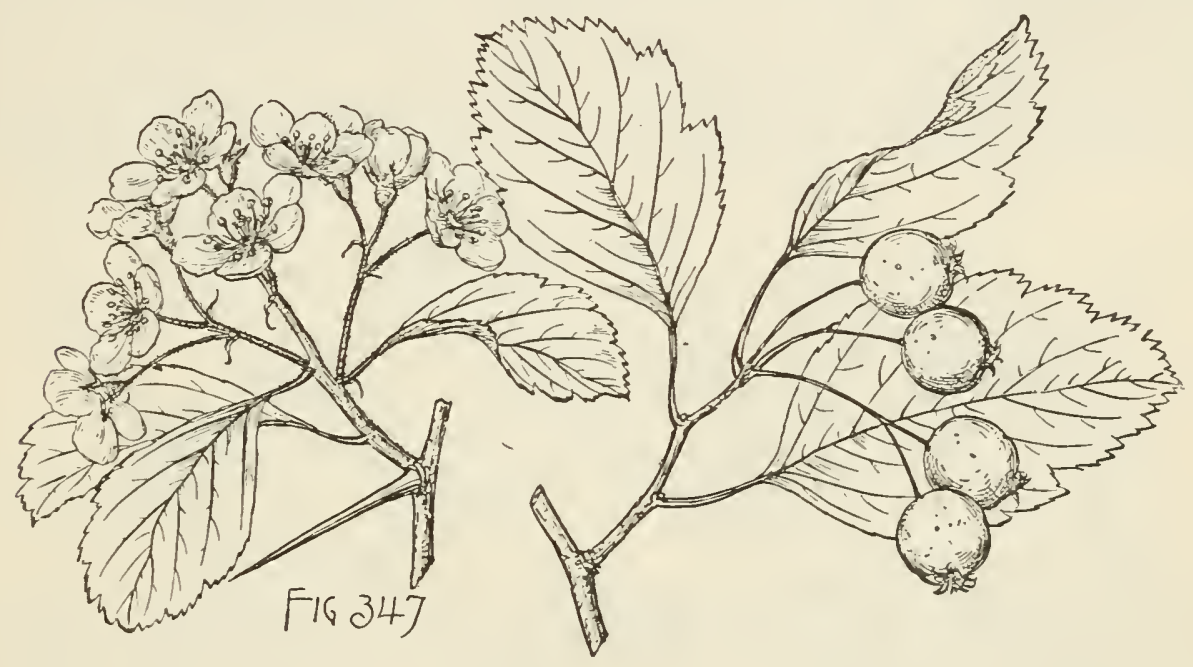

March coated above with short pale caducous hairs and below with thick hoary tomentum, and at maturity thin and firm in texture, glabrous, dark green, very lustrous on the upper surface, pale and pubescent on the lower surface, and usually about $3^{\prime}$ long and $2^{\prime}$ wide, with slender midribs, remote primary veins extending to the points of the lobes, conspicuous secondary veins and reticulate veinlets; their petioles more or less winged toward the apex, tomentose at first, beconing pubescent, $\frac{1^{\prime}}{2}-\frac{3^{\prime}}{4}$ long; on vigorous shoots often $5^{\prime}$ long and $3^{\prime}$ wide, with rounded acute lobes, and foliaceous lunate coarsely glandular-dentate stipules frequently $\frac{1^{\prime}}{2}$ in length. Flowers $\frac{3^{\prime}}{4}$ in diameter, on stout elongated hoary-tomentose pedicels, in broad loose many-flowered compound tomentose corymbs, with oblong-obovate to lanceolate finely glandular-serrate villose conspicuous bracts and bractlets; calyxtube broadly obconic, covered with thick pale tomentum, the lobes broad, acute, very coarsely glandular-serrate, tomentose on the outer surface and villose on the inner surface; stamens 20, anthers yellow; styles 5, surrounded at the base by tufts of white hairs. Fruit ripening after the middle of October, on slender elongated pedicels, in loose drooping clusters, short-oblong to subglobose, scarlet, about $\frac{1^{\prime}}{2}$ long; calyx much enlarged, with coarsely serrate villose lobes erect and persistent; flesh thin, yellow, dry and mealy; nutlets 5 , rounded and occasionally obscurely grooved on the back, about $\frac{1^{\prime}}{4}$ long. 
A tree, $15^{\circ}-20^{\circ}$ high, with a tall straight stem $8^{\prime}-10^{\prime}$ in diameter, covered with thin dark brown furrowed bark, spreading branches forming a broad open head, and branchlets hoary-tomentose at first, soon puberulous, dull reddish brown or yellowbrowu by midsummer, becoming asliy gray late in the autumn, and armed with few straight gray spines about $1^{\prime}$ in length.

Distribution. Low rich woods on the bottom-lands of the Brazos River at Columbia and Brazoria, Texas.

\section{++ Anthers rose color.}

\section{Cratægus corusca, Sarg.}

Leaves ovate, acute, truncate, rounded or slightly cordate at the broad base, regularly divided into 4 or 5 pairs of short acute lateral lobes, and doubly serrate, with straiglit glandular teeth, when they unfold covered above with short soft pale hairs and glabrous below, about one third grown when the flowers open the middle of May, and at maturity thin but firm and rigid in texture, glabrous, dark yellow-green and very bright and shining above, pale yellow-green below, $2^{\prime}-2 \frac{1}{2}^{\prime}$ long and wide, with

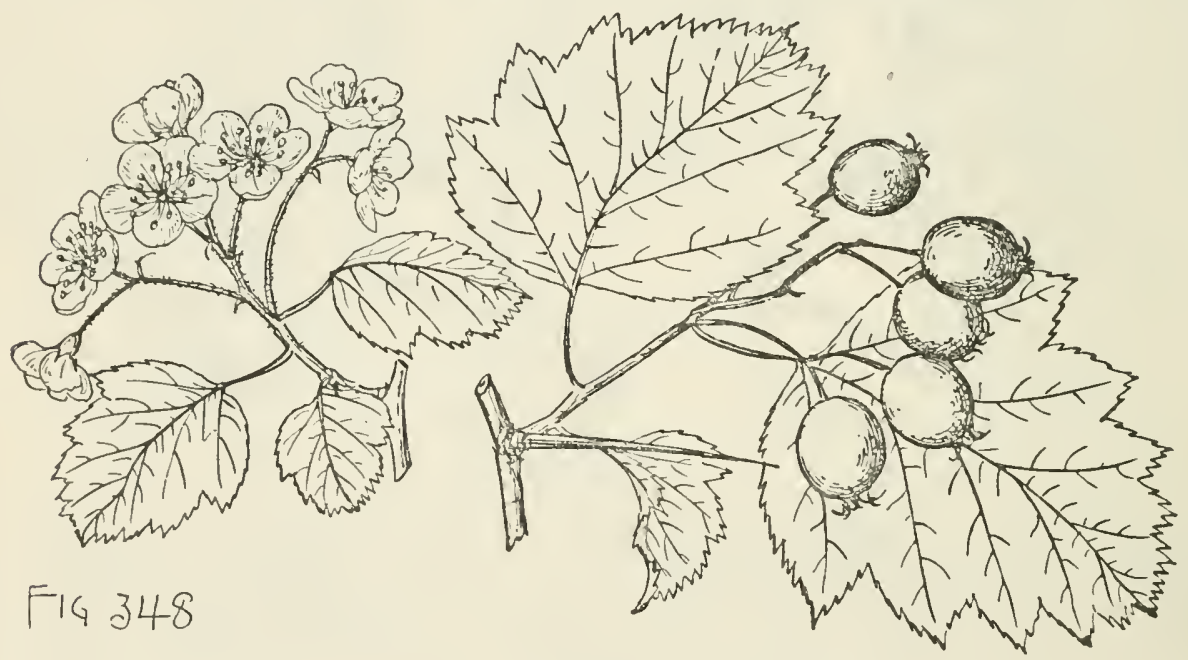

slender pale midribs and primary veins; their petioles slender, nearly terete, villose at first, soon becoming glabrous and dark red below the middle, $1 \frac{1}{2}^{\prime}-2 \frac{1}{2}^{\prime}$ long; on vigorous shoots frequently divided into narrow acute lateral lobes, and often $3 \frac{1^{\prime}}{2}-4^{\prime}$ long and wide, with lunate coarsely dentate stipules $\frac{1^{\prime}}{2} \frac{3}{4}^{\prime}$ broad. Flowers $\frac{3^{\prime}}{4}$ in diameter, on stout villose pedicels, in compact narrow compound many-flowered corymbs covered with matted pale hairs; calyx-tube narrowly obconic, glabrous or villose below, the lobes narrowed from broad bases, acute, coarsely glandular-serrate, villose on the inner surface; stamens 20; anthers small, pale pink; styles 4 or 5 . Fruit beginning to ripen and fall about the middle of September and continuing to fall until the end of October, on stout pedicels, in glabrous few-fruited clusters, oblong or obovate, bright cherry-red, lustrous, marked by dark scattered pale dots, $\frac{5^{\prime}}{8}-\frac{3^{\prime}}{4}$ long, $\frac{1}{2}-\frac{5}{8}$ ' wide; calyx little enlarged, the lobes gradually narrowed, slightly glandularserrate, usually deciduous before the fruit ripens; flesh thick, yellow, dry and mealy; nutlets 4 or 5 , dark-colored, rounded on the back, $\frac{1}{4}^{\prime}$ long.

A tree, $18^{\circ}-20^{\circ} \mathrm{high}$, with a tall trunk $8^{\prime}-10^{\prime}$ in diameter, wide-spreading branches 
forming a haudsome symmetrical head, and stout branchlets dark green and coated with matted pale hairs when they first appear, becoming light red-brown, and light orange-brown and very lustrous in their second year, and armed with thick nearly straight bright chestnut-brown spines often $3^{\prime}$ in length.

Distribution. Sandy shores of Lake Zurich, Lake County, Illinois.

\section{Cratægus Kelloggii, Sarg.}

Leaves broadly ovate to suborbicular, rounded and often short-pointed at the apex, rounded, broadly cuneate or truncate at the entire base, coarsely serrate above, with straight gland-tipped teeth, and divided usually only above the middle into

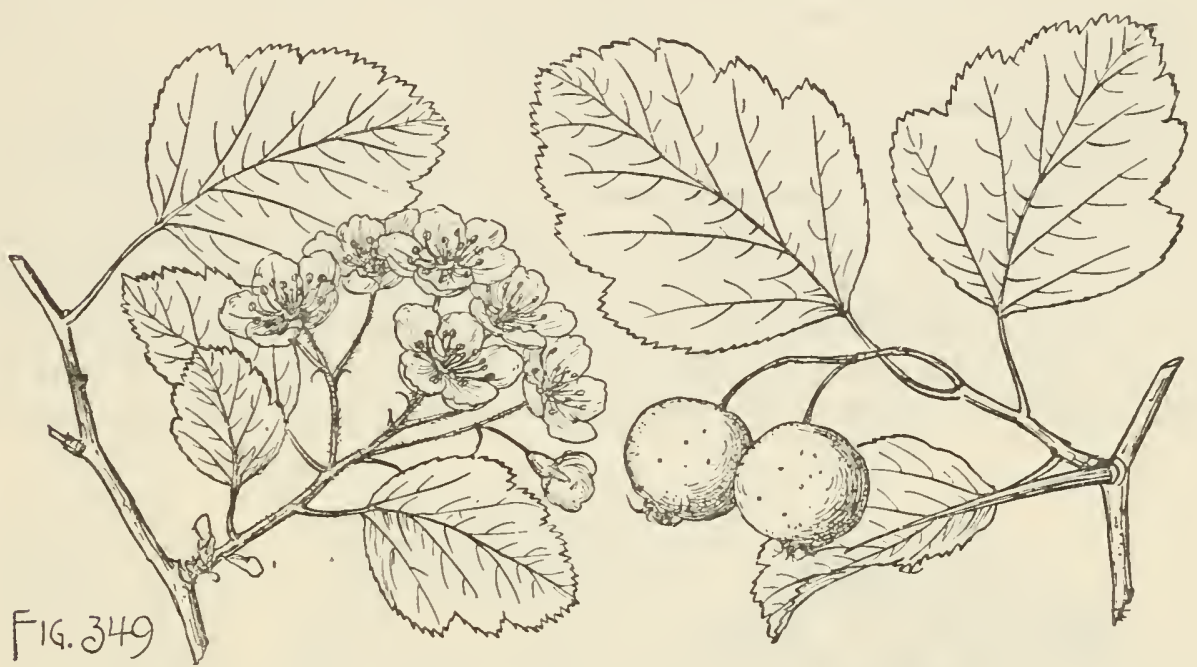

several short broad acute or acuminate lobes, about half grown when the flowers open during the last week of April and then very thin, yellow-green, covered above with short pale hairs and pubescent below along the midribs and veins, and at maturity thin but firm in texture, dark yellow-green, glabrous and smooth on the upper surface, pale and glabrous on the lower surface with the exception of a few hairs near the base of the thin yellow midribs and of the 4 or 5 pairs of slender prominent primary veins arching to the points of the lobes, $2^{\prime}-2 \frac{1}{2}^{\prime}$ long, $1 \frac{3}{4}^{\prime}-2 \frac{1}{2}^{\prime}$ wide, and often broader than long; their petioles slender, slightly winged at the apex, villose while young, with long matted white hairs, becoming glabrous, and $\frac{3^{\prime}}{4}-1^{\prime}$ long. Flowers $\frac{5}{8}$ in diameter, on slender hairy pedicels, in compact 5-10-flowered villose compound corymbs, with oblong-obovate to linear acuminate glandular bracts and bractlets mostly persistent until the flowers open; calyx-tube broadly obconic, slightly hairy at the base, glabrous above, the lobes slender, acuminate, glandular, with minute dark red stipitate glands, or entire, glabrous on the outer, sparingly villose on the inner surface; stamens 20; anthers pale rose color; styles 5. Fruit ripening at the end of September and soon falling, on long slender glabrous pedicels, in few-fruited drooping clristers, subglobose to short-ovate, bright yellow, marked by many small pale dots, $\frac{3 \prime}{4}-1^{\prime}$ in diameter; calyx small, with spreading reflexed lobes slightly villose toward the apex and often deciduous from the ripe fruit; flesh thin, yellow, dry and mealy; nutlets 5, rounded and very slightly grooved on the back, about $\frac{3^{\prime}}{8}$ long.

A tree, $20^{\circ}-25^{\circ}$ high, with a tall trunk $4^{\prime}-5^{\prime}$ in diameter, covered with nearly black 
deeply furrowed bark, erect branches, and nearly straight branchlets dark green tinged with red and slightly villose when they first appear, bright red-brown and lustrous at the end of their first season, becoming dark dull reddish brown the following year, and unarmed, or armed with slender nearly straight bright chestnutbrown shining spines usually about $1^{\prime}$ long.

Distribution. Banks of the Desperes River, St. Louis, Missouri; not common.

\section{Cratægus Texana, Buckl.}

Leaves broadly ovate, acute or rarely rounded at the apex, broadly concave-cuneate, and on leading shoots sometimes truncate or slightly cordate at the entire base, coarsely and doubly glandular-serrate above, and usually divided above the middle into 4 or 5 pairs of wide acute lobes, covered above when they unfold with short soft pale hairs and below with a thick coat of hoary tomentum, more than half grown when the flowers open late in March, and at maturity thick and firm, dark green and lustrous above, pale and pubescent or tomentose below, particularly on the stout midribs, primary veins, prominent secondary veins, and reticulate veinlets, $3^{\prime}-4^{\prime}$ long, $2 \frac{1^{\prime}}{2}-3^{\prime}$ wide; their petioles stout, deeply grooved, more or less winged above, at first tomentose, ultimately nearly glabrous, $\frac{1^{\prime}}{2}-\frac{3}{4}$ long. Flowers $\frac{3^{\prime}}{4}$ in diameter, on elongated slender pedicels, in broad open many-flowered compound tomentose corymbs, with oblong or oblong-obovate acute conspicuous villose bracts and bractlets often $1 \frac{1}{2}^{\prime}$ in length; calyx-tube broadly obconic, coated with pale tomentum,

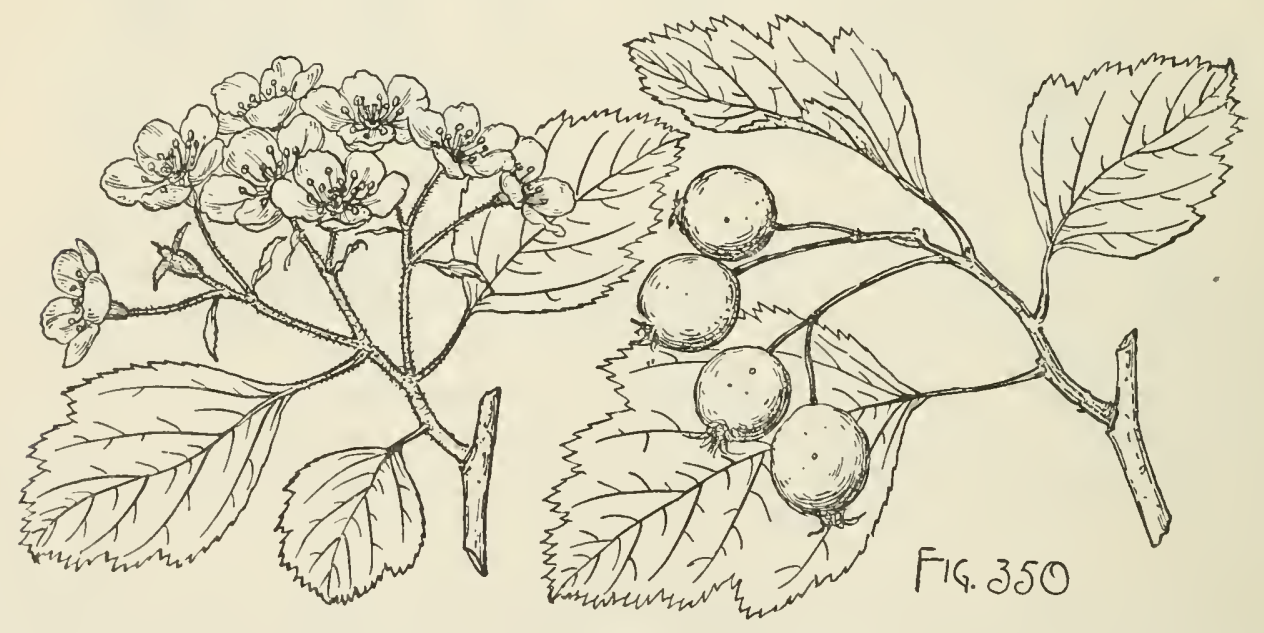

the lobes foliaceous, gradually narrowed from broad bases, acuminate, coarsely glandular-serrate, and villose, with long matted pale hairs; stamens 20; anthers large, dark red; styles 5, surrounded at the base by a narrow ring of pale tomentum. Fruit ripening toward the end of October, in drooping many-frnited tomentose ultimately glabrous clusters, pear-shaped and tomentose until nearly grown, and when fully ripe short-oblong or slightly obovate, rounded at the ends, bright scarlet, marked by occasional large pale dots, puberulous at the apex, $\frac{3^{\prime}}{4}-1^{\prime}$ long; calyx enlarged, with glandular-serrate usually erect lobes, dark red at the base on the upper side, often deciduous before the ripening of the fruit; flesh thick, yellow, sweet, and edible; nutlets 5 , thick, slightly grooved on the back, $\frac{1^{\prime}}{4}-\frac{1}{3}$ long.

A tree, often $30^{\circ}$ high, with a tall trunk sometimes a foot in diameter, thick branches ascending while the tree is young, forming an open irregular crown and 
spreading in old age into a broad symmetrical round-topped head, and branchlets dark bronze-green and covered with long matted white hairs when they first appear, becoming dull reddish brown and ultimately pale ashy gray, and armed with occasional thin nearly straight bright chestnut-brown lustrous spines usually about 2' long, or often unarmed.

Distribution. Rich bottom-lands, central and western Texas.

\section{Cratægus quercina, Ashe.}

Leaves oval to obovate, usually acute or occasionally rounded at the apex, full and rounded and gradually or abruptly narrowed to the entire base, irregularly

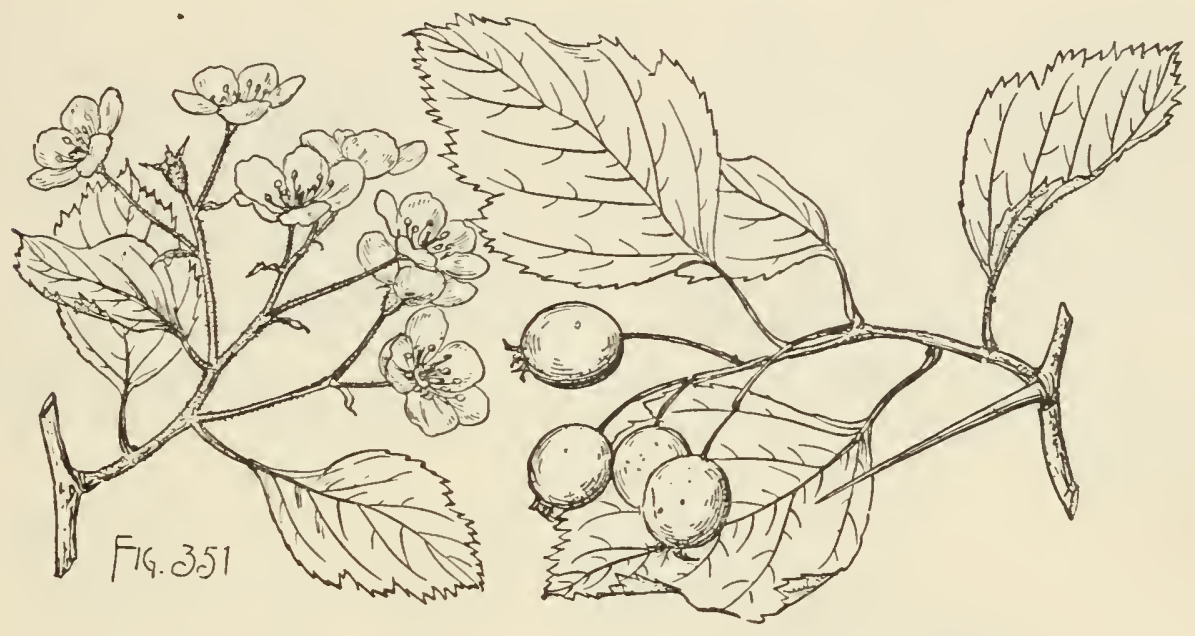

doubly serrate above, with slender glandular teeth, when they unfold conspicuously plicate, often dark red and coated with long soft pale hairs and covered below with a thick coat of silvery white shining tomentum, about one third grown when the flowers open from the middle to the end of March, and at matnrity thin but firm in texture, dark green, lustrous and scabrous above, pale and pubescent or tomentose below, $2^{\prime}-2 \frac{1}{2}^{\prime}$ long and broad, with slender midribs, 4 or 5 pairs of thin primary veins, and conspicuous reticulate veinlets; their petioles stout, tomentose, about $\frac{1^{\prime}}{2}$ long; on leading shoots broadly ovate or oblong-oval, full and rounded at the base, somewhat divided into 3 or 4 pairs of short acute lobes, frequently $4^{\prime}$ long and broad, with foliaceous lunate coarsely glandular-dentate stipitate stipules $\frac{3^{\prime}}{4}$ long. Flowers $\frac{3^{\prime}}{4}$ in diameter, on long slender tomentose pedicels, in broad many-flowered lax hoarytomentose corymbs, with oblong-obovate glandular-serrate villose bracts and bractlets; calyx-tube narrowly obconic, hoary-tomentose, the lobes short, acute, coarsely glandular-serrate, and tomentose; stamens 20; anthers small, dark red; styles 5, surrounded at the base by tufts of long snow-white hairs. Fruit ripening after the middle of October, on slender nearly glabrous pedicels, in few-fruited tomentose spreading clusters, subglobose but often rather longer than broad, full and rounded at the ends, tomentose until nearly fully grown, glabrous at maturity, dark red, marked by numerous large pale dots, about $\frac{1^{\prime}}{2}$ in diameter; calyx prominent, with. short spreading often deciduous lobes; flesh thin, light yellow, hard and dry, generally shrivelling before the fruit falls; nutlets 5, rounded and ridged on the back, about $\frac{1^{\prime}}{4}$ long.

A tree, remarkable for the lustre of its white tomentum, occasionally $25^{\circ}$ high, 
with a tall trunk $6^{\prime}-8^{\prime}$ in diameter, covered with light gray scaly bark, becoming near the base of old trees deeply furrowed and nearly black, ascending branches forming a broad symmetrical head, and branchlets coated when they first appear with hoary tomentum, becoming light red-brown and more or less villose during their first season, glabrous and rather darker in their second year, and armed with numerous straight or slightly curved chestnut-brown shining spines usually $1^{\prime}-1 \frac{1}{4}^{\prime}$ long.

Distribution. Sandy bottom-lands in open Live Oak forests on the Brazos River, Columbia, Texas.

\section{Cratægus pyriformis, Britt.}

Leaves oval or broadly ovate, acute and often short-pointed at the apex, gradually narrowed and concave-cuneate at the entire base, sharply and sometimes doubly serrate above, with straight glandular teeth, and often slightly and irregularly lobed above the middle, fully grown when the flowers open about the 10th of May and then membranaceous, light yellow-green, roughened above by short rigid pale hairs and pubescent on the lower surface, particularly along the slender midribs and 5 or 6 pairs of remote primary veins, and at maturity thin and firm, lustrous and scabrous above, pale and pubescent below, generally about $3^{\prime}$ long and $2^{\prime}$ wide; their petioles slender, winged at the apex, tomentose, ultimately pubescent, $1^{\prime}-1 \frac{1}{4}^{\prime}$ long; on vigorous shoots usually ovate, coarsely serrate, more deeply lobed and

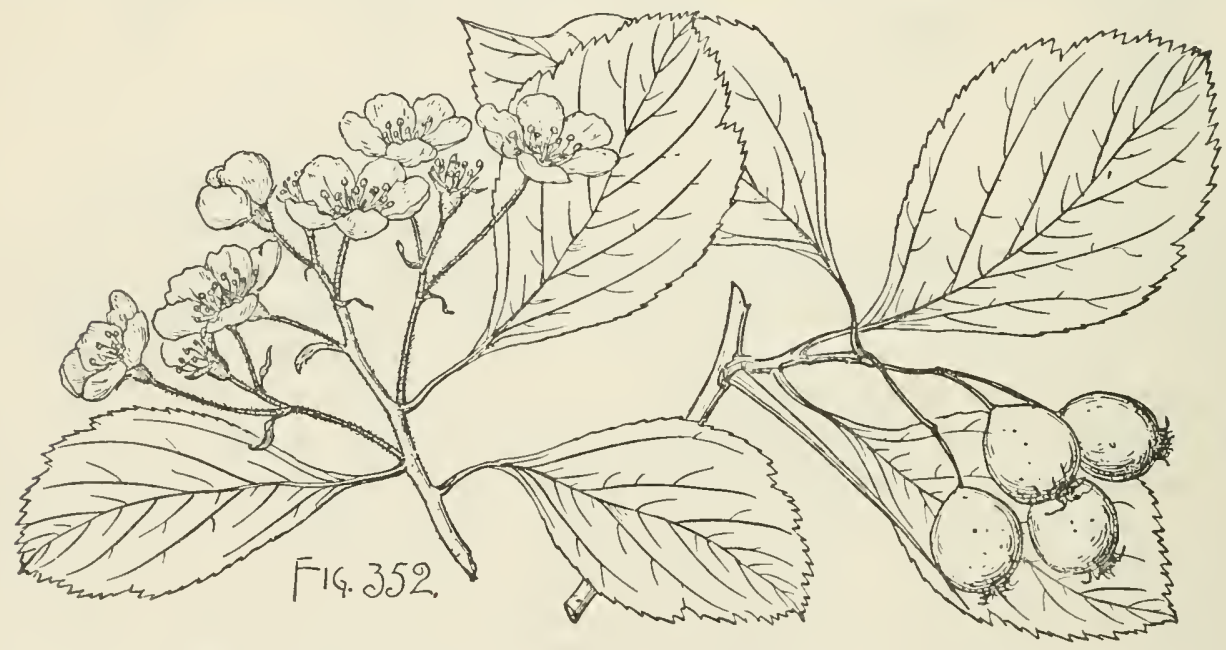

frequently $4^{\prime}-5^{\prime}$ long and $3^{\prime}-4^{\prime}$ wide, with foliaceous lunate acuminate villose coarsely serrate stipules sometimes $\frac{1^{\prime}}{2}$ in length. Flowers $1^{\prime}$ in diameter, on elongated slender tomentose pedicels, in broad compound many-flowered lax corymbs; calyx-tube narrowly obconic, villose, the lobes narrow, acuminate, glandular-serrate, and covered more or less thickly with pale hairs; stamens 20; anthers pale rose color; styles 4 , or usually 5 , surrounded at the base by a broad ring of pale tomentum. Fruit ripening in October, on long slender pubescent pedicels, in drooping few-fruited clusters, obovate, full and rounded at the ends, bright cherry-red, lustrous, marked by occasional large pale dots, about $\frac{5^{\prime}}{8}$ long, $\frac{1}{2}^{\prime}$ wide, the calyx prominent, with linear glandularserrate closely appressed lobes often deciduous before the fruit ripens; flesh thin, light yellow, juicy; nutlets 4 , usually 5 , deeply divided along the back into 2 rounded ridges, dark brown, $\frac{5}{8}$ long. 
A tree, $25^{\circ}-30^{\circ}$ high, with a trunk a foot in diameter, spreading branches form. ing a broad symmetrical head, and branchlets light green and villose when they first appear, with long matted pale bairs, dull red-brown and pubescent in their first season, becoming glabrous the following year, and armed with occasional thin nearly straight bright chestnut-brown shining spines usually about $1 \frac{1}{2}$ long.

Distribution. Rich bottom-lands of the streams of Ridley County, southeastern Missouri.

\section{Cratægus lanuginosa, Sarg.}

Leaves ovate to suborbicular, acute or rounded and short-pointed at the apex, broadly cuneate or rounded at the entire base, coarsely and sharply doubly serrate
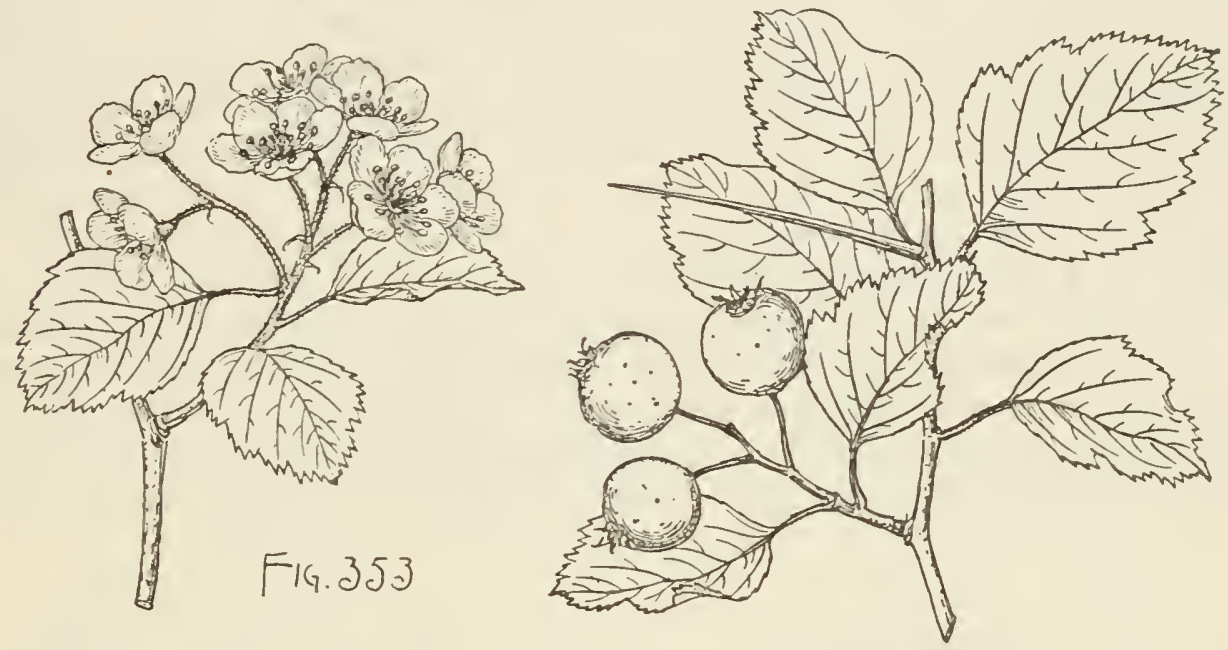

above, with glandular teeth, and often irregularly divided above the middle into short broad acute lateral lobes, less than half grown when the flowers open during the last week of April and then dark green and villose above and covered below with a thick coat of hoary tomentum, and at maturity subcoriaceous, dark bluegreen, lustrous, and scabrate on the upper surface, yellow-green and tomentose on the lower surface, $1 \frac{1^{\prime}}{2}-2^{\prime}$ long, $1^{\prime}-1 \frac{1^{\prime}}{2}$ wide, with thick midribs and 3-5 pairs of stout primary veins extending obliquely to the points of the lobes; their petioles stout, tomentose, $\frac{1}{2}^{\prime}-\frac{3}{4}^{\prime}$ long; on vigorous shoots often broad, ovate, very coarsely glandular-serrate, rounded or truncate at the base, frequently $3^{\prime}$ long and broad, their stipules lunate, coarsely serrate, subcoriaceous, $\frac{3^{\prime}}{8}-\frac{1}{2}$ long. Flowers $\frac{3^{\prime}}{4}$ in diameter, on short stout pedicels covered with long matted pale hairs, in compact many* flowered hoary-tomentose corymbs, with large glandular-serrate conspicuous bracts and bractlets persistent until the flowers open; calyx-tube broadly obconic, hairy, the lobes short, broad, acute, glandular, with minute stipitate glands, densely villose on the outer, slightly villose on the inner surface; stamens 20; anthers rose color; styles 5, surrounded at the base by large tufts of snow-white hairs. Fruit ripening at the end of October, on short tomentose erect pedicels, in few-fruited clusters, subglobose to short-oblong, full and rounded and slightly hairy at the ends, $\frac{1}{2}^{\prime}$ in diameter; calyx enlarged, with villose coarsely serrate usually erect spreading or incurved persistent lobes, bright red on the upper side near the base; flesh thin, orange color, dry and mealy; nutlets 5 , thin, rounded and very irregularly ridged on the back, about $\frac{1^{\prime}}{4}$ long. 
A tree, sometimes $25^{\circ}$ high, with a stout trunk covered with pale bark, spreading and erect branches, and stout zigzag branchlets light green and villose at first, dull red-brown and sparingly villose or pubescent at the end of their first year, becoming dark or light gray-brown, and armed with many long straight purple shining ultimately ashy gray spines $1 \frac{1^{\prime}}{4}-3 \frac{1}{2}{ }^{\prime}$, usually about $2 \frac{3^{\prime}}{4}$ long.

Distribution. Southwestern Missouri; common near Webb City; well distinguished by the distinctly blue color of the small leaves, and by the dark crimson hard fruits and the remarkable development of the spines unusual in this group.

\section{Cratægus induta, Sarg. Turkey Apple.}

I.eaves oblong-obovate, acute, cuneate, rounded or rarely truncate at the broad entire base, very coarsely and doubly serrate above, with glandular teeth, and slightly and irregularly divided into broad acute lateral lobes, about one third grown when the flowers open from the middle to the end of April and then thin, light yellowgreen and roughened above by short lustrous white hairs and hoary-tomentose below, and at maturity thin, dark yellow-green and scabrate on the upper surface, pale and tomentose or pubescent on the lower surface, particularly along the stout midribs and 4 or 5 pairs of prominent primary veins, $3^{\prime}-4^{\prime}$ long, $2 \frac{1}{2}^{\prime}-3^{\prime}$ wide; their petioles slender, more or less wing-margined at the apex, glandular, hoary-tomentose while young, becoming sparingly villose in the autumn, $1 \frac{1}{4}^{\prime}-1^{\prime}{ }^{\prime}$ long. Flowers $\frac{3}{4}{ }^{\prime}$ in diameter, on slender tomentose pedicels, in broad many-flowered hoary-tomentose compound corymbs; calyx-tube narrowly obconic, thickly coated with long densely matted white hairs, the lobes small, acuminate, glandular-serrate, villose; stamens

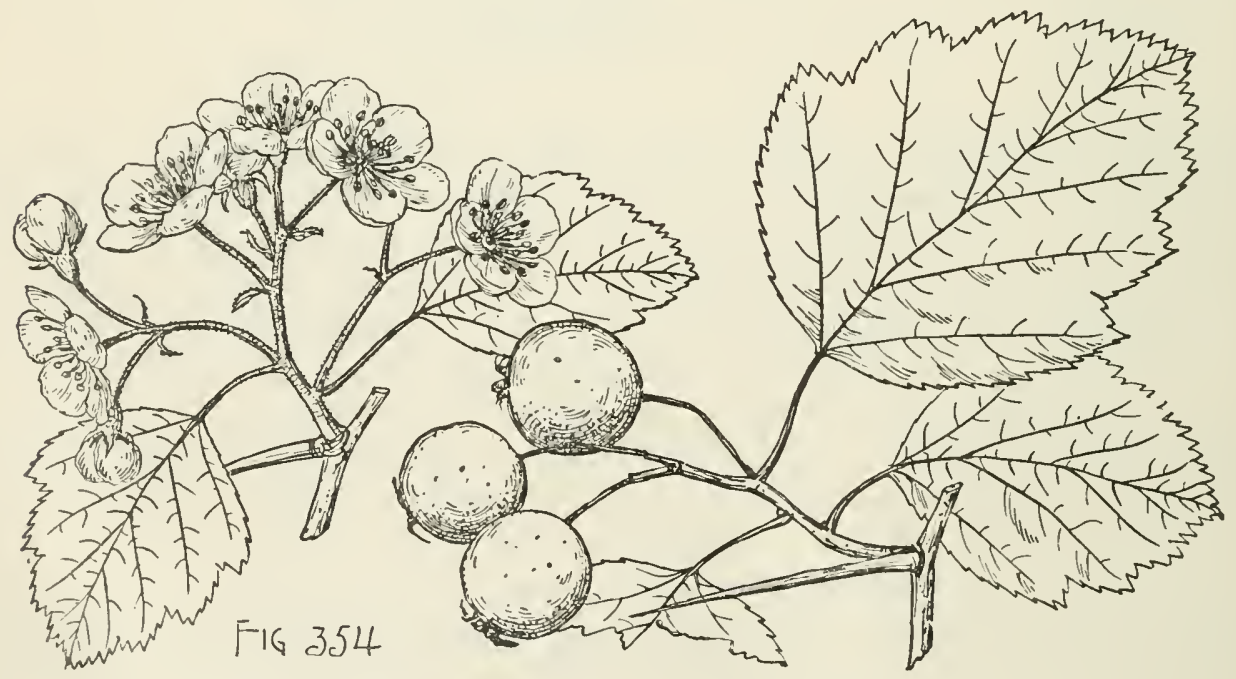

20; anthers small, rose color; styles 5, surrounded at the base by a broad ring of snow-white hairs. Fruit ripening the middle of October, on stout villose pedicels, in few-fruited clusters, short-oblong, full and rounded and villose at the ends, crimson or reddish yellow, lustrous, marked by small pale dots, $\frac{3^{\prime}}{4}-2^{\prime}$ in diameter; calyx prominent, with a short tomentose tube and much enlarged coarsely glandular-serrate hairy erect incurved lobes often deciduous from the ripe fruit; flesh thick, orange-colored, with an astringent subacid flavor; nutlets 5 , thin, rounded and slightly grooved on the back, $\frac{5}{16} \mathbf{1}^{\prime}-\frac{3}{8}$ long.

A tree, sometimes $25^{\circ}$ high, with a trunk often a foot in diameter, covered with 
thick dark brown furrowed bark, large spreading and ascending branches forming an open irregular head, and stout branchlets covered at first with long matted white hairs, light orange-brown, lustrous, and puberulous at the end of their first season, becoming ashy gray or light grayish brown the following year, and armed with very numerous stout nearly straight dark purple shining spines usually about $2 \frac{1}{2}^{\prime}$ long.

Distribution. Dry upland woods, valley of the Red River near Fulton, Arkansas; common.

\section{** Stamens 10.}

+ Anthers yellow.

\section{Cratægus Arnoldiana, Sarg.}

Leaves broadly ovate or rarely oval, acute, regularly divided above the middle into numerous short acute lobes, and coarsely doubly serrate, with straight glandular teeth except at the rounded truncate or occasionally cuneate base, when they unfold

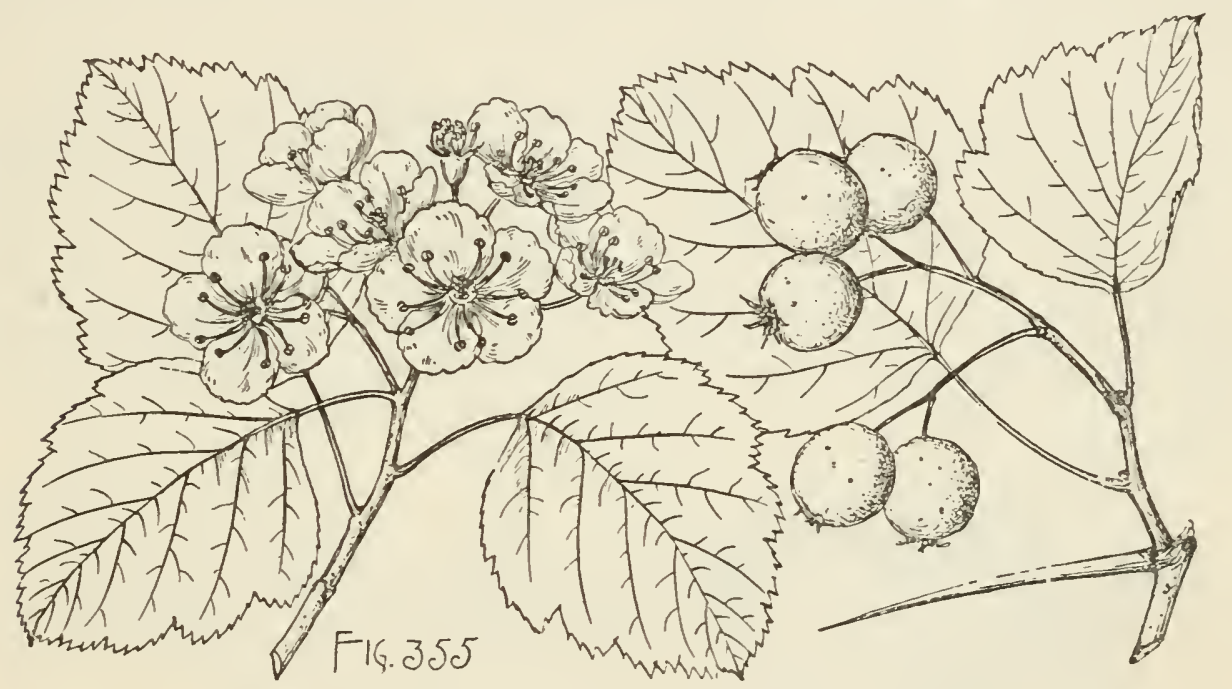

coated with dense matted pale hairs, about half grown when the flowers open at the end of May or early in June and then roughened above by stout stiff hairs and softpubescent below, and at maturity membranaceous, smooth, very dark green and lustrous above, paler below, $2^{\prime}-3^{\prime}$ long and broad, slightly villose on the under side of the slender midribs and thin prominent remote primary veins extending to the points of the lobes; their petioles slender, at first densely villose, becoming puberulous, $\frac{3^{\prime}}{4}-1 \frac{1}{2}$ long. Flowers about $\frac{3^{\prime}}{4}$ in diameter, on slender pedicels, in broad compound many-flowered tomentose corymbs; calyx-tube broadly obconic, densely tomentose, the lobes narrow, elongated, acuminate, glandular-serrate, villose on both surfaces; stamens 10; anthers large, pale yellow; styles $3-5$, usually 3 or 4 , surrounded at the base by a broad ring of thick hoary tomentum. Fruit ripening about the middle of August and mostly falling before the first of September, on stout pedicels, in erect spreading or rarely drooping few-fruited villose clusters, subglobose but rather longer than broad, briglit crimson marked by many large pale dots, villose, particularly toward the ends, with long scattered white hairs, $\frac{8^{\prime}}{4}$ long; calyx little enlarged, with elongated coarsely glandular-serrate wide-spreading lobes often deciduous before the fruit ripens; flesh thick, bright yellow, subacid; nutlets 3 or 4 , 
light-colored, prominently ridged on the back, with a high rounded ridge, about $\frac{1^{\prime}}{4}$ long.

A tree, $15^{\circ}-20^{\circ}$ high, with a short trunk $10^{\prime}-12^{\prime}$ in diameter, stout ascending branches forming a broad open irregular head, and slender very zigzag branchlets clothed at first with long matted pale hairs, becoming dark orange-brown and very lustrous before midsummer, glabrous or puberulous during their first winter, bright orange-brown or gray-brown during their first season, and armed with numerous stout straight or slightly curved bright chestnut-brown shining spines $2 \frac{1}{2}-3^{\prime}$ long.

Distribution. Thickets on a dry bank in the Arnold Arboretum and in the valley of the Mystic River at Medford, Massachusetts.

Often cultivated in the parks and gardens in the neighborhood of Boston; very conspicuous and easily recognized in winter by its ascending remarkably zigzag branchlets.

\section{Cratægus Champlainensis, Sarg.}

Leaves ovate, acute, rounded, truncate, slightly cordate or broadly cuneate at the base, usually divided into 2 or 3 pairs of short narrow acute lobes, and coarsely and frequently doubly serrate, with glandular teeth, roughened above by short pale hairs and villose below when they unfold, nearly fully grown when the flowers open early in June, and at maturity thick and firm in texture, conspicuously blue-green and glabrous above, light yellow-green and somewhat pubescent below on the slender midribs and remote primary veins, $2^{\prime}-2 \frac{1}{2}^{\prime}$ long and $1^{\prime}-1 \frac{1}{2}^{\prime}$ wide; their petioles slender, more or less tomentose at first, usually becoming glabrous and light red below the middle before autumn, and $\frac{3^{\prime}}{4}-\mathbf{1}^{\prime}$ long. Flowers $\frac{3^{\prime}}{4}$ in diameter, on short slender villose pedicels, in compact few-flowered compound densely villose corymbs;

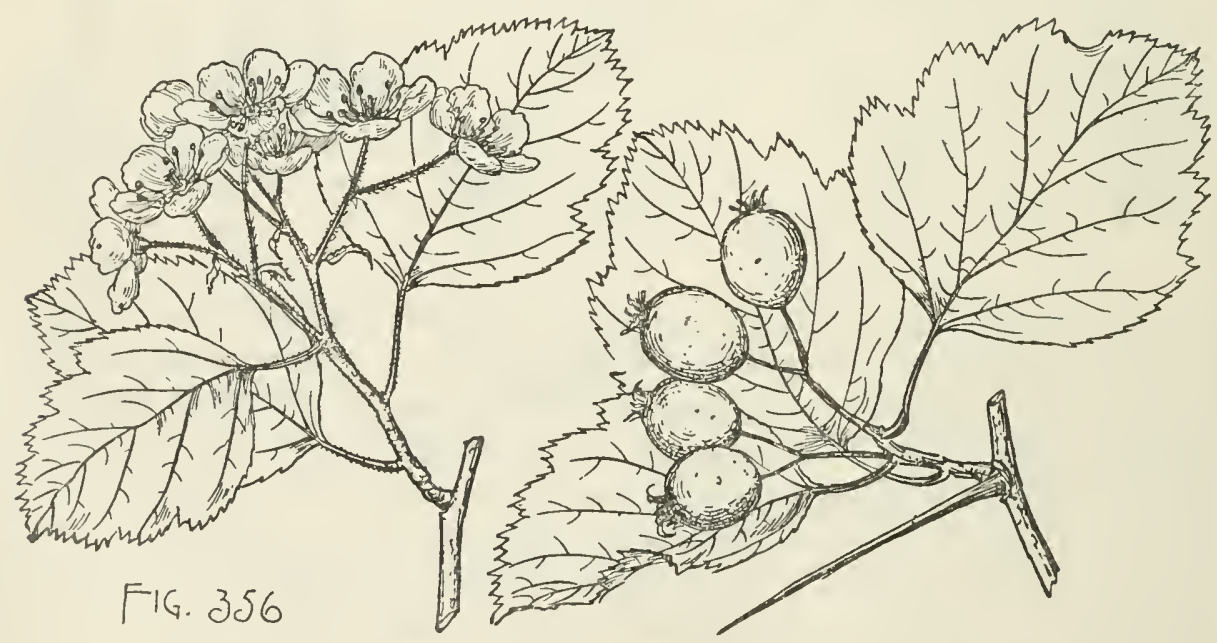

calyx-tube narrowly obconic, coated with thick hoary tomentum, the lobes lanceolate, finely glandular-serrate, tomentose on the outer surface, usually only below the middle, villose on the inner surface; stamens 10; anthers small, light yellow; styles 5, surrounded at the base by tufts of pale hairs. Fruit ripening early in September and usually remaining on the branches during the remainder of the year, on short pedicels, in compact erect villose clusters, obovate or oblong, bright scarlet, marked by scattered pale dots, more or less villose or pubescent toward the ends; calyx prominent, persistent, with a long tube, the lobes gradually narrowed from broad bases, acumi- 
nate, finely glandular-serrate, villose, dark red on the upper side below the middle, spreading or erect; flesh thick, yellow, dry and mealy; nutlets 5 , broadly ridged on the back, $\frac{5}{16}$ long.

A tree, $15^{\circ}-20^{\circ}$ high, with a tall stem $8^{\prime}-10^{\prime}$ in diameter, covered with deeply fissured bark separating into thin loose plate-like scales, stout wide-spreading branches forming a broad round-topped of ten symmetrical head, and slender somewhat zigzag branchlets coated at first with hoary tomentum, soon becoming glabrous and light chestnut-brown and lustrous, and armed with straight or slightly curved chestnutbrown spines $1 \frac{1^{\prime}}{2}-2^{\prime}$ long.

Distribution. Limestone ridges; valley of the St. Lawrence River near Montreal, southward through the Champlain valley.

\section{Cratægus submollis, Sarg.}

Leaves orate, acute, gradually narrowed and cuneate at the nearly entire base, coarsely doubly serrate above, with straight glandular teeth, and divided into 3 or 4

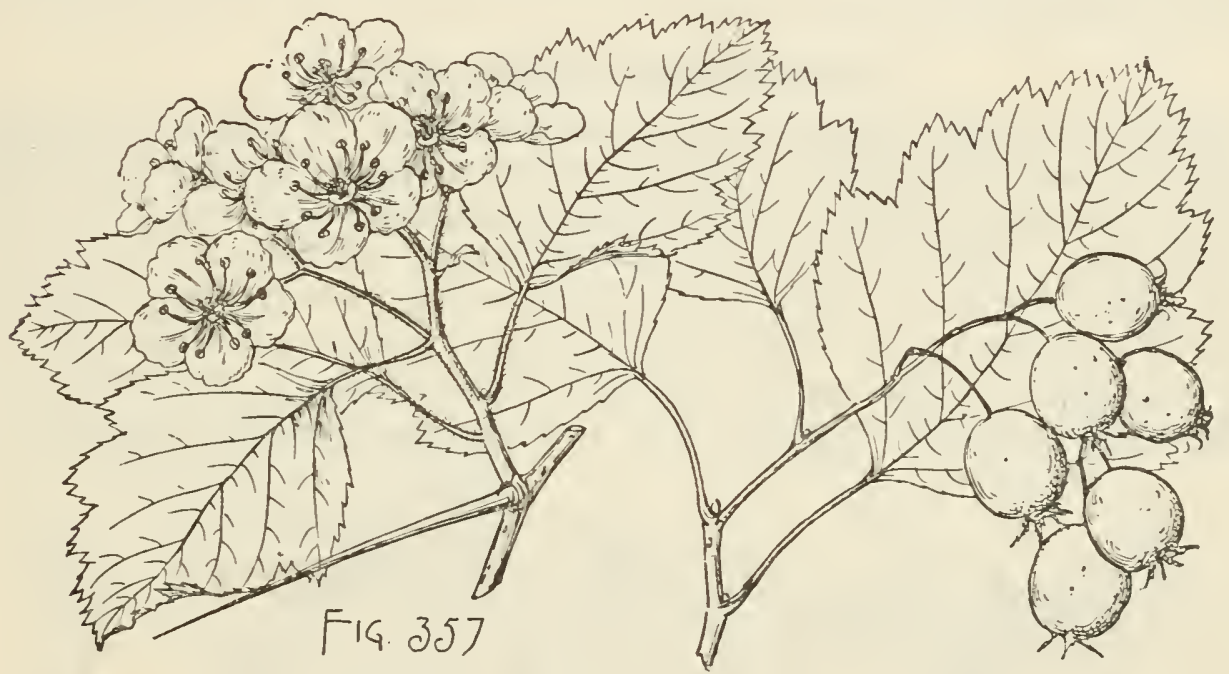

pairs of short acute lobes, half grown at the end of May or early in June when the flowers open and then roughened above by short stiff pale hairs and soft-pubescent below, particularly along the midribs and veins, and at maturity membranaceous, dark yellow-green and scabrous above, pale below, $33^{\prime}-3 \frac{1}{2}^{\prime}$ long, $2^{\prime}-2 \frac{1}{2}^{\prime}$ wide, with thick yellow midribs and remote primary veins puberulous on the lower side; their petioles stout, nearly terete, more or less winged at the apex, at first tomentose, puberulous at maturity, often bright red toward the base, $1^{\prime}-2^{\prime}$ long; on vigorous shoots broadly ovate, cuneate, rounded, truncate, or occasionally slightly cordate at the base, often $4^{\prime}$ long and $3^{\prime}-3 \frac{1}{2}^{\prime}$ wide, with lunate coarsely glandular-dentate stipules frequently nearly $1^{\prime}$ long. Flowers $1^{\prime}$ in diameter, on long slender pedicels, in broad many-flowered tomentose compound corymbs; calyx-tube narrowly obconic, covered with a thick coat of long matted white hairs, the lobes gradually narrowed from broad bases, acute, glandular, with large red stipitate glands, glabrous or villose on the onter surface; stamens 10 ; anthers small, pale yellow; styles $3-5$, surrounded at the base by a narrow ring of long white hairs. Fruit ripening and falling during the first half of September, on elongated slender villose pedicels, in broad gracefully drooping many-fruited clusters, pear-shaped, bright orange-red, lustrous, marked by 
large scattered pale dots, puberulous toward the base, about $\frac{8^{\prime}}{4}$ long; calyx nuch enlarged, with erect coarsely glandular-serrate persistent lobes; flesh yellow, thin, subacid, dry and mealy; nutlets usually 5 , rounded and slightly ridged on the back, about $\frac{1}{8}^{\prime}$ long.

A tree, $20^{\circ}-25^{\circ}$ high, with a tall trunk occasionally a foot in diameter, ascending or spreading ashy gray branches forming a broad handsome head, and branchlets dark green and coated with hoary tomentum when they first appear, light or dark orange-brown and still slightly tomentose at midsummer, becoming glabrous, lustrous, and light red-brown or dark orange-brown, and armed with numerous thin straight or somewhat curved bright chestnut-brown shining spines $2 \frac{1^{\prime}}{2}-3^{\prime}$ in length.

Distribution. Rich damp hillsides and the borders of woods and roads, valley of the St. Lawrence River in the Province of Quebec to that of the Penobscot River and Gerrish Island, Maine, to the coast of eastern Massachusetts, and near Albany, New York.

$+\rightarrow$ Anthers rose color.

\section{Cratægus anomala, Sarg.}

Leaves ovate, acute, divided above the middle into 5 or 6 pairs of short acute or acuminate lobes, and coarsely doubly serrate, with spreading glandular teeth except toward the broadly cuneate or occasionally rounded base, when they unfold conspicuously plicate, scabrous above, with short appressed pale hairs, and villose below, particularly along the slender midribs and thin remote primary veins arching to the points of the lobes, about one third grown when the flowers open at the end of May, and at maturity membranaceous, light yellow-green, smooth and glabrous above, paler and villese below, $2 \frac{1}{2}^{\prime}-3^{\prime}$ long, $2^{\prime}-3^{\prime}$ wide; their petioles stout, glandular on the

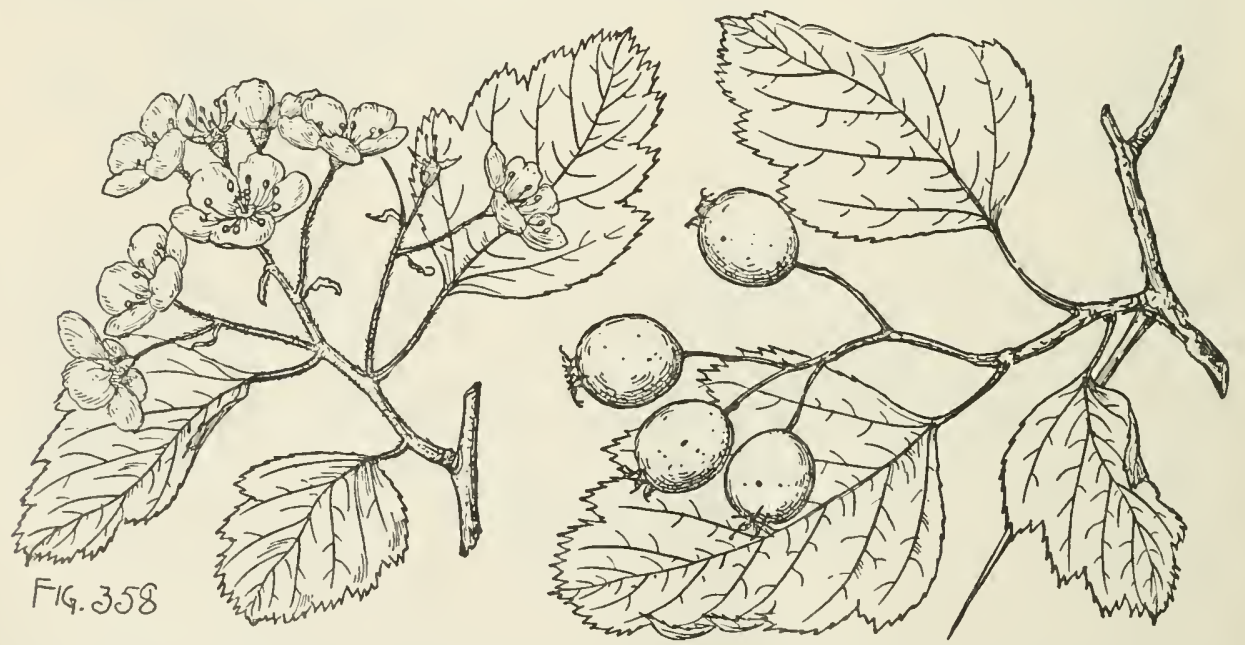

upper side, with scattered dark glands, $\frac{8^{\prime}}{4}-\mathbf{1}^{\prime}$ long. Flowers saucer-shaped, $\frac{1}{2}^{\prime}$ in diameter when fully expanded, on elongated slender hairy pedicels, in broad loose many-flowered villose corymbs; calyx-tube narrowly obconic, coated with long matted pale hairs, the lobes elongated, acuminate, coarsely glandular-serrate, pubescent on the lower surface and tomentose on the upper; stamens usually 10 , occasionally 7 or 8 ; anthers large, bright red; styles 4 or 5 , surrounded at the base by a narrow ring of pale tomentum. Fruit ripening in October, on long slender pedicels, in loose 
many-fruited slightly villose clusters, obovate to oblong, gradually narrowed to the rounded base, crimson, lustrous, marked by large pale dots, slightly villose, particularly toward the full and rounded apex, $\frac{3^{\prime}}{4}-\frac{7^{\prime}}{8}$ long, $\frac{1^{\prime}}{2}-\frac{5^{\prime}}{8}$ wide; calyx large and prominent, with elongated acuminate lobes abruptly narrowed from broad bases, dark red on the upper side, tomentose on the lower, finely glandular-serrate, spreading or closely appressed, often deciduous before the ripening of the fruit; flesh thin, light yellow, somewhat juicy; nutlets 4 or 5 , thin, prominently and irregularly ridged on the back, $\frac{1^{\prime}}{4}-\frac{5}{16}{ }^{\prime}$ long.

A bushy tree, sometimes $20^{\circ}$ high, with a short trunk $6^{\prime}$ in diameter, covered with pale gray-brown scaly bark, stout ascending branches, and slender somewhat zigzag branchlets at first dark green and villose, with long matted white hairs, and puberulous and light orange-brown during their first season, becoming glabrous and orangebrown or bright red, and armed with numerous stout straight or slightly curved bright chestnut-brown spines $1 \frac{1^{\prime}}{4}-2^{\prime}$ long.

Distribution. Low limestone ridges near the banks of the St. Lawrence River in the Caughnawaga Indian Reservation opposite Lachine in the Province of Quebec.

\section{Cratægus Ellwangeriana, Sarg.}

Leaves oval, acute, full and rounded or broadly cuneate at the entire base, irregularly divided usually only above the middle into numerous short acute lobes, and coarsely and often doubly serrate, with straight or incurved glandular teeth, about

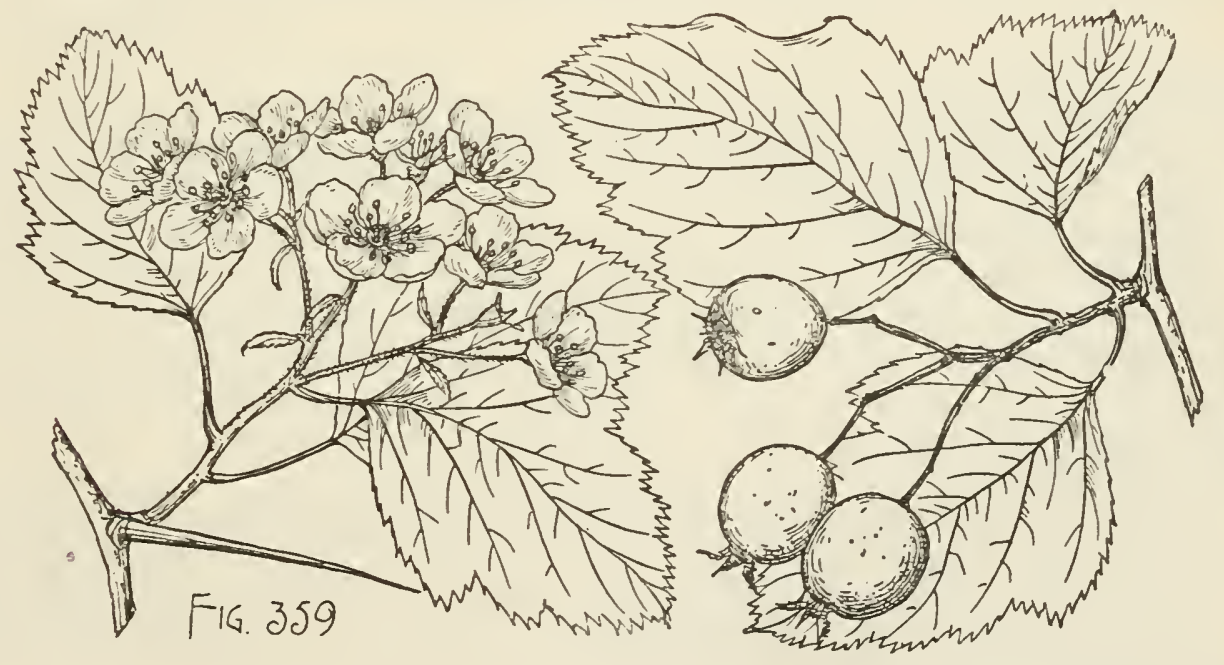

half grown when the flowers open the middle of May, and then roughened above by short pale hairs and villose below along the slender midribs and primary veins, and at maturity membranaceous, light green and scabrous on the upper surface, pale and nearly glabrous on the lower surface, $2 \frac{1}{2}^{\prime}-3 \frac{1}{2}^{\prime}$ long and $2^{\prime}-3^{\prime}$ wide; their petioles slender, at first villose, finally glabrous, $11^{\prime}-2^{\prime}$ long; stipules oblong-obovate, acute, villose, coarsely glandular-serrate, $\frac{1}{2}^{\prime}$ long, those of the upper leaves mostly persistent until after the ripening of the fruit. Flowers $1^{\prime}$ in diameter, on short stont hairy pedicels, in many-flowered densely villose corymbs; calyx-tube broadly obconic and villose, the lobes elongated, lanceolate, glandular, with small pale stalked glands, villose on both surfaces; stamens 10, sometimes 8; anthers small; rose color; styles 3-5. Fruit ripening and falling at the end of September, on slender glabrous pedicels, in droop- 
ing villose many-fruited erowded elusters, oblong, full and rounded at the ends, bright erimson, very lustrous, covered at the ends with seattered pale hairs, $1^{\prime}$ long, and $\frac{1^{\prime}}{2}-\frac{3}{4}$ wide; ealyx little enlarged, the lobes elongated, glandular-serrate above the mildle, villose on the iuner surface, and spreading, or ereet and inenrved; flesh thin, yellow, juiey and aeid; nutlets $3-5$, thiek, pale brown, deeply and of ten doubly and irregularly grooved on the baek, $\frac{1}{4}-\frac{1}{3}$ long.

A tree, sometimes $20^{\circ}$ high, with a tall trunk often a foot in diameter, eovered with pale gray sealy bark, stout aseending branehes forming a broad symmetrieal head, and slender zigzag branehlets dark green and eovered at first with long matted pale hairs, beeoming in their first summer light ehestnut-brown and slightly villose, dark ehestnut-brown and very lustrous in their seeond year, and armed with stout straight or somewhat eurved dark ehestnut-brown shining spines $1 \frac{1}{2}-2^{\prime}$ long.

Distribution. Common in the neighborhood of Rochester, New York.

\section{FLABELLAT王.}

Stamens 20; leaves yellow-green and seabrate above.

Leaves ovate; fruit obovate to short-oblong, bright red, often slightly pruinose; anthers deep rose-purple.

75. C. Neo-Londinensis (A).

Leaves oblong-ovate ; fruit obovate, crimson, lustrous; anthers pink.

76. C. Hillii (A).

Stamens 10-20, usually 10 ; leaves broadly ovate, dull dark green and scabrate above; fruit short-oblong to slightly obovate, dull red to crimson; anthers pinkish purple.

Stamens usually 10.

77. C. assurgens (A).

Fruit on short stout pedicels; leaves yellow-green and glabrous above.

Leaves oval, drooping, conspicuously concave ; fruit short-oblong, dark dull red, villose at the ends; anthers purple.

78. C. Pringlei (A).

Leaves oval to oblong-ovate ; fruit short-oblong, crimson, very lustrous; anthers dark reddish purple.

79. C. lobulata (A).

Fruit on long slender pedicels; leaves broadly ovate to obovate or rhomboidal, dark rich green and scabrate above; fruit short-oblong, bright scarlet and lustrous; anthers rose color.

80. C. pedicellata (A).

Stamens usually $5 \mathbf{5}$, rarely 10 .

Fruit short-oblong.

Leaves oval or ovate, conspicuously yellow-green ; fruit short-oblong, crimson, lustrous ; anthers dark reddish purple.

81. C. Holmesiana (A).

Leaves oblong-ovate, deep yellow-green, nearly smooth above; fruit short-oblong, yellowish red, glaucous; anthers pink.

Fruit globose to obovate.

Leaves broadly ovate, light yellow-green, lustrous and glabrous above; fruit bright red or scarlet, becoming purplish; anthers dark rose color. 83. C. delecta (A).

Leaves oblong-ovate, dark yellow-green and seabrate above; fruit crimson; anthers pale rose color.

84. C. sertata (A).

Leaves oblong-ovate, subcoriaceous, dark dull green and glabrous above; fruit bright cherry-red, pruinose; anthers deep rose eolor.

85. C. Eamesi (A). 
*Stamens 20.

\section{Cratægus Neo-Londinensis, Sarg., n. sp.}

Leaves ovate, acute or acuminate, full and rounded, truncate or broadly concavecuneate at the wide entire or glandular base, sharply often doubly serrate above, with straight glandular teeth, and divided into numerous short narrow acuminate lateral lobes, about half grown when the flowers open the middle of May and

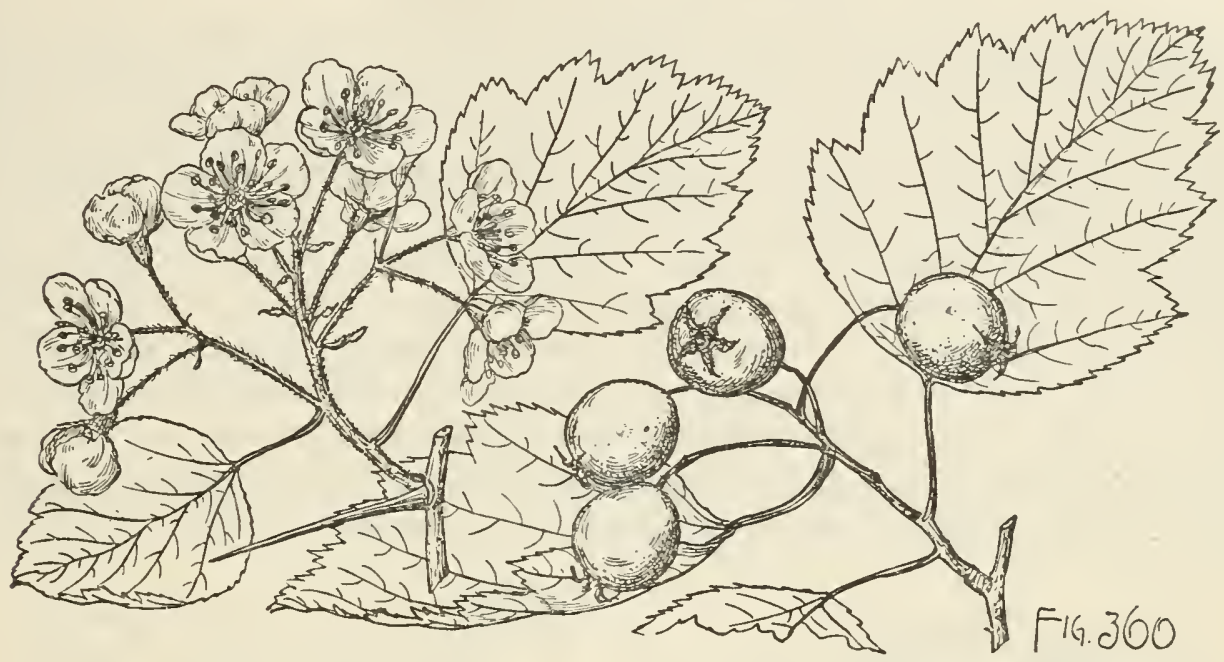

then very thin, light yellow-green and roughened above by short white rigid hairs and paler and sparingly hairy below, and at maturity membranaceous, lax and spreading, dull yellow-green and scabrate on the upper surface, pale green and glabrous below, or occasionally slightly hairy along the under side of the stout yellow midribs and thin remote primary veins arching to the points of the lobes, $3^{\prime}-4^{\prime}$ long, $2 \frac{1}{2}^{\prime}-3 \frac{1}{2}^{\prime}$ wide, and only slightly larger on vigorous shoots; their petioles slender, nearly terete, glandular, at first slightly hairy, becoming glabrous and purplish toward the base, $1^{\prime}-2^{\prime}$ long. Flowers $1^{\prime}-1 \frac{1}{8}^{\prime}$ in diameter, on slender sparingly villose pedicels, in lax slightly drooping usually 5-12-flowered villose or nearly glabrous corymbs, with linear often slightly falcate glandular bracts and bractlets, persistent until after the flowers open; calyx-tube narrowly obconic, covered with short matted pale hairs, the lobes gradually narrowed from broad bases, acuminate, coarsely glandular-serrate below the middle, glabrous on the outer, villose on the inner surface; stamens 17-21, usually 20; anthers deep rose-purple; styles 4 or 5, usually 5 , surrounded at the base by a narrow ring of pale tomentum. Fruit ripening and beginning to fall early in September, on stout villose or glabrous pedicels, in large drooping few-fruited clusters, obovate or short-oblong, bright red, often slightly pruinose, marked by numerous minute pale dots, $\frac{5^{\prime}}{8}-\frac{3}{4}^{\prime}$ long, $\frac{1}{2}^{\prime}-\frac{5}{8}^{\prime}$ wide; calyx enlarged, prominent, with spreading or erect and incurved coarsely serrate persistent lobes, their upper surface bright red below the middle and covered above with soft white hairs; flesh thick, orange-yellow, soft, juicy and acidulous; nutlets 4 or 5 , thin, narrowed at the ends, acute at the base, rounded at the apex, rounded and sometimes broadly grooved on the back, about $\frac{5{ }^{\prime}}{16}$ long and $\frac{3{ }^{\prime}}{16}$ high.

A tree, often $20^{\circ}$ high, with a tall trunk $8^{\prime}-10^{\prime}$ in diameter, covered with light grayish brown slightly fissured bark, large spreading and drooping branches forming 
an open head often $20^{\circ}$ across, and slender branchlets olive-green and slightly hairy at first, dull red-brown and marked by many large pale lenticels during their first season, becoming light gray and rather lustrous, and armed with stout straight dark purple shining ultimately gray spines often $2^{\prime}$ long.

Distribution. Borders of woods near the shores of Fisher's Island Sound, Munford's Point, Groton (once a part of New London), and Lyme, Connecticut (C. B. Graves).

\section{Cratægus Hillii, Sarg.}

Leaves oblong-ovate, acuminate, rounded or rarely cuneate at the broad entire base, coarsely donbly serrate above, with straight glandnlar teeth, and divided into numerous short acuminate lateral lobes, when they unfold coated above with short lustrous white hairs and densely tomentose below, particularly on the midribs and veins, about one fourth grown when the flowers open the middle of May and then roughened above by short hairs and still villose below, and at maturity thin but firm in texture, light yellow-green and scabrate on the upper surface, pale yellow-green on the lower surface, $2 \frac{1}{2}^{\prime}-3^{\prime}$ long, $2^{\prime}-2 \frac{1^{\prime}}{2}$ wide, with slender midribs often slightly hairy near the base and 4 or 5 pairs of thin primary veins extending obliquely to the points of the lobes; their petioles slender, densely villose early in the season, slightly hairy in the autumn, and $\frac{5^{\prime}}{8}-1 \frac{1}{2}^{\prime}$ long; stipules oblong, often elongated, coarsely glandular-serrate, villose, usually persistent until the flowers open; on vigorous

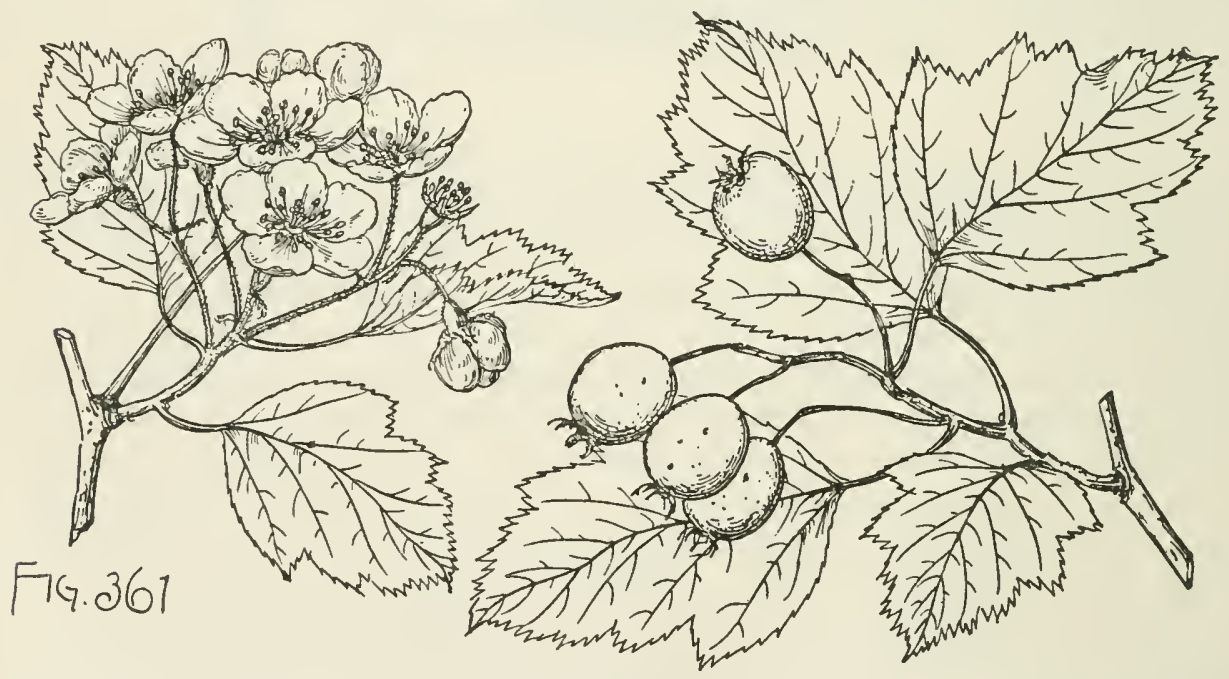

shoots often truncate or slightly cordate at the base, deeply lobed, with broad triangular lobes, and $3 \frac{1}{2}-4^{\prime}$ long and broad, with stont rose-colored glandular petioles and hairy lunate glandular-serrate stipules. Flowers about $\frac{3 \prime}{4}$ in diameter, on slender densely villose pedicels, in broad many-flowered hairy compound corymbs, their large linear to oblong bracts and bractlets occasionally persistent until midsummer; calyx-tube narrowly obconic, thickly covered with long spreading white hairs, the lobes abruptly narrowed at the base, broad, acuminate, coarsely glandular-serrate, glabrous on the outer, villose on the inner surface; stamens 20; anthers pink; styles 4 or 5 , surrounded at the base by a narrow ring of pale tomentum. Fruit ripening from the middle to the end of September, on slender puberulous pedicels, in drooping fewfruited clnsters, obovate, full and rounded at the apex, gradually narrowed to the rounded base, crimson, lustrous, marked by small pale dots, $\frac{1^{\prime}}{2}-\frac{5}{8}$ long, $\frac{3^{\prime}}{8}-\frac{1^{\prime}}{2}$ wide; 
calyx only slightly enlarged, with closely appressed coarsely serrate lobes often deciduous from the ripe fruit; flesh yellow, thin, acidulous, juicy; nutlets 4 or 5 , thin, gradually narrowed and acute at the ends, irregularly ridged and sometimes grooved on the back, about $\frac{3^{\prime}}{8}$ long.

A tree, $25^{\circ}-30^{\circ}$ high, with a trunk sometimes a foot in diameter and $6^{\circ}$ or $7^{\circ} \mathrm{long}$, covered with close light gray bark tinged with red and divided by shallow fissures into small plates, stout ascending branches forming an open irregular often roundtopped head, and slender nearly straight branchlets densely villose when they first appear, dark orange color tinged with red and sparingly villose when the flowers open, becoming bright red-brown and lustrous at the end of their first season and dark dull reddish brown the following year, and sparingly armed with slender nearly straight red-brown shining spines $1 \frac{1^{\prime}}{2}-2^{\prime}$ long.

Distribution. Open woods near the borders of streams in moist rich soil; northeastern Illinois, Thatcher's Park, Glendon Park, and River Forest, near Chicago; not common.

** Stamens 10-20, usually 10.

\section{Cratægus assurgens, Sarg.}

Leaves broadly ovate, acuminate, rounded or rarely cuneate at the wide entire base, sharply doubly serrate above, with straight gland-tipped teeth, and slightly

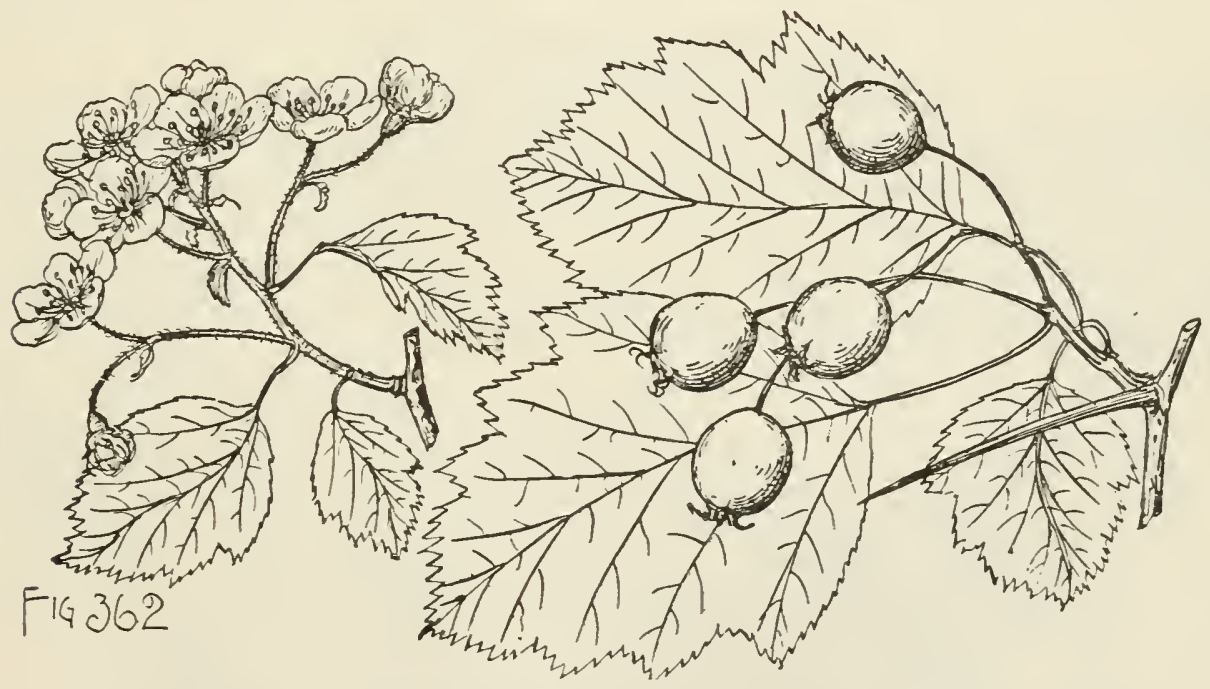

divided into 3 or 4 pairs of small acuminate lobes, about one third grown when the flowers open the middle of May and then roughened above by short white hairs and glabrous or sparingly villose below, with persistent hairs along the slender yellow midribs, and the reins arching obliquely to the points of the lobes, and at maturity membranaceous, dull dark green and scabrate on the upper surface, light yellowgreen on the lower surface, $2 \frac{3}{4}^{\prime}-3 \frac{1}{2}^{\prime}$ long, $2 \frac{1}{4}^{\prime}-2 \frac{3}{4}^{\prime}$ wide; their petioles slender, villose early in the season, becoming pubescent, $1^{\prime}-1 \frac{1}{2}^{\prime}$ long; on vigorous shoots often deeply lobed, very coarsely serrate, sometimes $4^{\prime}$ long and wide, with long stout glandular petioles, and foliaceous lunate acuminate coarsely glandular-serrate persistent stipules. Flowers $\frac{3^{\prime}}{4}-\frac{7^{\prime}}{8}$ in diameter, on short villose pedicels, in compact 8-15-flowered hairy corymbs, with oblong, acuminate, glandular bracts and bractlets, deciduous 
with the opening of the flowers; calyx-tube narrowly obconic, sparingly villose, the lobes elongated, narrow, acuminate, tipped with minute red glands, finely glandularserrate, glabrous on the outer, pubesecnt on the imer surface; stamens 10-20, usually 10; anthers pinkish purple; styles 4 or 5 , surrounded at the base by tufts of pale hairs. Fruit ripening from the 15th to the 20th of September, aud usually falling about the 1st of October, on short glabrous pedicels, in drooping few-fruited elusters, short-oblong to slightly obovate, dull red to crimson, $\frac{1^{\prime}}{2}-\frac{55^{\prime}}{8}$ long, about $\frac{1^{\prime}}{2}$ wide; calyx sessile, with spreading closely appressed serrate usually persistent lobes; flesh thin, pale ycllow or nearly white, acidulous; nutlets 4 or 5, broad, narrowed and ncute at the ends, prominently ridged on the back, with a high narrow ridge, or of ten grooved, about $\frac{1}{4}$ long.

A tree, sometimes $25^{\circ}$ high, with a trunk $2^{\prime}-6^{\prime}$ in diameter and of ten $6^{\circ}-9^{\circ}$ long, covered with close dark gray bark, ascending branches forming an oblong, open head, and slender branchlets light orange-yellow and covered when they first appear witin long seattered caducous white hairs, beconing bright red-brown and lustrous, and dark gray-brown the following year, and armed with many stout usually slightly curved bright red shining spines, $1^{\prime}-1 \frac{1}{2}^{\prime}$ long.

Distribution. River banks and low woods in rich soil; northeastern Illinois, Leyden township, Lagrange, and Thatcher's Park, near Chicago.

\section{*** Stamens usually 10.}

\section{Cratægus Pringlei, Sarg.}

Leaves oval, acute, rounded or often abruptly narrowed and cuneate at the base, occasionally irregularly lobed above the middle, with short broad acute lobes, and coarsely and often doubly serrate, with glandular tceth, as they unfold villose on both surfaces, and often more or less tinged with red, when the flowers open, usually in the last week of May, roughened above by short closely appressed pale hairs and glabrous below with the exception of a few hairs on the slender midribs and remote

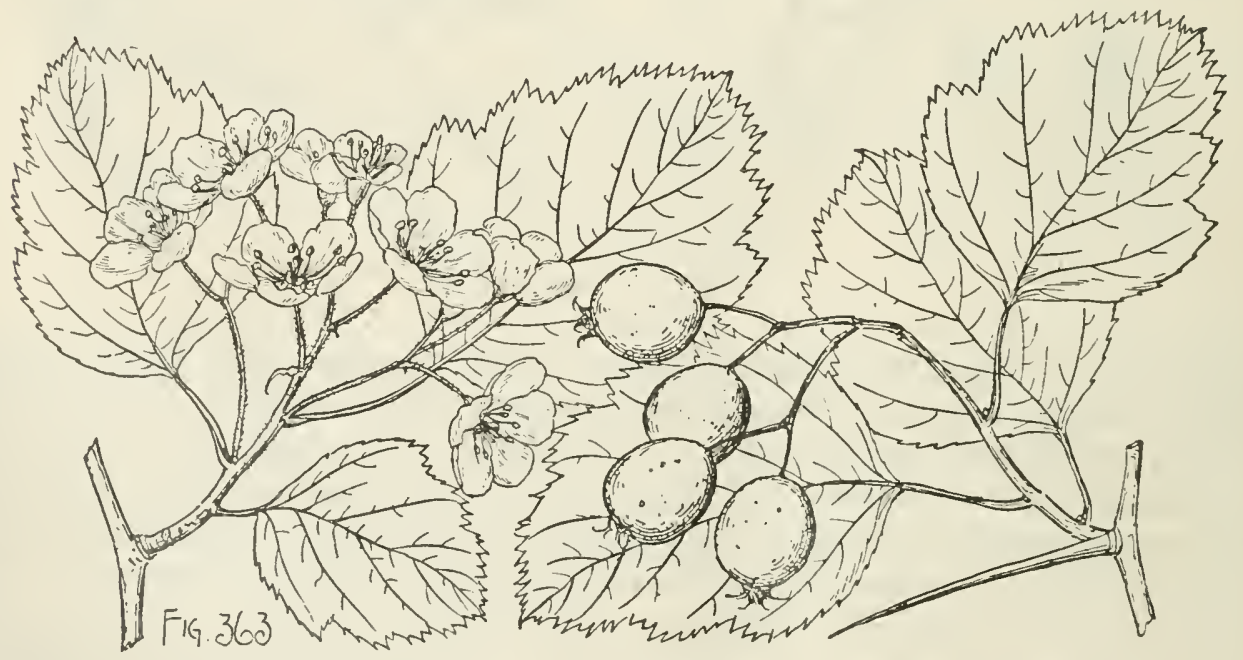

primary veins, and at maturity thin, glabrous, and bright yellow-green on the upper surface, pale below, $2^{\prime}-2 \frac{1}{2}^{\prime}$ long, $1 \frac{3^{\prime}}{4}-2 \frac{1^{\prime}}{4}$ wide, usually conspicuously concave by the gradual turning down of the blades from the midribs to the margins, and drooping 
on long thin slender glandular petioles at first villose, ultimately glabrous, from 1'$1 \frac{3}{4}$ long; on vigorous shoots sometimes truncate or slightly cordate at the base and frequently $3^{\prime}$ long and broad. Flowers about $\frac{3}{4}$ in diameter, on stout hairy pedicels, in many-flowered compound villose corymbs; calyx-tube narrowly obconic, villose, particularly toward the base, the lobes narrow, acuminate, coarsely glandular-serrate, villose on both surfaces or only on the inner surface; stamens 10 , occasionally 5-10; anthers small, purple; styles $3-5$, surrounded at the base by conspicuous tufts of pale tomentum. Fruit ripening and falling late in September or early in October, on stout pedicels, in erect villose mostly few-fruited clusters, short-oblong, dark dull red, marked by few dark dots, villose at the ends, with long scattered pale hairs, $\frac{3 \prime}{4}$ long and $\frac{5^{\prime}}{8}$ thick; calyx little enlarged, the lobes gradually narrowed from broad bases, acuminate, glandular-serrate, often erect; flesh thick, yellow, dry and acid, with a disagreeable flavor; nutlets $3-5$, rounded and slightly ridged on the back, $\frac{1}{3}^{\prime}$ long.

A tree, occasionally $25^{\circ}$ high, with a tall trunk $10^{\prime}-12^{\prime}$ in diameter, with thin bark readily separating into large flakes covered with small loose dark red-brown seales, stout branches forming a wide symmetrical head, and slightly zigzag branchlets at first dark green and villose, soon becoming glabrous, chestnut-brown and lustrous, bright orange-brown during their second year, and armed with thick straight or somewhat curved chestnut-brown spines often $1 \frac{1}{2}^{\prime}$ long.

Distribution. Southern New Hampshire, through southern Vermont to western Massachusetts, western New York and Ontario, and through the southern peninsula of Michigan to northeastern Illinois.

\section{Cratægus lobulata, Sarg. Red Haw.}

Leaves oval to oblong-ovate, acute at the apex, broadly cuneate or rounded at the entire base, sharply and often doubly serrate above, with straight glandular teeth,

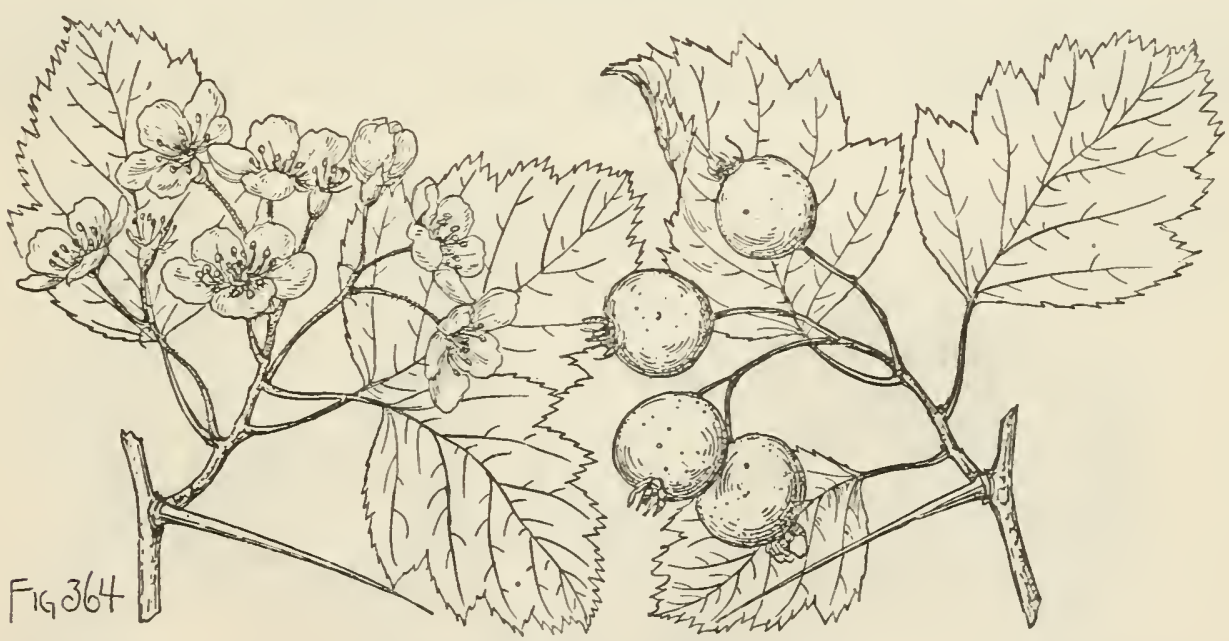

and deeply divided into numerous narrow acute or acuminate lobes spreading or pointing to the apex or to the base of the leaf, when they first appear and until after the opening of the flowers during the last week in May covered above with short soft pale hairs and slightly pubescent below along the slender midribs and thin primary veins arching to the points of the lobes, and at maturity thin, dark yellowgreen and glabrous on the upper surface, paler on the lower surface, with occasional short white hairs toward the base of the midribs, $2 \frac{1}{2}^{\prime}-3 \frac{1}{2}^{\prime}$ long, and $2^{\prime}-2 \frac{1}{2}^{\prime}$ wide; 
their petioles slender, nearly terete, at first tomentose, particularly at the base, beeoming pubescent or nearly glabrons and bright red, and $1^{\prime}-11_{2}^{\prime} \operatorname{long}$. Flowers $\frac{3}{4}$ in dianeter, on elongated slender pedieels, in rather eompact many-flowered tomentose eomponnd eorymbs, with linear-lanceolate glandular-serrate bright red braets and bractlets; calyx-tube broadly obconie, grabrous or villose toward the base, dark red, the lobes gradnally narrowed from broad bases, glabrous, eoarsely glandular-serrate, with large dark red stipitate glands; stanens usually 10 , oeeasionally $5-10$; anthers small, dark reddish purple; styles $3-5$, sometimes surromded at the base by a ring of pale tomentum. Fruit ripening and falling early in Oetober, on short stout pedieels, in ereet eompact tomentulose clusters, short-oblong, somewhat flattened at the full and romuded ends, bright erimson, very lustrons, marked by oeensional small white dots, about $\frac{8^{\prime}}{4}$ long and $\frac{5^{\prime}}{8}$ thiek; ealyx little enlarged, the lobes small, laneeolate, eoarsely glandular-serrate, tomentose on the upper surfaee, ereet and inenrved, persistent; Hesh thiek, yellow, sweet and juiey; nutlets $3-5$, thin, dark-eolored, ridged and of ten grooved on the baek, $\frac{1 \prime}{4}$ long.

A tree, oeeasionally $35^{\circ}$ high, with a straight trunk often a foot in diameter, covered with dark red-brown fissured bark broken into small thick plate-like seales, stout generally aseending branehes forming an open usually narrow irregnlar head, and slender branchlets, dark green and eovered with matted pale hairs when they first appear, becoming bright ehestnut-brown and very lustrous during their first season and light orange-brown the following year, and armed with many stout nearly straight ehestnut-brown spines rarely more than $1^{\prime}$ in length.

Distribution. Burlington, Vermont, and southward through the Champlain valley, and western Massaehusetts to northern Connectieut; eommon.

\section{Cratægus pedicellata, Sarg.}

Leaves broadly ovate or oceasionally obovate or rhomboidal, acute or acuminate, broadly euneate or rounded at the entire base, eoarsely often doubly serrate above, with spreading glandular teeth, and divided above the middle into 4 or 5 pairs of

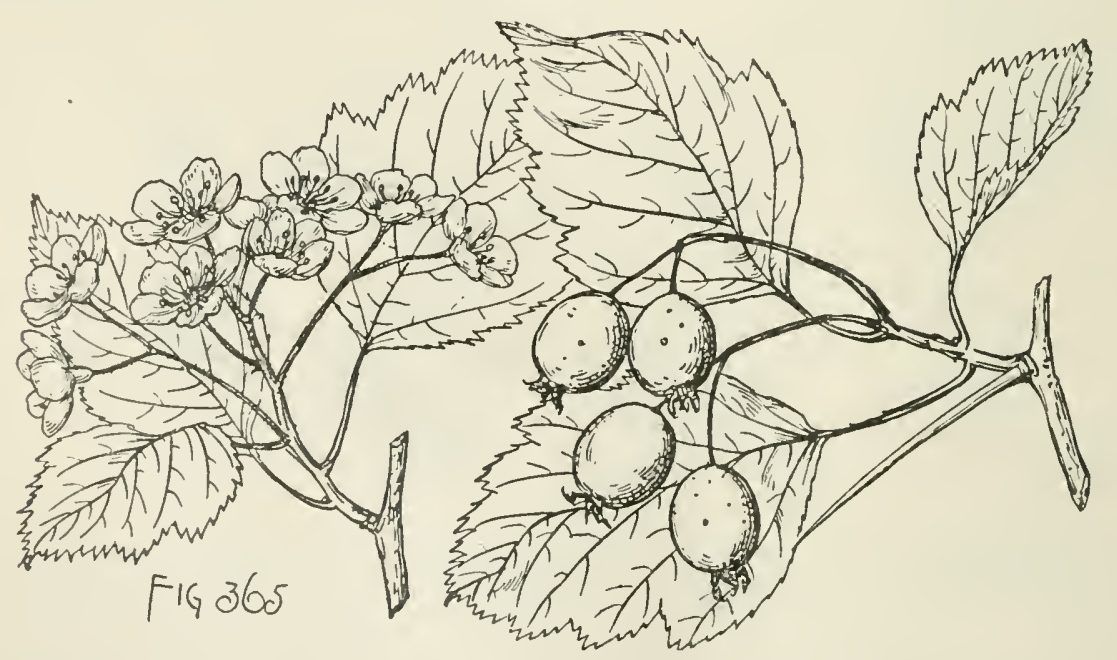

short aeute or acuminate lobes, nearly two thirds grown when the flowers open during the last week in May, and then ronghened above by short rigid pale hairs and glabrous below, and at maturity membranaeeous, dark rich green and seabrous on the 
upper surface, pale on the lower surface, $3^{\prime}-4^{\prime}$ long and $2^{\prime}-3^{\prime}$ wide, with slender midribs, and thin remote primary veins arching to the points of the lobes; their petioles slender, nearly terete, glandular, with minute scattered dark glands, at first villose, becoming glabrous, $1 \frac{1}{2}^{\prime}-2 \frac{1}{2}^{\prime}$ long; on vigorous shoots sometimes truncate or slightly cordate at the base; their stipules strongly falcate, stipitate, coarsely glandular-serrate, and often $\frac{1}{3}^{\prime}$ long. Flowers $\frac{1}{2}^{\prime}$ in diameter, on thin elongated pedicels, in loose lax many-flowered slightly villose corymbs; calyx-tube narrowly obconic, glabrous, the lobes broad, acute, very coarsely glandular-serrate; stamens usually 10; anthers rose color; styles 5, surrounded at the base by a conspicuous ring of pale tomentum. Fruit ripening and falling during September, on long slender pedicels, in few-fruited drooping glabrous clusters, pyriform until nearly fully grown, becoming short-oblong when fully ripe, rounded at the ends, bright scarlet, lustrous, marked by numerous small dark dots, $\frac{3^{\prime}}{4}$ long and $\frac{1}{2}^{\prime}-\frac{5^{\prime}}{8}$ thick; calyx large and conspicuous, the lobes much enlarged, coarsely serrate, and usually erect and incurved; flesh pale, thin, dry and mealy; nutlets 5, narrowed and acute at the ends, rounded and deeply grooved on the back, about $\frac{1}{3}^{\prime}$ long.

A tree, $18^{\circ}-20^{\circ}$ high, with a tall trunk sometimes a foot in diameter, covered with close red-brown scaly bark, comparatively slender elongated spreading or ascending branches forming a handsome symmetrical head, and thin branchlets dark chestnutbrown and slightly villose at first, becoming very lustrous and ashy gray in their second year, and armed with straight or slightly curved shining chestnut-brown spines $1 \frac{1^{\prime}}{2}-2^{\prime}$ long.

Distribution. Western New York and southern Ontario; common.

Stamens usually 5-7.

\section{Cratægus Holmesiana, Ashe.}

Leaves oval or ovate, acute or acuminate at the apex, rounded or broadly cuneate at the base, coarsely and doubly serrate above the middle, with straight teeth tipped

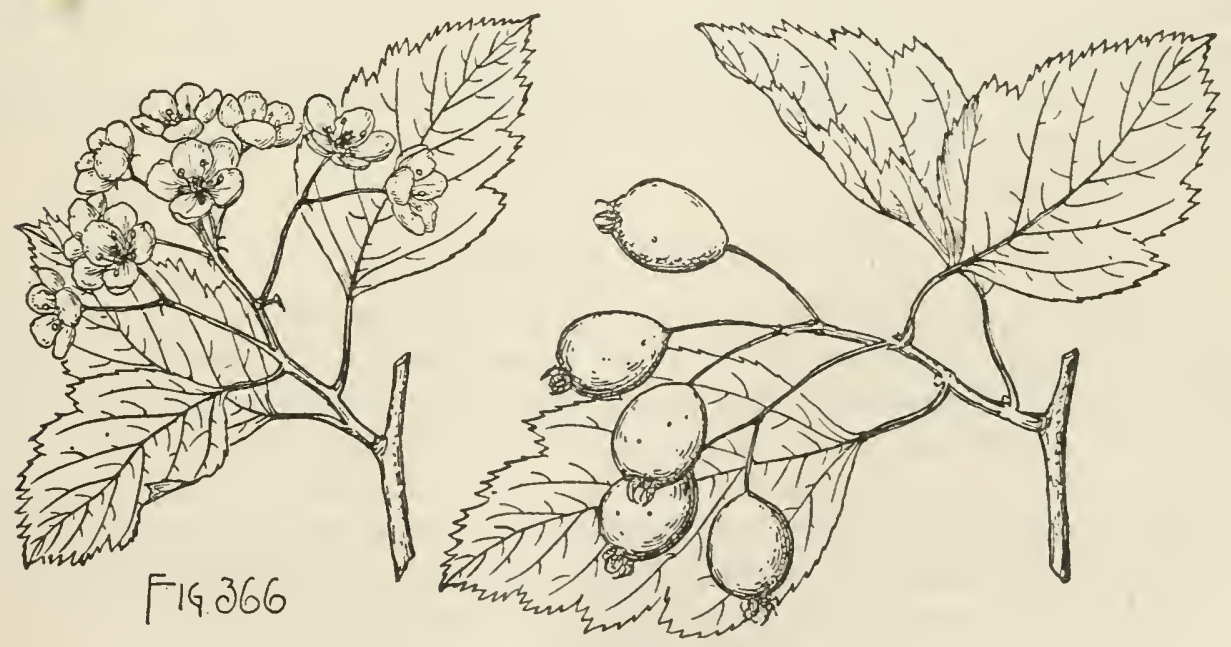

at first with prominent dark red caducous glands, and usually divided into 3 or 4 pairs of short acute or acuminate lateral lobes, when they unfold dark red, roughened by rigid pale hairs on the upper surface, and glabrous or sometimes villose on the lower surface, scabrous above, pale yellow-green and nearly half grown when the flowers 
open early in May, and at maturity thick and firm, almost smooth, conspicuously yellow-green, usually about $2^{\prime}$ long and $1 \frac{3^{\prime}}{4}$ wide, with prominent midribs often bright red on the lower side toward the base, and 4-6 pairs of slender primary veins arching to the points of the lobes; their stipules slender, nearly terete, glandular, glabrous or sometimes puberulous while young, $1^{\prime}-1 \frac{1^{\prime}}{2}$ long; on vigorous shoots often broadly ovate, truncate or slightly cordate at the base, more coarscly serrate and more deeply lobed and frequently $4^{\prime}$ long and $3^{\prime}$ wide. Flowers cup-shaped, $\frac{1}{2}-\frac{8}{4}$ in dianeter, on slender elongated pedicels, in loose compound glabrous or rarely puberulous manyflowered corymbs, witl oblanceolate or linear acute glandular cadncous bracts and bractlets; ealyx-tube narrowly obconie, glabrous, more or less deeply tinged with red, the lobes elongated, aeuminate, glandular-serrate, or often nearly entire; stamens usually 5, sometimes 6-8; anthers large, dark reddish purple; styles usually 3 , surrounded at the base by a narrow ring of pale tomentum. Fruit ripening and falling early in September, on long slender pedieels, in many-fruited drooping clusters, shortoblong, full and rounded at the ends, crimson, very lustrous, marked by occasional small dark dots, about $\frac{1^{\prime}}{2}$ long; calyx enlarged, conspienous, with erect and incurved glandular-serrate lobes, bright red toward the base on the upper side; flesh thin, yellow, dry and mealy, with a disagreeable flavor; nutlets usually 3 , light chestnntbrown, prominently grooved and ridged on the back, with a broad rounded ridge, about $\frac{1^{\prime}}{4}$ long.

A tree, often $30^{\circ}$ high, with a tall straight trunk $10^{\prime}-15^{\prime}$ in diameter, covered with pale gray-brown or nearly white scaly bark, stout ascending branches forming an open irregnlar rather compact head, and stout glabrous branehlets dark green more or less tinged with red when they first appear, becoming bright chestnut-brown or orange-brown and lustrous, and ultimately ashy gray, and armed with occasional thick mostly straight bright ehestnut-brown shining spines $1 \frac{1}{2}^{\prime}-2^{\prime}$ long.

Distribution. Rich moist hillsides and the borders of streams and swamps, neighborhood of Montreal and southern Ontario to the coast of southern Maine, central and western Massachusetts, western New York, Rhode Island, and eastern Pennsylvania; most abundant and of its largest size on the hills of Worcester County, Massachusetts. In Sellersville, Bucks Connty, Pennsylvania, in a form of this species (var. villipes, Ashe) the young branehlets, petioles, and corymbs are often puberulous and the under surface of the leaves more or less hairy, particularly on the midribs and veins.

\section{Cratægus acclivis, Sarg.}

Leaves oblong-ovate, acuminate, broadly cuneate or rounded at the entire base, coarsely doubly serrate above, with straight gland-tipped teeth, and deeply divided into numerous wide-spreading aeuminate lateral lobes, when they unfold tinged with red, densely villose on the upper surface, pubescent along the midribs and veins below, about half grown when the flowers open during the last week of May and then light yellow-green, slightly ronghened above by short white hairs and pubescent along the midribs and veins below, and at maturity membranaceous, dark yellowgreen and nearly smooth above, pale yellow-green and glabrous below, $2 \frac{1}{2}-3^{\prime}$ long, $2^{\prime}-2 \frac{1}{2}^{\prime}$ wide, with stout yellow midribs and 5 or 6 pairs of primary veins extending obliquely to the points of the lobes; their petioles slender, slightly wing-margined at the apex, glandular, with numerous small dark glands, densely villose early in the season, bccoming puberulous or glabrous in the autumn, $1 \frac{1}{2}-2^{\prime}$ long; on vigorous shoots broadly ovate, acuminate, cordate at the wide base, deeply divided into wide 
acute lateral lobes, and often $4^{\prime}-5^{\prime}$ long and wide, with foliaceous, lunate, coarsely glandular-serrate stipules, $1 \frac{1}{2}^{\prime}$ wide, and persistent throughout the season. Flowers

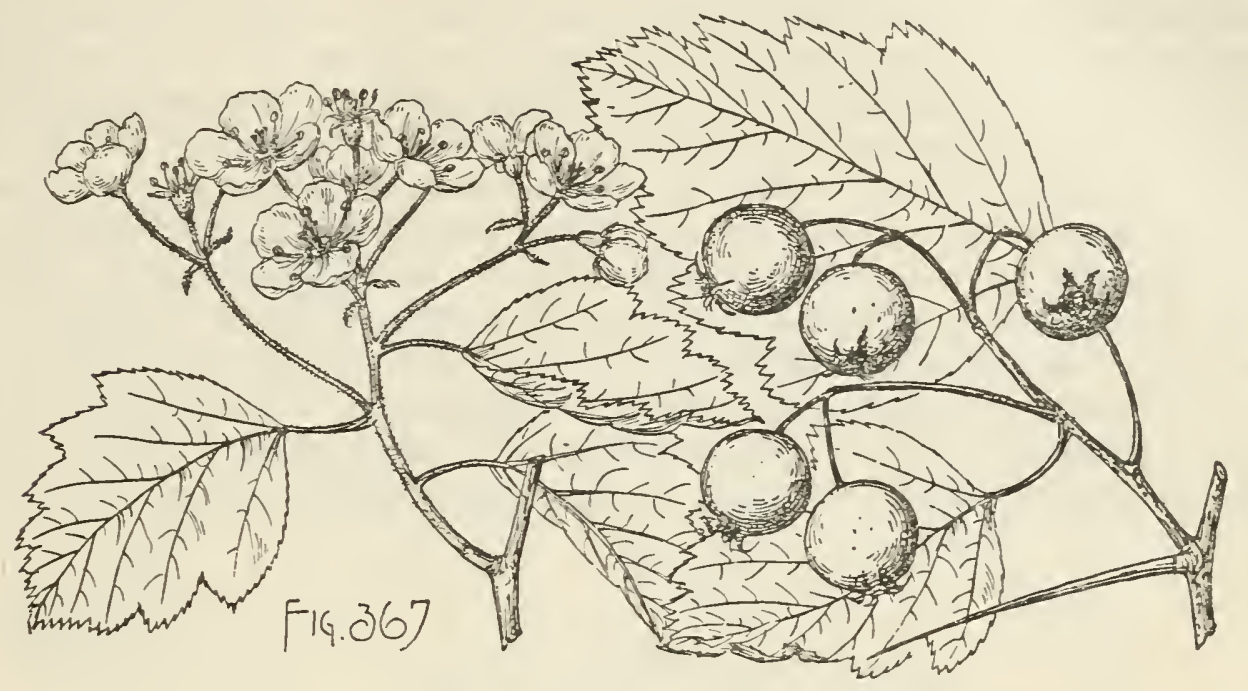

$\frac{3 \prime}{4}$ in diameter, on slender densely villose pedicels, in broad lax many-flowered longbranched hairy corymbs, the lower peduncles from the axils of upper leaves and often several-flowered, their bracts lanceolate, glandular, large and conspicuous, persistent until after the flowers open; calyx-tube narrowly obconic, covered with a thick coat of long matted hairs, the lobes slender, elongated, acuminate, serrate, with occasional large gland-tipped teeth, glabrous on the outer, slightly villose on the inner surface; stamens usually 5 ; anthers pink; styles mostly 5 . Fruit ripening the middle of September and soon falling, on long slender slightly hairy pedicels, in manyfruited drooping clusters, short-oblong, full and rounded at the ends, yellowish red, glaucous, marked by occasional pale dots, about $\frac{3^{\prime}}{4}$ long and $\frac{5^{\prime}}{8}$ 'wide; calyx sessile, with usually erect enlarged coarsely serrate lobes villose on the upper side and often deciduous from the ripe fruit; flesh thick, yellow, rather juicy; nutlets usually 5, narrowed and acute at the ends, ridged with a high broad ridge, or rounded and slightly grooved on the back, about $\frac{5^{\prime}}{8}$ long.

A tree, $25^{\circ}-30^{\circ}$ high, with a short trunk occasionally $4^{\prime}-5^{\prime}$ in diameter, covered with smooth light gray bark, numerous erect branches forming an oblong open very irregular head, and stout slightly zigzag branchlets coated when they first appear with long matted pale hairs, light red-brown and lustrous, marked by small pale lenticels and pubescent at the end of their first season, becoming dull red or orangebrown the following year, and armed with stout straight or curved bright red-brown shining spines $1 \frac{1^{\prime}}{4}-2^{\prime}$ long.

Distribution. Steep banks of the gorge of the Genesee River at Rochester, and banks of the Niagara River, Niagara Falls, New York; common.

\section{Cratægus delecta, Sarg., n. sp.}

Leaves broadly ovate, acute or acuminate at the apex, full and rounded or broadly cuneate at the entire base, sharply often doubly serrate above, with straight glandular teeth, and divided usually only above the middle into numerous short acuminate lateral lobes, when they unfold tinged with red and covered with glistening white 
hairs more abundant below than above, nearly half grown when the flowers open during the first half of May and then roughened on the upper surface by short white hairs and glabrous or sparingly villose on the midribs and veins below, with seattered hairs sometimes persistent throughout the season, and at maturity membranaceous, light yellow-grecn, lustrous and glabrous above, paler below, $1_{\frac{1}{2}}^{\prime}-2^{\prime}$ long and broad, with stout yellow midribs and 6 or 7 pairs of slender primary veins arching obliquely to the points of the lobes, turning purplish in the autumn before falling; their petioles slender, covered at first with matted pale hairs, becoming glabrous, slightly glandular, of ten tinged with red below the middle, $\frac{3^{\prime}}{4}-1^{\prime}$ long; stipules lanceolate to linear, glandular, with stipitate dark red glands tinged with red, caducous; on vigorous shoots sometimes long-pointed at the apex and slightly cordate at the base, more deeply lobed and more coarsely serrate, and often $3^{\prime}-4^{\prime}$ long and broad. Flowers $\frac{3^{\prime}}{4}-1^{\prime}$ in diameter, on long slender slightly hairy pedicels; in broad villose 10-15flowered sparingly villose corymbs, with glandular caducous bracts and bractlets; calyx-tube broadly obconic, villose or nearly glabrous, the lobes acuminate, coarsely

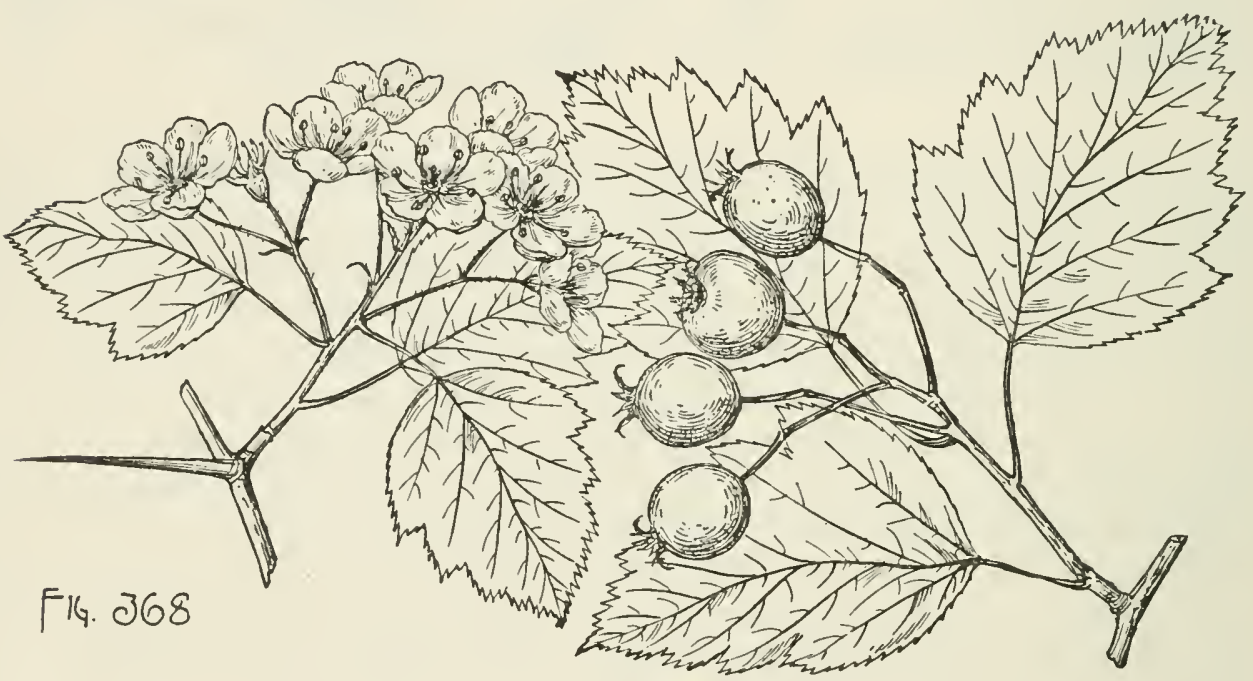

glandular-serrate; glabrous on the outer and villose on the inner surface; stamens 510, usually 5; anthers dark rose color; styles $3-5$, usually 5 . Fruit ripening from the first to the middle of September and soon falling, on stout glabrous pedicels, in drooping few-fruited clusters, globose to slightly obovate, bright red or scarlet, becoming purple when fully ripe, $\frac{1^{\prime}}{2}-\frac{3^{\prime}}{4}$ long, $\frac{2^{\prime}}{3}-\frac{3^{\prime}}{4}$ wide; calyx prominent, with erect and incurved coarsely serrate lobes; flesh thick, yellow, juicy, mildly acid and edible; nutlets $3-5$, usually 5 , narrowed and acute at the ends, rounded and very irregularly ridged on the back, $\frac{1^{\prime}-\frac{5}{4}}{1^{\prime}}$ long.

A tree, sometimes $30^{\circ}$ high, with a trunk rarely $1^{\circ}$ in diameter and $6^{\circ}-9^{\circ}$ long, covered by light gray slightly fissured smooth bark, spreading or ascending branches forming an oblong open head, and slender branchlets at first slightly villose, becoming glabrous, dull red, and ultimately gray or olive-gray, and armed with stout nearly straight spines much thickened below the middle, dark chestnut-brown and lustrous, becoming dull brown or gray, and usually $1^{\prime}-2^{\prime}$ long.

Distribution. Pastures, open woods or their borders; northeastern Illinois, Wauconda, Fort Sheridan, Deerfield, Lake Forest, Lockport (E. J. Hill). 


\section{Cratægus sertata, Sarg.}

Leaves oblong-ovate, acuminate, rounded, truncate, subcordate or rarely cuneate at the broad base, finely and often doubly serrate, with straight gland-tipped teeth, and deeply divided into 5 or 6 pairs of wide acuminate lobes, when they unfold coated above with short pale hairs and villose below on the midribs and veins, about

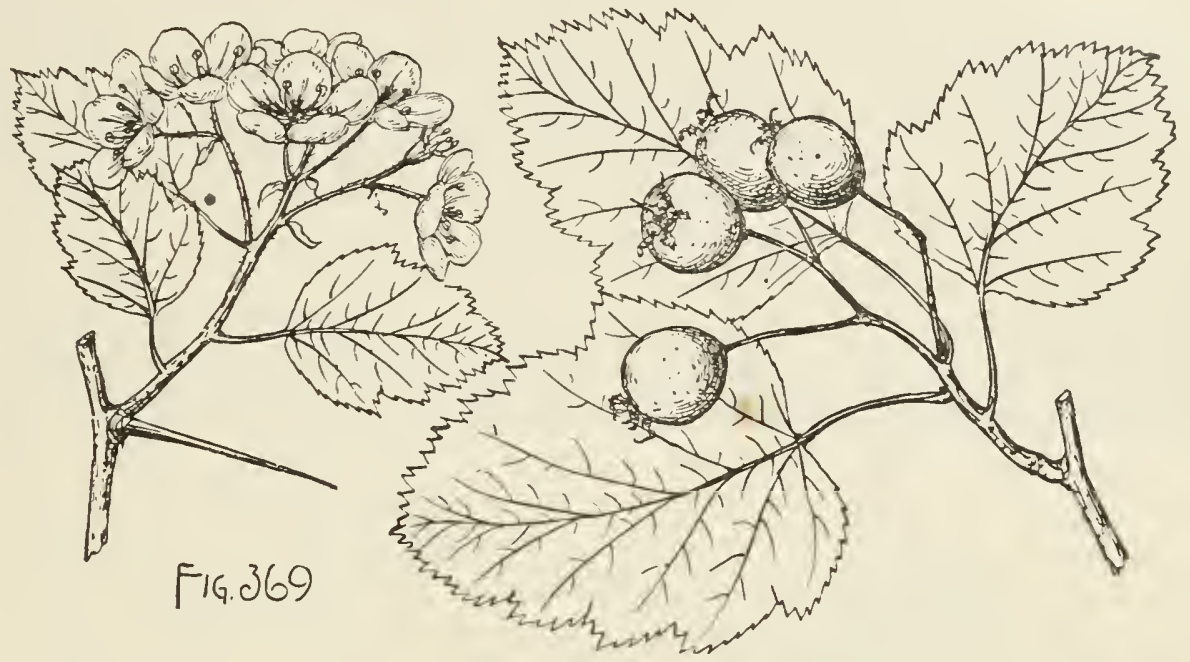

half grown and villose when the flowers open during the first half of May, and at maturity membranaceous, dark yellow-green and scabrate on the upper surface, pale yellow-green and glabrous on the lower surface, $2 \frac{1}{2}-3^{\prime}$ long, $1 \frac{1^{\prime}}{2}-2^{\prime}$ wide, with thin yellow midribs and slender primary veins arching obliquely to the points of the lobes; their petioles slender, slightly grooved, villose early in the season, ultimately glabrous, sparingly glandular, $1 \frac{1^{\prime}}{2}-3^{\prime}$ long. Flowers $\frac{3^{\prime}}{4}-1^{\prime}$ in diameter, on slender pedicels, in broad 10-15-flowered compound densely villose corymbs, with linear to linear-obovate glandular large and conspicuous caducous bracts and bractlets; calyxtube broadly obconic, glabrous above, villose below, the lobes abruptly narrowed from the base, broad, acuminate, tipped with small red glands, coarsely glandularserrate, glabrate on the onter, pubescent on the inner surface; stamens 5-10, usually 5 ; anthers pale rose color; styles $3-5$, surrounded at the base by tufts of pale hairs. Fruit ripening about the middle of September and soon falling, on slender villose or pubescent pedicels, in drooping many-fruited clusters, subglobose to slightly obovate, full and rounded at the ends, bright red and lustrous, becoming darker or crimson when fully ripe, marked by occasional large pale dots, about $\frac{1}{2}^{\prime}$ long and wide; calyx prominent, with enlarged mostly erect incurved serrate lobes; flesh thin, yellow, aromatic, pleasantly acid; nutlets $3-5$, usually 4 , thin, narrow and acute at the ends, slightly ridged on the back, with a wide or narrow ridge, $\frac{3^{\prime}}{8}$ long.

A tree, $10^{\circ}-20^{\circ}$ high, with a trunk $6^{\prime}-8^{\prime}$ in diameter, and often $4^{\circ}-5^{\circ}$ long, covered with close dark gray bark separating into long narrow thin plate-like scales, stout spreading branches forming a handsome open head, and slender nearly straight branchlets thickly coated when they first appear with matted pale hairs, light brown and lustrons at the end of their first season, and dark gray-brown the following year, and unarmed or armed with stout nearly straight or curved spines $1^{\prime}-2 \frac{1}{2}^{\prime}$ long.

Distribution. Open woods and pastures in rich moist soil; northeastern Illinois, Barrington, Mokena, Glendon Park, and Lake Zurich. 


\section{Cratægus Eamesi, Sarg., n. sp.}

Leaves oblong-ovate, acute or acuminate, concave-cuncate or rounded at the entire or glandular base, sharply often doubly serrate above, with straight glandular teeth, and divided into numerous short acute lateral lobes, about half grown when the flowers open the middle of May, and then membranaceous, light yellow-green and roughened above by short rigid white hairs and pale and glabrous below with the exception of a few hairs on the midribs and slender primary veins arching to the points of the lobes, and at maturity subcoriaceous, glabrous, dark rather dull green and smooth above, pale yellow-green below, $3^{\prime}-3 \frac{1_{2}^{\prime}}{l} \operatorname{long}, 2^{\prime}-2 \frac{1}{2}^{\prime}$ wide; their petioles slender, wing-margined above, villose at first, becoming glabrous, $1^{\prime}-1 \frac{1}{2}^{\prime}$ long; on vigorous shoots usually rounded or truncate at the broad base, more deeply lobed, often $3 \frac{1^{\prime}}{2}-4^{\prime}$ long and $3 \frac{1^{\prime}}{2}$ wide. Flowers about $\frac{3^{\prime}}{4}$ in diameter, on slender slightly hairy pedicels, in crowded compact 5-25, usually 15-18-flowered sparingly villose compound corymbs, with linear obovate coarsely glandular reddish bracts and bractlets, mostly deciduous before the flowers open; calyx narrowly obconic, glabrous, the lobes slender, elongated, glandular, with large bright red stipitate glands, glabrous

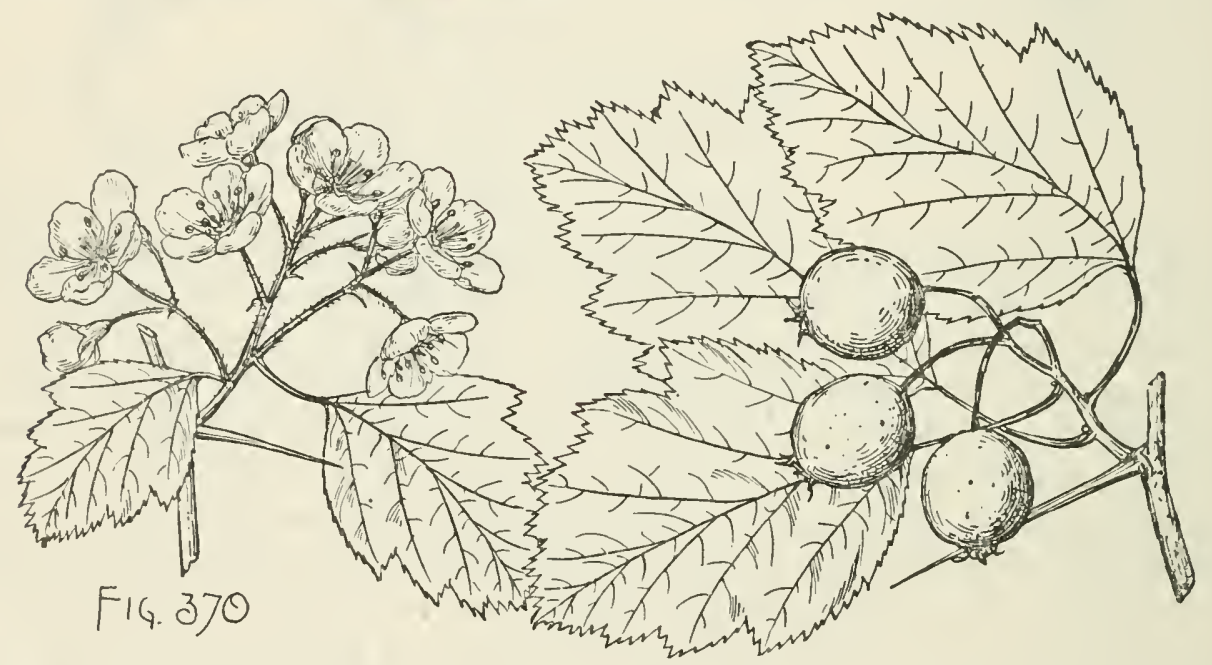

on the outer, slightly villose on the inmer surface; stamens $5-10$, usually $5-8$; anthers deep rose-purple; styles 4 or 5 , surrounded at the base by a narrow ring of pale pubescence. Fruit ripening early in September and soon falling, on stout glabrous pedicels, in large many-fruited drooping clusters, oblong to slightly ovate, full and rounded at the ends, bright cherry red, lustrous, pruinose, marked by few large dark dots, $\frac{5^{\prime}}{8}-_{4}^{\prime}$ long, about $\frac{1^{\prime}}{2}$ wide; calyx only slightly enlarged, the lobes erect and incurved, coarsely serrate, dark red on the upper side below the middle, their tips deciduous from the ripe fruit; flesh thick, pale yellow, juicy; nutlets 4 or 5 , narrowed at the ends, irregularly ridged, often with a high broad ridge, and sometimes grooved on the back, about $\frac{1}{4}^{\prime}$ long.

A tree, occasionally $20^{\circ}$ high, with a trunk a foot in diameter, ascending branches forming a narrow open head, and stout glabrous branchlets bright reddish brown and rather lustrous during their first season, becoming light gray slightly tinged with red in their second year, and armed with stout straight or slightly curved spines $1^{\prime}-1 \frac{1}{2}^{\prime}$ long; or occasionally shrubby, with a short trunk divided near the ground into several spreading stems. 
Distribution. Rich moist ground, Stratford, Connecticut (E. H. Eames); Ansonia, Connecticut (E. B. Harger).

\section{DILATAT王.}

Flowers in broad 6-12-flowered corymbs.

Leaves broadly ovate; fruit bright scarlet.

86. C. dilatata (A)

Leaves nearly orbicular to oval; fruit dull red, blotched with green or orange-red.

87. C. suborbiculata (A). 88. C. Hudsonica (A).

Leaves ovate to slightly obovate; fruit crimson, pruinose.

Flowers in very compact $\check{\partial}-7$-flowered corymbs ; leaves broadly ovate ; fruit usually broader than high, much flattened at the ends, dark crimson, very lustrous.

89. C. coccinioides (A).

\section{Cratægus dilatata, Sarg.}

Leaves broadly ovate, acute, truncate, cordate, or slightly rounded at the broad base, coarsely and generally doubly and irregularly serrate above, with straight teetl tipped with large dark glands, unequally lobed, usually with 2 or 3 pairs of acute or acuminate lateral lobes, about one third grown when the flowers open at the end of May, and then light vellow-green, conspicuously plicate, roughened on the upper surface with short stiff white hairs and glabrous on the lower surface, and at maturity smooth and glabrous, dark green above, pale below, $2^{\prime}-2 \frac{1}{2}^{\prime}$ long and almost as wide as long, with slender midribs and 4 or 5 pairs of thin primary veins; their petioles slender, somewhat glandular, at first villose, soon glabrous, often dark red toward the base after midsummer, $1^{\prime}-2^{\prime}$ long; on vigorous shoots often $4^{\prime}-5^{\prime}$ long and frequently

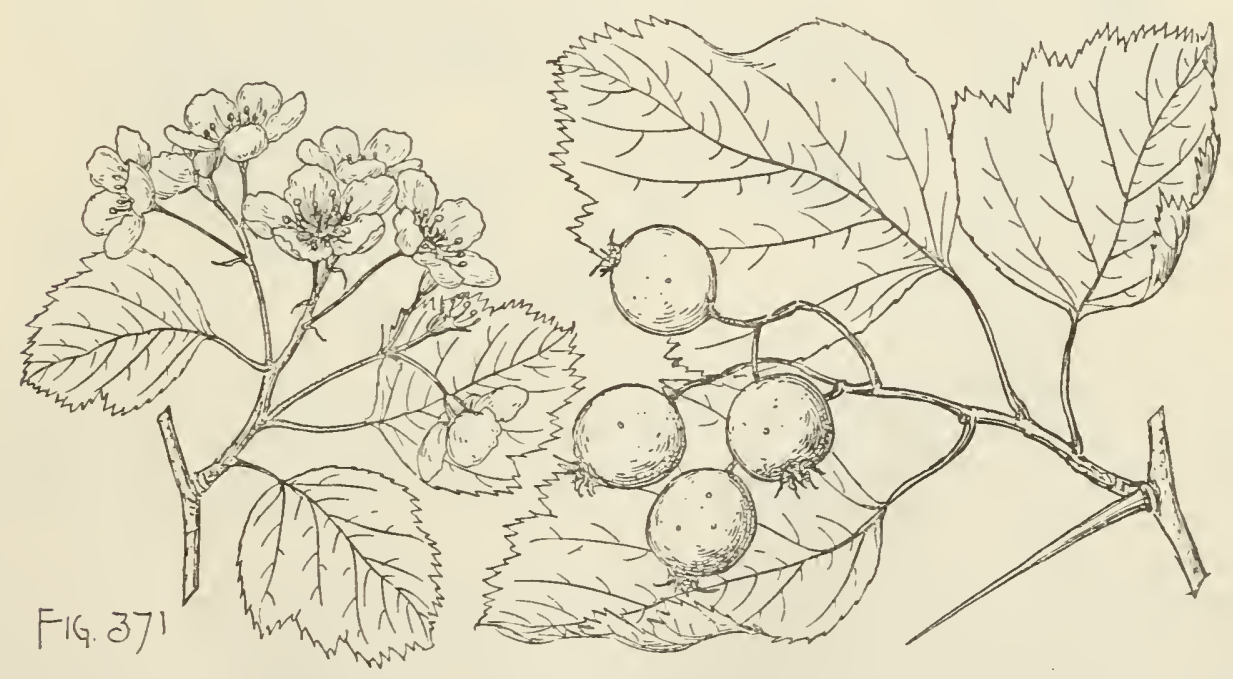

rather broader than long, their stipules foliaceous, lunate, and often $\frac{1^{\prime}}{2}$ in length. Flowers $1^{\prime}-1 \frac{1}{8}^{\prime}$ in diameter, on slender elongated hairy pedicels, in broad, loose, usually 8-12-flowered slightly villose corymbs, with lanceolate bracts and bractlets glandular like the inner bud-scales, with dark red glands; calyx-tube broadly obconic, covered toward the base with matted pale hairs, nearly glabrous, the lobes broad, acuminate, coarsely glandular, with large scattered red glands, glabrous on the outer and generally slightly villose on the inner surface; stamens 20; anthers large, rose color; styles usually 5 , surrounded at the base by small tufts of white hairs. Fruit 
ripening and falling early in September, on slender pedicels, in many-fruited drooping clusters, subglobose, bright scarlet, marked by numerous small dark dots, about $\frac{3^{\prime}}{4}$ in diameter; the calyx much enlarged, with spreading coarsely serrate lobes bright red on the upper side toward the base; flesh thin, sweet and yellow; mutlets 5, thin,

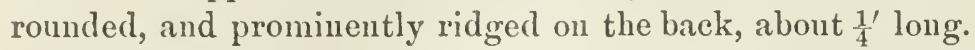

A tree, occasionally $20^{\circ}$ high, with a tall straight truuk covered with light graybrown scaly bark, branches spreading into a wide round-topped symmetrical head, and slender glabrous slightly zigzag branchlets armed with few stout straiglit light brown shining spines $1^{\prime}-2^{\prime}$ long.

Distribution. Low borders of salt marshes and estnaries, Ipswich to Somerset, Massachusetts, and on the shores of Mt. Hope Bay at Tiverton, Rhode Island.

\section{Cratægus suborbiculata, Sarg.}

Leaves nearly orbicular to oval or rarely to oblong, short-pointed at the apex, full and rounded or broadly cuneate at the entire base, sharply and doubly serrate above, with slender straight or incurved glandular teeth, and often divided above

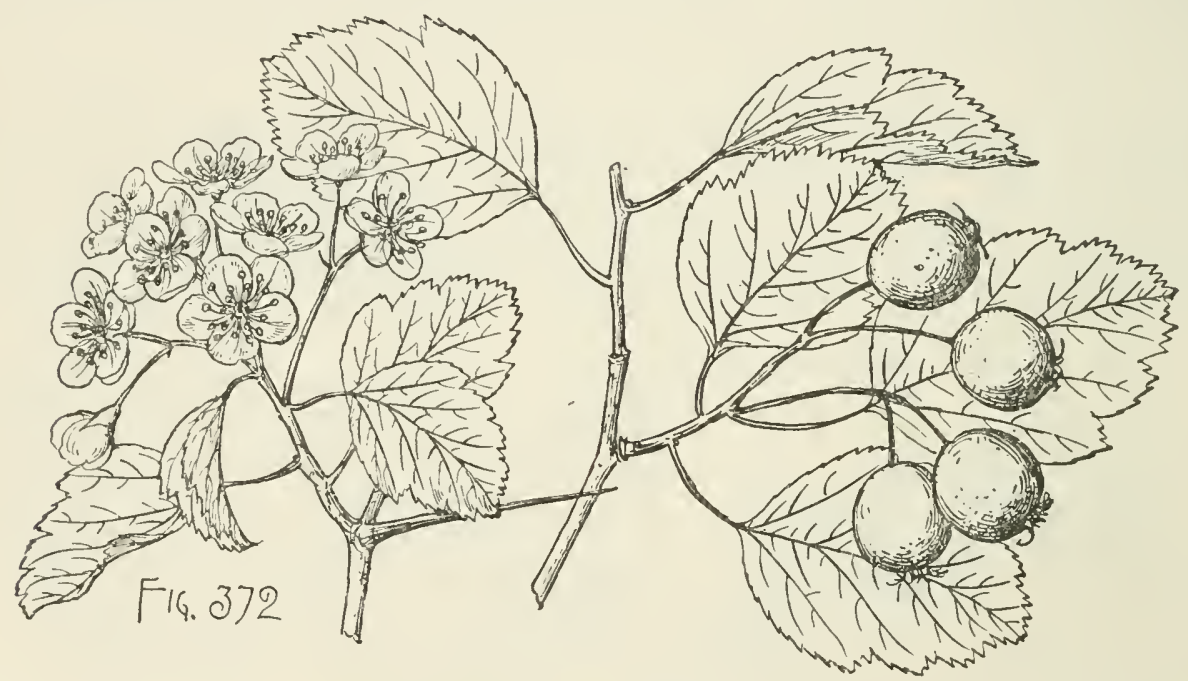

the middle into 3 or 4 pairs of short acute lobes, when they unfold pale yellowgreen, and somewhat villose on the upper surface toward the base and below in the axils of the principal veins, about one third glown when the flowers open during the first week of June, and at maturity thin but firm in texture, dull dark green above, paler below, usually about $1 \frac{1}{2}^{\prime}$ long and broad, with slender midribs and 4 or 5 pairs of thin primary veins; their petioles slender, slightly glandular, more or less winged above, $\frac{5 \prime}{8}-\mathbf{1}^{\prime}$ long; on vigorous shoots nearly orbicular to short-oval, more coarsely serrate and more deeply lobed, and frequently $3^{\prime}$ long and broad, their petioles often broadly winged and conspicuously glandular. Flowers $\frac{3^{\prime}}{4}$ in diameter, on short stout pedicels, in compact 6-12-flowered glabrous'compound corymbs; calyx broadly obconic, the lobes gradually narrowed from broad bases, elongated, acuminate, entire or occasionally obscurely denticulate; stamens 20; anthers small, rose color; styles 5 , surrounded at the base by a broad ring of hoary tomentum. Fruit falling in October without becoming mellow, on short rigid pedicels, in few-fruited erect clusters, subglobose, of ten rather longer than broad, about $\frac{5}{8}$ in diameter, dull red more or less blotched with green, or often wholly green on one face, or scarlet in one 
form; calyx enlarged, prominent, with a broad deep cavity and nearly entire widespreading lobes; flesh yellow, thin, dry and hard; nutlets 5, broad and thick, narrower and rounded at the ends, obscurely and unequally grooved on the back, about $\frac{1 \prime}{4}$ long.

A tree, rarely more than $15^{\circ}-20^{\circ}$ high, with a well-developed trunk $5^{\prime}-6^{\prime}$ in diameter, stout spreading branches forming a broad low flat-topped head, and branchlets armed with thick straight or slightly curved bright chestnut-brown shining spines $1^{\prime}-2$ ' in length.

Distribution. Low limestone ridges opposite Lachine near the south bank of the St. Lawrence River and on the Island of Montreal, Province of Quebec.

\section{Cratægus Hudsonica, Sarg., n. sp.}

Leaves ovate or slightly obovate, acute, gradually and abruptly narrowed and mostly concave-cuneate at the entire base, sharply and often doubly serrate above, with straight or incurved glandular teeth, and frequently slightly divided above the middle into short acute lobes, nearly fully grown when the flowers open at the end of May, and then thin, light yellow-green, smooth and glabrous above with the exception of a few short white scattered hairs along the midribs, and pale and glabrous below, and at maturity thin but firm in texture, glabrous, $2^{\prime}-2 \frac{1}{2}^{\prime}$ long, $1 \frac{1}{2}^{\prime}-1 \frac{3}{4}^{\prime}$ wide, with slender yellow midribs and 5 or 6 pairs of thin primary veins extending obliquely to the points of the lobes; their petioles slender, wing-margined above, glandular,

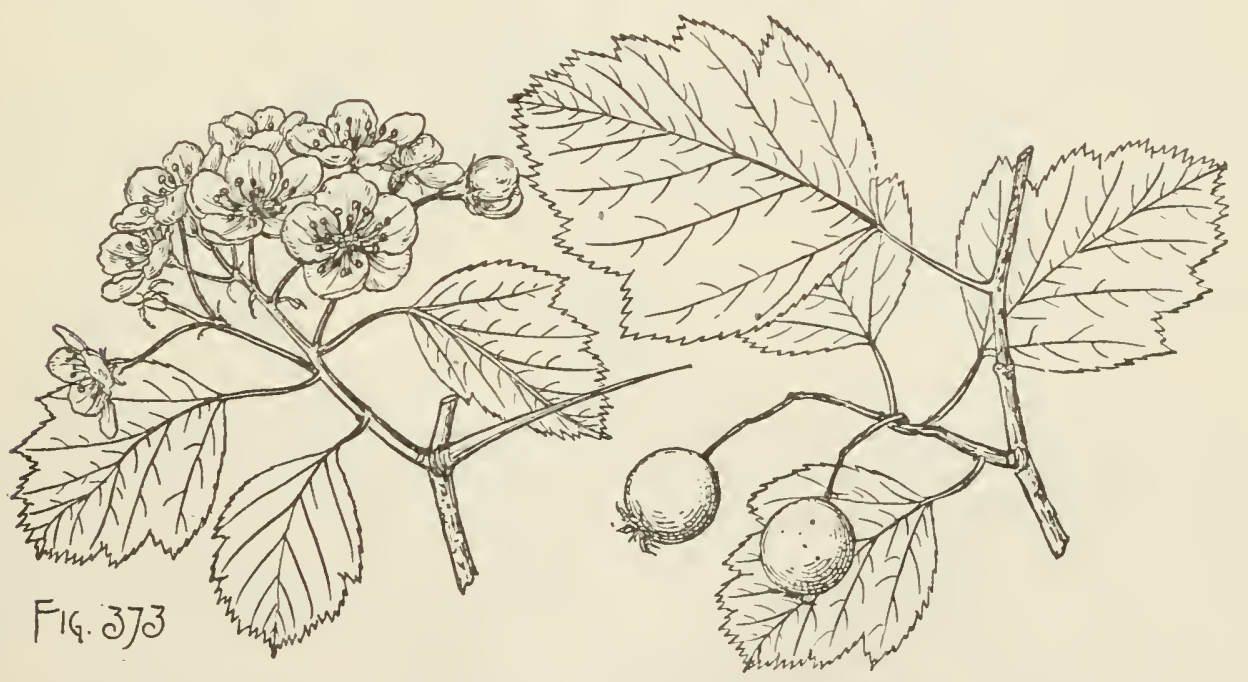

at first slightly hairy, becoming glabrous and rose color toward the base, $\frac{3^{\prime}}{4}-1^{\prime}$ long; on vigorous shoots broadly ovate to suborbicular, full and rounded or broadly cuneate at the wide base, deeply divided into broad lateral lobes, and $2^{\prime}-3^{\prime}$ long and broad. Flowers about $\frac{3}{4}$ ' in diameter, on long slender pedicels, in broad usually 10-12-flowered compound glabrous corymbs; calyx-tube narrowly obconic, glabrous, the lobes gradually narrowed from broad bases, acuminate, glandular-serrate often only below the middle, glabrous on the outer, slightly hairy on the inner surface; stamens 20; anthers rose color; styles 3-5. Fruit ripening early in September, in few-fruited drooping clusters, subglobose, crimson, pruinose, marked by numerous pale dots, about $\frac{5}{8}$ ' in diameter; calyx enlarged, with a deep broad cavity, and closely appressed serrate lobes villose on the upper side; flesh thick, yellow, dry and mealy; nutlets 
$3-\overline{-}$, full and ronded at the base and narrowed and rounded at the apex, rounded and sometimes ridged on the back, with a high ronnded ridge, about $\frac{5{ }^{\prime}}{16}$ long.

A tree, sometimes $20^{\circ}$ high, with a tall trunk $8^{\prime}-10^{\prime}$ in dianeter, covered with pale scaly bark, heavy ascending and spreading branches forming a broad open head, stout aseending glabrous branchlets dark orange color when they first appear and light orange-brown and lustrous during their first winter, and armed with numerous slender straight or slightly curved bright red-brown shining spines $1 \frac{1^{\prime}}{2}-2^{\prime}$ long; sometimes a broad bush, with numerous stout spreading stems.

Distribution. Rolling hills in the valley of the Hudson River, near Albany, New York (C.H. Peck).

\section{Cratægus coccinioides, Ashe.}

Leaves broadly ovate, acute, fnll and rounded or truncate at the base, sharply and often doubly serrate, with straight glandular teeth, and divided above the middle

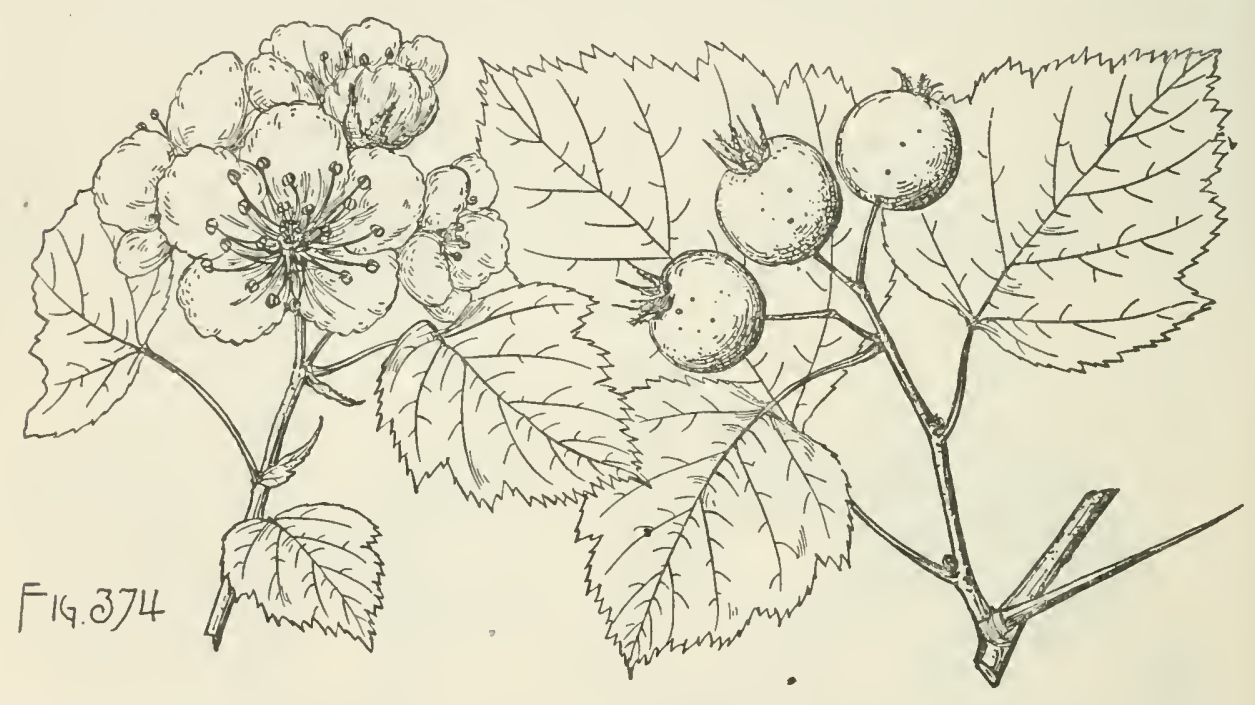

into short acute lobes, as they unfold conspicuously plicate, very lustrous, yellowgreen, and villose on the lower side of the midribs, with a few short pale hairs usually persistent during the season, about half grown when the flowers open early in May, and at maturity thin but firm in texture, rather rigid, dull dark green and smooth on the upper surface, pale on the lower surface, $2 \frac{1}{2}^{\prime}-3^{\prime}$ long, with thin pale yellow midribs deeply impressed above and often bright red toward the base after midsummer, and slender primary veins arching to the points of the lobes, turning late in October gradually bright orange and scarlet; their petioles glandular on the upper side, with minute-stalked dark red glands, at first villose, soon glabrous, often bright red or pink toward the base, $\frac{3^{\prime}}{4}-\mathbf{1}^{\prime}$ long; on vigorous shoots more or less cordate at the base and usually $3 \frac{1^{\prime}}{2}-4^{\prime}$ long and broad; their stipules lunate, coarsely glandular-serrate, foliaceous, and $\frac{1^{\prime}}{2}-\frac{3^{\prime}}{4}$ long. Flowers $\frac{3^{\prime}}{4}$ in diameter, in very compact 5-7-flowered glabrous or slightly villose corymbs, with coarsely serrate oblongobovate acute bracts and bractlets, conspicuously glandular, like the inner bud-scales, with large bright red glands; calyx-tube broadly obconic, glabrous, the lobes gradually narrowed from broad bases, acute and coarsely glandular-serrate; stamens 20; anthers large, rose color; styles 5 , surrounded at the base by a ring of pale tomentum. Fruit ripening early in October and falling gradually during a month or six 
weeks, on stout pedicels, in few-fruited compact erect clusters, subglobose, much flattened at the ends, often obscurely angled, dark crimson, very lustrous, marked by numerous large pale dots, $\frac{3}{4}$ long, $\frac{7^{\prime}}{8}$ broad; calyx much enlarged and conspicuous, with spreading or erect lobes bright red on the upper side near the base; flesh thick, firm, subacid, more or less deeply tinged with red; nutlets 5, comparatively small, light-colored, narrowed at the ends, acute at the apex, rounded at the base, rounded and slightly ridged on the back, about $\frac{1}{3}^{\prime}$ long.

A tree, sometimes $20^{\circ}$ high, with a stem $\delta^{\prime}-10^{\prime}$ in diameter, stout spreading light gray branches forming a broad handsome head, and stout nearly straight glabrous bright chestnut-brown very lustrous branchlets armed with thick dark reddish purple shining spines $1 \frac{1^{\prime}}{2}-2^{\prime}$ long.

Distribution. Dry woods in the neighborhood of St. Louis, Missouri, to eastern Kansas.

\section{COCCINE王。}

Stamens 10 ; leaves coriaceous.

Leaves elliptical or obovate; fruit subglobose, dark crimson; anthers pale yellow.

90. C. coccinea (A).

Leaves elliptical or ovate; fruit short-oblong to oblong-obovate, bright carmine red; anthers rose color.

91. C. Jonesæ (A). Stamens 20 ; leaves subcoriaceous, rhomboidal to oblong-obovate ; fruit short-oblong to subglobose, dark dull red or rusty orange-red; anthers pale yellow.

92. C. Margaretta (A, C).

\section{Cratægus coccinea, L. Scarlet Haw.}

Leaves elliptical or obovate, acute or acuminate, gradually narrowed from above the middle to the cuneate and entire base, finely and often doubly serrate above, with incurved or straight teeth tipped with minute dark glands, and divided above the

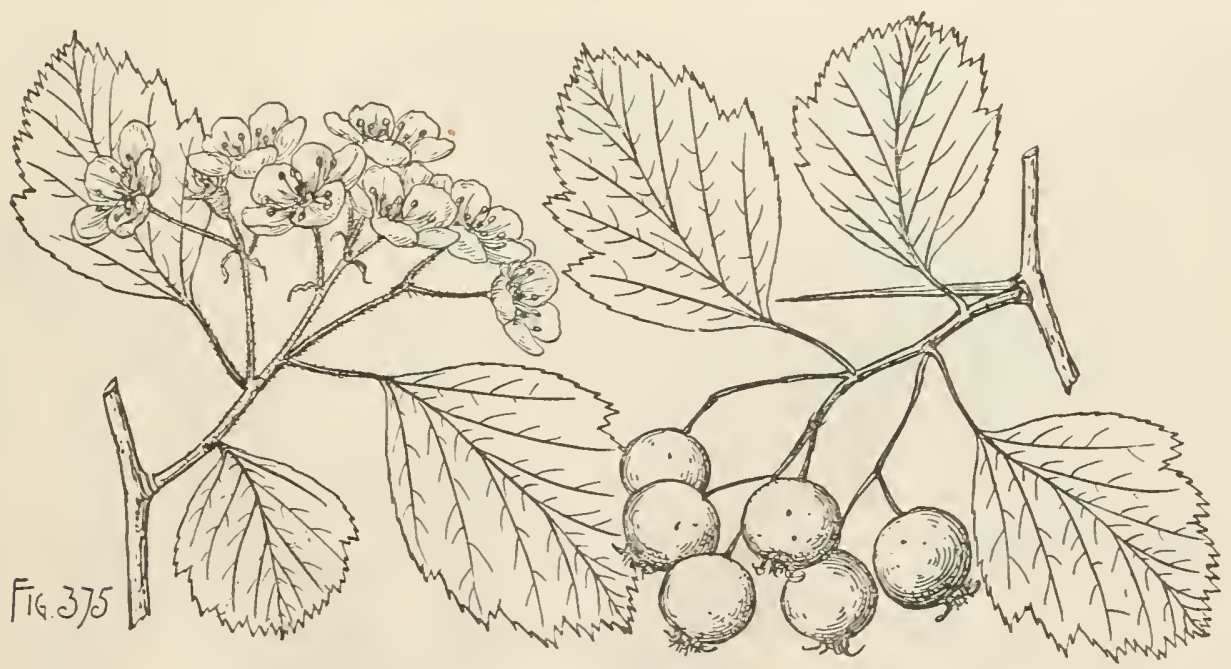

middle into several short acute lateral lobes, about half grown when the flowers open at the end of May, and then membranaceous, light yellow-green, covered on the upper surface with soft pale hairs, and pubescent along the under side of the thin midribs and 4 or 5 pairs of erect primary veins extending to the points of the lobes, and at maturity coriaceous, dark green, smooth and very lustrous on the upper surface, paler and rarely pilose on the veins below, $1 \frac{1}{2}^{\prime}-2^{\prime}$ long, $1^{\prime}-1 \frac{1}{2}^{\prime}$ wide; their petioles 
slender, glandular, slightly winged at the apex, at first villose, nsually becoming glabrous, often dark red toward the base, $3^{\prime}-1^{\prime}$ long; on vigorous shoots oblong-ovate, oval or often nearly orbicular, more deeply lobed and frequently $2 \frac{1}{2}^{\prime}-3^{\prime}$ long. Flowers $\frac{1}{2}-{ }^{3}{ }^{\prime}$ in diameter, on slender pedicels, in broad loose compound manyflowered villose or tomentose corymbs; ealyx-tube broadly obconic, tomentose or villose, the lobes gradually narrowed from broad bases, acute, eoarsely glandularserrate, glabrous or villose, often bright red toward the apex; stamens 10; anthers small, pale yellow; styles 3 or 4. Fruit ripening and falling late in October, on short stout pedicels, in drooping many-fruited pilose elusters, subglobose but occasionally rather longer than broad, dark erimson, marked by seattered dark dots about $\frac{1^{\prime}}{2}$ in diameter; calyx cnlarged, eonspicuous, the lobes bright red on the upper side, toward the base, wide-spreading or erect; flesh thin, yellow, dry and sweet; mntlets 3 or 4 , full and rounded at the ends, prominently ridged on the back, with a high grooved ridge, about $\frac{1^{\prime}}{4}$ long.

A bushy tree, occasionally. $20^{\circ}$ high, with a short trunk $8^{\prime}-10^{\prime}$ in diameter, covered with dark red-brown scaly bark, stout ascending branches forming a broad round-topped symmetrical head, slender branchlets light green and eovered with long matted pale hairs when they first appear, soon becoming glabrous, bright red-brown and lustrous during their first year, and nltimately ashy gray, and armed with many stout straight or slightly curved chestnut-brown shining spines $1^{\prime}-1 \frac{1}{2}^{\prime}$ long.

Distribution. Slopes of low hills and the high banks of salt marshes nsually in rich well drained soil; Newfoundland to Connecticut, usually in the neighborhood of the sea, and through the valley of the St. Lawrence River to western Quebee. A form, var. rotundifolia, Sarg., with glabrous young branchlets, leaves, and corymbs, is a common New England shrub ranging southward to eastern Pennsylvania.

\section{Cratægus Jonesæ, Sarg.}

Leaves elliptical to ovate, aeute, gradually narrowed or broadly cuneate at the entire base, coarsely doubly serrate above, with spreading or ineurved teeth tipped with deeiduous dark red glands, and usually divided above the middle into 2 or 3

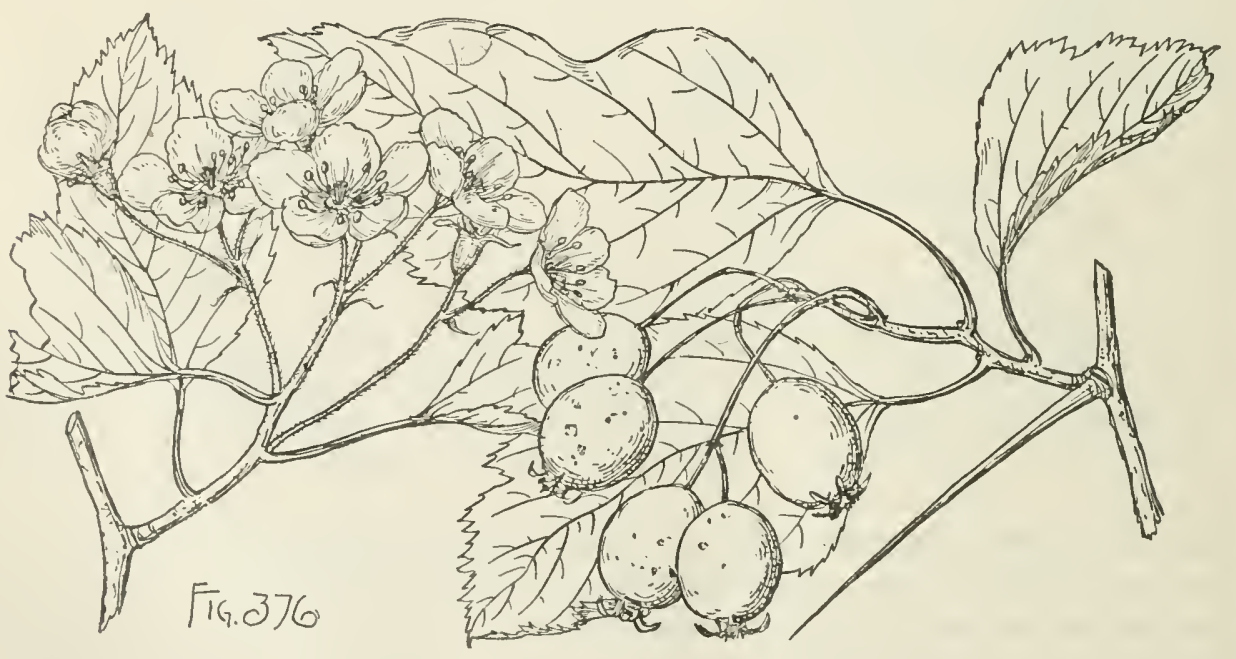

pairs of short acute or acuminate lobes, more than half grown when the flowers open during the first week of June, and then membranaceous and coated with soft pale 
hairs most abundant on the under side of the midribs and principal veins, and at maturity thick and coriaceous, dark green and lustrous on the upper surface, pale and puberulous on the lower surface, $3^{\prime}-4^{\prime}$ long and $2^{\prime}-3^{\prime}$ broad, with stout midribs, 4-6 pairs of primary veins and conspicuous secondary veinlets; their petioles stout, more or less winged toward the apex, villose, ultimately glabrous, tinged with red below the middle, $1 \frac{1}{2}-2^{\prime}$ long, after midsummer often twisted at the base, bringing the lower surface of the leaf to the light; on vigorous shoots usually more coarsely serrate and much more deeply lobed, with broadly winged petioles, and falcate coarsely glandular-serrate stipules sometimes $1^{\prime}$ in length. Flowers $1^{\prime}$ in diameter, on long slender pedicels, in broad loose lax compound many-flowered tomentose corymbs; calyx-tube narrowly obconic and tomentose, the lobes abruptly narrowed from broad bases, elongated, acute, entire, villose; stamens 10; anthers large, rose color; styles 2, or generally 3, surrounded at the base by a narrow ring of pale tomentum. Fruit, ripening usually early in October, on slender elongated pedicels, in broad many-fruited drooping glabrous or puberulous clusters, short-oblong to oblong-obovate, full and rounded at the ends, bright carmine-red, marked by occasional large dots, $\frac{3}{4}-1^{\prime}$ long, $\frac{3^{\prime}}{4}$ broad; calyx conspicuous, with enlarged and elongated closely appressed lobes; flesh thick, yellow, sweet and mealy; uutlets 3 or rarely 2 , thick, narrowed and acute at the base, full and rounded at the apex, rounded and ridged on the back, with a high broad ridge, about $\frac{\tau^{\prime}}{1^{\prime}}$ long.

A tree, sometimes $20^{\circ}$ high, with a tall trunk often a foot in diameter, covered with dark brown scaly bark, ascending or spreading branches forming a broad open irregular head, and stout branchlets at first tomentose, becoming orange-brown, glabrous, and very lustrous during their first season and light gray the following year, and armed with stout straight or curved chestnut-brown shining spines $2^{\prime}-3^{\prime}$ long and usually pointed toward the base of the branch.

Distribution. Rocky shores of sounds and bays southeastern Maine, Islesboro, and Belfast Bay to the island of Mount Desert.

\section{Cratægus Margaretta, Ashe.}

Leaves broadly rhomboidal, oblong-obovate to rarely ovate, acute or rounded at the apex, gradually narrowed and usually entire below, coarsely oftell doubly crenatelyserrate above, with mostly glandless teeth, and divided above the middle or frequently only at the apex into short broad rounded or acute lobes, membranaceous when the flowers open in May, and roughened above by short pale hairs and glabrous below, and at maturity firm and rather leathery in texture, or subcoriaceous, glabrous, smooth, dark green, and somewhat lustrous on the upper surface, pale on the lower surface, $1^{\prime}-1 \frac{1^{\prime}}{4}$ long, $1^{\prime}$ wide, with yellow midribs and $3-5$ pairs of primary veins extending very obliquely to the points of the lobes; their petioles slender, often slightly winged toward the apex, glandular at first, with minute dark red caducous glands, $\frac{1}{2}^{\prime}-1^{\prime}$ long; on vigorous shoots broadly ovate or semiorbicular, usually more deeply and more generally lobed, often $3^{\prime}$ long and $2^{\prime}-3^{\prime}$ wide. Flowers about $\frac{3^{\prime}}{4}$ in diameter, on slender elongated pedicels, in 3-12-flowered compound thin-branched slightly villose corymbs; calyx-tube narrowly obconic, slightly villose toward the base, or glabrous, the lobes gradually narrowed from below, acuminate or short-pointed at the apex, finely and irregularly glandular-serrate, glabrous, or villose on the inner surface; stamens usually 20; anthers small, light yellow; styles 2 or 3 , surrounded at the base by a narrow ring of pale tomentum, and villose below the middle, with occasional long spreading hairs. Fruit ripening and falling at the end of Septem- 
ber, in few-fruited drooping elusters, short-oblong, full and rounded at the ends, or subglobose and flattened at the ends, dull dark red or rusty orange-red nuarked by
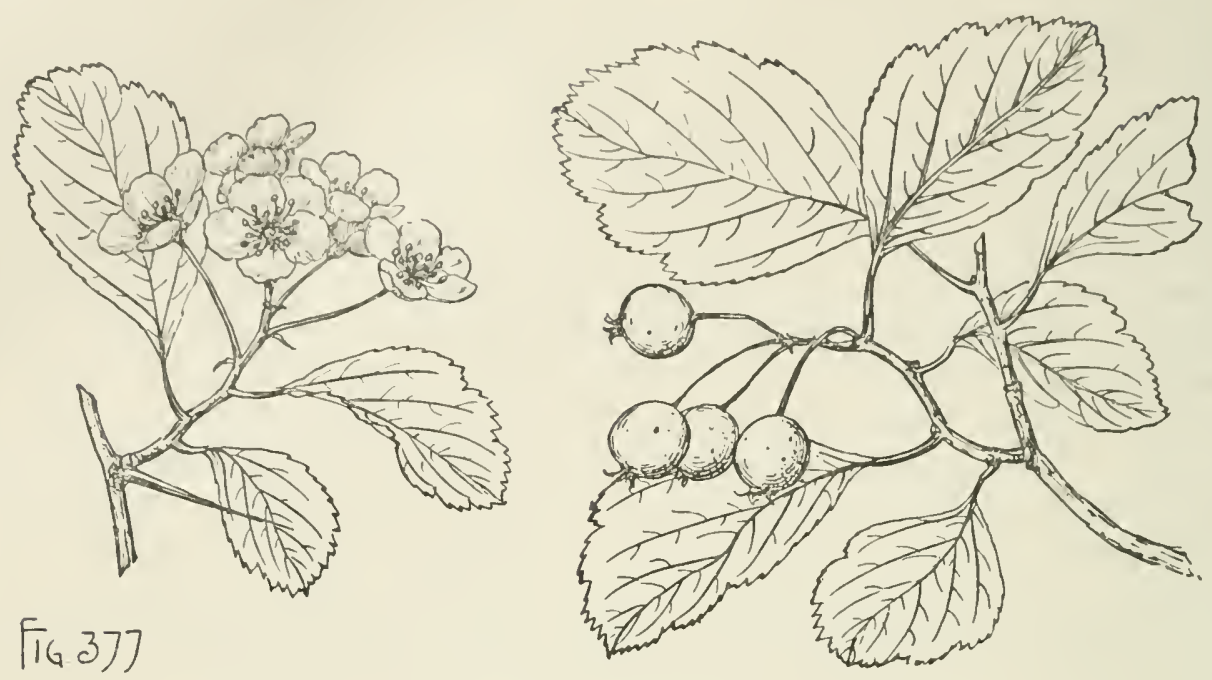

occasional dark dots, and about $\frac{1^{\prime}}{2}$ long; calyx only slightly enlarged, the lobes spreading or erect and frequently deciduous before the fruit ripens; flesh thin, yellow, dry and mealy; nutlets 2 or 3 , broad and rounded at the base, acute at the apex, conspicuously grooved and ridged on the back, with a broad rounded ridge, about $\frac{1^{\prime}}{4}$ long.

A tree, occasionally $25^{\circ}$ high, with a straight trunk $4^{\prime}-6^{\prime}$ in diameter, covered with thin dark gray-brown bark, thin rather erect branches forming a narrow open head, and slender branchlets, orange-green, glabrous or sometimes pubescent when they first appear, becoming bright chestnut-brown and lustrous, and ashy gray or gray tinged with red during their second year, and armed with thin straight or slightly curved bright chestnut-brown spines $\frac{3^{\prime}}{4}-1 \frac{1}{2}^{\prime}$ long.

Distribution. Banks of streams and open hillsides; Ontario, central Michigan, central Iowa, Missouri from Webster in the neighborhood of St. Louis to Springfield, and in middle Tennessee.

\section{INTRICAT平.}

Stamens 10; leaves broadly ovate to oval.

Fruit depressed-globose, yellow-green flushed with russet red; anthers pale yellow ; calyxlobes without stalked glands.

93. C. Boyntoni (A, C).

Fruit subglobose, red or russet-red; anthers pale rose color; calyx-lobes with stalked glands.

Stamens 20.

94. C. Buckleyi (A).

Leaves oval to ovate or oblong-obovate; fruit short-oblong, dull red, often with a bright russet face; stamens usually 5-15; anthers small, pale yellow. 95 . C. venusta (C).

Leaves oblong-ovate to elliptical or obovate; fruit subglobose to short-oblong, yellow or orange-yellow, more or less flushed with red; anthers large, purple.

96. C. Sargenti (C).

\section{Cratægus Boyntoni, Beadl.}

Leaves broadly ovate to oval, acute, full and rounded or cuneate at the entire glandular base, sharply and often doubly serrate above, with glandular teeth, and 
frequently divided into 2 or 3 pairs of short broad acute lateral lobes, when they unfold deep bronze-red, slightly glandular and viscid, nearly fully grown when the flowers open early in May, and then membranaceous and glabrous or occasionally slightly pilose, and at maturity thick and firm, glabrous, yellow-green on the upper surface, pale on the lower surface, $1^{\prime}-2 \frac{1}{2}^{\prime}$ long, $1^{\prime}-2^{\prime}$ wide, with thin pale yellow midribs and 4-7 pairs of slender veins; their petioles stout, glandular often to the base, witl bright red glands, slightly winged above, usually about $\frac{1}{2}$ long; on vigorous shoots of ten as broad as long, truncate or cordate at the base, and more coarsely dentate and more deeply lobed. Flowers about $\frac{3^{\prime}}{4}$ in diameter, on short slender pedicels, in compact 4-10-flowered compound corymbs; calyx-tube broadly obconic, the lobes abruptly narrowed from broad bases, acute or rounded at the apex, entire or obscurely and irregularly glandular-serrate above the middle; stamens 10; antliers large, pale yellow; styles $3-5$, surrounded at the base by a broad thick ring of hoary tomentum.

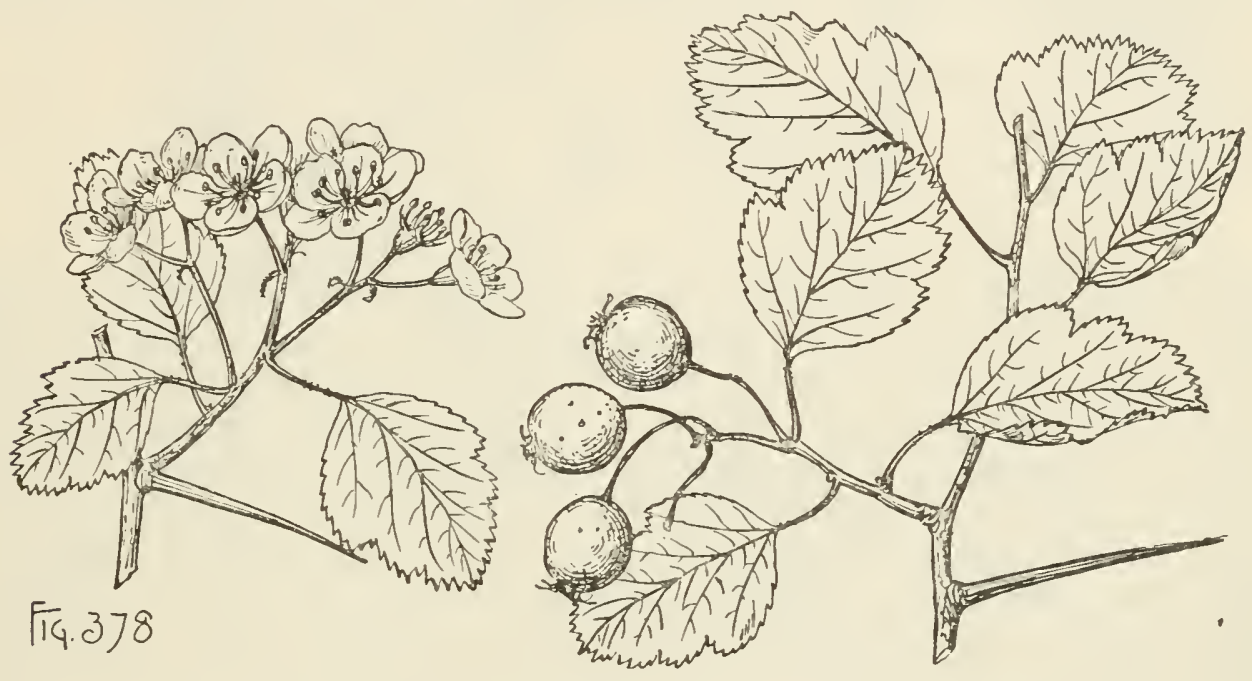

Fruit ripening and falling early in October, on short stout pedicels, in few-fruited erect clusters, depressed-globose, more or less angled, yellow-green flushed with russet-red, marked with small dark dots, usually about $\frac{1^{\prime}}{2}$ in diameter; calyx prominent, the large spreading lobes of ten deciduous before the fruit ripens; nutlets $3-5$, acute or acuminate at the apex, rounded at the narrow base, prominently ridged on the back, with a high rounded ridge, about $\frac{1^{\prime}}{4}$ long.

A tree, occasionally $20^{\circ}$ high, with a tall straight trunk $6^{\prime}-8^{\prime}$ in diameter, sometimes armed with long gray compound spines, stont ascending branches forming a narrow open irregularly or occasionally a round-topped head, and glabrous branchlets furnished with many thin nearly straight light chestnut-brown spines $1 \frac{1}{2}^{\prime}-2^{\prime}$ long; or more often a shrub, with numerous stems.

Distribution. Banks of streams, the borders of fields and upland woods in the southern Appalachian foothill region from southern Virginia to northern Georgia and Alabama, southeastern Kentucky, and Teunessee, sometimes ascending to elevations of $3000^{\circ}$ above the sea.

\section{Cratægus Buckleyi, Beadl.}

Leaves broadly ovate or oval, acnte, rounded or subcordate, or narrowed and concave-cuneate at the entire base, coarsely often doubly serrate above, with straight 
glandular teeth, and more or less inciscly lobed, with acuminate lateral lobes, more than half grown when the flowers open about the middle of May and then palc green and glabrous with the cxception of a few caducous hairs along the upper side of the

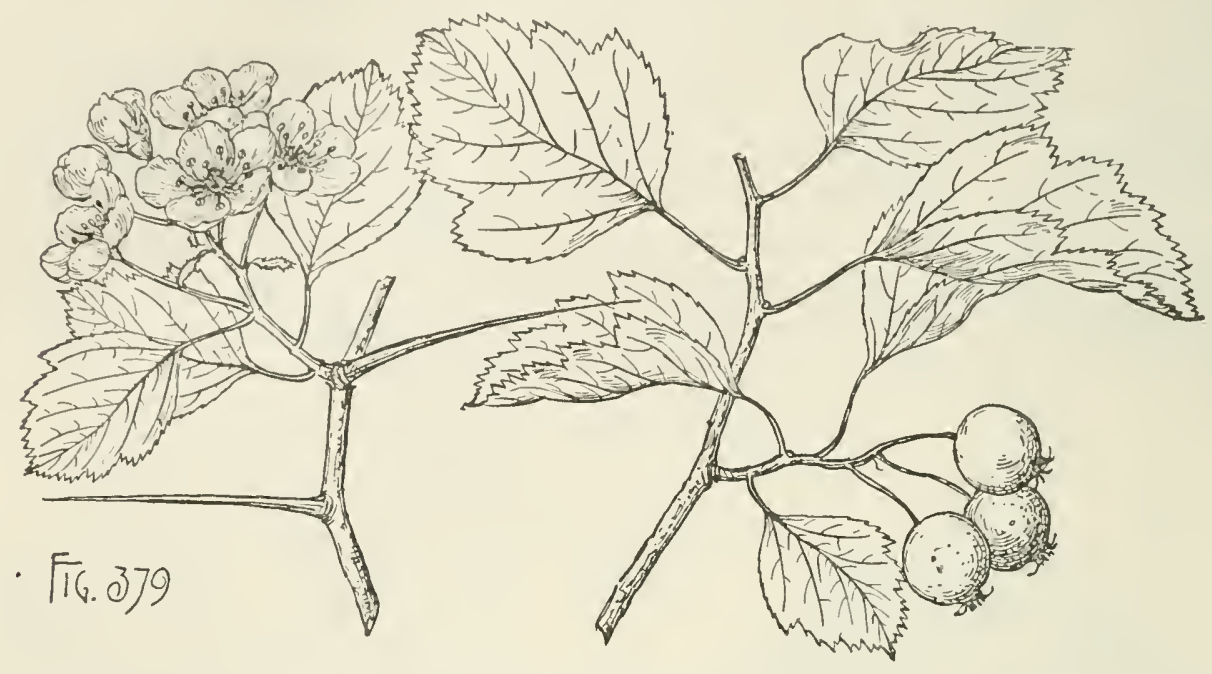

base of the midribs, and at maturity thick and firm in texture, dark green above, paler below, $1 \frac{1}{2}^{\prime}-2^{\prime}$ long, $11^{\prime}-2^{\prime}$ wide, and on vigorous shoots sometimes wider than long; their petioles stout, conspicuously glandular above the base, wing-margined at the apex, glabrous, $\frac{1^{\prime}}{2}-\frac{3^{\prime}}{4}$ long. Flowers about $\frac{3^{\prime}}{4}$ in diameter, on slender glabrous pedicels, in compact 3-7-flowered simple corymbs, with conspicuously glandular bracts and bractlets; calyx-tube broadly obconic, glabrous, the lobes broad, acuminate, laciniately cut toward the apex, and glandular, with stipitate glands; stamens 10; anthers pale rose color; styles $3-5$, surrounded at the base by tufts of pale hairs. Fruit ripening late in September or in October, subglobose, usually angled, red or russet red, about $\frac{1}{2}$ ' in diameter; calyx little enlarged, with spreading or reflexed lobes; flesh thin, dry and mealy; nutlets 3-5, full and rounded at the base, rounded at the slightly narrowed apex, prominently ridged on the back, with a broad grooved ridge, about $\frac{5}{16}$ long.

A tree, often $25^{\circ}$ high, with a trunk $4^{\prime}-7^{\prime}$ in diameter, and sometimes $10^{\circ}-12^{\circ}$ long, and covered with gray or often dark brown scaly bark, stout spreading or ascending branches, and thick glabrous red-brown branchlets armed with thin straight shining spines $\frac{1^{\prime}}{2}$ long, becoming much longer and branched on the trunk and large branches.

Distribution. Southwestern Virginia, through western North Carolina to eastern Tennessee; usually at elevations between $2000^{\circ}$ and $3000^{\circ}$ above the sea; common on wooded slopes with Oaks, Hickories, and Pines.

\section{Cratægus venusta, Beadl.}

Leaves oval to ovate or occasionally to oblong-obovate, acute, gradually or abruptly narrowed and cuneate or rounded at the entire base, finely serrate above, with usually incurved glandular teeth, and frequently slightly and irregularly divided above the middle into 1-3 pairs of short broad acute lobes, when they unfold dark bronze color, with a, few scattered pale caducous hairs on the upper surface, about half grown when the flowers open from the 20th to the end of April, and then 
yellow-green, smooth and glabrous, and at maturity thick and firm in texture, dark dull green above, pale below, $2 \frac{1}{2}^{\prime}$ long, $1 \frac{1}{2}^{\prime}$ wide, with stout midribs and 4-7 pairs of thin primary veins, late in the autumn turning, especially those on leading shoots, deep orange or scarlet; their petioles stout, glandular, more or less winged above, $\frac{1^{\prime}}{2}-\frac{3^{\prime}}{4}$ long, and in the autumn often bright red below the middle; on vigorous shoots generally broadly ovate, full and rounded at the base, deeply lobed, with broad lobes, and often $3 \frac{1^{\prime}}{2}$ long and $3^{\prime}$ wide. Flowers $1^{\prime}$ in diameter, on short pedicels, in 4-9-flowered compact corymbs, their bracts and bractlets like the inner bud-scales coarsely glandular-serrate and bright red before falling; calyx-tube broadly obconic, the lobes gradually narrowed from broad bases, acute, coarsely glandular-serrate of ten only below the middle; stamens $15-20$, usually $15-17$; anthers small, pale yellow; styles 3-5, surrounded at the base by a ring of pale hairs. Fruit ripening and falling from the 1st to the middle of October, on stout pedicels often $1^{\prime}$ long, in few-fruited clusters, short-oblong, full and rounded at the ends, dull red, of ten with a bright russet
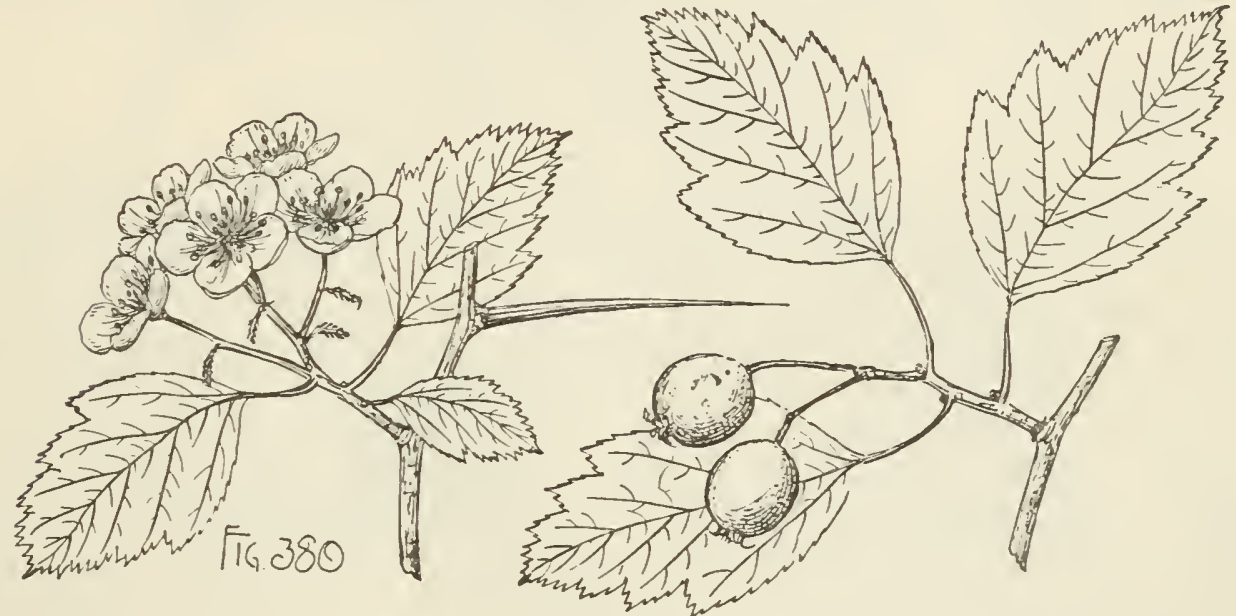

face, marked by occasional large dark dots; calyx prominent, with a long tube, and spreading lobes often deciduous before the fruit ripens; flesh thick, yellow, dry and mealy; nutlets $3-5$, narrowed and acute at the base, full and rounded at the apex, thick, full and rounded on the back, about $\frac{1^{\prime}}{4}$ long.

A bushy tree, often $25^{\circ}$ high, with a short trunk a foot in diameter and armed like the large branches with innumerable stout much-branched spines frequently $6^{\prime}$ long, and stout branchlets furnished with numerous straight or slightly curved dark chestnut-brown shining spines frequently pointing toward the base of the branch and $1 \frac{1}{2}^{\prime}-2 \frac{1}{2}^{\prime}$ long.

Distribution. Open Oak and Hickory woods on the dry slopes of Red Mountain in the southern part of the city of Birmingham, Alabama.

\section{Cratægus Sargenti, Beadl.}

Leaves oblong-ovate to elliptical or rarely to ovate, acute or acuminate at the apex, gradually or abruptly cuneate or rounded at the nearly entire base, irregularly doubly serrate above, with straight or incurved glandular teeth, and usually irregularly divided into 3 or 4 pairs of short broad acute or acuminate lobes, nearly fully grown when the flowers open late in April, and then subcoriaceous, pale yellowgreen, and villose along the midribs, with scattered pale caducous hairs, and at 
maturity lustrous, dark yellow-green above, pale below, $2^{\prime}-3^{\prime}$ long, $1 \frac{1^{\prime}}{2}-2^{\prime}$ wide, with thin midribs and $5-7$ pairs of thin light yellow veins and conspicuous reticulate veinlets, turning in the antumn bright yellow and red; their petioles slender, glandnlar,

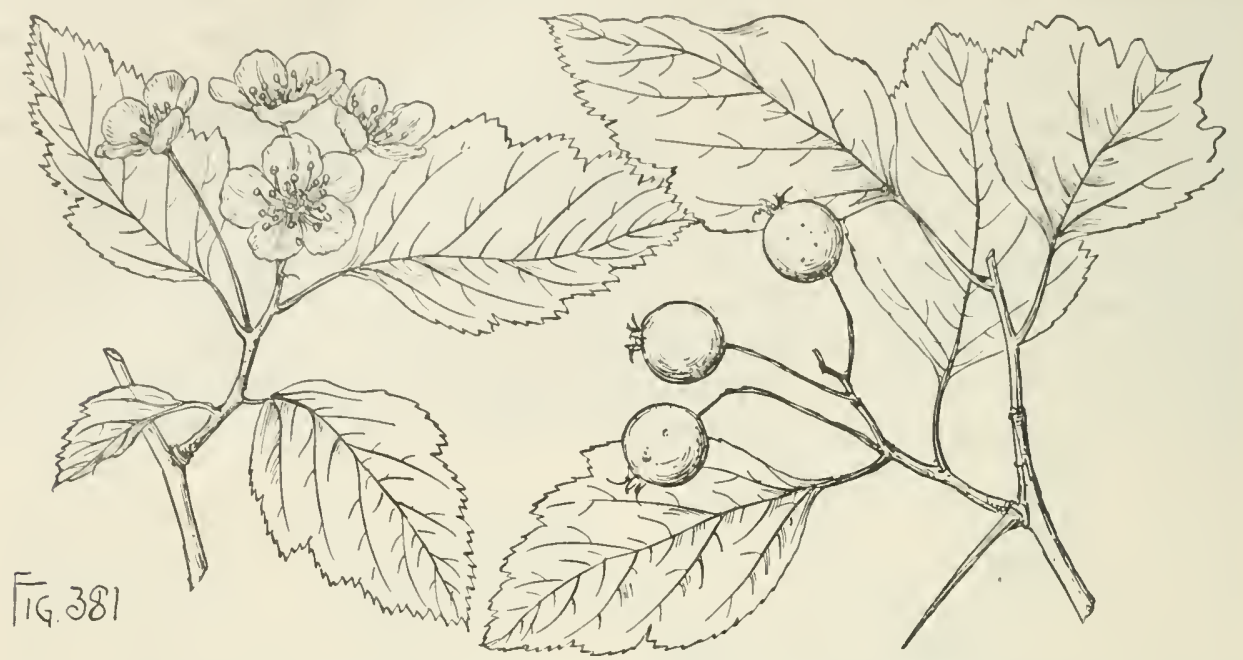

more or less broadly winged toward the apex, $\frac{1^{\prime}}{2}-3^{\prime}$ long. Flowers nearly $1^{\prime}$ in diameter, on long thin slightly villose pedicels, in $2-5$ usually 3 -flowered simple corymbs, with coarsely glandular-serrate bracts and bractlets; calyx-tube narrowly obconic, glabrons or slightly villose, the lobes foliaceous, acute, coarsely glandular-serrate above the middle; stamens 20; anthers large, purple; styles $3-5$, usually 4 , surrounded at the base by a narrow ring of pale hairs. Fruit ripening and falling abont the middle of September, often only a single fruit maturing from a flowerclnster, subglobose to short-oblong, full and rounded at the ends, yellow or orangeyellow, generally more or less flushed with red, marked by occasional large dark dots, $\frac{1^{\prime}}{3}-\frac{1^{\prime}}{2}$ long; calyx prominent, with an elongated tube and closely appressed lobes; flesh yellow, thin, and firm; nutlets $3-5$, usually 4 , rounded at the narrow ends, prominently ridged and grooved on the back, about $\frac{1^{\prime}}{4}$ long.

An intricately branched tree, rarely more than $20^{\circ}$ high, with a tall trunk $6^{\prime}-7^{\prime}$ in diameter, stout ascending branches forming a narrow or sometimes a round flattopped head, and glabrous branchlets armed with thin straight or slightly curved dark chestnut-brown shining spines, $\frac{3^{\prime}}{4}-1 \frac{1}{2}^{\prime}$ long, or often a large shrub, with few or many stems.

Distribution. Rocky woods and bluffs in the foothill region of northern Georgia, southeastern Tennessee and northeastern Alabama; very abundant in Alabama at Valley Head and on the low ridges extending sonthward to the neighborhood of Birmingham.

\section{PULCHERRIMA.}

Leaves oval to ovate or nearly orbicular, their lobes acute or rounded; fruit bright red.

97. C. opima (C).

Leaves ovate to oval or obovate, their lobes acute; fruit orange-red.

98. C. Robur (C).

\section{Cratægus opima, Beadl.}

Leaves oval to ovate or nearly orbicular, acute, gradually or abruptly narrowed and cuneate at the entire base, finely serrate above, with incurved teeth, and usually 
divided above the middle into short acute, acuminate or rounded lobes, half grown when the flowers open the middle of April, and then glabrous with the exception of a few short caducous hairs along the midribs and veins, and at maturity thin but firm in texture, light green on the upper surface, pale on the lower surface, $1 \frac{1^{\prime}}{2}$ long, $1 \frac{1^{\prime}}{4}$ wide, with slender midribs and 5 or 6 pairs of arcuate primary veins spreading to the points of the lobes; their petioles narrowly winged at the apex, usually about $\frac{3^{\prime}}{4}$ long; on vigorous shoots sometimes rounded or nearly truncate at the base and $1 \frac{1}{2}{ }^{\prime}-$ $2 \frac{1}{2}$ long and broad. Flowers about $\frac{2 \prime}{3}$ in diameter, on short slender pedicels, in compact few-flowered glabrous compound corymbs; calyx-tube broadly obconic, glabrous, the lobes gradually narrowed from broad bases, acute, entire or sparingly glandular-serrate, tipped with dark red glands, glabrous on the outer, puberulous on the inner surface; stamens 20; anthers purple; styles 3-5, surrounded at the base by a narrow ring of snowy white tomentum. Fruit ripening about the 1st of October and then remaining on the branches for several weeks, on short stout pedicels, in compact few-fruited erect or drooping clusters, subglobose, often rather longer than

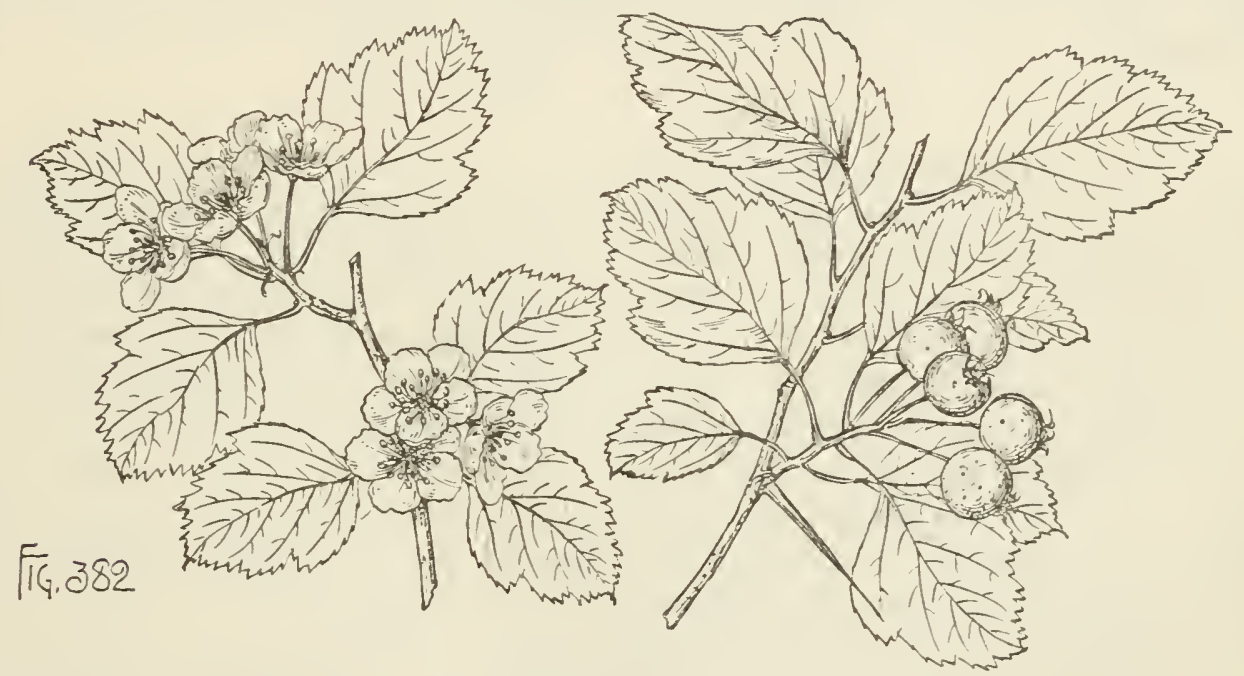

wide, bright red, about $\frac{1^{\prime}}{4}$ in diameter; calyx prominent, with a well-developed tube and much enlarged closely appressed lobes often deciduous with the tube before the fruit becomes entirely ripe; flesh thin, yellow, dry and mealy; nutlets $3-5$, thin, slightly grooved and ridged on the back, $\frac{1^{\prime}}{8}$ long.

A tree, $20^{\circ}-25^{\circ}$ high, with a tall, slender often spiny trunk covered with ashy gray bark nearly black at the base of old trees, spreading and ascending branches forming a rounded or oval usually open head, and thin nearly straight bright redbrown glabrous branchlets becoming gray tinged with red or brown in their second season, and armed with thin nearly straight bright chestnut-brown lustrous spines, $1^{\prime}-1 \frac{1^{\prime}}{2}$ long.

Distribution. Open woods in clay soil in the neighborhood of Greenville, Alabama; common.

\section{Cratægus Robur, Beadl.}

Leaves ovate, oval or obovate, acute or acuminate, entire or sparingly glandular below, finely serrate above, with incurved glandular teeth, and incisely lobed above the middle, with numerous short acute lobes, nearly fully grown when the flowers open at the end of March, and then membranaceous and dark yellow-green and lustrous, 
and at maturity thin but firm in texture, ycllow-grecn, $1 \frac{1^{\prime}}{2}-2^{\prime} \operatorname{long}, \mathbf{1}^{\prime}-1 \frac{1}{2}$ wide, with slender yellow midribs and thin primary vcins extending very obliquely to the points

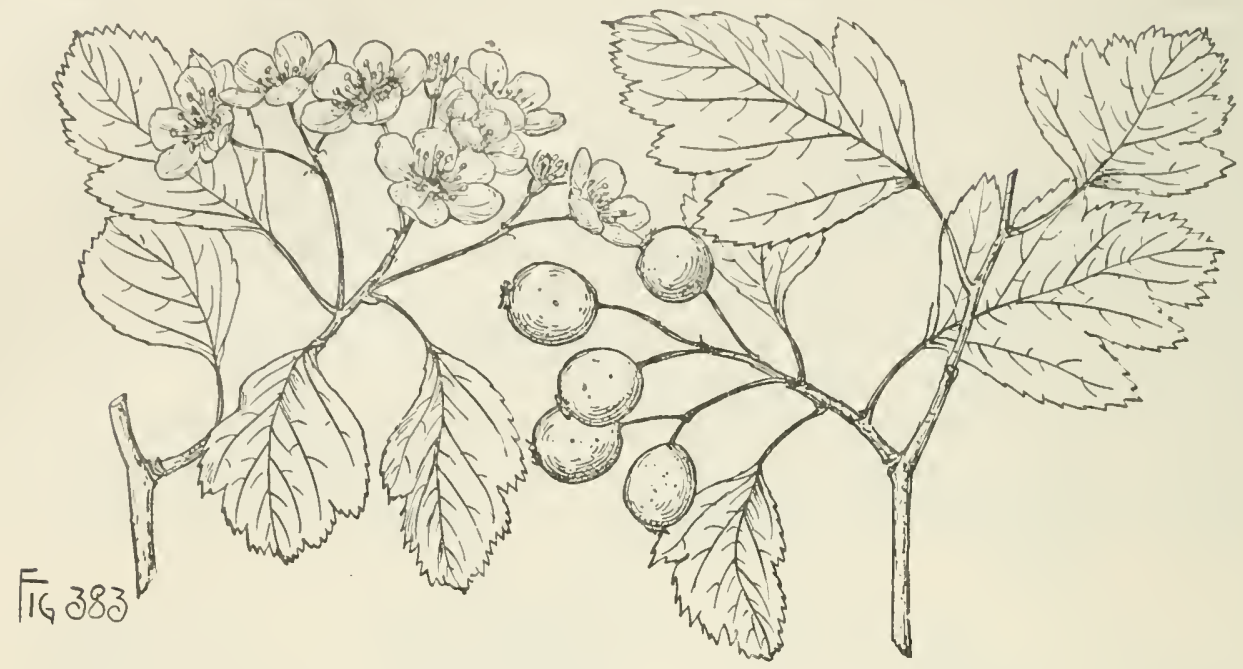

of the lobes, turning in the autumn orange, yellow, or brown; their petioles slender, slightly wing-margined toward the apex, sparingly glandular, $\frac{1}{2}^{\prime}-1^{\prime}$ long; on vigorous shoots broadly ovate, cuneate or nearly truncate at the wide base, deeply divided into broad lateral lobes, often $2^{\prime}-3^{\prime}$ long and broad, with stout broadly winged petioles frequently $1^{\prime}$ long. Flowers $1 \frac{1^{\prime}}{8}-1 \frac{1}{4}^{\prime}$ in diameter, on long slender pedicels, in 5-10-flowered compound glabrous corymbs, with large conspicuously glandular bracts and bractlets ; calyx-tube narrowly obconic, glabrous, the lobes gradually narrowed from broad bases, glabrous, entire or sparingly serrate; stamens 20; anthers pale purple; styles $3-5$, surrounded at the base by a narrow ring of pale hairs. Fruit ripening in September and October, on elongated, slender pedicels, in few-fruited drooping clusters, subglobose, orange-red, about $\frac{1}{2}^{\prime}$ in diameter ; calyx-lobes deciduous before the maturity of the fruit, leaving a narrow ring round the shallow cavity; flesh thin and firm; nutlets $3-5$, full and rounded at the ends, barely grooved on the rounded back, $\frac{3{ }^{\prime}}{16}$ long and nearly as broad.

A tree, $20^{\circ}-25^{\circ}$ high, with a trunk $4^{\prime}-6^{\prime}$ in diameter, covered with gray or brown scaly bark, spreading or ascending branches, and slender red-brown branchlets unarmed or armed with stout spines $\frac{3^{\prime}}{4}-1^{\prime}$ long; more often a large much-branched shrub, with one or more stems.

Distribution. Woods and borders of fields, northwestern Florida; common in the neighborhood of Tallahassee.

\section{BRACTEAT円.}

Leaves oval to broadly obovate; corymbs many-flowered; stamens $10-20$, usually 20 ; fruit bright red or orange-red.

99. C. Harbisoni (C).

Leaves broadly ovate or rarely obovate; corymbs $3-10$-flowered; stamens 20 ; fruit bright red.

100. C. Ashei (C).

\section{Cratægus Harbisoni, Beadl.}

Leaves oval or broadly obovate, acute at the apex, cuneate or full and rounded at the entire base, and coarsely serrate above, with straight glandular teeth, when 
they unfold roughened above by stout, rigid pale hairs, and soft and pubescent below, nearly fully grown early in May whell the flowers open, and then thin, dark yellowgreen above and pale below, and at maturity thick and firm ; dark green, lustrous, and scabrate on the upper surface, pale on the lower surface, $2^{\prime}-2 \frac{1}{2}^{\prime}$ long and $1^{\prime}-1 \frac{1}{2}^{\prime}$ wide, with stout midribs and primary veins deeply impressed on the upper side of the leaf, and conspicuous reticulate veinlets; their petioles stout, villose, more or less winged above, $\frac{1}{4}^{\prime}-1^{\prime}$ long; and furnished like the base of the leaf-blade with numerous large stipitate dark glands; on vigorous shoots broadly ovate, cuneate and decurrent on their stouter petioles, $3^{\prime}-x^{\prime}$ long and $2 \frac{1}{2}^{\prime}-3^{\prime}$ wide, with lunate coarsely glandular-dentate stipules frequently $\frac{1^{\prime}}{2}$ long. Flowers $\frac{3 \prime}{4}$ in diameter, in broad loose compound villose usually 10-12-flowered corymbs, with broad acute conspicuous glandular-serrate bracts and bractlets; calyx-tube broadly obconic, densely villose at the base and glabrous or pubescent above, the lobes foliaceous, elongated, gradually narrowed from broad bases, acute, bright green, more or less hairy, coarsely glandular-serrate, with large stipitate dark red glands; stamens 10-20, usually 20; anthers large, light yellow; styles 3-5. Fruit ripening and falling early in October, subglobose, often rather longer than broad, bright red or orange-red, marked by numerous large dark

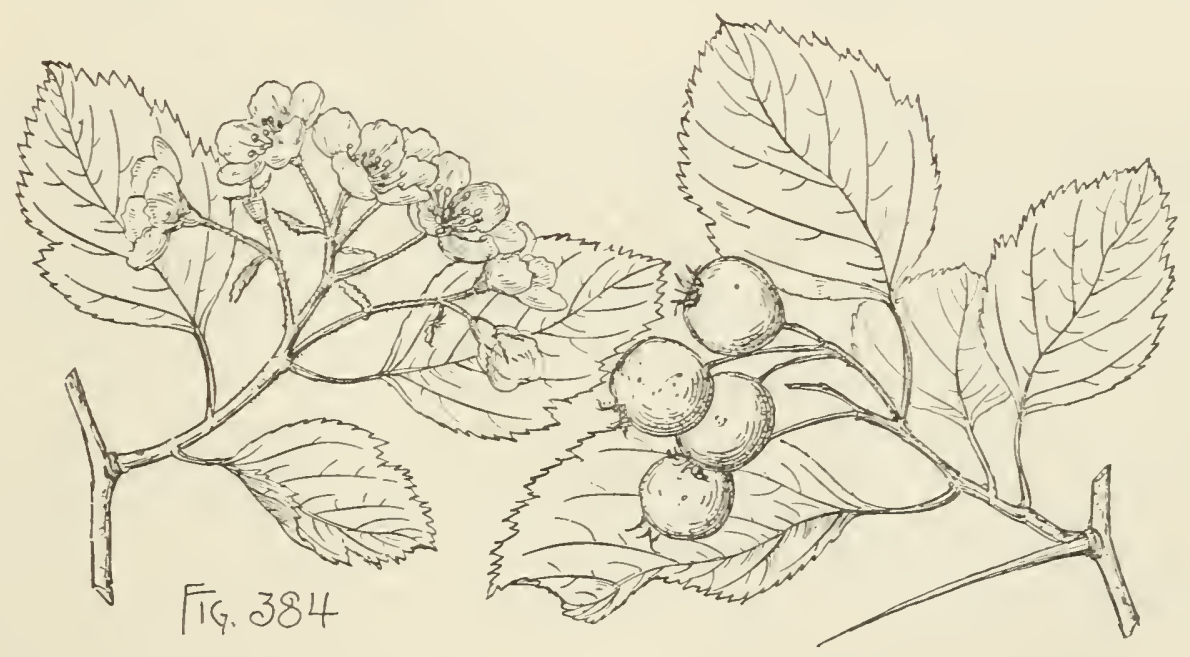

dots; calyx enlarged, with spreading glandular lobes often deciduous before the fruit ripens; flesh yellow, thick, dry and mealy; nutlets $3-5$, narrowed and rounded at the ends, sometimes prominently ridged on the back, $\frac{1}{4}^{\prime}$ long.

A tree, sometimes $25^{\circ}$ high, with a trunk $10^{\prime}-12^{\prime}$ in diameter, covered with light gray or gray-brown bark and often armed with straight or much-branched spines, wide-spreading light gray or reddish branches forming a rather open symmetrical head, and slender branchlets coated when they first appear with long spreading white hairs, pubescent or glabrous and light red-brown or orange-brown during their first season, becoming dark or light gray the following year, and furnished with numerous usually stout straight dark reddish brown shining spines $1 \frac{1^{\prime}}{2}-2^{\prime}$ long.

Distribution. Dry limestone hills and ridges; West Nashville, Tennessee; common.

\section{Cratægus Ashei, Beadl.}

Leaves broadly ovate or occasionally obovate, acute and generally short-pointed at the apex, gradually or abruptly narrowed and cuneate and usually entire at the base, 
coarsely and occasionally doubly scrrate above, with straight or incurved teeth tipped with small dark glands, when they unfold roughened on the upper surface with short pale hairs and pubescent below, nearly fully grown and membranaccous when the

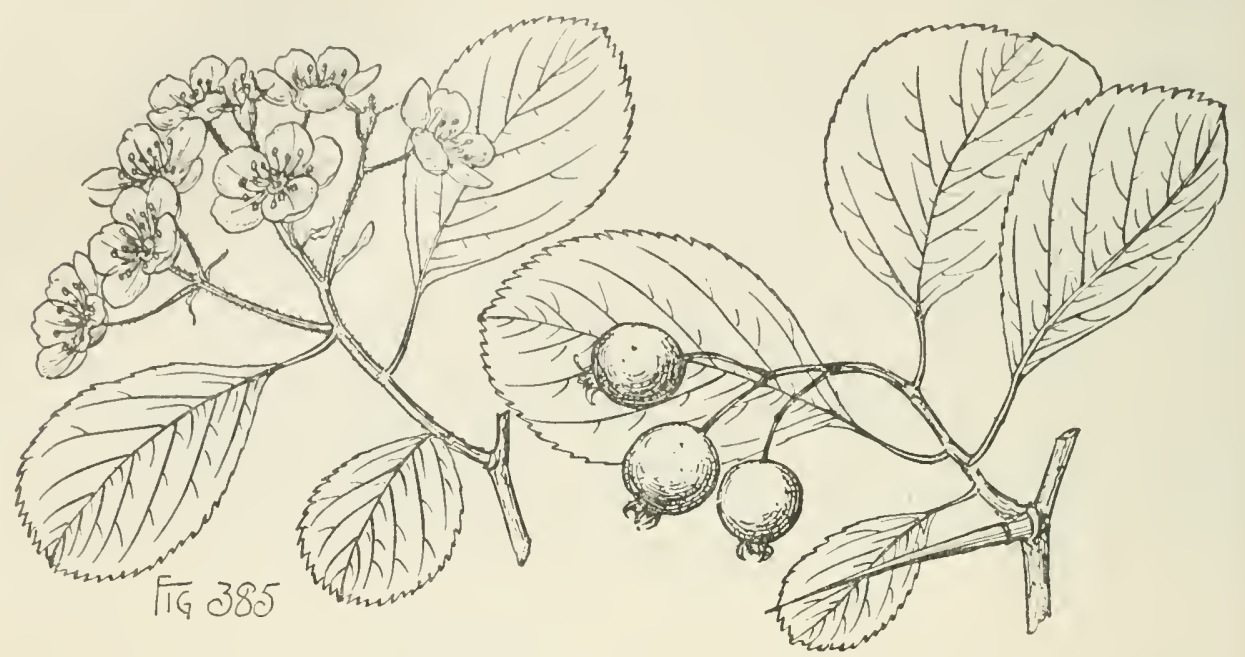

flowers open early in May, and at maturity thin but firm in texture, dark green, lustrous and scabrate on the upper surface, pale and puberulous on the lower surface along the slender midribs and primary veins, about $2^{\prime}$ long and $1 \frac{1}{2}^{\prime}$ wide; their petioles stout, broadly winged above, glandular, pubescent at first but ultimately nearly glabrous, about $\frac{1^{\prime}}{2}$ long; on vigorous shoots usually broadly oval or nearly orbicular, rounded or short-pointed at the apex, $2 \frac{1}{2}^{\prime}-3^{\prime}$ long and $2^{\prime}-2 \frac{1}{2}^{\prime}$ wide. Flowers $\frac{8^{\prime}}{4}$ in diameter, on slender hairy pedicels, in 3-10-flowered simple or compound villose corymbs, with broad conspicuous glandular bracts and bractlets; calyx-tube broadly obconic, thickly coated with long matted reflexed white hairs, the lobes foliaceous, broad, acute, nearly glabrous on the outer surface, villose on the inner surface, glandular, with small stout stipitate glands; stamens 20 ; anthers small, yellow; styles $3-5$, surrounded at the base by a narrow ring of pale hairs. Fruit ripening and falling late in September or early in October, on stout villose or glabrous pedicels, in fewfruited clusters, globose or rather longer than broad, bright red, marked by large scattered dots, more or less villose toward the ends, about $1^{\prime}$ in diameter; calyx conspicuous, with elongated coarsely glandular-serrate lobes, erect, incurved or reflexed; flesh thick and yellow; nutlets 3-5, thin, narrowed and acute at the ends, deeply grooved and ridged on the back, $\frac{1}{3}^{\prime}$ long.

A tree, rarely more than $20^{\circ}$ high, with a slender trunk covered with smooth light gray or red-brown bark becoming fissured and scaly on old individuals, stout ascending branches forming a pyramidal or oval head, and slender branchlets coated at first with long pale matted reflexed hairs, soon becoming nearly glabrous, lustrous, orangebrown or reddish brown, and light gray or gray tinged with red during their second season, and armed with straight or slightly curved thin dark red-brown shining spines $1^{\prime}-1 \frac{1}{2}^{\prime}$ long.

Distribution. Abandoned fields, and woods; growing usually on clay soils near Montgomery, Alabama. 


\section{FLAV円.}

Stamens 20.

Anthers purple or pink.

Leaves elliptical to broadly obovate, Jellow-green; fruit dark orange-brown.

101. C. flava (C).

Leaves ovate to nearly orbicular, bright green; fruit globose to depressed-globose, bright red.

102. C. consanguinea (C).

Leaves obovate, bright green; fruit oval to short-oblong, orange-red; anthers pink.

103. C. tristis (C).

Leaves ovate to obovate or orbicular, bright yellow-green; fruit pear-shaped, dark orange color, with a red cheek.

104. C. visenda (C).

Leaves obovate or ovate, dark green ; fruit subglobose to short-oblong, red or orangered.

Anthers yellow. (Doubtful in 109 and 114.)

105̃. C. ignava (C).

Leaves yellow-green.

Leaves obovate-cuneate, often 3-lobed at the apex; fruit pear-shaped to subglobose, bright orange-red and lustrous ; corymbs tomentose. 106. C. Floridana (C).

Leaves obovate; fruit subglobose to short-oblong, dull brownish yellow; corymbs glabrous.

107. C. lacrimata (C).

Leaves obovate, rounded or abruptly short-pointed at the broad apex; fruit globose to short-oblong, bright orange-red.

108. C. Ravenelii (C).

Leaves obovate to obovate-cuneiform ; fruit globose, bright red. 109. C. senta (A).

Leaves obovate, subcoriaceous; fruit globose or depressed-globose, orange-yellow, with a red cheek. 110 . C. panda (C).

Leaves obovate to oblong-obovate, with entire slightly undulate margins; fruit globose, red.

Leaves spathulate, subcoriaceous; fruit pyriform, red.

111. C. integra (C).

Leaves obovate to oval or orbicular; fruit subglobose to oval, orange-red or red and orange.

113. C. annosa (C).

Leaves conspicuously blue-green, broadly ovate to orbicular ; fruit subglobose to short-

oblong, light red, puberulous at the ends.

114. C. dispar (C).

Stamens 10; anthers yellow; leaves broadly oborate to oval or rhomboidal, dark yellowgreen; fruit subglobose, dull orange-red, often slightly villose at the ends.

115. C. aprica $(\mathrm{A}, \mathrm{C})$.

* Stamens 20.

+ Anthers purple or pink.

\section{Cratægus flava, Ait.}

Leaves elliptical to broadly obovate, acute or rarely rounded at the apex, gradually narrowed and cuneate at the glandular base, and coarsely doubly serrate above, with broad straight or incurved teeth tipped with large dark red stipitate glands, when they unfold bronze color, villose above, with short pale caducous hairs most abundant near the base of the midribs, and pubescent below on the midribs and veins, about half grown when the flowers open from the 10 th to the 20 th of April, and at maturity membranaceous, yellow-green, usually about $2^{\prime}$ long and $1 \frac{1^{\prime}}{2}$ wide, with slender yellow midribs and 3 or 4 pairs of primary veins usually puberulous on the under side and only slightly impressed above; their petioles slender, glandular, winged nearly to the base, generally about $\frac{1}{2}^{\prime}$ long, more or less villose, and after midsummer often light red on the lower side; on vigorous shoots frequently $3^{\prime}$ long and $2^{\prime}$ wide, and sometimes broadly ovate, 3 -lobed or divided into 2 or 3 pairs of lateral lobes, with petioles $1^{\prime}-1 \frac{1}{2}^{\prime}$ long, broadly winged and conspicuously glandular, 
and foliaceous lunate or elliptical coarsely glandular-serrate stipules. Flowers about $\frac{3^{\prime}}{4}$ in diameter, on short slender pedieels, in few-flowered simple or eompound slightly villose compact corymbs, with lanceolate acute coarsely glandular-serrate bracts and braetlets; ealyx-tnbe broadly obconic and glabrous, the lobes wide, aeute, usually laciniately divided, very glandular; stamens 20; anthers large, purple. Fruit ripening early in October and soon falling, in few-fruited drooping elnsters, short-oblong, full and rounded at the ends, dark orange-brown, $\frac{1}{2}-\frac{5}{8}$ long, $\frac{1}{3}-\frac{1}{2}$ wide; ealyx prominent, with a long narrow tube, and enlarged closely appressed lobes often deciduous before the fruit ripens; flesh thiek, orange eolor, dry and mealy; nutlets 5, ridged and gradually narrowed and rounded at the ends, ridged and deeply grooved on the back, with a high narrow ridge, about $\frac{1}{4}$ long.

A tree, $15^{\circ}-20^{\circ}$ high, with a tall trunk $8^{\prime}-10^{\prime}$ in diameter, covered with thin dark brown bark tinged with red and divided into narrow rounded ridges, stout aseending branches forming an open and somewhat irregular head sometimes $20^{\circ}$ aeross, and

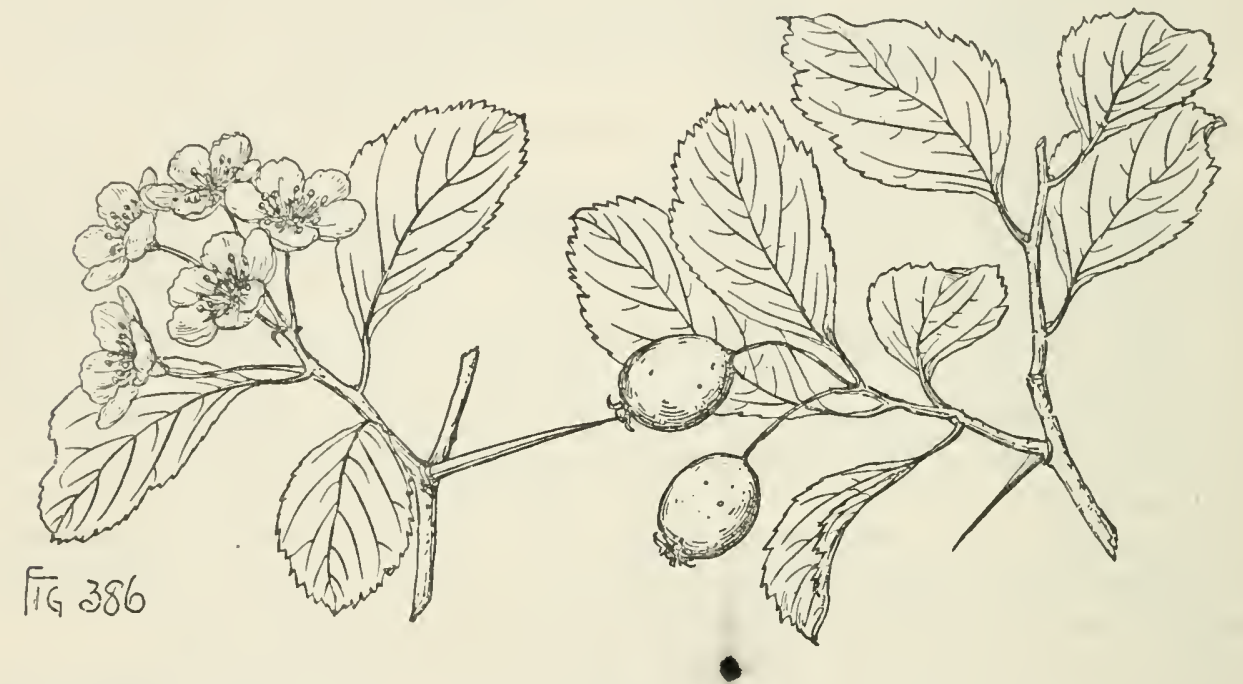

slender slightly zigzag glabrous branchlets dark green deeply tinged with red when they first appear, becoming dnll red-brown or orange-brown during their first season, darker the following year, and ultimately dark gray-brown, and armed with thin nearly straight bright ehestnut-brown spines $\frac{3^{\prime}}{4}-1 \frac{1}{4}^{\prime}$ long.

Distribution. Dry sandy soil on the sand hills of Summerville, west of the eity of Augusta, Georgia, and at River Junction, Florida.

\section{Cratægus consanguinea, Beadl.}

Leaves broadly ovate, nearly orbicular, occasionally oval or rhomboidal, acute and generally short-pointed at the apex, gradually narrowed and concave-cuneate or sometimes rounded at the entire base, finely and often doubly serrate, with glandular teeth, and frequently irregularly divided above the middle into short acute lobes, nearly fully grown when the flowers open at the end of March or early in April, and then very thin, blue-green, slightly villose, especially on the midribs and veins, and at maturity thin but firm in texture, bright green, glabrous with the exeeption of a few hairs on the under side of the slender midribs, and thin primary veins extending very obliquely toward the end of the leaf, about $1^{\prime}$ long, $\frac{3^{\prime}}{4}-\frac{7^{\prime}}{8}$ wide, and on vigorous shoots $1 \frac{1}{2}^{\prime}-2^{\prime}$ long and wide; their petioles slender, glandular, wing-mar- 
gined above, at first villose, becoming glabrous, $\frac{1^{\prime}}{3}-\frac{3^{\prime}}{4}$ long. Flowers $\frac{3^{\prime}}{4}$ in diameter, on slender elongated hairy pedicels, in simple 1-5-flowered corymbs, with oblanceolate acuminate bright red caducous bracts and bractlets; calyx-tube broadly obconic,

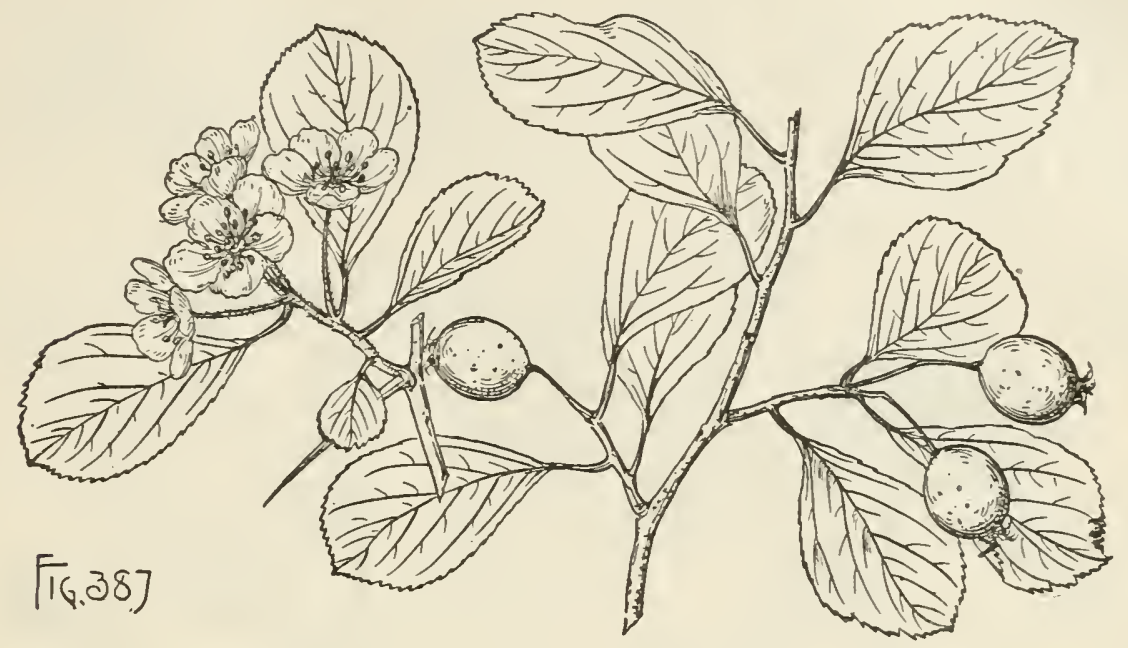

sparingly hairy, with long pale caducous hairs, the lobes gradually narrowed from broad bases, acute, glandular, with minute bright red glands, glabrous; stamens 20; anthers small, purple; styles 3-5, surrounded at the base by a narrow ring of short pale hairs. Fruit ripening and falling about the middle of September, on slender glabrous pedicels, often only a single fruit in a cluster developing, globose to depressed-globose, bright red, marked by small dark dots, nearly $\frac{1}{2}^{\prime}$ in diameter; calyx prominent, with enlarged appressed lobes; flesh thin, yellow, dry and mealy; nutlets 3-5, thick, narrowed and rounded at the base, full and rounded at the apex, ridged ou the back, with a broad low rounded ridge, about $\frac{55^{\prime}}{16}$ long.

A tree, often $20^{\circ}$ high, with a tall trunk $6^{\prime}-8^{\prime}$ in diameter, covered with nearly black deeply furrowed bark brokentinto short thick closely appressed scales, widespreading often pendulous branches forming a broad symmetrical handsome head, and slender slightly zigzag branchlets covered when they first appear with pale caducous hairs, soon becoming bright red-brown and lustrous, and dull reddish brown in their second season, and armed with short nearly straight gray or chestnutbrown spines $\frac{1^{\prime}}{3}-\frac{3^{\prime}}{4}$ long.

Distribution. Dry upland Oak woods in western Florida from the neighborhood of Tallahassee to the Appalachicola River; abundant in the neighborhood of River Junction and at Aspalaga.

\section{Cratægus tristis, Beadl.}

Leaves obovate, acute, acuminate, or rounded and often more or less undulatelobed at the broad apex, gradually narrowed from above the middle and concavecuneate at the glandular base, and serrate above, with blunt glandular teeth, about half grown when the flowers open at the end of April, and then slightly pilose on the upper and hairy on the lower surface along the thin midribs and in the axils of the slender veins extending obliquely to the points of the lobes, and at maturity thin but firm in texture, bright green and glabrous, $11^{\prime}-1 \frac{1}{2}^{\prime}$ long, about $\frac{3^{\prime}}{4}$ wide, turning in the autumn yellow, brown, and orange; their petioles slender, wing-margined above, 
conspicuously glandular, slightly puberulous, $\frac{1}{2}-y^{\prime}$ long; on vigorous shoots oblongobovate, often deeply and irregrularly divided into broal acnte lateral lobes, and frequently $1 \frac{1}{2}^{\prime}-2^{\prime}$ long and nearly as broad. Flowers $\frac{5^{\prime}}{g^{\prime}}-4^{\prime}$ in cliameter, on slender villose pedicels, in simple 3-j̃-flowered corymbs, with rose-colored and conspicuously glandnlar bracts and bractlets; ealyx-tube broally obconic, hairy toward the base, with long seattered pale hairs, the lobes gradually narrowed from broad bases, acuminate, glandular, with large dark red glands, and entire or coarsely serrate above the middle; stamens 20; anthers pink; styles 3-5. Fruit ripening and falling late in

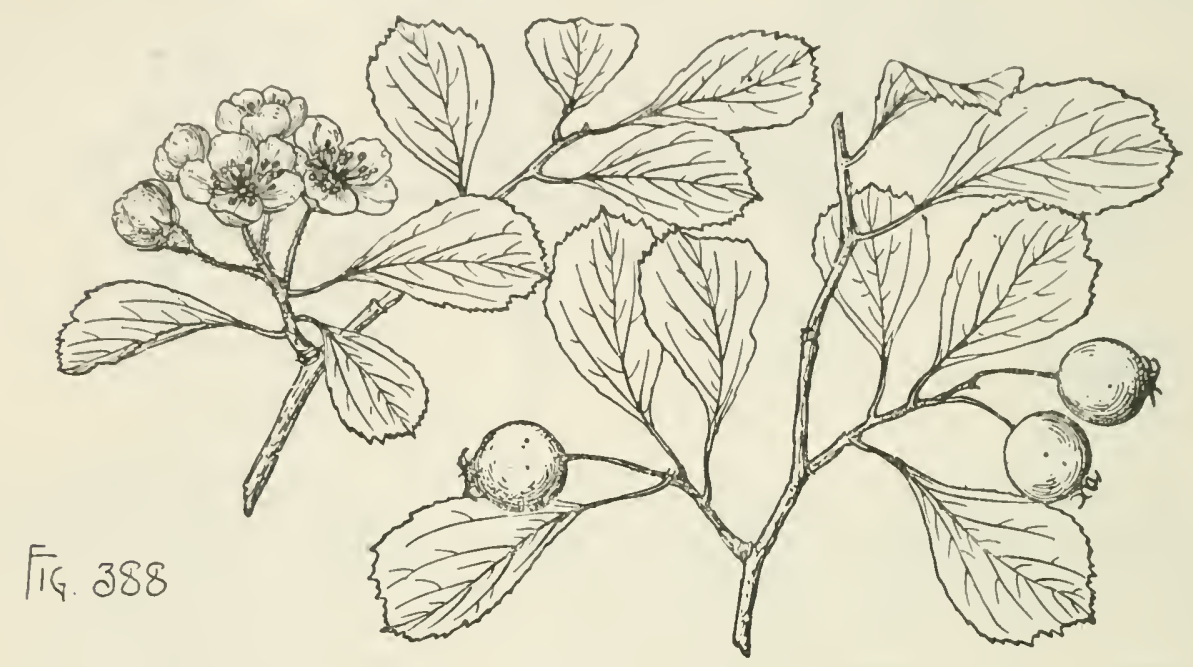

August or early in September, oval or short-oblong, orange-red, about $\frac{1}{2}^{\prime}$ long, with soft flesh; calyx little enlarged, with recurved persistent lobes; nutlets $3-5$, full and rounded at the base, gradually narrowed and acute at the apex, rounded and ridged on the back, with a broad low slightly grooved ridge, about $\frac{5}{1 \overline{6}^{\prime}}$ long.

A tree, sometimes $25^{\circ}$ high, with a trunk $8^{\prime}-10^{\prime}$ in diameter, covered witl dark sometimes nearly black deeply furrowed bark, stout pendulous branches forming a broad shapely handsome head, and slender branchlets hoary-tomentose at first, bright red-brown and puberulous at the end of their first season, becoming dark gray-brown, and armed with few slender straight spines $1 \frac{1}{4}^{\prime}-1 \frac{1}{2}^{\prime}$ long; or often a large shrub.

Distribution. Slopes of low hills, northwestern Georgia; common in the neighborhood of Rome.

\section{Cratægus visenda, Beadl.}

Leaves ovate, obovate, or orbicular, short-pointed and acute or occasionally broad and rounded at the apex, concave-cuneate and gradually narrowed at the mostly entire base, finely serrate above, with rounded teeth, glandular, with bright red glands, and divided above the middle iuto short acute lobes, nearly fully grown when the flowers open at the end of March, and then glabrous with the exception of a few short pale hairs on the two surfaces near the base of the midribs, and at maturity thin and firm in texture, bright yellow-green and lustrous above, pale below, glabrous, $1^{\prime}-1 \frac{1}{2}^{\prime}$ long, $\frac{3{ }^{\prime}}{4}-1^{\prime}$ wide, with slender midribs, and thin primary veins extending very obliquely to the points of the lobes, turning yellow, orange, or brown in the autumn; their petioles slender, broadly wing-margined above, conspicuously 
glandular, sparingly villose at first, becoming nearly glabrous, $\frac{1 \prime}{2}-\frac{3 \prime}{4}$ long. Flowers about $\frac{3}{4}$ in diameter, on short villose pedicels, in simple 3-6-flowered corymbs;

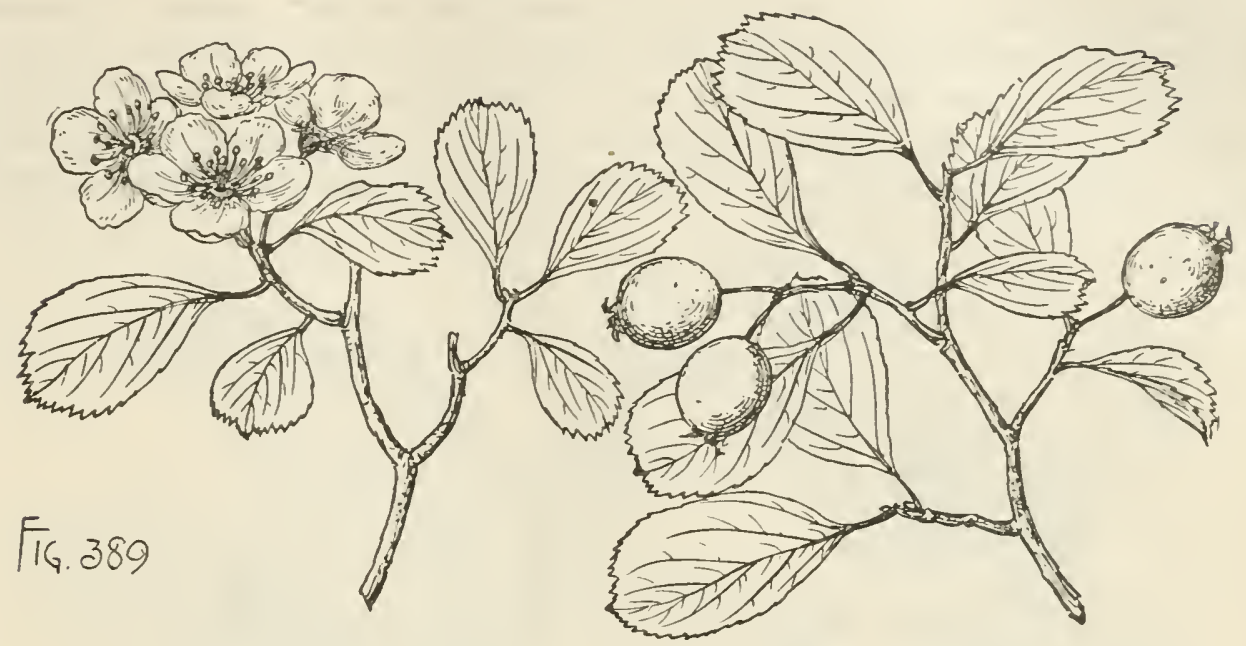

calyx-tube broadly obconic, hairy near the base, with scattered pale hairs, glabrous above, the lobes broad, acuminate, glandular-serrate, glabrous on the outer, pilose on the inner surface; stamens 20 ; anthers pale purple; styles $3-5$, surrounded at the base by small tufts of white hairs. Fruit ripening and falling late in August and early in September, on stout pedicels, usually in 1 or 2 -fruited clusters, pearshaped, dark orange-colored, with a red cheek, $\frac{1}{2}^{\prime}-\frac{5}{8}^{\prime}$ long, nearly $\frac{1}{2}^{\prime}$ wide; calyx enlarged, the lobes coarsely glandular-serrate, puberulous on the upper surface, closely appressed; flesh soft and yellow; nutlets $3-5$, obtuse and rounded at the ends, rounded and slightly ridged on the back, about $\frac{3^{\prime}}{8}$ long.

A tree, sometimes $30^{\circ}$ high, with a trunk $10^{\prime}-12^{\prime}$ in diameter, covered with dark gray or brownish bark, crooked horizontal or ascending branches forming a broad irregular head, and stout often contorted branchlets villose at first, soon glabrous, dull reddish brown to ashy gray, and armed with slender straight spines $\frac{1^{\prime}}{2}-\frac{5}{8}$ long.

Distribution. Sandy soil near Bristol, Florida.

\section{Cratægus ignava, Beadl.}

Leaves obovate to ovate, acute, gradually narrowed from near the middle to the concave-cuneate glandular base, sharply often doubly serrate above, with glandular teeth, and usually divided toward the apex into short acute lobes, nearly fully grown when the flowers open at the end of April, and then membranaceous, glabrous with the exception of a few hairs along the midribs above and along the midribs and slender veins below, and at maturity subcoriaceous, bright green and lustrous on the upper surface, pale and still hairy on the lower surface, $1 \frac{1^{\prime}}{2}-2^{\prime}$ long and $1^{\prime}-1 \frac{1}{2}^{\prime}$ wide, turning in the autumn yellow and brown sometimes flushed with red; their petioles slender, wing-margined at the apex, glandular, $\frac{1^{\prime}}{4}-\frac{1}{2}^{\prime}$ long. Flowers about $\frac{3^{\prime}}{4}$ in diameter, on slender glabrous pedicels, in 3-6-flowered simple corymbs, with lanceolate conspicuously glandular reddish bracts and bractlets; calyx-tube broadly obconic, glabrous, the lobes abruptly narrowed from the base, wide, glabrons, glandular, with dark red stipitate glands, and often coarsely serrate above the middle; stamens 20; anthers large, purple; styles 3-5, surrounded at the base by a ring of pale hairs. Fruit ripening and falling at the end of September and early in October, on slender 
erect pedicels, in few-fruited clusters, subglobose to short-oblong, orange-red, marked by numerous pale dots, about $\frac{3}{8}$ ' long; calyx enlarged and prominent, with spreading lobes often deciduous from the ripe fruit; flesh thick and soft; nutlets $3-5$, rounded at the ends, prominently but irregularly ridged and grooved on the back, $\frac{1{ }^{\prime}}{4}$ long.

A tree, sometimes $10^{\circ}-12^{\circ}$ high, with a slender trunk covered with ashy gray fissured scaly bark often tinged with brown and frequently nearly black near the ground, stout ascending branches, and slender zigzag glabrous branchlets bright red-

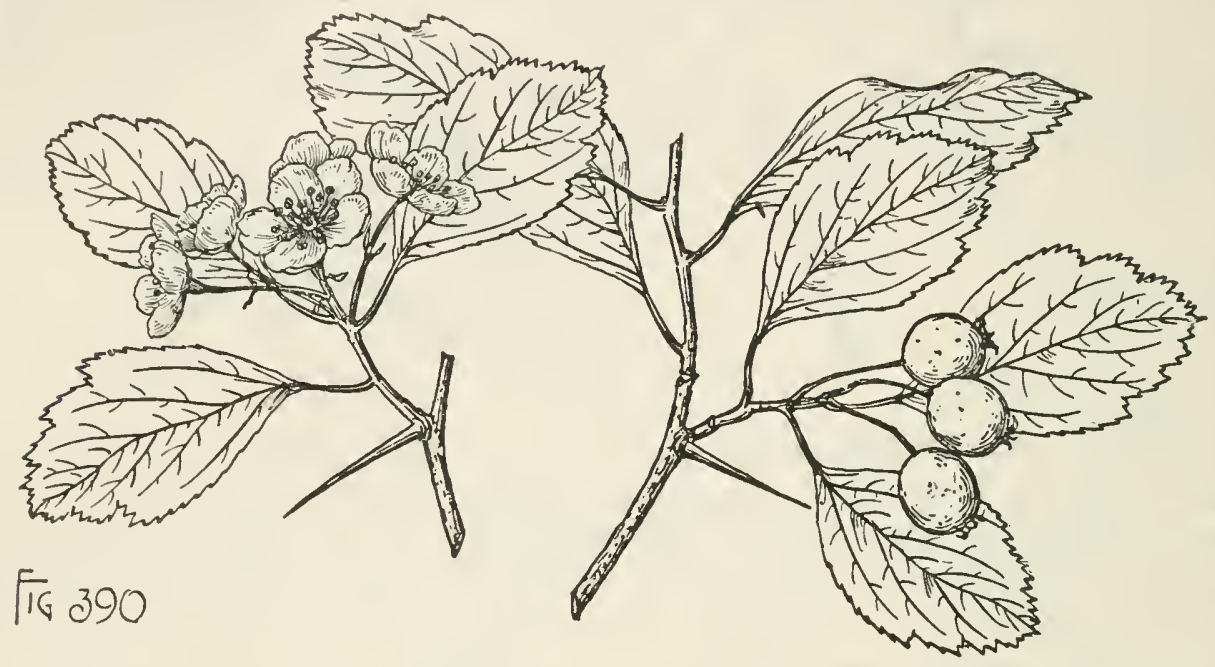

brown during their first season, becoming dark gray-brown, and armed with many very slender red-brown lustrous ultimately ashy gray spines $1^{\prime}-1 \frac{1}{2}^{\prime}$ long.

Distribution. Northeastern Alabama; common on Lookout Mountain above Valley Head, and at Collinsville and Gadsden.

$+\rightarrow$ Anthers yellow.

\section{Cratægus Floridana, Sarg.}

Leaves obovate-cuneate, frequently 3 -lobed at the apex, with short rounded lobes, gradually narrowed and cuneate at the entire base, finely serrate above, with straight or incurved teeth tipped with showy ultimately dark persistent glands, 3-nerved, with slender nerves, and numerous thin secondary veins and reticulate veinlets, slightly villose above as they unfold, nearly fully grown when the flowers open about the middle of March, and then light yellow-green and glabrous with the exception of a few persistent hairs along the upper side of the nerves and in their axils, and at maturity thick and firm, dark green and lustrous on the upper surface, pale on the lower surface, $1^{\prime}-1 \frac{1}{2}^{\prime}$ long and about $\frac{1^{\prime}}{2}$ wide; their petioles slender, glandular, more or less winged toward the apex, tomentose, becoming pubescent or glabrous, usually about $\frac{1}{2}^{\prime}$ long; on vigorous shoots frequently $2^{\prime}$ long, and sometimes divided by deep rounded sinuses into numerous narrow lateral lobes, their stipules lunate, foliaceous, pointed, coarsely glandular-serrate. Flowers about $\frac{5}{8}$ in diameter, on slender tomentose pedicels, in few usually 3 -flowered simple compact corymbs; calyx-tube broadly obconic, coated with long matted white hairs, the lobes narrow, acuminate, glandular, with bright red stipitate glands, villose toward the base on the outer surface, and on the inner surface; stamens 20; anthers small, pale yellow; styles 4 or 5 , surrounded 
at the base by a broad ring of long shining white hairs. Fruit ripening from the middle to the end of Angust, on short stout pubescent pedicels, solitary or in 2 or 3 -fruited drooping clusters, obovate to short-oblong, usually about $\frac{3 \prime}{4}$ long, bright orange-red, lustrous, marked by numerous pale dots; calyx prominent, with an elongated tube puberulous on the outer surface, and reflexed glandular-serrate lobes; flesh thin, yellow, dry and mealy; nutlets 4 or 5 , acute at the base, full and rounded at the apex, rounded and occasionally slightly ridged on the back, about $\frac{1^{\prime}}{3}$ long.

A tree, rarely more than $15^{\circ}$ high, with a long straight trunk $6^{\prime}-8^{\prime}$ in diameter, covered with thick nearly black deeply furrowed bark broken into short thick platelike scales, small drooping branches forming a handsome symmetrical head, and slender conspicuously zigzag pendulous branchlets coated at first with long pale

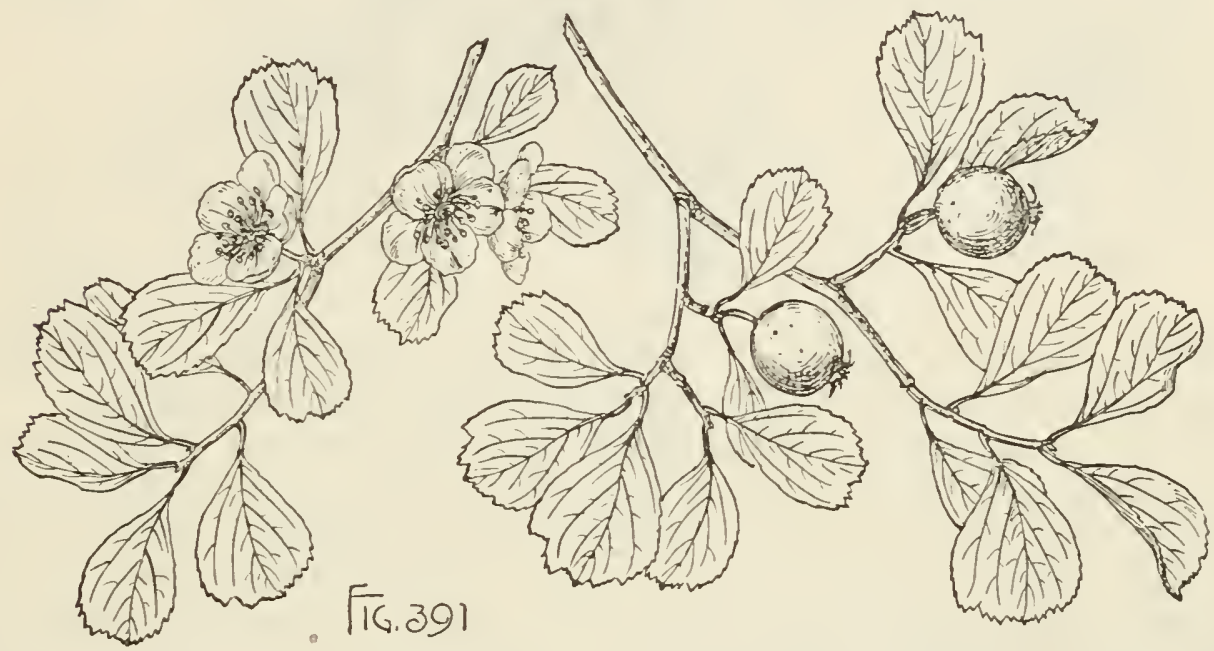

matted hairs, becoming during their first season dark red-brown and more or less villose, and dark brown the following year, and armed with thin straight spines $\frac{3^{\prime}}{4}-1^{\prime}$ long, or unarmed.

Distribution. Dry sandy soil of the Pine barrens of northeastern Florida; abundant in the neighborhood of Jacksonville.

\section{Cratægus lacrimata, Small.}

Leaves obovate, rounded or acute and glandular-serrate at the apex, usually with incurved teeth, entire and glandular below, gradually narrowed from above the middle to the base, and 3-nerved, with slender yellow nerves, numerous thin secondary veins and reticulate veinlets, when the flowers open early in April nearly fully grown, light yellow, glabrous, with the exception of small tufts of pale caducous hairs in the axils of the nerves below, and at maturity subcoriaceous, lustrous, $\frac{1^{\prime}}{4}-\frac{3^{\prime}}{4}$ long, about $\frac{1}{3}$ wide; their petioles slender, wing-margined toward the apex, dark orange-brown, at first puberulous, soon becoming glabrous, $\frac{1}{4}^{\prime}-\frac{1}{2}^{\prime}$ long. Flowers about $\frac{2^{\prime}}{3}$ in diameter, on short stout glabrous pedicels, in 3-5-flowered simple corymbs, with long linear entire caducous bracts and bractlets turning red in fading; calyz-tube broadly obconic, glabrous, the lobes gradually narrowed from broad bases, acuminate, entire, tipped with large dark glands; stamens 20; anthers large, light yellow; styles usually 3 , surrounded at the base by a narrow ring of pale hairs. Fruit ripening toward the end of August, on slender pedicels, in 1 or 2-fruited clusters, subglobose to short-oblong, full and rounded at the ends, dull brownish 
yellow marked by occasional dark dots, about $\frac{1^{\prime}}{3}$ in diameter; calyx prominent, with au clongated tube, and spreading lobes nsually deciduous before the fruit ripens;

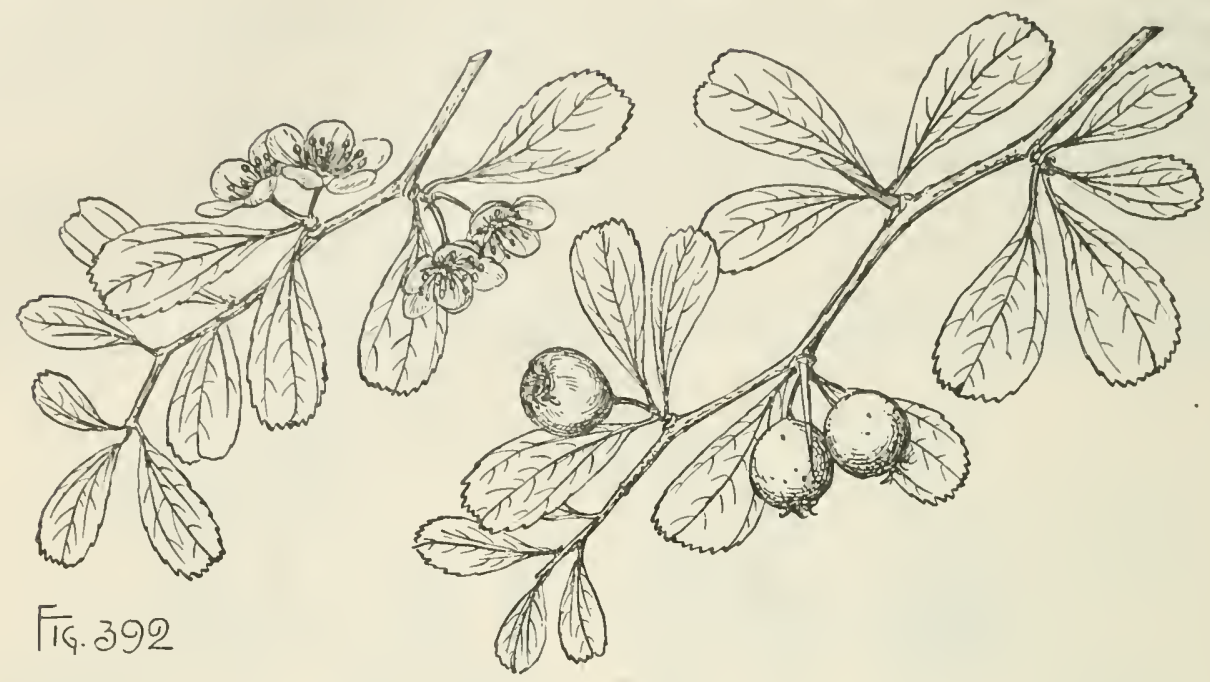

flesh thin, yellow, dry and mealy; nutlets 3 , very broad, full and rounded at the ends, rounded and sometimes obscurely grooved on the back, about $\frac{3^{\prime}}{8}$ long.

A tree, occasionally $20^{\circ}$ but usually not more than $10^{\circ}$ high, with a tall trunk $4^{\prime}-6^{\prime}$ in diameter, covered with thick deeply furrowed black bark broken on the surface into thick plate-like closely appressed scales, long slender drooping branches forming a handsome symmetrical round-topped head, and thin glabrous very zigzag branchlets light orange-brown when they first appear, soon becoming reddish brown and lustrous, and dark gray-brown in their second year, and armed with many small nearly straight dark chestnut-brown spines $\frac{1^{\prime}}{2}-\frac{3^{\prime}}{4}$ long.

Distribution. Western Florida, Pensacola to De Funiak Springs; sometimes in moist sand; more often in dry barrens; common and often a conspicuous feature of vegetation.

\section{Cratægus Ravenelii, Sarg.}

Leaves obovate, rounded and abruptly short-pointed or acute at the broad sometimes slightly lobed apex, gradually narrowed from above the middle to the elongated cuneate base, more or less undulate on the margins, and coarsely and usually doubly glandular-serrate above, with large bright red ultimately dark persistent glands, nearly fully grown when the flowers open the middle of April, and then coated with long pale caducous hairs, and at maturity thin but firm in texture, yellow-green, scabrous on the upper surface, pale and pubescent on the lower surface along the slender veins, $\mathbf{1}^{\prime}-\mathbf{1}^{\prime} \frac{1}{2}^{\prime}$ long and about $\frac{3^{\prime}}{4}$ wide; their petioles slender, glandular, winged above, tomentose at first, becoming pubescent, $\frac{1}{4}^{\prime}-\frac{1}{2}^{\prime}$ long; stipules linear to lunate, conspicuously glandular-serrate, tomentose, caducous; on vigorous shoots often $2^{\prime}$ long and $1 \frac{1}{2}^{\prime}$ wide, and frequently divided above the middle into 2 or 3 pairs of broad lateral lobes. Flowers about $\frac{3^{\prime}}{4}$ in diameter, on slender tomentose pedicels, in few-flowered simple corymbs; calyx-tube narrowly obconic, thickly coated with long white hairs, the lobes lanceolate, villose on the outer, glabrous on the inner surface, glaudular, with small red glands; stamens 20; anthers small, pale yellow; styles 5 , surrounded at the base by a broad ring of pale tomentum. Fruit ripening 
early in October, on short thick pedicels, in few-fruited drooping or spreading clusters, globose to short-oblong, bright orange-red, marked by occasional dark dots, puberulous at the ends, $\frac{1}{3}^{\prime}-\frac{1}{2}^{\prime}$ in diameter; calyx prominent, with enlarged spreading and appressed lobes; flesh thick, yellow, subacid; nutlets 5, narrowed and acute at the ends, ridged on the back, with a narrow elevated ridge, $\frac{1}{2}^{\prime}$ long.

A tree, $25^{\circ}-30^{\circ}$ high, with a trunk often $14^{\prime}$ or $15^{\prime}$ in diameter, covered with thick dark brown bark deeply divided into narrow interrupted ridges broken on the surface into short thick plate-like scales, heavy ascending or spreading branches forming an open irregular head, and stout zigzag branchlets thickly coated at first with hoary

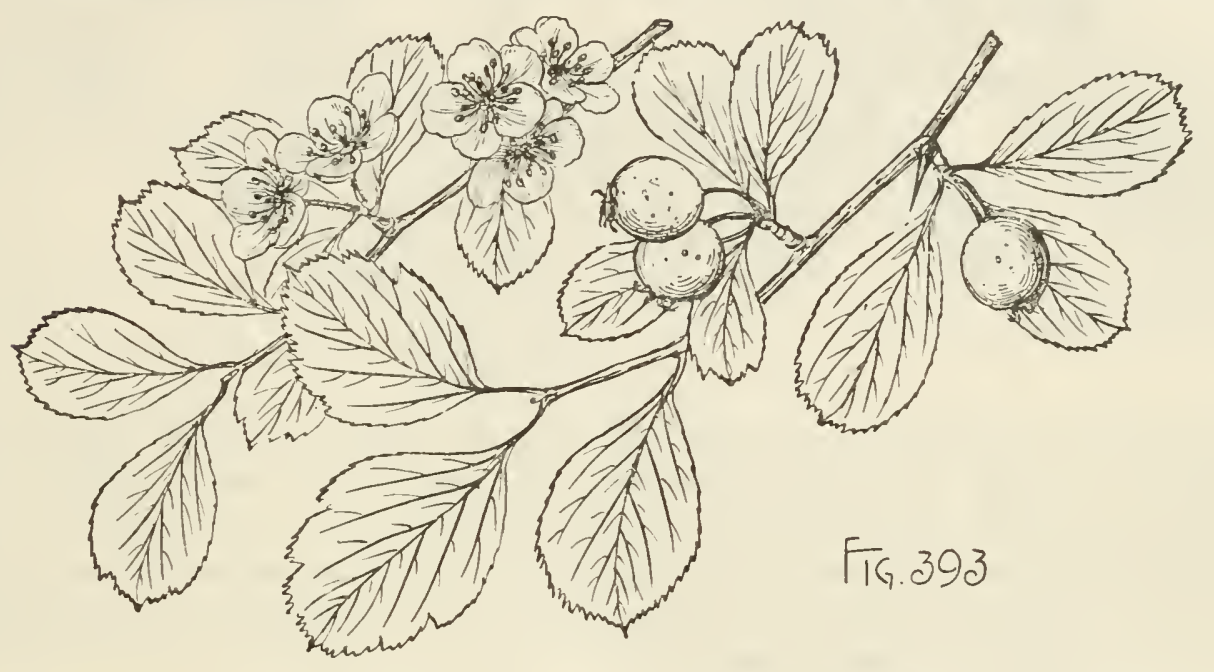

tomentum, dark purple or red-brown and pubescent during their first summer, becoming dark red-brown and glabrous the following season, and armed with thick straight dull gray-brown spines usually about $1_{\frac{1}{2}}^{\prime}$ long.

Distribution. Sand hills near Aiken, South Carolina, and in Summerville near Augusta, Georgia.

\section{Cratægus senta, Beadl.}

Leaves obovate or obovate-cuneiform, acute or sometimes rounded and frequently slightly divided into several short acute lobes at the broad apex, gradually narrowed from above the middle to the entire base, and serrate or doubly serrate above, with incurved conspicuously glandular teeth, when they unfold often dark red, covered above with long pale caducous hairs and villose below along the midribs and veins, nearly fully grown when the flowers open from the 1st to the 10th of May and then bright yellow-green and almost glabrous with the exception of the persistent tufts of pale hairs in the axils of the veins, and at maturity thin but firm in texture, dark green and lustrous above, paler below, usually about $1 \frac{1^{\prime}}{2}$ long and $1^{\prime}$ wide, with orange-colored midribs, generally 3 pairs of slender primary veins extending obliquely to the points of the lobes, and dark conspicuous reticulate veinlets, turning red, yellow, or brown in the autumn; their petioles slender, glandular, wing-margined above, at first tomentose, becoming pubescent or nearly glabrous, about $\frac{3^{\prime}}{4}$ long; on vigorous shoots broadly ovate, often nearly orbicular, more deeply lobed, with broad rounded or acute lobes, $2^{\prime}-2 \frac{1}{2}^{\prime}$ in diameter, their stipules lunate, coarsely glandulardentate, sometimes $\frac{1}{2}^{\prime}$ long. Flowers $\frac{3^{\prime}}{4}$ in diameter, on slender elongated pedicels coated with long matted pale hairs, in lax compound $3-6$-flowered hairy corymbs, 
with lanceolate straight or falcate glandular bracts and bractlets; calyx-tube broadly obconic, villose particularly toward the base, the lobes narrow, elongated, acuminate, nearly glabrous, coarsely and irregularly glandular-serrate; stamens 20 ; styles $3-5$,

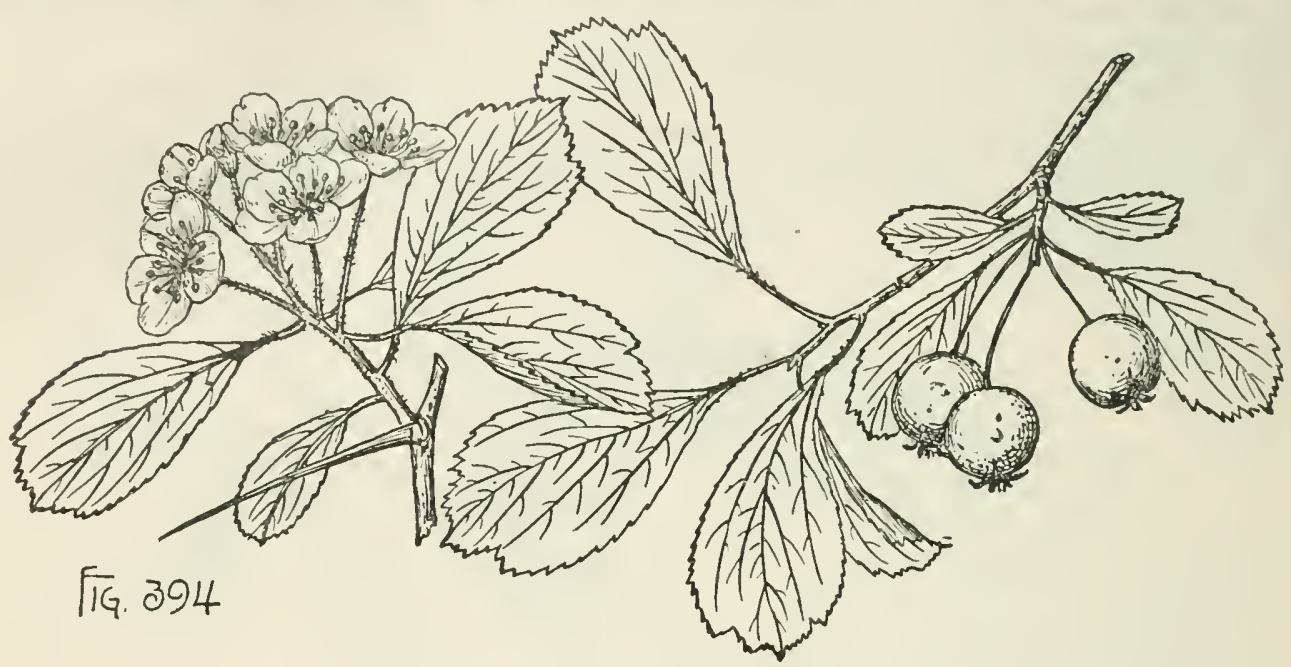

surrounded at the base by a broad ring of hoary tomentum. Fruit ripening and falling at the end of September or early in October, on slender slightly hairy elongated pedicels, in few-fruited drooping clusters, globose, bright red, $\frac{1}{3}^{\prime}-\frac{1}{2}^{\prime}$ in diameter; calyx enlarged, with closely appressed lobes; flesh yellow, dry and mealy; nutlets 3-5, full and rounded at the apex, narrowed and acute at the base, slightly grooved on the back, about $\frac{1^{\prime}}{2}$ long.

Distribution. Abandoned fields and open Pine woods near Asheville, North Carolina, at elevations of about $2200^{\circ}$ above the level of the sea.

\section{Cratægus panda, Beadl.}

Leaves obovate, rounded and short-pointed or abruptly narrowed and acute at the broad occasionally slightly lobed apex, concave-cuneate and glandular at the

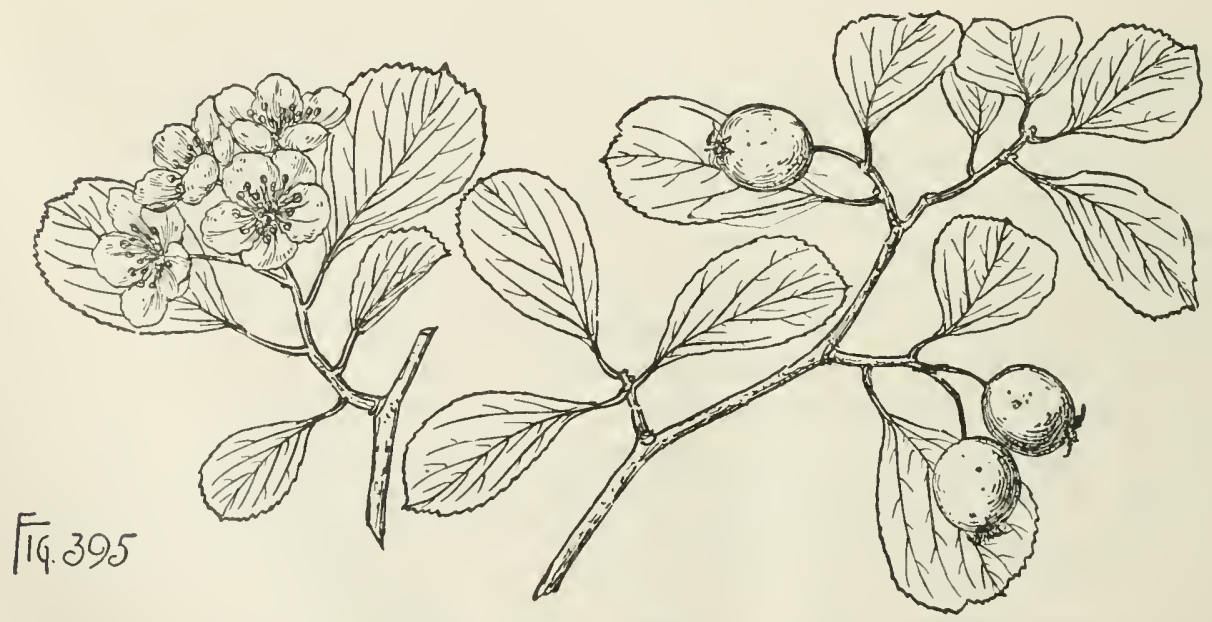

entire base, and finely serrate above, with minute incurved glandular teeth, when they unfold tinged with red and sparingly villose, nearly fully grown when the 
flowers open the 1st of April and then roughened above by short pale rigid hairs and villose above and below on the midribs and on the veins below, and at maturity glabrous, or puberulous on the under surface of the slender midribs, subcoriaceous, light green and lustrous, glandular, $\mathbf{1}^{\prime}-\mathbf{1}_{4}^{\prime}$ long, $\frac{3^{\prime}}{4}-\mathbf{1}^{\prime}$ wide, with slender primary veins extending very obliquely toward the end of the leaf, turning yellow-brown or orange color in the autumn before falling; their petioles slender, slightly wingmargined at the apex, villose at first, becoming glabrous, glandular, about $\frac{3^{\prime}}{8}$ long; on vigorous shoots broadly ovate, rounded, apiculate and lobed at the apex, puberulous and villose along the midribs and veins on the lower surface, often $1 \frac{3^{\prime}}{4}$ long and $2^{\prime}$ wide. Flowers $\frac{5^{\prime}}{8}-\frac{3^{\prime}}{4}$ in diameter, on slender hairy pedicels, in compact $3-5$ flowered simple corymbs; calyx-tube narrowly obconic, covered with matted white hairs, the lobes gradually narrowed from broad bases, acuminate, glandular-serrate, more or less villose; stamens 20 ; anthers nearly white; styles $3-5$, surrounded at the base by a narrow ring of pale hairs. Fruit ripening and falling at the end of August or early in September, on stout pedicels, in erect few-fruited clusters, globose or depressed-globose, orange-yellow, with a red cheek, $\frac{3^{\prime}}{8}-\frac{3^{\prime}}{4}$ in diameter; calyx slightly enlarged, with closely appressed often deciduous lobes; flesh thick, succulent, orangeyellow; nutlets $3-5$, narrowed and acute at the ends, grooved on the rounded back, with a broad shallow groove, about $\frac{1}{4}^{\prime}$ long.

A tree, $20^{\circ}-25^{\circ}$ high, with a trunk sometimes a foot in diameter, covered with dark rough bark, crooked recurved branches forming an open irregular head, and stout branchlets covered at first with matted pale hairs, reddish brown and puberulous during their first season, becoming gray, and unarmed, or occasionally armed with stout spines $\frac{1}{2}^{\prime}-1^{\prime}$ long.

Distribution. Dry sandy soil near Tallahassee, Florida.

\section{Cratægus integra, Beadl.}

Leaves obovate to oblong-obovate, narrowed from near the middle to the acute apex, concave-cuneate and gradually narrowed to the slender base, conspicuously glandular on the entire often slightly undulate margins, nearly half grown when the flowers

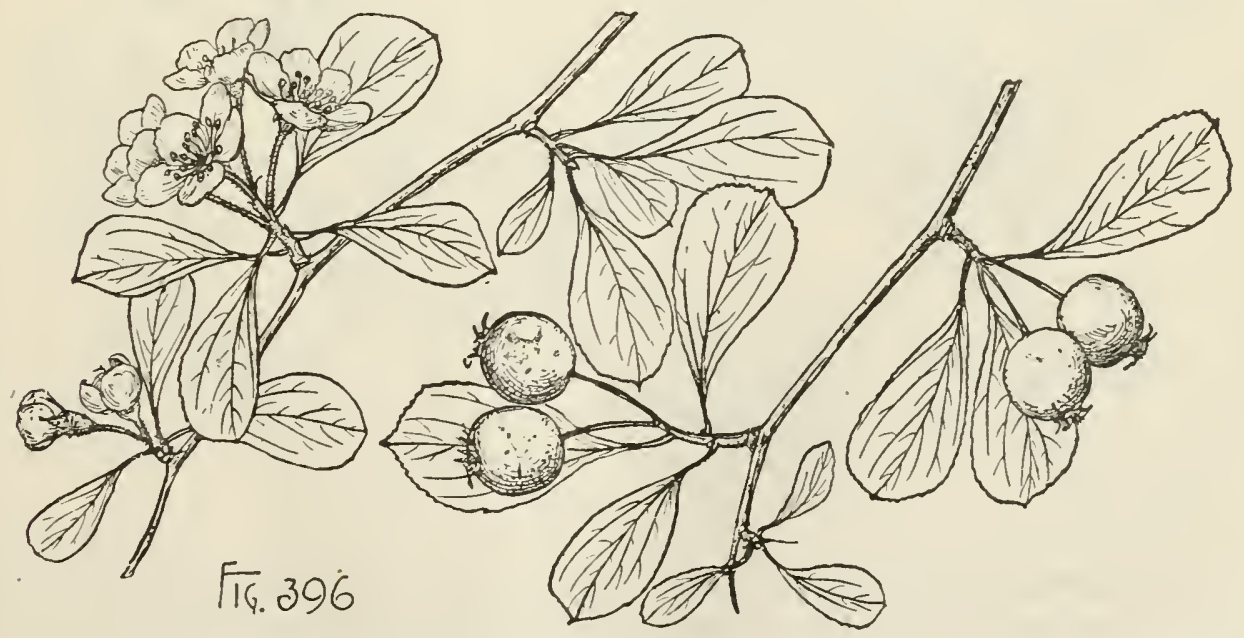

open about the 20th of March, and then slightly hairy along the midribs and on the under side of the veins, and at maturity subcoriaceous, bright green, lustrous, and glabrous above, paler below, $1^{\prime}-1 \frac{1}{4}^{\prime}$ long and about $\frac{3^{\prime}}{4}$ wide, with thin yellow midribs 
puberulous below, slender primary veins extending very obliquely to the end of the leaf, with 1 or 2 pairs near the middle of the blade more prominent than those below and above them, turning in the autumn yellow, orange, and brown; their petioles slender, narrowly wing-margined above, glandular, at first loary-tomentose, becoming pubeseent or puberulous, $\frac{1}{4}-\frac{3}{4}$ 'long; on vigorous shoots broadly obovate, short pointed at the apex, slightly undulate-lobed above the middle, eonspieuously retieulate-venulose, sometimes $1 \frac{1}{2}^{\prime}$ long and broad. Flowers $\frac{5^{\prime}}{8}-\frac{3 \prime}{4}$ in diameter, on slender elongated loary-tomentose pedieels, in 3-5-flowered simple eorymbs; calyxtube narrowly obeonic, thiekly covered with matted white hairs, the lobes gradually narrowed from broad bases, aemminate, glandular, pilose on the outer, sparingly pilose on the inner surface; stamens 20 ; anthers pale yellow; styles $3-5$, surrounded at the base by a thick ring of white hairs. Fruit ripening and falling in August, on slender erect pubescent pedieels, globose, red, about $\frac{1}{2}^{\prime}$ in diameter; ealyx deeiduous; flesh thin, orange-yellow, and succulent; nutlets 3-5, narrowed and aeute at the base, rounded at the apex, flat and grooved on the back, with a narrow shallow groove, about $\frac{5 \prime}{16}$ long.

A tree, $12^{\circ}-15^{\circ}$ high, with a trunk sometimes $8^{\prime}$ in diameter, covered with thiek nearly blaek eheckered bark, drooping branches forming a handsome symmetrieal head, and slender very zigzag branchlets clothed at first with hoary tomentum, rather bright reddish brown and roughened by minute tubereles at the end of their first season, becoming gray or grayish brown, and unarmed, or armed with occasional short slender spines.

Distribution. Sandy woods and abandoned fields; central Florida; common near Eustis.

\section{Cratægus recurva, Beadl.}

Leaves spatulate, rounded or aeute or sometimes obovate and obtusely 3-lobed at the apex, and finely glandular-serrate, with bright red glands, nearly half grown

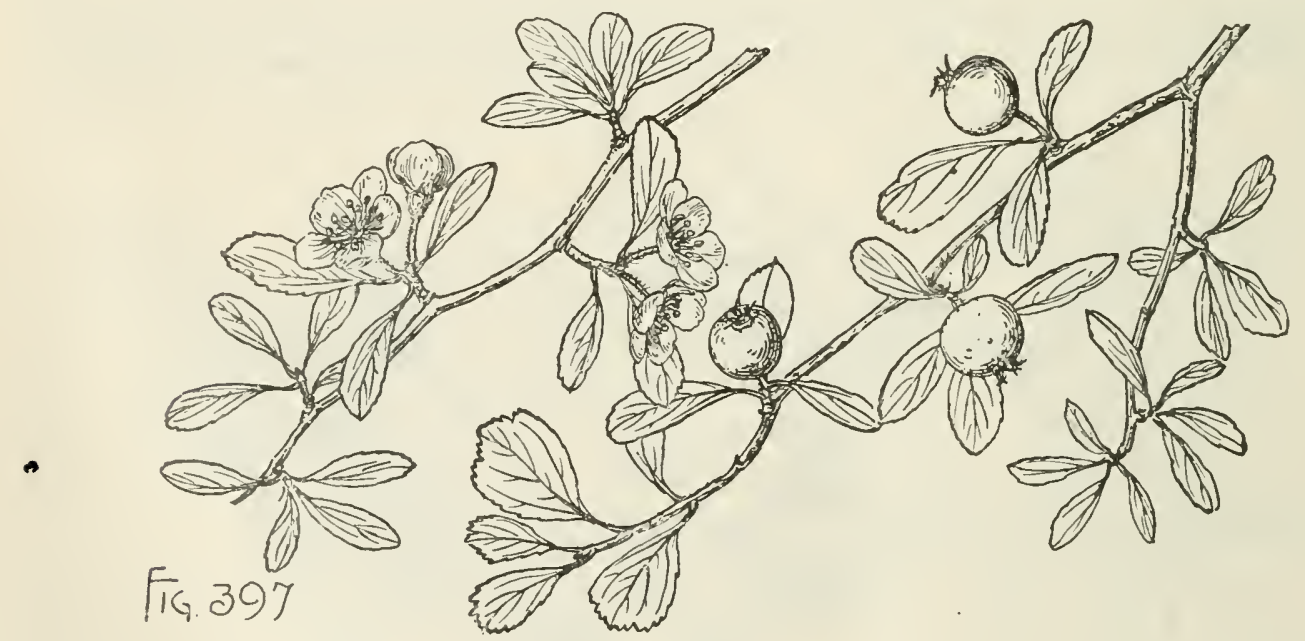

when the flowers open abont the 20th of Mareh and then almost glabrons above, slightly hairy near the base below, and at maturity subcoriaeeous, glabrous, about $\mathbf{1}^{\prime}$ long and $\frac{1}{4}^{\prime}-\frac{1}{2}^{\prime}$ wide, with slender yellow midribs and one pair of veins often more prominent than the others and nearly parallel with the margins of the blade, turning in the autumn yellow, orange, and brown; their petioles slender, conspicuously 
glandular, villose at first, becoming glabrous, $\frac{1^{\prime}}{4}-\frac{1^{\prime}}{2}$ long; on vigorous shoots broadly obovate, deeply divided into narrow lateral ascending rounded lobes, concave-cuneate at the base, with stouter midribs and veins arching to the points of the lobes, and often $\mathbf{1}^{\prime}$ long and $\frac{3^{\prime}}{4}$ wide. Flowers $\frac{1^{\prime}}{2}-\frac{5^{\prime}}{8}$ in diameter, on stout pedicels thickly covered with matted pale hairs, solitary or in 2-flowered simple corymbs; calyx-tube broadly obconic, pilose below, nearly glabrous above, the lobes slender, acuminate, glandularserrate, slightly hairy on the outer, glabrous on the inner surface; stamens 20 ; anthers pale yellow; styles 3-5. Fruit ripening in August, erect on short stout pedicels, pyriform, red, $\frac{1^{\prime}}{2}$ long; calyx little enlarged, often deciduous; flesh thick and soft; nutlets $3-5$, full and rounded at the ends, rounded and obseurely grooved on the back, about $\frac{1^{\prime}}{4}$ long.

A tree, $15^{\circ}-18^{\circ}$ high, with a short trunk $5^{\prime}-6^{\prime}$ in diameter, covered with gray or brownish rough bark, slender pendulous branches forming a broad symmetrical head, and slender very zigzag branchlets, villose at first, becoming bright chestnut-brown and very lustrous and ultimately dark reddish brown, and armed with numerous slender straight spines usually about $\frac{1^{\prime}}{2}$ long.

Distribution. Dry sandy soil, Ocala, Florida.

\section{Cratæegus annosa, Beadl.}

Leaves obovate, oval, or oblanceolate, cuneate and glandular at the base, sharply and often doubly glandular-serrate above, and usually slightly lobed toward the short-pointed acute apex; more than half grown when the flowers open early in

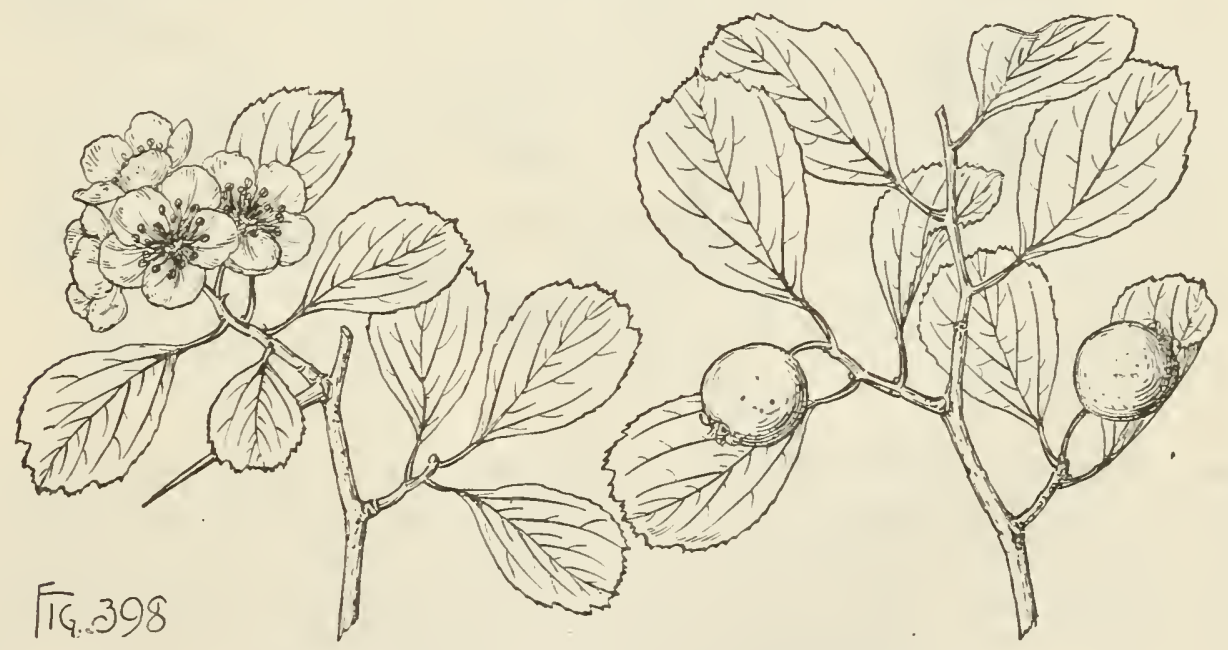

April and then pale yellow-green and scurfy above, with a few slort pale hairs above and below near the base of the midribs, and at maturity thin and firm, bright green, $1^{\prime}-1 \frac{1}{2}$ long and $\frac{3^{\prime}}{4}-1^{\prime}$ wide, with prominent pale yellow midribs, and remote slender veins extending very obliquely to the points of the lobes, turning in the autumn yellow, orange, or brown; their petioles slender, narrowly winged above, conspicuously glandular, with large dark glands, $\frac{1^{\prime}}{2}-{ }^{3}{ }^{\prime}$ long; on vigorous shoots broadly ovate to obovate or suborbicular, coarsely serrate, conspicuously reticulate-venulose, sometimes $2^{\prime}$ long and broad, with broadly winged petioles and foliaceous coarsely dentate persistent stipules often $\frac{3^{\prime}}{4}$ long. Flowers $\frac{3^{\prime}}{4}$ in diameter, on stont villose pedicels, in simple 3-5-flowered villose corymbs; calyx-tube narrowly obconic, sparingly villose toward the base, the lobes acute, glandular-serrate, glabrous on the 
outer, puberulous on the imer surface; stamens 20; anthers almost white; styles 3-5, surronnded at the base by a broad ring of snow-white tomentum. Fruit ripening and falling late in August or carly in September, subglobose or oval, orange-red or red and orange, about $\frac{1}{2}$ long; calyx little enlarged, the lobes puberulous on the npper side and reflexed; Hesh thick and soft; nutlets 3-5, full and rounded at the base, narrowed and rounded at the apex, rounded and ridged on the back, with a broad low rounded ridge, abont $\frac{5^{\prime}}{16}$ long and $\frac{3{ }^{\prime}}{16}$ wide.

A trec, $20^{\circ}-25^{\circ}$ high, with a trunk sometimes a foot in diameter, covered with dark rough often black bark, stout spreading or ascending branches, and thick dnll red-brown ultimately dark gray or nearly black branchlets armed with straight rather stout spines $\mathbf{1}^{\prime}-\mathbf{1}_{2}^{\prime}{ }^{\prime}$ long.

Distribution. Eastern central Alabama; common near Phœnix and Gerard.

\section{Cratægus dispar, Beadl.}

Leaves broadly ovate or orbicular, 3-nerved, acute or rounded at the apex, generally narrowed and cmeate or concave-cuneate at the glandular entire base, serrate or doubly serrate above, with straight or incurved glandular teeth, and mostly divided

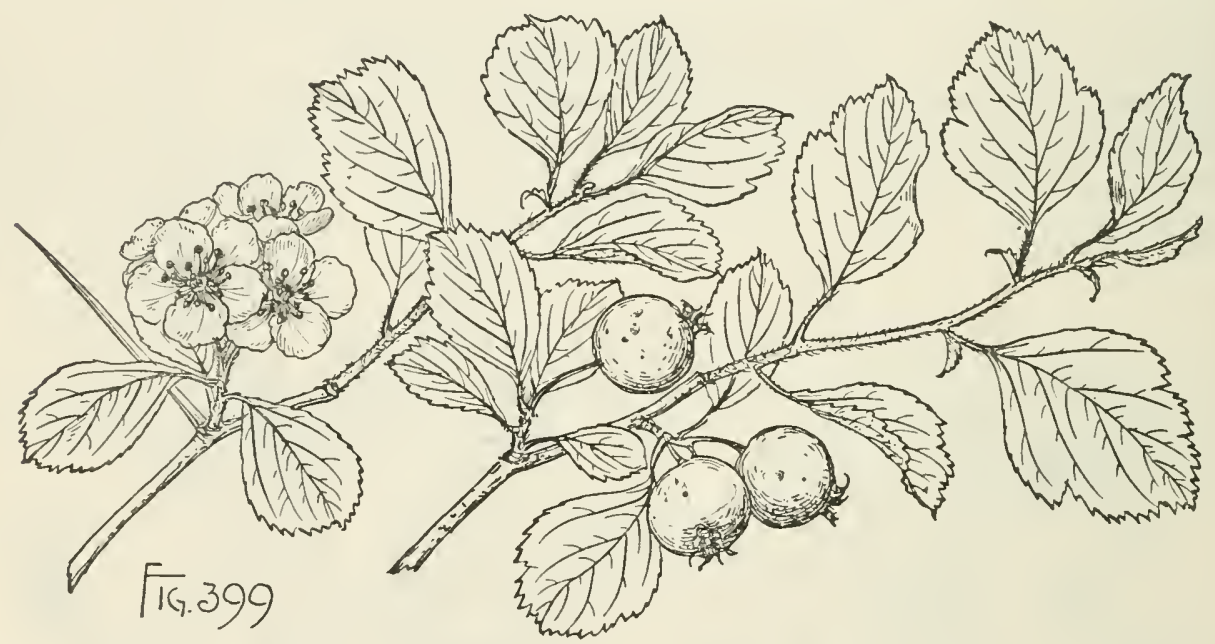

above the middle into short acute lobes, when they unfold coated with long matted white hairs most abundant on the lower surface, more than half grown when the flowers open abont the middle of April and then blue-green and villose above and tomentose below, and at maturity thin but firm in texture, blue-green and glabrous on the upper surface, pale and slightly pubescent on the lower surface, usually about $\mathbf{1}^{\prime}$ long and $\frac{3^{\prime}}{4}-\mathbf{1}^{\prime}$ wide, turning red, yellow, or brown in the autumn; their petioles slender, tomentose, becoming pubescent or villose, glandular, slightly wingmargined above, usually about $\frac{1^{\prime}}{3}$ long; stipules lunate, coarsely glandnlar-serrate, $\frac{1}{16}-\frac{1}{3}$ ' long, caducous; on vigorous shoots broadly ovate or suborbicular, full and rounded at the broad base, coarsely serrate, and often deeply divided above the middle into 3 wide acute lobes broader than long. Flowers about $\frac{5 \prime}{8}$ in diameter, on slender hoary-tomentose pedicels, in simple 3-7-flowered corymbs, with narrow obovate acnte glandular bracts and bractlets; calyx-tube narrowly obconic, coated with hoary tomentum, the lobes narrow, acute, glandular-serrate, with minute bright red glands, tomentose on the nuter surface below the middle, glabrous above, tomentose on the inner surface; stamens 20 ; styles $3-5$, surrounded at the base by a ring 
of pale tomentum. Fruit ripening late in August or early in September, on slender pubescent pedicels, in few-fruited clusters, subglobose to short-oblong, light red, puberulous toward the ends, about $\frac{1}{3}$ in diameter; calyx prominent, with reflexed closely appressed lobes tomentose at the base; flesh thin, yellow, subacid; nutlets $3-5$, broad, rounded at the ends, ridged on the back, with a broad low ridge, dark brown, $\frac{1}{4}^{\prime}$ long.

A tree, $20^{\circ}-25^{\circ}$ high, with a short trunk a foot in diameter, heavy ascending branches forming a broad irregular head, and stout zigzag branchlets at first hoarytomentose, dark red-brown and pubescent during their first summer, becoming darker colored and glabrous the following seasoll, and armed with thick or thin nearly straight dark red-brown ultimately gray spines $1 \frac{1^{\prime}}{2}-2^{\prime}$ long.

Distribution. Dry sand hills near Aiken and Trenton, South Carolina, and abundant at Summerville, near Augusta, Georgia.

** Stamens 10 ; anthers yellow.

\section{Cratægus aprica, Beadl.}

Leaves broadly obovate, oval, or rhomboidal, acute and short-pointed or rounded and often somewhat lobed at the apex, gradually or abruptly narrowed and cuneate at the entire base, and serrate usually only above the middle, with small incurved teeth terminating in conspicuous rose-colored ultimately dark red persistent glands, when they unfold deep orange color, roughened above by short pale appressed hairs and sparingly villose below, particularly along the slender midribs and remote primary veins, nearly fully grown when the flowers open about the 10th of May, and at maturity thick and firm, glabrous, very smooth, dark yellow-green on the upper surface, paler on the lower surface, $1^{\prime}-11^{\prime}$ long, and $1^{\prime}$ wide; their petioles stout, conspicuously

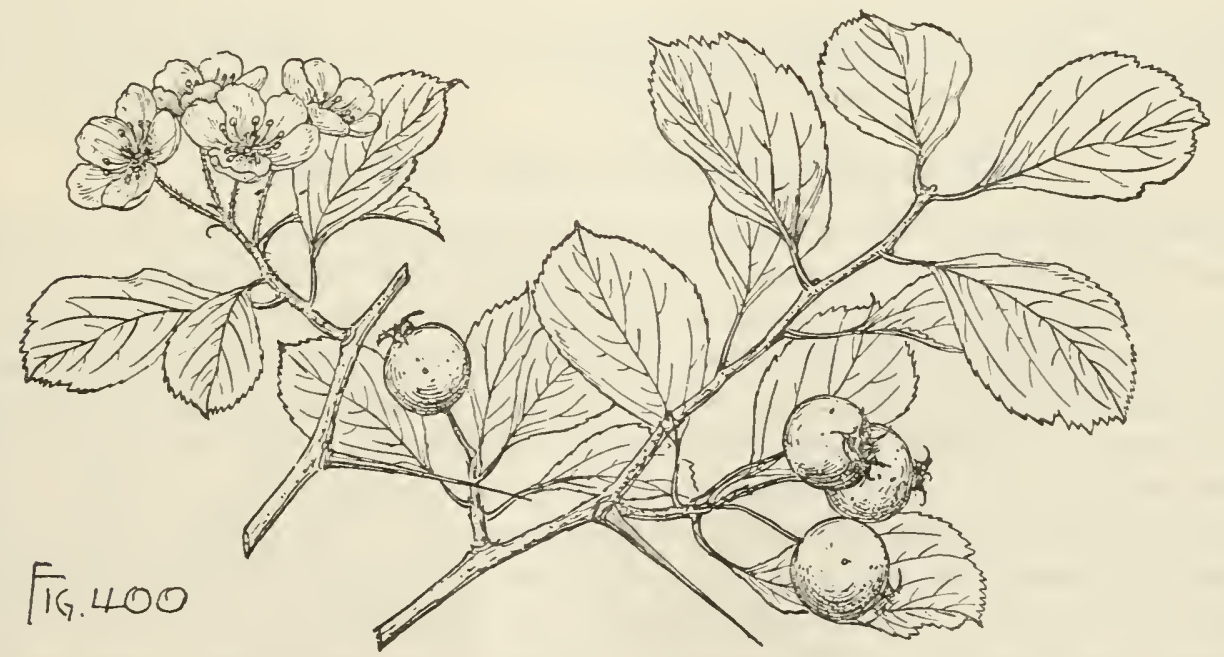

glandular, more or less winged toward the apex, at first villose, ultimately nearly glabrous, usually bright red on the lower side toward the base after midsummer, about $\frac{1^{\prime}}{2}$ long; on vigorous shoots often nearly orbicular, frequently more deeply lobed, $1 \frac{1}{2}-2^{\prime}$ long and wide, with stout broad-margined petioles, and foliaceous lunate stipules. Flowers $\frac{3 \prime}{4}$ in diameter, on slender villose pedicels, in small 3-6-flowered compact simple corymbs; calyx-tube broadly obconic, villose at the base, glabrous 
above, the lobes gradually narrowed from broad bases, acuminate, glabrous, eoarsely glandular-serrate; stamens 10; anthers small, bright yellow; styles $3-5$, surrounded at the base by a narrow ring of pale hairs. Fruit ripening late in the autumn, on stout glabrous or slightly villose pedieels, in ereet or drooping usually 2 or 3 -fruited eluster's, subglobose, rarely rather longer than broad, about $\frac{11}{2}$ in diameter, dull orange-red, often slightly villose at the ends, marked by mumerous small dark dots; ealyx much enlarged, with a broad prominent deep tube and wide-spreading coarsely glandular aeuminate lobes bright red at the base on the upper side; flesh thin, light yellow, sweet and rather juicy; nutlets $3-5$, full and rounded at the ends, rounded and ridged on the baek, with a broad low ridge, about $\frac{1^{\prime}}{4}$ long.

A tree, oecasionally $20^{\circ}$ high, with a stem $6^{\prime}-8^{\prime}$ in diameter, eovered with deeply furrowed dark gray bark broken irregularly into small persistent plate-like scales, and beeoming on old stems often nearly black, spreading of ten elongated contorted branches forming a broad open liead, and slender zigzag branchlets at first dark green tinged with red and villose, soon becoming nearly glabrous, light orangebrown at midsummer, dark reddish brown or purple before winter, and ultimately ashy gray, and armed with thin nearly straight chestnut-brown spines $1^{\prime}-1 \frac{1}{2}^{\prime}$ long; or frequently a mueh-branched shrub, with several stout spreading stems.

Distribution. Dry woods in the foothill region of the southern Appalachian Mountains; sonthwestern Virginia throngh western North Carolina to eastern Tennessee, northern Georgia and Alabama, usually at elevations between $1500^{\circ}$ and $3500^{\circ}$ above the sea; common.

\section{MICROCARP王.}

Fruit short-oblong; leaves orbicular to broadly ovate, pinnately 5-7-cleft.

116. C. apiifolia (C).

Fruit subglobose.

Leaves broadly ovate to triangular, long-stalked.

Leaves spatulate to oblanceolate, short-stalked.

117. C. cordata $(A, C)$. 118. C. spathulata (C).

\section{Cratægus apiifolia, Michx. Parsley Haw.}

Leaves broadly ovate to orbicular, acute, truneate, slightly cordate, or wedgeshaped at the broad base, and pinnately 5-7-eleft, witl shallow acute or deep wide sinuses, and incisely lobed broad or acute segments serrate toward the apex, with spreading glandular teetl, when they unfold pilose above, with long pale hairs, and mostly glabrous below, fully grown when the flowers open late in March or early in April, and at maturity membranaeeous, bright green and rather lnstrous above, paler and glabrous or pilose below along the prominent midribs and primary veins, or on occasional plants pubescent on both surfaees, $\frac{2}{3}^{\prime}-1_{\frac{1}{2}}^{\prime}$ broad; their petioles slender, pubeseent, beeoming glabrous, $\mathbf{1}^{\prime}-\mathbf{1}^{\prime}{ }^{\prime}$ long; on vigorous shoots often divided nearly to the midrib, with foliaceous lunate coarsely glandular-serrate short-stalked stipules sometimes $\frac{1}{2}^{\prime}$ long. Flowers $\frac{1}{2}^{\prime}$ in diameter, on long slender hairy pedieels, in erowded densely villose compound usually 10-12-flowered corymbs; calyx-tube narrowly obeonic, glabrous or covered with long matted pale hairs, the lobes lanceolate, acute, glabrous, usually glandular-serrate, often tinged with red toward the apex; stamens 20; anthers bright rose eolor; styles 1-3. Fruit ripening in October and persistent on the branches until the beginning of winter, oblong, bright scarlet, $\frac{1}{3}$ ' long; ealyx prominent, the lobes elongated, reflexed, often deciduous from the 
ripe fruit; flesh thin; nutlets $1-3$, full and ronnded at the ends, rounded and prominently ridged and grooved on the back, about $\frac{1}{3}^{\prime}$ long.

A tree, occasionally $20^{\circ}$ high, with a trunk rarely $6^{\prime}-8^{\prime}$ in diameter, branches spreading nearly at right angles and forming a wide irregular open head, and slender

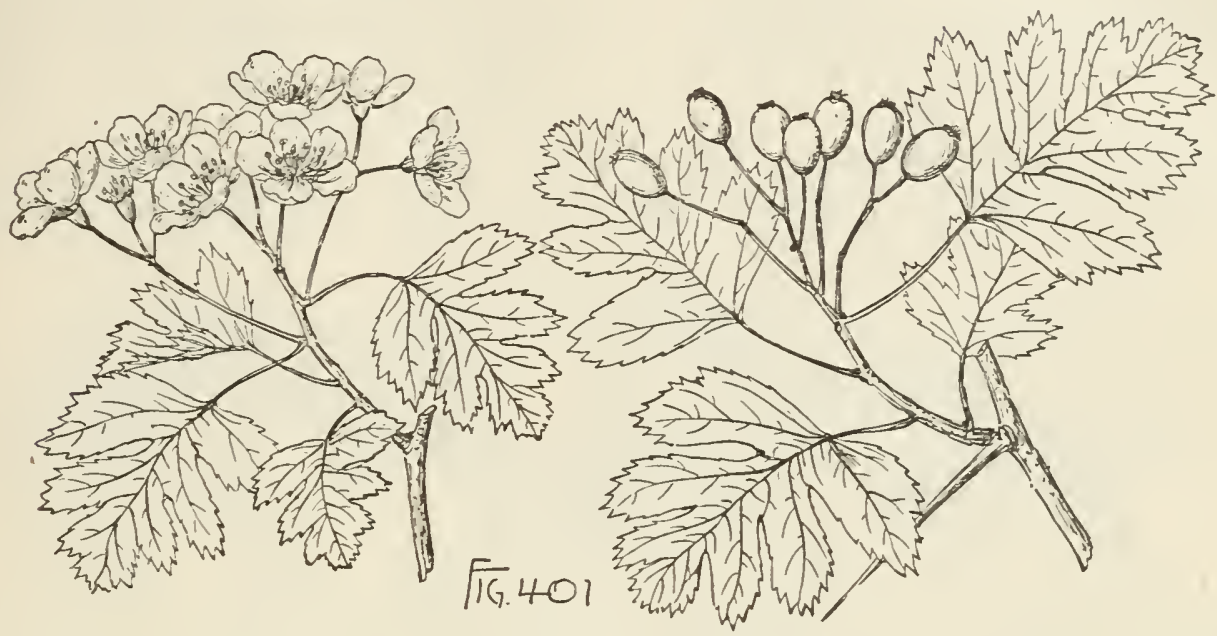

more or less zigzag often contorted branchlets covered at first with long pale hairs, light red or pale orange-brown and usually puberulous in their first winter, ultimately light brown or ashy gray, and armed with stout straight chestnut-brown spines $1^{\prime}-1 \frac{1}{2}^{\prime}$ long.

Distribution. Borders of streams and swamps or on hummocks in Pine barrens through the coast region of the south Atlantic states from southern Virginia to central Florida, and westward to southern Arkansas and the valley of the Trinity River, Texas; most abundant and of its largest size in southern Arkansas and western Louisiana.

\section{Cratægus cordata, Ait. Washington Thorn.}

Leaves broadly ovate to triangular, acute or acuminate, truncate, slightly wedgeshaped, rounded or cordate at the entire base, and coarsely serrate above, with acute spreading often gland-tipped teeth, and more or less incisely lobed, or often 3-lobed, tinged with red when they unfold and sparingly pilose above, with long pale caducous hairs, fully grown when the flowers open at the end of May, and at maturity thin but firm, dark green and lustrous above, pale below, or rarely pubescent on the lower surface, especially on the conspicuous orange-colored midribs and primary veins, $1 \frac{1}{2}^{\prime}-2^{\prime}$ long, $1^{\prime}-1 \frac{1}{2}^{\prime}$ wide, turning late in the autumn bright scarlet and orange; their petioles slender, terete, glabrous, $\frac{3^{\prime}}{4}-1 \frac{1}{2}^{\prime}$ long. Flowers on slender pedicels, in rather compact many-flowered glabrous corymbs; calyx-tube broadly obconic, glabrous, the lobes short, nearly triangular, entire, abruptly contracted at the apex into minute points, glabrous on the outer, pubescent on the inner surface, ciliate on the margins; stamens 20; anthers rose color; styles 2-5, surrounded at the base by conspicuous tufts of pale hairs. Fruit ripening in September and October and persistent on the branches until late in the spring of the following year, depressed-globose, scarlet, lustrous, $\frac{1}{4}^{\prime}$ in diameter; calyx deciduons from the ripe fruit, leaving a wide circular scar surrounding the persistent erect tips of the carpels; 
nutlets 3-5, narrowed and acute at the base, full and rounded at the apex, rounded and obscurely ridged on the back, about $\frac{1}{8}$ long.

A tree, $20^{\circ}-30^{\circ}$ high, with a straight trunk sometimes a foot in dianeter, generally dividing $4^{\circ}-5^{\circ}$ above the ground into slender usually upright branches forming an oblong or occasionally round-topped head, slender zigzag glabrous bright chestuntbrown lustrous branchlets, becoming dark gray or reddish brown, and armed with slender sliarp spines $1 \frac{1}{2}-2^{\prime}$ long; often much smaller and sometimes a broad spreading bush.

Distribution. Banks of streams in rich soil; valley of the upper Potomac River, Virginia, southward in the foothill region of the Appalachian Mountains to northern

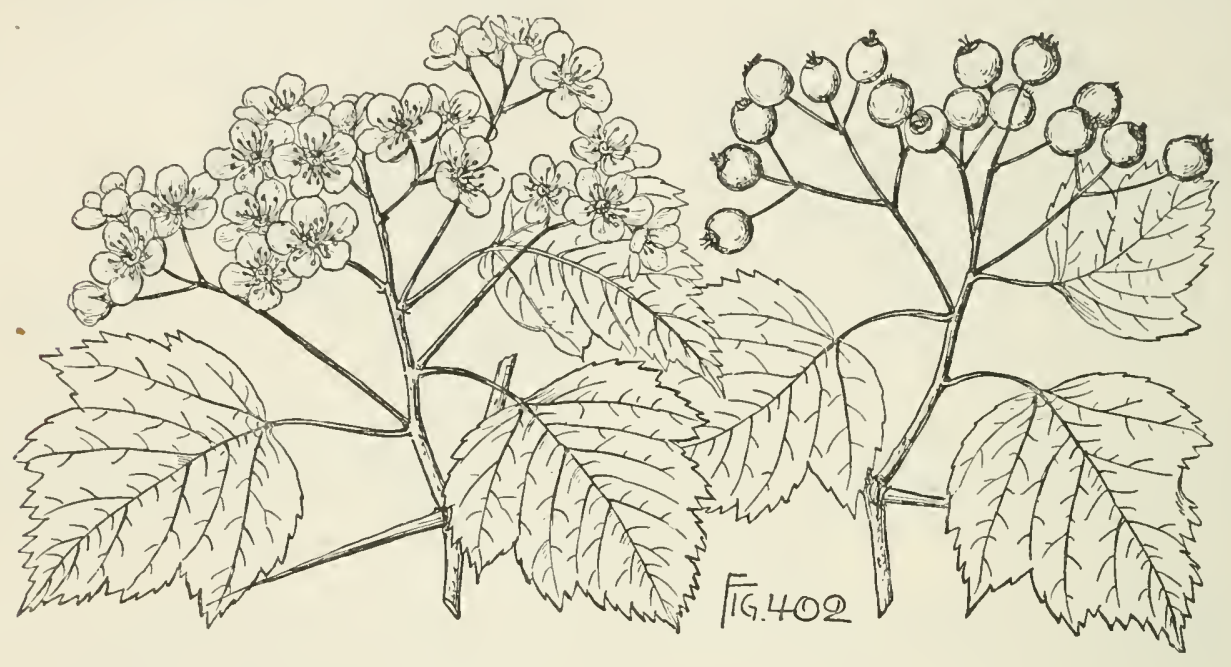

Georgia and Alabama, and westward through middle Temnessee and Kentucky to the valley of the lower Wabash River, Illinois, Osage, Missouri, and southeastern Missouri to northwestern Arkansas; nowhere common.

Often cultivated in the eastern states and in western Europe; hardy as far north as eastern Massachusetts.

\section{Cratægus spathulata, Michx.}

Leaves spatulate to oblanceolate, rounded or acuminate and sometimes 3-lobed at the apex, gradually narrowed from above the middle to the slender concavecuneate entire base, and crenately serrate above, nearly fully grown when the flowers open from March to May and then sparingly villose above, with long white caducons hairs, and at maturity subcoriaceous, glabrous, dark green and lustrous above, paler below, reticulate-venulose, with obscure yellow midribs and primary veins, $1^{\prime}-2^{\prime}$ long, $1^{\prime}-1 \frac{1^{\prime}}{2}$ wide, and clustered at the ends of short lateral branchlets; their petioles slender, wing-margined to the base, $\frac{1}{8}^{\prime}-\frac{1}{4}^{\prime}$ long; on vigorous shoots often deeply 3 -lobed above the middle, with rounded coarscly crenately serrate lobes, narrowed below into long winged petioles, $1^{\prime}-2^{\prime}$ long, and $1^{\prime}-1 \frac{1}{2}^{\prime}$ wide, with broad thick midribs often pilose on the lower surface, their stipules foliaceous, lunate, sharply serrate, stalked, often $\frac{1}{2}^{\prime}$ broad. Flowers, $\frac{1}{2}^{\prime}$ in diameter, on long slender pedicels, in glabrous many-flowered narrow compound corymbs; calyx-tube broadly obconic, glabrous, the lobes short, nearly triangular, almost entire, minutely glandnlar-apiculate; stamens 20; anthers bright rose color; styles 2-5. Fruit ripening in 
October, subglobose, bright scarlet, lustrous, about $\frac{1}{8}^{\prime}$ in diameter; calyx only slightly enlarged, wi reflexed lobes; flesh thin, dry and mealy; nutlets $3-\tilde{b}$, full

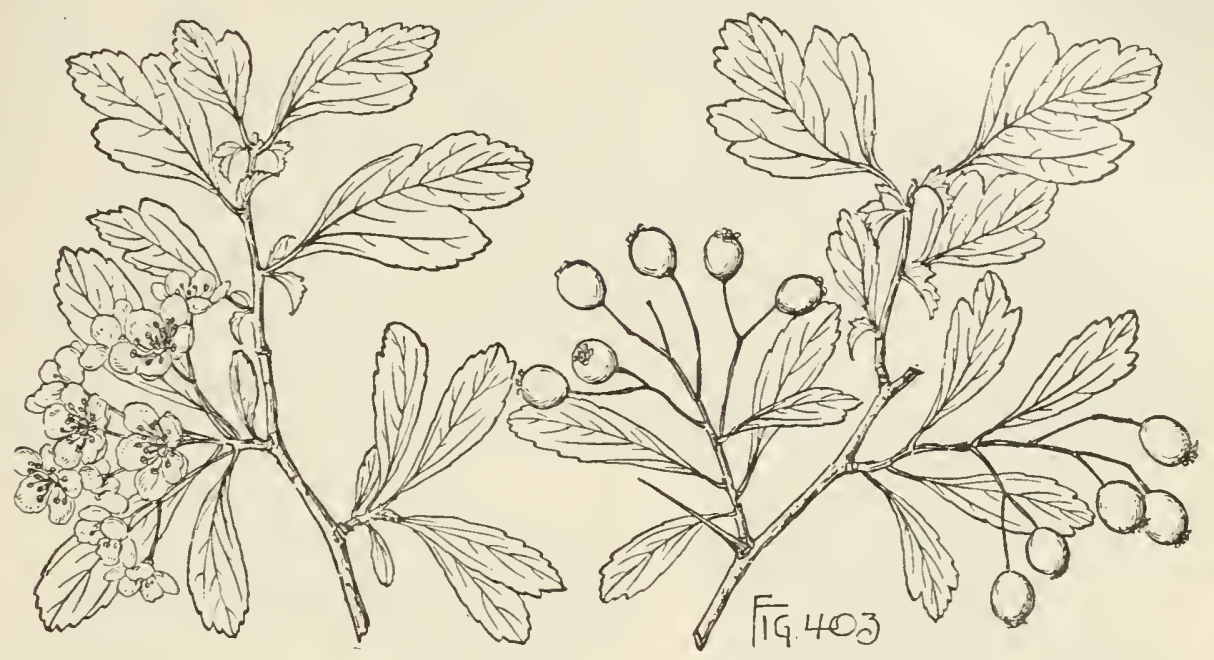

and rounded at the apex, narrowed at the base, rounded and sometimes slightly ridged on the back, $\frac{1}{16}^{\prime}-\frac{1}{8}^{\prime}$ long.

A tree, $18^{\circ}-25^{\circ}$ high, with a straight trunk occasionally $8^{\prime}-10^{\prime}$ in diameter, slender upright and spreading branches forming a broad open head, and thin zigzag glabrous light reddish brown branchlets, unarmed, or armed with straight stout light brown spines $1^{\prime}-1 \frac{1}{2}^{\prime}$ long; more often a shrub, with numerous spreading stems.

Distribution. Rich soil usually near the banks of streams or swamps, or low depressions in Pine forests; coast region of the south Atlantic states from southern Virginia to northern Florida, and through the Gulf states to the valleys of the Washita River, Arkansas, and of the Colorado River, Texas; very abundant and of its largest size on the bottom-lands of western Louisiana, eastern Texas, and southern Arkansas.

\section{BRACHYACANTHÆ.}

Leaves lanceolate-oblong to ovate or rhomboidal; ovate to nearly triangular on vigorous shoots; fruit subglobose to obovate, bright blue covered with a glancous bloom.

119. C. brachyacantha (C).

Leaves narrowly rhomboidal to oral; lanceolate-acuminate on vigorous shoots; fruit globose, blue-black, very lustrous.

120. C. saligna (F).

\section{Cratægus brachyacantha, Sarg. \& Engelm. Pomette Bleue.}

Leaves lanceolate-oblong to ovate or rhomboidal, acute or rounded at the apex, gradually narrowed to the concave-cuneate entire base, crenulate-serrate above, with minute incurved glaudular teeth, slightly puberulous when they unfold on the upper and glabrous on the under surface, nearly fully grown when the flowers open at the end of April and early in May, and at maturity subcoriaceous, glabrous, dark green and lustrous, $1^{\prime}-2^{\prime}$ long, $\frac{1}{2}^{\prime}$ to nearly $1^{\prime}$ wide, with thin inconspicuous midribs and veins; their petioles slender, narrowly wing-margined above, $\frac{1}{2}^{\prime}-\frac{3^{\prime}}{4}$ long, on vigorous shoots sometimes broadly ovate or almost triangular, wedge-shaped, truncate, or heart-shaped at the broad base, more or less deeply lobed, frequently $2 \frac{1}{2}^{\prime}$ long and $2^{\prime}$ wide, with foliaceous broadly ovate to triangular acute stalked stipules sometimes $\mathbf{1}^{\prime}$ 
long. Flowers $\frac{1^{\prime}}{3}$ in diameter, on slender pediecls, in erowded glabrons many-flowered eompound corymbs; calyx-tube narrowly obconic, glabrous, the lobes short, nearly triangnlar, gradually narrowed to the gland-tipped apex, cntire; petals turning bright orangc eolor in fading; stamens $15-20$; styles $3-5$. Fruit ripening and falling the middle of Angnst, on slender erect pediecls, in few-fruited elusters, subglobose or rarely obovate, bright blue covered with a glaneous bloom, $\frac{\lambda^{\prime}}{3}-\frac{1}{2}$ in diameter; calyx slightly cularged, with spreading lobes; flesh thin; nutlets 3-5, narrowed and acute at the base, full and rounded at the apex, rounded and slightly grooved on the back, about $\frac{1^{\prime}}{4}$ long.

A tree, $40^{\circ}-50^{\circ}$ high, with a tall trunk $18^{\prime}-20^{\prime}$ in diameter, eovered with thiek dark brown decply furrowed sealy bark, and divided nsually $5^{\circ}-10^{\circ}$ from the ground into stont spreading light gray branehes forming a broad compact round-topped head, and branehlets light green and slightly pubescent at first, soon beeoming
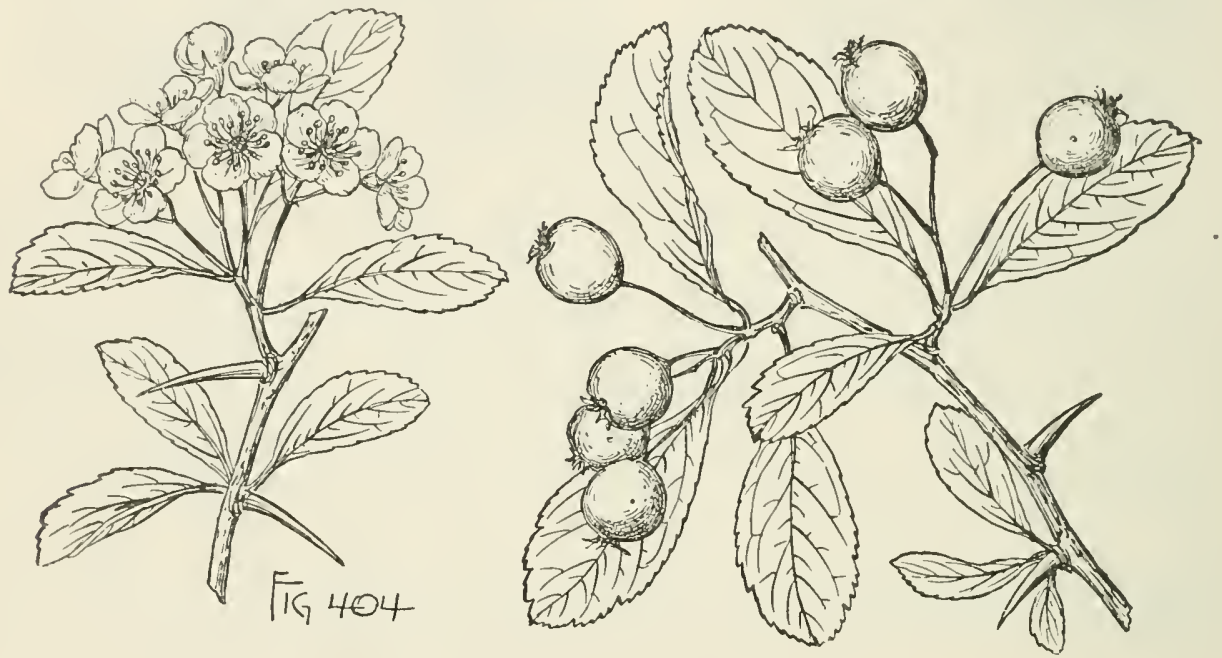

glabrous and pale red-brown and ultimately ashy gray, and armed with numerous short stout generally eurved or sometimes straight slender spines $\frac{1}{3}^{\prime}-2^{\prime}$ long and often terminal also on the lateral branehlets of vigorous shoots.

Distribution. Borders of streams in rich moist soil; Texarkana, sonthern Arkansas, throngh western Louisiana to the valley of the Sabine River, Texas; in the neighborhood of Opelousas, Lonisiana, surrounding with dense groves low wet prairies, and a conspienous and beautiful feature of the arboreseent vegetation.

\section{Cratægus saligna, Greene.}

Leaves narrowly rhombic to oval, gradually narrowed at the ends, aeute or acuminate and apiculate at the apex, entire toward the base, finely serrate above, with incurved teeth tipped with minute bright red glands, nearly fully grown when the flowers open toward the middle of June, light yellow-green, covered above with short pale hairs and pale and glabrous below, and at maturity thick and firm, dark green, glabrous and lustrous above, pale below, $1 \frac{1}{2}^{\prime}-2^{\prime}$ long and $\frac{3^{\prime}}{4}-1^{\prime}$ wide, with stout midribs rose color on the upper side, dark obseure forked vcins, and reticulate veinlets, turning late in the autımn to brilliant shades of orange and bright searlet; their petioles slender, about $\frac{1}{3}^{\prime}$ long and glandular near the base, with 2 or 3 large stipitate dark red cadueons glands; on vigorous leading shoots laneeolate, aeuminate, 
coarsely serrate, often irregularly and deeply divided into 2 or 3 acute lateral lobes, $3^{\prime}-3 \frac{1^{\prime}}{2}$ long and $1 \frac{1}{4}^{\prime}-1 \frac{1}{2}^{\prime}$ wide, their stipules often $\frac{3^{\prime}}{4}$ long. Flowers about $\frac{5^{\prime}}{8}$ in diameter, on short slender pedicels, in compact glabrous few or many-flowered

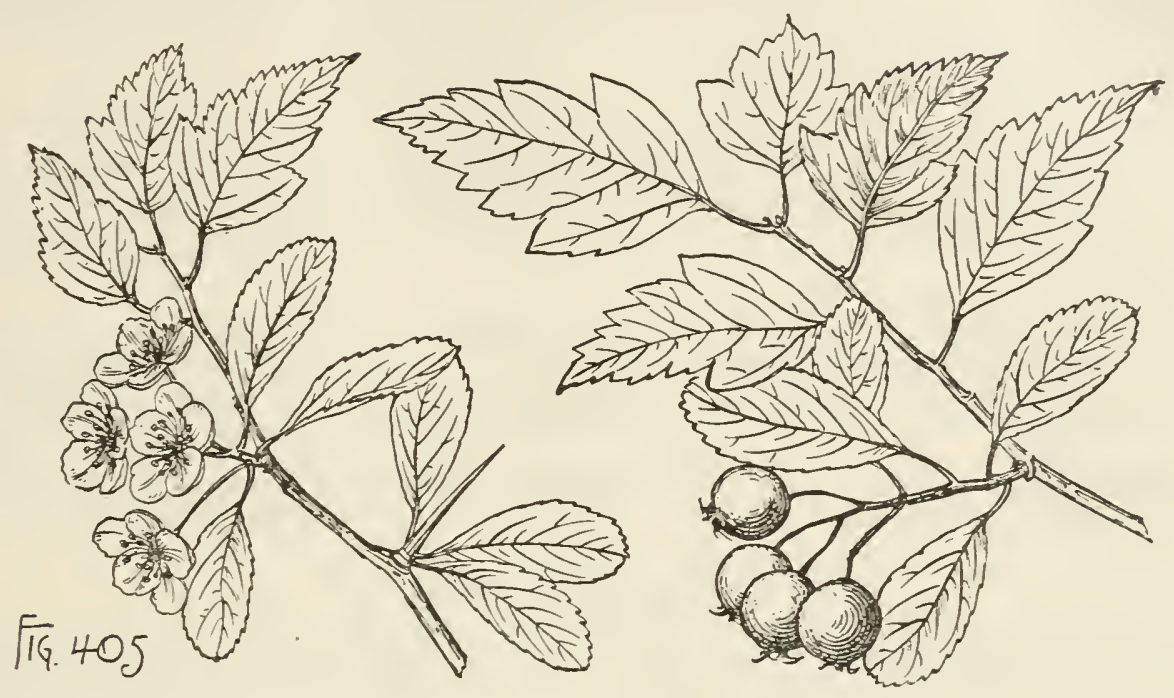

compound corynibs; calyx-tube glabrous, the lobes nearly triangular, entire, often briglit red toward the apex; stamens 20; anthers small, yellow; styles 5. Fruit ripening toward the end of September, on stout pedicels, in compact drooping clusters, globose, $\frac{1^{\prime}}{4}$ in diameter, dull vinous red and very lustrous when fully grown, ultimately blue-black; calyx small, with reflexed persistent lobes; flesh thin, yellow, dry and sweet; nutlets 5, thick, rounded and slightly ridged on the back, $\frac{1^{\prime}}{8}-\frac{3}{16}$ long.

A tree, occasionally $20^{\circ}$ high, with a short stem, and long slender spreading branches gracefully drooping at the ends, covered with bright red or reddish brown bark, separating on old trunks near the ground into long slightly attached narrow plate-like gray scales, and slender glabrous bright red lustrous branchlets armed with numerous straight slender spines $\frac{3^{\prime}}{4}-1 \frac{1}{2}^{\prime}$ long; of ten forming clumps or small thickets with numerous stems $8^{\circ}-15^{\circ}$ tall springing from a single root.

Distribution. Banks of the Cimmaron, Gunnison, White, and other Colorado streams on both slopes of the continental divide at elevations of $6000^{\circ}-8000^{\circ}$ above the sea.

\section{TOMENTOS丑.}

Leaves thin, with midribs and veins only slightly impressed on their upper surface; anthers rose color or red.

Mature leaves pale pubescent below.

Leaves ovate to ovate-oblong; fruit in erect clusters, pear-shaped, orange-red; stamens 20 .

121. C. tomentosa $(\mathrm{A}, \mathrm{C})$.

Leaves ovate, oval, or obovate, in drooping clusters, globose to subglobose, bright red; stamens 10.

122. C. Chapmani (A, C).

Mature leaves glabrous (slightly pubescent on the midribs and veins below in 129).

Stamens 20.

Leaves elliptical to suborbicular, smooth above; fruit in drooping clusters, subglobose to short-oblong.

123. C. Gaultii (A). 
Leaves elliptical, scabrate above; fruit in erect clusters, subglobose.

124. C. vegeta (A).

Stamens 10 ; leaves ovate, scabrate above; fruit short-oblong.

125. C. Deweyana (A).

Leaves subcoriaceous to coriaceous, with midribs and veins deeply impressed on their upper surface and pubescent below.

Authers rose color.

Stamens 20.

Leaves elliptical, acnte at the ends; fruit globose.

126. C. succulenta (A).

Leaves broadly oval or obovate; fruit subglobose to short-oblong.

Stamens 10.

127. C. gemmosa (A).

Leaves broadly obovate or oval; fruit globose, villose at the ends; calyx-lobes coarsely glandular-serrate.

128. C. Illinoiensis (A).

Leaves broadly obovate to oval or rhomboidal; fruit subglobose; calyx-lobes entire.

129. C. integriloba (A).

Anthers yellow; stamens 10 ; leaves broadly obovate to elliptical or oval ; fruit in erect clusters, globose.

130. C. macracantha (A).

\section{Cratægus tomentosa, $\mathbf{L}$.}

Leaves ovate to ovate-obloug, acute, abruptly acuminate or rarely rounded at the apex, gradually narrowed to the cmeate entire base, sharply and usually doubly serrate above, with broad spreading often glandular teeth, and often divided above the middle into several short lateral lobes, nearly fully grown when the flowers open from the 1st to the middle of June, and at maturity thin but firm in texture, graygreen, coated below with pale persistent pubescence, puberulous or ultimately glabrous above, conspicuously reticulate-venulose, $2^{\prime}-5^{\prime}$ long, $1^{\prime}-3^{\prime}$ wide, with broad

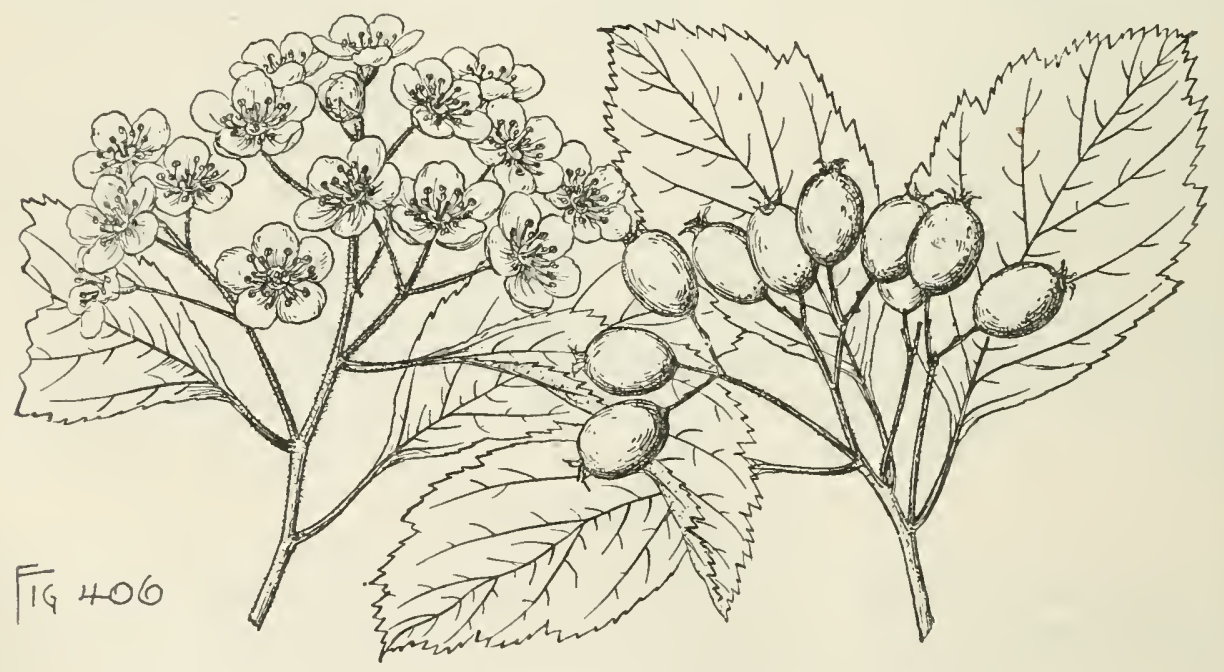

midribs and primary veins, turning brilliant orange and scarlet in the autumu before falling; their petioles stont, glandular, wing-margined, $\frac{1}{2}^{\prime}-\frac{3}{4}^{\prime}$ long. Flowers $\frac{1^{\prime}}{2}$ in diameter, on slender villose pedicels, in broad compound many-flowered villose corymbs; calyx-tube obconic, hoary-tomentose, the lobes lanceolate, acute, coarsely or pinnately serrate, usually glandular; stamens 20 ; anthers pale rose color; styles 2-5. Fruit ripening in October, on slender erect pubescent pedicels, in broad manyfruited clusters, pear-shaped or rarely subglobose, $\frac{1^{\prime}}{2}$ in diameter, erect, dull orange- 
red, translucent when fully ripe, mostly persistent on the branches until the following spring; flesh thick, orange-yellow, sweet aud succulent; nutlets 2 or 3 , about $\frac{1}{4}$ long and broad, full and rounded at the ends, rounded and prominently ridged on the back, the ventral cavities broad and deep.

A tree, $15^{\circ}-20^{\circ}$ high, with a trunk $5^{\prime}-6^{\prime}$ in diameter, covered with smooth pale gray or dark brown furrowed bark, slender spreading often nearly lorizontal smooth gray branches forming a wide flat head, and slender branchlets covered at first with thick hoary tomentum, becoming dark orange color and puberulous in their first winter, and ashy gray in their second season, and unarmed, or armed with occasional slender straight dull ashy gray or very rarely bright chestuut-brown spines $1^{\prime}-1_{\frac{1}{2}}^{\prime}$ long.

Distribution. Near Troy, New York, to eastern Pennsylvania, and westward through central New York to central Michigan, southern Minnesota, Iowa, Missouri, and eastern Kansas, and southward aloug the Appalachian Mountains to northern Georgia and central Tenuessee.

Occasionally cultivated as an ornamental tree in the gardens of western Europe.

\section{Cratægus Chapmani, Ashe.}

Leaves ovate, oval, or obovate, acuminate, gradually narrowed and acute or concave-cuneate at the entire base, sharply serrate above, with glandular teeth, and

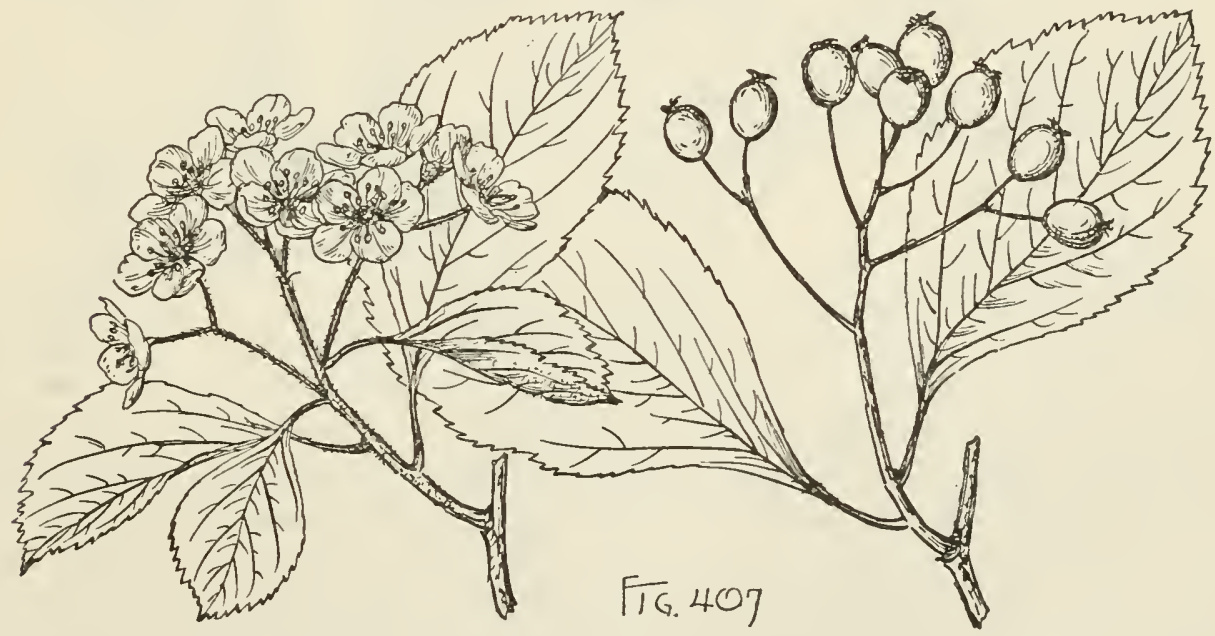

often slightly lobed above the middle, about half grown when the flowers open early in June and then covered above with short soft pale hairs and pale-tomentose below, and at maturity dark dull green and smootl or scabrate above, pale-tomentulose below, especially along the slender yellow midribs and primary veins, $2 \frac{1}{2}^{\prime}-3^{\prime}$ long, $1 \frac{1}{2}^{\prime}-2 \frac{1}{2}^{\prime}$ wide, and on vigorous shoots sometimes $6^{\prime}$ long and $4^{\prime}$ wide, turning yellow or brown in the autumn before falling; their petioles stout, wing-margined at the apex, at first tomentose, becoming nearly glabrous, $\frac{1}{2}^{\prime}-\frac{3}{4}^{\prime}$ long. Flowers about $\frac{3^{\prime}}{8}$ in diameter, on long stout hoary-tomentose or pubescent pedicels, in broad compound many-flowered tomentose corymbs; calyx-tube narrowly obconic, tomentose, the lobes acuninate, glandular-serrate, sparingly villose; stamens 10; anthers rose color; styles 2 or 3. Fruit ripening the middle of September, on elongated slightly villose pedicels, in broad lax drooping many-fruited clusters, globose to subglobose, bright red, about $\frac{5^{\prime}}{8}$ in diameter; calyx only slightly enlarged, with reflexed coarsely glandular- 
serrate lobes; flesh juicy, succulent, yellow; nutlets 2 or 3 , abont $\frac{3 \prime}{4}$ long and nearly as broad, thin, full and rounded at the obtuse ends, rounded and obscurely ridged on the back, the ventral cavities broad and deep.

A tree, sometimes $20^{\circ}$ ligh, with a short trunk $6^{\prime}-8^{\prime}$ in diameter, covered with gray scaly bark, erect branches forming a broad open head, and slender branchlets at first hoary-tomentose, becoming bright red-brown and lustrous, and armed with occasional stout straight or curved bright chestnut-brown spines $1 \frac{1}{2}^{\prime}-2^{\prime}$ long.

Distribution. Low rich soil on the banks of streams in the Appalachian region from Virginia to northern Georgia and eastern Tennessee.

\section{Cratægus Gaultii, Sarg.}

Leaves elliptical to suborbicular, acute or rounded at the apex, concave-cuneate or rounded at the entire base, coarsely doubly serrate above, with straight glandular teeth, and occasionally divided above the middle into short acute lobes, nearly fully

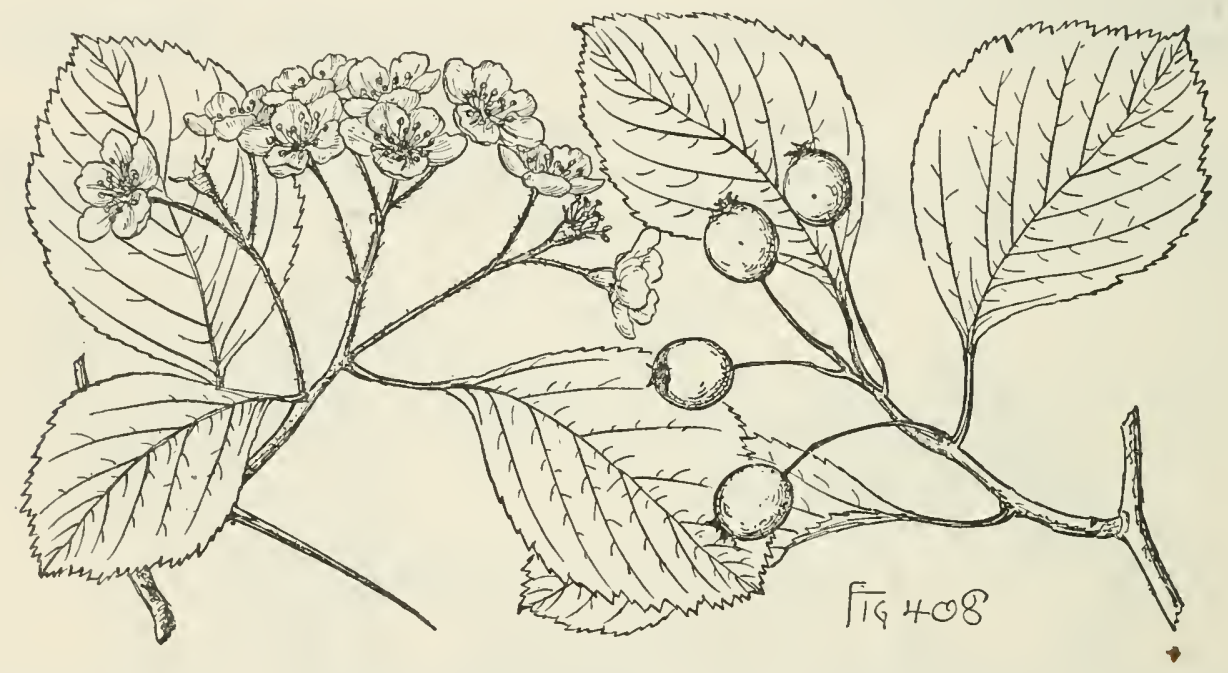

grown when the flowers open at the end of May and then very thin, yellow-green and sparingly villose above, pale and slightly pubescent below, and at maturity thin but firm in texture, glabrous, dark dull green on the upper surface, pale on the lower surface, $21^{\prime}-3^{\prime}$ long, $2^{\prime}-2 \frac{3^{\prime}}{4}$ wide, with stout yellow midribs deeply impressed above, and 6 or 7 pairs of primary veins extending obliquely to the points of the lobes; their petioles stout, wing-margined to below the middle, villose on the upper side early in the season, with matted white hairs, beconing nearly glabrous, $\frac{1}{2}^{\prime}-1^{\prime}$ long. Flowers $\frac{5}{8}$ in diameter, on long slender slightly villose pedicels, in broad many-flowered hairy compound corymbs, with 3-flowered peduncles from the axils of the 2 upper leaves, their bracts and bractlets linear, acuminate, glandular, mostly persistent until the flowers open; calyx-tube narrowly obconic, glabrous, the lobes broad, acuminate, coarsely glandular-serrate, glabrous on the outer, villose on the imner surface; stamens 18-20; anthers pale pink; styles 2 or 3. Fruit ripening from the middle to the end of Septenıber, on slender slightly hairy pedicels, in few-fruited drooping clusters, subglobose to short-oblong, $\frac{1}{2}^{\prime}-\frac{5}{8}$ long; calyx prominent, with spreading appressed coarsely serrate lobes; flesh thick, yellow, soft and juicy; nutlets 2 or 3 , full and rounded at the ends, about $\frac{8}{16}$ long and nearly as wide, full and rounded on the back, with a high rounded ridge, the ventral cavities long, deep, and narrow.

A tree, $20^{\circ}-25^{\circ}$ ligh, with a trunk often $10^{\prime}$ in diameter and $6^{\circ}-7^{\circ}$ long, spread- 
ing branches forming a broad round-topped head, and slender slightly zigzag glabrous light red-brown lustrous branchlets, unarmed, or armed with occasional straight slender dark purple shining spines $1 \frac{11^{\prime}}{4}-1 \frac{3^{\prime}}{4}$ long.

Distribution. Open pastures, Milton Township, Du Page County, and Glen Ellyn and Mokena, northeastern Illinois.

\section{Cratægus vegeta, Sarg.}

Leaves elliptical, acuminate, gradually narrowed and concave-cuneate at the entire base, finely often doubly serrate above, with straight glandular teeth, and slightly divided above the middle into numerous short acute lobes, nearly fully grown when

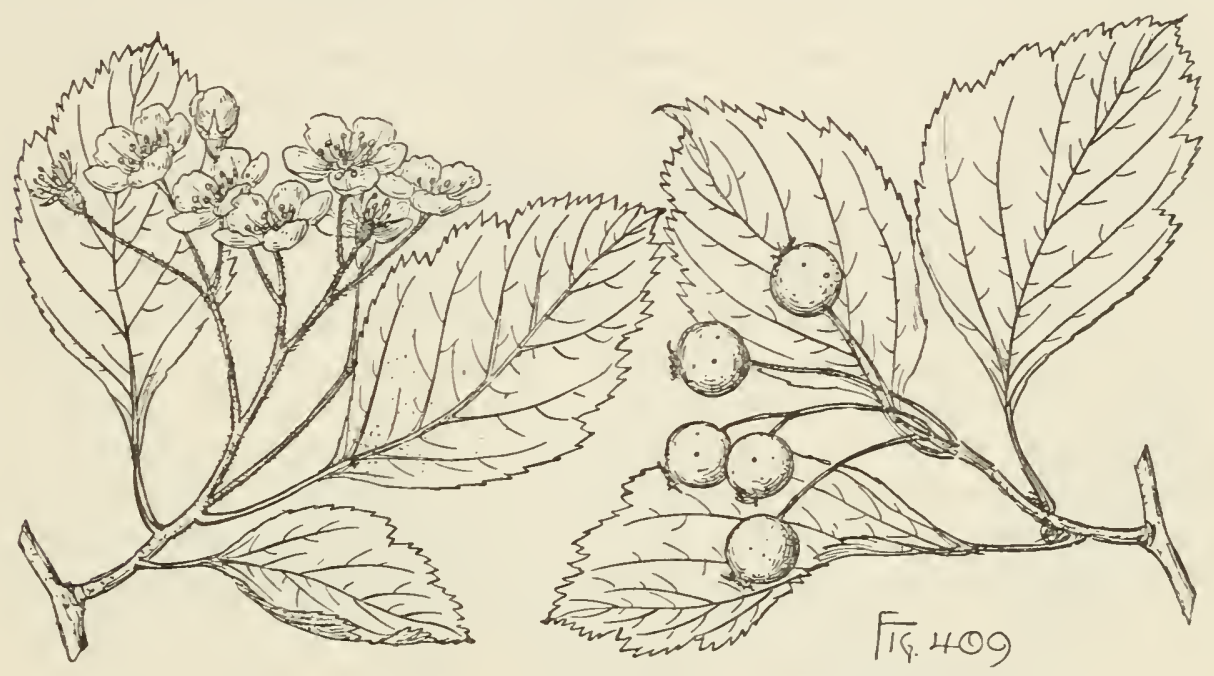

the flowers open at the end of May and then membranaceous, dark yellow-green and roughened above by short rigid pale hairs and densely pubescent below, and at maturity thin but firm in texture, dark dull green and scabrate on the upper surface, pale and pubescent on the lower surface along the slender midribs and 5 or 6 pairs of thin primary veins arching obliquely to the points of the lobes, $3^{\prime}-4^{\prime}$ long, $1 \frac{3^{\prime}}{4}-2 \frac{1^{\prime}}{2}$ wide; their petioles slender, broadly wing-margined at the apex, villose on the upper side early in the season, becoming glabrous and rose color in the autumn, $\frac{1^{\prime}}{2}-\frac{3^{\prime}}{4}$ long. Flowers $\frac{5^{\prime}}{8}-\frac{8^{\prime}}{4}$ in diameter, on long slender villose pedicels, in usually 10-12-flowered hairy compound corymbs, with linear to linear-obovate acute glandular bracts and bractlets becoming reddish and mostly persistent until after the flowers open; calyx-tube narrowly obconic, villose, the lobes slender, acuminate, glandular-serrate, villose; stamens 20; anthers small, light pink or red; styles 2 or 3 , usually 3 . Fruit ripening late in September, on slender elongated rigid slightly villose pedicels, in few-fruited erect clusters, subglobose, scarlet, lustrous, marked by small pale dots, about $\frac{3^{\prime}}{8}$ in diameter; calyx prominent, with a short tube and spreading reflexed serrate lobes; flesh thin, yellow, dry and mealy; nutlets 2 or $3, \frac{1}{4}^{\prime}$ long and nearly as broad, full and rounded at the ends, prominently ridged on the back, with a high grooved ridge, the ventral cavities broad and deep.

A tree, $20^{\circ}-25^{\circ}$ high, with a tall straight trunk sometimes $8^{\prime}$ in diameter, stout widespreading branches forming a symmetrical round-topped head, and very slender nearly straight branchlets, light orange-green when they first appear, becoming bright redbrown and lustrous at the end of their first season and darker the following year, 
and unarmed, or sparingly armed with slender nearly straight purple shining spines about $4^{\prime}$ long.

Distribution. Oak woods in moist rich soil near the banks of the Calumet River, Calumet, Illinois.

\section{Cratægus Deweyana, Sarg.}

Leaves orate, acuminate or abruptly long-pointed at the apex, abruptly narrowed and concave-eneate at the entire often unsymmetrieal base, eoarsely doubly serrate above, with straight or ineurved gland-tipped teeth, and slightly divided above the middle into several pairs of small aeuminate spreading lobes, about one third grown when the flowers open during the last week of May and then membranaeeons, dark yellow-green, and eovered above with short lustrous white hairs and light yellowgreen and glabrous below, and at maturity thin, yellow-green and seabrate on the upper surfaee, pale on the lower surface, $3^{\prime}-4^{\prime}$ long, $2^{\prime}-\frac{3^{\prime}}{4}$ wide, with stout midribs deeply impressed on the upper side and 6 or 7 pairs of thin primary veins arehing to the points of the lobes; their petioles stout, wing-margined at the apex, deeply grooved, sparingly villose along the upper side, soon glabrous, glandular, with oeeasional minute dark glands, usually dull orange eolor in the autumn, $\frac{3^{\prime}}{4}-1^{\prime}$ long; on vigorous shoots more deeply lobed and more eoarsely serrate, subeoriaceous, often $4^{\prime}$ long and $3 \frac{1^{\prime}}{2}$ wide, and gradually narrowed into stout broad-winged eoarsely glandular petioles, their stipules foliaceous, stipitate, lunate, aentely lobed, glandular-serrate, with minute dark red glands, sometimes $\frac{1^{\prime}}{2}$ long, persistent through the season. Flowers about $\frac{1^{\prime}}{2}$ in diameter, on slender hairy pedieels, in wide lax many-flowered slightly villose eompound eorymbs; ealyx-tube narrowly obeonie, villose at the base, glabrous above, the lobes slender, elongated, aeuminate, finely glandular-serrate usually only above the middle, dark green and glabrous on the outer surface, villose on the imner surface; stamens $7-10$, usually 10 ; anthers small, dark rose eolor;

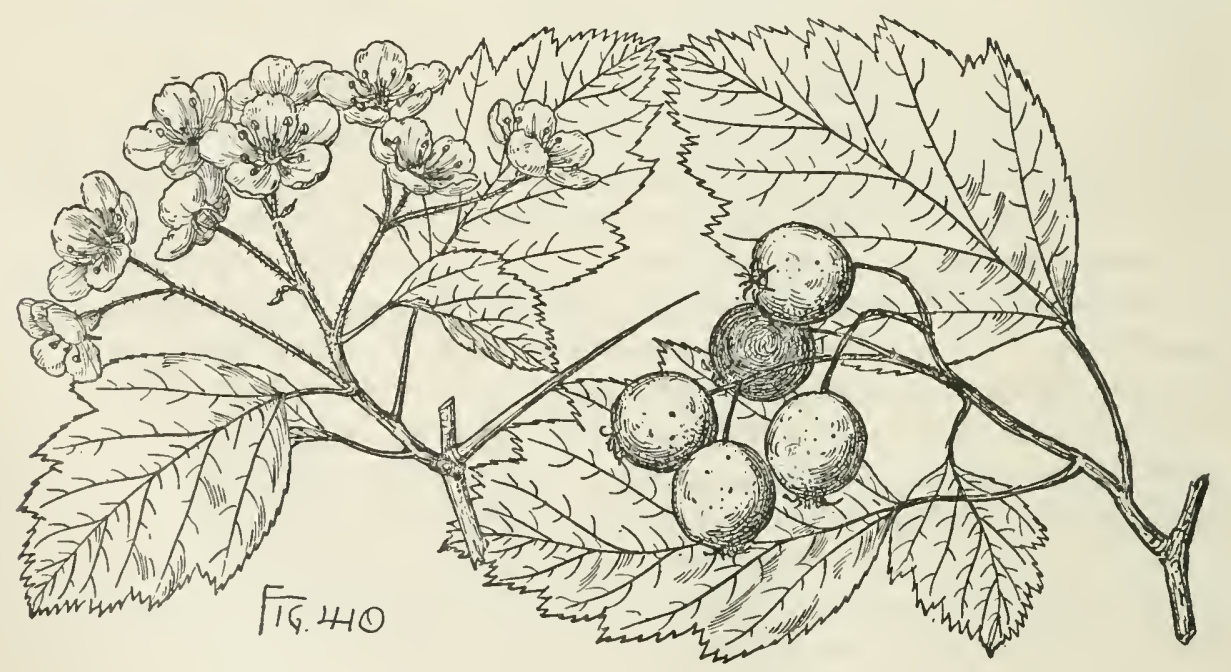

styles 2 or 3, usually 2. Fruit ripening from the first to the middle of October and falling a few weeks later, on long slender puberulous pedicels, in wide many-fruited drooping elusters, subglobose to short-oblong, full and rounded at the ends, searlet, lustrous, marked by oeeasional large pale dots, $\frac{1}{2}^{\prime}$ in diameter; ealyx prominent, with elongated glandular-serrate lobes dark red on the upper side near the base, usually 
erect and incurved, mostly persistent on the ripe fruit; flesh when fully ripe thick, yellow, and sweet; nutlets usually 2 , occasionally 3 , about $\frac{3^{\prime}}{16}$ long and $\frac{1^{\prime}}{8}$ wide, full and rounded at the ends, rounded and conspicuously ridged on the back, with a broad low doubly grooved ridge, the ventral cavities broad and shallow.

A tree, $20^{\circ}-25^{\circ}$ high, with a tall trunk sometimes $10^{\prime}$ in diameter, covered with light gray bark, becoming rough and scaly near the base, slender branches, the lower horizontal and wide-spreading, the upper ascending and forming a wide open irregular head, and stout glabrous branchlets dark orange-brown when they first appear, deep red-brown and lustrous on the upper, gray-brown and lustrous on the lower side during their first winter, becoming gray slightly tinged with red the following year, and armed with numerous stout curved chestnut-brown or purple spines $1 \frac{1}{2}-2^{\prime}$ long and occasionally persistent on old stems.

Distribution. Hagaman Swamp, Rochester, and at Rush, New York; not common.

\section{Cratægus succulenta, Link.}

Leaves elliptical, acute or acuminate at the apex, gradually narrowed from near the middle and entire at the base, coarsely and usually doubly serrate above, with spreading glandular teeth, and divided above the middle into numerous short acute

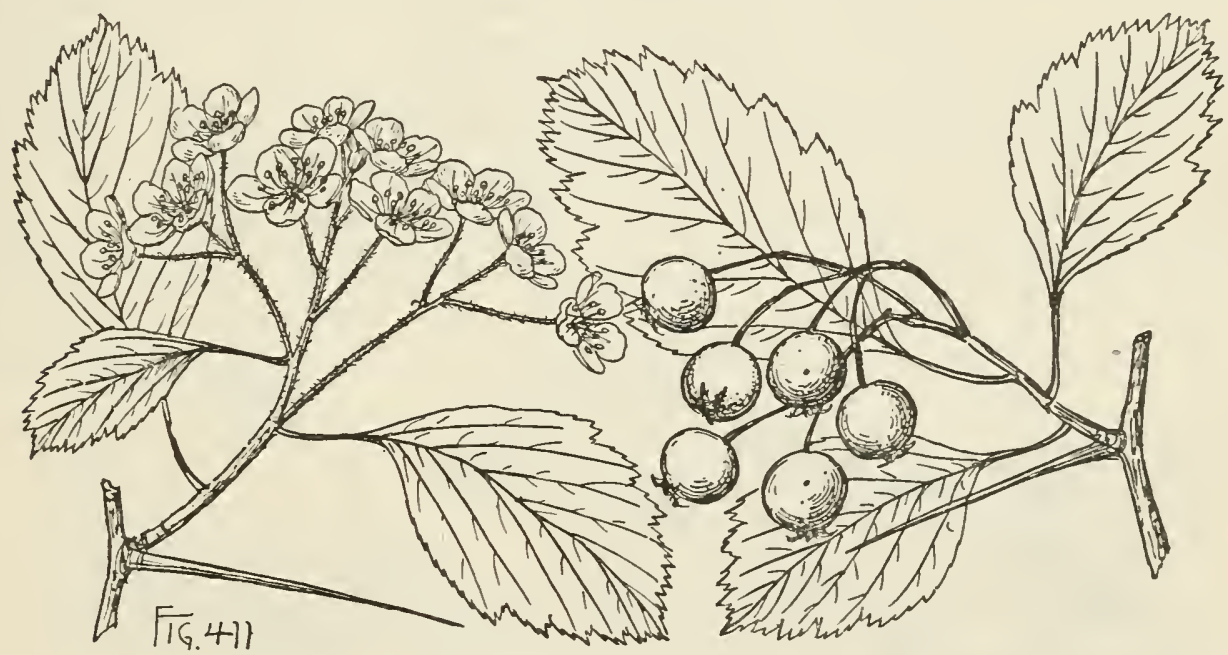

lobes, nearly fully grown when the flowers open at the end of May or early in June and then membranaceous, covered above with soft pale hairs and puberulous or rarely nearly glabrous below, and at maturity coriaceous, dark green, glabrous, and somewhat lustrous above, pale yellow-green and mostly puberulous beneath along the stout yellow midribs and 4-7 pairs of slender veins extending obliquely to the points of the lobes and deeply impressed on the upper side, usually $2^{\prime}-2 \frac{1}{2}^{\prime}$ long and $1^{\prime}-1 \frac{1^{\prime}}{2}$ wide; their petioles stout, more or less winged above, generally about $\frac{1}{2}^{\prime}$ long, frequently bright red after midsummer; on vigorous shoots occasionally ovate and of ten $2 \frac{1}{2}$ long and $3^{\prime}$ wide. Flowers about $\frac{2^{\prime}}{3}$ in diameter, on long slender hairy pedicels, in broad lax compound many-flowered villose corymbs; calyx-tube narrowly obconic, villose or glabrous, the lobes broad, acute, laciniate, glandular, with bright red glands, and generally villose; stanens usually 20 , sometimes 15 ; anthers small, rose color; styles 2 or 3 , surrounded at the base by a ring of pale hairs. Fruit beginning to ripen about the middle of September and sometimes remaining on the branches 
mintil the end of October, on slender elongated pedicels, in broad loose many-fruited drooping clusters, globose, bright scarlet, marked by large pale dots, $\frac{1}{3}-\frac{2}{3}$ in diameter; calyx prominent, with a broad shallow depression, and much cnlarged coarscly serrate closely appressed persistent lobes; flesh thiek, yellow, jniey, swect and pulpy; nntlets 2 or $3, \frac{1^{\prime}}{3}$ long, $\frac{x^{\prime}}{4}$ broad, prominently ridged on the back, with a broad rounded donbly grooved ridge, the ventral cavities wide and deep.

A tree, occasionally $20^{\circ}$ high, with a short trunk $5^{\prime}-6^{\prime}$ in diamcter, covered with dark red-brown scaly bark, stout aseending branches forming a broad irregular liead, and stout more or less zigzag glabrous dark orange-brown lustrous branehlets beeoming dull gray-brown in their second seasou and ultimately ashy gray, and armed with numerous stout slightly curved bright chestnut-brown shining spines $1 \frac{1}{2}^{\prime}-2 \frac{1}{2}^{\prime}$ long; or usually shrnbby and mueh smaller, and often flowering when only a few feet high.

Distribution. Valley of the St. Lawrence River near Montreal to the coast of New England, and through northern New York and southern Ontario to northern Illinois.

\section{Cratægus gemmosa, Sarg.}

Leaves broadly oval or rarely broadly obovate, gradually narrowed and cuneate or occasionally rounded at the entire base, sharply and usually doubly serrate from below the middle, with straight glandular teeth, and often slightly lobed toward the acute or aeuminate apex, with short aeute lobes, dark red and villose as they unfold, nearly fully grown when the flowers open from the middle to the end of May and then membranaceous, light yellow-green, nearly glabrous above and pale and villose below, and at maturity thiek and firm in texture, very dark dull green on the upper surface, pale and pubescent on the lower surface along the stout yellow midribs,

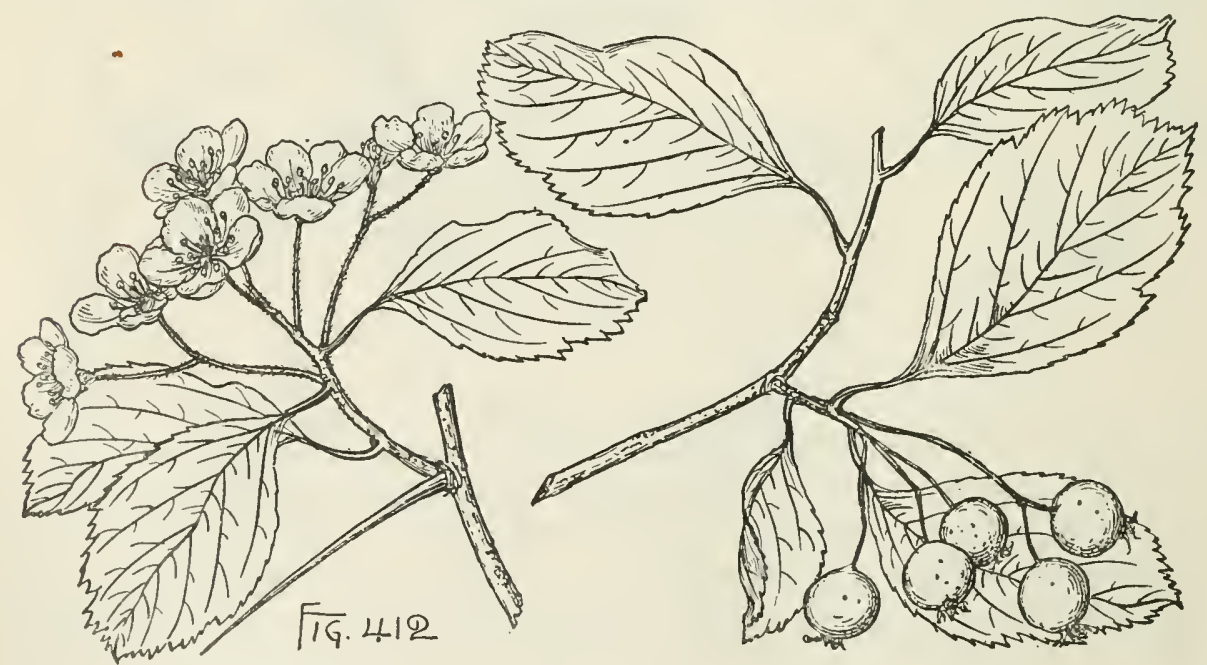

deeply impressed and oceasionally puberulous above, and along the 4 or 5 pairs of slender primary veins extending obliquely to the end of the leaf, $1 \frac{1}{2}^{\prime}-2 \frac{1}{2}^{\prime}$ long, $1^{\prime}-2^{\prime}$ wide; their petioles stout, villose or pubeseent, more or less winged above, glandular while young, with minute bright red cadueous glands, usually pink in the autumn, $\frac{1^{\prime}}{4}-\frac{1^{\prime}}{2}$ long; on vigorons shoots more coarsely serrate, frequently divided into short aente lateral lobes, and often $4^{\prime}$ long and $3^{\prime}$ wide, with rose-eolored midribs and stout spreading primary veins, their stipules often lunate, acuminate, coarsely gland- 
ular-serrate, frequently $\frac{1^{\prime}}{4}$ long. Flowers $\frac{1^{\prime}}{2}-\frac{3}{4}^{\prime}$ in diameter, on slender hairy pedicels, in broad open compound villose many-flowered corymbs, with lanceolate or oblanceolate acuminate glandular-serrate conspicuous bracts and bractlets; calyxtube narrowly obconic, more or less villose, with matted pale hairs, or nearly glabrous, the lobes lanceolate, acuminate, glabrous or villose on the onter surface, villose on the inner surface, coarsely glandular-serrate, with bright red glands; stamens 20; anthers small, rose color; styles 2 or 3 , surrounded at the base by a narrow ring of pale tomentum. Fruit ripening early in October and becoming very succulent just before falling, on long slender pedicels, in drooping many-fruited glabrous or puberulous clusters, subglobose to short-oblong, scarlet, lustrous, $\frac{1}{2}^{\prime}$ in diameter; calyx prominent, with an elongated narrow tube and reflexed villose lobes bright red toward the base on the upper side; flesh thick, bright yellow, sweet and succulent; nutlets usually 3 , or $2, \frac{1^{\prime}}{4}$ long, broad and flat, full and rounded at the ends, and ridged on the back, with a prominent rounded ridge, the ventral cavities broad and deep.

A tree, occasionally $30^{\circ}$ high, with a tall trunk $10^{\prime}-12^{\prime}$ in diameter, covered with dark brown scaly bark, stout spreading or ascending branches forming a broad rather open symmetrical head, stout zigzag glabrous red-brown or gray-brown lustrous branchlets armed with straight or slightly curved thick chestnut-brown spines usually about $2^{\prime}$ long, and winter-buds sometimes $\frac{1^{\prime}}{4}$ in diameter.

Distribution. Rich forest glades, or the margins of woods, usually in low rich soil; Rochester, New York, to Toronto, Ontario, and through Ontario to the southern peninsula of Michigan; very abundant and of its largest size in Michigan.

\section{Cratægus Illinoiensis, Ashe.}

Leaves broadly obovate to oval, rounded or rarely acute at the wide apex, broadly cuneate and entire at the base, coarsely and often doubly serrate above, with straight or incurved teeth tipped with minute deciduous glands, and sometimes

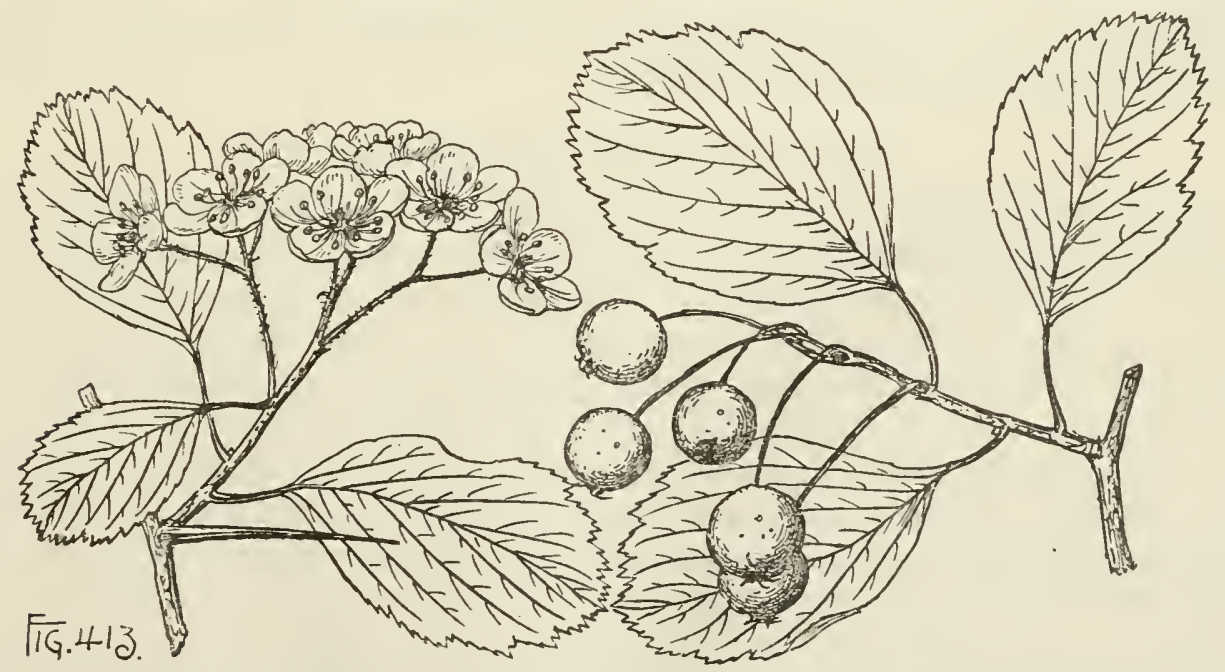

slightly and irregularly divided toward the apex into short acute lobes, when they unfold covered below with a thick coat of hoary tomentum and pilose above, and when the flowers open about the 20th of May membranaceous, yellow-green, covered above with short pale hairs, pubescent below, and at maturity thick and firm in tex- 
ture, dark green and glabrons on the upper surfaee, pale and pubescent on the lower surface, particularly along the stout midribs and 4-6 pairs of primary veins decply impressed on the npper side, $2^{\prime}-2 \frac{1}{2}$ long, $1 \frac{1}{2}-2^{\prime}$ wide; their petioles stont, slightly winged toward the apex, usually $\frac{1}{2}-\frac{2}{8}$ long, and generally bright red below the middle after midsummer; on vigorous shoots usually elliptical, acute or acuminate, more closely dentate and nore often lobed, sometimes deeurrent nearly to the base of the stout petioles, $3^{\prime}-4^{\prime}$ long and $2 \frac{1}{2}^{\prime}-3^{\prime}$ wide, with foliaecons lunate coarsely glandnlar-dentate stalked stipules often $\frac{3^{\prime}}{4}$ in length. Flowers about $\frac{5}{8}$ in diameter, on slender slightly hairy pedicels, in broad compact many-flowered villose compound corymbs; ealyx-tube narrowly obconic, coated with long matted palc hairs, the lobes broad, aeuminate, very coarsely glandnlar-serrate, with large stipitate bright red glands, glabrous on the outer surface except at the base, villose on the inner surface; stamens 10; anther's rose color; styles 2, or usually 3. Fruit ripening early in October and persistent on the branehes until after the beginning of winter, on stout bright red pedicels, in few-fruited drooping villose clusters, globose, scarlet; lustrous, marked by occasional dark dots, more or less villose at the ends, $\frac{1}{2}$ in diameter; calyx promiuent, with a short villose tube, and spreading lobes gradually narrowed from broad bases, sparingly glandular-serrate or nearly entire, villose, mostly decidnous before the fruit ripens; flesh thin, yellow, dry and mealy; nutlets 2 or $3, \frac{1}{4}^{\prime}$ long, broad and thick, rounded at the ends, prominently ridged and grooved on the back, with a high broad ridge, the ventral eavities broad and deep.

A tree, rarely more than $18^{\circ}$ high, with a trunk $4^{\prime}-5^{\prime}$ in diameter, covered with thin close bark broken on the surface into pale plate-like scales, and divided into several long erect and spreading slender branehes forming a wide open-topped head, and stout somewhat zigzag branehlets covered at first with scattered pale cadncous hairs, bright orange-brown and lustrous during their first season, becoming dark brown in their seeond year and ultimately ashy gray, and armed with numerous slender straight or somewhat curved bright ehestnut-brown shining spines $1 \frac{1}{2}^{\prime}-3^{\prime}$ long.

Distribution. Open woods along the gravelly banks of small streams in Stark and Peoria counties, Illinois; not common.

\section{Cratægus integriloba, Sarg.}

Leaves broadly obovate, oval or rhomboidal, acute, gradually or abruptly narrowed and cuneate below the middle, entire toward the base, coarsely doubly serrate above, with spreading glandular teeth, and irregularly divided into numerous short acute or acuminate lobes, coated in early spring with soft pale caducous hairs, nearly fully grown when the flowers open during the first week in June, and at maturity glabrous, thin but firm in texture, dark green and lustrous on the upper surface, pale yellow-green on the lower surface, $1 \frac{1}{2}^{\prime}-3^{\prime}$ long, $1 \frac{1}{4}^{\prime}-2^{\prime}$ wide, witl slender midribs often dark red at the base and 4-6 pairs of slender primary veins deeply impressed on the upper side; their petioles stout, more or less broadly winged toward the apex, at first puberulous, soon glabrous, often red on the lower side, $\frac{1^{\prime}}{3}-\frac{3^{\prime}}{4}$ long. Flowers $\frac{3}{4}$ in diameter, on elongated slender villose pedicels, in broad open many-flowered crowded compound villose corymbs; calyx-tube broadly obconie, eoated toward the base with long matted white hairs and glabrous above, the lobes linear-laneeolate, elongated, entire or very rarely furnished with occasional caducous glands; stamens 10; anthers large, rose color; styles 2 or 3, surrounded at the base by a narrow ring of snow-white hairs. Fruit ripening at the end of September or early in Oetober, on 
short stout pedicels, in drooping or erect many-fruited slightly villose clusters, subglobose, bright scarlet, lustrous, marked by large pale dots, $\frac{1}{3}^{\prime}-\frac{1}{2}^{\prime}$ in diameter; calyx enlarged, prominent, with elongated entire lobes, dark red on the upper side at the

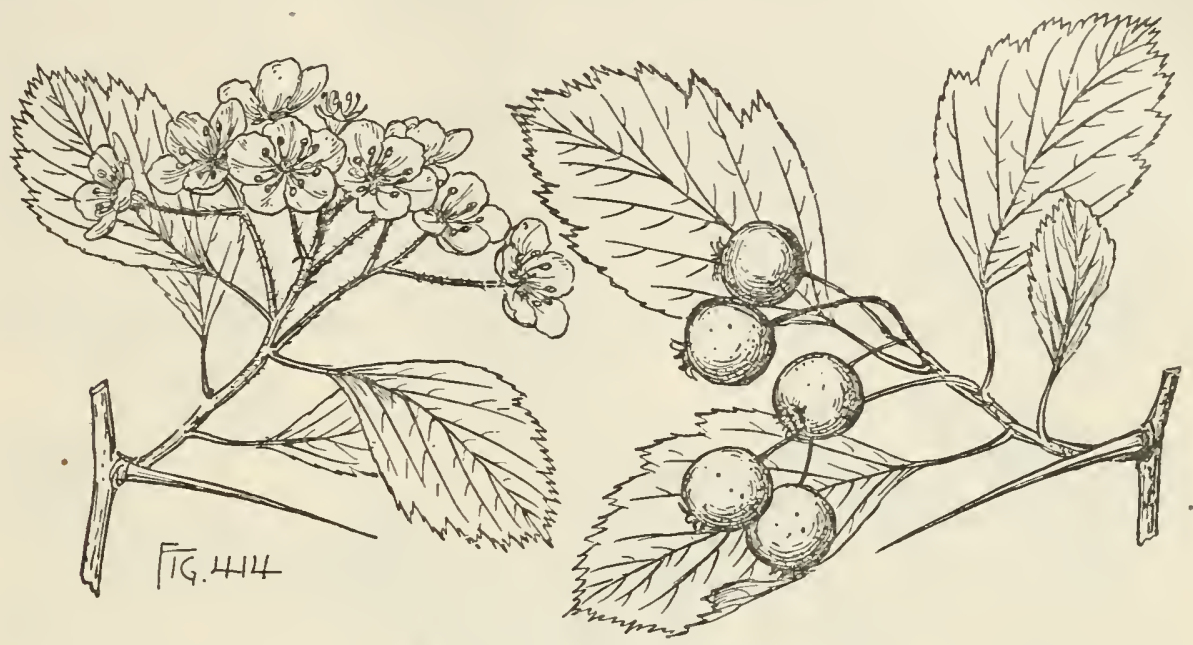

base, much reflexed and persistent; flesh thin, yellow, sweet and pulpy; nutlets 2 or 3 , about $\frac{1}{4}^{\prime}$ long, thick and broad, rounded at the narrowed ends, the ventral cavities broad and deep.

A tree, occasionally $18^{\circ}-20^{\circ}$ high, with a straight erect trunk $6^{\prime}-8^{\prime}$ in diameter, wide-spreading or erect branches forming an open irregular head, and stout nearly straight or occasionally slightly zigzag glabrous branchlets, lustrous and red-brown or orange-brown during their first summer and ultimately dull ashy gray, and armed with stout nearly straight bright chestnut-brown shining spines $1 \frac{1}{2}^{\prime}-2 \frac{1}{2}$ long and often pointed toward the base of the branch.

Distribution. Low limestone ridges, Province of Quebec, sontl of the St. Lawrence River near the Lachine Rapids, and at Canghnawaga, Rockfield, and Adirondack Junction.

\section{Cratægus macracantha, Koehne.}

Leaves broadly obovate to elliptical or oval, acute or rounded and sometimes short-pointed at the apex, gradually or abruptly narrowed and cuneate at the entire base, coarsely and often doubly serrate above, with straight or incurved gland-tipped teeth, and usually divided above the middle into numerons short acute or acuminate lobes, when they unfold often bright red and coated on the upper surface with soft pale hairs, more than half grown when the flowers open late in May and then dull yellow-green, nearly glabrous on the upper surface and pale and puberulous on the lower surface, and at maturity coriaceous, dark green and glabrous above, frequently puberulons below along the stont midribs and 4-6 pairs of slender primary veins extending obliquely to the points of the lobes and deeply impressed on the upper side, usually $2^{\prime}-2 \frac{1}{2}^{\prime}$ long, $1 \frac{1}{2}^{\prime}-2^{\prime}$ wide; their petioles stout, more or less winged above, generally about $\frac{1^{\prime}}{2}$ long, and frequently bright red after midsummer; on vigorous shoots often full and rounded at the base, coarsely dentate, $3^{\prime}-4^{\prime}$ long and $2 \frac{1^{\prime}}{2}-3^{\prime}$ wide. Flowers about $\frac{3^{\prime}}{4}$ in diameter, on long slender hairy pedicels, in broad more or less villose many-flowered compound corymbs; calyx-tube narrowly obconic, more or less villose or nearly glabrous, the lobes narrow, elongated, acuminate, glandular, 
with minute dark glands, glabrous on the outer, slightly villose on the inner surface; stamens usually 10 , but occasionally $8-12$; anthers pale yellow; styles $2-3$, surrounded at the base by a broad ring of hoary tomentum. Fruit ripening at the end of September and often remaining on the branches for several weeks longer, on erect slender pedicels, in broad open many-fruited usually slightly villose clusters, globose, often hairy at the ends milil nearly ripe, crimson, very lustrons, $\frac{1^{\prime}}{4}-\frac{1^{\prime}}{3}$ in diameter; calyx large and conspicuous, the lobes coarsely serrate, reflexed and persistent; flesh thin, dark yellow, dry and mealy; nutlets 2 or 3 , about $\frac{1^{\prime}}{4}$ long and broad, full and rounded at the ends, rounded and ridged on the back, with a wide high ridge, the ventral cavities deep and irregular.

A tree, occasionally $15^{\circ}$ high, with a tall stem $5^{\prime}-6^{\prime}$ in diameter, covered with pale close bark, stout wide-spreading branches forming an open rather irregular head,

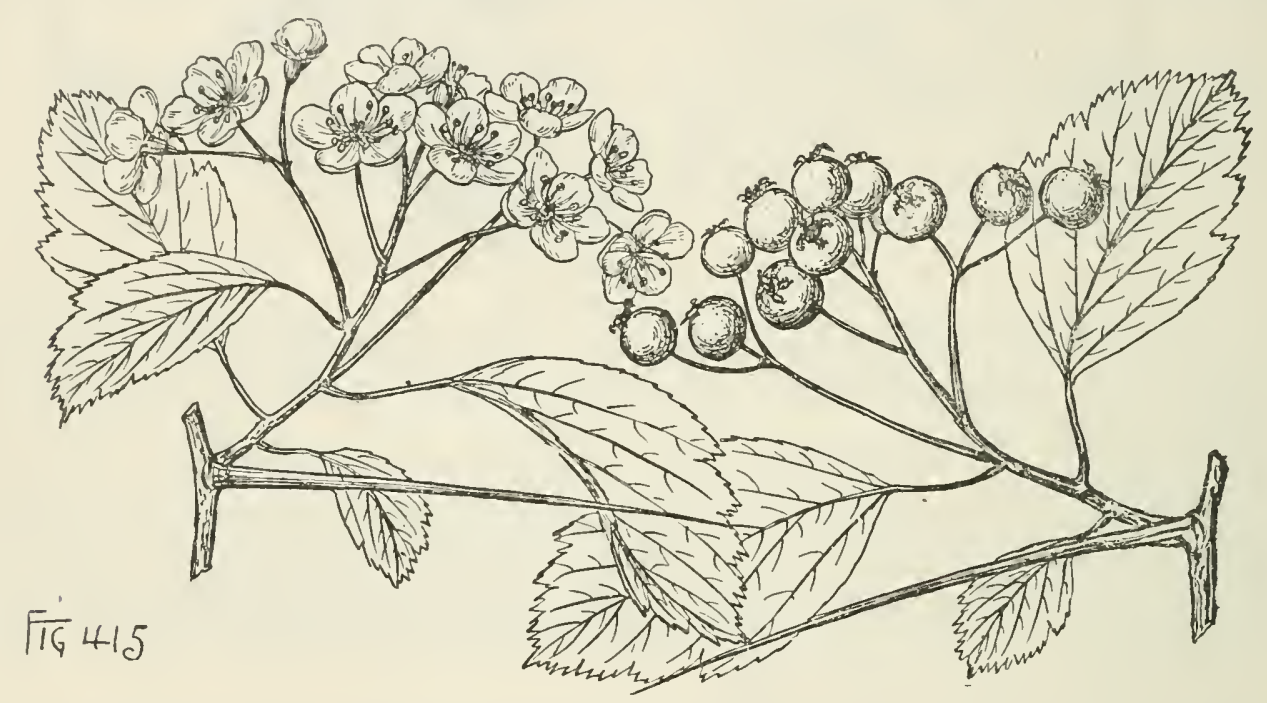

and stout slightly zigzag glabrous light chestnut-brown very lustrous branchlets, becoming dull reddish brown in their second year, and armed with numerous slender nsually curved very sharp bright chestnut-brown shining spines $2 \frac{1}{2}^{\prime}-4^{\prime}$ long.

Distribution. Usually on rich hillsides, often in limestone soil and near the banks of streams; valley of the St. Lawrence River in the neighborhood of Montreal, through New England to eastern Pennsylvania, and through the region south of the Great Lakes to northern Illinois.

\section{DOUGLASIANÆ.}

Leaves broadly ovate to obovate ; fruit subglobose to short-oblong; calyx-lobes serrate, deciduous from the fruit.

131. C. Douglasii (A, B, F, G).

Leaves lanceolate to oblong-obovate, narrowed at the ends ; fruit short-oblong; calyx-lobes entire, persistent on the fruit.

132. C. rivularis (F).

\section{Cratægus Douglasii, Lindl.}

Leaves broadly ovate to obovate, gradually narrowed below to the cuneate entire base, finely serrate above, with minute glandular teeth, and often incisely lobed toward the acute apex, nearly fully grown and coated above and on the midribs and veins below with short pale hairs when the flowers open in May, and at maturity subcoriaceous, glabrous, dark green and lustrous above, paler below, $1^{\prime}-2^{\prime}$ long and 
$\frac{1^{\prime}}{2}-1 \frac{1^{\prime}}{2}$ wide; their petioles slender, wing-margined above, sparingly glandular, at first villose, becoming glabrous, $\frac{1^{\prime}}{2}-\frac{3^{\prime}}{4}$ long; on vigorous shoots broadly obovate, incisely lobed at the broad apex, often deeply divided into lateral lobes, or occasionally 3-lobed, $3^{\prime}-4^{\prime}$ long and $2^{\prime}-3^{\prime}$ wide. Flowers $\frac{1^{\prime}}{3}-\frac{1}{2}{ }^{\prime}$ in diameter, on elongated slender

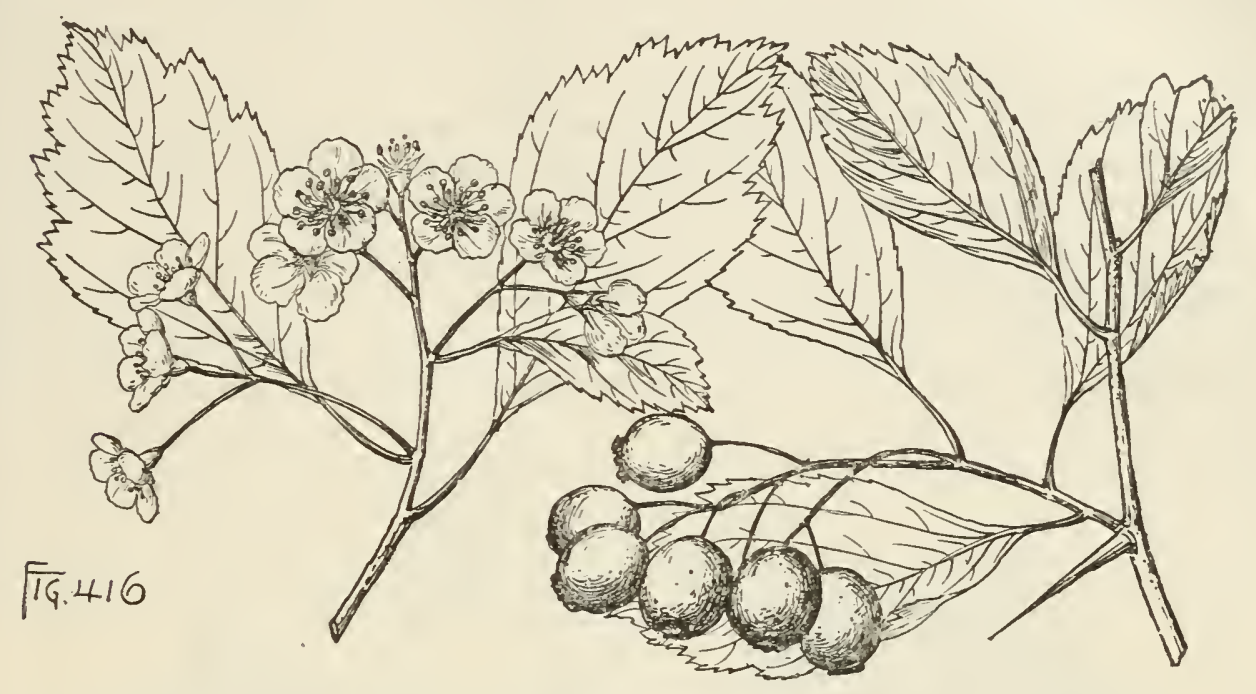

pedicels, in broad many-fluwered glabrous corymbs; calyx-tube broadly obconic, glabrous, the lobes gradually narrowed from the broad base, acute or acuminate, usually glandular-serrate above the middle, glabrous on the outer, villose on the inner surface, often tinged with red or purple; stamens 20; anthers small, pale yellow; styles 2-5, surrounded at the base by tufts of long pale hairs. Fruit ripening and falling in August and September, on slender pedicels, in compact, many-fruited drooping clusters, short-oblong, truncate at the apex, black and lustrous, about $\frac{1}{2}$ long; calyx deciduous, leaving a broad deep cavity; flesh thick, sweet, light yellow; nutlets $3-5, \frac{1^{\prime}}{4}$ long, narrowed at the base, full and rounded at the apex, ridged on the back, with a narrow ridge, the rentral cavities small and shallow.

A tree, $30^{\circ}-40^{\circ}$ high, with a long trunk $18^{\prime}-20^{\prime}$ in diameter, stout branches spreading and ascending and forming a compact round-topped head, and slender rigid glabrous bright red lustrous branchlets nnarmed, or armed with straight or slightly curved blunt or acute bright red ultimately ashy gray spines $\frac{3^{\prime}}{4}-1^{\prime}$ long; or often shrubby, and spreading into wide thickets.

Distribution. Banks of mountain streams; valley of the Parsnip River, British Columbia, through Washington and Oregon to the Valley of the Pitt River, California, and eastward in the United States through the northern Rocky Mountain region to the Bighorn Mountains, Wyoming; in northern Michigan (Clifton and Thunder Bay), and on Michipicoten Island, Lake Superior.

\section{Cratægus rivularis, Nutt.}

Leaves lanceolate to narrowly oblong-obovate, acute, acuminate, or abruptly acuminate at the apex, gradually narrowed and concave-cuneate at the long entire base, and very finely crenately serrate above, with glandular teeth, when they unfold tinged with red, villose above and coated below with matted pale hairs, more than half grown when the flowers open late in May and then hairy on the midribs and veins above and pale and glabrous below, and at maturity membranaceous, dull bluish 
green and smooth on the upper surface, palc yellow-green on the lower surface, about ' 2 ' long and $\frac{3^{\prime}}{4}$ widle, with slender yellow midribs and 3 or 4 pairs of thin obscure primary veins; their petioles slender, slightly winged at the apex, at first villose, becoming glabrous and rose-colored below the middle, abont $\frac{1}{2}$ long; on vigorous shoots often rlomboidal, coarsely serrate, often slightly incisely lobed, coriaceous, $3^{\prime}$ long and $2^{\prime}$ wide, with stout broadly winged petioles. Flowers $\frac{1^{\prime}}{2}$ in dianeter, on long slender pedicels, in rather compact globose many-flowered compound corymbs; calyx-tube broadly obconic, glabrous, the lobes linear, entire or glandular, with minute caducous glands, glabrons on the onter, sparingly villose on the inner surface, often tinged with red; stamens 20; anthers pale yellow. Fruit ripening in September, on long pedicels, in drooping few-fruited clusters, shortoblong, full and rounded at the ends, dark crimson and marked by many large

- white dots when fully grown, becoming black and lnstrous at maturity, $\frac{1}{3}^{\prime}-1^{\prime}$ long; calyx slightly enlarged, persistent, with elongated closely appressed entirc lobes

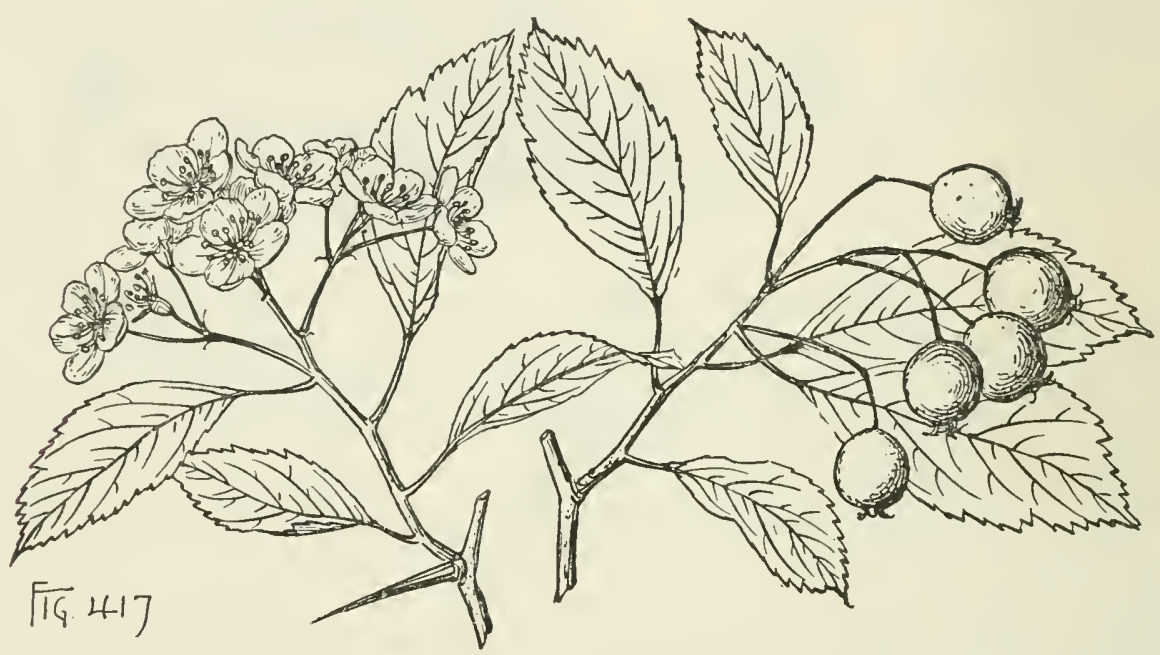

slightly villose and dark red on the upper side below the middle; flesh thin, yellow, dry and mealy; nutlets $3-5, \frac{1}{4}^{\prime}$ long, narrowed and rounded at the ends, slightly ridged on the back, the ventral cavities broad and shallow.

A tree, occasionally $20^{\circ}$ high, with a slender stem covered with dark brown scaly bark, erect branches forming a narrow rather open head, and slender bright redbrown lustrons branchlets marked by numerons pale lenticels, and unarmed, or armed with straight slender spines usually about $\mathbf{1}^{\prime}$ long.

Distribution. Banks of mountain streams, often forming thickets; Wyoming to southwestern Colorado and western Utah; most abundant on the Wasatch Mountains of Utah.

\section{CERCOCARPUS, H. B. K. Mountain Mahogany.}

Trees or shrubs, with scaly bark, rigid terete branches, short lateral spur-like branchlets conspicuously ronghened for many years by the crowded narrow horizontal scars of fallen leaves, minute buds, the scales of the inner rows accrescent on the growing shoots and often colored. Leaves alternate, simple, entire, or serrate, coriaceons, straiglit-veined, short-petiolate, persistent; stipules minute, adnate to the base of the petiole, deciduous. Flowers axillary on the short lateral branchlets, sessile or short-pedicellate, solitary or fascicled; calyx-tube long and cylindrical, abruptly 
expanded at the apex into a cup-shaped, 5-lobed deciduous limb, the lobes imbricated in the bud; disk thin, slightly glandular, adnate to the tube of the calyx; petals $\checkmark$; stamens $15-30$, in 2 or 3 rows; filaments incurved in the bud, free, short, terete; anthers oblong, pubescent or tomentose, distinct and united by a broad connective; ovary composed of a single carpel inserted in the bottom and included in the tube of the calyx, acute, terete, smooth, striate or sulcate, sericeous, rarely bicarpellate; style terminal, filiform, villose or glabrate, crowned with a minute obtuse stigma; ovule solitary, subbasilar, ascending; raphe dorsal; micropyle inferior. Fruit a linear-oblong coriaceous slightly ridged angled or sulcate akene, included in the persistent tube of the calyx and tipped with the elongated persistent style clothed with long white hairs. Seed solitary, linear, acute, erect; hilum conspicuous, lateral above the oblique base; testa membranaceous; embryo filling the cavity of the seed; cotyledons ovate-oblong, elongated, fleshy; radicle inferior.

Cereocarpus is confined to the dry interior and mountainous regions of North America. Five species are distinguished; of these four occur within the territory of the United States, and the fifth inhabits the mountains of southern Mexico. The heavy hard brittle wood of all the species makes valuable fuel and is occasionally used in the manufacture of small articles for domestic and industrial use.

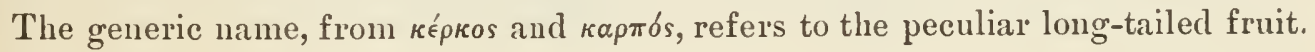

\section{CONSPECTUS OF SPECIES OF THE UNITED STATES.}

Flowers in 2-5-flowered clusters; leaves coarsely serrate above the middle.

Leaves oval to semiorbicular, cinereo-tomentose below, sinuate-dentate; flowers usually in 4 -5-flowered clusters.

1. C. Traskiæ (G).

Leaves cuneate-obovate, pubescent below, glandular-serrate; flowers usually in 2-3$\begin{array}{ll}\text { flowered clusters. } & \text { 2. C. parvifolius (F, G). }\end{array}$ Flowers solitary or rarely in pairs; leaves entire or occasionally slightly dentate toward the apex.

Leaves entire, narrowly lanceolate, acute at the ends, pale or rufous-pubescent below.

3. C. ledifolius (B, F, G)

Leaves occasionally dentate toward the apex, oblong-obovate to nearly elliptical, villose below.

4. C. breviflorus $(\mathrm{E}, \mathrm{H})$.

\section{Cercocarpus Traskiæ, Eastw.}

Leaves oval to semiorbicnlar, rounded or acute at the apex, cuneate, rounded or occasionally somewhat cordate at the narrow base, revolute on the margins, entire below, coarsely sinuate-dentate above the middle, with slender teeth tipped with minute dark glands, when they unfold covered above with soft pale hairs and below with thick hoary tomentum, and at maturity coriaceous, dark green and lustrous on the upper surface, cinereo-tomentose on the lower surface, $1 \frac{1}{2}^{\prime}-2^{\prime}$ long, $1^{\prime}-1 \frac{1}{2}^{\prime}$ wide, with prominent primary veins running obliquely to the points of the teeth, and, like the stout midribs, conspicnously impressed on the upper side; their petioles stout, hoarytomentose, about $\frac{1^{\prime}}{4}$ long; stipules acuminate, scarious, covered on the margins with long white hairs, $\frac{1}{4}^{\prime}$ long. Flowers appearing early in March, nearly sessile, in axillary usually 4-5-flowered clusters, hoary-tomentose, $\frac{1}{2}^{\prime}-\frac{3}{4}$ long; calyx broad, glabrous on the inner surface; anthers tomentose. Fruit: mature calyx spindle-shaped, light reddish brown, villose-pnbescent, deeply cleft at the apex, $\frac{1^{\prime}}{2}$ long; akene slightly ridged on the back, $\frac{1}{3}^{\prime}$ long, covered with long lustrous white hairs; style $1 \frac{1}{2}^{\prime}-2^{\prime}$ in length. 
A tree, occasionally $25^{\circ}$ high, with a trunk often inclining, usually much contorted, $2^{\prime}-10^{\prime}$ in diameter and $6^{\circ}-8^{\circ}$ long, stout wide-spreading branches, and stout branchlets, hoary-tomentose at first, marked by numerous small scattered lenticels, bright

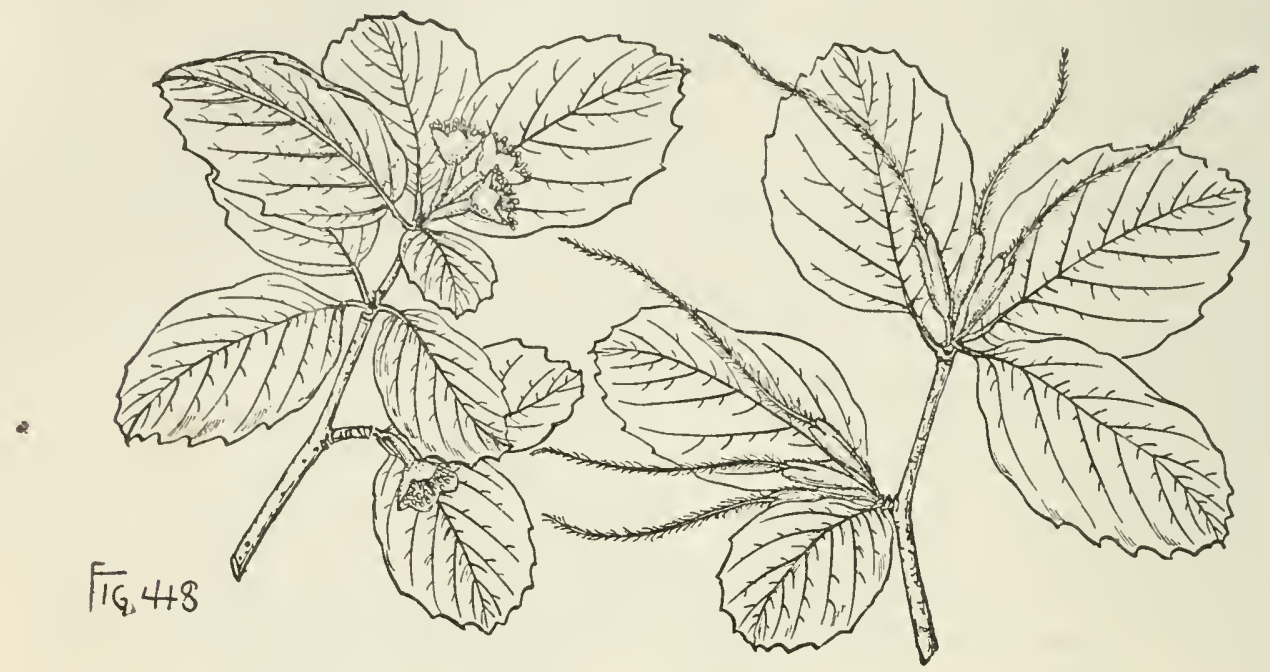

reddish brown during two or three years, ultimately dark gray-brown and conspicuously roughened by the enlarged ring-like leaf-scars. Bark light gray, sometimes slightly broken by shallow fissures and marked by irregular cream-colored blotches.

Distribution. Steep sides of a deep narrow arroyo on the south coast of Santa Catalina Island, California.

\section{Cercocarpus parvifolius, Nutt.}

Leaves cuneate-obovate, rounded, obtuse or rarely acuminate, gradually contracted at the base, coarsely glandular-serrate above the middle, or rarely almost

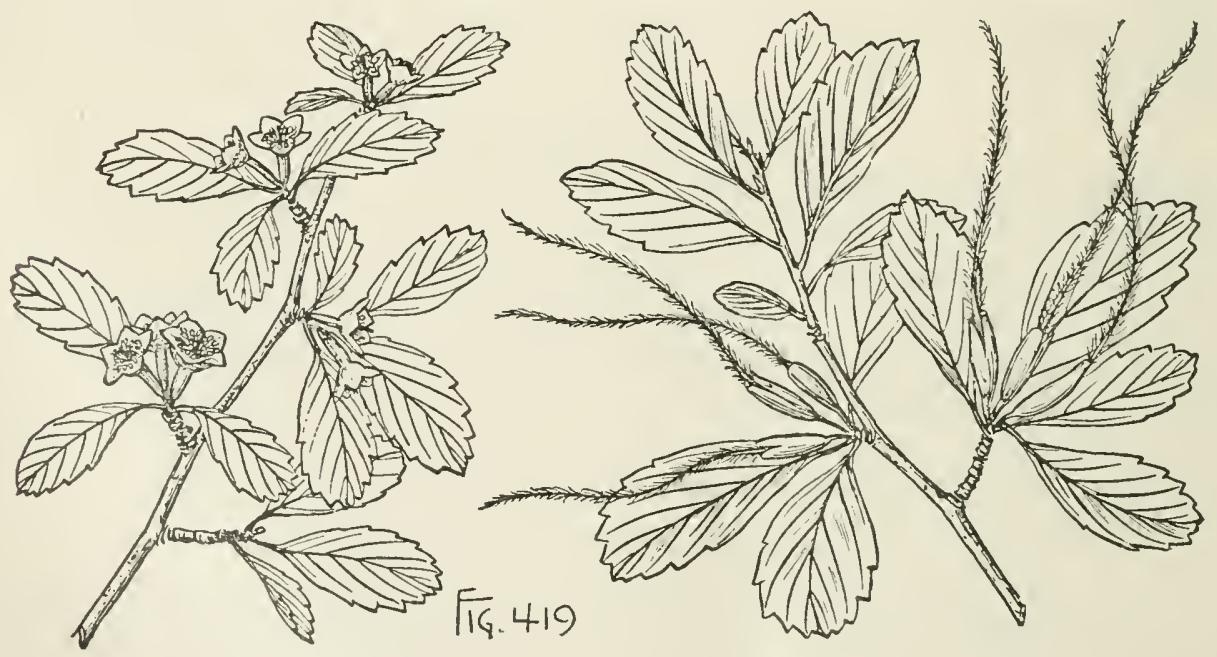

entire, or slightly 3-toothed or apiculate at the apex, when they unfold coated with pale pubescence, and at maturity subcoriaceous, dark yellow-green, puberulous or glabrous on the upper surface, paler, slightly pubescent, and often nearly white or 


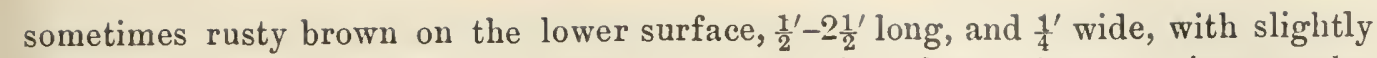
thickened revolute margins, broad midribs, 4-6 pairs of conspicuous primary veins and reticulate veinlets; their petioles broad, channeled, $\frac{1}{8}^{\prime}$ to nearly $\frac{1}{2}^{\prime}$ long; stipules lanceolate, acuminate, apiculate, $\frac{1^{\prime}}{8}-\frac{1^{\prime}}{4}$ long. Flowers on slender hairy pedicels, usually in 2 or 3-flowered clusters $\frac{1^{\prime}}{4}$ long; calyx-tube slender, hoary-tomentose on the outer surface, with a narrow obtusely lobed limb. Fruit : mature calyx-tube spindle-shaped, light chestnut-brown, slightly puberulous, deeply cleft at the apex, $\frac{1^{\prime}}{2}-\frac{3}{4}$ ' long; akene more or less conspicuously sulcate on the back, covered with long white hairs; style of ten $4^{\prime}-5^{\prime}$ in length.

A bushy tree, with aromatic leaves and branches sometimes $20^{\circ}-30^{\circ}$ high, with a trunk rarely more than $10^{\prime}$ in diameter, slender rigid upright branches, and branchlets clothed at first with pale silky pubescence, soon glabrous, rather bright brown and marked by occasional oblong light-colored lenticels during their first year, becoming dark gray or brown and covered with conspicuous ring-like leaf-scars. Bark about $\frac{1}{16}$ thick, generally smooth, divided by narrow shallow fissures and broken into small square persistent red-brown scales. Wood light red-brown, with thin light brown sapwood of about 20 layers of amnual growth.

Distribution. Monntain ranges of the arid portions of western North America from western Nebraska to the northern slopes of the Siskiyou Mountains, Oregon, and to western Texas and northern New Mexico; common on the California coast ranges southward to the San Jacinto Mountains; on Santa Cruz Island, California, and on the mountains of Lower California. On the California coast ranges frequently with rather larger fruit and larger and proportionally broader often glabrous leaves (var. betuloides, Sarg.).

\section{Cercocarpus ledifolius, Nutt.}

Leaves narrowly lanceolate, acute at the ends, apiculate, entire, with thick revolute margins, coriaceous, reticulate-veined, usually puberulous while young, at
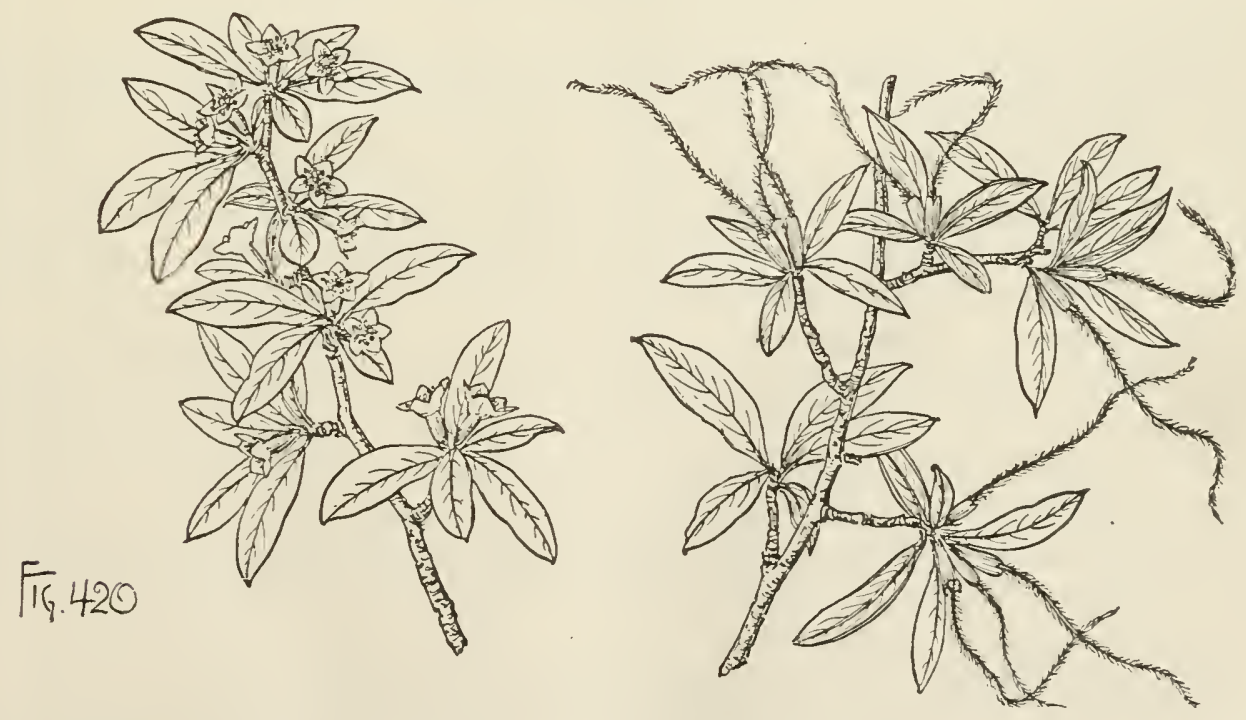

maturity dark green, lustrous and glabrous on the upper surface and more or less coated with pale or rufous pubescence on the lower surface, resinous, $\frac{1}{2}^{\prime}-1^{\prime}$ long, and $\frac{1}{3}-\frac{2}{3}$ ' wide, with broad thick midribs deeply grooved on the upper side, and obscure 
primary veins, persistent until the end of their second summer; their petioles broad, about $\frac{1}{8}$ long; stipules nearly triangular. Flowers solitary, sessile in the axils of the clustered leaves, $\frac{2 \prime}{3}$ long; calyx hoary-tomentose. Fruit: matnre calyx-tube almost $\frac{1}{2}$ long, nearly cylindrical, rather larger above than below, 10-ribbed, obscurely 10-angled, slightly cleft at the apex, hoary-tomentose; akene pointed at the ends, obscurely angled, chestuut-brown, $\frac{1^{\prime}}{4}$ long, covered with long pale or tawny hairs; style $2^{\prime}-3^{\prime}$ long, generally contracted by 1 or 2 partial corkscrew twists.

A resinous slightly aromatic tree, occasionally $40^{\circ}$ high, with a short trunk sometimes $2 \frac{1}{2}^{\circ}$ in diametcr, stout spreadiug usually contorted branches forming a round compact head, and red-brown branchlets coated at first with pale pubescence, soon becoming glabrous, frequently covered with a glaucous bloom, silver gray or dark brown in their second year, and for many years marked by the conspicuous elevated leaf-scars. Bark red-brown, divided by deep broad furrows, and broken on the surface into thin persistent plate-like scales, becoming on old trunks 1 ' thick. Wood bright clear red or rich dark brown, with thin yellow sapwood of 15-20 layers of annual growth.

Distribution. Dry gravelly arid slopes at elevations of $5000^{\circ}-9000^{\circ}$ above the sea; sometimes on almost precipitous cliffs and on rocky ridges as a densely hranched contorted shrub, with linear revolute leaves, and smaller flowers and fruits (var. intricatus, M. E. Jones); mountain ranges of the interior region of the United States from western Wyoming to the western slopes of the Rocky Mountains of Montana, the Cœur d'Alene Mountains of Idaho, the Blue Mountains of Washington and Klamath County, Oregon, and sonthward through the Wasatch Mountains and the ranges of the Great Basin to the eastern slopes of the Sierra Nevada, the northern slopes of the San Bernardino Mountains, California, and to the monntains of northern New Mexico and Arizona; most abundant and of its largest size on the high foothill slopes of the mountain ranges of central Nevada at elevations of $6000^{\circ}-8000^{\circ}$.

\section{Cercocarpus breviflorus, Gray.}

Leaves oblong-obovate to narrowly elliptic, acute or ronnded and often apiculate at the apex, gradually narrowed from above the middle and acute at the base, their margins revolute, often undulate, and entire or dentate toward the apex, with few small straight or incurved apiculate teeth, when they unfold coated with hoary tomentum, and at maturity thick, gray-green on the upper surface, pale on the lower surface, covered with soft pale hairs most abundant on the under side of the midribs and primary veins, $\frac{1^{\prime}}{2}-1^{\prime}$ long and usually about $\frac{1^{\prime}}{4}$ wide; their petioles stout, tomentose, nltimately sometimes light red, and pubescent or nearly glabrous, $\frac{1}{5}-\frac{1}{16}$ ' long; stipules linear-lanceolate, tomentose, about half as long as the petioles. Flowers appearing from March to May and often again in Augnst, nearly sessile, solitary or in pairs in the axils of the crowded leaves; calyx-tube slender, $\frac{1}{1 \frac{1}{6}}-\frac{1}{4}$ long, coated on the outer surface, like the short rounded lobes, with dense white tomentum. Fruit: mature calyx-tube stalked, spindle-shaped, light red-brown, pubescent above, tomentose toward the base, deeply cleft at the apex, about $\frac{1}{4}^{\prime}$ long; akene nearly terete, covered with long white hairs; style $\mathbf{1}^{\prime}-\mathbf{1} \frac{1^{\prime}}{2}$ long.

A tree, $20^{\circ}-25^{\circ}$ high, with a long straight trunk sometimes $6^{\prime}-8^{\prime}$ in diameter, erect rigid branches forming a narrow open or irregnlar head, and slender bright red-brown lustrous branchlets marked irregularly by large scattered pale lenticels, covered at first with a thick cont of hoary tomentum, villose or pubescent for two or three years and ultimately ashy gray or gray tinged with red, the spur-like lateral 
branchlets much roughened by the ring-like scars of fallen leaves. Bark about $\frac{1}{8}^{\prime}$ thick, divided by shallow fissures and broken on the surface into small light redbrown scales.

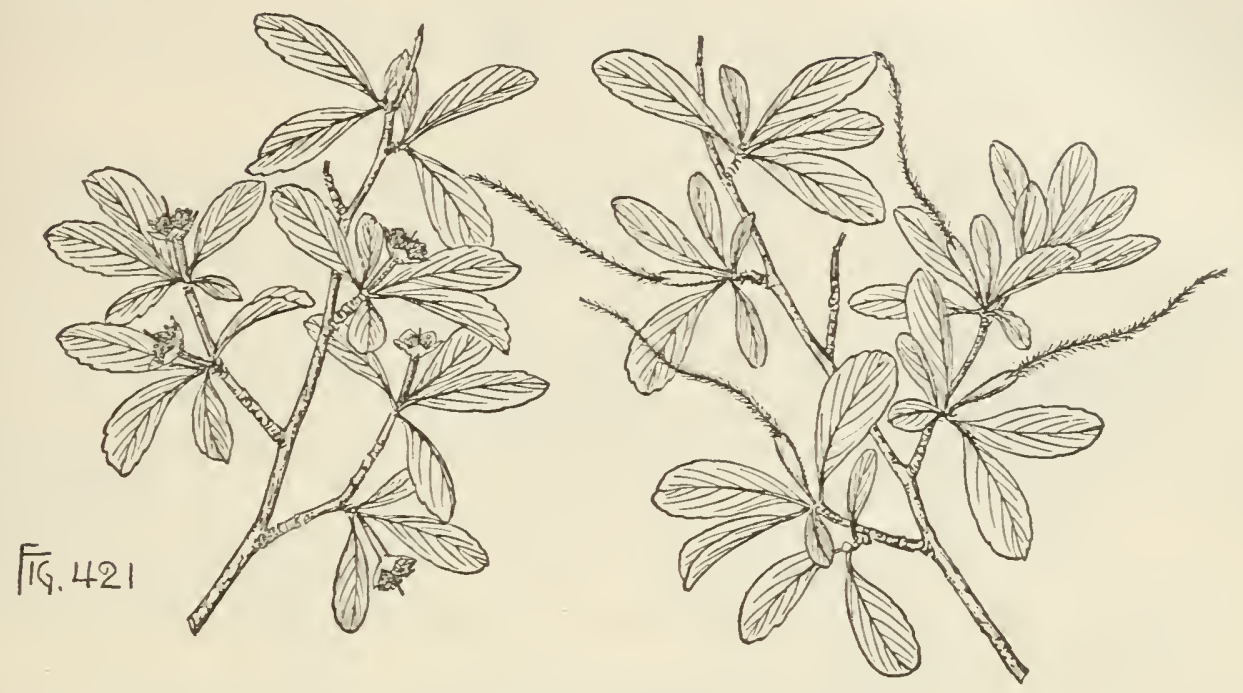

Distribution. In forests of Pines and Oaks on the dry ridges of the mountains of southern Arizona and New Mexico, and of western Texas, usually at elevations of about $5000^{\circ}$ above the sea, and southward over the mountains of northern Mexico.

\section{PRUNUS, B. \& H. Plum and Cherry.}

Trees or shrubs, with bitter astringent properties, slender branchlets, marked by the usually small elevated horizontal leaf-scars, with 2 or 3 fibro-vascular bundlescars, and small scaly buds, their scales imbricated in many rows, those of the inner rows accrescent and often colored. Leaves conduplicate or convolute in the bud, alternate, simple, usually serrate, petiolate, deciduous or persistent; stipules free from the petiole, usually lanceolate and glandular, often minute, early deciduous. Flowers in axillary umbels or corymbs, or in terminal or axillary racemes, appearing from separate buds before, with, or later than the leaves, or on leafy branches; calyx 5-lobed, the lobes imbricated in the bud; disk thin, adnate to the calyx-tube, glandular, often colored; petals 5, white, deciduous; stamens usually 15-20, inserted with the petals in 3 rows, those of the outer row 10, opposite the petals, those of the next row alternate with them and with those of the inner row, sometimes 30 in 3 rows; filaments filiform, free, incurved in the bud; anthers oval, attached on the back; ovary inserted in the bottom of the calyx-tube, 1-celled; style terminal, dilated at the apex into a truncate stigma; ovules 2 , suspended; raphe ventral, the micropyle superior. Fruit a 1-seeded drupe; flesh thick and pulpy or dry and coriaceous; stone bony, smooth, rugose, or pitted, compressed, indehiscent. Seed filling the cavity of the nut, suspended; seed-coat thin, membranaceous, pale brown; cotyledons thick and fleshy; radicle superior.

Prunus with about one hundred and twenty species is generally distributed over the temperate region of the northern hemisphere, and is abundant in North America, eastern Asia, western and central Asia and central Europe, ranging southward in the New World into tropical America, and to southern Asia in the Old World. Of the twenty-five or thirty species which occur in the United States, eighteen are 
arboreseent in habit. Several of the species bear fruits which are important articles of human food; many contain in the seeds and leaves hydroeyanic acid, to which is due their peculiar odor, and the fruit of some of the speeies is used to flavor eordials. 'The wood of Prunus is elose-grained, solid, and durable, and a few of the speeies are important timber-trees.

Prunus is the elassieal name of the Plum-tree.

\section{CONSPECTUS OF THE NORTH AMERICAN ARBORESCENT SPECIES.}

1. Flowers in sessile axillary umbels; fruit often slightly 2-lobed by a ventral groove. Plums.

Leaves conduplicate in the bud.

Fruit red or orange-colored, usually destitute of bloom, $\frac{1^{\prime}}{2}-1^{\prime}$ in diameter.

Leaves oblong to obovate, broad, thick, and dull.

Calyx-lobes glandular, glabrous on the inner surface; stone compressed; petioles biglandular.

1. P. nigra (A).

Calyx-lobes entire, pubescent on the inner surface; stone turgid; petioles usually without glands.

2. P. Americana (A, C, F).

Leaves ovate-lanceolate to lanceolate, narrow, thin, and lustrous ; petioles glandular ; stone turgid.

Calyx-lobes pubescent; leaves ovate-lanceolate.

Calyx-lobes glabrous; leaves lanceolate to oblong-lanceolate.

3. P. hortulana $(\mathrm{A}, \mathrm{C})$.

4. $P$. angustifolia (C).

Fruit blue, covered with a glaucous bloom, $\frac{1}{3}^{\prime}-\frac{1}{2}^{\prime}$ in diameter ; leaves lanceolate to oblong-ovate; petioles usually withont glands.

Leaves convolute in the bud.

5. P. Alleghaniensis (A).

Fruit often 1' or more in diameter, red or yellow, nearly destitute of bloom; leaves broadly ovate to orbicular; petioles mostly without glands.

Fruit $\frac{1^{\prime}}{2}$ in diameter or less.

6. P. subcordata (G).

Fruit dark blue or black, covered with a glancous bloom; leaves ovate-lanceolate to oblong; petioles mostly without glands.

7. P. umbellata (C).

Fruit yellow, red, blue, or black, covered with a glancous bloom; leaves oblong to obovate; petioles conspicuously biglandular.

8. P. tarda (C).

2. Flowers in axillary umbels or corymbs; fruit globose, $\frac{1}{2}{ }^{\prime}$ in diameter or less, bright red and lustrons; leaves conduplicate in the bud. Bird Cherries.

Leaves usually oblong-lanceolate, acuminate or rarely acute.

9. P. Pennsylvanica (A, B, F).

Leaves usually oblong-obovate and obtuse.

10. P. emarginata (B, F, G).

3. Flowers in terminal racemes on leafy branches of the year; fruit globose ; leaves conduplicate in the bud. Wird Cherries.

Calyx-lobes deciduous from the fruit; leaves broadly oval or oblong-obovate, usually abruptly acuminate.

11. P. demissa $(B, F, G)$.

Calyx-lobes persistent on the fruit.

Leaves oblong or lanceolate-oblong, usually narrowly cuneate.

Leaves ovate-oblong or elliptic.

12. P. serotina (A, C, E, H).

Leaves obovate, oval or elliptic, clothed below with pale or rufous matted hairs.

14. P. australis (C).

4. Flowers racemose in the axils of persistent leaves of the previous year; fruit globose or slightly 2-lobed; leaves conduplicate in the bud. Cherry Laurels.

Calyx-lobes rounded, with undulate margins; stone broadly ovate, cylindrical; leaves entire or rarely remotely spinulose-serrate.

15. P. Caroliniana (C). 
Calyx-lobes acute, with laciniate margins; stone depressed-globose; leaves entire.

16. P. sphærocarpa (D).

Calyx-lobes acute, entire; stone ovate, slightly compressed.

Leaves coarsely spinulose-toothed.

17. P. ilicifolia (G).

Leaves entire or occasionally remotely and minutely dentate.

1S. P. integrifolia $(\mathrm{G})$.

1. Flowers in axillary umbels; fruit usually more than $\frac{1}{2}^{\prime}$ in diameter. PuUms.

\section{Prunus nigra, Ait. Red Plum. Canada Plum.}

Leaves oblong-ovate to obovate, abruptly contracted at the apex into long narrow points, wedge-shaped, truncate or slightly heart-shaped at the base, and doubly crenulate-serrate, with small dark glandular teeth, when they unfold faintly tinged with red and pubescent on the under surface or glabrous with the exception of conspicuous tufts of slender white or rufous hairs in the axils of the primary veins, and

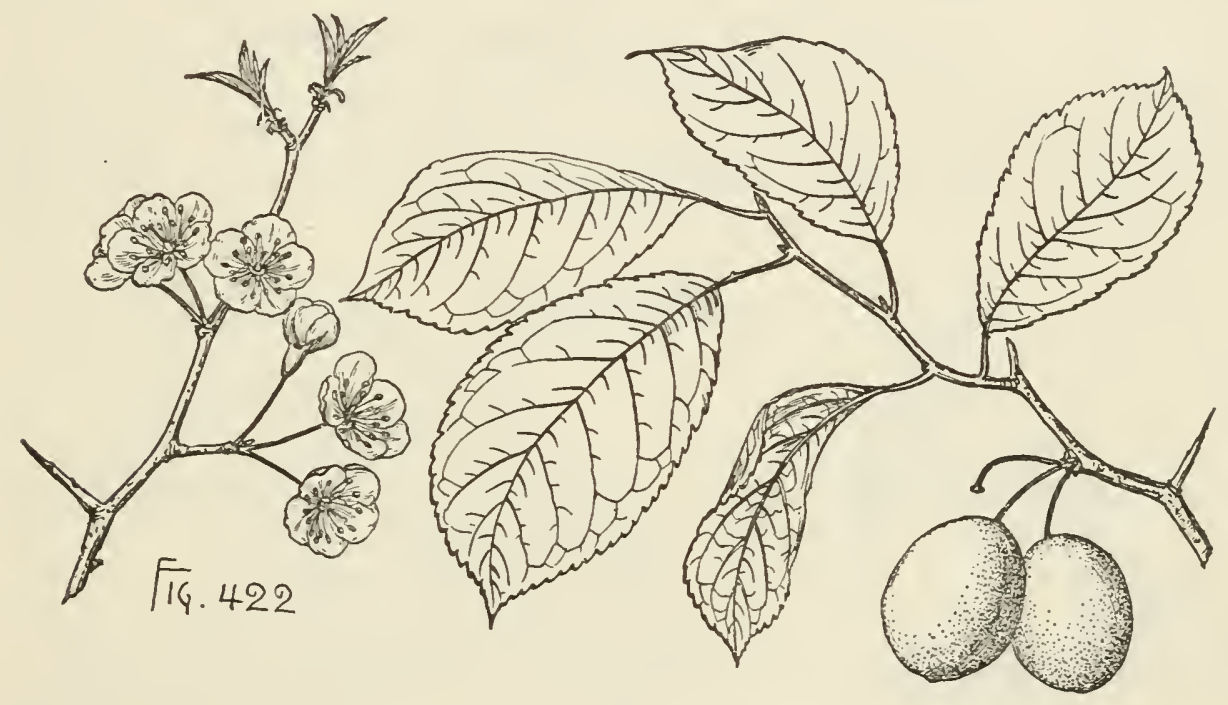

at maturity thick and firm, dull dark green on the upper, pale on the lower surface, $3^{\prime}-5^{\prime}$ long and $1 \frac{1}{2}-3^{\prime}$ wide, with conspicuous pale midribs and slender veins; their petioles stout, $\frac{1^{\prime}}{2}-1^{\prime}$ long, and biglandular at the apex, with 2 large dark glands; stipules lanceolate or on vigorous shoots often 3-5-lobed, glandular-serrate, $\frac{1}{2}^{\prime}$ long, early deciduous. Flowers appearing in early spring with or before the leaves, $\frac{1^{\prime}}{4}$ in diameter, on slender glabrous dark red pedicels, $\frac{1}{2}^{\prime}-\frac{2}{3}^{\prime}$ long, in 3 or 4-flowered umbels; calyx-tube broadly obconic, dark red on the outer, bright red on the inner surface, the lobes narrow, acute, glandular, glabrous or occasionally pubescent on the outer surface, reflexed after the flowers open; petals broadly ovate, rounded at the apex, more or less erose on the margins, contracted at the base into short claws, white, turning pink in fading. Fruit ripening from the middle to the end of August, oblonge oval, $1^{\prime}-1 \frac{1}{4}^{\prime}$ long, with a tough thick orange-red skin nearly destitute of bloom, yellow rather austere flesh, and an oval compressed stone, $1^{\prime}$ long, $\frac{2 \prime}{3}$ wide, thick-walled, acutely ridged on the ventral and slightly grooved on the dorsal suture.

A tree, $20^{\circ}-30^{\circ}$ high, with a trunk sometimes $5^{\prime}-6^{\prime}$ in diameter, divided usually $5^{\circ}-6^{\circ}$ from the ground into a number of stout upright branches forning a narrow rigid head, stout slightly zigzag branchlets marked by numerous pale excrescences, 
bright green, glabrous or puberulous at first, and dark brown tinged with red in their second season, and stont spiny lateral spur-like secondary branchlets. Winter-buds acuminate, $\frac{1^{\prime}}{8}-1^{\prime}$ long, with chestnut-brown triangular scales pale and scarious on the margins. Bark about $\frac{1}{8}^{\prime}$ thick, light gray-brown, with a smooth outer layer exfoliating in large thick plates of several papery layers, and in falling exposing the darker slightly fissured scaly imer bark. Wood heavy, hard, strong, close-grained, rich bright red-brown, with thin lighter colored sapwood.

Distribution. Neighborhood of streams in rich alluvial soil, or on low limestone hills in open glades, or wood borders; Newfoundland, through the valley of the St. Lawrence River to the valleys of the Rainy and Assiniboine rivers, the southern shores of Lake Manitoba, and southeastern Minnesota.

Often cultivated in Canadian gardens and occasionally in those of the worthern states as a fruit-tree or for the beauty of its flowers, and now sparingly naturalized along the northern borders of the United States. Varieties are propagated by pomologists.

\section{Prunus Americana, Marsh. Wild Plum.}

Leaves oval or slightly obovate, acuminate, narrowed and occasionally rounded at the base, and sharply and often doubly serrate, when they unfold nearly glabrous or furnished below with conspicuous axillary tufts of pale hairs, and at maturity thick

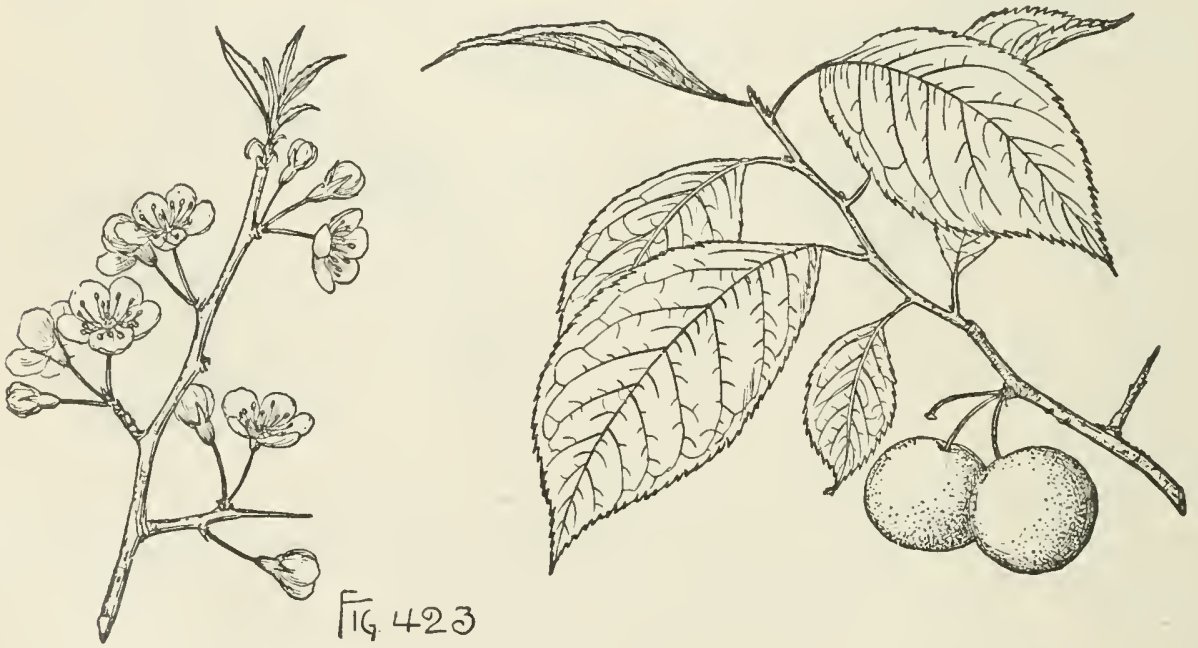

and firm, more or less rugose, dark green on the upper, pale and glabrous on the lower surface, $3^{\prime}-4^{\prime}$ long, and $1 \frac{1^{\prime}}{2}$ wide, with slender midribs and primary veins; their petioles slender, $\frac{1^{\prime}}{2}-\frac{2^{\prime}}{3}$ long, usually without glands; stipules linear, often 3-lobed, sharply serrate, $\frac{1^{\prime}}{2}-\frac{3^{\prime}}{4}$ long, early deciduous. Flowers appearing in early spring when the leaves are nearly fully grown, $1^{\prime}$ in diameter, bad-smelling, on slender glabrous green pedicels $\frac{1^{\prime}}{3}-\frac{2}{3}$ long, in 2-5-flowered umbels; calyx-tube narrowly obconic, light red, glabrous or puberulous, green on the inside, the lobes acuminate, entire, reflexed after the flowers open, slightly pubescent on the outer, pilose on the imner surface; petals rounded and irregularly laciniate at the apex, contracted below into long narrow claws, bright red at the base, $\frac{1}{2}^{\prime}$ long and $\frac{1}{4}^{\prime}$ wide. Fruit ripening in June at the south and from the end of August to early October at the north, subglobose or rarely slightly elongated, usually rather less than $\mathbf{1}^{\prime}$ in diameter, in ripening 
turning from green to orange, often with a red cheek, bright red when fully ripe, destitute of bloom and more or less conspicuously marked by pale spots, with tough thick acerb skin, bright yellow succulent rather juicy acid flesh, and an oval slightly rugose stone pointed at the apex, more or less contracted at the base, $\frac{5^{\prime}}{8}-\frac{3}{4}$ long and often as thick as broad, slightly and acutely ridged on the ventral and obscurely grooved on the dorsal suture.

A tree, $20^{\circ}-35^{\circ}$ high, with a trunk rarely exceeding a foot in diameter, and divided usually $4^{\circ}-5^{\circ}$ from the ground into many spreading branches often pendulous at the ends and forming a broad graceful head, branchlets at first light green, glabrous, puberulous or coated with dense pale tomentum, light orange-brown during their first winter, becoming darker and often tinged with red and marked by minute circular raised lenticels, and long slender remote sometimes spinescent lateral branchlets. Winter-buds acute, $\frac{1}{8}^{\prime}-\frac{1}{4}^{\prime}$ long, with chestnut-brown scales more or less erose on the margins, the inner scales when fully grown foliaceous, $\frac{1}{2}$ long, oblong, acute, remotely serrate, with two narrow acuminate lateral lobes. Bark about $\frac{1}{2}$ thick, dark brown tinged with red, the outer layer separating into large thin persistent plates. Wood heavy, hard, close-grained, strong, dark rich brown tinged with red, with thin lighter colored sapwood. The fruit is sometimes used in the preparation of jellies and preserves, and is eaten raw or cooked.

Distribution. In the middle and northern states in rich soil, growing along the borders of streams and swamps, and frequently forming thickets of considerable extent; in the south Atlantic states often in river swamps; west of the Mississippi River on bottom-lands and dry limestone rplands; middle and northern New Jersey, and central New York to Nebraska; the valley of the upper Missouri River in Montana, the eastern slopes of the Rocky Mountains of Colorado, and sonthward to the Chattahoochee region of western Florida, the valley of the Rio Grande in southern New Mexico, and the mountains of Northern New Mexico; most abundant and of its largest size in southern Arkansas and eastern Texas.

West of the Mississippi River from Missouri to Texas the common form (var. lanata, Sndw.) is pubescent through the season on the under surface of the leaves, the calyx-lobes, pedicels, and branchlets, and should perhaps be considered a distinct species.

Often cultivated in the eastern states as an ornamental or fruit tree. Numerous varieties are propagated by pomologists.

\section{Prunus hortulana, Bailey. Wild Plum.}

Leaves ovate-lanceolate, contracted at the apex into long slender points, wedgeshaped or more or less rounded at the narrow base, and finely serrate, with incurved lanceolate glandular teeth, when they unfold pilose, with slender white hairs, and at maturity glabrous above, pilose below in the axils of the primary veins and along the midribs, thin but firm, dark green and lustrous on the upper, paler on the lower surface, $4^{\prime}-6^{\prime}$ long, $1^{\prime}-1 \frac{1^{\prime}}{2}$ wide, with broad conspicuous orange-colored midribs, primary veins connected near the margins of the leaf, and prominent reticulate veinlets; their petioles slender, orange-colored, $1^{\prime}-1 \frac{1}{2}^{\prime}$ long and furnished above the middle with numerous scattered dark glands; stipules lanceolate-acuminate, glandular-serrate, early decidnous. Flowers appearing in April or early in May when the leaves are about one third grown, $\frac{2^{\prime}}{3}-1^{\prime}$ in diameter, on slender puberulons pedicels $\frac{1}{2}$ ' long, in 2-4-flowered umbels; calyx-tube narrowly obconic, puberulous on the outer surface, the lobes ovate, acute or rounded at the apex, glandular-serrate, 
pubescent on the outer, pubescent or tomentose on the inner snrface, reflexed after the unfolding of the narrowly obovate petals rounded and occasionally emarginate at the apex, contracted below into long narrow claws, entire, erose, or occasionally

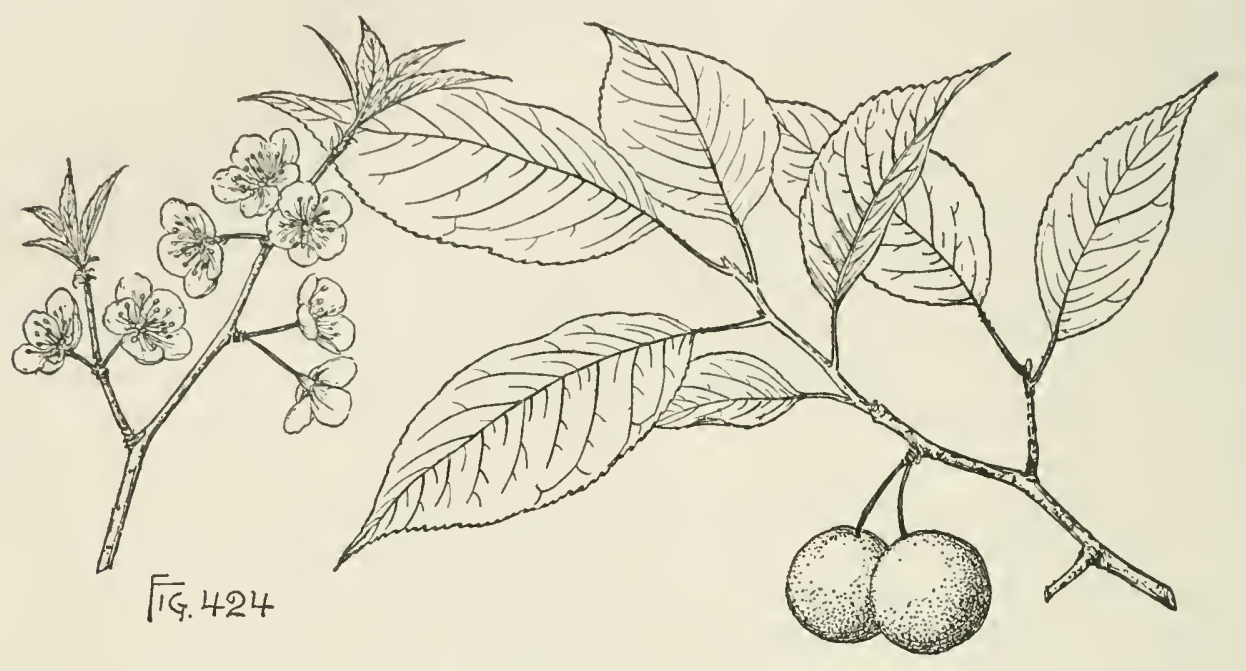

serrate, and pure white or often marked with orange toward the base. Fruit ripening in September and October, on stout stems, globose to short-oblong, $\frac{8^{\prime}}{4}-1^{\prime}$ in diameter, with thick acid deep red or sometimes yellow skin, hard austere thin flesh, and a turgid stone $\frac{2^{\prime}}{3}-\frac{3}{4}$ long, compressed at the ends, abruptly short-pointed at the apex, conspicuously ridge-margined on the ventral and broadly and deeply grooved on the dorsal suture, thick-walled, rugbse, and deeply pitted.

A tree, $20^{\circ}-30^{\circ}$ high, with a slender often inclining trunk, frequently $5^{\prime}-6^{\prime}$ or occasionally $10^{\prime}-12^{\prime}$ in diameter, dividing usually several feet above the ground into

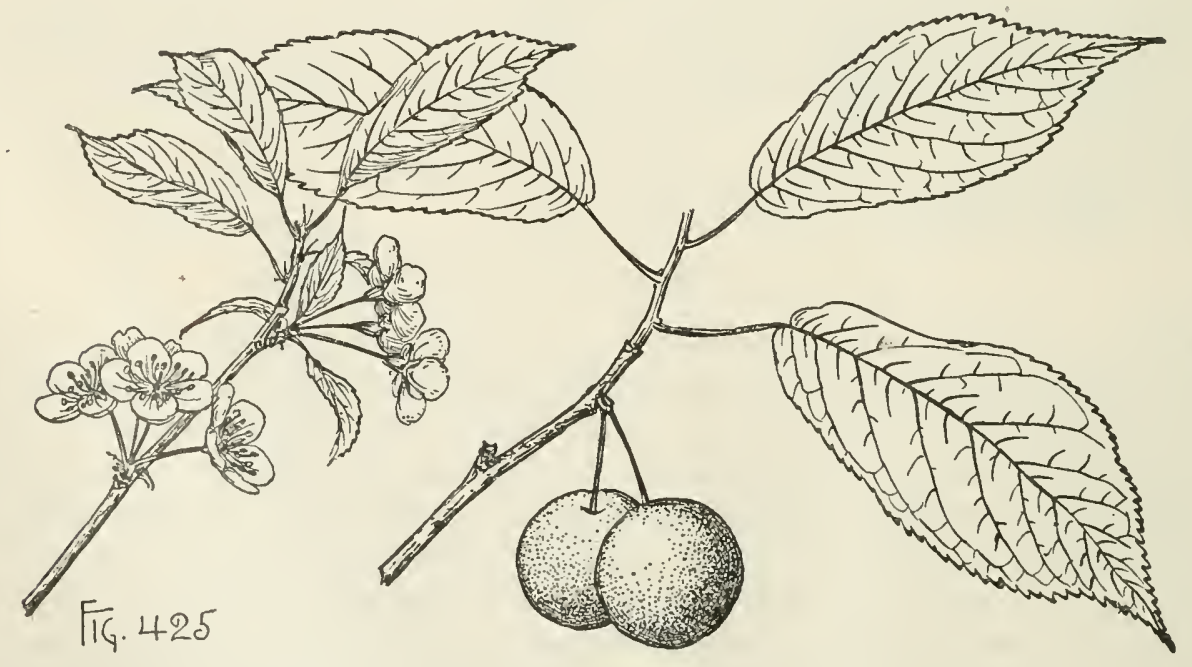

stont spreading branches, and stout rigid branchlets marked by minute pale lenticels, glabrous or slightly puberulous during their first summer, rather dark brown, and usually unarmed or on vigorous trees armed with stout spinescent lateral branchlets; or often a shrub, with many stems forming thicket-like clumps. Winter- 
buds minute, obtuse, with chestnut-brown scales slightly ciliate on the margins, those of the inner ranks becoming oblong-lanceolate, acute, glandular-serrate, sometimes $\frac{1{ }^{\prime}}{2}$ long. Bark thin, dark brown, separating into large thin persistent plates, and displaying the light brown inner layers.

Distribution. Low banks of streams in rich moist soil; Maryland and Virginia to southeastern Kansas and Texas; sometimes considered a natural hybrid between Prunus Americana and Prunus angustifolia.

Prunus hortulana, var. Mineri, Bailey (f. 425), with thicker rather duller somewhat obovate and more coarsely serrate leaves, is an Illinois and Missouri form or perhaps a distinct species related to Prunus Americana.

Often cultivated by pomologists in many forms of garden origin.

\section{Prunus angustifolia, Marsh. Chickasaw Plum.}

Leaves lanceolate to oblong-lanceolate, pointed at the ends, apiculate at the apex, and sharply serrate, with minute glandular teeth, glabrous or at first sometimes furnished with axillary tufts of long pale hairs, bright green and lustrous on the

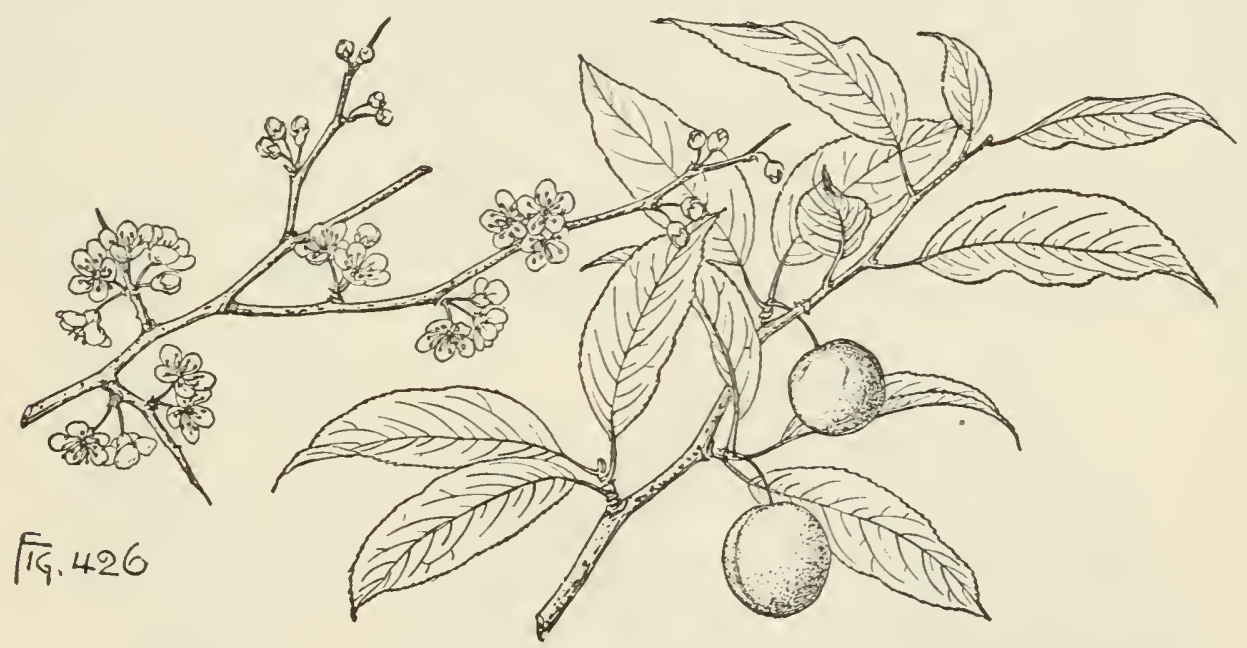

upper, paler aud rather dull on the lower surface, $1^{\prime}-2^{\prime}$ long and $\frac{1}{3}^{\prime}-2^{\prime}$ wide; their petioles slender, glabrous or puberulous, biglandular near the apex, with 2 conspicnous red glands, bright red, $\frac{1}{4}^{\prime}-\frac{1^{\prime}}{2}$ long; stipules linear or lobed, glandular-serrate, $\frac{1^{\prime}}{2}$ long. Flowers appearing before the leaves from the beginning of March at the south to the middle of April at the north, $\frac{1^{\prime}}{3}$ across, on slender glabrous pedicels $\frac{1}{4}^{\prime}-\frac{1}{2}^{\prime}$ long, in 2-1-flowered umbels; calyx-tube campanulate, glabrous, the lobes oblong, obtuse, ciliate on the margins, with slender hairs, pale-pubescent on the inner surface, reflexed at maturity; petals obovate, rounded at the apex, contracted at the base into short broad claws, white or creamy white. Fruit ripening between the end of May and the end of July, globose or subglobose, about $\frac{1^{\prime}}{2}$ in . diameter, bright red, rather lustrous, nearly destitute of bloom, with a thin skin, juicy subacid flesh, and a turgid rugose stone compressed at the ends, nearly $\frac{1}{2}^{\prime}$ long, more or less thickmargined on the ventral and grooved on the dorsal suture.

A tree, $15^{\circ}-25^{\circ}$ high, with a trunk rarely exceeding $8^{\prime}$ in diameter, slender spreading branches, and bright red and lustrous branchlets glabrous or covered at first with short caducous hairs, becoming in their second year dull, darker and often brown, marked with occasional horizontal orange-colored lenticels, and frequently armed 
with long thin spinescent lateral branchlets; oftcu sprcading into thickets. Winterbuds acuminate, ${ }_{1 \frac{1}{}}^{\prime}$ loug, with chestmut-brown scales. Bark about $\frac{1^{\prime}}{8}$ thick, dark reddish brown, and slightly furrowed, the surface broken into long thick appressed scalcs. Wood heavy, although rather soft, not strong, light brown or red, with lighter colored sapwood. The fruit is often sold in the nuarkets of the middle and southern states.

Distribution. Widcly naturalized especially in the south Atlantic and Gulf states from sontheru Delaware and Kentucky to ecutral Florida and eastern Texas, occupying the margins of fields and other waste places near human habitations usually in riclı soil; its origin still nuccrtain.

A number of varieties derived from this species are cultivated as fruit-trees in the southern states.

\section{Prunus Alleghaniensis, Port. Sloe.}

Leaves lanceolate to oblong-ovate, often long-pointed, finely and sharply serrate, with glandular teeth, and furnished at the base with 2 large rather conspicuous glands, when they unfold covered with soft pubescence, and at maturity puberulous on the upper and glabrous with the exception of a few hairs in the axils of the veins, or covered, especially along the broad midribs and conspicuous veins, with rufous pubescence on the lower surface, rather thick and firm in texture, dark green above and paler below, $2^{\prime}-3 \frac{1}{2}^{\prime}$ long and $\frac{2}{3}^{\prime}-1 \frac{1}{4}^{\prime}$ wide; their petioles slender, grooved, pubescent or puberulous, $\frac{1}{4}^{\prime}-\frac{1}{3}^{\prime}$ long. Flowers appearing in May with the unfolding of the leaves, $\frac{1}{2}^{\prime}$ in diameter, on slender puberulous pedicels $\frac{1}{2}^{\prime}-\frac{2}{3}^{\prime}$ long, in 2-4flowered umbels; calyx-tube narrowly obconic, pubescent or puberulous on the

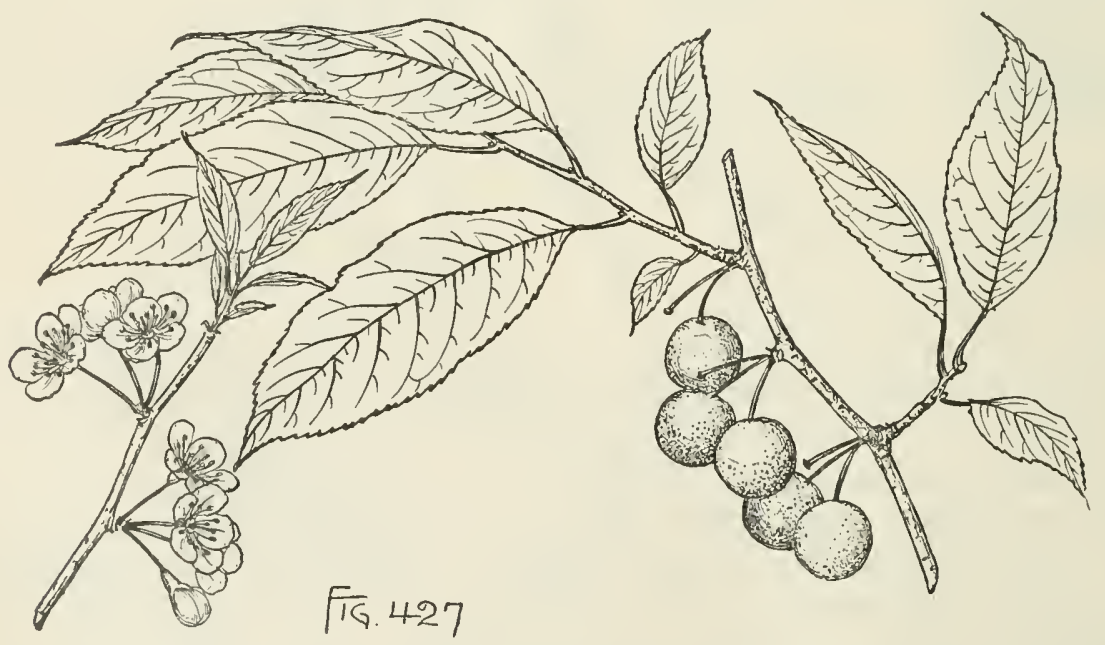

outer surface, the lobes ovate-oblong, rounded at the apex, scarious on the margins, and coated with pale tomentum on the inner surface; petals rounded at the apex, contracted at the base into short claws, turning pink in fading. Fruit ripening the middle of August, on stout puberulous pedicels, subglobose or slightly oval to obovate, $\frac{1}{3}-\frac{2}{3}$ in diameter, with thick rather tough dark reddish purple skin covered with a glaucous bloom, yellow juicy austere flesh, and a thin-walled turgid stone two thirds as thick as broad, $\frac{1^{\prime}}{4}-\frac{1}{2}$ long, pointed at the ends, ridged on the ventral, and slightly grooved on the dorsal suture.

A slender tree, occasionally $18^{\circ}-20^{\circ}$ high, with a trunk sometimes $6^{\prime}-8^{\prime}$ in diameter, 
dividing into numerous erect rigid branches, and branchlets at first coated with pale caducous pubescence, becoming dark red and rather lustrous in their first winter, and ultimately nearly black, and unarmed, or sometimes amed with stout spinescent lateral spur-like branchlets. Winter-buds acuminate or obtuse, $\frac{1}{16}{ }^{\prime}$ long, their inner scales accrescent, scarious, oblong, acute, $\frac{2 \prime}{3}$ long, bright red at the apex. Bark $\frac{1^{\prime}}{4}$ thick, dark brown, fissured and broken on the surface into thin persistent scales. Wood heavy, hard, close-grained, brown tinged with red, with thin pale sapwood of 10-12 layers of annual growth. The fruit is made into preserves, jellies, and jams.

Distribution. Low moist soil, often forming shrubby thickets sometimes of considerable extent, and dry ridges; slopes of 'Tussey's Mountain in the northwestern part of Huntingdon County, and over the main range of the Alleghany Mountains into Clearfield and Elk counties, Pennsylvania; of its largest size on limestone bluffs south of the Little Juniata River.

\section{Prunus subcordata, Benth. Wild Plum.}

Leaves broadly ovate or orbicular, usually cordate, sometimes truncate or rarely cuneate at the base, and sharply and often doubly serrate, when they unfold puberulous on the upper and pubescent on the lower surface, and at maturity glabrous or

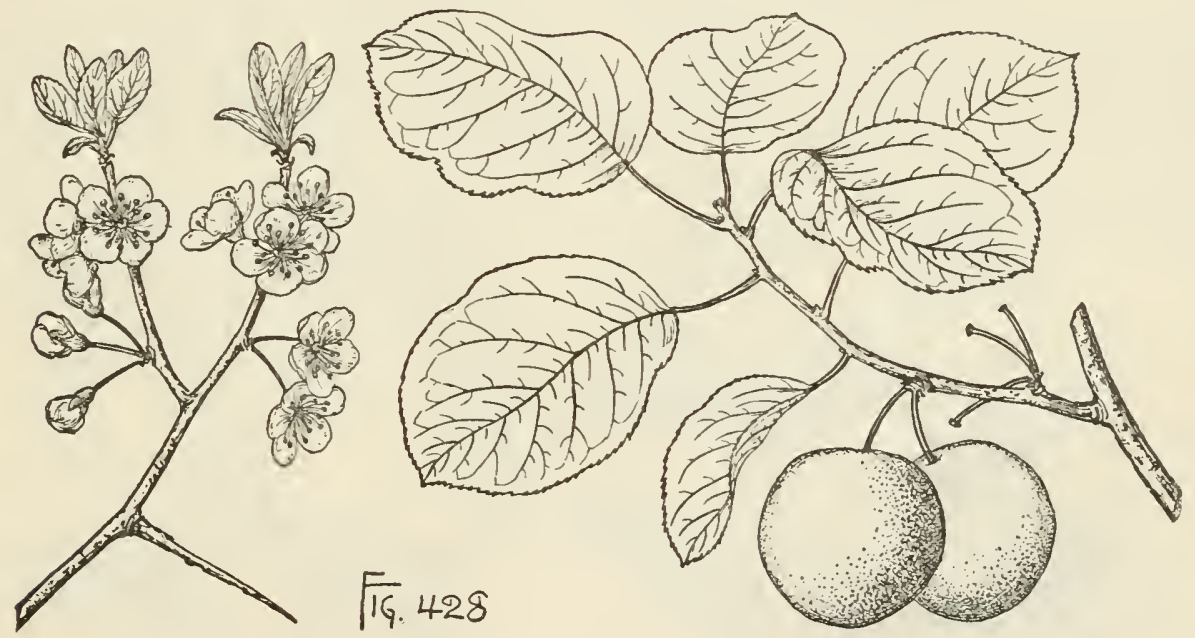

puberulous below, $1^{\prime}-3^{\prime}$ long, $\frac{1^{\prime}}{2}-2^{\prime}$ broad, slightly coriaceous, dark green above and pale below, with broad midribs and conspicuous veins, northward turning brilliant scarlet and orange or red and yellow in the autumn before falling; their petioles slender, usually with glands, $\frac{1^{\prime}}{2}-\frac{3^{\prime}}{4}$ long; stipules lanceolate, acute, glandular-serrate. Flowers appearing before the leaves in March and April, $\frac{2^{\prime}}{3}$ in diameter, on slender glabrous or pubescent pedicels $\frac{1^{\prime}}{4}-\frac{1}{2}^{\prime}$ long, in $2-4$-flowered umbels; calyx-tube campanulate, glabrous or puberulous, the lobes oblong-obovate, rounded at the apex, pubescent on the outer, more or less clothed with pale hairs on the inner surface, half as long as the obovate white petals rounded above and narrowed below into short claws. Fruit ripening in August and September, on stout pedicels $\frac{1^{\prime}}{2}-\frac{2}{3}$ long, oblong, $\frac{1}{2}-1 \frac{1}{4}^{\prime}$ long, with dark red or sometimes bright yellow skin, more or less subacid flesh, and a flattened or turgid stone, acute at the ends, $\frac{1}{3}^{\prime}-\mathbf{1}^{\prime}$ long, narrowly wing-margined on the ventral, conspicuously grooved on the dorsal suture. 
A trec, $20^{\circ}-25^{\circ}$ ligh, with a trunk sometimes a foot in diameter, dividing $6^{\circ}-8^{\circ}$ from the ground into stout almost horizontal branches, and glabrous or pubescent briglit red branclilets nuarked by occasional minute pale lenticels, bccoming darker red or purple in their second year, and ultimately dark brown or asliy gray; or of ten a bush, with stont ascending stems $10^{\circ}-12^{\circ}$ tall, or a low much-branched shrub. Winter-buds acute, $\frac{1^{\prime}}{8} \mathrm{long}$, with chestunt-brown scales, scarious on the margins, those of the inner rows $\frac{1}{4}$ long at maturity, oblong, acute, and generally briglit red. Bark about $\frac{1^{\prime}}{4}$ thick, gray-brown, deeply fissured, and divided into long thick plates broken on the surface into minute persistent scales. Wood heavy, hard, closegrained, pale brown, with thin lighter colored sapwood of 5 or 6 layers of annual growtl.

Distribution. Dry rocky hills and open woods usually in the neighborhood of streams, sometimes forming thickets of cousiderable extent; southern Oregon to central California in the region west of the Cascade and Sierra Nevada Mountains, and as a low shrub in the Klamath Lake region east of the Cascade Mountains; common in central California and on the foothills of the western slopes of the Sierra Nevala; of its largest size on the borders of small streams in southern Oregon and northern California; at high elevations and in arid regions usually a low shrub producing sparingly small acid fruit.

\section{Prunus umbellata, Ell. Sloe. Black Sloe.}

Leaves obovate-lanceolate to oblong, acute at the ends or sometimes rounded or slightly cordate at the base, finely and sharply serrate, with remote incurved glandular teeth, and usually furnished with 2 large dark glands at the basc, when they

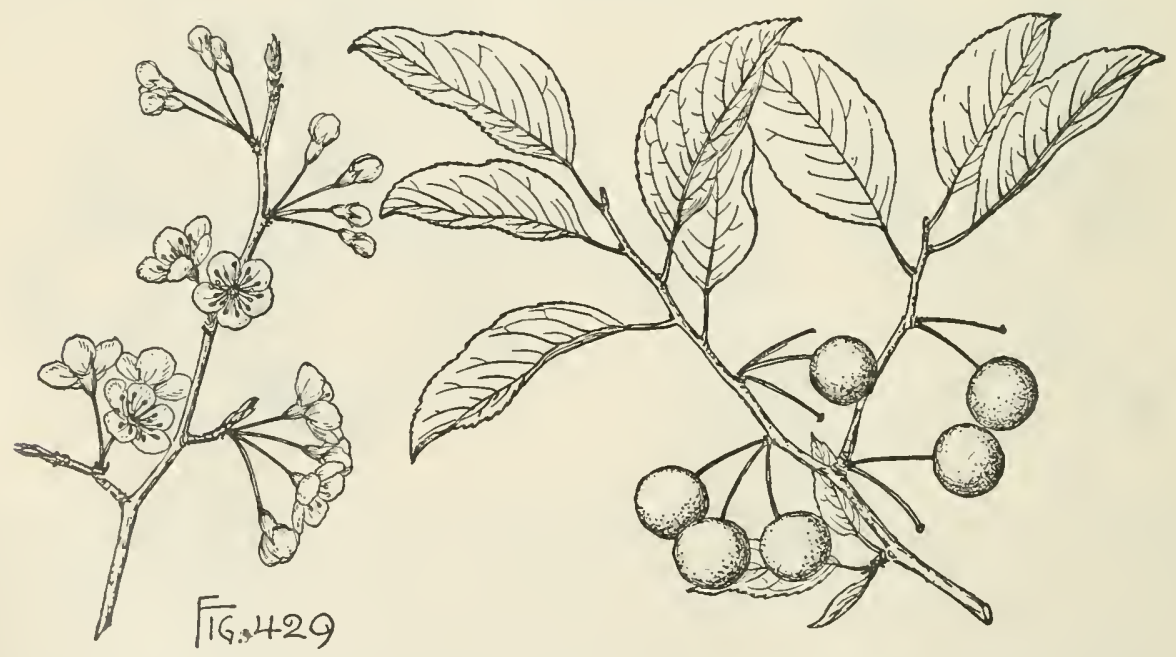

unfold bright bronze-green, with red margins, midribs, and petioles, glabrous above and pubescent or glabrous below with the exception of a few hairs along the prominent orange-colored midribs and primary veins, and at maturity membranaceous, dark green above, paler below, $2^{\prime}-2 \frac{1^{\prime}}{2}$ long and $1^{\prime}-1 \frac{1 \prime}{2}$ wide; their petioles stout, glabrous or pubescent, about $\frac{1}{3}$ long; stipules lanceolate, setaceous, glandular-serrate, $\frac{1}{4}^{\prime}-\frac{2^{\prime}}{3}$ long. Flowers opening in March and April before the appearance of the leaves, $\frac{2}{3}^{\prime}$ in diameter, on slender glabrous pedicels $\frac{1^{\prime}}{2}$ long, in 3 or 4 -flowered umbels; calyx-tube broadly obconic, glabrous or puberulous, the lobes sometimes slightly clavate at the acute red apex, scarious on the margins, and hoary-tomentose 
on the inner surface; petals linear, orbicular, contracted at the base into short claws. Fruit ripening from July to September, on slender pedicels $\frac{1^{\prime}}{2}$. to nearly $1^{\prime}$ long, globose, without a basal depression, about $\frac{1}{2}$ in diameter, with a tough thick black skin covered with a glaucous bloom, thick acid flesh, and a flattened stone, with thin brittle walls, $\frac{1^{\prime}}{2}$ long, $\frac{1}{4}^{\prime}-\frac{5}{16}{ }^{\prime}$ wide and half as thick, acute at the ends, slightly rugose, conspicuously ridged on the ventral, and slightly grooved on the dorsal suture.

A tree, sometimes $15^{\circ}-20^{\circ}$ high, with a short often crooked or inclining trunk $6^{\prime}-10^{\prime}$ in diameter, slender unarmed branches forming a wide compact flat-topped head, and slender branchlets more or less densely coated at first with pale pubescence, soon becoming glabrous, lustrous, and bright red, and in their second year dark dull brown and marked by occasional orange-colored oblong lenticels; or frequently a low shrub. Winter-buds about $\frac{1^{\prime}}{16}$ long, with acute chestnut-brown apiculate scales, those of the inner rows at maturity $\frac{1}{4}^{\prime}$ long and red at the apex. Bark $\frac{1}{4}^{\prime}$ thick, dark brown, separating into small appressed persistent scales. Wood heavy, hard, close-grained, dark reddish brown, with thick lighter colored sapwood of about 30 layers of annual growth. The fruit is used in large quantities in making jellies and jams.

Distribution. Saudy bottom-lands and along the borders of the forest of Longleaved Pine; South Carolina to Mosquito Inlet, Florida, usually in the neighborhood of the coast, and from Tampa Bay to western Lonisiana and southern Arkansas. Variable in the amount of its pubescence and slightly variable in the shape of the fruit, and passing into

\section{Prunus umbellata, var. injucunda, Sarg.}

A small tree, with branchlets at first hoary-tomentose, becoming pubescent and in their second season puberulous, villose pedicels, calyx, and ovary, leaves more or less tomentose below, and subglobose to short-oblong fruit.
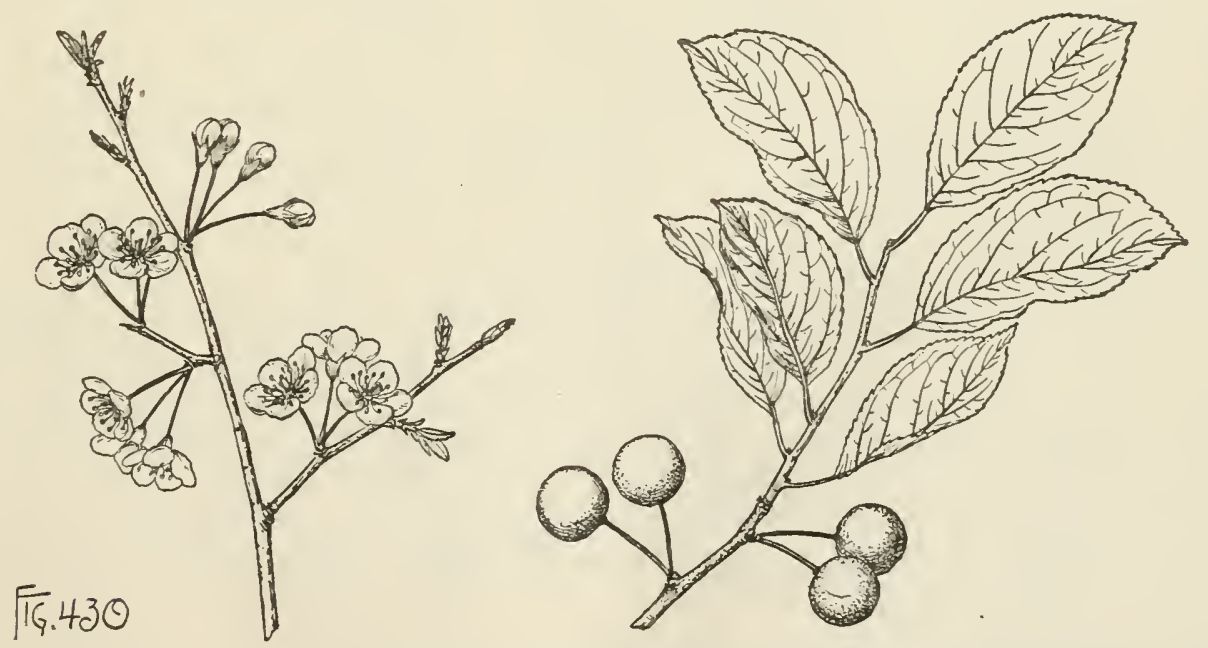

Distribution. Base of Stone Mountain and Little Stone Mountain, De Kalb County, central Georgia.

\section{Prunus tarda, Sarg. Sloe.}

Leaves oblong or occasionally somewhat obovate, acute or acuminate and shortpointed at the apex, gradually narrowed and rounded or cuneate at the base, finely 
serrate, with straight or incurved teeth tipped with dark minute persistent glands, when they unfold glabrous or rarely scabrous or puberulous above and cinereotomentose below, and at maturity thick and firm, dark yellow-green and glabrous on the upper surface, pale and pubescent or puberulous on the lower surface, particularly along the prominent light yellow midribs and thin primary veins, $1 \frac{1}{2}-3^{\prime}$ long,

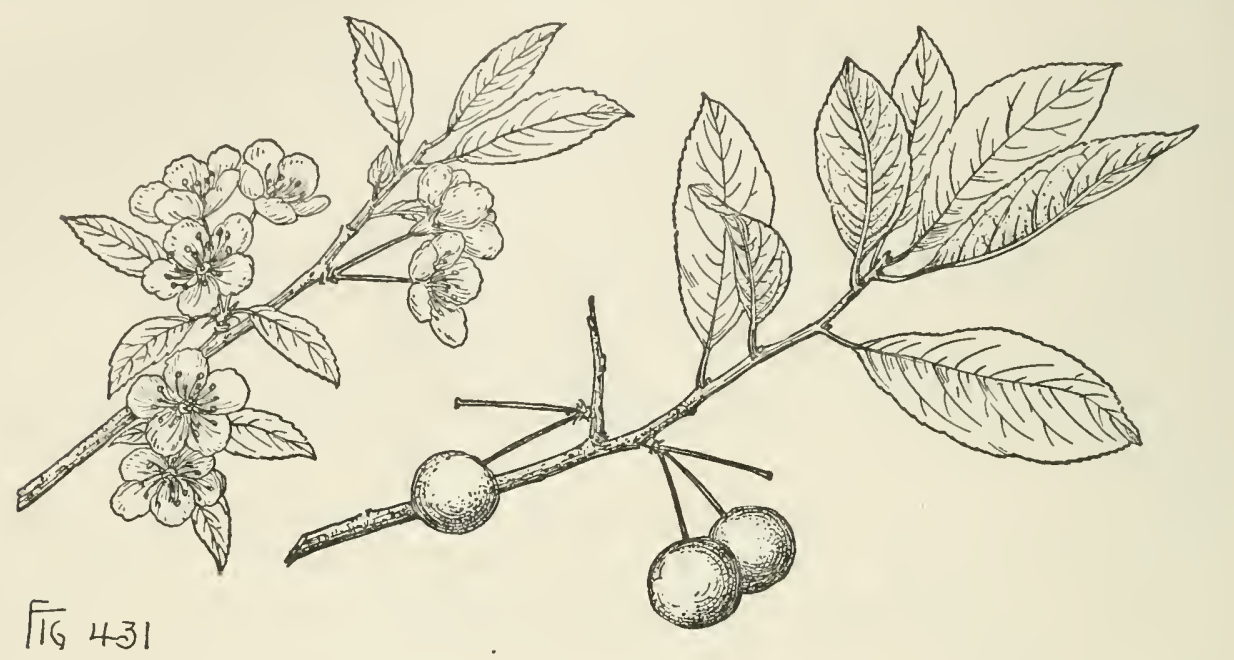

$\frac{3}{4}-1 \frac{11^{\prime}}{4}$ wide; their petioles stout, tomentose or ultimately pubescent, $\frac{1}{3}^{\prime}-\frac{1}{2}^{\prime}$ long, glandular at the apex, with 2 large round stalked dark glands, or often eglandular; stipules acicular, often bright red, about $\frac{1^{\prime}}{3}$ long. Flowers appearing early in April with or before the leaves, about $\frac{3^{\prime}}{4}$ in diameter, on slender glabrous pedicels, in 2 or 3 -flowered umbels; calyx-tube narrowly obconic, glabrous toward the base, villose above, the lobes acute, entire, villose on the outer surface, hoary-tomentose on the inner surface; petals oblong-obovate, gradually contracted below into short claws. Fruit ripening late in October or early in November, on stout rigid pedicels, shortoblong to subglobose, $\frac{1}{3}-\frac{1}{2}$ ' long; clear bright yellow on some trees, bright red on others, and on others purple, dark blue, or black, with tough thick skin, thick very acid flesh firmly attached to the ovoid more or less compressed very rugose stone obscurely ridged on the ventral and slightly grooved on the dorsal suture, acute and apiculate at the apex, rounded at the base.

A tree, $20^{\circ}-25^{\circ}$ high, with a tall trunk $18^{\prime}-20^{\prime}$ in diameter, wide-spreading branches forming an open symmetrical head, and slender branchlets marked by small scattered dark lenticels, light-green and hoary-tomentose when they first appear, becoming glabrous, light red-brown and lustrous during their first summer and darker at the end of the second year. Winter-buds narrow, acute, the color of the branchlets, $\frac{1^{\prime}}{1^{\prime}}-\frac{1}{8}^{\prime}$ long. Bark $\frac{1^{\prime}}{2}-\frac{5^{\prime}}{8}$ thick, light brown tinged with red, and divided by shallow interrupted fissures into flat ridges broken on the surface into small loose plate-like scales.

Distribution. Glades and open woods in the neighborhood of Marshall, Texas, to western Louisiana and southern Arkansas. 
2. Flowers in axillary umbels or corymbs; fruit $\frac{1}{2}^{\prime}$ in diameter or less. Bird Cherries.

\section{Prunus Pennsylvanica, L. Wild Red Cherry. Bird Cherry.}

Leaves oblong-lanceolate, sometimes slightly falcate, acuminate or rarely acute, and finely and sharply serrate, with incurved teeth often tipped with minute glands, when they unfold bronze-green, pilose below and slightly viscid, soon becoming green and glabrous, and at maturity bright and lustrous on the upper, rather paler on the lower surface, $3^{\prime}-4 \frac{1}{2}^{\prime}$ long and $\frac{3^{\prime}}{4}-1 \frac{1}{4}^{\prime}$ wide, turning bright clear yellow some time before falling in the autumn; their petioles slender, glabrous or slightly pilose, $\frac{1^{\prime}}{2}-1^{\prime}$ long, and often glandular above the middle; stipules acuminate, glandular-serrate, early deciduous. Flowers appearing in early May when the leaves are about half grown, or at the extreme north and at high elevations as late as the 1st of July, $\frac{1^{\prime}}{2}$ in diameter, on slender pedicels nearly $1^{\prime}$ long, in 4 or 5 -flowered umbels or corymbs ; calyx-tube broadly obconic, glabrous, marked in the mouth of the throat by a conspicuous light orange-colored band, the lobes obtuse, red at the apex, and reflexed after the flowers open; petals $\frac{1}{4}^{\prime}$ long, nearly orbicular, contracted at the base into

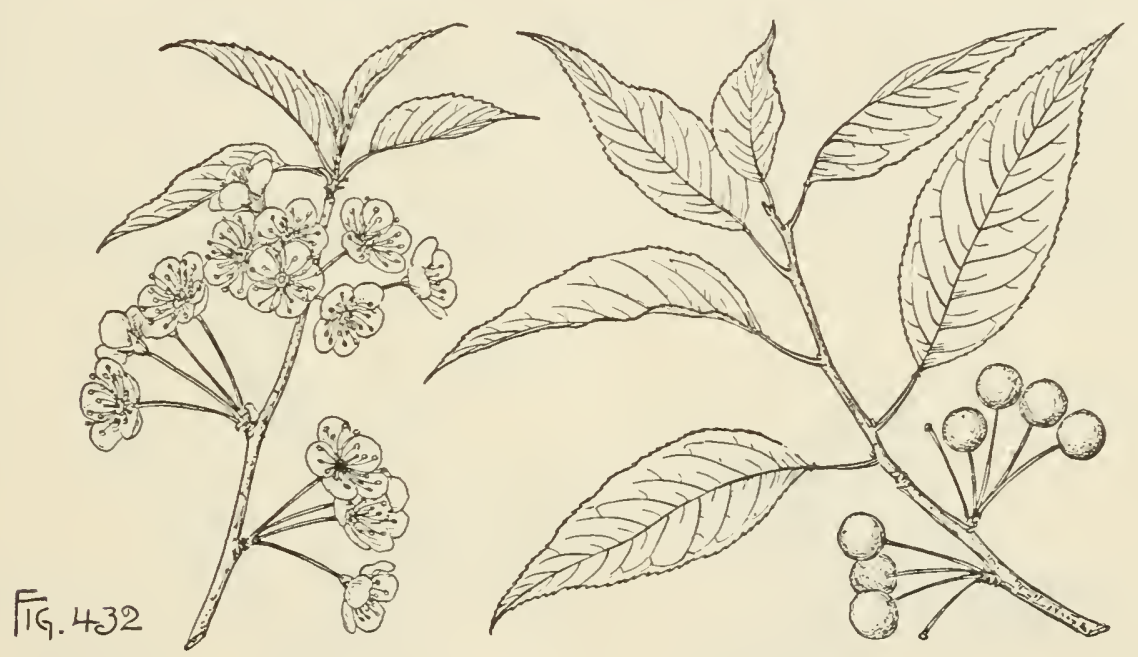

short claws, creamy white. Fruit ripening from the 1st of July to the 1st of September, globose, $\frac{1}{4}^{\prime}$ in diameter, with a thick light red skin, thin sour flesh, and an oblong thin-walled slightly compressed stone, pointed at the apex, rounded at the base, about $\frac{3}{1 \overline{6}}$ long, and ridged on the ventral suture.

A tree, with bitter aromatic bark and leaves, $30^{\circ}-40^{\circ}$ high, with a trunk often $18^{\prime}-$ $20^{\prime}$ in diameter, regular slender horizontal branches forming a narrow head usually more or less rounded at the summit, and slender branchlets light red and sometimes slightly puberulous at first, soon glabrous, bright red, Iustrous and covered with pale raised lenticels in their first winter, and developing in their second year short thick spur-like lateral branchlets and then covered with dull red bark marked by bright orange-colored lenticels, the outer coat easily separable from the brilliant green inner bark; at the extreme northern and western limits of its range often a low shrub. Bark of young stems and of the branches smooth and thin, bright reddish brown, becoming on old trunks $\frac{1^{\prime}}{3}-\frac{1}{2}^{\prime}$ thick, and separating horizontally into broad persistent papery lark red-brown plates marked by irregular horizontal bands of orange-colored lenticels and broken into minute persistent scales. Wood light, soft, 
close-grained, light brown, with thin yellow sapwood. The fruit is often used domestically and in the preparation of congl mixtures.

Distribution. Newfomndland to the shores of Hudson's Bay, and westward in British America to the eastern slopes of the coast range of British Columbia in the valley of the Frazer River, and sonthward through the northern states to Pennsylvania, central Michigan, northern Illinois, central Iowa, and to the high mountains of North Carolina and Tennessee, and on the eastern slopes of the Rocky Mountains of Colorado; common in all the forest regions of the extreme northern states, growing in moist rather rich soil; often occupying to the exclusion of other trees large areas cleared by fire of the original forest-covering; common and attaining its largest size on the western slopes of the Big Smoky Mountains in Tennessee.

\section{Prunus emarginata, Walp. Wild Cherry.}

Leaves oblong-obovate to oblanceolate, rounded and usually obtuse or sometimes acute at the apex, cuneate and furnished at the base with 1 or 2 and sometimes 3 or 4 large dark glands, and serrate, with minute subulate glandular teeth, when they unfold puberulous or pubeseent on the lower surface and slightly viscid, and at maturity glabrous or pubescent below (var. villosa, Sudw.), $1^{\prime}-3^{\prime}$ long, $\frac{1}{3}^{\prime}-1 \frac{1}{2}^{\prime}$ wide, dark green above and paler below; their petioles short, stout, usually pubescent; stipules lanceolate, acuminate, glandnlar-serrate, deciduous. Flowers appearing when the leaves are about half grown, at the end of April at the level of the ocean or as late as the end of June at high elevations, $\frac{1}{3}^{\prime}-\frac{1}{2}$ in diameter, on slender pedicels from the axils of foliaceous glabrous glandular-serrate bracts, in 6-12-flowered
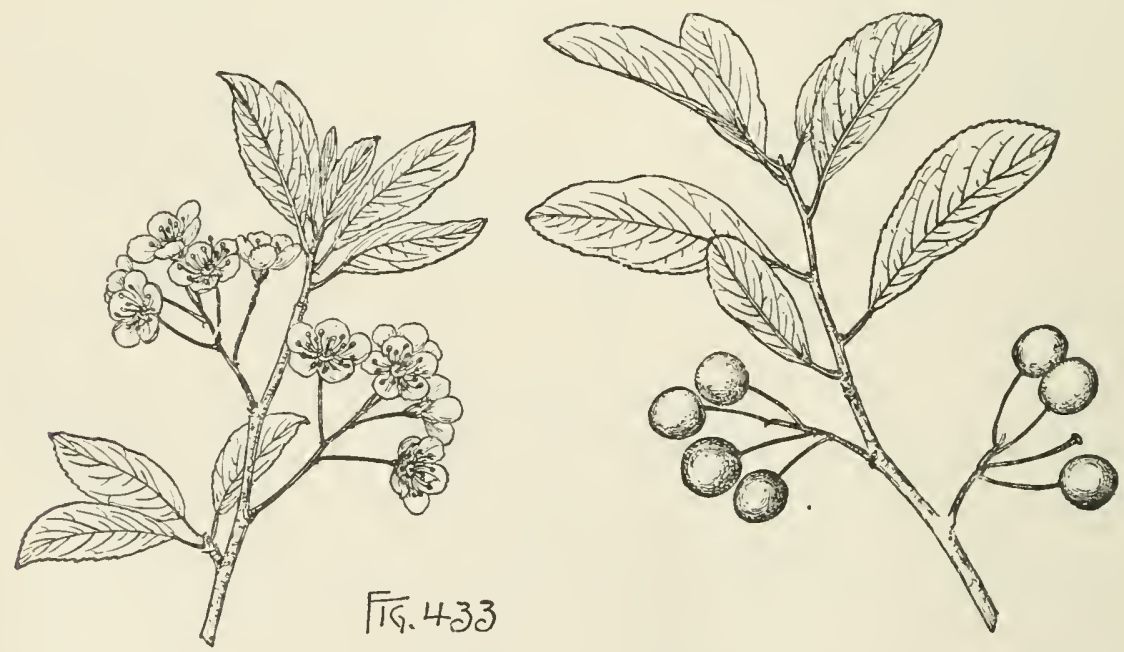

glabrous or pubescent corymbs $1^{\prime}-1 \frac{1^{\prime}}{2}$ long; calyx-tube obconic, glabrous or puberulons, bright orange-colored in the throat, the lobes short, rounded, emarginate, or slightly cleft at the apex, sometimes slightly glandular on the margins, reflexed after the flowers open; petals obovate, rounded or emarginate at the apex, contracted below into short claws, white faintly tinged with green. Fruit ripening from June to August, on slender pedicels, in long-stalked corymbs often $2^{\prime}$ long, globose, $\frac{1}{4}^{\prime}-\frac{1}{2}^{\prime}$ in diameter, more or less translucent, with a thick skin bright red at first when fully grown, becoming darker and almost black, thin bitter astringent flesh, and an ovoid turgid stone about $\frac{1^{\prime}}{8}$ long, pointed and compressed at the ends, with thick brittle 
slightly pitted walls, ridged and prominently grooved on the ventral and rounded and slightly grooved on the dorsal suture.

A tree, with exceedingly bitter bark and leaves, occasionally $30^{\circ}-40^{\circ}$ high, with a trunk $12^{\prime}-14^{\prime}$ in diameter, slender rather upright branches forming a symmetrical oblong head, and slender flexible branchlets coated at first with pale pubescence, dark red-brown during their first winter, bright red, conspicuously marked by large pale lenticels in their second season, and furnished with short lateral branchlets; frequently a shrub, with spreading stems $3^{\circ}-10^{\circ}$ tall. Winter-buds acute, $\frac{1}{8}^{\prime}$ long, with chestnut-brown scales often slightly scarious on the margins, those of the inner ranks becoming acuminate, glandular-serrate above the middle, scarions, and $\frac{1}{2}$ ' long, with bright red tips. Bark about $\frac{1^{\prime}}{4}$ thick, with a generally smooth dark brown surface marked by horizontal light gray interrupted bands and by rows of oblong orange-colored lenticels. Wood close-grained, soft and brittle, brown streaked with green, with paler sapwood of 8-10 layers of annual growth.

Distribution. Usually near the banks of streams in low rich soil, or less commonly on dry hillsides; valley of the upper Jocko River, Montana, on the mountain ranges of Idaho and Washington and of southern British Columbia to Vancouver Island, and southward on the coast ranges to the neighborhood of the bay of San Francisco, on the western slopes of the Sierra Nevada up to elevations of $5000^{\circ}-$ $6000^{\circ}$ above the sea to the head of Kern River, on the Santa Lucia, San Rafael, and San Bernardino Mountains, California, and to the Washoe Mountains, Nevada, and the San Francisco peaks, Arizona; of its largest size on Vancouver Island, in western Oregon and Washington, and on the Santa Lucia Mountains; on the coast ranges of middle California and on the Sierra Nevada commonly a shrub $5^{\circ}-8^{\circ}$ high.

\section{Flowers in terminal racemes on leafy branches of the year. Wild Cherries.}

\section{Prunus demissa, Walp. Choke Cherry.}

\section{(Prunus Virginiana, Silva N. Am. iv. 41, in part.)}

Leaves broadly oval to oblong-obovate, acute, acuminate, or abruptly shortpointed at the apex, subcordate, rounded, or rarely wedge-shaped at the base, and finely serrate, with slender callous teeth, when they unfold glabrous or pubescent and occasionally furnished with axillary tufts of pale hairs, and at maturity thick and firm to subcoriaceous, dark green, lustrous and glabrous above, pale or glancous and glabrous or rarely puberulous below, $2^{\prime}-4^{\prime}$ long, $1^{\prime}-2^{\prime}$ wide, with stout yellow midribs, and thin remote primary veins united at some distance from the margins, turning yellow in the autumn before falling; their petioles slender, glabrous or rarely villose, glandular near the apex, with 2 or several glands $\frac{1^{\prime}}{2}-\frac{3^{\prime}}{4}$ long. Flowers opening from April at the south to the middle of June at the north, $\frac{1}{3}^{\prime}-\frac{1}{2}^{\prime}$ in diameter, on slender glabrous or puberulous pedicels in the axils of scarious caducons bracts, in slender many-flowered erect or nodding racemes $3^{\prime}-6^{\prime}$ long; calyx-tube cup-shaped, glabrous or rarely puberulous, the lobes short, broad, obtuse, laciniate or more or less glandular on the margins, deciduous from the fruit; petals orbicular, contracted below into short claws, pure white. Fruit $\frac{1^{\prime}}{4}-\frac{1}{2}$ in diameter, globose or occasionally somewhat elongated, nearly black, with a thick lustrous skin, dark juicy slightly astringent flesh of agreeable flavor, and an oblong-ovate stone, about $\frac{1}{4}^{\prime}$ long, acute at the apex, broadly ridged on the ventral and slightly grooved on the dorsal suture. 
A tree, with strong-scented bark and leaves, rarely $30^{\circ}-35^{\circ}$ high, with a short often crooked or inclining trunk sometimes a foot in diameter, small erect or horizontal branches, and stout branchlets light brown or bronze-green and glabrous,

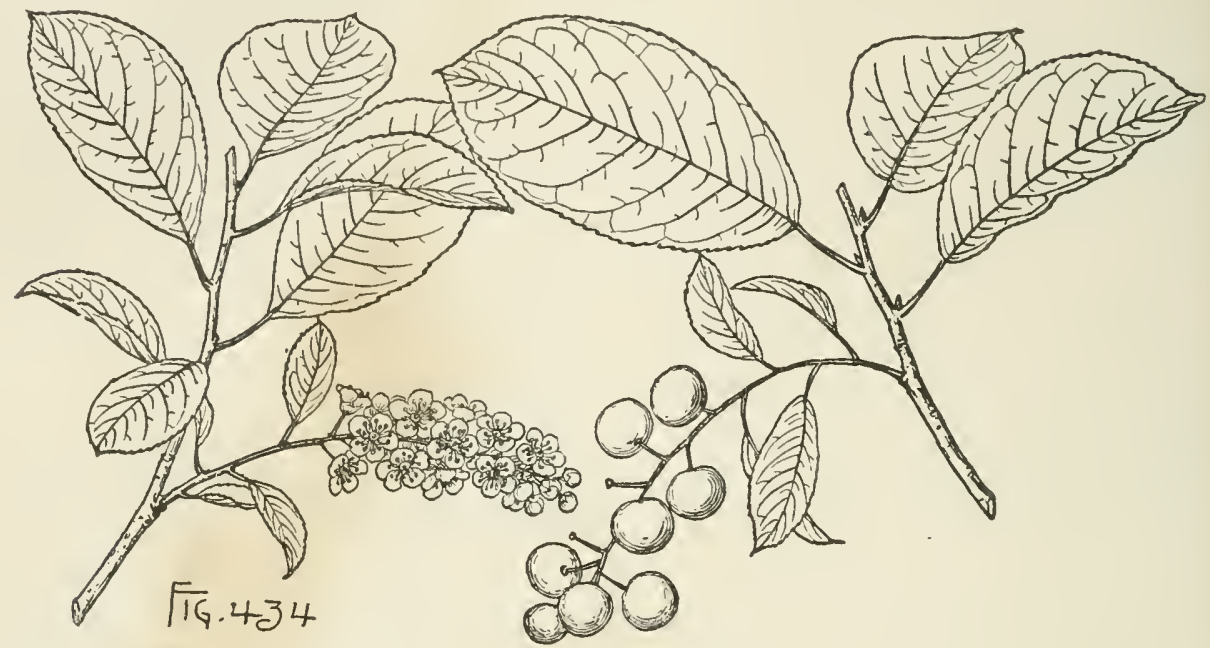

puberulous, or sometimes pubescent at first, becoming light brown or brown tinged with red and marked by large oblong lenticels during their first winter, and darker brown in their second year; more often a low shrub. Winter-buds acute or obtuse, with pale chestnut-brown scales more or less scarious on the margins and rounded at the apex, those of the inner rank becoming lanceolate or ligulate, sharply and often glandular-serrate, and $\frac{1}{2}^{\prime}-1^{\prime}$ long. Bark about $\frac{1}{8}^{\prime}$ thick, slightly and irregularly fissured, broken on the surface into small persistent dark red-brown scales, and often marked by irregular pale excrescences. Wood heavy, hard, close-grained, although not strong, light brown, with thick lighter colored sapwood of 15-20 layers of annual growth.

Distribution. Low valleys and slopes of mountain ranges, northern British Columbia over the mountain ranges of western North America and eastward to western Nebraska and Kansas.

\section{Prunus serotina, Ehrh. Wild Black Cherry. Rum Cherry.}

Leaves oval, oblong to lanceolate-oblong, gradually or sometimes abruptly acuminate or rarely rounded at the apex, cuneate or occasionally rounded at the base, finely serrate, with appressed incurved callous teeth, and furnished at the very base with 1 or more dark red conspicuous glands, when they unfold slightly hairy below on the midribs and often bronze-green, and at maturity glabrous, thick and firm, subcoriaceous, dark green and very lustrous above, paler below, $2^{\prime}-5^{\prime}$ long, $1^{\prime}-1 \frac{1}{2}^{\prime}$ wide, with thin conspicuous midribs and slender veins, in the autumn turning clear bright yellow before falling; their petioles slender, $\frac{1^{\prime}}{2}-\frac{3^{\prime}}{4}$ long; stipules lanceolate, acuminate, glandular-serrate, $\frac{1}{2}^{\prime}-\frac{3^{\prime}}{4}$ in length, early deciduous. Flowers appearing when the leaves are about half grown, from the end of March in Texas to the first week of June in the valley of the St. Lawrence River, $\frac{1^{\prime}}{4}$ in diameter, on slender glabrous or puberulons pedicels from the axils of minute scarious caducous bracts, in erect or ultimately spreading narrow many-flowered racemes $4^{\prime}-6^{\prime}$ long; calyxtube cup-shaped, glabrous or puberulous, the lobes short, ovate-oblong, obtuse, 
slightly laciniate on the margins, reflexed after the flowers open, persistent on the ripe fruit; petals broadly obovate, pure white. Fruit ripening from June to October, in drooping racemes, depressed-globose, slightly lobed, $\frac{1}{3}^{\prime}-\frac{1}{2}^{\prime}$ in diameter, dark red when fully grown, almost black when ripe, with a thin skin, dark purple juicy. flesh of a pleasant vinous flavor, and an oblong-obovate thin-walled stone, abont $\frac{1}{3}$ long, acute at the apex, gradually narrowed at the base, broadly ridged on the ventral and acute on the dorsal suture.

A tree, with bitter aromatic bark and leaves, sometimes $100^{\circ}$ high, with a trunk $4^{\circ}-5^{\circ}$ in diameter, small horizontal branches forming a narrow oblong head, and slender rather rigid glabrous branchlets at first pale green or bronze color, soon becoming bright red or dark brown tinged with red, red-brown or gray-brown and marked by minute pale lenticels during their first winter, and bright red the following year; usually much smaller and occasionally toward the northern limits of its range shrub-like in habit. Winter-buds obtuse, or on sterile shoots acute, with bright chestnut-brown broadly ovate scales keeled on the back and apiculate at the apex, those of the inner ranks becoming scarious at maturity, acuminate, and $\frac{1^{\prime}}{2}-\frac{2}{3}{ }^{\prime}$ long. Bark $\frac{1^{\prime}}{2}-\frac{3^{\prime}}{4}$ thick, broken by reticulated fissures into small irregular plates scaly on the surface, and dark red-brown, or near the Gulf coast light gray or nearly white.

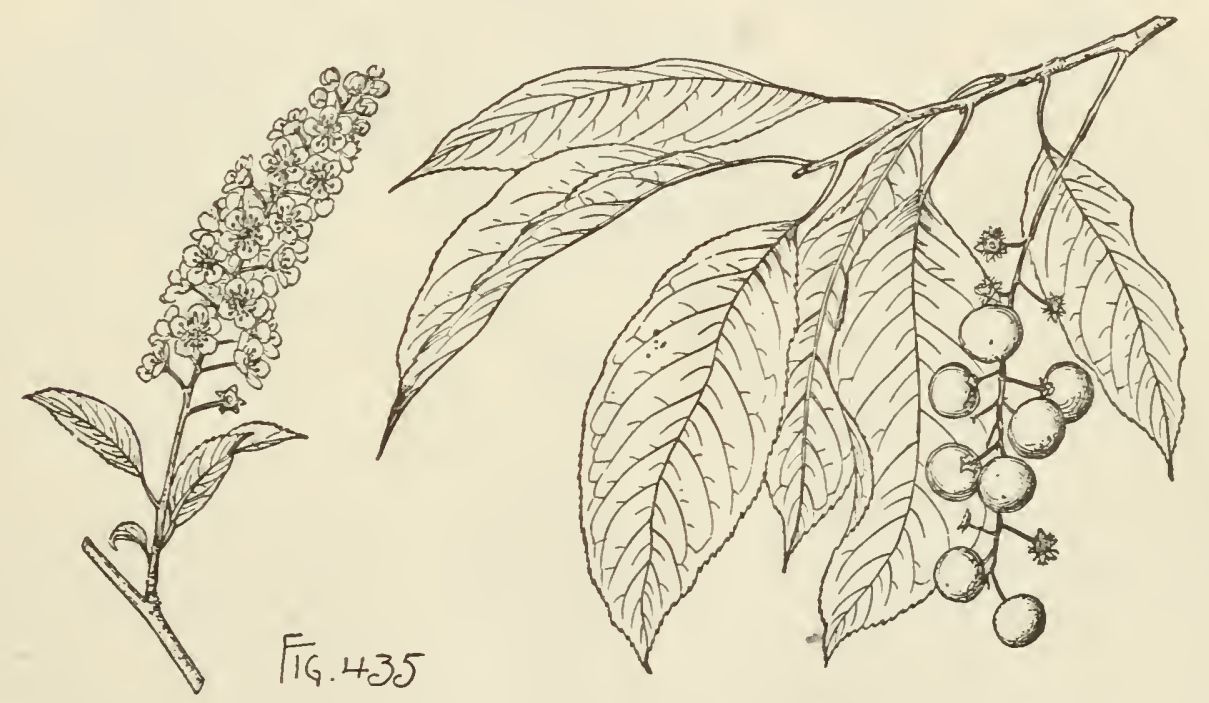

Wood light, strong, rather hard, close straight-grained, with a satiny surface, light brown or red, with thin yellow sapwood of 10-12 layers of annual growth; largely used in cabinet-making and the interior finish of houses. The bark, especially that of the branches and roots, yields hydrocyanic acid used in medicine as a tonic and sedative. The ripe fruit is used to flavor alcoholic liquors.

Distribution. Nova Scotia westward through the Canadian provinces to the northern shore of Lake Superior, and southward through the eastern states to the shores of Matanzas Inlet and Tampa Bay, Florida, and westward to Dakota, eastern Nebraska and Kansas, the Indian Territory and eastern Texas; on the mountain ranges of western Texas, southern New Mexico and Arizona, and southward to Colombia and Peru; in the United States usially in rich moist soil; once very abundant in all the Appalachian region, reaching its greatest size on the slopes of the high Alleghany Mountains from west Virginia to Georgia and Alabama; sometimes on low sandy soil, and often in New England on rocky cliffs within reach of the spray 
of the ocean; not common in the coast region of the southern states; in the southwest only in the bottoms of mountain cañons at elevations of $5000^{\circ}-7000^{\circ}$ above the level of the sea.

\section{Prunus Alabamensis, Mohr. Wild Cherry.}

Leaves oval, broally ovate, or occasionally obovate, acute, short-pointed or rounded at the apex, cuneate, rounded or rarely slightly obcordate at the base, and

- finely serrate, with incurved teeth tipped with minute or sometimes near the base of the blade with larger dark glands, when they unfold coated below and on the npper side of the midribs with fine pubescence, and at maturity thick and firm in texture, $4^{\prime}-5^{\prime}$ long, about $2^{\prime}$ wide, dark dull green and glabrous on the upper surface, dull and covered on the lower surface with short simple or forked accrescent hairs most abundant and sometimes rufescent on the slender midribs and primary veins;

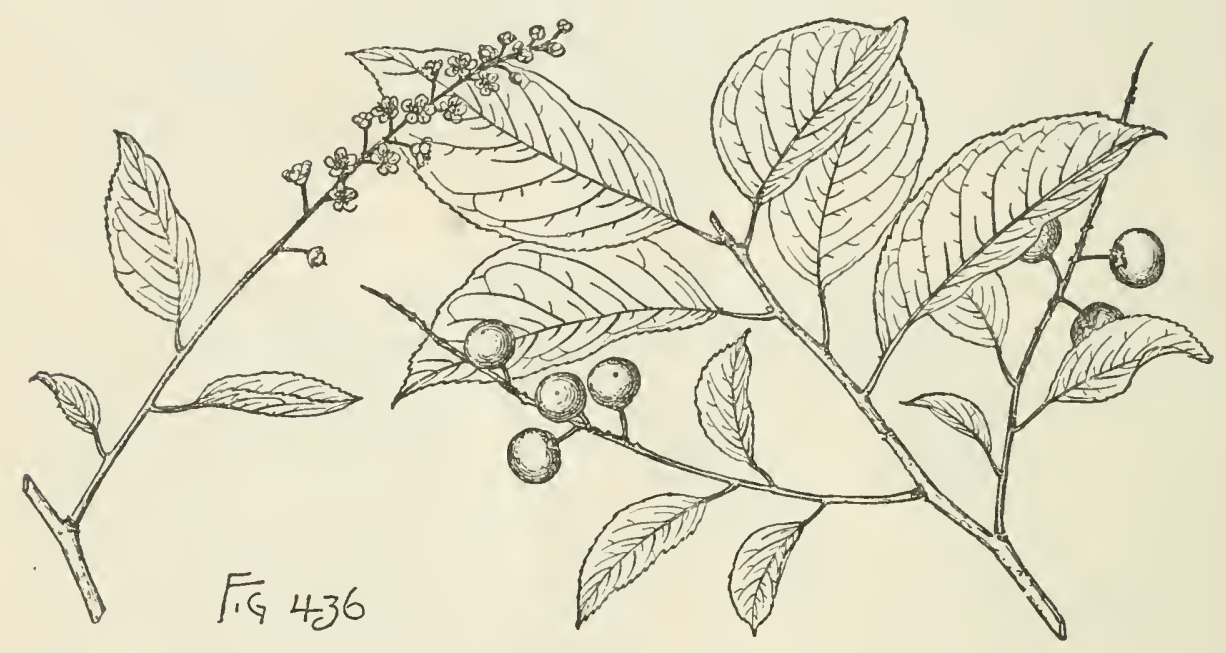

their petioles stout, tomentose, becoming pubescent, eglandular or occasionally furnished near the apex with 1 or 2 large dark glands, $\frac{1}{4}^{\prime}-\frac{1}{2}^{\prime}$ long; stipules lanceolate, acuminate, glandular-serrate, bright red, $\frac{1}{2}^{\prime}$ long, caducous. Flowers appearing during the first week of May, when the leaves are about half grown, $\frac{1}{4}$ in diameter, on pubescent pedicels from the axils of ovate or obovate acuminate bright pink caducous bracts, in'spreading or erect slender pulescent racemes $3^{\prime}-4^{\prime}$ long; calyxtube broad, cup-shaped, puberulons, with short almost triangular lobes persistent on the fruit; petals white, nearly orbicular. Fruit ripening late in September, subglobose to short-oblong, $\frac{1^{\prime}}{3}$ in diameter, dark red or finally nearly black, with thin acid flesh, and an ovoid somewhat compressed stone pointed at the ends, $\frac{1}{4}^{\prime}$ long, ridged on the ventral suture, with a broad low ridge, and slightly grooved on the dorsal suture.

A tree, $25^{\circ}-30^{\circ}$ high, with a short trunk rarely $10^{\prime}$ in diameter, spreading somewhat drooping branches, and slender branchlets coated at first with pale tomentum, dark red-brown during their first season, becoming nearly glabrous before winter, and much darker in their second year. Bark of the trunk dark, rough, separating freely into small thin scales.

Distribution. Summits of the low mountains of Central Alabama; rare and local. 


\section{Prunus australis, Beadl. Wild Cherry.}

Leaves obovate, oval or elliptical, gradually narrowed and obtusely short-pointed or sometimes acute at the apex, rounded or sometimes cuneate at the narrowed base,

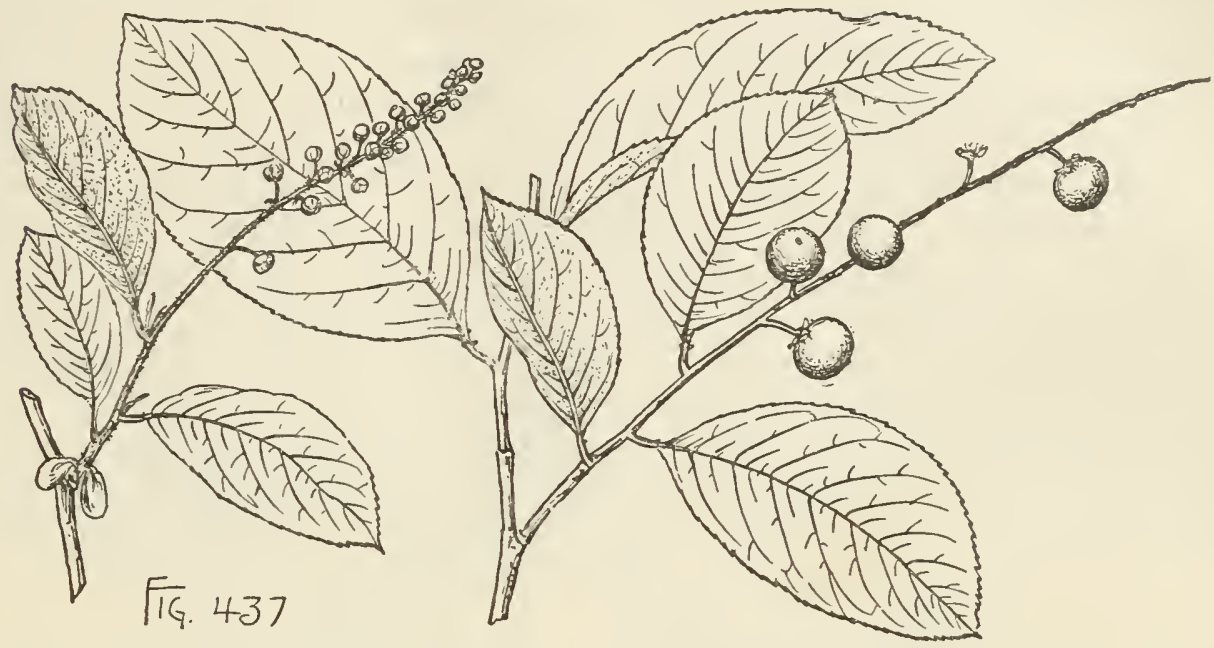

and finely serrate, with slender teeth tipped with minute dark red glands, when they unfold membranaceous, pale yellow-green and glabrous above, witl the exception of occasional pale hairs along the midribs, and coated below with pale or ferrugineous pubescence, and at maturity thin but firm, dark dull green above, covered below with matted rufous hairs most abundant on the thin broad midribs, and slender primary veins extending nearly to the margins of the leaf, conspicuously reticulatevenulose, $2 \frac{1}{2}^{\prime}-4^{\prime}$ long, $1 \frac{1^{\prime}}{2}-21_{2}^{\prime}$ wide; their petioles stout, rusty-tomentose, biglandular at the apex, with large dark red glands, about $\frac{1}{4}^{\prime}$ long; stipules linear to linear-lanceolate, glandular, bright rose color, $\frac{1}{4}^{\prime}-\frac{1}{2}^{\prime}$ long. Flowers probably opening toward the end of April, on short pedicels from the axils of minute rose-colored caducous bracts, in slender spreading hoary-pubescent racemes $3^{\prime}-4^{\prime}$ long; the expanded flowers not known. Fruit ripening and falling late in July, on pedicels $\frac{1^{\prime}}{4}$ long, globose, surrounded at the base by the calyx-lobes and remuants of the stamens, dark purple when fully ripe, about $\frac{1^{\prime}}{4}$ in diameter.

A tree, sometimes $60^{\circ}$ tall, with a trunk $12^{\prime}-16^{\prime}$ in diameter, spreading or ascending branches forming an oblong head, and slender branchlets coated at first with pale pubescence, becoming puberulous, dull red-brown, and roughened by numerous small pale elevated lenticels at the end of the first season, and glabrous or puberulous in their second year. Bark of young stems and of the branches thin, silvery gray, and roughened by long horizontal lenticels, becoming on older trunks $\frac{1}{3}^{\prime}$ thick, ashy gray or brownish black, deeply fissured and broken into thick persistent platelike scales.

Distribution. Clay soil at Evergreen, southern Alabama; common.

4. Flowers racemose in the axils of the persistent leaves of the previous year. CHERRY LAURELS.

\section{Prunus Caroliniana, Ait. Wild Orange. Mock Orange.}

Leaves oblong-lanceolate, acuminate, mucronate, with entire thickened slightly revolute margins, or rarely remotely spinulose $_{-}$serrate, glabrous, coriaceous, dark 
green and lustrous on the upper, paler on the lower surface, $2^{\prime}-4 \frac{1}{2}$ long, $\frac{8^{\prime}}{4}-1_{2}^{1 \prime}$ wide, obscurely veined, with narrow pale midribs, persistent until their seeond year; their petioles stout, broad, orange-colored; stipules foliaceous, lanceolate-aeuminate. Flowers appearing from February to April, on slender club-shaped pedicels from the axils of long acuminate scarious red-tipped bracts, in dense racemes shorter than leaves; calyx-tube narrowly obconic, the lobes small, thin, rounded, undulate on the margins, reflexed after the flowers open, deciduous; petals boat-shaped, minute, crean-colored; stamens exserted, orange-colored, with glabrous filaments and large pale anthers; ovary gradually narrowed into a slender erect style enlarged above into a club-shaped stigma. Fruit ripening in the autumn, remaining on the branches until after the flowering period of the following year, oblong, short-pointed, black and lustrous, $\frac{1^{\prime}}{2}$ long, with a thick skin, thin dry flesh, and an ovate pointed nearly cylindrical stone nearly $\frac{1}{2}^{\prime}$ long, full and rounded at the base, with thin fragile walls, obscurely ridged on the ventral and deeply grooved on the dorsal suture.

A tree, $30^{\circ}-40^{\circ}$ high, with a straight or inclining trunk sometimes $10^{\prime}$ in diameter, slencler horizontal branches forming a narrow oblong or sometimes a broad head, and glabrous branchlets marked by occasional pale lenticels, slightly angled, at first

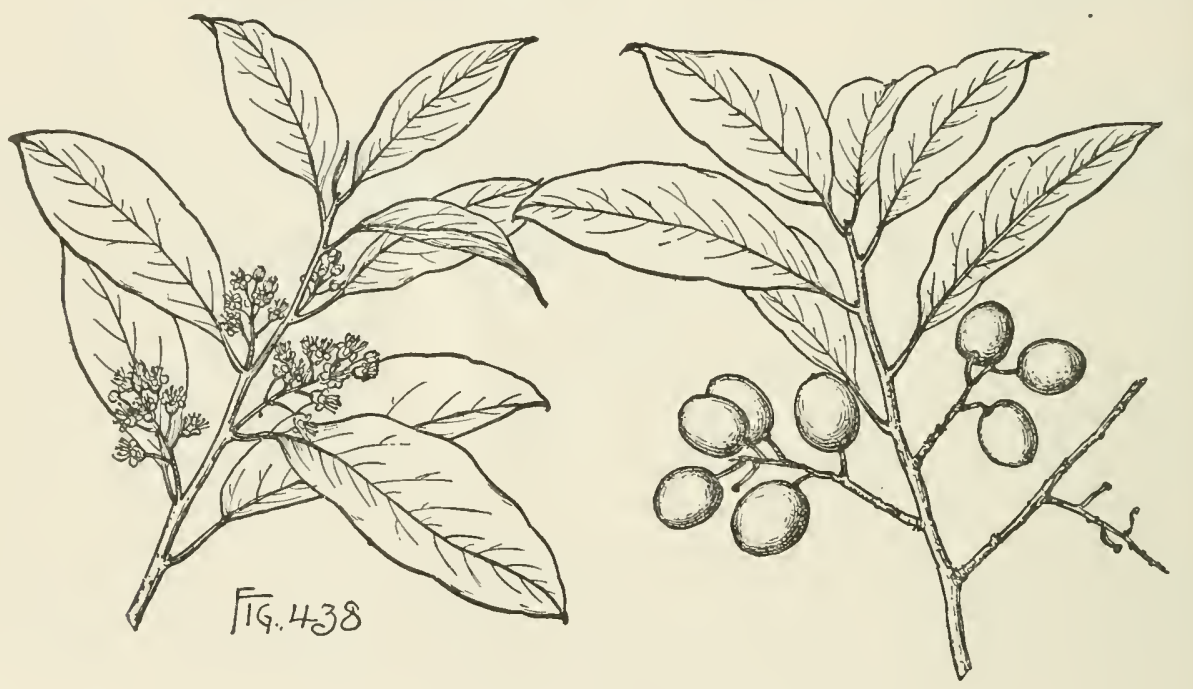

light green, becoming bright red, and in the second season light brown or gray. Winter-buds acuminate, $\frac{1}{8}^{\prime}$ long, covered with narrow pointed dark chestnutbrown scales rounded on the back. Bark about $\frac{1}{8}^{\prime}$ thick, gray, smooth or slightly roughened by longitudinal fissures, and marked by large irregular dark blotches. Wood heavy, hard, strong, close-grained, light red-brown or sometimes rieh dark brown, with thick lighter colored sapwood. The partially withered leaves and young branches are often fatal to animals browsing upon them, owing to the considerable quantities of hydrocyanie aeid which they contain.

Distribution. Deep rich moist bottom-lands; valley of the Cape Fear River to the shores of Bay Biseayne and the valley of the Kissimee River, Florida, and through southern Alabama, Mississippi, and Louisiana to the valley of the Guadalupe River, Texas; in the Atlantic and eastern Gulf states nowhere common, and only in the immediate neighborhood of the sea, rarely ranging inland more than fifteen or twenty miles; most abundant and of its largest size in the valleys of eastern Texas, and here often forming impenetrable thickets of considerable extent. 
Often cultivated in the southern states as an ornamental plant and to form hedges.

\section{Prunus sphærocarpa, $\mathbf{S w}$.}

Leaves elliptical to oblong-ovate, gradually or abruptly contracted into broad obtuse points, or less commonly rounded or rarely emarginate at the apex, wedgeshaped at the base, entire, with slightly thickened undulate margins, glabrous,

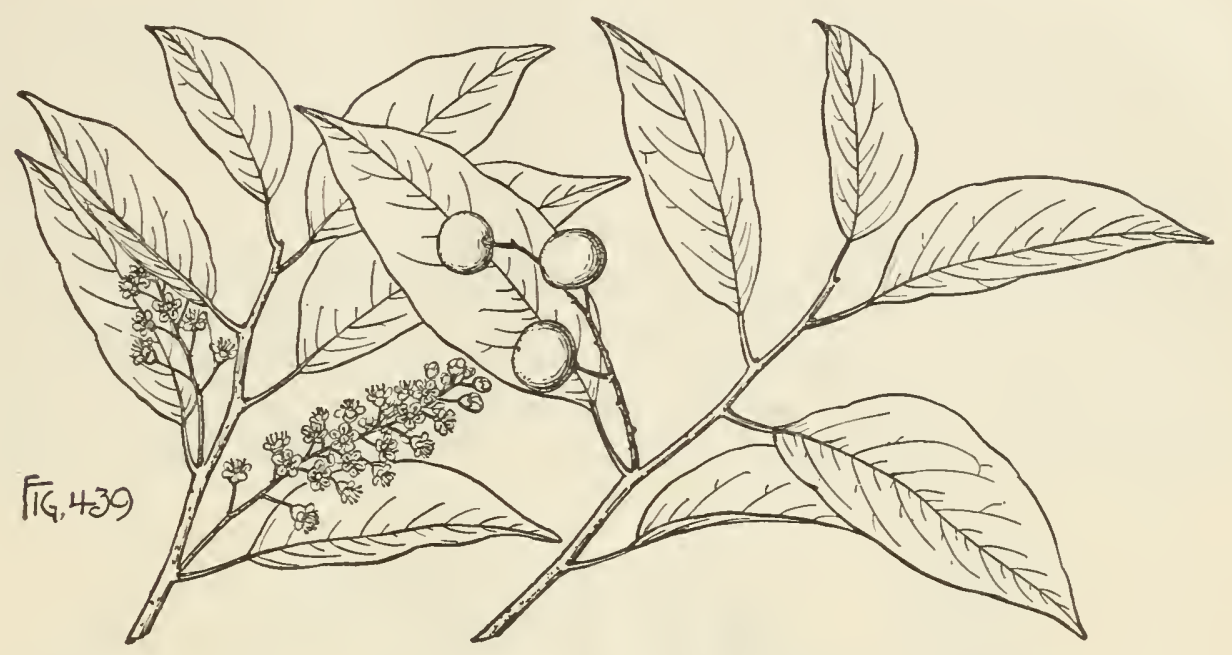

eglandular, subcoriaceous, yellow-green and lustrous on the upper, paler on the lower surface, obscurely veined, $2^{\prime}-4 \frac{1^{\prime}}{2}$ long, $1^{\prime}-1 \frac{1}{2}^{\prime}$ broad, persistent; their petioles slender, orange-brown, $\frac{1}{2}^{\prime}$ to nearly $1^{\prime}$ long; stipules foliaceous, lanceolate-acuminate, entire, $\frac{1^{\prime}}{4}$ long, early deciduous. Flowers opening in Florida in November, $\frac{1}{8}^{\prime}$ in diameter, on thin orange-colored pedicels $\frac{1}{4}-\frac{2}{3}$ long, in slender many-flowered erect racemes shorter than the leaves; calyx-tube obconic, bright orange-colored on the outer surface, marked by an orange band in the throat, the lobes thin, minute, acute, laciniate on the margins, deciduous, much shorter than the obovate rounded or acuminate white petals, marked with yellow on the inner surface toward the base; contracted below into short claws, reflexed at maturity; stamens exserted, with slender orange-colored subulate filaments and small yellow anthers; ovary sessile, contracted into a short stout style, crowded into a large club-shaped stigma. Fruit produced in Florida very sparingly, ripening either in the spring or early summer, subglobose to short-oblong, apiculate, orange-brown, $\frac{1}{3}^{\prime}-\frac{1}{2}^{\prime}$ long, with thin dry flesh adherent to the thin-walled cylindrical stone slightly narrowed at the apex, obscurely ridged on the ventral suture.

A glabrous tree, in Florida rarely $25^{\circ}-30^{\circ}$ high, with a trunk $5^{\prime}-6^{\prime}$ in diameter, slender upright branches and slender orange-brown branchlets, becoming ashy gray or light brown tinged with. red and marked by small circular pale lenticels. Bark thin, smooth, or slightly reticulate-fissured, light brown tinged with red. Wood heavy, hard, close-grained, light clear red, with thick pale sapwood.

Distribution. Rich hummock land, occasionally near the borders of small streams and ponds, and in the United States only near the shore of Bay Biscayne; through the West Indies to Brazil. 


\section{Prunus ilicifolia, Walp. Islay.}

Leaves ovate to ovate-laneeolate, aente, ronnded or emarginate at the apex, cumeate and rounded or trineate at the base, with thickened coarsely spinosely toothed margins, the stout teeth near the base of the leaf often tipped with large dark glands, thick and coriaceons, dark green and lustrous above, paler and yellowgreen below, $1^{\prime}-21_{2}^{\prime}$ long, $1^{\prime}-1 \frac{1^{\prime}}{2}$ wide, with slender yellow midribs and obsenre veins, deeiduous during their second summer; their petioles broad, $\frac{1}{8}^{\prime}-\frac{1^{\prime}}{2}$ long; stipules acuminate, obsenrely denticulate, $\frac{1}{4}$ long. Flowers opening from Mareh to May, $\frac{1}{3}$ in diameter, on short slender pedieels from the axils of aemminate searious bracts $\frac{1^{\prime}}{4}$ in length and mostly deeiduous before the opening of the flower-buds, in slender erect racemes $1 \frac{1}{2}-3^{\prime}$ long; ealyx-tnbe cup-shaped, orange-brown, the lobes minute, aemminate, reflexed at matnrity, decidnous, about one third as long as the obovate white petals rounded above and narrowed below into short claws; stamens slightly exserted, with slender incurved filaments and minute yellow antliers; ovary sessile, abruptly contracted into a slender style usually bent near the summit at a right angle or rarely erect, and surmounted by a large orbicular stigma. Fruit ripening in November and December, subglobose, often compressed, $\frac{1}{2}^{\prime}-\frac{2}{3}^{\prime}$ in diameter, dark red when fully grown, purple or sometimes nearly blaek at maturity, with thin slightly

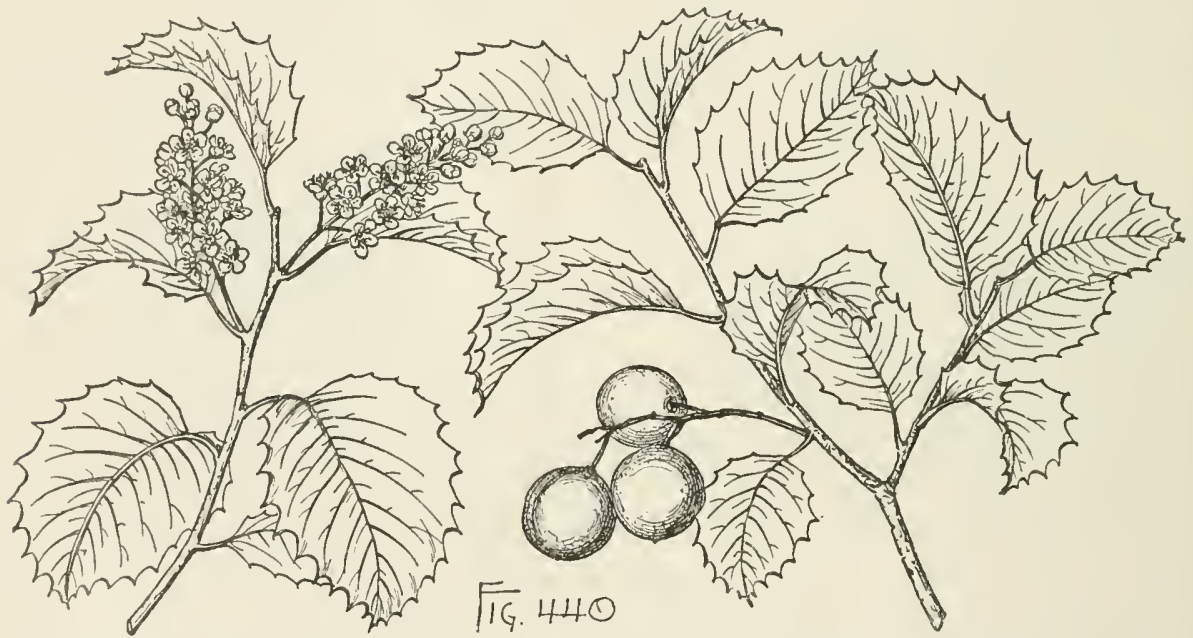

acid astringent flesh easily separable from the ovate slightly compressed stone $\frac{1}{2}^{\prime}-\frac{5}{8}$ long, short-pointed at the apex, with thin brittle walls, light yellow-brown, conspieuonsly marked with retienlate orange-colored vein-like lines, with 3 orange bands radiating from the base to the apex along one suture, and a single narrow band along the other suture.

A glabrous tree, $20^{\circ}-30^{\circ}$ high, with a trunk rarely $2^{\circ}$ in diameter or more than $10^{\circ}-12^{\circ}$ long, stout spreading branches forming a dense compact head, and branchlets at first yellow-green or orange color, soon becoming gray or reddish brown and more or less conspienously marked by minnte pale lenticels, and in their second or third years by the large leaf-sears; usually much smaller and often a shrub sometimes only a foot or two high. Bark $\frac{1^{\prime}}{3}-\frac{1}{2}^{\prime}$ thick, dark red-brown, and divided by deep fissures into small square plates. Wood heavy, hard, strong, elose-grained, light red-brown, with thin lighter colored sapwood of 8-10 layers of annual growth; occasionally used for fuel. 
Distribution. Borders of streams and moist sandy soil in the bottoms of cañons, and as a low shrub on dry hillsides and mesas from the shores of the Bay of San Francisco sonthward through the coast ranges of California to the foothills of the San Bernardino Mountains, and on Santa Cruz and Santa Rosa islands.

Occasionally cultivated as an ornamental plant in western and southern Europe.

\section{Prunus integrifolia, Sarg., nov. nom.}

(Prunus ilicifolia, var. integrifolia, Silva N. Am. iv. 54.)

Leaves ovate to lanceolate, acuminate or abruptly narrowed into short points at the apex, wedge-shaped, truncate or rounded at the base, with thickened revolute

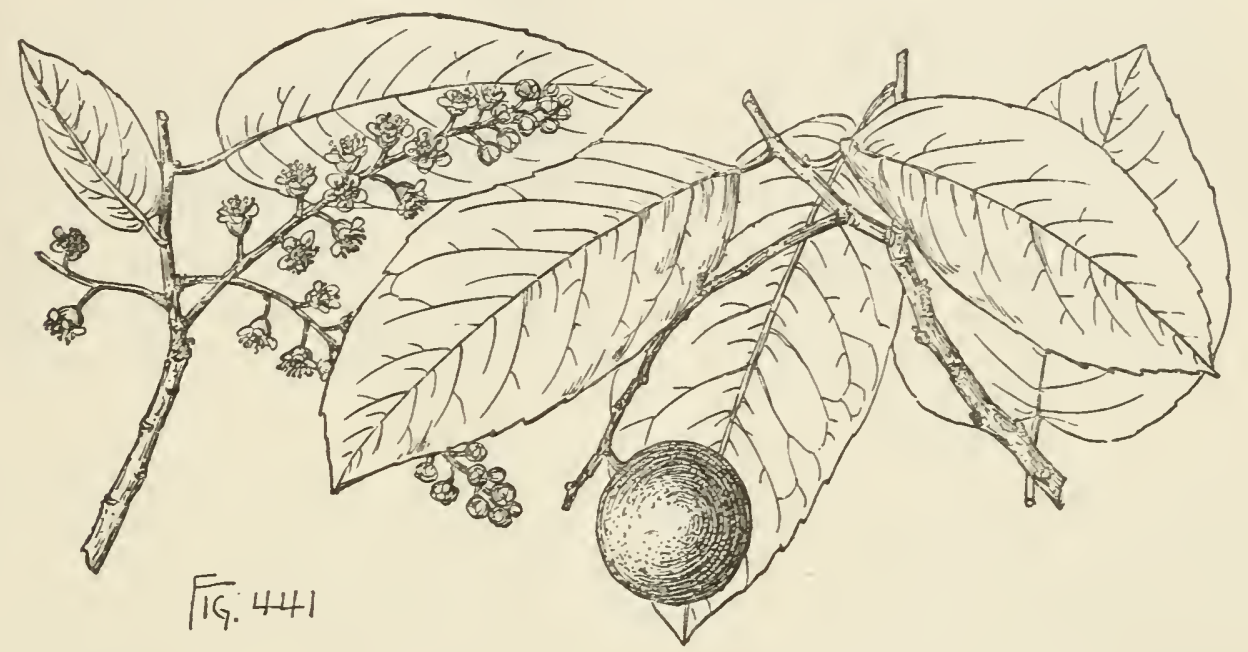

undulate entire or occasionally, especially on vigorous shoots, remotely and minutely spinulose-dentate margins, glabrous, coriaceous, dark green and lustrous above, paler below, reticulate-renulose, $2^{\prime}-3^{\prime}$ long, and $\frac{1^{\prime}}{2}-2 \frac{1}{2}^{\prime}$ wide, with stout midribs and obscure veins, persistent; their petioles stout, yellow, $\frac{1^{\prime}}{3}-\frac{1^{\prime}}{2}$ long. Flowers appearing from March to June, about $\frac{1}{4}$ in diameter, on slender pedicels from the axils of acuminate caducous bracts, in crowded many-flowered glabrous racemes $3^{\prime}-4^{\prime}$ long; calyx-tube cup-shaped, orange-brown, the lobes acute, apiculate, reflexed after the flowers open, deciduous, about one third as long as the obovate petals rounded and undulate above and narrowed below into short claws; stamens slightly exserted, with incurved filaments and small yellow anthers; ovary raised on a short stipe, the style bent near the apex and terminating in a large orbicular stigma. Fruit ripening late in the autumn, on stout pedicels, in drooping few-fruited racemes, subglobose to shortoblong, dark purple or nearly black at maturity, $\mathbf{1}^{\prime}-\mathbf{1}_{4}^{\prime}$ in diameter, with thick luscious flesh sometimes $\frac{1}{4}$ thick, and easily separable from the ovate to obovate slightly compressed thin-walled stone about $\frac{3^{\prime}}{4}$ long, pointed at the apex, pale yellow-brown, conspicuously marked by reticulate orange-colored lines, and by 3 dark bands radiating from the base to the apex along one suture, and by a single narrow line on the other suture.

A bushy tree, sometimes $25^{\circ}-30^{\circ}$ high, with one or several stout erect or spreading stems $1^{\circ}-3^{\circ}$ in diameter, spreading branches forming a broad compact head, and stout branchlets light yellow-green when they first appear, becoming light and ultimately dark reddish brown, and much roughened by the large elevated leaf-scars. 
Winter-buds acute or obtuse, witl dark red scales. Bark of the trunk $\frac{1}{3}-\frac{1}{2}$ thick and dark reddish brown. Wood leavy, hard, very elose-grained, pale reddish brown, with hardly distinguishable sapwood.

Distribution. Islands of sonthern California, in all exposures from the fertile valleys and cañons at the water's edge up to elevations of $3000^{\circ}$ on the dry interior ridges; and in Lower California.

\section{CHRYSOBALANUS, L.}

Trees or shrubs, with stout branchlets covered with pale lenticels, and fibrous roots. Leaves alternate, entire, coriaccous, short-petiolate, persistent; stipules minute, deciduous. Flowers perfect, short-pedicellate, small, creamy white, in axillary or terminal dichotomously branched slender canescent cymes, with conspicuous deciduous bracts; calyx turbinate-campanulate, 5-lobed, the lobes imbricated in the bud, without bracts, deciduous; disk thin, adnate to the calyx-tube; petals 5 , alternate with the lobes of the calyx, spatulate, deciduous; stamens (in the arborescent specics) indefinite in a single continuous series, inserted with the petals on the margin of the disk; filaments filiform, hairy, free or slightly united at the base; anthers ovoid, ovary sessile in the bottom of the calyx-tube, hirsute or glabrous, 1-celled; style rising from the base of the ovary, filiform, terminated by a minute truncate stigma; ovules 2, collateral, ascending; raphe dorsal, the micropyle inferior. Fruit a fleshy 1-seeded drupe with pulpy flesh, a coriaceous or crustaceous stone, 5 or 6 -angled toward the base and imperfectly 5 or 6 -valved, the valves reticulate-veined. Seed erect; seed-coat chartaceous, light brown; embryo filling the cavity of the seed; cotyledons thick and fleshy; radicle inferior, very short.

Chrysobalanus is represented in the south Atlantic states by a shrubby species confined to the coast region from Georgia to Alabama, and by a second species occasionally attaining the size of a small tree, an inhabitant of the shores of southern Florida, widely distributed throngh the maritime regions of tropical America, and found in various forms on the coast of western tropical Africa.

The generic name is from $\chi \rho v \sigma \delta s$ and $\beta a ́ \lambda \alpha \nu o s$, in allusion to the supposed golden fruit of one of the species.

\section{Chrysobalanus Icaco, L. Cocoa Plum.}

Leaves broadly elliptical or round-obovate, rounded or slightly emarginate at the apex, wedge-shaped at the base, glabrous, coriaceous, obscurely reticulate-veined, dark green and lustrous on the upper and light yellow-green on the lower surface, $1^{\prime}-3 \frac{1}{2}^{\prime}$ long, $1^{\prime}-2 \frac{1}{2}^{\prime}$ wide, with broad conspicuous midribs rounded on the upper side and thin primary veins, standing on the branches at an acute angle and appearing to be pressed against them; their petioles stout, $\frac{1}{8}^{\prime}-\frac{1}{4}^{\prime}$ long; stipules acuminate, $\frac{1}{8}^{\prime}$ long. Flowers $\frac{1}{3}^{\prime}$ long, on short thick club-shaped hoary-tomentose pedicels, in cymes $1^{\prime}-2^{\prime}$ in length, appearing in Florida continuously during the spring and summer months on the growing branches; calyx hoary-tomentose, the lobes nearly triangular, acute, more or less pubescent on the inner surface and about half as long as the narrow white petals; ovary hoary-pubescent; style long and slender, clothed nearly to the apex with pale hairs. Fruit nearly globose or often slightly ovoid, $\frac{2 \prime}{3}-\mathbf{1}^{\prime}$ in diameter, with smooth bright pink, yellow, purple, creamy white, or sometimes nearly black skin, white sweet juicy flesh often $\frac{1^{\prime}}{4}$ thick, and more or less adherent to the stone pointed at the ends, 5 or 6 -angled below the middle, $\frac{1^{\prime}}{2}-1 \frac{1^{\prime}}{4}$ long 
and twice as long as broad, indehiscent or finally separating into 5 or 6 valves, the walls composed of a thin red-brown dry outer layer and a thick interior layer of hard woody fibre; seed-coat lined with a thick white reticulated fibrous coat.

A tree, $25^{\circ}-30^{\circ}$ high, with a long straight trunk occasionally a foot in diameter, and dark reddish brown branches glabrous or sometimes slightly pilose at first, bəcoming brown or gray-brown in their second year; more often a tall broad bush

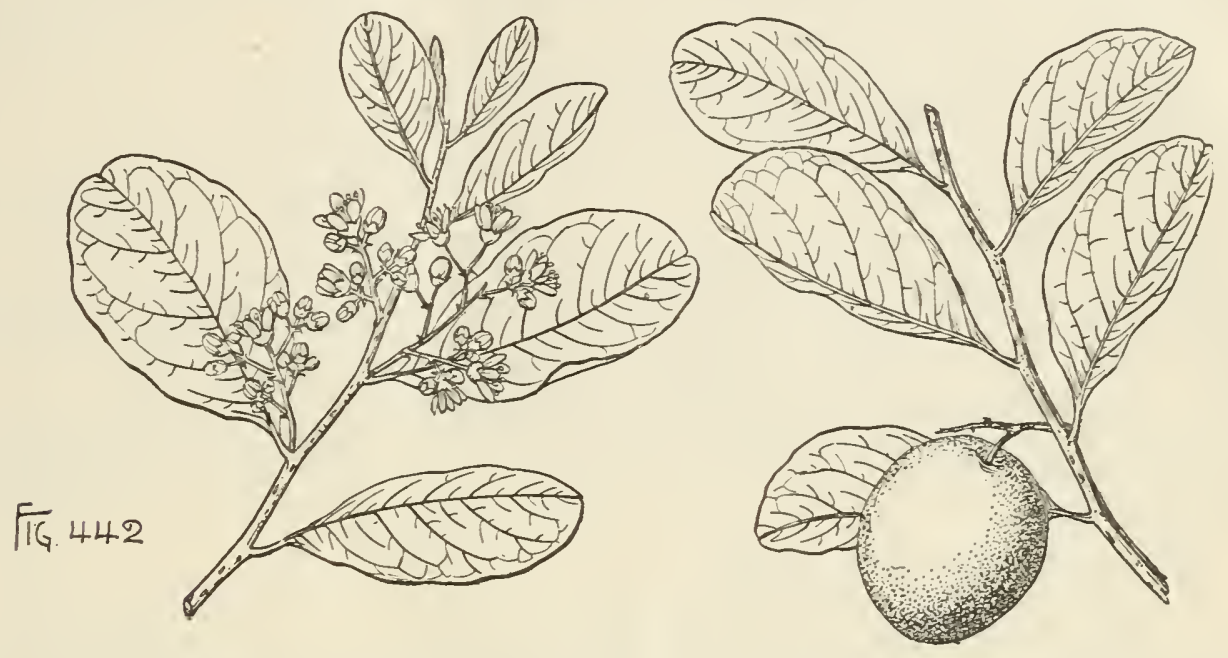

with many upright spreading branches, or often in exposed situations a semiprostrate shrub $1^{\circ}-2^{\circ}$ high. Bark of the trunk $\frac{1}{8}^{\prime}$ thick, with a light gray surface tinged with red, separating into long thin scales. Wood heary, hard, strong, close-grained, light brown often tinged with red, with thin lighter colored sapwood of about 10 layers of annual growth. The insipid fruit is eaten by negroes; the seeds contain a considerable quantity of oil; and the astringent bark, leaves, and roots have been used medicinally.

Distribution. Usually on saline shores in Florida; Cape Canaveral to Bay Biscayne, and on the west coast from Caximbas Bay to the southern keys; generally shrubby; arborescent only on the islands of the Everglades near Bay Biscayne, and on the Miami River; through the West Indies to southern Brazil, and on the west coast of Africa from Senegambia to the Congo Free State.

\section{LEGUMINOSA.}

Trees or shrubs, with alternate usually compound leaves, regular or papilionaceous usually perfect flowers; stamens 10 or indefinite, with diadelphous or distinct filaments and 2-celled anthers, the cells opening longitudinally; ovary superior, 1 or many-celled, inserted on the bottom of the calyx. Fruit a legume. Of the four hundred and thirty genera of the Pea family now recognized and widely distributed in all temperate and tropical regions, seventeen have arborescent representatives in the United States.

\section{CONSPECTUS OF THE NORTH AMERICAN ABORESCENT GENERA.}

Subfamily 1. MInosordex. Calyx 4-6-toothed, the teeth valvate in the bud; petals as many as the teeth of the calyx, valvate in the bud; ovules numerous, suspended in 2 ranks from the inner angle of the ovary, superposed, anatropous, the micropyle superior; sta- 
mens much exserted; leaves twice pinnate; cotyledons oval or orbicular, flat; radicle straight.

Stamens numerous (more than 10); seeds without albumen.

Filaments more or less united into a tube.

Filaments muited.

Valves of the pods not separating at maturity from the margins.

Valves of the pods separating at maturity from the persistent margins.

1. Zygia.

2. Lysiloma.

Filaments free or the inner ones slightly united at the base.

3. Acacia.

Stamens 10; filaments free; seeds with albumen.

Legume plano-compressed, dehiscent; flowers in globose heads.

Legume terete or compressed, indehiscent; flowers in cylindrical spikes.

4. Leucæna.

5. Prosopis.

Subfamily 2. CAsalpinioide. Calyx 5-lobed or toothed, the divisions usually valvate in the bud; corolla imperfectly papilionaceous or nearly regular; petals 5 , imbricated in the bud, the upper one inside and inclosed by the others; stamens 10 or less; filaments free; anthers introrse ; ovules numerous (sometimes 2 in one species of Gleditsia), superposed, anatropous, the micropyle superior; seeds albuminous.

Flowers imperfectly papilionaceous; calyx 5-toothed; legume flat, wing-margined; leaves simple.

6. Cercis.

Flowers regular.

Flowers polygamous or diœcious.

Calyx-tube elongated, 5-lobed; petals 5 ; stamens 10 , shorter than the petals; legume thick and woody; leaves twice pinnate.

7. Gymnocladus.

Calyx-tube short, $3-5$-lobed; petals $3-5$; stamens $3-5$, longer than the petals; legume leathery; leaves once and twice pinnate.

8. Gleditsia.

Flowers perfect.

Legumes linear, torulose, acuminate at the ends, the valves contracted between the seeds; rachis of the leaf spinescent.

9. Parkinsonia.

Legumes oblong-compressed, rachis of the leaf not spinescent. 10. Cercidium.

Subfamily 3. Papilionates. Calyx of 5 more or less united sepals; corolla of 5 irregular petals, papilionaceous, the upper petal (standard) larger than the others and inclosing them in the bud, usually turned backward or spreading, the 2 lateral petals (wings) oblong, exterior to the 2 lower connivent more or less united petals (keel) inclosing the stamens and pistil; stamens 10,9 of them united into a tube cleft on the upper side, the 10th and upper one separate, or all distinct; ovary 1 or many-celled by cross partitions; ovules amphitropous, the micropyle superior; seeds usually without albumen; leaves once pinnate.

Stamens distinct.

Flowers in racemes; legume terete, contracted between the seeds. 11. Sophora.

Flowers in panicles; legume compressed.

12. Cladrastis.

Stamens diadelphous (9 and 1).

Flowers in racemes.

Leaves glandular-dotted.

Leaves many-foliolate; petals free and distinct.

13. Eysenhardtia.

Leaves simple; wings and keel-petals adnate to the tube of the stamens.

Leaves without glandular dots.

14. Dalea.

Legume compressed; stipules becoming spinescent, persistent. 15. Robinia.

Legume turgid, the valves unequally convex by the growth of the seeds; stipules 0 .

16. Olneya.

Flowers in axillary panicles; pod linear, longitudinally 4-winged.

17. Icthyomethia. 


\section{ZYGIA, P. Br.}

Trees or shrubs, with slender branches armed with the persistent spinescent stipules. Leaves petiolate, bipinnate, the pinnæ few-foliolate, their rachises generally marked by numerous glands between the pinnæ and between the leaflets. Flowers perfect or polygamous, from the axils of minute bracts, in pedunculate globose heads or oblong cylindrical spikes, their peduncles in terminal panicles or axillary fascicles; calyx campanulate, short-toothed; corolla funnel-shaped, the petals as many as the teeth of the calyx, joined for more than half their length; stamens numerous, united at the base into a tube free from the corolla; anthers minute, versatile; ovary stipitate, contracted into a slender filiform style, with a minute terminal stigma. Legume compressed, 2-valved, dehiscent, the valves contiuuous or interrupted within. Seeds compressed, suspended transversely; funicle filiform or expanded into a fleshy aril; hilum near the base of the seed; seed-coat thin or thick, marked on each of the 2 surfaces of the seed by a faint oval ring or oblong depression; embryo filling the cavity of the seed; the radicle included or slightly exserted.

Zygia with more than a hundred species is widely distributed through the tropical and subtropical regions of the two worlds, and is most abundant in tropical America. Of the four species found within the territory of the United States three are arborescent.

The generic name, from $\zeta v \gamma \delta s$, is the classical name of some other tree.

\section{CONSPECTUS OF THE NORTH AMERICAN ARBORESCENT SPECIES.}

Pinnæ with 1 pair of leaflets; valves of the legume much contorted after opening; seeds surrounded by the enlarged ariloid funicles.

1. Z: Unguis-cati (D).

Pinnæ with more than 1 pair of leaflets; valves of the legume not contorted after opening; funicle of the seed not enlarged and ariloid.

Pinnæ with 3-. pairs of leaflets; legume short-stalked, the valves submembranaceous; seeds not in separate compartments.

2. Z. brevifolia (E).

Pinnæ with 2-3 pairs of leaflets; legume sessile, the ralves thick and woody, tardily dehiscent; seeds in separate compartments.

3. Z. flexicaulis (E).

\section{Zygia Unguis-cati, Sudw. Cat's Claw.}

Leaves persistent, long-petiolate, with a single pair of bifoliolate pinnæ, and slender petioles faintly grooved on the upper side, $\frac{1}{2}^{\prime}-1^{\prime}$ long, and slightly and abruptly enlarged at the base; rachis glandular between the short stout petiolules and between leaflets; leaflets obtuse, orbicular or broadly oblong, very oblique and obtuse or rarely emarginate at the apex, entire, membranaceous or somewhat coriaceous, reticnlateveined, bright green and lustrous on the npper and paler on the lower surface, $\frac{1}{2}-2^{\prime}$ long and $\frac{1}{2}^{\prime}-1 \frac{1}{2}^{\prime}$ wide. Flowers polygamous, pale yellow, glabrous or slightly pnberulous, opening in Florida in March and continuing to appear until midsummer, in globular heads, on slender peduncles $1^{\prime}-1 \frac{1}{2}^{\prime}$ long fascicled in the axils of upper leaves or collected in ample terminal panicles, their bracts lanceolate, acuminate, chartaceous, $\frac{1^{\prime}}{4}$ long, caducous; calyx rather less than $\frac{1}{12}^{\prime}$ long, broadly toothed, one quarter as long as the acuminate petals barely exceeding the tube formed by the union of the filaments; stamens purple, $\frac{1}{2}^{\prime}$ long; ovary glabrous, long-stalked, minute or rudimentary in the sterile flower. Fruit compressed, slightly torulose, stipitate, rounded or acnte at the apex, $2^{\prime}-4^{\prime}$ long, $\frac{1}{4}^{\prime}-\frac{1}{2}^{\prime}$ wide, the valves reticulate-veined, thickened on the margins, bright reddish brown and after opening greatly and variously contorted; seeds 
irregularly obovate or sometimes nearly triangular, compressed or thickened, dark chestnut-brown, lustrous, marked by faint oval rings, $\frac{1}{3}$ long, surrounded at the base by the enlarged bright red ariloid funicle; seed-coat thin, cartilaginous.

A tree, sometimes $20^{\circ}-25^{\circ}$ high, with a slendcr trunk $7^{\prime}-8^{\prime}$ in diameter, ascending. and spreading branches forming a low flat irregular liead, and slender somewhat zigzag branchlets at first slightly striately angled, becoming terete, light gray-brown or dark reddish brown, covered with minute pale lenticels, and armed with the straight persistent rigid stipular spines broad at the base and $\frac{1^{\prime}}{4}$ long, or rarely minute; more

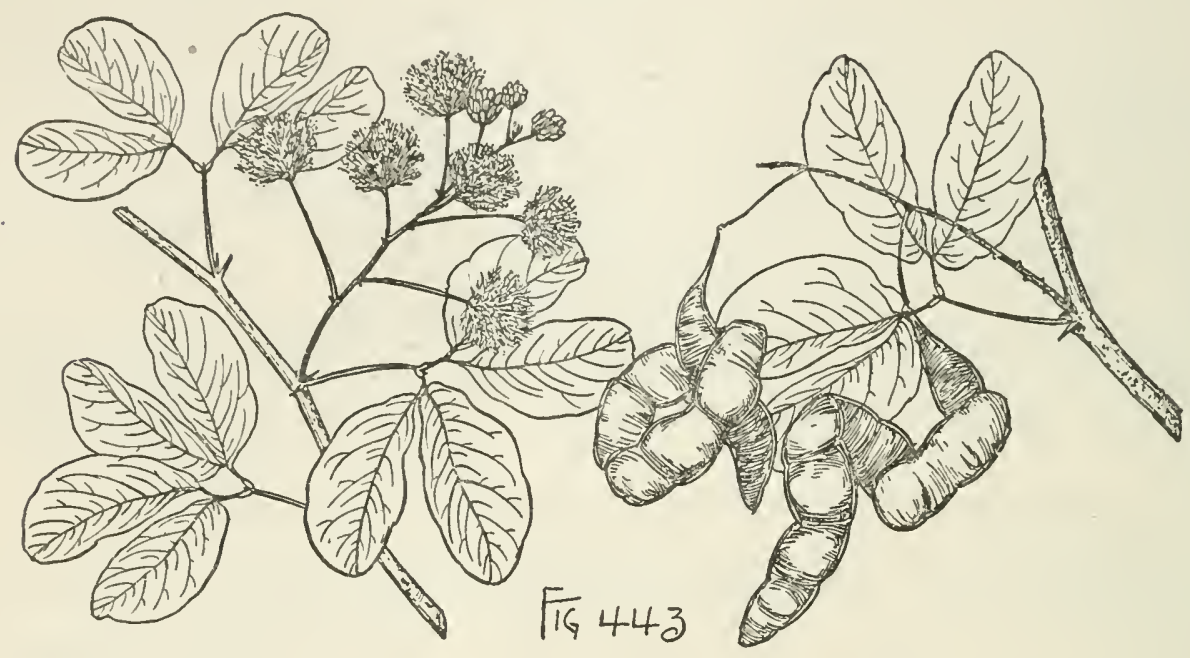

often a shrub, with many vine-like almost prostrate stems. Bark of the trunk $\frac{1^{\prime}}{4}$ thick, reddish brown and divided by shallow fissures into sniall square plates. Wood very heavy, hard, close-grained, rich red varying to purple, with thin clear yellow sapwood. The bark is astringent and diuretic, and was once used in Jamaica as a cure for many diseases.

Distribution. Florida, shores of Caximbas Bay and on many of the southern keys; most abundant in its arborescent form on the larger of the eastern keys, and probably of its largest size in Florida on Elliott's Key; often forming shrubby thickets; common and widely distributed through the Antilles to Venezuela and New Granada.

\section{Zygia brevifolia, Sudw. Huajillo.}

Leaves $2^{\prime}-3^{\prime}$ long, $2^{\prime}$ wide, long-petiolate, with 8-12 10-20-foliolate pinnæ and slender terete petioles $\mathbf{1}^{\prime}$ long and furnished near the middle with a dark oblong gland, when they unfold coated with pale tomentum and at maturity glabrous with the exception of the puberulous petioles and rachises, persistent or tardily deciduous; leaflets oblong-linear, obtuse or acute at the apex, oblique at the base, very shortpetiolate, $\frac{1}{6}-\frac{1}{4}$ long, light green on the upper, paler on the lower surface. Flowers white to violet-yellow, in globose or oblong heads $\frac{1}{2}^{\prime}$ in diameter, on thin pubescent peduncles bracteolate at the apex, coated at first, like the flower-buds, with thick white tomentum, developed from the axils of lanceolate acute scarious deciduous bracts, and arranged in short terminal racemes; calyx shortly 5-lobed, pubernlous on the outer surface, about $\frac{1}{24}{ }^{\prime}$ long and one fourth the length of the puberulous petals persistent with the stamens at the base of the matnre fruit; stamens nearly $\frac{1}{2}^{\prime}$ long. Fruit ripening at midsummer and often persistent on the branches after 
opening until the trees flower the following year, straight, compressed, slightly torulose, short-stalked, contracted at the apex into a short slender point, $4^{\prime}-6^{\prime}$ long and $\frac{2^{\prime}}{3}$ wide, its valves somewhat membranaceous, thick-margined, reddish brown on the

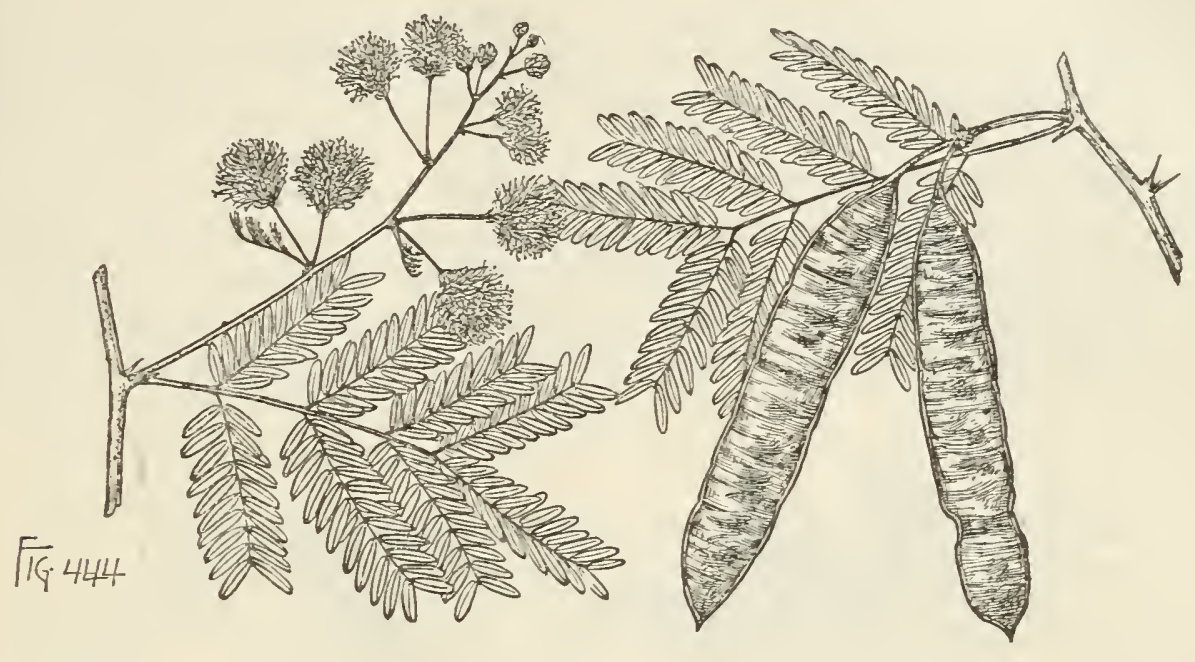

outer, yellow tinged with red on the inner surface, reticulate-veined; seeds suspended by slender coiled and somewhat dilated funicles, compressed, ovate to nearly orbicular, dark chestnut-brown, very lustrous, $\frac{1^{\prime}}{4}$ long, and faintly marked by large oval depressions; seed-coat thin, cartilaginous.

A tree, $25^{\circ}-30^{\circ}$ high, with a trunk rarely $5^{\prime}-6^{\prime}$ in diameter, slender upright branches forming a narrow irregular head, and branchlets slightly striately angled, covered with minute white lenticels, light gray and puberulous when they first appear, becoming dark brown in their second year, and armed with stout rigid stipular spines sometimes $\frac{1}{2}^{\prime}$ long and persistent for many years; more often a shrub, sometimes only $2^{\circ}-3^{\circ}$ tall. Bark of the trunk smooth, light gray somewhat tinged with red, and of ten marked by large pale blotches. Wood dark-colored, hard, and heary.

Distribution. Bluffs and bottom-lands of the lower Rio Grande, Texas; usually a low shrub spreading into broad clumps, but occasionally in the rich and comparatively moist soil of the river lagoons a slender tree; in Mexico more abundant; of its largest size from the mouth of the Rio Grande to the Sierra Madre of Nuevo Leon.

\section{Zygia flexicaulis, Sudw. Ebony.}

Leaves persistent, $1 \frac{1^{\prime}}{2}-2^{\prime}$ long, $2 \frac{1}{2}^{\prime}-3^{\prime}$ wide, long-petiolate, with slender puberulous petioles glandular near the middle and furnished at the apex with small orbicular solitary glands, and 4-6 usually 6 -foliolate pinnæ, the lowest pair of ten the shortest, persistent; leaflets ovate-oblong, rounded at the apex, reticulate-veined, membranaceous or subcoriaceous, glabrous, dark green and lustrons on the upper surface, paler on the lower, $\frac{1}{4}^{\prime}-\frac{1}{3}^{\prime}$ long, petiolules short and broad. Flowers light yellow or cream color, very fragrant, sessile in the axils of minute caducous bracts, appearing from June until August, in cylindrical dense or interrupted spikes $1 \frac{1}{2}$ long, on stout pubescent peduncles fascicled in the axils of the upper leaves of the previous year; corolla four or fire times as long as the calyx and like it pubernlous on the outer surface, and about as long as the tube formed by the union of the filaments; stamens 
$\frac{1^{\prime}}{8}$ long; ovary glabrous, sessile. Fruit ripening in the autumn and remaining on the branches until after the flowering season of the following year, sessile, tardily dehiscent, flattened, turgid, straight or slightly falcate, oblique at the base, rounded and contracted into a short broad point at the apex, $4^{\prime}-6^{\prime}$ long, $1^{\prime}-1_{\frac{1}{4}}^{\prime \prime}$ broad, with thick woody valves lined with a thick pithy substance inclosing and scparating the seeds; seeds suspended on very short straight funicles, bright red-brown, $\frac{1^{\prime}}{2}$ long, $\frac{1}{4}^{\prime}$ wide, irregularly obovate, faintly marked by short oblong depressions; seed-coat thick, crustaceous.

A tree, $20^{\circ}-30^{\circ}$ high, with a straight trunk $2^{\circ}-3^{\circ}$ in diameter, scparating $8^{\circ}-10^{\circ}$ from the ground into short spreading branches forming a wide round head, and stout zigzag branchlets, puberulous, light green or dark reddish brown when they first appear, becoming in their second year glabrous or rarely puberulous, dark reddish brown or light gray, and armed with the persistent stipular pale chestnut-brown

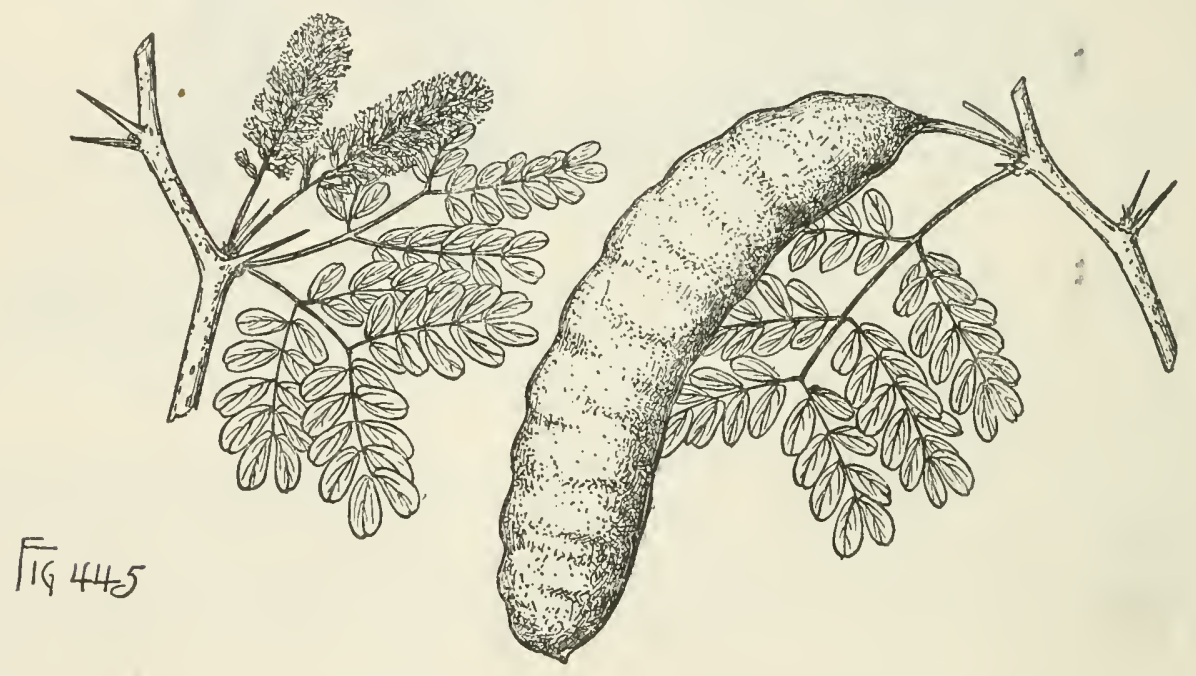

spines $\frac{1^{\prime}}{4}-\frac{1^{\prime}}{2}$ long. Wood exceedingly heavy, hard, compact, close-grained, dark rich red-brown slightly tinged with purple, with thin clear bright yellow sapwood; almost indestructible in contact with the ground and largely used for fence-posts; valued by cabinet-makers and for fuel, and considered more valuable than that of any other tree of the Rio Grande valley. The seeds are palatable and nutritious, and are boiled when green or roasted when ripe by the Mexicans, who use their thick shells as a substitute for coffee.

Distribution. Shores of Matagorda Bay, Texas, to the Sierra Nevada of Nuevo Leon, and in Lower California; common on the bluffs of the Gulf coast and on both banks of the lower Rio Grande; south of the Rio Grande one of the commonest and most beautiful trees of the region.

\section{LYSIIOMA, Benth.}

Trees or shrubs, with slender unarmed branches, abruptly bipinnate long-petiolate persistent leaves, their petioles marked by large conspicuous glands, and small leaflets in many pairs; stipules large, membranaceous, persistent or deciduous. Flowers perfect or rarely polygamous, minute, usually white or greenish white, from the axils of minute bractlets more or less dilated at the apex, in globose 
many-flowered heads, on axillary solitary or fascicled peduncles; calyx campanulate, 5-toothed; corolla funnel-shaped, of 5 petals united for more than half their length; stamens generally $12-30$, exserted; filaments filiform, united at the base into a tube free from the corolla; anthers minute, ovate, versatile; ovary sessile, contracted into a slender subulate style, with a minute terminal stigma. Legume broad, straight, compressed, submembranaceous, the valves at maturity separating from the undivided margins, continuous within, their outer layer thin and papery, dark-colored, the inner rather thicker, pale yellow. Seeds compressed, transverse, suspended by long slender funicles, the hilum near the base; seed-coat thin, crustaceous; radicle slightly exserted.

Lysiloma with about ten species inhabits tropical America from southern Florida and the Bahama Islands, the West Indies, Mexico and Lower California, to Central America and Bolivia. Several of the species produce valuable timber.

The generic name, from $\lambda \dot{v} \sigma$ เs and $\lambda \hat{\omega} \mu \alpha$, refers to the separation of the valves from the margins of the legume.

\section{Lysiloma Bahamensis, Benth. Wild Tamarind.}

\section{(Lysiloma latisiliqua, Silva N. Am. iii. 129.)}

Leaves $4^{\prime}-5^{\prime}$ long, glabrous or sometimes slightly puberulous, with slender petioles $1^{\prime}$ long, marked near the middle with an elevated gland, and 2-5 pairs of shortstalked 40-80-foliolate pinnæ; their petioles enlarged and slightly glandular at the
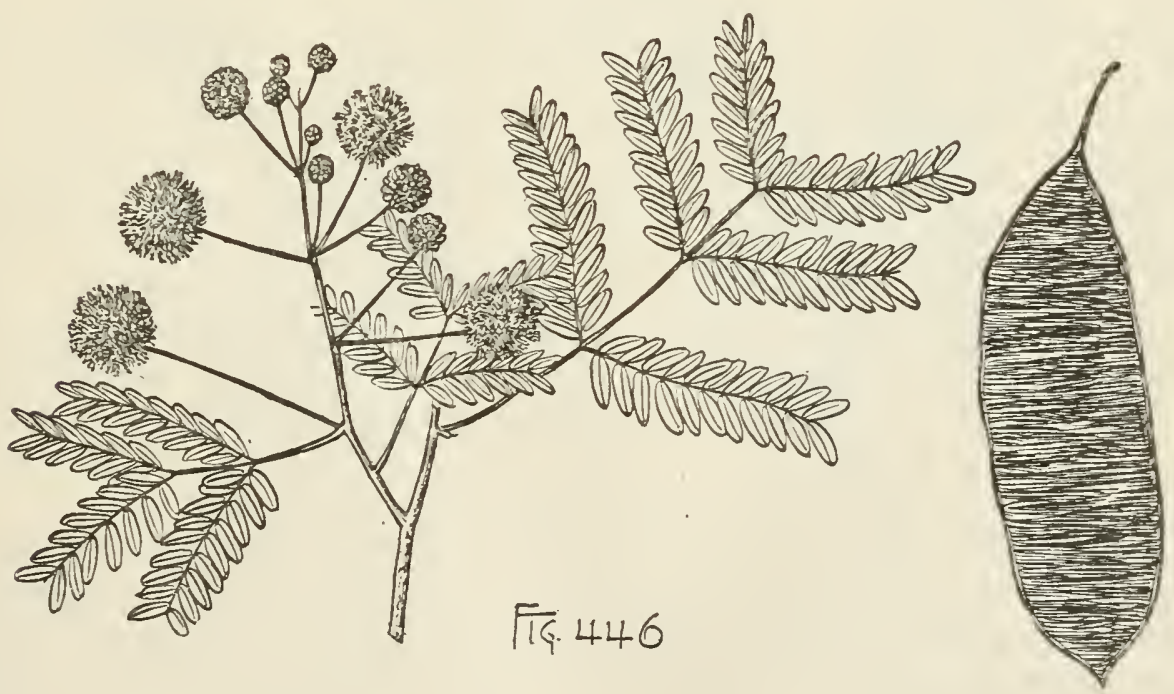

base; stipules foliaceous, ovate or ovate-oblong, acuminate, auriculate and semicordate at the base, $\frac{1}{2}^{\prime}$ long, usually caducous; leaflets obliquely ovate or oblong, obtuse or acute, more or less united at the base by the greater development of one of the sides, sessile or short-petiolulate, entire, reticulate-veined, light green, paler on the lower than on the upper surface, $\frac{1}{4}^{\prime}-\frac{1}{2}^{\prime}$ long and $\frac{1}{8}^{\prime}-1^{\prime}{ }^{\prime}$ wide. Flowers about $\frac{1}{3}$ long, in heads appearing in Florida early in April, coated before the flowers open with thick pale tomentum, and after the exsertion of the stamens $\frac{2}{3}$ in diameter, on peduncles $\frac{3^{\prime}}{4}-1 \frac{1}{2}^{\prime}$ long, solitary or fascicled in the axils of upper leaves, their bracts and bractlets acute, membranaceous, caducous; calyx broadly 5 -toothed, pilose on the 
outer surface, especially above the middle, $\frac{1}{1^{\prime}}$ long, and lialf as long as the 5-lobed corolla with reflexed lobes; stamens about 20 , twice as long as the corolla, mited for one fourth of their length into a slender tube. Fruit stipitate, gradually narrowed and acute at the ends, $4^{\prime}-5^{\prime}$ long, $1^{\prime}$ broad, with a slender stem $1^{\prime}-2^{\prime}$ long, ripening in the autumn and persistent on the branches until after the flowering period of the following year, in clnsters of 2-3 on short peduncles abruptly and conspicuously enlarged at the apex; valves thin and papery, bronze-green when fully grown, becoming dark red-brown, separating slowly from the margins; seeds oval or obovate, dark brown, lustrous, $\frac{1}{2}$ long.

A tree, $40^{\circ}-50^{\circ}$ high, with a trunk $2^{\circ}-3^{\circ}$ in diameter, stout spreading branches forming a wide flat head, and glabrous or somewhat pilose branchlets, conspicuously verrucose, bright red-brown when they first appear, becoming pale or light reddish brown in their second year. Bark of the trunk of young trees and of the branches smooth, light gray tinged with pink, becoming on old trunks $\frac{1^{\prime}}{4}-\frac{1}{2}$ thick, dark brown and separating into large plate-like scales. Wood heavy, hard, not strong, tough, close-grained, rich dark brown tinged with red, with nearly white sapwood $1^{\prime}-1 \frac{1}{2}^{\prime}$ thick, of 4 or 5 layers of annual growth; in Florida occasionally used and valued for boat and shipbuilding.

Distribution. Key Largo, Elliott's, Plantation, and Boca Chica keys, Florida; not common; on the Bahama Islands.

\section{ACACIA, Adans.}

Trees or shrubs, with slender brancles armed with spinescent stipules or infrastipular spines. Leaves alternate on young branches and fascicled in earlier axils, bipinnate, with usually small leaflets, persistent. Flowers perfect or often polygamous, small, in the axils of minute linear bractlets more or less dilated and often peltate at the apex, in globose heads or cylindrical spikes, on axillary solitary or fascicled peduncles; calyx campanulate, 5 or 6 -toothed; petals as many as the divisions of the calyx, more or less united; stamens numerous, usually more than 50, exserted, free or slightly and irregularly united at the base, inserted under or just above the base of the ovary; filaments filiform; anthers small, attached on the back, versatile; ovary contracted into a long slender style terminating in a minute stigma. Legume nearly cylindrical or flat, indehiscent, continuous or divided within. Seeds transverse, compressed; seed-coat thick, crustaceous, marked on each face of the seed by an oval depression or ring; radicle straight, included, or slightly exserted.

Acacia with more than four hundred species is widely distributed through Australia, where it is most largely represented, tropical and southern Africa, northern Africa, southwestern China, the warmer regions of southern Asia, the islands of the south Pacific, tropical and temperate South America, the West Indies, Central America and Mexico to the southwestern boundaries of the United States where ten or twelve species occur; of these four are arborescent. Acacia is astringent, and many species yield valuable tan bark. Gum arabic is produced by different Old World species; many of the species yield hard heavy durable wood, and some of the Australian species are large and valuable timber-trees. Many species are cultivated for their graceful foliage and handsome fragrant flowers.

The generic name, from ákaкía, relates to the spines with which the branches are usually armed. 


\section{CONSPECTUS OF THE ARBORESCENT SPECIES OF THE UNITED STATES.}

Flowers in globose heads; corolla õ-lobed; ovary sessile; stipules persistent, becoming spines.

Legume cylindrical, glabrous, its sutures conspicuously thickened and grooved; seeds in 2 ranks.

1. A. Farnesiana (E).

Legume flattened, pubescent, its sutures not thickened, slightly grooved; seeds in 1 rank.

2. A. tortuosa (E).

Flowers in elongated slender spikes; corolla of 5 petals only slightly united at the base; ovary stalked; stipules caducous; branchlets armed with infrastipular spines.

Legume $1^{\prime}$ wide, straight or slightly contracted between the seeds, not becoming twisted and contorted at maturity; seeds narrowly obovate or ovate. 3. A. Wrightii (E).

Legume $\frac{1}{2}-\frac{3}{4}$ ' wide, often conspicuously contracted between the seeds, becoming twisted and contorted at maturity; seeds nearly orbicular.

4. A. Greggii (E, G, H).

\section{Acacia Farnesiana, Willd. Huisache. Cassie.}

Leaves $2^{\prime}-4^{\prime}$ long, with $2-8$, usually 4 or 5 , pairs of pinnæ, generally somewhat puberulous on the short petioles and rachises, in Texas mostly falling at the beginning of winter; pinnæ sessile or short-stalked, remote or close together, with 10-25

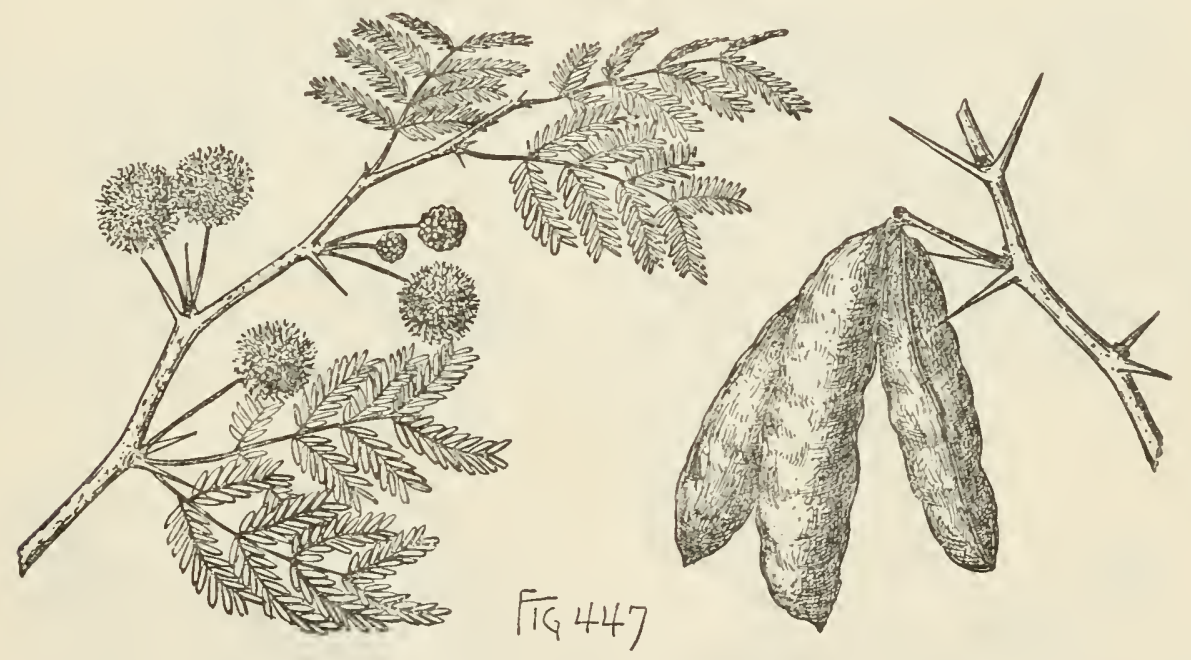

pairs of linear acute leaflets tipped with minute points, unequal at the base, sessile or short-petiolulate, glabrous or puberulous, bright green, $\frac{1}{8}^{\prime}-\frac{1}{4}^{\prime}$ long. Flowers bright yellow, very fragrant, $\frac{1}{1 \frac{1}{1}}$ long, opening during the summer and autumn from the axils of minute clavate pilose bractlets, in heads $\frac{2}{3}$ in diameter, on axillary solitary slender puberulous peduncles, most often 2 or 3 together and $1^{\prime}-1 \frac{1}{2}^{\prime}$ long, with two minute dentate connate bracts forming an involucral cup immediately under the flowerhead; calyx about half as long as the petals and like them somewhat pilose on the outer surface; stamens two or three times as long as the corolla; ovary short-stipitate, covered with long pale hairs. Fruit oblong, cylindrical or spindle-shaped, thick, turgid, straight or curved, slightly contracted between the seeds, short-stalked, narrowed at the apex into a short thick point, $2^{\prime}-3^{\prime}$ long, $\frac{1^{\prime}}{2}-\frac{2}{3}$ broad, dark red-purple, lustrous, and marked by broad light-colored bands along the thickened grooved sutures, the outer coat of the walls thin and papery, inclosing a thick pithy pulplike substance surrounding the seeds, each in a separate thin-walled compartment; 
seeds ovate, thick, flattened on the inner surface by mutual pressure, $\frac{1}{4}$ long, suspended transversely in 2 ranks on short straight funicles, light brown, lustrous, and faintly marked by large oval rings.

A tree, $20^{\circ}-30^{\circ}$ high, with a straight trunk $12^{\prime}-18^{\prime}$ in diameter, separating $6^{\circ}-8^{\circ}$ from the ground into numerons long pendulons branehes forming a wide round spreading head, and slender terete or slightly striate angled branehlets, glabrous or at first pubernlous, and armed with straight rigid tcrete spines developed from the persistent stipnles and sometimes $1 \frac{1{ }^{\prime}}{2}$ long. Bark of the trunk thin, reddish brown, irregularly broken by long reticnlated ridges, exfoliating in large thin scales. Wood heavy, hard, elose-grained, rich reddish brown, with thin pale sapwood; in India used for the knees of small vessels and in agrieultural implements.

Distribution. Now widely spread by eultivation through the tropical and subtropical regions of the two worlds and probably a native of America from western Texas to northern Chili; growing in Texas apparently naturally in the arid and almost uninhabited region between the Nueces and Rio Grande.

Largely cultivated in southern Europe for its fragrant flowers used in the manufacture of perfumery, as an ornament of gardens in all warm countries, and in India as a hedge plant.

\section{Acacia tortuosa, Willd.}

Leaves generally less than $1^{\prime}$ long, short-petiolate, with slender puberulous raehises and usually 3 or 4 pairs of pinnæ, early deciduous; pinnæ sessile or short-stalked, remote, with 10-15 pairs of linear somewhat falcate leaflets, acute, tipped with minute points, subsessile, light green, glabrous, $\frac{11^{\prime}}{2 \overline{0}}-\frac{1}{16}{ }^{\prime}$ long. Flowers minute, bright yellow, very fragrant, in the axils of clavate pilose bractlets, in heads $\frac{1^{\prime}}{4}-\frac{8^{\prime}}{8}$ in diameter, appearing in March with or just before the unfolding leaves, on clustered or solitary slender puberulous peduncles, $\frac{1^{\prime}}{2}-\frac{3^{\prime}}{4}$ long, and furnished at the apex with 2 minute connate bracts; calyx only about one third as long as the corolla, with short
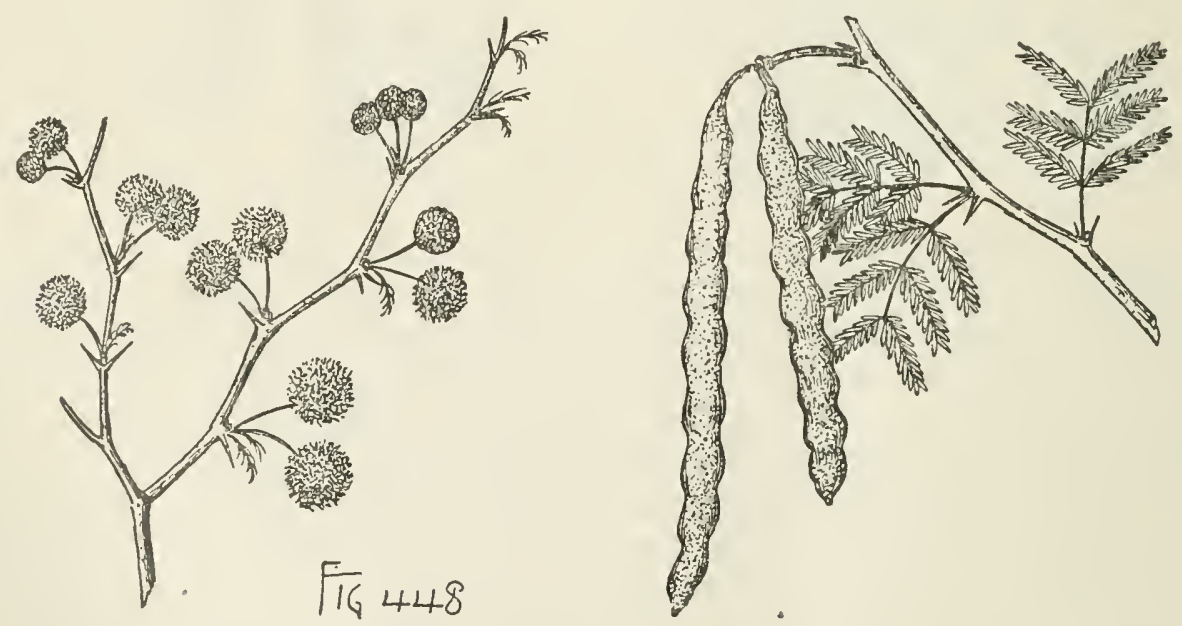

puberulous lobes; corolla puberulous at the apex, less than one half as long as the filaments; ovary covered with short close pubescenee. Fruit elongated, linear, slightly eompressed, somewhat eonstrieted between the seeds, $3^{\prime}-5^{\prime}$ long, about $\frac{1^{\prime}}{4}$ wide, dark red-brown and cinereo-puberulous; seeds in 1 series, obovate, compressed, dark red-brown, lustrous, about $\frac{1 \prime}{4}$ long, faintly marked by large oval rings. 
A tree, occasionally $15^{\circ}-20^{\circ}$ high, with a straight trunk $5^{\prime}-6^{\prime}$ in diameter, stout wide-spreading branches forming an open irregular head, and slender somewhat zigzag slightly angled reddish brown branchlets roughened by numerous minute round lenticels, villose, with short pale hairs, and armed with thin terete puberulons spines occasionally $\frac{3^{\prime}}{4}$ long; in Texas usually shrubby, with numerous stems forming a symmetrical round-topped bush only a few feet high. Bark dark brown or nearly black, and deeply furrowed.

Distribution. Valley of the Rio Cibolo to Eagle Pass on the Rio Grande, Texas; and in northern and southern Mexico, the West Indies, Venezuela, and on the Galapagos Islands; in Texas probably arborescent only on the plains of the Rio Grande near Spofford.

\section{Acacia Wrightii, Benth. Cat's Claw.}

Leaves $1^{\prime}-2^{\prime}$ long, slightly pubescent, especially on the petioles and rachises, with 1-3 pairs of pimn, slender petioles $1 \frac{1^{\prime}}{3}$ long, and eglandular or glandular, with small convex glands, and linear acute caducous stipules $\frac{1}{16}^{\prime}$ long; pinnæ short-stalked,
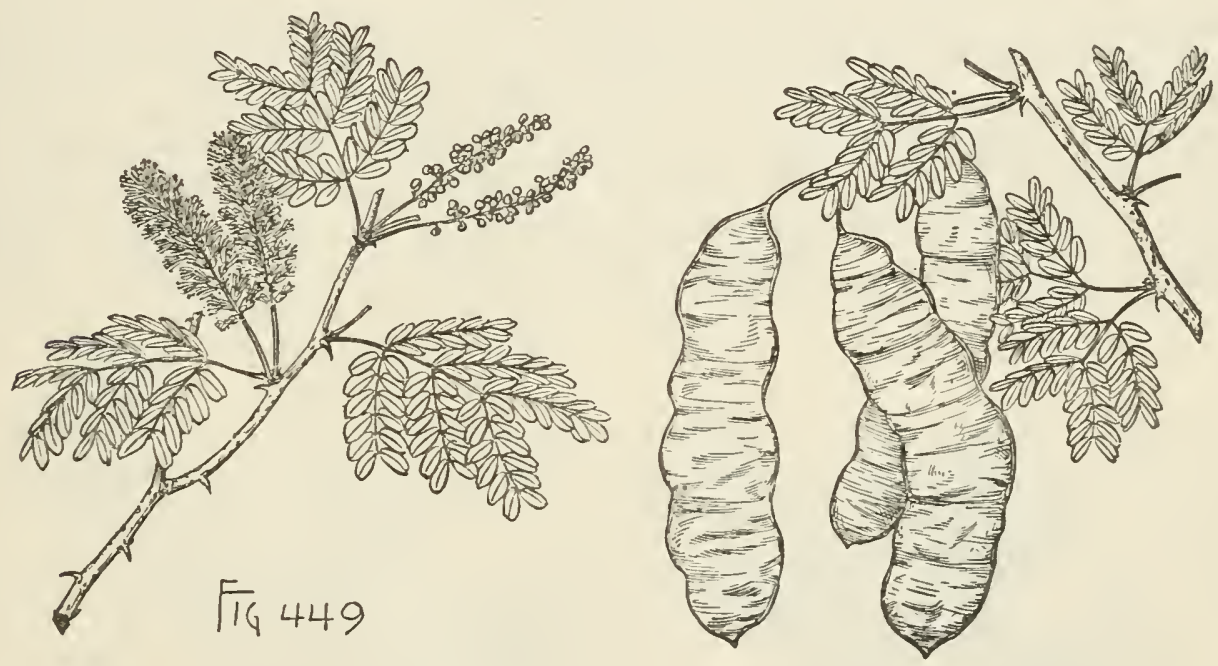

with 2-5 pairs of obliquely obovate-oblong leaflets, obtuse, rounded, and often apiculate at the apex, sessile or short-petiolulate, 2 or sometimes 3-nerved, reticulateveined, rigid, bright green and rather paler on the lower than on the upper surface, $\frac{1}{16}-\frac{1}{4}^{\prime}$ long. Flowers light yellow, fragrant, appearing from the end of March to the end of May, on slender pubescent pedicels from the axils of minute caducous bracts, in narrow spikes. $\mathbf{1}^{\prime}{ }^{\prime}$ long, often interrupted below the middle, on slender fascicled pubescent or sometimes glabrous peduncles; calyx obscurely 5 -lobed, pubescent on the outer surface, half as long as the spatulate petals slightly united at the base, and ciliate on the margins; stamens $\frac{1^{\prime}}{4}$ long; ovary long-stalked, covered with long pale hairs. Fruit fully grown early in the summer, deciduous in the autumn, slightly falcate, compressed, stipitate, oblique at the base, rounded and short-pointed at the apex, $2^{\prime}-4^{\prime}$ long, $1^{\prime}$ wide, with thick straight or irregularly contracted margins and thin papery walls conspicuously marked by narrow horizontal reticulate veins; seeds narrowly obovate, compressed, $\frac{1^{\prime}}{4}$ long, suspended transversely on long slender funicles, light brown, markèd by large oval depressions.

A tree, occasionally $25^{\circ}-30^{\circ}$ high, with a short trunk $10^{\prime}-12^{\prime}$ in diameter, spread- 
ing branches forming a low wide or irregular head, and branchlets when they first appear somewhat striately angled, glabrous, pale yellow-brown or dark red-brown, turning pale gray in their second year, and armed with occasional stout recurved infrastipular chestnut-brown spines $\frac{1}{4}$ long, compressed toward the broad base and very sharp-pointed, or rarely unarmed. Bark of the trunk about $\frac{1}{8}^{\prime}$ thick, furrowed, divided by shallow furrows into broad ridges separating on the surface into thin narrow scales. Wood very heavy, hard, close-grained, bright clear brown streaked with red and yellow, with thin clear yellow sapwood of 6 or 7 layers of annual growth; valued and largely used as fnel.

Distribution. Valley of the Guadalupe River in the neighborhood of New Braunfels, Texas, to the Sierra Madre of Nuevo Leon; most abnudant and of its largest size south of the Rio Grande on dry gravelly mesas and foothills.

\section{Acacia Greggii, Gray. Cat's Claw. Uña de Gato.}

Leaves $1^{\prime}-3^{\prime}$ long, pubescent or puberulous, with 1-3 pairs of pinnæ, short slender petioles furnished near the middle with a minute oblong chestnut-brown gland, and linear stipules $\frac{\frac{1}{16}}{16}$ long and caducous; pinnæ short-stalked, with 4-5 pairs of obovate oblique leaflets rounded or truncate at the apex and unequally contracted at the base into short petiolules, thick and rigid, 2-3-nerved, reticulateveined, hoary-pubescent, $\frac{11^{\prime}-1^{\prime}}{16}$ long. Flowers fragrant, bright creamy yellow, in dense oblong pubescent spikes, on peduncles $\frac{1^{\prime}}{2}-\frac{2^{\prime}}{3}$ long, and fascicled nsually 2 or 3 together toward the ends of the branches; calyx obscurely 5 -lobed, puberulous on the outer surface, half as long as the petals slightly united at the base and paletomentose on the margins; stameus $\frac{1}{4}$ long; ovary long-stalked, covered with long
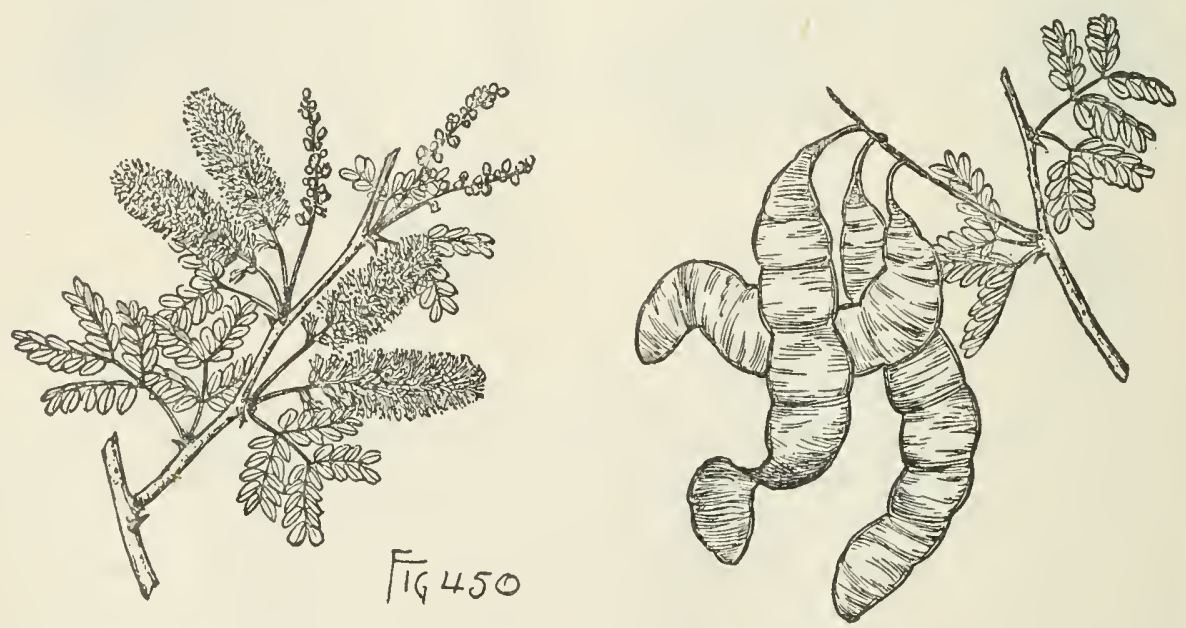

pale hairs. Fruit fully grown at midsummer and hanging unopened on the branches until winter or the following spring, compressed, straight or slightly falcate, obliquely narrowed at the base into a short stalk, acnte or rounded at the apex, more or less contracted between the seeds, $2^{\prime}-4^{\prime}$ long, $\frac{1^{\prime}}{2}-\frac{3 \prime}{4}$ wide, curling and often contorted when fully ripe, the valves thin and membranaceous, thick-margined, light brown, conspicnously transversely reticulate-veined; seeds nearly orbicular, compressed, dark brown and lustrous, $\frac{1}{4}^{\prime}$ in diameter, marked by small oval depressions.

A tree, rarely $30^{\circ}$ high, with a trunk $10^{\prime}-12^{\prime}$ in diameter, numerous spreading branches, and striately angled puberulous pale brown branchlets faintly tinged with 
red and armed with stout recurved infrastipular spines flat at the base and $\frac{1}{4}$ long and broad. Bark of the trunk about $\frac{1}{8}^{\prime}$ thick, furrowed, the surface separating into thin narrow scales. Wood heavy, very hard, strong, close-grained, durable, rich brown or red, with thin light yellow sapwood of 5 or 6 layers of annual growth.

Distribution. Dry gravelly mesas, the sides of low cañons and the banks of mountain streams; valley of the Rio Grande, western Texas, through southern New Mexico and Arizona to southern California; and in northern Mexico.

\section{LEUCANA, Benth.}

Trees or shrubs, with slender unarmed branches. Leaves persistent, abruptly bipinnate, with numerous pinnæ and small leaflets in many pairs, petiolate, their petioles often furnished with a conspicuous gland below the lower pair of pinnæ; stipules minute and caducous, or becoming spinescent and persistent. Flowers minute, white mostly perfect, sessile or short-pedicellate, in the axils of small peltate bracts villose at the apex, in globose many-flowered pedunculate heads, the peduncles in axillary fascicles or in leafless terminal racemes; calyx tubular-campanulate, minutely 5 -toothed; petals 5 , free, acute or rounded at the apex, narrowed at the base; stamens 10, free, inserted under the ovary, exserted; filaments filiform; anthers oblong, versatile; ovary stipitate, contracted into a long slender style, with a minute terminal slightly dilated stigma. Legume many-seeded, stipitate, linear, compressed, dehiscent, the valves thickened on the margins, rigid, membranaceous, continuous within, their outer coat thin and papery, dark-colored, the inner rather thicker, woody, pale brown. Seeds obovate, compressed, transverse, the hilum near the base, suspended on long slender funicles; seed-coat thin, crustaceous, brown and lustrous; embryo inclosed on its two sides by a thin layer of horny albumen; radicle slightly exserted.

Leucæna with nine or ten species is confined to the warmer parts of America from western Texas to Peru and Venezuela, and to the islands of the Pacific Ocean from New Caledonia to Tahiti, where one species has been recognized. Of the three indigenous species found in the territory of the United States, two are arborescent. Leuccena glauca, L., a small tree or shrub, cultivated in all warm countries, and a native probably of tropical America, is now naturalized on Key West, Florida.

The generic name, from $\lambda \in v \chi a i \nu \omega$, refers to the color of the flowers.

\section{CONSPECTUS OF THE NORTH AMERICAN SPECIES.}

Peduncles bibracteolate at the apex; leares 10-14-pinnate; pinnæ with 15-30 pairs of leaflets; stipules becoming spinescent, persistent.

1. L. Greggii (E).

Peduncles without bracts; leaves 30-36-pinnate; pinnæ with 30-60 pairs of leaflets; stipules minute, caducous.

2. L. pulverulenta (E).

\section{Leucæna Greggii, Wats.}

Leaves $6^{\prime}-7^{\prime}$ long and broad, with slender rachises furnished on the upper side with a single elongated bottle-shaped gland between the stalks of each pair of pinuæ; pinnæ 10-14, remote, short-stalked, with 15-30 pairs of leaflets; stipules gradually narrowed into long slender points, becoming rigid and spinescent, $\frac{1}{3}^{\prime}$ to nearly $\frac{1}{2}$ long and persistent for two or three years; leaflets lanceolate, acute or acuminate, often somewhat falcate, nearly sessile or short-petiolulate, full and rounded toward the base on the lower margin, nearly straight on the upper margin, gray-green, 
ultimately nearly glabrous, $\frac{1}{4}^{\prime}-\frac{1}{3}$ long, about $\frac{1}{8}^{\prime}$ wide, with narrow midveins and obseure lateral nerves. Flowers on slenter pedicels, in leads $\frac{8^{\prime}}{4}-\mathbf{1}^{\prime}$ in diameter, on stont peduneles $2^{\prime}-3$ ' long furnished at the apex with 2 irregularly 3 -lobed braets, and solitary or in pairs; ealyx eoated with hairs only near the apex, much shorter than the spatulate glabrous more or less boat-shaped petals; ovary villose, with a few short scattered hairs. Fruit $6^{\prime}-8^{\prime} \operatorname{long}, \frac{1}{3}^{\prime}-\frac{1}{2}^{\prime}$ wide, narrowed below into a short stout

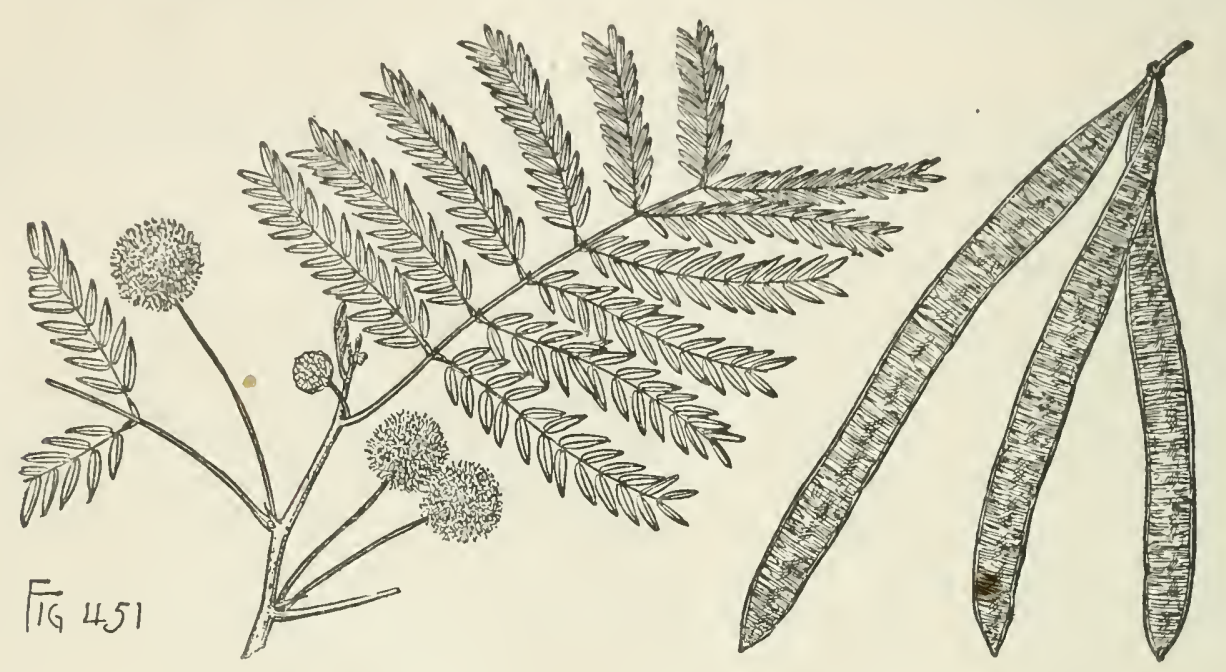

stipe, acuminate and crowned at the apex with the thickened style, $\frac{1}{3}^{\prime}-\frac{8}{4}$ long, cinereo-pubeseent until nearly fully grown, becoming nearly glabrous at maturity, much compressed, with narrow wing-like margins; seeds conspieuously notehed by the hilum, $\frac{1}{2}^{\prime}$ long, $\frac{1}{3}^{\prime}$ wide.

A tree, $15^{\circ}-20^{\circ}$ high, with a stem $4^{\prime}-5^{\prime}$ in diameter, and stout zigzag red-brown branchlets marked by numerous pale lenticels, eoated at first with short spreading lustrous yellow deciduous hairs found also on the young petioles and lower surface of the unfolding leaflets, the peduneles of the flower-heads and their braets. Bark about $\frac{3^{\prime}}{8}$ thick, dark brown, divided into low ridges and broken on the surface into small elosely appressed persistent seales. Wood heavy, hard, close-grained, rich brown streaked with red, with thin elear sapwood.

Distribution. Mountain ravines and the steep banks of streams; western 'Texas from the valley of the upper San Saba River to that of Devil's River; and southward into Mexico.

\section{Leucæna pulverulenta, Benth. Mimosa.}

Leaves $4^{\prime}-7^{\prime}$ long and $3^{\prime}-4^{\prime}$ broad, with slender petioles usually marked by a large dark oblong gland between the somewhat enlarged base and the lowest pair of pinnæ, 30-36 nearly sessile erowded pinnæ, each with 30-60 pairs of leaflets, and minute cadneous stipules; when they unfold covered like the peduneles and flower-buds with dense hoary tomentum, and at maturity puberulous on the petioles and rachises; leaflets linear, acute, rather oblique at the base by the greater development of the upper side, sessile or very short-petiolulate, pale bright green, $\frac{1^{\prime}}{6}-\frac{1^{\prime}}{4}$ long. Flowers sessile, in heads $\frac{1}{2}^{\prime}$ in diameter, appearing in suceession as the branches grow from early spring to midsummer, on slender pednncles $1^{\prime}-1 \frac{1}{2}^{\prime}$ long and fascieled in the axils of upper leaves; ealyx one fourth as long as the acute petals and like them pilose 
on the outer surface; stamens twice as long as the petals; ovary coated with long pale hairs. Fruit conspicuously thick-margined, $4^{\prime}-14^{\prime}$ long, long-stalked, tipped with short straight or recurved points, 2 or 3 together on a common peduncle thickened at the apex; seeds $\frac{5}{16}$ long.

A tree, $50^{\circ}-60^{\circ}$ high, with a straight trunk $18^{\prime}-20^{\prime}$ in diameter, separating $20^{\circ}-30^{\circ}$ from the ground into slender spreading branches forming a loose round head, and branchlets at first more or less striately grooved and thickly coated with pulverulent caducous tomentum, becoming at the end of a few weeks terete, pale cimnamon-brown and puberulous. Bark about $\frac{1^{\prime}}{4}$ thick, bright cinnamon-brown, and roughened by

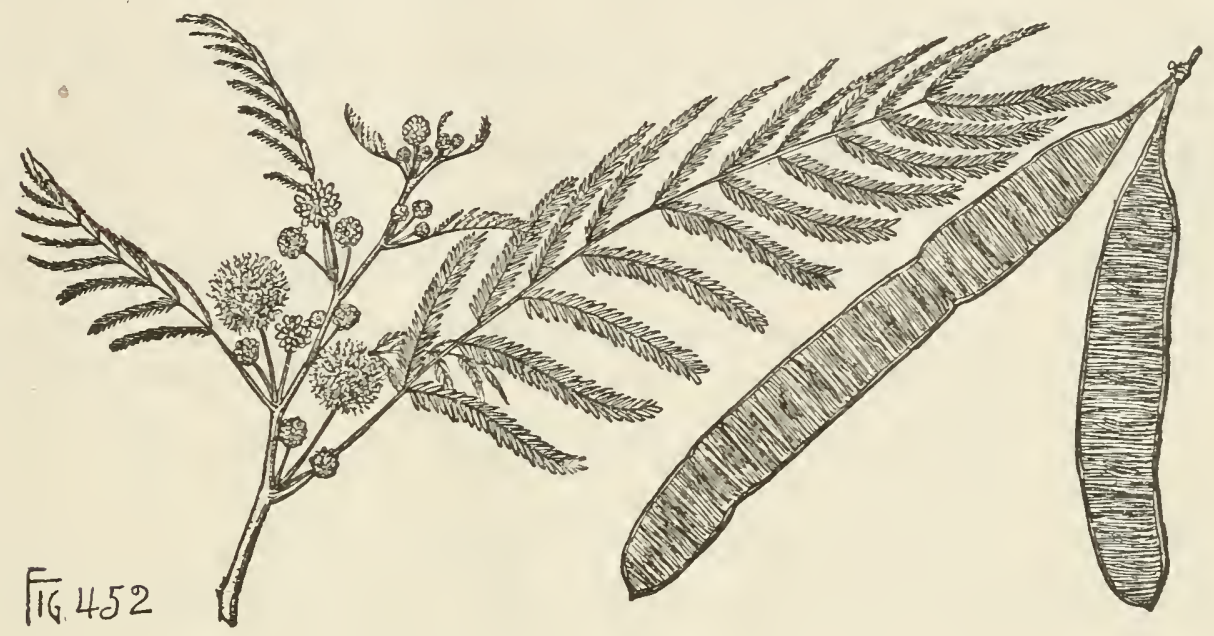

thick persistent scales. Wood heavy, hard, very close-grained, rich dark brown, with thin clear yellow sapwood of 2 or 3 layers of annual growth; considered valuable and sometimes manufactured into lumber.

Distribution. Rich moist soil of river banks and the borders of lagoons and small streams; valley of the lower Rio Grande; in Texas only for a few miles near its mouth; more abundant from Matamoras to Monterey in Nuevo Leon; and southward to the neighborhood of the City of Mexico.

Occasionally planted as a shade and ornamental tree in the towns of the lower Rio Grande valley.

\section{PROSOPIS, L. Mesquite.}

Trees or shrubs, with branches without terminal buds and armed with geminate supra-axillary persistent spines, and small obtuse axillary buds covered with acute apiculate dark brown scales. Leaves alternate on branches of the year and fascicled in earlier axils, deciduous, bipinnate, with many-foliolate pinnæ; petioles glandular at the apex, with a minute gland, and tipped with the small spinescent rachis; stipules linear, membranaceous or spinescent, deciduous. Flowers greenish white, sessile, in axillary pedunculate spikes; calyx campanulate, 5 -toothed, or slightly 5 -lobed, deciduous; petals 5 , connate below the middle or ultimately free, glabrous or tomentose on the inner surface toward the apex, sometimes puberulous on the outer surface; stamens 10 , free, inserted with the petals on the margin of a minute disk adnate to the calyx-tube, those opposite the lobes of the calyx rather longer than the others; filaments filiform; anthers oblong, versatile, their connective tipped with a minute deciduous gland, the cells opening by marginal sutures; ovary stipitate, villose; 
style filiform, with a minute terminal stigma. Legume linear, compressed or subterete, straight or faleate, or contorted or twisted into a more or less regular spiral, indehiscent; the outer coat thin, woody, palc yellow, inclosing a thiek spongy inner coat of sweet pulp eontaining the seeds placed obliquely and scparately inclosed, their envelopes forming nut-like joints. Seeds oblong, compressed, the hilum near the base; seed-coat erustaeeous, light brown, lustrous; embyro surrounded by a layer of horny albumen; radicle short, slightly exserted.

Prosopis is distributed in the New World from southern Kansas to Patagonia, and in the Old World is confined to tropical Africa, and to southwestern and tropical Asia. Sixteen or seventeen species have been distinguished. Of the three species found in the territory of the United States two are small trecs.

Prosopis produces hard durable wood, particularly valuable as fuel, and the pods are used as fodder.

The gencric name is from $\pi \rho \sigma \sigma \omega \pi$ is, employed by Dioscorides as a name of the Burdock.

\section{CONSPECTUS OF THE NORTH AMERICAN ARBORESCENT SPECIES.}

Legume compressed or ultimately convex, pinnæ 12-16-foliolate. 1. P.juliflora (C,E, G,H). Legume thick, spirally twisted; pinnæ 10-16-foliolate. 2. P. pubescens (E, F, G, H).

\section{Prosopis juliflora, DC. Mesquite. Honey Locust.}

Leaves with 2 or rarely 4 pinnæ and slender terete petioles abruptly enlarged and glandular at the base; stipules linear, acute, membranaceous, deciduous. Flowers appearing in successive crops from May to the middle of July, fragrant,

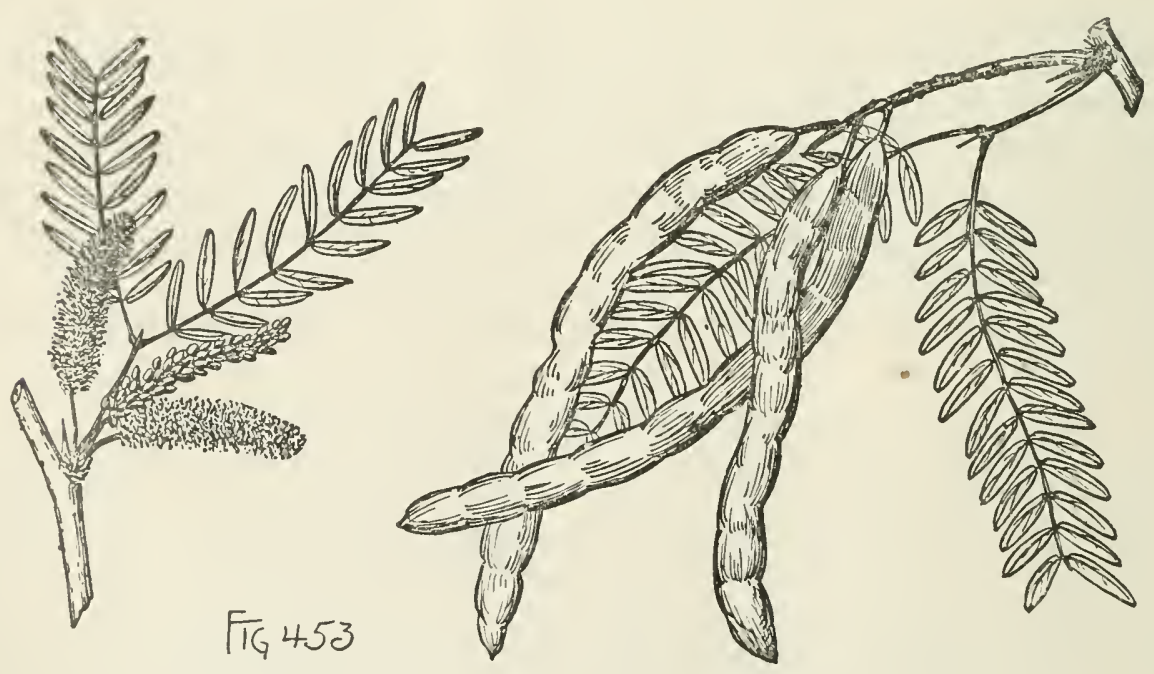

about $\frac{1}{12}$ long, on short pedicels, in slender cylindrical spikes $1 \frac{1}{2}^{\prime}-4^{\prime}$ long, on stout peduneles $\frac{1^{\prime}}{2}-\frac{3}{4}$ in length; ealyx glabrous or puberulous, about one fourth as long as the narrowly oblong acute petals glabrous or puberulous on the onter surface and covered on the inner surfaee toward the apex with hoary tomentum; stamens twice as long as the eorolla, the dark-colored conneetive of the anther-cells furnished at the apex with a stalked gland; ovary short-stalked, clother with silky hairs. Fruit in drooping clusters, linear, at first flat, becoming subterete at maturity, constricted 
between the $10-20$ seeds, straight or falcate, contracted at the ends, $4^{\prime}-9^{\prime}$ long, $\frac{1}{4}^{\prime}-\frac{1^{\prime}}{2}$ wide; seeds about $\frac{1^{\prime}}{4}$ long.

A low tree, with a large thick taproot descending frequently to the depth of $40^{\circ}-$ $50^{\circ}$, and furnished with radiating horizontal roots spreading in all directions and forming a dense mat, a trunk $6^{\prime}-8^{\prime}$ in diameter, divided a short distance above the ground into many irregularly arranged crooked branches forming a loose straggling head, and slender branchlets at first pale yellow-green, turuing darker in their second year, furnished in the axils of the leaves of their first season with short spur-like excrescences covered with chaffy scales, and armed with stout straight terete supra-axillary persistent spines $\frac{1^{\prime}}{2}-2^{\prime}$ long, or rarely unarmed; more often a shrub, with numerous stems only a few feet high. Bark of the trunk thick, dark reddish brown, divided by shallow fissures, the surface separating into short thick scales. Wood heavy, close-grained, rich dark brown or sometimes red, with thin clear yellow sapwood; almost indestructible in contact with the soil, and largely used for fence-posts, railway-ties, the underpinnings of buildings, and occasionally in the manufacture of furniture, the fellies of wheels, and the pavements of city streets; the best fuel of the region, and largely made into charcoal. The ripe pods supply Mexicans and Indians with a nutritious food, and are devoured by most herbivorous animals. A gum, resembling gum-arabic, exudes from the stems.

Distribution. Western Texas and eastern New Mexico, and on the island of Jamaica ; eastward and westward diverging into two extreme forms. These are

\section{Prosopis juliflora, var. glandulosa, Sarg.}

Leaves with distant linear mostly acute glabrous dark green leaflets often $2^{\prime}$ long and $\frac{1}{8}^{\prime}-\frac{1}{4}^{\prime}$ wide. Flowers with a usually glabrous calyx.

A round-topped tree, often $20^{\circ}$ high, with a trunk a foot in diameter, and long gracefully drooping branches forming a symmetrical round-topped head.

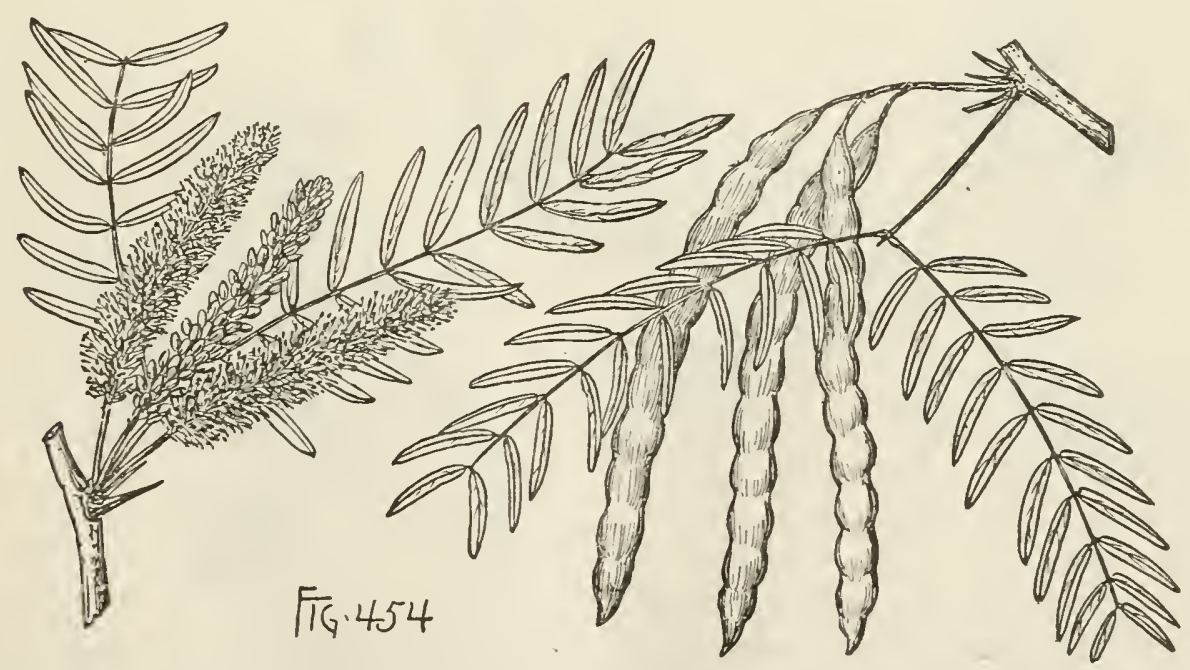

Distribution. Eastern Texas to southern Kansas, and southward into northern Mexico. The common Mesquite of eastern Texas; reappearing with rather shorter and more crowded leaflets in Arizona, southern California, and Lower California. 


\section{Prosopis juliflora, var. velutina, Sarg.}

Leaves $55^{\prime}-6^{\prime}$ long, often fascicled, cinereo-pubescent, with short petioles and 1222 pairs of oblong or lincar-oblong obtuse or acute crowded pale green leaflets $\frac{1^{\prime}}{4}-\frac{1^{\prime}}{2}$ long. Flowers in densely-flowered spikes $2^{\prime}-3^{\prime}$ long; calyx villose.
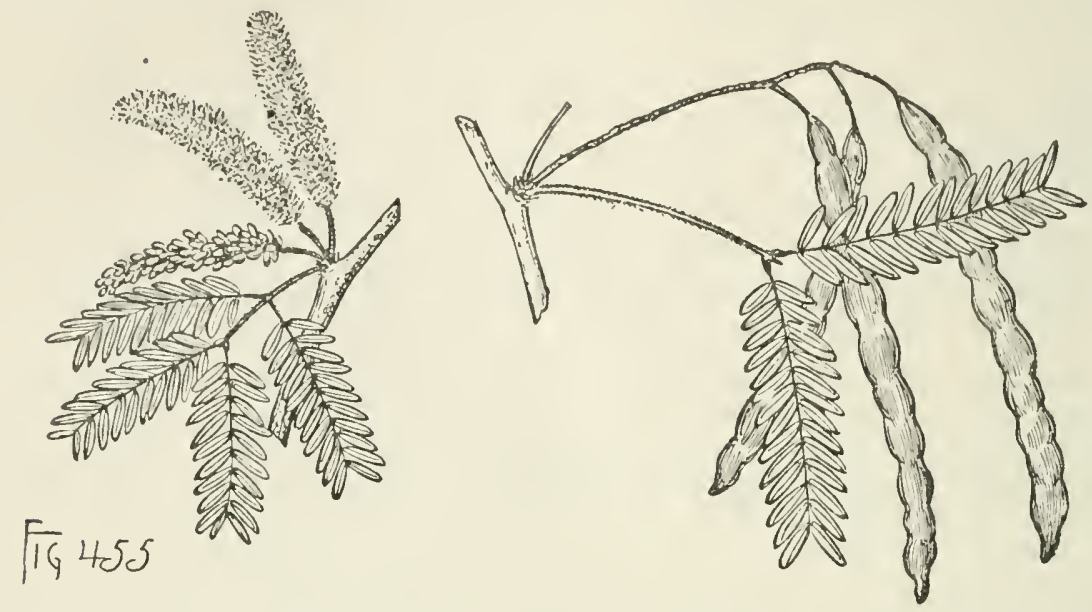

A tree, often $50^{\circ}$ high, with a trunk $2^{\circ}$ in diameter, covered with rough dark brown bark, and heavy irregularly arranged usually crooked branches.

Distribution. Hot valleys of southern Arizona and Sonora.

\section{Prosopis pubescens, Benth. Screw Bean. Screw Pod Mesquite.}

Leaves canescently pubescent, $2^{\prime}-3^{\prime}$ long, with slender petioles $\frac{1^{\prime}}{3}-\frac{2}{3}$ in length, and pinnæ $1 \frac{1}{2}^{\prime}-2^{\prime}$ long and 10-16-foliolate; stipules spinescent, deciduous; leaflets

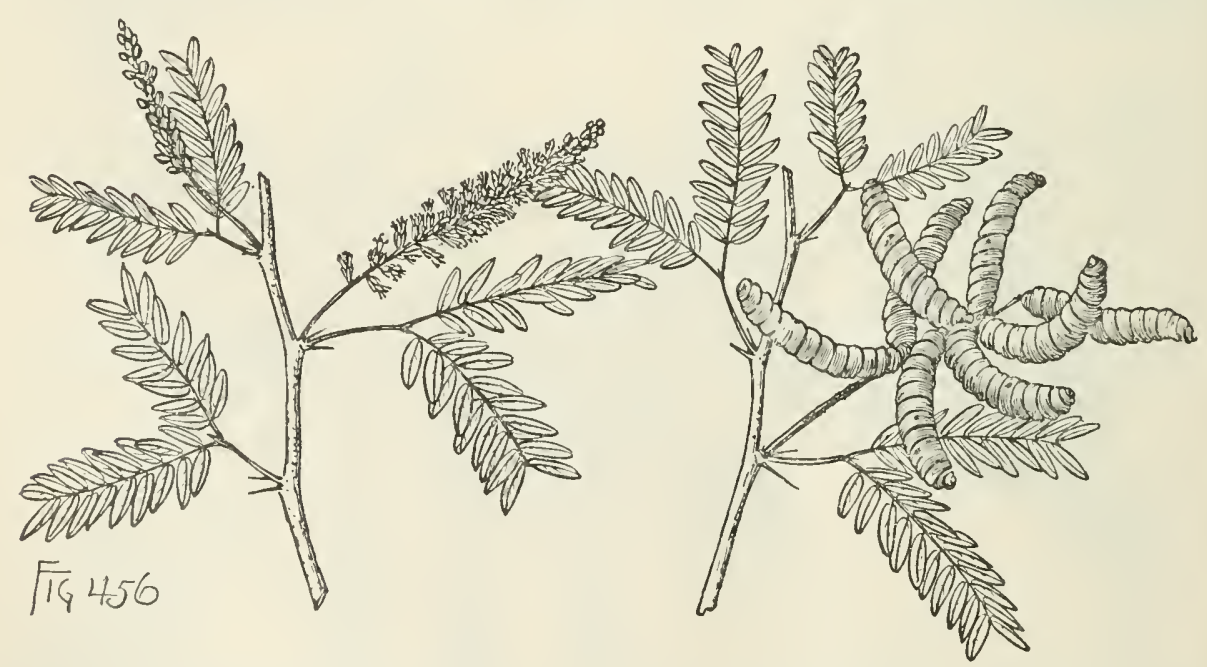

oblong or somewhat falcate, acute, sessile or short-petiolulate, often apiculate, conspicuously reticulate-veined, $\frac{1^{\prime}}{3}-\frac{2{ }^{\prime}}{3}$ long, $\frac{1}{8}^{\prime}$ wide. Flowers beginning to open in early spring, and produced in successive crops from the axils of minute scarious bracts, in dense or interrupted cylindrical spikes $2^{\prime}-3^{\prime}$ long ; calyx obscurely 5-lobed, pubescent on the outer surface, one third to one fourth as long as the narrow acute petals coated on the inner surface near the apex with thick white tomentum, 
and slightly puberulous on the outer surface; ovary and young fruit hoary-tomentose. Fruit ripening throughout the summer and falling in the autumn, in dense racemes, sessile, twisted with from $12-20$ turns into a narrow straight spiral $1^{\prime}-2^{\prime}$ long; seeds $\frac{1}{1 \frac{\prime}{6}}$ long.

A tree, $25^{\circ}-30^{\circ}$ high, with a slender trunk sometimes a foot in diameter, and terete branches canescently pubescent or glabrate when they first appear, becoming glabrous and light red-brown in their third year, and armed with stout spines $\frac{1^{\prime}}{3}-\frac{1}{2}^{\prime}$ long. Bark of the trunk thick, light brown tinged with red, separating in long thin persistent ribbon-like scales. Wood heavy, exceedingly hard, close-grained, not strong, light brown, with thin lighter colored sapwood of 6 or 7 layers of annual growth; used as fuel and occasionally for fencing. The sweet, nutritious legumes are used for fodder.

Distribution. Sandy or gravelly bottom-lands; valley of the Rio Grande in western Texas, and through New Mexico and Arizona to southern Utah and Nevada, and to San Diego County, California, and northern Mexico; attaining its largest size in the United States in the valleys of the lower Colorado and Gila rivers, Arizona.

\section{CERCIS, L.}

Trees or shrubs, with scaly bark, slender unarmed branchlets prolonged by an upper axillary bud, marked by numerous minute pale lenticels, and in their first winter by small elevated horizontal leaf-scars showing the ends of two large fibrovascular bundles, and small scaly obtuse axillary buds covered by imbricated ovate chestnut-brown seales. Leaves simple, entire, 5-7-nerved, with prominent nerves, long-petiolate, deciduous; their petioles slender, terete, abruptly enlarged at the apex; stipules ovate, acute, small, membranaceous, caducous. Flowers appearing in early spring before or with the leaves on thin jointed pedicels, in simple fascicles or racemose clusters produced on branches of the previons or earlier years, or on the trunk, with small scale-like bracts often imbricated at the base of the inflorescence, and minute bractlets; calyx disciferous, shortly turbinate, purplish, persistent, the tube oblique at the base, campanulate, enlarged on the lower side, 5-toothed, the short broad teeth imbricated in the bud; corolla subpapilionaceous; petals nearly equal, rose color, oblong-ovate, rounded at the apex, unguiculate, slightly auricled on one side of the base of the blade, the npper one slightly smaller and inclosed in the bud by the wings encircled by the broader slightly imbricated keelpetals; stamens 10 , inserted in 2 rows on the margin of the thin disk, free, declinate, those of the inner row opposite the petals and rather shorter than the others; filaments enlarged and pilose below the middle, persistent until the fruit is grown; anthers uniform, oblong, attached on the back near the base; ovary short-stalked, inserted obliquely in the bottom of the calyx-tube; style filiform, fleshy, incurved, with a stod; obtuse terminal stigma; ovules 2-ranked, attached to the imner angle of the crary. Legume stalked, oblong or broadly linear, straight on the upper, curve's on the lower edge, acute at the ends, compressed, tipped with the thickened reminants of the style, many-seeded, 2-valved, the valves coriaceo-membranaceous, $\mathrm{p}_{1}$ iny-veined, tardily dehiscent by the dorsal and often by the wing-margined ventral suture, dark red-purple and lustrous at maturity. Seeds suspended transversely on slender funicles, ovate or oblong, compressed, the small depressed hilum near the apex; seed-coat crustaceous, bright reddish brown; embryo surrounded by a thin layer of horny albumen, compressed; cotyledons oval, flat, the radicle short, straight or obliquely incurved, slightly exserted. 
Cercis is confined to eastern and western North America, southern Europe, and to southwestern, central, and eastern Asia. Of the seven species now distinguished, three occur in North America. Two of these are arborescent.

The generic name is from $\kappa \epsilon \rho$ is, the Greek name of the European species, from a fancied resemblance of the fruit to the weaver's implement of that name.

\section{CONSPECTUS OF THE NORTH AMERICAN ARBORESCENT SPECIES.}

Flowers in sessile clusters; leaves ovate, acute, cordate or truncate at the base.

1. C. Canadensis (A, C).

Flowers fascicled or slightly racemose; leaves reniform.

2. C. Texensis (C).

\section{Cercis Canadensis, L. Redbud. Judas-tree.}

Leaves broadly ovate, acute or acuminate and often abruptly contracted at the apex into short broad points, truncate or more or less cordate at the base, entire, glabrous with the exception of axillary tufts of white hairs, or sometimes more or less pubescent below, $3^{\prime}-5^{\prime}$ long and broad, turning in the autumn before falling bright clear yellow; their petioles $2^{\prime}-5^{\prime}$ long. Flowers $\frac{1}{2}^{\prime}$ long, on pedicels $\frac{1}{3}^{\prime}-\frac{1}{2}^{\prime}$ in length and fascicled 4- 8 together. Fruit fully grown in the south by the end of May and at the north at midsummer, and then pink or rose color, $2 \frac{1}{2}^{\prime}-3 \frac{1}{2}^{\prime}$ long, falling late in the autumn or in early winter; seeds about $\frac{1^{\prime}}{4}$ long.

A tree, sometimes $40^{\circ}-50^{\circ}$ high, with a straight trunk usually separating $10^{\circ}-12^{\circ}$ from the ground into stout branches covered with smooth light brown or gray bark, and forming an upright or often a wide flat head, and slender glabrous somewhat angled branchlets, brown and lustrous at first, becoming dull and darker the following year and ultimately dark or grayish brown. Bark of the trunk about $\frac{1}{2}$ thick

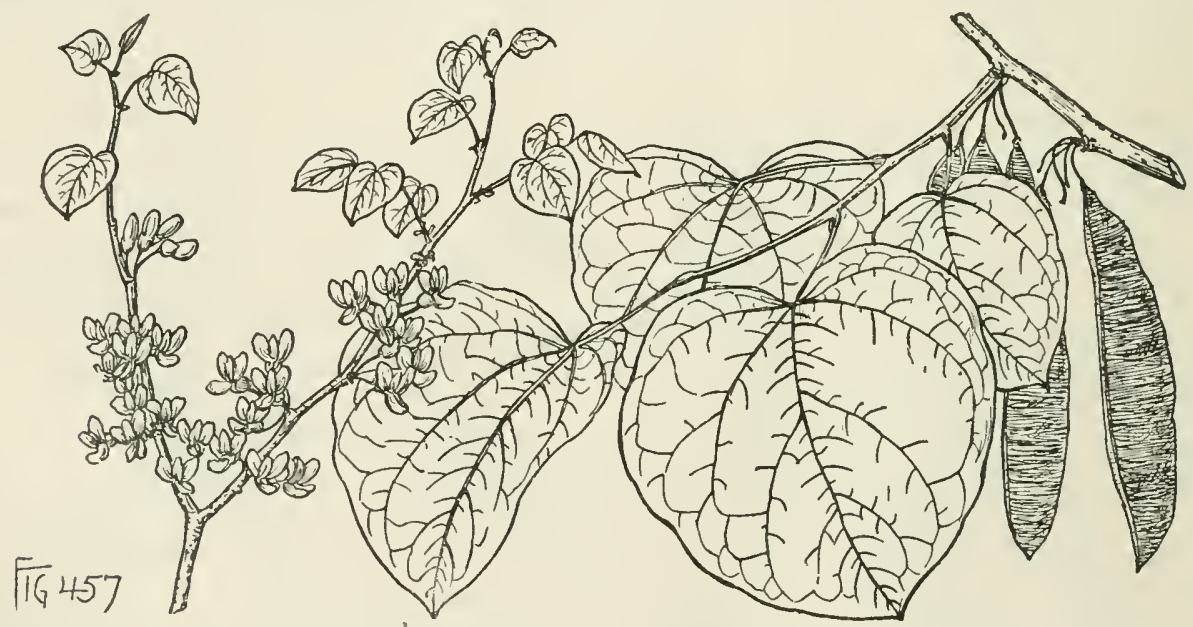

and divided by deep longitudinal fissures into long narrow plates, the bright redbrown surface separating into thin scales. Wood heavy, hard, not strong, closegrained, rich dark brown tinged with red, with thin lighter colored sapwood of 8-10 layers of annual growth.

Distribution. Borders of streams and rich bottom-lands, forming, especially west of the Alleghany Mountains, an abundant undergrowth to the forest; valley of the Delaware River, New Jersey, southward to the shores of Tampa Bay and to northern Alabama and Mississippi, and westward to southern Ontario, eastern Nebraska, the 
to single leaflets; pinnæ and leaflets usually alteruatc; stipules foliaccons, carly deciduous; leaflets membranaceous, ovate, cutirc, petiolulatc. Flowers regular, diceious, greenish white, long-pediccllate, the slender pedicels from the axils of long lanceolate scarious eaducous bracts, bibracteolatc near the middle; staninate in a short terminal racemose eorymb; pistillate in elongated terminal racemes, on pedicels much longer than those of the staminate flowers; calyx tubular, elongated, 10-ribbed, lined with a thin glandular disk, 5-lobed, lanceolate, acute, nearly equal, erect; petals 4 or 5, oblong, rounded or acute at the apex, pubescent, as long as the calyx-lobes or rather longer and twiee as broad, inserted on the margin of the disk, sprcadiug or reflexed; stamens 10 , free, inscrted with the pctals, erect, included; filaments filiform, pilose, those opposite the petals shorter than the others; anthers oblong, uniform, small and sterile in the pistillate flower; ovary sessile or sliglitly stipitate, acute; styles short, erect, obliquely dilated into 2 broad lobes stigmatic on their inuer surface, rudimentary or 0 in the stcrile flower; ovules numerous, suspended from the angle opposite the posterior petals. Legume obloug, subfalcate, turgid or slightly compressed, several-seeded, 2-valved, tardily dehiseent, the thin tough woody valves thiekened on the margins into narrow wings, pulpy between the seeds. Seeds ovoid or slightly obovoid, suspended by long slender fuuicles; seed-coat thick, bony, brown and opaque, of 3 layers; embryo surrounded by a thin layer of horny albumen; cotyledons ovate, orange-colored, thick and fleshy, the radicle short, erect.

Gymnocladus, with two species, is confined to eastern North America and to southern China.

Gymnocladus is slightly astringent and purgative, and the detersive pulp surrounding the seeds of the Asiatic species is used in China as a substitute for soap.

The generic name, from $\gamma u \mu \nu \delta_{s}$ and $\kappa \lambda \alpha$ $\delta o s$, relates to the stout branches destitute of spray.

\section{Gymnocladus dioicus, K. Koch. Kentucky Coffee-tree.}

Leaves $1^{\circ}-3^{\circ}$ long, $18^{\prime}-24^{\prime}$ wide, obovate, 5-9 pinnate, the piunæ 6-14-foliolate, covered when they unfold with hoary tomentum except on the upper surface of the leaflets, their petioles abruptly and conspicuously enlarged at the base, at first hoarytomentose, becoming glabrous at maturity, turning bright clear yellow in the autumn before falling; stipules lanceolate or slightly obovate, glandular-serrate toward the apex, $\frac{1}{3}$ 'long; leaflets ovate, acute, often mucronate, especially while young, wedgeshaped or irregularly rounded at the base, pink at first, soon becoming bronze-green and lustrous, glabrous on the upper surface with the exeeption of a few scattered hairs along the midribs, and at maturity membranaceous, obscurely veined, dark green above, pale sellow-green and glabrous below, witl the exeeption of a few short hairs seattered along the narrow midribs, $2^{\prime}-2 \frac{1}{2}^{\prime}$ long and $1^{\prime}$ wide, or those replacing the lowest or oceasionally the 2 lower pairs of pinnæ sometimes twice as large. Flowers: infloreseence of the staminate tree $3^{\prime}-4^{\prime}$ long, the lower branehes usually 3 or 4-flowered; inflorescenee of the pistillate tree $10^{\prime}-12^{\prime}$ long, the flowers on stout pedicels $1^{\prime}-2 \frac{1}{2}^{\prime}$ long or twice to five times as long as those of the staminate flowers; flowers hoary-tomentose in the bud; calyx $\frac{2^{\prime}}{3}$ long, conspieuously ribbed, covered on the outer surface when the flowers open with pale hairs and on the inner surface with hoary tomentum; petals keeled, pilose on the back, slightly grooved, tomentose on the inner surface; anthers bright orange color; ovary hairy. Fruit $6^{\prime}-10^{\prime}$ long, $1 \frac{1}{2}^{\prime}-$ $2^{\prime}$ wide, dark red-brown, covered with a glaucous bloom, on stout stalks $1^{\prime}-2^{\prime}$ long, 
remaining unopened on the branches throughout the winter; seeds separated by a thick layer of dark-colored sweet pulp, $\frac{3^{\prime}}{4}$ long.

A tree, $75^{\circ}-110^{\circ}$ high, with a trunk $2^{\circ}-3^{\circ}$ in diameter, usually dividing $10^{\circ}-15^{\circ}$ from the ground into 3 or 4 principal stems spreading slightly and forming a narrow round-topped head, or occasionally sending up a tall straight shaft destitute of branches for $70^{\circ}-80^{\circ}$, and branchlets coated at first with short dense pubescence faintly tinged with red, and bearing at their base the conspicuous orange-green obovate pubescent bud-scales $1^{\prime}$ long at maturity, $\frac{1}{4}^{\prime}-1^{\prime}$ thick at the end of their first season, very blunt, dark brown, often slightly pilose, marked by orange-colored

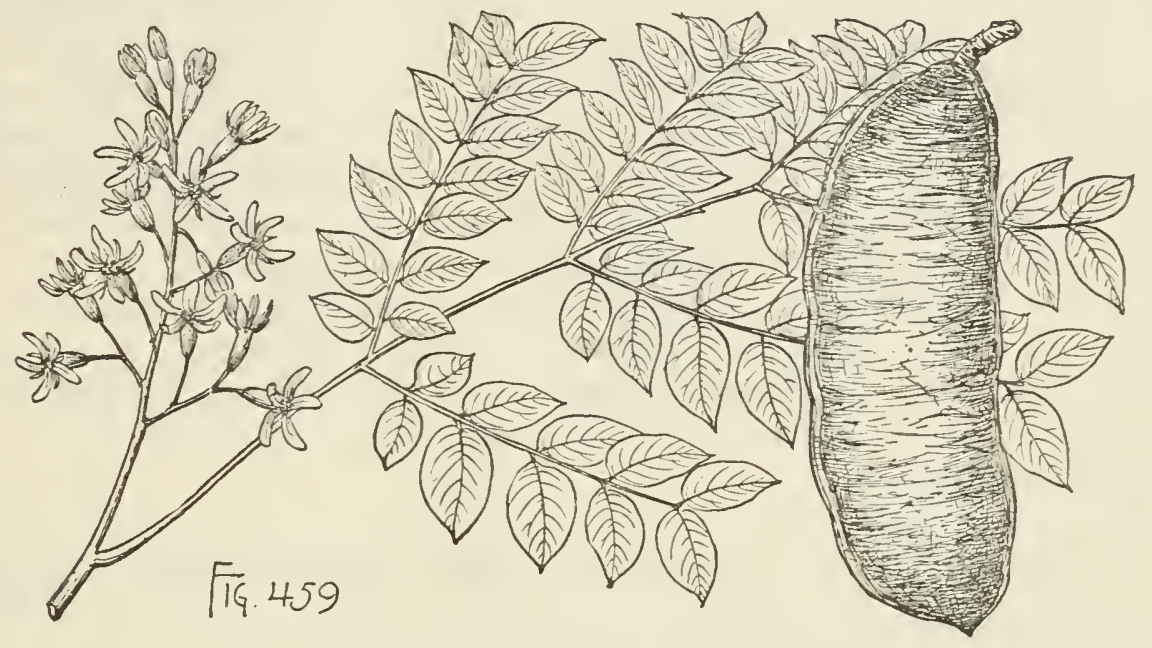

lenticels, and roughened by the large pale broadly heart-shaped leaf-scars displaying the ends of 3 or 4 conspicuous fibro-vaseular bundles. Bark of the trunk $\frac{3}{4}^{\prime}-1^{\prime}$ thick, deeply fissured, dark gray tinged with red, and roughened by small persistent scales. Wood heavy although not hard, strong, coarse-grained, very durable in contact with the soil, rich light brown tinged with red, with thin lighter colored sapwood of 5 or 6 layers of annual growth; occasionally used in cabinet-making and for fence-posts, rails, and in construction. The seeds were formerly used as a substitute for coffee; a decoction of the fresh green pulp of the unripe fruit is used in homœopathic practice.

Distribution. Bottom-lands in rich soil; central New York and western Pennsylvania, through southern Ontario and southern Michigan to the valley of the Minnesota River, and to eastern Nebraska, eastern Kansas, southwestern Arkansas, the Indian Territory, and middle Tennessee; nowhere common.

Occasionally cultivated in the gardens and parks of the eastern United States, and of northern and central Europe.

\section{GLEDITSIA, L.}

Trees, with furrowed bark, slender terete slightly zigzag branchlets thickened at the ends and prolonged by axillary buds, thick fibrous roots, the trunk and branches often armed with stout simple or branched spines or abortive branches developed from supra-axillary or adventitious buds imbedded in the bark. Winter-buds minute, 3 or 4 together, superposed, the 2 or 3 lower without scales and covered by the scar left by the falling of the petiole, the upper larger, nearly surrounded by the base of the petiole and covered by small scurfy scales. Leaves long-petiolate, often fascicled in earlier axils, abruptly pinnate or bipinnate, the pinnæ increasing in length 
from the base to the apex of the leaf, the lowest sometimes reduced to single leaflets, deciduous; stipules minute, eaducous; leaflets membranaceous, their margins irregularly crenate, without stipels. Flowers regular, polyganous, minute; green or white on short pedicels, in axillary or lateral simple or fascicled racemes, with minute scale-like caducous bracts; calyx campanulate, lined with the disk, $3-5$-lobed, the narrow lobes nearly equal; petals as many as the lobes of the calyx, uearly equal; stamens 6-10, inserted with the petals on the margin of the disk, exserted; filaments free, filiform, erect; anthers uniform, much smaller and abortive in the pistillate flower; ovary subsessile, rarely bicarpellary, rudimentary or 0 in the staminate flower; styles short; stigma terminal, more or less dilated, often oblique; ovules 2 or many, suspended from the angle opposite the posterior petal. Legume compressed, many-seeded, elongated, straight and indehiscent, or 1 or 2-seeded, ovate and tardily dehiscent. Seeds transverse, ovate to suborbicular, flattened, attached by long slender funicles; seed-coat thin, crustaceous, light brown; embryo surrounded by a layer of horny albumen, orange-colored; cotyledons subfoliaceous, compressed; radicle short, erect, slightly exserted.

Gleditsia is confined to eastern North America, where three species occur, southwestern Asia, China, Japan, and west tropical Africa. It produces strong, durable, coarse-grained wood. In Japan the pods are used as a substitute for soap.

The generic name is in honor of Johann Gottlieb Gleditsch (1714-1786), professor of botany at Berlin.

\section{CONSPECTUS OF THE NORTH AMERICAN ARBORESCENT SPECIES.}

Legume linear-oblong, elongated, many-seeded, indehiscent.

Legumes $12^{\prime}-18^{\prime}$ long, with pulp between the seeds; ovary hoary-tomentose.

Legumes $4^{\prime}-5^{\prime}$ long, without pulp between the seeds.

1. G. triacanthos $(A, C)$. 2. G. Texana (C). Legume oval, oblique, 1 or 2 -seeded, without pulp, tardily dehiscent; ovary glabrous.

3. G. aquatica (C).

\section{Gleditsia triacanthos, L. Honey Locust.}

Leaves $7^{\prime}-8^{\prime}$ long, 18-28-foliolulate or sometimes bipinnate, with 4-7 pairs of pinnæ, those of the upper pair $4^{\prime}-5^{\prime}$ long, when they unfold hoary-tomentose, and at maturity pubescent on the petioles and rachises, the short stout petiolules, and the under surface of the midribs of the leaflets, turning in the autumn pale clear yellow; leaflets lanceolate-oblong, unequal at the base, acute or slightly rounded at the apex, remotely crenulate-serrate, dark green and lustrous above, dull yellow-green below, $1^{\prime}-1 \frac{1}{2}^{\prime}$ long and $\frac{1}{2}^{\prime}$ wide. Flowers appearing in June when the leaves are nearly fully grown from the axils of leaves of previons years; staminate in short manyflowered pubescent racemes $2^{\prime}-2 \frac{1}{2}^{\prime}$ long and often clustered; pistillate in slender graceful few-flowered usually solitary racemes $2 \frac{1}{2}^{\prime}-3 \frac{1}{2}^{\prime}$ long; calyx campanulate, narrowed at the base, the acute lobes thickened, revolute and ciliate on the margins, villose with pale hairs, rather shorter than and half as wide as the erect acute petals; filaments pilose toward the base; anthers green; pistil rarely of 2 carpels, hoarytomentose. Fruit $12^{\prime}-18^{\prime}$ long, dark brown, pilose and slightly falcate, with straight thickened margins, 2 or 3 together in short racemes on stalks $1^{\prime}-\mathbf{1}^{\prime}{ }^{\prime}$ long, their walls thin and tough, contracting in drying by a number of corkscrew twists, and falling late in the autumn or early in winter; seeds oval, $\frac{1}{3}^{\prime}$ long, separated by thick succulent pulp. 
A tree, $75^{\circ}-140^{\circ}$ high, with a trunk $2^{\circ}-3^{\circ}$ or occasionally $5^{\circ}-6^{\circ}$ in diameter, slender spreading somewhat pendulous branches forming a broad open rather flattopped head, branchlets marked by minute lenticels, at first light reddish brown and slightly puberulous, soon becoming lustrous and red tiuged with green and in their second year greenish brown, and armed with stout rigid long-pointed simple

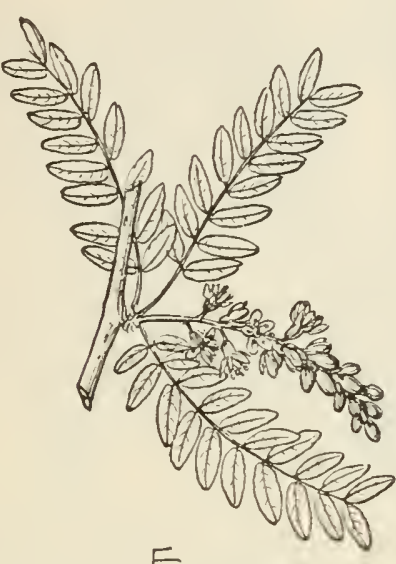

$\sqrt{16} 460$

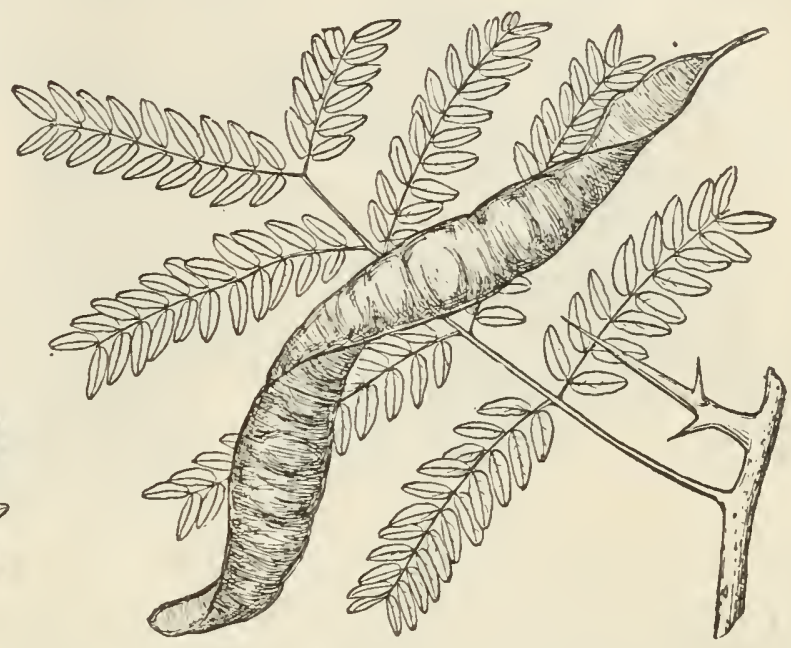

or 3-forked spines at first red and bright chestnut-brown when fully grown, or rarely unarmed. Bark of the trunk $\frac{1^{\prime}}{2}-\frac{3}{4}$ thick, divided by deep fissures into long narrow longitudinal ridges and roughened on the surface by small persistent scales. Wood hard, strong, coarse-grained, very durable in contact with the ground, red or bright red-brown, with thin pale sapwood of 10-12 layers of annual growth; largely used for fence-posts and rails, for the hubs of wheels, and in construction.

Distribution. Borders of streams and intervale lands, in moist fertile soil, usually growing singly or occasionally covering almost exclusively considerable areas; less commonly on dry sterile gravelly hills; western slope of the Alleghany Mountains of Pennsylvania, westward through Ontario and Michigan to southeastern Minnesota, eastern Nebraska and Kansas, and the Indian Territory, and southward to northern Alabama and Mississippi and to the valley of the Brazos River, Texas; attaining its largest size in the valleys of small streams in southern Indiana and Illinois; now often naturalized in the region east of the Alleghany Mountains.

Often cultivated as an ormamental and shade tree in all countries of temperate climates.

\section{Gleditsia Texana, Sarg. Locust.}

Leaves $6^{\prime}-7^{\prime}$ long, with a slender rachis at first puberulous, ultimately glabrous, and 12-22-foliolulate, or often bipiunate, usually with 6 or 7 pairs of pinnæ, the lower pairs frequently reduced to single large leaflets; leaflets obloug-ovate, often somewhat falcate, rounded or acute or apiculate at the apex, obliquely rounded at the base, finely crenately serrate, thick and firm in texture, dark green and lustrous above, pale below, $\frac{1}{2}^{\prime}-1^{\prime}$ long, with short petiolules coated while young, like the base of the slender orange-colored midribs, with soft pale hairs. Flowers appearing toward the end of April, the staminate dark orange-yellow, in slender glabrous often clustered racemes leugthening after the flowers begin to open and finally $3^{\prime}-4^{\prime}$ long; calyx campanulate, with acute lobes thickened on the margins, villose-pubescent and rather shorter and narrower than the puberulous petals; stamens with slender 
filaments villose near the base and green anthers; pistillate flowers unknown. Fruit $4^{\prime}-5^{\prime}$ long, $1^{\prime}$ wide, straight, much compressed, rounded and short-pointed at the

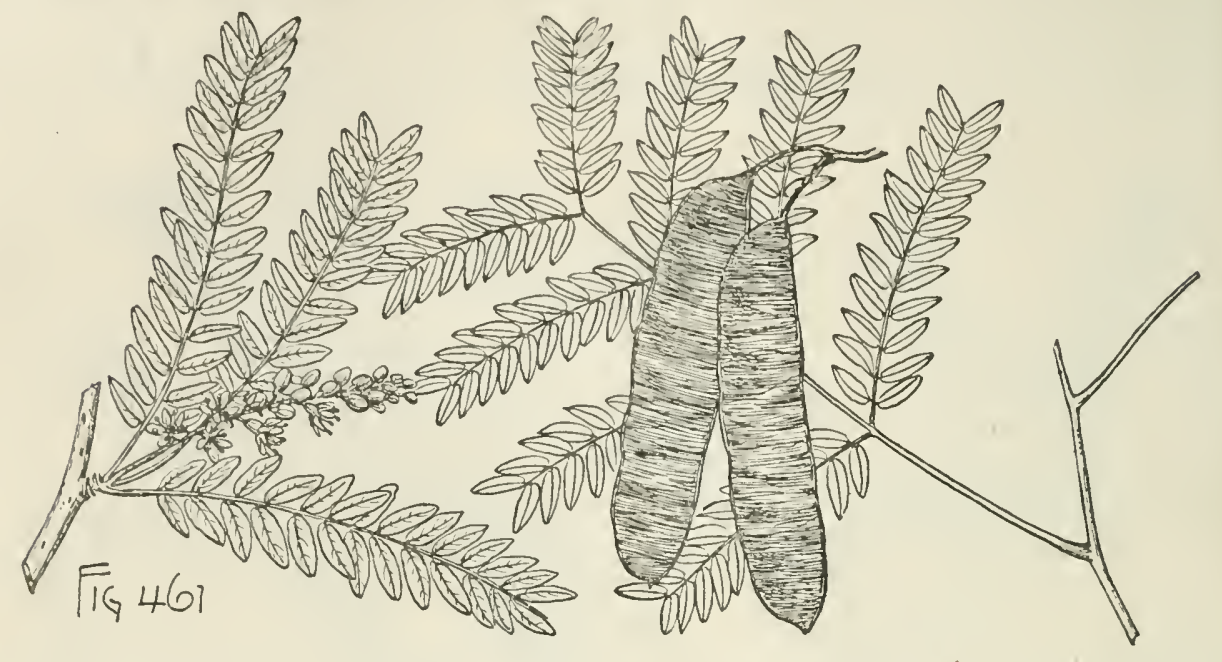

apex full and rounded at the broad base, thin-walled, dark chestnut-brown, puberulous, slightly thickened on the margins, many-seeded, without pulp; seeds oval, compressed, dark chestnut-brown, very lustrous, $\frac{1}{2}^{\prime}$ long.

A tree, $100^{\circ}-120^{\circ}$ high, with a trunk rarely exceeding $2 \frac{1}{2}^{\circ}$ in diameter, ascending and spreading branches forming a narrow head, and comparatively slender more or less zigzag branchlets roughened by numerous small round lenticels, light orangebrown when they first appear, gray or orange-brown during their first year, ashy gray the following season, and unarmed. Bark thin and smooth.

Distribution. Only in a single grove on the bottom-lands of the Brazos River, near the town of Brazoria, Texas.

\section{Gleditsia aquatica, Marsh. Water Locust.}

Leaves $5^{\prime}-8^{\prime}$ long, 12-18-foliolate, or doubly pinnate, with 3 or 4 pairs of pinnæ; leaflets ovate-oblong, usually rounded or rarely emarginate at the apex, unequally wedge-shaped at the base, slightly and remotely crenate or often entire below the middle, glabrons with the exception of a few hairs on the short stout petiolules, dull yellow-green and lustrous on the upper surface, dark green on the lower surface, about $1^{\prime}$ long and $\frac{1^{\prime}}{3}-\frac{1^{\prime}}{2}$ wide. Flowers appearing in May and June after the leaves are fully grown on short stout purple puberulous pedicels, in slender racemes $3^{\prime}-4^{\prime}$ long; calyx-tube covered with orange-brown pubescence, the lobes narrow, acute, slightly pilose on the two surfaces, as long as but narrower than the green erect petals rounded at the apex; filaments hairy toward the base; anthers large, green; ovary long-stipitate, glabrous. Fruit fully grown in August, pendent in graceful racemes, obliquely ovate, long-stalked, crowned with a short stout tip, thin, $1^{\prime}-2^{\prime}$ long, $1^{\prime}$ broad, without pulp, its valves thin, tough, papery, bright chestnut-brown, lustrous and somewhat thickened on the margins; seeds 1 or 2 , flat, nearly orbicular, orange-brown, $\frac{1^{\prime}}{2}$ in diameter.

A tree, $50^{\circ}-60^{\circ}$ high, with a short trunk $2^{\circ}-2 \frac{1}{2}^{\circ}$ in diameter, usually dividing a few feet from the ground into stout spreading often contorted branches forming a wide irregular flat-topped head, and glabrous orange-brown branchlets becoming in their second year gray or reddish brown, marked by occasional large pale lenticels, 
and armed with usually flattened simple or short-branched straight or falcate sharp rigid spines $3^{\prime}-5^{\prime}$ long, about $\frac{1^{\prime}}{2}$ broad at the base, and dark red-brown and lustrous: Bark $\frac{1 \prime}{8}-\frac{1^{\prime}}{4}$ thick, smooth, dull gray or reddish brown, and divided by shallow fissures into small plate-like scales. Wood lieavy, very hard and strong, coarse-

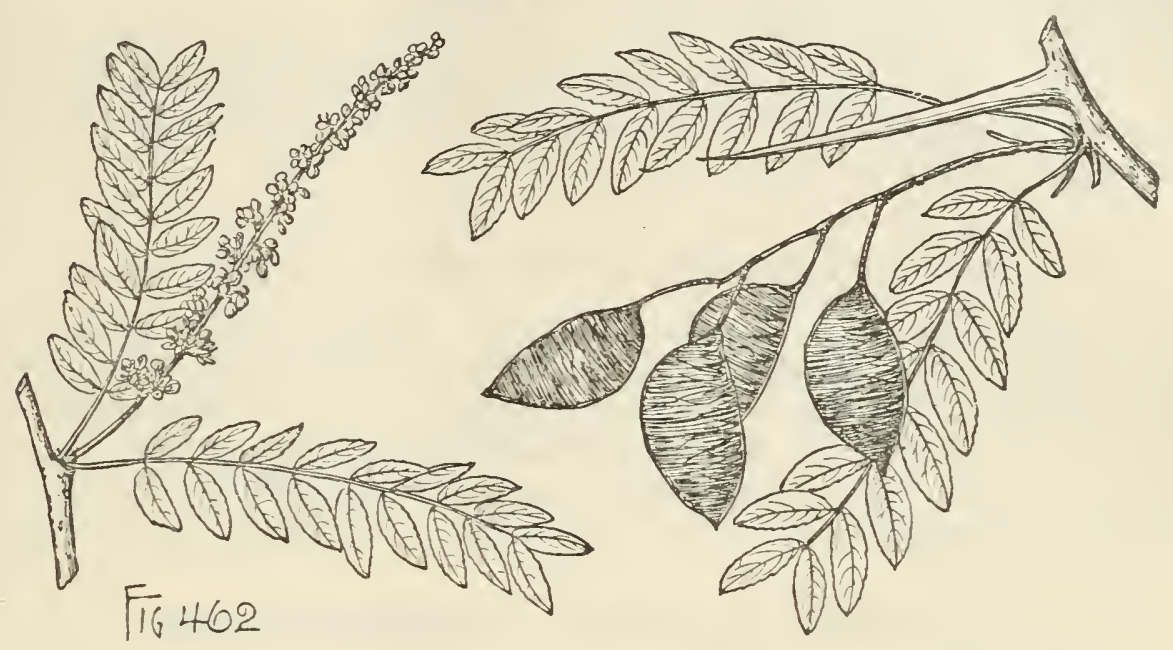

grained, rich bright brown tinged with red, with thick light clear yellow sapwood of about 40 layers of annual growth.

Distribution. South Carolina to Matanzas Inlet, Florida, through the coast region of the Gulf states to the valley of the Brazos River, Texas, and northward through western Louisiana and southern Arkansas to middle Kentucky and Tennessee, the bottoms of the Mississippi at La Pointe, Saint Charles County, Missouri, and western and southern Illinois and Indiana; rare east of the Mississippi River and only in deep river swamps; very abundant and of its largest size westward on rich bottom-lands; and in Louisiana and Arkansas often occupying extensive tracts submerged during a considerable part of the year.

\section{PARKINSONIA, L.}

Trees or shrubs, with smooth thin bark, and terete branches often armed with simple or 3-forked spines. Leaves abruptly bipinnate, alternate or fascicled from earlier axils, short-petiolate, the rachis short and spinescent, with $2-4$ secondary elongated rachises bearing numerous minute opposite entire leaflets without stipels; stipules short, persistent and spinescent, or caducous. Flowers on thin elongated jointed pedicels from the axils of minute caducous bracts, in slender axillary solitary or fascicled racemes; calyx short-campanulate, 5-lobed, the lobes slightly imbricated or subvalvate in the bud, narrow, membranaceous, nearly equal, becoming reflexed, deciduous; petals bright yellow, unguiculate, much longer than the lobes of the calyx, spreading, the upper one rather broader than the others and glandular at the base of the claw; stamens 10 , inserted in 2 rows on the margin of the thin disk, free, slightly declinate, those of the outer row opposite the sepals and rather longer than the others; filaments villose below the middle, the upper one enlarged at the base and gibbous on the upper side; anthers uniform, versatile; ovary short-stipitate, pilose, contracted into a slender filiform incurved style infolded in the bud and tipped with a minute stigma; ovules numerous, suspended from the inner angle of the ovary. Legume linear, torulose, acuminate at the ends, 2 -valved, the valves thin 
and coriaceous, convex by the growth of the seeds, contracted between and beyond them, longitudinally striate. Seeds oblong, suspended longitudinally on slender funicles; hilum minute, near the apex; seed-coat thin, crustaceous, light brown; embryo inclosed on the sides only by thick layers of horny albumen; cotyledons oval, flat, slightly fleshy, the radicle very short and straight.

Parkinsonia, with three species, is confined to the warm parts of America and to southern Africa. Two species occur within the limits of the United States.

The genus is named for John Parkinson (1567-1650), an English botanical author and herbalist to James I.

\section{CONSPECTUS OF THE NORTH AMERICAN SPECIES.}

Flowers in long slender racemes; petals imbricated in the bud; stamens shorter than the petals; legumes 1-8-seeded $12^{\prime}-18^{\prime}$ long; leaves $7^{\prime}-8^{\prime}$ long; rachises of the pinnæ flat, wing-margined, 50-60-foliolate; branches with spines.

1. P. aculeata $(\mathrm{G}, \mathrm{H})$. Flowers in short racemes; petals valvate in the bud; stamens longer than the petals; legumes 1-2-seeded; leaves about $1^{\prime}$ long; rachises of the pinnæ terete, 8-12-foliolate; branches without spines.

2. P. microphylla $(\mathrm{G}, \mathrm{H})$.

\section{Parkinsonia aculeata, I. Retama. Horse Bean.}

Leaves of two forms, short-petiolate, persistent, light green and glabrous, except for a few hairs on the lower part of the young secondary rachises, $12^{\prime}-18^{\prime}$ long; primary leaves on young branches, with 2-4 pimm, and spinescent rachises developing into stout ridged persistent short-pointed chestnut-brown spines $1^{\prime}-1_{\frac{1}{2}}^{\prime}$ long and marked near the base by the prominent scars left by the fall of the piunæ; their stipules persistent, appearing as lateral spiny branches on the spines; secondary leaves fascicled

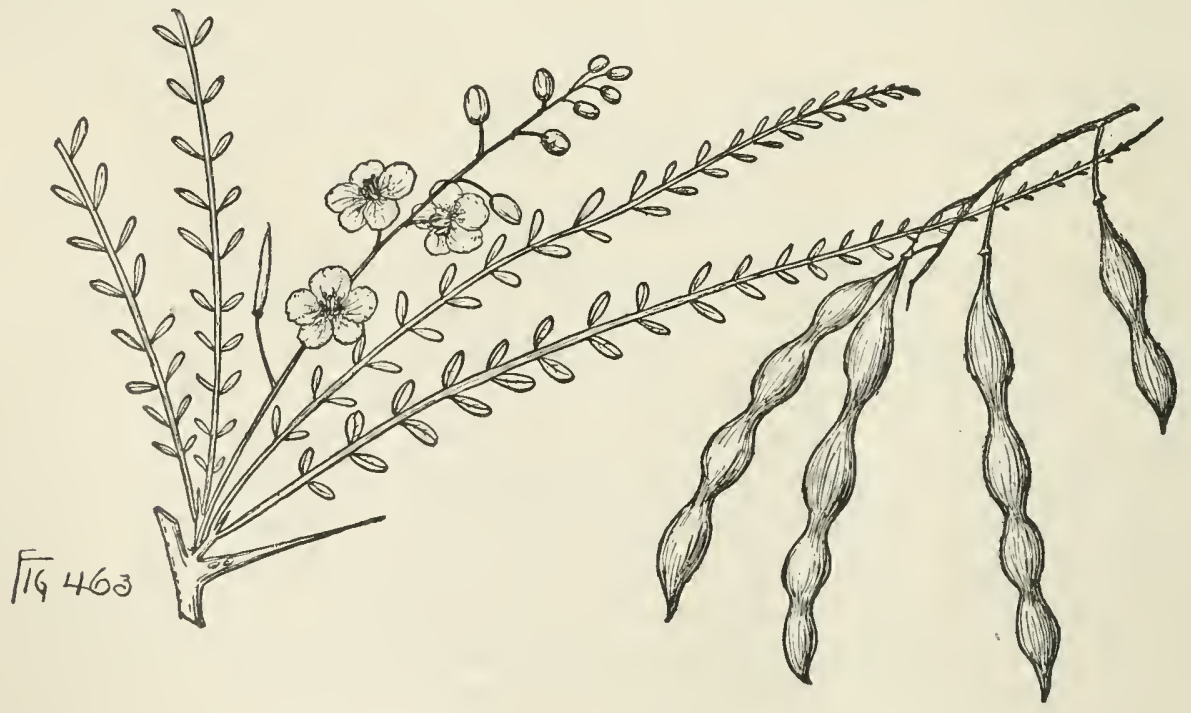

from the axils of the primary leaves, with short terete spinescent rachises and 2 pinnæ; pinnæ flat, $7^{\prime}-8^{\prime}$ long, wing-margined, acute at the apex, with 25-30 pairs of ovate or obovate petiolulate leaflets, $\frac{1^{\prime}}{1^{\prime}}-\frac{1^{\prime}}{8}$ long. Flowers appearing on the growing branches during the spring and summer, and in the tropics throughout the year, in slender erect racemes $5^{\prime}-6^{\prime}$ long; petals bright yellow, the upper one marked 
near the base on the inner surface with conspicuous red spots; stamens shorter than the petals. Fruit hanging in graceful racemes, $2^{\prime}-4^{\prime}$ long, long-pointed, dark orange-brown, slightly pilose, compressed between the remote seeds; seeds $\frac{1^{\prime}}{3}$ long, nearly terete, with thick albumen and bright yellow embryos.

A tree, $18^{\circ}-30^{\circ}$ high, with a trunk sometimes a foot in diameter, usually separating $6^{\circ}-8^{\circ}$ from the ground into slender spreading somewhat pendulous branches forming a wide graceful head, and slightly zigzag branchlets puberulous and yellow-green during their first season, becoming glabrous, gray or light orange color and roughened by lenticels in their second and third years. Bark of the trunk about $\frac{1^{\prime}}{8}$ thick, brown tinged with red, the generally smooth surface broken into small persistent plate-like scales. Wood heavy, hard, close-grained, with very thick lighter colored sapwood tinged with yellow.

Distribution. Low moist soil, valley of the lower Rio Grande, Texas; common in northern Mexico and in the valley of the Colorado River, Arizona, and in Lower California; naturalized on Key West, the Bahamas, the West Indian islands, and in many other tropical countries.

Cultivated in most warm countries as an ornament of gardens, and to form hedges.

\section{Parkinsonia microphylla, Torr.}

Leaves $1^{\prime}$ long, pale, densely tomentose when they unfold, pubescent at maturity, deciduous at the end of a few weeks; rachises short, rarely spinescent, or more commonly 0 ; leaflets in 4-6 pairs, distant, entire, sessile, broadly oblong or nearly orbicular, obtuse or somewhat acute at the apex, oblique at the base, $\frac{1 \prime}{6}$ long; stipules
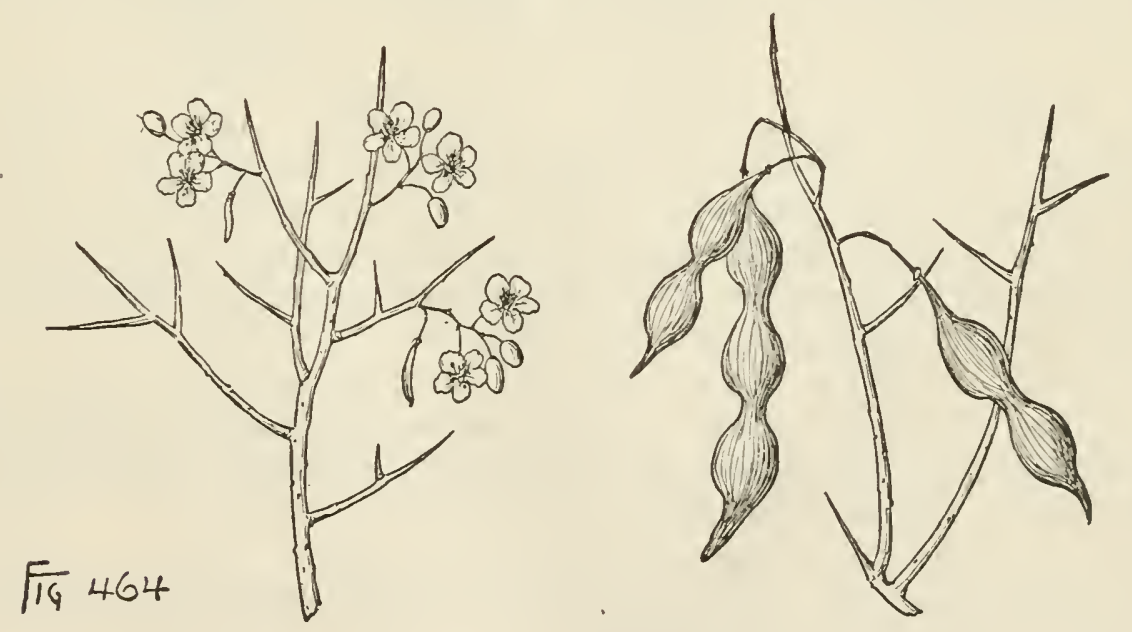

caducous. Flowers opening in May or early June before the leaves, on slender pedicels, in racemes $\mathbf{1}^{\prime}$ or less long in the axils of leaves of the previous year, pale yellow; stamens longer than the petioles. Fruit persistent on the branches for at least a year, frequently 1 or 2, rarely 3-seeded, $2^{\prime}-3^{\prime}$ long, slightly puberulous, especially toward the base, with a long acuminate often falcate apex; seelis compressed, $\frac{1}{8}$ 'long, with bright green embryos.

An intricately branched tree, occasionally $20^{\circ}-25^{\circ}$ high, with a trunk a foot in diameter, and stout pale yellow-green rigid branchlets terminating in stout spines, covered at first with deciduous tomentum, slightly puberulous during their first and second seasons, and often marked by the persistent scales of undeveloped 
buds. Bark dark orange color, generally smooth, although sometimes roughened by scattered clusters of short pale gray horizontal ridges, becoming on old trees $\frac{1}{4}$ thick. Wood heavy, hard, close-grained, dark orange-brown streaked with red, with thick light brown or yellow sapwood of 25-30 layers of annual growth.

Distribution. Deserts of southern Arizona and adjacent regions of California, Sonora, and Lower California; known to attain the size and habits of a tree only in the neighborhood of Wickenburg, Arizona.

\section{CERCIDIUM, Tulasne.}

Trees or shrubs, with stout tortuous branches, covered with bright green bark and armed with slender straight axillary spines. Leaves alternate, abruptly pinnate, petiolate, early deciduous; pinnæ 2 or occasionally $3,7-8$-foliolate; stipules inconspicuous or 0 ; leaflets ovate or obovate, without stipels. Flowers in short fewflowered axillary racemes, solitary or fascicled, with minnte membranaceous early deciduous bracts; calyx 5-lobed, the lobes equal, acute, reflexed at maturity, their margins scarious, slightly revolute; petals orbicular or oblong, unguiculate, bright yellow, the upper one broader and longer clawed than the others, slightly anriculate at the base of the blade, the claw conspicuously glandular at the base; stamens $\mathbf{1 0}$, inserted with the petals on the margin of the disk, free, slightly declinate, exserted; filaments filiform, pilose below, the upper one enlarged at the base and gibbous on the upper side; anthers uniform, ovate, versatile; ovary short-stalked, inserted at the base of the calyx-tube; styles slender, involute, infolded in the bud, with minute terminal stigmas; ovules suspended from the angle of the ovary opposite the posterior petal. Legume linear-oblong, compressed or somewhat turgid, straight or slightly contracted between the seeds, thickened on the margins, the ventral suture acute, or slightly grooved, tipped with the remnants of the style, tardily dehiscent, 2 -valved, the valves membranaceous or subcoriaceous, obliquely veined. Seeds suspended longitudinally on long slender funicles, ovate, compressed, the minute hilum near the apex; seed-coat thin, crustaceous; embryo compressed, light green, covered on the sides only by a thin layer of horny albumen; cotyledons oval, flat, rather fleshy; radicle very short, erect, near the hilum.

Cercidium is confined to the warmer parts of the New World, where it is distributed with four or five species from the southern borders of the United States through Mexico, Central America, and Venezuela to Mendoza. Of the three species found within the territory of the United States two are small trees.

Cercidium produces hard wood sometimes used as fuel.

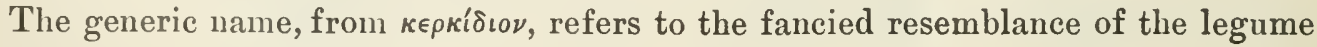
to the weaver's instrument of that name.

\section{CONSPECTUS OF THE NORTH AMERICAN ARBORESCENT SPECIES.}

Legume compressed, with straight margins; leaflets green, slightly glandular.

1. C. floridum (E). Legume somewhat turgid, the margins often slightly contracted between the seeds; leaflets glaucous.

2. C. Torreyanum $(\mathrm{G}, \mathrm{H})$.

\section{Cercidium floridum, Benth. Green-barked Acacia.}

Leaves $1^{\prime}-1 \frac{1}{2}^{\prime}$ long, with 2 or rarely 3 pinnæ, broad pubescent petioles and rachises, and oval or somewhat obovate dull green puberulous minutely glandular leaflets 
about $\frac{1}{16}$ in length, rounded or slightly emarginate at the apex, and when they unfold covered on the lower surface with scattered white hairs; their petiolules short, stout, pubescent, appearing in April and deciduous in October. Flowers opening with the leares, and produced in successive crops during three or four months, $\frac{3 \prime}{4}$ in diameter, on slender pedicels, in 4 or 5 -flowered racemes $11^{\prime}-2^{\prime}$ long, with small acute minute membranaceous eaducous bracts. Fruit compressed, oblong, straight or slightly falcate, acute, narrow and acutely margined on the ventral suture, glabrous, 2 or 3 -seeded, $2^{\prime}-2 \frac{1}{2}^{\prime}$ long, $\frac{1}{2}^{\prime}$ broad, tardily dehiscent, the valves papery, yellow tinged with brown on the outer surface, and bright orange color within; seeds $\frac{1^{\prime}}{3}$ long.

A tree, $18^{\circ}-20^{\circ}$ high, with a short crooked trunk $8^{\prime}-10^{\prime}$ in diameter, stout spreading branches covered with thin smooth bright green bark, forming a low wide head,
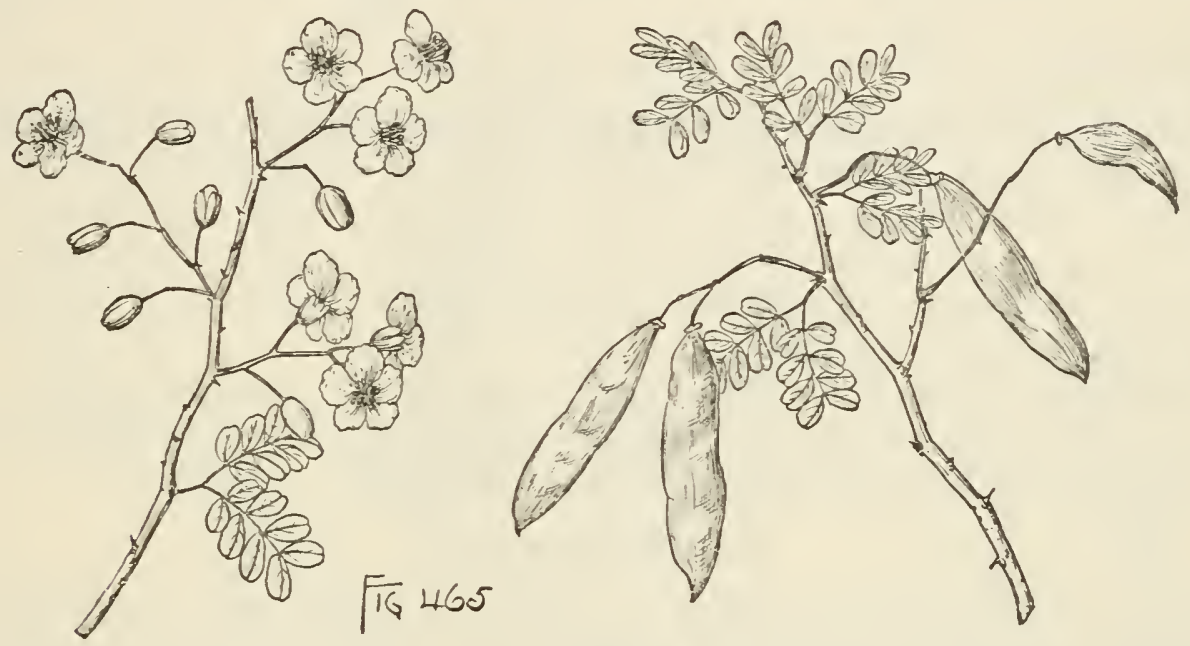

and branchlets light or dark olive-green, slightly puberulous at first, soon glabrous, marked by occasional black lenticels, and armed with slender spines $1^{\prime}$ or less long. Bark $\frac{1}{16}$ thick, light brown tinged with red, with numerous short horizontal light gray ridge-like excrescences. Wood light, soft, close-grained, pale yellow tinged with green, with thick lighter colored sapwood.

Distribution. Shores of Matagorda Bay to Hidalgo County, Texas, and in northern Mexico; not common in Texas; very abundant and a conspicuous feature of vegetation in Mexico from the mouth of the Rio Grande to the foothills of the Sierra Madre.

\section{Cercidium Torreyanum, Sarg. Green-barked Acacia. Palo Verde.}

Leaves few and scattered, $1^{\prime}$ long, at first hoary-tomentose, puberulous at maturity, with slender petioles and 2 pinuæ, each with 2 or 3 pairs of oblong obtuse glaucous leaflets narrowed toward the somewhat oblique base, $\frac{1}{12}{ }^{\prime}-\frac{1}{6}^{\prime}$ long, unfolding in March and April and falling almost inmediately when fully grown. Flowers $\frac{3^{\prime}}{4}$ in diameter, on slender pedicels, in 4 or 5-flowered racemes, about $1^{\prime}$ long, with small acute membranaceous caducous bracts. Fruit ripening and falling in July, $3^{\prime}-4^{\prime}$ long, 2-8-seeded, slightly turgid, often somewhat contracted between the seeds, frequently grooved on the ventral suture; seeds turgid, $\frac{1}{3}$ long.

A low intricately branched tree, leafless for most of the year, $25^{\circ}-30^{\circ}$ high, with a short often inclining trunk $18^{\prime}-20^{\prime}$ in diameter, stout branches covered witl yellow 

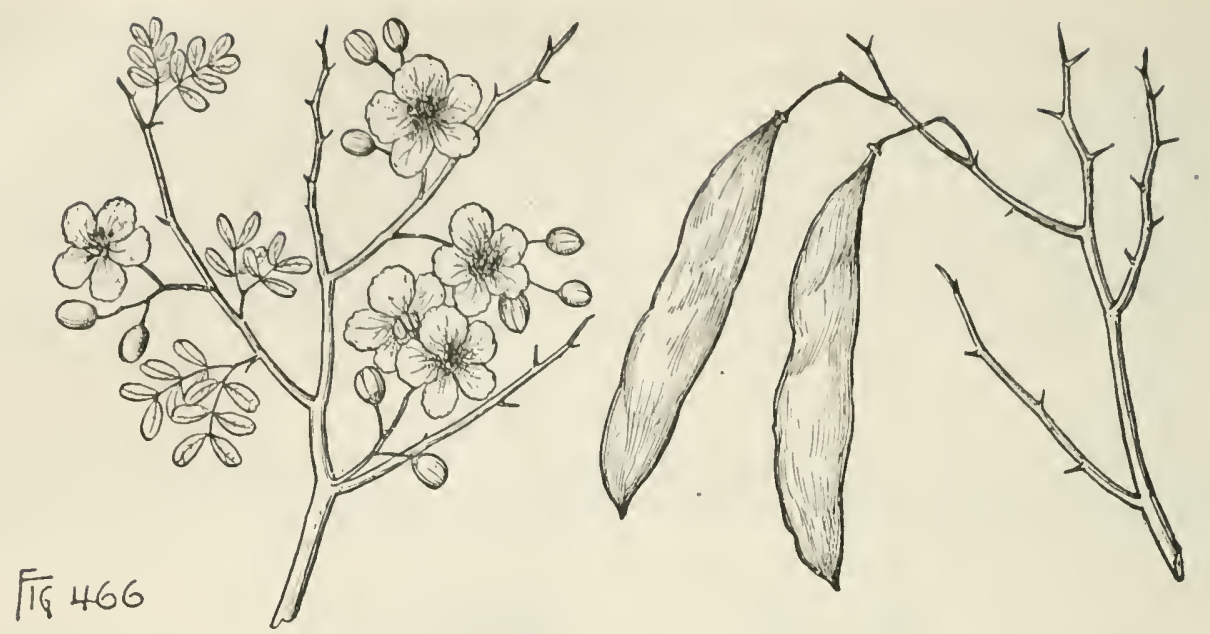

or olive-green bark, forming a narrow upright irregular head, and glabrous slightly zigzag light yellow or pale olive-green and glaucous branchlets armed with thin straight or curved spines $\frac{1^{\prime}}{4}$ long. Bark thin, smooth, pale olive-green, becoming near the base of old trunks reddish brown, $\frac{1}{8}^{\prime}$ thick, furrowed and separating into thick plate-like scales. Wood heavy, not strong, soft, close-grained, light brown, with clear light yellow sapwood.

Distribution. Sides of low cañons and depressions, and sandhills of the desert; valley of the lower Gila River, Arizona, to the Colorado Desert of southern California, and southward into Sonora and Lower California.

\section{SOPHORA, L.}

Trees or shrubs, with minute scaly buds, unarmed terete branches prolonged by an upper axillary bud, and fibrous roots. Leaves unequally pinnate, with numerous small or few and ample membranaceous or coriaceous leaflets; stipules minute, deciduous; stipels often 0 . Flowers in terminal or axillary racemes, with linear minute deciduous bracts and bractlets; calyx broadly campanulate, often slightly turbinate or obconic at the base, obliquely truncate, the short teeth nearly equal or the 2 upper subconnate and often somewhat larger than the others; disk cupuliform, glandnlar, adnate to the calyx-tube; corolla papilionaceous; petals white or violet blue, unguiculate; standard obovate or orbicular, usually shorter than the keel-petals; wings oblong-oblique; keel-petals oblong, suberect, as long as the wings or rather longer, overlapping each other at the back, barely united; stamens free, or 9 of them slightly united at the base, uniform; anthers attached on the back near the middle; ovary short-stipitate, contracted into an incurved style, with a minute truncate or slightly rounded capitate stigma; ovules numerous, suspended from the inner angle of the ovary, superposed, amphitropous. Legume terete, much contracted between the seeds, woody or fleshy, usually many-seeded, each seed inclosed in a separate cell, indehiscent. Seed, oblong or oval, sometimes somewhat compressed; seed-coat thick, membranaceous or crustaceous; cotyledons thick and fleshy; radicle short and straight or more or less elongated and incurved.

Sophora is scattered over the warmer parts of the two hemispheres, with about twenty species; of the six Nortl American species two are small trees. Several of the species produce valuable wood, and from the pods and flower-buds of the Chinese Sophora Japonica, L., a dye is obtained used to dye white cloth yellow and blue clotb 
green. This tree is often cultivated as an ornament of parks and gardens in northern China, the eastern United States, and in western, central, and southern Europe.

The generic name is from Sophera, the Arabic name of some tree with pea-shaped flowers.

\section{CONSPECTUS OF THE NORTH AMERICAN ARBORESCENT SPECIES.}

Flowers violet blue, in terminal racemes; the upper calyx-lobes larger than the others and united; legume woody; seeds without albumen; leaves coriaceous, persistent.

1. S. secundiflora (C, E, H).

Flowers white, in axillary racemes; calyx-lobes equal; legume fleshy; seeds with albumen; leaves membranaceous, deciduous.

2. S. affinis (C).

\section{Sophora secundiflora, DC. Frijolito. Coral Bean.}

Leaves persistent, covered at first, especially on the lower surface of the leaflets, with silky white hairs, and at maturity $4^{\prime}-6^{\prime}$ long, with stout puberulous petioles slightly enlarged at the base, and 7-9 elliptical-oblong leaflets rounded, emarginate or sometimes mucronate at the apex, gradually contracted at the base into short thick

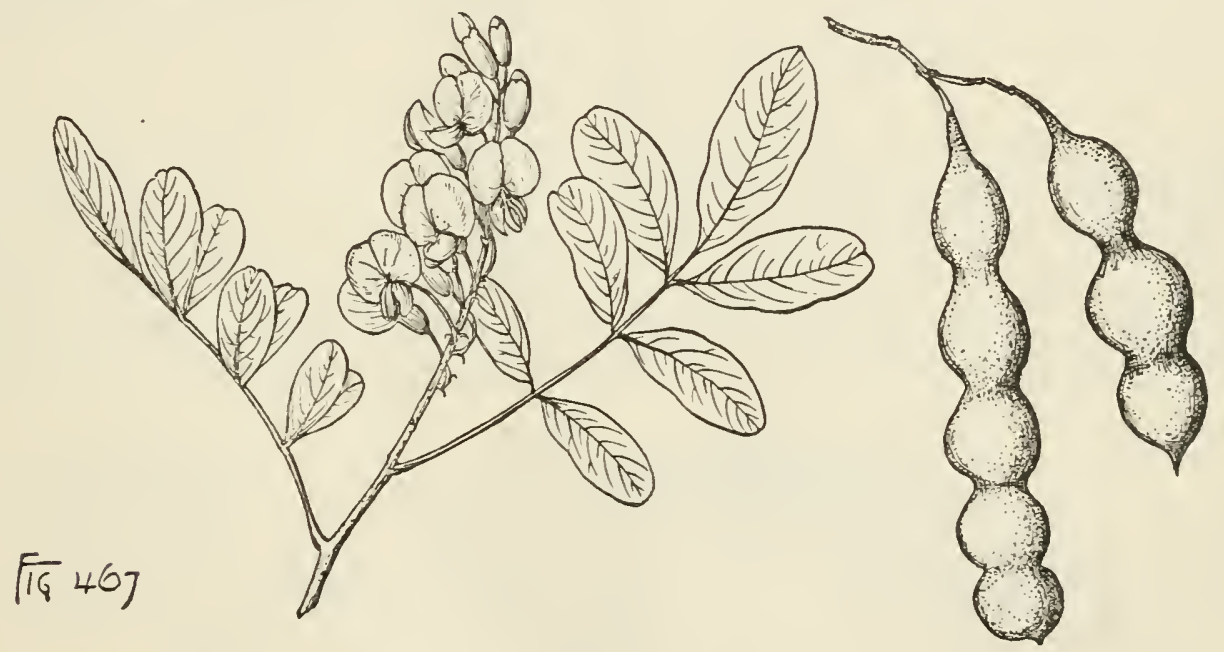

petiolules, coriaceous, lustrous and dark yellow-green above, rather paler below, glabrous or sometimes slightly puberulous along the under surface of the stout midribs, entire, with thickened margins, conspicuously reticulate-veined, $1^{\prime}-2 \frac{1^{\prime}}{2}$ long, $\frac{1^{\prime}}{2}-1 \frac{1}{2}^{\prime}$ wide, without stipels. Flowers with a powerful and delicious fragrance, appearing with the young leaves in very early spring, $1^{\prime}$ long, on stout pedicels sometimes $1^{\prime}$ in length, from the axils of subulate deciduous bracts $\frac{1}{2}^{\prime}$ or more long, and bibracteolate, with 2 acute bractlets, in terminal 1 -sided canescent racemes $2^{\prime}-3^{\prime}$ in length; calyx campanulate, slightly enlarged on the upper side, the 3 lower teeth triangular and nearly equal, the 2 upper rather larger and united almost throughout; petals shortly unguiculate, violet blue, the broad erect standard marked on the inner surface near the base with a few darker spots; ovary coated with long silky white hairs. Fruit terete, $1^{\prime}-7^{\prime}$ long, $\frac{1^{\prime}}{2}$ thick, stalked, crowned with the thickened remnants of the style, covered with thick hoary tomentum, indehiscent, 1-8-seeded, with hard woody walls $\frac{1^{\prime}}{4}$ thick; seeds oblong, rounded, $\frac{1}{2}^{\prime}$ long, bright scarlet, with a small pale hilum and a bony seed-coat; albumen 0; cotyledons thick, orangecolored, filling the cavity of the seed; radicle short and straight. 
A tree, $25^{\circ}-35^{\circ}$ high, with a straight trunk $6^{\prime}-8^{\prime}$ in diameter, separating several feet from the gronnd into a number of upright branehes forming a narrow head, and branehlets coated at first with fine hoary tomentum, beeoming glabrons or nearly glabrous in their second year and pale orange-brown; more often a shrub, with low chnstered stems. Wood very heavy, hard, elose-grained, orange-eolored, streaked with red, with thiek bright yellow sapwood of 10-12 layers of annual growth. The seeds contain a poisonous alkaloid, sophorin, with strong nareotic properties.

Distribution. Borders of streams, forming thiekets or small groves, in low rather moist limestone soil; shores of Matagorda Bay, Texas, to the mountain eañons of New Mexieo, and to those of Nuevo Leon and San Luis Potosi; of its largest size in the neighborhood of Matagorda Bay; south and west, especially west of the Pecos River, rarely more than a shrub.

\section{Sophora affinis, T. \& G.}

Leaves deciduous, eoated when they unfold with hoary pubeseence, $6^{\prime}-9^{\prime}$ long, with slender puberulous petioles, and 13-19 elliptieal obtuse or retuse slightly mueronate leaflets eontraeted at the base into short stont pubescent petiolules, entire or with slightly wavy thiekened margins, membranaeeous, pale yellow-green and glabrous above, paler and eovered with scattered hairs or nearly glabrous below, $1^{\prime}-1 \frac{1^{\prime}}{2}$ long, and $\frac{1^{\prime}}{2}$ wide, with prominent orange-eolored midribs, slender primary veins, and conspicuous reticulate veinlets. Flowers $\frac{1^{\prime}}{2}$ long, appearing in early spring with the young leaves, on slender eaneseent pedieels nearly $\frac{1^{\prime}}{2}$ long, from the axils of minute deeiduous braets, in slender pubescent semipendent racenes, $3^{\prime}-5^{\prime}$ long, from the axils of the leaves at the ends of the branehes; calyx short-campanulate, abruptly narrowed at the base, somewhat enlarged on the upper side, slightly pubeseent,

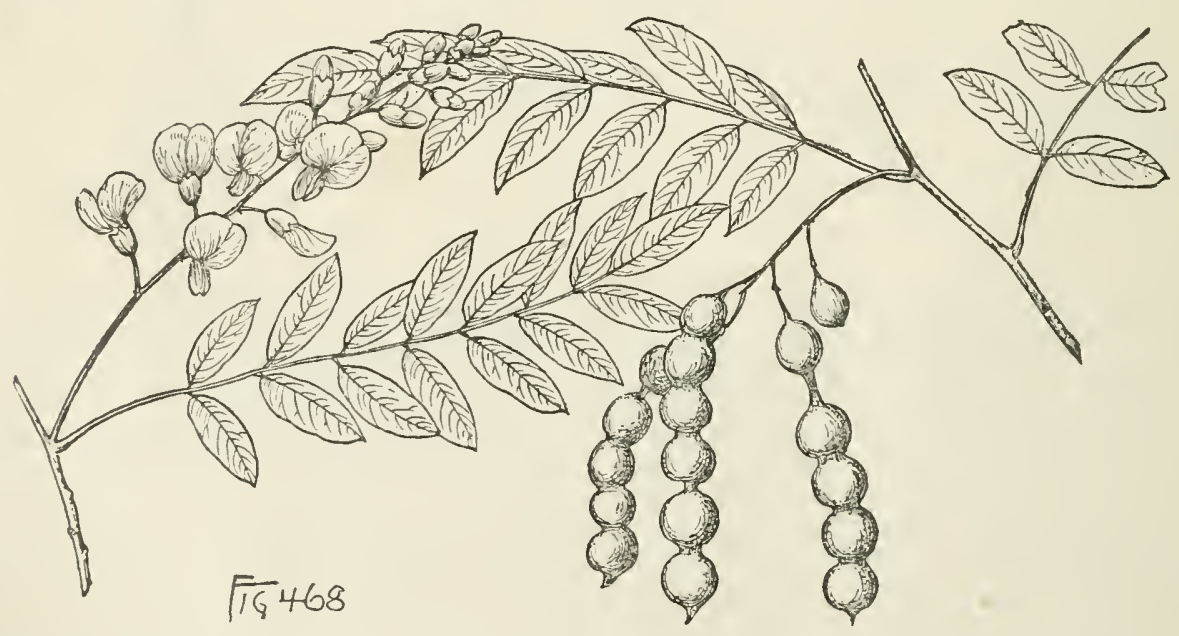

espeeially on the margins of the short nearly triangular teeth; petals shortly unguieulate, white tinged with rose eolor; standard nearly orbicular, slightly emarginate, reflexed, as long and twiee as broad as the ovate auricnlate wings and keelpetals; ovary eonspicuously stipitate, villose. Fruit $\frac{1^{\prime}}{2}-3^{\prime}$ long, indehiseent, blaek, more or less pubeseent, crowned with the thiekened remnants of the style, 4-8seeded, or rarely 1 -seeded and then subglobose, with thin fleshy rather sweet walls, persistent on the branehes during the winter; seeds oval, slightly eompressed, with 
a thin crustaceous bright chestnut-brown seed-coat; cotyledons surrounded by a thin layer of horny albumen, bright green; radicle long and incurved.

A tree, $18^{\circ}-20^{\circ}$ high, with a trunk $8^{\prime}-10^{\prime}$ in diameter, dividing into a number of stout spreading branches forming a handsome round-topped head, slender terete slightly zigzag branchlets at first orange-brown or dark brown and slightly puberulous, bright green marked by narrow brown ridges, and in their second year by the elevated tomentose leaf-scars. Winter-buds depressed, minute, almost surrounded by the base of the petioles, with broad scales coated on the outer surface with dark brown tomentum and on the inner surface with thicker pale tomentum, and persistent on the base of the growing shoot. Bark of the trunk about $\frac{1^{\prime}}{8}$ thick, dark reddish brown, and broken into numerous oblong scales, the surface exfoliating in thin layers. Wood heavy, very hard and strong, light red in color, with thick bright clear yellow sapwood of 10-12 layers of annual growtl.

Distribution. Usually on limestone hills, or on the borders of streams, ravines, or depressions in the prairie, often forming small groves; valley of the Arkansas River, Arkansas, to that of the San Antonio, Texas, and westward in Texas to the upper waters of the Colorado River.

\section{CLADRASTIS, Raf.}

A tree, with copious watery juice, smooth gray bark, slender slightly zigzag terete branchlets without terminal buds, fibrous roots, and naked axillary buds, 4 together, superposed, flattened by mutual pressure into an acuminate cone, and inclosed collectively in the hollow base of the petiole, the largest and upper one only developing, the lowest minute and rudimentary. Leaves unequally pinnate, petiolate, with stout terete petioles abruptly enlarged at the base, 7 -11-foliolate, deciduous; leaflets usually alternate, broadly oval, the terminal one rhombic-ovate, contracted at the apex into short broad points, wedge-shaped at the base, entire, petiolulate, without stipels, covered at first like the young shoots with fine silvery pubescence, or on the midribs with lustrous brown tomentum, at maturity thin, glabrous, dark yellow-green on the upper, pale on the lower surface, the midribs and numerous primary veins conspicuous, light yellow below; stipules 0 . Flowers on slender puberulous pedicels, bibracteolate near the middle, with scarious caducous bractlets, in long gracefully nodding stalked terminal panicles, the lower branches racemose, and often springing from the axils of 1-flowered pedicels, the main axis slightly zigzag, and, like the branches, covered at first with a glaucous bloom and slightly pilose; bracts lanceolate, scarious, pale, caducous; calyx cylindrical-canıanulate, enlarged on the upper side, and obliquely obconic at the base, puberulous, 5 -toothed, the teeth imbricated in the bud, nearly equal, short and obtuse, the 2 upper slightly united; disk cupuliform, adnate to the interior of the calyx-tube; corolla papilionaceous; petals white, unguiculate; standard nearly orbicular, entire or slightly emarginate, reflexed above the middle, barely longer than the straight oblong wings, slightly biauriculate at the base of the blade, marked on the inner surface with a pale yellow blotch; keel-petals free, oblong, nearly straight, obtuse, slightly subcordate or biauriculate at the base; stamens 10, free; filaments filiform, slightly incurved near the summit, glabrous; anthers versatile; ovary linear, stipitate, bright red, villose, with long pale hairs, contracted into a long slender glabrous slightly incurved subulate style; stigma terminal, minute; ovules numerous, suspended from the inner angle of the ovary, superposed. Legume glabrous, short-stalked, linear- 
eompressed, the upper margin slightly thiekened, tipped with the remnants of the persistent style,4-6-seeded, ultimately dehiseent, the valves thin and membranaeeous. Seeds oblong-eompressed, attaehed by slender funieles; without albumen; seed-coat thin, membranaeeous, dark brown; embryo filling the cavity of the seed; cotyledons fleshy, oblong, flat; radiele short, inflexed.

The genus eonsists of a single speeies of the southern United States.

Cladrastis, from $\kappa \lambda a ́ \delta o s$ and $\theta \rho a v \sigma \tau o ́ s$, relates to the brittleness of the branches.

\section{Cladrastis lutea, K. Koch. Yellow Wood. Virgilia.}

Leaves $8^{\prime}-12^{\prime}$ in length, with leaflets $3^{\prime}-4^{\prime}$ long and $1 \frac{1}{2}^{\prime}-2^{\prime}$ wide, the terminal one rather shorter than the others and $33^{\prime}-3 \frac{1^{\prime}}{2}$ wide, turning bright elear yellow rather late in the autumn some time before falling. Flowers appearing about the middle

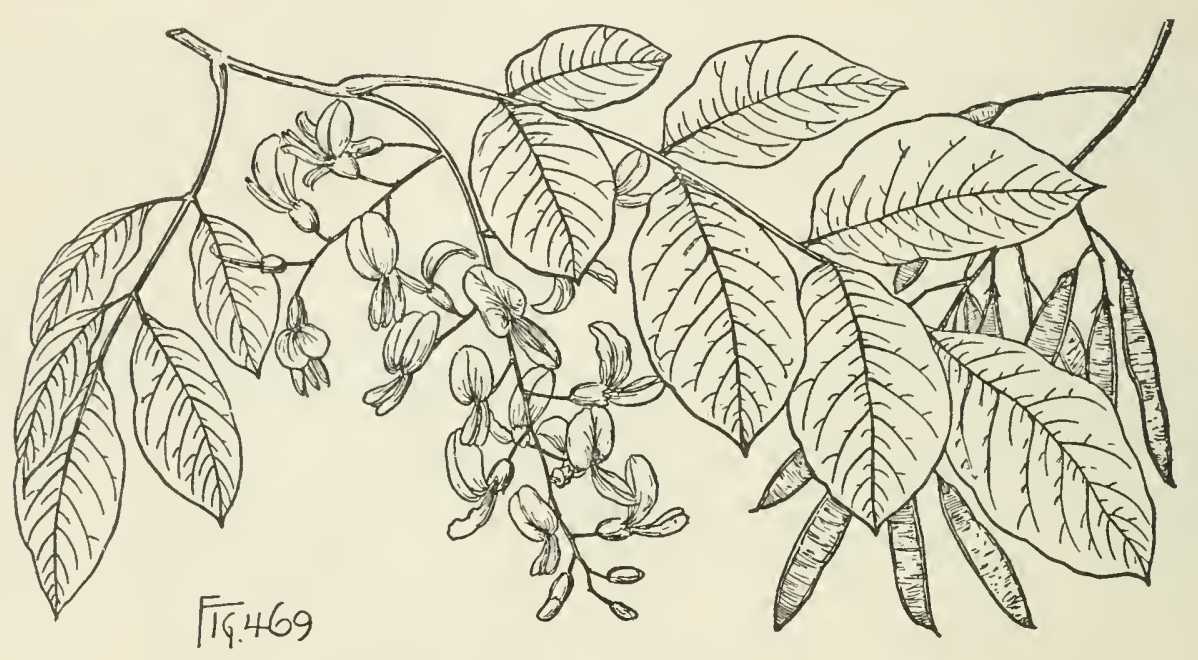

of June, slightly fragrant, in panieles $12^{\prime}-14^{\prime}$ long and $5^{\prime}-6^{\prime}$ wide. Fruit fully grown by the middle of August, ripening in September and soon falling.

A tree, sometimes $50^{\circ}-60^{\circ}$ high, with a trunk $1 \frac{1}{2}^{\circ}-2^{\circ}$ or exeeptionally $4^{\circ}$ in diameter, usually divided $6^{\circ}-7^{\circ}$ from the ground into 2 or 3 stems, slender widespreading more or less pendulous brittle branehes forming a wide graeeful head, and zigzag branchlets elothed with pubeseenee when they first appear, soon beeoming glabrous, during their first season.light brown tinged more or less with green, very smooth and lustrous, eovered by numerous darker eolored lentieels, bright red-brown in their first winter and marked by large elevated leaf-sears surrounding the buds, and dark dull brown the following year. Bark of the trunk $\frac{1^{\prime}}{8}-\frac{1}{4}^{\prime}$ thiek, with a silvery gray or light brown surface and rather darker eolored than that of the branches. Wood heavy, very hard, strong and elose-grained, with a smooth satiny surfaee, bright elear yellow ehanging to light brown on exposure, with thin nearly white sapwood; used for fuel, oeeasionally for gun-stoeks, and yielding a elear yellow dye.

Distribution. Limestone eliffs and ridges generally in rieh soil, and often overhanging the banks of mountain streams; eentral Kentueky and eentral Tennessee to northern Alabama, the western slopes of the high mountains of eastern Tennessee, and to Cherokee County, North Carolina; rare and loeal; most abundant and of its largest size in the neighborhood of Nashville, Temessee. 
Often planted in the eastern United States as an ornamental tree, and hardy as far north as New England; and rarely in western and southern Europe.

\section{EYSENHARDTIA, H.B. K.}

Small glandular-punctate trees or shrubs, with slender terete branches. Leaves alternate, equally pinnate, petiolate; leaflets oblong, mucronate or emarginate at the apex, short-petiolulate, numerous, stipellate; stipules subulate, caducous. Flowers short-pedicellate, in long spicate racemes, terminal or axillary, with subulate caducous bracts; calyx-tube campanulate, conspicuously glandular-punctate, 5 -toothed, the acute teeth nearly equal, persistent; disk cupuliform, adnate to the base of the calyx-tube; corolla subpapilionaceous; petals erect, free, nearly equal, oblong-spatulate, rounded at the apex, unguiculate, creamy white; standard concave, slightly broader than the wings and keel; stamens 10 , inserted with the petals, the superior one free, shorter than the others, the remainder united to above the middle into a tube; anthers uniform, oblong; ovary subsessile, contracted into a long slender uncinate style geniculate and conspicuously glandular below the apex; stigma introrse, oblique; ovules 2 or 3 , rarely 4 , attached to the imner angle of the ovary, superposed. Legume small, oblong or linear-falcate, compressed, tipped with the remnants of the style, indehiscent, pendent. Seeds usually solitary, rarely 2, oblong-reniform, witlout albumen; seed-coat coriaceous; embryo filling the cavity of the seed; cotyledons flat, fleshy; radicle superior, short and erect.

Eysenhardtia is confined to the warmer parts of the New World, and is distributed from western Texas and Arizona to southern Mexico, Lower California, and Guatemala. Four species are distinguished; of these three species occur within the territory of the United States, and in northern Mexico, and one species is found only in Guatemala. Of the North American species one is a small tree.

The generic name is in honor of Karl Wilhelm Eysenhardt (1791-1825), Professor of Botany in the University of Königsberg.

\section{Eysenhardtia orthocarpa, Wats.}

Leaves $4^{\prime}-5^{\prime}$ long, with pubescent rachises grooved on the upper side, 10-23 pairs of leaflets, and small scarious deciduons stipules; leaflets oval, rounded or slightly emarginate at the apex, with stout petiolules and minute scarious deciduous

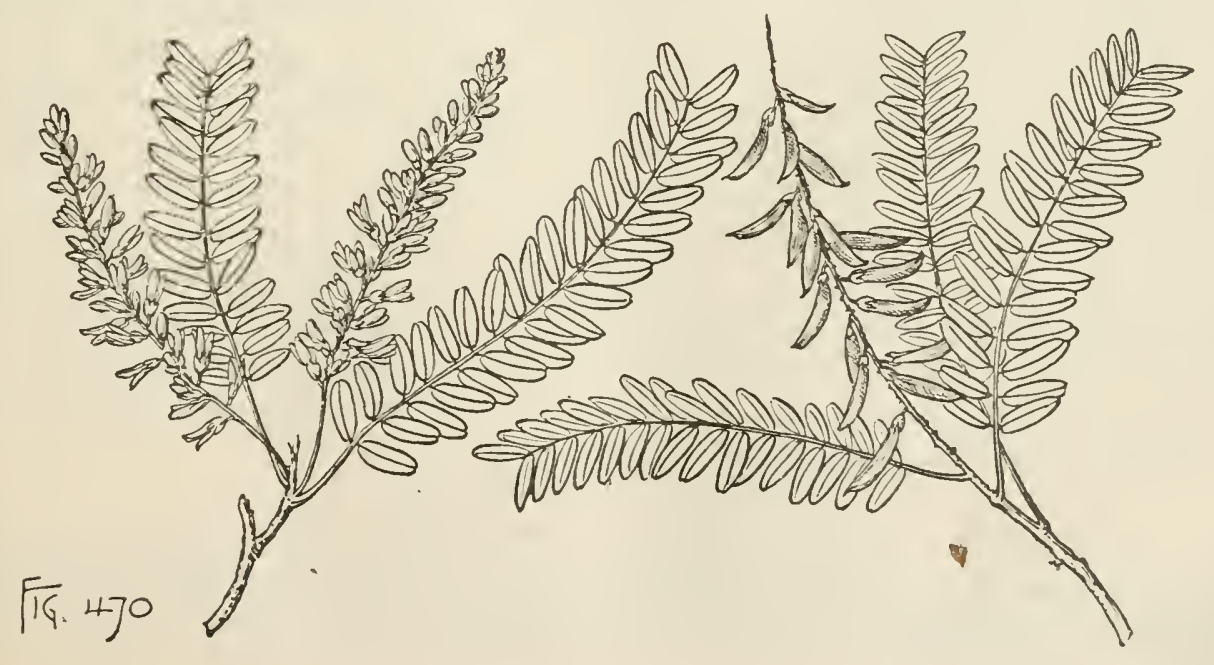


stipels, pale gray-grecn, glabrous and slightly puberulous on the upper surface, conspicuously glandular, with chestmut-brown glands, and pubcscent especially on the prominent midribs on the lower surfacc, rcticulate-veined, $\frac{1}{2}-\frac{2}{3}$ long, $\frac{1}{8}-\frac{1}{4}$ wide, with thickened slightly, revolute nnargins. Flowers opening in May, nearly $\frac{1}{2}$ long, on slender pubescent pedicels, in axillary pubescent spikes $3^{\prime}-4^{\prime}$ long; calyx many-ribbed, pubeseent, conspicuously glandular, half as long as the whitc petals ciliatc on the margins, and of nearly equal size and shape. Fruit $\frac{1}{2}$ long, pendent, nearly straight or slightly falcate, thickened on the edges, with usually a single sced near the apcx; seed compressed, light reddish brown, $\frac{1}{4}^{\prime}$ long.

A tree, occasionally $18^{\circ}-20^{\circ}$ high, with a trunk $6^{\prime}-8^{\prime}$ in diameter, separating $3^{\circ}-$ $4^{\circ}$ above the ground into a number of slender branches, and branchlets coated at first with ashy gray pubescence disappearing during the second year, and then reddish brown and roughened by numerous glandular excrescences; or more often a low rigid shrub. Bark of the trunk about $\frac{1}{16}$ thick, light gray, and broken into large plate-like scales, exfoliating on the surface into thin layers. Wood heavy, hard, close-grained, light reddish brown, with thin clear yellow sapwood of 7 or 8 layers of annual growth.

Distribution. Dry gravelly soil, on arid slopes and dry ridges; valley of the upper Guadalupe River, western 'Texas, to the Santa Catalina and Santa Rita Mountains, southern Arizona, and southward into northern Mexico; arborescent only near the summit of the Santa Catalina Mountains.

\section{DALEA, L.}

Glandular-punctate herbs, small shrubs, or rarely trees. Leaves alternate, unequally pinnate, or simple in the arborescent species; stipules generally minute, subulate, deciduous. Flowers in racemes, their bracts membranaceous or setaceous, broad, concave above, glandular-dentate; calyx 5-toothed or lobed, persistent, the divisions nearly equal; corolla papilionaceous; petals unguiculate; standard cordate, free, inserted in the bottom of the tubular disk connate to the calyx-tube, rather shorter than the wings and keels, the claws adnate to and jointed upon the staminal tube; stamens 10, or sometimes 9 through the suppression of the superior one, united into a tube cleft above and cup-shaped toward the base; anthers uniform, often surmounted by a gland; ovary sessile or short-stalked, contracted into a slender subulate style, with a minute terminal stigma; ovules 4-6 attached to the inner angle of the ovary, superposed. Legume ovate, sometimes conspicuously ribbed, more or less inclosed in the calyx, membranaceous, indehiscent, 1-seeded; seed reniform, without albumen; testa coriaceous; embryo filling the cavity of the seed; cotyledons broad and flat; radicle superior, accumbently reflexed:

Dalea is confined to the New World, where it is distributed from the central, western, and southwestern regions of the United States through Mexico and Central America to Chili, Peru, and the Galapagos Islands; usually herbs or low undershrubs. One species of the United States occasionally assumes the habit and attains the size of a small tree.

The generic name is in honor of Samuel Dale (1659-1739), an English botanist. and writer on the materia medica.

\section{Dalea spinosa, Gray.}

Leaves few, simple, irregularly scattered near the base of the spinose branchlets, cuneate or linear-oblong, sessile or nearly sessile, marked by few large glands, 
especially on the entire wavy margins, hoary-pubescent, $\frac{3^{\prime}}{4}-1^{\prime}$ long, $\frac{1}{8}^{\prime}-\frac{1}{2}^{\prime}$ wide, with broad midribs and three pairs of lateral ribs, on vigorous young shoots or seedling plants remotely and coarsely serrate, remaining only for a few weeks on the branches; stipules minute, ovate, acute, pubescent. Flowers $\frac{1^{\prime}}{2}$ long, appearing in June on short pedicels from the axils of minute bracts, in racemes $1^{\prime}-1 \frac{1}{2}^{\prime}$ long, their rachises slender, spinescent, hoary-pubescent; calyx-tube 10-ribbed, with usually 5 glands between the dorsal ribs, the lobes short, ovate, rounded or more or less ciliate on the margins, reflexed at maturity; petals dark violet blue; standard cordate, reflexed, furnished at the base of the blade with two conspicuous glands, wings and
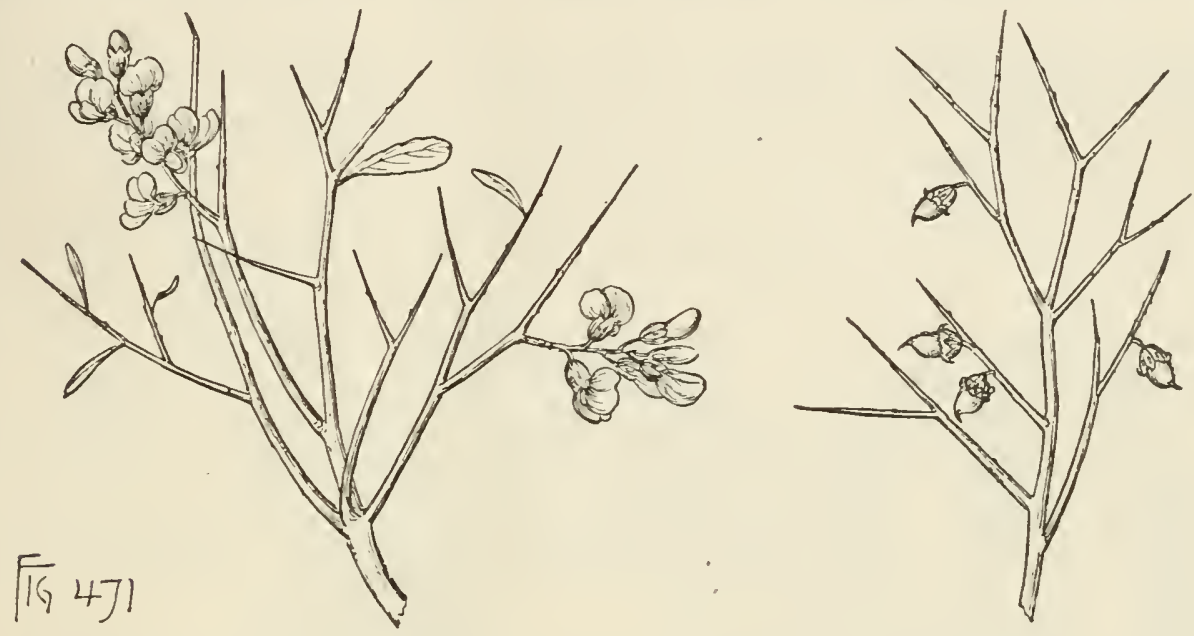

keel attached to the staminal tube by their bases only and nearly equal in size, rounded at the apex, more or less irregularly lobed at the base; ovary pubescent, glandular-punctate. Fruit ovate, pubescent, glandular, twice as long as the calyx, tipped with the remnants of the recurved style; seed $\frac{1^{\prime}}{8}$ long, pale brown irregularly marked with dark spots.

A tree, $18^{\circ}-20^{\circ}$ high, with a short stout contorted trunk sometimes $20^{\prime}$ in diameter and divided near the ground into several upright branches, and branchlets reduced to slender sharp spines coated with fine pubescence, bearing minute nearly triangular scarious caducous bracts, marked by occasional glandular fistules, and developed from stonter branches hoary-pubescent when young, becoming glabrous in their third year and covered with pale brown bark roughened with lenticels and as it exfoliates showing the pale green inner bark; more often a low rigid intricately branched shrub. Bark of the trunk dark gray-brown, nearly $\frac{1}{4}^{\prime}$ thick, deeply furrowed, and roughened on the surface by small persistent scales. Wood light, soft, rather close-grained, walnut-brown in color, with nearly white sapwood of 12-15 layers of annual growth.

Distribution. Valley of the lower Gila River, Arizona, to the Colorado Desert of California, and southward into Sonora and Lower California.

\section{ROBINIA, L. Locust.}

Trees or shrubs, with slender terete or slightly many-angled zigzag branchlets, without terminal buds, minute naked subpetiolar depressed-globose axillary buds 3 or 4 together, superposed, protected collectively in a depression by a scale-like 
covering lined on the inner surface with a thick eoat of tomentum and opening in early spring, its divisions persistent during the season on the base of the branchlet developed usually from the upper bud. Leaves unequally pinnate, petiolate, deciduous; leaflets entire, penniveined, stipellate, retieulate-venulose, petiolulate; stipules setaceous, becoming spinescent at maturity, persistent. Flowers on long pedieels, in short pendulous racemes from the axils of leaves of the year, with small acuminate caducous bracts and bractlets; calyx campanulate, 5-toothed or cut, the upper lobes shorter than the others, cohering for part of their length; corolla papilionaeeous, petals shortly unguiculate, inserted on a tubular disk glandular on the inner surface and connate with the base of the ealyx-tube; standard large, reflexed, barely longer than the wings and keel, naked on the inner surface, obcordate, reflexed; wings oblong-falcate, free; keel-petals ineurved, obtuse, united below; stamens 10, inserted with the petals, the 9 inferior united into a tube often enlarged at the base and cleft on the upper side, the superior one free at the base and eonnate in the middle with the staminal tube, or finally free; anthers ovate; ovary inserted at the base of the calyx, linear-oblong, stipitate; style subulate, inflexed, bearded along the inner side near the apex, with a small terminal stigma; ovules numerous, suspended from the inner angle of the ovary, in two ranks, superposed. Legumes in drooping many-fruited racemes, many-seeded, linear-compressed, alimost sessile, 2 -valved, the seed-bearing suture narrow-winged; valves thin and membranaeeous. Seed oblong-oblique, transverse, attached by a stout persistent incurved funiele enlarged at the point of the attaehment to the placenta; seed-coat thin, erustaceous; albumen thin, membranaceous; cotyledons oval, fleshy; radiele short, much reflexed, aeeumbent.

Robinia with seven or eight species is eonfined to the United States and Mexico; of the three or four species found in the United States three are arboreseent.

The generie name eommemorates the botanical labors of Jean and Vespasien Robin, arborists and herbalists of the king of France in the sixteenth and seventeenth centuries.

\section{CONSPECTUS OF THE ARBORESCENT SPECIES OF THE UNITED STATES.}

Legume without glandular hairs; flowers white.

Legume glandular-hispid; flowers rose color.

Glands not viscid.

Glands exuding a clammy sticky substance.
1. R. Pseudacacia (A, C).

2. R. Neo-Mexicana (F, H). 3. $R$. viscosa (A).

\section{Robinia Pseudacacia, L. Locust. Acacia. Yellow Locust.}

Leaves 8 '-14' long, with slender puberulous petioles, and 7-9 leaflets, turning pale elear yellow late in the autumn just before falling; stipules $\frac{1}{2}^{\prime}$ long, linear, subulate, membranaceous, at first pubescent and tipped with small tufts of eaducous brown hairs, becoming straight or slightly recurved spines persistent for many years and ultimately often more than $1^{\prime}$ long; leaflets oval, rounded or slightly truneate and minutely apieulate at the apex, when they unfold eovered with eaducous silvery pubescence, at maturity very thin, dull dark blue-green above, pale below, glabrous with the exception of the slight pubescence on the under side of the slender midribs, $1 \frac{1}{2}-2^{\prime}$ long and $\frac{1}{2}^{\prime}-\frac{3}{4}^{\prime}$ wide; their petiolules stont, $\frac{1}{8}^{\prime}-\frac{1}{4}^{\prime}$ long; stipels minute, linear, membranaceous, early deciduous. Flowers opening late in May or early in June, filled with nectar, very fragrant, on slender pedicels $\frac{1^{\prime}}{2}$ long, and dark red or red 
tinged with green, in loose puberulous racemes $4^{\prime}-5^{\prime}$ long; calyx conspicuously gibbous on the upper side, ciliate on the margins, dark green blotched with red, especially on the upper side, the lower lobe acuminate and much longer than the nearly triangular lateral and upper lobes; petals pure white, with a large pale yellow blotch marking the inner surface of the standard. Fruit ripening late in the antumn, $3^{\prime}-4^{\prime}$ long and $\frac{1}{2}$ 'wide, with bright red-brown valves, usually 4-8-seeded, mostly persistent until the end of winter or early spring; seeds $\frac{3}{16}$ long, dark orange-brown, with irregular darker markings.

A tree, $70^{\circ}-80^{\circ}$ high, with a trunk $3^{\circ}-4^{\circ}$ in diameter, small brittle usually erect branches forming a narrow oblong head, and slender terete or sometimes slightly many-angled branchlets marked by small pale scattered lenticels, coated at first with short appressed silvery white deciduous pubescence, pale green and puberulous during their first season, becoming light reddish brown and glabrous or nearly so toward autumn. Bark of the trunk $1^{\prime}-1 \frac{1}{2}^{\prime}$ thick, deeply furrowed, dark brown

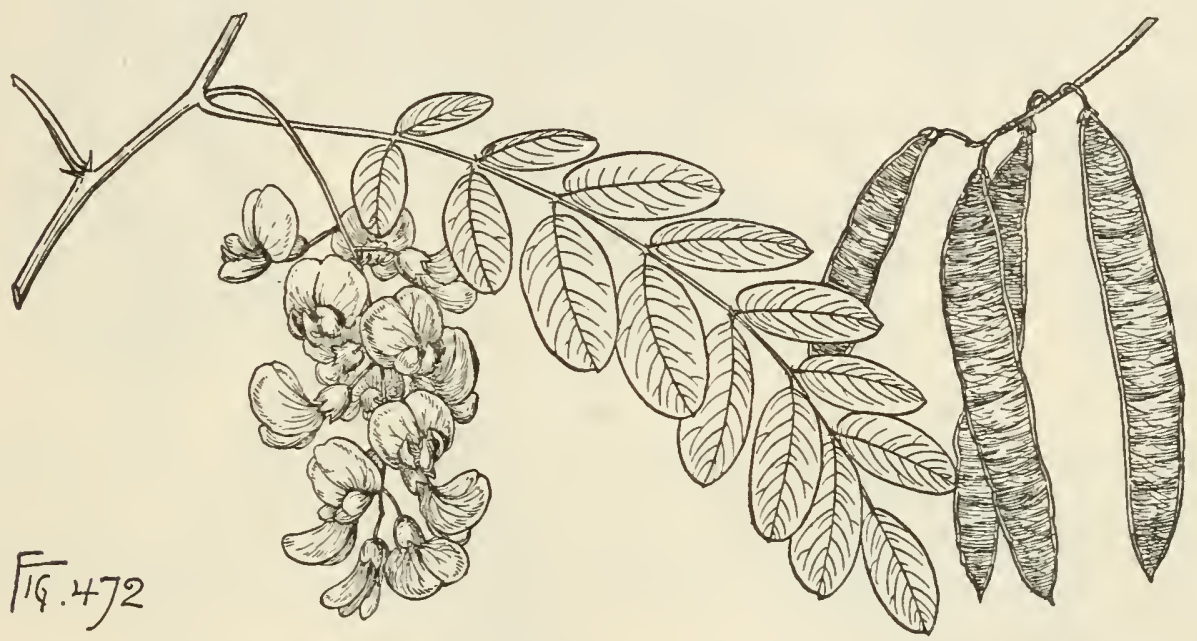

tinged with red, and covered by small square persistent scales. Wood heavy, exceedingly hard and strong, close-grained, very durable in contact with the ground, brown or rarely light green, with pale yellow sapwood of 2 or 3 layers of annual growth; extensively used in shipbuilding, for all sorts of posts, in construction and turnery; preferred for treenails, and valued as fuel.

Distribution. Slopes of the Appalachian Mountains, Pennsylvania, to northern Georgia; now widely naturalized in most of the territory of the United States east of the Rocky Mountains, and perhaps indigenous as a low shrub in northeastern and western Arkansas and in the Indian Territory; nowhere common; in the Appalachian forest growing singly or in small groups; most abundant and of its largest size on the western slopes of the Alleghanies of West Virginia; often spreading by underground stems into broad thickets of small and often stunted trees.

Formerly much planted as an ornamental and timber tree in the eastern states; very frequently used in Europe, with numerous seminal varieties of peculiar foliage or habit, for the decoration of parks and gardens, and to shade the streets of cities.

\section{Robinia Neo-Mexicana, Gray. Locust.}

Leaves $6^{\prime}-12^{\prime}$ long, with stout pubescent petioles, and 15-21 leaflets; stipules chartaceous, covered with long silky brown hairs, becoming at maturity stout 
slightly reeurved flat brown or bright red spines sometimes 1' or more long; leaflets elliptical-oblong, ronnded or sometimes slightly emarginate at the mueronate apex, wedge-shaped or sometimes ronnded at the hase, $1_{\frac{1}{2}}^{\prime}$ long and $1^{\prime}$ broad, coated at first on the lower surfaee and on the margins with soft brown hairs, and silvery-pubescent on the upper surface, and at maturity thin, pale blne-green, eonspienonsly reticulate-veined, and glabrous with the exeeption of the slightly puberulons lower side of the slender nidribs and stout petiolules; stipels membranaeeons, ${ }_{4}^{\prime \prime}$ long, of ten reeurved, sometimes persistent through the season. Flowers appearing in May,

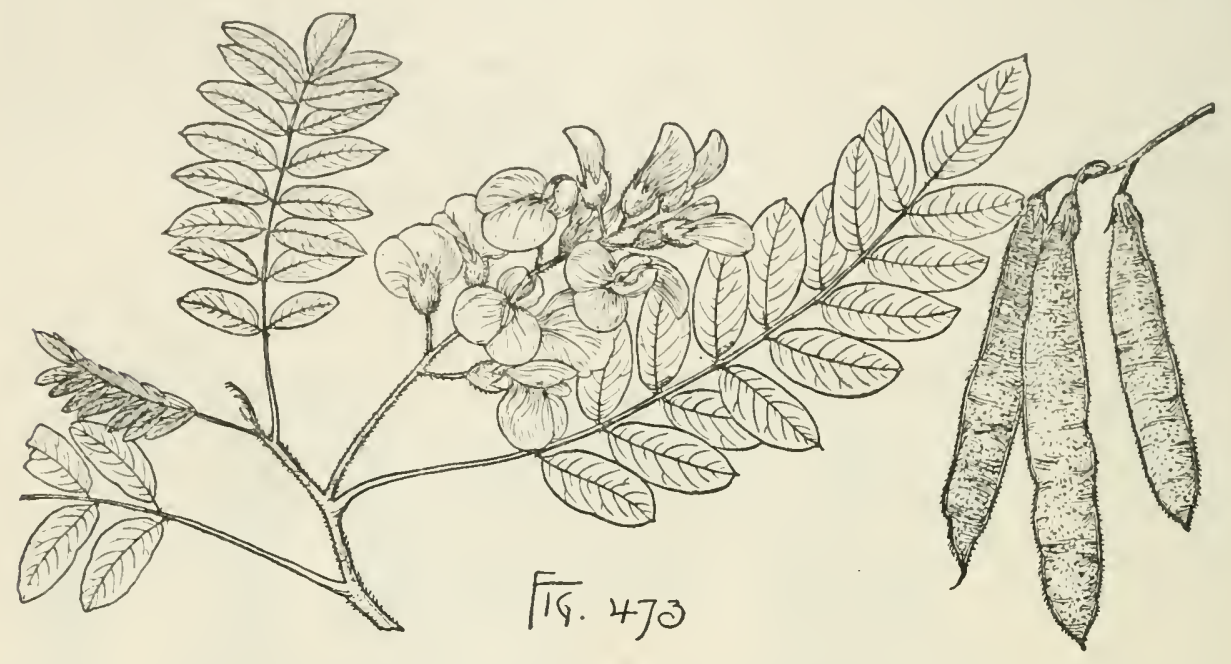

$1^{\prime}$ long, on slender pedieels $\frac{1}{2}^{\prime}$ in length and covered with stout glandular hairs, in short compact many-flowered glandular-hispid long-stemmed racemes; corolla pale rose color or sometimes almost white, with a broad standard and wing-petals. Fruit $3^{\prime}-4^{\prime}$ long, abont $\frac{1^{\prime}}{3}$ wide, glandular-hispid, with a narrow wing; seeds dark brown, slightly mottled, $\frac{1}{16}$ ' long.

A tree, sometimes $20^{\circ}-25^{\circ}$ high, with a trunk $6^{\prime}-8^{\prime}$ in diameter, and branehlets at first pale and coated with rusty brown glandular hairs increasing in length during the summer, and slightly puberulons, bright reddish brown, often covered with a glaneous bloom, and marked by a few small seattered pale lenticels during their first winter; more often a low shrub. Bark of the trunk thin, slightly furrowed, light brown, the surface separating into small plate-like seales. Wood heavy, exceedingly hard, strong, close-grained, yellow streaked with brown, with light yellow sapwood of 4 or 5 layers of annual growth.

Distribution. Banks of mountain streams; valley of the Purgatory River, Colorado, through northern New Mexico to the Santa Catalina and Santa Rita Mountains, Arizona, up to elevations of $7000^{\circ}$ above the sea-level, and to southern Utah; probably of its largest size near Trinidad, Colorado.

Occasionally cultivated as an ornamental tree in the eastern states, and in western Europe.

\section{Robinia viscosa, Vent. Clammy Locust.}

Leaves $7^{\prime}-12^{\prime}$ long, with stout nearly terete dark glandular-hispid clammy petioles, and 13-21 leaflets; stipules subulate, chartaeeous, of ten deciduous or developing into short slender spines; leaflets ovate, sometimes acuminate, mucronate, rounded or pointed at the apex, and wedge-shaped at the base, when they unfold eovered 
below with soft white pubescence, and slightly puberulous above, and at maturity dark green and glabrous on the upper surface, pale and pubescent on the lower surface, especiaily along the slender yellow midribs and primary veins and on the stout glandular-hispid petiolules, $1 \frac{1^{\prime}}{2}-2^{\prime}$ long and $\frac{2^{\prime}}{3}$ wide; stipels slender, deciduous. Flowers $\frac{2^{\prime}}{3}$ long, almost inodorous, appearing in June, on slender hairy pedicels from the axils of large lanceolate acuminate dark-red bracts contracted at the apex into long setaceous points exserted beyond the flower-buds and mostly deciduous before the flowers open, in short ovate crowded glandular-hispid racemes; calyx dark red, coated on the outer surface and on the margins of the subulate lobes with long pale hairs; corolla pale rose or flesh color, with a narrow standard marked on the inner face by a pale yellow blotch, and broad side petals. Fruit linear-lanceolate, narrowly winged, glandular-hispid, $2^{\prime}-3 \frac{1^{\prime}}{2}$ long; seeds $\frac{1^{\prime}}{8}$ long, dark reddish brown and mottled.

A tree, $30^{\circ}-40^{\circ}$ high, with a trunk $10^{\prime}-12^{\prime}$ in diameter, slender spreading branches, and dark reddish brown branchlets covered with conspicuous dark glandular hairs exuding, like those on the petioles and legumes, a clammy, sticky substance, during their first winter bright red-brown, covered with small black lenticels and very sticky, becoming in their second year light brown and dry; or a shrub, often only

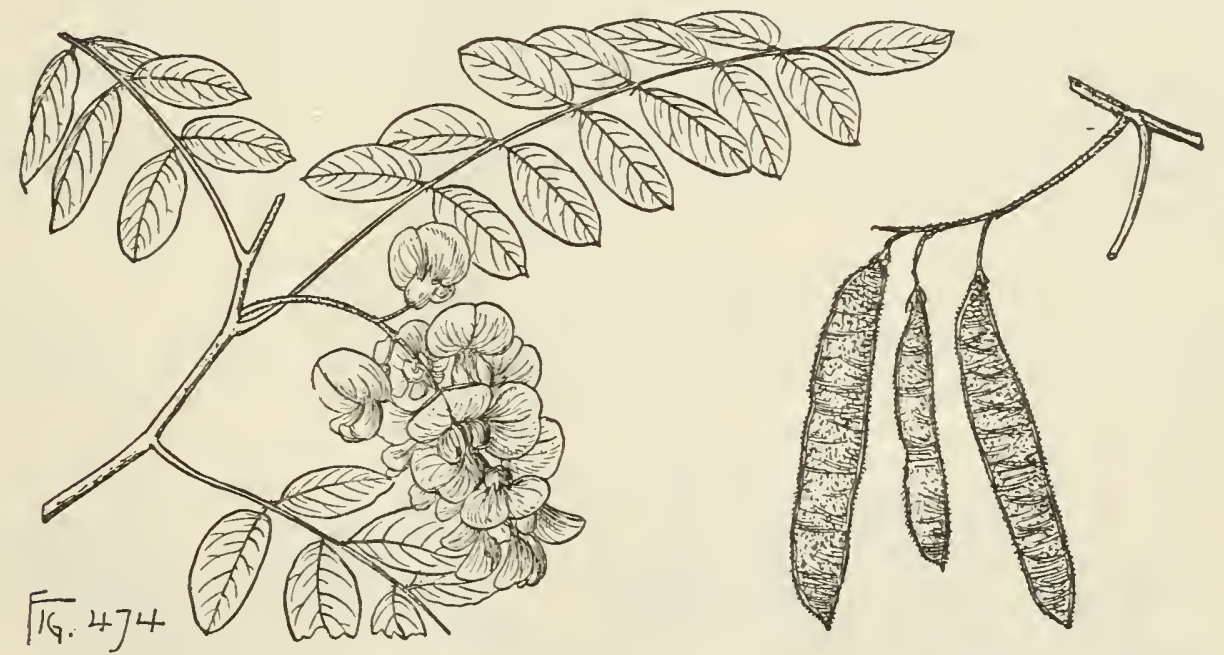

$5^{\circ}-6^{\circ}$ tall. Bark of the trunk $\frac{1^{\prime}}{8}$ thick, smooth, dark brown tinged with red, Wood heavy, hard, close-grained, brown, with light yellow sapwood of 2 or 3 layers of annual growth.

Distribution. Mountains of North and South Carolina, and now naturalized in many parts of the United States east of the Mississippi River and as far north as eastern Massachusetts.

Often planted as an ornament of parks and gardens in all countries with temperate climate.

\section{OLNEYA, Gray.}

A tree, with thin scaly bark, and stout terete hoary-canescent slightly angled branchlets armed with stont infrastipular spines. Leaves equally or unequally pinnate, hoary-canescent, persistent, 10-15-foliolulate, destitute of stipules and stipels, short-petiolate, often fascicled in earlier axils; leaflets cuneate, oblong or obovate, entire, obtuse, often mucronate, rigid, short-petiolulate, reticulate-veined, with broad 
conspicuous midribs. Flowers on stont pedicels rather longer than the calyx, in short axillary few-Howered hoary-eanesecnt racemes, with acute minute bracts and bractlets deciduous before the expausion of the flowers; calyx hoary-cauesecnt, the lobes ovate, obtuse, almost equal, the two npper comnate nearly thronghont; disk cupuliform, adnate to the tube of the calyx; corolla papilionaceons; petals unguiculate, purple or violet, inserted on the disk; standard orbicular, decply emarginate, reflexed, furnished at the base of the blade with two infolded ear-shaped appendages covering 2 prominent callosities; wings oblique, oblong, slightly anricnlate at the base of the blade on the upper side, free, as long as the broad obtuse incurved keel-petals; stamens 10, the superior one free, filling the slit in the tube formed by the nnion of the others; filaments filiform; anthers of the same length, oblong, uniform; ovary sessile or slightly stipitate, pilose; style inflexed, bearded above the middle; stigma thick and fleshy, depressed-capitate; ovnles numerous, suspended from the inner angle of the ovary, superposed. Legume oblique, compressed, glandular-hairy, light brown, 2-valved, often tipped with the remuants of the long persistent style, 1-5-seeded, the valves thick and coriaceous, becoming unequally and interruptedly convex at maturity. Seeds broadly ovate, slightly angled on the ventral side, suspended by short thick funicles, withont albumen; seed-coat thin, membranaceous, bright chestnut-brown and lustrous; embryo filling the cavity of the seed; cotyledons thick and fleshy, accumbent on the short incurved radicle.

The genus is represented by a single species of southern Arizona, California, and northwestern Mexico.

Olneya is in memory of Stephen T. Olney (1812-1878), author of a catalogue of the plants of Rhode Island.

\section{Olneya Tesota, Gray. Ironwood.}

Leaves $1^{\prime}-2 \frac{1}{2}^{\prime}$ long, with leaflets $\frac{1^{\prime}}{2}-\frac{3^{\prime}}{4}$ in length, appearing in June and persistent until the following spring. Flowers unfolding with the leaves, nearly $\frac{1}{2}$ long.

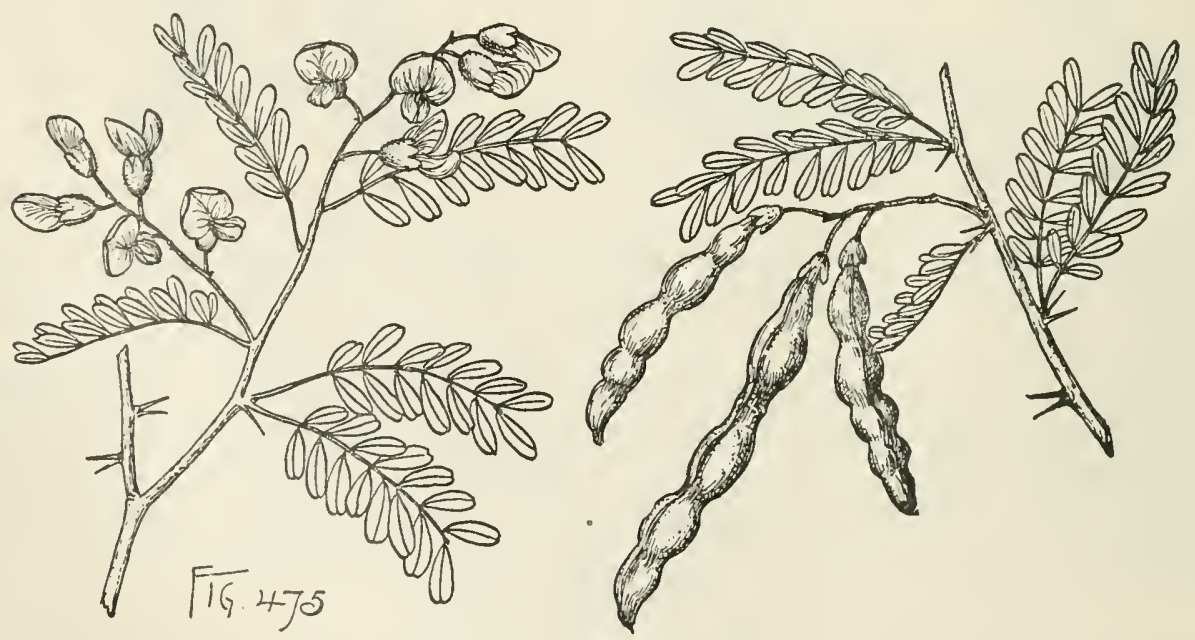

Fruit light brown, very glandular, fully grown at midsummer, ripening before the end of August, $2^{\prime}-2 \frac{1^{\prime}}{2}$ long.

A tree, sometimes $25^{\circ}-30^{\circ}$ high, with a short trunk occasionally $18^{\prime}$ in diameter and usually divided $4^{\circ}-6^{\circ}$ above the ground into a number of stont upright branches, 
and slender branchlets thickly coated at first with hoary-canescent pubescence disappearing early in their second year, and then pale green and more or less spotted and streaked with red, becoming pale brown in their third season, their spines straight or slightly curved, very sharp and rigid, $\frac{1}{8}^{\prime}-\frac{1}{4}^{\prime} l o n g$, and persistent at least during two years. Bark of the trunk thin, exfoliating in long longitudinal dark redbrown scales. Wood very heavy, hard and strong, although brittle, rich dark brown striped with red, with thin clear yellow sapwood; valued as fuel and sometimes manufactured into canes and other small objects.

Distribution. Sides of low depressions and arroyos in the desert; valley of the Colorado River south of the Mohave Mountains, California, to southwestern Arizona, and to Sonora and Lower California; most abundant and of its largest size in Sonora.

\section{ICTHYOMETHIA, P. Br.}

A tree, with thin scaly bark, stout terete branchlets without terminal buds, coated at first with thick rufous pubescence disappearing during the first summer, becoming glabrous or glabrate, bright reddish brown, conspicuously marked by oblong longitudinal lenticels and large elevated horizontal slightly obcordate leaf-scars marked by the ends of numerous small scattered fibro-vascular bundles, and obtuse axillary buds with thin scales clothed with silky rufous hairs. Leaves unequally pinnate, long-petiolate, $\check{5}-11$-foliolate, deciduous ; leaflets opposite, oval, obovate or broadly oblong, obtuse or shortly acuminate at the apex, rounded or wedge-shaped at the base, with thick pubescent petiolules, at first coated like the petioles with rufous hairs, at maturity coriaceous, glabrous and dark green above, pale and more or less clothed below with rufous or canescent pubescence along the elevated conspicuous midribs and numerous thin primary veins arching and united at the entire undulate thickened margins, or sometimes covered with soft silky pubescence below. Flowers papilionaceous, on slender pedicels enlarged at the ends, bibracteolate, in canescent ovate densely flowered or elongated thyrsoidal panicles with short 3-12-flowered branches, from axils of the fallen leaves of the previous year; bracts and bractlets minute, scarious, coriaceous; calyx campanulate, canescent, 5-lobed, persistent, the lobes imbricated in the bud, short and broad, the two upper subcomnate, the lower broadly triangular; petals inserted on an annular glandular disk adnate to the interior of the calyx-tube, unguiculate, white tinged with red; standard uearly orbicular, emarginate, hoary-canescent on the outer, marked with a green blotch on the inner surface, its claw as long as the calyx; wings oblong-falcate, auriculate at the base of the blade on the upper side; keel-petals broadly falcate, the claws comuate; stamens 10, the filament of the upper one free at the base only, united above with the others into a long tube; anthers oblong, uniform, versatile; ovary sessile, sericeous, contracted into a filiform incurved style, with a capitate stigma; ovules numerous, suspended from the imer angle of the ovary, 2-ranked. Legume linear-compressed, raised on a stalk longer than the calyx, slightly contracted between the numerous seeds, tomentose-canescent or glabrate, thin-walled, indehiscent, longitudinally 4-winged, the wings developed from the dorsal and ventral sutures, and broad, continuous or interrupted by the abortion of some of the ovules, membranaceous, softly pubescent, their margius undulate or irregularly cut. Seeds oval, compressed, without albumen, laterally attached by short thick funicles; seed-coat thin, crustaceous, red-brown, not lustrous; embryo filling the cavity of the seed; cotyledons planoconvex, oval, fleshy; radicle short, inflexed. 
The genus is represented by a single species distributed from southern Florida through the West Indies to sonthern Mexico.

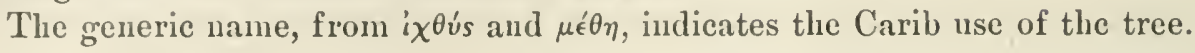

\section{Icthyomethia Piscipula, A. S. Hitch. Jamaica Dogwood.}

Leaves $4^{\prime}-9^{\prime}$ long, with stout petioles, and leaflets $3{ }^{\prime}-4 \frac{1}{2}$ long and $1^{\prime}-2 \frac{1}{2}$ wide, their petiolules thick, $\frac{1}{2}$ long, appearing after the flowers and deciduous in early spring. Flowers opening in May, $\frac{3^{\prime}}{4}$ long, on slender pedicels sometimes $1 \frac{1}{2}^{\prime}$ long, in clusters frequently $10^{\prime}-12^{\prime}$ in length, with long few-flowered branches, or compact, densely-flowered, and $2^{\prime}-4^{\prime}$ long. Fruit ripening in July and August, light brown, $3^{\prime}-4^{\prime}$ long, $1^{\prime}-1 \frac{1 \prime}{2}$ across the thin papery wings.

A tree, $40^{\circ}-50^{\circ}$ high, with a trunk often $2^{\circ}-3^{\circ}$ in diameter, stout erect sometimes contorted branches forming an irregular head. Bark of the trunk about $\frac{1}{8}^{\prime}$ thick,

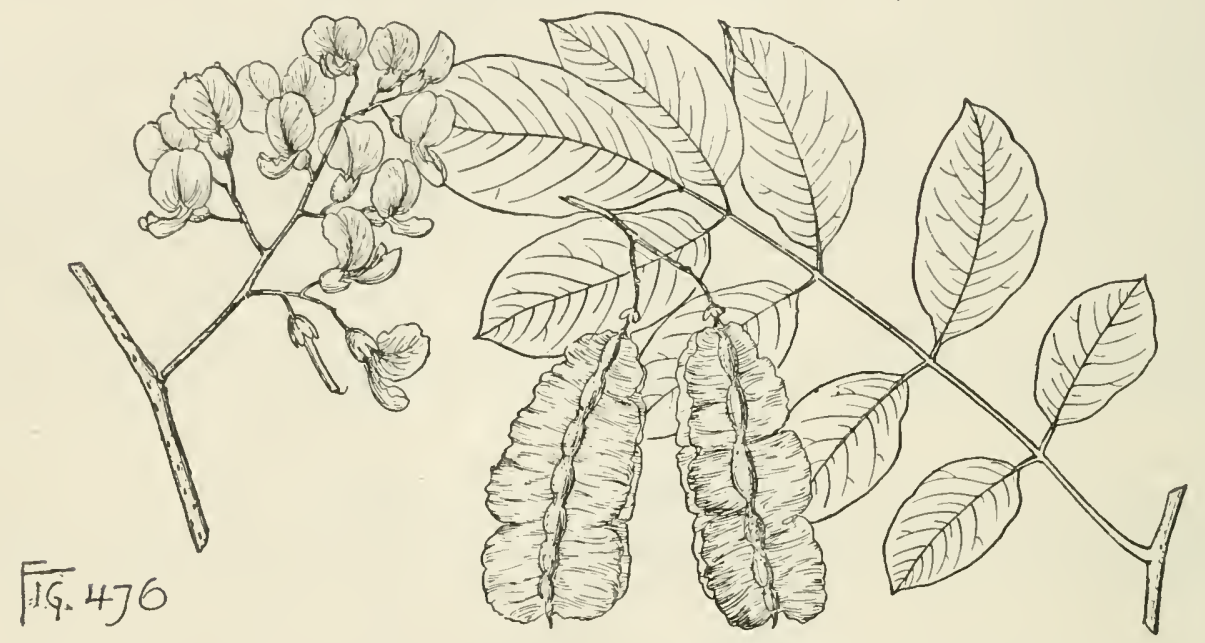

with a light red-brown surface covered with small square scales. Wood very heavy, hard, close-grained, clear yellow-brown, with thick lighter colored sapwood, very durable in contact with the ground; largely used in Florida for boatbuilding, for firewood and charcoal. All parts of the tree, but especially the bark of the roots, contain an active principle, Piscidin, which is said to be effective in producing sleep. In the West Indies the bark of the roots, young branches, and powdered leaves were used by the Caribs to stupefy fish and facilitate their capture.

Distribution. One of the commonest of the tropical trees of Florida from the shores of Bay Biscayne and the southern keys, and on the west coast from the neighborhood of Peace Creek to Cape Sable; in many of the Antilles and in southern Mexico.

\section{ZYGOPHYLLACE丹.}

Trees or shrubs, with hard resinous wood, and opposite pinnate leaves with stipules. Flowers perfect, regular; calyx 5-lobed, the lobes imbricated in the bud; petals as many as the calyx-lobes, imbricated in the bud, hypogynous; stamens twice as many as the petals, hypogynous; filaments distinct; anthers introrse, 2-celled, the cells opening longitudinally ; ovary 5-celled; styles united, terminating in a minute 5-lobed or entire stigma; ovules numerous, suspended, anatropous; raphe ventral. Fruit capsular, angled or 
winged, separating at maturity into 5 indehiscent carpels. Seeds solitary or in pairs in each cell; seed-coat thick and fleshy; embryo straight or nearly so ; cotyledons oval, foliaceous ; radicle short, superior.

Of the fourteen genera of this family, mostly confined to the warmer parts of the northern hemisphere, one only, Guaiacum, has an arborescent representative in the United States.

\section{GUAIACUM, L. Lignum-vitæ.}

Trees or shrubs, with scaly bark, and stout terete alternate branchlets often with swollen nodes. Leaves petiolate, abruptly pinnate, with 2-14 entire reticulateveined leaflets, and minute mostly deciduous stipules. Flowers terminal, solitary or unbellate-fascicled, pedunculate, from the axils of minute deciduous bracts; calyxlobes slightly united at the base, unequal, deciduous; petals broadly obovate, more or less unguiculate; stamens inserted on the inconspicuous elevated disk opposite to and alternate with the petals; filaments filiform, naked or bearing at the base on the inner surface a minute membranaceous scale; anthers oblong; ovary raised on a short thick stalk, obovate or clavate, 5 -lobed, contracted into a slender subulate acute style; ovules 8-10 in each cell, suspended in pairs from the inner angle. Fruit fleshy, 5-celled, smooth, coriaceous, narrowed at the base into a short stem, with 5 wing-like angles, ventrally and sometimes dorsally dehiscent. Seeds suspended, ovoid; seed-coat easily separable from the hard bony nucleus closely invested with a thin indistinct tegumen.

Guaiacum is confined to the New World, and is distributed from southern Florida through the Antilles, Mexico, and Central America to the Andes of Peru. Seven or eight species are distinguished.

Guaiacum produces heavy close-grained wood, the cells of the heartwood filled with dark-colored resin. The lignum-vitæ of commerce, largely used for the sheaths of ship-blocks, mallets, skittle-balls, ten-pin balls, etc., is produced principally by Guaiacum officinale, L., of the Antilles and South America, and by Guaiacum sanctum, L. Guaiacum resin is a stimulating diaphoretic sometimes used in the treatment of gout and rheumatism.

The generic name is from the Carib Guaiaco or Guayacon, the aboriginal name of the Lignum-vitæ.

\section{Guaiacum sanctum, $\mathbf{L}$.}

Leaves $3{ }^{\prime}-1^{\prime}$ long, with $3-4$ pairs of obliquely oblong or obovate mucronate subsessile leaflets, membranaceous, light green and puberulous below when they first appear, becoming subcoriaceous, glabrous, dark green and lustrous on both surfaces, $1^{\prime}$ long and nearly $\frac{1}{2}^{\prime}$ wide, persistent until the appearance of the new growth in March or early April; stipules bro̊adly acuminate, tipped with a short mucro, pubescent, $\frac{1^{\prime}}{8}$ long, usually caducous, but sometimes persistent during the season. Flowers $\frac{2 \prime}{3}$ in diameter, opening almost immediately after the appearance of the new growth, and continuing to open during several weeks, solitary on slender pubescent peduncles shorter than the leaves and usually produced 3 or 4 together at the end of the branches from the axils of the upper leaves, their bracts acuminate, minute, the 2 lateral rather smaller than the others; calyx-lobes obovate, slightly pubescent, especially on the outer surface near the base, and smaller than the blue petals twisted below from left to right, and thus appearing to be obliquely inserted; filaments naked; ovary obovate, prominently 5-angled, glabrous, contracted at the base into 
a short stont stalk. Fruit broadly obovate, $\frac{8^{\prime}}{4}$ long, $\frac{\lambda^{\prime}}{2}$ wide, bright orange color, opening at maturity by the splitting of the thick rather fleshy valves; seeds black, with a thick fleshy scarlet aril-like outer coat.

A gnarled round-headed tree, sometimes $25^{\circ}-30^{\circ}$ high, with a short stout trunk occasionally $2 \frac{1}{2}^{\circ}-3^{\circ}$ in diametcr, slender pendulous branches, and branchlets conspicuonsly enlarged at the nodes, slightly angled, pubescent at first, becoming in

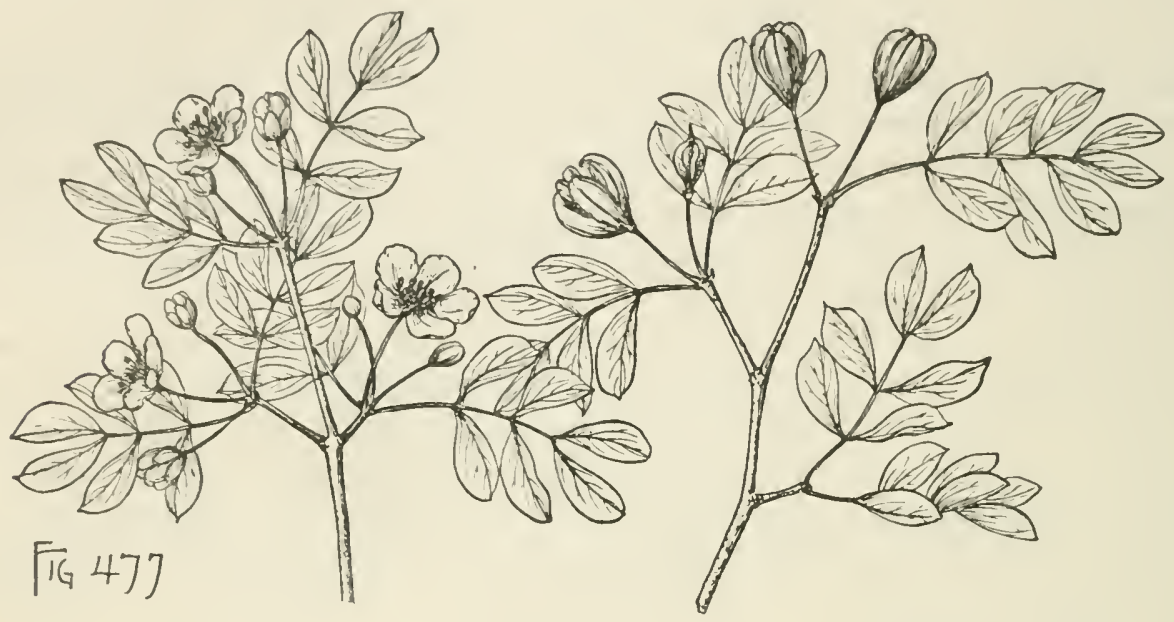

their second year glabrous, nearly white, and roughened by numerous small excrescences. Bark of the trunk rarely more than $\frac{1}{8}$ thick, separating on the surface into thin white scales. Wood dark green or yellow-brown, with thin clear yellow sapwood.

Distribution. Keys of southern Florida from Key West eastward; on the Bahama Islands and on several of the Antilles.

\section{RUTACE円.}

Trees or shrubs, abounding in a pungent or bitter aromatic volatile oil, with simple or compound usually glandular-punctate leaves without stipules or rarely with stipular spines. Flowers regular, perfect or unisexual, in paniculate or corymbose cymes; calyx 3-5-lobed, the lobes more or less united at the base, imbricated in the bud; petals $3-5$, imbricated in the bud; stamens as many or twice as many as the petals; filaments distinct or united below; anthers introrse, 2-celled, the cells opening longitudinally; pistils 1-4, separate or united into a compound ovary sessile or stipitate on a glandular disk ; styles mostly united; ovules usually 2 in each cell of the ovary, pendulous, anatropous or amphitropous; raphe ventral; micropyle superior. Fruit a capsule, samara, or drupe. Seeds solitary or several ; seed-coat bony or crustaceous, furrowed or punctate; embryo axile in fleshy albumen; radicle short, superior.

Of this large family, widely distributed over the warm and temperate parts of the earth's surface, four genera only have arborescent representatives in the United States. Citrus vulgaris, Risso, the Bitter-sweet Orange, a native of Asia, has long been naturalized in the peninsula of Florida, where other species of this genus have escaped from cultivation and are now growing spontaneously. 
CONSPECTUS OF THE ARBORESCENT GENERA OF THE UNITED STATES.

Fruit a 2-valved 1-2-seeded capsule ; flowers diœcious or polygamous.

1. Fagara.

Fruit of 3 or 4 winged indehiscent 1 -seeded carpels ; flowers perfect.

2. Helietta.

3. Ptelea.

Fruit a winged samara ; flowers polygamous.

Fruit a 1-seeded drupe; flowers perfect or polygamous.

4. Amyris.

\section{FAGARA, I.}

Trees or shrubs, with acrid aromatic bark, pellucid aromatic-punctate fruit and foliage, scaly buds, and usually stipular spines. Leaves alteruate, unequally or rarely equally pinnate; leaflets generally opposite, often oblique at the base, entire or crenulate. Flowers small, diœcious or polygamous, in axillary or terminal broad or contracted pedunculate cymes; calyx and petals hypogynous; disk small or obscure; stamens as many as the petals and alternate with them, hypogynous, effete, rudimentary or wanting in the female flower; filaments filiform or subulate; pistils 1-4, oblique, raised on the summit of a fleshy gynophore, connivent, sometimes slightly united below, rudimentary, simple or $2-5$-parted in the sterile flower; ovaries 1-celled; styles short and slender, more or less united toward the summit; stigmas capitate; ovules collateral, pendulous from the inner angle of the cell. Fruit a capsule of 1-5 coriaceous or fleshy 1 -seeded carpels, broadly obovate, sessile or stipitate, ventrally dehiscent. Seed oblong or globular, suspended on a slender funiculus, often hanging from the carpel at maturity; seed-coat black, shining, conspicuously marked by the broad hilum; cotyledons oval or orbicular, foliaceous.

Fagara is widely distributed through tropical and extratropical regions and is most abundant in tropical America. It is represented in North America by four arborescent species of the southern states. The resin contained in the bark, especially in that of the roots, is a powerful stimulant and tonic occasionally used in medicine.

The generic name, of Arabic origin, was used by the Greeks to designate a plant now unknown.

CONSPECTUS OF THE ARBORESCENT SPECIES OF THE UNITED STATES.

Flowers in axillary contracted cymes; branches armed with stipular spines.

Flowers in terminal cymes.

1. F. Fagara (D, E).

Calyx-lobes and petals 5 ; leaves unequally pinnate.

Leaves deciduous; branches armed with stout spines.

Leaves persistent; branches without spines.

2. F. Clava-Herculis (C).

3. F. flava (D).

Calyx-lobes and petals 3 ; leaves equally pinnate, persistent.

4. F. coriacea (D).

\section{Fagara Fagara, Small. Wild Lime.}

\section{(Xanthoxylum Fagara, Silva N. Am. i. 73.)}

Leaves persistent, $3^{\prime}-4^{\prime}$ long, with broadly winged jointed petioles, and 7-9 oborate leaflets rounded or emarginate at the apex, minutely crenulate-toothed above the middle, sessile, $\frac{1^{\prime}}{2}$ long or less, coriaceous, glandular-punctate, bright green and lustrous, with minute hooked deciduous stipular prickles. Flowers on short pedicels from the axils of minute ovate obtuse deciduous bracts, in short axillary contracted cymes, appearing singly or in pairs from April until June, on branches of the previous year, from minute dark brown globular buds, the staminate and pistillate on different trees; sepals 4 , membranaceous, much shorter than the 4 ovate yellow-green petals; 
stamens 4, with slender exserted filaments, 0 in the fertile flower; pistils 2 , with ovatc sessile ovaries, gradually contracted into long slender snbulate exscrted styles united near the apex and crowned with obliquely spreading stigmas, rudimentary in the

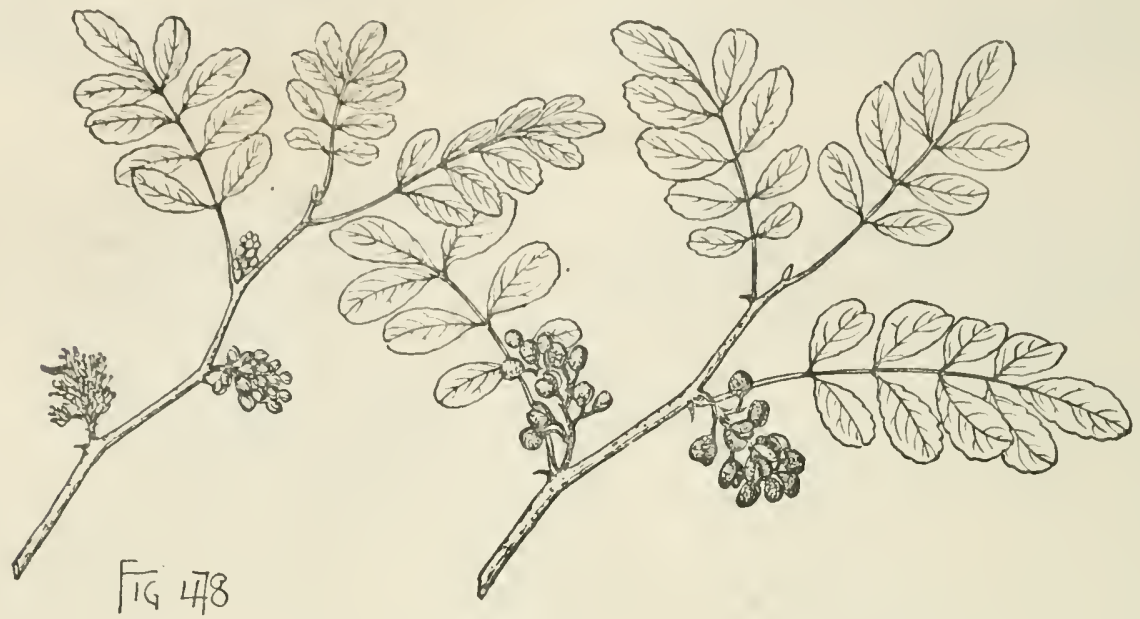

staminate flower. Fruit ripening in September, obovate, rusty brown and rugose, $\frac{1}{8}-\frac{1}{4}$ long; seed solitary, dark and lustrons.

A tree, occasionally $25^{\circ}-30^{\circ}$ high, with a slender often inclining trunk, fastigiate branches, and more or less zigzag slender dark gray branchlets armed with sharp hooked stipular spines; more frequently a tall or low shrub. Bark of the trunk about $\frac{1^{\prime}}{8}$ thick, the smooth light gray surface broken into small appressed persistent scales. Wood heavy, hard, very close-grained, brown tinged with red, with thin yellow sapwood of 10-12 layers of annual growtl.

Distribution. Coast and islands of southern Florida, and Texas from Matagorda Bay to the Rio Grande; one of the commonest of the south Florida plants and arborescent on the rich hmmmock soil of Elliott's Key and the shores of Bay Biscayne; in Texas generally shrubby; common in northern Mexico, and widely distributed through the Antilles, southern Mexico, and Central and South America to Brazil and Peru.

\section{Fagara Clava-Herculis, Small. Prickly Ash. Toothache-tree.}

\section{(Xanthoxylum Clava-Herculis, Silva N. Am. i. 67.)}

Leaves $5^{\prime}-8^{\prime}$ long, with stout pubescent or glabrous spiny petioles, and 3-9 pairs of ovate or ovate-lanceolate sometimes slightly falcate subcoriaceous leaflets usually oblique at the base, crenulate-serrate, sessile or short-stalked, $1^{\prime}-2 \frac{1}{2}^{\prime}$ long, green and lnstrons above, paler and often somewhat pubescent below, especially when they unfold, persistent until late in the winter or until the appearance of the new leaves in early spring. Flowers on slender pedicels $\frac{1^{\prime}}{3}-1^{\prime}$ long, from the axils of minute lanceolate decidnous bracts, in ample wide-branched cymes $4^{\prime}-5^{\prime}$ long and $2^{\prime}-3^{\prime}$ broad, appearing when the leaves are about half grown, the staminate and pistillate on different individuals; sepals minute, membranaceous, persistent, barely one fourth the length of the oval green petals $\frac{1^{\prime}}{8}-\frac{1^{\prime}}{4}$ long; stamens 5, with slendar filiform filaments, conspicuously exserted from the male flowers, rudimentary or wanting in the female flowers; pistils 3 , rarely 2, with sessile ovaries and short styles crowned by a slightly 2-lobed stigma. Fruit ripening in August and September, in dense often 
nearly globose clusters; matıre carpels obliquely ovoid, 1 -seeded, chestnut-brown, $\frac{1}{4}^{\prime}$ long, with a rugose or pitted surface; seeds hanging at maturity outside the carpels.

A round-headed tree, $25^{\circ}-30^{\circ}$, or exceptionally $50^{\circ}$ high, with a short trunk $12^{\prime}$ $18^{\prime}$ in diameter, numerous branches spreading nearly at right angles, and stout "branchlets covered when they first appear with brown pubescence, becoming glabrous and light gray in their second year, and marked by small glandular spots and by large elevated obcordate leaf-scars displaying a row of large fibro-vascular bundle-scars, and armed with stout straight or sometimes slightly curved sharp chestnut-browu spines $\frac{1}{2}^{\prime}$ or more long, with perpendicularly flattened enlarged bases; or often a low shrub. Winter-buds short, obtuse, dark brown or nearly black. Bark of the trunk barely $\frac{1}{16}$ thick, light gray, and roughened by corky tubercles, with ovoid dilated bases sometimes $1^{\prime}$ or more across and thick and rounded at the apex. Wood light,

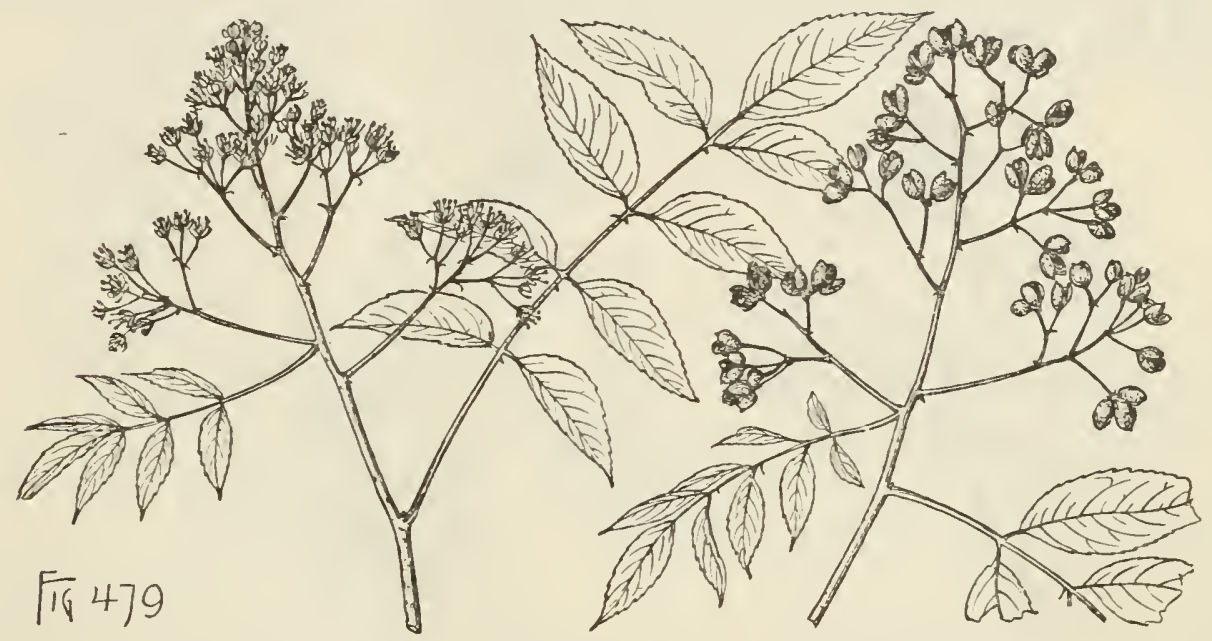

soft, close-grained, and light brown, with yellow sapwood. The bark, which is collected in large quantities by the negroes of the southern states, is used as a cure for toothache and in the treatment of rheumatism.

Distribution. Southern Virginia southward near the coast to the shores of Bay Biscayne and Tampa Bay, Florida, and westward through the Gulf states to northern Louisiana and southern Arkansas, and through Texas to the valley of the Devil's River; in the Atlantic states not abundant, and confined to the immediate neigliborhood of the coast, growing in light sandy soil and often on the low bluffs of islands or on river banks; on the Gulf coast ranging farther inland, especially west of the Mississippi River; most abundant in eastern Texas, and of its largest size on the rich intervale lands of the streams flowing into the Trinity River. In southern Florida and western Texas a form occurs (var. fruticosa, Sarg., nov. nom.), with short sometimes 3-foliolate more or less pubescent leaves, with small ovate or oblong blunt and conspicuous crenulate rather coriaceous leaves; this is the common form of western Texas, growing usually as a low shrub.

\section{Fagara flava, Kr. \& Urb. Satinwood.}

\section{(Xanthoxylum flavum, Silva N. Am. xiv. 98.)}

Leaves unequally pinnate, persistent, usually $6^{\prime}-9^{\prime} \mathrm{long}$, with stout glandular petioles enlarged at the base, and usually 5 , sometimes 3 , or rarely 1 leaflet, unfold- 
ing in Florida during the month of June, densely covered with tomentum when they first unfold, and at matnrity sparingly hairy on the petioles and midribs of the leaflets; leaflets ovate-laneeolate or clliptieal and obtuse, often slightly falcate, sometimes oblique at the base, nearly sessile or long-stalked, $2^{\prime}-3^{\prime}$ long, $1 \frac{1^{\prime}}{2}-2^{\prime}$ broad, entire or slightly crenulatc, coriaceous, pale yellow-green and eonspieuously marked by large pellucid glands. Flowers appearing in Florida in Junc, on slender pubescent pedieels $\frac{1}{4}^{\prime}$ or more long, in wide-spreading pubeseent sessile eymes, the male and female on different trees; ealyx-lobes 5, minute, acuminate, eiliate on the margins, barely onc eighth of the length of the ovate greenish whitc petals reflexed when the flowers are fully expanded; stamens 5, with slender filaments much longer than the petals, 0 in the pistillate flower; pistils 2 or sometimes 1 , with a stipitate obovate ovary and a short style with a spreading entire stigma, minute and depressed in the staminate flower. Fruit ripening in autumn and early winter and sometimes persistent unitil the spring of the following year; mature carpels obliquely obovate,
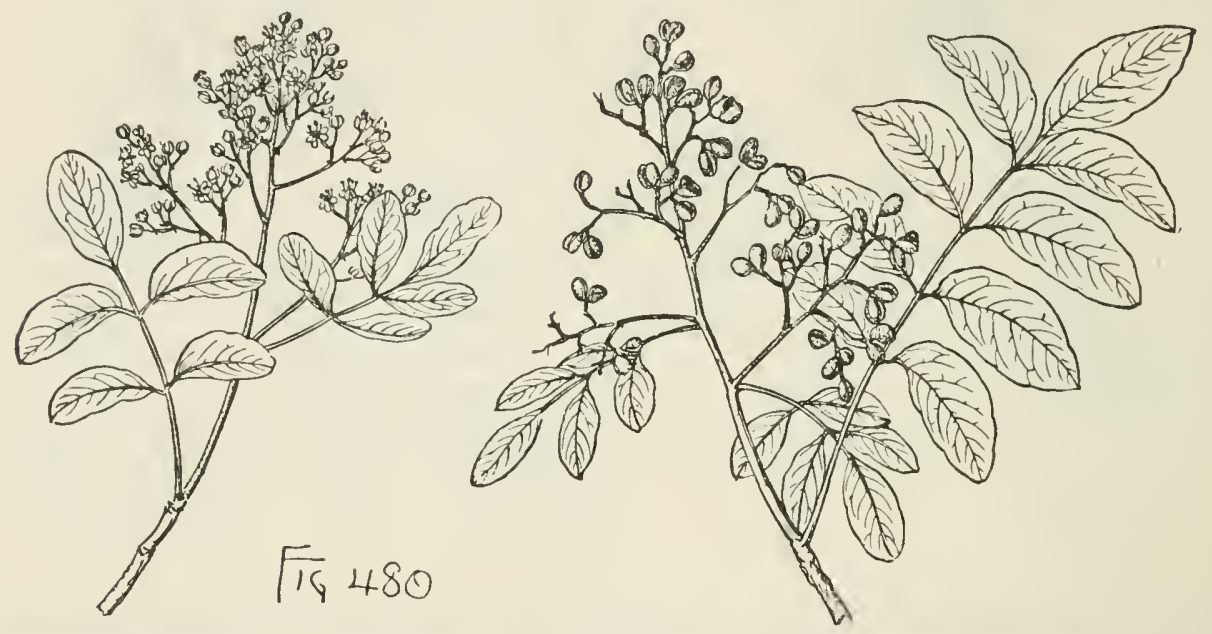

short-stalked, 1-seeded, pale chestnut-brown at maturity, about $\frac{1}{3}^{\prime}$ long, faintly marked by minute glands.

A round-headed tree, $30^{\circ}-35^{\circ}$ high, with a trunk $12^{\prime}-18^{\prime}$ in diameter, and stout brittle branchlets coated at first with thick silky pubescence, beeoming light gray, rngose, conspieuously marked by large triangular leaf-scars, and puberulous during their second and third years. Winter-buds narrowly acuminate, $\frac{1}{2}^{\prime}$ long, coated with short thick pale tomentum. Bark of the trunk $\frac{1}{4}^{\prime}$ thick, with a smooth light gray surface divided by shallow furrows and broken into numerous short appressed scales. Wood very heavy, exceedingly hard, brittle, not strong, light orange-eolored, with thin rather lighter colored sapwood; oceasionally used in southern Florida in the manufacture of furniture, for the handles of tools, and other objects of domestie use.

Distribution. In Florida on the Marquesas Keys and on South Bahia Honda and Boca Chica Keys; on the Bahama Islands, Bermuda, San Domingo, and Porto Rico.

\section{Fagara coriacea, $\mathbf{K r}$. \& Urb.}

Leaves equally pinnate, persistent, $2^{\prime}-3^{\prime}$ long, with stout grooved petioles, and 6-8 oblong-obovate stalked coriaceous dark yellow-green lustrous leaflets rounded or rarely emarginate at the apex, $1^{\prime}-1 \frac{33^{\prime}}{4}$ long and $\frac{5^{\prime}}{8}-\frac{3^{\prime}}{4}$ wide, with much-thickenèd 
revolute entire margins, stout midribs, slender obscure spreading primary veins, and reticulate veinlets. Flowers yellow, appearing in March on short stout pedicels,

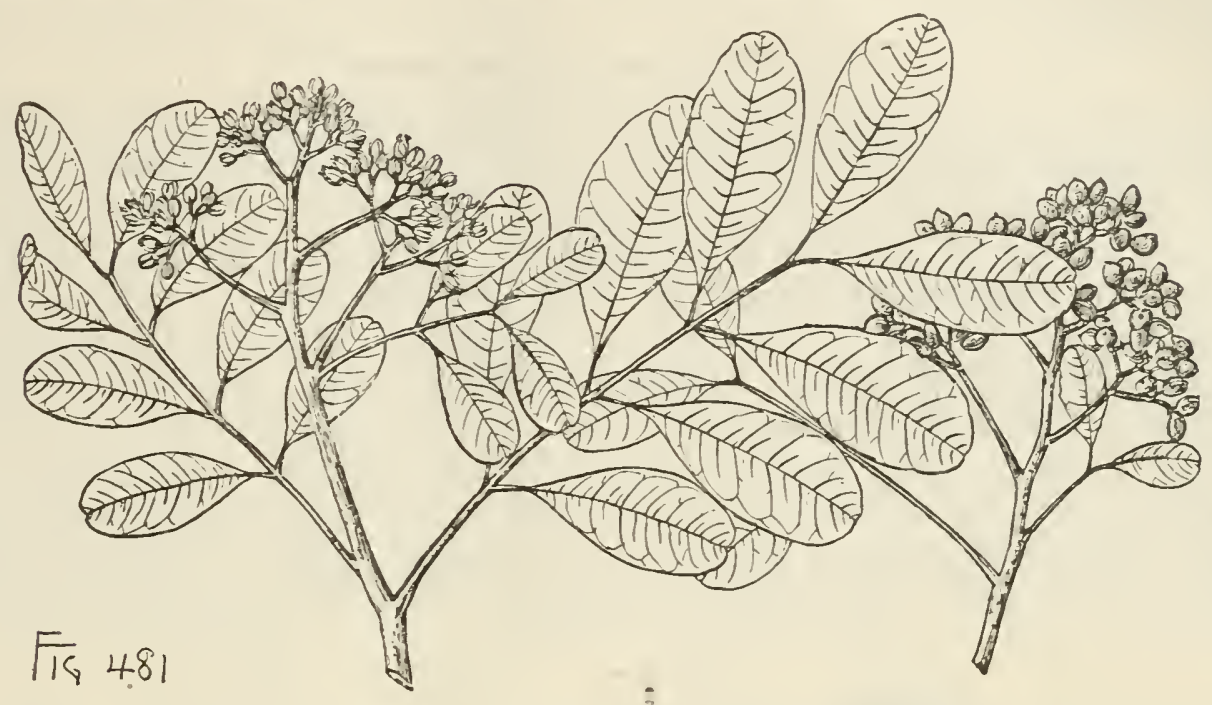

in densely flowered terminal cymes; sepals 3, minute, united below, free above, much shorter than the 3 oval or obovate petals rounded at the apex; stamens 3 ; filaments about as long as the petals; anthers ovate or oval; ovary 3-celled, globoseovate; styles thick, 3 (teste Urban). Fruit: mature fruit not seen.

A glabrous tree, sometimes $18^{\circ}-20^{\circ}$ high, with a slender stem and stout red-brown branches unarmed in Florida specimens, or in the West Indies furnished with short recurved spines; more often shrubby.

Distribution. Shores of Bay Biscayne and at Fort Lauderdale, Florida; rare and still very imperfectly known; on the Bahama Islands and in Cuba.

\section{HELIETTA, Tul.}

Trees or shrubs, with slender terete branches. Leaves opposite, long-petiolate, trifoliate, persistent; leaflets sessile, obovate-oblong, obtuse, entire or crenate, subcoriaceous, grandular-punctate, the terminal the largest. Flowers regular, perfect, on slender bibracteolate pedicels, in terminal or axillary panicles; calyx 4-parted, the divisions imbricated in the bud, slightly united at the base, persistent; petals 4 , imbricated in the bud, hypogynous, oblong, concave, glandular-punctate, reflexed at maturity; stamens inserted under the disk; filaments shorter than the petals, slightly flattened, glabrous; anthers ovate, cordate at the base, attached on the back below the middle; disk free, cup-shaped, erect, subcorrugated, with a sinuate margin, 4-lobed, the lobes entire or crenate and opposite the petals; ovary minute, sessile, depressed, 4-lobed, glandular-verrucose or minutely pilose, the lateral lobes slightly compressed, 4-celled; styles united into a single slender column crowned by the globose 3-4-lobed stigma; ovules collateral, anatropons. Fruit obconical, composed of 3 or 4 dry woody 1 -seeded indehiscent carpels with a cartilaginous endocarp and with prominent horizontal wings, separating at inaturity. Seed linear, oblong, seed-coat crustaceous, fragile, black; cotyledons straight, obtuse.

Helietta is distributed from the valley of the Rio Grande in Texas to Brazil and 
Paraguay. Four species are recognized; one species extends across the Rio Grande into western 'Texas.

The generic name is in honor of $\mathrm{J}_{\mathcal{E}}$ wis Theodore IIélic (1801-1867), a distinguished French physician.

\section{Helietta parvifolia, Benth.}

Leaves $1 \frac{1}{2}-2^{\prime}$ long, with sțout slightly elub-shaped petioles, at first puberulent, soon becoming glabrous, and oblong or narrowly obovate leaflets rounded or sometimes slightly emarginate at the apex, gradually and regularly contracted at the base, entire or slightly and remotely crenulate-scrrate, yellow-green and lustrous above, paler bclow, conspicuously marked by black glandular dots, the terminal leaflet $\frac{1^{\prime}}{2}-1 \frac{1}{2}^{\prime}$ long, sometiures $\frac{1}{2}^{\prime}$ wide, and nearly twice as large as the others, persistent on the branches until early spring. Flowers appearing in April and May, on slender pediccls covered at first like the petioles and calyx with short dense pubescence, with minute acuminate early deciduous bracts, in dichotymously branched subsessile panicles on branches of the year from the axils of the upper leaves; petals white, ovate, $\frac{1}{8}^{\prime}$ long, with scattered hairs on the outer surface, and thin scabrons margins, and four or five times longer than the calyx-lobes ; ovary 4-lobed, glandular-punctate
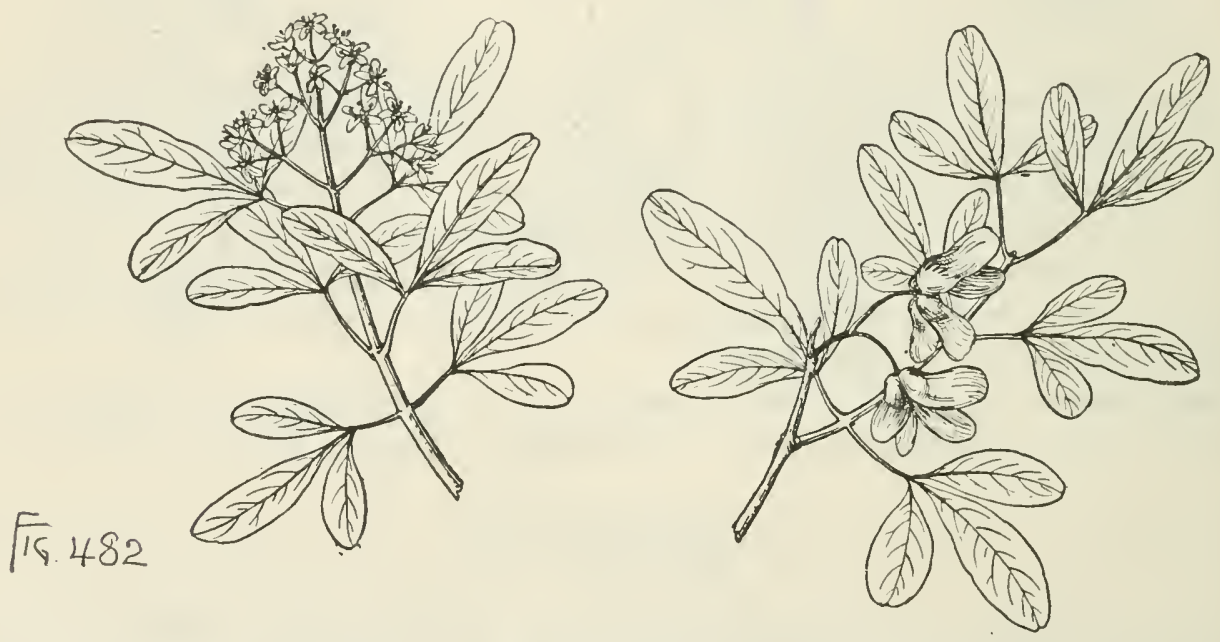

like the slender style. Fruit ripening in October, oblong, $\frac{1}{4}^{\prime}-\frac{1}{3}^{\prime}$ long, with a rigid broadly ovate sometimes slightly falcate wing rounded at the apex, $\frac{1}{2}$ long, and conspicuously reticulate-veined.

A slender tree, $20^{\circ}-25^{\circ}$ high, with a trunk $5^{\prime}-6^{\prime}$ in diameter, rather erect branches forming a small irregular head, and slender pale branchlets covered with minute wart-like excrescences, faintly puberulous when they first appear, soon becoming glabrous, and marked during their second year by small inconspicuous leaf-scars; or a low shrub. Bark of the trunk about $\frac{1}{8}^{\prime}$ thick, covered with rark brown closely appressed scales separating in large irregular patches and leaving when they fall a smooth pale yellow surface. Wood hard, very heavy, close-grained, light orange brown, with rather lighter colored sapwood.

Distribution. Often forming thickets of considerable extent and abundant near Rio Grande city, Texas; mesas south of the lower Rio Grande; of its largest size and tree-like in habit on the limestone ridges of the Sierra Madre of Nuevo Leon. 


\section{PTELEA, L.}

Sinall unarmed trees or shrubs, with smooth bitter bark, slender terete branches without terminal buds, small depressed lateral buds covered with pale tomentum, and nearly inclosed by the narrow obcordate leaf-scars marked by the ends of 2 or 3 small fibro-vascular bundles, and thick fleshy acrid roots. Leaves alternate or rarely opposite, without stipules, long-petiolate, usually trifoliolate, the leaflets conduplicate in the bud, ovate or oblong, entire or crenulate-serrate, punctate with pellucid dots. Flowers polygamous, on slender bracteolate pedicels, in terminal or compound cymes, greenish white; calyx 4 or 5-parted; petals 4 or 5, hypogynous; stamens 3 or 4 , alternate with and as long as the petals, hypogynous, much shorter in the pistillate flower, with imperfect or rudimentary anthers; filaments subulate, more or less pilose, especially toward the base; anthers ovate or cordate; pistil raised on a short gynophore, abortive and nearly sessile in the staminate flower; ovary compressed, 2-3-celled; style short; stigma 2-3-lobed; ovules superposed, amphitropous, the upper ovule only fertilized. Fruit a 2 or 3 -celled broadly winged or rarely wingless indehiscent samara surrounded by a broad reticulate wing. Seed oblong, acute at the apex, rounded at the base, ascending; seed-coat smooth or slightly wrinkled, coriaceous; cotyledons ovate-oblong.

Ptelea is confined to the United States and Mexico, where four or five species are known; of these one is a small tree. The bark and foliage of Ptelea is bitter and strong-scented and possesses tonic properties.

The generic name is from $\pi \tau \epsilon \lambda \epsilon ́ a$, a classical name of the Elm-tree.

\section{Ptelea trifoliata, L. Hop-tree. Wafer Ash.}

Leaves with sessile ovate or oblong pointed leaflets, the terminal one generally larger and more gradually contracted at the base than the others, entire or finely

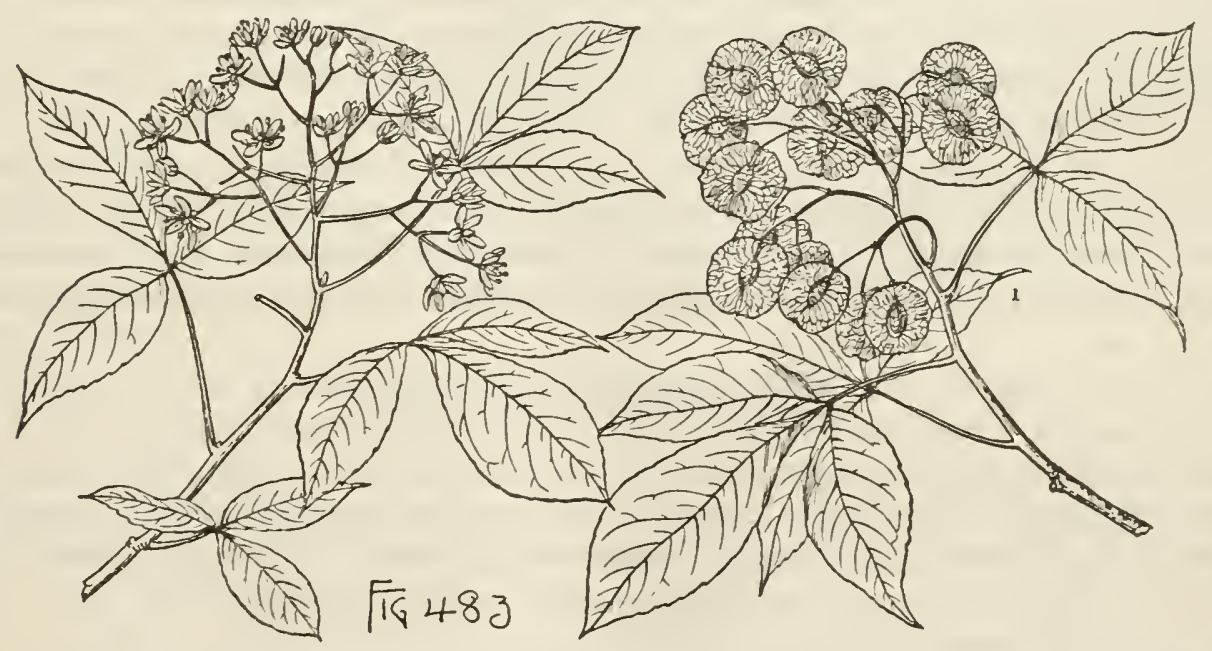

serrate, covered at first with short close pubescence, becoming glabrous and rather coriaceous at matnrity, dark green and lustrous above, pale below, $4^{\prime}-6^{\prime}$ long, $2 \frac{1}{2}^{\prime}-3^{\prime}$ wide, with prominent midribs and primary veins, turning clear yellow in the autumn before falling ; their petioles stout, thickened at the base, and $2 \frac{1}{2}^{\prime}-3^{\prime}$ long. Flowers appearing in early spring on slender pubescent pedicels $1^{\prime}-1 \frac{1}{2}^{\prime}$ long, the pistillate 
and staminate produced together, the staminate usually less numerons and falling soon after the opening of the anther-eells; ealyx and petals pubeseent; ovary puberulous. Fruits with thin ahnost orbicular sometimes slightly obovate wings, nearly $1^{\prime}$ aeross, on long slender reflexed pedieels, in dense drooping clusters renilining on the branehes throngh the winter; seeds $\frac{1}{3}$ long, dark red-brown.

A round-headed tree, rarely $20^{\circ}-25^{\circ}$ high, with a straight slender trunk $6^{\prime}-8^{\prime}$ in diameter, small spreading or ereet branches, and slender branchlets covered at first with short fine pubeseence, becoming glabrons, dark brown, and lustrous, and marked by wart-like exerescences and by the eonspienons leaf-sears; more often a low spreading shrub. Winter-buds depressed, nearly round, palc or almost white. Wood heavy, hard, elose-grained, ycllow-brown, with thin hardly distinguisliable sapwood of 6-8 layers of annual growth. The bitter bark of the roots is sometimes used in the form of tinetures and fluid extracts as a tonie, and the fruit is oceasionally employed domestically as a substitute for hops in brewing beer.

Distribution. Generally on rocky slopes near the borders of the forest, often in the shade of other trees; Point Pelee on the northern shore of Lake Ontario, Long Island, New York, Pennsylvania, and westward to Minnesota and southward to Florida, and through Texas and New Mexico to the valley of the Mimbres River, the monntains of Colorado, and northern Mexico.

Often planted as an ornament of parks and gardens.

\section{AMYRIS, L.}

Glabrous glandular-punctate trees or shrubs, with balsamic resinous juices. Leaves opposite or rarely opposite and alternate, 3-foliolate, without stipules, persistent; leaflets opposite, petiolulate, entire or creuate. Flowers white, minute, on slender bibracteolate pedicels, usually in 3-flowered corymbs in terminal or axillary branched panicles; calyx 4-toothed, persistent; petals 4, hypogynous, much larger than the calyx-lobes, spreading at maturity; disk of the staminate flower inconspicuous, that of the pistillate and perfect flowers thickened and pulvinate; stamens 8 , hypogynous, opposite and alternate with the petals; filaments filiform, exserted; antliers ovate, attached ou the back below the middle; ovary ellipsoidal or ovoid, 1-celled, rudimentary in the staminate flower; style short, terminal, or wanting; stigma capitate; ovules collateral, suspended near the apex of the ovary, anatropous. Fruit a globose or ovoid aromatic drupe; stone 1-seeded by abortion, ehartaceous. Seed pendulons, without albumen ; seed-coat membranaceous; cotyledons plano-convex, fleshy, glandular-punetate.

Amyris is confined to tropical America and northern Mexico. Of the twelve or fourteen species which have been distinguished two extend into the territory of the United States; one of these is a snall West Indian tree common on the shores of southern Florida, and the other a Mexican shrub found growing in Texas near the mouth of the Rio Grande. Amyris is fragrant and yields a balsamic aromatic and stimulant resin, and heavy hard close-grained wood valuable as fuel and sometimes used in cabinet-1naking.

The generie name, from $\mu$ '́p’pa, relates to the balsamie properties of the plants of this genus.

\section{Amyris Elemifera, L. Torch Wood.}

Leaves 3-foliolate, with slender petioles $1^{\prime}-1 \frac{1}{2}^{\prime}$ long, and broadly ovate or rounded obtuse acute or acuminate leaflets wedge-shaped at the base or sometimes ovate- 
lanceolate or rhombic-lanceolate, entire or remotely crenulate, coriaceous, lustrous, dark yellow-green, conspicuously reticulate-veined, covered below with minute glandular dots, $1^{\prime}-2 \frac{1}{2}^{\prime}$ long, with slender petiolules, that of the terminal leaflet often $1^{\prime}$ or more long and twice as long as those of the lateral leaflets. Flowers in terminal pedunculate or nearly sessile panicles appearing in Florida from August to December. Fruit ripening in the spring, ovoid, often nearly $\frac{1^{\prime}}{2}$ long, black covered with a glaucous bloom, with thin flesh filled with an aromatic oil and of rather agreeable flavor.

A slender tree, $40^{\circ}-50^{\circ}$ high, with a trunk sometimes, although rarely, a foot in diameter, and slender terete branchlets covered with wart-like excrescences, at first

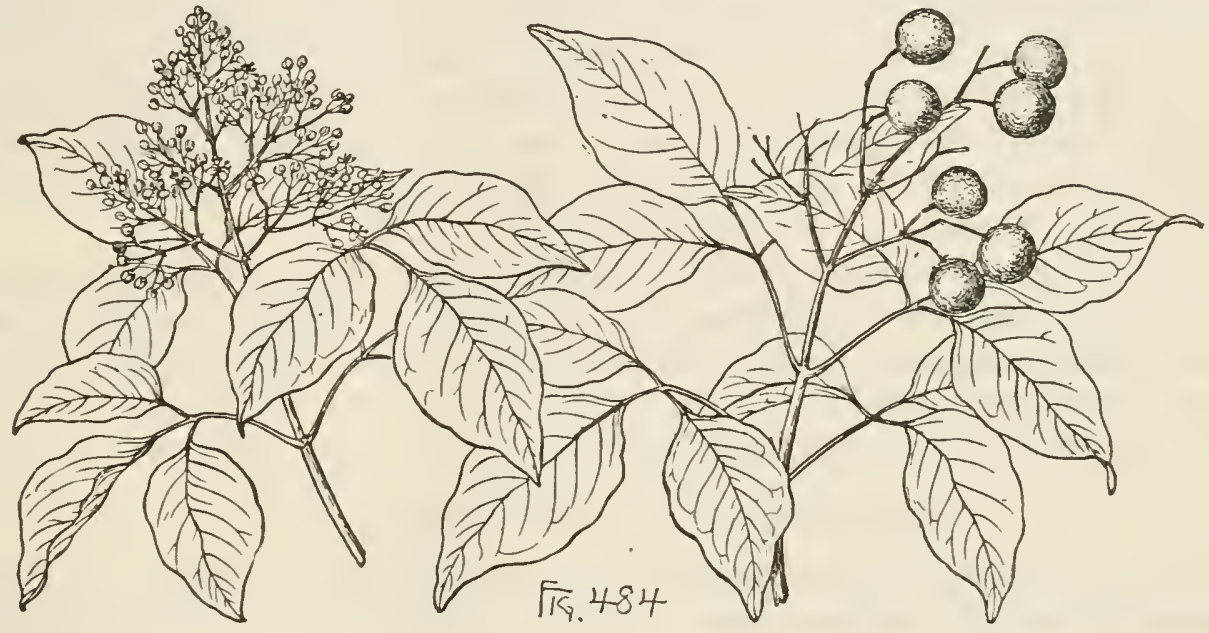

light brown, becoming gray during their second season. Bark of the trunk thin, gray-brown, slightly furrowed and broken into short appressed scales. Winterbuds acute, flattened, $\frac{1}{8}^{\prime}$ long, with broadly ovate scales slightly keeled on the back. Wood heavy, exceedingly hard, strong, close-grained, very resinous, extremely durable, light orange color, with thin rather lighter colored sapwood of 12-15 layers of ammal growth; often used as fuel.

Distribution. Southern Florida from Mosquito Inlet to the southern keys; common in the immediate neighborhood of the coast to the rich hummocks of the interior, and of its largest size on Umbrella Key; on the Bahama Islands and on many of the Antilles.

\section{SIMARUBACE王.}

Trees or shrubs, with bitter juice. Leaves alternate, pinnate, persistent, without stipules. Flowers regular, diœecious ; calyx 5 -lobed, the lobes imbricated in the bud; petals 5 , imbricated in the bud, hypogynous; stamens 10 , inserted under the disk; pistil of 5 united carpels; ovary 5 -celled ; ovule solitary in each cell, anatropous; raphe ventral; micropyle superior. Fruit a drupe.

Of the twenty-eight genera of this family, confined chiefly to the tropics and to the warmer parts of the northern hemisphere, only Simaruba has an arborescent representative in the flora of North America. Ailanthus glandulosa, Desf., the so-called Tree of Heaven, a native of northern China, has been largely planted as an ornament and shade tree in the eastern United States, and is now sparingly naturalized southward. 


\section{SIMARUBA, Aubl.}

Trees, with bitter resinous juiee and tonic properties. Leaves long-petiolate, abruptly pinnate; leatlets usmally alternate, long-petiolnlate, conduplieate in the bud, entire, coriaceous, glabrous or slightly puberulous below, feather-veined. Flowers in elongated widely branched axillary and terminal panicles; disk enp-shaped, depressed in the sterile flower, pubeseent; stamens as long as the petals, in the pistillate flower reduced to minute seales; filaments free, filiform, thiekened toward the base, inserted on the baek of a minute eiliate seale; anthers oblong, slightly emarginate, introrse, attached on the back below the middle, 2 -eelled, the cells opening longitudinally; ovary sessile on the disk, deeply 5-lobed, the lobes opposite the petals, rudimentary, lobulate, minutc or wanting in the staminate flower; styles united into a short eolnmn, with a 3-5-lobed spreading stigma. Fruit eomposed of 1-5 scssile spreading drupes; flesh thin; stone crustaceous. Seeds inverse, without albumen; seed-eoat membranaeeous; cotyledons plano-convex, fleshy, the radiele very short, partly included between the cotyledons, superior.

Sinaruba with four speeies is eonfined to tropical America, and is distributed fron the eoast of southern Florida to Brazil and Guatemala. The plants of this family eontain a small amount of resin, a volatile oil, and an exceedingly bitter principle, quasin, with tonic properties.

The generic name is formed from Simarouba, the Carib name of one of the species.

\section{Simaruba glauca, DC. Paradise-tree.}

Leaves $66^{\prime}-10^{\prime}$ long and glabrous, with stout petioles $2^{\prime}-3^{\prime}$ in length, and usually 6 pairs of opposite or alternate ovate obovate or oval leaflets, rounded or slightly

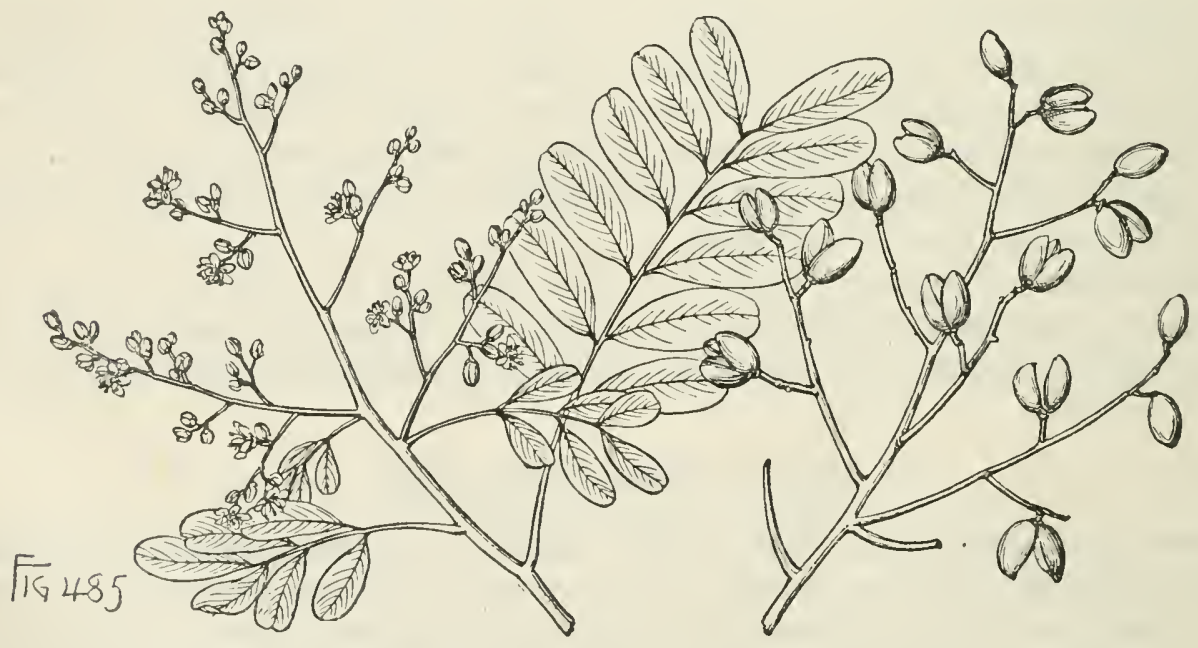

mucronate at the apex, of ten oblique at the base, thin, membranaceons and dark red when they first unfold, soon becoming eoriaceous, dark green, very lustrous above, pale and glaucous on the lower surfaee, $2^{\prime}-3^{\prime}$ long and $1^{\prime}-1 \frac{1}{2}^{\prime}$ wide, with revolute inargins, prominent midribs, remote conspicuous primary veins, and stont petiolules $\frac{1}{4}^{\prime}-\frac{1}{3}^{\prime}$ in length. Flowers appearing in early spring, $\frac{1}{8}^{\prime}-\frac{1}{4}^{\prime}$ long, on short stont clubshaped glancous pedieels, in panieles $12^{\prime}-18^{\prime}$ long and $18^{\prime}-24^{\prime}$ broad, witli a stout pale glaueous stem and spreading branches from the axils of small acute scarious 
deciduous bracts; petals fleshy, oval, often acute, pale yellow, and four or five times longer than the glaucous calyx. Fruit nearly fully grown by the end of April and then bright scarlet, about $1^{\prime}$ long, ovate, sometimes falcate, and slightly angled on the ventral suture, becoming dark purple when fully ripe; seeds papillose, orangebrown, about $\frac{3^{\prime}}{4}$ long.

A round-headed tree, growing occasionally in Florida to the height of $50^{\circ}$, with a straight trunk $18^{\prime}-20^{\prime}$ in diameter, slender spreading branches, and stout branchlets pale green and glabrous when they first appear, becoming light brown before the end of the summer, rugose and conspicuously marked during their second season by the large oval leaf-scars. Bark of the trunk $\frac{1^{\prime}}{2}-3^{\prime}$ thick, light red-brown and broken on the surface into broad thick appressed scales. Wood light, soft, close-grained, light brown, with thick rather darker colored sapwood.

Distribution. Southern Florida from Cape Canaveral to the southern keys and the shores of Bay Biscayne; also in Cuba, Jamaica, Nicaragua, and Brazil.

\section{BURSERACE丑.}

Trees or shrubs, with resinous bark and wood. Leaves alternate, pinnate, without stipules. Flowers perfect or polygamous, in clustered racemes or panicles; calyx 4-5 lobed, the lobes imbricated in the bud, persistent; petals 4-5, imbricated in the bud, distinct or slightly united, deciduous; stamens twice as many as the petals, inserted under the annular or cup-shaped disk; filaments distinct, subulate; anthers introrse, 2-celled, the cells opening longitudinally; pistil of $2-\check{5}$ united carpels; ovary $2-5$-celled; styles united: stigma 2-5-lobed; ovules 2 in each cell, pendulous, collateral, anatropous, micropyle superior; raphe ventral. Fruit drupaceous. Seeds without albumen ; seed-coat membranaceous; embryo straight; cotyledońs foliaceous; radicle short, superior.

Of the sixteen genera of this family, which is widely distributed through the tropics of the two hemispheres, one only, Bursera, occurs in the United States, reaching the shores of southern Florida with a single arborescent species, and southern Arizona with one shrubby species.

\section{BURSERA, Jacq.}

Trees, with balsamic resinóus juices. Leaves alternate, unequally pinnate; leaflets opposite, petiolulate, entire or subserrate, membranaceous. Flowers polygamous, small, on fascicled or rarely solitary pedicels, in short or elongated lateral simple or branched panicles; calyx minute, membranaceous, petals ovate-oblong inserted on the base of an annular crenate disk, reflexed at maturity above the middle; stamens inserted on the base of the disk; anthers oblong, attached on the back above the base, usually effete in the pistillate flower; ovary sessile, ovoid, 3-celled, rudimentary in the staminate flower; style short; stigma capitate, obtuse, 3-lobed; ovules, suspended below the apex from the central angle. Fruit with a valvate epicarp, globose or oblong-oblique, indistinctly 3-angled; flesh coriaceo-carnose, 2-3-valved; nutlets 1-3, usually solitary, adnate to a persistent fleshy axis, 1-celled, 1-seeded, covered with a thin membranaceous coat. Seed ovoid, without albumen; seed-coat membranaceous; hilum ventral, below the apex; embryo straight; cotyledons contortuplicate.

Bursera with about forty species is confined to Mexico, Central and South America, and the West Indies. 
The generic name is in honor of Joachin Burser (1593-1649), a German botanist and physician.

\section{Bursera Simaruba, Sarg. Gumbo Limbo. West Indian Birch.}

Leaves confined to the ends of the branchlets, $6^{\prime}-8^{\prime}$ long, $4^{\prime}-8^{\prime}$ broad, with long slender petioles, and usually 5 , rarely 3 or 7 leaflets, coriaceous at maturity, oblongovate, oblique at the base, contracted at the apex into a long or short point, $2 \frac{1^{\prime}}{2}-3^{\prime}$ long, $11_{2}^{\prime}-2^{\prime}$ broad, with stout petiolules often $\frac{1^{\prime}}{2}$ long, deciduous in early winter or occasionally persistent until the following spring. Flowers about $\frac{3{ }^{\prime}}{16}$ in diameter, appearing before the leaves or as they unfold, on slender pedicels $\frac{1^{\prime}}{3}-\frac{1^{\prime}}{2}$ long, in slender raceme-like panicles, those of the staminate plant $4^{\prime}-5^{\prime}$ long or nearly twice as long as those of the pistillate plant; sepals and petals 5 ; petals ovate-lanceolatc, acute, revolute on the margins, and nearly four times as long as the slender acute calyx-lobes;

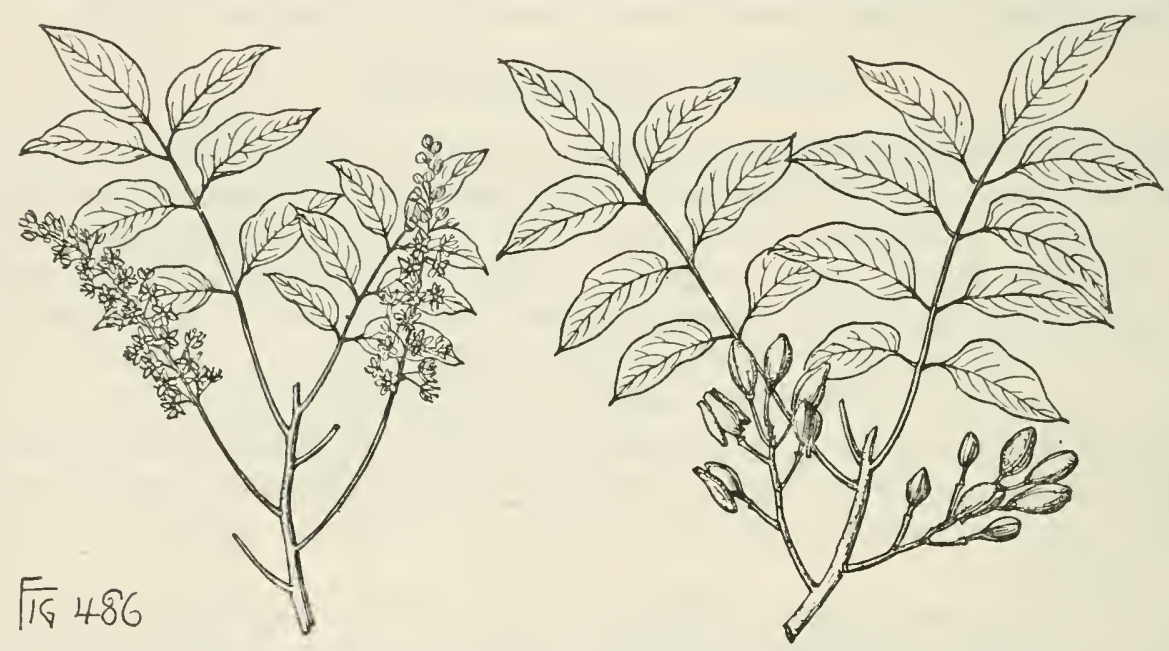

stamens of the staminate flower as long as the petals and in the pistillate flower not more than half as long, with smaller often effete anthers. Fruit in short racemelike clusters, $\frac{1}{4}^{\prime}-\frac{1^{\prime}}{3}$ long, 3 -angled, with a thick dark red outer coat, separating readily into 3 broad ovate valves, and containing 1 or rarely 2 bouy triangular nutlets rounded at the base, pointed at the apex, and covered with a thin membranaceous light pink coat; seeds 1 or 2 , triangular, rose color.

A glabrous tree, $50^{\circ}-60^{\circ}$ high, with a trunk $2 \frac{1}{2}^{\circ}-3^{\circ}$ in diameter, massive primary branches spreading nearly at right angles, and stout terete branchlets light gray during their first season, becoming reddish brown during the second year, covered with lenticular spots and conspicuously marked by large elevated obcordate yellow leaf-scars. Winter-buds short, rounded, obtuse, witl broadly ovate dark red seales slightly scarious on the margins. Bark of the trunk and large branches $\mathbf{1}^{\prime}$ thick, glandular dotted, separating freely into thin papery bright red-brown scales exposing in falling the dark red-brown or gray inner bark. Wood spongy, very light, exceedingly soft and weak, light brown, with thick sapwood, soon becoming discolored by decay. Pieces of the trunk and large branches set in the ground soon produce roots and grow rapidly into large trees. The aromatic resin obtained by incisions cut in the trunk was formerly used in the treatment of gout, and in the West Indies is manufactured into varnish. An infusion of the leaves is sometimes used in Florida as a substitute for tea. 
Distribution. Florida from Cape Canaveral to the southern keys, and on the west coast on the Caloosa River and the shores of Caximbas Bay; one of the largest and most common of the south Florida trees, and the only one which sheds its foliage during the autumn and winter; on most of the West Indian islands, in tropical Mexico, Guatemala, New Granada, and Venezuela.

\section{MELIACE㞔.}

Trees or shrubs, with hard wood and dotless alternate pinnate leaves without stipules. Flowers in panicles, perfect, regular; calyx 5-lobed, the lobes contorted (in Swietenia) in the bud, persistent; petals 5, convolute in the bud; stamens inserted at the base of the disk; filaments united into a tube; anthers introrse, 2 -celled, the cells opening longitudinally ; ovary $3-5$-celled, free, surrounded at the base by an annular or cup-shaped disk; styles united, dilated into a 5-lobed stigma; ovules numerous in each cell, suspended, semianatropous; raple ventral; micropyle superior. Fruit a capsule (Swietenia) or drupe. Seeds often winged; embryo with leafy cotyledons.

A family with about forty genera chiefly confined to the tropics, with a single representative, Swietenia, in southern Florida. Melia Azedarach, L., of this family, the China-tree or Pride of India, with drupaceous fruits, has long been cultivated in the southern states, where it now often grows spontaneously.

\section{SWIETENIA, Jacq.}

Trees, with heavy dark red wood. Leaves abruptly pinnate, glabrous, long-petiolate, persistent; leaflets opposite, petiolate, usually oblique at the base. Flowers perfect, small, in axillary or subterminal panicles produced near the ends of the branches; calyx minute; petals spreading; staminal tube urn-shaped, connate with the petals, 10 -lobed, the lobes convolute in the bud; anthers 10 , fixed by the back below the sinuses of the staminal tube, included; ovary ovoid, 5-celled, the cells opposite the petals; style erect, longer than the tube of the stamens; stigma discoid, 5-rayed. Fruit a 5-celled 5-valved capsule septicidally dehiscent from the base, the valves separating from a persistent 5 -angled axis thickened toward the apex and 5 -winged toward the base. Seeds suspended from near the summit of the axis, imbricated in 2 ranks, compressed, emarginate, produced above into a long membranaceous wing with the hilum at its apex and transversed by the raphe; embryo transverse; cotyledons conferruminate with each other and with the thin fleshy albumen; radicle short, papillæform.

Swietenia with three species is confined to tropical America and west tropical Africa, with one species reaching the shores of sonthern Florida.

The generic name is in honor of Baron von Swieten (1700-1772), the distinguished Dutch physician, founder of the Botanic Garden and of the Medical School at Vienna.

\section{Swietenia Mahagoni, Jacq. Mahogany.}

Leaves $4^{\prime}-6^{\prime}$ long, with slender glabrous petioles thickened at the base and 3 or 4 pairs of ovate lanceolate leaflets rounded at the base on the upper side, narrowly wedge-shaped or nearly straight on the lower side, entire, coriaceous, pale yellowgreen or slightly rufous on the under surface, $3^{\prime}-4^{\prime}$ long, $1^{\prime}-1 \frac{1}{2}^{\prime}$ wide, with prominent reddish brown midribs, conspicuous reticulate veins, and stont grooved petiolules $\frac{1}{4}^{\prime}$ long. Flowers appearing in July and August on slender puberulous pedicels, 
bibracteolate near the middle, 1 or 2 together at the ends of the branches of slender panicles in the axils of leaves of the year; calyx glabrous, cup-shaped, much shorter than the ovate elliptical petals $\frac{1^{\prime}}{8}$ long and slightly cmarginate at the apex. Fruit ripening in the autumn or early winter, long-stalked, $4^{\prime}-5^{\prime}$ long, and $2 \frac{1^{\prime}}{2}$ broad, with

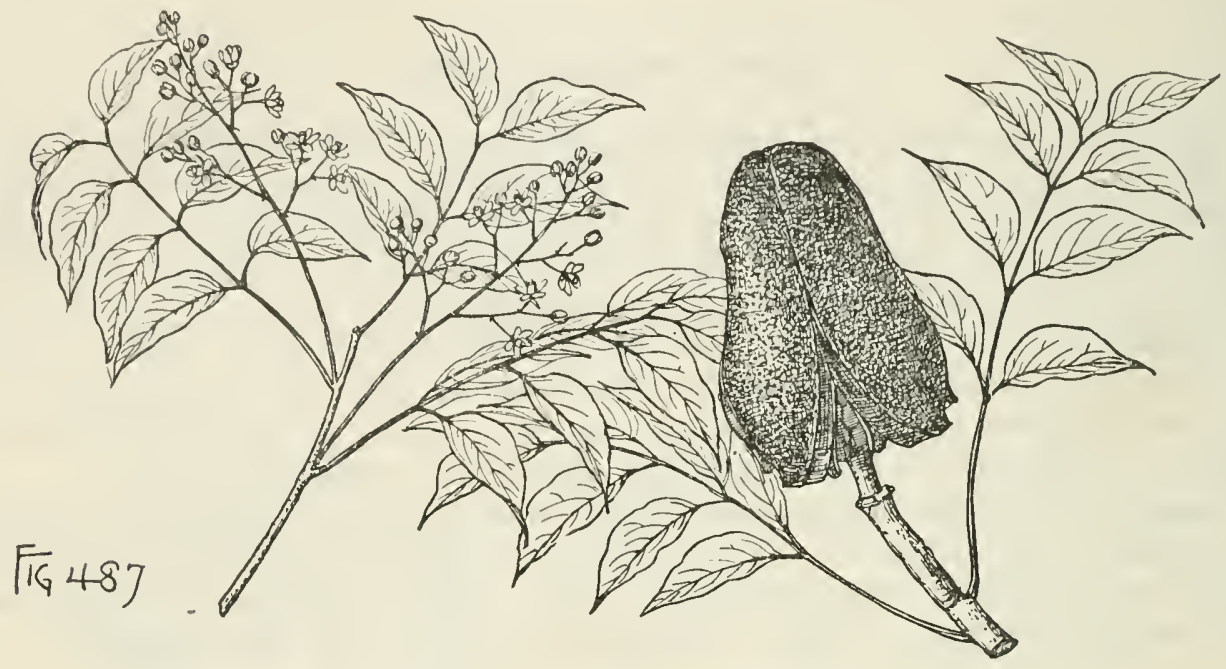

thick dark brown valves rugose and pitted on the surface; its axis $3^{\prime}$ or $4^{\prime}$ long, $1^{\prime}-1 \frac{1}{2}^{\prime}$ thick, dark red-brown, marked near the apex by the dark scars left by the falling seeds; seeds $\frac{3}{4}$ long, almost square, thickened at the base and nearly one fourth as long as their ovate rugose red-brown wings rounded or truncate at the apex and gradually contracted below.

A tree, in Florida rarely more than $40^{\circ}-50^{\circ}$ high or with a trunk exceeding $2^{\circ}$ in diameter, and slender glabrous angled branclılets covered during their first season with pale red-brown bark, becoming lighter or gray faintly tinged with red and thickly coyered with lenticels during their second year; much larger in the West Indies and Central America. Winter-buds about $\frac{1^{\prime}}{8}$ long, with broadly ovate minutely apiculate loosely imbricated light red scales. Bark of the trunk in Florida $\frac{1^{\prime}}{2}-2^{\prime}$ thick, with a dark red-brown surface broken into short broad rather thick scales. Wood heavy, exceedingly hard and strong, close-grained, very durable, rich redbrown, becoming darker with age and exposure, with thin yellow sapwood of about 20 layers of annual growth; the most esteemed of all woods for cabinet-making, and also largely used in the interior finish of houses and railroad cars, and formerly in ship and boatbuilding. The bark is bitter and astringent and has been used as a substitute for quinine in the treatment of intermittent fevers.

Distribution. In Florida only on Key Largo and Elliott's Key; rare and now nearly exterminated; on the Bahama and many of the West Indian islands; widely distributed through tropical Mexico and Central America, and in Peru.

\section{EUPHORBIACEA.}

Trees or shrubs, with milky acrid juice, ând alternate leaves, with stipules. Flowers monœcious or diœcious; calyx 3-6-lobed or parted, the divisions inbricated in the bud, or wanting; corolla 0 ; stamens 2 or 3 , or as many or twice as many as the calyx-lobes; anther's 2-celled, opening longitudinally; 
ovules 1 or 2 in each cell, suspended, anatropous; raphe ventral; micropyle superior. Fruit a drupe or capsule. Seeds albuminous; cotyledons flat, much longer than the superior radicle.

The Euphorbia family, widely distributed over the tropical and temperate regions, with some one hundred and thirty genera and over three thousand species, is represented in the United States by three arborescent genera, with only five species, and by many shrubby herbaceous and annual plants.

\section{CONSPECTUS OF THE ARBORESCENT GENERA OF THE UNITED STATES.}

Fruit drupaceous.

Nutlets usually 1-celled and 1-seeded; stamens as many or twice as many as the calyxlobes, free.

1. Drypetes.

Nutlets 6-S-celled and 6-S-seeded; stamens 2 or 3 , united into a column.

Fruit a 3-lobed capsule splitting into 8 2-valved 1-seeded carpels.

2. Hippomane.

3. Gymnanthes.

\section{DRYPETES, Vahl.}

Trees or shrubs, with thick juice, and terete branchlets. Leaves involute in the bud, petiolate, penniveined, coriaceous, persistent; stipules minute, caducous. Flowers axillary, sessile or pedicellate, their pedicels from the axils of minute deciduous bracts, ebracteolate, the males in many-flowered clusters, the females solitary or in few-flowered clusters; calyx divided nearly to the base into 4 or 5 lobes rounded or acute at the apex, decidıous or persistent under the fruit; stamens inserted under the margin of a flat or concave slightly lobed disk, 0 in the pistillate flower; filaments filiform; anthers ovate, emarginate, attached on the back near the base, extrorse or introrse, 2-celled, the cells affixed to a broad oblong connective; ovary sessile, ovoid, 1 or rarely 2 -celled, with 1 or 2 sessile or subsessile peltate or reniform stigmas, rudimentary or wanting in the staminate flower; ovules collateral, descending, attached to the central angle of the cell, operculate, with a hood-like body developed from the placenta. Fruit drupaceous, ovoid or subglobose, tipped with the withered remnants of the stigmas; flesh thick and corky or thin and crustaceous; stone thick or thin, bony or crustaceous, 1-celled and 1-seeded, or rarely 2-celled and 2-seeded. Seed filling the cavity of the nut; seed-coat crustaceous or membranaceous; embryo erect in thin fleshy albumen.

Drypetes is confined to the tropical regions of the New World, and is distributed from southern Florida through the West Indies to eastern Brazil. Of the eleven species now distinguished, two inhabit the coast of southern Florida.

The generic name, from $\delta \rho v i \pi \pi$, relates to the character of the fruit.

\section{CONSPECTUS OF THE NORTH AMERICAN SPECIES.}

Calyx 5-lobed; stamens $S$; ovary 1-celled; fruit oblong; outer coat thick and mealy; stone thick-walled.

1. D. Keyensis (D).

Calyx 4-lobed; stamens 4; ovary 2-celled; fruit subglobose; outer coat thin, crustaceous ; stone thin-walled.

2. D. lateriflora (D).

\section{Drypetes Keyensis, Urb. White Wood.}

Leaves appearing in early spring and falling during the second year, entire, oval or oblong, often more or less falcate, acute, acuminate, rounded or rarely emarginate at the apex, rounded or wedge-shaped at the base, when they unfold thin and mem- 
branaceous, light green or green tinged with red and pilose, with scattered pale hairs, and at maturity thick and coriaceous, dark green and lustrons, rather paler on the lower than on the upper surface, $3^{\prime}-5^{\prime} \operatorname{long}$ and $1^{\prime}-2^{\prime}$ wide, with broad thick pale midribs raised and rounded on the upper side and obscure primary veins arcuate and united near the thick revolnte cartilaginons margins and connected by conspicnous coarsely reticulated veinlets; their petioles stout, yellow, grooved above, $\frac{1^{\prime}}{2}$ long; stipules nearly triangular, rather less than $\frac{1}{16}$ long, caducous. Flowers on pedicels rather shorter than the petioles, opening in early spring from the axils of leaves of the previous year, the staminate in many-flowered clusters, the pistillate usually solitary or occasionally in 2-3-flowered clusters; calyx yellow-green, lirsute on the outer surface, $\frac{1}{1^{\prime}}$ long, and divided nearly to the base into 5 ovate acutc boat-shaped lobes deciduous from the fruit; stamens about 8 , inserted on the borders of the slightly lobed pulvinate concave disk; filaments unequal in length, rather longer than the calyx-lobes and a little longer than the broadly ovate enarginate pilose extrorse anthers, with broad ovate acute comnectives; ovary sessile, hirsute, 1-cclled, crowned with a broad sessile slightly stalked oblique pulvinate stigma, wanting in the staminatc flower. Fruit ripening in the autumn, decidnous at maturity from its stont

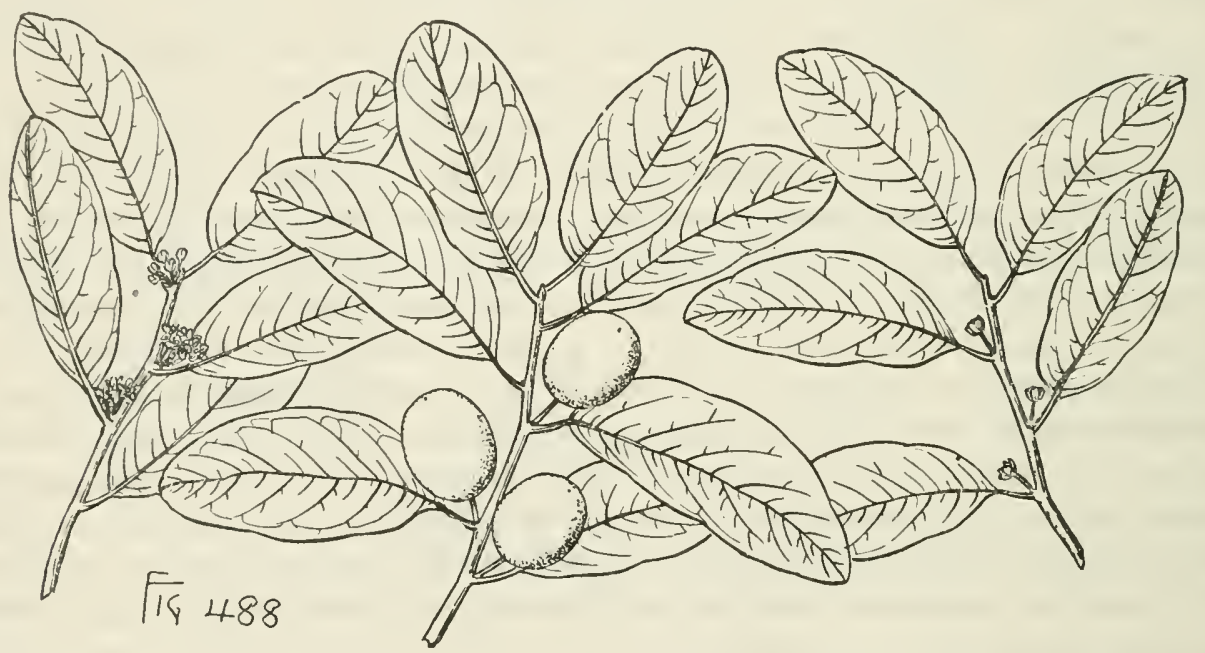

erect stalk much enlarged at the apex and $\frac{1^{\prime}}{3}$ long, ovoid, $\mathbf{1}^{\prime}$ long, ivory-white, with thick dry mealy flesh closely investing the light brown stone narrowed at the base into a long point, with bony walls $\frac{1}{8}^{\prime}$ thick and penetrated longitudinally by large fibro-vascular bundle-chanuels; seed oblong, rounded at the ends, nearly $\frac{1}{2}$ long, covered with a thin membranaceous light brown coat marked by conspicuous veins radiating from the small hilum.

A tree, occasionally $30^{\circ}-40^{\circ}$ high, with a trunk sometimes a foot in diameter, stout usually erect branches forming an oblong round-topped head, and stout branchlets light green tinged with red and covered with pale scattered caducous hairs when they first appear, becoming ashy gray and roughened by numerous elevated circular pale lenticels and later by the large prominent orbicular leaf-scars displaying the ends of . 3 conspicuous fibro-vascular bundles. Winter-buds minute, obtuse, partly immersed in the bark and coated with brown resin. Bark of the trunk about $\frac{1}{2}^{\prime}$ thick, smooth, milky white and often marked by large irregular gray or pale browu patches. Wood heavy, hard, not strong, brittle, close-grained, and brown streaked with bright yellow, with thick yellow-brown sapwood. 
Distribution. Dry sandy soil on Key West, Umbrella and Elliott's Keys, southern Florida; one of the rarest of the tropical trees of Florida.

\section{Drypetes lateriflora, Urb. Guiana Plum.}

Leaves appearing in Florida in early spring and falling during their second year, oblong, acute or acuminate at the apex, gradually narrowed at the base, and entire, when they unfold thin and covered with scattered pale hairs, and at maturity thick and subcoriaceous, dark green and lustrous, $3^{\prime}-4^{\prime}$ long, $\frac{1}{2}^{\prime}-1 \frac{1}{2}^{\prime}$ wide, with conspicuous

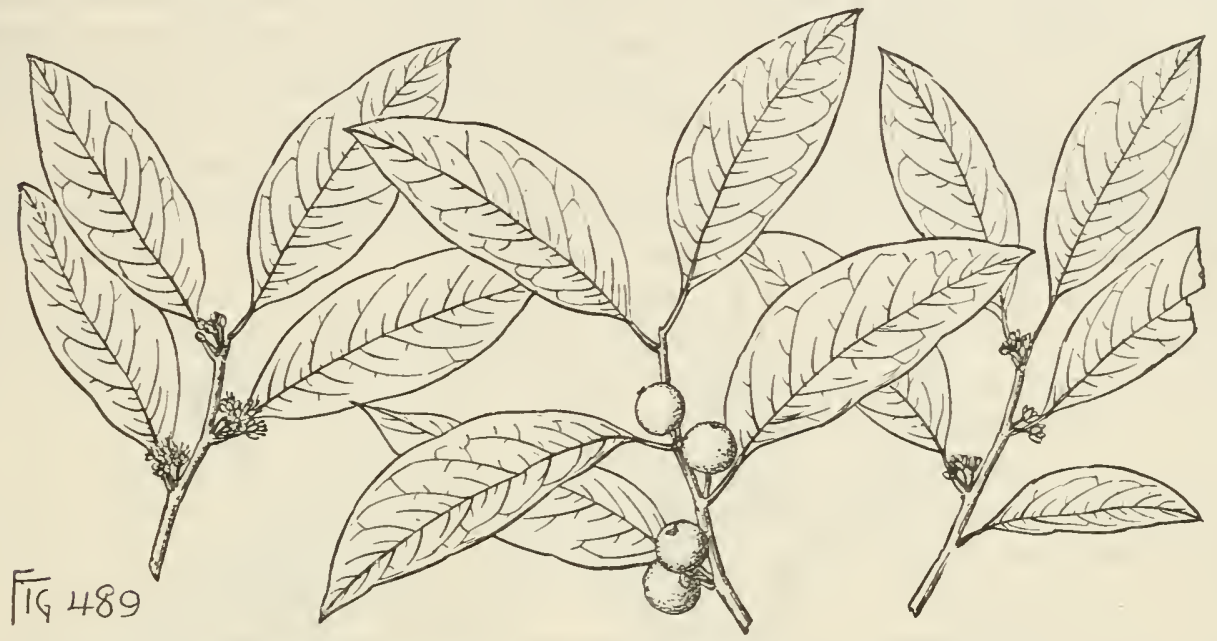

light-colored midribs rounded above, and pale and obscure primary veins arcuate and united near the slightly thickened revolnte margins and connected by slenter reticulate veinlets; their petioles slender, grooved, $\frac{1^{\prime}}{4}$ long. Flowers on pedicels shorter than the petioles, opening late in the autumn or in early winter on branches one or two years old, in the axils of leaves or from leafless nodes, in many or few-flowered clusters; calyx greenish white, hirsute on the outer surface, divided to the base into 4 ovate rounded lobes, persistent under the fruit; stamens 4 , inserted nnder the margin and between the lobes of the flat tomentose disk; filaments slender, exserted; anthers introrse, emarginate, pilose, wanting in the pistillate flower; ovary ovate, tomentose, 2-celled, with 2 nearly sessile oblique spreading cushion-like stigmas. Fruit ripening during the spring and early summer, subglobose, $\frac{1}{3}$ ' in diameter, tipped with the conspicuous blackened remnants of the stigmas, dark brown, covered with soft pubescence, solitary or in clusters of 2 or 3 , decidnous at maturity from its stout stalk enlarged at the apex and $\frac{1^{\prime}}{4}$ long; fiesh thin and crustaceous, closely investing the thin-walled crustaceous stone; seed usually solitary by abortion, obovate, gibbous, $\frac{1}{8}^{\prime}$ lorfg, narrowed below, narrowed and marked at the apex by the elevated pale hilum and on the inner surface by the broad conspicuous raphe.

A tree, $20^{\circ}-30^{\circ}$ high, with a short trunk $5^{\prime}-6^{\prime}$ in diameter, small erect branches, and slender branchlets, light green tinged with red when they first appear, becoming in their first winter ashy gray and marked by scattered pale lenticels, and at the end of their second year by the small elevated oval leaf-scars displaying the ends of 3 fibro-vascular bundles. Winter-buds minute, acute or obtuse, chestnut-brown, and covered with pale hairs. Bark of the trunk about $\frac{1}{1 \frac{}{16}}$ thick, light brown tinged with red, the generally smooth surface separating into small irregular scales. Wood heavy, hard, brittle, close-grained, ricli dark brown, with thick yellow sapwood. 
Distribution. Shores of Bay Biscayne and on many of the southern keys, Florida; common on the Bahama Islands and on several of the Antilles.

\section{HIPPOMANE, L.}

A glabrons tree, with thick acrid juice, scaly bark, and stout pithy branchlets marked by circular raised lenticels, and oblong or semiorbicular horizontal elevated leaf-scars displaying a row of obscure fibro-vascular bundie-scars, and nearly cncircled at the nodes by ring-like sears left by the falling of the stipules. Winter-buds ovate, acute, covered by many loosely imbricated long-pointed chestnut-brown scales. Leaves alternate, involnte in the bud, tardily decidnous, broadly ovate, abruptly rounded at the apex into broad points terminating in slender mucros, rounded or subcordate at the base, remotely crenulate-serrate, with minute gland-tipped teeth, penniveined, long-petiolate, at first pilose, with occasional long pale liairs, soon becoming glabrous, and at maturity thick and coriaceous, dark yellow-green and lustrous above, paler and dull below, with stout light yellow midribs raised and ronnded on the upper side, and slender primary veins remote, arcuate, and united at some distanee from the margins and connected by conspicuons coarsely reticulate veinlets more prominent on the upper than on the lower side; their petioles elongated, slender, rigid, light yellow, romded below, obscurely grooved above, marked at the apex by large orbicular dark red glands; stipules ovate-lanceolate, abruptly narrowed from broad bases, slightly laciniate near the apex, membranaceous, light chestnutbrown, caducous. Inflorescence terminal, spicate, appearing in early spring usually before the unfolding leaves, the stout fleshy rachis often bearing at the base acute sterile deciduous bracts, or 1 or 2 small leaves, the minute pistillate flowers solitary in their axils or in the axils of ovate acute lanceolate bracts furnished with 2 lateral glandular bractlets; staminate flowers minute, articulate on slender pedicels, clustered in 8-15-flowered fascicles in the axils of simple bracts higher on the rachis and extending to its apex; calyx usually 3-lobed, the lobes imbricated in the bud, that of the staminate flower yellow-green, membranaceous, divided below into 3 or sometimes into 2 acute lobes; calyx of the pistillate flower ovate, yellow-green, divided nearly to the base into 3 ovate acute concave divisions rounded on the back; stamens 2 or often 3 , exserted, more or less connate by their filaments into a stout column, free and spreading at the apex; anthers ovoid, light yellow, surmounted by the short prolonged connective, attached on the back below the middle, erect, extrorse; ovary 6-8-celled, narrowed at the base, gradually contracted above into a short simple cylindrical style separating into 6-8 long radiating flattened abruptly reflexed lobes stigmatic on the inner face; ovule solitary in each cell. Fruit drupaceous, poneshaped, obscurely 6-8-lobed, raised on a thickened woody stem; skin thin, light yellow-green or yellow and red; flesh thick, lactescent, adherent to the thick-walled rugose deeply winged 6-8-celled, 6-8 seeded subglobose stone flattened at the ends, the cells divided throughout by thin dark radial plates, ultimately separable, penetrated near the summit by oblique canals filled by the funicles of the seeds. Seeds oblong-ovate, marked by a minute slightly elevated hilum and on the ventral face by an obscure raphe; seed-coat membranaceous, separable into 2 layers, the outer dark, the imner thinner, light brown; embryo surrounded by thick fleshy albumen.

The genus is represented by a single species abounding in exceedingly poisonous caustic sap which produces cutaneous eruptions and when taken internally destroys the mucous membranc; formerly employed by the Caribs to poison their arrows. 
The generic name is from " $\pi \pi$ os and $\mu a v i a$, and was first used by the Greeks to distinguish some plant with properties excitant to horses.

\section{Hippomane Mancinella, L. Manchineel.}

Leaves $3^{\prime}-4^{\prime}$ long, $1 \frac{1}{2}-2^{\prime}$ wide, unfolding in early spring and persistent in Florida until the spring of the following year; their petioles $2 \frac{1}{2}^{\prime}-4^{\prime}$ long. Flowers opening in March before the leaves of the year; rachis of the inflorescence $4^{\prime}-6^{\prime}$ long, dark purple, more or less covered with a glaucous bloom. Fruit ripening in the autumn or early winter and often persistent on the branches until after the appearance of the flowers of the following year, $1^{\prime}-1 \frac{1}{2}^{\prime}$ in diameter, light yellow-green, with a bright red cheek; seeds about $\frac{1}{4}$ long.

A tree, in Florida rarely more than $12^{\circ}-15^{\circ}$ high, with a short trunk $5^{\prime}-6^{\prime}$ in diameter, long spreading pendulous branches forming a handsome round-topped head; or in the West Indies often $50^{\circ}-60^{\circ}$ tall, with a trunk occasionally $3^{\circ}$ in diameter.

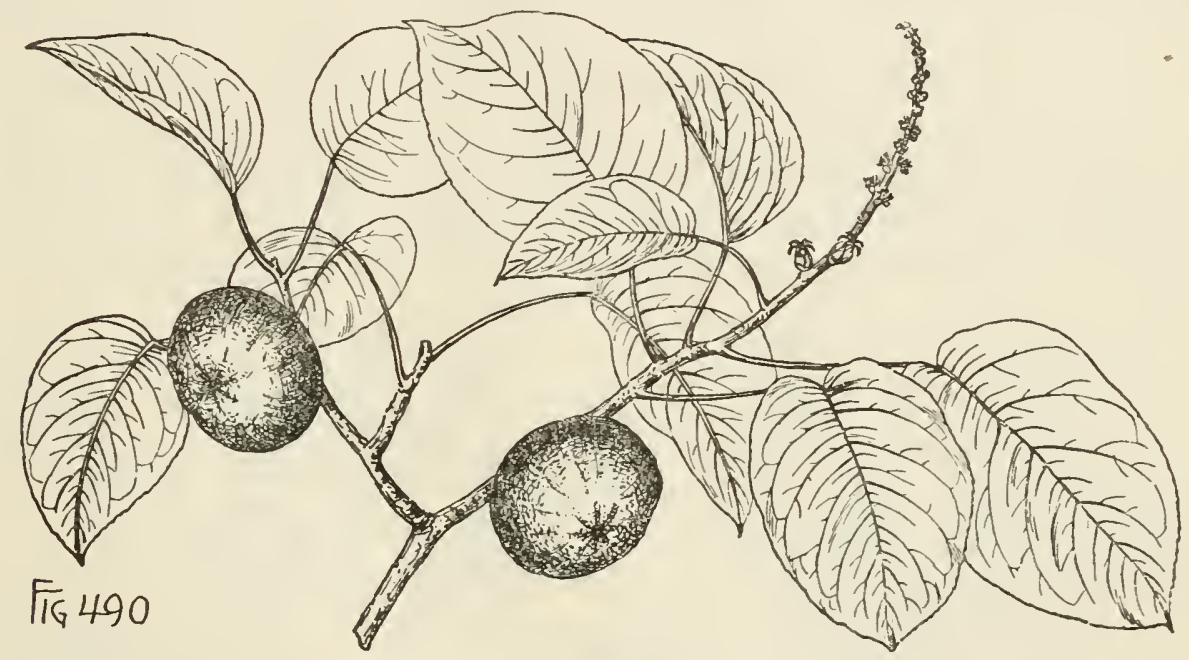

Bark of the trunk $\frac{1^{\prime}}{4}-\frac{1}{2}^{\prime}$ thick, dark brown and broken on the surface into small thick appressed irregularly shaped scales, or in the West Indies sometimes smooth, light gray or nearly white. Wood light and soft, close-grained, dark brown, with thick light brown or yellow sapwood.

Distribution. Sandy beaches and dry knolls in the immediate neighborhood of the ocean ; keys off the southern coast of Florida; on the Bahama Islands, through the Antilles to the northern countries of South America, and to southern Mexico and the eastern and western coasts of Central Anerica.

\section{GYMNANTHES, Sw.}

Glabrous trees or shrubs, with milky juice and slender terete branches. Leaves conduplicate in the bud, petiolate, entire or crenulate-serrate, coriaceous, penniveined, persistent; stipules membranaceous, minute, caducons. Flowers monœcions or rarely diœcious; inflorescence buds covered with closely imbricated chestnutbrown scales, lengthening in anthesis, bearing in the 11pper axils numerons 3branched clusters of staminate flowers, their branches furnished with minute ovate bracts, and in the lower axils 2 or 3 long-stalked pistillate flowers; calyx of the staminate flower minute or 0 ; stamens 2 or rarely 3 ; filaments filiform, inserted on 
the slightly enlarged torus, frec or slightly comnate at the base; anther's attached on the back below the mildle, erect, ovoid, 2-celled, the cells parallel; calyx of the pistillate flower reduced to 3 bract-like seales; ovary ovatc, 3-cellecl, narrowed into 3 recurved styles free or slightly united at the base, stigmatic on their inner face; ovule solitary in cach cell. Fruit a 3-lobed capsule scparating from the persistent axis into 32 -valved 1-seeded carpels dehisecnt on the dorsal and partly dehiscent on the ventral suture. Seed ovoid or subglobose, strophiolate; seed-coat crustaceous; cmbryo erect in fleshy albumen.

Gymmanthes with about ten species is confined to the tropies of the New World and is distributed from sonthern Florida, where one species occurs, through the West Indies to Mexico and Brazil.

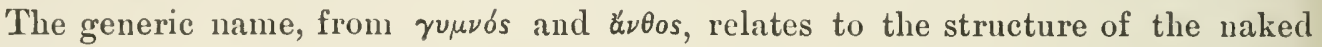
flowers.

\section{Gymnanthes lucida, Sw. Crab Wood.}

Leaves oblong-ovate or ovate-lanceolate, obscurely and remotely crenulate-serrate or often entire, when they unfold thin and membranaceons, deeply tinged with red, and glandular on the teeth, with minute caducous dark glands, and at maturity thick and coriaceous, dark green and lustrous on the upper and pale and dull on the lower surface, $2^{\prime}-3^{\prime}$ long, $\frac{2^{\prime}}{3}-1 \frac{1}{2}^{\prime}$ wide, with broad pale midribs raised and rounded on the upper side, obscure primary veins arcuate and nnited near the margins and connected by prominent coarsely reticulate veinlets, appearing in Florida in early

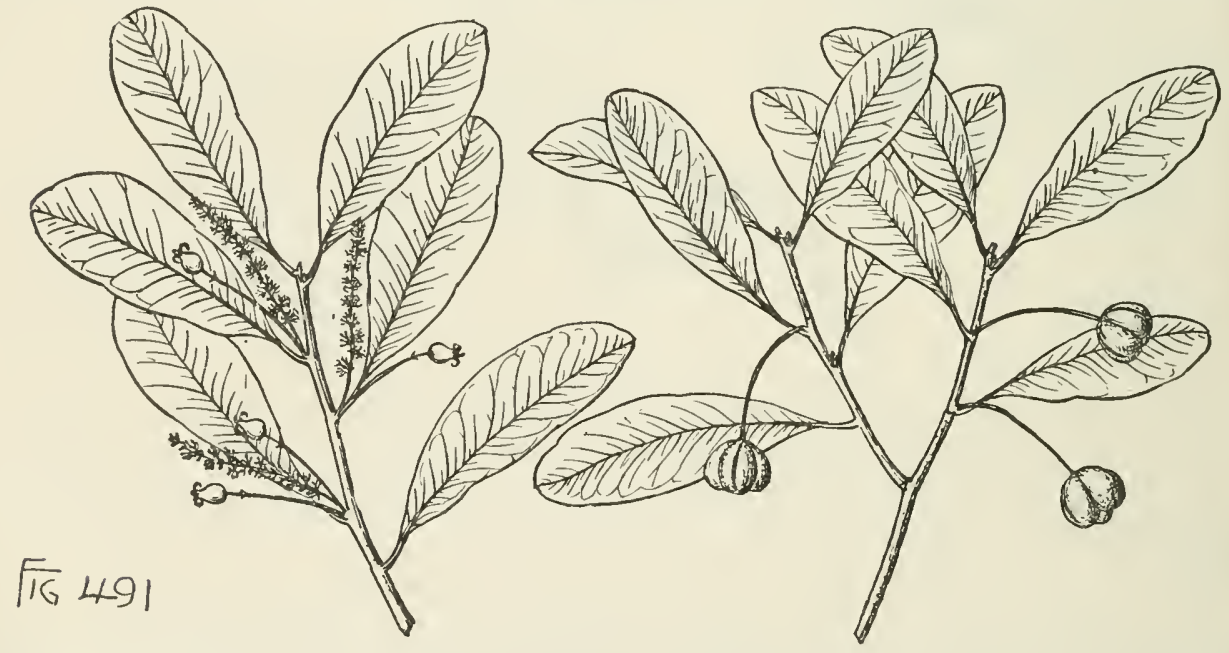

spring and remaining on the branches through their second summer; their petioles broad, slightly grooved, about $\frac{1^{\prime}}{4}$ long; stipules ovate, acute, light brown, clothed on the margins with long pale hairs, about $\frac{1}{16}$ long. Flowers: inflorescence buds appearing in Florida late in the antumn in the axils of leaves of the year and beginning to lengthen in spring, the inflorescence becoming $1 \frac{1^{\prime}}{2}-2^{\prime}$ long, with a slender glabrous angled rachis, the scales broadly ovate, pointed, concave, rounded and thickened at the apex, puberulous and ciliate on the margins, those inclosing the male flowers connate with the flowers and persistent under the calyx, those subtending the female flowers at the base of the inflorescence and not raised on their peduncles. Fruit produced in Florida sparingly, ripening in the autumn, slightly obovate, dark reddish brown or nearly black, $\frac{1}{3}$ in diameter, covcred with thin dry flesh and pendent on a slender stem $\mathbf{1}^{\prime}$ or more in length; seeds ovoid. 
A tree, occasionally $20^{\circ}-30^{\circ}$ high, with a trunk $6^{\prime}-8^{\prime}$ in diameter and of ten irregnlarly ridged, the rounded ridges spreading near the surface of the ground into broad buttresses, slender erect branches forming a narrow open oblong head, and slender upright branchlets light green more or less deeply shaded with red when they first appear, becoming in their first winter light gray-brown faintly tinged with red and ronghened by numerous oblong pale lenticels, ultimately ashy gray and marked at the end of their second year by the semiorbicular elevated leaf-scars displaying the ends of 4 fibro-vascular bundle-scars superposed in pairs. Winter-buds ovate, obtuse, covered with chestnnt-brown scales, about $\frac{1}{1 \frac{\prime}{16}}$ long. Bark of the trunk dark red-brown, about $\frac{11^{\prime}}{1 \overline{6}}$ thick, separating into large thin scales, in falling displaying the light brown inner bark. Wood very heavy, hard, close-grained, rich dark brown streaked with yellow, with thick bright yellow sapwood; in Florida occasionally manufactured into canes, and used as fuel.

Distribution. Common in low woods from the shores of Bay Biscayne to the Marquesas Keys, Florida; on the Bahama Islands, and on many of the Antilles.

\section{ANACARDIACE丹.}

Trees and shrubs, with terete pithy branchlets, resinous juice, and alternate simple or pinnate leaves without stipules, and scaly or naked buds. Flowers regular, minute, diœcious, polygamo-diœcious, or polygamo-ınonœcious; calyx-lobes and petals 5 , imbricated in the bud; stamens as many as the petals and alternate and inserted with them on the margin or under an hypogynous annular fleshy slightly 5-lobed disk; filaments filiform; anthers oblong, introrse, 2-celled, the cells opening longitudinally; ovary 1-celled; ovule solitary, suspended from the apex of a slender funicle rising from the base of the cell, anatropous; micropyle superior; styles 3, united or spreading; stigmas terminal. Fruit drupaceous. Seed without albumen; seed-coat thin and membranaceons; embryo filling the cavity of the seed; cotyledons flat, accumbent on the short radicle.

'The Sumach family of nearly sixty genera is mostly confined to the warmer parts of the earth's surface and contains the Mango, Pistacia, and other important trees. In the flora of the United States three genera have arborescent representatives.

\section{CONSPECTUS OF THE ARBORESCENT GENERA OF THE UNITED STATES.}

Flowers usually diœcious by abortion; styles lateral, spreading; pedicels of the abortive flowers becoming long and plumose at maturity; fruit compressed, very oblique ; leaves simple, deciduous.

1. Cotinus.

Flowers mostly diœcious ; styles terminal, short, united ; stigma 3-lobed ; fruit ovate, glabrous; leaves unequally pinnate, persistent.

2. Metopium.

Flowers polygamo-diœcious or polygamo-monœcious; styles terminal, spreading; fruit usually globose. naked or clothed with acrid hairs; leaves unequally pinnate, trifoliolate or rarely simple, deciduous or rarely persistent.

3. Rhus.

\section{CotinUs, L.}

Small trees or shrubs, with scaly bark, small acute winter-buds, with numerous imbricated scales, fleshy roots, and strong-smelling juice. Leaves simple, petiolate, oval, obovate-oblong or nearly orbicular, glabrous or more or less pilose-pubescent, deciduous. Flowers regular, diœcious by abortion or rarely polygamo-diœcious, 
greenish yellow, on slender pedicels aecrescent after the flowering period, mostly abortive and then becoming conspicnously tomentose-villose at maturity, in ample loose terminal or lateral pyramidal or thyrsoidal panicles, the branches from the axils of linear acnte or spatulate deciduous bracts; ealyx-lobes ovate-lanceolate, obtnsc, persistent; disk eoherent with the base of the ealyx and surrounding the base of the ovary; petals oblong, acute, twiee as long as the calyx, inserted mnder the free margin of the disk opposite its lobes, deciduous; stamens shorter than the petals, usually rudimentary or wanting in the pistillate flower; ovary sessile, obovate, compressed, rudimentary in the staminate flower; styles 3 , short and spreading from the lateral apex of the ovary; stigmas large, obtuse. Fruit oblong-oblique, compressed, glabrous, conspicuously retieulate-veined, light red-brown, bearing on the side near the middle the remnants of the persistent styles, the outer coat thin and dry; stone thiek and bony.

Cotinus is widely distributed through southern Europe and the Himalayas to northern China with a single speeies, and is represented in the sonthern United States by another species.

The Old World Cotinus Cotinus, Sarg, the Smoke-tree of gardens, is often eultivated in the United States.

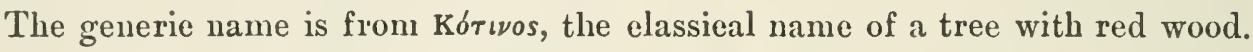

\section{Cotinus Americanus, Nutt. Chittam Wood.}

Leaves oval or obovate, rounded or sometimes slightly emarginate at the apex, gradually contracted at the base, entire, with slightly wavy revolute margins, when
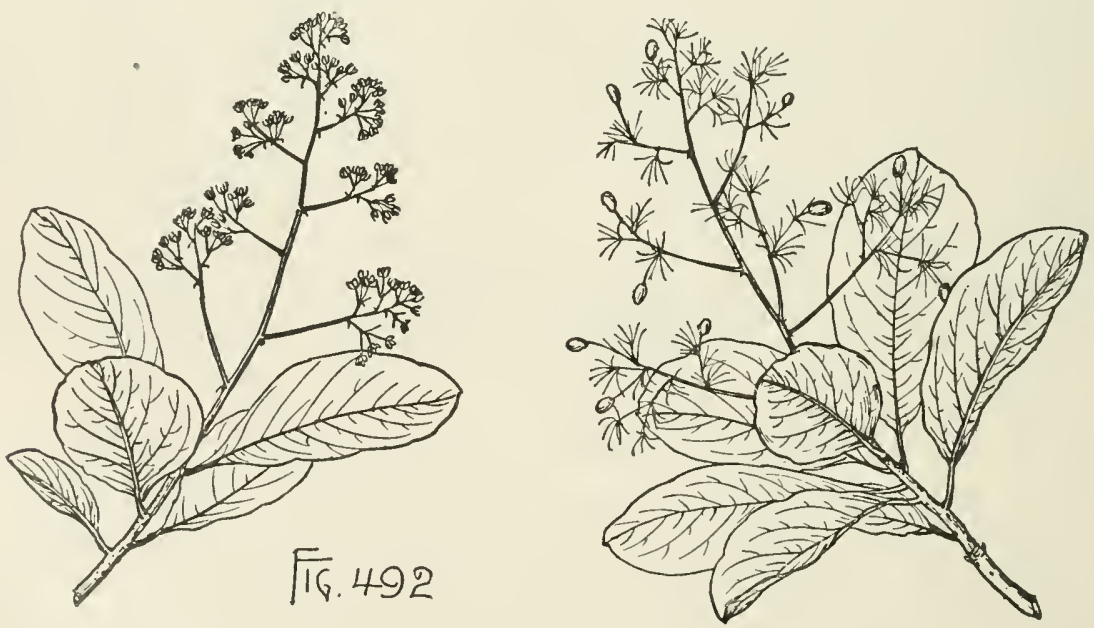

they unfold light purple and covered below with fine silky white hairs, and at maturity dark green on the upper surface, pale on the lower surface, and puberulous along the under side of the broad midribs and primary veins, $4^{\prime}-6^{\prime}$ long, $2^{\prime}-3^{\prime}$ wide, turning in the autumn brilliant shades of orange and searlet; their petioles stout, $\frac{1}{2}^{\prime}-\frac{3^{\prime}}{4}$ long. Flowers appearing late in April or early in May on pedicels $\frac{1^{\prime}}{2}-\frac{3^{\prime}}{4}$ long, and usually collected 3 or 4 together in loose umbels near the ends of the principal branches of puberulons terminal slender long-branched few-flowered panicles $5^{\prime}-6^{\prime}$ long and $2 \frac{1}{2}^{\prime}-3^{\prime}$ broad, the staminate and pistillate on different individuals. Fruit produced very sparingly, about $\frac{1^{\prime}}{8}$ long, on stems $2^{\prime}-3^{\prime}$ in length; sterile pedicels beeoming 
$1 \frac{1}{2}-2^{\prime}$ long at maturity and covered with short not very abundant rather inconspicuous pale purple or brown hairs; seed kidney-shaped, pale brown, about $\frac{1}{16}$ long.

A tree, $25^{\circ}-35^{\circ}$ high, with a straight trunk occasionally $12^{\prime}-14^{\prime}$ in diameter, usually dividing $12^{\circ}-14^{\circ}$ from the ground into several erect stems separating into widespreading often slightly pendulous branches, and slender branchlets purple at first, soon becoming green, bright red-brown and covered with small white lenticels and marked by large prominent leaf-scars during their first winter, and dark orangecolored in their second year. Winter-buds $\frac{1}{8}^{\prime}$ long and covered with thin dark redbrown scales. Bark of the trunk $\frac{1}{8}$ thick, light gray, furrowed and broken on the surface into thin oblong scales. Wood light, soft, rather coarse-grained, bright clear rich orange color, with thin nearly white sapwood; largely used locally for fenceposts and very durable in contact with the soil; yielding a clear orange-colored dye.

Distribution. Southern slopes of the Cumberland Mountains near Huntsville, Alabama, on the Cheat Mountains in eastern Tennessee, banks of Grand River, Indian Territory, valley of the Medina River, western Texas, and sonthwestern Missouri; nowhere common and only in small isolated groves or thickets scattered along the sides of rocky ravines or dry slopes.

Occasionally cultivated in the eastern United States and hardy as far north as eastern Massachusetts, and rarely in Europe.

\section{METOPIUM, P. Br.}

Trees or shrubs, with naked buds, fleshy roots, and milky exceedingly caustic juice. Leaves unequally pimnate, persistent; leaflets coriaceous, lustrous, long-petiolulate. Flowers diœcions, yellow-green, on short stout pedicels, in narrow erect axillary clusters at the ends of the branches, with minute acute deciduous bracts and bractlets, the males and females on different trees; calyx-lobes semiorbicular, about half as long as the ovate obtuse petals; stamens 5 , inserted under the margin of the disk; filaments shorter than the anthers, minute and rudimentary in the pistillate flower; ovary ovate, sessile, minute in the staminate flower; style terminal, short, undivided; stigma 3-lobed. Fruit ovate, compressed, smooth and glabrons, crowned with the remnants of the style; outer coat thick and resinous; stone crustaceous. Seed nearly quadrangular, compressed; seed-coat smooth, dark browu and opaque, the broad funicle covering its margin.

Metopium with two species is confined to southern Florida and the West Indies.

The generic name, from ö $\pi$ os, was the classical name of an African tree now unknown.

\section{Metopium Metopium, Small. Poison Wood. Hog Gum.}

\section{(Rhus Metopium, Silva N. Am. iii. 13.)}

Leaves clustered near the ends of the branches, $9^{\prime}-10^{\prime}$ long, with stout petioles swollen and enlarged at the base, and 5-7 leaflets, or often 3 -foliolate, unfolding in March and persistent until the following spring; leaflets ovate, rounded or usually contracted toward the acute or sometimes slightly emarginate apex, rounded or sometimes cordate or wedge-shaped at the base, $3^{\prime}-4^{\prime}$ long, $2^{\prime}-3^{\prime}$ broad, with thickened slightly revolute margins, prominent midribs, primary veins spreading at right angles, numerous reticulate veinlets, and stout petiolules $\frac{1^{\prime}}{2}-1^{\prime}$ long, that of the terminal leaflet often twice as long as the others. Flowers about $\frac{1}{8}^{\prime}$ in diameter, in clusters as long or rather longer than the leaves; petals yellow-green, marked on the 
inner surface by dark longitudinal lines; stamens rather shorter than the petals. Fruit ripening in November and December, pendent in long graceful clusters, orange-colored, rather lustrous, $\frac{8^{\prime}}{4}$ long; seed about $\frac{f^{\prime}}{4}$ long.

A tree, with exceedingly acrid poisonons juice, frequently $35^{\circ}-40^{\circ}$ high, with a short trunk sometimes $2^{\circ}$ in diameter, stout spreading often pendulous branches

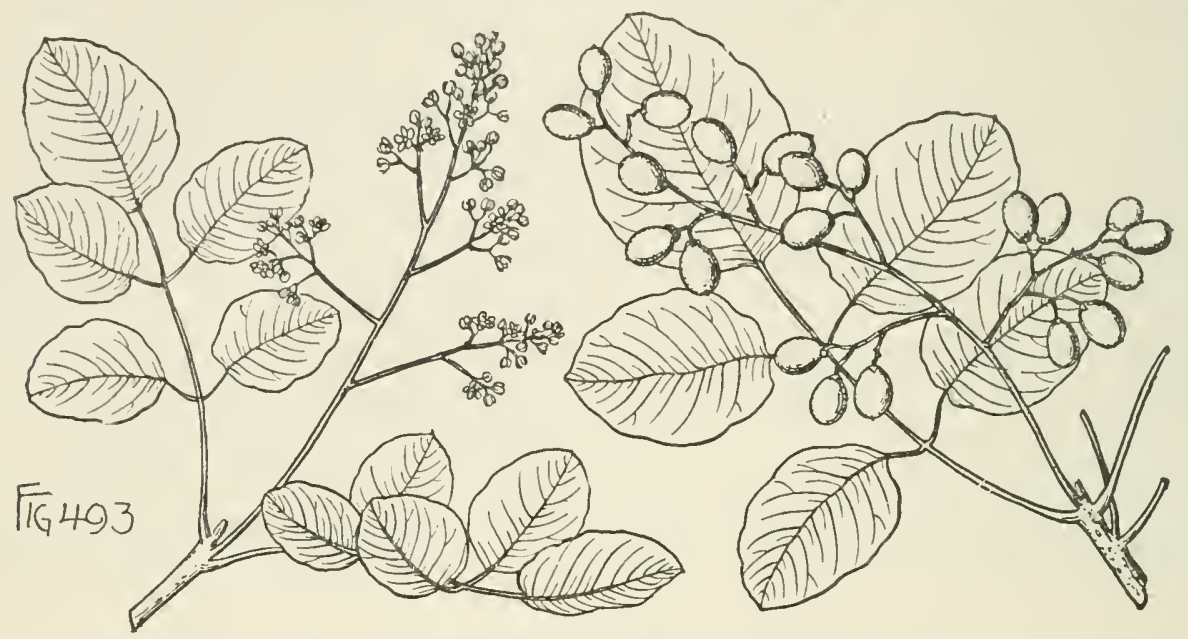

forming a low broad head, and reddish brown branchlets marked by prominent leafscars and numerous orange-colored lenticels. Winter-buds large, rufous-pubescent. Bark of the trunk about $\frac{1^{\prime}}{8}$ thick, light reddish brown tinged with orange, often marked by dark spots caused by the exuding of the resinous gum, and separating into large thin plate-like scales displaying the bright orange color of the inner bark. Wood heavy, hard, not strong, rich dark brown streaked with red, with thick light brown or yellow sapwood of 25-30 layers of annual growth. The resinous gum obtained from incisions made in the bark is emetic, purgative, and dinretic.

Distribution. Shores of Bay Biscayne and the keys of southern Florida; very abundant; also in the Bahamas, Cuba, Jamaica, and Honduras.

\section{RHUS. L.}

Trees or shrubs, with pithy branchlets, fleshy roots, and milky sometimes caustic or watery juice. Leaves unequally pinnate, or rarely simple. Flowers mostly diœcious, rarely polygamons, white or greenish white, in more or less compound axillary or terminal panicles, the staninate and - pistillate usually produced on separate plants; calyx-lobes united at the base only, generally persistent; disk surrounding the base of the free ovary, coherent with the base of the calyx; petals longer than the calyx-lobes, inserted under the margin of the disk, opposite its lobes, deciduous; stamens 5 , inserted on the margin of the disk alternate with the petals; filaments longer than the anthers; ovary ovoid or subglobose, sessile; styles 3 , terminal, free or slightly connate at the base, rising from the centre of the ovary. Fruit usually globose, smooth or covered with hairs; outer coat thin and dry, more or less resinous; stone crustaceous or bony. Seed ovoid or reniform, commonly transverse; cotyledons foliaceous, generally transverse; radicle long, uncinate, laterally accumbent.

Rhus is widely distributed, with more than one hundred species, in the extratropical regions of the northern and sonthern hemispheres. In North America the genus is widely and generally distributed from Canada to southern Mexico and from 
the shores of the Atlantic to those of the Pacific Ocean, with sixteen or seventeen species within the territory of the United States. Of these, four attain the habit of small trees. The acrid poisonous juice of Rhus vernicifera, DC., of China, furnishes the black varnish used in China and Japan in the manufacture of lacquer, and other species are valued for the tannin contained in their leaves or for the wax obtained from the fruit.

The name of the genus is from 'Pov̂s, the classical name of the European Sumach.

\section{CONSPECTUS OF NORTH AMERICAN ARBORESCENT SPECIES.}

Flowers in terminal thyrsoidal panicles; fruit globular, clothed with acrid hairs; leaves unequally pinnate, deciduous; branchlets without terminal buds. SuMAcHs.

Branches and leaf-stalks densely velvety hairy; leaflets 11-31, pale on the lower surface; fruit corered with long hairs; buds inclosed in the enlarged bases of the petioles; juice milky.

1. R. hirta (A, C).

Branches and leaf-stalks pubescent; rachis winged; leaflets $9-21$, green on the lower surface; fruit pilose; buds not inclosed by the petioles; juice watery.

2. R. copallina (A, C).

Flowers in axillary slender panicles; fruit glabrous, white; leaves unequally pinnate, deciduous; leaflets $7-13$; branchlets with terminal buds.

3. R. Vernix $(A, C)$.

Flowers in short compact terminal panicled racemes; fruit pubescent; leaves ovate, entire or serrate, simple or rarely trifoliolate, persistent.

4. R. integrifolia $(G)$.

\section{Rhus hirta, Sudw. Staghorn Sumach.}

Leaves $16^{\prime}-24^{\prime}$ long, with stout petioles usually red on the upper side and covered with soft pale hairs, enlarged at the base and surrounding and inclosing the buds developed in their axils, and 11-31 oblong often falcate rather remotely and sharply serrate or rarely laciniate long-pointed nearly sessile or short-stalked leaflets rounded

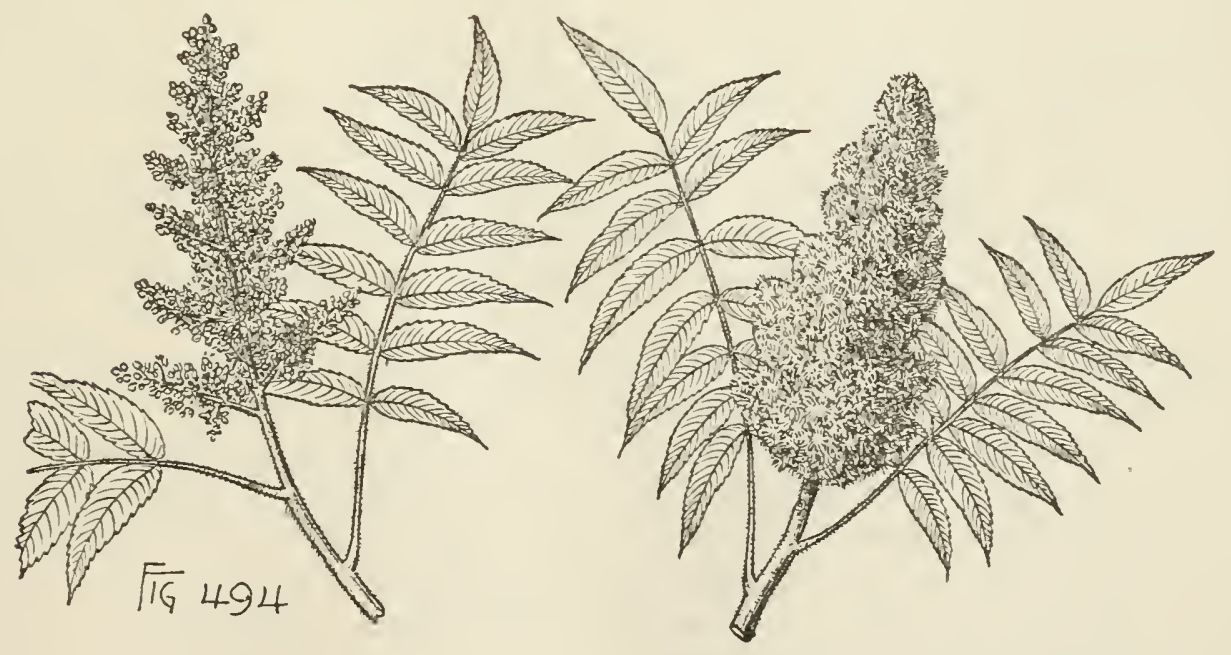

or slightly heart-shaped at the base, at first covered above like the petioles and young shoots with red caducous hairs, bright yellow-green until half grown, and at maturity dark green and rather opaque on the upper surface, pale or often nearly white on the lower surface, glabrous with the exception of the short fine hairs on the under side of the stout midribs, and primary veins forked near the margins, opposite, or the lower ones slightly alternate, those of the 3 or 4 middle pairs considerably longer than 
those at the ends of the leaf and $2^{\prime}-5^{\prime}$ long and $1^{\prime}-1 \frac{1}{2}$ wide, turning in the autumn before falling bright scarlet with shades of crimson, purple, and orange. Flowers opening gradually and in succession in carly summer, the pistillate a weck or ten days later than the staminate, on slender pedicels from the axils of small acute pubescent bracts, in dense panicles, with pubescent stcms and branchlets and acuminate bracts $\frac{1^{\prime}}{2}$ to nearly $2^{\prime}$ long and deciduous with the opening of the flowers; panicle of the staminate flowers $8^{\prime}-12^{\prime}$ long and $5^{\prime}-6^{\prime}$ broad, with wide-spreading branches and nearly one third larger than the morc compact panicle of the pistillate plant; calyxlobes acutc, covercd on the outer surface with long slender hairs, much shorter than the petals in the staninate flower, and almost as long in the pistillate flower; petals of the staminate flower yellow-green sometimes tinged with red, strap-shaped, rounded at the apex, becoming reflexed above the middle at maturity; petals of the pistillate flower green, narrow and acuminate, with a thickened and slightly hooded apex, remaining erect; disk bright red and conspicuous; stamens slightly exserted, with slender filaments and large bright orange-colored anthers; ovary ovoid and pubescent, the 3 short styles slightly connate at the base, with large capitate stigmas, in the staminate flower glabrous, much smaller, unusually rudimentary. Fruit fully grown and colored in August and ripening late in the autumn in dense panicles $6^{\prime}-8^{\prime}$ long and $2^{\prime}-3^{\prime}$ wide, depressed-globular, with a thin outer covering clothed with long acrid crimson hairs and a small pale brown bony stone; seed slightly reniform, orange-brown.

A tree, occasionally $35^{\circ}-40^{\circ}$ high, with copious white viscid juice turning black on exposure, a slender often slightly inclining trunk occasionally $12^{\prime}-14^{\prime}$ in diameter, stout upright often contorted branches forming a low flat open head, and thick branchlets covered with long soft brown hairs gathered also in tufts in the axils of the leaves, becoming glabrous after their third or fourth year, and in their second season marked by large narrow leaf-scars and by small orange-colored lenticels enlarging vertically and persistent for several years; more frequently a tall shrub, spreading by mnderground shoots into broad thickets. Winter-buds conical, thickly coated with long silky pale brown hairs, about $\frac{1}{4}^{\prime}$ long. Bark of the trunk thin, dark brown, generally smooth, and occasionally separating into small square scales. Wood light, brittle, soft, coarse-grained, orange-colored, streaked with green, with thick nearly white sapwood. From the young shoots pipes are made for drawing the sap of the Sugar Maple. The bark, especially that of the roots, and the leaves are rich in tamnin.

Distribution. Usually on uplands in good soil, or less commonly on sterile gravelly banks and on the borders of streams and swamps; New Brunswick, through the valley of the St. Lawrence River to southern Ontario and Minnesota, and southward through the northern states and along the Alleghany Mountains to northern Georgia. and to central Alabama and Mississippi; more abundant on the Atlantic seaboard than in the region west of the Appalachian Mountains.

Occasionally cultivated as an ornamental plant in the United States, and very commonly in central and northern Europe.

\section{Rhus copallina, L. Sumach.}

Leaves $6^{\prime}-8^{\prime}$ long, with slender pubescent petioles and rachises more or less broadly wing-margined between the leaflets, the wings increasing in width toward the apex of the leaf, and 9-21 oblong or ovate-lanceolate leaflets entire or remotely serrate above the mirldle, sharp-pointed or rarely emarginate at the apex, acute or 
obtuse and often unequal at the base, the lower pairs short-petiolulate and smaller than those above the middle of the leaf, the others sessile with the exception of the terninal leaflet sometimes contracted into a long winged stalk, when they unfold dark green and slightly puberulous above, especially along the midribs, and covered

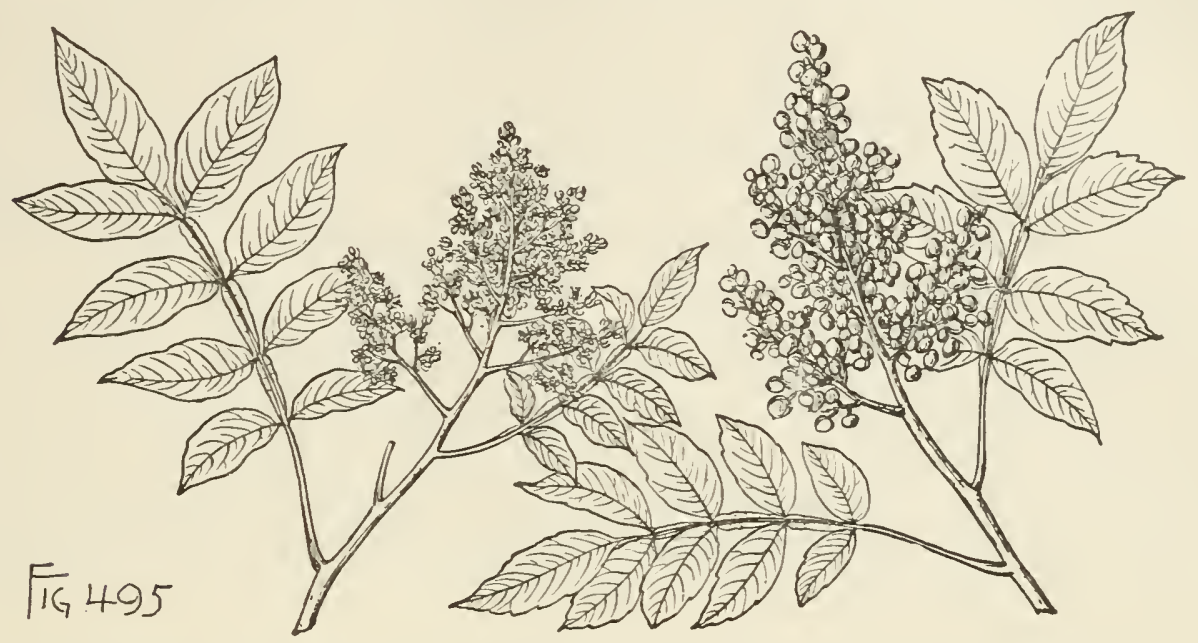

below with fine silvery white pubescence, at maturity subcoriaceous, dark green and lustrous above, pale and pubescent below, $1 \frac{1}{2}^{\prime}-2 \frac{1}{2}^{\prime}$ long and about $\frac{8^{\prime}}{4}$ wide, with slightly thickened revolute margins, prominent midribs and primary veins, turning in the autumn before falling dark rich maroon color on the upper surface. Flowers appearing from June at the south to August at the north, those of the staminate plant opening in succession during nearly a month and continuing to unfold long after the petals of the pistillate plant have fallen, on stout pubescent pedicels, $\frac{1}{8}^{\prime}-\frac{1}{4}^{\prime}$ long, in short compact pubescent panicles, the lower branches from the axils of the upper leaves, $4^{\prime}-6^{\prime}$ long, $3^{\prime}-4^{\prime}$ broad, and usually smaller on the female than on the male plant, their bracts and bractlets ovate or oblong, densely cinereo-pilose, deciduous before the expansion of the flowers; calyx puberulous on the outer surface, with ovate acute lobes one third as long as the ovate greenish yellow petals rounded at the apex, becoming reflexed above the middle; disk red and conspicuous; stamens somewhat longer than the petals, with slender filaments and large orange-colored anthers, in the pistillate flower much shorter than the petals, with mimte rudimentary anthers; ovary ovate, pubescent, glabrous, much smaller in the staminate flower. Fruit ripening in five or six weeks and borne in stout conpact often nodding pubescent clnsters sometimes persistent on the branches until the beginning of the following summer, $\frac{1^{\prime}}{8}$ across, slightly obovate, more or less flattened, with a thin bright red coat covered with short fine glandular hairs, and a smooth bony orange-brown stone; seed reniform, smooth, orange-colored, with a broad funicle.

A tree, $25^{\circ}-30^{\circ}$ high, with colorless watery juice, a short stout trunk $8^{\prime}-10^{\prime}$ in diameter, erect spreading branches, and branchlets at first dark green tinged with red and more or less densely clothed with short fine or sometimes ferrugineous pubescence, appearing slightly zigzag at the end of the first season from the swellings formed by the prominent leaf-scars, and then pale reddish brown, slightly puberulous and marked by conspicuous dark-colored lenticels; or at the north a low shrub rarely more than $4^{\circ}-5^{\circ}$ tall. Winter-buds axillary, minute, nearly globose, and covered with dark rusty brown tomentum. Bark of the trunk $\frac{1^{\prime}}{3}-\frac{1^{\prime}}{2}$ thick, light brown tinged 
with red, and marked by large elevated dark red-brown eirenlar excrescences, and separating into large thin papery seales. Wood light, soft, coarse-grained, light brown streaked with green and often tinged with red, with thin lighter colored sapwood of 4 or 5 layers of annmal growth. The leaves are rich in tannin and are gatlicred in large quantities and ground for enring leather and for dyeing.

Distribution. D) ry hillsides and ridges; widely and generally distributed from northern New England to Manitee and the shores of Caximbas Bay, Florida, and to eastcru Nebraska and Kansas and the valley of the San Antonio River, Texas; also in Cnba; in the United States arborescent only in southern Arkansas and castern Texas; east of the Mississippi River rarely more than a few fect high and spreading by mindergronnd stems on gravelly sterile soil into broad thickets; varying considerably in the size and form of the leaflets. The most distinct and probably the most constant of these varietics is var. lanceolata, Gray, a small trec growing on the prairics of eastern Texas to the valley of the Rio Grande, often forming thickets on river bluffs or on the banks of small streams, and distinguished by its narrow acute often falcate narrow leaflets and by its larger inflorescence and fruit. It is a tree sometimes $25^{\circ}-30^{\circ}$ high, with a trunk occasionally $8^{\prime}$ in diameter, covered by dark gray bark marked by lenticular excrescences. The flowers appear in July and August and the dull red or sometimes green fruit ripens in early autumn and falls before the beginning of winter.

Occasionally cultivated as an ornamental plant in the eastern United States, and in western and northern Europe.

\section{Rhus Vernix, L. Poison Dogwood. Poison Sumach.}

Leaves $\mathbf{7}^{\prime}-14^{\prime}$ long, with slender usually light red or red and green petioles, and 7-13 obovate-oblong entire leaflets slightly unequal at the base and narrowed at the acute or rounded apex, bright orange color and coated, especially on the margins

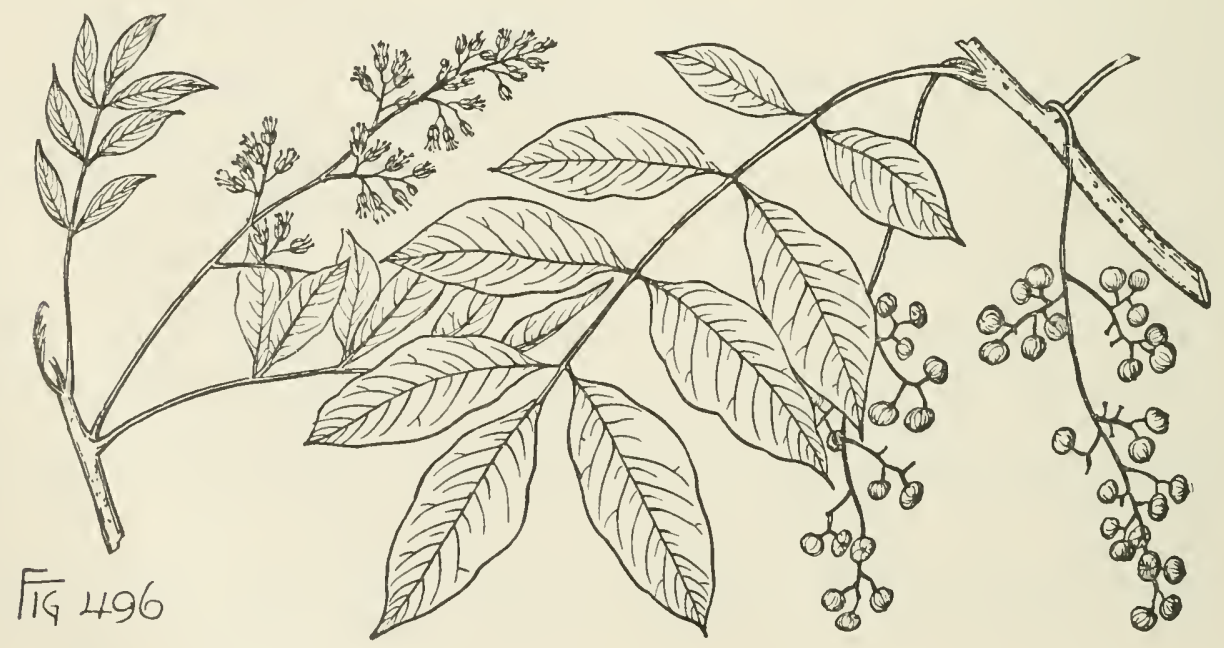

and under surface, with fine pubescence when they unfold, soon becoming glabrous, and at maturity $3^{\prime}-4^{\prime}$ long, $1 \frac{1^{\prime}}{2}-2^{\prime}$ wide, dark green and lustrous above, pale below, with prominent midribs scarlet above, primary veins forked near the margins, conspicnous reticulate veinlets, and revolnte margins, turning early in the autumn before falling to brilliant shades of scarlet or orange and scarlct. Flowers about $\frac{1^{\prime}}{8}$ long, 
appearing in early summer on slender pubescent pedicels bibracteolate near the middle, in long narrow axillary pubescent panicles crowded near the ends of the branches, with acute pubescent early deciduous bracts and bractlets; calyx-lobes acute, one third the leugth of the yellow-green acute petals erect and slightly reflexed toward the apex; stamens nearly twice as long as the petals, with slender filaments and large orange-colored anthers, in the fertile flower not more than half the length of the petals, with small rudimentary anthers, ovary ovoid-globose, with short thick spreading styles terminating in large capitate stigmas. Fruit ripening in September and often persistent on the branches until the following spring, in long graceful racemes, ovate, acute, often flattened and slightly gibbous, tipped with the dark remnants of the styles, glabrous, striate, ivory-white or white tinged with yellow, very lustrous, and about $\frac{1^{\prime}}{2}$ long; stone conspicuously grooved, thin, membranaceous; seed pale yellow.

A tree, with acrid poisonous juice turning black on exposure, occasionally $20^{\circ}$ high, with a trunk $5^{\prime}-6^{\prime}$ in diameter, slender rather pendulous branches forming a narrow round-topped head, and slender glabrous branchlets reddish brown and covered with minute orange-colored lenticels when they first appear, orange-brown at the end of their first season, becoming light gray and marked by large elevated conspicnous leaf-scars; more often a shrub, with several slender clnstered stems. Winter-buds acute and covered with dark purple scales puberulous on the back and ciliate on the margins, with short pale hairs, the terminal $\frac{1}{8}^{\prime}-3^{\prime}$ long and two or three times larger than the axillary buds. Bark of the trunk thin, light gray, smooth or sometimes slightly striate. Wood light, soft, coarse-grained, light yellow streaked with brown, with lighter colored sapwood.

Distribution. Wet swamps often inundated during a portion of the year; northern New England to northern Georgia and Alabama, westward to northern Minnesota, Arkansas, and western Louisiana; common and one of the most dangerous plants of the Northern American flora. An infusion of the young branches and leaves is employed in homœopathic practice, and the juice can be used as a black lustrous durable varnish.

\section{Rhus integrifolia, B. \& F. Mahogany.}

Leaves simple or very rarely 3 -foliolate, persistent, acute or rounded at the apex, with thickened revolute or spinosely toothed margins, puberulous when young, and at maturity $1 \frac{1}{2}^{\prime}-3^{\prime}$ long, $1^{\prime}-1 \frac{1}{2}^{\prime}$ wide, thick and coriaceous, dark yellow-green above, paler below, and glabrous with the exception of the stont petioles, broad thick midribs, and prominent reticulate veins. Flowers appearing from February to April, $\frac{1}{4}^{\prime}$ in diameter when expanded, on short stout pedicels, with 2-4 broadly ovate pointed persistent scarious ciliate pubescent bracts, in short dense racemes forming hoary* pubescent terminal panicles $1^{\prime}-3^{\prime}$ in lengtlı; sepals rose-colored, orbicular, concave, ciliate on the margins, rather less than half the length of the rounded ciliate reflexed rose-colored petals; stamens as long as the petals, with slender filaments and pale anthers, minute and rudimentary in the pistillate flower; ovary broadly ovate, pubescent, with 3 short thick connate styles and very large 3-lobed capitate stigmas. Fruit $\frac{1}{2}$ ' long, ovate, flattened, more or less gibbous, thick, dark red, densely pubescent; stone kidney-shaped, smooth, light chestnut-brown, with thick walls; seed flattened, pale, with a broad dark-colored funicle covering its side.

A tree, rarely $30^{\circ}$ high, with a short stout trunk $2^{\circ}-3^{\circ}$ in diameter, numerous spreading branches, and stout branchlets covered when they first appear with thick 
pale pubescence disappearing in their second and third years, and bright reddish brown and marked by numerous small elevated lenticels; or usually a small often almost prostrate shrub. Winter-buds small, obtuse, covered with a thick coat of
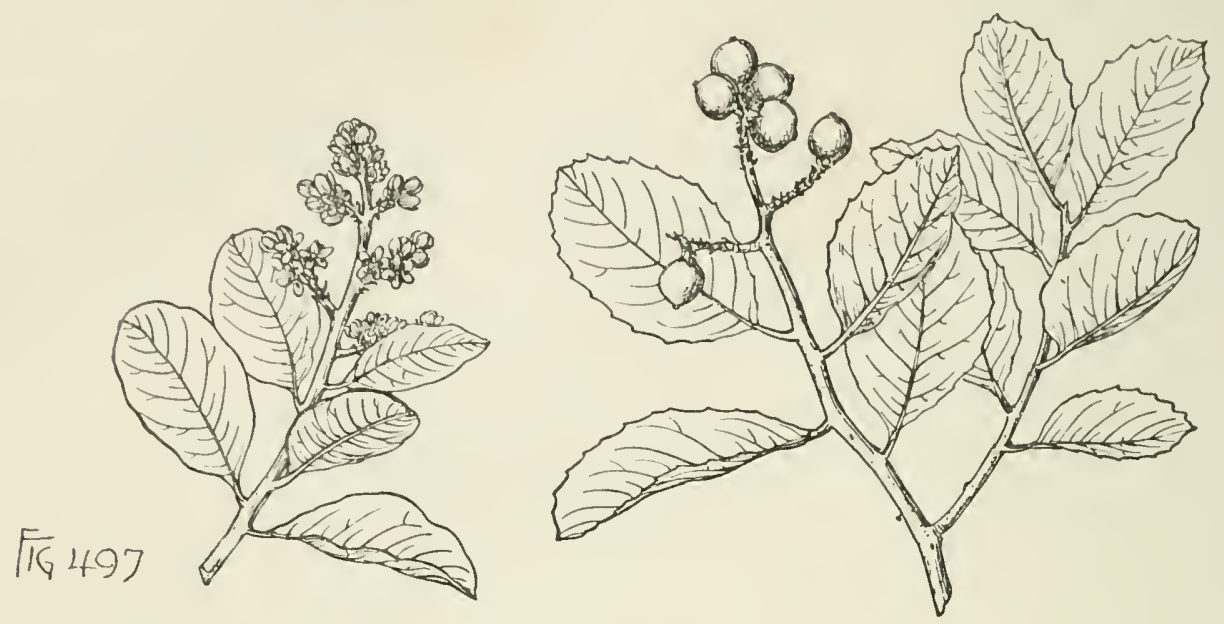

pale tomentum. Bark of the trunk $\frac{1}{4}{ }^{\prime}-\frac{1}{2}$ ' thick, bright reddish brown, exfoliating in large plate-like scales. Wood hard, heavy, bright clear red, with thin pale sapwood of 8-10 layers of annual growtlı; valued and largely used as fuel. 'The fruit is occasionally employed in the preparation of a cooling beverage.

Distribution. Sandy sterile soil along sea beaches and bluffs in the immediate neighborhood of the ocean; Santa Barbara, California, to the shores of Magdalena Bay, Lower California, and on the Santa Barbara and Cedros islands; on the mainland usnally shrubby, forming close impenetrable thickets; in more sheltered situations and on the islands becoming arborescent; probably of its largest size on the shores of Todos Santos Bay, Lower California.

\section{CYRILLACE王.}

Trees or shrubs, with small scaly buds and watery juice. Leaves alternate, entire, subcoriaceous, without stipules, persistent or tardily deciduous. Flowers small, regular, perfect, on slender bibracteolate pedicels, in terminal or axillary racemes; calyx 5-8-lobed, persistent, the lobes imbricated in the bud; petals $5-8$, hypogynous; stamens $5-10$, hypogynous, those opposite the petals shorter than the others; anthers oblong, introrse, 2-celled, the cells laterally dehiscent, opening longitudinally; ovary 2-4-celled; ovules suspended, anatropous; raphe dorsal; micropyle superior. Fruit an indehiscent capsule. Seed suspended; seed-coat membranaceous; albumen fleshy, radicle superior.

A family confined to the warmer parts of America, with three genera, of which two are represented by small trees in the southern states.

\section{CONSPECTUS OF THE GENERA OF THE UNITED STATES.}

Flowers in axillary racemes; calyx 5-lobed; petals 5, contorted in the bud; fruit without wings, 2-celled, with 2 seeds in each cell.

1. Cyrilla.

Flowers in terminal racemes; calyx 5-8-lobed; petals 5-8, imbricated in the bud; fruit with 2-4 wings, 3 or rarely 4 -celled, with 1 seed in each cell.

2. Cliftonia. 


\section{CYRILLA, L.}

A glabrous tree or shrub, with spongy bark, slender terete branchlets conspicuously marked by large leaf-scars, and narrow acute winter-buds covered with chestnut-brown scales. Leaves usually clustered near the ends of the branches, oblong or obovate-oblong, pointed, rounded, or slightly emarginate at the apex, conspicuously reticulate-veined, short-petiolate, without stipules. Flowers on pedicels from the axils of narrow alternate persistent bracts, in slender racemes from the axils of fallen leaves or of small deciduous bracts near the extremities of the branches of the previous year; calyx minute, divided nearly to the base into 5 ovate-lanceolate acute coriaceous lobes; petals 5 , contorted in the bud, white or rose color, inserted on an annular disk, three or four times longer than the calyx-lobes, oblong-lanceolate, acute, concave, subcoriaceous, furnished below the niddle on the inner surface with a broad glandular nectary; stamens 5 , opposite the divisions of the calyx, inserted with and shorter than the petals; filaments subulate, fleshy; anther-cells united above the point of the attachment of the filament, free below; ovary free, sessile, ovoid, pointed, 2-celled; styles short, thick; stigma 2-lobed, with spreading lobes; ovules 3 in each cell, suspended from an elongated placental process developed from the apex of the cell. Fruit 2-celled, broadly ovoid, crowned with the remnants of the persistent style; pericarp spongy. Seeds 2 in each cell, elongated, acuminate; embryo minute, cylindrical, 2-lobed.

Cyrilla is represented by a single species of the coast region of the south Atlantic and Gulf states and of the Antilles and eastern tropical South America.

The name commemorates the scientific labors of Domenico Cirillo (1734-1799), the distinguished Italian naturalist and patriot.

\section{Cyrilla racemiflora, $\boldsymbol{L}$. Ironwood. Leather Wood.}

Leaves $2^{\prime}-3^{\prime}$ long, $\frac{1}{4}^{\prime}-1^{\prime}$ broad, with stout petioles $\frac{1}{8}^{\prime}-1^{\prime}$ long, turning late in the autumn and early winter to brilliant sharles of orange and scarlet and then deciduous, or southward persistent with little change of color until the beginning of the

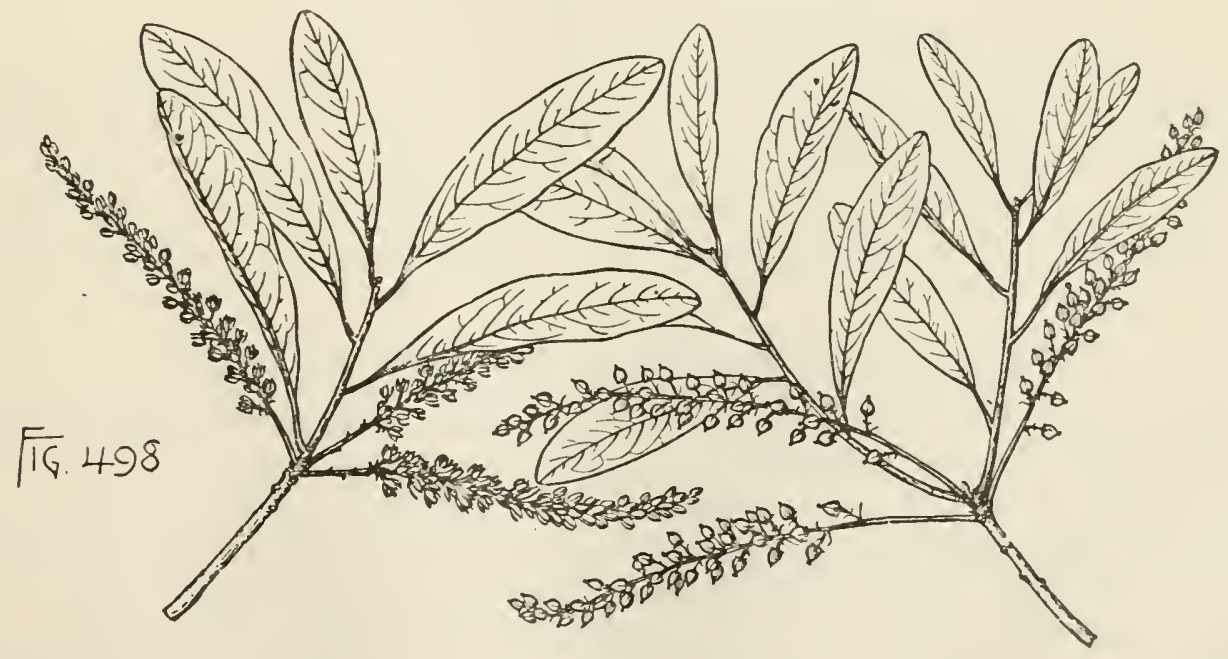

following summer. Flowers appearing late in June or early in July, in racemes usually 6-10 together and $4^{\prime}-6^{\prime}$ long, at first erect, becoming pendulous before the 
fruit ripens. Fruit ripcning in Angust and September, rarely more than $\frac{1}{16}$ 'long; seeds light brown.

A slender trec, occasionally $30^{\circ}-35^{\circ}$ high, with a stout often cccentric trunk $10^{\prime}-14^{\prime}$ in diameter, dividing several feet above the ground into numerons wide-spreading branches, and slender branchlets bright brown during their first season and ultimately ashy gray; or often a broad bush sending up many slender stems $15^{\circ}-20^{\circ}$ high. Winter-buds about $\frac{1^{\prime}}{8}$ long. Bark of the trunk rarcly more than $\frac{1^{\prime}}{2}$ thick except near the base of old trees, and covered by large thin bright red-brown scales. Wood heavy, hard, close-grained, not strong, brown tinged with red, with rather lighter colored sapwood. The spongy bark at the base of the trunk is pliable, absorbent, and astringent, and is recommended as a styptic.

Distribution. Rich shaded river-bottoms, the borders of sandy swamps and shallow ponds of the coast Pine belt, or on high sandy exposed ridges rising above streams near the Gulf coast; North Carolina soutlıward near the coast to about latitude 30 in the Florida peninsula, on the keys of southern Florida, and westward along the Gulf coast to the valley of the Neches River, Texas; and in Cuba, Jamaica, Demarara, and Brazil.

\section{CLIFTONIA, Gærtn. f.}

A glabrous tree or shrub, with thick dark brown scaly bark, slender terete branchlets marked by conspicuous leaf-scars, and small acmminate buds covered by chestnut-brown scales. Leaves oblong-lanceolate, rounded or slightly emarginate at the apex, glandular-punctate, short-petiolate, persistent. Flowers on pedicels from the axils of large acuminate membranaceous alternate bracts deciduous before the opening of the flowers, in short terminal erect racemes; calyx 5-8-lobed, equal or unequal, broadly ovate, romded or acuminate at the apex, much shorter than the 5-8 obovate unguiculate concave white or rose-colored sepals; stamens 10, opposite and alternate with the sepals, inserted with and shorter than the petals, 2-ranked, those of the outer rank longer than the otliers; filaments laterally enlarged near the middle, flattened below, snbulate above; disk cup-shaped, surromding the base of the oblong 2-4-winged 2-4-celled ovary; stigma subsessile, obscurely 2-4-lobed; ovules 2 in each cell, suspended from its apex. Fruit oblong, 2-4-winged, crowned with the remnants of the persistent style, 3 or rarely 4-celled; pericarp spongy, the wings thin and membranaceous. Secd 1 in each cell, terete, tapering to the ends, suspended; cotyledons very short.

Cliftonia is represented by a single species of the south Atlantic and Gulf states.

The generic name is in honor of Dr. Francis Clifton (d. 1736), an English physician.

\section{Cliftonia monophylla, Sarg. Titi. Ironwood.}

Leaves $1 \frac{1^{\prime}}{2}-2^{\prime}$ long, $\frac{1^{\prime}}{2}-1^{\prime}$ wide, bright green and lustrous on the upper, paler on the lower surface, persistent until the autumn of their second year. Flowers fragrant, appearing in February and March, in nodding racemes becoming erect, and conspicuons from the long exserted dark red-brown caducous bracts. Fruit about $\frac{1^{\prime}}{4}$ long, ripening in August and September; seeds $\frac{11^{\prime}}{1^{\prime}}-\frac{1^{\prime}}{8}$ long, light brown.

A tree, occasionally $40^{\circ}-50^{\circ}$ ligh, with a stout often crooked or inclining trunk, occasionally $15^{\prime}-18^{\prime}$ in diameter and usually divided $12^{\circ}-15^{\circ}$ from the ground into a number of stout ascending branches, and slender rigid bright red-brown branchlets, becoming paler during their second and third seasons; or sometimes a shrub, with 
numerous straggling stout or slender stems frequently only a few feet high or often $30^{\circ}-40^{\circ}$ high. Winter-buds about $\frac{1}{4}^{\prime}$ long. Bark of young stems and of large branches thin, the surface separating into small persistent scales $1^{\prime}-2^{\prime}$ long, becoming near the base of old trees deeply furrowed, dark red-brown, $\frac{1}{4}^{\prime}$ thick, and broken

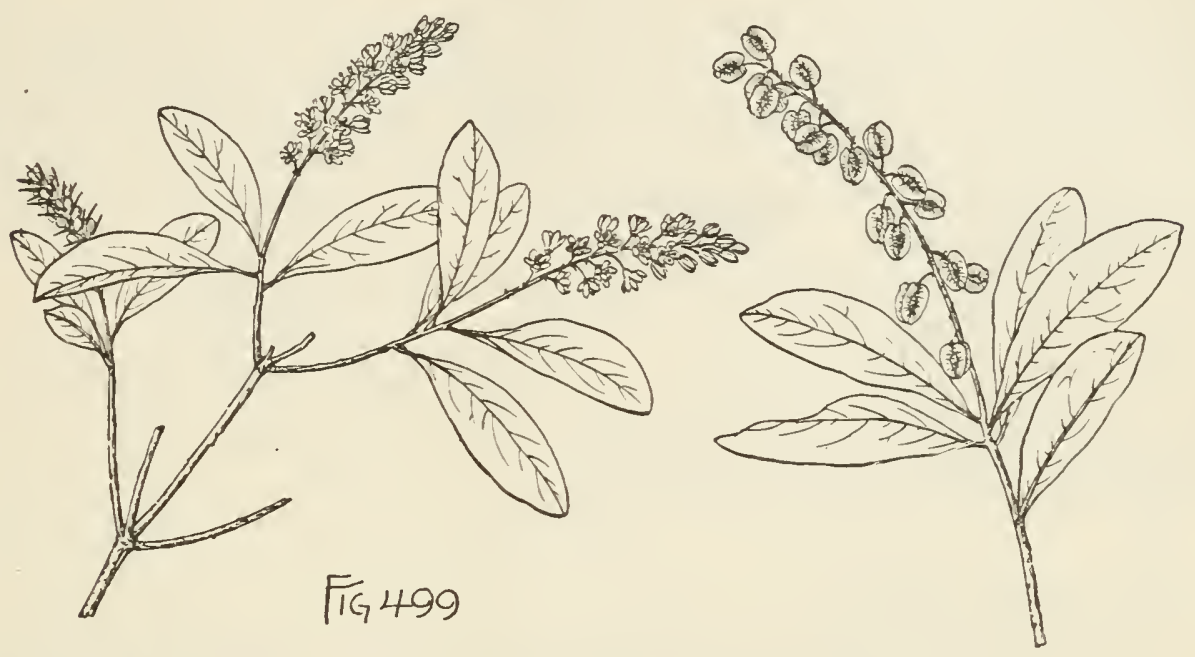

on the surface into short broad scales. Wood heavy, close-grained, moderately hard, brittle, not strong, brown tinged with red, with thick lighter colored sapwood of 40-50 layers of annual growth; burning with a clear bright flame, and valued as fuel.

Distribution. Damp sandy peat soil in swamps almost submerged for several months in the year, or often in shallow rarely overflowed swamps; coast region of the south Atlantic states from the valley of the Savannah River to northern Florida, and through the maritime Pine belt of the Gulf coast to eastern Louisiana.

\section{AQUIFOLIACE王.}

Trees or shrubs, with terete branchlets, scaly buds, and alternate simple entire crenate or pungently toothed petiolate persistent or deciduous leaves, with minute stipules. Flower's axillary, solitary or cymose, small, greenish, dicecious ; calyx 4-6-lobed, the lobes imbricated in the bud, hypogynous ; petals 4-6, imbricated in the bud; disk 0 ; stamens as many as and alternate with the petals and adnate to the base of the corolla; anthers introrse, 2-celled, the cells opening longitudinally, small and sterile in the pistillate flower ; pistil compound; ovary 4-8-celled, minute and rudimentary in the staminate flower ; style short or 0 ; stigmas as many as the cells of the ovary, nearly confluent; ovule generally solitary in each cell, suspended, anatropous ; raphe usually dorsal, the micropyle superior. Fruit a drupe, with as many indehiscent bony or crustaceous 1-seeded nutlets as carpels; sarcocarp thin and fleshy. Seed narrowed at the ends, suspended; seed-coat membranaceous, pale brown ; embryo minute in the apex of the copious fleshy albumen; cotyledons plain; the radicle superior.

The Holly family with five genera is distributed in temperate and tropical regions of the two hemispheres. Of the five genera now recognized, only Ilex is important in the number of species or is widely distributed. 


\section{Characters of the family.}

\section{ILEX, L.}

Ilex with about one hundred and seventy-five species is found in all tropical and temperate regions of the world with the exception of western North America, Australia, New Zealand, Tasmania, and New Guinea, the largest number of species occurring in Brazil and Gniana. Of the thirteen species which inhabit eastern North America, five are small trees. Ilex contains a bitter principle, ilicin, and possesses tonic properties. Ilex Paraguariensis, St. Hilaire, of South America, furnishes the maté or Paraguay tea, and is the most useful of the species. The European Ilex Aquifolium, L., is a favorite garden plant, and is sometimes planted in the middle and southern United States.

Ilex is the classical name of the Evergreen Oak of southern Europe.

\section{CONSPECTUS OF THE NORTH AMERICAN ARBORESCENT SPECIES.}

Parts of the flower in 4's; pedicels with bractlets at the base ; nutlets prominently ribbed on the back and sides; leaves persistent.

Leaves armed with spiny teeth; young branchlets glabrous or sparingly pubescent.

Leaves serrate or entire.

1. I. opaca $(A, C)$.

Leaves oblanceolate or obovate-oblong, mostly entire; young branchlets pubescent; calyx-lobes acuminate.

2. I. Cassine (C).

Leaves elliptical or elliptical-oblong, coarsely crenulate-serrate; young branchlets puberulous; calyx-lobes obtuse.

3. I. vomitoria (C).

Parts of the flower in 4's or 5's, rarely in 6's; pedicels without bractlets; nutlets striate, many-ribbed on the back; leaves deciduous.

Leaves oblong-spatulate or lanceolate-obovate, remotely crenulate-serrate; calyx-lobes broadly triangular.

4. I. decidua $(\mathrm{A}, \mathrm{C})$.

Leaves ovate or lanceolate-oblong, sharply serrate; calyx-lobes acute.

\section{Ilex opaca, Ait. Holly.}

5. I. monticola (A).

Leaves elliptical to obovate-oblong, pungently acute, with thickened undulate margins and few stout spinose teeth, or occasionally quite entire, especially on the upper branches, thick, coriaceous, dull yellow-green, paler and often yellow on the lower surface, $2^{\prime}-4^{\prime}$ long, with prominent midribs and conspicuous veins, persistent on the branches for three years, finally deciduous in the spring; their petioles short, stout, thickened at the base, grooved above, slightly pubernlent; stipnles minute, broadly acute or nearly deltoid, persistent. Flowers appearing in spring on slender puberulous pedicels, with minute acute bractlets, in short pedunculate cymes from the axils of young leaves or scattered along the base of the young shoots, 3-9-flowered on the staninate and 1 or rarely 2 or 3 -flowered on the pistillate plant; calyx-lobes acute, ciliate on the margins; stigmas broad and sessile. Fruit ripening late in the autumn, persistent on the branches dnring the winter, spherical or ovoid, dull red or rarely yellow, $\frac{1}{4}$ in diameter; nutlets prominently few-ribbed on the back and sides, rather narrower at the apex than at the base.

A tree, sometimes $40^{\circ}-50^{\circ}$ high, with a trunk $2^{\circ}, 3^{\circ}$, or exceptionally $4^{\circ}$ in diameter, short slender branches forming a narrow pyramidal head, and stout branchlets covered at first with fine rufous pubescence disappearing during their first season, and becoming glabrous and pale browu. Winter-buds short, obtuse or acuminate; $\frac{1}{8}^{\prime}-\frac{1^{\prime}}{4}$ long, with narrow acnminate ciliate scales. Bark about $\frac{1}{2}^{\prime}$ thick, light gray and 
roughened by wart-like excrescences. Wood light, tough, not strong, close-grained, nearly white when first cut, turning brown with age and exposure, with thick rather

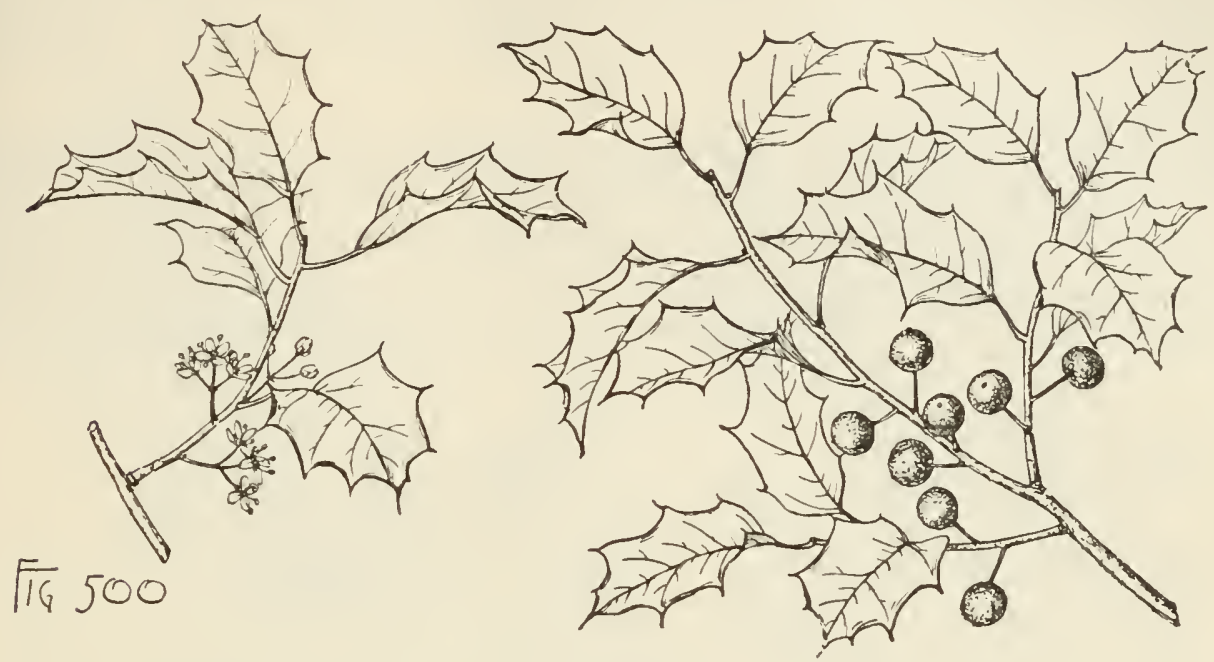

lighter colored sapwood; valued and mnch used in cabinet-making, in the interior finish of houses, and in tnrnery. The branches are used in large quantities for Christmas decoration.

Distribution. Coast of Massachusetts, in the city of Quincy, southward generally near the coast to the shores of Mosquito Inlet and Charlotte Harbor, Florida, valley of the Mississippi River from southern Indiana to the Gulf of Mexico, and through Missouri, Arkansas, and Louisiana to eastern Texas; rare and of small size east of the Hndson River and rare in the Alleghany Mountain region and the country immediately west of it; most abundant and of its largest size on the bottom-lands of the streams of southern Arkansas and eastern Texas; at the north in dry rather gravelly soil often on the margins of Oak woods, southward on the borders of swampy river-bottoms, in rich humid soil.

Occasionally cultivated in the eastern states as an ornamental plant.

\section{Ilex Cassine, L. Dahoon.}

Leaves oblanceolate to obovate-oblong, acute, mucronate or rarely rounded and occasionally emarginate at the apex, gradually narrowed and cuneate at the base, revolute and entire or sometimes serrate above the niddle, with sharp mucronate teeth, puberulons above and densely pubescent below when they first nnfold, becoming glabrous at maturity with the exception of scattered hairs on the lower surface of the broad midribs, dark green and lustrous above, pale below, $1 \frac{1}{2}-3^{\prime}$ long, and $\frac{1^{\prime}}{2}-\mathbf{1}^{\prime}$ wide; their petioles short, stout, thickened at the base, sparingly villose, Flowers on hairy pedicels, with acute scarious bractlets, in pedunculate clusters, 3-9-flowered on the staminate plant, usually 3-flowered on the pistillate plant, sometimes nearly $\mathbf{1}^{\prime}$ long, from the axils of leaves of the year or occasionally of the previous year; calyx-lobes acute, ciliate. Fruit ripening late in the autumn, persistent until the following spring, globose, sometimes $\frac{1^{\prime}}{4}$ in diameter, bright or occasionally dull red or nearly yellow, solitary or often in clusters of 3 's; nutlets prominently few-ribbed on the back and sides; ronnded at the base, acute at the apex.

A tree, $25^{\circ}-30^{\circ}$ high, with a trunk $12^{\prime}-18^{\prime}$ in diameter, and branches coated at 
first with dense silky pubescence persistent until the end of the second or third year, ultimately dark brown and marked by occasional lenticels; or often a low shrub. Winter-buds minute, acute, with lanccolate scales thickly coated with pale silky pubescence. Bark of the trunk abont $\frac{1}{1 \overline{8}}$ thick, dark gray, thickly covered and roughened by lenticcls. Wood light, soft, close-grained, not strong, pale brown, with thick nearly white sapwood.

Distribution. Cold swamps and on their borders, in rich moist soil, or occasionally on the high sandy banks of Pine-barren strcams; southern Virginia southward in the immediate neighborhood of the coast to the shores of Bay Biscayne and Tampa Bay, Florida, and along the Gulf coast to western Louisiana; nowhere abundant on the Atlautic coast; most common in western Florida and southern Alabama; passing

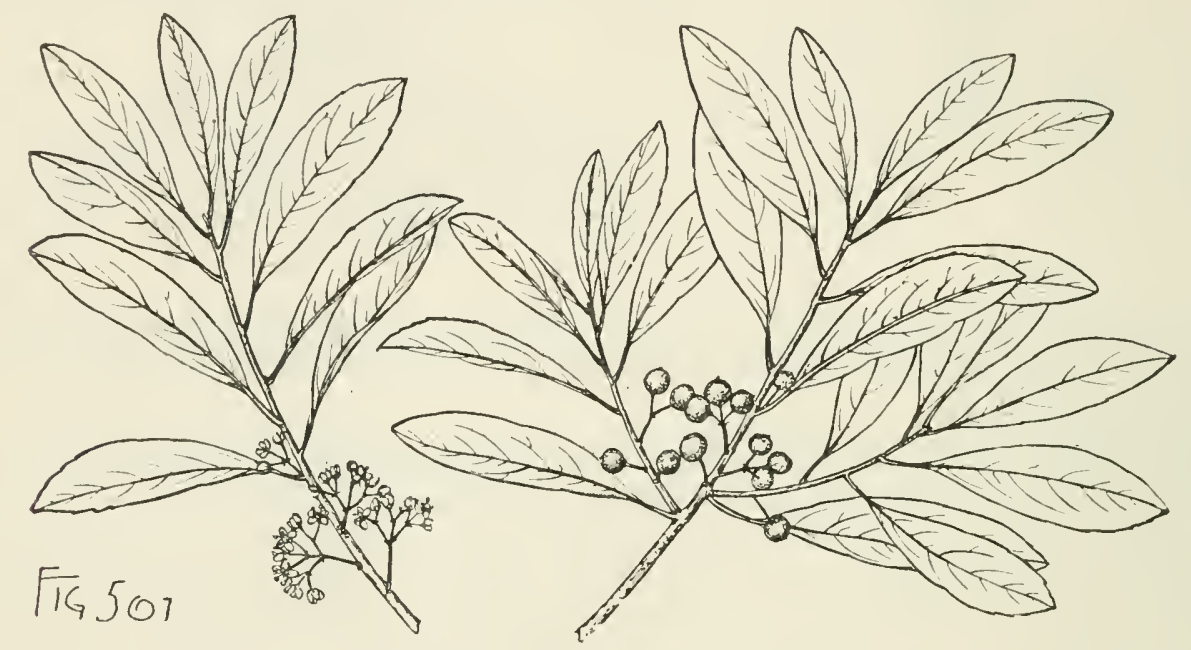

through forms with elongated narrow leaves into the variety myrtifolia, Sarg. This is a low slirub or occasionally a sleuder wide-branched tree, with pale nearly white bark, puberulous branchlets, and crowded generally entire mucronate leaves $\frac{1^{\prime}}{2}-1^{\prime}$ long, $\frac{1^{\prime}}{8}$ wide, with strongly reflexed margins, very short petioles, and broad prominent midribs; an inhabitant of Cypress swamps and Pine-barren ponds or their margins, in the neighborhood of the coast, North Carolina to Louisiana; perhaps to be considered a distinct species.

\section{Ilex vomitoria, Ait. Cassena. Yaupon.}

Leaves elliptical to elliptical-oblong, obtuse, coarsely and remotely crenulateserrate, coriaceons, dark green and lustrous above, pale and opaque below, $1^{\prime}-2^{\prime}$ long, $\frac{1^{\prime}}{4}-1^{\prime}$ broad, persistent for two or three years, generally falling just before the appearance of the new growth of their third season; their petioles short, broad, and grooved. Flowers on slender club-shaped glabrous pedicels, with minute bractlets at the base, in short glabrous cymes on branchlets of the previous year, those of the staminate plant short-stemmed and many-flowered, those of the pistillate plant sessile and 1 or 2 -flowered; calyx-lobes rounded, obtuse, often slightly ciliate; ovary contracted below the broad flat stigma. Fruit produced in grcat abundance, on stems not more than $\frac{1}{4}$ long, ripening late in the autumn or in early winter, soon deciduous, or persistent until spring, scarlet, nearly globose, about $\frac{1}{4}$ in diameter; nutlets obtuse at the ends, and prominently few-ribbed on the back and sides. 
A small much-branched tree, $20^{\circ}-25^{\circ}$ high, with a slender often inclining trunk rarely more than $6^{\prime}$ in diameter and stout branchlets standing at right angles with the stem, slightly angled and puberulous during the first season, becoming glabrous
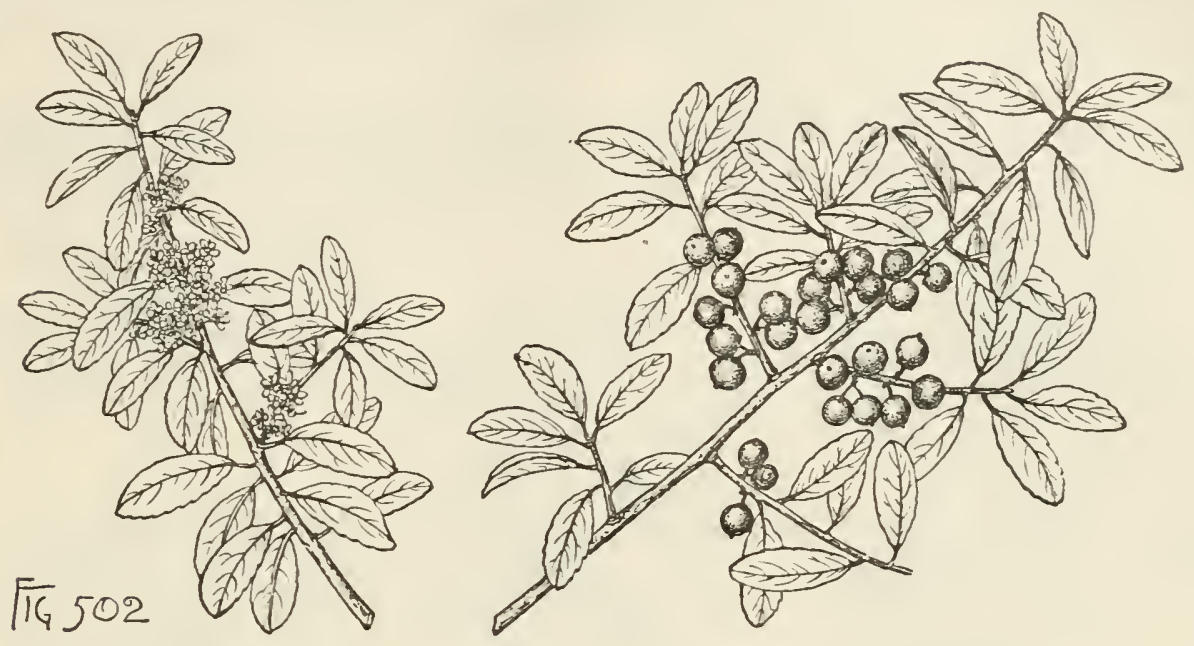

or nearly glabrous, terete and pale gray in their second year; generally a tall shrub, with numerous stems forming dense thickets. Winter-buds minute, obtuse, with narrow dark brown or often nearly black scales. Bark of the trunk $\frac{1}{16}-\frac{1}{8}$ thick, the light red-brown surface broken into thin minute scales. Wood heavy, hard, close-grained, nearly white, turning yellow with exposure, with thick lighter colored sapwood.

Distribution. Southern Virginia to the St. John's River and Cedar Keys, Florida, and westward to the shores of Matagorda Bay and the valley of the upper Rio Blanco, Texas, and to southern Arkansas; in the Atlantic and east Gulf states rarely far from salt water and usually not more than $10^{\circ}-15^{\circ}$ high; of its largest size and of tree-like habit only on the rich bottom-lands of eastern Texas. The branches covered with the fruit are sold during the winter months for decorative purposes. An infusion of the leaves, which are emetic and purgative, was used by the Indians, who formerly visited the coast in large numbers every spring to drink it.

\section{Ilex decidua, Walt.}

Leaves deciduous, except on vigorous shoots fascicled at the ends of short spurlike lateral branchlets, oblong-spatulate or spatulate-lanceolate, acuminate, obtuse, or emarginate at the apex, gradually narrowed below, remotely crenulate-serrate, $2^{\prime}-3^{\prime}$ long, $\frac{1}{3}^{\prime}-1^{\prime}$ wide, membranaceous, becoming thick and firm at maturity, light green above and pale and sparingly hairy along the narrow midribs beneath; their petioles slender, grooved, pubescent, abont $\frac{1}{4}^{\prime}$ long; stipules filiform, membranaceous. Flowers on slender pedicels, those of the staminate plant often $\frac{1^{\prime}}{2}$ long and longer than those of the pistillate plant, in 1 or 2 -flowered glabrous cymes crowded at the ends of the lateral branclies of the previous season, or rarely solitary on branchlets of the year; calyx-lobes triangular, with smooth or sometimes ciliate margins, Fruit on short stout stems, ripening in the early antumn, often remaining on the branches until the appearance of the leaves the following spring, globose or depressed-globose, orange or orange-scarlet, $\frac{1}{4}$ in diameter; nutlets narrowed and rounded at the base, acute or acuminate at the apex, many-ribbed on the back. 
A tree, $20^{\circ}-30^{\circ}$ high, with a slender trunk $6^{\prime}-10^{\prime}$ in diameter, stout spreading branches, and slender glabrous pale silver gray branchlets; more often a tall straggling shrub. Winter-buds minute, obtuse, with ovate light gray scales. Bark of the trunk rarely more than $\frac{1^{\prime}}{16}$ thick, light brown, and roughened by wart-like excrescences. Wood heavy, hard, close-grained, creamy white, with rather lighter colored sapwood.

Distribution. Borders of streams and swamps in low moist soil; southern Virginia to western Florida in the region between the eastern base of the Appalachian
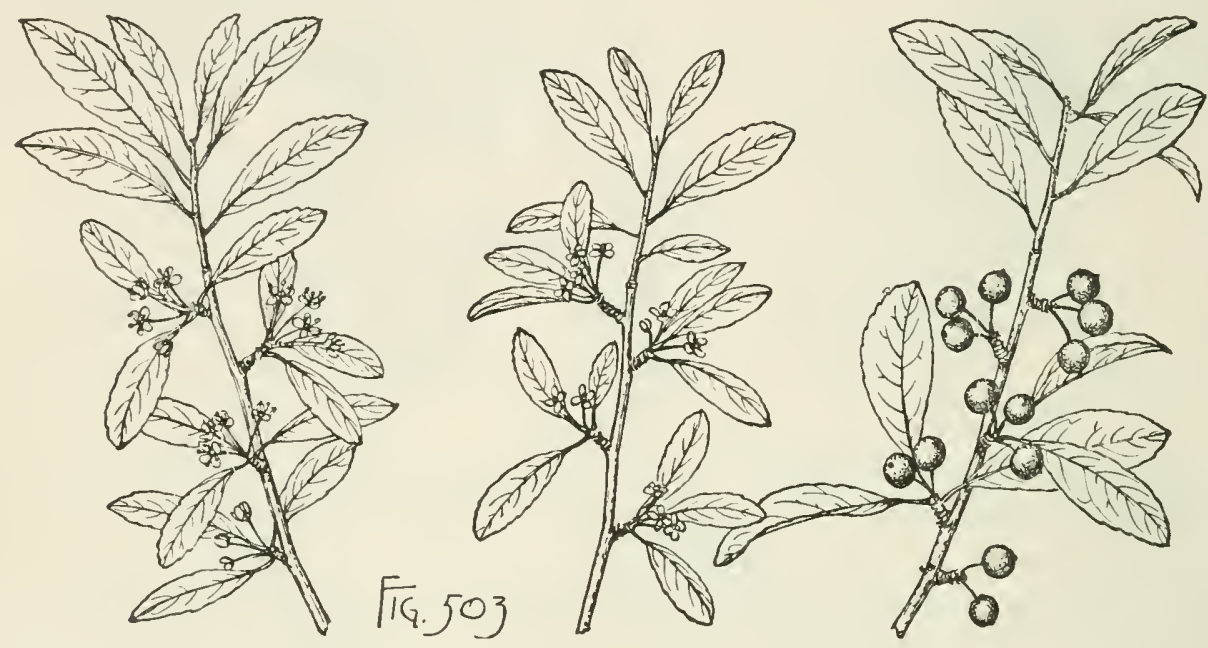

Mountains and the neighborhood of the coast, and through the Gulf states to the valley of the Colorado River, Texas, and through Arkansas and Missouri to southern Illinois; usually shrubby east of the Mississippi River and only arborescent in Missouri, southern Arkansas, and eastern Texas. In Florida a form (var. Curtissii, Fern.) occurs with leaves only $\frac{1}{3}^{\prime}-\frac{2}{3}^{\prime}$ long and fruit about $\frac{1}{4}^{\prime}$ in diameter.

\section{Ilex monticola, Gray.}

Leaves deciduous, ovate to lanceolate-oblong, acute at the apex, cuneate or rounded at the base, sharply and rather remotely serrate, with minute glandular teeth, membranaceous, glabrous, or sparingly hairy along the prominent midribs and veins, $4^{\prime}-5^{\prime}$ long, $\frac{1^{\prime}}{2}-2^{\prime}$ wide, light green above and pale below; their petioles slender, $\frac{1^{\prime}}{3}-\frac{1}{2}^{\prime}$ long. Flowers appearing in June when the leaves are more than half grown, on slender pedicels $\frac{1}{2}^{\prime}$ long on the staminate plant and much longer on the pistillate plant, in 1-2-flowered cymes crowded at the ends of lateral spur-like branchlets of the previous year, or solitary on branchlets of the year; calyx-lobes acute, ciliate; ovary contracted below the broad flat stigma. Fruit globose, bright scarlet, nearly $\frac{1}{2}^{\prime}$ in diameter; nutlets narrowed at the ends, prominently ribbed on the back and sides.

A tree, $30^{\circ}-40^{\circ}$ ligh, with a short trunk sometimes $10^{\prime}-12^{\prime}$ in diameter, slender branches forming a narrow pyramidal head, and more or less zigzag glabrous branchlets pale red-brown at first, becoming dark gray at the end of their first season; more often a low shrub, with spreading stems. Winter-buds broadly ovate to subglobose, about $\frac{1}{8}^{\prime}$ long, with ovate keeled apiculate light brown scales. Bark of the trunk usually less than $\frac{1}{16}^{\prime}$ thick, with a light brown surface roughened by numerous lenticels. Wood hard, heavy, close-grained, and creamy white. 


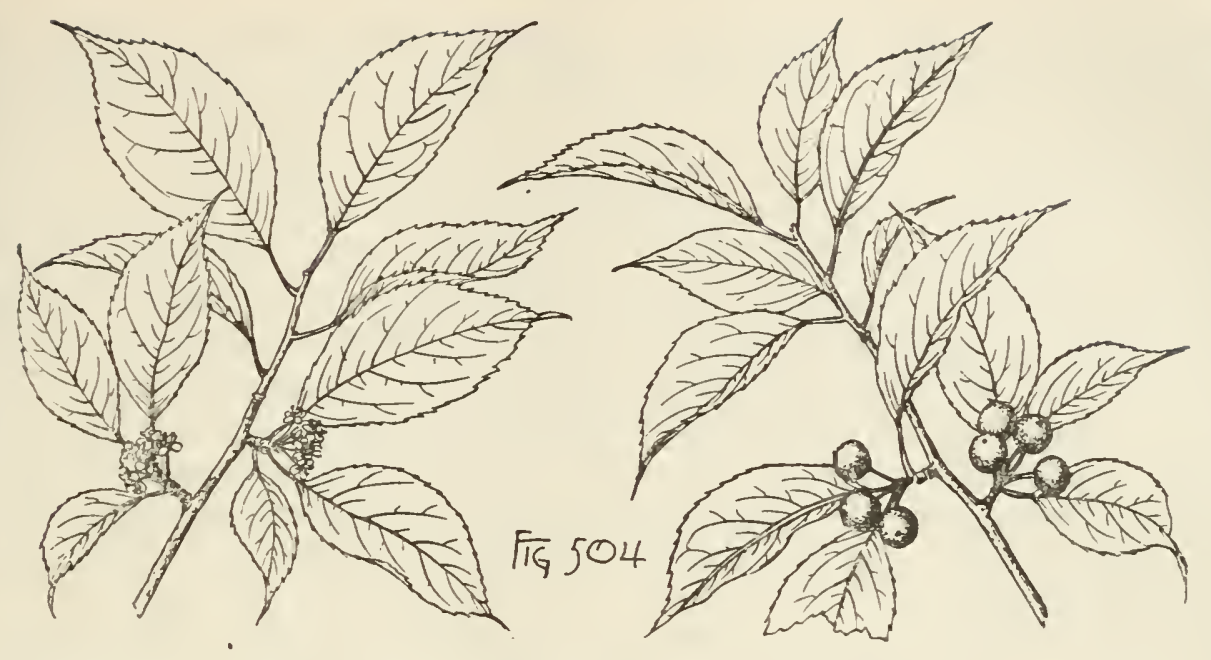

Distribution. Central and western New York, southward along the Alleghany Mountains to northern Alabania; arborescent only on the banks of streams flowing from the Blue Ridge in North and South Carolina.

\section{CELASTRACE王.}

Trees or shrubs, with watery juice, and opposite or alternate simple persistent or deciduous leaves with or without stipules. Flowers regular, perfect, polygamous or diœcious, pedicellate in axillary clusters; calyx $4-5$-lobed, the lobes imbricated in the bud; petals 4 or 5 , imbricated in the bud; stamens 4 or 5 ; anthers introrse, 2 -celled, the cells opening longitudinally; ovary $2-5$ celled; ovules 2 or solitary in each cell ( 6 in Canotia), anatropous, or subhorizontal Y in Canotia). Fruit a capsule or drupe. Seed with copious albumen ; embryo axile.

A family of about thirty-eight genera widely distributed over the tropical and warm temperate parts of the world, with four arborescent representatives in the United States.

\section{CONSPECTUS OF THE ARBORESCENT GENERA OF THE UNITED STATES.}

Parts of the flower in 4's.

Leaves opposite, deciduous; flowers polygamous ; fruit a fleshy 3-5-celled capsule ; seed surrounded by a colored aril.

1. Evonymus.

Leaves alternate, persistent; flowers diœcious ; fruit a drupe ; seed without an aril.

Leaves often crenately serrate above the middle; stipules minute, cadncous; fruit usually 1 -seeded; branchlets quadrangular.

Leaves entire; stipules 0 ; fruit 2-seeded; branchlets terete.

2. Gyminda. Lus. ol

3. Schæfferia.

Parts of the flower in 5's, leaves 0 ; flowers perfect; fruit a woody 5-celled capsule, the valves 2-lobed at the apex.

4. Canotia.

\section{EVONYMUS, L.}

Small generally glabrous trees or shrubs, with usually square branchlets, bitter drastic bark, slender obtuse or acuminate winter-buds, and fibrous roots. Leares opposite, petiolate, entire, crenate or dentate; stipules minute, caducous. Flowers perfect or polygamo-diœcious, in dichotomous axillary usually few-flowered cymes; calyx 4-lobed (in the North American arborescent species); disk thick and fleshy, 
cohering with and filling the short tube of the calyx, flat, 4-angled or lobed, elosely surrounding and adhering to the ovary; petals inserted in the simnses of the calyx under the free border of the disk, as many as and much longer than the ealyx-lobes, spreading, decidnons; stamens as many as the petals and alternate with them, inserted on the summit of the disk; filaments very short, subulate, ereet or recurved; anthers 2-celled, the cells nearly parallel or spreading below; ovary 4-celled; styles sliort, terminating in a depressed stigna; ovules usually 2 in each ccll, ascending from the central angle, raphe ventral, micropyle inferior, or pendulous, the raphe then dorsal and the micropyle superior. Fruit capsular, 4-lobed and celled, fleshy, angled or winged, smooth (in the North American arborescent species), loculicidally 4 -valved, the valves septifcrous. Seeds 2 in each cell, or commonly solitary by abortion, ascending, surrounded by a colored aril; seed-coat chartaceous; albumen fleshy; embryo axile; cotyledons broad, coriaccous, parallel with the raphe; the radicle short, inferior.

Evonymus is widely distributed through the northern hemisphere, extending south of the equator to the islands of the Indian Archipelago and to Australia. About forty species are distinguished, the largest number occurring in the tropical regions of southern Asia, and in China and Japan. Of the four species found within the territory of the United States onc only is a small tree. Many of the species are rich in bitter and astringent principles, and are drastic and slightly stimulant. Many are valued as ormaments of gardens and parks.

The generic name is from the classical name of one of the European species.

\section{Evonymus atropurpureus, Jacq. Burning Bush. Wahoo.}

Leaves elliptical-ovate, acuminate, minutely serrate or biserrate, membranaceous, puberulous below, $2^{\prime}-5^{\prime}$ long, $1^{\prime}-2^{\prime}$ broad, with stout midribs and primary veins, turning pale yellow in the autumn and falling in October; their petioles stout, $\frac{1}{2}^{\prime}-1^{\prime}$

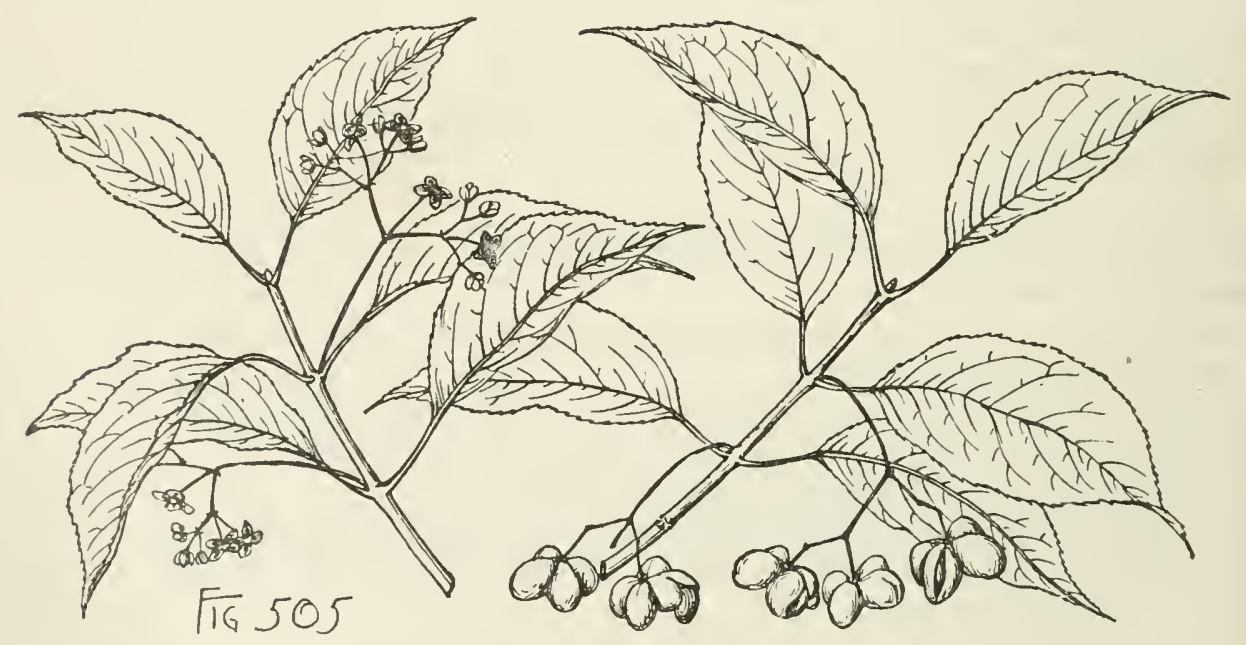

long. Flowers appearing from May to the middle of June, nearly $\frac{1}{2}^{\prime}$ across, with 4 rounded or rarely acute mostly entire calyx-lobes, broadly obovate undulate petals often erose on the margins, and spreading anthers, in twice or thrice dicliotomous usually 7-15-flowered cymes borne on slender peduncles $1^{\prime}-2^{\prime}$ long and conspicuously marked by the scars of minute bracts. Fruit ripening in October, usually persistent on the branches until midwinter, deeply lobed, $\frac{1}{2}^{\prime}$ across, with light purple 
valves; seeds sometimes gibbous on the dorsal side, broad and rounded above, narrowed below, $\frac{1}{4}$ long, with a thin light chestnut-brown wrinkled coat and a thin scarlet aril.

A tree, rarely $20^{\circ}-25^{\circ}$ high, with a trunk $4^{\prime}-6^{\prime}$ in diameter, spreading branches, and slender terete branchlets dark purple-brown at first, becoming lighter colored in the second season, often covered with small crowded lenticels, and marked by prominent leaf-scars; more often a slırub, $6^{\circ}-10^{\circ}$ tall. Winter-buds $\frac{1}{8}^{\prime}$ long, acute, with narrow purple apiculate scales scarious on the margins and covered by a glaucous bloom. Bark thin, ashy gray, and covered by thin minute scales. Wood heavy, hard, very close-grained, white tinged with orange.

Distribution. Borders of woods in rich soil; western New York to Nebraska, southeastern South Dakota and eastern Kansas, and in the valley of the upper Missouri River, Montana, and southward to northern Florida, southern Arkansas, and the Indian Territory; arborescent only in southern Arkansas and eastern Texas.

Occasionally cultivated as an ornament of gardens in the eastern United States and in Europe.

\section{GYMINDA, Sarg.}

Trees or shrubs, with pale quadrangular branchlets and minute acuminate buds. Leaves opposite, short-petiolate, oblong-obovate, rounded and sometimes emarginate at the apex, entire or remotely crenulate-serrate above the middle, with revolute thickened margins, feather-veined, coriaceous, persistent; stipules minute, acuminate, membranaceous, caducous. Flowers unisexual, pedicellate, in axillary pedunculate few-flowered dichotomously branched cymes bibracteolate at the apex; calyx minute, 4-lobed, persistent, with a short urceolate tube and rounded lobes; disk fleshy, filling the tube of the calyx, cup-shaped, slightly 4-lobed; petals entire, obovate, white, rounded at the apex, reflexed, much longer than the lobes of the calyx; stamens 4 , opposite the sepals, inserted in the lobes of the disk, exserted, 0 in the pistillate flower; filaments slender, subulate, incurved; anthers oblong; ovary 2-celled, oblong, sessile, confluent with the disk, crowned with a large 2-lobed sessile stigma, rudimentary and deeply cleft in the staminate flower; ovule solitary, suspended from the apex of the cell; raphe dorsal; micropyle superior. Fruit drupaceous, 2-celled, 1 or 2-seeded, black or dark blue, oval or obovate, crowned with the remnants of the persistent stigma, often 1-celled by abortion; flesh thin; stone thick, crustaceous. Seed oblong, suspended; seed-coat membranaceous; albumen thin, fleshy; embryo axile; cotyledons ovate, foliaceous; radicle superior, next the hilum.

Gyminda with a single species is distributed from southern Florida to Trinidad and southern Mexico, and is represented in Central America by what is perbaps a second species.

The generic name is formed by transposing the first three letters of Myginda, to which this plant had been referred.

\section{Gyminda Grisebachii, Sarg.}

Leaves $1 \frac{1^{\prime}}{2}-2^{\prime}$ long, $\frac{3{ }^{\prime}}{4}-1^{\prime}$ broad, pale yellow-green. Flowers produced on shoots of the year from April to June. Fruit ripening in November, $\frac{1}{4}^{\prime}$ long.

A tree, sometimes $20^{\circ}-25^{\circ}$ high, with a trunk rarely more than $6^{\prime}$ in diameter, and branchlets becoming terete during their third season and covered with thin slightly grooved roughened bright red-brown bark. Bark of the trunk thin, brown tinged with red, separating into thin minute scales. Wood very heary, hard, close-grained, 
dark brown or nearly black, with thick light brown sapwood of 75-80 layers of annual growth.

Distribution. Common and generally distributed over the keys of southern

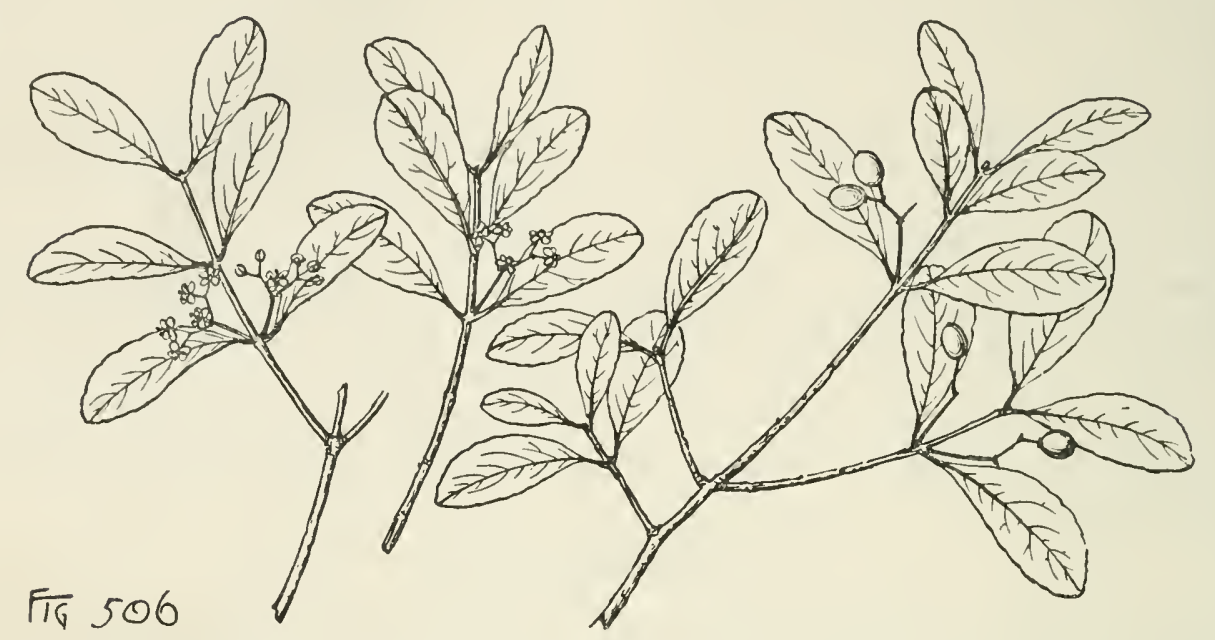

Florida from the Marquesas to Metacombe Key; also in Cuba, Porto Rico, Trinidad, and southern Mexico. A form (var. glaucescens, Sarg.) with smaller less coriaceous very glaucous leaves occurs in Cuba.

\section{SCHÆFFERIA, Jacq.}

Glabrous trees or shrubs, with slender rigid terete branches and small obtuse buds. Leaves alternate, or fascicled on short spur-like branchlets, entire, obovate or spatulate, acute and minutely apiculate or gradually narrowed to the rounded or emarginate apex, cuneate below, persistent, without stipules. Flowers diœcious, pedicellate in axillary clusters from buds covered by scale-like persistent bracts; calyx 4-lobed, the lobes orbicular, persistent, much shorter than the 4 hypogynous, oblongobtuse, white or greenish white petals; stamens 4, hypogynous, inserted under the margin of the small inconspicuous disk opposite the lobes of the calyx, wanting in the pistillate flower; filaments subulate, incurved; anthers oblong-ovate; ovary 2-celled, ovoid, sessile, free, rudimentary in the staminate flower; style very short, gradually enlarged into the large 2-lobed stigma, with spreading lobes; ovule solitary, ascending; raphe thin, ventral; the nicropyle inferior. Fruit a small 2-seeded fleshy drupe, ovate or obovate, crowned with the remnants of the persistent style, indistinetly 2-lobed by longitudinal grooves, slightly flattened; flesh thin and tuberculate; nutlets 2, obovate, rounded at the ends, with a thick bony shell. Seed solitary, ascending; seed-coat membranaceous; albumen fleshy; cotyledons broad, foliaceous; the radicle very short, inferior, next the hilum.

Two species of Schæfferia are recognized, one a small tree widely distributed through the Antilles and reaching the islands of southern Florida and central America, the second a little-known shrub of the arid region of westeru Texas and northern Mexico.

The generic name is in honor of Jakob Christian Schaeffer (1718-1790), the distinguished German naturalist. 


\section{Schæfferia frutescens, Jacq. Yellow Wood. Box Wood.}

Leaves bright yellow-green, $2^{\prime}-2 \frac{1}{2}^{\prime}$ long, $\frac{1}{2}^{\prime}-1^{\prime}$ wide, with thick revolute margins, appearing in Florida in April and persistent on the branches until the spring of the following year; their petioles short and broad. Flowers opening in spring on branchlets of the year, $\frac{1}{8}^{\prime}$ across, the staminate generally 3 or 5 together on pedicels rarely more than $\frac{1^{\prime}}{6}$ long, the pistillate solitary or 2 or 3 together on pedicels rather longer than the petioles. Fruit ripening in Florida in November, slightly grooved, compressed, bright scarlet, with an acrid disagreeable flavor.

A glabrous tree, $35^{\circ}-40^{\circ}$ high, with a trunk sometimes $8^{\prime}-10^{\prime}$ in diameter, erect branches, and slender many-angled branchlets pale greenish yellow during their first season, becoming light gray during the second year and then conspicuously marked

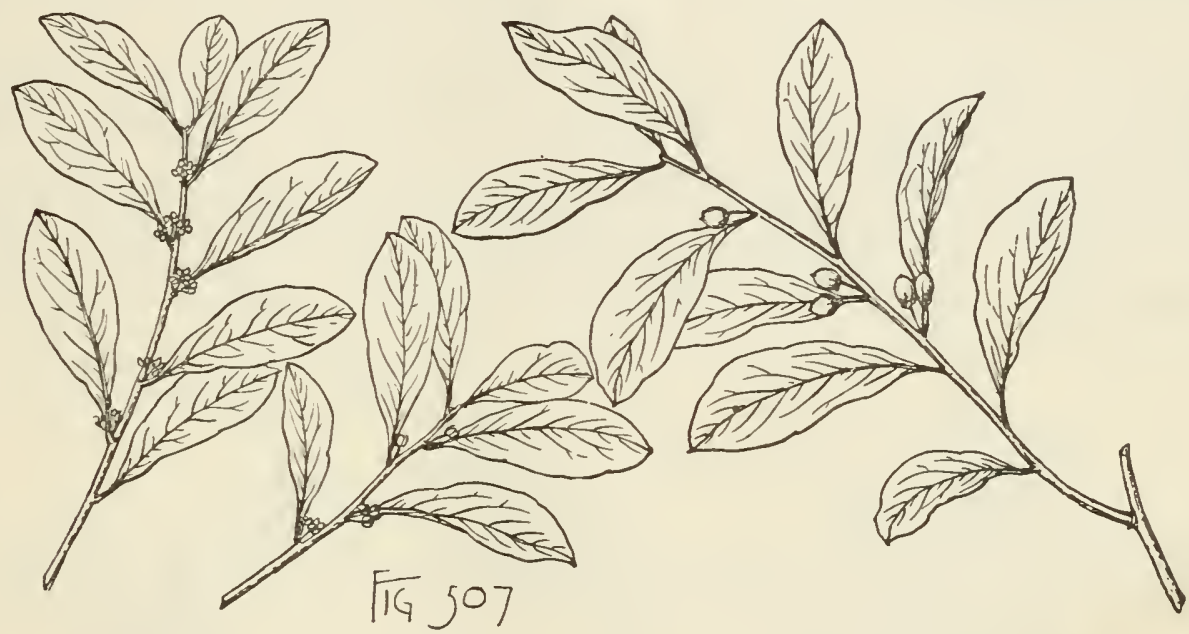

by the remains of the persistent wart-like clusters of bud-scales; or often a tall or low shrub. Bark of the trunk rarely more than $\frac{1}{12}^{\prime}$ thick, pale brown faintly tinged with red, the surface divided by long shallow fissures, and ultimately separating into long narrow scales. Wood heavy, close-grained, bright clear yellow, with thick rather lighter colored sapwood; sometimes used as a substitute for boxwood in wood engraving.

Distribution. Metacombe Key eastward along the keys, in the neighborhood of the Caloosa River, and sparingly on the reef keys, Florida; on the Bahama Islands, and widely distributed through the West Indies to Venezuela.

\section{CANOTIA, Torr.}

A glabrous leafless tree, with light brown deeply furrowed bark, stout terete alternate branches terminating in rigid spines, pale green and striate, their bases and those of the peduncles surrounded by black triangular persistent cushion-like processes minutely papillose on the surface. Flowers perfect, on slender spreading pedicels joined below the middle, 3-7 together, in short-stemmed fascicles or corymbs near the ends of the branches, from the axils of minute ovate subulate bracts; calyx 5-lobed, minute, persistent, much shorter than the oblong obtuse white hypogynous petals imbricated in the bud, reflexed at maturity above the middle, deciduous; stamens 5, hypogynous, opposite the lobes of the calyx; filaments awl-shaped, rather shorter than the petals, persistent on the fruit; anthers oblong, cordate, introrse, 
minutely apiculate, attached below the middle, grooved on the back; ovary raised upon and confluent with a fleshy slightly 10-angled gynophore, papillose-glandular on the surface, 5-celled, the cells opposite the petals, terminating in a fleshy elongated style; stigma slightly 5-lobed; ovules 6 in each cell, inserted in 2 ranks on its inner angle, subhorizontal; micropyle inferior. Fruit a woody terete oblong capsule tapering at the ends, crowned with a subulate persistent style, septicidally 5 -valved, the valves 2 -lobed at the apex; outer coat thin, fleshy; inner coat woody. Seed solitary or in pairs, ascending, subovate, flattened; seed-coat subcoriaceous, papillate, produced below into a subfaleate membranaceous wing; embryo surrounded by thin fleshy albumen, erect; cotyledons oval, compressed; radicle very short, inferior.

The genus is represented by a single species.

The generic name is that by which this plant was known to the Mexicans of Arizona at the time of its discovery.

\section{Canotia holacantha, Torr.}

Leaves 0. Flowers $\frac{1^{\prime}-1^{\prime}}{4}$ in diameter, appearing from June until October. Capsule $1^{\prime}$ long; seed about $\frac{8^{\prime}}{4}$ long.

A small shrub-like tree, sometimes $20^{\circ}-30^{\circ}$ high, with a short stout trunk rarely a foot in diameter; or often a low spreading shrub.

Distribution. Dry gravelly mesas on the Arizona foothills, from the White

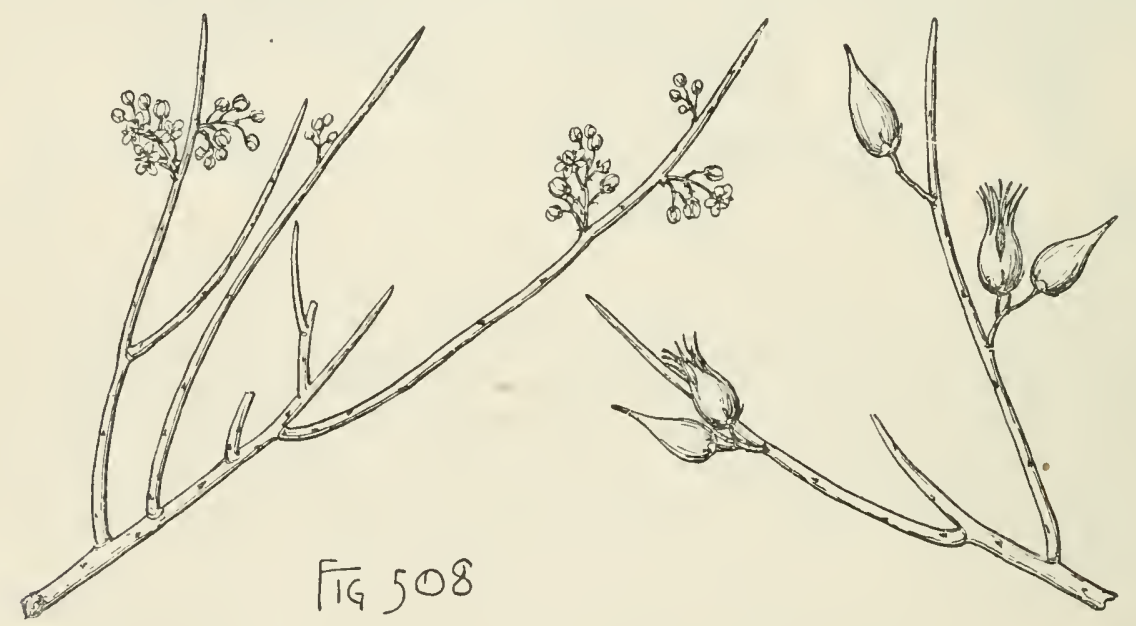

Mountain region to the valley of Bill Williams's Fork in the northwestern part of the territory, and on Providence Mountain in southern California.

\section{ACERACE届.}

Trees or rarely shrubs, with limpid juice, terete branches, scaly buds, their inner scales accrescent and marking the base of the branchlets with ring-like scars, and fibrous roots. Leaves opposite, long-petioled, simple, palmately 3-7-lobed or pinnately 3-5-foliolulate, usually without stipules, deciduous, in falling leaving small U-shaped narrow scars showing the ends of 3 equidistant fibro-vascular bundles. Flowers regular, diœcionsly or monœciously polygamous, rarely perfect or diœcious, in fascicles produced from separate lateral buds appearing before the leaves or in terminal and lateral racemes or panicles 
appearing with or later than the leaves; bracts minute, caducous; calyx colored, generally 5 -parted, the lobes imbricated in the bud; petals usually 5 , imbricated in the bud, or 0 ; disk annular, fleshy, more or less lobed, with a free margin; stamens $4-10$, usually 7 or 8 , inserted on the summit or inside of the disk, hypogynous; filaments distinct, filiform, comnionly exserted in the staminate, shorter and generally abortive in the pistillate flower; anthers oblong or linear, attached at the base, introrse, 2-celled, the cells opening longitudinally; ovary 2-lobed, 2-celled, compressed contrary to the dissepiment, wing-margined on the back; styles 2 , inserted between the lobes of the ovary, connate below and divided into 2 linear branclies stigmatose on their inner surface; ovules 2 in each cell, collateral, rarely superposed, ascending, attached by their broad bases to the inner angle of the cell, anatropous or amplitropous ; micropyle inferior. Fruit composed of 2 samaras separable from a small persistent axis, the nut-like carpels compressed laterally, produced on the back into large chartaceous or coriaceous reticulated obovate wings thickened on the lower margin. Seed solitary by abortion, or rarely 2 in each cell, ovate, compressed, irregularly 3-angled, ascending obliquely, without albumen; seed-coat membranaceous, the inner coat often fleshy; embryo conduplicate ; cotyledons thin, foliaceous or coriaceous, irregularly plicate, incumbent or accumbent on the elongated descending radicle turned toward the hilum.

A family of two genera, one widely distributed, the other, Dipteronia, distinguished by the broad wings encircling the mature carpels, and represented by a single Chinese species.

\section{ACER, L. Maple.}

Characters of the family.

Acer with sixty or seventy species is widely distributed over the northern hemisphere, with a single species extending south of the equator to the mountains of Java. Acer produces light close-grained moderately hard wood valued for the interior finish of houses and in turnery. The bark is astringent, and the limpid sweet sap of some of the American species is manufactured into sugar.

Acer is the classical name of the Maple-tree.

\section{CONSPECTUS OF THE NORTH AMERICAN SPECIES.}

1. Leaves simple.

* Hlowers appearing with or after the leaves from terminal buds; fruit ripening in the autumn.

Flowers with petals, appearing after the leaves.

Flowers in erect dense racemes; leaves 3 or slightly 5-lobed.

1. A. spicatum (A).

Flowers in drooping racemes.

Ovary and young fruit glabrous; leaves 3 -lobed at the apex.

Ovary and young fruit hairy; leaves deeply 5-lobed.

2. A. Pennsylvanicum (A).

3. A. macrophyllum (G).

Flowers in terminal pendent corymbs.

Leaves palmately 7-9-lobed.

4. A. circinatum $(B, G)$.

Leaves 3-lobed or 3-parted.

5. A. glabrum (B, F, G).

Flowers without petals, appearing after the leaves, in nearly sessile umbel-like terminal and lateral pendent corymbs.

Corymbs sessile. 
Leares pale or glancous beneatl.

Leaves dark green above, glabrous beneath at maturity, their lobes coarsely toothed or rarely entire.

6. A. Saccharum $(\mathrm{A}, \mathrm{C})$.

Leaves pale pubescent beneath, their lobes short and obtuse.

7. A. Floridanum (C).

Leaves green beneatl.

Leaves yellow-green above, more or less hirsute-pubescent, especially beneath and on the petioles, their lobes entire or undulate, the basal sinus often closed by the overlapping lobes.

8. A. nigrum (A).

Leaves tomentulose or rarely glabrous beneath, their lobes slightly lobnlate, sometimes acuninate.

9. A. leucoderme (C).

Corymbs short-stalked; leaves pale and nsually pubescent beneath, 3-lobed, the lobes distinctly lobulate, acute or obtuse.

10. A. grandidentatum $(\mathrm{F}, \mathrm{H})$.

**Flowers appearing before the leaves in umbel-like fascicles from separate lateral buds; fruit ripening in spring or early summer.

Flowers sessile or short-stalked, without petals; ovary and young fruit tomentose, leaves deeply 5-lobed.

11. A. saccharinum (A, C).

Flowers on long pedicels, with petals ; ovary and young fruit glabrous; leaves $3-5$ lobed.

12. A rubrum (A, C).

2. Leaves pinnately or ternately divided; flowers diœcious, without petals.

13. A. Negundo (A, C, F, G).

1. Leaves simple.

* Flowers appearing with or after the leaves; fruit ripening in the autumn.

\section{Acer spicatum, Lam. Mountain Maple.}

Leaves subcordate or sometimes truncate at the base, conspicuously 3-nerved, 3 or slightly 5-lobed, with gradually narrowed pointed lobes, and sharply and coarsely

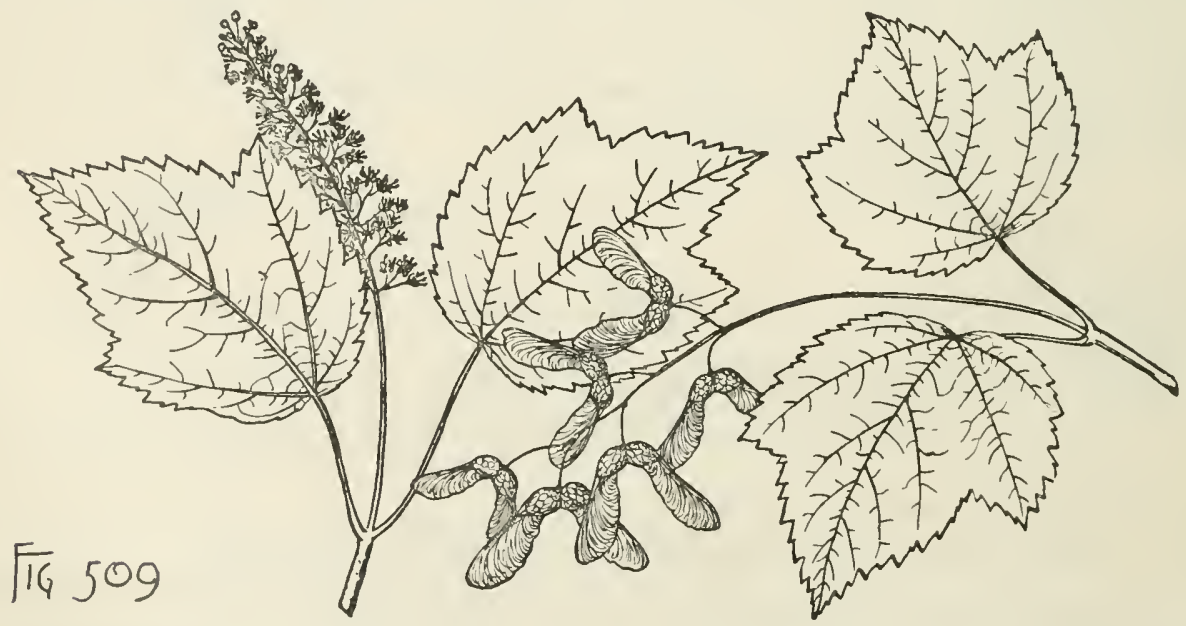

glandular-serrate, when they unfold puberulous on the upper and densely tomentose on the lower surface, and at maturity membranaceous, $4^{\prime}-5^{\prime}$ long and broad, turning in the autumn to various shades of orange and scarlet; their petioles slender, enlarged at the base, $2^{\prime}-3^{\prime}$ long, often becoming scarlet in summer. Flowers opening in June after the leaves are fully grown, on slender pedicels $\frac{1}{2}^{\prime}-\frac{3}{4}^{\prime}$ in length, $\frac{1}{4}^{\prime}$ in diameter, the pistillate toward the base and the staminate at the apex of narrow many-flowered 
long-stemmed upright slightly compound pubescent racemes; calyx-lobes narrowly obovate, yellow, pubescent on the outer surface, much shorter than the linear spatulate pointed yellow petals; stamens 7 or 8 , inserted inmediately under the ovary, with slender glabrous filaments as long as the petals in the sterile flower, about as long as the sepals in the pistillate flower, and glandular anthers; ovary hoarytomentose, reduced to a minute point surrounded by a tuft of pale hairs in the staminate flower; style columnar, almost as long as the petals, with short stigmatic lobes. Fruit fully grown and bright red in July, turning brown late in the autumn, almost glabrous, with more or less divergent wings about $\frac{1^{\prime}}{2}$ long; seeds smooth, dark red brown, $\frac{1^{\prime}}{8}$ long.

A bushy tree, occasionally $25^{\circ}-30^{\circ}$ high, with a short trunk $6^{\prime}-8^{\prime}$ in diameter, small upright branches, and slender branchlets light gray and pubescent when they first appear, becoming glabrous during the summer, bright red during their first winter, gray or pale brown the following season, and blotched or streaked with green toward the base; more often a tall or low shrub. Winter-buds acute; termiual $\frac{1^{\prime}}{8}$ long, with bright red outer scales more or less coated with hoary tomentum, those of the inner ranks becoming at maturity $\mathbf{1}^{\prime}$ or more long and then lanceolate, pale and papery; axillary much smaller and glabrous or puberulous. Bark of the trunk very thin, reddish brown, smooth or slightly furrowed. Wood light, soft, close-grained, light brown tinged with red, with thick lighter colored sapwood.

Distribution. Moist rocky hillsides usually in the shade of other trees, and really arborescent only on the western slopes of the high mountains of Tennessee and North Carolina; valley of the lower St. Lawrence River to northern Minnesota and the Saskatchewan, and southward through the northern states and along the Appalachian Mountains to northern Georgia.

Occasionally cultivated as an ornament of parks and gardens in the northern states.

\section{Acer Pennsylvanicum, L. Striped Maple. Moose Wood.}

Leaves rounded or cordate at the base, palmately 3-nerved, 3-lobed at the apex, with short lobes contracted into tapering serrate points, and finely and sharply doubly serrate, when they unfold thin and membranaceous, pale rose color and coated with ferrugineous pubescence, especially on the lower surface and on the petioles, and at maturity glabrous with the exception of tufts of ferrugineous hairs in the axils of the principal nerves on the two surfaces, membranaceous, pale green above, rather paler below, $\tilde{5}^{\prime}-6^{\prime}$ long and $4^{\prime}-5^{\prime}$ wide, turning in the autumn clear light yellow; their petioles stout, grooved, $1 \frac{1^{\prime}}{2}-2^{\prime}$ long, with enlarged bases nearly encircling the branch. Flowers bright canary-yellow, opening toward the end of May or early in June when the leaves are nearly fully grown, on slender pedicels $\frac{1}{4}^{\prime}-\frac{1}{2}^{\prime}$ long, in slender drooping long-stemmed racemes $4^{\prime}-6^{\prime}$ in length, the staminate and pistillate usually in different racemes on the same plant; sepals linear-lanceolate to obovate, $\frac{1^{\prime}}{4}$ long and a little shorter and narrower than the obovate petals; stamens $7-8$, shorter than the petals in the staminate flower, rudimentary in the pistillate flower; ovary purplish brown, glabrous, in the staminate flower reduced to a minute point; style stout, united near the top, with spreading recurved stigmas. Fruit in long drooping racemes, glabrous, with thin spreading wings $\frac{3^{\prime}}{4}$ long, and marked on one side of each nutlet by a small cavity; seeds $\frac{1}{4}$ long, dark red-brown, and slightly rugose.

A tree, $30^{\circ}-40^{\circ}$ high, with a short trunk $8^{\prime}-10^{\prime}$ in diameter, small upright branches, and sleuder smooth branchlets pale greenish yellow at first, bright reddish 
brown during their first winter, and at the end of two or three years striped like the trunk with broad pale lines; or often much smaller and shrubby in habit. Winterbuds: terminal, conspicuously stipitate, sometimes almost $\frac{1^{\prime}}{2}$ long, much longer than

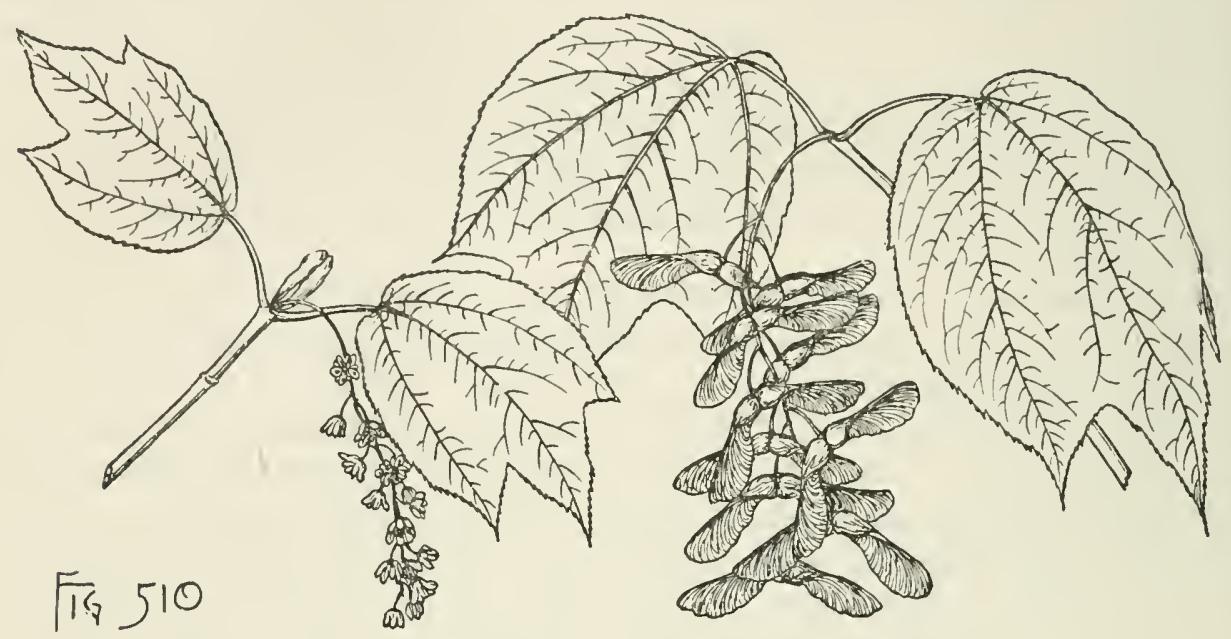

the axillary buds, covered by two thick bright red spatulate boat-shaped scales prominently keeled on the back, the inner scales green and foliaceous, becoming $1 \frac{1^{\prime}}{2}-2^{\prime}$ long, $\frac{1}{2}^{\prime}$ wide, pubescent, and bright yellow or rose color. Bark of the trunk $\frac{1^{\prime}}{8}-\frac{1^{\prime}}{4}$ thick, reddish brown, marked longitudinally by broad pale stripes, and roughened by many oblong horizontal excrescences. Wood light, soft, close-grained, light brown, with thick lighter colored sapwood of 30-40 layers of annual growth.

Distribution. Usually in the shade of other trees, often forming in northern New England a large part of their shrubby undergrowth; shores of Ha-Ha Bay, Quebec, westward along the shores of Lake Ontario and the islands of Lake Huron to northeastern Minnesota, and southward through the Atlantic states and along the Appalachian Mountains to northern Georgia; common in the north Atlantic states, especially in the interior and elevated regions; of its largest size on the slopes of the Big Smoky Mountains, Tennessee, and of the Blue Ridge in North and South Carolina.

Sometimes cultivated as an ornamental tree in the northern states, and occasionally in Europe.

\section{Acer macrophyllum, Pursh. Broad-leaved Maple.}

Leaves cordate at the base by a deep narrow sinus deeply $3-5$-cleft, with sinuate acuminate divisions furnished with 2 or 3 acute lobes, and prominently 3-5-nerved, puberulous when they unfold, especially on the upper surface along the principal veins, and at maturity subcoriaceous, dark green and lustrous on the upper, pale on the lower surface, $8^{\prime}-12^{\prime}$ in diameter, turning in the autumn bright orange color before falling; their petioles stout, $10^{\prime}-12^{\prime}$ long, with enlarged bases united and encircling the stem and often furnished on the inside with small tufts of white hairs. Flowers bright yellow, fragrant, $\frac{1}{4}^{\prime}$ long, on slender pubescent often branched pedicels $\frac{1^{\prime}}{2}-\frac{3}{4}$ long, the staminate and pistillate together in graceful pendulous slightly puberulous racemes $4^{\prime}-6^{\prime}$ long, appearing in April and May after the leaves are fully grown; sepals petaloid, obovate, obtuse and a little longer and broader than the spatulate petals; stamens 9-10, with long slender filaments hairy at the base, exserted 
in the staminate and included in the pistillate flower, and orange-colored anthers; ovary hoary-tomentose, reduced in the staminate flower to a minute point; styles united at the base only; stigmas long and exserted. Fruit fully grown by the 1st of July and ripening late in the autumn; carpels covered with long pale hairs, their wings $1 \frac{1}{2}^{\prime}$ loug, $\frac{1}{2}^{\prime}$ wide, slightly divergent and glabrous with the exception of a few hairs on the thickened edge; seeds dark-colored, rugose and pitted, $\frac{1}{4}^{\prime}$ long.

A tree, $80^{\circ}-100^{\circ}$ high, with a tall straight trunk $2^{\circ}-3^{\circ}$ in diameter, stout often pendulous branches forming a compact handsome head, and stout branchlets smooth and pale green at first, becoming bright green or dark red in their first winter, covered more or less thickly with small longitudinal white lenticels, and in their second summer gray or grayish brown. Winter-buds obtuse; terminal $\frac{1}{4}$ long, with slwort broad slightly spreading dark red ciliate outer scales rounded on the back, those of the imer ranks green and foliaceous, and at maturity $1 \frac{1}{2}^{\prime}$ long, colored and puberulous; axillary buds minute. Bark of the trunk $\frac{1^{\prime}}{2}-\frac{3}{4}^{\prime}$ thick, brown faintly tinged with red or bright reddish brown, deeply furrowed and broken on the surface into small square plate-like scales. Wood light, soft, not strong, close-grained, rich

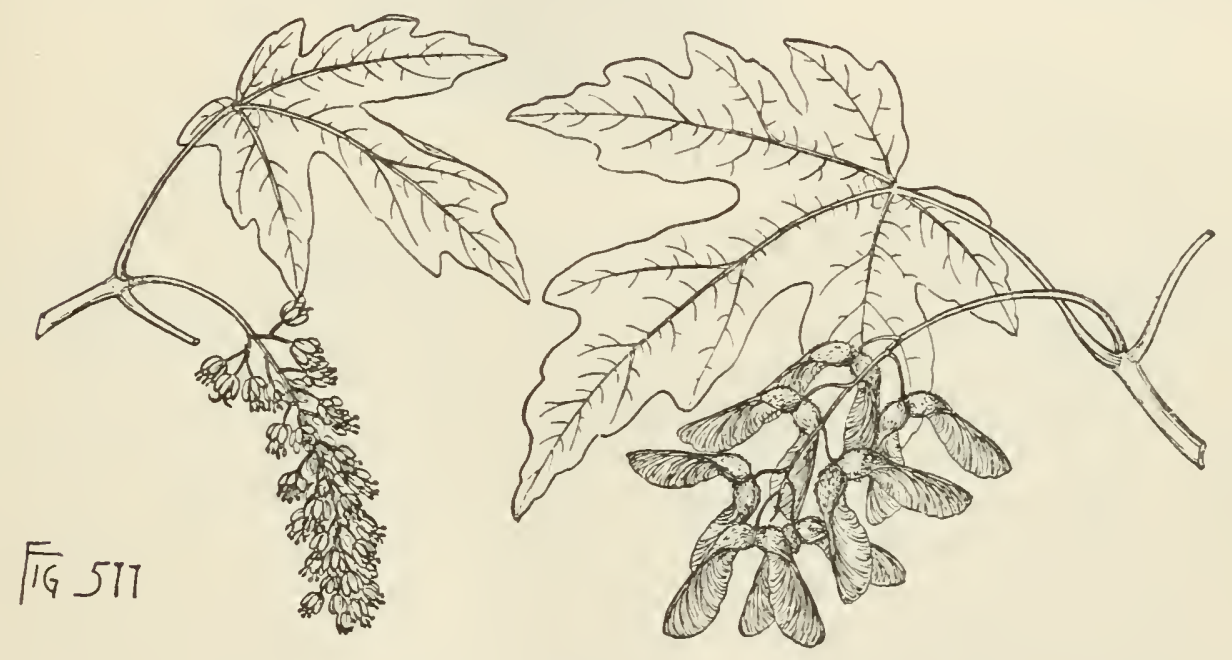

brown tinged with red, with thick lighter colored often nearly white sapwood of 60-80 layers of annual growth; more valuable than the wood produced by other deciduous trees of western North America, and in Washington and Oregon largely used in the interior finish of buildings, for furniture, and for axe and broom-handles.

Distribution. Banks of streams or on rich bottom-lands or the rocky slopes of mountain valleys; coast of Alaska south of latitude $55^{\circ}$ north, southward along the islands and coast of British Columbia, through Washington and Oregon west of the Cascade Mountains, and southward along the coast ranges and the western slopes of the Sierra Nevada to the San Bernardino Mountains, and to Hot Spring Valley, San Diego County, California; rarely ascending to more than $2000^{\circ}$ above the level of the sea; most abundant and of its largest size in the humid climate and rich soil of the bottom-lands of southwestern Oregon, forming extensive forests; in California usually much smaller, especially on the coast ranges.

Occasionally cultivated in the eastern states, and hardy as far north as eastern Pennsylvania. 


\section{Acer circinatum, Pursh. Vine Maple.}

Leaves almost circular in ontline, cordate at the base by a broad shallow sinus, or sometimes almost truncate, palmately 7-9-lobed occasionally ncarly to the middle, with acnte lobes sharply and irregularly doubly serrate, and conspicuonsly palmately nerved, with prominent veinlets, when they unfold tinged with rose color and puberulous, especially on the lower surface and on the petioles, and at maturity glabrous

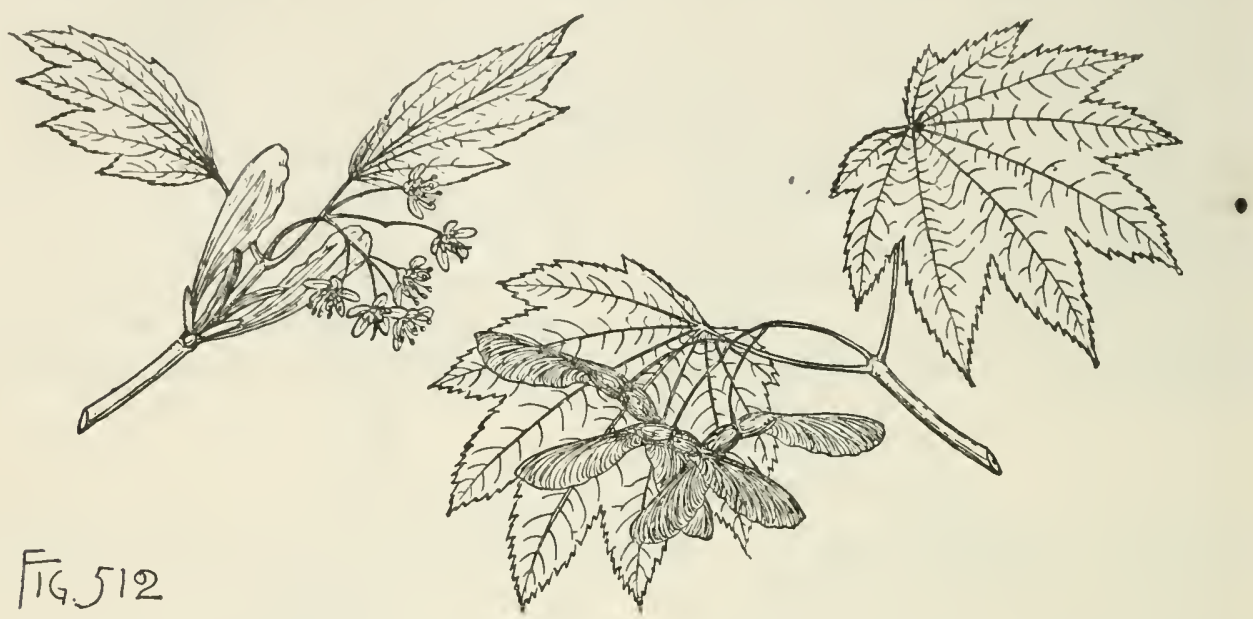

with the exception of tufts of pale hairs in the axils of the large veins, thin and membranaceous, dark green above, pale below, and $2^{\prime}-7^{\prime}$ in diameter, in the antumn turning orange and scarlet; their petioles stout, grooved, $1^{\prime}-2^{\prime}$ long, clasping the stem by their large bases. Flowers appearing when the leaves are about half grown, in loose 10-20-flowered umbel-like corymbs pendent on long stems from the ends of slender 2-leaved branchlets, the staminate and pistillate flowers produced together; sepals oblong to obovate, acute, villous, purple or red, much longer than the greenish white broadly cordate petals folded together at the apex; stamens 6-8, with slender filaments villous at the base, exserted in the staminate flower, much shorter than the petals in the pistillate flower; ovary glabrous, with spreading lobes, in the staminate flower reduced to a small point surronnded by a tuft of pale hairs; style divided nearly to the base into long exserted stigmas. Fruit with thin wings, $1 \frac{1^{\prime}}{2}$ long, spreading almost at right angles, red or rose color like the carpels in early summer, ripening late in the autumn; seeds smooth, pale chestnut-brown, $\frac{1}{8}-\frac{1^{\prime}}{4}$ long.

A tree, rarely $30^{\circ}-40^{\circ}$ high, often vine-like or prostrate, with a trunk $10^{\prime}-12^{\prime}$ in diameter, and glabrons pale green or reddish brown branchlets frequently covered during their first winter with a glaucous bloom, and occasionally marked by small lenticels; often a low wide-spreading shrub. Winter-buds $\frac{1}{8}^{\prime}$ long, rather obtuse, with thin bright red outer scales rounded on the back and obovate-spatulate inner scales, rounded at the apex, contracted into long narrow claws, bright rose-colored and more or less pubescent, especially on the outer surface, and when fully grown often $2^{\prime}$ long and $\frac{1^{\prime}}{4}$ broad. Bark of the trunk thin, smooth, bright red-brown, marked by numerous shallow fissures. Wood heavy, hard, close-grained, not strong, light brown, sometimes nearly white, with thick lighter colored sapwood; used for fuel, the handles of axes and other tools, and by the Indians of the northwest coast for the bows of their fishing-nets. 
Distribution. Banks of streams; coast of British Columbia southward through Washington and Oregon to Hendocino County, California; one of the nost abundant of the deciduous-leaved trees of Washington and Oregon up to elevations of $4000^{\circ}$ above the sea, and of its largest size on the low alluvial soil of bottom-lands, its vine-like stems in such situations springing 4 or 5 together from the ground, spreading in wide curves and sending out long slender branches rooting when they touch the ground and forming impenetrable thickets of contorted and interlaced trunks, often many acres in extent; in California smaller and less abundant, growing along streams in the coniferous forest.

Occasionally cultivated as an ornamental plant in Europe, and in the eastern states, and hardy as far north as eastern Massachusetts.

\section{Acer glabrum, Torr. Dwarf Maple.}

Leaves glabrous, membranaceous, rounded in outline, cordate-truncate or wedgeshaped at the base, 3-5-lobed or often 3-parted or 3-foliolate, with acute or obtuse doubly serrate lobes, $1^{\prime}-5^{\prime}$ in diameter, dark green and lustrous on the upper, paler

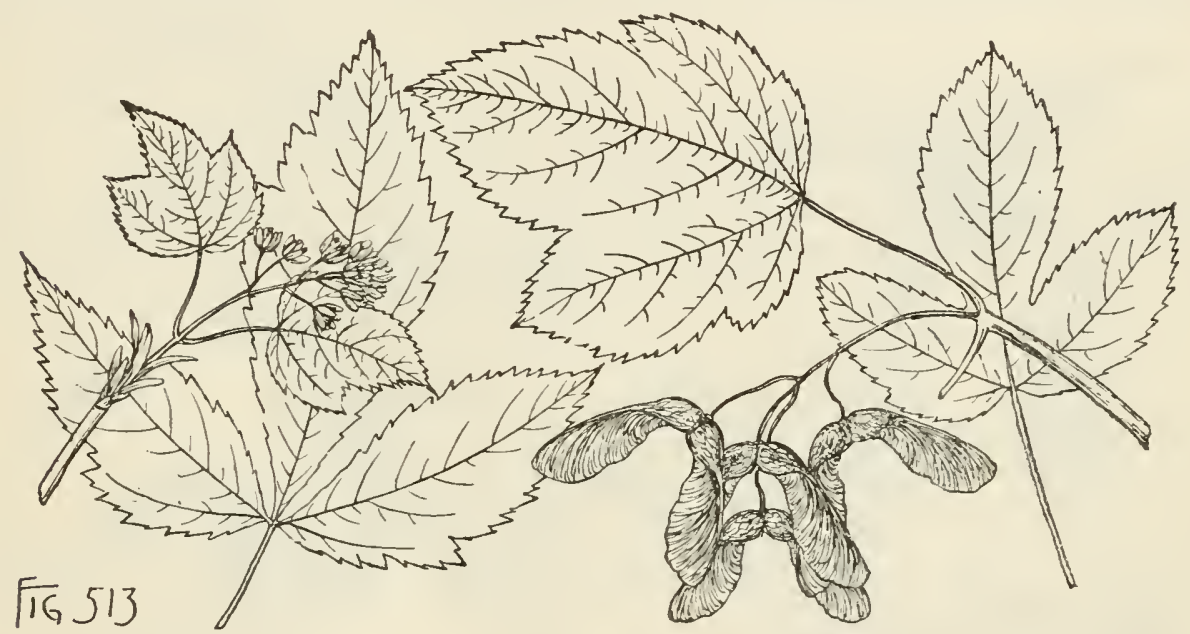

on the lower surface, with conspicuous veinlets ; their petioles stout, grooved, $\mathbf{1}^{\prime}-6^{\prime}$ long, and often bright red. Flowers about $\frac{1}{8}$ in length on short slender pedicels, in loose few-flowered glabrous racemose corvmbs, on slender drooping peduncles from the ends of 2-leaved branchlets, the staminate and pistillate usually produced separately on different plants; sepals oblong, obtuse, petaloid, as long as the greenish yellow petals; stamens 7 or 8 , with glabrous unequal filaments shorter than the greenish yellow linear petals, much shorter or rudimentary in the pistillate flower; ovary glabrous, with short obtuse lobes, rudimentary or 0 in the staminate fiower; style divided to the base into 2 spreading stigmatic lobes as long as the petals. Fruit glabrous, with broad nearly erect or slightly spreading wings $\frac{3^{\prime}}{4}-\frac{7^{\prime}}{8}$ lorrg, often rosecolored during the summer; seeds ovate, bright chestnut-brown, about $\frac{1^{\prime}}{4}$ long.

A low tree, occasionally $40^{\circ}$ high, with a short trunk $18^{\prime}$ in diameter, small upright branches, and slender glabrous branchlets often slightly many-angled, pale greenish brown at first, becoming bright red-brown during their first winter; usually smaller, and more often a shrub $4^{\circ}-5^{\circ}$ high. Winter-buds acute, $\frac{1}{8}^{\prime}$ long, with bright red or occasionally yellow scales, those of the inner ranks pale brown tinged with pink, tomentose on the inner surface, becoming $1_{\frac{1}{2}}^{\prime}$ long and narrowly spatulate. Bark 
of the trunk thin, smooth, and dark reddish brown. Wood heavy, hard, close-grained, light brown or often nearly white, with thick lighter colored sapwood.

Distribution. Borders of mountain streams usually at elevations of $5000^{\circ}-6000^{\circ}$ above the sea, and northward sometimes descending to the sea-level; lead of Lynn Canal, Alaska, over the mountain ranges of western America, extending sonthward in California along the Sierra Nevada to the west fork of the Kaweal River, and eastward to northwestern Nebraska, the eastern slopes of the Rocky Mountains of Colorado, eastern New Mexico and Arizona; of its largest size on the coast of Vancouver Island and on the Blue Mountains of Oregon; also arborescent in some of the elevated cañons of Idaho, New Mexico, and Arizona; usually shrubby.

Occasionally cultivated in the eastern states, and hardy as far north as eastern Massachusetts.

\section{Acer Saccharum, Marsh. Sugar Maple. Rock Maple.}

Leaves heart-shaped by a broad sinus, truncate or sometimes wedge-shaped at the base, 3-5-lobed, with rounded sinuses, usually acute sparingly sinuate-toothed

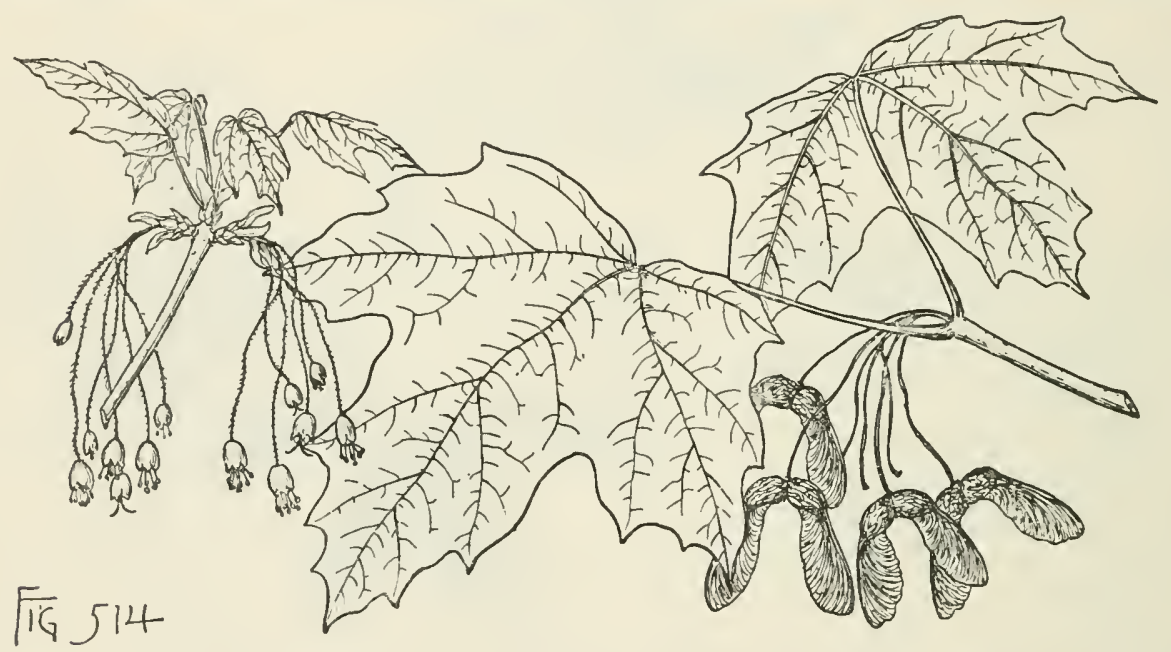

lobes, 3-5 conspicuous nerves, and reticulate veinlets, when they unfold coated below with pale pubescence, glabrous at maturity, $4^{\prime}-5^{\prime}$ in diameter, often rather coriaceons, dark green and opaque on the upper, pale on the lower surface, turning in the autumn brilliant shades of deep red, scarlet and orange or clear yellow; their petioles slender, glabrous, $1 \frac{1}{2}^{\prime}-3^{\prime}$ long. Flowers appearing with the leaves on slender hairy pedicels $2 \frac{1}{2}^{\prime}-3^{\prime}$ long, in nearly sessile umbel-like corymbs from terminal leaf-buds and lateral leafless buds, the staminate and pistillate in separate clusters on the same or on different trees; calyx broadly campanulate, 5-lobed by the partial union of the obtuse sepals, greenish yellow, hairy on the outer surface; corolla 0 ; stamens 7-8, with slender glabrous filaments twice as long as the calyx in the staminate flower and much shorter in the pistillate flower; ovary obtusely lobed, pale green, covered with long scattered hairs, in the staminate flower rednced to a minute point; styles united at the base only, with 2 long exserted stigmatic lobes. Fruit ripening in the antumn, glabrous, with broad, thin, and usually divergent wings $\frac{1^{\prime}}{2}-1^{\prime}$ long; seeds smooth, bright red-brown, $\frac{1}{4}$ long.

A tree, $100^{\circ}-120^{\circ}$ high, with a trunk often $3^{\circ}-4^{\circ}$ in diameter, rising sometimes in the forest to the height of $60^{\circ}-70^{\circ}$ without branches, or in open situations devel- 
oping $8^{\circ}-10^{\circ}$ from the ground stout upright branches forming while the tree is young a narrow egg-shaped head, ultimately spreading into a broad round-topped dome often $70^{\circ}-80^{\circ}$ across, and slender branchlets green at first, becoming reddish brown by the end of their first season, lustrous, marked by numerous large pale oblong lenticels, and in their second winter pale brown tinged with red. Winterbuds acute, $\frac{1}{4}$ long, with purple slightly puberulous outer scales, and inner scales becoming $1 \frac{1^{\prime}}{2}$ loug, narrowly obovate, short-pointed at the apex, thin, pubescent, and bright canary yellow. Bark of young stems and of large branches pale, smooth or slightly fissured, becoming on large trunks $\frac{1^{\prime}}{2}-\frac{3^{\prime}}{4}$ thick and broken into deep longitudinal furrows, the light gray-brown surface separating into small gray-brown scales. Wood heavy, liard, strong, close-grained, tough, light brown tinged with red, with thin sapwood of 30-40 layers of annual growth; largely used for the interior finish of buildings, especially for floors, in the manufacture of furniture and in turnery, in shipbuilding, shoe-lasts and pegs, and largely as fuel. Accidental forms with the grain curled and contorted, known as curly maple and bird's eye maple, are common and are highly prized in cabinet-making. The ashes of the wood are rich in alkali and yield large quantities of potash. Maple sugar is principally made from the sap of this tree. Southward passing into

\section{Acer Saccharum, var. Rugelii, Rehd.}

A large tree, with subcoriaceous leaves usually rather broader than long, pale or glaucous and pubescent or rarely glabrous below, cordate, with a broad open sinus, or truncate at the base, and usually 3 -lobed, with open round sinuses and acuminate

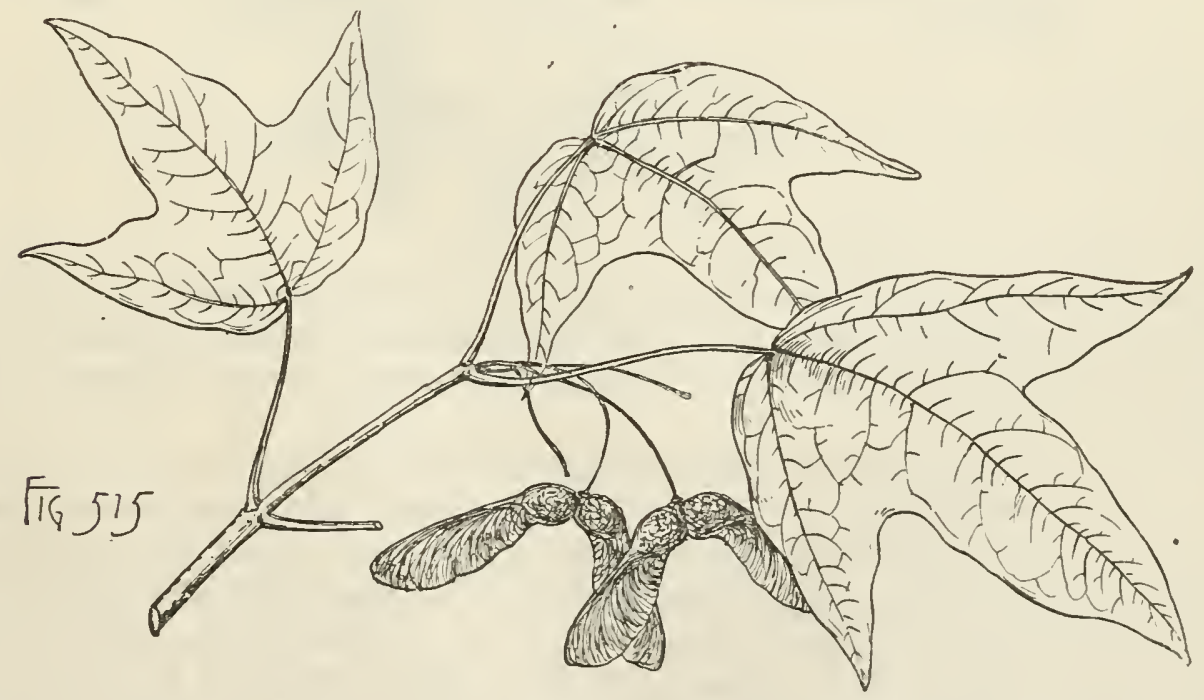

generally entire lobes. This is the common and frequeutly the ouly form of the Sugar Maple in the region from North Caroliua and Georgia to Missouri, and it occasionally occurs northward to Michigan and Prince Edward's Islaud, leaves of this form sometimes appearing on the upper branches of trees bearing on their lower branches typical leaves of the northeru Sugar Maple.

Very frequently plauted as a shade and ornamental tree in the northern states. In the streets and gardens of the towns and cities of northern Alabama and northern Georgia the variety Rugelii is largely used. 


\section{Acer Floridanum, Pax. Sugar Maple.}

(Acer Saccharum, var. Floridanum, Silva N. Am. xiii. 7.)

Leaves rounded, truncate or slightly cordate at the broad base, 3-5-lobed, with short obtuse or acute entire or lobulate lobes, when they unfold sparingly hairy on the upper and hoary-tomentose on the lower surface, and at maturity membranaceous, dark green and lustrous above, palc and pubescent below, $1 \frac{1}{2}-3^{\prime}$ in diamcter, and prominently 3-j-nerved, with stout spreading lateral vcins and conspicuous reticulate veinlets, turning yellow and scarlet in the autumn beforc falling; their petioles slender, glabrous, or pubescent becoming glabrous, $1 \frac{1}{2}^{\prime}-3^{\prime}$ long, with enlarged bases nearly encircling the branchlet. Flowers appearing with the leaves on slender elongated sparingly hairy ultimately glabrous pediccls, in many-flowered drooping nearly sessile corymbs; calyx campanulate, yellow, about $\frac{1^{\prime}}{8}$ long, persistent

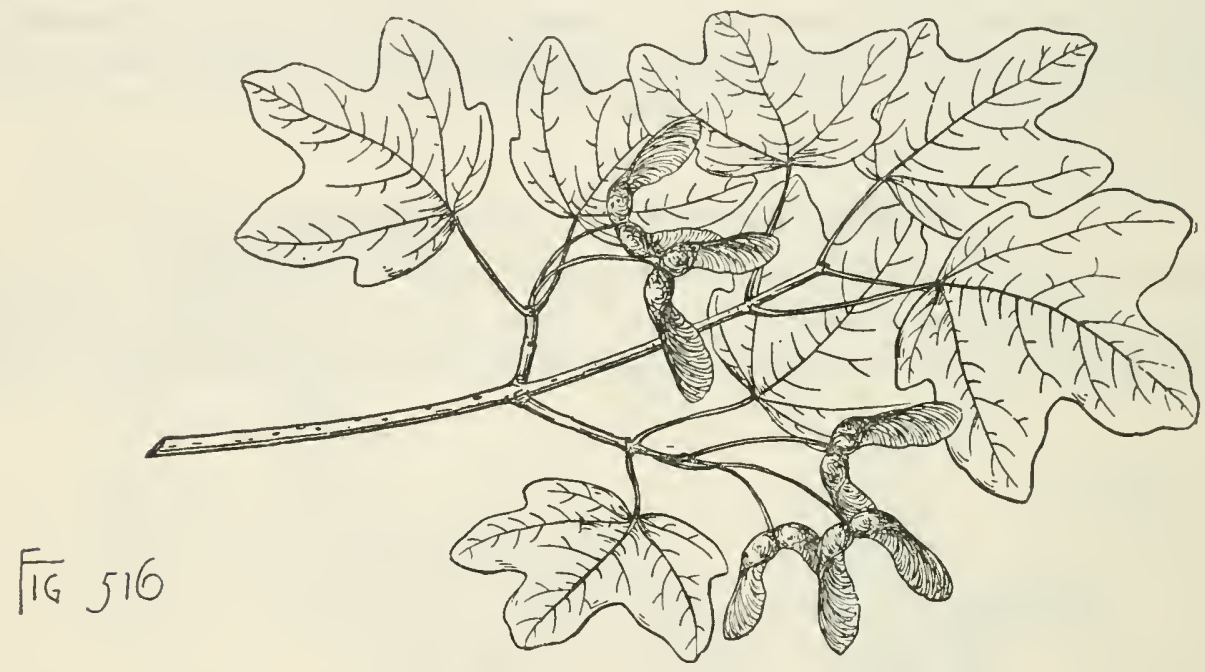

under the fruit, the short lobes ciliate on the margin, with long pale hairs; corolla 0 . Fruit green, sparingly villose until fully grown, usually becoming glabrous, with spreading occasionally erect wings $\frac{1^{\prime}}{2}-\frac{3^{\prime}}{4}$ long; seeds smooth, bright red-brown, about $\frac{1}{4}$ long.

A tree, occasionally $50^{\circ}-60^{\circ}$ high, with a trunk rarely $3^{\circ}$ in diameter, small erect and spreading branches, and slender glabrous branchlets, light green at first, becoming rather light red-brown during their first season, and covered with minute pale lenticels; usually smaller, and westward generally a low shrub. Winter-buds obtuse, about $\frac{1^{\prime}}{8}$ long, with dark chestnut-brown obtuse scales and bright rose-colored linearspatulate inner scales often $1^{\prime}$ long when fully grown. Bark of the trunk thin, smooth, pale, becoming near the base of old trees thick, dark, and deeply furrowed.

Distribution. River swamps, southern Georgia and western Florida to Louisiana, southern Arkansas, and eastern Texas, and westward on the banks of streams usually as a shrub to the valley of the upper Rio Cibolo, Texas, and on the Sierra Madre of Nuevo Leon.

\section{Acer nigrum, Michx. Black Maple.}

Leaves generally 3 or occasionally 5 -lobed, with acute or acuminate lobes, undulate and narrowed from broad shallow sinuses, or rarely furnished with short 
lateral spreading lobes, cordate, with a broad sinus usually more or less closed by the approximation or imbrication of the basal lobes, covered below when they

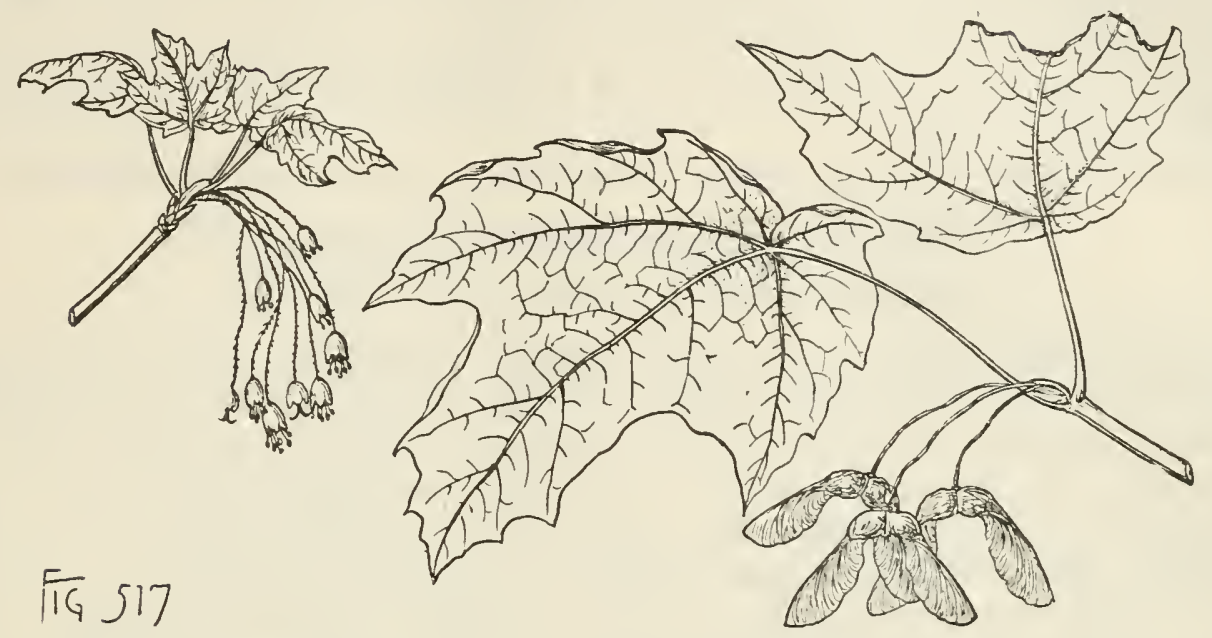

unfold with hoary tomentum and above with caducous pale hairs, and at maturity thick and firm in texture, dull green on the upper surface, yellow-green and softpubescent, particularly along the yellow veins on the lower surface, and $5^{\prime}-6^{\prime}$ across, with drooping sides, turning bright clear yellow in the autumn; their petioles stout, tomentose or pubescent, sometimes becoming glabrous at maturity, usually pendent, $3^{\prime}-5^{\prime}$ long, much enlarged at the base, frequently nearly inclosing the buds, in falling leaving narrow scars almost encircling the branchlet, and furnished in their axils with tufts of long pale hairs; stipules triangular and dentate or foliaceous, sessile or stipitate, oblong, acute, tomentose or pubescent, sometimes slightly lobed, frequently $1 \frac{1^{\prime}}{2}$ long. Flowers yellow, about $\frac{1^{\prime}}{4}$ long, on slender hairy pedicels $2 \frac{1}{2}^{\prime}-3^{\prime}$ long, in many-flowered nearly sessile umbel-like corymbs, the staminate and pistillate in separate or in the same clusters on the same or on different trees; calyx broadly campanulate, 5-lobed by the partial union of the sepals, pilose on the outer surface near the base; corolla 0 ; stamens 7 or 8 , with slender glabrous filaments, in the staminate flower nearly twice as long as the calyx and in the pistillate flower shorter than the calyx; ovary obtusely lobed, pale green, covered with long seattered hairs, minute in the sterile flower. Fruit glabrous, with convergent or wide-spreading wings $\frac{1^{\prime}}{2}-1^{\prime}$ long; seeds smooth, bright red-brown, $\frac{1^{\prime}}{4}$ long.

A tree, sometimes $80^{\circ}$ high, with a trunk frequently $3^{\circ}$ in diameter, stout spreading or often erect branches, and stout branchlets marked by oblong pale lenticels, when they first appear orange-green and pilose, with scattered pale caducous hairs, orange or orange-brown and lustrons during their first year, becoming dull pale graybrown the following season. Winter-buds sessile, ovate, acute, $\frac{1}{8}^{\prime}$ long, witl dark red-brown acute scales hoary-pubescent on the outer surface and of ten slightly ciliate on the margins, and yellow puberulous inner scales, $\frac{1^{\prime}}{2}-1^{\prime}$ long at maturity. Bark of young stems and of the branches thin, smooth, pale gray, becoming on old trunks thick, deeply furrowed, and sometimes almost black.

Distribution. Valley of the St. Lawrence River in the neighborhood of Montreal, southward to the valley of Cold River, New Hampshire, through western Vermont, and westward through northern New York, Ontario, the sonthern peninsula of Michigan, Indiana, Illinois, and Iowa, to northeastern South Dakota, western 
Missouri, eastern Kansas, and southward through western New York and Pemusylvania to southwestern Virginia, and Kentucky; comparatively rare near Montreal and in Verunont, more abundant farther west, almost entirely replacing Acer Saccharum in Iowa, and the only Sugar Maple of Sonth Dakota; easily distinguished in summer by its heavy drooping leaves, and at all seasons of the ycar by the orange color of the branchlets.

Occasionally planted in the region where it grows naturally as a shadc-tree.

\section{Acer leucoderme, Small. Sugar Maple.}

(Acer Saccharum, var. leucoderme, Silva N. Am. xiii. 7.)

Leaves usually truncate or slightly cordate at the base, more or less deeply divided into 3-5 acute caudate-acuminate lobes coarsely and sinuately dentate or undulate, when they unfold coated bclow with long matted pale caducous hairs, and at maturity thin, dark yellow-green above, bright yellow-green and covered below with soft close velvety pubescence, $2^{\prime}-3 \frac{1^{\prime}}{2}$ in diameter, often turning in the autumn bright scarlet on the upper surface before falling; their petioles slender, glabrous, $1^{\prime}-1 \frac{1}{2}^{\prime}$ long. Flowers yellow, about $\frac{1^{\prime}}{8}$ long, on slender, glabrous pedicels, in nearly sessile clusters; calyx campanulate, glabrons or slightly villose, with rounded ciliate lobes; corolla 0 ; stamens 7 or 8 , their filaments longer than the calyx, much shorter

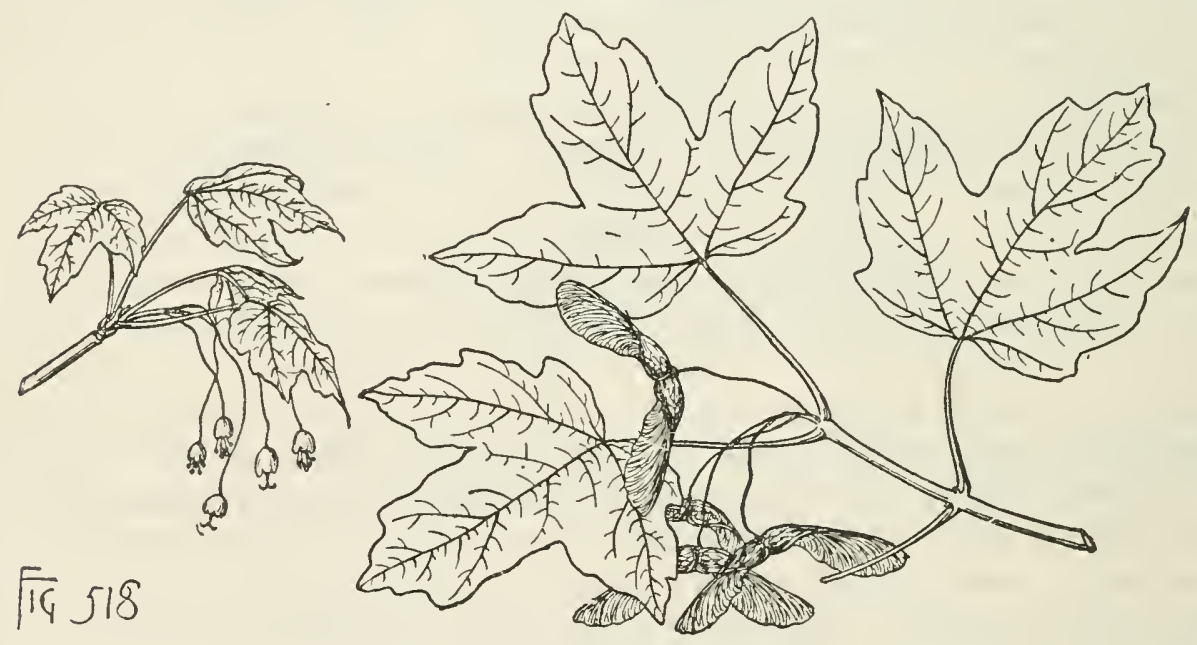

than the calyx in the pistillate flower; style elongated, with short spreading lobes. Fruit villose, with long scattered pale hairs until nearly grown, becoming glabrous at maturity, the wings wide-spreading or divergent, $\frac{1^{\prime}}{2}-\frac{3^{\prime}}{4}$ long; seeds smooth, light red-brown, about $\frac{1^{\prime}}{4}$ long.

A tree, usually $20^{\circ}-25^{\circ}$ high, with a trunk a foot in diameter, occasionally $40^{\circ}$ high, with a trunk $18^{\prime}-20^{\prime}$ in diameter, short slender branches forming a rather compact round-topped head, and slender glabrous branchlets dark green when they first appear, becoming bright red-brown and lustrous during their first summer, and marked by numerous small oblong pale lenticels, gradually growing darker in their second year and finally light gray-green. Winter-buds ovate, acute, dark brown, glabrous, rather more than $\frac{1^{\prime}}{16}$ long, the inner scales becoming bright crimson and very conspicuous when the trees are in flower in early spring. Bark of young stems and large branches close, light gray or grayish brown, becoming near the base of old 
individuals dark brown or often nearly black and broken by deep furrows into narrow ridges covered by closely appressed scales.

Distribution. Banks of streams and rocky gorges; valley of the Yadkin River, North Carolina, to uorthern Georgia, eastern Tennessee, central Alabama, western Louisiana, and soutleern Arkansas.

Occasionally planted as a shade-tree in the streets of the towns of northern Georgia and Alabama.

\section{Acer grandidentatum, Nutt. Sugar Maple.}

(Acer Saccharum, var. grandidentatum, Silva N. Am. xiii. 8.)

Leaves cordate or truncate at the base, with broad shallow sinuses, 3-lobed, with acute or obtuse entire or slightly 3-lobed divisions, when they unfold slightly hairy

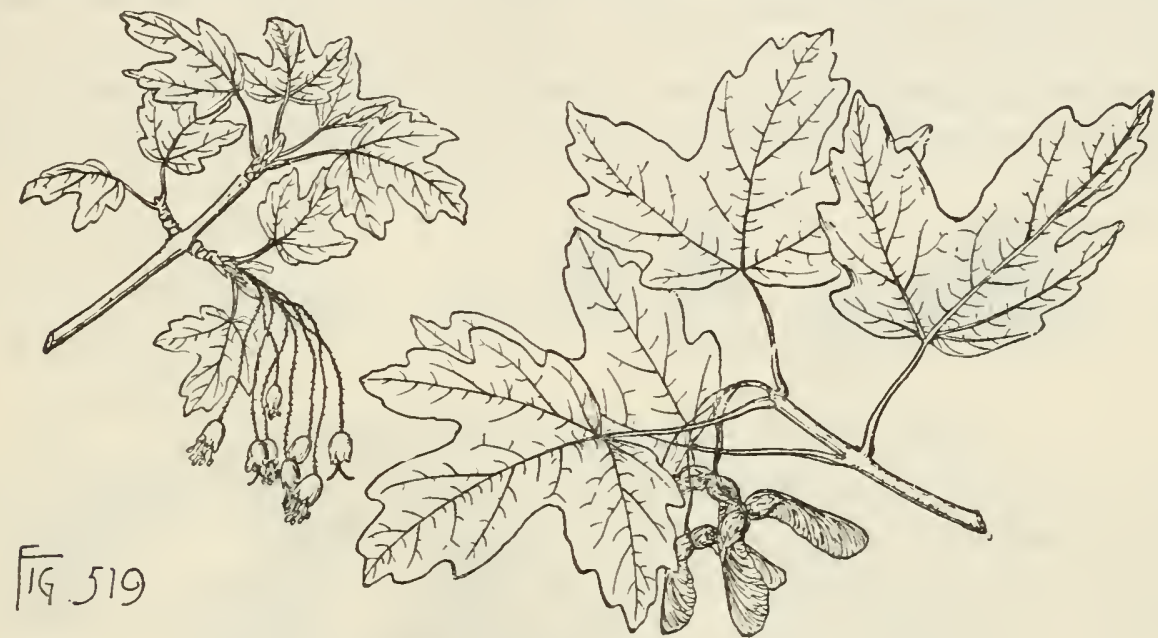

on the upper and thickly coated with dense pale tomentum on the lower surface, and at maturity thick and firm, dark green and lustrous above, pale and pubescent below, especially on the stout nerves and veins, or rarely glabrous, $2^{\prime}-5^{\prime}$ in diameter, turning in the autumn before falling yellow and scarlet; their petioles stout, $1^{\prime}-2^{\prime}$ long, glabrous, often red after midsummer, encircling the branchlet with their large bases villose on the inner surface. Flowers appearing with the leaves on long slender drooping villose pedicels, in short-stalked corymbs; calyx campanulate, yellow, sparingly hairy, with long pale hairs, about $\frac{1^{\prime}}{4}$ long, with broad rounded lobes, often persistent under the fruit; corolla 0 ; stamens 7 or 8 , much longer than the calyx, in the pistillate flower shorter than the calyx; ovary usually glabrous, with long spreading stigmatic lobes, 0 or rudimentary in the staminate flower. Fruit often rosecolored at midsummer, green at maturity, glabrous or rarely sparingly hairy, with spreading or erect wings $\frac{1^{\prime}}{2}-1^{\prime}$ long; seeds smooth, light red-brown, about $\frac{1^{\prime}}{4}$ long.

A tree, occasionally $30^{\circ}-40^{\circ}$ high, with a trunk $8^{\prime}-10^{\prime}$ in diameter, stout nsually erect branches, and slender glabrous bright red branchlets marked by numerous small pale lenticels and nearly encircled by the narrow leaf-scars, with conspicuous bands of long pale hairs in their axils. Winter-buds acute or acuminate, about $\frac{1}{16}$ long, bright red-brown, with puberulous-ciliate outer scales and obovate apiculate inner scales sometimes $\frac{1^{\prime}}{2}$ long when fully grown. Bark of the truuk thin, dark brown, separating on the surface into plate-like scales. Wood heavy, hard, closegrained, bright brown or nearly white, with thick sapwood. 
Distribution. Banks of mountain streams usually at elevations of $5000^{\circ}-6000^{\circ}$ above the sea; rare and local; valley of the Columbia River in northern Montana, Wasatch Mountains of Utah, mountains of sonthern Arizona and New Mexico and of western Texas, and in Coahuila.

\section{** Flowers appearing before the leaves; fruit ripening in the spring or early summer.}

\section{Acer saccharinum, L. Silver Maple. Soft Maple.}

Leaves truncate or somewhat heart-shaped at the base, deeply 5 -lobed by narrow sinuses, with acute irregularly and remotely dentate lobes, the middle lobe often 3-lobed, $6^{\prime}-7^{\prime}$ long, nearly as broad, membranaceous, bright pale green above, silvery white and at first slightly hairy below, especially in the axils of the primary veins, turuing pale yellow in the autumn before falling; their petioles slender, drooping, bright red, $4^{\prime}-5^{\prime}$ long. Flowers greenish yellow, opening during the first warm days of the late winter or early spring long before the appearance of the leaves, on very short pedicels, in sessile axillary fascicles on shoots of the previous year, or on short

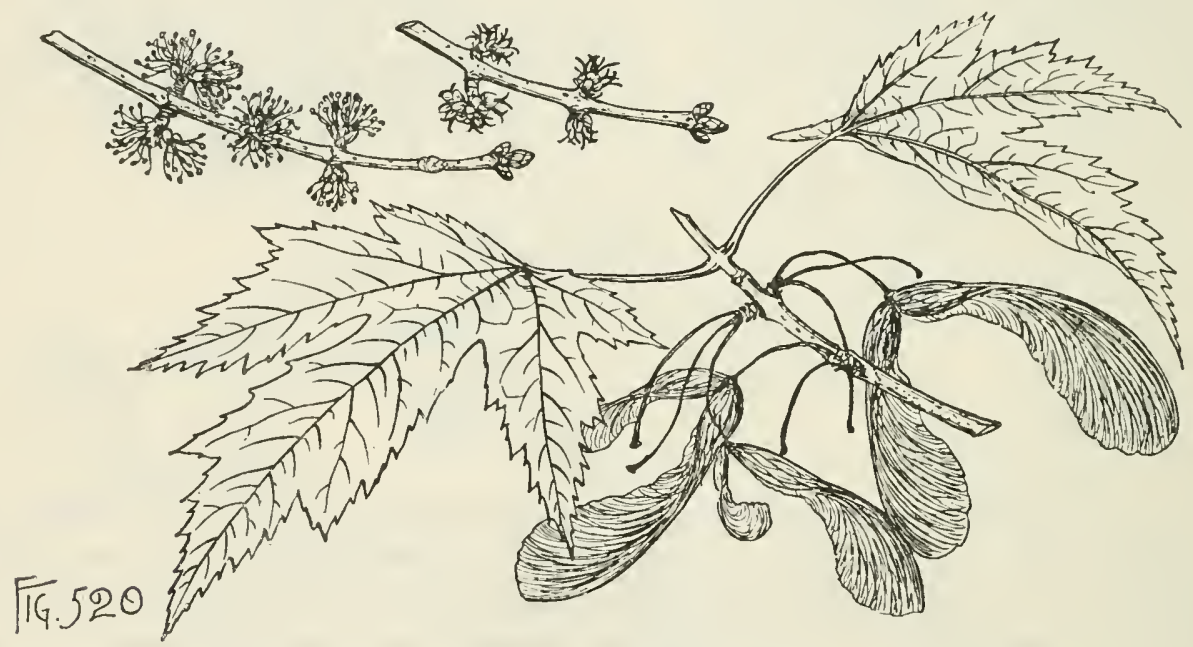

spur-like branchlets developed the year before from wood of the preceding season, the staminate and pistillate in separate clusters, sometimes on the same and sometimes on different trees, and produced from clustered obtuse buds covered with thick ovate pubescent red and green scales ciliate on the margins, with a thick fringe of long rufous hairs; calyx slightly 5-lobed, more or less pubescent on the outer surface, long and narrow in the staminate and short and broad in the pistillate flower; corolla 0 ; stamens $3-7$, with slender filaments, three times as long as the calyx of the staminate flower and about as long as the calyx of the pistillate flower; ovary covered, like the young fruit, with a thick coat of pubescence, rudimentary in the sterile flower; styles united at the base only, with long exserted stigmatic lobes. Fruit ripening in April and May before the appearance of the leaves, on slender drooping pedicels, $1 \frac{1}{2}^{\prime}-2^{\prime}$ long, glabrous, $1 \frac{1}{2}^{\prime}$ to nearly $3^{\prime}$ long, with thin almost straight conspicuously falcate divergent wings sometimes $\frac{3^{\prime}}{4}$ broad, prominently reticulate-veined and pale chestnut-brown; seeds $\frac{1}{2}$ long, with a pale reddish brown wrinkled coat, germinating as soon as they fall to the ground, and producing plants with several pairs of leaves before the end of the summer.

A tree, $90^{\circ}-120^{\circ}$ high, with a trunk $3^{\circ}-4^{\circ}$ in diameter, generally dividing $10^{\circ}-15^{\circ}$ 
from the ground into 3 or 4 stout upright secondary stems destitute of branches. for a considerable length, brittle pendulous branchlets light green and covered with lenticels when they first appear, soon becoming darker, bright chestnut-brown, smooth and lustrous in the autumn and winter of their first year, and in their second season pale rose color or gray faintly tinged with red. Winter-buds $\frac{1^{\prime}}{8}$ long, with thick ovate bright red outer scales rounded on the back, minutely apiculate, and ciliate on the margins, and acute inner scales pubescent on the inner surface, becoming pale green or yellow and about $1^{\prime}$ long. Bark of young stems and large branches smooth and gray faintly tinged with red, becoming on old truuks $\frac{1^{\prime}}{2}-\frac{3^{\prime}}{4}$ thick, reddish brown and more or less furrowed, the surface separating into large thin scales. Wood hard, strong, close-grained, easily worked, rather brittle, pale brown, with thick sapwood of 40-50 layers of anuual growth; now sometimes used for flooring and in the manufacture of furniture. Sugar is occasionally made from the sap of this tree.

Distribution. Sandy banks of streams; valley of the St. John's River, New Brunswick, to southern Ontario, southward to western Florida, and westward to eastern Dakota and Nebraska, the valley of the Blue River, Kansas, and the Indian Territory; rare in the immediate neighborhood of the Atlantic coast and on the high Appalachian Mountains; of its largest size on the banks of the lower Ohio and its tributaries.

Now often cultivated with several varieties in the eastern states, and in western and northern Europe.

\section{Acer rubrum, L. Red Maple. Scarlet Maple.}

Leaves truncate, more or less cordate by a broad shallow sinus, rounded or wedgeshaped at the base, 3-5-lobed by acute siuuses, with irregularly doubly serrate or toothed lobes, the middle lobe often longer than the others, when they unfold pubescent especially beneath, and at maturity light green and glabrous on the upper and

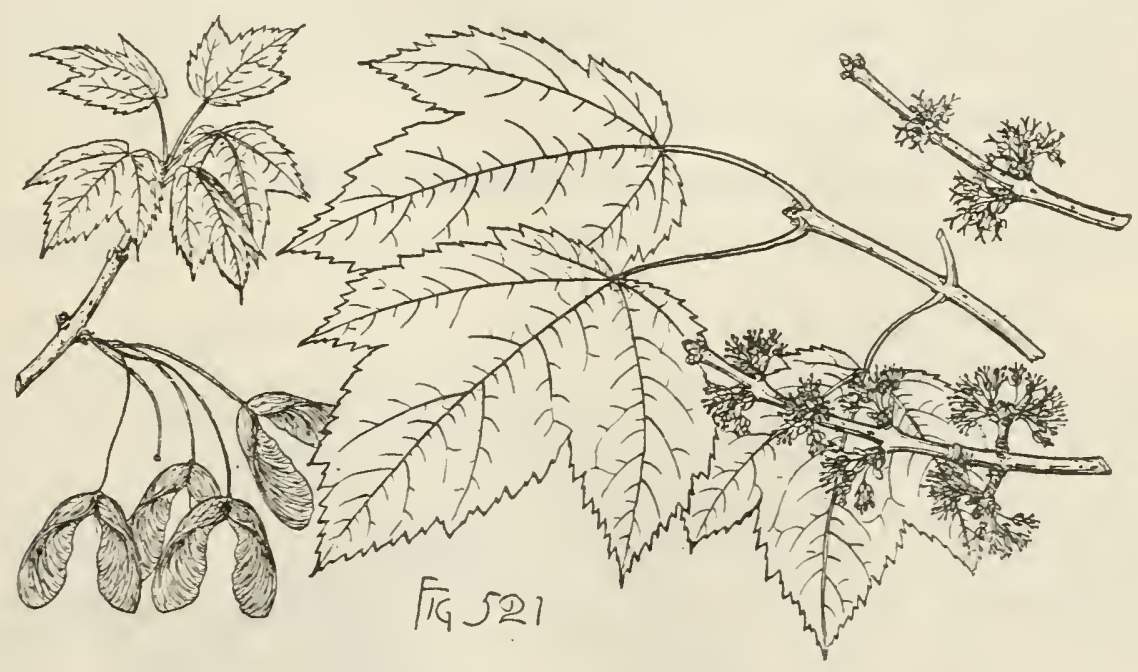

white and more or less pubescent on the lower surface, particularly along the principal veins, chartaceous or sometimes almost coriaceous, $1 \frac{1^{\prime}}{2}-6^{\prime}$ long and rather longer than broad, turning in the early autumn to brilliant shades of scarlet or scarlet and orange; their petioles slender, $2^{\prime}-4^{\prime}$ long, red or green. Flowers opening in March and April before the appearance of the leaves, bright scarlet or dull yellowish red, 
on long slender pedicels, in few-flowered fascicles on branches of the previous year, from elustered obtuse buds, the staminate and pistillate in separate elusters on the same or on different trees; sepals oblong, obtnse, as long as and broader than the oblong or linear petals; stannens 5-8, searlet, with slender filaments exserted in the staminate and ineluded in the pistillate flower; ovary glabrous on a narrow slightly lobed glindular disk; styles slightly united above the base, with long exserted stigmatic lobes. Fruit ripening in the spring or early summer on drooping stems $3^{\prime}-4^{\prime}$ long, scarlet, dark red or brown, with thin erect wings, convergent at first, divergent at maturity, $\frac{1^{\prime}}{2}-1^{\prime}$ long and $\frac{1^{\prime}}{4}-\frac{1}{2}^{\prime}$ wide; seeds dark red, with a rugose coat, $\frac{1^{\prime}}{4}$ long, germinating as soon as it falls to the ground.

A tree, $80^{\circ}-120^{\circ}$ high, with a tall trunk $3^{\circ}-4_{2}^{\circ}$ in diameter, upright branches usually forming a rather narrow head, and branehlets green or dark red when they first appear, becoming dark or bright red and lustrous at the end of their first summer and marked by numerous longitudinal white lentieels, and gray faintly tinged with red in their second year. Winter-buds obtuse, $\frac{1^{\prime}}{8}$ long, with thick dark red outer scales, rounded on the baek and ciliate on the margins, and inner scales becoming $\frac{3^{\prime}}{4}-1^{\prime}$ long, narrowly oblong, rounded at the apex and bright scarlet. Bark of young stems and of the branehes smooth and light gray, becoming on old trunks $\frac{1^{\prime}}{4}-\frac{1^{\prime}}{2}$ thick, dark gray, and divided by longitudinal ridges separating on the surface into large plate-like seales. Wood very heavy, close-grained, not strong, light brown often slightly tinged with red, with thick rather lighter colored sapwood; used in large quantities in the mannfacture of ehairs and other furnitnre, in turnery, for wooden ware and gun-stocks.

Distribution. Borders of streams, low wet swamps, and rarely on hillsides; latitnde $49^{\circ}$ north in Quebec and Ontario, southward to the Indian and Caloosa rivers, Florida, and westward to western Wisconsin, western Iowa, and the valley of the Trinity River, Texas; one of the most common and generally distributed trees of eastern North America; most abundant in the south, espeeially in the valley of the Mississippi River, and of its largest size in the river swamps of the lower Ohio and its large tributaries; at the north often covering low wet swamps almost to the exclusion of other trees. Passing into

\section{Acer rubrum, var. Drummondii, Sarg.}

An inhabitant of the deep river swamps of southern Arkansas, eastern Texas,

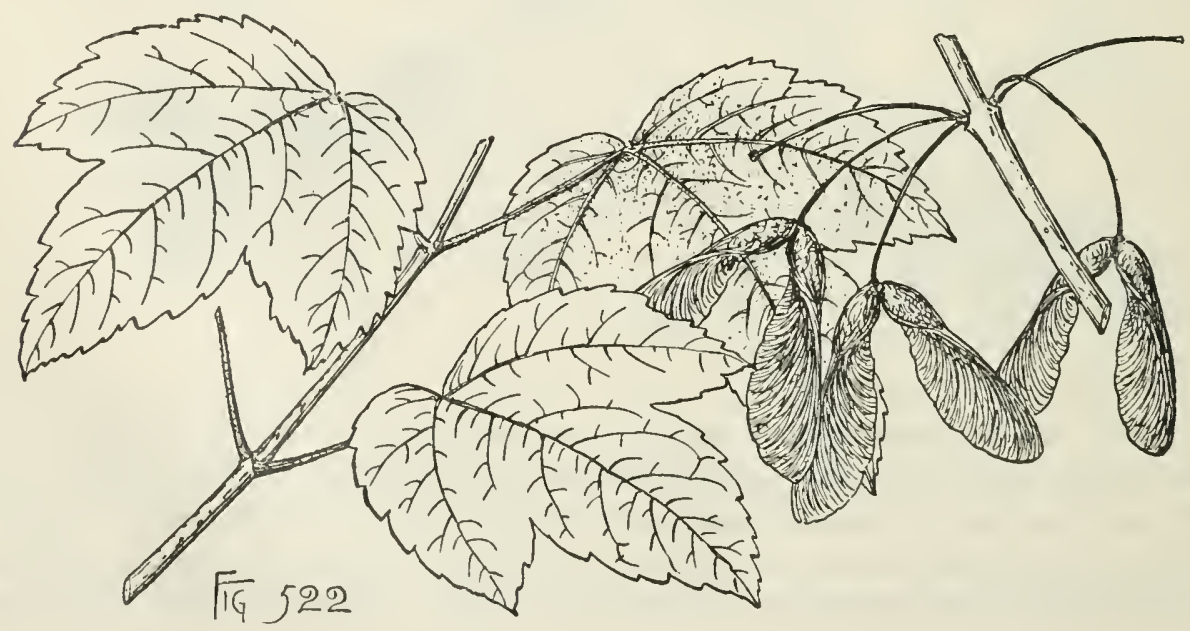


and western Louisiana, with leaves usually rounded or sometimes cordate at the base, 3-lobed, with short broad lobes, and covered on the lower surface like the young shoots and the petioles with thick hoary tomentum, and bright scarlet flowers and fruit. Fruit ripening late in March and April, with large convergent wings; $2^{\prime}-2 \frac{1^{\prime}}{2}$ long and $\frac{1^{\prime}}{2}-\frac{3^{\prime}}{4}$ broad. More distinct is

\section{Acer rubrum, var. tridens, Wood. Red Maple.}

Leaves obovate, usually narrowed from above the middle to the rounded or rarely cuneate base, 3-lobed at the apex, with acute or acuminate lobes, simple or furnished with short lateral secondary lobes, remotely serrate except toward the base, with

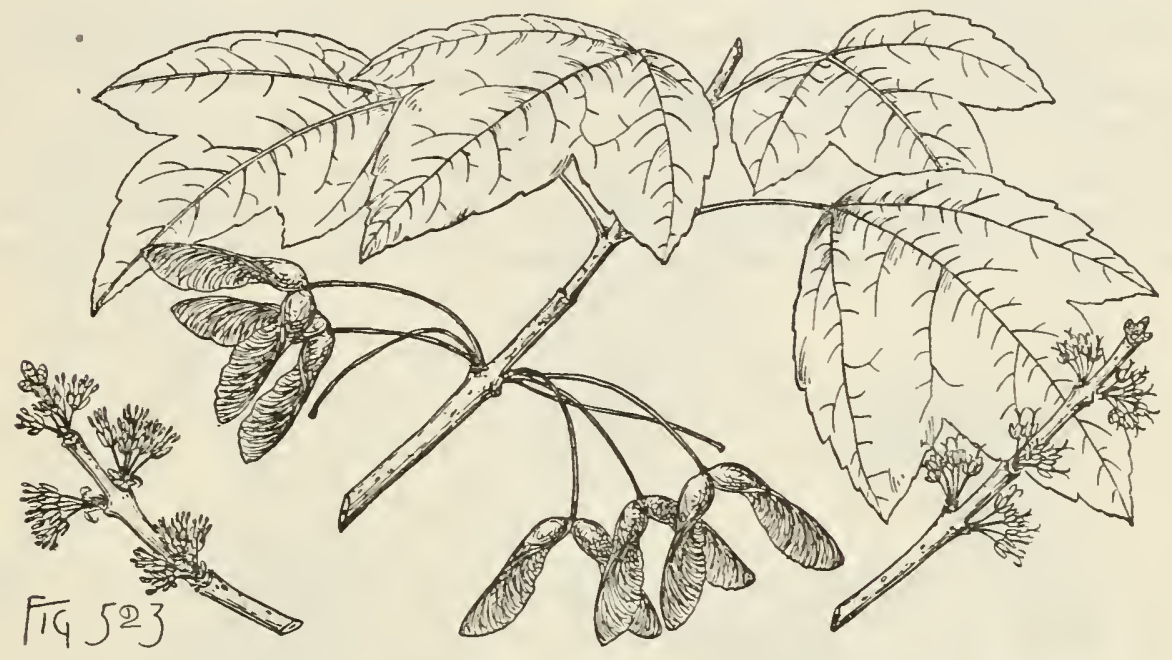

incurved glandular teeth, and often ovate by the suppression of the lateral lobes and acute, thick and firm in texture, glaucous and usually pubescent or rarely tomentose below, $2^{\prime}-3^{\prime}$ long, $1 \frac{1}{2}^{\prime}-2 \frac{1}{2}^{\prime}$ wide. Flowers sometimes tawny yellow. Fruit usually much smaller and rarely also yellow.

Distribution. Southern New Jersey southward through the coast region and middle districts to southern Florida and along the Gulf coast to eastern Texas.

\section{Leaves compound.}

\section{Acer Negundo, L. Box Elder. Ash-leaved Maple.}

Leaves 3-5-foliolate, with slender petioles $2^{\prime}-3^{\prime}$ in length, enlarged at the base and often furnished with a minute fringe of deciduous white hairs, and in falling leaving large conspicuous scars surrounding the stem; leaflets ovate or oval, acute, rounded or wedge-shaped at the base, coarsely and irregularly serrate above the middle, or sometimes 3-lobed, when they unfold coated below with tomentum, and at maturity smooth or more or less pubescent, membranaceous, prominently veined, bright green, paler on the under than on the upper surface, $2^{\prime}-4^{\prime}$ long, $2^{\prime}-3^{\prime}$ broad, on stout petiolules, that of the terminal leaflet often $1^{\prime}$ long or twice as long as those of the smaller lateral leaflets, turning yellow in the autumn before falling. Flowers minute, apetalous, yellow-green, the staminate and pistillate on separate trees, expanding just before or with the leaves from buds developed in the axils of the last leaves of the previous year, the staminate fascicled on slender hairy pedicels $1 \frac{1^{\prime}}{2}-2^{\prime}$ long, the pistillate in narrow drooping racemes; calyx 5-lobed, hairy, cam- 
panulate in the staminate flower, much smaller in the pistillate flower and divided to the base into 5 narrow sepals; corolla 0 ; stamens $4-6$, with slender exserted hairy filaments and long linear anthers surmounted by the point of the eonneetive, 0 in the pistillate flower; ovary on a narrow rudinentary disk, pubeseent, only partly inclosed by the ealyx; style separating from the base into 2 long stigmatic lobes. Fruit attaining its full size early in the summer, pendent ou stems $1^{\prime}-2^{\prime}$ long, in graeefnl raeemes $6^{\prime}-8^{\prime}$ in length, ripening in the antumu, deciduous from the stems persistent on the branehes until the following spring, $1 \frac{1}{2}-2^{\prime}$ long, with narrow acute nutlets diverging at an acute angle, and thin retieulate straight or faleate wings undulate toward the apex; seeds narrowed at the ends, smooth bright red-brown, $\frac{1^{\prime}}{2}$ long.

A tree, $50^{\circ}-70^{\circ}$ high, with a trunk $2^{\circ}-4^{\circ}$ in diameter, dividing near the ground into a number of stout wide-spreading branehes, and slender branchlets pale green and glabrous or slightly pubescent at first, marked in their first winter by a few dark lenticels and bright green and lustrous or sometimes pale purple, with a glaucous bloom. Winter-buds: terminal, aeute, $\frac{1^{\prime}}{8}$ long, rather longer than the obtuse lateral buds, the outer seales often rudimentary and frequently coated with pale

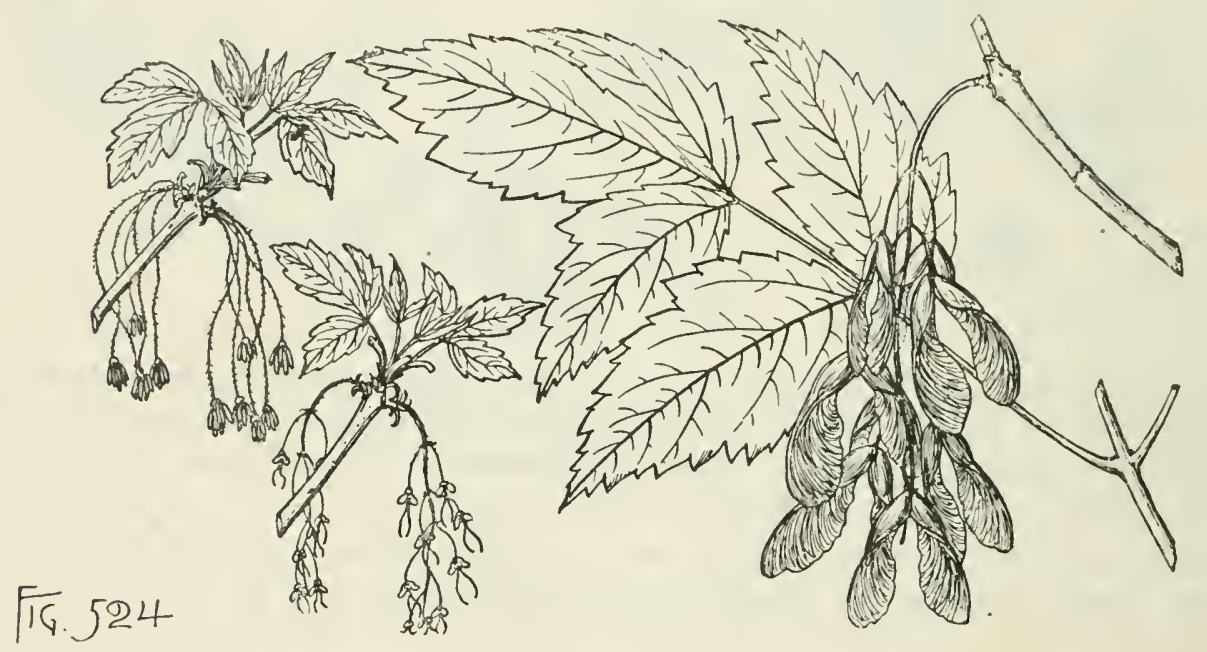

tomentum, those of the inner pairs accrescent, becoming $1^{\prime}$ long at maturity, deeidnous, leaving eonspicuous sears visible at the base of the branehlet for two or three years. Bark of the trunk $\frac{1^{\prime}}{4}-\frac{1}{2}^{\prime}$ thick, pale gray or light brown and deeply divided into broad rounded ridges separating on the surfaee into short thiek seales. Wood light, soft, close-grained, "not strong, ereamy white, with thiek hardly distinguishable sapwood; oceasionally manufactured into cheap furniture, and sometimes used for the interior finish of houses, for wooden ware, eooperage, and paper pulp. Small quantities of maple sugar are occasionally made from this tree.

Distribution. Banks of streams and lakes and the borders of swamps; western Vermont and central New York, southward to northern Florida and westward to the eastern slope of the Roeky Mountains, and to Utah, New Mexieo, and eastern Arizona; rare east of the Appalachian Mountains; most eommon in the Mississippi basin, and of its largest size in the valley of the lower Ohio River. Westward varying in the pubescence of the leaves and in the number of leaflets. An extreme form is 


\section{Acer Negundo, var. Californicum, Sarg. Box Elder.}

Leaves trifoliolate, with larger more coarsely serrate and more frequently lobed leaflets densely coated at maturity on the lower surface with pale pubescence.

A tree, $50^{\circ}-60^{\circ}$ high, with darker colored bark, winter-buds covered with thick tomentum, and pubescent branchlets and ripe fruit.

Distribution. Valley of the lower Sacramento River and the interior valleys of the coast ranges from the Bay of San Francisco to about latitude $35^{\circ}$, and in high

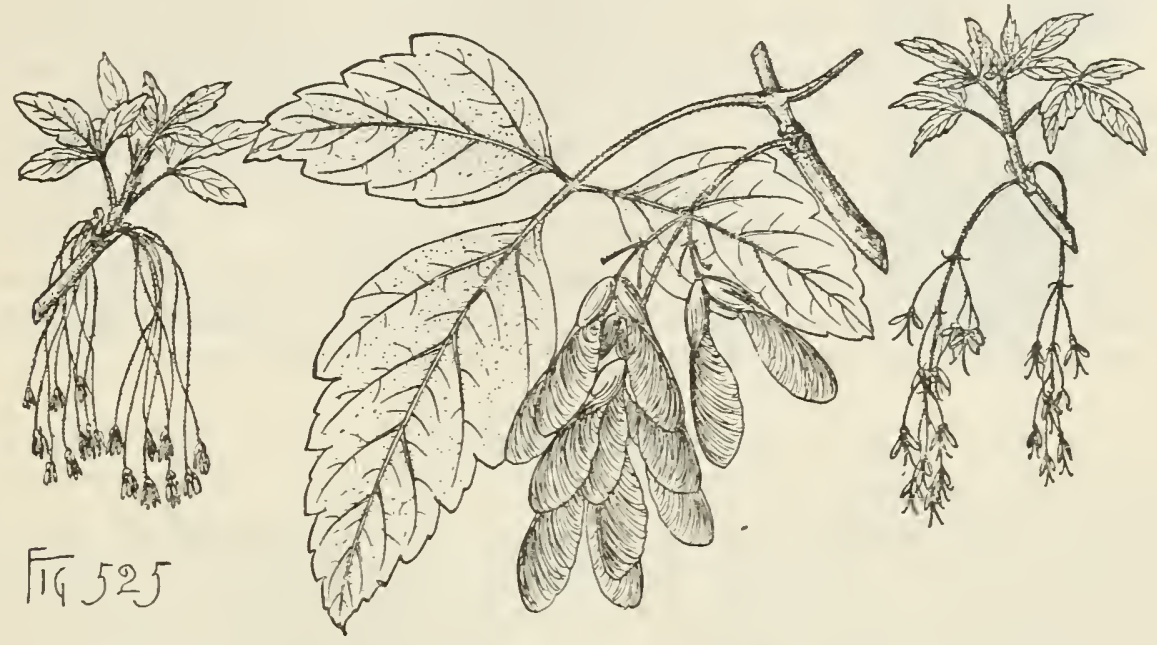

cañons on the western slopes of the San Bernardino Mountains, California; connected by intermediate forms from Arizona to Texas, the Indian Territory, and Missouri, with the eastern tree.

Often planted in the United States as an ornamental tree or for wind-breaks in the treeless central part of the continent, and largely, with numerous varieties, as an ornamental tree in western and northern Europe.

\section{HIPPOCASTANACEA.}

Trees or rarely shrubs, with stout terete branchlets conspicuously marked by triangular leaf-scars, fetid bark, thick fleshy roots, and large scaly winter-buds, the outer scales sometimes coated with resin, the inner accrescent with the young shoots and often brightly colored. Leaves opposite, digitately compound, without stipules, deciduous; leaflets 5-9, lanceolate or ovate, serrate, pinnately veined. Flowers polygamo-monœeious, showy, white, red, or pale yellow, on stout jointed pedicels from the axils of minute caducous bracts, racemose or nearly unilateral on the branches of large terminal thyrsi or panicles, appearing later than the leaves, only those near the base of the branches of the inflorescence perfect and fertile; calyx $\check{5}$ or rarely 2 -lobed, the lobes imbricated in the bud, unequal ; calyx campanulate or tubular, 5-lobed, the lobes imbricated in the bud, mostly oblique or posteriorly gibbous at the base; disk hypogynous, annular, depressed, lobed, more or less gibbous posteriorly; petals 4 or 5 , imbricated in the bud, alternate with the lobes of the calyx, deciduous, the anterior one often abortive, unguiculate, the margins of the claw commonly involute ; stamens 6-8, rarely 5, generally 7 , inserted on the disk, free, unequal ; filaments filiform; anthers elliptical, glandular-apiculate, attached on the back 
below the middle, introrse, 2-celled, the contiguous cells opening longitudinally ; ovary sessile, oblong or lanceolate, 3-celled, eehinate or glabrous, rudimentary in the staninate flower; style slender, elongated, generally more or less curved : stigma terminal, entire, mostly acute ; ovules 2 in each cell, borne on the middle of its imer angle, amphitropous, the upper ascending, the micropyle inferior, the lower pendulous, the micropyle superior. Fruit an echinate roughened or' smooth coriaceous capsule, 3-celled and loculicidally 3-valved, the cells 1 -seeded by abortion, often by suppression 1 or 2-celled, and then 1 or 2 -seeded, the remmants of the abortive cells and seeds commonly visible at its maturity. Seeds without albumen, round when one is developed, or, when more than one, flattened by mutual pressure; seed-coat coriaceous, chestunt-brown, smooth and shiny, with a broad opaque light-colored hilum; embryo filling the cavity of the seed; cotyledons very thick and fleshy, often conferruminate, unequal, incurved on the short conical radicle, remaining under ground in germination; plumule conspicuously 2-leaved.

The Horsechestnut family is composed of the widely distributed genus $\mathbb{E}_{\mathrm{s}}$ culus and of Billia, Peyr., a genus of two species of Mexican and Central American trees, differing from Esculus in its 3-foliolate leaves.

\section{1. ÆSCULUS, L.}

Characters of the family.

Esculus with ten or eleven species is represented in the floras of the three continents of the northern hemisphere. It produces soft straight-grained light-colored wood and bitter and astringent bark. 'The seeds contain a bitter principle, æsculin. Esculus Hippocastanum, L., of the mountains of Greece, the common Horsechestnut of gardens, is largely planted as an ornamental tree in all countries with temperate climates, and now occasionally grows spontaneously in the eastern states.

The generic name is the classical name of an Oak-tree.

\section{CONSPECTUS OF THE ARBORESCENT SPECIES OF NORTH AMERICA.}

Winter-buds without resinous coating.

Calyx campanulate; leaflets mostly glabrous below.

Petals nearly equal, shorter than the stamens; fruit tuberculate.

1. A. glabra (A, C).

Petals unequal, longer than the stamens; fruit smooth.

2. 平. octandra $(\mathrm{A}, \mathrm{C})$.

Calyx tubular; leaflets tomentulose below; petals unequal, shorter than the stamens; fruit smooth.

3. A. austrina (C).

Winter-buds resinous.

Calyx 2-lobed; petals nearly equal, much shorter than the stamens; fruit smooth.

4. E. Californica (G).

\section{Fssculus glàbra, Willd. Ohio Buckeye. Fetid Buckeye.}

Leaves with slender petioles $4^{\prime}-6^{\prime}$ long, enlarged at the ends and often furnished on the upper side with clusters of dark brown chaff-like scales surrounding the base of the petiolules, and 5-7, usually 5, oval oblong or obovate acuminate leaflets gradually narrowed to the elongated entire base, finely and unequally serrate above, at first sessile, becoming slightly petiolulate at maturity, covered on the lower surface like the petioles when they first appear with short soft deciduous pubescence, and at maturity glabrous with the exception of a few hairs along the under side of the conspicuous yellow midribs and in the axils of the principal veins, yellow-green, paler 
on the lower than on the upper surface, $4^{\prime}-6^{\prime}$ long and $1 \frac{1}{2}^{\prime}-2 \frac{1}{2}^{\prime}$ wide, turning yellow in the autumn before falling. Flowers pale yellow-green, mostly unilateral, $\frac{1^{\prime}}{2}-1^{\prime}$

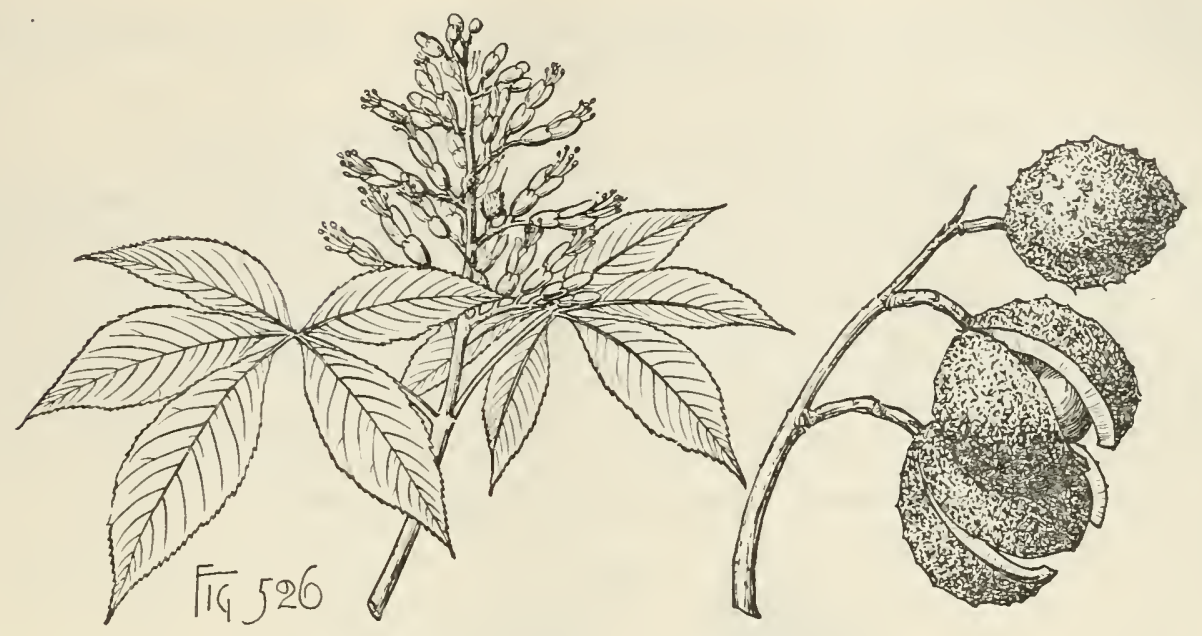

long or more than twice as long as the pedicels, appearing in April and May in clusters $5^{\prime}-6^{\prime}$ long, $2^{\prime}-3^{\prime}$ wide, and more or less densely covered with pubescence, with short usually 4-6-flowered branches; calyx campanulate; petals nearly equal, puberulous, the thin limb about twice as long as the claw, in the lateral pair broadly ovate or oblong, and in the superior oblong-spatulate, much narrower, sometimes marked with red stripes; stamens usually 7 , with long exserted curved pubescent filaments and orange-colored slightly hairy anthers; ovary pubescent, covered with long slender deciduous prickles thickened and tubercle-like at the base. Fruit on a stont stem $\frac{1^{\prime}}{2}-1^{\prime}$ long, orate or irregularly obovate, pale brown, $1^{\prime}-2^{\prime}$ long, with thin or sometimes thick valves, roughened by the enlarged persistent prickles of the ovary; seeds $1^{\prime}-1 \frac{1^{\prime}}{2}$ broad.

A tree, occasionally $70^{\circ}$ high, with a trunk rarely $2^{\circ}$ in diameter, small spreading branches, and branchlets orange-brown and covered at first with short fine pubescence; soon glabrous, reddish brown, and marked by scattered orange-colored lenticels, usually much smaller, and rarely more than $30^{\circ}$ high. Winter-buds $\frac{2}{3}^{\prime}$ long, acuminate, with thin nearly triangular pale brown scales, the outer bright red on the inner surface toward the base, the inner pair strap-shaped, prominently keeled on the back, minutely apiculate and slightly ciliate along the margins, and at maturity $1 \frac{1}{2}-2^{\prime}$ long and bright yellow. Bark of young stems and of the branches dark brown and scaly, becoming on old trees $\frac{3}{4}$ thick, ashy gray, densely furrowed, and broken into thick plates roughened on the surface by numerous small scales. Wood light. soft, close-grained, not strong, often blemished by dark lines of decay, nearly white, with thin dark-colored sapwood of 10-12 layers of annual growth; used in the manufacture of artificial limbs, wooden ware, wooden hats, and paper pulp; occasionally sawed into lumber. An extract of the bark has been used as an irritant of the cerebro-spinal system.

Distribution. River-bottoms and the banks of streams in rich moist soil; western slopes of the Alleghany Mountains, Pennsylvania, to northern Alabama, and westward to southern Iowa, central Kansas, the Indian Territory, southern Nebraska, and eastern Kansas; nowhere abundant; most common and of its largest size in the valley of the Tennessee River in Tennessee and northeru Alabama. A form (var. 
Buckleyi, Sarg.) with 6-7-foliolate leaves and uarrower lanceolate more acuminate and usually more sharply and doubly serrate leaflets, ranges from Iowa to Kansas and eastern 'Texas.

Occasionally cultivated as an ornamental plant in the eastern United States and in Europe, and hardy as far north as Massacliusetts.

\section{Asculus octandra, Marsh. Sweet Buckeye.}

Leaves with slender glabrous or slightly pubescent petioles $4^{\prime}-6^{\prime}$ long, and 5-7 elliptical or obovate-oblong leaflets, sharply and equally serrate, short-petiolulate, glabrous above except on the midribs and veins, sometimes clothed with reddish brown pubescence, when they unfold more or less canescent-pubescent on the lower surface, becoming glabrous at maturity with the exception of a few hairs along the midribs and in the axils of the principal veins, dark yellow-green, duller on the lower than on the upper surface, $4^{\prime}-6^{\prime}$ long, $1 \frac{1}{2}^{\prime}-2 \frac{1^{\prime}}{2}$ wide, turning yellow in the autumn before falling. Flowers opening in early spring when the leaves are about

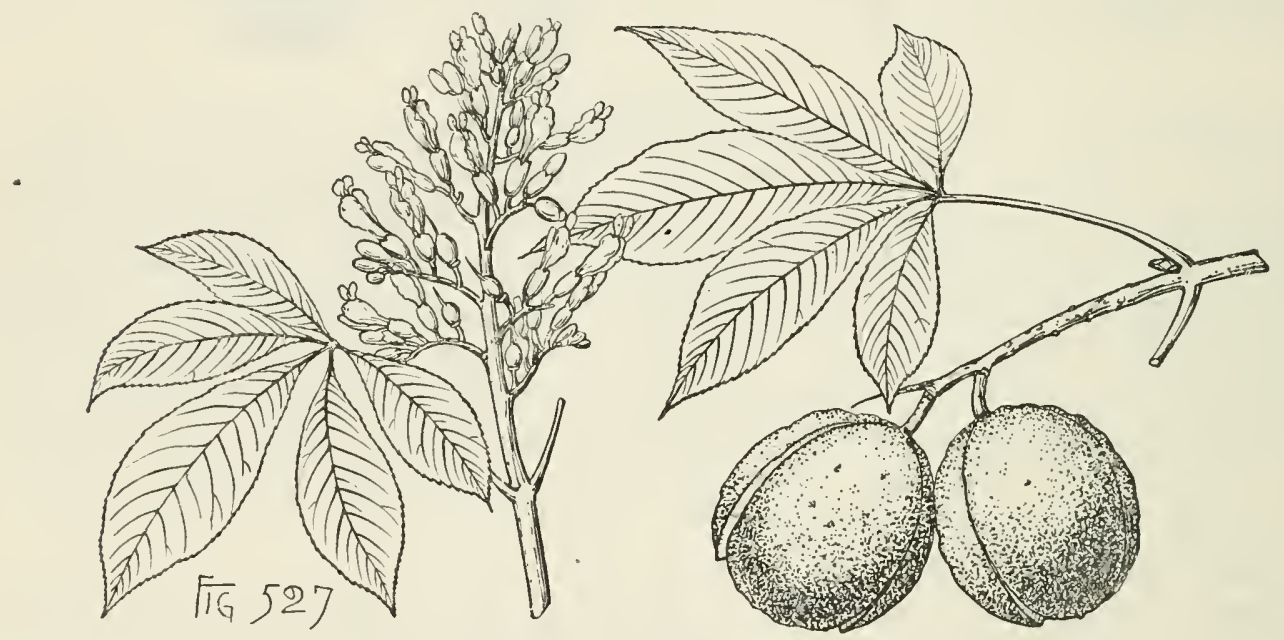

half grown, $1^{\prime}-1^{\prime} \frac{1^{\prime}}{}$ long, pale or dark yellow, on short pedicels mostly unilateral on the branches of the pubescent clusters $5^{\prime}-7^{\prime}$ in length; calyx campanulate, sparingly villose; petals connivent, very unequal, puberulent, the claws villose witlin, limb of the superior pair spatulate, minute, the long claws exceeding the lobes of the calyx, those of the lateral pair obovate or nearly round and subcordate at the base; stamens usually 7 , rather shorter than the petals, with straight or inclining subulate villous filaments; ovary pubescent. Fruit $2^{\prime}-3^{\prime}$ long, generally 2 -seeded, with thin smooth or slightly pitted pale brown valves; seeds $1 \frac{1}{2}^{\prime}$ to nearly $2^{\prime}$ wide.

A tree, sometimes $90^{\circ}$ high, with a tall straight trunk $2 \frac{1}{2}^{\circ}-3^{\circ}$ in diameter, small rather pendulous branches, and glabrous or nearly glabrous branchlets orange-brown when they first appear, becoming in their second year pale brown and marked by numerous irregularly developed lenticels; or toward the southeru and southwestern limits of its range a low shrub. Winter-buds $\frac{2 \prime}{3}$ long, rather obtuse, with broadly ovate pale brown outer scales rounded on the back, minutely apiculate, ciliate, without resin, and slightly covered with a glaucous bloom, the inner scales becoming sometimes $2^{\prime}$ long, bright yellow or occasionally scarlet. Bark of the trunk about $\frac{3}{4}$ thick, dark browll, divided by shallow fissures and separating on the surface into small thin scales. Wood light, soft, close-grained, difficult to split, creamy 
white, with thick hardly distinguishable sapwood; used in the manufacture of artificial limbs, for woodeu ware, wooden hats, paper pulp, and occasionally sawed into lumber.

Distribution. Rich soil of river-bottoms and moist mountain slopes, Allegheny County, Pennsylvania, and southward along the mountains to the neighborhood of Augusta, Georgia, and northern Alabama, and westward to southern Iowa, the Indian Territory, and western Texas; most common and of its largest size on the high mountains of Tennessee and North Carolina. A form (var. hybrida, Sarg.) with purple or red flowers and leaves clothed on the under sulface, like the petioles and inflorescence, with dense pale pubescence, and with lighter colored bark, is not rare on the Alleghany Mountains from West Virginia southward.

Often cultivated in western and central Europe and in the eastern United States, especially the form with red flowers, as an ornament of parks and gardens.

\section{Asculus austrina, Small. Buckeye.}

Leaves with slender grooved villose or pubescent usually ultimately glabrous petioles $3^{\prime}-\tilde{o}^{\prime}$ long, and usually 5 oblong-obovate or elliptical acuminate leaflets, gradually narrowed from near the middle and acute at the entire base, finely or coarsely and sometimes doubly crenulate-serrate above, dark green, lustrous and glabrous except along the slender yellow midribs and veins on the upper surface, lighter colored and tomentulose on the lower surface, nearly sessile or petiolulate, $4^{\prime}-5^{\prime}$ long, $1 \frac{1^{\prime}}{2}-2^{\prime}$ wide.

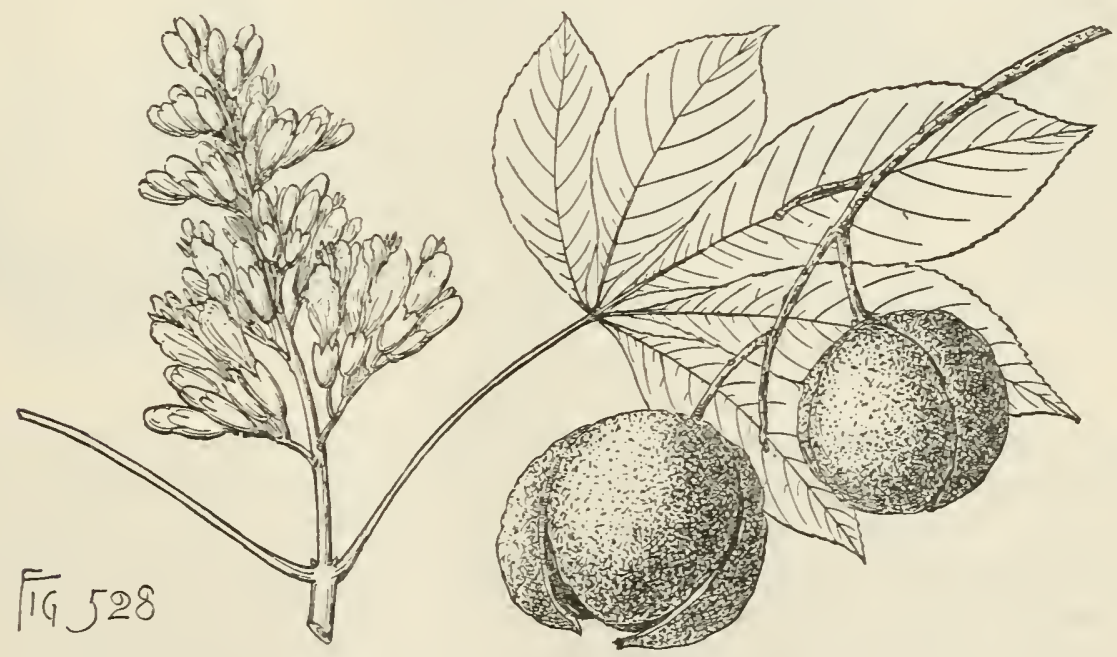

Flowers opening from the first to the middle of April, bright red, usually $\frac{3^{\prime}}{4}-1^{\prime}$ long, on slender pubescent pedicels much thickened on the fruit, sometimes $\frac{1}{4}$ long, and mostly aggregated toward the ends of the short branches of the narrow pubescent inflorescence $6^{\prime}-8^{\prime}$ in length; calyx tubular, short and broad or elongated, puberulous on the outer surface, tomentose on the inner surface, with rounded lobes; petals shorter than the stamens, connivent, unequal, oblong-obovate, rounded at the apex, puberulous on the outer surface and glandular, with minute dark glands, those of the superior pair about half as wide as those of the lateral pair, with claws much longer than the calyx; filaments and ovary villose. Fruit ripening and falling in October, usually only a few fruits maturing on a cluster, generally pear-shaped or occasionally subglobose, nostly 2 -seeded, $1 \frac{1}{2}^{\prime}-2 \frac{1}{2}^{\prime}$ long, with very thin pale brow'n 
slightly pitted valves; seeds light yellow-brown, sometimes $1 \frac{1^{\prime}}{2}$ in diameter, with a comparatively small hilum and a thin shell.

A tree, occasionally $25^{\circ}-30^{\circ}$ high, with a straight trnnk $5^{\prime}-6^{\prime}$ in diameter, stout branches forming a narrow symmetrical head, and slender branchlets marked by numerous small pale lenticels, green and puberulous at first, becoming gray slightly tinged with red during their first winter and only slightly darker in their second year; or often a shrub. Winter-buds broadly ovate, obtusely pointed, about $\frac{1}{4}$ long, with ovate rounded apiculate light red-brown outer scales. Bark thin, smooth, and pale.

Distribution. Rich npland woods; neighborhood of Memphis, Temnessee, and southern Missouri to eastern Texas and northwestern Alabama.

\section{Fsculus Californica, Nutt. Buckeye.}

Leaves with slender grooved petioles $3^{\prime}-4^{\prime}$ long, and 4-7 usually 5 oblong-lanceolate acute leaflets narrowed and obtuse or somewhat rounded at the base, sharply serrate, $4^{\prime}-6^{\prime}$ long, $1 \frac{1}{2}^{\prime}-2^{\prime}$ wide, dark green above, paler below, slightly pubescent at

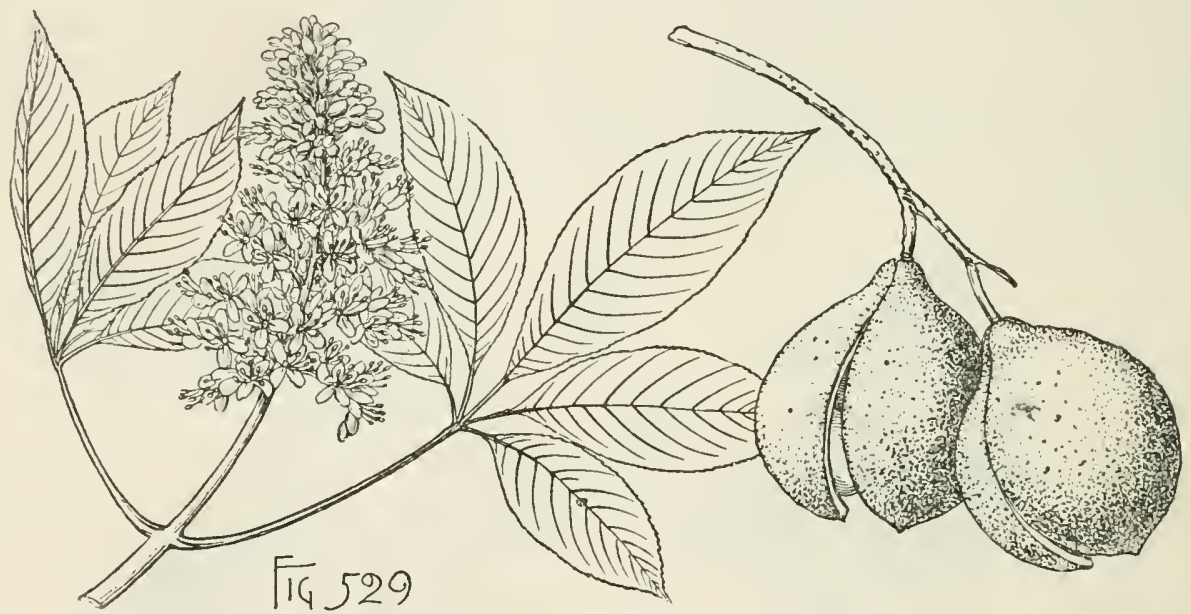

first, becoming glabrous or nearly so, their petiolules $\frac{1^{\prime}}{2}-1^{\prime}$ long, falling early, often by midsummer. Flowers white or pale rose color, $1^{\prime}-1^{\prime}{ }^{\prime}$ long, appearing from May to July when the leaves are fully grown, on short pedicels mostly unilateral on the long branches of the densely flowered long-stemmed pubescent cluster $3^{\prime}-6^{\prime}$ in length; calyx 2-lobed, slightly toothed, much shorter than the narrow oblong petals; stamens 5-7, with long erect exserted slender filaments and bright orange-colored anthers; ovary densely pubescent. Fruit obovate, often somewhat gibbous on the outer side, with thin smooth pale brown valves, usually 1 -seeded, $2^{\prime}-3^{\prime}$ long, on a slender stalk $\frac{1}{4}^{\prime}-\frac{1}{2}^{\prime}$ in length; seeds $1 \frac{1}{2}^{\prime}-2^{\prime}$ broad.

A tree, rarely $30^{\circ}-40^{\circ}$ high, with a short trunk $2^{\circ}-3^{\circ}$ in diameter, often much enlarged at the base, stout wide-spreading branches, and branchlets glabrous and pale reddish brown when they first appear, becoming darker in their second season; more often a shrub, with spreading stems $10^{\circ}-15^{\circ}$ high forming broad dense thickets. Winter-buds acute, covered with narrow dark brown scales rounded on the back and thickly coated with resin. Bark of the trunk abont $\frac{1^{\prime}}{4}$ thick, smooth, and light gray or nearly white. Wood soft, light, very close-grained, white or faintly tinged with yellow, with thin hardly distinguishable sapwood of 10-12 layers of annnal growth. 
Distribution. Borders of streams; valley of the upper Sacramento River, Mendocino County, California, southward along the coast ranges to San Luis Obispo County, and on the western foothills of the Sierra Nevada to the northern slopes of the Tejon Pass, and in Antelope Valley, Los Angeles County; of its largest size in the cañons of the coast ranges north of San Francisco Bay.

Occasionally cultivated as an ornamental plant in western and southern Europe.

\section{SAPINDACE王.}

Trees or shrubs, with alternate pinnate petiolate persistent or deciduous leaves without stipules. Flowers regular or irregular, polygamo-diœecious, polygamo-monœcious or polygamous; calyx of 4 or 5 sepals or lobes, imbricated in the bud; petals 4 or 5 , imbricated in the bud; disk annular, fleshy, 5 -lobed, or unilateral and oblique; stamens usually $7-10$, inserted on the disk; filaments free; anthers introrse, 2-celled, the cells opening longitudinally; ovary $2-4$ or 3 -celled; styles terminal; stigmas capitate or lobed; ovule solitary or 2 in each cell, anatropous or amphitropous. Fruit a drupe or capsule. Seed usually solitary, without albumen; seed-coat bony, coriaceous or crustaceous.

Of the one hundred and eighteen genera of this family, which is chiefly confined to the tropics and is more abundant in the Old than in the New World, four have arborescent representatives in the United States。

\section{CONSPECTUS OF THE ARBORESCENT GENERA OF THE UNITED STATES.}

Fruit baccate.

Fruit dark orange-color or yellow, with thin semitranslucent coriaceous flesh; ovules 1 in each cell of the ovary; leaflets subcoriaceous to coriaceous.

1. Sapindus.

Fruit purple, with thick juicy flesh; ovules 2 in each cell of the ovary; leaflets membranaceous, persistent.

Fruit a drupe ; leaves 3-foliolate, persistent.

Fruit a 3-valved capsule; leaves 4- or 5-, rarely 3-foliolate, deciduous.

2. Exothea.

3. Hypelate.

4. Ungnadia.

\section{SAPINDUS, L.}

Trees or shrubs, with terete branches withont terminal buds, marked by large obcordate leaf-scars, showing the ends of 3 equidistant fibro-vascular bundles, small globose axillary buds often superposed in pairs, the upper bud the larger, and thick fleshy roots. Leaves equally or rarely unequally pinnate, persistent. Flowers regular, minute, polygamo-diœcious, on short pedicels from the axils of minute deciduous bracts, in ample axillary or terminal panicles; sepals 4 or 5 , unequal, slightly united at the base; petals 4 or 5 , equal, alternate with the sepals, inserted under the thick edge of the annular fleshy entire crenately lobed disk, unguiculate, naked or furnished at the summit of the claw on the inside with a 2-cleft scale, deciduous; stamens usually 8 or 10, inserted on the disk immediately under the ovary, equal; filaments subulate or filiform, often pilose, exserted in the staminate, much shorter in the pistillate flower; anthers oblong; attached near the base; pistils 2 or 3, united; ovary sessile, entire or 2-4-lobed, 2-4-celled, narrowed into a short columnar style, rudimentary in the staminate flower; stigma 2-4-lobed, the lobes spreading; ovule solitary in each cell, ascending from below the inner angle of the cell; raphe ventral; micropyle inferior. Fruit baccate, coriaceous, 1-3-seeded, usually formed of 1 globose coriaceous carpel, with the rudiments of the others remaining at its base, or of 2 or sometimes 3 carpels more or less connate by their bases and then 2-3-lobed: 
Seed solitary in each carpel, obovate or globose; seed-coat bony, smooth, black or dark brown; tegmen membranaceous or fleshy; hilum oblong, surrounded by an ariloid tuft of long pale silky hairs; embryo incurved or straight; cotyledons thick and fleshy, incumbent; radicle very short, inferior, near the hilum.

Sapindus is widely distributed through the tropics, especially in Asia, occasionally extending into colder regions. Abont forty species have been distinguished; of these three are found within the territory of the United States.

Sapindus contains a detersive principle which causes the pulp of the fruit to lather in water, and makes it valuable as a substitute for soap. The bark, which is bitter and astringent, has been used as a tonic. The seeds of several of the species are strung for chaplets and bracelets and are used as buttons.

The generic name, from sapo and Indus, refers to the detersive properties and use of the first species known to Europeans, a native of the West Indies.

\section{CONSPECTUS OF THE SPECIES OF THE UNITED STATES.}

Leaves persistent.

Rachis of the leaf interruptedly winged, with usually broad wings; leaflets 4-9, oblonglanceolate and acute to elliptical-ovate or oblong, tomentulose below; petals without scales; fruit globose, orange-brown.

1. S. Saponaria (D).

Rachis of the leaf without wings, narrowly margined or marginless ; leaflets 7-13, lanceolate-oblong, acuminate, often somewhat falcate, glabrous below; petals with scales; fruit somewhat oblong, dorsally keeled, yellow.

2. S. marginatus $(\mathrm{C})$. Leaves deciduous, their rachises without marginal borders; leaflets $8-19$, lanceolate, mostly falcate, soft-pubescent or ultimately glabrous below; petals with scales; fruit globose, not keeled, turning black in drying.

3. S. Drummondi (C, E).

\section{Sapindus Saponaria, L. Soapberry.}

Leaves $6^{\prime}-7^{\prime}$ long, with broadly winged rachises, their wings narrow and often nearly obsolete below the lowest pair of leaflets, and sometimes nearly $\frac{1}{2}$ wide below

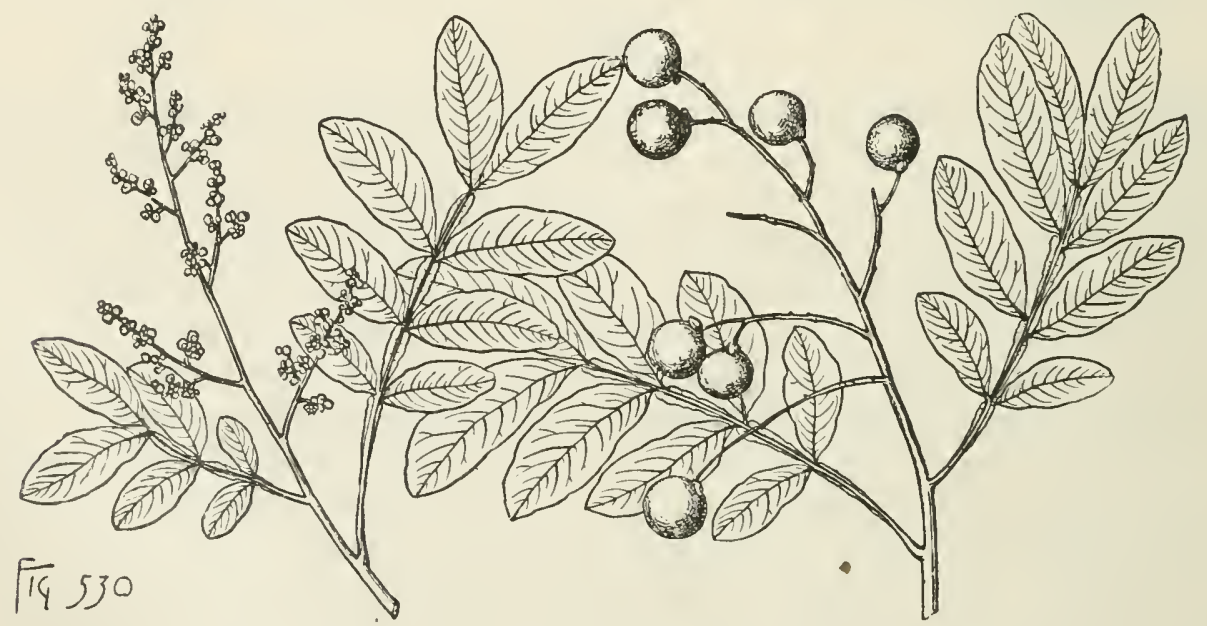

the upper pair, and usually 6-9 leaflets gradually narrowed at the base, very shortpetiolulate, when they unfold glabrous on the upper surface with the exception of a few hairs on the midveins, softly pubescent on the lower surface, and at maturity rather coriaceous, yellow-green, paler and tomentulose below, prominently reticulate-venulose, $3^{\prime}-4^{\prime}$ long and $1 \frac{1^{\prime}}{2}$ wide, with yellow midribs and primary veius, those of 
the lowest pair smaller than the others; rarely reduced to a single leaflet. Flowers usually produced 3 together on short pedicels, in terminal panicles $7^{\prime}-10^{\prime}$ in length, with angulate peduncles and branches, appearing in Florida in November; calyxlobes rounded, concave, ciliate on the margins, the 2 outer rather smaller than those of the inner rank; petals without scales, white, ovate, short-clawed, rounded at the apex and covered, especially toward their base, with long scattered hairs; stamens included or slightly exserted, with hairy filaments broadened at the base. Fruit ripening in spring or in early summer, globose, $\frac{2^{\prime}}{3}-\frac{3^{\prime}}{4}$ in diameter, with thin orangebrown semitranslucent flesh; seeds obovate, black, $\frac{1^{\prime}}{2}$ in diameter.

A tree, sometimes $25^{\circ}-30^{\circ}$ high, with a trunk rarely exceeding $10^{\prime}-12^{\prime}$ in diameter, erect branches and slender branchlets at first slightly many-angled and puberulous, soon glabrous, orange-green and marked by white lenticels, becoming in their second season terete, pale brown faintly tinged with red. Bark of the trunk $\frac{1^{\prime}}{4}-\frac{1}{2}^{\prime}$ thick, light gray and roughened by oblong lighter colored excrescences, the outer layer exfoliating in large flakes exposing the nearly black inner bark. Wood heavy, rather hard, close-grained, light brown tinged with yellow, with thick yellow sapwood.

Distribution. Southern Florida, shores of Cape Sable, shores and islands of Caximbas Bay, Key Largo, Elliott's Key, and the shores of Bay Biscayue; in Florida most common on Cape Sable, and of its largest size on some of the Thousand Islands; generally distributed through the West Indies to Venezuela.

\section{Sapindus marginatus, Willd. Soapberry.}

Leaves $6^{\prime}-7^{\prime}$ long, with slender wingless or narrowly margined or marginless rachises, and 7-13 lance-oblong acuminate more or less falcate leaflets, glabrous, dark green, and lustrous on the upper, paler and glabrous or puberulous on the

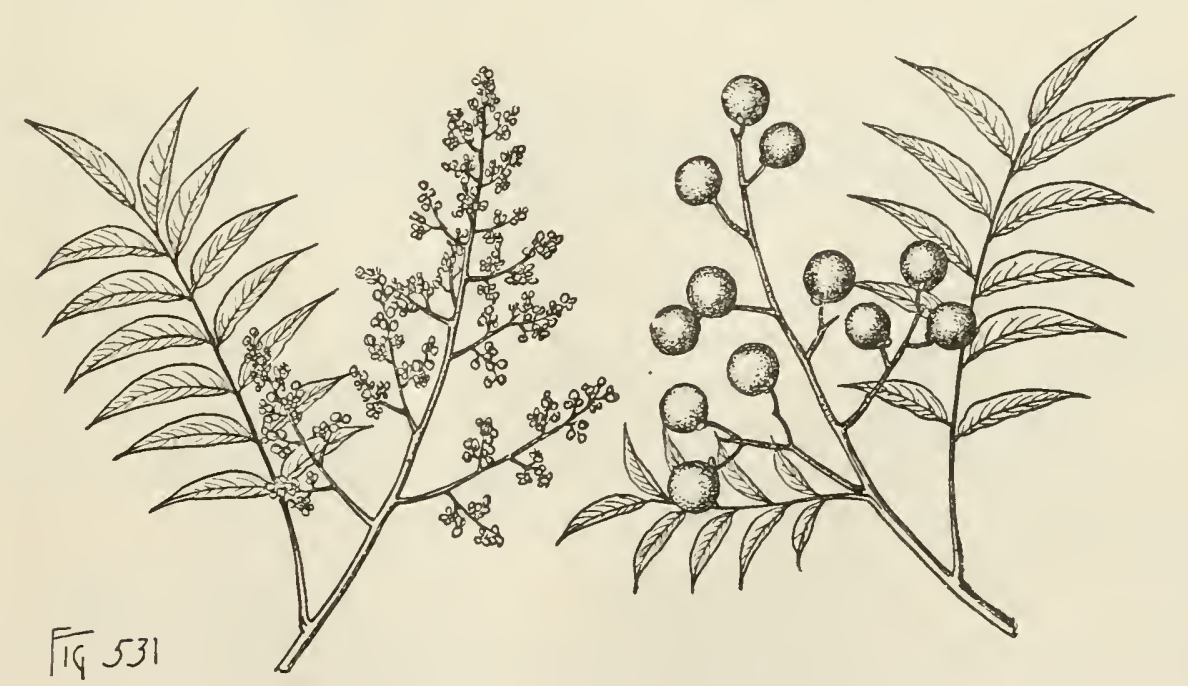

lower surface along the slender midnerves, sessile or very short-petiolulate, $2^{\prime}-5^{\prime}$ long, $\frac{3^{\prime}}{4}-1 \frac{1^{\prime}}{4}$ wide, the lower usually alternate, the upper opposite. Flowers more or less tinged with red and nearly $\frac{1^{\prime}}{8}$ in diameter, on short stout tomentose pedicels, appearing in early spring in panicles $4^{\prime}-5^{\prime}$ long and usually about $3^{\prime}$ wide, with villose stems and branches; sepals rounded at the apex, villose on the outer surface toward the base, ciliate on the margins, the outer much narrower than the inner; petals ovate-oblong, short-clawed, ciliate, furnished on the inner surface near the 
base with a 2-lobed villose scale. Fruit conspicuously keeled on the back, shortoblong, about $\frac{3^{\prime}}{4}$ long, with thin light yellow translucent flesh; seeds obovate, dark brown.

A tree, rarely more than $25^{\circ}-30^{\circ}$ high, with a trunk sometimes $1^{\circ}$ in diameter, and stout pale brown or ultimately ashy gray branchlets.

Distribution. Coast of Florida from the month of the St. John River and Cedar Keys southward; rare and still imperfectly known.

\section{Sapindus Drummondi, Hook. \& Arn. Soapberry. Wild China-tree.}

Leaves appearing in March and April, with slender grooved puberulons rachises, without wings, and 4-9 pairs of alternate obliquely lanceolate acuminate leaflets,
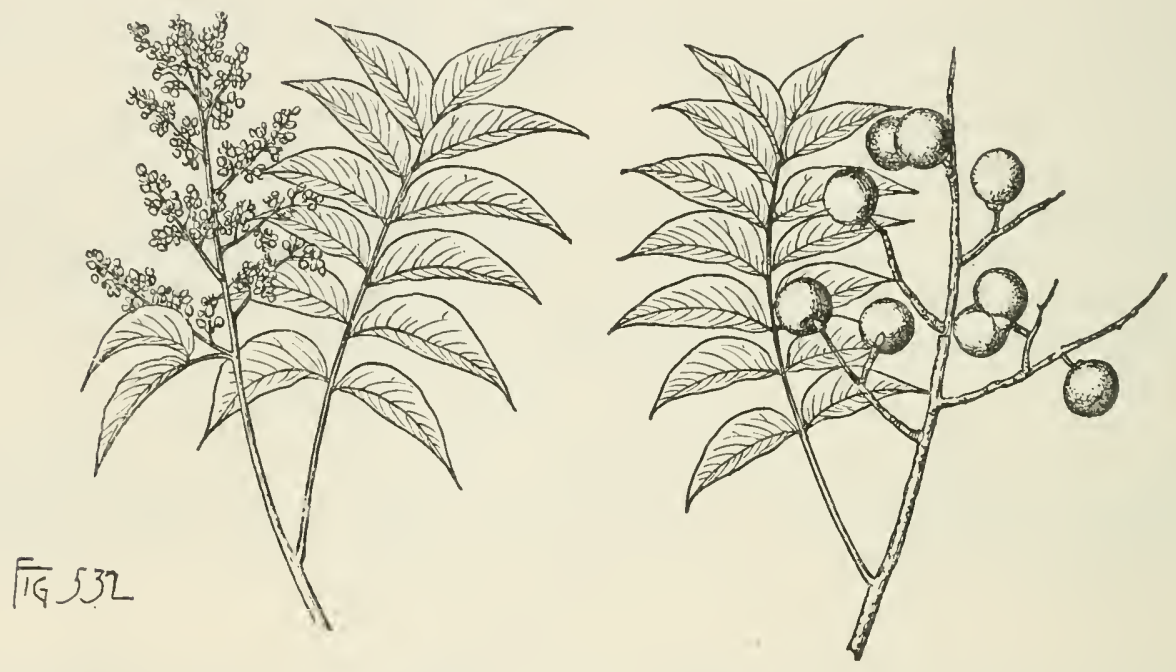

glabrous on the upper and covered with short pale pubescence on the lower surface, rather coriaceous, prominently reticulate-venulose, pale yellow-green, $2^{\prime}-3^{\prime}$ long, $\frac{1}{2}-\frac{2}{3}$ wide, short-petiolulate, deciduous in the autumn or early winter. Flowers appearing in May and June in clusters $6^{\prime}-9^{\prime}$ long and $5^{\prime}-6^{\prime}$ wide, with pubescent many-angled stems and branches; sepals acute and concave, ciliate on the margins, much shorter than the white obovate petals rounded at the apex, contracted into long claws, hairy on the inner surface and furnished at the base with a deeply cleft scale hairy on the margins; filaments hairy, with long soft hairs. Fruit ripening in September and October, persistent on the branches until the following spring, glabrous, not keeled, yellow, $\frac{1}{2}^{\prime}$ in diameter, turning black in drying; seeds obovate, dark brown.

A tree, $40^{\circ}-50^{\circ}$ high, with a trunk sometimes $1 \frac{1}{2}^{\circ}-2^{\circ}$ in diameter, usually erect branches and branchlets at first slightly many-angled, pale yellow-green, pubescent, becoming in their second year terete, pale gray, slightly puberulous, and marked by numerous small lenticels. Bark of the trunk $\frac{1}{3}-\frac{1}{2}$ thick, separating by deep fissures into long narrow plates broken on the surface into small red-brown seales. Wood heavy, strong, close-grained, light brown tinged with yellow, with lighter colored sapwood of about 30 layers of aunual growth; splitting easily into thin strips and largely used in the manufacture of baskets used in harvesting cotton, and for the frames of pack-saddles.

Distribution. Moist clay soil or dry limestone uplands; western Louisiana to the 
valley of the Washita River, Arkansas, and southeru Kansas, and through Texas to the mountain valleys of southern New Mexico, southern Arizona, and northern Mexico.

\section{EXOTHEA, Macf.}

A tree, with thin scaly bark, and terete branchlets covered with lenticels. Leaves petiolate, abruptly pinnate or 3 - or rarely 1 -foliolate, glabrous, without stipules, persistent; leaflets oblong or oblong-ovate, acute, rounded or emarginate at the apex, with entire undulate margins, obscurely veined, membranaceous, dark green and listrous on the upper and slightly paler on the lower surface. Flowers regular, polygamo-diœcious, on short pedicels from the axils of minute deciduous bracts covered with thick pale tomentum, in ample terminal or axillary wide-branched panicles clothed with orange-colored pubescence; sepals 5 , ovate, rounded at the apex, ciliate on the margins, puberulons, persistent; petals 5 , white, ovate, rounded at the apex, shortly unguiculate, alternate with and rather longer and narrower than the sepals; disk annular, fleshy, irregularly 5-lobed, puberulous; stamens 7 or 8 , inserted on the disk, as long as the petals in the staminate flower, much shorter in the pistillate flower; filaments filiform, glabrous, anthers oblong, with a broad connective, rudimentary in the staminate flower; ovary sessile on the disk, conical, pubescent, 2-celled, contracted into a short thick style, rudimentary in the staminate flower, stigma large, declinate, obtuse; ovules 2 in each cell, suspended from the summit of the inner angle, collateral, anatropous, raphe ventral; micropyle superior. Fruit a nearly spherical 1-seeded berry containing the rudiment of the second cell and tipped with the short remnant of the style, surrounded at the base by the persistent reflexed sepals; flesh becoming thick, dark purple, and juicy at maturity. Seed oblong, short to subglobose, solitary, suspended; seed-coat thin, coriaceous, orange-brown, and lustrous; embryo subglobose, filling the cavity of the seed; cotyledons fleshy, plano-convex, puberulous; radicle superior, very short, uncinate, turned toward the small hilum and inclosed in a lateral cavity of the seed-coat.

The genus is represented by a single West Iudian species.

The generic name is from ${ }^{\xi} \xi \omega \theta \epsilon$ ' $\omega$, in allusion to its removal from a related genus.

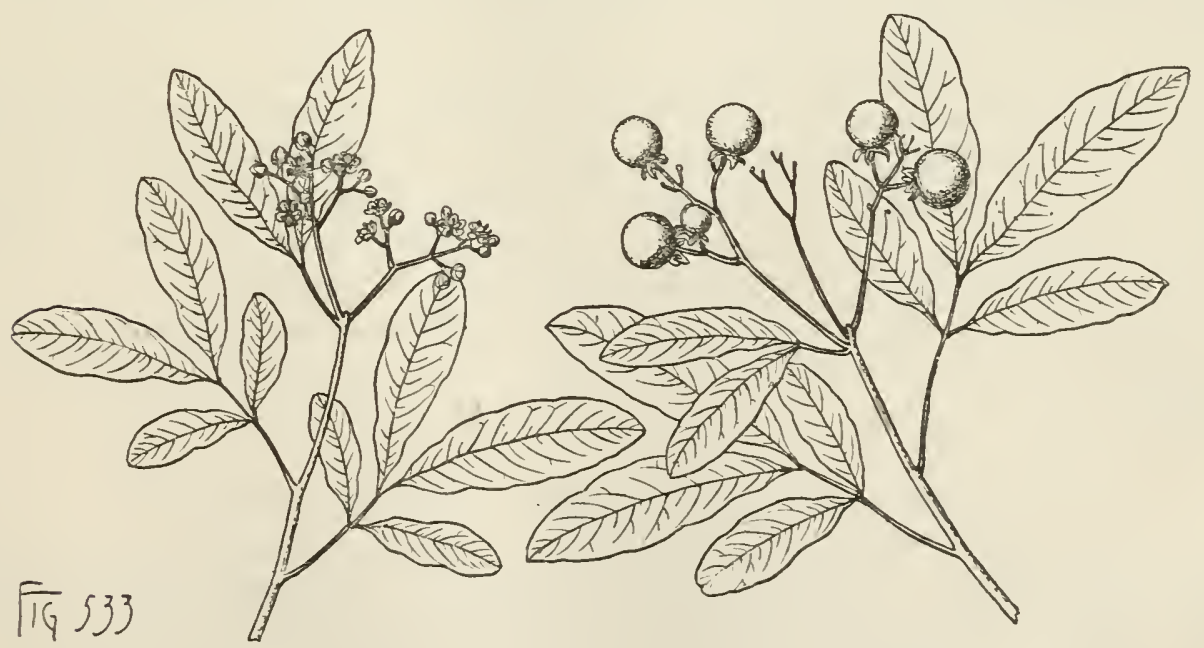

1. Exothea paniculata, Radlk. Ironwood. Ink Wood.

Leaves appearing in April on stout grooved petioles $\frac{1^{\prime}}{2}-1^{\prime}$ long; leaflets $4^{\prime}-5^{\prime}$ 
long and $12^{\prime}-2^{\prime}$ wide. Flowers opening in Florida in April, $\frac{1}{4}^{\prime}$ across when expanded, the staminate and pistillate on separate plants. Fruit fully grown by the end of June and then $\frac{1}{2}-\frac{5}{8}$ long, dull orange color, remaining on the branches during the summer, ripcning in the autumn, and becoming juicy and dark purple at maturity; seeds $\frac{1^{\prime}}{4}-\frac{3}{8}$ in dianeter.

A tree, sometimes $40^{\circ}-50^{\circ}$ high, with a trunk $12^{\prime}-15^{\prime}$ in diameter, slender upright branchlets orange-brown when they first appear, becoming reddish brown in their second year and thickly covered by small white lenticels. Bark of the trunk $\frac{1^{\prime}}{8}-\frac{1^{\prime}}{4}$ thick, the bright red surface separating into large scales. Wood very liard and heavy, strong, close-grained, bright red-brown, with lighter colored sapwood of 10-12 layers of annual growth; valued for piles and also used in Florida in boatbuilding, for the liandles of tools, and many small articles.

\section{HYPELATE, P. Br.}

A glabrous tree or shrub, with smooth bark and slender terete branchlets. Leaves long-petioled, the petioles sometimes narrow-winged, 3 -foliolate, the terminal leaflet rather larger than the others, persistent; leaflets sessile, obovate, rounded or rarely acute or emarginate at the apex, entire, with thickened revolute margins and prominent midribs, coriaceons, feather-veined, the veins arcuate and connected near the margins, dark green and lustrous on the upper, bright green on the lower surface. Flowers regular, polygamo-monœcious, minute, on slender pedicels from the axils of minute deciduous bracts, in few-flowered long-stemmed wide-branched terminal or axillary panicles; calyx 5 -lobed, the lobes ovate, rounded at the apex, slightly puberulous on the outer surface, ciliate on the margins, deciduous by a circumcissile line, petals 5 , rather longer than the calyx-lobes, rounded, spreading, ciliate on the margins, white; stamens 7 or 8 , inserted on the lobes of the annular fleshy disk; filaments filiform, as long as the petals in the staminate flower, much shorter in the pistillate flower; anthers oblong, attached on the back near the bottom, the cells spreading from above downward; ovary sessile on the disk, slightly 3-lobed, 3-celled, contracted into a short stout style, rudimentary in the staminate flower; stigma large, declinate, obscurely 3 -lobed; ovules 2 in each cell, borne on the middle of its inner angle, superposed, amphitropous, the upper ascending, with the micropyle inferior, the lower pendulous, with the micropyle superior. Fruit an ovate black drupe crowned with the remnants of the persistent style and supported on the persistent base of the disk; flesh thin and fleshy; walls of the stone thick and crnstaceous. Seed solitary by the abortion of the upper ovule, suspended, obovate; seed-coat thin, slightly wrinkled; embryo conduplicate, filling the cavity of the seed; cotyledons thin, foliaceous, irregularly folded, incumbent on the long radicle.

The genus with a single species is distributed from southern Florida to Cuba and Jamaica.

Hypelate is the ancient name of the Butcher's Broom.

\section{Hypelate trifoliata, Sw. White Ironwood.}

Leaves unfolding in June and persistent until their second season or longer; petioles stout, $1 \frac{1}{2}^{\prime}-2^{\prime}$ long, with narrow green wings; leaflets $1 \frac{1^{\prime}}{2}-2^{\prime}$ long, and $\frac{3 \prime}{4}-1 \frac{1^{\prime}}{4}$ wide. Flow ers appearing in Florida in June, rather less than $\frac{1}{8}^{\prime}$ in diameter, in fewflowered panicles $3^{\prime}-4^{\prime}$ in length, on slender peduncles, the staminate and pistillate in separate panicles on the same tree. Fruit ripening in September, $\frac{3}{8}^{\prime}$ long, with a sweet rather agreeable flavor. 
A tree, sometimes $35^{\circ}-40^{\circ}$ high, with a trunk occasionally $18^{\prime}-20^{\prime}$ in diameter, and branchlets pale green when they first appear, becoming gray during their first season and bright red-brown the following year; generally much smaller. Bark of the trunk rarely $\frac{1^{\prime}}{8}$ thick, marked by shallow depressions and numerous minute
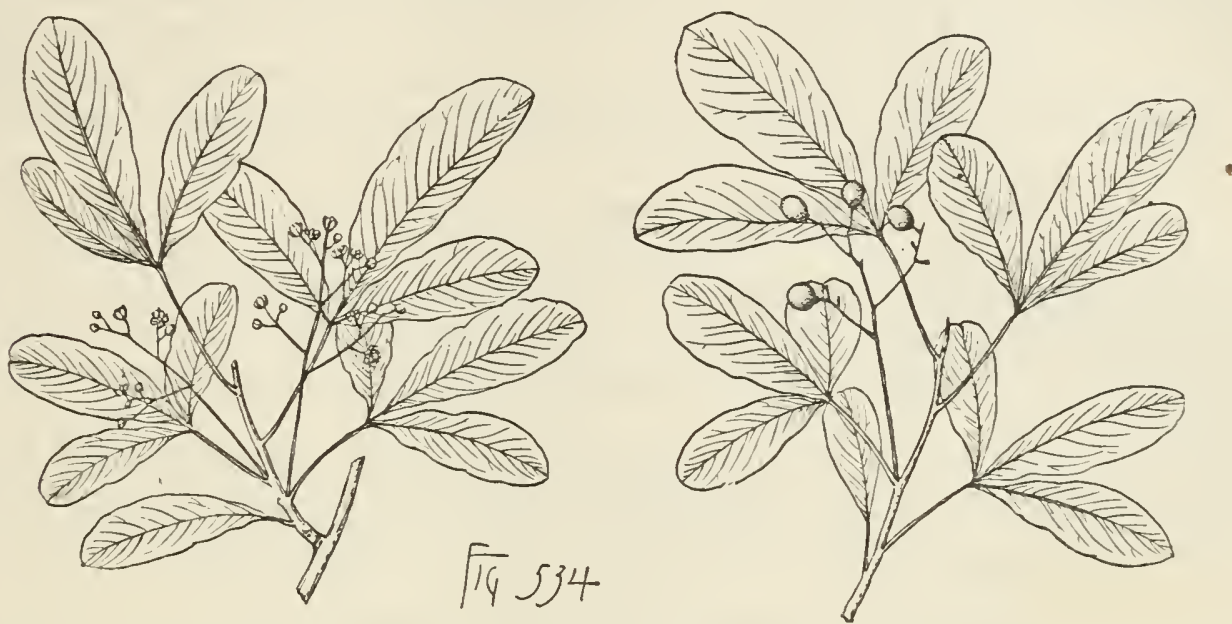

lenticels. Wood very heavy, hard, close-grained, rich dark brown, with thin darker colored sapwood of 4 or 5 layers of annual growth; very durable in contact with the soil and valued in Florida for posts; also used in shipbuilding and for the handles of tools.

Distribution. Upper Metacombe and Umbrella Keys, Florida; rare; in Cuba and Jamaica.

\section{UNGINADIA, Endl.}

A tree or shrub, with thin pale gray fissured bark, slender terete slightly zigzag branchlets without terminal buds, marked by large conspicuous obcordate leaf-scars, small obtuse nearly globose axillary winter-buds covered with numerous chestnutbrown imbricated scales, and thick fleshy roots. Leaves long-petioled, 5 or 7 or rarely 3-foliolate, deciduous; leaflets ovate-lanceolate, acuminate, rounded or wedge-shaped, and often oblique at the base, irregularly crenulate-serrate, coated at first on the lower surface like the petioles with dense pale tomentum, pilose above, glabrous at maturity with the exception of a few hairs on the lower surface along the principal veins, pinnately veined, reticulate-venulose, the terminal one longpetiolulate, the others short-petiolulate to subsessile. Flowers irregular, polygamous, in small pubescent fascicles or corymbs appearing just before or with the leaves from the axils of those of the previous year, usually from separate buds, or occasionally from the base of leafy branches; calyx 5-lobed, hypogynous, oblong-lanceolate, somewhat united irregularly at the base only, deciduous; petals 4 by the suppression of the anterior one, or 5 and then alternate with the lobes of the calyx, hypogynous on the margin of a thickened truncate torus, unguiculate, bright rose color, deciduous, the claw as long as the lobes of the calyx, nearly erect, clothed with tomentum, especially on the inner surface, conspicuously appendaged at the summit with a fimbricated erest of short fleshy tnfted hairs, the blade obovate, spreading, often erose-crenulate; disk unilateral, oblique, tongne-shaped, surrounding and connate with the base of the stipe of the ovary; stamens $7-10$, usually 8 or 9 , inserted on the oblique edge of the disk, much exserted and unequal, the anterior ones shorter 
than the others, equal or almost so and shorter than the petals in the pistillate flower; filaments filiform; anthers oblong, attached near the base; ovary ovoid, 3-celled, pilose, raised on a long stipe, rudimentary in the staminate flower; style subulate, filiform, elongated, slightly curved upward; stigma minute, terminal; ovules 2, borne on the inner angle of the cell near its middle, ascending, the micropyle inferior. Fruit a coriaceous 3-celled loculicidally 3-valved broadly ovate eapsule, conspicnonsly stipitate, crowned with the remmants of the style, rugosely roughened and dark reddish brown, loculicidally 3 -valved, the valves somewhat cordate, bearing the dissepiment on the middle. Seed generally solitary by abortion, almost globosc; seed-coat coriaccous, very smooth and shining, dark chestnut-brown or almost black; hilum broad; tegmen thin; embryo filling the cavity of the seed; cotyledons thick and fleshy, nearly hemispherical, conferruminate, incumbent on the short conical descending radicle turned toward the hilım, remaining below ground in germination.

Ungnadia with a single species is confined to Texas, New Mexico, and northern Mexico.

The name is in honor of Baron Ferdinand von Ungnad, Ambassador of the Emperor Rudolph II. at the Ottoman Porte who sent seeds of the Horsechestnut-tree from Constantinople to Vienna in the middle of the sixteenth century.

\section{Ungnadia speciosa, Endl. Spanish Buckeye.}

Leaves appearing from March to April with or just after the flowers, $6^{\prime}-12^{\prime}$ long, with stout petioles $2^{\prime}-6^{\prime}$ long, rather coriaceous leaflets, dark green and lustrous on

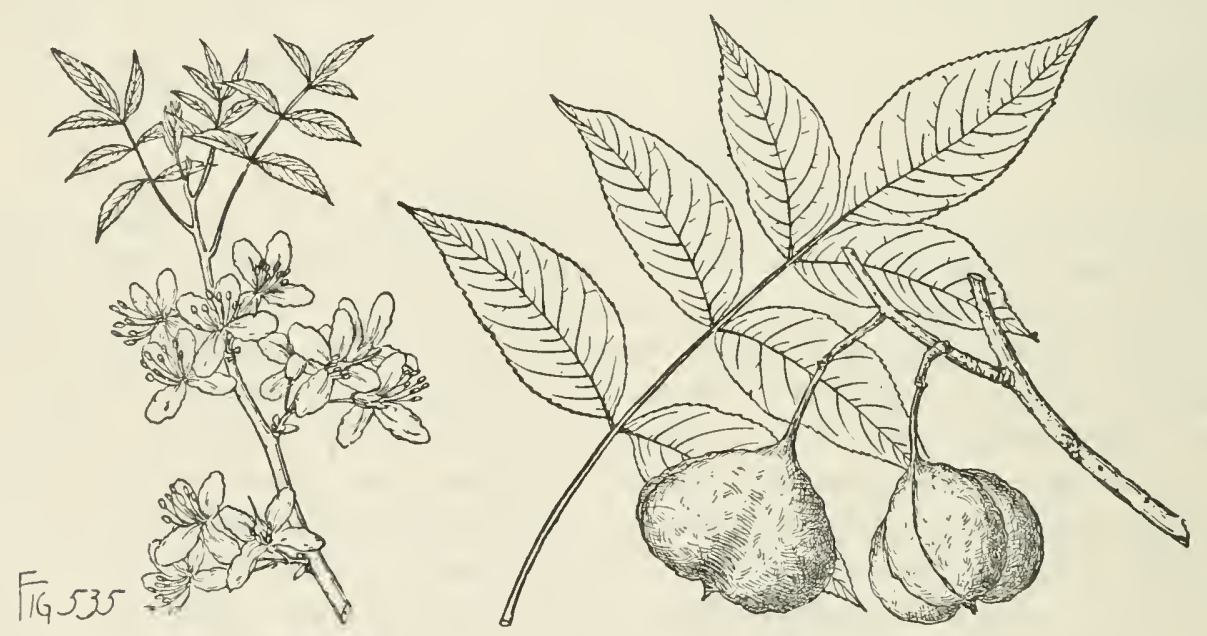

the upper and pale and rugose on the lower surface, $3^{\prime}-5^{\prime}$ long and $1 \frac{1}{2}^{\prime}-2^{\prime}$ wide, the terminal leaflet on a petiolule $\frac{1^{\prime}}{4}-1^{\prime}$ long. Flowers $1^{\prime}$ across when expanded, in crowded clusters $1 \frac{1}{2}^{\prime}-2^{\prime}$ long. Fruit $2^{\prime}$ broad, opening in October, the empty pods often remaining on the branches until the appearance of the flowers the following year; seeds $\frac{1}{2}^{\prime}-\frac{5}{8}^{\prime}$ in diameter.

A tree, occasionally $25^{\circ}-30^{\circ}$ high, with a trunk $6^{\prime}-8^{\prime}$ in diameter, dividing at some distance from the ground into a number of small upriglit branches, and branchlets light orange-brown and covered during their first season with short fine pubescence, pale brown tinged with red, glabrous and marked by scattered lenticels in their second year; more often a shrub, with numerous stems. Winter-buds about $\frac{1}{8}$ in diameter. Bark of the trunk rarely more than $\frac{1}{4}$ thick, light gray and broken by 
numerous shallow reticulated fissures. Wood heavy, close-grained, rather soft and brittle, red tinged with brown, with lighter colored sapwood. The sweet seeds possess powerful emetic properties and are reputed to be poisonous.

Distribution. Borders of streams, limestone hills, and westward on the sides of mountain cañons; valley of the Trinity River, Texas, to the Oran Mountains, New Mexico, and southward into Mexico; most common and of its largest size forty to fifty miles from the Texas coast west of the Colorado River.

Occasionally cultivated as an ornamental plant in the southern United States.

\section{RHAMNACE王.}

Trees or shrubs, with scaly or naked buds, watery bitter astringent juice, simple leaves, and minute deciduous stipules (persistent in Krugiodendron). Flowers small, mostly greenish, perfect (polgyumo-dioecious in one species of Rhamnus); calyx 4-5-lobed, the lobes valvate in the bud; petals 4-5, inserted on the calyx near the margin of the conspicuous disk lining the short calyxtube, and infolding the stamens, or 0 ; stamens as many as and alternate with the calyx-lobes, free, inserted at or below the margins of the disk; filaments slender, subulate; anther's introrse, versatile, 2-celled, the cells opening longitudinally ; pistils of $2-3$ united carpels; ovary $2-3$, or rarely 1 -celled by abortion, partly immersed in the disk; style terminal; stigma 2-4-lobed; ovules 1 in each cell, erect, anatropous; raphe ventral; micropyle inferior. Fruit drupaceous, supported on the tube of the calyx and bearing the remnants of the style. Seed usually with scanty oily albumen; embryo with broad cotyledons; radicle inferior, next the hilum.

\section{CONSPECTUS OF THE ARBORESCENT GENERA OF THE UNITED STATES.}

Fruit more or less fleshy.

Fruit with a single stone; petals 0 .

Sepals without crests.

Leaves alternate; branches spinescent.

1. Condalia.

Leaves nearly opposite; branches not spinescent.

Sepals crested; leaves mostly opposite.

Fruit with 2 or 3 nutlets; petals 4 or 5, or 0 ; leaves alternate.

2. Reynosia.

3. Krugiodendron.

4. Rhamnus. Fruit crustaceous, 3-lobed, separating into 3 longitudinally 2 -valved nutlets.

Sepals inflexed; petals narrowed into long slender claws.

Sepals spreading; petals sessile.

5. Ceanothus.

6. Colubrina.

\section{CONDALIA, Cav.}

Trees or shrubs, with rigid spinescent branches and minute scaly buds. Leaves alternate, subsessile, obovate or oblong, entire, feather-veined. Flowers axillary, solitary or fascicled, greenish white, on short pedicels; calyx with a short broadly obconical tube and 5 -lobed limb, the lobes ovate, acute, membranaceous, spreading and persistent; disk fleshy, flat, slightly 5-angled, surrounding the free base of the ovary; petals 0 ; stamens 5 , inserted on the free margin of the disk between the lobes of the calyx; filaments incurved, shorter than the calyx-lobes; 1-celled, conical, gradnally narrowed into a short thick style; stigma 3-lobed; ovule ascending from the base of the cell. Fruit ovoid or subglobose; flesh thin; stone thick-walled, crustaceous. Seed compressed; seed-coat thin and smooth; cotyledons oval, flat.

Condalia with nine or ten species is confined to the New World and is distributed 
from western Texas and southern California to Patagonia and Brazil. Of the six species found within the territory of the United States one is a small tree.

The gencric name commemorates that of Antonio Condal, a Spanish physician of the eighteenth century sent to South America on a scientific mission in 1754 .

\section{Condalia obovata, Hook. Purple Haw. Log Wood.}

Leaves oftcn fascicled on short spinescent lateral branchlets, spatulate to oblongcuneate, mucronate, pubescent, especially on the lower surface, when they first appear,

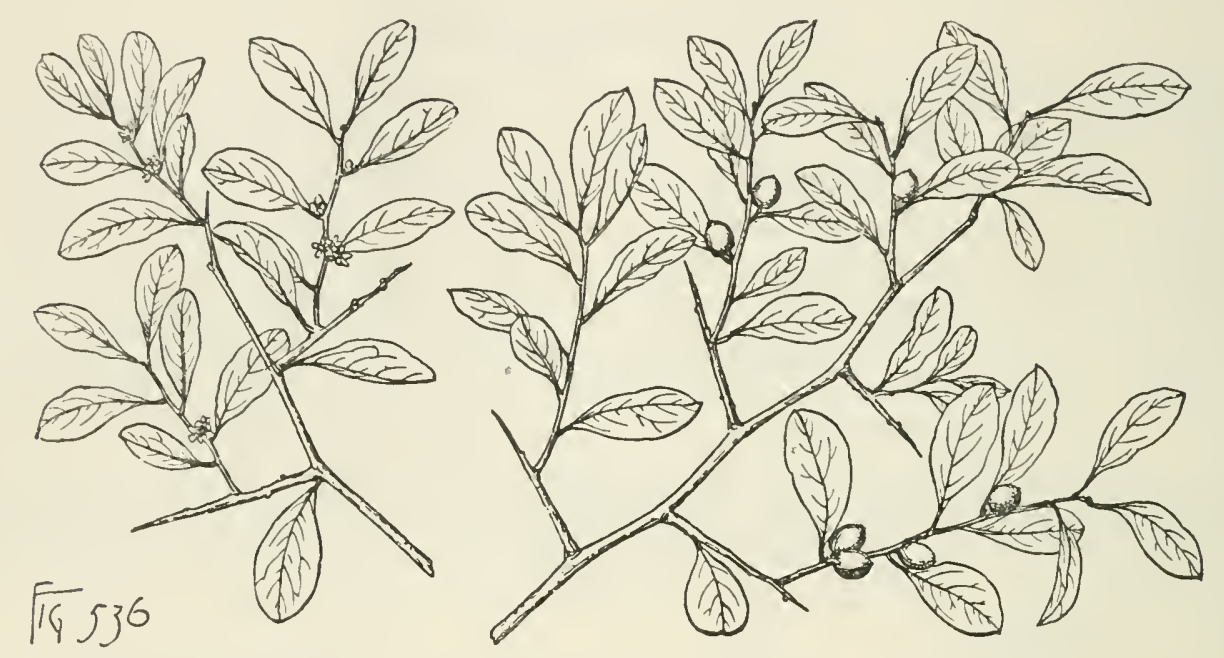

at maturity glabrous, rather thin, pale yellow-green, $1^{\prime}-1 \frac{1}{2}^{\prime}$ long, and about $\frac{1}{3}^{\prime}$ wide, with conspicuous midribs and usually 3 pairs of prominent primary veins, unfolding in May and June and falling irregularly during the winter. Flowers in 2-4flowered short-stemmed fascicles, on branchlets of the year. Fruit ripening irregularly during the summer, $\frac{1}{4}$ long, dark blne or black, with a sweet pleasant flavor.

A tree, sometimes $30^{\circ}$ high, with a trunk $6^{\prime}-8^{\prime}$ in diameter, erect rigid zigzag branchlets terminating in stout spines and covered at first with soft velvety pubescence, becoming glabrous before the end of the first season, pale red-brown and often covered with thin scales; more often a shrub. Bark of the trunk about $\frac{1^{\prime}}{8}$ thick, divided into flat shallow ridges, the dark brown surface tinged with red separating into thin scales. Wood very heavy, hard, close-grained, light red, with light yellow sapwood of 7-8 layers of annual growtlı; burning with an intense leat and valued as fuel.

Distribution. Western Texas from the shores of Matagorda Bay to the Rio Grande, and through the drier portions of northern Mexico; of tree-like habit and of its largest size on the high sandy banks of the lower Rio Grande and its tributaries; often covering large areas with dense impenetrable chapparal.

\section{REYNOSIA, Griseb.}

Trces or shrubs, with rigid nnarmed terete branches, and scaly buds. Leaves mostly opposite, entire, coriaceons, short-petiolate, reticulate-veined, persistent. Flowers minnte, on stout pedicels bibracteate near the base and two or three times longer than the flower, in small axillary sessile umbels; calyx persistent, 5-lobed, the lobes deltoid, acuminate, spreading, petaloid, deciduous; disk fleshy; petals 0 ; 
stamens 5, inserted on the margin of the disk, rather shorter than the calyx-lobes; filaments incurved; anthers oval; ovary free from the disk, almost superior, conical, 2-3-celled, contracted into a short erect thick style; stigma 2-3-lobed. Fruit drupaceous; flesh thin; stone crustaceo-membranaceous. Seed ovoid or subglobose; seed-coat very thin, conspicuously rugose and tuberculate; embryo axile in copious subcorneous ruminate albumen; cotyledons oblong.

Reynosia is distributed from southern Florida and the Bahama Islands to the Antilles. Four species are recognized; of these, one, a small tree, extends into southern Florida.

The generic name is in honor of Alvaro Reynoso (1830-1888), the distinguished Cuban chemist and writer on agriculture and scientific subjects.

\section{Reynosia septentrionalis, Urb. Red Ironwood. Darling Plum.}

(Reynosia latifolia, Silva N. Am. ii. 21.)

Leaves oval or oblong, or sometimes nearly orbicular, rounded, truncate or frequently emarginate and usually minutely apiculate at the apex, gradually narrowed at the base into short broad petioles, very thick and coriaceous, dark green on the upper, rather paler or often rufous on the lower surface, $1^{\prime}-1 \frac{1}{2}^{\prime}$ long and $\frac{1^{\prime}}{2}$ broad,

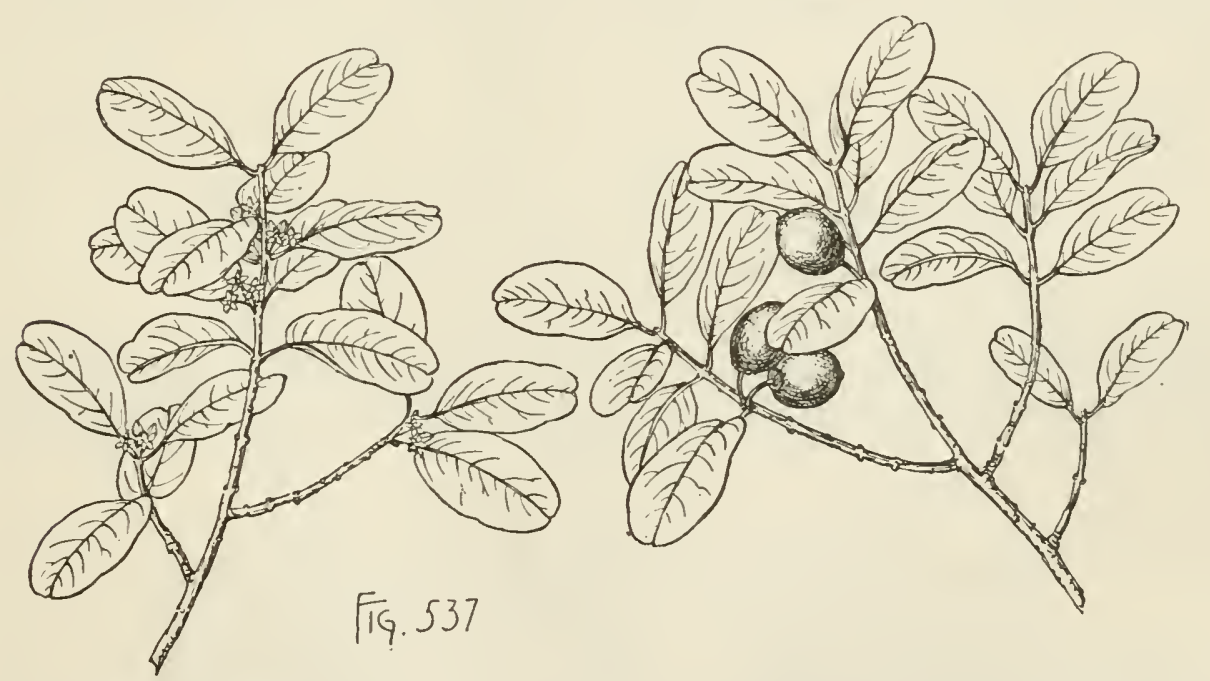

with thickened revolute margins, stout broad midribs, about five pairs of primary veins spreading nearly at right angles, and numerous reticulate veiulets, unfolding in April and remaining on the branches for one and sometimes for two years. Flowers appearing in May, $\frac{1}{12}$ long. Fruit ripening in Florida in November or frequently not until the following spring, short-obovate $\frac{1}{2}^{\prime}$ long, purple or nearly black, edible, with an agreeable flavor.

A tree, $20^{\circ}-25^{\circ}$ high, witl a trunk $6^{\prime}-8^{\prime}$ in diameter, stout terete rigid brancllets slightly puberulous at first, soon becoming glabrous and gray faintly tinged with red, growing darker in their second season, then often covered by small tubercles and marked by the prominent elevated leaf-scars. Winter-buds minute, chestnut-brown. Bark of the trunk $\frac{1}{16}-\frac{1}{8}$ thick, dark red-brown, and divided into large thick platelike scales. Wood heavy, exceedingly hard, strong, close-grained, rich dark brown, with light brown sapwood of 15-20 layers of annual growth.

Distribution. Coast and islands of southern Florida from the Marquesas group 
to the shores of Bay Biseayne; common and gencrally distributed; also on the Bahama Islands.

\section{KRUGIODENDRON, Urb.}

A small tree or shrub, with slender unarmed terete branches ronghened by numerous small lenticels, and minnte scaly buds. Leaves opposite or obliquely opposite, or sometimes alternate on lower branches, ovate or oval, often emarginate, coriaceous, entire, short-petiolate, feather-veined, persistent. Flowers greenish yellow, on short slender pedicels, in axillary simple or dichotomously branched cymes; calyx broadly obconical, 5-lobed, the lobes triangular, acute, erect or spreading, crested on the inner surface, deciduous; disk annular, broad, fleshy, 5 -lobed, surrounding the base of the ovary; petals 0 ; stamens 5 , inserted under the margin of the disk; anthers ovate or ovate-orbicular, obtuse; ovary conical, imperfectly 2-celled; styles short and thick, united nearly to the apex, the branches spreading and stigmatic on the inner face; ovule ascending from the base of the cell. Fruit 1-seeded, ovate or ovoid; flesh thin; walls of the stone thin and bony. Seed ellipsoidal, compressed, withont albumen; seed-coat membranaceous; embryo filling the cavity of the seed; cotyledons thick and fleshy, obovate or elliptical.

Krugiodendron with a single species is confined to southern Florida and the West Indies.

The generic name is in honor of Leopold Krug (1833-1898), a student of the flora of the Antilles.

\section{Krugiodendron ferreum, Urb. Black Ironwood.}

(Rhamnidium ferreum, Silva N. Am. ii. 29.)

Leaves bright green and lustrous on the upper, pale yellow-green on the lower surface, glabrous with the exception of a few scattered hairs on the upper surface and on the petioles, $1^{\prime}-1 \frac{1}{2}^{\prime}$ long, $\frac{3^{\prime}}{4}-1^{\prime}$ wide, with entire or slightly undulate margins,

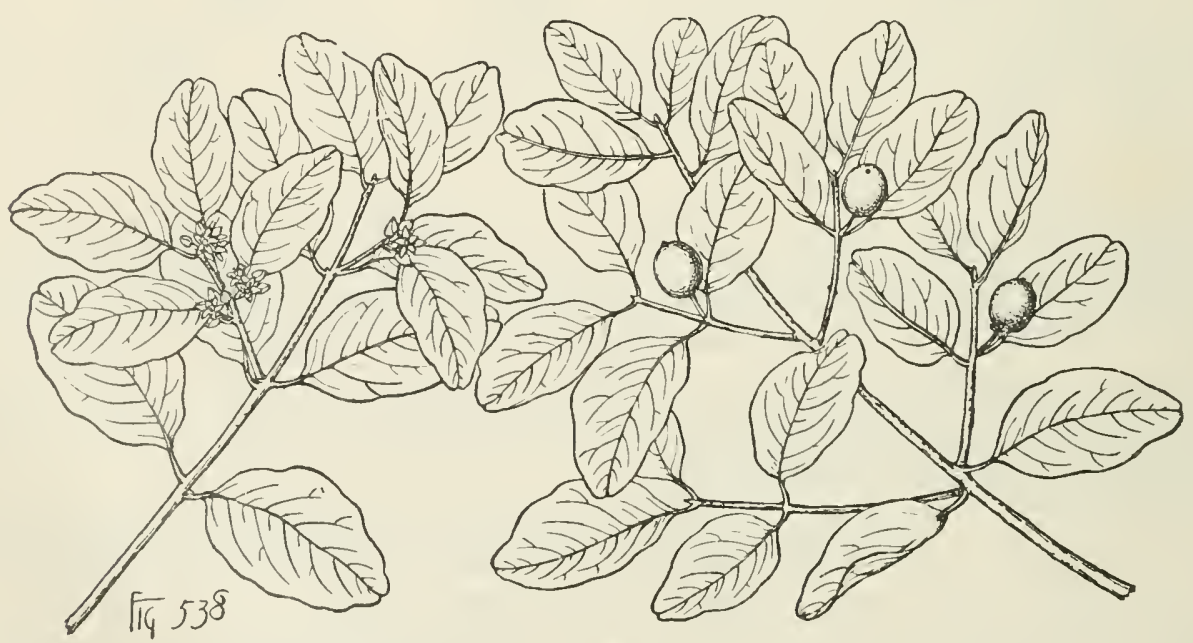

persistent for two or three years; their petioles stont, $\frac{1}{4}^{\prime}$ long; stipules acuminate, persistent. Flowers on bibracteolate pedicels $\frac{1}{4}^{\prime}$ long, in 3-5-flowered cymes on peduncles sometimes $\frac{1^{\prime}}{2}$ long, usually much shorter and often branched near the apex, on branchlets of the year; calyx about $\frac{11}{16}$ long, the acuminate lobes conspicuously 
crested on the inner surface. Fruit generally solitary on a stem $\frac{1}{3}^{\prime}-\frac{1}{2}^{\prime}$ long, $\frac{1}{3}^{\prime}$ in length, with thin black flesh.

A tree, sometimes $30^{\circ}$ high, with a trunk $8^{\prime}-10^{\prime}$ in diameter, and very slender branchlets at first green and covered with dense velvety pubescence, becoming glabrous in their second year, and then gray faintly tinged with red and roughened by small crowded lenticels; generally much smaller and more often shrubby than arborescent. Bark of the trunk about $\frac{1^{\prime}}{4}$ thick and divided into prominent rounded longitudinal ridges broken on the surface into short thick light gray scales. Wood exceedingly heavy, hard, strong, close-grained, brittle, rich orange-brown, with thin lighter colored sapwood.

Distribution. Florida, from Cape Canaveral on the west coast, through the southern keys to the shores of Bay Biscayne; one of the commonest of the small trees of the region; also on the Bahama and West Indian islands.

\section{RHAMNUS, L.}

Trees or shrubs, with terete often spinescent branches, without terminal buds, and scaly or naked axillary buds and acrid bitter bark. Leaves alternate or rarely obliquely opposite, conduplicate in the bud, petiolate, feather-veined, entire or dentate. Flowers perfect or polygamo-diœcious, in axillary simple or compound racemes or fascicled cymes; calyx campanulate, 4 -5-lobed, the lobes triangular-ovate, erect or spreading, keeled on the imner surface, deciduous; disk thin below, more or less thickened above; petals 5 , inserted on the margin of the disk, ovate, unguiculate, emarginate, infolded round the stamens, decidnous, or 0 ; stamens 4 or 5 ; filaments very short; anthers oblong-ovate or sagittate, rudimentary and sterile in the pistillate flower; ovary free, ovoid, included in the tube of the calyx, 2-4-celled, rudimentary in the staminate flower; styles united below, with spreading stigmatic lobes or terminating in a 2-3-lobed obtuse stigma; orule erect from the base of the cell. Fruit drupaceous, oblong or spherical; flesh thick and succulent, inclosing $2-4$ separable cartilaginous 1 -seeded nutlets. Seeds erect, obovate, grooved longitudinally on the back, with a cartilaginous seed-coat, the raphe in the groove, or convex on the back, with a membranaceous seed-coat, the raphe lateral next to one margin of the cotyledons; embryo large, surrounded by thin fleshy albumen; cotyledons oval, foliaceous, with revolute margins, or flat and fleshy.

Rhamuns with about sixty species is widely distributed in nearly all the temperate and in many of the tropical parts of the world with the exception of Australia and the islands of the Pacific Ocean. Of the five species indigenous to the United States three attain the size of small trees. The fruit and bark of Rhamnus are drastic, and yield yellow and green dyes. The European Rhamnus cathartica, L., the Buckthorn, has long been used as a hedge plant in northern Europe, and in eastern North America, where it has now become sparingly naturalized.

The generic name is from páuvos, the classical name of the Buckthorn.

\section{CONSPECTUS OF THE NORTH AMERICAN ARBORESCENT SPECIES.}

Flowers polygamo-diœcious, in sessile umbels; calyx 4-lobed; petals 0 ; anthers oblong-ovate; lobes of the stigma elongated, spreading ; fruit red; seed grooved on the back; seed-coat cartilaginous ; leaves often sharply toothed, persistent ; winter-buds scaly.

1. R. crocea $(G)$.

Flowers perfect, in pedunculate umbels; calyx 5-lobed; petals 5; anthers sagittate ; lobes of the stigma short and obtuse ; fruit black; seed rounded on the back; seed-coat membranaceous; leaves deciduous; winter-buds naked. 
Peduncles shorter than the petioles.

2. R. Caroliniana $(\mathrm{C})$.

Peduncles longer than the petioles.

3. R. Purshiana (B, G).

\section{Rhamnus crocea, Nutt.}

Leaves persistent, clliptical, broadly ovate or subrotund, or rarely lanceolateacuminate, mucronate or rounded at the apex, acutely or often glandular-denticulate, sometimes revolnte, coriaceons, yellow-green and lustrous on the upper surface, paler or frequently bronzed or copper color on the lower surface, glabrous or often puberulous, especially when young, on the under surface of the midribs and petioles, $\frac{1^{\prime}}{4}-3^{\prime}$ long, with prominent midribs grooved above and broad conspicuous primary veins; their petioles short and stout. Flowers polygamo-diœcious, on slender often puberulous pedicels $\frac{1^{\prime}}{8}$ long, in small clnsters from the axils of the leaves or of small lanceolate persistent bracts on shoots of the year; calyx 4-lobed, with acuminate lobes, about $\frac{1}{8}^{\prime}$ long; petals 0 ; stamens shorter than the calyx, with short stout incurved filaments and large ovate anthers, minute and rudimentary in the pistillate flower;

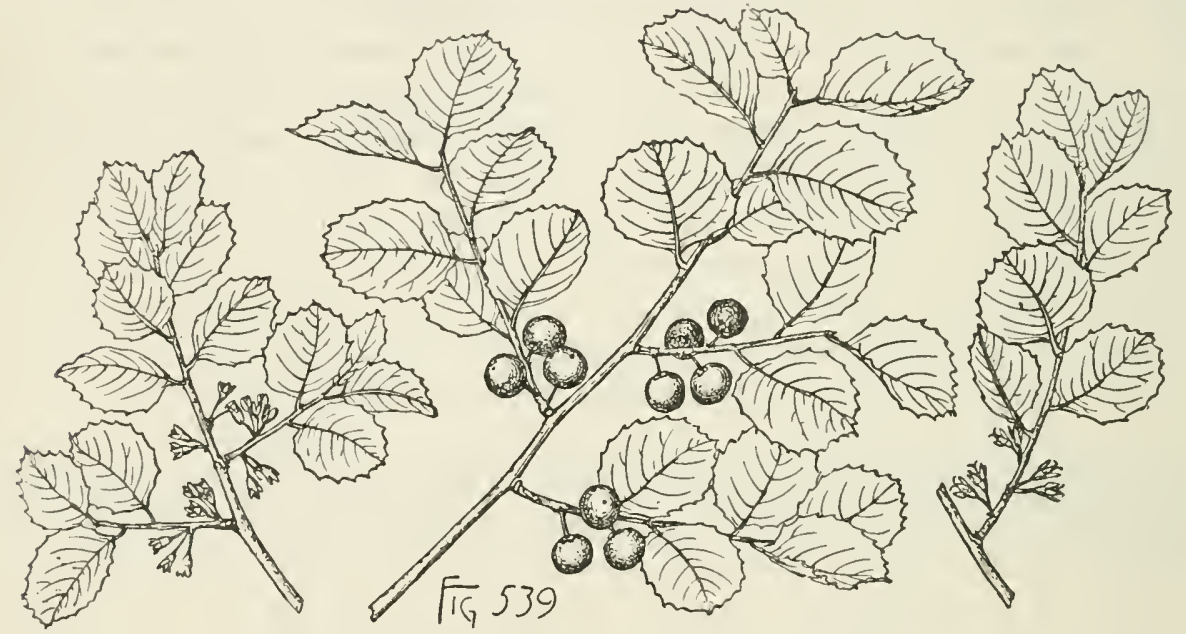

ovary ovate, contracted into a long slender style divided above the middle into 2 wide-spreading acuminate stigmatic lobes, rudimentary in the staminate flower. Fruit red, obovoid, slightly grooved or lobed at maturity, $\frac{1^{\prime}}{4}$ long, with thin dry flesh and 1-3 nutlets; seeds broadly ovate, pointed at the apex, deeply grooved on the back, and $\frac{1}{8}^{\prime}$ long, with a thin membranaceous pale chestnut-colored coat.

A tree, occasionally $20^{\circ}$ high, with a trunk $6^{\prime}-8^{\prime}$ in diameter, spreading rigid sometimes spinescent branches, and slender branchlets yellow-green and puberulous or glabrate when they first appear, becoming dark red or reddish brown and glabrous in their second season; more frequently a low densely branched shrub, with stems a few feet high forming thickets of considerable extent. Winter-buds obtnse, barely more than $\frac{1}{16}$ long, with small puberulous apiculate imbricated scales ciliate on the margins. Bark of the trunk usually $\frac{1}{16}-\frac{1}{8}$ thick, the dark gray surface slightly roughened by minute tubercles.

Distribution. Valley of the upper Sacramento River, California, southward along the Sierra Nevada to about latitude 28 on the mainland and to Guadaloupe Island, Lower California; usually an undershrub under the shade of trees and along the borders of the forest or in sheltered ravines; sometimes appearing in exposed situations on sunny hillsides in the neighborhood of streams; arborescent only in some 
of the interior valleys of southern California and on Cedros Island and the Santa Barbara Islands. Passing into

\section{Rhamnus crocea, var. insularis, Sarg.}

A form with less prominently toothed leaves, rather larger flowers, with shorter and broader calyx-lobes, a less deeply divided style, and larger fruits. This is a tree

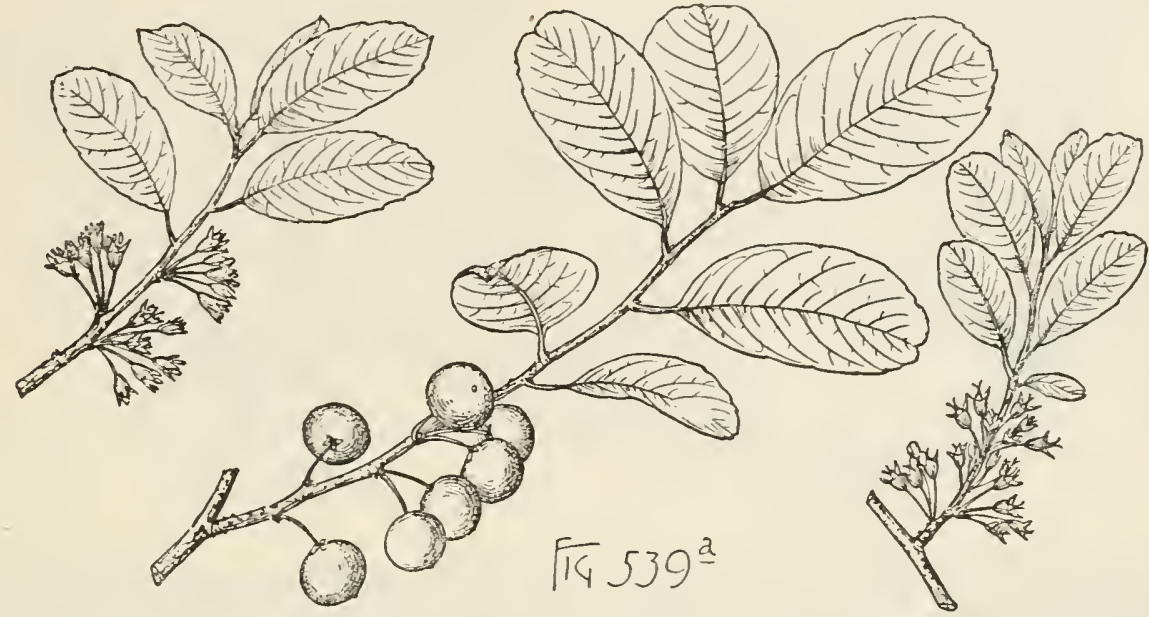

of ten growing to the height of $25^{\circ}-30^{\circ}$, flowering later than the brdinary form, and not uncommon on the islands of the Santa Barbara group and on the mountains of the adjacent mainland. A form (var. pilosa, M. K. Curr.) with narrow revolute leaves and densely pilose throughout, inhabits the Santa Maria valley of the mountains near San Diego.

\section{Rhamnus Caroliniana, Walt. Indian Cherry.}

Leaves deciduous, elliptical-oblong or broadly elliptical, acute or acuminate, wedge-shaped or somewhat ronnded at the base, remotely and obscurely serrate or crenulate, densely coated when they appear with rusty brown tomentum, and at maturity membranaceons, dark yellow-green above, paler below, glabrous or somewhat hairy on the lower surface, $2^{\prime}-6^{\prime}$ long, $1^{\prime}$ to nearly $2^{\prime}$ wide, with prominent yellow midribs and about 6 pairs of conspicuous yellow primary veins, turning yellow in the autumn before falling; their petioles slender, pubescent, $\frac{1^{\prime}}{2}$ to nearly $1^{\prime}$ long; stipules nearly triangular. Flowers appearing from April to June when the leaves are almost fully grown, on slender pedicels abont $\frac{1}{4}^{\prime}$ long, in few-flowered pubescent nmbels, on peduncles varying from $\frac{1}{8}^{\prime}-\frac{1}{2}^{\prime}$ in lengtlı; calyx 5-lobed, with a narrow turbinate tube and triangular lobes; petals 5 , broadly ovate, deeply notched at the apex and folded round the short stamens; ovary contracted into a long columnar style terminating in a slightly 3-lobed stigma. Fruit ripening in September and sometimes remaining on the branches until the beginning of winter, globose, $\frac{1}{3}$ in diameter, black, with thin sweet rather dry flesh and 2-4 nutlets; seeds obtuse at the apex, rounded on the-back, reddish brown, about $\frac{1^{\prime}}{5}$ long.

A tree, $30^{\circ}-40^{\circ}$ high, with a trunk $6^{\prime}-8^{\prime}$ in diameter, small spreading nnarmed branches, and slender branchlets light red-brown and puberulent or covered with a glaucous bloom when they first appear, becoming slightly angled, gray, and glabrons, and marked by the small horizontal oval leaf-scars during their second season; more often a tall shrub, with numerous stems $15^{\circ}-20^{\circ}$ higlı. Winter-buds naked, hoary- 
tomentose. Bark of the trunk about $\frac{1^{\prime}}{8}$ thick, slightly furrowed, ashy, gray and often marked with large black blotelıes. Wood rather hard, light, close-grained, not strong, light brown, with lighter colored sapwood of 5 or 6 layers of annual growth.

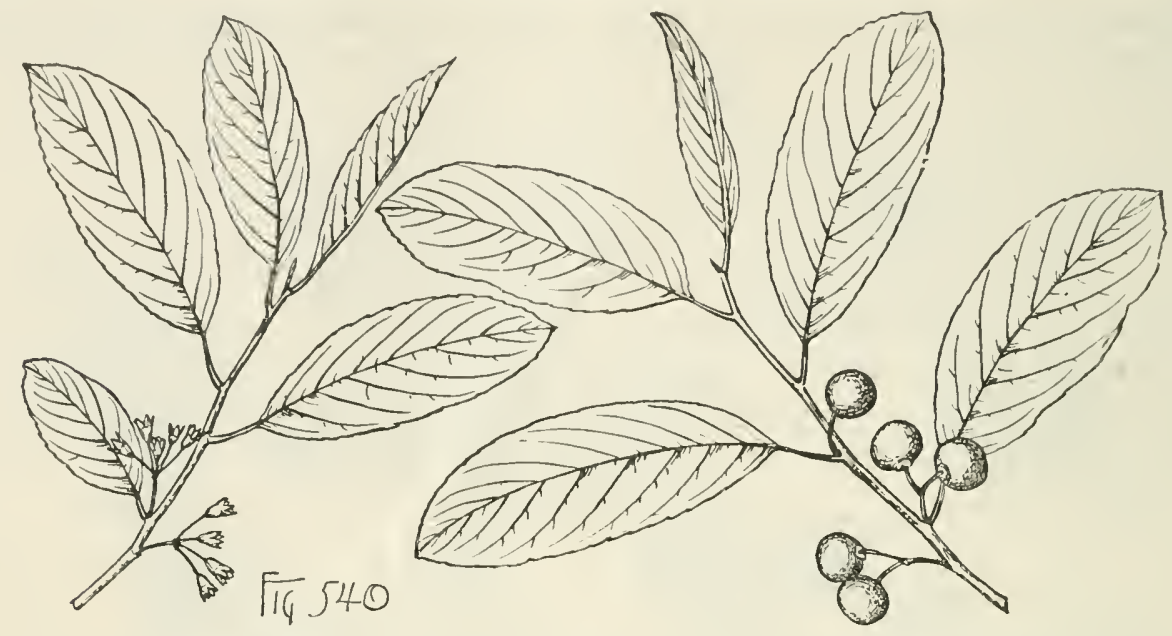

Distribution. Borders of streams on rich bottom-lands, and on limestone ridges; Virginia to northeru Florida and westward through the valley of the Ohio River to eastern Nebraska, eastern Kansas, and eastern Texas; occasionally tree-like in western Florida and Mississippi, and of its largest size only in southern Arkansas and the adjacent portions of Texas; very abundant on the limestone barrens of easteru Kentucky and Temnessee.

\section{Rhamnus Purshiana, DC. Bearberry. Coffee-tree.}

Leaves deciduous, broadly elliptical, obtuse or bluntly pointed at the apex, rounded or slightly cordate at the base, finely serrate, or often nearly entire, with undulate margins, membranaceous, villose, with short hairs on the lower surface and on the veins above, $2^{\prime}-7^{\prime}$ long, conspicuously netted-veined, with broad and prominent midribs and primary veins, turning pale yellow late in the autumn before falling; their petioles stout, often pubescent, $\frac{1}{2}^{\prime}-1^{\prime}$ long; stipules membranaceous, acuminate. Flowers on slender pubescent pedicels $\frac{1}{4}^{\prime}-\mathbf{1}^{\prime}$ long, in axillary cymes on slender pubescent peduncles $\frac{1}{2}^{\prime}-\mathbf{1}^{\prime}$ in length on shoots of the year; calyx nearly campanulate, with 5 spreading acuninate lobes; petals 5 , minute, ovate, deeply notched at the apex, and folded round the short stamens; stigma 2 or 3-lobed. Fruit globose or broadly obovoid, black, $\frac{1^{\prime}}{3}-\frac{1}{2}^{\prime}$ in diameter, slightly or not at all lobed, with thin rather juicy flesh, and 2 or 3 obovate nutlets usually $\frac{1}{3}^{\prime}$ long, rounded on the back, flattened on the inner surface, with 2 bony tooth-like enlargements at the base, 1 on each side of the large scar of the hilum, and a thin gray or pale yellowgreen shell; seeds obtuse at the apex, rounded on the back; seed-coat thin and papery, yellow-brown on the outer surface, bright orange color on the inner surface like the cotyledons.

A tree, $35^{\circ}-40^{\circ}$ high, with a slender trunk often $18^{\prime}-20^{\prime}$ in diameter, separating $10^{\circ}-15^{\circ}$ from the ground into numerous stout upright or sometimes nearly horizontal branches, and slender branchlets coated at first with fine soft pubescence, pale yellow-green or reddish brown, and pubescent, glabrous, or covered with scattered hairs in their second season and then marked by the elevated oval horizontal leaf-scars; 
often shrubby and occasionally prostrate. Winter-buds naked, hoary-tomentose. Bark of the trunk rarely more than $\frac{1^{\prime}}{4}$ thick, dark brown to light brown or gray tinged with red, broken on the surface into short thin scales. Wood light, soft, not

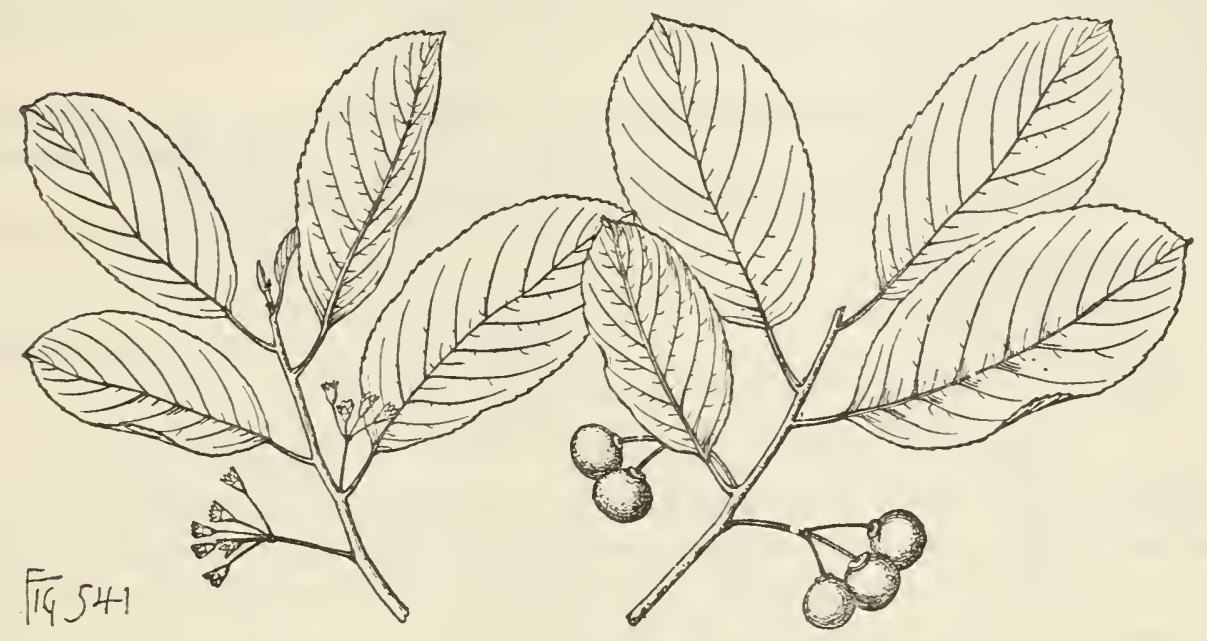

strong, brown tinged with red, with thin lighter colored sapwood. The bark possesses the drastic properties peculiar to that of other species of the genus, and is a popular domestic remedy in Oregon and California, and under the name of Cascara Sagrada has been admitted into the American materia medica.

Distribution. Rich bottom-lands and the sides of cañons, usually in coniferous forests; shores of Puget Sound eastward along the mountain ranges of northern Washington to the Bitter Root Mountains of Idaho and the shores of Flat Head Lake, Montana, and southward into northern California.

Occasionally cultivated in the gardens of western Europe and of the eastern United States.

\section{CEANOTHUS, L.}

Small trees or shrubs, with slender terete branches, without terminal buds, and small scaly axillary buds. Leaves petiolate, triple-veined from the base, or rarely pinnately veined, persistent. Flowers on colored pedicels, in umbellate fascicles collected in dense or prolonged terminal or axillary thyrsoid cymes or panicles, blue or white; calyx colored, with a turbinate or hemispherical tube and 5 triangular membranaceous petaloid lobes; disk fleshy, thickened above; petals 5 , inserted under the margin of the disk, unguiculate, wide-spreading, deciduous, the long claw infolded round the stamens; stamens 5 , inserted with and opposite the petals, persistent; filaments spreading; ovary partly immersed in and more or less adnate to the disk, 3-celled, sometimes 3-angled, the angles often surmounted by a fleshy gland persistent on the fruit; styles short, united below; stigmas 3-lobed, with spreading lobes; ovule erect from the base of the cell. Fruit 3-lobed, subglobose, with a thin outer coat, soon becoming dry and separating into 3 crustaceous or cartilaginous longitudinally 2 -valved nutlets. Seeds erect, obovate-lenticular, with a broad basal excrescence surrounding the hilım; seed-coat thin, crustaceous; raphe ventral; albumen fleshy; embryo axile; cotyledons oval or obovate.

Ceanothus is confined to the temperate and warmer regions of North America, with about thirty species, mostly belonging to California. The leaves, bark, and 
roots are astringent and tonic. Of the species of the United States three are small trees.

The generic name is frọ̣ $\kappa \epsilon a ́ v \omega \theta 0 s$, the classical name of some spiny plaut.

\section{CONSPECTUS OF 'THE ARBORESCEN'T SPECIES OF' THE UNI'TED STATES.}

Branchlets not spinose.

Leaves broadly ovate to elliptical, subcordate or rounded at the base, pale and tomentose below.

1. C. arborescens (G).

Leaves elliptical, acute at the base, glabrous except on the veins below.

Branchlets spinose.

2. C. thyrsiflorus (G).

Leaves mostly elliptical, rounded or subcordate at the base, glabrous.

\section{Ceanothus arboreus, Greene.}

3. C. spinosus (G).

(Ceanothus velutinus, var. arboreus, Silva $N . A m$. ii. 45.)

Leaves broadly ovate or elliptical, acute, conspicuously glandular-crenate, dark green and softly puberulent on the upper surface, pale and densely tomentose on the lower surface, $2 \frac{1}{2}^{\prime}-4^{\prime}$ long, $1^{\prime}-2 \frac{1^{\prime}}{2}$ wide, with prominent veins; their petioles stout, pubescent, $\frac{1^{\prime}}{2}-1^{\prime}$ long; stipules subulate from a broad triangular base, $\frac{1}{4}^{\prime}$ long. Flowers opening in July and August on slender hairy pedicels $\frac{1^{\prime}}{2}-1^{\prime}$ long, from the

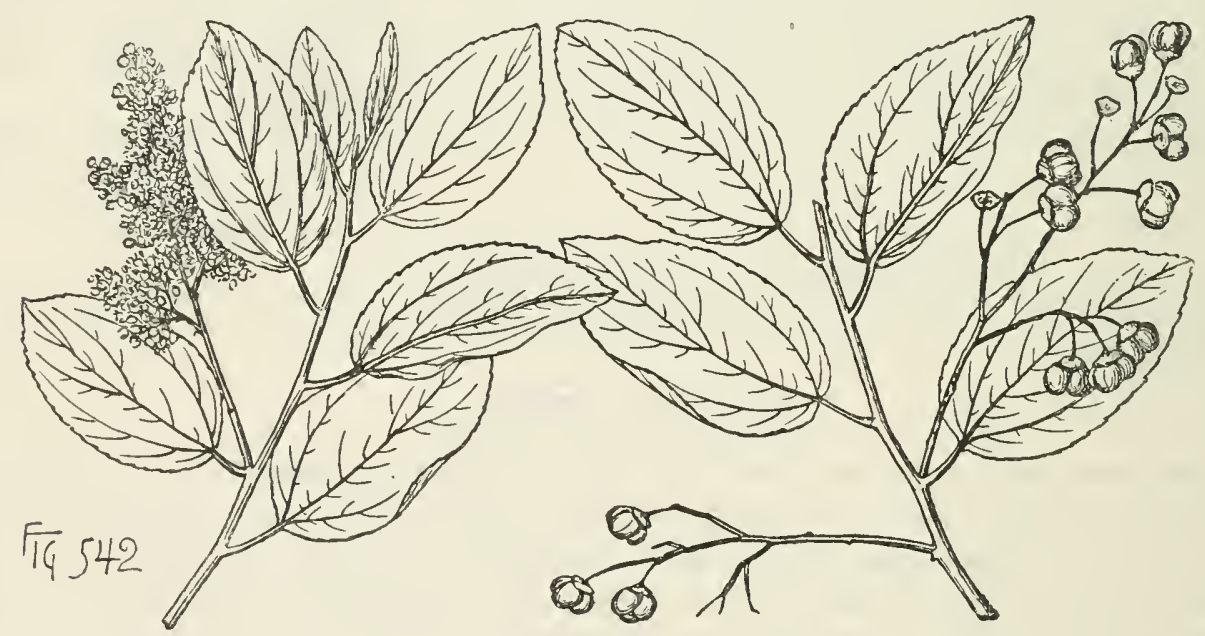

axils of large scarious caducous bracts, in ample compound densely hoary-pubescent thyrsoidal clusters $3^{\prime}-4^{\prime}$ long and $11^{\prime}-2^{\prime}$ wide on leafy or naked axillary peduncles at the extremities of young branches. Fruit $\frac{1^{\prime}}{4}$ across and black.

A round-headed tree, $20^{\circ}-25^{\circ}$ high, with a straight trunk $6^{\prime}-10^{\prime}$ in diameter, dividing $4^{\circ}-5^{\circ}$ from the ground into many stout spreading branches, and slender slightly angled pale brown branchlets covered with short dense tomentum, becoming: in their second season terete, nearly glabrous, ronghened with scattered lenticels and marked by large elevated leaf-scars; often a shrub. Bark of the trunk dark brown, about $\frac{1}{8}$ thick, and broken into small square plates separating into thick scales.

Distribution. Santa Catalina, Santa Cruz, aid Santa Rosa islands of the Santa Barbara group off the coast of California; most abundant and of its largest size on the northern slopes of Santa Cruz; usually shrubby on the other islands, with numerous slender stems. 


\section{Ceanothus thyrsiflorus, Eschs. Blue Myrtle. California,Lilac.}

Leaves oblong or oblong-ovate, minutely glandular-serrate, smooth and lustrous on the upper and paler and slightly pubescent on the lower surface, especially along

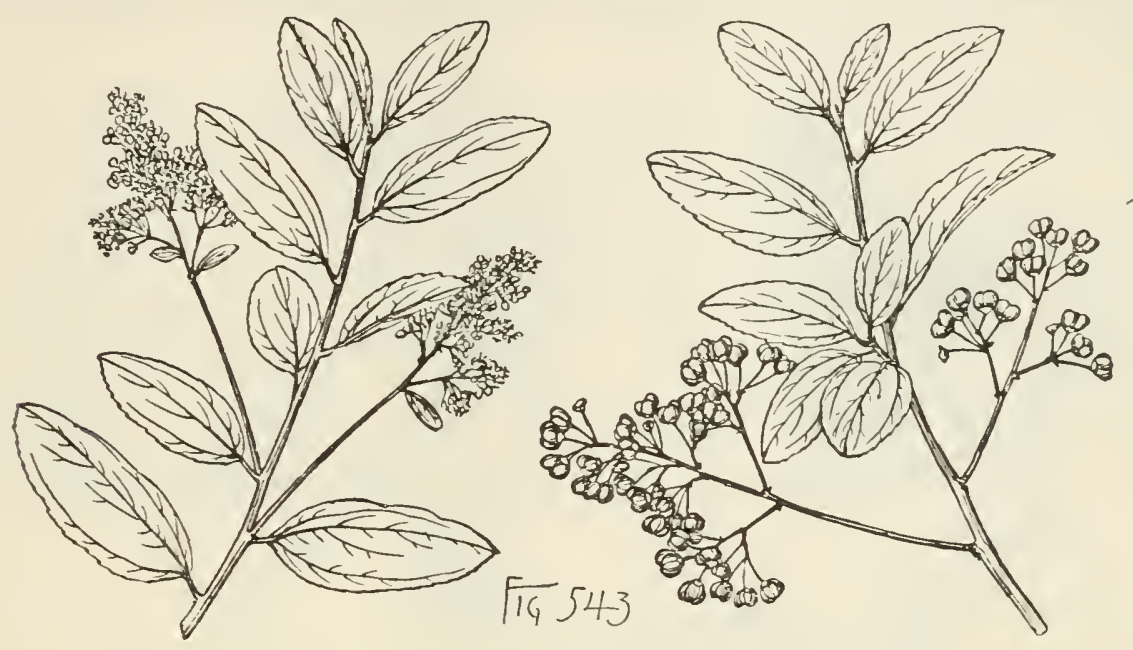

the 3 prominent ribs, $1^{\prime}-1 \frac{1}{2}^{\prime}$ long, $\frac{1}{2}^{\prime}-1^{\prime}$ wide; their petioles stout, $\frac{1}{3}^{\prime}-\frac{1}{2}^{\prime}$ in length; stipules membranaceous, acute. Flowers blue or white, appearing in early spring in small pedunculate corymbs from the axils of minute deciduous bracts, and collected into slender rather loose thyrsoid clusters $2^{\prime}-3^{\prime}$ long in the axils of upper leaves or of small scarious bracts, and usually surmounted by the terminal leafy shoot of the branch. Fruit ripening from July to December, black; seeds $\frac{1}{1 \frac{1}{2}}$ long, smooth, dark brown or nearly black.

A tree, occasionally $35^{\circ}$ high, with a trunk $12^{\prime}-14^{\prime}$ in diameter, dividing $5^{\circ}-6^{\circ}$ from the ground into many small wide-spreading branches, and couspicuously angled pale yellow-green branchlets slightly pubescent at first bit soon.becoming glabrous; inore often a tall or low shrub. Bark of the trunk thin, with a bright red-brown surface separating into thin narrow appressed scales. Wood close-grained, rather soft, light brown, with thin darker colored sapwood.

Distribution. Shady hillsides on the borders of the forest and often in the neighborhood of streams; coast mountains of California from Mendocino County to the valley of the San Luis Rey River; of its largest size northward, and in the Redwood forests of the Santa Cruz Mountains; southward often a low shrub, frequently flowering on the wind-swept shores of the ocean when only $1^{\circ}-2^{\circ}$ high.

\section{Ceanothus spinosus, Nutt. Lilac.}

Leaves rarely 3 -nerved, elliptical, full and rounded, apiculate or often slightly emarginate or gradually narrowed and pointed or rarely 3-lobed at the apex, rounded or cuneate at the base, when they unfold villose-pubescent below along the stout midribs and obscure primary veins, soon glabrous, coriaceous, usually about $1^{\prime}$ long and $\frac{1}{2}^{\prime}$ wide; their petioles stout, $\frac{1}{6}^{\prime}-\frac{1}{3}^{\prime}$ long, at first villose, becoming nearly glabrons; on vigorous shoots sometimes ovate, conspicuously 3-nerved, irregularly serrate, with incurved apiculate teeth, or coarsely dentate and often $1 \frac{1}{2}^{\prime}$ long and $\frac{5}{8}^{\prime}$ wide; stipules minute, acute. Flowers light or dark blue, very fragrant, opening from March until May, in lax corymbs from the axils of acute pubescent red cadu- 
cous bracts on upper leafy branchlets of the ycar, the whole infloreseence forming an open thyrsus often $5^{\prime}-6^{\prime}$ long and $3^{\prime}-4^{\prime}$ thick, and without leaves toward the apex. Fruit depressed, obscurely lobed, crestless, black, $\frac{1^{\prime}}{4}-\frac{1}{3}$ in diameter.

A tree, $18^{\circ}-20^{\circ}$ high, with a trunk $5^{\prime}-6^{\prime}$ in diameter, upright branches forming a narrow open head, and slender divaricate angled branchlets pubescent or puberulous
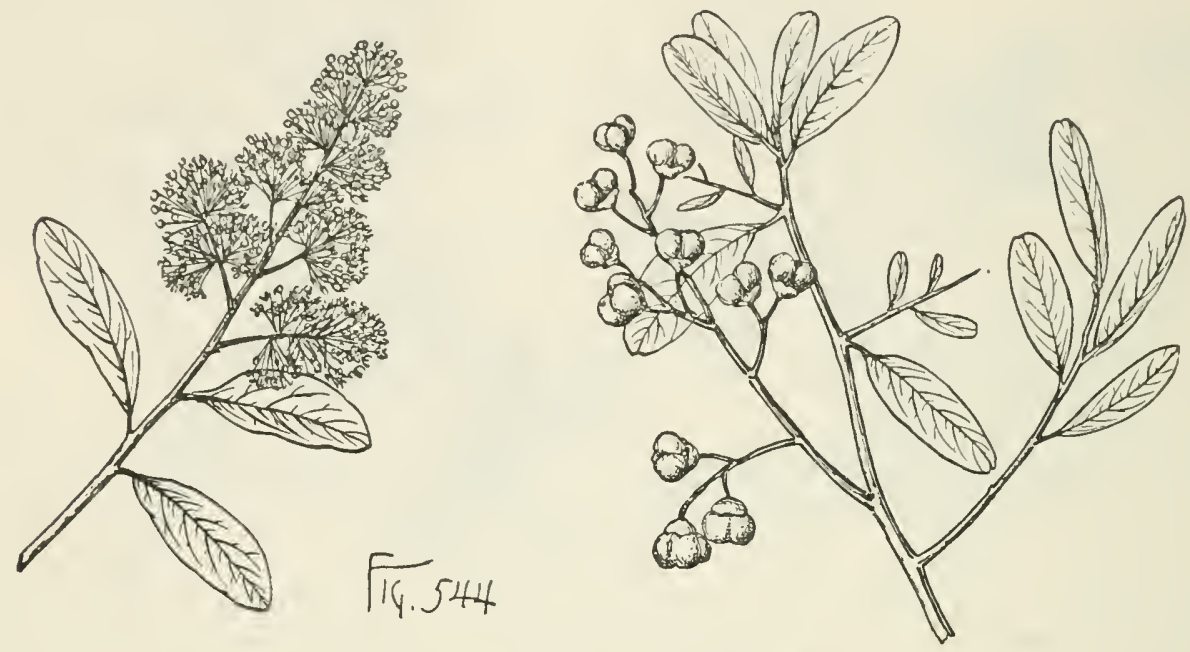

when they first appear, soon glabrous, bright green, ultimately reddish brown, frequently terminating in sharp leafless thorn-like points; more often shrubby. Bark of the trunk thin, red-brown, roughened by small closely appressed scales.

Distribution. A common inhabitant of mountain cañons near the coast of Santa Barbara, Ventura, and Los Angeles counties, California; often forming a dense undergrowth in the forest, which it enlivens for many weeks in early spring with its large clusters of bright blue flowers.

\section{COLUBRINA, Brong.}

Trees or shrubs, with terete branches and scaly buds. Leaves petiolate, pinnately veined or triple-veined from the base, often ferrugineo-tomentose on the lower surface. Flowers axillary, in contracted few-flowered cymes or fascicles, yellow or greenish yellow; calyx-tube hemispherical, persistent, 5-lobed, the lobes spreading, triangular-ovate, conspicuously keeled on the inner surface, deciduous by a circumscissile line; disk fleshy, annular, 5 -angled or indistinctly 5 or 10-lobed; petals 5, inserted under the margin of the disk, shorter than the lobes of the calyx, cucullate, unguiculate, infolding the stamens; stamens 5, opposite to and inserted with the petals; filaments incurved; anthers ovate; ovary surrounded by and confluent with the disk, 3-celled, subglobose, contracted into a slender 3-lobed style, the obtuse lobes stigmatic on the inner face; ovule erect, from the base of the cell. Fruit subglobose, 3-lobed; outer coat thin and septicidally dehiscent into 31 -seeded crustaceous nutlets 2-valved at the apex. Seeds erect, broadly obovate, compressed, 3angled; seed-coat coriaceous, smooth and shining; embryo axile in thick fleshy albumen; cotyledons orbicular, flat or incurved, thin or fleshy.

Colubrina with about a dozen species is confined to the tropics, with the largest number of species in the New World. Of the four species found within the territory of the United States one is arborescent in habit. 
The generic name is from coluber, a serpent, probably on account of the peculiar twisting of the deep furrows on the stems of some of the species.

\section{Colubrina reclinata, Brong. Naked Wood.}

Leaves persistent, elliptical, ovate or lanceolate, usually contracted at the apex into a blunt point, entire, wedge-shaped or somewhat rounded and furnished with 2 conspicuous marginal glands at the base, when they unfold in early summer thin and membranaceous, glabrous or finely puberulent on the lower surface and along the principal veins, and at maturity yellow-green, $2 \frac{1}{2}^{\prime}-3^{\prime}$ long, $1 \frac{1}{2}^{\prime}$ to nearly $2^{\prime}$ wide, with stout midribs and arcuate primary veins, persistent until their second year; their petioles slender, $\frac{1}{2}^{\prime}$ long. Flowers in clusters rather shorter than the petioles, on shoots of the year, pubescent, soon becoming glabrate. Fruit $\frac{1^{\prime}}{4}$ in diameter and dark orange-red, ripening late in the autumn, on pedicels $\frac{1}{2}^{\prime}$ long; seeds light redbrown, $\frac{1}{8}^{\prime}$ long.

A tree, $50^{\circ}-60^{\circ}$ high, with a trunk $3^{\circ}-4^{\circ}$ in diameter, divided by numerous irregular deep furrows multiplying and spreading in all directions, and branchlets at first

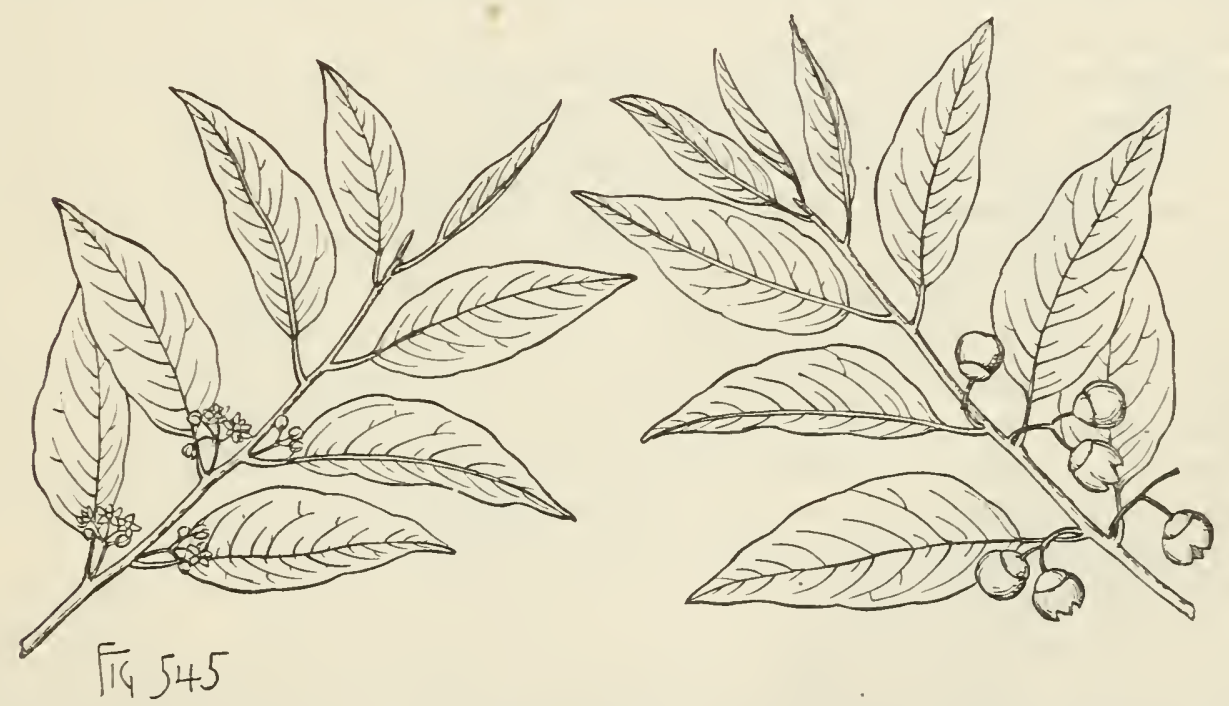

slightly angled, puberulent and reddish brown, soon becoming glabrate, and in their second season nearly terete, gray or light brown, and marked by numerous small light-colored lenticels. Bark of the trunk thin, orange-brown, exfoliating in large papery scales. Wood heavy, hard, very strong, dark brown tinged with yellow, with thin light yellow sapwood of 8-10 layers of annual growth.

Distribution. Florida on Umbrella Key, the north end of Key Largo, and on some of the small keys south of Elliott's Key; of its largest size and forming a forest of considerable extent on Umbrella Key; also on the Bahama Islands and many of the Antilles.

\section{TILIACEA.}

Trees, shrubs, or herbs, with alternate simple leaves, and free stipules. Flowers regular, perfect; sepals valvate in the bud, deciduous; corolla hypogynous; stamens numerous, with 2-celled anthels, the cells opening longitudinally; pistil compound; styles united into 1 ; stigma capitate. Fruit capsular or nut-like. Seeds with albumen; embryo with broad foliaceous cotyledons. 
The Linden family with about thirty-five genera is chiefly tropical, with more representatives in the southern than in the northern hemisphere. Of the three North American genera only Tilia is arborescent.

\section{TILIA, L. Linden.}

Trees, with terete moderatcly stout branchlets, without terminal buds, large compressed acute axillary buds, with numerous imbricated scales, those of the inner rank accrescent, mucilaginous juice, and tongh fibrons imner bark. Leaves conduplicate in the bud, long-petiolate, 2-ranked, cordate or truncate at the oblique base, acnte or acuminate, serrate, deciduons, their petioles in falling leaving large elevated horizontal leaf-scars displaying the ends of numerous fibro-vasenlar bundles; stipules ligulate, membranaceons, caducous. Flowers nectariferous, fragrant, on slender clavate pedicels, in axillary or terminal eymes, with minute caducous bracts at the base of the branches, their peduncles more or less connate with the axis of a large membranaceous light green ligulate of ten obovate persistent conspicuously reticulateveined bract; sepals 5, distinct; petals 5, imbricated in the bud, alternate with the sepals, sometimes thickened and glandular at the narrow base, creamy white, decidnous; stamens inserted on a short hypogynous receptacle; filaments filiform, forked near the apex, collected into 5 clusters and united at the base with each other and (in the American species) with a spatulate petaloid scale (staminodium) placed opposite each petal, the branches of the filament bearing oblong extrorse half anthers; ovary sessile, tomentose, 5-celled, the cells opposite the sepals; style erect, dilated at the apex into 5 spreading stigmatic lobes; ovules 2 in each cell, ascending from the middle of its inner angle, semianatropons, the micropyle centripetal-inferior. Fruit nut-like, woody, subglobose to short-nblong or ovoid, sometimes ribbed, tomentose, 1-celled by the obliteration of the partitions, 1 or 2 -seeded. Seeds obovate, semianatropous, ascending; seed-coat cartilaginons, light reddish brown; embryo large, often curved, in fleshy albumen; cotyledons reniform or cordate, palmately 5-lobed, the margins irregularly involute or crumpled; radicle inferior.

Tilia with eighteen or twenty species is widely distributed in the temperate regions of the northern hemisphere with the exception of western America, central Asia, and the Himalayas. Tilia produces soft straight-grained pale-colored light wood, largely used for the interior finish of buildings, in cabinet-making, for the sounding-boards of pianos, wood-carving and wooden ware, and in the manufacture of paper. The tough inner bark is largely manufactured into mats, cords, fish-ncts, coarse eloths, and shoes. Lime-flower oil, obtained by distilling the flowers of the Enropean species, is used in perfumery. The flowers yield large quantities of nectar, and honey made near forests of Tilia is unsurpassed in flavor and delicacy. Many of the species are planted as shade and ornamental trees, and several of the European species are now common in the gardens and parks of the eastern United States.

\section{CONSPECTUS OF SPECIES OF THE UNITED STATES.}

Branchlets glabrous.

Leaves glabrous.

Leaves green on both surfaces.

1. T. Americana $(\mathrm{A}, \mathrm{C})$.

Leaves pale on the lower surface.

Peduncles and pedicels glabrous; staminodia entire; leaves mostly cordate at the base.

2. T. australis (C). 
Peduncles and pedicels puberulous ; staminodia emarginate; leaves mostly obliquely truncate at the base.

3. T. Floridana $(\mathrm{C})$.

Leaves pubescent or tomentulose below.

Leaves more or less stellate-pubescent below, with conspicuous axillary tufts of hairs.

Leaves hoary-tomentulose below, without axillary tufts of hairs.

4. T. Michauxii (A, C).

5. T. heterophylla (A, C).

Branchlets stellate-pubescent; leaves rusty-tomentulose below.

6. T. pubescens (C).

\section{Tilia Americana, L. Linden. Bass Wood.}

Leaves broadly oval, obliquely cordate or sometimes almost truncate at the base, contracted at the apex into slender acmminate entire points, coarsely serrate, with incurved glandular teeth, glabrous with the exception of tufts of rusty brown hairs in the axils of the principal veins below, thick and firm, dark dull green on the upper, lightcr and yellow-green and lustrous on the lower surface, $5^{\prime}-6^{\prime}$ long, $3^{\prime}-4^{\prime}$ broad, turning pale yellow in the antumn before falling; their petioles slender, $1 \frac{1}{2}-2^{\prime}$ long.

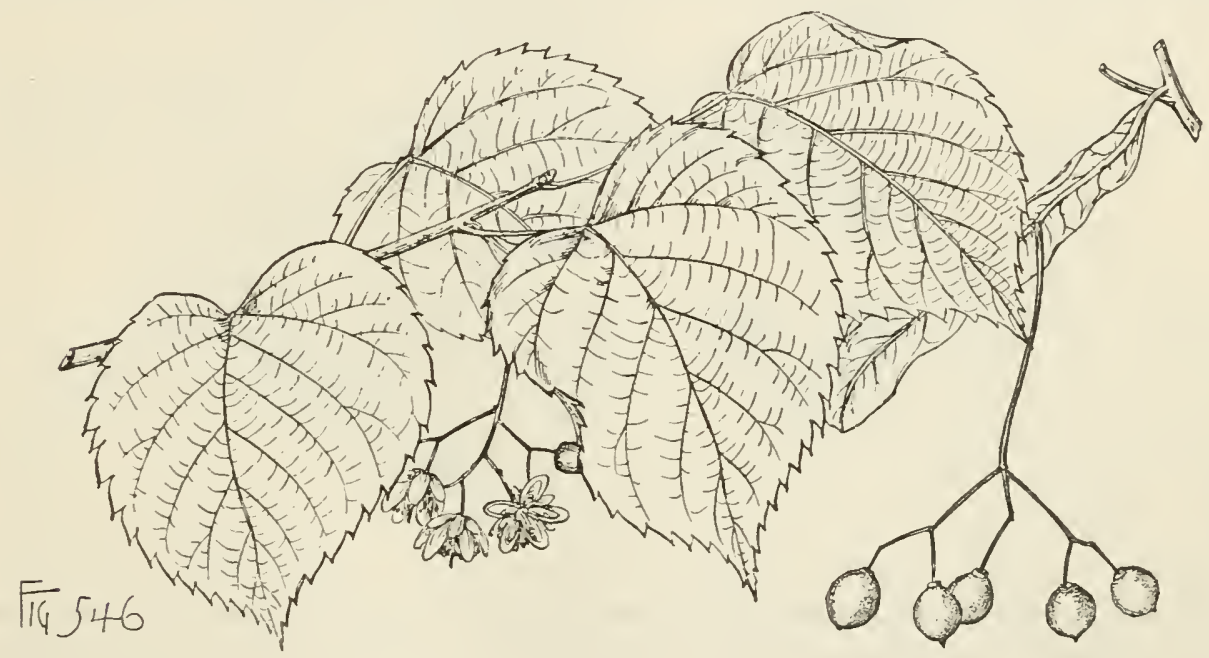

Flowers opening during the first week of July; pedunculate bract $4^{\prime}-5^{\prime}$ long, $1^{\prime}-1 \frac{1}{2}^{\prime}$ broad, rounded or pointed at the apex, decurrent nearly to the base or to within $\frac{1}{2}^{\prime}-1^{\prime}$ of the base of the peduncle; peduncle slender, glabrous, the free portion $3 \frac{1}{2}-4^{\prime}$ long; pedicels slightly angled, puberulous, about $\frac{1^{\prime}}{3}$ long; sepals ovate, acumiuate, densely hairy on the inner and slightly pubescent on the outer surface, about $\frac{1}{4}^{\prime}$ long and one third shorter than the lanceolate petals. Fruit oblong to oblong-obovate, rounded or pointed at the apex, $\frac{1}{3}^{\prime}-\frac{1}{2}$ loug, and covered with short thick rufons tomentum.

A tree, usually $60^{\circ}-70^{\circ}$, or sometimes $120^{\circ}-130^{\circ}$ high, with a tall trunk $3^{\circ}-4^{\circ}$ in diameter, small of ten pendulous branches forming a broad round-topped head, slender smooth glabrous light gray or light brown branchlets marked with numerous oblong dark lenticels, becoming darker in their second and dark gray or brown and conspicuously rugose in their third year. Winter-buds dark red, ovate, about $\frac{1}{4}$ long. Bark of the trunk about $\mathbf{1}^{\prime}$ thick, deeply furrowed, the light brown surface broken into small thin scales. Wood light brown faintly tinged with red, with thick hardly distinguishable sapwood of 55-65 layers of annual growth; employed in the manufacture of paper pulp, and under the name of white wood largely used in wooden ware, cheap furniture, the panels of carriages, and for the inner soles of shoes. 
Distribution. Rich often moist soil, formerly often in mostly pure forests; northern New Brunswiek to the eastern shores of Lake Superior, and northeastward to the sonthern shores of Lake Wimipeg and the valley of the Assiniboine River, and sonth in the United States to Virginia, along the Appalachian Mountains to Georgia and Alabana, and to eastern Dakota, eastern Nebraska, Kansas, the Indian Territory, and eastern Texas; more common northward than southward, and of its largest size on the bottom-lands of the tributaries of the lower Ohio River.

Often eultivated as a shade and ornamental tree in the northeastern states, and oceasionally in Europe.

\section{Tilia australis, Small. Linden.}

Leaves ovate, abruptly acuminate at the apex, mostly eordate by a broad shallow simus at the oblique base, sharply serrate, with prominently glandular teetl, thin, dark green and lustrous above, glaucous beneath, sparingly hairy while young on the
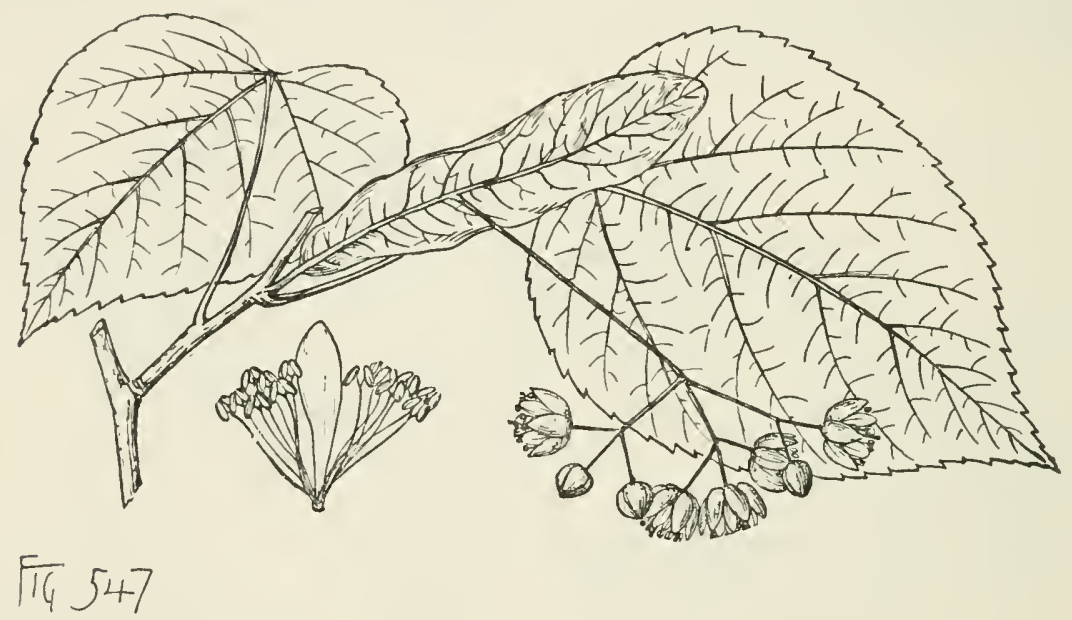

under side of the slender midribs and in the axils of the thin primary veins, beeoming glabrous, $4^{\prime}-6^{\prime}$ long, $3 \frac{1}{2}^{\prime}-4^{\prime}$ wide; their petioles slender, $2^{\prime}-3^{\prime}$ in length. Flowers : pedunculate braet decurrent nearly to the base of the peduncle, glaueous, glabrous, about $3 \frac{1^{\prime}}{2}$ long and $\frac{7^{\prime}}{8}$ wide; pedunele slender, glabrous, the free portion about $1 \frac{1^{\prime}}{4}$ long; pedicels glabrous, about $\frac{1}{4}$ in length; sepals narrowly ovate to ovate-laneeolate, hoary-tomentose along the margins on the inner surface and toward the apex on the outer surface, about $\frac{1}{8}^{\prime}$ long and one third shorter than the lanceolate petals; staminodia entire. Fruit not seen.

A tree, sometimes $60^{\circ}$ high.

Distribution. Rich wooded hillsides at elevations of $800^{\circ}$ above the sea on Warnoek Mountain, Blount County, Alabama (C. Mohr, 1895); still little known.

\section{Tilia Floridana, Small. Linden.}

Leaves ovate or ovate-oval, abruptly narrowed and acuminate at the apex, mostly obliquely truneate or unequally euneate at the base, remotely erenulate-serrate, with glandular teeth, dark green above, pale below, glabrous with the exception of minute tufts of brownish hairs in the axils of the slender veins beneath, $4^{\prime}-6^{\prime}$ long, $3^{\prime}-3 \frac{1}{2}^{\prime}$ wide, their petioles $1 \frac{1}{4}^{\prime}-1_{\frac{1}{2}}^{\prime}$ in length. Flowers : peduneulate bract decurrent to within $1^{\prime}-\frac{g^{\prime}}{4}$ of the base of the pedunele, puberulons, $3^{\prime}-4^{\prime}$ long, $\frac{8^{\prime}}{4}-1^{\prime}$ 


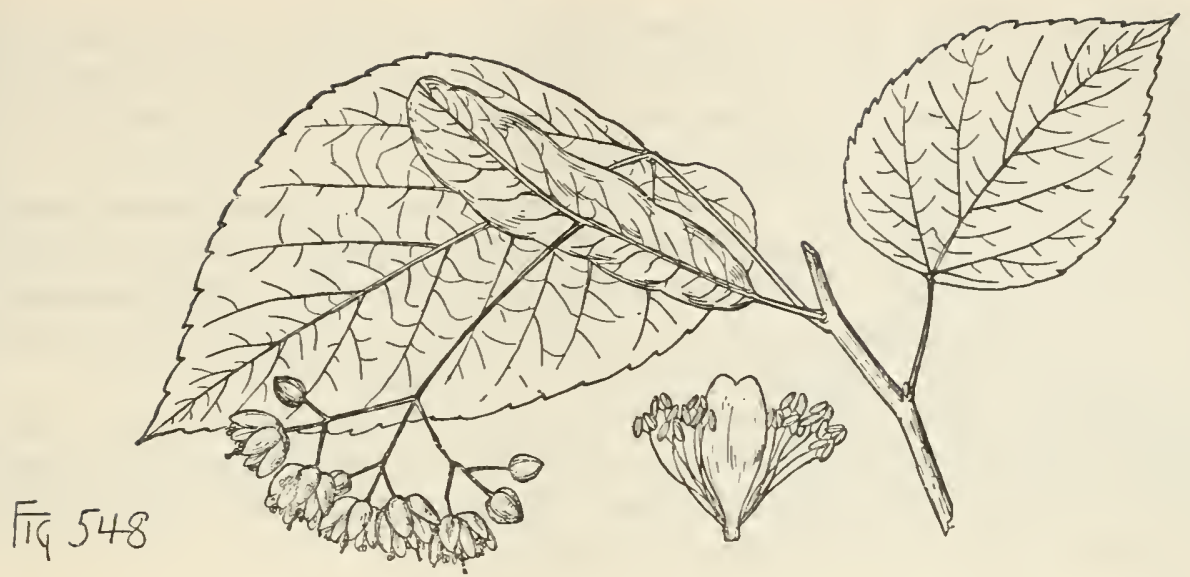

wide; peduncle slender, puberulous, the free portion $\frac{3^{\prime}}{4}-1^{\prime}$ long; pedicels puberulous, about $\frac{1}{4}$ long; sepals lanceolate to linear-lanceolate, hoary-tomentulose on the outer surface, much shorter than the lanceolate petals; staminodia emarginate. Fruit not seen.

A tree, $25^{\circ}-30^{\circ}$ high.

Distribution. Rich woods; Lake Charm, Orange County (T. L. Mead, 1887), and in Jackson County, Florida; still little known.

\section{Tilia Michauxii, Nutt. Linden. Bass Wood.}

Leaves broadly ovate, abruptly narrowed into short acute entire points, obliquely cordate by a broad sinus or rarely truncate at the base, sharply serrate, with long straight or incurved glandular teeth, thick, dark green and lustrous and glabrous or sparingly stellate-pubescent above, pale and more or less stellate-pubescent below, with small conspicuous axillary tufts of pale hairs, usually $5^{\prime}-6^{\prime}$ long and $3 \frac{1^{\prime}}{2}-4^{\prime}$ wide, with slender orange-brown or yellow midribs and primary veins, turning yellow in the autumn before falling; their petioles stout, at first puberulous, becoming glabrous, $1 \frac{1^{\prime}}{2}-2^{\prime}$ long. Flowers: pedunculate bract decurrent nearly to the base

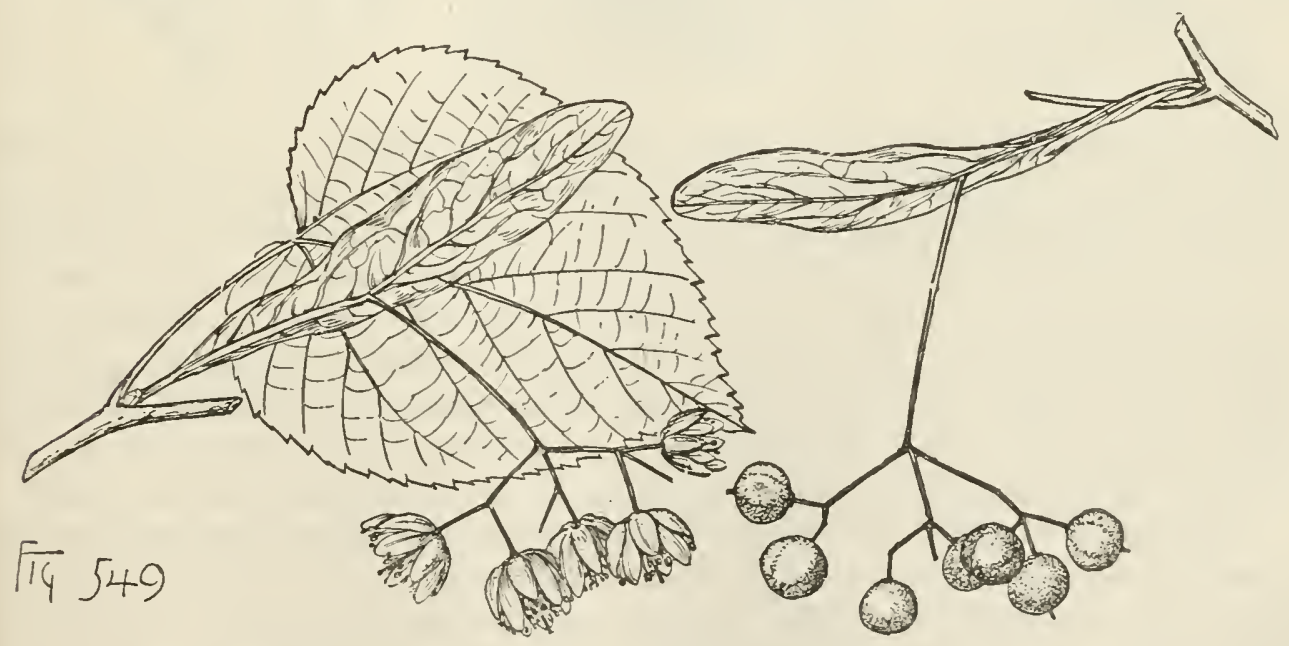

or to within $\frac{1^{\prime}}{2}-\frac{3^{\prime}}{4}$ of the base of the peduncle, narrowly obovate, tomentulose on the upper, glabrous on the lower surface, $5^{\prime}-6^{\prime}$ long; peduncle slender, glabrous, the free 
portion about $1 \frac{8^{\prime}}{4}$ long; pedicels puberulous, $\frac{1^{\prime}}{4}-\frac{1}{2}$ long; sepals ovate, acuminate, pale pubescent on the onter surface, coated on the inner surface with matted white hairs, about one third as long as the lanceolate to ovate petals. Fruit subglobose to shortoblong, hoary-tomentose, about $\frac{1^{\prime}}{3}$ in diameter.

A tree, $70^{\circ}-80^{\circ}$ high, with a trunk $2^{\circ}-3^{\circ}$ in diameter, small of ten pendulous branches forming a round-topped head, and branchlets bright red and lustrons during their first winter and reddish brown in their second season. Winter-buds $\frac{1^{\prime}}{4}-\frac{t^{\prime}}{3}$ long, with pale red-brown scales. Bark of the trunk about $1^{\prime}$ thick, deeply furrowed, reddish brown and covered with small thin scales.

Distribution. Rich woods; valley of the St. Lawrence River near Montreal, near Rochester and Ithaca, New York, to eastern Pennsylvania, Delaware, Ohio, and southward to northern Georgia and eastern Texas; probably often confounded with Tilia pubescens, Ait., and still imperfectly known.

\section{Tilia heterophylla, Vent. Linden. Bee-tree.}

Leaves gradually narrowed and short-pointed at the apex, obliquely truncate or cordate at the base, finely serrate, with short slender glandular teeth, membranaceons, bright green and pubescent while young along the midribs above, becoming

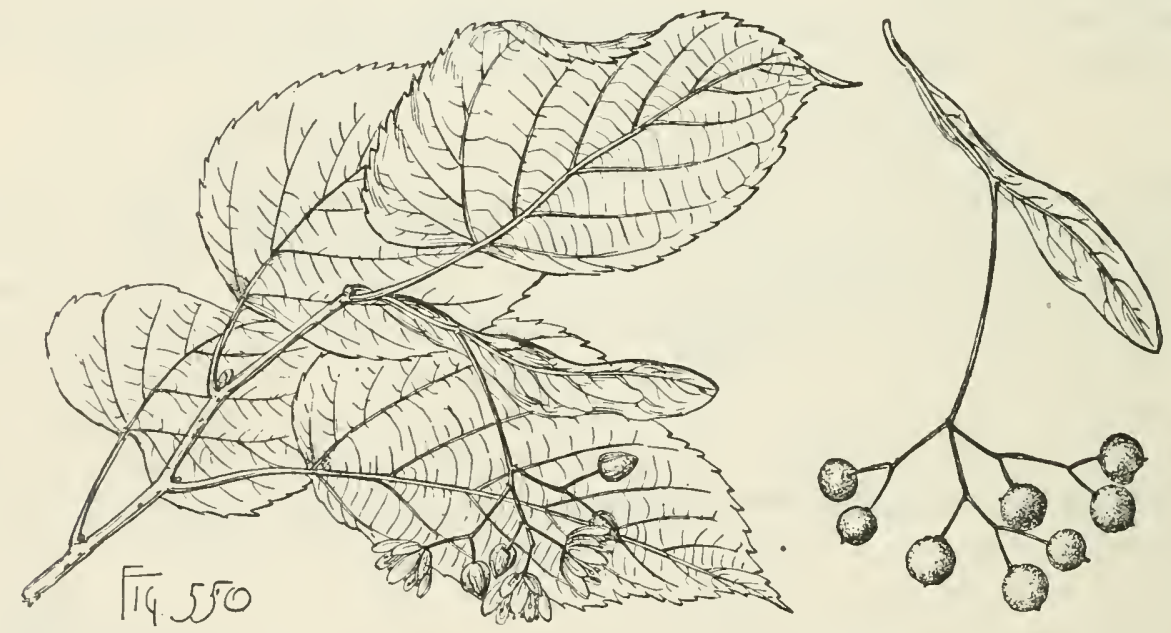

glabrons, silvery white and tomentulose on the lower surface, $4^{\prime}-7^{\prime}$ long, $4^{\prime}-5^{\prime}$ wide, with slender midribs and primary veins; their petioles slender, glabrous, $2^{\prime}-3^{\prime}$ long. Flowers appearing during the month of June; pedunculate bract usually decurrent to within about $\frac{1^{\prime}}{4}$ of the base of the peduncle, or sometimes to the base, generally about $4^{\prime}$ long and $\frac{1}{2}^{\prime}-1^{\prime}$ wide; peduncle slender, stellate-pubescent, becoming glabrous, the free portion $1 \frac{1}{2}^{\prime}-2^{\prime}$ long; pedicels slender, about $\frac{1}{4}^{\prime}$ long, nearly glabrous; sepals narrow, acuminate, puberulous on the outer, tomentulose on the imner surface, nearly $\frac{1}{4}^{\prime}$ long and one third shorter than the narrow acuminate petals. Fruit subglobose, $\frac{1}{3}^{\prime}$ in diameter, tomentulose, with short closely appressed cinereous hairs.

A tree, $50^{\circ}-60^{\circ}$ high, with a trunk $3^{\circ} \mathbf{-}^{\circ}$ in diameter, slender branches forming generally a narrow rather pyramidal head, and glabrous green or bright red branchlets gradually turning brown during their second year, and narked by numerous large oblong pale lenticels. Winter-buds broadly ovate, bright red, covered with a slight glaucous bloom, $\frac{1^{\prime}}{3}-\frac{1^{\prime}}{2}$ long. Bark of the trunk about $\frac{1^{\prime}}{2}$ thick, deeply furrowed, the surface broken into short thin light brown scales. Wood light brown 
faintly tinged with red, with thin hardly distinguishable sapwood of 5 or 6 layers of annual growth.

Distribution. Rich wooded slopes in moist soil or near the banks of streams; often on limestone; near Ithaca, New York, southward along the Appalachian Mountains to northern Alabama, and westward to middle Temnessee, Kentucky, and southern Indiana and Illinois; most abundant and of its largest size on the high mountains of North Carolina and Tennessee.

\section{Tilia pubescens, Ait. Linden. Bass Wood.}

Leaves ovate, acuminate, obliquely truncate at the base, coarsely glandular-serrate, when they unfold dark red and coated above with matted pale hairs and hoarytomentose below, and at maturity membranaceous, dark green, pubescent or glabrous

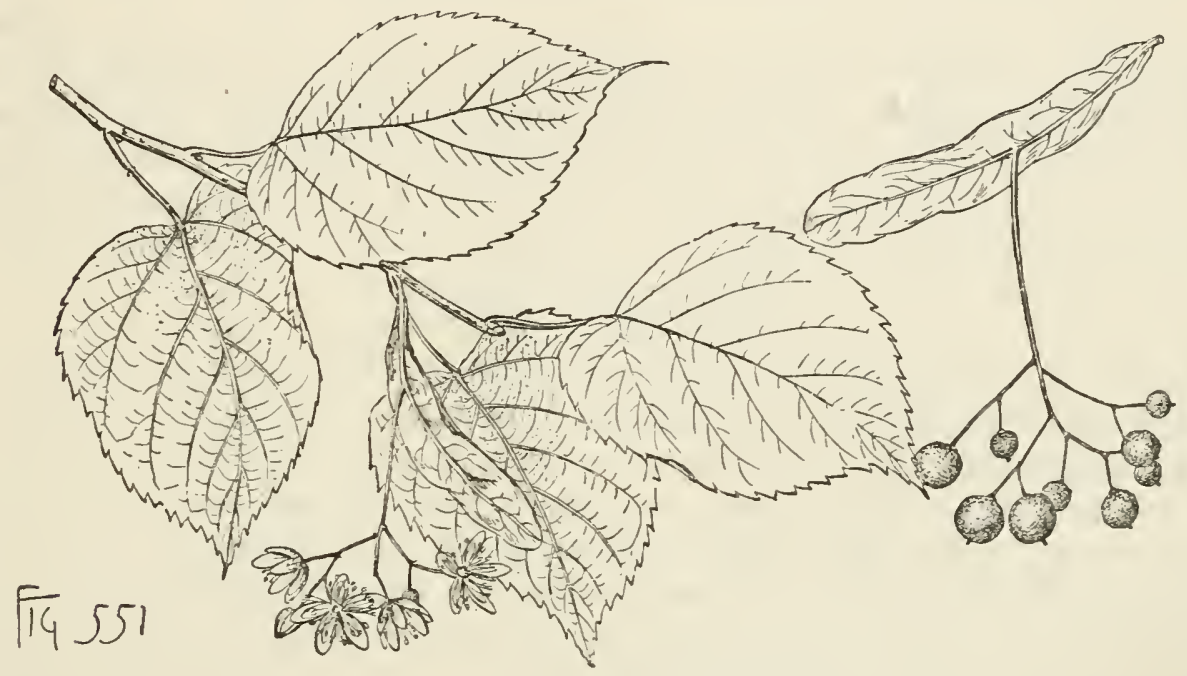

above, rusty-tomentulose below, usually $4^{\prime}-5^{\prime}$ long, $2 \frac{1^{\prime}}{2}-3^{\prime}$ wide, their petioles slender, at first tomentose, becoming glabrous, about $\frac{3^{\prime}}{4}$ long. Flowers appearing in May; pedunculate bract decurrent to the base of the peduncle, hardly obovate, sometimes falcate, $3^{\prime}-4^{\prime}$ long, about $\frac{5^{\prime}}{8}$ wide, villose on the upper, glabrous on the lower surface; peduncle slender, stellate-pubescent, the free portion about $\mathbf{1}_{\frac{1}{2}}^{\prime}$ long; pedicels short, stellate-pubescent; sepals narrow-acuminate, pale-tomentose on the outer, sparingly hairy on the inner surface, about $\frac{1^{\prime}}{4}$ long, and rather shorter than the narrow acuminate petals. Fruit subglobose to short-oblong, $\frac{1}{4}^{\prime}-1^{\prime}$ in diameter, rusty tomentose.

A tree, $30^{\circ}-40^{\circ}$ high, with a trunk rarely exceeding $12^{\prime}-15^{\prime}$ in diameter, and slender branchlets densely rusty stellate-pubescent during their first season, becoming glabrous during their third year, red-brown, rugose and marked by occasional small lenticels. Winter-buds acuminate, dark reddish brown, covered with short rusty pubescence. Bark of the trunk $\frac{1^{\prime}}{2}-\frac{2^{\prime}}{3}$ thick, furrowed and divided into numerous parallel ridges, the red-brown surface broken into numerous slort thick scales. Wood light brown faintly tinged with red, with thick hardly distinguishable sapwood.

Distribution. Coast of North Carolina southward in the neighborhood of the coast to northern Florida, and westward along the Gulf coast to the valley of the Rio Blanco, Texas, and southern Arkansas; not common. 


\section{STERCULIACEA.}

Trees or shrubs, with bitter astringent juice, mucilaginous bark, and alternate simple leaves with stipules. Flowers perfect, regular ; calyx of 5 sepals, imbricated in the bud; corolla 0 (in Fremontodendron); anthers extrorse; pistil of 5 united carpels; ovary 5-celled; styles united; ovules anatropous.

A family of about fifty genera mostly confined to the tropics, its most important species, Theobroma Cacao, L., of the West Indies producing chocolate from the cotyledons. Sterculia platanifolia, L. f., of this family and a native of southern China, is often planted as an ornamental tree in the southern states and in California.

\section{FREMONTODENDRON, Cov.}

A tree or shrub, with stellate pubescence and naked buds. Leaves palmately lobed, thick, prominently veined, usually rufous on the lower surface, persistent; stipules minute, deciduous. Flowers solitary, terminal or opposite the leaves, pedunculate, subtended by 3 or rarely 5 minute caducous bracts; calyx subcampanulate, hypogynous, deeply 5-lobed, the lobes imbricated in the bud, petaloid, yellow, spreading, obovate, often mucronate, $\mathbf{1}^{\prime} \mathrm{long}$, the 3 outer a little smaller than the others, pubescent on the outer surface, with a hairy cavity at the base of the inner surface; corolla 0; stamens 5; filaments alternate with the sepals, nnited to the middle into a column; anthers oblong-linear, incurved at the ends, 2-celled, the cells opening longitudinally; ovary 5-celled, the cells opposite the sepals; style filiform, elongated, terminated by an acute undivided stigmatic point; ovules numerous in each cell, horizontal. Fruit an ovate acuminate 4 or 5-valved loculicidally dehiscent capsule densely coated with long matted hairs, the inner surface of the cells villose-pubescent. Seeds oval; seed-coat crustaceous, puberulous, with a small fleshy marginal deciduous ariloid appendage on the chalaza; embryo straight, in thick fleshy albumen; cotyledons oblong, foliaceous, three or four times longer than the short radicle.

Fremontodendron, named in honor of John C. Frémont, the distinguished soldier and traveler, is represented by a single species.

\section{Fremontodendron Californicum, Cov. Slippery Elm.}

Leaves usually 3-lobed, rarely entire or sometimes 5 -7-lobed, $1 \frac{1}{2}^{\prime}$ in diameter; their petioles stout, $\frac{1^{\prime}}{2}-\frac{2^{\prime}}{3}$ long. Flowers appearing in July in great profusion on short spur-like lateral branchlets. Fruit $1^{\prime}$ long; seeds very dark red-brown, about $\frac{3}{16}$ long.

A tree, $20^{\circ}-30^{\circ}$ high, with a short trunk $12^{\prime}-14^{\prime}$ in diameter, stout rigid branches spreading almost at right angles, and stout terete branchlets thickly coated at first with rufous pubescence, becoming glabrous and light red-brown; more often a low intricately branched shrub. Bark of the trunk rarely more than $\frac{1}{4}^{\prime}$ thick, deeply furrowed, the dark red-brown surface broken into numerous short thick scales. Wood hard, heavy, close-grained, dark brown tinged with red, with thick lighter colored sapwood. The mucilaginous inner bark is sometimes used domestically in poultices.

Distribution. Lower slopes of the California mountains; western base of Mt. Shasta to Lower California; nowhere common west of the Sierra Nevada, but of its largest size on their western foothills; most abundant east of the Sierra Nevada in 

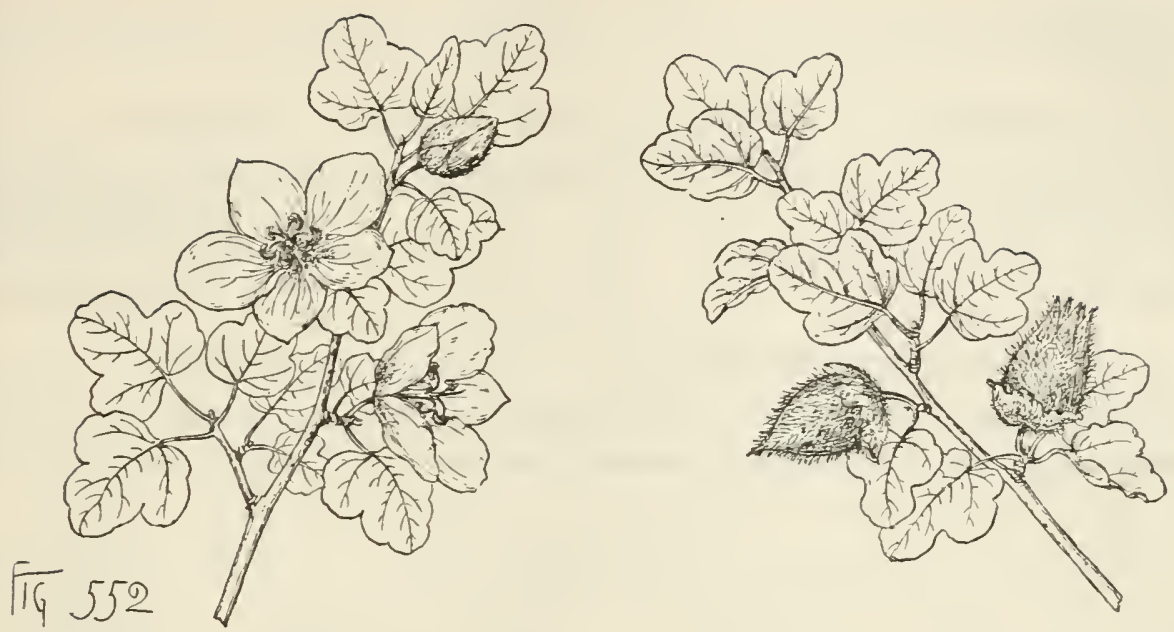

the region of the Mohave Desert, growing as a low shrub and sometimes forming thickets several acres in extent.

Occasionally cultivated in western and southern Europe as an ormamental plant.

\section{THEACE㘴.}

Trees or shrubs, with simple alternate leaves without stipules. Flowers perfect, regular, hypogynous; sepals and petals 5 , imbricated in the bud; stamens numerous; anthers 2-celled, the cells opening longitudinally; pistil of $3-5$ united carpels; ovary $3-5$-celled; styles as many as the cells of the ovary, partly united. Fruit capsular; embryo with large cotyledons.

The Camellia family with sixteen genera is principally confined to the tropics of the New World and to southern and eastern Asia. Two genera are represented in the flora of the southern United States, and of these Gordonia is arborescent. The most important genus, Camellia of eastern Asia contains the Tea plant, Camellia Thea, Link, and several species cultivated for the beauty of their flowers.

\section{GORDONIA, Ell.}

Trees or shrubs, with terete branchlets, without terminal buds, slender acuminate naked axillary buds, and watery juice. Leaves pinnately veined, entire or crenate, subcoriaceous and persistent, or membranaceous and deciduous. Flowers axillary, solitary, long-stalked or subsessile; calyx subtended by $2-5$ eaducous bracts; sepals unequal, rounded, concave, coriaceous, persistent; petals free or slightly united, obovate, concave, white, deciduous; stamens numerous, filaments short, united at the base into a fleshy cup adnate to the base of the petals and inserted with them, or long and inserted directly on the petals; anthers introrse, yellow; ovary sessile; style elongated, erect, $\tilde{5}$-lobed at the stigmatic apex; ovules $4-8$ in each cell, pendulous iu 2 series from its inner angle, collateral, anatropous. Fruit a woody oblong or subglobose 5-celled capsule loculicidally 5 -valved, with a persistent axis angled by the projecting placentas. Seeds $2-8$ in each cell, pendulous, flat, without albumen; seed-coat woody, usually produced upward into au oblong wing; embryo mostly straight or oblique, with oblong flat or oblique cotyledons; radicle short, superior.

Gordonia with about ten species is confined to the south Atlantic states of North America and to tropical Asia and the Malay Archipelago. 
The generic name is in honor of James Gordon (1728-1791), a well-known London nurseryman.

\section{CONSPECIUS OF THE NORTH AMERICAN SPECIES.}

Flowers long-pedunculate; filaments united into a cup; capsule ovoid; seeds winged; leaves persistent.

1. G. Lasianthus (C).

Flowers subsessile; filaments distinct; capsule globose; seeds without wings; leaves deciduous.

2. G. Altamaha (C).

\section{Gordonia Lasianthus, Ell. Bay. Loblolly Bay.}

Leaves coriaceous, lanceolate to oblong, acute at the apex, gradually narrowed to the cuneate base, finely or remotely crenately serrate, usually above the middle only,

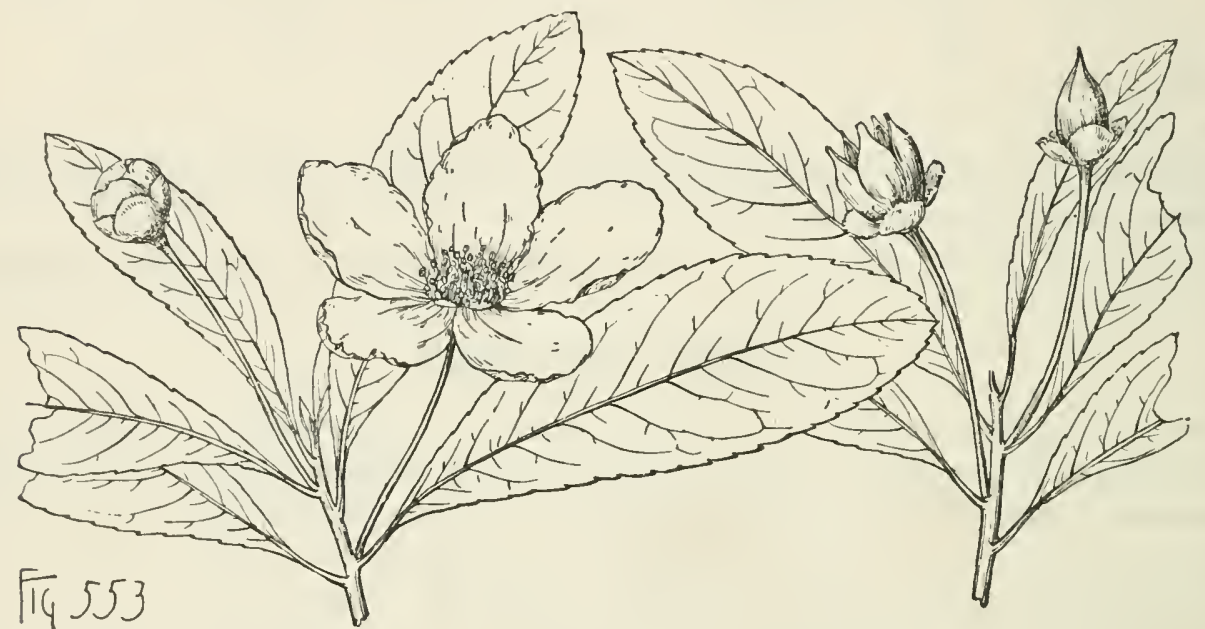

dark green, smooth and lustrous, $4^{\prime}-5^{\prime}$ long and $1 \frac{1}{2}^{\prime}-2^{\prime}$ wide, persistent; their petioles stout, wing-margined toward the apex, channeled, about $\frac{1}{2}^{\prime}$ long. Flowers about $2 \frac{1}{2}$ in diameter, expanding in Jnly and continuing to open successively during several weeks, on stout red peduncles thickening from below upward, and $2 \frac{1}{2}-3^{\prime}$ long, with usually 3 or 4 ovate minute subfloral bracts; sepals ovate to oval, $\frac{1}{2}^{\prime}$ long, ciliate on the margins, with long white hairs, and covered on the outer surface with dense velvety pale lustrous pubescence; petals rounded at the apex, gradually contracted at the base, silky-puberulent on the back, white, $1 \frac{1}{4}^{\prime}-1 \frac{1^{\prime}}{2}$ long and $1^{\prime}$ broad; stamens united into a shallow fleshy deeply 5-lobed cup pubescent on the inner surface and adnate to the base of the petals; ovary ovate, pubescent, gradually contracted into the stout style. Fruit ovoid; seeds winged, nearly square, slightly concave on the inner and rounded on the outer surface, rugose, dotted with small pale brown excrescences, nearly $\frac{1}{16}$ long and half the length of the thin membranaceous oblique pale brown wing pointed or rounded at the apex; embryo filling the cavity of the seed, nearly straight; cotyledons subcordate, foliaceous.

A short-lived tree, $60^{\circ}-75^{\circ}$ high, with a tall straight trunk $18^{\prime}-20^{\prime}$ in diameter, small branches growing upward at first and ultimately spreading into a rather narrow compact head, and dark brown rugose branchlets marked dnring several years by the horizontal slightly obcordate leaf-scars; or rarely a low shrub. Winter-buds $\frac{1}{4}-\frac{1}{3}$ ' long, and covered with pale silky lustrous pubescence. Bark of the trunk nearly $1^{\prime}$ thick, deeply divided into regular parallel rounded ridges, their dark red-brown scaly surface broken into many irregular shallow furrows. Wood light, 
soft, close-grained, not durable, light red, with lighter colored sapwood of 40-j0 layers of amnual growth; occasionally used in cabinet-making.

Distribution. Shallow swamps and moist depressions in the Pine barrens; southern Virginia southward near the coast to Cape Malabar and Cape Romano, Florida, and westward along the Gulf coast to the valley of the Mississippi River; most abundant in Georgia and east Florida; gradually becoming less abundant westward.

\section{Gordonia Altamaha, Sarg. Franklinia.}

Leaves obovate-oblong, rounded or pointed at the apex, gradnally narrowed to the base, long-cuneate, remotely serrate, usually above the middle only, with small glandular teeth, bright green and lustrous on the upper, pale on the lower surface, $5^{\prime}-6^{\prime}$ long, $1 \frac{1}{2}-2^{\prime}$ wide, turning scarlet in the autumu before falling; their petioles

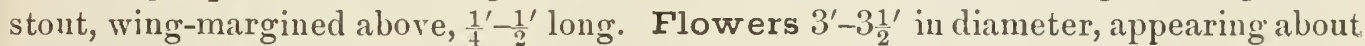
the middle of September, on short stout peduncles at first pubescent, finally glabrous, from the axils of crowded upper leaves, and marked by the broad conspicuous scars of 2 minute lateral subfloral pubescent bracts; sepals nearly circular, $\frac{1}{2}^{\prime}$ in diameter, ciliate on the margins, and covered on the outer surface with short lustrons silky pale hairs; petals obovate, crenulate on the margins, white, membranaceous, $1^{\prime}-1 \frac{1}{2}^{\prime}$ long, $\mathbf{1}^{\prime}$ broad, and densely coated on the outer surface with fine pubescence; filaments distinct, inserted on the petals; ovary conspicuonsly ridged, pubescent, truncate, and crowned with a slender deciduous style nearly as long as the stamens.

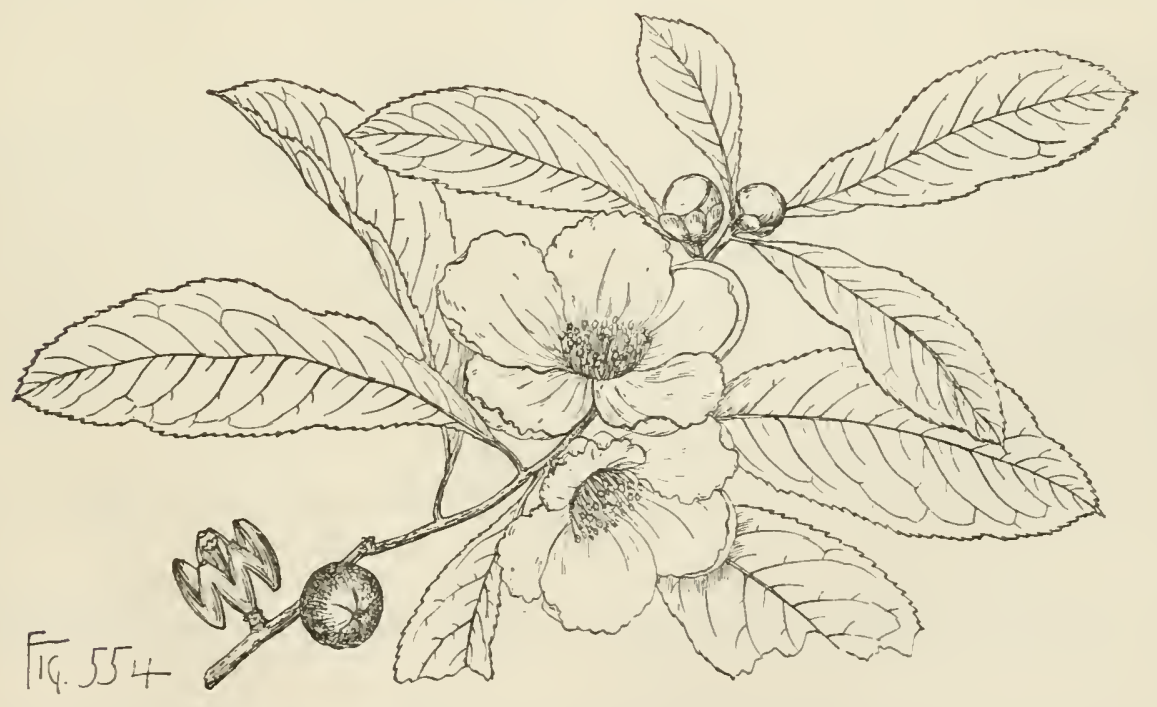

Fruit globose, septicidally 5 -valved from the base to the middle; seeds $6-8$, or by abortion fewer in each cell, closely packed together on the whole length of the thick axile placenta, nearly $\frac{1}{2}^{\prime}$ long, angled by mutual pressure, without wings.

A tree, $15^{\circ}-20^{\circ}$ high, with stout slightly angled dark red-brown branchlets covered with small pale oblong horizontal lenticels, and conspicuously marked by large prominent obcordate leaf-scars, with a marginal row of large fibro-vascular bnudlescars. Winter-buds compressed, reddish brown, puberulous, $\frac{1^{\prime}}{3}-\frac{1}{4}{ }^{\prime}$ long. Bark of cultivated plants smooth, thin, dark brown.

Distribution. Near Fort Barrington on the Altamaha River, Georgia; not seen in a wild state since 1790 , and now only known by cultivated plants. 
Often cultivated in the eastern states and hardy as far north as Philadelphia, and occasionally in western and central Enrope.

\section{CANELLACE丑.}

Trees, with pungent aromatic bark, alternate pellucid-punctate entire penniveined persistent leaves without stipules. Flowers perfect, regular, cymose ; sepals and petals imbricated in the bud; stamens numerous, hypogynous, with filaments united into a tube inclosing the pistil, and narrow extrorse anthers adnate to the tube and longitudinally 2-celled; pistil of 2-3 united carpels; ovary free, 1-celled, with 2-5 parietal placentas; styles thick; stigmas 2-5lobed; ovules 2 or many. Fruit a berry; seeds 2 or several ; seed-coat thick, erustaceous : embryo small in fleshy oily albumen.

The Wild Cinnamon family with four genera and few species is confined to tropical America, south Africa, and Madagascar, a single species reaching tile shores of southern Florida.

\section{CANELLA, P. Br.}

A tree, with scaly bark, stout ashy gray branchlets conspicuously marked by large orbicular leaf-scars, and minute buds. Leaves obovate, rounded or slightly emarginate at the apex, gradually narrowed to the cuneate base, petiolate, coriaceous. Flowers small, in many-flowered subcorymbose terminal or subterminal panicles of several dichotomously branched cymes from the axils of upper leaves or from minnte caducous bracts; sepals 3, suborbicular, concave, coriaceous, erect, their margins ciliate, persistent; petals 5, hypogynous, in a single row on the slightly convex receptacle, oblong, concave, rounded at the apex, fleshy, twice as long as the sepals, white or rose color; stamens about 20 , staminal tube crenulate at the summit and slightly extended above the anthers; ovary cylindrical or oblong-conical, 1-celled. with 2 parietal placentas; style short, fleshy, terminating in a 2 or 3-lobed stigma; ovules unmerous, arcuate, horizontal or descending, attached by short funicles, imperfectly anatropous; micropyle superior. Fruit globose or slightly ovate, fleshy, minutely pointed with the base of the persistent style, 2-4-seeded. Seeds reniform, suspended; seed-coat black and shining; embryo curved in the copions albumen; cotyledons oblong; radicle next the hilum.

The genus consists of a single West Indian tree, extending into southern Florida and to Venezuela.

The generic name is from canella, the diminutive of the Latin cana or canna, a cane or reed, first applied to the bark of some Old World tree from the form of a roll or quill which it assumed in drying.

\section{Canella Winterana, Gærtn. Cinnamon Bark. White Wood. Wild Cinnamon.}

Leaves contracted into short stont grooved petioles, $3 \frac{1^{\prime}}{2}-5^{\prime}$ long, $1 \frac{1}{2}-2^{\prime}$ wide, bright green and lustrous. Flowers about $\frac{1}{8}^{\prime}$ in diameter, opening in the autumn. Fruit ripening in March and April, bright crimson, soft and fleshy, $\frac{1}{2}$ in diameter; seeds about $\frac{3{ }^{\prime}}{1 \overline{6}}$ long.

A tree, in Florida $25^{\circ}-30^{\circ}$ high, with a straight trunk $8^{\prime}-10^{\prime}$ in diameter, and slender horizontal spreading branches forming a compact round-headed top. Bark of the trunk $\frac{1^{\prime}}{8}$ thick, light gray, broken on the surface into numeroms short thick scales rarely more than $2^{\prime}-3^{\prime}$ long and about twice as thick as the pale yellow aro- 
matic inner bark. Wood very heavy, exceedingly hard, strong, close-grained, dark red-brown, with thick light brown or yellow sapwood of 25-30 layers of annual

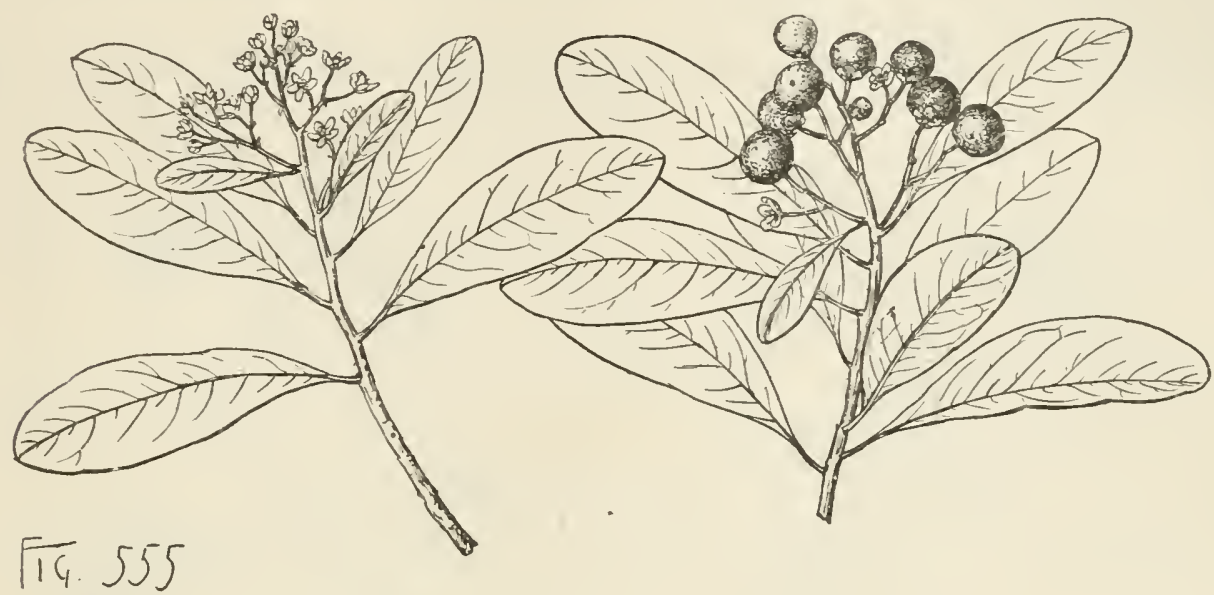

growth. The bitter acrid inner bark is the wild cinnamon bark of commerce. It has a pleasant cinnamon-like odor and is an aromatic stimulant and tonic.

Distribution. In Florida common and widely distributed on the southern keys, usually growing in the shade of other trees.

\section{KOBBERLINIACEA.}

An intricately branched almost leafless tree or shrub, with thin red-brown scaly bark, stout alternate glabrous branchlets covered with pale green bark and terminating in sharp rigid straight or slightly curved spines. Leaves minute, early deciduous, alternate, narrowly obovate, rounded at the apex. Flowers perfect, on slender club-shaped puberulous pedicels from the axils of minute scarious deciduous bracts, in slort umbel-like racemes below the ends of the branches; calyx of 3 or 4 minute sepals imbricated in the bud, deciduous; petals 4, convolute in the bud, hypogynous, obovate. or oblong, subunguiculate, white, much longer than the sepals; disk 0 ; stamens 8 , free, liypogynous, as long as the petals; filaments thickened in the middle, subulate at the ends; anther's oval, attached on the back near the base, 2-celled, the cells opening longitudinally; ovary ovoid, 2-celled, contracted at the base into a short stalk and above into a simple subulate style; stigma terminal, obtuse, slightly emarginate; ovules numerous, adnate in several series to the fleshy placenta, horizontal or dependent, anatropous. Fruit a 2 -celled berry, black at maturity, subglobose, tipped with the remnants of the pointed style; flesh thin and succulent, the cells 1 or 2 -seeded by abortion. Seed vertical, circinatecochleate; seed-coat crustaceous, slightly rugose, striate; albumen thin; embryo annular; cotyledons semiterete; the radicle ascending.

The family is represented by a single genus.

\section{KOEBERLINIA, Zucc.}

Characters of the family.

Koberlinia with one species is North American.

The generic name is in honor of L. Koeberlin, a German botanist. 


\section{Kœberlinia spinosa, Zucc.}

Leaves not more than $\frac{1^{\prime}}{8}$ long. Flowers appearing in May and Jume, about $y_{\dagger}^{\prime}$ in diameter. Fruit $\frac{3^{\prime}{ }^{\prime}-\frac{1^{\prime}}{4}}{4}$ in diameter.

A bushy tree, rarely $20^{\circ}-25^{\circ}$ high, with a short stout trunk sometimes $6^{\circ}-8^{\circ}$ long

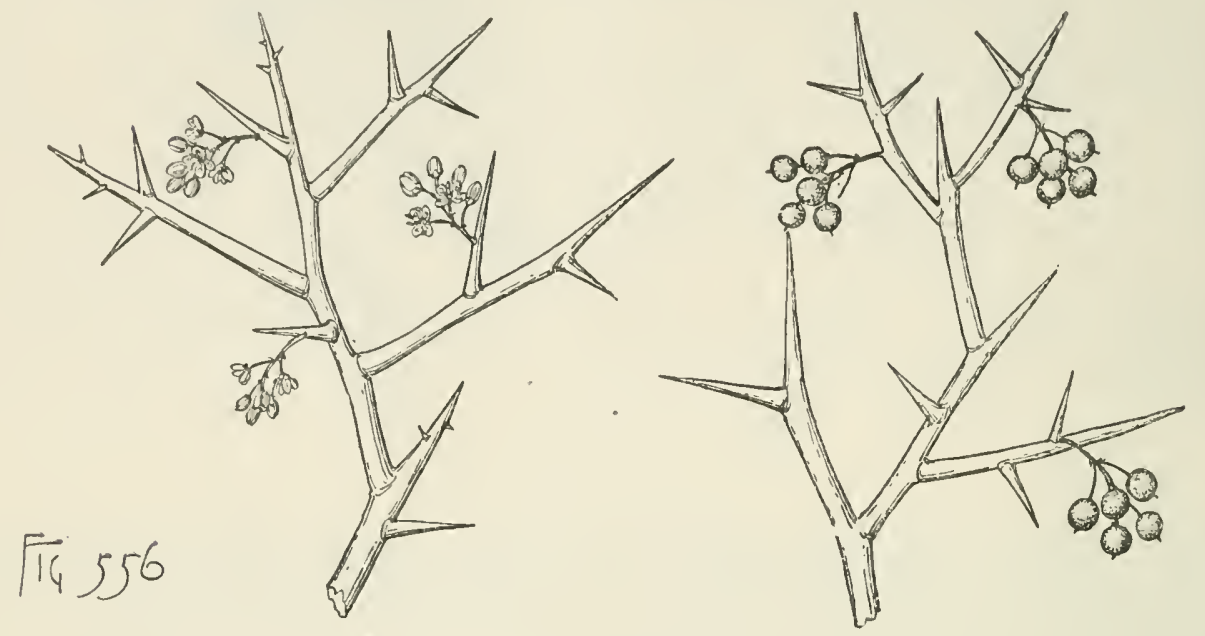

and a foot in diameter; more often a low branching shrub forming impenetrable thickets often of considerable extent. Wood very hard, heavy, close-grained, dark brown somewhat streaked with orange, becoming almost black ou exposure, with thin yellow or nearly white sapwood of 12-15 layers of ammual growth.

Distribution. Dry gravelly mesas and foothills; valley of the lower Rio Grande, Texas, westward to southerı Arizona, and southward through northern Mexico.

\section{CARICACE平.}

'Trees or shrubs, with bitter milky juice, alternate long-petiolate persistent simple or digitately compound leaves, without stipules. Flowers unisexual or perfect, the perianth of the male and female flowers dissimilar; stamens in two series, inserted on the corolla; filaments free; anthers introrse. Fruit baccate.

The Pawpaw family with two genera is tropical American and Mexican, a single representative of one of the genera reaching the shores of southern Florida.

\section{CARICA. I.}

Short-lived trees, with erect simple or rarely brauched stems composed of ' a thin shell of soft fibrous wood surrounding a large central cavity divided by thin soft cross partitions at the nodes, covered with thin green or gray bark marked by the ring-like scars of fallen leaf-stalks, and stout soft fleshy roots. Leaves simple, palmately lobed or digitate, crowded toward the top of the stem and branches, large, flaccid, subpeltately palmately nerved, and usually deeply and often compoundly lobed. Flowers regular, monœeious or polygamo-diœcious, white, yellow, or greenish white, in axillary cymose panicles, the staminate elongated, pedunculate, and manyflowered, the pistillate abbreviated and few or usually 3-flowered, generally unisexnal and diœcions, occasionally polygamo-diœcions, each flower in the axil of a minute 
ovate acute bract; calyx minute, 5-lobed, the lobes alternate with the petals; corolla of the staminate flower salverform, gamopetalous, the tube elongated, 5-lobed, the lobe oblong or linear, contorted in the bud; stamens 10; filaments free, those of the outer row alternate with the lobes of the corolla and elongated, the others alternate with them and abbreviated; anthers 2-celled, erect, opening longitudinally, often surmounted by their slightly elongated comnective; ovary rudimentary, subulate; pistillate flower, calyx minute, 5-lobed, persistent under the fruit; corolla polypetalous, petals $\check{5}$, linear-oblong, erect, ultimately spreading above the middle, leciduous; ovary free, sessile, 1-celled or more or less spuriously 5-celled; style 0 or abbreviated; stigmas 5, linear, radiating, dilated and subpalmately lobed at the apex; ovules indefinite, inserted in two rows on the placenta, anatropous, longstalked; micropyle superior; raphe ventral; hermaphrodite flower, corolla gamopetalous, tubular-campanulate, the lobes erect and spreading or subreflexed; stamens 10 , in 2 ranks, or 5; ovary obovoid-oblong, longer than the tube of the corolla, more or less spuriously 5-celled below. Fruit slightly 5-lobed, 1-celled or more or less completely 5-celled, filled with soft pulp, many-seeded, that produced from the hermaphrodite flowers long-stalked, pendulous, usually unsymmetrical, gibbous, and smaller than that from the pistillate flowers. Seeds ovoid, inclosed in membranaceous silvery white sac-like arils, occasionally germinating within the fruit; seedcoat crustaceons, closely investing the membranaceous inner coat, the outer coat becoming thick, rugose, succulent, and ultimately dry and leathery; embryo in the axis of fleshy albumen; cotyledons ovate, foliaceous, compressed, longer than the terete radicle turned toward the minute pale subbasilar hilum.

Carica with about twenty species is distributed from southern Florida through the West Indies to southern Brazil and Argentina, and from southern Mexico to Chili One species grows probably indigenously in Florida. The milky juice of Carica contains papain, which las the power of digesting albuminous snbstances, and the leares are often used in tropical countries to make meat tender.

The generic name is formed from the Carib name of one of the species.

\section{Carica Papaya, L. Pawpaw.}

Leaves ovate or orbicular, deeply parted into 5-7 lobes divided more or less deeply into acute 'lateral lobes, these secondary divisions entire or rarely lobed, the lowest lobes forming a deep basal sinus, thin, flaccid, yellow-green, $15^{\prime}-24^{\prime}$ in diameter, with broad flat yellow or orange-colored primary veins radiating from the end of the petiole through the lobes, and small secondary veins extending to the points of the lateral lobes and comnected by conspicuons reticulate veinlets; their petioles stont, yellow, hollow, enlarged and cordate at the base, sometimes becoming $3^{\circ}-1^{\circ}$ long before the leaves fall. Flowers often beginning to appear on plants only $3^{\circ}$ or $4^{\circ}$ high and a few months old, producd continuously throughout the year, staminate in clusters on slender spreading or pendulons peduncles 4'-12' long, pistillate in 1-3-flowered short-stalked cymes; staminate flowers fragrant, filled with nectar, their corolla $\frac{3^{\prime}}{4}-1 \frac{1^{\prime}}{4}$ long, with a slender tube and acute lobes; anthers oblong, orange-colored, surmounted by the ronnded thickened end of the connective, those of the inner row almost sessile and one third larger than those of the outer row, shorter than their flattened filaments covered, like the comnectives, with long slender white hairs; pistillate flowers about $1^{\prime}$ long, with erect petals, without staminodia; ovary ovoid, ivory-white, slightly and obtusely 5-angled, 1-celled, and narrowed into a short slender style crowned by a pale green stigma divided to the 
base into 5 radiating lobes dilated and 3-nerved at the apex. Fruits hanging close together against the stem at the base of the leaf-stalks, obovate, ellipsoidal and obtusely short-pointed, yellowish green to briglit orange color; in southern Florida not more than $4^{\prime}$ long and $3^{\prime}$ thick, and usually smaller, with a thiek skin closely

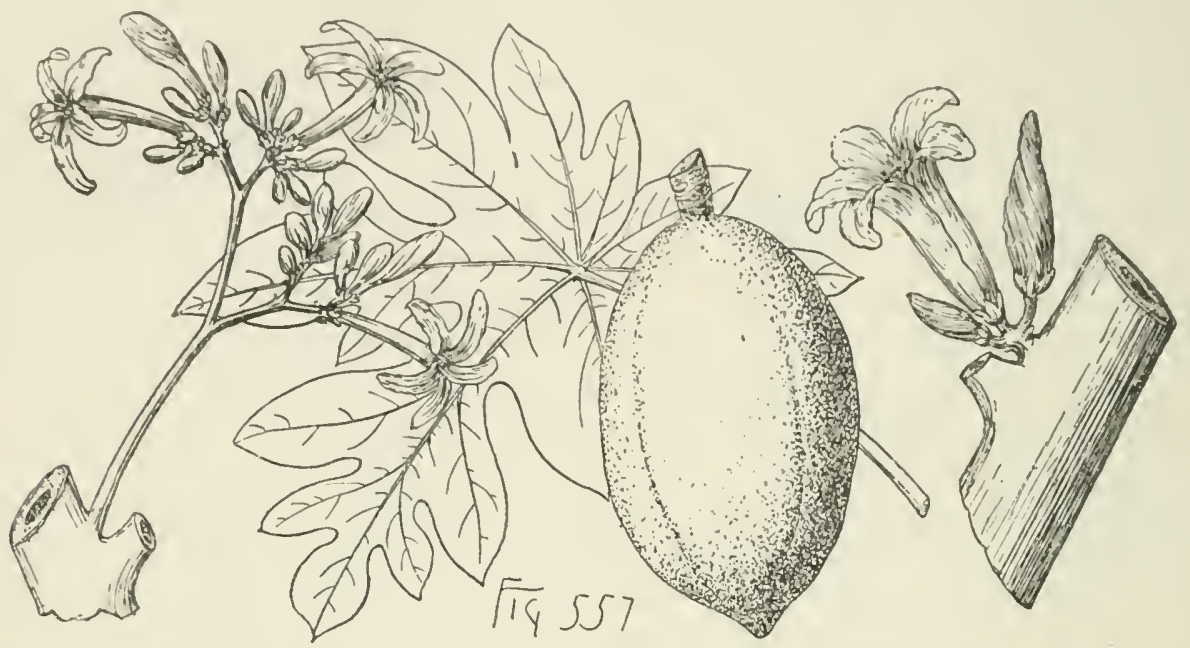

adherent to the sweet insipid flesh forming a thin layer ontside the central cavity; seeds full and rounded, about $\frac{3{ }^{\prime}}{16}$ long; outer portion of the seed-eoat rugose at first when the fruit is fully grown but still green, ivory-white, very succulent, and usually separable from the smooth paler chestnut-brown lustrous interior portion, the outer part turning blaek as the fruit ripens and beeoming adherent to the inner portion closely investing the thin lustrous light red-brown inner coat.

A short-lived tree, in Florida attaining a height of $12^{\circ}-15^{\circ}$, with a trunk seldom more than $6^{\prime}$ in diameter; in the West Indies and other tropieal countries often twice as large, with a trunk oceasionally dividing into a number of stout upright branches. Bark thin, light green, becoming gray toward the base of the stem.

Distribution. Florida from the southern shores of Bay Biseayne on the west coast and Indian River on the east eoast to the southern keys, growing sparingly in rich hummocks; common in all the West Indian islands, in southern Mexico, and in the tropieal countries of Sonth Ameriea; now naturalized in most of the warm regions of the world, where it is universally cultivated for its fruit, which is considered one of the most wholesome of all tropical fruits, and has been much improved by selection.

\section{B. Ovary inferior (partly inferior in Rhizophora).}

\section{XIIII. CACTACE王.}

Súcculent trees or shrubs, with copious watery juice, numerous spines springing from cushions of small bristles (areolce), and minute caducous alternate leaves, or leafless. Flowers large and showy, perfect, usually solitary ; calyx of numerous spirally imbricated sepals forming a tube, those of the inner series petal-like; corolla of numerous imbricated petals, in many series; stamens inserted on the tube of the calyx, very numerous, in several series, with slender filaments and introrse 2-celled oblong anthers, the cells opening longitudinally; 
pistil of several united carpels ; ovary 1-celled, with several parietal placentas; styles united, terminal; stigmas as many as the placentas; ovules numerous, horizontal, anatropous. Fruit a fleshy berry. Seeds numerous, with albumen; cotyledons foliaceous; radicle turned toward the hilum.

The Cactus family with twenty genera and a very large number of species is most abundant in the dry region adjacent to the boundary of the United States and Mexico, with a few species ranging northward to the northern United States and southward to the West Indian islands, Brazil, Peru, and the Galapagos Islands. 'Two of the genera liave arborescent representatives in the flora of the United States.

\section{CONSPECTUS OF THE ARBORESCENT GENERA OF THE UNITED STATES.}

Branches and stems columnar, ribbed, continuous; leaves 0 ; flower-bearing and spinebearing areolæ distinct; flowers close above spine-bearing areolæ; tube of the flower elongated; seeds dark-colored.

1. Cereus.

Branches jointed, tuberculate; leaves scale-like; flower-bearing and spine-bearing areolæ not distinct; tube of the flower short and cup-shaped; seeds pale.

2. Opuntia.

\section{CEREUS, Haw.}

Trees or shrubs, with columnar ribbed stems, and buds on the back of the ridges from the axils of latent leaves, geminate, superposed, the upper producing a branch or flower, the lower arrested and developed into a cluster of spines snrrounded by an elevated cushion or areola of chaffy tomentose scales. Flowers lateral, elongated, the calyx lobes forming an elongated tube, those of the outer ranks adnate to the ovary, scale-like, only their tips free, those of the inner ranks free, elongated ; petals cohering by their bases with the top of the calyx-tube, larger than its interior lobes, spreading, recurved; stamens numerous; filaments adnate by their base to the tube of the calyx, those of the interior ranks free, the exterior united into a tube ; style filiform, divided into numerous radiating linear branches stigmatic on the inner face; stalks of the ovules long and slender, becoming thick and juicy in the fruit. Seeds with very thin albumen; embryo straight; cotyledons abbreviated, hooked at the apex; radicle conical.

Cereus with abont two hundred species inhabits the dry southwestern region of North America, the West Indies, tropical Sonth America, and the Galapagos Islands. Of the numerous species found within the territory of the United States only one assumes the habit and size of a tree. The fruit of several species is edible, and the ribs of the durable woody frames of the stems of the large arborescent species are used for the rafters of houses and for fuel. Many of the species are planted in warm dry countries in hedges to protect cultivated fields, and others are popular garden plants valued for their beautiful flowers, which are sometimes nocturual and exceedingly fragrant.

The generic name relates to the candle-like form of the stem of some of the species.

\section{Cereus giganteus, Engelm. Suwarro.}

Leaves 0 . Flowers $4^{\prime}-4 \frac{1}{2}^{\prime}$ long and $2 \frac{1}{2}^{\prime}$ wide, opening from May to July in great numbers near the top of the stem, each surrounded on the lower side by the radial spines of the cluster below it; ovary ovoid, 1' long, rather shorter than the stout tube of the flower, and covered, like the base of the tube, by the thick imbricated green outer scale-like sepals, with small free triangular acute scarious mucronate 
tips, furnished in their axils with short tufts of rufons hairs and occasionally with clusters of chartaceous spines, gradually passing into thin oblong ovate or obovate larger sepals, mucronate or rounded at the apex and closely imbricated in many ranks; petals $25-35$, obovate-spatulate, obtuse, entire, thick and flesly, creamy white, $\frac{2}{3}$ long and much reflexed after anthesis; stamens, with linear anthers emarginate at the ends, and filaments united for half their length to the walls of the calyx-tube, those of the exterior rows joined below into a long tube, surrounding the stout colummar style glandular at the base and divided at the apex into 12-15 green stigmas.

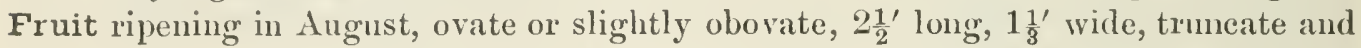
covered at the apex by the depressed pale scar left by the falling of the flower, light red at maturity, separating into 3 or 4 fleshy valves bright red on their inner surface and inclosing the bright scarlet juicy mass of the enlarged funiculi and inumerable seeds; seeds obovate, rounded, $\frac{1}{6}$ ' long, lustrous, dark chestmut-brown.

A tree, $50^{\circ}-60^{\circ}$ high, with a trunk sometimes $2^{\circ}$ in diameter, thickest below the middle and tapering gradually toward the ends, marked by transverse superficial lines into rings $4^{\prime}-8^{\prime}$ long, representing the amount of longitudinal growth, 8-12ribbed at the base, with olstuse ribs $4^{\prime}-5^{\prime}$ broad, and at the summit $18-20$-ribbed, with obtuse deep compressed ribs, branchless or furnished above the middle with a few, usually 2 or 3, stout alternate or sometimes opposite upright branches shorter but otherwise resembling the principal stem composed of a thick tongh green epidermis, a fleshy covering $3^{\prime}-6^{\prime}$ thick saturated with bitter juice, and a circle of bundles of wood fibres making, with annual layers of exogenous growth, dense tongh elastic columns placed opposite the depressions between the ribs, $\frac{1^{\prime}}{2}-3^{\prime}$ in diameter and frequently united by branches growing at irregular intervals between them, the woody

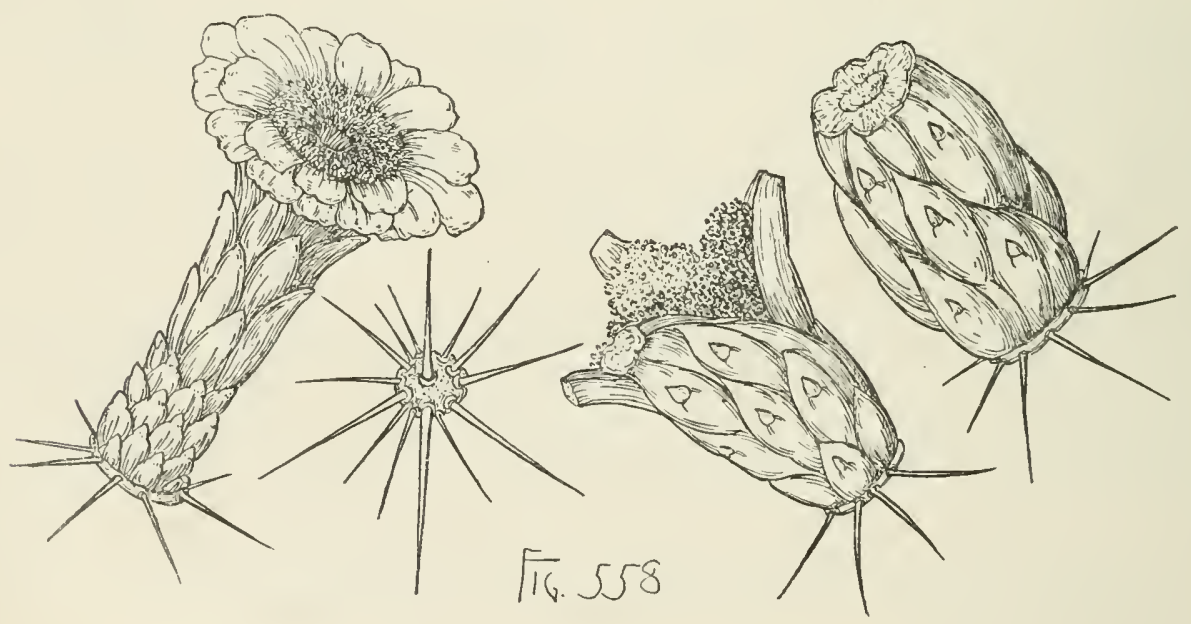

frame remaining standing after the death of the plant and the decomposition of its fleshy covering. Areolæ pale, elevated, about $\frac{1}{2}^{\prime}$ in diameter, bearing clusters of stout straight spines with large dark fulvous bases, sulcate or angled, tinged with red, with thick stout spines in the centre of each cluster, the lowest 4 horizontal or slightly inclined downward, the lowest being the longest and stoutest and sometimes $1 \frac{1}{2}^{\prime}$ long and $\frac{1}{1}^{\prime}$ thick, the upper shorter, more slender and slightly turned upward, witl a row of shorter and thinner radial spines 12-16 in number surrounding the central group. Wood of the columns strong, very light, rather coarse-grained, 
with numerous conspicuous medullary rays, and light brown tinged with yellow; almost indestructible in contact with the ground, little affected by the atmosphere and largely used for the rafters of houses, for fences, and by Indians for lances, bows, etc. The fruit is consumed in large quantities by Indians.

Distribution. Low rocky hills and dry mesas of the desert; valley of Bill Williams River through central and southern Arizona to the valley of the San Pedro River, and southward in Sonora.

\section{OPUNTIA, Adans.}

Trees or usually shrubs, in the arborescent species of the United States with subcylindrical or clavate articulate tuberculate branches, covered with small sunken stomata, and containing tubular reticnlated woody skeletons, and thick fleshy or fibrous roots. Leaves scale-like, terete, subulate, caducous, bearing in their axils oblong or circular cushion-like areolæ of chaffy or woolly scales terminal on the branches and furnished above the middle with many short slender slightly attached sharp barbed bristles and toward the base with numerous stout barbed spines surrounded in some species, except at the apex, by loose papery sheaths. Flowers diurnal, lateral, produced from areolæ on branches of the previons year between the bristies and spines, sessile, cup-shaped; sepals flat, erect, deciduous; corolla rotate; petals obovate, united at the base, spreading; stamens shorter than the petals; filaments free or slightly united below; anthers oblong; style cylindrical, longer than the stamens, obclavate below, divided at the apex into 3-8 elongated or lobulate lobes stigmatic on the inner face. Fruit sometimes proliferous, covered by a thick skin, succulent and often edible, or dry, pyriform, globose or elliptical, concave at the apex, surmounted by the marcescent tube of the flower, tuberculate, areolate, or rarely glabrous, trnncate at the base, with a broad umbilicus at the apex. Seeds immersed in the pulpy placentas, compressed, discoid, often margined with a bony raphe; testa pale, bony, sometimes marked by a narrow darker marginal commissure; embryo coiled around the copious or scanty albumen; cotyledons large; radicle thin, obtuse.

Opuntia with about one hundred and thirty species is distributed from southern New England southward in the neighborhood of the coast to the West Indies, and through western North America to Chili, Brazil, and Argentina, the largest number of species occurring near the boundary of the United States and Mexico. Of the species of the United States three attain the size and habit of small trees. Cochineal is derived from a scale-insect which feeds on the juices of some of the Mexican species, and the fruit of several species is refreshing and is consumed in considerable quantities in semitropical countries. The large-growing species with flat branches are employed in many countries to form hedges for the protection of gardens and fields; and the branches saturated with watery juice are sometimes stripped of their spines and bristles and fed to cattle.

Opuntia is the classical name of some plant which grew in the neighborhood of the city of Opus in Bæotia.

\section{CONSPECTUS OF THE ARBORESCENT SPECIES OF THE UNITED STATES.}

Tubercles of the branches full and rounded below the areolie.

Joints pale olive color, easily separable, their tubercles broad, mammillate; spines yellow; flowers pink; fruit proliferous, usually spineless, often sterile.

1. O. fulgida (H). 
Joints green or purple, their tubercles narrow, ovate; spines white to reddish brown; flowers purple; fruit yellow, sparingly spinescent, rarely proliferons.

2. O. spinosior $(\mathrm{H})$.

Tubercles of the branches not full and rounded below the areolæ; joints elongated, dark green or purple, their tubercles elongated; spines brown or reddish brown; flowers green, tinted with red or yellow; fruit green, spinescent, rarely proliferous.

3. O. versicolor $(\mathrm{H})$.

\section{Opuntia fulgida, Engelm. Cholla.}

Leaves light green, gradually narrowed to the acuminate apex, $\frac{1}{2}-1^{\prime}$ long. Flowers appearing from June to September, the earliest from tubercles at the ends
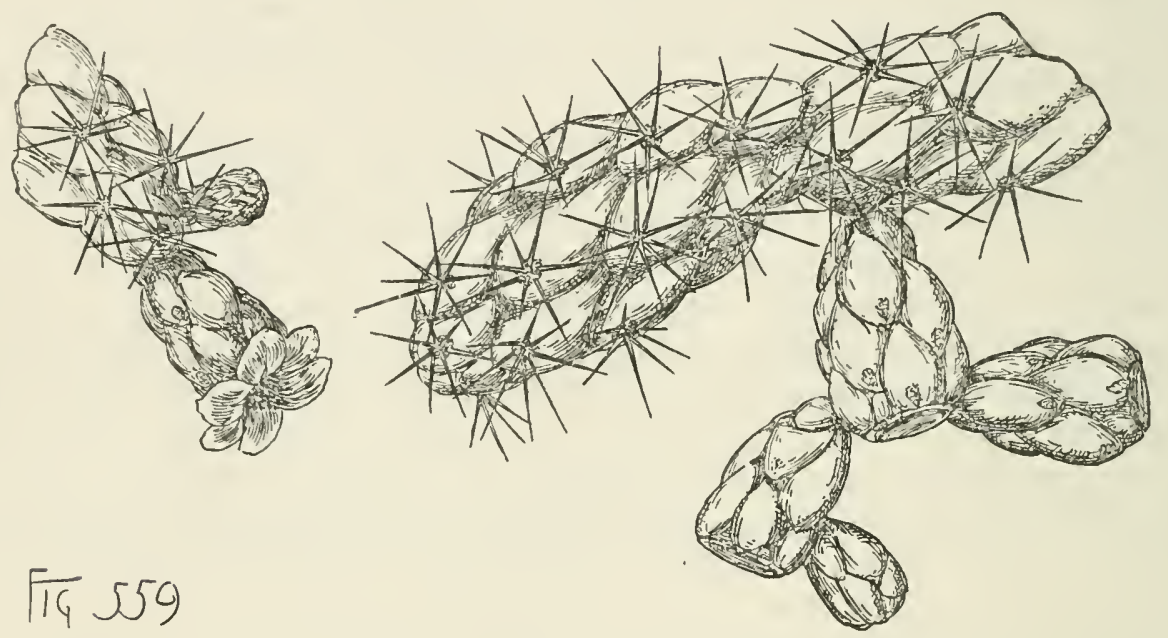

of the branches of the previous year, the others from the terminal tubercles of the immature fruit developed from the earliest flowers of the season, $1^{\prime}$ in diameter when fully expanded, with ovaries nearly $\mathbf{1}^{\prime}$ long, 8-10 obtuse crenulate sepals, 5 erect stigmas, and 8 light pink petals, those of the outer ranks cuneate, retuse, crenulate on the margins, shorter than the lanceolate acute petals of the inner ranks, the whole strongly reflexed at maturity. Fruit proliferous, oval, rounded, $1^{\prime}-1 \frac{1}{4}$ ' long and nearly as broad, more or less tuberculate, conspicuously marked by large pale tomentose areolæ bearing numerous small bristles, usually spineless or occasionally armed with small weak spines, hanging in pendulous clusters usually of 6 or 7 and occasionally of 40-50 fruits in a cluster, one growing from the other in continuous succession, the first the largest and containing perfect seeds, the others frequently sterile, dull green when fully ripe, with dry flesh, falling nsually during the first winter or occasionally persistent on the branches during the second season, and then developing flowers from the tubercles; seeds compressed, thin, very angular, $\frac{1}{12}{ }^{\prime}-\frac{1}{6}{ }^{\prime}$ in diameter.

A tree, with a more or less flexuous trunk occasionally $12^{\circ}$ in height and sometimes a foot in diameter, a symmetrical head of stout wide-spreading branches and thick pendulous joints sometimes almost hidden by the long conspicuous spines and beginning to develop their woody skeletons during their second or occasionally during their third season, the terminal or ultimate joints ovate or ovate-cylindrical, tumid, crowded at the ends of the limbs, pale olive color, $3^{\prime}-8^{\prime}$ long, often $2^{\prime}$ in diameter, with broad ovate-oblong tubercles, $\frac{1}{2}^{\prime}-\frac{3^{\prime}}{4}$ long. Areolæ of pale straw-colored 
tomentum and short slender pale bristles, each areola bearing at first 5-15 stout stellate-spreading light yellow spines of nearly equal length, $\frac{3^{\prime}}{4}-1^{\prime}$ long and inclosed in loose lustrous sheaths, additional spines developing in succeeding years at the upper margins of the areolæ, the tubercles of old branches being sometimes furnished with from 40-60 spines persistent on the branches for $4-6$ years. Bark of the trunk and of the large limbs about $\frac{1^{\prime}}{4}$ thick, separating freely on the surface into large thin loosely attached scales varying in color from brown to nearly black on the largest stems, and unarmed, the spines mostly falling with the outer layers from branches $3^{\prime}-4^{\prime}$ thick. Wood of old trunks light, hard, pale yellow, with broad conspicuous medullary rays, well marked layers of annual growth, and a thick pith.

Distribution. Plains of Arizona south of the Colorado plateau, and in the adjacent region of Sonora; not rare; apparently most abundant and of its largest size on the mesas near Tucson, at elevations between $2000^{\circ}$ and $3000^{\circ}$ above the sea.

\section{Opuntia spinosior, Toumey. Tassajo.}

Leaves terete, tapering gradually to the setulose apex, about $\frac{1^{\prime}}{4}$ long, remaining on the branches four to six weeks. Flowers opening in April and May and remaining open for two or three days, $2^{\prime}-2 \frac{1}{2}^{\prime}$ in diameter, with ovaries about $1^{\prime}$ long, obovate sepals, broadly obovate dark purple petals, sensitive red stamens, and a 6-9-parted stigma. Fruits clustered at the ends of the branches of the previous year, persistent on the branches during the winter and occasionally during the following summer and then sometimes proliferous, oval or rarely globose or hemispherical, frequently $2^{\prime}$ long and $1 \frac{1}{2}^{\prime}$ thick, with yellow acrid flesh and 20-30 tubercles very prominent during the summer, nearly disappearing as the fruit ripens and enlarges, leaving
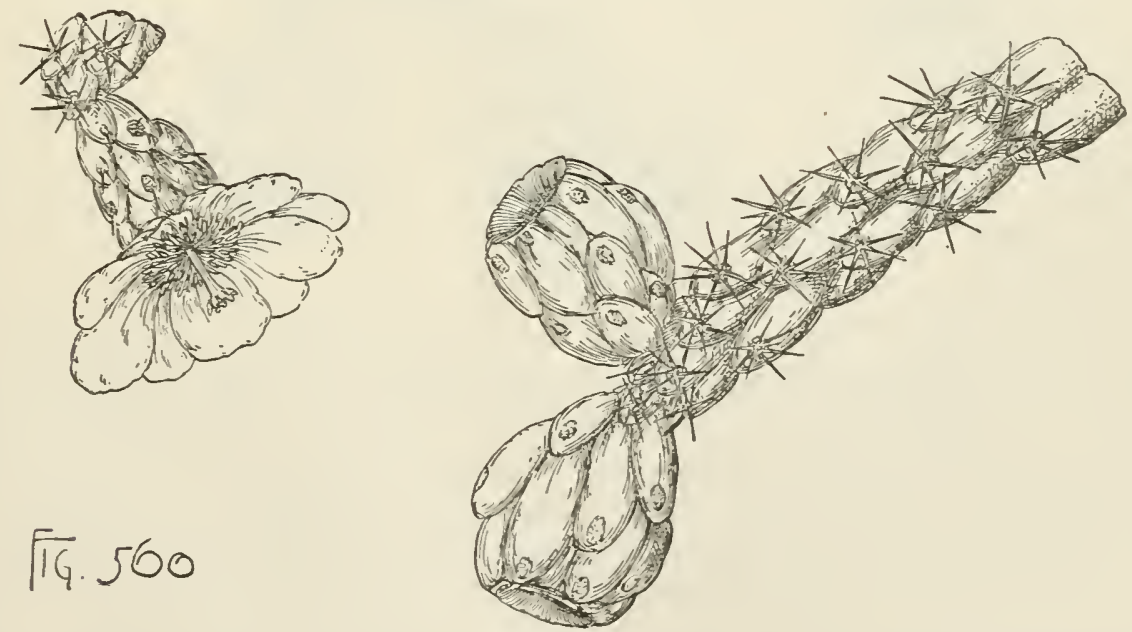

it marked only by the small oval areolæ covered with short bristles, and bearing numerons slender spines decidnons in December as the fruit begins to turn yellow; seeds nearly orbicular, slightly or not at all beaked, $\frac{1^{\prime}}{6}-\frac{1^{\prime}}{5}$ in diameter, and marked by linear conspicuous commissures.

A tree, with an erect trunk occasionally $10^{\circ}$ high and $5^{\prime}-10^{\prime}$ in diameter, numerons stout spreading limbs forming an open irregular head, and branches with joints $4^{\prime}$ $12^{\prime}$ long, $\frac{3^{\prime}}{4}-1^{\prime}$ thick, covered with a thick epidermis varying from green to purple and usnally developing woody skeletons during their second season, their tubercles prominent, compressed, ovate, $\frac{1^{\prime}}{2}-\frac{1^{\prime}}{2}$ long. Areolæ oval, clothed with pale tomentum 
and short light brown bristles, their spines $5-15$ on the tubereles of young joints and 30-50 on those of older branches, and slender, white to light reddish brown, closely invested in white glistening sheaths, stellate-spreading, $\frac{1}{2}-\frac{3 \prime}{4}$ long, those in the interior sometimes considerably longer than the radial spines. Bark of the trunk and of the larger limbs abont $1^{\prime}$ thick, spineless, nearly black, broken into clongated ridges, and finally much roughened by numerons closely appressed scales. Wood light, soft, pale reddish brown, and conspicnously reticulate, with conspicuons medullary rays and well defined layers of anmal growth; sometimes uscd in the manufacture of light furniture, cancs, picture-frames, and other small articles.

Distribution. Widely seattered over the mesas of southern Arizona south of the Colorado plateau and over the adjacent regions of Sonora.

\section{Opuntia versicolor, Coult.}

Leaves terete, abruptly narrowed to the spinescent apex, $\frac{1}{3}^{\prime}-\frac{1}{2}^{\prime}$ long, persistent on the branches four to six weeks. Flowers opening in May, about $1 \frac{1}{2}^{\prime}$ in diameter,

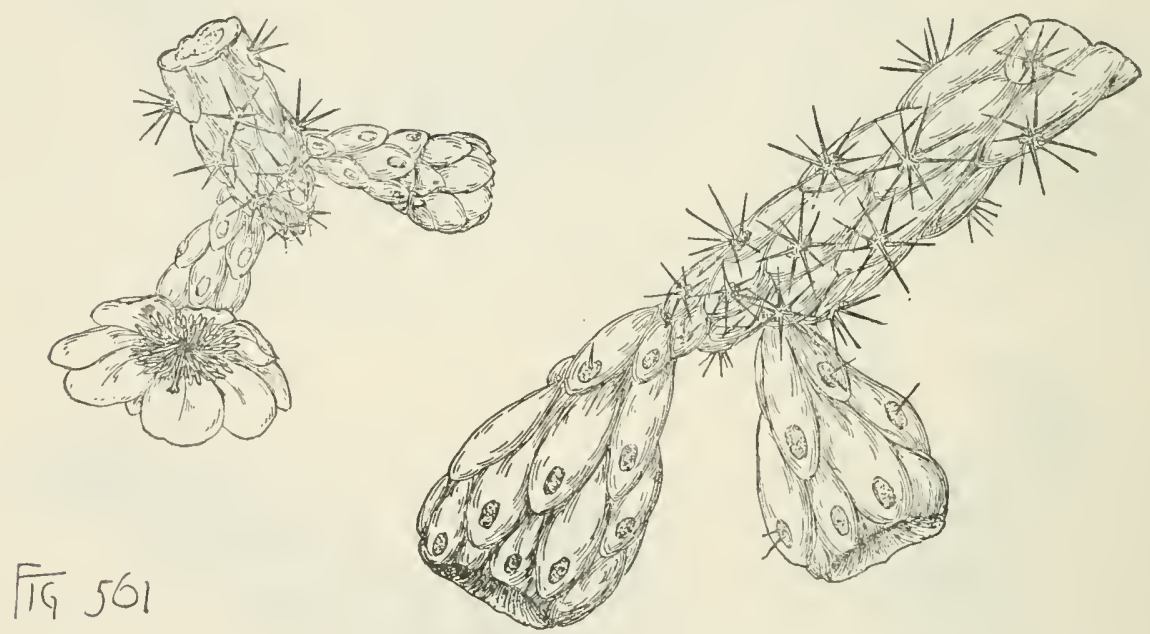

with ovaries $\frac{5}{8}$ long, broadly ovate acute sepals, and narrow obovate petals rounded above and green tinged with red or with yellow. Fruit usually clavate, $2^{\prime}-2 \frac{1^{\prime}}{2}$ long, nearly $1 \frac{1^{\prime}}{2}$ in diameter, with areolæ generally only above the middle and usually furnished with 1-3 slender reflexed persistent spines about $\frac{1 \text { ' }}{2}$ long, or occasionally spineless, rarely neariy spherical and only about $\frac{3^{\prime}}{4}$ in diameter, ripening from December to February, and at maturity the same color as the joints on which it grows, usually withering, drying, and splitting open on the tree, or remaining fleshy and persistent on the branches until the end of the following summer, and sometimes through a second winter, or often becoming imbedded in the end of a more or less elongated joint; seeds irregnlarly angled, with narrow commissures.

A tree, with an erect trunk occasionally $6^{\circ}-S^{\circ}$ high and $S^{\prime}$ in diameter, numerous stout irregularly spreading often upright branches, and cylindrical terminal joints generally $6^{\prime}-12^{\prime}$ but sometimes $2^{\circ}$ in length, $\frac{3^{\prime}}{4}-1^{\prime}$ in diameter, covered with a thick dark green or purple epidermis, marked by linear flattened tubercles, their woody skeletons usually formed during their second season. Areolæ large, oval, clothed with gray wool, generally bearing a cluster of small bristles, and slender stellatespreading brown or reddisli brown spines, with close early deciduous straw-colored 
sheaths, 4-14 and on old tubercles $20-25$ in number, the inner 1-4 in number, usually deflexed and unequal in length, the longest about $\frac{1}{3}$ long and longer than the radial spines. Bark of the trunk and of the large branches smooth, light brown or purple, usually unarmed, $\frac{1^{\prime}}{2}-3^{\prime}$ thick, finally separating into small closely appressed black scales. Wood reticulate, hard, compact, light reddish brown and rather lustrous, with thin conspicuous medullary rays, well-defined layers of annual growth, and thick pale or nearly white sapwood.

Distribution. Foothills and low mountain slopes of southeru Arizona and northern Sonora; very abundant.

\section{XIIV. RHIZOPHORACE王。}

Glabrous trees or shrubs, with terete branchlets, and usually opposite coriaceous entire persistent leaves with interpetiolar stipules. Flowers in axillary clusters; calyx-lobes valvate in the bud, persistent; petals inserted on the tube of the calyx and as many as its lobes; stamens inserted at the base of a conspicuous disk; anthers 2-celled, the cells opening longitudinally; pistil of $2-5$ united carpels; ovary $2-5$-celled; ovules usually 2 in each cell, suspended from its apex, collateral, anatropous; raphe ventral; micropyle superior. Fruit usually indehiscent, 1-celled and 1-seeded.

The Mangrove family is tropical, with most of its fifteen genera confined to the Old World, one species of the widely distributed Rhizophora reaching the shores of southern Florida.

\section{RHIZOPHORA, L. Mangrove.}

Trees, with pithy branchlets, thick astringent bark, and adventitious fleshy roots. Leaves ovate or elliptical, glabrous, petiolate; stipules elongated, acumiuate, infolding the bud, caducous. Flowers perfect, yellow or creamy white, sessile or pedicellate, bibracteolate, the bractlets united into an involucral cup, in pedunculate dichotomously or trichotomously branched clusters, the base of their branches surrounded by an involucre of 2 ovate 3 -lobed persistent bracts, or 1-flowered; calyx 4-lobed, the lobes acute, coriaceous, ribbed on the inner surface and thickened on the margins, $t$ wo or three times longer than the turbinate globose tube, reflexed at maturity, persistent; petals 4 , induplicate in the bud, alteruate with and longer than the calyx-lobes, inserted on a fleshy disk-like riug in the month of the calyx-tube, involute on the margins, coated on the inner surface with long pale hairs, or flat and naked, caducous; stamens 8-12; filaments short or 0 ; anthers attached at the base, introrse, elougated, connivent, areolate; ovary partly iuferior, conical, 2-celled, coutracted into two subulate spreading styles stigmatic at the apex. Fruit a conical coriaceous berry surrounded by the reflexed calyx-lobes and perforated at the apex by the germinating embryo. Seed germinating in the fruit before falling, the apex surrounded by a thin albuminous cup-like aril; seed-coat thick and fleshy; embryo surrounded by a thin layer of albumen; cotyledons dark purple; radicle elongated, clavate, and when fully grown separating from the narrow exserted woody tube inclosing the plumule and developed from the cotyledons after the ripening of the fruit.

Rhizophora with three species is widely and generally distributed on the shores of tidal marshes in the tropical regions of the two hemispheres. It possesses astringent properties; the bark has been used in tamning leather, in dyeing, and as a 
febrifuge. The wood is hard, durable, and dark-colored. By means of the aerial germination of its seeds and in its power to develop roots from trunks and branches, Rhizophora is especially adapted to maintain itself on low tidal shores and is an important factor in protecting and extending them into the ocean. Roots springing from the stems at a considerable distance above the gronnd and arehing ontward descend into the water and fix themselves in the mnd beneath, while roots growing down from the branches enter the ground and gradually thicken into stems. The fully grown radicle ready to put forth roots and leaves, and often $10^{\prime}-12^{\prime}$ loug, is thicker and heavier at the root end than at the other, and in detaching itself from the cotyledons and in falling the heavy end sticks in the mud, while the phumule at the other end, held above the shallow surface of the water, soon unfolds its leaves.

The generic name, from $\beta \iota \zeta \alpha$ and $\phi \epsilon ́ \rho \epsilon \nu$, was used by early anthors to designate various climbing plants with thickened roots.

\section{Rhizophora Mangle, L. Mangrove.}

Leaves oval or elliptical, rounded or acnte at the apex, gradually narrowed at the base, dark green and very lustrons on the upper, paler on the lower surface, $3 \frac{1^{\prime}}{2}-5^{\prime}$ long, $1^{\prime}-2^{\prime}$ wide, with slightly thickened margins, broad midribs, and reticulate veinlets, persistent for one or two years; their petioles $\frac{1^{\prime}}{2}-1 \frac{1}{2}^{\prime}$ long; stipules lanceolate, acute, $1 \frac{1}{2}^{\prime}$ long, deciduons as the leaf unfolds. Flowers produced thronghont the year from the axils of young leaves, $1^{\prime}$ in diameter, on stout 2 or 3 -branched peduncles $1 \frac{1^{\prime}}{2}-2^{\prime}$ long, with pale yellow petals coated on the inner surface with long pale hairs, 8 stamens, and villose filaments. Fruit $1^{\prime}$ long, rusty brown, slightly roughened with minute bosses, the hard woody thick-walled tube developed from the

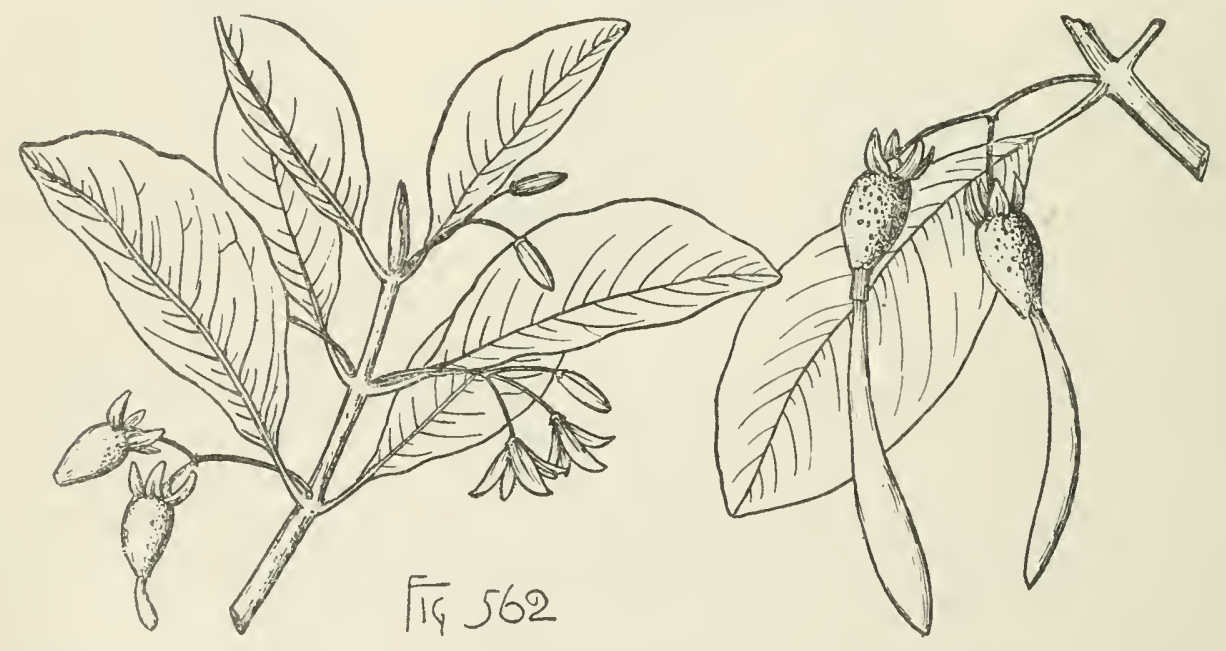

cotyledons protruding $\frac{1^{\prime}}{2}-\frac{2^{\prime}}{3}$ from its apex after the germination of the seeds, covering the plumule, and holding the dark brown radicle marked with occasional orange-colored lenticels and when fnlly grown $10^{\prime}-12^{\prime}$ long and $\frac{1}{4}^{\prime}-1^{\prime}$ thick near the apex.

A round-topped bushy tree, with spreading branches usually $15^{\circ}-20^{\circ}$ high, forming almost impenetrable thickets with its numerous aerial roots or occasionally $70^{\circ}$ $80^{\circ}$ high, with a tall straight trunk clear of branches for more than half its length, a narrow head, and stout glabrons dark red-brown branchlets, becoming lighter colored in their second year and then conspicuously marked by large oval slightly elevated 
leaf-scars. Bark of young stems and of the branches smooth, light reddish brown, becoming on old trunks $\frac{1^{\prime}}{3}-\frac{1}{2}^{\prime}$ thick, and gray faintly tinged with red, the surface irregularly fissured and broken into thin appressed scales. Wood exceedingly heavy, hard, close-grained, strong, dark reddish brown streaked with lighter brown, with pale sapwood of 40-50 layers of ammual growth; used for fuel and wharf-piles.

Distribution. Shores of Florida from Mosquito Inlet on the east coast and Cedar Keys on the west coast to the southern islands; most abundant south of latitude $29^{\circ}$, following the coast with wide thickets and ascending the rivers for many miles; on Cape Sable and the shores of Bay Biscayne sometimes growing at a little distance from the coast on ground not submerged by the tide, and here attaining its largest size, with tall straight trunks producing few aerial roots; also on Bermuda, the Bahamas, the Antilles, the west coast of Mexico, lower California, the Galapagos Islands, and from Central America along the northeast coast of South America to the limits of the tropics.

\section{MYRTACE㞋.}

Trees or shrubs, abounding in pungent aronatic volatile oil, with minute scaly buds. Leaves opposite, simple, mostly entire, pellucid-punctate, penniveined, persistent, the slender obscure veins arcuate and united within the thickened revolute margins; stipules 0 . Flowers perfect, regular; calyx 4-5-lobed, the lobes imbricated in the bud, or lid-like and deciduous; petals $2-5$, imbricated in the bud, inserted on the margin of the disk, or 0 ; stamens very numerous, inserted in many ranks with the petals; filaments slender, inflexed in the bud, exserted; anthers introrse, 2-celled, the cells opening longitudinally; ovary 2-4-celled; style simple. filiform, crowned witl a minute stigma ; ovules numerous or 2 or 3 in each cell, attached on a central placenta, anatropous or semianatropous ; raple ventral ; micropyle superior. Fruit baccate, crowned witl the persistent calyx-lobes, 1-4-seeded. Seeds without albumen ; seed-coat membranaceous.

The Myrtle family with seventy-two genera is chiefly tropical and Australasian, with representatives in southern Europe, extratropical Africa, and extratropical South America. 'Three genera are represented by small trees in the flora of southern Florida. 'To this family, beside the Myrtle, belong the Australian Eucalypti, large and important timber-trees largely planted in California, and the Guava, cultivated in Florida for its fruit.

\section{CONSPECTUS OF THE ARBORESCENT GENERA OF THE UNITED STATES.}

Calyx 4 or $\tilde{j}$-lobed, with persistent lobes; petals 4 or 5 .

Flowers in axillary racemes or fascicles.

Flowers in mostly dichotomously branched cymes.

1. Eugenia.

Calyx closed in the bud by an orbicular lid-like deciduous limb; petals 0.

\section{EUGENIA, L.}

2. Anamomis.

3. Chytraculia.

Trees or shrubs, with hard durable wood and scaly bark. Flowers often large and conspicuous, on short bibracteolate pedicels, in axillary racemes or fascicles, with minute caducous bracts and bractlets; calyx campanulate, scarcely produced above the ovary, the limb 4 or rarely 5 -lobed; petals usually 4 , free and spreading; ovary 2 or rarely 3 -celled; ovules numerous in each cell, semianatropous. Frnit $1-1$-seeded. Seeds globose or flattened; seed-coat membranaceous or cartilaginous; embryo thick 
and fleshy; cotyledons thick, more or less conferruminate into a homogeneous mass; radicle very short, turned toward the hilum.

Engenia with some five hundred species is common in all tropical regions, with five species reaching the shores of sonthern Florida; of these four are small trees. Several species are valued for their stimulant and digestive properties; some produce useful timber or edible fruit, and other's are cultivated for the beanty of their flowers. Cloves are the flower-buds of Eugenia aromatica, Baill., a native of the Molueca Islands; and Eugenia Jambos, L., the Rose Apple, of southeastern Asia, is cultivated in all tropical countries as a shade-tree and for its delicately fragrant fruit.

The generic name commemorates the interest in botany and gardening taken by Prince Eugene of Savoy, who built the Belvidere Palace near Vienna in the beginning of the eightecnth century, and made a collection of rare plants in its gardens.

\section{CONSPECTUS OF THE ARBORESCENT SPECIES OF THE UNITED STATES.}

Flowers in short solitary or clustered axillary racemes.

Leaves ovate or obovate, rounded at the apex, slort-petiolate; fruit subglobose to shortoblong, black, $\frac{1^{\prime}}{3}$ in diameter.

1. E. buxifolia (D)

Leaves ovate, contracted at the apex into broad points, distinctly petiolate; fruit globose, black, $\frac{1}{2}$ in diameter.

Flowers in axillary fascicles.

2. E. axillaris (D).

Leaves usually broadly ovate, narrowed at the apex into short points, subcoriaceous; fruit subglobose, rather broader than ligh, $\frac{2^{\prime}}{3}-1^{\prime}$ in diameter, becoming black at maturity.

3. E. rhombea (D).

Leaves ovate-oblong, narrowed at the apex into long points, coriaceous; fruit subglobose to obovate, $\frac{1}{4}^{\prime}-\frac{1}{3}^{\prime}$ long, bright scarlet.

4. E. confusa (D).

\section{Eugenia buxifolia, Willd. Gurgeon Stopper. Spanish Stopper.}

Leaves ovate or obovate, rounded at the apex, sessile or narrowed into short thick petioles, occasionally slightly and remotely cremulate-serrate above the middle, thick

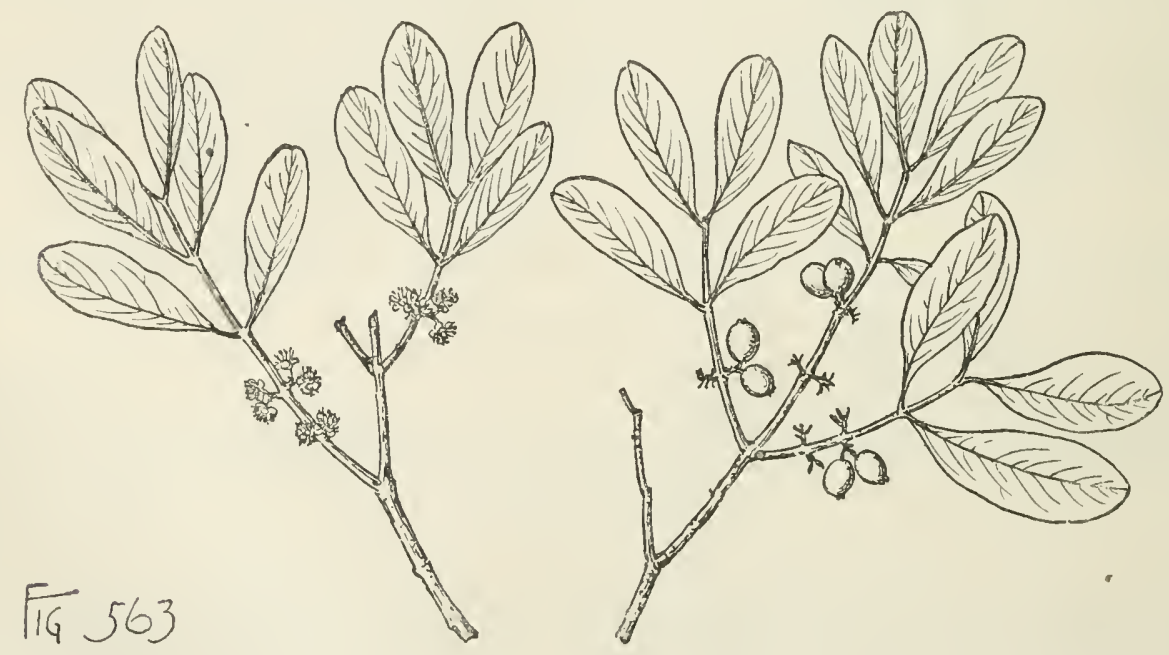

and coriaceous, dark green on the upper, yellow-green and marked with minute black dots on the lower surface, $1^{\prime}-1 \frac{1}{2}^{\prime}$ long and about $1^{\prime}$ broad, with narrow conspicuous midribs, usually unfolding in November and remaining on the branches until the. 
end of their second winter, and often turning red or partly red before falling. Flowers appearing in Florida from midsummer until early autumn, $\frac{1}{8}^{\prime}$ in diameter, on short thick pedicels, in short rufous pubescent racemes clustered in the axils of old or fallen leaves, witl minute lanceolate acute persistent bracts, and broadly ovate acute bractlets immediately below the flowers; calyx glandular-punctate, pubescent on the outer surface, with 4 ovate rounded lobes much shorter than the 4 ovate white petals rounded at the apex, ciliate on the margins, and glandular-punctate. Fruit subglobose to short-oblong, black, glandular-roughened, crowned with the large calyx-lobes, usually 1-seeded and about $\frac{1}{3}^{\prime}$ in diameter, with thin aromatic flesh; seeds $\frac{1^{\prime}}{8}$ in diameter, with a thick pale brown lustrous cartilaginous coat and a pale olive-green embryo.

A shrubby tree, in Florida rarely $20^{\circ}$ high, with a short trunk occasionally a foot in diameter, small mostly erect branches, and terete slender branchlets coated at first with rufous pubescence, becoming at the end of a few months ashy gray or gray tinged with red, and often more or less twisted or contorted. Bark of the trunk rarely more than $\frac{1}{8}^{\prime}$ thick, light brown tinged with red, and broken into small thick square scales. Wood very heavy, exceedingly hard, strong, close-grained, dark brown shaded with red, with thick lighter colored sapwood of 10-20 layers of annual growth; sometimes used for fuel.

Distribution. Cape Canaveral to the southern keys, and from the banks of the Caloosa River to Cape Sable, Florida; one of the commonest plants on the keys, forming on the coral rock a large part of the shrubby second growth now occupying ground from which the original forest has been removed; also on the Bahamas and on several of the Antilles.

\section{Eugenia axillaris, Willd. Stopper. White Stopper.}

(Eugenia monticola, Silva N. Am. v. 45.)

Leaves ovate, gradually or abruptly narrowed at the apex into short wide points, ronnded at the narrowed base, thick and coriaceous, dark green on the upper, paler

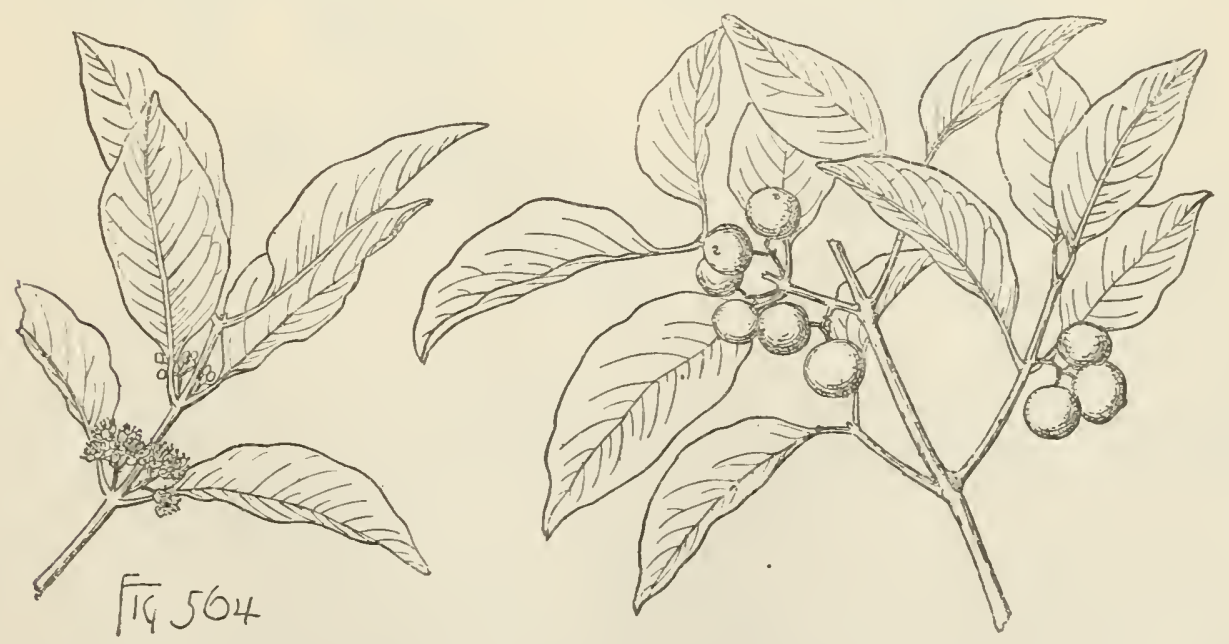

and covered with minute black dots on the lower surface, $1 \frac{1}{2}^{\prime}-2 \frac{1}{2}^{\prime}$ long, $\frac{1}{2}^{\prime}$ wide, with broad midribs deeply impressed above; their petioles stout, slightly winged, about $\frac{1}{3}^{\prime}$ long. Flowers appearing at midsummer, about $\frac{1}{8}^{\prime}$ in diameter, on stout pedicels 
$\frac{1}{16}{ }^{\prime}-1^{\prime}$ long, covered with pale white hairs, and furnished near the middle or toward the apex with 2 acute minute persistent bractlets, in short axillary racemes; calyx, glandular-punctate, covered on the outcr surface with pale hairs, 4-lobed, with ovate rounded lobes shorter than the 4 ovate glandular white petals. Fruit ripening in succession from November to April, globose, black, glandular-punctate, usually 1-seeded, $\frac{1}{2}^{\prime}$ in diameter, edible, rather juicy, with a sweet agreeable flavor; seeds subglobose, $\frac{1}{4}$ 'in diameter, with a pale brown chartaceous coat and light olive-green cotyledons.

A tree, $20^{\circ}-25^{\circ}$ high, with a trunk occasionally a foot in diameter, small branches, and terete stont rigid ashy gray branchlets of ten slightly tinged with red and covered with small wart-like excrescences; or toward the northern limits of its range a low shrub. Bark of the trunk about $\frac{1^{\prime}}{8}$ thick and divided by irregular shallow fissures into broad ridges finally separating on the surface into small thin light brown scales. Wood heavy, hard, strong, very close-grained, brown often tinged with red, with thin darker colored sapwood of 5-6 layers of annual growth.

Distribution. Shores of the St. Joln's River to the southern keys, Florida; nowhere common; on the Bahamas and on several of the Antilles.

\section{Eugenia rhombea, Kr. \& Urb. Stopper.}

\section{(Eugenia procera, Silva N. Am. v. 47.)}

Leaves broadly ovate, narrowed into broad points rounded at the apex, and abruptly or gradually narrowed and cuneate at the base, when they unfold thin

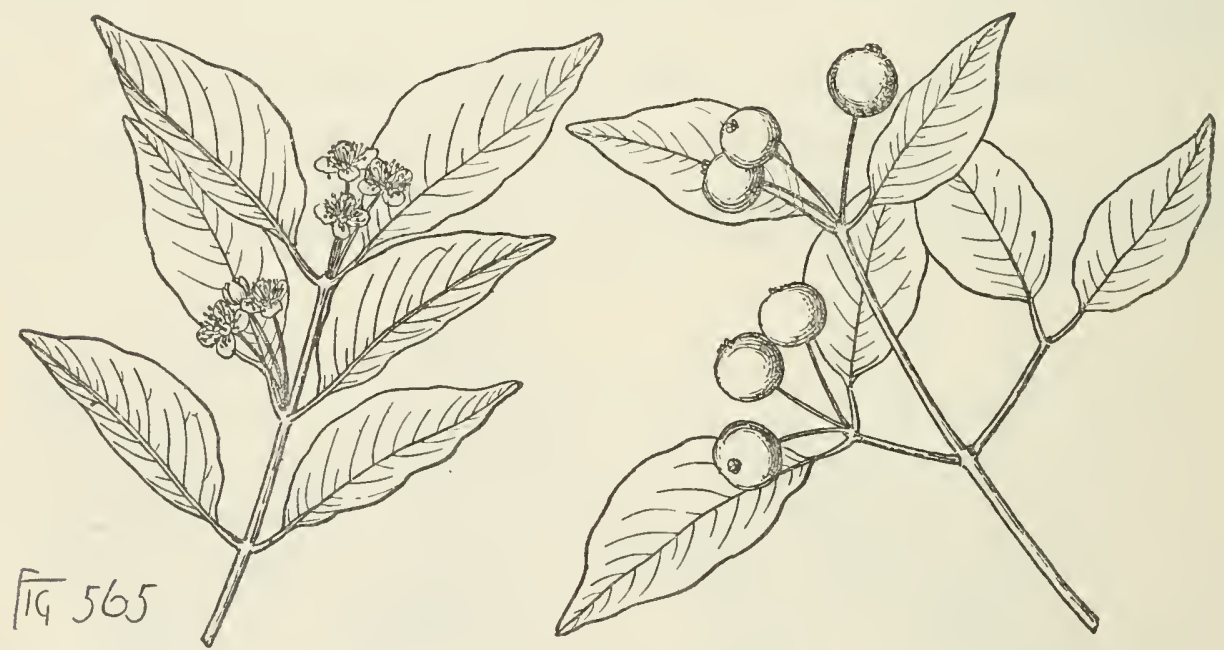

and light red, and at maturity subcoriaceous, conspicuously marked with black dots, olive-green on the upper and paler on the lower surface, $2^{\prime}-2 \frac{1^{\prime}}{2}$ long and $1^{\prime}-1 \frac{1}{2}^{\prime}$ wide, with narrow midribs, unfolding in Florida in May; their petioles narrow-winged, $\frac{1^{\prime}}{3}-\frac{1}{2}^{\prime}$ long. Flowers $\frac{1}{2}^{\prime}$ in diameter, appearing in Florida in April or May on slender glandular pedicels $\frac{1}{3}^{\prime}-2^{\prime}{ }^{\prime}$ long and furnished at the apex with 2 lanceolate acute persistent bracts ciliate on the margins, in sessile axillary many-flowered clusters; calyxtube, much shorter than the limb, divided into 4 glandular narrow lobes rounded at the apex and one half the length of the broadly ovate rounded glandular white petals. Fruit ripening in Florida from September to November, $\frac{2^{\prime}}{3}-1^{\prime}$ in diameter, slightly glandular-roughened, orange color, with a bright red cheek when fully grown, be- 
coming black at maturity; flesh thin and dry; seeds almost globose, nearly $\frac{1}{2}^{\prime}$ in diameter, with a thick pale chestnut-brown lustrous coat and olive-green cotyledons.

A tree, $20^{\circ}-25^{\circ}$ high, with a trunk usually a foot in diameter, small branches, and slender terete branchlets at first light purple and covered with a glaucous bloom, becoming ashy gray or almost white. Bark of the trunk about $\frac{1}{16}$ thick, with a smooth light gray surface slightly tinged with red. Wood heavy, hard, closegrained, light brown, with hardly distinguishable sapwood.

Distribution. Key West and Umbrella Key, Florida; on the Bahamas and on many of the Antilles.

\section{Eugenia confusa, DC. Red Stopper.}

\section{(Eugenia Garberi, Silva N. Am. v. 49.)}

Leaves ovate-oblong, abruptly or gradually contracted into long narrow points rounded or acute at the apex, wedge-shaped or occasionally rounded at the base, thin and light red when they unfold, and at maturity dark green and very lustrous on the upper, paler and marked with minute black dots on the lower surface, $1 \frac{1}{2}^{\prime}-2^{\prime}$
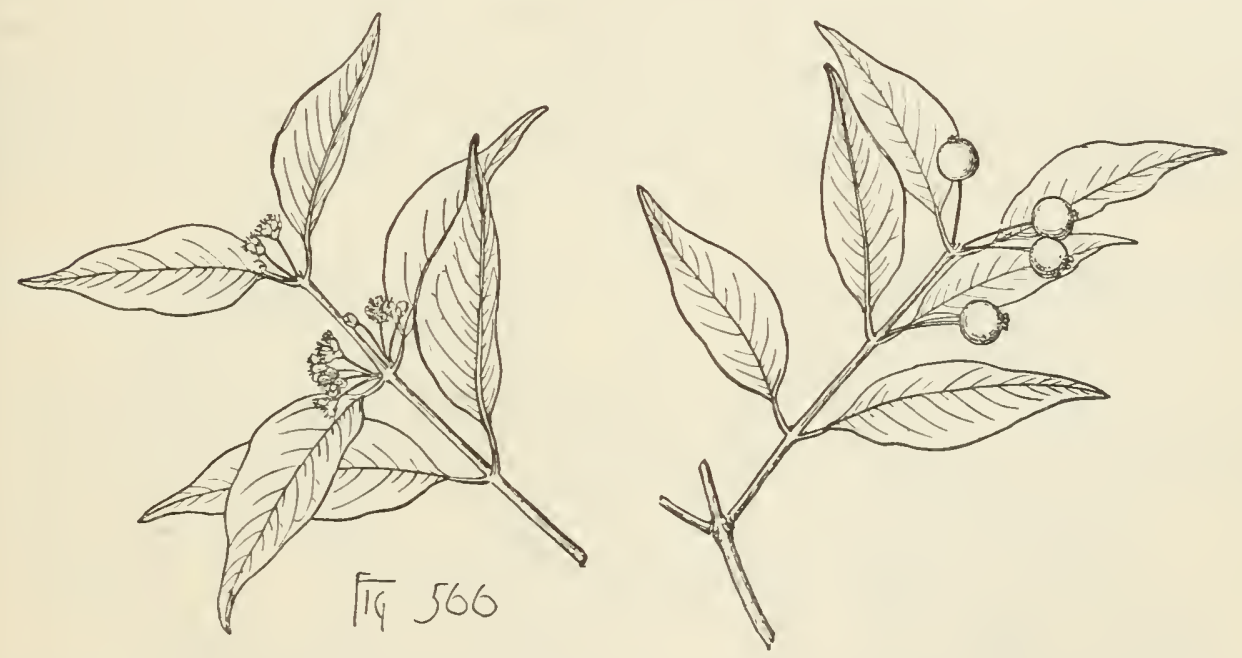

long, $\frac{1^{\prime}}{3}-\frac{2^{\prime}}{3}$ wide, with thick orange-colored midribs barely impressed above and prominent reticulate veinlets; their petioles stout, about $\frac{1^{\prime}}{4}$ long. Flowers barely $\frac{1^{\prime}}{8}$ in diameter, appearing in September on slender pedicels $\frac{1}{4}^{\prime}-1^{\prime}$ long and furnished near the apex with 2 minute acute bractlets, in many-flowered axillary clusters; calyx glandular-punctate, with 4 ovate acute lobes much shorter than the 4 broadly ovate rounded white petals. Fruit ripening in March and April, subglobose to obovate, bright scarlet, $\frac{1^{\prime}}{4}-\frac{1^{\prime}}{3}$ long, glandular-roughened, usually solitary and 1-seeded, with thin dry flesh; seeds nearly globose, about $\frac{1}{8}^{\prime}$ in diameter, with a thin crustaceous light brown lustrous coat and an olive-green embryo.

A tree, $50^{\circ}-60^{\circ}$ high, with a straight trunk $18^{\prime}-20^{\prime}$ in diameter, stout upright branches forming a narrow compact head, and slender terete ashy gray branchlets. Bark of the trunk about $\frac{1^{\prime}}{8}$ thick, bright cinnamon-red, separating freely into small thin scales. Wood very heavy, exceedingly hard, strong, close-grained, bright redbrown, with thick dark-colored sapwood of 50-60 layers of annual growth.

Distribution. Rich hummocks near the shores of Bay Biscayne, and on Old Rhodes and Elliott's Keys, Florida; on the Bahamas and on several of the Antilles. 


\section{ANAMOMIS, Griseb.}

Trees, with terete slender branchlets and chartaceous or coriaceous leaves. Flowers in pedinculate usually 3 , sometimes $5-7$, or occasionally 1 -flowered cymes, with axillary dichotomously branched or rarely simple peduncles furmished immediately below the apex of each division with 2 lanceolate acute deciduous bractlets; calyx ovoid, with 4 ovate acute persistent lobes; petals 4, ovate, acute, glandular-punctate, spreading after anthesis; ovary 2-4-celled; ovules numerous in each cell, attached irregularly to the central placenta, semianatropous. Fruit subglobose or more or less obliquely oblong, aromatic, 1 or sometimes 2-seeded. Seed reniform; embryo aromatic; cotyledons distinct, obovate, thick and fleshy, flat and rounded or more or less pointed, incurved and varionsly infolded at the apex; radicle basilar, terete, accumbent, $\frac{1}{4}-\frac{1}{3}$ the length of the cotyledons.

Anamomis with four or five species is confined to the West Indies, one species reaching the shores and islands of southern Florida.

The generic name is from $\alpha \dot{\alpha} \alpha{ }^{\prime}$ and $\alpha \mu \omega \mu$ is, in allusion to the aromatic properties of these plants.

\section{Anamomis dichotoma, Sarg. Naked Wood.}

Leaves ovate or obovate, acute or rounded and occasionally enarginate at the apex, cuneate at the base, entire, chartaceous when they unfold, becoming subcoriaceous, glabrous, covered with minute black dots, $1^{\prime}-1 \frac{1}{4}^{\prime}$ long and $\frac{1}{2}^{\prime}-2^{\prime}$ wide, with stout

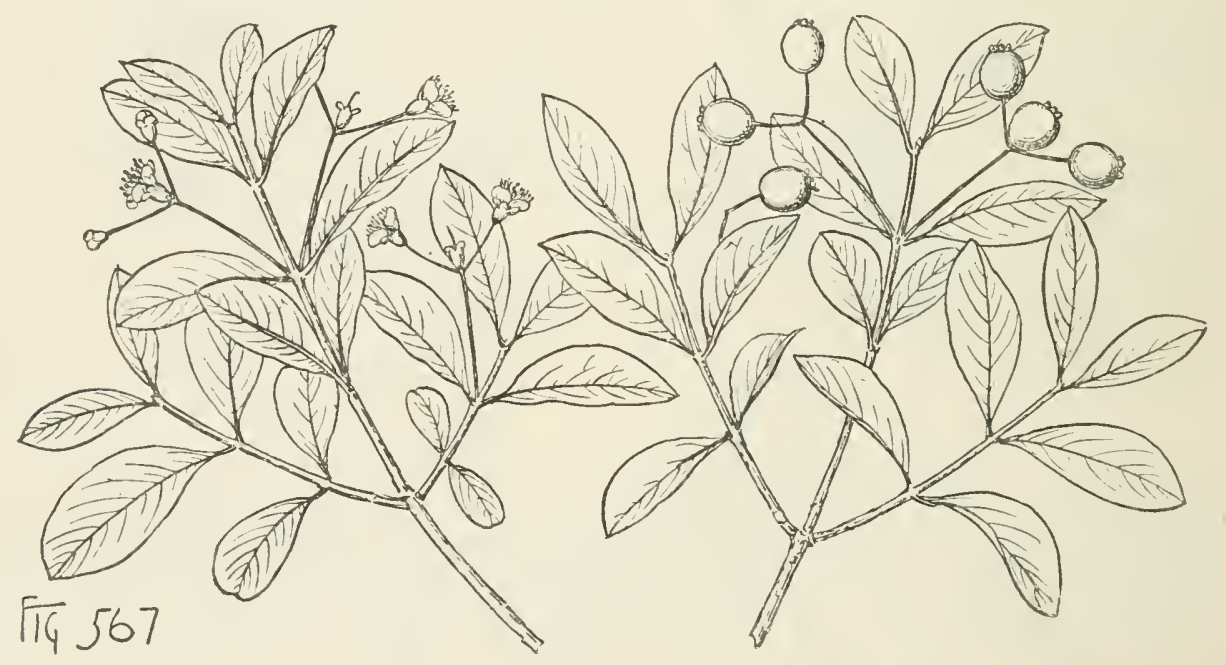

midribs; their petioles stout, enlarged at the base, coated at first with silky hair's, finally glabrous. Flowers appearing in Florida in May, $\frac{1 \prime}{4}$ in diameter, in cymes produced near the ends of the branches, in the axils of leaves of the year, on slender pednncles coated with pale silky hairs, sometimes 1-flowered and not longer than the leaves, more often longer than the leaves, dichotomously branched and 3-flowered, with 1 flower at the end of the principal division in the fork of its branches, or oceasionally 5-7-flowered by the development of peduncles from the axils of the bracts of the secondary divisions of the inflorescence, each branch of the inflorescence furnished immediately beneath the flower with 2 lanceolate acute bracts nearly as long as the calyx-tube; calyx hoary-tomentose, with the ovate lobes rounded at the apex and much shorter than the ovate acute glandular-punctate white petals. Fruit ripening 
in Florida in August, red'dish brown, $\frac{1^{\prime}}{4}$ long, obliquely oblong, obovate or subglobose, roughened by minute glands; flesh thin, rather dry and aromatic; seeds reniform, light brown, exceedingly fragrant.

A tree, $20^{\circ}-25^{\circ}$ high, with a trunk $6^{\prime}-8^{\prime}$ in diameter, and slender terete branchlets - at first light red and coated with pale silky hairs, becoming glabrous in their second year and covered with light or dark brown bark separating into small thin scales;

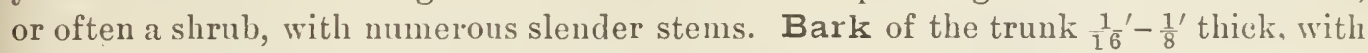
a smooth light red or red-brown surface separating into minute thin scales. Wood very heavy, hard, close-grained, light brown or red, with thick yellow sapwood of 40-50 layers of annual growth.

Distribution. Rocky woods; Mosquito Inlet to Cape Canaveral, and from the banks of the Caloosa River to the shores of Cape Romano, on Key West, and in the neighborhood of Bay Biscayne, Florida; on the Bahamas and on several of the West Indian islands.

\section{CHYTRACULIA, P. Br.}

Aromatic trees or shrubs, with terete or angled branchlets. Leaves complanate in the bud, penniveined, petiolate. Flowers minute, in subterminal or axillary pednnculate many-flowered panicles, their primary and secondary branches often racemose, and the ultimate branches cymose; calyx-tube turbinate, produced above the ovary, closed in the bud by a slightly 4 or 5 -lobed lid-like orbicular limb, opening in anthesis by a circumscissile line, the limb at first attached laterally, finally deciduous; disk lining the tube of the calyx; petals $2-5$, minute, or 0 ; ovary 2 or 3 -celled; ovules 2 or 3 in each cell, collateral, ascending, anatropous. Fruit baccate, 2-4seeded. Seed subglobose; seed-coat shining; cotyledons foliaceous, contortuplicate; radicle elongated, incurved.

Chytraculia with seventy or eighty species is confined to tropical America, with a single species reaching southern Florida.

The generic name is from $\chi$ v́tpa in reference to the peculiar lid-like limb which closes the calyx before the opening of the flower.

\section{Chytraculia Chytraculia, Sudw.}

\section{(Calyptranthes Chytraculia, Silva N. Am. v. 35.)}

Leaves oblong or ovate-oblong, elongated and rounded or acnte at the apex, gradually narrowed at the base, pellucid-punctate above, marked with dark glands below, when they unfold pink or light red and covered with pale silky hairs, and at maturity coriaceous, dark green and lustrous on the upper, coated with pale pubescence on the lower surface, $2 \frac{1^{\prime}}{2}-3^{\prime}$ long, $\frac{1}{2}^{\prime}-\frac{3^{\prime}}{4}$ wide, with broad midribs orange-colored beneatli; their petioles stout, $\frac{1^{\prime}}{3}-\frac{1}{2}^{\prime}$ long. Flowers sessile, $\frac{1}{8}^{\prime}$ long, covered with rufous pubescence on the outer surface of the calyx, in subterminal and axillary long-stalked clnsters $2 \frac{1}{2}^{\prime}-3^{\prime}$ long and wide, with slender divaricate branches, the flowers of the ultimate divisions in 3's. Fruit oblong or nearly globose, dark reddish brown and puberulous, with thin dry flesh; seeds oblong, romded at the ends.

A tree, in Florida sometimes $20^{\circ}-25^{\circ}$ high, witl a trunk $3^{\prime}-4^{\prime}$ in diameter, small branches forming a narrow head, and slender branchlets at first wing-angled between the nodes and coated, like the branches of the flower-clusters, bracts, and flowerbuds, with short rufous silky tomentum, becoming in their second or third year terete, thickened at the nodes, light gray tinged with red and covered with small thin scales. Bark of the trunk abont $\frac{1^{\prime}}{8}$ thick, with a generally smooth light gray 


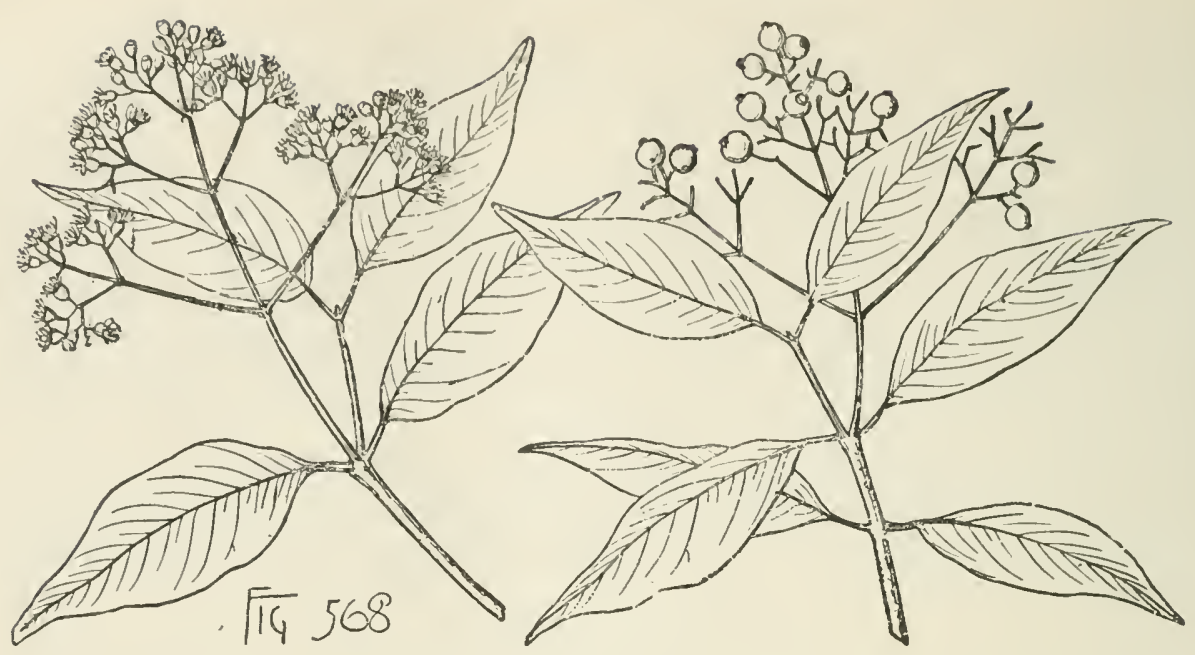

or almost white surface occasionally separating into irregular plate-like scales. Wood very heavy, hard, close-grained, brown tinged with red, with lighter colored sapwood of 30-40 layers of annual growth.

Distribution. Shores of Lake Worth, in the neighborhood of Bay Biscayne, and on Key West and Key Largo, Florida; on the Bahamas, on many of the Antilles and in southern Mexico.

\section{COMBRETACEA.}

Trees or shrubs, with astringent juice, naked buds, and alternate or opposite simple entire coriaceous persistent leaves without stipules. Flowers regular, perfect, or polygamous; calyx 5-lobed, the lobes valvate in the bud; petals 5 , valvate in the bud, inserted at the base of the calyx, or 0 ; disk epigynous; stamens 5-10, inserted on the limb of the calyx ; filaments slender, filiform. distinct, exserted ; anthers introrse, 2-celled, the cells opening longitudinally ; ovary 1-celled; style slender, subulate ; stigma minute, terminal, entire ; ovules usually 2 , suspended from the apex of the cell, collateral, anatropous; raphe ventral ; micropyle superior. Fruit drupaceous, often crowned with the accrescent calyx. Seed solitary; albumen 0 ; embryo straight, with convolute cotyledons; radicle minute, turned toward the hilum.

Of the fifteen genera of this family, widely distributed through the tropics, three have arborescent representatives in southern Florida.

\section{CONSPECTUS OF THE ARBORESCENT GENERA OF THE UNITED STATES.}

Corolla 0 ; leaves alternate.

Calyx deciduous; flowers in capitate heads ; seeds winged.

Calyx persistent; flowers in spikes; seeds without wings.

1. Conocarpus.

2. Buceras.

Corolla of 5 petals; calyx persistent; leaves opposite.

3. Laguncularia.

\section{CONOCARPUS, L.}

A tree or shrub, with angled branchlets. Leaves alternate, short-petiolate, narrowly ovate or obovate, acute, gradually contracted and biglandular at the base, glabrous or sericeous. Flowers perfect, minute, in dense capitate heads in narrow leafy terminal panicles, with acute caducous bracts and bractlets coated with pale hairs, on stout hoary-tomentose peduncles bibracteolate near the middle; calyx-tube 
truncate, obliquely compressed at the base, clothed with pale bairs, the limb campannlate, parted to the middle, the lobes ovate, acute, erect, pubescent on the outer and puberulous on the inner surface, deciduous; petals 0 ; disk 5 -lobed, hairy; stamens usually 5 , inserted in 1 rank, or rarely 7 or 8 in 2 ranks; anthers cordate, minute; style thickened and villose at the base. Fruits scale-like, broadly obovate, pointed, recurved, and covered at the apex with short pale hairs, densely imbricated in ovoid reddish heads; flesh coriaceous, corky, produced into broad lateral wings; stone thin-walled, crustaceous, inseparable from the flesh. Seed irregularly ovoid; seed-coat membranaceous, pale chestnut-brown.

The genus consists of a single species of tropical America and Africa.

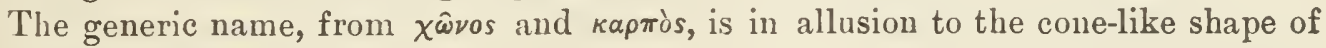
the heads of fruits.

\section{Conocarpus erecta, L. Buttonwood.}

Leaves slightly puberulous on the lower surface when they first appear or coated with pale silky persistent pubescence (var. sericea, DC.), $2^{\prime}-4^{\prime}$ long, $\frac{1}{2}^{\prime}-1^{\prime} \frac{1}{2}^{\prime}$ wide, lustrous, dark green or pale on the upper surface, paler on the lower surface, with

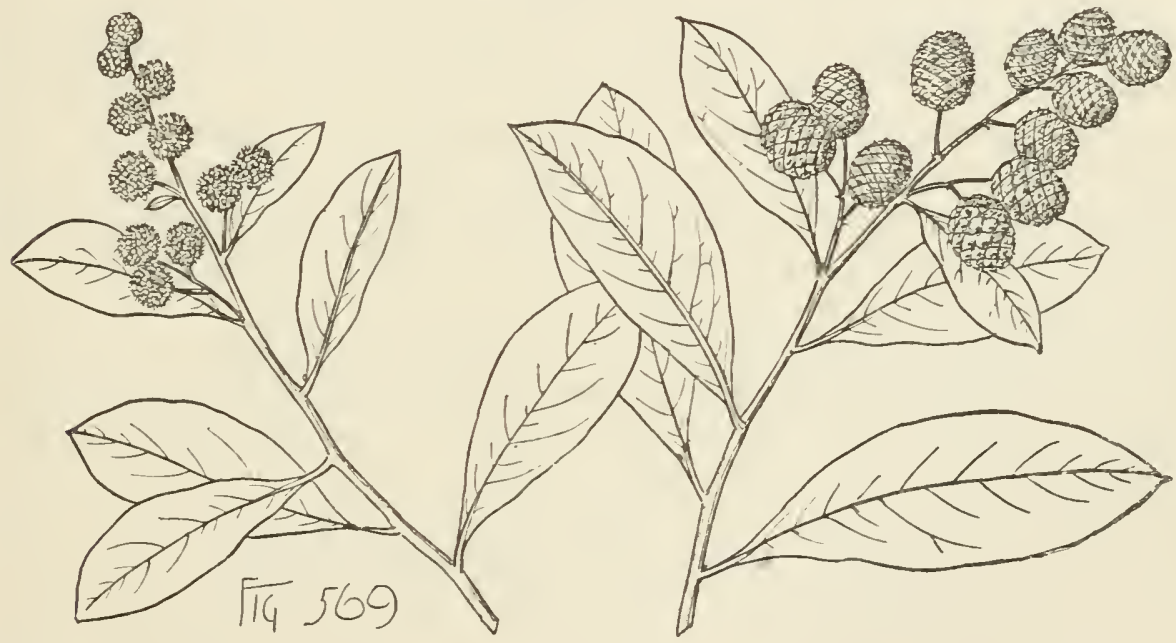

broad orange-colored midribs, obscure primary veins, and reticulate veinlets; their petioles stout, broad, $\frac{1^{\prime}}{2}$ long. Flowers produced throughout the year, in heads $\frac{1^{\prime}}{3}$ in diameter on peduncles $\frac{1^{\prime}}{2}-1 \frac{1}{2}^{\prime}$ in length, in panicles $6^{\prime}-12^{\prime}$ long. Cones of fruit about $1^{\prime}$ in diameter.

A tree, $40^{\circ}-60^{\circ}$ high, with a trunk $20^{\prime}-30^{\prime}$ in diameter, small branches forming a narrow regular head, and slender branchlets conspicuously winged, light red-brown, usually glabrous, or silky pubescent (rar. sericea, DC.), becoming terete and marked by large orbicular leaf-scars in their second year; or sometimes a low shrub, with semiprostrate stems. Bark of the trunk dark brown, divided by irregular reticulating fissures into broad flat ridges broken on the surface into small thin appressed scales. Wood very heavy, hard, strong, close-grained, dark yellow-brown, with thin darker colored sapwood of about 10 layers of annual growth; burning slowly like charcoal and highly valued for fuel. The bark is bitter and astringent, and has been used in tanning leather, and in medicine as an astringent and tonic.

Distribution. Low muddy tide-water shores of lagoons and bays; Florida, Cape Canaveral and Cedar Keys to the southern keys; of its largest size in Florida on 
Lost Man's River near Cape Sable, and at its northern limits a low shrub; common in the Antilles, on the shores of Central Ameriea and tropical South America, on the Galapagos Islands, and on the west eoast of Africa.

\section{BUCID A, I.}

A tree or shrub, with terete often spinescent branchlets. Leaves alternate, crowded at the ends of spur-like lateral branchlets mueh thiekened and ronghened by the large elevated crowded leaf-sears, obovate to oblong-laneeolate, rounded and slightly cmarginate or mimntely apiculate at the apex, gradually narrowed and cuneate at the base, coriaceous, bhish green on the upper and yellow-green on the lower, surfaee, pubeseent while young, espeeially beneath, and glabrous at maturity with the exeeption of rufous hairs on the under surfaee of the stont midribs, and on the short stout petioles. Flowers perfect, greenish white, hairy on the onter surfaee, sessile in the axils of minute braets, in lax elongated axillary elustered rufons-pubeseent spikes; calyx-tube ovoid, eonstricted above the ovary, the limb campanulate, 5 -lobed, the lobes valvate in the bud, persistent; petals 0 ; stamens 10 , in two ranks, inflexerl in the bud, unequal, 5 longer than the others and inserted opposite the calyx-lobes under the hairy 5 -lobed disk, the others shorter, alternate with them and inserterl ligher on the calyx-tube; filaments incurved near the apex; anthers minute, sagittate; ovary ineluded in the tube of the ealyx; style thiekened and villose at the base; ovules suspended on elongated slender funienli. Fruit ovoid, conieal, oblique, and more or less faleate, irregularly 5-angled, eoriaeeous, light brown, pubernlous on the onter surface, with thin membranaeeous flesh inseparable from the crustaeeous stone porous toward the interior. Seed ovate, acute; seed-coat coriaceous, chestnutbrown; cotyledons fleshy; radicle superior.

Bneida with a single speeies is confined to tropieal America, where it is distributed from southern Florida through the West Indies to Guiana and Central America.

The generic name is from $\beta o v s$, in allusion to the fancied resemblance of the frnit to the horns of an ox.

\section{Bucida Buceras, P. Br. Black Olive Tree.}

(Terminalia Buceras, Silva N. Am. v. 21.)

Leaves $2^{\prime}-3^{\prime} \operatorname{long}, 1^{\prime}-1 \frac{1}{2}^{\prime}$ wide, their petioles $\frac{1^{\prime}}{3} \frac{1}{2}^{\prime}$ in length. Flowers appearing in Florida in April, $\frac{1^{\prime}}{8} \operatorname{long}$, on spiles $1 \frac{1}{2}^{\prime}-3^{\prime}$ in length. Fruit abont $\frac{1}{3}^{\prime}$ long.

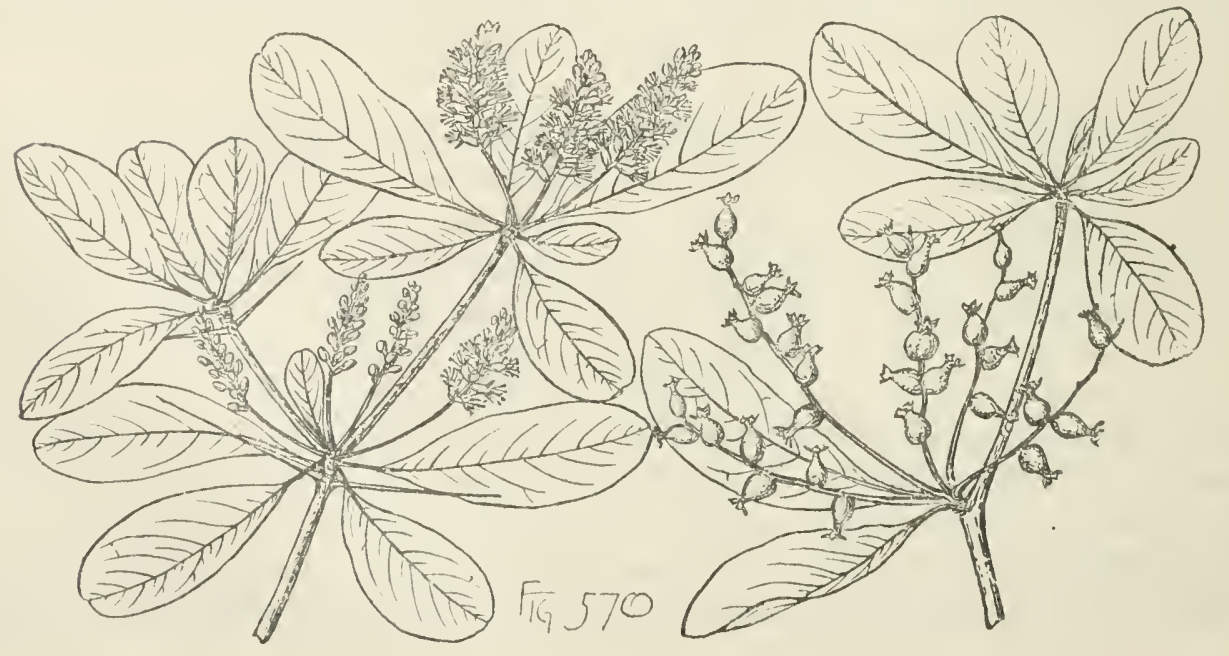


A tree, with a single straight trunk, or often with a short prostrate stem $2^{\circ}-3^{\circ}$ in diameter, producing several straight upright secondary stems $40^{\circ}-50^{\circ}$ high and $12^{\prime}-18^{\prime}$ in diameter, stout branches spreading nearly at right angles witl the trunk and forming a broad head, and branchlets clothed when they first appear with short pale rufous pubescence mostly persistent for two or three years, becoming light reddish brown and covered with bark separating into thin narrow shreds. Bark of the trunk and of the large branches thick, gray tinged with orange-brown, and broken into short appressed scales. Wood exceedingly heary, hard, close-grained, light yellow-brown sometimes slightly streaked with orange, with thick clear pale yellow sapwood of 30-40 layers of annual growth. The bark has been used in tanning leather.

Distribution. Florida, only on Elliott's Key; widely distributed in brackish marshes through the West Indies to the shores of the Caribbean Sea and the Bay of Panama.

\section{IAGUNCULARIA, Gærtn.}

A tree, with scaly bark, terete pithy branchlets, and naked buds. Leaves opposite, glabrous, thick and coriaceous, oblong or elliptical, obtuse or emarginate at the apex, marked toward the margin with minute tubercles; their petioles conspicuously biglandular. Flowers usually perfect or polygamo-moncecious, minute, flattened, greenish white, sessile, in simple terminal axillary tomentose spikes generally collected in leafy panicles, with ovate acute hoary-tomentose bracts and bractlets; calyxtube turbinate, with 5 prominent ridges opposite the lobes of the limb and 5 intermediate lesser ridges, bracteolate near the middle, with 2 minute persistent bracts, and coated with dense pale tomentum, the limb urceolate, 5-parted to the middle, the divisions triangular, obtuse or acute, erect, persistent; disk epigynous, flat, 10lobed, the 5 lobes opposite the petals broader than those opposite the calyx-lobes, hairy; petals $\bar{J}$, nearly orbicular, contracted into short claws inserted on the bottom of the calyx-limb, ciliate on the margins, caducous; stamens 10, inserted ju 2 ranks; anthers cordate, apiculate; ovary 1-celled; style short, crowned with a slightly 2-lobed capitate stigma. Fruit 10-ribbed, coriaceous, hoary-pubescent, elongated, obovoid, flattened, crowned with the calyx-limb, unequally 10-ribbed, the 2 lateral ribs produced into narrow wings, 1-seeded; flesh coriaceous, corky toward the interior, inseparable from the thin-walled crustaceous stone dark red and lustrous on the inner surface. Seed suspended, obovate or oblong; seed-coat membranaceous, dark red; radicle elongated, slightly longer and nearly inclosed by the green cotyledons.

Laguncularia consists of a single species of tropical America and Africa.

The generic name is from laguncula, in allusion to the supposed resemblance of the fruit to a flask.

\section{Laguncularia racemosa, Gærtn. Buttonwood. White Mangrove.}

Leaves slightly tinged with red when they unfold, and at maturity dark green on the upper and lighter green or pale on the lower surface, $1 \frac{1}{2}^{\prime}-2 \frac{1}{2}^{\prime}$ long, and $1^{\prime}-1 \frac{1}{2}^{\prime}$ wide; their petioles red, $\frac{1}{2}^{\prime}$ in length. Flowers $\frac{1}{4}^{\prime}$ long, in hoary-tomentose spikes produced thronghout the year from the axils of young leaves and $1 \frac{1^{\prime}}{2}-2^{\prime}$ long. Fruit about $\frac{1}{2}^{\prime}$ long.

A tree, $30^{\circ}-60^{\circ}$ high, with a trunk $12^{\prime}-20^{\prime}$ in diameter, stout spreading branches forming a narrow round-topped head, and slender glabrous brauchlets somewhat 
angled at first, often marked with mimnte pale spots and dark red-brown, beeoming in their second year terete, lighth reddish brown or ormge color, thickened at the nodes, and marked by conspienous ovate leaf-sears; or northward in Florida a low shrub. Bark of the trunk ${ }^{\prime}+$ thiek, brown slightly tinged with red, the surface
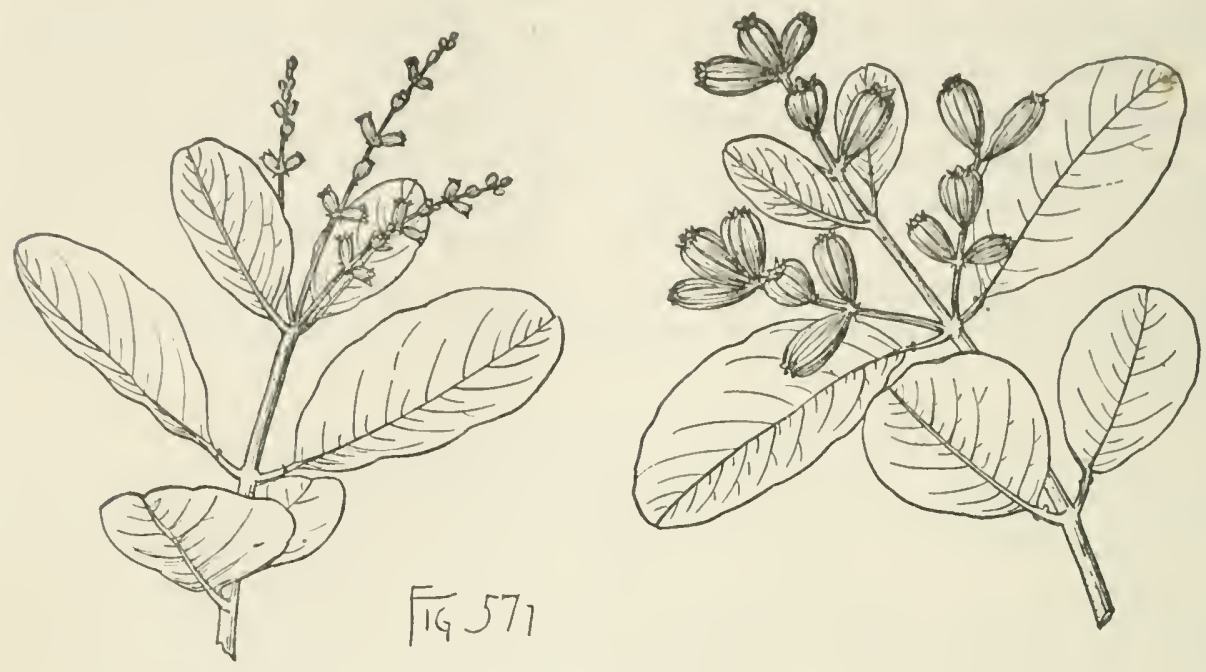

broken into long ridge-like scales. Wood heavy, hard, strong, elose-grained, dark yellow-brown, with lighter colored sapwood of 10-12 layers of annual growth. The bark contains a large amount of tannic acid and is sometimes used in tanning leather, and is astringent and tonic.

Distribution. Muddy tidal shores of bays and lagoons; common in southern Florida from Cape Canaveral and Cedar Keys to the southern islands; of its largest size in Florida on the shores of Shark River; common in Bermuda, the Bahamas, the Antilles, tropical Mexico and Central America, tropical South America and western Africa.

\section{XIVII. ARALIACER.}

'Trees, shrubs, or herbs, with watery juice and scaly buds. Leaves alternate, compound, petiolate, with stipules. Flowers in racemose or panicled $11 \mathrm{mbels}$; parts of the flower in 5's ; disk epigynous; ovule solitary, suspended from the apex of the cell, anatropous. Fruit baccate. Seeds with albumen.

The Aralia family with fifty genera is chiefly tropical, with a few genera extending beyond the tropics into the northern hemisphere, especially into North America and eastern Asia. 'The widely distributed and largely extratropical genus Aralia is represented by one arborescent species in the flora of the United States. Hedera, the Ivy, of this family, is commonly cultivated in the temperate parts of the United States, and some species of Panax and Acanthopanax from eastern Asia are found in gardens in the northeastern states.

\section{ARALIA, L.}

Aromatic spiny trees and shrubs, with stont pithy branchlets, and thick fleshy roots, or bristly or glabrous perennial herbs. Leaves alternate, digitate or once or twice pinnate, the pinne serrulate; stipules produced on the expanded and clasping base of the petiole. Flowers perfect, polygamo-monœcious or polygamo-diœcious, on 
slender jointed pedicels, small, greenish white; calyx-tube coherent with the ovary, the limb truncate, repand or minutely toothed, the teeth valvate in the bud; petals imbricated in the bud, inserted by their broad bases on the margin of the disk, ovate, obtuse or acute and slightly inflexed at the apex; stamens inserted on the margin of the disk, alternate with the petals; filaments filiform; anthers oblong or rarely ovate, attached on the back, introrse, 2-celled, the cells opening longitudinally; ovary 2-5-celled; styles 2-5, in the fertile flower distiuct and erect or slightly united at the base, spreading and incurved above the middle, or incurved from the base and sometimes inflexed at the apex, crowned with large capitate stigmas, in the sterile flower short and united. Fruit fleshy, 2-5-seeded, laterally compressed or 3-5-angled, crowned with the remnants of the style; nutlets $2-5$, orbicular, ovate or oblong, compressed, crustaceous, light reddish brown, 1-seeded. Seed compressed; seed-coat thin, light brown, adnate to the thin fleshy albumen; cotyledons ovateoblong, as long as the straight radicle.

Aralia with about thirty species is confined to North America and Asia.

The generic name is of obscure meaning.

\section{Aralia spinosa, L. Hercules' Club.}

Leaves clustered at the ends of the branches, twice pinnate, $3^{\circ}-4^{\circ}$ long, and $2 \frac{1}{2}^{\circ}$ wide, with stout light brown petioles $18^{\prime}-20^{\prime}$ in length, clasping the stem with enlarged bases and armed with slender prickles, or occasionally unarmed; pinnæ unequally

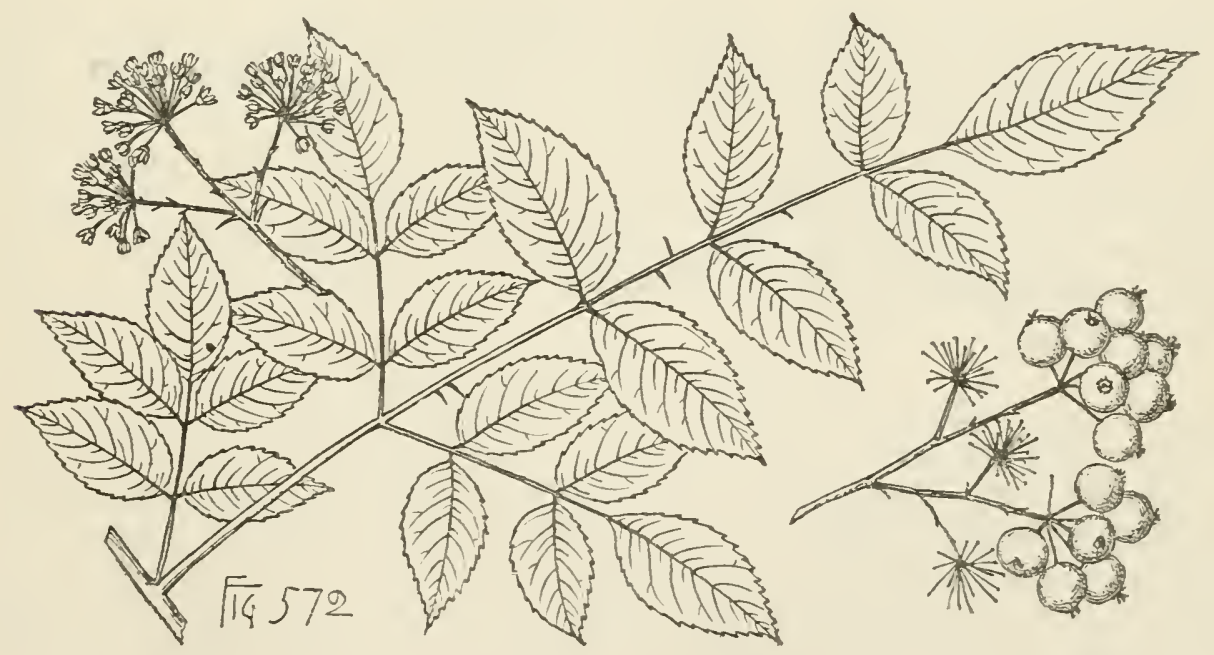

pinuate, usually with 5 or 6 pairs of lateral leaflets and a long-stalked terminal leatlet, and often furnished at the base with a pinnate or simple leaflet; leaflets ovate, acute, dentate or crenate, wedge-shaped or more or less rounded at the base, short-petiolulate, when they unfold lustrons, bronze-green, and slightly pilose on the midribs and primary veins, and occasionally furnished with small prickles on the midribs, and at maturity membranaceous, dark green above, pale beneath, $2^{\prime}-3^{\prime}$ long, and $1 \frac{1^{\prime}}{2}$ wide, with thin midribs and slender primary veins nearly parallel with their margins, in the autumn turning light yellow before falling; stipules acute, about $1^{\prime}$ long, at first puberulous on the back and ciliate on the margins. Flowers appearing in midsummer on long slender pubescent straw-colored pedicels, in many-flowered umbels arranged in compound panicles, with light brown puberulous branches 
beconing purple in the autumn, forming a terminal raeemose cluster $3^{\circ}-4^{\circ}$ long, and rising solitary or 22 or 3 together above the spreading leaves; braets and bractlets lanceolate, acnte, scarious, persistent. Flowers $\frac{16^{\prime}}{16}$ long, perfect or' often unisexual by the abortion of the ovary, with acute white petals inflexed at the apex, and connivent styles. Fruit ripening in August, blaek, $\frac{1}{8}^{\prime}$ in diameter, globose, 3-5-angled, crowned with the blackened styles, with thin purple very juicy Hesh; seeds oblong, rounded at the ends, about $\frac{1}{10}{ }^{\prime}$ long.

A tree, $30^{\circ}-35^{\circ}$ high, with a trunk $6^{\prime}-S^{\prime}$ in diancter, stont wide-spreading branches, and branchlets $\frac{11}{2}-\frac{2}{3}$ in diameter, armed like the branches and young trunks with stont straight or slightly ineurved orange-colored scattered prickles, and nearly eneircled by the conspienous narrow leaf-sears marked by a row of prominent fibrovascular bundle-scars, light orange-colored in their first season, lustrons and marked irregularly with oblong pale lenticels, becoming light brown in their second year, with bright green imner bark; more often a shrub, with a cluster of unbrancherl stems $6^{\circ}-20^{\circ}$ tall. Winter-buds: terminal conical, blunt at the apex, $\frac{1^{\prime}}{2}-\frac{3^{\prime}}{4}$ long, with thin eliestnut-brown scales; axillary triangular, flattened, abont $\frac{1^{\prime}}{4}$ long and broad. Bark of the trunk dark brown, abont $\frac{1}{8}^{\prime}$ thiek, and divided by broad shallow fissures into wide rounded ridges irregularly broken on the surface. Wood closegrained, light, soft, brittle, brown streaked with yellow, with lighter colored sapwood of 2 or 3 layers of annual growtl. The bark of the roots and the berries are stimnlant and diaphoretic, and are sometimes used in medicine and in domestie practice.

Distribution. Deep moist soil in the neighborhood of streams; western slope of the Alleghany Mountains, Pennsylvania, to southern Indiana and southeastern Missouri, and southward to northern Florida, western Lonisiana, and eastern Texas; probably of its largest size on the foothills of the Big Smoky Monntains in Tennessee; also in Manchuria and Japan in slightly modified forms.

Oceasionally cultivated as an ornamental plant in the eastern states and in western Europe; less frequently seen in gardens than the more robust Manchurian plant.

\section{CORNACEAE.}

Trees or shrubs, with terete branchlets, scaly buds, and alternate or opposite deciduous leaves without stipules. Flowers perfect or polygamo-diœcious; calyx 4 or 5 -toothed; petals 4 or 5 ; stamens inserted on the margin of the epigynous disk ; anthers oblong, introrse, 2-celled, the cells opening longiturinally; ovary 1 or 2-celled; ovule solitary, suspended from the interior angle of the apex of the cell, anatropous; micropyle superior. Fruit drupaceous, 1 or 2-seeded. Seed oblong-ovate; seed-coat membranaceous; embryo in copious fleshy albumen; cotyledons foliaceous ; radicle terete, turned toward the hilum.

The widely distributed Cornel family with fifteen genera, more numerous in temperate than in tropical regions, has arborescent representatives of two genera in North America.

\section{CONSPECTUS OF THE NORTH AMERICAN ARBORESCENT GENERA.}

Flowers polygamo-diœcious; petals imbricated in the bud; stigma lateral; leaves alternate.

1. Nyssa.

Flowers perfect; petals valvate in the bud; stigma terminal; leaves opposite or rarely alternate.

2. Cornus. 


\section{NYSSA, L.}

Trees, with alternate leaves conduplicate in the bud, petiolate, sometimes remotely angulate or toothed, mostly crowded at the ends of the branches. Flowers polygamodiœcious, minute, greenish white; staminate on slender pedicels from the axils of minute caducous bracts, in simple or compound clusters on long axillary peduncles bibracteolate near the middle or at the apex or sometimes without bractlets; calyx disciform or cup-shaped, the limb 5-toothed; petals 5 , imbricated in the bud, equal or unequal, ovate or linear-oblong, thick, inserted on the margin of the conspicuous pulvimate entire or lobed disk, erect; stamens 5, exserted; filaments filiform; anthers oblong; ovary 0 ; pistillate flowers on axillary peduncles, in 2 or few-flowered clusters, sessile or nearly so, in the axils of conspicuous bracts and furnished with 1 or 2 small lateral bractlets, or solitary and surrounded by $2-4$ bractlets; calyx-tube campanulate, sometimes slightly urceolate, the limb 5-toothed; petals small, thick, and spreading; stamens 5-10; filaments short; anthers fertile or sterile; disk less developed than in the staminate flower, depressed in the centre; ovary 1 or 2-celled; style terete, elongated, recurved, stigmatic toward the apex or the inner face; raphe ventral. Fruit oblong, fleshy, urceolate at the apex; flesh thin, oily, acidulous; stone thick-walled, bony, terete or compressed, ridged or winged, 1 or rarely 2-celled, usually 1-seeded. Seed filling the cavity of the stone; seed-coat pale; embryo straight.

Nyssa with fire species is confined to the eastern United States and to southern Asia, where a single species is distributed from the eastern Himalayas to the island of Java. The American species produce tough wood, with intricately contorted and twisted grain.

Nyssa, the name of a nymph, was given to this genus from the fact that one of the species grows in water.

\section{CONSPECTUS OF THE NORTH AMERICAN SPECIES.}

Pistillate flowers in 2 or few-flowered cluster's; fruit blue, not more than $\frac{2}{3}$ long; stone with low broad rounded ridges.

Stone indistinctly ridged; leaves linear-oblong to oval or obovate.

1. N. sylvatica (A, C).

Stone prominently ribbed; leaves oblanceolate to oblong or elliptic.

2. N. biflora (C).

Pistillate flowers solitary; fruit 1' or more long; stone with prominent wings or acute ridges.

Fruit red; stone with prominent, wings; leaves oblong-oval or obovate, usually obtuse at the apex.

3. N. Ogeche (C).

Fruit purple; stone with acute ridges; leaves oval or oblong, acute or acuminate at the apex.

4. N. aquatica $(A, C)$.

\section{Nyssa sylvatica, Marsh. Tupelo. Pepperidge.}

Leaves crowded at the ends of lateral branchlets or remote on vigorous shoots, linear-oblong, lanceolate, oval or obovate, acute or acuminate or sometimes contracted into short broad points at the apex, wedge-shaped or occasionally rounded at the base, entire, with slightly thickened margins, or rarely coarsely dentate, when they unfold coated with rufous tomentum, especially on the lower surface, or pubescent or sometimes nearly glabrous, and at maturity thick and firm, dark green and very lustrous above, pale and often hairy below, principally along the broad midribs 
and on the primary veins, $2^{\prime}-5^{\prime} \mathrm{long}, \frac{1}{2}^{\prime}-3^{\prime}$ wide, turning in the antumn before falling bright scarlet on the upper surface only; their petioles slender or stout, terete or wing-margined, ciliate, $\frac{1}{4}-11_{2}^{\prime}$ long, and often bright red. Flowers appearing when the leaves are about one third grown on slender pubesecnt or tomentose peduncles $\frac{1}{2}^{\prime}-1 \frac{1}{2}^{\prime}$ long, the males in inany-flowered dense or lax compound heads, the
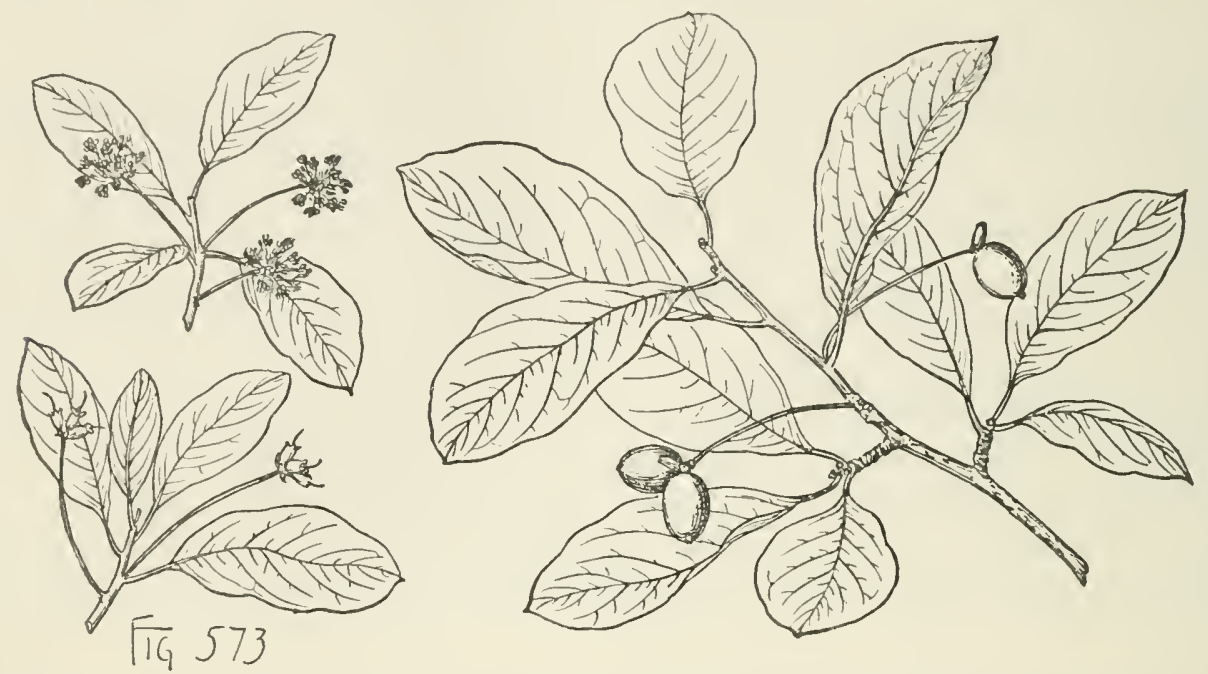

females in 2 to several-flowered clusters, sessile in the axils of conspicuous often foliaceous bracts, and furnished with 2 smaller acute hairy bractlets; calyx of the staminate flower disciform; petals thick, ovate-oblong, acute, rounded at the apex, erect or slightly spreading, early deciduous; stamens exserted in the staminate flower, shorter than the petals in the pistillate flower; stigma stout, exserted, reflexed above the middle, 0 in the staminate flower. Fruits ripening in October, 1-3 from each flower-cluster, ovoid, $\frac{1^{\prime}}{3}-\frac{2}{3}$ long, dark blue, with thin acrid flesh; stone light brown, ovoid, rounded at the base, pointed at the apex, terete, or more or less flattened, and 10-12-ribbed, with narrow indistinct pale ribs rounded on the back.

A tree, occasionally $100^{\circ}$ high, with a trunk sometimes $5^{\circ}$ in diameter, many slender pendulous tough flexible branches forming a liead sometimes short, cylindrical, and flat-topped, sometines low and broad, or on trees crowded in the forest narrow, pyramidal, or conical, and sometimes inversely conical and broad and flat at the top, branchlets at first light green to orange color, and in their first winter nearly glabrous or pale or rufous-pubescent, light red-brown marked by minute scattered pale lenticels and by small lunate leaf-scars displaying the ends of 3 conspicuous groups of fibro-vascular bundles, later becoming darker and developing short stout spurlike lateral branchlets, and long thick hard roots; generally in the northern and extreme southern states much smaller, and rarely more than $50^{\circ}-60^{\circ}$ tall. Winterbuds obtuse, $\frac{I^{\prime}}{4}$ long, with ovate acute apiculate dark red puberulons imbricated scales, those of the inner ranks accrescent, bright-colored at maturity, and marking the base of the branchlet with obscure ring-like scars. Bark of the trunk $\frac{3^{\prime}}{4}-\mathbf{1}^{\prime}{ }^{\prime}$ thick, light brown often tinged with red, and deeply fissured, the surface of the ridges covered with small irregularly shaped scales. Wood heary, soft, strong, very tough, not durable, light yellow or nearly white, with thick lighter colored sapwood of 80-100 layers of annual growtl; used for the hubs of wheels, rollers in glass factories, ox-yokes, wharf-piles, and sometimes for the soles of shoes. 
Distribution. Borders of swamps in wet imperfectly drained soil, and southward often on high wooded mountain slopes; valley of the Kennebec River, Maine, to southern Ontario, central Michigan, and southeastern Missouri, and southward to the shores of the Kissimee River and Tampa Bay, Florida, and to the valley of the Brazos River, Texas; of its largest size on the southern Appalachian Mountains.

Occasionally cultivated as an ornamental tree in the eastern states.

\section{Nyssa biflora, Walt.}

(Nyssa sylvatica, var. biflora, Silva N. Am. v. 76.)

Leaves oblanceolate, oblong, elliptic or rarely ovate, acute or acuminate or occasionally rounded at the narrow apex, cuneate or rounded at the gradually narrowed base, and entire, when they unfold silky-villose above and hoary-tomentose beneath, soon becoming glabrous, dark yellow-green and lustrous on the upper,

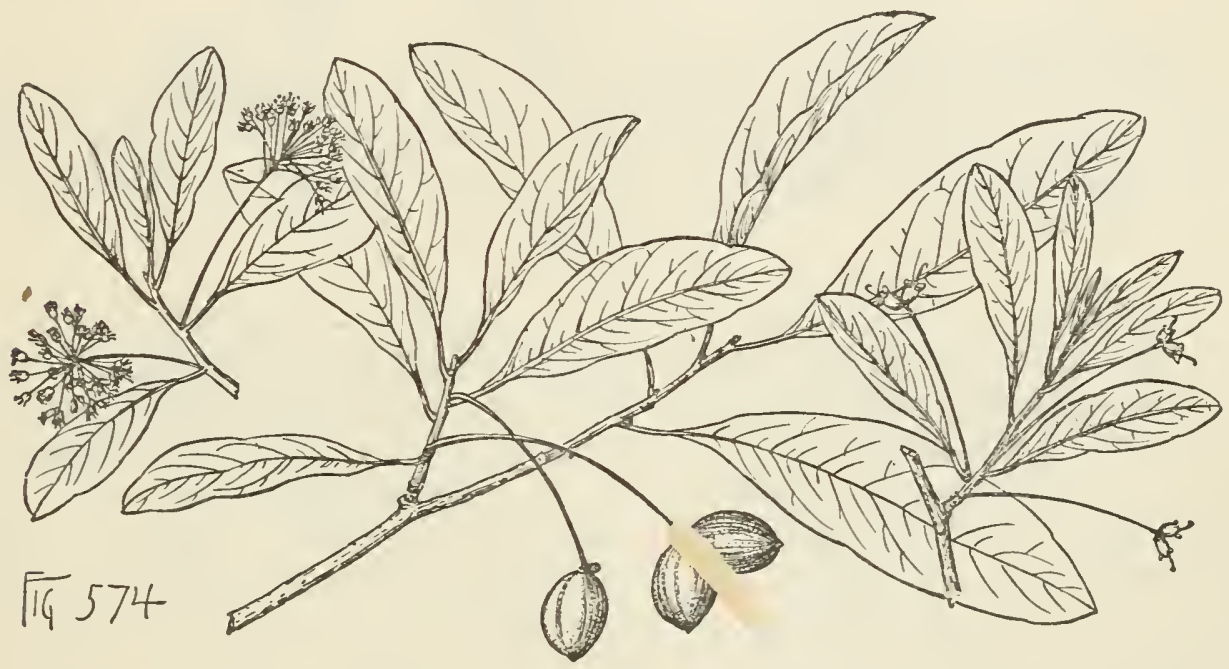

paler and sometimes glancous on the lower surface, $2^{\prime}-4^{\prime}$ long and $\frac{3^{\prime}}{4}-1^{\prime}$ wide, with prominent midribs and numerous slender veins; their petioles stout, $\frac{1}{4}^{\prime}-\frac{1}{2}^{\prime}$ long. Flowers appearing when the leaves are nearly fully grown; staminate on slender villose pedicels, in many-flowered loose clusters on slender hairy peduncles $1^{\prime}-1 \frac{1}{2}^{\prime}$ in length; pistillate in pairs on rather stouter peduncles usually about $1^{\prime}$ long; calyx of the staminate flower disciform; petals ovate-oblong, rounded at the apex, white, erect or slightly spreading, early deciduous. Fruit solitary or in pairs, on peduncles $1^{\prime}-1 \frac{1}{2}^{\prime}$ long, oval or ellipsoidal, dark blue, lustrous, about $\frac{1}{3}^{\prime}$ long, with acrid pulp; stone oval, compressed, narrowed at the ends, and prominently ribbed.

A tree, rarely more than $30^{\circ}$ high, with a slender trunk gradually tapering upward from a swollen and much enlarged base, small spreading branches forming a narrow pyramidal or round-topped head, and branchlets slightly villose when they first appear, soon glabrous, and bright reddish brown in their first winter, becoming darker the following year, and numerous erect thick roots rising from the surface of the water. Winter-buds acute, dark red-brown, puberulous, and about $\frac{1}{8}$ long, the inner scales hoary-tomentose. Bark about $\mathbf{1}^{\prime}$ thick, deeply furrowed, very dark reddish brown.

Distribution. Small Pine-barren ponds in the neighborhood of the coast; North Carolina to Louisiana. 


\section{Nyssa Ogeche, Marsh. Ogeechee Lime. Sour Tupelo.}

Leaves oblong, oval or obovate, aente, rouncled or rarely obtuse and apiculate at the apex, gradually or abruptly wedge-shaped or sometimes rounded at the base,

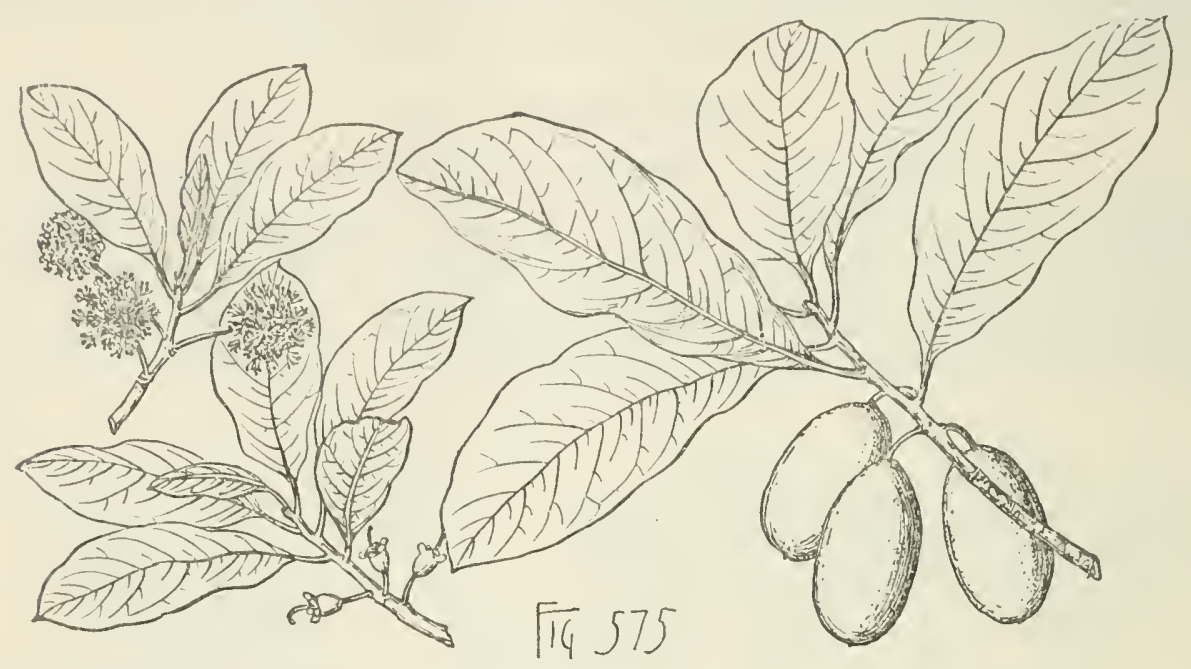

and entire, when they unfold covered on the lower surface with thick hoary tomentum and on the upper surface with short scattered pale hairs, and at maturity thick and firm, dark green, lustrous and slightly pilose above, pale below, $4^{\prime}-6^{\prime}$ long, $2^{\prime}-2 \frac{1^{\prime}}{}$ wide, with stout midribs, 9 or 10 pairs of prinary veins covered on the lower side with rufons pubescence or often nearly glabrous, and obscure reticulate veinlets; their petioles stout, grooved, $\frac{1}{2}^{\prime}-1^{\prime}$ long. Flowers greenish yellow, appearing in March and April; staminate minute, in capitate clusters on slender hairy peduncles $\frac{1}{2}$ long, bibracteolate near the middle, and developed from the axils of the inner scales of the terminal bud, covered with long pale hairs on the outer surface of the short obscurely 5-toothed calyx and on the oblong petals rounded at the apex; filaments longer than the petals; anthers oval and conspicuously tuberculate-roughened; pistillate solitary, $\frac{1}{16}$ long, on short stout woolly peduncles from the axils of bud-scales, and furnished at the apex with 2 acute hairy bractlets; calyx coated, like the minute rounded spreading petals, with hoary tomentum; stamens included, with short filaments, and small mostly fertile anthers; style stont, exserted, reflexed from near the base. Fruit bright or dull red, on slender tomentose stems enlarged at the apex and $\frac{1}{2}-\frac{2}{3}$ long, ripening in July and Angust, and sometimes persistent on the branches until after the falling of the leaves, oblong or obovate, $1^{\prime}-1 \frac{1}{2}$ in length, tipped with the thickened and pointed remnants of the style; flesh thick, juicy, very acid; stone oblong, compressed, narrowed at the ends, romded at the base, acute at the apex, with walls produced into 10 or 12 broad thin papery white wings, about $1^{\prime}$ long, and 1 or rarely 2 -seeded.

A tree, rarely $60^{\circ}-70^{\circ}$ high, with 1 or several stems occasionally $2^{\circ}$ in diameter, spreading branches forming a narrow round-topped head, and slender branchlets coated when they first appear with rufous tomentum, light reddish brown or green tinged with red and puberulous during their first summer, turning gray or reddish brown in their first winter, and marked by large lunate or nearly triangular leafscars displaying the ends of 3 groups of fibro-vascular bundles; often a shrub, with 
numerous slender clustered diverging stems. Winter-buds obtuse, $\frac{1}{8}^{\prime}$ long, with orate apiculate imbricated scales ronnded on the back and clothed with thick hoary tomentum, those of the inner ranks becoming at maturity ovate-oblong or obovate, rounded at the apex, bright red, and $\frac{1}{2}^{\prime}-\frac{3}{4}^{\prime}$ long. Bark of the trunk about $\frac{1^{\prime}}{8}$ thick, irregnlarly fissured, with a dark brown surface broken into thick appressed persistent plate-like scales. Wood light, soft, tongh, not strong, white, with thin hardly distinguishable sapwood of about 10 layers of annual growth. A preserve with an agreeable subacid flavor, known as Ogeechee limes, is sometimes made from the fruit in Georgia and South Carolina. The flowers abound in nectar, and are much visited by bees.

Distribution. Deep often inundated river swamps or their borders; Sonth Carolina in the neighborhood of the coast, through the valley of the Ogeechee River, Georgia, in northern and western Florida, and in the valley of the lower Appalachicola River; rare and local.

\section{Nyssa aquatica, Marsh. Cotton Gum. Tupelo Gum.}

Leaves ovate-oblong, acute or acuminate and often long-pointed at the apex, wedge-shaped, rounded, or subcordate at the base, entire or remotely and irregularly angulate-toothed, the teeth often tipped with long slender mucros, when they unfold light red and coated below and on the petioles with pale tomentum and pubescent

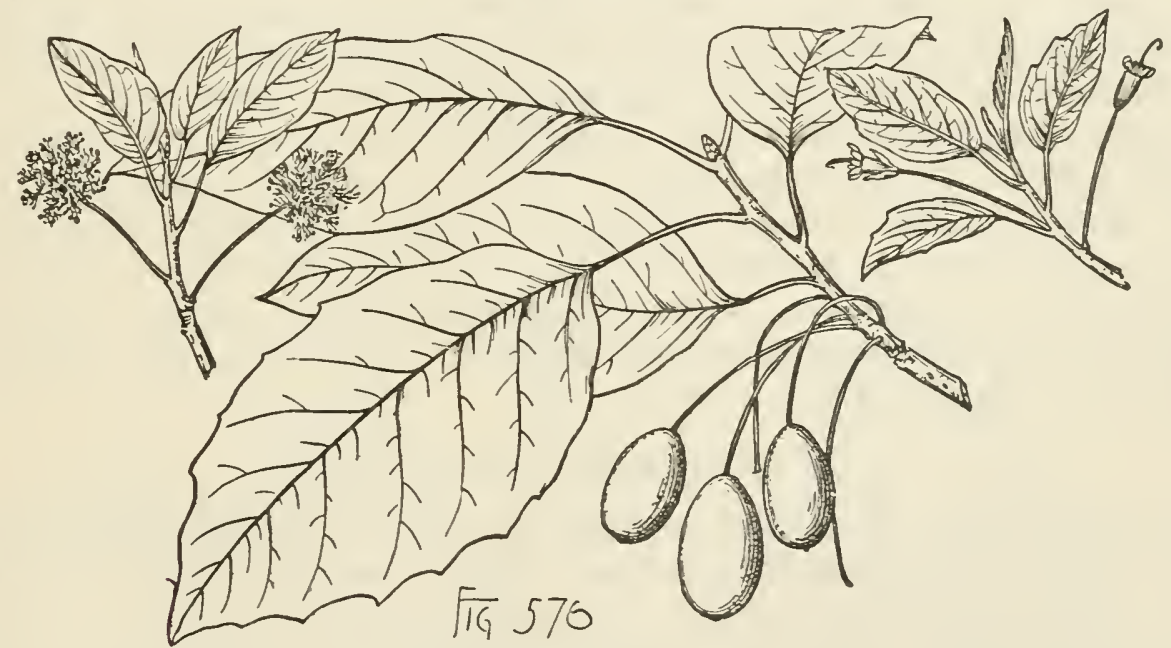

above, especially on the midribs, and at.maturity thick and firm, dark green and lustrous on the upper, pale and more or less downy-pubescent on the lower surface, $5^{\prime}-7^{\prime}$ long and $2^{\prime}-4^{\prime}$ wide, with broad thick midribs, and 10-12 pairs of primary veins forked near the margins and connected by conspicuous cross veins; their petioles stout, grooved, hairy, enlarged at the base, $1 \frac{1}{2}^{\prime}-2 \frac{1}{2}^{\prime}$ long. Flowers appearing in March and April on long slender hairy pednncles in the axils of the inner scales of the terminal bud; staminate in dense capitate clusters, their peduncles furnished near the middle and occasionally at the apex with long linear ciliate bractlets; calyx-tube cup-shaped, obscurely 5-toothed, one third as long as the oblong erect petals rounded at the apex and nuch shorter than the stamens; pistillate solitary, surrounded by 2-4 strap-shaped scarious ciliate bractlets often $\frac{1}{2}^{\prime}$ long and more or less united below into an involucral cup; calyx-tube oblong and much longer than the ovate minute spreading petals; stamens included, with small mostly fertile anthers: 
style stont, tapering, reflexed above the middle, and revolnte into a close coil. Fruit ripening early in the antmmu, on slenler drooping stalks $3^{\prime}-t^{\prime}$ in length, oblong or slightly obovate, crowned with the pointed l'cmunts of the style, dark purple, marked by conspienous seattered pale dots, and $1^{\prime}$ long, with thick tough skin and thin aeid flesh; stone obovate, rounded at the narrow apex, pointed at the base, flattened, light brown or nearly white, and about 10-ridged, the ridges acute and wing-like, with thin separable margins, and sometimes mited by short intermediate ridges.

A tree, $80^{\circ}-100^{\circ}$ high, with a trunk $3^{\circ}-4^{\circ}$ in diameter above the greatly enlarged tapering base, comparatively small spreading branches forming a narrow oblong or pyramidal head, stout pithy branchlets dark red and coated with pale tomentum when they first appear, soon beeoming glabrous or nearly so, and in their first winter light or bright red-brown and marked by small scattered pale lenticels and by the conspicnous elevated nearly orbienlar leaf-scars displaying the ends of 3 large fibrovascular bundles, and thick corky roots. Winter-buds: terminal nearly globose, with broad ovate light chestnut-brown scales keeled on the back and rounded and apiculate at the apcx, those of the imner ranks accrescent and at maturity ovateoblong or obovate-oblong, rounded at the apex, 1' or more long, and bright yellow; axillary minute, obtuse, nearly imbedded in the bark. Bark of the trunk about $\frac{1}{4}^{\prime}$ thiek, dark brown, longitudinally furrowed, and roughened on the surface by small seales. Wood light, soft, not strong, close-grained, difficult to split, light brown or often nearly white, with thick sapwood sometimes composed of more than 100 layers of annual growth; used in the manufaeture of wooden ware, broom-handles, and wooden shoes, and largely for fruit and vegetable boxes. The wood of the roots is sometimes employed instead of cork for the floats of nets.

Distribution. Deep swamps inundated during a part of every year; coast region of the Atlantic states from sonthern Virginia to northern Florida, through the Gulf states to the valley of the Nuees River, Texas, and through Arkansas and southern and sontheastern Missouri to western Kentucky and Tennessee, and to the valley of the lower Wabash River, Illinois; of its greatest size in the Cypress swamps of western Louisiana and eastern Texas.

\section{CORNUS, L. Dogwood.}

Trees and shrubs, with astringent bark, opposite or rarely alteruate deeiduous leaves conduplicate or involute in the bud. Flowers small, perfect, white, greenish white or yellow; calyx-tube minutely 4-toothed, the teeth valvate in the bud; disk pulvinate, depressed in the centre, or obsolete; petals 4, valvate in the bud, oblongovate, inserted on the margin of the disk; stamens 4 , alternate with the petals; filaments slender, exserted; ovary 2-celled; style exserted, simple, columnar, crowned with a single capitate or truncate stigma; raphe dorsal. Fruit ovoid or oblong; flesh thin and succulent; nut bony or crustaceons, 2-celled, 2 or sometimes 1-seeded. Seed compressed; embryo straight or slightly incurved.

Cornus with forty to fifty species is widely distributed through the three continents of the northern hemisphere, and south of the equator is represented in Peru by a single species. Of the sixteen or seventeen species of the United States four are arborescent. Cornus is rich in taninic acid, and the bark and oecasionally the leaves and unripe fruit are used as tonics, astringents, and febrifnges. Of exotic speeies, Cornus mas, L., is often planted in the eastern states as an ornamental tree, and its edible fruit is used in Europe in preserves and eordials. 'The wood of Cornus is hard, elose-grained, and durable, and is used in turnery and for charcoal. 
The generic name, from cornu, relates to the hardness of the wood produced by plants of this family.

\section{CONSPECTUS OF THE ARBORESCENT SPECIES OF THE UNITED STATES.}

Flowers greenish, in a dense cymose head surrounded by a conspicuous corolla-like involucre of 4-6 white or rarely red scales, from terminal buds formed the previous summer; fruit ovoid, bright red.

Heads of flower-buds inclosed by the involucre during the winter; involucral scales 4 , obcordate or notched at the apex; leaves ovate to elliptical.

1. C. florida (A, C).

Heads of flower-buds not inclosed by the involucre during the winter; involucral seales $4-6$, oblong to obovate, usually acute at the apex; leaves ovate or rarely obovate.

2. C. Nuttallii (B, G).

Flowers cream color, in a flat cymose head, without involucral scales, terminal on shoots of the year; fruit subglobose, white or dark blue.

Leaves opposite, scabrous above; fruit white.

3. C. asperifolia (A, C).

Leaves mostly alternate and clustered at the ends of the branches, smooth above; fruit dark blue.

4. C. alternifolia (A, C).

\section{Cornus florida, L. Flowering Dogwood.}

Leaves ovate to elliptical or rarely slightly obovate, acute and often contracted into slender points at the apex, gradually narrowed at the base, remotely and obscurely crenulate-toothed on the somewhat thickened margins, and mostly clustered at the ends of the branches, when they unfold pale and pubescent below and puberulous above, and at maturity thick and firm, bright green and covered with minute

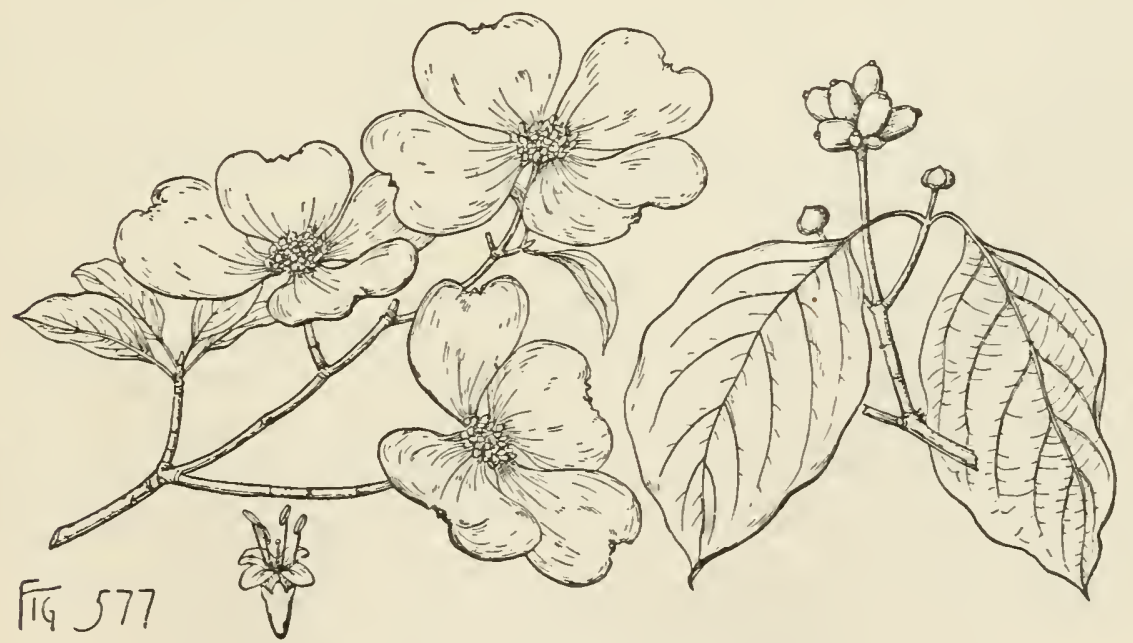

appressed hairs on the upper surface, pale or sometimes almost white and more or less pubescent on the lower surface, $3^{\prime}-6^{\prime}$ long and $1 \frac{1}{2}^{\prime}-2^{\prime}$ wide, with prominent light-colored midribs deeply impressed above, and 5 or 6 pairs of primary veins parallel with their sides and connected by obscure reticulate veinlets, in the autumn turning bright scarlet on the upper surface; their petioles grooved, $\frac{1^{\prime}}{2}-\frac{3^{\prime}}{4}$ long. Flowers: head of flower-buds appearing during the summer between the upper pair of lateral leaf-buds, inclosed by 4 involucral scales remaining light brown and more or less covered with pale hairs during the winter and borne on a stout clubshaped puberulous peduncle $\frac{1^{\prime}}{4}$ long or less during the winter and becoming $1^{\prime}-1 \frac{1}{2}^{\prime}$ 
in length; involueral bracts beginning to unfold, enlarge and grow white in early spring and when the flowers open in March at the south to May at the north, when the leaves are nearly fully grown, forming a flat corolla-like cup $3^{\prime}-4^{\prime}$ in diameter, becoming at maturity obcordate, $1^{\prime}-1 \frac{1}{2}$ wide, gradually narrowed below the middle and notched at the rounded apex, reticulate-veined, pure white, pink, or rarely bright red, deciduous after the fading of the flowers; flowers in dense many-flowered cymose heads, in the axils of broadly ovate nearly triangular minutely apiculate glabrous light green deciduous bractlets $\frac{1}{8}$ in diameter; calyx terete, slightly urceolate, puberulous, obtusely 4-lobed, light green; corolla-lobes strap-shaped, rounded or acute at the apex, slightly thickened on the margins, pnberulous on the outer surface, reflexed after anthesis, green tipped with yellow; disk large and orange-colored; style crowned with a truncate stigma. Fruit ripening in October, ovoid, crowned with the remnants of the narrow persistent calyx and with the style, bright scarlet, $\frac{1^{\prime}}{2}$ long, $\frac{1}{4}^{\prime}$ broad, with thin mealy flesh, and a smooth thick-walled slightly grooved stone acute at the ends and 1 or 2-seeded; seeds oblong, pale brown.

A bushy tree, rarely $40^{\circ}$ high, with a short trunk $12^{\prime}-18^{\prime}$ in diameter, slender spreading or upright branches, and divergent branchlets turning upward near the ends, pale green or green tinged with red when they first appear, glabrous or slightly puberulous, bright red or yellow-green during their first winter and nearly surrounded by the narrow ring-like leaf-scars, later becoming light brown or gray tinged with red; frequently toward the northern limits of its range a much-branched shrub. Winter-buds formed in midsummer; the terminal covered by 2 opposite acute pointed scales rounded on the back and joined below for half their length, and accompanied by 2 pairs of lateral buds, each covered by a single scale, those of the lower pair shedding their scales in the autumn and remaining undeveloped. Bark of the trunk $\frac{1^{\prime}}{8}-\frac{1}{4}^{\prime}$ thick, with a dark red-brown surface divided into quadrangular or many-sided plate-like scales. Wood heavy, hard, strong, close-grained, brown sometimes changing to shades of green and red, with lighter colored sapwood of 30-40 layers of annual growth; largely used in turnery, for the bearings of machinery, the hubs of small wheels, barrel-hoops, the handles of tools, and occasionally for engravers' blocks.

Distribution. Usually under the shade of taller trees in rich well-drained soil; eastern Massachusetts to sonthern Ontario and southeastern Kansas, and southward to central Florida and the valley of the Brazos River, Texas; and on the mountains of northern Mexico; comparatively rare at the north; one of the commonest and most generally distributed inhabitants of the deciduous-leaved forests of the middle and southern states, ranging from the coast nearly to the summits of the high Alleghany Mountains.

Often planted as an ornament of parks and gardens in the eastern states.

\section{Cornus Nuttallii, Aud. Dogwood.}

Leaves ovate or slightly obovate, acute and often contracted into short points at the apex, wedge-shaped at the base, faintly crenulate-serrate, and generally clustered toward the ends of the branches, when they unfold coated below with pale tomentum and puberulous above, and at maturity membranaceous, bright green and slightly puberulous, with short appressed hairs on the upper, and woolly pubescent on the lower surface, $4^{\prime}-5^{\prime}$ long, $1 \frac{1}{2}^{\prime}-3^{\prime}$ wide, with prominent pale midribs impressed above, about 5 pairs of slender primary veins parallel with the margins and connected by remote reticulate veinlets, in the autumn turning bright orange and 
scarlet before falling; their petioles stout, grooved, pubescent, $\frac{1^{\prime}}{2}-2^{\prime}$ long, with large clasping bases. Flowers : head of flower-buds appearing during the summer between the upper pair of lateral leaf-buds, surrounded at the base but not inclosed by the involucral scales during the winter, hemispherical, $\frac{1}{2}$ in diameter, usually nodding on a stout hairy peduncle $\frac{3^{\prime}}{4}-1^{\prime}$ long; involucral scales becoming when the flowers open $1 \frac{1^{\prime}}{2}-3^{\prime}$ long, and $1 \frac{1}{2}-2^{\prime}$ wide, white or white tinged with pink, narrowly oblong to obovate or sometimes nearly orbicular, acute, acuminate, or obtuse and entire and thickened at the apex, puberulous on the outer surface, gradually narrowed

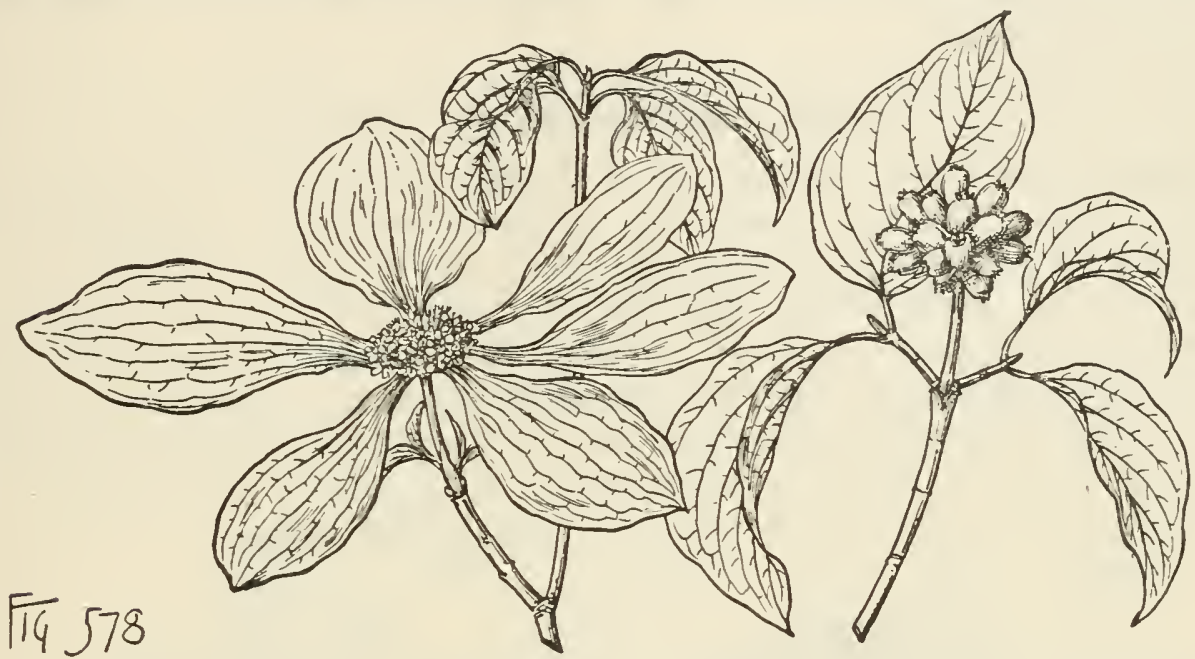

below the middle and conspicuously 8-ribbed, the spreading ribs united by reticulate veinlets; flowers in dense cymose heads from the axils of minute acuminate scarious deciduous bracts; calyx terete, slightly urceolate, puberulous on the outer surface, yellow-green, or light purple, with dark red-purple lobes; petals strap-shaped, rounded at the apex, spreading, somewhat puberulous on the outer surface, with thickened slightly inflexed margins, yellow-green; style crowned with a truncate stigma. Fruit ripening in October, in dense spherical heads of 30-40 drupes surrounded at the base by a ring of abortive pendulous ovaries, $\frac{1}{2}$ long, ovoid, much flattened, crowned with the broad persistent calyx, bright red or orange-colored, with thin mealy flesh, and a thick-walled 1 or 2 -seeded stone obtuse at the ends and scarcely grooved; seeds oblong, compressed, with a very thin pale papery coat.

A tree, $40^{\circ}-60^{\circ}$, or exceptionally $100^{\circ}$ high, with a trunk $1^{\circ}-2^{\circ}$ in diameter, small spreading branches forming an oblong conical or ultimately round-topped head, and slender light green branchlets coated while young with pale hairs, becoming glabrous or puberulous, dark reddish purple or sometimes green in their first winter and conspicuously marked by the elevated lunate leaf-scars, ultimately becoming light brown or brown tinged with red. Winter-buds formed in July; the terminal acute, $\frac{1}{3}^{\prime}$ long, covered by 2 narrowly ovate acute long-pointed puberulous light green opposite scales accompanied by 2 pairs of lateral buds, each covered by a single scale, those of the lower pair shedding their scales in the autumn and remaining undeveloped, those of the upper pair clothed with pale hairs, especially toward the apex, their scales thickening, turn dark purple, lengthening in the spring with the inclosed shoots, finally becoming scarious and developing into small leaves, and in falling marking the base of the branchlets with ring-like scars. Bark of the trunk about $\frac{1^{\prime}}{4}$ thick, brown tinged with red, and divided on the surface into small 
thin appressed scales. Wood heavy, exceedingly hard, strong, close-grained, light brown tinged with red, with lighter colored sapwood of 30-40 layers of annual growth; used in cabinet-making, for mauls and the handles of tools.

Distribution. Usually in moist well-drained soil under the shade of coniferous forests; valley of the lower Fraser River and Vancouver Island, British Columbia, southward through western Washington and Oregon, on the coast ranges of California to the San Bernardino Mountains, and on the western slopes of the Sierra Nevada; southward ascending to clevations of $4000^{\circ}-5000^{\circ}$ above the level of the sea; of its largest size near the shores of Puget Sound and in the Redwood forests of northern California.

\section{Cornus asperifolia, Michx. Dogwood.}

Leaves ovate or oblong, gradually or abruptly contracted at the apex into long slender points, gradually narrowed or rounded and cuneate at the base, and slightly thickened on the undulate margins, when they unfold coated with lustrous silvery tomentum, and nearly fully grown when the flowers open from the middle of May in Texas to the middle of July at the north, and then dark green and roughened above by short rigid white hairs, and pale, often glaucous or rough-pubescent below, and at maturity membranaceous, scabrous on the upper, pubescent or puberulous on the lower surface, $3^{\prime}-4^{\prime}$ long and $1 \frac{1}{2}^{\prime}-2^{\prime}$ wide, with thin midribs and 4-6 pairs of slender primary veins parallel with their sides; their petioles stont, grooved, pubescent,

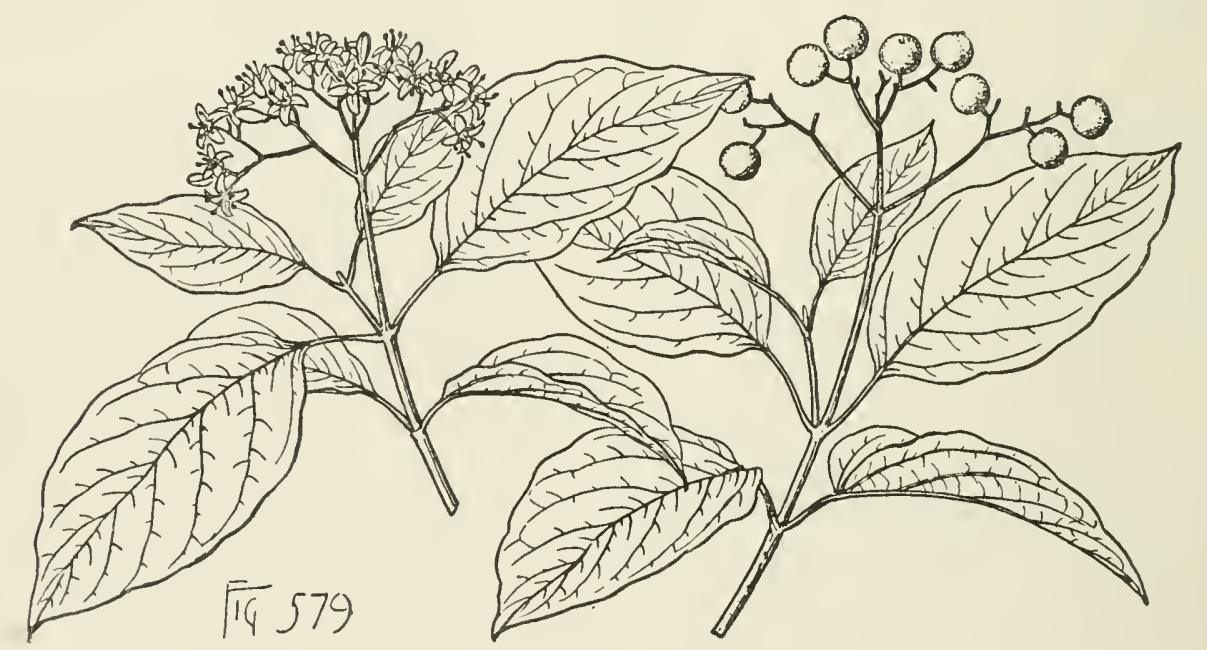

usually about $\frac{1^{\prime}}{2}$ long. Flowers cream color, on slender pedicels, in loose broad or narrow often panicled pubescent cymes, on peduncles frequently $\mathbf{1}^{\prime}$ in length; calyx oblong, cup-shaped, obscurely toothed, covered with fine silky white hairs; corollalobes narrowly oblong, acute, about $\frac{1^{\prime}}{8}$ long, and reflexed after the flowers open; style thickened at the apex into a prominent stigma. Fruit ripening from the end of August until the end of October, in loose spreading red-stemmed clusters, subglobose, white, tipped with the remnants of the style, about $\frac{1^{\prime}}{4}$ in diameter, with thin dry and bitter flesh; and a full and rounded stone broader than high, somewhat oblique, slightly grooved on the edge, and 1 or 2 -seeded; seeds nearly $\frac{1}{4}^{\prime}$ long, with a pale brown coat.

A tree, sometimes nearly $50^{\circ}$ high, with a short trunk $8^{\prime}-10^{\prime}$ in diameter, thin 
erect wand-like branches forming a narrow irregular rather open head, and slender branchlets marked by numerous small pale lenticels, light green and puberulous when they first appear, pale red, lustrous, and puberulous during their first winter, light reddish brown in their second year, and ultimately light gray-brown or gray; usually shrubby. Winter-buds acute, compressed, pubescent, sessile, or stalked, about $\frac{1^{\prime}}{8}$ long, with 2 pairs of opposite scales, the terminal nearly twice as large as the compressed lateral buds. Bark of the trunk about $\frac{1}{8}^{\prime}$ thick, and divided by shallow fissures into narrow interrupted 'ridges broken into small closely appressed dark redbrown scales. Wood close-grained, hard, pale brown, with thick cream-colored sapwood.

Distribution. Northeru shores of Lake Erie to Minnesota, eastern Nebraska and Kansas, and through Missouri and the Indian Territory to eastern Texas, Mississippi, Alabama, South Carolina, and Florida; probably only arborescent on the rich botton-lands of southern Arkansas and eastern Texas.

\section{Cornus alternifolia, L. Dogwood.}

Leaves mostly alternate, clustered at the ends of the branches, rarely opposite, oval or ovate, gradually contracted at the apex into long slender points, wedgeshaped or occasionally somewhat rounded at the base, obscurely crenulate-toothed

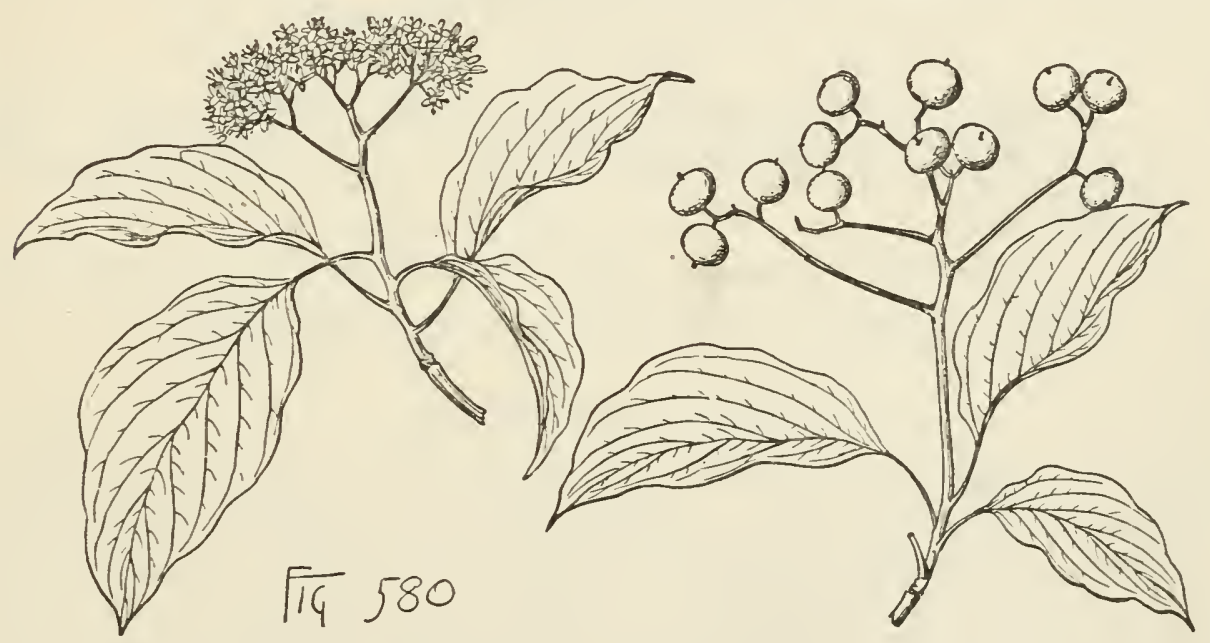

on the slightly thickened and reflexed margins, when they unfold coated on the lower surface with dense silvery white tomentum, and faintly tinged with red and pilose above, and at maturity membranaceous, bright yellow-green, glabrous or sparsely pubescent on the upper, pale or sometimes nearly white and covered with appressed hairs on the lower surface, $3^{\prime}-5^{\prime}$ long, $2 \frac{1}{2}^{\prime}-3 \frac{1}{2}^{\prime}$ wide, with broad orangecolored midribs slightly impressed above, and about 6 pairs of primary veins parallel with their sides, in the antumn turning yellow or yellow and scarlet; their petioles sleuder, pubescent, grooved, $1 \frac{1^{\prime}}{2}-2^{\prime}$ long, with enlarged clasping bases. Flowers cream color, opening from the beginning of May to the end of June on slender jointed pedicels $\frac{1}{8}^{\prime}-\frac{1}{4}^{\prime}$ long, in terminal flat puberulous many-flowered cymes $1 \frac{1}{2}^{\prime}-2 \frac{1}{2}^{\prime}$ wide, mostly on lateral branchlets; calyx cup-shaped, obscurely toothed; corollalobes narrow, oblong, rounded at the apex, $\frac{1^{\prime}}{8}$ long, reflexed after anthesis; style enlarged into a prominent stigma. Fruit in loose spreading red-stemmed clusters, ripening in October, subglobose, dark blue-black, $\frac{1^{\prime}}{3}$ in diameter, tipped with the 
remnants of the style rising from the bottom of a small depression, with thin and bitter flesh; and an obovoid nutlet, pointed at the base, gradually longitudinally many-grooved, thick-walled, and 1 or 2-seeded; seeds lunate, $\frac{1^{\prime}}{4}$ long, with a thin membranaceous pale coat.

A flat-topped tree, rarely $25^{\circ}-30^{\circ}$ high, with a short trunk $6^{\prime}-8^{\prime}$ in diameter, long slender alternate diverging horizontal branches, and numerous short upright slender branchlets pale orange-green or reddish brown when they first appear, mostly light green or sometimes brown tinged with green during their first winter, later turning darker green and marked by pale lunate leaf-sears, and small scattered pale lenticels; often a shrub, with numerous stems. Bark of the trunk about $\frac{1}{8}$ thick, dark reddish brown, and smooth or divided by shallow longitudinal fissures into narrow ridges irregularly broken transversely. Wood heavy, hard, close-grained, brown tinged with red, with thick lighter colored sapwood of 20-30 layers of annual growth.

Distribution. Rich woodlands, the margins of the forest, and on the borders of streams and swamps, in moist well-drained soil; New Brunswick and Nova Seotia, westward along the valley of the St. Lawrence River to the northern shores of Lake Superior and to Minnesota, and southward through the northern states and along the Alleghany Mountains to northern Georgia and Alabama.

Occasionally cultivated as an ornamental plant in the eastern states.

Section 2. Gamopetalæ. Corolla of united petals (divided in Elliottia in Ericacea; 0 in some species of Fraxinus in Oleacece).

A. Ovary superior (inferior in Vaccinium in Ericacea, partly inferior in Symplocacece and Styraceo).

\section{ERICACEA.}

Trees or shrubs, with scaly buds, and alternate simple leaves without stipules. Flowers perfect, regular ; calyx 4-5-lobed; corolla hypogynous, 5-lobed (of 4 petals in Elliottia), the lobes imbricated in the bud; stamens hypogynous, mostly free from the corolla, as many, or twice as many as its lobes; anthers introrse, 2-celled, opening by terminal pores, often appendaged; ovary 4-10-celled (inferior in Vaccinium); styles terminal, simple ; stigma terminal; ovules numerous, anatropous or amphitropous; raphe ventral; micropyle superior. Fruit capsular, drupaceous, or baccate. Seeds with fleshy or horny albumen; embryo small; cotyledons small and short.

'The Heath family with about sixty-seven genera is widely distributed over the temperate and tropical parts of the earth's surface. Of the twenty-one genera found in the United States seven have arborescent representatives.

\section{CONSPECTUS OF THE ARBORESCENT GENERA OF THE UNITED STATES.}

Ovary superior.

Fruit capsular.

Corolla of 4 petals; flowers in erect terminal racemose panicles; leaves deciduous.

1. Elliottia.

Capsule septicidal, the valves in opening separating from the persistent placentiferous axis ; calyx-lobes imbricated in the bud; leaves persistent. 
Flowers in terminal clusters; corolla 5-cleft; inflorescence-buds conical, covered with closely imbricated scales; leaves revolute on the margins.

2. Rhododendron.

Flowers in axillary clusters; corolla saucer-shaped, with a short narrow tube and 10 pouches below the short limb, the anthers in the pouches in the bud; inflorescence-buds elongated, covered with loosely imbricated scales; leaves flat.

3. Kalmia.

Capsule loculicidal, the valves in opening bearing the partitions and separating from the persistent placentiferous axis; calyx-lobes valvate in the bud.

Capsule ovoid-pyramidal ; flowers in terminal panicles of secund racemes ; anthercells opening longitudinally from the apex to the middle; leaves deciduous.

4. Oxydendrum.

Capsule oblong; flowers in axillary fascicles; anthers opening below the apex by 2 oblong pores; leaves persistent.

5. Xylosma.

Fruit drupaceous; flowers in terminal panicles; anthers bearing a pair of reflexed awns on the back, each cell opening at the apex anteriorally by a terminal pore; leaves persistent.

6. Arbutus.

Ovary inferior; fruit baccate ; flowers axillary, racemose or solitary; anther-cells terminating in tubular appendages and opening by terminal pores.

7. Vaccinium.

\section{ELLIOTTIA, Ell.}

A glabrous tree or shrub, with slender terete branchlets, scaly buds, and fibrous roots. Leaves petiolate, oblong or oblong-obovate, acute at the ends or occasionally rounded at the apex, entire, meinbranaceous, dark green and glabrous above, pale and villose below, particularly on the thin yellow midribs and obscure forked veins, deciduous; their petioles slender and flattened, with an abruptly enlarged base nearly covering the small axillary buds. Flowers perfect, on slender elongated pedicels, in erect terminal elongated racemose panicles, with minute acute scarious caducous bracts and bractlets; calyx short, tubular, puberulous, dark red-brown, 4-toothed, the broad apiculate teeth erose on the margins and imbricated in the bud; petals 4 , imbricated in the bud, spatulate-linear, sessile; stamens 8, hypogynous, shorter than the petals; filaments broad, flattened; anthers oblong-ovate, the cells callous-mucronate, free at the apex of the spreading lobes, opening from above downward; disk much thickened, fleshy; ovary sessile, subglobose, 4-lobed, 4-celled, concave at the apex; style elongated, slender, gradually enlarged and club-shaped above and incurved at the apex; stigma 3-5-lobed, smaller than the thickened end of the style; ovules numerous in each cell, attached on the inner angle of a tursid placenta, ascending, anatropous. Fruit unknown.

Elliottia with a single species is confined to the southern United States.

The genus is named in honor of Stephen Elliott (1771-1830), the distinguished botanist of South Carolina.

\section{Elliottia racemosa, Ell.}

Leaves $3^{\prime}-4^{\prime} \operatorname{loug}, 1^{\prime}-1 \frac{1}{2}^{\prime}$ wide; their petioles $\frac{1}{3}^{\prime}-\frac{1}{2}^{\prime}$ in length. Flowers about $\frac{1^{\prime}}{2}$ long, opening from the middle to the end of June, in clusters $7^{\prime}-10^{\prime}$ in length.

A tree, $15^{\circ}-20^{\circ}$ high, with a trunk $4^{\prime}-5^{\prime}$ in diameter, short ascending branches forming a pyramidal head, and erect branchlets light red-brown and pilose when they first appear, bright orange-brown, lustrous, and nearly glabrous during their first winter, and roughened by slightly raised oblong-obovate leaf-scars with conspicuous central fibro-vascular bundle-scars, becoming light brown slightly tinged 
with red during their second season and dark gray-brown the following year; or more frequently shrubby. Winter-buds terminal, broadly ovate, acute, about $\frac{1^{\prime}}{8}$

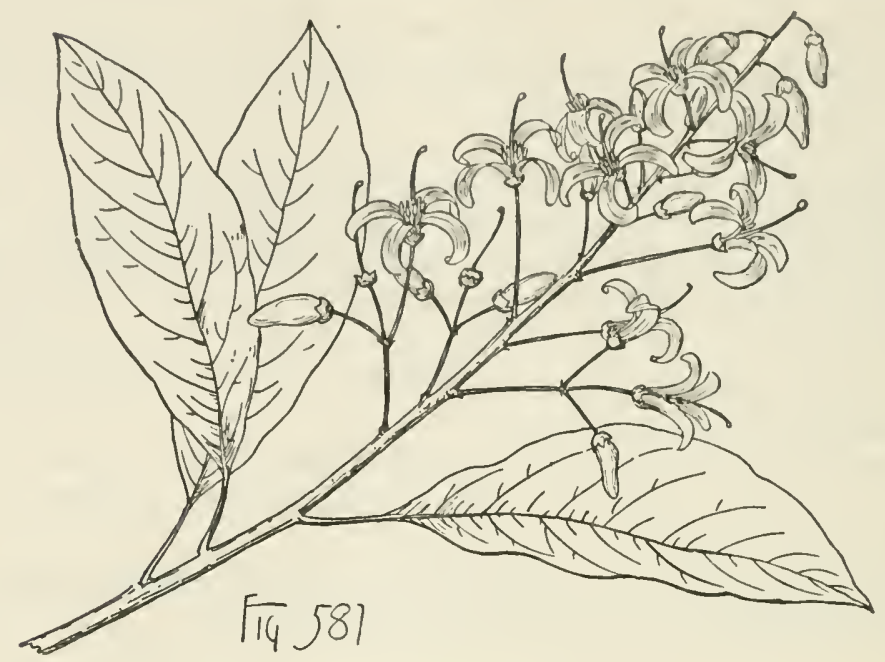

long, with much thickened bright chestnut-brown shining scales conspicuously whitepubescent near the margins toward the apex, the lateral smaller, ovate, compressed, rounded or short-pointed at the apex. Bark thin, smooth, pale gray.

Distribution. Sandy woods in a few isolated situations in the valley of the Savanmah River, near Augusta, and in Burke and Bullock counties, Georgia.

\section{RHODODENDRON, Maxim.}

Trees or shrubs, with scaly bark, terete branchlets, terminal buds formed in summer, and fibrous roots. Leaves usually clustered at the ends of the branches, revolute and entire on the margin. Flowers in terminal umbellate corymbs from buds with numerous caducous scales; calyx 5-parted or toothed, persistent under the fruit; corolla 5-cleft, deciduous; stamens more or less unequal, nltimately spreading; filaments subulate-filiform, pilose at the base; disk thick and fleshy, crenately lobed; ovary 5-celled; style slender, crowned with a capitate stigma and persistent on the fruit; ovules numerous in each cell, attached in many series to an axile 2-lipped placenta projected from the inner angle of the cell, anatropous. Fruit a woody septicidal many-seeded capsule. Seed scobiform; seed-coat loose, reticulate, produced at the ends beyond the nucleus into short often laciniate appendages; embryo minute, cylindrical, axile in fleshy albumen; cotyledons oblong, shorter than the radicle turned toward the hilum.

Rhododendron (including Azalea) with more than two hundred species abounds in western Thibet and on the Himalayas, southwestern China, the Malay Peniusnla and Archipelago, New Guinea, northern China and Corea, Japan, the mountains of central Asia, and in eastern and western North America. Of the seventeen or eighteen North American species one only is arborescent.

Rhododendron possesses astringent narcotic properties. It produces hard closegrained compact wood sometimes used in turnery and for fuel. Many of the species are cultivated in gardens for the beauty of their large and conspicuous flowers.

The generic name is from $\hat{\phi} \delta \delta o \nu$ and $\delta \epsilon \epsilon_{\nu} \rho o \nu$, the Rose-tree. 


\section{Rhododendron maximum, L. Great Laurel. Rose Bay.}

Leaves revolute in the bud, ovate-lanceolate or obovate-lanceolate, acute or shortpointed at the apex, narrowed or wedge-shaped or rounded at the narrow base, when they unfold covered with a thick pale or ferrugineous tomentum of gland-tipped hair's, and at maturity glabrous, thick and coriaceous, dark green and lustrous on the upper, usually pale or whitish on the lower surface, $4^{\prime}-12^{\prime}$ long, $1 \frac{1}{2}^{\prime}-2 \frac{1}{2}^{\prime}$ wide, with broad pale midribs and obscure reticulate veinlets, persistent two or three years; tleir petioles stout, ridged above, rounded below, $1^{\prime}-1 \frac{1}{2}^{\prime}$ long. Flowers: inflorescence-buds surrounded at first by several loose narrow leaf-like scales, and when fully grown in September cone-shaped, $1 \frac{1}{2}^{\prime}$ long and $\frac{1}{2}^{\prime}$ broad, with many imbricated ovate scales rounded and contracted at the apex into long slender points, begimning to open late in Jume after the shoots of the year from buds in the axils of upper leaves have reached their full length; flowers on slender pink pedicels covered with glandular white hairs and furnished at the base with two linear scarious bractlets from the axils of the scales of the imner ranks of the inflorescence-buds, in 16-24-flowered umbellate clusters $4^{\prime}-5^{\prime}$ in diameter, with accrescent scarious resinous puberulous bracts, those of the outer ranks becoming $1^{\prime}$ long and $\frac{1^{\prime}}{3}$ wide, and shorter than the lanceolate bracts of the inner ranks contracted into long slender points;

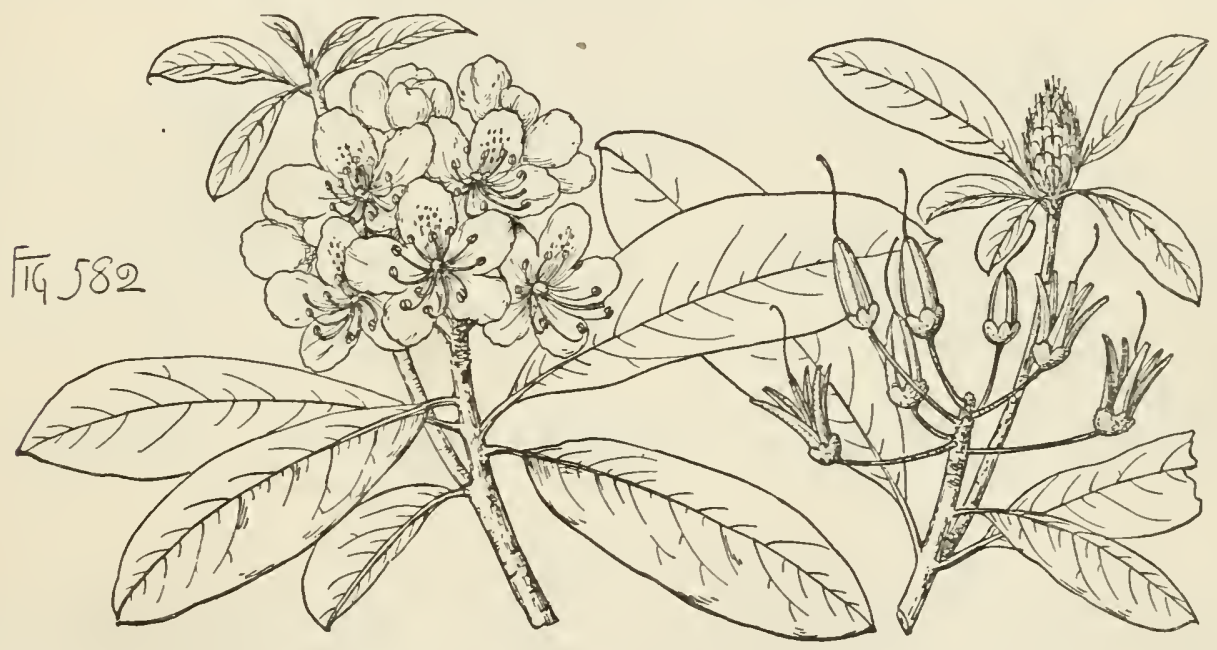

calyx light green and puberulous, with rounded remote lobes; corolla prominently 5 -angled or ridged in the bud, campanulate, gibbous on the posterior side, puberulous in the throat, light rose color, purplish, or white, $1^{\prime}$ long, cleft to the middle into oval rounded lobes, with couspicuous central veins, the upper lobe marked on the inner face by a cluster of yellow-green spots, and glandular on the outer surface at the bottom of each sinus, with a conspicuous dark red gland; stamens 8-12, white, inserted on the bright green disk; filaments enlarged and flattened at the base, slightly bent inward above the middle, and bearded with stiff white hairs, the 4 or 5 short ones at the back of the flower for more than half their leigth and the others only near the base; ovary ovate, green, coated with short glandular pale lairs, crowned with a long slender glabrous white declining style club-shaped and inflexed at the apex and terminating in a 5-rayed scarlet stignia. Fruit dark red-brown, ovate, $\frac{1}{2}^{\prime}$ long, glandular-hispid, ripening and shedding its seeds in the autumn, the clusters of open capsules remaining on the branches until the following summer; 
seeds oblong, flattened, the coat prolonged at the ends into scarious fringed appendages.

A buslry tree, $30^{\circ}-40^{\circ}$ high, with a short crooked often prostrate trunk occasionally $10^{\prime}-12^{\prime}$ in diameter, stout contorted branches forming a round head, and branchlets green tinged with red and covered with dark red or slightly ferrugineous glandular-hispid hairs when they first appear, dark green and glabrous in their first winter, gradually turning bright red-brown in their second year, and ultimately gray tinged with red, the thin bark separating on branches four or five years old into persistent scales; more often a broad shrub, with many divergent twisted stems $10^{\circ}-12^{\circ}$ high. Winter-buds: leaf-buds conical, dark green, axillary, or terminal on barren shoots, with many closely imbricated scales; those of the inner ranks accrescent, increasing in length from the onter to the inner, and at maturity $1 \frac{1}{2}^{\prime}$ long, $\frac{1^{\prime}}{4}$ wide, gradually narrowed at the base, and terminating at the apex in a long slender point, light green, glabrous, closely held against the sloot by a resinous exudation from the glandular hairs, and in falling marking the branchlet with numerous conspicuous narrow remote scars persistent for three or four years. Bark of the trunk about $\frac{1}{16}$ thick, light red-brown, broken on the surface into small thin appressed scales. Wood heavy, hard, strong, rather brittle, close-grained, light clear brown, with thin lighter colored sapwood; occasionally made into the handles of tools and used as a substitute for boxwood in engraving. A decoction of the leaves is occasionally employed in domestic practice in the treatment of rheumatism.

Distribution. Nova Scotia to the northern shores of Lake Erie, and southward through New York and New England, and along the Appalachian Mountains to northern Georgia; rare at the north and an inhabitant of deep cold swamps in a few isolated stations; more abundant on the mountains of western Pennsylvania, becoming exceedingly common farther south and occupying the steep banks of streams up to elevations of $3000^{\circ}$ above the sea; of its largest size on the high mountains of eastern Tennessee and the Carolinas, and here often forming thickets hundreds of acres in extent.

Often cultivated as an ornament of parks and gardens in the United States, and in Europe, and one of the parents of a number of distinct and beautiful hybrids.

\section{KALMIA, L.}

Trees or shrubs, with scaly bark, terete branchlets without terminal buds, minute axillary leaf-buds, elongated axillary inflorescence-buds covered by inbricated scales, and fibrous roots. Leaves ovate-oblong or linear, short-petiolate, with flat entire margins, coriaceous, persistent. Flowers on slender pedicels bibracteolate at the base, from the axils of foliaceous coriaceous ovate or acute persistent bracts, in axillary nmbels; calyx 5-parted, the divisions imbricated in the bud, persistent under the fruit; corolla 5-lobed, rose-colored, purple, or white, saucer-shaped, with a short tube and 10 pouches just below the 5-parted limb, the lobes ovate, acute, before anthesis prominently 10 -ribbed from the pouches to the acute apex of the bud, the salient keels of the ribs running to the points of the lobes and to the sinuses; stamens 10, shorter than the corolla; filaments filiform; anthers oblong, each cell opening by a short apical oblong longitudinal pore, at first free in the bud, the filaments then erect, later received in the pouches of the corolla, the filaments becoming bent back by its enlargement and expansion, straightening elastically and incurving on the release of the anthers, and in straightening discharging the pollen-grains; disk prominently 10-lobed; ovary subglobose, 5-celled; style filiform, 
exserted, crowned with a capitate stigma; ovules numerous in each cell, inserted on a 2-lipped placenta, pendulous or spreading from near the top of the thin columella, few-ranked, anatropous. Fruit a septicidal woody many-seeded globose slightly 5-lobed 5-celled capsule, tardily septicidally 5-valved, the valves crustaceous, ultimately opening down the middle by a narrow slit and separating from the persistent placenta-bearing axis. Seeds oblong or subglobose, minute; seed-coat crustaceous or membranaceous; embryo in fleshy albumen, terete, near the hilum; radicle erect, rather shorter than the oblong cotyledons.

Kalmia with five or six species is North American and Cuban, one species occasionally becoming under favorable conditions a small tree.

The generic name is in honor of the Swedish traveler and botanist, Peter Kalm (1715-1779).

\section{Kalmia latifolia, L. Laurel. Mountain Laurel.}

Leaves sometimes in pairs or in 3's, conduplicate in the bud, each leaf in the bud inclosed by the one immediately below it, oblong or elliptical-lanceolate, acute

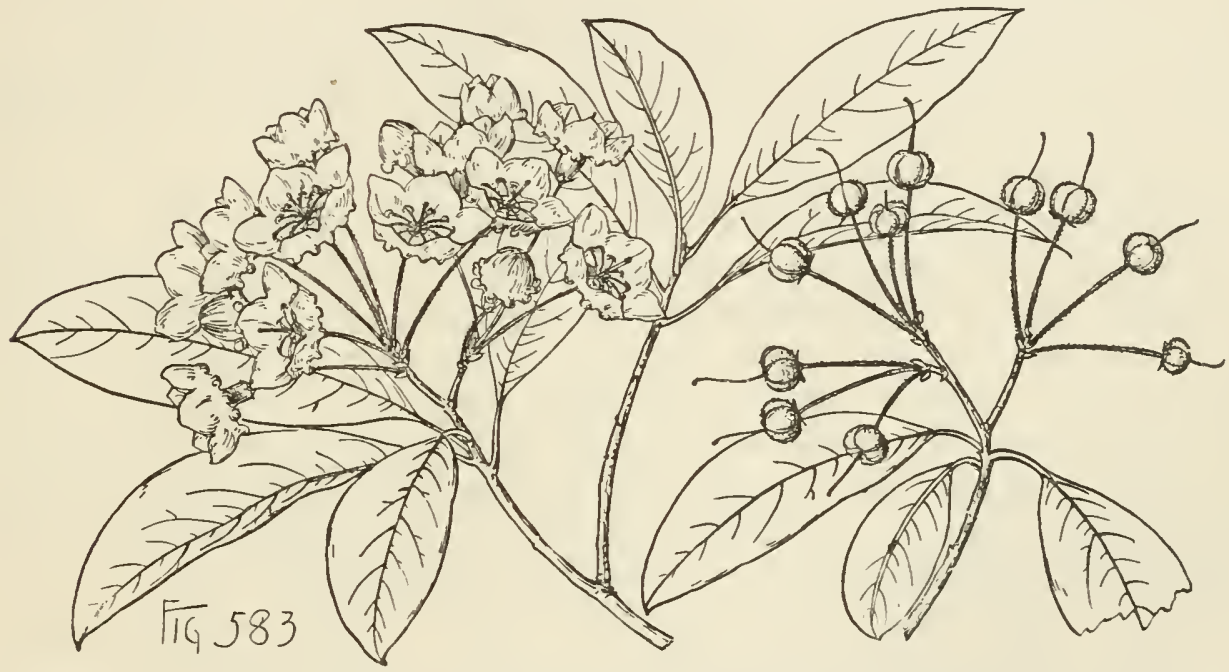

or rounded and tipped at the apex with callous points, and gradually narrowed at the base, when they unfold slightly tinged with pink and covered with glandular white hairs, and at maturity thick and rigid, dark rather dull green above, light yellowgreen below, $3^{\prime}-4^{\prime}$ long, $1^{\prime}-1 \frac{1^{\prime}}{2}$ wide, with broad yellow midribs and obscure immersed veins, beginning to fall during their second summer; their petioles stout, terete or slightly flattened, about $\frac{2}{3}$ long. Flowers: inflorescence-buds appearing in the autumn from the axils of upper leaves, beginning to lengthen with the first warm days of spring and usually developing 2 or several lateral branches, the whole forming a compound many-fiowered corymb of numerous crowded fascicles more or less covered with dark scurfy scales, $4^{\prime}-5^{\prime}$ in diameter, and overtopped at the flowering time by the leafy branches of the year; flowers nearly $1^{\prime}$ in diameter, opening in May and June on long slender red or green pedicels covered with glandular hairs, and furnished at the base with 2 minute acute bractlets developed from the axils of acute persistent bracts sometimes $\frac{1}{3}$ long; calyx divided nearly to the base irto narrow acute thin green lobes; corolla white, rose-color, or pink, viscid-pubescent, marked on the inner surface with a waving dark rose-colored line and with delicate purple penciling above the sacs. Fruit ripening in September, crowned with the 
persistent style, $\frac{3^{\prime}}{16}$ in diameter, and covered with viscid hairs, remaining on the branches mitil the following year; seeds oblong, light brown, scattered by the opening of the valves.

A tree, rarely $30^{\circ}-40^{\circ}$ high, with a short crooked and contorted trunk sometimes $18^{\prime}-20^{\prime}$ in diameter, stout forked divergent branches forming a round-topped compact head, and slender branchlets light green tinged with red and covered with soft white glandular-viscid hairs when they first appear, soon becoming glabrous, and in their first winter green tinged with red and very histrous, turning bright red-brown during their second year and paler the following season, the bark then separating into large thin papery scales exposing the cinnamon-red inner bark, and marked with large deeply impressed leaf-scars showing near the centre a crowded cluster of fibro-vascular bundle-scars; more often a dense broad shrub $6^{\circ}-10^{\circ}$ high, with numerous crooked stems. Winter-buds formed before midsummer in the axils of the leaves just below those producing the inflorescence-buds, their inner scales accrescent, and at maturity often $1^{\prime}$ long and $\frac{1}{2}^{\prime}$ wide, ovate, acute, light green, covered with glandular white hairs, and in falling marking the base of the shoots with conspicuous broad scars. Bark of the trunk hardly more than $\frac{1}{16}{ }^{\prime}$ thick, dark brown

- tinged with red, and divided by longitudinal furrows into narrow ridges separating into long narrow scales. Wood heavy, hard, strong, rather brittle, close-grained, brown tinged with red, with slightly lighter colored sapwood; used for the handles of tools, in turnery, and for fuel.

Distribution. New Brunswick to the northern shores of Lake Erie and sonthward generally in the neighborhood of the Appalachian Mountains to western Florida, and through the Gulf states to western Louisiana and the valley of the Red River, Arkansas; often growing in low moist ground near the margins of swamps or on dry slopes under the shade of deciduous-leaved trees, or on rich rocky hillsides; most abundant and often forming dense impenetrable thickets on the southern Appalachian Mountains up to elevations of $3000^{\circ}-4000^{\circ}$ above the level of the sea; usually shrubby, and only arborescent in a few secluded valleys between the Blue Ridge and the Alleghany Monntains of North and South Carolina.

Often cultivated as an ornament of parks and gardens in the eastern states, and in Europe.

\section{OXYDENDRUM, DC.}

A tree, with thick deeply furrowed bark, slender terete glabrous light red or brown branchlets without terminal buds, marked by elevated nearly triangular leaf-scars displaying a lunate row of crowded fibro-vascular bundle-scars, and numerous elevated oblong dark lenticels, acid foliage, and fibrous roots. Winter-buds axillary, minute, partly immersed in the bark, obtıse, covered with opposite broadly ovate dark red scales rounded at the apex, those of the inner ranks accrescent. Leaves alternate, revolute in the bud, oblong or lanceolate, acite, gradually contracted at the base into long slender petioles, serrate, with minnte incurved callous teeth, penniveined, with conspicuous bright yellow midribs and reticulate veinlets, thin and firm, dark green and lustrous on the upper, pale and glancous on the lower surface, glabrous or at first slightly puberulons, decidnous. Flowers on clavate erect pedicels coated with hoary pubescence and bibracteolate above the middle, with linear acute cadncons bractlets, in puberulous panicles of secund racemes appearing in summer and terminal on axillary leading shoots of the year, the lower racemes in the axils of upper leaves; calyx free, divided nearly to the base, the divisions valvate in the bud, 
ovate-lanceolate, acute, pubescent or puberulous on the outer surface, persistent under the fruit; corolla hypogynous, cylindrical to ovate-cylindrical, white, puberulous, 5-lobed, the lobes minute, ovate, acute, reflexed; stamens 10, included; filaments subulate, broad, pilose, inserted on the very base of the corolla; anthers linearoblong, narrower than the filaments, the cells opening from the apex to the middle; disk thin, obscurely 10-lobed; ovary broadly ovoid, pubescent, 5-celled; style columnar, thick, exserted, crowned with a simple stigma; ovules attached to an axile placenta rising from the base of the cell, ascending, amphitropous. Fruit a 5-celled ovoid-pyramidal many-seeded capsule crowned with the remnants of the persistent style, 5-lobed, puberulous, loculicidally 5-valved, the valves woody, separating from the central persistent placentiferous axis, many-seeded. Seeds ascending, elongated; seed-coat membranaceous, loose, reticulated, produced at the ends into long slender points; embryo minnte, axile in fleshy albumen, cylindrical; radicle terete, next the hilum.

The genus consists of a single species.

The generic name is from ớźs and $\delta \epsilon^{\prime} \nu \delta \rho o \nu$, in allusion to the acid foliage.

\section{Oxydendrum arboreum, DC. Sorrel-tree. Sour Wood.}

Leaves when they unfold bronze green, very lustrous and glabrous with the exception of a slight pubescence on the upper side of the midribs and a few scattered hairs on the under side of the midribs and on the petioles, and at maturity $5^{\prime}-7^{\prime}$ long, $1 \frac{1^{\prime}}{2}-2 \frac{1}{2}^{\prime}$ wide, turning bright scarlet in the antumn before falling; their petioles $\frac{2^{\prime}}{3}$ long. Flowers opening late in July or early in August, $\frac{1^{\prime}}{3}$ long, in panicles $7^{\prime}-S^{\prime}$ in length. Fruit $\frac{1}{3}^{\prime}-\frac{1}{2}^{\prime}$ long, hanging in drooping clusters sometimes a foot in length,

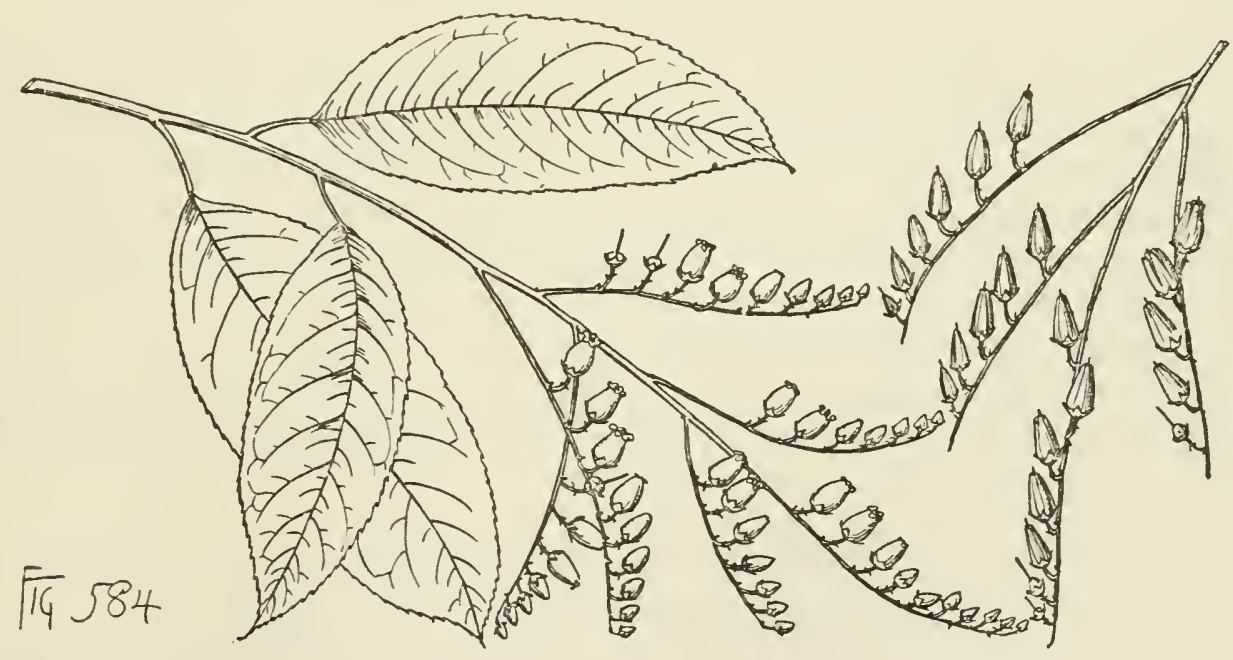

ripening in September, the empty capsules often persistent on the branches until late in the autumn; seeds about $\frac{1}{8}$ long, pale brown.

A tree, occasionally $50^{\circ}-60^{\circ}$ high, with a tall straight trunk $12^{\prime}-20^{\prime}$ in dianeter, slender spreading branches forming a narrow oblong round-topped head, and glabrous branchlets yellow-green and marked by orange-colored lenticels when they first appear, becoming in their first winter orange-colored to reddish brown. Winter-buds about $\frac{1}{16}^{\prime}$ long, their inner scales at maturity $1^{\prime}$ in length, $\frac{1}{8}^{\prime}$ wide, spatulate, acute at the apex, and slightly puberulous on the inner surface and on the margins. Bark of 
the trunk $\frac{2^{\prime}}{3}-1^{\prime}$ thick, gray tinged with red, and divided by longitudinal furrows into broad rounded ridges covered with small thick appressed scales. Wood heavy, hard, very close-grained, brown tinged witl red, with lighter colored sapwood of 80-90 layers of annual growth; sometimes used locally for the haudles of tools and the bearings of machinery. The leaves have a pleasant acidulous taste, and are reputed to be tonic, refrigerant, and diuretic, and are occasionally used in domestic practice in the treatment of fevers.

Distribution. Well-drained gravelly soil on ridges rising above the banks of streams; southeastern Peunsylvania to southern Indiana and middle Tennessee, and southward to the coast of Virginia and aloug the Alleghany Mountains to western Florida, the shores of Mobile Bay, and through the elevated regions of the Gulf states to western Louisiana; of its largest size on the western slopes of the Big Smoky Mountains, Tennessee.

Often cultivated as an oruamental plant in the eastern states and hardy as far north as eastern New England, and occasionally in western and central Europe.

\section{XOLISMA, Raf.}

Trees or shrubs, with slender terete branchlets, and fibrous roots. Leaves petiolate, membranaceous or coriaceous. Flowers on slender pedicels from the axils of ovate acute bracts, in axillary and terminal umbellate fascicles or panicled racemes; calyx persistent, 4-5-toothed or parted, the divisions valvate in the bud; corolla globular, 4-5-toothed or lobed, the lobes imbricated in the bud; stamens 8-10, included; filaments flat, incurved, usually slightly adnate to the base of the corolla, dilated and bearded at the base, geniculate; anther oblong, the cells opening below the apex by large oblong pores; disk 10-lobed; ovary 5 -celled, depressed in the centre; style columnar, stigmatic at the apex; ovules attaclied to a placenta borne near the summit of the axis, anatropous. Fruit ovoid, many-seeded, loculicidally 5 -valved, the valves septiferous and separating from the placentiferous axis, 5-ribbed by the thickening of the valves at the dorsal sutures, the rils more or less separable in dehiscence. Seeds minute, pendulous, narrow-oblong; seed-coat loose, thin, cellularreticulate, produced at the ends beyond the nucleus into short fringe-like wings; embryo axile in fleshy albumen, cylindrical, elongated; cotyledons much shorter than the terete radicle turned toward the hilum.

Xolisma with about sixteen species is confined to North America, the West Indies, and Mexico. Of the two species which occur in the United States one is a small tree.

The generic name is of doubtful derivation.

\section{Xolisma ferruginea, Hell.}

\section{(Andromeda ferruginea, Silva N. Am. v. 131.)}

Leaves cuneate-obovate, rhombic-obvate or cuneate-oblong, acnte or rounded at the apex, usually tipped with a cartilaginous mucro, gradually wedged-shaped at the base, and entire, with thickened revolute margins, scurfy when they unfold, and at maturity thick and firm, pale green, smooth and shining or sometimes obscurely lepidote above, covered below with ferrugineous or pale scales, $1^{\prime}-3^{\prime}$ long, $1^{\prime}-1 \frac{1}{2}^{\prime}$ wide, with prominent midribs and primary veins and broad conspicuous reticulate veinlets, appearing in early spring and persistent until the summer or autumn of their second year'; their petioles short, thick, much enlarged at the base. Flowers $\frac{1}{8}^{\prime}$ in diameter, chiefly produced on branches of the year or occasionally on those of the previous 
year, opening from February until April when the leaves are fully grown, on slender recurved pedicels much shorter than the leaves, in crowded axillary short-stemmed

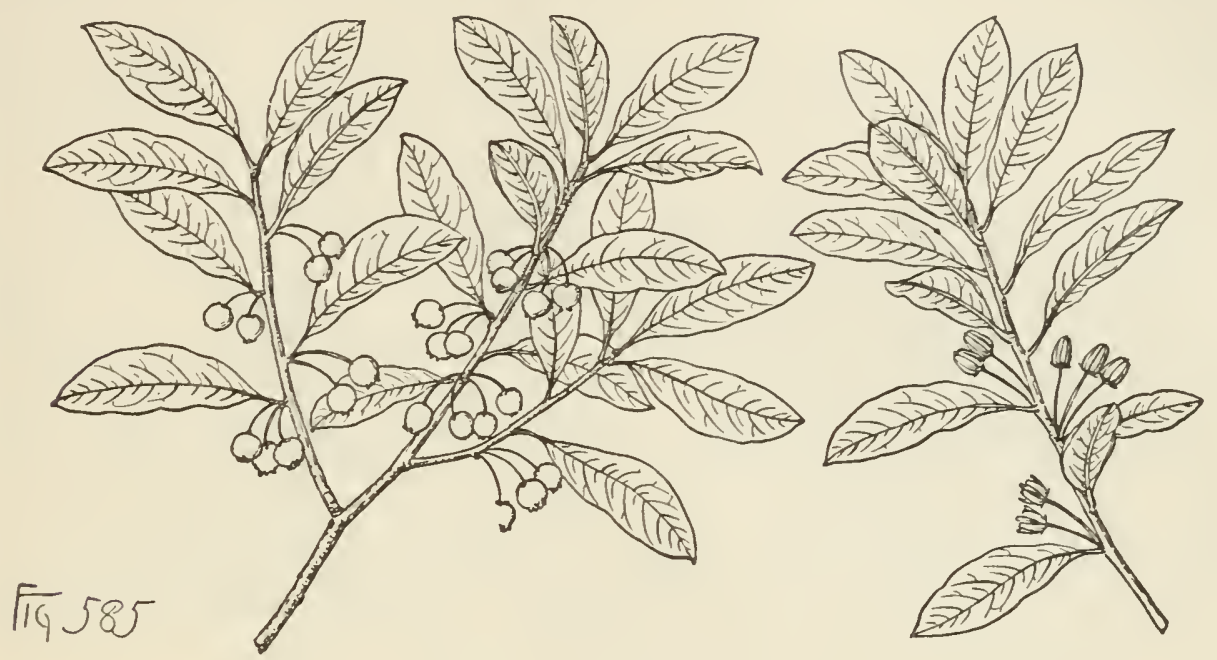

or sessile ferrugineous-lepidote fascicles, with minute acute deciduous bracts and bractlets; calyx 5-lobed, with acute lobes, covered on the outer surface with ferruginecus scales, and about one third as long as the white pubescent corolla, with short reflexed acute teeth slightly thickened and ciliate on the margins; filaments shortened by a conspicuous geniculate fold in the niddle; ovary coated with thick white tomentum; style stout, as long or a little longer than the corolla. Fruit on a stout erect stem, oblong, 5-angled, $\frac{1}{4}^{\prime}$ long; seed pale brown.

A tree, occasionally $20^{\circ}-30^{\circ}$ high, with a slender crooked or often prostrate trunk sometimes $10^{\prime}$ in diameter, thin rigid divergent branches forming a tall oblong irregular head, and slender branchlets coated when they first appear with minute ferrugineous scales and covered in their second year with glabrous or pubescent light or dark red-brown bark smooth or exfoliating in small thin scales; often a shrub, sometimes only $2^{\circ}-3^{\circ}$ tall. Bark of the trunk $\frac{1^{\prime}}{8}-\frac{1}{4}^{\prime}$ thick, divided into long narrow ridges by shallow longitudinal furrows, reddish brown and separating into short thick scales. Winter-buds minute, acute, and covered with ferrugineous scales. Wood heavy, hard, close-grained although not strong, light brown tinged with red, with thick lighter colored sapwood.

Distribution. Coast region of South Carolina to the shores of Bay Biscayne and the neighborhood of Appalachicola, Florida; in the United States arborescent in the rich soil of the woody hummocks rising from the sandy Pine-covered coast plain, and as a low shrub in the dry sandy sterile soil of Pine barrens; also in the West Indies and Mexico.

\section{ARBUTUS, L.}

Trees or shrubs, with astringent bark exfoliating from young stems in large thin scales, smooth terete red branches, and thick hard roots. Leaves petiolate, entire or dentate, obscurely penniveined, persistent. Flowers on clavate pedicels bibracteolate at the base from the axils of ovate bracts, in simple terminal compound racemes or panicles, with scarious scaly persistent bracts and bractlets; calyx free from the ovary, 5-parted nearly to the base, the divisions imbricated in the bud, ovate, acute, 
scarious, persistent; corolla ovoid-urceolate, white, 5-toothed, the teeth obtuse and recurved; stamens 10, shorter than the corolla; filaments subulate, dilated and pilose at the base, free, inserted in the bottom of the corolla; anthers short, compressed laterally, dorsally 2-awned, the cclls opening at the top internally by a terminal pore; ovary glandular-roughened, glabrous or tomentose, sessile or slightly immersed in the glandular 10-lobed disk, 5 or rarely 4 -celled; style columnar, simple, exserted; stigma obscurely 5-lobed; ovules attached to a central placenta developed from the inner angle of cach cell, amphitropous. Fruit drupaceons, globose, smooth or glandular-coated, 5-celled, many-seeded; flesh dry and mealy; stone cartilaginous, often incompletely developed. Seeds small, compressed or angled, narrowed and often apiculate at the apex; seed-coat coriaceous, dark red-brown, slightly pilose; embryo axile in copious horny albumen, clavate; radicle terete, erect, turned toward the hilum.

Arbutus with ten or twelve species inhabits southern and western North America, Central America, eastern, southern, and southwestern Europe, Asia Minor, northerı Africa, and the Canary Islands. Three species occur within the territory of the United States. Arbutus produces hard close-grained valuable wood often made into charcoal, used in the manufacture of gunpowder. The fruit possesses narcotic properties, and the bark and leaves are astringent.

Arbutus is the classical name of the species of southern Europe.

\section{CONSPECTUS OF THE SPECIES OF THE UNITED STATES.}

Bark of old trunks dark red-brown.

Ovary glabrous; leaves oval or oblong, entire or serrate.

Ovary pubescent ; leaves oval, ovate, or lanceolate.

1. A. Menziesii (B, G).

2. A. Xalapensis (C).

Bark of old trunks ashy gray; ovary glabrous, conspicuously porulose ; leaves lanceolate or rarely narrowly oblong.

3. A. Arizonica (H).

\section{Arbutus Menziesii, Pursh. Madroña.}

Leaves oval or oblong, rounded or contracted into short points at the apex, and rounded, subcordate, or wedge-shaped at the base, with slightly thickened revolute entire or occasionally on young plants sharply serrate margins, when they unfold light green or often pink, especially on the lower surface, and glabrous or slightly puberulous, and at maturity thick and coriaceons, dark green and lustrous above, pale or often nearly white below, $3^{\prime}-5^{\prime}$ long, $1 \frac{1}{2}^{\prime}-3^{\prime}$ wide, with thick pale midribs and conspicuously reticulated veinlets, persistent until midsummer of their second year and then turning orange and scarlet and falling gradually and irregularly; their petioles stont, grooved, $\frac{1}{2}^{\prime}-1^{\prime}$ long, often slightly wing-margined toward the apex. Flowers about $\frac{1}{3}^{\prime}$ long, with glabrous ovaries, appearing from March to May on short slender puberulous pedicels from the axils of acute scarious bracts ciliate on the margins, in spicate pubescent racemes forming a terminal cluster $5^{\prime}-6^{\prime}$ long and broad. Fruit ripening in the autumn, subglobose or occasionally obovate or oval, $\frac{1}{2}^{\prime}$ long, bright orange-1'ed, with thin glandular flesh and a 5-celled more or less perfectly developed thin-walled cartilaginous stone; seeds several in each cell, tightly pressed together and angled, dark brown and pilose.

A tree, $80^{\circ}-100^{\circ}$ high, with a tall straight trunk $4^{\circ}-7^{\circ}$ in diameter, stout upright or spreading branches forming a narrow oblong or broad round-topped head, and slender branchlets light red, pea-green, or orange-colored and glabrous when they first appear, or on vigorous young plants sometimes covered with pale scattered deciduous hairs, becoming in their first winter bright reddish brown. Winter-buds obtuse, $\frac{1}{3}$ 
long, with numerous imbricated broadly ovate bright brown scales keeled on the back, apiculate at the apex, and slightly ciliate. Bark of young stems and of the branches smooth, bright red, separating into large thin scales, becoming on old trunks $\frac{1}{8}^{\prime}-\frac{1^{\prime}}{2}$ thick, dark reddish brown, and covered with small thick plate-like scales. Wood heavy, hard, strong, close-grained, light brown shaded with red, with thin lighter

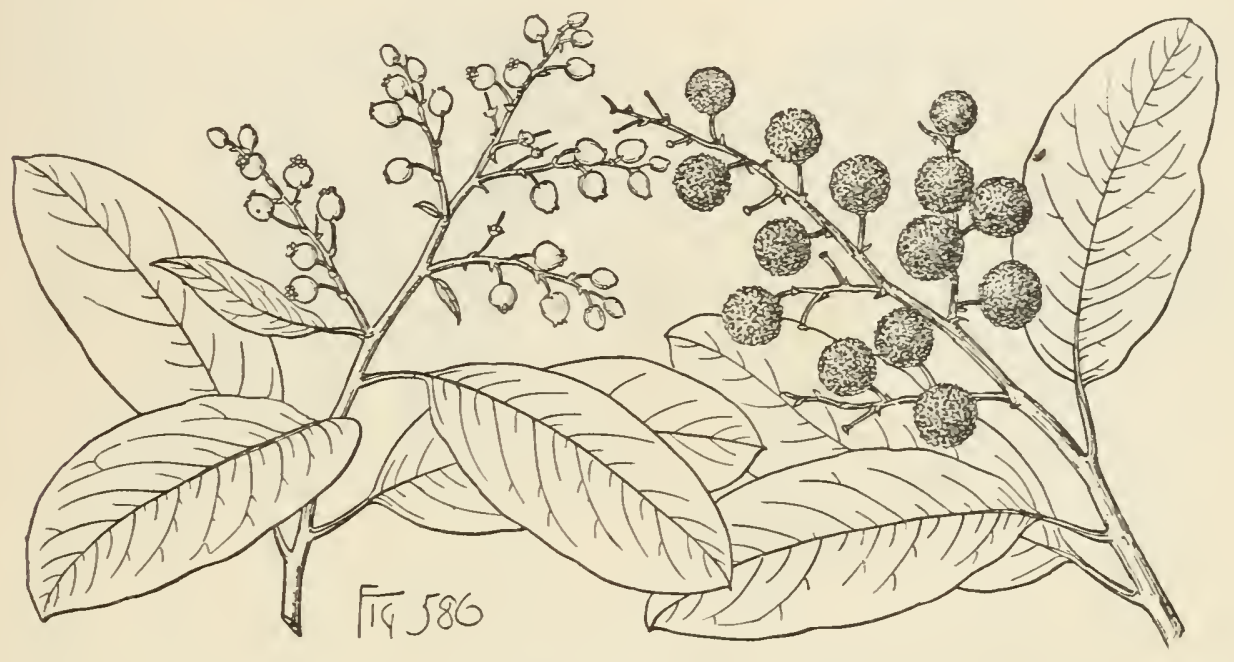

colored sapwood of 8-12 layers of annual growth; used for furniture and largely for charcoal. The bark is sometimes employed in tanning leather.

Distribution. High well-drained slopes usually in rich soil; islands of British Columbia at Seymour Narrows, southward through the coast region of Washington and Oregon, and over the California coast ranges to the Santa Lucia Mountains; common and of its largest size in the Redwood forests of northern California; farther north and south and on the dry eastern slopes of the California mountains much smaller; south of the Bay of San Francisco often shrubby in habit.

Occasionally cultivated in the gardens of western and southern Europe.

\section{Arbutus Xalapensis, H. B. K. Madroña.}

Leaves oval, ovate, or lanceolate, rounded, acute, and often apiculate at the apex, and rounded or wedge-shaped at the base, with slightly thickened usually entire or remotely crenulate-toothed or coarsely serrate margins, when they unfold often tinged with red, especially on the petioles, midribs, and margins, or sometimes pubescent below along the upper side of the midribs and on the petioles, and at maturity thick and coriaceous, dark green, lustrous and glabrous above, pale and glabrous or cinereo-pubescent below, $1^{\prime}-3^{\prime}$ long, $\frac{2}{3}^{\prime}-1_{\frac{1}{2}}^{\prime}$ wide, with thick light colored midribs sometines puberulous on the upper side, and reticulate veinlets; their petioles stout, pubescent, $1^{\prime}-1 \frac{1}{2}^{\prime}$ long and often furnished toward the apex with several dark glands. Flowers $\frac{1}{4}^{\prime}$ long, with ovaries sparingly or densely covered with long scattered white hairs, appearing in March on stout reddish pubescent recurved pedicels from the axils of ovate acute scarious bracts, in compact conical pubescent panicles $2 \frac{1}{2}^{\prime}$ long. Fruit usnally produced very sparingly, ripening in summer, dark red, $\frac{1}{3}^{\prime}$ in diameter, with thin granular flesh and a rather thick more or less completely formed stone; seeds numerous in each cell, compressed, puberulous.

A tree, in Texas rarely more than $18^{\circ}-20^{\circ}$ high, with a short often crooked trunk 
$8^{\prime}-10^{\prime}$ in diameter, separating a foot or two above the gromnd into several stout spreading branches, and branchlets light red and thickly coated with pubeseenee when they first appear, becoming dark red-brown and covered with small plate-like scales;

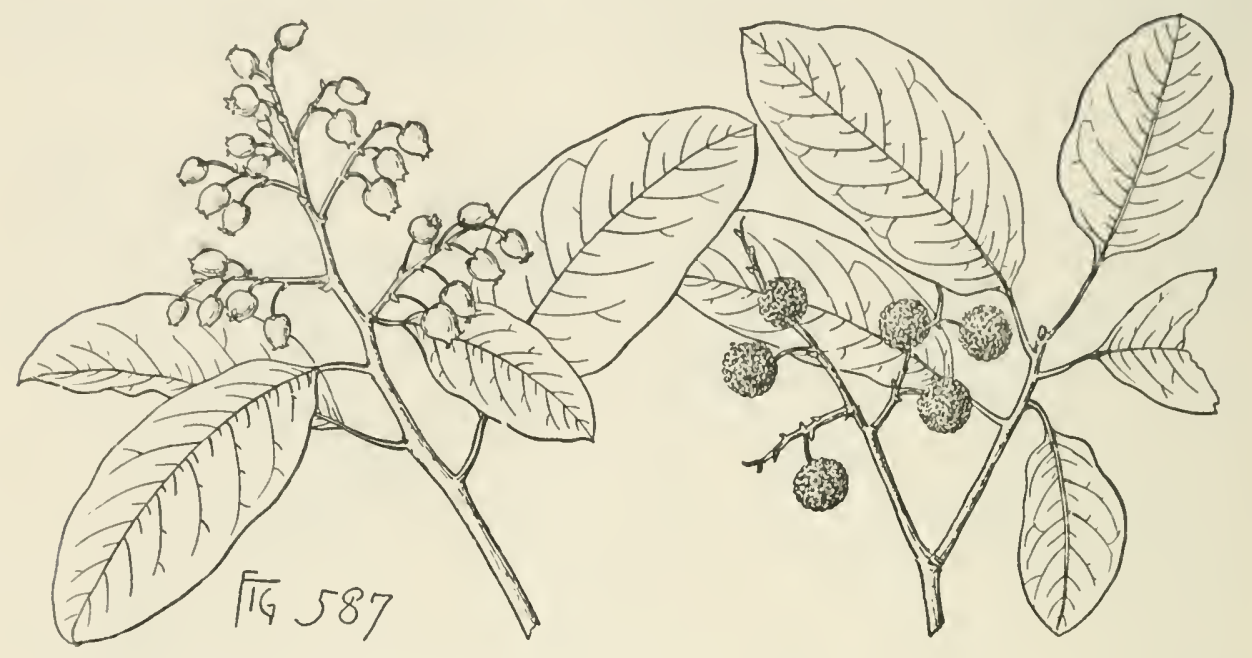

often a broad irregularly shaped bush, with numerous contorted stems. Bark of young stems and of the branches thin, tinged with red, separating into large papery scales exposing the light red or flesh-colored inner bark, becoming at the base of old trunks sometimes $\frac{1}{4}^{\prime}$ thick, deeply furrowed, dark reddish brown, and broken into thick square plates. Wood heavy, hard, close-grained, brown tinged with red, with a lighter colored sapwood of 10-12 layers of annual growth; sometimes used in Texas for the handles of small tools and in the manufacture of mathematical instruments.

Distribution. Dry limestone hills; Travis County and the valley of the Rio Blanco, Hays County, westward to the Guadaloupe and Eagle Mountains, Texas; common on the mountains of Nuevo Leon and southward in Mexico.

\section{Arbutus Arizonica, Sarg. Madroña.}

Leaves lanceolate to rarely oblong, acute or rounded and apiculate at the apex, and wedge-shaped or occasionally rounded at the base, with thickened entire or rarely denticulate margins, when they unfold membranaceous, tinged with red, and slightly puberulous, especially on the petioles and margins, and at maturity thin, firm and rigid, light green on the upper, pale on the lower surface, $1 \frac{1}{2}-3^{\prime}$ long and $\frac{1^{\prime}}{2}-1^{\prime}$ wide, with slender yellow midribs and obscure reticulate veinlets, appearing in May and after the summer rains in September, and persistent for at least a year; their petioles slender, often $1^{\prime}$ long. Flowers $\frac{1^{\prime}}{4}$ long, with corollas much contracted in the middle, and glabrous porulose ovaries, opening in May on short stout hairy pedicels from the axils of conspicuous ovate rounded scarious bracts collected in rather loose terminal clusters $2^{\prime}-2 \frac{1}{2}^{\prime}$ long and broad, their lower branches from the axils of upper leaves. Fruit ripening in October and November, globose or oblong, dark orange-red, granulate, $\frac{1}{3}^{\prime}$ in diameter, with thin sweetish flesh, and a papery usually incompletely developed stone; seeds compressed, puberulous.

A tree, $40^{\circ}-50^{\circ}$ high, with a tall straight trunk $18^{\prime}-24^{\prime}$ in diameter, stout spreading branches forming a rather compound round-topped head, and thick tortuous 
divergent branchlets reddish brown and more or less pubescent or light purple, pilose, and covered with a glaucous bloom when they first appear, becoming bright red at the end of their first season, with bark separating freely into thin more or less persistent scales. Bark of young stems and of the branches thin, smooth, dark red, exfoliating in large thin scales, becoming on old trunks $\frac{1}{3}^{\prime}-\frac{1}{2}^{\prime}$ thick, irregularly broken by longitudinal furrows and divided into square appressed plate-like light gray or

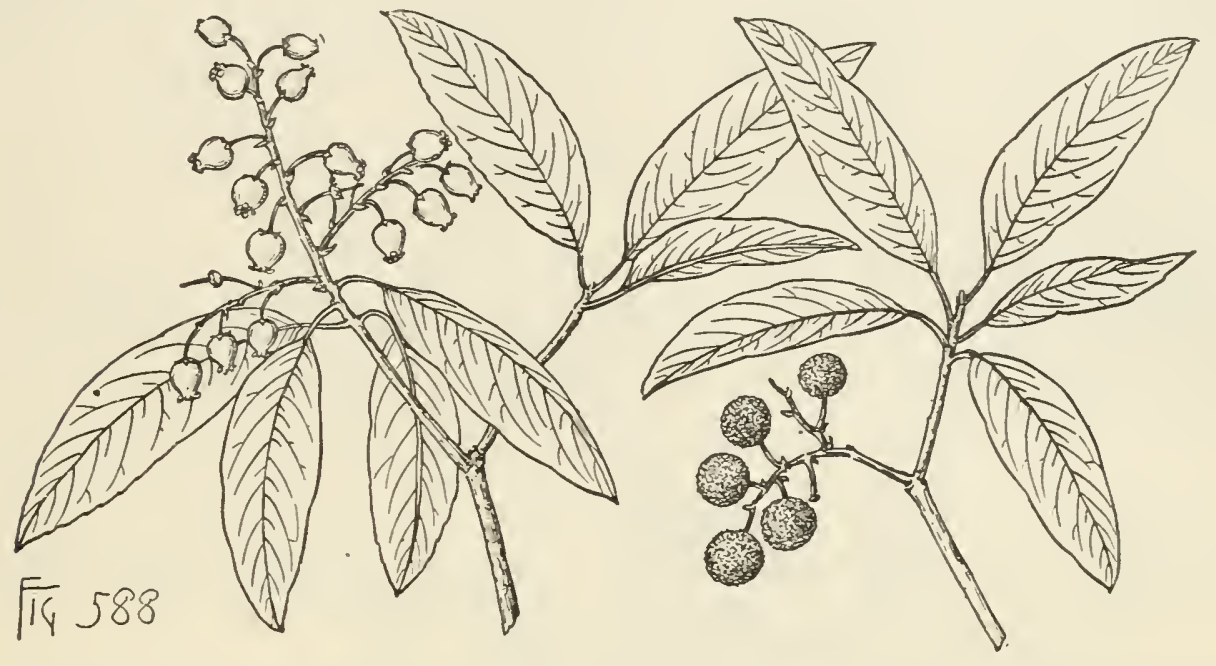

nearly white scales faintly tinged with red on the surface. Wood heary, closegrained, soft and brittle, light brown tinged with red, with lighter colored sapwood of 30-40 fayers of annual growth.

Distribution. Dry gravelly benches at elevations of $6000^{\circ}-8000^{\circ}$ above the sea on the Santa Catalina and Santa Rita Mountains, southern Arizona, and southward along the Sierra Nevada of Chihuahua.

\section{VACCINIUM, L.}

Shrubs or rarely small trees, with slender branchlets, and fibrous roots. Leaves membranaceous or coriaceons, deciduous or persistent. Flowers small, on bibracteolate pedicels, in many-branched axillary racemes, or solitary, their bracts small or foliaceous; calyx-tube adnate to the ovary, 4-5-lobed, the lobes valvate in the bud, persistent; corolla epigynous, 4 or 5 -toothed, the teeth imbricated in the bud, urceolate-campanulate; stamens 8-10, inserted on the base of the corolla under the thick obscurely lobed epigynons disk; filaments filiform, free, nsually hirsute; anthers awned on the back, the cells produced upward into erect spreading tubes dehiscent by terminal pores; ovary inferior, 4 or 5 -celled, the cells sometimes imperfectly divided by the development from the back of a false partition; style filiform, erect; stigma minute; ovules attached to the interior angle of the cell by a 2-lipped placenta, anatropous. Fruit a berry crowned with the calyx-limb, 4 or 5 or imperfectly 8 or 10-celled, the cells many-seeded. Seed minute, compressed, ovoid or reniform; seed-coat crustaceous; embryo clavate, minute, surrounded by fleshy albumen, axile, erect; cotyledons ovate; radicle terete, turned toward the hilum.

Vaccinium with about one hundred species is distributed through the boreal and temperate regions of the northern hemisphere, and occurs within the tropics at high elevations above the sea north and south of the equator. Of the twenty-five or thirty 
species which occur in North America one is a small tree. The fruits of many of the species are edible, the most valuable being the North American Vaccinium macrocarpum, L., the Cranberry.

Vaccinium is the classical name of one of the Old World species.

\section{Vaccinium arboreum, Marsh. Farkleberry. Sparkleberry.}

Leaves obovate, oblong-oval or occasionally orbicular, acute, or rounded and apiculate at the apex, gradually or abruptly wedge-shaped at the base, obscurely glandular-dentate or entire, with thickened slightly revolute margins, when they unfold light red and more or less pilose or puberulous, and at maturity coriaceous, dark green and lustrous above, paler below, glabrous or of ten puberulous on the midribs and veins, reticulate-venulose, $\frac{1^{\prime}}{2}-2 \frac{1}{2}^{\prime}$ long, $\frac{1^{\prime}}{4}-1^{\prime}$ wide, and sessile or shortpetiolate, southward persistent for a year, northward deciduous during the winter. Flowers appearing from March to May on slender drooping pedicels $\frac{1^{\prime}}{2}$ long, bibracteolate near the middle, with 2 minute acute scarious caducous bractlets, solitary in the axils of leaves of the year or arranged in terminal puberulous racemes

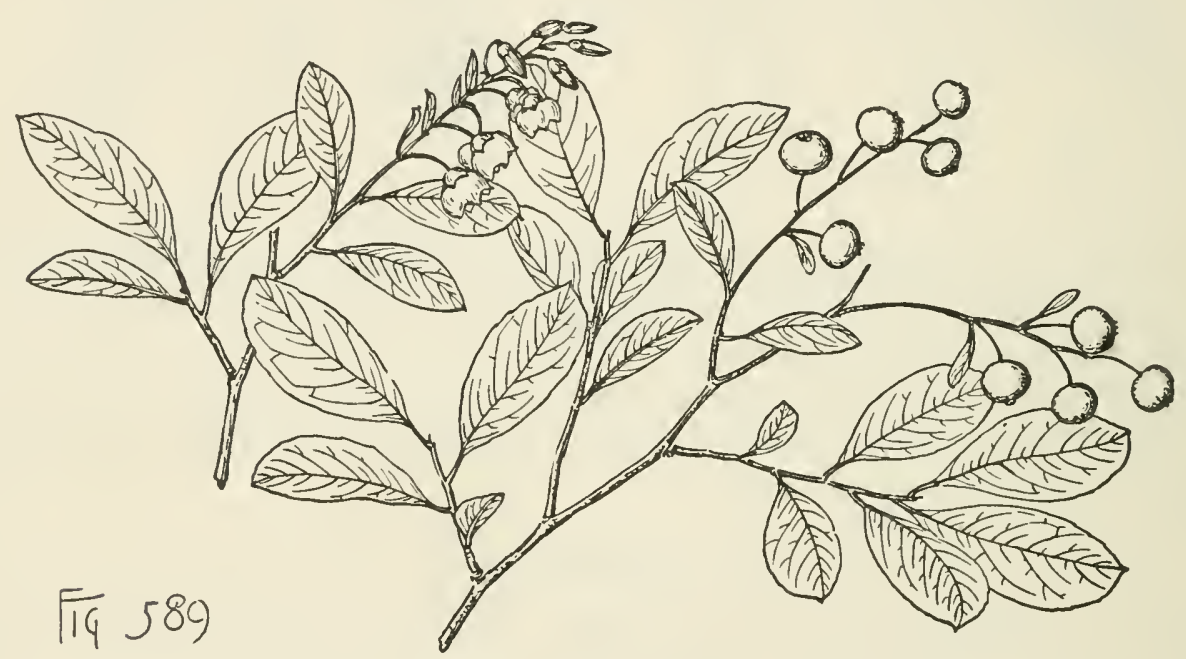

$2^{\prime}-3^{\prime}$ long from the axils of leafy or minute acute scarious bracts; corolla white, open-campanulate, slightly 5-lobed, with acute reflexed lobes, longer than the 10 stamens; filaménts hirsute; anther-cells opening by oblique elongated pores. Fruit ripening in October, sometimes persistent on the branches until the end of winter, globose, $\frac{1 \prime}{4}$ in diameter, black and listrous, with dry glandular slightly astringent flesh of a pleasant flavor.

A tree, $20^{\circ}-30^{\circ}$ high, with a short often crooked trunk occasionally $8^{\prime}-10^{\prime}$ in diameter, slender more or less contorted branches forming an irregular round-topped head, and slender branchlets light red and covered with pale pubescence when they first appear, glabrous or puberulous and bright red-brown in their first winter, later becoming dark red and marked by minute elevated nearly orbicular leaf-scars; or northward generally reduced to a low shrub, with numerous divergent stems. Winter-buds obtuse, nearly $\frac{1}{16}$ long, with imbricated ovate acute chestnut-brown scales often persistent on the base of the branchlet throughout the season. Wood heavy, hard, very close-grained, light brown tinged with red, with thick hardly distinguishable sapwood; sometimes used for the handles of tools and in the manufac- 
ture of other small articles. Decoctions of the astringent bark of the root and of the leaves are sometimes employed domestically in the treatment of diarrhœa. The bark has been used by tanners.

Distribution. Usually in moist sandy soil along the banks of ponds and streams; North Carolina, from the coast to the valleys of the high Appalachian Mountains, to Hernando County, Florida, through the Gulf states to the shores of Matagorda Bay, Texas, and through Arkansas and Missouri to southern Illinois; common in the maritime Pine belt of the south Atlantic and Gulf states, and of its largest size near the coast of eastern Texas; in the interior less abundant and usually of small size.

\section{MYRSINACE王.}

Trees or shrubs, with watery juice, alternate entire coriaceous punctate leaves without stipules. Flowers regular, perfect; calyx persistent under the fruit; corolla without staminodia, glandular-punctate; stamens inserted on the corolla, as many as and opposite its lobes; ovary 1-celled, with an undivided style and a minute terminal stigma; ovules peltate, immersed in the fleshy central placenta, amphitropous. Fruit a drupe. Seed solitary, globose, with copious cartilaginous albumen; seed-coat membranaceous.

A family of twenty-nine genera confined to tropical and semitropical regions, with one arborescent species of Icacorea reaching the shores of southern Florida.

\section{ICACOREA, Aubl.}

Glabrous trees or shrubs, with leaves punctate below, with immersed resinous dots. Flowers resinous-punctate, pedicellate, the pedicels bibracteolate at the base or ebracteolate, in terminal or rarely axillary branched panicles, with minute scarious deciduous or caducous bracts and bractlets; calyx free, 5 or rarely 4-lobed or parted, the divisions contorted or imbricated in the bud; corolla 5 or rarely 4-6-parted, the divisions extrorsely or sinistrorsely contorted in the bud, short or elongated, white or rose color; stamens exserted; filaments short or nearly obsolete, free, inserted on the throat of the corolla; anthers usually sagittate-lanceolate, attached on the back just above the base, introrse, 2-celled, the cells opening longitudinally sometimes nearly to the base; ovary globose; ovules numerous, immersed in the globose resinous-punctate placenta. Fruit globose, with thin usually dry flesh and a 1-seeded stone with a usually crustaceous or bony shell. Seed concave or more or less lobed at the base, resinous-punctate; hilum basilar, concave, conspicuous; embryo cylindrical, transverse; cotyledons flat on the inner face, rounded on the back, shorter than the slender radicle.

Icacorea with about two hundred species inhabits tropical and subtropical regions of the two hemispheres. 'The genns has few useful properties, but a number of species are cultivated for the beauty of their handsome evergreen foliage and brightcolored frnits.

The generic name is of Carib origin.

\section{Icacorea paniculata, Sudw. Marlberry. Cherry.}

Leaves ovate to lanceolate-oblong or lanceolate-obovate, acute or rounded at the narrow apex, wedge-shaped and gradually contracted at the base, entire, with thickened and slightly revolute margins, $3^{\prime}-6^{\prime}$ long, $1^{\prime}-1 \frac{1}{2}^{\prime}$ wide, thick and coriaceous, glabrous, marked by minute scattered dark dots, dark yellow-green on the upper, 
pale on the lower surface, with broad midribs yellow and conspicuous on the under side, slender primary veins and reticulate veinlets, appearing in the summer or early autum and falling before the appearance of the flowers the following year; their petioles stout, grooved, $\frac{1^{\prime}}{4}-\frac{1}{2}$ long. Flowers fragrant, usually opening in November or occasionally as early as July, on slender elongated pedicels without bractlets, developed from the axils of linear acute cadncous bracts, in terminal rusty brown puberulous panicles $3^{\prime}-4^{\prime}$ long and broad, their lower branches often from the axils of upper leaves; calyx ovate, divided nearly to the base into 5 ovate acute lobes scarious and ciliate on the margins and marked on the back with dark lines; corolla 5-parted, with oblong rounded divisions sinistrorsely overlapping, or with 1 lobe wholly outside and 1 inside in the bud, conspicuously marked with red spots on the inner surface near the base, becoming reflexed; stamens, with short broad filaments, contracted by a geniculate fold in the middle, and large orange-colored anthers

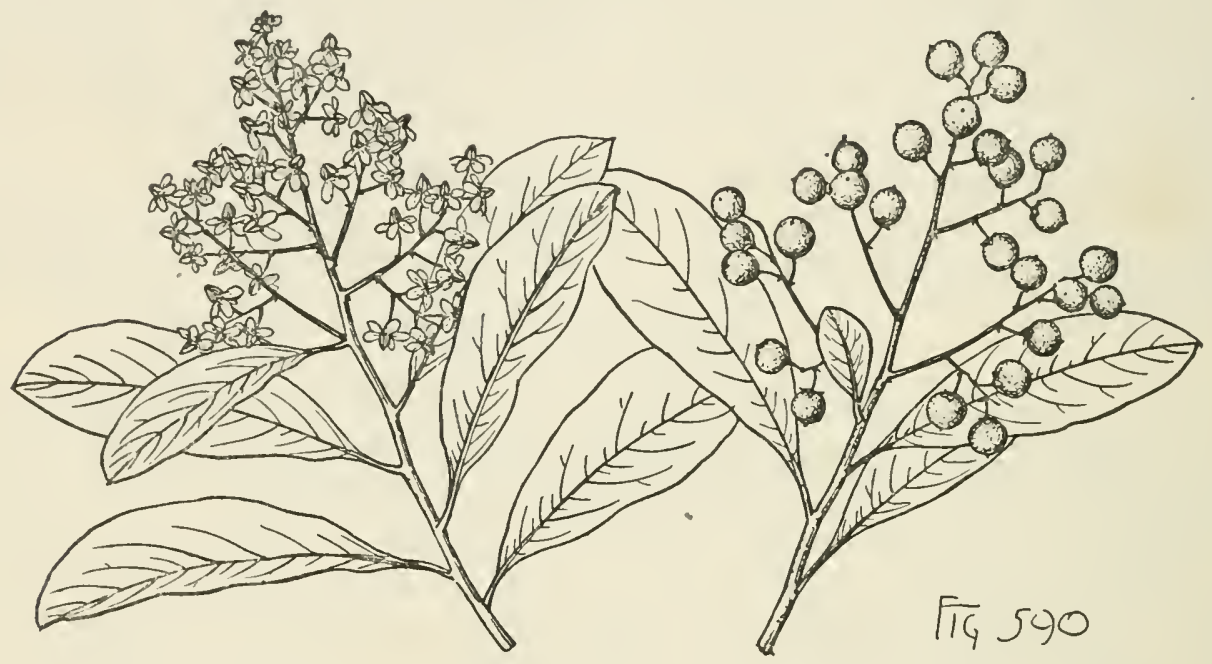

longer than the filaments, their cells opening almost to the base; ovary globose, glandular, gradually contracted into a long slender style tipped with a simple stigma. Fruit ripening in early spring, globose, $\frac{1^{\prime}}{4}$ in diameter, tipped with the remnants of the style, and roughened by resinous glands, dark brown at first when fully grown, ultimately becoming black and lustrous, with a thin-walled crustaceous brown stone; seed conspicuously lobed at the base, bright red-brown, about $\frac{1}{8}^{\prime}$ in diameter.

A slender tree, in Florida rarely more than $20^{\circ}$ high, with a short trunk $4^{\prime}-5^{\prime}$ in diameter, numerous thin upright branches forming a narrow head, and stout terete often contorted branchlets, rusty brown or dark orange-colored and slightly puberulous at first, becoming in their second year dark brown or ashy gray, and marked by many minute circular lenticels and by thin nearly orbicular flat leaf-scars displaying in the centre a group of fibro-vascular bundle-scars. Winter-buds rusty brown; terminal slender, acuminate, $\frac{1^{\prime}}{8}-\frac{1}{4}$ long; axillary globose, minute, nearly immersed in the bark. Bark of the trunk about $\frac{1^{\prime}}{8}$ thick, light gray or nearly white, roughened by minute lenticels, and separating into large thin papery plates. Wood heavy, hard, very close-grained, rich brown beautifully marked by darker medullary rays, with thick lighter colored sapwood.

Distribution. Florida, from Mosquito Inlet to the southern keys on the east 
coast, and from the shores of the Caloosa River to Cape Romano on the west coast; usually a shrub, occasionally arborescent on the shores of Bay Biscayne and on some of the southern keys; also on the Bahama Islands, Cuba, and in southern Mexico.

\section{THEOPHRASTACE王.}

Trees or shrubs, with watery juice, and entire coriaceous persistent leaves. Flowers perfect, regular; calyx campanulate, with 5 sepals imbricated in the bud; corolla 5-lobed, the lobes imbricated in the bud, with 5 staminodia attached below the sinuses; stamens 5, attached to the base of the corolla-tube, opposite the lobes; ovary 1-celled, with a simple style and a slightly 5-lobed stigma; ovules peltate, numerous, attached to a central fleshy placenta, amphitropous. Fruit baccate, many-seeded. Seeds immersed in the thickened placenta filling the cavity of the fruit; seed-coat membranaceous ; embryo surrounded by thick cartilaginous albumen.

\section{JACQUINIA, Jacq.}

Trees or shrubs, with terete or slightly many-angled branchlets, and fibrous roots. Leaves often punctate, with pellncid dark glands. Flowers on slender ebracteolate pedicels from the axils of minute ovate acute persistent bracts, in terminal or axillary clusters; calyx slightly ciliate on the margins, rounded at the apex, persistent; corolla hypogynous, the lobes obtuse and spreading, furnished with 5 petal-like ovate obtuse spreading staminodia; stamens inserted on the corolla opposite its lobes near the base of the short tube; filaments flattened, broad at the base; anthers oblong or ovate, attached on the back above the base, extrorse, 2-celled, the cells opening longitudinally; ovary ovoid. Fruit ovoid or subglobose, crowned by the remnants of the persistent style, with a thin crustaceous outer coat, inclosing the thick enlarged mucilaginons placenta. Seeds oblong; seed-coat punctate; embryo eccentric; cotyledous ovate, shorter than the elongated inferior radicle turned toward the broad ventral hilum.

Jacquinia with thirty-three species is confined to tropical America, with one species reaching southern Florida.

The generic name is in honor of Nicholas Joseph Jacquin (1728-1818).

\section{Jacquinia Keyensis, Metz. Joe Wood.}

(Jacquinia armillaris, Silva N. Am. vi. 157.)

Leaves subverticillate, alternate, or sometimes opposite, crowded near the ends of the branches, cuneate-spatulate or obovate-oblong, rounded or emarginate or often apiculate at the apex, gradually narrowed below, entire, with thickened slightly revolute margins, thick and coriaceous, yellow-green, nearly veinless, with very obscure midribs, covered on the lower surface with pale dots, $1^{\prime}-3^{\prime}$ long, $\frac{1^{\prime}}{4}-1^{\prime}$ wide, persistent on the branches until the appearance of the new leaves the following year; their petioles short, stout, abruptly enlarged at the base. Flowers appearing in Florida from November until June, $\frac{1}{3}$ ' in diameter, pale yellow, on slender club-shaped pedicels $\frac{1^{\prime}}{2}$ long from the axils of minute ovate coriaceous reddish bracts slightly ciliate on the margins, in terminal and axillary many-flowered glabrous racemes $2^{\prime}-3^{\prime}$ long. Fruit ripening in the autumn, $\frac{1}{3}$ in diameter, orange-red when fully ripe; seeds light brown. 
A tree, $12^{\circ}-15^{\circ}$ high, with a straight trmk $6^{\prime}-7^{\prime}$ in diameter, stont rigid spreading branches forming a eompact regular round-topped head, and slightly manyangled branchlets yellow-green or light orange-colored and coated with short soft

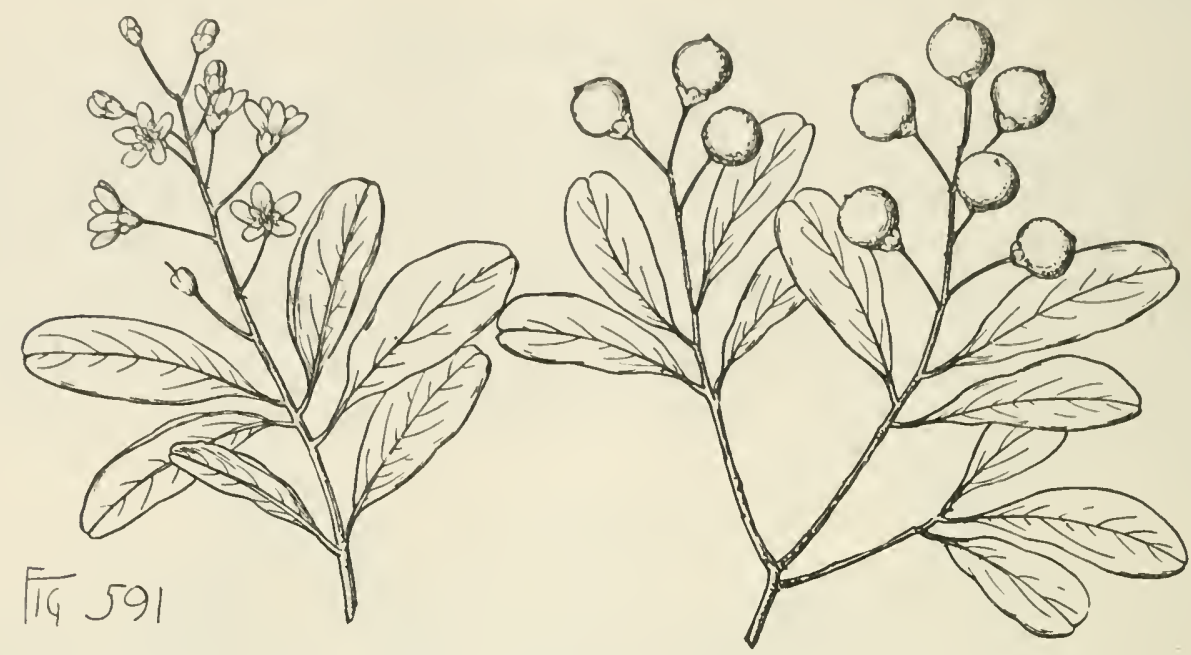

pale ferrugineous pubescence when they first appear, terete, darker and sometimes reddish brown and marked by orbicular depressed conspicnous leaf-scars and with many scattered pale lenticels in their second year, becoming glabrons and red-brown or ashy gray the following season, without terminal buds. Winter-buds axillary, minute, nearly globose, immersed in the bark. Bark of the trunk thim, smooth, bluegray, and usually more or less marked by pale or nearly white blotches. Wood heavy, hard, very close-grained, rich brown, beautifully marked with darker medullary rays.

Distribution. Dry coral soil in the immediate neighborhood of the shore; Sanibel Island to the southern keys, and to the borders of the Everglades, Florida; exceedingly rare and most abundant and of its largest size on the Marquesas keys; also on the Bahama Islands.

\section{SAPOTACE王.}

Trees or shrubs, with milky juice. Leaves alternate, simple, entire, pinnately veined, mostly coriaceous, petiolate, without stipules. Flowers perfect, regular, small, in axillary clusters; calyx of $5-8$ sepals imbricated in the bud, persistent under the fruit; corolla hypogynous, 5-8-cleft, the divisions imbricated in the bud, often with as many or twice as many internal appendages borne on its throat; disk 0 ; fertile stamens as many as and opposite the divisions of the corolla and inserted on its short tube, often with sterile filaments (staminodia) alternate with them ; anthers generally extrorse, 2-celled, the cells opening longitudinally; pistil of united carpels; ovary sessile, usually 5-celled; style simple; ovules solitary in each cell, attached to an axile placenta, ascending, anatropous; raphe ventral; micropyle inferior. Fruit baccate, bearing at the apex the remnant of the style, usually 1-celled and 1-seeded. Seed with or without albumen ; embryo large; radicle terete, inferior.

This family with thirty-one genera is chiefly tropical and subtropical, with only Bumelia extending in North America into temperate regions. Some of the 
species produce valuable timber or edible and agreeable fruits. From Isonandra Gutta, Hook., of the Malay Peninsula, gutta-percha is obtained. Five genera are represented by trees in the flora of the United States.

\section{CONSPECTUS OF THE GENERA OF THE UNITED STATES.}

Calyx of $う$ sepals in a single series.

Staminodia 1 in each sinus of the corolla.

Appendages of the corolla 0 ; staminodia slender, scale-like.

Appendages of the corolla present; staminodia petaloid.

Staminodia linear, fimbriate; seeds with copious albumen.

1. Sideroxylum.

Staminodia petaloid, entire or denticulate; seeds without albumen.

2. Dipholis.

๖. Bumelia.

Staminodia 0 ; appendages of the corolla 0 ; leaves covered below with lustrous coppercolored or golden pubescence.

4. Chrysophyllum.

Calyx of 6-8 sepals in 2 series; corolla with 6-8 lobes, and 2 appendages in each sinus inside of a scale-like or petaloid staminodia.

5. Mimusops.

\section{SIDEROXYLUM, L.}

Trees, with terete branchlets, naked buds, and long-petiolate persistent leaves, the veins remote and counected by reticulate veinlets. Flowers minute, on ebracteolate pedicels from the axils of minute decidnous bracts, in crowded many-flowered axillary fascicles; calyx 5 -parted, the divisions in one series, nearly equal, corolla furnished with 5 or 6 staminodia, and 5 or rarely 6 -lobed; filaments slender, elongated, bent outward at the apex; anthers oblong, the cells at first extrorse, sometimes becoming sublateral; staminodia linear, scale-like; ovary contracted into a subulate style tipped with a minute slightly 5-lobed stigma. Fruit dry, 1-seeded, oblong, with thin coriaceous flesh. Seed obovate or oblong; seed-coat lustrous, light brown, folded on the inner face into 2 obscure lobes rounded at the apex; hilum elevated, subbasilar or lateral, oblong or linear; embryo erect in thick fleshy albumen; radicle much shorter than the oblong fleshy cotyledons.

Sideroxylum with about sixty species is widely distributed through the tropics of the two hemispheres, and occurs with a few species in Australia, Madeira, southern Africa, New Zealand, and Norfolk Island, a single species reaching the shores of southern Florida. Some of the species are large and valuable timber-trees, producing hard handsome durable wood.

The generic uame, from $\sigma i \delta \eta \rho o s$ and $\xi \dot{u} \lambda \circ \nu$, is in reference to the hardness of the wood.

\section{Sideroxylum Mastichodendron, Jacq. Mastic.}

Leaves inostly clustered near the ends of the branches, appearing irregularly from early spring until autumn, oval, acute or rounded and slightly emarginate at the apex, and gradually narrowed at the base, with thickened cartilaginous slightly involute margins, when they unfold silky-canescent beneath, and at maturity thin and firm, glabrous, bright green and lustrous above, lustrous and yellow-green below, $3^{\prime}-5^{\prime}$ long, $1 \frac{1}{2}^{\prime}-2^{\prime}$ wide, with broad pale conspicuous midribs deeply impressed on the upper side and inconspicuous primary veins arcuate near the margins; their petioles slender, $1^{\prime}-1 \frac{1}{2}^{\prime}$ long. Flowers usually appearing in Florida in the autumn and also in early spring and during the summer on stout orange-colored puberulous pedicels from the axils of minute acute scarious bracts usually decidnous before the opening of the flower-buds, from the axils of young leaves or on the branches of the previous year from leafless nodes; calyx yellow-green, puberulous on the outer 
surface and deeply divided into broadly ovate rounded lobes rather shorter than the ovate oblong rounded divisions of the light yellow corolla ; staminodia lanceolate, nearly entire, tipped with subulate points and mnch shorter than the stamens; ovary oblong-ovate, glabrous, gradually contracted into an clongated style stigmatic at the apex. Fruit ripening in April and May on a much thickened woody stem erect or nearly at right angles to the branch, $1^{\prime}$ long, separating from the calyx in falling, with tongh yellow skin, and thin dry flesh of a plcasant subacid flavor; seed, obovate, rounded above, narrowed at the base, $\frac{1}{2}^{\prime}$ long, $\frac{1}{3}^{\prime}$ wide.

A tree, in Florida $60^{\circ}-70^{\circ}$ high, with a massive straight trunk $3^{\circ}-4^{\circ}$ in diameter, stout upright branches forming a dense irregular hcad, and thick terete branches orange-colored and slightly puberulons when they first appear, becoming quite glabrous,

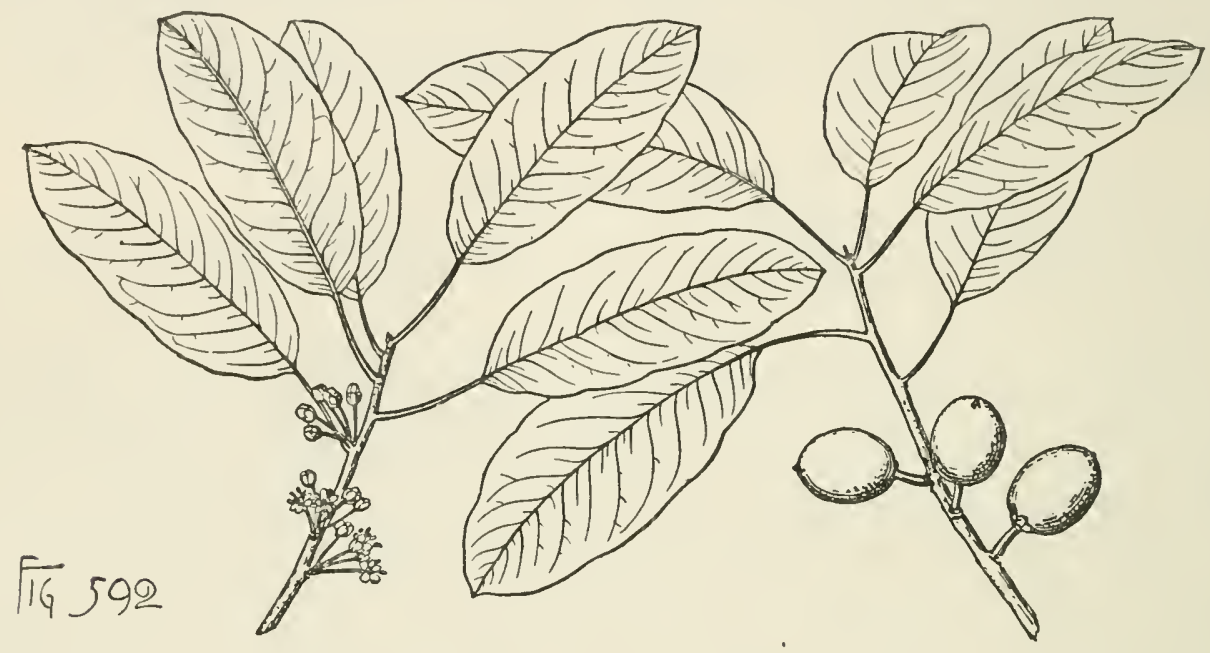

brown more or less tinged with red, and marked by the conspicnous nearly orbicular leaf-scars displaying 3 large fibro-vascular bundle-scars, and conspicuously roughened by the thickened persistent bases of the fruit stalks. Bark of the trunk $\frac{1}{3}^{\prime}-1^{\prime}$ thick, dark gray to light brown tinged with red and broken into thick platelike scales separating into thin layers. Wood heavy, hard, strong, bright orange-colored, with thick yellow sapwood of 40-50 layers of annual growth; in Florida used in boatbuilding.

Distribution. Cape Canaveral and Cape Romano to the southern keys, Florida; on the Bahamas and many of the Antilles.

\section{DIPHOLIS, A. DC.}

Trees or shrnbs, with naked bnds, and persistent leaves, the slender veins arcuate and united near the margins. Flowers minute, on clavate ebracteolate pedicels from the axils of minnte decidnous bracts, in the axils of existing leaves or from the leafless nodes of previons years; calyx ovate, deeply 5-lobed, the lobes nearly eqnal, ovate, rounded at the apex; corolla campanulate, white, 5-lobed, the spreading lobes furnished on each side at the base with linear or subulate appendages; stamens exserted; filaments filiform; anthers oblong-sagittate, extrorse; staminodia 5 , petaloid, ovate, acute, fimbriately cut on the margins, oblique, keeled on the back, inserted in the same rank and alternate with the stamens; ovary oblong or narrowly ovate, gradually contracted into a slender style shorter than the corolla and stigmatic at the apiculate apex. Fruit ovate-oblong, with thin dry flesh. Seed ovate; seed-coat 
thick, coriaceous and lustrous; hilum oblong, basilar or slightly lateral; embryo erect in thick fleshy albumen; cotyledons ovate, flat, much longer than the short radicle turned toward the hilum.

Dipholis with three species is confined to the West Indies and southern Florida.

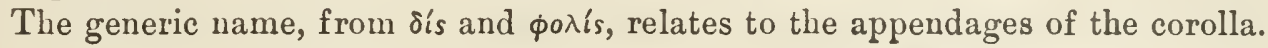

\section{Dipholis salicifolia, A. DC. Bustic. Cassada.}

Leaves oblong-lanceolate or narrowly obovate, acute, acuminate, or rounded at the apex, gradually contracted at the base, with slightly thickened cartilaginous wavy margins, when they unfold thickly coated with lustrous rufous pubescence, and at maturity thin and firm, dark green and lustrous above, pale yellow-green below, $3^{\prime}-5^{\prime}$ long, $\frac{1^{\prime}}{2}-1 \frac{1}{4}^{\prime}$ wide, and glabrous or slightly puberulous on the lower side of the narrow pale midribs, with inconspicuous veins and reticulate veinlets, appearing in Florida in the spring and remaining on the branches between one and two years; their petioles slender, $\frac{1^{\prime}}{2}-1^{\prime}$ long. Flowers opening during March and April, $\frac{1^{\prime}}{8}$ long, on thick pedicels $\frac{1^{\prime}}{4}$ in length from the axils of minute ovate acute scarious bracts and coated with rufous pubescence, in dense many-flowered fascicles crowded on branchlets of the year or of the previous year for a distance of $8^{\prime}-12^{\prime}$; calyx half the length of the corolla, coated on the outer surface with rusty silky pubescence; appendages

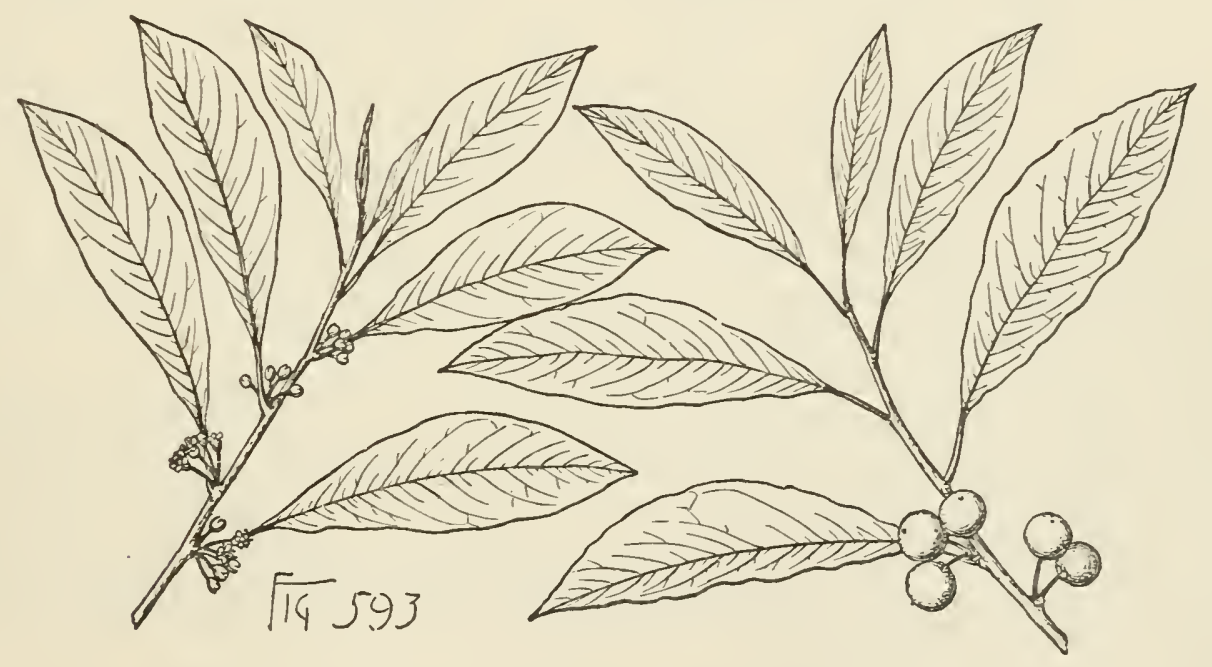

of the corolla as long as the oval acute irregularly toothed staminodia; ovary narrowly ovate, glabrous, gradually contracted into a slender style shorter than the corolla and stigmatic at the apex. Fruit solitary or rarely clustered, ripening in the autumn, oblong to subglobose, black, $\frac{1^{\prime}}{4}$ long; seed pale brown, about $\frac{3^{\prime}}{16}$ in length.

A tree, in Florida sometimes $40^{\circ}-50^{\circ}$ high, with a straight trunk $18^{\prime}-20^{\prime}$ in diameter, small upright branches forming a narrow graceful head, and slender branchlets coated with rufous pubescence when they first appear, becoming asliy gray or light brown tinged with red and marked by numerous circular pale lenticels and by small elevated orbicular leaf-scars displaying near the centre a compact cluster of fibrovascular bundle-scars. Bark of the trunk about $\frac{1}{3}^{\prime}$ thick and broken into thick square plate-like brown scales tinged with red. Wood very heavy, exceedingly hard, strong, close-grained, dark brown or red, with thin sapwood of 4 or 5 layers of annual growth. 
Distribution. Rich hmmmock soil; shores of Bay Biscaync, and on several of the southern keys, Florida; also on the Bahanas and on many of the Antilles.

\section{BUMELIA, Sw.}

Sunall trees or shrubs, with terete usually spineseent branchlets, scaly buds, and fibrons roots. Leaves often faseicled on spur-like lateral branchlets, conduplicate in the bud, coriaccous or membranaccons, short-petiolate, obovate, obtuse, or elliptical, clothed on the lower surface with silky pubescence or tomentum, or nearly glabrous, with rather ineonspicnons veins arcnate near the entire margins and conspicuous reticnlate veinlets, decidnous or persistent. Flowers on slender clavate ebracteolate pedicels from the axils of lanceolate acute scarious deciduons braets, in many-flowered crowded fascicles in the axils of existing leaves or from the leafless nodes of previous years; ealyx ovate to subcampanulate, 5-lobed, the lobes in one series imbrieated in the bnd, ovate or oblong, rounded at the apex, nearly equal; corolla campamnlate, white, with 5 spreading broadly ovate lobes rounded at the apex and furnished on each side at the base with an acutc ovate or lanceolate petaloid appendage; stamens 5; filaneuts filiform; anthers ovate-sagittate, attached on the baek below the middle, the cells opening by subextrorse slits; staminodia petal-like, ovate or ovate-laneeolate, entire or obseurely dentieulate, flattened or keeled on the back, sometimes furnished at the base with a pair of minute scales; ovary hirsute, ovate to ovate-eonieal, gradually or abruptly contraeted into a slender short or elongated simple style stigmatie at the acute apex. Fruit oblong-obovate or globose, black, solitary or in 2 or 3-fruited clusters; flesh thin and dry or succulent. Seed ovate or oblong, apiculate or rounded at the apex, without albumen; seed-coat thick, crustaceons, light brown, smooth and shining, folded more or less conspicuonsly on the baek into 2 lobes rounded at the apex; embryo filling the cavity of the seed; cotyledons thick and fleshy, hemispherical, usually consolidated; radicle very short, turned toward the basilar or subbasilar orbieular or elliptical hilum.

Bumelia with about twenty species is confined to the New World, where it is distributed from the southern United States throngh the West Indies to Mexico, Central Ameriea, and Brazil. Of the five speeies in the United States four are small trees.

Bumelia produces hard heavy strong wood, that of the North American species containing bands of numerous large open dicts defining the layers of amnual growth and connected by eonspicuous branched groups of similar ducts, presenting in crosssection a retieulate appearanee.

The generic name is from $\beta o v \mu \epsilon \lambda i$, a classical name of the Ash-tree.

\section{CONSPECTUS OF THE ARBORESCENT SPECIES OF THE UNITED STATES.}

Lower surface of the leaves pubescent or tomentose.

Leaves oblanceolate-spatulate to cuneate-obovate, covered below with pale or ferrugineous lustrous pubescence.

Leaves oblong-obovate to cuneate-obovate, dull tomentose on the lower surface.

Leaves glabrous or nearly so.

2. B. lanuginosa (A, C).

Leaves oblanceolate to oblong-obovate, acute or acuminate, finely reticulate-venulose, thin, deciduous.

3. B. lycioides $(\mathrm{A}, \mathrm{C})$.

Leaves spatulate or linear-oblong to broadly obovate-cuneate, obtuse, obseurely reticulate-venulose, coriaceous, persistent.

4. B. angustifolia (D, E). 


\section{Bumelia tenax, Willd. Ironwood.}

Leaves oblanceolate-spatulate to cuneate-obovate, rounded or acute and sometimes apiculate or emarginate at the apex and wedge-shaped at the base, when they unfold coated with thick pale or light red silky pubescence, and at maturity thin and firm, dark dull green, glabrous and finely reticulate-venulose on the upper, coated

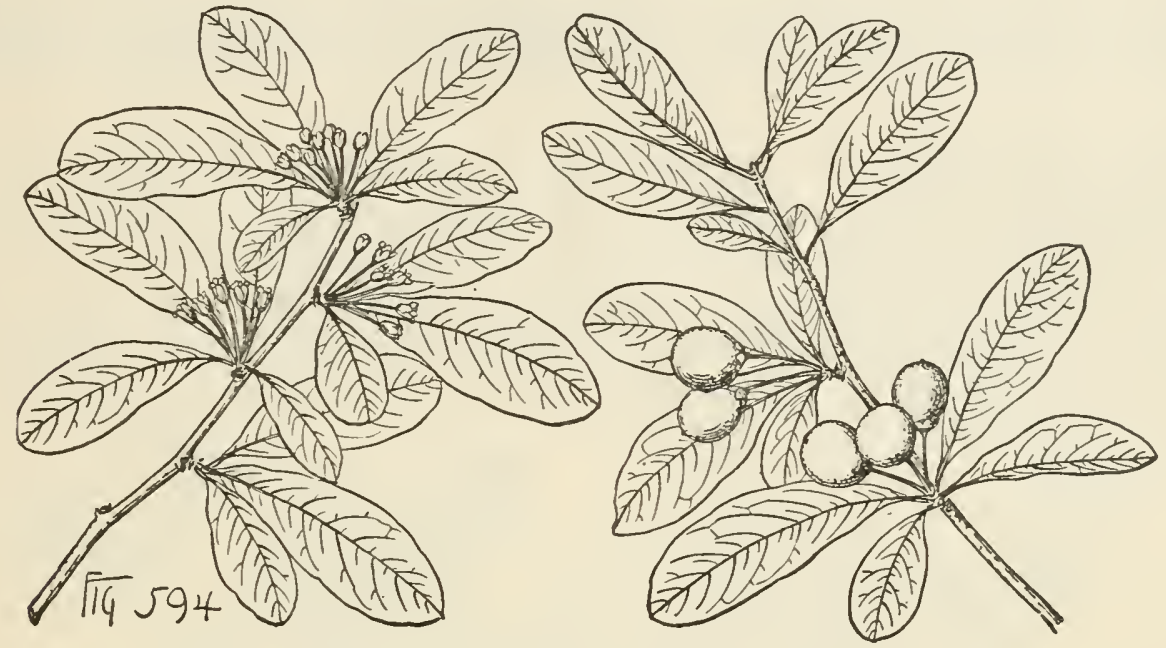

on the lower surface with soft silky golden ferrugineous pubescence, $1^{\prime}-3^{\prime}$ long and $\frac{1^{\prime}}{2}-\frac{2 \prime}{3}$ wide, turning yellow and falling irregularly during the winter; their petioles slender, hairy, grooved, $\frac{1}{2}^{\prime}$ long. Flowers appearing from May in Florida to July in North Carolina, $\frac{1^{\prime}}{8}$ loug, on pedicels $\mathbf{1}^{\prime}$ in length and coated like the calyx with rufous silky pubescence, in many-flowered crowded fascicles; calyx ovate, with oblong lobes; appendages of the corolla large, ovate, acute, crenate, shorter than the ovate staminodia about as long as the lobes of the corolla; ovary narrowly ovate, gradually contracted into an elongated style. Fruit ripening and falling in the autumn, oblong, $\frac{1^{\prime}}{3} \frac{1}{2}^{\prime}$ in length; seed oblong, short-pointed at the apex, $\frac{1}{4}^{\prime}-\frac{1}{3}^{\prime}$ long.

A tree, $20^{\circ}-30^{\circ}$ high, with a trunk occasionally $5^{\prime}-6^{\prime}$ in diameter, straight spreading flexible tough branches unarmed or armed with straight stout rigid spines sometimes $\mathbf{1}^{\prime}$ in length, and slender branchlets coated when they first appear with silky pale pubescence often tinged with red and soon rusty brown, becoming glabrous before winter, and then dark red and slightly ronghened by occasional minnte dark lenticels. Winter-buds minute, subglobose, with imbricated ovate scales rounded at the apex and clothed with rusty brown tomentum. Bark of the trunk thick, brown tinged with red, and divided irregularly by deep fissures into narrow flat reticulate ridges covered with minute appressed scales. Wood heavy, hard, closegrained, light brown streaked with white, with lighter colored sapwood.

Distribution. Dry sandy soil in the neighborhood of the coast; North Carolina to Cape Canaveral and Cedar Keys, Florida.

\section{Bumelia lanuginosa, Pers. Gum Elastic. Chittam Wood.}

Leaves oblong-obovate to cuneate-obovate, rounded and often apiculate at the apex and gradually narrowed at the base, when they unfold coated with pale ferrugineous tomentum dense on the lower and loose on the upper surface, and at maturity thin and firm, dark green and lustrous above, more or less thickly covered below with 
loose dull usually pale tomentum, $1^{\prime}-2 \frac{1}{2}^{\prime}$ long and $\frac{1}{3}^{\prime}-3^{\prime}{ }^{\prime}$ wide, falling irregularly during the winter; their petioles short, slender, and hairy. Flowers opening in summer on hairy pedicels $\frac{1^{\prime}}{8}$ in length, in 16-18-flowered faseicles; calyx ovate, with ovate rounded lobes coated on the onter surface with pale or ferrugineous tomentum and rather shorter than the tube of the corolla; staminodia ovate, acute, remotely and slightly denticulate, as long as the corolla-lobes furnished with small ovate acute appendages; ovary hirsute, abruptly contracted into a slender elongated style. Fruit on sleuder drooping stalks ripening and falling in the autumn, oblong or slightly obovate, $\frac{1}{2}^{\prime}$ long; with thick flesh; seed oblong, rounded at the apcx, about $\frac{1}{4}^{\prime}$ in lengtl.

A tree, sometimes $50^{\circ}-60^{\circ}$ high, witl a tall straight trunk occasionally $3^{\circ}$ in diametcr, short thick tough rigid branches forming a narrow oblong round-topped liead, unarmed, or armed with stout rigid straight slightly curved spines frequently developing into spinescent leafy lateral branchlets, and slender often somewhat zigzag branchlets coated with thick rufous or pale tomentum when they first appear, becoming in their first winter red-brown to ashy gray and glabrous or nearly so and

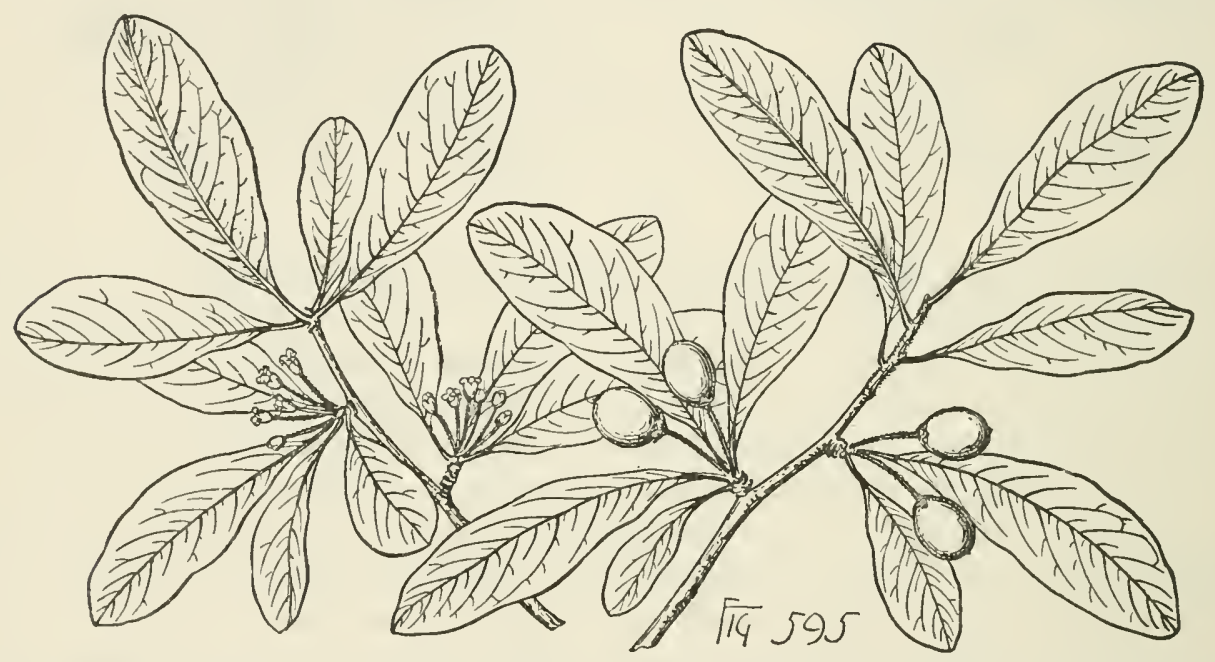

marked by occasional minute lenticels and by small semiorbicular leaf-scars displaying 2 clusters of fibro-vascular bundle-scars; much smaller in the region east of the Mississippi River, and there rarely more than $20^{\circ}$ tall. Winter-buds obtuse, $\frac{1}{8}{ }^{\prime}$ long, covered with broadly obovate rusty tomentose scales. Bark of the trunk $\frac{1}{2}$ thick, dark gray-brown and usually divided into narrow ridges broken into thick appressed scales. Wood heavy, rather soft, not strong, close-grained, light brown or yellow, with thick lighter colored sapwood; producing in Texas considerable quantities of clear viscid gum from the freshly cut wood.

Distribution. Southern Georgia and northern Florida to the shores of Mobile Bay, Alabama, and southern Illinois and southern Missouri through Arkansas and Texas to the mountain slopes of Nuevo Leon; east of the Mississippi River usually in dry rather sandy soil and nowhere common; abundant and of its largest size in the river-bottoms of eastern Texas. In the region adjacent to the southern boundary of the United States from western Texas and Nuevo Leon to Arizona a form (var. rigida, Gray) occurs, with more rigid spinescent branches and with thick coriaceous obovate to cuneate-oblanceolate leaves rather more than $1^{\prime}$ long and $\frac{1}{4}^{\prime}$ wide, and covered at maturity on the lower surface with sparse pale tomentum, or nearly gla- 
brous. This is a small tree, $18^{\circ}-25^{\circ}$ high, with a short trunk covered with red-brown bark divided into long appressed ridge-like scales broken into minute flakes, and an inhabitant of dry gravelly mountain slopes in the neighborhood of streams. Wood of this form heavy, hard, very close-grained, light rich brown or yellow, with thick lighter colored sapwood.

\section{Bumelia lycioides, Gærtn. f. Ironwood. Buckthorn.}

Leaves oblanceolate to oblong-obovate, acute, acuminate, or rarely rounded at the apex, gradually narrowed at the base, bright green and glabrous on the upper,

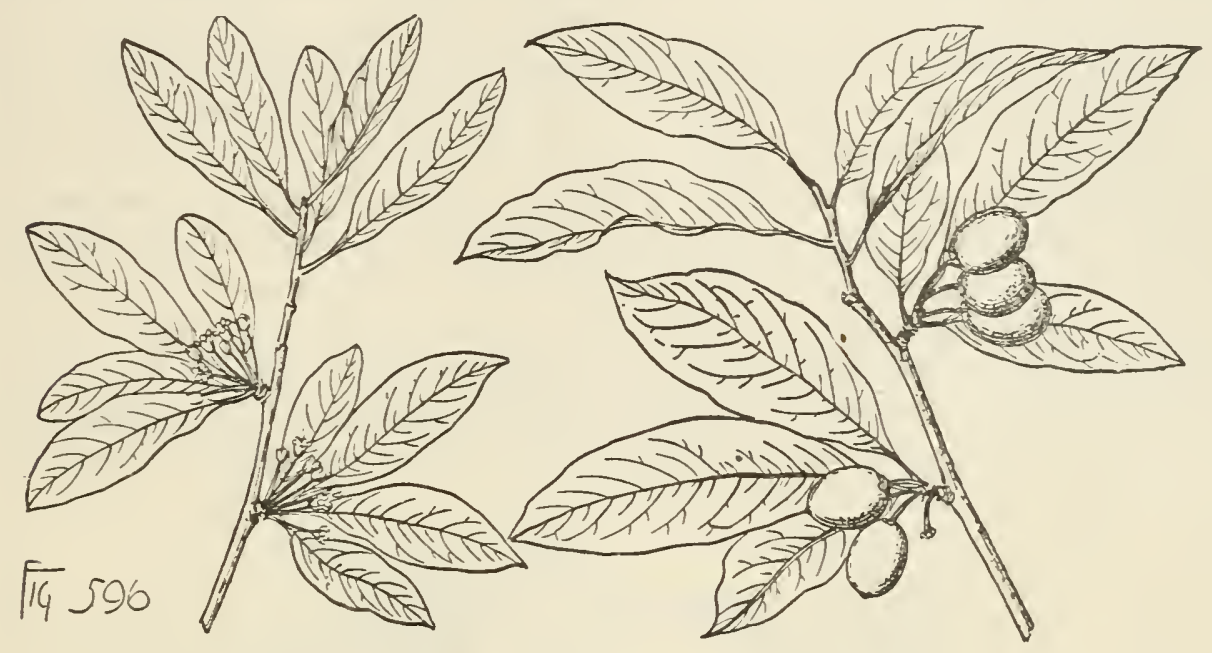

light green and sometimes coated at first on the lower surface with pale pubescence, thin and rather firm, finely reticulate-venulose, $1 \frac{1}{2}^{\prime}-4^{\prime}$ long, $\frac{1}{2}^{\prime}-1 \frac{1}{2}^{\prime}$ wide, with pale thin conspicuons midribs and primary reins, deciduous in the autumn; their petioles slender, slightly grooved, about $\frac{1^{\prime}}{2}$ long. Flowers appearing at midsummer on slender glabrous pedicels $\frac{1}{2}^{\prime}$ long, in crowded many-flowered fascicles; calyx glabrous, ovate-campanulate, with rounded lobes rather shorter than the corolla; staminodia broadly ovate, denticulate, nearly as long as the narrow appendages; ovary ovate, slightly hairy toward the base only, gradually contracted into a short thick style. Fruit ripening and falling in the autumn, ovoid or obovate, abont $\frac{2}{3}$ in length; flesh thick; seed oblong, rounded at the apex, nearly $\frac{1^{\prime}}{4}$ long.

A tree, $25^{\circ}-30^{\circ}$ high, with a short trunk rarely more than $6^{\prime}$ in diameter, stont flexible branches usually unarmed or furnished with short stout slightly curved spines occasionally developing into leafy spinescent branches, and short thick spur-like lateral branchlets slightly puberulous when they first appear, soon becoming glabrous, light red-brown, rather lustrous and marked by numerous pale lenticels, and in their second year dark or light brown tinged with red or ashy gray. Winter-buds minute, obtuse, nearly immersed in the bark, with pale dark brown glabrous scales. Bark of the trunk thin, light red-brown, the generally smooth surface broken into small thin persistent scales. Wood heavy, hard, not strong, close-grained, light brown or yellow, with thick lighter colored sapwood.

Distribution. Low moist soil along the borders of swamps and streams; coast of Virginia and southern Illinois to Mosquito Inlet and the shores of Caloosa River, Florida, and through southern Missouri, Arkansas, and Texas, to the valley of the Rio Concho. 


\section{Bumelia angustifolia, Nutt. Ants' Wood. Downward Plum.}

Leaves spatulate or linear-obloug to broadly obovate-cuneate, rounded and oceasionally emargiuate at the apex, and gradually narrowed at the base, with slightly thickened revolute margins, glabrons, thick and coriaceous, pale blue-green on the upper, paler on the lower surface, $1^{\prime}-11^{\prime}$ long and $\frac{1}{4}^{\prime}-1 \frac{1}{4}^{\prime}$ wide, with pale slender midribs and very obscure veius and veinlets, usually persistent on the branches until the end of their second winter; their petioles stout, grooved, and rarely $\frac{1}{4}$ in length. Flowers generally appearing in October and November, about $\frac{1}{1 \overline{6}}$ long, on slender glabrous pedicels seldom more than $\frac{1^{\prime}}{2}$ in length, in few or many-flowered crowded fascicles; calyx glabrous, divided nearly to the base into narrow ovate lobes rounded at the apex and half the length of the divisions of the corolla furnished with linear-lanccolate appendages as long as the ovate acute denticulate staminodia; ovary narrowly ovate, slightly hairy at the base only, gradually contracted into an elongated style. Fruit ripening in the spring, on slender drooping stems, usually 1 fruit only being developed from a fascicle of flowers, oblong-oval, $\frac{2}{3}$ long, with thick sweet flesh; seed oblong, rounded at the apex, $\frac{1}{2}$ long.

A tree, sometimes $20^{\circ}$ high, with a short trunk rarely exceeding $6^{\prime}-8^{\prime}$ in diameter, graceful pendulous branches forming a compact round head, and rigid spinescent divergent lateral branchlets often armed with acute slender spines sometimes $\mathbf{1}^{\prime}$ in

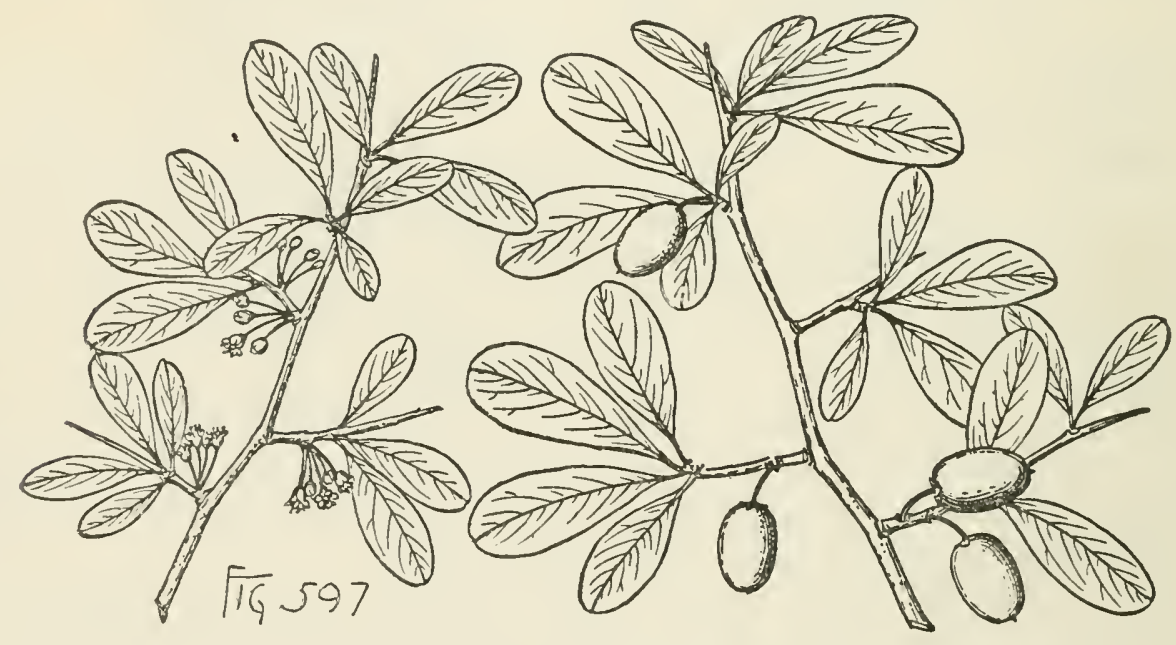

length, and when they first appear thickly coated with loose pale or dark brown deciduous tomentum, becoming light browu tinged with red or ashy gray; occasionally in Texas a low shrub, with spreading stems. Winter-buds ovate, acute, and covered with rufous tomentum. Bark of the trunk $\frac{1}{3}^{\prime}-\frac{1}{2}^{\prime}$ thick, gray tinged with red, and deeply divided by longitudinal and cross fissures into oblong or nearly square plates. Wood heavy, hard, although not strong, very close-grained, light brown or orangecolored, with thick lighter-colored sapwood.

Distribution. Florida, shores of Indian River to the southern keys, and from Cedar Keys to Cape Romano; on the west coast less abundant and usually on rocky shores and in the interior of low barren islands; Texas, valley of the Rio Grande below Laredo; in Nuevo Leon and on the Bahama Islands. 


\section{CHRYSOPHYLLUM.}

Trees, with terete branchlets usually coated while young with dense tomentum, and naked buds. Leaves short-petiolate, bright green and glabrous on the upper surface and coated on the lower with britliant silky pubescence or tomentum, persistent. Flowers on ebracteolate pedicels from the axils of minute acute deciduous bracts, minute, in dense many-flowered fascicles axillary or from leafless thickened nodes of previous years; calyx usually 5-parted, the divisions nearly equal, obtuse; corolla 5 or rarely 6 or 7-lobed, tubular, campanulate or subrotate, white or greenish white; filaments short, subulate or filiform, enlarged into broad connectives; anthers ovate or triangular, attached ou the back, extrorse or rarely partly introrse, the cells spreading below; ovary usually 5 -celled, villose, contracted into a glabrous short or elongated style crownéd by a 5 -lobed stigma. Fruit oblong or globose. Seed ovoid; seed-coat coriaceous, dull or lustrous; hilum subbasilar, elongated, conspicuous; embryo erect, surrounded by more or less pungent fleshy albumen; cotyledons oblong, foliaceous.

Chrysophyllum is tropical, with fifty or sixty species most abundant in the New World, with a small number of species in western and southern tropical Africa, southern Asia, Australia, and the Hawaiian Islands. The most valuable species, Chrysophyllum Cainito, L., a native of the West Indies and now cultivated in all tropical countries and naturalized in many parts of Central and South America, produces the so-called star-apple, a succulent edible blue or purple and green fruit the size and shape of a small apple.

The generic name, from $\chi \rho v \sigma \delta s$ and $\phi \dot{u} \lambda \lambda \alpha_{o \nu}$, is in allusion to the golden covering of the under surface of the leaves.

\section{Chrysophyllum oliviforme, Lam.}

Leaves revolute in the bud, oval, acute or contracted into short broad points or sometimes rounded at the apex, abruptly wedge-shaped at the base, thick and coriaceous, $2^{\prime}-3^{\prime}$ long, $1 \frac{1}{2}-2^{\prime}$ wide, bright blue-green on the upper and covered on the

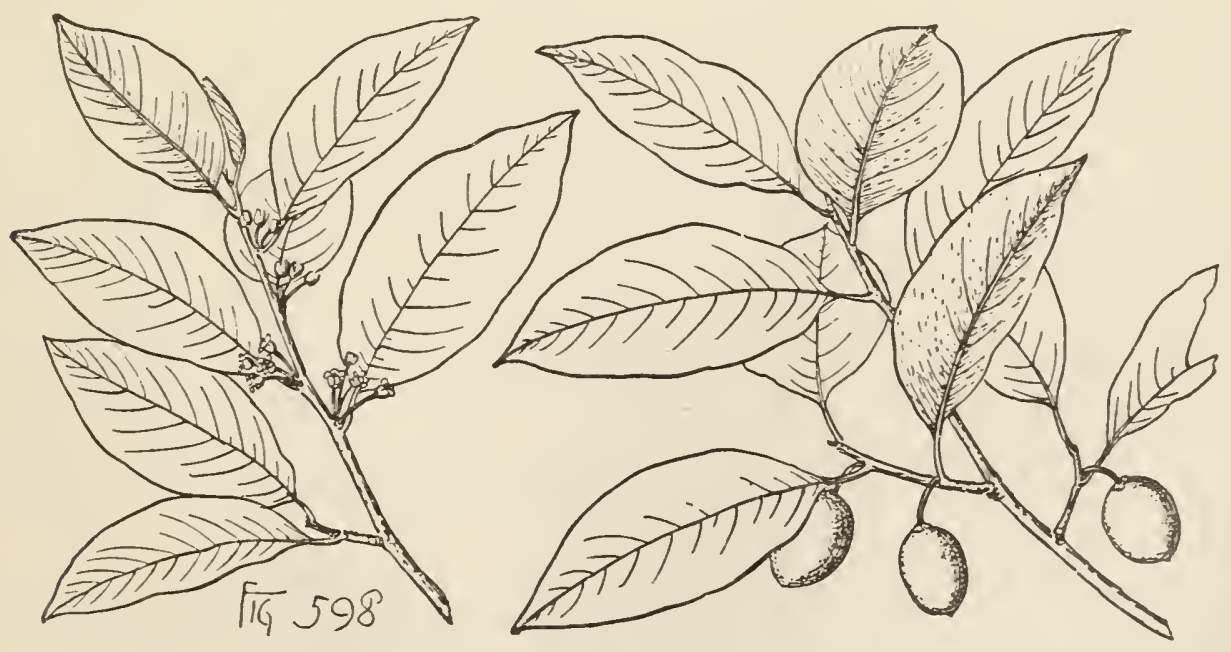

lower surface and on the petioles with brilliant copper-colored pubescence, with broad prominent midribs deeply impressed on the upper side and numerous straight veins 
arcuate near the margins; their petioles stont, $\frac{1}{2}-\frac{2}{3}$ long. Flowers appearing in Florida irregularly throughont the year and of ten found on the same braneh with ripe or half-grown fruits, on stout pedicels shorter than the petioles, covered like the ealyx with rufous tomentmm, in few or many-flowered fascieles in the axils of leaves or at the base of lateral branehlets in those of earlier years; ealyx divided nearly to the base into broad rounded lobes rather shorter than the tube of the subrotate white corolla, with short spreading rounded lobes withont staminodia or appendages; ovary 5-celled, pubescent, gradually contraeted into a short style crowned by a broad 5 -lobed stigma. Fruit usually 1 -seeded by abortion, on stems $\mathbf{1}^{\prime}$ long, usually only a single fruit being produced from a flower-eluster, ovoid or sometimes nearly globose, dark purple, roughened by oceasional cxcrescences, with a thick tough skin inelosing the juicy sweet mawkishly flavored flesh light purple on the extcrior, lighter toward the interior, and quite white in the centre; seed narrowed at the ends, $\frac{1}{2}^{\prime}$ long, covered witl a thin light brown coat closely invested with a white glutinous aril-like pulpy mass.

A tree, $25^{\circ}-30^{\circ}$ high, witl a tall straight trunk sometimes a foot in diameter, upright branches forming a compact oblong head, and slender slightly zigzag branehlets coated at first with ferrugineous tomentum, becoming in their seeond year light redbrown or ashy gray and eovered with small pale elevated circular lenticels. Bark of the trunk $\frac{1}{4}^{\prime}$ thick, light brown slightly tinged with red, and broken by shallow fissures into large irregularly shaped plates separating on the surface into small thin scales. Wood very heavy, hard, strong, close-grained, light brown shaded with red, with thin lighter colored sapwood.

Distribution. Sonthern Florida from Mosquito Inlet to the southern keys, and from the shores of Caloosa River to Cape Sable; local and nowhere common; also on the Bahamas and on many of the Antilles.

\section{MIMUSOPS, L.}

Trees or rarely shrubs, with stont terete branchlets, small naked buds, and sweet juice. Leaves usually clustered at the ends of the branches, with slender inconspicuons transverse veins and minnte retieulate veinlets, persistent. Flowers on clavate ebracteolate pedicels from the axils of minute deciduous bracts; ealyx 6-8-parted, the divisions in 2 series, those of the exterior series almost valvate in the bud; corolla white, barely longer than the ealyx, subrotate, usually dilated at the throat, 6-8-lobed, the lobes furnished at the base with a pair of petal-like appendages; stamens as many as the lobes of the eorolla; filaments short, dilated; anthers lanceolate, their eonnectives excurrent, aeute, or sometimes aristate at the apex; staminodia as many as the lobes of the corolla, seale-like or petaloid, entire, 2-lobed or laeiniate; ovary ovate, hirsute or puberulons, gradually narrowed into a slender style stigmatic at the apex. Frnit globose, 1 or 2-seeded, tipped with the much thickened elongated style; skin crustaeeous, indurate; flesh, thick and dry. Seed oblong-ovate, slightly compressed; seed-coat crustaceous, chestnut-brown and lustrous; hilum elongated, lateral or minute, basilar; embryo surrounded by thiek fleshy albumen; cotyledons flat, thick and fleshy, mueh longer than the short erect radiele.

Mimusops with thirty or forty species is widely distributed through the tropics of the two hemispheres, a single species reaching the shores of southern Florida. Several species produce hard heavy timber, edible fruits, or valuable milky juices.

The significance of the generic name, from $\mu \iota \mu \omega$ and $\partial \psi \iota s$ in allusion to the shape of the corolla, is not apparent. 


\section{Mimusops Sieberi, A. DC. Wild Dilly.}

Leaves clustered at the ends of the branches, involute in the bud, ellipticaloblong or occasioually slightly obovate, rounded or retuse at the apex, rounded or wedge-shaped at the base, witl slightly thickened revolute margins, when they unfold bright red, and slightly puberulous on the under surface of the midribs, and at

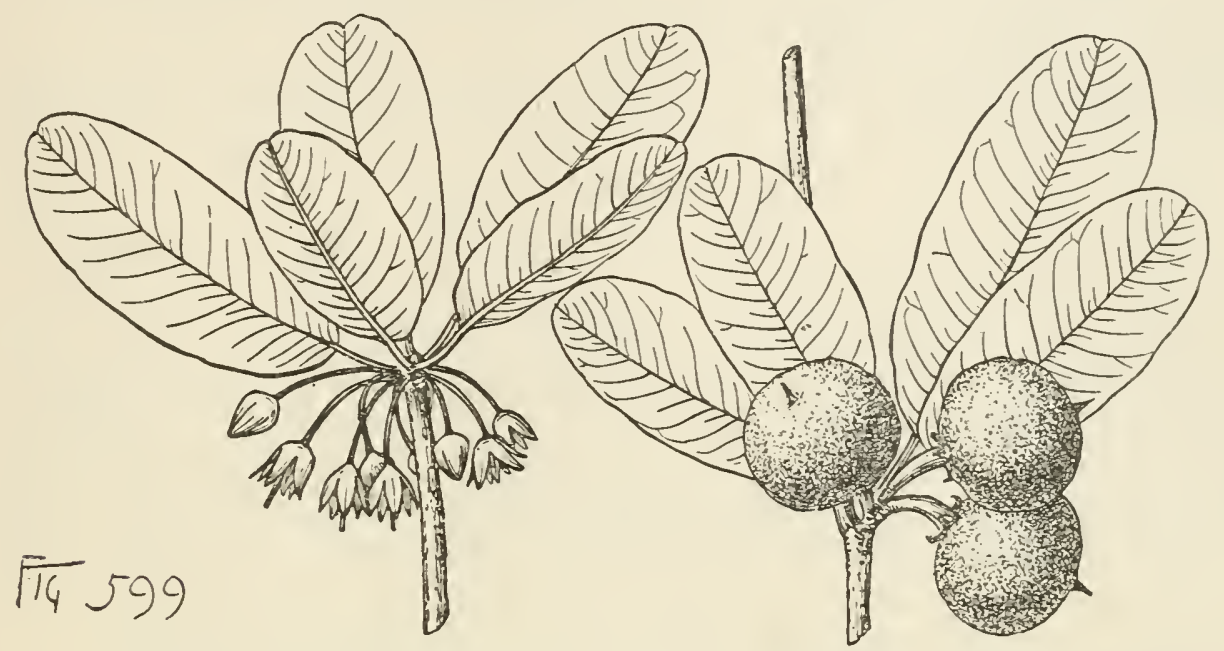

maturity thick and coriaceous, bright green and lustrous, covered on the upper surface with a slight glaucous bloom, conspicuously reticulate-venulose, $3^{\prime}-4^{\prime}$ long and $1^{\prime}-1 \frac{1^{\prime}}{2}$ wide, with stout midribs glabrous, or puberulous, witl rusty hairs below, and deeply impressed above, appearing in Florida in April and May and deciduous during their second year; their petioles slender, grooved, rusty-pubescent, especially while young, $\frac{1}{2}^{\prime}-\mathbf{1}^{\prime}$ loug. Flowers opening in the spring on slender pedicels near the ends of the branches coated with rusty tomentum and $\mathbf{1}^{\prime}$ or more long, from the axils of leaves of the year or from those of fallen leaves of the previous year; calyx narrowly ovate, divided nearly to the base into 6 lobes, those of the outer row lanceolate-acute, covered on the outer surface with rusty brown tomentum and on the inner surface with pale pubescence, thickened and usually marked at the base on the outer surface by black spots, those of the inner row ovate, acute, keeled toward the base, light greenish yellow and pale-pubescent; corolla light yellow tinged with green, $\frac{2^{\prime}}{3}$ in diameter, with 6 spreading lanceolate acute divisions entire or erosely toothed toward the apex, furnished at the base on each side with slender acute appendages one lialf to two thirds their length; staminodia minute, nearly triangular, entire; ovary narrowly ovate, dark red, puberulous toward the base, with pale hairs, and gradually uarrowed into an elongated exserted style stigmatic at the apex. Fruit ripening at the end of the year, in the spring, or in the early autumn, on a stout erect stem about $1^{\prime}$ long, and persistent until after the tree flowers the following year, subglobose to slightly obovate, flattened and compressed at the apex, $1^{\prime}-1_{\frac{1}{2}}^{\prime}$ in diameter, usually 1 -seeded by abortion, with a thick dry outer coat roughened by minute rusty brown scales, and thick spongy flesh filled with milky juice; seed $\frac{1}{2}$ long, with an elongated lateral hilum.

A tree, in Florida rarely more than $30^{\circ}$ high, with a short gnarled trunk $12^{\prime}-15^{\prime}$ in diameter and usually hollow and defective, thick branches forming a compact round head, and stout branchlets clustered at the ends of the branches of the previous year, 
coated when they first appear with dark rufous pubescence, becoming glabrons and light orange-brown at the end of a few wecks, and in their second year covered with thick ashy gray or light red-browu sealy bark and marked by elevated obcordate leaf-scars displaying 3 large dark conspieuons fibro-vascular bundle-scars. Winterbuds ovate, acute, rusty-tomentose. Bark of the trunk about $\frac{1{ }^{\prime}}{4}$ thick and irregularly divided by deep fissures into ridges rounded on the back and broken into small nearly square plates. Wood very heavy, hard, strong, close-grained, rich very dark brown, with light-colored sapwood.

Distribution. Florida only on the southern keys; not common; also on the Bahama Islands.

\section{EBENACEA.}

'Trees or shrubs, with watery juice, and alternate simple entire leaves without stipules. Flowers diœcious or polygamous, regular, axillary, articulate with the bibracteolate pedicels; calyx persistent; corolla hypogynous, regular ; disk 0 ; stamens more numerous than the lobes of the corollit, inserted on its base, fewer and rudimentary or 0 in the pistillate flower; filaments short; anthers introrse, 2-celled; ovary several-celled; ovules 2 in each cell, suspended from its apex, anatropous ; raphe dorsal; micropyle superior. Fruit a 1 or several-seeded berry. Seeds with copious albumen; embryo axile.

The Ebony family with five genera and a large number of species is widely distributed in tropical and temperate regions, with two representatives of its most important genus, Diospyros, in the flora of the United States.

\section{DIOSPYROS, L.}

Trees or shrubs, with terete branchlets without terminal buds, scaly axillary buds, coriaceous leaves revolute in the bud, and fibrous roots. Flowers mostly diœcious, from the axils of leaves of the year or of the previous year; staminate smaller than the pistillate and usually cymose, in short few-flowered bracted cymes; pistillate generally solitary; calyx 4-lobed, the lobes yalvate in the bud, accrescent under the fruit; corolla 4-lobed, the lobes sinistrorsely contorted in the bud, more or less contracted in the throat, the lobes spreading or recurved; stamens usually 16 , inserted on the bottom of the corolla in two rows and in pairs, those of the outer row rather longer than and opposite those of the inner row; filaments free, slender; anthers oblong, apiculate, the cells opening laterally by longitudinal slits; stamens rudimentary or 0 in the pistillate flower; ovary usually 4-celled, each cell more or less completely divided by the development of a false longitudinal partition from its anterior face, rudimentary or 0 in the staminate flower; styles 4 , spreading, 2-lobed at the apex; stigmas 2-parted or lobed; ovule solitary in each of the divisions of the cells. Fruit globose, oblong or conical, 1-10-seeded, surrounded at the base by the enlarged persistent calyx. Seeds pendulous, oblong, compressed; seed-coat thick and bony, dark, more or less lustrous; embryo axile, straight or somewhat curved; cotyledons foliaceous, ovate or lanceolate; radicle superior, cylindrical, turned toward the small hilum.

Diospyros, which is chiefly tropical, is widely distributed with about one hundred and sixty species in the two hemispheres, witl a few species extending beyond the tropics into eastern North America, eastern Asia, southwestern Asia, and the Mediterranean region.

Diosypros produces hard close-grained valuable wood, with dark or black heart- 
wood and thick soft yellow sapwood. The ebony of commerce is partly produced by different tropical species. The fruit is often edible, and some of the species are important fruit-trees in China and Japan.

The generic name, from $\Delta$ tós and $\pi v p o ́ s$ is in allusion to the life-giving properties of the fruit.

\section{CONSPECTUS OF THE SPECIES OF THE UNITED STATES.}

Flowers on branchlets of the year; anthers opening longitudinally nearly throughout their entire length ; filaments pubescent ; pistillate flowers with $S$ rudimentary stamens ; ovary nearly giabrous; leaves oval; fruit orange color.

1. D. Virginiana (A, C).

Flowers on branchlets of the previous year; anthers opening only near the apex ; filaments glabrous ; pistillate flowers without rudimentary stamens; ovary pubescent ; leaves cuneate-oblong or obovate; fruit black.

2. D. Texana (C).

\section{Diospyros Virginiana, L. Persimmon.}

Leaves oval, shortly acuminate at the apex, and abruptly or gradually narrowed or rounded or often cordate at the base, when they unfold light green or red, pubescent on the lower and puberulous on the upper surface, and ciliate on the margins, with long soft white hairs, and at maturity coriaceous, dark green and lustrous above, pale and often pubescent below, $4^{\prime}-6^{\prime}$ long and $2^{\prime}-3^{\prime}$ wide, with broad

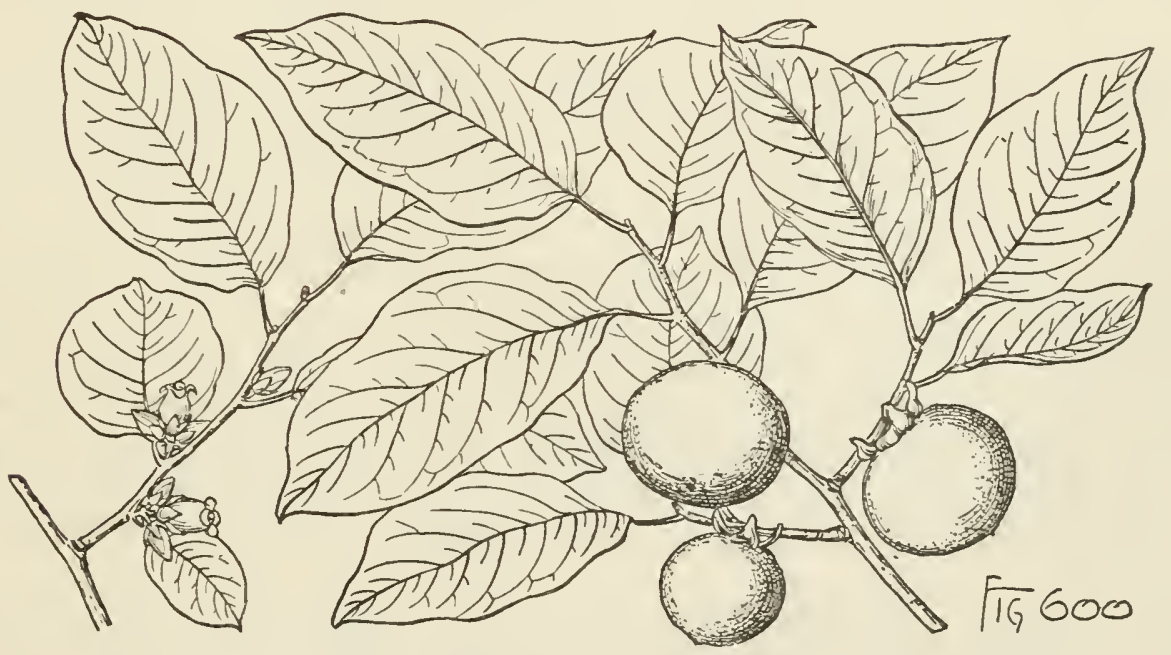

flat midribs, about 6 pairs of conspicuous primary veins arcuate near the margins and reticulate veinlets, falling early in the autumn without change of color or sometimes turning orange or scarlet; their petioles stout, pubescent, $\frac{1}{2}^{\prime}-1^{\prime}$ long. Flowers appearing when the leaves are more than half grown, on branchlets of the year; the staminate in 2-3-flowered pubescent pedunculate cymes, the pedicels in the axils of minute lanceolate acute caducous bracts and furnished near the middle with 2 minute caducous bractlets; the pistillate solitary, on short recurved peduncles covered with 2 conspicuous acute bractlets ciliate on the margins and often $\frac{1}{4}^{\prime}$ in length; corolla of the staminate flower tubular, $\frac{1}{3}^{\prime}$ long, slightly contracted below the short acute reflexed lobes forming before expansion a pointed 4-angled bud rather longer than the broadly ovate acute foliaceous ciliate calyx-lobes inflexed on the margins; stamens with short slightly hairy filaments, and linear lanceolate anthers opening throughout their length; pistillate flower $\frac{3^{\prime}}{4}$ long, with a greenish yellow or creamy 
white corolla nearly $\frac{1^{\prime}}{2}$ broad; stamens 8 , inserted in one row below the middle of the corolla, with short filaments and sagittate abortive or sometimes fertile anthers; ovary conical, pilose toward the apex, ultimately 8-eelled, and gradually narrowed into the 4 slender styles hairy at the base. Fruit on a short thick woody stem, ripening at midsummer at the sonth and late in the autumn at the north, persistent on the branches dming the winter, usually depressed-globose or slightly obovateoblong, 1'-1 $1_{\frac{1}{2}}^{\prime}$ in diameter, differing greatly in size, shape, and quality, pale orange color, often with a bright red cheek, and covered with a glancous bloom, turning yellowish brown when partly decayed by freezing, surrounded at the base by the spreading calyx $1^{\prime}-1 \frac{1}{2}^{\prime}$ in diameter, with broadly ovate pointed lobes recurved on the margins; flesh austere while green, yellowish brown, sweet and luscious when fully' ripe but not edible, except in the extreme south, without the action of frost; seeds oblong, much flattened, $\frac{1^{\prime}}{2}$ long, $\frac{1}{3}^{\prime}$ wide, with a thick hard lustrous brown pitted coat, a conspicuous truncate hilum, and a slender raphe.

A tree, usually $30^{\circ}-50^{\circ}$ high, with a short trunk rarely more than $12^{\prime}$ in diameter, spreading often pendulous branches forming a broad or narrow round-topped head, and slender slightly zigzag branchlets, with a thick pith or pith-cavity, light redbrown and more or less pale-pubescent when they first appear, becoming during their first winter pubescent or glabrous, light brown or ashy gray, and marked by occasional small orange-colored lenticels and by elevated semicircular leaf-scars, with deep horizontal lunate depressions containing the ends of the crowded fibro-vascular bundles, later turning reddish brown, with bark often somewhat broken by longitudinal fissures; or in the primeval forest, under the most favorable conditions, sometimes $100^{\circ}-115^{\circ}$ high, with a long slender trunk free of branches for $70^{\circ}-80^{\circ}$ and rarely exceeding $2^{\circ}$ in diameter. Winter-buds axillary, broadly ovate, acute, $\frac{1}{8}^{\prime}$ long, with thick imbricated dark red-brown or purple lustrous scales often persistent at the base of the young branchlets during the season. Bark of the trunk $\frac{3^{\prime}}{4}-1^{\prime}$ thick, dark brown tinged with red, or dark gray, and deeply divided into thick square plates broken into thin persistent scales. Wood heavy, strong, with dark brown or sometimes nearly black heartwood often undeveloped until the tree is over 100 years old; used in turnery, for shoe-lasts, plane-stocks, and preferred for shuttles to other American woods. The fruit contains tannin, to which it owes its astringent qualities, and is eaten in great quantities in the southern states. The inner bark is astringent and bitter.

Distribution. Light sandy well-drained soil, or in the Mississippi basin sometimes on the deep rich botton-lands of river valleys; Lighthouse Point, New Haven, Connecticut, southward to the banks of the Caloosa River and the shores of Bay Biscayne, Florida, southern Alabama and Mississippi, and from southern Ohio to southeastern Iowa, southern Missouri, Arkansas, Louisiana, eastern Kansas, the Indian Territory, and the valley of the Colorado River, Texas; very common in the south Atlantic and Gulf states, often covering with shrubby growth by means of its stoloniferous roots abandoned fields, and springing up by the sides of roads and fences.

Occasionally cultivated in the eastern United States, and rarely in Europe.

\section{Diospyros Texana, Scheele. Black Persimmon. Chapote.}

Leaves cuneate-oblong to obovate, rounded and often retuse at the apex and wedge-shaped at the base, when they unfold covered below with thick pale tomentum and above with scattered long white hairs, and at maturity thick and coriaceous, 
dark green and lustrous, glabrous or puberulous on the upper, paler and pubescent on the lower surface, $\frac{3^{\prime}}{4}-1 \frac{1}{2}^{\prime}$ long and about $1^{\prime}$ wide, with broad midribs and about 4 pairs of arcuate primary veins and reticulate veinlets, unfolding in February and March, and falling during the following winter without change of color; their petioles short, thick, and hairy. Flowers appearing in early spring when the leaves are

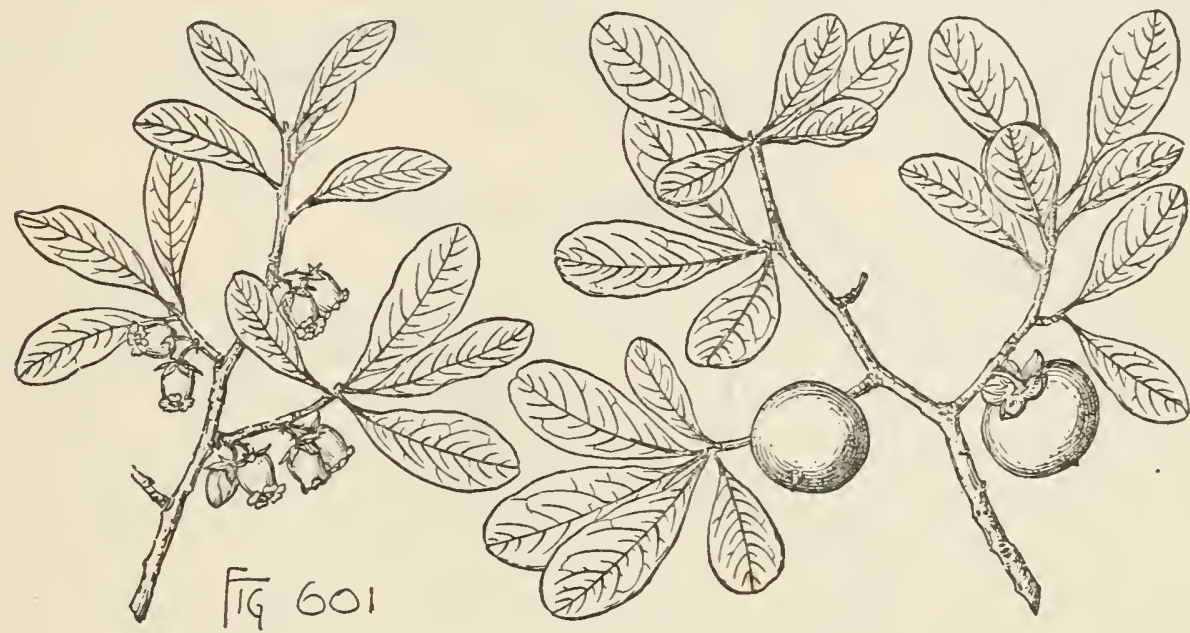

about one third grown, on branches of the previous year; staminate on slender drooping pedicels furnished near the middle with minute caducous bractlets, in 1-3-flowered crowded pubescent fascicles; pistillate on stouter club-shaped bibracteolate peduncles, solitary or rarely in pairs; calyx of the staminate flower $\frac{1^{\prime}}{8}$ long and deeply divided into 5 orate or lanceolate silky-tomentose lobes recurved after the opening of the flower, and much shorter than the corolla $\frac{1}{8}^{\prime}$ long, creamy white, and slightly contracted below the $\check{5}$ short spreading rounded lobes ciliate on the margins; stamens, with glabrous filaments shorter than the corolla, and linear-lanceolate anthers opening at the apex only by short slits; pistillate flowers without rudimentary stamens, $\frac{1^{\prime}}{3}$ long, with oblong acute silky tomentose calyx-lobes half the length of the pubescent corolla nearly $\frac{1}{2}^{\prime}$ across the short spreading lobes; ovary ovate, pubescent like the young fruit, ultimately 8-celled. Fruit ripening in Angust, subglobose, $\frac{1^{\prime}}{2}-\mathbf{1}^{\prime}$ in diameter, and 3-8 seeded, surrounded at the base by the large thickened leathery calyx sometimes $1^{\prime}$ in diameter, with oblong pubescent reflexed lobes, the thick tough black skin inclosing the thin sweet insipid juicy dark flesh; seeds triangular, rounded on the back, narrowed and flattened at the pointed apex, $\frac{1}{3}^{\prime}$ long, abont $\frac{1^{\prime}}{8}$ thick, with a bony lustrous light red pitted coat.

An intricately branched tree, occasionally $40^{\circ}-50^{\circ}$ high, with a trunk $18^{\circ}-20^{\circ}$ in diameter, dividing at some distance above the ground into a number of stout upright branches forming a narrow round-topped head, and slender terete slightly zigzag branchlets, coated at first with pale or rufous tomentum, ashy gray, glabrous or puberulous during their first winter, later becoming brown and marked by minute pale lenticels and by small elevated semiorbicular leaf-scars displaying a lunate row of fibro-vascular bundle-scars; often much smaller, and toward the northern and western limits of its range a low many-stemmed shrub. Winter-buds axillary, obtuse, barely more than $\frac{1}{16}{ }^{\prime}$ long, with broadly orate scales ronnded at the back and coated with rufous tomentum. Bark of the trunk smooth, light gray slightly tinged with red, the outer layer falling away in large irregularly shaped patches displaying the 
smooth gray inner bark. Wood heavy, with black heartwood often streaked with yellow and clear bright yellow sapwood; used in turnery and for the handles of tools. The fruit, which is cxcecdingly austerc until it is fully ripc, stains black, and is sometimes used by Mexicans in the valley of the Rio Grande to dye sheepskins.

Distribution. Valleys of the Colorado and Concho rivers, Texas, to Nuevo Leon; abundant in western and southern Texas; in the neighborhood of the coast on the borders of prairies in rich moist soil; westward on dry rocky mesas and in isolated eanons; vcry common and of its largest size in the region between the Sicrra Madre and the coast of the Gulf of Mexico in Nuevo Leon.

\section{SYMPLOCACEX.}

Trees or shrubs, with simple pubescence, watery juice, scaly buds, and fibrous roots. Leaves simple, alternate, coriaceous or membranaceous, pinnately veined, usually becoming yellow in drying, without stipules. Flowers regular, perfect, or polygamo-dicecious, on ebracteolate pedicels, in dense or lax axillary spikes or racemes, with small caducous bracts ; calyx campanulate, 5 -lobed, open in the bud, the tube adnate to the ovary, enlarged after anthesis; corolla divided nearly to the base into 5 lobes imbricated in the bud; disk 0 ; stamens numerous, inserted in many series on the base of the corolla; filaments filiform, more or less united below into clusters; anthers oblong, introrse, 2-celled, the cells lateral, opening longitudinally; ovary contracted into a simple style, with an entire or slightly lobed terminal stigma; ovules 2 or rarely 4 in each cell, suspended from its inner angle, anatropous; raphe ventral ; micropyle superior. Fruit a drupe (in the North American species), crowned with the persistent lobes of the calyx, with thin dry flesh and a bony 1 -seeded stone. Seed oblong, suspended; seed-coat membranaceous; embryo terete, erect in copious fleshy albumen; cotyledons much shorter than the long slender radicle turned toward the broad conspicuous hilum.

The family consists of the genus Symplocos.

\section{SYMPLOCOS, L'Her.}

Characters of the family.

Symplocos with two hundred and eighty described species inhabits chiefly the warmer parts of America, Asia, and Australia, one species occurring in the sonthern United States.

Symplocos contains a yellow coloring matter, and the bark and leaves of some species have medical properties.

The generic name, from $\Sigma \dot{v} \mu \pi \lambda$ окоs, relates to the union of the filaments of some of the species.

\section{Symplocos tinctoria, L'Her. Sweet Leaf. Horse Sugar.}

Leaves revolute in the bud, oblong, acute or acuminate at the apex, gradually narrowed at the base, obscurely crenulate-serrate, with remote teeth, or sometimes nearly entire, when they unfold coated with pale tomentum below, glabrous or tomentose above, and furnished on the margins with minute dark caducous glands, and at maturity subcoriaceous, dark green and lustrous above, paler and pubescent below, $5^{\prime}-6^{\prime}$ long and $1^{\prime}-2^{\prime}$ wide, with broad midribs rounded and sometimes puberulous on the upper side, inconspicnous arcuate veins, and reticulate veinlets, northward and at high elevations falling in the autumn, and southward remaining on the 
branches until after the opening of the flowers the following spring; their petioles stout, slightly winged, $\frac{1}{3}^{\prime}-\frac{1}{2}^{\prime}$ long. Flowers : flower-clusters inclosed in the bud by ovate acute orange-colored scales brown and ciliate on the margins, each of the flower-buds surrounded by 3 imbricated oblong bracts rounded or pointed at the apex and ciliate on the margins, the longest as long as the calyx and one third longer than the 2 lateral bracts; flowers fragrant, opening from the 1st of March at the south to the middle of May on the southern Appalachian Mountains, on short pedicels enlarged into thick hemispherical receptacles covered with long white hairs, in

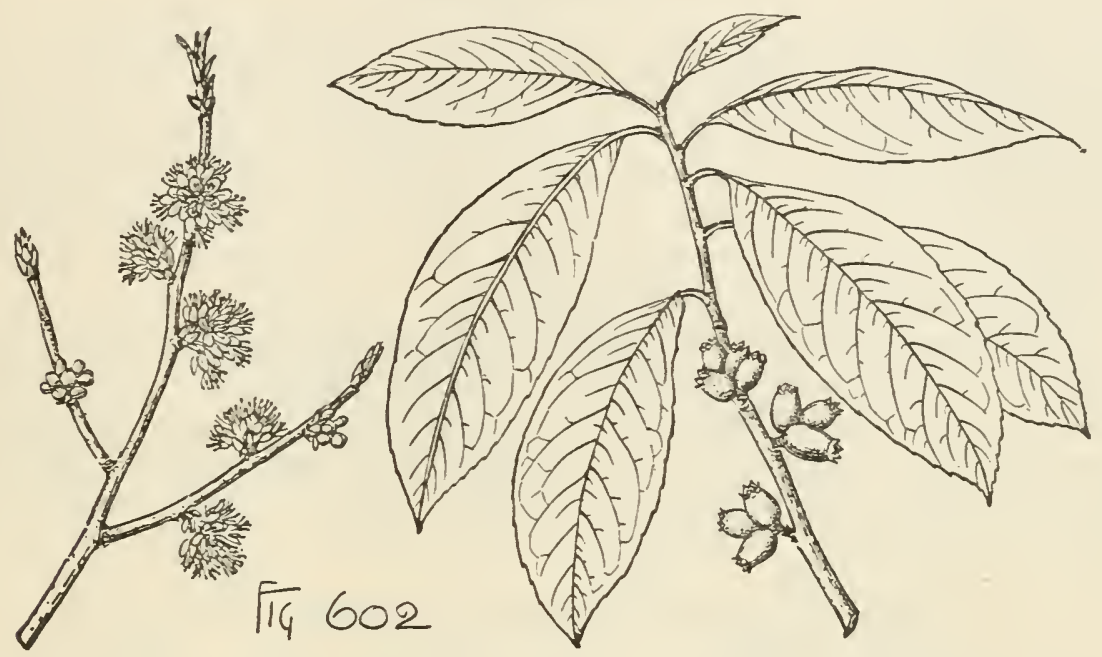

nearly sessile many-flowered clusters in the axils of leaves of the previous year; calyx oblong, cup-shaped, dark green and puberulous, with minute ovate scarious lobes rounded at the apex; corolla creamy white, $\frac{1}{4}^{\prime}$ long, with rounded lobes; stamens exserted, with slender filaments united at the base into 5 clusters, and orange-colored anthers; ovary 3-celled, furnished on the top with 5 dark nectariferous glands placed opposite the lobes of the calyx, and abruptly contracted into a slender style gradually thickened toward the apex and longer than the corolla. Fruit ripening in the summer or early autumn, ovate, $\frac{1}{3}$ long, dark orange-colored or brown; seed ovate, pointed, with a thin papery chestnut-brown coat.

A tree, occasionally $30^{\circ}-35^{\circ}$ high, with a short trunk barely exceeding $6^{\prime}-8^{\prime}$ in diameter, slender upright branches forming an open head, and stout terete pithy branchlets light green and coated with pale or rufous tomentum when they first appear, or sometimes glabrous and covered with scattered white hairs, reddish brown to ashy gray, tinged with red and usually more or less pubescent or often covered with a glaucous bloom during their first and second years, later growing darker, roughened by occasional small elevated lenticels and marked by the low horizontal obcordate leaf-scars displaying a central cluster of large fibro-vascular bundle-scars; or more often a shrub. Winter-buds ovate, acute, covered with broadly ovate nearly triangular acute scales, those of the inner rows accrescent on the young branchlets, and at maturity oblong-obovate, rounded and often apiculate at the apex, light green, glabrous or pilose, ciliate on the margins, and often $\frac{1}{2}^{\prime}$ in length. Bark of the trunk $\frac{1^{\prime}}{3}-\frac{1}{2}$ thick, ashy gray slightly tinged with red, divided by oceasional narrow fissures and roughened by wart-like excrescences. Wood light, soft, closegrained, light red or brown, with thick lighter colored often nearly white sapwood of 
18-20 layers of anmul growtl. The leaves are swect to the taste and are devoured in the antumu by cattle and horses, and, like the bark, yield a yellow dye occasionally used donestically. The bitter aromatic roots have been used as a tonic.

Distribution. Moist rich soil, often in the shade of dense forests; peninsula of Delaware to norther'n Florida and from the coast to clevations of nearly $3000^{\circ}$ on the Blue Ridge, and to castern Texas and southern Arkansas; in the Gulf states usually along the borders of Cypress swamps.

\section{STYRACEZE.}

Trees or shrubs, with more or less stellate or scurfy pubescence, watery juice, and scaly buds. Leaves alternate, simple, penniveined, without stipules. Flowers regular, perfect; calyx more or less adnate to the ovary; stamens in one series mostly adnate to the tube of the corolla; disk 0 ; anthers introrse, 2-celled, the cells opening longitudinally; ovary crowned with a simple style; ovules anatropous. Fruit drupaceous, with thin dry flesh, and a thick-walled 1-seeded bony stone. Seed with albumen.

The Storax family with seven genera and few species is confined to North and South America, the Mediterranean region, eastern Asia and the Malay Archipelago. Of the two North American genera Mohrodendron is arborescent. Storax and benzoin, aromatic resinous balsams, are obtained from Styrax officinale, L., of southern Europe and Asia Minor, and from Styrax Benzoin, DC., of the Molucca Islands.

\section{MOHRODENDRON, Britt.}

Trees or shrubs, with slender terete pithy branchlets without terminal buds, axillary buds with imbricated accrescent scales, and fibrous roots. Leaves involute in the bud, membranaceous, ovate-oblong, acute, denticulate, deciduous. Flowers on slender elongated drooping pubescent ebracteolate pedicels from the axils of foliaceous obovate or acute cadncous bracts, in fascicles or short racenes from the axils of leaves of the previous year; calyx-tube obconical or obpyramidal, 4-ribbed, coated with thick pale tomentım, the limb short, 4-toothed, with minute triangular teeth, open in the bud; corolla epigynous, campanulate, 4-lobed, or divided nearly to the base, the lobes convolute or imbricated in the bud, thin and white; stamens 8-16; filaments elongated, shorter than the corolla, slightly attached to the base, or sometimes free, flattened below; anthers oblong, adnate or free at the very basc; ovary 2 or 4-celled, gradually contracted into an elongate gịbrous or tomentose style stigmatic at the apex; ovules 4 in each cell, attached by elongated funiculi at the middle of the axis, the 2 upper ascending, the 2 lower pendulous; raphe dorsal; micropyle inferior and superior. Fruit elongated, obovate, gradually narrowed at the base, crowned witl the calyx-limb and the thickened persistent style; skin tough, separable, light green and lustrous, turning reddish brown late in the autumn; exocarp thick, becoming dry and eorky at maturity, produced into 2 or 4 broad thin wings, wedgeshaped at the base and ronnded at the apex; stone thick and bony, obovate, gradually narrowed at the base into an elongated slender stipe inclosed in the wings, tipped with the bony remnants of the style, usually irregularly 8-angled or sulcate, 1-4celled. Seed solitary in each cell, elongated, cylindrical; seed-coat thin, light brown, lustrous, adlierent to the walls of the stone, the delicate inner coat attached to the copious fleshy albumen; embryo terete, axile, erect; cotyledons oblong, as long as the elongated radicle turned toward the minute hilum. 
Mohrodendron is confined to the southern United States; of the three species two are trees.

The generic name is in honor of Dr. Charles Molr, author of the Flora of Alabama.

\section{CONSPECTUS OF THE ARBORESCENT SPECIES.}

Corolla slightly lobed; filaments glabrous; ovary 4-celled; fruit 4-winged; leaves oval or ovate-oblong.

1. M. Carolinum (A, C).

Corolla divided nearly to the base; filaments covered with pale hairs; ovary usually 2-celled; fruit 2-winged; leaves ovate or sometimes slightly obovate.

2. M. dipterum (C).

\section{Mohrodendron Carolinum, Britt. Silver Bell Tree.}

Leaves oval or ovate-oblong, gradually or abruptly contracted into long points acute or rounded at the apex, wedge-shaped or rounded at the base, finely serrate,

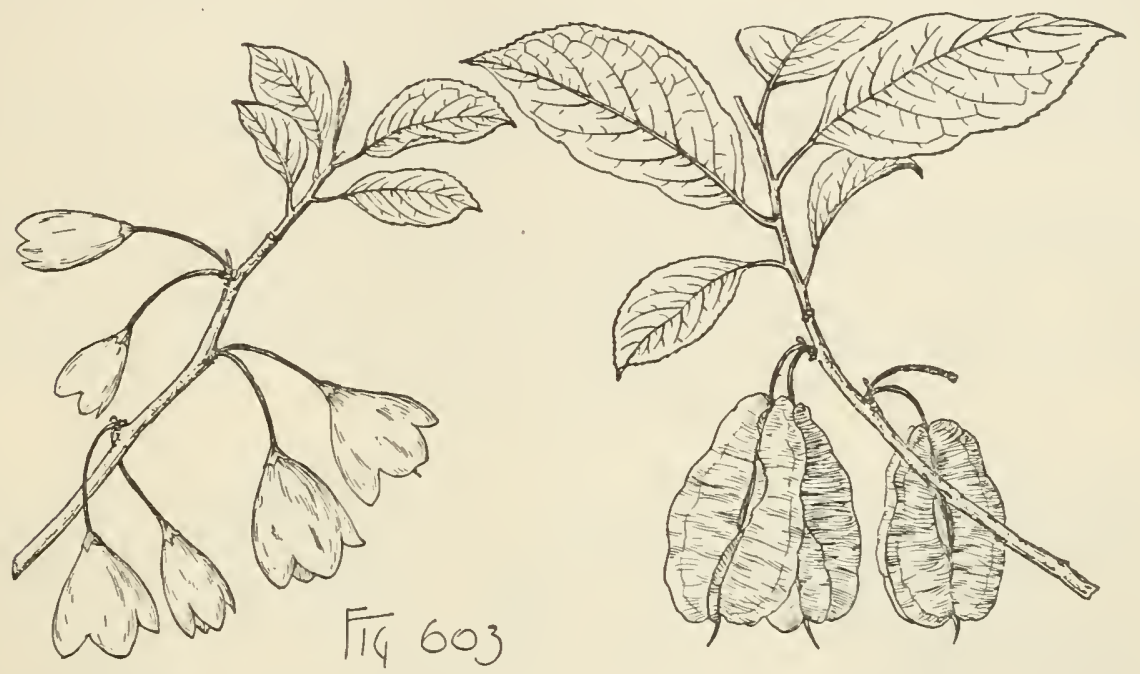

with remote callous teeth, when they unfold ciliate on the margins, coated below and on the petioles with dense pale tomentum, and bronze red and glabrous or pilose above, and at maturity thin and firm, light bright green and puberulous on the upper, paler and more or less pubescent on the lower surface, especially along the slender midribs and primary veins arcuate near the margins and connected by remote reticulate veinlets, $4^{\prime}-6^{\prime}$ long and $2^{\prime}-3^{\prime}$ wide, turning light yellow late in the autumn before falling; their petioles stout, $\frac{2^{\prime}}{3}$ long. Flowers nearly $1^{\prime}$ in length, appearing in early spring when the leaves are about one third grown, on slender drooping pedicels $1^{\prime}-2^{\prime}$ long from the axils of ovate yellow-green caducous bracts $\frac{1}{2}-\frac{2}{3}$ long and $\frac{1^{\prime}}{4}$ broad, in crowded fascicles or short few-flowered racemes; corolla slightly lobed, narrowed below into a short tube, and bronze-red before anthesis; stamens 10-16; filaments glabrous; ovary 4-celled. Fruit ripening late in the autumn and persistent until winter, ellipsoidal, equally 4 -winged, $1 \frac{1^{\prime}}{2}-2^{\prime}$ long, $1^{\prime}$ wide; stone broadly obovate, obscurely ridged, and contracted into a short or sometimes elongated stipe; seeds rounded at the narrow ends, about $\frac{1^{\prime}}{2}$ long.

A tree, occasionally $80^{\circ}-90^{\circ}$ high, with a straight trunk sometimes $3^{\circ}$ in diameter and $50^{\circ}-60^{\circ}$ long, short stout branches forming a narrow head, and slender branchlets coated at first with thick pale deciduous tomentum, light reddish brown, gla- 
brous or pubescent during their first summer and of ten covered with a glancous bloom, lustrous, reddish brown or orange color during their first winter and marked by large obcordate leaf-scars, growing darker the following year, their thin bark then sometimes separating into thread-like scales and beginning to display the pale shallow longitudinal fissures of old branches and young trunks; or usually much smaller, and of ten a shrub, with many stout wide-spreading stems. Winter-buds $\frac{1}{8}$ long, obtuse, with thick broadly ovate dark red scales rounded on the back and covered, especially at the base and above the middle, with pale hairs, those of the inner rows becoming strap-shaped, rounded at the apex, bright yellow, and sometimes $\frac{1}{2}$ in length. Bark of the trunk $\frac{1^{\prime}}{2}$ thick, bright red-brown, with broad rounded ridges separating on the surface into thin papery scales. Wood light, soft, close-grained, liglit brown, with thick lighter colored sapwood of 50-60 layers of amnual growth.

Distribution. Rich wooded slopes and the banks of streams; mountains of West Virginia to southeru Illinois, and south ward to middle Florida, central Alabama and Mississippi, and through Arkansas to western Louisiana and eastern Texas; most abundant in the elevated Appalachian region, and of its largest size on the western slopes of the high mountains of North Carolina and Tennessee.

Often cultivated as an ornamental plant in the eastern United States and hardy as far north as eastern Massachusetts, and in central and northern Europe.

\section{Mohrodendron dipterum, Britt. Snowdrop Tree. Silver Bell Tree.}

Leaves ovate or sometimes slightly obovate, acuminate, wedge-shaped or rounded at the base, and remotely serrate, with minute callous teeth, when they unfold coated with pale tomentum below and puberulous above, and at maturity

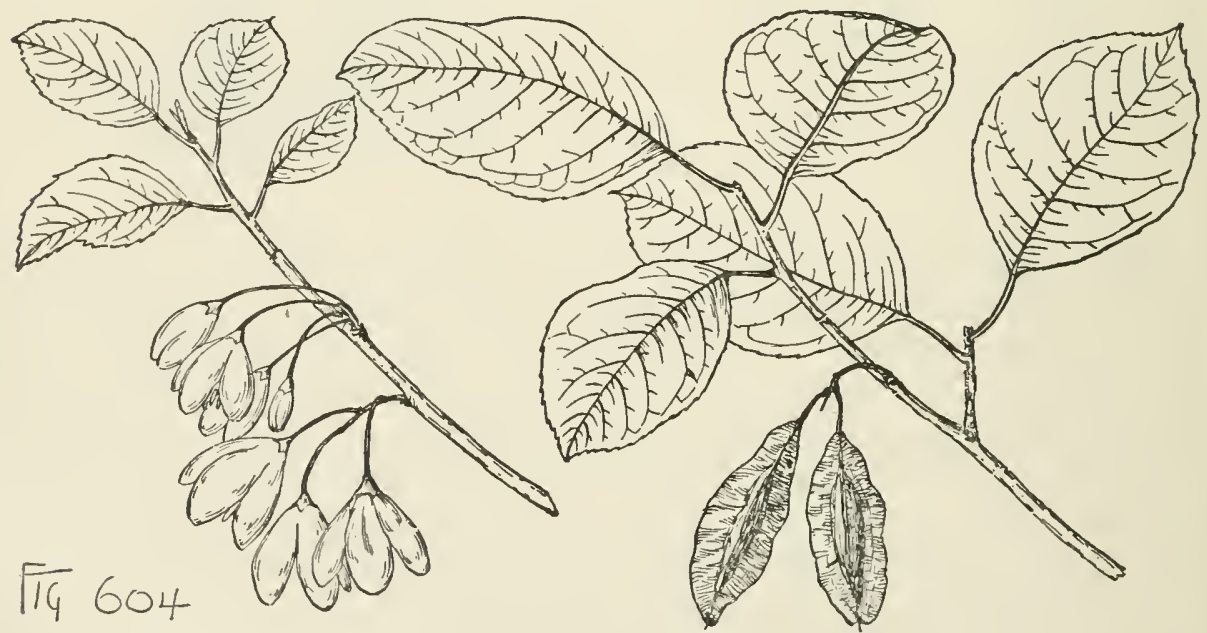

thin, light green, glabrous on the upper surface except along the narrow midribs, pubescent on the lower surface, $4^{\prime}-5^{\prime}$ long, $1 \frac{1}{2}^{\prime}-3^{\prime}$ wide, with conspicuous pale arcuate veins and reticulate veinlets; their petioles stout, $\frac{2^{\prime}}{3}$ in length. Flowers nearly $1^{\prime}$ long, opening from the middle of March to the end of April, on slender pedicels $1 \frac{1}{2}-2^{\prime}$ in length, in the axils of obovate acute puberulous caducous bracts often $\frac{1^{\prime}}{4}$ long; corolla puberulous on the outer surface, divided nearly to the base into slightly obovate spreading divisions; stamens $8-16$, usually 8 , nearly as long as the corolla, their filaments covered with pale hairs and sometimes free from the corolla; 
ovary usually 2 , rarely 4 -celled, and coated, like the exserted style, with pale tomentum. Fruit oblong, compressed, $1 \frac{1^{\prime}}{2}-2^{\prime}$ long, often nearly $1^{\prime}$ wide, with 2 broad wings and frequently with 2 or sometimes 3 narrow supplementary wings between them; stone narrowly obovate, conspicuously sulcate, with about 8 dark ridges, and contracted into a slender stipe sometimes $1^{\prime}$ in length; seeds acuminate at the ends, about $\frac{3^{\prime}}{4}$ long.

A tree, rarely $30^{\circ}$ high, with a short trunk occasionally $8^{\prime}-10^{\prime}$ in diameter, horizontal branches forming a low broad head, and slender branchlets, light green and more or less coated with pale pubescence at first, becoming usually glabrous in their first winter and orange color or reddish brown and lustrous, and marked with large elevated obcordate leaf-scars, and in their second year dark red-brown, with bark often separating into thread-like scales and dividing the following season into irregular pale longitudinal fissures; more often a shrub, with numerous stout spreading stems. Winter-buds $\frac{1}{16}$ long, ovate, obtuse, with broadly ovate acute light red pubescent scales, those of the inner ranks becoming strap-shaped, scarious, and $\frac{1^{\prime}}{4}$ in length. Bark of the trunk $\frac{1^{\prime}}{3}-\frac{1^{\prime}}{2}$ thick, brown tinged with red, and divided by irregular longitudinal often broad fissures, the surface separating into small thin appressed scales. Wood light, soft, strong, very close-grained, light brown, with thick lighter colored sapwood.

Distribution. Low wet woods and the borders of swamps; coast region of the south Atlantic and Gulf states from South Carolina to northern Florida and eastern Texas, and through Louisiana to central Arkansas.

Occasionally cultivated in the gardens of the southern states.

\section{OLEACEAE.}

Trees or shrubs, with watery juice, scaly buds, their inner scales accrescent, opposite leaves without stipules, and fibrous roots. Flowers perfect, diœecious or polygamous, regular; calyx 4-lobed, or 0 ; corolla of $2-4$ petals, or 0 ; disk 0 ; stamens $2-4$, rudimentary or 0 in unisexual pistillate flowers; anthers attached on the back below the middle, often apiculate by the prolongation of the connective, introrse, 2-celled, the cells opening longitudinally usually by lateral slits; ovary superior, free, 2 or rarely 3 -celled, rudimentary or 0 in the staminate flower; style simple; ovules 2 in each cell, pendulous, anatropous ; micropyle superior. Fruit (in the North American arborescent genera) a samara or berry. Seed pendulous; seed-coat membranaceous ; embryo straight in copious fleshy albumen; cotyledons flat, much longer than the short terete superior radicle turned toward the minute hilum.

The Olive family with twenty genera is widely distributed in temperate and tropical regions chiefly in the northern henisphere. Of the five genera indigenous to the United States three are arborescent. 'To this family belong Olea Europaca, L., the Olive-tree of the Mediterranean basin, now largely cultivated in California for its fruit, and the Lilacs, Forsythias, and Privets, favorite garden plants in all countries with temperate climates.

\section{CONSPECTUS OF THE ARBORESCENT GENERA OF THE UNITED STATES.}

Fruit a winged samara; leaves compound.

1. Fraxinus.

Fruit a fleshy drupe; leaves simple.

Corolla of 4 long linear petals united only at the base ; leaves deciduous.

Corolla tubular; leaves persistent.

2. Chionanthus.

3. Osmanthus. 


\section{FRAXINUS, L. Ash.}

Trees or shrubs, with light tongh wood, thick furrowed or rarely thin and scaly bark, usually ash-colored branchlets with thick pith, and compressed obtuse terminal buds much larger than the lateral buds. Leaves petiolate, unequally pinnate or rarcly reduced to a single lcaflet, deciduons; leaflcts conduplicate in the bud, usually serrate, petiolulate or sessile. Flowers diœcions or polygamous, rarely perfect, prodnced in early spring on slender clongated pedicels without bractlets, in open or compact slender-branched panicles, with obovate linear or lanccolate cadncous bracts, terminal on leafy shoots of the year, developed from the axils of new leaves, or from separate buds in the axils of leaves of the previons year, or at the base of young branchlets and covered by 2 ovate scales; calyx campanulate, deciduous or persistent under the fruit, or 0; corolla 2-4-parted, the divisions conduplicate in the bud, united at the base, or 0 ; stamens nsually 2, rarely 3 or 4 , inserted on the base of the corolla, or hypogynous; filaments terete, short or rarely elongated; anthers ovate or linear-oblong, the cells opening by lateral slits; ovary 2 or rarely 3-celled, contracted into a short or elongated style crowned with a 2-lobed stigma; ovules suspended in pairs from the inner angle of the cell; raphe dorsal. Fruit a 1 or rarely 2 or 3-seeded winged samara; body terete or slightly flattened contrary to the septum, with a dry or woody pericarp produced into an elongated terminal and more or less decurrent wing, usnally 1 -celled by abortion or sometimes 2 or 3-celled and winged. Seed solitary in each cell, oblong, compressed, gradually narrowed and rounded at the ends, filling the cavity of the fruit; seed-coat chestnut-brown.

Fraxinus with thirty to forty species is widely distributed in the temperate regions of the northern hemisphere, and within the tropics occurs on the islands of Cuba and Java. The North American species, with one exception, are arborescent.

Fraxinus prodnces tough straight-grained valuable wood, and some of the species are large and important timber-trees. The waxy exudations from the trunk and leaves of Fraxinus Ornus, L., of southern Enrope and Asia Minor furnish the manna of commerce nsed in medicine as a gentle laxative; and the Chinese white wax is obtained from the branches of species of eastern Asia.

Fraxinus is the classical name of the Ash-tree.

\section{CONSPECTUS OF THE ARBORESCENT SPECIES OF THE UNITED STATES.}

1. Flowers with petals, polygamous or perfect.

Panicles terminal on lateral leafy branches of the year; corolla 4-parted; leaflets $3-7$, lanceolate or ovate-lanceolate.

1. F. cuspidata $(\mathrm{E}, \mathrm{H})$.

Panicles axillary on branches of the year or of the previous year; leaflets $3-7$, narrowly spatulate to oblong-obovate; petioles wing-margined.

2. F. Greggii (E).

2. Flowers without petals, diœcious, polygamous or rarely perfect; panicles from separate buds in the axils of leaves of the previous year.

*Body of the fruit compressed, its wing broad and extending to the base of the body.

Branchlets 4-sided; flowers perfect; leaflets 5-9, ovate-oblong to lanceolate, minute, coarsely serrate, rounded or wedge-shaped at the base.

3. F. quadrangulata $(\mathrm{A}, \mathrm{C})$.

Branchlets terete.

Leaflets $3-11$; flowers diœcions ; fruit narrowed and acute at the base.

Leaflets acute or acuminate, $3-7$.

Fruit elliptical to spatulate, often 3 -winged, acute at the apex; leaflets $5-7$, ovate-oblong.

4. F. Caroliniana (C).

Fruit lanceolate to oblanceolate, rounded and emarginate at the apex; leaflets $3-5$, oblong.

5. F. Floridana (C). 
Leaflets gradually acuminate, 5-11, oblong-lanceolate, the lateral leaflets sessile ; flowers polygamous.

6. F. nigra $(\mathbf{A}, \mathrm{C})$.

Leaves mostly reduced to a single leaflet, rarely 2 or 3 -foliolate, branchlets 4-sided.

7. F. anomala (F).

**Body of the fruit nearly terete ; flowers dicecious ; calyx of the staminate flower minute or 0 (large in 12); calyx of the pistillate flower persistent.

Branchlets glabrous.

Leaflets 5-9; wing of the fruit terminal.

Leaflets usually 7 , ovate to oblong-lanceolate, acute or acuminate, pale below.

S. F. Americana (A, C).

Leaflets usually 5 , ovate to obovate, mostly rounded at the apex, pale below.

9. F. Texensis (C).

Leaflets $3-5$, oblong-lanceolate, usually acuminate ; wing of the fruit extending down its sides.

10. F. Berlandieri (E).

Branchlets and lower surface of the leaflets pubescent (branchlets and leaves glabrous in one form of 11, leaves sometimes glabrous in 14).

Lateral leaflets stalked.

Wing of the fruit extending down its sides; leaflets $7-9$.

Leaflets mostly coarsely serrate, oblong-lanceolate to ovate.

11. F. Pennsylvanica (A, C, F).

Leaflets with usually entire and undulate margins, lanceolate to ovatelanceolate; calyx large.

Wing of the fruit terminal.

Wing of the fruit linear-oblong; leaflets $7-9$, ovate-oblong to lanceolate, pale below.

13. F. Biltmoreana (A, C).

Wing of the fruit oblong-obovate.

Leaflets 3-9, lanceolate, mostly acuminate, narrowly cuneate at the base.

14. F. velutina (E, $G, H)$.

Leaflets 5 , ovate to oblong, acute, broadly cuneate or rounded at the base, subcoriaceous.

15. F. coriacea $(\mathrm{F}, \mathrm{G})$.

Lateral leaflets sessile or rarely short-stalked; leaflets $5-7$, oblong to ovate, acute at the ends; coriaceous.

16. F. Oregona $(B, G)$.

1. Flowers with petals.

\section{Fraxinus cuspidata, Torr.}

Leaves $5^{\prime}-7^{\prime}$ long, with slender pale petioles sometimes slightly wing-margined, and 3-7 lanceolate or ovate-lanceolate leaflets gradually uarrowed at the apex into long slender tips, wedge-shaped at the base, and coarsely and remotely serrate above the middle, with recurved teeth, when they unfold slightly puberulous on the lower surface and at maturity thin, dark green above, paler and covered with minute black dots below, $1 \frac{1}{2}^{\prime}-2^{\prime}$ long and $\frac{1}{4}^{\prime}-1^{\prime}$ wide, with pale midribs and obscure veins, and borne on slender petiolules sometimes nearly $\mathbf{1}^{\prime}$ in length. Flowers perfect, extremely fragrant, appearing in April, in open glabrous panicles $3^{\prime}-4^{\prime}$ long and broad, terminal on lateral leafy branchlets developed from the axils of leaves of the previous year; calyx cup-shaped, $\frac{1}{16}$ 'long, with acute apiculate teeth, decidnous; corolla $\frac{2 \prime}{3}$ long, thin and white, divided to below the middle into 4 linear-oblong lobes pointed at the apex, and much louger than the nearly sessile oblong long-pointed anthers; ovary 2-celled, with a thick 2-lobed nearly sessile stigma. Fruit spatulateoblong or obovate-oblong, $1^{\prime}$ long, the margined edges of the flat nerveless body gradually broadening upward into the shorter wing rounded and slightly emarginate at the apex, and $\frac{1}{4}^{\prime}$ wide. 
A tree, rarely $20^{\circ}$ high, with a short trunk $6^{\prime}-8^{\prime}$ in diameter, and slender terete branchlets light red-brown when they first appear, soon becoming darker and marked

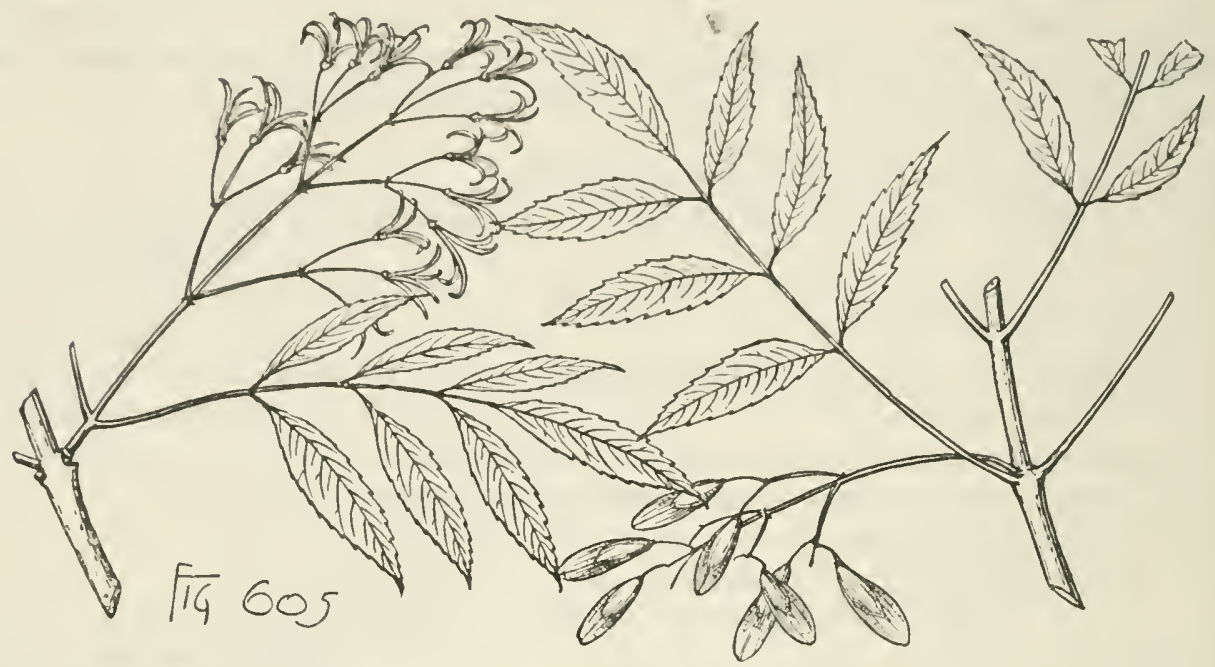

by scattered pale lenticels, and ashy gray and roughened by the dark elevated lunate leaf-scars in their second year; more of ten a shrub, with numerous slender spreading stems $6^{\circ}-8^{\circ}$ tall. Winter-buds terminal, acute, nearly $\frac{1}{2}^{\prime}$ long, with dark reddish brown glntinous scales.

Distribution. Rocky slopes and dry ridges; valley of the Rio Grande in southwestern Texas and southeastern New Mexico, and southward to the mountain slopes of Coahuila, Chihuahua, and Nuevo Leon; a shrub within the territory of the United States, and probably arborescent only on the mountains of Chihuahua; still very imperfectly known.

\section{Fraxinus Greggii, Gray.}

Leaves $1 \frac{1}{2}-3^{\prime}$ long, with winged petioles, and $3-7$ narrowly spatulate to oblongobovate leaflets entire or occasionally coarsely serrate above the middle, with remote

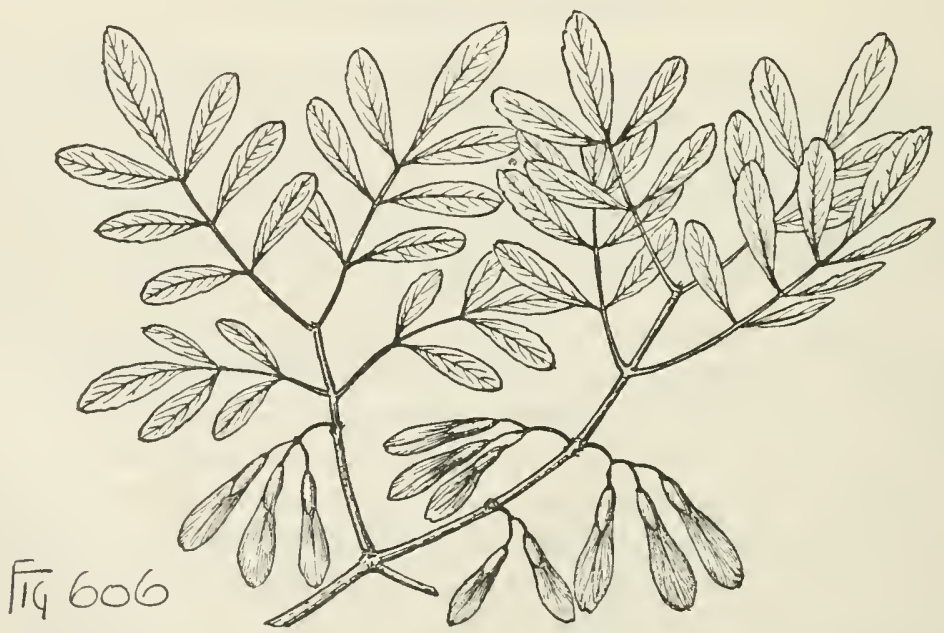

blunt teeth, slender midribs, and obscure reticulate veins, thick and coriaceous, dark green on the upper, rather paler and covered with small black dots on the lower 
surface, $\frac{1^{\prime}}{2}-1^{\prime}$ long, $\frac{1^{\prime}}{8}-\frac{1^{\prime}}{4}$ wide, and nearly sessile. Flowers unknown. Fruit oblonglinear to obovate, $\frac{1^{\prime}}{2}-\frac{2^{\prime}}{3}$ long, the thin wing decurrent on the short terete body, rounded and emarginate at the apex tipped with the elongated persistent conspicuous style, and about $\frac{1^{\prime}}{4}$ wide.

A tree, rarely $20^{\circ}-25^{\circ}$ high, with a trunk $8^{\circ}-10^{\circ}$ long and occasionally $8^{\prime}$ in diameter, and slender terete branchlets dark green and puberulous when they first ${ }^{\circ}$ appear, soon becoming ashy gray and roughened by numerous minute pale elevated lenticels, gradually turning dark gray or brown in their second and third years; more often a shrub, with numerous slender erect stems $4^{\circ}-12^{\circ}$ tall. Winter-buds terminal, about $\frac{1^{\prime}}{8}$ long, obtuse, with thick ovate light brown pubescent scales rounded on the back. Bark of the trunk thin, gray or light brown tinged with red, separating on the surface into large papery scales. Wood heavy, hard, closegrained, brown, with thick lighter colored sapwood.

Distribution. Dry limestone cliffs and ledges; valley of the Rio Grande, western Texas from the mouth of the San Pedro to tliat of the Pecos River, and southward on the mountains of northern Mexico; apparently most common and of its largest size on the Sierra Nevada of Nuevo Leon; still very imperfectly known.

\section{Flowers without petals.}

* Body of the fruit compressed.

\section{Fraxinus quadrangulata, Michx. Blue Ash.}

Leaves $8^{\prime}-12^{\prime}$ long, with slender petioles glabrous or puberulous toward the base, and 5-9 ovate-oblong to lanceolate long-pointed leaflets unequally rounded or wedgeshaped at the base, and serrate, with incurved teeth, when they unfold coated on the

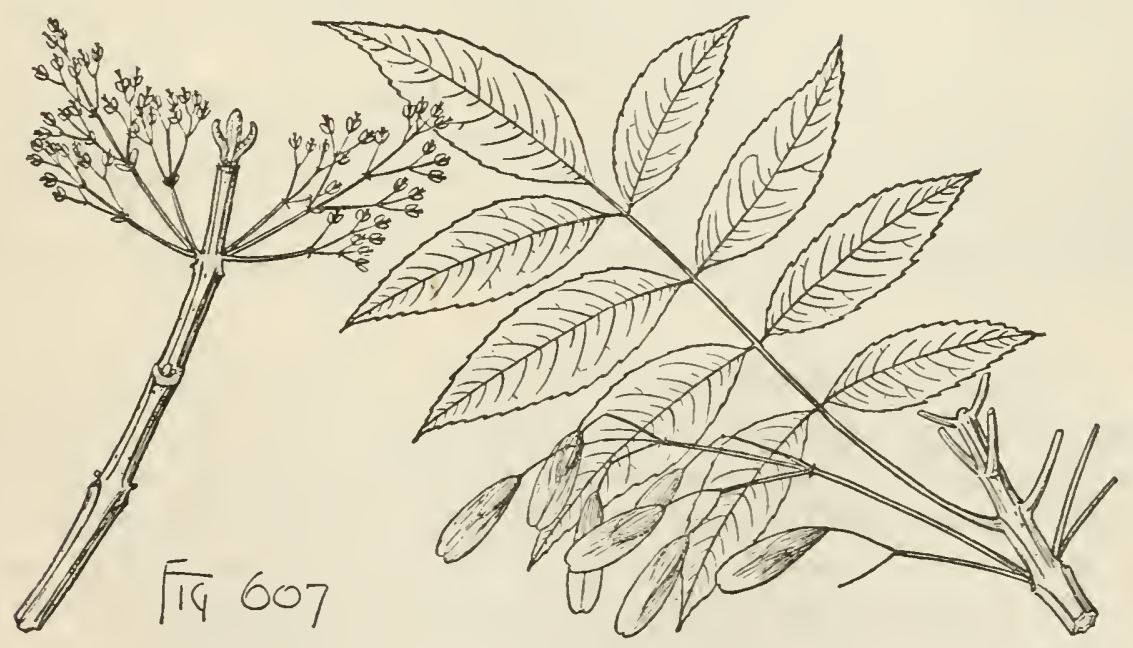

lower surface with thick brown tomentum, and at maturity thick and firm, yellowgreen and glabrous above, pale and glabrous or sometimes furnished with tufts of pale hairs along the base of the conspicuous midribs below, $3^{\prime}-5^{\prime}$ long and $1^{\prime}-2^{\prime}$ wide, with short broad petiolules grooved on the upper side and 8-12 pairs of veins arcuate near the margins, turning pale yellow in the autumn before falling. Flowers perfect, appearing as the terminal buds begin to expand, in loose-branched panicles from small obtuse buds in the axils of leaves of the previous year, with broadly ovate 
seales kecled on the back, apiculate at the apex, and covered with thick brown tomentum; ealyx reduced to an obsenre ring; eorolla 0 ; stamens 2 , with uearly sessile broad connectives and dark purple oblong obtuse anther-cells; ovary oblong-ovate, gradually narrowed into a short style divided at the apex into 2 light purple stigmatic lobes generally maturing and withering before the anthers open. Fruit linearoblong to cuneate-oblong, $1^{\prime}-2^{\prime}$ long, with wings usually conspicnously emarginate at the apex, surrounding the loug flat body faintly many-rayed on both snrfaces and nearly $1^{\prime}$ wide.

A tree, usually $60^{\circ}-70^{\circ}$ or occasionally $120^{\circ}$ high, with a trunk $2^{\circ}-3^{\circ}$ in diameter, small spreading branches forming a slender lead, and stont 4-angled branchlets more or less 4-winged between the nodes, dark orange color and covered with short rufous pubescence when they first appear, becoming gray tinged with red in their second year and marked by scattered pale lenticels and by the large elevated obcordate leaf-scars displaying a lnnate row of fibro-vascular bundle-scars, and in their third year light brown or ashy gray and then gradnally becoming terete. Winter-buds terminal, about $\frac{1^{\prime}}{4}$ long, with 3 pairs of scales, those of the onter row thick, rounded on the back, usually obscurely piunate toward the apex, dark reddish brown, slightly puberulous or often loary-tomentose, partly covering the bud, those of the inner rows strap-shaped, coated with light brown tomentum, often pinnate, becoming $1^{\prime}-1 \frac{1}{2}^{\prime}$ long. Bark of the trunk $\frac{1}{2}^{\prime}-\frac{2}{3}^{\prime}$ thick, irregularly divided into large plate-like scales, the light gray surface slightly tinged with red separating into thin minute scales. Wood heavy, hard, close-grained, rather brittle, light yellow streaked with brown, with thick lighter colored sapwood of 80-90 layers of annual growth; largely used for flooring and in carriage-building, and not often distinguished commercially from that of other species of the northern and middle states. A blue dye is obtained by macerating the inner bark in water.

Distribution. Rich limestone hills, occasionally descending into the bottom-lands of fertile valleys; southern Michigan to central Missouri, and southward to eastern Tennessee and northern Alabama, and through Iowa, Missouri, and northeastern Arkansas; nowhere very abundant; of its largest size in the basin of the lower Wabash River, Illinois, and on the western slopes of the Big Smoky Mountains, Tennessee.

Occasionally cultivated as an ormament of parks and gardens in the eastern United States.

\section{Fraxinus Caroliniana, Mill. Water Ash. Swamp Ash.}

Leaves $7^{\prime}-12^{\prime}$ long, with elongated stout terete pale petioles, and 5-7 long-stalked ovate to oblong acute leaflets rarely rounded at the apex, wedge-shaped or sometimes rounded or subcordate at the base, and coarsely serrate, with acute incurved teeth, or entire, when they unfold pilose above and more or less hoary-tomentose below, and at maturity thick and firm, $3^{\prime}-6^{\prime}$ long and $2^{\prime}-3^{\prime}$ wide, dark green above, paler or sometimes yellow-green and glabrous or pubescent beneath, especially along the conspicuons midribs and the numerous arcuate veins connected by obscure reticulate veinlets. Flowers diœcious, appearing in February and March in short or ultimately elongated panicles inclosed in the bud by chestnut-brown pubescent scales; staminate flower with a minnte or nearly obsolete calyx, and 2 or sometimes 4 stamens, with slender filaments and linear apiculate anthers; calyx of the pistillate flower cup-shaped, deeply divided and laciniate, as long as the ovary gradually narrowed into an elongated slender style 2-lobed and stigmatic at the apex. Fruit 
elliptical, obovate, or spatulate, frequently 3 -winged, surrounded at the base by the persistent calyx, $1 \frac{3^{\prime}}{4}-2^{\prime}$ long, often marked on the 2 faces by a conspicuous impressed midvein, the body short, compressed, and surrounded by the broad thin manynerved wing $\frac{1^{\prime}}{2}-\frac{3 \prime}{4}$ wide, acute and rounded or emarginate at the apex, and usually narrowed below into a stalk-like base.

A tree, rarely more than $40^{\circ}$ high, with a trunk sometimes $12^{\prime}$ in diameter, small branches forming a narrow often round-topped head, and slender terete branchlets light green and glabrous or coated with rufous deciduous tomentum when they first appear, light brown tinged with red and sometimes covered with a glaucous bloom in their first winter, light gray or yellow, occasionally marked by large pale lenticels, and by the elevated semiorbicular leaf-scars displaying a short row of conspicnous fibro-vascular bundle-scars. Winter-buds terminal, $\frac{1^{\prime}}{8}$ long, with 3 pairs of ovate acute chestnut-brown puberulous scales, those of the outer rank

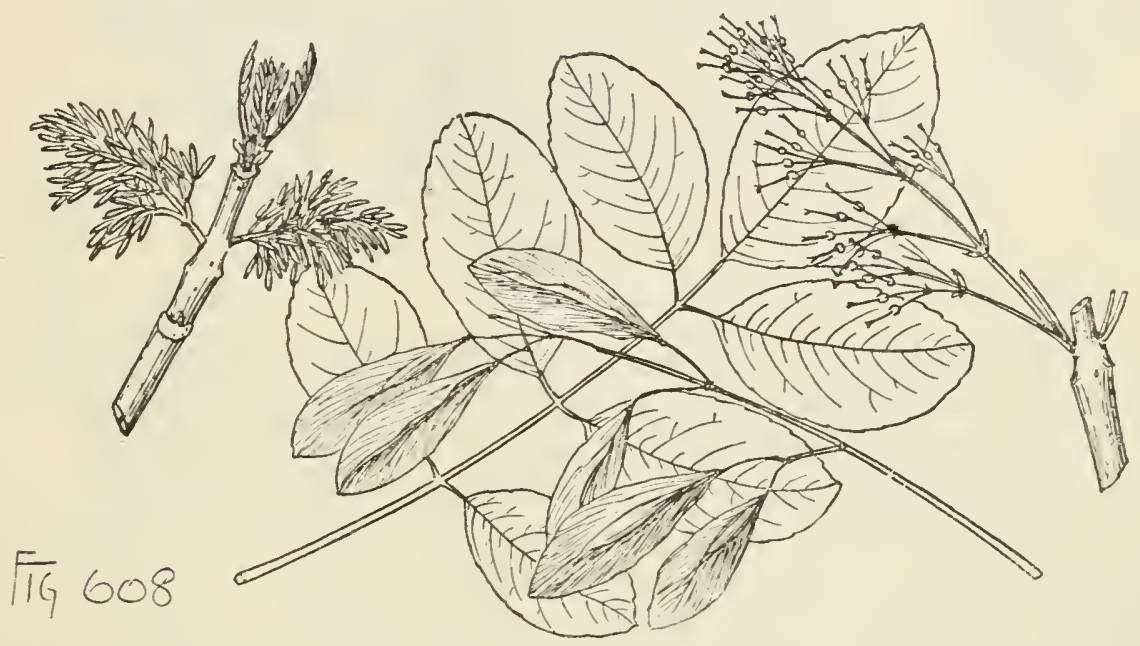

thickened at the base, rounded on the back, and shorter than the others. Bark of the trunk $\frac{1^{\prime}}{16}-\frac{1}{8}$ thick, light gray, more or less marked by large irregularly shaped round patches, and separating on the surface into small thin closely appressed scales. Wood light, soft, weak, close-grained, nearly white sometimes tinged with yellow, with thick lighter colored sapwood.

Distribution. Deep river swamps inundated during several months of every year, and usually under the shade of larger trees; coast region of the Atlantic and Gulf states, southern Virginia to Cape Canaveral and the Caloosa River, Florida, and the valley of the Sabine River, Texas, and northward through western Louisiana to southwestern Arkansas; also in Cuba.

\section{Fraxinus Floridana, Sarg. Water Ash.}

Leaves $5^{\prime}-9^{\prime}$ long, with elongated stout terete petioles, and ustally $3-5$ oblong acuminate long-stalked leaflets gradually narrowed and cuneate at the base, and remotely serrate, with small incurved teeth, when they unfold scurfy-pubescent above and hoary-tomentose below, and at maturity thick and firm, dark green and glabrous or puberulous on the upper and more or less tomentose on the lower surface, $3^{\prime}-4^{\prime}$ loug and $1^{\prime}-1 \frac{1}{4}$ ' wide, with slender midribs and thin primary veins arcuate and united within the thickened revolute margins. Flowers diœcious, appearing late in Febru- 
ary or early in Mareh, in elongated panicles inclosed in the bud by chestnut-brown pubescent seales; staminate flower composed of an annular disk and 2 or 3 stamens, with short filaments and apiculate anthers; calyx of the pistillate flower cup-shaped, slightly lobed, as long as the ovary gradually narrowed into the slender style 2-lobed and stigmatic at the apex. Fruit lanceolate or oblanceolate, surrounded at the

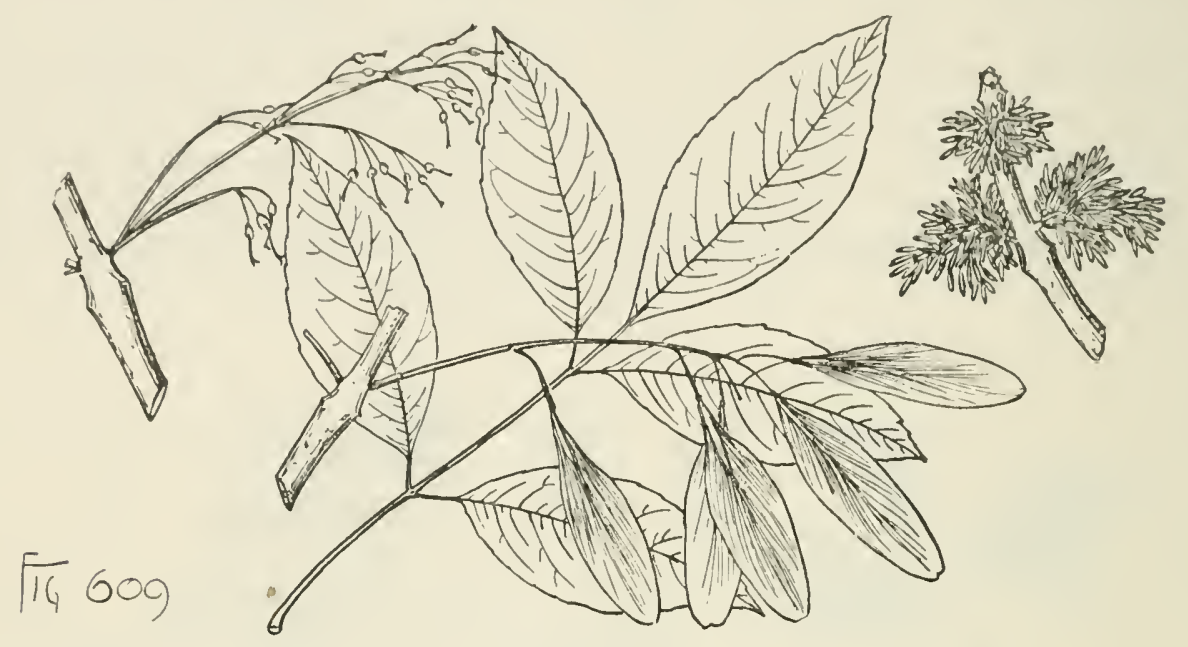

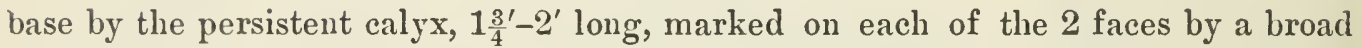
impressed midvein, the body short, surrounded by the thin many-nerved wing, narrowed, romded, and emarginate at the apex, and $\frac{1^{\prime}-1^{\prime}}{3}$ wide.

A tree, $30^{\circ}-40^{\circ}$ high, with a trunk sometimes $12^{\prime}$ in diameter, small spreading branches, and slender terete branchlets light orange-brown and occasionally marked by large pale lenticels during their first season, ashy gray and roughened the following year by the large horizontal obcordate elevated leaf-scars displaying a central ring of fibro-vascular bundle-scars. Winter-buds terminal, broadly ovate, acute, rusty-pubescent, about $\frac{1^{\prime}}{4}$ long. Bark of the trunk $\frac{1^{\prime}}{16}-\frac{1}{8}^{\prime}$ thick, light gray, and broken on the surface into small thin closely appressed scales.

Distribution. Deep swamps, valley of the St. Mary's River, southern Georgia, to the lower Appalachicola River, Florida.

\section{Fraxinus nigra, Marsh. Black Ash.}

Leaves $12^{\prime}-16^{\prime}$ long, with stout pale petioles, and 7-11 oblong or oblong-lanceolate long-pointed leaflets, unequally wedged-shaped or sometimes rounded at the base, remotely serrate, with small incurved teetl, the lateral sessile, the terminal on a long or short petiolnle, when they unfold covered especially below with rufons hairs, and at maturity thin and firm, dark green above, paler below, glabrous with the exception of occasional tufts of rufons hairs along the under side of the broad pale midribs, $4^{\prime}-5^{\prime}$ long and $1^{\prime}-2^{\prime}$ wide, with many conspicuous primary veins arcuate near the margins and obscurely reticulate veinlets, turning rusty brown and falling early in the autumn. Flowers polygamous, without a calyx, appearing before the leaves in compact or ultimately elongated panicles $4^{\prime}-5^{\prime}$ long, and covered in the bud by broadly ovate dark brown or nearly black scales rounded at the apex; staminate flowers on separate trees or mixed with perfect flowers, and consisting of 2 large deeply pitted oblong dark purple apiculate anthers attaclied on the back to short 
broad filaments; pistillate flower consisting of a long slender style deeply divided at the apex into 2 broad purple stigmas and often accompanied by 1 or 2 perfect or globose rndimentary pink anthers sessile or borne on long or short filaments. Fruit in open panicles $8^{\prime}-10^{\prime}$ in length, lanceolate-oblong to linear-oblong, $1^{\prime}-1 \frac{1^{\prime}}{2}$ long, with a thin wing about $\frac{1}{3}^{\prime}$ wide, surrounding the short flat faintly nerved body, and conspicuously emarginate at the apex.

A tree, occasionally $80^{\circ}-90^{\circ}$ high, with a tall trunk rarely exceeding $20^{\prime}$ in diameter, slender mostly upright branches forming a narrow head, and stout terete branchlets dark green and slightly puberulous when they first appear, soon becoming ashy gray or orange color and marked by large pale lenticels, growing darker during their first winter and then roughened by the large suborbicular leaf-scars displaying a semicircular row of conspicuous fibro-vascular bundle-scars; usually much smaller.

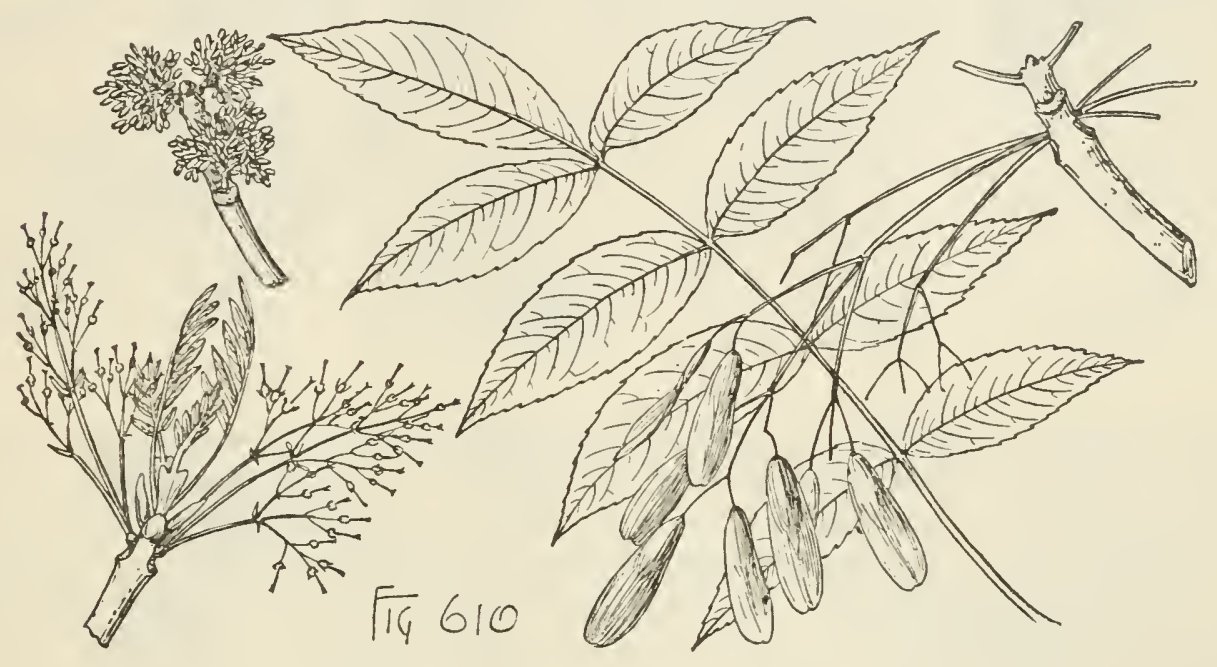

Winter-buds terminal, broadly ovate, acute, rather less than $\frac{1^{\prime}}{4}$ long, with 3 pairs of scales, those of the outer pair thick and rounded on the back at the base, gradually narrowed and acute at the apex, dark brown or almost black, slightly puberulous, falling as the bud begins to enlarge in the spring, and shorter than the scales of the inner rows coated on the outer surface with rufous pubescence, those of the second pair becoming strap-shaped, $1^{\prime}$ long, $\frac{1^{\prime}}{3}$ wide, and about one half as long as the pinnate usually foliaceous inner scales. Bark of the trunk gray slightly tinged with red, $\frac{1}{3}^{\prime}-1^{\prime}$ thick, and divided into large irregular plates separating into thin papery scales. Wood heavy, rather soft, not strong, tough, coarse-grained, durable, easily separable into thin layers, dark brown, with thin light brown often nearly white sapwood; largely used for the interior finish of houses and cabinet-making, and for fences, barrel hoops, and in the manufacture of baskets.

Distribution. Deep cold swamps and the low banks of streams and lakes; southern Newfoundland and the northern shores of the Gulf of St. Lawrence to Lake Winnipeg, and southward to New Castle County, Delaware, the mountains of Virginia, southern Illinois, central Missouri, and northwestern Arkansas.

\section{Fraxinus anomala, Wats.}

Leaves mostly reduced to a single leaflet but occasionally 2 or 3 -foliolate, the leaflets broadly ovate or sometimes orbicular, rounded or acute or rarely obcordate 
at the apex, wedge-shaped or eordate at the base, and entire, or sparingly erenately scrrate above the middle, covered above when they unfold with short pale hairs and pubescent beneath, and at maturity thin and rather coriaceous, dark green above, paler below, $1_{2}^{\frac{1}{2}}-2^{\prime}$ long and $1^{\prime}-2^{\prime}$ wide, or when more than one much smaller, with broad rather conspicuous inidribs and obscure veins, and when solitary raised on stont

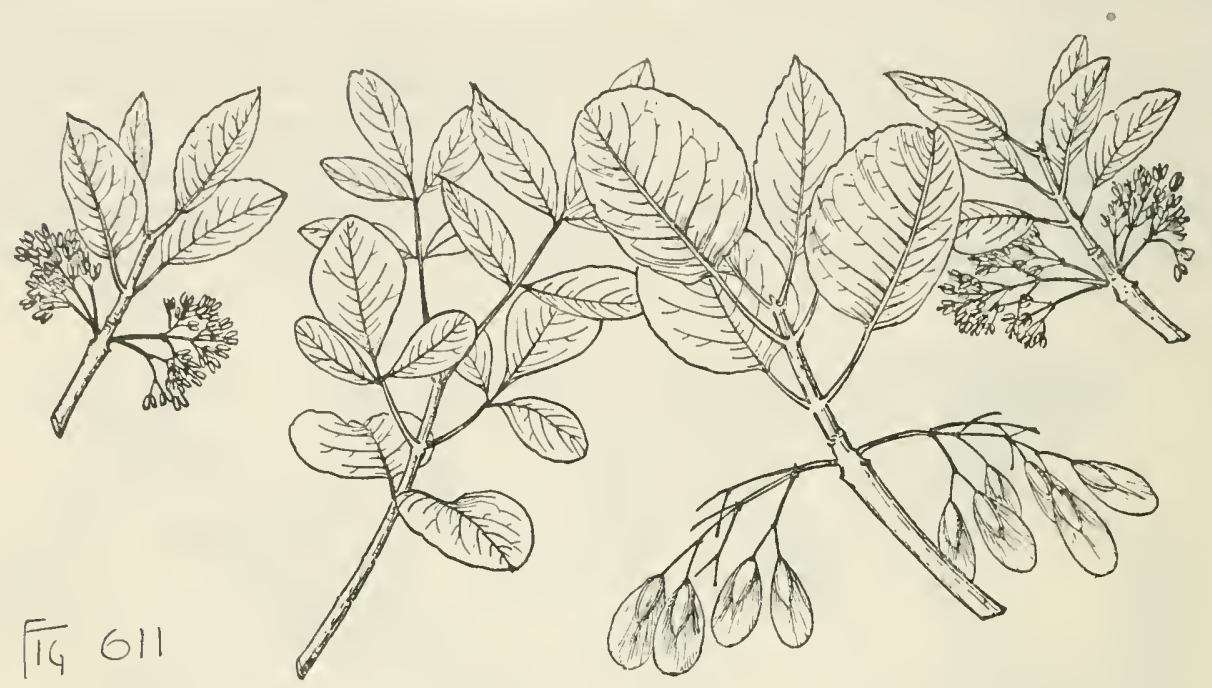

grooved petioles often $1 \frac{1{ }^{\prime}}{2}$ long, or short-petiolulate in the compound leaves. Flowers appearing when the leaves are about two thirds grown, in short compact pubescent panicles from the axils of leaves of the previous year, with strap-shaped or lanceolate acute bracts $\frac{1}{2}$ long and covered with thick brown tomentum, perfect or unisexual by the abortion of the stamens, the 2 forms occurring in the same panicle; calyx cupshaped, minntely 4-toothed; anthers linear-oblong, orange eolor, raised on slender filaments nearly as long as the stont columnar style divided at the apex into 2 stigmatie lobes. Fruit oblong or obovate-oblong, ${ }^{2} \frac{2}{3}$ long, with a wing rounded and sometimes slightly emarginate at the apex, surrounding the long flattened striately nerved body, and $\frac{1}{3}^{\prime}$ wide.

A tree, $18^{\circ}-20^{\circ}$ high, with a short trunk $6^{\prime}-7^{\prime}$ in diameter, stont contorted branehes forming a round-topped head, and branchlets at first quadrangular, dark green tinged with red and covered with pale pubescence, orange color and puberulous in their first winter and marked by elevated pale lenticels and narrow lunate leaf-scars, and in their second or third year terete and ashy gray; often a low shrub, with numerous spreading stems. Winter-buds terminal, broadly ovate, acuminate or obtuse, covered with thick orange-colored tomentum, and $\frac{1^{\prime}}{8}-\frac{1^{\prime}}{4}$ long. Bark of the trunk dark brown slightly tinged with red, $\frac{1}{4}^{\prime}$ thick, and divided by shallow fissures into narrow ridges separating into small thin appressed scales. Wood heavy, hard, close-grained, light brown, with thick lighter colored sapwood of 30-50 layers of annual growth.

Distribution. In the neighborhood of streams; valley of the McElmo River, southwestern Colorado, through southern Utah, and on the western slopes of the Charleston Mountains, southern Nevada; not rare. 
**B Body of the fruit nearly terete.

\section{Fraxinus Americana, L. White Ash.}

Leaves $8^{\prime}-12^{\prime}$ long, with stout grooved petioles, and 5 ovate to oblong-lanceolate generally falcate long-pointed leaflets wedge-shaped or often rounded at the base and entire or remotely and obscurely crenulate-serrate, when they unfold thin and glabrous or sometimes pubescent beneath, and at maturity thick and firm or subcoriaceous, dark green and often lustrous above, pale or frequently silvery white and glabrous or pubescent below, $3^{\prime}-5^{\prime}$ long and $1 \frac{1}{2}-3^{\prime}$ wide, with broad pale midribs and numerous conspicuous veins arcuate near the margins, falling early in the autumn after turning on some individuals deep purple and on others clear bright yellow. Flowers diœcious, opening before the leaves late in the spring, in compact ultimately elongated glabrous panicles from buds covered with dark ovate scales rounded at the apex and slightly keeled on the back; calyx campanulate, slightly 4-lobed in the staminate flower, and deeply lobed or laciniately cut in the pistillate flower; stamens 2 or occasionally 3, with short stout filaments and large oblong-orate apiculate anthers at first nearly black, later becoming reddish purple; ovary contracted into a long slender style divided into 2 spreading dark purple stigmatic lobes. Fruit $1^{\prime}-2^{\prime}$ in length, or at the south sometimes not more than $\frac{1}{2}^{\prime}$ long (var. microcarpa, Gray), in crowded clusters $6^{\prime}-8^{\prime}$ in length, lanceolate or oblong, surrounded at the base by the

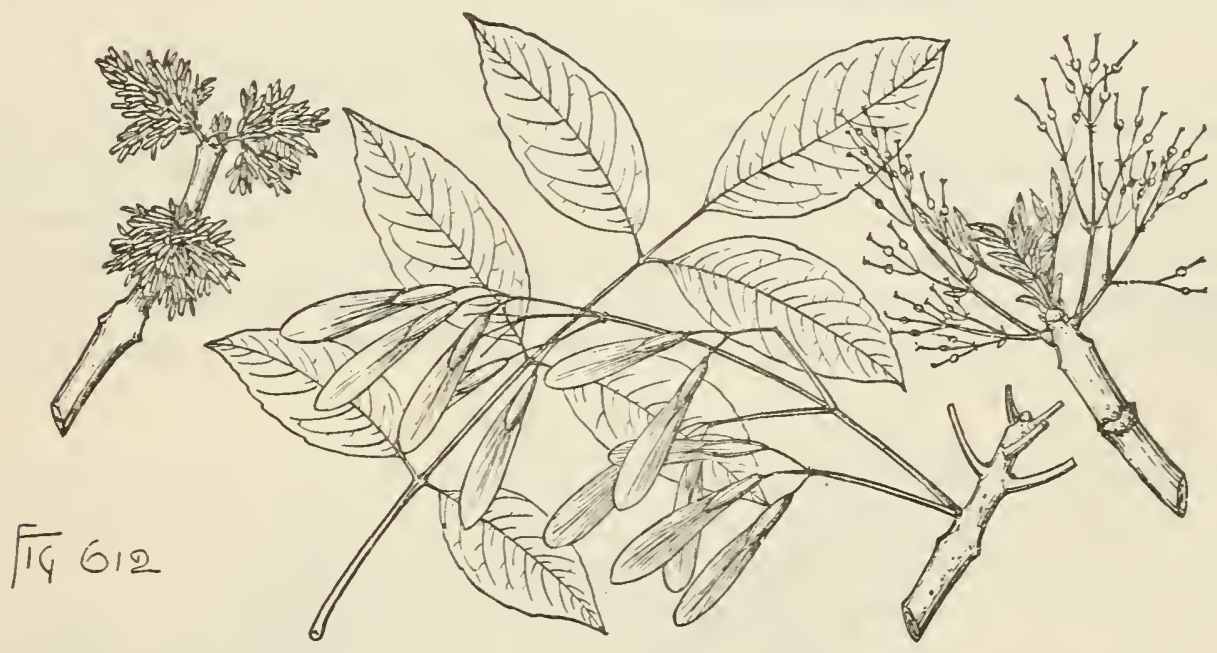

persistent calyx, with a terminal wing usually about $\frac{1}{4}^{\prime}$ wide, pointed or emarginate at the apex, and much longer than the short terete oblong marginless conspicuously many-rayed body.

A tree, sometimes $120^{\circ}$ high, with a tall massive trunk $5^{\circ}-6^{\circ}$ in diameter, stout upright or spreading branches forming in the forest a narrow crown, or with sufficient space a round-topped or pyramidal head, and thick terete branchlets dark green or brown tinged with red and covered with scattered pale hairs when they first appear, soon becoming light orange color or ashy gray and marked by pale lenticels, becoming in their first winter gray or light brown, lustrous, often covered with a glaucous bloom and roughened by the large pale semiorbicular leaf-scars displaying near the margins a line of conspicuous fibro-vascular bundle-scars. Winter-buds terminal, broadly ovate, obtuse, with 4 pairs of scales, those of the onter pair ovate, 
acute, apiculate, conspicuously keeled on the back, nearly black, slightly puberulous, about one half the length of the seales of the second pair rather shorter than those of the third pair, lengthening with the young shoots, and at maturity oblong-ovate, narrowed and rounded at the apex, keeled, $\frac{1}{2}^{\prime}$ long, and rusty-pubesecnt, the scales of the inner pair becoming $\frac{2 \prime}{3}$ long, ovate, pointed, kecled, sometimes slightly pinnatifid, green tinged with brown toward the apex, covered with pellucid dots and very lnstrous. Bark of the trunk $1^{\prime}-3^{\prime}$ thick, dark brown or gray tinged with red, and deeply divided by narrow fissures into broad flattened ridges separating on the surface into thin appressed scales. Wood heavy, hard, strong, close-grained, tongh, and brown, with thick lighter colored sapwood; used in large quantities in the manufacture of agricultural implements, for the handles of tools, in carriage-bnilding, for oars and furniture, and in the interior finish of buildings; the most valuable of the American species as a timber-tree.

Distribution. Common in rich rather moist soil on low hills, and in the neighborhood of streams; Nova Scotia, New Brunswick, and sonthern Ontario to northern Minnesota, southward to northern Florida, central Alabama, and Mississippi, and westward to eastern Ncbraska and Kansas, the Indian Territory, and the valley of the Trinity River, 'Texas; of its largest size on the bottom-lands of the basin of the lower Olio River; southward and west of the Mississippi River less common and of smaller size.

Often planted in the eastern states as a shade and ornamental tree, and occasionally in western and northern Europe.

\section{Fraxinus Texensis, Sarg. Mountain Ash.}

Leaves 5 ' $-8^{\prime}$ long, with elongated slender terete petioles, and 5 or occasionally 7 usinally long-stalked ovate broadly oval or obovate leaflets, rounded or acute at the apex, wedge-shaped, rounded or sometimes slightly cordate at the base, and coarsely crenulate-serrate, chiefly above the middle, when they unfold light green slightly tinged with red and pilose, with occasional pale caducous hairs, and at maturity thick and firm, dark green on the upper surface, pale and sometimes

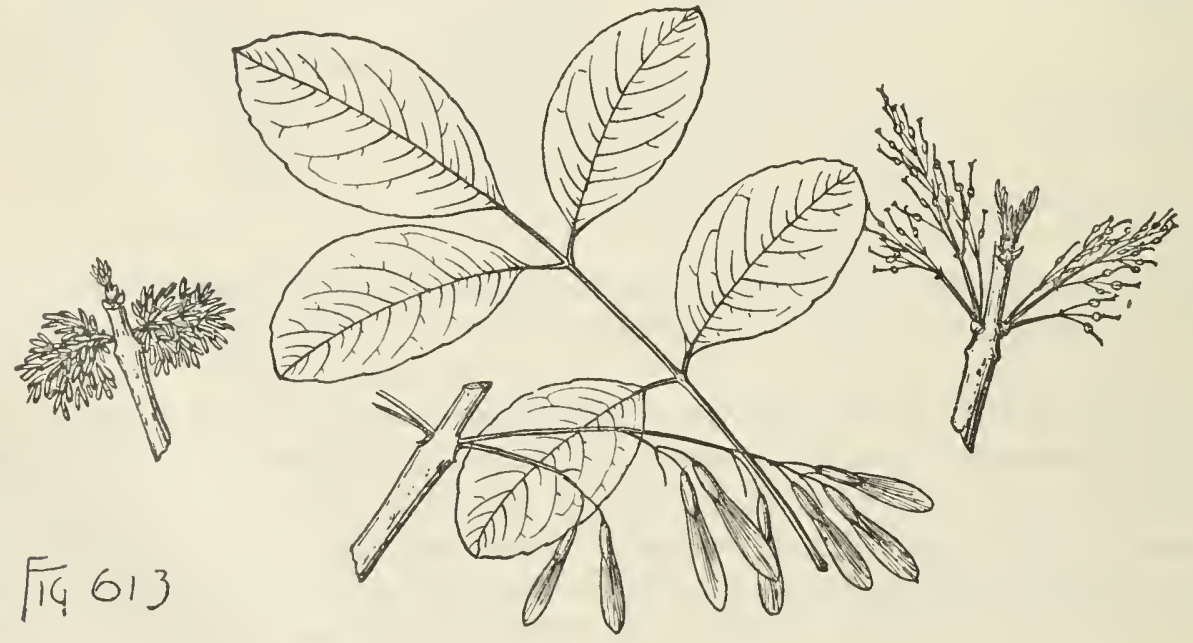

silvery white on the lower surface, $2^{\prime}-2 \frac{1}{2}^{\prime}$ long and $1^{\prime}-2^{\prime}$ wide, with broad midribs often furnished below witl tufts of short white hairs in the axils of the numerous 
conspicuous veins forked near the margins and connected by coarse reticulate veinlets. Flowers diceious, appearing in March as the leaves begin to unfold, in compact glabrous panicles from the axils of leaves of the previous year, and covered in the bud by ovate rounded orange-colored scales; staminate flower composed of a minute or nearly obsolete 4-lobed calyx and 2 stamens, with short filaments and linear-oblong light purple apiculate anthers; calyx of the female flower oblong, cupshaped, and divided to the base into 4 acnte lobes; ovary gradually narrowed into a long slender style terminating in 2 large stigmatic lobes. Fruit ripening in May, in short compact clusters, spatulate to oblong, surrounded at the base by the persistent calyx, $\frac{1^{\prime}}{2} \mathbf{1}^{\prime}$ long, with a terminal wing rounded or occasionally emarginate at the apex, $\frac{1}{4}^{\prime}$ wide, and abont 3 times as long as the short terete marginless manyrayed body.

A tree, rarely $50^{\circ}$ high, with a short trunk occasionally $2^{\circ}-3^{\circ}$ in diameter, thick spreading often contorted branches, and stont terete branchlets dark green tinged with red and slightly puberulous when they first appear, becoming light yellowbrown or light orange color during the summer, and in their first winter light brown marked by remote oblong pale lenticels and by large elevated lunate leaf-scars displaying a row of conspicıous fibro-vascular bundle-scars, and dark or reddish brown in their second or third season; usually mnch smaller. Winter-buds terminal, acnte, with 3 pairs of scales, those of the first pair broadly ovate, rounded at the apex, dark orange color, pilose toward the base, and rather shorter than the ovate rounded scales of the second pair coated with rufous tomentum and becoming $\frac{1}{2}$ ' long or about one half the length of the linear strap-shaped scales of the inner pair truncate or emarginate at the apex and orange color. Bark of the trunk $\frac{1^{\prime}}{2}-\frac{3^{\prime}}{4}$ thick, dark gray and deeply divided by narrow fissures into broad scaly ridges. Wood heavy, hard, strong, light brown, with thin lighter colored sapwood; valued as fuel and occasionally used for flooring.

Distribution. High dry limestone bluffs and ridges; northern, central, and western Texas from the neighborhood of the city of Dallas to the valley of the Devil's River.

\section{Fraxinus Berlandieriana, DC.}

Leaves $3^{\prime}-7^{\prime}$ long, with slender elongated petioles, and $3-5$ ovate or rarely obovate glabrous leaflets, pointed or rounded at the apex, gradually narrowed at the base into long petiolules, sharply and coarsely serrate above the middle, with acute teeth, or sometimes almost entire, thick and coriaceous, dark green and lustrous above, pale beneath, $1 \frac{1}{2}^{\prime}-4^{\prime}$ long and $\frac{1}{2}^{\prime}-1 \frac{1}{2}^{\prime}$ wide, with prominent midribs and primary veins connected by conspicuous reticulate veinlets. Flowers diœcious, in short glabrous panicles inclosed in the bud by broadly ovate rounded chestnut-brown pubescent scales; staminate flower with a minute obscurely lobed calyx and 2 linear-oblong apiculate anthers raised on short filaments; calyx of the pistillate flower cup-shaped, deeply divided, and as long as the ovary gradually narrowed into a slender style 2 -lobed and stigmatic at the apex. Fruit often 3 -winged, ovate or spatulate, surrounded at the base by the persistent calyx, $1^{\prime}-1 \frac{1}{2}^{\prime}$ long, with a short clavate body more or less margined by the thin ovate or obovate wing usually $\frac{3}{16}{ }^{\prime} \frac{1}{4}$ ' wide and mostly narrowed toward the acute or rounded and emarginate apex.

A tree, in the United States rarely more than $30^{\circ}$ high, or with a trunk more than a foot in diameter, and terete slender branchlets light green when they first appear, becoming in their first winter light brown tinged with red or ashy gray, and 
marked by oceasional lenticels and with the small clevated nearly circular leaf-sears displaying a short row of large fibro-vascular bundle-sears; in Mexico frequently

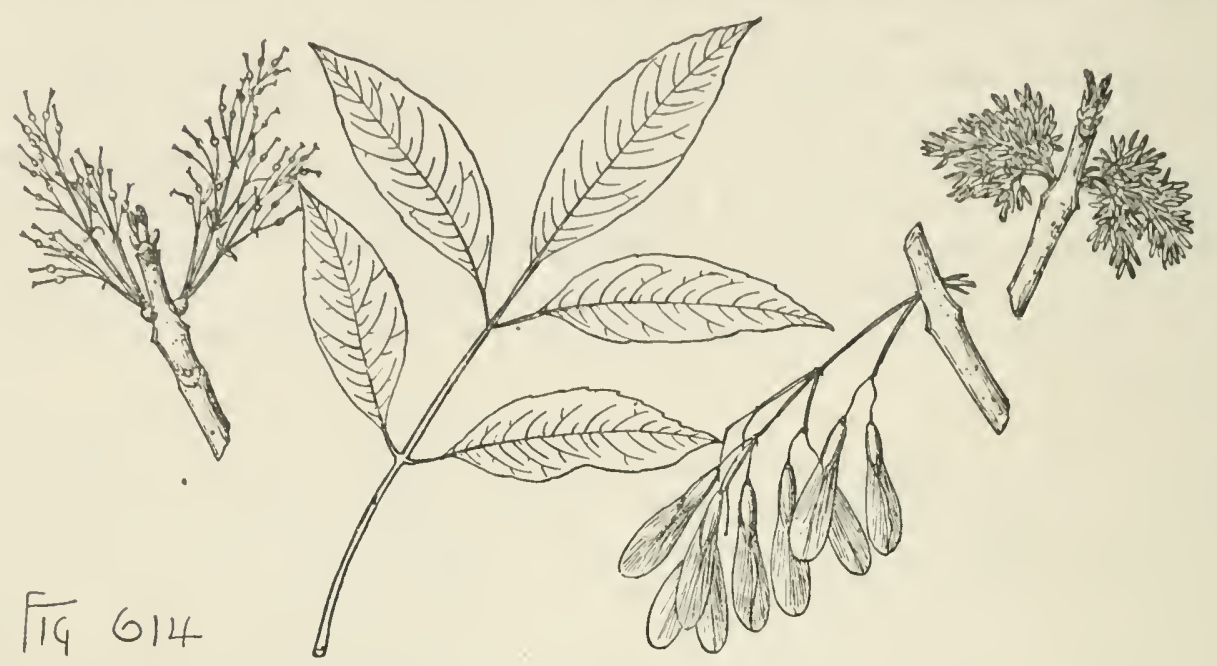

$60^{\circ}-70^{\circ}$ tall, with a trunk $6^{\circ}-8^{\circ}$ in diameter, and spreading branches forming a broad graceful head. Winter-buds terminal, acute, with dark brown puberulous scales. Bark of the trunk dark gray tinged with red, $1^{\prime}-1 \frac{1}{2}^{\prime}$ thick, and divided by shallow interrupted fissures into narrow ridges. Wood light, soft, close-grained, light brown, with thick lighter colored sapwood.

Distribution. Banks of streams, western Texas; not common, and possibly introduced; mountain forests of the state of Michoacan, southern Mexico; largely planted in the streets and plazas of the cities of the Mexican table-land, and unsurpassed by other Ash-trees in stateliness and beauty.

\section{Fraxinus Pennsylvanica, Marsh. Red Ash.}

Leaves $10^{\prime}-12^{\prime}$ long, with stout slightly grooved pubescent petioles, and 7-9 oblong-lanceolate or ovate leaflets gradually narrowed at the apex into long slender points, mnequally wedge-shaped at the base, and obscurely serrate, or often entire below the middle, when they unfold coated below and on the petioles with hoary tomentum, and lustrons and puberulous on the upper surface, and at maturity thin and firm, $4^{\prime}-6^{\prime}$ long, $1^{\prime}-1 \frac{1_{2}^{\prime}}{}$ wide, light yellow-green above and pale and covered below and on the thick grooved petiolules with silky pubescence, with conspicuous midribs and branching veins, in the autumn turning yellow or rusty brown before falling. Flowers diœcious, appearing late in the spring as the leaves begin to unfold, in rather compact tomentose panicles, covered in the bud with ovate rusty-tomentose scales; staminate flower with a minute obscurely toothed cup-shaped calyx, and 2 stamens, with linear-oblong light green anthers tinged with purple and raised on short slender filaments; calyx of the pistillate flower cup-shaped, deeply divided, as long as the ovary, gradually narrowed into an elongated style divided at the apex into 2 green stigmatic lobes. Fruit in open glabrous or pubescent panicles, $1^{\prime}-2^{\prime}$ long, surrounded at the base by the persistent calyx, linear or narrowly spatulate, with a slender terete many-rayed body tapering gradually from the summit to the base and margined above by the thin decurrent wing, $\frac{1{ }^{\prime}}{4}-1^{\prime}$ ' wide, narrowed, rounded, acute or apiculate at the apex, and as long as or somewhat longer than the body. 
A tree, $40^{\circ}-60^{\circ}$ high, with a trunk rarely exceeding $18^{\prime}-20^{\prime}$ in diameter, stout upright branches forming a compact irregularly shaped head, and slender terete branchlets more or less coated when they first appear with pale pubescence sometimes persistent until their second or third year or often disappearing during the first summer, ultimately becoming ashy gray or light brown tinged with red, frequently covered with a glaucous bloom and marked with pale lenticels, and in their first winter by the semicircular leaf-scars displaying a short row of large fibro-vascular bundle-scars. Winter-buds terminal, about $\frac{1}{8}^{\prime}$ long, with 3 pairs of scales coated with rufous tomentum, those of the outer pair acute, rounded on the back, truncate at the apex, and

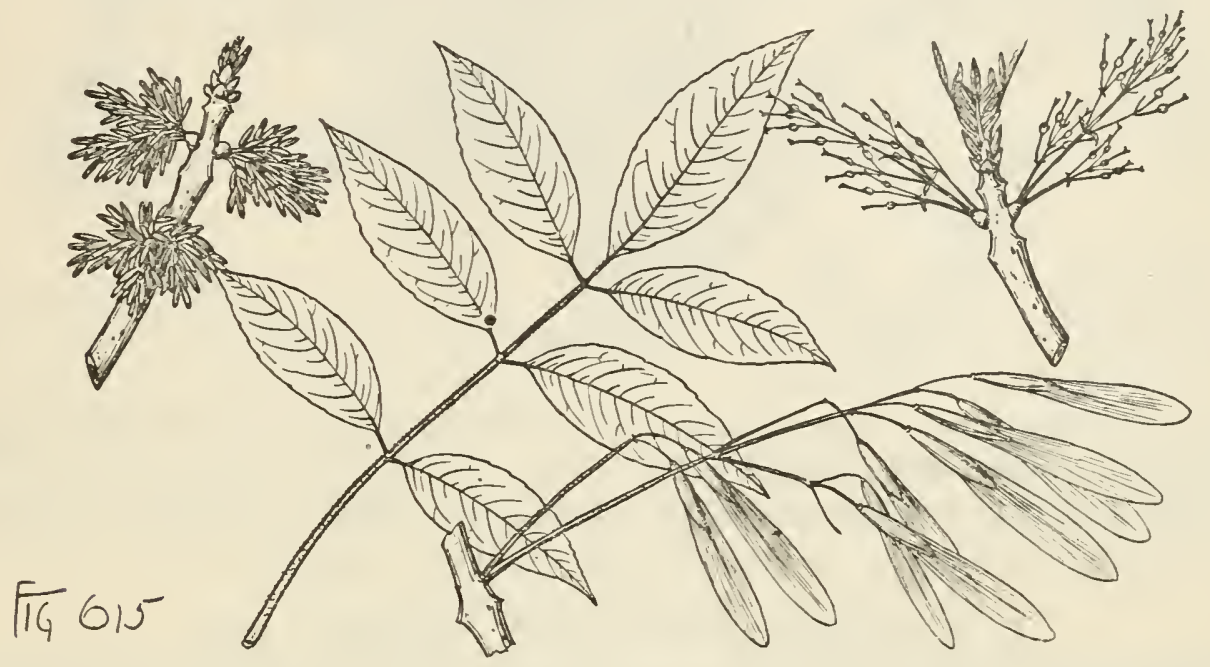

rather shorter than those of the other pairs $1^{\prime}-1 \frac{1}{2}^{\prime}$ long at maturity and sometimes pinnately cut toward the apex. Bark of the trunk $\frac{1^{\prime}}{2}-\frac{2^{\prime}}{3}$ thick, brown tinged with red, and slightly furrowed, the surface of the ridges separating into thin appressed scales. Wood heavy, hard, rather strong, brittle, coarse-grained, light brown, with thick lighter brown sapwood streaked with yellow; sometimes confounded commercially with the more valuable wood of the White Ash.

Distribution. Low rich moist soil near the banks of streams and lakes; New Brunswick to sonthern Ontario, eastern Nebraska and the Black Hills of Dakota, and southward to northern Florida and central Alabama; most common and of its largest size in the north Atlantic states; west of the Alleghany Mountains smaller and less abundant. Passing into

\section{Fraxinus Pennsylvanica, var. lanceolata, Sarg. Green Ash.}

Leaves with rather narrower and shorter and usually more sharply serrate leaflets lustrous and bright green on both surfaces.

A round-topped tree, rarely more than $60^{\circ}$ high, or with a trunk more than $2^{\circ}$ in diameter, slender spreading branches, ashy gray terete glabrous branchlets marked by pale lenticels, and rusty-pubescent bud-scales.

Distribution. Banks of streams; shores of Lake Champlain through the Appalachian region to western Florida, and west to the valley of the Saskatchewan, the valley of the Colorado River, Texas, the eastern ranges of the Rocky Mountains, the Wasatch Range, Utah, and the mountains of eastern and northern Arizona; comparatively rare east of the Alleghany Mountains; most abundant in the Mississippi 
basin, often eovering the banks of streans flowing east from the Rocky Mountains, and westward only in elevated eañons; in the region east of the Mississippi River

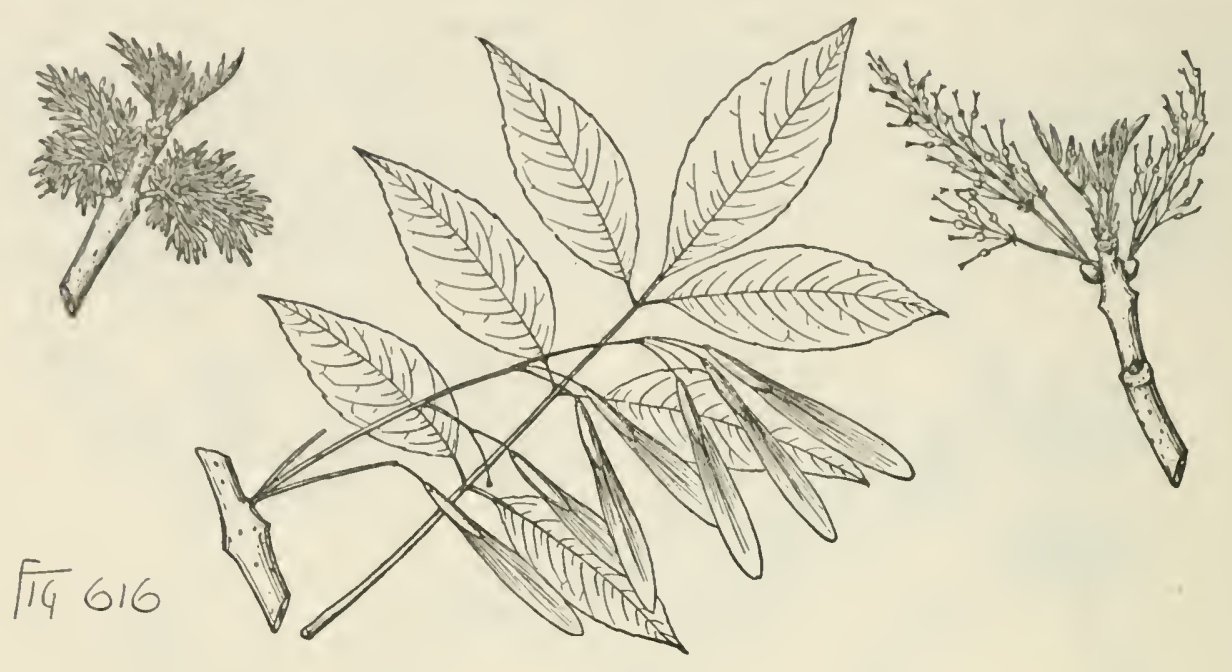

appearing distinct, but westward comnected with the Red Ash by intermediate forms, equally referable to eitlier tree.

Often planted as a shade and ornamental tree in the middle west, and occasionally in the northeastern states, but less desirable than the White Ash.

\section{Fraxinus profunda, Bush. Pumpkin Ash.}

Leaves $9^{\prime}-18^{\prime}$ long, with stout tomentose petioles, and usually 7 but occasionally 9 lanceolate or ovate-lanceolate long-stalked leaflets acuminate or abruptly longpointed at the apex, rounded or broadly cuneate and usually nusymmetrical at the base, when they minfold coated below, like the petiolules, with hoary tomentum, and pilose on the upper surface, with short pale hairs, particularly along the midribs and veins, and at maturity thick and firm in texture, dark yellow-green and nearly glabrous above, soft-pubescent below, $5^{\prime}-10^{\prime} \operatorname{long}$ and $2^{\prime}-5^{\prime}$ wide, with stout yellow midribs deeply impressed and puberulous above and numerons slender primary veins arcuate and connected near the undnlate and entire or slightly serrate margins. Flowers diœcious, in elongated much-branched pubescent panicles, with oblong or oblongobovate scarious bracts and bractlets; staminate flower with a minute campanulate obscurely 4-toothed calyx and 2 or 3 stamens, with oblong apiculate anthers and comparatively long slender filaments; pistillate flower with a large deeply lobed calyx accrescent and persistent under the fruit, and an ovary gradually contracted iuto a slender style divided into 2 dark spreading stigmatic lobes. Fruit in long drooping many-fruited clusters, oblong, $2^{\prime}-3^{\prime}$ in length, the wing often $\frac{1}{2}^{\prime}$ wide, sometimes falcate, rounded, apiculate, or emarginate at the apex, and decurrent to below the middle or nearly to the base of the thick terete many-rayed body.

A tree, occasionally $120^{\circ}$ high, with a slender trunk $3^{\circ}$ in diameter above the much enlarged and buttressed base, small spreading branches forming a narrow rather open head, and stout branclilets marked by large pale lenticels, coated at first with hoary tomentum, tomentose and pubescent during their first winter and light gray and pilose or glabrous the following year, and marked by the oblong slightly raised leafscars rounded at the base, obconic, and nearly surrounding the lateral buds; usually 


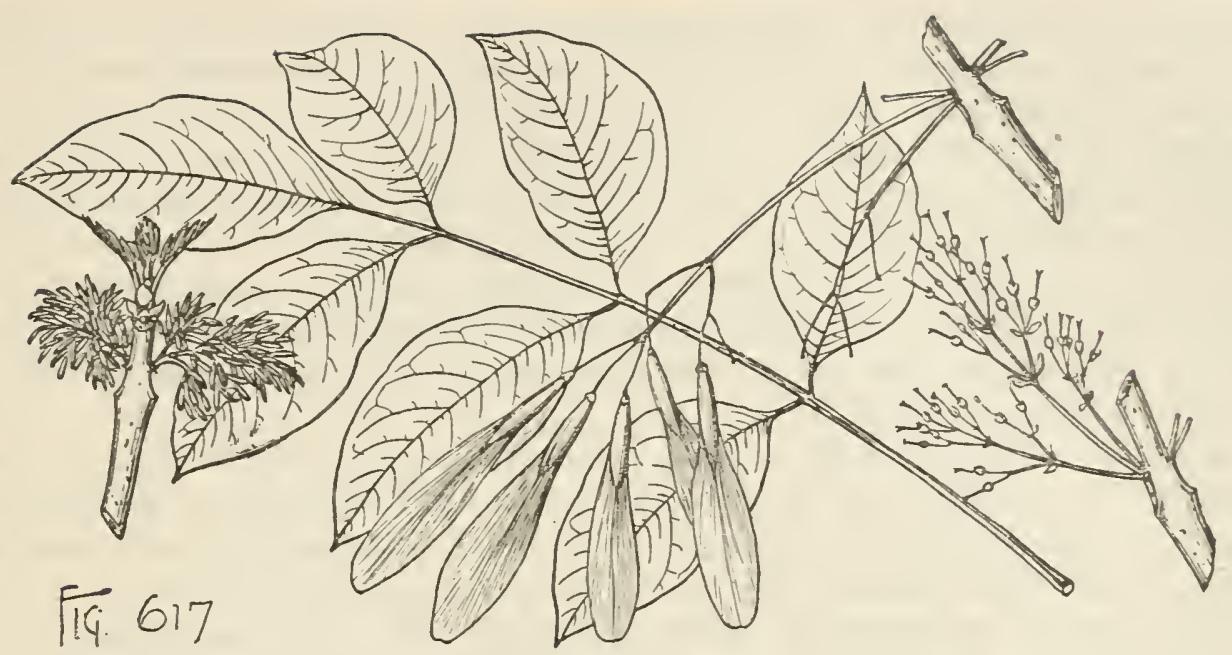

much smaller. Winter-buds terminal, broadly ovate, obtuse, light reddish brown, and covered with close pale pubescence. Bark of the trunk $\frac{1^{\prime}}{2}-\frac{3^{\prime}}{4}$ thick, light gray and divided by shallow fissures into broad flat or rounded ridges broken on the surface into thin closely appressed scales.

Distribution. Deep river swamps often inundated during several months of the year; southeastern Missouri, eastern Arkansas, and the valley of the lower Appalachicola River, Florida.

\section{Fraxinus Biltmoreana, Beadl.}

Leaves $10^{\prime}-12^{\prime}$ long, with stout pubescent or pubernlous petioles, and 7-9 ovateoblong or lanceolate often falcate leaflets acuminate at the apex, rounded or broadly

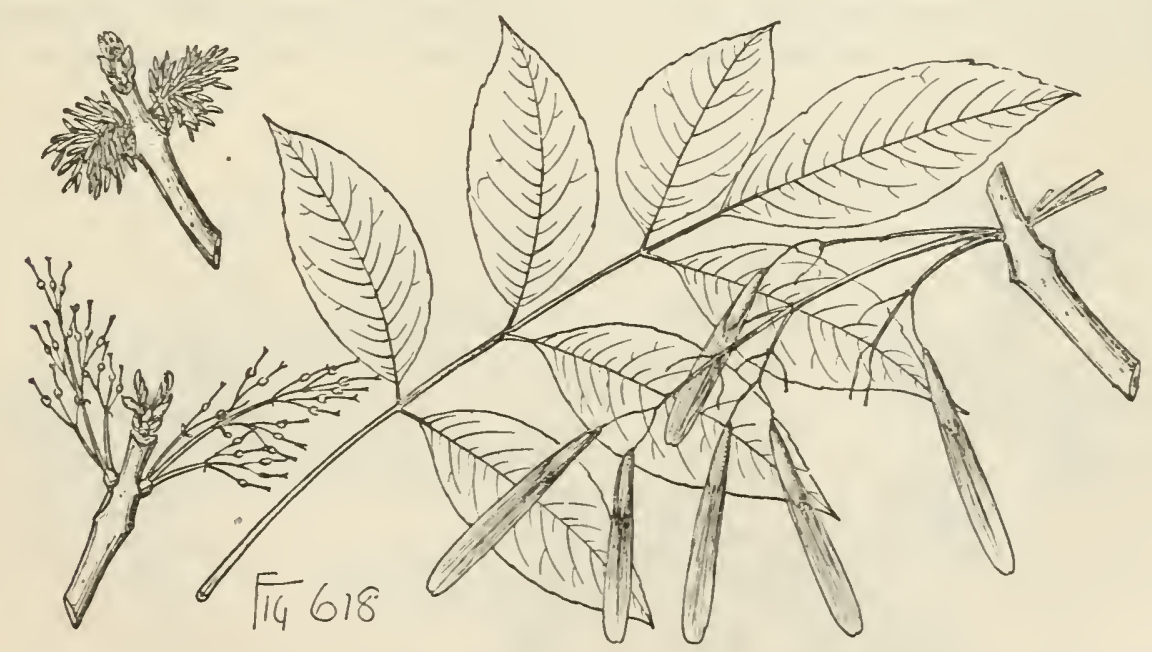

cuneate and often inequilateral at the base, and raised on stout elongated pubescent petiolules, when they unfold yellow-bronze color and nearly glabrous above, coated beneath, particularly on the midribs and veins, with long white hairs, and at ma-

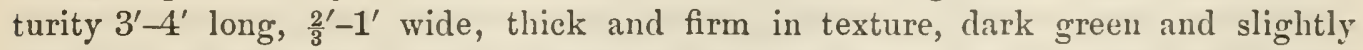
lustrous on the upper, pale or glaucous and puberulous below along the slender yellow midribs, and primary veins arcuate near the slightly thickened and incurved 
entire or remotely and obsenrely toothed margins. Flowers diœcious, appearing with the leaves about the 1st of May, in rather compact pubescent panieles, with scarious cadncous bracts and bractlets, from the axils of leaves of the previous year; staminate flower with a minute cup-shaped very obsenrely dentate calyx and nearly sessile oblong acnte anthers; calyx of the pistillate flower much larger and deeply lobed; ovary oblong, gradually narrowed into the slender style divided at the apex into 2 short stignatie lobes. Fruit in elongated glabrons or pulernlous elusters, $12_{2}^{\prime \prime}-13_{4}^{3 \prime}$ long, the wing only slightly narrowed at the ends, emarginate at the apex, about $\frac{y^{\prime}}{4}$ wide and two and one half to three times longer than the short elliptical marginless many-nerved body.

A tree, $40^{\circ}-50^{\circ}$ high, with a trunk seldom more than a foot in diameter, stout ascending or spreading branehes forming an open symmetrieal head, and stont light or dark gray branehlets soft-pubescent usually during two seasons, mueh ronghened during their first winter and often for two or three years by the large elevated mostly obeordate or sometimes orbicular leaf-sears displaying a marginal line of fibro-vascular bundle-sears. Winter-buds terminal, ovate, usually broader than long, and eovered with bright brown scales, those of the outer pair keeled on the back and apiculate at the apex, the others rounded, accrescent, and slightly villose. Bark of the trunk rough, dark gray, and slightly furrowed.

Distribution. Banks of streams or rarely on low river benches; northern West Virginia through the foothill region of the Appalachian Mountains to northern Georgia and Alabama, and to middle Tennessee.

\section{Fraxinus velutina, Torr.}

Leaves $3^{\prime}-6^{\prime}$ long, with stout grooved petioles, and 3-9-stalked lanceolate occasionally falcate leaflets acuminate and long-pointed at the apex, mostly wedgeshaped and often decurrent on the petiolnle or unequally rounded at the base, and entire or remotely serrate above the middle, with acute or recurved teeth, when they unfold light green or reddish brown, glabrous, pubescent or tomentose, especially

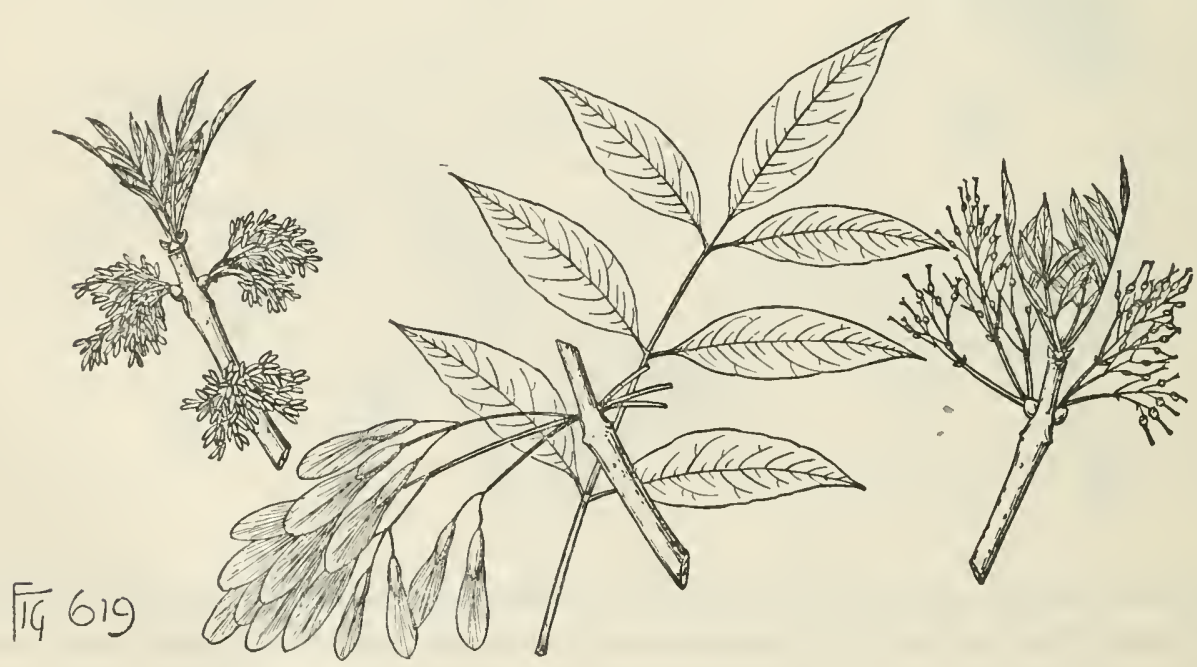

on the under surface, and at maturity subcoriaceous, dark yellow-green above, paler and of ten pubescent below, and oecasionally furnished with tufts of long pale hairs on the under side of the broad midribs, $3^{\prime}-5^{\prime}$ long, $\frac{1^{\prime}}{4}$ to nearly $1^{\prime}$ wide, with 
prominent veins arcuate near the margins and connected by conspicuous reticulate veinlets. Flowers dicecious, appearing at the end of May or early in June with the unfolding of the leaves, in short compact panicles from buds in the axils of leaves of the previous year covered by broadly ovate rusty-tomentose scales rounded at the apex; calyx cup-shaped, light green, larger and more deeply divided in the pistillate than in the staminate flower; anthers oblong, apiculate, and borne on short slender filaments; ovary gradually narrowed into a short style deeply divided into 2 stigmatic lobes. Fruit ripening in the summer or early autumu, in dense clusters $4^{\prime}-5^{\prime}$ long, spatulate-oblong, surrounded at the base by the persistent calyx, with a terminal wing acute, rounded, or emarginate at the apex, tipped with the remuants of the style, $\frac{1^{\prime}}{8}-\frac{1}{4}$ wide, and about as long as the terete nearly clavate conspicuously rayed marginless body.

A tree, $30^{\circ}-40^{\circ}$ high, with a trunk rarely exceeding $8^{\prime}$ in diameter, stout often spreading branches usually forming a round-topped handsome head, and slender terete branchlets coated when they first appear with pale pubescence or with thick white tomentum, and in their first winter red-brown or ashy gray, glabrous or tomentose, often covered with a glaucous bloom and narked by small pale lenticels and by semiorbicular slightly obcordate leaf-scars displaying a central lunate row of fibro-vascular bundle-scars. Winter-buds terminal, acute, $\frac{1}{8}^{\prime}$ long, with 3 pairs of broadly ovate pointed scales coated with thick rufous tonientum, the inner scales when fully grown $\frac{1^{\prime}}{2}$ long, strap-shaped, and rounded at the apex. Bark of the trunk $\frac{1}{3}^{\prime}-\frac{1}{2}^{\prime}$ thick, gray slightly tinged with red, and deeply divided into broad flat broken ridges separating on the surface into small thin scales. Wood heavy, rather soft, not strong, close-grained, light brown, with thick lighter colored sapwood; used locally for axe-handles and in the manufacture of wagons.

Distribution. Usually in the neighborhood of streams, in elevated cañons; mountains of western Texas through sonthern New Mexico and Arizona to southern Nevada, and to the Panamint Mountains and the shores of Owen's Lake, soutleastern California.

\section{Fraxinus coriacea, Wats.}

Leaves usually about $6^{\prime}$ long, with stout grooved pubescent petioles, and mostly 5 ovate or oblong leaflets, acute, acuminate, or rounded at the apex, broadly cuneate or rounded at the base, coarsely repand-serrate, long-petiolulate, coated as they appear with long pale hairs most abundant on the lower surface, and at maturity coriaceous, dark green and glabrous on the upper, pale and glabrous or pubescent on the lower surface, $2^{\prime}-3^{\prime}$ long and $1^{\prime}-2^{\prime}$ wide, on leading shoots sometimes reduced to single long-stalked leaflets, or 3-foliolate, with a large terminal leaflet and small lateral leaflets. Flowers diœcious, appearing about the middle of April with or before the unfolding of the leaves, in short compact panicles from buds in the axils of leaves of the previous year and covered by broadly ovate scales rounded and often short-pointed at the apex and rusty-tomentose on the onter surface; calyx cup-shaped, large and more deeply divided in the pistillate than in the staminate flower; anthers oblong, nearly sessile; ovary abruptly narrowed into the slender style slightly divided into 2 stigmatic lobes. Fruit ripening late in the autumu, in narrow clusters $2^{\prime}-3^{\prime}$ in length, slender, oblong, $\frac{3^{\prime}}{4}-1^{\prime}$ long, with a terminal wing rounded and often emarginate at the apex, about $\frac{1^{\prime}}{8}$ wide, and as long as the terete marginless body.

A tree, occasionally $30^{\circ}$ high, with a trunk $12^{\prime}-16^{\prime}$ in diameter, stout spreading 

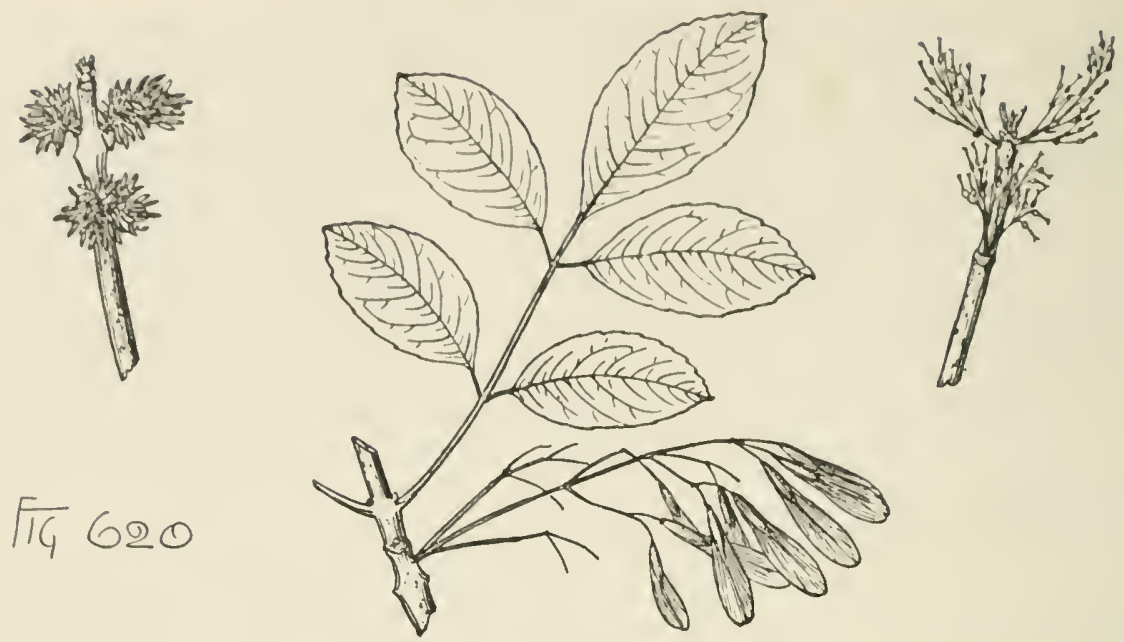

branches forming a round-topped head, and comparatively slender ashy gray branchlets tomentose when they first appear, coated with soft fine pubescence for one or two years and ultimately glabrous.

Distribution. Mesas and low plains; desert regions of southern Utah, northern Arizona, southern Nevada, and southeastern California.

\section{Fraxinus Oregona, Nutt.}

Leaves $5^{\prime}-14^{\prime}$ long, with stout grooved and angled pubescent or glabrous petioles, and 5-7 oblong or oval leaflets usually contracted at the apex into short broad points, gradually narrowed at the base, and entire or remotely and obscurely serrate; when they unfold usually coated below and on the petioles with thick pale tomentum and pubescent above, or nearly glabrous or pilose, with a few scattered hairs, and at maturity thick and firm in texture, light green above, paler and uswally tomentose or puberulous below, $3^{\prime}-7^{\prime}$ long and $1^{\prime}-1 \frac{1}{2}^{\prime}$ wide, with broad pale midribs, conspicuous veins arcuate near the margins, and reticulate veinlets, the terminal leaflet raised on a slender petiolule often $1^{\prime}$ in length, the lateral sessile or nearly so, turning yellow or russet brown in the autumn before falling. Flowers diœcious, appearing in April or May when the leaves begin to unfold, in compact glabrous panicles covered in the bud by broadly ovate scales coated with rufous pubescence; staminate flower composed of a minute calyx, short filaments, and short-oblong apiculate anthers; calyx of the pistillate flower laciniately cut and shorter than the ovary narrowed into a stout style divided into 2 long conspicuous stigmatic lobes. Fruit in ample crowded clusters, obovate, surrounded at the base by the persistent calyx, $1 \frac{1^{\prime}}{2}-2^{\prime}$ long, the body clavate and slightly compressed, with margined edges gradually widening upward into the long many-nerved wing narrowed, rounded, apiculate, or sometimes emarginate at the apex, and about $\frac{1}{3}^{\prime}$ wide.

A tree, frequently $70^{\circ}-80^{\circ}$ high, with a long trunk occasionally $4^{\circ}$ in diameter, stout branches forming a narrow upright head or a broad shapely crown, and thick terete branchlets at first glabrous or more or less thickly coated with pale or rarely rufous silky tomentum persistent during their second year or occasionally deciduous during their first summer, becoming light red-brown or orange color, glabrous or puberulous, often covered with a slight glaucous bloon, marked by small remote pale lenticels, and during their first and second winters by the large elevated semi- 
orbicular leaf-scars displaying a short row of conspicuous fibro-vascular bundle-scars. Winter-buds terminal, acute, $\frac{1^{\prime}-1^{\prime}}{4}$ long, with 4 pairs of scales covered with pale hairs or with rusty pubescence, those of the inner rows often foliaceous at maturity. Bark of the trunk $1^{\prime}-1 \frac{1^{\prime}}{2}$ thick, dark gray, or brown slightly tinged with red, and deeply divided by interrupted fissures into broad flat ridges separating on the surface into thin scales. Wood light, hard, brittle, coarse-grained, brown, with thick lighter colored sapwood; largely used in the manufacture of furniture, for the frames of carriages and wagons, in cooperage, the interior finish of houses, and for fuel.

Distribution. Usually in rich moist soil in the neighborhood of streams; shores

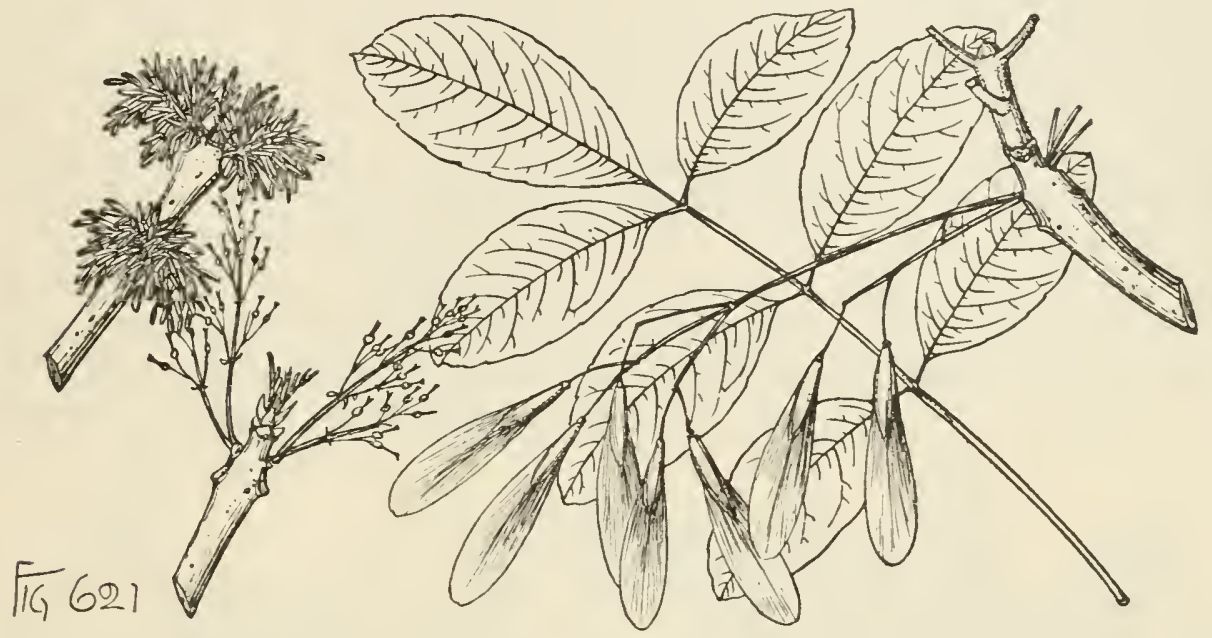

of Puget Sound and southward through western Washington and Oregon and the California coast region to the Bay of San Francisco, and along the western foothills of the Sierra Nevada to those of the mountains of San Bernardino and San Diego counties, California; most abundant and of its largest size on the bottom-lands of the rivers of southwestern Oregon; one of the most valuable of the deciduous-leaved timber-trees of Pacific North America.

\section{CHIONANTHUS, L.}

Trees or shrubs, with stout terete or slightly angled branchlets, thick pith, and buds with numerous opposite scales. Leaves simple, conduplicate in the bud, decidnons. Flowers perfect or andro-diœcious, on elongated ebracteolate pedicels, in 3-flowered clusters terminal on the slender opposite branches of ample loose panicles from separate buds in the axils of the upper leaves of the previous year, with foliaceous persistent bracts; calyx minute, deeply 4-parted, the divisions imbricated in the bud, persistent under the fruit; corolla white, deeply divided into 4 or rarely 5 or 6 elongated linear lobes conduplicate-valvate in the bud, united at the base into a short tube, or rarely separable; stamens 2, inserted on the base of the corolla opposite the axis of the flower, or rarely 4, included; filaments terete, short; anthers ovate, attached on the back below the middle, apiculate by the elongation of the connective, 2-celled, the cells opening by longitudinal lateral or subextrorse slits; ovary ovate, abruptly contracted into a short columnar style; stigma thick and fleshy, slightly 2-lobed; ovules laterally attached near the apex of the cell; raphe ventral. Fruit an ovoid or oblong, usually 1 or rarely 2 or 3 -seeded thick-skinned drupe tipped with the rem- 
nants of the style; flesh thin and dry; stone thick-walled, erustaceous. Seed filling the eavity of the stone, ovoid; seed-coat chestmut-brown; cotyledons flat, longer than the short terete superior radicle turned toward the hilum.

Chionanthus with two species inhabits the middle and southern United States, and northern and central China.

The specific name, from $\chi\llcorner\omega$ and $\not \nu \theta 0 s$, is in allusion to the light and graceful clusters of snow-white flowers.

\section{Chionanthus Virginica, L. Fringe-tree. Old Man's Beard.}

Leaves ovatc or oblong, acuminate, short-pointed or sometimes rounded at the apex, gradually narrowed below, entire, with undulate margins, and coarsely reticulate-vemulose, when they unfold yellow-green and lustrous above, pubescent below, and ciliate on the margins, and at maturity $4^{\prime}-8^{\prime}$ long, $\frac{1^{\prime}}{2}-4^{\prime}$ wide, thick and firm, dark green on the upper, pale and glabrous on the lower surface except along the stout midribs and conspicuons arcuate primary veins more or less covered with short white hairs, turning bright clear yellow before falling early in the autumn; their petioles stont, puberulous, $\frac{1^{\prime}}{2}-1^{\prime}$ long. Flowers slightly and agreeably fragrant, appearing when the leaves are about one third grown, in loose pubescent drooping panicles $4^{\prime}-6^{\prime}$ in length, the bracts at the base of the lower branches of the inflorescence oblong, glabrons on the upper, pubescent on the lower surface, and sometimes

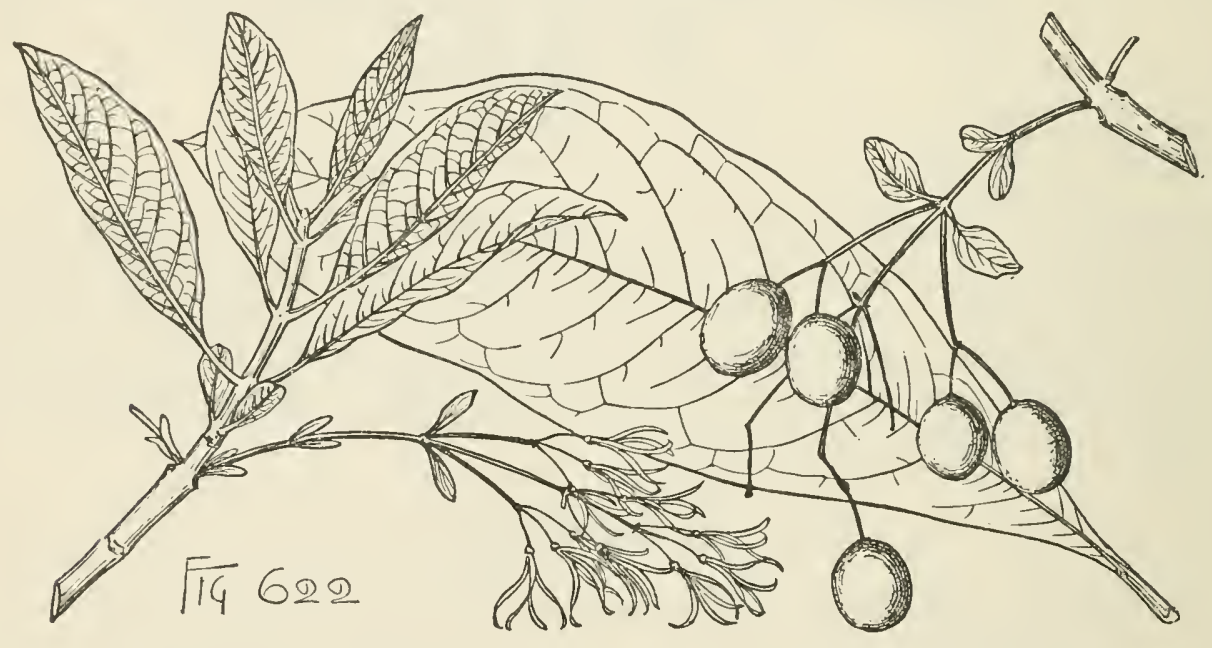

$1^{\prime}$ long, those at the base of the upper branches oval, successively smaller, and gradnally passing into the minute laciniate bracts subtending the lateral pedicels of the 3 -flowered clusters terminating the last divisions of the panicle; some individuals bearing flowers functionally perfect, others flowers with sterile anthers and welldeveloped stigmas, and others flowers with imperfectly developed stigmas and fertile anthers; calyx light green, glabrous, with acnte entire or laciniately cut lobes; corolla $1^{\prime}$ long, marked on the inner surface near the base by a row of bright purple spots; anthers light yellow, with a green connective. Fruit ripening in September, in loose few-fruited clusters, with leaf-like bracts sometimes $2^{\prime}$ in length, oval or oblong, $1^{\prime}$ long, dark blue or nearly black, and often covered with a glaucous bloom; seeds $\frac{1^{\prime}}{3}$ long, ovate, narrowed at the apex and covered with a thin light chestnut-brown coat marked by reticulate veins radiating from the hilum.

A tree, $20^{\circ}-30^{\circ}$ high, with a short trunk $8^{\prime}-10^{\prime}$ in diameter, stout ashy gray or light 
brown branches forming an oblong rather narrow head, and stout branchlets light green and covered witl pale pubescence or sometimes glabrous when they first appear, terete or slightly angled in their first winter, often much thickened below the nodes, light brown or orange color, and marked by large scattered darker colored lenticels and by the elevated semiorbicular leaf-scars displaying a semicircular row of conspicuous fibro-vascular bundle-scars; often a shrub, with several stout thick spreading stems. Winter-buds broadly ovate, acute, $\frac{1}{8}^{\prime}$ long, with about 5 pairs of scales increasing in length from the outer to the inner pair, and ovate, acute, keeled on the back, light brown and slightly pilose on the outer surface, bright green and lustrous on the inmer surface, and ciliate on the nlargins, with scattered white hairs, those of the imner pair at maturity obovate, gradually narrowed below, foliaceous, and $1^{\prime}-1 \frac{1^{\prime}}{2}$ long. Bark of the trunk $\frac{1}{4}^{\prime}-\frac{1}{2}^{\prime}$ thick, and irregularly divided into small thin appressed brown scales tinged with red. Wood heavy, hard, close-grained, and light brown, with thick lighter colored sapwood. The bark is tonic and is sometimes used in decoctions and in the treatment of intermittent fevers, or as an aperient and diuretic, and in homœopathic practice.

Distribution. Banks of streams in rich moist soil; Lancaster and Chester counties, southern Pennsylvania, to the shores of Tampa Bay, Florida, and through the Gulf states to southern Arkansas and the valley of the Brazos River, Texas.

Often cultivated as an ornamental plant in the eastern United States, and in western and central Europe.

\section{OSMANTHUS, Lour.}

Trees or shrubs, with terete or slightly angled branches, and fibrous roots. Leaves simple, persistent. Flowers fragrant, polygamo-diœecious or perfect, on ebracteolate pedicels subtended by scale-like bracts, in short axillary racemes or short axillary or rarely terminal fascicles; calyx minute, 4-toothed or divided, the divisions imbricated in the bud, persistent under the fruit; corolla tubular, 4-lobed, the lobes imbricated in the bud, ovate, obtuse, spreading after anthesis; stamens 2, inserted on the base of the corolla opposite the lateral lobes of the calyx, or rarely 4; filaments terete, short; anthers ovate or linear-oblong, blunt, or apiculate by the prolongation of the connective, attached on the back below the middle, 2-celled, the cells opening longitudinally by marginal slits, sometimes rudimentary or 0 in the pistillate flower; ovary subglobose; style columnar, short or elongated, crowned with an entire capitate stigma; ovules laterally attached near the apex of the cell; raphe ventral. Fruit a fleshy 1 -seeded ovoid or globose drupe tipped with the remnants of the style; flesh thin and succulent; stone hard and bony. Seed filling the cavity of the stone; cotyledons flat, much longer than the short superior radicle turned toward the hilum.

Osmanthus with tell species inhabits eastern North America, the Hawaiian Islands, Polynesia, Japan, and the Himalayas. Osmanthus fragrans, Lour., a native of China and the temperate Himalayas, is cultivated in China for its fragrant minute creamcolored or yellow flowers used by the Chinese to perfume tea, and is everywhere a favorite garden plant.

The generic name, from $\dot{\sigma} \sigma \mu \hat{\eta}$ and $\measuredangle \nu \theta 0 s$, relates to the fragrance of the flowers.

\section{Osmanthus Americanus, B. \& H. Devil Wood.}

Leaves lanceolate-oblong or sometimes obovate, acute or rarely emarginate at the apex and gradually narrowed at the base, with thickened revolute margins, when 
they unfold coated beneath with pale tomentum, and at maturity thick and eoriaceous, glabrous, bright green, lustrous above, obscurely reticulate-venulose, $4^{\prime}-\tilde{v}^{\prime}$ long and $\frac{1}{2}-2^{\prime}$ wide, with broad pale midribs and remote forked primary veins areuate near the margins, persistent until their second year; their petioles stont, $\frac{1}{2}-\frac{3}{4}$ long. Flowers opening in March from pilose infloreseence-buds formed the previous antumn in the axils of the leaves of the year, the staminate, pistillate, and perfect flowers on different individuals in 3-flowered clusters, sessile or short-pedicellate, in pedunculate eymes or short racenes, with scale-like nearly triangular acnte persistent bracts; calyx puberulous, with acute rigid lobes, and much shorter than the creamy white corolla $\frac{1}{8}^{\prime}$ long when expanded, with an elongated tube and short spreading ovate rounded lobes; stamens inserted on the middle of the tube of the eorolla, included or slightly exserted, small and often rudimentary in the pistillate flower; ovary abruptly contracted into a stout eolumnar style erowned with a large exserted capitate stigma, reduced in the staminate flower to a minute point. Fruit ripening early in the autumn, oblong or obovate, $1^{\prime}$ long, dark blue, with thin flesh

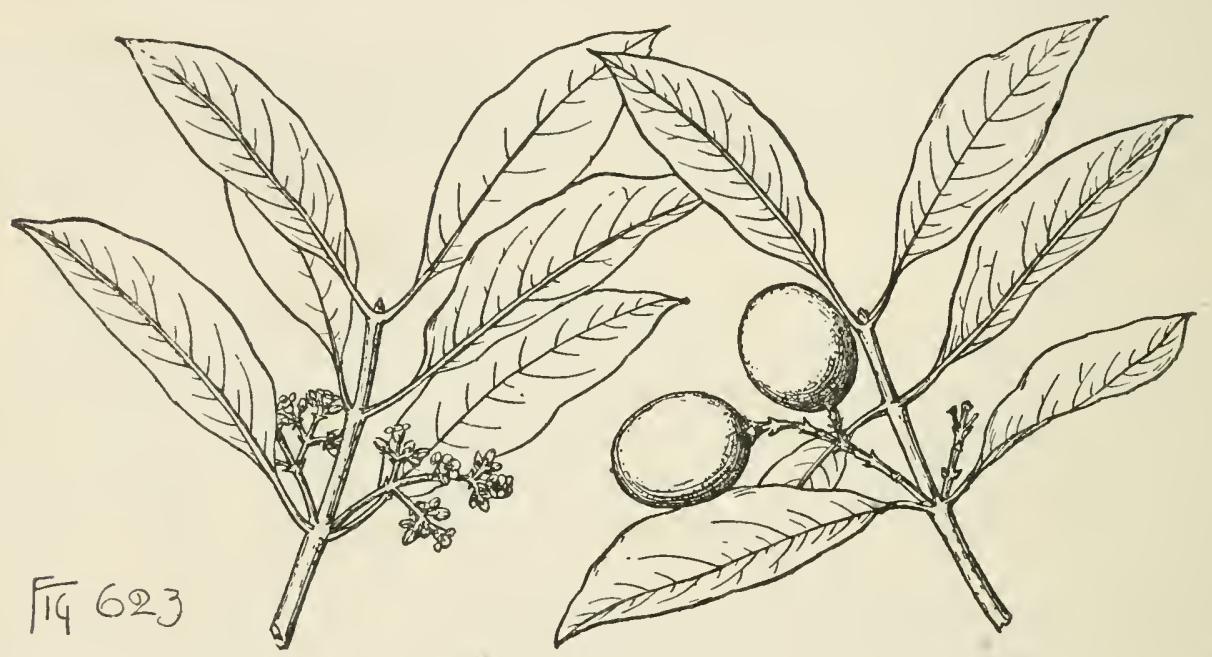

and a thick or sometimes thin-walled brittle ovate pointed stone; seed ovate, eovered with a ehestnut-brown eoat marked by broad conspieuous pale veins radiating from the short broad ventral hilum and encircling the seed.

A tree, oceasionally $40^{\circ}-50^{\circ}$ high, with a trunk sometimes a foot in diameter, and slender slightly angled ultimately terete branehlets light or red-brown and marked by minute pale lenticels, becoming ashy gray in their second year and roughened by the small elevated orbienlar leaf-sears displaying a ring of minute fibro-vaseular bundle-scars; usually much smaller and often shrubby. Winter-buds linear-laneeolate, $\frac{1^{\prime}}{2}$ long, with 2 thick lanceolate reddish brown pubernlons seales. Bark of the trunk thin, dark gray or gray tinged with red, and roughened by small thin appressed scales displaying in falling the dark einnamon red inner bark. Wood heavy, very hard and strong, elose-grained, difficult to work, dark brown, with thiek light brown or yellow sapwood.

Distribution. Usually in moist soil near the borders of streams and Pine-barren ponds and swamps, and occasionally on dry sandy uplands; coast region of the south Atlantic and Gulf states, from the valley of the Cape Fear River, North Carolina, to the shores of the Kissimmee River and Tampa Bay, Florida, and to eastern Louisiana. 


\section{BORRAGINACEA.}

Scabrous-pubescent trees or shrubs, with watery juice, and terete branchlets. Leaves simple, alternate or subverticillate, penniveined, persistent or tardily deciduous, without stipules. Flowers regular, perfect, in terminal or axillary dichotomous often scorpioid-branched cymes; calyx usually 5-lobed, persistent under the fruit; corolla hypogynous, 5-lobed, the lobes imbricated in the bud; stamens 5 , inserted on the tube of the corolla opposite its lobes; filaments filiform; anthers introrse, 2-celled, the cells opening longitudinally; pistil of 2 carpels; ovary undivided (in the arborescent genera of the United States), sessile on the hypogynous inconspicuous disk, more or less completely 4-celled; style single, 2-branched or parted toward the apex; stigmas clavate or capitate; ovule solitary in each cell. Fruit drupaceous (in the arborescent genera of the United States), tipped with the remnants of the style, with $2-4$ nutlets or cells. Seeds ascending; seed-coat membranaceous.

The Borage family with eighty-five genera, mostly of herbaceous plants, is widely distributed and most abundant in temperate regions, especially in the Mediterranean basin and central Asia.

\section{CONSPECTUS OF THE ARBORESCENT GENERA OF THE UNITED STATES.}

Branches of the style 2-branched; fruit partly or entirely inclosed in the enlarged calyx.

1. Cordia.

Branches of the style not branched; fruit not inclosed in the calyx.

Calyx valvately splitting into 5 minute teetlı; fruit with 2-4 1-seeded nutlets.

2. Bourreria.

Calyx 5-parted or cleft, the divisions imbricated in the bud; fruit with 22 -seeded nutlets.

\section{CORDIA, L.}

3. Ehretia.

Trees or shrubs, with petiolate entire persistent leaves and naked buds. Flowers in terminal scorpioid-branched cymes; calyx tubular or campanulate, conspicuously many-ribbed or rayed, the teeth valvate in the bud; corolla funnel form; anthers ovate-oblong; ovary 4-celled; style slender, elongated, 2-branched above the middle, the branches 2-parted, their division stigmatic to the base; ovule ascending, laterally attached below the middle to the inner angle of the cell, suborthotropous; micropyle superior. Fruit entirely or partly inclosed in the thickened calyx; flesh dry and corky or sweet and juicy; stone thick-walled, hard and bony, 1-4-celled, usually 1 or 2 -seeded. Seeds without albumen; embryo filling the cavity of the seed; cotyledons thick and fleshy or nembranaceous, longitudinally plicate or corrugated, much shorter than the superior radicle turned toward the hilum.

Cordia with nearly two hundred species inhabits the tropical and warm extratropical regions of the two hemispheres, the largest number of species being American. Of the four species found within the territory of the United States two are trees. Some of the species are valuable timber-trees, and others are cultivated for their edible fruits.

The generic name is in honor of Valerius Cordus (1515-1544), the German writer on pharmacy and botany.

\section{CONSPECTUS OF THE ARBORESCENT SPECIES OF THE UNITED STATES.}

Corolla orange or flame color; fruit inclosed in the smooth glabrous thickened ivory-white calyx; leaves ovate.

1. C. Sebestena (D). 
Corolla white with a yellow centre; fruit entirely or partly inclosed in the thin manyribbed tomentose orange-brown calyx; leaves oval or oblong-ovate.

2. C. Boissieri (E, H).

\section{Cordia Sebestena, L. Geiger-tree.}

Leaves unfolding through a large part of the year, ovate, short-pointed or rounded at the apex, rounded, subcordate, or wedge-shaped at the basc, cntire or remotely and coarsely serrate above the middle, when they nnfold covered, like the branches of the inflorescence, the outside of the calyx, and the young branchlets, with

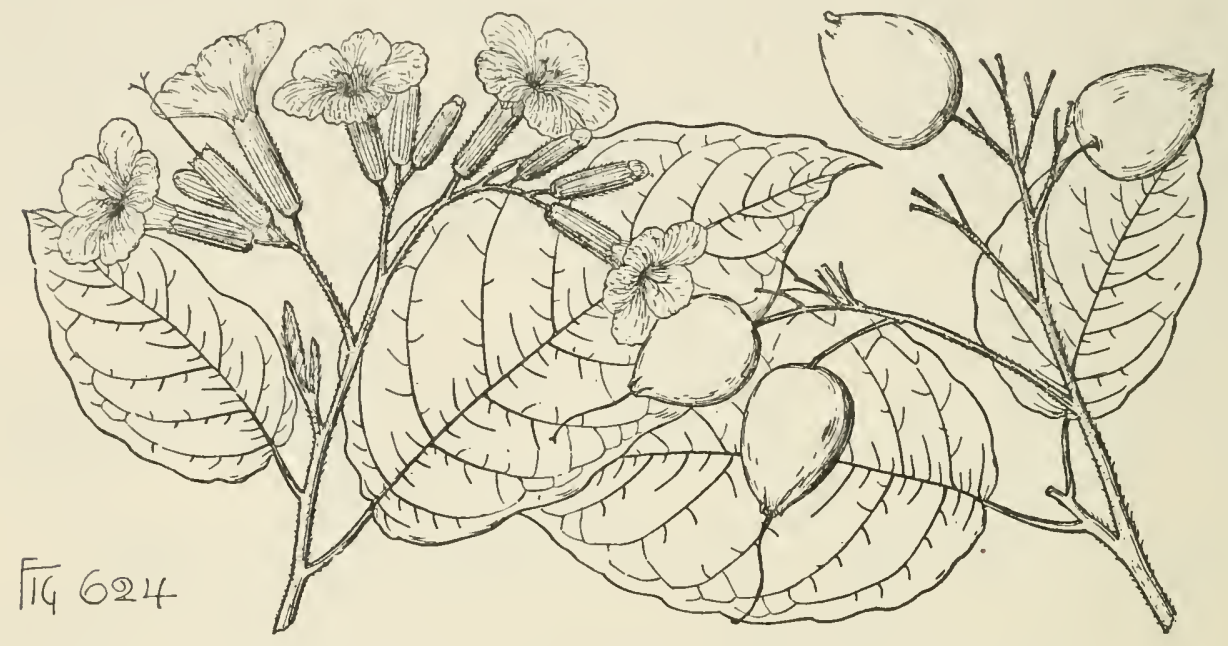

thick dense rusty tomentum and with short rigid pale hairs, and at maturity thick and firm, dark green, scabrous-pubescent, or often nearly glabrous bclow, reticulate-venulose, $5^{\prime}-6^{\prime}$ long and $3^{\prime}-4^{\prime}$ wide, with broad midribs usually covered below with pale hairs, especially in the axils of remote primary veins connected by conspicuous cross veinlets; their petioles stout, pubescent, $\mathbf{1}^{\prime}-\mathbf{1}_{\frac{2}{2}}^{\prime}$ long. Flowers appearing throughout the year on slender pedicels, in open flat cymes $6^{\prime}-7^{\prime}$ in diameter, some individuals producing flowers with short included stamens and elongated styles, and others with exserted stamens and included styles; calyx tubular, $\frac{1^{\prime}}{2}-\frac{2^{\prime}}{3}$ long, and obscurely manyrayed, with short nearly triangular rigid teeth; corolla orange or flame color, pubernlous on the outer surface, with a slender tube about twice as long as the calyx and spreading rounded lobes, irregularly undulate on the margins and $1^{\prime}-1 \frac{1}{2}$ in diameter when fully expanded; ovary conical, glabrous, contracted into a slender style branched near the apex. Fruit broadly ovate, rather abruptly narrowed and pointed at the apex, concave at the base, $1 \frac{1}{4}^{\prime}-1^{\prime} \frac{1}{2}$ long and about $\frac{3^{\prime}}{4}$ broad, inclosed in the thickened fibrous calyx smooth and ivory-white on the outer surface; flesh thin, pale, and corky, separable from the irregularly sulcate thick-walled stone gradually narrowed and acuminate at the apex, and deeply lobed at the base; seeds linear-lanceolate, $\frac{1 \prime}{2}$ long, with a delicate white seed-coat.

A tree, in Florida $25^{\circ}-30^{\circ}$ high, with a tall trunk $5^{\prime}-6^{\prime}$ in diameter, slender upright branches forming a narrow close round-topped head, and stout branchlets with thick pith, dark green at first, becoming ashy gray and marked by large nearly orbicular cordate leaf-scars displaying 2 central circular clusters of fibro-vascular bundle-scars. Bark of the trunk $\frac{1}{2}-\frac{3 \prime}{4}$ thick, dark brown, frequently nearly black, and deeply and irregularly divided into narrow ridges broken on the surface into short thick 
appressed scales. Wood heavy, hard, close-grained, dark brown, with thick light brown or yellow sapwood.

Distribution. Keys of southern Florida; common but possibly only as an escape from cultivation; also on the Bahama Islands, on most of the Antilles, and in Guiana and New Granada.

Often planted in tropical countries as an ornament of gardens.

\section{Cordia Boissieri, A. DC. Anacahuita.}

Leaves oval to oblong-ovate, acute or rounded at the apex, rounded or subcordate at the base, entire or obscurely crenulate-serrate, when they unfold covered like the branches of the infloresence, both surfaces of the calyx and the young branchlets with rusty or dark brown tomentum and short white usually matted hairs, thick and firm, dark green, minutely rugose and more or less scabrous above, coated below with thick soft pale or rufous tomentum, $4^{\prime}-5^{\prime}$ long, $3^{\prime}-4^{\prime}$ wide, with broad midribs and conspicuous primary veins forked near the margins and connected by cross veinlets, deciduous at the end of their first year; their petioles stont, tomentose, $1^{\prime}-1 \frac{1}{2}^{\prime}$ long. Flowers opening from April to June, slightly fragrant, sessile or short-pedicellate, in open terminal dichotomous cymes; calyx tubular or subcampanulate, conspicuously many-ribbed, with 5 linear acute teetl, and about half as long as the tube of

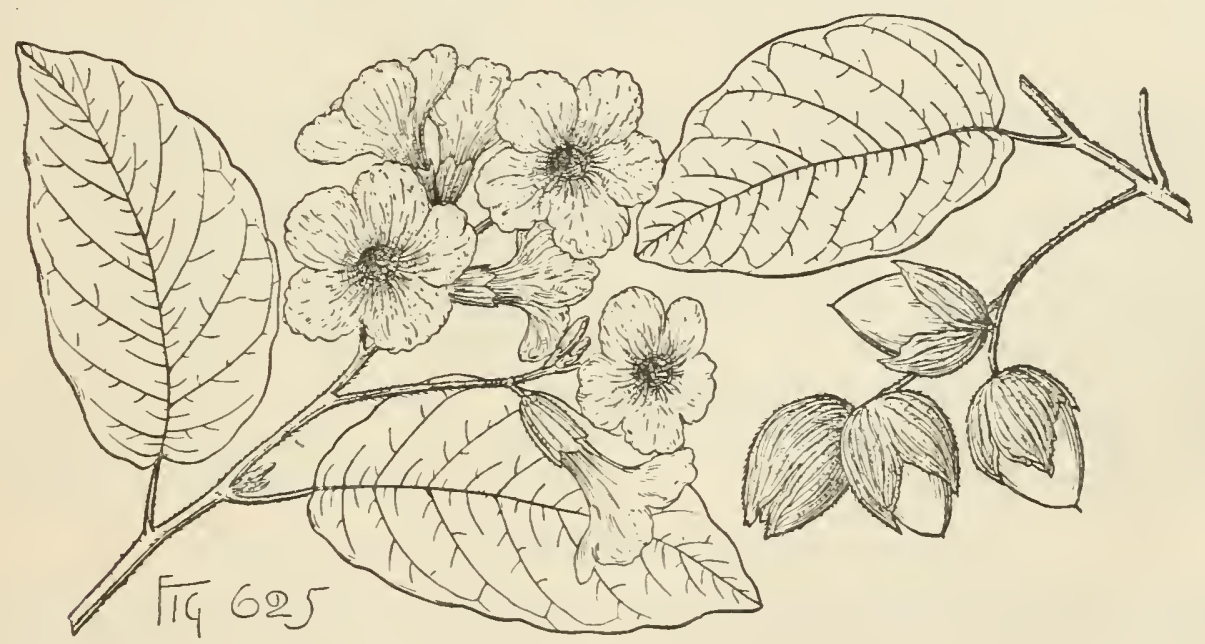

the white corolla, puberulous on the outer surface, marked in the throat witl a large light yellow spot, the lobes rounded, imbricated in the bud, and $2^{\prime}$ across when fully expanded; ovary glabrous, gradually narrowed into a slender 2-branched style. Fruit ovate, $\mathbf{1}^{\prime}$ long, about $\frac{3^{\prime}}{4}$ broad, pointed at the apex, lustrous, bright red-brown, and inclosed entirely or partly by the thin fibrous now conspicuously rayed orangebrown calyx, coated on the outer surface with thick short pale tomentum, and often splitting nearly to the base; flesh thin, sweet, and pulpy, separating easily from the ovate smooth light browl stone gradually narrowed from above the middle, faintly reticulate-veined, and marked by 4 longitudinal lines and at the acuminate apex by a deeply 4-lobed thin cap, thick-walled, hard and bony, deeply lobed at the base; seeds ovate, acute, $\frac{1}{4}^{\prime}$ long, with a thin delicate pure white coat.

A tree, occasionally $20^{\circ}-25^{\circ}$ high, with a short often crooked trunk $6^{\prime}-8^{\prime}$ in diameter, stout spreading branches forming a low round-topped head, and stout branchlets, becoming in their second year dark gray or brown, slightly puberulous, and 
marked by occisional large lenticels and by clevated obcordate leaf-scars; or of ten a shrub, with numerous stems sometimes only $2^{\circ}$ or $3^{\circ}$ tall. Bark of the trunk thin, gray tinged with red, and irregularly divided into broad flat ridges, the surfaec ultimately scparating into long thin papery scales. Wood light, rather soft, closegrained, and dark brown, with thick light brown sapwood.

Distribution. Dry limestone ridges, and depressions in the desert; valley of the Rio Grande, Texas, and southern New Mexico, southward into Mexieo; most abundant and of its largest size in Nnevo Leon between the nuoutl of the Rio Grande and the base of the Sierra Madre.

\section{BOURRERIA, P. Br.}

Trees or slrubs, with obovate-oblong or ovate leaves involute in the bud, persistent. Flowers on slender bracteolate pedicels, in terminal eorymbose many-flowered cymes, with linear-lanceolate caducous bracts and bractlets; calyx campanulate, 5-toothed, the divisions closed and valvate in the buả; corolla white, eampamnlate, the lobes broadly ovate, spreading after anthesis; anthers ovate, rngulose, apiculate; ovary incompletely 4 -celled by the development of the 2 parietal plaeentas, narrowed into a terminal style 2-parted at the apex, the divisions more or less eoalescent; stigmas capitate; ovules attached on the back near the middle of the inner faee of the revolute placentas, anatropous; raphe ventral; micropyle superior. Fruit subglobose, flesh thin; stone somewhat 4-lobed and separable into 4 thick-walled bony 1-seeded nutlets rounded and furnished on the back with a thick spongy longitndinal manyridged appendage, flattened on their converging inner faces and attached at the apex to a filiform columm. Seed terete, filling the seminal cell, longitudinally incurved round a rather small eavity opposite an elevated oblong scar on one of the inner faces of the nutlet and counected with the hilum by a narrow passage; seed-coat membranaceous, light brown; embryo axile in fleshy albumen; cotyledons plane; radiele slender, elongated, turned toward the hilum.

Bourreria with sixteen to eighteen species is confined to tropical America, one speeies reaching the shores of southern Florida.

The generic name is in honor of J. A. Bourrer, an apothecary at Nuremberg.

\section{Bourreria Havanensis, Miers. Strong Back.}

Leaves obovate-oblong or ovate, acute, rounded, apiculate, or emarginate at the apex, wedge-shaped at the base, and entire, with thiekened revolute margins, covered when they unfold with soft pale cadueous hairs, and at maturity thiek and coriaceous, eonspicuously reticulate-venulose, dark green and lustrous, or in one form (var. radula, Gray) tuberculate-scabrous or hispidulous on the upper surface, pale yellow-green and glabrous or pubescent on the lower surface, $22^{\prime}-3 \frac{1}{2}^{\prime}$ long, $1^{\prime}-1 \frac{1}{2}^{\prime}$ wide, with broad orange-eolored midribs and thin areuate veins, usually persistent through their seeond summer; their petioles slender, rigid, grooved, $\frac{3^{\prime}}{4}-1^{\prime}$ long. Flowers opening in the spring and late in the autumn on pedicels $\frac{1^{\prime}}{2}$ long and furnished near the middle with a scarious braetlet $\frac{1^{\prime}}{8}$ in length and caducous from a persistent base, in open glabrous cymes $3^{\prime}-4^{\prime}$ in diameter, with slender branches, and small braets; calyx-teeth acute, ciliate on the margins; corolla subcampanulate, creamy white, with a short tube somewhat enlarged in the throat, and broadly ovate spreading lobes $\frac{3^{\prime}}{4}$ across when expanded; ovary conical, glabrous, gradually contracted into a slender exserted style divided only toward the apex or sometimes nearly entire, and crowned with 2 capitate stigmas. Fruit ripening early in the autumn, 
or in early spring from autumnal flowers, bright orange-red, $\frac{1}{2}^{\prime}$ in diameter, with a thick tough skin and thin dry flesh inclosing the 4 nutlets, the enlarged spreading calyx becoming sometimes $\frac{1^{\prime}}{2}$ across.

A tree, in Florida occasionally $40^{\circ}-50^{\circ}$ high, with a buttressed and often fluted trunk $8^{\prime}-10^{\prime}$ in diameter, and slender branchlets light red and pilose, with pale deciduous hairs when they first appear, becoming in their first winter dark red,
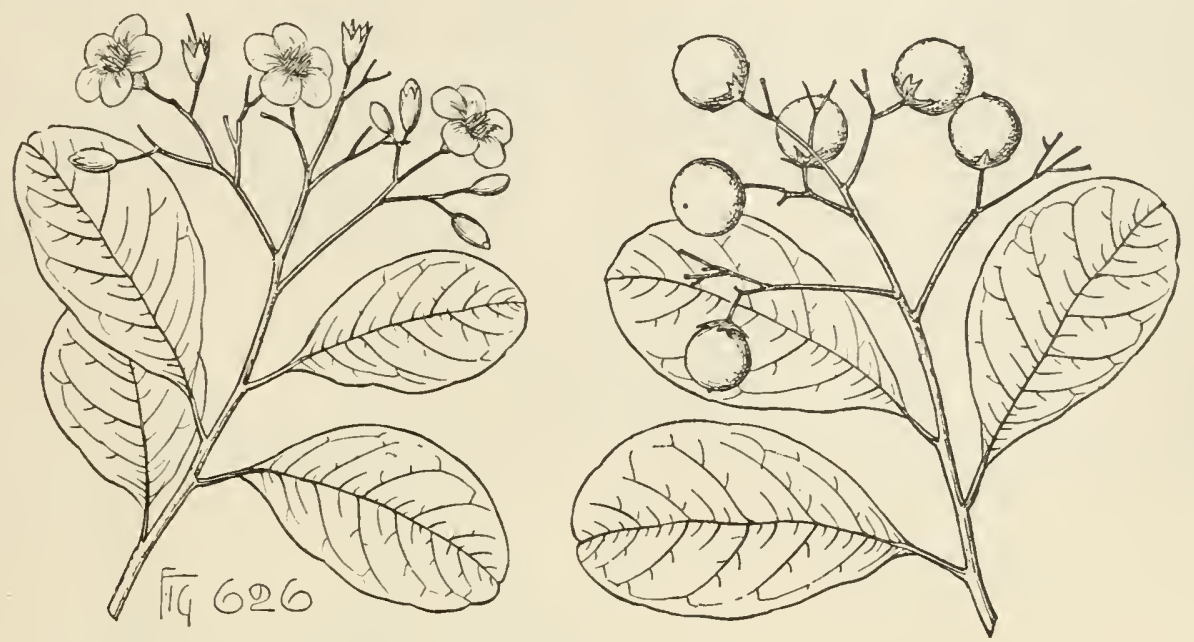

orange color or ashy gray, and sometimes roughened by pale lenticels, their thin bark often separating into delicate scales; usually much smaller and often a shrub, with numerous spreading stems. Winter-buds minute, globose, covered with hoary tomentum, nearly immersed in the bark. Bark of the trunk $\frac{1}{16}-\frac{1}{8}^{\prime}$ thick, light brown tinged with red, more or less fissured and divided on the surface into thick plate-like irregular scales. Wood hard, strong, very close-grained, brown streaked with orange, with thick hardly distinguishable sapwood.

Distribution. Keys of southern Florida; common; also on the Bahama Islands and on many of the Antilles.

\section{EHRETIA, P. Br.}

Trees or shrubs, with entire or dentate leaves, and scaly buds. Flowers small, in terminal and axillary scorpioid clusters; calyx open or closed in the bud, the divisions imbricated, ovate or linear; corolla usually white, with a short or cylindrical tube and spreading obtuse lobes; ovary oblong-conical, 1-celled before anthesis, becoming incompletely 4-celled by the development of the 2 parietal placentas; style columnar, parted into 2 divisions terminating in capitate stigmas; ovules attached laterally near the middle on the inner face of the revolute placentas, anatropous; raphe ventral; micropyle superior. Fruit fleshy, small, globose, with thin flesh; stone separable into 2 2-celled thick-walled bony nutlets rounded on the back, plane on the inner face, and attached to a thin axile column. Seed terete, usually erect, filling the longitudinally incurved seminal cavity; seed-coat thin, membranaceous, light brown; embryo axile in thin albumen; cotyledons ovate, plane, shorter than the elongated superior radicle turned toward the hilum.

Ehretia with about fifty species is widely distributed through tropical and warm extratropical regions of the two hemispheres, with a single species extending into southwestern Texas. 
The generic name commemorates the artistic and scientific labors of the German botanical artist, George Dionysius Ehret (1705-1770).

\section{Ehretia elliptica, DC. Anaqua. Knackaway.}

Leaves oval or oblong, pointed and apiculate at the apcx, gradually rounded or wedgc-sliaped at the base, entire or occasionally furnisbed above the middle with a few broad teeth, conspicuously reticulate-venulose, unfolding late in the winter and then thin, light green, lustrous, minutely tuberculate and pilose above, and covered below like the branches of the inflorescence, the outer surface of the calyx, and the young branchlets with ridged pale hairs, often furuished with axillary tufts of white hairs, and at maturity thick and subcoriaceous, dark grcen and ronghened above by the enlarged circular crowded pale tubercles, and more or less covered with soft pale or rufous pubescence below, especially on the narrow midribs and numerous primary veins arcuatc near the margins, irregularly deciduous during the winter; their petioles stout, grooved, pubescent. Flowers opening from the autumn to early spring, in compact racemose scorpioid-branched panicles 2 ' $-3^{\prime}$ long and broad, on short leafy branches of the year, with linear acute deciduous bracts about $\frac{1^{\prime}}{4}$ long; calyx open in the bud, divided to the base into 5 linear acute divisions and nearly as long as

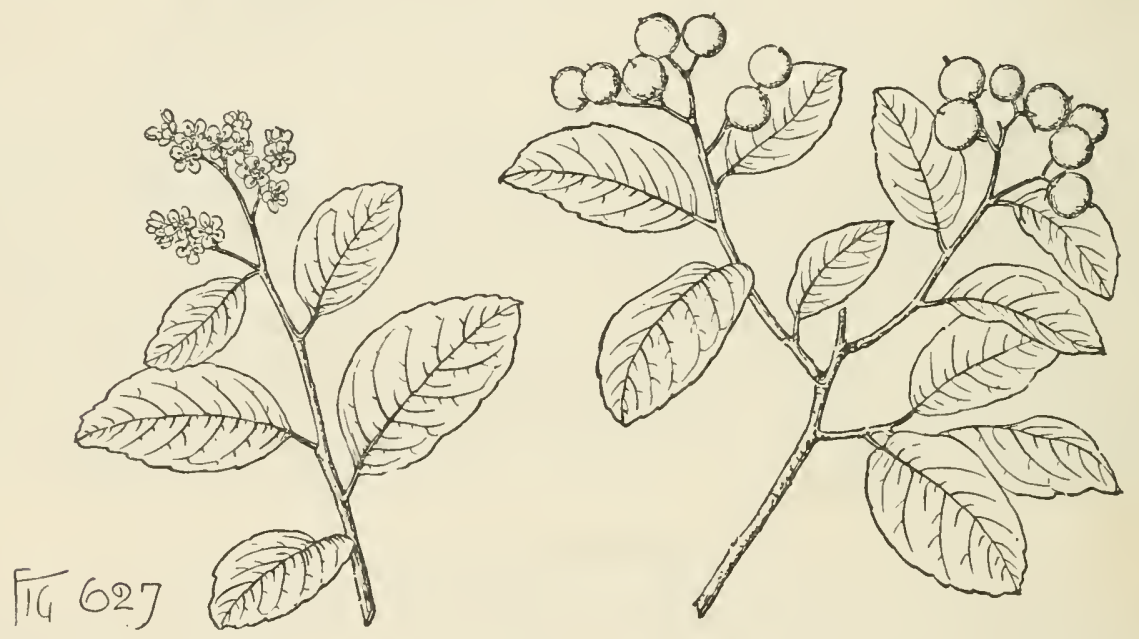

the campanulate tube of the corolla, with ovate thin white lobes $\frac{1}{2}^{\prime}$ across when expanded. Fruit ripening in the autumn and in the spring, light yellow, $\frac{1}{4}$ in diameter, with thin sweet rather juicy edible flesh, and 2 2-seeded nutlets.

A trec, sometimes $40^{\circ}-50^{\circ}$ high, with a trunk occasionally $3^{\circ}$ in diameter, stout spreading branches forming a handsome compact round-topped head, and slender branchlets without terminal buds, covered when they first appear, like the under surface of the leaves, the branches of the inflorescence, and the outer surface of the calyx of the flower, with rigid hirsute pale hairs, becoming in their first winter light brown tinged with red, sometimes puberulous, often roughened by numerous pale lenticels, and by small depressed obcordate leaf-scars displaying a short lunate row of fibro-vascular bundle-scars; usually much smaller within the territory of the United States, and often a low shrub. Winter-buds axillary, minute, 1 or 2 together, superposed, buried in the bark, and covered by 2 pairs of dark scales persistent on the base of the growing branchlet and at maturity acute, dark chestnut-brown, 
coated with pale lairs, and sometimes $\frac{1^{\prime}}{4}$ in length. Bark of young stems and of the branches thin, light brown, and broken into thick appressed scales, becoming on old trunks sometimes $\mathbf{1}^{\prime}$ thick, deeply furrowed and divided into long thick irregular plate-like scales gray or reddish brown on the surface and separating into thin flakes. Wood heavy, hard, not strong, close-grained, difficult to split, light brown, with thick slightly lighter colored sapwood.

Distribution. River valleys in fertile soil, or as a shrub on dry barren ridges; valley of the upper San Marcos River, western Texas, to the Rio Grande; often extremely common on the bottom-lands of western Texas, and probably of its largest size in the United States on the Guadalupe and Nueces rivers sixty or seventy miles from the coast of the Gulf of Mexico; also through Nuevo Leon and Coahuila to the mountains of San Luis Potosí.

Often planted as a shade-tree in the streets of cities and towns of western Texas and northern Mexico.

\section{VERBEN ACEA.}

Trees or shrubs, with opposite simple entire persistent leaves without stipules. Flowers perfect; calyx 5-toothed or parted, persistent under the fruit; corolla 4 or 5-lobed, the lobes imbricated in the bud; stamens 4 , inserted on the tube of the corolla in pairs of different lengths, introrse; anthers 2-celled, the cells opening longitudinally; ovary sessile on the annular disk; style simple, 2-lobed and stigmatic at the apex. Fruit a fleshy drupe or a capsule.

'The Verbena family with nearly seventy genera, largely composed of herbaceous plants, is widely scattered through temperate and tropical regions. Some of the species are important timber-trees, the most valuable being the Teak, Tectoria grandis, L. f., of southeastern Asia and the Malay Archipelago, and some of the tropical species of Vitex.

\section{CONSPECTUS OF THE ARBORESCENT GENERA OF THE UNITED STATES.}

Flowers in axillary or terminal racemes ; staminodium 1; ovary imperfectly 4-celled; ovule $l$ in each cell; fruit a fleshy drupe.

1. Citharexylon.

Flowers cymose in pedunculate spikes or heads; staminodium 0 ; ovary 1-celled; ovules suspended from the summit of a free central placenta; fruit a capsule; seed naked, germinating within the fruit.

2. Avicennia.

\section{CITHAREXYLON, L.}

Trees or shrubs, with coriaceous lustrous leaves, slightly angled branchlets without terminal buds, and minute axillary buds. Flowers small, on short ebracteolate pedicels, alternate or scattered on the filiform rachis of slender racemes; calyx membranaceous, tubular-campanulate, truncate, minutely 5-toothed, spreading and cup-shaped under the fruit; corolla salver-form, usually white, the spreading limb somewhat oblique, 5-lobed, the lobes broadly ovate, rounded, slightly unequal, the 2 posterior exterior; stamens included; filaments short, filiform, slightly thickened at the base, the 2 anterior longer than the others; anthers oblong; staminodium 1, posterior, linear, acute, rarely fertile; ovary ovate, incompletely 4-celled by the development of two parietal placentas, gradually narrowed into a short included style; ovule solitary in each cell, erect, attached laterally near the base, ascending, anatropous; micropyle inferior. Fruit a 2 -stoned 4-seeded fleshy drupe tipped with the remnants of the style, with thin flesh and a thick-walled bony stone separable into 2 2-seeded 
compressed smooth light brown nutlets rounded on the back and concave on the immer face. Seed erect, without albumen, filling the seminal cavity; sced-coat menbranaceons, light brown; embryo subterete, straight; cotyledons thick and fleshy, oblong, much longer than the short inferior radicle turned toward the oblong basal hilum.

Citharexylon with fifteen to twenty species is confined to tropical America, where it is distributed from sonthern Florida through the West Indies to southerı Mexico, Lower California, Bolivia, and Brazil.

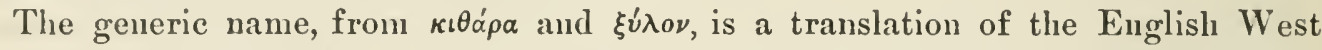
Indian name Fiddle Wood, a corruption of the earlier French-colonial Bois Fidèle, in allusion to the strength and toughness of the wood of the trees of this genus.

\section{Citharexylon villosum, Jacq. Fiddle Wood.}

Leaves oblong-obovate to oblong, acute, acuminate, rounded, or emarginate at che apex, and gradually narrowed at the base, with thickened slightly revolute margins, pubescent while young on the lower surface and at maturity glabrous, conspicuously reticnlate-venulose, pale green, $3^{\prime}-4^{\prime}$ long and $1^{\prime}-1 \frac{1}{2}^{\prime}$ wide, with broad

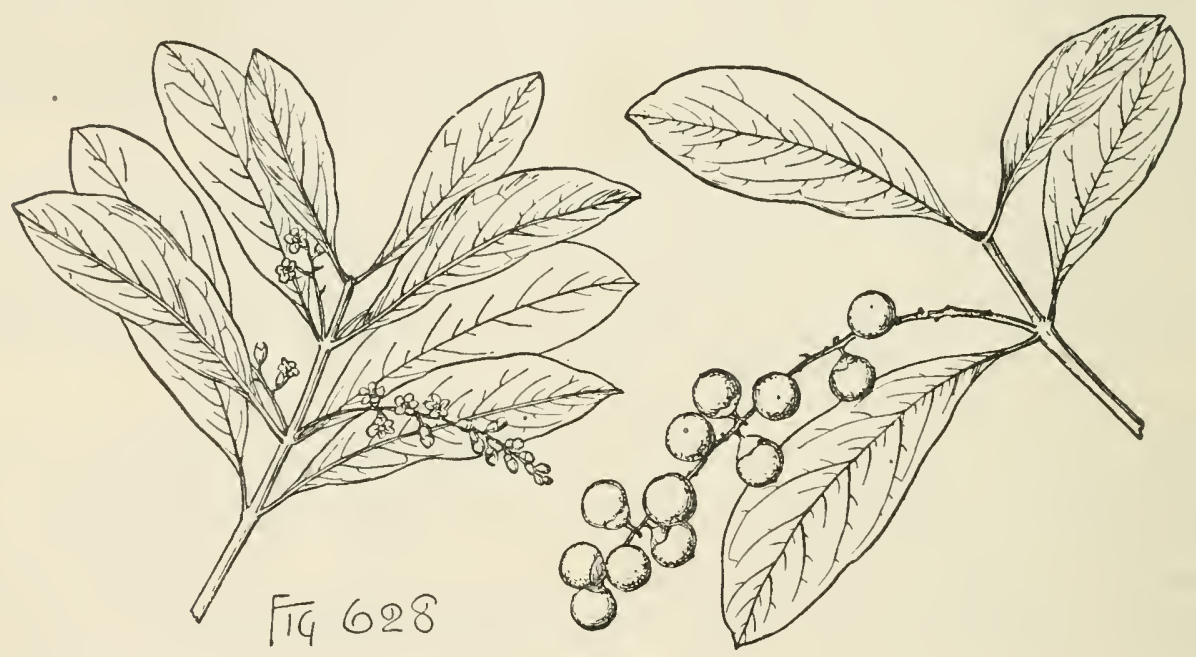

pale midribs rounded on the upper side and remote prominent arcuate veins; their petioles stout, grooved, $\frac{2}{3}$ in length, separating in falling from elevated nearly circular persistent woody bases. Flowers fragrant, appearing throughout the year on slender pedicels in the axils of scarious pubescent bracts, in drooping axillary pubescent racemes crowded near the ends of the branches and $2^{\prime}-4^{\prime}$ long; calyx coated with pale hairs, or sometimes nearly glabrous; corolla $\frac{1}{8}^{\prime}$ across the expanded lobes of the limb, and covered on the inner surface of the tube with pale hairs. Fruit subglobose to oblong-ovate, light red-brown, very lustrous, $\frac{1}{3}^{\prime}$ in diameter, with thin sweet rather juicy flesh, and inclosed nearly to the middle in the cup-like pale brown slightly and irregularly lobed or sometimes nearly entire calyx; seeds oblong, narrowed at the rounded ends, about $\frac{1}{8}^{\prime}$ long.

A tree, in Florida rarely more than $20^{\circ}$ high, with a trunk $4^{\prime}-6^{\prime}$ in dianieter, slender upright branches forming a narrow irregularly shaped head, and slender slightly many-angled branchlets light yellow and covered with pale simple caducous hairs when they first appear, becoming in their second year terete and ashy gray; 
or often a shrub, with numerous low stems. Winter-buds globose, nearly immersed in the bark, and covered with hoary pubescence. Bark of the trunk $\frac{1}{16}{ }^{\prime}-\frac{1}{8}{ }^{\prime}$ thick, light brown tinged with red, the surface separating into minute appressed scales. Wood heavy, exceedingly hard, strong, close-grained, clear bright red, with thin lighter colored sapwood.

Distribution. Cape Canaveral to the southern keys, Florida; common and of its largest size in the United States on the shores of Bay Biscayne near the mouth of the Miami River; northward usually a low shrub; also on the Bahamas and on many of the Autilles.

\section{AVICENNIA, L.}

Trees, with coriaceous persistent leaves, stout pithy branches thickened at the nodes and marked by interpetiolar lines, and long thick horizontal roots producing numerous short vertical thick and fleshy leafless stems rising above the surface of the soil. Flowers opposite, cymose, in centripetal pedunculate spikes or heads, closely invested by a bract and 2 bractlets, the peduncles solitary or in pairs in the axils of upper leaves and ternate on the ends of the branches, their bracts and bractlets concave, acute, apicnlate, keeled on the back, scarious, slightly ciliate on the margins, shorter than the corolla, persistent under the fruit; calyx cup-shaped, coated like the bracts and bractlets with canescent pubescence, divided nearly to the base into 5 concave ovate rounded lobes imbricated in the bud; corolla campanulate, white, with a straight cylindrical tube shorter than the glabrous or tomentose spreading 4-lobed limb, the posterior lobe usually larger than the others; stamens exserted; filaments short, filiform, slightly thickened at the base; anthers ovate; ovary ovate, pubescent, 1-celled, gradually narrowed into an elongated slender style divided at the apex into 2 lobes stigmatic on their inner face; ovules 4 , suspended from the summit of a free central placenta, orthotropous, naked. Fruit an ovate oblique compressed 1-seeded capsule apiculate at the apex; pericarp thin, light green, villose-pubescent on the outer surface, longitudinally veined on the inner surface, opening by the ventral suture and displaying the enlarging embryo before separating from the branch, ultimately 2-valved. Seed naked, without albumen; embryo filling the cavity of the fruit, light green; cotyledons thick and fleshy, broader than long, slightly pointed, deeply cordate at the base, mequal, conduplicate; radicle elongated, clavate, retrorsely hirsute, inferior, descending obliquely and included between the lobes of the cotyledons slightly attached near the apex in the bottom of the capsule to the withered columella by a minute papillose point; plumule hairy.

Avicennia with thirty species is widely distributed on maritime shores of the tropics of the two worlds, with one species reaching those of southern Florida. Avicennia produces hard strong wood. The bark is rich in tamnic acid, and is used for tanning leather. Its chief value is in the ability of these trees to live on low tidal shores, by the structure of the embryo, which is growing and ready to take root as soon as it falls into the soft mud, and of the long horizontal roots furnished with short vertical fleshy leafless branches or aerating roots and forming a close network which holds the soil together, preventing it from being washed away by outflowing tides and extending the growth of the tree by producing numerous stems soon forming dense thickets.

The generic name is in honor of the most illustrious physician of the Orient, Avicenna of Bokhara (980-1036). 


\section{Avicennia nitida, Jacq. Black Mangrove.}

Leaves oblong or lanceolate-elliptical, rounded or acute at the apex and gradually narrowed at the base, with slightly thickened revolute margins, dark green and often lustrous above, hoary-tomentulose below, $2^{\prime}-3^{\prime}$ long and $\frac{8^{\prime}}{4}-1 \frac{1}{2}^{\prime}$ wide, with broad midribs thickened and grooved toward the base on the upper side, oblique primary
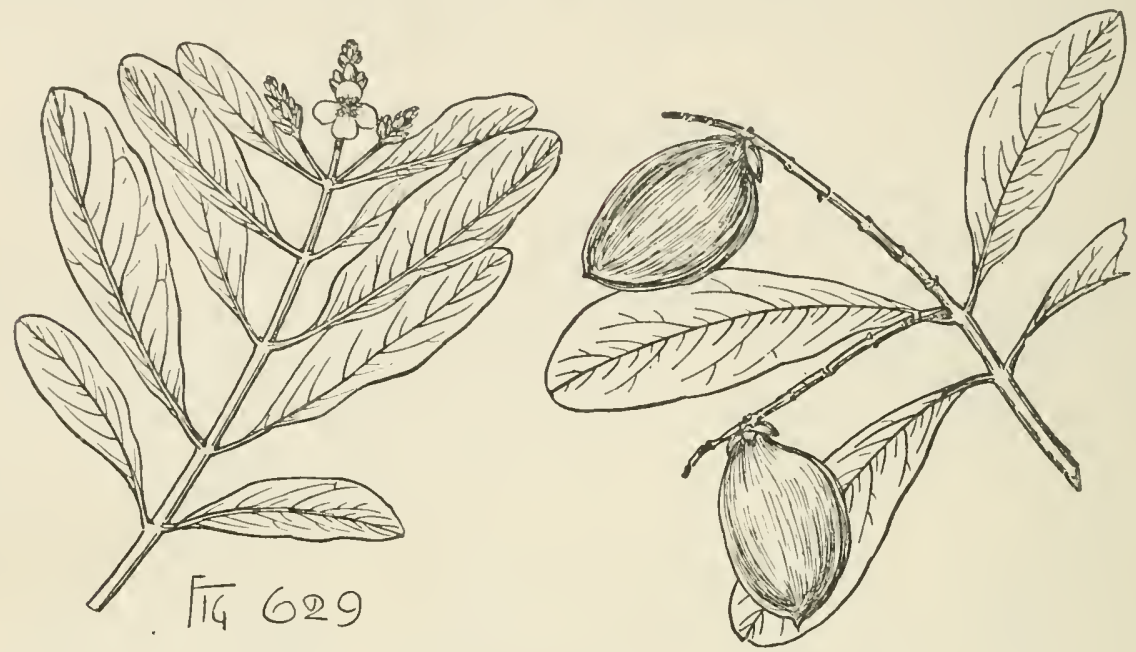

veins arcuate and joined close to the margins, conspicuous on the 2 surfaces, and connected by prominent reticulate veinlets, appearing irregularly and falling early in their second season; their petioles broad, channeled, enlarged at the base, and about $\frac{1}{2}^{\prime}$ long. Flowers produced continuously throughout the year, their bracts and bractlets nearly $\frac{1 \prime}{4}$ long, coated with pale or slightly rufous pubescence and about as long as the lobes of the calyx, in few-flowered short spikes or stout 4-angled canescent peduncles $\frac{1}{2}^{\prime}-\mathbf{1}_{2}^{\prime}$ in length, the lateral peduncles of the ternate terminal clusters subtended by oblong acute bracts $\frac{1}{2}^{\prime}$ long; corolla $\frac{1}{2}^{\prime}$ across the expanded slightly tomentose lobes, and nearly closed in the throat. Fruit $1^{\prime}-1 \frac{1}{2}^{\prime}$ long and $\frac{3^{\prime}}{4}-1^{\prime}$ wide.

A tree, occasionally $60^{\circ}-70^{\circ}$ high, with a short trunk rarely $2^{\circ}$ in diameter, spreading branches forming a broad round-topped head, and branchlets at first slightly angled, coated with fine hoary deciduous pubescence, and light orange color, becoming in their second year more or less contorted, light or dark gray, conspicuously marked by the interpetiolar lines and by horizontal leaf-scars displaying a central row of fibro-vascular bundle-scars; usually not more than $20^{\circ}-30^{\circ}$ tall, with short slender stems, and toward the northern limit of its range a low shrub. Bark of the trunk $\frac{1}{4}^{\prime}-\frac{1}{2}$ thick, roughened with thin irregularly appressed dark brown scales tinged with red, and in falling displaying the bright orange-red inner bark. Wood very heavy, hard, rather coarse-grained, with numerous medullary rays and eccentric layers of annual growtl, dark brown or nearly black, with thick brown sapwood.

Distribution. Florida, St. Augustine to the southern keys on the east coast, and from Cedar Keys to Cape Sable on the west coast; also on the Bahama Islands, on many of the Antilles, and southward to Brazil; in the United States of its largest size just north of Cape Sable; north of Matanzas Inlet on the east coast usually with stems only a few feet tall. 


\section{BIGNONIACE王.}

Trees or shrubs, with watery juice, and opposite or rarely alternate simple (in the arborescent genera of the United States) leaves without stipules. Flowers perfect, large and showy; calyx closed in the bud, bilabiately splitting in anthesis; corolla hypogynous, bilabiate, 5 -lobed, the lobes imbricated in the bud; stamens 2 or 4 , inserted on the corolla, introrse; anthers 2-celled, the cells opening longitudinally; staminodia 1 or 3 ; ovary sessile, 1 or 2-celled, gradually narrowed into a slender simple style 2-lobed and stigmatic at the apex; ovules numerous, horizontal, anatropous; raphe ventra!; micropyle superior. Fruit a linear woody loculicidally 2 -valved capsule, or a berry. Seeds without albumen; embryo filling the cavity of the seed.

The Bignonia family with about one hundred genera, many of them of scandent plants, is widely distributed in the tropics and most abundant in the New World, with a few genera extending into temperate regions. Of the five genera of the United States three are arborescent. Many of the species are important timber-trees.

\section{CONSPECTUS OF THE ARBORESCENT GENERA OF THE UNITED STATES.}

Fruit a linear woody capsule; ovary 2-celled; leaves membranaceous, deciduous.

Stamens 4 ; staminodium 1; leaves linear, often alternate or scattered. 1. Chilopsis.

Stamens 2; staminodia 3; leaves oblong-ovate, mostly opposite.

2. Catalpa.

Fruit a berry; stamens 4 ; staminodium 1; ovary 1-celled; leaves coriaceous, persistent.

3. Crescentia.

\section{CHILOPSIS, D. Don.}

A tree, with slender terete branches without terminal buds, minute compressed rusty-pubescent axillary buds covered by several imbricated scales, those of the inner rows accrescent, deeply furrowed bark, soft coarse-grained dark-colored wood, and fibrous roots. Leaves opposite, alternate or scattered, involute in the bud, linear or linear-lanceolate, long-pointed, entire, 3-nerved, the lateral nerves obscure, reticulate-venulose, membranaceous, light green, smooth or glutinous, short-petiolate or sessile from an enlarged base, deciduous, in falling leaving small elevated suborbicular scars. Flowers on slender pedicels from the axils of ovate acute scarious tomentose deciduous bracts and bibracteolate near the middle, in short puberulous crowded racemes terminal on leafy branches of the year; calyx coated with pale tomentum, closed before anthesis into an ovoid rounded apiculate bud splitting to the base into 2 ovate divisions, minutely toothed at the apex, the upper with 3 , the lower with 2 rigid teeth, membranaceous, dark green; corolla white shaded into pale purple, slightly obliqne, enlarged and blotched with yellow in the throat, the limb undulate-margined, the upper lip 2-lobed, the lower nnequally 3-lobed, the central lobe much longer than the others; stamens 4, inserted in 1 row near the base of the corolla, in pairs, introrse; filaments filiform, glabrous, the anterior nearly twice as long as the posterior; anther oblong, the cells divergent in anthesis; staminodium 1, posterior, linear, acute; ovary 2-celled, sessile on the thin nearly obsolete annular disk, conical, glabrous, gradually narrowed into a slender style divided at the apex into 2 ovate flat rounded lobes; ovules inserted in many series on a central placenta. Fruit a slender elongated thin-walled capsule gradnally narrowed from the middle to the ends, splitting loculicidally into 2 concave valves. Seeds nnmerous, inserted in 2 ranks near the margin of the thin flat woody septnm free from the walls of the capsule, compressed, 
oblong; seed-coat thin, light brown, longitudinally veined, produced into broad lateral wings divided at their rounded ends into long fringes of thin soft white hairs; cotyledons plane, broader than long, slightly 2-lobed and rounded laterally; radicle short, crect, turned toward the oblong basal hilum.

The genus is represented by a single species, a native of the region adjacent to the boundary betwecn the United States and Mexico.

The generic name, from $\chi \in \hat{\imath} \lambda$ os and ö $\psi$ เs, is without special significance.

\section{Chilopsis linearis, DC. Desert Willow.}

Leaves unfolding in early spring, $6^{\prime}-12^{\prime}$ long and $\frac{1}{4}^{\prime}-\frac{1}{3}^{\prime}$ wide, deciduous during the following winter. Flowers appearing in early summer in racemes $3^{\prime}-4^{\prime}$ long and continuing to open for several months in succession, $1 \frac{1}{2}^{\prime}$ long and about $1 \frac{11^{\prime}}{4}$ across the expanded lobes of the corolla. Fruit ripening in the autumn, $7^{\prime}-12^{\prime}$ long, $\frac{1{ }^{\prime}}{4}$ thick in the middle, persistent on the branches during the winter; seeds $\frac{1}{3}^{\prime}$ long and $\frac{1}{8}^{\prime}$ wide.

A tree, $20^{\circ}-30^{\circ}$ high, with a trunk usually more or less reclining, often hollow, and sometimes a foot in diameter, slender upright branches forming a narrow head, and branchlets glabrous or covered with dense tomentum when they first appear,

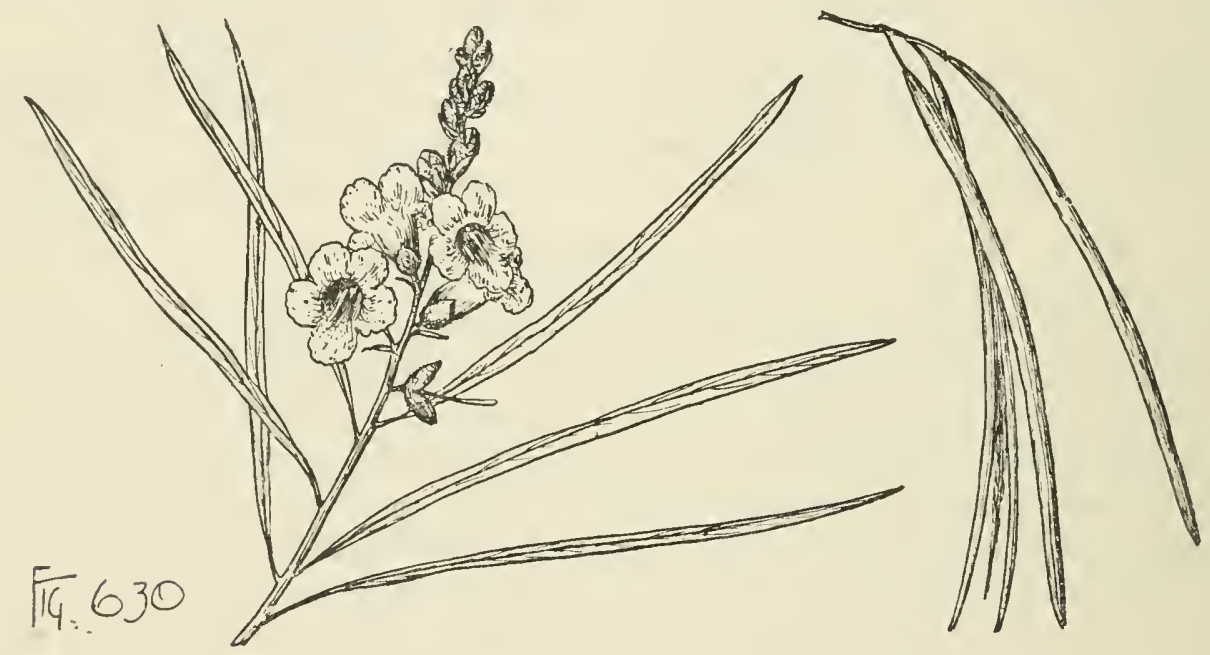

light chestnut-brown during their first season, later becoming darker and tinged with red, or sometimes ashy gray; or often a straggling shrub. Bark of the trunk $\frac{1^{\prime}}{8}-\frac{1}{4}^{\prime}$ thick, dark brown and divided into broad branching ridges broken on the surface into small thick plate-like scales. Wood soft, not strong, close-grained, brown streaked with yellow, with thin light-colored sapwood of 2 or 3 layers of annual growth.

Distribution. Banks of streams, and depressions in the desert, usually in dry gravelly porous soil; valley of the lower Rio Grande, through western Texas, southern New Mexico, Arizona, southern Utah and Nevada, to San Diego County, California, and northern Mexico.

Occasionally cultivated as an ornamental plant in the southern states, and in Mexico.

\section{CATALPA, Scop.}

Trees, with stout terete branchlets with thick pith, without terminal buds, minute globose axillary buds nearly immersed in the bark and covered by numerous scales, 
the inner accrescent, thin scaly bark, soft light-colored wood, and fibrous roots. Leaves opposite or in verticels of 3 , involute in the bud, entire or lobed, oblongovate, of ten cordate, long-petiolate, deciduous. Flowers on slender bracteolate pedicels, in terminal compound trichotomously branched panicles or corymbs, with linear-lanceolate deciduous bracts and bractlets; calyx membranaceous, subglobose, closed and apiculate in the bud, in anthesis splitting nearly to the base into 2 broadly ovate entire pointed apiculate lobes; corolla thin, membranaceous, variously marked and spotted on the inner surface, inserted on the nearly obsolete disk, the tube broad, campanulate, occasionally furnished on the upper side near the base with an external lobed appendage, and oblique and enlarged above into a broad bilabiate limb, with spreading lips undulate on the margins, the posterior 2-parted, the anterior deeply 3-lobed; stamens and staninodia inserted near the base of the corolla; stamens 2, anterior, included or slightly exserted; filaments flattened, arcuate; anthers oblong, carried to the rear of the corolla and face to face on either side of the stigma by a half turn of the filaments near their base, the cells divergent in anthesis; staminodia 3, free, filiform, minute or rudimentary; ovary 2-celled, sessile on the hypogynous nearly obsolete disk, abruptly contracted into an elongated filiform style divided at the apex into 2 stigmatic lobes exserted above the anthers; ovules inserted in many series on a central placenta. Fruit an elongated subterete capsule tapering from the middle to the ends, persistent on the branches during the winter, and ultimately splitting loculicidally into 2 valves. Seeds numerous, compressed, oblong, inserted in 2-4 ranks near the margin of the flat or more or less thickened woody septum free from the walls of the capsule; seed-coat thin, light brown or silvery gray, longitudinally veined, produced into broad lateral wings notched at the base of the seed and divided at their narrowed or rounded ends into tufts of long coarse white hairs; cotyledons plane, broader than long, slightly 2-lobed, rounded laterally; radicle short, erect, turned toward the oblong conspicuons basal hilum.

Catalpa with seven species is confined to the eastern United States, the West Indies, and eastern China, two of the species being North American. Catalpa contains a bitter principle and is a tonic and diuretic, and produces soft straight-grained durable wood.

The generic name is that by which one of the North American species was known anong the Cherokee Indians.

\section{CONSPECTUS OF THE NORTH AMERICAN SPECIES.}

Flowers in many-flowered crowded panicles; calyx glabrous; curolla thickly spotted on the inner surface; fruit slender, thin-walled; leaves short-acuminate.

1. C. Catalpa (C).

Flowers in few-flowered open panicles; calyx often sparingly villose or pubescent ; corolla inconspicuously spotted; fruit stout, thick-walled; leaves caudate-acuminate.

2. C. speciosa $(A, C)$.

\section{Catalpa Catalpa, Karst. Catalpa. Indian Bean.}

Leaves broadly ovate, rather abruptly contracted into slender points or sometimes rounded at the apex, cordate at the base, entire or often laterally lobed, when they unfold coated below with pale tomentum and pilose above, and at maturity thin and firm, light green and glabrous on the upper, pale and pubescent on the lower surface, $5^{\prime}-6^{\prime}$ long and $4^{\prime}-5^{\prime}$ wide, with prominent midribs and primary veins arcuate near the margins, connected by reticulate veinlets and furnished in the 
axils with elusters of dark liairs, turning black and falling after the first severe frost in the autumn; their petioles stout, terete, $5^{\prime}-6^{\prime}$ in length. Flowers on slender sparingly villose or glabrous pedicels, in compact many-flowered panicles $8^{\prime}-10^{\prime}$ long and broad, with light green branches tinged with purple; ealyx $\frac{1}{2}$ long, glabrous, green or light purple ; corolla white, nearly $2^{\prime}$ long, $1_{\frac{1}{2}}^{\prime}$ wide, marked on the

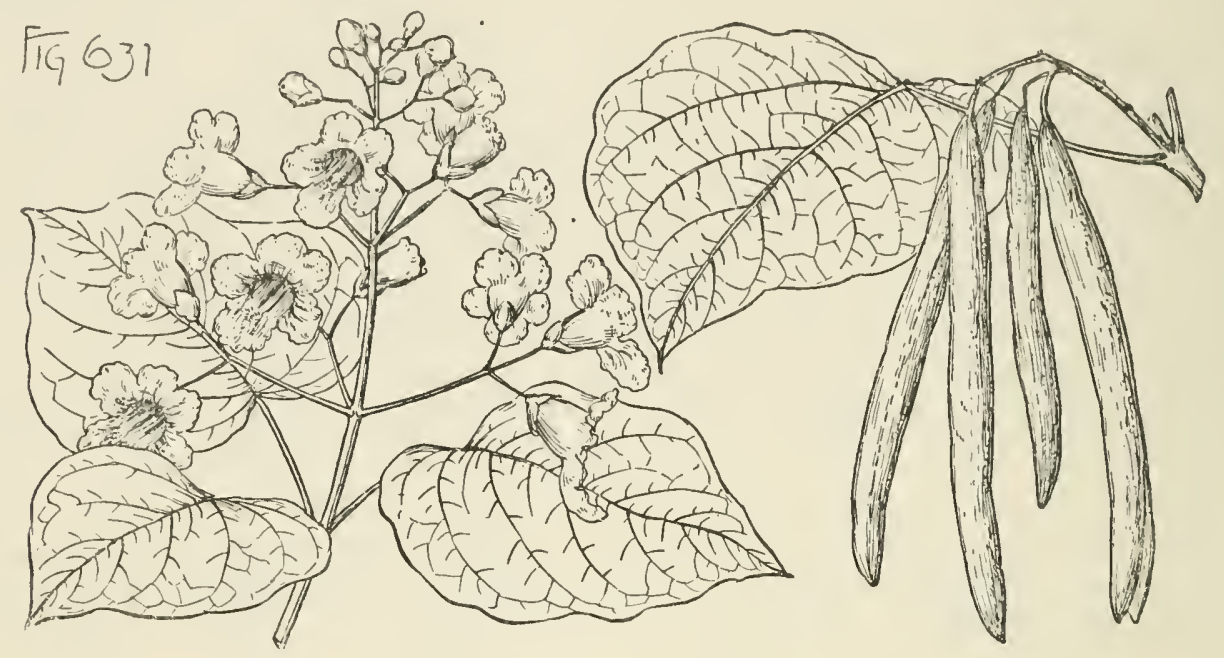

inner surface on the. lower side by 2 rows of yellow blotches following 2 parallel ridges or folds, and in the throat and on the lower lobes of the limb by crowded conspicuous purple spots. Fruit ripening in the autumn, in thick-branched orangecolored panicles, remaining unopened during the winter, $6^{\prime}-20^{\prime}$ long, and $\frac{1}{4}^{\prime}-\frac{1^{\prime}}{3}$ thick in the middle, with a thin wall bright chestnut-brown on the outer surface and light olive-brown and lustrous on the inner surface, splitting in the spring into 2 flat valves; seeds about $1^{\prime}$ long, $\frac{1^{\prime}}{4}$ wide, silvery gray, with pointed wings terminating in long peneil-shaped tufts of white hairs.

A tree, rarely $60^{\circ}$ high, with a short trunk $3^{\circ}-4^{\circ}$ in diameter, long heavy brittle branches forming a broad head, and dichotomous branchlets green shaded with purple when they first appear, and during their first winter thickened at the nodes, slightly puberulous, lustrous, light orange color or gray-brown, covered with a slight glaucous bloom, marked by large pale scattered lenticels, and by large oval elevated leaf-scars containing a circle of conspicuous fibro-vascular bundle-scars and persistent until the third or fourth year, when the branches are reddish brown and marked by a network of thin flat brown ridges. Winter-buds covered by chestnut-brown broadly ovate rounded slightly puberulous loosely imbricated scales, those of the inner ranks when fully grown bright green, pubescent, and sometimes 2 ' in length. Bark of the trunk $\frac{1}{4}^{\prime}-\frac{1}{3}^{\prime}$ thick, and light brown tinged with red, separating on the surface into large thin irregular scales. Wood soft, not strong, coarse-grained, very durable in contact with the soil, light brown, with lighter colored often nearly white sapwood of 1 or 2 layers of annual growth; used and lighly valued for fenceposts and rails.

Distribution. Usually supposed to be indigenous on the banks of the rivers of southwestern Georgia, western Florida, and central Alabama and Mississippi, and now widely naturalized through the south Atlantic states.

Often planted for the dccoration of parks and gardens in the eastern United 
States, and hardy as far north as easteru New Eugland, and iu westeru, central, and southern Europe.

\section{Catalpa speciosa, Engelm. Western Catalpa.}

Leaves oval, long-pointed, cordate at the base, and usually entire or furnished with 1 or 2 lateral teeth, when they unfold pilose above and covered below and on the petioles with pale or rufous tomentum, and at maturity thick and firm, dark green above and covered with soft pubescence below, especially along the stout midribs and the primary veins marked in their axils by large clusters of dark glands, $10^{\prime}-$ $12^{\prime}$ long, $7^{\prime}-8^{\prime}$ wide, turning black and falling after the first severe frost of the autumn; their petioles stout, terete, $4^{\prime}-6^{\prime}$ in length. Flowers appearing late in May or early in June, on slender purple glabrous pedicels furnished near the middle with 1-3 bractlets, in open few-flowered panicles $5^{\prime}-6^{\prime}$ long and broad, with green or purple branches marked by orange-colored lenticels, the lowest branches often in the axils of small leaves; calyx purple, often sparingly villose or pubescent on the outer surface; corolla white, conical, often spotted externally with purple near the base, about $2^{\prime}$ long and $2 \frac{1^{\prime}}{2}$ wide, and marked internally on the lower

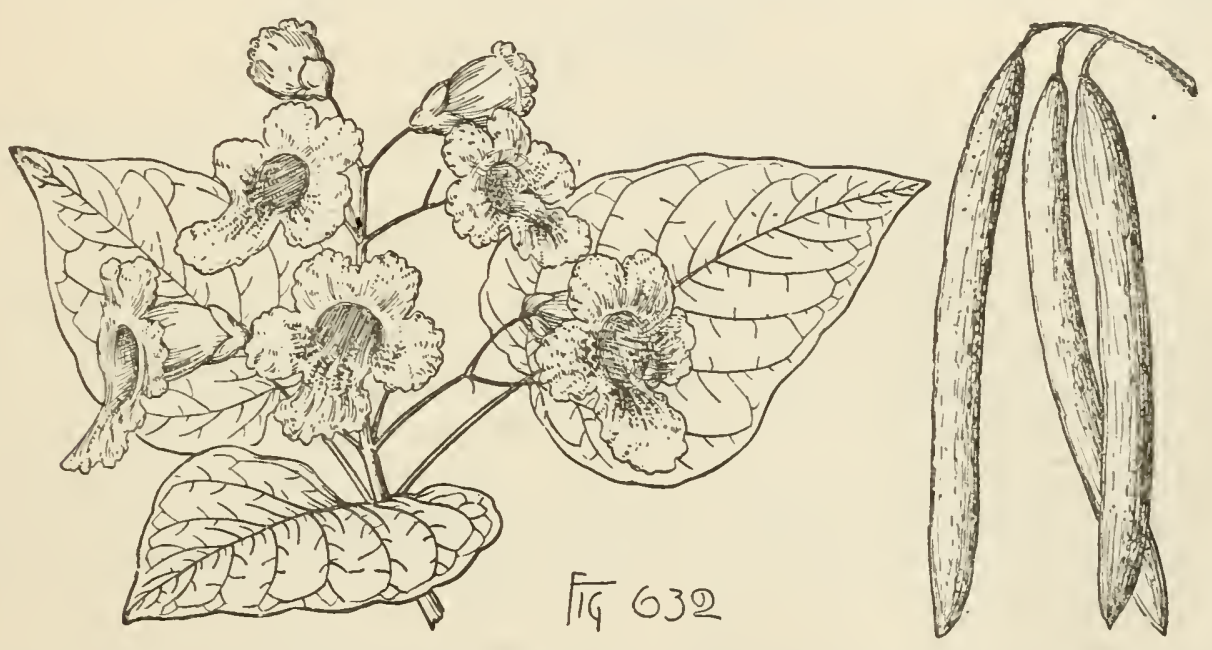

side by 2 bands of yellow blotches following 2 lateral ridges and with occasional purple spots spreading over the lobes of the lower lip of the limb; filaments marked near the base by oblong purple spots. Fruit $8^{\prime}-20^{\prime}$ long, $\frac{1^{\prime}}{2}-\frac{3}{4}$ in diameter near the middle, with a thick wall splitting toward spring into 2 concave valves; seeds $1^{\prime}$ long, $\frac{1}{3}^{\prime}$ wide, with a light brown coat and wings rounded at the ends and terminating in a fringe of short hairs.

A tree, in the forest occasionally $120^{\circ}$ high, with a tall straight truuk rarely $4 \frac{1}{2}{ }^{\circ}$ in diameter, slender branches forming a narrow round-topped head, and branchlets light green often tinged with purple and pilose, with scattered pale hairs, when they first appear, light orange color or reddish brown, covered with a slight bloom, during their first winter, and marked by numerous conspicuons pale lenticels and by the elevated oval leaf-scars $\frac{1^{\prime}}{4}$ long, displaying a circular row of large fibrovascular bundle-scars, becoming darker in their second and third years; usually smaller, and in open situations rarely more than $50^{\circ}$ high, with a short trunk and a broad head of spreading branches. Winter-buds covered by loosely imbricated ovate chestnut-brown scales keeled on the back, slightly apiculate at the apex, those 
of the inner ranks at maturity foliaccous, obovate, acute, gradually narrowed below to a sessile base, many-nerved, with dark veins, pubesecnt on the lower surface, and

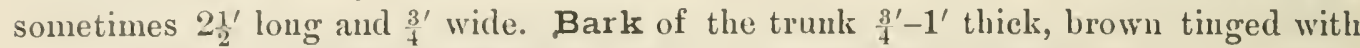
red, and broken on the surface into thick scales. Wood light, soft, not strong, coarse-grained, very durable in contact with the soil, light brown, with thin ncarly white sapwood of 1 or 2 layers of ammal growth; largely used for railway-ties, fence-posts, and rails, and occasionally for furniture and the interior finish of houses.

Distribution. Borders of streams and ponds, and fertile often inundated bottom-lands; valley of the Vermilion River, Illinois, through southern Illinois and Indiana, western Kentucky and Temnessee, southeastern Missouri and northeastem Arkansas; very abundant and probably of its largest size in sonthern Illinois and Indiana; naturalized through cultivation in southerı Arkansas, western Louisiana, and eastern Texas.

Often planted in the prairie region of the Mississippi basin as a timber-tree, and as an ornament of parks and gardens in the eastern states, and now in many other regions with temperate climates.

\section{CRESCENTIA, I.}

Trees, with scaly bark, and stout slightly angled branchlets. Leaves alternate, short-petiolate, persistent. Flowers solitary, or in few-flowered fascicles on long bibracteolate peduncles from the axils of upper leaves or from the sides of the branches; calyx coriaceous, splitting iu anthesis into 2 unequal broad divisions, or sometimes slightly 5-lobed, decidnous; corolla inserted under the hypogynous pulvinate fleshy disk, yellow streaked with purple, or dingy purple, tubular-campanulate, more or less ventricose on the lower side by a transverse fold, abruptly dilated into an oblique 2-lipped obscurely 5-lobed laciniately toothed limb; stamens 4, inserted in 2 ranks on the tube of the corolla, in pairs of different lengths, introrse, included or slightly exserted; filaments filiform; anthers oblong, the cells divergent; staminodium solitary, posterior, often 0 ; ovary sessile, 1 -celled, ovate-conical, gradnally narrowed into an elongated simple exserted style 2-lobed at the apex, the lobes stigmatic on their imner face; ovules in many ranks on 2 thickened 2-lobed lateral parietal placentas. Fruit baccate, many-seeded, with flesh ultimately becoming hard, light brown and separable into 2 layers, the inner thin and metmbranaceous, filled with the mited and thickened fleshy or spongy placentas attached at the base by a cluster of thick fibro-vascular bnndles. Seeds imbedded irregularly in the placental mass, compressed, suborbicular, cordate above and below and deeply grooved on the 2 faces; embryo filling the seminal cavity, flattened, and thick and fleshy, deeply grooved, becoming black in drying; radicle minute, turned toward the hilum.

Crescentia with five or six species is tropical American, and is distributed from southern Florida through the Antilles to southern Mexico and to Brazil. The Calabash-tree, Crescentia Cujete, L., a native of the West Indies, and now planted in all tropical countries, is the most useful member of the genus. The hard woody shell is largely used for drinking-cups, vases, and all sorts of domestic vessels; the pulp is emollient and astringent, and the wood is used in cabinet-making.

The generic name is in honor of Pietro de' Crescenzi (1233-1320), the distinguished Italian writer on agriculture. 


\section{Crescentia cucurbitina, L. Black Calabash Tree.}

Leaves crowded near the ends of the branches, obovate-oblong or ovate-oblong, contracted into short broad points or rarely rounded or emarginate at the apex, gradually narrowed at the base, and entire, with cartilaginous slightly revolute margins, coriaceous, dark green and lustrous above, paler and yellow-green below, $6^{\prime}-8^{\prime}$ long and $1 \frac{1}{2}^{\prime}-4^{\prime}$ wide, with broad stout midribs deeply impressed on the upper side,

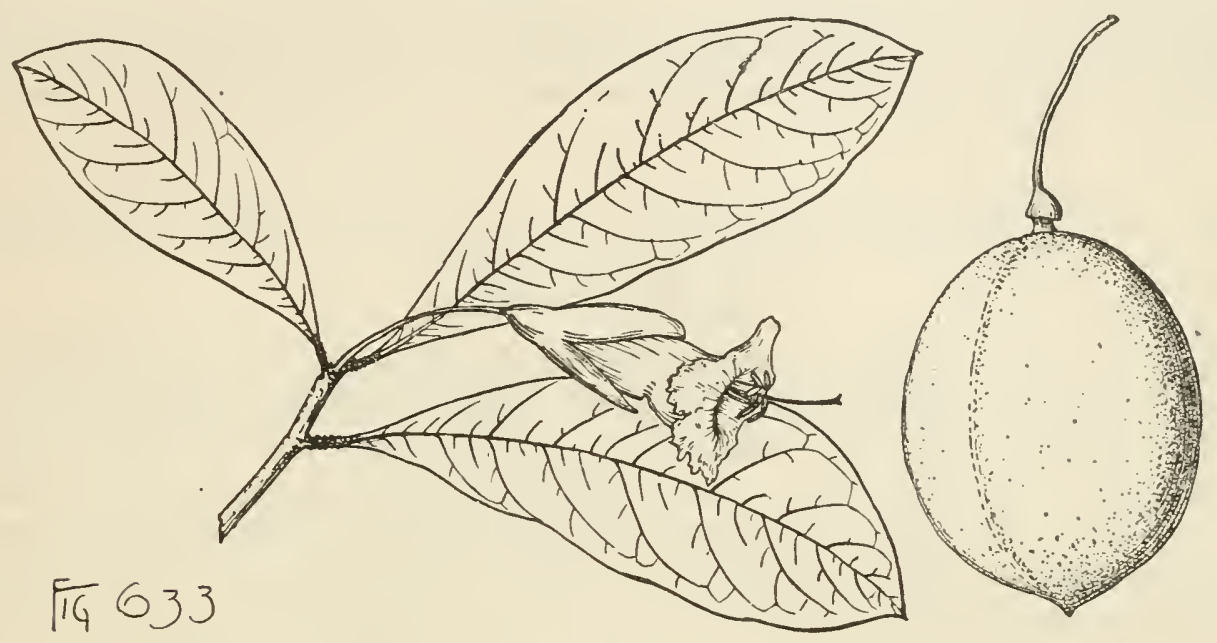

conspicuous primary veins arcuate and united near the margins, and reticulate veinlets, unfolding in the spring and persistent until their second year; their petioles thick, covered with glands, and about $\frac{1^{\prime}}{4}$ long. Flowers appearing in April and May and also in the autumn, bad-smelling, on thick drooping peduncles solitary in the axils of the upper leaves, $1 \frac{1}{2}^{\prime}-2^{\prime}$ long, furnished below the middle with 2 minute rigid acute bractlets and enlarged at the apex into the thick oblique receptacles; calyx light green and slightly glandular at the base, splitting nearly to the bottom into 2 ovate pointed lobes nearly as long as the tube of the corolla; corolla thick and leathery, dull purple or creainy white, and marked by narrow purple bands on the lower side, and $2^{\prime}$ long, with a narrow tube creamy white within and slightly contracted above the base, the limb erosely cut on the margins and obscurely 2-lipped, the upper lip slightly divided into 2 reflexed lobes, the lower obscurely 3-lobed; stamens inserted near the middle of the tube of the corolla, those of the anterior pair below the others and above the linear staminodium; ovary obliquely conical. Fruit ovate or oblong, $3^{\prime}-4^{\prime}$ long, $11_{2}^{\prime}-2^{\prime}$ wide, umbonate, dark green, minutely rugosepunctulate, and marked with 4 obscure longitudinal ridges corresponding with the margins and midribs of the carpellary leaves, raised on the thickened woody disk and pendent on a stout drooping stalk $1 \frac{1}{2}-2^{\prime}$ long and much enlarged at the apex; shell $\frac{1}{1 \frac{1}{16}}$ thick, ultimately hard and brittle, lustrous on the outer surface and lined with a thin membranaceous shining light brown coat marked by the broad placental scars; seeds $\frac{5^{\prime}}{8}$ long and broad and $\frac{1}{4}^{\prime}$ thick, with a minute lateral hilum just above the basal sinus; seed-coat of 2 layers, the outer thin, dark reddish brown, rugose, and separable from the thick pale felt-like inner layer; cotyledons with 2 ear-like folds near the base, inclosing the radicle in their lower sinus.

A tree, in Florida $18^{\circ}-20^{\circ}$ ligh, with a trunk $4^{\prime}-5^{\prime}$ in diameter, long slender drooping branches covered with wart-like excrescences, and stout slightly angled branch- 
lets roughened and somewhat cnlarged at the nodes by the thiekening of the large erowded enp-shaped persistent woody bases of the leaves, and covered with thin creany white bark becoming dark or ashy gray in their third year. Winter-buds with linear acnte apiculate scales becoming woody, and persistent for one or two years. Bark of the trmk about $\frac{1}{8}$ thiek, light brown tinged with red, and irregularly divided into large thin scales. Wood heavy, hard, very close-grained, thin, light brown or orange color, with lighter colored sapwood.

Distribution. Florida only near the shores of Bay Biscayme on rich hummocks; conmmon on the shores of the Bahamas and of many of the Antilles, and sonthward to souther'u Mexieo, the Pacific coast of the Isthmus of Panama, and to Venezuela.

\section{B. Ovary inferior (partly superior in Caprifoliacece).}

\section{RUBIACE丹.}

Trees or shrubs, with watery juice, and opposite simple entire leaves turning black in drying, with stipules. Flowers regular, perfect; calyx-tube adnate to the ovary, its limb 4 or 5 -lobed or toothed; corolla 4 or 5 -lobed; stamens inserted on the tube of the corolla, as many as and alternate with its lobes; filaments free, or united at the base; anther's introrse, 2-celled, the cells opening longitudinally; disk epigynous, annular; ovary inferior; style slender; ovules numerous, or 1 in each cell; raphe ventral ; micropyle superior. Fruit capsular, akene-like, or drupaceous. Seeds with albumen; seed-coat membranaceous.

The Madder family with some three hundred and fifty genera is chiefly tropical, with a few herbaceous genera confined exclusively to temperate regions. To this family belong the Coffee, the Cinchonas, South American trees yielding quinine from their bark, and the plant which produces ipecacuanha, a species of Cephaelis and a native of Brazil, the Gardenia and several other plants cultivated for their fragrant flowers.

\section{CONSPECTUS OF THE ARBORESCENT GENERA OF THE UNITED STATES.}

Fruit a capsule ; seeds numerous, surrounded by a wing; parts of the flower in 5's.

Calyx 5-lobed, the lobes unequal, sometimes developing into rose-colored leaf-like bodies ; filaments free, wing of the seeds broad, oblong-ovate, unsymmetrical on the sides; leaves deciduous.

1. Pinckneya.

Calyx 5-toothed ; filaments united into a short tube ; wing of the seed narrow, symmetrical ; leaves persistent.

2. Exostema.

Fruit akene-like, 1 or 2-seeded ; parts of the flower in 4's or rarely in 5's, flowers in pedunculate globose heads; leaves deciduous.

3. Cephalanthus. Fruit drupaceous, with a 4-celled stone; parts of the flower in 4's ; leaves persistent.

4. Guettarda.

\section{PINCKNEYA, MichX.}

A tree, with fibrous roots, scaly light brown bitter bark, resinous scaly buds, stout terete pithy branchlets eoated while young with hoary tomentum, becoming glabrous, and marked by seattered minute white lenticels and large nearly orbicular or obeordate leaf-scars displaying a luuate row of numerous erowded fibro-vascular bundlesears. Leaves complanate in the bud, oblong-oval or ovate, acute at the apex, wedgeshaped at the base, and gradually narrowed into long stout petioles, membranaceous, 
coated at first with pale pubescence, and at maturity dark green and puberulous above, paler and puberulous below, especially along the stout midribs and primary veins, deciduous; stipules interpetiolar, conspicuously glandular-punctate at the base on the inner face, inclosing the leaf in the bud, triangular, subulate, pink, becoming oblong, acute, scarious, light brown, caducous. Flowers in pedunculate terminal and axillary pubescent trichotomous few-flowered cymes, with linear-lanceolate acute bracts and bractlets at first pink, becoming scarious, deciduous, or sometimes enlarging and rose-colored; flower-buds sulcate, coated with thick pale tomentum; calyx-tube clarate, bracteolate at the base, covered with hoary tomentum, not closed in the bud, the limb 5-lobed, with subulate-lanceolate lobes green tinged with pink, scarious, or in the central flower of the ultimate division of the cyme with 1 or rarely with 2 of the lobes produced into oval or ovate acute rose-colored puberulous membranaceous leaf-like bodies, deciduons; corolla salver-form, light yellow, cinereotomentose, with a long narrow tube somewhat enlarged in the throat, 5-lobed, the lobes valvate in the bud, oblong, obtuse, marked by red lines and pilose, with long white hairs on the inner surface, recurved after anthesis; stamens exserted; filaments filiform, free; anthers oblong, emarginate; ovary 2-celled; style filiform, exserted, slightly enlarged, 2-lobed and stigmatic at the apex; ovules numerous, inserted in 2 ranks on a thin 2-lipped placenta longitudinally adnate to the inner face of the cell. Fruit a subglobose obscurely 2-lobed 2-celled capsule, loculicidally 2-valved, the valves thin and papery, light brown, puberulons, especially at the base, faintly rayed, marked by oblong pale spots and by the scars left by the falling of the deciduous calyx limb and style, sometimes tardily septicidally 2-parted to the niddle, persistent on the branches during the winter, the valves finally falling from the woody axis, their onter layer very thin, brittle, separable from the slightly thicker tough woody inner layer. Seeds horizontal, 2-ranked, minute, compressed; seed-coat thin, light brown, reticulate-veined, produced into a broad thin oblong-ovate wing, unsymmetrical on the sides, acute at the apex, and larger above than below the seeds; embryo elongated, immersed in the thick fleshy albumen; cotyledons ovate-oblong, foliaceous, larger than the terete radicle turned toward the hilum.

The genus is represented by a single species of the sonthern United States.

The generic name is in honor of Charles Cotesworth Pinckney (1746-1825) of South Carolina, the Revolutionary patriot.

\section{Pinckneya pubens, Michx. Georgia Bark.}

Leaves unfolding in March, $5^{\prime}-8^{\prime}$ long, $3^{\prime}-4^{\prime}$ wicie, their petioles $\frac{2^{\prime}}{3}-1 \frac{1^{\prime}}{2}$ in length. Flowers $1 \frac{1}{2}$ long appearing late in May and early in Jume, in open clusters $\tau^{\prime}-S^{\prime}$ across, their petaloid calyx-lobes sometimes $2 \frac{1}{2}^{\prime}$ long and $\frac{1}{2}^{\prime}$ wide. Fruit ripening in the autumn $1^{\prime}$ long and $\frac{2}{3}^{\prime}$ wide; seeds with their wings about $\frac{1}{2}^{\prime}$ long and $\frac{1}{3}^{\prime}$ wide.

A tree, $20^{\circ}-30^{\circ}$ high, with a trunk occasionally $8^{\prime}-10^{\prime}$ in diameter, slender spreading branches forming usually a narrow round-topped head, and branchlets coated when they first appear with hoary tomentum, soon turning light red-brown, pubescent during the summer, and slightly puberulous during their first winter, ultimately becoming glabrous. Winter-buds: terminal ovate, terete, $\frac{1^{\prime}}{2}$ long, contracted above the middle into slender points, and covered with the dark red-brown lanceolate-acnte stipules of the last pair of leaves of the previous year, often persistent at the base of the growing shoots and marked at the base by 2 broadly ovate pale scar-like slightly pilose elevations; axillary obtuse, minnte or nearly immersed in the bark. Bark of the trunk about $\frac{1^{\prime}}{4}$ thick, with a light brown surface divided into minute appressed 


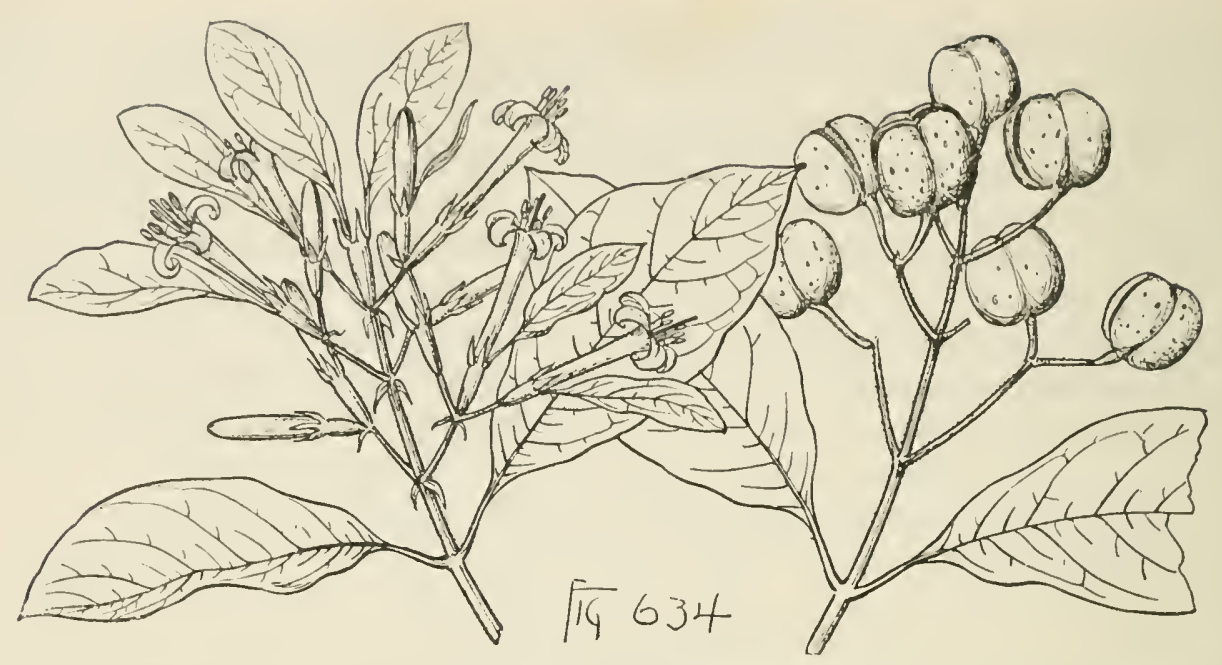

scales. Wood close-grained, soft, weak, brown, with lighter-colored sapwood of 8-10 layers of annual growth. The bark has been used in the treatment of intermittent fevers.

Distribution. I South Carolina to the basin of the upper Appalachicola River and its tributaries in Florida and Georgia; rare and local.

\section{EXOSTEMA, Rich.}

Trees or shrubs, with terete branchlets, and bitter bark. Leaves sessile or petiolate, persistent; stipules interpetiolar, deciduous. Flowers axillary, fragrant, pedunculate, the peduncles bibracteolate above the middle; calyx-tube ovoid, clavate or turbinate, the limb short, 5-lobed, its lobes nearly triangular, persistent; corolla 5-lobed, white, funnel-shaped, the tube long and narrow, erect, the lobes of the limb linear, elongated, spreading, imbricated in the bud; filaments filiform, united at the base into a tube inserted on and adnate to the tube of the corolla; anthers oblong, linear; ovary 2-celled; style elongated, slender, exserted; stigma capitate, simple or minutely 2-lobed; ovules numerous, attached on the 2 sides of a fleshy oblong peltate placenta fixed to the inner face of the cell, ascending. Fruit a manyseeded 2-celled capsule septicidally 2-valved, the valves 2-parted, their outer layer membranaceous, separable from the crustaceous inner layer. Seeds compressed, oblong, imbricated downward on the placenta; seed-coat chestnut-brown, lustrous, produced into a narrow wing; embryo minute, in fleshy albumen; cotyledons flat; radicle terete, inferior.

Exostema with abont twenty species is confined to the tropics of America, and is most abundant in the Antilles, one species reaching the shores of southern Florida. The bark contains active tonic properties, and has been used as a febrifuge.

The generic name, from ${ }^{\prime} \xi \omega$ and $\sigma \tau \tilde{\eta} \mu \alpha$, relates to the long exserted stamens.

\section{Exostema Caribæum, R. \& S. Prince Wood.}

Leaves oblong-ovate to lanceolate, contracted into slender points and apiculate at the apex, wedge-shaped and gradnally narrowed at the base, entire, thick and coriaceous, dark green on the upper surface and yellow-green on the lower, $1 \frac{1}{2}{ }^{\prime}-3^{\prime}$ long and $\frac{1}{2}-1 \frac{1}{4}$ wide, with prominent orange-colored midribs and conspicuous reticulate 
veinlets, unfolding in the autumn and in early spring and summer, and persistent for 1 or 2 years; their petioles slender, orange-colored, $\frac{1}{4}^{\prime}-\frac{1}{2}^{\prime}$ long; stipules nearly triangular, apiculate, with entire dentate or ciliate margins, about $\frac{1^{\prime}}{1 \overline{6}}$ long, and in falling marking the branchlets with ring-like scars. Flowers appearing from March until June, about 3 ' long, on 1-flowered peduncles; calyx-tube ovate; corolla glabrous; filaments united into a short tube. Fruit $\frac{2 \prime}{3}$ long, becoming black in drying; seeds oblong, $\frac{1}{8}$ long, with a dark brown papillose coat and a light browu wing.

A glabrous tree, in Florida sometimes $20^{\circ}-25^{\circ}$ high, with a trunk $10^{\prime}-12^{\prime}$ in diameter, slender erect branches forming a narrow head, and terete branchlets dark green

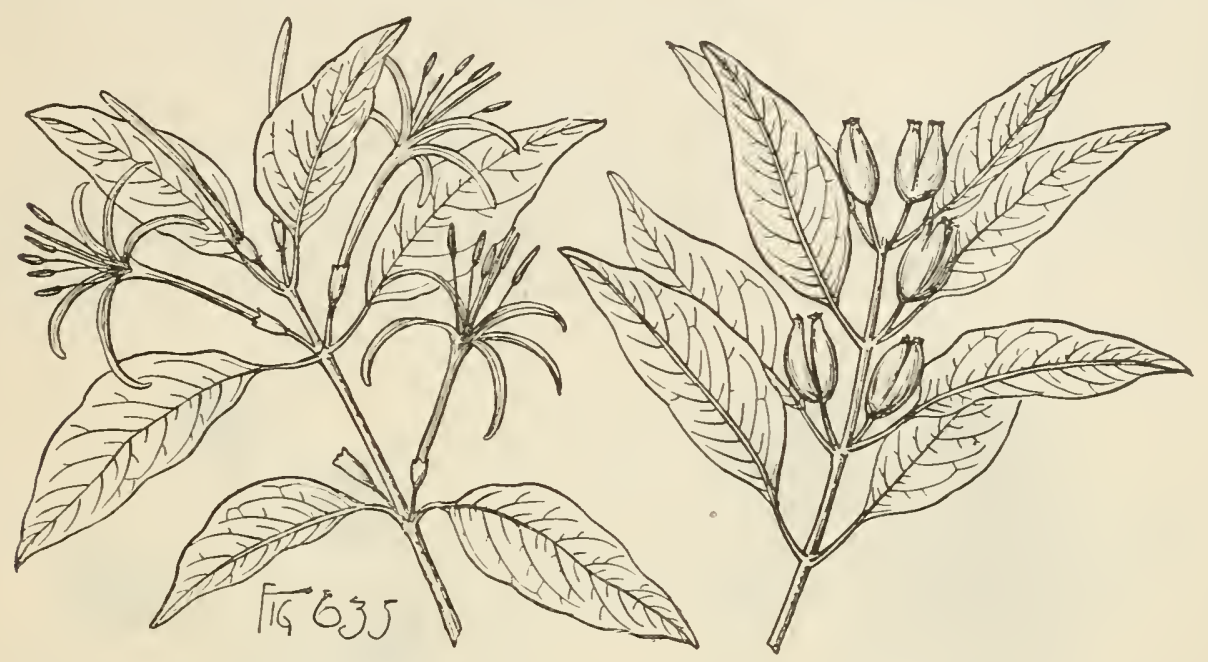

at first, soon becoming dark red-brown and covered with pale lenticels, and in their second year ashy gray and conspicuously marked by the elevated leaf-scars. Bark of the trunk about $\frac{1^{\prime}}{8}$ thick, and divided by deep fissures into square smooth pale or nearly white plates. Wood very heavy, exceedingly hard, strong, close-grained, light brown handsomely streaked with different shades of yellow and brown, with bright yellow sapwood of 12-20 layers of annual growth.

Distribution. Keys of southern Florida; abundant on Key West and Upper Metacombe Keys; also on many of the Antilles, in sonthern Mexico, and on the west coast of Nicaragua.

\section{CEPHALANTHUS, L.}

Small trees or shrubs, with opposite or verticillate petiolate leaves, interpetiolar stipules, and scaly buds. Flowers nectariferous, yellow or creamy white, sessile in the axils of glandular bracts, in dense globose pedunculate terminal or axillary solitary or panicled heads; receptacle globose, setose; calyx-tube obpyramidal, with a short limb unequally 4 or 5-toothed or lobed; corolla tubular funnel-form, divided into 4 or 5 short spreading or reflexed lobes nsually furnished with a minute dark gland at the base or on the side of each sinus, puberulous on the imner surface of the tube, the lobes imbricated in the bud; stamens inserted on the throat of the corolla; filaments short; anthers linear-oblong, sagittate, apiculate at the base; pistil of 2 carpels; ovary 2-celled; style filiform, elongated; stigma clavate, entire; ovule solitary in each cell, suspended from the apex of the cell on a short papillose funicle. Fruit obpyramidal, coriaceous, 2-coccous. Seeds oblong, pendulous, covered at the 
apex by a white spongy aril; cmbryo straight in cartilaginous albumen; cotyledons oblong, obtuse; radicle clongated, superior.

Cephalanthus with five species is widely distributed in North and Soutl America, and in sonthern and eastern Asia, and the Malay Archipelago.

The gencric name, from $\kappa € \phi \alpha \lambda \dot{\eta}$ and $\alpha \nu \theta o s$, relates to the capitate inflorescence.

\section{Cephalanthus occidentalis, $\boldsymbol{L}$. Button Bush.}

Leaves ovate or lanceolate, acute, acuminate or short-pointed at the apex, rounded or cuneate at the base, membranaceous, dark green on the upper, paler and glabrous or puberulous on the lower surface, $4^{\prime}-7^{\prime}$ long and $1^{\prime}-3 \frac{1^{\prime}}{2}$ wide, with stout light yellow midribs and 5 or 6 pairs of slender primary veins nearly. parallel with the sides of the leaf, deciduous or persistent during the winter; their petioles stout, grooved, glabrous or puberulons, $\frac{1^{\prime}}{2}-\frac{3}{4}$ in length; stipules minute, nearly triangular. Flowers: flower-heads panicled, $1^{\prime}-1 \frac{1}{2}^{\prime}$ in diameter; flowers creamy white, very fragrant, opcning from the middle of May in Florida and Texas to the middle of August in Canada and on the mountains of California; calyx usually 4 or occasionally 5-lobed, with short rounded lobes, and slightly villose toward the base; corolla glandular or

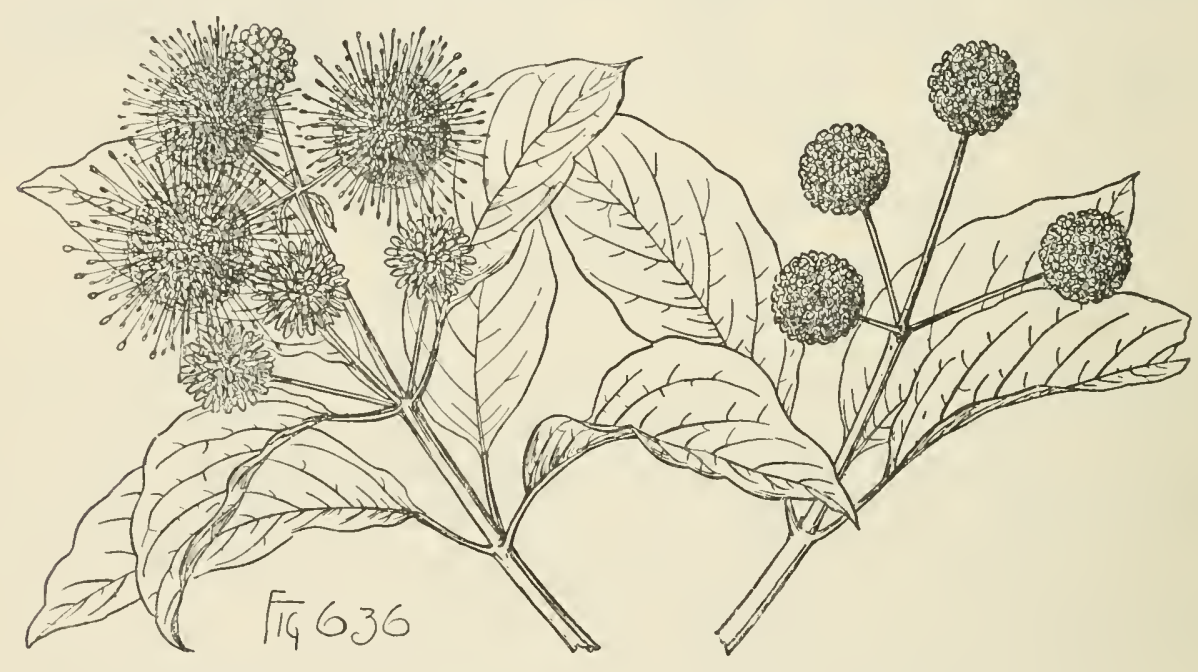

eglandular; anthers nearly sessile, included, discharging their pollen before the flowers open; disk thin and obscure. Fruit ripening late in the autumn in heads $\frac{5^{\prime}}{8}-\frac{3^{\prime}}{4}$ in diameter, green tinged with red and ultimately dark red-brown.

A tree, occasionally $40^{\circ}-50^{\circ}$ high, with a straight tapering trunk a foot in diameter, and frequentiy free of limbs for $15^{\circ}-20^{\circ}$, ascending and spreading branches, and stout branchlets with a thick pith, glabrous and marked by large oblong pale lenticels and developed mostly in verticels of 3's from the axillary buds of one of the upper nodes, withoui terminal buds, light green when they first appear, pale reddish brown, covered with a glaucous bloom during their first winter and then marked by small semicircular leaf-scars displaying semilunate fibro-vascular bundle-scars, and connected by the persistent black stipules or by their subulate scars, darker the following season, and dark brown in their third year, the bark then beginning to separate into the large loose scales found on the large branches and on the stems of small plants; usually a shrub, only a few feet high. Winter-buds axillary, single or in pairs or in 3's one above the other, minute, nearly immersed in 
the bark. Bark of large trunks dark gray-brown or often nearly black, divided by deep fissures into broad flat ridges broken on the surface into elongated narrow scales. The bark contains tannin, and has been used in the treatment of fevers and in homœopathic practice.

Distribution. Swamps and the low wet borders of ponds and streams; New Brunswick to Ontario and eastern Nebraska and Kansas, southward to Florida, Texas, New Mexico, and Arizona, and widely distributed in California; also in Mexico and Cuba; very rarely arborescent at the north and of its largest size on the margins of river-bottoms and swamps, and in pond holes in southern Arkansas and eastern Texas.

Occasionally cultivated in the northeastern states as an ornamental plant.

\section{GUETTARDA, Endl.}

Small trees or shrubs, with bitter bark, opposite or rarely verticellate leaves, interpetiolar deciduous stipules, and scaly buds. Flowers sessile, with or without bracts, in axillary forked pedumculate cymes, their bracts and bractlets lanceolate, acute, minute, deciduous; calyx globose, the limb produced above the ovary into an elongated 4-lobed tube; corolla salver-shaped, with an elongated cylindrical tube naked in the throat, and a 4-lobed limb, the oblong lobes imbricated in the bud; stamens included; filaments free, short; anthers oblong-linear; ovary 4-celled, the cells elongated, tubular; style stout; stigma capitate; ovule solitary, suspended on the thickened funicle from the inner angle of the cell. Fruit a Heshy 1-stoned 4-9-seeded subglobose drupe, with thin flesh, and a bony or ligneous globose stone obtusely angled or sulcate, 4-9-celled, the cells narrow and often curved upward. Seeds compressed, suspended on the thick funicles closing the orifice of the wall of the stone, straight or excurved; albumen thin and fleshy; embryo elongated, cylindrical or compressed; cotyledons flat, minute, not longer than the elongated terete radicle turned toward the hilum.

Guettarda with about fifty species is chiefly tropical American, with one species widely distributed on maritime shores from eastern tropical Africa to Australia and the islands of the Pacific Ocean. Of the two species found within the territory of the United States one is arborescent. The bark of some of the species is occasionally employed as a tonic and febrifuge, and a few species are cultivated in tropical gardens for the delightful fragrance of their white flowers.

The generic name is in honor of Jean Étienne Guettard (1715-1786), the distinguished French botanist and mineralogist.

\section{Guettarda elliptica, $\mathbf{S w}$.}

Leaves broadly oral to elliptical-oblong, acute or obtuse and apiculate at the apex, and wedge-shaped and rounded at the base, when they unfold covered witb pale silky hairs, and at maturity membranaceous, dark green, pilose or glabrate above, lighter colored and pubescent below, especially along the stont midribs and in the axils of the $4-6$ pairs of primary veins, $\frac{3}{4}^{\prime}-2 \frac{1}{2}^{\prime}$ long and $\frac{1}{2}^{\prime}-1^{\prime}$ wide, unfolding in Florida in May and June and persistent on the branches until the trees begin their growth the following year; their petioles stout, hairy, $\frac{1}{4}^{\prime}-\frac{1}{2}^{\prime}$ in length. Flowers appearing in Florida in June, yellowish white, $\frac{1}{4}$ long, in slender hairy-stemmed cymes from the axils of leaves of the year near the ends of the branches, or from bud-scales at the base of young shoots, their peduncles shorter than the leaves, 
forked near the apex, with a flower in the fork and 3 at the end of cach branch, or the lateral flowers of thesc clusters replaced by branches producing 3 flowers at their apex, the bractlets subtending the branches of the peduncle, and the lateral flowers of the ultimate divisions of the inflorescence linear-lanceolate, acute, coated

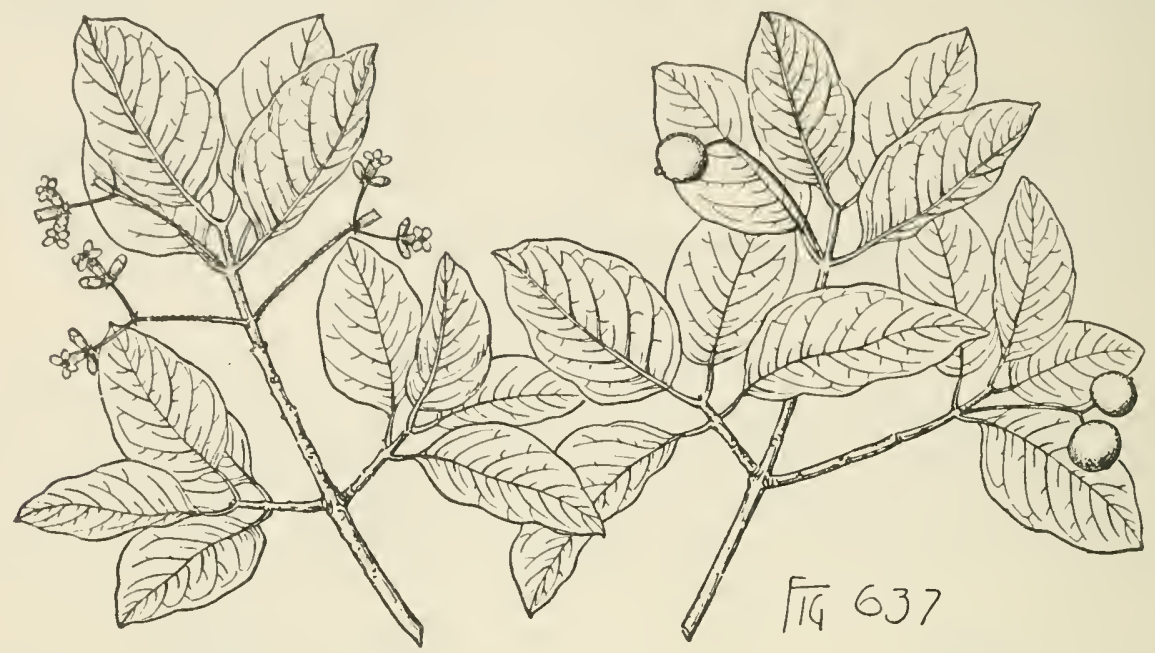

with hairs, about $\frac{1}{16}$ long, deciduous; calyx-lobes nearly triangular, acute, coated on the outer surface with long pale hairs, and half as long as the erect corolla canescent externally, with rounded lobes. Fruit ripening in November, dark purple, pilose, $\frac{1}{3}^{\prime}$ in diameter, crowned with the remiants of the persistent calyx-tube, the flesh sweet and mealy; stone obscurely ridged and usually $2-4$-seeded; seeds oblong-lanceolate, compressed, nearly straight, with a thin pale coat.

A tree, in Florida occasionally $18^{\circ}-20^{\circ}$ high, with an irregularly buttressed or lobed trunk $5^{\prime}-6^{\prime}$ in diameter, the deep depressions between the lobes continuous or often interrupted, small upright branches, and thin terete branchlets coated when they first appear with long pale or rufous hairs and light red-brown or ashy gray and conspicuously marked by pale lenticels, and in their second year by large elevated orbicular leaf-scars. Winter-buds acuminate, light brown, coated with pale pubescence, and about $\frac{1^{\prime}}{8}$ long. Bark of the trunk about $\frac{1^{\prime}}{16}$ thick, with a smooth dark brown surface covered with large irregularly shaped pale blotches and numerous small white spots. Wood heavy, hard, very close-grained, light brown tinged with red, with thin sapwood of 6-10 layers of annual growth.

Distribution. Coast of the southern keys, Florida; also on the Bahama Islands and Jamaica.

\section{CAPRIFOLIACEA.}

Trees or slirubs, with watery juice, opposite petiolate leaves involute in the bud, usually without stipules, scaly buds, and fibrous roots. Flowers regular, perfect, articulated with the pedicels in terminal compound cymes; calyxtube adnate to the ovary, 5-toothed; corolla epigynous, 5-lobed, the lobes imbricated in the bud; stamens 5 , inserted on the tube of the corolla, as many as and alternate with its lobes; filaments slender, free; anthers oblong, introrse, 2 -celled, the cells opening longitudinally; disk 0 (in the arborescent genera of the United States); ovary inferior or partly superior, 3-5 or 1-celled; style short, capitate, 3-5-lobed and stigmatic at the apex; ovule solitary, suspended 
from the apex of the cell, resupinate; raphe dorsal; micropyle superior. Fruit drupaceous, crowned'with the remnants of the style. Seeds with copious fleshy albumen ; seed-coat membranaceous, adherent to the albumen; embryo minute, near' the hilum ; cotyledons ovoid or ovate; radicle terete, erect.

The Honeysuckle family with ten genera is most abundant in the temperate regions of the northern hemisphere, witl a few species extending into the tropics and to beyond the tropics in the southern hemisphere. Many of the species, especially of Lonicera, Sambucus, and Viburnum, are cultivated in gardens for the beauty of their flowers and fruits.

\section{CONSPECTUS OF THE ARBORESCENT GENERA OF THE UNITED STATES.}

Leaves unequally pinnate ; fruit with $3-5$ nutlets.

Leaves simple; fruit with 1 stone.
1. Sambucus.

2. Viburnum.

\section{SAMBUCUS, L. Elder.}

Trees or shrubs, with stout branches containing thick white or dark yellow-brown pith, and scaly buds. Leaves unequally pinnate, deciduous, with serrate or laciniate leaflets, the base of the petioles naked, glandular or furnished with a stipule-like leaflet; stipels small, usually setaceous, often 0 . Flowers small, in broad terminal corymbose cymes, their bracts and bractlets lanceolate, acute, scarious, caducous, the bractlets sometimes 0 ; calyx-tube ovoid, the limb 3-5-lobed or toothed; corolla rotate or slightly campanulate, equally 3-5-parted; stamens 5; filaments filiform or subulate; ovary inferior or partly superior, 3-5-celled; style abbreviated, thick, and conical, 3-5-lobed, and stigmatic at the apex. Fruit subglobose, with juicy flesh, and 3-5 oblong cartilaginous punctate-rugulose 1 -seeded nutlets full and rounded on the back and rounded at the ends. Seeds filling the cavity of the nutlets, pale brown; cotyledons ovoid.

Sambucus with about twelve species is widely and generally distributed through the temperate parts of North America, Europe, and Asia, and inhabits high mountain ranges within the tropics, and Australia, Tasmania, and New Zealand. Of the four North American species two are arborescent. Sambucus possesses cathartic and emetic properties in the bark; the flowers are excitant and suclorific, and the juice of the fruit is alterative and laxative. The dried flowers of the European Sambucus nigra, L., are used in the preparation of an aromatic distilled water and in flavoring lard, and the hard and compact wood is made into combs and mathematical instruments. The large pithy shoots furnish children with pop-guns, pipes, and whistles; and the fruit of some of the species is cooked and eaten.

Sambucus, the name of the Elder-tree, is believed to have been derived from $\sigma \alpha \mu \beta \dot{v} \chi \eta$, a musical instrument, probably in allusion to the use of the pithy stems.

\section{CONSPECTUS OF THE ARBORESCENT SPECIES OF THE UNITED STATES.}

Leaves and young shoots more or less pubescent or cinereo-canescent; fruit without bloom.

1. S. Mexicana (E, G, H).

Leaves and soung shoots glabrous; fruit whitened by a glaucous bloom.

2. S. glauca (B, F, G). 


\section{Sambucus Mexicana, DC.}

(Sambucus Canadensis, var. Mexicana, Silva N. Am. v. 88.)

Leaves $3 \frac{1}{2}-7^{\prime}$ long, with stout pubescent or glabrate petioles usually naked at the base, and 5 ovate-lanceolate leaflets narrowed at the apex into long slender points, sharply serrate, with incurved glandular-tipped teeth, except at the entire wedge-shaped or more or less unequally romded base, when they unfold more or less covered with palc pubescence, and at maturity dark yellow-green, pubescent, especially on the broad midribs and primary veins, or learly glabrous, thick and firm, 1 $\frac{1}{2}^{\prime}-6^{\prime}$ long, $\frac{1}{2}^{\prime}-2 \frac{1}{2}^{\prime}$ wide, increasing in size from the base to the apex of the leaf, their petiolules sleuder, that of the terminal leaflet sometimes $\frac{3^{\prime}}{4}$ long and nmeh longer than those of the lateral leaflets; stipels on vigorous shoots sometimes

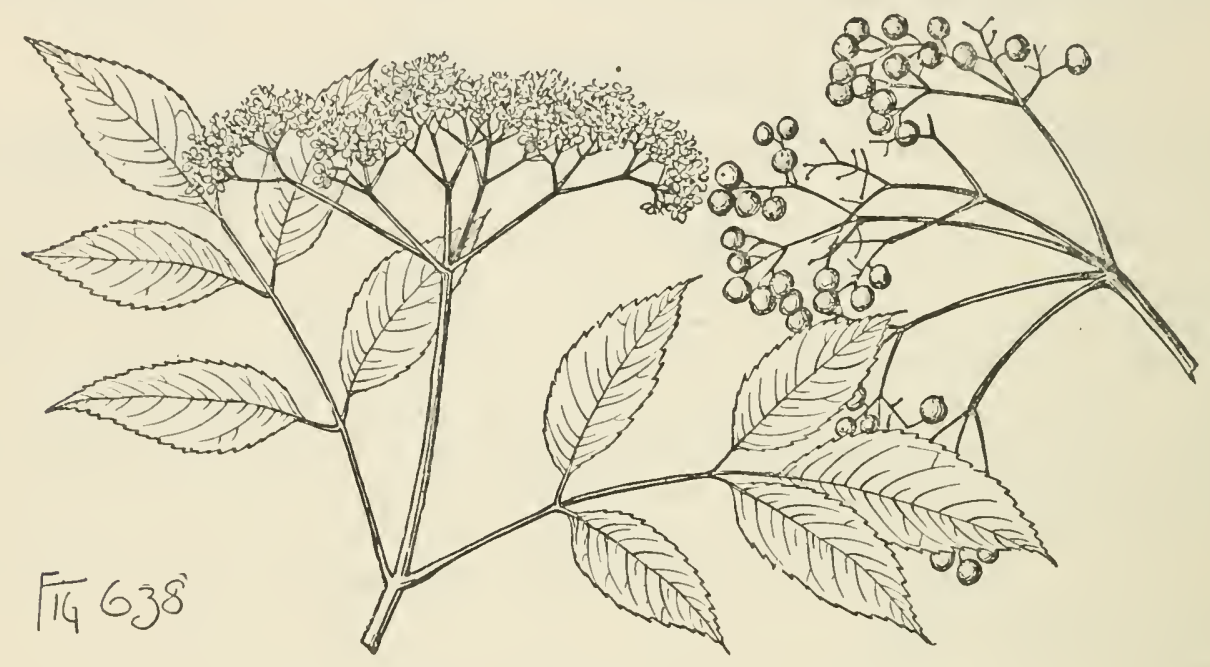

$\frac{1}{3}$ long, ovate, acute, serrate, and on fertile branches subulate or oblong, much smaller and often 0 . Flowers $\frac{1}{8}^{\prime}$ in diameter, appearing from March to July, in flat pubescent long-branched cymes $6^{\prime}-8^{\prime}$ in diameter; calyx 5-lobed; corolla rotate, 5-parted, creamy white, with ovate-oblong divisions rounded at the apex. Fruit $\frac{1^{\prime}}{4}$ in diameter, nearly black, lustrous, rather juicy.

A tree $25^{\circ}-30^{\circ}$ high, with a short trunk often abruptly enlarged at the base and sometimes a foot in diameter, stout spreading branches forming a compact roundtopped head, and branchlets light green when they first appear and more or less covered with pale pubescence, or glabrate or sometimes coated with canescent tomentım, and at the end of their first year pale, or light brown tinged with red, and roughened by elevated lenticels. Bark of the trunk about $\frac{1^{\prime}}{4}$ thick, the light brown snrface tinged with red and broken into long narrow horizontal ridge-like scales. Wood light, soft, close-grained, light brown, with thin lighter-colored sapwood of two or three layers of amnual growth.

Distribution. Bottom-lands iu moist gravelly loam; valley of the Nueces River, throngh western Texas, and southern New Mexico and Arizona to southern California and Lower California, and sonthward through Mexico to Central America, and on the Sierra Nevada Mountains in Plumas County, California.

Often planted in northern Mexico and in Lower California in the neighborhood of houses as a shade-tree, and for the fruit which is eaten by Mexicans and Indians. 


\section{Sambucus glauca, Nutt.}

Leaves $5^{\prime}-7^{\prime}$ long, with stout grooved petioles much enlarged and naked or sometimes furnished at the base with leaf-like appendages, and 5-9 ovate or narrowly oblong leaflets contracted at the apex into long narrow points, unequally wedgeshaped or rounded at the base, and coarsely serrate, with spreading or slightly

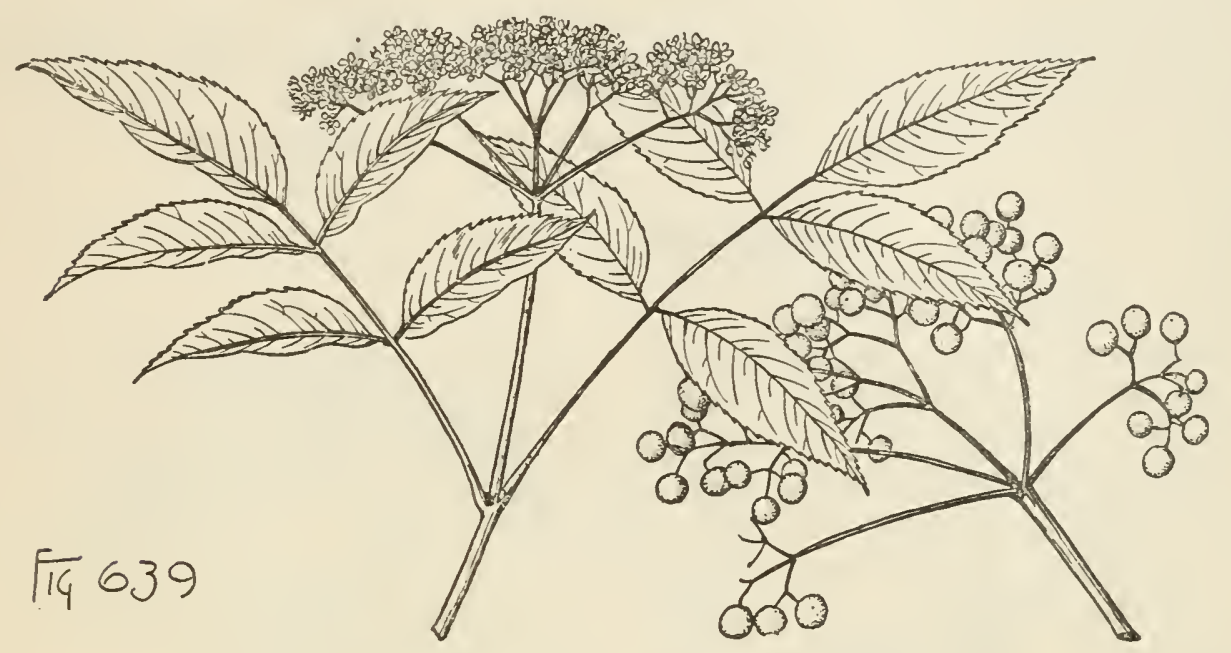

incurved callous-tipped teeth, the lower leaflets often 3-parted or pimnate and the terminal one sometimes furnished with 1 or 2 lateral stalked leaflets, when they unfold yellow-green on the upper, pale on the lower surface, and covered with scattered pale hairs, and at maturity glabrous, thin, rather firm in texture, bright green above and pale below, $2^{\prime}-6^{\prime}$ long and $\frac{1}{2}^{\prime}-1 \frac{1}{2}^{\prime}$ wide, with narrow pale midribs, inconspicuous veins, and slender petiolules $\frac{1^{\prime}}{4}-\frac{1}{2}^{\prime}$ long on the lateral leaflets and sometimes $1 \frac{1}{2}-2^{\prime}$ long on the terminal leaflet; stipels oblong-lanceolate, rounded or acute at the apex, entire, $\frac{1}{16}-\frac{1}{2}^{\prime}$ long, caducous, often 0 . Flowers $\frac{1}{8}^{\prime}$ in diameter, appearing from April in southern California to July in British Columbia, in flat long-branched glabrous cymes $4^{\prime}-6^{\prime}$ wide, with linear acute green caducous bracts and bractlets, the lower branches often from the axils of upper leaves; flower-buds globose, covered with a glaucous bloom, sometimes turning red before opening; calyx ovoid, and red-brown, with acute scarious lobes; corolla rotate, yellowish white, with oblong divisions rounded at the apex, as long as the stamens. Fruit subglobose, $\frac{1}{4}$ in diameter, blue-black, whitened with a thick mealy bloom; flesh rather sweet and juicy.

A tree, $30^{\circ}-50^{\circ}$ high, with a tall straight trunk sometimes enlarged at the base and $12^{\prime}-18^{\prime}$ in diameter, stout spreading branches forming a compact round-topped head, and branchlets usually without terminal buds, green tinged with red or brown when they first appear, and covered with short white caducous hairs, stont, slightly angled, covered with lustrous red-brown bark in their first winter and nearly encircled by the large triangular leaf-scars marked by conspicuous fibro-vascular bundlescars; often a broad shrub, with numerous spreading stems. Winter-buds axillary, generally in pairs, superposed or in clusters of 4 or 5, only the upper bud or sometimes the lower usually developing, covered with 2 or 3 pairs of opposite broadly ovate chestnut-brown scales, those of the inner rank accrescent, and at maturity acute, entire, green, $1^{\prime}$ long, and sometimes developing into pinnate leaves $2^{\prime}-3^{\prime}$ in length. 
Bark of the trunk deeply and irregularly fissured, the dark brown surface slightly tinged with red and broken into sniall square appressed seales. Wood light, soft, weak, coarse-grained, yellow tiuged with brown, with thin lighter colored sapwood.

Distribution. Gravelly rather dry soil of valleys and river-bottoms; British Columbia to the southern borders of California, and eastward to the Blue Mountains of Oregon, the Wasatch Mountains of Utah, and to northern Montana; very abundant in the coast region; comparatively rare in the interior; of its largest size in the valleys of western Oregon; northward, and east of the Cascade and Sierra Nevada Mountaius rarely arborescent.

Occasionally planted as an ornamental plant in the Pacific states.

\section{VIBURNUM, A. I. de Juss.}

'Trees or shrubs, with tough flexible branchlets, and large winter-buds enveloped in one pair of scales. Leaves deciduous, without stipules, the first pair rudimentary, with small blades and broad boat-shaped petioles, caducous (in the North American arborescent species). Flowers on short bracteolate or bibracteolate pedicels, in terminal or axillary unbel-like flat or panicled cymes, their bracts and bractlets minute, lanceolate, acute, caducous; calyx-tube cylindrical, the limb short, equally 5-lobed, persistent on the fruit; corolla rotate, equally 5-lobed, spreading and reflexed after anthesis; stamens inserted on the base of the corolla; filaments elongated, exserted; anthers bright yellow; ovary inferior, 1-celled; style conical, divided at the apex into three stigmatic lobes. Fruit 1-celled, with thin sweet acidulous or oily fleslı; stone (in the Nortl American arborescent species) coriaceous, oval, shortpointed at the apex, much flattened, dull reddish brown, slightly pitted. Seed filling the cavity of the stone, concave on the ventral face, bright reddish brown, the thin coat projected into a red narrow irregular often erose marginal border.

Viburnum with about eighty species is widely and generally distributed through the temperate regions of the northern hemisphere, and occurs on the mountains of central and western South America, on the Antilles, the islands of the Malay Archipelago, and Madagascar. Of the nifteen North American species three are small trees. Many of the species produce beautiful flowers and fruits, and are frequently cultivated as ornaments of parks and gardens.

Viburnum is the classical name of one of the European species.

\section{CONSPECTUS OF THE NORTH AMERICAN ARBORESCENT SPECIES.}

Petioles wing-margined.

Winter-buds long-pointed, scurfy-pubescent; leaves ovate, usually acuminate.

1. V. Lentago (A, C, F).

Winter-buds short-pointed, ferrugineo-tomentose; leaves elliptical-ovate or ellipticalobovate, usually rounded at the apex.

2. V. rufidulum (A, C). Petioles usually without margins; winter-buds short-pointed or obtuse, rufous-pubescent; leaves ovate, oval, or suborbicular, rounded or acute at the apex.

3. V. prunifolium $(\mathrm{A}, \mathrm{C})$.

\section{Viburnum Lentago, L. Sheepberry. Nannyberry.}

Leaves ovate, usually acuminate, with short or elongated points, or sometimes rominded at the apex, wedge-shaped; rounded or subcordate at the base and sharply serrate, with incurved callous-tipped teeth, when they unfold bronze-green, lustrous, 
coated on both surfaces of the midribs and on the petioles with thick rufous pubescence, slightly pilose on the upper surface and covered on the lower with short pale hairs, and at maturity bright green and lustrous above, yellow-green and marked by minute black dots below, $2 \frac{1}{2}^{\prime}-3^{\prime}$ long and $1^{\prime}-1_{2}^{1}$ wide, with slender midribs and primary veins connected by conspicuous reticulate veinlets, turning in the autumn before falling deep orange-red or red and orange color; their petioles broad, grooved, more or less interruptedly winged or occasionally wingless, $1^{\prime}-1 \frac{1^{\prime}}{2}$ long, those of the first pair of leaves covered with thick rufous tomentum. Flowers about $\frac{1}{4}^{\prime}$ in diameter, slightly fragrant, appearing from the middle of April to the 1st of June in stout-branched scurfy flat cymes $3^{\prime}-\overline{5}^{\prime}$ in diameter, with nearly triangular green caducous bracts and bractlets about $\frac{1{ }^{\prime}}{16}$ in length; calyx-tube slender, ovoid, with minute triangular acute lobes; corolla pale cream color or nearly white, with ovate lobes acute and slightly erose at the apex; style thick, light green, crowned with a broad stigma. Fruit

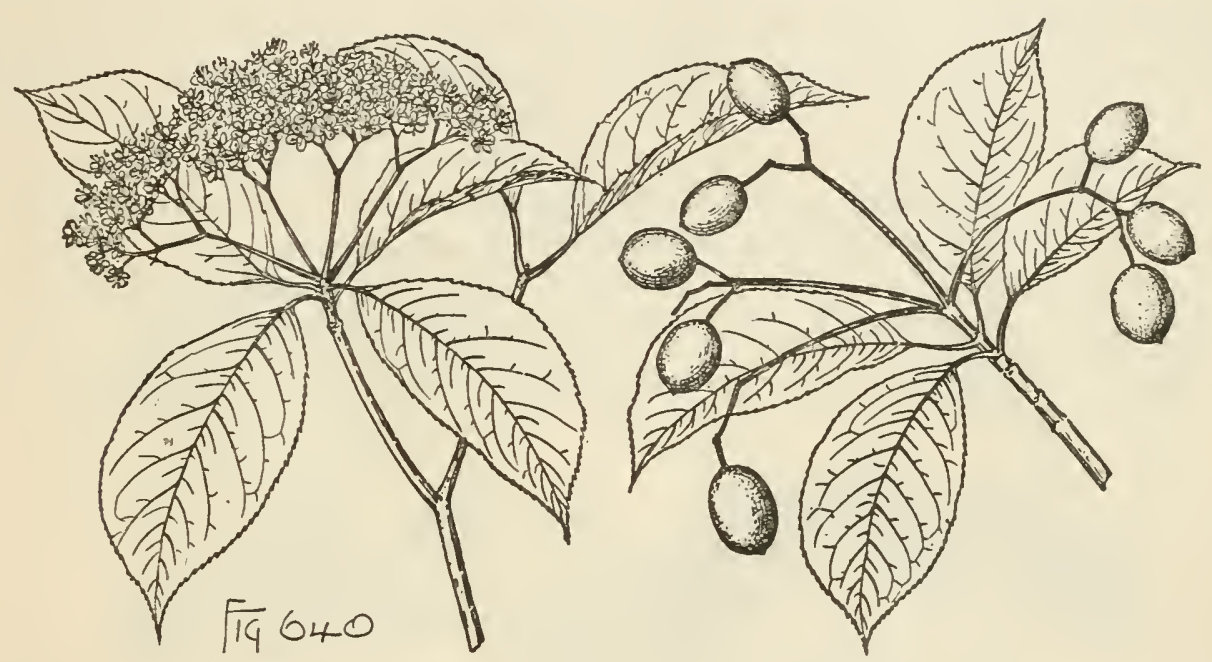

ripening in September on slender drooping stalks, in red-stemmed few-fruited clusters, oval, thick-skinned, sweet and rather juicy, black or dark blue, and covered with a glancous bloom; stone about $\frac{7^{\prime}}{8}$ long and $\frac{5{ }^{\prime}}{16}$ wide.

A bushy tree, $20^{\circ}-30^{\circ}$ high, with a short trunk $8^{\prime}-10^{\prime}$ in diameter, slender rather pendulons branches forning a compact round-topped head, and thin divergent branchlets light green, slightly covered with rufous pubescence at first, and in their first winter light red, scurfy, marked by occasional dark orange-colored lenticels and by narrow leaf-scars displaying 3 conspicuous fibro-vascular bundle-scars, becoming in their second year dark reddish brown and sometimes covered with a glaucous bloom. Winter-buds light red, generally covered with pale scurfy pubescence, those containing flower-bearing branchlets $\frac{3 \prime}{4}$ in length, obovate, swollen below the middle and then abruptly contracted into long narrow tapering points, and subtended by 2 minute lateral generally abortive buds formed in the axils of the last leares of the previous year, the buds inclosing sterile shoots lanceolate, acute, slightly angled, about $\frac{1}{2}$ long; axillary buds acute, flattened by pressure against the stem, and much smaller than the terminal buds. Bark of the trunk reddish brown and irregularly broken into small thick plates divided on their surface into minute thin appressed scales. Wood bad-smelling, heavy, hard, close-grained, dark orange-brown, with thin nearly white sapwood. 
Distribution. Rocky hillsides, along the borders of forests, or near the banks of streaus and the margins of swamps, in moist soil; valley of the Riviere du Loup, Proviuce of Quebec, to Saskatchewan, and southward through the northern states to souther'n Indiana, and along the Alleghany Mountaius to northern Georgia, and to easteru Kansas and Nebraska, South Dakota and the Big Horn Mountains of Wyoming; in northern Now England frequently springing "p in fence-rows and along the margins of roadsides.

Often cultivated as an ornament of parks and gardens in the eastern United States, and occasionally in Europe.

\section{Viburnum rufidulum, Raf. Black Haw.}

Leaves elliptical-ovate or elliptical-obovate, rounded and occasionally acnte or obtuse at the short-pointed apex, rounded or wedge-shaped at the base, and finely serrate, with slender apiculate straight or incurved teeth, when they mnfold covered below and on the wings of the petioles with thick ferrugineous tomentum and at maturity coriaceous, dark green and very lustrous above, pale and dull below, usually about $3^{\prime}$ long and $\frac{3 \prime}{4}-1 \frac{1}{2}^{\prime}$ wide, with stout yellow midribs, numerous slender primary veins, and reticulate veinlets more or less covered below throughout the season with the rufous tomentum also occasionally found on the upper side of the midribs; their petioles stout, grooved, $\frac{1}{2}^{\prime}-\frac{3}{4}$ long, and margined with broad or narrow wings. Flowers $\frac{1^{\prime}}{4}$ in diameter, in compound sessile or stalked 3-5 but usually 4-rayed thick-stemmed ferrugineo-pubescent corymbs often $5^{\prime}-6^{\prime}$ in diameter, with minute subulate bracts and bractlets; calyx obconic, with short rounded lobes; corolla creamy white, with

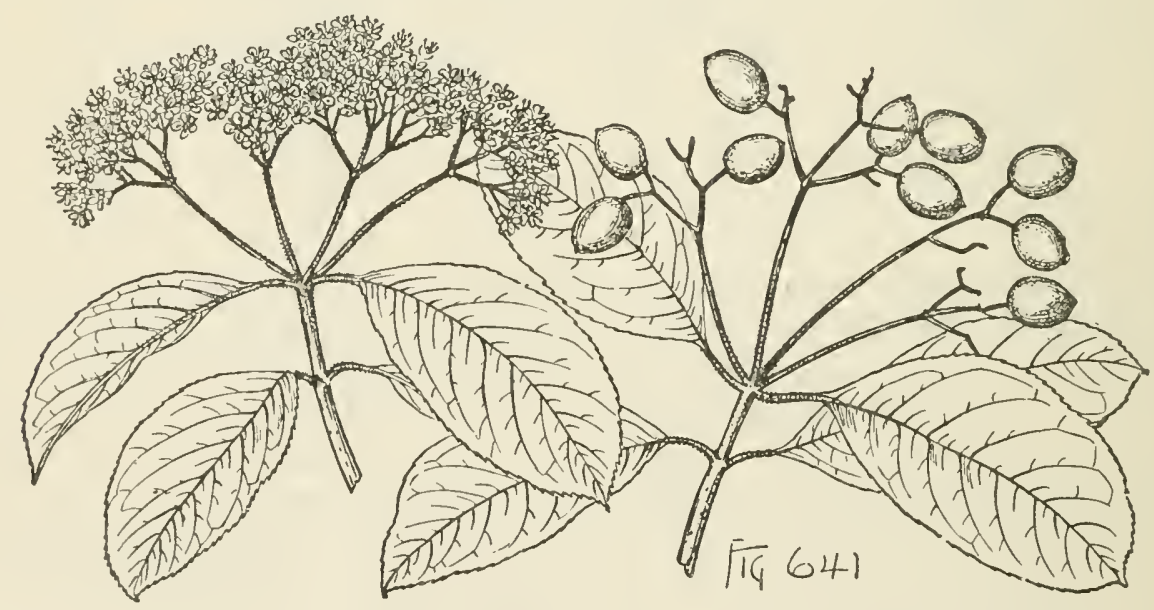

orbicular or oblong rounded lobes. Fruit ripening in October, in few-fruited drooping red-stemmed clusters, oblong or slightly obovate, bright blue covered with a glancous bloom, and $\frac{1}{2}^{\prime}-\frac{2^{\prime}}{3}$ long; stone $\frac{1^{\prime}}{2}$ long and about $\frac{1^{\prime}}{3}$ wide.

A tree, of ten $40^{\circ}$ high, with a trunk $12^{\prime}-18^{\prime}$ in diameter, short thick branches forming an open irregular head, and stout branchlets marked by numerous small red-brown or orange lenticels, when they first appear more or less coated with ferrugineous tomentum, ashy gray during their first winter, and dark dull red-brown in their second season. Winter-buds ferrugineo-tomentose, those containing flowerbearing branchlets broadly ovate, full and rounded at the base, abruptly narrowed above, and short-pointed and obtuse at the apex, compressed, often $\frac{1}{2}^{\prime}$ long and $\frac{1}{3}^{\prime}$ 
wide, and rather larger than those containing sterile branchlets; axillary buds acute, flattened by pressure against the stems, and much smaller than the terminal buds. Bark of the trunk $\frac{1^{\prime}}{4}-1^{\prime}$ thick, separating into narrow rounded ridges divided by numerous cross fissures, and roughened by small plate-like dark brown scales tinged with red. Wood bad-smelling.

Distribution. Dry upland woods and the margins of river-bottom lands; southwestern Virginia and southern Illinois to Hernando County, Florida, southeastern Kansas and the valley of the Guadalupe River, Texas; most abundant and of its largest size in southern Arkansas, western Louisiana, and eastern Texas.

Occasionally cultivated in the eastern states, and hardy as far north as eastern Massachusetts.

\section{Viburnum prunifolium, L. Black Haw. Stag Bush.}

Leaves ovate or rarely obovate, oval or suborbicular, rounded, acute, or shortpointed at the apex, wedge-shaped or rounded at the base, and usually rather remotely or sometimes finely serrate, with rigid incurved callous-tipped teeth, when

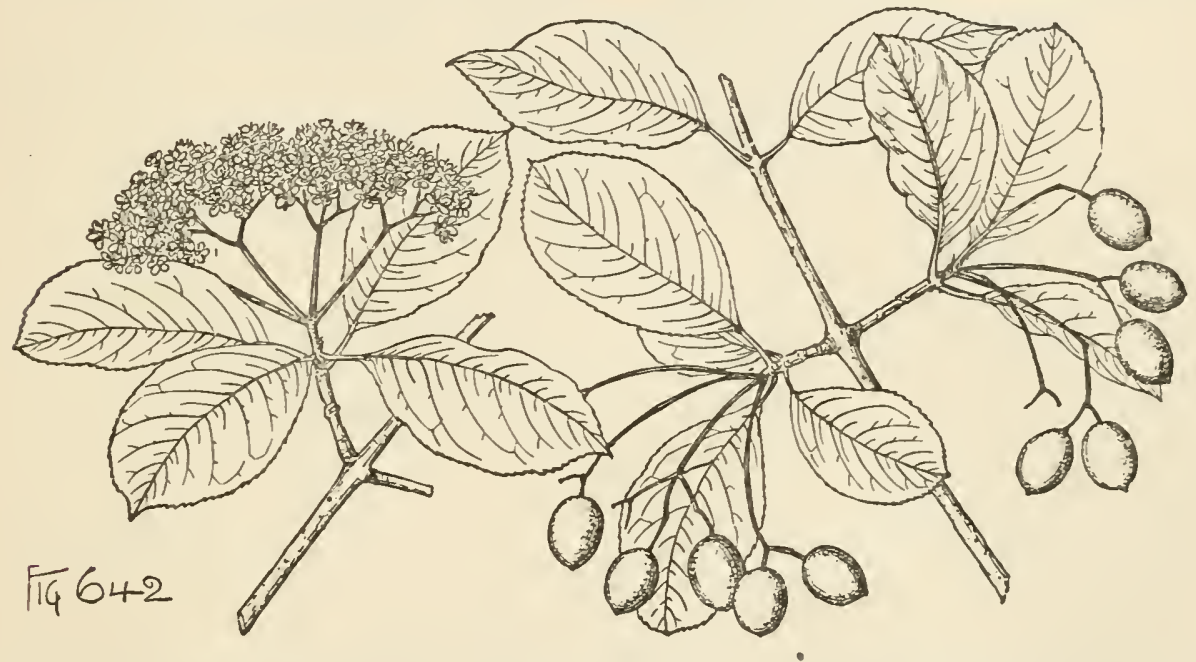

they unfold lustrous and tinged with red, glabrous on the lower surface and covered on the upper side of the midribs and on the bright red petioles with scattered reddish hairs, and at maturity firm or sometimes coriaceous, dark green and glabrous above, pale and glabrous below, with slender primary veins connected by reticulate veinlets, $1^{\prime}-3^{\prime}$ long and $\frac{1}{2}^{\prime}-3^{\prime}$ wide, in the autumn turning brilliant scarlet or dark vinous red before falling; their petioles terete, grooved, $\frac{1^{\prime}}{2}-\frac{2^{\prime}}{3}$ long, and on vigorous shoots sometimes narrowly wing-margined. Flowers $\frac{1^{\prime}}{4}$ in diameter on slender pedicels bibracteolate at the apex, in glabrous cymes $2^{\prime}-4^{\prime}$ in diameter, with subulate bracts about $\frac{1}{16}$ long, usually red above the middle, and caducous; calyx narrowly obovate, with short rounded lobes often tipped with pink; corolla pure white, with oval or nearly orbicular lobes. Fruit ripening in October, in few-fruited red-stemmed clusters, persistent on the branches until the beginning of winter, oval or slightly obovate, $\frac{1^{\prime}}{2}-2^{\prime}$ long, dark blue, and covered with a glaucous bloom; stone about $\frac{1}{2}^{\prime}$ long and $\frac{1}{3}^{\prime}$ wide.

A bushy tree, occasionally $20^{\circ}-30^{\circ}$ high, with a short and usually crooked trunk $6^{\prime}-8^{\prime}$ in diameter, stout spreading rigid branches beset with slender spine-like branchlets, bright red and glabrous when they first appear, soon turning green, and 
in their first winter gray tinged with red, eovered with a slight bloom, and marked by orange-colored lenticels and by the large lunate leaf-sears displaying 3 fibro-vaseular bundle-sears, and ultimately dark brown tinged with red; or often a low intrieately branched shrub. Winter-buds short-pointed or obtuse, rufons-pubeseent, those eontaining flower-bearing branehes about $\frac{1}{2}$ long and $\frac{1 \prime}{4}$ wide, and about twiee as large as those eontaining sterile branchlets; axillary buds aeute, flattened, mueh smaller than the terminal buds. Bark of the trunk $\frac{1^{\prime}-1^{\prime}}{3}$ thiek, and broken into thiek irregularly shitped plate-like red-brown seales. Wood heavy, hard, strong, brittle, elose-grained, brown tinged with red, with thiek nearly white sapwood of 20-30 layers of amual growth.

Distribution. 'Dry rocky hillsides, and fenee-rows and the sides of roads; Fairfield Comnty, Conneetient, and the valley of the lower Hudson River, New York, southward along the Alleghany Mountains to northern Georgia, and westward to sonthern Missouri.

Often eultivated as an ornament of parks and gardens in the eastern United States, and occasionally in western and northern Europe. 


\section{GLOSSARY OF TECHNICAL TERMS AND INDEX}





\section{GLOSSARY OF TECHNICAL TERMS}

Accrescent. Increasing in size with age.

Accumbent. Lying against, as the radicle against the edges of the cotyledons.

Acuminate. Gradually tapering to the apex.

Acute. Pointed.

Adnate. Congenitally united to.

Adventitious. Said of buds produced without order from any part of the stem.

Estivation. The arrangement of the parts of a flower in the bud.

Akene or achene. A small dry and hard, 1-celled, 1-seeded, indehiscent fruit.

Albumen. The deposit of nutritive material within the coats of a seed and surrounding the embryo.

Ament. A unisexual spike of flowers with scaly bracts, usually deciduous in one piece.

Amphitropous. Descriptive of ari ovule with the hilum intermediate between the micropyle and chalaza.

Anatropous. Descriptive of a reversed ovule, with the micropyle close by the side of the hilum, and chalaza at the opposite end.

Andro-diøcious. With perfect flowers on one individual and staminate flowers only on another.

Androgynous. An inflorescence composed of male and female flowers.

Angiospermæ. Plants with seeds borne in a pericarp. Annular. In the form of a ring.

Anterior. The front side of a flower, that is averse from the axis of inflorescence.

Anther. The part of the stamen containing the pollen. Anthesis. The act of opening of a flower.

Apetalous. Having no petals.

Apex. The top, as the end of the leaf opposite the petiole.

A piculate. Ending in a short pointed tip.

Apophysis. An enlargement or swelling of the surface of an organ.

Arcuate. Moderately curved.

Areolate. Marked by areolæ or spaces marked out on a surface.

Aril. An extraneous seed-coat or covering, or an appendage growing about the hilum of a seed.

Ariloid. Furnished with an aril.

Aristate. Furnished with awns.

Articulate. Jointed or having the appearance of a joint.

Auricled or auriculate. Furnished with an auricle or ear-shaped appendage.

Axil. The angle formed on the upper side of the attachment of a leaf with a stem.

Axillary. In or from an axil.

Baccate. Berry-like.

Bark. The rind or cortical covering of a stem.

Berry. A fruit with a homogeneous fleshy pericarp.

Bipinnate. Doubly or twice pinnate.

Bract. The more or less modified leaf of a flowercluster.

Bracteate. Furnished with bracts.

Bracteolate. Furnished with bractlets.

Bractlet. The bract of a pedicel or ultimate flowerstalk.

Branch. A secondary axis or division of a trunk.

Branchlet. An ultimate division of a branch.

Bud. The undeveloped state of a branch or flowercluster with or without scales.

Bud-scales. Reduced leaves covering a bud.

Calyx. The flower-cup or exterior part of a perianth.
Campanulate. Bell-shaped, or elongated cup-shaped. Campylotropous. Descriptive of an ovule or seed curved in its formation so as to bring the micropyle or apex down near the hilum.

Canescent. Hoary, with gray or whitisli pubescence. Capsule. A dry dehiscent fruit of more than one carpel.

Carpel. A simple pistil or an element of a compound pistil.

Cathin. The same as an ament.

Caudate. Furnished with a tail, or with a slender tip or appendage.

Centripetal. Developing from without toward the centre.

Chalaza. The part of an orule where the coats and nucleus are confluent.

Chartaceous. Having the texture of paper.

Ciliate. Fringed with hairs.

Cinereous. Ashy gray.

Circinnate. Involute from the apex into a coil.

Circumscissile. Circularly and transversely dehiscent.

Clarate. Club-shaped.

Cocci. Portions into which a lobed fruit with 1-seeded cells splits up.

Cochleate. Shell-shaped, spiral like the shell of a snail. Columella. The persistent axis of a capsule.

Commissure. The face by which 2 carpels unite.

Complanate. Flattened.

Conduplicate. Folded togetlier lengthwise.

Cone. An inflorescence or fruit formed of imbricated scales.

Conferruminate. Stuck together by adjacent faces.

Connate. United congenitally.

Connective. The portion of a stamen which connects the two cells or lobes of an anther.

Contortuplicate. Twisted and plaited, or folded.

Convolute. Rolled up from the sides.

Cordate. Heart-shaped.

Coriaceous. Of the texture of leather.

Corymb. A flat-topped or convex open flower-cluster, the flowers opening from the outside inward.

Corymbose. Said of flowers arranged in corymbs.

Cotyledons. The leaves of the embryo.

Crenate. Scalloped.

Crenulate. The diminutive of crenate.

Crustaceous. Of hard brittle texture.

Cucullate. Hooded or hood-shaped.

Cuneate. Wedge-shaped, or triangular with an acute angle downward.

Cyme. A flower-cluster, the flower opening from the centre outward.

Cymose. Bearing cymes or relating to a cyme.

Deciduous. Falling, said of leaves falling in the au. tumn, or of parts of a flower falling after anthesis. Declinate. Bent or curved downward.

Decompound. Several times compound or divided.

Decurrent. Running down, as of the blades of leaves extending down their petioles.

Decussate. In pairs alternately crossing at right angles.

Dehiscent. The opening of an anther or capsule by slits or valves.

Deltoid. Having the shape of the Greek letter $\Delta$

Dentate. Toothed.

Denticulate. Minutely toothed.

Diadelphons. Said of stamens combined by their filaments into 2 sets.

Dichotomous. Forked in pairs. 
Digitate. Said of a compond leaf in which the leaflets are horme at the ajex of the petiole.

Direcions. Unisexual, with the Howers of the '2 scxes borne by distinct individnals.

Disciferons. Bearing a disk.

Discifurm. Depressed and circular like a disk.

Discuil. Appertaining to a disk

Disk. The development of the torus or receptacle of a Hower within the calyx or within the corolla ant stamens.

Dissepiment. A partition in an ovary or pericarp.

Dorsal. Relating to the back.

Dorsal suture. The linc of opening of a carpel corresponding to its midrib.

Diupuceous. Resembling or relating to a drupe.

Drupe. A stone fruit.

Duct. An elongated cell or tubular vessel found especially in the woody parts of plants.

Eglandular. Witlout glands.

Ellipsoid. An elliptical solid.

Elliptical. Oval or oblong with regularly rounded ends.

Emarginate. Notched at the apex.

Embryo. The rudinentary plant formed in the secd.

Endlocarp. The inner layer of a pericarp.

Endogenous. Deseriptive of Endogens, monocotyledonous plants with stems increasing by internal accessions.

Epicarp. The thin filmy external layer of a pericarp.

Epigynous. Placed on the ovary.

Erose. Descriptive of an irregularly toothed or eroded margin.

Excurrent. Rumning through the apex or beyond.

Exocarp. The outer layer of a pericarp.

Exogenous. Descriptive of Exogens, plants witl stems increasing by the addition of a layer of wood on the outside beneath the constantly widening bark.

Extrorse. Directed outward, descriptive of an anther opening away from the axis of the flower.

Falcate. Scythe-shaped.

Fascicle. A close cluster of leaves or flowers.

Fascicled. Arranged in fascicles.

Feather-veined. Having veins extending from the sides of the midrib.

Ferrugineons. The color of iron rust.

Fibro-vascular. Consisting of woody fibres and ducts.

Filament. The stalk of an anther.

Filamentose. Composed of threads.

Fimbriate. Fringed.

Fistulose. Hollow through the whole length.

Flabellate. Fan-shaped; much dilated from a wedgeshaped base with the broader end rounded.

Foliaceous. Leaf-like in texture or appearance.

Foliolate. Having leaflets.

Foliole. A leaflet.

Funicle. The stalk of an ovule or seed.

Gamopelalæ. Plants with corollas of coalescent petals.

Gamopetalous. Descriptive of a corolla of coalescent petals.

Geniculate. Bent abruptly like a knee.

Gibbous. Swollen on one side.

Glabrate. Nearly glabrous or becoming glabrous.

Glabrous. Smooth, not pubescent or hairy.

Gland. A protuberance on the surface, or partly imbedded in the surface of any part of a plant, either secreting or not.

Glandular. Furnished with glands.

Glaucescent. Nearly or becoming glaucous.

Glaucous. Covered or whitened with a bloom.

Gymnospermæ. Plants with naked seeds, that is, not inclosed in a pericarp.

Gynophore. The stipe of a pistil.

Heartuood. The mature and dead wood of an exogenous stem.
Mermanhonlite. Witl staminate and pistillate organs in the same flower, equivalent to perfect.

Milum. The scar or place of attachment of a seed.

llisute. Hairy, with coarse or stiff hairs.

II isprillulous. Mimntely hispid.

IIypogynous. Under or free from the pistil.

Imbriealc. Overlapping, like the slingles on a roof.

Incumbent. Leaning or resting upon, as the radicle against the back of one of the cotyledons.

Incluplicate. With edges folderl in or turned inward.

Injerior. Said of an organ placed below another, like

a calyx below an ovary or an ovary below a superior calyx.

Infloreseence. Flower-cluster.

Infrapetiolar. Below the petioles.

Innate. Borne on the apex of the supporting part;

in an anther the counterpart of adnate.

Interpetiolar. Between the petioles.

Introrse. Turncd inward; descriptive of an anther opening toward the axis of the flower.

Inverse. Inverted.

Involucre. A circle of bracts surrounding a flowercluster.

Involute. Rolled inward.

Laciniate. Cut into narrow incisions or lobes.

Lactescent. Yielding milky juice.

Lamellate. Composed of thin plates.

Laminate. Composed of plates.

Lanceolate. Shaped like a lance; narrower than oblong and tapering to the ends, or at least to the apex

Leaf. Green expansions borne by the stem in which assimilation and the processes connected with it are carried on.

Leaflet. The separate division of a compound leaf.

Legume. The seed vessel of plants of the Pea family, composed of a solitary carpel normally dehiscent only by the ventral suture.

Lenticels. Lenticular corky growths on young bark. Lepidote. Beset with small scurfy scales.

Linear. Said of a narrow leaf several times narrower than long, with parallel margins.

Lobe. The division of an organ.

Lobulate. Divided into small lobes.

Loculicidal. Dehiscent into the cavity of a pericarp by the back, that is tlirough a dorsal suture.

Medullary rays. The rays of cellular tissue in a transverse section of an exogenous stem and extending from the pith to the bark.

Membranaceous. Thin and pliable like a membrane. Micropyle. The spot or point in the seed at the place of the orifice of the ovule.

Midrib. The central or main rib of a leaf.

Moncecious. Unisexual, with the flowers of the two sexes borne by the same individual.

Mucro. A small and abrupt tip to a leaf.

Mucronate. Furnished with a mucro.

IIricate. Rough, with short rigid excrescences.

Naked buds. Buds without scales.

Nectar. The sweet secretion of various parts of a flower.

Nectariferous. Nectar-bearing.

Node. The portion of the stem which bears a leaf or whorl of leaves.

Nucleus. The kernel of an ovule or seed.

Nut. A hard and indeliscent 1-seeded pericarp produced from a compound ovaly.

Nutlet. A diminutive nut or stone.

Obcordate. Inverted heart-shaped.

Oblanceolate. Lanceolate but tapering toward the base more than toward the apex.

Obovate. Ovate with the broader end toward the apex.

Obovoid. Solid ovate with the broader end toward the apex.

Obpyramidal. Inversely pyramidal. 
Obtuse. Blunt or rounded at the apex.

Operculate. Furnished with a lid.

Orbicular. A flat body circular in outline.

Orthotropous. Descriptive of a,ll ovule with a straight axis much enlarged at tle insertion and the orifice at the other end.

Ocal. Broadly elliptical.

Ovale. Of the shape of the longitudinal section of a hen's egg, with the broad end basal.

Ocoid. Solid ovate or solid oval.

Orule. The part of the flower which becomes a seed.

Palmate. Lobed or divided, with the sinuses pointing to or reaching the apex of the petiole or insertion. Panicle. A loose compound flower-cluster.

Papilionaceous. Butterfly-like.

Papilliform. The shape of papillæ.

Papillate. Bearing papillæ, minute nipple-shaped papillose projections.

Parietal placenta. A placenta borne on the wall of the ovary.

Pedicel. The stalk of a flower in a compound inflorescence.

Pelicellate. Borne on a pedicel.

Peduncle. A general flower-stalk supporting either a cluster of flowers, or a solitary flower.

Pedunculate. Borne on a peduncle.

Pellate. Descriptive of a plane body attached by its lower surface to the stalk.

Penniceined. Same as pinnately veined.

Perfect. Said of a flower with both stamens and pistil.

Perianth. The envelope of a flower consisting of calyx, corolla, or both

Pericarp. The fructified ovary.

Persistent. Said of leaves remaining on the branches over their first winter, and of a calyx remaining under or on the fruit.

Petal. A division of the corolla.

Petiolate. Having a petiole.

Petiole. The footstalk of a leaf.

Petiolulate. Having a petiolule.

Petiolule. The footstalk of a leaflet.

Pilose. Hairy, with soft and distinct hairs.

Pinnæ. The primary divisions of a twice pinnate leaf.

Pinnate. A leaf with leaflets arranged along each side of a common petiole.

Pistil. The female organ of a flower, consisting of ovary, style, and stigma.

Pistillate. Said of a unisexual flower without fertile stamens.

Pith. The central cellular part of a stem.

Placenta. That part of the ovary which bears the ovules.

Plumule. The bud or growing part of the embryo.

Pollen. The fecundating cells contained in the anther.

Polygamo-dicecious. Said of flowers sometimes perfect and sometimes unisexual, the 2 forms borne on different individuals.

Polygamo-monocious. Said of flowers sometimes perfect and sometimes unisexual, the 2 forms borne on the same individual.

Polygamous. Said of flowers sometimes perfect and sometimes unisexual.

Pome. An inferior fruit of 2 or several carpels inclosed in thick flesh.

Posterior. The side of an axillary flower next the axis of inflorescence.

Prickle. Outgrowth of the bark.

Proliferous. Bearing offshoots.

Puberulent. Very slightly pubescent.

Puberulous. Minutely pubescent.

Pubescence. A covering of short soft hairs.

Pubescent. Clothed with soft short hairs.

Pulvinate. Cushion-shaped.

Punctate. Dotted with depressions or translucent internal glands, or with colored dots.

Punctulate. Minutely punctate.
Raceme. An indeterminate or centripetal inflorescence with an elongated axis and flowers on pedicels of equal length.

Rachis. The axis of a spike or of a compound leaf.

Radial. Belonging to a ray.

Radicle. The initial stem in an embryo.

Receptacle. The axile portion of a blossom bearing sepals, petals, stamens, and pistils; the axis or rhachis of the head, spike, or other flower-cluster.

Reniform. Kidney-shaped.

Resupinate. Upside down.

Reticulate. Netted.

Retrorse. Directed backward or downward.

Retuse. With a shallow notch at a rounded apex.

Revolute. Rolled backward from the margins or a pex. Rhaphe. The adnate cord or ridge connecting the hilum with the chalaza in an anatropous ovule.

Rhombic. Having the shape of a rhomb.

Rhomboidal. Approaching a rhombic outline; quadrangular with the lateral angles obtuse.

Rind. The bark of some endogenous stems, like that of Palms.

Rostrate. Narrowed into a slender tip.

Rotate. Circular, flat and horizontally spreading.

Rugose. Wrinkled.

Rugulose. Slightly wrinkled.

Ruminate. Looking as if chewed, like the albumen of the nutmeg.

Sagittate. Shaped like an arrowhead.

Samara. An indehiscent winged fruit.

Sapwood. The young living wood of an exogenous stem.

Scales. Thin scarious bodies, usually degenerate leaves.

Scarious. Thin, dry and membranaceous, not green.

Scobiform. Having the appearance of sawdust.

Scorpioid. A form of unilateral inflorescence circinately coiled in the bud.

Scurfy. Covered with small bran-like scales.

Seed. The fertilized and mature ovule, the result of sexual reproduction in a flowering plant.

Segment. One of the divisions into which a leaf, calyx, or corolla may be divided.

Semianatropous. Same as amphitropous.

Sepals. The divisions of a calyx.

Septicidal. Descriptive of a capsule splitting through the lines of junction of the carpels.

Septum. A partition.

Serrute. Beset with teeth.

Serrulate. Serrate witl small fine teeth.

Sessile. Without a stalk.

Setose. Beset with bristles.

Setulose. Beset with minute bristles.

Sheath. A tubular or enrolled part or organ.

Sinistrorse. Turned or directed to the left.

Sinus. A recess between the lobes of a leaf.

Spatulate. Oblong with the lower end attenuated.

Spike. An indeterminate inflorescence with flowers sessile on an elongated common axis.

Spine. A sharp-pointed woody body, commonly a modified branch or stipule.

Spinescent. Ending in a spine.

Spinose. Furnished with spines.

stanien. One of the male organs of a flower.

Staminate. Said of unisexual flowers without pistils.

Staminodium. A sterile or much reduced stamen.

Stigma. The part or surface of a pistil which receives the pollen for the fecundation of the ovules.

Stignatic. Relating to the stigma.

Stipe. A stalk-like support of a pistil or of a carpel.

Stipel. An appendage to a leaflet analagous to the stipules of a leaf.

Stipitate. Having a stipe.

Stipulate. Having stipules.

Stipules. Appendages of a leaf, placed one on each sicie of the petiole at its insertion.

Stomata. Breathing pores or apertures in the epidermis of leaves convecting internal cavities with the external air.

Stomatiferous. Furnished with stomata. 
Stone. The hard endocarn of a drupe.

Strobile. 'The same as cone.

Strophiolute. Sitid of a seed bearing a strophiole or appendage at the hilum.

style. The attenuated portion of a pistil between the ovary and the stigma.

Subcordute. Slightly cordate.

subulate. Awl-shaped.

Sulcate. Grooved or furrowed.

Superior. Growing or placed above; also in a lateral Hower for the side next the axis.

Sulure. A junction, usually a line of opening of a carpel.

Suncarp. A multiple fruit.

Taproot. The primary descending root, a direct continuation from the radicle.

Tegmen. The inner coat of a seed.

Testa. The outer seed-coat.

Thyrsoidal. Relating to a thyrsus.

Thyrsus. A mixed inflorescence with the main axis indeterminate and the secondary or ultimate clusters cymose.

Tomentosc. Densely pubescent with matted wool or tomentum.

Tomcntulose. Slightly pubescent with matted wool.

Torose. Cylindrical, with contractions or bulges at intervals.

Torulose. Slightly torose.

Torus. The same as the receptacle of a flower.

Transverse. Horizontal.

Trichotomous. Three-forked.

Trifoliate. Three-lenved.

Trifoliolate. Descriptive of leaves, with 3 leaflets.

Truncale. As if cut off at the end.

Tubercle. A small tuber or excrescence.

Tuberculate. Beset with knobby excrescences.

Turbinate. Top-shaped.

Turgid. Swollen.

Umbel. An inflorescence with numerous pedicels springing from the same point like the rays of an umbrella.

Umbilicus. The hilum of a sced.

Umbo. A boss or protuberance.

Umbonate. Bearing nu unbo.

Uncinute. Hooked, bent, or curved at the tip in the form of a hook.

Unequally pinnate. Pinmate, with an odd terminal leatlet.

Unguiculate. Coutracted at the base into a claw or stalk.

Unisexual. Said of flowers with either the stamens or pistil 0 or abortive.

Urceolule. Hollow and contracted at or below the mouth like an urn or pitcher.

Utriclc. A small bladdery pericarp.

I'aleate. Said of a flower-bud in which the parts meet without overlapping.

Valve. One of the pieces into which a capsule splits.

Veinlet. One of the ultimate or smaller ramifications of a vein.

l'eins. Ramifications or threads of fibro-vascular tissue in a leaf or other flat organ.

Ventral. Belonging to the auterior or inner face of a carpel.

Ventricose. Swelling unequally or inflated on one side.

Vernation. The disposition of parts in a leaf-bud.

Verrucose. Covered with wart-like elevations.

Versatile. Said of an anther turning freely on its filament.

Verticillate. Arranged in a circle or whorl round an axis.

Villose. Hairy, with long and soft hairs.

Whorl. An arrangement of branches or leaves in a circle round an axis.

Wood. The hard part of a stem mainly composed of wood-cells, wood fibre, or tissue. 


\section{INDEX}

Names of Classes, Subclasses, Families, and Subfamilies are in small Capitals; Latin and English names of admitted genera and species in roman type; synonyms in italics.

Abies, 55 .

Abies amabilis, 59 .

Abies balsamea, 58 .

Abies concolor, 62 .

Abies Fraseri, 57.

Abies grandis, 60 .

Abies lasiocarpa, 61 .

Abies magnifica, 66 .

Abies magnifica, var. Shastensis, 67 .

Abies nobilis, 65 .

Abies renusta, 63 .

A BIETINiæ, 1.

Acacia, 540,572 .

Acacia Farnesiana, 541.

Acacia, Green-barked, 562, 563.

Acacia Greggii, 544.

Acacia tortuosa, 542.

Acacia Wrightii, 543 .

Acer, 625.

Acer circinatum, 630 .

Acer Floridanum, 634.

Acer glabrum, 631 .

Acer grandidentatum, 637.

Acer leucoderme, 636 .

Acer macrophyllum, 627 .

Acer Negundo, 641.

Acer Negundo, var. Californicum, 643.

Acer nigrum, 634 .

Acer Pennsylvanicum, 627.

Acer rubrum, 639.

Acer rubrum, var. Drummondii, 640 .

Acer rubrum, var. tridens, 641.

Acer saccharinum, 638 .

Acer Saccharum, 632.

Acer Saccharum, var. Floridanum, 634.

Acer Saccharum, var. grandidentatum, 637

Acer Saccharum, var. leucoderme, 636.

Acer Saccharum, var. Rugelii, 633.

Acer spicatum, 6:6.

ACERACEÆ, 624 .

Esculus, 641 .

Esculus austrina, 647 .

Esculus Californica, 648.

Fsculus glabra, 644 .

Æsculus glabra, var. Buckleyi, 646 .

Esculus octandra, 646 .

Esculus octandra, var. hybrida, 647.

Alder, 208.

Almond Willow, 170.

Alnus, 208.

Alnus acuminata, 214.

Alnus maritima, 215.

Alnus oblongifolia, 214.

Alnus Oregona, 210.

Alnus rhombifolia, 212.

Alnus Sitchenis, 209

Alnus tenuifolia, 211.

Amelanchier, 360.
Amelanchier alnifolia, 362 .

Amelanchier Canadensis, 360 .

Amelanchier Canadensis, var. to- Bay, Swamp, 317, 331

mentula, 361.

Amelanchier oboralis, 361.

Amyris, 588.

Amyris Elemifera, 588 .

Anacahuita, 783 .

ANaCARDIACE.E, 601.

Anamomis, 698 .

Anamomis dichotoma, 698 .

Anaqua, 786 .

Andromeda ferruginea, 726 .

A ITGIOSPERMIE, 102.

Anona, 328.

Anona glabra, 328

A NONACEE, 326.

Ants' Wood, Tt4.

APETAL 125.

Apple, 351

Apple, Crab, 352, 353, 354, 355

Apple, Haw, 399.

Apple, Pond, 328.

Apple, Turkey, 436.

AQUIFOLIACEE, 613.

A ralia, 704

A ralia spinosa, 705 .

AraliaCE.E, 704.

Arbor-vitæ, it.

Arbutus, 727.

Arbutus Arizonica, 730

Arbutus Menziesii, 728

Arbutus Xalapensis, 729 .

Ash, 758.

Ash, Black, 764.

Ash, Blue, 761 .

Ash, Green, 771.

Ash, Mountain, 356, 768 .

Ash, Prickly, $5 \$ 2$.

Ash, Pumpkin, 772.

Ash, Red, 770 .

Asl, Swainp, 762 .

Ash, Wafer, 587.

Ash, Water, $762,763$.

Ash, White, 767.

Ash-leaved Maple, 641.

Asimina, 326 .

A simina triloba, 326 .

Asp, Quaking, 154 .

Aspen, 154.

Aviceunia, 789.

A ricennia nitida, 790

Bald Cypress, 70, 71 .

Balm of Gilead, 159 .

Balsam, 157.

Balsam Cottonwood, 161

Balsam Fir, 57, 58, 61 .

Balsam, She, 57.

Bark, Georgia, 799.

Basket Oak, 271.

Bass Wood, 671, 673, 675 .

Bay, 678.

Bay, Loblolly, 678.
Bay, Sweet, 317.

Bean, Coral, 565.

Bean, Horse, 560 .

Bean, Indian, 793.

Bean, Screw, 550.

Bear Oak, $2+1$.

Bearberly, 664.

Beech, 217.

Beech, Blue, 190.

Bee-tree, 6it.

Betula, 194.

Betula Alaskana, 206

Betula coerulea, 201.

Betula cœrulea, var. Blanchardi, 202.

Betula fontinalis, 207.

Betula Kenaica, 205.

Betula lenta, 196.

Betula lutea, 197.

Betula nigra, 198

Betula occidentalis, 204.

Betula papyrifera, 202.

Betula papyrifera, var. cordifolia, 202.

Betula populifolia, 200 .

BETUlaCE伥, 189.

Big Bud Hickory, 143.

Big Shellbark, $1+1$.

Big Tree, 69.

BIGNONIACEÆ, 791.

Bilsted, 340.

Birch, 194, 204.

Birch, Black, 196, 205, 207.

Birch, Blue, 201.

Birch, Canoe, 202.

Birch, Cherry, 196.

Birch, Gray, 197, 200.

Birch, Paper, 202.

Birch, Red, 198, 205.

Birch, River, 198.

Birch, West Indian, 592.

Birch, White, 200, 206.

Birch, Yellow, 197.

Bird Cherries, 510.

Bird Cherry, 521.

Bitter Pecau, 134, 137.

Bitternut, 135.

Black Ash, 764 .

Black Birch, 196, 205, 207.

Black Calabash Tree, 797.

Black Cotton wood, 156, 161.

Black Haw, 810, 811 .

Black Ironwood, 660 .

Black Jack, 245.

Black Mangrove, 790.

Black Maple, 634 .

Black Oak, 234, 237, 239, 286.

Black Oaks, 227.

Black Olive Tree, 702 .

Black Persimmon, 750 .

Black Sloe, 518. 
Blnck Spruce, 39.

Black Waluut, IOS.

Black Willow, 16s, 169, 171, 173, 184

Blolly, 314.

Blue A sh, 761.

Blue lieeclı, 190

Blue lirirclı, :01.

Blue Jack, 250 (1.

Blue Myrtle, 667 .

Blue (lak, $27 \%$.

IBlue Spruce, 4 t.

BorRAGINACE

Bottom Shellbark, 141.

Bourreria, 784

Bourreria Havallensis, 781.

Boureria Havanensis, var. radula, 734.

Bow Wood, 307 .

Box Elder, $6+1,6+3$.

Box Wood, 6:3.

Brittle Thatclı, 105, 106.

Broad-leaved Maple, 6:7.

Bucida, 70:2

Bucida Buceras, 702 .

Buckeye, 647,648 .

Buckeye, Fetid, 6t4.

Buckeye, Olıio, $64 t$.

Buckeye, Spanish, 656 .

Buckeye, Sweet, 646 .

Buckthorn, 743 .

Bull Pine, 15, 23.

Bumelia, 740 .

Bumelia angustifolia, 744

Bumelia lanuginosa, 741 .

Bumelia lanuginosa, var. rigida, $7+2$.

Bumelia lycioides, 743 .

Bumelia tenax, $7+1$.

Burning Bush, 620.

Burr Oak, 267.

Bursera, 591.

Burzera Simaruba, 592.

BURSERACE.E, 591

Bush, Button, 802 .

Bush, Stag, 811.

Bustic, 739.

Butteruut, 126.

Button Bush, 802 .

Buttonwood, 34t, 701, 703.

Cabbage Palmetto, 108.

Cabbage Tree, 108.

Cactace 681.

CASALPINIOIDE, 534.

Calabash Tree, Black, 797.

California Laurel, 334.

California Lilac, 667.

California Nutmeg, 98.

Calyptranthes Chytraculia, 699 .

Canada Plum, 511.

Canella, 680.

Canella Winterana, 680 .

Canellace. 680 .

Canoe Birch, 202.

Canoe Cedar, 75

Canotia, 623.

Canotia holacantha, 624.

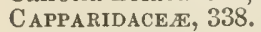

Capparis, 338.

Capparis Jaulaicensis, 338.

CAPRIFOLIACE 无, 804 .

Carica, 682.

Carica Papaya, 683

CARICACEÆ, 682 .

Carpinus, 190

Carpinus Caroliniana, 190.

Cassada, 739

Cassena, 616 .

Cassie, 541 .

Castauea, 219.
Castanea dentata, 200.

Castanea jumila, 2:21.

Castanopsis, '2*2.

Castanopsis clırysoplıylla, 223.

Catalpa, 79:2.

Catalpa Catalpa, 703.

Catalpa speciosa, 795.

Catalya, Westeru, 795.

Cat's Claw, 5i3.), 543, 544.

Ceanotlius, 665 .

Ceanotlıus arboreus, 666.

Cenuothus spinosis, 667.

Ceanotluns tliyrsitlorus, 667.

Ceanothus velutinus, var. arboreus, 6ibi.

Cedar, 93

Cedar, Canoe, 75.

Cedar Elm, 294.

Cedar, Incense, 73.

Cedar Pine, 28 .

Cedar, Port Orford, 84.

Cedar, Red, 75, 94, 95, 96.

Cedar, Rock, 93.

Cedar, Stinking, 98.

Cedar, White, 74, 82

Celastrace.e, 619.

Celtis, 298.

Celtis Mississippiensis, 300.

Celtis Mississippiensis, var. reticulata, 301

Celtis occidentalis, 299.

Celtis occidentalis, var. pumila, 300 .

Cephalanthus, 801.

Ceplualanthus occidentalis, 802 .

Cercidium, 562.

Cercidium floridum, 562

Cercidium Torreyanum, 563.

Cercis, 551.

Cercis Canadensis, 552.

Cercis Texensis, 553.

Cercocarpus, 504

Cercocarpus breviflorus, 508 .

Cercocarpus ledifolius, 507.

Cercocarpus ledifolius, var. intricatus, 508 .

Cercocarpus parvifolius, 506.

Cercocarpus parvifolius, rar. betuloides, 507.

Cercocarpus Traskiæ, 505.

Cereus, 685.

Cereus giganteus, 685 .

Champeyparis, 81 .

Chamrecyparis Lawsoniana, 84.

Chamrecyparis Nootkatensis, 83 .

Chamrecyparis thyoides, 82 .

Chapote, 750 .

Clıeckered-bark Juniper, 90.

Cherry, 509, 733.

Cherry Birch, 196.

Cherry, Bird, 521 .

Cherry, Choke, 523.

Cherry, Indian, 663.

Cherry Laurels, 510.

Cherry, Rum, 524.

Cherry, Wild, 522, 526, 527 .

Cherry, Wild Black, 524.

Cherry, Wild Red, 521.

Chestmut, 219.

Chestnut, Golden-leaved, 223.

Cliestnut Oak, 225, 272, 273.

Chestnut Oaks, 229.

Chickasaw Plum, 515.

Chilopsis, 791 .

Chilopsis linearis, 792 .

China-tree, Wild, 652.

Chinquapin, 221, 223.

Chionanthus, 777.

Chionanthus Virginica, 778.

Chittam Wood, 602, 741.

Choke Cherry, 523.

Cholla, 688.
Clirysobalanus, 532.

Chrysobalamus l caco, 532 .

Chrysoplıyllum, 745 .

Chrysopliyllum oliviforme, 745 .

Chytraculia, ties).

Clıytraculia Clıytraculia, 699

Cinmanon Bark, 681.

Cimmanon, Wilk, 680 .

Citlarexylon, 787 .

Citharexylon villosum, 788 .

Cladrastis, 567 .

Cladrastis lutea, 568 .

Clainmy Locust, 574.

Cliftonia, 612

Cliftonia monophylla, 612 .

Coccolobis, 311.

Coccolobis laurifolia, 312.

Coccolobis uvifera, 311.

Coccothrinax, 106 .

Coccothriuax jucunda, 106.

Cock-spur Thırm, 368.

Cocoa Plum, 532

Coffee-tree, 664.

Coffee-tree, Kentucky, 554 .

Colubrina, 668 .

Colubrina reclinata, 669 .

CoMbretacea, 700 .

Condalia, 657 .

Condalia obovata, 658 .

CoNIFER环 1

Conocarpus, T00.

Conocarpus erecta, 701.

Conocarpus erecta, var. sericea, 701.

Coral Bean, 565.

Cordia, 781 .

Cordia Boissieri, 783 .

Cordia Sebestena, 782 .

Cork Elm, 220.

Cork Wood, 151.

Cornace $\mathrm{Fe}, 706$.

Col'nus, 712 .

Cornus alternifolia, 717 .

Cornus asperfolia, 716 .

Cornus florida, 713

Cornus Nuttallii, 714.

Cotinus, 601.

Cotinus Americanus, 602.

Cotton Gum, 711 .

Cottonwood, 160, 162, 163, 164, 165.

Cottonwood, Balsain, 161.

Cottonwood, Black, 156, 161.

Cottonwood, Narrow-leaved, 159.

Cottonwood, Swamp, 156.

Cow Oak, 271.

Crab Apple, 352, 353, 354, 355.

Crab, Fragrant, 353.

Crab, Soulard, 355.

Crab Wood, 600.

Cratæous, 363

Cratægus acclivis, 450 .

Cratægus a cutifolia, 375 .

Cratægus æstivalis, 399.

Cratægus algens, 374.

Cratrogus amuicola, 322 .

Cratregus annosa, 483.

Cratægus anomala, 440.

Cratægus apiifolia, 486 .

Cratægus a piomorpha, 414.

Cratregus aprica, 485 .

Cratægus arborea, 377.

Cratægus Arduennæ, 373.

Cratægus Arkansana, 425.

Cratægus Arnoldiana, 437.

Cratæegus Ashei, 469.

Cratægus assurgens, 445.

Cratægus atrorubens, 408.

Cratæegus basilica, 420 .

Cratægus berberifolia, 383 .

Cratæegus Berlandieri, 429.

Cratægus blanda, 405 .

Cratægus Boyutoni, 462. 
Cratægus brachyacantha, 489 .

Cratægus Brazoria, 395.

Cratægus Buckleyi, 463.

Cratægus Bushii, 376.

Cratægus Canadensis, 428.

Cratægus Canbyi, 369.

Cratægus Champlainensis, 438.

Cratægus Chapmani, 493.

Cratregus coccinea, 459.

Cratægus coccinioides, 458.

Cratægus collina, 391 .

Cratægus consanguinea, 472 .

Cratægus cordata, 487 .

Cratægus corusca, 430 .

Cratægus crocina, 385 .

Cratægus Crus-galli, 368.

Cratægus Crus-galli, var. capillata, 369.

Cratægus Crus-galli, var. oblongata, 369.

Cratægus Crus-galli, var. pyracanthifolia, 369 .

Cratægus Crus-galli, var. salicifolia, 369.

Cratægus Dallasiana, 396.

Cratægus delecta, 451.

Cratægus denaria, 379 .

Cratægus depilis, 419 .

Cratægus Deweyana, 496 .

Cratægus dilatata, 455 .

Cratæegus dispar, 484 .

Cratægus Douglasii, 502.

Cratægus Eamesi, 454 .

Cratægus edita, 382 .

Cratægus edura, 384

Cratægus Ellwangeriana, 441.

Cratægus Engelmanni, 378.

Cratægus erecta, 375 .

Cratrgus fastosa, 393 .

Cratægus fecunda, 371 .

Cratægus fera, 386 .

Cratægus flava, 471 .

Cratægus Floridana, 476.

Cratrgus Gaultii, 494.

Cratægus gemmosa, 498 .

Cratægus Georgiana, 413.

Cratægus glabriuscula, 404 .

Cratægus gravida, 426 .

Cratægus Harbisoni, 468.

Cratægus Hillii, 444 .

Cratægus Holmesiana, 419 .

Cratregus Hudsonica, 457 .

Cratægus ignava, 475 .

Cratægus Illinoiensis, 499 .

Cratægus induta, 436.

Cratægus ingens, 409.

Cratægus integra, 481 .

Cratægus integriloba, 500 .

Cratægus Jonesæ, 460.

Cratægus Kelloggii, 431.

Cratægus lacera, 421 .

Cratægus lacrimata, 477 .

Cratægus lanuginosa, 435.

Cratægus Lettermani, 397.

Cratægus lobulata, 447.

Cratægus lucorum, 418.

Cratægus macracantha, 501 .

Cratægus Margaretta, 461 .

Cratægus micracantha, 410 .

Cratægus mitis, 407.

Cratægus Mohri, 387.

Cratægus mollis, 423

Cratægus Neo-Londinensis, 443.

Cratægus nitida, 406.

Cratægus opima, 466 .

Cratægus ovata, 402.

Cratægus Palmeri, 381

Cratregus panda, $\mathbf{4 8 0}$.

Cratægus paucispina, 415 .

Cratægus palisiaca, 390.

Cratægus pedicellata, 448 .
Cratægus penita, 409.

Cratægus pentandra, 416 .

Cratægus Peoriensis, 370 .

Cratægus pratensis, 398.

Cratxgus Pringlei, 446 .

Cratægus pruinosa, 411 .

Cratregus puuctata, 389 .

Cratægus pyriformis, 434 .

Cratægus quercina, 433.

Cratægus Ravenelii, 478 .

Cratægus recurva, 482 .

Cratægus regalis, 372 .

Cratægus rivularis, 503.

Cratægus Robur, 467.

Cratægus saligna, 490

Cratæegus Sargenti, 465.

Cratægus senta, 479 .

Cratægus sera. 424 .

Cratægus sertata, 453 .

Cratæegus signata, 380 .

Cratægus silvicola, 417 .

Cratægus sordida, 395 .

Cratægus spathulata, 488 .

Cratægus submollis, 439 .

Cratægus suborbiculata, 456.

Cratægus succulenta, 497 .

Cratægus tersa, 383

Cratægus Texana, 432.

Cratægus tomentosa, 492 .

Cratægus Treleasei, 427.

Cratægus tristis, 473.

Cratægus vegeta, 495 .

Cratægus vellusta, 464 .

Cratægus verruculosa, 394 .

Cratægus viridis, 401.

Crat:egus visenda, 474 .

Cratæegus vulsa, 403.

Crescentia, 796 .

Crescentia cucurbitina, 797

Cucumber-tree, 319.

Cucumber-tree, Larged-leaved, 320.

Cucumber-tree, Long-leaved, 322.

CUPREssinize, 2.

Cupressus, 77.

Cupressus Arizonica, 78 .

Cupressus Goveniana, 79.

Cupressus Lawsoniana. 84.

Cupressus Macnabiana, 80.

Cupressus macrocarpa. 77 .

Cupressus Nootkatensis, S3.

Cupressus pygmæa, 79 .

Cupressus thyoides, 82.

Cypress, 77, 78, 79, 80 .

Cypress, Bald, 70, 71 .

Cypress, Deciduous, 71.

Cypress, Lawson, 81.

Cypress, Monterey, 77.

Cypress, Sitka, 83.

Cypress, Yellow, 83.

Cyrilla, 611 .

Cyrilla racemiflora, 611 .

CYRILlace玉, 610.

Dahoon, 615.

Dalea, 570.

Dalea spinosa, 570.

Darling Plum, 659.

Deciduous Cypress, 71.

Desert Palm, 110.

Desert Willow, 792.

Devil Wood, 779 .

DicoTYLEDONS, 125.

Digger Pine, 23.

Dilly, Wild, 747 .

Diospyros, 748 .

Diospyros Texana, 750 .

Diospyros Virginiana, 749 .

Dipholis, 738.

Dipholis salicifolia, 739 .

Dogwood, 712.

Dogwood, Flowering, 713 .
Dogwood, Jamaica, 578.

Dogwood, Poison, 608.

Douglas Spruce, 53.

Downward Plum, 744 .

Drypetes, 595.

Drypetes Keyensis, 595.

Drypetes lateriflora, 597 .

Dwarf Maple, 631.

Ebenaces, 748.

Ebony, 537.

Ehretia, 785

Ehretia elliptica, 786 .

Elder, 805.

Elder, Box, 641, 643 .

Elkwood, 3:1.

Elliottia, 719 .

Elliottia racemosa, 719.

Elm, 287.

Elm, Cedar, 294.

Elm, Cork, 290.

Elm, Red, 293, 295.

Elm, Rock, 290.

Elm, Slippery, 293, 676.

Elm, Water, 297.

Elm, White, 289.

Elm, Winged, 291.

Encina, 256.

Engelmann Spruce, 43.

ERICACE

Eugenia, 693.

Eugenia axillaris, 695.

Eugenia buxifolia, 694 .

Eugenia confusa, 697 .

Eugenia Garberi. 697.

Eugenia monticola, 695.

Eugenia procera. 696.

Eugenia rhoinbea, 696 .

EUPHORBLACEAE, 594 .

Evergreen Oak, 278.

Evonymus, 619.

Evonymus atropurpureus, 620 .

Exostema, 800

Exostema Caribæum, 800 .

Exothea, 653.

Exothea paniculata, 653 .

Eysenhardtia, 569.

Eysenhardtia orthocarpa, 569.

FAGACE.s. 216.

Fagara, 581.

Fagara Clava-Herculis, 582.

Fagara coriacea, 581.

Fagara Fagara, 581.

Fagara flava, 583.

Fagnes, 217.

Fagus Americana, 217.

Fan Palm, 110.

Farkleberry, 732

Feltleaf Willow, $18 s$.

Fetid Buckeye, 644 .

Ficus, 308 .

Ficus aurea, 308 .

Ficus populnea, 310 .

Fiddle Wood, 788.

Fig, 308.

Fig, Wild, 308, 310.

Fir, 55 .

Fir, Balsam, $57,58,61$.

Fir, Red, 53, 65, 66, 67.

Fir, Silver, 63.

Fir. White, $59,60,62$.

Flowering Dogwood, 713

Foxtail Pine, 8, 9.

Foxtail Pines, 3.

Fragrant Crab, 353.

Franklinia, 679 .

Fraxiuus, 758 .

Fraxinus Americana, 767.

Fraxinus Americana, var. microcarpa, 767 . 
Fraximus anomala, 76.5.

Fraxinus Berlandieriana, 769.

Fraxiuus Biltmoreana, 773

Fraximus Carolinian, $76 \%$.

Fraximus coriacea, $77 \overline{7}$.

Fraxiuus cuspidata, 75 !?

Fraximus Floridana, 7ti3.

Fraximus Greggii, 760 .

Fraxinus nigra, 764

Fraximus Oregona, T76.

Fraxinus Penusylvanica, 770 .

Fraximus Penusylvauica, var. lanceolata, $7 \% 1$

Fraxinus profunda, 772.

Fraxinus quadrangulata, 761.

Fraxinus Texensis, 7 (is.

Fraxinus velutina, 774

Fremontodendron, 670 .

Fremontodendron Californicum, 676.

Frijolito, 565.

Fiinge-tree, 778 .

Gamopetala, 718 .

Geiger-tree, 782

Georgia Bark, 7 !9.

Glaucous Willow, 182.

Gleditsia, 55 i.

Gleditsia aquatica, 558 .

Gleditsia Texana, 5ё́.

Gleditsia triacanthos, 556 .

Golden-leaved Chestuut, 223.

Gordouia, 67\%.

Gordonia Altamaha, 679.

Gordonia Lasianthus, 678 .

Grape, Sea, 311.

Gray Birch, 197, 200.

Gray Pine, 27.

Great Laurel, 721 .

Green Ash, $7 \% 1$.

Green-barked Acacia, 562, 563.

Guaiacum, 579.

Guaiacum sanctum, 579.

Guettarda, 803.

Guettarda elliptica, 803.

Guiana Plum, 597.

Guin, Cotton, 711.

Gum Elastic, 741.

Gum, Hog, 603.

Gum, Sweet, 340 .

Gum, Tupelo, 711

Gumbo Limbo, 592.

Gurgeon Stopper, 694.

Gyminda, 621 .

Gyminda Grisebachii, 621.

Gyminda Grisebachii, var. glaucescens, 622 .

Gymnanthes, 599 .

Gymnanthes lucida, 600 .

Gymnocladus, 553.

Gymnocladus dioicus, 554.

GYMNoSPERMA, 1.

Hackberry, 299, 300.

HAMA MELIDACEA, 339.

Hamamelis, 341.

Hamanelis Virginiana, 342.

Haw, Apple, 399.

Haw, Black, 810, 811.

Haw, May, 399.

Haw, Parsley, 486 .

Haw, Purple, 658.

Haw, Red, 447.

Haw, Scarlet, 459 .

Hawthorn, 363.

Hazel, Witch, 341 .

Helietta, 585 .

Helietta parvifolia, 586.

Hemlock, 47, 48, 49, 50, 54 .

Hemlock, Mountain, 51 .

Hercules' Club, 705.
Heteromeles, 358.

IIeteromeles arbutifolia, 359.

Hickory, $131,145$.

Hickoly, Big 13nd, 14:3.

Ilickory, Nutmeg. 136.

Hickory l'ile, 9,33

Hickory, Slagbark, 139, 140

Hickory, Shellbark, 139.

Hickory, Swanl], 135.

Hickory, Water, 137 .

Hicoria, 131.

Hicoria alba, 143.

Hicoria aquatica, 137.

Hicoria Carolina - septentrionalis, 140.

Hicoria glabra, 144.

Hicoria glabra, var. odorata, 145.

Hicoria laciniosa, 141.

Hicoria minima, 135.

Hicoria myristicaformis, 136.

Hicoria ovata, 139.

Hicoria Pecan, 133.

Hicoria Texana, 134

Hicoria villosa, 145 .

HIPPOCASTANACEE, 643.

Hippomane, 598.

Hippomane Mancinella, 599 .

Hog Gum, 603.

Holly, 614 .

Honey Locust, $5 \pm 8,556$.

Hop Hornbeam, 191, 192.

Hop-tree, 587.

Hornbeam, 190 .

Hornbeam, Hop, 191, 192.

Horse Bean, 560.

Horse Sugar, 752 .

Huajillo, 536.

Huisache, 541

Hypelate, 654

Hypelate trifoliata, 654 .

Icacorea, 733 .

Icacorea paniculata, 733 .

Icthyomethia, 577.

Ictlyomethia Piscipula, 578.

Ilex, 614.

Ilex Cassine, 615.

Ilex decidua, 617

Ilex nionticola, 618 .

Ilex opaca, 614 .

Ilex vomitoria, 616 .

Incense Cedar, 73

Indian Bean, 793.

Indian Cherry, 663.

Ink Wood, 653.

Ironwood, 192, 193, 351, 576, 611, $612,653,741,743$.

Ironwood, Black, 660 .

Ironwood, Red, 659.

Ironwood, White, 654.

Islay, 530.

Jack Oak, 245.

Jack Pine, 27.

Jacquinia, 735 .

Jacquinia armillaris, 735 .

Jacquinia Keyensis, 735 .

Jamaica Dogwood, 578.

Jersey Pine, 30

Joe Wood, 735.

Joshua Tree, 122

Judas-tree, 552

JUGLANDACE不, 125.

Juglans, 126

Juglans Californica, 130

Juglans cinerea, 126.

Juglans nigra, 128.

Juglaus rupestris, 129.

Juniper, 85, 86, $87,88,89,90,91$, 92.

Juniper, Checkered-bark, 90 .
Juniperus, 85.

Juniperus 13arbadensis, 95.

Jumiperus Califormica, 87.

Juniperus connuunis, 86 .

Juniperus communis, var. Sibirica, 87.

Jumiperus flaccida, 89.

Juniperus monosperma, 92.

Juniperus occidentalis, 91.

Juniperus paclıyplılra, 90.

Juniperus sabinoides, 93.

Jumiperus scopulorum, 96.

Juniperus Utahensis, 88.

Jumiperus Virginiana, 94.

Kalmia, 722

Kalnia latifolia, 723

Kentucky Coffee-tree, 554 .

Kuackaway, 786 .

Knob-colle Piue, 22.

Kneberlinia, 681 .

Koberlinia spinosa, 682 .

KOEBERLINIACEE, 681 .

Krugiodendron, 660 .

Krugiodendron ferreum, 660 .

Laguncularia, 703.

Laguncularia racemosa, 703 .

Larch, 34, 35, 65 .

Large-leaved Cucumber-trce, 320.

Larix, 34.

Larix Americana, 35.

Larix Lyallii, 37.

Larix occidentalis, 36

LAURACEA, 329.

Laurel, 723.

Laurel, California, 334.

Laurel, Great, 721 .

Laurel, Mountain, 723.

Laurel Oak, 251.

Lawson Cypress, 84.

Leaf, Sweet, 752.

Leatlier Wood, 611.

LEGUMINOSA, 533

Leitneria, 151

Leitneria Floridana, 151.

LEITNERIACE正, 150

Leucæna, 545 .

Leucæuna Greggii, 515.

Leucana pulverulenta, 546 .

Libocedrus, 72.

Libocedrus decurrens, 73.

Lignum-vitæ, 579.

Lilac, 667.

Lilac, California, 667.

LILIACE $\not 115$.

Limbo, Gumbo, 592.

Lime, Ogeecliee, 710.

Lime, Wild, 581.

Linden, 670.

Liquidambar, 339.

Liquidambar Styraciflua, 340.

Liriodendron, 324

Liriodendron Tulipifera, 325 .

Live Oak, 253, 256, 257, 284.

Loblolly Bay, 678 .

Loblolly Pine, 19.

Locust, 557, 571.

Locust, Clammy, 574.

Locust, Honey, 548, 556.

Locust, Water, 558.

Locust, Yellow, 572.

Lodge Pole Pine, 27.

Log Wood, 658.

Long-leaved Cucumber-tree, 322.

Long-leaved Pine, 17.

Lyonothamnus, 350.

Lyonothamnus floribundus, 351.

Lysiloma, 538 .

Lysiloma Bahamensis, 539.

Lysiloma latisiliqua, 539. 
Madroña, 728, 729, 730.

Magnolia, 315.

Magnolia acuminata, 319.

Magnolia acuminata, var. cordata, 320 .

Magnolia foetida, 316.

Magnolia fottida, var. Exoniensis, 317.

Magnolia Fraseri, 322

Magnolia glauca, 317 .

Maguolia glauca longifolia, 318 .

Magnolia macrophylla, 320 .

Magnolia major, 318.

Magnolia, Mountain, 319, 322.

Magnolia pyramidata, 324 .

Iagnolia Thompsoniana, 318.

Magnolia tripetala, 321.

Mignoliace $\approx, 315$.

Malogany, 593, 609.

Mahogany, Mountain, 504.

Malus, 351.

Malus angustifolia, 352.

MIalus coronaria, 353.

Malus Ioensis, 354 .

Malus rivularis, 355 .

Malus Soulardi, 355.

Manchineel, 599.

Mangrove, 691

Mangrove, Black, 790.

Mangrove, White, 703 .

Maple, 625.

Maple, Ash-leared, 641.

Maple, Black, 634 .

Maple, Broad-leaved, 627.

Maple, Dwarf, 631.

Maple, Mountain, 626 .

Miple, Red, 639, 641.

Maple, Rock, 632.

Maple, Scarlet, 639.

Maple, Silver, 638.

Maple, Soft, $63 \mathrm{~S}$.

Maple, Striped, 627.

Maple, Sugar, 632, 634, 636, 637.

Maple, Vine, 630.

Marlberry, 733.

Marsh Pine, 20.

Mastic, 737 .

Maul Oak, 257.

May Haw, 399.

Meliace e, 593.

Mesquite, $\check{5} 47$.

Mesquite, Screw Pod, 550.

Metopium, 603.

Metopium Metopium, 603.

Mexican Mulberry, 305.

Mimosa, $5 \pm 6$.

Mimosolde:, 533.

Mimusops, 746 .

Mimusops Sieberi, 747

Mock Orange, 527.

MIockernut, 143 .

Mohrodendron, 754 .

Mohrodendron Carolinum, 755 .

Mohrodendron dipterum, 756 .

Monocotyledons, 102.

Monterey Cypress, 77.

Monterey Pine, 21.

Moose Woorl, 627 .

Moracez, 302.

Morus, 302.

Morus celtidifolia, 305 .

Morus rubra, 303.

Mossy Cup Oak, 267.

Mountain Ash, 356, 768 .

Mountain Hemlock, 51.

Mountain Laurel, 723.

Mountain Magnolia, 319, 322.

Mountain Mahogany, 504.

Mountain Maple, 626.

Mountain White Oak, 277.

Mulberry, 302.
Mulberry, Mexican, 305.

Mulberry, Red, 303.

Myrica, 147.

Myrica Californica, 149 .

Myrica cerifera, 147.

Myrica inodora, $14 \mathrm{~S}$.

MYRICACE E, 146.

MYRSINACE $Æ, 733$.

MrRTACEE, 693.

Myrtle, Blue, 667 .

Myrtle, Wax, 147, 148, 149.

Naked Wood, 669, 698.

Nannyberry, sos.

Narrow-leaved Cottonwood, 159.

Norway Pine, 25.

- Nut Pine, 10, 11, 12.

Nut Pines, 3.

Nutmeg, California, 98.

Nutmeg Hickory, 136.

NyctaginaceE, 313.

Nyssa, 707.

Nyssa aquatica, 711 .

Nyssa biflora, 709 .

Nyssa Ogeche, 710.

Nyssa sylvatica, 707 .

Nyssa sylvatica, vạ. biflora, 709.

Oak, 226

Oak, Basket, 271.

Oak, Bear, 241.

Oak, Black, 234, 237, 239, 286.

Oak, Blue, 277.

Oak, Burr, 267.

Oak, Chestnut, 225, 272, 273.

Oak, Cow, 271 .

Oak, Evergreen, 278.

Oak, Jack, 245 .

Oak, Laurel, 251.

Oak, Live, 253, 256, 257, 284.

Oak, Maul, 257.

Oak, Mossy Cup, 267.

Oak, Mountain White, 277.

Oak, Overcup, 268.

Oak, Pin, 232.

Oak, Post, 264.

Oak, Red, 230, 235, 244.

Oak, Rock Chestuut, 272.

Oak, Scarlet, 236 .

Oak, Scrub, 241, 255, 276, 283.

Oak, Shin, 263, 276 .

Oak, Shingle, 251 .

Oak, Spanish, $2 \pm 2$.

Oak, Swainp Spanish, 232, 244.

Oak, Swamp White, 268, 269.

Oak, Tan Bark, 225.

Oak, Turkey, 240.

Oak, Valley, 261.

Oak, Water, 246, 249.

Oak, White, 259, 261, 262, 263, 275, 279,280 .

Oak, Willow, 247.

Oak, Yellow, 273.

Oak, Yellow-bark, 237.

Ocotea, 332.

Ocotea Catesbyana, 333 .

Ogeechee Lime, 710.

Ohio Buckeye, 644 .

Old Field Pine, 19.

Old Man's Beard, 778.

Oleacese, 757.

Olive Tree, Black, 702.

Olueya, 575 .

Olneya Tesota, 576.

Opuntia, 687.

Opuntia fulgida, 688 .

Opuntia spinosior, 689 .

Opuntia versicolor, 690 .

Orange, Mock, 527 .

Orange, Osage, 307.

Orange, Wild, 527.
Oreodoxa regia, 113.

Osage Orange, 307.

Osmanthus, 779 .

Osmanthus Americanus, 779.

Ostrya, 191.

Ostrya Knowltoni, 193.

Ostrya Virginiana, 192.

Overcup Oak, 268.

Oxydendrum, 724 .

Oxydendrum arboreum, 725.

Palm, Desert, 110.

Palm, Fan, 110.

Palm, Royal, 112, 113.

PaLME, 10:2.

Palmetto, 107, 109.

Palmetto, Cabbage, 108.

Palmetto, Silver-top, 105.

Palins, 102.

Palo Verde, 563.

Paper Birch, 202.

Papilionat.e, 534.

Paradise-tree, 590

Parkinsonia, 559.

Parkinsonia aculeata, 560.

Parkinsonia microphylla, 561.

Parsley Haw, 486.

Pasania, 224.

Pasania densiflora, 225.

Pasania densiflora, var. echinoides, 226.

Patton Spruce, 51.

Pawpaw, 326, 683.

Peach Willow, 170.

Pecan, 133.

Pecan, Bitter, 134, 137.

Pepperidge, 707.

Persea, 3:9.

Persea Borbonia, 330

Persea pubescens, 331.

Persimmon, 749.

Persimmon, Black, 750 .

Petale, 315.

Picea, 38.

Picea Breweriana, 45.

Picea Canadeusis, 42.

Picea Engelmanni, 43.

Picea Mariana, 39.

Picea Parryana, 44.

Picea rubens, 41 .

Picea Sitchensis, 46.

Pigeon Plum, 312.

Pignut, 144.

Pin Oak, 232

Pinckneya, 798 .

Pinckneya pubens, 799 .

Pine, Bull, 15, 23.

Pine, Cedar, 28.

Pine, Digger, 23.

Pine, Foxtail, 8, 9.

Pine, Gray, 27.

Pine, Hickory, 9, 33.

Pine, Jack, 27

Pine, Jersey, 30.

Pine, Knob-cone, 22.

Pine, Loblolly, 19.

Pine, Lodge Pole, 27.

Pine, Long-leaved, 17.

Pine, Marsh, 20.

Pine, Monterey, 21.

Pine, Norway, 25.

Pine, Nut, 10, 11, 12.

Pine, Old Field, 19.

Pine, Pitch, 20, 24.

Pine, Pond, 20.

Pine, Prickle-cone, 32.

Pine, Red, '25.

Pine, Rocky Mountain White, 7.

Pine, Sand, 31.

Pine, Scrub, 26, 30.

Pine, Short-leaved, 29. 
Pine, Slash, 18.

Pine, Sonthern, 17.

Piue, Spruce, "ss, 31.

Piue, sugar, 5.

Pine, Swamp, 18.

line, 'Table Mountain, 33.

l'ine, 'lorrey's, 34.

Pine, White, 4, 5, 6, s.

Pine, Yellow, 14, 15, 29.

Piñon, 1(1, 11, 12.

Pinus, 2.

Pinus albicaulis, 8.

Piuus aristata, 9.

Pinus Arizonica, 14.

Pinus attenuata, 22.

Pinus B.1ltouriana, 8 .

Pinns Caribar, 18.

Pimus cembroides, 10 .

Pinus Chiluahuana, 14.

Pinus clausa, 31.

Piuus coutorta, 26.

Pinus contorta, var. Murrayana, 27.

Pinus Coulteri, 24.

Pinus divaricata, 27.

Piuus echiuata, 29.

Pinus edulis, 11.

Pinus flexilis, 7 .

Pinus glabra, 28 .

Pinus heterophylla, 18 .

Pinus Lambertiana, 5.

Pinus monophylla, 12.

Pinus monticola, 5 .

Pinus muricata, 32.

Pinus palustris, 17.

Pinus ponderosa, 15

Pinus ponderosa, var. Jeffreyi, 16.

Pinus ponderosa, var. scopulorum, 16.

Pinus pungens, 33 .

Pinus quadrifolia, 10.

Pinus radiata, 21.

Pinus resinosa, 25.

Pinus rigida, 20 .

Pinus Sabiniana, 23.

Pinus serotina, 20.

Pinus strobiformis, 6 .

Pinus Strobus, 4.

Pinus Treda, 19.

Pinus Torreyana, 34.

Pinus Virginiana, 30.

Pisonia, 313

Pisonia longifolia, 314.

Pisonir obtusata, 314.

Pitch Pine, 20, 24.

Pitch Pines, 12.

Planera, 296.

Planera aquatica, 297.

Plane-tree, $3+4$.

Platanaceat, 343

Platanus, 344.

Platanus occidentalis, 344.

Platanus racemosa, $3 \pm 6$.

Platanus Wrightii, 347.

Plum, 509.

Plum, Canada, 511.

Plum, Clickasaw, 515

Plum, Cocoa, 532.

Plum, Darling, 65.?.

Plum, Downward, 744 .

Plum, Guiana, 597.

Plum, Pigeon, 312.

Plum, Red, 511.

Plum, Wild, 512, 513, 517.

Plums, 510.

Poison Dogwood, 608.

Poison Sumach, 608.

Poison Wood, 603.

Polygonace $2,311$.

Polypetal $2,315$.

Pomette Bleue, 489.

Pond Apple, 328.
Fond Pine, 20.

l'oplar, 15\%. 155.

Poplar, Yellow, 325.

I'opulus, 15'.'.

I'ojulus acuminata, 160.

Populus angustifolia, 159.

Populus balsamifera, 167.

Populus balsamifera, var. candicaus, 15:1.

Popuhus deltoidea, 163.

Populus deltoidea, var. occidentalis, 164

Populus Fremontii, 164.

Populus graudidentata, 155.

Populus het erophylla, 156.

Populus Mexicaun, 162.

Populus tremuloides, 154.

Populus triclocarpa, 161.

Populus Wislizeni, 165.

Port Orford Cedar, 84.

Post Oak, 264.

Prickle-cone Pine, 32.

Prickly Ash, 582.

Prince Wood, 800 .

Prosopis, 547 .

Prosopis juliflora, 548.

Prosopis juliflora, var. glandulosa, 549 .

Prosopis juliflora, var. velutina, 550.

Prosopis pubescens, 550.

Prumus, 509

Prumus Alabamensis, 526.

Prumus Alleghaniensis, 516.

Prunus Americana, 512.

Prunus Americana, var. lanata, 513.

Prunus angustifolia, 515.

Prunus australis, 527.

Prunus Caroliniana, 527.

Prunus demissa, 523.

Prunus emarginata, 522.

Prunus emarginata, var. villosa, 522.

Prunus hortulana, 513.

Prunus hortulana, var. Mineri, 515.

Prunus ilicifolia, 530.

Prunus ilicifolia, var. integrifolia, 531.

Prunus integrifolia, 531.

Prumus nigra, 511

Prunus Pennsylvanica, 521.

Prunus serotina, 524

Prunus spliærocarpa, 529.

Prunus subcordata, 517.

Prunus tarda, 519.

Prunus umbellata, 518 .

Prunus umbellata, var. injucunda, 519

Prunus Virginiana, 523.

Pseudophoenix, 114.

Pseudophøenix Sargenti, 115.

Pseudotsuga, 52.

Pseudotsuga macrocarpa, 54.

Pseudotsuga mucronata, 53.

Ptelea, 587.

Ptelea trifoliata, 587

Pumpkin Ash, 772.

Purple Haw, 658.

Pyrus Americana, var. decora, 357.

Quaking Asp, 154

Quercus, 226.

Quercus acuminata, 273 .

Quercus agrifolia, 256 .

Quercus alba, 259.

Quercus Arizonica, 280.

Quercus brevifolia, 250.

Quercus breviloba, 275.

Quercus Californica, 239

Quercus Catesbæi, 240
Quercus Cliapmaui, 266.

(Quercus clirysolepis, "257.

(quercus clirysolejis, var. Palmeri, 458

(Quereus clirysolepis, var. vaccinifolia, "2:8.

Quercus coccinen, 236 .

Querems elemsiflor, 2,5

Quercus digritata, 242.

Quercus Douglasii, 277.

Quercus dumosa, 283.

Qucreus dumosa, var. revoluta, 284.

Quercus ellipsoidalis, '234.

Quercus limoryi, 286.

Quercus Engelmami, 278.

Quercus Gambclii, 263.

Quercus Garryana, "26".

Quercus Georgiana, "233.

Quercus lieteropliylla, 248.

Quercus liypoleuca, 252.

Quercus imbricaria, $2 \overline{1} 1$.

Quercus laurifolia, 249.

Quercus Leama, 252.

Quercus lobata, 261.

Quercus lyrata, 268.

Quercus macrocarpa, 267.

Quercus Marilandica, 245.

Quercus Miclauxii, 271.

Quercus minor, 264

Quercus myrtifolia, 255.

Quercus nana, 241.

Quercus nigra, 246.

Quercus oblongifolia, 279.

Quercus pagodrefolia, 244.

Quercus palustris, 232.

Quercus Phellos, 247.

Quercus platanoides, 269.

Quercus Prinus, 272.

Quercus reticulata, 282.

Quercus rubra, 230.

Quercus Rudkini, 248.

Quercus Texana, 235.

Quercus tomentella, 258.

Quercus Toumeyi, 281.

Quercus undulata, 276.

Quercus velutina, 237.

Quercus Virginiana, 284.

Quercus Virginiana, var. maritima, 286.

Quercus Virginiana, var. minima, 286.

Quercus Wislizeni, 253.

Red Ash, 770.

Red Bay, 330 .

Red Birch, 198, 205

Red Cedar, 75, 94, 95, 96.

Red Elm, 293, 295.

Red Fir, 53, 65, 66, 67.

Red Haw, 447.

Red Ironwood, 659.

Red Maple, 639, 641.

Red Mulberry, 303.

Red Oak, 230, 235, 244.

Red Pine, 25.

Red Plum, 511

Red Spruce, 41.

Red Stopper, 697.

Redbud, 552, 553.

Redwood, 68.

Retama, 560.

Reynosia, 658.

Reynosia latifolia, 659 .

Reynosia septentrionalis, 659.

RHAMNACEÆ, 657 .

Rhamnidium ferreum, 660 .

Rhamnus, 661.

Rhamnus Caroliniana, 663.

Rhamnus crocea, 662 .

Rhamnus crocea, var. insularis, 663 .

Rhamuus crocea, var. pilosa, 663. 
Rhamnus Purshiana, 664 .

Rhizopliora, (691.

Rhizophora Nangle, 692.

RHIzoPHORACE. (6)

Rhododendron, 720 .

Rhododendron maximum, 721.

Rhus, 60t.

Rhus copallina, 606.

Rhus copallina, var. Ianceolata, 608 .

Rhus hirta, 60J.

Rluus integrifolia, 609.

Rhus Metopium, 603.

Rhus Yernix, 608 .

River Birch, 198.

Robinia, 5i1.

Robinia Neo-Mexicana, 573.

Robinia Pseudacacia, 572.

Robinia viscosa, 574 .

Rock Cedar, 93.

Rock Chestuut Oak, 272 .

Rock Elm, 290.

Rock NIaple, 632.

Rocky Mountaiu White Pine, 7.

Rosace.e, 348.

Rose Bay, 721

Royal Palm, 112, 113.

Roystonea, 112.

Roystonea regia, 113.

RUBIACEE, T9S.

Rum Cherry, 52t.

Rutacex, 580.

Sabal, 107 .

Sabal Mexicana, 109

Sabal Palmetto, 108.

SAliCACEæ, 152.

Salix, 166.

Salix Alaxensis, 188.

Salix amplifolia, 185

Salix amygdaloides, 170.

Salix balsamifera, 178 .

Salix Bebbiana, 183.

Salix Bonplaudiana, 172.

Salix cordata, 181.

Salix cordata, var. Liackenzieana, 180.

Salix discolor, 182.

Salix fluviatilis, 175 .

Salix fluviatilis, var. argyrophylla, 176.

Salix fluriatilis, var. exigua, 176 .

Salix Hookeriana, 186.

Salix lævigata, $1 \mathrm{~m}$.

Salix lævigata, var. angustifolia, 171.

Salix lævigata, var. congesta, 172.

Salix lasiandra, 173.

Salix lasiandra, var. caudata, 174 .

Salix lasiandra, var. Lyallii, $17 \pm$.

Salix lasiolepis, 179.

Salix longipes, 169.

Salix lucida, $17 t$.

Salix Missouriensis, 181.

Salix nigra, 168.

Salix nigra, var. falcata, 168.

Salix Nuttallii, 184.

Salix Nuttallii, var. brachystachys, 185.

Salix occidentalis, 169.

Salix sessilifolia, 176

Salix Sitchensis, 187 .

Salix taxifolia. 177.

Salix Wardi, 169.

Sambucus, 805 .

Sambucus Canadensis, var. Mexicana, 806 .

Sambucus glauca, 807 .

Sambucus Mexicana. 806 .

Sand Bar Willow, 175.

Sand Pine, 31.

SAPINDACE $\approx, 6 \pm 9$.
Sapindus, 649 .

Sapindus Drummondi, 652.

Sapindus marginatus, 651.

Sapindus Saponaria, 650 .

SAPOTACEE, 736 .

Sassafras, 335 .

Sassafras Sassafras, 337.

Satinwood, $5 \$ 3$.

Savin, 94.

Scarlet Haw, 459 .

Scarlet Maple, 639, 611.

Scarlet Oak, 236 .

Schæfferia, 62:.

Schæfferia frutescens, 623.

Screw Bean, $5 \pi 0$.

Screw Pod Mesquite, 550 .

Scrub Oak, $241,255,276,283$.

Scrub Pine, 26, 30.

Sea Grape, 311.

Sequoia, 68.

Sequoia sempervirens, 68 .

Sequoia Wellingtonia, 69.

Serelloa, 111.

Serenoa arborescens, 111.

Service Berry, 360, 361, 362.

Shad Bush, 360, 361.

Shagbark Hickory, 139, 110.

She Balsam, 57 .

Sheepberry, 808 .

Shellbark, Big, $1+1$.

Shellbark, Bottom, 141 .

Shellbark Hickory, 139.

Shin Oak, 263, 276.

Shingle Oak, 251.

Shining Willow, 174.

Short-leaved Pine, 29.

Sideroxylum, 737 .

Sideroxylum Mastichoden dron, 737 .

Silver Bell Tree, 755 , 756 .

Silver Fir, 63.

Silver Maple, 638.

Silver-top Palmetto, 105.

Simaruba, 590 .

Simaruba glauca, 590.

SIMARUBACE. 589.

Sitka Cypress, 83.

Sitka Spruce, 46.

Slash Pine, 18.

Slippery Elm, 293, 676.

Sloe, $516,518,519$.

Sloe, Black, 518.

Snowdrop Tree, 756 .

Soapberry, 650, 651, 652 .

Soft Maple, 638.

Soft Pines, 3.

Sophora, 564

Sophora affinis, 566 .

Sophora secundiflora, 565 .

Sorbus, 356

Sorbus Americana, 356.

Sorbus Americana, var. decora, 357.

Sorrel-tree, 725 .

Soulard Crab, 355.

Sour Tupelo, 710 .

Sour Wood, 725.

Southern Pine, 17.

Spanish Bayonet, 117.

Spanish Buckeye, 6テ̋6.

Spanish Dagger, 117, 118, 119, 120 ,

$121,123,124$

Spanish Oak, 242.

Spauish Stopper, 694.

Sparkleberry, 732.

Spice-tree, 334 .

Spruce, 38.

Spruce, Black, 39

Spruce, Blue, 44.

Spruce, Douglas, 53.

Sprice, Eugelmann, 43.

Spruce, Patton, 51.

Spruce Pine, 28, 31 .
Spruce, Red, 41.

Spruce, Sitka, 46.

Spruce, Tideland, 46.

Spruce, Weeping, 45 .

Spruce, White, 42,43 .

Stag Bush, 811.

Staghorn Sumach, 605 .

STERCUliace E, 676 .

Stinking Cedar, 98.

Stone Pines, 3.

Stopper, 695 .

Stopper, Gurgeon, 694.

Stopper, Red, 697.

Stopper, Spanish, 694.

Stopper, White, 695.

Striped Maple, 627.

Strong Back, TSt.

STYRACEE, $75 t$.

Sugar, Horse, 752.

Sugar Maple, 632, 63 $, 636,637$.

Sugar Pine, 5.

Sugarberry, 299, 300.

Sumach, 606.

Sumach, Poison, 608.

Sumach, Staghorn, 605.

Suwarro, 685.

Swamp Ash, 762 .

Swamp Bay, 31 $\mathbf{\imath}, 331$.

Swamp Cottonwood, 156.

Swamp Hickory, 135.

Swamp Pine, 1S.

Swamp Spanish Oak, 232, 24 .

Swamp White Oak, 268, 269.

Sweet Bay, 317, 331.

Sweet Buckeye, 646 .

Sweet Gum, 340 .

Sweet Leaf, 752.

Swietenia, 593.

Swietenia Mahagoni, 593

Sycamore, $3 \pm t, 346,34 \%$.

SYMPLOCACEE, 75:2.

Symplocos, 752 .

Symplocos tiuctoria, 752 .

Table Mountain Pine, 33.

Tacmahac, 157

Tamarack, 35, 36, 37.

Tamarind, Wild, 539

Tan Bark Oak, 225

Tassajo, 689 .

TAXACEE, 97

TAXODIE, 2.

Taxodium, 70 .

Taxodium distichum, 71 .

Taxodium distichum, var. imbrica. rium, 72 .

Taxus, 99.

Taxus brevifolia, 100.

Taxus Floridana, 101

Terminalin Buceras, 702 .

Thatch, 103, 104.

Thatch, Brittle, 105, 106.

THEACE 2,677 .

Theophrastaces, 735 .

Thoru, Cock-spur, 368 .

Thorn, Washington, 437 .

Thrinax, 103.

Thriuax Floridana, 103.

Thrinax Keyeusis, 104.

Thrinax microcarpa, 105.

Thuya. 74 .

Thuya occidentalis, 74 .

Thuya plicata, 75 .

Tideland Spruce, 46.

Tilia, 670 .

Tilia Americana, 671 .

Tilia australis, 672.

Tilia Floridaua, $60^{\circ}$.

Tilia heterophylla, 674

Tilia Michauxii, 673.

Tilia pubescens, 675 . 
Tiliacese, 669.

Titi, 61:.

Tollon, 359.

Toothache-tree, 582.

Torch Wood, 558 .

Torreya, 98.

Torrey's Pine, 34.

Toxylon, 306 .

Toxylon pomiferum, 307.

Toyon, 359.

Tsuga, 47 .

Tsnga Camadensis, $4 \mathrm{~S}$.

Tsuga Caroliniana, 49.

Tsuga heterophylla, 50.

Tsuga Mertensiana, 51.

Tulip-tree, 325.

Tumion, 97.

Tunion Californicum, 9S.

Tumion taxifolimn, 98.

Tupelo, 707 .

Tupelo Gum, 711.

Tupelo, Sour, 710.

Turkey Ap]le, 436 .

Turkey Oak, 240.

ULMACEX, 287.

Ulmus, 287.

Ulmus alata, 291.

Ulmus Americana, 289.

Ulmus crassifolia, 294.

Ulmus fulva, 293.

Ulmus serotina, 295.

Ulmus Thomasi, 290.

Umbellularia, 334 .

Umbellularia Californica, 334 .

Umbrella-tree, 321.

Uña de Gato, $54 t$.

Ungnadia, 655.

Ungnadia speciosa, 656 .

Vaccinium, 731.

Vaccinium arboreum, 732 .

Valley Oak, '261.

Vauquelinia, 349 .

Vauquelinia Californica, $3+9$.

VERBENACE E, 787.

Viburnum, 808 .

Viburnum Lentago, 808.

Vibuinum prunifolium, 811.

Viburnum rufidulum, 810 .

Vine Maple, 630.

Virgilia, 568 .

Wafer Ash, 587.

Wahoo, 291, 620.

Walnut, $126,129,130$

Walnut, Black, 128 .
Washington Thorn, 487.

Washingtonia, 105.

Washingtonia filamentosa, 110 .

Water Ash, $76^{\circ}, 763$.

Water Film, :97.

Water Hickory, 137.

Water Locust, $5 i \mathrm{~s}$.

Water Oak, 246, 249 .

Wax Myrtle, 14\%, 148, 149.

Weejing Spruce, 45 .

West Indian Birch, 592.

Westeru Catal pa, 795.

White Ash, 767.

White Birch, 200, 206.

White Cedar, $74,8:$.

White Elm, 289?

Wlite Fir, 59, 60, 62.

White Ironwood, 654 .

White Mangrove, 703.

Wlite Oak, 259, 261, 262, 263, 275, $279,280$.

White Oaks, 229.

White Pine, 4, 5, 6, 8 .

Wlite Pines, 3.

White Spruce, 42, 43.

White Stopper, 695.

White Willow, 179 .

White Wood, 595,680 .

Wild Black Cherry, 524.

Wild Cherries, 510.

Wild Cherry, 522, 526, 527.

Wild Clina-tree, 652.

Wild Cinnamon, 680 .

Wild Dilly, $74 \pi$.

Wild Fig, 308, 310.

Wild Lime, 581.

Wild Orange, 527.

Wild Plum, 512, 513, 517.

Wild Red Cherry, 521.

Wild Tamarind, 539 .

Willow, 166.

Willow, Almond, 170

Willow, Black, 168, 169, 171, 173, Yucca gloriosa, var. recurvifolia $18 t$.

Willow, Desert, 792.

Willow, Feltleaf, 188.

Willow, Glaucous, 182.

Willow Oak, 247.

Willow Oaks, 228.

Willow, Peach, 170.

Willow, Sand Bar, 175

Willow, Shining, 174.

Willow, White, 179 .

Winged Elm, 291.

Witch Hazel, $3 \pm 1$.

Wood, Ants', 744.

Wood, Bass, 671, 673, 675 .
Wood, Bow, 307.

Wood, Box, 623.

Wood, Clittall, 602, 741

Wool, Cork, 151.

Wood, Crab, b(c).

Wood, Devil, 77!).

Wood, Fiddle, 788 .

Wood, Ink, 653.

Wood, Joe, 735.

Wood, Leather, 611.

Wood, Log, 658.

Wood, Moose, 627.

Wood, Naked, 669, 698.

Wood, Poison, 603.

Wood, Prince, 800 .

Wood, Sour, 725.

Wood, Torch, 588 .

Wood, White, 595, 680.

Wood, Yellow, 568, 623 .

Tanthoxylum Clava-Herculis, 582.

Xanthoxylum Fagara, 581.

Ianthoxylum flavum, 583.

Xolisma, 726.

Xolisma ferruginea, 726 .

Yaupon, 616.

Yellow-bark Oak, 237.

Yellow Birch, 197.

Yellow Cypress, 83.

Yellow Locust, 572.

Yellow Oak, 273.

Yellow Pine, 14, 15, 29.

Yellow Poplar, 325.

Yellow Wood, 568, 623.

Yew, 99, 100, 101

Yucca, 115.

Yucca aloifolia, 117.

Yucca arborescens, 122

Yucca constricta, 124 .

Yucca Faxoniana, 121

Yucca gloriosa, 123. 123.

Yucca macrocarpa, 118.

Yucca macrocarpa, 121.

Yucca Mohavensis, 119

Yucca radiosa, 124.

Yucca Schottii, 120.

Yucca Treculeana, 117.

YUCC \&, 115.

Zygia, 535 .

Zygia brevifolia, 536 .

Zygia flexicaulis, 537 .

Zygia Unguis-cati, 535

ZYGOPHYLLACEA, 578. 

The Itiuergito prege

Electrotyped and printed by H.O. Houghton \& Co. Cambridge, Mass., U.S. A. 


\title{
MANUAL OF THE TREES
}

\section{OF NOR'TH AMERICA \\ (EXCLUSIVE OF MEXICO)}

\author{
BY \\ CHARLES SPRAGUE SARGEN'T
}

Director of the Arnold Arboretum of Harvard University

Author of The Silva oi North America

WITH SIX HUNDRED AND FORTY-FOUR ILLUSTRATIONS

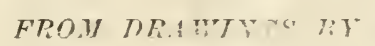

CHARLES EDWARD FAXON

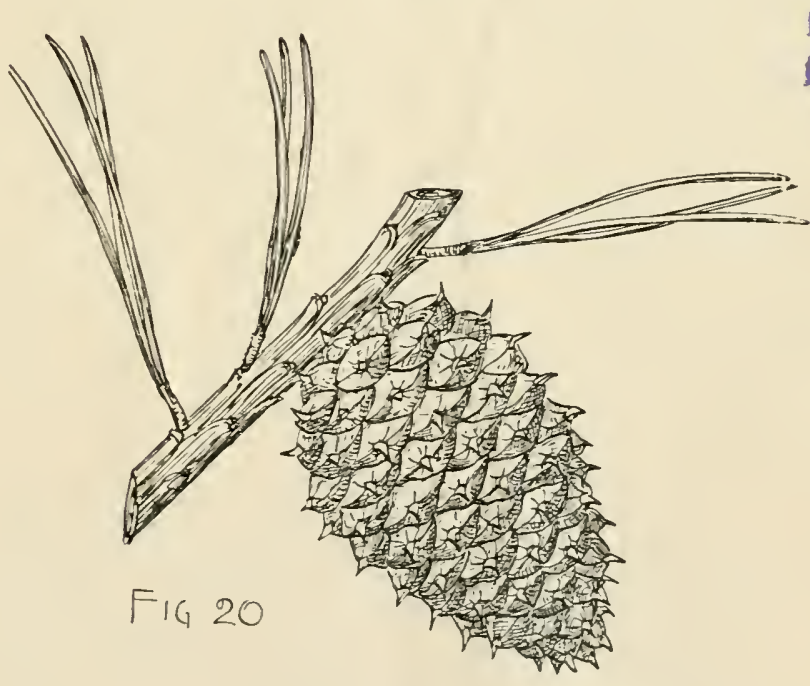

RiBRERY MEW YORK GUTANICAL GARDEN

Pimus rigida

HOUGHTON, MIFFLIN \& COMPANY

4 Park St., Boston: 85 Fifth Ave., New York 


\section{MANUAL OF 'THE \\ TREES OF NOR'TH AMERICA}

(EXCLUSIVE OF MEXICO)

\section{BY CHARLES SPRAGUE SARGEN'T \\ A uthor of "The Silve of North America," "Trees and Shrubs," etc.}

With 644 illustrations by C. E. Faxou. In green buckram, Svo, $\$ 6.00$, net. Postpaid.

DROFESSOR Sargent's new work contains brief descriptions in plain and simple language of some 630 trees, accompanied by a figure of the leaves, fruits, and flowers of each tree, with keys leading to a ready determination of the genera and species. 'The illustrations are a feature of the book. 'They are reproductions of drawings made by Mr. Charles E. Faxon, the artist who made the illustrations for "The Silva of North America," and exhibit in a remarkable degree his skill, knowledge, anc taste, - the salient or more characteristic features of each species being shown in an admirable manner.

Professor Sargent's descriptions bring out the botanical characters of each genus and species, its geographical distribution and economic value, and its relationship to other species of the same group growing in other parts of the world. The book represents in condensed form the life-work of the author and of the artist in studying, describing, and illustrating the trees of North America, which they have succeeded in making known as the trees of no other continent are known.

The Manual makes available in convenient form the most essential points of the treasures of information to be found in "The Silva of North America." It will be indispensable to every one interested in nature, but especially to all

BOTANISTS, TEACHERS, FORESTERS, LANDSCAPE-GARDENERS, HORTICULTURISTS, NURSERYMEN, PARK SUPERINTENDENTS,

AND THE OWNERS OF COUNTRY PLACES.

As a convenient handbook it will serve as a guide to the trees to persons travelling in different parts of this country. Professor Sargent is, without doubt, the greatest living authority on his subject, and his new work will fill a place similar to that long held by Gray's Manual of Botany. 


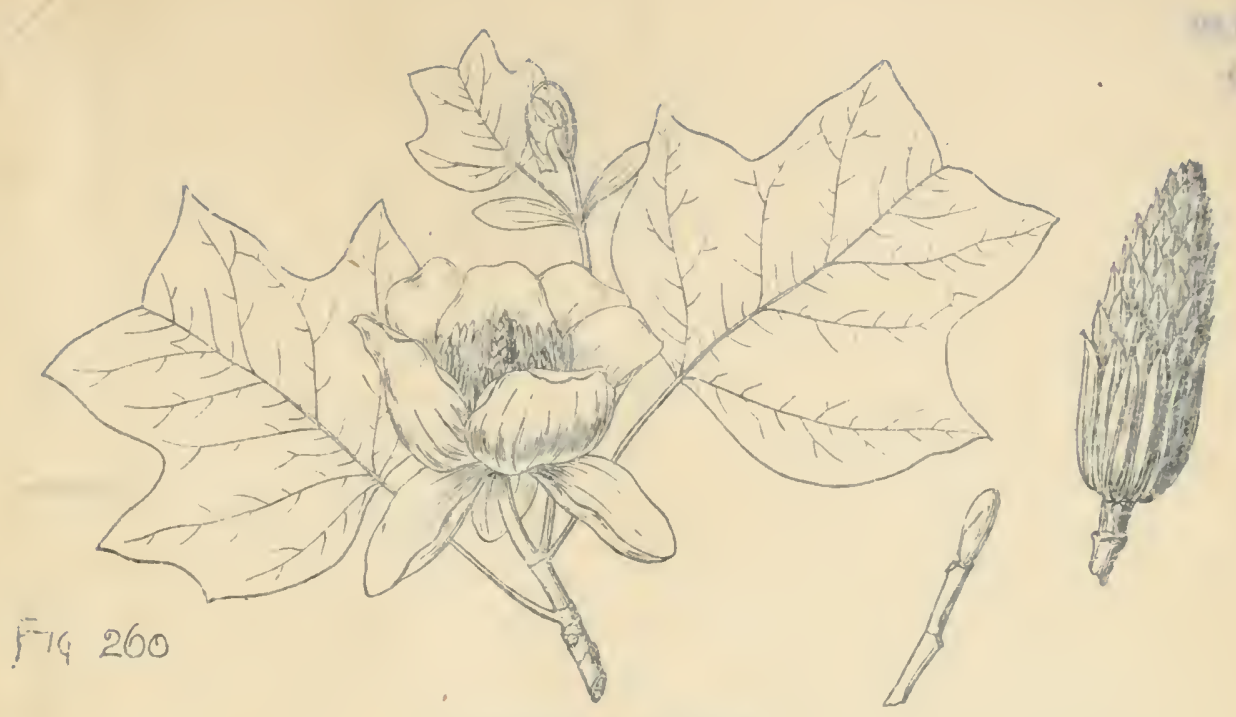

Liriodendron Tulipifera

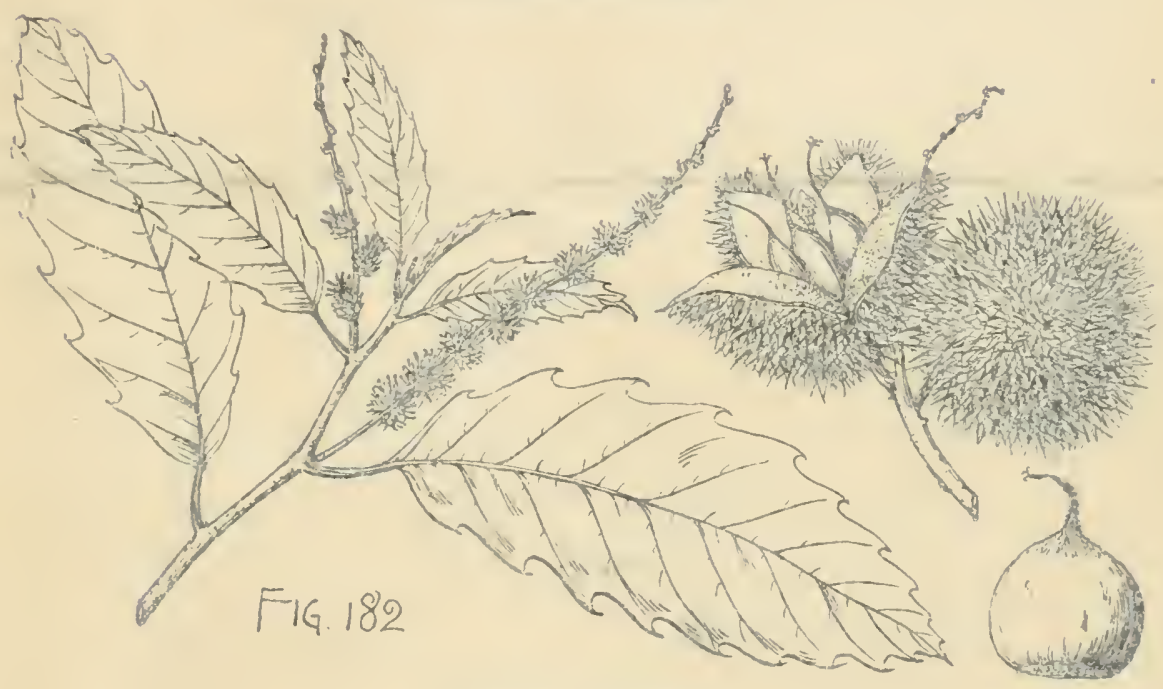

Castanea dentata

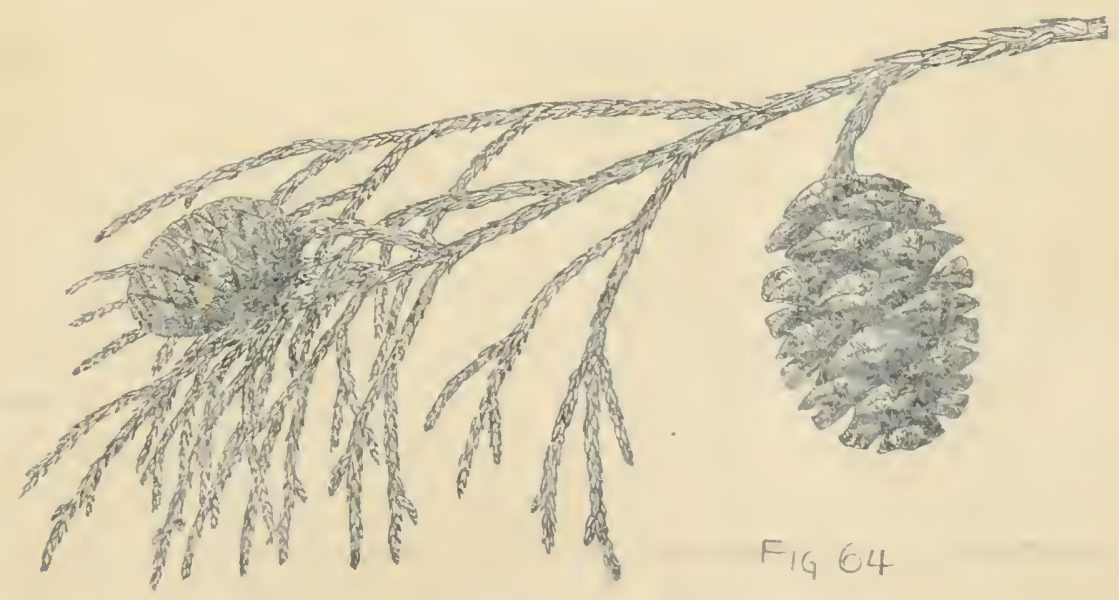

Sequoia grgantea 


\title{
ORDER BLANK
}

\author{
Dute
}

\section{HOUGHTON, MIFFLIN \& CO.}

\section{Siks :-}

For the enclosed check (or money order) for $\$ 1.00$ please send, postpaid, a copy of Sargent's "Manual of Trees" to the following address.

Name

Address 






\section{Qkfl New York Botanical Garden Library
Sargent. Charles Sp/Manual of the trees


